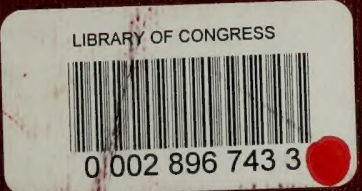


R

$=54^{4}$

(f(n)

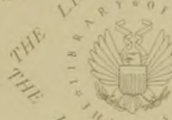
and
$\frac{29}{2}+2 w^{3}$

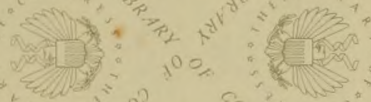

约

(1)

at

(ins

$1 \% 0$

(1)

$=\mathrm{A}^{0^{2}}$

ait 5

ro 


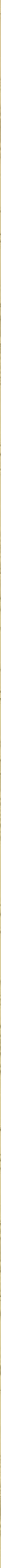







\author{
MARYLAND SHELL FISH COMMISSION \\ UNITED STATES BUREAU OF FISHERIES \\ UNITED STATES COAST AND GEODETIC SURVEY
}

\title{
SURVEY OF
}

\section{OYSTER BARS OF MARYLAND}

\section{6-1912}

By

CHARLES YATES

REPRESENTATIVE OF UNITED STATES COAST AND

GEODETIC SURVEY ON WORK OF

MARYLAND OYSTER SURVEY

CONTENTS

1. Summary

2. Anne Arundel County

3. Baltimore County

4. Calvert County

5. Charles County

6. Dorchester County

7. Kent County
8. Queen Annes County

9. St. Marys County

10. Somerset County

11. Talbot County

12. Wicomico County

13. Worcester County 


$$
\begin{gathered}
S H 365 \\
M 3 \\
1913 a
\end{gathered}
$$




\author{
DEPARTMENT OF COMMERCE \\ U. S. COAST AND GEODETIC SURVEY \\ o. H. TITTMANN, Superintendent
}

\title{
SUMMARY
}

OF

\section{SURVEY OF OYSTER BARS \\ OF}

MARYLAND

1906-1912

By C. C. YATES

Representative of the United States Coast and Geodetic Survey on the work of the Maryland Oyster Survey

WASHINGTON

GOVERNMENT PRINTING OFFICE

1913 
D. OF D.

NARR IS 1914 


\section{LETTER OF SUBMITTAL.}

\section{Departalent of Commerce, Coast and Geodetic Surver, Washington, May 23, 1913.}

SIR: I have the honor to transmit herewith the final report of the officer detailed from the United States Coast and Geodetic Survey as representative of that service on the work of the Maryland Oyster Survey.

The report, together with its accompanying index chart, is designed to serve both as a summary of and as an index to the 17 technical publications and 43 oyster charts resulting from the cooperation of the Maryland Shell Fish Commission, the United States Bureau of Fisheries, and the United states Coast and Geodetic Survey in the survey of the oyster resources of Maryland.

The work has been done under the provisions of the act of Congress entitled "An act to authorize the Secretary of Commerce and Labor to cooperate, through the Bureau of the Coast and Geodetic Survey and the Bureau of Fisheries, with the Shell Fish Commissioners of the State of Maryland in making surveys of the natural oyster beds, bars, and rocks in the waters within the State of Maryland," approved May 26, 1906, and of the acts of ('ongress making appropriations for sundry civil expenses of the Government for the fiscal years ending June 30, 1907, 1908, 1909, $1910,1911,1912$, and 1913.

Respectfully,

To Hon. Williay C. Redfield, Secretary of Commerce.
O. H. Titmmann, Superintendent. 



\section{CONTENTS.}

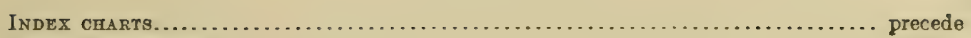

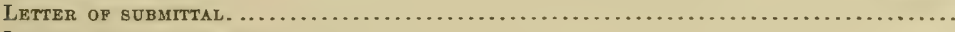

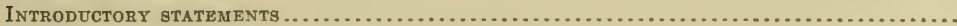

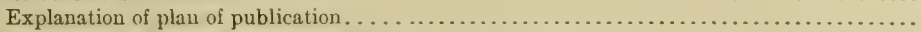

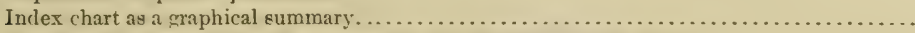

Relation of the work of the Government to the Maryland Oyster Survey ................

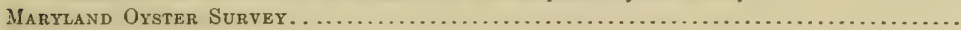

History.

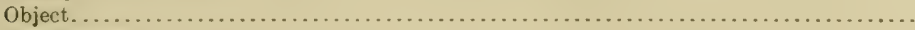

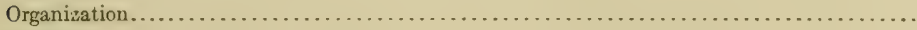

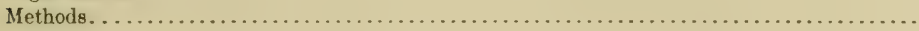

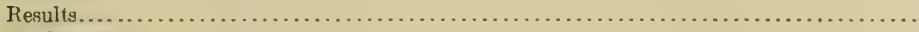

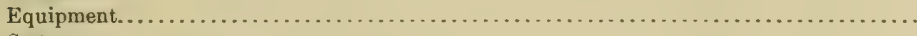

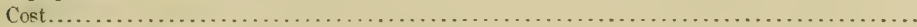

Chronological statement. . . . . . . . . . . . . . . . . . . . . . . . . . . . . . . .

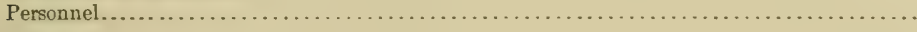

ConClusions

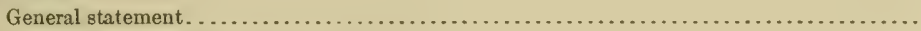

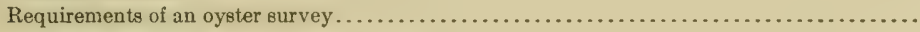

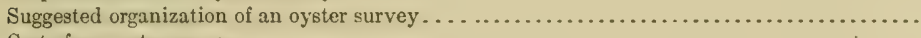

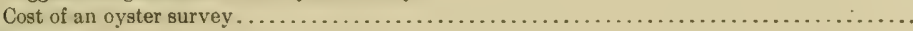

References.

TECHNXCAL INDEX TO PUBLICATIONS.

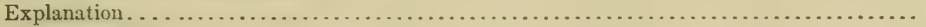

Natural oyster bars-

Alphabetical index.

Numerical index. .

Crab bottoms-

Alphabetical index.

Psa.

Clam beds-

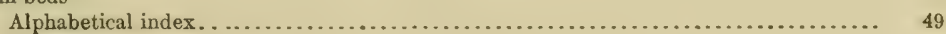

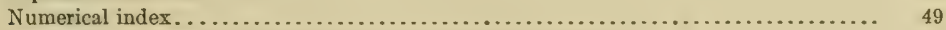

Landmarks (U. S. Coast and Geodetic Survey triangulation stations)-

Alphabetical index.

Numerical index. 



\title{
SUMMARY OF SURVEY OF OYSTERS BARS OF MARYLAND, 1906-1912.
}

\section{INTRODUCTORY STATEMENTS.}

\author{
EXPLANATION OF PLAN OF PUBLICATION.
}

It often happens that the rapid progress of modern science, eren when specialized by application to a single class of work, is the indirect cause of an accumulation of technical publications impossible to assimilate and apply to a special case without an amount of labor all out of proportion to the probable benefits to be derived. And this applies with particular force to the six years' work of the Maryland Oyster Survey, as evidenced by its publications consisting of a series of 17 official documents and 43 large-scale charts aggregating over 2,400 printed pages and 400 squaro feet of chart area.

For reasons similar to those just mentioned, the value of a modern technical publication describing a particular work is for a greater part dependent upon the fidelity with which it is confined to a record of methods and results which can be utilized in future operations of like character. And this end has been accomplished with remarkable suecess for the work of the Maryland Oyster Survey by Dr. Caswell Grave of Johns Hopkins University and a member of the Maryland Shell Fish Commission from 1906 to 1912, in his Fourth Report of the Shell Fish Commission of Maryland. $(X L I I I .)^{1}$

The intent of this "Summary" is to supplement Dr. (iruve's report, first, by an index chart which also serves as a graphical summary; second, by a brief explanation of the relation of the work of the Government to the Maryland Oyster Survey; third, by a summary of the essential features of the work of the Maryland Oyster Survey; fourth, by a statement of conclusions thought to be of value for use in connection with future oyster surveys; fifth, by a list of publications relating to the oyster industry of Maryland; and, sixth, by a technical index to all publications of the Government and the State directly resulting from the work of the Maryland Oyster Survey.

\section{INDEX CHART AS A GRAPHICAL SUMMARY.}

The best summary and index of the six years' work of the Maryland Oyster Survey, and probably the most useful and interesting feature of this publication, is the "Index Chart" in the folder.

The chart is self-explanatory as to details. But other considerations suggest that attention be directed to the magnitude of the shellfish resources of Maryland and to the magnitude of the actual work of the survey as indicated graphically by 
the green and red tinted areas on the water, the numerous small red triangles on the land, and the limits of the many large-scale charts required to represent these results in a practical form for future use.

RELATION OF THE WORK OF THE GOVERNMENT TO THE MARXLAND OTSTER SURVEY.

The Maryland Oyster Survey possessed the somewhat unusual character of having in its participants three separate Government bureaus and one State commission, ${ }^{1}$ all engaged in a common work leading to the conservation and the increase of the supply of food in the form of oysters.

In priority of the Government's interest in the subject of oysters, it is so selfevident that the United States Bureau of Fisheries comes first that this phase of the subject requires no explanation. ( $I X, X, X I, X I I, X I I I$, etc. $)^{2}$ And the connection of the work of the United States Bureau of Chemistry with the sanitary conditions of the oyster industry is made equally evident by the fact that it is this Bureau which administers the pure-food laws of this country. $(X X X V .)^{2}$ But the relation of the United States Coast and Geodetic Survey to such work is not so easy to explain. $(X X X I V .)^{2}$

The United States Const and Geodetic Survey includes among its many functions not only the supplying of the chart-making needs of navigation, but also the laying of the geodetic foundation for a large part of the geographic work of our country; and it naturally follows that this foundation part of an "oyster survey" should be laid by the institution normally performing this class of work. Just as in a similar sense, it is better and more economical to have the foundation of a building laid by those experienced in such work, even though in the end it is the superstructure erected on the foundation which is utilized and appreciated by the public.

Or stated in another way, it is only a question of the practical connection between the work of the United States Coast and Geodetic Survey in surveying and charting the waters of the coasts for the purposes of navigation, and the work of a so-called "oyster survey" in surveying and charting the oyster bottoms of these same waters of these same coasts for the purpose of developing the oyster industry of our country.

I U. S. Bureau of Fisheries, U. S. Cosst and Geodetic Survey, U. S. Bureau of Chemistry, and Margland Shell Fish Commission.

2 Bee "References," p. 19. 



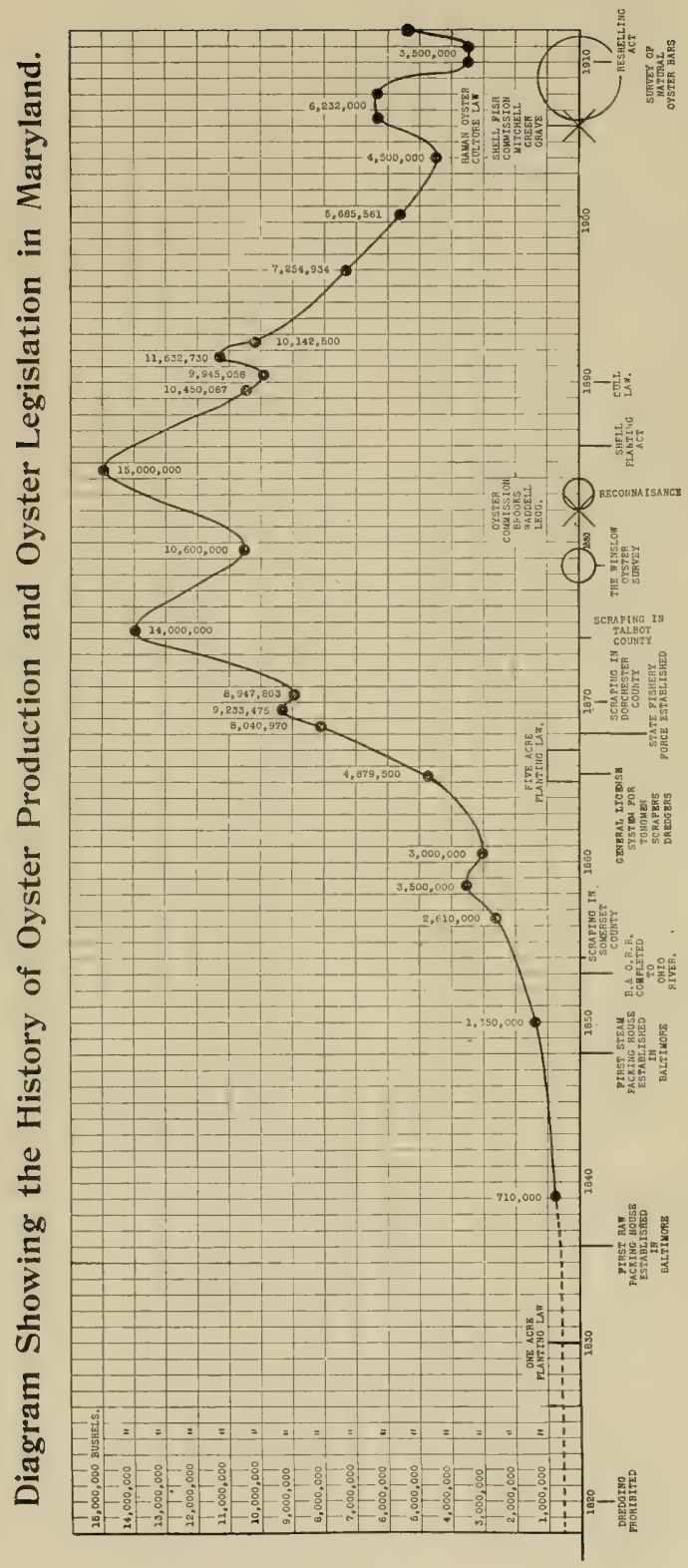




\section{MARYLAND OYSTER SURVEY.}

\section{HISTORY.}

$\Lambda$ summary view of the history of the oyster industry of Maryland is graphically represented by the diagram by Grave, which faces this page. $(X X X V I .)^{3}$

Another summary view of the same subject is presented by the chronological table of publications under the head of "References," 1 which were selected and arranged partly for that purpose.

The diagram and the table of publications, while being in most respects a sufficient historical statement for the purposes of this publication, do not do justice to the many whose unselfish activities for the benefit of the oyster industry of Maryland hare not followed the line of public work leading to a corresponding amount of printed records. And although these public-spirited citizens and officials are hundreds in number, there stands out at the head of this line of achievement, as do Brooks $(V)^{1}$ and Winslow $(I I)$ ' along their respective lines, the author ${ }^{2}$ of the Haman Oyster ('ulture Law (XLIII, pp. 353-372) ' ${ }^{1}$ who has most splendidly and persistently led the morement which has molded the history of oyster culture in Maryland for more than twenty years down to the present time. $(\text { VII. })^{1}$

\section{OBJECT,}

The immediate object of the Maryland Oyster Survey, as distinguished from the hopes of the ultimate benefits to be derived from that work, having been transformed into actual results, it is needless to emphasize this phase of the subject beyond referring to the statistical statements under the head of "Results" and to the graphic representation of these same facts on the "Index Chart."

But the ultimate object of the survey is another matter, and deals more nearly with what the pioneers of the oyster-culture movement in Maryland believed, and now have still more reason to believe, will be the form of the great oyster industry they expect to see erected on the foundation which has been laid for that purpose. $(V I I .)^{1}$

It now seems not only reasonable but probable that within the next generation the citizens of Maryland will be leasing and cultivating a probable 100,000 and a possible 300,000 acres $^{3}$ of so-called "barren bottoms" where oysters do not now grow in commercial quantities; that the more than 200,000 acres of natural oyster bars now reserved for the use of the oystermen as a result of the Maryland Oyster Survey will be so conserved and developed that they will produce, as they have done before, twice the amount they now yield; that the oyster industry of Maryland will then be based on an annual production of $20,000,000$ bushels of oysters where now it is

\footnotetext{
1 See "References," p. 19.

3. Howard Haman, of Baltimore, Md.

At the present date, May 23, 1813, some 36,000 acres have been applied for or leased.
} 
barely $5,000,000$; and that the physical valuation of the State-owned oyster lands will then be $\$ 100,000,000$, where now it is not more than $\$ 20,000,000$. ( $X X I V$, p. $208 ; X L I I$, pp. $35-46 ; X L V.)^{1}$

These are the large expectations that measured, and do still measure, the ultimate object of the Haman Oyster Culture Law, and which led to the building of the Maryland Oyster Survey in such a manner that it will serve as a foundation for even a greater development of the oyster industry of Maryland than was forecasted by its founders.

\section{ORGANIZATION.}

The organization of the Maryland Oyster Survey has been indicated in the "Introductory statements" and in the "Conclusions." It is also described in detail in the publications of the Maryland Shell Fish Commission (XLIII, pp. 11-25) ${ }^{1}$ and the United States Coast and Geodetic Survey (XLIV, pp. 19-21, 248-250). ${ }^{1}$

In a general way it is sufficient to state that the greater bulk of the work of this particular oyster survey was divided between the Maryland Shell Fish Commission ${ }^{2}$ and the United States Coast and Geodetic Survey in accordance with the laws (XLIV, pp. 243-246) ${ }^{1}$ authorizing the work and the natural division of the surveying operations of the cooperating forces.

The work of the Maryland Shell Fish Commission included all the oyster investigations, the special hydrographic operations required to delimitate the various shellfish bottoms, the surveying of the leased oyster lots, and all administrative matters pertaining to Maryland. The work of the United States Coast and Geodetic Survey included the establishing of the surveying foundation of triangulation, hydrography and topography, the preparation and publication of the technical and legal descriptions of the boundaries of the various shellfish bottoms reserved for the use of the public, and the preparation and publication of all the oyster charts showing the results of the work of the Maryland Oyster Survey.

Dr. H. F. Moore, the well-known scientist of the United States Bureau of Fisheries and representative of that bureau on the work of the Maryland Oyster Survey, has stated that "the Bureau of Fisheries has cooperated with the Coast and Geodetic Survey and the Maryland Shell Fish Commission principally as an adviser in matters relating to the biological and economic survey of oyster bars and the methods to be employed for that purpose." To which should be added in the way of explanation, that the part of the survey normally coming under the jurisdiction of the United States Bureau of Fisheries was in this case carried on by the State under the supervision of Dr. Caswell Grave, the scientific member of the Maryland Shell Fish Commission. If it had not been for this fortunate circumstance, to again quote Dr. Moore, "this work would have been conducted by the Bureau of Fisheries acting independently, as has been the case in certain other States than Maryland, the same ends being attained at greater expense to the Government." (XLIV, p. 20.) ${ }^{1}$

It should be stated also that the sanitary survey of the oyster-producing waters of Maryland by the United States Bureau of Chemistry was not carried on with the advantage of the same degree of cooperation as probably would have been the case if the character of this feature of the work could have been more nearly forecasted at the beginning. $(X X X V .)^{1}$ 
METHODS.

The methods employed on the work of the Maryland Oyster Survey being indicated in outline in the "Conclusions" and also explained in detail in the publications of the Maryland Shell Fish Commission (XLIII, pp. 4S-95) ${ }^{1}$ and the United States Coast and Geodetic Survey (XLIV, pp. 248-249, 172-177, 33-36, 20-21), it is not in harmony with the plan of this publication to repeat that information here.

But there is one point in the methods not adequately explained elsewhere in the publications of the Maryland Oyster Survey which it is believed should be emphasized. And that point relates to the advantages of the use of geographic coordinates in technically and legally defining boundaries of natural oyster bars and leased oyster bottoms.

This method of defining property lines under water was also used in the survey of the leased oyster bottoms of Delaware, and outlined in the following extract from the report of that work (XLVIII, pp. 69-74): ${ }^{1}$

The difficulties of accurately locating and permanently defining the boundaries of a farmer's plantation on land, even with the aid of monuments, public roads, streams of water, and other points of reference, are often great, judging from the disputes arising from this source. But be that as it may, there can be no doubt as to the difficulties of accurately locating and permanently defining the boundaries of an oysterman's plantation situated under water at a distance off shore from 1 to 6 miles, as is the case with the leased oyster bottoms of Delaware. (XLVIII, map.) $)^{2}$

There is only one point on the earth's surface at the intersection of any one parallel of latitude and any one meridian of longitude, and therefore, there can be no dispute as to the meaning of such a geographic definition of the location of a point, even though all the original triangulation station marks used in its determination, together with the chart on which its position was originally plotted, have been totally destroyed.

In the case of the destruction of an original triangulation station mark, or any other point defined by a geographic position, a competent geodetic engineer can reestablish its exact location by means of a new system of triangulation connecting with other distant triangulation station marks which have not been destroyed. In the case of the destruction of the chart on which the position of any such point on the earth's surface was originally plotted, this point can be replotted by its geographic position with any degree of accuracy permitted by the scale of any new chart constructed for that purpose.

If there be no question at the time of the original location and legal adoption of a geographic definition of the location of a point by a given latitude and longitude, there can be no techuical or legal question afterwards as to its exact meaning, or as to the exact redetermination of the location of this point, be it either on land or water at its newly determined position, or on a new chart in its newly plotted position.

For these reasons, the method of defining the location of boundary points by latitudes and longitudes (geographic positions) was adopted in the survey of the leased oyster bottoms of Delaware. This method is more or less an innovation in oyster surveys which was first used in connection with the work of the Maryland Oyster Survey. It possesses so many undoubted advantages, and at the same time is so simple in principle and application when once understood, that its adoption by other oyster surveys of other States than Maryland and Delaware seems probable.

\section{RESULTS.}

The results of the Maryland Oyster Survey are presented in many forms and in many places throughout the publications of that survey.

Graphically, they are represented on a large scale on the Maryland Oyster Charts, Nos. 1 to $42 . \quad(L I V .)^{1}$ On a medium-sized scale, they are partly shown on 
the "Progress maps" in the series of the 12 county publications of Survey of Oyster Bars of Maryland. ${ }^{1}$ On a much snaller scale they are represented as a whole on the "Index Chart" in the folder of this publication.

Statistically, the results are also described in various tables both in the publications of the Maryland Shell Fish Commission (XLIII, pp. 39-47, 102-103, 114-117, $126-127,132$, 145-149, 182-183, 189, 195-199, 206-210, 225-228, 239-241, 246, $321-322,336-339)^{1}$ and the United States Coast and Geodetic Survey (XVIII, pp. $18-19 ; X X$, p. $15 ; X X I I$, p. $16 ; X X V I$, p. $16 ; X X V I I I$, pp. $22-23 ; X X X$, p. $14 ; X X X I 1$, p. $14: X X X I X$, p. $18 ; X L$, p. $21 ; X L I V$, p. $25 ; X L V I$, pp. 23 , 180). ${ }^{1}$ But as these tables are too separated for the purposes of a summary view, their principle features will be given in groups of statistics arranged in accordance with the class of the results it is desired to present.

STATISTICS OF RESULTS PERTAINING TO SHELLFISH BOTTOMS RESERVED FOR PUBLIC USE.

Acres.

Natural oyster bars surveyed, technically defined, and reserved for the use of the public...... 215,845

Crab bottoms surveyed, technically defined, and reserved for the use of the public........... 43,991

Clam beds surveyed, technically defined, and reserved for the use of the public............. 506

STATISTICS OF RESULTS PERTAININE TO OYSTER BOTTOMS SUITABLE FOR OYSTER CULTURE.

Undeveloped, but known productive oyster culture bottoms owned by the State and subject to Acres. lease under the terms of the Haman Oyster Culture Law . . . . . . . . . . . . . . . . . . . . 100,000

Undeveloped, but estimated as being potentially productive oyster culture bottoms owned by the the State and subject to lease under the terms of the Haman Oyster Culture Law.......... 200,000

"Barren bottoms" of doubtful value for the growth of oysters, although in waters sufficiently salt for the purpose and subject to lease under the terms of the Haman Oyster Culture Law....... 460,000

STATISTICS OF RESULTS PERTAINING TO SURVEYING DATA USEFUL FOR SURVEY OPERATIONS OTHER THAN OYSTER SURVEYS.

Triangulation stations based on the standard datum of the United States Coast and Geodetic

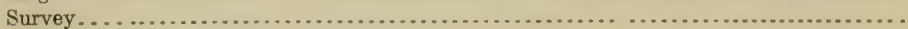

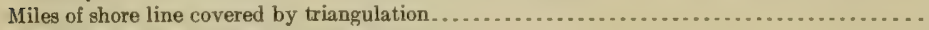

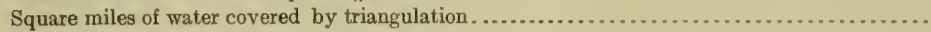

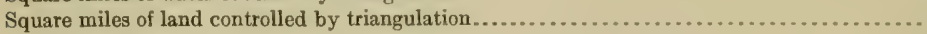

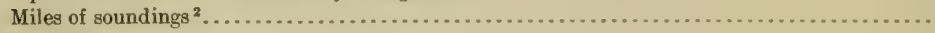

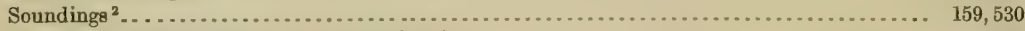

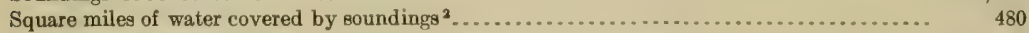

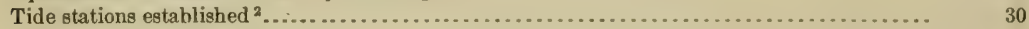

OTHER STATISTICS OF FTELD WORK INDICATING THE STANDARD OF THE SURVEYNG OPERATIONS ON WHICH THE RESULTS ARE BABED.

Oyster investigation stations occupied for examination of bottoms and other data........... 11,006

Miles of examination of shell bottoms with chain apparatus........................... 3,060

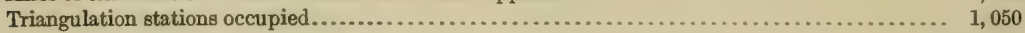

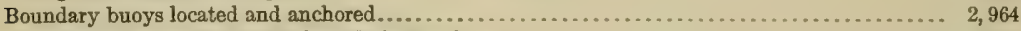

Monuments planted to mark triangulation stations. . . . . . . . . . . . . . . . . . . . . . . . . . . 1,000

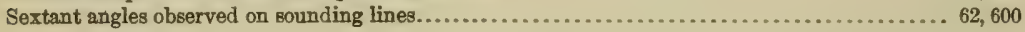

\footnotetext{
1 See "References," p. 19.

This part of the work was done under the immediate direction of Swepson Earle, Hydrographio Engineer of the Maryland Ehell Fish Commission.
} 
Hydrograhic positions plotted

Large-scale projections prepared, showing legal boundaries of shellfish bottoms...............

Geographic positions of triangulation stations computed...............................

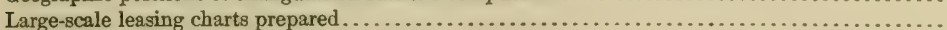

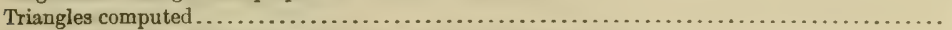

Description of triangulation stations prepered for publication.............................

Back azimuths and distances from comers of boundaries to triangulation stations computed..... 10,000
8,600

87

1,100

63

2,500

1,112

BTATISTICS OF PUBLCATIONB INDICATING QUANTITY OF WORE.

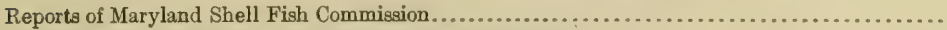

Printed pages in Maryland Shell Fish Commission reports................ . . . . . . . . . . . . . . 900

Publications of the United States Coast and Geodetic Survey ............................... 13

Printed pages in the United States Coast and Geodetic Survey publications............... I, 560

Progress maps in United States Coast and Geodetic Survey publications....................... 12

Oyster charts showing boundaries of shellfish bottoms published by United States Coast and

Geodetic Survey.

\section{EQUIPMENT.}

The equipment for the work of the Maryland Oyster Survey is fully described in the publications of the Maryland Shell Fish Commission (XLIII, pp. 34-36) ${ }^{1}$ and the United States Coast and Geodetic Survey (XVI, pp. 102-104).1

In a general way it may be stated that the equipment was ample and satisfactory, especially in respect to the large living and office quarters on the Maryland Shell Fish Commission houseboat Oyster (XLIII, p. 35) ${ }^{1}$ and the equipment of instruments furnished by the United States Const and Geodetic Survey for both the work of the Government and State.

cost.

On account of the divided administration that naturally goes along with cooptrative work of several independent institutions, the problem of fixing the cost of the six years' work of the Maryland Oyster Survey presents many difficulties. But Dr. Grave in the "Fourth Report of the Shell Fish Commission of Maryland" $(X L I I I, \text { p. } 33)^{1}$ has placed the figure at something more than a total of $\$ 200,000$ for all the work of both the Government and the State.

Accepting $\$ 200,000$ as the cost of the Maryland Oyster Survey, the following deductions will be of interest:

The total area of the tidewaters of Maryland covered by the Maryland Oyster Survey, including natural oyster bars, crab bottoms, clam beds, bottoms suitable for oyster culture, and all other bottoms interspaced between these shellfish areas, is approximately 1,600 square miles, or 1,020,000 acres. This makes the cost of surveying and charting this area approximately $\$ 125$ a square mile, or 20 cents an acre.

The total annual production of oysters in Maryland is now approximately $5,000,000$ bushels, and the estimated ultimate production is $20,000,000$ bushels. This makes a total cost of 1 cent per bushel for the estimated ultimate annual yield of the oyster industry to be operated on the surveying basis established by the 
Maryland Oyster Survey, or $1 \frac{1}{3}$ cents per bushel for the predicted 15,000,000-bushel increase in annual production.

The total physical valuation of the oyster industry of Maryland is estimated as being now approximately $\$ 20,000,000$, and the predicted ultimate valuation has been placed at $\$ 100,000,000$. This makes the cost of the Maryland Oyster Survey one-fifth of 1 per cent of the predicted ultimate value of the oyster industry to be based on that work, or one-quarter of 1 per cent of the predicted increase in valuation. $(X L I I, X L V .)^{3}$

\section{CHRONOLOGICAL STATEMENT.}

The chronological account of the six years' work of the Maryland Oyster Survey occupies many pages of both the publications of the Maryland Shell Fish Commission (XLIII, pp. 9-24,37-38) 1 and the United States Coast and Geodetic Survey (XVI, pp. 104-105; XVIII, pp. 17-18; XX, pp. 14-15; XXII, p. 15; XXVI, pp. 15-16; X.YVIII, pp. 21-22; XXX, pp. 13-14; XXXII, p. 13; XXXIX, pp. 17-18; $X L$, pp. 19-20; XLIV, pp. 23-25; XLVI, pp. 22-23). ${ }^{1}$ For the purposes of this publication it is thought that it will be sufficient to give a table of the dates of the begiming of the field work and the closing of the office work for ench county. The dates of the close of office work also being the dates of the filing of the certified charts and reports marking the legal opening of each county for the purpose of oyster culture under the provisions of the Haman Oyster Culture Law.

\begin{tabular}{|c|c|c|}
\hline County & $\underset{\text { work }}{\text { Beginning of field }}$ & $\begin{array}{l}\text { Close of office work } \\
\text { and date of filing of } \\
\text { certified charts and } \\
\text { reports }\end{array}$ \\
\hline $\begin{array}{l}\text { Anne Arundel } \\
\text { Somerset } \\
\text { Wicomico } \\
\text { Worcester } \\
\text { Calvert } \\
\text { Charles } \\
\text { St. Marys } \\
\text { Baltimore } \\
\text { Kent } \\
\text { Queen Annes } \\
\text { Talbot } \\
\text { Dorchester }\end{array}$ & $\begin{array}{l}\text { June 29, } 1906 \\
\text { May 2, } 1907 \\
\text { Aug. 27, } 1907 \\
\text { Nov. 8, } 1907 \\
\text { May 2, } 1908 \\
\text { Aug. 18, } 1908 \\
\text { May 2, } 1908 \\
\text { Apr. 14, } 1909 \\
\text { Apr. 14, } 1909 \\
\text { Apr. 14, } 1909 \\
\text { July 6, } 1909 \\
\text { Mar. 14, } 1910\end{array}$ & $\begin{array}{l}\text { June 20, } 1907 \\
\text { July } 1,1908 \\
\text { Dec. 1, } 1908 \\
\text { Apr. 12, } 1909 \\
\text { Dec. 14, } 1909 \\
\text { Jan. 27, } 1911 \\
\text { July 6, 1911 } \\
\text { Aug. 10, } 1911 \\
\text { Oct. 5, 1911 } \\
\text { Nov. 29, } 1911 \\
\text { July 20, } 1912 \\
\text { Aug. 17, } 1912\end{array}$ \\
\hline
\end{tabular}

PERSONNEL (1906-1912)

The following list of those directly connected with the work of the Maryland Oyster Survey, either as executives or technical experts, is given for purposes of reference only. So much could be said that is fine and true of the charactor and spirit of the work of many who were directly and indirectly connected with the six years' operations of the Maryland Oyster Survey, and the desire to say it is so great, that under the circumstances the only practical course in a summary publication of this sort is to omit all such comments. (XLIV, pp. 25-26; XLIII, pp. 11-25; XXXIV, p. 13. $)^{1}$ 
State of Maryland.

Maryland Shell Fish Commission.

Commissioners.

WALter J. MITChelL (1906-1912).

Caswell Grave (1906-1912).

BenjaMin K. GreEN (1906-1912).

Chief Engineer.

SWepson EARLE (1906-1912).
Assistant Engineers.

W. Gibson EMory (1906-1908).

ERNEST REPPENHAGEN (1907-1909).

T. H. Grave (1907-1911).

H. A. Marston (1908-1910),

H. E. Coluina (1910).

Hugk Mrtchell (1909-1912).

U. S. Department of Commerce.

U, 8, BUREAU OF FISHERIEG.

Representative of Bureau,

H. F. MOORE (1906-1912).

U. S. const AND Geodetic BURVEy.

Representative of Survey.

C. C. Yates (1906-1912).

Assistant Engineers.

Frank W. Seth (1906-1912).

E. A. Borst $(1906,1907,1909)$.

N. L. ARBUCELE (1906-1910).

Paul C. Whitney (1907).

J. J. Phelan (1907-1910).

Templeton Van de Bogert

(1911, 1912).

T. H. Grave (1911).
Draftsmen.

JoHN D. ToRREY (1906-1911).

G. C. Moore (1906-1911).

R. L. Ross (1911-1912).

T. J. Stockton (1911).

Georee W. Myers (1911).

Special Drafting Work.

DAVID M. HILDRETH.

C. R. Thompson.

ROBERT F. STORM.

J. C. MULFoRd. 


\section{CONCLUSIONS.}

GENERAL STATEMENT.

The Maryland Oyster Survey is probably the most extensive and complete work of its kind. And for that reason many of the conclusions resulting from experience gained in that work might be of public interest. But in harmony with the plan of this publication only those will be given which are thought to be of special value for use in connection with the consideration of future surreys of similar character.

The primary object of an oyster survey from a national point of view is to conserve and increase the national supply of food. And before this can be done intelligently and economically it is evident that an inventory (or a survey as it is more commonly called) of the oyster resources under investigation must be made and recorded on charts and in other forms. $(X X I I I, L I V .)^{1}$

As distinguished from a national point of view, the object of an oyster survey of a particular State or locality naturally partakes more of the character of a desire to develop the wealth of that State or locality by increasing its oyster industries or by revenues obtained from the leasing of the land underneath its oyster-producing waters. And like the Government, it is evident that a State can not accomplish these objects intelligently and economically without first having a survey made of its oyster resources. (XLIII, XLVIII. $)^{1}$

Considered from both these points of view, the cooperation of the General Government with a State government appears to be not only a legitimate and an economical arrangement, but also the best method of conducting an oyster survey.

\section{REQUIREMENTS OF AN OYSTER SURVEY.}

From the Crovernment stundpoint, the chief requirements of an oyster survey appear to be:

First. The representation on charts of the bottoms of the oyster-producing waters in such a manner as to show not only the limits of the natural growth of oysters as to locality and quantity, but also such other related information about these areas and the contiguous bottoms as will best indicate their value for the purpose of oyster culture. (XXIII, XLIX,LIV.) $)^{1}$

Second. A more detail description of the oyster bottoms than can be shown by symbols on the charts, and such other information as to the saltness of the water, the quantity and quality of the oyster food in the water, currents, tides, surrounding sanitary conditions, character of bottom, etc., as affect the growth and value of oysters. $(X, X X X V, X L I, X L I X \text {. })^{1}$

Third. The carrying on of the oyster survey in such a manner that whenever it is economical to do so the results of certain parts of the surveying operations made necessary by the requirements of the oyster survey can be utilized as a geographic 
foundation for chart-making surveys, mapping of the adjacent land regions, river and harbor improvements, etc. (XXXIV; XLIV, pp. 36-171; ILVIII, pp. 59-68.)'

From the State or local standpoint the desirable requirements of an oyster survey, in addition to those just stated, appear to be:

First. The well-defined representation on published charts, in a more or less arbitrary form, of the so-called "natural oyster bars" which are to be reserved for the use of the public by reason of ancient customs, public sentiment, or the laws of the State in which they are loeated. $(L I T .)^{1}$ And a similar well-defined representation on published charts of the boundaries of the bottoms leased from the State by private individuals for the purpose of oyster culture. (XLVIII, map.) ${ }^{1}$

Second. A more detail, technical, and legal deseription of the boundaries of these public natural oyster bars $\left(X^{*} L I V, P I^{2}, 172-242\right)^{1}$ and privato leased oyster hottoms (XLYIII, p). 69-108) than can be secured by their representation on the chart.s, in order that the State can fumish an easily defined and incontestible title to those oyster bottoms it may desire to lease for the purposes of revenue or for the encouragement of oyster culture.

Third. The representation of the information obtained by the oyster survey in such a mamner, both on charts and in publications, as will best combat the obstacles due to ignorance, prejudice, and polities, which are always to be found, to a greater or less extent, in every locality where oyster culture is in progress or being contemplated. (VII, XXIX, XXXIV, XXXVI, XXXVII, XXXVIII, XLI, XLII, $X L V, L I I I.)^{1}$

\section{SUGGESTED ORGANIZATION OF AN OYSTER SURVEY.}

A complete oyster survey includes a part of the normal scientific operations of three separate bureaus ${ }^{2}$ of the General Government, and for that reason, as has been previously indicated, an ideal survey of the oyster resources of any one State would involve the cooperation of these three Government bureaus with a State commission especially created for that purpose. $(X X X I V .)^{1}$

Arranged in the order of actual operations, and without reference to priority or magnitude of the interests involved, the distribution of the work of the suggested cooperative oyster survey would be as follows:

United States Coast and Geodetic Survey.-The establishment of a surveying foundation of triangulation, topography, and hydrography.

Lnited States Bureau of Fisheries.-The delimitation of the boundaries of the various classes of oyster hottoms and other scientific operations pertaining particularly to oysters. waters.

United States Bureau of Chemistry.-The sanitary survey of the oyster-producing

State Oyster Survey Commission.--The marking, defining, and eharting of the boundaries of both public and leased oyster bottoms, and the consideration of matters relating to the ceonomic development of the oyster inclustry to be based on the results of the oyster survey.

\footnotetext{
${ }^{2}$ See "References," p. 19. 2 Bureau of Fisheries, Coast and Geodetic Survey, and Bureau of Chemistry. $95112-13-2$
} 


\section{COST OF AN OYSTER SURVEY.}

There is no one thing more important to cither the layman or the engineer than to be able to make some sort of an estimate of the final cost of any engineering work being considered. And while the cost of any such work as the survey of the vast oyster resourees of Maryland is information which should be recorded, it is of value chiefly for the means it furnishes for estimating the cost of future engineering works of similar character.

Adopting the figures of Dr. Caswell Grave, ${ }^{1}$ the cost of a new oyster survey based on results obtained by the Maryland Oyster Survey would be approximately 20 cents an acre for the entire area to be covered without reference to the various bottoms as finally elassified. The legitimate share of the State's expenses being estimated at 11 cents and those of the Government at 9 cents an acre.

In considering the cost of an oyster survey, it should not be forgotten that the benefit to be derived by the Government from such operations would be not only in the form of an increase in the food supply of the country, but also in the form of a surveying foundation suitable for other chart and map making operations, river and harbor improvements, and so forth.

In further explanation it should be stated that all the uncertain elements of weather, season, character of the topography, refinement of results demanded, urgency for completion of work, and so forth, which make it so difficult to estimate the cost of a geographic survey on land, are further magnified in an oyster survey. Not only by waves produced by winds that would not deter work on land, but also by social and political conditions which are usually associated with such work.

It is also well to state in the way of warning that the preceding cost data when used as a basis for estimating the cost of oyster surveys in other States than Maryland may give only an approximately correct estimate under certain conditions. That for large open bodies of water, it might give an overestimate for good weather and an underestimate for bad weather, while for small bodies of water with complicated shore line and numerous small seattered oyster areas, it would probably furnish an underestimate because of the inereased detail of the work in proportion to the total area of the survey. 


\section{REFERENCES.}

Nore, -This list of publications was prepared solely for the purpose of furnishing such references as best suit the plan of this publication, and it should not be considered as being complete in any other sense.

\begin{tabular}{|c|c|c|c|c|c|}
\hline $\begin{array}{l}\text { Reference } \\
\text { number. }\end{array}$ & Date. & Title. & Aluthor or editor. & I'ublisher, - & Pages, etc. \\
\hline I & 1880 & $\begin{array}{l}\text { Report of the Commissioners of Fish- } \\
\text { eries of Maryland. }\end{array}$ & $\begin{array}{l}\text { T. B. Ferguson, Thos. } \\
\text { Hughlett, Wm. K. } \\
\text { Brooks, Francis } \\
\text { Winslow. }\end{array}$ & $\begin{array}{l}\text { Commission of Fish- } \\
\text { eries of Maryland. }\end{array}$ & 347 ; illus. \\
\hline II & 1881 & $\begin{array}{l}\text { Report on the oyster beds of the James } \\
\text { IRiver, Va., and of Tangier and } \\
\text { l'ocomoke Sounds, Mid. and Va. }\end{array}$ & Francis Winslow...... & $\begin{array}{l}\text { U. S. Coast and Geo } \\
\text { detic Survey. }\end{array}$ & 87; maps; illus. \\
\hline III & 1881 & $\begin{array}{l}\text { Report of Commissioner of Fisheries } \\
\text { of Maryland. }\end{array}$ & $\begin{array}{l}\text { T. B. Ferguson, John } \\
\text { A. Ryder, Francis } \\
\text { Winslow. }\end{array}$ & $\begin{array}{l}\text { Commission of Fish- } \\
\text { eries of Afaryland. }\end{array}$ & $158 ;$; illus. \\
\hline IV & 1881 & The oyster industry... & Ernest Ingersol....... & Bureau of Census...... & 251 ; illus. \\
\hline $\mathrm{V}$ & 1884 & $\begin{array}{l}\text { The development and protection of } \\
\text { the oyster in Maryland. }\end{array}$ & Wm. K. Brooks....... & $\begin{array}{l}\text { Johns Hokpins Uni- } \\
\text { versity. }\end{array}$ & 193; maps; illus. \\
\hline VI & $1 \leqslant 91$ & The oyster..... & $\ldots$ do $\ldots . . . .$. . & .... do....... & 230 ; illus. \\
\hline VII & 1893 & Oysters and roads... & B. Howard Haman... & $\begin{array}{l}\text { Maryland Road } \\
\text { League. }\end{array}$ & 44. \\
\hline VIII & 1893 & $\begin{array}{l}\text { Oyster records. Distances and bear- } \\
\text { ings of numbered corners of public } \\
\text { grounds, etc., of the State of Virginia. }\end{array}$ & J. B. Baylor.. & $\begin{array}{l}\text { Virginia Fish Com- } \\
\text { mission. }\end{array}$ & $\begin{array}{l}\text { Pamphlet for eac } \\
\text { county. }\end{array}$ \\
\hline IX & 1895 & The oyster industry of Maryland..... & Charles H. Stevenson.| & $\begin{array}{l}\text { U. S. Bureau of Fish- } \\
\text { eries. }\end{array}$ & 110 ; illus. \\
\hline $\mathrm{x}$ & 1897 & $\begin{array}{l}\text { Oysters and methods of oyster culture } \\
\text { with notes on clam culture. }\end{array}$ & H. F. Moore... & do & 78 ; illus. \\
\hline $\mathbf{X I}$ & 1899 & Report on the oyster beds of Louisiana & ..... do... & ..... đo. & 55 ; llus. \\
\hline XII & 1904 & $\begin{array}{l}\text { Investigations for the promotion of the } \\
\text { oyster industry of North Carolina. }\end{array}$ & Caswell Grave. & ..... do. & 95 ; map; illus. \\
\hline $\mathrm{XIII}$ & 1905 & The crab industry of Maryland....... & Winthrop A. Roberts. & ....do... & 18. \\
\hline $\mathrm{X} I \mathrm{~V}$ & 1907 & $\begin{array}{l}\text { First report of the Shell Fish Com- } \\
\text { mission of Maryland. }\end{array}$ & Caswell Grave.... & $\begin{array}{l}\text { Maryland Shell Fish } \\
\text { Commission. }\end{array}$ & 231; illas. \\
\hline XV & 1907 & $\begin{array}{l}\text { Survey of oyster bottoms in Matagorda } \\
\text { Bay, Tex. }\end{array}$ & H. F. Mioore... & $\begin{array}{l}\text { U. S. Bureau of Fish- } \\
\text { eries. }\end{array}$ & 86; map; illus. \\
\hline XVI & 1907 & $\begin{array}{l}\text { Survey of oyster bars, Anne Arundel } \\
\text { County, Mid. }\end{array}$ & C. C. Yates.. & $\begin{array}{l}\text { U. S. Coast and Geo- } \\
\text { detic Survey. }\end{array}$ & 106; map. \\
\hline XVII & 1903 & Fisheries of the United States........ & Bureau of Census...... & Bureau of Census ..... & 324. \\
\hline XVIII & 1908 & $\begin{array}{l}\text { Survey of oyster bars, Somerset Coun- } \\
\text { ty, Md. }\end{array}$ & C. C. Yates........... & $\begin{array}{l}\text { U. S. Coast and Geo- } \\
\text { detic Survey. }\end{array}$ & 118; map. \\
\hline $\mathrm{XIX}$ & 1909 & $\begin{array}{l}\text { Second report of the Shell Fish Com- } \\
\text { mission of Maryland.' }\end{array}$ & Caswell Grave... & $\begin{array}{l}\text { Maryland Shell Fish } \\
\text { Commission. }\end{array}$ & 149 ; illus. \\
\hline $\mathrm{xx}$ & 1909 & $\begin{array}{l}\text { Survey of oyster bars, Wicomico } \\
\text { County, Mrd. }\end{array}$ & C. C. Yates..... & $\begin{array}{l}\text { U. S. Coast and Geo- } \\
\text { detic Surrey. }\end{array}$ & 54; map. \\
\hline $\mathbf{X X I}$ & 1909 & Oyster supply of Maryland...... & Caswell Grave.... & $\begin{array}{l}\text { Conservation Commis- } \\
\text { sion of Maryland. }\end{array}$ & 13; illus. \\
\hline XXII & 1909 & $\begin{array}{l}\text { Survey of oyster bars, Worcester } \\
\text { County, Mrd. }\end{array}$ & C. C. Yates... & $\begin{array}{l}\text { U. S. Coast and Geo- } \\
\text { detic Survey. }\end{array}$ & 67; map. \\
\hline $\mathrm{X} x \mathrm{III}$ & 1910 & $\begin{array}{l}\text { Condition and extent of the oyster } \\
\text { beds of Jamos River, Va. }\end{array}$ & II. F, Moore... & $\begin{array}{l}\text { U. S. Bureau of Fish- } \\
\text { eries. }\end{array}$ & 83; map. \\
\hline XXIV & 1910 & Shell-fish industries. . . . . . . . . . . . . . . & James L. Kellogg...... & Henry Iolt \& Co..... & 361 ; illus. \\
\hline $\mathrm{XXV}$ & 1910 & $\begin{array}{l}\text { Oyster-culture experiments and in- } \\
\text { vestigations in Louisiana. }\end{array}$ & $\begin{array}{l}\text { H. F. Moore, T. E. B. } \\
\text { Pope. }\end{array}$ & $\begin{array}{l}\text { U. S. Bureau of Fish- } \\
\text { eries. }\end{array}$ & 54. \\
\hline XXVI & 1910 & $\begin{array}{l}\text { Survey of oyster bars, Calvert County, } \\
\text { Mrd. }\end{array}$ & C. C. Yates......... & $\begin{array}{l}\text { U. S. Coast and Geo- } \\
\text { detic Survey. }\end{array}$ & 94; map. \\
\hline XXVII & 1911 & $\begin{array}{l}\text { Condition and extent of the natural } \\
\text { oyster beds of Delaware. }\end{array}$ & II. F, Moore.. & $\begin{array}{l}\text { U. S. Bureau of Fish- } \\
\text { eries. }\end{array}$ & 29 ; map. \\
\hline
\end{tabular}


References-Continued.

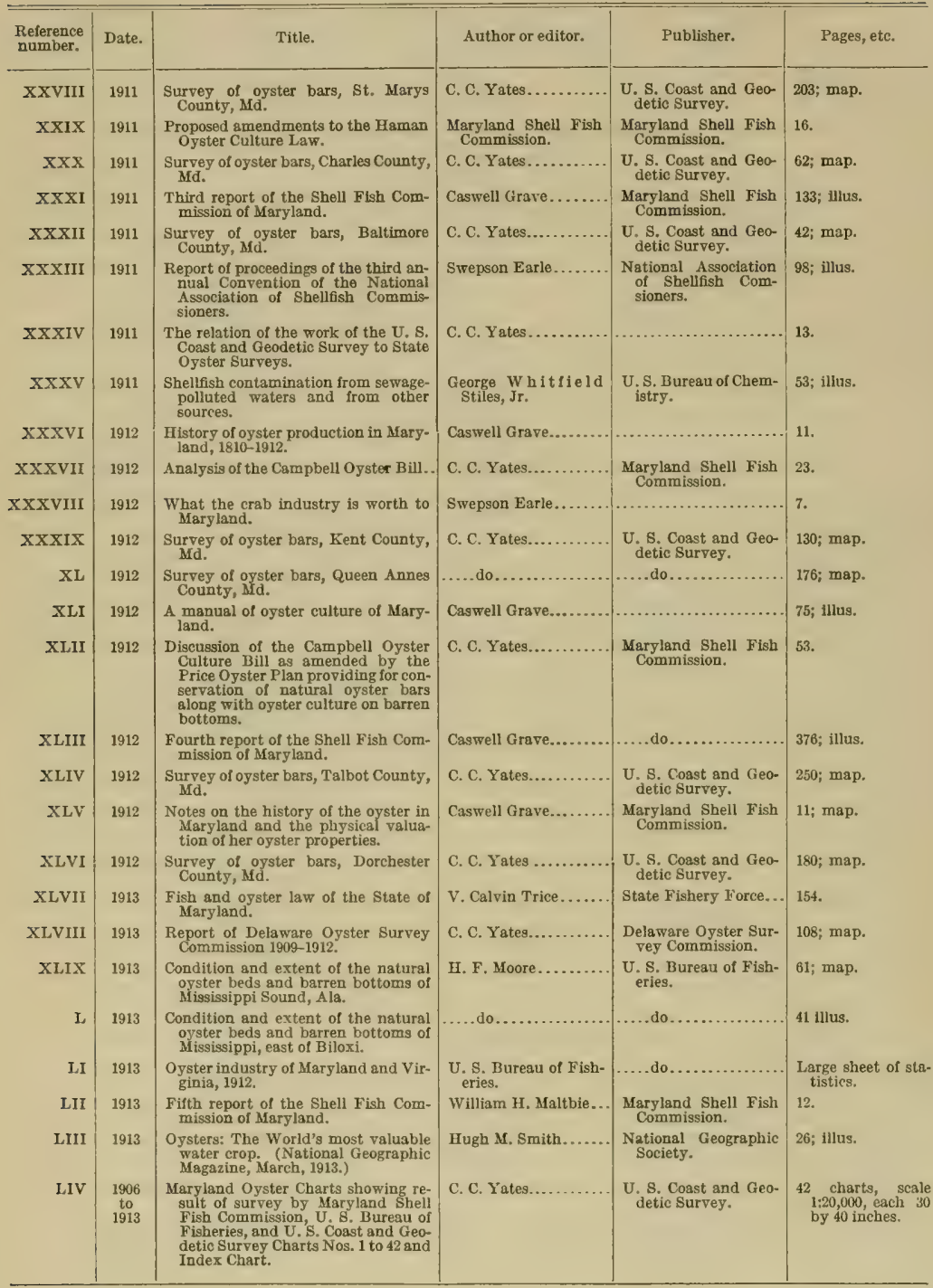




\title{
TECHNICAL INDEX TO PUBLICATIONS.
}

\author{
EXPLANATION.
}

The technical index to the publications of the Maryland Oyster Survey is divided into four sections of two parts each under the heads of "Natural oyster bars," "Crub bottoms," "Clam beds" and "Landmarks (U. S. Coast and Geodetic Survey triangulation stations)."

The first part of each section is an "Alphabetical index," which gives for each natural oyster bar, crab bottom, clam bed, or triangulation station, as the case may be-

1. The serial number of the Maryland oyster chart on which it is shown.

2. The approximate geographic location in latitude and longitude.

3. The county in which it is located.

4. The "County index number" by which it is indicated on the "Index chart."

5. The page number of the United States Coast and Geodetic Survey county publication of "Survey of oyster bars" on which it is technically described as to boundaries and locations.

6. The page number of the Fourth Report of the Shell Fish Commission, on which are described its characteristics pertaining particularly to oysters.

The second part of each section is a "Numerical index" arranged in a separate division for each county within which "Natural oyster bars," "Crab bottoms," "Clam beds," or "Triangulation stations" are located, and gives only the names of the bars, bottoms, beds, or stations, as the case may be, corresponding to the "County index number" of these same objects as shown on the "Index chart."

The "County index numbers" are arranged in numerical order on the "Index chart," commencing with No. 1 for each county, and in using an index number obtained from the "Index chart" it should be coupled with the name of the county in which it is located. The names of the different counties are given in large red letters on the "Index chart" and their boundaries are shown by red dash and dot lines. 


\section{NATURAL OYSTER BARS.}

ALPHABETIOAL INDEX.

NotE,-See Numerical Index for names of natural oyster bars corresponding to numbers on Index Chart.

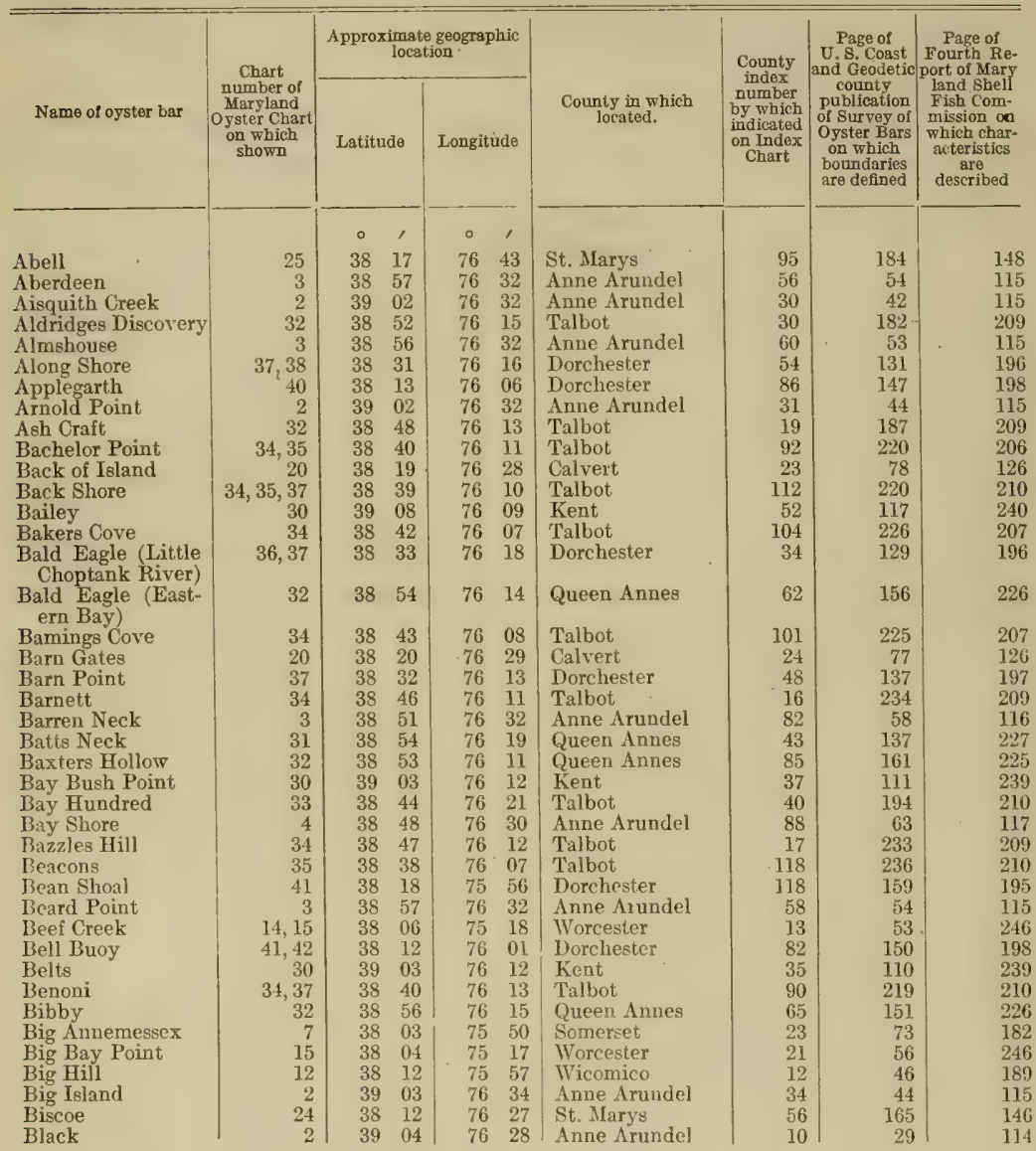


NATURAL OYSTER BARS.

Alphabetical Index to Natural Otster Bars-Continued.

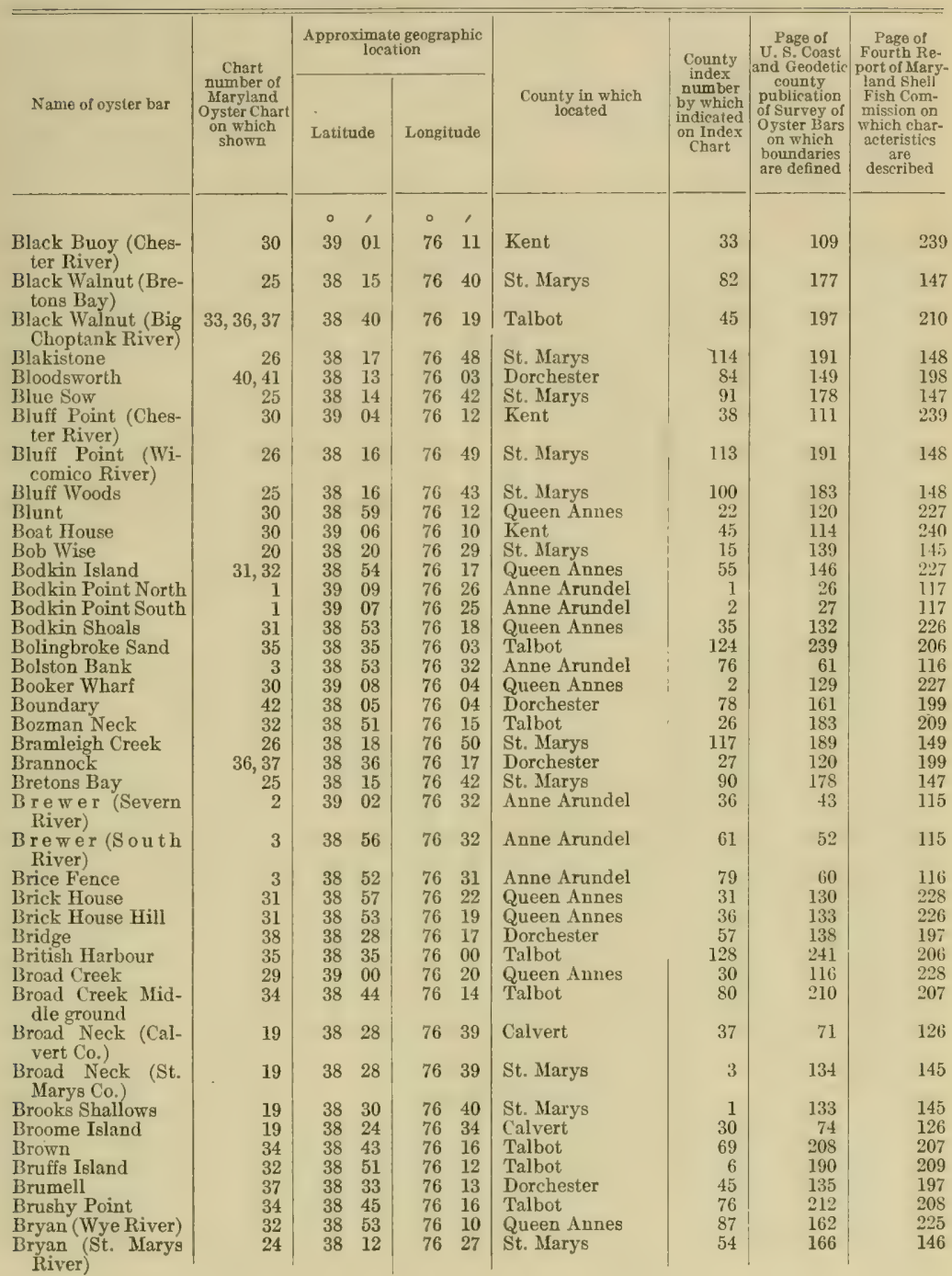


Alphabetical Index to Natural Otster Bars-Continued.

\begin{tabular}{|c|c|c|c|c|c|c|c|c|c|}
\hline \multirow[b]{2}{*}{ Name of oyster bar } & \multirow{2}{*}{$\begin{array}{c}\text { Chart } \\
\text { number of } \\
\text { Maryland } \\
\text { Oyster Chart } \\
\text { on which } \\
\text { shnwn }\end{array}$} & \multicolumn{4}{|c|}{$\begin{array}{c}\text { Approximate geographic } \\
\text { location }\end{array}$} & \multirow{2}{*}{$\begin{array}{l}\text { County in which } \\
\text { located }\end{array}$} & \multirow{2}{*}{$\begin{array}{l}\text { County } \\
\text { index } \\
\text { number } \\
\text { by which } \\
\text { indicated } \\
\text { on Index } \\
\text { Chart }\end{array}$} & \multirow{2}{*}{$\begin{array}{l}\text { Page of } \\
\text { U. S. Coast } \\
\text { and Geodetic } \\
\text { county } \\
\text { publication } \\
\text { of Survey of } \\
\text { Oyster Bars } \\
\text { on which } \\
\text { boundaries } \\
\text { are defined }\end{array}$} & \multirow{2}{*}{$\begin{array}{c}\text { Page of } \\
\text { Fourth Re- } \\
\text { port of Mary- } \\
\text { land Shell } \\
\text { Fish Com- } \\
\text { mission on } \\
\text { which char- } \\
\text { acteristics } \\
\text { are } \\
\text { described }\end{array}$} \\
\hline & & \multicolumn{2}{|c|}{ Latitude } & \multicolumn{2}{|c|}{ Longitude } & & & & \\
\hline & & $\circ$ & , & $\circ$ & , & & & & \\
\hline Buce & 3 & 38 & 53 & 76 & 32 & Anne Arundel & 73 & 62 & 116 \\
\hline Buckhorn & 32 & 38 & 58 & 76 & 15 & Queen Annes & 70 & 147 & 226 \\
\hline Bugby & 32 & 38 & 53 & 76 & 13 & Queen Annes & 77 & 158 & 226 \\
\hline Bullock & 26 & 38 & 15 & 76 & 49 & St. Marys & 110 & 193 & 148 \\
\hline Bullock Island & 26 & 38 & 15 & 76 & 48 & St. Marys & 109 & 193 & 148 \\
\hline Bungay & 41 & 38 & 17 & 76 & 01 & Dorchester & 110 & 155 & 195 \\
\hline Bunker Hill & 31 & 38 & 53 & & 20 & Queen Annes & 37 & 133 & 226 \\
\hline Buoy & 5 & 38 & 13 & 75 & 53 & Somerset & 3 & 62 & 183 \\
\hline Buoy Rock & 29,30 & 39 & 00 & 76 & 14 & Kent & 30 & 108 & 239 \\
\hline Butler & 22 & 38 & 06 & 76 & 20 & St. Marys & 32 & 148 & 149 \\
\hline Butterpot & 37 & 38 & 32 & 76 & 14 & Dorchester & 41 & 133 & 196 \\
\hline Buzzard Island & 19 & 38 & 29 & 76 & 40 & Calvert & 39 & 70 & 127 \\
\hline $\begin{array}{l}\text { Cabin Creek (Chop- } \\
\text { tank River) }\end{array}$ & 35 & 38 & 38 & 75 & 59 & Dorchester & 3 & 112 & 197 \\
\hline $\begin{array}{l}\text { Cabin Creek (Pros- } \\
\text { pect Bay) }\end{array}$ & 32 & 38 & 56 & 76 & 13 & Queen Annes & 74 & 154 & 226 \\
\hline $\begin{array}{l}\text { Cabin Creek En- } \\
\text { trance }\end{array}$ & 35 & 38 & 38 & 75 & 58 & Dorchester & 2 & 111 & 197 \\
\hline Camden Point & 34 & 38 & 44 & 76 & 07 & Talbot & 110 & 229 & 207 \\
\hline Canoe Creek & 25 & 38 & 15 & 76 & 44 & St. Marys & 101 & 182 & 148 \\
\hline Captain Point & 19 & 38 & 23 & 76 & 32 & St. Marys & 9 & 136 & 145 \\
\hline Carpenter Island & 30 & 39 & 01 & 76 & 11 & Queen Annes & 20 & 121 & 227 \\
\hline Carpenters Yard & 26 & 38 & 30 & 76 & 40 & Charles & 3 & 54 & 132 \\
\hline $\begin{array}{l}\text { Carroll Muds (Cal- } \\
\text { vert Co.) }\end{array}$ & 20 & 38 & 19 & 76 & 25 & Calvert & 15 & 82 & $126-127$ \\
\hline $\begin{array}{l}\text { Carroll Muds (St. } \\
\text { Marys Co.) }\end{array}$ & 20 & 38 & 19 & 76 & 25 & St. Marys & 22 & 142 & $145-149$ \\
\hline Carthagena Creek & 24 & 38 & 09 & 76 & 28 & St. Marys & 62 & 157 & 146 \\
\hline Carvel. & 29 & 39 & 00 & 76 & 17 & Queen Annes & 27 & 118 & 227 \\
\hline Cason & 37 & 38 & 32 & 76 & 15 & Dorchester & 38 & 132 & 196 \\
\hline Castle Haven & 35,37 & 38 & 38 & 76 & 12 & Dorchester & 18 & 118 & 199 \\
\hline Castle Haven Creek & 35 & 38 & 37 & 76 & 10 & Dorchester & 17 & 117 & 199 \\
\hline Cators & $36,37,38$ & 38 & 30 & 76 & 19 & Dorchester & 61 & 124 & 196 \\
\hline Cedar Island & 31 & 38 & 55 & 76 & 17 & Queen Annes & 57 & 144 & 227 \\
\hline $\begin{array}{l}\text { Cedar Point (West } \\
\text { River) }\end{array}$ & 3 & 38 & 51 & 76 & 31 & Anne Arundel & 84 & 58 & 116 \\
\hline $\begin{array}{l}\text { Cedar Point (St. } \\
\text { George River) }\end{array}$ & 24 & 38 & 09 & 76 & 30 & St. Marys & 76 & 171 & 147 \\
\hline $\begin{array}{l}\text { Cedar Point (Broad } \\
\text { Creek) }\end{array}$ & 34 & 38 & 44 & 76 & 14 & Talbot & 81 & 214 & 207 \\
\hline Cedar Point Hollow & 20,21 & 38 & 16 & 76 & 23 & St. Marys & 25 & 144 & 149 \\
\hline Cedar Shoal & 11 & 38 & 18 & 75 & 54 & Wicomico & 6 & 44 & 189 \\
\hline Chadwick & 24 & 38 & 10 & 76 & 31 & St. Marys & 79 & 173 & 147 \\
\hline Chain Shoal & 7 & 38 & 07 & 75 & 58 & Somerset & 11 & 67 & 183 \\
\hline Chancellor Point & 35 & 38 & 35 & 76 & 01 & Talbot & 127 & 240 & 206 \\
\hline Change & 33 & 38 & 43 & 76 & 18 & Talbot & 51 & 200 & 208 \\
\hline Chapel Point & 25 & 38 & 16 & 76 & 42 & St. Marys & 94 & 182 & 148 \\
\hline Chaptico Lumps & 26 & 38 & 20 & 76 & 51 & St. Marys & 121 & 187 & 149 \\
\hline Charleston Creek & 26 & 38 & 17 & 76 & 50 & Charles & 11 & 50 & 132 \\
\hline Chase & 2 & 39 & 01 & 76 & 31 & Anne Arundel & 28 & 41 & 114 \\
\hline $\begin{array}{l}\text { Cherry ( } \mathrm{R} \text { h o d e } \\
\text { River) }\end{array}$ & 3 & 38 & 53 & 76 & 31 & Anne Arundel & 72 & 60 & 115 \\
\hline $\begin{array}{l}\text { Cherry (St. Marys } \\
\text { River) }\end{array}$ & 24 & 38 & 07 & 76 & 28 & St. Marys & 66 & 154 & 146 \\
\hline
\end{tabular}


NATURAL OYSTER BARS.

Alphabetical Index to Natural Oyster Bars-Continued.

\begin{tabular}{|c|c|c|c|c|c|c|c|c|c|}
\hline \multirow{3}{*}{ Name of oyster bar } & \multirow{3}{*}{\begin{tabular}{c|} 
Chart \\
number of \\
Maryland \\
Oyster Chart \\
on which \\
shown
\end{tabular}} & \multicolumn{4}{|c|}{$\begin{array}{l}\text { Approximate geographic } \\
\text { location }\end{array}$} & \multirow{3}{*}{$\begin{array}{l}\text { County in which } \\
\text { located }\end{array}$} & \multirow{3}{*}{$\begin{array}{l}\text { County } \\
\text { index } \\
\text { number } \\
\text { by which } \\
\text { indicated } \\
\text { on Index } \\
\text { Chart }\end{array}$} & \multirow{2}{*}{$\begin{array}{l}\text { Page of } \\
\text { U. S. Coast } \\
\text { and Geodetic } \\
\text { county } \\
\text { publication } \\
\text { of Survey of } \\
\text { Oyster Bars } \\
\text { on which } \\
\text { boundaries } \\
\text { are defined }\end{array}$} & \multirow{2}{*}{$\begin{array}{c}\text { P'age of } \\
\text { Fourth Re- } \\
\text { port of Mary- } \\
\text { land Shell } \\
\text { Fish Com- } \\
\text { mission on } \\
\text { which char- } \\
\text { acteristics } \\
\text { ace } \\
\text { described }\end{array}$} \\
\hline & & \multicolumn{2}{|c|}{ Latitude } & \multicolumn{2}{|c|}{ Longitude } & & & & \\
\hline & & $\circ$ & , & $\circ$ & , & & & & \\
\hline Cherry Island & 37 & 38 & 34 & 76 & 13 & Dorchester & 44 & 136 & 197 \\
\hline $\begin{array}{c}\text { Cherry Tree }(\mathrm{Pa}- \\
\text { tuxent River }\end{array}$ & 20 & 38 & 19 & 76 & 27 & Calvert & 21 & 79 & 126 \\
\hline $\begin{array}{l}\text { Cherry Tree (Nan- } \\
\text { ticoke River) }\end{array}$ & 11 & 38 & 18 & 75 & 55 & Wicomico & 8 & 44 & 189 \\
\hline $\begin{array}{l}\text { Chester River Mid- } \\
\text { dleground }\end{array}$ & 30 & 39 & 05 & 76 & 11 & Kent & 39 & 112 & 239 \\
\hline Cheston Point & 3 & 38 & 52 & 76 & 31 & Anne Arundel & 80 & 59 & 116 \\
\hline Chicken Cock & 24 & 38 & 07 & 76 & 26 & St. Marys & 41 & 153 & 146 \\
\hline $\begin{array}{l}\text { Chinese Muds (Cal- } \\
\text { vert Co.) }\end{array}$ & 20 & 38 & 21 & 76 & 23 & Calvert & 13 & 83 & 127 \\
\hline $\begin{array}{l}\text { Chinese Muds (St. } \\
\text { Marys Co.) }\end{array}$ & 20 & 38 & 19 & 76 & 22 & St. Marys & 24 & 143 & 149 \\
\hline Chinks Point & 2 & 38 & 58 & 76 & 28 & Anne Arundel & 44 & 35 & 115 \\
\hline Chlora Point & 35 & 38 & 38 & 76 & 09 & Talbot & 117 & 235 & 210 \\
\hline Choptank Lumps & 34,37 & 38 & 40 & 76 & 14 & Talbot & 89 & 218 & 210 \\
\hline Church Creek & 8 & 37 & 59 & 76 & 05 & Somerset & 37 & 74 & 183 \\
\hline Church Hill & 33,34 & 38 & 41 & 76 & 18 & Talbot & 48 & 198 & 210 \\
\hline Clay Bank & 33,36 & 38 & 27 & 76 & 23 & Talbot & 43 & 196 & 210 \\
\hline Clay Island & 41 & 38 & 14 & 75 & 59 & Dorchester & 112 & 153 & 195 \\
\hline Clem Point & 2 & 39 & 01 & 76 & 32 & Anne Arundel & 37 & 42 & 115 \\
\hline Cliff & 30 & 39 & 06 & 76 & 09 & Kent & 56 & 118 & 239 \\
\hline Coad & 24 & 38 & 09 & 76 & 28 & St. Marys & 63 & 156 & 146 \\
\hline Coal Lump & 28 & 39 & 15 & 76 & 15 & Kent & 3 & 96 & 241 \\
\hline Cobb Point & 26 & 38 & 15 & 76 & 50 & Charles & 15 & 52 & 132 \\
\hline Coffee & 32 & 38 & 52 & 76 & 13 & Queen Annes & 80 & 158 & 226 \\
\hline Cohouck & 26 & 38 & 21 & 76 & 51 & St. Marys & 122 & 187 & 149 \\
\hline Collins Flats & 3 & 38 & 51 & 76 & 31 & Anne Arundel & 85 & 57 & 116 \\
\hline Commander & 35 & 38 & 35 & 76 & 07 & Dorchester & 14 & 116 & 199 \\
\hline Commegys Bight & 30 & 39 & 06 & 76 & 08 & Kent & 57 & 119 & 239 \\
\hline Cook Point & 36,37 & 38 & 39 & 76 & 17 & Dorchester & 22 & 118 & 199 \\
\hline Cooper Creek & 24 & 38 & 10 & 76 & 27 & St. Marys & 59 & 161 & 146 \\
\hline Coopers Point & 34 & 38 & 45 & 76 & 16 & Talbot & 74 & 211 & 208 \\
\hline Coppage & 24 & 38 & 10 & 76 & 27 & St. Marys & 60 & 161 & 146 \\
\hline Cormal & 7 & 38 & 08 & 75 & 50 & Somerset & 17 & 69 & 182 \\
\hline Corners IVharf & 37 & 38 & 37 & 76 & 13 & Dorchester & 19 & 129 & 199 \\
\hline Cove Point Bight & 20 & 38 & 22 & 76 & 22 & Calvert & 9 & 85 & 127 \\
\hline Cow Island & 36,37 & 38 & 33 & 76 & 18 & Dorchester & 33 & 128 & 196 \\
\hline Cox & 34 & 38 & 46 & 76 & 09 & Talbot & 15 & 235 & 209 \\
\hline Cox Neck & 31 & 38 & 54 & 76 & 17 & Anne & 56 & 145 & 227 \\
\hline Crab Alley Lumps & 31,32 & 38 & 55 & 76 & 16 & Queen Annes & 59 & 144 & 227 \\
\hline Crab Point & 40 & 38 & 16 & 76 & 08 & Dorchester & 89 & 147 & 198 \\
\hline Creces Cove & 2 & 38 & 59 & 76 & 29 & Arundel & 23 & 37 & 114 \\
\hline Curtis & 3 & 38 & 52 & 76 & 30 & Anne Arundel & 86 & 57 & 117 \\
\hline Daddie Dare & 17 & 38 & 34 & 76 & 30 & Calvert & 5 & 66 & 127 \\
\hline Dark Point & 40 & 38 & 18 & 76 & 10 & Dorchester & 94 & 144 & 198 \\
\hline Davis Creek & 30 & 39 & 07 & 76 & 10 & Kent & 47 & 115 & 240 \\
\hline Dawson & 34 & 38 & 41 & 76 & 17 & Talbot & 66 & 206 & 210 \\
\hline Deep Landing Hole & 28,29 & 39 & 09 & 76 & 16 & Kent & 11 & 101 & 241 \\
\hline Deep Neck & 34 & 38 & 44 & 76 & 15 & Talbot & 70 & 209 & 207 \\
\hline Deep Point & 30 & 39 & 07 & 76 & 07 & Kent & 59 & 119 & 239 \\
\hline Deep Point Mud & 20 & 38 & 18 & 76 & 26 & St. Marys & 21 & 142 & 145 \\
\hline Deep Shoal & 28 & 39 & 15 & 76 & 14 & Kent & 2 & 95 & 241 \\
\hline Deep Water & 15 & 38 & 04 & 75 & 17 & Worcester & 23 & 57 & 246 \\
\hline
\end{tabular}


Alphabetical Index to Natural Oyster Bars-Continued.

\begin{tabular}{|c|c|c|c|c|c|c|c|c|c|}
\hline \multirow{2}{*}{ Nane of oyster bar } & \multirow{2}{*}{$\begin{array}{c}\text { Chart } \\
\text { number of } \\
\text { Maryland } \\
\text { Oyster Chart } \\
\text { on which } \\
\text { shown }\end{array}$} & \multicolumn{4}{|c|}{$\begin{array}{c}\text { Approximate geographic } \\
\text { location }\end{array}$} & \multirow{2}{*}{$\begin{array}{l}\text { County in which } \\
\text { located }\end{array}$} & \multirow{2}{*}{$\begin{array}{c}\text { County } \\
\text { index } \\
\text { number } \\
\text { by which } \\
\text { intlicated } \\
\text { on Index } \\
\text { Chart }\end{array}$} & \multirow{2}{*}{$\begin{array}{l}\text { Page of } \\
\text { U. S. Coast } \\
\text { and Geoodetic } \\
\text { county } \\
\text { publication } \\
\text { of Survey of } \\
\text { Oyster Bars } \\
\text { on which } \\
\text { boundaries } \\
\text { are defined }\end{array}$} & \multirow{2}{*}{$\begin{array}{l}\text { Page of } \\
\text { Fourth Re- } \\
\text { port of Mary- } \\
\text { land Shell } \\
\text { Fish Com- } \\
\text { mission on } \\
\text { which char- } \\
\text { acteristies } \\
\text { are } \\
\text { described }\end{array}$} \\
\hline & & \multicolumn{2}{|c|}{ Latitude } & \multicolumn{2}{|c|}{ Longitude } & & & & \\
\hline Deep Water Point & & 0 & & 0 & & & & & \\
\hline $\begin{array}{l}\text { Deep Water Point } \\
\text { Diamond (Chesa- } \\
\text { peake Bay) }\end{array}$ & $\begin{array}{r}32 \\
36,37\end{array}$ & $\begin{array}{ll}38 & 4 \\
38 & 3\end{array}$ & $\begin{array}{l}48 \\
37\end{array}$ & $\begin{array}{ll}76 & 1 \\
76 & 2\end{array}$ & $\begin{array}{l}13 \\
20\end{array}$ & $\begin{array}{l}\text { Talbot } \\
\text { Dorchester }\end{array}$ & $\begin{array}{l}20 \\
25\end{array}$ & $\begin{array}{l}186 \\
120\end{array}$ & $\begin{array}{l}209 \\
199\end{array}$ \\
\hline $\begin{array}{l}\text { Diamond (Chinco- } \\
\text { teague Bay) }\end{array}$ & 14,15 & $\begin{array}{ll}38 & 0\end{array}$ & 06 & 751 & 17 & Worcester & 12 & 54 & 246 \\
\hline $\begin{array}{l}\text { Dickinson } \\
\text { Dividing }\end{array}$ & $\begin{array}{l}35 \\
32\end{array}$ & $\begin{array}{ll}38 & 3 \\
38 & 5\end{array}$ & $\begin{array}{l}36 \\
53\end{array}$ & $\begin{array}{ll}76 & 0 \\
76 & 1\end{array}$ & & $\begin{array}{l}\text { Talbot } \\
\text { Queen Annes }\end{array}$ & $\begin{array}{r}121 \\
96\end{array}$ & $\begin{array}{l}238 \\
166\end{array}$ & $\begin{array}{l}210 \\
225\end{array}$ \\
\hline Dixon & 35 & 383 & 36 & & & Dorchester & 5 & 112 & 197 \\
\hline Domi & 32 & 385 & 56 & & & Queen Annes & 66 & 151 & 226 \\
\hline Double Mills & 34 & $\begin{array}{ll}38 & 4 \\
30 & 0\end{array} \longrightarrow \longrightarrow$ & 44 & & & Talbot & 108 & 228 & 207 \\
\hline $\begin{array}{l}\text { Dredge Rock } \\
\text { Drum }\end{array}$ & $\begin{array}{l}29 \\
15\end{array}$ & 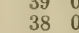 & $\begin{array}{l}01 \\
04\end{array}$ & $\begin{array}{ll}76 & 1 \\
75 & 1\end{array}$ & $\begin{array}{l}15 \\
16\end{array}$ & $\begin{array}{l}\text { Kent } \\
\text { Worcester }\end{array}$ & $\begin{array}{r}26 \\
19\end{array}$ & 106 & 239 \\
\hline $\begin{array}{l}\text { Drum } \\
\text { Drum Point (Chop- }\end{array}$ & $\begin{array}{l}15 \\
35\end{array}$ & 383 & 39 & & $\begin{array}{l}10 \\
57\end{array}$ & $\begin{array}{l}\text { Worcester } \\
\text { Dorchester }\end{array}$ & 19 & & 246 \\
\hline $\begin{array}{l}\text { Drum Point (Chop- } \\
\text { tank River) }\end{array}$ & & & & & & & 1 & 111 & 197 \\
\hline $\begin{array}{l}\text { Drum Point (Lang- } \\
\text { ford Creek) }\end{array}$ & 30 & 390 & 07 & 761 & 10 & Kent & 46 & 114 & 240 \\
\hline $\begin{array}{l}\text { Drum Point (Wye } \\
\text { River) }\end{array}$ & 32 & 385 & 53 & 761 & 11 & Queen Annes & 89 & 163 & 225 \\
\hline $\begin{array}{l}\text { Drum Point (Mano- } \\
\text { kin River) }\end{array}$ & 7 & 380 & 07 & 755 & 53 & Somerset & 19 & 71 & 182 \\
\hline $\begin{array}{l}\text { Drum Point (Broad } \\
\text { Creek) }\end{array}$ & 34 & 384 & 45 & 761 & 13 & Talbot & 82 & 214 & 207 \\
\hline Duck Island & 41 & 381 & 16 & 76 & 00 & Dorchester & 111 & 155 & 195 \\
\hline art Channel & $\begin{array}{l}25 \\
24\end{array}$ & $\begin{array}{lll}38 & 1 \\
38 & 0 & 0\end{array}$ & $\begin{array}{l}13 \\
07\end{array}$ & $\begin{array}{l}76 \\
76 \\
2\end{array}$ & $\begin{array}{l}45 \\
24\end{array}$ & t. Mar & $\begin{array}{r}104 \\
37\end{array}$ & $\begin{array}{l}179 \\
152\end{array}$ & $\begin{array}{l}147 \\
145\end{array}$ \\
\hline pont & 36,37 & 38 & 37 & 76 & 18 & Orchester & 26 & $\begin{array}{l}102 \\
120\end{array}$ & $\begin{array}{l}140 \\
199\end{array}$ \\
\hline Durdi & 30 & 39 & 02 & 76 & 12 & $\mathrm{Ke}$ & 34 & 109 & 239 \\
\hline Dutchman & 3 & 38 & 52 & 76 & 30 & Anne Arundel & 70 & 56 & 117 \\
\hline Dutchman Hollow & 3 & 38 & 52 & 76 & 31 & Anne Arund & 7. & 59 & 115 \\
\hline (1) & 3 & 38 & 57 & 76 & 32 & Anne Arundel & 5 & 53 & 115 \\
\hline $\begin{array}{l}\text { Eagle Point (Lang- } \\
\text { ford Creek) }\end{array}$ & 30 & 39 & 08 & 76 & 10 & Kent & 49 & 116 & 240 \\
\hline $\begin{array}{l}\text { Eagle Point (Harris } \\
\text { Creek) }\end{array}$ & 33 & 38 & 44 & 76 & 19 & Talbot & 52 & 201 & 208 \\
\hline $\begin{array}{l}\text { Earle Cove } \\
\text { East End }\end{array}$ & $\begin{array}{l}30 \\
32\end{array}$ & $\begin{array}{l}39 \\
38\end{array}$ & $\begin{array}{l}05 \\
50\end{array}$ & $\begin{array}{l}76 \\
76\end{array}$ & $\begin{array}{l}08 \\
13\end{array}$ & $\begin{array}{l}\text { Queen Annes } \\
\text { Talbot }\end{array}$ & $\begin{array}{r}10 \\
9\end{array}$ & $\begin{array}{l}126 \\
189\end{array}$ & $\begin{array}{l}228 \\
209\end{array}$ \\
\hline East Neck Bay & 29 & & 04 & 76 & 16 & $\mathrm{Ke}$ & 23 & 105 & 241 \\
\hline Easter Cove & 15 & & 04 & 75 & 19 & ester & 16 & 55 & 246 \\
\hline $\begin{array}{l}\text { Ebb Point } \\
\text { Edmund }\end{array}$ & $\begin{array}{l}30 \\
24\end{array}$ & $\begin{array}{l}39 \\
38\end{array}$ & $\begin{array}{l}06 \\
08\end{array}$ & $\begin{array}{l}76 \\
76\end{array}$ & $\begin{array}{l}09 \\
27\end{array}$ & $\begin{array}{l}\mathrm{K} \\
\mathrm{St}\end{array}$ & $\begin{array}{l}55 \\
64\end{array}$ & $\begin{array}{l}118 \\
155\end{array}$ & $\begin{array}{l}239 \\
146\end{array}$ \\
\hline & 26 & 38 & 31 & 76 & 40 & Charl & 2 & 53 & 132 \\
\hline 11 ow & $17, \begin{array}{l}18 \\
30\end{array}$ & 38 & 30 & 76 & 29 & Calve & 7 & 67 & 127 \\
\hline $\begin{array}{l}\text { Iollow } \\
\text { Vharf }\end{array}$ & $\begin{array}{l}30 \\
30\end{array}$ & $\begin{array}{l}39 \\
39\end{array}$ & 06 & $\begin{array}{l}76 \\
76\end{array}$ & 08 & $\begin{array}{l}\text { Annes } \\
\text { Annes }\end{array}$ & $\begin{array}{r}6 \\
11\end{array}$ & $\begin{array}{l}128 \\
125\end{array}$ & $\begin{array}{l}227 \\
228\end{array}$ \\
\hline $\begin{array}{l}\text { Emory Wharf } \\
\text { Ennis }\end{array}$ & 14 & 38 & 11 & 75 & 14 & $\begin{array}{l}\text { Queen Annes } \\
\text { Worcester }\end{array}$ & $\begin{array}{r}11 \\
5\end{array}$ & $\begin{array}{r}200 \\
50\end{array}$ & 228 \\
\hline Entrance Lumps & 29 & 39 & 03 & 76 & 15 & & 24 & 106 & 240 \\
\hline on Sanc & 31 & 38 & 55 & 76 & 19 & Innes & 45 & 138 & 22 \\
\hline Evans (Fishing Bay) & 41 & 38 & 15 & 76 & 01 & Dorcheste & 102 & 154 & 19 \\
\hline $\begin{array}{l}\text { Evans (Wicomico } \\
\text { River) }\end{array}$ & & 38 & 13 & 75 & 54 & Somerset & 4 & 62 & \\
\hline $\begin{array}{l}\text { Fairhaven } \\
\text { Fenwick }\end{array}$ & $\begin{array}{r}4 \\
26\end{array}$ & & $\begin{array}{l}45 \\
18\end{array}$ & $\begin{array}{l}76 \\
76\end{array}$ & $\begin{array}{l}33 \\
50\end{array}$ & $\begin{array}{l}\text { Anne Arundel } \\
\text { Charles }\end{array}$ & $\begin{array}{r}90 \\
9\end{array}$ & $\begin{array}{r}64 \\
49\end{array}$ & $\begin{array}{l}116 \\
132\end{array}$ \\
\hline Ferry (Kent Co.) & 29 & $\begin{array}{l}00 \\
39\end{array}$ & 00 & 76 & 15 & Ken & $\begin{array}{r}39 \\
29\end{array}$ & $\begin{array}{r}49 \\
107\end{array}$ & 239 \\
\hline $\begin{array}{l}\text { Ferry(Queen Annes } \\
\text { Co.) }\end{array}$ & 29 & & 00 & 76 & 15 & Queen Annes & 26 & 118 & 227 \\
\hline
\end{tabular}


Alphabetrcal Index to Natural Oyster Bars-Continued.

\begin{tabular}{|c|c|c|c|c|c|c|c|c|c|}
\hline \multirow[b]{2}{*}{ Name of oyster bar } & \multirow{3}{*}{$\begin{array}{c}\text { Chart } \\
\text { number of } \\
\text { Maryland } \\
\text { Oyster Chart } \\
\text { on which } \\
\text { shown }\end{array}$} & \multicolumn{4}{|c|}{$\begin{array}{c}\text { Approximate geographic } \\
\text { location }\end{array}$} & \multirow[b]{2}{*}{$\begin{array}{l}\text { County in which } \\
\text { lorated }\end{array}$} & \multirow{2}{*}{$\begin{array}{l}\text { County } \\
\text { index } \\
\text { number } \\
\text { by which } \\
\text { indiented } \\
\text { on Index } \\
\text { Chart }\end{array}$} & \multirow{2}{*}{$\begin{array}{l}\text { Page of } \\
\text { U. S. Coast } \\
\text { and Geodetic } \\
\text { county } \\
\text { publication } \\
\text { of Survey of } \\
\text { Oyster Bars } \\
\text { on which } \\
\text { boundaries } \\
\text { are defined }\end{array}$} & \multirow{2}{*}{$\begin{array}{l}\text { Page of } \\
\text { Fourth Re- } \\
\text { port of Mary- } \\
\text { land Shell } \\
\text { Fish Com- } \\
\text { mission on } \\
\text { which char- } \\
\text { acteristics } \\
\text { are } \\
\text { described }\end{array}$} \\
\hline & & \multicolumn{2}{|c|}{ Latitude } & \multicolumn{2}{|c|}{ Longiıude } & & & & \\
\hline & & $\circ$ & , & $\circ$ & , & & & & \\
\hline Ferry Point & 2 & 39 & 00 & 76 & 29 & Anne Arundel, & 24 & 37 & 114 \\
\hline Pish Hawk & 21,22 & 38 & 09 & 76 & 19 & St. Marys & 29 & 146 & 149 \\
\hline Fishing Creek & & & 32 & 76 & 12 & Dorchester & 50 & 138 & 197 \\
\hline Flag Pond & 18 & 38 & 26 & 76 & 26 & Calvert & 8 & 68 & 127 \\
\hline Flat Island & 3 & 38 & 53 & 76 & 32 & Anne Arundel & 74 & 62 & 116 \\
\hline Flat Rock & 41 & 38 & 20 & 76 & 00 & Dorchester & 106 & 157 & 195 \\
\hline Flatty & 34 & 38 & 43 & 76 & 08 & Talbot & 106 & 227 & 207 \\
\hline Flood Point & 29 & 38 & 59 & 76 & 15 & Queen Annes & 24 & 119 & 226 \\
\hline Fort & 24 & 38 & 08 & 76 & 26 & St. Marys & 42 & 155 & 146 \\
\hline Fox & 34 & 38 & 46 & 76 & 14 & Talbot & 86 & 216 & 207 \\
\hline Fox Island & 9 & 37 & 55 & 75 & 56 & Somerset & 26 & 75 & 183 \\
\hline Fox Hole & 34 & 38 & 41 & 76 & 11 & Talbot & 93 & 221 & 206 \\
\hline Fox Point & 3 & 38 & 56 & 76 & 31 & Anne Arundel & 54 & 51 & 115 \\
\hline France & 34 & 38 & 41 & 76 & 17 & Talbot & 65 & 206 & 210 \\
\hline Frog Point & 41 & 38 & 14 & 75 & 57 & Dorchester & 114 & 158 & 195 \\
\hline Gales Lumps & 28 & .39 & 13 & 76 & 17 & Kent & 6 & 96 & 241 \\
\hline Gatton & 19 & 38 & 24 & 76 & 34 & St. Marys & 8 & 136 & 145 \\
\hline Georges & 5,7 & 38 & 08 & 75 & 50 & Somerset & 15 & 64 & 182 \\
\hline Gibsons Flats & 34 & 38 & 47 & 76 & 12 & Talbot & 13 & 233 & 209 \\
\hline Goodwin & 20 & 38 & 19 & 76 & 28 & St. Marys & 18 & 140 & 145 \\
\hline Goose Cre & 41 & 38 & 16 & 76 & 01 & Dorchester & 103 & 154 & 195 \\
\hline Goose Neck & 34 & 38 & 42 & 76 & 10 & Talbot & 97 & 223 & 206 \\
\hline $\begin{array}{l}\text { Goose Point (St. } \\
\text { George River) }\end{array}$ & 24 & 38 & 08 & 76 & 29 & St. Marys & 69 & 168 & 147 \\
\hline $\begin{array}{l}\text { Goose Point (Chop- } \\
\text { tank River) }\end{array}$ & 35 & 38 & 36 & 76 & 00 & Talbot & 129 & 241 & 206 \\
\hline Gough & 25 & 38 & 15 & 76 & 40 & St. Marys & 83 & 176 & 147 \\
\hline Governors Run & 17,18 & 38 & 31 & 76 & 30 & Calvert & 6 & 67 & 127 \\
\hline Granary Point & 32 & 38 & 53 & 76 & 08 & Queen Annes & 98 & 167 & 225 \\
\hline Granger & $36,37,38$ & 38 & 30 & 76 & 20 & Dorchester & 62 & 124 & 196 \\
\hline Grapevine & 37 & 38 & 32 & 76 & 11 & Dorchester & 51 & 138 & 197 \\
\hline Gravelly Run & 24 & 38 & 11 & 76 & 26 & St. Marys & 51 & 162 & 146 \\
\hline Graves & 24 & 38 & 07 & 76 & 25 & St. Marys & 39 & 151 & 145 \\
\hline Great Bar & 34 & 38 & 43 & 76 & 15 & Talbot & 68 & 208 & 207 \\
\hline Great Marsh & 34 & 38 & 42 & 76 & 17 & Talbot & 64 & 207 & 208 \\
\hline Great Rock & 9 & 37 & 56 & 75 & 56 & Somerset & 25 & 75 & 183 \\
\hline Great Shoals & 12 & 38 & 13 & 75 & 53 & Wicomico & 13 & 47 & 189 \\
\hline Green Marsh & 35 & 38 & 35 & 76 & 04 & Dorchester & 9 & 114 & 199 \\
\hline Greenwood Creek & 32 & 38 & 53 & 76 & 12 & Queen Annes & 78 & 157 & 226 \\
\hline Greeves Cove & 31 & 38 & 55 & 76 & 20 & Queen Annes & 41 & 135 & $22 i$ \\
\hline Guest Marshes & 25 & 38 & 18 & 76 & 43 & St. Marys & 97 & 185 & 148 \\
\hline Gum & 39,40 & 38 & 20 & 76 & 12 & Dorchester & 97 & 142 & 198 \\
\hline Gum Spring & 29 & 39 & 07 & 76 & 15 & Kent & 19 & 103 & 240 \\
\hline Gum Thicket & 31 & 38 & 53 & 76 & 23 & Queen Annes & 32 & 131 & 228 \\
\hline Gunby & 10 & 37 & 56 & 75 & 46 & Somerset & 30 & 77 & 182 \\
\hline Hackett Point & 2 & 38 & 59 & 76 & 25 & Anne Arundel & 15 & 32 & 116 \\
\hline Hackley Creek & 26 & 38 & 14 & 76 & 47 & St. Marys & 107 & 194 & 148 \\
\hline Haddaway & 30 & 39 & 08 & 76 & 06 & Kent & 61 & 120 & 230 \\
\hline Hail Creek & 30 & 39 & 01 & 76 & 12 & Kent & 31 & 108 & 23 \\
\hline Hail Point & 30 & 39 & 00 & 76 & 12 & Kent & 32 & 109 & 239 \\
\hline Haines & 5 & 38 & 11 & 75 & 58 & Somerset & 7 & 61 & - 183 \\
\hline Half Pone & 20 & 38 & 22 & 76 & 31 & St. Marys & 13 & 138 & 14 \\
\hline Half Way Mark & 41 & 38 & 19 & 76 & 01 & Dorchester & 107 & 157 & 195 \\
\hline Halls Point & 5 & 38 & 12 & 75 & 57 & Somerset & 6 & 61 & 182 \\
\hline Hambleton & 32 & 38 & 50 & 76 & 14 & Talbot & 23 & 185 & 209 \\
\hline
\end{tabular}


Alphabetical Index to Natural Oyster Bars-Continued.

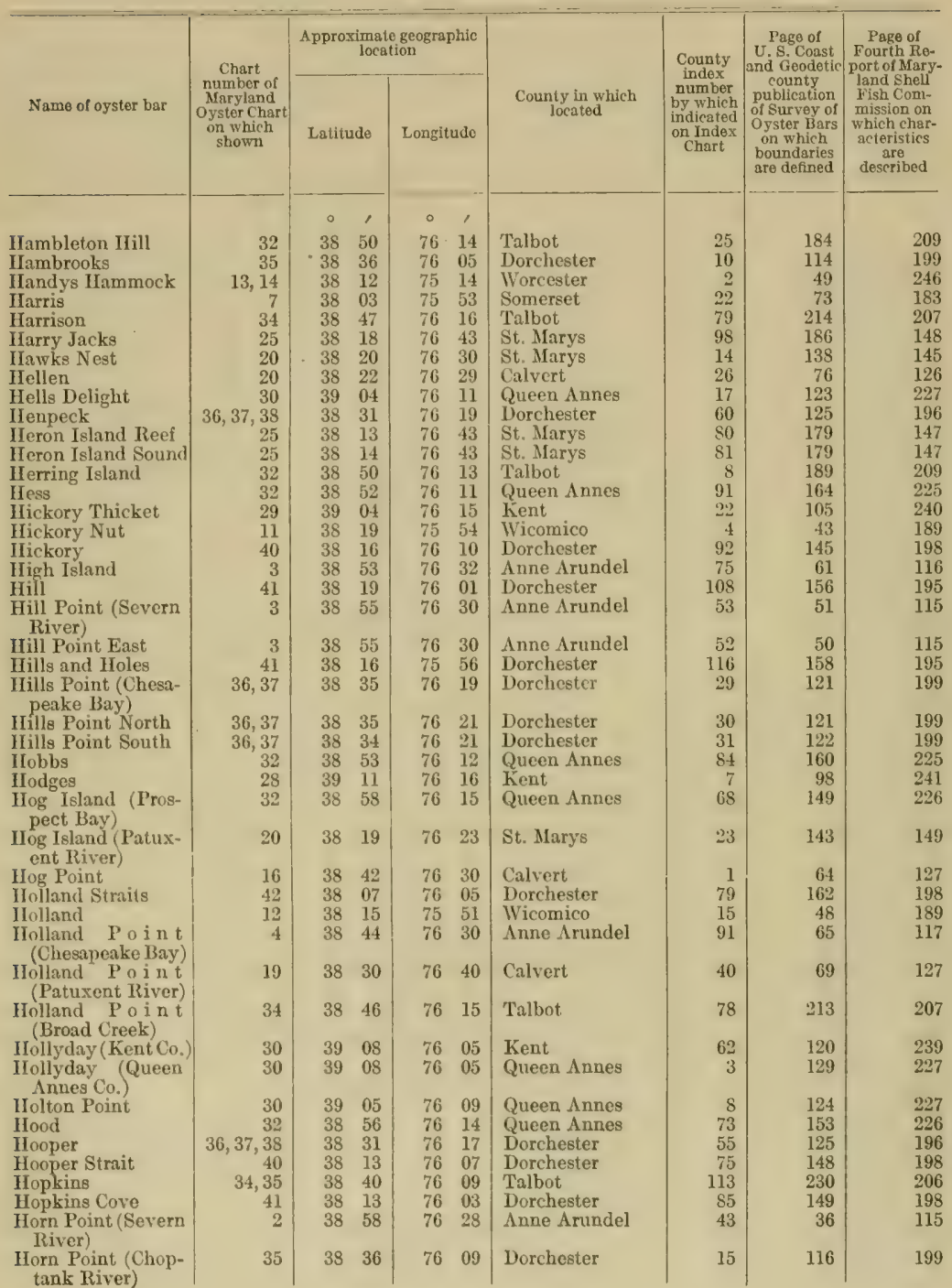


NATURAL OYSTER BARS.

Alphabetical Index to Natural Orster Bars-Continued.

\begin{tabular}{|c|c|c|c|c|c|c|c|c|c|}
\hline \multirow[b]{2}{*}{ Name of oyster bar } & \multirow{2}{*}{$\begin{array}{c}\text { Chart } \\
\text { number of } \\
\text { Maryland } \\
\text { Oyster Chart } \\
\text { on which } \\
\text { shown }\end{array}$} & \multicolumn{4}{|c|}{$\begin{array}{l}\text { Approximato geographic } \\
\text { location }\end{array}$} & \multirow[b]{2}{*}{$\begin{array}{l}\text { County in which } \\
\text { located }\end{array}$} & \multirow{2}{*}{$\begin{array}{c}\text { County } \\
\text { index } \\
\text { number } \\
\text { by which } \\
\text { indiented } \\
\text { on Index } \\
\text { Chart }\end{array}$} & \multirow{2}{*}{$\begin{array}{l}\text { Page of } \\
\text { U. S. Coast } \\
\text { anif Cieodetic } \\
\text { county } \\
\text { publication } \\
\text { of Survey of } \\
\text { Oyster lars } \\
\text { on which } \\
\text { boundaries } \\
\text { are defined }\end{array}$} & \multirow{2}{*}{$\begin{array}{l}\text { Page of } \\
\text { Fourth Re- } \\
\text { port of Aary } \\
\text { land Shell } \\
\text { Fish Com- } \\
\text { mission on } \\
\text { which char* } \\
\text { acteristies } \\
\text { are } \\
\text { described }\end{array}$} \\
\hline & & \multicolumn{2}{|c|}{ Latitude } & \multicolumn{2}{|c|}{ Longitude } & & & & \\
\hline & & $\circ$ & , & $\circ$ & , & & & & \\
\hline Horse & 25 & 38 & 14 & 76 & 44 & St. Marys & 103 & 180 & 147 \\
\hline Horschead North & 15 & 38 & 03 & 75 & 16 & Worcester & 27 & $5 \mathrm{~s}$ & 246 \\
\hline Horsehead South & 15 & 38 & 03 & 75 & 16 & Worcester & 28 & 59 & 246 \\
\hline $\begin{array}{l}\text { Iorse. Point Chan- } \\
\text { nel }\end{array}$ & 39.40 & 38 & 18 & 76 & 14 & Dorchester & 72 & 140 & 199 \\
\hline Horse Race & 30 & 39 & 02 & 76 & 11 & Queen Annes & 19 & 122 & 227 \\
\hline $\begin{array}{l}\text { Horseshoe (St. Ma- } \\
\text { rys River) }\end{array}$ & 24 & 38 & 12 & 76 & 27 & St. Marys & 53 & 165 & 146 \\
\hline $\begin{array}{l}\text { Horseshoe (Miles } \\
\text { River) }\end{array}$ & 32 & 38 & 52 & 76 & 14 & Talbot & 29 & 182 & 209 \\
\hline Howells Point & 35 & 38 & 37 & 76 & 07 & Talbot & 120 & 237 & 210 \\
\hline $\begin{array}{l}\text { Hudson (L i t t l e } \\
\text { Choptank River) }\end{array}$ & 37 & 38 & 33 & 76 & 15 & Dorchester & 39 & 133 & 19 \\
\hline $\begin{array}{l}\text { Hudson (Chester } \\
\text { River) }\end{array}$ & 30 & 39 & 06 & 76 & 11 & Kent & 43 & 113 & 240 \\
\hline Hungerford Hollow & 20 & 38 & 20 & 76 & 29 & Calvert & 25 & 76 & 126 \\
\hline Huntingfield & 29 & 39 & 07 & 76 & 15 & Kent & 18 & 103 & 240 \\
\hline Ifunts & 33 & 38 & 44 & 76 & 19 & Talbot & 55 & $20^{\prime 2}$ & 208 \\
\hline IIurdle & 24 & 38 & 08 & 76 & 29 & St. Marys & 68 & 167 & 147 \\
\hline Ingram Shoal & 12 & 38 & 14 & 75 & 52 & Wicomico & 14 & 47 & 189 \\
\hline Inner Round Point & 3 & 38 & 55 & 76 & 31 & Anne Arundel & 61 & 50 & $11 i$ \\
\hline Irish Creek & 34 & 38 & 41 & 76 & 13 & Talbot & 88 & 217 & 210 \\
\hline Inside Greenbury & 2 & 38 & 59 & 76 & 27 & Anne Arundel & 20) & 35 & 114 \\
\hline Island & $2 \overline{5}$ & 38 & 16 & 76 & 39 & St. Marys & 86 & 174 & 147 \\
\hline Island Cove & 31 & 38 & 57 & 76 & 19 & Queen Annes & 50 & 141 & 237 \\
\hline $\begin{array}{l}\text { Island Creek (Pa- } \\
\text { tuxent River) }\end{array}$ & 19 & 38 & 24 & 76 & 33 & Calvert & 29 & 74 & 126 \\
\hline $\begin{array}{l}\text { Island Creek (Chop- } \\
\text { tank River) }\end{array}$ & 34,35 & 38 & 40 & 76 & 08 & Talbot & 115 & 231 & 206 \\
\hline Island Point & 30 & 39 & 08 & 76 & 10 & Kent & 48 & 115 & 240 \\
\hline Island Shore & 24 & 38 & 08 & 76 & 29 & St. Marys & 70 & 168 & 147 \\
\hline Jackans & 3 & 38 & 53 & 76 & 31 & Anne Arundel & 77 & 61 & 116 \\
\hline Jacks Bay & 19 & 38 & 25 & 76 & 35 & Calvert & 32 & 73 & 126 \\
\hline Jacks Marsh & 19 & 38 & 26 & 76 & 37 & (alvert & 33 & 72 & 126 \\
\hline Jamaica Point & 35 & 38 & 37 & 75 & 59 & Talbot & 131 & 212 & 206 \\
\hline James Point & 36 & 38 & 33 & 76 & 22 & Dorchester & 6.5 & $12: 2$ & 199 \\
\hline Jane & 41 & 38 & 12 & 76 & 01 & Dorchester & 81 & 151 & 198 \\
\hline Joe Harris Flats & 34 & 38 & 44 & 76 & 13 & Talbot & 83 & 215 & 207 \\
\hline Joes Lumps & 26 & 38 & 19 & 76 & 51 & Charles & 7 & 48 & 132 \\
\hline Johnson Island & 31 & 38 & 56 & 76 & 17 & Queen Annes & 58 & 143 & 227 \\
\hline Johnston & 34 & 38 & 44 & 76 & 08 & Talbot & 109 & 229 & 207 \\
\hline $\begin{array}{l}\text { Jones (Little Chop- } \\
\text { tank River) }\end{array}$ & 37 & 38 & 33 & 76 & 12 & Dorchester & 46 & 136 & 197 \\
\hline $\begin{array}{l}\text { Jones St. Marys } \\
\text { River) }\end{array}$ & 24 & 38 & 10 & 76 & 26 & St. Marys & 46 & 159 & 116 \\
\hline Jones Hole & 31 & 38 & 56 & 76 & 19 & Queen Annes & 48 & 140 & 227 \\
\hline Judys Point & 34 & 38 & 45 & 76 & 1 & Talbot & 75 & 212 & 208 \\
\hline Juniper & 32 & 38 & 53 & 76 & 09 & Talbot & 1 & 193 & 209 \\
\hline Jutland & 24 & 38 & 07 & 76 & 25 & St. Marys & 38 & 151 & 145 \\
\hline Kedge Straits & 6 & 38 & 04 & 76 & 05 & Somerset & 35 & 65 & 183 \\
\hline Kennedy & 24 & 38 & 10 & 76 & 26 & St. Marys & 49 & 159 & 146 \\
\hline Kennel & 15 & 38 & 04 & 75 & 17 & Worcester & 20 & 56 & 246 \\
\hline $\begin{array}{l}\text { Kent Island Nar- } \\
\text { rows }\end{array}$ & 29 & 38 & 58 & 76 & 15 & Queen Annes & 25 & 120 & 226 \\
\hline Kent Point & 31 & 38 & 51 & 76 & 23 & Queen Annes & $3: 3$ & 131 & 228 \\
\hline
\end{tabular}


Alaphabetical Index to Natural Oyster Bars-Continued.

\begin{tabular}{|c|c|c|c|c|c|c|c|c|c|}
\hline \multirow[b]{2}{*}{ Name of oyster bar } & \multirow{2}{*}{$\begin{array}{l}\text { Chart } \\
\text { number of } \\
\text { Maryland } \\
\text { Oyster Chart } \\
\text { on which } \\
\text { shown }\end{array}$} & \multicolumn{4}{|c|}{$\begin{array}{l}\text { Approximate geographic } \\
\text { location }\end{array}$} & \multirow[b]{2}{*}{$\begin{array}{l}\text { County in which } \\
\text { located }\end{array}$} & \multirow{2}{*}{$\begin{array}{l}\text { County } \\
\text { index } \\
\text { number } \\
\text { by which } \\
\text { indicated } \\
\text { on Index } \\
\text { Chart }\end{array}$} & \multirow{2}{*}{\begin{tabular}{|} 
Page of \\
U. S. Coast \\
and Geodetic \\
county \\
publication \\
of Surrey of \\
Oyster Bars \\
on which \\
boundaries \\
aro defined
\end{tabular}} & \multirow{2}{*}{$\begin{array}{l}\text { Page of } \\
\text { Fourth Re- } \\
\text { port of Mary- } \\
\text { land Shell } \\
\text { Fish Com- } \\
\text { mission on } \\
\text { which char- } \\
\text { acteristics } \\
\text { are } \\
\text { described }\end{array}$} \\
\hline & & \multicolumn{2}{|c|}{ Latitude } & \multicolumn{2}{|c|}{ Longitude } & & & & \\
\hline & & 。 & , & $\circ$ & , & & & & \\
\hline Key & 26 & 38 & 22 & 76 & 51 & St. Marys & 123 & 186 & 149 \\
\hline Kings Creek & 30 & & 08 & & & Kent & 51 & 116 & 240 \\
\hline Kirby & 35 & 38 & 36 & 76 & 05 & Talbot & 122 & 238 & 210 \\
\hline Kitts Creek East & 10 & 37 & 58 & 75 & 42 & Somerset & 33 & 79 & 182 \\
\hline Kitts Creek West & 10 & & 58 & 75 & 43 & Somerset & 32 & 78 & 182 \\
\hline Kitts Marsh & 19 & 38 & 27 & 76 & 37 & Calvert & 35 & 71 & 126 \\
\hline La Grande & 20 & 38 & 18 & 76 & 27 & St. Marys & 19 & 141 & 145 \\
\hline La Trappe & 35 & 38 & 38 & 76 & 07 & Talbot & 119 & 236 & 206 \\
\hline Lakes Cove & 40 & 38 & 17 & 76 & 09 & Dorchester & 93 & 144 & 198 \\
\hline $\begin{array}{l}\text { Lambertson Land- } \\
\text { ing }\end{array}$ & 14 & 38 & 12 & 75 & 15 & Worcester & 4 & 50 & 246 \\
\hline Lancaster & 26 & 38 & 17 & 76 & 50 & Charles & 12 & 50 & .132 \\
\hline Langley Hollow & 21 & 38 & 09 & 76 & 26 & St. Marys & 43 & 156 & 146 \\
\hline Le Compte & 35 & 38 & 37 & 76 & 09 & Dorchester & 16 & 117 & 199 \\
\hline Levin Tump & 15 & 38 & $0 \frac{1}{3}$ & 75 & 16 & Worcester & 25 & 58 & 246 \\
\hline Light House & $34,35,37$ & 38 & 39 & 76 & 11 & Talbot & 91 & 219 & 210 \\
\hline Light House Lump & 20 & 38 & 19 & 76 & 25 & Calvert & 17 & 82 & 126 \\
\hline Limekiln & 30 & 39 & 05 & 76 & 12 & Kent & 40 & 112 & 240 \\
\hline Little Choptank & 36,37 & 38 & 31 & 76 & 19 & Dorchester & 59 & 126 & 196 \\
\hline Little Cove Point & 20 & 38 & 21 & 76 & 23 & Calvert & 10 & 85 & 127 \\
\hline $\begin{array}{l}\text { Little Neck (Swan } \\
\text { Creek) }\end{array}$ & 28,29 & 39 & 08 & 76 & 16 & Kent & 10 & 101 & 241 \\
\hline $\begin{array}{l}\text { Little Neck (Harris } \\
\text { Creek) }\end{array}$ & 33,34 & 38 & 46 & 76 & 18 & Talbot & 60 & 205 & 208 \\
\hline Little Pollard & 37 & 38 & 32 & 76 & 16 & Dorchester & 37 & 132 & 196 \\
\hline Little Sandy & 2 & 38 & 59 & 76 & 28 & Anne Arundel & 22 & 37 & 114 \\
\hline Lodges & 33 & 38 & 45 & 76 & 19 & Talbot & 57 & 203 & 208 \\
\hline Logans Hill & 37 & 38 & 39 & 76 & 13 & Dorchester & 20 & 129 & 199 \\
\hline $\begin{array}{l}\text { Long (Chesapeake } \\
\text { Bay) }\end{array}$ & 4 & 38 & 45 & 76 & 32 & Anne Arundel & 89 & 64 & 117 \\
\hline $\begin{array}{l}\text { Long (St. George } \\
\text { River) }\end{array}$ & 24 & 38 & 09 & 76 & 31 & St. Marys & 78 & 173 & 147 \\
\hline $\begin{array}{l}\text { Long Point (Ches- } \\
\text { ter River) }\end{array}$ & 29,30 & 39 & 00 & 76 & 14 & Queen Annes & 23 & 119 & 227 \\
\hline $\begin{array}{l}\text { Long Point (East- } \\
\text { ern Bay) }\end{array}$ & 31 & 38 & 52 & 76 & 20 & Queen Annes & 34 & 132 & 226 \\
\hline $\begin{array}{l}\text { Long Point (Poco- } \\
\text { moke Sound) }\end{array}$ & 9 & 37 & 57 & 75 & 49 & Somerset & 29 & 77 & 182 \\
\hline $\begin{array}{l}\text { Long Point (Hiles } \\
\text { River) }\end{array}$ & 34 & 38 & 46 & 76 & 11 & Talbot & 14 & 234 & 209 \\
\hline Long Point Woods & 34 & 38 & 42 & 76 & 16 & Talbot & 67 & 207 & 207 \\
\hline Long Shoal & 11 & 38 & 18 & 75 & 55 & Wicomico & 7 & 44 & 189 \\
\hline Louis Cove & 34 & 38 & 42 & 76 & 09 & Talbot & 100 & 224 & 206 \\
\hline $\begin{array}{l}\text { Love Point } \\
\text { Lovers Point }\end{array}$ & $\begin{array}{l}29 \\
25\end{array}$ & $\begin{array}{l}39 \\
38\end{array}$ & 03 & $\begin{array}{l}76 \\
76\end{array}$ & $\begin{array}{l}18 \\
39\end{array}$ & $\begin{array}{l}\text { Queen Annes } \\
\text { St. Marys }\end{array}$ & $\begin{array}{l}29 \\
84\end{array}$ & $\begin{array}{l}117 \\
175\end{array}$ & $\begin{array}{l}228 \\
147\end{array}$ \\
\hline $\begin{array}{l}\text { Lovers Foint } \\
\text { Lower Forrest }\end{array}$ & 19 & 38 & $\begin{array}{l}10 \\
25\end{array}$ & 76 & 36 & $\begin{array}{l}\text { St. Marys } \\
\text { St. Marys }\end{array}$ & 7 & 135 & 145 \\
\hline $\begin{array}{l}\text { Lower Newfound- } \\
\text { land }\end{array}$ & 41 & 38 & 19 & 75 & 55 & Dorchester & 120 & 160 & 195 \\
\hline Lower Steps & 16 & 38 & 38 & 76 & 31 & Calvert & 3 & 65 & 127 \\
\hline $\begin{array}{l}\text { Low er Thorough- } \\
\text { fare }\end{array}$ & 40 & 38 & 15 & 76 & 09 & Dorchester & 88 & 146 & 198 \\
\hline Lows Point & 31,33 & 38 & 48 & 76 & 20 & Talbot & 37 & 178 & 210 \\
\hline Lulu & 3 & 38 & 53 & 76 & 27 & Anne Arundel & 69 & 55 & 117 \\
\hline $\begin{array}{l}\text { Lumps East of Craig- } \\
\text { hill Channel }\end{array}$ & 1 & 39 & 07 & 76 & 22 & Anne Arundel & 3 & 26 & 117 \\
\hline
\end{tabular}


NATURAL OYSTER BARS.

Alphabetrcal Index to Natural Oyster Bars-Continued.

\begin{tabular}{|c|c|c|c|c|c|c|c|c|c|}
\hline \multirow{2}{*}{ Name of oyster bar } & \multirow{2}{*}{$\begin{array}{l}\text { Chart } \\
\text { number of } \\
\text { Maryland } \\
\text { Oyster Chart } \\
\text { on which } \\
\text { shown }\end{array}$} & \multicolumn{4}{|c|}{$\begin{array}{l}\text { Approximate geographic } \\
\text { location }\end{array}$} & \multirow{2}{*}{$\begin{array}{l}\text { County in which } \\
\text { located }\end{array}$} & \multirow{2}{*}{$\begin{array}{l}\text { County } \\
\text { index } \\
\text { number } \\
\text { by which } \\
\text { indicated } \\
\text { on Index } \\
\text { Chart }\end{array}$} & \multirow{2}{*}{$\begin{array}{l}\text { Page or } \\
\text { U. S. Coast } \\
\text { and Ceodetic } \\
\text { county } \\
\text { publication } \\
\text { of Survey of } \\
\text { Oyster Baars } \\
\text { on which } \\
\text { boundaries } \\
\text { are defined }\end{array}$} & \multirow{2}{*}{$\begin{array}{l}\text { Page of } \\
\text { Fourth Re- } \\
\text { port of Mary } \\
\text { land Shell } \\
\text { Fish Com- } \\
\text { mission on } \\
\text { which char- } \\
\text { acteristies } \\
\text { are } \\
\text { described }\end{array}$} \\
\hline & & \multicolumn{2}{|c|}{ Latitude } & \multicolumn{2}{|c|}{ Longitude } & & & & \\
\hline & & $\circ$ & & $\circ$ & & & & & \\
\hline Mckay & 21 & 38 & 10 & & & St. Marys & 28 & 146 & 149 \\
\hline Mc Keils Point & 37 & 38 & 33 & 76 & 14 & Dorchester & 42 & 134 & 196 \\
\hline Macks Hollow & 19 & 38 & 29 & 76 & 39 & Calvert & 38 & 70 & 127 \\
\hline Man O'War Shoals & 27 & 39 & 11 & 76 & 22 & Baltimore & 3 & 34 & 103 \\
\hline Manahowic Creek & 26 & 38 & 19 & 76 & 50 & St. Marys & 118 & 189 & 149 \\
\hline Mares Point & 34 & 38 & 42 & 76 & 09 & Talbot & 99 & 224 & 206 \\
\hline Marshall & $36,37,38$ & 38 & 29 & 76 & 20 & Dorchester & 64 & 123 & 197 \\
\hline Marshy & 34 & 38 & 43 & 76 & 09 & Talbot & 105 & 227 & 207 \\
\hline Marshy Island & 7 & 38 & 07 & 75 & 53 & Somerset & 18 & 70 & 182 \\
\hline Marshy Point & 3 & 38 & 54 & 76 & 29 & Anne Arundel & 67 & 48 & 115 \\
\hline Martin Point & 14,15 & 38 & 05 & 75 & 18 & IVorcester & 15 & 54 & 246 \\
\hline Marumsco & 10 & 37 & 57 & 75 & 44 & Somerset & 31 & 78 & 182 \\
\hline Marys Delight & 31 & 38 & 49 & 76 & 19 & Talbot & 36 & 178 & 210 \\
\hline Mattapex & 31 & 38 & 55 & 76 & 20 & Queen Annes & 42 & 136 & 227 \\
\hline Matthews & 34,35 & 38 & 40 & 76 & 08 & Talbot & 116 & 232 & 206 \\
\hline Mears (Calvert Co.) & 19,20 & 38 & 22 & 76 & 30 & Calvert & 27 & 75 & 126 \\
\hline $\begin{array}{l}\text { Mears (St. Marys } \\
\text { Co.) }\end{array}$ & 19,20 & 38 & 22 & 76 & 30 & St. Marys & 12 & 137 & 145 \\
\hline Melton Point & 30 & 39 & 08 & 76 & 04 & Kent & 63 & 121 & 239 \\
\hline Melvin & 32 & 38 & 53 & 76 & 10 & Queen Annes & 95 & 166 & 225 \\
\hline Middle Block & 31 & 38 & 54 & 76 & 18 & Queen Ann & 53 & 134 & 226 \\
\hline Middleground & 12 & 38 & 14 & 75 & 55 & Wicomico & 11 & 46 & 18 \\
\hline Midd leground & 24 & 38 & 08 & 76 & 27 & St. Marys & 65 & 155 & 146 \\
\hline Milbourne Shore & 24 & 38 & 08 & 76 & 29 & $\mathrm{~S}$ & 71 & 169 & 147 \\
\hline Mileys Creek & 05 & 38 & 16 & 76 & 43 & t. Marys & 99 & 183 & 148 \\
\hline Mill Dam & 35 & 38 & 36 & 75 & 59 & Talbot & 130 & 242 & 206 \\
\hline Mill Hill & 32 & 38 & 54 & 76 & 13 & Queen Annes & 76 & 156 & 226 \\
\hline $\begin{array}{l}\text { Mill Point (Chesa- } \\
\text { peake Bay) }\end{array}$ & 36,37 & 38 & 36 & 76 & 18 & Dorchester & 28 & 121 & 199 \\
\hline $\begin{array}{l}\text { Mill Point (Harris } \\
\text { Creek) }\end{array}$ & 33 & 38 & 45 & 76 & 18 & Talbot & 54 & 202 & 208 \\
\hline Millers Island & 27 & 39 & 13 & 76 & 21 & Baltimore & 2 & 34 & 103 \\
\hline Mills & 32 & 38 & 52 & 76 & 12 & Queen Anr & 83 & 160 & 225 \\
\hline Mills East & 26 & 38 & 20 & 76 & 51 & St. Marys & 120 & 188 & 149 \\
\hline Mills West & 26 & 38 & 20 & 76 & 51 & Charle & 6 & 47 & 132 \\
\hline Millstone & 20 & 38 & 18 & 76 & 26 & St. Marys & 20 & 141 & 145 \\
\hline Mink Tump & 15 & 38 & 04 & 75 & 19 & Worcester & 17 & 55 & 246 \\
\hline $\begin{array}{l}\text { Mitchells Bluff } \\
\text { Buoy }\end{array}$ & 28 & 39 & 13 & 76 & 16 & Kent & 5 & 97 & 241 \\
\hline Mouldy Creek & 25 & 38 & 16 & 76 & 38 & cys & 85 & 174 & 147 \\
\hline Mouth of Creek & 24 & & 07 & 76 & 2 & $M$ & 124 & & 146 \\
\hline Mouth of Rive & 26 & 38 & 15 & 76 & 49 & St. Ma & 111 & 192 & 148 \\
\hline $\begin{array}{l}\text { Mount Vernon } \\
\text { Wharf }\end{array}$ & 5 & 38 & 15 & 75 & 48 & Somerset & 1 & 63 & 183 \\
\hline Mountain Point & 1,2 & 39 & 05 & 76 & 25 & An & 4. & 27 & 117 \\
\hline Mud (Dorchester & 41 & 38 & 10 & 76 & 00 & Dorchester & 80 & 151 & 198 \\
\hline Mud (Chester River) & 29,30 & 39 & 01 & 76 & 14 & & 28 & 107 & 239 \\
\hline Mud (Somerset Co.) & 5 & 38 & 09 & 76 & 00 & Somerset & 9 & 60 & 183 \\
\hline Muddy Drain & 29 & 39 & 08 & 76 & 16 & Kent & 17 & 102 & 240 \\
\hline Mfulberry Point & 34 & 38 & 45 & 76 & 15 & Talbot & 71 & 209 & 207 \\
\hline ys Cove & 30 & 39 & 07 & 76 & 06 & Queen Annes & 4 & 129 & 227 \\
\hline Mussel Hole & 7 & 38 & 04 & 75 & 59 & Somerset & 12 & 66 & 183 \\
\hline Neale & 19,20 & 38 & 23 & 76 & $31 j$ & St. Marys & 111 & 137 & 145 \\
\hline
\end{tabular}


Alphabetical Index to Natural Oyster Bars-Continued.

\begin{tabular}{|c|c|c|c|c|c|c|c|c|c|}
\hline \multirow[b]{2}{*}{ Name of oyster har } & \multirow{2}{*}{$\begin{array}{c}\text { Chart } \\
\text { number of } \\
\text { Maryland } \\
\text { Ofster Chart } \\
\text { on which } \\
\text { shown }\end{array}$} & \multicolumn{4}{|c|}{$\begin{array}{l}\text { Approximate geographic } \\
\text { location }\end{array}$} & \multirow[b]{2}{*}{$\begin{array}{l}\text { County in which } \\
\text { lorated }\end{array}$} & \multirow{2}{*}{$\begin{array}{c}\text { County } \\
\text { index } \\
\text { number } \\
\text { by which } \\
\text { indicated } \\
\text { on Index } \\
\text { Chart }\end{array}$} & \multirow{2}{*}{$\begin{array}{c}\text { Page of } \\
\text { U. S. Coast } \\
\text { and Geodetic } \\
\text { county } \\
\text { publication } \\
\text { of Survey of } \\
\text { Oyster Bars } \\
\text { on which } \\
\text { boundaries } \\
\text { are defined }\end{array}$} & \multirow{2}{*}{$\begin{array}{l}\text { Page of } \\
\text { Fourth Re- } \\
\text { port of Mary- } \\
\text { land Shell } \\
\text { Fish Com- } \\
\text { mission on } \\
\text { which char- } \\
\text { acteristics } \\
\text { are } \\
\text { described }\end{array}$} \\
\hline & & \multicolumn{2}{|c|}{ Latitude } & \multicolumn{2}{|c|}{ Longitude } & & & & \\
\hline & & $\circ$ & & $\circ$ & & & & & \\
\hline New & 41 & 38 & 15 & 75 & 56 & Dorchester & 115 & 158 & 195 \\
\hline New Discovery & 39 & & 18 & 76 & 17 & Dorchester & 71 & 139 & 199 \\
\hline Newport & 13,14 & 38 & 12 & 75 & 14 & Worcester & 3 & 50 & 246 \\
\hline Newtown Flats & 25 & 38 & 14 & 76 & 43 & St. Marys & 93 & 181 & 148 \\
\hline Nichols & 30 & 39 & 05 & 76 & 11 & Kent & 42 & 113 & 239 \\
\hline Nine Acres & 36,37 & 38 & 31 & 76 & 18 & Dorchester & 58 & 126 & 196 \\
\hline Norman & 40 & 38 & 15 & 76 & 07 & Dorchester & 87 & 147 & 198 \\
\hline Normans Fine Eyes & 31,32 & 38 & 55 & 76 & 17 & Queen Annes & 60 & 145 & 227 \\
\hline Normans Marsh & 32 & 38 & 56 & 76 & 15 & Queen Annes & 64 & 152 & 226 \\
\hline $\begin{array}{l}\text { Northwest ( } \mathrm{K} \text { e } \mathrm{n} t \\
\mathrm{Co} \text { ) }\end{array}$ & 30 & 39 & 08 & 76 & 05 & Kent & 64 & 121 & 239 \\
\hline $\begin{array}{l}\text { Northwest (Queen } \\
\text { Annes Co) }\end{array}$ & 30 & 39 & 09 & 76 & 05 & Queen Annes & 1 & 130 & 227 \\
\hline $\begin{array}{l}\text { Northwest Middle- } \\
\text { ground }\end{array}$ & 42 & 38 & 07 & 76 & 11 & Dorchester & 76 & 160 & 199 \\
\hline Old Field & 30 & 39 & 05 & 76 & 10 & Queen Annes & 14 & 124 & 227 \\
\hline Old Fort & 2 & 38 & 59 & 76 & 28 & Anne Arundel & 21 & 36 & 114 \\
\hline Old Hare & 24 & 38 & 06 & 76 & 25 & St. Marys & 35 & 149 & 145 \\
\hline Old House & 41 & 38 & 18 & 76 & 02 & Dorchester & 104 & 156 & 195 \\
\hline Old House Point & 34 & 38 & 43 & 76 & 08 & Talbot & 102 & 225 & 207 \\
\hline Old Lump & 20 & 38 & 19 & 76 & 25 & Calvert & 16 & 82 & 126 \\
\hline $\begin{array}{l}\text { Old Orchard (Tan- } \\
\text { gier Sound) }\end{array}$ & 5 & 38 & 10 & 75 & 58 & Somerset & 8 & 60 & 183 \\
\hline $\begin{array}{l}\text { Old Orchard (Miles } \\
\text { River) }\end{array}$ & 34 & 38 & 47 & 76 & 12 & Talbot & 18 & 232 & 209 \\
\hline Old Woman & 3 & 38 & 54 & 76 & 28 & Anne Arundel & 49 & 47 & 117 \\
\hline Old Womans Patch & 11 & 38 & 18 & 75 & 54 & Wicomico & 5 & 43 & 189 \\
\hline Old Wreck & 25 & 38 & 14 & 76 & 44 & St. Marys & 102 & 181 & 148 \\
\hline Orem & 34 & 38 & 43 & 76 & 09 & Talbot & 107 & 228 & 207 \\
\hline Outer Hole & 41 & 38 & 18 & 75 & 55 & Dorchester & 119 & 159 & 195 \\
\hline Outer Magothy & 2 & 39 & 03 & 76 & 24 & Anne Arundel & 12 & 30 & 117 \\
\hline Outer Round Point & 3 & 38 & 55 & 76 & 30 & Anne Arundel & 65 & 50 & 115 \\
\hline $\begin{array}{l}\text { Oyster Creek (Lit- } \\
\text { tle Choptan k } \\
\text { River) }\end{array}$ & $36,37,38$ & 38 & 30 & 76 & 20 & Dorchester & 63 & 124 & 197 \\
\hline $\begin{array}{c}\text { Oys ter Creek } \\
\text { (Kedge Straits) }\end{array}$ & 6 & 38 & 04 & 76 & 04 & Somerset & 34 & 65 & 183 \\
\hline Oyster Shell Point & 35 & 38 & 35 & 76 & 00 & Dorchester & 6 & 113 & 197 \\
\hline Paca & 32 & 38 & 53 & 76 & 11 & Queen Annes & 86 & 161 & 225 \\
\hline Pagan & 24 & 38 & 12 & 76 & 27 & St. Marys & 57 & 164 & 146 \\
\hline Park & 2 & 39 & 05 & 76 & 29 & Anne $\Lambda$ rundel & 8 & 29 & 114 \\
\hline Parker Moore & 20 & 38 & 21 & 76 & 24 & Calvert & 11 & 84 & 127 \\
\hline Parkers Whari & 19 & 38 & 25 & 76 & 34 & Calvert & 31 & 73 & 126 \\
\hline Parsons Island & 32 & 38 & 54 & 76 & 16 & Queen Annes & 61 & 146 & 227 \\
\hline $\begin{array}{l}\text { Parsons Island Nar- } \\
\text { rows }\end{array}$ & 32 & 38 & 55 & 76 & 15 & Queen Annes & 63 & 155 & 226 \\
\hline Pattison & 37 & 38 & 34 & 76 & 11 & Dorchester & 47 & 137 & 197 \\
\hline Paul & 40 & 38 & 16 & 76 & 08 & Dorchester & 90 & 146 & 198 \\
\hline Paw Paw IIollow & 25 & 38 & 16 & 76 & 39 & St. Marys & 87 & 175 & 147 \\
\hline Pea Hill & 31 & 38 & 55 & 76 & 19 & Qileen Annes & 46 & 139 & 227 \\
\hline Peach Iiill & 2 & 39 & 05 & 76 & 27 & Anne Arundel & 6 & 28 & 114 \\
\hline Peach Orchart & 2 & 39 & 00 & 76 & 29 & Anne Arundel & 25 & 38 & 114 \\
\hline Peanut & 39,40 & 38 & 21 & 76 & 12 & Worchester & 98 & 142 & 198 \\
\hline Peanut Hill & 36,37 & 38 & 33 & 76 & 19 & Dorchester & 32 & 127 & 196 \\
\hline
\end{tabular}


NATURAL OYSTER BARS.

Alphabetical Index to Natural Oyster Bars-Continued.

\begin{tabular}{|c|c|c|c|c|c|c|c|c|c|}
\hline \multirow{2}{*}{ Name of oyster bar } & \multirow{2}{*}{$\begin{array}{c}\text { Chart } \\
\text { number of } \\
\text { Maryland } \\
\text { Oyster Chart } \\
\text { on which } \\
\text { shown }\end{array}$} & \multicolumn{4}{|c|}{$\begin{array}{c}\text { Approximate geographic } \\
\text { loration }\end{array}$} & \multirow{2}{*}{$\begin{array}{l}\text { County in which } \\
\text { located }\end{array}$} & \multirow{2}{*}{$\begin{array}{l}\text { County } \\
\text { index } \\
\text { number } \\
\text { by which } \\
\text { indicated } \\
\text { on Index } \\
\text { Chart }\end{array}$} & \multirow{2}{*}{$\begin{array}{c}\text { Page of } \\
\text { C. S. Coast } \\
\text { and Geodetic } \\
\text { county } \\
\text { publication } \\
\text { of Survey of } \\
\text { Oyster Bars } \\
\text { on which } \\
\text { boundaries } \\
\text { are defined }\end{array}$} & \multirow{2}{*}{$\begin{array}{l}\text { Page of } \\
\text { Fourth Re- } \\
\text { port of Mary- } \\
\text { land Shell } \\
\text { Fish Com- } \\
\text { mission on } \\
\text { which char- } \\
\text { acteristies } \\
\text { are } \\
\text { described }\end{array}$} \\
\hline & & \multicolumn{2}{|c|}{ Latitude } & \multicolumn{2}{|c|}{ Longitude } & & & & \\
\hline & & $\circ$ & , & $\circ$ & , & & & & \\
\hline Pecks Point & 34 & 38 & 42 & 76 & 10 & Talbot & 98 & 223 & 206 \\
\hline Persimmon & 2 & 39 & 03 & 76 & 26 & Anne Arundel & 11 & 30 & 114 \\
\hline Persimmon Tree & 32 & 38 & 51 & 76 & 13 & Queen Annes & 81 & 159 & 225 \\
\hline $\begin{array}{l}\text { Peterson (Calvert } \\
\text { Co.) }\end{array}$ & 19,20 & 38 & 24 & 76 & 31 & Calvert & 28 & 75 & 126 \\
\hline $\begin{array}{l}\text { Peterson (St. Marys } \\
\text { Co.) }\end{array}$ & 19,20 & 38 & 24 & 76 & 32 & St. Marys & 10 & 137 & 145 \\
\hline Philibys & 9 & 37 & 57 & 75 & 55 & Somerset & 24 & 74 & 183 \\
\hline Philips & 30 & 39 & 08 & 76 & 09 & Kent & 53 & 117 & 240 \\
\hline Phoenix Shoal & 28 & 39 & 17 & 76 & 13 & Kent & 1 & 95 & 241 \\
\hline Pin Cushion & 34 & 38 & 44 & 76 & 12 & Talbot & 84 & 215 & 207 \\
\hline Pine Tree & 31 & 38 & 54 & 76 & 20 & Queen Anres & 39 & 135 & 226 \\
\hline Piney Island East & 7 & 38 & 04 & 75 & 54 & Somerset & 21 & 72 & 183 \\
\hline Piney Island Swash & 7 & 38 & 07 & 75 & 55 & Somerset & 14 & 68 & 182 \\
\hline Piney Island West & 7 & 38 & 05 & 75 & 57 & Somerset & 13 & 67 & 183 \\
\hline $\begin{array}{l}\text { Piney Point (Kent } \\
\text { Co.) }\end{array}$ & 30 & 39 & 03 & 76 & 12 & Kent & 36 & 110 & 239 \\
\hline $\begin{array}{l}\text { Piney Point (Queen } \\
\text { Annes Co.) }\end{array}$ & 30 & 39 & 03 & 76 & 12 & Queen Annes & 18 & 122 & 227 \\
\hline Pleasant Hill & $33,34,36$ & 38 & 41 & 76 & 17 & Talbot & 47 & 198 & 210 \\
\hline Plum Point & 16,17 & 38 & 37 & 76 & 29 & Calvert & 4 & 66 & 127 \\
\hline Point(Severn River) & 2 & 39 & 02 & 76 & 32 & Anne Arundel & 29 & 42 & 114 \\
\hline Point (Fishing Bay) & 41 & 38 & 19 & 76 & 01 & Dcrchester & 109 & 156 & 195 \\
\hline Point Look-in & 22 & 38 & 05 & 76 & 19 & St, Marys & 33 & 148 & 149 \\
\hline Point Lookout & 22,23 & 38 & 03 & 76 & 19 & St. Marys & 34 & 149 & 149 \\
\hline Pompes & 34 & 38 & 45 & 76 & 16 & Talbot & 73 & 211 & 208 \\
\hline Pond Marsh & 31 & 38 & 56 & 76 & 19 & Queen Annes & 49 & 140 & 227 \\
\hline Pone & 33 & 38 & 42 & 76 & 22 & Talbot & 41 & 195 & 210 \\
\hline Poplar & 30 & 39 & 00 & 76 & 11 & Queen Annes & 21 & 121 & 227 \\
\hline Poplar Island & 31,33 & 38 & 46 & 76 & 23 & Talbot & 38 & 177 & 210 \\
\hline $\begin{array}{l}\text { Poplar Island Nar- } \\
\text { rows }\end{array}$ & 33 & 38 & 46 & 76 & 21 & Talbot & 39 & 193 & 208 \\
\hline Poplar Point & 32 & 38 & 53 & 76 & 10 & Talbot & 2 & 192 & 209 \\
\hline Poppin Point & 2 & 39 & 02 & 76 & 33 & Anne Arundel & 35 & 43 & 115 \\
\hline Possum Point & 30 & 39 & 05 & 76 & 07 & Queen Annes & 13 & 127 & 228 \\
\hline Potato Hill & 3 & 38 & 52 & 76 & 31 & Anne Arundel & 81 & 57 & 116 \\
\hline Prickly Point & 7 & 38 & 05 & 75 & 54 & Somerset & 20 & 72 & 183 \\
\hline Priest & 24 & 38 & 09 & 76 & 26 & St. Marys & 44 & 157 & 146 \\
\hline Prison Point & 19 & 38 & 27 & 76 & 37 & Calvert & 34 & 72 & 126 \\
\hline Prospect & 32 & 38 & 57 & 76 & 14 & Queen Annes & 72 & 150 & 226 \\
\hline Prospect Point & 32 & 38 & 53 & 76 & 12 & Queen Annes & 79 & 157 & 226 \\
\hline Punch Island Creek & 38 & 38 & 25 & 76 & 19 & Dorchester & 67 & 139 & 199 \\
\hline Purdy Flats & 3 & 38 & 56 & 76 & 31 & Anne Arundel & 62 & 52 & 115 \\
\hline Purnell Hammock & 14 & 38 & 06 & 75 & 17 & Worcester & 11 & 53 & 246 \\
\hline Rabbit Island & 34 & 38 & 46 & 76 & 17 & Talbot & 61 & 205 & 208 \\
\hline $\begin{array}{l}\text { Race Horse (Queen } \\
\text { Annes Co.) }\end{array}$ & 32 & 38 & 52 & 76 & 11 & Queen Annes & 93 & 165 & 225 \\
\hline $\begin{array}{l}\text { Race Horse (Talbot } \\
\text { Co.) }\end{array}$ & 32 & 38 & 52 & 76 & 11 & Talbot & 4 & 191 & 209 \\
\hline Ragged Point & 36,37 & 38 & 32 & 76 & 18 & Dorchester & 36 & 127 & 196 \\
\hline Ragged Point Flats & 36,37 & 38 & 33 & 76 & 17 & Dorchester & 35 & 128 & 196 \\
\hline Railway & 25 & 38 & 15 & 76 & 42 & St. Marys & 89 & 177 & 147 \\
\hline Raleys Shore & 24 & 38 & 09 & 76 & 26 & St. Marys & 45 & 158 & 146 \\
\hline Rattlesnake & 14,15 & 38 & 06 & 75 & 18 & Worcester & 14 & 54 & 246 \\
\hline
\end{tabular}
$9512-13-3$ 
Alphabetical Index to Natural Oyster Bars-Continued.

Red Buoy

Red Sector

Reed Point

Reeds

Richland

Rich Neck

Ringold M i d d l eground

Roaring Point, East

Roaring Point, West

Robins Cove

Robins Marsh

Rock Creek

Rockhall

Rock Point (South River)

Rock Point (Wicomico River)

Rock Point, Lower

Rock Point, Upper

Rocky Beach

Rollin

Rooks

Rosecroft Hollow

Ross

Rough Point

Round Bay

Royston

Ruler Flats

Russell

St. Catherine

St. Clement Entrance

St. George

St. Inigoes, North

St. Inigoes, South

St. Jerome

St. Margaret

Saltwork (Little Choptank River)

Saltworks (Severn River)

Sandgates

Sand Lump

Sand Shoal

Sand Spit

Sand Thistle

Sands

Sandy Hill

Sandy Hill Lumps

Sandy Point (Prospect Bay)

Sandy Point (Manokin River)

$$
\text { (1) }
$$

|


NATURAL OYSTER BARS.

Alphabetical Index to Natural Oyster Bars-Continued.

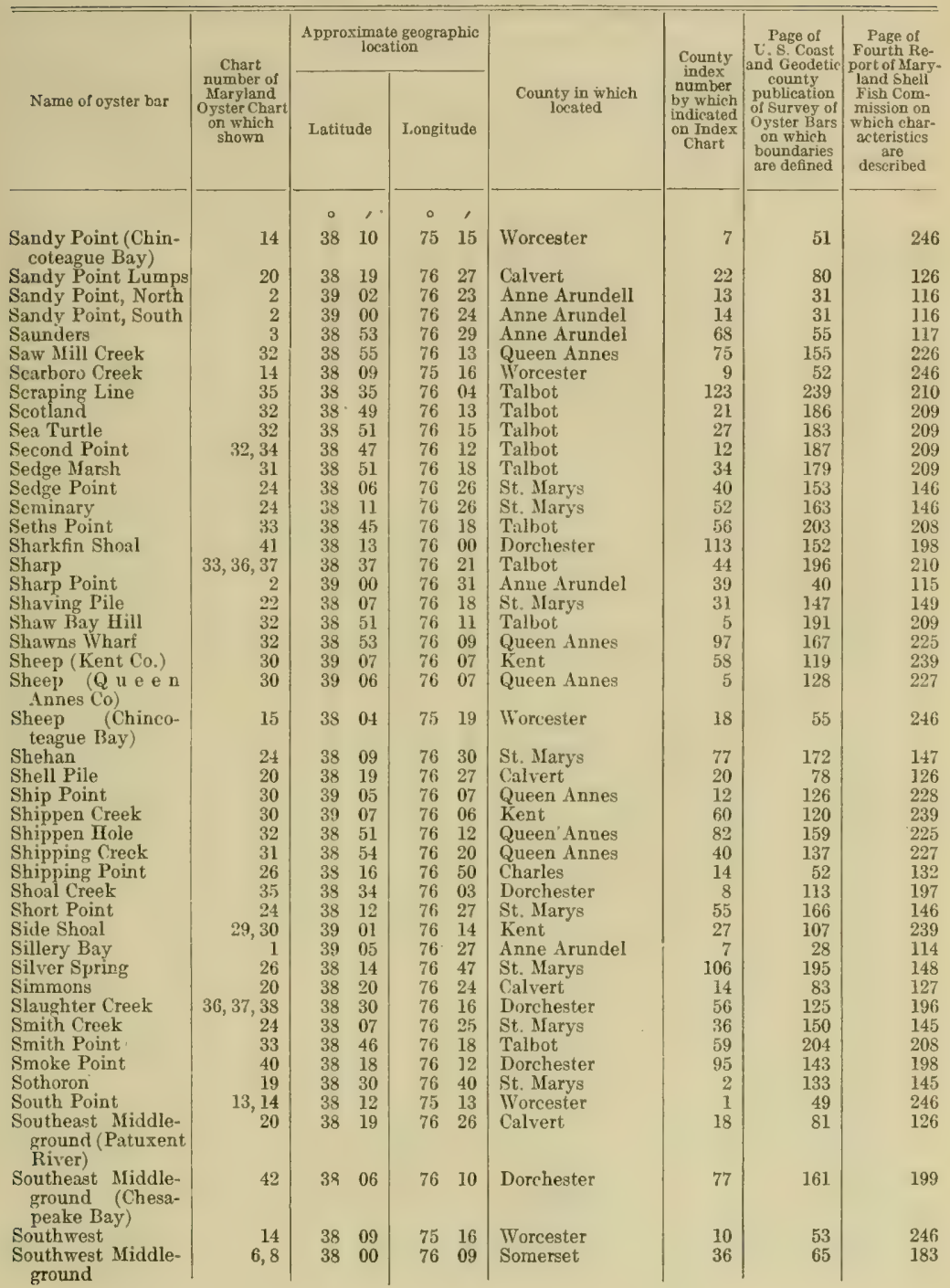


Alphabetical Index to Natural Oyster Bars-Continued.

\begin{tabular}{|c|c|c|c|c|c|c|c|c|c|}
\hline \multirow[b]{2}{*}{ Name of oyster bar } & \multirow{2}{*}{$\begin{array}{c}\text { Chart } \\
\text { number of } \\
\text { Maryland } \\
\text { Oyster Chart } \\
\text { on which } \\
\text { shown }\end{array}$} & \multicolumn{4}{|c|}{$\begin{array}{c}\text { Approximate geographic } \\
\text { location }\end{array}$} & \multirow{2}{*}{$\begin{array}{l}\text { County in which } \\
\text { located }\end{array}$} & \multirow{2}{*}{$\begin{array}{l}\text { County } \\
\text { index } \\
\text { number } \\
\text { by which } \\
\text { indicated } \\
\text { on Index } \\
\text { Chart }\end{array}$} & \multirow{2}{*}{$\begin{array}{c}\text { Page of } \\
\text { v. S. Coast } \\
\text { and Geodetic } \\
\text { county } \\
\text { publication } \\
\text { of Survey of } \\
\text { Oyster Bars } \\
\text { on which } \\
\text { boundaries } \\
\text { are defined }\end{array}$} & \multirow{2}{*}{$\begin{array}{l}\text { Page of } \\
\text { Fourth Re- } \\
\text { port of Mary- } \\
\text { land Shell } \\
\text { Fish Com- } \\
\text { mission on } \\
\text { which char- } \\
\text { acteristics } \\
\text { are } \\
\text { described }\end{array}$} \\
\hline & & \multicolumn{2}{|c|}{ Latitude } & \multicolumn{2}{|c|}{ Longitude } & & & & \\
\hline & & $\circ$ & , & $\circ$ & , & & & & \\
\hline Spaniard Point & 30 & & 06 & 76 & 09 & Queen Annes & 7 & 127 & 227 \\
\hline Spar Buoy & 35 & & 38 & 75 & 59 & Talbot & 132 & 242 & 206 \\
\hline Spedden & 36,37 & 38 & 38 & 76 & 19 & Dorchester & 24 & 119 & 199 \\
\hline Spencers & 20 & 38 & 19 & 76 & 29 & St. Marys & 16 & 139 & 145 \\
\hline Spout & 19 & 38 & 31 & 76 & 40 & Calvert & 41 & 69 & 127 \\
\hline States Bank & 35 & 38 & 34 & 76 & 02 & Dorchester & 7 & 113 & 197 \\
\hline Stevens & 31 & 38 & 55 & 76 & 19 & Queen Annes & 47 & 139 & 227 \\
\hline Stewart Island & 34 & 38 & 42 & 76 & 10 & Talbot & 96 & 222 & 206 \\
\hline Stoddard & 26 & 38 & 22 & 76 & 51 & Charles & 4 & 46 & 132 \\
\hline $\begin{array}{l}\text { Stone (Pocomoke } \\
\text { Sound) }\end{array}$ & 9 & 37 & 56 & 75 & 48 & Somerset & 27 & 76 & 182 \\
\hline $\begin{array}{l}\text { Stone (Chesapeake } \\
\text { Bay) }\end{array}$ & 33,36 & 38 & 39 & 76 & 22 & Talbot & 42 & 195 & 210 \\
\hline Stone Church & 34.35 & 38 & 41 & 76 & 11 & Talbot & 94 & 221 & 206 \\
\hline Stone Pile & 39 & 38 & 20 & 76 & 17 & Dorchester & 68 & 139 & 199 \\
\hline Stone Wharf & 32 & 38 & 52 & 76 & 11 & Queen Anues & 92 & 164 & 225 \\
\hline Stony & 25 & 38 & 16 & 76 & 40 & St. Marys & 88 & 176 & 147 \\
\hline Stony Hollow & 3 & 38 & 53 & 76 & 31 & Anne Arundel & 78 & 60 & 116 \\
\hline Straits & 24 & 38 & 08 & 76 & 30 & St. Marys & 72 & 170 & 147 \\
\hline Striking Marsh & 15 & 38 & 04 & 75 & 16 & Worcester & 24 & 57 & 246 \\
\hline Strong Bay & 29 & 39 & 01 & 76 & 17 & Queen Annes & 28 & 117 & 227 \\
\hline Sugar Loaf & 35 & 38 & 34 & 76 & 02 & Talbot & 126 & 240 & 206 \\
\hline Susquehanna & 37 & 38 & 31 & 76 & 16 & Dorchester & 53 & 132 & 196 \\
\hline Swan & 24 & 38 & 09 & 76 & 30 & St. Marys & 74 & 171 & 147 \\
\hline Swan Creek & 28 & 39 & 09 & 76 & 15 & Kent & 15 & 100 & 241 \\
\hline Swan Point & 28,29 & 39 & 08 & 76 & 18 & Kent & 8 & 99 & 241 \\
\hline Swan Reef & 3 & 38 & 55 & 76 & 29 & Anne Arundel & 51 & 49 & 115 \\
\hline Swash & 20 & 38 & 19 & 76 & 27 & Calvert & 19 & 80 & 126 \\
\hline Sycamore & 32 & 38 & 50 & 76 & 12 & Talbot & 10 & 188 & 209 \\
\hline Tanners Patch & 35 & 38 & 37 & 75 & 59 & Dorchester & 4 & 112 & 197 \\
\hline Tar Bay & 39 & 38 & 20 & 76 & 15 & Dorchester & 69 & 141 & 196 \\
\hline Tarkhill & 24 & 38 & 09 & 76 & 30 & St. Marys & 73 & 170 & 147 \\
\hline Tavern Creek & 28,29 & 39 & 09 & 76 & 16 & Kent & 9 & 102 & 241 \\
\hline Tea Table & 27 & 39 & 13 & 76 & 19 & Baltimore & 1 & 33 & 103 \\
\hline Teague & 26 & 38 & 32 & 76 & 40 & Charles & 1 & 53 & 132 \\
\hline Tenacres & 21 & 38 & 11 & 76 & 21 & St. Marys & 27 & 145 & 149 \\
\hline $\begin{array}{l}\text { The Black Buoy } \\
\text { (C hopt a n k } \\
\text { River) }\end{array}$ & 35 & 38 & 34 & 76 & 02 & Talbot & 125 & 239 & 206 \\
\hline The Haven & 28,29 & 39 & 09 & 76 & 15 & Kent & 13 & 101 & 241 \\
\hline $\begin{array}{l}\text { Thomas (Calvert } \\
\text { Co.) }\end{array}$ & 19 & 38 & 28 & 76 & 39 & Calvert & 36 & 71 & 126 \\
\hline $\begin{array}{l}\text { Thomas (St. Marys } \\
\text { Co.) }\end{array}$ & 19 & 38 & 27 & 76 & 38 & St. Marys & 4 & 134 & 145 \\
\hline Thomas Point North & 3 & 38 & 55 & 76 & 26 & Anne Arun & 47 & 46 & 116 \\
\hline Thomas Point South & 3 & 38 & 54 & 76 & 27 & Anne Arundel & 48 & 47 & 116 \\
\hline Thompson Creek & 24 & 38 & 09 & 76 & 27 & St. Marys & 61 & 158 & 146 \\
\hline Thompsons & 31 & 38 & 57 & 76 & 19 & Queen Annes & 52 & 143 & 227 \\
\hline Thorough & 41 & 38 & 19 & 76 & 02 & Dorchester & 105 & 157 & 195 \\
\hline Three Sisters & 3 & 38 & 51 & 76 & 29 & Anne Arundel & 87 & 56 & 117 \\
\hline $\begin{array}{l}\text { Thunder and Light- } \\
\text { ning }\end{array}$ & 3 & 38 & 56 & 76 & 31 & Anne Arundel & 55 & 52 & 115 \\
\hline Tidemill & 32 & 38 & 49 & 76 & 14 & Talbot & 22 & 185 & 209 \\
\hline Tilghman Wharf & 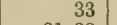 & 38 & 42 & 76 & 19 & Talbot & 50 & 200 & 208 \\
\hline Tilghmans Point & 31,32 & 38 & 52 & 76 & 16 & Talbot & 32 & 180 & 209 \\
\hline
\end{tabular}


NATURAL OYSTER BARS.

Alphabetical Index to Natural Oyster Bars-Continued.

\begin{tabular}{|c|c|c|c|c|c|c|c|c|c|}
\hline \multirow[b]{2}{*}{ Name of oyster bar } & \multirow{2}{*}{$\begin{array}{c}\text { Chart } \\
\text { number of } \\
\text { Mfaryland } \\
\text { Oyster Chart } \\
\text { on which } \\
\text { shown }\end{array}$} & \multicolumn{4}{|c|}{$\begin{array}{c}\text { Approximate geographic } \\
\text { location }\end{array}$} & \multirow[b]{2}{*}{$\begin{array}{l}\text { County in which } \\
\text { located }\end{array}$} & \multirow{2}{*}{$\begin{array}{l}\text { County } \\
\text { index } \\
\text { number } \\
\text { by which } \\
\text { indicated } \\
\text { on Index } \\
\text { Chart }\end{array}$} & \multirow{2}{*}{$\begin{array}{c}\text { Page of } \\
\text { U. S. Coast } \\
\text { and Greodetic } \\
\text { county } \\
\text { publication } \\
\text { of Survey of } \\
\text { oyster Bars } \\
\text { on which } \\
\text { boundaries } \\
\text { are defined }\end{array}$} & \multirow{2}{*}{$\begin{array}{l}\text { Page of } \\
\text { Fourth Re- } \\
\text { port of Mfary } \\
\text { land Shell } \\
\text { Fish Com- } \\
\text { mission on } \\
\text { which char- } \\
\text { acteristics } \\
\text { are } \\
\text { described }\end{array}$} \\
\hline & & \multicolumn{2}{|c|}{ Latitude } & \multicolumn{2}{|c|}{ Longitude } & & & & \\
\hline & & $\circ$ & ' & $\circ$ & ' & & & & \\
\hline Tobacco Stick & 37 & 38 & 32 & 76 & 14 & Dorchester & 52 & 133 & 196 \\
\hline Toby & 15 & 38 & 04 & 75 & 18 & Worcester & 22 & 57 & 246 \\
\hline Todd Point & 37 & 38 & 39 & 76 & 15 & Dorchester & 21 & 130 & 199 \\
\hline Tolchester Lump & 28 & 39 & 13 & 76 & 15 & Kent & 4 & 97 & 241 \\
\hline Tolly Point & 2,3 & 38 & 57 & 76 & 27 & Anne Arundel & 45 & 34 & 116 \\
\hline Town & 37 & 38 & 33 & 76 & 13 & Dorchester & 43 & 135 & 196 \\
\hline Town Creek & 20 & 38 & 19 & 76 & 29 & St. Marys & 17 & 140 & 145 \\
\hline $\begin{array}{l}\text { Town Point (Cor- } \\
\text { sica River) }\end{array}$ & 30 & 39 & 05 & 76 & 08 & Queen Annes & 9 & 125 & 228 \\
\hline $\begin{array}{l}\text { Town Point (Tred } \\
\text { Avon River) }\end{array}$ & 34 & 38 & 42 & 76 & 11 & Talbot & 95 & 222 & 206 \\
\hline Traces Hollow & 2 & 39 & 00 & 76 & 30 & Anne Arundel & 26 & 40 & 114 \\
\hline Travers & 36,38 & 38 & 30 & 76 & 22 & Dorchester & 66 & 123 & 199 \\
\hline Trippe & 34 & 38 & 43 & 76 & 07 & Talbot & 103 & 226 & 207 \\
\hline Tubbmans Drain & 39,40 & 38 & 21 & 76 & 13 & Dorchester & 99 & 142 & 198 \\
\hline Tucker & 3 & 38 & 51 & 76 & 32 & Anne Arundel & 83 & 59 & 116 \\
\hline Turkey Neck & 33 & 38 & 44 & 76 & 18 & Talbot & 53 & 201 & 208 \\
\hline $\begin{array}{l}\text { Turkey Point } \\
\text { (South River) }\end{array}$ & 3 & 38 & 55 & 76 & 30 & Anne Arundel & 66 & 48 & 115 \\
\hline $\begin{array}{c}\text { Turkey Point } \\
\text { (Eastern Bay) }\end{array}$ & 31 & 38 & 54 & 76 & 18 & Queen Annes & 54 & 134 & 226 \\
\hline Turnrow & 33,34 & 38 & 43 & 76 & 18 & Talbot & 63 & 199 & 208 \\
\hline Turpin & 14 & 38 & 10 & 75 & 15 & Worcester & 6 & 51 & 246 \\
\hline $\begin{array}{l}\text { Turtle Back (Chop- } \\
\text { tank River) }\end{array}$ & 35 & 38 & 36 & 76 & 06 & Dorchester & 11 & 114 & 199 \\
\hline $\begin{array}{l}\text { Turtle Back (Miles } \\
\text { River) }\end{array}$ & 32 & 38 & 51 & 76 & 14 & Talbot & 28 & 182 & 209 \\
\hline Turtle Egg Island & 5,7 & $38^{\prime}$ & 07 & 76 & 00 & Somerset & 10 & 59 & 183 \\
\hline Umphasis & & 39 & 04 & 76 & 29 & Anne Arundel & 9 & 29 & 114 \\
\hline Under the Bar & 29 & 39 & 06 & 76 & 16 & Kent & 20 & 104 & 240 \\
\hline Under the Cliffs & 20 & 38 & 21 & 76 & 24 & Calvert & 12 & 84 & 127 \\
\hline Under the Gums & 3 & 38 & 56 & 76 & 27 & Anne Arundel & 46 & 45 & 116 \\
\hline Upper Forrest & 19 & 38 & 25 & 76 & 36 & St. Marys & 6 & 135 & 145 \\
\hline Upper Harris Creek & $31,32,34$ & 38 & 47 & 76 & 16 & Talbot & 62 & 181 & 208 \\
\hline Upper Hill & 32 & 38 & 52 & 76 & 15 & Talbot & 31 & 181 & 209 \\
\hline $\begin{array}{l}\text { Upper Newfound- } \\
\text { land }\end{array}$ & 41 & 38 & 19 & 75 & 54 & Dorchester & 121 & 160 & 195 \\
\hline Upper Stake & 11 & 38 & 20 & 75 & 53 & Wicomico & 1 & 42 & 189 \\
\hline Upper Steps & 16 & 38 & 41 & 76 & 31 & Cal & 2 & 65 & 127 \\
\hline Wade & 2 & 39 & 00 & 76 & 30 & Anne Arundel & 40 & 39 & 115 \\
\hline Wades Point & 31 & 38 & 50 & 76 & 18 & Talbot & 35 & 179 & 209 \\
\hline Walnut & 33 & 38 & 46 & 76 & 18 & Talbot & 58 & 204 & 208 \\
\hline Walter White & 32 & 38 & 57 & 76 & 15 & Queen Annes & 67 & 150 & 226 \\
\hline $\begin{array}{l}\text { Ware (Chesapeake } \\
\text { Bay) }\end{array}$ & 39,40 & 38 & 17 & 76 & 13 & Dorchester & 73 & 140 & 199 \\
\hline $\begin{array}{l}\text { Ware (Langford } \\
\text { Creek) }\end{array}$ & 30 & 39 & 09 & 76 & 09 & Kent & 54 & 117 & 240 \\
\hline Ware Sands & 41 & 38 & 13 & 76 & 02 & Dorchester & 100 & 152 & 195 \\
\hline Waterloo & 26 & 38 & 14 & 76 & 47 & St. Marys & 105 & 195 & 148 \\
\hline Watermelon Point & 34 & 38 & 45 & 76 & 07 & Talbot & 111 & 229 & 207 \\
\hline Watkins & 9 & 37 & 56 & 75 & 48 & Somerset & 28 & 76 & 182 \\
\hline Weems Lower & 2 & 39 & 00 & 76 & 29 & Anne Arundel & 42 & 38 & 115 \\
\hline Weems Upper & 2 & 39 & 00 & 76 & 30 & Anne Arundel & 41 & 39 & 115 \\
\hline Welch & 2 & 39 & 05 & 76 & 27 & Anne Arundel & 5 & 28 & 114 \\
\hline Well Cove & 32 & 38 & 58 & 76 & 15 & Queen Annes & 711 & 148 & 226 \\
\hline
\end{tabular}


Alphabetical Index to Natural Oyster Bars-Continued.

\begin{tabular}{|c|c|c|c|c|c|c|c|c|c|}
\hline \multirow[b]{2}{*}{ Name of oyster bar } & \multirow{2}{*}{$\begin{array}{c}\text { Chart } \\
\text { number of } \\
\text { Maryland } \\
\text { Oyster Chart } \\
\text { on which } \\
\text { shown }\end{array}$} & \multicolumn{4}{|c|}{$\begin{array}{c}\text { Approximate geographic } \\
\text { location }\end{array}$} & \multirow{2}{*}{$\begin{array}{l}\text { County in which } \\
\text { located }\end{array}$} & \multirow{2}{*}{$\begin{array}{c}\text { County } \\
\text { index } \\
\text { number } \\
\text { by which } \\
\text { indicated } \\
\text { on Index } \\
\text { Chart }\end{array}$} & \multirow{2}{*}{$\begin{array}{c}\text { Page of } \\
\text { U. S, Coast } \\
\text { and Geodetic } \\
\text { county } \\
\text { publication } \\
\text { of Survey of } \\
\text { Oyster Hars } \\
\text { on which } \\
\text { boundaries } \\
\text { are defined }\end{array}$} & \multirow{2}{*}{$\begin{array}{l}\text { Page of } \\
\text { Fourth Re- } \\
\text { nort of Mary- } \\
\text { land Shell } \\
\text { Fish Com- } \\
\text { mission on } \\
\text { which char- } \\
\text { acteristics } \\
\text { are } \\
\text { described }\end{array}$} \\
\hline & & \multicolumn{2}{|c|}{ Latitude } & \multicolumn{2}{|c|}{ Longitude } & & & & \\
\hline & & $\circ$ & , & $\circ$ & , & & & & \\
\hline Well Point & 34 & 38 & 45 & 76 & 16 & Talbot & 72 & 210 & 208 \\
\hline West End & 32 & 38 & 50 & 76 & 13 & Talbot & 24 & 184 & 209 \\
\hline West St. Marys & 24 & 38 & 11 & 76 & 27 & St. Marys & 58 & 163 & 146 \\
\hline Wetipquin & 11 & 38 & 20 & 75 & 53 & Wicomico & 2 & 42 & 189 \\
\hline Whetstone & 32 & 38 & 52 & 76 & 10 & Queen Annes & 94 & 165 & 225 \\
\hline Whitehall & 2 & 38 & 58 & 76 & 27 & Anne Arundel & 19 & 33 & 114 \\
\hline Whitehall Creek & 2 & 39 & 00 & 76 & 26 & Anne Arundel & 18 & 32 & 114 \\
\hline White Horse & 28,29 & 39 & 09 & 76 & 15 & Kent & 12 & 100 & 241 \\
\hline White Marsh & 29 & 39 & 06 & 76 & 15 & Kent & 21 & 104 & 240 \\
\hline White Point & 26 & 38 & 17 & 76 & 49 & St. Marys & 136 & 190 & 148 \\
\hline White Point Hollow & 26 & 38 & 17 & 76 & 49 & St. Marys & 115 & 190 & 149 \\
\hline White Rock & 15 & 38 & 03 & 75 & 17 & Worcester & 26 & 58 & 246 \\
\hline White Wood & 39 & 38 & 19 & 76 & 14 & Dorchester & 70 & 141 & 196 \\
\hline Wickes Beach & 29 & 39 & 02 & 76 & 16 & Kent & 25 & 106 & 239 \\
\hline Wicomico Lumps & 26 & 38 & 21 & 76 & 51 & Charles & 5 & 47 & 132 \\
\hline $\begin{array}{l}\text { Wicomico Middle- } \\
\text { ground }\end{array}$ & 26 & 38 & 18 & 76 & 50 & Charles & 10 & 49 & 132 \\
\hline Wild Cherry Tree & 33 & 38 & 42 & 76 & 18 & Talbot & 49 & 199 & 208 \\
\hline $\begin{array}{l}\text { Wild Ground (East- } \\
\text { ern Bay) }\end{array}$ & 31 & 38 & 54 & 76 & 19 & Queen Annes & 38 & 135 & 226 \\
\hline $\begin{array}{l}\text { Wild Ground (Miles } \\
\text { River) }\end{array}$ & 32 & 38 & 49 & 76 & 13 & Talbot & 11 & 188 & 209 \\
\hline Willeys Island & 34 & 38 & 45 & 76 & 14 & Talbot & 85 & 216 & 207 \\
\hline $\begin{array}{l}\text { Willeys I s l a n d } \\
\text { Flats }\end{array}$ & 34 & 38 & 45 & 76 & 14 & Talbot & 77 & 212 & 207 \\
\hline Willis & 34,35 & 38 & 40 & 76 & 09 & Talbot & 114 & 230 & 206 \\
\hline Willow Bottom & 30 & 39 & 05 & 76 & 11 & Kent & 41 & 112 & 239 \\
\hline Wilson Shoals & 11 & 38 & 18 & 75 & 55 & Wicomico & 9 & 45 & 189 \\
\hline Wilsons Point & 30 & 39 & 09 & 76 & 11 & Kent & 50 & 116 & 240 \\
\hline Winders Bank & 32 & 38 & 52 & 76 & 10 & Talbot & 3 & 192 & 209 \\
\hline $\begin{array}{l}\text { Windmill (Wico- } \\
\text { mico River) }\end{array}$ & 26 & 38 & 19 & 76 & 51 & Charles & 8 & 48 & 132 \\
\hline $\begin{array}{l}\text { Windmill (Honga } \\
\text { River) }\end{array}$ & 40 & 38 & 16 & 76 & 10 & Dorchester & 91 & 145 & 198 \\
\hline Windmill Flats & 29 & 39 & 08 & 76 & 16 & Kent & 16 & 102 & 240 \\
\hline Wingate & 5 & 38 & 14 & 75 & 52 & Somerset & 2 & 63 & 183 \\
\hline Wreck Buoy & 2 & 38 & 58 & 76 & 26 & Anne Arundel & 16 & 34 & 116 \\
\hline Wroten Island & 39,40 & 38 & 19 & 76 & 12 & Dorchester & 96 & 143 & 198 \\
\hline Wye Island & 32 & 38 & 53 & 76 & 11 & Queen Annes & 88 & 162 & 225 \\
\hline $\begin{array}{l}\text { Wye River Middle- } \\
\text { ground }\end{array}$ & 32 & 38 & 53 & 76 & 11 & Queen Annes & 90 & 163 & 225 \\
\hline Wye Town & 32 & 38 & 51 & 76 & 12 & Talbot & 7 & 190 & 209 \\
\hline
\end{tabular}




\section{NATURAL OYSTER BARS.}

\section{NUMERICAL INDEX.}

NoTE.-See Alphabetical Index for other references relating to natural oyster bars.

ANNE ARUNDEL COUNTY.

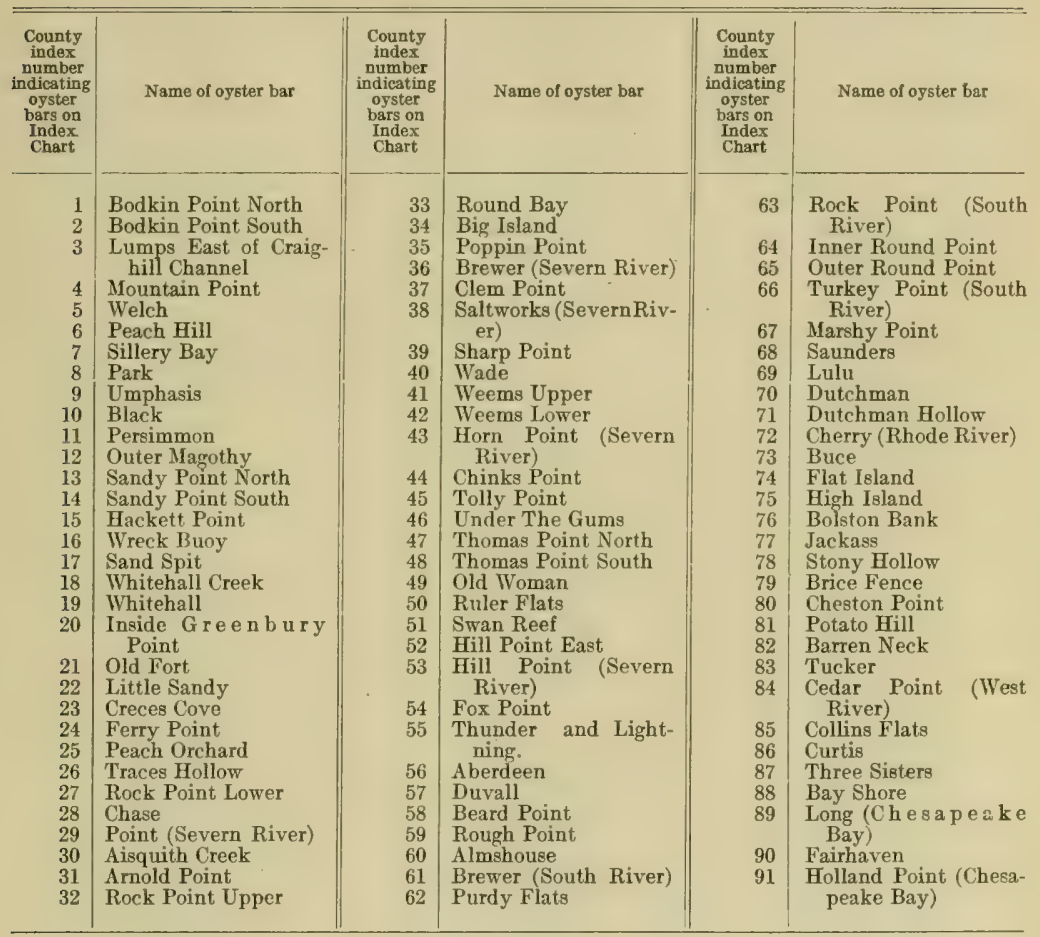

BALTIMORE COUNTY. 
Numerical Index to Natural Oygter Bars-Continued.

CALVERT COUNTY.

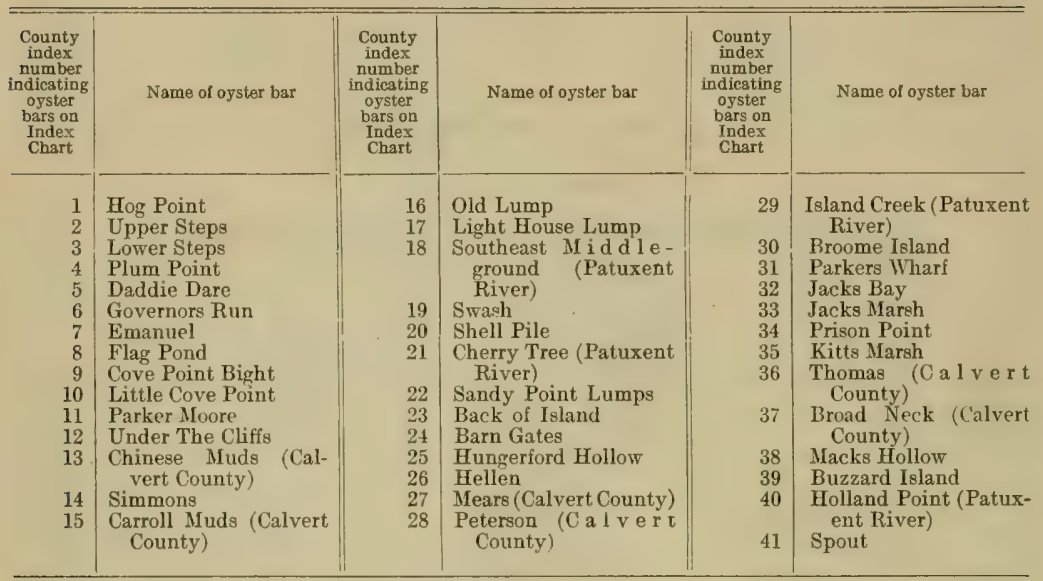

CHARLES COUNTY.

\begin{tabular}{|c|c|c|}
\hline Teague & 7 & Joes Lumps \\
\hline Elbow & 8 & Windmill (Wicomico \\
\hline Carpenterg Yard & & River) \\
\hline Stoddard & 9 & Fenwick \\
\hline $\begin{array}{l}\text { Wicomico Lumps } \\
\text { Mills West }\end{array}$ & 10 & $\begin{array}{l}\text { Wicomico Middle- } \\
\text { ground }\end{array}$ \\
\hline
\end{tabular}

11 Charleston Creek

12 Lancaster

13 Rock Point (Wicomico River)

14 Shipping Point

15 Cobb Point

DORCHESTER COUNTY.

\begin{tabular}{|c|c|c|c|c|c|}
\hline 1 & Drum Point (Choptank & $\begin{array}{l}20 \\
21\end{array}$ & $\begin{array}{l}\text { Logans Hill } \\
\text { Todd Point }\end{array}$ & 39 & Hudson (Little Chop- \\
\hline 2 & Cabin Creek Entrance & 22 & Cook Point & 40 & Ross \\
\hline 3 & Cabin Creek (Chop- & 23 & Red Buoy & 41 & Butterpot \\
\hline & $\operatorname{tank}$ River) & 24 & Spedden & 42 & McKeils Point \\
\hline 4 & Tanners Patch & 25 & Diamond (Chesapeake & 43 & Town \\
\hline 5 & Dixon & & Bay) & 44 & Cherry Island \\
\hline 6 & Oyster Shell Point & 26 & Dupont & 45 & Brumell \\
\hline 7 & States Bank & 27 & Brannock & 46 & Jones (Little Choptank \\
\hline 8 & Shoal Creek & 28 & Mill Point (Chesapeake & & River) \\
\hline 9 & Green Marsh & & Bay) & 47 & Pattison \\
\hline 10 & Hambrooks & 29 & Hills Point (Chesa- & 48 & Barn Point \\
\hline 11 & $\begin{array}{l}\text { Turtle Back (Chop- } \\
\text { tank River) }\end{array}$ & 30 & $\begin{array}{l}\text { peake Bay) } \\
\text { Hills Point North }\end{array}$ & 49 & $\begin{array}{l}\text { Saltwork (Little Chop- } \\
\text { tank River) }\end{array}$ \\
\hline 12 & Sandy Hill Lumps & 31 & Hills Point South & 50 & Fishing Creek \\
\hline 13 & Sandy Hill & 32 & Peanut Hill & 51 & Grapevine \\
\hline 14 & Commander & 33 & Cow Island & 52 & Tobacco Stick \\
\hline 15 & $\begin{array}{l}\text { Horn Point (Choptank } \\
\text { River) }\end{array}$ & 34 & $\begin{array}{l}\text { Bald Eagle (Little } \\
\text { Choptank River) }\end{array}$ & $\begin{array}{l}53 \\
54\end{array}$ & $\begin{array}{l}\text { Susquehanna } \\
\text { Along Shore }\end{array}$ \\
\hline 16 & Le Compte & 35 & Ragged Point Flats & 55 & Hooper \\
\hline 17 & Castle Haven Creek & 36 & Ragged Point & 56 & Slaughter Creek \\
\hline 18 & Castle Haven & 37 & Little Pollard & 57 & Bridge \\
\hline 19 & Corners Wharf & 38 & Cason & 58 & Nine Acres \\
\hline
\end{tabular}


NATURAL OYSTER BARS.

Numerical Index to Natural Oyster Bars-Continued.

DORCHESTER COUNTY-Continued.

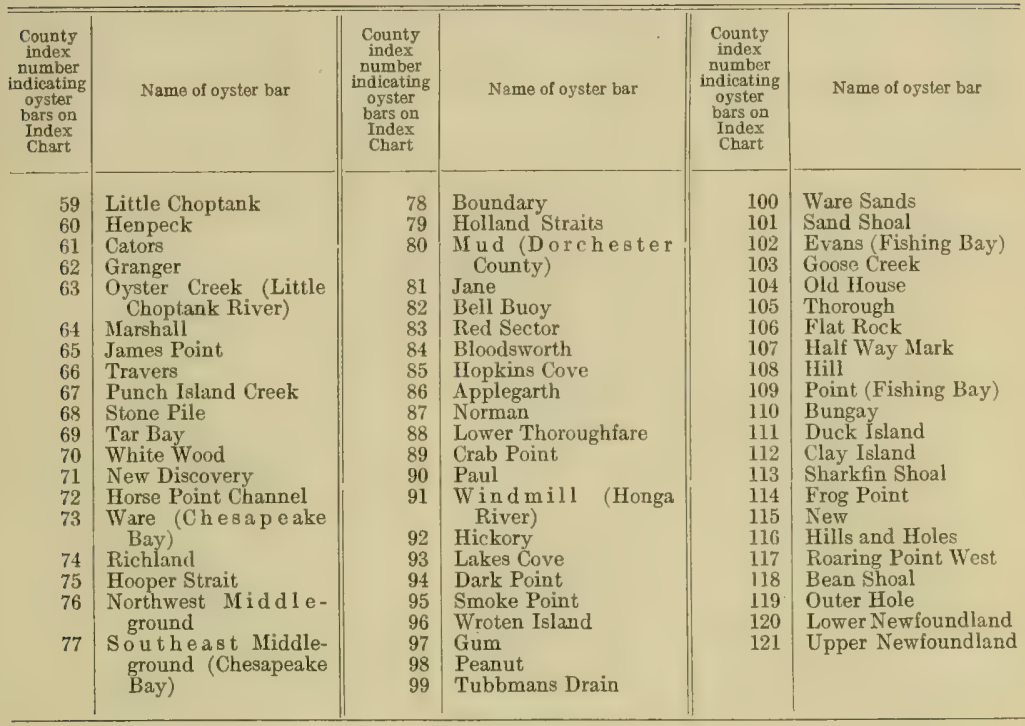

KFNT COUNTY.

Phoenix Shoal
Deep Shoal
Coal Lump
Tolchester Lump
Mitchells Bluff Buoy
Gales Lumps
Hodges
Swan Point
Tavern Creek
Little Neck (Swan
Creek)
Deep Landing Hole
White Horse
The Haven
Rockhall
Swan Creek
Windmill Flats
Muddy Drain
Huntingfield
Gum Spring
Under The Bar
White Marsh
Hickory Thicket
East Neck Bay
Entrance Lumps

Wickes Beach
Dredge Rock
Side Shoal
Mud (Chester River)
Ferry (Kent County)
Buoy Rock
Hail Creek
Hail Point
Black Buoy (Chester
River)
Durdin
Belts Point (Kent
Piney Pounty)
Bay Bush Point
Bluff Point (Chester
River)
Chester River Middle-
ground
Limekiln
Willow Bottom
Nichols
Hudson (Ch s e r
River)
Sand Thistle

45 Boat House

46 Drum Point (Langford Creek)

47 Davis Creek

48 Island Point

Eagle Point (Langford Creek)

50 Wilsons Point

51 Kings Creek

52 Bailey

53 Philips

54 Ware (Langford Creek)

55 Ebb Point

56 Cliff

57 Commegys Bight

58 Sheep (Kent County)

Deep Point

Shippen Creek

Haddaway Hollyday (Kent County)

63 Melton Point

64

Northwest (Kent County 
Numerical Index to Natdral Orster Barg-Continued. QUEEN ANNES COUNTY.

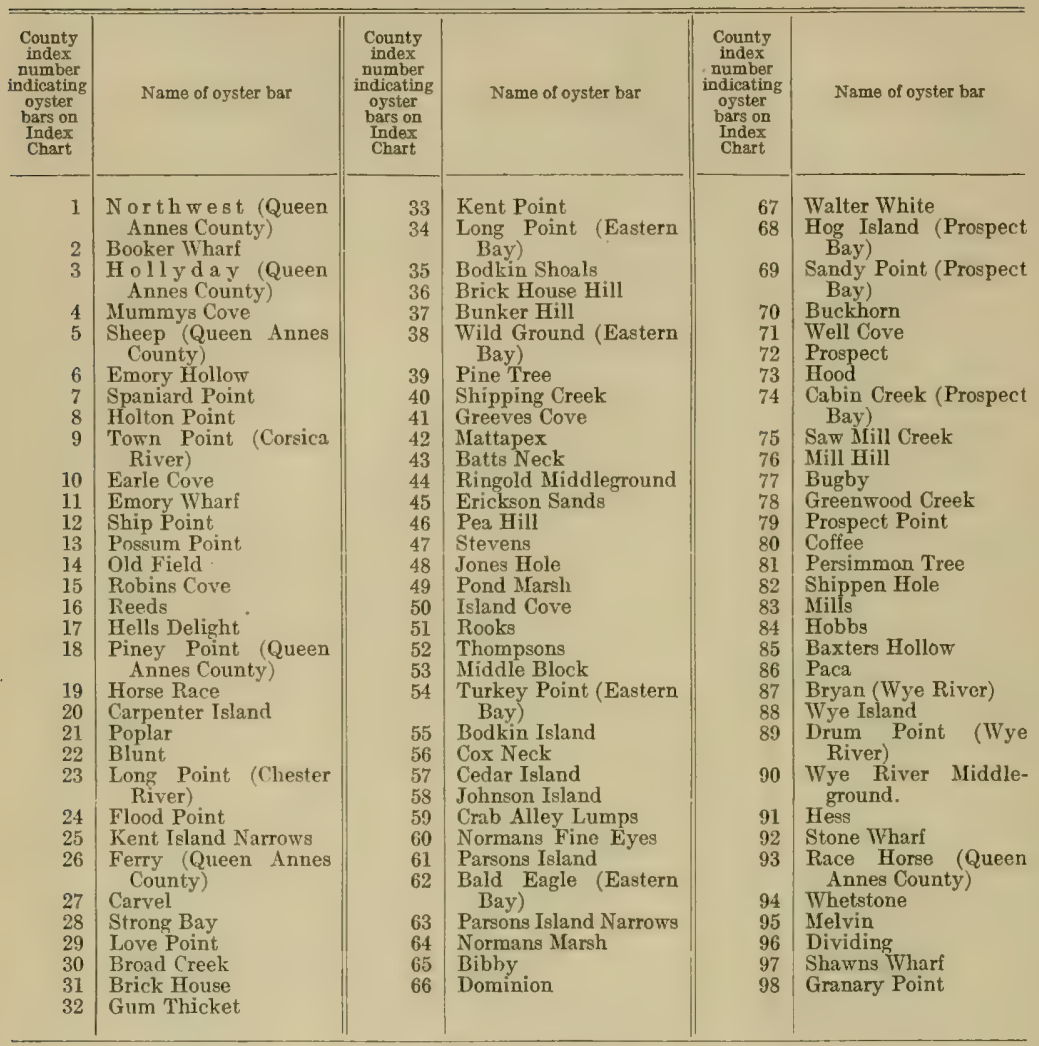

ST. MARYS COUNTY.

1 Brooks Shallows

2 Sothoron

3 Broad Neck (St. Marys County)

4 Thomas (St. Marys County)

5 Sandgates

6 Upper Forrest

7 Lower Forrest

8 Gatton

9 Captain Point

\begin{tabular}{|c|c|}
\hline 10 & $\begin{array}{l}\text { Peterson (St. Marys } \\
\text { County) }\end{array}$ \\
\hline 11 & Neale \\
\hline 12 & Mears (St. Marys Coun- \\
\hline 13 & Half Pone \\
\hline 14 & Hawks Nest \\
\hline 15 & Bob Wise \\
\hline & Spencers \\
\hline & Town Creek \\
\hline & \\
\hline
\end{tabular}

19 La Grande

20 Millstone

21 Deep Point Mud

22 Carroll Muds (St.Marys County)

23 Hog Island (Patuxent River)

24 Chinese Muds (St. Marys County)

25 Cedar Point Hollow

26 Rocky Beach 
NATURAL OYSTER BARS.

Numerical Index to Natural Oyster Bars-Continued.

ST, MARYS COUNTY-Continued.

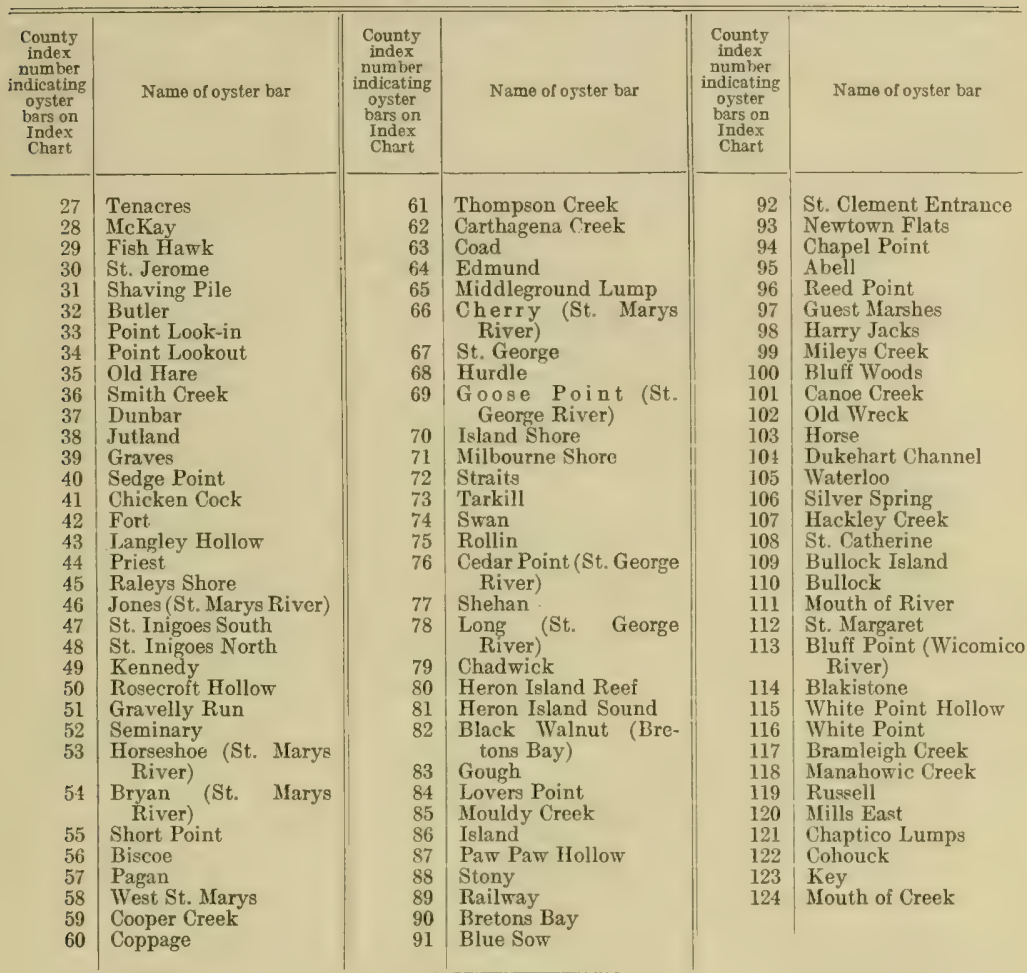

SOMERSET COUNTY.

\begin{tabular}{|c|c|c|c|c|c|}
\hline 1 & Mount Vernon Wharf & 14 & Piney Island Swash & 27 & Pocomoke \\
\hline 2 & Wingate & 15 & Georges & & Sound) \\
\hline 3 & Buoy & 16 & Sandy Point (Manokin & 28 & Watkins \\
\hline 4 & $\begin{array}{l}\text { Evans (Wicomico } \\
\text { River) }\end{array}$ & 17 & $\begin{array}{l}\text { River) } \\
\text { Cormal }\end{array}$ & 29 & $\begin{array}{l}\text { Long Point (Pocomoke } \\
\text { Sound) }\end{array}$ \\
\hline 5 & Rock Creek & 18 & Marshy Island & 30 & Gunby \\
\hline 6 & Halls Point & 19 & Drum Point (Manokin & 31 & Marumsco \\
\hline 7 & Haines & & River) & 32 & Kitts Creek West \\
\hline 8 & Old Orchard (Tangier & 20 & Prickly Point & 33 & Kitts Creek East \\
\hline & Sound) & 21 & Piney Island East & 34 & Oyster Creek (Kedge \\
\hline 9 & Mud (Somerset Co.) & 22 & Harris & & Straits) \\
\hline 10 & Turtle Egg Island & 23 & Big Annemessex & 35 & Kedge Straits \\
\hline 11 & Chain Shoal & 24 & Philibys & 36 & Southwest Middle- \\
\hline 12 & Mussel Hole & 25 & Great Rock & & ground \\
\hline 13 & Piney Island West & 26 & Fox Island & 37 & Church Creek \\
\hline
\end{tabular}


Numertoal Index to Natural Oyster Bars-Continued.

TALBOT COUNTY

\begin{tabular}{|c|c|c|c|c|c|}
\hline $\begin{array}{c}\text { County } \\
\text { index } \\
\text { number } \\
\text { indicating } \\
\text { oyster } \\
\text { bars on } \\
\text { Index } \\
\text { Chart }\end{array}$ & Name of oyster bar & $\begin{array}{c}\text { County } \\
\text { index } \\
\text { number } \\
\text { indicating } \\
\text { oyster } \\
\text { bars on } \\
\text { Index } \\
\text { Chart }\end{array}$ & Name of oyster bar & $\begin{array}{l}\text { County } \\
\text { index } \\
\text { number } \\
\text { indicating } \\
\text { oyster } \\
\text { bars on } \\
\text { Index } \\
\text { Chart }\end{array}$ & Name of oyster bar \\
\hline 1 & Juniper & 43 & Clay Bank & 86 & Fox \\
\hline 2 & Poplar Point & 44 & Sharp & 87 & Royston \\
\hline 3 & Winders Bank & 45 & Black Walnut (Big & 88 & Irish Creek \\
\hline 4 & Race Horse (Talbot & & Choptank River) & 89 & Choptank Lumps \\
\hline & County) & 46 & Sands & 90 & Benoni \\
\hline 5 & Shaw Bay Hill & 47 & Pleasant Hill & 91 & Light House \\
\hline 6 & Bruffs Island & 48 & Church Hill & 92 & Bachelor Point \\
\hline 7 & Wye Town & 49 & Wild Cherry Tree & 93 & Fox Hole \\
\hline 8 & Herring Island & 50 & Tilghman Wharf & 94 & Stone Church \\
\hline 9 & East End & 51 & Change & 95 & Town Point \\
\hline 10 & Sycamore & 52 & Eagle Point (Harris & & Avon River) \\
\hline 11 & Wild Ground (Miles & & Creek) & 96 & Stewart Island \\
\hline 12 & $\begin{array}{l}\text { River) } \\
\text { Second Point }\end{array}$ & $\begin{array}{l}53 \\
54\end{array}$ & $\begin{array}{l}\text { Turkey Neck } \\
\text { Mill Point }\end{array}$ & $\begin{array}{l}97 \\
98\end{array}$ & $\begin{array}{l}\text { Goose Neck } \\
\text { Pecks Point }\end{array}$ \\
\hline 13 & Gibsons Flats & 04 & Creek) & $\begin{array}{l}90 \\
99\end{array}$ & Mares Point \\
\hline 14 & Long Point (Miles & 55 & Hunts & 100 & Louis Cove \\
\hline 15 & $\begin{array}{l}\text { River) } \\
\text { Cox }\end{array}$ & $\begin{array}{l}56 \\
57\end{array}$ & $\begin{array}{l}\text { Seths Point } \\
\text { Lodges }\end{array}$ & $\begin{array}{l}101 \\
102\end{array}$ & $\begin{array}{l}\text { Bamings Cove } \\
\text { Old House Point }\end{array}$ \\
\hline 16 & Barnett & 58 & Walnut & 103 & Trippe \\
\hline 17 & Bazzles Hill & 59 & Smith Point & 104 & Bakers Cove \\
\hline 18 & $\begin{array}{l}\text { Old Orchard (Miles } \\
\text { River) }\end{array}$ & 60 & $\begin{array}{l}\text { Little Neck (Harris } \\
\text { Creek) }\end{array}$ & $\begin{array}{l}105 \\
106\end{array}$ & $\begin{array}{l}\text { Marshy } \\
\text { Flatty }\end{array}$ \\
\hline 19 & Ash Craft & 61 & Rabbit Island & 107 & Orem \\
\hline 20 & Deep Water Point & 62 & Upper Harris Creek & 108 & Double Mills \\
\hline 21 & Scotland & 63 & Turnrow & 109 & Johnston \\
\hline 22 & Tidemill & 64 & Great Marsh & 110 & Camden Point \\
\hline 23 & Hambleton & 65 & France & 111 & Watermelon Point \\
\hline 24 & West End & 66 & Dawson & 112 & Back Shore \\
\hline 25 & Hambleton Hill & 67 & Long Point Woods & 113 & Hopkins \\
\hline 26 & Bozman Neck & 68 & Great Bar & 114 & TVillis \\
\hline 27 & Sea Turtle & 69 & Brown & 115 & Island Creek (Chop- \\
\hline 28 & Turtle Back (Miles & 70 & Deep Neck & & tank River) \\
\hline & River) & 71 & Mulberry Point & 11 & Matthews \\
\hline 29 & Horseshoe (Miles & 72 & Vell Point & 117 & Chlora Point \\
\hline & River) & 73 & Pompes & 118 & Beacons \\
\hline 30 & Aldridges Discovery & $\begin{array}{l}74 \\
75\end{array}$ & & 119 & La Trappe \\
\hline $\begin{array}{l}31 \\
32\end{array}$ & $\begin{array}{l}\text { Upper Hill } \\
\text { Tilghmans Point. }\end{array}$ & $\begin{array}{l}75 \\
76\end{array}$ & $\begin{array}{l}\text { Judys Point } \\
\text { Brushy Point }\end{array}$ & $\begin{array}{l}120 \\
121\end{array}$ & $\begin{array}{l}\text { Howells Point } \\
\text { Dickinson }\end{array}$ \\
\hline 33 & Rich Neck & 77 & Willeys Island Flats & 122 & Kirby \\
\hline 34 & $\begin{array}{c}\text { Sedge Marsh (Tred } \\
\text { Avon River) }\end{array}$ & 78 & $\begin{array}{l}\text { Holland Point (Broad } \\
\text { Creek) }\end{array}$ & $\begin{array}{l}123 \\
124\end{array}$ & $\begin{array}{l}\text { Scraping Line } \\
\text { Bolingbroke Sand }\end{array}$ \\
\hline & Wades Point & 79 & Harrison & 125 & The Black Buoy \\
\hline 36 & Marys Delight & 80 & Broad Creek Middle- & & (Choptank River) \\
\hline 37 & Lows Point & & ground & 126 & Sugar Loaf \\
\hline 38 & Poplar Island & 81 & Cedar Point (Broad & 127 & Chancellor Point \\
\hline 39 & Poplar Island & & Creek) & 128 & British Harbour \\
\hline & rows & 82 & Drum Point (Broad & 129 & Goose Point (Choptank \\
\hline 40 & Bay Hundred & 83 & $\begin{array}{l}\text { Creek) } \\
\text { Joe Harris Flats }\end{array}$ & 130 & $\begin{array}{l}\text { River) } \\
\text { Mill Dam }\end{array}$ \\
\hline $\begin{array}{l}41 \\
42\end{array}$ & (Chesapeake & 84 & $\begin{array}{l}\text { Joe Harris Flats } \\
\text { Pin Cushion }\end{array}$ & 131 & $\begin{array}{l}\text { Mill Dam } \\
\text { Jamaica Point }\end{array}$ \\
\hline & Bay) & 85 & Willeys Island & 132 & Spar Buoy \\
\hline
\end{tabular}


Numerical Index to Natural Oyster Bars-Continued.

WICOMICO COUNTY.

\begin{tabular}{|c|c|c|c|c|c|}
\hline \multicolumn{6}{|c|}{ WORCESTER COUNTY. } \\
\hline $\begin{array}{r}1 \\
2 \\
3 \\
4 \\
5 \\
6 \\
7 \\
8 \\
9 \\
10\end{array}$ & $\begin{array}{l}\text { South Point } \\
\text { Handys Hammock } \\
\text { Newport } \\
\text { Lambertson Landing } \\
\text { Ennis } \\
\text { Turpin } \\
\text { Sandy Point (Chinco- } \\
\text { teague Bay) } \\
\text { Robins Marsh } \\
\text { Scarboro Creek } \\
\text { Southwest }\end{array}$ & $\begin{array}{l}11 \\
12 \\
13 \\
14 \\
15 \\
16 \\
17 \\
18 \\
19\end{array}$ & $\begin{array}{l}\text { Purnell Hammock } \\
\text { Diamond (Chinco- } \\
\text { teague Bay) } \\
\text { Beef Creek } \\
\text { Rattlesnake } \\
\text { Martin Point } \\
\text { Easter Cove } \\
\text { Mink Tump } \\
\text { Sheep (Chincoteague } \\
\text { Bay) } \\
\text { Drum }\end{array}$ & $\begin{array}{l}20 \\
21 \\
22 \\
23 \\
24 \\
25 \\
26 \\
27 \\
28\end{array}$ & $\begin{array}{l}\text { Kennel } \\
\text { Big Bay Point } \\
\text { Toby } \\
\text { Deep Water } \\
\text { Striking Marsh } \\
\text { Levin Tump } \\
\text { White Rock } \\
\text { Horsehead North } \\
\text { Horsehead South }\end{array}$ \\
\hline
\end{tabular}




\section{CRAB BOTTOMS.}

ALPHABETICAL INDEX.

Note. - See Numerical Index for names of crab bottoms corresponding to numbers on Index Chart.

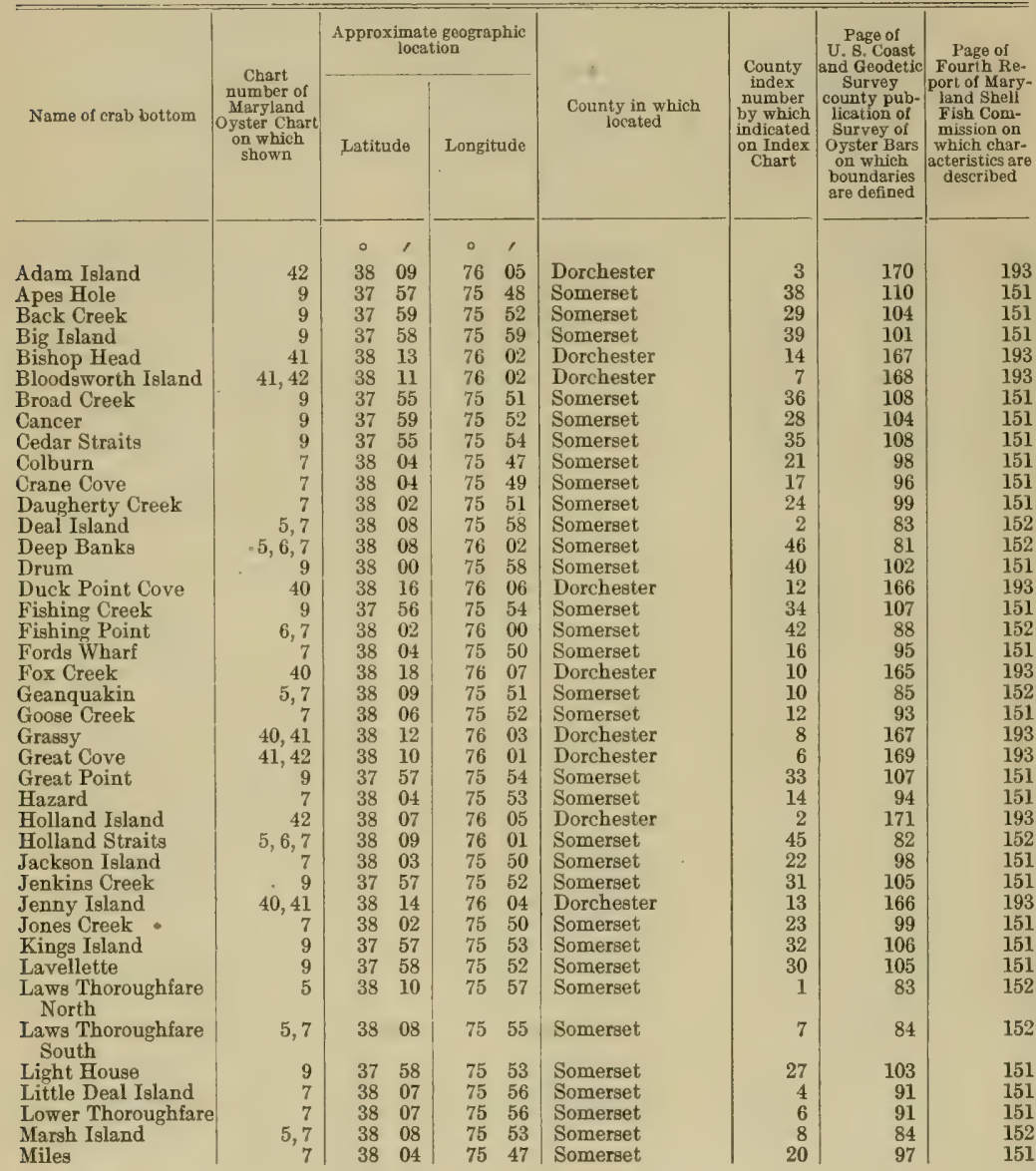


CRAB BOTTOMS.

Alphabetical Index to Crab Bottoms-Continued.

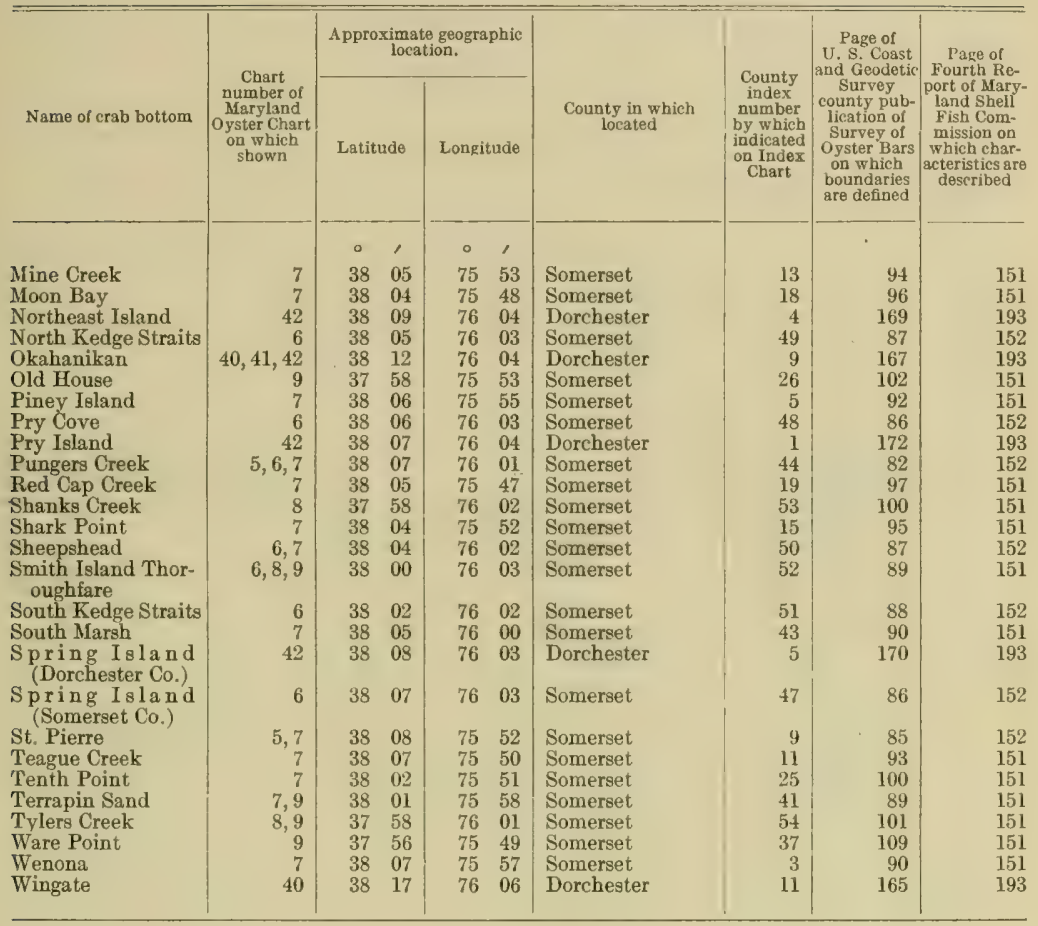




\section{CRAB BOTTOMS.}

NUMERICAL INDEX.

Nore-See Alphabetical Index for other references relating to crab bottoms. DORCHESTER COUNTY.

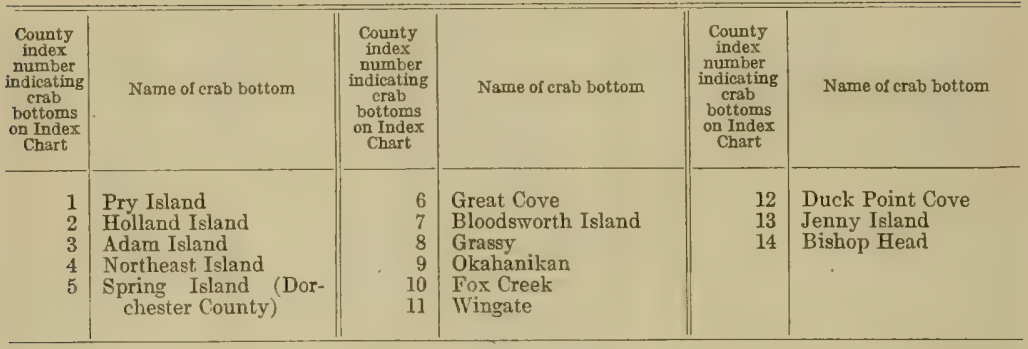

SOMERSET COUNTY.

\begin{tabular}{|c|c|c|c|c|c|}
\hline 7 & Tw Thoroughfare & 19 & Red Cap Creek - & 39 & Big Island \\
\hline & $\begin{array}{l}\text { L a w \& Inorougnare } \\
\text { North }\end{array}$ & 20 & $\begin{array}{l}\text { Miles } \\
\text { Map treek. }\end{array}$ & 40 & Drum \\
\hline 2 & Deal Island & 21 & Colburn & 41 & Terrapin Sand \\
\hline 3 & Wenona & 22 & Jackson Island & 42 & Fishing Point \\
\hline 4 & Little Deal Island & 23 & Jones Creek & 43 & South Marsh \\
\hline 5 & Piney Island & 24 & Daugherty Creek & 44 & Pungers Creek \\
\hline 6 & Lower Thoroughfare & 25 & Tenth Point & 45 & Holland Straits \\
\hline 7 & La w s Thoroughfare & 26 & Old House & 46 & Deep Banks \\
\hline & South & 27 & Light House & 47 & Spring Island (Somer- \\
\hline $\begin{array}{l}8 \\
9\end{array}$ & $\begin{array}{l}\text { Marsh Island } \\
\text { St. Pierre }\end{array}$ & $\begin{array}{l}28 \\
29\end{array}$ & $\begin{array}{l}\text { Cancer } \\
\text { Back Creek }\end{array}$ & 48 & $\begin{array}{l}\text { set County) } \\
\text { Pry Cove }\end{array}$ \\
\hline 10 & Geanguakin & 30 & Lavellette & 49 & North Kedge Straits \\
\hline 11 & Teague Creek & 31 & Jenkins Creek & 50 & Sheepshead \\
\hline 12 & Goose Creek & 32 & Kings Island & 51 & South Kedge Straits \\
\hline 13 & Mine Creek & 33 & Great Point & 52 & Smith Island Thor- \\
\hline 14 & Hazard & 34 & Fishing Creek & & oughfare \\
\hline 15 & Shark Point & 35 & Cedar Straits & 53 & Shanks Creek \\
\hline 16 & Fords Wharf & 36 & Broad Creek & 54 & Tylers Creek \\
\hline 17 & Crane Cove & 37 & Ware Point & & \\
\hline 18 & Moon Bay & 38 & Apes Hole & & \\
\hline
\end{tabular}




\section{CLAM BEDS.}

\section{ALPHABETICAI INDEX.}

NotE.-See Numerical Index for names of clam beds corresponding to number on Index Chart.

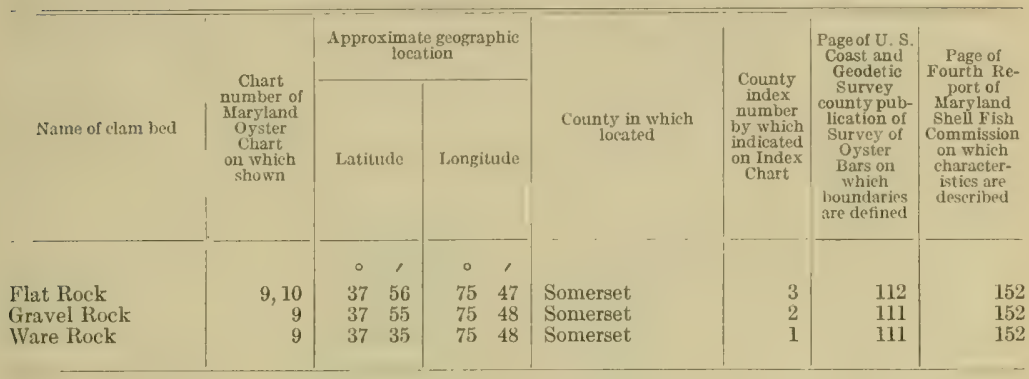

NUMERICAI, INDEX.

NotE.-See Alphabetical Index for other references relating to clam beds.

SOAERSET COUNTY.

\begin{tabular}{|c|c|c|c|c|c|}
\hline $\begin{array}{l}\text { County } \\
\text { index } \\
\text { number } \\
\text { indicating } \\
\text { clam beds } \\
\text { on Index } \\
\text { Chart }\end{array}$ & Name of clam bed & $\begin{array}{c}\text { County } \\
\text { index } \\
\text { number } \\
\text { indicating } \\
\text { clam beds } \\
\text { on Judex } \\
\text { Chart }\end{array}$ & Name of elam bed & $\begin{array}{l}\text { County } \\
\text { index } \\
\text { number } \\
\text { indicating } \\
\text { clam beds } \\
\text { on Index } \\
\text { Chart }\end{array}$ & Name of clam bed \\
\hline
\end{tabular}

$95112-13-4$ 


\section{LANDMARKS.}

\section{U. S. COAST AND GEODETIC SURVEY TRIANGULATION STATIONS.}

ALPHABETICAL INDEX,

NoTE.-See Numerieal Index for names of triangulation stations corresponding to numbers on Index Chart.

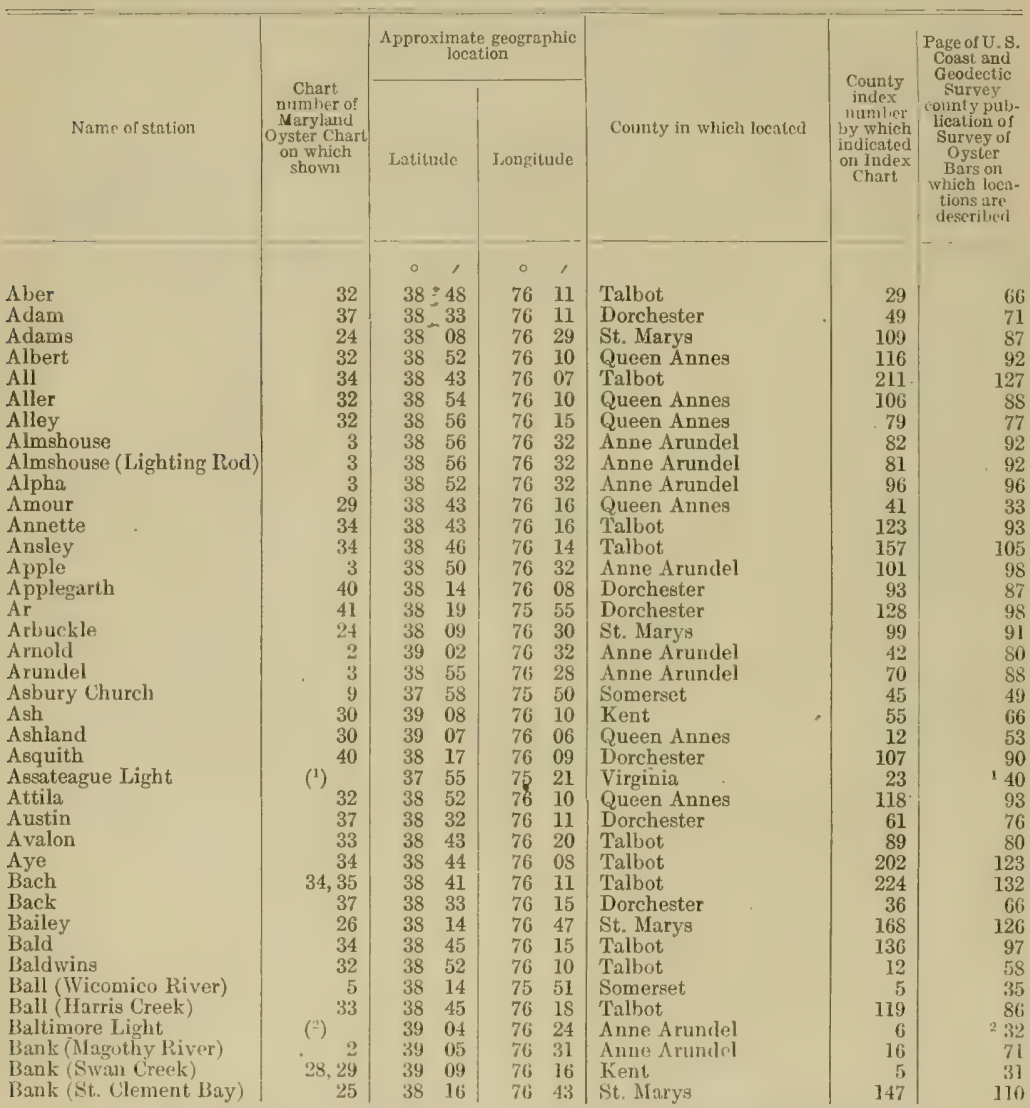

1 See Worcester County publication. $\quad$ 'see Queen Annes County publication. 


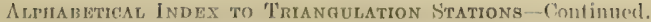

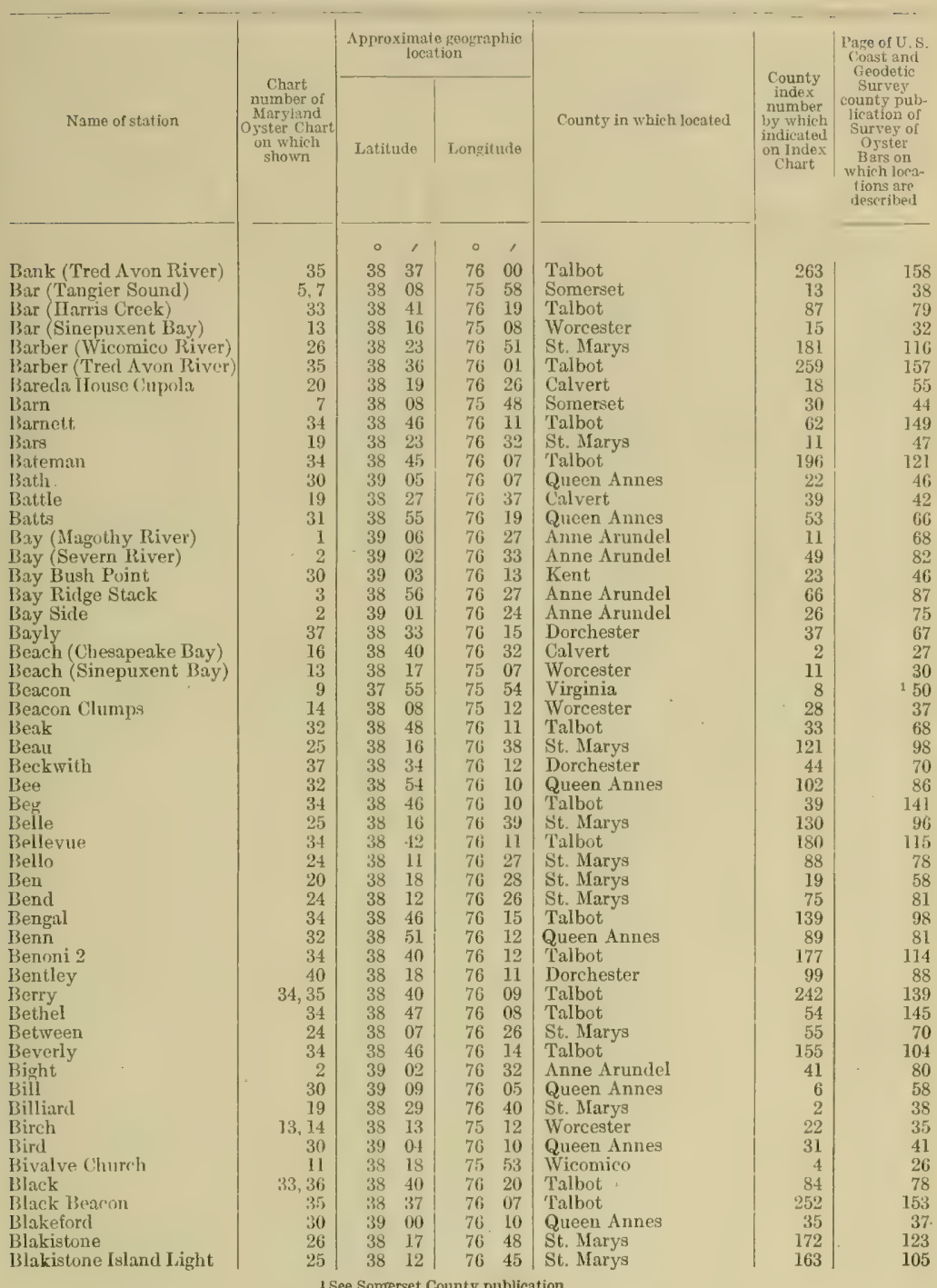


Alphabetcal Index to Trianculation Stations-Continued.

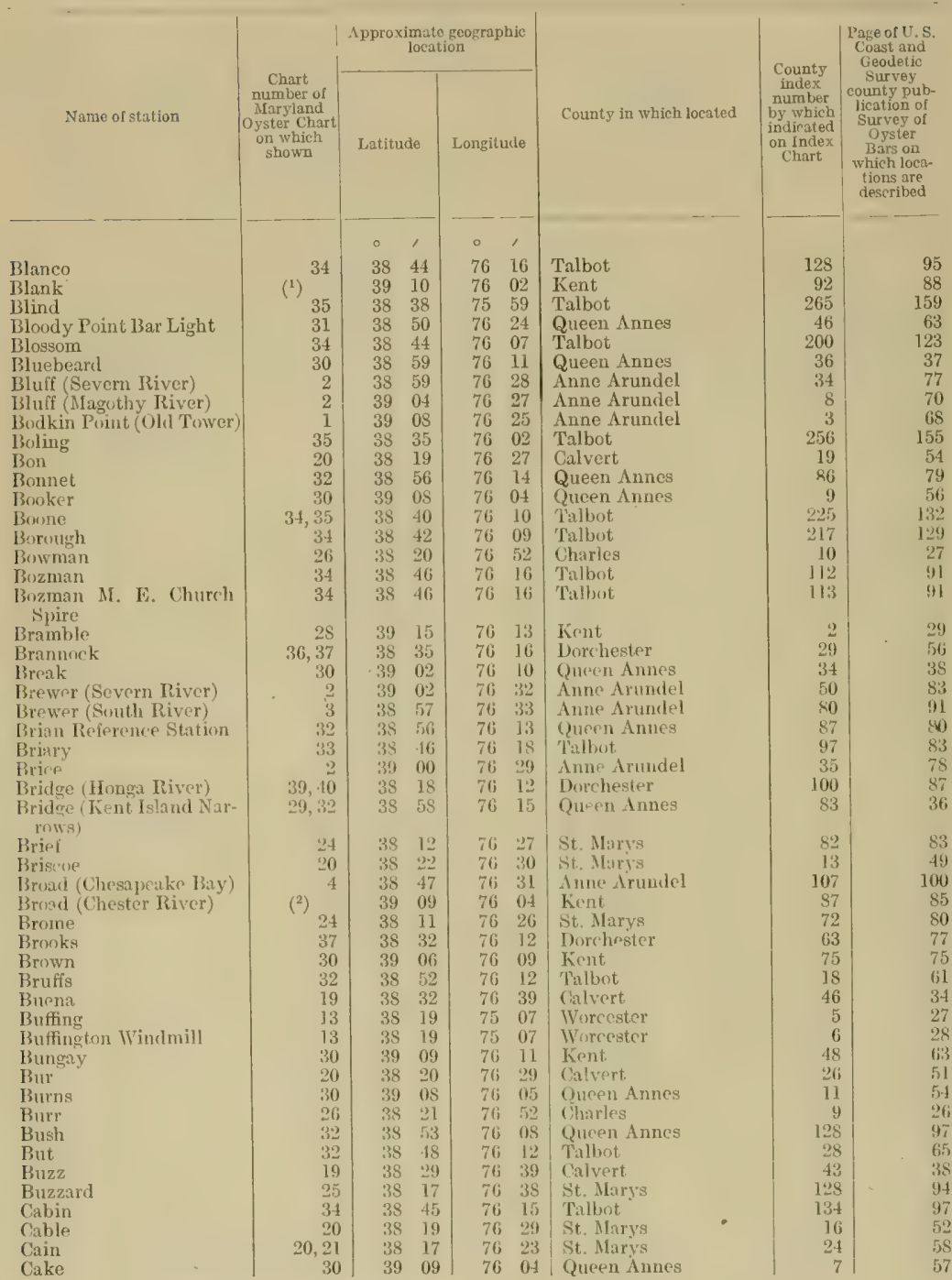


LANDMARKS.

Alphabetical Index to Triangulation itations-Continued.

\begin{tabular}{|c|c|c|c|c|c|c|c|c|}
\hline \multirow{3}{*}{ Name of station } & \multicolumn{5}{|c|}{$\begin{array}{l}\text { Approximate geographie } \\
\text { location }\end{array}$} & \multirow{3}{*}{ County in which lucatod } & \multirow{3}{*}{$\begin{array}{l}\text { County } \\
\text { index } \\
\text { number } \\
\text { by which } \\
\text { indieated } \\
\text { on Index } \\
\text { Chart }\end{array}$} & \multirow{3}{*}{$\begin{array}{l}\text { Pago of U.S. } \\
\text { Coast and } \\
\text { Geodetic } \\
\text { Survey } \\
\text { county put- } \\
\text { lication of } \\
\text { Sursey of } \\
\text { Oyster } \\
\text { Bars on } \\
\text { which lore- } \\
\text { tions are } \\
\text { deseribed }\end{array}$} \\
\hline & \multirow{2}{*}{$\begin{array}{l}\text { Chart } \\
\text { number of } \\
\text { Maryland } \\
\text { Oyster Chart } \\
\text { on which } \\
\text { shown }\end{array}$} & \multicolumn{2}{|c|}{ Latitude } & \multicolumn{2}{|c|}{ Longitule } & & & \\
\hline & & $\circ$ & 1 & $\circ$ & , & & & \\
\hline Calf & 3 & 38 & 53 & 76 & 32 & Anne Arundel & 91 & 95 \\
\hline Calvert Mommment & 21 & 38 & 11 & 76 & 26 & St. Marys & 73 & 81 \\
\hline Cam & 34 & 38 & 43 & 76 & 07 & Talbet & 212 & 127 \\
\hline Gambriclae & 35 & 38 & 35 & 76 & 05 & Dorehester & 16 & 50 \\
\hline Cambridge Stand I'ipe & 35 & 38 & 34 & 70 & 05 & Dorchester & 15 & 50 \\
\hline Camden & 34 & $3 s$ & 4.5 & 76 & 07 & Talbot & 199 & 122 \\
\hline Can & $36,37,38$ & 38 & 30 & 76 & 18 & 1)orchester & 81 & 59 \\
\hline Canoe & 25 & $3 s$ & 15 & 76 & 44 & Sit. Marys & 161 & 107 \\
\hline Carrie & 37 & 39 & 33 & 76 & 15 & Durzhester & 38 & 67 \\
\hline Car:oll 2 & 20 & 38 & 18 & 70 & 25 & St. Marys & 21 & 56 \\
\hline Castle & 35 & 38 & 38 & 76 & 10 & J)orchester & 24 & 53 \\
\hline Catholic Church Cruss & 20 & 38 & 20 & 76 & 28 & Calvert & 24 & 52 \\
\hline $\begin{array}{l}\text { Catholic Chureh Cross } \\
\text { (Bentedict) }\end{array}$ & 26 & 39 & 31 & 76 & 41 & cherles & 4 & 37 \\
\hline $\begin{array}{l}\text { Cathoic Churcl } \text { (Woss } \\
\text { (Newtown Neck) }\end{array}$ & 25 & 38 & 15 & 76 & 42 & St. Marys & 143 & 108 \\
\hline $\begin{array}{l}\text { Catholic Church Spire } \\
\text { (Annapolis) }\end{array}$ & 2 & 38 & 58 & 76 & 29 & Anne Arundel & 60 & 85 \\
\hline Cato & 3 & 38 & 52 & 76 & 31 & Anne Arundel & 88 & 94 \\
\hline Canlk & 34 & 38 & 45 & 76 & 16 & Talbot & 130 & 95 \\
\hline Cecil & 25 & 38 & 17 & 76 & 43 & St. Mary's & 148 & 112 \\
\hline Cedar (South River) & 3 & 38 & 56 & 76 & 32 & Anne Arundel & 83 & 92 \\
\hline Cedar (Serern River) & 2 & 39 & 04 & 76 & 34 & Anne Arundel & 45 & 81 \\
\hline ('edar (Bretons Bay) & 25 & 38 & 16 & 76 & 38 & St. Marys & 124 & 95 \\
\hline Ceclar (Broad (reck) & 34 & $3 s$ & 44 & 76 & 14 & Talbot & 166 & 109 \\
\hline Cedar Point Light & 20,39 & $3 S$ & is & 76 & 23 & St. Marys & 23 & 58 \\
\hline Cednak & 25 & 38 & 14 & 76 & 41 & St. Marys & 114 & 104 \\
\hline Chadwick & 24 & 38 & 10 & $76 \mathrm{i}$ & 31 & Sit. Marys & 102 & 92 \\
\hline Chalk & 3 & 35 & 50 & 76 & 32 & Ame Arundel & 99 & 97 \\
\hline Chan & 24 & 38 & 10 & 76 & 27 & St. Marys & 70 & 78 \\
\hline Chancellor & 35 & 38 & 35 & 76 & 02 & Talbot & 258 & 156 \\
\hline Change 1910 & 33,34 & 38 & 43 & 76 & 18 & Talbot & 121 & 86 \\
\hline Chap & 32 & 38 & 48 & 76 & 07 & Talbot & 50 & 70 \\
\hline Chapel & 25 & 38 & 16 & 76 & 42 & St. Marys & 144 & 108 \\
\hline Charles (Wicomico River) & 26 & 38 & 17 & 76 & 50 & Charles & 14 & $3 n$ \\
\hline Charles (Houga River) & 40 & 38 & 19 & 76 & 10 & Dorchester & 105 & 89 \\
\hline Charles (Island Creek) & 34,35 & 38 & 40 & 76 & 08 & Talbot & 231 & 135 \\
\hline Chase (Severn River) & 2 & 39 & 01 & 76 & 31 & Anne Arundel & 39 & 79 \\
\hline Chase (IVhitehall Bay) & & 39 & 00 & 76 & 26 & Anne Arundel & 30 & 76 \\
\hline Chef & $33,36,37$ & 38 & 38 & 76 & 17 & Dorchester & 27 & 55 \\
\hline Cherry & 24 & 38 & 08 & 76 & 28 & St. Marys & 93 & 86 \\
\hline Cherry Cove & 25 & 38 & 16 & 76 & 41 & Si. Marys & 135 & 100 \\
\hline Cherry Island Water Tank & 37 & 38 & 34 & 76 & 13 & Dorchester & 45 & 70 \\
\hline Ches & 3 & 38 & 52 & 76 & 31 & Anne Arundel & 95 & 96 \\
\hline Chester (Chester River) & 30 & 39 & 06 & 76 & 07 & Queen Annes & 15 & 51 \\
\hline Chester (Virginia) & (1) & 37 & 57 & 75 & 26 & Virginia & 21 & ${ }^{1} 41$ \\
\hline Chestnut & 24 & 38 & 10 & 76 & 25 & St. Marys & 63 & 76 \\
\hline Chew & 32 & 38 & 53 & 76 & 08 & Talbot & 4 & 55 \\
\hline Chief & 35 & 38 & 35 & 75 & 59 & Dorchester & 8 & 47 \\
\hline Chilk & 12 & 38 & 15 & 75 & 50 & W'icomico & 13 & 30 \\
\hline Chin & 32 & 38 & 54 & 76 & 10 & Queen $\Lambda$ nnes & 105 & 87 \\
\hline Chlora & 35 & 38 & 38 & 76 & 09 & Talbot & 245 & 150 \\
\hline Choptank River Light & $34,35,37$ & 38 & 39 & 76 & 11 & Talbot & 244 & 140 \\
\hline
\end{tabular}


Alphabetical Index to Triangulation Stations -Continued.

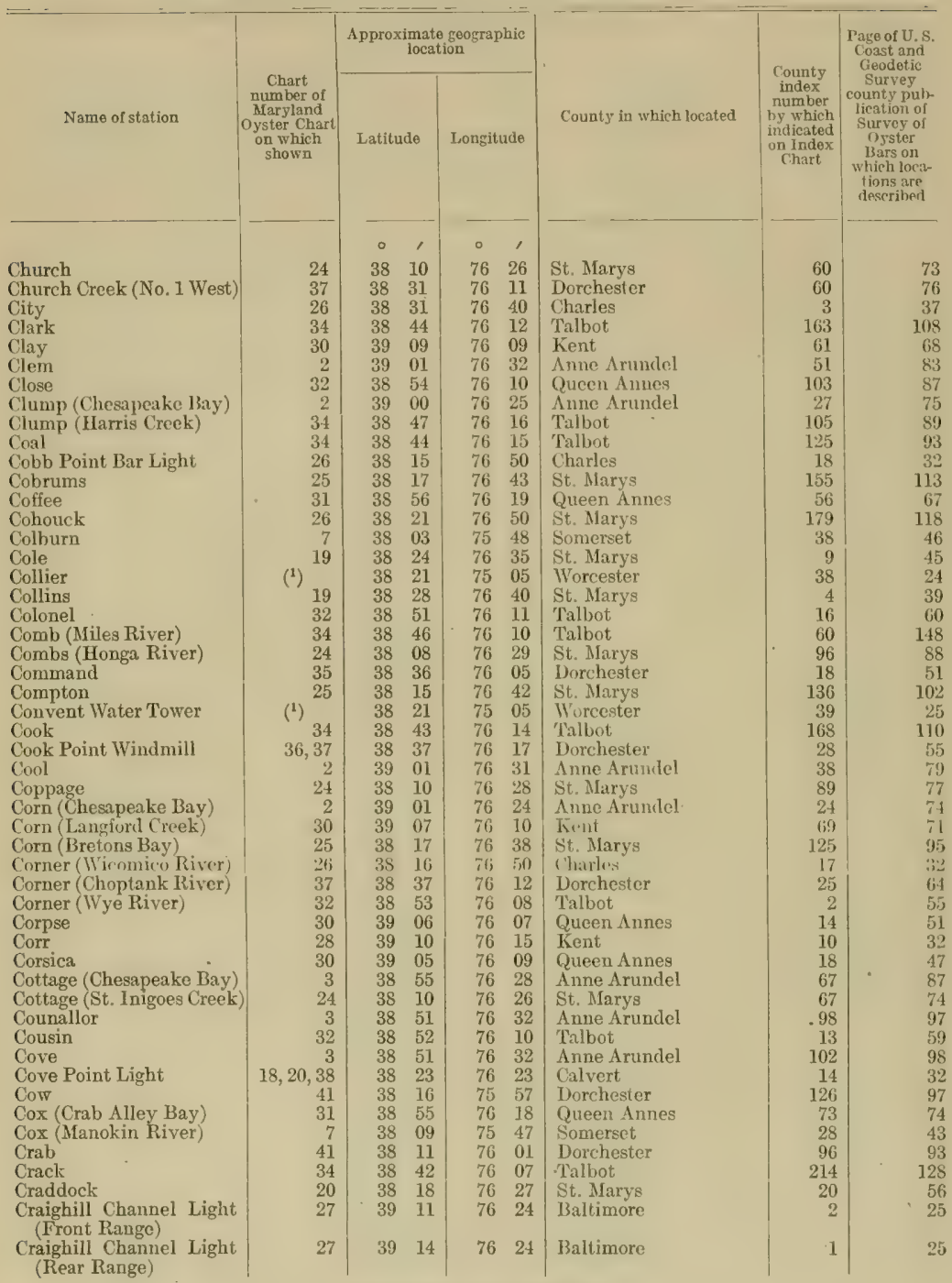


Alphabetical Index to Triangulation Sttations-Continued.

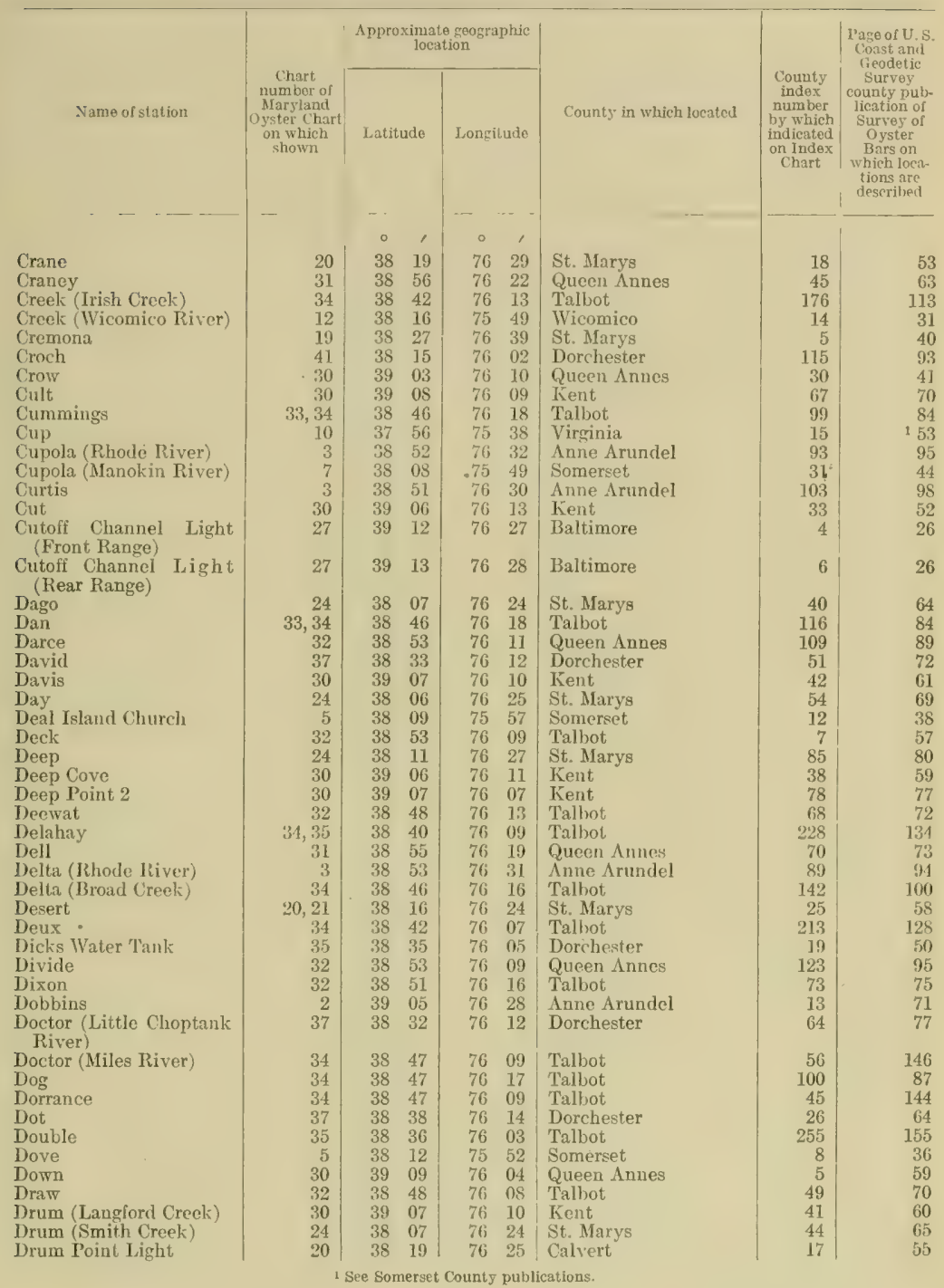


Alphabetical Index to Triangulation Stations-Continued.

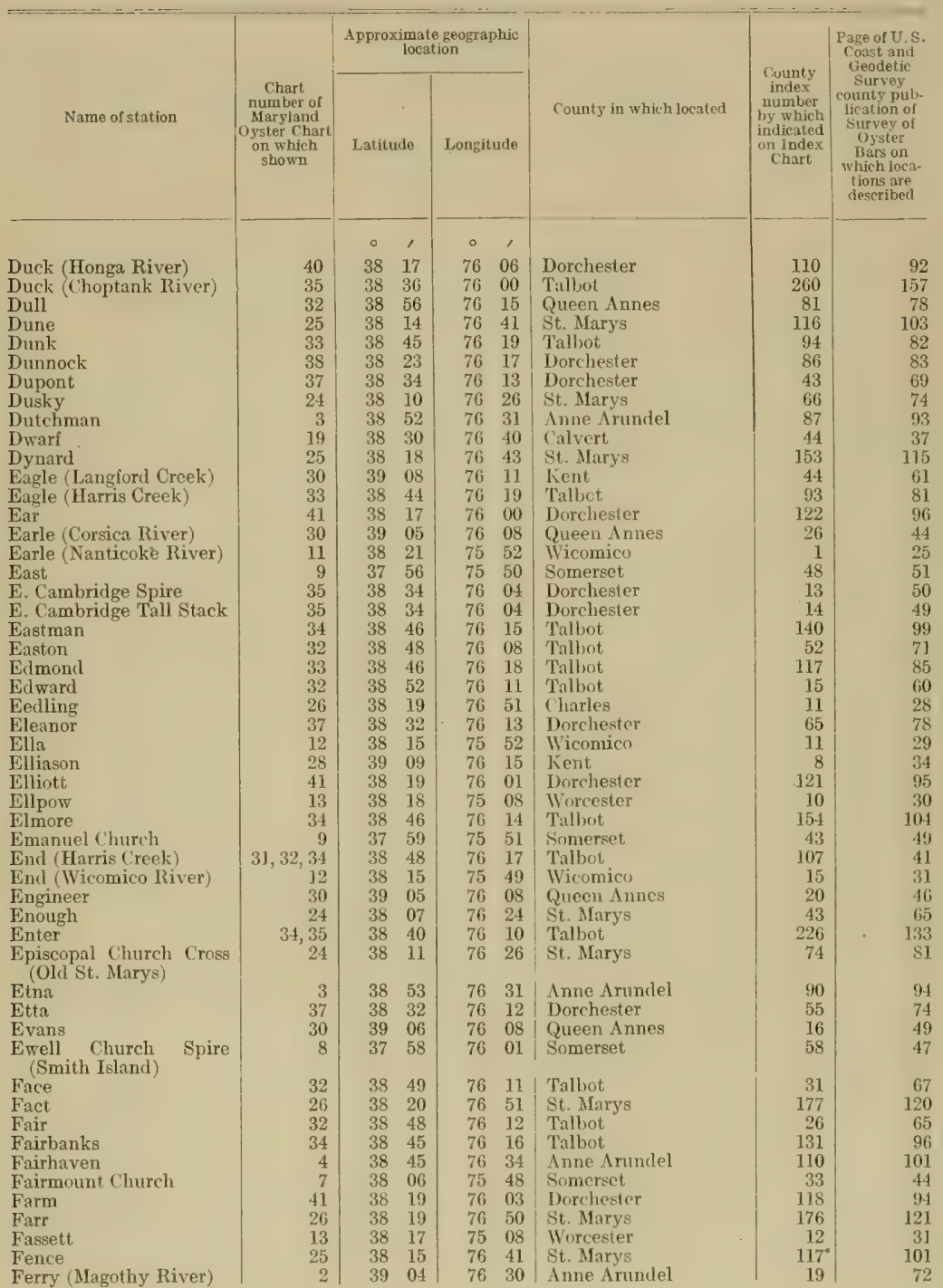


LANDMARKS.

Alphabetical Index to Triangulation Stations-Continued.

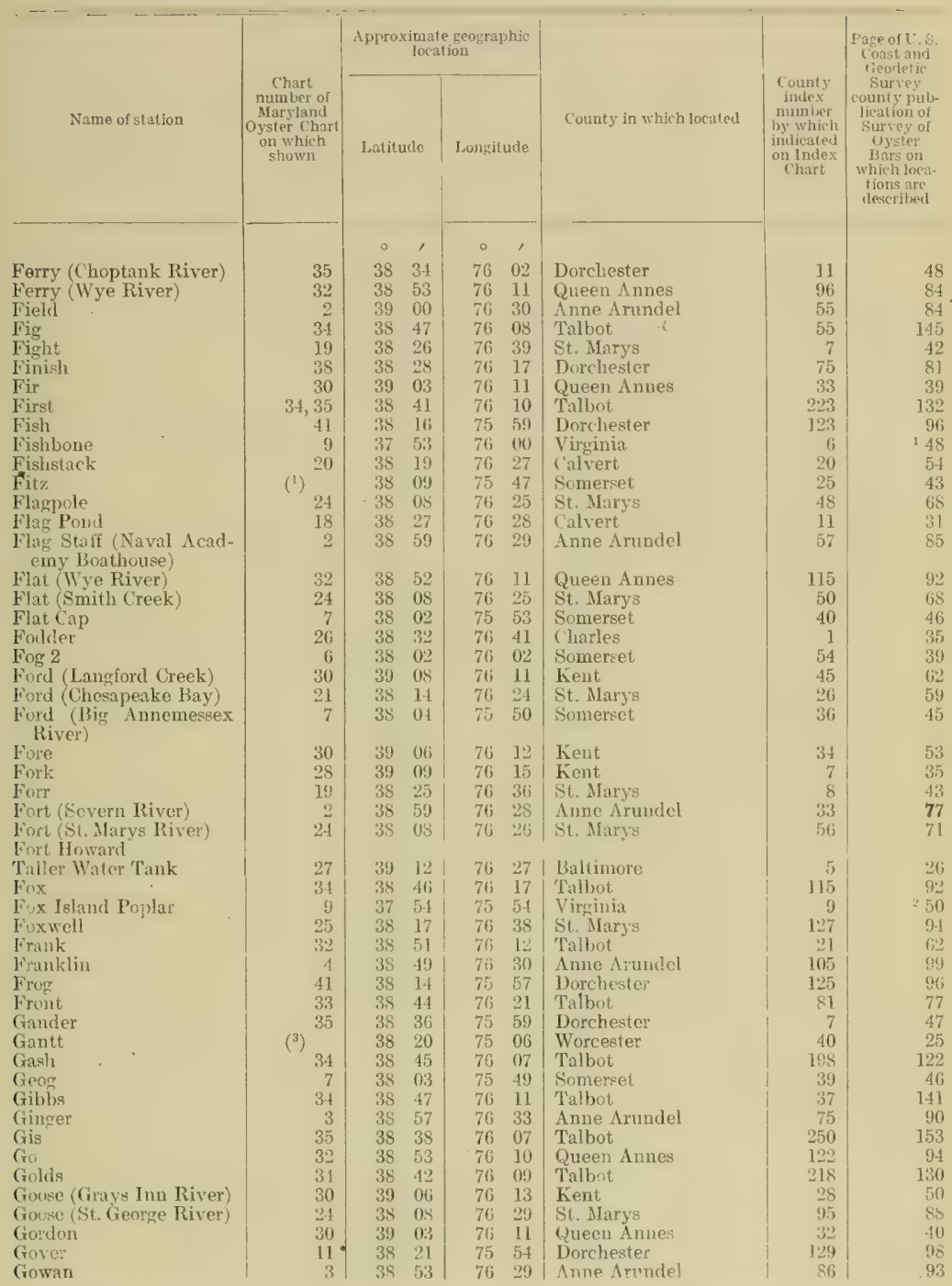

Somerset County publication.

2 Seo progress map in Worcester County publication. 3 See Somerset County publication. 
Alpiabetical Index to 'Triangulation S'tations - Contimed.

\section{Grace}

Grace M. E. Church

Gram (Severn River)

Gram (Broad Creek)

Granary

Grason

Gratitude

Grave

Gravel

Gray

Great

Great Shoals Jight

Greek

Green (Eastern Bay)

Green (Manokin River)

Green Run Inlet Life Saving Station Flagstaff.

Greenbury

Greenbury Point Light

Greenwell

Grind

Grove (Reeds (reek)

Grove (Bretons Bay)

Grubin

Guest

Guilberts (upola

Guither

Gull

Gunners

Gust

inst.

Gut

Hackett

Hadilaway

IInines

Hall (Potomae River)

Hall (Aliles River)

IIall House (Middle Chimney)

Hallowing

Ham (Magothy River)

Ham (Miles liver)

Hambrooks Bar Beacon

Hamilion

Hamnett

Handys Hammock

Hard

Harmon

Harp

Harper

Harringlon

Harrison

\begin{tabular}{|c|c|c|c|c|c|c|c|}
\hline \multirow{3}{*}{$\begin{array}{c}\text { Chart } \\
\text { number of } \\
\text { Noryiand } \\
\text { Oyster Chisi } \\
\text { on which } \\
\text { shnwn }\end{array}$} & \multicolumn{4}{|c|}{$\begin{array}{l}\text { Approximate geographic } \\
\text { location }\end{array}$} & \multirow[b]{2}{*}{ County in which locatell } & \multirow{2}{*}{$\begin{array}{l}\text { County } \\
\text { index } \\
\text { number } \\
\text { by which } \\
\text { inilicaled } \\
\text { on Index } \\
\text { Chart }\end{array}$} & \multirow{2}{*}{ 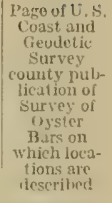 } \\
\hline & \multicolumn{2}{|c|}{ Latitude } & \multicolumn{2}{|c|}{ Longitude } & & & \\
\hline & 0 & , & $\circ$ & , & & & \\
\hline 34 & 38 & 46 & 76 & 17 & Talbot & 102 & S8 \\
\hline 15 & & 01 & & 23 & Virginia & 17 & 141 \\
\hline 3 & 38 & 57 & 76 & 28 & Anne Arundel & 64 & $s 6$ \\
\hline 34 & 38 & 46 & 76 & 15 & Talbot & 138 & 98 \\
\hline 32 & 38 & 53 & 76 & $0 \mathrm{~s}$ & Queen Amnes & 126 & 96 \\
\hline 24 & 38 & 10 & 76 & 26 & St. Marys & 61 & 75 \\
\hline 28,29 & 39 & $0 \mathrm{~s}$ & 76 & 16 & Kent & 16 & 37 \\
\hline 34 & $3 S$ & 46 & 76 & 14 & Talbot & 1.19 & $10^{2}$ \\
\hline 24 & 38 & 10 & 76 & 26 & St. Marys & 71 & 79 \\
\hline 30 & 39 & 06 & 76 & 13 & Kent & 30 & 51 \\
\hline 33 & 38 & 45 & 76 & 21 & Talbot. & 80 & 77 \\
\hline 12 & 38 & 13 & 75 & 53 & IVicomico & 10 & 35 \\
\hline 31 & $3 s$ & 56 & 76 & 18 & Queen Annes & 68 & 72 \\
\hline 32 & 38 & 54 & 76 & 12 & Queen Annes & 88 & so \\
\hline & 38 & 09 & 75 & 47 & Somerset & 29 & 44 \\
\hline 14,15 & 38 & 05 & 75 & 12 & Worcester & 31 & 38 \\
\hline 2 & 38 & 58 & 76 & 27 & Anne Arundel & 3] & 77 \\
\hline 2 & 38 & 58 & 76 & 27 & Anne Arundel & 32 & 77 \\
\hline 37 & 38 & 33 & 76 & 34 & Dorchester & 40 & 68 \\
\hline 21 & 38 & 10 & 76 & 27 & St. Marys & 90 & 76 \\
\hline 30 & 39 & 03 & 76 & 10 & Queeu Amnes & 29 & 42 \\
\hline 25 & 38 & 14 & 76 & 41 & St. Mlarys & 115 & 104 \\
\hline 35 & 38 & 38 & 76 & 07 & Talbot & 251 & 153 \\
\hline 25 & 38 & 18 & 76 & 13 & St. Mary's & 150 & 114 \\
\hline 14 & 38 & 09 & 75 & 17 & Worcester & 27 & $3 \mathrm{~s}$ \\
\hline 2.4 & 38 & 10 & 76 & 31 & St. Marys & 103 & 93 \\
\hline 13 & 38 & 19 & 75 & 06 & Worcesier & 7 & 28 \\
\hline 39,40 & 38 & 20 & 76 & 13 & Dorchester & 101 & $86 \mathrm{i}$ \\
\hline $26 ;$ & 38 & 19 & $76 ;$ & 51 & Clearles & 12 & 28 \\
\hline 32 & 38 & 53 & $76 i$ & 10 & Tallot & 10 & 58 \\
\hline 30 & 39 & 09 & $76 i$ & 09 & lient & 63 & 69 \\
\hline 2 & 38 & 59 & 76 & 25 & Amse trundel & 28 & $76 i$ \\
\hline $3: 3$ & 38 & 47 & 76 & 20 & Talbot & 77 & 76 \\
\hline 5 & $3 S$ & 11 & 75 & 57 & Somerset & 11 & 37 \\
\hline 22 & 38 & 04 & 76 & $2 \cdot 2$ & St. Marys & 36 & (62) \\
\hline 34 & 38 & 45 & 76 & 10 & Talbot & 61 & 148 \\
\hline 22 & 38 & 04 & 76 & 22 & St. Marys & 37 & 63 \\
\hline 19 & 38 & 31 & 76 & 40 & Calvert & 45 & 36 \\
\hline 2 & 39 & 05 & 76 & 30 & Anne Arundel & 15 & 71 \\
\hline 34 & 38 & 46 & 76 & 10 & Talbot & 59 & 147 \\
\hline 35 & 38 & 36 & 76 & 05 & Dorchester & 17 & 50 \\
\hline 13 & 38 & 20 & 75 & 05 & Worcester & 1 & 26 \\
\hline 24 & 38 & 13 & 76 & 28 & St. Marys & 78 & 85 \\
\hline 13,14 & 38 & 13 & 75 & 15 & Worcester & 25 & 36 \\
\hline 26 & 38 & 16 & 76 & 50 & Charles & 15 & 31 \\
\hline 13 & 38 & 20 & 75 & 07 & Worcester & 3 & 26 \\
\hline 30 & 39 & 09 & 76 & 09 & Kent & 60 . & 68 \\
\hline 34 & 38 & 46 & 76 & 14 & Talbot & $15 \mathrm{~S}$ & 106 \\
\hline 38 & 38 & 29 & 76 & 18 & Dorchester & 77 & 82 \\
\hline 34 & 38 & 47 & 76 & 17 & Talbot & 104 & 89 \\
\hline
\end{tabular}


Alphabeticar Index tó Triangulation Stations-Continued.

\begin{tabular}{|c|c|c|c|c|c|c|}
\hline \multirow{3}{*}{ Name of station } & \multirow{3}{*}{$\begin{array}{l}\text { Chart } \\
\text { number of } \\
\text { Maryland } \\
\text { Oyster Chart } \\
\text { on which } \\
\text { shown }\end{array}$} & \multicolumn{2}{|c|}{$\underset{\text { location }}{\text { Approximate geographic }}$} & \multirow[b]{2}{*}{ County in which located } & \multirow{2}{*}{$\begin{array}{l}\text { County } \\
\text { index } \\
\text { number } \\
\text { by which } \\
\text { indieated } \\
\text { on Index } \\
\text { ('hart }\end{array}$} & \multirow{2}{*}{$\begin{array}{l}\text { Page of U.S. } \\
\text { Coast and } \\
\text { Geodetic } \\
\text { survey } \\
\text { county pub- } \\
\text { licalion of } \\
\text { Survey of } \\
\text { Oyster } \\
\text { Bars on } \\
\text { which loct- } \\
\text { tinns are } \\
\text { tescribel }\end{array}$} \\
\hline & & Latitude & Lonyitude & & & \\
\hline & & $\circ$ & $0 \quad 1$ & & & \\
\hline Harry & 34,35 & $38 \quad 40$ & $\begin{array}{ll}76 & 08\end{array}$ & Talbot & 230 & 134 \\
\hline IIIas & & $\begin{array}{ll}38 & 04\end{array}$ & $\begin{array}{ll}75 & 52\end{array}$ & Somerset & 35 & 45 \\
\hline IIaven & 28,29 & 39.09 & $76 \quad 15$ & Kent & 13 & 35 \\
\hline llawk & & $38 \quad 45$ & $\begin{array}{ll}76 & 19\end{array}$ & Talbot & 95 & 82 \\
\hline Hayden & 26 & $\begin{array}{ll}38 & 21\end{array}$ & $\begin{array}{ll}76 & 52\end{array}$ & Charles & 8 & 26 \\
\hline Head & 41 & $\begin{array}{ll}38 & 13 \\
38 & 16\end{array}$ & $\begin{array}{ll}76 & 02 \\
76 & 30\end{array}$ & Dorchester & 114 & 93 \\
\hline $\begin{array}{l}\text { IJealey (Bretons Bay) } \\
\text { IIealey (1sland (reek) }\end{array}$ & $\begin{array}{r}25 \\
3+35\end{array}$ & $\begin{array}{ll}38 & 16 \\
35 & 40\end{array}$ & $\begin{array}{ll}76 & 39 \\
76 & 05\end{array}$ & St. Marys & 131 & 97 \\
\hline Iledney & 26 & $38 \quad 18$ & $\begin{array}{ll}76 & 08 \\
76 & 51\end{array}$ & $\begin{array}{l}\text { Talbot } \\
\text { Charles }\end{array}$ & $\begin{array}{r}238 \\
13\end{array}$ & $\begin{array}{r}137 \\
29\end{array}$ \\
\hline Hellen & & $38 \quad 21$ & $76 \quad 29$ & Calvert & 28 & 49 \\
\hline Ifen & & $38 \quad 44$ & $76 \quad 18$ & Talbot & 120 & 86 \\
\hline IIenderson & 32,34 & $\begin{array}{ll}38 & 47\end{array}$ & $\begin{array}{ll}76 & 08\end{array}$ & Talbot & 53 & 71 \\
\hline Henry & & $\begin{array}{ll}38 & 33\end{array}$ & $76 \quad 15$ & Dorchester & 34 & 66 \\
\hline Here & 31 & $\begin{array}{ll}38 & 57\end{array}$ & $76 \quad 20$ & Queen Annes & 57 & $6 S$ \\
\hline Heron & 25 & $38 \quad 13$ & $76 \quad 43$ & St. Marys & 164 & 105 \\
\hline Herr & 32 & $38 \quad 50$ & $76 \quad 13$ & Talbot & 23 & 63 \\
\hline Herring & 30 & $\begin{array}{ll}39 & 07\end{array}$ & $\begin{array}{ll}76 & 13\end{array}$ & Kent & 31 & 51 \\
\hline Herring Pond 2 & & $38 \quad 10$ & $76 \quad 41$ & Virginia & 1 & ${ }^{1} 105$ \\
\hline Hickory & 1 & $39 \quad 05$ & $\begin{array}{ll}76 & 27\end{array}$ & Anne Arundel & 12 & 69 \\
\hline High (Severn River) & 2 & $\begin{array}{ll}39 & 04\end{array}$ & $76 \quad 33$ & Anne Arundel & 44 & 81 \\
\hline High (Honga River) & 41 & $38 \quad 19$ & $76 \quad 01$ & Dorcliester & 120 & 95 \\
\hline IIigher & 34 & $\begin{array}{ll}38 & 43\end{array}$ & $\begin{array}{ll}76 & 07\end{array}$ & Talbot & 210 & 127 \\
\hline Hill & 3 & $38 \quad 55$ & $76 \quad 30$ & Anne Arundel & 71 & 88 \\
\hline $\operatorname{Hog} 2$ & 20 & $\begin{array}{ll}38 & 19\end{array}$ & $76 \quad 24$ & St. Marys & 22 & 56 \\
\hline Hog Point (IFolland 3) & 16 & $38 \quad 43$ & $76 \quad 32$ & Calvert & 1 & 26 \\
\hline $\begin{array}{l}\text { IIolland (Chesa peake } \\
\text { Bay }\end{array}$ & 4 & $38 \quad 44$ & $\begin{array}{ll}76 & 32\end{array}$ & Ame Arundel & 111 & 101 \\
\hline $\begin{array}{l}\text { Holland (W i com ico } \\
\text { River) }\end{array}$ & 12 & $38 \quad 15$ & $75 \quad 51$ & Wicomico & 12 & 30 \\
\hline IIolland Island Bar Light & 6 & $\begin{array}{ll}38 & 0.4\end{array}$ & $76 \quad 06$ & Somerset & 53 & 39 \\
\hline $\begin{array}{l}\text { Holland Island Church } \\
\text { Spire }\end{array}$ & 42 & $\begin{array}{ll}38 & 07\end{array}$ & $76 \quad 05$ & Dorchester & 95 & [01] \\
\hline Hollow & 25 & $38 \quad 16$ & $76 \quad 39$ & St. Marys & 132 & 98 \\
\hline Holly & 34 & $38 \quad 44$ & $\begin{array}{ll}76 & 12\end{array}$ & Talbot & 164 & 108 \\
\hline Ifolton Point & 30 & $\begin{array}{ll}39 & 05\end{array}$ & $\begin{array}{ll}76 & 09\end{array}$ & Queen Annes & 27 & 43 \\
\hline Iloo & 30 & $\begin{array}{ll}39 & 08\end{array}$ & $\begin{array}{ll}76 & 09\end{array}$ & Kent & 66 & 70 \\
\hline Ilook & 32 & $38 \quad 54$ & $76 \quad 11$ & Queen Annes & 98 & $8 \%$ \\
\hline Hooper Island Light & 39 & $38 \quad 15$ & $76 \quad 15$ & Dorchester & 92 & 81 \\
\hline Hooper Strait Light & 40 & $38 \quad 14$ & $76 \quad 05$ & Dorchester & 113 & 93 \\
\hline $\begin{array}{l}\text { Iloopersville Methodist } \\
\text { Church Cupola }\end{array}$ & 40 & $\begin{array}{ll}38 & 16\end{array}$ & $76 \quad 11$ & Dorchester & 98 & $8 \mathrm{~S}$ \\
\hline Hope & 31 & $38 \quad 58$ & $\begin{array}{ll}76 & 19\end{array}$ & Queen Annes & 63 & 70 \\
\hline Hopkins (Herring Bay) & 4 & $38 \quad 46$ & $76 \quad 33$ & Anne Arundel & 109 & 100 \\
\hline Hopkins (Broad Creek) & 34 & $38 \quad 45$ & $76 \quad 13$ & Talbot & 160 & 106 \\
\hline $\begin{array}{l}\text { Hopkins M e moria } 1 \\
\text { Church Cupola }\end{array}$ & 40 & $\begin{array}{ll}38 & 15\end{array}$ & $\begin{array}{ll}76 & 08\end{array}$ & Dorchester & 97 & S8 \\
\hline Horn (Magothy River) & 2 & $39 \quad 05$ & $76 \quad 31$ & Anne Arundel & 17 & 72 \\
\hline Horn (Severn River) & 2 & 3858 & $76 \quad 28$ & Anne Arundel & 62 & S5 \\
\hline Hornor & 30 & $\begin{array}{ll}39 & 08\end{array}$ & $\begin{array}{ll}76 & 10\end{array}$ & Kent & 53 & 65 \\
\hline Horse & 9 & $37 \quad 57$ & 7600 & Virginia & 5 & ${ }^{2} 49$ \\
\hline $\begin{array}{l}\text { Horseshoe (Chesapeake } \\
\text { Bay) }\end{array}$ & 3 & $38 \quad 50$ & $76 \quad 29$ & Anne Arundel & 104 & 99 \\
\hline
\end{tabular}


Alemabetical Index to Triangulation Stations-Continued.

Horseshoe (St. Marys River)

Hosier Memorial Church Spire

Hospital Cupola (Naval Academy)

\section{Hough}

House

H o w a rd (Choptank) River)

Howards (St. Clement Bay)

Howells

Huddle

IIudson

Hugh

Hunter

Hunting

Hut

Hutchins

Hydrographic

Ide

Ila

Ill 2

In

Indian (Patuxent River)

Indian (Chester River)

Inez

Inrraya

Inigoes

Inkquill

Inn

Iriah

lron

Island (Severn River)

Island (Jatuxent River)

laland (Grays Inn ('reek)

Isle

Ivee

Jam

James (('hesaprake Bay) James (Miles River)

Janes Island Light

Jarrett.

Jay

Jean

Jenifer

Jere

Johnson

Jones

Joreph

Joshua

Journey

Judge

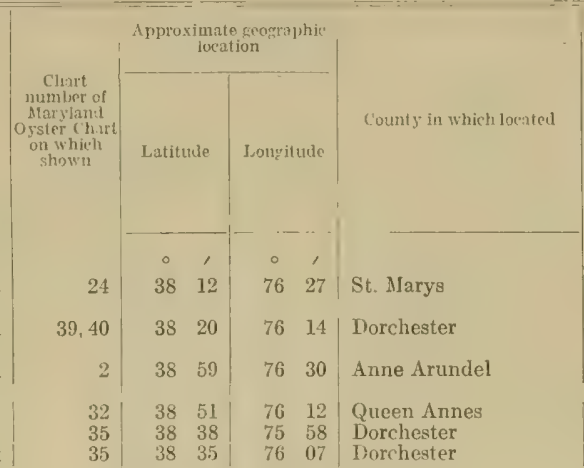

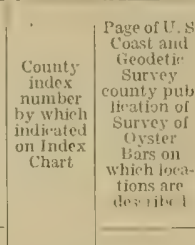

76

82

89

87

56

85

90

81

20

45
$5]$

\begin{tabular}{l|ll|ll|l}
25 & 38 & 16 & 76 & 42 & St. Marys
\end{tabular}

\begin{tabular}{l|ll|ll|l}
35 & 38 & 37 & 76 & 07 & Talbot
\end{tabular}

\begin{tabular}{l|ll|lll}
2 & 39 & 04 & 76 & 29 & Anne Arundel
\end{tabular}

\begin{tabular}{lllll|l}
38 & 32 & 76 & 15 & Dorchester
\end{tabular}

\begin{tabular}{l|ll|ll|l}
37 & 38 & 32 & 76 & 12 & Dorchester
\end{tabular}

\begin{tabular}{l|ll|ll|l}
34 & 38 & 43 & 76 & 08 & Talbot
\end{tabular}

\begin{tabular}{l|ll|ll|l}
34 & 38 & 46 & 76 & 10 & Talbot
\end{tabular}

\begin{tabular}{l|lllll|l}
35 & 38 & 38 & 75 & 58 & Dorchester
\end{tabular}

\begin{tabular}{l|ll|ll|l}
19 & 38 & 23 & 76 & 33 & St. Marys
\end{tabular}

30 $\quad \begin{array}{llllll}39 & 05 & 76 & 08 & \text { Queen Annes }\end{array}$

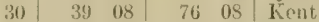

\begin{tabular}{l|ll|ll|l}
34 & 38 & 42 & 76 & 13 & Thalbot
\end{tabular}

\begin{tabular}{l|ll|ll|l}
16 & 38 & 39 & 76 & 32 & (alvert
\end{tabular}

\begin{tabular}{l|ll|ll|l}
24 & 38 & 07 & 76 & 24 & St. Marys
\end{tabular}

$\begin{array}{llllll}26 & 38 & 30 & 76 & 41 & \text { Charles }\end{array}$

\begin{tabular}{llllll|l}
30 & 39 & 07 & 76 & 06 & Queen Annes
\end{tabular}

\begin{tabular}{l|ll|ll|l}
35 & 38 & 38 & 76 & 07 & Talbot
\end{tabular}

\begin{tabular}{l|ll|ll|l}
13 & 38 & 14 & 75 & 10 & Worcester
\end{tabular}

$\begin{array}{lllllll}24 & 38 & 10 & 76 & 26 & \text { St. Marys }\end{array}$

$\begin{array}{llllll}13 & 38 & 18 & 75 & 07 & \text { Worcester }\end{array}$

30 $\quad 39 \quad 0.5 \quad 36 \quad 12 \quad$ Kent

\begin{tabular}{l|ll|ll|l}
04 & 38 & 42 & 76 & 14 & Tallot
\end{tabular}

\begin{tabular}{l|ll|ll|l}
2 & 39 & 0.3 & 76 & 29 & Anne Arundel
\end{tabular}

\begin{tabular}{lll|ll|l}
2 & 39 & 03 & 76 & 3.4 & Anne Arundel
\end{tabular}

\begin{tabular}{l|ll|ll|l}
19 & 38 & 21 & 76 & 32 & ('alvert
\end{tabular}

30 $\quad 39 \quad 06 \quad 36 \quad 12$ kient.

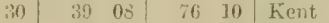

\begin{tabular}{lll|ll|l}
5 & 38 & 15 & 75 & 50 & Sumerset
\end{tabular}

\begin{tabular}{l|ll|ll|l}
35 & 38 & 37 & 75 & 59 & Talbot
\end{tabular}

\begin{tabular}{l|ll|ll|l}
36,37 & 38 & 32 & 76 & 20 & Dorchester
\end{tabular}

\begin{tabular}{lll|ll|l}
32 & is & 51 & 76 & 12 & Talbot
\end{tabular}

$\begin{array}{llllll}9 & 37 & 58 & 75 & 55 & \text { somerset }\end{array}$

\begin{tabular}{lll|ll|l}
30 & 39 & 08 & 76 & 05 & fient
\end{tabular}

\begin{tabular}{lll|ll|l}
34,35 & 38 & 49 & 76 & 08 & Talbot
\end{tabular}

$\begin{array}{llllll}5,7 & 38 & 09 & 75 & 51 & \text { Somerset }\end{array}$

\begin{tabular}{llllll|l}
37 & 38 & 33 & 76 & 15 & Dorchester
\end{tabular}

\begin{tabular}{llllll|l}
33,36 & 38 & 37 & 76 & 22 & Talbot
\end{tabular}

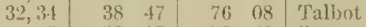

\begin{tabular}{llllll|l}
5 & 38 & 15 & 75 & 49 & Sommrset
\end{tabular}

6.8 $38 \quad 01 / 76 \quad 03 \quad$ Somerset

\begin{tabular}{rll|ll|l}
7 & 38 & 07 & 75 & 57 & Somermet
\end{tabular}

30 $\quad$\begin{tabular}{ll|ll|l}
39 & 08 & 76 & 04 & Queen Annes
\end{tabular}

\begin{tabular}{llllll|l}
34 & 39 & 45 & 76 & 14 & Talbot.
\end{tabular}

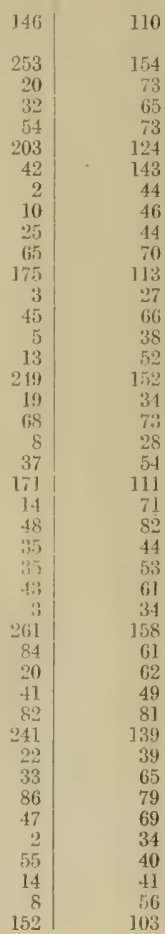


Alphabetical Innex to Trianculation Stations-C'mintimed.

\begin{tabular}{|c|c|c|c|c|c|c|c|c|}
\hline \multirow[b]{2}{*}{ Name of station } & \multirow{3}{*}{$\begin{array}{c}\text { Chart } \\
\text { numleer of } \\
\text { Maryland } \\
\text { Oyster Chart } \\
\text { on which } \\
\text { shown }\end{array}$} & \multicolumn{4}{|c|}{$\begin{array}{l}\text { Approximate geogranhic } \\
\text { iocation }\end{array}$} & \multirow[b]{2}{*}{ County in which located } & \multirow{3}{*}{$\begin{array}{c}\text { County } \\
\text { index } \\
\text { number } \\
\text { by which } \\
\text { indicated } \\
\text { on Index } \\
\text { Chart }\end{array}$} & \multirow{3}{*}{\begin{tabular}{|} 
Page of U.S. \\
Coast aud \\
Geodetic \\
Survey \\
county pub- \\
lication of \\
Surrey of \\
Oyster \\
Bars on \\
which loca- \\
tions are \\
described
\end{tabular}} \\
\hline & & \multicolumn{2}{|c|}{ Latitude } & \multicolumn{2}{|c|}{ Longitude } & & & \\
\hline Juliet & & 0 & , & 0 & , & & & \\
\hline $\begin{array}{l}\text { Juliet } \\
\text { Julius }\end{array}$ & 11 & 35 & 20 & 75 & 53 & Wicomico & 2 & \\
\hline ulius & 30 & & 09 & 76 & 03 & Queen Anne & 4 & 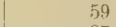 \\
\hline $\begin{array}{l}\text { June } \\
\text { Jutland }\end{array}$ & 32 & 38 & 54 & 76 & 10 & Queen Annes & 101 & 8 \\
\hline Kaywood & $\begin{array}{l}24 \\
25\end{array}$ & $\begin{array}{l}30 \\
38\end{array}$ & 14 & $\begin{array}{l}76 \\
76\end{array}$ & $\begin{array}{l}25 \\
42\end{array}$ & $\begin{array}{l}\text { St. Marys } \\
\text { St. Marys }\end{array}$ & $\begin{array}{r}47 \\
139\end{array}$ & 10 \\
\hline Keenes & 39,40 & 38 & 22 & 76 & 13 & Dorchester & 102 & 8 \\
\hline Kelley & 7 & 38 & 08 & 75 & 55 & Somerset & 19 & \\
\hline Kemp & 31 & 38 & 50 & 76 & 18 & Talbot & 76 & \\
\hline Kemp Tower & 31 & 38 & 50 & 76 & 18 & Talbot & 75 & \\
\hline Kennedy & 24 & 38 & 10 & 76 & 26 & st. Marys & $\left.6^{3}\right)$ & 7 \\
\hline Kent & 34,35 & 39 & 40 & 76 & 08 & Talbut & $2: 9$ & 13 \\
\hline Kerwin & 40 & $\therefore 8$ & 22 & 76 & 11 & Dorchester & 103 & 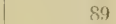 \\
\hline Key & 26 & 38 & 22 & 76 & 50 & St. Marys & 180 & 11 \\
\hline Killick Shonl I ight & (') & 38 & 57 & 75 & 23 & Virginia & 203 & 4 \\
\hline King & 30 & 39 & $0 \mathrm{~s}$ & 76 & 10 & Kent & 54 & \\
\hline Kinsley & 30 & 39 & 08 & 76 & 11 & Kent & 46 & 6 \\
\hline Kirby & 37 & 38 & 32 & 76 & 11 & Dorchester & 58 & \\
\hline Kirk & 34 & 38 & 46 & 76 & 09 & Talbot & 58 & 14 \\
\hline Kirwan & 32 & 38 & 57 & 76 & 15 & Queen $A$ menes & 82 & . \\
\hline Iit (Island (reek) & 34,35 & 38 & 11 & 76 & 07 & Talbot & 235 & 13 \\
\hline Kitt (Patuxent River) & 19 & 38 & 28 & 76 & 37 & Calvert & 40 & 4 \\
\hline Knee & 32 & 38 & 54 & 76 & 10 & Queen Annes & 99 & 8 \\
\hline $\begin{array}{l}\mathrm{K} \text {. of P. Flagstaff (Solo- } \\
\text { mons) }\end{array}$ & 20 & 38 & 19 & 76 & 27 & Calvert & 21 & \\
\hline Knob & 2 & 39 & 00 & 76 & 30 & Anne Arundel & 36 & $i$ \\
\hline Knock & 31 & 38 & 57 & 76 & 19 & Queen Annes & 64 & \\
\hline Koot & 34 & 38 & 46 & 76 & 17 & Talbot & 114 & \\
\hline Lahor & 24 & 38 & 06 & 76 & $2 \mathrm{~S}$ & St. Marys & 111 & \\
\hline Lakes & 40 & 38 & 19 & 76 & 09 & Dorchester & 106 & \\
\hline Lan & 35 & 38 & 38 & 76 & 07 & Talhot & 247 & 15 \\
\hline Landeve & 31,35 & 38 & 40 & 76 & 09 & Talbot & 243 & 13 \\
\hline Landing & 31 & 38 & 57 & $76 \mathrm{i}$ & 19 & Queen Innes & 65 & \\
\hline Tandlei & 14 & 38 & 07 & 75 & 18 & Worcester & 29 & 3 \\
\hline Laney & 37 & 38 & 32 & 76 & 13 & Dorchester & 66 & \\
\hline Langford & 30 & 39 & 06 & 76 & 10 & Kent & 73 & \\
\hline Large Water Tank & 35 & 38 & 38 & 76 & 10 & Dorchester & 23 & 0 \\
\hline Larramore & 3 & 38 & 57 & 76 & 34 & Anne Arundel & 79 & 9 \\
\hline Law & 32 & 38 & 51 & 76 & 12 & Talbot & 19 & \\
\hline Lawn & $31,32,34$ & 38 & 47 & 76 & 16 & Talbot & 106 & 4 \\
\hline Lawyer & 30 & 39 & 07 & 76 & 11 & Kent & 40 & . \\
\hline Layor & 34 & 38 & 43 & 76 & 08 & Talbot & 216 & 12 \\
\hline Layton & 37 & 38 & 33 & 76 & 12 & Dorchester & 50 & 7 \\
\hline Leary & 30 & 39 & 08 & 76 & 09 & Kent & 57 & \\
\hline Leaven & 32 & 38 & 53 & 76 & 11 & Queen Annes & 112 & \\
\hline Le Compte & 35 & 39 & 36 & 76 & 10 & Dorchester & 22 & 5 \\
\hline Lee & 37 & 38 & 33 & $76 \mathrm{j}$ & 13 & Dorchester & 46 & \\
\hline Leerls & 32 & 38 & 48 & 76 & 12 & Talbot & 35 & \\
\hline Leitch & 19 & 38 & 32 & 76 & 40 & Calvert & 47 & 3 \\
\hline Lend & 19,20 & 38 & 23 & 76 & 30 & Calvert & 30 & 4 \\
\hline Lerch Windmill & 3 & 38 & 50 & 76 & 32 & Anne Arundel & 100 & \\
\hline Le Seur & 32 & 38 & 52 & 76 & 10 & Queen Annes & 117 & 9 \\
\hline Little & 5 & 38 & 13 & 75 & 50 & Somerset & 7 & 3 \\
\hline Little Gum & 30 & 39 & 05 & 76 & 12 & Kent & 24 & 48 \\
\hline
\end{tabular}


Alphabetical Index to Triangulation Stations-Continued.

Liver

Locust (Chesapeako Bay)

Iocust (Iangford Creek)

Locust (Manokin River)

Long (Severn River)

Long (Miles River)

Long Point

Longwells Wirdmill

louise

Love Point I ight

Lovely

Iovers

Lowell

Inwindes

Iuce

Lucy

Lima

Lynch Point 3

Isyon

McConnell

Meloy

McKay

Mac

Mackall

Macum

Madison Southern M. E: church spire

Magothy

Maiden

Mais

Major

Make

Mansion

Marge

Marion

Mars

Marsh (Broad Creck)

Marsh (Manokin River)

Marshall

Marshy

Martin (St. Marys IRiver)

Martin (Tred $\Lambda$ von River)

Mary

Maryland

Maryland-Virginia (LifeSaving Station Beach)

Maryland-Virginia (Pope Island)

Maryland-Virginia (Railroad)

Maslin

Matta

\begin{tabular}{|c|c|c|}
\hline \multirow[t]{2}{*}{$\begin{array}{c}\text { Chart } \\
\text { number of } \\
\text { Maryland } \\
\text { Oyster Chart } \\
\text { on which } \\
\text { shown }\end{array}$} & Approx & ximat \\
\hline & 。 & , \\
\hline 31 & 38 & 57 \\
\hline 32 & 38 & 52 \\
\hline 1 & 39 & 06 \\
\hline 30 & 39 & 09 \\
\hline 7 & 38 & 09 \\
\hline 2 & 39 & 03 \\
\hline 34 & 38 & 46 \\
\hline 15 & 38 & 00 \\
\hline 13 & 38 & 15 \\
\hline 37 & 38 & 33 \\
\hline 29 & 39 & 03 \\
\hline 30 & 39 & 09 \\
\hline 25 & 38 & 16 \\
\hline 21 & 38 & 09 \\
\hline 32 & 38 & 48 \\
\hline 2 & 39 & 01 \\
\hline 30 & 39 & 06 \\
\hline 34 & 38 & 45 \\
\hline$\left({ }^{2}\right)$ & 38 & 03 \\
\hline 26 & 38 & 18 \\
\hline & 38 & 47 \\
\hline 24 & 38 & 13 \\
\hline 24 & 38 & 11 \\
\hline 37 & 38 & 32 \\
\hline 19,20 & 38 & 23 \\
\hline $2 y$ & 39 & 00 \\
\hline 37 & 38 & 30 \\
\hline 2 & 39 & 02 \\
\hline 34 & 38 & 46 \\
\hline 32 & 38 & 48 \\
\hline 30 & 39 & 07 \\
\hline 30 & 39 & 09 \\
\hline 25 & 38 & 16 \\
\hline 34 & 38 & 47 \\
\hline 34 & 38 & 47 \\
\hline 34 & 38 & 46 \\
\hline $\begin{array}{r}3-1 \\
7\end{array}$ & $\begin{array}{l}38 \\
38\end{array}$ & $\begin{array}{l}44 \\
08\end{array}$ \\
\hline 34 & 38 & 44 \\
\hline 32 & 38 & 57 \\
\hline 24 & 38 & 12 \\
\hline 34 & 38 & 43 \\
\hline 37 & 38 & 32 \\
\hline $36,37,38$ & 38 & 29 \\
\hline 15 & 38 & 02 \\
\hline 15 & 38 & 02 \\
\hline 15 & 38 & 01 \\
\hline $\begin{array}{r}34,35 \\
31\end{array}$ & $\begin{array}{l}38 \\
38\end{array}$ & $\begin{array}{l}40 \\
54\end{array}$ \\
\hline & & \\
\hline
\end{tabular}

$31 \quad 38$
County in which located

Longitude

$76 \quad 19 \mid$ Queen Annes

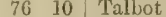

$\begin{array}{ll}76 & 26 \\ \text { Anne Arundel }\end{array}$

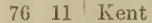

7548 sumerset

\begin{tabular}{ll|l}
76 & 33 & Anne Arundel
\end{tabular}

$\begin{array}{lll}76 & 10 & \text { Talbot }\end{array}$

$\begin{array}{lll}75 & 22 & \text { Virginia }\end{array}$

$\begin{array}{lll}75 & 09 & \text { Worcester }\end{array}$

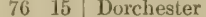

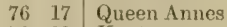

$\begin{array}{lll}76 & 09 & \text { Kent }\end{array}$

$\begin{array}{lll}76 & 39 & \text { St. Marys }\end{array}$

$\begin{array}{lll}76 & 30 & \text { St. Marys }\end{array}$

$\begin{array}{lll}76 & 08 & \text { Talbot }\end{array}$

$76 \quad 31$ Amne Arundel

$\begin{array}{lll}76 & 13 & \text { Kent }\end{array}$

$\begin{array}{lll}76 & 16 & \text { Talloot }\end{array}$

$\begin{array}{lll}76 & 31 & \text { Virginia }\end{array}$

7650 St. Marys

\begin{tabular}{ll|l}
76 & 09 & Talbot
\end{tabular}

\begin{tabular}{ll|l}
76 & 28 & St. Marys
\end{tabular}

$\begin{array}{lll}76 & 27 & \text { St. Marys }\end{array}$

$\begin{array}{lll}76 & 13 & \text { Dorchester }\end{array}$

$\begin{array}{lll}76 & 30 & \text { Calvert }\end{array}$

76; 17 Queen Annes

7613 Dorchester

$76 \quad 25$ Anne Arundel

7611 Talbot

$76 \quad 11$ Talbot

$76 \quad 10$ Kent

$\begin{array}{lll}76 & 05 & \text { Kent }\end{array}$

$\begin{array}{lll}76 & 42 & \text { St. Marys }\end{array}$

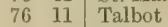

$\begin{array}{lll}76 & 16 & \text { Talbot }\end{array}$

$\begin{array}{lll}76 & 15 & \text { Talbot }\end{array}$

$\begin{array}{lll}76 & 13 & \text { Talbot }\end{array}$

$\begin{array}{lll}75 & 53 & \text { Somerset }\end{array}$

\begin{tabular}{ll|l}
76 & 12 & Talbot
\end{tabular}

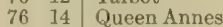

$\begin{array}{lll}76 & 27 & \text { St. Marys }\end{array}$

$\begin{array}{lll}76 & 09 & \text { Talbot }\end{array}$

7 (j 12 Dorchester

$\begin{array}{ll}76 & 17 \text { Dorchester }\end{array}$

7515 Worcester

7515 Worcester

75 2:3. Worcester

\begin{tabular}{ll|l}
76 & 08 & Talbot
\end{tabular}

\begin{tabular}{ll|l}
76 & 20 & Queen Annes
\end{tabular}

'See St. Marys County publication. $\begin{array}{r}68 \\ 59 \\ 68 \\ 63 \\ 42 \\ 82 \\ 141 \\ 141 \\ 33 \\ 68 \\ 33 \\ 69 \\ 99 \\ 91 \\ 69 \\ 84 \\ 50 \\ 96 \\ 70 \\ 122 \\ 146 \\ 85 \\ 79 \\ 78 \\ 46 \\ 35 \\ 79 \\ 74 \\ 74 \\ 149 \\ 67 \\ 72 \\ 84 \\ 109 \\ 140 \\ 100 \\ 101 \\ 109 \\ 42 \\ 107 \\ 79 \\ 84 \\ 117 \\ 74 \\ 58 \\ 39 \\ 39 \\ 39 \\ 42 \\ 65 \\ \hline\end{array}$

\begin{tabular}{|c|c|}
\hline $\begin{array}{c}\text { County } \\
\text { index } \\
\text { number } \\
\text { by which } \\
\text { indicated } \\
\text { on Index } \\
\text { Chart }\end{array}$ & $\begin{array}{l}\text { l'age of U.S. } \\
\text { Coast and } \\
\text { Geodetic } \\
\text { Survey } \\
\text { county pul- } \\
\text { lication of } \\
\text { Survey of } \\
\text { Oyster } \\
\text { Bars on } \\
\text { which loca- } \\
\text { tions are } \\
\text { described }\end{array}$ \\
\hline 59 & \\
\hline 14 & 59 \\
\hline $\begin{array}{r}4 \\
49\end{array}$ & $\begin{array}{l}68 \\
63\end{array}$ \\
\hline 24 & 42 \\
\hline 47 & 82 \\
\hline $\begin{array}{l}38 \\
18\end{array}$ & $\begin{array}{c}141 \\
14]\end{array}$ \\
\hline 16 & 33 \\
\hline 39 & 68 \\
\hline $\begin{array}{l}42 \\
6^{\circ}\end{array}$ & $\begin{array}{l}33 \\
69\end{array}$ \\
\hline 120 & 99 \\
\hline 100 & 91 \\
\hline 48 & 69 \\
\hline $\begin{array}{l}53 \\
97\end{array}$ & 84 \\
\hline $\begin{array}{r}27 \\
133\end{array}$ & $\begin{array}{l}50 \\
96\end{array}$ \\
\hline 2 & ${ }^{2} 70$ \\
\hline $\begin{array}{r}175 \\
57\end{array}$ & 122 \\
\hline $\begin{array}{l}37 \\
79\end{array}$ & $\begin{array}{r}146 \\
85\end{array}$ \\
\hline 86 & 79 \\
\hline $\begin{array}{l}67 \\
32\end{array}$ & $\begin{array}{l}78 \\
46\end{array}$ \\
\hline 39 & 35 \\
\hline 68 & 79 \\
\hline 23 & 74 \\
\hline $\begin{array}{l}63 \\
32 \\
2\end{array}$ & 149 \\
\hline 71 & $\begin{array}{l}17 \\
72\end{array}$ \\
\hline 86 & 84 \\
\hline $\begin{array}{r}145 \\
36\end{array}$ & 109 \\
\hline 143 & $\begin{array}{l}140 \\
100\end{array}$ \\
\hline 147 & 101 \\
\hline 165 & 109 \\
\hline $\begin{array}{r}20 \\
162\end{array}$ & 107 \\
\hline $\begin{array}{r}102 \\
85\end{array}$ & $\begin{array}{r}08 \\
79\end{array}$ \\
\hline $\begin{array}{r}77 \\
786\end{array}$ & 84 \\
\hline 56 & 74 \\
\hline 73 & 58 \\
\hline & \\
\hline 35 & 39 \\
\hline 36 & 42 \\
\hline $\begin{array}{r}239 \\
50\end{array}$ & $\begin{array}{r}138 \\
65\end{array}$ \\
\hline
\end{tabular}




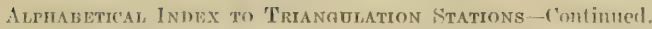

\begin{tabular}{|c|c|c|c|c|c|c|c|c|}
\hline \multirow{3}{*}{ Name of station } & \multirow{3}{*}{$\begin{array}{c}\text { Chart } \\
\text { number of } \\
\text { Maryland } \\
\text { osster Chart } \\
\text { on which } \\
\text { shown }\end{array}$} & \multicolumn{4}{|c|}{$\begin{array}{l}\text { Ipproximate grographic } \\
\text { location }\end{array}$} & \multirow[b]{2}{*}{ County in which located } & \multirow{3}{*}{$\begin{array}{c}\text { County } \\
\text { index } \\
\text { number } \\
\text { by which } \\
\text { indieated } \\
\text { on Index } \\
\text { Chart }\end{array}$} & \multirow{2}{*}{$\begin{array}{l}\text { Page of U.S. } \\
\text { Coast and } \\
\text { Geodetic } \\
\text { Survey } \\
\text { county pub- } \\
\text { lication of } \\
\text { Survey of } \\
\text { Oster } \\
\text { Bars on } \\
\text { which loca- } \\
\text { tjons are } \\
\text { deseribed }\end{array}$} \\
\hline & & \multicolumn{2}{|c|}{ Latitude } & \multicolumn{2}{|c|}{ Longitude } & & & \\
\hline & & 0 & , & $\circ$ & , & & & \\
\hline Matter & 32 & 38 & 53 & 76 & 09 & Talbot & 6 & 56 \\
\hline May & 34 & 38 & 44 & 76 & 08 & Talbot & 190 & 119 \\
\hline Mayo & 3 & 38 & 55 & 76 & 31 & Anne Arundel & 84 & 92 \\
\hline Mean & 34,35 & 38 & 40 & 76 & 08 & Talbot & 240 & 138 \\
\hline Melfield & 30 & 39 & 04 & 76 & 07 & Queen Annes & 23 & 45 \\
\hline Melon & 34 & 38 & 45 & 76 & 07 & Talbot & 197 & 121 \\
\hline Melton & 30 & 39 & 08 & 76 & 04 & Kent & 83 & 82 \\
\hline M. E. Church (Solomons) & 20 & 38 & 19 & 76 & 28 & Calvert & 23 & 53 \\
\hline $\begin{array}{l}\text { M. E. Church (Tilghman } \\
\text { Island) }\end{array}$ & 33 & 38 & 42 & 76 & 20 & Talbot & 88 & 80 \\
\hline Miles & 7 & 38 & 06 & 76 & 00 & Somerset & 16 & 41 \\
\hline Mileys & 25 & 38 & 16 & 76 & 43 & St. Marys & 158 & 110 \\
\hline Mill (Langford Creek) & 30 & 39 & 08 & 76 & 11 & Kent. & 51 & 64 \\
\hline Mill ('atuxent River) & 20 & 38 & 20 & 76 & 30 & St. Marys & 15 & 51 \\
\hline Mill (chincoteague Bay) & 15 & 38 & 03 & 75 & 20 & Worcester & 33 & 42 \\
\hline Miller & 34 & 38 & 47 & 76 & 16 & Talbot & 110 & 90 \\
\hline Millwind & 32 & 38 & 48 & 76 & 13 & Talbot & 67 & 72 \\
\hline Mink & 34 & 38 & 47 & 76 & 17 & falbot & 103 & 89 \\
\hline Mint & 39 & 38 & 21 & 76 & 14 & Dorchester & 87 & 85 \\
\hline Mistle & 34 & 38 & 43 & 76 & 08 & Talbot & 215 & 120 \\
\hline Mitchell & 37 & 38 & 33 & 76 & 15 & Dorchester & 35 & 66 \\
\hline Mitchells Bluff 2 & 28 & 39 & 13 & 76 & 14 & Kent & 3 & 29 \\
\hline Moke & 34,35 & 38 & 40 & 76 & 07 & Talbot & 236 & 137 \\
\hline Money & 15 & 38 & 01 & 75 & 23 & Virginia & 16 & 141 \\
\hline Monkey & 9 & 37 & 57 & 75 & 48 & Somerset & 49 & 52 \\
\hline Moon & 7 & 38 & 04 & 75 & 48 & Somerset & 37 & 45 \\
\hline Muore & $36,37,38$ & 38 & 30 & 76 & 17 & Dorchester & 79 & 59 \\
\hline Morn & 32 & 38 & 53 & 76. & 08 & Queen Annes & 127 & 96 \\
\hline Morepl & 19 & 38 & 29 & 76 & 39 & falvert & 42 & 39 \\
\hline Mos & 10 & 37 & 54 & 75 & 46 & Virginia & 10 & ${ }^{2} 54$ \\
\hline Mouldy & 25 & 38 & 16 & 76 & 38 & St. Marys & 122 & 97 \\
\hline Mount Pleasant Church & 9 & 37 & 59 & 75 & 51 & Somerset & 44 & 49 \\
\hline $\begin{array}{l}\text { Mount Vernon M. E. } \\
\text { Church }\end{array}$ & 5 & 38 & 15 & 75 & 50 & Somersei & $4 \mid$ & 35 \\
\hline $\begin{array}{l}\text { Mt. Zion M. E. Church } \\
\text { Spire }\end{array}$ & 39,40 & 38 & 19 & 76 & 14 & Dorchester & 91 & 87 \\
\hline Mouth. & 31 & 38 & 52 & 76 & 20 & Queen Annes & 49 & 64 \\
\hline Mud (Tred Avon River) & 34 & 38 & 42 & 76 & 09 & Talbot & 219 & 130 \\
\hline Mud (Sinepuxent Bay) & 13 & 38 & 15 & 75 & 08 & Worcester & 18 & 33 \\
\hline Muddy & 29,30 & 38 & 59 & 76 & 14 & Queen Annes & 37 & 36 \\
\hline Mutton & 34 & 38 & 41 & 76 & 11 & Talbot & 178 & 114 \\
\hline Myrtle (Choptank River) & 35 & 38 & 39 & 75 & 58 & Dorchester & 1 & 44 \\
\hline Myrtle (Broad Creek) & 34 & 38 & 44 & 76 & 16 & Talbot & 124 & 93 \\
\hline Nanti & 12 & 38 & 14 & 75 & 54 & Wicomico & 8 & 29 \\
\hline Nanticoke Church & 11,12 & 38 & 16 & 75 & 54 & Wicomicn & 6 & 26 \\
\hline Narrows & 33 & 38 & 43 & 76 & 19 & Talbot & 92 & 81 \\
\hline Narrows Point & 29,30 & 39 & 01 & 76 & 13 & Kent & 20 & 40 \\
\hline Nat (Langford (reek) & 30 & 39 & 08 & 76 & 11 & Kent & 50 & 64 \\
\hline Nat (Patuxent River) & 30 & 38 & 21 & 76 & 30 & St. Marys & 14 & 50 \\
\hline Neck (Langford (reek) & 30 & 39 & 07 & 76 & 10 & Kent & 70 & 72 \\
\hline Neck (Tred Avon River) & 34 & 38 & 45 & 76 & 07 & Talbot & 192 & 120 \\
\hline Neck (Chincoteague Bay) & 13 & 38 & 14 & 75 & 12 & Worcester & 23 & 35 \\
\hline Ned & 34 & 38 & 44 & 76 & 17 & Talbot & 129 & 95 \\
\hline
\end{tabular}


Alpiabrtical Index to Triangulation Stations-Continued.

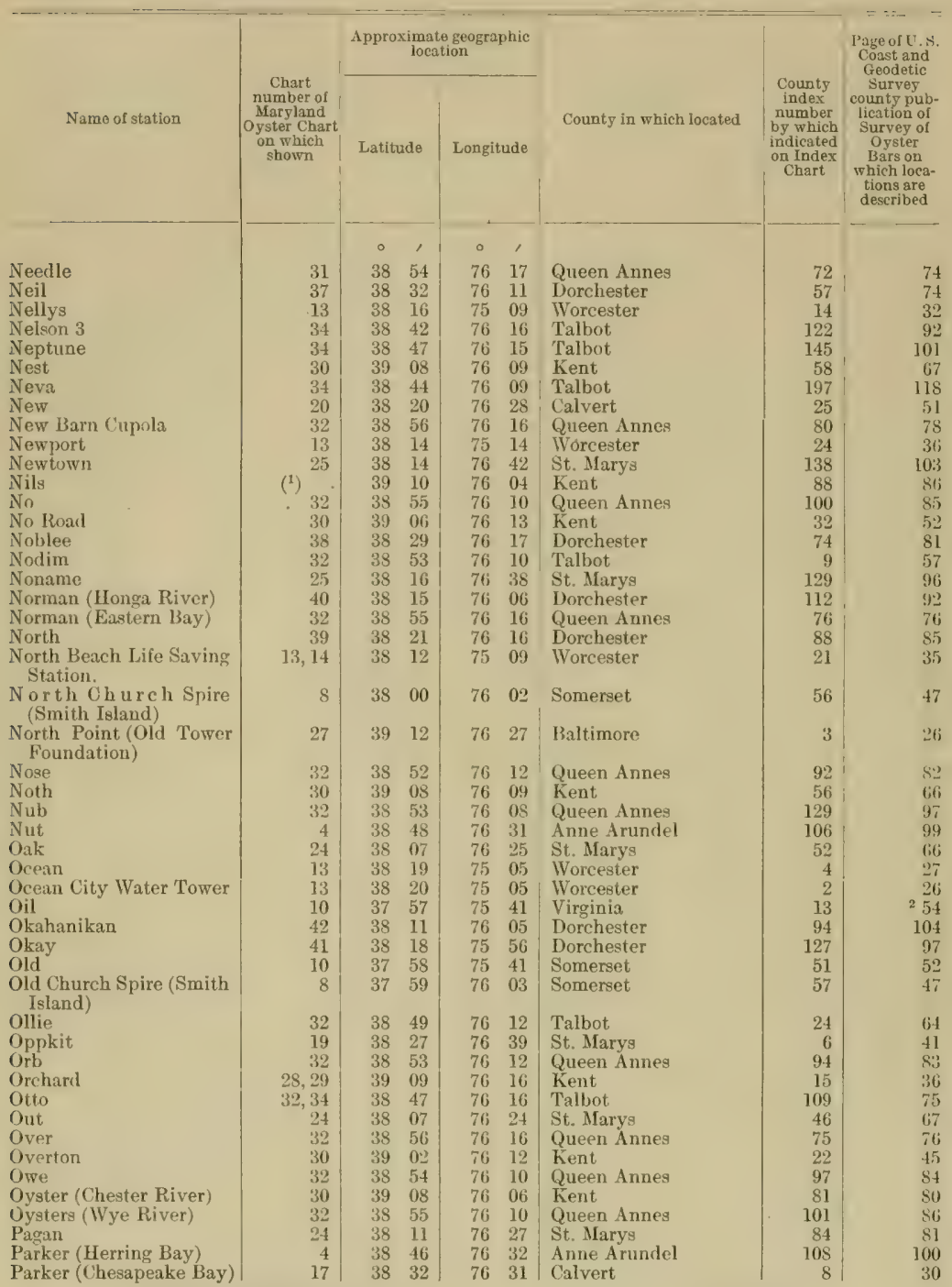


LANDMARKS.

Alphabetical Index to Triangulation Stationg-Continued.

\begin{tabular}{|c|c|c|c|c|c|c|c|c|}
\hline \multirow{3}{*}{ Name of station } & \multirow{3}{*}{$\begin{array}{c}\text { Chart } \\
\text { number of } \\
\text { Maryland } \\
\text { Oyster Chart } \\
\text { on which } \\
\text { shown }\end{array}$} & \multicolumn{4}{|c|}{$\begin{array}{c}\text { Approximate geographic } \\
\text { location }\end{array}$} & \multirow{3}{*}{ County in which located } & \multirow{3}{*}{$\begin{array}{c}\text { County } \\
\text { index } \\
\text { number } \\
\text { by which } \\
\text { indicated } \\
\text { on Index } \\
\text { Chart }\end{array}$} & \multirow{2}{*}{$\begin{array}{c}\text { Page of U.S } \\
\text { Cosst and } \\
\text { Geodetic } \\
\text { Survey } \\
\text { county pub- } \\
\text { lication of } \\
\text { Survey of } \\
\text { Oyster } \\
\text { Bars on } \\
\text { which loca- } \\
\text { tions are } \\
\text { described }\end{array}$} \\
\hline & & \multicolumn{2}{|c|}{ Latitude } & \multicolumn{2}{|c|}{ Longitude } & & & \\
\hline & & $\bullet$ & , & 。 & , & & & \\
\hline Parsons & 32 & 38 & 54 & 76 & 15 & Queen Annes & 77 & 77 \\
\hline $\begin{array}{l}\text { Parsons Island Water } \\
\text { Tank }\end{array}$ & 32 & 38 & 55 & 76 & 15 & Queen Annes & 78 & 77 \\
\hline Pat & 20 & 38 & 22 & 76 & 23 & Calvert & 16 & 57 \\
\hline Patch & 17 & 38 & 33 & 76 & 31 . & Calvert & 7 & 29 \\
\hline Paul (Honga River) & 40 & 38 & 17 & 76 & 07 & Dorchester & 109 & 91 \\
\hline $\begin{array}{l}\text { Paul (Little Choptank } \\
\text { River) }\end{array}$ & $\left({ }^{1}\right)$ & 38 & 32 & 76 & 10 & Dorchester & 59 & 75 \\
\hline $\mathrm{Paw}$ & 25 & 38 & 16 & 76 & 40 & St. Marys & 134 & 99 \\
\hline Peach & 30 & 39 & 06 & 76 & 10 & Kent & 72 & 72 \\
\hline Peach Hill & 2 & 39 & 05 & 76 & 25 & Anne Arundel & 5 & 70 \\
\hline Peak & 19 & 38 & 25 & 76 & 31 & Calvert & 34 & 45 \\
\hline Pearson & 32 & 38 & 51 & 76 & 15 & Talbot & 72 & 74 \\
\hline Peary & 34 & 38 & 43 & 76 & 14 & Talbot & 169 & 110 \\
\hline Peck & 34 & 38 & 42 & 76 & 10 & Talbot & 182 & 116 \\
\hline Peebee & 34 & 38 & 44 & 76 & 07 & Talbot & 191 & 119 \\
\hline Pen (Chesapeake Bay) & 17 & 38 & 34 & 76 & 31 & Calvert & 6 & 29 \\
\hline Pen (Manokin River) & $\left({ }^{2}\right)$ & 38 & 09 & 75 & 47 & Somerset & 27 & 43 \\
\hline Peoples Chapel & 33 & 38 & 43 & 76 & 20 & Talbot & 91 & 81 \\
\hline Perry & 26 & 38 & 21 & 76 & 50 & St. Marys & 178 & 119 \\
\hline Phil (Magothy River) & 1 & 39 & 05 & 76 & 26 & Anne Arundel & 10 & 69 \\
\hline $\begin{array}{l}\text { Phil (Little Choptank } \\
\text { River) }\end{array}$ & 37 & 38 & 34 & 76 & 13 & Dorchester & 42 & 69 \\
\hline Philip (Langford Creek) & 30 & 39 & 09 & 76 & 09 & Kent & 64 & 69 \\
\hline Philip (Wye River) & 32 & 38 & 53 & 76 & 09 & Queen Annes & 125 & 96 \\
\hline Photo & 19 & 38 & 26 & 76 & 36 & Calvert & 38 & 42 \\
\hline Pick & 32 & 38 & 52 & 76 & 08 & Talbot & 1 & 54 \\
\hline Pier (Chesapeake Bay) & 16,17 & 38 & 36 & 76 & 30 & Calvert & 5 & 28 \\
\hline Pier (Smith Creek) & 24 & 38 & 07 & 76 & 24 & St. Marys & 42 & 64 \\
\hline Pine (Bretons Bay) & 25 & 38 & 16 & 76 & 38 & St. Marys & 123 & 96 \\
\hline Pine (Broad Creek) & 34 & 38 & 45 & 76 & 16 & Talbot & 132 & 96 \\
\hline Piney & 32 & 38 & 53 & 76 & 12 & Queen Annes & 95 & 83 \\
\hline Piney Point Light & 21 & 38 & 08 & 76 & 32 & St. Marys & 113 & 94 \\
\hline Pink & 34 & 38 & 47 & 76 & 16 & Talbot & 111 & 90 \\
\hline Pipe & 24 & 38 & 07 & 76 & 24 & St. Marys & 41 & 65 \\
\hline Place & 25 & 38 & 17 & 76 & 42 & St. Marys & 149 & 113 \\
\hline Plain & $3 \frac{1}{4}$ & 38 & 43 & 76 & 09 & Talbot & 184 & 116 \\
\hline Plow & 34 & 38 & 43 & 76 & 07 & Talbot & 209 & 126 \\
\hline Plum 3 & 16 & 38 & 37 & 76 & 31 & Calvert & 4 & 28 \\
\hline Poco & 34,35 & 38 & 40 & 76 & 07 & Talbot & 237 & 137 \\
\hline Point & 2 & 39 & 02 & 76 & 31 & Anne Arundel & 40 & 79 \\
\hline Point Agin & 21 & 38 & 11 & 76 & 21 & St. Marys & 28 & 60 \\
\hline Point Look-in & 22 & 38 & 06 & 76 & 20 & St. Marys & 33 & 61 \\
\hline Point Lookout Light & 22,23 & 38 & 02 & 76 & 19 & St. Marys & 35 & 62 \\
\hline Point No Point & 22 & 38 & 09 & 76 & 19 & St. Marys & 29 & 60 \\
\hline Point No Point Light & 22 & 38 & 08 & 76 & 17 & St. Marys & 30 & 60 \\
\hline Point of Rocks & 18 & 38 & 25 & 76 & 25 & Calvert & 13 & 31 \\
\hline Pole & 11 & 38 & 18 & 75 & 54 & Wicomico & 3 & 26 \\
\hline Pomona & 30 & 39 & 09 & 76 & 05 & Kent & 84 & 83 \\
\hline Pond & 24 & 38 & 08 & 76 & 28 & St. MIarys & 92 & 71 \\
\hline Pont & 34 & 38 & 42 & 76 & 14 & Talbot & 172 & 112 \\
\hline
\end{tabular}

1 See progress map in Dorchester County publications.

2 See progress map in Somerset County publications. $95112-13-5$ 
Alphabetical Index to Triangulation Stations-Continued.

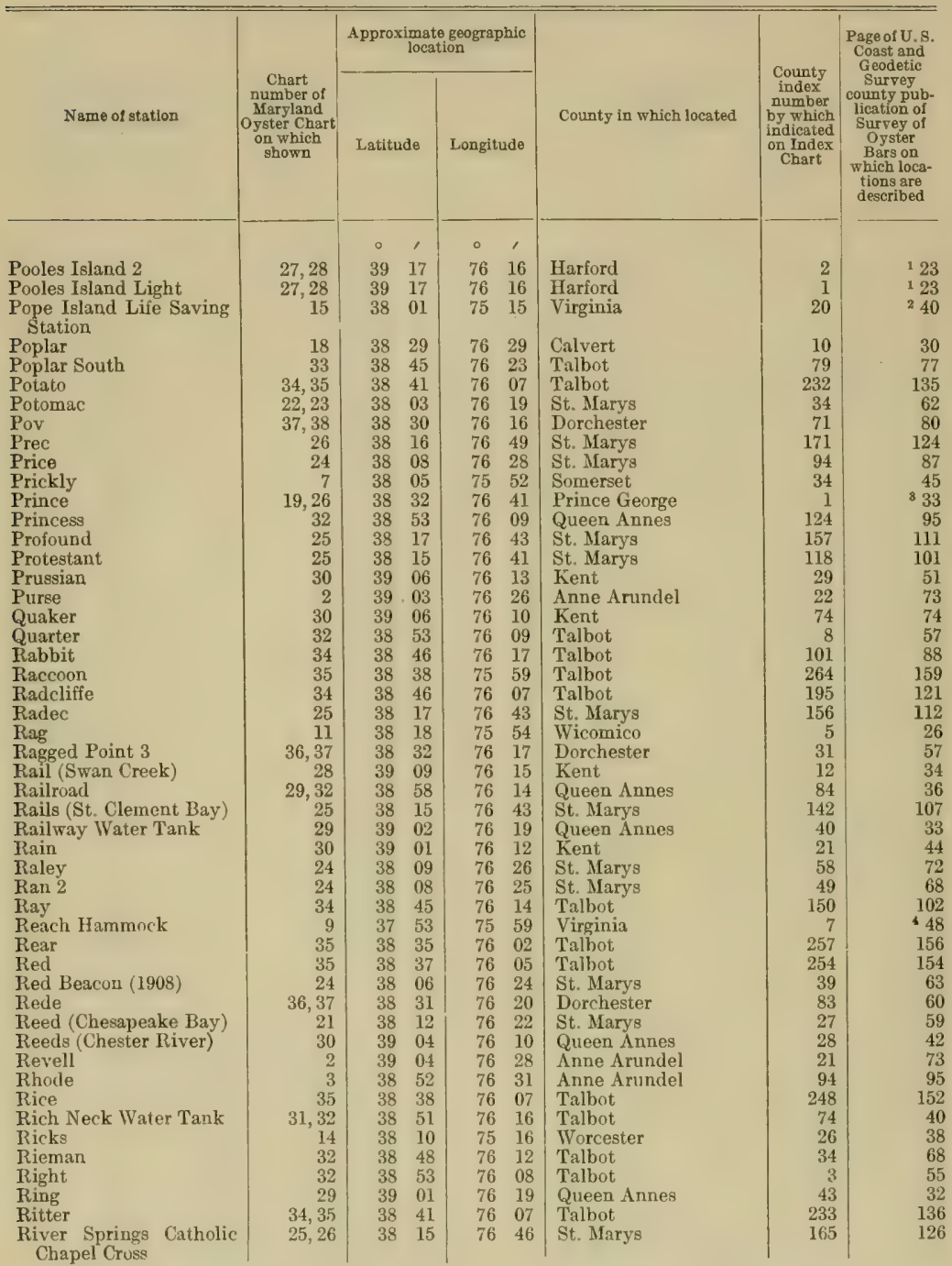


Alphabetical Index to Triangulation Stations-Continued.

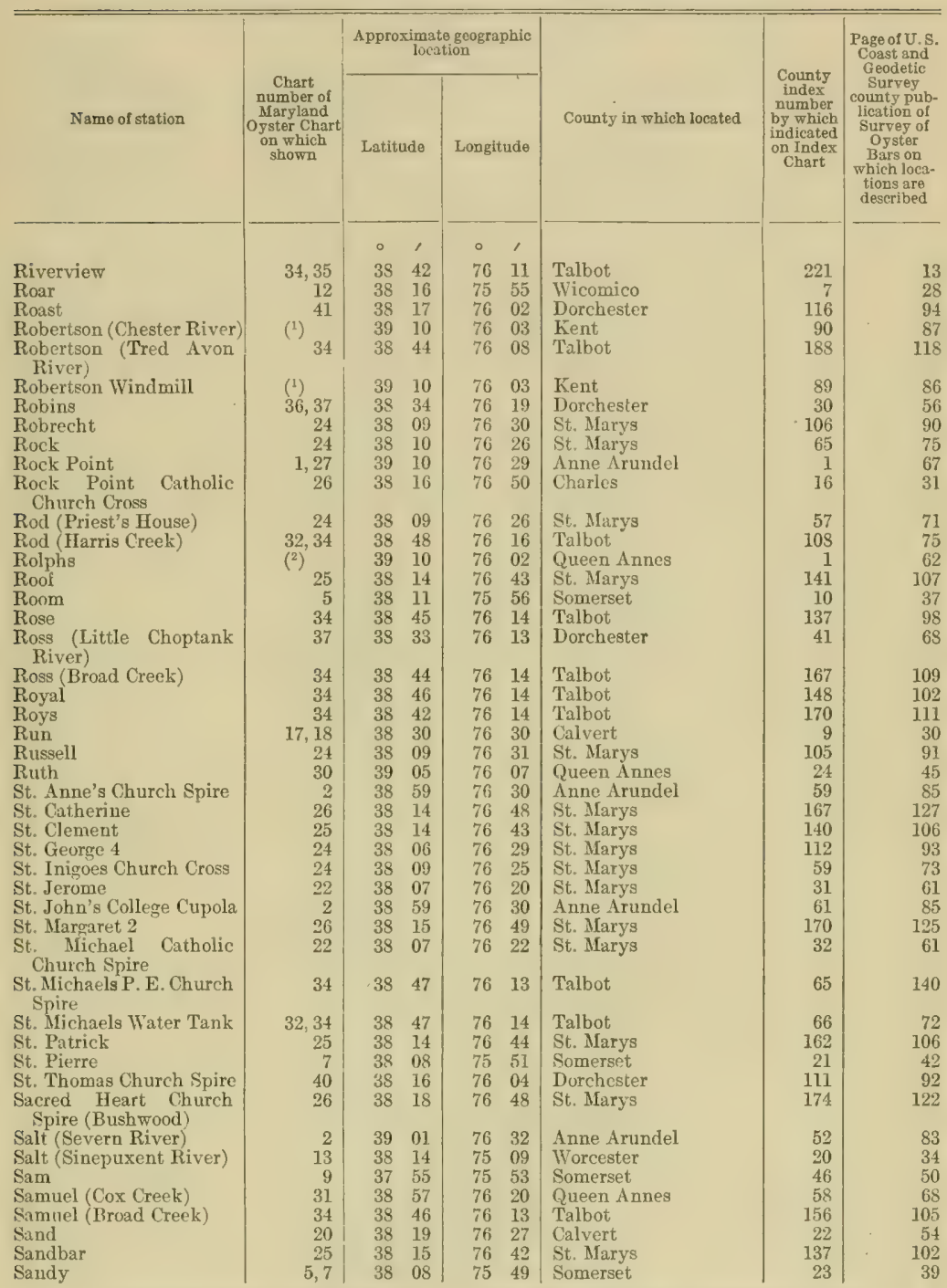


Alphabetical Index to Triangulation Stationg-Continued.

\begin{tabular}{|c|c|c|c|c|c|c|}
\hline \multirow[b]{2}{*}{ Name of station } & \multirow[b]{2}{*}{$\begin{array}{c}\text { Chart } \\
\text { nunaber of } \\
\text { Maryland } \\
\text { Oyster Chart } \\
\text { on which } \\
\text { shown }\end{array}$} & \multicolumn{2}{|c|}{$\begin{array}{c}\text { Approximate geographic } \\
\text { location }\end{array}$} & \multirow[b]{2}{*}{ County in which located } & \multirow[b]{2}{*}{$\begin{array}{l}\text { County } \\
\text { index } \\
\text { number } \\
\text { by which } \\
\text { indicated } \\
\text { on Index } \\
\text { Chart }\end{array}$} & \multirow{2}{*}{$\begin{array}{l}\text { Page of U.S. } \\
\text { Coastand } \\
\text { Geodetic } \\
\text { Survey } \\
\text { county pub- } \\
\text { lication of } \\
\text { Survey of } \\
\text { Oyster } \\
\text { Bars on } \\
\text { which locs- } \\
\text { tions are } \\
\text { described }\end{array}$} \\
\hline & & Latitude & Longitude & & & \\
\hline & & o & , & & & \\
\hline Sandy Point Light & 2 & $\begin{array}{ll}39 & 01\end{array}$ & $76 \quad 23$ & Anne Arundel & 25 & 74 \\
\hline Sang. & 32 & $38 \quad 53$ & $76 \quad 10$ & Queen Annes & 120 & 94 \\
\hline Sanpoi & 13 & $38 \quad 15$ & $\begin{array}{ll}75 & 09\end{array}$ & Worcester & 17 & 33 \\
\hline Sara & 32 & $38 \quad 49$ & $76 \quad 14$ & Talbot & 70 & 73 \\
\hline Saw & 35 & $\begin{array}{ll}38 & 37\end{array}$ & $75 \quad 58$ & Dorchester & 4 & 45 \\
\hline Saxis Church Spire & 10 & $37 \quad 55$ & $75 \quad 43$ & Virginia & 12 & ${ }^{1} 54$ \\
\hline Schoolhouse Cupola & 33 & $\begin{array}{ll}38 & 43\end{array}$ & $\begin{array}{ll}76 & 20\end{array}$ & Talbot & 90 & 81 \\
\hline Scot & 10 & $37 \quad 58$ & $75 \quad 44$ & Somerset & 50 & 52 \\
\hline Search & 34 & $\begin{array}{ll}38 & 47\end{array}$ & $76 \quad 10$ & Talbot & 40 & 142 \\
\hline Seaside & 13. & $38 \quad 18$ & $75 \quad 06$ & Worcester & 9 & 29 \\
\hline Second & 32 & $39 \quad 48$ & $\begin{array}{ll}76 & 12\end{array}$ & Talbot & 27 & 65 \\
\hline Selby & 3 & $38 \quad 55$ & $76 \quad 30$ & Anne Arundel & 85 & 93 \\
\hline Senator & $5,6,7$ & $\begin{array}{ll}38 & 08\end{array}$ & $\begin{array}{ll}76 & 01\end{array}$ & Somerset & 15 & 27 \\
\hline $\begin{array}{l}\text { Seth (Little Choptank } \\
\text { River) }\end{array}$ & 37 & $38 \quad 34$ & $\begin{array}{ll}76 & 11\end{array}$ & Dorchester & 48 & 71 \\
\hline Seth (Miles River) & 32 & $38 \quad 50$ & $\begin{array}{ll}76 & 15\end{array}$ & Talbot & 71 & 74 \\
\hline Seven Foot Knoll Light & 1,27 & $\begin{array}{ll}39 & 09\end{array}$ & $76 \quad 25$ & Anne Arundel & 2 & 68 \\
\hline Shanks Hummock 2 & 8 & $37 \quad 55$ & $\begin{array}{ll}76 & 03\end{array}$ & Virginia & 4 & 147 \\
\hline Sharkfin Shoal Light & 41 & $\begin{array}{ll}38 & 12\end{array}$ & $75 \quad 59$ & Dorchester & 124 & 103 \\
\hline Sharp & 2 & $\begin{array}{ll}39 & 03\end{array}$ & $76 \quad 34$ & Anne Arundel & 46 & 81 \\
\hline Sharps Island Light & 33,36 & $38 \quad 38$ & $76 \quad 23$ & Talbot & 85 & 79 \\
\hline Shaw & 32 & $38 \quad 52$ & $76 \quad 11$ & Talbot & 17 & 60 \\
\hline Shehan & 24 & $\begin{array}{ll}38 & 10\end{array}$ & $\begin{array}{ll}76 & 31\end{array}$ & St. Marys & 101 & 92 \\
\hline Shell (West River). & 3 & 3851 & $76 \quad 32$ & Anne Arundel & 97 & 96 \\
\hline Shell (Choptank River) & 35 & $38 \quad 35$ & $\begin{array}{ll}76 & 00\end{array}$ & Dorchester & 9 & 48 \\
\hline Sheridan & 19 & $38 \quad 28$ & $76 \quad 39$ & Calvert & 41 & 40 \\
\hline Ship & 30 & 3905 & $\begin{array}{ll}76 & 07\end{array}$ & Queen Annes & 21 & 46 \\
\hline Shippen & 30 & $\begin{array}{ll}39 & 07\end{array}$ & $\begin{array}{ll}76 & 06\end{array}$ & Kent & 80 & 79 \\
\hline Shipping & 25 & $\begin{array}{ll}38 & 16\end{array}$ & $76 \quad 43$ & St. Marys & 159 & 109 \\
\hline Shoal & 35 & $38 \quad 34$ & $\begin{array}{ll}76 & 03\end{array}$ & Dorchester & 12 & 49 \\
\hline Shore & 13 & $\begin{array}{ll}38 & 16\end{array}$ & $\begin{array}{ll}75 & 07\end{array}$ & Worcester & 13 & 31 \\
\hline Short & 5 & $\begin{array}{ll}38 & 12\end{array}$ & $75 \quad 53$ & Somerset & 9 & 37 \\
\hline Show & 34,35 & $\begin{array}{ll}38 & 41\end{array}$ & $\begin{array}{ll}76 & 07\end{array}$ & Talbot & 234 & 136 \\
\hline Sig & 22,24 & $\begin{array}{ll}38 & 06\end{array}$ & $\begin{array}{ll}76 & 24\end{array}$ & St, Marys & 38 & 63 \\
\hline Sillery & 1,2 & $\begin{array}{lll}39 & 05 & \end{array}$ & $\begin{array}{ll}76 & 27\end{array}$ & Anne Arundel & 9 & 69 \\
\hline Skid & $36,37,38$ & $38 \quad 30$ & $76 \quad 20$ & Dorchester & 82 & 60 \\
\hline Skinner & 34 & $38 \quad 45$ & $76 \quad 15$ & Talbot & 135 & 97 \\
\hline Sleep & 24 & $\begin{array}{ll}38 & 10\end{array}$ & $\begin{array}{ll}76 & 25\end{array}$ & St. Marys & 64 & 76 \\
\hline Slim & 19 & $38 \quad 25$ & $76 \quad 35$ & Calvert & 37 & 43 \\
\hline Smack & 24 & $\begin{array}{ll}38 & 07\end{array}$ & $76 \quad 28$ & St. Marys & 110 & 86 \\
\hline Smith & 33 & $\begin{array}{ll}38 & 46\end{array}$ & $\begin{array}{ll}76 & 19\end{array}$ & Talbot & 96 & 83 \\
\hline Smith Point Light & 8,23 & $\begin{array}{ll}37 & 53\end{array}$ & $\begin{array}{ll}76 & 11\end{array}$ & Virginia & 3 & ${ }^{2} 63$ \\
\hline Smoke & 24 & $\begin{array}{ll}38 & 10\end{array}$ & $76 \quad 25$ & St. Marys & 62 & 75 \\
\hline Snout & 32 & $\begin{array}{ll}38 & 52\end{array}$ & $\begin{array}{ll}76 & 11\end{array}$ & Queen Annes & 113 & 91 \\
\hline Suub & 30 & 3906 & $\begin{array}{ll}76 & 11\end{array}$ & Kent & 39 & 59 \\
\hline Soak & 24 & $\begin{array}{ll}38 & 12\end{array}$ & $\begin{array}{ll}76 & 28\end{array}$ & St. Marys & 80 & 84 \\
\hline Sollers & 19,20 & $\begin{array}{ll}38 & 23\end{array}$ & $\begin{array}{ll}76 & 30\end{array}$ & Calvert & 31 & 47 \\
\hline Solomon & 37 & $38 \quad 34$ & $76 \quad 12$ & Dorchester & 47 & 70 \\
\hline Solomons Lump Light & 6,7 & $\begin{array}{ll}38 & 03\end{array}$ & $\begin{array}{ll}76 & 01\end{array}$ & Somerset & 17 & 39 \\
\hline Some & 31 & $\begin{array}{ll}38 & 55\end{array}$ & $\begin{array}{ll}76 & 20\end{array}$ & Queen Annes & 52 & 66 \\
\hline Somers Cove Light & 9 & $\begin{array}{ll}37 & 58\end{array}$ & $75 \quad 53$ & Somerset & 42 & 49 \\
\hline Sothoron & 19 & $\begin{array}{ll}38 & 30\end{array}$ & $\begin{array}{ll}76 & 40\end{array}$ & St. Marys & 1 & 37 \\
\hline Sound & 26 & $\begin{array}{ll}38 & 15\end{array}$ & $\begin{array}{ll}76 & 47\end{array}$ & St. Marys & 169 & 126 \\
\hline
\end{tabular}


Alphabetical Index to Triangulation Stations-Continued.

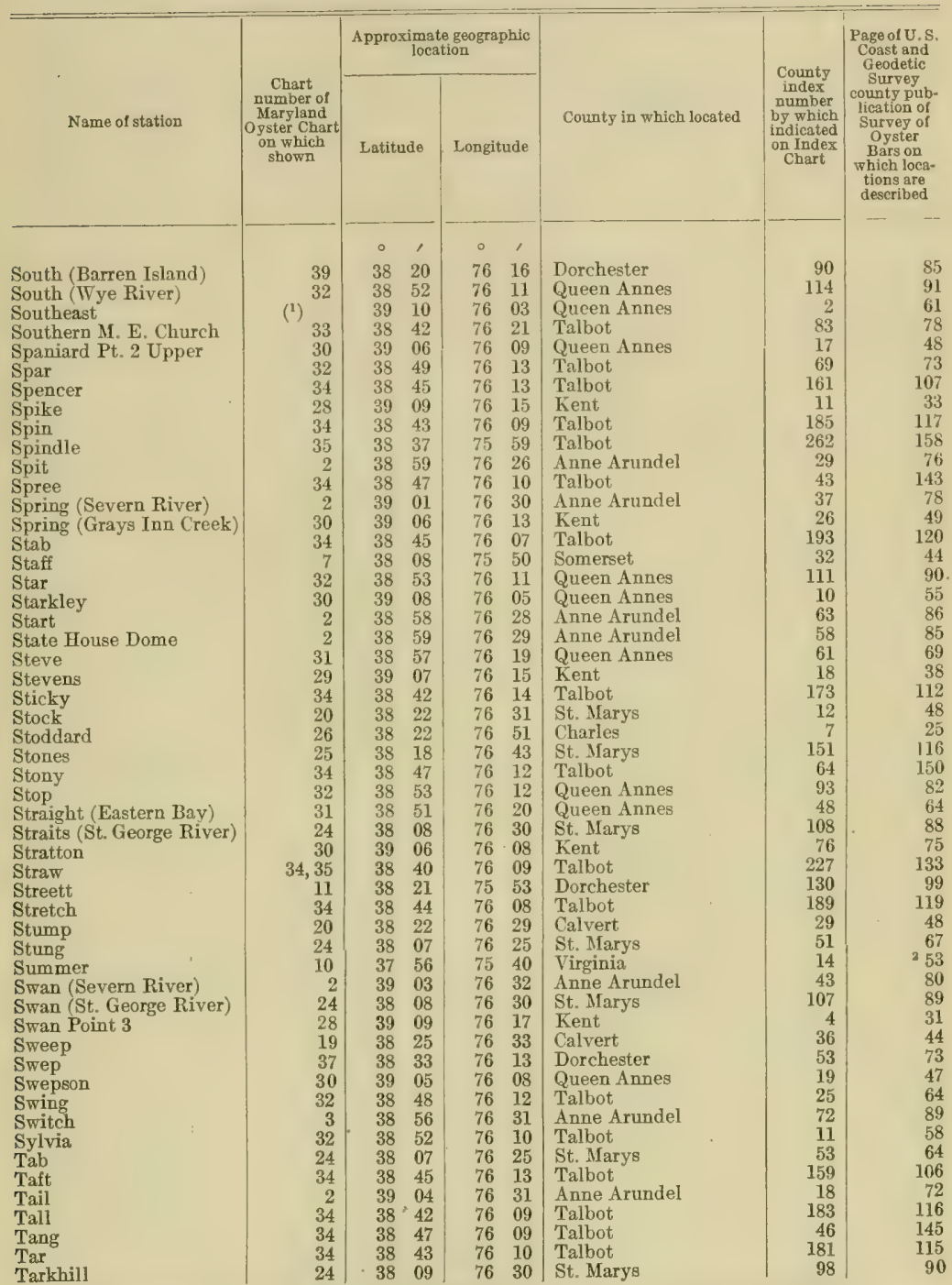

\footnotetext{
1 See progress map in Queen Annes County publication. $\quad 2$ See Somerset County publication.
} 
Azphabetical Index to Triangulation Stations-Continued.

\begin{tabular}{|c|c|c|c|c|c|c|c|c|}
\hline \multirow[b]{2}{*}{ Name of station } & \multirow{2}{*}{$\begin{array}{c}\text { Chart } \\
\text { number of } \\
\text { Maryland } \\
\text { Oyster Chart } \\
\text { on which } \\
\text { shown }\end{array}$} & \multicolumn{4}{|c|}{$\begin{array}{c}\text { Approximate geographic } \\
\text { location }\end{array}$} & \multirow[b]{2}{*}{ County in which located } & \multirow{2}{*}{$\begin{array}{l}\text { County } \\
\text { index } \\
\text { number } \\
\text { by which } \\
\text { indieated } \\
\text { on Index } \\
\text { Chart }\end{array}$} & \multirow{2}{*}{$\begin{array}{l}\text { Page of U. S. } \\
\text { Coast and } \\
\text { Geodetic } \\
\text { Survey } \\
\text { county pub- } \\
\text { lication of } \\
\text { Survey of } \\
\text { Oyster } \\
\text { Bars on } \\
\text { which loca- } \\
\text { tions are } \\
\text { described }\end{array}$} \\
\hline & & \multicolumn{2}{|c|}{ Latitude } & \multicolumn{2}{|c|}{ Longitude } & & & \\
\hline Taste & & $\circ$ & ' & $\circ$ & ' & & & \\
\hline $\begin{array}{l}\text { Taste } \\
\text { Tavern }\end{array}$ & 30 & 39 & 09 & 76 & 05 & Kent & 85 & 84 \\
\hline Taylor (South River) & 28 & 39 & 09 & 76 & 16 & Kent & 6 & 32 \\
\hline Taylor (Slaughter Creek) & $\begin{array}{r}3 \\
38\end{array}$ & $\begin{array}{l}38 \\
38\end{array}$ & $\begin{array}{l}57 \\
28\end{array}$ & 76 & 34 & $\begin{array}{l}\text { Anne Arundel } \\
\text { Dorchester }\end{array}$ & 78 & 91 \\
\hline Taylor (St. George River) & $\begin{array}{l}38 \\
24\end{array}$ & $\begin{array}{l}38 \\
38\end{array}$ & $\begin{array}{l}20 \\
08\end{array}$ & $\begin{array}{l}76 \\
76\end{array}$ & $\begin{array}{l}18 \\
30\end{array}$ & $\begin{array}{l}\text { Dorchester } \\
\text { St. Marys }\end{array}$ & $\begin{array}{l}76 \\
97\end{array}$ & 82 \\
\hline Teague & 26 & 38 & 32 & 76 & 40 & $\begin{array}{l}\text { St. Marys } \\
\text { Charles }\end{array}$ & $\begin{array}{r}97 \\
2\end{array}$ & $\begin{array}{l}89 \\
36\end{array}$ \\
\hline Tenk & 31 & 38 & 50 & 76 & 22 & Queen Annes & 47 & 64 \\
\hline Tenuate & 24 & 38 & 12 & 76 & 27 & St. Marys & 81 & 83 \\
\hline Terrapin & 7 & 38 & 01 & 75 & 58 & Somerset & 18 & 40 \\
\hline Thelma & 34 & 38 & 46 & 76 & 14 & Talbot & 153 & 104 \\
\hline Then & 31 & 38 & 55 & 76 & 20 & Queen Annes & 51 & 65 \\
\hline Thin & 29 & 38 & 59 & 76 & 15 & Queen Annes & 38 & 35 \\
\hline Thomas & 3 & 38 & 54 & 76 & 27 & Anne Arundel & 68 & 88 \\
\hline $\begin{array}{l}\text { Thomas Point Shoal } \\
\text { Light }\end{array}$ & 3 & 38 & 54 & 76 & 26 & Anne Arundel & 69 & 88 \\
\hline Thompson (Cox Creek) & 31 & 38 & 57 & 76 & 19 & Queen Annes & 62 & 69 \\
\hline $\begin{array}{l}\text { Thompson (St. Marys } \\
\text { River) }\end{array}$ & 24 & 38 & 09 & 76 & 28 & St. Marys & 91 & 72 \\
\hline Thorn & 30 & 39 & 07 & 76 & 07 & Kent & 79 & 78 \\
\hline Thoro & 41 & 38 & 20 & 76 & 01 & Dorchester & 119 & 95 \\
\hline Thorofare & $\left({ }^{1}\right)$ & 38 & 21 & 75 & 06 & Worcester & 37 & 24 \\
\hline Thorsten & $\left({ }^{2}\right)$ & 39 & 10 & 76 & 03 & Kent & 91 & 87 \\
\hline Timber & 31 & 38 & 57 & 76 & 18 & Queen Annes & 66 & 71 \\
\hline Tizz & 15 & 38 & 04 & 75 & 20 & Worcester & 32 & 43 \\
\hline Tobacco Stick & 37 & 38 & 32 & 76 & 14 & Dorchester & 69 & 79 \\
\hline Tobe & 34 & 38 & 45 & 76 & 15 & Talbot & 126 & 94 \\
\hline Tobine & 32 & 38 & 53 & 76 & 10 & Queen Annes & 119 & 93 \\
\hline $\begin{array}{l}\text { Toddville M. E. Church } \\
\text { Spire }\end{array}$ & 40 & 38 & 18 & 76 & 04 & Dorchester & 117 & 91 \\
\hline Toe & $\begin{array}{r}34 \\
3\end{array}$ & 38 & 43 & 76 & 08 & Talbot & 206 & 125 \\
\hline $\begin{array}{l}\text { Tom (Little Choptank } \\
\text { River) }\end{array}$ & $\begin{array}{r}3 \\
37\end{array}$ & $\begin{array}{l}38 \\
38\end{array}$ & $\begin{array}{l}57 \\
32\end{array}$ & $\begin{array}{l}76 \\
76\end{array}$ & $\begin{array}{l}27 \\
12\end{array}$ & $\begin{array}{l}\text { Anne Arun } \\
\text { Dorchester }\end{array}$ & $\begin{array}{l}65 \\
62\end{array}$ & $\begin{array}{l}86 \\
76\end{array}$ \\
\hline Tom (Cox Creek) & 31 & 38 & 56 & 76 & 19 & Queen Annes & 69 & 72 \\
\hline Tomakokin & 25 & 38 & 18 & 76 & 44 & St. Marys & 154 & 114 \\
\hline Ton & 20 & 38 & 21 & 76 & 28 & Calvert & 27 & 50 \\
\hline Toot & 35 & 38 & 36 & 76 & 08 & Dorchester & 21 & 52 \\
\hline Top & 31 & 38 & 55 & 76 & 19 & Queen Annes & 54 & 67 \\
\hline Torrey & $36,37,38$ & 38 & 30 & 76 & 16 & Dorchester & 72 & 57 \\
\hline $\begin{array}{l}\text { Town (Little Choptank } \\
\text { River) }\end{array}$ & 37 & 38 & 33 & 76 & 13 & Dorchester & 52 & 72 \\
\hline Town (Patuxent River) & 20 & 38 & 19 & 76 & 29 & St. Marys & 17 & 52 \\
\hline Town (Tred Avon River) & 34 & 38 & 42 & 76 & 10 & Talbot & 220 & 131 \\
\hline Trappe & 35 & 38 & 38 & 76 & 07 & Talbot & 246 & 151 \\
\hline Travers 2 & 38 & 38 & 28 & 76 & 20 & Dorchester & 85 & 83 \\
\hline Tray & 30 & 39 & 06 & 76 & 12 & Kent & 36 & 53 \\
\hline Treasure & 28,29 & 39 & 09 & 76 & 15 & Kent & 14 & 36 \\
\hline Tred & 34 & 38 & 42 & 76 & 11 & Talbot & 179 & 115 \\
\hline Trees & 25 & 38 & 16 & 76 & 39 & St. Marys & 133 & 98 \\
\hline Trent & 19 & 38 & 29 & 76 & 40 & St. Marys & 3 & 39 \\
\hline Trippe & 34 & 38 & 43 & 76 & 08 & Talbot & 207 & 125 \\
\hline Tug & 34 & 38 & 47 & 76 & 10 & Talbot & 41 & 142 \\
\hline Tuli & 31 & 38 & 56 & 76 & 17 & Queen Anne & 74 & 74 \\
\hline
\end{tabular}


Alphabetical Index to Triangulation Stations-Continued.

\begin{tabular}{|c|c|c|c|c|c|c|c|c|}
\hline \multirow[b]{2}{*}{ Name of station } & \multirow{2}{*}{$\begin{array}{c}\text { Chart } \\
\text { number of } \\
\text { Margland } \\
\text { Oyster Chart } \\
\text { on which } \\
\text { shown }\end{array}$} & \multicolumn{4}{|c|}{$\begin{array}{l}\text { Approximate geographic } \\
\text { location }\end{array}$} & \multirow[b]{2}{*}{ County in which located } & \multirow{2}{*}{$\begin{array}{c}\text { County } \\
\text { index } \\
\text { number } \\
\text { by which } \\
\text { indicated } \\
\text { on Index } \\
\text { Chart }\end{array}$} & \multirow{2}{*}{$\begin{array}{l}\text { Page of U.S } \\
\text { Coast and } \\
\text { Geodetic } \\
\text { Survey } \\
\text { county pub } \\
\text { lication of } \\
\text { Survey of } \\
\text { Oyster } \\
\text { Bars on } \\
\text { which loca- } \\
\text { tions are } \\
\text { described }\end{array}$} \\
\hline & & \multicolumn{2}{|c|}{ Latitude } & \multicolumn{2}{|c|}{ Longitude } & & & \\
\hline & & $\circ$ & , & $\circ$ & , & & & \\
\hline Turf (Rhode River) & 3 & 38 & 53 & 76 & 31 & Anne Arundel & 92 & \\
\hline Turf (St. Clement Bay) & 25 & 38 & 18 & 76 & 43 & St. Marys & 152 & 115 \\
\hline Turkey & 31 & 38 & 54 & 76 & 18 & Queen Annes & 71 & 7 \\
\hline Turn & 32 & 38 & 53 & 76 & 10 & Queen Annes & 121 & 9 \\
\hline Turnagain & 14,15 & 38 & 05 & 75 & 13 & Worcester & 30 & 3 \\
\hline Tuxon & 31 & 38 & 57 & 76 & 19 & Queen Aunes & 60 & 6 \\
\hline Twin & 34 & 38 & 43 & 76 & 08 & Talbot & 205 & 12 \\
\hline Twist & 32 & 38 & 53 & 76 & 10 & Queen Annes & 107 & 8 \\
\hline Twixt & 32 & 38 & 53 & 76 & 11 & Queen Annes & 110 & 9 \\
\hline Two & 32 & 38 & 49 & 76 & 11 & Talbot & 30 & 66 \\
\hline $\mathrm{Up}$ & 35 & 38 & 39 & 75 & 58 & Talbot & 266 & 159 \\
\hline Upper & 26 & 38 & 22 & 76 & 52 & Charles & 6 & 24 \\
\hline Urie & 28 & 39 & 09 & 76 & 15 & Kent & 9 & 3 \\
\hline Valley & 25 & 38 & 17 & 76 & 38 & St. Marys & 126 & 9 \\
\hline Valliant & 33 & 38 & 46 & 76 & 23 & Talbot & 78 & 7 \\
\hline Veith & $36,37,38$ & 38 & 30 & 76 & 17 & Dorchester & 80 & 5 \\
\hline Venture & 34 & 38 & 43 & 76 & 07 & Talbot & 208 & 126 \\
\hline Venus & 34 & 38 & 46 & 76 & 15 & Talbot & 146 & 101 \\
\hline Villa (Miles River) & 32 & 38 & 48 & 76 & 07 & Talbot & 51 & 7 \\
\hline Ville (Cox Creek) & 31 & 38 & 57 & 76 & 18 & Queen Annes & 67 & 7 \\
\hline Vine & 33,34 & 38 & 46 & 76 & 18 & Talbot & 98 & 8 \\
\hline Vue & 34 & 38 & 42 & 76 & 13 & Talbot & 174 & 113 \\
\hline Wab & (1) & 38 & 09 & 75 & 47 & Somerset & 26 & 4 \\
\hline Waggaman & 3 & 38 & 57 & 76 & 32 & Anne Arundel & 74 & 8 \\
\hline Waggaman IVindmill & 3 & 38 & 57 & 76 & 32 & Anne Arundel & 73 & 8 \\
\hline Wall (St. George River) & 24 & 38 & 09 & 76 & 31 & St. Marys & 104 & 92 \\
\hline Wall (Tred Avon River) & 34 & $3 S$ & 44 & 76 & 07 & Talbot & 201 & 123 \\
\hline Walnut & 5 & 38 & 15 & 75 & 48 & Somerset & 1 & 3 \\
\hline Wann & 30 & 39 & 08 & 76 & 09 & Kent & $6 \hat{8}$ & 7 \\
\hline Wap & 33 & 38 & 42 & 76 & 21 & Talbot & 82 & 78 \\
\hline War & 35 & 38 & 36 & 75 & 58 & Dorchester & 6 & 4 \\
\hline Ware & 31 & 38 & 56 & 76 & 19 & Queen Annes & 55 & 67 \\
\hline Warrior & 33 & 38 & 45 & 76 & 18 & Talbot & 118 & 85 \\
\hline IVash & 29,31 & 38 & 58 & 76 & 21 & Queen Annes & 44. & 275 \\
\hline Water & 34 & 38 & 45 & 76 & 07 & Talbot & 194 & 120 \\
\hline Water Tower (Porto Bello) & 24 & 38 & 11 & 76 & 27 & St. Marys & 87 & 78 \\
\hline Waterloo & 26 & 38 & 14 & 76 & 47 & St. Marys & 166 & 127 \\
\hline Watermelon Hummock & 9 & 37 & 57 & 75 & 50 & Somerset & 47 & 51 \\
\hline Weather Bureau Staff & 34,35 & 38 & 41 & 76 & 10 & Talbot & 222 & 131 \\
\hline Weave & 34 & 38 & 43 & 76 & .09 & Talbot & 204 & 124 \\
\hline Weeks & 30 & 39 & 05 & 76 & 12 & Kent & 25 & 49 \\
\hline Weems & 2 & 39 & 00 & 76 & 30 & Anne Arundel & 54 & 84 \\
\hline Weiss & 26 & 38 & 17 & 76 & 49 & St. Marys & 173 & 123 \\
\hline Welch & 2 & 39 & 04 & 76 & 26 & Anne Arundel & 7 & 70 \\
\hline West & 30 & 39 & 08 & 76 & 10 & Kent & 52 & 64 \\
\hline IVest Hollow & 24 & 38 & 12 & 76 & 27 & St. Marys & 83 & 82 \\
\hline Westcotts Windmill & 30 & 39 & 07 & 76 & 07 & Kent & 77 & 76 \\
\hline Whale (Langford Creek) & 30 & 39 & 09 & 76 & 11 & Kent & 47 & 63 \\
\hline Whale (Wye River) & 32 & 38 & 53 & 76 & 08 & Talbot & 5 & 56 \\
\hline Wharf (Saxis Pier) & 10 & 37 & 56 & 75 & 44 & Virginia & 11 & ${ }^{8} 54$ \\
\hline What & 25 & 38 & 15 & 76 & 40 & St. Marys & 119 & 100 \\
\hline
\end{tabular}

1 See progress map in Bomerset County publication. 2 See Anne Arundel County publication.

a See Somerset County publication. 
Alphabetical Index to Triangulation Stations-Continued.

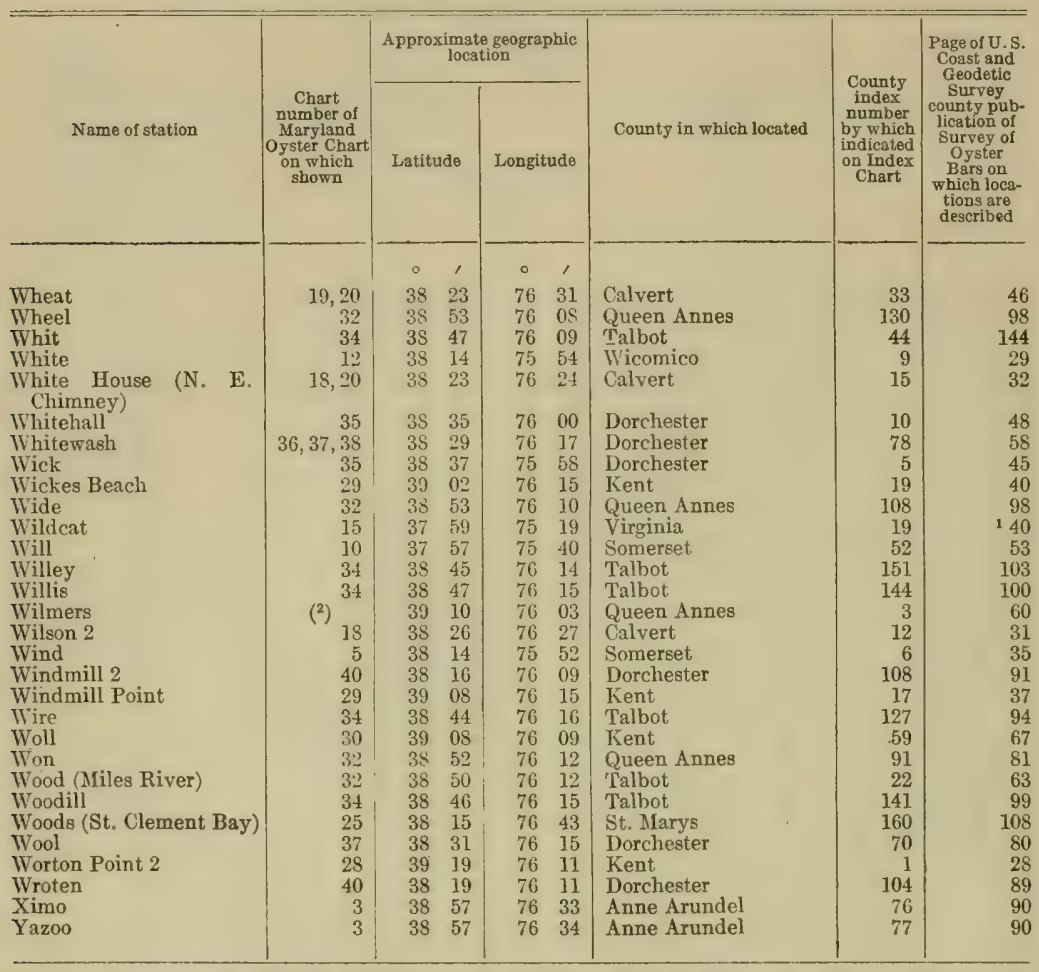




\section{LANDMARKS}

\section{U. S. COAST AND GEODETIC SURVEY TRIANGULATION STATIONS.}

NUMERICAL INDEX.

Nort -See Alphabetical Index for other references relating to triangulation stations.

ANNE ARUNDEL COUNTY.

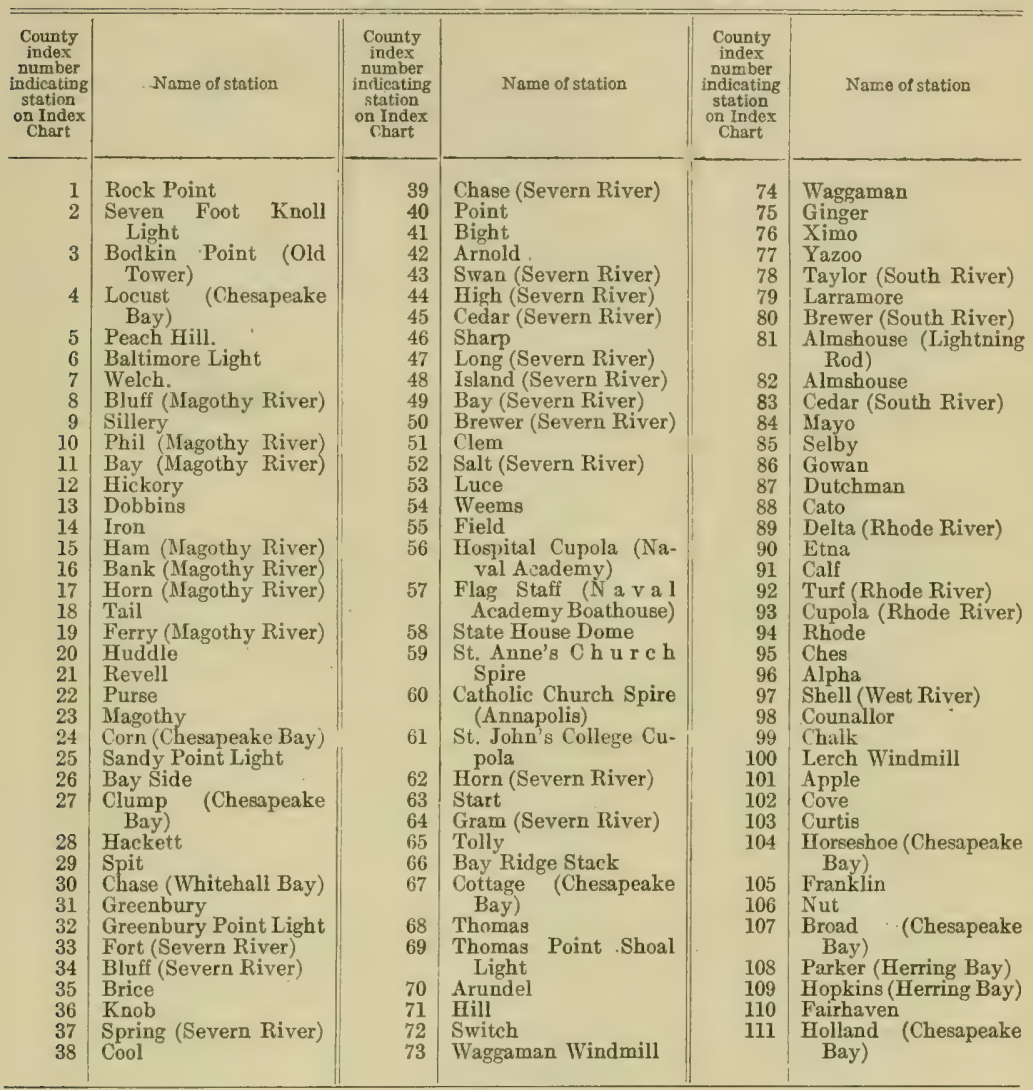

BALTIMORE COUNTY.

1 Craighill $\mathrm{Ch}$ an $\mathrm{n}$ e 1 Light (Rear Range)

2 Craighill $\mathrm{Ch}$ a $\mathrm{n} \mathrm{n} \mathrm{e}$ Light (Front Range)
3 North Point (Old Tower Foundation)

4 Cutoff Channel Light (Front Range)
5 Fort Howard Taller Water Tank

6 Cutoff Channel Light (Rear Range) 
Numerical Index to Triangulation Stationg-Continued.

CALVERT COUNTY.

\begin{tabular}{|c|c|c|c|c|c|}
\hline $\begin{array}{c}\text { County } \\
\text { index } \\
\text { number } \\
\text { indicating } \\
\text { station } \\
\text { on Index } \\
\text { Chart }\end{array}$ & Name of station & $\begin{array}{l}\text { County } \\
\text { index } \\
\text { number } \\
\text { indicating } \\
\text { station } \\
\text { on Index } \\
\text { Chart }\end{array}$ & Name of station & $\begin{array}{l}\text { County } \\
\text { index } \\
\text { number } \\
\text { indicating } \\
\text { station } \\
\text { on Index } \\
\text { Cbart }\end{array}$ & Name of station \\
\hline $\begin{array}{r}1 \\
2 \\
3 \\
4 \\
5 \\
6 \\
7 \\
8 \\
9 \\
10 \\
11 \\
12 \\
13 \\
14 \\
15\end{array}$ & $\begin{array}{l}\text { Hog Point (Holland 3) } \\
\text { Beach (C h e s apeake } \\
\text { Bay) } \\
\text { Ill } 2 \\
\text { Plum } 3 \\
\text { Pier (Chesapeake Bay) } \\
\text { Pen (Chesapeake Bay) } \\
\text { Patch } \\
\text { Parker (Chesapeake } \\
\text { Bay) } \\
\text { Run } \\
\text { Poplar } \\
\text { Flag Pond } \\
\text { Wilson } 2 \\
\text { Point of Rocks } \\
\text { Cove Point Light } \\
\text { White House (N. E. } \\
\text { Chimney) }\end{array}$ & $\begin{array}{r}16 \\
17 \\
18 \\
19 \\
-\quad 20 \\
21 \\
\\
22 \\
23\end{array}$ & $\begin{array}{l}\text { Pat } \\
\text { Drum Point Light } \\
\text { Bareda House Cupola } \\
\text { Bon } \\
\text { Fishstack .. } \\
\text { K. of P. Flagstaff (Solo- } \\
\text { mons) } \\
\text { Sand } \\
\text { M. E. Church (Solo- } \\
\text { mons) } \\
\text { Catholic Church Cross } \\
\text { New } \\
\text { Bur } \\
\text { Ton } \\
\text { Hellen } \\
\text { Stump } \\
\text { Lend } \\
\text { Sollers }\end{array}$ & $\begin{array}{l}36 \\
37 \\
38 \\
39 \\
40 \\
41 \\
42 \\
43 \\
44 \\
45 \\
46 \\
47\end{array}$ & $\begin{array}{l}\text { Mackall } \\
\text { Wheat } \\
\text { Peak } \\
\text { Island (P a t u x e } t \\
\quad \text { River) } \\
\text { Sweep } \\
\text { Slim } \\
\text { Photo } \\
\text { Battle } \\
\text { Kitt (Patuxent River) } \\
\text { Sheridan } \\
\text { Morsel } \\
\text { Buzz } \\
\text { Dwarf } \\
\text { Hallowing } \\
\text { Buena } \\
\text { Leitch }\end{array}$ \\
\hline
\end{tabular}

CHARLES COUNTY.

\begin{tabular}{|c|c|c|c|c|c|}
\hline 1 & Fodder & 7 & Stoddard & 14 & (Wicomico \\
\hline 3 & City & 9 & Burr & 15 & Hard \\
\hline 5 & $\begin{array}{l}\text { Indian (P a t u x e } \mathrm{nt} \\
\text { River) }\end{array}$ & $\begin{array}{l}12 \\
13\end{array}$ & $\begin{array}{l}\text { Gust } \\
\text { Hedney }\end{array}$ & 17 & $\begin{array}{l}\text { Corn e r (IVicomico } \\
\text { River) }\end{array}$ \\
\hline
\end{tabular}

DORCHESTER COUNTY.

\begin{tabular}{|c|c|c|c|c|c|}
\hline 1 & M yrtle (Choptank & 19 & Dicks Water Tank & 40 & Greenwell \\
\hline & River) & 20 & Howard (Choptank & 41 & Ross (Little Choptank \\
\hline 2 & Hut & 21 & River) & 40 & River) \\
\hline 4 & Saw & $\begin{array}{l}21 \\
22\end{array}$ & Le Compte & 42 & $\begin{array}{l}\text { Ril (litte Cnoptank } \\
\text { River) }\end{array}$ \\
\hline 5 & Wick & 23 & Large Water Tank & 43 & Dupont \\
\hline 6 & War & 24 & Castle & 44 & Beckwith \\
\hline 7 & Gander & 25 & Corn er (Choptank & 45 & Cherry Island Water \\
\hline 8 & Chief & & River) & & Tank \\
\hline 9 & She 11 (Choptank & 26 & Dot & 46 & Lee \\
\hline & River) & 27 & Chef & 47 & Solomon \\
\hline 10 & Whitehall & 28 & Cook Point Windmill & 48 & Seth (Little Choptank \\
\hline 11 & F e r y (Choptank & 29 & Brannock & & River) \\
\hline & River) & 30 & Robins & 49 & Adam \\
\hline 12 & Shoal & 31 & Ragged Point 3 & 50 & Layton \\
\hline 13 & E. Cambridge Spire & 32 & Hudson & 51 & David \\
\hline 14 & $\begin{array}{l}\text { E. Cambridge Tall } \\
\text { Stack }\end{array}$ & 33 & $\begin{array}{l}\text { Jenifer } \\
\text { Henry }\end{array}$ & 52 & $\begin{array}{l}\text { Town (Little Choptank } \\
\text { River) }\end{array}$ \\
\hline 15 & Cambridge Stand Pipe & 35 & Mitchell & 53 & Swep \\
\hline 16 & Cambridge & 36 & Back & 54 & Hugh \\
\hline 17 & Hambrooks Bar Bea- & 37 & Bayly & 55 & Etta \\
\hline & con & 38 & Carrie & 56 & Mary \\
\hline 18 & Command & 39 & Loulse & 57 & Neil \\
\hline
\end{tabular}


LANDMIARKS.

Numerical Index to Triangulation Stations-Continued.

DORCHESTER COUNTY-Continued.

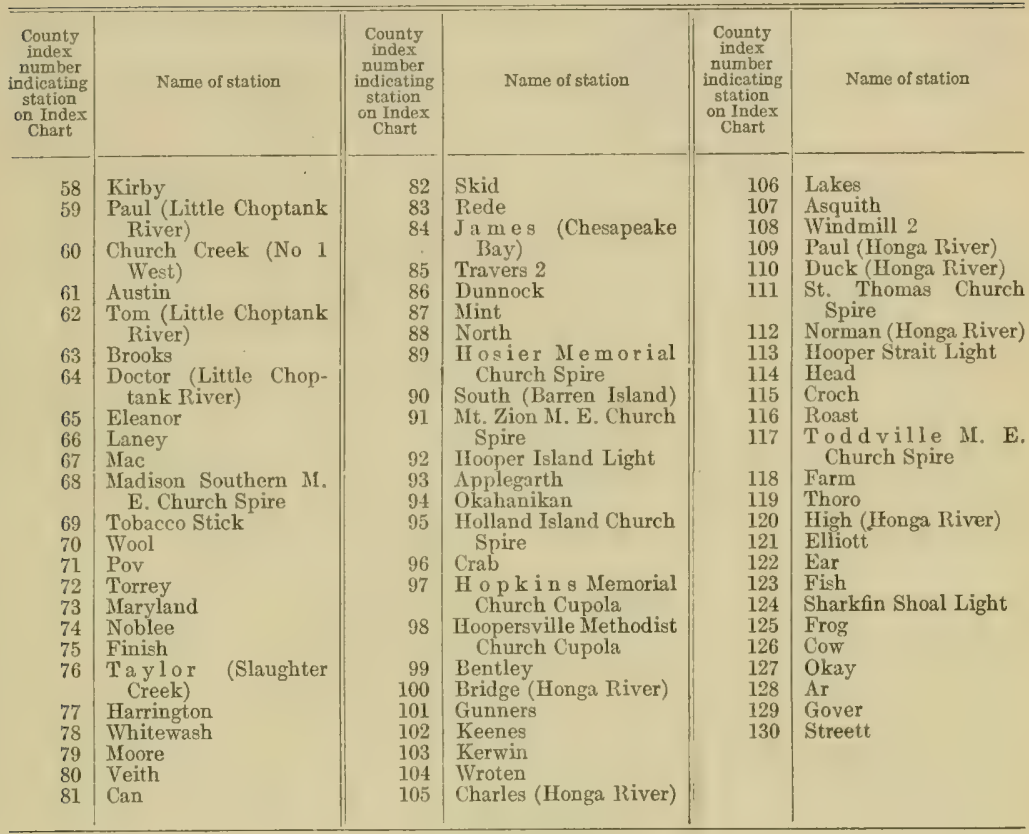

HARFORD COUNTY.

\begin{tabular}{r|r|l|l|}
\hline Pooles Island Light & 2 & Pooles Island 2 & ! \\
\hline
\end{tabular}

KENT COUNTY.

1 Torton Point 2

2 Bramble

3 Mitchells Bluff 2

4 Swan Point 3

5 Bank (Swan Creek)

6 Tavern

7 Fork

8 Elliason

9 Urie

10 Corr

11 Spike

12 Rail (Swan Creek)

13 Haven

14 Treasure

15 Orchard

16 Gratitude
17 Windmill Point

18 Stevens

19 Wickes Beach

20 Narrows Point

21 Rain

22 Overton

23 Bay Bush Point

24 Little Gum

25 Weeks

26 Spring (Grays Inn 27 Creek)

28 Goose (Grays Inn

29 Prussian

30 Gray

\begin{tabular}{l|ll}
31 & Herring \\
32 & No Road \\
33 & Cut \\
34 & Fore \\
35 & Island (Grays Inn \\
& \multicolumn{2}{|c}{ Creek) } \\
36 & Tray \\
37 & Inn \\
38 & Deep Cove \\
39 & Snub \\
40 & Lawyer \\
41 & Drum (Langford Creek) \\
42 & Davis \\
43 & Isle \\
44 & Eagle (Langford Creek) \\
45 & Ford (Langford Creek)
\end{tabular}


Numerical Index to Triangulation Stationg-Continued.

KENT COUNTY-Continued.

\begin{tabular}{|c|c|c|c|c|c|}
\hline $\begin{array}{c}\text { County } \\
\text { index } \\
\text { number } \\
\text { indicating } \\
\text { station } \\
\text { on Index } \\
\text { Chart }\end{array}$ & Name of station & $\begin{array}{l}\text { County } \\
\text { index } \\
\text { number } \\
\text { indicating } \\
\text { station } \\
\text { on Index } \\
\text { Chart }\end{array}$ & Name of station & $\begin{array}{l}\text { County } \\
\text { index } \\
\text { number } \\
\text { indicating } \\
\text { station } \\
\text { on Index } \\
\text { Chart }\end{array}$ & Name of station \\
\hline 46 & Kinsley & 61 & Clay & 77 & Westcotts Windmill \\
\hline 47 & $\begin{array}{l}\text { Whale (Langford } \\
\text { Creek) }\end{array}$ & $\begin{array}{l}62 \\
63\end{array}$ & $\begin{array}{l}\text { Lovely } \\
\text { Gut }\end{array}$ & $\begin{array}{l}78 \\
79\end{array}$ & $\begin{array}{l}\text { Deep Point } 2 . \\
\text { Thorn. }\end{array}$ \\
\hline 48 & Bungay & 64 & Philip (Lang ford & 80 & Shippen \\
\hline 49 & Locust ( L angford & 65 & (reek) & 81 & Oyster (Chester River) \\
\hline 50 & Nat (Langiord Creek) & 66 & Hoo & $\begin{array}{l}83 \\
83\end{array}$ & Melton \\
\hline 51 & Mill (Langford Creek) & 67 & Cult & 84 & Pomona \\
\hline 52 & West & 68 & Wann & 85 & Taste \\
\hline 53 & Hornor & 69 & Corm (Langford Creek) & 86 & Make \\
\hline 54 & King & 70 & Neck (Langford Creek) & 87 & Broad (Chester River) \\
\hline 55 & $\mathrm{Ash}$ & 71 & Major & 88 & Nils \\
\hline 56 & Noth & 72 & Peach & 89 & Robertson Windmill \\
\hline 57 & Leary & 73 & Langford & 90 & Robertson (Chester \\
\hline 58 & Nest & 74 & Quaker & & River) \\
\hline 59 & Woll & 75 & Brown & 91 & Thorsten \\
\hline 60 & Harp & 76 & Stratton & 92 & Blank \\
\hline
\end{tabular}

PRINCE GEORGE COUNTY.

QUEEN ANNES COUNTY.

Rolphs
Southeast
Wilmers
Julius
Down
Bill
Cake
Journey
Booker
Starkley
Burns
Ashland
Indian (Chester River)
Corpse
Chester (C h e s t e r
River)
Evans
Spaniard Pt. (2 Upper)
Corsica
Swepson
Engineer
Ship
Bath
Melfield
Ruth
Hydrographic
Earle (Corsica River)
Holton Point
Reeds (Chester River)
Grove (Reeds Creek)

\begin{tabular}{|l} 
Crow \\
Bird \\
Gordon \\
Fir. \\
Break \\
Blakeford \\
Bluebeard \\
Muddy \\
Thin \\
Macum \\
Railway Water Tank \\
Amour \\
Love Point Light \\
Ring \\
Wash \\
Craney \\
Bloody Point Bar \\
Light \\
Tenk \\
Straight (Eastern Bay) \\
Mouth \\
Matta \\
Then \\
Some \\
Batts \\
Top \\
Ware \\
Coffee \\
Here \\
Samuel (Cox Creek)
\end{tabular}

Liver
Tuxon
Steve
Thompson (Cox Creek)
Hope
Knock
Landing
Timber
Ville (Cox Creek)
Greek
Tom (Cox Creek)
Dell
Turkey
Needle
Cox (Crab Alley Bay)
Tull
Over
Norman (Eastern Bay)
Parsons
Parsons Island Water
Tank
Alley
New Barn Cupola
Dull
Kirwan
Bridge (Kent Island
Narrows)
Railroad
Marshy
Bonnet


Numerical Index to Triangulation Stationg-Continued.

QUEEN ANNES COUNTY-Continued.

\begin{tabular}{|c|c|c|c|c|c|}
\hline $\begin{array}{c}\text { County } \\
\text { index } \\
\text { nuzaber } \\
\text { indicating } \\
\text { station } \\
\text { on Index } \\
\text { Chart }\end{array}$ & Name of station & $\begin{array}{c}\text { County } \\
\text { index } \\
\text { number } \\
\text { indicating } \\
\text { station } \\
\text { on Index } \\
\text { Chart }\end{array}$ & Name of station & $\begin{array}{l}\text { County } \\
\text { index } \\
\text { number } \\
\text { indicating } \\
\text { station } \\
\text { on Index } \\
\text { Chart }\end{array}$ & Name of station \\
\hline
\end{tabular}

ST. MARYS COUNTY.

\begin{tabular}{|l|} 
Sothoron \\
Billiard \\
Trent \\
Collins \\
Cremona \\
Oppkit \\
Fight \\
Forr \\
Cole \\
Hutchins \\
Bars \\
Stock \\
Briscoe \\
Nat (Patuxent River) \\
Mill (Patuxent River) \\
Cable \\
Town (Patuxent Riv- \\
er) \\
Crane \\
Ben \\
Craddock \\
Carroll 2 \\
Hog 2 \\
Cedar Point Light \\
Cain \\
Desert \\
Ford (Chesapeake Bay) \\
Reed(Chesapeake Bay) \\
Point Agin \\
Point No Point \\
Point No Point Light \\
St. Jerome \\
St. Michael Catholic \\
Church Spire \\
Point Look-in \\
Potomac \\
Point Lookout Light \\
Hall (Potomac River)
\end{tabular}

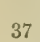

38

39

40

41

42

43

44

45

460

47 Jutland

48 Flagpole

49 Ran 2

50 Flat (Smith Creek)

51 Stung

52 Oak

$53 \mathrm{Tab}$

54 Day

55 Between

56 Fort (St, Marys River)

57 Rod (Priest's House)

58 Raley

59

Cross

61 Grason

62 Smoke

63 Chestnut

64 Sleep

65 Rock

66 Dusky

67 Cottage (St. Inigoes Creek)

68 Inigoes

69 Kennedy

70 Chan

71 Gravel
Brome

Calvert Monument

74 Episcopal Church Cross (Old St. Marys)

75 Bend

76 Horseshoe (St. Marys River)

77 Martin (St. Marys River)

78 Hammett

79 McCoy

80 Soak

81 Tenuate

82 Brief

83 IVest Hollow

84 Pagan

85 Deep

86 Mckay

87 Water Tower (Porto

8 Bello)

89 Coppag

90 Grind

91 Thompson (St. Marys

River

93 Cherry

94 Price

95 Goose (St. George River)

96 Combs (Honga River)

97 Taylor (St. George River)

98 Tarkhill

99 Arbuckle

100 Lowell

101 Shehan

102 Chadwick 
Numerical Index to Triangulation Stationg-Continued.

ST. MARYS COUNTY-Continued.

\begin{tabular}{|c|c|c|c|c|c|}
\hline $\begin{array}{l}\text { County } \\
\text { index } \\
\text { number } \\
\text { indicating } \\
\text { station } \\
\text { on Index } \\
\text { Chart }\end{array}$ & Name of station & \begin{tabular}{|c|} 
County \\
index \\
number \\
indicating \\
station \\
on Index \\
Chart
\end{tabular} & Name of station & $\begin{array}{c}\text { County } \\
\text { index } \\
\text { number } \\
\text { indicating } \\
\text { station } \\
\text { on Index } \\
\text { Chart }\end{array}$ & Name of station \\
\hline 103 & Guither & 131 & Healey (Bretons Bay) & 157 & Profound \\
\hline 104 & $\begin{array}{l}\text { Wall (St. George Riv- } \\
\text { er) }\end{array}$ & $\begin{array}{l}132 \\
133\end{array}$ & $\begin{array}{l}\text { Hollow } \\
\text { Trees }\end{array}$ & $\begin{array}{l}158 \\
159\end{array}$ & $\begin{array}{l}\text { Mileys } \\
\text { Shipping }\end{array}$ \\
\hline 105 & Russell & 134 & Paw & 160 & Woods (St. Clement \\
\hline $\begin{array}{l}106 \\
107\end{array}$ & $\begin{array}{l}\text { Robrecht } \\
\text { Swan (St. George }\end{array}$ & $\begin{array}{l}135 \\
136\end{array}$ & $\begin{array}{l}\text { Cherry Cove } \\
\text { Compton }\end{array}$ & 161 & $\begin{array}{l}\text { Bay) } \\
\text { Canoe }\end{array}$ \\
\hline & River) & $\begin{array}{l}130 \\
137\end{array}$ & Sandbar & 162 & St. Patrick \\
\hline 108 & $\underset{\text { River) }}{\text { Straits }}$ (St. George & $\begin{array}{l}138 \\
139\end{array}$ & $\begin{array}{l}\text { Newtown } \\
\text { Kaywood }\end{array}$ & 163 & $\begin{array}{l}\text { Blakistone I s l a n d } \\
\text { Light }\end{array}$ \\
\hline 109 & Adams & 140 & St. Clement & 164 & Heron \\
\hline 110 & Smack & 141 & Roof & 165 & River Springs Catholic \\
\hline 111 & Labor & 142 & $\mathrm{R}$ a i l s (St. Clement & & Chapel Cross \\
\hline 112 & St. George 4 & & Bay) & 166 & Waterloo \\
\hline 113 & Piney Point Light & 143 & Catholic Church Cross & 167 & St. Catherine \\
\hline 114 & Cedoak & & (Newtown Neck) & 168 & Bailey \\
\hline 115 & Grove (Bretons Bay) & 144 & Chapel & 169 & Sound \\
\hline 116 & Dune & 145 & Mansion & 170 & St. Margaret 2 \\
\hline 117 & Fence & 146 & Howards (St. Clement & 171 & Prec \\
\hline 118 & Protestant & & Bay) & 172 & Blakistone \\
\hline 119 & What & 147 & Bank (St. Clement & 173 & Weiss \\
\hline 120 & Lovers & & Bay) & 174 & Sacred Heart Church \\
\hline 121 & Beau & 148 & Cecil & & Spire (Bushwood) \\
\hline 122 & Mouldy & 149 & Place & 175 & Lyon \\
\hline 123 & Pine (Bretons Bay) & 150 & Guest & 176 & Farr \\
\hline 124 & Cedar (Bretons Bay) & 151 & Stones & 177 & Fact \\
\hline 125 & Corn (Bretons Bay) & 152 & Turf (St. Clement Bay) & 178 & Perry \\
\hline 126 & Valley & 153 & Dynard & 179 & Coliouck \\
\hline 127 & Foxwell & 154 & Tomakokin & 180 & Key \\
\hline 128 & Buzzard & 155 & Cobrums & 181 & Barber (IVicomico \\
\hline 129 & Noname & 156 & Radec & & River) \\
\hline 130 & Belle & & & & \\
\hline \multicolumn{6}{|c|}{ SOMERSET COUNTY. } \\
\hline 1 & Walnut & 23 & Sandy & 43 & Emanuel Church \\
\hline 2 & Jones & 24 & Locust ( $\mathrm{M}$ a noki n & 44 & Moun t Pleasant \\
\hline 3 & Ivee & & River) & & Church \\
\hline 4 & $\begin{array}{l}\text { Mount Vernon M. E. } \\
\text { Church }\end{array}$ & $\begin{array}{l}25 \\
26\end{array}$ & $\begin{array}{l}\text { Fitz } \\
\text { TVab }\end{array}$ & $\begin{array}{l}45 \\
46\end{array}$ & $\begin{array}{l}\text { Asbury Church } \\
\text { Sam }\end{array}$ \\
\hline 5 & Ball (Wicomico River) & 27 & Pen (Manokin River) & 47 & Watermelon $\mathrm{H} \mathrm{u} \mathrm{m}$ \\
\hline 6 & Wind & 28 & Cox (Manokin River) & & mock \\
\hline 7 & Little & 29 & Green (Manokin & 48 & East \\
\hline 8 & Dove & & River) & 49 & Monkey \\
\hline 9 & Short & 30 & Barn & 50 & Scot \\
\hline 10 & Room & 31 & Cupola (M a nokin & 51 & Old \\
\hline 11 & Haines & & River) & 52 & Will \\
\hline 12 & Deal Island Church & 32 & Staff & 53 & Iolland Island Bar \\
\hline 13 & Bar (Tangier Sound) & 33 & Fairmount Church & & Light \\
\hline 14 & Joshua & 34 & Prickly & 54 & $\operatorname{Fog} 2$ \\
\hline 15 & Senator & 35 & Has & 55 & Josepli \\
\hline 16 & Miles & 36 & Ford (Big Annemes- & 56 & North Church Spire \\
\hline 17 & Solomons Lump Light & & sex River) & & (Smith Island) \\
\hline 18 & Terrapin & 37 & Moon & 57 & old Church Spire \\
\hline 19 & Kelley & 38 & Colburn & & (Smith Tsland) \\
\hline 20 & Marsh (M a nokin & 39 & Geog & 58 & Ewell Church Spire \\
\hline & River) & 40 & Flat Cap & & (Smith Island) \\
\hline 21 & St. Pierre & 41 & Janes Island Light & & \\
\hline 22 & Jean & 42 & Somers Cove Light & & \\
\hline
\end{tabular}


LANDMARKS.

Numerical Index to Trianaulation Stations-Continued.

TALBOT COUNTY.

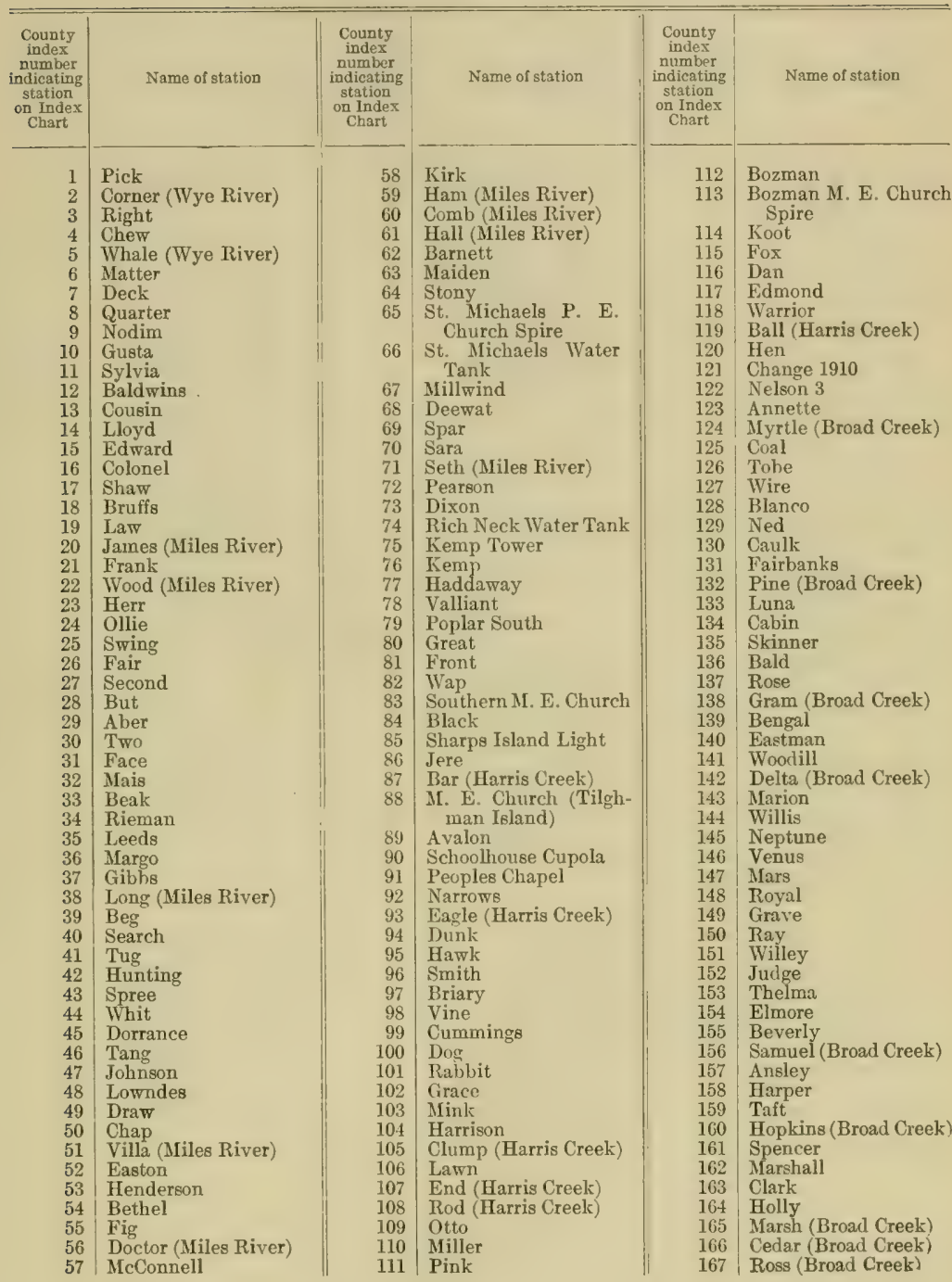


SUMMARY OF SURVEY OF OYSTER BARS OF MARYLAND.

Numerical Index to Triangulation Stations-Continued.

TALBOT COUNTY-Continued.

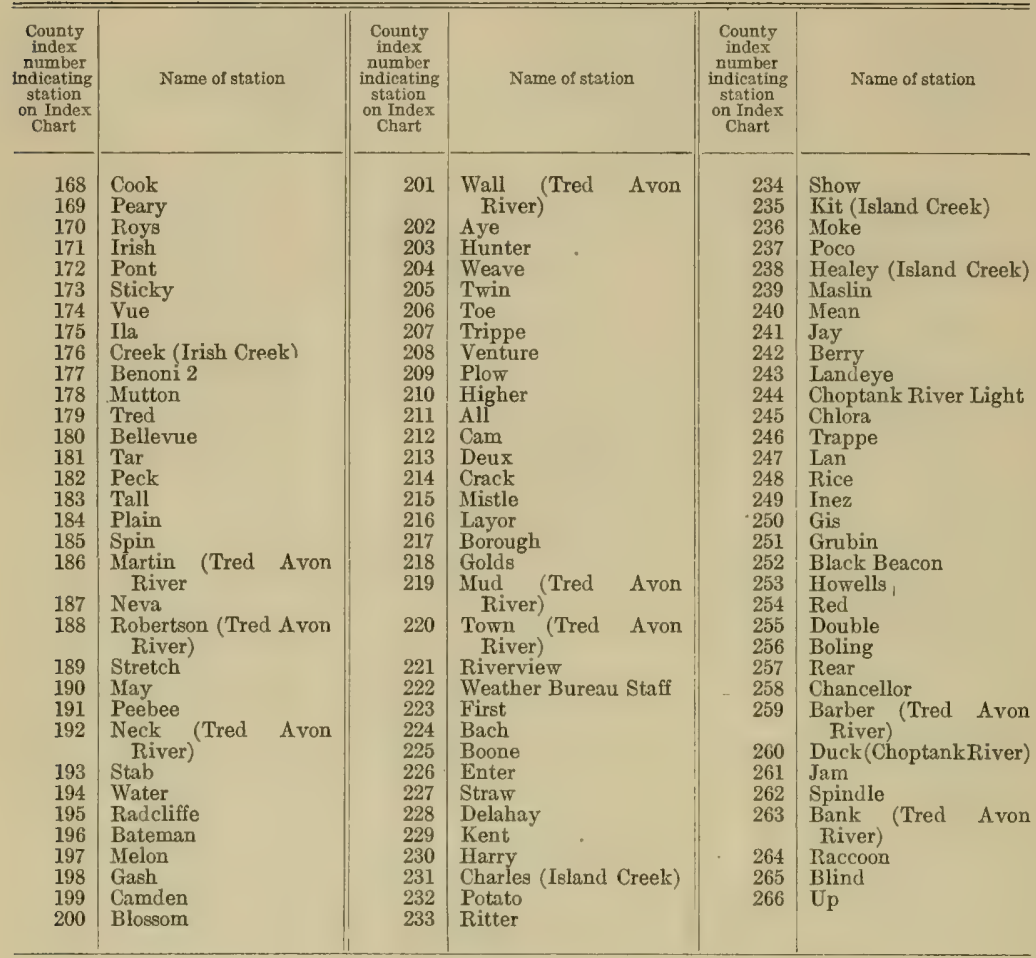

VIRGINIA.

\begin{tabular}{l|l||r|l||l|l}
\hline 1 & Herring Pond 2 & 9 & Fox Island Poplar & 17 & Grace M. E. Church \\
2 & Lynch Point 3 & 10 & Mos & Long Point \\
3 & Smith Point Light & 11 & Wharf (Saxis Pier) & 19 & Wildcat \\
4 & Shanks Hammock 2 & 12 & Saxis Church Spire & 20 & Pope Island Life-Sav- \\
5 & Horse & 13 & Oil & ing Station \\
6 & Fishbone & 14 & Summer & Chester (Virginia) \\
7 & Reach Hammock & 15 & Cup & 22 & Killick Shoal Light \\
8 & Beacon & 16 & Money & Assateague Light & \\
\hline
\end{tabular}


LANDMARIS.

Numerical Index to Triangulation Stations-Continued.

WICOMICO COUNTY.

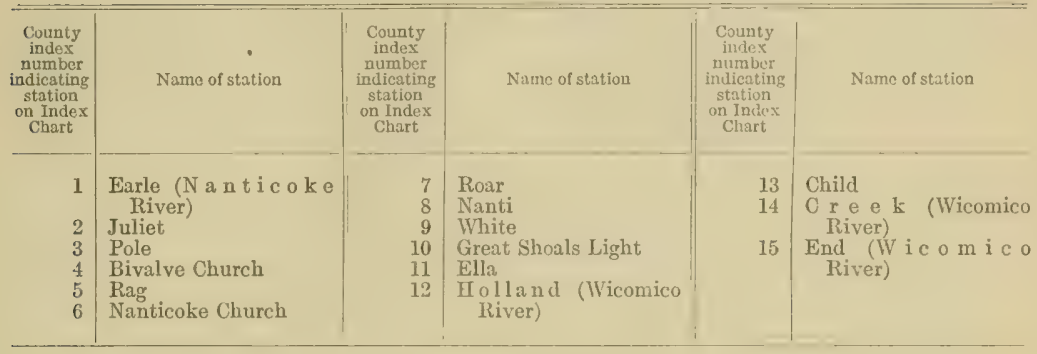

WORCESTER COUNTY.

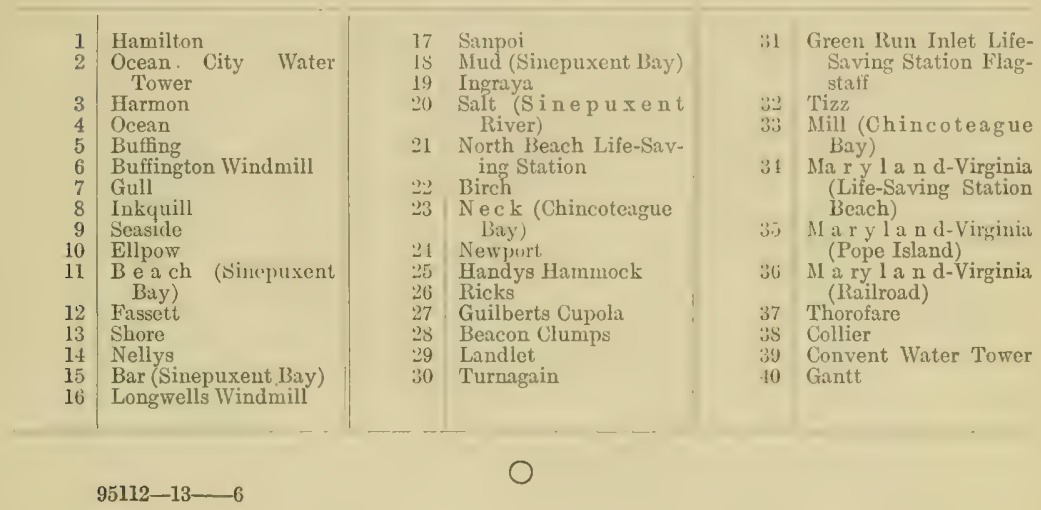




DEPARTMENT OF COMMERCE AND LABOR

COAST AND GEODETIC SURVEY

O. H: 'TITTMANN, Superintendent

\title{
SURVEY OF OYSTER BARS
}

\section{ANNE ARUNDEL COUNTY MARYLAND}

DESCRIPTION OF BOUNDARIES AND LANDMARKS AND REPORT OF WORK OF UNITED STATES COAST AND GEODETIC SURVEY IN COOPERATION WITH MARYLAND SHELL FISH COMMISSION

\author{
By C. C. YATES
}

ASSISTANT AND CHIEF OF PARTY. COAST AND GEODETIC SURVEY

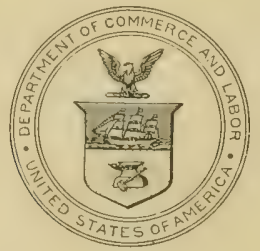

WASHINGTON

GOVERNMENT PRINTING OFFICE

1907 
DEPARTMENT OF COMMERCE AND LABOR

Document No. 77.

COAST AND GEODETIC SURVEY 


\title{
LET'TER OF SUBMITTAL.
}

\author{
DHPARTMENT OF COMMERCE AND LABOR, \\ Coast and Geodetic Survey, \\ Washington, June 1,1907 .
}

SiR: I have the honor to transmit herewith the report of the officer detailed from the Coast and Geodetic Survey to cooperate with the Maryland Slrell Fish Commission in surveying the oyster beds of the State of Maryland, under the provisions of the act of Congress entitled "An act to authorize the Secretary of Commerce and Labor to cooperate, through the Bureau of the Coast and Geodetic Survey and the Bureau of Fisheries, with the shellfish commissioners of the State of Maryland in making surveys of the natural oyster beds, bars, and rocks in the waters within the State of Maryland," approved May 26, I906, and certain results which are necessary for the interpretation and use of the plats of the survey.

Respectfully,

To Hon. Oscar S. Straus,

O. H. Titmanan, Superintendent.

Secretary of Commerce and Labor. 



\section{CER T IFICA TION.}

Anvapolis, MD., May 29, 1907.

The following publication is certified to contain correct technical descriptions of all boundaries and landmarks established in Anne Arundel County and contiguous waters by the Maryland Shell Fish Commission in cooperation with the United States Coast and Geodetic Survey.

C. C. YATLS,

Assistant and Chicf of Parts in the Coast and Geodctic Survey.

Examined and certified to be correct.

ANNAPOLIS, MD., June 6, I907.

WALTER J. MITCHELL,

BenJAMin K. GREEN,

CASWELL, GRAVE,

Maryland Shell Fish Commissioners.

SwEPSON EARI.E,

Hydrographic Engineer.

NoTE.-Copies of this publication and of the charts of the natural oyster bars of "Anne Arundel County and Adjacent Waters" were filed in the office of the clerk of the circuit court of Anne Arundel County and in the office of the Board of Shell Fish Commissioners at Annapolis on June 20, 1907 . 



\section{CON'TENTS.}

Page.

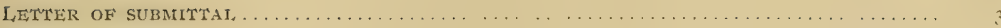

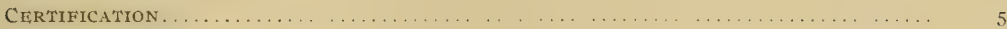

INTRODUCTION:

Publications . . . . . . . . . . . . . . . . . . . . . . . . . . . . . . .

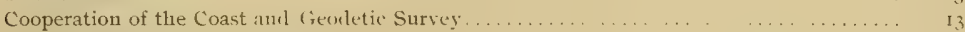

Laws relating to the conperationt. . . . . . . . . . . . . . . . . . . . . .

CHARTS AND MAPS:

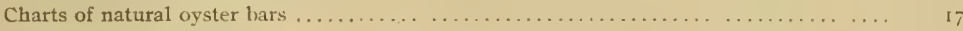

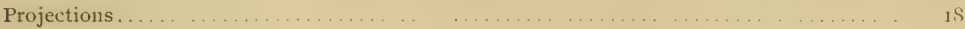

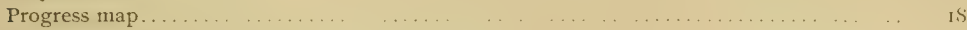

BOUNDARIES OF COUNTY WATERS:

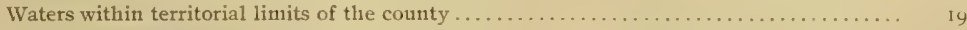

Waters contiguous to the county . . . . . . . . . . . . . . . . . . . .

Limits of dredging area adjacent to Craighill Channel. . . . . . . . . . . . . . . . . . .

List of natural oyster bars within dredging area of county $\ldots \ldots \ldots \ldots \ldots \ldots \ldots \ldots \ldots \ldots \ldots$

BOUNDARIES OF NATURAT, OYSTER BARS:

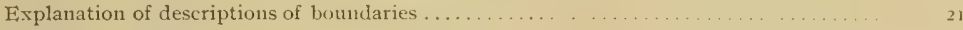

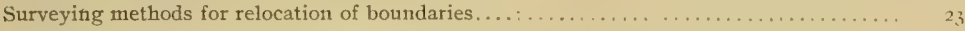

Natural oyster bars-

Chart No. I (Fort Carroll to Magothy River)-

Lumps Fast of Craighill Cliannel (see also Chart No. 2) . . . . . . . . . . . . . 26

Bodkin Point North . . . . . . . . . . . . . . . . . . . . . . . . . . .

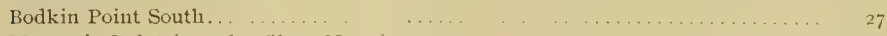

Mountain Point $($ see also Chart No. 2 ) ..............................

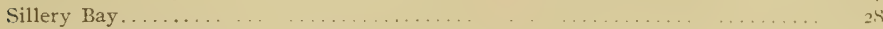

Chart No. 2 (Mlagothy River to Annapolis Roads) -

Lumps East of Craighill Channel (see also Chart No. I) . . . . . . . . . . . . . . .

Mountain Point (see also Chart No. I) . . . . . . . . . . . . . . . . . . . .

Peach Hill . . . . . . . . . . . . . . . . . . . . . . . . . . . . . . . .

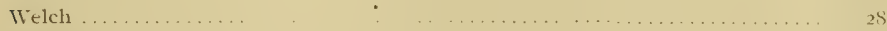

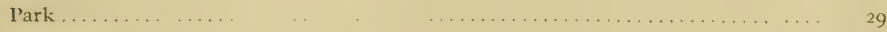

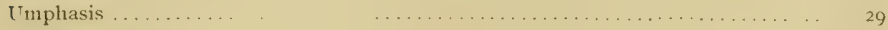

Black . . . . . . . . . . . . . . . . . . . . . . . . . . . . . . .

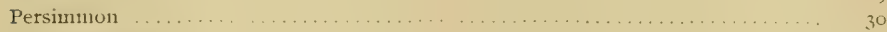

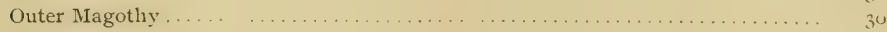

Sandy Point North . . . . . . . . . . . . . . . . . . . . . . . . . . .

Sandy Point South . . . . . . . . . . . . . . . . . . . . . . . . . . . . .

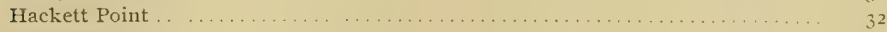

Whitehall Creek . . . . . . . . . . . . . . . . . . . . . . . . . . . 32

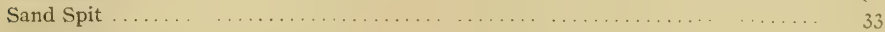

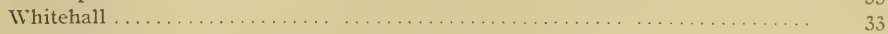

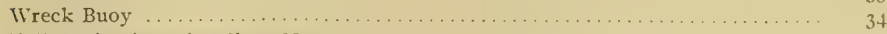

Tolly Point $($ see also (liart No. 3 ) . . . . . . . . . . . . . . . . . . . . 34

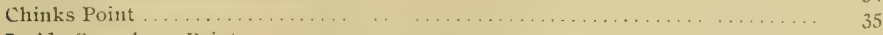

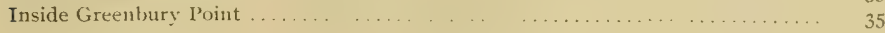


BOUNDARIES OF NATURAL OYSTER BARS-Continued.

Natural oyster bats-Continued.

Chart No. 2 (Magothy River to Annapolis Roads)-Continued.

Horn Point.....

old Fort

Little Samdy

Creces cone

Ferry Point.

Peach Urchard

Weems Lower

IVeeus I pper.

Viale

Traces Hollow

Sharp Point

Saltwork .

Rock Point L_ower

Chise..

Clenu Point

Point

Aisquith Creek

Brewer (Severn River)

Poppin Point.

Arnold Point

Bigr Island.

Round Bay

Rock Point Upper .

Chart No.3 (Annapolis Roads to Horseshoe Point)-

Tolly Point (see alsu Cllart No. 2)

Under The Gums...

Thomas Point North

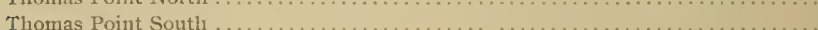

Old Woman .

Marshy Puint.

Turkey Puint.

Ruler Filats

Swan Reef.

Outer Rounil Point

Inner Round Point

Hill Point East.

Hill Point .

Rock Point (South River)

Fox Point.

Purdy Flats.

Thunder and Lightning.

Brewer (South River).

Alushouse.

Duvall.

Aberdeen.

Beard Point

Rough I'tiut

I'age 36

Saunclers

Lulu.

Dutelinian

Three sisters

ciurt is 
BOUNDARIES OF NATURAI, OYSTER BAKS-Continued,

Page.

Natural oyster bars-Continued.

Chart No. 3 (Annapolis Roads to Horseshoe Point)-Continued.

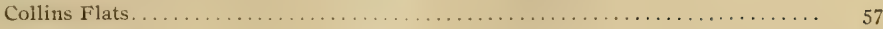

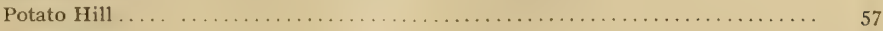

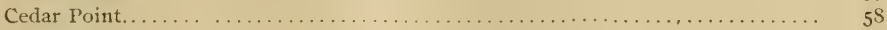

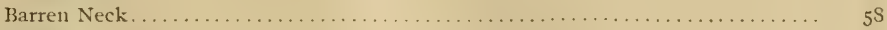

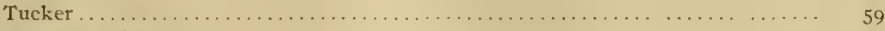

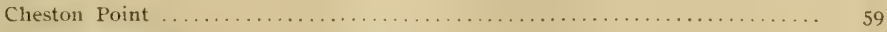

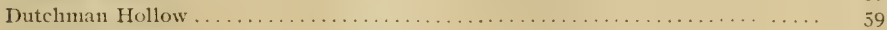

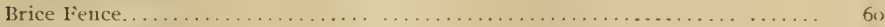

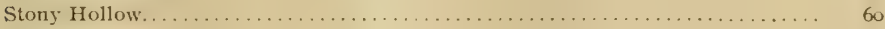

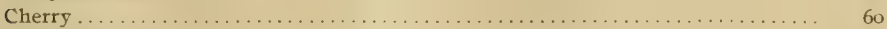

Jackass . . . . . . . . . . . . . . .

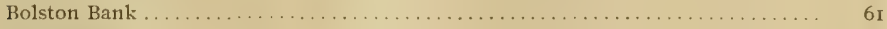

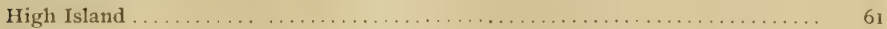

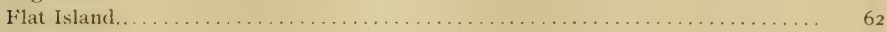

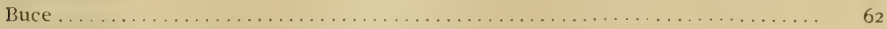

Chart No. + (Horseshoe Point to Holland Point)-

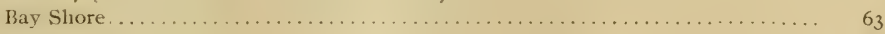

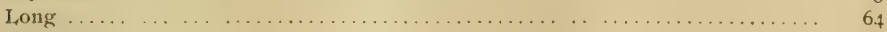

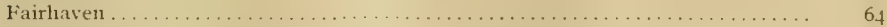

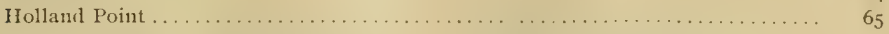

LANDMARKS (U. S. COAST AND GEODFTIC SURVEY TRIANGULATION STATIONS):
Explanation of description of landmarks $\ldots \ldots \ldots \ldots \ldots \ldots \ldots \ldots \ldots \ldots \ldots \ldots \ldots \ldots \ldots \ldots \ldots \ldots \ldots \ldots$

Triangulation stations-

Chart No, I (Fort Carroll to Magothy River)-

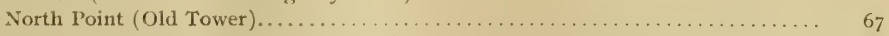

Craighill Channel Light (Front Range) $\ldots \ldots \ldots \ldots \ldots \ldots \ldots \ldots \ldots \ldots \ldots \ldots \ldots \ldots \ldots \ldots \ldots \ldots \ldots$

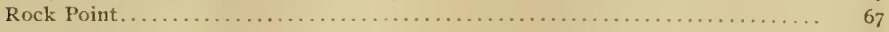

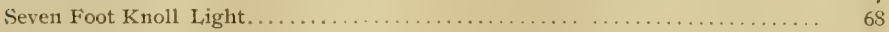

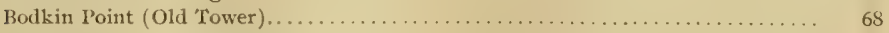

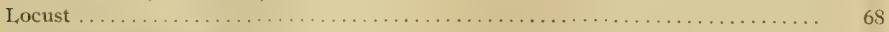

Bay (Magothy River) . . . . . . . . . . . . . . . . . . . . . . . . 68

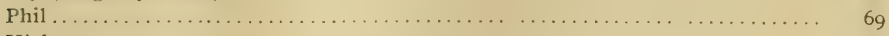

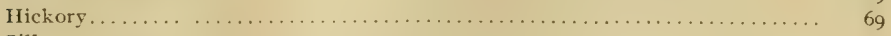

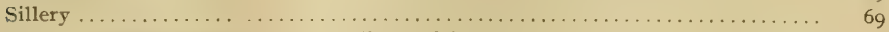

Chart No. 2 (Magothy River to Annapolis Roads)-

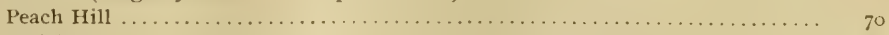

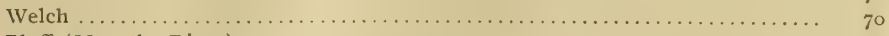

Bluff (Magothy River) ....................................

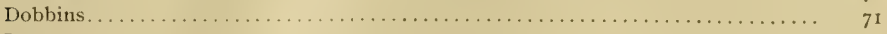

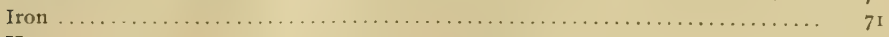

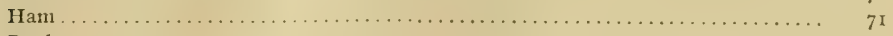

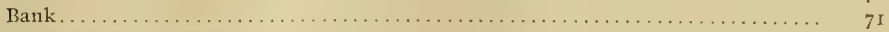

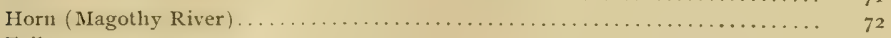

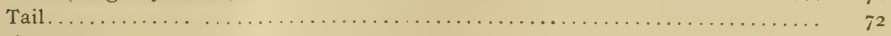

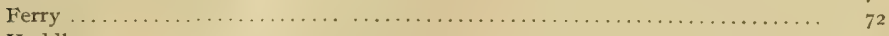

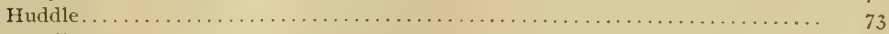

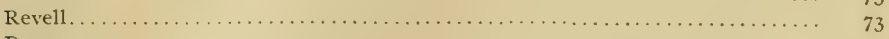

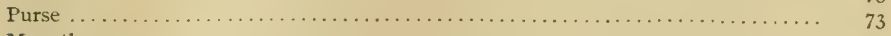

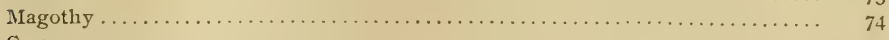

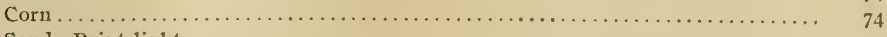

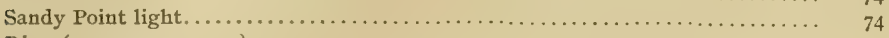

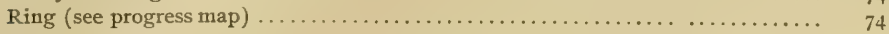

$330-07-1 \frac{1}{2}$ 
LANDMARKS (U. S. COAST AND GEODETIC SURVEY TRIANgulation STATIONS)-Continued. Page. Triangulation stations-Continued. Chart No. 2 (Magothy River to Annapolis Roads)-Continued.

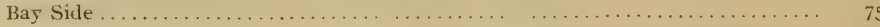

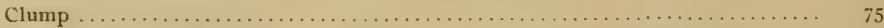

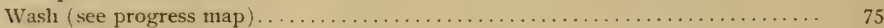

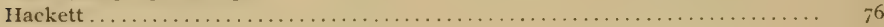

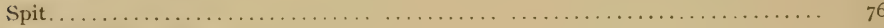

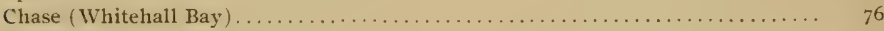

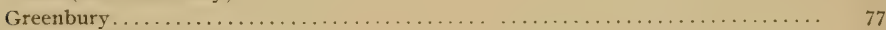

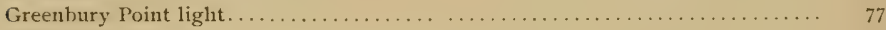

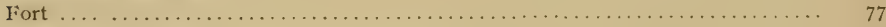

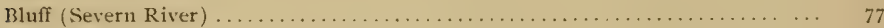

Brice. . . . . . . . . . . . . . . .

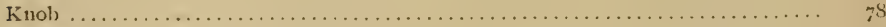

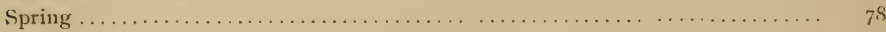

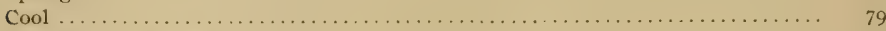

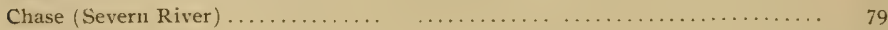

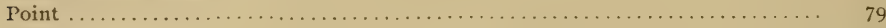

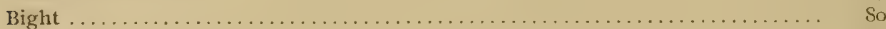

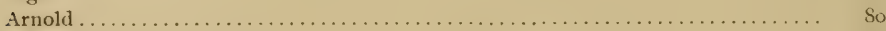

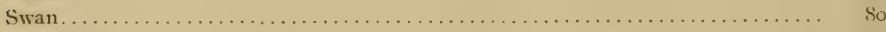

High . . . . . . . . . . . . .

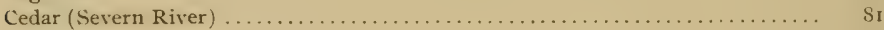

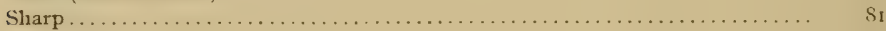

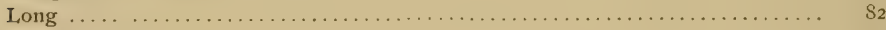

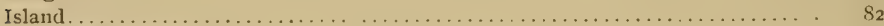

Bay (Severn River) . . . . . . . . . . . . . . . . . . . . . . $\mathrm{S}_{2}$

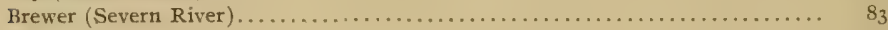

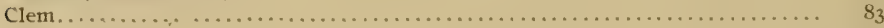

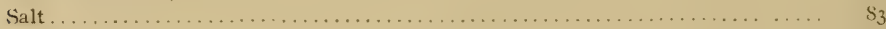

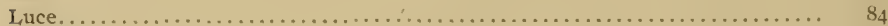

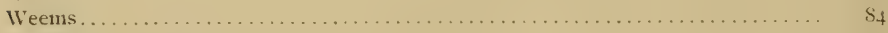

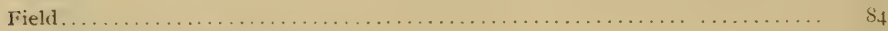

Hospital Cupola (Naval Academy) ................................. 85

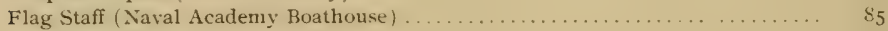

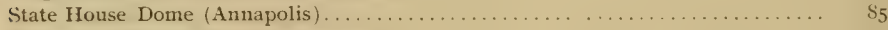

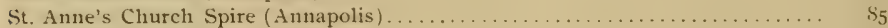

Catholic Church Spire (Annapolis) . . . . . . . . . . . . . . . . . . 85

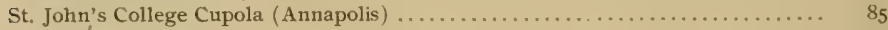

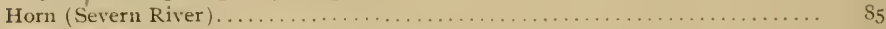

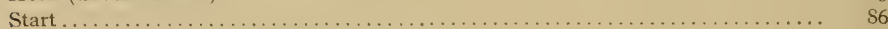

Chart No. 3 (Anuapolis Roads to Horseshoe Point)-

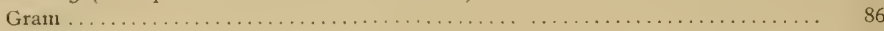

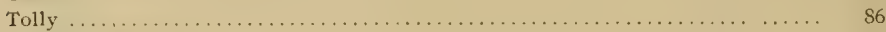

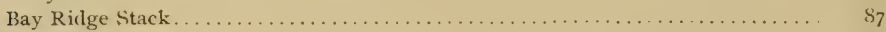

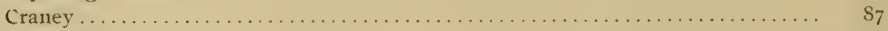

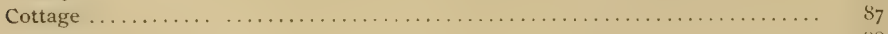

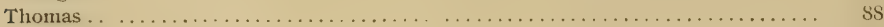

Thomas Point Light........................................ 88

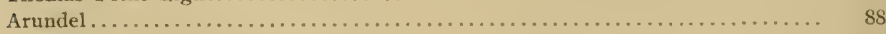

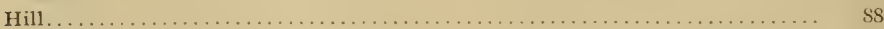

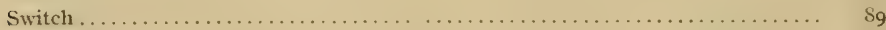

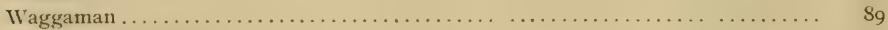

Waggaman Windmill $\ldots \ldots \ldots \ldots \ldots \ldots \ldots \ldots \ldots \ldots \ldots \ldots \ldots \ldots \ldots \ldots \ldots \ldots \ldots \ldots \ldots \ldots \ldots, S_{g}$ 


\section{Contents.}

LANDMARKS (U. S. COAST AND GEODETIC SURVEY TRIANGULATION Stations)-Continued. Page. Triangulation stations-Continued.

Chant No. 3-(Annapolis Roads to Horseshoe Point)--Continued.

Ginger

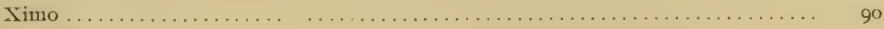

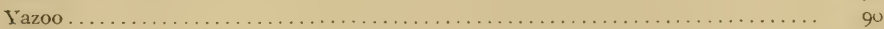

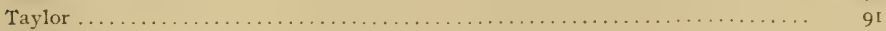

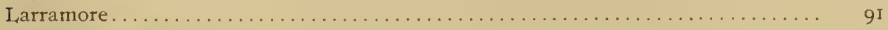

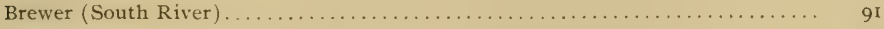

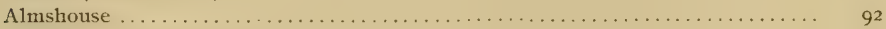

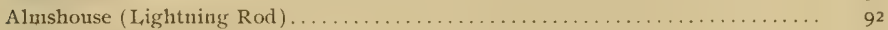

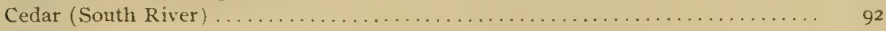

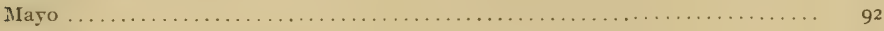

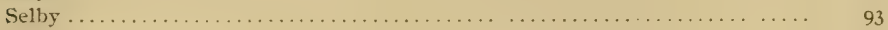

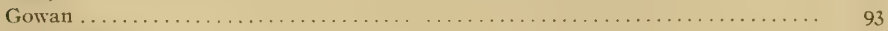

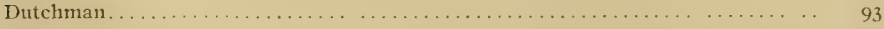

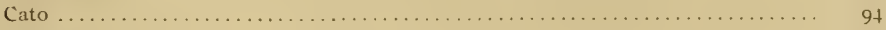

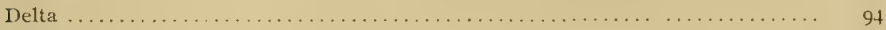

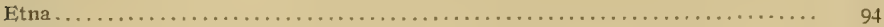

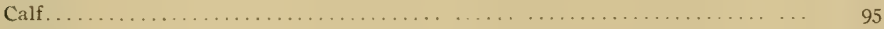

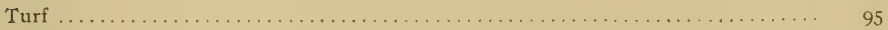

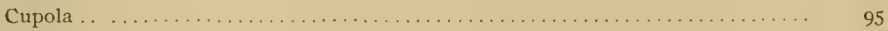

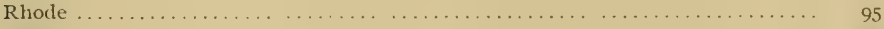

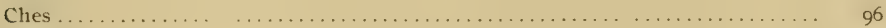

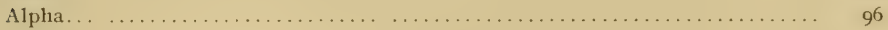

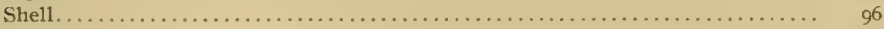

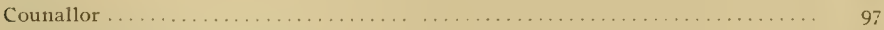

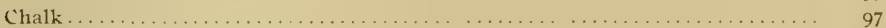

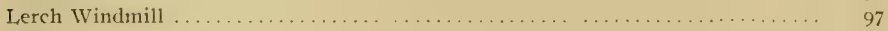

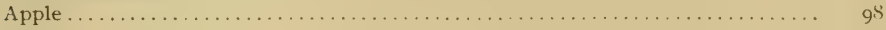

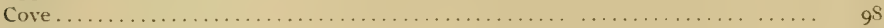

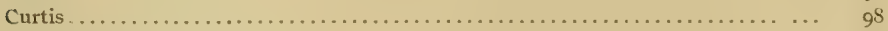

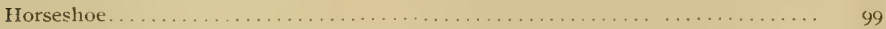

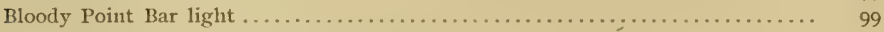

Chart No. 4 (Horseshoe Point to Holland Point)-

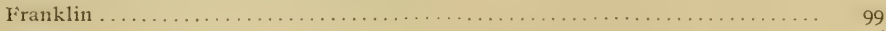

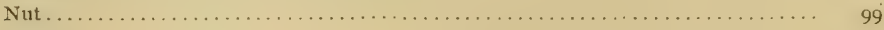

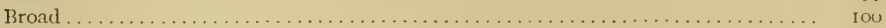

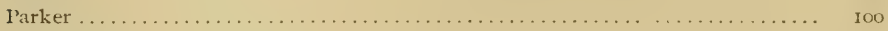

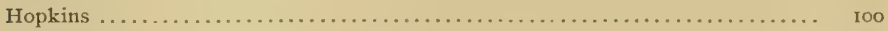

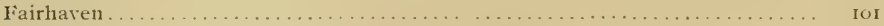

Holland . . . . . . . . . . . . . . . . .

REPORT OF THE WORK OF THE COAST AND GEODETIC SURVEY:

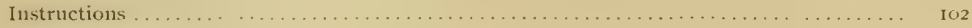

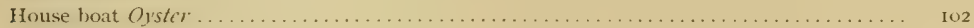

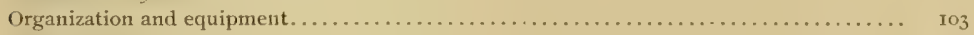

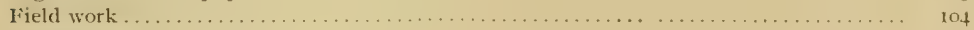

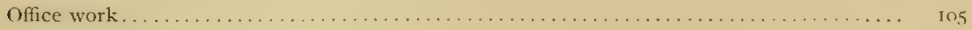

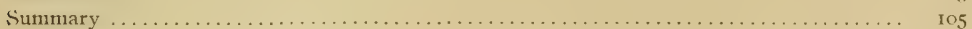

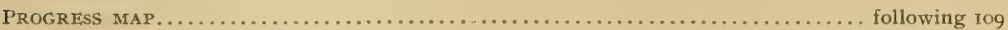





\section{SURVEY OF OYS'TER BARS, ANNE ARUNDEL COUNTY, MD.}

\section{INTRODUCTION}

\section{PUBLICATIONS.}

The preparation of publications relating to the survey of the natural oyster bars of Maryland has been divided between the Government and the State in accordance with the laws authorizing the work and the natural division of the surveying operations of the cooperating forces.

The part prepared under the direction of the Superintendent of the Coast and Geodetic Survey consists of this publication and a series of large-scale charts. The charts show all legal boundaries of natural oyster bars within the waters opened up for leasing with Anne Arundel County and the location of all landmarks (Coast and Geodetic Survey triangulation stations) used in comnection with the delineation of these boundaries. This publication gives a technical description of the oyster-bar boundaries and landmarks shown on the charts, and includes the report of the representative of the Coast and Geodetic Survey.

The part to be published by the Shell Fish Commission will include a report of the work executed by the commission under the provisions of the oyster-culture laws of Maryland, descriptions of oyster investigations and the delimitation of oyster bars, and other important legal and scientific information.

\section{COOPERATION OF THE COAST AND GEODETIC SURVEY.}

The work of the Coast and Geodetic Survey, as the name of the service indicates, includes a survey of the coasts of the United States made on a geodetic basis. This has involved the gradual construction of a great framework of interstate triangulation for use as a foundation for detail hydrographic and topographic surveys, from which there has been compiled and published a complete set of charts of the coasts of the United States, including all waters of Maryland where oysters grow. This existing triangulation, hydrography, and topography is essential for a correct and practical survey of natural oyster bars; and it being one of the fundamental functions of the Coast and Geodetic Survey to furnish such data for all surveying, charting, and other allied purposes within the area of the operations of the service, the cooperation of the Coast and Geodetic Survey with the Maryland Shell Fish Commission is a practical and useful development of Government work. 


\section{LAWS RELATING TO THE COOPERATION.}

The work of the Coast and Geodetic Survey and of the Bureau of Fisheries, in cooperation with the Maryland Shell Fish Commission, in surveying and publishing charts of natural oyster bars, establishing permanent landmarks over triangulation stations, and preparing for publication the necessary technical and legal descriptions of boundaries and landmarks delineated on the charts, has been executed in compliance with a request from the Governor of the State of Maryland to the Secretary of Commerce and Labor, and by authority of the following laws of the United States and Maryland:

[Act of Congress approved May 26, 1906.]

AN ACT to authorize the Secretary of Commerce and Labor to cooperate, through the Bureau of the Coast and Geodetic Survey and the Bureau of Fisheries, with the Shell Fish Commissioners of the State of Maryland in making surveys of the natural oyster beds, bars, and rocks in the waters within the State of Maryland.

Be it enacted by the Senate and House of Representatizes of the United States of Anerica in Congress assembled, That the Secretary of Commerce and Labor be, and he is hereby, authorized and directed, upon the request of the governor of the State of Maryland, to designate such officers, experts, and employees of the liureau of the Coast and Geodetic Survey and of the Bureau of Fisheries as may be necessary to cooperate with the Maryland State Board of Shell Fish Commissioners in making a survey of and locating the natural oyster beds, bars, and rocks in the waters within the State of Maryland; and the Secretary of Commerce and Labor is hereby authorized and directed to furnish to the officers, experts, and employees of said Bureaus so detailed as aforesaid such instruments, appliances, and steam launches as may be necessary to make the survey aforesaid; and the Secretary of Commerce and Labor is hereby authorized to have made in the Bureay of the Coast and Geodetic Survey all the plats necessary to show the results of the aforesaid survey and the locations of the said natural oyster beds, bars, and rocks in the waters within the State of Maryland, and to furnish to the Board of Shell Fish Commissioners of the State of Maryland such copies as may be necessary, and for this purpose to employ, in the District of Columbia and elsewhere, such techuically qualified persons as may be necessary to carry out the purpose of this act.

SEC, 2. That the Secretary of Commerce and Labor is hereby further authorized to have erected or constructed by the officers so detailed as aforesaid, while making such survey, such structures as may be necessary to mark the points of triangulation, so that the same may be used for such future work of the Coast and Geodetic Survey as the said 'Bureau may be hereafter required to perform in prosecuting the Government coast survey of the navigable waters of the United States located within the State of Maryland.

SrC, 4. That this act shall take effect from the date of its passage.

[Act of Congress approved March 4, 190\%]

AN AC'T making appropriations for sundry civil expenses of the Government for the fiscal year ending June thirtieth, nineteen hundred and eight, and for other purposes.

Be it enacted by the Senate and House of Kepresentalives of the United States of Anerica in Congress assembled, That the following sums be, and the same are hereby, appropriated for the objects hereinafter expressed, for the fiscal year ending June thirtieth, nineteen liundred and eight, ramely: *** *

COAST AND GEODETIC SURvey: * * * For any special surveys * * * including expenses of surveys in aid of the Shell Fish Commission of the State of Maryland, to be immediately available and to continue available until expended, twenty-five thousand dollars. * * * 
[Act of the legislature of Maryland approved April 2, Ig06.]

AN ACT to establish and promote the industry of oyster culture in Maryland, to define and mark natural oyster beds bars and rocks lying under the waters of this state, to prescribe penalties for the infringement of the provisions of this act, and ***

Section I. Be it enacted by the general assembly of Maryland, That the following sections be, and they are hereby, added to article 72 of the Code of Public General Laws, title "Oysters." * * *

SEC. S6. The Board of Shell Fish Commissioners shall, as soon as practicable after the passage of this act, cause to be made a true and accurate survey of the natural oyster beds, bars, and rocks of this State, said survey to be made with reference to fixed and permanent objects on the shore, giving courses and distances, to be fully described and set out in a written report of said survey, as hereinafter required. A true and accurate delineation of the same shall be made on copies of published maps and charts of the United States Const and Geodetic Survey, which said copies shall be filed in the office of the said Commissioners in the city of Annapolis; and the said Commissioners shall further cause to be delineated upon copies of the published maps and charts of the United States Coast and Geodetic Survey, of the largest scale, one copy for each of the counties of this State in the waters of which there are natural oyster beds, bars, and rocks, all natural beds, bars, and rocks 1ying within the waters of such county, which maps shall be filed in the office of the clerks of the circuit courts for the respective counties wherein the grounds so designated may lie.

SFC. 87. The governor of this State is hereby requested to ask the assistance of the United States Coast and Geodetic Survey, and of the United States Fish Commissioner, to aid in the carrying out of the provisions of the preceding section. * * *

SEC. S9. As soon as practicable after the first day of April, 1906, the said Commissioners shall organize and shall at once proceed, with the assistance of such person or persons as may be detailed by the United States Coast and Geodetic Survey, and the United States Fish Commissioner, to aid them in their work, and of such persons as may be appointed under the preceding section, to have laid out, surveyed, and designated on the said charts the natural beds, and hars, and shall cause to be marked and defined as accurately as practicable the limits and boundaries of the natural beds, bars, and rocks, as established by said survey, and they shall take true and accurate notes of said survey in writing, and make an accurate report of said survey, setting forth such a description of landmarks as may be necessary to enable the said Board, or their successors, to find and ascertain the boundary lines of the said natural oyster beds, bars, and rocks as shown by a delineation on the maps and charts provided in this act; said report shall be completed and filed in the office of the Board in the city of Annapolis within ninety days after the completion of the survey of any county. Said Commissioners shall cause the same to be published in pamphlet form, and transmit copies of the same to the clerk of the circuit court for the respective counties, where the charts have been filed or directed to be filed, as hereinafter provided; the said report to be filed by the clerks of the several counties in a book kept for that purpose. And the said survey and report, when filed, subject to the right of appeal hereafter provided for in this act, shall be taken in all of the courts of this State as conclusive evidence of the boundaries and limits of all natural oyster beds, bars, and rocks lying within the waters of the county wherein such survey and report are filed, and shall be construed to mean in all of the said courts that there are no natural oyster beds, bars, or rocks lying within the waters of the counties wherein such report and survey are filed other than those embraced in the survey authorized by this act, and that all areas of the Chesapeake Bay and its tributaries within the Strate of Maryland not shown in the survey to be natural oyster beds, bars, or rocks shall be construed in all the courts of the State to be barren bottoms, and open for disposal by the State for the purpose of private planting or propagation of oysters thereon under the provisions of this act; provided that the said survey and report shall not be so construed as to affect in any manner the holdings by citizens of this State in any lot which may have been appropriated or taken up under the laws of this State prior to the approval of this act. *** 
The law of the State of Maryland, passed March 9, I 842 , authorizing officers of the U. S. Coast and Geodetic Survey to enter upon the lands within the State limits for the purposes of the Survey, is as follows:

AN ACT concerning the survey of the coast of Maryland.

SECTION I. Be it enacted by the general assembly of Maryland, that it shall and may be lawful for any person or persons employed under and by virtue of an act of the Congress of the United States, * * * at any time hereafter to enter upon lands within this State for the purpose of exploring, surveying, triangulating, or leveling, or doing any other matter or thing which may be necessary to effect the objects of said act, and to erect any works, stations, buildings, or appendages requisite for that purpose, doing no unnecessary injury to private or other property.

SEC. 2. And be it enacted, That in case the person or persons employed under the act of Congress aforesaid can not agree with the owners or possessors of the land so entered upon and used as to the amount of damage done thereto by reason of the removal of fences, cutting of trees, or injury to the crop or crops growing on the same, it shall and may be lawful for the said parties or either of them to apply to the chief justice for the time being, or one of the associate judges of the judicial district in which such land may be situated, who shall thereupon appoint three disinterested and judicious freeholders, residents of the same judicial district, to proceed with as much despatch as possible to the examination of the matter in question and the faithful assessment of the damages sustained by the owners or possessors aforesaid, and the said freeholders or a majority of them, having first taken and subscribed an oath or affirmation before the chief or associate justice aforesaid or other person duly authorized to administer the same, that they will well and truly examine and assess as aforesaid, and having given five days' notice to both parties of the time of their meeting, shall proceed to the spot, and then and there upon their own view and, if required, upon the evidence of witnesses (to be by them sworn or affirmed and examined), shall assess the said damages, and shall afterwards make report thereof and of their proceerlings in writing under their hands and seals and file the same within five days thereafter in the office of the clerk of the county in which the land aforesaid is situated, subject to an appeal by either party to the county court of the said county within ten days after filing as aforesaid, and the said report so made as aforesaid, if no appeal as aforesaid be taken, shall be held to be final and conclusive as between the said parties, and the amount so assessed and reported shall be paid to the said owners or possessors of the land so damaged within twenty days after the filing of said report, and the said chief or associate justice as aforesaid shall have authority to tax and allow, upon the filing of said report, such costs, fees, and expenses to the said freeholders for the performance of their duty as he shall think equitable and just, which allowance shall be paid by the person or persons employed under the act of Congress aforesaid, within the time last above limited, but if an appeal as aforesaid be taken, the case shall be set down for hearing at the first term of county court aforesaid ensuing upon and after said appeal, and it shall be lawful for either party imnediately after the entry of such appeal to take out summous for such witnesses as may be necessary to be examined upon the hearing aforesaid, and the said court shall have power in its discretion to award costs against whichever the final judgment shall be entered, and such appeal, at the option of either party, may and shall be heard before, and the damages assessed by, a jury of twelve men to be taken from the regular panel and elected as in other cases.

SEC. 3. And be it enacted, That if any person or persons shall wilfully injure or deface or remove any signal, monument, or building, or any appendage thereto, erected, used, or constructed under and by virtue of the act of Congress aforesaid, such person or persons so offending shall severally forfeit and pay the sum of fifty dollars, with costs of suit, to be sued for and recovered by any person who shall first prosecute the same before any justice of the peace of the county where the person so offending may reside, and shall also be liable to pay the amount of damages thereby sustained, to be recovered with costs of suit in an action on the case, in the name and for the use of the United States of America, in any court of competent juriscliction. 


\section{CHAR'TS AND MAPS.}

CHARTS OF NATURAL OYSTER BARS.

The charts ${ }^{a}$ of the natural oyster bars of "Anne Arundel County and Adjacent Waters," published by the Coast and Geodetic Survey from results of surveys of the Government in cooperation with the Maryland Shell Fish Commission, consist of a series of four sheets, covering the west shore of Clesapeake Bay from Fort Carroll to Holland Point. They are published on the scale of I part in 20,000 (approximately $3 \frac{1}{6}$ inches to a statute mile), and are constructed on polyconic projections and based on the United States standard datum of the Coast and Geodetic Survey.

These charts show all oyster bar and other boundaries established by the Commission, and are certified by them for the purpose of filing in the office of the clerk of the circuit cont of Ame Arundel Connty and in the office of the Commission at Annapolis, as required by the oyster-culture laws of Maryland.

In addition to the boundaries, the charts show the location and name of all landmarks (U. S. Coast and Geodetic Survey triangulation stations) used in making the survey, together with the hydrography and topography necessary to make the technical definitions and delineations of boundaries readily understandable, both by the people engaged in oyster industry and the general public who may become interested through leasing of barren bottoms for oyster culture.

The names of the oyster bars are those used locally, as nearly as could be ascertained by the hydrographic engineer of the Commission, and are not designated by numbers, as might suggest itself on first thought as being the best method when the great number of oyster bars in the whole State are considered. By the use of local names, it is believed that much confusion will be avoided in the location of oyster bars, especially by those not familiar with charts.

The corners of the oyster bars are numbered from I to the total number of corners in each bar under consideration. Where bars adjoin, making one point a corner of two or more bars, these points have two or more numbers, each corresponding to the bar in which the figure is located. The numbers of the corners correspond with the technical and legal descriptions given in this publication under the heading "Boundaries of natural oyster bars."

The natural oyster bars and landmarks have been grouped in the contents of this publication in accordance with the charts upon which they are shown. To find a particular oyster bar or landmark which is only known by name, consult the "Contents," and the desired chart and general location will be indicated. To find the name of a bar or landmark which is only known by location, consult the progress map at the end of this publication for the number of the chart on which it is to be found, and then examine the known locality on the chart for the name of the bar or landmark in question.

The contours for the depth of water at mean low tide have been taken from the hydrographic sheets of the Coast and Geodetic Survey at Washington. Four curves

$a$ For copies of these clarts apply to the Superintendent of the Coast and Geodetic Survey at, Washington, D. C.

$330-07-2$ 
were selected as being the most convenient for taking off from the original hydrographic sheets and the ones of greatest value to those interested in the oyster industry. The I-fathom contour ( 6 feet) and the 5 -fathom contour (3o feet) practically include all the natural oyster bars surveyed, while the 3 -fathom contour ( 8 feet) furnishes the curve of about the average depth. The Io-fathom contour ( 60 feet) serves in a general way to indicate the outer limits of probable oyster culture.

The boundaries of the waters within the territorial limits of the county and the boundaries of waters not within these limits but opened up for the leasing with the county are plainly indicated on the charts. A full technical description of these boundaries is given in this publication under the heading "Boundaries of county waters."

The areas in acres of the natural oyster bars were determined under the direction of the hydrographic engineer of the Commission by two independent planimeter measurements made of the area of the bars as delineated on the smooth projections of the Coast and Geodetic Survey. These areas are given in small figures on the face of the chart within the boundaries of the bars.

The symbols used on the charts for the different kinds of boundaries, triangulation stations, contours of depth of water, etc., require no other explanation than that given in the notes on the charts.

\section{PROJECTIONS.}

The polyconic projections, like the charts which are described in the preceding section, were all constructed by draftsmen of the Coast and Geodetic Survey. These draftsmen also plotted the sextant positions on the smooth projections which determine the location of the legal boundaries of the natural oyster bars as delineated by the Shell Fish Commission.

A copy of each of these projections, with all the plotted positions of triangulation stations, shore line, sextant positions, and boundaries of oyster bars, was made under the direction of the hydrographic engineer of the commission, by pricking through with a sharp needle the intersections of the projection lines and all other points as plotted on the original sheets.

These projections (in duplicate) are the original. records of all natural oyster bar and other boundaries established by the commission. One set of these projections is filed in the archives of the Coast and Geodetic Survey at Washington and the other set is filed in the office of the Shell Fish Commission at Annapolis.

\section{PROGRESS MAP.}

The progress map" attached to this publication is on a scale of one part in a hundred thousand, and shows in outline the work accomplished by the U. S. Coast and Geodetic Survey in Anne Arundel County and contiguous waters. It gives the scheme of all the charts and smooth projections constructed in connection with the survey of the natural oyster bars, the location and names of all triangulation stations used as a basis for the surveying work, and the "Boundaries of county waters" established

$a$ For this map, see folder at end of this publication. 
by the commission for the purpose of carrying out the laws of Maryland relating to oyster culture.

Besides indicating the amount of work done by the Coast and Geodetic Survey in connection with the work of the Shell Fish Commission, the progress map will be of special value for index purposes to engineers and others, searching for the particular chart or projection covering the locality of the oyster bars or landmarks that may be under consideration.

\section{BOUNDARIES OF COUNTY WA'TERS,}

\section{WATERS WITHIN TERRITORIAL, LIMITS OF THE COUNTY.}

The laws relating to oyster culture under which the Maryland Shell Fish Commission is executing its survey, provide that "no person shall be permitted, by lease, assignment, or in any other manner, to acquire a greater amount of land than ten acres situated within the territorial limits of any of the counties, or one hundred acres in any other place."

The boundary line ${ }^{a}$ between the waters "within the territorial limits" of Anne Arundel County and the waters in "auy other place," as established by the Shell Fish Commission and delineated on the charts and the smooth projections of the Coast and Geodetic Survey, is technically described and defined as follows :

Commencing at a point defined by the intersection of the northern boundary line of Anne Arundel County with the center line of Fort McHenry Chrnnel; thence along the center line of Fort McHenry Channel past Fort Carroll to a point at the intersection of the center line of Fort McHenry Channel and the center line of Brewerton Channel; thence along the center line of Brewerton Chaniel to a point defined by the intersection of the center line of Brewerton Channel and a straight line between North Point (Old Tower) and a point defined by latitude $b 39^{\circ}$ og' $59 \cdot 3^{\prime \prime}$ and longitude ${ }^{b} 76^{\circ} 28^{\prime} 39.7^{\prime \prime}$, situated. on Rock Point; thence in a straight line to a point defined by latitude $39^{\circ} 09^{\prime} 59.3^{\prime \prime}$ and longitude $76^{\circ}$ $2 S^{\prime} 39.7^{\prime \prime}$ situated on Rock Point; thence following the mean low-water line along the shore of the bay to a point defined by latitude $39^{\circ} \circ \$^{\prime} 10.6^{\prime \prime}$ and longitude $76^{\circ} 26^{\prime} 2$ I. $2^{\prime \prime}$, situated on Frankie Point; thence in a straight line across the mouth of Bodkin Creek to a point situated at the center of the old light-house tower on Bodkin Point; thence following the mean low-water line along the shore of the bay to a point defined by latitude $39^{\circ} \mathrm{O}^{\prime} 35.2^{\prime \prime}$ and longitude $76^{\circ} 25^{\prime} 56.4^{\prime \prime}$, situated on. Mountain Point; thence in a straight line across the mouth of Magothy River to a point defined by latitude $39^{\circ} \circ 3^{\prime}$ II. I" and longitude $76^{\circ} 26^{\prime}$ I8. $7^{\prime \prime}$, situated on Persimmon Point; thence following the mean low-water line along the shore of the bay around Sandy Point to a point defined by latitude $38^{\circ} 59^{\prime}$ Io. I' and longitude $76^{\circ} 25^{\prime} 33.4^{\prime \prime}$, situated on Hackett Point; thence in a straight line across the mouth of Whitehall Bay to a point defined by latitude $38^{\circ} 5^{8^{\prime}} 25.0^{\prime \prime}$ and longitude $76^{\circ} 27^{\prime} 19.0^{\prime \prime}$, situated on Greenbury Point; thence in a straight line across the mouth of Severn River to a point defined by latitude $38^{\circ} 56^{\prime} 28.0^{\prime \prime}$ and longitude $76^{\circ} 27^{\prime} 00.0^{\prime \prime}$, situated on Tolly Point; thence following the mean low-water line along the shore of the bay to a point defined by latitude $3^{\circ} 54^{\prime} 42.0^{\prime \prime}$ and longitude $76^{\circ} 27^{\prime} 25 \cdot 2^{\prime \prime}$, situated on a point of land on the north side of Fishing Creek; thence in a straight line across the

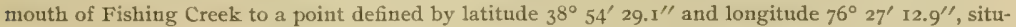
ated on Thomas Point; thence in a straight line across the mouth of South River to a point defined by latitude $38^{\circ} 53^{\prime} 13.6^{\prime \prime}$ and longitude $76^{\circ} 29^{\prime} 21.9^{\prime \prime}$, situated on Saunders Point; thence following the mean low-water line along the shore of the bay to a point defined by latitude $38^{\circ} 52^{\prime} 10.4^{\prime \prime}$ and longi-

a See Charts of Natural Oyster Bars, published by the U, S. Coast and Geodetic Survey, and the progress map at the end of this publication.

${ }^{b}$ Latitudes and longitudes based on the United States standard datum of the U. S. Coast and Geodetic Survey. 
tude $76^{\circ} 30^{\prime} 35.6^{\prime \prime}$, situated on Dutchman Point; thence in a straight line across the mouth of West River to a point defined by latitude $38^{\circ} 5 \mathrm{x}^{\prime} 12.8^{\prime \prime}$ and longitude $76^{\circ} 29^{\prime} 53.8^{\prime \prime}$, situated on Curtis Point ; thence following the mean low-water line along the shore of the bay to a point defined by latitude $38^{\circ} 48^{\prime} 02.8^{\prime \prime}$ and longitude $76^{\circ} 30^{\prime} 36.6^{\prime \prime}$, situated on a point about three-quarters of a mile north of Broadwater Creek; thence in a straight line across the mouth of Broadwater Creek to a point defined by latitude $38^{\circ} 47^{\prime} 21.3^{\prime \prime}$ and longitude $76^{\circ} 31^{\prime} 26.3^{\prime \prime}$, situated on a point at the southern entrance to Broadwater Creek; thence following the mean low-water line along the shore of the bay to a point defined by latitude $38^{\circ} 46^{\prime} 22.2^{\prime \prime}$, and longitude $76^{\circ} 32^{\prime} 23.5^{\prime \prime}$, situatel on Parker Island; thence in a straight line across the mouth of Herring Bay to a point defined by latitude $38^{\circ} 43^{\prime} 40.6^{\prime \prime}$ and longitude $76^{\circ} 3 \mathrm{I}^{\prime} 37.8^{\prime \prime}$, situated on Holland Point; thence following the mean low-water line along the shore of the bay to the southern boundary line of Anne Arundel County in the vicinity of Hog Point.

\section{WATERS CONTIGUOUS TO THE COUNTY.}

The oyster-culture laws of Maryland provide that a true and accurate delineation of all natural oyster bars shall be made on copies of charts of the United States Coast and Geodetic Survey, "which said copies shall be filed in the office of the said Commissioners in the city of Annapolis;" and "in the office of the clerks of the circuit courts for the respective counties wherein the grounds so designated may lie."

For the purpose of carrying out the latter part of this section of the law, and for the purpose of establishing the limits of the oyster-culture area to be opened up for the leasing with Anne Arundel County, a boundary line between the waters contiguous to, but not within the territorial limits of Anne Arundel County and the waters contiguous to, but not within the territorial limits of adjacent counties, has been established by the Shell Fish Commission. This boundary line ${ }^{a}$ has been delineated on the charts of the natural oyster bars published by the Coast and Geodetic Survey and is technically described and defined as follows:

Commencing at a point defined by the intersection of the center line of Brewerton Channel and a straight line between North Point (Old Tower) and a point defined by latitude $39^{\circ} \circ 9^{\prime} 59 \cdot 3^{\prime \prime}$ and longitude $76^{\circ} 2 S^{\prime} 39.7^{\prime \prime}$, situted on Rock Point; thence along the center line of Brewerton Channel and a continuation of the same line to a point defined by latitude $39^{\circ} \circ 9^{\prime} 10.6^{\prime \prime}$ and longitude $76^{\circ} 21^{\prime} 00.0^{\prime \prime}$,

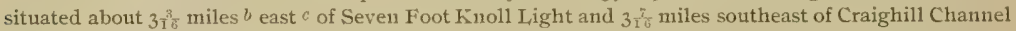
Light (Front Range); thence due south in a straight line to a point defined by latitude $39^{\circ} \circ 3^{\prime} 30.0^{\prime \prime}$ and longitude $76^{\circ} 2 \mathrm{I}^{\prime} \mathrm{00} . \mathrm{O}^{\prime \prime}$, situated about 258 miles from Baltimore Light, nearly on a straight line between Baltimore Light and Love Point Light; thence in a straight line to a point defined by latitude $39^{\circ} \mathrm{oo}^{\prime} 57.2^{\prime \prime}$ and longitude $76^{\circ} 2 \mathrm{I}^{\prime} 34.0^{\prime \prime}$, situated about $\mathrm{I}_{1}^{5} \frac{5}{\mathrm{~s}}$ miles east of Sandy Point Light; thence in a straight line to a point defined by latitude $38^{\circ} 53^{\prime} 56.2^{\prime \prime}$ andlongitude $76^{\circ} 24^{\prime} 32.0^{\prime \prime}$, situated about $1 \frac{1}{16}$ miles east of Thomas Point Light; thence in a straight line to a point defined by latitude $38^{\circ} 50^{\prime}$ or. $\mathrm{I}^{\prime \prime}$ and longitude $76^{\circ} 26^{\prime} 15.0^{\prime \prime}$, situated about $21 / 2$ miles west of Bloody Point Bar Light; thence in a straight line to a point defined by latitude $38^{\circ} 42^{\prime} 33.4^{\prime \prime}$ and longitude $76^{\circ} 27^{\prime} 40.0^{\prime \prime}$, situated about $3 \frac{5}{8}$ miles east of Hog Point; thence in a straight line to a point defined by the intersection of the mean low-water line of the shore of the bay and the southern boundary line of Anne Arundel County, in the vicinity of Hog Point.

\section{LIMITS OF DREDGING AREA ADJACENT TO CRAIGHILL CHANNEL.}

The oyster laws of the State of Maryland define the limits of the area adjacent to Craighill Channel in which dredging for oysters is prohibited, and the boundaries of the natural oyster bars established by the Maryland. Shell Fish Commission in that 
vicinity have been delineated accordingly. The law defining the boundaries of the prohibited area is as follows:

[Code of Mraryland, article 72 , section 50.$]$

Any person dragging, raking, or dredging for oysters within five hundred yards of either edge of the channel at the mouth of the Patapsco River, known as the Craighill Channel, extending from Seven Foot Knoll to the mouth of Magothy River, or within five hundred yards of either edge of, the cut-off connecting the Brewerton and Craighill channels, shall forfeit his boat or vessel; and it shall be lawful for any justice of the peace of the county or city in which such person shall be arrested to try such person, and on conviction to condemn said boat or vessel and sell the same on five days' notice, and fine the said offender a sum of not less than five dollars, nor more than twenty-five dollars, for each and every offense; and said justice of the peace shall pay over one-half of said fines and forfeitures to the informer, and the other half to the school board of said county or city.

\section{I,IST OF NATURAI, OYSTER BARS WITHIN DREDGING AREA OF COUNTY.}

The natural oyster bars open under the existing laws of Maryland for tonging or dredging, as the case may be, are not so classed and shown on the published charts, as it is a matter more or less subject to change by legislation independent of the oysterculture laws of Maryland.

However, the Commission in establishing the legal boundaries of the oyster bars have so fixed the limits of certain bars that in every case their boundaries are within or coincident with the boundary line between the tonging and dredging areas. In establishing these boundaries, the Commission have adopted the tonging-dredging limits furnished to them through the courtesy of the Commander of the State Fishery Force.

Most of the natural oyster bars open for dredging are of large area but few in number, and a complete list of the dredging bars in "Anne Arundel County and Adjacent Waters," is given below to facilitate the search of anyone desiring to locate them on the published charts:

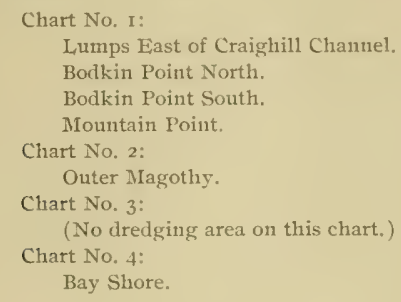

BOUNDARIES OF NATURAL OYSTER BARS.

EXPLANATION OF DESCRIPTIONS OF BOUNDARIES.

The natural oyster bars of Anne Arundel County are 9 I in number, and their total area as marked out by buoys placed by the hydrographic engineer of the commission is 33,666 acres. As provided by law, the limits of the oyster bars are all straight lines, but they inclose areas of all shapes from triangles to complicated ninesided figures, and of all sizes from 4 acres in the rivers to 7,548 acres in the bay. 
The sides vary in length from 93 to 7,529 yards, and in some cases the corners of the boundaries are practically at the triangulation stations from which they are located, while in other instances they are over IO, O0O yards from the landmarks most available for the purposes of fixing their positions.

The varied characteristics of the legal boundaries of the oyster bars indicated by the above statement, together with the complicated requirements of the law under which the survey has been executed, and the magnitude of the work with the consequent need of fixed and uniform methods, has made the problem of describing the boundaries, one of considerable difficulty and importance.

The boundaries of the natural oyster bars of Anne Arundel County, as established by the Shell Fish Commission and delineated on the Coast and Geodetic Survey charts and projections, are technically defined and described by a method somewhat different from that used in other oyster surveys. But it is believed that the forms finally adopted will fulfill all needs of the survey, and that they can be continued, with sliglit modifications to the end of the work.

The descriptions have been arranged in tabular form, thus avoiding many liundred repetitions of the same words by making one explanation of the tables sufficient for all oyster bars in the county.

At the top of each tabular form is given the legal name of the natural oyster bar to be described, its general locality, and the number of the chart on which its legal boundaries are shown.

The first column under the heading of "Corner of bar" gives the number corresponding to the corner of the boundary as shown on the charts and to the number on the buoy marking the actual corner of the bar. The numbers of the corners have been assigned by naming the southerumost point No. I, thence proceeding in a clock-wise direction around the bar; but where a corner of one bar is identical with the corner of one or more other bars, only the number of the corner of the oyster bar being described in the table is given in this column.

The second and third columns under the headings of "Latitude" and "Longitude" give the geographic positions of the corners. These positions have been adopted by the commission as the primary technical definition of the corners, and should be considered as final in case of a dispute arising from discrepancies caused by other means of location. The latitudes and longitudes given in these columns are based on the United States standard datum of the Coast and Geodetic Survey, and the points thus defined can be relocated from distant triangulation stations of the Survey, even though all the landmarks and buoys originally used for their location have been destroyed by natural causes or by the acts of vandals desiring to defeat the purposes of the oyster-culture law.

The fourth and fifth columns, under the general heading of "True bearings" a and the specific headings "Forward" and "Back," give bearings measured from a true north and south line. The three "Forward" bearings are from the corner of the boundary designated in the first column to the triangulation stations named on the corresponding lines in the last column, and the three "Back" bearings are from these same stations in the last column to the corresponding corner of boundary in the first column. The

a The mean magnetic declination in Anne Arundel County in 1907 was $5^{\circ} 45^{\prime}$ west of north and the annual increase $3^{\prime}$. 
difference in minutes of arc between the forwarch and back bearings shown in some cases is actual and not accidental, and is due to the fact that the computations took into account the spheroidal shape of the earth.

The sixth column under the heading of "Distance" gives the three computed distances in yards from the corner of the bar noted in the first column to the triangulation stations named on the corresponding lines in the last column, and vice versa.

The seventh and last column, under the heading of "U.S. C. \& G.S. Triangulation Station, " " gives the names of the landmarks from which were computed the corresponding "Latitude," "Longitude," "True bearing," and "Distance" of the "Corner of the bar" designated in the first column. A full description of the location and markings of these triangulation stations is given in another part of this publication, under the heading of "Descriptions of landmarks."

\section{SURVEYING MITHODS FOR RELOCATION OF BOUNDARIES.}

There are a number of methods that can be used in the relocation of the actual boundaries of the natural oyster bars as technically described in this publication and delineated on the published charts of the Coast and Geodetic Survey.

The following brief descriptions of five of these more or less different methods assume a certain amount of experience and knowledge on the part of the engineer in the particular kind of surveying under consideration, and are only intended as reminders of ways and means that cau be used.

There are two problems that are likely to present themselves to those interested in the boundaries of natural oyster bars. One, to determine whether the buoys marking the corners have been dragged or otherwise moved from their correct positions, and the other, to relocate or reestablish a buoy at the point from which it was removed. The different ways of solving these two problems partly depend upon the instruments possessed by the engineer and his assistants, and partly on his training and experience.

(I) Triangulation. - This method is the one that will give the greatest accuracy, but on account of its requiring special data and instruments, and being an operation rarely used by engineers not engaged in geodetic surveying, it is recommended only for cases in dispute that can not be settled satisfactorily by some other method. An explanation of this class of work would be too long for a report of this sort, and those not familiar with this method are referred to the publications on the subject by the Coast and Geodetic Survey.

(2) Hydrographic.-This method is the most simple and satisfactory one that can be adopted if the surveyor can obtain the use of the necessary instruments and assistants. It is the one best suited. for the work of the engineers of the Commission in locating corners of boundaries, as it gives results of the accuracy ordinarily required and is rapid in execution. Besides, it has the advantage of being available whenever three triangulation stations of suitable relative positions are visible from the off-shore points needing relocation.

Most navigators and others familiar with the use of a sextant are well acquainted with the graphic three-point method of fixing a position on water, and only a brief description of the operation will be stated.

${ }^{a}$ Geographic positions of these triangulation stations can be obtained by application to the Superintendent of the Coast and Geodetic Survey at Washington. 
In the case where there is only one engineer having a single sextant, the threepoint method can be used, but not until the two angles determining the position of any buoy have been calculated from the "Forward bearing" given in the tabular forms describing the boundaries of the oyster bars. For example, take "Traces Hollow" bar, described on page - and assume that "Corner No. 3" is to be examined as to its position. The angle between the two landmarks "Cool" and "Weems," as determined from the forward bearings from this corner, is $\mathrm{IOI}^{\circ} \mathrm{Oz}^{\prime}$ and the angle between "Weems" and "Field" is $68^{\circ} 52^{\prime}$. Having these two angles, the engineer proceeds to the buoy of doubtful location and measures the actual sextant angles between the landmarks for whicl the calculations were made. If the measured and calculated angles do not agree, the buoy is not in its correct position and the boundary corner must be relocated. This is accomplished by moving the boat about until a point is reached where the angles do agree, and this point being the desired location, the buoy can be placed in its correct position.

If the engineer can obtain the use of both a sextant and a three-arm protractor ("position finder"), the availability of the hy'drographic method is increased, as the use of the protractor is essential in case of the washing away or destruction of one or more of the landmarks originally used in describing the boundaries. Under these circumstances, any three landmarks of suitable relative positions that are visible from the point to be located can be utilized. For example, the engineer can proceed to the buoy of doubtful position and measure the two adjacent sextant angles between the three landmarks selected. These two angles are set on the three-arm protractor and the actual position of the buoy plotted on the chart by shifting the protractor about until the edges of each of the three arms passes through the center of the symbols on the chart marking the position of the three landmarks selected. The center of the hub of the protractor will indicate on the chart the actual position of the buoy, and if the point thus obtained does not coincide with the true positions of the corner of the boundary as given on the chart, the surveyor can proceed to locate the buoy correctly by reversing the operation. This is done by placing the center point of the hub of the protractor over the corner of the boundary in question and measuring on the chart the two adjacent protractor angles between the three selected landmarks. One of the angles thus obtained is set on the sextant and the boat moved about until the two landnarks are shown by the sextant to stibtend the same angle obtained from the protractor. 'The second angle is then placed on the sextant and the same operation gone through, and so on, first using one angle on the sextant then the other, until a point is reached where both observed sextant angles are practically identical with the protractor angles. The point thus located is the desired one and the buoy can be placed to mark the true position of the corner of the boundary in question.

If the engineer possesses two sextants and a protractor this problem is far easier of solution, as the two angles can be placed on separate sextants and the observer can quickly find the desired point where they agree with the protractor angles by using one sextant after the other without the need of resetting either.

If there are two observers, two sextants, and a protractor, it can be seen that the best conditions for both rapid and accurate hydrographic locations of points are attained; in fact, this is the method by which the buoys at the corners of the boundaries were originally placed by the hydrographic engineer to the Commission. 
(3) Magnetic bearings from offshore. - This method of fixing a position on water is a simple and well-known one in navigation. It is available to anyone having a boat compass, and will be of special use to the State Fishery Force in investigating cases where buoys are supposed to have been moved for illegal purposes.

In the case where a buoy is supposed to have been moved from its true position the observer takes compass bearings to the three landmarks given in the last column of the tables opposite the boundary corner in question. These bearings are then corrected for the local declination, ${ }^{a}$ and if the results agree with the published bearings, the buoy is correctly located.

In the case where the buoy is not in its correct position, or has disappeared altogether, the desired point can be determined by maneuvering the vessel until the corrected bearings agree with the ones in the tabular descriptions, when the buoy can be anchored in its proper location.

In the case where the landmarks for which the bearings are published have been destroyed or washed away, any landmark whose position is indicated on the charts can be used by getting their bearings directly from the chart by parallel rulers or a protractor aud then applying them in the same manner as the ones published in the tables.

(4) Magnetic bearings from shore.-This method will be of special value to engineers having an ordinary surveyor's compass. The compass can be set over the point marking a "triangulation station" on shore, the name of which is given in the last column opposite the "corner" in question. The instrument is then set at the corresponding "back" bearing (corrected for local nnagnetic declination), given in the fourth column of the tables opposite the "corner" in question and on line with the name of the "station" being occupied. The direction thus determined will give one range on which the desired point must be located. The compass can then be noved to a second triangulation station and another range located in a sinilar manner. The intersection of these two range lines will give the desired point; but in general it should be checked by an additional range line determined from a third station.

(5) Horizontal angles measured at landmarks. -This process is a modification of the triangulation method, and will be useful to engineers who have a transit and desire considerable accuracy.

The instrument is placed over a "triangulation station," the name of which appears in the last column of the tabular description opposite the "corner" in question. The telescope is then pointed to the landmark indicated in the "Description of landmarks" as having a direction of $0^{\circ} \circ O^{\prime} \circ O^{\prime \prime}$ from the triangulation station being occupied by the transit. The tabular description of the boundaries is next examined and the "back" bearing of the questionable boundary "corner," from the landmark being occupied, is taken out. The angle calculated from the "back" bearing and the bearing given in parentheses alongside the zero landmark in the "Description of landmarks" is then laid off on the transit and a range line established, on which the desired point must be located. A similar process is then carried on at a second station, and so on until the position of the buoy is satisfactorily fixed.

"The nean magnetic declination for Anne Arumlel County (in 1907) is $5^{\circ}$ and $45^{\prime}$ west of north, and the annual increase is $3^{\prime}$.

$$
33(1-07-3
$$




\section{LUMPS EAST OF CRAIGHILL CHANNEL,}

(Chesapeake Bay east of Craighill and Cutoff dredged channels-Charts Nos. I and 2.)

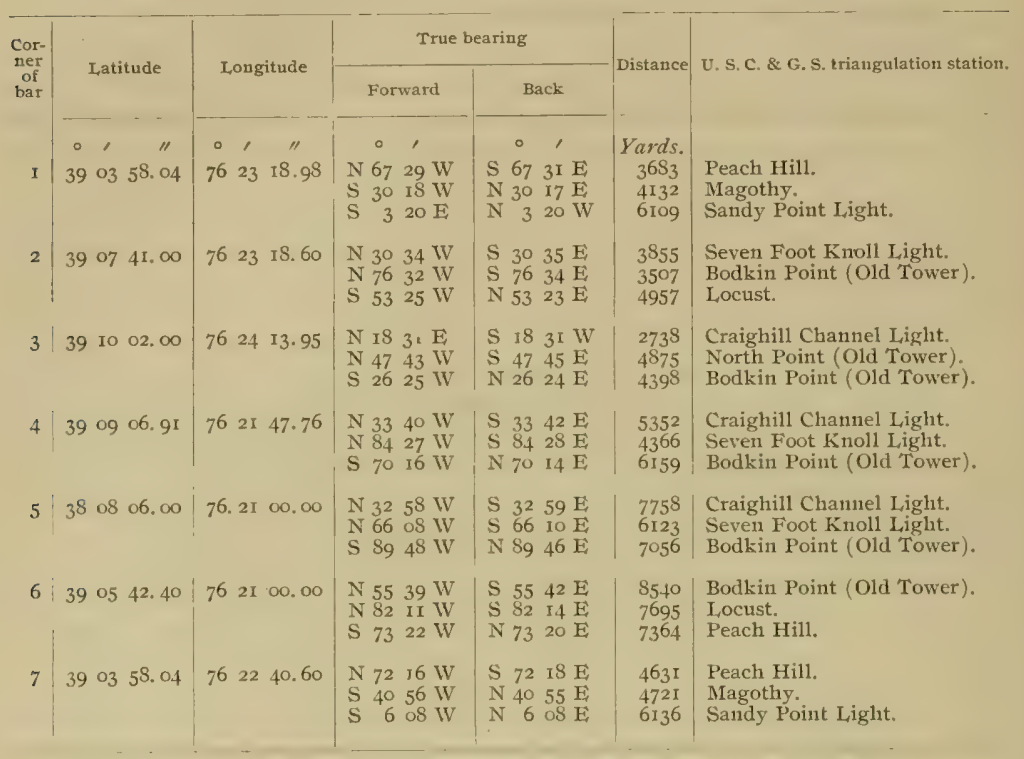

\section{BODKIN POINT NORTH.}

(Chesapeake Bay off Bodkin Creek-Chart No. I.)

\begin{tabular}{|c|c|c|c|c|c|c|c|c|c|c|c|}
\hline & 0,1 & 11 & o & , & "I & $\circ$ & , & 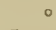 & , & Yards. & \\
\hline I & 39 os & 09.93 & 76 & 24 & 48. 59 & $\begin{array}{l}\text { N } 9 \\
\text { S } 8 \mathrm{I} \\
\text { S } 22\end{array}$ & $\begin{array}{l}45 \mathrm{E} \\
\mathrm{I} 9 \mathrm{~W} \\
20 \mathrm{~W}\end{array}$ & $\begin{array}{l}\text { S } 9 \\
\text { N } 81 \\
\text { N } 22\end{array}$ & $\begin{array}{l}45 \mathrm{WV} \\
19 \mathrm{E} \\
20 \mathrm{E}\end{array}$ & $\begin{array}{l}2377 \\
1060 \\
4251\end{array}$ & $\begin{array}{l}\text { Seven Foot Knoll Light. } \\
\text { Bodkin Point (Old Tower). } \\
\text { Locust. }\end{array}$ \\
\hline 2 & 39 os & 12.00 & 76 & 25 & 34.63 & $\begin{array}{l}\mathrm{S} 35 \\
\mathrm{~N} 35 \\
\mathrm{~N} \\
\mathrm{I} 2\end{array}$ & $\begin{array}{l}{ }_{3} \mathrm{E} \\
20 \mathrm{~F} \\
02 \mathrm{~W}\end{array}$ & $\begin{array}{ll}\mathrm{N} & 35 \\
\mathrm{~S} & 35 \\
\mathrm{~S} & \mathrm{I} 2\end{array}$ & $\begin{array}{l}\text { I2 W } \\
2 \mathrm{IW} \\
03 \mathrm{E}\end{array}$ & $\begin{array}{r}281 \\
2786 \\
7144\end{array}$ & $\begin{array}{l}\text { Bodkin Point (Old Tower). } \\
\text { Seven Foot Knoll Light. } \\
\text { North Point (Old Tower). }\end{array}$ \\
\hline 3 & $39 \circ 9$ & 17.05 & 76 & 25 & 55.94 & $\begin{array}{ll}S & 16 \\
N & 87 \\
N & 10\end{array}$ & $\begin{array}{l}35 \mathrm{E} \\
54 \mathrm{E} \\
59 \mathrm{~W}\end{array}$ & $\begin{array}{l}\text { N } 16 \\
S 87 \\
S \text { Io }\end{array}$ & $\begin{array}{l}35 \mathrm{~W} \\
54 \mathrm{~W} \\
59 \mathrm{E}\end{array}$ & $\begin{array}{l}2528 \\
2173 \\
4884\end{array}$ & $\begin{array}{l}\text { Bodkin Point (Old Tower). } \\
\text { Seven Foot Knoll Light. } \\
\text { North Point (Old Tower). }\end{array}$ \\
\hline 4 & 3909 & 34.25 & 76 & 25 & $3 \mathrm{~S} .55$ & $\begin{array}{lr}S & 5 \\
S & 16 \\
N & 18\end{array}$ & $\begin{array}{l}03 \mathrm{E} \\
16 \mathrm{E} \\
13 \mathrm{WW}\end{array}$ & $\begin{array}{lr}N & 5 \\
N & 16 \\
S & 18\end{array}$ & $\begin{array}{l}\mathrm{O} 2 \mathrm{~W} \\
\mathrm{I} 5 \mathrm{~W} \\
\mathrm{r}_{3} \mathrm{E}\end{array}$ & $\begin{array}{l}3015 \\
1786 \\
4437\end{array}$ & $\begin{array}{l}\text { Bodkin Point (Old Tower). } \\
\text { Seven Foot Knoll Light. } \\
\text { North Point (Old Tower). }\end{array}$ \\
\hline 5 & ${ }_{3}^{8}$ o8 & 49.70 & 76 & 25 & 04.52 & $\begin{array}{l}\text { N } 39 \\
\text { N } 21 \\
\text { S } 22\end{array}$ & $\begin{array}{l}20 \mathrm{E} \\
44 \mathrm{~W} \\
44 \mathrm{~W}\end{array}$ & $\begin{array}{ll}\text { S } & 39 \\
\text { S } 21 \\
\text { N } 22\end{array}$ & $\begin{array}{l}20 \mathrm{~W} \\
45 \mathrm{E} \\
43 \mathrm{E}\end{array}$ & $\begin{array}{l}1296 \\
6155 \\
1627\end{array}$ & $\begin{array}{l}\text { Seven Foot Knoll Light. } \\
\text { North Point (Old Tower). } \\
\text { Bodkin Point (Old Tower). }\end{array}$ \\
\hline
\end{tabular}


BODKIN POINT SOUTH.

(Chesapeake Bay-Sonth of Bodkin Point-Chart No. I.)

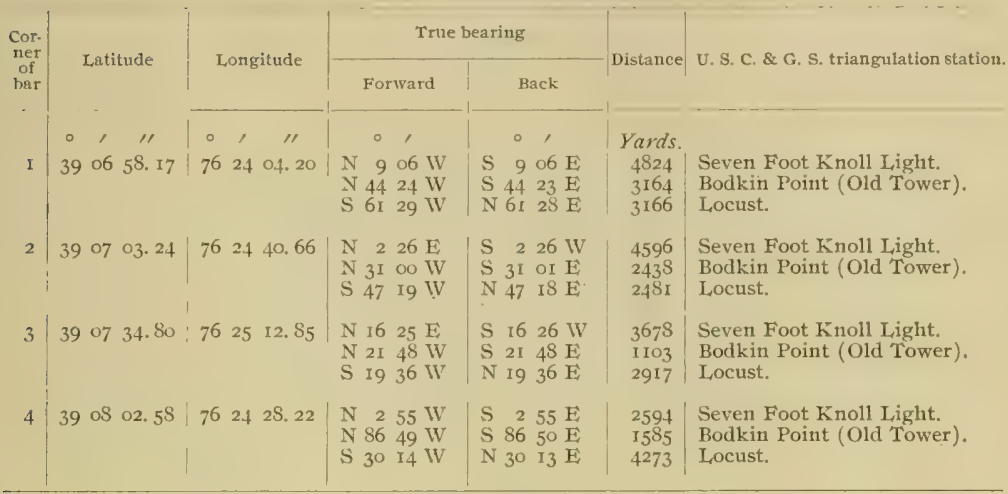

MOUNTAIN POINT.

(Chesapeake Bay between Magothy River and Bodkin Point-Charts No. I and 2.)

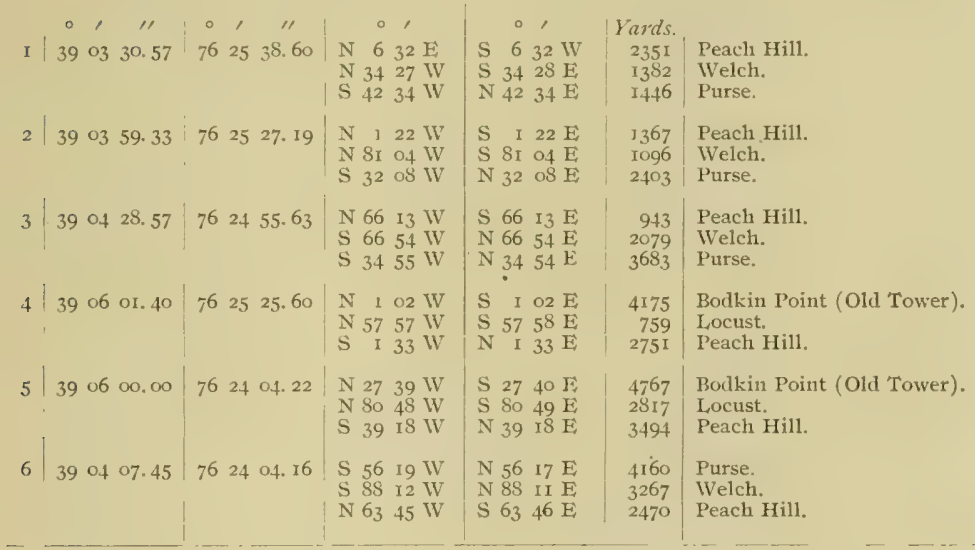


SILLERY BAY.

(Magothy River-Chart No, r.)

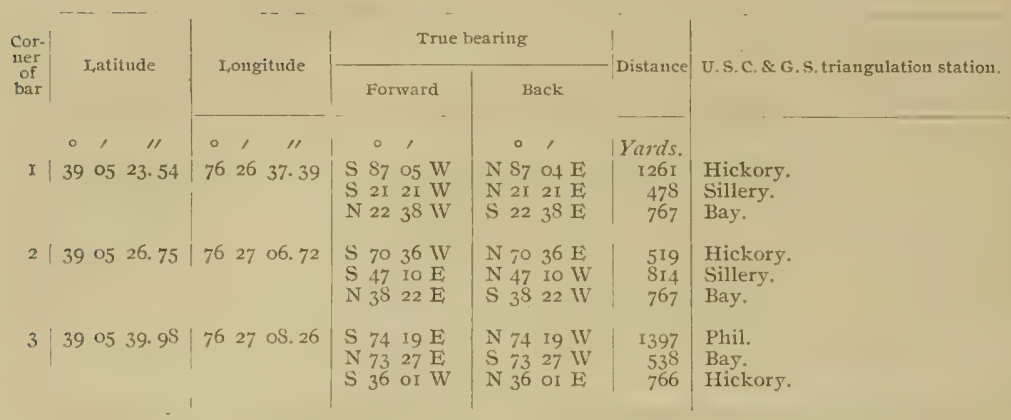

PEACH HILI.

(Magothy River-Chart No. 2.)

\begin{tabular}{|c|c|c|c|c|c|c|}
\hline & $\begin{array}{ccc}\circ & \prime \prime \prime \\
39 & 04 & 48.75\end{array}$ & $\begin{array}{ccc}0 & \prime & \prime \prime \\
76 & 27 & 07.25\end{array}$ & 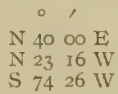 & $\begin{array}{ccc}\circ & 1 \\
\text { S } 40 & 00 \mathrm{WV} \\
\mathrm{S} & 23 & \mathrm{I} \\
\mathrm{N} & \mathrm{E} \\
\mathrm{N} & 26 \mathrm{E}\end{array}$ & $\begin{array}{r}\text { Yards. } \\
949 \\
\times 206 \\
677\end{array}$ & $\begin{array}{l}\text { Sillery. } \\
\text { Hickory. } \\
\text { Dobbins. }\end{array}$ \\
\hline & $\begin{array}{llll}39 & 02 & 02 . & 8\end{array}$ & $\begin{array}{llll}76 & 27 & 03.85\end{array}$ & 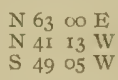 & $\begin{array}{llll}\mathrm{S} & 63 & 00 \mathrm{~W} \\
\mathrm{~S} & 4 \mathrm{I} & 14 & \mathrm{E} \\
\mathrm{N} & 49 & 05 & \mathrm{E}\end{array}$ & $\begin{array}{l}585 \\
858 \\
984\end{array}$ & $\begin{array}{l}\text { Sillery. } \\
\text { Hickory. } \\
\text { Dobbins. }\end{array}$ \\
\hline & 390451.06 & $\begin{array}{llll}76 & 26 & 49.96\end{array}$ & $\begin{array}{llll}\mathrm{N} & \mathrm{I} & \circ 9 \mathrm{E} \\
\mathrm{N} & 4 \mathrm{I} & 59 \mathrm{~W} \\
\mathrm{~S} & 76 & 50 \mathrm{WV}\end{array}$ & $\begin{array}{llll}\mathrm{S} & 1 & 09 & \mathrm{~W} \\
\mathrm{~S} & 42 & 00 & \mathrm{E} \\
\mathrm{N} & 76 & 50 & \mathrm{E}\end{array}$ & & $\begin{array}{l}\text { Bay. } \\
\text { Hickory. } \\
\text { Dobbins. }\end{array}$ \\
\hline
\end{tabular}

WELCH.

(Magothy River-Chart No.2.)

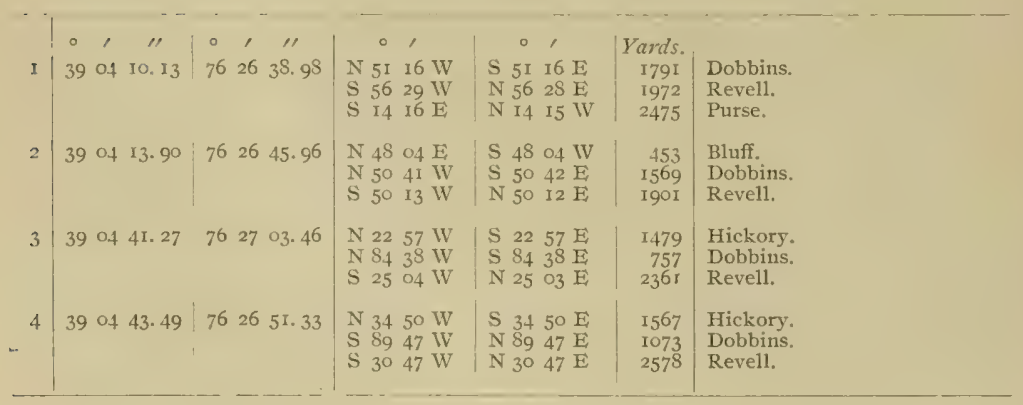


PARK.

(ATagolhy River-Chart No. 2.)

\begin{tabular}{|c|c|c|c|c|c|c|c|}
\hline \multirow{2}{*}{$\begin{array}{c}\text { Cor- } \\
\text { ner } \\
\text { of } \\
\text { bar }\end{array}$} & \multirow{2}{*}{\multicolumn{2}{|c|}{ Latitude }} & \multirow{2}{*}{ Longitude } & \multicolumn{2}{|c|}{ True bearing } & \multirow{2}{*}{ Distance } & \multirow{2}{*}{ U.S.C. \& G.S. triangulation station. } \\
\hline & & & & Forward & Back & & \\
\hline 1 & $\begin{array}{c}0 \\
39\end{array}$ & $\begin{array}{c}\prime \prime \prime \\
0424.25\end{array}$ & $\begin{array}{ccc}0 & 1 & \prime \prime \\
76 & 28 & 47.64\end{array}$ & $\begin{array}{lccc} & 0 & 1 \\
\mathrm{~N} & 27 & 06 & \mathrm{E} \\
\mathrm{S} & 85 & 32 & \mathrm{WV} \\
\mathrm{S} & 9 & \text { OI } & \mathrm{WV}\end{array}$ & $\begin{array}{cccc} & 0 & 1 \\
S & 27 & 06 & W \\
N & 85 & 3 I & E \\
N & 9 & \text { OI } & E\end{array}$ & $\begin{array}{r}\text { Yards. } \\
825 \\
2137 \\
796\end{array}$ & $\begin{array}{l}\text { Iron. } \\
\text { Ferry. } \\
\text { Huddle. }\end{array}$ \\
\hline 2 & 39 & 0439.77 & 762905.54 & 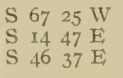 & $\begin{array}{llll}\mathrm{N} & 67 & 24 & \mathrm{E} \\
\mathrm{N} & \mathrm{I} & 43 & \mathrm{~W} \\
\mathrm{~N} & 6 & 36 & \mathrm{WV}\end{array}$ & $\begin{array}{l}1798 \\
1355 \\
3040\end{array}$ & $\begin{array}{l}\text { Ferry. } \\
\text { Huddle. } \\
\text { Revell. }\end{array}$ \\
\hline $3 \mid$ & 39 & 0443.82 & $76 \quad 2859.65$ & $\begin{array}{lrrr}\mathrm{S} & 65 & 3 \mathrm{I} & \mathrm{W} \\
\mathrm{S} & 7 & 3 \mathrm{I} & \mathrm{E} \\
\mathrm{S} & 42 & 44 & \mathrm{E}\end{array}$ & $\begin{array}{lrl}\mathrm{N} & 65 & 30 \mathrm{E} \\
\mathrm{N} & 7 & 3 I \mathrm{IV} \\
\mathrm{N} & 42 & 43 \mathrm{WV}\end{array}$ & $\begin{array}{l}1994 \\
1459 \\
3028\end{array}$ & $\begin{array}{l}\text { Ferry. } \\
\text { Huddle. } \\
\text { Revell. }\end{array}$ \\
\hline 4 & 39 & 0427.92 & $\begin{array}{llll}76 & 28 & 39.59\end{array}$ & $\begin{array}{llll}\mathrm{N} & \mathrm{I} & 02 & \mathrm{E} \\
\mathrm{S} & 82 & 56 & \mathrm{WV} \\
\mathrm{S} & 20 & 17 & \mathrm{~W}\end{array}$ & $\begin{array}{llll}\mathrm{S} & 15 & 02 & \mathrm{~W} \\
\mathrm{~N} & 82 & 55 & \mathrm{E} \\
\mathrm{N} & 20 & 17 & \mathrm{E}\end{array}$ & $\begin{array}{r}632 \\
2360 \\
971\end{array}$ & $\begin{array}{l}\text { Iron. } \\
\text { Ferry. } \\
\text { Huddle. }\end{array}$ \\
\hline
\end{tabular}

UMPHASIS.

(Magothy River-Chart No. 2.)

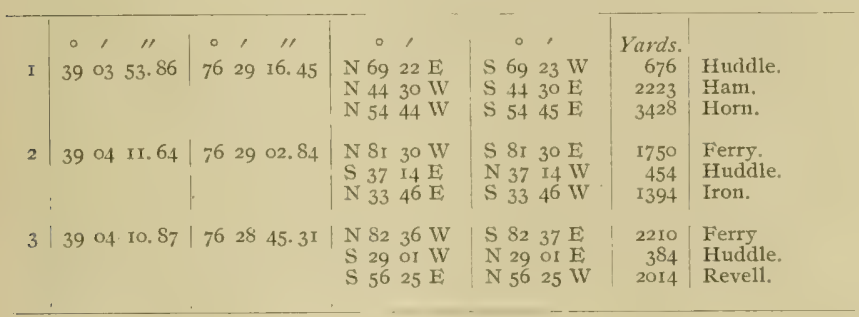

\section{BLACK.}

(Magothy River-Chart No, 2.)

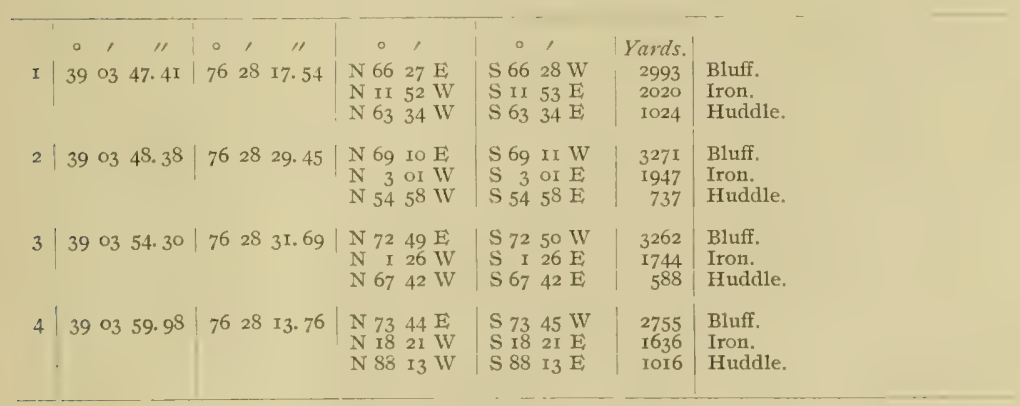




\section{PERSIMIMON.}

(Magothy River-Chart No. 2.)

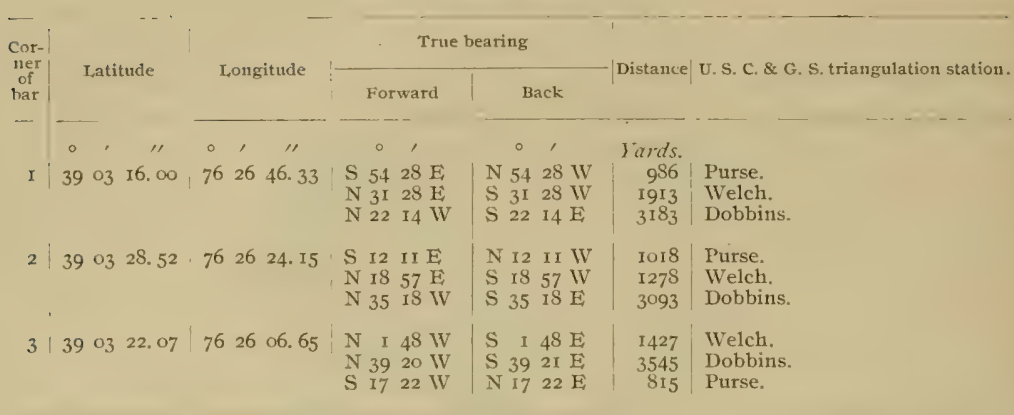

\section{OUTER MAGOTHY.}

(Chesapeake Bay between Sandy Point and Magothy River-Chant No. 2.)

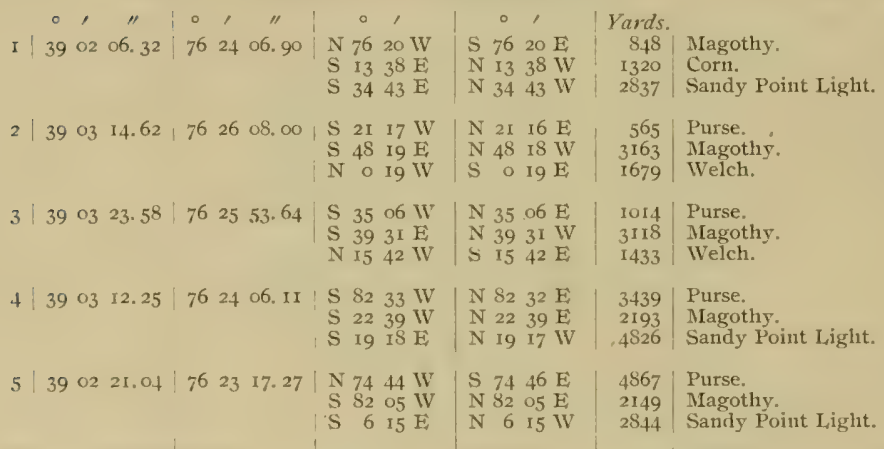




\section{SANDY POINT NORTH.}

(Chesapeake Bay-North of Sandy Point-Chart No. 2.)

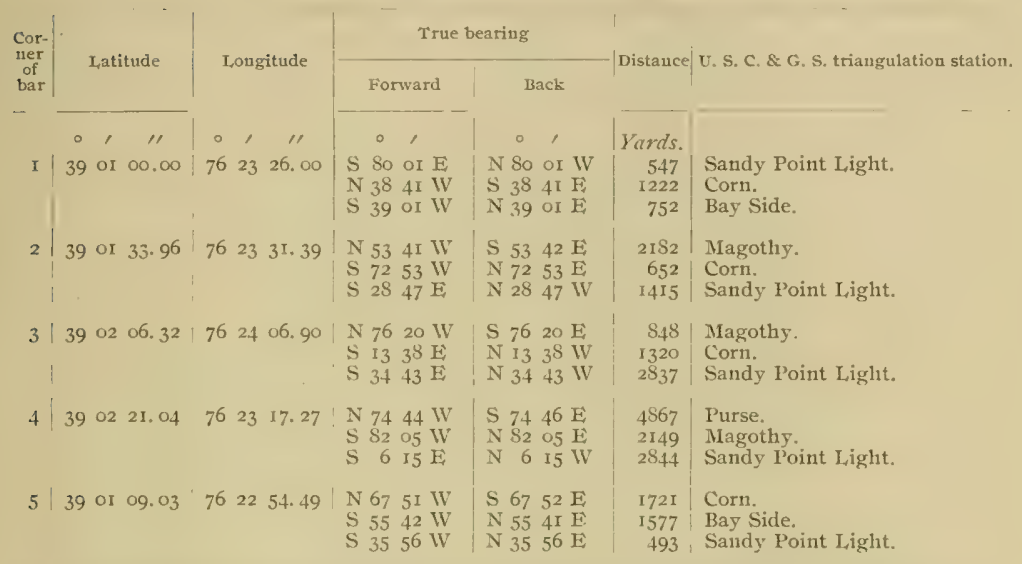

\section{SANIUY POINT SOUTH.}

(Chesapeake Bay between Sandy Point and Sezern Kiver-Chart No. 2.)

\begin{tabular}{|c|c|c|c|c|c|c|c|c|c|c|c|c|}
\hline 1 & $\begin{array}{c}\circ \\
38\end{array}$ & $\begin{array}{l}1 \\
59\end{array}$ & $\begin{array}{c}\prime \prime \\
25.24\end{array}$ & $\begin{array}{c}\circ \\
76\end{array}$ & $\frac{1}{24}$ & 12,60 & $\begin{array}{l}0 \\
\text { N } 29 \\
\text { N } 54 \\
\text { S } 76\end{array}$ & $\begin{array}{l}39 \mathrm{~F} \\
24 \mathrm{WV} \\
4 \mathrm{IV}\end{array}$ & $\begin{array}{c}0 \\
\text { S } 29 \\
\text { S } 54 \\
\text { N } 76\end{array}$ & $\begin{array}{l}40 \mathrm{WV} \\
25 \mathrm{E} \\
40 \mathrm{E}\end{array}$ & $\begin{array}{l}\text { Yards. } \\
3568 \\
\text { I1 } 35 \\
\text { ISS9 }\end{array}$ & $\begin{array}{l}\text { Sandy Point Light. } \\
\text { Clump. } \\
\text { Hackett. }\end{array}$ \\
\hline 2 & $3^{S}$ & 59 & 31.59 & 76 & 24 & 22.86 & $\begin{array}{l}\text { N } 35 \\
\text { N } 55 \\
\text { S } 67\end{array}$ & $\begin{array}{l}\text { II } \mathrm{E} \\
3 S \mathrm{WV} \\
30 \mathrm{WV}\end{array}$ & $\begin{array}{l}\text { S } 35 \\
\text { S } 55 \\
\text { N } 67\end{array}$ & $\begin{array}{l}12 \mathrm{~W} \\
38 \mathrm{E} \\
29 \mathrm{E}\end{array}$ & $\begin{array}{r}3532 \\
792 \\
1697\end{array}$ & $\begin{array}{l}\text { Sandy Point Liglit. } \\
\text { Clump. } \\
\text { Hackett. }\end{array}$ \\
\hline 3 & 39 & $\infty$ & 09.70 & 76 & 24 & 09.40 & $\begin{array}{l}\text { N } 46 \\
\text { N } 3 I \\
\text { S } 50\end{array}$ & $\begin{array}{l}24 \mathrm{E} \\
\text { OI E } \\
\mathrm{I}+\mathrm{W}\end{array}$ & $\begin{array}{l}\text { S } 46 \\
\text { S } 3 I \\
\text { N } 50\end{array}$ & $\begin{array}{l}24 \mathrm{~W} \\
\text { or W } \\
\text { I. E }\end{array}$ & $\begin{array}{l}2322 \\
1298 \\
1311\end{array}$ & $\begin{array}{l}\text { Sandy Point Light. } \\
\text { Bay Side. } \\
\text { Clump. }\end{array}$ \\
\hline 4 & 39 & $\infty$ & 40,02 & 76 & 23 & I9. 79 & $\begin{array}{l}\text { N } 33 \\
\text { N } 81 \\
\text { S } 51\end{array}$ & $\begin{array}{l}\text { OI E } \\
59 \mathrm{~W} \\
\text { I2 } \mathrm{W}\end{array}$ & $\begin{array}{l}\text { S } 33 \\
\text { S Si } \\
\text { N } 51\end{array}$ & $\begin{array}{l}\text { or W } \\
59 \mathrm{E} \\
\text { II } \mathbf{E}\end{array}$ & $\begin{array}{r}690 \\
643 \\
2969\end{array}$ & $\begin{array}{l}\text { Sandy Point Light. } \\
\text { Bay Side. } \\
\text { Clump. }\end{array}$ \\
\hline 5 & 39 & $\infty$ & 39.60 & 76 & 23 & 10. 25 & $\begin{array}{l}N \text { II } \\
N 8_{3} \\
S \text { S } 54\end{array}$ & $\begin{array}{l}55 \mathrm{E} \\
20 \mathrm{~W} \\
15 \mathrm{~W}\end{array}$ & $\begin{array}{l}\text { S } 11 \\
\text { S } 83 \\
\text { N } 54\end{array}$ & $\begin{array}{l}55 \mathrm{~W} \\
20 \mathrm{E} \\
14 \mathrm{E}\end{array}$ & $\begin{array}{r}608 \\
893 \\
3161\end{array}$ & $\begin{array}{l}\text { Sandy Point Light. } \\
\text { Bay Side. } \\
\text { Clump. }\end{array}$ \\
\hline 6 & 39 & oo & 09. 44 & 76 & 23 & 25. So & 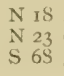 & $\begin{array}{l}21 \mathrm{E} \\
\text { O7 } \mathrm{W} \\
57 \mathrm{~W}\end{array}$ & $\begin{array}{l}\mathrm{S} 18 \\
\mathrm{~S} 23 \\
\mathrm{~N}\end{array}$ & $\begin{array}{l}22 \mathrm{~W} \\
07 \mathrm{E} \\
56 \mathrm{E}\end{array}$ & $\begin{array}{l}1696 \\
1222 \\
2310\end{array}$ & $\begin{array}{l}\text { Sandy Point Light. } \\
\text { Bay Side. } \\
\text { Clump. }\end{array}$ \\
\hline 7 & $3^{8}$ & 59 & 30.91 & 76 & 24 & 00.00 & $\begin{array}{l}N 26 \\
N 69 \\
\text { S } 73 \\
-\end{array}$ & $\begin{array}{l}14 \mathrm{E} \\
29 \mathrm{WV} \\
54 \mathrm{WV}\end{array}$ & $\begin{array}{l}\text { S } 26 \\
\text { S } 69 \\
\text { N } 73\end{array}$ & $\begin{array}{l}\text { I5 W } \\
29 \mathrm{E} \\
53 \mathrm{E}\end{array}$ & $\begin{array}{l}3244 \\
\mathbf{I} 340 \\
225^{S}\end{array}$ & $\begin{array}{l}\text { Sandy Point Light. } \\
\text { Clump. } \\
\text { Hackett. }\end{array}$ \\
\hline
\end{tabular}




\section{HACKETT POIN'T.}

(Annapolis Roads-Chart No. 2.)

\begin{tabular}{|c|c|c|c|c|c|c|c|c|c|c|}
\hline \multirow{2}{*}{$\begin{array}{l}\text { Cor- } \\
\text { ner } \\
\text { of } \\
\text { bar }\end{array}$} & \multirow{2}{*}{\multicolumn{3}{|c|}{ Latitude }} & \multirow{2}{*}{\multicolumn{2}{|c|}{ Longitude }} & \multicolumn{3}{|c|}{ True bearing } & \multirow{2}{*}{ Distance } & \multirow{2}{*}{ U. S. C. \& G. S. triankulation station } \\
\hline & & & & & & & orward & Back & & \\
\hline I & $3^{\circ}$ & $\frac{1}{57}$ & $\begin{array}{c}\prime \prime \\
49.56\end{array}$ & $\begin{array}{c}\circ \\
76\end{array}$ & $\begin{array}{c}\prime \prime \prime \\
25 \\
5 \text { T. } 90\end{array}$ & $\begin{array}{lr} & 0 \\
N & 15 \\
N & 76 \\
\text { S } & 35\end{array}$ & $\begin{array}{lll}5 & 32 & \mathrm{E} \\
6 & 4 \mathrm{I} & \mathrm{WV} \\
5 & 05 & \mathrm{WV}\end{array}$ & $\begin{array}{lccc} & 0 & \\
\mathrm{~S} & \mathrm{I} & 32 & \mathrm{~W} \\
\mathrm{~S} & 76 & 42 & \mathrm{E} \\
\mathrm{N} & 35 & 04 & \mathrm{E}\end{array}$ & $\begin{array}{r}\text { Yards } \\
2897 \\
228 \mathrm{r} \\
3260\end{array}$ & $\begin{array}{l}\text { Hackett. } \\
\text { Greenbury Point Light, } \\
\text { Tolly. }\end{array}$ \\
\hline 2 & $3 \hat{8}$ & $5^{8}$ & 13.82 & 76 & 2605.14 & $\begin{array}{l}\text { N } 29 \\
S \quad 8 I \\
S \quad 23\end{array}$ & $\begin{array}{ll}9 & 40 \mathrm{E} \\
\mathrm{I} & \text { OS W } \\
3 & 38 \mathrm{~W}\end{array}$ & $\begin{array}{llll}\mathrm{S} & 29 & 4 \mathrm{r} & \mathrm{W} \\
\mathrm{N} & 8 \mathrm{r} & \text { o7 } & \mathrm{E} \\
\mathrm{N} & 23 & 37 & \mathrm{E}\end{array}$ & $\begin{array}{l}2271 \\
1894 \\
3806\end{array}$ & $\begin{array}{l}\text { Hackett. } \\
\text { Greenbury Point Light. } \\
\text { Tolly. }\end{array}$ \\
\hline 3 & 38 & $5^{8}$ & 49.60 & 76 & 2550,84 & $\begin{array}{ll}N & 44 \\
N & 17 \\
S & 56\end{array}$ & $\begin{array}{lll}4 & 17 & \mathrm{E} \\
7 & 06 & \mathrm{WV} \\
6 & 19 & \mathrm{WV}\end{array}$ & $\begin{array}{llll}\mathrm{S} & 44 & 17 & \mathrm{~W} \\
\mathrm{~S} & 17 & 06 & \mathrm{E} \\
\mathrm{N} & 56 & 18 & \mathrm{E}\end{array}$ & $\begin{array}{l}1073 \\
1960 \\
2702\end{array}$ & $\begin{array}{l}\text { Hackett. } \\
\text { Chase. } \\
\text { Greenbury Point Light. }\end{array}$ \\
\hline 4 & $3^{8}$ & $5^{8}$ & 52.60 & 76 & $25 \quad 22.77$ & $\begin{array}{l}\mathrm{N} 27 \\
\mathrm{~N} \\
\mathrm{~S}\end{array}$ & 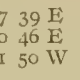 & $\begin{array}{lrll}S & 27 & 40 & \mathrm{~W} \\
\mathrm{~S} & 0 & 46 \mathrm{~W} \\
\mathrm{~N} & 6 \mathrm{I} & 48 & \mathrm{E}\end{array}$ & $\begin{array}{r}1989 \\
665 \\
3388\end{array}$ & $\begin{array}{l}\text { Clump. } \\
\text { Hackett. } \\
\text { Greenbury Point Light. }\end{array}$ \\
\hline 5 & $3^{8}$ & 59 & 3I. 59 & 76 & 2422.86 & $\begin{array}{l}N 35 \\
N 55 \\
\text { S } 67\end{array}$ & $\begin{array}{lll}5 & \text { II } & \mathrm{E} \\
5 & 38 \mathrm{~W} \\
7 & 30 \mathrm{WV}\end{array}$ & $\begin{array}{llll}\mathrm{S} & 35 & 12 & \mathrm{IV} \\
\mathrm{S} & 55 & 38 & \mathrm{E} \\
\mathrm{N} & 67 & 29 & \mathrm{E}\end{array}$ & $\begin{array}{r}3532 \\
792 \\
1697\end{array}$ & $\begin{array}{l}\text { Sandy Point Light. } \\
\text { Clump. } \\
\text { Hackett. }\end{array}$ \\
\hline 6 & $3^{S}$ & 59 & 25.24 & 76 & $24 \quad 12.60$ & $\begin{array}{l}\text { N } 29 \\
N \\
N 4 \\
S 76\end{array}$ & $\begin{array}{lll}9 & 39 & \mathrm{~F} \\
4 & 24 & \mathrm{WV} \\
6 & 4 \mathrm{I} & \mathrm{WV}\end{array}$ & $\begin{array}{l}\mathrm{S} 2940 \mathrm{WV} \\
\mathrm{S} 5425 \mathrm{E} \\
\mathrm{N} 7640 \mathrm{E}\end{array}$ & $\begin{array}{l}3568 \\
\text { Ir } 35 \\
\text { I } 889\end{array}$ & $\begin{array}{l}\text { Sandy Point Light. } \\
\text { Clump. } \\
\text { Hackett. }\end{array}$ \\
\hline 7 & $3^{S}$ & 59 & 02.50 & 76 & 2418.26 & $\begin{array}{l}N 28 \\
N 78 \\
S 67\end{array}$ & $\begin{array}{ll}29 & \mathrm{~W} \\
5 & 54 \mathrm{~W} \\
35 \mathrm{~W}\end{array}$ & $\begin{array}{llll}\mathrm{S} & 28 & 29 & \mathrm{E} \\
\mathrm{S} & 78 & 54 & \mathrm{E} \\
\mathrm{N} & 67 & 33 & \mathrm{E}\end{array}$ & $\begin{array}{l}1625 \\
1721 \\
5068\end{array}$ & $\begin{array}{l}\text { Clump. } \\
\text { Hackett. } \\
\text { Greenbury Point Light. }\end{array}$ \\
\hline 8 & 38 & 57 & $54 \cdot 3^{8}$ & 76 & 2454.95 & $\begin{array}{l}\mathrm{N} 15 \\
\mathrm{~N} 84 \\
\mathrm{~S} 50\end{array}$ & $\begin{array}{lll}5 & 23 & \mathrm{~W} \\
4 & 25 \mathrm{~W} \\
0 & 00 \mathrm{~W}\end{array}$ & $\begin{array}{llll}\mathrm{S} & 15 & 23 & \mathrm{E} \\
\mathrm{S} & 84 & 26 & \mathrm{E} \\
\mathrm{N} & 49 & 59 & \mathrm{E}\end{array}$ & $\begin{array}{l}2726 \\
3737 \\
4404\end{array}$ & $\begin{array}{l}\text { Hackett, } \\
\text { Greenbury Point Light. } \\
\text { Tolly. }\end{array}$ \\
\hline
\end{tabular}

WHITEHALL CREEK.

(Whitchall Bay-Chart No. 2.)

\begin{tabular}{|c|c|c|c|c|c|c|c|}
\hline I & $\begin{array}{ccc}0 & \prime & \prime \prime \\
3^{8} & 59 & 30.4 \mathrm{I}\end{array}$ & $\begin{array}{c}\circ \quad \\
7625\end{array}$ & ${ }^{\prime \prime}$ & 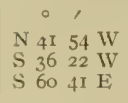 & 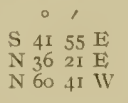 & $\begin{array}{r}\text { Yards. } \\
667 \\
3571 \\
479\end{array}$ & $\begin{array}{l}\text { Chase. } \\
\text { Greenbury Point Light. } \\
\text { Spit. }\end{array}$ \\
\hline 2 & $3^{S} 593^{6} .9^{9}$ & $76 \quad 26$ & 27.62 & 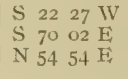 & $\begin{array}{l}\mathrm{N} 2227 \mathrm{E} \\
\mathrm{N} 7002 \mathrm{WW} \\
\mathrm{S}^{\prime} 5454 \mathrm{~W}\end{array}$ & $\begin{array}{r}3351 \\
1335 \\
479\end{array}$ & $\begin{array}{l}\text { Greenbury Point Light. } \\
\text { Spit. } \\
\text { Chase. }\end{array}$ \\
\hline 3 & $3^{8} 5939.6 \mathrm{r}$ & $76=6$ & 27.17 & 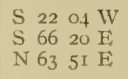 & $\begin{array}{l}\mathrm{N} 2204 \mathrm{E} \\
\mathrm{N} 6620 \mathrm{WW} \\
\mathrm{S} 635 \mathrm{I}\end{array}$ & $\begin{array}{r}3437 \\
1357 \\
423\end{array}$ & $\begin{array}{l}\text { Greenbury Point Light. } \\
\text { Spit. } \\
\text { Chase. }\end{array}$ \\
\hline 4 & $3^{8} 59 \quad 39.62$ & 7626 & 606.79 & 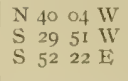 & $\begin{array}{l}\mathrm{S} 4004 \mathrm{E} \\
\mathrm{N} 2950 \mathrm{E} \\
\mathrm{N} 522 \mathrm{I} \mathrm{W}\end{array}$ & $\begin{array}{r}243 \\
3672 \\
892\end{array}$ & $\begin{array}{l}\text { Chase. } \\
\text { Greenbury Point Light. } \\
\text { Spit. }\end{array}$ \\
\hline 5 & $3^{8} 5948.92$ & 7625 & 53.42 & $\begin{array}{llll}\mathrm{S} & 75 & 56 \mathrm{~W} \\
\mathrm{~S} & 22 & 27 \mathrm{E} \\
\mathrm{S} & 85 & 27 & \mathrm{E}\end{array}$ & $\begin{array}{l}\text { N } 7555 \text { E } \\
\text { N } 2227 \mathrm{~W} \\
\text { N } 8526 \mathrm{~W}\end{array}$ & $\begin{array}{r}524 \\
930 \\
1736\end{array}$ & $\begin{array}{l}\text { Chase. } \\
\text { Spit. } \\
\text { Clump. }\end{array}$ \\
\hline
\end{tabular}


SAND SPI'T.

(Whitehall Bay-Chart No. 2.)

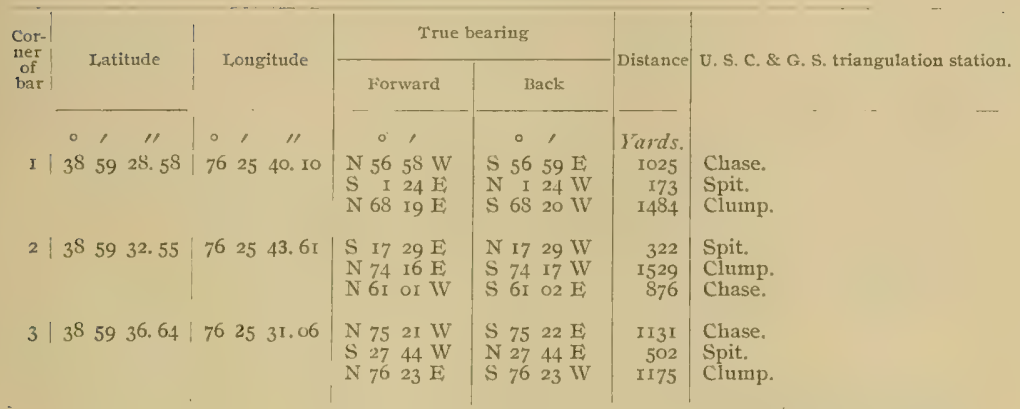

\section{WHITEHALL.}

(Annapolis Roads-Chart No. 2.)

\begin{tabular}{|c|c|c|c|c|c|c|c|c|c|c|c|c|}
\hline & $\begin{array}{l}0 \\
{ }_{3} S\end{array}$ & ' & 34.40 & $\begin{array}{c}\circ \\
76\end{array}$ & $\begin{array}{l}\prime \\
26\end{array}$ & $\begin{array}{c}\prime \prime \prime \\
50.62\end{array}$ & 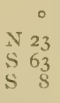 & $\begin{array}{l}37 \mathrm{~W} \\
\text { I } \mathrm{W} \\
3 \mathrm{~S} \\
\mathrm{WV}\end{array}$ & $\begin{array}{l}0 \\
S \\
N \\
N\end{array} 63$ & $\begin{array}{l}1 \\
38 \mathrm{E} \\
13 \mathrm{E} \\
3 \mathrm{SE}\end{array}$ & $\begin{array}{r}\text { Yards. } \\
1912 \\
2154 \\
2183\end{array}$ & $\begin{array}{l}\text { Greenbury. } \\
\text { Gran. } \\
\text { Tolly. }\end{array}$ \\
\hline & $3^{8}$ & 57 & $5^{8.45}$ & 76 & 27 & 23. 80 & $\begin{array}{l}\text { S I0 } \\
\text { N } 41 \\
\text { N } 66\end{array}$ & $\begin{array}{l}26 \mathrm{WV} \\
27 \mathrm{E} \\
\mathrm{r}_{3} \mathrm{WV}\end{array}$ & $\begin{array}{l}\text { N } 10 \\
\text { S } 41 \\
\text { S } 66\end{array}$ & $\begin{array}{l}26 \mathrm{E} \\
27 \mathrm{~W}^{\prime} \\
13 \mathrm{E}\end{array}$ & $\begin{array}{r}3018 \\
302 \\
1801\end{array}$ & $\begin{array}{l}\text { Tolly. } \\
\text { Greenbury Point Light. } \\
\text { Horn. }\end{array}$ \\
\hline & $3^{S}$ & $5^{8}$ & 31. 52 & 76 & 26 & 46.72 & $\begin{array}{l}N \text { Ig } \\
S \\
S \\
S\end{array}$ & $\begin{array}{l}48 \mathrm{~F} \\
35 \mathrm{~W} \\
\text { os } \mathrm{W}\end{array}$ & $\begin{array}{l}\text { S } 19 \\
\text { N } 78 \\
N \\
\text { NI }\end{array}$ & $\begin{array}{l}49 \mathrm{~W} \\
35 \mathrm{E} \\
\text { OS E }\end{array}$ & $\begin{array}{r}2645 \\
8 \$ 6 \\
1183\end{array}$ & $\begin{array}{l}\text { Chase. } \\
\text { Greenbury. } \\
\text { Greenbury Point Light. }\end{array}$ \\
\hline & $3^{8}$ & $5^{S}$ & 57.50 & 76 & 26 & 47.47 & $\begin{array}{l}\mathrm{S} 23 \\
\mathrm{~N} 63 \\
\mathrm{~N} 29\end{array}$ & $\begin{array}{l}12 \mathrm{~W} \\
46 \mathrm{E} \\
38 \mathrm{E}\end{array}$ & 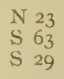 & $\begin{array}{l}12 \mathrm{E} \\
47 \mathrm{~W} \\
38 \mathrm{~W}\end{array}$ & $\begin{array}{l}1920 \\
1982 \\
1848\end{array}$ & $\begin{array}{l}\text { Greenbury Point Iight. } \\
\text { Spit. } \\
\text { Chase. }\end{array}$ \\
\hline & $3^{8}$ & 59 & 20. 75 & 76 & 26 & 27.40 & $\begin{array}{l}S 26 \\
N \\
N \\
N\end{array}$ & $\begin{array}{l}45 \mathrm{WV} \\
49 \mathrm{E} \\
08 \mathrm{E}\end{array}$ & $\begin{array}{ll}\mathrm{N} & 26 \\
\mathrm{~S} & 85 \\
\mathrm{~S} & 25\end{array}$ & $\begin{array}{l}45 \mathrm{E} \\
49 \mathrm{WV} \\
08 \mathrm{WV}\end{array}$ & $\begin{array}{r}2855 \\
1252 \\
911\end{array}$ & $\begin{array}{l}\text { Greenbury Point Light. } \\
\text { Spit. } \\
\text { Chase. }\end{array}$ \\
\hline & $3^{8}$ & 59 & 09.60 & 76 & 26 & 21.62 & $\begin{array}{l}\text { N } 66 \\
\text { N II } \\
\text { S } 46\end{array}$ & $\begin{array}{l}55 \mathrm{E} \\
\mathrm{O}^{2} \mathrm{E} \\
20 \mathrm{VW}^{\gamma}\end{array}$ & $\begin{array}{l}\text { S } 66 \\
\text { S II } \\
\text { N } 46\end{array}$ & $\begin{array}{l}56 \mathrm{WV} \\
\mathrm{O} 2 \mathrm{WV} \\
20 \mathrm{E}\end{array}$ & $\begin{array}{l}\text { II92 } \\
\text { I222 } \\
2114\end{array}$ & $\begin{array}{l}\text { Spit. } \\
\text { Chase. } \\
\text { Greenbury. }\end{array}$ \\
\hline & $3^{8}$ & $5^{S}$ & 45. 22 & 76 & 26 & 28.90 & $\begin{array}{l}\text { N } 44 \\
\text { N II } \\
\text { S } 64\end{array}$ & $\begin{array}{l}59 \mathrm{E} \\
53 \mathrm{E} \\
31 \mathrm{~W}\end{array}$ & $\begin{array}{ll}\text { S } & 44 \\
\text { S } & \text { II } \\
\text { N } 64\end{array}$ & $\begin{array}{l}59 \mathrm{WV} \\
53 \mathrm{WW} \\
3 \mathrm{I} \mathrm{E}\end{array}$ & $\begin{array}{l}1 S 23 \\
2065 \\
1482\end{array}$ & $\begin{array}{l}\text { Spit. } \\
\text { Chase. } \\
\text { Greenbury. }\end{array}$ \\
\hline & $3^{8}$ & $5^{S}$ & 06.96 & 76 & 26 & 17. 16 & $\begin{array}{l}\text { N } 33 \\
\text { S } 87 \\
\text { S } 20\end{array}$ & $\begin{array}{l}\text { I0 } \mathrm{E} \\
45 \mathrm{~W} \\
22 \mathrm{~W}\end{array}$ & $\begin{array}{l}\text { S } 33 \\
\text { N } 87 \\
N \quad 20\end{array}$ & $\begin{array}{l}\text { I0 W } \\
45 \mathrm{E} \\
22 \mathrm{E}\end{array}$ & $\begin{array}{l}2633 \\
1556 \\
3473\end{array}$ & $\begin{array}{l}\text { Hackett. } \\
\text { Greenbury Point Light. } \\
\text { Tolly. }\end{array}$ \\
\hline
\end{tabular}




\section{WRECK BUOY.}

(Annapolis Roads-Chant No. 2.)

\begin{tabular}{|c|c|c|c|c|c|c|}
\hline \multirow{2}{*}{$\begin{array}{c}\text { Cor- } \\
\text { ner } \\
\text { of } \\
\text { bar }\end{array}$} & \multirow{2}{*}{ Latitude } & \multirow{2}{*}{ Longitude } & \multicolumn{2}{|c|}{ True bearing } & \multirow{2}{*}{ Distauce } & \multirow{2}{*}{ U. S. C. \& G. S. triangulation station. } \\
\hline & & & Forward & Back & & \\
\hline I & $\begin{array}{ccc}\circ & 1 & \prime \prime \\
3^{8} & 57 & 45.00\end{array}$ & $\begin{array}{ccc}\circ & \prime \prime & \prime \prime \\
76 & 26 & 08.80\end{array}$ & $\begin{array}{ccc} & 0 & 1 \\
N & I & 28 \mathrm{~W} \\
N & 69 & 03 \mathrm{~W} \\
\mathrm{~S} & 29 & 36 \mathrm{~W}\end{array}$ & $\begin{array}{ccc} & 0 & 1 \\
\text { S } & I & 28 \\
\text { S } & 69 & 03 \\
\text { N } & 29 & 36 \\
\text { E E }\end{array}$ & $\begin{array}{c}\text { Yards. } \\
4053 \\
1901 \\
2893\end{array}$ & $\begin{array}{l}\text { Chase. } \\
\text { Greenbury Point Light. } \\
\text { Tolly. }\end{array}$ \\
\hline 2 & $3^{8} 57 \cdot 45 \cdot 74$ & $\begin{array}{lll}76 & 26 & 24.60\end{array}$ & $\begin{array}{llll}\mathrm{N} & 4 & 26 & \mathrm{E} \\
\mathrm{N} & 64 & \mathrm{I} & \mathrm{W} \\
\mathrm{S} & 21 & 45 & \mathrm{~W}\end{array}$ & $\begin{array}{llll}\mathrm{S} & 4 & 26 & \mathrm{~W} \\
\mathrm{~S} & 64 & 17 & \mathrm{E} \\
\mathrm{N} & 21 & 44 & \mathrm{E}\end{array}$ & $\begin{array}{l}4039 \\
1508 \\
2735\end{array}$ & $\begin{array}{l}\text { Chase. } \\
\text { Greenbury Point Light. } \\
\text { Tolly. }\end{array}$ \\
\hline 3 & $3^{8} 5756.16$ & $\begin{array}{lll}76 & 26 & 26.80\end{array}$ & $\begin{array}{lrll}\mathrm{N} & 5 & 45 & \mathrm{E} \\
\mathrm{N} & 76 & 53 & \mathrm{~W} \\
\mathrm{~S} & 18 & 17 & \mathrm{~W}\end{array}$ & $\begin{array}{lrl}\mathrm{S} & 5 & 45 \mathrm{~W} \\
\mathrm{~S} & 76 & 54 \\
\mathrm{~N} & \mathrm{E} & \mathrm{E} \\
\mathrm{I} & \mathrm{E}\end{array}$ & $\begin{array}{l}3694 \\
1336 \\
3045\end{array}$ & $\begin{array}{l}\text { Chase. } \\
\text { Greenbury Point Light. } \\
\text { Tolly. }\end{array}$ \\
\hline 4 & $3^{8} 5757.21$ & $762557.4 \mathrm{I}$ & $\begin{array}{llll}\mathrm{N} & 6 & 20 \mathrm{~W} \\
\mathrm{~N} & 82 & 38 \mathrm{~W} \\
\mathrm{~S} & 30 & 34 \mathrm{~W}\end{array}$ & 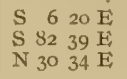 & $\begin{array}{l}3662 \\
2092 \\
3400\end{array}$ & $\begin{array}{l}\text { Chase. } \\
\text { Greenbury Point Light. } \\
\text { Tolly. }\end{array}$ \\
\hline
\end{tabular}

TOLLY POINT.

(Annapolis Roads-Charts Nos. 2 and 3.)

\begin{tabular}{|c|c|c|c|c|c|c|c|}
\hline I & $\mid \begin{array}{cc}\circ & \\
38 & 55\end{array}$ & 51.02 & $\begin{array}{ccc}\circ & \prime & \prime \prime \\
76 & 25 & 58.66\end{array}$ & $\begin{array}{lll} & 0 & 1 \\
N & 24 & 18 \mathrm{~W} \\
N & 51 & 56 \mathrm{WV} \\
\mathrm{S} & 4 & 31 \mathrm{VW}\end{array}$ & 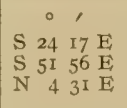 & $\begin{array}{r}\text { Yards. } \\
4963 \\
2154 \\
3883\end{array}$ & $\begin{array}{l}\text { Greenbury Point Light. } \\
\text { Tolly. } \\
\text { Thomas Point Light. }\end{array}$ \\
\hline 2 & $3^{8} 56$ & $45 \cdot 5^{2}$ & $\begin{array}{lll}76 & 27 & 13.00\end{array}$ & 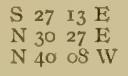 & $\begin{array}{llll}\mathrm{N} & 27 & 12 & \mathrm{~W} \\
\mathrm{~S} & 30 & 28 & \mathrm{~W} \\
\mathrm{~S} & 40 & 09 & \mathrm{E}\end{array}$ & $\begin{array}{r}573 \\
5744 \\
2884\end{array}$ & $\begin{array}{l}\text { Tolly. } \\
\text { Hackett. } \\
\text { Start. }\end{array}$ \\
\hline 3 & $3^{8} 57$ & 728.74 & $\begin{array}{lll}76 & 27 & 32.60\end{array}$ & 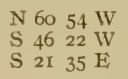 & $\begin{array}{llll}\mathrm{S} & 60 & 54 & \mathrm{E} \\
\mathrm{N} & 46 & 22 & \mathrm{E} \\
\mathrm{N} & 2 \mathrm{I} & 35 & \mathrm{~W}\end{array}$ & $\begin{array}{l}1537 \\
1130 \\
2115\end{array}$ & $\begin{array}{l}\text { Start. } \\
\text { Gram. } \\
\text { Tolly. }\end{array}$ \\
\hline 4 & $3^{8} 57$ & 742,02 & $\begin{array}{lll}76 & 27 & 10.60\end{array}$ & $\begin{array}{l}\mathrm{N} \text { to } 44 \mathrm{WV} \\
\mathrm{S} 48 \mathrm{WW} \\
\mathrm{S} 442 \mathrm{E}\end{array}$ & 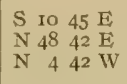 & $\begin{array}{r}794 \\
1859 \\
2422\end{array}$ & $\begin{array}{l}\text { Greenbury Point Light. } \\
\text { Gram. } \\
\text { Tolly. }\end{array}$ \\
\hline 5 & $3^{8} 57$ & $7 \quad 13.35$ & $\begin{array}{llll}76 & 26 & 5 \text { I. } 19\end{array}$ & 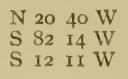 & 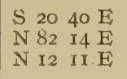 & $\begin{array}{l}1867 \\
1926 \\
1481\end{array}$ & $\begin{array}{l}\text { Greenbury Point Light. } \\
\text { Gram. } \\
\text { Tolly. }\end{array}$ \\
\hline 6 & $3^{8} 57$ & 703.78 & $\begin{array}{llll}76 & 26 & 25.24\end{array}$ & $\begin{array}{llll}\mathrm{N} & 20 & 52 & \mathrm{E} \\
\mathrm{N} & 33 & \mathrm{O} 2 \mathrm{~W} \\
\mathrm{~S} & 4 \mathrm{I} & 3 \mathrm{I} & \mathrm{W}\end{array}$ & $\begin{array}{llll}\mathrm{S} & 20 & 53 & \mathrm{~W} \\
\mathrm{~S} & 33 & \mathrm{O} 2 & \mathrm{E} \\
\mathrm{N} & 41 & 31 & \mathrm{E}\end{array}$ & $\begin{array}{l}4640 \\
2463 \\
1503\end{array}$ & $\begin{array}{l}\text { Hackett. } \\
\text { Greenbury Point Light. } \\
\text { Tolly. }\end{array}$ \\
\hline 7 & $3^{8} 56$ & $513.8 \mathrm{I}$ & $\begin{array}{ll}76 & 25 \\
32.62\end{array}$ & $\begin{array}{llll}\mathrm{N} & 2 & 33 & \mathrm{E} \\
\mathrm{N} & 36 & 00 \mathrm{~W} \\
\mathrm{~N} & 76 & 46 & \mathrm{~W}\end{array}$ & $\begin{array}{llll}\mathrm{S} & 2 & 33 & \mathrm{~W} \\
\mathrm{~S} & 36 & \text { OI } & \mathrm{E} \\
\mathrm{S} & 76 & 46 & \mathrm{E}\end{array}$ & $\begin{array}{l}6027 \\
464 I^{\prime} \\
2447\end{array}$ & $\begin{array}{l}\text { Hackett. } \\
\text { Greenbury Point Light. } \\
\text { Tolly. }\end{array}$ \\
\hline
\end{tabular}


CHINKS POINT.

(Annapolis Roads-Chart No. 2.)

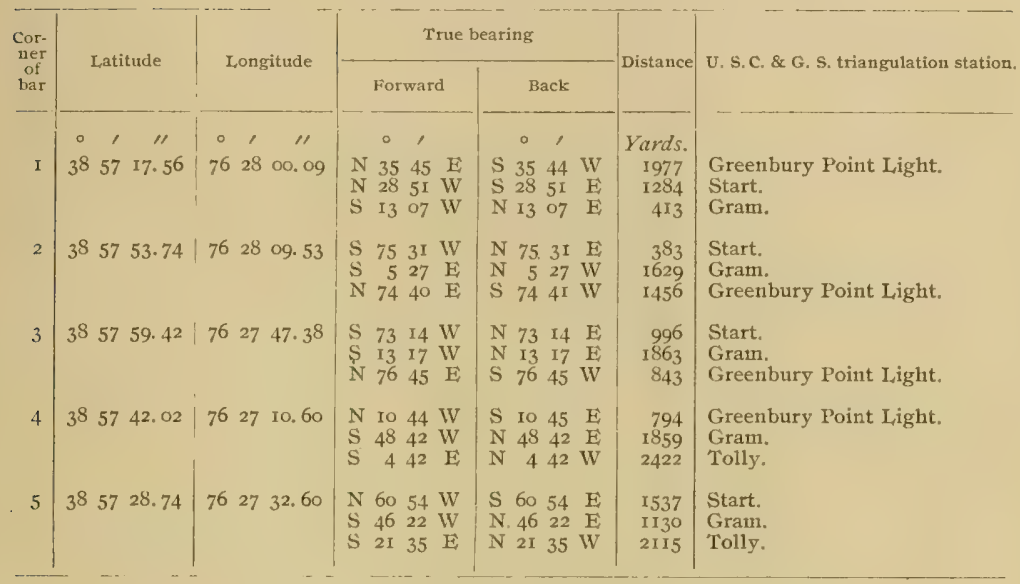

INSIDE GREENBURY POINT.

(Lower Sevent River-Chart No. 2.)

\begin{tabular}{|c|c|c|c|c|c|c|}
\hline I & $\begin{array}{ccc}\circ & \prime & \prime \prime \\
38 & 58 & 13.37\end{array}$ & $\begin{array}{ccc}0 & \prime & \prime \prime \\
76 & 27 & 29.65\end{array}$ & 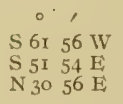 & \begin{tabular}{ccc} 
& $\circ$ \\
N & \multicolumn{1}{c}{} & \\
N & 55 & $\mathrm{E}$ \\
$\mathrm{S}$ & $54 \mathrm{~W}$ \\
$\mathrm{~S}$ & 30 & $56 \mathrm{~W}$
\end{tabular} & $\begin{array}{r}\text { Yards. } \\
16 \text { Io } \\
449 \\
510\end{array}$ & $\begin{array}{l}\text { Start. } \\
\text { Greenbury Point Light. } \\
\text { Greenbury. }\end{array}$ \\
\hline 2 & $3^{8} \quad 5^{8} \times 4.06$ & $\begin{array}{llll}76 & 27 & 36.89\end{array}$ & $\begin{array}{l}\mathrm{S} 57.35 \mathrm{~W} \\
\text { S } 6 \mathrm{I} \text {. } 66 \mathrm{E} \\
\text { N } 4734 \mathrm{E}\end{array}$ & $\begin{array}{l}\text { N } 5735 \mathrm{E} \\
\text { N } 6106 \mathrm{~W} \\
\text { S } 4734 \mathrm{~W}\end{array}$ & $\begin{array}{r}1457 \\
622 \\
612\end{array}$ & $\begin{array}{l}\text { Start. } \\
\text { Greenbury Point Light. } \\
\text { Greenbury. }\end{array}$ \\
\hline 3 & $3^{8} 5^{8} 55.75$ & $\begin{array}{llll}76 & 27 & 29.30\end{array}$ & 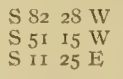 & $\begin{array}{llll}\mathrm{N} & 82 & 28 & \mathrm{E} \\
\mathrm{N} & 5 \mathrm{I} & \mathrm{I} & \mathrm{E} \\
\mathrm{N} & \mathrm{EI} & 24 & \mathrm{WW}\end{array}$ & $\begin{array}{l}3156 \\
1927 \\
1741\end{array}$ & $\begin{array}{l}\text { State House Dome. } \\
\text { Horn. } \\
\text { Greenbury Point Light. }\end{array}$ \\
\hline 4 & $3^{8} 5^{8} 54.5^{\circ}$ & $\begin{array}{lll}76 & 27 & 18.35\end{array}$ & $\begin{array}{l}\mathrm{S} 8348 \mathrm{~W} \\
\mathrm{~S} 5659 \mathrm{~W} \\
\mathrm{~S} \text { I } 56 \mathrm{E}\end{array}$ & 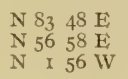 & $\begin{array}{l}3438 \\
2137 \\
1666\end{array}$ & $\begin{array}{l}\text { State House Dome. } \\
\text { Horn. } \\
\text { Greenbury Point Ligltt. }\end{array}$ \\
\hline
\end{tabular}


HORN POINT.

(Mouth of Severn River-Chart No. 2.)

\begin{tabular}{|c|c|c|c|c|c|c|c|c|c|}
\hline \multirow{2}{*}{$\begin{array}{c}\text { Cor- } \\
\text { ner } \\
\text { of } \\
\text { bar }\end{array}$} & \multirow{2}{*}{\multicolumn{3}{|c|}{ Iatitude }} & \multirow{2}{*}{\multicolumn{2}{|c|}{ Lougitude }} & \multicolumn{2}{|c|}{ True bearing } & \multirow{2}{*}{ Distance } & \multirow{2}{*}{ U.S.C. \& G.S. triangulation station. } \\
\hline & & & & & & Forward & Back & & \\
\hline I & ${ }_{3}^{\circ}$ & $\frac{1}{57}$ & $\begin{array}{c}\prime \prime \\
59.5^{S}\end{array}$ & $\begin{array}{cc}\circ & 1 \\
76 & 28\end{array}$ & 13.62 & 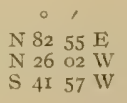 & 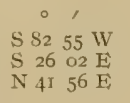 & $\mid \begin{array}{r}\text { Yards. } \\
\mathbf{1 5 2 3} \\
766 \\
395\end{array}$ & $\begin{array}{l}\text { Greenbury Point Light. } \\
\text { Horn. } \\
\text { Start. }\end{array}$ \\
\hline 2 & 38 & $5^{8}$ & 25.61 & 7628 & 314.43 & $\begin{array}{llll}\mathrm{N} & 72 & 44 \mathrm{~W} \\
\mathrm{~S} & 58 & 57 & \mathrm{WV} \\
\mathrm{S} & 65 & 46 & \mathrm{E}\end{array}$ & $\begin{array}{llll}\mathrm{S} & 72 & 45 & \mathrm{E} \\
\mathrm{N} & 5 \mathrm{~S} & 57 & \mathrm{E} \\
\mathrm{N} & 65 & 46 & \mathrm{~W}\end{array}$ & $\begin{array}{r}2028 \\
367 \\
1681\end{array}$ & $\begin{array}{l}\text { State House Dome. } \\
\text { Horn. } \\
\text { Greenbury Point Light. }\end{array}$ \\
\hline 31 & 38 & $5^{8}$ & $34.3^{8}$ & 7628 & 346.21 & $\begin{array}{llll}\mathrm{S} & 67 & 25 & \mathrm{E} \\
\mathrm{N} & 20 & 20 & \mathrm{E} \\
\mathrm{N} & 74 & 27 & \mathrm{WV}\end{array}$ & $\begin{array}{llll}\text { N } 67 & 26 & \text { WV } \\
\text { S } & 20 & 20 & \text { WV } \\
\text { S } & 74 & 28 & \text { E }\end{array}$ & $\begin{array}{l}2566 \\
1339 \\
1146\end{array}$ & $\begin{array}{l}\text { Greenbury Point Light. } \\
\text { Bluff. } \\
\text { State House Dome. }\end{array}$ \\
\hline 4 & 38 & $5^{8}$ & 49.44 & 7625 & 817.05 & $\begin{array}{llll}\text { N } 22 & 0_{3} & \mathrm{WV} \\
\mathrm{S} & 83 & 54 & \mathrm{~W} \\
\mathrm{~S} & 47 & 00 & \mathrm{E}\end{array}$ & $\begin{array}{llll}\mathrm{S} & 22 & \mathrm{O} & \mathrm{E} \\
\mathrm{N} & 83 & 53 & \mathrm{E} \\
\mathrm{N} & 46 & 59 & \mathrm{WV}\end{array}$ & $\begin{array}{r}806 \\
1883 \\
2190\end{array}$ & $\begin{array}{l}\text { Bluff. } \\
\text { State House Dome, } \\
\text { Greenbury Point Light. }\end{array}$ \\
\hline 5 & 38 & $5^{8}$ & 40.06 & $76 \quad 28$ & 306.03 & $\begin{array}{l}\text { N } 29 \text { o8 W } \\
\text { N } 8656 \mathrm{~W} \\
\text { S } 48 \text { o5 E }\end{array}$ & 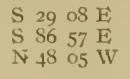 & $\begin{array}{l}1217 \\
2165 \\
1763\end{array}$ & $\begin{array}{l}\text { Bluff. } \\
\text { State House Dome. } \\
\text { Greenbury Point Light. }\end{array}$ \\
\hline 6 & $3^{8}$ & $5^{8}$ & 07.42 & $76 \quad 27$ & 749.50 & 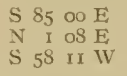 & 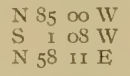 & $\begin{array}{r}879 \\
1695 \\
1056\end{array}$ & $\begin{array}{l}\text { Greenbury Point Light. } \\
\text { Fort. } \\
\text { Start. }\end{array}$ \\
\hline
\end{tabular}

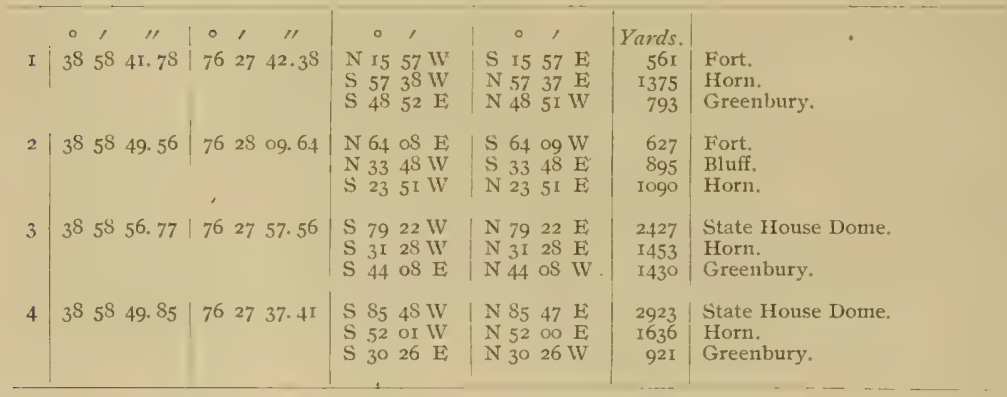




\title{
LITTLE SANDY.
}

\author{
(Lower Severn River-Chart No. 2.)
}

\begin{tabular}{|c|c|c|c|c|c|c|c|c|c|c|c|}
\hline \multirow{2}{*}{$\begin{array}{l}\text { Cor. } \\
\text { ner } \\
\text { of } \\
\text { bar }\end{array}$} & \multirow{2}{*}{\multicolumn{2}{|c|}{ Latitude }} & \multirow{2}{*}{\multicolumn{3}{|c|}{ Longitude }} & \multicolumn{4}{|c|}{ True bearing } & \multirow{2}{*}{-Distance } & \multirow{2}{*}{ U. S. C. \& G. S. triangulation station. } \\
\hline & & & & & & For & rward & & ack & & \\
\hline$I$ & $\begin{array}{c}\circ \\
38\end{array}$ & $\begin{array}{cc}\prime \prime & 49.5^{\prime}\end{array}$ & $\begin{array}{c}\circ \\
76\end{array}$ & 's & $\begin{array}{c}\prime \prime \\
09.6 .4\end{array}$ & $\begin{array}{l}0 \\
\text { N } 64 \\
\text { N } 33 \\
\text { S } 23\end{array}$ & $\begin{array}{l}1 \\
\text { os } \mathrm{E} \\
48 \mathrm{~W} \\
5 \mathrm{I} \mathrm{W}\end{array}$ & $\mid \begin{array}{ll} & 0 \\
S & 64 \\
S & 33 \\
N & 23\end{array}$ & $\begin{array}{ll}, \\
\text { og } \mathrm{WV} \\
4 \mathrm{~S} \\
51 \\
5 \mathrm{E}\end{array}$ & $\left|\begin{array}{r}\text { Yards. } \\
627 \\
895 \\
1090\end{array}\right|$ & $\begin{array}{l}\text { Fort. } \\
\text { Bluff. } \\
\text { Horn. }\end{array}$ \\
\hline 2 & $3^{S}$ & $5^{S} 59 \cdot 7^{2}$ & 76 & 28 & 16. $9 \mathrm{I}$ & $\begin{array}{l}\text { N } 37 \\
\text { S } 73 \\
\text { S } 40\end{array}$ & $\begin{array}{l}24 \mathrm{~W} \\
45 \mathrm{~W} \\
58 \mathrm{E}\end{array}$ & $\begin{array}{l}\text { S } 37 \\
\text { N } 73 \\
\text { N } 40\end{array}$ & $\begin{array}{l}24 \mathrm{E} \\
44 \mathrm{E} \\
57 \mathrm{~W}\end{array}$ & $\begin{array}{r}504 \\
1954 \\
2438\end{array}$ & $\begin{array}{l}\text { Bluff. } \\
\text { State House Dome. } \\
\text { Greenbury I ight. }\end{array}$ \\
\hline 3 & $3^{8}$ & $5^{8} 56.77$ & 76 & 27 & 57.56 & $\begin{array}{l}\text { S } 79 \\
\text { S } 3 I \\
\text { S } 44\end{array}$ & $\begin{array}{l}22 \mathrm{WV} \\
2 \mathrm{~S} \mathrm{WV} \\
08 \mathrm{E}\end{array}$ & $\begin{array}{l}\text { N } 79 \\
\text { N } 31 \\
\text { N } 44\end{array}$ & $\begin{array}{l}22 \mathrm{E} \\
28 \mathrm{E} \\
08 \mathrm{WV}\end{array}$ & $\begin{array}{l}2427 \\
1453 \\
1430\end{array}$ & $\begin{array}{l}\text { State House Dome. } \\
\text { Horn. } \\
\text { Greenbury. }\end{array}$ \\
\hline
\end{tabular}

\section{CRECES COVE.}

(Lower Severn River-Chart No. 2.)

\begin{tabular}{|c|c|c|c|c|c|c|c|c|c|}
\hline I & $\begin{array}{cc}\circ & 1 \\
38 & 59\end{array}$ & ${ }^{\prime \prime}{ }^{\prime \prime} .44$ & $\mid \begin{array}{cc}0 & 1 \\
76 & 28\end{array}$ & ${ }_{38.63}^{\prime \prime}$ & $\begin{array}{lc} & 0 \\
\text { N } & 39 \\
\text { S } & 52 \\
\text { S } & 76\end{array}$ & $\begin{array}{l}\text { Is W } \\
15 \mathrm{WV} \\
47 \mathrm{E}\end{array}$ & 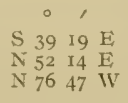 & $\begin{array}{r}\text { I'ards. } \\
\text { I } 194 \\
1646 \\
272\end{array}$ & $\begin{array}{l}\text { Brice. } \\
\text { State House Dome. } \\
\text { Bluff. }\end{array}$ \\
\hline 2 & $3^{8} 59$ & 23. $3 \mathrm{I}$ & $\begin{array}{ll}76 & 28\end{array}$ & 39.65 & $\begin{array}{l}\text { N } 50 \\
\text { S } 43 \\
\text { S } 9\end{array}$ & $\begin{array}{l}59 \mathrm{~W} \\
34 \mathrm{~W} \\
\mathrm{I}_{7} \mathrm{E}\end{array}$ & 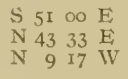 & $\begin{array}{r}938 \\
1854 \\
2164\end{array}$ & $\begin{array}{l}\text { Brice, } \\
\text { State House Dome. } \\
\text { Horn }\end{array}$ \\
\hline 3 & $3^{8} 59$ & 23.65 & | 7628 & 33. 55 & $\begin{array}{l}\text { S } 85 \\
\text { S } 46 \\
\text { S } 5\end{array}$ & $\begin{array}{l}24 \mathrm{WV} \\
43 \mathrm{WV} \\
\text { of } \mathrm{E}\end{array}$ & 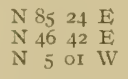 & $\begin{array}{l}1498 \\
1975 \\
2155\end{array}$ & $\begin{array}{l}\text { Hospital Cupola, } \\
\text { State House Dome. } \\
\text { Horn. }\end{array}$ \\
\hline 4 & $3^{8} 59$ & 13.78 & $76 \quad 28$ & 33. 22 & $\begin{array}{l}\text { N } 44 \\
\text { S } 54 \\
\text { S } 59\end{array}$ & $\begin{array}{l}34 \mathrm{WV} \\
46 \mathrm{WV} \\
03 \mathrm{E}\end{array}$ & 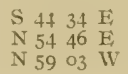 & $\begin{array}{r}128 \mathrm{I} \\
\mathrm{I} 77 \mathrm{I} \\
\mathrm{I} 43\end{array}$ & $\begin{array}{l}\text { Brice. } \\
\text { State House Dome. } \\
\text { Bluff. }\end{array}$ \\
\hline
\end{tabular}

\section{FERRY POINT.}

(Lover Sezern Rizer-Chart No. 2.)

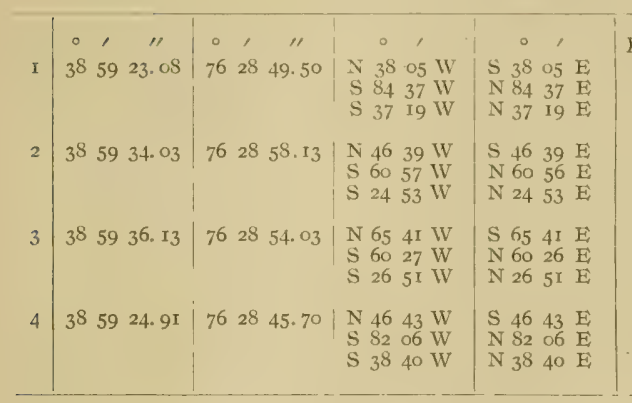

\begin{tabular}{r|l}
\hline Yards. & \\
760 & Brice. \\
1078 & Hospital Cupola. \\
1679 & State House Dome. \\
334 & Brice. \\
.669 & Hospital Cupola. \\
I879 & State House Dome. \\
385 & Brice. \\
1098 & Hospital Cupola. \\
1959 & State House Dome. \\
783 & Brice. \\
II85 & Hospital Cupola. \\
1789 & State House Dome.
\end{tabular}




\section{PEACH ORCHARD.}

(Middle Severn River-Chart No. 2.)

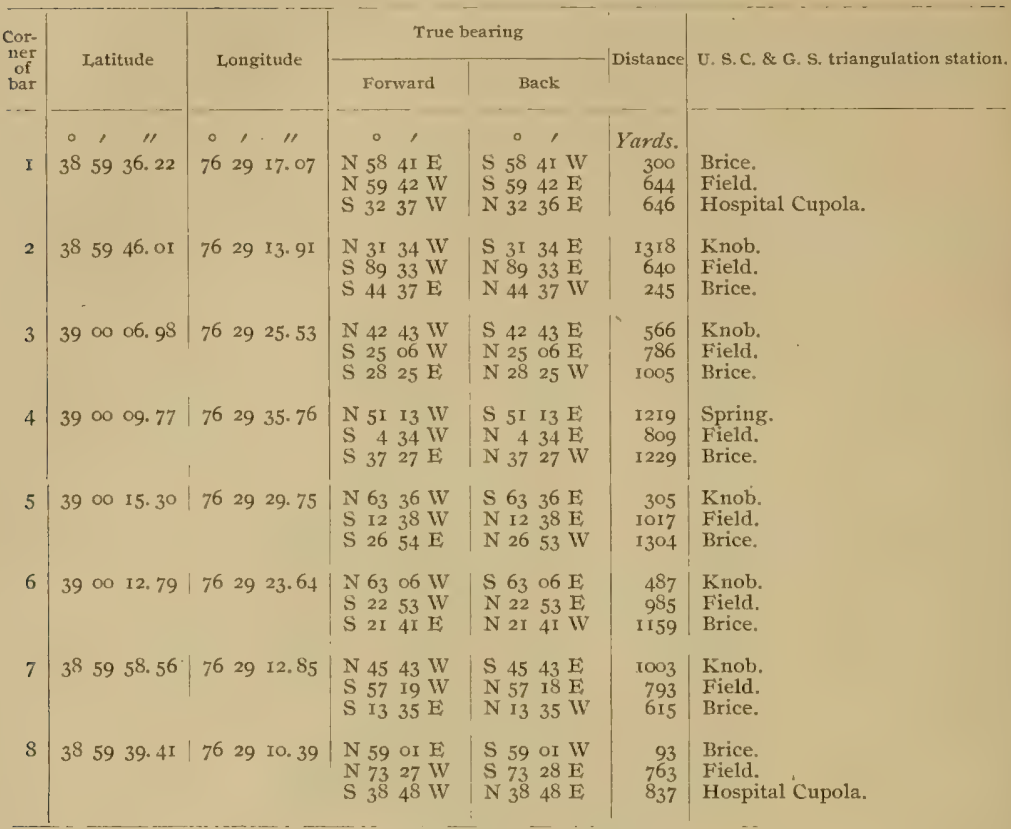

\section{WEEMS LOWER.}

(Middle Seitern River-Chart No. 2.)

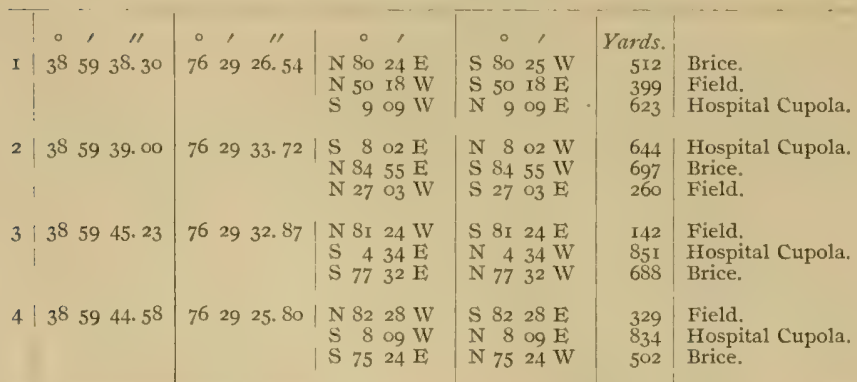


WEEMS UPPER.

(Middle Severn River-Chart No.2.)

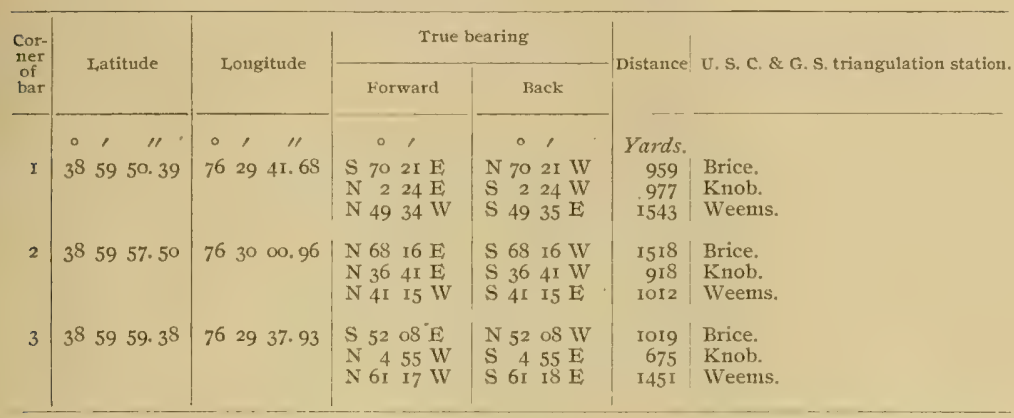

IVADE.

(Middle Severn River-Chart No. 2.)

\begin{tabular}{|c|c|c|c|c|c|c|c|c|c|}
\hline & 。 & 1 & "I & 0 , & "I & 0, & 0, & Yards. & \\
\hline I & 39 & 00 & 02.43 & $76 \quad 20$ & 54.00 & $\begin{array}{llll}\mathrm{S} & 59 & 18 & \mathrm{E} \\
\mathrm{N} & 32 & 39 & \mathrm{E} \\
\mathrm{N} & 24 & 57 & \mathrm{WV}\end{array}$ & $\begin{array}{llll}\text { N } 59 & 18 & \text { W } \\
\text { S } & 32 & 39 & \text { W } \\
\text { S } & 24 & 57 & \text { E }\end{array}$ & $\begin{array}{r}1427 \\
677 \\
\text { II } 5\end{array}$ & $\begin{array}{l}\text { Brice. } \\
\text { Knob. } \\
\text { Spring. }\end{array}$ \\
\hline 2 & 39 & $\infty$ & I5. OI & 7630 & 2S. 50 & $\begin{array}{llll}\mathrm{S} & 6 \mathrm{r} & 39 & \mathrm{E} \\
\mathrm{N} & 83 & 29 & \mathrm{E} \\
N_{3} & 4 \mathrm{I} & \mathrm{E}\end{array}$ & $\begin{array}{llll}\mathrm{N} & 61 & 38 & \mathrm{~W} \\
\mathrm{~S} & 83 & 30 & \mathrm{WV} \\
\mathrm{S} & 36 & 41 & \mathrm{WV}\end{array}$ & $\begin{array}{r}2427 \\
1282 \\
732\end{array}$ & $\begin{array}{l}\text { Brice. } \\
\text { Knob. } \\
\text { Spring. }\end{array}$ \\
\hline 3 & 39 & $\infty$ & II. 88 & 7630 & 06.26 & $\begin{array}{llll}\mathrm{S} & 55 & 58 & \mathrm{E} \\
\mathrm{N} & 69 & 57 & \mathrm{E} \\
\mathrm{N} & 12 & 03 & \mathrm{WV}\end{array}$ & 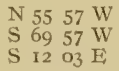 & $\begin{array}{r}1871 \\
732 \\
709\end{array}$ & $\begin{array}{l}\text { Brice. } \\
\text { Knob. } \\
\text { Spring. }\end{array}$ \\
\hline
\end{tabular}




\section{TRACES HOLLOW.}

(Middle Severn River-Chart No.2.)

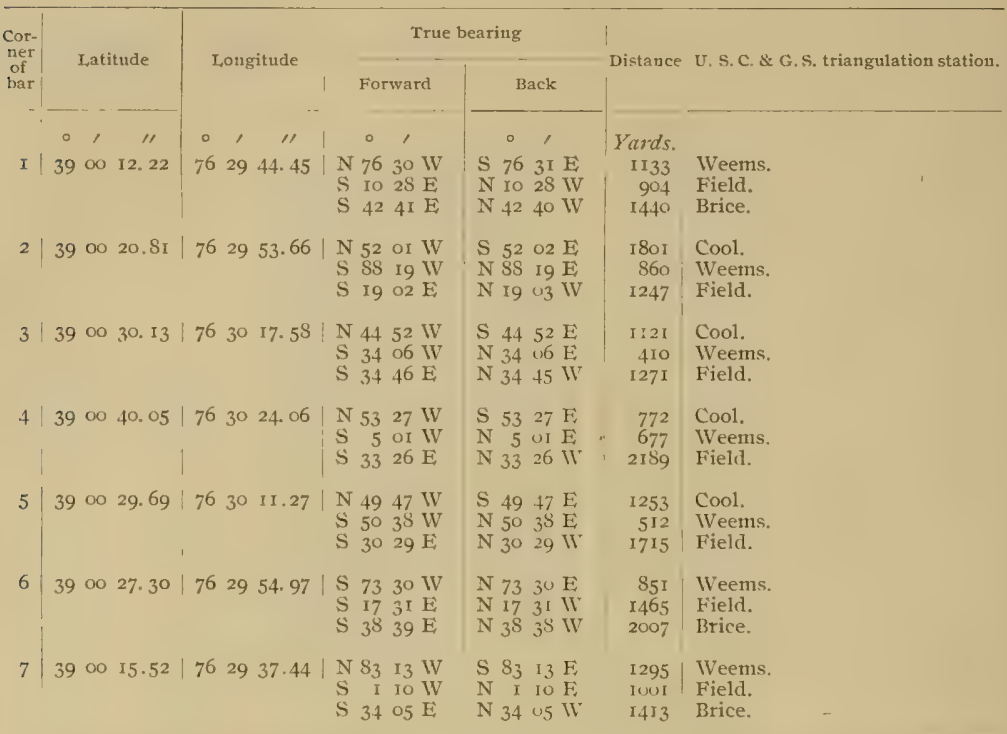

\section{SHARP POINT.}

(Middle Sezem River-Chart No. 2.)

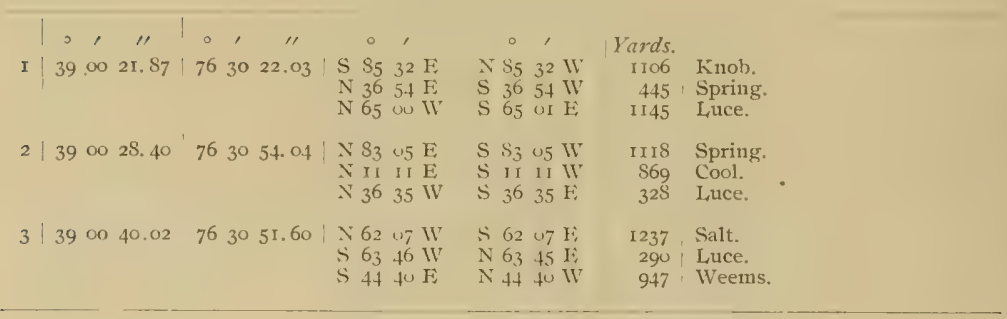




\section{SALTIVORK.}

\section{(Upper Severn River-Chart No. 2.)}

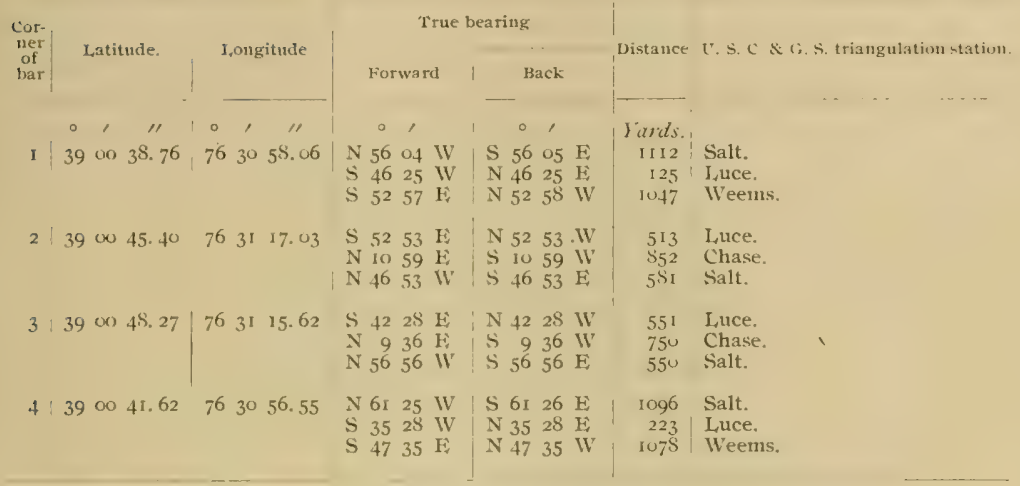

\section{ROCK POINT LOWER.}

(Upper Sezern River-Chart No.2.)

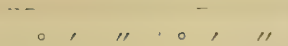

I $\quad 3900 \quad 48.77,76 \quad 30 \quad 47.67$

\begin{tabular}{lll|l|l|l|l}
2 & 3900 & 53.50 & 76 & 30 & 55.06
\end{tabular}

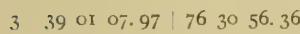

\begin{tabular}{l}
0,1 \\
\hline
\end{tabular} N 40 IO S 5939 F

N $3625 \mathrm{VV}$ S 16 Io V S $5758 \mathrm{E}$

N 7848 IV S 7 10 W S 26 ० E

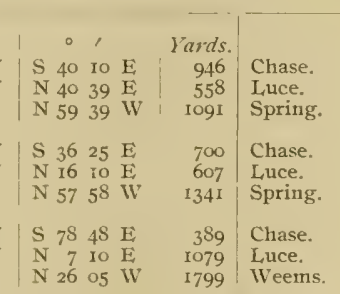

CHASE

(Upper Severn River-Chart No. 2.)

\begin{tabular}{|c|c|c|c|c|c|c|c|c|c|c|c|}
\hline 0 & , & $\prime \prime$ & 。 & , & $\prime \prime$ & o & , & o & , & Yards. & \\
\hline 39 & UI & 06.64 & $7^{6}$ & $3 I$ & I6. 52 & S 60 & $06 \mathrm{E}$ & $\mathrm{N} 60$ & o6 W & 877 & Cool. \\
\hline & & & & & & $N 51$ & $03 \mathrm{E}$ & $S 5 I$ & $03 \mathrm{~W}$ & 191 & Chase. \\
\hline & & & & & & N 62 & I2 W & S 62 & I $2 \mathrm{E}$ & $68 \mathrm{I}$ & Clenı. \\
\hline 39 & OI & 21.97 & 76 & $3 I$ & I7. 74 & $\mathrm{~N}_{27}$ & 5 I W & S 27 & $5 \mathrm{IE}$ & 355 & Point. \\
\hline & & & & & & S 70 & $47 \mathrm{WV}$ & N 70 & $47 \mathrm{E}$ & 605 & Clem. \\
\hline & & & & & & S 25 & $5 \mathrm{I} \mathrm{W}$ & N 25 & $5 \mathrm{I} \mathrm{E}$ & $93^{\circ}$ & Salt. \\
\hline 39 & OI & 0.5. 33 & 76 & $3 I$ & II. 62 & S $5 I$ & $57 \mathrm{E}$ & $\mathrm{N}_{5 \mathrm{I}}$ & $57 \mathrm{WV}$ & $\mathrm{So} 2$ & Cool. \\
\hline & & & & & & $\mathrm{N} 17$ & $30 \mathrm{E}$ & S 17 & $30 \mathrm{WV}$ & 67 & Chase. \\
\hline & & & & & & $\mathrm{N} 70^{\circ}$ & $22 \mathrm{WV}$ & S 70 & $23 \mathrm{E}$ & $77 \mathrm{~S}$ & Clem. \\
\hline
\end{tabular}


CLEM POINT.

\section{(Upper-Severn River-Chart No. 2.)}

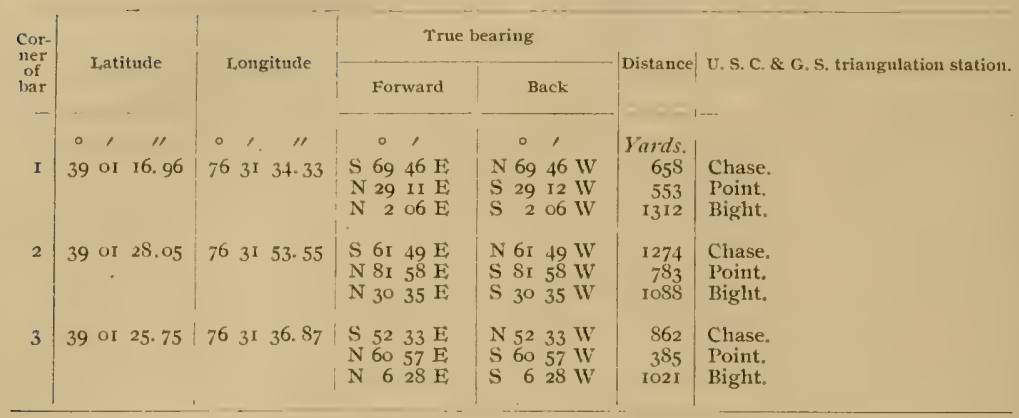

\section{POINT.}

(Upper-Sezem River-Chart No. 2.)

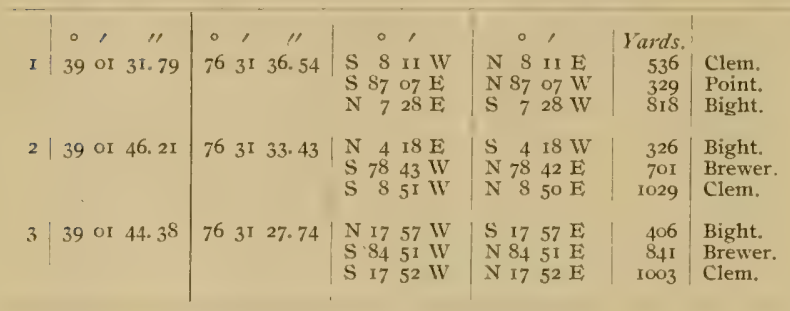

\section{AISQUITH CREEK.}

(Upper Severn River-Chart No. 2.)

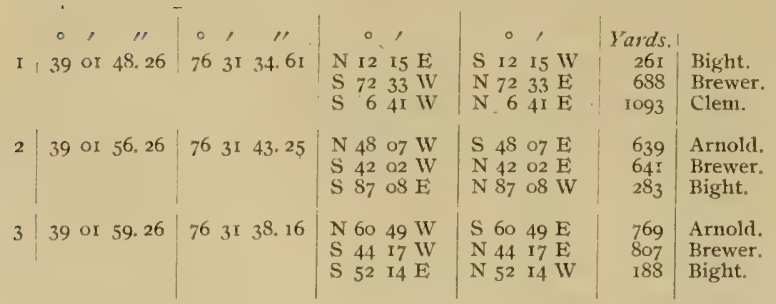


Survey of Oyster Bars, Anne Arundel County, Md.

BREWER (SEVERN RIVER).

(Upper-Sezern River-Chart No. 2.)

\begin{tabular}{|c|c|c|c|c|c|c|c|}
\hline \multirow{2}{*}{$\begin{array}{l}\text { Cor- } \\
\text { ner } \\
\text { of } \\
\text { hat }\end{array}$} & \multirow{2}{*}{\multicolumn{2}{|c|}{ I,atitude }} & \multirow{2}{*}{ Longitude } & \multicolumn{2}{|c|}{ True bearing } & \multirow{2}{*}{ Distance } & \multirow{2}{*}{ U. S. C. \& G. S. triangulation station. } \\
\hline & & & & Forward & Back & & \\
\hline I & $\begin{array}{c}\circ \\
39\end{array}$ & $\begin{array}{cc}\prime \prime \prime \\
\text { OI } & 5.2 .03\end{array}$ & $\begin{array}{ccc}0 & \prime \prime \\
76 & 32 & 38.08\end{array}$ & 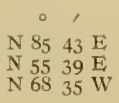 & $\begin{array}{lccc} & \circ & \\
\mathrm{S} & 85 & 44 & \mathrm{~W} \\
\mathrm{~S} & 55 & 40 & \mathrm{~W} \\
\mathrm{~S} & 68 & 36 & \mathrm{E}\end{array}$ & $\begin{array}{r}\text { Yards. } \\
1726 \\
1097 \\
877\end{array}$ & $\begin{array}{l}\text { Bight. } \\
\text { Arnold. } \\
\text { Bay. }\end{array}$ \\
\hline 2 & 39 & oI 59.72 & $76 \quad 32 \quad 26.03$ & $\begin{array}{llll}\mathrm{S} & 49 & 35 & \mathrm{E} \\
\mathrm{N} & 58 & 39 & \mathrm{E} \\
\mathrm{N} & 47 & 53 & \mathrm{WV}\end{array}$ & $\begin{array}{llll}\mathrm{N} & 49 & 34 \mathrm{WV} \\
\mathrm{S} & 58 & 39 & \mathrm{~W} \\
\mathrm{~S} & 47 & 54 & \mathrm{E}\end{array}$ & $\begin{array}{r}914 \\
687 \\
2149\end{array}$ & $\begin{array}{l}\text { Brewer. } \\
\text { Arnold. } \\
\text { Long. }\end{array}$ \\
\hline 3 & 39 & or $56.5^{8}$ & 7632 or. 65 & $\begin{array}{lrll}\text { S } & 88 & \text { oS } & \text { E } \\
N & 6 & 3 I & W \\
N & 84 & 37 & W\end{array}$ & 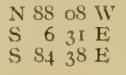 & $\begin{array}{r}768 \\
468 \\
1783\end{array}$ & $\begin{array}{l}\text { Bight. } \\
\text { Arnold. } \\
\text { Bay. }\end{array}$ \\
\hline
\end{tabular}

\section{POPPIN POINT.}

(Upper-Sevenn River-Chart No. 2.)

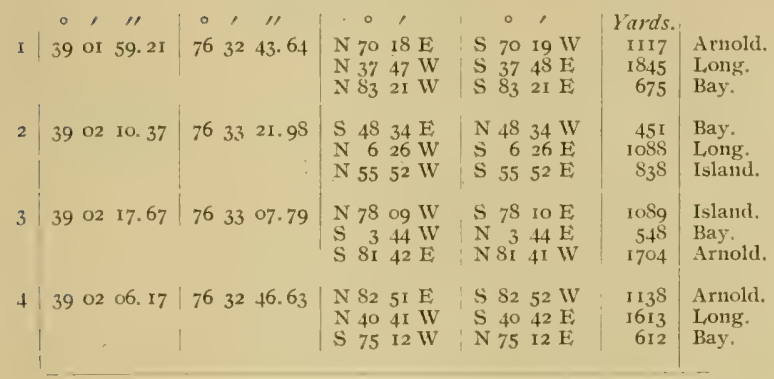


ARNOLD POINT.

(Upper-Severn Rizer-Chart No. 2.)

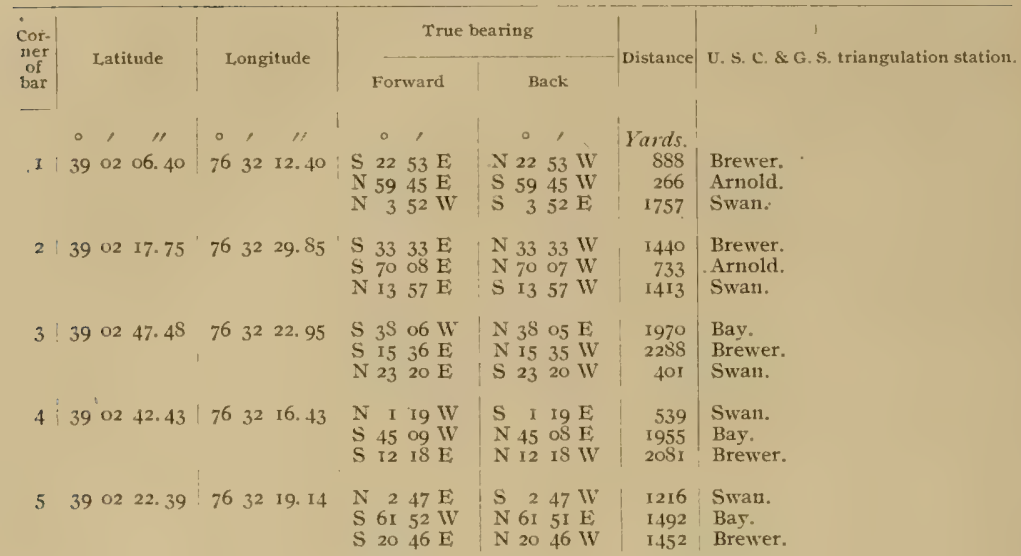

BIG ISLAND,

(Upper Severn Rizer-Chart No.2.)

\begin{tabular}{|c|c|c|c|c|c|c|c|c|c|}
\hline & $\begin{array}{ccc}0 & 1 & \prime \prime \\
39 & 02 & 28.99\end{array}$ & ${ }^{\circ}$ & $\begin{array}{c}\prime \prime \prime \\
34\end{array}$ & $\begin{array}{c}0 \\
S 55 \\
N \quad 63 \\
N \quad 20\end{array}$ & $\begin{array}{l}, \\
36 \mathrm{E} \\
04 \mathrm{E} \\
15 \mathrm{E}\end{array}$ & $\begin{array}{c} \\
0 \\
\text { N } 55 \\
\text { S } 63 \\
\text { S } 20\end{array}$ & $\begin{array}{l}36 \mathrm{~W} \\
04 \mathrm{WV} \\
15 \mathrm{WV}\end{array}$ & \begin{tabular}{|c} 
Yards. \\
1639 \\
1002 \\
1613
\end{tabular} & $\begin{array}{l}\text { Bay. } \\
\text { Long. } \\
\text { Sharp. }\end{array}$ \\
\hline & $3902 \quad 33.62$ & 763 & 3404.88 & $\begin{array}{l}\text { S } 53 \\
\text { N } 73 \\
\text { N } 26\end{array}$ & $\begin{array}{l}34 \mathrm{E} \\
32 \mathrm{E} \\
20 \mathrm{E}\end{array}$ & $\begin{array}{l}\text { N } 53 \\
\text { S } 73 \\
\text { S } 26\end{array}$ & & $\begin{array}{l}1822 \\
1050 \\
1515\end{array}$ & $\begin{array}{l}\text { Bay. } \\
\text { Long. } \\
\text { Sharp. }\end{array}$ \\
\hline & 39 & 763 & 3356. So & $\begin{array}{l}\text { S } 45 \\
\text { N } 79 \\
\text { N } 20\end{array}$ & $\begin{array}{l}27 \mathrm{E} \\
37 \mathrm{E} \\
52 \mathrm{E}\end{array}$ & $\begin{array}{l}\text { N } 45 \\
\text { S } 79 \\
\text { S } 20\end{array}$ & $\begin{array}{l}26 \mathrm{WW} \\
38 \mathrm{~W} \\
52 \mathrm{WV}\end{array}$ & $\begin{array}{r}1760 \\
807 \\
1290\end{array}$ & $\begin{array}{l}\text { Bay. } \\
\text { Long. } \\
\text { Sharp. }\end{array}$ \\
\hline
\end{tabular}

ROUNI BAY.

(Upper-Sezern Rizer-Chast No. 2.)

\begin{tabular}{|c|c|c|c|c|c|c|}
\hline 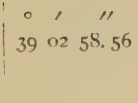 & $\begin{array}{cc}0 & 1 \\
76 & 33\end{array}$ & 31.65 & 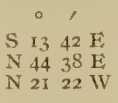 & \begin{tabular}{lll} 
& \multicolumn{1}{c}{} \\
$\mathrm{N}$ & $\mathrm{I}$ & $42 \mathrm{~W}$ \\
$\mathrm{~S}$ & 44 & $3 \mathrm{~S}$ \\
$\mathrm{~S}$ & 21 & $22 \mathrm{E}$
\end{tabular} & $\begin{array}{r}\text { Jards. } \\
558 \\
1676 \\
554\end{array}$ & $\begin{array}{l}\text { Long. } \\
\text { High. } \\
\text { Sharp. }\end{array}$ \\
\hline $\begin{array}{llll}39 & 03 & 06.69\end{array}$ & 7633 & 34.04 & $\begin{array}{llll}\mathrm{S} & 13 & 26 & \mathrm{E} \\
\mathrm{N} & 53 & 28 & \mathrm{E} \\
\mathrm{N} & 29 & 53 & \mathrm{~W}\end{array}$ & $\begin{array}{llll}\mathrm{N} & 13 & 26 & \mathrm{~W} \\
\mathrm{~S} & 53 & 28 \mathrm{~W} \\
\mathrm{~S} & 29 & 53 & \mathrm{E}\end{array}$ & $\begin{array}{r}840 \\
1544 \\
279\end{array}$ & $\begin{array}{l}\text { Long. } \\
\text { High. } \\
\text { Sharp. }\end{array}$ \\
\hline 390304.34 & 7633 & x. 90 & $\begin{array}{llll}N & 40 & 10 & E \\
N & 59 & 07 & W \\
S & 15 & 22 & W\end{array}$ & $\begin{array}{llll}\mathrm{S} & 40 & 10 & \mathrm{~W} \\
\mathrm{~S} & 59 & 07 & \mathrm{E} \\
\mathrm{N} & 15 & 22 & \mathrm{E}\end{array}$ & $\begin{array}{r}1307 \\
626 \\
766\end{array}$ & $\begin{array}{l}\text { High. } \\
\text { Sharp. } \\
\text { Long. }\end{array}$ \\
\hline
\end{tabular}


ROCK POINT UPPER.

(Upper Severn River-Chart No, 2.)

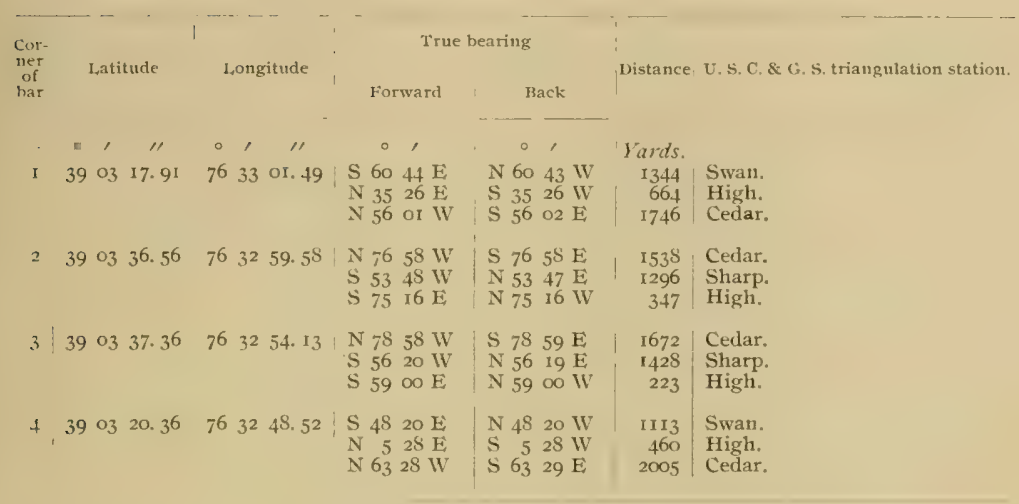

\section{INIER THE GUMS.}

(Chesapcake Bay hetw'cen Annapolis Roads and Thomas Point-Chart No.3.1

\begin{tabular}{|c|c|c|c|c|c|c|c|}
\hline & 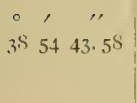 & $\mid \begin{array}{cc}0 & 1 \\
76 & 27\end{array}$ & $\begin{array}{lc}\prime & 11 \\
27 & 13.97\end{array}$ & 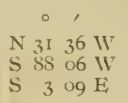 & 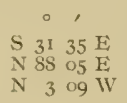 & $\begin{array}{r}\text { Jards. } \\
1262 \\
1441 \\
488\end{array}$ & $\begin{array}{l}\text { Cottage. } \\
\text { Arundel. } \\
\text { Thomas. }\end{array}$ \\
\hline & $3^{4} 55 \quad 53.62$ & 7627 & $27.32 . \$ 2$ & $\begin{array}{l}S \quad 714 \mathrm{~W} \\
S 1025 \mathrm{E} \\
\times 2529 \mathrm{E}\end{array}$ & $\begin{array}{llll}\mathrm{N} & 7 & 14 & \mathrm{E} \\
\mathrm{N} & 10 & 25 \mathrm{~W} \\
\mathrm{~S} & 25 & 29 & \mathrm{~W}\end{array}$ & $\begin{array}{r}1298 \\
2891 \\
934\end{array}$ & $\begin{array}{l}\text { Cottage. } \\
\text { Thomas. } \\
\text { Bay Ridge Stack. }\end{array}$ \\
\hline & $3^{3} 56$ i7. II & $76 \quad 26$ & 2659.76 & $\begin{array}{l}\mathrm{N} \text { IO } 58 \mathrm{~W} \\
\mathrm{~N} \mathrm{~S}_{3} 43 \mathrm{~W} \\
\mathrm{~S} 2630 \mathrm{~W}\end{array}$ & $\begin{array}{llll}\mathrm{S} & 10 & 58 \mathrm{E} \\
\mathrm{S} & 83 & 43 & \mathrm{E} \\
\mathrm{N} & 26 & 29 & \mathrm{E}\end{array}$ & $\begin{array}{r}457 \\
471 \\
2324\end{array}$ & $\begin{array}{l}\text { Tolly. } \\
\text { Bay Ridge Stack. } \\
\text { Cottage. }\end{array}$ \\
\hline & $3^{S} 56$ (19.06. & $76 \quad 26$ & $26+5 . S_{7}$ & 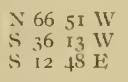 & $\begin{array}{llll}\mathrm{S} & 66 & 5 \mathrm{I} & \mathrm{E} \\
\mathrm{N} & 36 & 12 & \mathrm{E} \\
\mathrm{N} & \mathrm{I} 2 & 48 & \mathrm{WW}\end{array}$ & $\begin{array}{r}821 \\
2242 \\
4594\end{array}$ & $\begin{array}{l}\text { Bay Ridge Stack. } \\
\text { Cottage. } \\
\text { Thomas Point Light. }\end{array}$ \\
\hline & 3. $5525 \cdot 4^{1}$ & 7626 & 26.56 .64 & $\begin{array}{llll}\mathrm{N} & 17 & 03 & \mathrm{~W} \\
\mathrm{~S} & 73 & 17 & \mathrm{~W} \\
\mathrm{~S} & 22 & 07 & \mathrm{E}\end{array}$ & $\begin{array}{llll}\mathrm{S} & 17 & 04 & \mathrm{E} \\
\mathrm{N} & 73 & 17 & \mathrm{E} \\
\mathrm{N} & 22 & 07 & \mathrm{~W}\end{array}$ & $\begin{array}{l}18_{7} 8 \\
1169 \\
32.48\end{array}$ & $\begin{array}{l}\text { Bay Ridge Stack. } \\
\text { Cottage. } \\
\text { Thomas Point I, ight. }\end{array}$ \\
\hline & ${ }_{3}^{3} 5450.14$ & $\begin{array}{ll}76 & 26\end{array}$ & $26+9.45$ & 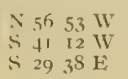 & $\begin{array}{llll}\mathrm{S} & 56 & 5.3 \mathrm{E} \\
\mathrm{N} & 4 \mathrm{I} & 12 & \mathrm{E} \\
\mathrm{N} & 29 & 37 & \mathrm{WW}\end{array}$ & $\begin{array}{r}1563 \\
937 \\
2091\end{array}$ & $\begin{array}{l}\text { Cottage. } \\
\text { Thomas. } \\
\text { Thomas Point Light. }\end{array}$ \\
\hline
\end{tabular}




\section{THOMAS POINT NORTH.}

(North of Thomas Point Light-Chart No. 3.)

\begin{tabular}{|c|c|c|c|c|c|c|c|c|c|}
\hline \multirow{3}{*}{$\begin{array}{l}\text { Cor- } \\
\text { ner } \\
\text { of } \\
\text { bar }\end{array}$} & \multirow{3}{*}{\multicolumn{2}{|c|}{ Latitude }} & \multirow{3}{*}{\multicolumn{3}{|c|}{ Longitude }} & \multirow{2}{*}{\multicolumn{2}{|c|}{ True bearing }} & \multirow{4}{*}{\begin{tabular}{|} 
Distance \\
Yards \\
4167 \\
2604 \\
5612
\end{tabular}} & \\
\hline & & & & & & & & & \multirow{2}{*}{ U. S. C. \& G. S. triangulation station. } \\
\hline & & & & & & Forward & Back & & \\
\hline 1 & $\begin{array}{l}0 \\
3 \mathrm{~S}\end{array}$ & $\begin{array}{c}\prime \prime \prime \\
53 \quad 44.24\end{array}$ & & $\begin{array}{c}1 \\
25\end{array}$ & $\begin{array}{c}\prime \prime \prime \\
\text { 52. } 57\end{array}$ & $\begin{array}{lcc} & 0 \\
N & 42 & \text { I } 8 ~ W V \\
N & 54 & 26 \\
\text { S } & 79 & 25 \\
\text { WV }\end{array}$ & 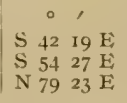 & & $\begin{array}{l}\text { Cottage. } \\
\text { Thomas. } \\
\text { Gowan. }\end{array}$ \\
\hline 2 & 38 & 5355.73 & 76 & 26 & 23. OI & $\begin{array}{llll}\mathrm{N} & 87 & \text { os } & \mathrm{E} \\
\mathrm{N} & 36 & 45 \mathrm{~W} \\
\mathrm{~S} & 73 & \mathrm{I} & \mathrm{W}\end{array}$ & $\begin{array}{llll}\mathrm{S} & 87 & 08 & \mathrm{WV} \\
\mathrm{S} & 36 & 46 & \mathrm{E} \\
\mathrm{N} & 73 & \mathrm{II} & \mathrm{E}\end{array}$ & $\begin{array}{r}337 \\
3357 \\
4924\end{array}$ & $\begin{array}{l}\text { Thomas Point Light. } \\
\text { Cottage. } \\
\text { Gowan. }\end{array}$ \\
\hline 3 & $3^{8}$ & 5409.43 & 76 & 26 & 21.37 & $\begin{array}{llll}\mathrm{N} & 63 & 57 & \mathrm{WV} \\
\mathrm{S} & 68 & 26 & \mathrm{WV} \\
\mathrm{S} & 33 & 23 & \mathrm{E}\end{array}$ & \begin{tabular}{|llll}
$\mathrm{S}$ & 63 & 57 & $\mathrm{E}$ \\
$\mathrm{N}$ & 68 & 24 & $\mathrm{E}$ \\
$\mathrm{N}$ & 33 & 23 & $\mathrm{WV}$
\end{tabular} & $\begin{array}{r}1512 \\
5116 \\
533\end{array}$ & $\begin{array}{l}\text { Thomas. } \\
\text { Gowan. } \\
\text { Thomas Point Light. }\end{array}$ \\
\hline 4 & $3^{8}$ & 544 I. 78 & 76 & 26 & 54.87 & $\begin{array}{llll}\mathrm{N} & 45 & 4 \mathrm{I} & \mathrm{WV} \\
\mathrm{S} & 47 & 34 & \mathrm{~W} \\
\mathrm{~S} & 37 & 26 & \mathrm{E}\end{array}$ & \begin{tabular}{|llll}
$\mathrm{S}$ & 45 & 41 & $\mathrm{E}$ \\
$\mathrm{N}$ & 47 & 34 & $\mathrm{E}$ \\
$\mathrm{N}$ & 37 & 26 & $\mathrm{WV}$
\end{tabular} & $\begin{array}{r}1628 \\
644 \\
1932\end{array}$ & $\begin{array}{l}\text { Cottage. } \\
\text { Thomas. } \\
\text { Thomas Point Light. }\end{array}$ \\
\hline 5 & $3^{8}$ & 5450.14 & 76 & 26 & 49.48 & $\begin{array}{llll}\text { N } 56 & 53 & W \\
\text { S } & 4 I & \text { I } & \text { W } \\
\text { S } 29 & 38 & \text { E }\end{array}$ & $\mid \begin{array}{llll}\mathrm{S} & 56 & 53 & \mathrm{E} \\
\mathrm{N} & 4 \mathrm{I} & \mathrm{I} 2 & \mathrm{E} \\
\mathrm{N} & 29 & 37 & \mathrm{WV}\end{array}$ & $\begin{array}{r}1563 \\
937 \\
2091\end{array}$ & $\begin{array}{l}\text { Cottage. } \\
\text { Thomas. } \\
\text { Thomas Point Light. }\end{array}$ \\
\hline 6 & & $55 \infty .30$ & 76 & 26 & 22.75 & $\begin{array}{llll}\mathrm{N} & 75 & 45 & \mathrm{WV} \\
\mathrm{S} & 5 \mathrm{I} & 32 & \mathrm{WV} \\
\mathrm{S} & 8 & 40 & \mathrm{E}\end{array}$ & $\begin{array}{llll}S & 75 & 46 & E \\
N & 5 I & 3 I & E \\
N & 8 & 40 & W\end{array}$ & $\begin{array}{l}2073 \\
1690 \\
2185\end{array}$ & $\begin{array}{l}\text { Cottage. } \\
\text { Thomas. } \\
\text { Thomas Point Light. }\end{array}$ \\
\hline 7 & $3^{8}$ & 5448.8 I & 76 & 25 & 55.02 & $\begin{array}{llll}\mathrm{N} & 7 \mathrm{I} & 53 & \mathrm{~W} \\
\mathrm{~S} & 72 & 06 & \mathrm{~W} \\
\mathrm{~S} & \mathrm{I} 2 & 45 & \mathrm{~W}\end{array}$ & $\begin{array}{llll}S & 71 & 54 & \mathrm{E} \\
\mathrm{N} & 72 & 05 & \mathrm{E} \\
\mathrm{N} & 12 & 45 & \mathrm{E}\end{array}$ & $\begin{array}{l}2887 \\
2159 \\
1819\end{array}$ & $\begin{array}{l}\text { Cottage. } \\
\text { Thomas. } \\
\text { Thomas Point Light. }\end{array}$ \\
\hline 8 & $3^{8}$ & 5423.04 & 76 & 26 & 02.85 & $\begin{array}{l}\text { N } 55 \text { og W } \\
\text { N } 83 \\
\text { S.12 } \\
\text { 10 W W }\end{array}$ & $\begin{array}{llll}\mathrm{S} & 55 & 09 & \mathrm{E} \\
\mathrm{S} & 83 & 39 & \mathrm{E} \\
\mathrm{N} & \mathrm{I} 2 & \mathrm{IO} & \mathrm{E}\end{array}$ & $\begin{array}{r}3094 \\
1859 \\
925\end{array}$ & $\begin{array}{l}\text { Cottage. } \\
\text { Thomas. } \\
\text { Thomas I'oint Light. }\end{array}$ \\
\hline
\end{tabular}


THOMAS POINT SOUTH.

(Off entrance to South River-Chart No.3.)

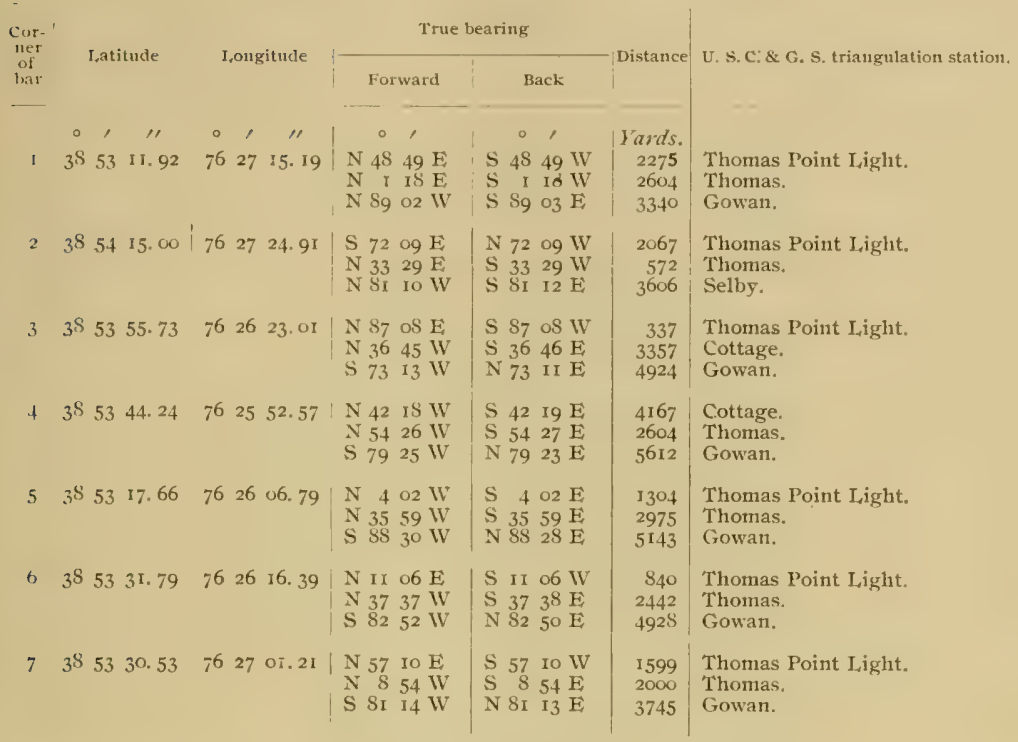

OLD IVOMAN.

(Chesapeake Bay-Entrance to South Rizer-Chart No. 3.)

\begin{tabular}{|c|c|c|c|c|c|c|c|c|c|c|}
\hline & 。 & , & "' & - & , & & 0,1 & 0 , & Yards. & \\
\hline 1 & $3^{8}$ & 53 & II. 92 & 76 & 27 & I5. 19 & $\begin{array}{llll}\mathrm{N} & 48 & 49 & \mathrm{E} \\
\mathrm{N} & \mathrm{I} & \mathrm{I} & \mathrm{E} \\
\mathrm{N} & 89 & 02 & \mathrm{~W}\end{array}$ & $\begin{array}{lrll}\mathrm{S} & 48 & 49 & \mathrm{~W} \\
\mathrm{~S} & \mathrm{I} & \mathrm{IS} & \mathrm{W} \\
\mathrm{S} & 89 & 03 & \mathrm{E}\end{array}$ & $\begin{array}{l}2275 \\
2604 \\
3340\end{array}$ & $\begin{array}{l}\text { Thomas Point Light. } \\
\text { Thomas. } \\
\text { Gowan. }\end{array}$ \\
\hline 2 & $3^{8}$ & 53 & $20.6 \mathrm{I}$ & 76 & 28 & 06.36 & $\begin{array}{llll}\mathrm{N} 68 & 35 & \mathrm{E} \\
\mathrm{N} & 3 \mathrm{I} & 2 \mathrm{I} & \mathrm{E} \\
\mathrm{S} & 83 & 14 & \mathrm{~W}\end{array}$ & $\begin{array}{llll}\mathrm{S} & 68 & 36 & \mathrm{WV} \\
\mathrm{S} & 31 & 21 \mathrm{~W} \\
\mathrm{~N} & 83 & 13 & \mathrm{E}\end{array}$ & $\begin{array}{l}3287 \\
2706 \\
2006\end{array}$ & $\begin{array}{l}\text { Thomas Point Light. } \\
\text { Thomas. } \\
\text { Gowan. }\end{array}$ \\
\hline 3 & $3^{S}$ & 54 & II. $\infty$ & 76 & 28 & 25.29 & $\begin{array}{l}\mathrm{S} 82 \text { or } \mathrm{E} \\
\mathrm{N} 22 \text { I I E } \\
\mathrm{N} 7044 \mathrm{~W}\end{array}$ & $\begin{array}{llll}\mathrm{N} & 82 & 03 & \mathrm{~W} \\
\mathrm{~S} & 22 & 4 \mathrm{I} & \mathrm{W} \\
\mathrm{S} & 70 & 45 & \mathrm{E}\end{array}$ & $\begin{array}{l}3594 \\
\text { II } 38 \\
2089\end{array}$ & $\begin{array}{l}\text { Thomas Point Light. } \\
\text { Arundel. } \\
\text { Selby. }\end{array}$ \\
\hline 4 & $3^{8}$ & 54 & 15.00 & 76 & 27 & 24. 9I & 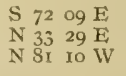 & $\begin{array}{llll}\mathrm{N} & 72 & 09 & \mathrm{~W} \\
\mathrm{~S} & 33 & 29 & \mathrm{~W} \\
\mathrm{~S} & 8 \mathrm{I} & \mathrm{I} 2 & \mathrm{E}\end{array}$ & $\begin{array}{r}2067 \\
572 \\
3606\end{array}$ & $\begin{array}{l}\text { Thomas Point Liglit. } \\
\text { Thomas. } \\
\text { Selby. }\end{array}$ \\
\hline
\end{tabular}




\section{MARSHY POINT.}

(Mouth of South River-Chart No.3.)

\begin{tabular}{|c|c|c|c|c|c|c|c|c|}
\hline \multirow{2}{*}{$\begin{array}{l}\text { Cor- } \\
\text { ner } \\
\text { of } \\
\text { hat }\end{array}$} & \multirow{2}{*}{\multicolumn{3}{|c|}{ Latitude }} & \multirow{2}{*}{ L,ongitude } & \multicolumn{2}{|c|}{ True bearing } & \multirow{2}{*}{ Distance } & \multirow{2}{*}{ U. S. C. \& G. S. triangulation station. } \\
\hline & & & & & Forward & Back & & \\
\hline I & $3^{\circ}$ & 53 & $20.6 \mathrm{I}$ & $\begin{array}{ccc}\circ & \prime \prime \\
76 & 28 & 06.3^{6}\end{array}$ & $\begin{array}{lccc} & 0 & 1 \\
N & 68 & 35 & \mathrm{E} \\
\mathrm{N} & 3 \mathrm{I} & 2 \mathrm{I} & \mathrm{E} \\
\mathrm{S} & \mathrm{S}_{3} & 14 & \mathrm{~W}\end{array}$ & $\begin{array}{lccc} & \circ & 1 \\
\mathrm{~S} & 6 S & 36 & \mathrm{~W} \\
\mathrm{~S} & 31 & 21 & \mathrm{WV} \\
\mathrm{N} & \mathrm{S}_{3} & \mathrm{I}_{3} & \mathrm{E}\end{array}$ & $\begin{array}{r}\text { Yards } \\
3287 \\
2706 \\
2006\end{array}$ & $\begin{array}{l}\text { Thomas Point Light. } \\
\text { Thomas. } \\
\text { Gowan. }\end{array}$ \\
\hline 2 & $3 s$ & 53 & 49. 82 & $76 \quad 2924.70$ & 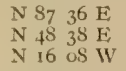 & $\begin{array}{llll}S & 87 & 38 & W \\
S & 48 & 39 & W \\
S & 16 & 08 & W\end{array}$ & $\begin{array}{l}5129 \\
2671 \\
1461\end{array}$ & $\begin{array}{l}\text { Thomas Point Jight. } \\
\text { Arundel. } \\
\text { Sellyy. }\end{array}$ \\
\hline 3 & 38 & 54 & 15.82 & 762931.20 & $\begin{array}{llll}\mathrm{S} & 82 & 53 & \mathrm{E} \\
\mathrm{N} & 67 & 48 & \mathrm{E} \\
\mathrm{N} & 24 & 02 & \mathrm{~W}\end{array}$ & 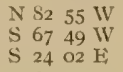 & $\begin{array}{r}5337 \\
2349 \\
576\end{array}$ & $\begin{array}{l}\text { Thomas Point I,ight. } \\
\text { Arundel. } \\
\text { Selby. }\end{array}$ \\
\hline 4 & $3^{8}$ & 54 & 29. 17 & $\begin{array}{llll}76 & 28 & 38.13\end{array}$ & $\begin{array}{llll}\mathrm{N} & 87 & 20 & \mathrm{~W} \\
\mathrm{~S} & 24 & 22 & \mathrm{~W} \\
\mathrm{~N} & 60 & 36 & \mathrm{E}\end{array}$ & $\begin{array}{llll}\mathrm{S} & 87 & 20 & \mathrm{E} \\
\mathrm{N} & 24 & 2 \mathrm{I} & \mathrm{E} \\
\mathrm{S} & 60 & 37 & \mathrm{~W}\end{array}$ & $\begin{array}{r}1635 \\
2797 \\
892\end{array}$ & $\begin{array}{l}\text { Selby. } \\
\text { Gowain. } \\
\text { Arundel. }\end{array}$ \\
\hline 5 & $3^{s}$ & $5+$ & 35.04 & $\begin{array}{lll}76 & 28 & 19.55\end{array}$ & 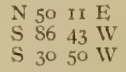 & 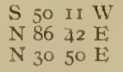 & $\begin{array}{r}375 \\
2126 \\
3199\end{array}$ & $\begin{array}{l}\text { Arundel. } \\
\text { Selby. } \\
\text { Gowan. }\end{array}$ \\
\hline 6 & $3^{8}$ & 54 & II. $\infty$ & $\begin{array}{llll}76 & 28 & 25.29\end{array}$ & $\begin{array}{llll}\mathrm{S} & \mathrm{S}_{2} & \text { OI } & \mathrm{E} \\
\mathrm{N} & 22 & 4 \mathrm{I} & \mathrm{E} \\
\mathrm{N} & 70 & 44 & \mathrm{WV}\end{array}$ & $\begin{array}{llll}\mathrm{N} & 82 & 03 & \mathrm{IV} \\
\mathrm{S} & 22 & 4 \mathrm{I} & \mathrm{WV} \\
\mathrm{S} & 70 & 45 & \mathrm{E}\end{array}$ & $\begin{array}{l}3594 \\
1 \times 38 \\
2089\end{array}$ & $\begin{array}{l}\text { Thomas I'oint Light. } \\
\text { Arundel. } \\
\text { Selby. }\end{array}$ \\
\hline
\end{tabular}

\section{TURKEY POINT.}

(Lower South River-Chart No.3.)

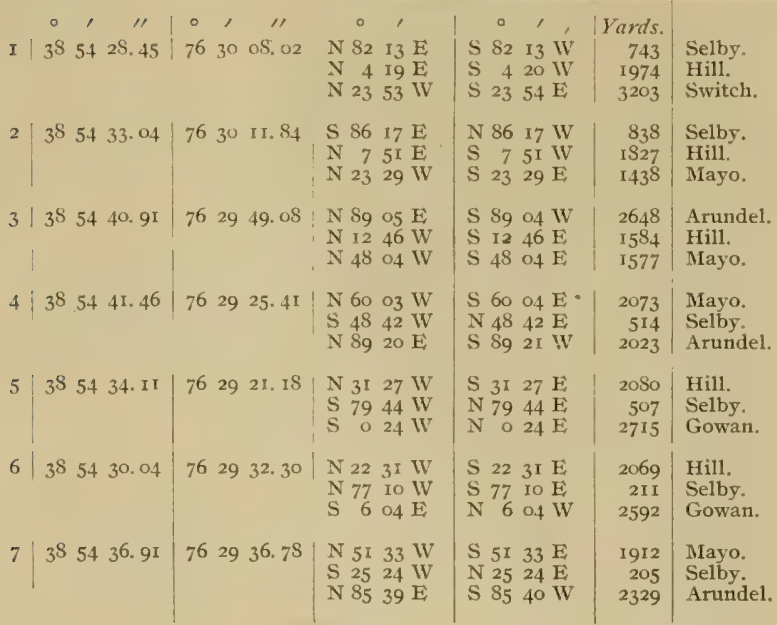


RULER FLATS.

(Lower South Rizer-Chart No.3.)

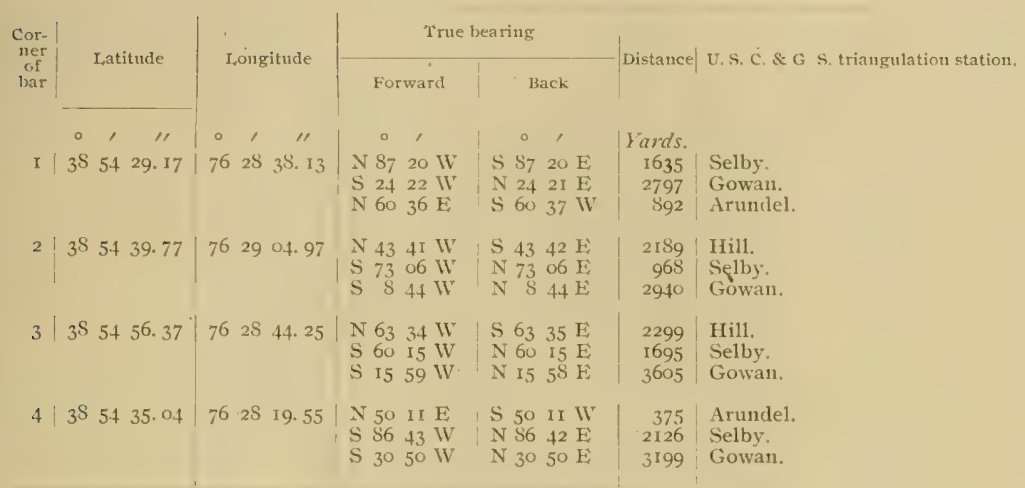

\section{SWAN REEF.}

(Lower-South River-Chart No. 3.)

\begin{tabular}{|c|c|c|c|c|c|c|c|c|c|c|c|c|}
\hline I & $\begin{array}{c}0 \\
3 S\end{array}$ & ' & $\begin{array}{c}\text { "I } \\
\text { 39. } 77\end{array}$ & $\begin{array}{c}0 \\
76\end{array}$ & $\begin{array}{c}1 \\
29\end{array}$ & $\begin{array}{c}\prime \prime \\
04.97\end{array}$ & $\begin{array}{ll} & 0 \\
N & 43 \\
\text { S } & 73 \\
\text { S } & S\end{array}$ & $\begin{array}{c}\text { ' } \\
4 \mathrm{I} \mathrm{WV} \\
06 \mathrm{WV} \\
44 \mathrm{WV}\end{array}$ & 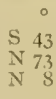 & $\begin{array}{l}1 \\
42 \mathrm{E} \\
06 \mathrm{E} \\
44 \mathrm{E}\end{array}$ & $\begin{array}{r}\text { Yards. } \\
2189 \\
968 \\
2910\end{array}$ & $\begin{array}{l}\text { Hill. } \\
\text { Selhy. } \\
\text { Gowan. }\end{array}$ \\
\hline 2 & $3^{S}$ & 54 & 55.47 & 76 & 29 & 45.06 & $\begin{array}{l}N 23 \\
N \quad 66 \\
\text { S } 9\end{array}$ & $\begin{array}{l}2 \mathrm{I} \mathrm{W} \\
15 \mathrm{WV} \\
\text { OS E }\end{array}$ & $\begin{array}{lr}S & 23 \\
S & 66 \\
N & 9\end{array}$ & $\begin{array}{l}2 \mathrm{I} \mathrm{E} \\
\text { I5 } \mathrm{E} \\
\text { oS } \mathrm{WV}\end{array}$ & $\begin{array}{r}1148 \\
1398 \\
821\end{array}$ & $\begin{array}{l}\text { Hill. } \\
\text { Mayo. } \\
\text { Selby. }\end{array}$ \\
\hline 3 & $3^{S}$ & 55 & 20. 53 & 76 & 29 & 21,14 & $\begin{array}{lr}N & 79 \\
\text { S } & 16 \\
\text { S } & 0\end{array}$ & $\begin{array}{l}07 \mathrm{WV} \\
4 \mathrm{SW} \\
16 \mathrm{~W}\end{array}$ & $\begin{array}{lr}\text { S } & 79 \\
\text { N } & 16 \\
\text { N } & 0\end{array}$ & $\begin{array}{l}08 \mathrm{E} \\
48 \mathrm{E} \\
\mathrm{I} 6 \mathrm{E}\end{array}$ & $\begin{array}{l}\text { I } 106 \\
\text { I730 } \\
42 S 1\end{array}$ & $\begin{array}{l}\text { Hill. } \\
\text { Selhy. } \\
\text { Gowan. }\end{array}$ \\
\hline 4 & 35 & 55 & 17.03 & 76 & 29 & 06.64 & $\begin{array}{lr}\text { N } & 77 \\
\text { S } & 29 \\
\text { S } & 5\end{array}$ & $\begin{array}{l}27 \mathrm{~W} \\
50 \mathrm{~W} \\
3 \mathrm{I} \mathrm{W}\end{array}$ & $\begin{array}{lr}\mathrm{S} & 77 \\
\mathrm{~N} & 29 \\
\mathrm{~N} & 5\end{array}$ & $\begin{array}{l}28 \mathrm{E} \\
50 \mathrm{E} \\
3 \mathrm{I} \mathrm{E}\end{array}$ & $\begin{array}{l}\text { I } 504 \\
\text { I } 773 \\
4181\end{array}$ & $\begin{array}{l}\text { Hill. } \\
\text { Selby. } \\
\text { Gowan. }\end{array}$ \\
\hline 5 & $35^{\circ}$ & 54 & 56.37 & 76 & 28 & 44.25 & $\begin{array}{l}\text { N } 63 \\
\text { S } 60 \\
\text { S } 15\end{array}$ & $\begin{array}{l}34 \mathrm{~W} \\
15 \mathrm{WV} \\
59 \mathrm{~W}\end{array}$ & $\begin{array}{l}\mathrm{S} 63 \\
\mathrm{~N} 60 \\
\mathrm{~N} \\
\mathrm{I}\end{array}$ & $\begin{array}{l}35 \mathrm{E} \\
\text { I } 5 \mathrm{E} \\
58 \mathrm{E}\end{array}$ & $\begin{array}{l}2299 \\
1695 \\
3605\end{array}$ & $\begin{array}{l}\text { Hill. } \\
\text { Selby. } \\
\text { Gowan. }\end{array}$ \\
\hline
\end{tabular}

$33^{0} \quad 07-6$ 
OUTER ROUND POINT.

(Lower South River-Chart No. 3.)

\begin{tabular}{|c|c|c|c|c|c|c|c|c|c|}
\hline \multirow{2}{*}{$\begin{array}{c}\text { Cor- } \\
\text { ner } \\
\text { of } \\
\text { bar }\end{array}$} & \multirow{2}{*}{\multicolumn{3}{|c|}{ Latitude }} & \multirow{2}{*}{\multicolumn{2}{|c|}{ Longilude }} & \multicolumn{2}{|c|}{ True bearing } & \multirow{2}{*}{ Distance } & \multirow{2}{*}{ U. S. C. \& G. S. triangulation station, } \\
\hline & & & & & & Forward & Back & & \\
\hline I & $\begin{array}{c}0 \\
38\end{array}$ & 54 & $\begin{array}{c}\prime \prime \\
39 \cdot 32\end{array}$ & $\begin{array}{c}\circ \\
76\end{array}$ & $\begin{array}{c}\prime \prime \prime \prime \\
3007.50\end{array}$ & $\begin{array}{lrll} & 0 & \\
\mathrm{~S} & 69 & 46 & \mathrm{E} \\
\mathrm{N} & 4 & 5 \mathrm{I} & \mathrm{E} \\
N_{3} & 50 & \mathrm{WW}\end{array}$ & $\begin{array}{lrlll} & \circ & \\
N & 69 & 45 & W \\
S & 4 & 5 I & W \\
S & 3 I & 5 I & E\end{array}$ & $\mid \begin{array}{r}\text { rards. } \\
769 \\
1604 \\
1304\end{array}$ & $\begin{array}{l}\text { Selby. } \\
\text { Hill. } \\
\text { Mayo. }\end{array}$ \\
\hline 2 & $3^{8}$ & 55 & 02.57 & 76 & 3027.19 & $\begin{array}{llll}\mathrm{S} & 49 & 45 & \mathrm{E} \\
\mathrm{N} & 38 & 46 & \mathrm{E} \\
\mathrm{N} & 27 & 34 & \mathrm{~W}\end{array}$ & $\begin{array}{llll}\mathrm{N} & 49 & 45 \mathrm{~W} \\
\mathrm{~S} & 38 & 46 \mathrm{~W} \\
\mathrm{~S} & 27 & 34 & \mathrm{E}\end{array}$ & $\begin{array}{r}1625 \\
1044 \\
365\end{array}$ & $\begin{array}{l}\text { Selby. } \\
\text { Hill. } \\
\text { Mayo. }\end{array}$ \\
\hline 3 & $3^{8}$ & 55 & $0_{5} . S_{3}$ & & 3021.40 & $\begin{array}{llll}\mathrm{S} & 43 & 15 & \mathrm{E} \\
\mathrm{N} & 35 & 30 & \mathrm{E} \\
\mathrm{N} & 56 & 25 & \mathrm{WV}\end{array}$ & $\begin{array}{llll}\mathrm{N} & 43 & \mathrm{I} & \mathrm{WV} \\
\mathrm{S} & 35 & 30 & \mathrm{WV} \\
\mathrm{S} & 56 & 25 & \mathrm{E}\end{array}$ & $\begin{array}{r}\text { I588 } \\
866 \\
386\end{array}$ & $\begin{array}{l}\text { Selby. } \\
\text { Hill. } \\
\text { Mayo. }\end{array}$ \\
\hline 4 & $3^{8}$ & 54 & 50.26 & & 2953.36 & $\begin{array}{llll}\mathrm{S} & 84 & 2 \mathrm{I} & \mathrm{E} \\
\mathrm{N} & 10 & 57 & \mathrm{WV} \\
\mathrm{N} & 55 & 09 & \mathrm{~W}\end{array}$ & $\begin{array}{llll}\mathrm{N} & 84 & 20 & \mathrm{~W} \\
\mathrm{~S} & 10 & 57 & \mathrm{E} \\
\mathrm{S} & 55 & 10 & \mathrm{E}\end{array}$ & $\begin{array}{l}2773 \\
1252 \\
\mathrm{I} 293\end{array}$ & $\begin{array}{l}\text { Arundel. } \\
\text { Hill. } \\
\text { Mayo. }\end{array}$ \\
\hline
\end{tabular}

INNER ROUND POINT.

(Lower South Rizer-Chart No. 3.)

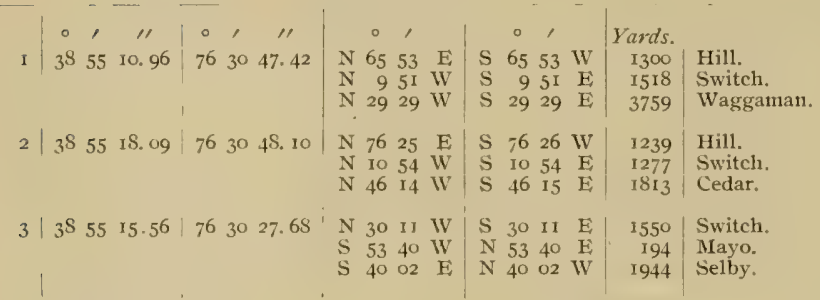

HILL POINT EAST.

(Lower South Rizer-Chavt No. 3.)

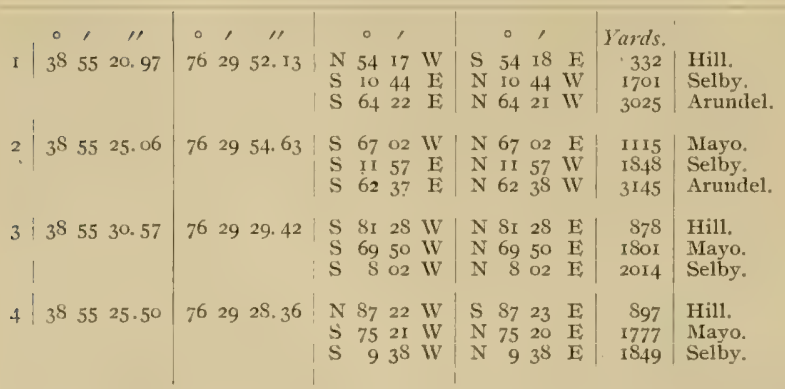


HILL, POINT.

(Lower South Rizer-Chart No. 3.)

\begin{tabular}{|c|c|c|c|c|c|c|}
\hline \multirow{2}{*}{$\begin{array}{c}\text { Cor- } \\
\text { ner } \\
\text { of } \\
\text { bar }\end{array}$} & \multirow{2}{*}{ I.atitude } & \multirow{2}{*}{ Longitude } & \multicolumn{2}{|c|}{ True bearing } & \multirow{2}{*}{ Distance } & \multirow{2}{*}{ U. S.c. \& G. S. triangulation station } \\
\hline & & & Forward & Back & & \\
\hline I & $\begin{array}{ccc}\circ & \prime & \prime \prime \\
38 & 55 & 04.97\end{array}$ & $\begin{array}{ccc}\circ & \prime \prime \\
76 & 30 & 00 .\end{array}$ & $\begin{array}{ccc} & 0 & \\
\mathrm{~N} & 4 & 29 \mathrm{~W} \\
\mathrm{~N} & 74 & 36 \mathrm{WV} \\
\mathrm{S} & 25 & 04 \\
\end{array}$ & 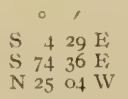 & \begin{tabular}{|r} 
Yourds. \\
736 \\
913 \\
1249
\end{tabular} & $\begin{array}{l}\text { Hill. } \\
\text { Mayo. } \\
\text { Selby. }\end{array}$ \\
\hline 2 & $3^{8} 55 \quad 22.80$ & $\begin{array}{llll}76 & 30 & 18.57\end{array}$ & $\begin{array}{llll}\mathrm{S} & 30 & 20 \mathrm{E} \\
\mathrm{N} & 73 & 10 \mathrm{E} \\
\mathrm{N} & 42 & 56 & \mathrm{~W}\end{array}$ & $\begin{array}{llll}\mathrm{N} & 30 & 19 \mathrm{~W} \\
\mathrm{~S} & 73 & 10 & \mathrm{~W} \\
\mathrm{~S} & 42 & 56 & \mathrm{E}\end{array}$ & $\begin{array}{r}2007 \\
456 \\
1497\end{array}$ & $\begin{array}{l}\text { Selby. } \\
\text { Hill. } \\
\text { Switch. }\end{array}$ \\
\hline 3 & $3^{3} 55 \quad 39.26$ & $76 \quad 30 \quad 07.76$ & 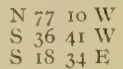 & $\begin{array}{llll}\mathrm{S} & 77 & \text { II } & \mathrm{E} \\
\mathrm{N} & 36 & 4 \mathrm{I} \\
\mathrm{N} & \mathrm{IS} & 34 & \mathrm{WW}\end{array}$ & $\begin{array}{r}2.432 \\
1140 \\
446\end{array}$ & $\begin{array}{l}\text { Cedar. } \\
\text { Mayo. } \\
\text { Hill. }\end{array}$ \\
\hline
\end{tabular}

ROCK POINT.

(Lower South River-Chart No. 3.)

\begin{tabular}{|c|c|c|c|c|c|c|c|c|c|c|c|c|}
\hline & 。 & , & $" \prime$ & a & , & "I & 0 & , & 。 & , & Yards. & \\
\hline I & $3^{8}$ & 55 & 20.49 & 76 & 30 & 47.71 & $\begin{array}{l}\text { N So } \\
\text { N } 12 \\
N \text { S }\end{array}$ & $\begin{array}{l}\text { or } \mathrm{E} \\
\text { of } \mathrm{WV} \\
22 \mathrm{WV}\end{array}$ & $\begin{array}{ll}\text { S } & \text { So } \\
\text { S } & 12 \\
\text { S } & 48\end{array}$ & $\begin{array}{l}02 \mathrm{~W} \\
07 \mathrm{E} \\
22 \mathrm{E}\end{array}$ & $\begin{array}{l}1213 \\
1201 \\
1765\end{array}$ & $\begin{array}{l}\text { Hill. } \\
\text { Switch. } \\
\text { Cedar. }\end{array}$ \\
\hline 2 & $3^{8}$ & 55 & $2 \mathrm{~S}, 2 \mathrm{~S}$ & 76 & 30 & 56. of & $\begin{array}{lr}\mathrm{S} & \mathrm{S} 7 \\
\mathrm{~N} & 2 \\
\mathrm{~N} & 50\end{array}$ & $\begin{array}{l}52 \mathrm{E} \\
05 \mathrm{WV} \\
24 \mathrm{~W}\end{array}$ & 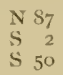 & $\begin{array}{l}52 \mathrm{WV} \\
\mathrm{O} 5 \mathrm{E} \\
24 \mathrm{E}\end{array}$ & $\begin{array}{r}1414 \\
912 \\
1427\end{array}$ & $\begin{array}{l}\text { Hill, } \\
\text { Switch. } \\
\text { Cedar. }\end{array}$ \\
\hline 3 & $3^{S}$ & 55 & 29.48 & 76 & 30 & $40.5 \mathrm{I}$ & $\begin{array}{ll}S & 17 \\
\text { S } & S 4 \\
\text { N } & 26\end{array}$ & $\begin{array}{l}21 \mathrm{E} \\
42 \mathrm{E} \\
52 \mathrm{WV}\end{array}$ & $\begin{array}{ll}N & 17 \\
N & 84 \\
S & 26\end{array}$ & $\begin{array}{l}2 \mathrm{I} \mathrm{W} \\
42 \mathrm{WW} \\
52 \mathrm{E}\end{array}$ & $\begin{array}{r}612 \\
1009 \\
977\end{array}$ & $\begin{array}{l}\text { Mayo. } \\
\text { Hill. } \\
\text { Switch. }\end{array}$ \\
\hline
\end{tabular}

FOX POINT.

(Lower South Rizer-Chart No. 3.)

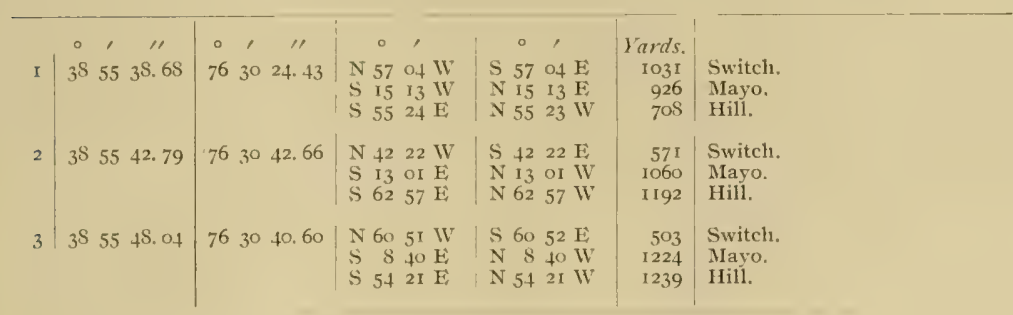


PURDY FLATS.

(Middle South Rizer-Chart No.3.)

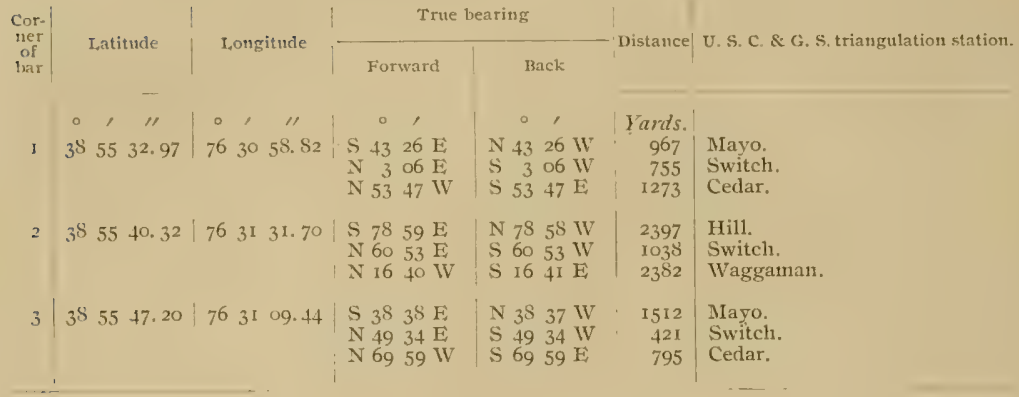

\section{THUNDER AND LIGHTNING.}

(Moddle South Rizer-Chart No.3.)

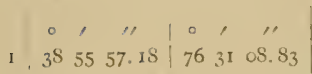

$2 \quad 3856 \quad 30.5^{8} \mid 7^{\frac{1}{6}} \quad 31 \quad 20.96$

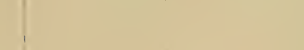

\begin{tabular}{l|llll|llll}
3 & $3 \mathrm{~S}$ & 56 & IS. & 78 & 76 & 31 & 0.72
\end{tabular}

$+\quad 385558.24763102 .95$ $\circ$,

N $3654 \mathrm{WV}$

S 85 II WV

S 3 I $26 \mathrm{E}$

S $86 \quad 39$ WV

S $2026 \mathrm{~W}$

S $2745 \mathrm{E}$

N $8043 \mathrm{WV}$

S $4742 \mathrm{WV}$

S $1355 \mathrm{E}$

$\mathrm{N} 4038 \mathrm{IV}$

$\mathrm{S} \mathrm{S}_{3} 46 \mathrm{WW}$

$\mathrm{S} 2627 \mathrm{E}$

\begin{tabular}{|c|c|c|}
\hline 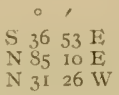 & $\begin{array}{r}\text { Yards. } \\
2142 \\
766 \\
1779\end{array}$ & $\begin{array}{l}\text { Waggaman. } \\
\text { Cedar. } \\
\text { Mayo. }\end{array}$ \\
\hline $\begin{array}{llll}N & 56 & 39 & \mathrm{E} \\
N & 20 & 26 & \mathrm{E} \\
N & 27 & 40 & \mathrm{~W}\end{array}$ & $\begin{array}{l}1480 \\
1271 \\
1344\end{array}$ & $\begin{array}{l}\text { Almshouse. } \\
\text { Cedar. } \\
\text { Switch. }\end{array}$ \\
\hline $\begin{array}{llll}S & S 0 & 43 & \mathrm{E} \\
\mathrm{N} & 47 & 42 & \mathrm{E} \\
\mathrm{N} & 13 & 55 & \mathrm{WV}\end{array}$ & $\begin{array}{r}1930 \\
1179 \\
816\end{array}$ & $\begin{array}{l}\text { Alurshouse. } \\
\text { Cedar. } \\
\text { Switch. }\end{array}$ \\
\hline $\begin{array}{llll}\mathrm{S} & 40 & 38 \mathrm{E} \\
\mathrm{N} & 83 & 46 & \mathrm{E} \\
\mathrm{N} & 26 & 27 & \mathrm{~W}\end{array}$ & $\begin{array}{r}2212 \\
923 \\
1736\end{array}$ & $\begin{array}{l}\text { Waggaman. } \\
\text { Cedar. } \\
\text { Mayo. }\end{array}$ \\
\hline
\end{tabular}

BREWER

(Middle South Rizer-Chart No.3.)

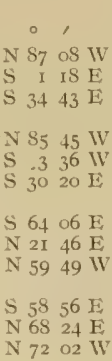

Iards.

1554 Switch.

1699 Waggaman.

I288 Almshouse L. R.

1699 Switch.

1655 Waggaman

II I Almshouse L. R.

Almshouse.

Cedar.

Switch.

1002

769 Almshouse,

5 IS Cedar.?

616 Switch. 
AIMSHOUSE.

(Upper South Rizer-Chart No.3.)

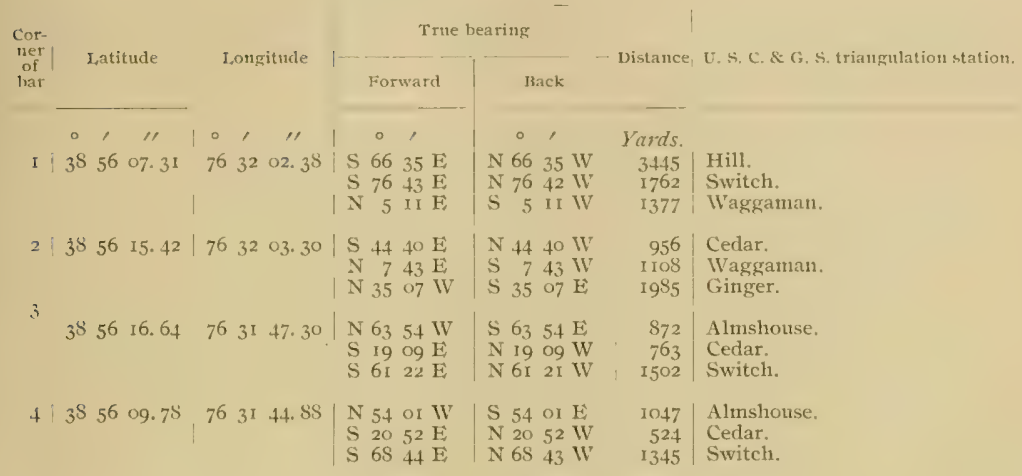

\section{DUVALI.}

(Upper South Rizer-Chart No. 3.)

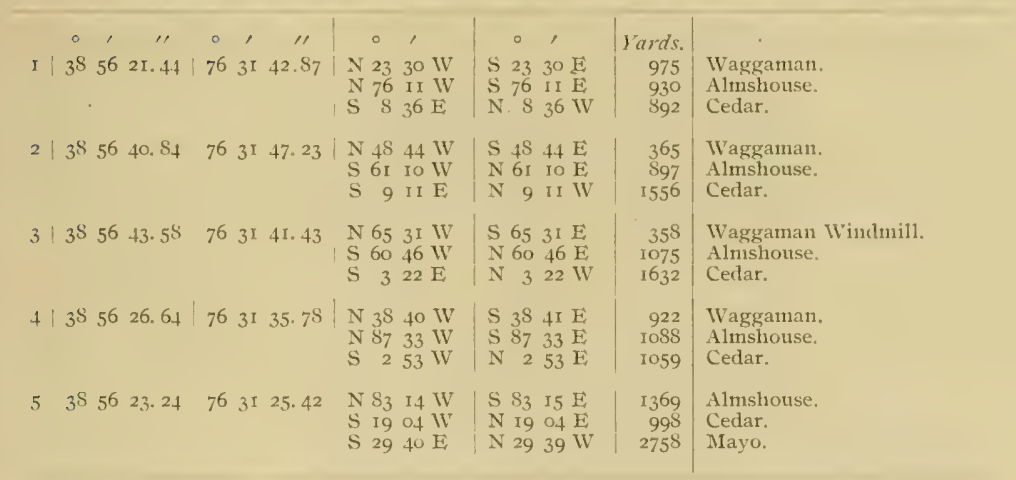




\section{ABERDEEN.}

(Upper South Rizer-Chart No. 3.)

\begin{tabular}{|c|c|c|c|c|c|c|c|c|}
\hline \multirow{2}{*}{$\begin{array}{l}\text { Cor- } \\
\text { ner } \\
\text { of } \\
\text { bar }\end{array}$} & \multirow{2}{*}{ Latitude } & \multirow{2}{*}{\multicolumn{2}{|c|}{ Longitude }} & \multicolumn{3}{|c|}{ True bearing } & \multirow{2}{*}{ Distance } & \multirow{2}{*}{ U. S. C. \& G. S. triangulation station. } \\
\hline & & & & & Forward & Back & & \\
\hline I & $\begin{array}{ccc}\circ & \prime \prime \\
3^{8} & 56 & 37.57\end{array}$ & $\begin{array}{cc}0 & 1 \\
76 & 31\end{array}$ & 59. 68 & $\begin{array}{l}\mathrm{N} \\
\mathrm{S} \\
\mathrm{S}\end{array}$ & 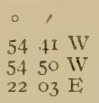 & 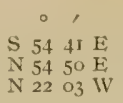 & \begin{tabular}{|r|} 
Yards. \\
1516 \\
559 \\
1539
\end{tabular} & $\begin{array}{l}\text { Ginger. } \\
\text { Almshouse. } \\
\text { Cedar. }\end{array}$ \\
\hline 2 & $3^{8} 56 \quad 48.89$ & $76 \quad 32$ & I5. IS & $\begin{array}{l}S \\
S \\
S\end{array}$ & $\begin{array}{rll}63 & 4 \mathrm{I} & \mathrm{W} \\
3 & 59 & \mathrm{WV} \\
86 & \mathrm{x} & \mathrm{E}\end{array}$ & $\begin{array}{lrll}N & 63 & 41 & E \\
N & 3 & 59 & E \\
N & 56 & 12 & W\end{array}$ & $\begin{array}{l}588 \\
705 \\
463\end{array}$ & $\begin{array}{l}\text { Brewer. } \\
\text { Almshouse. } \\
\text { Waggaman. }\end{array}$ \\
\hline 3 & $3^{8} 57$ 06. 13 & $76 \quad 32$ & or. os & $\begin{array}{l}\mathrm{S} \\
\mathrm{S} \\
\mathrm{S}\end{array}$ & $\begin{array}{lll}\mathrm{S}_{5} & 53 & \mathrm{~W} \\
46 & 46 & \mathrm{~W} \\
\mathrm{IS} & 07 & \mathrm{~W}\end{array}$ & $\begin{array}{llll}N_{S} & S_{5} & 53 & \mathrm{E} \\
\mathrm{N} & 46 & 45 & \mathrm{E} \\
\mathrm{N} & \mathrm{I} 8 & 07 & \mathrm{E}\end{array}$ & $\begin{array}{l}1203 \\
1229 \\
1363\end{array}$ & $\begin{array}{l}\text { Ginger. } \\
\text { Brewer. } \\
\text { Almshouse. }\end{array}$ \\
\hline
\end{tabular}

BEARD POINT.

(Upper South River-Chavt No.3.)

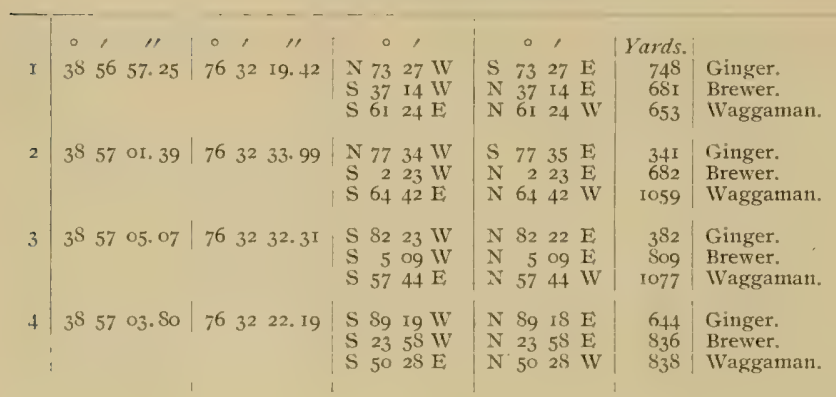

\section{ROUGH POINT.}

(Upper South Rizer-Chart No.3.)

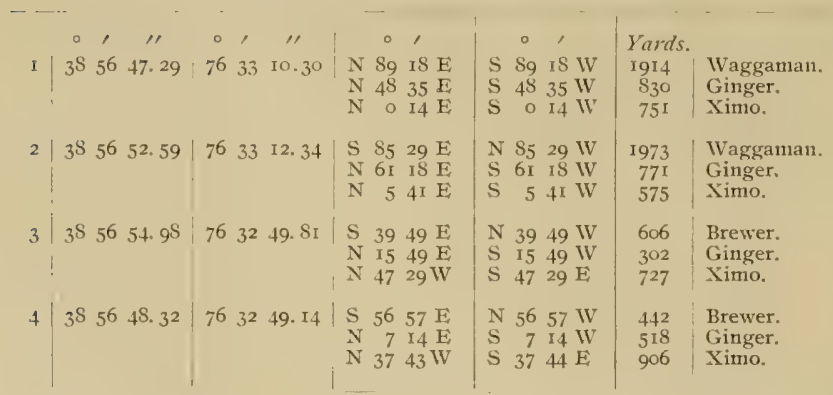


SAUNDERS.

(Chesapeake Bay off entrance to South River-Chart No.3.)

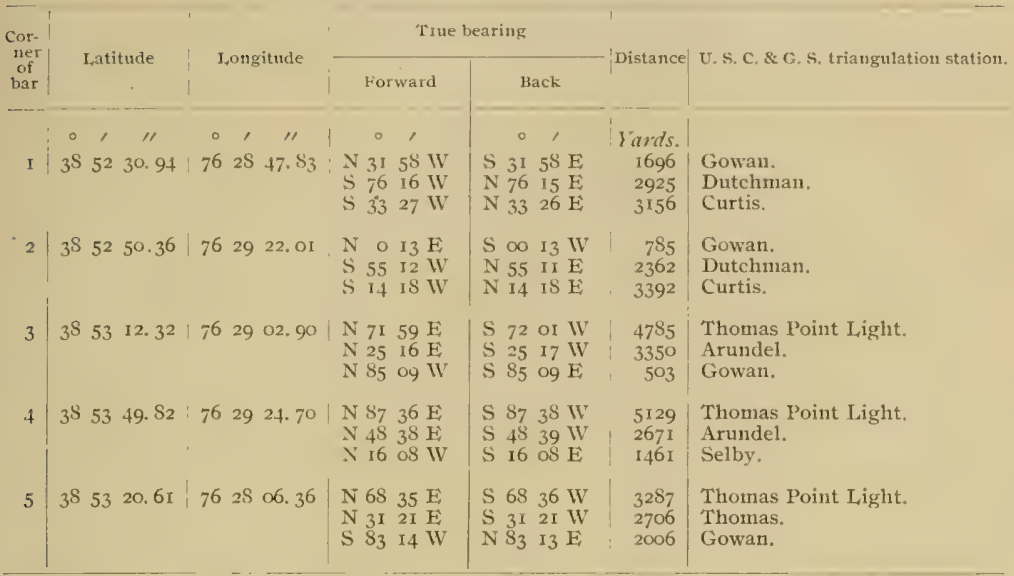

L,ULU.

(Chesapeake Bay, between South and West rizers--(Chart No.3.)

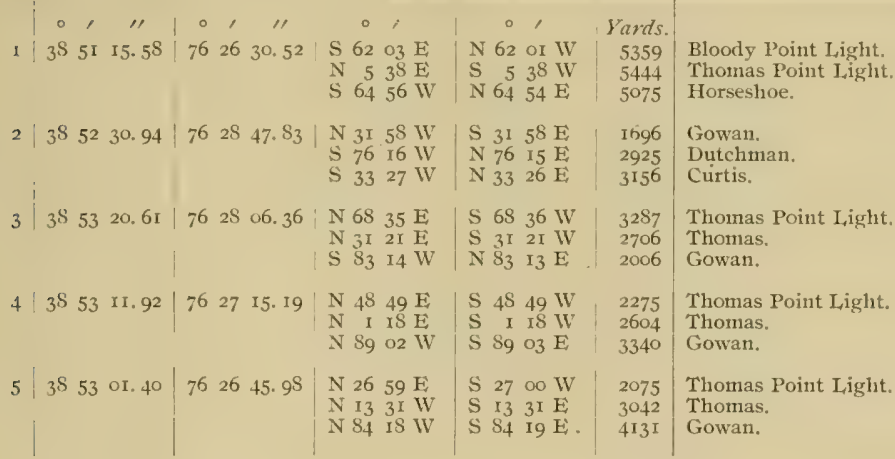


DUTCHMAN.

(Chesapeake Bay off entrance to West River-Chart No.3.)

\begin{tabular}{|c|c|c|c|c|c|c|c|c|c|c|c|}
\hline \multirow{2}{*}{$\begin{array}{c}\text { Cor- } \\
\text { ner } \\
\text { of } \\
\text { bar }\end{array}$} & \multirow{2}{*}{\multicolumn{2}{|c|}{ Latitude }} & \multirow{2}{*}{\multicolumn{3}{|c|}{ I.ongitude }} & \multicolumn{4}{|c|}{ True bearing } & \multirow{2}{*}{ Distance } & \multirow{2}{*}{ U. S. C. \& G. S. triangulation station } \\
\hline & & & & & & & Forwatd & & Back & & \\
\hline I & 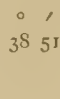 & $\begin{array}{c}\prime \prime \\
52.42\end{array}$ & $\begin{array}{c}0 \\
76\end{array}$ & $\begin{array}{c}1 \\
29\end{array}$ & II I I & $\begin{array}{l}\mathrm{N} \\
\mathrm{N}\end{array}$ & $\begin{array}{rl}0 & , \\
5 & 55 \\
74 & 48 \\
40 & 13 \\
4\end{array}$ & $\begin{array}{lr} & 0 \\
S & 5 \\
S & 74 \\
\mathrm{~S} & 40\end{array}$ & $\begin{array}{l}1 \\
55 \mathrm{E} \\
49 \mathrm{E} \\
\mathrm{J} 2 \mathrm{E}\end{array}$ & $\begin{array}{r}\text { Yards. } \\
2753 \\
2307 \\
1743\end{array}$ & $\begin{array}{l}\text { Gowan. } \\
\text { Dutchman. } \\
\text { Curtis. }\end{array}$ \\
\hline 2 & ${ }_{3} S 5$ I & 54.62 & 76 & 30 & 41.05 & & $\begin{array}{l}7200 \mathrm{~W} \\
4 \mathrm{I} \text { 30 E } \\
\text { I5 } \mathrm{II} \mathrm{E}\end{array}$ & $\begin{array}{ll}\mathrm{N} & 72 \\
\mathrm{~N} & 4 \mathrm{I} \\
\mathrm{S} & \mathrm{I} 5\end{array}$ & $\begin{array}{l}00 \mathrm{E} \\
30 \mathrm{WV} \\
11 \mathrm{WW}\end{array}$ & $\begin{array}{r}\mathrm{S}_{31} \mathrm{I} \\
\mathrm{I} \mathrm{S}_{0} \\
550\end{array}$ & $\begin{array}{l}\text { Clies. } \\
\text { Curtis. } \\
\text { Dutchwan. }\end{array}$ \\
\hline 3 & ${ }_{3} 8 \frac{1}{52}$ & 250.36 & 76 & 29 & 22. OI & & $\begin{array}{lll}0 & \text { I3 } & \mathrm{E} \\
55 & \text { I2 } & \text { W } \\
\text { I4 } & \text { IS } & \text { W }\end{array}$ & $\begin{array}{l}\mathrm{S} \quad 0 \\
\mathrm{~N} 55 \\
\mathrm{~N}^{-} \mathbf{1 4}\end{array}$ & $\begin{array}{l}\text { I3 W } \\
\text { II E } \\
\text { is E }\end{array}$ & $\begin{array}{r}785 \\
2362 \\
3392\end{array}$ & $\begin{array}{l}\text { Gowan. } \\
\text { Dutchman. } \\
\text { Curtis. }\end{array}$ \\
\hline 4 & $3^{8} 52$ & 230.94 & 76 & 28 & $47 \cdot S_{3}$ & $\begin{array}{l}\mathrm{N} \\
\mathrm{S} \\
\mathrm{S}\end{array}$ & $\begin{array}{lll}3 \mathrm{I} & 58 \mathrm{WV} \\
76 & \mathrm{I} 6 & \mathrm{WV} \\
33 & 27 & \mathrm{WV}\end{array}$ & $\begin{array}{l}S 3 I \\
N \\
N \\
N \\
33\end{array}$ & $\begin{array}{l}58 \mathrm{E} \\
15 \mathrm{E} \\
26 \mathrm{E}\end{array}$ & $\begin{array}{l}1696 \\
2925 \\
3156\end{array}$ & $\begin{array}{l}\text { Gowan. } \\
\text { Dutchnan. } \\
\text { Curtis. }\end{array}$ \\
\hline
\end{tabular}

\section{THREE SISTERS.}

(Chesapeake Bay off West River-Chart No. 3.)

\begin{tabular}{|c|c|c|c|c|c|c|c|c|c|c|c|c|}
\hline I & $\begin{array}{c}\circ \\
3^{8}\end{array}$ & $\frac{1}{49}$ & $\stackrel{\text { II }}{35 \cdot 36}$ & $\begin{array}{c}\circ \\
76\end{array}$ & $\begin{array}{c}1 \\
29\end{array}$ & II. 96 & $\begin{array}{lc} & 0 \\
\mathrm{~N} & 2 \mathrm{~S} \\
\mathrm{~N} & \mathrm{r} 5 \\
\mathrm{~S} & 3 \mathrm{~S}\end{array}$ & $\begin{array}{l}1 \\
33 \mathrm{E} \\
25 \mathrm{~W} \\
04 \mathrm{WV}\end{array}$ & $\begin{array}{lc} & 0 \\
\mathrm{~S} & 28 \\
\mathrm{~S} & 15 \\
\mathrm{~N} & 38\end{array}$ & $\begin{array}{l}35 \mathrm{WV} \\
25 \mathrm{E} \\
04 \mathrm{E}\end{array}$ & $\begin{array}{l}\text { Yards. } \\
\text { I00I5 } \\
1276 \\
168 \mathrm{I}\end{array}$ & $\begin{array}{l}\text { Thomas Point I.ight. } \\
\text { Horseslioe. } \\
\text { Franklin. }\end{array}$ \\
\hline 2 & $3^{8}$ & 51 & ${ }_{3} S .65$ & 76 & 29 & II. 74 & $\begin{array}{l}\text { N } 4 \\
N 64 \\
\text { S } 5 \text { I }\end{array}$ & $\begin{array}{l}47 \mathrm{~W} \\
\text { II W } \\
55 \mathrm{~W}\end{array}$ & $\begin{array}{lr}\mathrm{S} & 4 \\
\mathrm{~S} & 64 \\
\mathrm{~N} & 5 \mathrm{I}\end{array}$ & $\begin{array}{l}47 \mathrm{E} \\
\text { II E } \\
54 \mathrm{E}\end{array}$ & $\begin{array}{l}3213 \\
2455 \\
1410\end{array}$ & $\begin{array}{l}\text { Gowan. } \\
\text { Dutchman. } \\
\text { Curtis. }\end{array}$ \\
\hline 3 & 38 & $5^{x}$ & 52.42 & 76 & 29 & II. I/4 & $\begin{array}{lr}N & 5 \\
N & 74 \\
\text { S } & 40\end{array}$ & $\begin{array}{l}55 \mathrm{~W} \\
48 \mathrm{~W} \\
13 \mathrm{~W}\end{array}$ & $\begin{array}{lr}S & 5 \\
\text { S } 74 \\
\text { N } \\
40\end{array}$ & $\begin{array}{l}55 \mathrm{E} \\
49 \mathrm{E} \\
12 \mathrm{E}\end{array}$ & $\left|\begin{array}{l}2753 \\
2307 \\
1743\end{array}\right|$ & $\begin{array}{l}\text { Gowan. } \\
\text { Dutchman. } \\
\text { Curtis. }\end{array}$ \\
\hline 4 & $3 S$ & 52 & 30.94 & 76 & $2 S$ & $47.8_{3}$ & $\begin{array}{l}\text { N } 3 I \\
\text { S } 76 \\
\text { S } 33\end{array}$ & $\begin{array}{l}5^{8} \mathrm{WV} \\
\mathrm{I} 6 \mathrm{WV} \\
27 \mathrm{~W}\end{array}$ & $\begin{array}{l}\mathrm{S} 3 \mathrm{I} \\
\mathrm{N} \\
\mathrm{N} \\
\mathrm{N} \\
33\end{array}$ & $\begin{array}{l}58 \mathrm{E} \\
\text { I5 E } \\
26 \mathrm{E}\end{array}$ & $\begin{array}{l}1696 \\
2925 \\
3156\end{array}$ & $\begin{array}{l}\text { Gowan. } \\
\text { Dutchman. } \\
\text { Curtis. }\end{array}$ \\
\hline 5 & $3^{8}$ & $5^{I}$ & $15.5^{\mathrm{S}}$ & 76 & 26 & 30.52 & $\begin{array}{l}\text { S } 62 \\
\text { N } 5 \\
\text { S } 64\end{array}$ & $\begin{array}{l}03 \mathrm{E} \\
38 \mathrm{E} \\
56 \mathrm{~W}\end{array}$ & $\begin{array}{l}\mathrm{N} 62 \\
\mathrm{~S} 5 \\
\mathrm{~N} 64\end{array}$ & $\begin{array}{l}\text { or W } \\
38 \mathrm{~W} \\
54 \mathrm{E}\end{array}$ & $\begin{array}{l}5359 \\
5444 \\
5075\end{array}$ & $\begin{array}{l}\text { Bloody Point Light. } \\
\text { Thomas Point Light. } \\
\text { Horseshoe. }\end{array}$ \\
\hline 6 & $3 S$ & 49 & 42. 70 & 76 & 27 & 33.13 & $\begin{array}{l}N \text { I } \\
N \text { 7I } \\
\text { S } 66\end{array}$ & $\begin{array}{l}20 \mathrm{E} \\
32 \mathrm{~W} \\
4 \mathrm{I} \cdot \mathrm{W}\end{array}$ & $\begin{array}{ll}S & 14 \\
S & 71 \\
N & 66\end{array}$ & $\begin{array}{l}2 \mathrm{IV} \\
34 \mathrm{E} \\
40 \mathrm{E}\end{array}$ & $\begin{array}{l}8824 \\
3106 \\
3968\end{array}$ & $\begin{array}{l}\text { Thomas Point Light. } \\
\text { Horseshoe, } \\
\text { Franklin. }\end{array}$ \\
\hline
\end{tabular}


CURTIS.

(Chesapeake Bay off entrance to West River-Chart No. 3.)

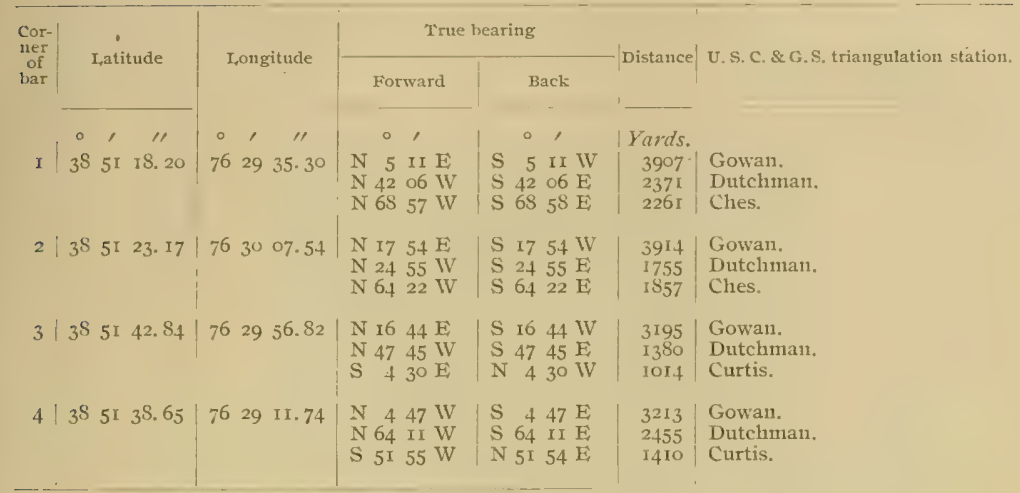

COLLINS FLATS.

(West River-Chart No. 3.)

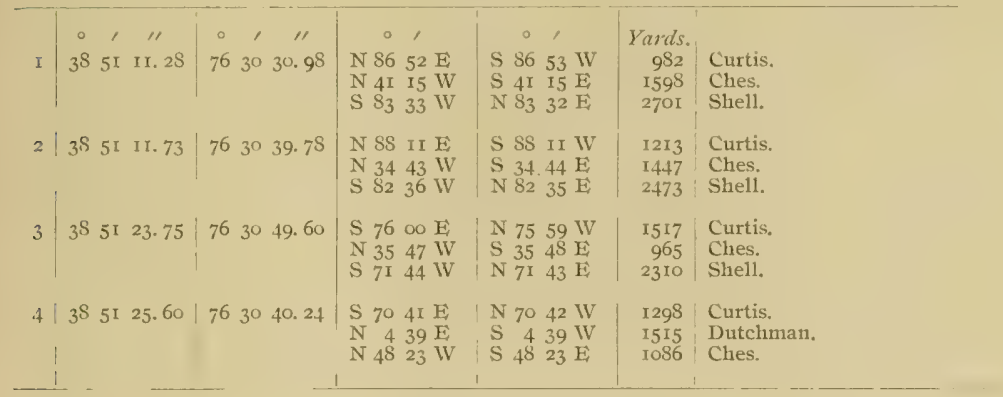

\section{POTATO HILI.}

(West River-Chart No.3.)

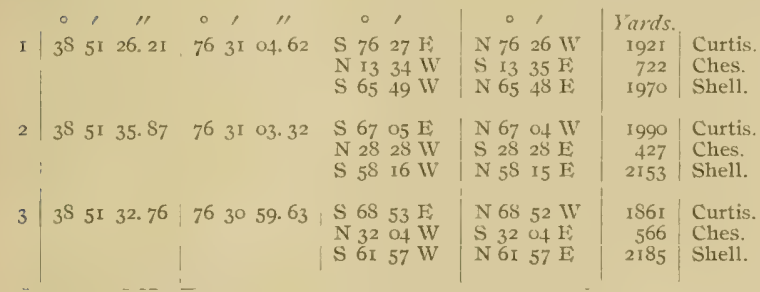


CEDAR POINT.

(West River-Chart No. 3.)

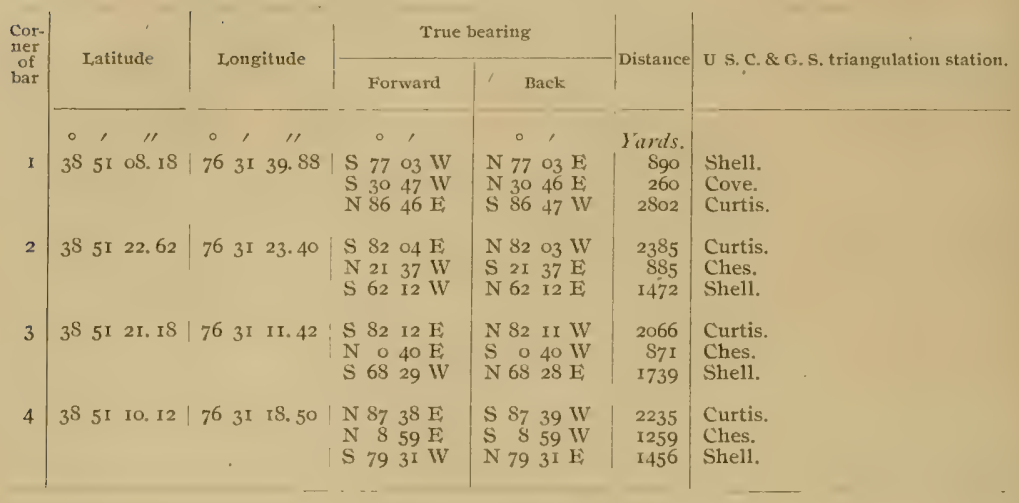

BARREN NECK.

(West River-Chart No.3.)

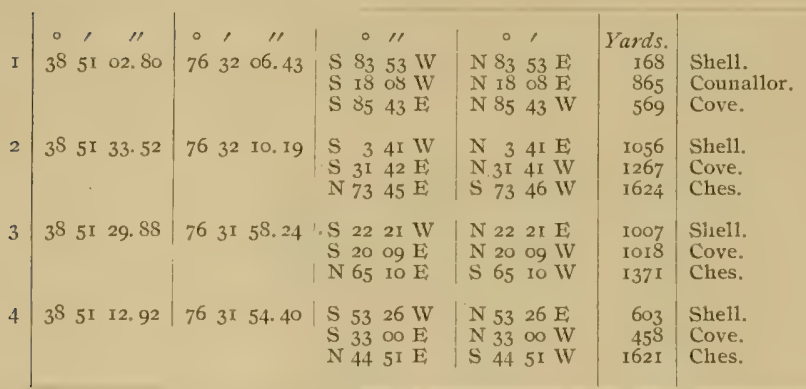


TUCKER.

(West River-Chart No 3.)

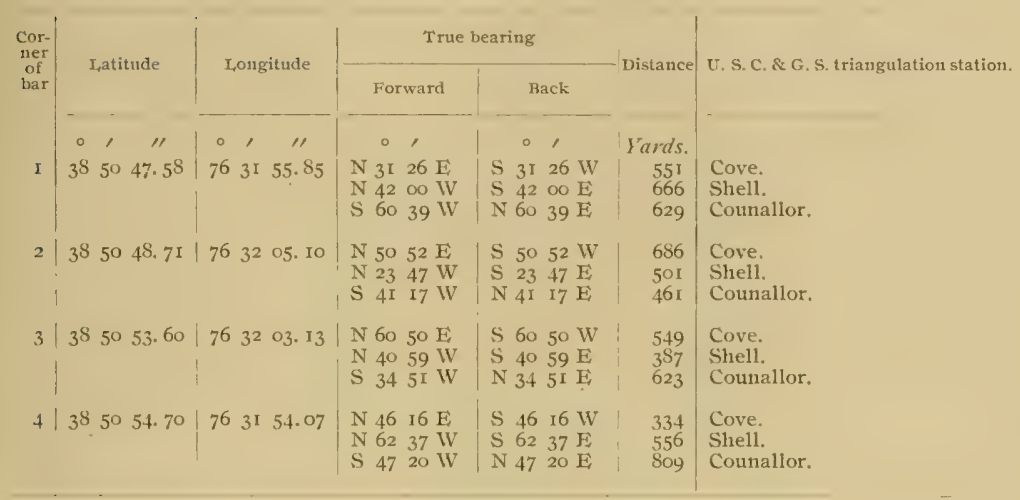

\section{CHESTON POINT.}

(Rhode River-Chart No.3.)

\begin{tabular}{|c|c|c|c|c|c|c|}
\hline & $\begin{array}{ccc}\circ & \prime \prime \\
38 & 51 & 40.62\end{array}$ & $\begin{array}{ccc}\circ & , & \prime \prime \\
76 & 31 & 05.16\end{array}$ & 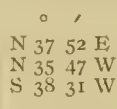 & $\begin{array}{ccc} & \circ \\
\mathrm{S} & 37 & 52 \mathrm{WV} \\
\mathrm{N} & 35 & 47 \mathrm{E} \\
\mathrm{N} & 38 & 31 \mathrm{E}\end{array}$ & $\begin{array}{r}Y a r d s \\
1271 \\
265 \\
1684\end{array}$ & $\begin{array}{l}\text { Dutchman } \\
\text { Ches. } \\
\text { Cove. }\end{array}$ \\
\hline & $3^{8} 52 \quad 18.00$ & $7631 \quad$ o6. Ss & 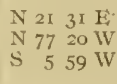 & $\begin{array}{llll}\mathrm{S} & 2 \mathrm{I} & 3 \mathrm{II} \\
\mathrm{S} & 77 & 20 \mathrm{E} \\
\mathrm{N} & 5 & 59 \mathrm{E}\end{array}$ & $\begin{array}{r}645 \\
600 \\
1051\end{array}$ & \begin{tabular}{|l} 
Defta, \\
Rhode. \\
Clies.
\end{tabular} \\
\hline & $\begin{array}{llll}38 & 52 & \text { ग } 3.74\end{array}$ & $7631 \quad 00.99$ & $\begin{array}{llll}\mathrm{S} & 16 & 23 & \mathrm{~W} \\
\mathrm{~S} & 74 & 48 & \mathrm{E} \\
\mathrm{N} & 6 & \mathrm{I} & \mathrm{E}\end{array}$ & $\begin{array}{llll}N & 16 & 22 & \mathrm{E} \\
\mathrm{N} & 74 & 47 & \mathrm{WV} \\
\mathrm{S} & 6 & 15 & \mathrm{WV}\end{array}$ & $\begin{array}{l}939 \\
401 \\
748\end{array}$ & $\begin{array}{l}\text { Ches. } \\
\text { Cato. } \\
\text { Delta. }\end{array}$ \\
\hline & $3^{8} 5146.5^{8}$ & $76 \quad 3057.55$ & $\begin{array}{l}\text { N } 3550 \mathrm{E} \\
\text { N } 3743 \mathrm{~W} \\
\mathrm{~S} 3927 \mathrm{~W}\end{array}$ & $\begin{array}{lll}\mathrm{S} & 35 & 50 \mathrm{WV} \\
\mathrm{S} & 8743 \mathrm{E} \\
\mathrm{N} & 3926 \mathrm{E}\end{array}$ & $\begin{array}{r}990 \\
355 \\
1967\end{array}$ & $\begin{array}{l}\text { Dutchman. } \\
\text { Ches. } \\
\text { Cove. }\end{array}$ \\
\hline
\end{tabular}

\section{DUTCHMAN HOLLOW.}

(Rhode River-Chart No.3.)

\begin{tabular}{|c|c|c|c|c|c|c|c|}
\hline & $\begin{array}{cc}\circ & \\
38 & 52\end{array}$ & $=17.54$ & $\begin{array}{ccc}\circ & \prime \prime \prime \\
76 & 30 & 48.48\end{array}$ & 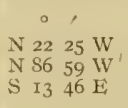 & 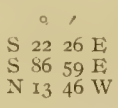 & \begin{tabular}{|} 
Yards. \\
666 \\
544 \\
$24 \mathrm{I}$
\end{tabular} & $\begin{array}{l}\text { Delta. } \\
\text { Rhode. } \\
\text { Cato. }\end{array}$ \\
\hline & $3^{8} 5^{2}$ & 2. 21.98 & 76 30 54.43 & $\begin{array}{llll}\mathrm{N} & \text { II } & 06 & \mathrm{~W} \\
\mathrm{~S} & 72 & 37 & \mathrm{~W} \\
\mathrm{~S} & 29 & \text { 12 } & \mathrm{E}\end{array}$ & $\begin{array}{lll}\text { S } & \text { II } & \text { of } \\
N & 72 & 3 \\
\text { N } 29 & \text { I }\end{array}$ & & $\begin{array}{l}\text { Delta. } \\
\text { Rhode. } \\
\text { Cato. }\end{array}$ \\
\hline & $3^{8} 5^{2}$ & 28,1 & $76 \quad 30 \quad 50.55$ & 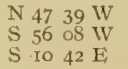 & 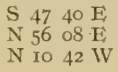 & $\begin{array}{r}\text { rr59 } \\
588 \\
607\end{array}$ & $\begin{array}{l}\text { Turf. } \\
\text { Rhode. } \\
\text { Cato. }\end{array}$ \\
\hline
\end{tabular}


BRICE FENCE.

(Rhode River-Chart No. 3.)

\begin{tabular}{|c|c|c|c|c|c|c|c|c|}
\hline \multirow{2}{*}{$\begin{array}{l}\text { Cor- } \\
\text { ner } \\
\text { of } \\
\text { bat }\end{array}$} & \multirow{2}{*}{\multicolumn{2}{|c|}{ Latitude }} & \multirow{2}{*}{\multicolumn{2}{|c|}{ Iongitude }} & \multicolumn{2}{|c|}{ True bearing } & \multirow{2}{*}{ Distance } & \multirow{2}{*}{ U.S.C. \& G.S. triangulation station. } \\
\hline & & & & & Forward & Back & & \\
\hline I & $\begin{array}{cc}0 & , \\
38 & 52\end{array}$ & $\begin{array}{c}\prime \prime \\
19.3^{8}\end{array}$ & $\begin{array}{c}0 \\
76 \\
71\end{array}$ & II. 05 & \begin{tabular}{lccc}
-0 & \multicolumn{1}{c}{} \\
$\mathrm{S}$ & 57 & 00 & $\mathrm{E}$ \\
$\mathrm{N}$ & 32 & 03 & $\mathrm{E}$ \\
$\mathrm{N}$ & 16 & 29 & $\mathrm{WV}$
\end{tabular} & \begin{tabular}{cccc} 
& 0 & \multicolumn{1}{c}{} \\
$\mathrm{N}$ & 57 & 00 & $\mathrm{WV}$ \\
$\mathrm{S}$ & 32 & 03 & $\mathrm{WV}$ \\
$\mathrm{S}$ & 16 & 29 & $\mathrm{E}$
\end{tabular} & $\begin{array}{r}\text { Yards. } \\
6 \mathrm{I} \\
653 \\
1122\end{array}$ & $\begin{array}{l}\text { Rhode. } \\
\text { Delta. } \\
\text { Turf. }\end{array}$ \\
\hline 2 & ${ }_{3} 852$ & 23.90 & 763 & 24.86 & $\begin{array}{lrll}\mathrm{S} & 65 & 54 & \mathrm{E} \\
\mathrm{N} & 60 & 33 & \mathrm{E} \\
\mathrm{N} & 2 & 5 \mathrm{I} & \mathrm{E}\end{array}$ & $\begin{array}{lrrrr}\mathrm{N} & 65 & 54 & \mathrm{~W} \\
\mathrm{~S} & 60 & 33 & \mathrm{WV} \\
\mathrm{S} & 2 & 5 \mathrm{I} & \mathrm{WV}\end{array}$ & $\begin{array}{l}455 \\
8 \mathrm{I} 6 \\
924\end{array}$ & $\begin{array}{l}\text { Rhode. } \\
\text { Delta. } \\
\text { Turf. }\end{array}$ \\
\hline 3 & $3^{S} 5^{2}$ & 24.29 & 7631 & I4. 78 & $\begin{array}{llll}\mathrm{S} & 36 & 58 \mathrm{E} \\
\mathrm{N} & 48 & 50 & \mathrm{E} \\
\mathrm{N} & \mathbf{1} & 35 & \mathrm{~W}\end{array}$ & $\begin{array}{llll}\mathrm{N} & 36 & 58 \mathrm{~W} \\
\mathrm{~S} & 48 & 50 & \mathrm{~W} \\
\mathrm{~S} & 13 & 35 & \mathrm{E}\end{array}$ & $\begin{array}{l}249 \\
589 \\
936\end{array}$ & $\begin{array}{l}\text { Rhode. } \\
\text { Delta. } \\
\text { Turf. }\end{array}$ \\
\hline
\end{tabular}

STONY HOLLOW.

(Rhode River-Chart No. 3.)

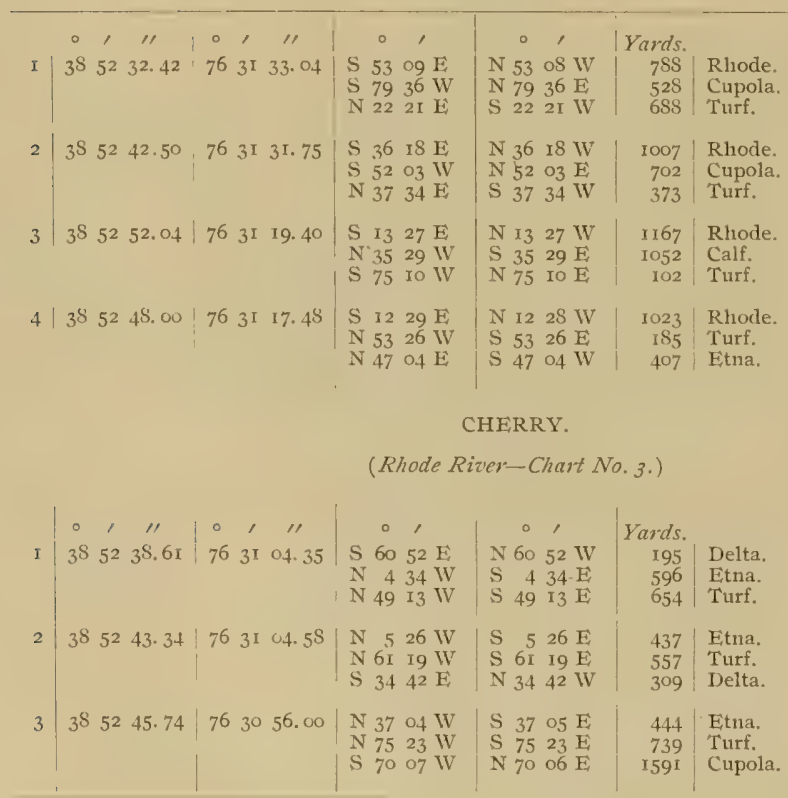




\section{JACKASS,}

(Rhode River-Chart No.3.)

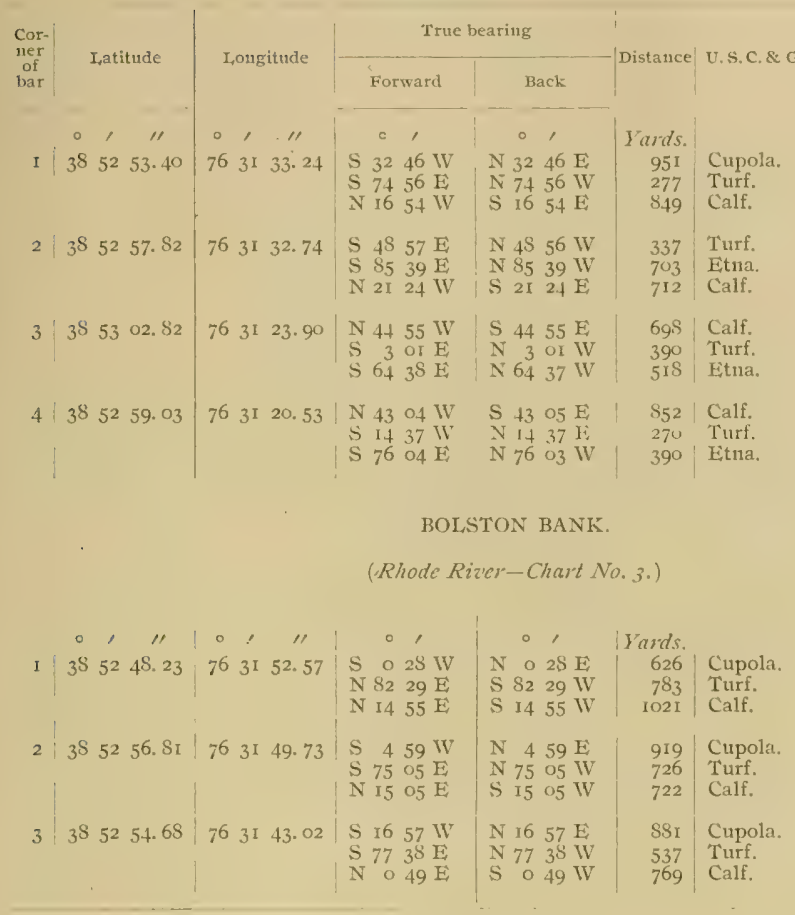

\section{HIGH ISLAND.}

(Rhode River-Chart No.3.)

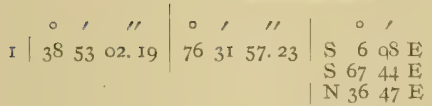

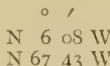
Yards.
$\begin{array}{llll}N & 67 & 43 \mathrm{WI} \\ \mathrm{S} & 36 & 48 \mathrm{WV}\end{array}$
I IO2 Cupola.
97 I Turf.
$2 \mid$\begin{tabular}{lll|lll}
38 & 53 & 10.24 & 76 & 3 I & 53. IS
\end{tabular}
$\begin{array}{lrr}\mathrm{S} & 0 & 28 \mathrm{E} \\ \mathrm{S} & 5 \mathrm{r} & 05 \mathrm{E} \\ \mathrm{N} & 58 & 48 \mathrm{E}\end{array}$
$\mathrm{N} \circ 28 \mathrm{~W}$
$6+4$ Calf.
$\begin{array}{llll} & 51 & 05 & 11 \\ S & 58 & 48 & \text { IV }\end{array}$
IOIS Cupo
$\begin{array}{lrll}\mathrm{S} & 4 & 26 \mathrm{~W} \\ \mathrm{~S} & 5 \mathrm{I} & \mathrm{O} 2 \mathrm{E}\end{array}$
\begin{tabular}{ll|l|l|l}
$\mathrm{N}$ & $426 \mathrm{E}$ & 1284 & Cupola.
\end{tabular}
$3\left|3^{8} 53 \quad 07.64\right| 76$ 3I 49.00 


\section{FLAT ISLAND.}

(Rhode River-Chart No. 3.)

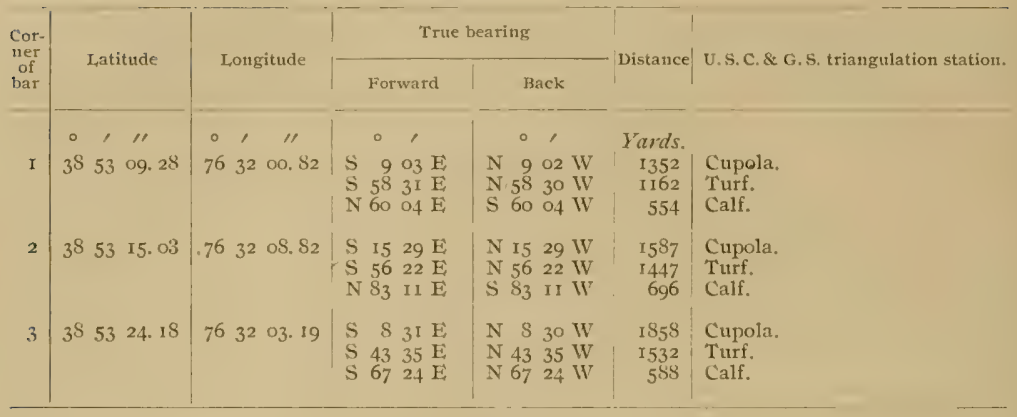

BUCE.

(Rhode River-Chart No. 3.)

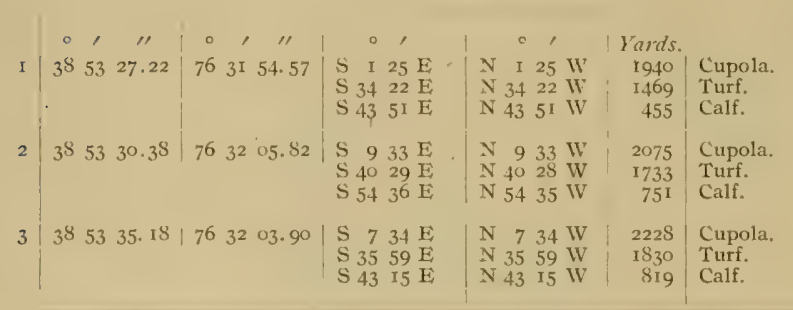


Survey of Oyster-Bars, Anne Arundel County, Md.

BAY SHORE.

(Chesapeake Bay between West River and Herring Bay-Chart No. 4.)

\begin{tabular}{|c|c|c|c|c|c|c|c|c|c|c|c|}
\hline \multirow{2}{*}{$\begin{array}{c}\text { Cor- } \\
\text { net } \\
\text { of } \\
\text { bat }\end{array}$} & \multirow{2}{*}{\multicolumn{3}{|c|}{ Latitude }} & \multirow{2}{*}{\multicolumn{3}{|c|}{ Lougitude }} & \multicolumn{3}{|c|}{ True bearing } & \multirow{2}{*}{ 'Distance| } & \multirow{2}{*}{ U. S. C. \& G.S. triangulation station } \\
\hline & & & & & & & Forward & & Back & & \\
\hline I & i & $\frac{1}{46}$ & $2 \mathrm{I}, 04$ & $\begin{array}{c}\circ \\
76\end{array}$ & ', & $\begin{array}{c}\prime \prime \prime \\
55.90\end{array}$ & 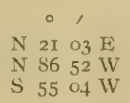 & $\begin{array}{ll}S & 2 \\
S & 5 \\
N & 5\end{array}$ & 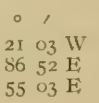 & $\begin{array}{r}\text { Yards. } \\
2175 \\
728 \\
3819\end{array}$ & $\begin{array}{l}\text { Broad. } \\
\text { Parker. } \\
\text { Fairhaven. }\end{array}$ \\
\hline 2 & $3^{8}$ & 47 & 45.64 & 76 & 30 & 33.40 & $\begin{array}{lrll}\mathrm{N} & 25 & 05 \mathrm{E} \\
\mathrm{N} & 8 & 22 & \mathrm{~W} \\
\mathrm{~S} & 59 & 30 & \mathrm{WV}\end{array}$ & $\mid \begin{array}{l}\mathrm{S} \\
\mathrm{S} \\
\mathrm{N}\end{array}$ & $\begin{array}{rl}25 & 06 \mathrm{WV} \\
8 & 22 \mathrm{E} \\
59 & 29 \mathrm{E}\end{array}$ & $\begin{array}{r}2624 \\
584 \\
1621\end{array}$ & $\begin{array}{l}\text { Franklin. } \\
\text { Nut. } \\
\text { Broad. }\end{array}$ \\
\hline 3 & 38 & 48 & 5 I. 50 & 76 & 28 & 52.60 & $\begin{array}{llll}\mathrm{N} & 17 & 25 & \mathrm{WV} \\
\mathrm{N} & 84 & 16 & \mathrm{~W} \\
\mathrm{~S} & 59 & 07 & \mathrm{~W}\end{array}$ & $\begin{array}{l}\mathrm{S} \\
\mathrm{S} \\
\mathrm{N}\end{array}$ & $\begin{array}{ll}17 & 25 \mathrm{E} \\
84 & 16 \mathrm{E} \\
59 & 06 \mathrm{E}\end{array}$ & $\begin{array}{l}28+0 \\
1555 \\
3199\end{array}$ & $\begin{array}{l}\text { Horseshoe. } \\
\text { Franklin. } \\
\text { Nut. }\end{array}$ \\
\hline 4 & $3^{S}$ & 49 & $35 \cdot 36$ & 76 & 29 & ir. 96 & $\begin{array}{llll}\mathrm{N} & 28 & 33 & \mathrm{E} \\
\mathrm{N} & 15 & 25 \mathrm{~W} \\
\mathrm{~S} & 38 & 04 & \mathrm{WV}\end{array}$ & $\mid \begin{array}{ll}S & 2 \\
S & 1 \\
N & 3\end{array}$ & $\begin{array}{l}2835 \mathrm{~W} \\
1525 \mathrm{E} \\
3804 \mathrm{E}\end{array}$ & $\begin{array}{r}10015 \\
1276 \\
168 \mathrm{I}\end{array}$ & $\begin{array}{l}\text { Thomas Point Light. } \\
\text { Horseshoe. } \\
\text { Franklin. }\end{array}$ \\
\hline 5 & $3^{S}$ & 49 & 42.70 & 76 & 27 & 33.13 & $\begin{array}{llll}\mathrm{N} & 14 & 20 & \mathrm{E} \\
\mathrm{N} & 7 \mathrm{I} & 32 & \mathrm{IV} \\
\mathrm{S} & 66 & 4 \mathrm{I} & \mathrm{WV}\end{array}$ & $\mid \begin{array}{l}S \\
S \\
S \\
N\end{array}$ & $\begin{array}{l}\text { If } 2 \mathrm{I} \mathrm{W} \\
7 \mathrm{I} \\
66 \\
66 \mathrm{E}\end{array}$ & $\begin{array}{l}8 S 24 \\
3106 \\
3968\end{array}$ & $\begin{array}{l}\text { Thomas Point Light. } \\
\text { Horseshoe. } \\
\text { Franklin. }\end{array}$ \\
\hline 6 & $3^{8}$ & $4^{8}$ & 54.54 & 76 & 27. & 58.99 & $\begin{array}{llll}\mathrm{N} & 40 & 58 \mathrm{~W} \\
\mathrm{~N} & 88 & 59 & \mathrm{~W} \\
\mathrm{~S} & 67 & 15 & \mathrm{~W}\end{array}$ & $\begin{array}{l}\mathrm{S} \\
\mathrm{S} \\
\mathrm{N}\end{array}$ & $\begin{array}{l}4059 \mathrm{E} \\
89 \text { oo } \mathrm{E} \\
67 \mathrm{I} 4 \mathrm{E}\end{array}$ & $\begin{array}{l}3452 \\
2955 \\
4510\end{array}$ & $\begin{array}{l}\text { Horseshoe. } \\
\text { Franklin. } \\
\text { Nut. }\end{array}$ \\
\hline 7 & 38 & 48 & 42.60 & 76 & $2 S$ & 31.60 & $\begin{array}{llll}\mathrm{N} & 25 & 00 \mathrm{~W} \\
\mathrm{~N} & 77 & 45 & \mathrm{WV} \\
\mathrm{S} & 67 & 52 \mathrm{WV}\end{array}$ & $\begin{array}{l}\mathrm{S} 2 \\
\mathrm{~S} 7 \\
\mathrm{~N}\end{array}$ & $\begin{array}{l}2459 \mathrm{E} \\
7746 \mathrm{E} \\
675 \mathrm{I} \mathrm{E}\end{array}$ & $\begin{array}{l}3321 \\
2150 \\
3562\end{array}$ & $\begin{array}{l}\text { Horseshoe, } \\
\text { Franklin. } \\
\text { Nut. }\end{array}$ \\
\hline S & $3^{S}$ & 46 & 30.66 & 76 & 29 & 45.60 & $\begin{array}{llll}\mathrm{N} & 23 & 26 & \mathrm{~W} \\
\mathrm{~N} & 57 & 18 & \mathrm{~W} \\
\mathrm{~S} & 86 & 06 & \mathrm{~W}\end{array}$ & $\begin{array}{l}\mathrm{S} \\
\mathrm{S} \\
\mathrm{N}\end{array}$ & $\begin{array}{ll}23 & 25 \mathrm{E} \\
57 & 19 \\
\mathrm{~S} 6 & 04 \mathrm{E}\end{array}$ & $\begin{array}{l}3386 \\
3158 \\
4 I 78\end{array}$ & $\begin{array}{l}\text { Nut. } \\
\text { Broad. } \\
\text { Parker. }\end{array}$ \\
\hline 9 & ${ }_{3} \mathrm{~S}$ & 46 & 21.72 & 76 & 30 & 20.82 & $\begin{array}{lrrr}\mathrm{N} & 6 & 58 \mathrm{~W} \\
\mathrm{~N} & 40 & 43 & \mathrm{~W} \\
\mathrm{~N} & 89 & 4 \mathrm{I} & \mathrm{W}\end{array}$ & $\begin{array}{l}\mathrm{S} \\
\mathrm{S} \\
\mathrm{S}\end{array}$ & $\begin{array}{l}659 \mathrm{E} \\
4044 \mathrm{E} \\
8943 \mathrm{E}\end{array}$ & $\begin{array}{l}3434 \\
2649 \\
3238\end{array}$ & $\begin{array}{l}\text { Nut. } \\
\text { Broad. } \\
\text { Parker. }\end{array}$ \\
\hline
\end{tabular}


LONG.

(Chesapeake Bay off entrance to Herring Bay-Chant No.4.)

\begin{tabular}{|c|c|c|c|c|c|c|}
\hline \multirow{2}{*}{$\begin{array}{l}\text { Cor- } \\
\text { ner } \\
\text { of } \\
\text { har }\end{array}$} & \multirow{2}{*}{ Latitude } & \multirow{2}{*}{ Longitude } & \multicolumn{2}{|c|}{ True bearing } & \multirow{2}{*}{ Distance } & \multirow{2}{*}{ U. S. C. \& G. S. triangulation station } \\
\hline & & & Forward & Back & & \\
\hline I & $\begin{array}{ccc}\circ & \prime & \prime \prime \\
3^{8} & 44 & 23.03\end{array}$ & $\mid \begin{array}{ccc}0 & 1 & \prime \prime \\
76 & 32 & 15 . \\
\end{array}$ & 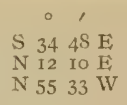 & 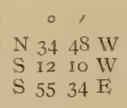 & $\left|\begin{array}{r}\text { Yards. } \\
1740 \\
6148 \\
3170\end{array}\right|$ & $\begin{array}{l}\text { Holland. } \\
\text { Broad. } \\
\text { Fairhaven: }\end{array}$ \\
\hline 2 & $3^{8} 44 \quad 22.57$ & $7^{6} \quad 32 \quad 37.02$ & $\begin{array}{llll}\mathrm{S} & 48 & 54 & \mathrm{E} \\
\mathrm{N} & 5 & 04 & \mathrm{E} \\
\mathrm{N} & 48 & 29 & \mathrm{WV}\end{array}$ & $\begin{array}{lll}\mathrm{N} & 47 & 53 \mathrm{WV} \\
\mathrm{S} & 5 & 04 \mathrm{WV} \\
\mathrm{S} & 48 & 30 \mathrm{E}\end{array}$ & $\begin{array}{l}2108 \\
4051 \\
2729\end{array}$ & $\begin{array}{l}\text { Holland. } \\
\text { Parker. } \\
\text { Fairhaven. }\end{array}$ \\
\hline 3 & $3^{8} 46 \quad 2$ I. 04 & $763^{3} \quad 55.90$ & $\begin{array}{llll}\mathrm{N} & 21 & 03 & \mathrm{E} \\
\mathrm{N} & \mathrm{S} 6 & 52 & \mathrm{WV} \\
\mathrm{S} & 55 & 04 & \mathrm{WV}\end{array}$ & $\begin{array}{llll}\mathrm{S} & 21 & 03 & \mathrm{~W} \\
\mathrm{~S} & 86 & 52 & \mathrm{E} \\
\mathrm{N} & 55 & 03 & \mathrm{E}\end{array}$ & $\begin{array}{r}2175 \\
728 \\
3819\end{array}$ & $\begin{array}{l}\text { Broad. } \\
\text { Parker. } \\
\text { Fairhaven. }\end{array}$ \\
\hline 4 & $3^{8} 46$ 21. 72 & $76 \quad 30 \quad 20.62$ & $\begin{array}{llll}N & 6 & 58 & W \\
N & 40 & 43 & W \\
N & 89 & 41 & W\end{array}$ & $\begin{array}{lrrr}\mathrm{S} & 6 & 59 & \mathrm{E} \\
\mathrm{S} & 40 & 44 & \mathrm{E} \\
\mathrm{S} & 89 & 43 & \mathrm{E}\end{array}$ & $\begin{array}{l}3434 \\
2649 \\
3238\end{array}$ & $\begin{array}{l}\text { Nut. } \\
\text { Broad. } \\
\text { Parker. }\end{array}$ \\
\hline 5 & $3^{8} 45 \quad 17.50$ & $\begin{array}{lll}76 & 31 & 28.94\end{array}$ & $\begin{array}{llll}N & 0 & 58 & E \\
N & 33 & 24 & W \\
S & 89 & 21 & W\end{array}$ & $\begin{array}{llll}\mathrm{S} & 0 & 5 \mathrm{~S} & \mathrm{~W} \\
\mathrm{~S} & 33 & 25 \mathrm{E} \\
\mathrm{N} & 89 & 20 & \mathrm{E}\end{array}$ & $\begin{array}{l}4173 \\
2615 \\
3842\end{array}$ & $\begin{array}{l}\text { Broad. } \\
\text { Parker. } \\
\text { Fairhaven. }\end{array}$ \\
\hline 6 & $3^{8} 444^{6} .50$ & $\begin{array}{lll}76 & 3 & 39.63\end{array}$ & $\begin{array}{llll}\mathrm{N} & 3 & 52 & \mathrm{E} \\
\mathrm{N} & 19 & 43 & \mathrm{~W} \\
\mathrm{~N} & 74 & 16 & \mathrm{~W}\end{array}$ & $\begin{array}{rrrr}\mathrm{S} & 3 & 52 & \mathrm{~W} \\
\mathrm{~S} & 19 & 44 & \mathrm{E} \\
\mathrm{S} & 74 & 18 & \mathrm{E}\end{array}$ & $\begin{array}{l}5231 \\
3430 \\
3696\end{array}$ & $\begin{array}{l}\text { Broad. } \\
\text { Parker. } \\
\text { Fairhave11. }\end{array}$ \\
\hline
\end{tabular}

\section{FAIRHAVEN.}

(Herring Bay off Fairhaien-Chart No. 4.)

\begin{tabular}{|c|c|c|c|c|c|c|c|}
\hline I & $\begin{array}{c}\circ \\
3^{8}\end{array}$ & 4433.63 & $\begin{array}{ccc}0 & 1 \\
76 & 32 & 47.46\end{array}$ & 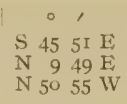 & 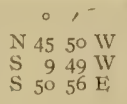 & $\begin{array}{r}\text { Yards. } \\
2566 \\
3716 \\
2277\end{array}$ & $\begin{array}{l}\text { Holland. } \\
\text { Parker. } \\
\text { Fairhaven. }\end{array}$ \\
\hline 2 & $3^{8} 44$ & 44 39. 19 & ${ }_{76} 33$ r. 47 & $\begin{array}{l}\mathrm{S} 5 \mathrm{r} 25 \mathrm{E} \\
\mathrm{N} 2003 \mathrm{E} \\
\mathrm{N} 42 \mathrm{I} \\
\mathrm{N}\end{array}$ & $\begin{array}{llll}\mathrm{N} & 5 \mathrm{I} & 26 \mathrm{WV} \\
\mathrm{S} & 20 & 03 \mathrm{~W} \\
\mathrm{~S} & 42 & 16 & \mathrm{E}\end{array}$ & $\begin{array}{l}3165 \\
3699 \\
1686\end{array}$ & $\begin{array}{l}\text { Holland. } \\
\text { Parker. } \\
\text { Fairhaven. }\end{array}$ \\
\hline 3 & 3845 & 4504.65 & $763^{2} 56.40$ & $\begin{array}{llll}\text { N } & 18 & 23 & \mathrm{E} \\
\text { N } & \text { I4 } & 04 & \mathrm{WV} \\
\text { N } & 75 & 44 & \mathrm{~W}\end{array}$ & $\begin{array}{llll}\mathrm{S} & \mathrm{IS} & 24 & \mathrm{~W} \\
\mathrm{~S} & \mathrm{I} 4 & 04 & \mathrm{E} \\
\mathrm{S} & 75 & 45 & \mathrm{E}\end{array}$ & $\begin{array}{l}2757 \\
232 \mathrm{I} \\
\mathrm{I} 5 \mathrm{SI}\end{array}$ & $\begin{array}{l}\text { Parker. } \\
\text { Hopkins. } \\
\text { Fairhave1. }\end{array}$ \\
\hline 4 & $3^{8} 45$ & $45 \quad 47.06$ & $\begin{array}{lll}76 & 33 & 27.00\end{array}$ & $\begin{array}{l}\mathrm{S} 3450 \mathrm{WV} \\
\mathrm{S} 34 \mathrm{o5} \mathrm{E} \\
\mathrm{N} 5445 \mathrm{E}\end{array}$ & $\begin{array}{l}\mathrm{N} 3449 \mathrm{E} \\
\mathrm{N} 34 \text { o4 WV } \\
\mathrm{S} 54 \quad 45 \mathrm{~W}\end{array}$ & $\begin{array}{l}1267 \\
5148 \\
2054\end{array}$ & $\begin{array}{l}\text { Fairhaven. } \\
\text { Holland. } \\
\text { Parker. }\end{array}$ \\
\hline 5 & $3^{8} 45$ & $45 \quad 27.79$ & $\begin{array}{llll}76 & 32 & 27 . & \text { So }\end{array}$ & $\begin{array}{llll}\mathrm{N} & 3 & 34 & \mathrm{E} \\
\mathrm{N} & 4 \mathrm{I} & 54 & \mathrm{WV} \\
\mathrm{S} & 80 & \mathrm{I} & \mathrm{WW}\end{array}$ & $\begin{array}{llll}\mathrm{S} & 3 & 34 \mathrm{IV} \\
\mathrm{S} & 4 \mathrm{I} & 54 \mathrm{E} \\
\mathrm{N} & \text { So } & 17 & \mathrm{E}\end{array}$ & $\begin{array}{l}1839 \\
1975 \\
2321\end{array}$ & $\begin{array}{l}\text { Parker. } \\
\text { Hopkins. } \\
\text { Fairhaven. }\end{array}$ \\
\hline
\end{tabular}


HOLIAND POINT.

(Chesapeake Bay, northeast of Holland Point-Chart No.4.)

\begin{tabular}{|c|c|c|c|c|c|c|c|}
\hline \multirow{2}{*}{$\begin{array}{l}\text { Cor- } \\
\text { ner } \\
\text { of } \\
\text { bar }\end{array}$} & \multirow{2}{*}{\multicolumn{2}{|c|}{ Latitude }} & \multirow{2}{*}{ Longitude } & \multicolumn{2}{|c|}{ True bearing } & \multirow{2}{*}{ Distance } & \multirow{2}{*}{ U. S. C. \& G. S. triaugulation station. } \\
\hline & & & & Forward & Back & & \\
\hline I & $\begin{array}{c}\circ \\
38\end{array}$ & $\begin{array}{cc}\prime \prime \\
43 & 30.91\end{array}$ & $\begin{array}{ccc}\circ & \prime & \prime \prime \\
76 & 29 & 59.52\end{array}$ & 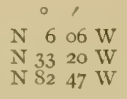 & $\begin{array}{lll} & 0 & \prime \\
\mathrm{S} & 6 & 06 \mathrm{E} \\
\mathrm{S} & 33 & 2 \mathrm{I} \\
\mathrm{S} & 82 & 48 \mathrm{E}\end{array}$ & $\mid \begin{array}{r}\text { Yards. } \\
9221 \\
6914 \\
2617\end{array}$ & $\begin{array}{l}\text { Nut. } \\
\text { Parker. } \\
\text { Holland. }\end{array}$ \\
\hline 2 & 38 & $4334 \cdot 30$ & $76 \quad 3059.24$ & $\begin{array}{llll}\mathrm{N} & 3 & 46 & \mathrm{E} \\
\mathrm{N} & 2 \mathrm{I} & 26 \mathrm{~W} \\
\mathrm{~N} & 53 & 24 & \mathrm{~W}\end{array}$ & $\begin{array}{lrrr}\mathrm{S} & 3 & 47 & \mathrm{~W} \\
\mathrm{~S} & 2 \mathrm{I} & 27 & \mathrm{E} \\
\mathrm{S} & 53 & 25 \mathrm{E}\end{array}$ & $\begin{array}{l}9074 \\
6084 \\
5762\end{array}$ & $\begin{array}{l}\text { Nut. } \\
\text { Parker. } \\
\text { Fairhaven. }\end{array}$ \\
\hline 3 & 38 & 4404.64 & $\begin{array}{llll}76 & 32 & 28.49\end{array}$ & $\begin{array}{lrll}S & 58 & 52 & \text { W } \\
N & 1 & 38 & \mathbb{E} \\
N & 43 & 15 & W\end{array}$ & $\begin{array}{lrll}\mathrm{N} & 58 & 52 & \mathrm{E} \\
\mathrm{S} & \mathrm{I} & 38 & \mathrm{~W} \\
\mathrm{~S} & 43 & \mathrm{I} & \mathrm{E}\end{array}$ & $\begin{array}{l}1564 \\
4641 \\
3313\end{array}$ & $\begin{array}{l}\text { Holland. } \\
\text { Parker. } \\
\text { Fairhaven. }\end{array}$ \\
\hline 4 & 38 & $4533 \cdot x_{3}$ & $76 \quad 30 \quad 30.77$ & $\begin{array}{llll}N & I & 45 \\
N & 60 & 54 & W \\
S & 25 & 02 & W\end{array}$ & 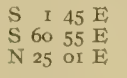 & $\begin{array}{l}5049 \\
3404 \\
4179\end{array}$ & $\begin{array}{l}\text { Nut. } \\
\text { Parker. } \\
\text { Holland. }\end{array}$ \\
\hline 5 & $3^{8}$ & $4543 \cdot 72$ & 76294 4I. 78 & $\begin{array}{llll}N & 17 & 09 & \mathrm{~W} \\
\mathrm{~N} & 73 & 04 & \mathrm{~W} \\
\mathrm{~S} & 36 & 31 & \mathrm{WW}\end{array}$ & 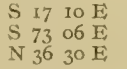 & $\begin{array}{l}4908 \\
4462 \\
515 \mathrm{I}\end{array}$ & $\begin{array}{l}\text { Nut. } \\
\text { Parker. } \\
\text { Holland. }\end{array}$ \\
\hline 6 & 38 & 4436.67 & $\begin{array}{llll}76 & 29 & 21.57\end{array}$ & $\begin{array}{llll}N & 15 & 54 & \text { IV } \\
N & 53 & 26 & \mathrm{~W} \\
\mathrm{~S} & 62 & 18 & \mathrm{WV}\end{array}$ & $\begin{array}{llll}\mathrm{S} & \mathrm{I} & 55 & \mathrm{E} \\
\mathrm{S} & 53 & 28 & \mathrm{E} \\
\mathrm{N} & 62 & 17 & \mathrm{E}\end{array}$ & $\begin{array}{l}7228 \\
5977 \\
4064\end{array}$ & $\begin{array}{l}\text { Nut. } \\
\text { Parker. } \\
\text { Holland. }\end{array}$ \\
\hline
\end{tabular}

\section{LANDMARKS (U. S. COAST AND GEODETIC SURVEY TRIANGURATTION STATIONS).}

\section{EXPLANATION OF DESCRIPTION OF LANDMARKS.}

The oyster-culture laws of Maryland authotizing the survey of natural oyster bars provide for "an accurate report of said survey, setting forth such a description of landmarks as may be necessary to enable the said Board, or their successors, to find and ascertain the boundary lines of said natural oyster beds, bars, and rocks, as shown by delineation on the maps and charts." The law of the United States authorizing the cooperation of the Department of Commerce and Labor in the survey of natural oyster bars of Maryland provides for the erection of "such structures as may be necessary to mark the points of triangulation, so that the same may be used for such future work of the Coast and Geodetic Survey as the said Bureau may be hereafter required to perform in prosecuting the Government coast survey of the navigable waters of the United States located within the State of Maryland."

Under the provisions of the sections of the laws stated above the markings and descriptions of landmarks must be sufficient for the present and future needs of both the Government and the State. With this end in view considerable effort has been expended in erecting permanent monuments at the triangulation stations and in the proper description of their location.

$$
330-07-s
$$


An effort has been made to arrange the description of stations in a uniform and logical manner. The descriptions start with the assumption that the inclividual seeking the station has only an indefinite idea of its location. They then gradually proceed from general descriptions of the surroundings of a landmark to the specific details of the character of the center and reference markings. An examination of the descriptions themselves will best indicate the method followed.

The heading of each description is the name by which the landmark is known and designated in all work and records executed by the commission. Where the same name is used for two or more stations, as is the case in several instances in Anne Arundel County, the general locality of the station being described is given in parentheses alongside its name.

In the first paragraph, under the heading of "Locality," is given a description of the general locality of the landmark and the serial number of the published chart of the oyster bars of Anne Arundel County which best shows its location. The second paragraph, under this same heading, furnishes the description of the immediate locality of the landmark and refers to the bearing and distance of the cement monument marking the reference station, as it is the first object that is likely to catch the eye when the immediate vicinity of the desired station is reached.

Under the heading of "Marks" a description is given of the markings of the "observed station" and the "reference station." It will be noted that although the "observed station" is the one "occupied" and "observed on" for horizontal angles, it is not marked as well as the reference station, and in many instances has only a pine stub to indicate its position. This is the case, for the reason that the necessity of intervisibility of triangulation stations usually made it compulsory to locate these stations on edges of banks and ends of points of land, which in Chesapeake Bay and tributaries generally means that they will be washed away in a short period of years. The past experience of the Coast and Geodetic Survey in this region showed the necessity of reference marks, if the reestablishment of a new framework of triangulation was to be avoided in the near future.

The marks designated in the descriptions as "the center point of triangle on standard cement monument" are all exactly alike. They are made out of cement, sand, and gravel and are 2 feet long and 8 inches square at top and bottom. Their tops are all marked with the same brass mold and show a center hole surrounded by a triangle, with the letters "M. S. F. C." arranged around the vertex and the letters "U.S. C. S." underneath the base of the triangle. All of these monuments have been planted in the same manner, with their tops projecting 3 or 4 inches above the surface of the ground. As the above facts in reference to the "standard cement monuments" are a constant element in all the descriptions, their needless repetition is avoided by this one statement.

It is the expectation that the "reference stations," the character of. which is explained above, will be used in the hear future in the place of the original stations. This has been made possible by the careful measurements of direction and distance of these stations from the "observed station" which are recorded under the heading of "References." "

"To obtain the geographic positions of any of the "observed stations" or of the "reference stations," application should be made to the Superintendent of the Coast and Geodetic Survey at Washington. 
Under the heading of "References" are given the directions and distances of all objects that might be useful in locating the stations when the surface marks can not be found. It is also contemplated that for general purposes of topography or location of boundaries of oyster bars, these references will be sufficient in many cases, to relocate the "observed station" or "reference station" when both of them have been destroyed but the reference objects remain.

The first reference object given in the descriptions is always a triangulation station visible from the station being described. Its direction is taken as being $\mathrm{o}^{\circ} \mathrm{oo}^{\prime} \mathrm{oo}^{\prime \prime}$, and the directions of all other objects are measured from it as an initial point, the angles being taken in a clockwise direction (left to right).

The true bearing ${ }^{a}$ of the initial object is always given, in parentheses alongside the name. This furnishes means for the calculation of the bearings of any of the reference objects for the purposes of locating a station by compass bearings, or the relocation of corner buoys of oyster-bar boundaries by the method of horizontal angles described under the heading of "Boundaries of natural oyster bars."

The distances in the last column under "References" are given in three different units, which vary according to their accuracy. The "miles" are statute miles and may be considered only as rough estimates. The "yards" are more accurate, but must be looked on as results generally obtained by pacing or careful estimating. The "meters," however, are accurate to the degree indicated by their decimals and in every case have been measured with a steel tape.

\section{NORTH POINT (OLD TOWER).}

Locality.-South of North Point about I50 yards offshore. (See Chart No. I.)

Marks.-Observed station is center point of lantern on old stone tower formerly used as a lighthouse.

\section{References.-}

"Craighill Channel Light (Front Range)"..... S SI $20 \mathrm{E} \ldots \ldots 21 / 2$ miles.

\section{CRAIGHILL, CHANNEL, LIGHT (FRONT RANGE).}

Locality.-Offshore about $2 \frac{1}{2}$ miles east by south of North Point and about 4 miles north-northeast of Bodkin Point. (See Chart No, r.)

Marks.-Observed station is center point of black lantern on brown structure known as Craighill Channel Front Range Light-house.

References.-

"North Point (Old Tower)".............. N SI I9 IV .... $2 \frac{1}{2}$ miles.

\section{ROCK POINT.}

Locality._South side of entrance to Rock Creek on Rock Point. (See Chart No. I.)

Observed station is near the extreme end of point about 7o yards southeast from a small tower and 12 yards from the sea wall.

Marks.-Observed station is center point of triangle on standard cement monument.

References.-

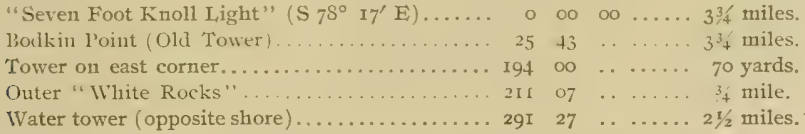

"The mean magnetic declination for Anne Arundel County (in 1907) is $5^{\circ} 45^{\prime}$ west of north, and it is increasing at the rate of $3^{\prime}$ yearly. 
SEVEN FOOT KNOLI, LIGHT.

Locality.-Offshore about $\mathrm{r} / 2$ miles north-northeast of Bodkin Point and $3^{1 / 4}$ miles southeast by south of North Point. (See Chart No. I.)

Marks -Observed station is center of lantern on brown. screw pile structure known as Seven Foot Knoll Light-house.

References.-

"Bodkin Point (Old Tower)"................ S $300_{3}$ W ..... I I m miles.

\section{BODKIN POINT (OLD TOWER).}

Locality.-South side of entrance to Bodkin Creek, on Bodkin Point, about 15 yards east of old stone house. (See Chart No, r.)

Observed station is on top and at center of old tower formerly used as a light-house.

Marks.-Observed station is center point of a drill hole about 2 inches in diameter and 3 inches deep.

Referenas.-

"Seven Foot Knoll Light"............... N $30 \quad 04 \mathrm{E} \ldots \ldots$ I I $1 / 2$ miles.

\section{LOCUST.}

Locality.-On shore of bay, midway between Bodkin Point Tower and the mouth of Magothy River. Counting down the bay from Bodkin Tower the station is located on the fifth bluff and near the center of it. (See Chart No. I.)

Observed station is on the top of a bluff 20 feet high. It is 25 feet back from the edge of the bluff and just outside of a large orchard. Cement monument marking reference station is 6.77 meters west of observed station.

$M$ I $>k s$. - Observed station is a nail in a wooden stub set flush with ground. Reference station is the center point of triangle on standard cement monument.
References.-
"Seven Foot Knoll Light" ' $\left(\mathrm{N} \mathrm{I} 7^{\circ} 49^{\prime} \mathrm{E}\right)$.... o o o

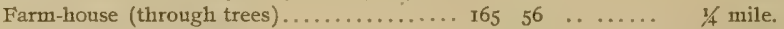
REFERENCE STATION................. $242 \quad 22 \quad 20 \ldots \ldots 6.77$ meters.
Nail in blaze on tree.................. $24943 \quad \ldots \ldots .6 .59$ meters.
Nail in blaze on tree ( 6 inches diameter) ... 333 12 $\quad \ldots \ldots \ldots .15 .57$ meters.
Bodkin Point (Old Tower) ............ $35043 \ldots \ldots .21 / 4$ miles.

\section{BAY (MAGOTHY RIVER).}

Locality.-Magothy River, on north shore of Sillery Bay, about $1 / 2$ mile west of Long Point and I $\pi / 2$ miles northeast of Dobbins Island. (See Chart No. I.)

Observed station is on edge of woods, about 2 feet above and 20 feet back from high-water mark. Cement monument marking reference station is 4.55 meters north of observed station.

Marks.-Observed station is a nail in a stub surrounded by a pine box projecting 6 inches above the ground. Reference station is the center point of triangle on standard cement monument.

References.-

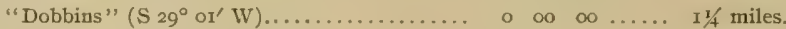

Right tangent Dobbins Island............ 9 I5 ...... II/2 miles.

Right tangent small island............. I9 II ...... I I/ miles.

Nail in blaze on tree ( 12 inches diameter) . . . $112 \quad 15 \quad \ldots \ldots .6 .98$ meters.

REFERENCE STATION ................... I49 I9 10 ... 4.55 meters.

Nail in blaze on tree ( 12 inches diameter).... $23253 \quad \ldots \ldots .4$. . meters.

Right tangent Gibson Island ............ $326 \quad 53 \quad \ldots \ldots \ldots$ I $1 \frac{1}{2}$ miles. 
PHIL.

Locality. - North end of Gibson Island on point on south side of entrance to the cove making out from Sillery Bay. This cove nearly separates the island from the mainland. (See Chart No. I.)

Observed station is on the northwestern sire of a low sand spit at about high-water mark. Cement monument marking reference station is 0.95 meters northeast of observed station.

MIarks.-Observed station is a broad pole signal with bottom of pole set in a wooden box projecting 6 inches above the ground. Reference station is the center point of a triangle on standard cement monument.

References.-

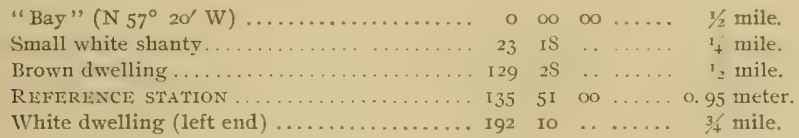

\section{HICKORY.}

Locality.-Northwest shore of Sillery Bay on Hickory Bar Point, about $3 / 4$ mile north by east of Dobbins Island and 3/4 mile west by south of entrance to cove separating Gibson Island from mainland. (See Chart No. I.)

Observed station is I foot above and 30 feet back from high-water mark and a short distance from the extreme point. Cement monument marking reference station is 2.38 meters northwest of observed station.

MTarks.- Observed station is a nail in a stub set in a box projecting 6 inches above the ground, Reference station is the center point of a triangle on standard cement monument.

References.-

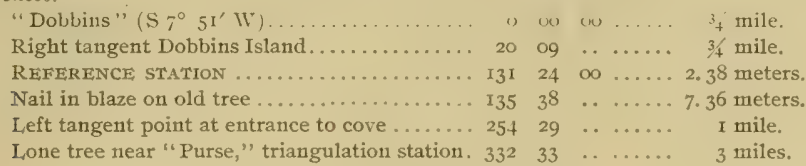

\section{SILLERY.}

Locality.-West shore of Sillery on the northwest point of Gibson Island about I mile northeast of Dobbins Island. (See Chart No. 1.)

Observed station is on top of a bluff 6 feet high and 15 feet back from the edge. It is about 50 feet south of the break of the bluff where a low marsh commences. A small stump stands about I foot distant with blaze facing station. Cement monument marking reference station is 5.99 meters southeast of observed station.

Marks.-Observed station is a nail in a wooden stub set flush with the ground. Reference station is center point of triangle on standard cement monument.

\section{Referenices.-}

"Hickory" ( $\left.70^{\circ} 4 \mathrm{I}^{\prime} \mathrm{WW}\right)$.

Nail in blaze on hickory tree ( 6 inches diam-

eter $) \ldots \ldots \ldots \ldots \ldots \ldots \ldots \ldots \ldots \ldots \ldots$ I

Nail in blaze on locust tree ( 4 inches diameter). 174

REFERENCE STATION ................. I97

Unpainted building (seen through trees).... 208

Left tangent Dobbins Island ............. 303

Chimney on house (opposite shore) . . . . . 350

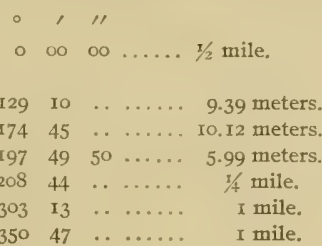




\section{PEACH HILL.}

Locality.-Summit of a prominent hill on Gibson Island about $1 / 4$ mile back from shore of bay and $x^{1} / 4$ miles north of entrance to Magothy River. (See Chart No. I.)

Observed station is on the second hill south of the sand beach connecting Gibson Island with the mainland and $1 /$ mile south of a white dwelling house. Cement monument marking reference station is ro. 75 meters soltheast of observed station.

Marks.-Observed station is the intersection of two cross lines on the top of a granite monument projecting 4 inches above the ground. Reference station is the center point of a triangle on standard cement monument.

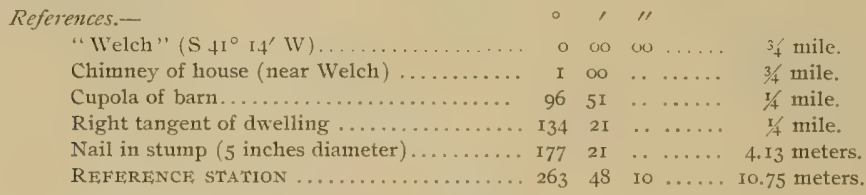

\section{WELCH.}

Locality.-Southern end of Gibson Island on top of prominent hill about $1 / 2$ mile north by west of Mountain Point and $x / 2$ miles southeast of Dobbins Island. (See Chart No. 2.)

Observed station is in the side yard of house belonging to James Ellison and is 29.60 meters soutin of the northeast corner of house.

Marks.-Observed station is center point of triangle on standard cenent monument.

References.-

"Revel1" ( $\left(\mathrm{S} 69^{\circ} 56^{\prime} \mathrm{W}\right) \ldots \ldots \ldots \ldots \ldots \ldots$.

Nail in blaze on stump ( 15 inches diameter).. 71 I 13 ....... 23.60 meters.

Northeast corner of porch of house ......... I16 $\quad$ I2 $\ldots \ldots \ldots . .629 .60$ meters.

Nail in blaze on tree $(6$ inches diameter $) \ldots \ldots$ I70 $3 \mathrm{I}$....... 30.83 meters.

Left tangent of Sandy Point............ 256 oo $\ldots \ldots \ldots . \quad 3$ miles.

\section{BLUFF (MAGOTHY RIVER).}

Locality. -West side of Gibson Island and northwest shore of Magothy River, about $\mathrm{x}$ mile northwest of Mountain Point. It is near the center of the third prominent bluff from Mountain Point. (See Chart No, 2.)

Observed station is on the top of a bluff 20 feet high. It is in a thick woods about 15 feet from the edge of the bluff. Cement monument marking reference station is 5 meters northeast by east of observed station.

Marks. - Observed station is a nail in a wooden stub set flush with ground. Reference station is center point of triangle on standard cement monument.

References.-

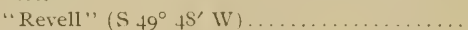

Left tangent Dobbins Island ............. 55

Chimney of white house on Dobbins Island ... 6

Right tangent Dobbius Island................ 64 mille.

Nail in blaze on tree ( 15 inches diameter).... I3I $59 \quad \ldots \ldots \ldots 7.94$ tneters.

REFERENCF, STATION .................. IS9 $43 \quad 20 \ldots \ldots .5$ meters.

Nail in blaze on tree ( 12 inches diameter) .... $216 \quad 5^{8} \ldots \ldots .6 .35$ meters.

Lone tree (near "Purse" triangulationstation). 302 50 . . . . 2 miles. 


\section{DOBRINS.}

Locality.-North side of Magothy River on extreme east end of Dobbins Island. (See Cliart No, 2.)

Observed station is on top of a bluff 25 feet high and about 30 feet back from the edge. Cement monument marking reference station is 3.37 meters west of station.

Marks. - Observed station is a nail in a stub projecting 3 inches above-ground. Reference station is center point of a triangle on standard cement monument.

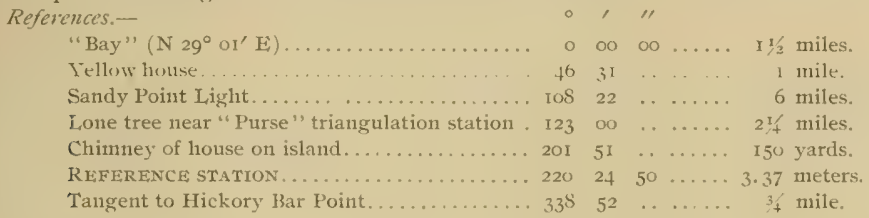

\section{IRON.}

Locality.-North shore Magothy River on extreme southeast end of Park Point and between entrances to Park and Broad creeks. (See Chart No. 2.)

Observed station is on the top of a bluff about 15 feet high and is 15 feet back from the edge. Cement monument marking reference station is 5.01 meters northwest by west of station.

Marks. - Observed station is a nail in a wooden stub projecting 3 inches above the ground. Reference station is center point of triangle on standard cement monument.
References.-
"Huddle" (S $\left.18^{\circ} 13^{\prime} \mathrm{W}^{\mathrm{r}}\right) \ldots \ldots \ldots \ldots \ldots \ldots \ldots$.
0 co $00 \ldots . . \quad$ I mile.
Nail in blaze on tree ( 12 inches diameter) . . . $9547 \quad \ldots . \ldots .8 .96$ meters.
REFERENCE STATION ................ 122 IS $20 \ldots \ldots$ 5. OI meters.
Nail in blaze on tree................ I28 I9 ....... 10, 46 meters.
Nail in blaze on forked tree........... 190 $57 \ldots \ldots \ldots 4.37$ meters.
House on Dobbins Island.............. 258 if $\ldots \ldots \ldots$ mile.
Lone tree near "Purse" triangulation station. 298 r $3 \ldots \ldots . \ldots .3$ miles.

HAM.

Locality.-North shore of upper end of Magothy River opposite Ferry Point on first point west of mouth of Blackhole Creek. (See Chart No. 2.)

Observed station is on a low flat sandy point making out from a bluff I5 feet high. It is 3 feet above and to feet back from high-water mark. Cement monument marking reference station is 7.34 meters north of observed station.

Marks.-Observed station is a nail in a wooden stub projecting 3 inches above the ground. Reference station is the center point of triangle on standard cement monument,

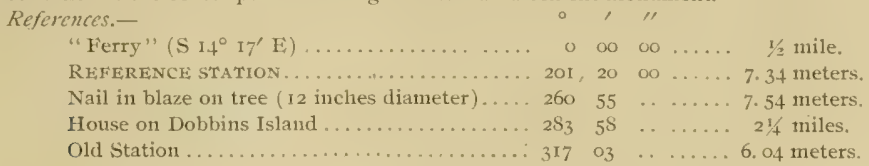

BANK.

Locality. - North shore of upper end of Magothy River about $3 \frac{4}{4}$ mile northwest from mouth of Blackhole Creek and nearly abreast of Cypress Creek. (See Chart No. 2.)

Observed station is at the base of a bluff about 20 feet high. It is 2 feet above and 2 feet back from high-water mark. Several large brown bowlders are scattered in front of the station. Cement monument marking reference station is II.86 meters northeast by north of the observed station on the top of bluff. It can not be seen from the observed station. 
Marks.-Observed station is a pole signal with the lower eud of the pole sunk in a box projecting I foot above the ground. Reference station is the center point of a triangle on standard cement monument.

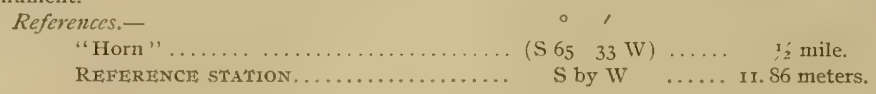

\section{HORN (MAGOTHY RIVER).}

Locality.-South shore of upper end of Magothy River about $1 / 2$ mile southeast from mouth of Cattail Creek and $1 / 2$ mile north of Cypress Creek. (See Chart No. 2.)

Observed station is on a point about 2 feet above and io feet back from high-water mark. Slope of bank begins at station and rises to an elevation of 20 feet and is covered with woods. A pile of stone surrounds station. Cement monument marking reference station is 4.5 I meters south by east of station.

Marks.-Observed station is a nail in a wooden stub 3 inclies below the surface of the ground. Reference station is the center point of triangle on standard cement monument.

References.-

\begin{tabular}{|c|c|c|c|c|}
\hline $\begin{array}{l}\left.\text { "Huddle" ( } 6_{3}^{\circ} \text { o6' } \mathrm{E}\right) \ldots \ldots \ldots \ldots \ldots \ldots \ldots \\
\text { white house near mouth of Dividing Creek... }\end{array}$ & $\begin{array}{r}0 \\
38\end{array}$ & $\begin{array}{l}\text { oo } \\
\text { os }\end{array}$ & & $\begin{array}{l}2 \text { If miles. } \\
3 / 4 \text { mile. }\end{array}$ \\
\hline REFERENCE STATION . . . . . . . . . . & 42 & 02 & 40 & 4. 51 meters. \\
\hline Nail in blaze on tree ( 4 inclies diameter).... & 49 & $I_{3}$ & $\cdots$ & 7.82 meters. \\
\hline Nail in blaze on forked tree........ & 78 & 22 & . & 5. 21 meters. \\
\hline Chimney of white house across river... & 254 & 59 & $\ldots \ldots$ & mile. \\
\hline
\end{tabular}

TAIL.

Locality.-South shore of upper end of Magothy River on Stony Point at eastern side of entrance to Dividing Creek. (See Chart No. 2.)

Observed station is on the upper edge of a bluff 15 feet high. Cement monument marking reference station is 6.94 meters south-southeast of station.

Marks.-Observed station is a pole signal with base stuck in a vertical box. Reference station is center point of triangle on standard cement monument.

References.-

\begin{tabular}{|c|c|c|c|c|c|}
\hline 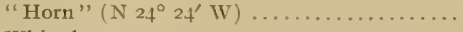 & o & $\infty$ & $\infty$ & & 3/4 mile. \\
\hline White house $\ldots \ldots \ldots \ldots \ldots \ldots \ldots \ldots \ldots \ldots$ & 17 & 24 & $\cdots$ & & I/4 miles. \\
\hline Nail in blaze on tree ( 8 inches diameter)..... & 129 & IS & $\cdots$ & & II. 22 \\
\hline REFERENCE STATION . . . . . . . . . . . . . & $17 \mathrm{I}$ & $\mathrm{I}_{3}$ & $\infty$ & & 6.94 \\
\hline $\begin{array}{l}\text { Nail in blaze on tree ( } 6 \text { inches diameter)..... } \\
\text { Stnall hill on point on mouth of Dividing }\end{array}$ & I92 & 47 & $\cdots$ & & 3. 1 \\
\hline $\begin{array}{l}\text { Creek } \ldots \ldots \ldots \ldots \ldots \ldots \ldots \ldots \ldots \ldots \ldots \ldots \\
\text { Chimney on house on west shore of Dividing }\end{array}$ & 2.42 & 50 & $\cdots$ & & aile \\
\hline Creek ........................... & 267 & os & $\cdots$ & $\ldots$ & nile. \\
\hline
\end{tabular}

\section{FERRY.}

Locality. - South shore of Magothy River on Ferry Point about $1 / 2$ mile east of mouth of Dividing Creek. (See Chart No. 2.)

Observed station is 15 feet from and 3 feet above high-water mark. There are five cedar trees in close proximity to the station. Cement monument marking reference station is 5.05 meters southwest by south from observed station.

Marks.-Observed station is a nail in cement in a tile pipe buried I foot below the surface. Reference station is center point of triangle on standard cement monument.

References.-

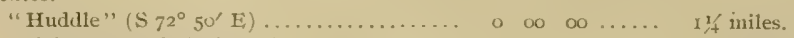

Nail in blaze on forked tree ( 4 inches diameter) $28 \quad 34 \quad \ldots \ldots .9 .74$ meters.

Nail in blaze on tree ( 6 inches diameter) ... $57 \quad 46 \ldots \ldots \ldots 22.70$ meters. 


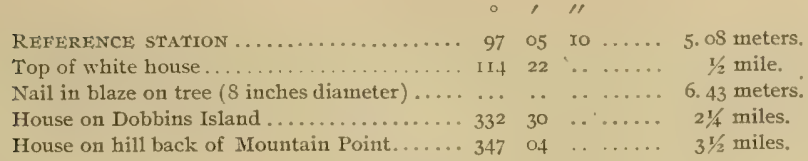

\section{HUDDLE.}

Locality. - South shore of Magothy River on Huddles Point about $3 / 4$ mile northeast of inner entrance to Forked Creek. (See Chart No. 2.)

Observed station is about ro feet from the edge of a sandy bank $\delta$ feet high. Cement monument marking reference station is 4.99 meters sout1-southwest from observed station.

Marks.-Observed station is a nail set in cement in a tile pipe projecting I inch above the sand. Reference station is center point of triangle on standard cement monument.

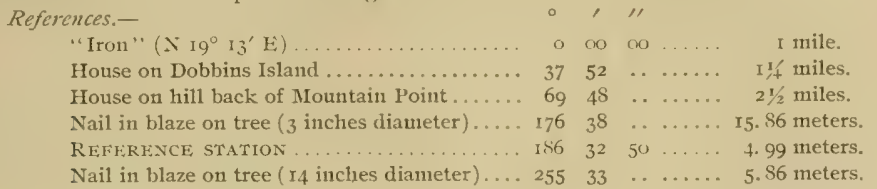

\section{REVELL.}

Locality. - South shore of Magothy River, about I 1/4 miles west-northwest of Persimmon Point and $I 1 / 4$ miles south of east end of Dobbins Island. (See Chart No. 2.)

Observed station is on a bluff 6 feet high and 22 feet from the edge. It is in a large cleared space about roo yards west of woods. Cement monument marking reference station is 5.54 meters south southwest of observed station.

Marks.-Observed station is a nail in a wooden stub projecting 4 inches above the ground. Reference station is the center point of triangle on standard cement monument.

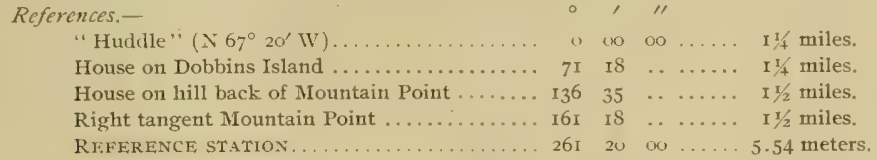

PURSE.

Locality. - South of entrance to Magothy River on a prominent hill about $1 /+$ mile south southeast of Persimnon Point. (See Chart No. 2.)

Observed station is on the nearer of two summits, the other one being occupied by a lone cedar tree. The observed station is almost on line between this cedar tree and Mountain Point. Cement monument marking reference station is 8.93 meters south of observed station.

Marks.-Observed station is a nail in a wooden stub projecting 4 inches above the ground. Reference station is the center point of triangle on standard cement monument.

References.-

"Bluff" ( $\left.\mathrm{N} 9^{\circ} \mathrm{Io}^{\prime} \mathrm{IV}\right)$

Tangent to shore toward Sandy Point...... $.3 t$

Right tangent to Gibson Island........... 34

Left chimney of farmhouse with red roof..... I I 33

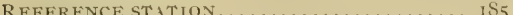

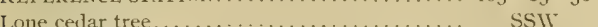

Left of two prominent trees $\ldots \ldots \ldots \ldots \ldots \ldots$. 8 s' $27 \quad \ldots \ldots \ldots$ I/ mile

Right of two prominent trees........... $29507 \quad \ldots \ldots \ldots+$ + mile.

$330-07-9$ 


\section{MAGOTHY}

Locality.-West shore of bay, about halfway between Persimmon Point and Sandy Point. It is about 2 miles northwest of Sandy Point Light and about 2 miles south-southeast of Mountain Point. (See Chart No. 2.)

Observed station is about 20 feet back from the edge of a bluff 20 feet high. It is just outside an orchard about midway between a group of farm buildings and a grove of trees to the westward. Cement monument marking reference station is I1. 63 meters west of observed station.

Marks.-Observed station is a nail in a wooden stub projecting 3 inches above ground. Reference station is center point of triangle on standard cement monument.

References.-

"Welch" (N $\left.32^{\circ} 08^{\prime} \mathrm{WV}\right) \ldots$

Right tangent Gibson Island ............ 2I 02

West peak of farmbiouse

Nail in blaze on tree................. I58 $52 \ldots \ldots .62: 3$ meters.

REFERENCE STATION ................. 287 44 IO ..... Ix.63 meters.

Nail in blaze on tree................. 336 14 $\ldots \ldots .32 .92$ meters.

CORN.

Locality. - West shore of bay, about I mile northwest of Sandy Point Light. (See Chart No, 2.) Observed station is in a cultivated field about I8 feet back from edge of a bluff $x_{5}$ feet high. Cement monument marking reference station is 9.42 meters west of observed station.

Marks.-Observed station is a nail in a stub set flush with ground. Reference station is center point of triangle of standard cement monument.

Refercnces.--

Extreme north tangent of Kent Island.

Sandy Point Light ................. $149 \quad 34 \ldots \ldots$ I mile.

Lone oak tree ( 2 inches diameter) ........ 229 I4 $\ldots \ldots \ldots$ 1/4 mile.

East peak of red roof of barn or house $\ldots \ldots \ldots 243$ o $8 \quad \ldots \ldots \ldots .34$ mile.

REFERENCE STATION ................. 258 5I $30 \ldots . .9 .425$ meters.

\section{SANDY POINT LIGHT.}

Locality._East of Sandy Point about $1 / 2$ mile offshore. (See Chart No. 2.) house.

MIarks.-Center point of black lantern on brown caisson structure known as Sandy Point Light-

References.-

"Bay Side" ......................... s $64 \quad 14 \mathrm{~W} \ldots \ldots, y / 2$ mile.

RING.

Locality.-Shore of bay on west side of Kent Island about 2 miles south-southwest of Love Point and 3 miles east of Sandy Point Light. (See Progress map.)

Observed station is about 20 feet above and 35 feet back from high-water mark. It is in a cultivated field on top of bank and about 6 feet back from edge. Cement monument marking reference station is 9.36 meters east of observed station.

Marks,-Observed station is center of a 4 -inch tile pipe with its top 3 inches below the surface. Reference station is center point of triangle on standard cement monument.

References.-

\begin{tabular}{|c|c|c|c|c|}
\hline "Sandy Point Light" (N $\left.84^{\circ} 56^{\prime} \mathrm{WV}\right)$ & o & OO & & 3 miles. \\
\hline Cupola on barn ................. & $x y 7$ & $5 \mathrm{I}$ & & I mile. \\
\hline South chimney on white house ...... & I4I & $\infty$ & & $1 / 4$ mile. \\
\hline REFERENCE STATION ............ & 164 & 17 & IC & ter: \\
\hline Lone tree ( 2 inches diameter). & 224 & Io & & ard \\
\hline South chimney on white house. & 238 & 56 & & rard \\
\hline
\end{tabular}




\section{BAY SIDE.}

Locality.-West shore of bay on Sandy Point about $1 / 2$ mile west-southwest of Sandy Point Light and about $1 / 4$ mile southeast of Bay Side Farm dwellings. (See Chart No. 2.)

Observed station is on low sandy point about 2 feet above and 75 yards back from high-water mark and $I_{4}$ paces east of road to Bay Side house. A number of small locust trees stand in the immediate vicinity.

Marks.-Observed station is center point of triangle on standard cement monument.

References.-

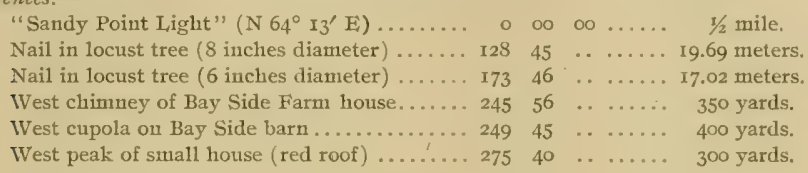

\section{CLUMP.}

Locality. -West shore of bay about one-third way from Hackett Point to Sandy Point on the narrow neck of land east of Goose Pond. (See Chart No. 2.)

Observed station is 3 feet above and 15 feet back from high-water mark. A group of pine trees stand west of station. Cement monument marking reference station is 6.24 meters west of observed station.

Marks.-Observed station is a nail in a stub set flush with ground. Reference station is center point of triangle on standard cement monument.

References.-

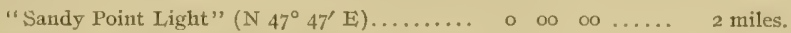

West chimney of white louse on Kent Island abreast of station ................ 62 12 . .... 4 miles.

Nail in blaze on pine tree (Io inches diameter). I85 $5^{S} \quad \ldots \ldots \ldots 8.00$ meters.

St. Anne's Church spire in Annapolis....... $202 \quad 44 \quad \ldots \ldots \ldots .4$ miles.

Statehouse Dome .................... $206 \quad 35 \quad \ldots \ldots \ldots .4$ miles.

RIFERENCE STATION.................... 218 or $40 \ldots .42$ meters.

Nail in blaze on pine tree (1o inches diameter). $247 \quad 17 \quad \ldots \quad \ldots .8 .68$ meters.

West chimney of white house.............. $3{ }^{13}$ og ..... I mile.

\section{WASH.}

Locality.-East shore of bay, on west side of Kent Island, about $1 / 2$ mile south of entrance to Broad Creek: (See Progress map.)

Observed station is in a cultivated field about 30 feet back from edge of bluff $x_{5}$ feet high and about I5 feet south of a small gully making in from bay. Cement monument marking reference station is 12.90 meters east of observed station.

Marks.-Observed station is a nail in a stub fiush with ground, Reference station is center of triangle on standard cement monument.

\section{References.-}

"Sandy Point Light" ( $\left.\mathrm{N}_{3} 6^{\circ} \mathrm{Ig}^{\prime} \mathrm{W}\right)$

West chimney of house

East chimney of white house............... 149

REFERENCE STATION................ 156 I

Cupola on barn.................... I64

Lone tree $\left(2 \frac{1}{2}\right.$ feet diameter $) \ldots \ldots \ldots \ldots \ldots$ I95 32

Tree ( 15 inches diameter) ............... $208 \quad 34$

East chimney on white house ............ $234 \quad 3$

Thomas Point Liglit................. 260

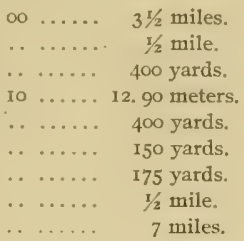

$1 / 2$ mile. 90 meters.

7 miles. 
HACKETT.

Locality. - North side of Annapolis Roads, on the east side of Hackett Point, about 2 miles northeast of Greenbury Light and 3 miles southwest of Sandy Point Light. (See Chart No. 2.)

Observed station is in a cultivated field about 2I feet back from edge of a bluff 15 feet high. It is about go feet north of the extreme southeast end of point. A number of large sandstone bowlders are at the foot of the bluff near the station and a group of several stumps stand on edge of bank opposite station. Cement monument marking reference station is S.68 meters northwest of observed station.

Marks.-Observed station is a nail in a pine stub set flush with ground. Reference station is center point of triangle on standard cement monument.

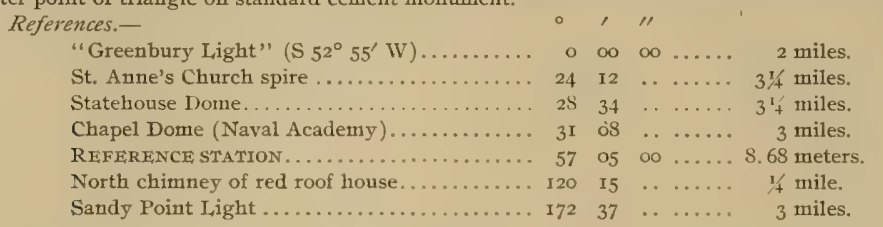

SPIT.

Locality.-East shore of Whitehall Bay on west side Hackett Point about $1 / 2$ mile south of Whitehall wharf and 2 miles northeast of Greenbury Point. (See Chart No. 2.)

Observed station is on low sand point about 4 feet above and 50 yards back from end of point at high water mark and is on round sand knoll abont 2 feet high.

Marks.-Observed station is center point of triangle on standard cement monument.

References.-

"Greenbury Light" (S $43^{\circ} 50^{\prime} \mathrm{W}$ ) ........... o 00 oo ..... 2 miles.

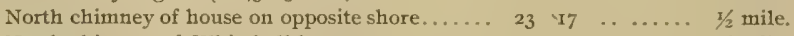

North chimney of Whitehall house.......... r 13 I $25 \quad \ldots \ldots \ldots, 1 / 2$ mile.

North chimney of white house.............. 13928 . 28 .....

Peak of small house on Whitehall wharf $\ldots \ldots \ldots$ I55 $37 \quad \ldots \ldots \ldots, \quad \ldots 1 / 2$ mile.

Northwest corner of small shanty.......... IS6 $40 \ldots \ldots$ roo yards.

Nail in locust tree ( 4 inches diameter) $\ldots \ldots \ldots .23 \mathrm{I} \quad 30 \quad \ldots \ldots \ldots, 35$ yards.

Chimney on small house.................. 250 I5 $\ldots \ldots .$. r50 yards.

\section{CHASE (WHITEHALL BAY).}

Locality.-West shore of Whitehall Bay on point between Mill and Whitehall creeks about $3 / 4$ mile northwest of Hackett Point and $1 / 2$ mile west by south of Whitehall wharf. (See Chart No. 2.)

Observed station is in young peach orchard about 30 feet back from edge of a bank 18 feet high. Cement monument marking reference station is 8.87 meters northeast of observed station.

Marks.-Observed station is a nail in stub flush with ground. Reference station is center point of triangle on standard cement monument.

Reforences.--

"Greenbury Light" ( $\left(\mathrm{S}_{26} 6^{\circ} 22^{\prime} \mathrm{W}\right) \ldots \ldots \ldots \ldots$ o

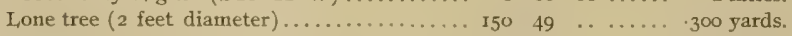

REFERENCE STATION .................. IgI 27 o0 ..... 8.87 meters.

Center of Whitehall wharf house........... $230 \quad 49$.. . . . .

West chimney on red roof house (opposite shore) $265 \quad 50 \quad \ldots \ldots \ldots . \quad 3.4$ mile.

West edge of small shanty on beach (opposite

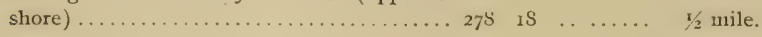




\section{GREENBURY.}

Locality. - North side of entrance to Severn River, on Greenbury Point, about 1/4 mile north of Greenbury Light-house. (See Clart No. 2.)

Observed station is 60 feet back from end of point and 15 feet above high-water mark.

Marks.-Observed station is center point of triangle on standard cement monument.

References.-

"Greenbury Light" ( $\left.7^{\circ} 20^{\prime} \mathrm{E}\right) \ldots \ldots \ldots \ldots \ldots$. o $\quad 00 \quad 00 \ldots .250$ yards.

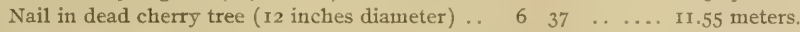

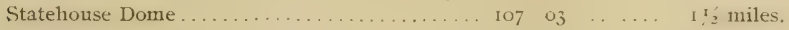

Chapel Dome (Naval Academy) ............ II4 $37 \quad \ldots \ldots \ldots$ I $1 / 2$ miles.

Center of water tower opposite Naval Academy. I44 $32 \ldots \ldots$ I I/4 miles.

\section{GREENBURY POINT JiIGHT.}

Locality. - North side of entrance to Annapolis Harbor, about 250 yards off shore south of Greenbury Point. (See Chart No. 2.)

Marks.-Center of black lantern on screw pile structure known as Greenbury Point Light-liouse. References.-

$$
\text { "Greenbury" ............................. } 250 \text { yards. }
$$

\section{FORT.}

Locality.-Northeast side of entrance to Severn River, about I mile northwest of Greenbury Point and I mile northeast of Naval Academy sea wall. (See Chart No. 2.)

Observed station is 6 feet back from top of bank protected by a masonry wall that has fallen down in places, Io feet above high-water mark, and 2 feet north of a brick gutter on top of bank. Cement fnonument marking reference station is 9.12 meters north of observed station.

Marks.-Observed station is center of a 4-inch tile pipe, with top flush with surface of ground. Reference station is center point of triangle on standard cement monument.

References.-

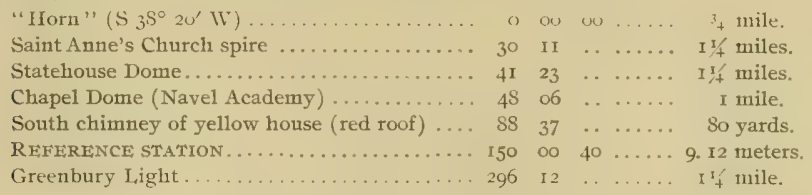

BLUFF (SEVERN RIVER).

Locality.-East side of Severn River, on high bluff, opposite Santee Wharf of Naval Academy. (See Chart No, 2.)

Observed station is 6 feet back from edge of bank 25 feet high. Cement monument marking reference station is 11.842 meters northeast of observed station.

Marks. - Observed station is center of a 4-inch tile pipe, with top 6 inches below surface of ground. Referenee station is center point of triangle on standard cement monument.

References.-

\begin{tabular}{|c|c|c|c|c|}
\hline "Hospital" (N $\left.80^{\circ} 00^{\prime} \mathrm{W}\right) \ldots \ldots \ldots \ldots \ldots$ & 0 & $\infty$ & $\infty$ & \\
\hline West chimney of yellow house ............ & $5 \mathrm{I}$ & -0 & & \\
\hline $\begin{array}{l}\text { Tail in blaze on locust tree (IS inches } \\
\text { diameter) } \ldots \ldots \ldots \ldots \ldots \ldots \ldots \ldots \ldots \ldots \ldots \ldots \ldots \ldots\end{array}$ & & og & & \\
\hline 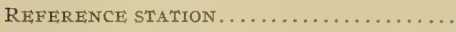 & 126 & 56 & 2 & \\
\hline WEe & 163 & 46 & . & \\
\hline (1) & $3 \times 8$ & 54 & .. & \\
\hline adem & & oI & .. & ... \\
\hline aint John's College. .... & 329 & 25 & 0 & \\
\hline
\end{tabular}




\section{BRICE.}

Locality.-Northeast shore of Severn River on Brice Point near northeast end of County Bridge. (See Chart No. 2.)

Observed station is 15.40 meters northeast of end of rail of County Bridge about 9 yards north of center of County road and 25 yarás west of small pond. It is 3 feet above and 75 feet back from highwater mark.

Marks.-Observed station is center point of triangle on standard cement monument.

References.-

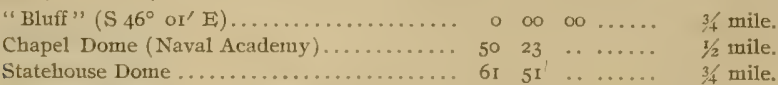

Lowest bolt head in end post of ground rail

on County Bridge................... $65 \quad 24 \quad \ldots \ldots \ldots .15 .40$ meters.

Chimney on bridge-tender's house......... ror Is ...... 14 mile.

South chimney of yellow house.......... 157 50 $\ldots \ldots \ldots$. 34 mile.

Chimney on slate-covered house.......... 190 I8 ...... $1 / 2$ mile.

North chimney of yellow house......... $19926 \ldots \ldots . \quad 1 / 2$ mile.

Nail in blaze on locust tree ( 4 inches diameter) 208 I5 ...... I0.89 meters.

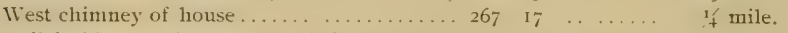

Nail in blaze on locust stump ( 4 inches diam-

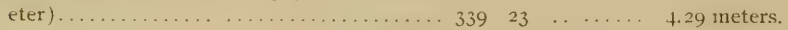

\section{KNOB.}

Locality.-North shore of Severn River about 150 yards northwest by north of north end Maryland Electric Railway Bridge. (See Chart No. 2.)

Observed station is on round knob-hill about 15 feet above and 30 feet back from high-water mark. Cement monument marking reference station is II. 28 meters northeast of observed station.

Marks.-Observed station is a nail in pine stub projecting 4 inches above ground. Reference station is center point of triangle on standard cement monument.

R'eferences. -

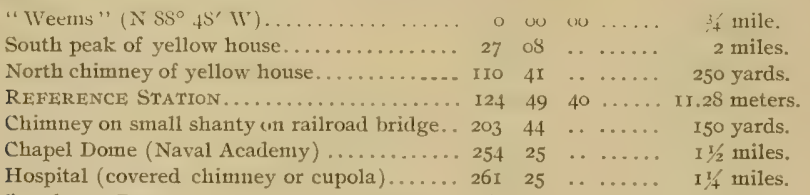

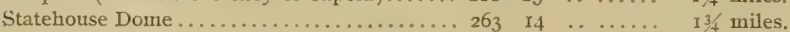

SPRING

Locality.-Northeast shore of Severn River about $3 / 4$ mile above the Maryland Electric Railway Bridge and on first point southeast of mouth of Cool Creek. (See Chart No. 2.)

Observed station is on low sand point about 2 feet above and 45 feet back from high-water mark. It is about 15 yards west of small pond and 100 yards west of a bluff 25 feet high.

Marks. - Observed station is center point of triangle on standard cement monument. (NorE.This monument replaces a 4 -inch tile pipe marking old station.)
References.-
"Field" (S $29^{\circ} 24^{\prime}$ E $)$.... . . .

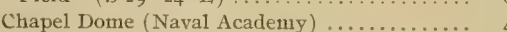
North chimney on red house (opposite shore).. 74
Chimney on white house (opposite shore) ..... 9o
North chimney of yellow house........... 207
Oak stump ( 5 inches diameter) ............ 228
Nail in blaze on locust tree ( 8 inches diameter) $29 \mathrm{I}$
Water tower (opposite Naval Academy) ...... 340

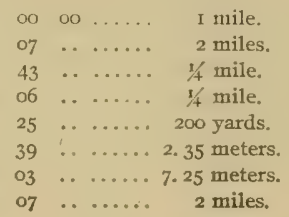


COOL.

Localily.-Northeast shore of Severn River on point between Chase and Cool Spring creeks and about $x 1 / 4$ miles above the Maryland Electric Railway Bridge. (See Chart No. 2.)

Observed station is on low point of land about 2 feet above and 20 feet back from high-water mark and is 7 feet south of small drain ditch 2 feet wide. Cement monument marking reference station is 7.25 meters north-northeast of observed station.

Marks.-Observed station is center of 4-inch tile pipe flush with surface of ground. Reference station is center point of triangle on standard cement monument.

Reforences.-

"Wcens" I S $26^{\circ} \mathrm{H}^{\prime} \mathrm{F}$ ) $\ldots$

"

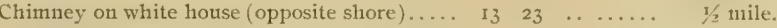

Chimney on small white shanty (opposite

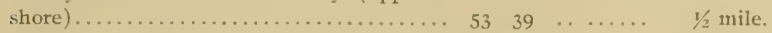

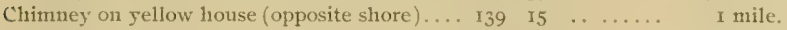

West chimney of house.................. ISo 42 . . . . . $1 / 3$ mile.

Nail in blaze on persinmon tree (4 inches

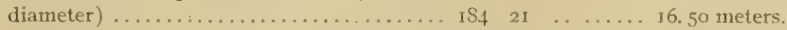

RIFERENCE STATION .................. 22I 29 IO ..... 7.25 meters.

Nail in blaze on oak tree ( 12 inclies diameter). $31 \mathrm{~T} \quad 04 \ldots \ldots \ldots$. 4.82 meters.

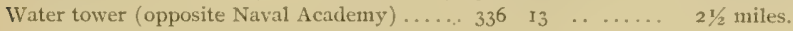

\section{CHASE (SEVERN RIVER).}

Locality,-Northeast shore of Severn River on point on northwest side of entrance to Chase Creek. (See Chart No. 2.)

Observed station is on low marshy point about 2 feet above and I8 feet back from high-water mark and 25 yards southwest of foot of a bluff 50 feet high. Cement monument marking reference station is 7.05 meters north of observed station.

Marks.-Observed station is center of 4 -inch tile-drain flush with ground. Reference station is center point of triangle on standard cement monument.

References.-

"Cool" ( $\left.\mathrm{S} 47^{\circ} 3 \mathrm{~S}^{\prime} \mathrm{E}\right)$

Chimney on yellow house (opposite shore) $\ldots . .30 \quad 34 \quad \ldots \ldots \ldots \quad 1 / 2$ mile.

Chimney on small shanty (opposite shore) ... 38 or $\ldots \ldots \ldots . \quad 1 / 2$ mile.

Middle window of yellow holise (abreast of

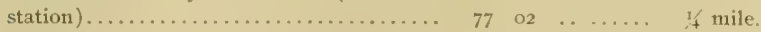

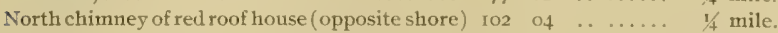

Chimney on yellow house (opposite shore) $\ldots \ldots$ I $46 \quad 26 \quad \ldots \ldots \ldots .1 / 2$ mile.

REFERENCE STATION .................... 24i 31 I $30 \ldots \ldots 7.05$ meters.

North chimney of white house $\ldots \ldots \ldots \ldots \ldots .306 \quad 34 \quad \ldots \ldots \ldots$ I mile.

\section{POINT.}

Locality. - Northeast shore of Severn River about $1 / 2$ mile east-southeast of Brewer Point and on second point northwest of mouth of Chase Creek. (See Chart No. 2.)

Observed station is back of a long, low marsh point and about 25 feet up side of slope. Two lone cedar trees stand on prominent hill about I5o yards to, the northeast of station. Several old apple trees stand in the immediate vicinity of station.

Marks. - Observed station is center point of triangle on standard cement monument. (NoTw.This monument replaces a 4-inch drain tile marking old station.)

References.-

"Salt" (S Io $\left.\mathrm{I}^{\prime} \mathrm{W}\right)$. ......................

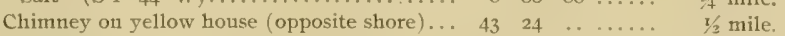

Southwest corner of house .............. I39 $43 \quad \ldots \ldots \ldots . \quad 3 / 4$ mile.

Nail in apple tree ( 12 inches diameter) $\ldots \ldots .233 \quad 34 \quad \ldots \ldots \ldots .12 .55$ meters.

Windmill............................... 255 I5 250 yards.

Nail in apple tree ( 15 inches diameter) .... $280 \quad 38 \ldots \ldots .5 .70$ meters. 


\section{BIGHT.}

Locality.-Northeast shore of Severn River about $\pi / 2$ mile northeast of Brewer Point and $1 / 2$ mile southeast of Arnold Point. (See Chart No. 2.)

Observed station is on low, narrow neck of land and about 2 feet above and 5 feet back from high-water mark. It is $x_{5}$ feet south of foot of slope to a yellow sand bluff 60 feet high. A group of holly trees stand about Io feet east of station. Cement monument marking reference station is 11.64 meters northeast of observed station.

Marks.-Observed station is a nail in a stub set in center of a 4 -inch tile pipe. Reference station is center point of triangle on standard cement monument.

Refencess.
"Clem" (S $7{ }^{\circ} 45^{\prime} \mathrm{W}$ )
(opposite shore)
Northwest corner of unpainted house (opposite shore) $\ldots \ldots \ldots \ldots \ldots \ldots \ldots \ldots \ldots \ldots \ldots \ldots \ldots \ldots \ldots \ldots \ldots$ I4
Nail in blaze on leaning pine tree ( 12 inches

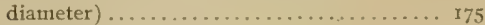
REFERENCE STATION............... 201
Nail in blaze on holly tree ( 4 inches diameter). 25 I
East cedar tree of two standing close together
(first hill south)

$\begin{array}{rccccc}0 & \prime & \prime \prime & & \\ 0 & 00 & 00 & \ldots \ldots & 1 / 4 \text { mile. } \\ 36 & 56 & \ldots & \ldots & 1 / 2 \text { mile. } \\ 144 & 17 & \ldots & \ldots & 1 / 4 \text { mile. } \\ 175 & 29 & \ldots & \ldots & 3.72 \text { meters. } \\ 201 & 34 & 20 & \ldots & 11.64 \text { meters. } \\ 251 & 05 & \ldots & \ldots & 3.79 \text { meters. } \\ 353 & 09 & \ldots & \ldots & 1 / 2 \text { mile. }\end{array}$

ARNOLD.

Locality.-Northeast shore of Severn River on Arnold Point on northwest side of entrance to Aisquith Creek and about $1 / 2$ mile north of Brewer Point. (See Cliart No, 2.)

Observed station is at foot of slope meeting a long, narrow, low neck of land extending about 200 yards southeast of station. It is 3 feet above and 12 feet back from high-water mark. A small holly tree stands about 15 feet east of station. Cement monument marking reference station is 3.75 meters north of observed station.

Mavks.-Observed station is a nail in stub set in a tile pipe with top 3 inches below surface of ground. Reference station is center point of triangle on standard cement monument.

References.-

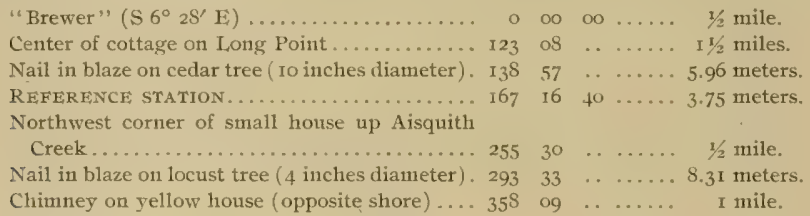

\section{SWAN.}

Locality:-Northeast shore of Round Bay in Severn River on north side of entrance to Ringold Cove about I $1 / \neq$ miles northeast by east of Long Point. (See Chart No. 2.)

Observed station is about roo yards north of entrance to Ringold Cove; about 2 feet above and 15 feet back from high-water mark and 25 feet west of a bluff 25 feet high. Cement monument marking reference station is 7.78 meters east of observed station.

Marks.-Observed station is center of a 4-inch tile pipe with top I foot below surface of ground. Reference station is center point of triangle on standard cement monument.

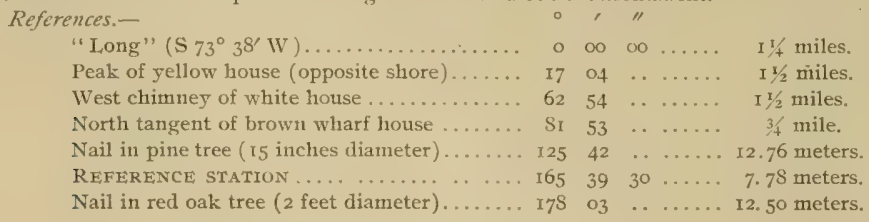




\section{HIGH.}

Locality.-Northeast shore of Round Bay in Severn River on Eaglenest Point and on ground occupied by the Round Bay Resort. (See Chart No. 2.)

Observed station is 15 feet back from the edge of a bank 20 feet high and 25 paces sonthwest of the southwest corner of the dancing pavilion. Cement monument marking reference station is 8.66 meters northeast of observed station.

Marks.-Observed station is center of a 4 -inch tile pipe with top I foot below surface of ground. Reference station is center point of triangle on standard cement monument.

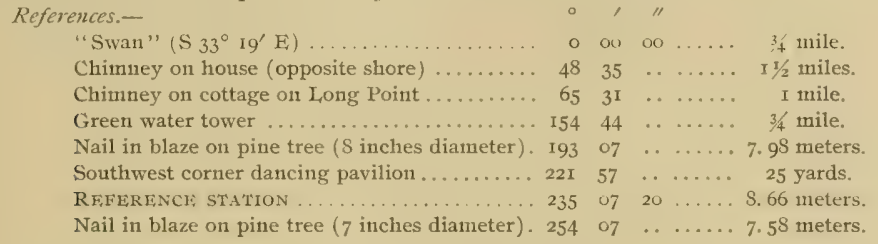

\section{CEDAR (SEVERN RIVER).}

Locality. - Upper end of Round Bay in Severn River on Cedar Point. It is on the sontheast side of entrance to Yantz Creek, (See Chart No, 2,)

Observed station is 2 feet above and 50 feet back from high-water mark at the extreme west end of Cedar Foint. Several redar trees stand just east of station. Cement monument marking reference station is 7.92 meters east of observed station.

Marks. - Observed station is center of a 4 -inch tile pipe with top $x$ foot below surface of ground. Reference station is center point of triangle on standard cement monument.

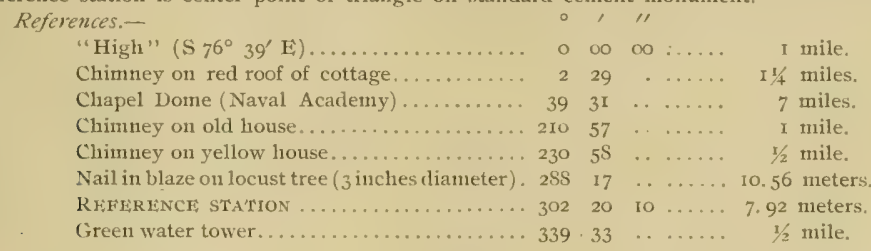

\section{SHARP.}

Locality.-Southwest shore of Round Bay in Severn River about $1 / 2$ mile northwest of Long Point and $1 / 2$ mile southeast of Cedar Point. (See Chart No. 2.)

Observed station is on the first low point above Long Point, and is 2 feet above and 25 feet back from ligh-water mark. A wooded bluff is roo, feet west of station. Cement monument marking reference station is 5.31 meters southwest of observed station.

Marks.-Observed station is center of a 4 -inch tile pipe with top I foot below surface of ground. Reference station is center point of triangle on standard cement monument.

References.-

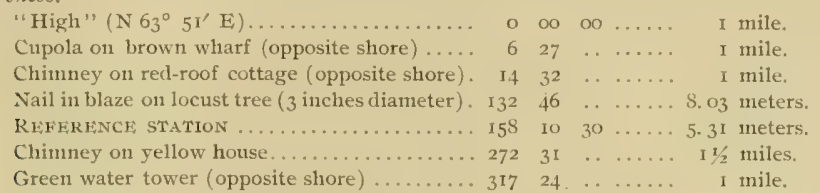

$330-07-10$ 
L,ONG.

Locality.-North side of entrance to Little Round Bay in Severn River on Long Point, about $3 / 2$ mile northeast of St. Helena Island. (See Chart No. 2.)

Observed station is on a low marsh point about 2 feet above and 12 feet back of high-water mark. A small cottage stands about 30 yards north of station. Cement monument ninarking reference station is 5.05 meters northwest of observed station.

Marks.-Observed station is center of a 4 -inch tile pipe with top I foot below surface of ground. Reference station is center point of triangle of standard cement monument.

Refercuces.-

\begin{tabular}{|c|c|c|c|c|c|}
\hline Bay & $u$ & טo & & & \\
\hline IVest chimney on house (opposite shore) ..... & I4 & 59 & & & \\
\hline $\begin{array}{l}\text { iches di- } \\
\ldots . .\end{array}$ & $9 i$ & II & $\cdots$ & & \\
\hline REI & 136 & $5^{8}$ & 20 & & 5. \\
\hline ?ea & & 36 & $\cdots$ & & \\
\hline ). & 170 & $5^{2}$ & . & & 0 \\
\hline & 2. & 32 & $\cdots$ & & \\
\hline himney & 2. & og & $\ldots$ & $\ldots \ldots$ & nile \\
\hline
\end{tabular}

\section{ISLAND,}

Locality.-Little Round Bay in Serern River on the southeast point of St. Helena Island. (See Chart No. 2.)

Observed station is on a low marsh point about 2 feet above and 15 feet back from high-water mark and 25 feet south of foot of round hill $\mathrm{r}_{5}$ feet high. Cenent monument marking reference station is 7.74 meters nortliwest of station.

Marks. -Observed station is center of a 4 -inch tile pipe with top I foot below surface of ground. Reference station is center point of triangle on standard cement monument.

lieferences.-

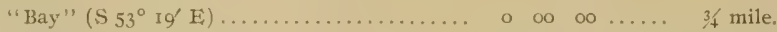

Sonth climmey on house.............. $95 \quad 35 \quad \ldots \ldots \ldots$ I $1 / 2$ miles.

RHFERENCE STATION ................. I95 $4740 \ldots \ldots 7.74$ meters.

Nail in blaze on twin tree ( 6 inclues ciameter). $202 \quad 0.4 \ldots \ldots .9 .01$ meters.

Nail in blaze on twin black haw tree ( 6 inches

diameter $) \ldots \ldots \ldots \ldots \ldots \ldots \ldots \ldots \ldots \ldots .244 \quad 50 \quad \ldots \ldots \ldots 5.42$ meters,

Chinmey on red-roof cottage (opposite shore). $280 \quad 29 \quad \ldots \ldots \ldots$ I $1 \frac{1}{2}$ miles.

North peak of white barn (opposite shore) ... $294 \quad 38 \quad \ldots \ldots .$. I $1 / 2$ miles.

Chimney on north end small house (opposite

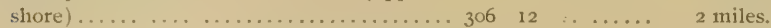

\section{BAY (SEVERN RIVER).}

Locality.-Sonthwest shore of Severn River on south side of entrance to Round Bay, about 3't mile southeast of St. Helena Island and 34 mile south by east of Long Point. (See Cliart No, 2.)

Observed station is at high-water niark at foot of a bluff 25 feet high. Cement monument marking reference station is on slope 7.31 meters soutliwest of observed station.

Marks.-Observed station is center of 4 -inch tile pipe projecting 10 inches above the surface of ground. Reference station is center point of triangle on standari cement monument.

References. -

"Arnold" ( $\left.\mathrm{N} \mathrm{SO} \mathrm{IO}^{\prime} \mathrm{E}\right)$.

Nortl chimney of white house (opposite shore)

Nail in blaze on white oak tree ( 2 feet diameter)

REIEERENCE STATION ................ I 16

Nail in blaze on oak stump ( 8 inches diameter) 156

Nail in blaze on chestnut oak ( 15 inches diann-

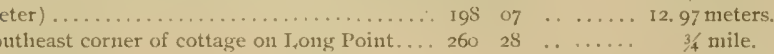

I mile.

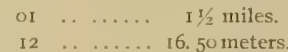

$5720 \ldots .7 .31$ meters.

39 ..... 3. 73 meters. 
BREWER (SEVERN RIVER).

Locality.-Southwest shore of Severn River on Brewer P'oint and north of mouth'of Brewer Creek. (See Chart No, 2.)

Observed station is on a low sand point about 2 feet above and Io feet back from high-water mark and about 30 yards northwest of extreme end of point. A snull lone holly tree stands southwest of station and a bluff 30 feet high is 25 feet southwest. Cement monument marking reference station is 8. ro meters south of observed station.

Marks.-Observed station is a 4 -inch tile pipe with top 6 inches below surface of gronnd. Reference station is center point of triangle on standard cement monument.

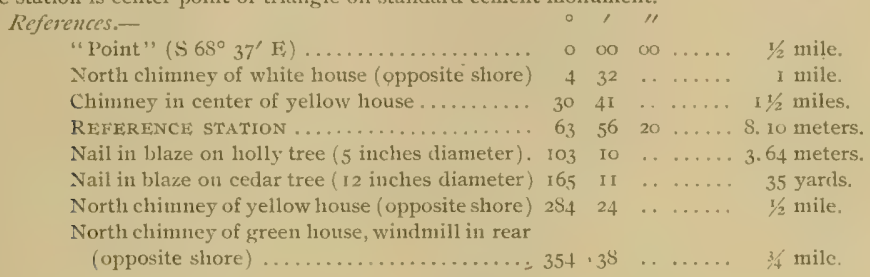

\section{CLEM.}

Localily.-Southwest shore of Severn River on point between Clement Creek and Brewer Creek. (See Chart No. 2.)

Observed station is on a low sand point about 2 feet above and 35 feet back from high-ivater matk. Cement monument marking reference station is 10.07 meters west of observed station.

Marks.-Observed station is a nail in stub flush with ground, set in 4 -inch tile pipe with top 4 inches below surface of ground. Reference station is center point of triangle on standard cement monument.
References.-

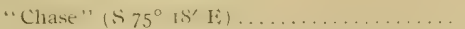
Water tower (opposite Naval Academy) .....
Chimney in center of yellow house ..........
Nortli climney of liouse (sonth side of Clement Creck) ........................... 6

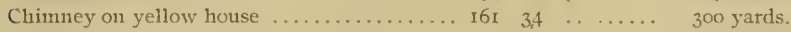
Sunall locust tree $\left(2 \frac{1 / 2}{1}\right.$ inches diameter $) \ldots \ldots 222$ I5 $\ldots \ldots . \ldots 30$ yards.

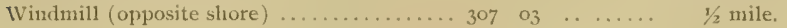

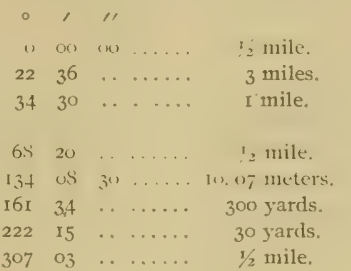

\section{SALT.}

Locality.-Sonthwest shore Severn River between Clement and Saltwork creeks and abreast of Chase Creek. (See Chart No. 2.)

Observed station is to feet back from edge of a bank io feet high. A number of small cedar trees stand on edge of bank in front of station. Cement monument marking reference station is 8.07 meters west of observed station.

Marks.-Observed station is a nail in stub in a 4 -incl tile pipe with top 2 inches below surface of ground. Reference station is center point of triangle on standard cenent monument.
References.-
"Cool" (S $84^{\circ} 23^{\prime}$ (B)
Chimney in center of sellow house........ $34 \quad 45$

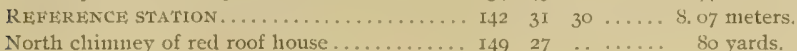


Center of large oak tree $\left(2^{\mathrm{x} / 2}\right.$ feet diameter $) \ldots 206 \quad 22 \quad \ldots \ldots \ldots$ 50 yards.

Chimney on yellow house $\ldots \ldots \ldots \ldots \ldots \ldots .223 \quad 27 \quad \ldots \ldots \ldots$ 1/2 mile.

Nail in blaze on twin cedar tree ( 3 inches

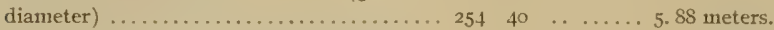

Nail in blaze on cedar tree ( 8 inches diameter). $328 \quad 44 \ldots \ldots \ldots 7.20$ meters.

South chimney standingalone (oppositeshore). $\begin{array}{llll}332 & 35 & \ldots & \ldots\end{array}$ I mile.

\section{LUCE.}

Locality.-Southwest shore of Severn River about 200 yards northwest of entrance to Luce Creek and I $\$$ miles above Railway Bridge. (See Chart No, 2.)

Observed station is on low island at mouth of Hammond Fish Pond and about 2 feet above and is feet back from high-water mark. A number of small trees stand in the immediate vicinity. Cement monument marking reference station is 7.32 meters southwest of observed station.

Marks.-Observed station is center of a 4 -inch tile pipe with top flush with surface of ground. Reference station is center point of triangle on standard cenent monument.

References.-

\begin{tabular}{|c|c|c|c|c|c|}
\hline "Spring" (S $\left.84^{\circ} 24^{\prime} \mathrm{E}\right)$. & 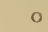 & $\infty$ & 00 & & \\
\hline Chimney on yellow house first bill south. & 56 & 34 & . & & $1 / 4$ \\
\hline Twin cedar tree ( 3 inches diameter) ..... & 88 & 27 & & & ers. \\
\hline$y$ on small $w$ & 93 & 28 & . & & ds. \\
\hline TCE STA & 125 & $\circ 9$ & 40 & & ers, \\
\hline Chi & 218 & 26 & .. & & \\
\hline $\begin{array}{l}\text { East } \\
\text { Chin }\end{array}$ & 61 & 38 & . & & e \\
\hline $\begin{array}{l}\text { (opposite shore) } \ldots \ldots \ldots \ldots \ldots . . . . . \\
\text { on persimmon tree ( } 5 \text { inches }\end{array}$ & & II & & & mile. \\
\hline & & 22 & & & \\
\hline
\end{tabular}

\section{WEEMS.}

Locality. -Southwest shore of Severn River on first point south of Luce Creek and about $3 / 4$ mile above the Railway Bridge. (See Chart No. 2.)

Observed station is on low sand point covered with myrtle bushes about $21 / 2$ feet above and 75 feet back from high-water mark at end of point. The ground rises abruptly about 150 yards west of station.

Marks.-Observed station is center point of triangle on standard cement monument. (NoTE.This monument replaces tile marking old station.)

References.-

"Field" $\left(\mathrm{S} 47^{\circ} 4 \mathrm{o}^{\prime} \mathrm{E}\right) \ldots \ldots \ldots \ldots \ldots \ldots \ldots$ I mile.

South chimney (red house) ............. 99 of ..... 200 yards.

Chimney in center of white house.......... I42 II ..... 250 yards.

North chimney of white house (opposite shore). $23247 \quad \ldots \ldots \ldots \quad 1 / 2$ mile.

North chimney of yellow house (opposite shore). $255 \quad 4$ I $\ldots \ldots \ldots .1 / 2$ mile.

Windmill (opposite shore) ............... 280 $56 \quad \ldots \ldots \ldots$. $1 / 2$ mile.

North chimney of yellow house (opposite shore). $\begin{array}{llllll}308 & 28 & \ldots & \ldots & \ldots & 31 \\ 4 & \text { mile. }\end{array}$

Water tower (opposite Naval Academy)...... 350 oo $\ldots \ldots \ldots 2$ miles.

FIELD.

Locality.-Southwest shore of Severn River on first point east of Railway Bridge and 1/4 mile north of County Bridge. (See Chart No. 2.)

Observed station is on round knob hill about ro feet above high-water mark and I $_{5}$ feet west of edge of low sand point extending 50 yards to the west. 
MTarks.-Observed station is center point of triangle on standard cenent monument. (Nork. This monument replaces tile marking old station.)

References.-

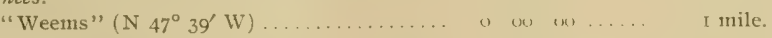

Center chimney of lead-colored house (oppo-

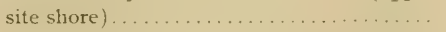

North chimney of yellow house (opposite shore $\ldots \ldots \ldots \ldots \ldots \ldots \ldots \ldots \ldots \ldots \ldots$ t9 $31, \ldots \ldots \ldots$ mile.

Blaze on pine tree ( 12 inches diameter) ..... I6r 26 . . . . . I0. 30 meters.

Chapel Dome (Naval Academy) .......... $206 \quad 15 \ldots \ldots . \quad$ I mile.

Ilospital cupola................... $2 \mathrm{r} 4 \mathrm{f}$ 10 . .... $3 / 4$ mile

Blaze on poplar tree $(12$ inches diameter $\} \ldots 326$, $\ldots$. . . . 7.18 meters,

\section{HOSPITAL CUPOLA (NAVAL ACADEMY).}

Locality.-Sonthwest shore of Severn River on prominent hill. It is a short distance back from shore and just south of County Bridge. (See Cliart No. 2.)

Marks.-Center point of cupola on new Naval Hospital.

Refercuces.-None necessary.

\section{FLAGSTAFF (NAVAL ACADEMY BOATHOUSE).}

Locality.-Naval Academy grounds near Santee Wharf. (See Chart No, 2.) Masks.--Center of flagstaff on northwest end of boathouse at Naval Academy.

References.-None necessary.

\section{STATEHOUSE DOME (ANNAIOLIS).}

Locality.-City of Amapolis. (See Chart No. 2.)

Marks.-Center of Statehouse Dome.

References.-None necessary.

\section{ST, ANNE'S CHURCH SPIRE (ANNAPOLIS).}

Locality.-City of Annapolis. (See Chart No. 2.)

Marks.-Center of spire on St. Anne's Church.

References.-None necessary.

\section{CATHOLIC CHURCH SPIRE (ANNAPOLIS).}

Loculity.-City of Annapolis, (See Chart No, 2.)

Marks.-Center of spire on Catholic Church.

References.-None necessary.

\section{ST. JOHN'S COLLEGE CUPOLA (ANNAPOLIS).}

Locality:-City of Annapolis, (See Chart No. 2.)

Marks. - Center of belfry on St. John's College.

References.-None necessary.

\section{HORN (SEVERN RIVER).}

Locality. - Southwest shore of Severn River, on Horn Point, about $3 / 4$ mile southeast of wharves in Annapolis Harbor and on south side of entrance to Spa Creek. (See Chart No. 2.)

Observed station is about 30 yards north of wire fence and 200 yards northwest of white louse with red tin roof. Cement monument marking reference station is II.24 meters west of observed station. 
Marks. - Ouserved station is center of a 4 -inch tile pipe with top flush with ground. Reference station is center point of triangle on standard cement monument.

liefirenic's.

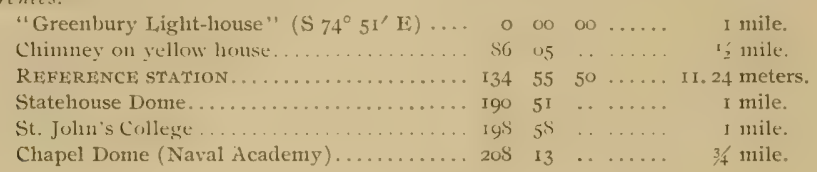

START.

Locality. - Southwest shore of Amnapolis Roads, about $1 / 2$ mile south of Horn Point and I mile west of Greenbury Light-house. (See Chart No. 2.)

Observed station is on wooded shore 15 feet back from edge of a bank 7 feet high. Cement monument marking reference station is 8.45 meters west of ohserved station.

Marks.-Observed station is a nail in a stub set flush with ground. Reference station is center point of triangle on standard cement monument.

References.-

\begin{tabular}{|c|c|c|c|c|}
\hline nbury Iight' & o & & & \\
\hline Tangent to Tolly Point.......... & 67 & $\infty 0$ & $\ldots$ & 2 miles. \\
\hline Extreme west point of roof of Bay Ridge Hotel & 72 & 20 & & niles. \\
\hline Nail in blaze on oak tree ( $\mathrm{r} 2$ inches diameter). & $\mathrm{I} 44$ & 41 & & I6. 26 meters. \\
\hline REHERENCE STATION . . . . . . . . . & 171 & 22 & 20 & 8. 45 metres. \\
\hline Nail in blaze on oak tree ( $\$$ inches diamete & 236 & 32 & .. & II. 38 meters. \\
\hline Vater tower (opposite Naval Academy). & 286 & 27 & $\cdots$ & $I^{1}+$ miles. \\
\hline
\end{tabular}

\section{GRAM.}

Locality.-Southwest shore of Annapolis Roads near northwest entrance to Cat Hole Creek and about $x / 2$ miles south-sonthwest of Greenbury Light. (See Chart No. 3.)

Observed station is 55 feet back from edge of a bluff 30 feet high. A small round knoll is 60 feet west and 5 feet higher than station.

Mfarks.-Observed station is center point of triangle on standard cement monument.

References.-

"Greenbury Light" ( $\left.\mathrm{N} 3 \mathrm{I}^{\circ} 53^{\prime} \mathrm{E}\right) \ldots \ldots \ldots$. . .

Nail in blaze on small locust tree ( 3 inches diameter $\ldots \ldots \ldots \ldots \ldots \ldots \ldots \ldots \ldots \ldots, 9734 \ldots \ldots . \ldots \ldots .40$ meters.

North tangent of roof of old Bay Ridge Hotel, I03 is ...... I mile.

Nail in blaze on locust stump ( 4 inclies dian-

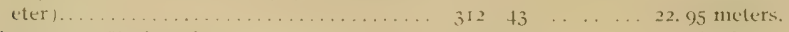

Tangent to Horn Point................. 314 I $15 \ldots \ldots$ I miles.

Vater tower (opposite Naval Acarlemy) .... 322 15 $\quad \ldots \ldots \ldots . \quad 2$ miles.

South chimney of house on Greenbury Point.. 35x $46 \quad \ldots \ldots \ldots 2$ miles.

TOLLY

Locality.-South side of entrance to Annapolis Roads about 150 yards northwest of Tolly Point. (See Chart No. 3.)

Observed station is on low point of land. It is about 1 foot above and I2 feet back from highwater mark, and 175 yards northeast of old Bay Ridge Hotel. Cement monument marking reference station is 10.86 meters southwest of observed station.

Marks.-Observed station is a nail in stub flush with ground. Reference station is center point of triangle on standard cement monument. 


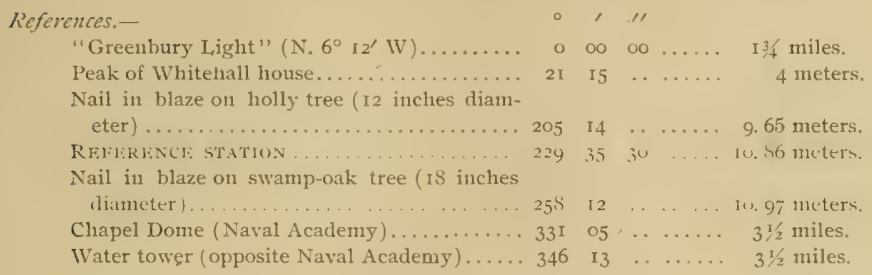

\section{BAY RIDGE STACK.}

Locality. - Bay Ridge Resort on Tolly Point. (See Chart No. 3.)

Marks. - Center of highest part of brick smokestack.

References.-None necessary.

\section{CRANEY.}

Locality.-Eastern shore of bay on west side of Kent Island, about $1 / 2$ mile north of Craney Creek and $4 \frac{1}{2}$ miles east of Tolly Point. (See Chart No. 3.)

Observed station is 3 feet above and 30 feet back from high-water mark, on a low sandy cultivated field. A group of farm buildings stand about it mile away. Cement monument narking reference station is 4.SS meters east-northeast of observel station.

Marks. - Observer station is a nail in a wooden stub projecting 3 incles above the ground. Reference station is center point of triangle on standard cenent momument.

References.-

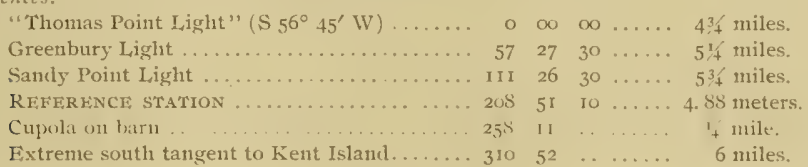

\section{COTTAGE.}

Locality.-West shore of bay near group of cottages called "Arunkel on the Bay' abont 2 iniles northwest of Thomas Point Light. (See Chart No. 3.)

Observed station is 12 feet back from edge of a bank iS feet high. It is about 25 yards north of steamboat wharf and 3 yards east of east edge of a foot-board walk 36 paces southeast of Concord Cottage. Cennent monument marking reference station is 13.70 meters west of observed station.

Marks.-Observed station is a nail in a stub set flush with grounc. Reference station is center point of triangle on standard cement montument.

hicferences.-

"Thomas P'oint Light" ( $\mathrm{S}_{4} \mathrm{I}^{\circ} \mathrm{I} 2^{\prime} \mathrm{E}$ ) ............

Tangent to Thomas Point.............. r r

Green ball on north end of playhouse ....... 26

Fiag prole on pariliom ............... 6i Io

REFERENCF STATION ................ I14 57

Peak of circular red roof bath house in water. $21 \mathrm{t}$

Stack at Bay Ridge....................... 3236 of yards.

North flag pole on wharf ............... $305 \quad 37 \quad \ldots \quad \ldots . \quad 75$ yards. 
THOMAS.

Locality.-West shore of bay on a small island known as Thomas Point. It is on the north side of entrance to South River and about I1/4 miles northwest of Thomas Point Light. (See Chart No. 3.)

Observed station is 30 feet back from top of bank and about Ioo feet west of extreme east end of point. Cement monument marking reference station is 7.66 meters north of observed station.

Marks,-Observed station is a nail in stub set flush with ground. Reference station is center point of triangle on standard cement monument.
References. -

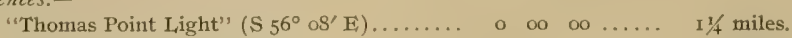

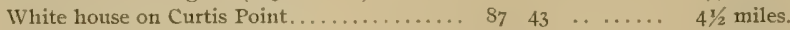

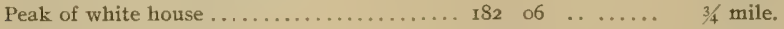
Flag pole on wharf house $\ldots \ldots \ldots \ldots \ldots \ldots \ldots$ Ir $\mathrm{Ir}_{5} \quad 45 \ldots \ldots \ldots$ I $\ldots \ldots$ miles.
REFERENCE STATION................. 2IS $43 \quad 20 \ldots \ldots 7.66$ meters.
Nail in blaze on ash tree ( 15 inches diameter). $284 \quad 59$. . . . I3. 31 meters.
Nail in blaze on locust tree ( 5 inches diameter). $353 \quad 34 \quad \ldots \ldots \ldots 9.64$ meters.

\section{THOMAS POINT LIGHT.}

Locality.-Off entrance to South River and about I/4 miles southeast of Thomas Point, (See (hart No. 3.)

Mlarks. - Center of black lantern on white hexagonal screw pile structure known as Thomas Point Light-House.

References.-

"Thomas"

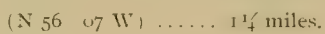

\section{ARUNDEL.}

Locality.-North side of entrance to South River on narrow neck of land between Fishing Creek and South River. (See Chart No. 3.)

Observed station is about 5 feet above and 75 feet back from high-water mark in Fishing Creek. A sand road is 25 feet west of station. Cement monument marking reference station is 4.07 meters northeast of observed station.

Marks.-Ohserved station is center point of a 4-inch tile pipe with top I foot below the surface of ground. Reference station is center point of triangle on standard cement monument.

References.-

\begin{tabular}{|c|c|c|c|c|}
\hline 'Sellyy" (S $\left.\mathrm{SI}^{\circ} 2 \mathrm{~S}^{\prime} \mathrm{W}\right)$ & 0 & Ou & ue & $1_{+}^{1}+$ miles. \\
\hline South peak of white house (opposite shore)... & I & 55 & & $2 \frac{1}{2}$ miles. \\
\hline Tangent to Point. & 34 & 5o & & iles. \\
\hline REFERENCE STATION.... & 144 & If & 40 & 4.07 \\
\hline $\begin{array}{l}\text { Nail in blaze on twin locust tree }(6 \text { inches diam- } \\
\text { eter) } \ldots \ldots \ldots \ldots \ldots \ldots \ldots \ldots \ldots \ldots \ldots \ldots \ldots \ldots \ldots \ldots \ldots \ldots \ldots\end{array}$ & 5 & 25 & $\cdots$ & 7.22 \\
\hline South peak of long barn across Fishing Creek. . & I54 & 49 & . & $1 / 2$ \\
\hline in apple tree ( 15 inches diameter). & 234 & 30 & .. & 8.77 \\
\hline cottage & $25 \mathrm{I}$ & II & - & 300 \\
\hline
\end{tabular}

HILI.

Locality.-Northeast shore of South River on Hills Point and on west sicle of entrance to Duvalls Creek. (See Chart No. 3.)

Observed station is 50 feet back from the extreme south end of Hills Point and 35 feet above highwater mark. Cement monument marking reference station is 8,07 meters northeast of observed station.

Marks,-Observed station is a nail in a pine stub projecting 3 inches above ground. Reference station is center point of triangle on standard cenent monument. 


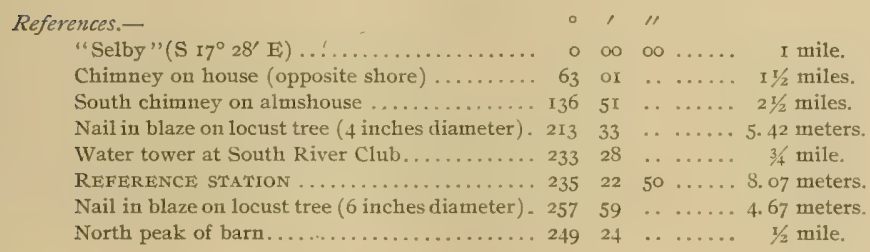

\section{SWITCH.}

Locality.-Northeast shore of South River on point on southwest side of entrance to Aberdeen Creek. (See Chart No. 3.)

Observed station is on the south side of a low sand point and at high-water mark. A number of cedar trees stand in the immediate vicinity. Cement monument marking reference station is $8.4 \mathrm{I}$ meters north of observed station.

Marks.-Observed station is center of a 4 -inch tile pipe with top 2 inches below surface of ground. Reference station is center point of triangle on standard cement monument.

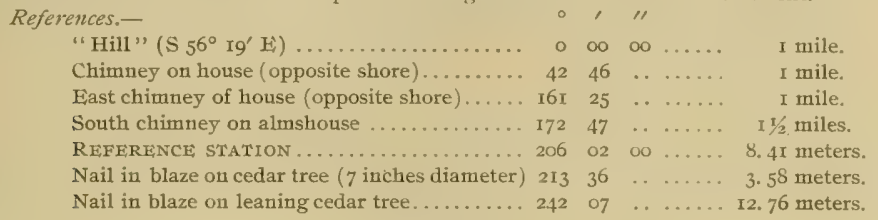

\section{WAGGAMAN}

Locality.-Northeast shore of South River on first point to south of entrance to Cross Creek and about go meters north of Ferry Point and Waggaman wharf house. (See Chart No. 3.)

Observed station is on top of a bluff 25 feet high and I5 feet back from the edge. Waggaman's dwelling is about 100 yards east of station. Cement monument marking reference station is 2.57 meters east of observed station.

Marks.-Observed station is a nail in a pine stub set flush with ground. Reference station is center point of triangle on staudard cement monument.

References.-

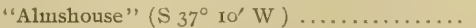

North chimney of almshouse..............

Cupola on barn (opposite shore) ........... 3

North peak of Lee wharf house ........... 5

Nail in blaze on pine tree ( 4 inches diameter). I98

REFERENCE STATION ............... 223

Waggaman's windmill................. 233

Nail in blaze on locust tree (S inches diameter). 257

Flag pole on Waggaman's house . . . . . . . . $302 \quad 33$

$\begin{array}{ccccc}00 & 00 & \ldots & \ldots & 1 / 2 \text { mile. } \\ 21 & \ldots & \ldots & 1 / 2 \text { mile. } \\ 18 & \ldots & \ldots & 1 / 2 \text { mile. } \\ 10 & \ldots & \ldots & 1 \text { m } \\ 56 & \ldots & \ldots & \ldots & 4.70 \text { meters. } \\ 30 & 50 & \ldots & \ldots & 2.57 \text { meters. } \\ 03 & \ldots & \ldots & \ldots & \text { 100 yards. } \\ 50 & \ldots & \ldots & 9.41 \text { meters. } \\ 33 & \ldots & \ldots & 9 & \text { roo yards. }\end{array}$

\section{WAGGAMAN WINDMILL.}

Locality. - Northeast shore of South River on Ferry Point. Marks. - Observed station is center of Waggaman's windmill. References.-None necessary.

$$
330-07-\text { II }
$$




\section{GINGER.}

Locality.-Northeast shore of South River, on prominent point on north side of Church Creek, about $1 / 2$ mile east of South River Bridge. (See Chart No. 3.)

Observed station is 17 feet back from edge of a bluff 35 feet high. A number of trees stand in the immediate vicinity. Cement monument marking reference station is $7.8 \mathrm{i}$ meters north of olserved station.

Marks.-Observed station is center of a 4-inch tile pipe with top 2 inches below surface of grount. Reference station is center point of triangle on standard cement monument.

References.-

\begin{tabular}{|c|c|c|c|c|}
\hline - & o &.$\infty 0$ & oo & \\
\hline Nail in blaze on oak tree ( 18 inches diameter). & 19 & 36 & & 9. 05 meters. \\
\hline eak of Edgewater post-office. & 21 & 28 & & 1/2 mile. \\
\hline $\begin{array}{l}\text { Nail in blaze on mulberry tree }(2 \text { inches diam- } \\
\text { eter }) . . . \ldots \ldots \ldots \ldots \ldots \ldots \ldots \ldots \ldots \ldots \ldots \ldots \ldots\end{array}$ & 45 & 27 & & 12 \\
\hline ATION & 97 & 48 & to & 7. $8 \mathrm{r}$ \\
\hline on locust tree & I87 & 46 & & $5 \cdot 9^{2}$ \\
\hline & 197 & 07 & & \\
\hline ort & 239 & 05 & .. & \\
\hline upol & 272 & 58 & & $1 / 2$ \\
\hline eak of wharf ho & & 45 & & $1 / 2$ mile. \\
\hline
\end{tabular}

XIMO.

Locality. - Upper end of South River, near north entrance to South River Bridge crossing river at Edgewater. (See Chart No. 3.)

Observed station is about to feet from high-water mark on sand beach near east eilge of South

River Road. It is on line with east guard rail of bridge and 18 feet distant from end of rail.

MFarks.--Observed station is center point of triangle on standard cement monument.

References.-

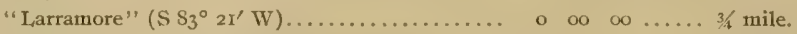

East peak of roof of Edgewater post-office........ II9 $45 \quad \ldots \ldots \ldots 75$ yards.

North chimney of almshouse............... $234 \quad 48 \quad \ldots \ldots$. I mile.

North peak of wharf house................. $294 \quad 51 \quad \ldots \ldots \ldots, 1 / 4$ mile.

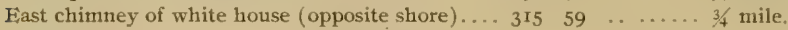

YAZOO.

Locality._North shore of upper South River about $1 / 4$ mile above South River Bridge. (See Chart No. 3.)

Observed station is on low marsh point about 1 foot above and 8 feet back from high-water mark. A lone tree stands west of station on opposite shore. Cement monument marking reference station is 9.96 meters northwest of observed station.

MFarks.-Observed station is a nail in pine stub flush with ground. Reference station is center point of triangle on standard cement monument.

References.-

"Larramore" (S $26^{\circ} 29^{\prime} \mathrm{W}$ ).

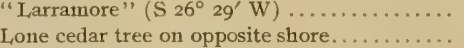

North peak of whari house...............

REFERENCE, STATION ................. ru

Nail in blaze on twin oak tree ( 5 inches di-

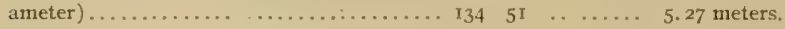

Nail in blaze on red-oak tree ( 5 inches di-

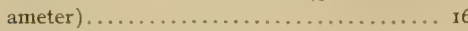

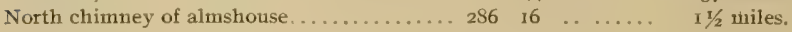

North peak of Lee's wharf house........ $303 \quad 32 \ldots \ldots . \quad 3 / 4$ mile. 
TAYLOR.

Locality.-North shore of upper South River about $3 / 4$ mile above County bridge and opposite the entrance to Beards Creek. (See Chart No. 3.)

Observed station is 17 paces back from the extreme south end of a low sand point. It is $\mathrm{I}$ foot ahove and 8 feet back from high-water mark. Several small persimmon trees stand near station. Cement monument marking reference station is 4.22 meters west of observerl station.

Marks. - Observed station is a nail in a pine stub set flush with ground. Reference station is center point of triangle on standard cement monument.

References.-

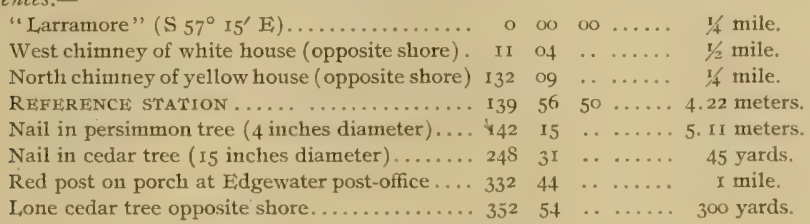

\section{LARRAMORE.}

Locality.--South shore of upper South River near mouth of Beard Creek and about 1/2 mile northeast of County Bridge. (See Chart No. 3.)

Observed station is 2 feet above and 18 feet back from high-water mark. A lone cedar tree stands near the shore about 75 yards back from station. Cement monument marking reference station is 7.96 meters southwest of station.

Marks.-Observed station is a nail in a wooden stub set in a 4 -inch tile pipe with top 3 inches below ground. Reference station is center point of triangle on standard cement monument.

References.-

"Taylor" (N $\left.57^{\circ} \mathrm{r}^{\prime} \mathrm{W}\right)$

Nail in blaze on leaning mulberry tree ( 18 inches diameter $) \ldots \ldots \ldots \ldots \ldots \ldots \ldots \ldots$.

Lone cedar tree.......................

West chimriey of house at Edgewater postoffice........................... i 136

South peak of Lee's wharf house ........... 175

East chimney of white house (first hill south), 200

\section{BREWER (SOUTH RIVER).}

Locality.-Southwest shore of South River on point on northwest side of mouth of Almshouse Creek about $1 / 4$ mile northwest by north of County almshouse and $1 / 2$ mile west by south of Ferry l'oint. (See Chart No. 3.)

Observed station is I foot above and to feet from high-water mark. Cement monument marking reference station is 7.67 meters southwest of observed station.

Marks, - Observed station is a nail in a pine stub set flush with ground. Reference station is center point of triangle on standard cement monument.

\section{References.-}

"Ginger" (N $\left.22^{\circ} \mathrm{wo}^{\prime} \mathrm{W}\right)$.

Peak of yellow house (opposite shore) .........

Waggaman windmill.................. 1 iow of

Flag pole on Waggaman Club house........ I05 15

North chimney on almshouse $\ldots \ldots \ldots \ldots \ldots \ldots \ldots \ldots$

Nail in blaze on leaning red oak tree ( 12 inches

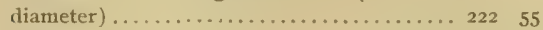

RFFERENCE STATION ................. 257 or

Nail in blaze on white oak tree ( 3 inches diam-

$$
\begin{aligned}
& \text { ' } \\
& \text {........ } \quad 1 \frac{1}{2} \text { miles. } \\
& \text {....... \& mile. } \\
& \text {.. ..... 34 mile. } \\
& \text {....... 1/4 mile. }
\end{aligned}
$$

....6.6.6I meters.

wo.... 7.67 meters.

44 ....... 9.11 meters. 


\section{ALMSHOUSE,}

Locality, - Southwest shore of South River about halfway between Glebe and Almshouse creeks and about 200 yards east of County Almshouse. (See Chart No. 3.)

Observed station is on a low sod point about 6 inches above high-water mark. A group of locust trees stands just southwest of station and an old white house stands on a hill about loo yards southwest. Cement monument marking reference station is 9.87 meters southwest of station.

Marks.-Observed station is center of a 4 -inch tile pipe set flush with surface of ground. Reference station is center point of triangle on standard cement monument.

\section{References.-}

\begin{tabular}{|c|c|c|c|c|}
\hline "Waggaman" ( $\left.\mathrm{N}_{37}^{\circ} \mathrm{IO}^{\prime} \mathrm{E}\right) \ldots \ldots \ldots \ldots \ldots$ & o & OO & ○o & le. \\
\hline Waggaman's windmill........ & 5 & o8 & . & $1 / 2$ mile. \\
\hline Nail in blaze on locust tree ( 5 inches diameter) & 160 & 15 & . & 9. 76 meters. \\
\hline REFERENCE STATION . . . . . . . . . . . . & $17 x$ & 06 & oo & meters. \\
\hline Nail in blaze on locust tree ( 5 inches diameter) & I96 & os & $\cdots$ & neters. \\
\hline North chimney of almshouse.... & 245 & 17 & . & yards. \\
\hline eak of Edgewater post-office... & 279 & 57 & . $\cdots \cdots$ & miles. \\
\hline
\end{tabular}

\section{ALMSHOUSE (LIGHTNING ROD).}

Locality. - Southwest shore of South River between Glebe and Almshouse creeks near County almshouse. (See Chart No. 3.)

Marks.-Lightning rod on south chimney of almshouse.

References.-None necessary.

\section{CEDAR (SOUTH RIVER).}

Locality. - Southwest shore of South River on point between Glebe and Lonehouse creeks. (See Chart No. 3.)

Observed station is on low sand point about I foot above and 6 feet back from high-water mark. A number of small cedar trees stand southwest of station. Cement monument marking reference station is $5.6 \mathrm{I}$ meters south of observed station.

Marks.-Observed station is a nail in a stub set flush with ground, Reference station is center point of triangle on standard cement monument.

References.-

"Switch" ( $\left.89^{\circ} 57^{\prime} \mathrm{E}\right) \ldots \ldots \ldots \ldots \ldots \ldots \ldots$ o $\ldots \ldots \ldots$ 3t mile.

REFERENCE STATION................ I22 I4 10 .... 5.6r meters.

Nail in blaze on twin cedar tree ( 4 inches diam-

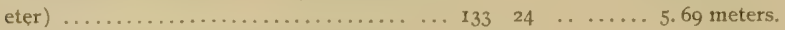

Nail in blaze on locust tree ( 4 inches diameter). $21329 \ldots \ldots .5$. 1 I meters.

South chimney on almshouse........... 223 o6 ...... I mile.

Flagstaff on Waggaman Clubliouse $\ldots \ldots \ldots \ldots 253 \quad 54 \ldots \ldots$ I mile.

Waggaman windmill.................... $256 \quad 43 \quad \ldots \ldots$ I mile.

North chimney on brown house (opposite shore) $3 \pi 433 \ldots \ldots .3 \%$ mile.

MIAYO.

Locality.-Southwest shore of South River on Mayo Point. (See Cliart No. 3.)

Observed station is about 6 feet above and 40 feet back from high-water mark. A low holly bush stands 25 feet northeast and a low sand knoll io feet north of station. Cement monument marking reference station is 5.95 meters southwest of observed station.

Marks.-Observed station is a nail in a wooden stub set flush with ground. Reference station is center point of triangle on standard cement monument.
References.-
"Selbr" (S $\left.45^{\circ} 44^{\prime} \mathrm{E}\right)$
0 oo $00 \ldots \ldots$ i mile.
REFERENCE STATION.................. 87 58 $10 \ldots \ldots .95$ meters.
Nail in blaze on red oak tree ( 12 inclies dianeter) $108 \quad 35 \ldots \ldots .6 .07$ meters.
Nail in blaze on cedar tree ( 8 inches diameter). $140 \quad 33 \quad \ldots \ldots .99 .30$ meters.
South chimney on almshouse $\ldots \ldots \ldots \ldots \ldots \ldots 177 \quad 27 \quad \ldots \ldots \ldots .214$ miles. 
North chimney on Waggaman house....... $19254 \ldots \ldots$. 54 miles.

South chimney on red roof house (oppositeshore) $223 \quad 53 \quad \ldots \quad \ldots \ldots .34$ mile.

Green water tower (South River Club) ...... 270 50 $\ldots \ldots \ldots t 1 / 2$ miles.

North peak of old barn ............... I 281 os $\ldots \ldots$ mile.

\section{SELRY.}

Locality.-Southwest shore of South River on Turkey Point. (See Chart No. 3.)

Observed station is 6 feet above high-water mark and about 250 yards south of the extreme north end of Turkey Point. A lone locust tree stands about 12 yards sonth of station. Cement monument marking reference station is $7.8 \mathrm{r}$ meters southwest of observed station.

Marks.-Observed station is center point of a pine stub set flush with ground. Reference station is center point of triangle on standard cement monument.

Reforences.-

\begin{tabular}{|c|c|c|c|c|}
\hline "Arundel" (N Si ${ }^{\circ} 2 \gamma^{\prime} \mathrm{E}$ & (1) & (") & "11 & $\mathrm{I}_{+}^{+}$miles. \\
\hline Locust stump ( $1 / 2$ feet high) & 7 & 30 & & 11. 30 meters. \\
\hline Thom :s Point J,ight. . & $\dot{2}$ & is & & 3 miles. \\
\hline Nail in blaze on locust tree ( 12 inches diameter) & 113 & I0 & $\cdots$ & I0. 65 meters. \\
\hline REFERENCE STATION ...... & 1,37 & 31 & oo & 7.81 meters. \\
\hline Water tower (South River Club). & 276 & $3 I$ & $\ldots$ & niles. \\
\hline Peak of red roof house (opposite shore). & 278 & 23 & $\ldots$ & $11 / 2$ miles. \\
\hline Peak of white house (opposite shore)....... & 307 & 50 & . & I $1 / 2$ miles. \\
\hline
\end{tabular}

\section{GOWAN,}

Locality.-Western shore of bay on Saunders Point between entrances to South River and West River. (See Chart No. 3.)

Observed station is 21 feet back from edge of bluff 25 feet high. Two blazed cedar trees stand about 12 yards south of station. Cement monument marking reference station is 11.320 meters west of observed station.

Marks.-Observed station is a nail in a pine stub set flush with ground. Reference station is center point of triangle on standard cement monument.

\begin{tabular}{|c|c|c|c|c|}
\hline eferences.- & $\circ$ & & $\prime \prime$ & \\
\hline "Thomas Point Light" (N $\left.74^{\circ} 06^{\prime} \mathrm{E}\right) \ldots \ldots$ & o & oo & $\infty$ & 3 miles. \\
\hline Nail in blaze on cedar tree (Io inches diameter) & 102 & $4 \mathrm{x}$ & . & ${ }_{13} .02$ meters. \\
\hline Nail in blaze ou cedar tree ( 12 inches diameter) & 129 & 43 & .. & 9.44 meters. \\
\hline Peak of white house .................. & $17 I$ & os & .. & 1/4 mile. \\
\hline REFERENCE STATION . . . . . . . . . & I 80 & I3 & $50 \ldots$ & II. 32 meters. \\
\hline South chimney of house .............. & 240 & 12 & . . . & Ioo yards. \\
\hline
\end{tabular}

\section{DUTCHMAN.}

Locality. - North side of entrance to West River on Dutchman Point between shore of bay and Rlinde River. (See Chart No. 3.)

Observed station is on top of a bank 12 feet high and is Io feet back from the edge. A small lone. locust tree stands about II yards northwest of station. Cement monument marking reference station is ro.6r meters north of observed station.

Marks.-Observed station is center of a tile pipe with top 6 inches below surface of ground. Reference station is center point of triangle on standard cement monument.

References. -

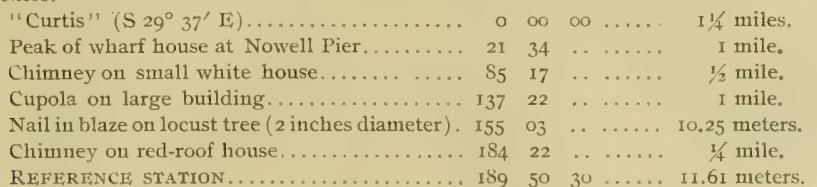


CATO.

Locality:- North shore of West River on point at east side of entrance to Rhode River. (See (hart No. 3.)

Observed station is the extreme west end of a low sand point and is awash at high tide. A bank I 2 feet high is 75 yards east of station. Cement monument marking reference station is 20.01 meters east-southeast of observed station.

Marks.-Observed station is an auger hole in a pine stub projecting 2 inches above the ground. Reference station is center point of triangle on standard cement monument.

References.-

Peak of wharf house (Nowell Pier)......... $20 \quad 4 \mathrm{I} \quad \ldots \ldots \ldots$ i mile,

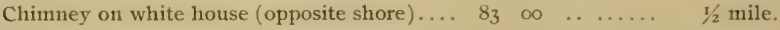

Cupola on large building................ I $455 \quad 34 \ldots \ldots \ldots . \quad$ I mile.

South peak of packing house. $1 \ldots \ldots \ldots \ldots$ I6I $31 \ldots \ldots$ I mile.

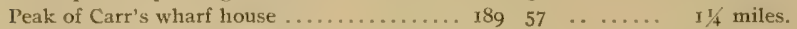

Chimney on red-roof house............. $213 \quad 50 \ldots \ldots$ 1/4 mile.

REFERENCE STATION ................. $310 \quad 52 \quad 20 \ldots \ldots$. 20.01 meters.

\section{DFITA.}

Locality. -East shore of Rhode River on point south of entrance to Cadle Creek, about $1 / 2$ mile north of mouth of Rhode River. (See Chart No. 3.)

Observed station is in a cultivated field about 300 yards southeast of Stiner's house and I5 yards hack from edge of a bluff 12 feet high. Cement monument marking reference station is 4.32 meters northeast of observed station.

Marks.-Observed station is an auger lole in a pine stub. Reference station is center point of triangle on standard cement monument.

\section{References.-}

"Rhode" (S $\left.26^{\circ} 42^{\prime} \mathrm{W}\right)$. $\circ, 11$

Cupola on large building (opposite shore) ... 55 II $\ldots \ldots \ldots, \quad 1 / 2$ mile.

South peak of old packing house (opposite

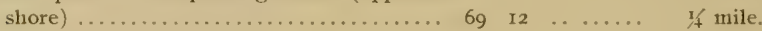

Southeast corner of Carr's wharf house...... I24 $3 I$ I $\ldots . \ldots . \quad 3 / 4$ mile.

Chimney on yellow house................ I49 43 .......

REFERENCE STATION.................. 193 o9 10 ..... 4.32 meters.

Chimney on red-roof house.............. $280 \quad 50 \quad \ldots \ldots \ldots, 300$ yards.

Nail in blaze on small locust tree ( 3 inches

diameter $) \ldots \ldots \ldots \ldots \ldots \ldots \ldots \ldots \ldots \ldots, 354$ 4I $\ldots \ldots \ldots, 17.19$ meters.

\section{ETNA.}

Locality.-East shore of Rhode River, about 400 yards north of mouth to Caclle Creek. (See Chart No. 3.)

Observed station is 6 feet back from edge of a bank 12 feet high and is in front of the second louse north of Cadle Creek, which stands about 25 yards northeast of station. Cement monument marking reference station is 5.40 meters northeast of observed station.

Marks.-Observed station is an auger hole in a pine stub projecting 3 feet above the ground. Reference station is center point of triangle on standard cement monument.

References.-

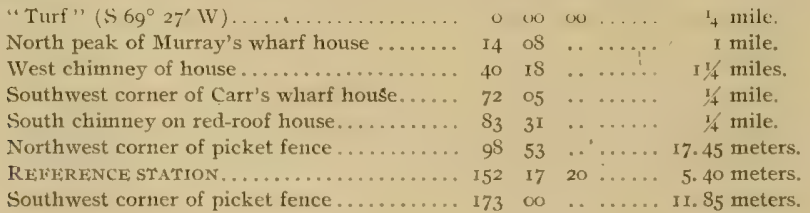


CALF.

Locality.-Northern shore of upper Rhode River between Whitemarsh and Waters creeks abont If mile west by north of Carr's wharf. (See Chart No. 3.)

Observed station is 25 feet back from edge of a bank 15 feet high. It is abreast of High Island and about 300 yards northwest of the extreme southeast end of a point of land between Whitemarsh and Waters creeks. Cement monument marking reference station is 4.96 meters northeast of observed station.

Marks,--Observed station is a nail in a pine stub flush with ground. Reference station is center point of a triangle on standard cenent monument.

References.-

"Turf" (S $\left.30^{\circ} \mathrm{IU}^{\prime} \mathrm{F}\right) \ldots \ldots \ldots \ldots \ldots \ldots \ldots$ o o w $00 \ldots \ldots$. $1 / 2$ mile.

Cupola on large house (opposite shore)...... $55 \quad 07 \quad \ldots \ldots \ldots \quad \ldots / 2$ mile.

Chimney on small white house (opposite shore). II5 $05 \ldots \ldots \ldots$. $1 / 2$ mile.

West chimney on red-roof house (first hill

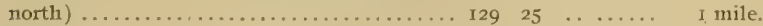

Nail in blaze on pine tree ( 4 inches diameter).. $20148 \ldots \ldots .5 .17$ meters.

REFERENCE STATION.................. 242 I7 $20 \ldots .96$ meters.

Southwest corner of Carr's wharf ........... $307 \quad 46 \quad \ldots \ldots 300$ yards.

Nail in blaze on small white oak tree ( 2 inches diameter) .......................... $327 \quad 30 \quad 00 \ldots 9.15$ meters.

TURF.

Locality. - West shore of Rhode River on point at right-angle bend in river and $1 / 2$ mile south of Carr's wharf. (See Chart No. 3.)

Observed station is on a low marshy point just above high-water mark. A large frame tobacco barn stands about $1 / 4$ mile southwest of station. Cement monument marking reference station is 4.83 meters west of observed station.

Marks.-Observed station is a nail in a pine stub. Reference station is center point of triangle on standard cement monument.

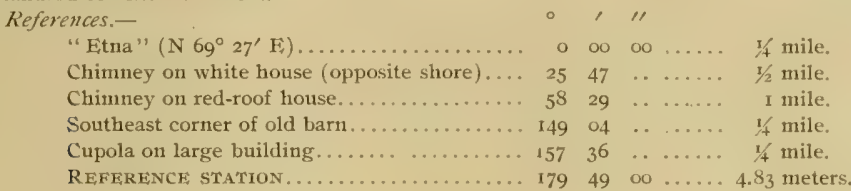

\section{CUPOLA.}

Locality,-On west side of Rhode River about $3 / 4$ mile above its mouth and $1 / 4$ mile back from shore, (See Chart No. 3.) spindle.

Marks.-Center of spindle on belfry cupola on dark colored frame barn. Bell in cupola under

References.-None necessary.

\section{RHODE} No. 3.)

Locality.-West shore of Rhode River on point about $1 / 2$ mile north of its mouth. (See Chart

Observed station is on a low sand point just above high-water mark and about 60 feet west of the extreme east end of point. Cement monument marking reference station is 7.39 meters west of observed station.

Marks.-Observed station is a nail in a pine stub fush with ground. Reference station is center point of triangle on standard cement monument. 


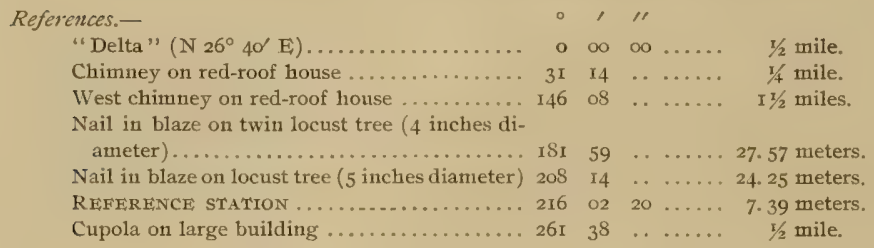

\section{CHES.}

Locality.-North shore of West River on point at west side entrance to Rhode River and abont 300 yards east of entrauce to Chestons Creek. (See Chart No. 3.)

Observed station is $2 \mathrm{r}$ feet back from the edge of a bank 15 feet high. A twin locust stump stands about 2 yards southeast of station. Cement monument marking reference station is 8.7I meters northwest of observed station.

Marks,- Observed station is a nail in a pine stub flush with ground. Reference station is center point of triangle on standard cement monument.

References.-

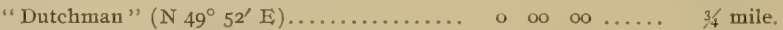

Chimney on small house (opposite shore) ... Ior $19 \ldots \ldots$ I mile.

West chimney on red-roof house (opposite

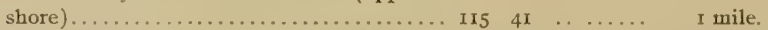

East chimney on white house (opposite shore). 157 I3 $\ldots \ldots \ldots$ I mile.

Chimney on small house.............. $219 \quad 35 \quad \ldots \ldots .200$ yards.

REFERENCE: STATIUN ............... $253 \quad 53 \quad 30 \ldots \ldots$ S.7I meters

ALPHA.

Locality.-North shore of West River between Scaffold and Chestons creeks and about $3 / 4$ mile north of Cedar Point. (See Chart No. 3.)

Observed station is about ro feet above and 5 feet back from high-water mark. It is about 100 yards east of Scaffold Creek and 200 yards west of a small white shanty. Cement monument marking reference station is 8.26 meters north of observed station.

Mlarks.-Observed station is an auger hole in a hickory stump. Reference station is center point of triangle on standard cement monument.

References.-

"Cove" $\left(\mathrm{S} \mathrm{x}^{\circ} 2 \mathrm{I}^{\prime} \mathrm{E}\right) \ldots \ldots \ldots \ldots \ldots \ldots \ldots \ldots$. 0 . 00 . $00 \ldots \ldots$ mile.

Tangent to Counallor Point ............ $20 \quad 57 \quad \ldots \ldots \ldots$ I mile.

Peak of white house................ 68 I7 $\ldots \ldots . .1 / 2$ mile.

Nail in blaze on hickory tree ( 7 inches diam-

eter) ........................ I35 $00 \ldots \ldots$ II. 33 meters.

Nail in blaze on black oak tree ( 7 inches

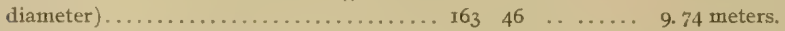

REFERENCE STATION .................. 167 o1 $00 \ldots .26$ meters.

Nail in blaze on black oak ............ 230 is $\ldots \ldots .7 .5^{8}$ meters.

Vest chimney on house (opposite shore) $\ldots . .354 \quad 54 \quad \ldots \ldots \ldots$ I mile.

SHELL.

Locality.-West shore of Upper West River about 300 yards north of entrance to Cox Creek and $1 / 2$ mile west of Cedar Point. (See Chart No. 3.)

Observed station is on an oyster shell bank about 8 feet above and 3 feet back from high-water mark. Cement monument marking reference station is II.2I meters northwest of observed station. 
Marks.-Observed station is a nail in a pine stub projecting I 8 inches above ground, Reference station is center point of triangle on standard cement monument.

References.-

\begin{tabular}{|c|c|c|c|c|c|}
\hline "Cove" (S $88^{\circ}$ & o & & 00 & & \\
\hline Chimney on small white house (opposite shore) & II & & . & & \\
\hline $\begin{array}{l}\text { forth chimney on red-roof house (opposite } \\
\text { shore) } \ldots \ldots \ldots \ldots \ldots \ldots \ldots \ldots \ldots \ldots \ldots \ldots\end{array}$ & 70 & & & & \\
\hline $\begin{array}{l}\text { West chimney on house belonging to Mr. Lerch } \\
\text { (opposite shore) } \ldots \ldots \ldots \ldots \ldots \ldots \ldots \ldots \ldots\end{array}$ & $65^{\circ}$ & & & & \\
\hline Nail in blaze on gum tree ( 2 feet diameter)... & 120 & 07 & & & \\
\hline NCE STAT & 200 & 02 & I0 & & II .2 \\
\hline aze on c & $2 I$ & & & & 0.6 \\
\hline Southwest corner & & & & & \\
\hline
\end{tabular}

\section{COUNALLOR.}

Locality.-West shore of upper West River about 250 yards north of steamboat wharf at Galesville and on south side of entrance to Cox Creek. (See Chart No, 3.)

Observed station is about 22 feet back from edge of a bluff $\mathrm{x} 2$ feet high. An old dead stump stands about 6 feet to the south of station. Cement monument marking reference station is ro.93 meters west of observed station.

Marks.-Observed station is a nail in a pine stub flush with ground. Reference station is center point of triangle on standard cement monument.

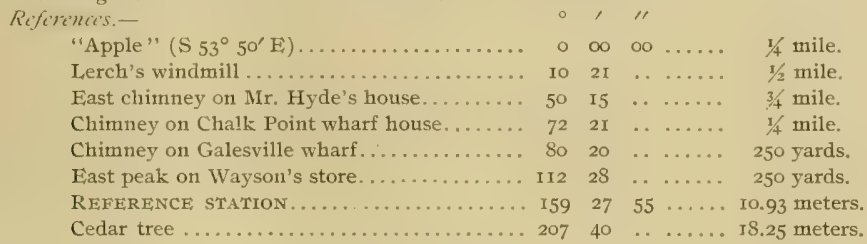

CHALK.

Locality.-Upper West River on west side of Chalk Point about $1 / 4$ mile southeast of Galesville and 200 yards east of Chalk Point steamboat wharf. (See Chart No. 3.)

Observed station is about 4 feet above and 27 feet back from high-water mark. It is about $S$ yards west of a blazed locust tree standing on edge of bank. Cement monument marking reference station is $\mathrm{S}_{1}, 15$ meters west of observed station.

Marks.-Observed station is a nail in a pine stub flush with ground. Reference station is center point of triangle on standard cement monument.

References.-

"Apple" ( $\left.49^{\circ} 35^{\prime} \mathrm{E}\right)$

$\circ, 11$

Lerch's windmill ..................... 25

Chimney on yellow house (opposite shore) .....

East chimney on Mr. Hyde's house....... I24 $35 \quad \ldots \ldots \ldots$ 1/4 mile.

REFERENCE STATION ................. 20I $5935 \ldots \ldots$. I5 meters.

Chimney on small yellow house.......... 216 $43 \ldots \ldots$ Ioo yards.

Chimney on Galesville wharf house $\ldots \ldots \ldots 284 \quad 27 \quad \ldots \ldots \ldots 300$ yards.

\section{LERCH WINDMILL.}

Locality.-Upper West River about $1 / 2$ mile east of Chalk Point and 3/4 mile southeast of Galesville near house of Mr. Lerch.

Marks.-Center of shaft at highest point of windmill.

References.-None necessary.

$330-07-12$ 
APPLE:

Locality.-East shore of Upper West River, abreast of Galesville, and about $3 / 4$ mile south by west of Cedar Point. (See Chart No. 3.)

Observed station is 28 feet back from edge of bank, 8 feet high. It is about 45 yards east of the southwest corner of V. Hartge's house. Cement monument marking reference station is 7 .17 meters east of observed station.

Marks.-Observed station is a nail in a pine stub flush with ground. Reference station is center point of triangle on standard cement monument.

References.-

"Chalk" (S $\left.49^{\circ} 35^{\prime} \mathrm{W}\right) \ldots \ldots \ldots \ldots \ldots \ldots$. o oo

...... 1/ mile.

East peak of Wayson's store............. 4 I $36 \quad \ldots \ldots .1 / 2$ mile.

Chimney on store ................ $64 \quad 27 \quad \ldots \ldots .1 / 2$ mile.

Southwest corner of Hartge wharf house..... $154 \quad 38 \quad \ldots \ldots$ mile.

Apple tree $(6$ inches diameter $) \ldots \ldots \ldots \ldots \ldots 203 \quad 02 \quad \ldots \ldots .7 .22$ meters.

REFERENCE STATION ................ $236 \quad 25 \quad 30 \ldots . \quad 7.17$ meters.

Twin apple tree..................... 294 or $\ldots$ II. 40 meters.

\section{COVE.}

Locality.-South shore of West River, about $3 / 4$ mile northeast of Galesville, on Cedar Point. (See Chart No. 3.)

Observed station is on a low narrow neck of land, about 125 yards from its extreme south end. It is about 6 inches above high-water mark and 5 yards west of a blazed cedar stump. Cement monument marking reference station is $5.4 \mathrm{I}$ meters northeast of observed station.

Marks.-Observed station is a nail in a pine stub flush with ground. Reference station is center point of triangle on standard cement monument.

References.-

"Counallor" (S $47^{\circ}$ oo $\left.\mathrm{WV}\right) \ldots \ldots \ldots \ldots \ldots \ldots$ o

Southwest corner of small shanty (opposite

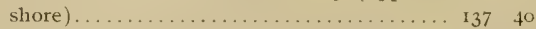

Chimney on white house (opposite shore)... I56 4 I

REFERENCE STATION ................ I7I

Nail in blaze on cedar stump ( 15 inches diameter $\ldots \ldots \ldots \ldots \ldots \ldots \ldots \ldots \ldots \ldots$ 196 03

Northwest corner of Hartge wharf house .... $316 \quad 46$

Lerch's windmill.................... 318 26

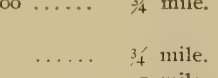

$\ldots \ldots$ I mile.

$30 \ldots .5 .4$ I meters.

..... 4.60 meters.

$\ldots . .350$ yards.

...... I mile.

\section{CURTIS.}

Locality. - South side of entrance to West River on west side of Curtis Point. (See Chart No. 3.)

Observed station is about io feet above and 6 feet back from edge of bank. It is north of entrance to Parish Creek and about 250 yards northwest of a house standing back in the woods. A line of sight was cut through woods in order to see Bloody Point Bar Light. Cement monument marking reference station is about 10.82 meters southeast of observed station.

Marks. - Observed station is a nail in a pine stub flush with ground. Reference station is center point of triangle on standard cement monument.

References.-

"Dutchman" ( N $\left.29^{\circ} 36^{\prime} \mathrm{WV}\right)$

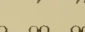

Peak of white house (opposite shore) ........ $25 \quad 43$

Nail in blaze on gum tree ( 4 inches diameter). I48 05

REFERENCE STATION .................. I56 04

Nail in blaze on locust tree ( 5 inches diameter) I97 56

South peak of wharf house............ $273 \quad 32$

East chimney of yellow house.......... $28 \mathrm{I} 50$

$$
\begin{aligned}
& \text { oo ...... I, I miles. } \\
& \text {..... } 2 \text { miles. } \\
& \text {..... 13.63 meters. } \\
& 20 \ldots . . \text { 10. } 82 \text { meters. } \\
& \text {..... } 15.65 \text { meters. } \\
& \text {..... } 1 / 2 \text { mile. } \\
& \text {..... } 3 / 4 \text { mile. }
\end{aligned}
$$




\section{Survey of Oyster Bars, Anne Arundel County, $M d$.}

\section{HORSESHOE.}

No. 3.)

Locality. - On shore of bay about 1/4 mile south of eastern edge of Horseshoe Point. (See Chart

Observed station is on low marshy point nearly awash at high tide. It is about 300 yards east of a yellow house with three lightning rods. This house is surrounded by cedar trees. Cement monument marking reference station is II.24 meters northwest of observed station.

Marks.-Observed station is a nail in a stub set in center of a tile pipe projecting 2 inches above ground. Reference station is center point of triangle on standard cement monument.

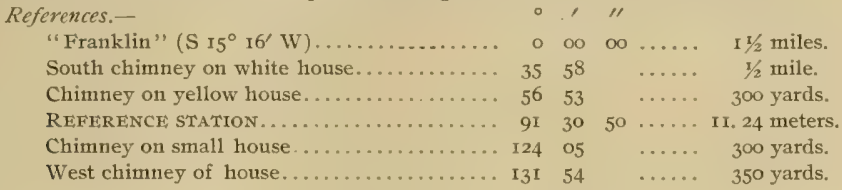

\section{BLOODY POINT BAR LIGHT.}

Locality. $\rightarrow$ Off eastern shore of bay, about $\mathrm{I} / / 4$ miles due west of the southernmost point of Kent Island and about $3 / 4$ mile west-southwest from mouth of Bloody Point Creek. (See Chart No. 3.)

Marks. - Center point of black lantern on brown caisson structure known as Bloody Point Bar I.ight.

References.-

"Horseshoe" ( ${\left.\mathrm{N} 87^{\circ} 45^{\prime} \mathrm{W}\right) \ldots \ldots \ldots \ldots \ldots \ldots \ldots \ldots \ldots \ldots \ldots \ldots \ldots \ldots \ldots \ldots \ldots \ldots \ldots}^{1 / 4}$ miles.

\section{FRANKLIN.}

Localify.-Western shore of bay on Franklin Point, about halfway between West River and Herring Bay. (See Chart No. 4.)

Observed station is on low point, covered with tufts of marsh grass, situated between the marsh and shore. It is just above high-water mark and about so yards in front of the northeast point of a round grove of small oak trees. Cement monument marking reference station is 6.36 meters northwest of observed station.

Marks.-Observed station is a nail in a pine stub flush with ground. Reference station is center of triangle on standard cement monument.

References.-

"Horseshoe" (N I5 I5' E) .................

Black oak tree at southeast point of round grove of trees ( 12 inches diameter) ...... 217 50 $\ldots \ldots$ I00 yards.

White oak tree abreast of station ( 2 feet di-

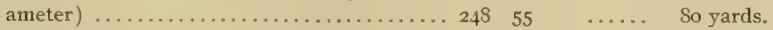

REFERENCE STATION ................ $274 \quad 4740 \ldots \ldots 6.36$ meters.

Peak of small white shanty ............. 342 o9 $\quad \ldots \ldots .3 / 4$ mile.

South peak of yellow house back of Horseshoe

Point ................. $1 / 2$ miles.

NUT.

Locality. -Western shore of bay, about 3/4 miles northeast of mouth of Broadwater Creek. (See (hart No. 4.)

Observed station is on low marshy point, about 50 feet west of its extreme eastern end. A large brick house stands on edge of woods, about 1/ mile northwest of station. Cement monument marking reference station is 13.40 meters northwest of observed station. 
Marks.-Observed station is a nail in a pine stub flush with ground. Reference station is center point of triangle on standard cement monument.

References.-

"Franklin" ( $\left.\mathrm{N} 33^{\circ} 37^{\prime} \mathrm{E}\right) \ldots \ldots \ldots \ldots \ldots \ldots$

Peak of white barn on south side Broadwater

Creek ............................ $x^{1 / 2}$ miles.

REFERENCE STATION................. 260 28 10 .... I3.40 meters.

North chimney of brick house $\ldots \ldots \ldots \ldots \ldots 273 \quad 46 \ldots \ldots$ 1/4 mile.

East peak of old barn................ $330 \quad 4 \mathrm{I} \ldots \ldots .3 / 4$ mile,

East tangent to grove on Franklin Point... 359 o0 . . . . 1 1/4 miles.

BROAD.

Locality. - Western shore of bay, on south side of entrance to Broadwater Creek, on the extreme north end of a narrow neck of land between the creek and the bay. (See Chart No. 4.)

Observed station is about 25 feet back from edge of bank 4 feet high. A number of cedar trees stand 20 yards northwest of station. Cement monument marking reference station is 13.29 meters northwest of observed station.

Marks.-Observed station is a nail in a pine stub fiush with ground. Reference station is center point of triangle on standard cement monument.

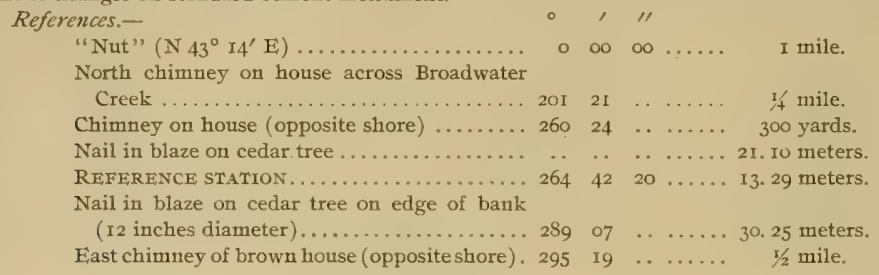

\section{PARKER.}

Locality.-Western shore of bay, on north side of entrance to Herring Bay. (See Chart No. 4.) Observed station is on a small detached sand island south of Parker Island, about 25 yards from the extreme south end and just above high-water mark. Cement monument marking reference station is 5.57 meters north of observed station.

Marks.-Observed station is a nail in a pine stub flush with ground. Reference station is center point of triangle on standard cement monument.

References.-

"Fairhaven" ( $\left.47^{\circ} \mathrm{xI}^{\prime} \mathrm{W}\right) \ldots \ldots \ldots \ldots \ldots .$.

Chimney on white house..................

Chimney on small house.................

West chimney on small white house.........

West chimney on red-roof house

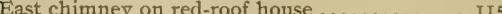

REFERENCE STATION................ I32 30 IO .... 5.57 meters.

\section{HOPKINS.}

Locality.-North side of Herring Bay, on east side of entrance to Herring Creek and about $I \mathrm{I} / 2$ miles north by west of Fairhaven Wharf. (See Chart No. 4.)

Observed station is 2 feet above and I5 feet back from high-water mark, and is nearly on line with south face of house standing just east of station. Cement monument marking reference station is 5. I5 meters northwest of observed station. 
Marks.-Observed station is a nail in a stub flush with ground. Reference station is center point of triangle on standard cement monument.

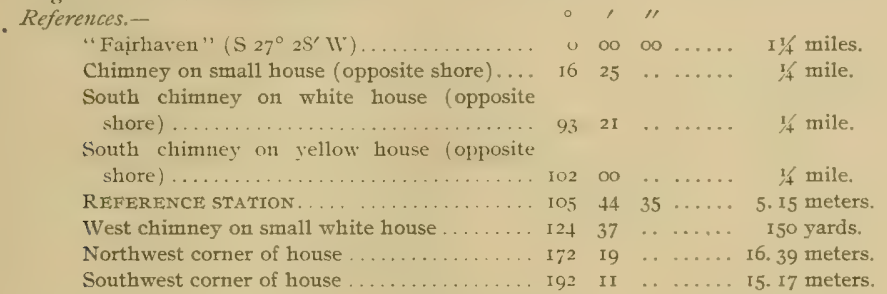

\section{FAIRHAVEN.}

Locality.-IVestern shore of Herring Bay on prominent bold hill about $1 /$ mile back from shore and $3 / 4$ mile west by north of Fairhaven wharf. (See Chart No. 4.)

Observed station is about 25 yards south of a lone chestnut tree 3 feet in diameter and about 100 yards north of highway to Friendship. Cement monument marking reference station is $6.0 \mathrm{~S}$ meters north of observed station.

Mlarks.-Observed station is the center of a 4 -inch tile pipe with top 8 inches below the surface. Reference station is center point of triangle on standard cement monument.

References.-

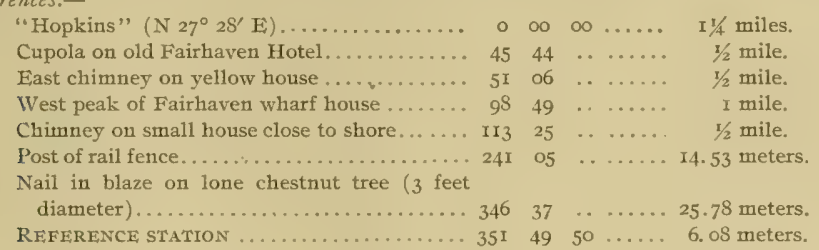

\section{HOLLAND.}

Locality.-Western shore of bay on south side of entrance to Herring Bay about 30 yards west of Holland Point. (See Chart No. 4.)

Observed station is 5 feet back from top of a bank 7 feet high. Two large blazed trees stand south and west of station at distance 12 and 25 yards respectively. Cement monument marking reference station is I2.SS meters southwest of observed station.

Marks,-Observed station is a nail in a pine stub flush with ground. Reference station is center point of triangle on standard cement monument.

References.-

"Fairhaven" ( $\mathrm{N}_{4} 8^{\circ}, \mathrm{r}^{\prime}$ ' W $) \ldots \ldots \ldots \ldots \ldots$

Nail in blaze on red oak tree $\left(2 \frac{1}{2}\right.$ feet

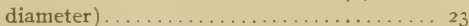

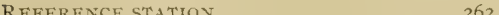

Nail in blaze on red oak tree $(2 \pi / 2$ feet

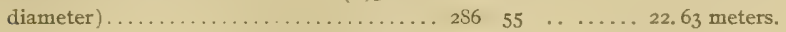




\section{REPOR'T OF THE WORK OF THE COAST AND GEODETIC SURVEY.}

\section{INSTRUCTIONS.}

The two following letters, together with the laws ${ }^{a}$ of , the United States relating to the subject, constitute the "instructions" of the representative of the Survey. They are short and definite, but furnish ample authority and leeway for all legitimate development of the cooperation of the Government and the State in the survey of natural oyster bars. The "free hand" permitted by these orders proved very beneficial and was greatly appreciated.

\section{DEPARTMENT OF COMMERCE AND LABOR, OFFICE OF THE SECRETARY, Washington, June 2, 1906.}

SiR: In reply to your letter of May 28, requesting me to designate officers of the Coast and Geodetic Survey and of the Bureau of Fisheries to cooperate with the State of Maryland in making survey of and locating the natural oyster beds, I have the honor to inform you that Mr. C. C. Yates will be designated to cooperate on the part of the Coast and Geodetic Survey as soon as Congress makes the provisions of the act effective by providing an appropriation for the purpose. Respectfully,

His Excellency Hon. EDWIN WARFIELD,

LAWRENCE, O. MURRAy, Assistant Secretary.

Governor of Maryland, Annapolis, Mr.

\section{DEPARTMENT OF COMMERCE AND LABOR, COAST AND GeODETIC SURVEy, Washington, July 3, 1906.}

SIR: Upon the receipt of these instructions you will surrender the command, accounts, etc., of the steamer Endeazor to the Hydrographic Inspector. * * *

As soon as this transfer is completed you will enter upon the duties of Coast Survey representative on the Shell Fish Commission of Maryland.

You will consult the commissioners, prepare a programme of work, and submit estimates in the usual form.

You are authorized to come to Washington for consultation from time to time as may be necessary.

Very respectfully,

Capt. C. C. YATES,

O. H. Trtmiann, Superintendent.

U.S. C. and G. S. Steamer "Endeazor," Baltimore, Mld.

$$
\text { HOUSE BOAT "OYSTER." }
$$

While arranging to turn over the command of the steamer Endeavor, the representative of the Survey, acting under preliminary instructions from the Superintendent, was engaged in frequent consultation with the Shell Fish Commissioners in reference to the programme of future work. In addition to these duties, he undertook for the commissioners the planuing and supervision necessary to convert the old side-wheel steamer Thomas L. Worthley into a house buat for the surveying parties of both the Commission and the Government. 
The Worthley, now called the house boat Oyster, was in excellent condition when purchased by the Commission. The keelsons and timbers were sound and the upper works strong. After the removal of the old engine and boiler, the house boat was docked and her hull thoroughly examined. The outside planking below the water line was found in good condition, and although it was recalked, it was done as an additional precaution, the hull having been absolutely water-tight from the day of purchase.

The Oyster is about I 35 feet over all and 35 feet in beam. The main deck contains living quarters for $27 \mathrm{men}$, the officers mess room and the galley. The upper deck has I I staterooms, 5 for the 3 commissioners and their 2 hydrographic engineers, 4 for the Coast Survey officers, I for the representative of the U. S. Bureau of Fisheries, and I for the local county oyster commissioner. Besides these rooms, there are located on this deck a large drafting room, a laboratory for oyster investigations, and an office room. Coal for the two Government launches and the galley is stored in the hold, which also contains fresh-water tanks having a capacity of about 7,000 gallons. Signal lumber is carried on the main deck aft of the officers' mess room.

As a whole, the Oyster is plainly and practically equipped for the work to be done. She has added much to the amount of the surveying accomplished during the season, and the Coast and Geodetic Survey representative greatly appreciates the practical advantages furnished to his party by their quarters on the house boat. When the large party of the combined surveying forces is taken into consideration with the limited accommodations usually obtainable on shore, the attending difficulties of a scattered party, the uncertain location and supply of coal and water for launches and sufficient lumber for signals, it is easily to be seen that the amount of work accomplished would have been reduced greatly, if there had been no such house boat as the Oyster to supply all requirements of the surveying operations.

With reasonable care and repairs, the Oyster will be a valuable asset to the Commission at the completion of the oyster survey of the State, besides having paid her first cost several times over in both quality and quantity of work accomplished.

\section{ORGANIZATION AND EQUIPMENT.}

The command of the Endeavor was turned over to the hydrographic inspector July 9, I9o6, and from that date to the commencement of active field work the Survey representative was engaged on organization of party, collection of surveying data, general supervision of the construction of the house boat, and preparation of field equipment.

Some delay was experienced in completing repairs to the Survey steam launch Inspector, and by the difficulties of obtaining surveying assistants who were qualified to receive an appointment under civil-service rules. In fact, the last field assistant did not take his oath of office until the middle of October.

The field organization of the party, when fully completed, remained the same during the season, and was as follows:

C. C. Yates, assistant, Coast and Geodetic Survey, and chief of party.

E. A. Borst, triangulator.

N. L. Arbuckle, topographic draftsman.

F. W. Seth, surveyman and computer.

One launch coxswain.

One launch engineer.

Five seamen and hands. 
Later two additional draftsmen, J. D. Torrey and G. C. Moore, were appointed and assigned to duty in the office in Washington, where they were employed on the preparation for publication of the charts of natural oyster bars, making in all a party of six officers from the Coast and Geodetic Survey engaged on the work. During the last weeks of the field work, Mr. Paul C. Whitney, assistant, Coast and Geodetic Survey, was assigned to temporary duty in the party in place of Mr. E. A. Borst, who resigned.

The equipment of the party, in addition to the quarters and accommodations on the house boat Oyster, consisted of the large Coast and Geodetic Survey steam launch Inspector, an excellent whaleboat, a large ship's cutter, and a fishing dory. The Survey also furnished a complete outfit of theodolites, levels, sextants, and other instruments necessary for the work of the Government and State surveying parties, and the usual outfit of tools, sails and oars, stationery, etc.

\section{FIELD WORK.}

The launch Inspector and outfit were moved to Annapolis on August 10, I906, on which date the actual field work of the Coast and Geodetic Survey party commenced.

Previous to this time a number of signals had been erected over old Coast and Geodetic Survey triangulation stations on the Severn River by the hydrographic engineer of the Commission. By using the triangulation so established, considerable oyster bar location was accomplished.

After the arrival of the Coast Survey party, the erection of signals and the observations of horizontal angles necessary to establish a framework of triangulation were kept well ahead of the oyster bar locations and other oyster investigations.

The methods of triangulation were those established by the Coast and Geodetic Survey and require no explanation other than that given by the publications of the Survey.

In all there are 123 triangulation stations involved in the survey of Anne Arundel County natural oyster bars. These stations are scattered along the western shore line of the bay from Fort Carroll to Holland Point, and are located at intervals frequently less than a half and rarely more than a mile apart. The triangulation was carried on with energy and good judgment, but the scattered condition of the work, composed of a mixture of new and old stations, increased the number of observations without the usual proportionate increase in number of new stations established.

After the appointment of a topographic draftsman on September I9, all boat sheets for both the hydrographic and oyster investigation parties were prepared and much other drafting work was done to facilitate the operations of the commissioners. Besides this work, the draftsman cliecked the computations and kept up the smooth projections as far as the new field work permitted.

Considerable difficulty was experienced in bringing up the computations to the immediate requirements of the work, especially in West River and to the south along the shore of the bay, where practically all old triangulation stations had been washed away. This situation was much relieved by the appointment of a surveyman on October 15. who had received some training in the computing division of the Survey at Washington. 
The operations in the vicinity of Severn and South rivers were completed September I3, when the house boat Oyster was moved to West River. Up to this time the party had lived on shore and suffered many of the resulting inconveniences and delays due to scattered lodgings, uncertain meal hours, etc. The advantages of the hotise boat were immediately shown in the results, and in spite of much bad weather the work in the vicinity of West River was completed and the Oyster moved to Magothy River on November 9. Here the house boat remained until the end of the month, when she was moved to Bodkin Creek. On December 9 the main body of the field work for the season was completed and the Oyster went to Annapolis for the winter. Quarters were taken up on shore, the parties reduced in number; and offices established in the state house.

During the following winter the unfinished ends of triangulation, construction and planting of permanent monuments, and new descriptions of stations, occupied about a third of the time of the triangulator.

Besides the training and assistance required by an entirely new organization, and the systematizing of a new class of work, the representative of the Coast and Geodetic Survey devoted much time and took much interest in the work of the Commission in general as affecting both the surveying and other operations of the oyster-culture laws of Maryland.

\section{OFFICE WORK.}

After October I5, a greater part of the original computations were made by the strveyman of the party and were checked by the triangulator and the topographic draftsman. This work included the computations of 166 triangles, 67 geodetic positions, and 1,083 back comptations of geodetic positions required for the technical descriptions of the boundaries of natural oyster bars. These computations, together with the making out of the abstract of horizontal angles, the lists of geographic positions, the lists of directions, and the reduction to center for 8 eccentric stations, make up a creditable amount of computation for the short season's work.

The drafting consisted of the preparation of nearly all boat sheets used by the hydrographic and oyster-investigation parties, the construction of 9 projection sheets, and the plotting of 2,596 sextant positions on the projections. Besides this drafting, the progress map was prepared for the lithographer, the boundaries of gi natural oyster bars were plotted on the projections, the geographic positions of 361 corners of bars were scaled off the sheets, and $I, 083$ distances to landmarks from corners of bars taken off the projections for use in checking computations. This work was done neatly and accurately, and represents a larger amount of labor than this statement would indicate.

The great amount of necessary work required to prepare for publication the 4 large scale charts of the natural oyster bars and the report containing the description of boundaries and landmarks to accompany charts, can be seen from an inspection of the charts and reports.

\section{SUMMARY.}

The results obtained from the work of the Coast and Geodetic Survey in cooperation with the Maryland Shell Fish Commission need no other summary than is indicated by the published charts of the natural oyster bars and the scheme of $330-07-\mathrm{I}_{3}$ 
projections and triangulation shown on the progress map at the end of this report.

The work completed will stand the test of time, and it will be recognized ultimately that both time and money have been saved by having the work done systematically and accurately.

The geographic positions of the permanent landmarks and signals have been determined with the usual precision of a trigonometric survey, and their locations at all points necessary to provide ample foundation for the surveying and charting operations permitted great accuracy of definition and location for the natural oyster bar and other boundaries established. At the same time, the very important element of permanency of the positions of boundaries has been secured, as the relocation of geodetic positions can always be accomplished by a competent surveyor, even though the original landmarks and monuments have been washed away, as has been the fate of hundreds of such points established by the Coast and Geodetic Survey on the shores of the Chesapeake Bay during the last sixty-five years.

Before ending this report the representative of the Coast and Geodetic Survey deems it both desirable and natural to make a statement of appreciation of the ever courteous actions of everyone connected with the Maryland Shell Fish Commission ${ }^{a}$ and of his colleague ${ }^{b}$ from the Department of Commerce and Labor. This excellent relationship made true cooperation possible and aided greatly in the successful accomplishment of much work.

a Walter J. Mitchell, chairman, Dr. Caswell Grave, secretary, Benjamin K. Green, treasurer, commissioners; Thomas H. Robinson, counsel; Swepson Earle, hydrographic engineer; W. Gibson Emory, assistant engineer; Joseph E. Smith, local oyster commissioner for Anne Arundel County; H. Courtney Jenifer, chief clerk; Samuel A. Harper, clerk; Ernest Reppenhagen, draftsman.

$b$ Dr. H. F. Moore, scientific assistant in the U. S. Bureau of Fisheries. 




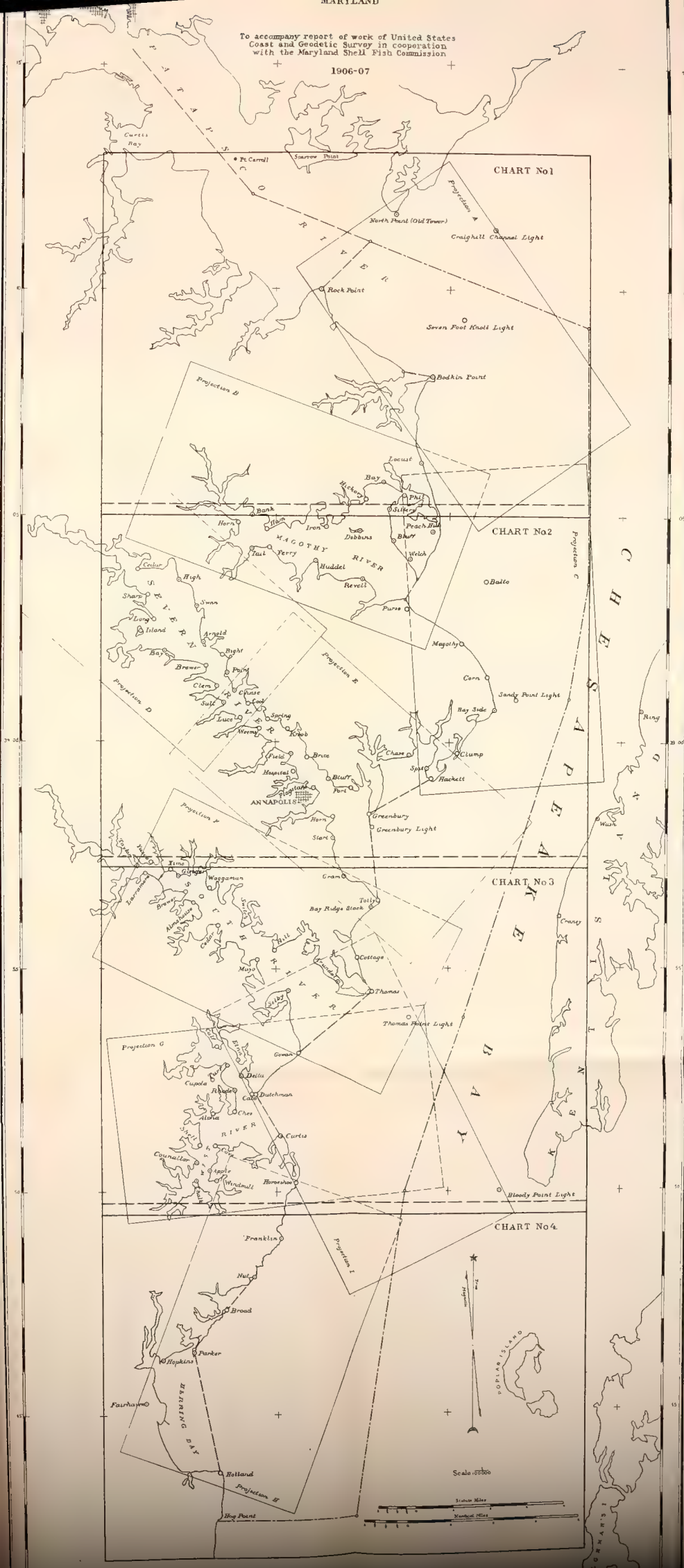





DEPARTMENT OF COMMERCE AND LABOR

COAST AND GEODETIC SURVEY

O. H. TITTMANN, Superintendent

\section{SURVEY OF OYSTER BARS BALTIMORE COUNTY MARYLAND}

DESCRIPTION OF BOUNDARIES AND LANDMARKS AND REPORT OF WORK OF UNITED STATES COAST

AND GEODETIC SURVEY IN COOPERATION

WITH UNITED STATES BUREAU OF

FISHERIES AND MARYLAND

SHELL FISH COMMISSION

By C. C. YATES

CHIEF OF COAST AND GEODETIC SURVEY PARTY

ASSISTANT, COAST AND GEODETIC SURVEY

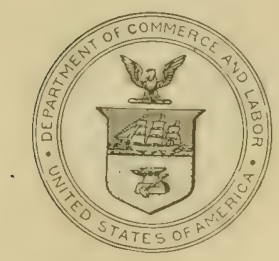

WASHINGTON

GOVERNMENT PRINTING OFFICE

เมี 



\title{
LETT'TER OF SUBMITTAL.
}

\author{
DEPARTMENT OF COMMERCE AND LABOR, \\ COAST AND GeOdetic SURVEY, \\ Washington, August IO, IOII.
}

SIR: I have the honor to transmit herewith a report of the officer detailed from the Coast and Geodetic Survey to cooperate with the Bureau of Fisheries and the Maryland Shell Fish Commission in surveying the oyster bars of the State of Maryland, together with certain technical results which are necessary for the interpretation and use of the plats of the survey made by the Government.

This work has been done under the provisions of the act of Congress entitled "An act to authorize the Secretary of Commerce and Labor to cooperate, through the Burcau of the Coast and Geodetic Survey and the Bureau of Fisheries, with the shell fish commissioners of the State of Maryland in making surveys of the natural oyster beds, bars, and rocks in the waters within the State of Maryland," approved May 26, I906, and of the acts of Congress making appropriations for sundry civil expenses of the Government for the fiscal years ending June 30, 1907, 1908, 1909, 1910, 191 r, and 1912.

Respectfully,

To Hon. Charles Nagel,

O. H. Tirmmann, Superintendent.

Secretary of Commerce and Labor. 



\section{CERTIFICA TION.}

Baltimore, MD., August io, rgit.

The following publication is certified to contain correct technical descriptions of all boundaries and landmarks established in Baltimore County by the Naryland Shell Fish Commission in cooperation with the United States Coast and Geodetic Survey.

$$
\text { C. C. Yates, }
$$

Chief of Coast and Geodetic Survey Party, Assistant, Coast and Geodetic Survey.

Examined and certified to be correct.

BALTIMORE, MD., August io, IgII.

$$
\begin{aligned}
& \text { WALTER J. MITChell, } \\
& \text { Casweli, Grave, } \\
& \text { Benjamin K. GREEN, } \\
& \text { Maryland Shell Fish Commission. } \\
& \text { SWEPSON EARLE, } \\
& \text { Hydrographic Engineer. }
\end{aligned}
$$

NOTE.-Certified copies of this publication and of the charts of the natural oyster bars of Baltimore County were filed in the office of the clerk of the circuit court of Baltimore County and in the office of the board of shell fish commissioners on August IO, I II I. 



\section{CONTENTS.}

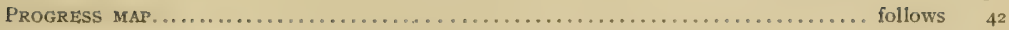

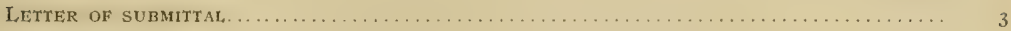

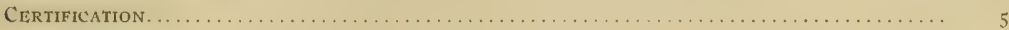

\section{INTRODUCTION:}

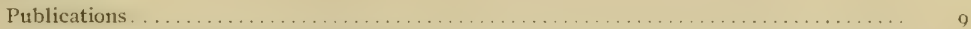

Cooperation of the Coast and Goedetic Survey . . . . . . . . .

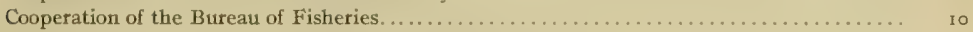

General statement of work of Coast and Geodetic Survey..................... 10

REPORT OF THE WORK OF THE COAST AND GEODETIC SURVEY:

Instructions.

Organization and equipment.

Chronological statement of work.

Statistics. . .

General remarks.

CIIARTS AND MAPS:

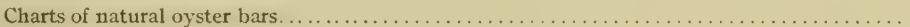

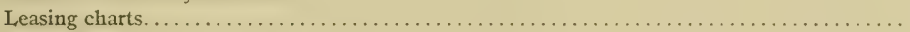

Projections. . . . . . . . . . . . . .

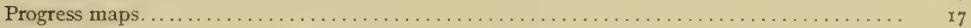

BOUNDARIES OF THE COUNTY WATERS:

Waters within territorial limits of county . . . . . .

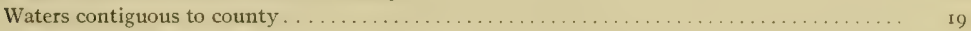

LANDMARKS (U. S. COAST AND GEODETIC SURVEY TRIANGULATION STATIONS):

Explanation

Method of describing triangulation stations.

Descriptions of triangulation stations in county and adjacent waters-

Chart No. 27 (Chesapeake Bay between Patapsco River and Pooles Island) -

Pooles Island Light.

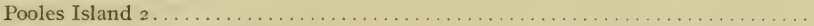

Worton Point 2 (see Progress map) . . . . . . . . . . . . . . . . . . . .

Bramble (see Progress map).

Mitchells Bluff 2 (see Progress map).

Craighill Channel Light (Rear Range)

Craighill Channel Light (Front Range). .

North Point (Old Tower Foundation)

Fort Howard Taller Water Tank . . . . . . . . . . . . . . . . . . . . .

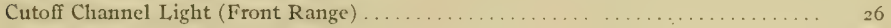

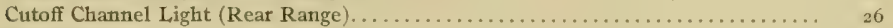

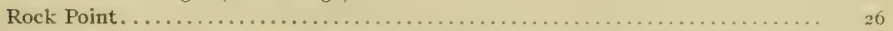

Bodkin Point (Old Tower) (sce Progress map) . . . . . . . . . . . . . . . . . . 27

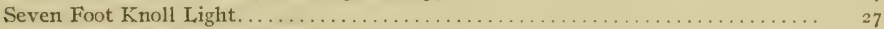

Swan Point 3 (sce Progress map) ............................... $\quad 27$ 
BOUNDARIES OF OYSTER BARS:

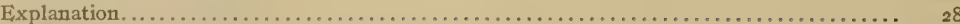

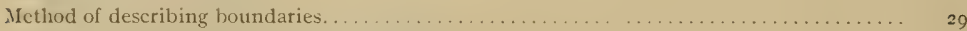

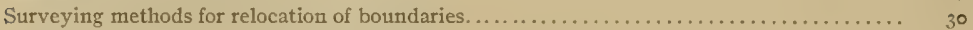

Boundaries of natural oyster bars in county-

Chart No. 27 (Chesapeake Bay) -

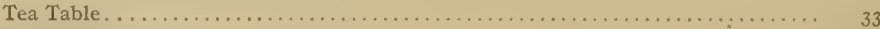

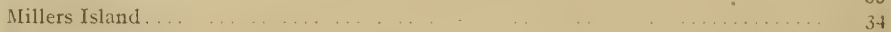

Man $\mathrm{O}^{\prime} \mathrm{War}$ Shoals. . . . . . . . . . . 34

APPENDIXES:

Appendix A.-Laws relating to the cooperation of the Coast and Geodetic Survey and Bureau of Fisheries with the Maryland Shell Fish Commission.

Appendix B.- "The Haman Oyster Culture Law" (extract from Second Report of Shell Fish Commission).

Appendix C.-Summary of the particular surveying operations which constitute an "oyster survey" as now being carried on in Maryland

Appendix D.-Statistics of results of the combined operations of the Government and State. . 


\title{
SURVEY OF OYSTER BARS, BAL'TIMORE COUN'TY, MD.
}

\section{INTRODUCTION.}

\author{
PUBL,ICATIONS.
}

The preparation of publications relating to the survey of the oyster bars of Maryland has been divided between the Government and the State in accordance with the laws ${ }^{1}$ authorizing the work and the natural division of the surveying operations ${ }^{2}$ of the cooperating forces.

The publications prepared and issued by the Government under the direction of the Superintendent of the Coast and Geodetic Survey consists of a series of charts and a technical report for each county surveyed. ${ }^{3}$ The charts show all legal boundaries of oyster bars within the adopted boundaries of the waters opened up for leasing with each county, and the location of all landmarks (Coast and Geodetic Survey triangulation stations) used as a foumdation for the delineation of these various boundaries. The technical report gives technical and legal description of all oyster bar and other boundaries, and descriptions of all landmarks shown on the charts, and includes the report of the representative of the Coast and Geodetic Survey in charge of the work of that service in cooperation with the Bureau of Fisheries and the Maryland Shell Fish Commission. These charts and technical reports are prepared and certified for file with the courts and the commission, as required by the laws of the State, and contain all information necessary to make a permanent record of the work of the commission and the Government for all future requirements of the courts, or for any resurveys that may become necessary. ${ }^{4}$

The publications prepared and issued by the State under the direction of the Shell Fish Commission consist of annual reports ${ }^{5}$ of all the operations of the commission performed under the provisions of the laws of Maryland, ${ }^{8}$ including results of biological

\footnotetext{
1 See Appendix A for laws relating to the cooperation of the Coast and Geodetic Survey and Bureau of Fisheries with the Maryland Shell Fish Commission.

"See Appendix C for a summary of the particular surveying operations wnich constitute an "oyster survey" as now being cartied on in Maryland,

3 These charts and technical reports can be obtained by application to the Superintendent of the Coast and Geodetic Survey at Washington, D.C. The publications now ready for issue are those for Anne Arundel, Somerset, Wicomico, Worcester, Calvert, Charles, St. Marys, and Baltimore Counties.

"The technical records and charts for each county are published separately on account of the requiremrats of the oyster" culture laws of the State and the practical considerations ivhich make it desirable to have each county "opened up" for oyster culture as soon as practicableafter the completion of itssurvey. For these reasons and thefact that these reports are each arranged for distribution and use in one county only without reference to other published records, much of the text of this publication is of necessity identical with similar previous pu" : zations for other counties.

"These reports can be obtained by application to tt S.jell Fish Commission, Mrarine Bank Building, Baltimore, Md. They are issued annually in October, and the first and secon 1 reports are now available for distribution.

"See Appendix B for an extract from the "Second Report of the Maryland Shell Fish Commission," giving a concise sum. mary of the "Haman oyster-culture law,"
} 
and economic oyster investigations, methods and results of the hydrographic survey of the boundaries of oyster bars and crab bottoms, the administrative report and financial statement of the commission, information relating to oyster culture, methods of surveying and leasing of oyster lots, and much other important matter of legal and scientific value.

These two sets of publications are planned and arranged to supplement each other without unnecessary duplication, and when combined they form a complete report of operations, methods, and results of the work of both the Government and State. ${ }^{1}$

\section{COOPERATION OF THE COAST AND GEODETIC SURVEY.}

The work of the Coast and Geodetic Survey, as the name of the service indicates, includes a survey of the coasts of the United States made on a geodetic basis. This has involved the gradual construction of a great framework of interstate triangulation for use as a foundation for detail hydrographic and topographic surveys, from which there has been compiled and published a complete set of charts of the coasts of the United States, including all waters of Maryland where oysters grow. This existing triangulation, hydrography, and topography is essential as a foundation for a correct and practical survey of natural oyster bars; and it being one of the fundamental functions of the Coast and Geodetic Survey to furnish such data, the cooperation of the Coast and Geodetic Survey with the Bureau of Fisheries and the Maryland Shell Fish Commission is a practical and natural development of Government work leading to the conservation and increase of the supply of food.

\section{COOPERATION OF THE BUREAU OF FISHERIES.}

The Bureau of Fisheries has cooperated with the Coast and Geodetic Survey and the Maryland Shell Fish Commission principally as an adviser in matters relating to the biological and economic survey of oyster bars and the methods to be employed for that purpose. ${ }^{2}$ A steam launch, rowing boat, and certain apparatus have also been furnished.

The primary function of the Bureau of Fisheries is to increase the productiveness of marine and fresh waters by such measures as may be best suited to the purpose, and the services rendered in connection with the survey of the oyster bars of Maryland are strictly in line with the fundamental law under which it acts. In certain States other than Maryland similar work has been conducted by the bureau acting independently, the same ends being attained at greater expense to the Government.

\section{GENERAL STATEMENT OF WORK OF COAST AND GEODETIC SURVEY. ${ }^{3}$}

The results obtained from the work of the Coast and Geodetic Survey in cooperation with the Bureat of Fisheries and the Maryland Shell Fish Commission need very little other summary than is indicated by the published "Charts of Natural Oyster Bars" and the index of hydrographic projections and triangulation stations slown on the county progress maps attached to each report.

\footnotetext{
1 See Appendix D of this publication for "Statistics of results of combined operations of the Government and State."

2 Hon. George M. Bowers, Commissioner of Fisheries, has detailed for this service Dr. H. F. Moore, Assistant, Bureau of Fisheries,

${ }^{8}$ For a detail statement of the very large amount of excellent oyster-survey work of the Maryland Shell Fish Commission see the "Annual Reports of the Maryland Shell Fish Commission."
} 
The triangulation has been carried on in accordance with the standard metlods of the Coast and Geodetic Survey, making this work and that of the "Descriptions of Triangulation Stations" of permanent value, not only to the State of Maryland in the survey of her oyster bars but also to the Government for any future work it may do in the regions covered by the oyster-survey operations.

The hydrographic projections and published charts are prepared with all the accuracy permitted by their large scale, especially as to the boundaries of the various shell-fish bottoms in relation to landmarks, but this accuracy of location on the charts is further added to and permanently fixed by published technical descriptions which should minimize the probahility of any future dispute as to cither landmarks or boundaries.

Stated another way, and quoting from the report of the "Survey of Oyster Bars of Anne Arundel County":

The geographic positions of the permanent landmarks and signals have been determined with the usual precision of a trigonometric survey, and their locations at all points necessary to provide ample foundation for the surveying and charting operations permitted great accuracy of definition and location for the natural oyster-bar and other boundaries established. At the same time, the very important element of permanency of the positions of boundaries has been secured, as the relocation of geodetic positions can always be accomplished by a competent surveyor, even though the original landmarks and monuments have been washed away, as has been the fate of hundreds of such points established by the Coast and Geodetic Survey on the shores of the Chesapeake Bay during the last 65 years. 


\section{REPORT OF THE WORK OF THE COAST AND GEODETIC SURVEY IN BALTIMORE COUNTY.}

\section{INSTRUCTIONS.}

The following letters, together with the laws ${ }^{1}$ of the United States relating to the subject, constitute the "instructions" received by the chief of the Coast and Geodetic Survey party engaged on work in connection with the Maryland Shell Fish Commission. They are short and definite, but furnish ample authority and leeway for all legitimate development of the cooperation of the Government and the State in the survey of oyster bars. The "free hand" permitted by these orders, together with the aid and many valuable suggestions received from the officers of the survey at Washington, have proved very beneficial to the work and are greatly appreciated:

\section{DEPARTMENT OF COMMERCE AND LABOR, OFFICE OF THE SECRETARY, Washington, June 2, 1906.}

SiR: In reply to your letter of May 28, requesting me to designate officers of the Coast and Geodetic Survey and of the Bureat of Fisheries to cooperate with the State of Maryland in making survey of and locating the natural oyster beds, I have the honor to inform you that Mr. C. C. Yates will be designated to cooperate on the part of the Coast and Geodetic Survey as soon as Congress makes the provisions of the act effective by providing an appropriation for the purpose.

Respectfully,

His Fxcellency Hon. EDWIN WARFIELD,

LaWrence O. Murray, Assistant Secretary. Governor of Maryland, Annapalis, Md.

\section{DEPARTMENT OF COMMERCE AND LABOR, Coast and Geodetic Survey, Washington, July 3, Igo6.}

SrR: Upon the receipt of these instructions you will surrender the command, accounts, etc., of the steamer Endeavor to the Hydrographic Inspector * * *

As soon as this transfer is completed you will enter upon the duties of Coast Survey representative on the Shell Fish Commission of Maryland.

You will consult the Commissioners, prepare a program of work, and submit estimates in the usual form.

You are authorized to come to Washington for consultation from time to time as may be necessary. Very respectfully,

O. H. TrTmanN, Superintendent.

Capt. C. C. Yates,

U.S. C. \& G. S. Steamer "Endeavor," Baltimore, Md.

\section{ORGANIZATION AND EQUIPMENT.}

The personnel and occupation of the party of the Coast and Geodetic Survey have remained practically unchanged since the beginning of the "oyster survey." Besides

\footnotetext{
1 For these laws see Appendix A.
} 
the chief of party, it consists of the necessary triangulators, computers, draftsmen, and temporary employees required to carry on both the surveying operations in the field and the preparation for publication of oyster charts and technical records in the office at Washington.

The equipment for the work of the party has been ample and satisfactory. The large living and office quarters furnished the Government on the Maryland Shell Fish Commission house boat Oyster have been very convenient for the work, besides facilitating efficient cooperation with the survering and oyster investigation parties of the State. In addition to the accommodations on the Oyster, the Coast and Geodetic Survey party has had the constant use of the large steam launch Inspector and several other boats furnished by its own service, and the occasional use of the Bureau of Fisheries launch Canvasback ${ }^{1}$ and the steamer Governor $M c$ Lane $^{2}$ of the State fishery force.

The greater part of the equipment of instruments for the operations of both the Government and State has been furnished by the Coast and Geodetic Survey and consists of all necessary theodolites, lerels, sextants, drafting instruments, hydrometers, etc., required for all field and office work.

\section{CHRONOLOGICAL STATEMENT OF WORK.}

The field work of the Coast and Geodetic Survey in Baltimore County ${ }^{3}$ dates from April 14, I 909 , when the Maryland Shell Fish Commission house boat $O_{y}$ 'ster was moved from her winter quarters in Baltimore to an anchorage of Rock IJall Ianding in Kent County. The surveying operations carried on from this harbor covered a period of about six weeks, when practically all the triangulation of the Chesapeake Bay shores of both Baltimore and Kent Counties was completed.

On May 26, I909, the Oyster was moved from Rock Hall Landing to near Cliffs Landing in the upper part of Chester River, and no further work was done in Baltimore County from that date to July 22, 1909, when the anchorage of the Oyster was changed back to Rock Hall to complete some unfinished details of the oyster survey work in that vicinity.

On August 5, 1909, the house boat was again moved, this time to Worton Creek, the extreme northern limit of oyster growth in Chesapeake Bay. From this harbor all the remaining oyster survey work of the Coast and Geodetic Survey in both Baltimore and Kent Counties was completed, although some weeks later a party of the Maryland Shell Fish Commission returned to finish certain oyster invest igations and hydrographic observations in these waters.

The office work connected with the oyster survey of Baltimore County, including compilations and drafting necessary for the preparation for publication of the oyster charts and the technical records, was continued intermittingly with the office work of other counties from the beginning of the field work in Baltimore County to the time of filing of the certified oyster charts and technical reports in the archives of the Commission and with the clerk of the circuit court of Baltimore County on August ro, Igr I.

\footnotetext{
1 By courtesy of Dr, H. F, Moore, United States Bureau of Fisheries.

2 By courtesy of Capt. James A. Tumer, commanding.

3 The field work of Baltimore and Kent Counties was so intermixed in Chesapeake Bay that the chronological statement of work for one of these counties necessarily includes a considerable part of the work of the other county.
} 


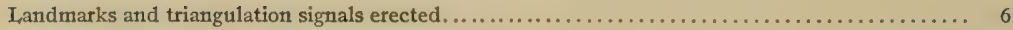

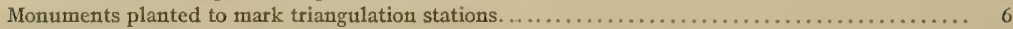

Triangulation stations occupied for observations of horizontal angles. . . . . . . . . . . . . . . . 3

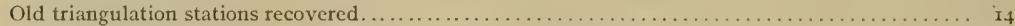

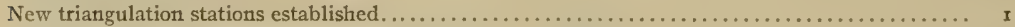

Total old and new triangulation stations marked and described $\ldots \ldots \ldots \ldots \ldots \ldots \ldots \ldots \ldots \ldots \ldots \ldots$

Linear miles of shore line covered by triangulation (approximate) $\ldots \ldots \ldots \ldots \ldots \ldots \ldots \ldots \ldots \ldots \ldots \ldots$

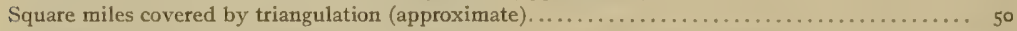

Hydrographic projections prepared and completed as records of oyster boundaries............. 4

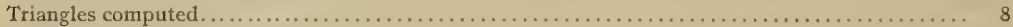

Greographic positions computed . . . . . . . . . . .

Corners of oyster boundaries established by computation $\ldots \ldots \ldots \ldots \ldots \ldots \ldots \ldots \ldots \ldots \ldots \ldots \ldots \ldots \ldots$

Back azimuths and distances computed from corners of boundaries to triangulation stations..... 39

Descriptions of triangulation stations prepared for publication $\ldots \ldots \ldots \ldots \ldots \ldots \ldots \ldots \ldots \ldots \ldots \ldots \ldots$

Descriptions of oyster boundaries prepared for publication. . . . . . . . . . . . . . . . . . 3

"Charts of Natural Oyster Bars" prepared for publication. . . . . . . . . . . . . . . . . . . I

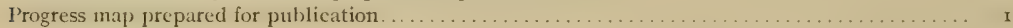

\section{GENERAL, REMARKS.}

Before ending this report the representative of the Coast and Geodetic Survey wishes to renew his statement of appreciation of the courteous assistance received from various Government and State officials and others interested in the oyster industry of Maryland, especially to the following:

To his colleague from the Department of Commerce and Labor, Dr. H. F. Moore, of the Burcau of Fisheries, whose well-known scientific knowledge of all matters relating to ovsters has been of great value to the work.

To Mr. Walter J. Mitchell, chairman of the Maryland Shell Fish Commission, who, by his administrative ability in carrving out the complicated requirements of the oyster laws and by his unfailing tact, has made the cooperation of the various services engaged on the work both agreeable and effective.

To Dr. Caswell Grave, secretary of the commission, who, as editor of the commission's annual report and commissioner in charge of the biological and economic oyster investigations, has been brought into constant contact with the Government work and aided its operations in every way.

To Mr. Benjamin K. Green, treasurer of the commission, who has looked after the equipment and commissary of the house boat in such a way as to add greatly to the comfort and convenience of the party of the Coast and Geodetic Survey.

To Mr. Swepson Earle, hydrographic engineer to the commission, whose knowledge of the work from former service in the Coast and Geodetic Survey has greatly facilitated his practical use of the technical data furnished by the Government.

And to the many others connected with the commission or who as residents in the locality where the work was being carried on have greatly assisted by furnishing important information or willing services.

\footnotetext{
I These statistics only include field and office work directly performed by the party of the Coast and Geodetic Survey in connection with the oyster survey of Baltimore County, and do not include the many thousands of soundings and examinations of the character of the bottom made by the engineers of the commission, which are of considerable value to the Coast and Geodetic Survey as hydrographic records for future use in connection with the preparation of new editions of charts of the waters of Maryland. See Appendix D of this publication for "Statistics of results of combined operations of the Government and the State."
} 


\section{CHARTS AND MAPS. ${ }^{1}$}

\section{CHARTS OF NATURAL OYSTER BARS.}

The chart of the natural oyster bars of Baltimore County, published by the Coast and Geodetic Survey from results of surveys of the Government in cooperation with the Maryland Shell Fish Commission, covers that portion of the upper Chesapeake Bay and tributaries in Baltimore County in which the waters are sufficiently salt for the growth of oysters. This chart is published on a scale of I part in 20,000 (approxinately $3 \frac{1}{6}$ inches to a statute mile). It is constructed on a polyconic projection and is based on the United States standard datum of the Coast and Geodetic Survey.

This chart shows all oyster bars and other boundaries established by the commission, and is certified for the purpose of filing in the office of the clerk of the circuit court of Baltimore County and in the office of the Maryland Shell Fish Commission, as required by the oyster laws of Maryland.

In addition to the oyster bar and other houndaries, the "Naryland Oyster Charts" show the location and name of all landmarks (United States Coast and Geodetic Survey triangulation stations) used in making the survey, together with the hydrography and topography necessary to make the technical definitions and delineations of boundaries readily understandable both by the people engaged in the oyster industry and the general public who may become interested through leasing of barren bottoms for oyster culture. $^{2}$

The names of the oyster bars are those used locally, as nearly as could be ascertained by the hydrographic engincer of the commission. When there was no local name in common use, a name was selected from one of the prominent features of the vicinity. By the use of recognized names or those that would nat urally suggest certain sections of water, it is believed that much confusion will be avoided in the location on the charts of the oyster bars, especially by those not familiar with the use of maps.

The corners of the oyster bars are numbered from i to the total number of corners in each area under consideration. Where boundaries adjoin, making one point a coner of two or more oyster bars, these points have two or more numbers, each number corresponding to the bar in which the figure is located. The numbers of the corners correspond with the technical and legal descriptions of this publication under the heading "Boundaries of natural oyster bars."

The landmarks and oyster bars have been grouped in the "Contents" of the Coast and Geodetic Survey oyster survey publication in accordance with the charts upon which they are shown. To find a particular oyster bar or landmark which is only known by name, consult the "Contents" and the desired chart and general location will be

1 These charts can be obtained by application to the Superintendent of the Coast and Geodetic Survey, at Washington, D. C

2 Much of the detail of the inshore topography was obtained from the excellent map of Baltimore County. prepared and published by the Maryland Geological Survey under the direction of Dr. William Bullock Clark from surveys of the Maryland
} Geological Survey in cooperation with the U. S. Geological Survey. 
indicated. To find the name of a bar or landmark which is only known by location, consult the progress map at the end of the publication for the number of the chart on which it is to be found, and then examine the known locality on the chart for the name of the bar or landmark in question.

The contours on the charts showing the depth of water at mean low tide have been taken from the hydrosraphic sheets of former work of the Coast and Geodetic Survey. Four curves were selected as being the most convenient for taking off from the original hydrographic sheets and the ones of greatest value to those interested in shellish industries. The $I$-fathom contour ( 6 feet) and the 5 -fathom curve (3o feet) correspond in a general way to the inner and outer limits of all the oyster bars surveyed. The 3 -fathom contour ( 8 feet) furnishes the curve of about the average depth of water on the oyster bars and the ro-fathom contour (6o feet) serves in a general way to indicate the outer limits of probable oyster culture.

The boundaries of the waters within the "territorial limits of the county" and the boundaries of the "waters contiguous to the county" opened up for the leasing with each county are plainly indicated on the charts. A full technical description of these boundaries is given in this publication under the heading "Boundaries of county waters."

The areas in acres of the oyster bars were determined under the direction of the hydrographic engineer of the commission by two independent planimeter measurements of the areas as delineated on the smooth projections of the Coast and Geodetic Survey. These areas are given in small figures in parentheses on the face of the chart within the boundaries of the different shellfish bottoms.

The symbols used on the charts for the different kinds of boundaries, triangulation stations, contours of depth of water, etc., require no other explanation than that given in the legend and other notes on the face of the charts.

\section{LEASING CHARTS.}

The leasing charts of Baltimore County, like those for Anne Arundel, Somerset, Wicomico, Worcester, Calvert, Charles, and St. Marys counties, have been prepared under the direction of the hydrographic engineer of the commission. These charts are constructed on polyconic projections and are based on the United States standard datum of the Coast and Geodetic Survey. They are made on the scales of I part in 5,000 , or I part in 10,000 , as the needs of oyster culture may require. Anne Arundel County required $\mathrm{I}_{3}$ leasing charts; Somerset County, 12 charts; Wicomico County, 2 charts; IVorcester County, 3 charts; Calvert County, 5 charts; Charles County, 2 charts; St. Marys County, 8 charts; and Baltimore County, I chart, to cover their oyster bottoms.

These charts show all the oyster bars, crab bottoms, and clam beds and other boundaries established by the commission, and also all boundaries of oyster lots leased for the purpose of oyster culture, thus making them comprehensive and valuable records of the results of the operations of the oyster-culture laws.

The lots leased under the provision of the "old 5-acre law" are frequently of irregular shape, but the lots leased under the provision of the new oyster laws must be of rectangular shape by the terms of that act. For this latter purpose the leasing charts have been divided by parallels of latitude and meridians of longitude into small rectan- 
gles of $\mathrm{I}$ acre or 5 acres, as may be best suited to the area under consideration, and prospective leaseholders by the rules of the commission are compelled to select whole rectangles as far as possible.

For reasons of the present changeable nature of the number of lots leased and the large number of charts required, the leasing charts are not likely to be published for some years, but they can be seen at any time on file at the offices of the commission, in the Marine Bank Building at Baltimore.

\section{PROJECTIONS.}

The polyconic projections ${ }^{2}$ covering Baltimore County waters are four in number and on the scale of I part in I0,000. They were constructed by draftsmen of the Coast and Geodetic Survey, but the sextant positions which determine the location of the legal boundaries of the oyster bars as delineated by the Shell Fish Commission were plotted by the draftsman of the commission.

A copy of each of these projections, with all the plotted positions of triangulation stations, shore line, sextant positions, and boundaries of oyster bars, was made under the direction of the hydrographic engineer of the commission by pricking through with a sharp needle the intersections of the projection lines and all other points as plotted on the original sheets.

These projections (in duplicate) are the original records of all oyster-bar and other boundaries established by the commission, one set being filed in the archives of the Coast and Geodetic Survey, at Washington, and the other set in the archives of the Shell Fish Commission.

\section{PROGRESS MAPS.}

The progress map to be found at the end of this publication is on a scale of $\mathrm{x}$ part in 100,000 , and shows in outline the work accomplished by the United States Coast and Geodetic Survey in Baltimore County and contiguous waters. It gives the scheme of all the charts and smooth projections constructed in connection with the survey, the location and names of all triangulation stations used as a basis for the surveying work, and the "boundaries of county waters" established by the commission for the purpose of carrying out the laws of Maryland relating to oyster culture.

Besides indicating the amount of work done by the Coast and Geodetic Survey in connection with the work of the Shell Fish Commission, this progress map will be of special value for index purposes to engineers and others searching for the particular chart or projection covering the locality of the oyster bars or landmarks that may be under consideration.

The progress maps ${ }^{2}$ accompanying the first and second annual reports of the Maryland Shell Fish Commission were prepared under the direction of the hydrographic engineer of the commission. They are on the scale of I part in 400,000 , and show the outline of the tide-water counties of Maryland, with shaded areas to inclicate the waters already covered by the operations of the oyster survey.

\footnotetext{
1 For the scheme of these projections see the progress map at the end of this publication.

2 These maps and reports can be obtained by application to Maryland Shell Fish Commission, Marine Bank Building, Baltimore, $\mathrm{Md}$.
}

$$
8 \times 20-\mathrm{x} \longrightarrow 2
$$




\section{BOUNDARIES OF THE COUNTY WATERS. ${ }^{1}$}

\section{WATERS WITHIN TERRITORIAL LIMITS OF COUNTY.}

The laws of Maryland relating to oyster culture provide that "no person shall be permitted, by lease, assignment, or in any other manner, to acquire a greater amount of land than ten acres situated within the territorial limits of any of the counties, or one hundred acres in any other place."

The boundary line ${ }^{2}$ between the waters "within the territorial limits" of Baltimore County and the waters in "any other place," as established by the Shell Fish Commission for the purpose of carrying out the oyster laws, and delineated on the "oyster" charts and the smooth projections of the Coast and Geodetic Survey, is technically described and defined as follows:

Following the boundary line in the middle of Gunpowder River between Baltimore and Harford counties to a point at the intersection of this boundary with a straight line between the northeastern end of Millers Island and the southwestern end of Sprys Island defined by latitude $39^{\circ}{ }_{16} 6^{\prime} 5^{8.8^{\prime \prime}}$ and longitude $76^{\circ} 20^{\prime}$ ro. $0^{\prime \prime}$; thence in a straight line across a part of the waters of the mouth of Gunpowder River to a point on the northeastem end of Millers Island defined by latitude $39^{\circ}$ I $5^{\prime} 5^{\mathrm{I}} .6^{\prime \prime}$ and longitude $76^{\circ} 2 x^{\prime} \circ 9.0^{\prime \prime}$; thence along the mean low-water line of the Chesapeake Bay shore of Millers Island or a line across the mouth of all inlets less than roo yards in width, as the case may be, to a point on the southwestern end of Millers Island defined by latitude $39^{\circ} 15^{\prime} 19.5^{\prime \prime}$ and longitude $76^{\circ} 22^{\prime} 51.9^{\prime \prime}$; thence in a straight line across the waters and small marsh islands between Millers Island and Hart Island to a point on the northeastern end of Hart Island defined by latitude $39^{\circ} I 5^{\prime} 08.5^{\prime \prime}$ and longitude $76^{\circ} 22^{\prime}$ I $8.0^{\prime \prime}$; thence along the mean low-water line of Chesapeake Bay shore of Hart Island or a line across the mouth of all inlets less than roo yards in width, as the case may be, to a point on the southwestern end of Hart Island defined by latitude $39^{\circ} \mathrm{I}^{\prime} 47 \cdot 5^{\prime \prime}$ and longitude $76^{\circ} 23^{\prime} 46.0^{\prime \prime}$; thence in a straiglit line across the waters between Hart Island and the mainland to a point on the mainland of Baltimore County defined by latitude $39^{\circ} 13^{\prime} 45.5^{\prime \prime}$ and longitude $76^{\circ} 23^{\prime} 56.8^{\prime \prime}$; thence along the mean low-water line of the Chesapeake Bay shore of Baltimore County or a line across the mouth of all inlets less than roo yards in width, as the case may be, to a point on the northeastem side of the entrance to Shallow Creek defined by latitude $39^{\circ} 12^{\prime} I 5 \cdot 3^{\prime \prime}$ and longitude $76^{\circ} 25^{\prime} 57 \cdot 4^{\prime \prime}$; thence in a straight line across the mouth of Shallow Creek to a point on the southwestern side of the entrance to Shallow Creek defined by latitude $39^{\circ} \mathrm{I2}^{\prime} \mathrm{II} \mathrm{I}^{\prime \prime}$ and longitude $76^{\circ}{ }_{2}^{\prime} 6^{\prime} 12.4^{\prime \prime}$; thence along the mean low-water line of the Chesapeake Bay shore of Baltimore County or a line across the mouth of all inlets less than roo yards in width, as the case may be, to a point located on North Point at the extreme southern end of Baltimore County defined by latitude $39^{\circ} \times \mathrm{x}^{\prime} 43.8^{\prime \prime}$ and longitude $76^{\circ} 26^{\prime} 34.2^{\prime \prime}$; thence in a straight line to a point located in Chesapeake Bay about 150 yards offshore on the foundation of an old stone lighthouse tower defined by latitude $39^{\circ} \mathrm{II}^{\prime} 39.2^{\prime \prime}$ and longitude $76^{\circ} 26^{\prime} 31.4^{\prime \prime}$; thence in a straight line across a part of the waters of the mouth of Patapsco River to a point defined by the intersection of the center line of Brewerton Channel and a straight line between "North Point (Old Tower Foundation)" and a point defined by latitude $39^{\circ} \circ 9^{\prime} 59 \cdot 3^{\prime \prime}$ and longitude $76^{\circ} 28^{\prime} 39 \cdot 7^{\prime \prime}$, situated on Rock Point; thence along the center line of Brewerton Channel to a point defined by the intersection of this line with the center line of Fort. McHenry Channel; thence along the center line of Fort McHenry Channel to a point defined by the intersection of this line with the southern boundary line of Baltimore County. ${ }^{3}$

1 For a complete historical and legal description of the boundaries of the counties of Maryland, the valuable publication er1titled "The Counties of Maryland-Their Origin, Boundaries, and Election Districts," prepared by Dr. Edward B. Mathews and published by the Maryland Geological Survey under the direction of Dr. William Bullock Clark, superintendent, should be consulted, as the boundaries described in this publication have been established and technically defined for the purpose of carrying out the oyster laws of the State, and may or may not be correct for other purposes.

2 See "Charts of Natural Oyster Bars," published by the Coast and Geodetic Survey, and the progress map at the end of this publication.

s Lat itudes and longitudes based on the United States standard datum of the United States Coast and Geodetic Survey. 


\section{WATERS CONTIGUOUS TO COUNTY.}

The oyster laws of Maryland provide that a true and accurate delineation of all natural oyster bars shall be made on copies of charts of the United States Coast and Geodetic Survey, "which said copies shall be filed in the office of the said commissioners," and "in the office of the clerks of the circuit courts for the respective counties wherein the grounds so designated may lie."

For the purpose of carrying out the latter part of this section of the law and for the purpose of establishing the limits of the oyster-culture area to be opened up for leasing with each county surveyed, it is necessary for the Shell Fish Commission to establish a boundary line between the waters contiguous to but not within the territorial linits of each connty and the waters contiguous to but not within the territorial limits of adjacent counties.

This boundary line has been delineated on the "Charts of Natural Oyster Bars," published by the Coast and Geodetic Survey and is technically described and defined as follows:

Commencing at a point situated in the mouth of the Gunpowder River at the intersection of the boundary between Baltimore and Harford counties and a straight line between the northeastern end of Millers Island and the southwestern end of Sprys Island and defined by latitude $39^{\circ}{ }^{\prime} 6^{\prime} 5^{8} .8^{\prime \prime}$ and longitude $76^{\circ} 20^{\prime} 10.0^{\prime \prime}$; thence in a straight line across a part of Chesapeake Bay to a point situated about $1 \frac{1}{16}$ miles south of the southern end of Pooles Island and defined by latitude $39^{\circ} \times 5^{\prime} 30.0^{\prime \prime}$ and longitude $76^{\circ} I 6^{\prime} 20.4^{\prime \prime}$; thence in a straight line along the waters of Chesapeake Bay to a point situated about $31^{3}$ ' miles east of "Seven Foot Kroll Light" and $31^{7}$ miles southeast of "Craighill Channel Light (Front Range)" and defined by latitude $39^{\circ} \circ 9^{\prime} 10.6^{\prime \prime}$ and longitude $76^{\circ} 21^{\prime} 00.0^{\prime \prime}$; thence in a straight line along the continuation of the center line of Brewerton Channel to Brewerton Channel, and thence along the center line of Brewerton Channel to a point defined by the intersection of this line and a straight line between "North Point (Old Tower Foundation)" and a point defined by latitude $39^{\circ} \circ 9^{\prime} 59 \cdot 3^{\prime \prime}$ and longitude $76^{\circ} 28^{\prime} 39 \cdot 7^{\prime \prime}$, situated on Rock Point.

\footnotetext{
1 Iatitudes and longitudes liased on the United States standard datum of the United States Coast and Geodetic Survey.
} 


\section{LANDMARKS (U. S. COAST AND GEODETIC SURVEY TRIANGULATION STATIONS).}

\section{FXPLANATION.}

The oyster laws of Maryland authorizing the survey to be made by the shell fish commission provide for "an accurate report of said suryey, setting forth such a description of landmarks as may be necessary to enable the said board, or their successors, to find and ascertain the boundary lines of said natural oyster beds, bars, and rocks, as shown by delineation on the maps and charts." The law of the United States authorizing the cooperation of the Department of Commerce and Labor in the survey of natural oyster bars of Maryland provides for the erection of "such structures as may be necessary to mark the points of triangulation, so that the same may be used for sucl future work of the Coast and Geodetic Survey as the said bureau may be hereafter required to perform in prosecuting the Government coast survey of the navigable waters of the United States located within the State of Maryland."

Under the provisions of the sections of the laws stated above, the markings and descriptions of landmarks must be sufficient for the present and future needs of both the Government and the State. With this end in view, considerable work has been expended in erecting permanent monuments at the triangulation stations and in the proper description of their location.

An effort has been made to arrange the descriptions of location and character of landmarks in a uniform and logical manner. The descriptions start with the assumption that the individual seeking a landmark has only an indefinite idea of its location. They gradually proceed from description of the general locality of a landmark to the descriptions of its immediate surroundings. This is followed by specific details of the character of the center and reference marks and a "round" of reference angles and distances which in themselves frequently contain enough information to furnish an independent and reliable location of the triangulation station.

\section{METHOD OF DESCRIBING TRIANGULATION STATIONS.}

The separate descriptions of triangulation stations should not be used without reading the following explanation of the method of describing the triangulation stations, as it contains certain details that are common to all the landmarks described in this publication and which are omitted in the separate descriptions as being needless repetitions:

Name.-The title at the top of each separate description is the name by which the landmark or triangulation station is known and designated in all work and published oyster records or oyster charts of both the Government and State. The selection of the name is usually left to the triangulator establishing the station, and it may or may not have geographic or other significance in reference to the locality. 
Gencral locality.-Under this heading is given the general locality of the landmark in reference to well-known and prominent natural or artificial features, such as the nearest body of water, town, river, steamer wharf, well-defined point of land, church, or any other feature that is likely to remain both permanent and prominent.

This heading also covers a reference to the published chart or map which shows the location of the station most clearly. -Nearly all the triangulation stations described in this publication are plainly indicated by name and a triangulation symbol on the published charts of oyster bars of Maryland. In this case they are referred to by serial number only, the words "charts of oyster bars of Maryland" being omitted to avoid needless repetition. These published oyster charts are on the large scale of I part in 20 ,0oo (approximately $3 \frac{1}{6}$ inches to a statute mile) and show the locations of the triangulation stations so clearly that in many cases the written descriptions will not be required to find them.

Immediate locality.-Under this heading is given the description of the "observed station" in reference to its immediate surroundings. This is supposed to include a statement of the station's estimated elevation above high water or some other welldefined level of the locality, such as a road or house; the character of the ground on which it is located, such as marsh land, sand beach, cultivated field, or meadow; estimated bearings in points of the compass and estimated distances in yards from (not to) easily recognized features, such as extreme end of point, edge of bluff, bank of creek, line of telephone poles, shore line, barn, house, fence, ditch, trees, or any other definite detail, such as being on range with the tangent of an island and a church; and so forth.

When a standard monument has been established near the station as a "reference station," this heading also covers a statement of the true bearing of the monument in degrees and minutes and its measured distance in meters, as it is the first object that is likely to catch the eye when the immediate vicinity of the desired station is reached and might be mistaken for the center mark of the "observed station" unless special attention is called to it.

The distinction between the "observed station" and "reference station" should be carefully noted by anyone making use of the description of stations for any future surveying operations.

The "observed station" is located at the particular triangulation point covered by the description of stations, and is the one whose geographic position is first computed, as it is the point which was "occupied" and "observed on" for horizontal angles. However, in spite of the primary importance of the location of the "observed station," it will be noted from the description of stations that frequently it is not marked as well as the "reference station," and in some instances has only a pine stub to indicate its position. This is the case for the reason that the necessity of intervisibility of landmarks usually made it compulsory to locate "observed stations" on edges of banks and ends of points of land, which in the tide-water section of Maryland generally means they will be washed away in a short period of years. The past experience of the Coast and Geodetic Survey in this region has shown the great need of "reference stations," if the frequent reestablishment of a new framework of triangulation is to be avoided.

The chief reason and need for the establishment of the "reference station," or secondary station, as it might be well named, is explained in the preceding paragraph, but in several instances other reasons, such as the location of the "observed station" 
on an unstable sand dunc, in a cultivated field, in front of a residence, or other places objectionable to the landowner, have led to establishment of "reference stations." The location of the "reference station" in relation to the "observed station" is fixed for plotting on charts or for computation of its gcographic position by checked measurements of its distances and azimuth from the "observed station." 1

- Marks.-Under this heading is given a description of the character of the permanent monuments or other marks of the location of the "observed station," and of the "reference station" where one has been established.

All the marks designated in the descriptions as "the center point of triangle on standard cement monument" are exactly alike. These monuments are made of cement, sand, and gravel, and are 2 feet long and 8 inches square at top and bottom. Their tops are all marked with the same brass nold and show a center hole surrounded by a triangle, with the letters "M. S. F. C." arranged around the vertex and the letters "U. S. C. S." underneath the base of the triangle. The center hole is always in the center of the top of the monument by construction, and if this is found to have been broken off withont disturbing the bottom, the center of its square section can be used as the location of the station.

As the above facts in reference to the "standard cement monuments" are a constant element in all cases, the repetition of these facts in the description of stations is made needless by this one statement.

References.-Under this heading are given the "rounds" of directions and distances to all objects that might be useful in locating the stations when the surface marks can not be found. It is also contemplated that for general purposes of topography, hydrography, or location of boundaries of oyster bars these references will be sufficient in many cases to relocate the position of an "observed station" or "reference station" when both of them have been destroyed.

The first reference object given in the descriptions is always a triangulation station visible from the station being described, this, if possible, being a lighthouse, church spirc, or other permanent and prominent point. Its direction is taken as being $\mathrm{O}^{\circ} \mathrm{oo}^{\prime} \mathrm{oO}^{\prime \prime}$, and the directions of all other objects are measured from it as an initial point, the angles being taken in a clockwise direction (left to right).

The true bearing ${ }^{2}$ of the initial object is always given in parentheses alongside its name. This furnishes means for the calculation of the bearings of any of the other reference objects for the purposes of locating a station by horizontal angles or for the relocation of corner buoys of oyster-bar boundaries by the method of compass directions described in this publication under the heading of "Boundaries of oyster bars."

The distances in the last column under "References" are given in three different units, which vary according to their accuracy. The "miles" are statute miles, and may be considered only as rough estimates. The "yards" are more accurate, but must be looked on as results generally obtained by pacing or careful estimating. The "meters," however, are accurate to the degree indicated by their decimals and in every case have been measured with a steel tape. In the same manner, the accuracy of the directions are indicated by the refinement of angular measure with which they are recorded.

\footnotetext{
1 Geographic coordinates (latitude, longitude, distance, and azimuth) relating to any of the "observed stations" or of the "reference stations" described in this publication can be obtained by application to the Superintendent of the Coast and Geodetic Survey, at Washington, D. C.

${ }^{2}$ The mean maguetic variation for Baltimore County was $6^{\circ} 15^{\prime}$ west of north in $191 \mathrm{r}$ and increasing at the rate of $5^{\prime}$ yearly.
} 


\title{
DESCRIPTIONS OF TRIANGUI,ATION STATIONS.
}

\author{
POOLES ISLAND LIGHT.
}

General localily.-Upper Chesapeake Bay on northwest side of Pooles Island. (See Chart No. 27.) Immediate locality.-Observed station is on a detached tower known as Pooles Island Lighthouse. Marks.-Observed station is center point of lantern on tower. Refercnces-

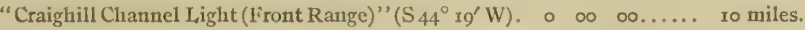

\section{POOLES ISLAND 2.}

General locality.--Upper Chesapeake Bay on Pooles Island, about $1 / 4$ mile southeast of Pooles Island Light and $1 / 4$ mile north by west of Pooles Island wharf. (See Chart No. 27.)

Immediale locality.-Observed station is in a peach orchard, on highest ground on northern part of Pooles Island, about 500 yards southeast of Pooles Island Light and 370 yards north by west of farmhouse. The angle at the southwest corner of the farmhouse between the windmill at the barn and the observed station is $84^{\circ}$, and the angle at the observed station between the light tower and the fog-bell tower is $2^{\circ} 47^{\prime}$.

Marks.-Observed station is center point of triangle on standard cement monument projecting 4 inches above surface of ground. Subsurface mark is center of 2 -inch tile pipe buried with top 2 inches below base of monument. (Note: These marks replace old ones of 1896. )

References.-

"Pooles Island Light" ( $\left.\mathrm{N}_{47^{\circ}} \mathrm{I} 6^{\prime} \mathrm{W}\right)$

(1)

Break in bluff on east shore of bay showing through peach trees.................. I

Center of chimney of small house in rear of dwelling. ........................

Center of middle one of three chimneys on dwelling................................

Center of cupola on small building. . ...... 220

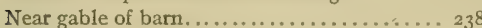

Windmill . . . . . . . . . . . . . . . . . 24

Center one of four nails in apple tree....... 33
- $0000 \ldots \ldots$.

I2 $\ldots \ldots \ldots \quad 3 \frac{3}{4}$ miles.

I5 $00 \ldots \ldots \ldots$ ín milc.

$8 \quad 03 \ldots \ldots \ldots . . \ldots \quad 1 / 4$ mile.

50 $\ldots \ldots . . .1 / 4$ mile.

o6 .. ..... $1 / 4$ mile.

$56 \ldots \ldots \ldots \quad 1 / 4$ mile.

24 10 .... 33. 72 meters. 
WORTON POINT 2.

General locality.-Eastern shore of Chesapeake Bay on Worton Point, about $\mathrm{I} 3 \mathrm{\&}$ miles north of mouth of Worton Creek and $4 \frac{1}{2}$ miles northeast of north end of Pooles Island. (See Progress map.)

Immediate locality.-Observed station is on tree and bush fringed bluff about 30 feet above high water, 2 yards east-southeast of edge of bluff and I yard south-southwest of a very small ravine. Cement monument marking reference station is 14.05 meters $S 61^{\circ} 17^{\prime} \mathrm{E}$ of observed station.

Marks,-Observed station is center of 4 -inch tile pipe with top 6 inches below surface of ground. Subsurface mark is center of 4 -inch tile pipe buried with top 2 inches below base of surface pipe. Reference station is center point of triangle on standard cement monument projecting 4 inches above surface of ground.

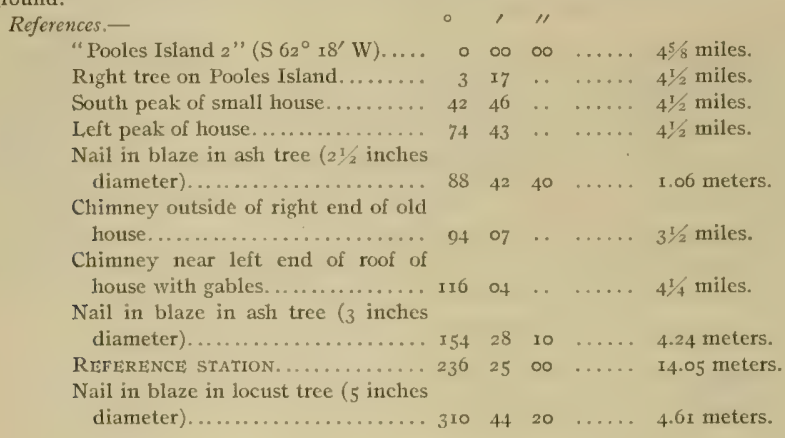

BRAMBLE:

General locality,--Eastern shore of Chesapeake Bay, about 3 miles southeast of center of Pooles Island, 3 miles north-northeast of Tolchester Beach, and $1 \frac{1}{4}$ miles southwest of entrance to Fairlce Creek. (See Progress map.)

Immediate locality.-Observed station is on a tree and bush fringed bluff about 30 feet above high water, 3 yards east of edge of bluff, 3 yards west of edge of cultivated field, 35 yards southwest of trees at edge of gully, and 200 yards west of other trees. Cement monument marking reference station is 47.16 meters $\mathrm{N} 67^{\circ} 05^{\prime} \mathrm{E}$ of observed station.

Marks.-Observed station is 2 -inch stub projecting 3 inches above surface of ground. Subsurface mark is beer bottle buried below base of stub. Reference station is center point of triangle on standard cement motument projecting 2 inches above surface of ground.

References.-

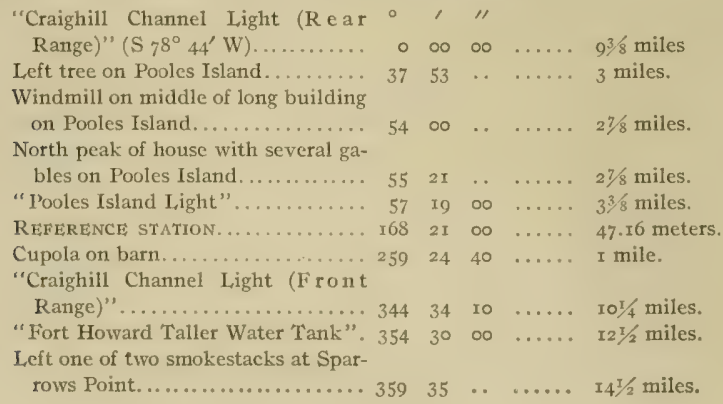




\section{MITCHELLS BLUFF 2.}

General locality.-Eastern shore of Chesapeake Bay on Mitchells Bluff, just north of first break in bluff, about $5 / 8$ miles north-11ortheast of Tolchester Beach Wharf. (See Progress map.)

Immediate locality.-Observed station is in cultivated ground about 30 fect above high water, I3 yards southeast of edge of bluff, 50 yards northeast of point of gully where fishermen haul up gear, 70 yards south of small clump of trees, and $1 / 4$ mile northwest of a large farmhouse.

Marks.-Observed station is center point of triangle on standard cement monunent projecting 4 inches above surface of ground. Subsurface mark is wire in center of 2 -inch tile pipe buried with top 2 inches below base of monument. (Note: Subsurface mark is either a part or replaces the original one of 1896 .)

References.-

\begin{tabular}{|c|c|c|c|c|c|}
\hline $\begin{array}{l}\text { "Craighill Channel Light (Rear } \\
\left.\text { Range)" (N } 87^{\circ} 52^{\prime} \mathrm{W}\right) \ldots \ldots \ldots \ldots\end{array}$ & $\circ$ & & $\infty$ & & miles. \\
\hline $\begin{array}{l}\text { thimney at left end of house on op- } \\
\text { posite shore.................... }\end{array}$ & 57 & $\infty$ & . & & uiles. \\
\hline $\begin{array}{l}\text { Chimney at leit end of llouse on } \\
\text { Pooles Island................... }\end{array}$ & 71 & II & . & & ailes. \\
\hline $\begin{array}{l}\text { Chimmey on middle of roof of build- } \\
\text { ing beyond trees............... }\end{array}$ & 170 & Io & $\ldots$ & & $5 / 8$ mile. \\
\hline $\begin{array}{l}\text { Spindle of weather vane on middle } \\
\text { cupola of bam................ }\end{array}$ & 200 & 28 & 30 & & aile. \\
\hline $\begin{array}{l}\text { Near comer of large west chimney of } \\
\text { house.......................... }\end{array}$ & 210 & 54 & $\cdots$ & & $2 / 4$ \\
\hline 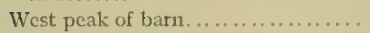 & 260 & 07 & .. & $\ldots \ldots$ & $3 / 8$ mile. \\
\hline $\begin{array}{l}\text { "Seven Foot Knoll Light"......... } \\
\text { "Craighill Channel Light (I ront }\end{array}$ & 330 & 18 & 30 & $\ldots \ldots$ & Io $/ 4$ miles. \\
\hline Range)"... & $3+1$ & 20 & 40 & & $s, f$ miles. \\
\hline
\end{tabular}

\section{CRAIGHILI, CHANNEI, LIGHT (REAR RANGE).}

General locality.-Western side of upper Chesapeake Bay, about 200 yards offshore from the southwestern end of Hart Island. (See Chart No. 27.)

Immediate locality.-Observed station is on a tall square pyramidal skeleton steel frame structure known as Craighill Channel Light (Rear Range).

Marks,--Observed station is center point of lantern on Craighill Channel Light (Rear Range!.

References.-

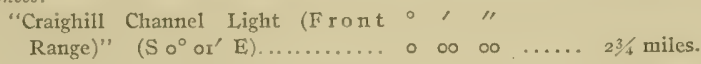

\section{CRAIGHILL CHANNEL LIGHT (FRONT RANGE).}

General locality. - Western side of Chesapeake Bay, about 2 miles offshore and about $23 / 4$ miles east of North Point at entrance to Patapsco-River. (See Chart No. 27.)

Immediate locality.-Observed station is on dwelling on cylindrical foundation known as Craighill Channel Light (Front Range).

Marks.-Observed station is center point of lantern on Craighill Channel Light (Front Range)

References.--

$$
\begin{aligned}
& \text { "Craighill Channel Light (Rear 0. , " }
\end{aligned}
$$

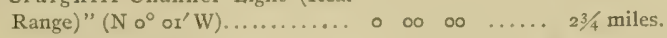




\section{NORTH POIN'T (OLD TOWLR HOUNDATION).}

Gencral locality, - Northern side of entrance to Patapsco River near North Point. (See Chart No. 27.)

Immediate locality. - Observed station is on an old stone tower foundation about 150 yards offshore from North Point.

Marks.-Observed station is center point of foundation of stone tower formerly used as a lightlouse.

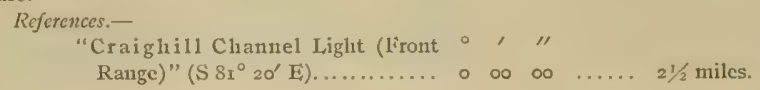

\section{FORT HOWARD TALLER WATER TANK.}

General locality.-Northern side of entrance to Patapsco River about 1/2 mile north-northwest of North Point. (Sce Chart No. 27.)

Immediate locality.-Observed station is the taller of two stecl water tanks on steel towers at Fort Howard.

Marks.- Observed station is center point of pipe attached to center of bottom of tank.

References.-None necessary.

\section{CUTOIF CHANNEL, LIGH'T (FRON'T RANGE).}

General locality,- Northern side of entrance to Patapsco River about 125 yards offshore and $1 / 4$ mile west-northwest of North Point. (See Chart No. 27.)

Immediate locality.-Observed station is an octagonal brick tower known as Cutoff Channel Light (Front Range).

Marks,-Observed station is center point of lantern on Cutoff Channel Light (Front Range).

References.-

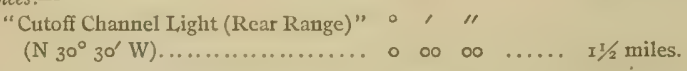

\section{CUTOFF CHANNEL, LIGHT (REAR RANGE).}

General locality.-Northeastern side of Patapsco River on western side of entrance to Jones Creek, about I $3 / 4$ miles north-northwest of North Point and I mile east of the towu of Sparrows Point. (See Chart No. 27.)

Immediate locality.-Observed station is on a square pyramidal skeleton steel frame structure known as Cutoff Cliannel Light (Rear Range).

Marks.-Observed station is center point of lantern on Cutoff Channel Light (Rear Range).

References.-

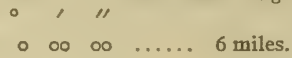

$$
\text { Bodkin Light (Oid Tower) }\left(\mathrm{S}_{2} 0^{\circ} \mathrm{ra}^{\prime} \mathrm{E}\right) \text { ) } 00 \text { oo ..... } 6 \text { miles. }
$$

\section{ROCK POINT.}

General locality.-Southwestern shore of Patapsco River on Rock Point at southeastern side of entrance to Rock Creek and about $25 / 8$ miles southwest of North Point. (See Chart No. 27.)

Immediate locality.-Observed station is near the extreme end of point about I2 yards from sea wall, and 70 yards southeast of a small. tower.

Marks,-Observed station is center point of triangle on standard cement monument.

References.-

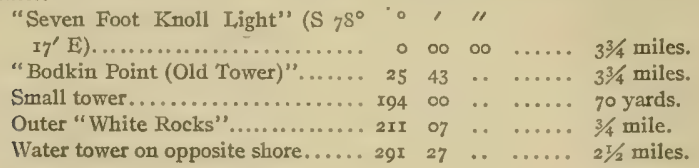




\section{BODKIN POINT (OLD TOWËR).}

General locality.-Southern side of entrance to Bodkin Creck on Bodkin Point. (See Progress map.) Immediate locality.-Observed station is about 15 yards east of an old stone dwelling on top of an old tower formerly used as a lighthouse.

Marks.-Observed station is center of drill lole about 2 inches in diancter and 3 inches deep in stone platform on and near center of top of tower.

References.--

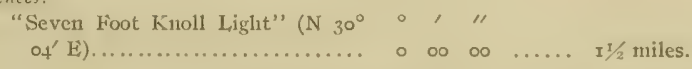

\section{SEVIEN-IOOOT KNOLI, LIGHT.}

General locality.-Western side of Chesapeake Bay off entrance to Patapsco River about $21 / 2$ miles north-northeast of Bodkin Point and $3 \frac{1}{4}$ miles southeast of North Point. (See Cliart No. 27.)

Immediate locality. - Observed station is on an octagonal screw pile structure known as Seven-Foot Knoll Lighthouse.

Marks.-Observed station is center point of lantern on Seven-I'oot Knoll I,ight.

References.-

$$
\begin{aligned}
& \text { "Bodkin Point (Old Tower)" ( } \mathrm{S}_{3} 0^{\circ} \circ, \text {, " }
\end{aligned}
$$

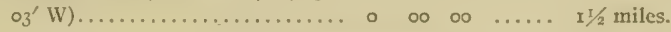

\section{SWAN POINT 3 .}

General locality.-Eastern shore of Chesapeake Bay on Swan Point about 5 T/2 miles south-soththwest of Tolchester Beach Wharf and 7 miles north of Love=Point. (See Progress map.)

Inmediate locality.-Observed station is on sand and marsh point about 2 feet above high water, 5 feet east of shore, 60 yards south-southwest of a fisherman's cabin, and 250 yards from the extreme end of Swan Point. Cement monument marking old reference station is in marsh 21.43 meters N $89^{\circ}{ }^{\prime} 3^{\prime} \mathrm{E}$ of observed station. Standard cement monument marking new reference station is on line to old reference station 13.26 meters $\mathrm{N} 89^{\circ} \mathrm{I} 3^{\prime} \mathrm{E}$ of observed station.

Marks.-Observed station is $1 / 4$-inch copper rod set in an 8 -inch square cement monument with top about 5 inches below surface of ground. Subsurface mark is the neck of a flask set in cement about 4 feet below the surface. New reference station is center point of triangle on standard cement monument. Old reference station is eastern one of two $1 / 4$-inch copper rods in an 8 -inch cement monument.

References.-

"Love Point Light" ( $\left.\mathrm{S}_{2}{ }^{\circ} \mathrm{II}^{\prime} \mathrm{W}\right) \ldots$

"Baltimore Light".

Stack on garbage plant at Bodkin

Point.....................

"Sever-Foot Knoll Light" ......... 95

Left stack at Sparrows Point....... rII

"Fort Howard Taller Water Tank". . iा

"Craighill Channel Light (Front

Range)" .................... II

"Craighill Channel Light (Rear

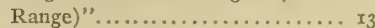

miney of cabin.............. $203 \quad 54 \quad \ldots \ldots \ldots .58$ yards.

Gable of Rockhall wharf house.... $264 \quad 07 \quad \ldots \quad \ldots . . \quad x$ mile.

OLD REHERENCE STATION.......... 267 O2 20 .... 21.43 meters.

N E W REFERINCE STATION

(STANDARD CEMENT MONUMENT). $267 \quad 02 \quad 20$..... 13.26 meters.

Chimney of house to right of Wind-

mill Point.................. 292 I2 $\ldots \ldots . . .2$ miles.

Gable of barn................. $303 \quad 49 \quad \ldots \quad \ldots . .21 / 2$ miles.

Gable of barn near Wickes Beach... $340 \quad 52 \quad \ldots \quad \ldots . .75 / 8$ miles. 


\section{BOUNDARIES OF OYSTER BARS.}

\section{EXPLANATION.}

The law of the United States authorizing the cooperation of the Department of Commerce and Labor in the survey of natural oyster bars of Maryland provides for the designation and enuployment by the Department of Commerce and Iabor of such officers, experts, and other technically qualified persons "as may be necessary to cooperate with the Maryland State Board of Shell Fish Commissioners in making a survey of and locating the natural oyster beds, bars, and rocks in the waters within the State of Maryland." The oyster laws of Maryland provide that the Maryland Shell Fish Commissioners, with the aid of such persons as may be designated by the Government, shall proceed "to have laid out, surveyed, and designated on the said charts the natural beds and bars, and shall cause to be marked and defined as accurately as practicable the limits and boundaries of the natural beds, bars, and rocks as established by said survey, and they shall take true and accurate notes of said survey in writing, and make an accurate report of said survey, setting forth such a description of landmarks as may be necessary to enable the said board, or their successors, to find and ascertain the boundary lines of the said natural oyster beds, bars, and rocks, as shown by a delineation on the maps and charts." The oyster laws of Maryland also provide in another section that there shall "be made a true and accurate survey of the natural oyster beds, bars, and rocks **** with reference to fixed and permanent objects on the shore, giving courses and distances, to be fully described and set out in a written report of said survey."

Under the provisions of the laws quoted above the State of Maryland, in cooperation with the Department of Commerce and Labor, must define the loundaries of the natural oyster bars "as accurately as practicable" and also "witl reference to fixed and permanent objects on the shore, giving courses and distances." The requirement of "as accurately as practicable" is easily fulfilled by definition of the location of the corners of the oyster bars by latitude and longitude. In fact, this method is probably the most satisfactory and accurate one that could be used for all purposes of legal definition or for relocation of the oyster-har boundarics by competent engineers. Therefore the additional requirement of "giving courses and distances" is superfluous and is only fulfilled in the published definitions on account of the specific provisions of the law making it compulsory. This part of the description of boundaries has involver an immense amount of extra computations in order to prevent technical discrepancies between the latitude and longitude of a corner of an oyster bar and its distance and bearing from objects on shore of known latiturle and longitude without adding anything to the accuracy and very little to the convenience of practical use of the descriptions of the oyster-bar boundaries.

As provided by law the boundaries of the oyster bars are all straight lines, but in the work already completed they have inclosed areas of all shapes from triangles to 
complicated 14 -sided figures, and of all sizes from 4 acres to 7,548 acres. The sides have varied in length from 93 to 7,529 yards, and in some cases the corners of the boundaries have been practically at the triangulation stations from which they are located, while in other instances they were over 13,600 yards from the landmarks most available for the purpose of fixing their position.

The varied characteristics of the legal boundaries of the oyster bars indicated by the above statement, together with the complicated requirements of the law under which the survey has been made and the magnitude of the work with the consequent need of fixed and uniform methods, have made the problem of describing the bonndaries one of considerable difficulty and great importance.

The boundaries of the oyster bars of Maryland, as established by the Shell Fish Commission and delineated on the Coast and Geodetic Survey charts and projections and on the leasing charts of the commission, are technically defined and described by a method somewhat different from that used in other oyster surveys. . But it is believed that the forms finally adopted will fulfill all needs of the survey for both the present and the future.

\section{METIIOD OF DESCRIBING BOUNDARIES.}

The descriptions have been arranged in tabular form, thus avoiding many hundred repetitions of the same ivords by making one explanation of the tables sufficient for all oyster bars in eacli county.

Title.-At the top of each tabular form is given the legal name of the oyster bar to be described, and the one by which it is known and designated in the published oyster records and on the oyster charts. The adopted name of the oyster bar is the one used locally, as nearly as could be ascertained by the hydrographic engineer of the commission; and when there was no local name in common use a name was selected from one of the prominent features of the vicinity that would naturally suggest the section of the waters where the oyster bar was located.

Underneath the name, in parentheses, is given the general locality of the oyster bar and the serial number of the "Maryland Oyster Chart" on which its legal boundaries are shown. ${ }^{1}$

First column.-This column, under the heading of "Corner of bar," gives the number corresponding to the comer of the boundary as shown on the charts and to the number on the buoy marking the actual corner of the bar. The numbers of the corners have been assigned by naming the southernmost point No. $\mathrm{I}$, thence proceeding in a clockwise direction around the bar. Where a corner of one oyster bar is identical with the corner of the boundaries of one or more other oyster bars, only the number of the comer of the oyster bar being described in the table is given in this column.

Second and third columns.-These two columns, under the headings of "Latitude" and "Longitude," give the geographic positions of the corners. These positions have been adopted by the commission as the primary technical definition of the location of the corners, and should be considered as final in case of a dispute arising from discrepancies caused by other means of location. The latitudes and longitudes given in these columns are based on the United States standard datum of the Coast and Geodetic

\footnotetext{
1 These charts can be obtained by application to the Superintendent of the Coast and Geodetic Survey at Washington, D. C.
} 
Survey, and the points thus defined can be relocated from distant triangulation stations of the survey, even though all the landmarks and buoys originally used for their location have been destroyed by natural or other causes.

Fourth and fifth columns. -These two columns, under the general heading of "True bearing" 1 and the specific headings "Forward" and "Back," give bearings measured from a true north-and-south line. The three "Forward" bearings are from the corner of the boundary clesignated in the first column to the triangulation stations named on the corresponding lines in the last column, and the three "Back" bearings are from these same stations in the last column to the corresponding corner of boundary in the first column. The difference in minutes of are between the forward and back bearings shown in some cases is actual and not accidental, and is due to the fact that the computations took into account the spheroidal shape of the earth.

Sixth column.-This column, under the heading of "Distance," gives the three computed distances in yards from the corner of the bar noted in the first column to the three triangulation stations named on the corresponding lines in the last column, and vice versa.

Seventh column.-This column, under the heading of "U. S. C. \& G. S. triangulation station," ${ }^{2}$ gives the names of the landmarks from which were computed the corresponding "Latitude," "Longitude," "True bearing," and "Distance" of the "Corner of the bar" designated in the first column. A full description of the location and markings of these triangulation stations is given in another part of this publication under the heading of "Descriptions of triangulation stations."

\section{SURVEYING METHODS FOR RELOCATION OF BOUNDARIES.}

There are a number of methods that can be used in the relocation of the actual boundaries of the natural oyster bars as technically described in this publication and delineated on the published charts of the Coast and Geodetic Survey and the leasing charts of the Shell Fish Commission.

The following brief descriptions of five of these more or less different methods assume a certain amount of experience and knowledge on the part of the engineer in the particular kind of surveying under consideration, and are only intended as reminders of ways and means that can be used.

There are two problens that are likely to present themselves to those interested in the boundaries of natural oyster bars: one, to determine whether the buoys marking the corners have been dragged or otherwise moved from their correct positions, and the other, to relocate or reestablish a buoy at the point from which it was removed. The different ways of solving these two problems partly depend upon the instruments possessed by the engincer and his assistants and partly on his training and experience.

(I) Triangulation.-This method is the one that will give the greatest accuracy, but on account of its requiring special data and instruments, and being an operation rarely used by engineers not engaged in geodetic surveying, it is recommended only for cases in dispute that can not be settled satisfactorily by some other method. An explanation of this class of work would be too long for a report of this sort, and those

1 'The mean magnetic variation for Baltimore County was $6^{\circ} \mathrm{rs}^{\prime}$ west of north in rgrr and increasing at the rate of $5^{\prime}$ yearly.

2 Geographic positions of these triangulation stations can be obtained by application to the Superintendent of the Coast and Geodetic Survey, Washington, D. C. 
not familiar with this method are referred to the publications on the subject by the Coast and Geodetic Survey.

(2) Hydrographic.-This method is the most simple and satisfactory one that can be adopted if the surveyor can obtain the use of the necessary instruments and assistants. It is the one best suited for the work of the engineers of the commission in relocating corners of boundaries, as it gives results of the accuracy ordinarily required and is rapid in execution. Besides, it has the advantage of being axailable whenever three triangulation stations of suitable relative positions are visible from the offshore points needing relocation.

Most navigators and others familiar with the use of a sextant are well acquainter with the graphic three-point method of fixing a position on water, and only a brief description of the operation will be stated.

In the case where there is only one engineer having a single sextant, the three-point method can be used if the two angles determining the position of a buoy are first deriver from the "Forward" bearings given in the tabular forms describing the boundaries of the oyster bars. For example, take "Tea Table" oyster bar, which is the first one described in this publication, and assume that "Comer No. 3 ," is to be examined as to its position. 'The angle between the two landmarks "Pooles Island 2" and "Craighill Channel Light (rear range)" as determined from right to left from the forward bearings from this corner is $122^{\circ} 06^{\prime}$ and the angle between "Craighill Channel Light (rear range)" and "Swan Point 3 " is $86^{\circ} 06^{\prime}$. Having these two angles, the engineer proceeds to the buoy of doubtful location and measures the actual sextant angles between the landmarks for which the calculations were made. If the measured and calculated angles do not agree, the buoy is not in its correct position and the boundary corner must be relocated. This is accomplished by moving the boat about tuntil a point is reached where the angles do agree, and this point being the desired location, the buoy can be placed in its correct position.

If the engineer can obtain the use of both a sextant and a three-arm protractor (position finder), the availability of the hydrographic method is increased, as the use of the protractor is essential in case of the washing away or destruction of one or more of the landmarks originally used in describing the boundaries. Under these circumstances, any three landmarks of suitable relative position that are visible from the point to be located can be utilized. For example, the engineer can proceed to the buoy of doubtful position and measure the two adjacent sextant angles between the three landmarks selected. These two angles are set off on the three-arm protractor and the actual position of the buoy plotted on the chart by shifting the protractor about until the edge of each of the three arms passes through the center of the symbols on the chart marking the position of the three landmarks selected. The center of the hub of the protractor will indicate on the chart the actual position of the buoy, and if the point thus obtained does not coincide with the true position of the corner of the boundary as given on the chart, the surveyor can proceed to locate the buoy correctly by reversing the operation. This is done by placing the center point of the hub of the protractor over the corner of the boundary in question and measuring on the chart the two adjacent protractor angles between the three selected landmarks. One of the angles thus obtained is set on the sextant and the boat moved about until the two landmarks are shown by the sextant to subtend the same angle obtained from the protractor. The second angle is then placed 
on the sextant and the same operation gone through, and so on, first using one angle on the sextant, then the other, until a point is reached where both observed sextant angles are practically identical with the protractor angles. The point thus located is the desired one and the buoy can be placed to mark the true position of the corner of the boundary in question.

If the engineer possesses two sextants and a protractor, this problem is far easier of solution, as the two angles can be set off on separate sextants and the observer can quickly fint the desired point where they agree with the protractor angles by using one sextant after the other without the need of resetting either.

If there are two observers, two sextants, and a protractor, it can be seen that the best conditions for both rapid and accurate hydrographic location of a point is attained. In fact, this is the method by which the buoys at the corners of the boundaries were originally placed by the hydrographic engineer to the commission.

(3) Magnetic bearings from offshore.-This method of fixing a position on water is a simple and well-known one in navigation. It is available to anyone having a boat compass and will be of special use to the State fishery force in investigating cases where buoys are supposed to have been moved for illegal purposes.

In the case where a buoy is supposed to have been moved from its true position the observer can take compass bearings to the three landmarks given in the last column of the tables opposite the boundary corner in question. These bearings are then corrected for the local declination, ${ }^{1}$ and if the results agree with the published bearings the buoy is correctly located.

In the case where the buoy is not in its correct position, or has disappeared altogether, the desired point can be determined by maneuvering the vessel until the corrected bearings agree with the ones in the tabular descriptions, when the buoy can be anchored in its proper location.

In the case where the landmarks for which the bearings are published have been destroyed or washed away, any landmarks whose positions are indicated on the charts can be used. This can be done by getting their bearings directly from the chart by parallel rulers or a protractor and then applying these new bearings in the same manner as the ones published in the tables.

(4) Magnetic bearings from shore.-This method will be of special value to engineers having an ordinary surveyor's compass. The compass can be set over the point marking a "triangulation station" on shore, the name of which is given in the last column opposite the "corner" in question. The instrument is then set at the corresponding "back" bearing (corrected for local magnetic declination) given in the fifth column of the tables opposite the "corner" in question. The direction thus determined will give one range on which the desired point must be located. The compass can then be moved to a second triangulation station and another range located in a similar manner. The intersection of these two range lines will give the desired point; but in general it should be checked by an additional range line determined from a third station.

(5) Horizontal angles measured at landmarks.--This process is a modification of the triangulation method, and will be useful to engineers who have a transit and desire considerable accuracy.

${ }^{1}$ The mean maguetic variation for Baltimore County is $6^{\circ} 15^{\prime}$ west of north in IgII and increasing at the rate of $5^{\prime}$ yearly. 
The instrument is placed over a "triangulation station," the name of which appears in the last column of the tabular description opposite the "corner" in question. The telescope is then pointed to the landmark indicated in the "Descriptions of landmarks" as having a direction of $\mathrm{O}^{\circ} \mathrm{OO}^{\prime} \mathrm{OO}^{\prime \prime}$ from the triangulation station being occupied by the transit. The tabular description of the boundaries is next examined and the "back" bearing of the questionable boundary "corner" from the landmark being occupied is taken out. The angle calculated from this "back" bearing and the bearing given in parentheses alongside the zero landmark in the "Descriptions of landmarks" is then set off on the transit and a range line established on which the desired point must be located. A similar process is then carried on at a second station, and so on until the position of the buoy is satisfactorily fixed.

BOUNDARIFS OF NATURAL, OYSTER BARS.

TEA TABLE.

(Chesapeake Bay-Chart No.27.)

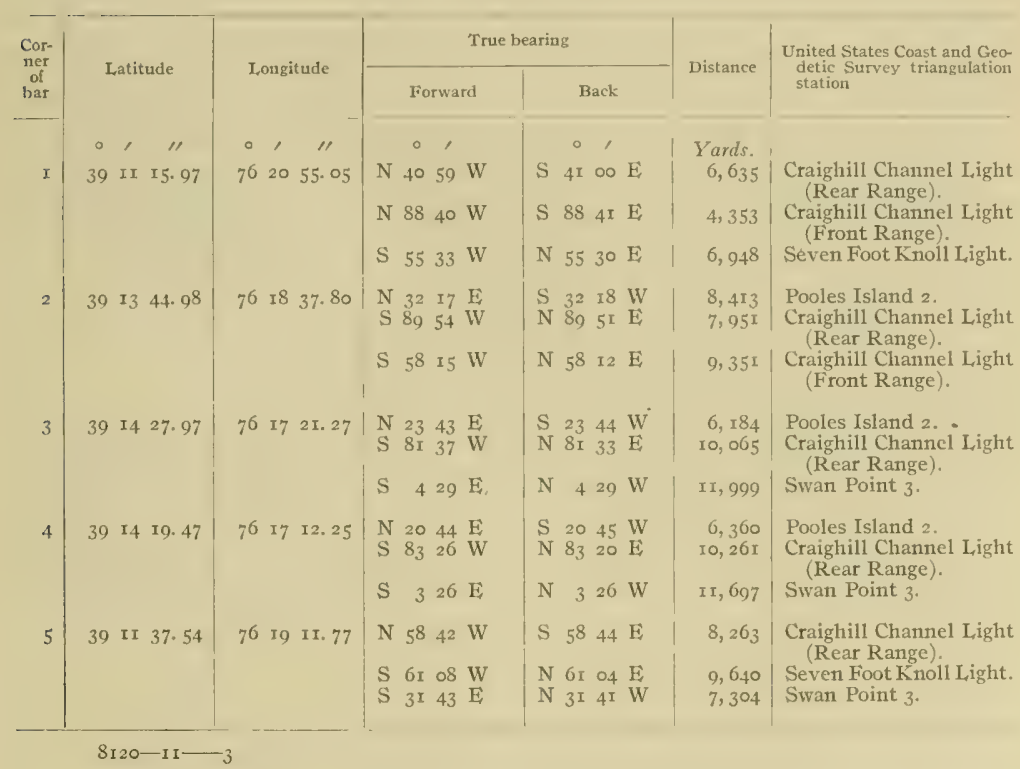


BOUNDARIES OF NATURAL OYSTER BARS-continued.

MILLERS ISLAND.

(Chesapeake Bay-Chart No. 27.)

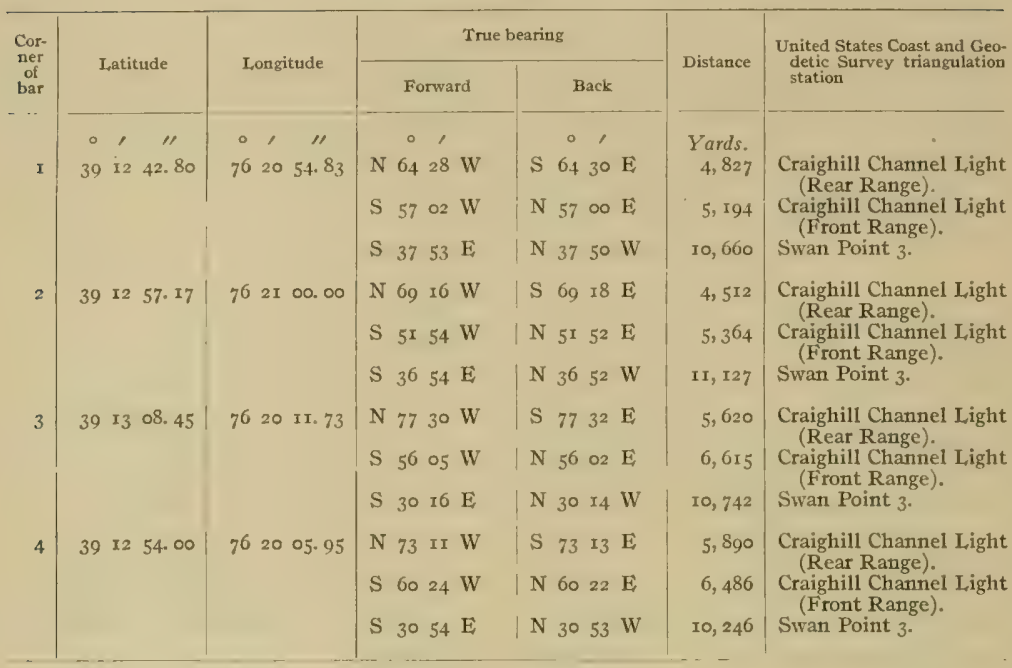

MAN O'WAR SHOALS.

(Chesapeake Bay-Chart No.27.)

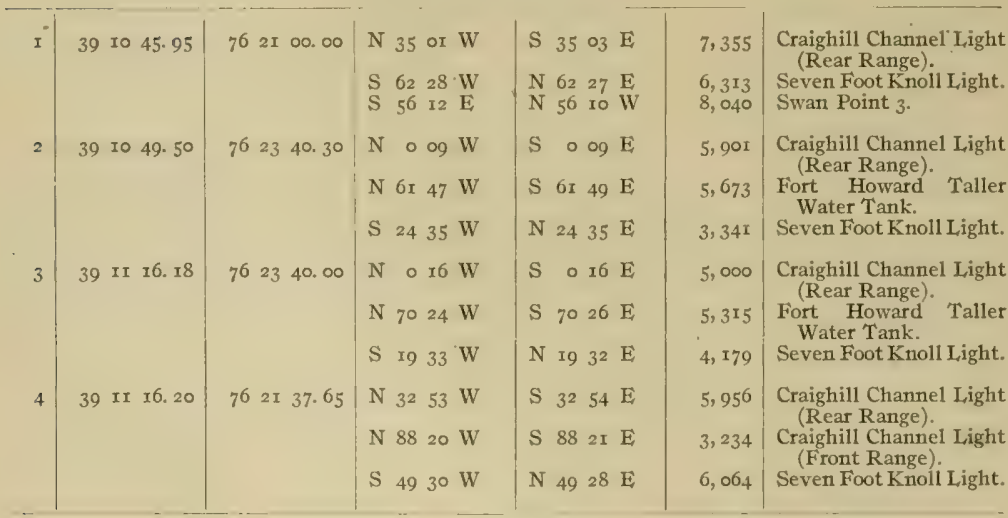




\section{A P P ENDIXES.}

\section{APPENDIX A.-LAWS RELATING TO THI COOPERATION OF THE COAST AND GEODETIC SURVEY AND BUREAU OF FISHERIES WITH THE MARYIAND SHELI, FISH COM- MISSION,}

The work of the Coast and Geodetic Survey and of the Bureau of Fisheries, in cooperation with the Maryland Shell Fish Commission, in surveying the oyster bars, establishing permanent landmarks at triangulation stations, and preparing for publication the necessary charts and technical and legal descriptions of boundaries and landmarks shown on these charts, has been executed in compliance with a request from the governor of the State of Maryland to the Secretary of Commerce and Labor, and by the authority of the following laws of the United States and Maryland:

\section{[Act of Congress approved May 26, 1906.]}

AN ACT Toauthorize the Secretary of Commerce and Labor to cooperate, through the Bureau of the Coast and Geodetic Survey and the Bureau of Fisheries, with the shellfish commissioners of the State of Maryland in making surveys of the natural oyster beds, bars, and rocks in the waters within the State of Maryland.

Be it enacted by the Senate and House of Representatives of the United States of America in Congress assembled, That the Secretary of Commerce and Labor be, and he is hereby, authorized and directed, upon the request of the governor of the State of Maryland, to designate such officers, experts, and employees of the Bureau of the Coast and Geodetic Survey and of the Bureau of Fisheries as may be necessary to cooperate with the Maryland State board of shellfish commissioners in making a survey of and locating the natural oyster beds, bars, and rocks in the waters within the State of Maryland; and the Secretary of Commerce and Labor is hereby authorized and directed to furnish to the officers, experts, and employees of said Bureaus so detailed as aforesaid such instruments, appliances, and steam launches as may be necessary to makc the survey aforesaid; and the Secretary of Commerce and Labor is hereby authorized to have made in the Bureau of the Coast and Geodetic Survey all the plats necessary to show the results of the aforesaid survey and the locations of the said natural oyster beds, bars, and rocks in the waters within the State of Maryland, and to furnish to the board of shellfish commissioners of the State of Maryland such copies as may be necessary, and for this purpose to employ, in the District of Columbia and elsewhere, such technically qualified persons as may be necessary to carry out the purpose of this act.

SEC. 2. That the Secretary of Commerce and Iabor is hereby further authorized to have erected or constructed by the officers so detailed as aforesaid, while making such survey, such structures as may be necessary to mark the points of triangulation, so that the same may be used for such future work of the Coast and Geodetic Survey as the said Bureau may be hereafter required to perform in prosecuting the Government coast survey of the navigable waters of the United States located within the State of Maryland.

SEC. 4. That this act shall take effect from the date of its passage.

[Act of Congress approved June 30, rgo6.]

AN ACT Making appropriations for sundry civil expenses of the Government for the fiscal year ending June thirtieth, nineteen hundred and seven, and for other purposes.

Be it enacted by the Senate and House of Representatives of the United States of America in Congress assembled, That the following sums be, and the same are hereby, appropriated, for the objects hereinafter expressed, for the fiscal year ending June thirtieth, nineteen hundred and seven, namely: * * *

Coast and Geodetic Survey: * * * For any special surveys * * * including the expenditures authorized under Public Act Numbered One hundred and eighty-one, approved May 
twenty-sixth, nineteen hundred and six, and contingent expenses incident thereto, five thousand dollars, together with the unexpended balance under this appropriation for nineteen hundred and six and prior years which is hereby reappropriated and made available on this account for the fiscal year nineteen hundred and seven ****

\section{[Act of Congress approved March 4, rgo7.]}

AN ACT Making appropriations for sundry civil expenses of the Government for the fiscal year ending June thirtieth, nineteen hundred and eight, and for other purposes.

Be it enacted by the Senate and House of Representatizes of the United States of America in Congress assembled, That the following sums be, and the same are liereby, appropriated, for the objects hereinafter expressed, for the fiscal year ending June thirtieth, nineteen hundred and eight, namely: * * *

COAST AND GEODETrC SURvEY: * * * For any special surveys * * * including expenses of surveys in aid of the shellfish commission of the State of Maryland, to be immediately available and to continue available until expended, twenty-five thousand dollars * * *.

\section{[Act of Congress approved May 27, rgos.]}

AN ACT Mfaking appropriations for sundry civil expenses of the Government for the fiscal year ending June thirtieth, nineteen hundred and nine, and for other purposes.

Be it enacted by the Senate and House of Representatives of the United States of America in Congress assembled, That the following sums be, and the same are hereby, appropriated, for the objects hereinafter expressed, for the fiscal year ending June thirtieth, nineteen hundred and nine, namely: * * *

COAST AND GEODETTC SURVEY: * * * For any special surveys * * * including expenses of surveys in aid of the shellfish commission of the State of Maryland, which expenses, including cost of plats and charts, shall not exceed fifteen thousand dollars in any one year, to be immediately available, twenty thousand dollars.

\section{[Act of Congress approved March 4, I90g.]}

AN ACT Making appropriation for sundry civil expenses of the Government for the fiscal year ending June thirtieth, nineteen hundred and ten, and for other purposes.

Be it enacted by the Senate and House of Representatives of the United States of America in Congress assembled, That the following sums be, and the same are hereby, appropriated, for the objects hereinafter expressed, for the fiscal year ending June thirtieth, nineteen hundred and ten, namely: * * *

COAST AND GEODETIC SURVEY: * * * For any special surveys * * * including expenses of surveys in aid of the shellfish commission of the State of Maryland, which expenses, including cost of plats and charts, shall not exceed fifteen thousand dollars in any one year, to be immediately available, twenty thousand dollars.

\section{[Act of Congress approved June 25, 1910.]}

AN ACT Making appropriations for sundry civil expenses of the Government for the fiscal year ending June thirtieth, nineteen hundred and eleven, and for other purposes.

Be il enacted by the Senate and House of Representatives of the United States of America in Congress assembled, That the following sums be, and the same are hereby, appropriated, for the objects hereinafter expressed, for the fiscal year ending June thirtieth, nineteen hundred and eleven, namely: * * *

COAST AND GEODETIC SURveY: * * * For any special surveys * * * including expenses of surveys in aid of the shellfish commission of the State of Maryland, to be immediately available, fifteen thousand dollars. 
[Act of Congress approved March 4, rgrs.]

AN ACT Making appropriations for sundry civil expenses of the Government for the fiscal year ending June thirtieth, nineteen hundred and twelve, and for other putposes.

Be it enacted by the Senate and House of Representalives of the United States of America in Congress assembled, That the following sums be, and the same are hereby, appropriated, for the objects hereinafter expressed, for the fiscal year ending June thirticth, ninetecn hundred and twelve, namely: * * *

COAST AND GEODETIC SURveY: * * * For any special surveys * * * including expenses of surveys in aid of the shellfish commission of the State of Maryland, to be immediately available, thirteen thousand dollars ***.

[Act of the Legislature of Maryland approved April 2, rgo6.]

AN AC'T To establish and promote the industry of oyster culture in Maryland, to define and mark natural oyster beds. bars and rocks lying under the waters of this State, to prescribe penalties for the infringement of the provisions of this Act. and $* * *$.

Section I. Be it enacted by the General Assembly of Maryland, That the following sections be, and they are hereby, added to article 72 of the Code of Public General Laws, title "Oysters." * * *

SEc. 86. The Board of Shell Fish Commissioners shall, as soon as practicable after the passage of this Act, cause to be made a true and accurate survey of the natural oyster beds, bars and rocks of this State, said survey to be made with reference to fixed and permanent objects on the shore, giving courses and distances, to be fully described and set out in a written report of said survey, as hereinafter required. A true and accurate delineation of the same shall be made on copies of published maps and charts of the United States coast and geodetic survey, which said copies shall be filed in the office of the said commissioners in the city of Annapolis, and the said commissioners shall further cause to be delineated upon copies of the published maps and charts of the United States coast and geodetic survey, of the largest scale, one copy for each of the counties of this State in the waters of which there are natural oyster beds, bars and rocks, all natural beds, bars and rocks lying within the waters of such county, which maps shall be filed in the offices of the clerks of the Circuit Court for the respective counties wherein the grounds so designated may lie * * *.

SEC. 87. The Governor of this State is hereby requested to ask the assistance of the United States coast and geodetic survey, and of the United States Fish Commissioner, to aid in the carrying out of the provisions of the preceding section.

SEC. 89. As soon as practicable after the first day of April, Igo6, the said commissioners shall organize, and shall at once proceed, with the assistance of such person or persons as may be detailed by the United States coast and geodetic survey and the United States Fish Commissioner, to aid them in their work, and of such persons as may be appointed under the preceding section, to have laid out, surveyed and designated on the said charts, the natural beds and bars, and shall cause to be marked and defined as accurately as practicable the limits and boundaries of the natural beds, bars, and rocks as established by said survey, and they shall take true and accurate notes of said survey in writing, and make an accurate report of said survey, setting forth such a description of landmarks as may be necessary to enable the said board, or their successors, to find and ascertain the boundary lines of the said natural oyster beds, bars and rocks, as shown by a delineation on the maps and charts provided in this Act; said report shall be completed and filed in the office of the board in the city of Annapolis within ninety days after the completion of the survey of any county. Said commissionets shall cause the same to be published in pamphlet form, and transmit copies of the said to the Clerks of the Circuit court for the respective counties, where the cliarts have been filed or directed to be filed as hereinafter provided; the said report to be filed by the clerks of the several counties in a book kept for that purpose. And the said survey and report, when filed, subject to the right of appeal hereafter provided for in this Act, shall be taken in all of the courts of this State as conclusive evidence of the boundaries and limits of all natural oyster beds, bars and rocks, lying within the waters of the county wherein such survey and report are filed, and shall be construed to mean in all of the said courts that there are no natural oyster beds, bars or rocks lying within the waters of the counties wherein such report and survey are filed other than those embraced in the survey authorized by this Act, and that all areas of the Chesapeake Bay and its tributaries within the State of Maryland, not shown in the survey to be natural oyster beds, bars or rocks shall be construed in all the courts of the State to be barren bottoms and open for disposal by the State for the purpose of private planting or propagation of oysters thereon 
under the provisions of this Act; provided, that the said survey and report shall not be construed as to affect in any manner the holdings by citizens of this State in any lot which may have been appropriated or taken up under the laws of this State prior to the approval of this Act.

The law of the State of Maryland, passed March 9, 1842 , authorizing officers of the United States Coast and Geodetic Survey to enter upon the lands within the State limits for the purposes of the survey, is as follows:

\footnotetext{
AN ACT Concerning the Survey of the Coast of Maryland.
}

SEction I. Be it enacted by the General Assembly of Maryland, That it shall and may be lawful for any person or persons employed under and by virtue of an act of the Congress of the United States, * * * at any time hereafter to enter upon lands within this State for the purpose of exploring, surveying, triangulating, or leveling, or doing any other matter or thing which may be necessary to effect the objects of said act, and to erect any works, stations, buildings, - or appendages requisite for that purpose, doing no unnecessary injury to private or other property.

SEC. $2{ }^{1}$ And be it enacted, That in case the person or persons employed under the act of Congress aforesaid, can not agree with the owners or possessors of the land so entered upon and used as to the amount of damage done thereto by reason of the removal of fences, cutting of trees or injury to the crop or crops growing on the same, it shall and may be lawful for the said parties or either of them to apply to the chief justice for the time being or one of the associate judges of the judicial district in which such land may be situated, who shall thereupon appoint three disinterested and judicious freeholders, residents of the same judicial district, to proceed with as much despatch as possible to the examination of the matter in question, and the faithful assessment of the damages sustained by the owners or possessors aforesaid, and the said frceholders or a majority of them, having first taken and subscribed an oath or aftirmation before the chief or associate justice aforesaid or other person duly authorized to administer the same, that they will well and truly examine and assess as aforesaid, and having given five days' notice to both parties of the time of their meeting, shall proceed to the spot, and then and there upon their own view and if required, upon the evidence of witnesses (to be by them sworn or affirmed and examined), shall assess the said damages, and shall afterward make report thereof and of their proceedings in writing under their hands and seals and filc the same within five days thereafter in the office of the clerk of the county in which the land aforesaid is situated, subject to an appeal by either party to the county court of the said county within ten days after filing as aforesaid, and the said report so made as aforesaid if no appeal as aforesaid be taken, shall be held to be final and conclusive as between the said parties, and the amount so assessed and reported shall be paid to the said owners or possessors of the land so damaged within twenty days after the filing of said report, and the said chief or associate justice as aforesaid, shall have authority to tax and allow upon the filing of said report, such costs, fees and expenses to the said freeholders for the performance of their duty as he shall think equitable and just, which allowance shall be paid by the person or persons employed under the act of congress aforesaid, within the time last above limited, but if an appeal as aforesaid be taken, the case shall be set down for hearing at the first term of county court aforesaid, ensuing upon and after appeal, and it shall be lawful for either party immediately after the entry of such appeal, to take out summons for such witnesses as may be necessary to be examined upon the hearing aforesaid, and the said court shall have power in its discretion to award costs against which ever the final judgment shall be entered, and such appeal at the option of either party may and shall be heard before and the damage assessed by a jury of twelve men to be taken from the regular panel and elected as in other cases.

SEC. 3. And be it enacted, That if any person or persons shall wilfully injure or deface or remove any signal, monument or building or any appendage thereto, erected, used or constructed under and by virtue of the act of congress aforesaid, such person or persons so offending shall severally forfeit and pay the sum of fifty dollars with costs of suit to be sued for and recovered by any person who shall first prosecute the same before any justice of the peace of the county where the person so offending may reside, and shall also be liable to pay the amount of damages thereby sustained, to be recovered with costs of suit in an action on the case, in the name and for the use of the United States of America, in any court of competent jurisdiction.

1 Under the rulings of the Comptroller of the Treasury no damages can be collected cxcept through the United States Court of Clains unless an agreement has been made in advance. 


\section{APPENDIX B.-THE HAMAN OYSTER CULTURE LAW.}

[Eixtract from Second Report of Shell Fish Commission.]

OBJECT.

"The legislature in placing chapter $7 \mathrm{I}$ of the acts of 1906 , better known as the Haman oyster culture law, upon the statute books of Maryland, had a twofold object in view:

" $\mathbf{I}$. To encourage an industry in oyster culture upon the barren bottoms beneath the tidewaters of the State.

"2. To prevent the leasing of natural oyster bars for the purpose of oyster culture."

SURVIYY.

"To make the leasing of barren bottoms possible and the leasing of natural bars impossible, provision was made for a survey of the natural bars for the purpose of accutately locating and marking the same. It was definitely provided that 10 barren bottoms should be leased in any part of the State until the natural bars of that region had becn surveyed, charted, and marked with buoys."

\section{DEFINITION OF A NATURAL OYSTER BAR.}

\section{NATURAL BAR NOT DIFININE.}

"The Shell Fish Commission is instructed by section 90 of the Haman oyster culture law to exercise its judgment liberally in favor of the natural bars when surveying, charting, and buoying them, but other than this the commission is uninstructed in this important matter. The responsibility of defining a natural bar is placed upon the commission."

\section{DIVERSITY OF OPINION.}

"No definition of a natural oyster bar could be formulated by any man or body of men which would meet with the approval of all parties concerned. Oystermen, as a rule, hold that all bottoms where oysters grow or have grown naturally, even though now practically barren of oysters, should be considered natural bars. Other citizens of the State, who are not directly interested in the oyster business but interested in the oyster industry from the standpoint of revenue, hold, as a rule, that no bottoms should be excluded from leasing for oyster culture which by methods known to oyster culturists may be made to yield a greater number of oysters than they now produce.

"It should be evident to everyone that neither of these definitions could be adopted by the commission as a working basis for determining which of the grounds surveyed are natural oyster bars."

\section{THE GOLDSBOROUGH DEFINITION.}

The definition of a natural oyster bar which very nearly approaches a reasonable and satisfactory compromise between the views of the subject held by oystermen on one hand and by oyster culturists on the other is that contained in an opinion rendered by Judge Charles F. Goldsborough in the circuit court for Dorchester County in the July term, I88r, in the case of William T. Windsor and George R. Todd $v$. Job T. Moore.

This definition has been adopted by the Shell Fish Commission as the basis for the determination of the status of the various oyster bottoms surveyed, and is as follows:

What, then, is a natural bar or bed of oysters? It would be a palpable absurdity for the State to attempt to promote the propagation and growth of oysters and to encourage its citizens, by a grant of land, to engage in their culture, if the lands authorized to be taken up were only those upon which oysters do not and can not be made to grow. That there may be lands covered by water in the State where no oysters can be found, but where, if planted, they could be cultivated successfully, may be possible; but if so, I imagine that their extent must be too limited for them to be of much practical general advantage for the purposes of such a law as the one under discussion; but there are thousands of acres of hard and shifting sands where oysters not only are not found, but where it would be folly to plant them, and these latter it can not be supposed that the State intended to offer to give away, for the simple reason that the State could not help knowing that nobody would have them.

Upon the other hand there are large and numerous tracts where oysters of ratural growth may be found in moderate numbers, but not in quantities sufficient to make it profitable to catch them, and yet where oysters may be successfully planted and propagated. In my opinion these can not be 
called natural bars or beds of oysters within the meaning of the act of assembly, and it is just such lands as these that the State meant to allow to be taken up under the provisions of the above-mentioned section of the act.

But there is still another class of lands where oysters grow naturally and in large quantities and to which the public are now and have been for many years in the habit of resorting with a view to eaming a livelihood by catching this natural growth, and here, I think, is the true test of the whole question. Land can not be said to be a natural oyster bar or bed merely because oysters are scattered here and there upon it and because if planted they will readily live and thrive there; but whenever the natural growth is so thick and abundant that the public resort to it for a livelihood, it is a natural oyster bar or bed and comes within the above-quoted restriction in the law, and can not be located or appropriated by any individual.

APPLICATION OF DEFINITION.

Before this definition may be of use in determining accurately and scientifically the status of an oyster ground, its central idea, "livelihood," must be expanded into accurately determinable factors, and these factors must be combined into a practical scheme of investigating the condition of the ground under consideration.

Stated briefly, a livelihood is represented by a sum of money obtained from the sale, at a fixed price, of a certain quantity of oysters gathered in a given time from an allotted area of ground.

Knowing the value of each of these factors, it becomes possible to calculate the number of oysters an oyster ground must produce per square yard in order that oystermen may secure a livelihood by working upon it.

NOTE. - The factors into which the commission resolved the livelihood problem, the value assigned to each factor, and the scheme devised for practical use in examining and applying the definition to oyster bottoms are given in outline in their second report under the lieading of the preceding extract, and in detail in their first report on pages 32 to 69 .

\section{APPENDIX C.-SUMMARY OF THE PARTICULAR SURVEYING OPERATIONS WHICH CON- STITUTE AN "OYSTER SURVEY" AS NOW BEING CARRIED ON IN MARYLAND.}

Explanation.-A brief account of the particular surveying operations which constitute an "oyster survey" as now being carried on in Maryland, will assist in the interpretation of records contained in the technical part of this report, and will be of interest to many who may not understand the necessity for the great amount of work being done or its complicated character.

To those familiar with methods used in surveying and charting the characteristic features of large bodies of water there is an evident necessity for the various operations performed, especially when it is known that the boundaries of the public oyster bars and of the private lots leased for purposes of oyster culture must be surveyed and charted with the greatest practical accuracy. To others it will be sufficient to state that the actual experience gained from oyster surveys in other States has proven that in order to avoid endless dissatisfaction and litigation it is necessary to accurately locate and permanently establish oyster boundaries as is now being done in Maryland.

Triangulation survey.-Such refinement of survey work as that demanded by the conditions of an oyster survey when carried on at considerable distances offshore can only be obtained by the use of a system of triangulation as a framework or foundation. Therefore, a triangulation survey, including the permanent marking of the positions of landmarks with monuments, and a record of the descriptions of their locations for future recovery is a necessary operation of a complete oyster survey.

Topographic survey.-The technical records which establish the relation between the offshore oyster boundaries and triangulation landmarks are sufficient for the requirements of engineers in making resurveys, but do not supply the needs of others who are interested in the same boundaries by reason of their occupation as oystermen concerned as to the public oyster bars, or oyster culturists concerned as to the leasable bottoms. For these it is necessary to have the charts of the survey show the relation of the shore line and other topographic features to the boundaries of the public oyster bars and private oyster farms. Therefore a topographic survey is a necessary operation of a complete oyster survey.

Hydrographic survey,-In the settlement of the important question of what is or what is not a natural oyster bar, and in the consideration of bottoms to be selected for purposes of oyster culture, information as to the depth of water and the character of the bottom is required. Therefore a hydrographic survey is a necessary operation of a complete oyster survey. 
Necessary foundation for an oyster survey.-Consequently, the necessary components of a satisfactory foundation for a complete oyster survey are the three classes of survey operations technically named triangulation, topography, and hydrography, or, stated in another way, the foundation of a practical oyster survey includes the surveying operations usually followed by the Coast and Geodetic Survey leading up to the preparation and publication of nautical charts.

Special surveys and investigations pertaining to oysters.-Having obtained this cartographic survey for a foundation, partly by new work and partly from records of previous work of the Government, the combined operations" making up an "oyster survey" are completed by superimposing on this foundation special surveys and investigations pertaining particularly to oysters or other shell fish.

The special surveys pertaining to oysters furnish information as to the location and outline of oystershell bottoms, and are carried on by the sounding-boat party in addition to the usual hydrographic work. ${ }^{2}$ This operation consists of the observation and record of the character of vibration of a wire and chain apparatus which is dragged over the bottom, the vibrations or lack of vibrations indicating the presence and quantity of shells or absence of shells.

The special oyster investigations ${ }^{3}$ consist of the actual determination of the kind and quantity of oysters on the bottom, and such economic and biological studies of the supply of oyster food, density of water, character of the bottom, and other important matters as affect the growth of oysters. In this work the oyster investigation stations are located and buoyed by the hydrographic party while engaged in the survey of the oyster-shell limits. They are selected with the view of obtaining characteristic data which can be used for the interpretation of the recorded vibrations of the chain apparatus at all other points covered by the survey.

Preparation of results.-The actual surveying operations and oyster investigations having been completed for any one county, there still remains technical work of nearly equal magnitude to that described." This work consists of the preparation of charts and technical descriptions of boundaries and landmarks for publication by the Government, the preparation of that part of the annual report of the commission covering the special oyster surveys and investigations, the making of the leasing charts and finished projections, and finally the filing of the oyster charts and records with the courts and the commission, thus opening a county for oyster culture.

Summary.-From the foregoing account it can be scen that a complete oyster survey properly conducted so as to answer all practical requirements of the present and permanency of results for the future is a very complicated affair, involving many lines of surveying and other scientific work, and requiring the professional services of experts in the various operations of cartographic surveying and shell-fish investigations.

\footnotetext{
${ }^{1}$ See Appendix D of this publication for "Statistics of results of combined operations of the Government and State."

2 See pp. 104 to 123 of "First Annual Report of Maryland Shell Fish Commission."

3 See pp. 30 to 67 and 129 to 199 of "First Annual Report of Maryland Shell Fish Commission."

* No mention is made here of the large amount of administrative work of the commission, which is greatly complicated and increased by the effect of the oyster-survey operations on many thousands of people whose interests are more or less involved; or of the large amount of survey work involved in the survey and record of the boundaries of oyster lots leased from the State by private individuals for the purposes of oyster culture.
} 


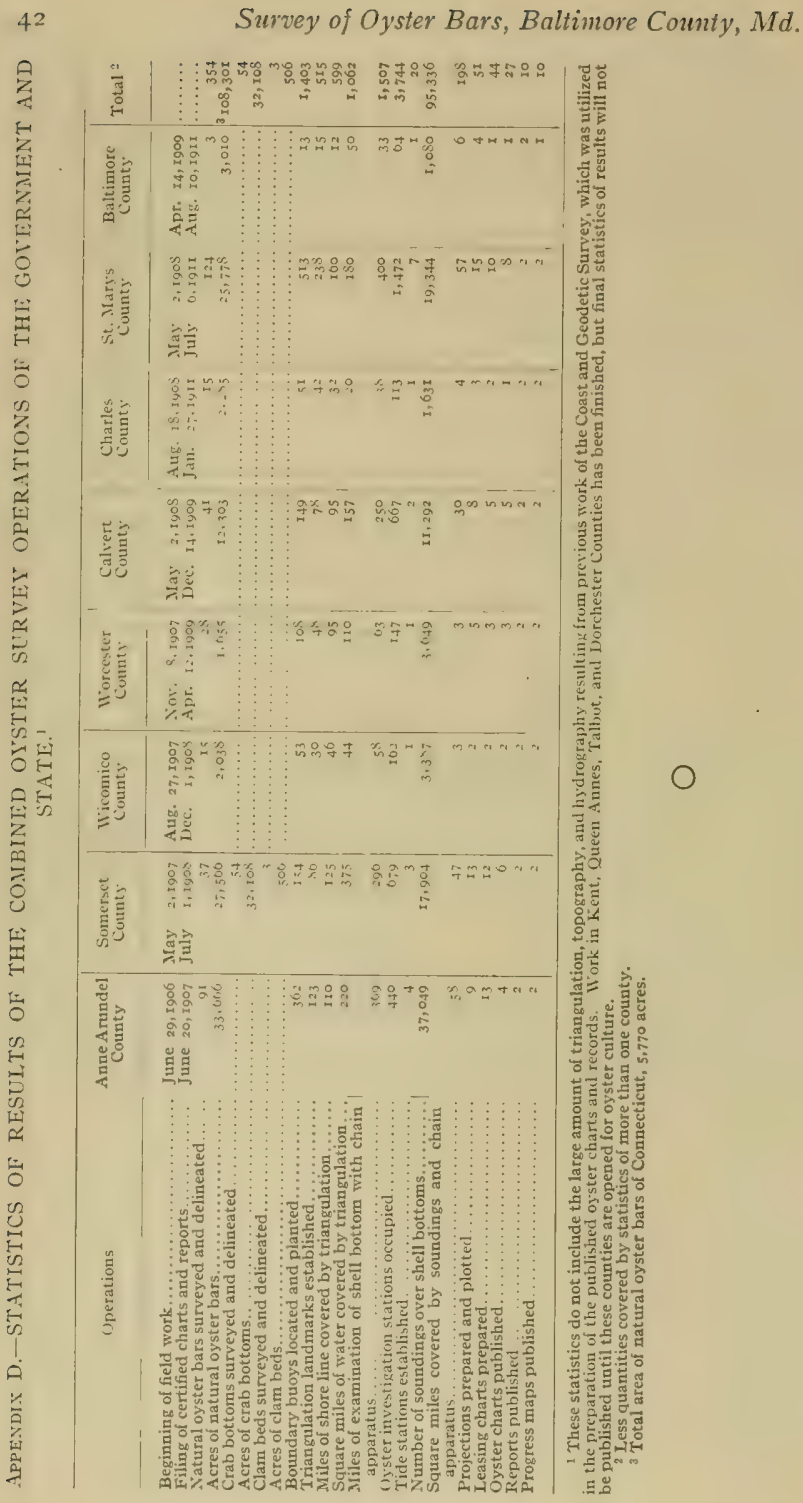




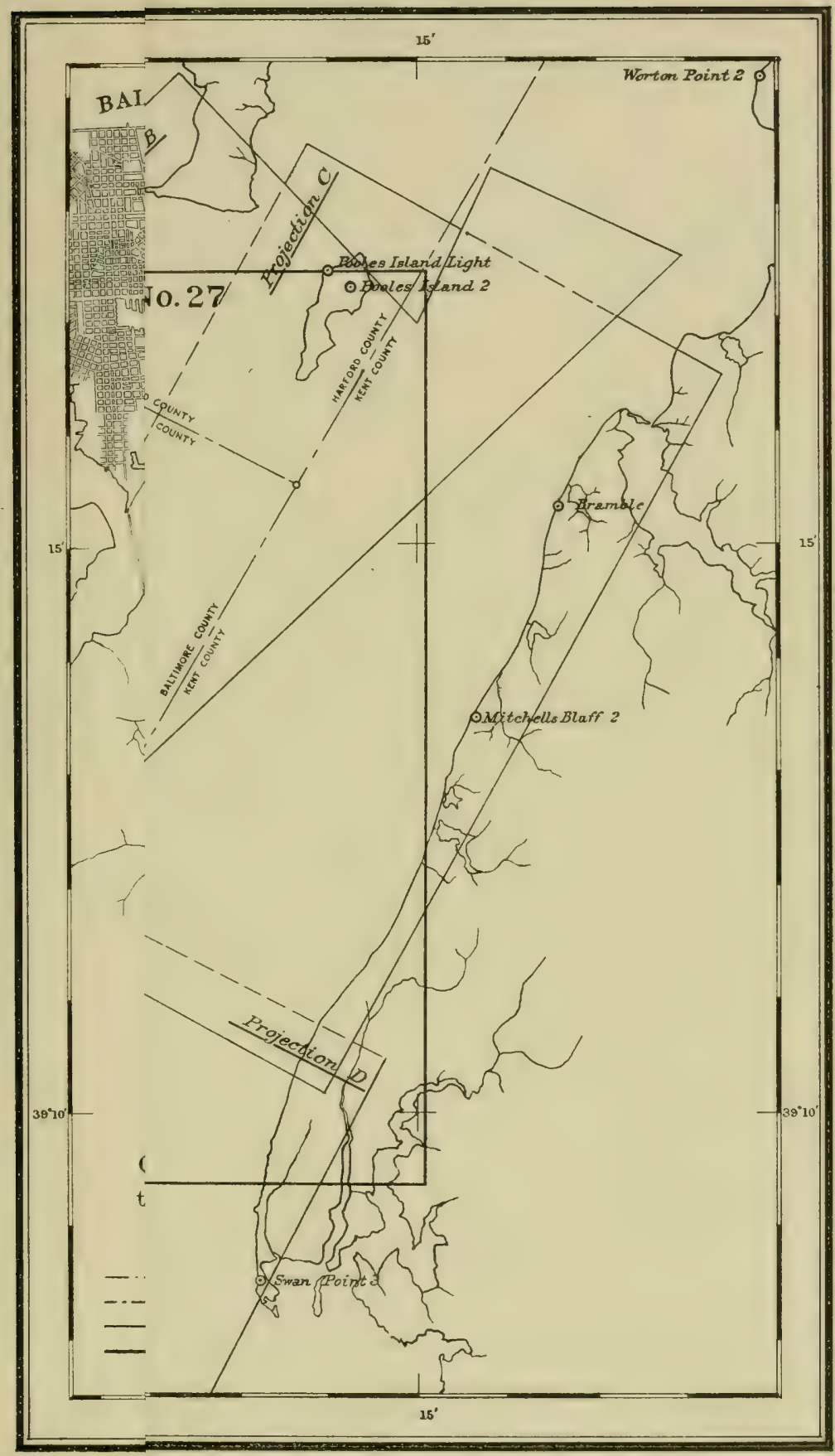







\title{
DEPARTMENT OF COMMERCE AND LABOR
}

COAST AND GEODETIC SURVEY

O. H. TITTMANN, Superintendent

\section{SURVEY OF OYSTER BARS \\ CALVERT COUNTY MARYLAND}

DESCRIPTION OF BOUNDARIES AND LANDMARKS AND REPORT OF WORK OF UNITED STATES COAST AND GEODETIC SURVEY IN COOPERATION WITH UNITED STATES BUREAU OF FISHERIES AND MARYLAND SHELL FISH COMMISSION

\author{
By C. C. YATES
}

CHIEF OF COAST AND GEODETIC SURVEY PARTY ASSISTANT, COAST AND GEODETIC SURVEY

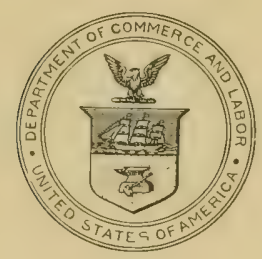

WASHINGTON

GOVERNMENT PRINTING OFFICE

1910 



\title{
LE'TTER OF SUBMITTAL.
}

\author{
DEPARTMENT OF COMMERTE AND LABOR, \\ Coast and Geonetic Survey, \\ Washington, December 2I, I9og.
}

SIR: I have the honor to transmit herewith a report of the officer detailed from the Coast and Geodetic Survey to cooperate with the Bureau of Fisheries and the Maryland Shell Fish Commission in surveying the oyster bars of the State of Maryland, and certain technical results which are necessary for the interpretation and use of the plats of the survey made by the Government.

This work has been done under the provisions of the act of Congress entitled "An act to authorize the Secretary of Commerce and Labor to cooperate, through the Bureau of the Coast and Geodetic Survey and the Bureau of Fisheries, with the shell fish commissioners of the State of Maryland in making surveys of the natural oyster beds, bars, and rocks in the waters within the State of Maryland," approved May 26, 1906, and of the acts of Congress making appropriations for sundry civil expenses of the Government for the fiscal years ending June 30, 1907, 1908, 1909, and 1910.

Respectfully,

To Hon. Charles Nagei,

O. H. Titrmann, Superintendent.

Sccretary of Commerce and Labor. 



\section{CERTIFICA TION.}

BaLtIMORE, MD., December IO, I9O9.

The following publication is certified to contain correct technical descriptions of all boundaries and landmarks established in Calvert County by the Maryland Shell Fish Commission in cooperation with the United States Coast and Geodetic Survey.

C. C. Yates,

Chief of Coast and Geodetic Survey Party,

Assistant, Coast and Geodetic Survey.

BALTIMORE, MD., December io, roo9.

Examined and ccrtified to be correct.

WALTER J. MiTCHELL,

Casweli, Grave,

Benjamin K. GREen,

Maryland Shell Fish Commission.

SWEPSON EARLE,

Hydrographic Engineer.

NorE:-Certified copies of this publication and of the charts of the natural oyster bars of Calvert County were filed in the office of the clerk of the circuit court of Calvert County and in the office of the Board of Shell Fish Commissioners, at Annapolis, on December I4, 1909 . 



\section{CONTENTS.}

PROGRESS MAP _.

LETTER OF SUBMTTAL

CERTIFICATION

INTRODUCTION:

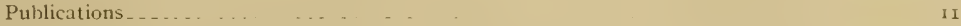

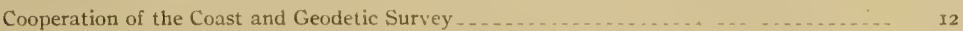

Cooperation of the Bureau of Fisheries .......... 12

General statement of work of Coast and Geodetic Survey _................... 12

REPORT OF THE WORK OF THE COAST AND GEODETIC SURVEY:

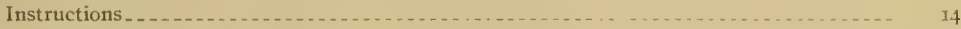

Organization and equijument _.. _... _.

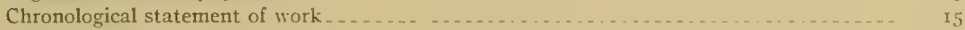

Statistics .............

General remarks ............. . . . . . . . . . . Iú

CHARTS AND MAPS:

Charis of natural oyster bars. . _ _ . . . . . . . . . . .

I.easing charts.... . . . . . . $\quad$.

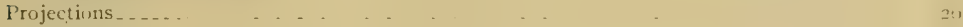

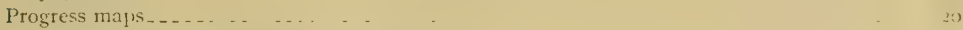

BOUNDARIES OF THE COUNTY WATERS:

Waters within territorial limits of county _...

llaters contiguous to county _.... . . . . . . 2 I

Landmarks (U. S. Coast and Geodetic SURvey triangulation Stations):
Explanation

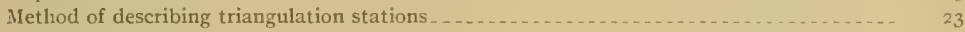

Descriptions of triangulation stations-

Chart No. I6 (Chesapeake Bay)-

Holland ................... . . . . . . . . 26

Hog I'uint (Holland 3) .. ... . . . . . 20

Beach _...

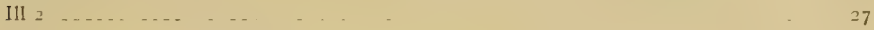

Plum 3 - . .

Pier (see also Chart No. I7)

Sharps Island Light _...

Chart No. I7 (Chesapeake Bay)-

Pier (see alse) Chart No. 16) _... 28

Pen

Patch . 2...

Parker $\ldots$. 30

Run (see also Chare lo ris _..

Chart No. I8 (Chesapeake Bay)-

Run (see also Chart No. 17) _........ 3n 
LANDMARKS (U. S. COAST AND GEODETIC SURVEY TRIANGUlation STATrons)-Continued. Descriptions of triangulation stations-Continued.

Chart No, IS (Chesapeake Bay)-Continued.

Poplar

Flag Pond.

Wilson

Point of Rocks.

Cove Point Light (see also Chart No. 20) -

White House (N. E. chimney) (see also Chart No, 20)

Travers 2

Chart No. 19 (Upper Patuxent River)-

Prince.

Leitch.

Fodder

Buena -

Teague

City

- Hallowing

Indian

Dwarf

Sothoron

Buzz

Billiard.

Morsel

Trent

Collins

Sheridan.

Cremona.

Kitt ....

Oppkit.

Battle

Photo

Fight

Slim

Forr

Sweep-1 -

Island .

Peak

Cole

Hutchins

Wheat (see also Chart No. 20)

Mackall (see also Chart No. 20)

Sollers (see also Chart No. 20)

Bars .

Lend (see also Chart No. 20)

Chart No. 20 (Lower Patuxent River)-

IVheat (see also Chart No. 19) -

Mackall (see also Chart No, 19)

Lend (see also Chart No. 19)

Stock

Stump

Briscoe

Page.

Hellen 
LANDMARKS (U. S. COAST AND GEODETIC SURVEY TRIANGULATION STATIONS)-Continued. Descriptions of triangulation stations-Continued.

Chart No. 20 (Lower Patuxent River)-Continued.

Ton.

Mill

Bur

New

Catholic Church Cross

Cable

Town

Crane

M. E. Church (Solomons) -

K. of P. Flagstafi (Solomons) ....

Sand

Fishstack

Bon

Barediz House Cupola .

Drum Point Light

Ben .....

Craddock

Carroll 2

Hog 2.

Pat

White House (N. E. chimney) (see also Chart No. 18)

Cove Point Light (see also Chart No. I8)

Cedar Point Light

Cain ....................

Desert -

BOUNDARIES OF OYSTER BARS:

Explanation

Method of describing boundaries

Surveying methods for relocation of boundaries

Boundaries of natural oyster bars-

Chan No. 16 (Chesapeake Bay)-

Hog Point

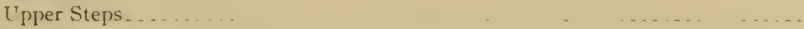

Lower Steps.

Plum Point (see also Chart No. $1 / \bar{z}$ )..

Chart No. ${ }_{7}$ (Chesapeake Bay)-

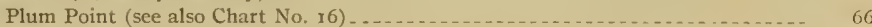

Daddie Dare................... . . . . . . . . . 66

Governors Run (see also Chart No. 18)

Emanuel (see also Chart No. I8) . . . . . . . . . . .

Chart No. I\& (Chesapeake Bay)-

Governors Run (see also Chart No. 17) _... 67

Emanuel (see also Chart No. 17 ) . . . . . . . . . . . . 67

Flag Pond .... ..... ... . . . . . . . . . . . . . . . 68

Chant No. In (Upper Patuxent River)-

Spout . . . . . . . . . . . . .

Holland Point (Calvert County)

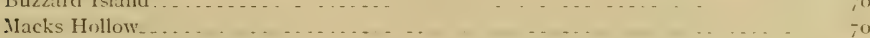

Broad Neck (Calvert County)

Thomas (Calvert County) ......... . . . . . . ; r

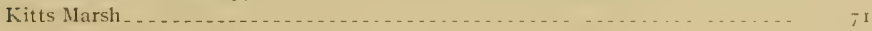


BOUNDARIES OF QYSTER BARS-Continued.

Boundaries of natural oyster bars-Continued.

Chart No. 19 (Upper Patuxent River)-Continued. Page.

Prison Point ... . . . 72

Jacks Marsh _ _ . . .

Jacks Bay _.....

Parkers Wharf ......... 73

Broome Island . .

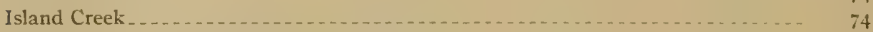

Peterson (Calvert County) (see also Chart No. 20) _.......... 75

Mears (Calvert County) (see also Chart No. 20) _. . . . . . . . . . . . . 75

Chart No. 20 (Lower Patuxent River)-

Peterson (Calvert County) (see also Chart No. 19) _...

Mears (Calvert County) (see also Chart No. 19) . . . . . . . . . . . . . . . . . 75

Hellen . . . . .

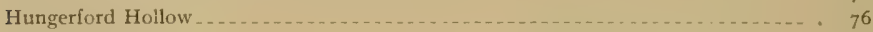

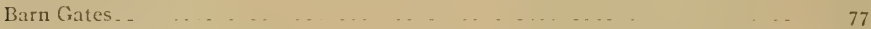

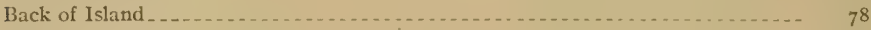

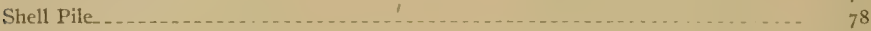

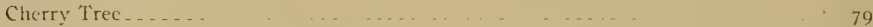

Swash _...

Sandy Point Lumps . .

Southeast Middle-ground $\ldots \ldots \ldots \ldots \ldots \ldots \ldots \ldots$. 8 I

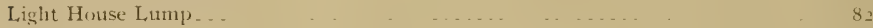

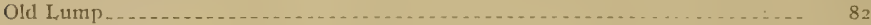

Carroll Muds (Calvert County) _. . . . .

Simmons _. _ .

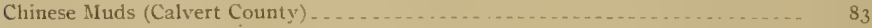

Parker Moore _...

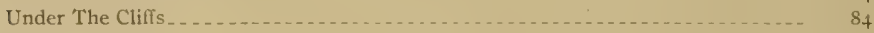

Lit le Cove Point_._.

Cove Point Bight

APPENDIXES:

Appendix A.-Laws relating to the cooperation of the Coast and Geodetic Survey and Bureau of Fisheries with the Maryland Shell Fish Commission.

Appendix B.- "The Haman Oyster Culture Law" (extract from Second Report of Shell Fish Commission)

Appendix C.-Summary of the particular surveying operations which constitute an "oyster survey" as now being carried on in Maryland.

Appendix D.-Statistics of results of the combined operations of the Government and State_ 


\title{
SURVEY OF OYSTER BARS, CALVERT COUNTY, MD.
}

\section{INTRODUCTION.}

\author{
PUBLICATIONS.
}

The preparation of publications relating to the survey of the oyster bars of Maryland has been divided between the Government and the State in accordance with the laws ${ }^{a}$ authorizing the work and the natural division of the surveying operations ${ }^{b}$ of the cooperating forces.

The publications prepared and issued by the Government under the direction of the Superintendent of the Coast and Geodetic Survey consist of a series of charts and a technical report for each county surveyed. ${ }^{c}$ The charts show all legal boundaries of oyster bars within the adopted boundaries of the waters opened up for leasing with each county, and the location of all landmarks (Coast and Geodetic Survey triangulation stations) used as a foundation for the delineation of these various boundaries. The technical report gives technical and legal descriptions of all oyster-bar and other boundaries, and descriptions of all landmarks shown on the charts, and includes the report of the representative of the Coast and Geodetic Survey in charge of the work of that Service in cooperation with the Bureau of Fisheries and the Maryland Shell Fish Commission. These charts and technical reports are prepared and certified for file with the courts and the Commission, as required by the laws of the State, and contain all information necessary to make a permanent record of the work of the Commission and the Government for all future requirements of the courts, or for any resurveys that may become necessary. ${ }^{d}$

The publications prepared and issued by the State under the direction of the Shell Fish Commission consist of annual reports of all the operations of the Commission

a See Appendix A for laws relating to the cooperation of the Coast and Geodetic Survey and Bureau of Fisheries with the Maryland Shell Fish Commission.

b See Appendix C for a summary of the particular surveying operations which constitute an "oyster survey" as now being carried on in Maryland.

c These charts and technical reports can be obtained by application to the Superintendent of the Coast and Geodetic Survey, at Washington, D. C. The publications ready for issue are those for Anne Arundel, Somerset, Wicomico, Worcester, and Calvert counties; those for St. Marys and Charles counties are now being prepared.

$d$ The technical records and charts for each county are published separately on account of the reçuirements of the oyster-culture laws of the State and the practical cunsiderations which make it desirable to have each county "opened up" for oyster culture as soon as practicable after the completion of its survey. For these reasons and the fact that these reports are each arranged for distribution and use in one county only without reference to other published records, much of the text of this publication is of necessity identical with similar previous publications for other counties.

e These reports can be obtained by application to the Shell Fish Commission, Annapolis, Md. They are issued annually in October, and the first and second reports are now available for distribution. 
performed under the provisions of the laws of Maryland, ${ }^{a}$ including results of biological and economic oyster investigations, methods and results of the hydrographic survey of the boundaries of oyster bars and crab bottoms, the administrative report and financial statement of the Commission, information relating to oyster culture, methods of surveying and leasing of oyster lots, and much other important matter of legal and scientific value.

These two sets of publications are planned and arranged to supplement each other without unnecessary duplication, and when combined they form a complete report of operations, methods, and results of the work of both the Government and State. ${ }^{b}$

COOPERATION OF THE COAST AND GEODETIC SURVEY.

The work of the Coast and Geodetic Survey, as the name of the Service indicates, includes a survey of the coasts of the United States made on a geodetic basis. This has involved the gradual construction of a great framework of interstate triangulation for use as a foundation for detail hydrographic and topographic surveys, from which there has been compiled and published a complete set of charts of the coasts of the United States, including all waters of Maryland where oysters grow. This existing triangulation, hydrography, and topography is essential as a foundation for a correct and practical survey of natural oyster bars; and it being one of the fundamental functions of the Coast and Geodetic Survey to furnish such data, the cooperation of the Coast and Geodetic Survey with the Bureau of Fisheries and the Maryland Shell Fish Commission is a practical and natural development of Government work leading to the conservation and increase of the supply of food.

\section{COOPERATION OF THE BUREAU OF FISHERIES.}

The Bureau of Fisheries has cooperated with the Coast and Geodetic Survey and the Maryland Shell Fish Commission principally as an arviser in matters relating to the biological and economic survey of oyster bars and the methods to be employed for that purpose. $^{c}$ A steam launch, rowing boat, and certain apparatus have also been furnished.

The primary function of the Bureau of Fisheries is to increase the productiveness of marine and fresh waters by such measures as may be best suited to the purpose, and the services rendered in connection with the survey of the oyster bars of Maryland are strictly in line with the fundamental law under which it acts. In certain States other than Maryland similar work has been conducted by the Bureau acting independently, the same ends being attained at greater expense to the Government.

GENERAL STATEMENT OF WORK OF COAST AND GEODETIC SURVEY. ${ }^{2}$

The results obtained from the work of the Coast and Geodetic Survey in cooperation with the Bureau of Fisheries and the Maryland Shell Fish Commission need very

a See Appendix B for an extract from the "Second Report of the Maryland Shell Fish Commission," giving a concise summary of the "Haman Oyster Culture Law."

$b$ See Appendix D of this publication for "Statistics of results of combined operations of the Government and State."

$c$ Hon. George M. Bowers, Commissioner of Fisheries, has detailed for this service Dr. H. F. Moore, Assistant, Bureau of Fisheries.

$d$ For a detail statement of the very large amount of excellent oyster survey work of the Mlaryland Shell Fish Commission see the "Annual Reports of the Maryland Shell Fish Commission." 
little other summary than is indicated by the published "Charts of Natural Oyster Bars" and the scheme of hydrographic projections and triangulation stations shown on the county progress maps attached to each report.

The triangulation has been carried on in accordance with the standard methods of the Coast and Geodetic Survey, making this work and that of the "Descriptions of Triangulation Stations" of permanent value, not only to the State of Maryland in the survey of her oyster bars, but also to the Government for any future work it may do in the regions covered by the oyster-survey operations.

The boundaries of the various shellfish bottoms in relation to landmarks and the adjacent topography have been shown with all the accuracy permitted by the largescale oyster charts published especially for that purpose.

The technical and legal descriptions of the boundaries and the description of the location of landmarks have been prepared and published in such a manner as to minimize the probability of future disputes in reference to their location.

Stated another way and quoting from the report of the "Survey of Oyster Bars of Anne Arundel County:"

The geographic positions of the permanent landmarks and signals have been determined with the usual precision of a trigonometric survey, and their locations at all points necessary to provide ample foundation for the surveying and charting operations permitted great accuracy of definition and location for the natural oyster bar and other boundaries established. At the same time, the very important element of permanency of the positions of boundaries has been secured, as the relocation of geodetic positions can always be accomplished by a competent surveyor, even though the original landmatks and monuments have been washed away, as has been the fate of hundreds of such points established by the Coast and Geodetic Survey on the shores of the Chesapeake Bay during the last sixty-five years.

In fact, when the survey of the oyster bars of Maryland is completed, it is believed that it will stand the test of time and practical use as a working foundation for whatever form the oyster legislation of the future may assume, and that the doing of the work systematically and accurately, once for all, will lead finally to the development of a great natural food resource in the form of real oyster culture which will bring ample reward for all expenditures of the "oyster survey." 


\title{
REPORT OF THE WORK OF THE COAST AND GEODETIC SURVEY IN CALVERT COUNTY.
}

\author{
INSTRUCTIONS.
}

The following two letters, together with the laws ${ }^{a}$ of the United States relating to the subject, constitute the "instructions" received by the chief of the Coast and Geodetic Survey party engaged on work in connection with the Maryland Shell Fish Commission. They are short and definite, but furnish ample authority and-leeway for a!l legitimate development of the cooperation of the Government and the State in the survey of oyster bars. The "free hand" permitted by these orders, together with the aid and many valuable suggestions received from the officers of the Survey at Washington, have proved very beneficial to the work, and are greatly appreciated.

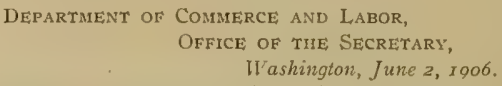

SIR: In reply to your letter of May 28 , requesting me to designate officers of the Coast and Geodetic Survey and of the Bureau of Fisheries to cooperate with the State of Maryland in making survey of and locating the natural oyster beds, I have the honor to inform you that Mr. C. C. Yates will be designated to cooperate on the part of the Coast and Geodetic Survey as soon as Congress makes the provisions of the act effective by providing an appropriation for the purpose.

\section{Respectfully;}

His Iixcellency Hon. EDWIN IVARFIELD,

LaWrence O. Murray, Assistant Secretary.

Governor of Maryland, Annapolis, Md.

DEPARTMENT OF COMMERCE AND LABOR,

CoAst and Geodetic Strver,

IVashington, July 3, 1906.

SIR: Upon the receipt of these instructions you will surrender the command, accounts, etc., of the steamer Endeavor to the Hydrographic Inspector.

As soon as this transfer is completed you will enter upon the duties of Coast Survey representative on the Shell Fish Commission of Maryland.

You will consult the commissioners, prepare a programme of work, and submit estimates in the usual form.

You are authorized to come to Washington for consultation from time to time as may he necessary.

Very respectfully,

O. H. Titrmann, Supcrintendent.

Capt. C. C. Yates,

U.S. C. and G. S. Stcamer Endear'r, Baltimore, Md.

a For tliese laws see Appendix A. 
ORGANIZATION AND EQUIPMENT.

The personnel and occupation of the party of the Coast and Geodetic Survey have remained practically unchanged since the beginning of the "oyster survey." Besides the chief of party, it consists of the necessary triangulators, computers, draftsmen, and temporary employees required to carry on both the surveying operations in the field and the preparation for publication of oyster charts and technical records in the Office at Washington.

The equipment for the work of the party has been ample and satisfactory. The large living and office quarters furnished the Government on the Maryland Sheil Fish Commission house boat Oyster have been very convenient for the work, besides facilitating efficient cooperation with the surveying and oyster investigation parties of the State. In addition to the accommodations on the Oyster the Coast and Geodetic Survey party has had the constant use of the large steam launch Inspector and several other boats furnished by their own Service, and the occasional use of the Bureau oi Fisheries launch Canvasback ${ }^{a}$ and the steamer Governor McLane ${ }^{b}$ of the State fishery force.

The greater part of the equipment of instruments for the operations of both the Government and State have been furnished by the Coast and Geodetic Survey and consist of all necessary theodolites, levels, sextants, drafting instruments, hydrometers, etc., required for all field and office work.

CHRONOLOGICAI, STATEMENT OF WORK.

The field work of the Coast and Geodetic Survey in Calvert County ${ }^{c}$ dates from May 2, I goS, when the house boat Oyst r left Baltimore for an anchorage in the Patuxent River, inside of Solomons Island. She remained in this harbor for three months, it practically being the only suitable anchorage for the work for the entire Chesapeake Bay shore of Calvert County, as well as for the lower Patuxent River. During this period there was a great amount of windy weather and consequent rough seas, which prevented work in the open bay, and in general the triangulation foundation for the oyster survey made very slow progress.

On August 4, 1908, the part of the work necessarily done from the mouth of the Patuxent River was completed, and the Oyster was moved about 7 miles up the river to St. Leonards Creek.

On August 18, 1908, the headquarters for the field work was again changed by moving the house boat $O y$ ster 8 miles still farther up the river to an anchorage in Battle Creek, where she remained until the completion of that part of the field work which naturally included all the Patuxent River work of Charles and St. Marys counties as well as that of Calvert County, although the results are published separately.

On September 3, 1908, the house boat finally left the Patuxent River for a new anchorage in a tributary of the Potomac River, and the field work of Calvert County

$a$ By courtesy of Dr. H. F. Moore, U. S. Bureau of Iisheries.

$b$ By courtesy of Capt. James A. Turner, commanding.

$c$ The field work of Calvert, Charles, and St. Marys counties was so intermixed in the Patuxent River that the chronological statement of work for any one of these counties necessarily includes a considerable part of the work of the other two counties. 
was dropped from that date until July 27, 1909, when it was again taken up for a period of four days to add a few details of the triangulation required for the descriptions of stations.

On December 2, 1909, it was again found necessary to obtain further triangulation details for the publication of the technical report for Calvert County, and field work was carried on for that purpose from that date to December 8, I909.

The office work connected with the "oyster survey" of Calvert County, including computations and drafting necessary for the preparation of oyster charts and technical records for publications, was continued intermittingly with the office work of other counties surveyed during same season from the beginning of field work of Calvert County to the time of the filing of the certified oyster charts and reports in the archives of the Commission and with the clerk of the circuit court of Calvert County on December I4, 1909 .

\section{STATISTICS. ${ }^{a}$}

Landmarks and triangulation signals erected . . . . . . . . 69

Monuments planted to mark triangulation stations

Triangulation stations occupied for observations of horizontal angles . . . .

Old triangulation stations recovered

New triangulation stations established

Total old and new triangulation stations marked and described .

Linear miles of shore line covered by triangulation (approximate) $\ldots \ldots \ldots$

Square miles covered by triangulation (approximate) $\ldots \ldots$.

Hydrographic projections prepared and completed as records of oyster boundaries _........ 8

Triangles computed _.

Geographic positions computed _. 59

Corners of oyster boundaries established by computation

Back azimuths and distances computed from corners of boundaries to triangulation stations_._ 615

Descriptions of triangulation stations prepared for publication

Descriptions of oyster boundaries prepared for publication

"Charts of Natural Oyster Bars" prepared for publication .

Progress map prepared for publication . . . . . .

GENERAL, REMARKS.

Before ending this report the representative of the Coast and Geodetic Survey wishes to renew his statement of appreciation of the courteous assistance received from various Government and State officials and others interested in the oyster industry of Maryland, especially to the following:

To his colleague from the Department of Commerce and Labor, Dr. H. F. Moore of the Bureau of Fisheries, whose well-known scientific knowledge of all matters relating to oysters has been of great value to the work.

a These statistics only include field and office work directly performed by the party of the Coast and Geodetic Survey in connection with the oyster survey of Calvert County, and do not include the many thousands of soundings and examinations of the character of the bottom made by the engineers of the Commission, which are of considerable value to the Coast and Geodetic Survey as hydrographic records for future use in connection with the preparation of new editions of charts of the waters of Maryland. See Appendix D of this publication for "Statistics of results of combined operations of the Government and the State." 
To Mr. Walter J. Mitchell, chairman of the Maryland Shell Fish Commission, who, by his administrative ability in carrying out the complicated requirements of the oyster laws and by his unfailing tact, has made the cooperation of the various services engaged on the work both agreeable and effective.

To Dr. Caswell Grave, secretary of the Commission, who, as editor of the Commission's annual report and Commissioner in charge of the biological and economic oyster investigations, has been brought into constant contact with the Government work and aided its operations in every way.

To Mr. Benjamin K. Green, treasurer of the Commission, who has looked after the equipment and commissary of the house boat in such a way as to add greatly to the comfort and convenience of the party of the Coast and Geodetic Survey.

To Mr. Swepson Earle, hydrographic engineer to the Commission, whose knowledge of the work from former service in the Coast and Geodetic Survey has greatly facilitated his practical use of the technical data furnished by the Government.

To Mr. Thomas H. Robinson, counsel to the Commission, for courteously furnishing valuable information relating to county boundaries.

And to the many others connected with the Commission or who as residents in the locality where the work was being carried on have greatly assisted by furnishing important information or willing services.

$20908-10-2$ 


\section{CHARTS AND MAPS.}

\section{CHARTS OF NATURAL, OYSTER BARS.}

The charts ${ }^{a}$ of the natural oyster bars of Calvert County, published by the Coast and Geodetic Survey from results of surveys of the Government in cooperation with the Maryland Shell Fish Commission, consist of five sheets covering a portion of the waters of Chesapeake Bay and all of Patuxent River, including all oyster-producing bottoms of Calvert County. They are published on a scale of I part in 20,000 (approximately $3 \frac{1}{6}$ inches to a statute mile) arid are constructed on polyconic projections and based on the United States standard datum of the Coast and Geodetic Survey.

These charts show all oyster bars and other boundaries established by the Commission, and are certified for the purpose of filing in the office of the clerk of the circuit court of Calvert County and in the office of the Commission at Annapolis, as required by the oyster laws of Maryland.

In addition to the oyster-bar and other boundaries, the charts show the location and name of all landmarks (U. S. Coast and Geodetic Survey triangulation stations) used in making the survey, together with the hydrography and topography ${ }^{b}$ necessary to make the technical definitions and delineations of boundaries readily understandable both by the people engaged in the oyster industry and the general public who may become interested through leasing of barren bottoms for oyster culture.

The names of the oyster bars are those used locally, as nearly as could be ascertained by the hydrographic engineer of the Commission. When there was no local name in common use, a name was selected from one of the prominent features of the vicinity. By the use of recognized names or those that would naturally suggest certain sections of water, it is believed that much confusion will be avoided in the location on the charts of the oyster bars, especially by those not familiar with the use of maps.

The corners of the oyster bars are numbered.from I to the total number of corners in each area under consideration. Where boundaries adjoin, making one point a corner of two or more oyster bars, these points have two or more numbers, each number corresponding to the bar in which the figure is located. The numbers of the corners correspond with the technical and legal descriptions of this publication under the heading "Boundaries of natural oyster bars."

The landmarks and oyster bars have been grouped in the "Contents" of this publication in accordance with the charts upon which they are shown. To find a particular oyster bar or landmark which is only known by name, consult the "Contents" and

a These charts can be obtained by application to the Superintendent of the Coast and Geodetic Survey, at Washington, D. C.

$b$ Much of the detail of the inshore topography was obtained from the excellent map of Calvert County prepared and published by the Maryland Geological Survey under the direction of Dr. William Bullock Clark from surveys of the Maryland Geological Survey in cooperation with the U. S. Geological Survey. 
the desired chart and general location will be indicated. To find the name of a bar or landmark which is only known by location, consult the progress map at the end of this publication for the number of the chart on which it is to be found, and then examine the known locality on the chart for the name of the bar or landmark in question.

The contours on the charts showing the depth of water at mean low tide have been taken from the hydrographic sheets of former work of the Coast and Geodetic Survey. Four curves were selected as being the most convenient for taking off from the original hydrographic sheets and the ones of greatest value to those interested in shellish industries. The 1 -fathom contour ( 6 feet) and the 5 -fathom curve (30 feet) correspond in a general way to the inner and outer limits of all the oyster bars surveyed. The 3 -fathom contour (18-feet) furnishes the curve of about the average depth of water on the oyster bars and the io-fathom contour (6o feet) serves in a general way to indicate the outer limits of probable oyster culture.

The boundaries of the waters within the "territorial limits of the county" and the boundaries of the "waters contiguous to the county" opened up for the leasing with Calvert County are plainly indicated on the charts. A full technical deseription of these boundaries is given in this publication under the heading "Boundaries of county waters."

The areas in acres of the oyster bars were determined under the direction of the hydrographic engineer of the Commission by two independent planimeter measurements of the areas as delineated on the smooth projections of the Coast and Geodetic Survey. These areas are given in small figures in parentheses on the face of the chart within the boundaries of the different shellfish bottoms.

The symbols used on the charts for the different kinds of boundaries, triangulation stations, contours of depth of water, etc., require no other explanation than that given in the legend and other notes on the face of the charts.

\section{I.EASING CHARTS.}

The leasing charts of Calvert County, like those for Anne Arundel, Somerset, Wicomico, and Worcester counties, have been prepared under the direction of the hydrographic engineer of the Commission. These charts are constructed on polyconic projections and are based on the United States standard datum of the Coast and Geodetic Survey. They are made on the scales of I part in 5,000 or I part in 10,00o, as the needs of oyster culture may require. Anne Arundel County required 13 leasing charts; Somerset County, 12 charts; Wicomico County, 2 charts; Worcester County, 3 charts; and Calvert County 5 charts, to cover their oyster bottoms.

These charts show all the oyster bars, crab bottoms, and clam beds and other boundaries established by the Commission, and also all boundaries of oyster lots leased for the purpose of oyster culture, thus making them comprehensive and valuable records of the results of the operations of the oyster-culture laws.

The lots leased under the provision of the "old 5-acre law" are frequently of irregular shape, but the lots leased under the provision of the new oyster laws must be of rectangular shape by the terms of that act. For this latter purpose the leasing charts have been divided by parallels of latitude and meridians of longitude into small rectangles of $\mathrm{I}$ acre or 5 acres, as may be best suited to the area under consideration; 
and prospective leaseholders by the rules of the Commission are compelled to select whole rectangles as far as practicable.

For reasons of the present changeable nature of the number of lots leased and the large number of charts required, the leasing charts are not likely to be published for some years, but they can be seen at any time on file at the offices of the Commission, in Annapolis.

\section{PROJECTIONS.}

The polyconic projections ${ }^{a}$ covering Calvert County waters are 8 in number and on the scale of I part in I0,000. They were constructed by draftsmen of the Coast and Geodetic Survey, but the sextant positions which determine the location of the legal boundaries of the oyster bars as delineated by the Shell Fish Commission were plotted by the draftsman of the Commission.

A copy of each of these projections, with all the plotted positions of triangulation stations, shore line, sextant positions, and boundaries of oyster bars, was made under the direction of the hydrographic engineer of the Commission by pricking through with a sharp needle the intersections of the projection lines and all other points as plotted on the original sheets.

These projections (in duplicate) are the original records of all oyster-bar and other boundaries established by the Commission, one set being filed in the archives of the Coast and Geodetic Survey, at Washington, and the other set in the office of the Shell Fish Commission, at Annapolis.

PROGRESS MAPS.

The progress map to be found at the end of this publication is on a scale of I part in 100,000 , and shows in outline the work accomplished by the U. S. Coast and Geodetic Survey in Calvert County and contiguous waters. It gives the scheme of all the charts and smooth projections constructed in connection with the survey, the location and names of all triangulation stations used as a basis for the surveying work, and the "boundaries of county waters" established by the Commission for the purpose of carrying out the laws of Maryland relating to oyster culture.

Besides indicating the amount of work done by the Coast and Geodetic Survey in connection with the work of the Shell Fish Commission, this progress map will be of special value for index purposes to engineers and others searching for the particular chart or projection covering the locality of the oyster bars or landmarks that may be under consideration.

The progress maps ${ }^{b}$ accompanying the first and second annual reports of the Maryland Shell Fish Commission were prepared under the direction of the hydrographic engineer of the Commission. They are on the scale of I part in 400,000 , and show the outline of the tide-water counties of Maryland, with shaded areas to indicate the waters already covered by the operations of the oyster survey.

$a$ For the scheme of these projections see the progress map at the end of this publication.

$b$ These maps and reports can be obtained by application to Maryland Shell Fish Commission, Annapolis, Md. 


\section{BOUNDARIES OF THE COUNTY WATERS. ${ }^{a}$}

\section{WATERS WITHIN TERRITORIAL LIMITS OF COUNTY.}

The laws of Maryland relating to oyster culture provide that "no person shall be permitted, by lease, assignment, or in any other manner, to acquire a greater amount of land than ten acres situated within the territorial limits of any of the counties, or one hundred acres in any other place."

The boundary line ${ }^{b}$ between the waters "within the territorial limits" of Calvert County and the waters in "any other place," as established by the Shell Fish Commission for the purpose of carrying out the oyster laws, and delineated on the charts and the smooth projections of the Coast and Geodetic Survey, is technically described and defined as follows:

Commencing at a point defined by the intersection of the mean low-water line of the western shore of Chesapeake Bay in the vicinity of Hog Point and the boundary line between Anne Arundel and Calvert counties; thence along the mean low-water line of the Chesapeake Bay shore of Calvert County across the mouth of all inlets less than roo yards in width, around Plum Point and Cove Point, to a point defined by latitude $38^{\circ} 19^{\prime} 09^{\prime \prime} .8$ and longitude $76^{\circ} 25^{\prime} 21^{\prime \prime} .0$ situated on Drum Point on the northern side of the entrance to Patuxent River; thence along a straight line ending at a point defined by latitude $38^{\circ}{ }_{1} 8^{\prime} 35^{\prime \prime} .9$ and longitude $76^{\circ} 23^{\prime} 59^{\prime \prime} .8$ situated on Hog Point on the southern side of the entrance to Patuxent River, to a point defined by the intersection of this straight line and the Patuxent River channel boundary line between Calvert and St. Marys counties as laid down on "Chart No. 20, Natural Oyster Bars, Maryland;" thence up the channel of Patuxent River following the channel boundary line between Calvert and St. Marys counties and the channel boundary line between Calvert and Charles counties and the channel boundary line between Calvert and Prince Georges counties as laid down on "Charts Nos. I9 and 20, Natural Oyster Bars, Maryland;" thence continuing up the channel of Patuxent River following the channel boundary line between Calvert and Prince Georges counties to its end on the boundary line between Anne Arundel and Calvert counties. $c$

\section{WATERS CONTIGEOUS TO COUNTY.}

The oyster laws of Maryland provide that a true and accurate delineation of all natural oyster bars shall be made on copies of charts of the U. S. Coast and Geodetic Surver, "which said copies shall be filed in the office of the said Commissioners in the city of Annapolis," and "in the office of the clerks of the circuit courts for the respective counties wherein the grounds so designated may lie."

a For a complete historical and legal description of the boundaries of the counties of Maryland, the valuable publication entitled "The Counties of Maryland-Their Origin, Boundaries, and Etlection Districts," prepared by Dr. Edward B. Mathews and published by the Maryland Geological Survey under the direction of Dr. William Bullock Clark, Superintendent, should be consulted, as the boundaries described in this publication have been established and technically defined for the purpose of carrying out the oyster laws of the State, and may or may not be correct for other purposes.

$b$ See "Charts of Natural Oyster Bars," published by the Coast and Geodetic Survey, and the progress map at the end of this publication.

c Latitudes and longitudes based on the United States standard datum of the U. S. Coast and Geodetic Survey. 
For the purpose of carrying out the latter part of this section of the law and for the purpose of establishing the limits of the oyster-culture area to be opened up for leasing with each county surveyed, it is necessary for the Shell Fish Commission to establish a boundary line between the waters contiguous to but not within the territorial limits of each county and the waters contiguous to but not within the territorial limits of adjacent counties.

This boundary line ${ }^{a}$ has been delineated on the "Charts of Natural Oyster Bars," published by the Coast and Geodetic Survey, and is technically described and defined as follows:

Commencing at a point defined by the intersection of the mean low-water line of the western shore of Chesapeake Bay in the vicinity of Hog Point and the boundary line between Anne Arundel and Calvert counties; thence in a straight line along the Chesapeake Bay boundary between Anne Arundel and Calvert counties as laid down on "Charts Nos. 4 and 16, Natural Oyster Bars, Maryland," to a point defined by latitude $38^{\circ} 42^{\prime} 33^{\prime \prime} .4$ and longitude $76^{\circ} 27^{\prime} 40^{\prime \prime} .0$ situated about $3 \frac{5}{8}$ miles east of Hog Point; thence in a straight line along the Chesapeake Bay boundary between Calvert and Talbot counties and Calvert and Dorchester counties as laid down on "Charts Nos. 16,17 , and $\times 8$, Natural Oyster Bars, Maryland," to a point defined by latitude $38^{\circ} 30^{\prime} 00^{\prime \prime} .0$ and longitude $76^{\circ} 25^{\prime} 30^{\prime \prime}$. 0 situated about $43 / 8$ miles east of Governors Run; thence in a straight line along the Chesapeake Bay boundary between Calvert and Dorchester counties as laid down on "Charts Nos. 17, 18, and 20, Natural Oyster Bars, Maryland," to a point defined by latitude $38^{\circ} 23^{\prime} 10^{\prime \prime} .3$ and longitude $76^{\circ} 20^{\prime} \mathrm{oO}^{\prime \prime} .0$ situated about $25 / 8$ miles east of Cove Point Light; thence in a straight line along the Chesapeake Bay boundary between Calvert and Dorchester counties as laid down on "Charts Nos. 18 and 20, Natural Oyster Bars, Maryland," to a point defined by latitude $38^{\circ} 19^{\prime} 37^{\prime \prime} .7$ and longitude $76^{\circ} 19^{\prime} 19^{\prime \prime} .0$ situated about $51 / 4$ miles southeast of Cove Point Light and about $5 \frac{1}{4}$ miles east by north of Drum Point Light; thence along the Chesapeake Bay boundary between Calvert and St. Marys counties as laid down on "Chart No. 20, Natural Oyster Bars, Maryland," to a point defined by the intersection of this boundary and a straight line between a point situated on Hog Point on the southern side of the entrance to Patuxent River defined by latitude $38^{\circ}$ I $8^{\prime} 35^{\prime \prime} .9$ and longitude $76^{\circ} 23^{\prime} 59^{\prime \prime} .8$ and a point situated on Drum Point on the northern side of the entrance to Patuxent River defined by latitude $38^{\circ} 19^{\prime} 09^{\prime \prime} .8$ and longitude $76^{\circ} 25^{\prime} 21^{\prime \prime} .0$; thence in a straight line to a point at the end defined by latitude $38^{\circ} 19^{\prime} 09^{\prime \prime} .8$ and longitude $76^{\circ} 25^{\prime} 21^{\prime \prime} .0$ situated on Drum Point on the northern side of the entrance to Patuxent River.

$a$ See progress map at the end of this publication. 


\section{LANDMARKS (U. S. COAST AND GEODETIC SURVEY TRIANGULATION STATIONS).}

EXPLANATION.

The oyster laws of Maryland authorizing the survey to be made by the Shell Fish Commission provide for "an accurate report of said survey, setting forth such a description of landmarks as may be necessary to enable the said board, or their successors, to find and ascertain the boundary lines of said natural oyster beds, bars, and rocks, as shown by delineation on the maps and charts." The law of the United States authorizing the cooperation of the Department of Commerce and Labor in the survey of natural oyster bars of Maryland provides for the erection of "such structures as may be necessary to mark the points of triangulation, so that the same may be used for such future work of the Coast and Geodetic Survey as the said. Bureau may be hereafter required to perform in prosecuting the Government coast survey of the navigable waters of the United States located within the State of Maryland."

Under the provisions of the sections of the laws stated above, the markings and descriptions of landmarks must be sufficient for the present and future needs of both the Government and the State. With this end in view, considerable work has been expended in erecting permanent monuments at the triangulation stations and in the proper description of their location.

An effort has been made to arrange the descriptions of location and character of landmarks in a uniform and logical manner. The descriptions start with the assumption that the individual seeking a landmark has only an indefinite idea of its location. They gradually proceed from description of the general locality of a landmark to the descriptions of its immediate surroundings. This is followed by specific details of the character of the center and reference marks and a "round" of reference angles and distances which in themselves frequently contain enough information to furnish an independent and reliable location of the triangulation station.

\section{METHOD OF DESCRIBING TRIANGULATION STATIONS.}

The separate descriptions of triangulation stations should not be used without reading the following explanation of the method of describing the triangulation stations, as it contains certain details that are common to all the landmarks described in this publication and which are omitted in the separate descriptions as being needless repetitions:

Name.-The title at the top of each separate description is the name by which the landmark or triangulation station is known and designated in all work and published oyster records or oyster charts of both the Government and State. The selection of the name is usually left to the triangulator establishing the station, and it may or may not have geographic or other significance in reference to the locality.

General locality.- Under this heading is given the general locality of the landmatk in reference to well-known and prominent natural or artificial features, such as the 
nearest body of water, town, river, steamer wharf, well-defined point of land, church, or any other feature that is likely to remain both permanent and prominent.

This heading also covers a reference to the published chart or map which shows the location of the station most clearly. Nearly all the triangulation stations described in this publication are plainly indicated by name and a triangulation symbol on the published charts of oyster bars of Maryland. In this case they are referred to by serial number only, the words "charts of oyster bars of Maryland" being omitted to avoid needless repetition. These published oyster charts are on the large scale of I part in 20,000 (approximately $3 \frac{\mathrm{I}}{6}$ inches to a statute mile) and show the location of the triangulation stations so clearly that in many cases the written descriptions will not be required to find them.

Immediate locality.-Under this heading is given the description of the "observed station" in reference to its immediate surroundings. This is supposed to include a statement of the station's estimated elevation above high water or some other welldefined level of the locality, such as a road or house; the character of the ground on which it is located, such as marsh land, sand beach, cultivated field, or meadow; estimated bearings in points of the compass and estimated distances in yards from (not to) easily recognized features, such as extreme end of point, edge of bluff, bank of creek, line of telephone poles, shore line, barn, house, fence, ditch, trees, or any other definite detail, such as being on range with the tangent of an island and a church; and so forth.

When a standard monument has been established near the station as a "reference station," this heading also covers a statement of the true bearing of the monument in degrees and minutes and its measured distance in meters, as it is the first object that is likely to catch the eye when the immediate vicinity of the desired station is reached and might be mistaken for the center mark of the "observed station" unless special attention is called to it.

The distinction between the "observed station" and "reference station" should be carefully noted by anyone making use of the description of stations for any future surveying operations.

The "observed station" is located at the particular triangulation point covered by the description of stations, and is the one whose geographic position is first computed, as it is the point which was "occupied" and "observed on" for horizontal angles. However, in spite of the primary importance of the location of the "observed station," it will be noted from the description of stations that frequently it is not marked as well as the "reference station," and in many instances has only a pine stub to indicate its position. This is the case for the reason that the necessity of intervisibility of landmarks usually made it compulsory to locate "observed stations" on edges of banks and ends of points of land, which in the tide-water section of Maryland generally means they will be washed away in a short period of years. The past experience of the Coast and Geodetic Survey in this region has shown the great need of "reference stations," if the frequent reestablishment of a new framework of triangulation is to be avoided.

The chief reason and need for the establishment of the "reference station," or secondary station, as it might be well named, is explained in the preceding paragraph, but in several instances other reasons, such as the location of the "observed station" on an unstable sand dune, in a cultivated field, in front of a residence, or other places 
objectionable to the landowner, have led to establishment of "reference stations." The location of the "reference station" in relation to the "observecl station" is fixed for plotting on charts or for computation of its geographic position hy checked measurements of its distances and azimuth from the "observed station." a

Marks.--Under this heading is given a description of the character of the permanent monuments or other marks of the location of the "observed station," and of the "reference station" where one has been established.

All the marks designated in the descriptions as "the center point of triangle on standard cement monument" are exactly alike. These monuments are made of cement, sand, and gravel, and are 2 feet long and 8 inches square at top and bottom. Their tops are all marked with the same brass mold and show a center hole surrounded by a triangle, with the letters "M. S. F. C." arranged around the vertex and the letters "U. S. C. S." underneath the base of the triangle. The center hole is always in the center of the top of the monument by construction, and if this is found to have been broken off without disturbing the bottom the center of its square section can be used as the location of the station.

All the "standard cement monuments," whether used for marking the "observed station" or "reference station," have been planted upright in exactly the same manner, with their tops projecting 3 or + inches above the surface of the ground, unless otherwise stated.

Therefore, as the above facts in reference to the "standard cement monuments" are a constant element in all cases, the repetition of these facts in the description of stations is made needless by this one statement.

References.-Under this heading are given the "rounds" of directions and distances to all objects that might be useful in locating the stations when the surface marks can not be found. It is also contemplated that for general purposes of topography, hydrography, or location of boundaries of oyster bars these references will be sufficient in many cases to relocate the position of an "observed station" or "reference station" -when both of them have been destroyed.

The first reference object given in the descriptions is always a triangulation station visible from the station being described, this, if possible, being a light-house, church spire, or other permanent and prominent point. Its direction is taken as being $\mathrm{O}^{\circ} \mathrm{OO}^{\prime} \mathrm{OO}^{\prime \prime}$, and the directions of all other objects are measured from it as an initial point, the angles being taken in a clockwise direction (left to right).

The true bearing ${ }^{b}$ of the initial object is always given in parenthesis alongside its name. This furnishes means for the calculation of the bearings of any of the other reference objects for the purposes of locating a station by horizontal angles or for the relocation of corner buoys of oyster-bar boundaries by the method of compass directions described in this publication under the heading of "Boundaries of oyster bars."

The distances in the last column under "References" are given in three different units, which vary according to their accuracy. The "miles" are statute miles and may

a Geographic coordinates (latitude and longitude) and the distance and azimuth relating to any of the "observed stations" or of the "reference stations" described in this publication can be obtained by application to the Superintendent of the Coast and Geodetic Survey, at Washington, D. C.

$b$ The mean magnetic variation for Calvert County was $5^{\circ} 50^{\prime}$ west of north in 1909 and increasing at the rate of $3^{\prime}$ yearly. 
be considered only as rough estimates. The "yards" are more accurate, but must be looked on as results generally obtained by pacing or careful estimating. The "meters," however, are accurate to the degree indicated by their decimals and in every case have been measured with a steel tape. In the same manner the accuracy of the directions are indicated by the refinement of angular measure with which they are recorded.

\section{DESCRIPTIONS OF TRIANGULATION STATIONS.}

\section{HOLLAND.}

General locality.-Western shore of Chesapeake Bay, on south side of entrance to Herring Bay on Holland Point. (See Chart No. 16.)

Immediale locality.-Observed station is about 30 yards west of point, 5 feet back from the top of a bank 7 feet high, 12 yards north of a large blazed tree and 25 yards east of another large blazed tree. Cement monument marking reference station is 12.88 meters $\mathrm{S} 33^{\circ} .52^{\prime} \mathrm{W}$ of observed station.

Marks.-Observed station is a nail in a pine stub. Reference station is center point of triangle on standard cement monument.

References."Fairhaven" $\left(\mathrm{N}+8^{\circ} 13^{\prime} \mathrm{W}\right)$.
Nail in blaze on red-oak tree $(2 \mathrm{I} / 2$ feet diam-
eter $)$

REFERENCE STATION-

Nail in blaze on red-oak tree $(21 / 2$ feet diam-

$$
\text { eter) _............ } 286 \quad 55 \quad \ldots .63 \text { meters. }
$$

NoTE.-This station was established and described in 1906 during the survey of the oyster bars of Anne Arundel County.

$$
\text { HOG POINT (HOLLAND 3). }
$$

General locality.-Western shore of Chesapeake Bay, about half way between Herring Bay and Chesapeake Beach, on Hog Point, which is near the land end of boundary line between Anne Arundel and Calvert counties. (See Chart No. 16.)

Immediate locality.-Observed station is about 5 feet above high water mark on a narrow strip of solid land 25 yards by ro yards between the edge of a large marsh and the bay shore, about 60 yards north of the point where the shore line changes direction from north and south to northeast and southwest. It is about 4 yards west of the bay shore, 4 yards east of top edge of hummock near marsh, 7 yards east of edge of marsh, 9 yards north northwest of point of a hummock, and 18 yards south by west of point of another hummock. Cement monument marking reference station of 1908 is 2.13 meters $\mathrm{S} 80^{\circ} 38^{\prime} \mathrm{WV}$ of observed station.

Marks.-Observed station is nail in center of drain tile set in cement, with top flush with ground, the cement being roughly scribed "U. S. C. \& G. S., r907." Subsurface marks to observed station were reported in 1907 as being two hexagonal drain tiles placed one directly over the other, with top of upper 3 feet below the surface of the ground. Reference station of 1907 is marked the same as the observed station, except that only one drain tile was used as subsurface mark. Reference station of 1908 is center point of triangle on standard cement monument.

References.-

"Sharps Island Light" (S $58^{\circ} 46^{\prime} \mathrm{E}$ ) .....

Left tangent of North Chesapeake Beach wharf

Flagstaff on center of Carousel roof

Large brick chimney .......

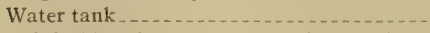

Nail in blaze in white oak ( 16 inches diameter)

REFERENCE STITION Igos icement mont1ment) ........ 
Nail in blaze in pin oak ( 18 inclies diam- $\circ, '$ '

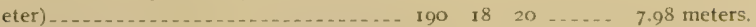

Nail in blaze in pin oak ( 16 inches diam-

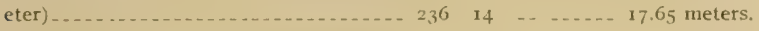

Nail in blaze in pin oak ( 18 inches diam-

eter) _......... $250 \quad 02 \quad 20 \ldots 2$..... 26 meters.

REFERENCE STATION 1907 (tile) _...... 255 18 50 .... 11.13 meters.

Left tangent of woods on eastern shore of

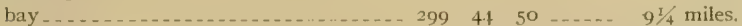

Note.-This station is also known as "Holland 3 of 1907 ," but the name has been changed to "Hog Point (Holland 3)" in the oyster survey work of Calvert County, in order to avoid confusion with "Holland 1906," which is only I mile to the north.

\section{$\mathrm{BEACH}$}

General locality.-Western shore of Chesapeake Bay, about $\mathrm{x}$ mile south of Chesapeake Beach and $1 / 2$ mile south of the first marshy slotgh south of Chesapeake Beach. (See Chart No. I6.)

Immediate locality.-Observed station is about 1 ro feet above high water and 7 yards back from the edge of the highest bluff in this vicinity. The ground falls off rapidly to the southwest and west of the station, and is covered with brush and small locust trees. A cultivated field extends to within Io yards of the station on the northwest. Cement monument marking reference station of 1908 is II.40 meters $\mathrm{N} 85^{\circ} \mathrm{o} 5^{\prime} \mathrm{W}$ of observed station.

Marks.-Observed station is a nail in center of drain tile set in cement, with top flush with ground. Subsurface marks to observed station were reported in 1907 as being two hexagonal drain tiles placed one directly over the other, with top of upper 3 feet below the surface of the ground. Reference station of 1907 is marked the same as the observed station, except that only one drain tile was used as a subsurface matk. Reference station of 1908 is center point of triangle on standard cement monument.

References.-

"Hog Point (Holland 3)" ( $\left.\mathrm{N}_{2}^{\circ} 55^{\prime} \mathrm{E}\right)$-.-

Outside end of wharf at North Chesapeake

Beach.

o 00 o0 $\ldots . . . \quad 21 / 2$ miles.

Outside end of wharf near Chesapeake Beach .............................

"Sharps Island Light" ............... 1

Nail in blazed locust tree............

REFERENCE STATION (cement monument, 1908) . . . .

OLD REFERENCE POINT (tile-I907) _... 282 I3 10 ..... 10. 25 meters.

Nail in blazed locust tree .............. $289 \quad 58 \quad 20 \ldots \ldots$..... 8.47 meters.

Near gable of house ................ 343 16 ....... 1 mile.

High View Hotel ................. $344 \quad 57 \quad \ldots \ldots$ mile.

Cupola at Chesapeake Beach _..._._... 348 o4 _...... 34 mile.

Flagpole of "merry-go-round" at Chesapeake Beach........... 3/4 mile.

Left corner of house at North Chesapeake Beach .................. 2 miles.

IL I, 2

General locality.-Western shore of Chesapeake Bay about $2 \pi / 4$ miles south of Chesapeake Beach and $23 \% 4$ miles north of Plum Point. (See Chart No. 16.)

Immediate locality.-Observed station is about 90 feet above high water and 12 feet west of edge of bluff which rises rapidly from the south. It is in a cultivated field about roo yards south of a fence and trees running east and west and 7 feet west of a wire fence along edge of cliff. No other permanent reference objects near station. Cement monument marking reference station is 23.84 meters $\mathrm{S} 80^{\circ}$ $43^{\prime}$ IV of station. 
Marks.-Observed station is nail in cement in center of drain tile with top flush with ground. Subsurface marks to observed station were reported in 1907 as being two hexagonal drain tiles placed one directly over the other with top of upper 3 feet below the surface of the ground. Reference station of 1907 is marked the same as the observed station, except that only one drain tile was used as a subsurface mark. Reference station of 1908 is center point of triangle on standard cement monument. -

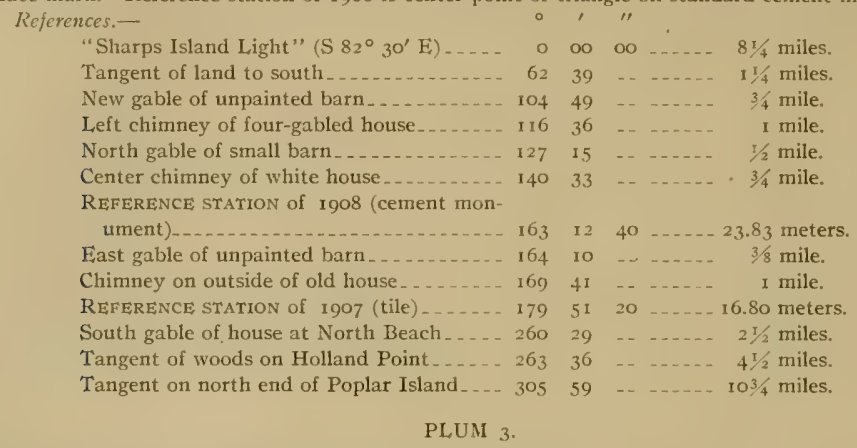

General locality.-Western shore of Chesapeake Bay about $1 \frac{1}{4}$ miles north by west of Plum Point wharf and about $1 / 2$ mile north by west of Plum Point. (See Chart No. 16.)

Immediate locality. - Observed station is about 7 yards west of edge of first bluff north of low land above Plum Point wharf and 12 yards south of rail fence and a line of bushes and cedar trees. Cement monument marking reference station of 1908 is 14.03 meters S $81^{\circ} 43^{\prime}$ W of observed station. No other reference objects near station.

Marks.-Observed station is center of drain tile with top flush with ground. Subsurface marks to observed station were reported in 1907 as being two hexagonal drain tiles placed one directly above the other with the top of the upper tile 3 feet below the surface of the ground. Reference station of 1907 is marked the same as the observed station except that only one drain tile was used as a subsurface mark. Reference station of 1908 is center point of triangle on standard cement monument.

References.-

"Sharps Island Light" (N $\left.8 \mathrm{I}^{\circ} 3 \mathrm{I}^{\prime} \mathrm{E}\right) \ldots . .$.

Peak of near gable of large house

Outer end of Plum Point wharf

Chimney outside of north end of house .... I

Southwest peak of barn . . . . . . . . . . . 150

REFERENCE STATION 1908 (cement monument) .................. I

REFERENCE STATION 1907 (tile) _. . . . . . 213

Tangent to Holland Point .............. 273

Right tangent Chesapeake Beach wharf . . 273

Left tangent Poplar Island_... . . . . . . . 312

Large lone tree Poplar Island . . . . . . . . . . 319

Leit climney of house . . . . . . . . . . 326

Left chimney of house. . . . . . . . . . . . . 334

Steeple on church or lzouse Tilghman Island_ 34 I

\begin{tabular}{|c|c|c|c|}
\hline OO & ০o & 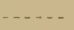 & $75 / 8$ miles. \\
\hline I5 & -- & $\ldots . .$. & $81 / 4$ miles. \\
\hline I3 & $\cdots$ & $\ldots \ldots$ & $13 / 4$ miles. \\
\hline 22 & $\therefore$ & $\ldots \ldots$ & $1 \mathrm{I} / 4$ miles. \\
\hline 27 & -- & $\ldots$ & $3 / 4$ mile. \\
\hline I 2 & 20 & $\ldots . .$. & 14.03 meters. \\
\hline 12 & 10 & $\ldots \ldots$ & 14.23 meters. \\
\hline 31 & -. & $\ldots \ldots$ & $71 / 2$ miles. \\
\hline 56 & $\cdots$ & $\ldots \ldots$ & $43 / 4$ miles. \\
\hline 43 & 10 & 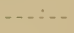 & $12,1 / 2$ miles. \\
\hline 39 & 10 & $\ldots \ldots$ & I 2 miles. \\
\hline 30 & $\therefore$ & $\ldots+\cdots$ & 1234 miles. \\
\hline 55 & -- & $\ldots \ldots$ & I I $\mathrm{mil}$ \\
\hline 02 & 00 & $\therefore \ldots$ & 10 miles. \\
\hline
\end{tabular}

PIER.

General locality.-Western shore of Chesapeake Bay about south southeast of Plum Point on outer end of wharf at Plum Point Landing. (See Charts Nos. 16 and 17.) 
Immediate locality.-Observed station is on outer part of wharf known as Plum Point Landing about 20 yards from extreme end and nearly on line with northern side of warehouse.

Marks.-Observed station is an auger hole bored in plank flooring of wharf surrounded by a triangle marked by nails.

References.-

Northeast corner of calf pen . . . . . . . . . Southeast . . . .... 6.68 meters.

Northwest corner of calf pen_... . . _. . . South southeast_... 4.48 meters.

Rail of fence on south edge of wharf . .... South ........... 2.03 meters.

Prolongation of line of north side of ware-

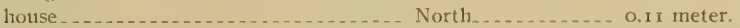

South rail of wharf track _.......... North_. . . . . . . 0.92 meter.

North rail of wharl track. North..... $\quad 2.36$ meters.

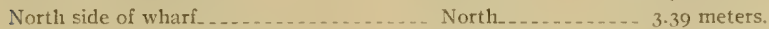

West side of warehouse . . . . . . . . . . . East _......... 8.60 meters.

SHARPS ISLAND LIGHT.

General locality.-Easterly side of Chesapeake Bay off entrance to Choptank River on a shoa? about $I^{1 / 8}$ miles north northwest of Sharps Island. (See Chart No. I6.)

Immediate locality.-Observed station is on light-house known as "Sharps Island Light."

Marks.-Observed station is center point of black lantern on top of tower on a cylindrical caisson foundation.

Reference.-

"Parker" ( $\left.44^{\circ} 36^{\prime} \mathrm{W}\right)$

o 00 0o _......... Io miles.

PEN.

General locality.-Western shore of Chesapeake Bay about half way between Plum Point and Governors Run on the outer end of Dares Wharf. (See Chart No. 17.)

Immediate locality.-Observed station is on outer part of Dares Wharf about 30 yards from the extreme end, 12 yards west of warehouse, and I yard north of south side of wharf.

Marks.-Observed station is auger hole in plank flooring surrounded by a triangle marked by nails.

References.-

\begin{tabular}{|c|c|c|}
\hline \multicolumn{3}{|l|}{ South } \\
\hline corner on angle in & East by sc & 5.09 meter: \\
\hline South edge of wharf & South _.. & 0.95 meter. \\
\hline South rail of straight track at point of fro & North. & 2. I3 meters. \\
\hline d track... & North _.. & 0.90 meter. \\
\hline North edge of wharf & North & 4.15 meters. \\
\hline Southwest corner of cattle per & Northeast_ & 7.12 meters. \\
\hline f & ortheast by north & 9.63 meter \\
\hline thwest corner of warehouse & ortheast by north. & 12.80 mete \\
\hline
\end{tabular}

PATCH.

General locality.-Western shore of Chesapeake Bay about I mile south of Dares Wharf. (See Chart No. 17.)

Immediate locality.-Observed station is on a high bluft of land about 65 yards back from its edge. Station is in a cultivated field and on a high knoll and the land slopes away from it on all sides. A locust thicket stands northwest of the station and the land slopes steeply from the station to the thicket. Cement monument marking reference station is 9.07 meters $\mathrm{N} 52^{\circ} 4 \mathrm{r}^{\prime} \mathrm{W}$ of observed station.

Marks.- Observed station is nail set in cement in tile pipe buried with top about is inches below the surface of the ground. Reference station is center point of triangle on standard cement monument

References:-

"Sharps Island Light" (N $\left.50^{\circ} 39^{\prime} \mathrm{F}\right)$..... 0 o 00 oo ...... 10 miles.

"Cove Porint Light" .... - . or 20 or 1.5 miles.

Tangent to Point of Rocks........... 98 30 ..... 4 miles. 


\begin{tabular}{|c|c|c|c|}
\hline East end of Governors Run wharf ...... I12 & 57 & .. & $1 / 2$ miles. \\
\hline East end of roof of barn $\ldots \ldots$ & 25 & - & I mile. \\
\hline Nail in blazed locust (old reference mark) _. 210 & 17 & 50 & I I.93 meters. \\
\hline Nail in blazed locust (old reference mark) _- 226 & 02 & 50 & 12.04 meters. \\
\hline REFERENCE STATION (cement monument)- 256 & 49 & 10 & 9.07 meters. \\
\hline East peak of large barn on hill $\ldots \ldots \ldots \ldots$ & 14 & .. & iile. \\
\hline East end of Plum Point wharf ........ 316 & 50 & $\ldots .$. & $3 \mathrm{I} / 2$ miles. \\
\hline
\end{tabular}

PARKER

General locality.-Western shore of Chesapeake Bay about 2 miles north of Governors Run wharf and $21 / 2$ miles south of Dares Wharf. (See Chart No. 17.)

Immediate locality.-Observed station is about roo feet above high water, to yards west of edge of bluff, 50 yards north of a small stream in a deep gully, and 25 yards east of cultivated field back of a growth of locust trees. The land slopes rapidly to the small stream from a point about ro yards south of the station. Reference station is 23.29 meters $N 83^{\circ} 45^{\prime} \mathrm{W}$ of observed station.

Marks.-Observed station is nail in center of tile pipe filled with cement. Reference station is center point of triangle on standard cement monument.

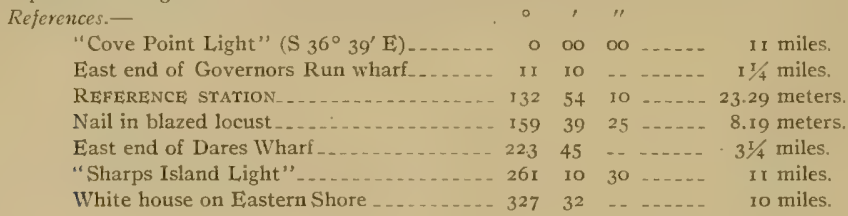

RUN.

General locality.-Western shore of Chesapeake Bay on Governors Run wharf. (See Charts Nns, 17 and 18 .)

Immediate locality.-East peak of wharf house. wharf.

Marks.-Observed station is braced pole with cage on east peak of wharf house on Governors Run

References.-None necessary.

\section{POPLAR}

General locality.-Western shore of Chesapeake Bay about 2 miles south of Governors Run wharf (See Chart No. I8.)

Immediate locality. - Observed station is in a cultivated field about 60 feet above high water, 50 feet west from edge of bluff, 25 yards south of a ravine which starts at shore, 115 yards north of where high cliff covered with trees commences to rise rapidly, and zo yards from a large poplar tree on opposite side of a ravine with sycamore, cherry, and locust trees along its edge. Another bluff rises rapidly on opposite side of ravine.

Marks.-Observed station is center point of triangle on standard cement monument with a subsurface mark of a nail in a short stub.

References.-

"Sharps Island Light" (N $\left.27^{\circ} 4 \mathrm{I}^{\prime} \mathrm{F}\right) \ldots \ldots$ Tangent of James Point woods .......... 18

White house on Eastern Shore . . . . ....... 65

Chimney on house _................... 198

East peak of barn .................. 203

East end of Governors Run wharf .... . . 309

Chimney on white house above "Parker" - 310

South peak of barn ................... 31

Peak of unpainted barn.

$\begin{array}{rrrr}00 & 00 & \ldots \ldots & 12 \text { miles. } \\ 28 & \ldots & \ldots & 8 \text { miles. } \\ 00 & \ldots & \ldots \ldots & 8 \text { miles. } \\ 25 & \ldots & \ldots \ldots & 1 \text { mile. } \\ 37 & \ldots & \ldots \ldots & 13 / 4 \text { miles. } \\ 18 & \ldots & \ldots \ldots & 15 / 2 \text { miles. } \\ 45 & \ldots & \ldots \ldots & 21 / 2 \text { miles. } \\ 47 & \ldots & \ldots \ldots & 23 / 4 \text { miles. } \\ 23 & \ldots & \ldots \ldots & 3 \text { miles. }\end{array}$




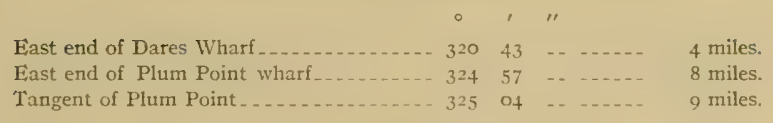

FLAG POND.

General locality.-Western shore of Chesapeake Bay, $3 \frac{3}{4}$ miles north-northwest of Point of Rocks and 4 miles southeast of Governors Run. (See Chart No. 18.)

Immediate locality.-Observed station is on sand and grass land between bay shore and swamp about 5 feet above high water, 35 yards south of shore, 20 yards northwest of shore, 9 yards northwest of cedars between shore and station, ro yards west of cedars and bushes, 25 yards west of shore, and 10 yards northeast of swamp. Cement monument marking reference station is 9.02 meters $N$ $87^{\circ} 33^{\prime} \mathrm{W}$ of observed station.

Marks.-Observed station is a spike in cement in a stovepipe 4 inches in diameter and I foot long placed on top of a cement post 6 inches square with a $1 / 4$-inch galvanized iron rod core. Reference station is center point of triangle on standard cement monument.

References.-

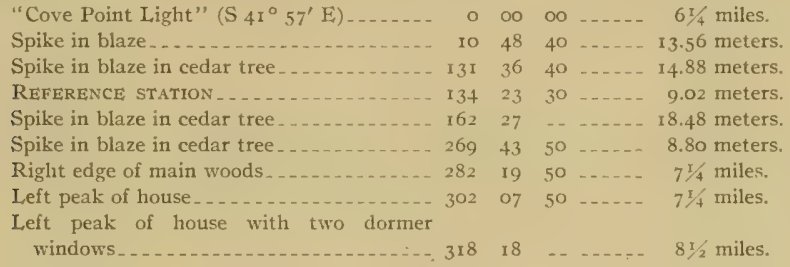

WILSON 2 .

General locality. - Western shore of Chesapeake Bay, about 5 miles northwest of "Cove Point Light." (See Chart No. 18.)

Immediate locality.-Observed station is on a sand bluff about 80 feet above high water, 30 yards south from one edge of bank, 15 yards southwest of another edge of bank, 20 yards northwest from point where decline begins toward southeast, 3 yards south of cultivated land, about $1 / 4$ mile northnortheast of house with two large chimneys on each end, and about $1 / 2$ mile northeast of a barn. Cement monument marking reference station is 1.56 meters $\mathrm{N} 88^{\circ} 28^{\prime} \mathrm{E}$ of observed station.

Marks.-Observed station is a $1 / 4$-inch galvanized wire set in center of cement post about 6 inches square with top about 6 inches below surface of ground. Reference station is center point of triangle on standard cement monument with top 6 inches above ground.

References.-

\begin{tabular}{|c|c|c|c|c|}
\hline "Sharps Island Light" ( $\left(\mathrm{N}_{14}{ }^{\circ} 54^{\prime} \mathrm{E}\right) \ldots$ & o & $\infty$ & oo & I4 miles. \\
\hline Left of main woods & 18 & 23 & -. & $15 \% /$ miles. \\
\hline REFERENCE STATION _. - & 73 & $3+$ & 20 & 1.56 meters. \\
\hline Left peak of house..... & 84 & 40 & 40 & 8 miles. \\
\hline $\begin{array}{l}\text { Near corner of near chimney of Wilson } \\
\text { house }\end{array}$ & I9I & 02 & $\ldots$ & \\
\hline Peak of barn ..... & 225 & 25 & -. & $1 / 2$ mile. \\
\hline
\end{tabular}

\section{POINT OF ROCKS.}

General locality. - Western shore of Chesapeake Bay, on Point of Rocks, about $23 / 4$ miles nortluwest of Cove Foint Light. (See Chart No. 18.) 
Irumediate locality.-Observed station is in dense woods on a bluff about go feet high, 5 yards west of edge at extreme point, 8 yards south of edge of bluff, and 5 yards northwest of edge of bluff. Cement monument marking reference station is 9.42 meters $\mathrm{S} 66^{\circ} 44^{\prime} \mathrm{W}$ of observed station.

Marks.-Observed station is nail in center of round stake 4 inches in diameter with top flush with ground driven into a 6 -inch drain tile with top 6 inches below the surface. Subsurface matk was reported in 1898 as a 6 -inch drain tile set just below upper tile. Reference station is center point of triangle on standard cement monument with top 4 inches above surface of ground.

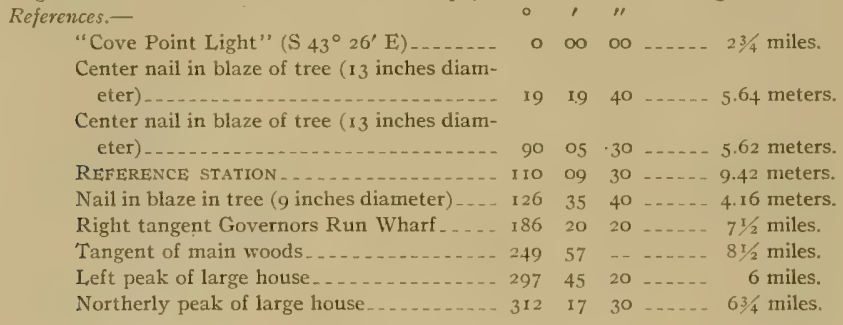

\section{COVE POINT LIGHT.}

General locality.-Western shore of Chesapeake Bay on Cove Point, which is about 5 miles to northward of entrance to Patuxent River. (See Charts Nos. 18 and 20.)

Immediate locality.--Observed station is on white tower known as "Cove Point Light" which is near white detached dwelling and white detached fog signal house.

Marks.-Observed station is center point of black lantern on white tower.

References.-

$$
\text { "Cedar Point Light" (S 7 } \left.{ }^{\circ} 6^{\prime} \mathrm{E}\right) \text {....... } 0 \text { o } 00 \text {..... } 6 \text { miles. }
$$

\section{WHITE HOUSE (N. E. CHIMNEY).}

General locality,-Western shore of Chesapeake Bay about I mile southwest of Cove Point Light and $1 / 4$ mile southwest of Cove Point Landing. (See Charts Nos. 18 and 20.)

Immediate locality. - Observed station is a chimmey standing alone about 300 yards southwest of Cove Point Landing which was formerly the more northeasterly of two chimneys on a house that was destroyed by fire. This chimney is near a white house which was built to replace the destroyed house.

Marks.-A chimney standing apart from a small white house owned by Mrs. Hagland.

References.-

"Cove Point Light" ( $\left.39^{\circ} 54^{\prime} \mathrm{E}\right)$...... o oo oo _..... I mile.

\section{TRAVERS 2.}

General locality.-Eastern shore of Chesapeake Bay on western side of Taylors Island about 4 miles south of James Point. (See Chart No. 18.)

Immediate locality.-Observed station is about 4 feet above high water mark in a field which was once under cultivation but is now covered with water bushes, about 40 yards east of shore and $\mathrm{I}_{5}$ feet north of a wire fence which starts at the shore and runs east. A stone used as an old reference mark

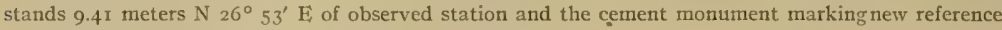
station is 9.52 meters $\mathrm{N} 77^{\circ} 20^{\prime}$ W of observed station.

Marks.-Observed station is a granite post projecting above the ground with cross lines running approximately north to south and east to west. New reference station is center point of triangle on standard cement monument. Old reference station is a cross on a granite post projecting above the ground with one of the cross lines running in the direction of Cove Point Light. 
References.-

"Cove Point Light" (S $26^{\circ} 15^{\prime} \mathrm{WW}$ ) _.... o oo

Governors Run Wharf _........... $77 \quad 12$

Tangent of woods at waters edge _...... $123 \quad 40$

Near peak of two-story house _..._._. $173 \quad 23$

OLD REFERENCE STONE (granite post) -... I80 38

Chimney of I I/2 story house _....... 19547

NEW REFERENCE STATION (cement monu-

ment) _...

Near corner of small cabin _........ 271

Near chimney of house among trees $\ldots \ldots-\ldots 300$

Near peak of small house............. 304

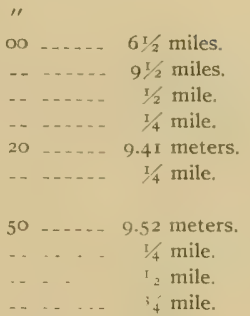

\section{PRINCE,}

General locality.-Western shore of Patuxent River about $1 / 4$ mile north of mouth of Swanson Creek. (See Chart No. 19.)

Immediate locality.--Observed station is in pasture about 20 feet above high water, 15 yards northwest of edge of bank, 75 yards northeast of a grove of trees and roo yards southwest of another grove of trees. Locust trees form a fringe along edge of bank.

Marks.-Observed station is center point of triangle on standard cement monument.

References.-

"Leitch" ( $\mathrm{S} 83^{\circ}$ or' E)
Chuare chimney on house
Chimney on store at Buena lista.
Vista.

Nearest chimney on Gourley house on Hallowing Point

Nail in blaze in locust tree (3 inches diameter) . . . $39 . \ldots . \ldots 4$ meters.

Nail in blaze in locust tree (4 inches diameter) . . . . . . . . . . . . . . . . . . . I 10

Outside chimney on large house on hill ...

Near end of peak of roof _............ 2

Middle of clump of trees ................ 273

Nail in blaze in crotch of locust tree $(6$ inches diameter)

$\begin{array}{rrrrrr}0 & 00 & 00 & \ldots & 3 / 4 \text { mile. } \\ 0 & 02 & \ldots & \ldots & 3 / 4 \text { mile. } \\ 19 & 15 & \ldots & \ldots & 13 / 4 \text { miles. } \\ 21 & 07 & \ldots & \ldots & 13 / 4 \text { miles. } \\ 55 & 16 & \ldots & \ldots & 212 \text { miles. } \\ 79 & 38 & 30 & \ldots \ldots & 15.94 \text { meters. } \\ & & & & \\ 110 & 13 & 30 & \ldots \ldots & 14.55 \text { meters. } \\ 150 & 45 & \ldots & & 3 / 4 \text { mile. } \\ 226 & 02 & \ldots & \ldots \ldots & 3 / 4 \text { mile. } \\ 273 & 00 & \ldots & \ldots \ldots & 100 \text { yards. } \\ 311 & 04 & \ldots & \ldots & 13 / 4 \text { miles. } \\ & & & & \end{array}$

LEITCH.

General locality.-Eastern shore of Patuxent River on prominent point opposite mouth of Swanson Creek given on chart as Gods Grace Point but known locally as Leitchs Point. (See Chart No. 19.)

Immediate locality.-Observed station is on sand and grass land about I foot above high water and 3 yards north of straight line connecting two round points. It is about I 3 yards northwest of the lower of these two points and 9 yards east of upper point. A creek 3 feet wide has its mouth about r 9 yards east by south of the station. There are no permanent objects near station.

Marks,-Observed station is center point of triangle on standard cement monument.

References,-

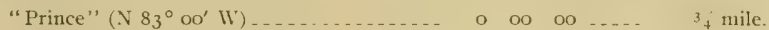

Near end of corner peak of roof of large

house on hill

Near end of peak of whatf-house roof

Right chimney of house $--{ }^{-}$

Right chimney of house

$\begin{array}{lllll}0 & 00 & 00 & \ldots \ldots & 3 \\ 25 & 02 & \ldots & \ldots \ldots & \text { I } 34 \text { mile. } \\ 77 & 46 & \ldots & \ldots \ldots & \text { I miles. } \\ 83 & 32 & \ldots & \ldots \ldots & \text { Is mile. }\end{array}$

$20908-10-3$ 


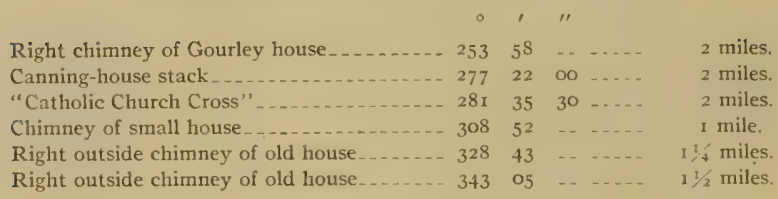

\section{FODDER.}

General localily.-Western shore of Patuxent River on the southern side of the mouth of Swanson Creek about I mile west-southwest of Leitch Whatf and $3 / 4$ mile west-northwest of Point Judith (locally known as Teague Point). (See Chart No. 19.)

Immediate locality.-Observed station is on the edge of cultivated land about ro feet above highwater mark, 4 yards west of edge of bank, and 9 yards north of another edge. Cement monument marking reference station is 15.21 meters $\mathrm{S} 60^{\circ} 52^{\prime}$ W of observed station.

Marks,-Observed station is center point of triangle on standard cement monument with a top 9 inches square and 8 inches above surface of ground. Reference station is center point of triangle on standard cement monument with a top about 8 inches square and 5 in hes above surface of ground.

\begin{tabular}{|c|c|c|c|c|}
\hline "Prince" ( $\left.\mathrm{N}_{25^{\circ}} \mathrm{oo}^{\prime} \mathrm{E}\right)$ & 0 & $\mathrm{OO}$ & oo - & 1/2 mile. \\
\hline Near peak of large house on bluff ......... & 17 & 55 & ....... & 2 miles. \\
\hline Right corner of house $\ldots \ldots \ldots$ & 24 & 08 & $\ldots \ldots$ & $13 / 4$ miles. \\
\hline Near peak of Leitch Wharf house ........ & 35 & II & $\ldots-$ & $11 / 4$ miles. \\
\hline Left peak of Leitch house & 48 & 37 & $\ldots$ & $11 / 4$ miles. \\
\hline Front peak of house at Buena Vista . ..... & 75 & oo & . . ...... & I $1 / 4$ miles. \\
\hline Chimney outside left end of house on hill__._- & 87 & 16 & . . ..... & 2 miles. \\
\hline Near peak of small house & 101 & 33 & $\ldots$ & $3 / 8$ mile. \\
\hline $\begin{array}{l}\text { Large chimney on small house } \\
\text { Left side of left chimney outside Bowling }\end{array}$ & 174 & 43 & -. - & I mile. \\
\hline house $\ldots \ldots \ldots$ & $2 \mathrm{II}$ & 47 & .. - & $3 / 4$ mile. \\
\hline REFERENCE STATION & 215 & 52 & $30 \ldots$ & 15.21 meters. \\
\hline Left corner of house on top of hill_............ & 318 & 27 & - $\ldots . .$. & I mile. \\
\hline
\end{tabular}

\section{BUENA.}

General localily.-Eastern shore of Patuxent River about $13 / 4$ miles northeast of Benedict at place known as Buena Vista. (See Chart No. 19.)

Immediate locality.-Observed station is in a field on land adjoining house owned by S. V. Smith and occupied by Doctor Huggins. It is about 10 feet above high water, 8 yards east of edge of bank, and 12 yards south of a rail fence. Cement monument marking reference station is 1 i.1 m meters N $5^{\circ} 42^{\prime}$ E of observed station and near fence.

Marks.-Observed station is nail in stub with top 2 inches above ground. Reference station is center point of triangle on standard cement monument.

References -

"Hallowing" (S $\left.27^{\circ} 22^{\prime} 11^{\circ}\right) \ldots . . . . . . .$.

Center of red roof on square house near Benedict

Canning-house stack

"Catholic Churcli Cross" . . . . . . . . .

Nail in blaze in locust tree ( 4 inches diam-

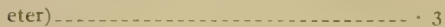

Left chimney of old house _.............. 66

Left chimney. of old house

$\begin{array}{rrrrr}0 & \prime & & & \\ 0 & 00 & 00 & \ldots & 1,1,2 \text { miles. } \\ 18 & 05 & \ldots & \ldots \ldots & 2 \text { miles } \\ 21 & 30 & \ldots & \ldots & 13 / 4 \text { miles. } \\ 29 & 04 & 10 & \ldots \ldots & 13 / 4 \text { miles. } \\ 31 & 48 & 40 & \ldots \ldots & 8.58 \text { meters. } \\ 66 & 15 & \ldots & \ldots \ldots & 3 \text { miles. } \\ 72 & 52 & \ldots & \ldots \ldots & 3 \text { miles. }\end{array}$


Nail in blaze on cherry tree ( 2 inches diameter)

Peak of roof of large house . . . . . . . . . . .

Chimney of house near Leitch Wharf . . . . 108

Nail in blaze on fence post . ............ 143

REFERENCE STATION_............... 158

Near corner of house _. . _ _ _. . . . . 159

Cherry tree on fence line ( 15 inches diameter) :-

\begin{tabular}{|c|c|c|}
\hline 05 & $\ldots$ & 9.70 meters. \\
\hline 15 & .. & 4 miles, \\
\hline 52 & $\ldots \ldots$ & I mile. \\
\hline 33 & 50 & I1.18 meters. \\
\hline 20 & 20 & II.11 meters. \\
\hline 44 & $\ldots \ldots$ & 25 yards \\
\hline
\end{tabular}

Double apple tree (30 inches diameter)

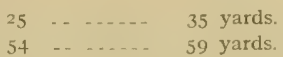

\section{TEAGUE}

General locality.-Western shore of Patuxent River on point on southern side of entrance to Swanson Creek, locally known as Teague Point, and given on chart as Point Judith. (See Chart No. 19.)

Immediate locality.-Observed station is on gravel and grass land about 3 feet above high water, about 11 yards from south side, 16 yards from north-northeast side, and 75 yards west by north of extreme end of point. Bushes stand between station and north side of point. There are no permanent reference objects near station.

Marks.-Observed station is center point of triangle on standard cement monument.

References.-.

\begin{tabular}{|c|c|c|c|c|c|}
\hline "Buena" ( $\left.\mathrm{N} 85^{\circ} \cdot 24^{\prime} \mathrm{E}\right) \ldots \ldots \ldots$ & 0 & oo & oo & & I $/ 2$ miles. \\
\hline Tangent of Teague Point_-- & 20 & Oo & & & 75 yards. \\
\hline \multirow{2}{*}{\multicolumn{6}{|c|}{$\begin{array}{l}\text { Near corner of right chimney of Gourley } \\
\text { house near Hallowing Point }\end{array}$}} \\
\hline & & 45 & -. & & 1 $1 / 4$ miles. \\
\hline Canning-house stack_ & 106 & 18 & oo & & $1 / 4$ miles. \\
\hline ear end of peak of hotel. ... & 108 & 12 & .. & & $I^{1} / 4$ miles. \\
\hline of two ivy-covered chimneys_.. & 110 & 25 & - - & & I mile. \\
\hline "Catholic Church Cross" - & 114 & $1 \mathrm{I}$ & 10 & & nile. \\
\hline Slye House & ${ }_{130}$ & 30 & -. & & 2 miles. \\
\hline r hill & 144 & 57 & -. & & es. \\
\hline Tangent of high-water mark & 168 & oo & -. & & rards. \\
\hline Near end of peak of roof & 223 & 41 & -. & & iile. \\
\hline Chimney on large house on hill & 2.43 & 20 & -. & & niles. \\
\hline Left chimney on house. .................. & 301 & 17 & -- & & I mile. \\
\hline f roof on store at Bue & & & & & \\
\hline (2. & 355 & 59 & .. & & $11 / 4$ miles. \\
\hline
\end{tabular}

CITY.

General locality.-Western shore of Patuxent River on Town Point about $1 / 4$ mile north-northeast of Benedict steamboat wharf. (See Chart No. 19.)

Immediate locality.-Observed station is on gravel and shell point about 4 feet above high water, 12 yards northwest of the shore, 63 yards west-southwest of a shanty, about 100 yards west-southwest of extreme end of point, and II yards southeast of a slough. There are no permanent reference objects near station.

Marks.-Observed station is center point of triangle on standard cement monument.

References.-

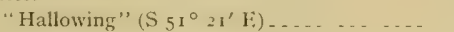

Windmill near Sheridan Point _.......... 2

Two middle chimneys at Dowells........ 2

I.eft tangent of peak of wharf-house roof ... $8 \mathrm{r}$

Center of reof of square house.......... 84

Canning-house stack ................... 95

Nearest ivy-covered chimney of old house.. I30

"Catholic Cliurch Cross" . . . . . . . . . . . . 142

\begin{tabular}{|c|c|c|}
\hline & 00 & I - mile. \\
\hline & oo & $\pi / 2$ miles \\
\hline & oo - & $31 / 2$ miles \\
\hline & -. - & $1 / 4$ mile. \\
\hline & 20 & $1 / 2$ mile. \\
\hline & oo & mile \\
\hline & - & $\mathrm{mi}$ \\
\hline & $5^{\circ}$ & if tinite \\
\hline
\end{tabular}




\begin{tabular}{|c|c|c|c|c|}
\hline & 0 & , & $\prime \prime$ & \\
\hline Left square chimney of house & 245 & 42 & $\ldots$ & $x 3 / 4$ miles. \\
\hline Near end of peak of roof of Huggins house & 280 & 54 & - & $11 / 2$ miles. \\
\hline Near corner of shanty . . . . . & 300 & 44 & . & 63 yards. \\
\hline Right chimney of Gourley house ... & 339 & 20 & - & $3 / 4$ mile. \\
\hline Chimney of old building behind wharf & $35^{2}$ & or & -- & $3 / 4$ mile \\
\hline
\end{tabular}

\section{HALLOWING.}

General locality.-Eastern shore of Patuxent River on point opposite Benedict known locally as Holland Point, but given on charts as Hallowing Point. (See Chart No. r9.)

Immediate locality.-Observed station is on a rounded gravel and grass point about 250 yards south of wharf on Holland Point, about 2 feet above high water, ro yards north of shore, 8 yards east of shore and 15 yards outside of a group of locust trees, sugar-berry trees, and bushes.

Marks.-Observed station is center point of triangle on standard cement monument.

References.-

"City" (N $\left.5 \mathrm{I}^{\circ} 2 \mathrm{I}^{\prime} \mathrm{W}\right)$

Left end of peak of roof of wharf house on Holland Point

Chimney of store at Buena Vista

Nail in blaze in nearest one of group of four sugar-berry trees (each 8 inches diameter).

Nail in blaze in sugar-berry tree (ro inches diameter) _........................ I

Nail in blaze in locust tree ( 4 inches diameter) _.................... I67

Smokepipe on Trent Hall Wharf building -- 227

Outside chimney of detached house at Sothorons

Center of roof on square house . . ....... 314

Canning-house stack _.............. . 333

"Catholic Church Cross" _..._.......... 347

$\begin{array}{ccccc}0 & 00 & 00 & \ldots \ldots & 3 / 4 \text { mile. } \\ 23 & 15 & \ldots & \ldots \ldots & 250 \text { yards. } \\ 77 & 27 & \ldots & \ldots \ldots & 13 / 4 \text { miles. } \\ 92 & 24 & \ldots & \ldots \ldots & 12.88 \text { meters. } \\ 09 & 58 & 50 & \ldots \ldots & 15.74 \text { meters. } \\ 67 & 55 & 40 & \ldots \ldots & 11.90 \text { meters: } \\ 27 & 35 & \ldots & \ldots \ldots & 21 / 4 \text { miles. } \\ & & & & \\ 309 & 54 & \ldots & \ldots & 1 / 2 \text { miles. } \\ 14 & 15 & \ldots & \ldots \ldots & 3 / 4 \text { mile. } \\ 33 & 16 & \ldots & \ldots \ldots & 1 / 2 \text { mile. } \\ 37 & 44 & 20 & \ldots \ldots & 3 / 4 \text { mile. }\end{array}$

INDIAN.

General locality.-Western shore of Patuxent River on north side of entrance to Indian Creek and alout one-fourth mile below Benedict steamboat wharf. (See Chart No. 19.)

Immediate locality.-Observed station is about 3 feet above high water, 7 yards west of shore, I6 yards northeast of a fence and a line of trees, 13 yards southwest of a lone locust tree, about 250 yards to the south-southeast of a large square house, and 125 yards east-northeast of another house.

Marks,-Observed station is center point of triangle on standard cement monument.

References. -

"Sothoron" (S $\left.23^{\circ} \mathrm{II}^{\prime} \mathrm{E}\right)$

0 oo 00 - I mile.

Nail in blaze in locust tree near fence (s inches diameter)

Nail in blaze in middle branch of locust tree (6 inches diameter) ................ 66

Square chimney on old house . _........ 137

Right chimney of square house ........... I

Near end of peak of roof of hotel _... _. _. 206

Canning-house stack_................... 213

Right tangent of Benedict Wharf _........ 2

Chimey of house near "Buena Vista" .... 2

Chimney of Gourley house............ 2

IVindmill at Dowell's on Sheridan Point... 3

Left of right chimney on Dowell house ... 3

Nail in blaze in left branch of locust tree ( 5 inclies diameter) ....... $\begin{array}{llll}22.5 & 28 & \ldots & \end{array} 2.90$ meters. 


\section{DWARF}

General locality.-Eastern shore of Patuxent River about 2 miles north-northwest of Sheridan Point and about $\mathrm{I} / 2$ miles southeast of Benedict on a point of land opposite the mouth of Indian Creek. (See Chart No. 19.)

Immediate locality.-Observed station is on sand and grass land about I foot above high-water mark, 6 yards northeast from extreme end of point, 4 yards east of one edge of shore and 6 yards north of another edge of shore. Point on which station is located has a sugar-berry tree, several small locust trees and water bushes, and a pond behind bushes and trees about roo yards to the east.

Marks.-Observed station is center point of triangle on standard cement monument.

References.-

\begin{tabular}{|c|c|c|c|c|c|}
\hline \multicolumn{6}{|l|}{ 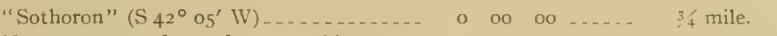 } \\
\hline $\begin{array}{l}\text { Nearest corner of top of nearest chimney on } \\
\text { tenant house }\end{array}$ & 80 & 31 & .. & & 2 miles. \\
\hline Center of roof of square house & 83 & I6 & . & & I mile: \\
\hline ail in blaze in locust tree ( 4 inches diame- & & & & & \\
\hline ter) $\ldots . . . . . .$. & 93 & 38 & 30 & - & 4.22 meters. \\
\hline Canning-house stack & 95. & 03 & 33 & & $x^{1 / 4}+$ miles. \\
\hline "Catholic Church Cross" & 99 & 03 & 10 & & $14_{4}^{1}$ miles. \\
\hline Left tangent of wharf & 124 & 19 & -- & & nile. \\
\hline Nail in sugar-berry tree (1o inches diameter) & 152 & 38 & 30 & & 8.94 meters. \\
\hline Nail in blaze in locust tree ( 3 inches diam- & & & & & \\
\hline 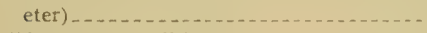 & 196 & 22 & 20 & & 2.68 meters. \\
\hline Chimney on small house $\ldots \ldots$ & 258 & $4^{8}$ & -. & & 2 miles. \\
\hline Left point of peak of roof of Dowvell's... & 287 & 30 & -- & & $2 \frac{1}{4}$ miles. \\
\hline Left end of peak of roof of Trent Hall Wharf & 315 & 35 & -- & & $x^{1} / 2$ miles. \\
\hline 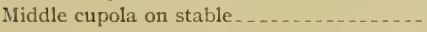 & 321 & 12 & 20 & & $1 / 2$ miles. \\
\hline Right pillar on Sothoron house porch & 359 & $2 \mathbf{I}$ & -- & $\ldots \ldots$ & I mile. \\
\hline
\end{tabular}

\section{SOTHORON.}

Gencral locality.-Western shore of Patuxent River on Long Point between entrances to Indian and Trent Hall creeks. (See Chart No. r9.)

Immediate locality.-Observed station is on sand and grass lowland about $\mathrm{x}$ foot above high-water mark among cedar trees, about 24 yards west by north of extreme end of point, 12 yards north of one edge of shore and 30 yards southwest of another edge of shore.

Marks.-Observed station is center point of triangle on standard cement monument.

References.-

"Hallowing" ( $\left.\mathrm{N}_{13}{ }^{\circ} 51^{\prime} \mathrm{E}\right)$

Nearest chimney on Gourley house

Nail in blaze in locust tree ( 4 inches diameter) -

Left end of peak of roof of Dowell house... I 20

Middle cupola on Trent Hall stable....... I 50

Point of middle attic window on John Bullinger house

Left pillar of porch of Sothoron house $\quad \begin{aligned} & 187 \\ & 206\end{aligned}$

Nail in blaze in cedar tree ( 12 inches diame-

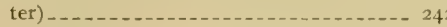

Near corner of nearest chimney oa Slye house ........................... 291

Nail in blaze in locust tree ( 4 inches diame-

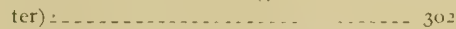

Right one of two outside chimneys on old house on hill on property of A. B. Slye _. 307

Center of roof on square house _... _..... $323 \quad 3$

Nail in blaze in locust tree ( 6 inches diameter)

$\begin{array}{ccccc}0 & 00 & 00 & \ldots \ldots & I^{1 / 4} \text { miles. } \\ 3 & 55 & \ldots & \ldots \ldots & 1 / 4 \text { miles. } \\ 30 & 49 & \ldots & \ldots \ldots & 3.35 \text { meters. } \\ 20 & 35 & \ldots & \ldots \ldots & 2^{1 / 4} \text { miles. } \\ 50 & 25 & 00 & \ldots \ldots & I^{1 / 4} \text { miles. } \\ & & & & 1 \\ 87 & 42 & \ldots & \ldots \ldots & \text { I mile. } \\ 66 & 23 & \ldots & \ldots \ldots & 1 / 2 \text { mile. }\end{array}$
$42 \quad 51$ I $\quad$ o5 29 31 39 350
24 10 _... 12.81 meters 


\section{BUZZ.}

General locality.-Northeast shore of Patuxent River on southwest side of Buzzards Island near mouth of Buzzards Island Creek. (See Chart No. 19.)

Immediate locality.-Observed station is on marsh, clay, and grass land on wooded island about $=$ feet above high water, 5 yards northeast of river shore and 40 yards northwest of extreme point of island. Cement monument marking reference station is 8.97 meters $\mathrm{N} 42^{\circ} 23^{\prime} \mathrm{E}$ of observed station.

Marks.-Observed station is nail in stub with top flush with ground. Reference station is center point of triangle on standard cement monument.

References.-

\begin{tabular}{|c|c|c|c|c|c|}
\hline "Morsel" (S $\left.25^{\circ} 23^{\prime} \mathrm{E}\right)$ & o & 0 & oo & & \\
\hline Smoke pipe on roof of storehouse & 39 & II & - & & les. \\
\hline Near corner of near chimney $\ldots . . . . .$. & 40 & 36 & - & & iles. \\
\hline Chimney of Trent Hall & 50 & 48 & -- & & $1 / 4$ \\
\hline Nearest of three cupolas on stable & 54 & 36 & 50 & & $11 / 4$ \\
\hline Left piazza post at Sothorons ........... & 102 & 41 & -- & & I $1 / 4$ miles. \\
\hline Center of roof of square house & 155 & $\mathbf{r}_{5}$ & - & & $13 / 4$ \\
\hline "Catholic Church Cross" & 164 & 56 & -- & & ailes. \\
\hline Nail in blaze in oak tree ( 18 inches diam- & I 72 & 14 & & & +.5 \\
\hline $\begin{array}{l}\text { Nail in blaze in oak tree ( } 18 \text { inches diam- } \\
\text { eter) } \\
\text { Nail in blaze in oak tree ( } 24 \text { inches diam- }\end{array}$ & 98 & 36 & 40 & & 13 \\
\hline eter) & 235 & o8 & 30 & & 9.6 \\
\hline REFERENCE STATION & 252 & 45 & 45 & & 8.97 meters. \\
\hline ine tree $(5$ inches dia & 255 & 43 & & & \\
\hline 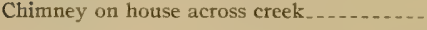 & 313 & 23 & & & \\
\hline
\end{tabular}

\section{BILLIARD.}

General locality.-Southwest shore of Patuxent River about $1 / 4$ mile southeast of entrance to Trent Hall Creek. (See Chart No. :9.)

Immediate locality.-Observed station is on marsh land about I foot above high-water mark, 6 yards west of shore, 70 yards north of curve in shore and about 100 to I 50 yards north to northwest of a fence which runs to water's edge. No permanent reference objècts near station.

Marks.-Observed station is center point of triangle on standard cement monument.

References. -

"Trent" ( $\mathrm{S}$ 320 53 "

Middle cupol on

Chimney on Trent Hall ..........

Two trees . . . . . . . . . . . . .

Tangent of curve in water line .........

Chimney of, $2 \mathrm{~T} / 2$-story house.............

Right corner of Sothoron house .......... I

Near corner of chimney on Slye house .... $x$

Right tangent of wharf
Middle of three chimneys on Gourley house

Chimney on house among trees. Nearest end of peak roof of Dowell house at Dukes Wharf _................ 3

Right tangent of Sheridan Point _... . . - 34

Left tangent Trent Hall II'harf . Hall Wharf

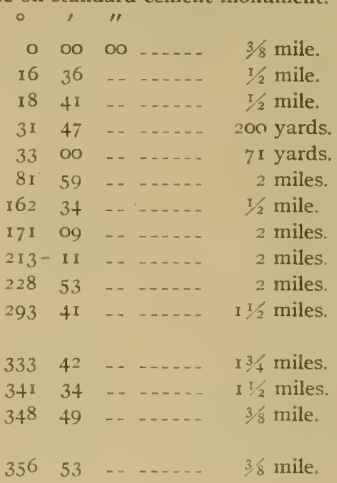


MORSEL.

General locality.-Northeast shore of Patuxent River about $\mathrm{x}$ mile north by west of Sheridan Point. (See Chart No. 19.)

Immediate locality.-Observed station is in a wheat field on a cliff about 60 feet above high water, about 5 yards northeast of edge of bank, I 10 yards north northwest of rail fence at woods, 103 yards west southwest of woods, and 167 yards west northwest of corner of field at creek and woods. Trees grow out of face of cliff below station.

Marks.-Observed station is center point of triangle on standard cement monument.

References.-

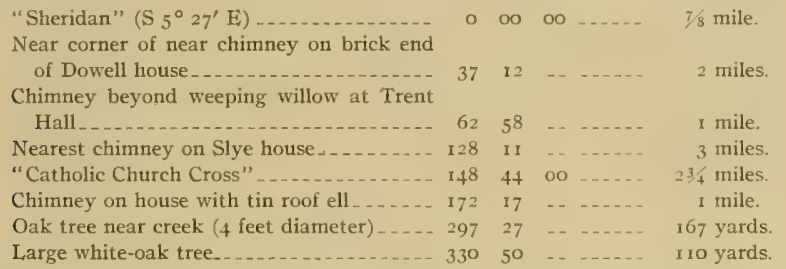

\section{TRENT.}

General locality,-Southwest shore of Patuxent River on White Point about 50 yards west of Trent Hall Wharf. (See Chart No. 19.)

Immediate locality.-Observed station is I foot above high-water mark on sand and grass land between river and marsh, about 47 yards west of small house on land end of Trent Hall Wharf, about 64 yards northwest of extreme end of White Point, 5 yards southwest of high-water mark, about 428 yards north of Trent Hall and 105 yards south by east of mouth of creek. Cement monument marking reference station is 17.18 meters $\mathrm{S} 69^{\circ} 4 \mathrm{O}^{\prime} \mathrm{WV}$ of observed station.

Marks.-Observed station is nail in stub flush with ground. Reference station is center point of triangle on standard cement monument.

References. -

\begin{tabular}{|c|c|c|c|c|c|}
\hline "Sheridan" (S $\left.57^{\circ} 3 \mathrm{I}^{\prime} \mathrm{E}\right)$ & o & OO & $\infty$ & & $1 \mathrm{~T} / 8$ miles. \\
\hline Tangent of point & 32 & 17 & 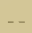 & & $1 / 2$ mile. \\
\hline Large lone tree ............ & 50 & 15 & - & & ${ }^{\top}{ }_{2}^{\prime}$ mile. \\
\hline Right corner of Trent Hall & 74 & 08 & -. & & 428 yards. \\
\hline Right cupola of three on Trent Hall stable - & 99 & 40 & -- & & 300 yards. \\
\hline Large lone tree & 113 & $5 \mathrm{I}$ & -. & & ards. \\
\hline REFERENCE STATION & 127 & 10 & 30 & & 17.18 meters. \\
\hline "Catholic Church Cross" & 219 & 22 & 20 & & $23 / 4$ miles. \\
\hline Right end of peak of roof of Holland Point & & & & & \\
\hline Whatf & 233 & 05 & - & & $21 / 4$ miles. \\
\hline $\begin{array}{l}\text { Right chimney of smaller of two houses } \\
\text { among trees }\end{array}$ & 284 & or & - & & miles. \\
\hline Right chimney of house & 300 & 35 & -. & $\ldots$ & $51 / 2$ miles. \\
\hline Right corner of shanty & 300 & 36 & $\ldots$ & $\ldots$ & 47 yards. \\
\hline
\end{tabular}

\section{COLLINS.}

General locality.-Southwest shore of Patuxent River about I/4 mile northeast of entrance to Washington Creek on point opposite Sheridan Point. (See Chart No. 19.)

Immediate locality.-Observed station is on marsh land about I foot above high-water mark, I6 yards west of shore, 20 yards northwest of shore, 21 yards southwest of shore, 300 yards northeast of a tall lone tree and 300 yards southeast of house known as Trent Hall. 
Marks.-Observed station is center point of triangle on standard cement monument.
References.-
"Sheridan" (S $\left.80^{\circ} 59^{\prime} \mathrm{E}\right)$

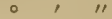
Left end of peak of roof of De La Brooke
Pier
Right side of right chimney of large painted brick house
Near corner of Thomas house (Cremona) -.-
Smoke pipe in chimney on store..........
Large lone tree . . . . . . . . . . . . . . . . . I
Small lone tree
Near corner of Trent Hall Wharf house
Chimney on end of roof of house among

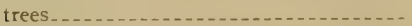
Left corner of left chimney of Dowell house

\section{SHERIDAN.}

General locality.-Northeast shore of Patuxent River on Sheridan Point. (See Chart No. 19.)

Immediate locality.-Observed station is on sand and grass point near edge of the grass, about 2 feet above high-water mark, 6 yards east of extreme edge of grass on point, 8 yards north of grass edge and 7 yards south of grass edge. Cement monument marking reference station is 14.13 meters $\mathrm{N} 49^{\circ} 56^{\prime} \mathrm{E}$ of observed station.

Marks-Observed station is nail in stub with top 6 inches above ground. Reference station is center point of triangle on standard cement monument.

References.-

"Kitt" (S $66^{\circ} 05^{\prime} \mathrm{E}$ )

\begin{tabular}{rrrrr}
0 & \multicolumn{1}{c}{$l$} & & \\
0 & 00 & 00 & $\ldots \ldots$ & $1^{1} / 4$ miles. \\
10 & 41 & $\ldots$ & $\ldots \ldots$ & 6 miles. \\
56 & 13 & $\ldots$ & $\ldots \ldots$ & $13 / 4$ miles. \\
02 & 38 & $\ldots$ & $\ldots$ & $11 / 4$ miles. \\
24 & 25 & $\ldots$ & $\ldots \ldots$ & $11 / 4$ miles. \\
92 & 00 & $\ldots$ & $\ldots \ldots$ & 1 mile. \\
16 & 56 & $\ldots$ & $\ldots \ldots$ & $31 / 2$ miles. \\
96 & 01 & 00 & $\ldots \ldots$ & $1+13$ meters. \\
25 & 23 & $\ldots$ & $\ldots \ldots$ & $1 / 4$ mile.
\end{tabular}

Right tangent of brick house..........

Left end of peak of roof of De La Brooke

Pier...

Left corner of left chimney of Thomas house (Cremona) . . . . . . . . . . . . . .

Smoke pipe on several gable house ....... I

Right tangent of Trent Hall Wharf...... r

Catholic Church at Benedict ............. 216

REFERENCE STATION_._............ 296

Near chimney of Dowell house .......... 325

\section{CREMONA.}

General locality.-Southwest shore of Patuxent River about half way between Cremona and Persimmon creeks. (See Chart No. 19.)

Immediate locality.-Observed station is in orchard on farm known as Cremona, about 6 feet above high-water mark, ro yards south of eage of river bank, 7 yards south of rail fence which runs west and east to door yard fence, 36 yards east of rail fence of cornfield, 75 yards north of rail fence at cornfield and 53 yards west of picket fence. Several mountain dwarf cherry trees stand between fence and river bank edge.

Marks.-Observed station is center point of triangle on standard cement monument.

References.-

"Kitt" ( $\left.\mathrm{N} 84^{\circ} \mathrm{1}^{\prime} \mathrm{E}\right) \ldots$ house

Nail in blaze in apple tree $(24$ inches diameter)

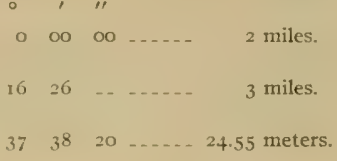


Nail in blaze in apple tree ( 16 inches diameter) ...................... 624330 ..... 12 meters.

Nail in blaze in apple tree ( 15 inches diameter) ................. 100 33 30 ..... 16.1 1 meters.

Corner of field ........... I 8 I, $55 \quad \ldots \quad \ldots 7$ yards.

Corner of field ............ 333 yards.

\section{KITT}

General locality.-Northeast shore of Patuxent River on Kitts Marsh Point, which is about halfway between Battle Creek and Sheridan Point. (See Chart No. 19.)

Immediate locality.-Observed station is on the point of a long marsh neck, about 15 yards northeast of extreme end of point, 13 yards north of edge of marsh, and 13 yards east of edge of marsh. There are no permanent reference objects near station. Cement monument marking reference station is 15.84 meters $\mathrm{N} 10^{\circ} 23^{\prime} \mathrm{E}$ of observed station..

Marks.-Observed station is nail in stub flush with surface of marsh. Reference station is center point of triangle on standard cement monument.

References.-

\begin{tabular}{|c|c|c|c|c|c|}
\hline 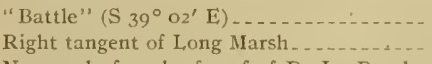 & $\begin{array}{l}0 \\
7\end{array}$ & $\begin{array}{l}00 \\
53\end{array}$ & oo & & $\begin{array}{l}\text { I I } / 8 \text { miles. } \\
2 \text { miles. }\end{array}$ \\
\hline $\begin{array}{l}\text { Vear end of peak of roof of De La Brooke } \\
\text { Pier }\end{array}$ & 73 & 52 & - & & $1 / 2$ miles. \\
\hline $\begin{array}{l}\text { ear corner of near chimney of Thomas } \\
\text { house }\end{array}$ & 83 & 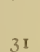 & & & 34 mile \\
\hline Large house & 167 & 38 & & & I mile. \\
\hline Square chimney of large house & 185 & 23 & -. & & $1 / 4$ mile. \\
\hline REFERENCE STATION & 229 & 24 & 40 & & 15.84 meters. \\
\hline Left chimney of hous & 243 & 56 & - & & $2 \mathrm{I} / 2$ miles. \\
\hline (1) & 299 & I3 3 & & & 2 miles. \\
\hline $\begin{array}{l}\text { Right chimney of house among trees o } \\
\text { hill }\end{array}$ & & & & & \\
\hline t chim & 336 & 9 & & & 4 miles. \\
\hline
\end{tabular}

()PPKIT

General locality. - Southwest shore of Patuxent River on Marsh Point. (See Chart No. 19.)

Immediate locality.-Observed station is on sand and grass ridge between sand beach and marsh, about I foot above high water, 3 yards southwest of high water mark, 60 yards west-northwest of one point of the beach, 64 yards south of another point of the beach, and 85 yards north-northwest of an oyster watch house on piles. There are no permanent reference objects near station.

Marks.-Observed station is center point of triangle on standard cement monument.

References.-

"Kitt" ( ${\left.\mathrm{N} 56^{\circ} 3 \mathrm{r}^{\prime} \mathrm{E}\right)}_{\text {Near end of peak of roof of Williams }}$

Wharf house

Left corner of watch house. . .

Left point of peak of roof of De La Brooke Pier corner of right chimney of brick house . ........ . . . 326

Chimney on house near trees - 126

Highest chimney on Cremona House..... 254

Point of roof of Dukes IVharf........... 310

Chimney on house with ell . . . . . . _.... 330

Large square brick chimney on house with ell

Nearest chimney of pair on end of house.- 35.3

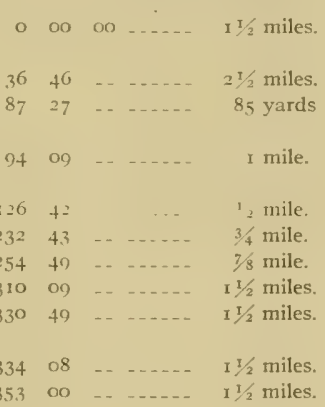




\section{BATTLE,}

General locality.-Northeast shore of Patuxent River on west side of entrance to Battle Creek on Prison Point. (See Chart No. 19.)

Immediate locality.-Observed station is on sand and grass land between marsh and river, about I foot above high water, 85 yards south of a field, 6 yards northeast of shore, 20 yards southwest of edge of a pool, 100 yards southwest by west of a lone tree, 200 yards west of a small house among trees, and 100 yards west to northwest of several dwarf trees between house and beach.

Marks.-Observed station is center point of triangle on standard cement monument.

References-

\begin{tabular}{|c|c|c|c|c|}
\hline "Forr" (S 3 ${ }^{\circ}$ I $\left.^{\prime} \mathrm{E}\right)$ & o & 0 & oo & $21 / 4 \pi$ \\
\hline Chimney on middle of roof of house & I & 52 & -- & $21 / 4$ miles. \\
\hline $\begin{array}{l}\text { eft corner of left chimney of very large } \\
\text { house }\end{array}$ & 8 & 36 & - & $21 / 4$ \\
\hline $\begin{array}{l}\text { Riglit chimney of large } 21 / 2 \text {-story brick } \\
\text { house }\end{array}$ & 82 & $\infty 0$ & -- & p. \\
\hline Tangent to Sheridan Point & 129 & 20 & & les. \\
\hline $\begin{array}{l}\text { ight end of peak of roof of } 21 / 2 \text {-story } \\
\text { house }\end{array}$ & & & & \\
\hline ory house on hill & I55 & 19 & $\cdots$ & es. \\
\hline 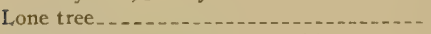 & 254 & 41 & - & 80 \\
\hline y of house on hill & 264 & in & . & 3 miles. \\
\hline rees & 282 & I5 & - & 100 \\
\hline ng Marsh $\ldots \ldots$ & 341 & 45 & - & $1 \mathrm{I} / 2$ \\
\hline -story house $\ldots \ldots \ldots$ & 348 & 38 & -- & es. \\
\hline y house & 352 & 57 & $\ldots$. & es. \\
\hline rrest Wharf .......... & 357 & 59 & & 1 $1 / 2$ miles. \\
\hline
\end{tabular}

PHOTO.

General locality.-Northeast side of Patuxent River on east side of entrance to Jacks Bay. (See Chart No. 19.)

Immediate locality.-Observed station is in a cultivated field, about 150 yards north-northeast of a marshy point, to feet above high-water mark, 49 yards east of shore, 110 yards north northwest of shore, and 68 yards northeast of right end of clump of trees at edge of field and beginning of marsh point.

Marks.-Observed station is nail in stub with top 2 inches above surface of ground. Subsurface mark is center point of triangle on standard cement monument with top 12 inches below surface.

References. -

"Slim" $\left(\mathrm{S} 52^{\circ} .3^{\prime} \mathrm{E}\right)$
Chimney on old house
Left corner of house
Smoke pipe on house behind trees.
Left tangent of Forrest Wharf
Tree.
Watchhouse on point
Right chimney on $21 / 2$-story brick house...
Locust tree (20 inches diameter)
Left chimney of house...
Willow tree.......

$\begin{array}{rrrrr}0 & 00 & 00 & \ldots \ldots & 1 / 3 \text { miles. } \\ 51 & 21 & \ldots & \ldots & 2 \text { miles. } \\ 60 & 00 & \ldots & \ldots & 85 \text { yards. } \\ 73 & 03 & \ldots & \ldots & 2 \text { miles. } \\ 8 & 08 & 00 & \ldots \ldots & 2 \text { miles. } \\ 81 & 00 & 20 & \ldots \ldots & 21 / 4 \text { miles. } \\ 0 & 10 & \ldots & \ldots & 70 \text { yards. } \\ 8 & 52 & \ldots \ldots & 1 / 2 \text { mile. } \\ 50 & 37 & \ldots & \ldots & 5 \text { miles. } \\ 41 & 23 & \ldots & \ldots \ldots & 135 \text { yards. } \\ 22 & 45 & \ldots & \ldots \ldots & 1 / 2 \text { mile. } \\ 31 & 27 & \ldots & \ldots \ldots & 140 \text { yards }\end{array}$

FIGHT.

General locality.-Southwest shore of Patuxent River opposite mouth of Battle Creek on a prominent low point. (See Chart No. 19.)

Immediate locality.-Observed station is on land known as Horsehead Marsh, about I foot above ordinary high-water mark, 12 yards south-southwest of extreme end of point, 15 yards west-northwest of shore at small creek, 40 yards northeast of woods, and r ro yards east-southeast of a bluff 50 feet high. 
Marks.-Observed station is center point of triangle on standard cement monument. References.-

\begin{tabular}{|c|c|c|c|c|c|}
\hline \multirow{2}{*}{\multicolumn{6}{|c|}{$\begin{array}{l}\left.\text { "Battle" ( } 50^{\circ} 45^{\prime} \mathrm{E}\right) \\
\text { Outside chimney in center of group of build- }\end{array}$}} \\
\hline & & 30 & - & & $21 / 4 \mathrm{mil}$ \\
\hline Left chimney of house on top of hill & 23 & 44 & - & & $33 / 4 \mathrm{mil}$ \\
\hline Left tangent of Forrest Wharf & 82 & 06 & Io & & mile \\
\hline ear end of peak of roof of $2 \mathrm{t} / 2$-story build- & & & & & \\
\hline ing .. - & 83 & 47 & $\ldots$ & & $\mathrm{r} 3 / 4 \mathrm{mi}$ \\
\hline Large square chimney on large building -. - & 91 & 19 & -- & & $1 \mathrm{mulc}$ \\
\hline Left corner of left chimney of large house. - & 262 & 40 & -. & & mil \\
\hline Dowells windmill & 300 & 28 & -- & & $21 / 2$ mile \\
\hline Left chimney on small house adjoining & & & & & \\
\hline large house & 321 & 41 & $\ldots$ & & $21 / 4 \mathrm{mil}$ \\
\hline Chimney of small house & 325 & 38 & -- & $\ldots . .$. & 2 mil \\
\hline
\end{tabular}

General locality.-Northeast shore of Patuxent River about half way between Battle and Island creeks and $1 / 2$ mile west northwest of Parkers Wharf. (See Chart No, 19.)

Immediate locality.--Observed station is in a field on a sand bluff, about 40 feet above high water, I3 yards northeast of edge of bluff, 90 yards southeast of a point of woods at top of a ravine, about I 89 yards southwest of another point of woods, 150 yards west-northwest of a rail fence, and 7 I yards northwest by west of a large sycamore tree.

Marks.-Observed station is nail in round chestnut stub with top about 6 inches above the surface of the ground. Subsurface mark is center point of triangle on standard cement monument with top ro inches below the surface of the ground.

References.-

\begin{tabular}{|c|c|c|c|c|c|}
\hline Island" (S $\left.59^{\circ} 3 I^{\prime} \mathrm{E}\right)$ - & o & 8 & oo & & 272 \\
\hline Cedar in field ....... & 2 & 38 & 50 & & 200 \\
\hline Large sycamore tree & 29 & & -. & & $7 x$ \\
\hline $\begin{array}{l}\text { eat end of peak of roof of Jones Wharf } \\
\text { house }\end{array}$ & & 27 & - & & $2 \mathrm{~m}$ \\
\hline Chimney on middle of roof of a long house-- & 109 & 34 & 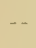 & & s. \\
\hline $\begin{array}{l}\text { Utside chimney of house near Forre } \\
\text { Wharf }\end{array}$ & 125 & 26 & -- & & \\
\hline $\begin{array}{l}\text { Nearest chimney on Thomas large bric } \\
\text { house }\end{array}$ & 166 & 16 & & & \\
\hline of Long Point marsh & 171 & 24 & -- & & $11 / 2$ \\
\hline on point & 191 & 06 & $\cdots$ & & 90 ya \\
\hline $\begin{array}{l}\text { h trees close together near rigt } \\
\text { f point of woods. }\end{array}$ & 284 & 27 & & & \\
\hline (n- & 298 & 20 & -- & & \\
\hline of of barn & 304 & 23 & - & & \\
\hline
\end{tabular}

FORR.

Gencral locality. -Southwest shore of Patuxent River just below Forrest Wharf. (See Chart No. 19.) Immediate locality.-Observed station is about I foot above high-water mark on sand and grass land, 7 yards south from extreme high-water mark, 45 yards southeast of land end of Forrest Wharf, 7o yards east by south of an old $2 \mathrm{~T} / 2$-story building, and 65 yards northeast of a saloon.

Marks.-Observed station is center point of triangle on standard cement monument.

References.-

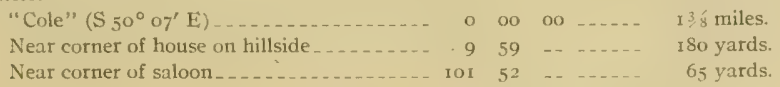




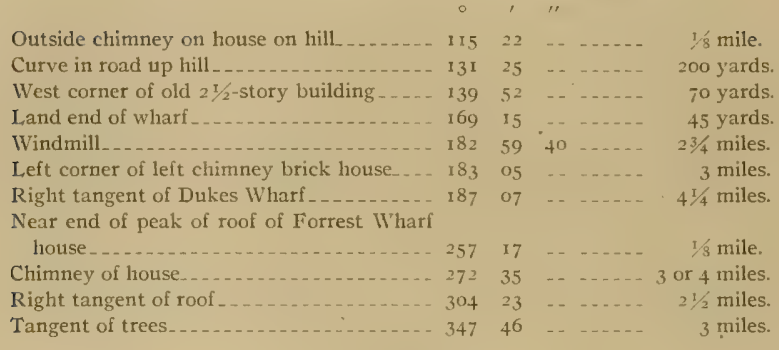

SWEEP.

General locality.- Northeast shore of Patuxent River on northwest side of mouth of Island Creek near inner end of neck of land joining Broome Island to the mainland. (See Chart No. 19.)

Immediate locality.-Observed station is in a field about 4 feet above high water, 4 feet northwest of a wire fence, 24 yards south by west of a stable, 60 yards south-southwest of a house, and Ioo yards south-southeast of a pine grove. Cement monument marking reference station is 21.70 meters $N 59^{\circ}$ $39^{\prime} \mathrm{E}$ of station and near fence line.

Marks.-Observed station is the center of an oblong wooden box 4 inches square with top 4 inches above the ground. Reference station is center point of triangle on a standard cement monument.

References

\begin{tabular}{|c|c|c|c|c|c|}
\hline "Bars" (S $\left.15^{\circ} 10^{\prime} \mathrm{E}\right)$ & 0 & & oo & & \\
\hline Right chimney of house & 14 & 48 & - & -.... & miles. \\
\hline Peak of roof of Gadden house & 25 & 34 & 20 & & I $5 / 8$ miles. \\
\hline Tangent of Broome Island Point $\ldots . . . . . .$. & 43 & 21 & -. & & $1 / 2$ mile. \\
\hline Chimney on house on hill & 51 & 57 & .. & & nilés. \\
\hline Gilt ball on lightning rod. & 62 & 03 & -. & & 3,8 mile. \\
\hline Chimney on house. & 96 & 06 & -. & & $1 / 4$ mile. \\
\hline roods & 13.5 & to & -. & & $17 / 8$ miles. \\
\hline Chimney of house. & 186 & 34 & -. & & 150 yards. \\
\hline Tile smoke pipe on house .... & 203 & 24 & -. & & 140 yards. \\
\hline Near corner of house & 230 & 35 & - & & 60 yards. \\
\hline Near corner of barn. & 237 & 32 & -. & -. & 24 yards. \\
\hline REFERENCE STATION & 254 & 49 & 20 & & meters. \\
\hline Right chimney of four on house. & 279 & 25 & - & & 1/4 mile. \\
\hline Top of tower of house & 301 & $5+$ & .. & $\ldots \ldots$ & $2 \mathrm{I} / 2$ miles. \\
\hline
\end{tabular}

ISLAND.

General locality.- Northeast shote of Patuxent River on the extreme southeast point of land about $1 / 2$ mile to the east of the mouth of Island Creek. (See Chart No. 19.)

Immediate locality.-Observed station is on a marshy point at about extreme high-water mark, 30 yards north of extreme end of point, 25 yards east of one side of point, and 20 yards west of another side of point. Old tile pipe used as a reference station is 16.98 meters $\mathrm{N} 12^{\circ} 39^{\prime} \mathrm{E}$ and cement monument marking new reference station is 30.93 meters $\mathrm{N}_{2}^{\circ} 40^{\prime} \mathrm{E}$ of observed station.

Marks.-Observed station is, nail in stub with top flush with marsh. Old reference station is center of 4 -inch tile pipe set in cement with top projecting about 10 inches above ground. New reference station is center point of triangle on standard cement monument.

References.-

"Wheat" (S $\left.53^{\circ} 15^{\prime} \mathrm{E}\right)$.

Left end of peak of roof of Sotterly Whari house

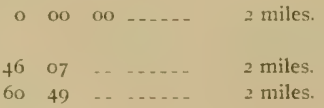

Pinnacle of large house in trees ......... $60 \quad 49 \quad \ldots \ldots \ldots . .2$ miles. 


\begin{tabular}{|c|c|c|c|c|c|}
\hline \multirow{3}{*}{$\begin{array}{l}\text { Left chimney of large house back on hill.-- } \\
\text { Chimney on middle of large } 21 / 2 \text {-story house- } \\
\text { Middle of railing on top of roof of } 21 / 2 \text {-story }\end{array}$} & \multicolumn{3}{|c|}{, I } & \multirow{2}{*}{\multicolumn{2}{|c|}{2 miles. }} \\
\hline & 67 & 54 & -. & & \\
\hline & 109 & 59 & -- & - & I $1 / 2$ miles. \\
\hline house & 120 & oo & .. & & 3 miles. \\
\hline Chimney of Broome house & 143 & $4 \pi$ & .. & & $3 / 4$ mile. \\
\hline Weather vane on Bro & 148 & 33 & 30 & & aile. \\
\hline Right chim & 178 & 21 & -- & & 3 miles. \\
\hline Right chimney of house & 193 & 27 & .. & & 2 miles. \\
\hline REFERENCE STATION (cement monument) - & 235 & 55 & oo & & 30.93 meters. \\
\hline REFERENCE STATION (tile pipe) & 245 & 54 & 20 & & 16.98 meters. \\
\hline moke pipe of & 333 & 29 & -. & & \\
\hline ower of Peterson house & 356 & 08 & & & 2 miles. \\
\hline
\end{tabular}

PEAK.

General locality.-Northeast shore of Patuxent River, about in middle of inner slore of a large bay between St. Leonard and Island creeks. (See Chart No. 19.)

Immediate locality.-Observed station is on Parran house, located near shore at extreme end of a road leading to Wallville.

Marks.-Observed station is ball on tip of tower.

References.-None necessary.

COLE.

General locality. - Southwest shore of Patuxent River, about $1 / 4$ mile northwest of Cole Creek. (See Chart No. 19.)

Immediale locality.-Observed station is about 35 feet above high-water mark on a grass peninsula, 3 yards south-southwest of edge of a bluff which is washing rapidly, 8 yards west of extreme edge of bluff, where it turns inland and is not washing, but slopes gradually to the water, 8 yards north of another edge of the bluff, ro yards northwest of trees on slope of bank, and 20 yards west of a cherry tree 2 feet in diameter. Cement monument marking reference station is 13.53 meters $\mathrm{S} 83^{\circ} 10^{\prime} \mathrm{W}$ of observed station and nearly on line with large cherry tree.

Marks.-Observed station is nail in stub with top flush with ground. Reference station is center point of triangle on standard cement monument.

References.-

"Hutchins" (S $\left.67^{\circ} 12^{\prime} \mathrm{E}\right)$............

Left end of peak of roof on Jones Wharf house

Nail in blaze on limb of oak tree (4 inches diameter)

Screw in blaze in crotch of oak tree ( 15 inches diameter at base) ..............

Nail in blaze of cedar tree ( 6 inches diameter) (.

Nail in blaze on cherry tree $(2+$ inches di-

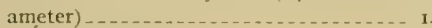

REFERENCE STATION _...

Right chimney of house _... . . . . . . . 179

Right end of peak of roof of Forrest Wharf house.

Right end of house $\ldots \ldots \ldots \ldots . . \ldots 25$

Left end of peak of house _............... 280

Gilt ball on Broome house ............. 32

Right tangent of Broome Island

$\begin{array}{cccccc}0 & \text { a0 } & 00 & \ldots \ldots & 2 \text { miles. } \\ 6 & 25 & \ldots & \ldots & 11 / 2 \text { miles. } \\ 22 & 05 & \ldots & \ldots \ldots & 10.80 \text { meters. } \\ 38 & 18 & \ldots & \ldots & 12.67 \text { meters. } \\ 63 & 40 & 40 & \ldots \ldots & 8.43 \text { meters. } \\ 147 & 11 & \ldots & \ldots \ldots & 18.65 \text { meters. } \\ 150 & 22 & 00 & \ldots \ldots & 13.53 \text { meters. } \\ 179 & 11 & \ldots & \ldots \ldots & 1 / 4 \text { mile. } \\ & & & & 1 / 2 \text { miles. } \\ 202 & 21 & \ldots & \ldots \ldots & 3 \text { miles. } \\ 251 & 05 & \ldots & \ldots \ldots & 3 \text { miles. } \\ 280 & 23 & \ldots & \ldots \ldots & 2 \text { miles. } \\ 321 & 30 & 30 & \ldots \ldots & 13 / 4 \text { miles. } \\ 334 & 17 & \ldots & \ldots \ldots & \end{array}$




\section{HUTCHINS.}

General locality.-Southwest shore of Patuxent River opposite Broome Island on Captain Point, about $1 / 4$ mile northwest of mouth of Cole Creek. (See Chart No. 19.)

Immediatc locality.-Observed station is in garden on point of a bluff 50 feet ligh on Hutchins estate near house occupied by Mr. Gadden, about 6 yards south by east of extreme point of bluff, 2 yards southwest of edge of bluff, 4 yards southeast of edge of bluff, 30 yards north by west from house, 30 yards west of a wire fence running north and south, and 15 yards east of another north-and-south wire fence. Cement monument marking reference station is 7.57 meters $\mathrm{S} 59^{\circ} 39^{\prime} \mathrm{WW}$ of observed station.

Marks.-Observed station is nail in a stub with top flush with ground. Reference station is center point of triangle on standard cement monument.

Refercuces.-

"Bars" (S $\left.68^{\circ} \mathrm{o}^{\prime} \mathrm{E}\right)$

Left corner of extension of Gadden house.- $\quad 5^{8}$

Right front corner of Gadden house.......

Near corner of well house ............. I

Near corner of shed .............. II9

REFERENCE STATION _................ 127

Nail in blaze in apple tree ( 22 inches diame-

ter) - . .

Right tangent of Parkers Whatf _._._._-_. 228

Gilt ball on Broome house on Broome Island 249

Near end of peak of house _._._._._._. 263

Tip of tower on Peterson house ........ 332

$\begin{array}{rrrrr}0 & 00 & 00 & \ldots \ldots & 7 / 8 \text { mile. } \\ 8 & 17 & \ldots & \ldots & 30.90 \text { meters. } \\ 4 & 56 & \ldots & \ldots & 28.57 \text { meters. } \\ 2 & 15 & \ldots & \ldots & 30.44 \text { meters. } \\ 9 & 43 & \ldots & \ldots & 45 \text { yards. } \\ 7 & 46 & \ldots & \ldots & 7.57 \text { meters. } \\ 8 & 06 & 20 & \ldots \ldots & 9.35 \text { meters. } \\ 8 & 12 & \ldots & \ldots \ldots & 21 / 2 \text { miles. } \\ 9 & 55 & \ldots & \ldots & 12 \text { miles. } \\ 3 & 17 & \ldots & \ldots \ldots & 4 \text { miles. } \\ 2 & 52 & \ldots & \ldots & 21 / 2 \text { miles. }\end{array}$

WHEAT.

General locality.-Northeast shore of Patuxent River on westerly side of mouth of St. Leonard Creek. (See Charts Nos. I9 and 20.)

Immediate locality.-Observed station is on a bluff about 40 feet above high water, about 5 yards west of edge of bank, 7 yards south of another edge, and $3 / 8$ mile west of Peterson house. Cement monument marking reference station is 12.80 meters $\mathrm{N} 61^{\circ} 55^{\prime} \mathrm{E}$ of observed station and on line to Peterson house.

Marks.-Observed station is center of a 4 -inch tile pipe set in cement with top projecting about 4 inches above ground. Reference station is center point of triangle on standard cement monument.

References.-

\begin{tabular}{|c|c|c|c|c|c|}
\hline "Stump" (S $\left.36^{\circ} 23^{\prime} \mathrm{E}\right)$ & 0 & & 00 & & $21 / 4$ \\
\hline Left chimney of Judge Crane house $\ldots . . .$. & 10 & 07 & & & $43 / 4$ miles. \\
\hline Near end of peak of roof of Marburger house. & I5 & 05 & & & $41 / 4$ miles. \\
\hline Left end of roof of St. Cuthbert Wharf & 24 & og & & & $21 / 4$ miles. \\
\hline Chimney on roof of house $\ldots \ldots \ldots$ & 60 & 05 & -. & & I $1 / 2$ miles. \\
\hline Chimney on store at Sotterly & 93 & 41 & & & I $1 / 2$ miles. \\
\hline Left end of barn roof. & 193 & 27 & - & & iles. \\
\hline REFERENCE STATION . & 278 & 17 & 30 & & 12.80 meters. \\
\hline Center chimney of Peterson house & $28 \mathrm{I}$ & 22 & J & & $1 / 4$ mile. \\
\hline Chimney of house & 298 & 03 & 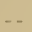 & & nilc. \\
\hline Chimney on house on Breeden estate & 310 & 04 & -. & & 2 miles. \\
\hline
\end{tabular}

MACKALL。

General locality.-Northwest shore of Patuxent River on west side of entrance to St. Leonard Creek on first point inside of Peterson Point. (See Charts Nos. 19 and 20.)

Immediate locality.-Observed station is about 50 feet above high water, 9 feet northwest of edge of bluff, 7 yards northeast of bushes, and 3 yards southwest of other bushes. Cement monument marking reference station is 3.80 meters $\mathrm{N} 35^{\circ} \mathrm{o} 8^{\prime} \mathrm{WI}$ of observed station.

Marks.-Observed station is the center of an oblong wooden box 4 inches square with top 3 inches above the ground. Reference station is center point of triangle on standard cement monument. 
References. -

\begin{tabular}{|c|c|c|c|c|}
\hline "Stock" (S $\left.34^{\circ} 38^{\prime} \mathrm{W}\right)$ & o & 00 & 00 & $13 / 4$ miles. \\
\hline Peak of front gable of Bond house & 0 & 39 & 10. & I $3 / 4$ miles. \\
\hline Chimney on negro house & 54 & $3 I$ & $\ldots$ & $3 / 8$ mile. \\
\hline Chimney on Peterson house $\ldots . \ldots$ & 66 & 25 & -. - & I/4 mile. \\
\hline REFERENCE STATION & IIO & I3 & 50 & 3.80 meters. \\
\hline Chimney on negro house & 135 & 49 & -. & $3 / 8$ mile. \\
\hline Chimney on ell of house on hill ..... & I53 & 46 & - & $1 / 2$ mile. \\
\hline Chimney on small house back of Sollers & & & & \\
\hline Wharf & 229 & 40 & -. & $x$ mile. \\
\hline Nearest outside chimney on $1 / 2$-story house. & 236 & 08 & -. & miles. \\
\hline Large chimney on Sollers house....... & 237 & 02 & $\ldots$ & $3 / 4$ mile. \\
\hline Large chimney on Taylor house $\ldots \ldots . . . .$. & 285 & 27 & .. & 1/2 mile. \\
\hline Front peak of Briscoe house & 334 & 30 & -. - ..... & $25 / 8$ miles. \\
\hline
\end{tabular}

SOL,LERS.

General locality.-Northeast shore of Patuxent River on east side of entrance to St. Leonard Creek. (See Charts Nos, ig and 20.)

Immediate locality.-Observed station is about 50 feet above high water, 6 feet east of edge of bank, 20 yards north-northeast of a clump of trees, 14 yards and 8 yards south-southwest of other trees, and 75 yards north-northwest of a rail fence. Cement monument marking reference station is 13.68 meters S. $44^{\circ} \mathrm{Oo}^{\prime} \mathrm{E}$ of observed station with top buried 12 inches below surface.

Marks.-Observed station is the center of an oblong wooden box 5 inches square with top 3 inches above ground. Reference station is center point of triangle on standard cement monument with top 12 inches below surface.

\begin{tabular}{|c|c|c|c|c|c|}
\hline \multicolumn{6}{|l|}{ Refcrences.- } \\
\hline "Stock" (S $\left.44^{\circ} 24^{\prime} \mathrm{WV}\right)$ & o & oo & oo & - & I $5 / 8$ miles. \\
\hline Middle of front gable of Bond house & $\dot{0}$ & 34 & - - & & I $3 / 4$ miles. \\
\hline Chimney of store at Sotterly Wharf & 26 & $5^{8}$ & -. & ....... & $21 / 8$ miles. \\
\hline Near corner of outside chimney on house. - & 27 & 18 & $\ldots$ & & $2 \frac{1}{2}$ miles. \\
\hline Chimney on top of Gadden house & 46 & 14 & -- & -. & $27 / 8$ miles. \\
\hline Near corner of top chimney on Peterson & 78 & 27 & $\ldots$ & & $1 / 2$ mile. \\
\hline Right end of peak of roof of Mackall house & $150^{\circ}$ & 16 & -. & & $1 / 2$ mile. \\
\hline REFERENCE STATION _... & 271 & 35 & 30 & & I3.68 meters. \\
\hline Near corner of large chimney on Taylor & & & & & \\
\hline house $\ldots \ldots$ & 272 & 35 & -- & & I/s mile. \\
\hline Top of front gable on Briscoe house...... & 331 & 36 & -- & - & $13 / 4$ miles. \\
\hline
\end{tabular}

\section{BARS.}

General locality.-Southwest shore of Patuxent River on Sotterly Point about $1 / 4$ mile northwest of Sotterly Wharf. (See Chart No, 19.)

Immediate locality. - Observed station is on a bluff about 30 feet above high water, 5 yards south of edge of bank at rail fence, and 2 yards east of this same fence. Cement monument marking reference station is. 14.53 meters $\mathrm{S} 9^{\circ} 54^{\prime} \mathrm{W}$ of observed station and near fence line.

Marks.-Observed station is center of a 3 -inch tile pipe set in cement. Reference station is center point of triangle on standard cement monument.

References.-

Chimney on middle of $21 / 2$-story house . . . .

Windmill

Chimney of house

REFERENCE STATION _................ II

Smoke pipe on right end of house ....... 157

Tangent of point of land _............. 250

Peterson house chimney.
I $1 / 2$ miles

6 miles.

3 miles.

4 miles.

$4800 \ldots . . .14 .53$ meters.

$37 \quad \ldots \ldots . . .5 \quad 1 / 4$ mile.

$47 \quad \ldots \ldots . . .11 / 2$ miles

$22 \quad 13 \%$ miles 


\section{LEND.}

General locality.-Northeast shore of Patuxent River on a narrow strip of land or peninsula in mouth of Mears Creek about I/2 mile southeast of St. Leonard Creek. (See Charts Nos. I9 and 20.)

Immediate locality.-Observed station is in the midst of many cherry, oak, and locust trees about I5 feet above high-water mark, I5 yards east-northeast of high ground, 5 yards west of edge and $x_{7}$ yards north of extreme point of top of peninsula.

Marks.-Observed station is center point of triangle on standard cement monument.

References.-

"Wheat" ( $\left.50^{\circ} 51^{\prime} \mathrm{W}\right)$

Nail in blaze in cherry tree $(4$ inche $(4$ inches diameter) ..................... II $8 \quad 28 \quad 30 \ldots 3.58$ meters.

Right chimney of house across creek_.... I 139 5 51 ..... $1 / 4$ mile.

Nail in blaze in oak tree ( 8 inches diameter). $2295 \mathrm{I} \ldots \ldots .68$ meters.

Outside chimney on left end of Briscoe house _............... 1 I $/ 2$ miles.

Near peak of Bond house _............ $297 \quad 57 \quad \ldots \ldots \ldots$ I $5 / 8$ miles.

Chimney on storehouse at Sotterly ..... 318 19 _..... 2 2/4 miles.

Near end of peak of roof of Sotterly Whari house _... 319 o7 _.... $2 \frac{7}{4}$ miles.

Chimney on Gadden house .......... $330 \quad 47 \ldots \ldots . \ldots 3 / 4$ miles.

Nail in blaze in cherry tree ( 6 inches diameter)

STOCK.

General locality.-Southwest shore of Patuxent River about $x$ mile southeast of Sotterly Point. (See Chart No. 19.)

Immediate locality.-Observed station is on a bluff, about 20 feet above high water, 3 yards southwest of edge of bluff, about 50 yards east by north of front door of the house of Mr. Bond, 30 yards west-northwest of extreme end of point of bluff, 35 yards northeast of detached house, and about 43 yards east by south of yard fence at edge of bluff.

Marks.-Observed station is center point of triangle on standard cement monument.

References,-

\begin{tabular}{|c|c|c|c|c|c|}
\hline "Lend" (N 66 $\left.48^{\prime} \mathrm{E}\right)$ - & 0 & OO & $\infty$ & & $15 / 3$ miles. \\
\hline Right chimney of house on Dickson place-- & I & 35 & $\therefore$ & & I $3 / 4$ miles. \\
\hline Right chimney of old $11 / 2$-story louse ..... & 19 & & .. & & ailes. \\
\hline Tangent of bluff & $5^{8}$ & 00 & -. & & ile. \\
\hline $\begin{array}{l}\text { Chimney on house on point } \\
\text { Nail in blaze in locust tree }\end{array}$ & 59 & 03 & -- & & le. \\
\hline diameter) & 99 & 48 & 30 & & ers. \\
\hline er of outhouse, corner farthest & 161 & 29 & 30 & & ers. \\
\hline eft corner of house & 180 & $3 \mathrm{I}$ & 30 & & 31.13 \\
\hline r) & 183 & 39 & 30 & & $20.5^{8}$ \\
\hline (1) & 205 & 29 & 40 & & heters. \\
\hline cust tree ( 4 inches diameter) . . . . . . & 210 & $3 I$ & 40 & .... & 8.83 meters. \\
\hline - & 230 & 31 & -. & $-\ldots$ & ards. \\
\hline (no nail or blaze) -- & 237 & 39 & 20 & $\ldots$ & 34.27 meters. \\
\hline
\end{tabular}

STUMP.

General locality.-Northeast shore of Patuxent River about $1 / 2$ mile northwest of Hellen Creek. (See Chart No. 20.)

Immediate locality.-Observed station is on a bank about 20 feet above high water, io yards northnortheast of edge of bank at extreme end of point, about 20 yards southeast of edge of bank, and about 
150 yards northwest of a clump of cedar and locust trees at edge of bank. Cement monument marking first reference station is $\mathrm{I} \mathrm{I} .29$ meters $\mathrm{N} 6 \mathrm{I}^{\circ} 5 \mathrm{I}^{\prime} \mathrm{E}$ of observed station with top ro inches below surface of field. Cement monument marking second reference station is 26.22 meters $N 60^{\circ} 42^{\prime} \mathrm{E}$ of observed station about on line with first reference station.

Marks.-Observed station is center of 4 -inch tile pipe set in cement with top flush with ground. First reference station is center point of triangle on standard cement monument with top ro inches below the surface of ground. Second reference station is center point of triangle on standard cement monument with top 6 inches above surface of ground.

References.-

"Wheat" (N 36 $23^{\prime}\left(\mathrm{I}^{\mathrm{r}}\right) \ldots$

Chimney in center of house ...........

SECOND REFERENCE STATION . . . . . . .

FIRST REFERENCE STATION _.........

Apple tree ... . . . . . . . . . . . . . . . . 15

Left chimney of house

Near end of peak of roof of Marburger

house _.............. 209

Left chimney of house $\ldots$

Nail in blaze in stump (30 inches daimeter) - 250

Nail in blaze in tree ( 8 inches diameter) -. 352

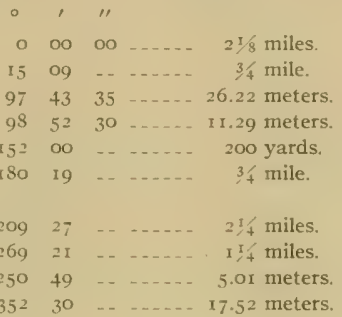

\section{BRISCOE.}

General locality.-Southeast shore of Patuxent River about 1/4 mile northwest of St. Cuthbert Wharf. (See Chart No. 19.)

Immediate locality.-Observed station is in a cultivated field, about 20 feet above high water, 80 yards southwest of trees on bank, 50 yards southeast of a creek bed, 46 yards northwest of a clump of trees, 105 yards east of a corner of fence on road, and about 300 yards northeast of another fence with woods back of it. Cement monument marking reference station is 12.52 meters $\mathrm{N} 79^{\circ} 35^{\prime} \mathrm{W}$ of observed station.

Marks.-Observed station is a nail in a stub with top flush with ground and a subsurface mark of a standard cement monument with top buried II inches below the surface. Reference station is center of triangle on standard cement monument with top 5 inches above surface of ground.

\section{References.-}

\begin{tabular}{|c|c|c|c|c|c|}
\hline Hellen" (S $\left.71^{\circ} 37^{\prime} \mathrm{E}\right)$ - & 0 & & & & \\
\hline ear corner of house & 45 & II & - & & $3 / 4$ \\
\hline & 57 & 18 & & & \\
\hline 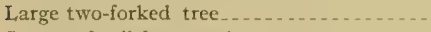 & 129 & 17 & & & 130 \\
\hline & I 36 & 34 & -- & & Io \\
\hline & 172 & OI & 40 & & $2.5^{2}$ \\
\hline 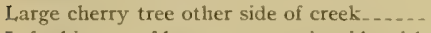 & 195 & oo & & & 68 \\
\hline (- & & & & & \\
\hline ar tree. & 308 & 59 & & & \\
\hline
\end{tabular}

\section{HELLEN.}

General locality.-Northeast shore of Patuxent River on east side of mouth of Hellen Creek. (See Chart No. 20.)

Immediate locality.-Observed station is at high-water mark on edge of grass and bushes, about 16 yards west-southwest of a bluff is feet high, and about 40 yards north-northwest of bluff at edge of water. Cement monument marking reference station is 12.45 meters $\mathrm{N} 75^{\circ} \mathrm{I} \mathrm{f}^{\prime} \mathrm{E}$ of observed station.

Marks.-Observed station was the center of a tile pipe with a subsurface mark of a green yeastpowder bottle but at date of publication these marks are reported to have been washed away. Reference station ic center point of triangle on standard cement monument.

$$
\text { 20908-10-4 }
$$




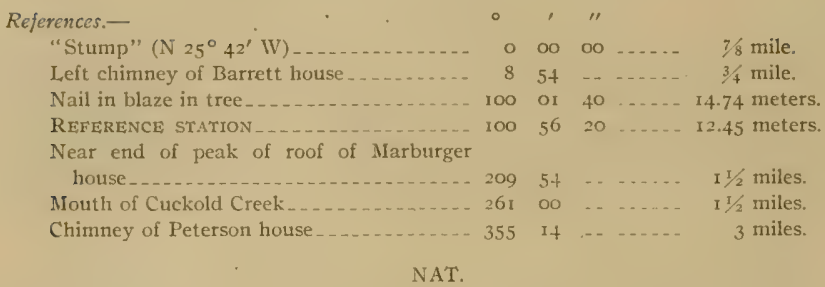

General locality.--Southwest shore of Patuxent River about $1 / 2$ mile above mouth of Cuckold Creek. (See Chart No. 20.)

Immediate locality. - Observed station is near edge of a cultivated field on a bluff of sand and gravel about 20 feet above high water, 4 feet east of edge of bluff, and I5o yards north of a rail fence. Cement monument marking reference station is 18.44 meters $\mathrm{S} 29^{\circ} 47^{\prime}$ W of observed station with top 8 inches below surface of ground.

Marks.-Observed station is center of 3 -inch tile pipe embedded in cement. Reference station is center point of triangle on standard cement monument.

References.-

"Hellen" (N 69 29' E)

Near end of peak of roof of Marburger house on Point Patience.

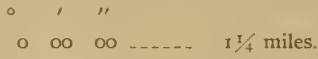

REFERENCE STATION

68 or … I $1 / 2$ miles.

. $140 \quad 1800 \ldots \ldots$..... 18.44 meters.

Large chimney on house .......... 28 I $58 \ldots 3$ miles.

Right chimney of house with two gable roofs. 309

2 miles.

TON.

General locality.-Eastern shore of Patuxent River about I mile northeast of Point Patience. (See Chart No. 20.)

Immediate locality.-Observed station is on a bluff about 15 feet above high water, ro yards east from edge of bluff, 50 yards south-southwest of edge of a gully and a clump of trees, and about 220 yards west-northwest of a cherry tree $3 \frac{1}{2}$ feet in diameter. Cement monument marking reference station is 13.64 meters $\mathrm{S} 62^{\circ} 29^{\prime} \mathrm{E}$ of observed station.

Marks.-Observed station is a spike set in cement. Reference station is center point of triangle on standard cement monument buried below surface ro inches.

Rejerences.-

"Mill" (S $65^{\circ}$ oo W)

Chimney on far end of Wallace house

Chimney on middle of roof on McCorry store_..................................

Near end of peak of St. Cuthbert Wharf house .

Near end of peak of roof of Parran oyster watch house _..........................

Chimney on Peterson house ............

Cemented chimney on near end of George old house........................ 94

I.eft chimney. of Costen house .......... Ix

Nail in blaze in tree . . . . . . . . . . $\times 37$

REFERENCE STATION _... .

Left chimney of Marburger house . . . . . . . 329

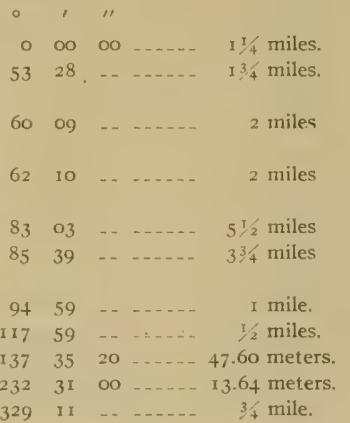


MILL.

General locality.-Southwest shore of Patuxent River about 1/2 mile southeast of mouth of Cuckold Creek and $1 / 2$ mile northwest of Point Patience. (See Chart No. 20.)

Immediate locality.-Observed station is on a sand bluft about 20 feet above high water, 7 yards southwest of the edge of the biff, 40 yards southeast of a fence and a line of cedar trees, and about roo yards northwest of another fence at bottom of hill. Cement monument marking reference station is 13.76 nicters $\$ 28^{\circ} 14^{\prime}$ WV of observed station.

Marks.-Observed station is center point of 3 -inch tile pipe embedded in cement. Reference station is center point of triangle on standard cement monument.

Rejcrences.-

\begin{tabular}{|c|c|c|c|c|c|}
\hline \multicolumn{6}{|l|}{$\begin{array}{l}\left.\text { "Ton" ( } \mathrm{N} 64^{\circ} 59^{\prime} \mathrm{E}\right) \\
\text { Nearest chimney of Marburger house on }\end{array}$} \\
\hline Point Patience & 39 & or & $\cdots$ & & 36 \\
\hline lic Church $\mathrm{Cr}$ & 43 & 03 & 40 & & \\
\hline Episcopal & 49 & 23 & 30 & & \\
\hline & 82 & 22 & & & \\
\hline ear Dent hi & 136 & & & & \\
\hline & 143 & 14 & 40 & & \\
\hline & 293 & 28 & 40 & & $4^{1 / 4}$ \\
\hline-- & 304 & 02 & -. & & $23 / 4$ \\
\hline & 323 & $3 i$ & -. & & 3 \\
\hline cet to & 338 & 17 & - & & \\
\hline & & & & & \\
\hline
\end{tabular}

BUR.

General locality.-East shore of Patuxent River, on northwest side of Point Patience, about $1 / 4$ mile northeast of its extreme end. (See Chart No. 20.)

Immediatc locality.-Observed station is on sand and grass land, about I foot above high water, 12 yards southeast of high-water mark on one side of point, 36 yards northwest of high-water mark on other side of point, and about 300 yards northeast of extreme end of point. Cement monument marking teference station is 12.15 meters $\mathrm{N} 85^{\circ} 20^{\prime} \mathrm{E}$ of observed station.

Marks.-Observed station is a 3 -inch tile pipe set in cement with top about I inch above the surface of the ground. Reference station is center point of triangle on standard cement monument.

References.-

\begin{tabular}{|c|c|c|c|c|c|}
\hline "Ton" ( $\left.\mathrm{N}_{37^{\circ}}{ }_{5} 6^{\prime} \mathrm{E}\right)$ & o & 00 & $\infty 0$ & & I mile. \\
\hline Left chimney of Marburger house & I6 & 08 & -. & & $1 / 4$ mile. \\
\hline EFERENCE STATION_... & 47 & 24 & 30 & & 12.15 meters. \\
\hline "Methodist Episcopal Church Spire"- - & 75 & 32 & 10 & & I 38 \\
\hline Middle gable of Judge Crane house & 139 & 09 & & & nile. \\
\hline $\begin{array}{l}\text { ail in blaze in pine tree (8 inches diam- } \\
\text { eter) }\end{array}$ & 162 & 40 & IO & & \\
\hline Square chimney on Dent house..... & 228 & 30 & . & & $3 / 4$ mile. \\
\hline himn & 268 & 52 & - & & $15 / 8$ miles. \\
\hline Left climney of house.. & 346 & 39 & - & - & $1 / 2$ miles. \\
\hline Right chinney of louse & $35^{8}$ & $3 I$ & & ... & I' ' miles. \\
\hline
\end{tabular}

NEII?

General locality. - Northeast side of Patuxent River, about $3 / 4$ mile east of Point Patience and about I 14 miles northwest of Sandy Point. (See Chart No. 20.)

Immediate locality.-Observed station is about 20 feet above high-water mark in the middle of a cultivated field on Strathmore farm, about 230 yards northeast of shore of Patuxent River, about 82 yards southeast of a creek, about 162 yards northwest of a small creek or ditch, 230 yards northeast of a large oak tree, and 250 yards north of another large oak tree. 
Marks.-Observed station is center point of triangle on standard cement montument with top II inches below the surface of the ground.

\begin{tabular}{|c|c|c|c|c|c|}
\hline \multicolumn{6}{|l|}{ References.- } \\
\hline "Ben" ( $\left.\mathrm{S}_{2}^{\circ}{ }^{\circ} 0^{\prime} \mathrm{E}\right)$ - & 0 & ০o & ০o & & 2 miles. \\
\hline Chimney on flat-roof house & 6 & 59 &.- & & $13+4$ miles. \\
\hline Chimney on main part of a house on Town & & & & & \\
\hline Creek ......... & 27 & II & .. & & $\mathrm{I}^{1}+$ miles. \\
\hline Oak tree about 18 inches diameter on edge & & & & & \\
\hline of field & 43 & 54 & - & & 227 yards. \\
\hline Right tangent of Spencers wharf.- & 56 & of & .. & & I mile. \\
\hline Corner of field & 67 & oo & -- & - & 3 1o yàrds. \\
\hline Exposed chimney on left of house & 67 & 36 & -. & $\ldots$ & I $1 / 2$ miles. \\
\hline Left chimney on house $\ldots \ldots$ & 88 & 57 & $\ldots$ & -..... & $1 / 2$ miles. \\
\hline Corner of field & 206 & oo & -. & $\ldots$ & 240 yards. \\
\hline Corner of field & 258 & oo & -. & $\ldots$ & 300 yards. \\
\hline Silver-tipped tower on Philip Vale house.. & 307 & 08 & 20 & $\ldots$ & $1 / 2$ mile. \\
\hline Oak at edge of field & $3+3$ & 35 & -. & - ..... & 300 yards. \\
\hline
\end{tabular}

\section{CATHOLIC CHURCH CROSS.}

General locality.-Southeast side of Patuxent River, about halfway to Back Creek and $3 / 4$ mile northwest of Solomons wharf. (See Chart No. 20.)

Immediate locality.-Observed station is on Catholic Church, known as St Marys Star of the Sea, located in small village of Johnstown on mainland near Solomons Island, and about 250 yards north of causeway to Solomons Island.

Marks.-Observed station is center of cross on bell cupola.

References.-None necessary.

\section{CABLE.}

General iocality. - Southwest shore of Patuxent River, on east side of entrance to Kings Creek, and about $3 / 4$ mile west of Town Point. (See Chart No. 20.)

Immediate locality.-Observed station is on pasture land near the end of high land at the beginning of a long, low peninsula which almost closes the mouth of Kings Creek, about 30 feet above high-water mark, about 20 yards south of edge of bank on river side, about 15 yards east northeast of edge of bank on creek side, $3^{8}$ yards southeast of extreme edge of top of bank, and 30 yards west of a persimmon tree.

Marks.-Observed station is center point of triangle on standard cement monument buried with top ro inches below the surface of ground.

References._-
"Bur" (N $35^{\circ}{ }_{17}^{\prime}$ E)
Left chimney of Marburger house near Point

TOWN.

General locality. - Southwestern shore of Patuxent River, on Town Point, ahout $3 \_$mile southeast of Point Patience. (See Chart No. 20.)

Immediate locality.-Observed station is about 20 feet above high-water mark, 9 yards west of edge of bluff, 3 yards south of edge of bluff, to yards southeast of extreme edge of high land, 3 yards south of a rail fence, and 2 yards north of cultivated land. 
Marks.-Observed station is center point of triangle on standard cement monument. References.-

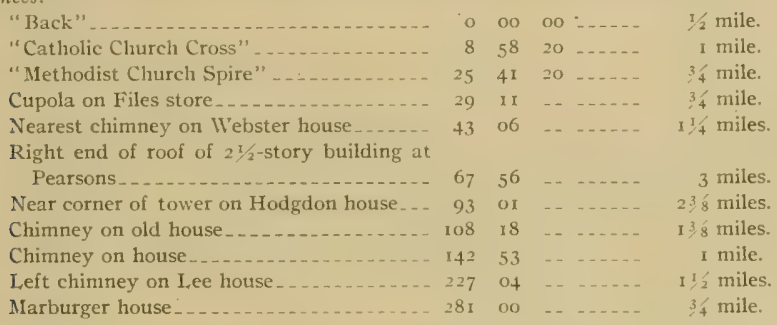

CRANE,

General locality.-Southwest side of Patuxent River, on northeast side of Town Creek, about $1 / 4$ mile southwest of Town Point. (See Chart No. 20.)

Immediate locality. - Observed station is in a cultivated field on Judge Crane farm, about 8 feet above high-water mark, 58 yards east northeast of Town Creek, 105 yards west of a fence, 115 yards westnorthwest of a large cherry tree, 200 yards southeast of several detached buildings, and 20 yards east of top of a ravine.

Marks.-Observed station is center point of triangle on standard cement monument with top ro inches below ground.

References.—
"New" (N $\left.36^{\circ} 5 \mathrm{I}^{\prime} \mathrm{E}\right) \ldots$
"Catholic Church Cross"

\section{E. CHURCH (SOLOMONS).}

General locality.-Northeastern shore of Patuxent River, on upper end of Solonons Island, about I/2 mile northwest of Sandy Point. (See Chart No. 20.)

Immediate locality.-Observed station is on Methodist Church at upper end of Solomons Island near beginning of causeway to mainland.

Marks.-Observed station is tip of pyramidal tower on Methodist Church.

References.-None necessary.

\section{K. OF P. FLAGSTAFF (SOLOMONS)}

General locality:- Northeastern side of Patuxent River, on Solomons Island, in the town of Solomons. (See Chart No, 20.)

Immediate locality.-Observed station is on flagstaf in front of Knights of Pythias Building. 
Marks.-Observed station is center of flagstaff at about the same height as roof of the $\mathrm{K}$. of $\mathrm{P}$. Hall. References.-None necessary.

SAND.

General locality.- Northeastern side of Patuxent River on Sandy Point on extreme southern point of Solomons Island. (See Chart No. 20.)

Immediate locality.-Observed station is on pasture land about 5 feet above high water, 30 yards north of extreme point of planking protecting the shore from washing, 15 yards northeast of the extreme edge of sand and grass line, and about 13 yards east of top of bank. Cement monument marking reference station is 13.64 meters $\mathrm{N}^{\circ} 19^{\prime} \mathrm{E}$ of observed station.

Marks.-Observed station is nail in southwest side of a 6 -inch pile driven into ground with top 6 inches above the surface. Reference station is center point of triangle on standard cement monument.

References.-

\begin{tabular}{|c|c|c|c|c|c|}
\hline "Drum Point Light" (N $\left.83^{\circ} 57^{\prime} \mathrm{E}\right) \ldots \ldots$ & 0 & oo & ○o & & $2 \mathrm{n}$ \\
\hline Right tangent of woods on Hog Point & I4 & 36 & -- & & iiles. \\
\hline $\begin{array}{l}\text { Left end of peak of roof on } 2 \frac{1}{2} \text {-story build- } \\
\text { ing at Pearsons }\end{array}$ & $5 \mathrm{I}$ & $\mathrm{O}_{3}$ & & & 2 miles. \\
\hline Chimney on storehouse at Millstone...... & 74 & I 8 & - & & $13 / 4$ miles. \\
\hline $\begin{array}{l}\text { Near point of gable of Hodgdon large } \\
\text { house with square tower }\end{array}$ & 93 & 54 & -- & & $1 \mathrm{x} / 2$ \\
\hline $\begin{array}{l}\text { Jear end of peak of roof of Marburger } \\
\text { house }\end{array}$ & 225 & 22 & & & \\
\hline Warren house opposite Johnson store & 261 & 22 & $\cdots$ & & $1 / 4$ \\
\hline E STATION & 278 & 22 & 10 & & 13.64 mete \\
\hline "K, ol & $29 \mathrm{I}$ & $5^{8}$ & & & mile \\
\hline sh house & 320 & 38 & - & & \\
\hline "Bareda House Cupola" ........ & 347 & $4^{8}$ & 30 & & $11 / 2$ mile \\
\hline
\end{tabular}

\section{FISHSTACK.}

General locality.-Northeastern side of Patuxent River on northeastern side of entrance to Mill and Back creeks. (See Chart No. 20.)

Immediate locality.-Observed station is on mainland on fish fertilizer factory located on opposite side of creek from Solomons Island.

Marks.-Observed station is center of smokestack on fish factory.

References.-None necessary.

BON.

General locality. - North shore of Patuxent River about $1 \mathrm{t} / 4$ miles west-northwest of Drum Point Light and about $1 / 2$ mile east-northeast of Solomons Island. (See Chart No. 20.)

Immerlate loculity. - Observed station is on cultivated land, alsout 5 feet above high water, about 7 yards north of shore, about 90 yards southeast of a $1 \frac{1}{2}$-story house on land ro feet ligher than station, and alout 75 yards suth of a $I^{\prime}$ '-story brick house. Cement monument marking reference station is 0.67 meters $\mathrm{N} 45^{\circ} 29^{\prime} \mathrm{E}$ of observed station.

Marks.-Observed station is an inverted nail in center of cement in a 6-inch tile pipe with top flush with surface of ground. Reference station is center point of triangle on standard cement monument.
Reforinces.
"Drum Point Light" (S $\left.73^{\circ}+3^{\prime} \mathrm{E}\right)$-....-
Smoke pipe on oyster watch house .......
Left end of peak of roof on $2 \mathrm{~T} / 2$-story build-
ing at Pearsons end of peak of roof on house with piazza

$\begin{array}{rcccc}0 & \prime & \prime \prime & & \\ 0 & 00 & 00 & \ldots \ldots & 11 / 4 \text { miles. } \\ 33 & 32 & \ldots & \ldots \ldots & 1 / 2 \text { mile. } \\ 52 & 06 & \ldots & \ldots \ldots & 21 / 4 \text { miles. } \\ 82 & 29 & \ldots & \ldots \ldots & 21 / 2 \text { miles. }\end{array}$




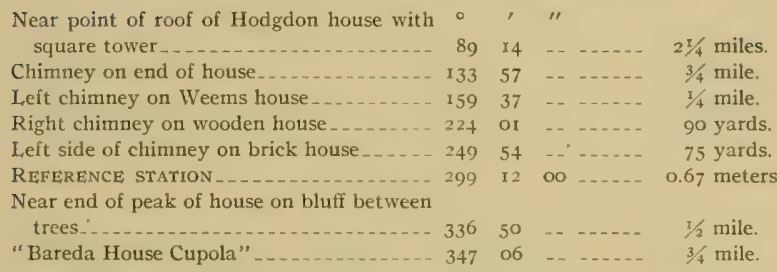

\section{BAREDA HOUSE CUPOLA.}

General locality,-North side of Patuxent River about $1 / 2$ mile northwest of Drum Point Light. (See Chart No. 20.)

Immediate locality.-Observed station is on Bareda House which is a large 3 -story square mansion with square cupola with three windows on each side and a porch all around ground floor, located about roo yards back from shore on high land.

Marks.-Observed station is center of ornamental design of four brackets on center of cupola.

References.-None necessary.

\section{DRUM POINT LIGHT}

General locality.-Northeastern side of entrance of Patuxent River and a short distance off shore from Drum Point. (See Chatt No. 20.) House.

Immediate locality.-Observed station is on a screw pile structure known as Drum Point Light-

Marks.-Observed station is center of black lantern on Drum Point Light-House.

Reference.-

"Cedar Point Light" (S $\left.64^{\circ} 33^{\prime} \mathrm{E}\right) \ldots \ldots$ o $\ldots 0$ oo ....... $31 / 4$ miles.

BE: :

General locality.-Southwestern shore of Patuxent River about I mile south-southwest of Sandy Point and $11 / 4$ miles south-southeast of Town Point. (See Chart No. 20.)

Immediate locality. - Observed station is on a clay and sand bluff in a cultivated field, about 20 feet above high-water mark, about ro feet west of edge of bank, 3 feet south of point covered with scrub pines, about 15 yards northeast of one edge of plateau, Io yards southeast of another edge of plateau, about 65 yards north of point of woods, and ro yards south of cut in bank which is washing rapidly. Cement monument marking reference station is 8.42 meters $\mathrm{S} 56^{\circ} 15^{\prime}$ W of station.

Marks.-Observed station is nail in cement in 6-inch tile pipe with top flush with ground. Reference station is center point of triangle on standard cement monument.

References.-

"Drum Point Light" (N $68^{\circ} \mathrm{o} 7^{\prime} \mathrm{E}$ ) - . .

Left tangent of trees on Hog Point .......

Near end of peak of roof of large $2 \mathrm{~T} / 2$-story

Near piazza post of Millstone Hotel .......

Chimney of Craddock house .............

Chimney on end of cabin .................

Tall pine tree................... I

REFERENCE STATION diameter) .........................

Nail in blaze in pine tree (4 inches diameter) _......... 223 40 40 ..... 87 meters. 


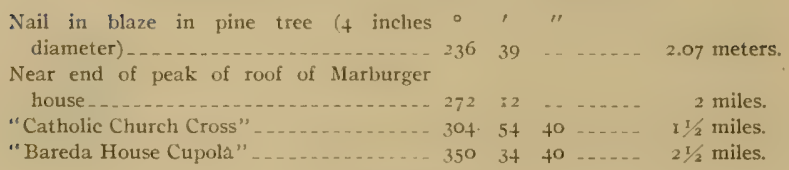

\section{CRADDOCK.}

General locality.-Southern shore of Patuxent River, about $23 / 3$ miles south-southeast of Drum Point Light and $1 / 4$ mile west of Millstone Landing. (See Chart No. 20.)

Immediate locality.-Observed station is on lawn about 15 feet above high-water mark, about ro yards south from top edge of bank, 15 yards from bottom edge of bank and fence, 30 yards east of extreme edge of point, 30 yards northeast of trees along shore of pond, about I xo yards northwest of Craddock house and several outbuildings among poplar trees, 50 yards east of fence, and 70 yards west of driveway to house.

Marks.-Observed station is center point of triangle on standard cement monument, with top flush with lawn.

References.-

"Drum Point Light" ( $\left.37^{\circ} 15^{\prime} \mathrm{E}\right)$

Left tangent of woods on Carroll Point

Near end of peak of roof of $21 / 2$-story building at Pearsons ....................

Chimney on hotel at Millstone

Cottonwood tree ( 14 inches diameter)

Chimney on roof of Craddock $2 \frac{1}{2}$-story

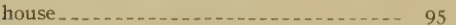

Nail in stump ( 14 inches diameter) ...... 309

"Fishstack"

$\begin{array}{rrrrr}0 & , & \prime \prime & & \\ 0 & 00 & 00 & \ldots \ldots & 21 / 2 \text { miles. } \\ 21 & 52 & \ldots & \ldots \ldots & 1^{3} 4 \text { miles. } \\ 42 & 25 & & \ldots & 1 \frac{1}{4} \text { miles. } \\ 64 & 56 & \ldots & \ldots \ldots & 1 / 2 \text { mile. } \\ 68 & 54 & \ldots & \ldots \ldots & 80 \text { yards. } \\ & & & & \\ 95 & 27 & \ldots & \ldots \ldots & 110 \text { yards. } \\ 309 & 25 & 50 & \ldots \ldots & 5.35 \text { meters. } \\ 317 & 30 & 50 & \ldots \ldots & 2 \text { miles. }\end{array}$

\section{CARROLL 2.}

General locality.-South side of Patuxent River, about I mile south-southwest of Hog Point and about I mile south of Drum Point Light. (See Chart No. 20.)

Immediate locality.-Observed station is on a sandy clay bluff in a cultivated field, about 50 feet above high-water mark, 4 feet south of top edge of bluff, 180 yards east of trees and ravine beyond cultivated field, 60 yards west of trees and ravine beyond cultivated field, 300 yards north of large square chimney on old-faslioned farmhouse, and 250 yards north of large tree to right of farmhouse. Cement monument marking reference station is 13.32 meters $\mathrm{S} 54^{\circ} 30^{\prime} \mathrm{WV}$ of observed station. Another reference station is a nail in the east side of cement in a 6 -inch tile pipe 14.64 meters S $13^{\circ} 20^{\prime} \mathrm{E}$ of observed station and on range with Drum Point Light.

Marks.-Observed station is center of 5 -inch tile pipe with top 8 inches below surface of ground. Reference station is nail in cement on east side of a 6 -inch tile pipe with top 6 inches below surface of ground. Another reference station is center point of triangle on standard cement monument with top 9 inches below surface of ground.

References.-

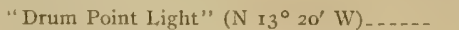

Left tree on Hog Point

Right of bushes at edge of ravine........ I

Tree ( 12 inches diameter) .................. 164

REFERENCE STATION (tile) _.............. 179

Tree (20 inches diameter) _............ 183

Chimney of Susquehanna farmhouse ...... 192

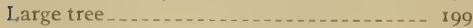

REFERENCE STATION (monument) _...... 247

Right climney of Fenner Lee house . . . ... 302

$\begin{array}{cccccc} & \prime & \prime \prime & & \\ 0 & 00 & 00 & \ldots \ldots & \text { I mile. } \\ 81 & 59 & 40 & \ldots \ldots & \text { I mile. } \\ 2 & 00 & \ldots & \ldots \ldots & 75 \text { yards } \\ 4 & 48 & \ldots & \ldots \ldots & 1 / 8 \text { mile. } \\ 9 & 59 & 45 & \ldots \ldots & 14.64 \text { meters } \\ 3 & 25 & \ldots & \ldots \ldots & 1 / 8 \text { mile. } \\ 2 & 10 & \ldots & \ldots \ldots & 300 \text { yards. } \\ 9 & 08 & \ldots & \ldots \ldots & 250 \text { yards. } \\ 7 & 50 & 00 & \ldots \ldots & 13.32 \text { meters. } \\ 2 & 45 & \ldots & \ldots \ldots & 41 / 2 \text { miles. }\end{array}$




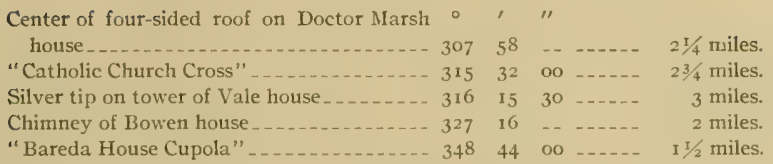

HOG 2

General locality.-Southern shore of entrance to Patuxent River on Hog Point, about $17 / 8$ miles west-northwest of Cedar Point light. (See Chart No. 20.)

Immediate locality.-Observed station is on a sand beach at high-water mark, 30 yards northwest of point of woods, and 200 yards north-northeast of nearest shore of Parsons Creek. Cement monument marking reference station is 33.35 meters $\mathrm{S}+2^{\circ} 22^{\prime} \mathrm{E}$ of observed station on a point of high land.

Marks.-Observed station is nail set in cement in a 6 -inch tile pipe, with top $\mathrm{I}$ foot below the surface. Reference station is center point of triangle on standard cement monument.

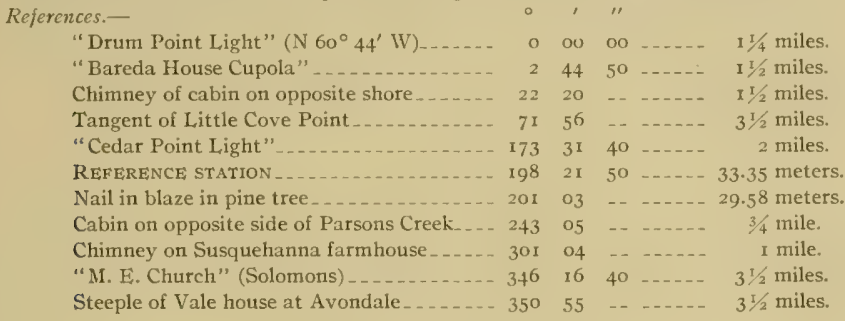

PAT.

Generai locality.- IVestern shore of Chesapeake Bay on Little Cove Point, about $13 / 4$ miles south by west of Cove Point Light. (See Chart No. 20.)

Immediate locality.-Observed station is on the highest point of a thickly wooded bluft, about 75 feet above high-water mark, 4 yards west of edge of bluff, and 15 yards southwest of extreme point. Cement monument marking reference station is 24.57 meters $S 71^{\circ} 26^{\prime}$ W of observed station.

Marks.-Observed station is a 3 -inch round stake set in cement, with top about 4 inches above surface of ground. Reference station is center point of triangle on standard cement monument.

References.

"Cedar Point Light" ( $\left.\mathrm{S} \mathrm{I}^{\circ} 54^{\prime} \mathrm{E}\right) \ldots \ldots$
Near piazza post of house._...

\section{CEDAR POINT LIGHT.}

General locality.-Western shore of Chesapeake Bay on Cedar Point, $3 \frac{1}{4}$ miles east-southeast of Drum Point Light and 6 miles south by east of Cove Point Light. (See Chart No. 201.)

Immediate locality.-Observed station is on a brick dwelling known as Cedar Poir t Light-House. Marks.-Observed station is center point of lantern on Cedar Point Light-House

Reference.-

"Cove Point Light" (N $\left.7^{\circ} 16^{\prime} \mathrm{W}\right) \ldots \ldots$ miles. 


\section{CAIN.}

General locality.-Western shore of Chesapeake Bay, about $15 / 8$ miles southwest of Cedar Point Light. (See Chart No. 20.)

Immediate locality.-Observed station is on a bank about 5 feet above high-water mark, about 20 yards northwest of ordinary high water, 5 yards northwest of extreme high water, roo yards southsouthwest of old-fashioned house among several large trees, and about 250 yards below small wharf and canning house. Cement monument marking reference station is 6.45 meters $\mathrm{N} \cdot 16^{\circ} 56^{\prime} \mathrm{E}$ of observed station.

Marks.-Observed station is a nail set in cement in a 3 -inch pipe with top about 2 inches above ground. Reference station is center point of triangle on standard cement monument.

References.-

\begin{tabular}{|c|c|c|c|c|c|}
\hline "Cedar Point Light" ( ${ }_{4} 6^{\circ} 4$ & & & & & \\
\hline Steeple on church & 28 & 26 & $\ldots$ & & $91 / 2$ miles. \\
\hline "Hoopers Island Light" & 56 & 28 & 40 & & $73 / 4$ miles. \\
\hline "Point No Point Light" - & 106 & 05 & 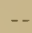 & & $1 \times 3 / 4$ miles. \\
\hline Right chimney on Tarleton 1 & 135 & 12 & -. & & $3 \frac{1}{4}$ miles. \\
\hline Near end of peak of 2-story & 148 & 41 & -. & & $13 / 4$ miles. \\
\hline REFERENCE STATION_..... & 330 & 10 & 40 & & 6.45 \\
\hline Near & 335 & 13 & -- & & 100 \\
\hline Aspen tree in house yard... & 339 & 35 & $5^{\circ}$ & & Ioo yards. \\
\hline
\end{tabular}

DESERT.

General locality.-Western shore of Chesapeake Bay, about 3 miles south-southwest of Cedar Point Light. (See Chart No. 20.)

Immediate locality.-Observed station is on sand and grass land, about 25 yards west from ordinary high-water mark, about at level of extreme high-water mark, 40 yards south of a fence, 1o yards east of a fence, 45 yards south of a creek, about 50 yards north of point of pine woods, and about 300 yards east of woods across marsh. Cement monument marking reference station is 5.29 meters N $3 I^{\circ} 24^{\prime} \mathrm{WV}$ of observed station.

Marks.-Observed station is a 4 -inch tile pipe projecting about 2 inches above surface of sand. Reference station is center point of triangle on standard cement monument.

References.-

\begin{tabular}{|c|c|c|c|c|c|}
\hline 'Cedar Point Light" ( $\mathrm{N}_{34^{\circ}} \mathrm{o}^{\prime} \mathrm{E}$ E) ...... & 0 & oo & 00 & & les. \\
\hline 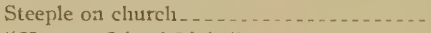 & 34 & 19 & 40 & & I0 $1 / 2$ miles. \\
\hline "Hoopers Island Light" ............... & 59 & 08 & to & & 8 miles. \\
\hline "Point No Point Light" ................ & 113 & 27 & 30 & & iles. \\
\hline Near end of peak of roof of Turleton house & 1 35 & 09 & -. & & 2 miles. \\
\hline Point of woods & 146 & 00 & - . & & 5o yards. \\
\hline $\begin{array}{l}\text { Nail in blaze in pine tree (14 inches ciam- } \\
\text { cter) }\end{array}$ & 294 & 30 & 40 & & $7 \cdot 6$ \\
\hline REFERENCE STATIOX -.. & 294 & 30 & 40 & & 5.29 meters \\
\hline $\begin{array}{l}\text { Chimney on near end of house } \\
\text { Large square chimney on larger of two }\end{array}$ & 336 & 38 & - & & $1 / 2$ mile. \\
\hline es.-... & 344 & 48 & & & \\
\hline
\end{tabular}




\section{BOUNDARIES OF OYSTER BARS.}

\section{EXPLANATION.}

The law of the United States authorizing the cooperation of the Department of Commerce and Labor in the survey of natural oyster bars of Maryland provides for the designation and employment by the Department of Commerce and Labor of such officers, experts, and other technically qualified persons "as may be necessary to cooperate with the Maryland State Board of Shell Fish Commissioners in making a survey of and locating the natural oyster beds, bars, and rocks in the waters within the State of Maryland." The oyster laws of Maryland provide that the Maryland Shell Fish Commissioners, with the aid of such persons as may be designated by the Government, shall proceed "to have laid out, surveyed, and designated on the said charts the natural beds and bars, and shall cause to be marked and defined as accurately as practicable the limits and boundaries of the natural beds, bars, and rocks as established by said survey, and they shall take true and accurate notes of said survey in writing, and make an accurate report of said survey, setting forth such a description of landmarks as may be necessary to enable the said board, or their successors, to find and ascertain the boundary lines of the said natural oyster beds, bars, and rocks, as shown by a delineation on the maps and charts." The oyster laws of Maryland also provide in another section that there shall "be made a true and accurate survey of the natural oyster beds, bars, and rocks * * * with reference to fixed and permanent objects on the shore, giving courses and distances, to be fully described and set out in a written report of said survey."

Under the provisions of the laws quoted above the State of Maryland, in cooperation with the Department of Commerce and Labor, must define the boundaries of the natural oyster bars "as accurately as practicable" and also "with reference to fixed and permanent objects on the shore, giving courses and distances." The requirement of "as accurately as practicable" is easily fulfilled by definition of the location of the corners of the oyster bars by latitude and longitude. In fact, this method is probably the most satisfactory and accurate one that could be used for all purposes of legal definition or for relocation of the nyster-bar boundaries by competent engineers. Therefore the additional requirement of "giving courses and distances" is superfluous and is only fulfilled in the published definitions on account of the specific provisions of the law making it compulsory. This part of the description of boundaries has involved an immense amount of extra computations in order to prevent technical discrepancies between the latitude and longitude of a comer of an oyster bar and its distance and bearing from objects on shore of known latitude and longitude without adding anything to the accuracy and very little to the convenience of practical use of the descriptions of the oyster-bar boundaries. 
As provided by law the boundaries of the oyster bars are all straight lines, but in the work already completed they have inclosed areas of all shapes from triangles to complicated I4-sided figures, and of all sizes from 4 acres to 7,548 acres. The sides have varied in length from 93 to 7,529 yards, and in some cases the comers of the boundaries have been practically at the triangulation stations from which they are located, while in other instances they were over 13,600 yards from the landmarks most available for the purpose of fixing their position.

The varied characteristics of the legal boundaries of the oyster bars indicated by the above statement, together with the complicated requirements of the law under which the survey has been made and the magnitude of the work with the consequent need of fixed and uniform methods, have made the problem of describing the boundaries one of considerable difficulty and great importance.

The boundaries of the oyster bars of Maryland, as established by the Shell Fish Commission and delineated on the Coast and Geodetic Survey charts and projections and on the leasing charts of the Commission, are technically defined and described by a method somewhat different from that used in other oyster surveys. But it is believed that the forms finally adopted will fulfill all needs of the survey for both the present and future.

\section{METHOD OF DESCRIBING BOUNDARIES.}

The descriptions have been arranged in tabular form, thus avoiding many hundred repetitions of the same words by making one explanation of the tables sufficient for all oyster bars in each county.

Tille.-At the top of each tabular form is given the legal name of the oyster bar to be described, and the one hy which it is known and designated in the published oyster records and on the oyster charts. The adopted name of the oyster bar is the one used locally, as nearly as could be ascertained by the hydrographic engineer of the Commission; and when there was no local name in common use a name was selected from one of the prominent features of the vicinity that would naturally suggest the section of the waters where the oyster bar was located.

Underneath the name, in parenthesis, is given the general locality of the oyster bar and the serial number of the "Maryland Oyster Chart" on which its legal boundaries are shown ${ }^{a}$

First column.-This column, under the heading of "Comer of bar," gives the number corresponding to the corner of the boundary as shown on the charts and to the number on the buoy tnarking the actual corner of the bar. The numbers of the corners have been assigned by naming the southernmost point No. 1 , thence proceeding in a clockwise direction around the bar; but where a corner of one oyster bar is identical with the comer of the boundaries of one or more other oyster bars only the number of the corner of the oyster bar being described in the table is given in this column.

Sccond and third columns. - These two columns, under the headings of "Latitude" and "Longitude," give the geographic positions of the comers. These positions have been adopted by the Commission as the primary technical definition of the location of the corners, and should be considered as final in case of a dispute arising from discrep-

a These charts can be obtained by application to the Superintendent of the Coast and Geodetic Survey at Washington, D. C. 
ancies caused by other means of location. The latitudes and longitudes given in these columns are based on the United States standard datum of the Coast and Geodetic Survey, and the points thus defined can be relocated from distant triangulation stations of the Survey, even though all the landmarks and buoys originally used for their location have been destroyed by natural or other causes.

Fourth and fifth columns. - These two columns, under the general heading of "True bearing" and the specific headings "Forward" and "Back," give bearings measured from a true north-and-south line. The three "Forward" bearings are from the corner of the boundary designated in the first column to the triangulation stations named on the corresponding lines in the last column, and the three "Back" bearings are from these same stations in the last column to the corresponding corner of boundary in the first column. The difference in minutes of arc between the forward and back bearings shown in some cases is actual and not accidental, and is due to the fact that the computations took into account the spheroidal shape of the earth.

Sixth column.-This column, under the heading of "Distance," gives the three computed distances in yards from the corner of the bar noted in the first column to the three triangulation stations named on the corresponding lines in the last column, and vice versa.

Seventh column.-This column, under the heading of "U. S. C. \& G. S. triangulation station,"b gives the names of the landmarks from which were computed the corresponding "Latitude," "Longitude," "True bearing," and "Distance" of the "Corner of the bar" designated in the first column. A full description of the location and markings of these triangulation stations is given in another part of this publication under the heading of "Descriptions of triangulation stations."

\section{SURVEYING METHODS FOR RELOCATION OF BOUNDARIES}

There are a number of methods that can be used in the relocation of the actual boundaries of the natural oyster bars as technically described in this publication and delineated on the published charts of the Coast and Geodetic Survey and the leasing charts of the Shell Fish Commission.

The following brief descriptions of five of these more or less different methods assume a certain amount of experience and knowledge on the part of the engineer in the particular kind of surveying under consideration, and are only intended as reminders of ways and means that can be used.

There are two problems that are likely to present themselves to those interested in the boundaries of natural oyster bars: One, to determine whether the buoys marking the corners have been dragged or otherwise moved from their correct positions, and the other, to relocate or reestablish a buoy at the point from which it was removed. The different ways of solving these two problems partly depend upon the instruments possessed by the engineer and his assistants and partly on his training and experience.

$a$ The mean magnetic variation for Calvert County was $5^{\circ} 50^{\prime}$ west of north in rgog and increasing at the rate of $3^{\prime}$ yearly.

$b$ Geographic positions of these triangulation stations can be obtained by application to the Superintendent of the Coast and Geodetic Survey, IVashington, D. C. 
(I) Triangulation.-This method is the one that will give the greatest accuracy, but on account of its requiring special data and instruments, and being an operation rarely used by engineers not engaged in geodetic surveying, it is recommended only for cases in dispute that can not be settled satisfactorily by some other method. An explanation of this class of work would be too long for a report of this sort, and those not familiar with this method are referred to the publications on the subject by the Coast and Geodetic Survey.

(2) Hydrographic.- This method is the most simple and satisfactory one that can be adopted if the surveyor can obtain the use of the necessary instruments and assistants. It is the one best suited for the work of the engineers of the Commission in relocating corners of boundaries, as it gives results of the accuracy ordinarily required and is rapid in execution. Besides, it has the advantage of being available whenever three triangulation stations of suitable relative positions are visible from the ofishore points needing relocation.

Most navigators and others familiar with the use of a sextant are well acquainted with the graphic three-point method of fixing a position on water, and only a brief description of the operation will be stated.

In the case where there is only one engineer having a single sextant, the three-point method can be used if the two angles determining the position of a buoy are first derived from the "Forward" bearings given in the tabular forms describing the boundaries of the oyster bars. For example, take "Hog Point" bar, which is the first one described in this publication, and assume that "Corner No. I" is to be examined as to its position. The angle between the two landmarks "Hog Point" and "Beach," as determined from right to left from the forward bearings from this corner is $67^{\circ} 35^{\prime}$ and the angle between "Beach" and "II1 2 " is $17^{\circ} 16^{\prime}$. Having these two angles, the engineer proceeds to the buoy of doubtful location and measures the actual sextant angles between the landmarks for which the calculations were made. If the measured and calculated angles do not agree the buoy is not in its correct position and the boundary corner must be relocated. This is accomplished by moving the boat about until a point is reached where the angles do agree, and this point being the desired location the buoy can be placed in its correct position.

If the engineer can obtain the use of both a sextant and a three-arm protractor ("position finder"), the availability of the hydrographic method is increased, as the use of the protractor is essential in case of the washing away or destruction of one or more of the landmarks originally used in describing the boundaries. Under these circumstances, any three landmarks of suitable relative position that are visible from the point to be located can be utilized. For example, the engineer can proceed to the buoy of doubtful position and measure the two adjacent sextant angles between the three landmarks sclected. These two angles are set off on the three-arm protractor and the actual position of the buoy plotted on the chart by shifting the protractor about until the edge of each of the three arms passes through the center of the symbols on the chart marking the position of the three landmarks selected. The center of the hub of the protractor will indicate on the chart the actual position of the buoy, and if the 
point thus obtained does not coincide with the true position of the corner of the boundary as given on the chart the surveyor can proceed to locate the buoy correctly by reversing the operation. This is done by placing the center point of the hub of the protractor over the corner of the boundary in question and measuring on the chart the two adjacent protractor angles between the three selected landmarks. One of the angles thus obtained is set on the sextant and the boat moved about until the two landmarks are shown by the sextant to subtend the same angle obtained from the protractor. The second angle is then placed on the sextant and the same operation gone through, and so on, first using one angle on the sextant, then the other, until a point is reached where both observed sextant angles are practically identical with the protractor angles. The point thus located is the desired one and the buoy can be placed to mark the true position of the corner of the boundary in question.

If the engineer possesses two sextants and a protractor this problem is far easier of solution, as the two angles can be set off on separate sextants and the observer can quickly find the desired point where they agree with the protractor angles by using one sextant after the other without the need of resetting either.

If there are two observers two sextants, and a protractor, it can be seen that the best conditions for both rapid and accurate hydrographic locations of points are attained; in fact, this is the method by which the buoys at the corners of the boundaries were originally placed by the hydrographic engineer to the Commission.

(3) Magnetic bearings from offshore. - This method of fixing a position on water is a simple and well-known one in navigation. It is available to anyone having a boat compass, and will be of special use to the State Fishery Force in investigating cases where buoys are supposed to have been moved for illegal purposes.

In the case where a buoy is supposed to have been moved from its true position the cbserver takes compass bearings to the three landmarks given in the last column of the tables opposite the boundary corner in question. These bearings are then corrected for the local declination, ${ }^{a}$ and if the results agree with the published bearings the buoy is correctly located.

In the case where the buoy is not in its correct position, or has disappeared altogether, the desired point can be determined by maneuvering the vessel until the corrected bearings agree with the ones in the tabular descriptions, when the buoy can be anchored in its proper location.

In the case where the landmarks for which the bearings are published have been destroyed or washed away, any landmarks whose positions are indicated on the charts can be used by getting their bearings directly from the chart by parallel rulers or a protractor and then applying them in the same manner as the ones published in the tables.

(4) Magnetic bearings from shore.-This method will be of special value to engineers having an ordinary surveyor's compass. The compass can be set over the point marking a "triangulation station" on shore, the name of which is given in the last column

a The mean magnetic variation for Calvert County is $5^{\circ} 50^{\prime}$ west of north in 1909 and increasing at the rate of $3^{\prime}$ yearly. 
opposite the "corner" in question. The instrument is then set at the corresponding "back" bearing (corrected for local magnetic declination) given in the fifth column of the tables opposite the "corner" in question, and the direction thus determined will give one range on which the desired point must be located. The compass can then be moved to a second triangulation station and another range located in a similar manner. The intersection of these two range-lines will give the desired point; but in general it should be checked by an additional range line determined from a third station.

(5) Horizontal angles measured at landmarks.-This process is a modification of the triangulation method, and will be useful to engineers who have a transit and desire considerable accuracy.

The instrument is placed over a "triangulation station," the name of which appears in the last column of the tabular description opposite the "corner" in question. The telescope is then pointed to the landmark indicated in the "Descriptions of landmarks" as having a direction of $\mathrm{O}^{\circ} \mathrm{OO}^{\prime} \mathrm{OO}^{\prime \prime}$ from the triangulation station being occupied by the transit. The tabular description of the boundaries is next examined and the "back" bearing of the questionable boundary "corner" from the landmark being occupied is taken out. The angle calculated from this "back" bearing and the bearing given in parenthesis alongside the zero landmark in the "Descriptions of landmarks" is then set off on the transit, and a range line established on which the desired point must be located. A similar process is then carried on at a second station, and so on until the position of the buoy is satisfactorily fixerl.

BOUNDARIES OF NATURAL OYSTER BARS.

HOG POINT.

(Chesapeake Bay-Chart No. x6.)

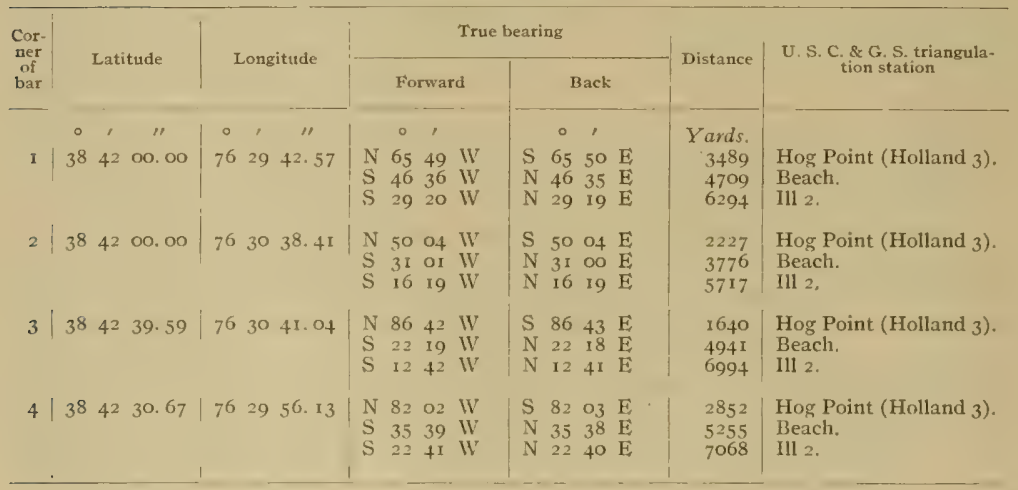


UPPER STEPS.

(Chesapeake Bay-Chart No. 16.)

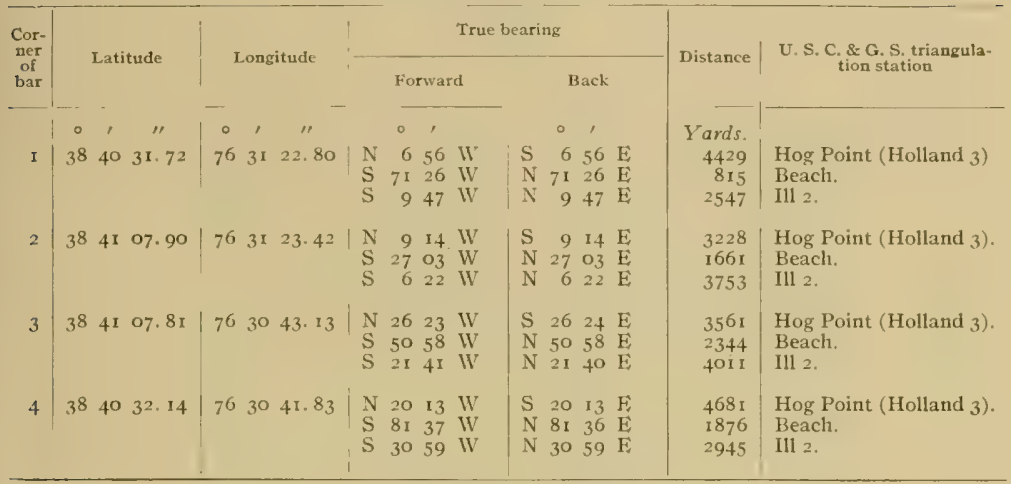

\section{LOWER STEPS}

(Chesapeake Bay-Chart Vo. I6.)

\begin{tabular}{|c|c|c|c|c|c|c|c|c|c|c|c|c|c|c|}
\hline & 。 & , & $\prime \prime$ & - & , & $" \prime$ & 。 & , & & o & , & & Yards. & \\
\hline I & 38 & 37 & 54.20 & 76 & 30 & 09.22 & $\begin{array}{lr}N & 40 \\
\text { S } & 47 \\
\text { S } & 9\end{array}$ & $\begin{array}{ll}20 & W \\
33 & W \\
30 & W\end{array}$ & $\begin{array}{l}\mathrm{S} \\
\mathrm{N} \\
\mathrm{N}\end{array}$ & $\begin{array}{r}40 \\
47 \\
9\end{array}$ & $\begin{array}{l}2 \mathrm{I} \\
33 \\
30\end{array}$ & $\begin{array}{l}\mathrm{E} \\
\mathrm{E} \\
\mathrm{E}\end{array}$ & $\begin{array}{l}3676 \\
1590 \\
2967\end{array}$ & $\begin{array}{l}\text { Ill } 2 . \\
\text { Plum } 3 . \\
\text { Pier. }\end{array}$ \\
\hline 2 & 38 & 38 & 22.74 & 76 & $3 x$ & or. 84 & $\begin{array}{lr}N & 17 \\
N & 28 \\
S & 6\end{array}$ & $\begin{array}{l}5^{8} \mathrm{~W} \\
13 \mathrm{~W} \\
09 \mathrm{E}\end{array}$ & $\begin{array}{l}\mathrm{S} \\
\mathrm{S} \\
\mathrm{N}\end{array}$ & $\begin{array}{r}17 \\
28 \\
6\end{array}$ & $\begin{array}{l}58 \\
\text { I } 4 \\
08\end{array}$ & $\begin{array}{l}\mathrm{E} \\
\mathrm{E} \\
\mathrm{W}\end{array}$ & $\begin{array}{l}4299 \\
2088 \\
2047\end{array}$ & $\begin{array}{l}\text { Beach. } \\
\text { III } 2 \text {, } \\
\text { Plum } 3 .\end{array}$ \\
\hline 3 & 38 & 39 & 03.00 & 76 & $3 x$ & 10. $5^{\circ}$ & $\begin{array}{lr}N & 2 I \\
N & 57 \\
S & 7\end{array}$ & $\begin{array}{ll}53 & W \\
35 & W \\
3 \mathrm{I} & \mathrm{E}\end{array}$ & $\begin{array}{l}\mathrm{S} \\
\mathrm{S} \\
\mathrm{N}\end{array}$ & $\begin{array}{r}21 \\
57 \\
7\end{array}$ & $\begin{array}{l}53 \\
35 \\
31\end{array}$ & $\begin{array}{l}\mathrm{E} \\
\mathrm{E} \\
\mathrm{W}\end{array}$ & $\begin{array}{r}2944 \\
898 \\
3422\end{array}$ & $\begin{array}{l}\text { Beach. } \\
\text { Ill } 2 . \\
\text { Plum } 3 .\end{array}$ \\
\hline 4 & 38 & 39 & 03.40 & 76 & 30 & 40.60 & $\begin{array}{lr}N & 34 \\
N & 73 \\
\text { S } & 5\end{array}$ & $\begin{array}{ll}46 & W \\
\text { I I } & W \\
53 & W\end{array}$ & $\begin{array}{l}\mathrm{S} \\
\mathrm{S} \\
\mathrm{N}\end{array}$ & $\begin{array}{r}34 \\
73 \\
5\end{array}$ & $\begin{array}{l}47 \\
12 \\
53\end{array}$ & $\begin{array}{l}\mathrm{E} \\
\mathrm{E} \\
\mathrm{E}\end{array}$ & $\begin{array}{l}3310 \\
1619 \\
3346\end{array}$ & $\begin{array}{l}\text { Beach, } \\
\text { Ill } 2 . \\
\text { Plum } 3 .\end{array}$ \\
\hline 5 & 38 & $3^{8}$ & oo. 00 & $7^{6}$ & 29 & 21.95 & $\begin{array}{ll}N & 54 \\
S & 62 \\
\text { S } & 29\end{array}$ & $\begin{array}{ll}19 & W \\
23 & W \\
09 & W\end{array}$ & $\begin{array}{l}\mathrm{S} \\
\mathrm{N} \\
\mathrm{N}\end{array}$ & $\begin{array}{l}54 \\
62 \\
29\end{array}$ & $\begin{array}{l}20 \\
22 \\
08\end{array}$ & $\begin{array}{l}\mathrm{E} \\
\mathrm{E} \\
\mathrm{E}\end{array}$ & $\begin{array}{l}4467 \\
2735 \\
3574\end{array}$ & $\begin{array}{l}\text { Ill } 2 . \\
\text { Plum } 3 . \\
\text { Pier. }\end{array}$ \\
\hline
\end{tabular}

$20908-10-5$ 
PLUM POINT.

(Chesapeake Bay-Charts Nos. 16 and 77 .)

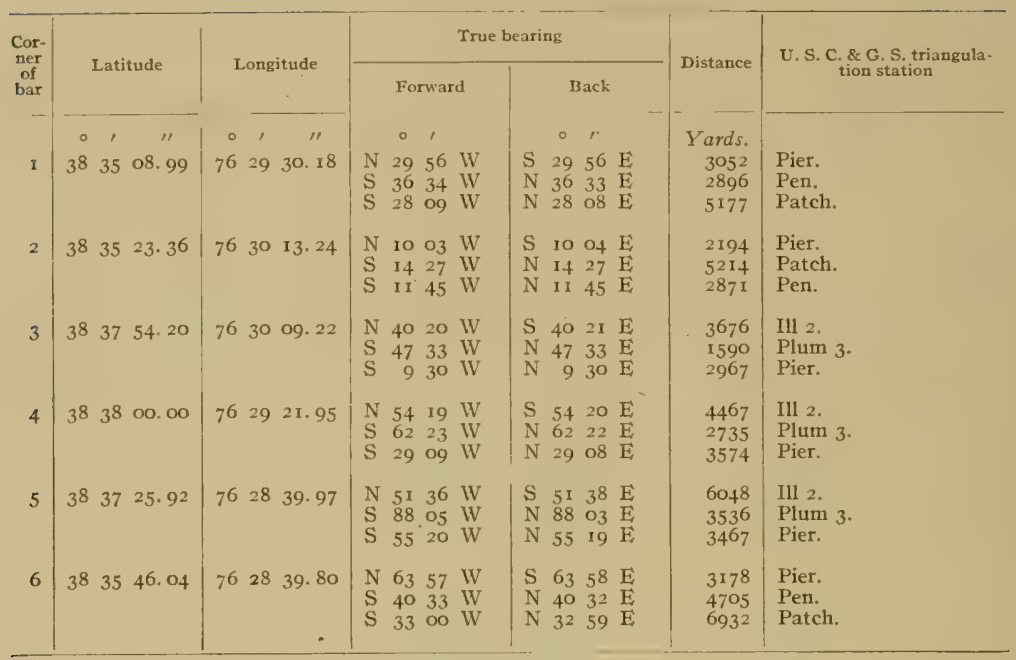

DADDIE DARE.

(Chesapeake Bay-Chart No. 17.)

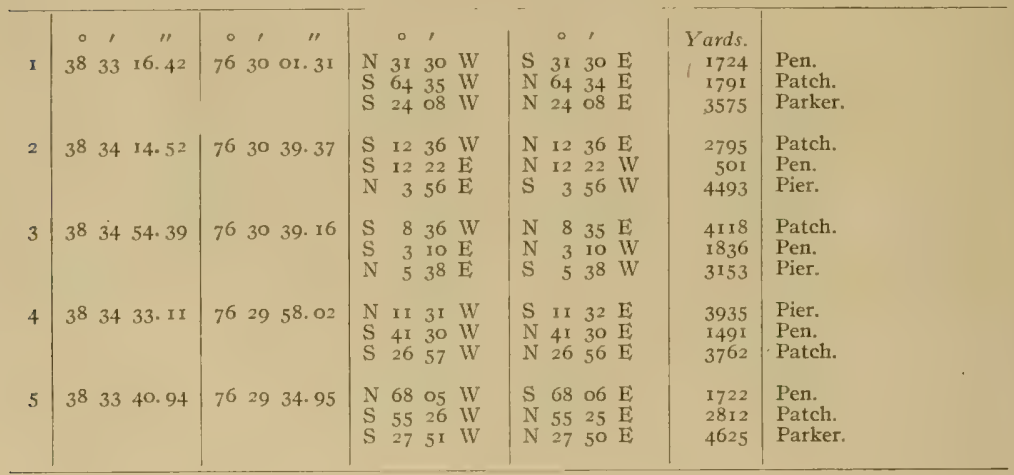


GOVERNORS RUN.

(Chesapeake Bay-Charts Nos. I7 and I8.)

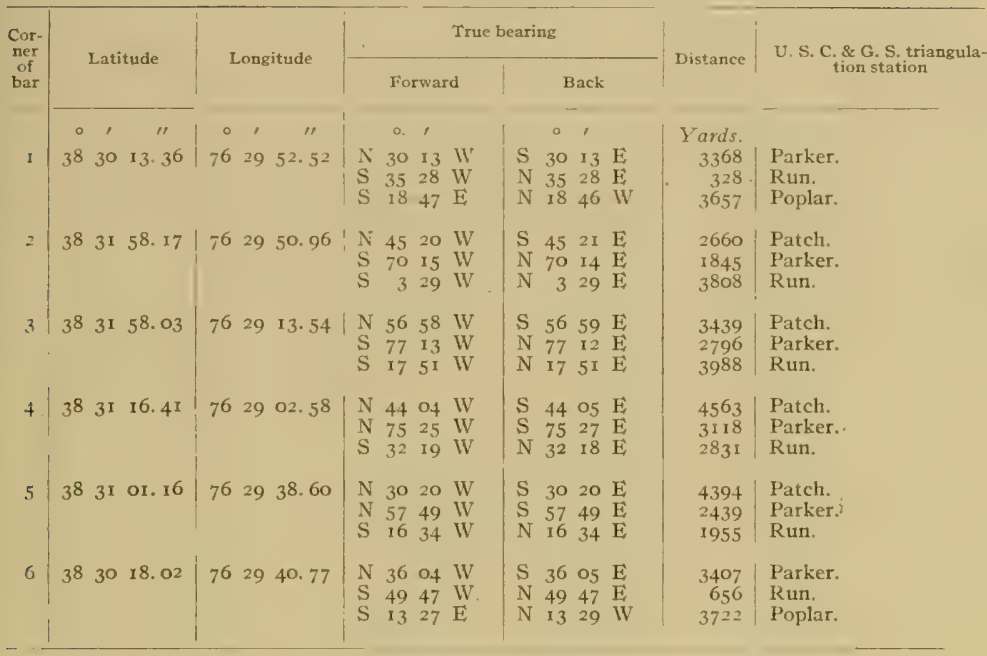

\section{EMANUEL.}

(Chesapeake Bay-Charts Nos. 17 and I8.)

\begin{tabular}{|c|c|c|c|c|c|c|c|c|c|c|c|c|c|}
\hline & 。 & , & $\prime \prime$ & 。 & , & 11 & & 0 & , & 0 & , & Yards. & \\
\hline I & 38 & 28 & 19.22 & 76 & 28 & 25.90 & $\begin{array}{l}\mathrm{N} \\
\mathrm{N} \\
\mathrm{S}\end{array}$ & $\begin{array}{l}34 \\
70 \\
32\end{array}$ & $\begin{array}{ll}45 & \mathrm{IV} \\
56 & \mathrm{IV} \\
20 & \mathrm{E}\end{array}$ & $\begin{array}{ll}\mathrm{S} & 34 \\
\mathrm{~S} & 70 \\
\mathrm{~N} & 32\end{array}$ & $\begin{array}{ll}46 & \mathbf{E} \\
56 & \mathbf{E} \\
20 & \mathrm{~W}\end{array}$ & $\begin{array}{l}4360 \\
1184 \\
2596\end{array}$ & $\begin{array}{l}\text { Run. } \\
\text { Poplar. } \\
\text { Flag Pond. }\end{array}$ \\
\hline 2 & 38 & 30 & 1.3. 36 & 76 & 29 & $5^{2} \cdot 5^{2}$ & $\begin{array}{l}\mathrm{N} \\
\mathrm{S} \\
\mathrm{S}\end{array}$ & $\begin{array}{l}30 \\
35 \\
\times 8\end{array}$ & $\begin{array}{ll}\text { I3 } & W \\
28 & W \\
47 & E\end{array}$ & $\begin{array}{ll}\mathrm{S} & 30 \\
\mathrm{~N} & 35 \\
\mathrm{~N} & \mathrm{I} 8\end{array}$ & $\begin{array}{ll}13 & \vec{E} \\
28 & \vec{E} \\
46 & \text { W }\end{array}$ & $\begin{array}{r}3368 \\
328 \\
3657\end{array}$ & $\begin{array}{l}\text { Parker } \\
\text { Run. } \\
\text { Poplar. }\end{array}$ \\
\hline 3 & 38 & 30 & I 8.02 & 76 & 29 & 40.77 & $\begin{array}{l}\mathrm{N} \\
\mathrm{S} \\
\mathrm{S}\end{array}$ & $\begin{array}{l}36 \\
49 \\
13\end{array}$ & $\begin{array}{ll}04 & \text { W } \\
47 & \text { IV } \\
27 & \mathrm{E}\end{array}$ & $\begin{array}{l}\text { S. } 36 \\
\text { N } 49 \\
\text { N } \\
\text { I } 3\end{array}$ & $\begin{array}{ll}05 & \mathrm{E} \\
47 & \mathrm{E} \\
29 & \mathrm{WV}\end{array}$ & $\begin{array}{r}3407 \\
656 \\
3722\end{array}$ & $\begin{array}{l}\text { Parker. } \\
\text { Run. } \\
\text { Poplar. }\end{array}$ \\
\hline 4 & 38 & 30 & 35.16 & 76 & 29 & or. 32 & $\begin{array}{l}\mathrm{N} \\
\mathrm{S} \\
\mathrm{S}\end{array}$ & $\begin{array}{r}54 \\
57 \\
2\end{array}$ & $\begin{array}{ll}30 & \text { WV } \\
\text { O4 } & \text { WV } \\
27 & \text { WV }\end{array}$ & $\begin{array}{lr}\mathrm{S} & 54 \\
\mathrm{~N} & 57 \\
\mathrm{~N} & 2\end{array}$ & $\begin{array}{ll}3 \mathrm{I} & \mathrm{E} \\
04 & \mathrm{E} \\
27 & \mathrm{E}\end{array}$ & $\begin{array}{l}3748 \\
1843 \\
4202\end{array}$ & $\begin{array}{l}\text { Parker. } \\
\text { Runt. } \\
\text { Poplar. }\end{array}$ \\
\hline 5 & 38 & 28 & 53.66 & 76 & 28 & or. 74 & $\begin{array}{l}\mathrm{N} \\
\mathrm{S} \\
\mathrm{S}\end{array}$ & $\begin{array}{l}52 \\
66 \\
12\end{array}$ & $\begin{array}{l}14 \mathrm{IV}^{7} \\
15 \mathrm{IV} \\
3+\mathrm{E}\end{array}$ & $\begin{array}{ll}S & 52 \\
N & 66 \\
N & 12\end{array}$ & $\begin{array}{ll}\text { I5 } & \mathrm{E} \\
\text { I4 } & \mathrm{E} \\
34 & \mathrm{IV}\end{array}$ & $\begin{array}{l}3953 \\
1923 \\
3437\end{array}$ & $\begin{array}{l}\text { Run. } \\
\text { Poplar. } \\
\text { Flag Pond. }\end{array}$ \\
\hline
\end{tabular}


FLAG POND.

(Chesapeake Bay-Chant No. I8.)

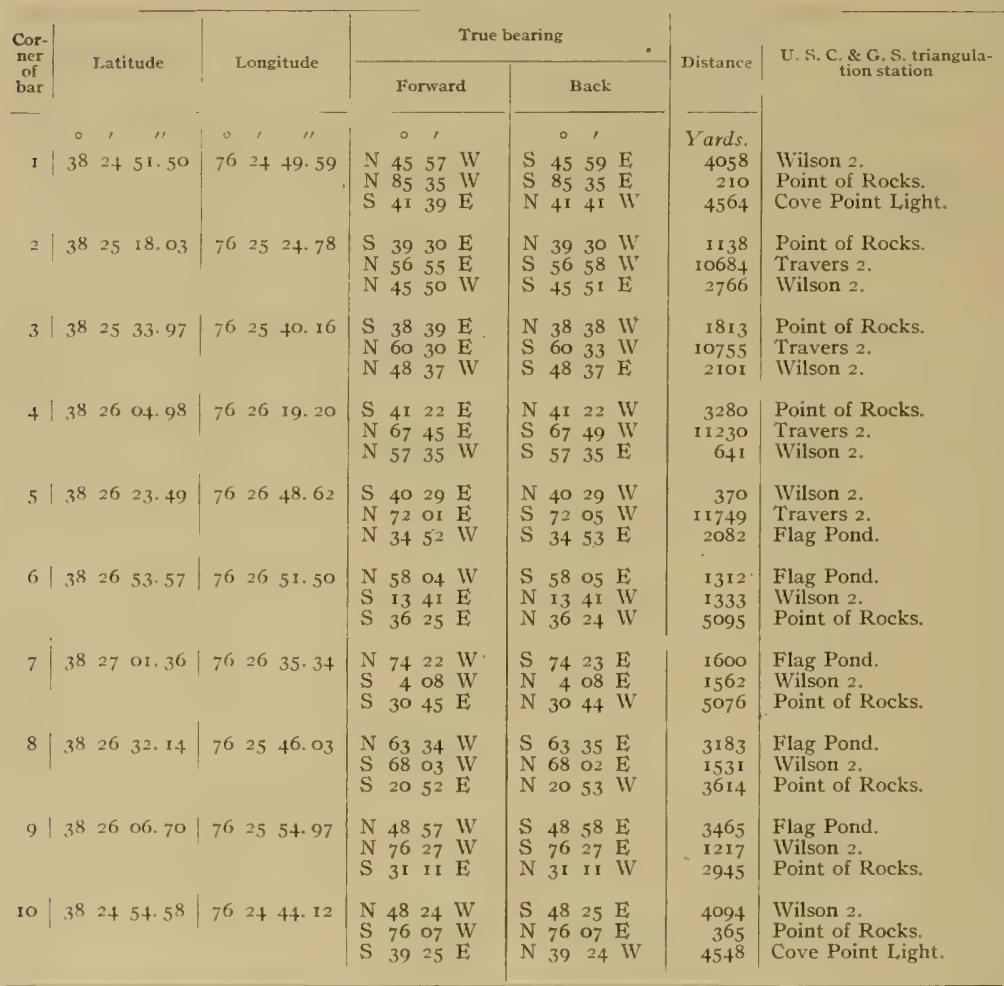


SPOUT.

(Upper Patuxent River-Chart No. I9.)

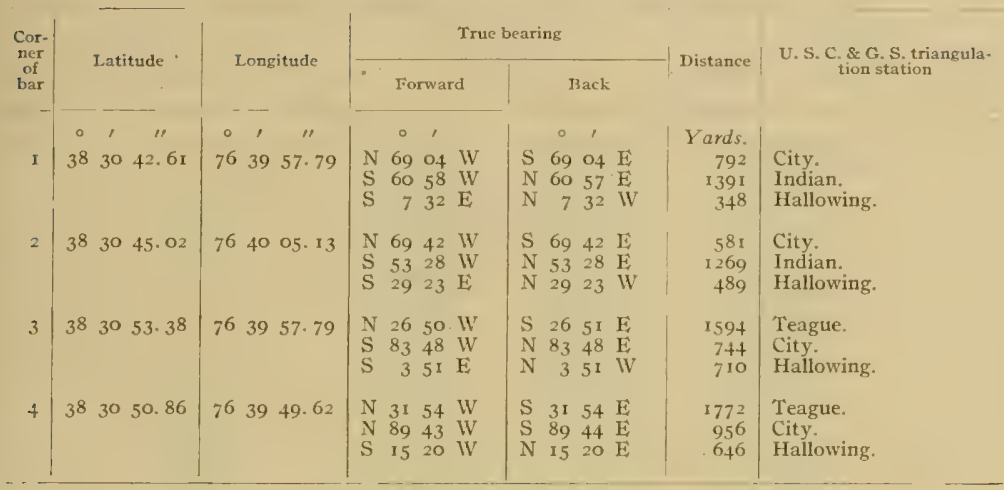

HOLLAND POINT (CALVERT COUNTY).

(Upper Patuxent Rizer-Chart No. 19.)

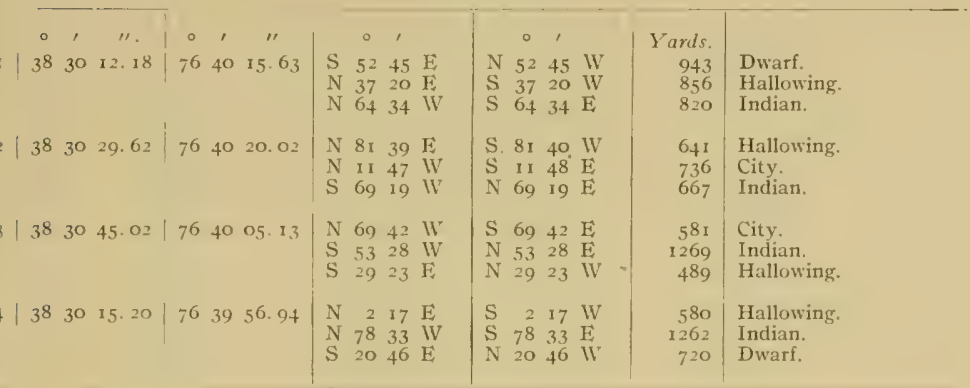


BUZZARD ISLAND.

(Upper Patuxent River-Chart No. I9.)

\begin{tabular}{|c|c|c|c|c|c|c|c|c|c|c|c|}
\hline \multirow{2}{*}{$\begin{array}{c}\text { Cor- } \\
\text { ner } \\
\text { of } \\
\text { bar }\end{array}$} & \multirow{2}{*}{\multicolumn{2}{|c|}{ Latitude }} & \multirow{2}{*}{\multicolumn{3}{|c|}{ Longitude }} & \multicolumn{4}{|c|}{ True bearing } & \multirow{2}{*}{ Distance } & \multirow{2}{*}{$\begin{array}{c}\text { U.S. C. \& G. S. triangula- } \\
\text { tion station }\end{array}$} \\
\hline & & & & & & & Forward & & Back & & \\
\hline I & $\begin{array}{c}0^{\prime} \\
38\end{array}$ & 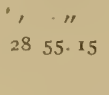 & & 39 & $\begin{array}{c}\prime \prime \prime \\
26.67\end{array}$ & $\begin{array}{l}\mathrm{N} \\
\mathrm{S} \\
\mathrm{S}\end{array}$ & $\begin{array}{ccc}\circ & , \\
18 & 46 & \mathrm{E} \\
81 & 44 & \mathrm{~W} \\
39 & 30 & \mathrm{~W}\end{array}$ & $\begin{array}{ll}\mathrm{S} & \mathrm{I} \\
\mathrm{N} & 8 \\
\mathrm{~N} & 3\end{array}$ & 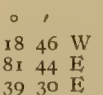 & $\begin{array}{r}\text { Yards. } \\
\text { I } 35 \\
933 \\
888\end{array}$ & $\begin{array}{l}\text { Buzz. } \\
\text { Billiard. } \\
\text { Trent. }\end{array}$ \\
\hline & & Then & 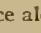 & ong & count & bou & undary as & lineat & ated on $\mathrm{Ch}$ & t No. 19 & o corner No. 2. \\
\hline 2 & $3^{8}$ & $2934 \cdot 74$ & 76 & 395 & $54 \cdot 7^{8}$ & $\begin{array}{l}N \\
S \\
S\end{array}$ & $\begin{array}{rrl}\mathrm{r}_{5} & 53 & \mathrm{E} \\
76 & 27 & \mathrm{~W} \\
6 & 50 & \mathrm{~W}\end{array}$ & $\begin{array}{ll}\mathrm{S} & \mathrm{I} \\
\mathrm{N} & 7 \\
\mathrm{~N} & 7\end{array}$ & $\begin{array}{rll}15 & 53 & \mathrm{~W} \\
76 & 27 & \mathrm{E} \\
6 & 50 & \mathrm{E}\end{array}$ & $\begin{array}{r}720 \\
561 \\
1479\end{array}$ & $\begin{array}{l}\text { Dwarf. } \\
\text { Sothoron. } \\
\text { Billiard. }\end{array}$ \\
\hline 3 & 38 & 2943.62 & 76 & 394 & $49 \cdot 40$ & & $\begin{array}{rll}7.58 & \mathrm{E} \\
57 & 50 & \mathrm{~W} \\
\mathrm{IO} & \mathrm{I} & \mathrm{W}\end{array}$ & $\begin{array}{ll}\mathrm{S} & \\
\mathrm{N} & 5 \\
\mathrm{~N} & \mathrm{I}\end{array}$ & $\begin{array}{rrr}7 & 58 & \mathrm{~W} \\
57 & 50 & \mathrm{E} \\
\text { I0 } & \mathrm{x} & \mathrm{E}\end{array}$ & $\begin{array}{r}396 \\
809 \\
\times 792\end{array}$ & $\begin{array}{l}\text { Dwarf. } \\
\text { Sothoron. } \\
\text { Billiard. }\end{array}$ \\
\hline 4 & 38 & 2902.08 & 76 & $39 x$ & 12.63 & & $\begin{array}{rrl}45 & 34 & \mathrm{~W} \\
58 & 59 & \mathrm{E} \\
0 & 27 & \mathrm{~W}\end{array}$ & $\begin{array}{l}\mathrm{N} \\
\mathrm{N} \\
\mathrm{S}\end{array}$ & $\begin{array}{rrl}45 & 33 & \mathrm{E} \\
5^{8} & 5^{8} & \mathrm{~W} \\
0 & 27 & \mathrm{E}\end{array}$ & $\begin{array}{r}1312 \\
643 \\
844\end{array}$ & $\begin{array}{l}\text { Trent. } \\
\text { Morsel. } \\
\text { Buzz. }\end{array}$ \\
\hline
\end{tabular}

\section{MACKS HOLLOW.}

(Upper Pafuxent River-Chant No. I9.)

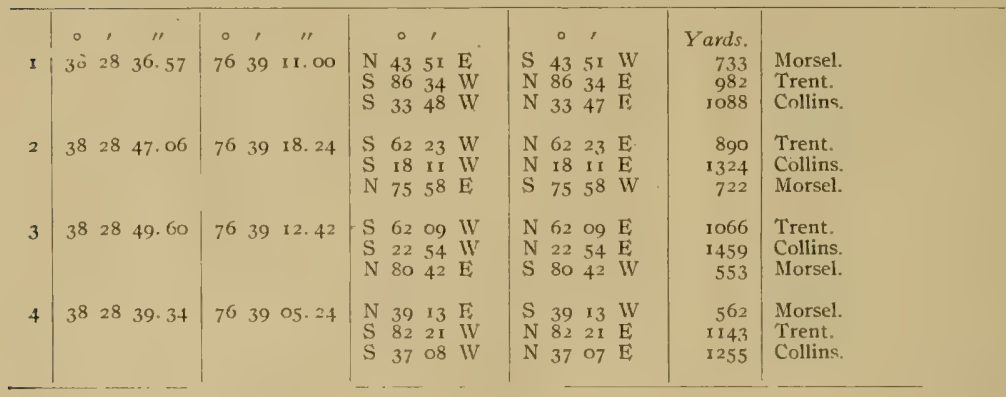


BROAD NECK (CALVERT COUNTY).

(Upper Patuxent River-Chart No. 19.)

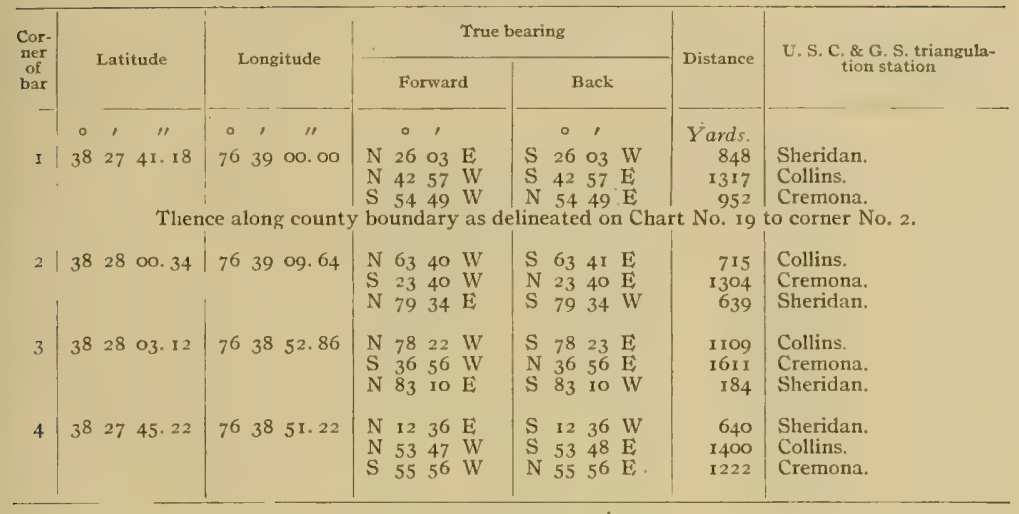

THOMAS (CALVERT COUNTY).

(Upper Patuxent River-Chart No. ro.)

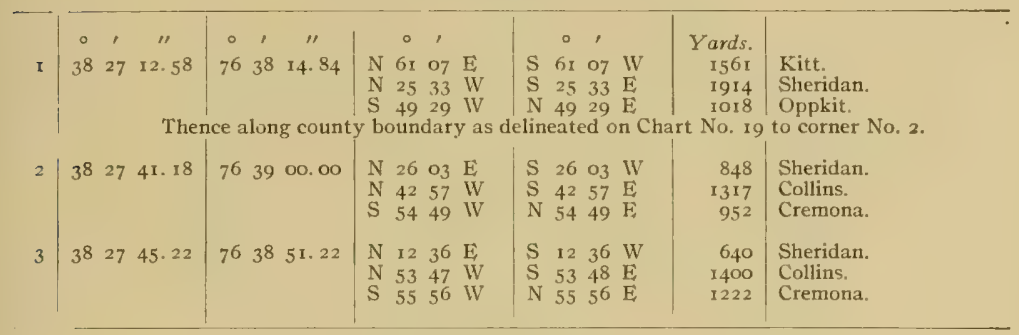

\section{KITTS MARSH.}

(Upper Patuxent River-Chant No, I9.)

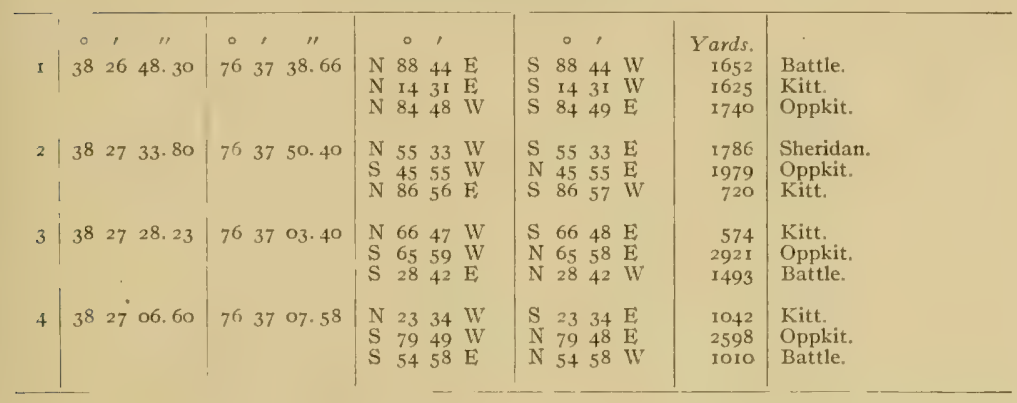


PRISON POINT.

(Upper Patuxent River-Chart No. I9.)

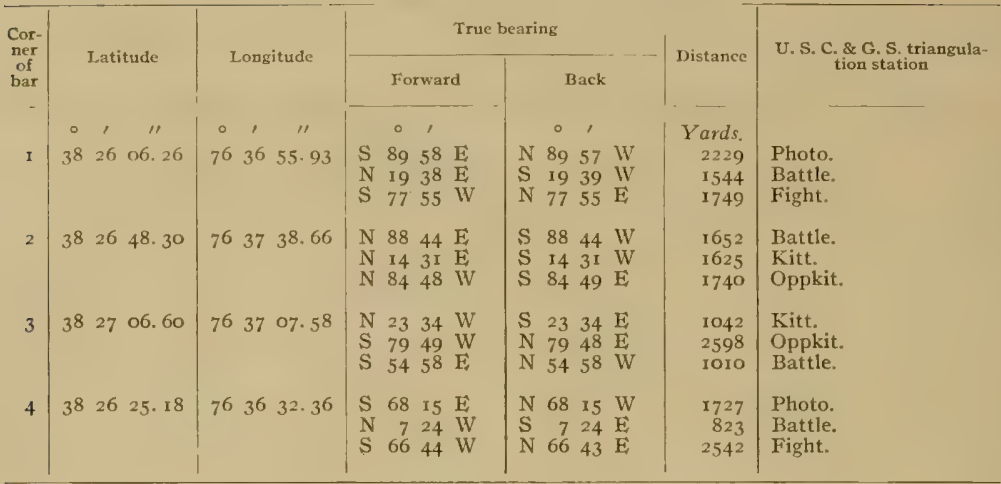

JACKS MARSH.

(Middle Patuxent River-Chart No. I9.)

\begin{tabular}{|c|c|c|c|c|c|c|c|c|c|c|c|c|}
\hline & & & & & & & & & & & & \\
\hline I & $\begin{array}{c}\circ \\
3^{8}\end{array}$ & $\frac{1}{25}$ & $4^{\prime \prime} 60$ & $\begin{array}{c}\circ \\
76\end{array}$ & $\frac{1}{36}$ & $\begin{array}{c}\prime \prime \\
35.83\end{array}$ & $\begin{array}{lr} & 0 \\
N & 68 \\
N & 0 \\
N & 82\end{array}$ & $\begin{array}{ll}42 & \mathrm{E} \\
23 & \mathrm{~W} \\
27 & \mathrm{~W}\end{array}$ & $\begin{array}{rr} & 0 \\
\text { S } & 68 \\
\text { S } & 0 \\
\text { S } & 82\end{array}$ & $\begin{array}{ll}43 & W \\
23 & E \\
26 & E\end{array}$ & $\begin{array}{r}\text { Yards. } \\
1820 \\
2116 \\
2263\end{array}$ & $\begin{array}{l}\text { Photo. } \\
\text { Battle. } \\
\text { Fight. }\end{array}$ \\
\hline 2 & 38 & 26 & o6. 26 & 76 & 36 & 55.93 & $\begin{array}{ll}\text { S } & 89 \\
\text { N } & 19 \\
\text { S } & 77\end{array}$ & $\begin{array}{ll}58 \mathrm{E} \\
38 \mathrm{E} \\
55 \mathrm{~W}\end{array}$ & $\begin{array}{ll}\text { N } & 89 \\
\text { S } & 19 \\
\text { N } & 77\end{array}$ & $\begin{array}{l}57 \mathrm{IV} \\
39 \mathrm{IV} \\
55 \mathrm{E}\end{array}$ & $\begin{array}{l}2229 \\
1544 \\
1749\end{array}$ & $\begin{array}{l}\text { Photo. } \\
\text { Battle. } \\
\text { Fight. }\end{array}$ \\
\hline 3 & $3^{8}$ & 26 & 25.18 & 76 & 36 & 32.36 & $\begin{array}{lr}\text { S } & 68 \\
N & 7 \\
\text { S } & 66\end{array}$ & $\begin{array}{ll}15 & E \\
24 & W \\
44 & W\end{array}$ & $\begin{array}{lr}\mathrm{N} & 68 \\
\mathrm{~S} & 7 \\
\mathrm{~N} & 66\end{array}$ & $\begin{array}{l}\text { I5 IV } \\
24 \overrightarrow{\mathrm{E}} \\
43 \mathrm{E}\end{array}$ & $\begin{array}{r}1727 \\
823 \\
2542\end{array}$ & $\begin{array}{l}\text { Photo. } \\
\text { Battle. } \\
\text { Fight. }\end{array}$ \\
\hline 4 & 38 & 26 & I1. 08 & 76 & 36 & $20.3^{8}$ & $\begin{array}{ll}\mathrm{S} & 82 \\
\mathrm{~N} & 18 \\
\mathrm{~S} & 78\end{array}$ & $\begin{array}{ll}43 & \mathrm{E} \\
10 & \mathrm{WW} \\
44 & \mathrm{IV}\end{array}$ & $\begin{array}{ll}N & 82 \\
S & 18 \\
N & 78\end{array}$ & $\begin{array}{lll}43 & \mathrm{IV} \\
10 & \mathrm{E} \\
43 & \mathrm{E}\end{array}$ & $\begin{array}{l}1297 \\
1359 \\
2704\end{array}$ & $\begin{array}{l}\text { Photo. } \\
\text { Battle. } \\
\text { Fight. }\end{array}$ \\
\hline
\end{tabular}


JACKS BAY.

(Middle Patuxent River-Chart No. 19.)

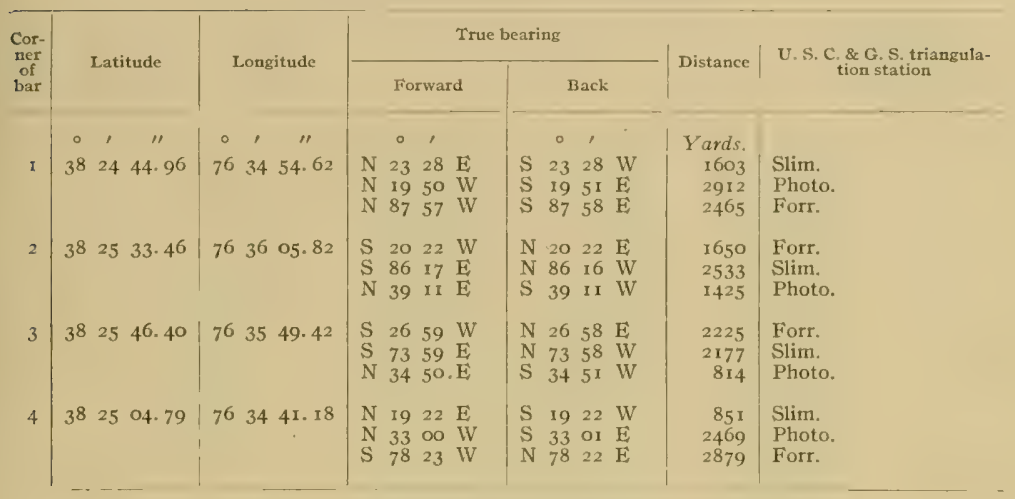

\section{PARKERS WHARF.}

(Middle Patuxent River-Chart No. 19.)

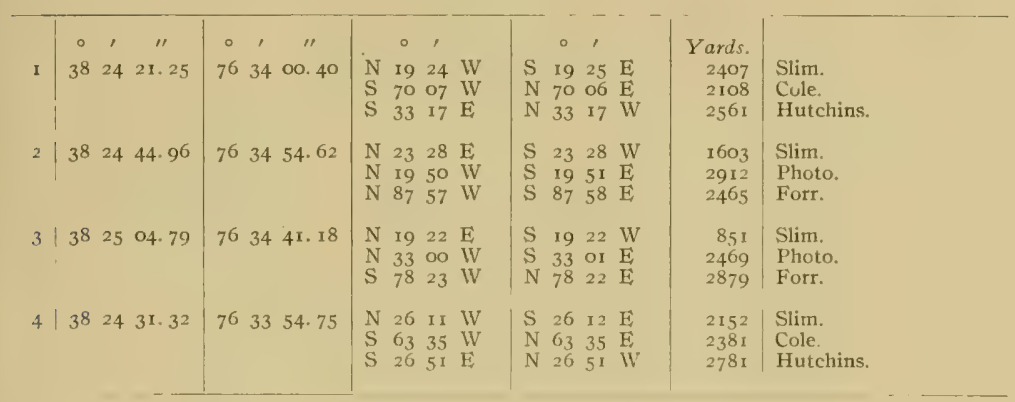


BROOME ISLAND.

(Middle Patuxent River-Chant No. 19.)

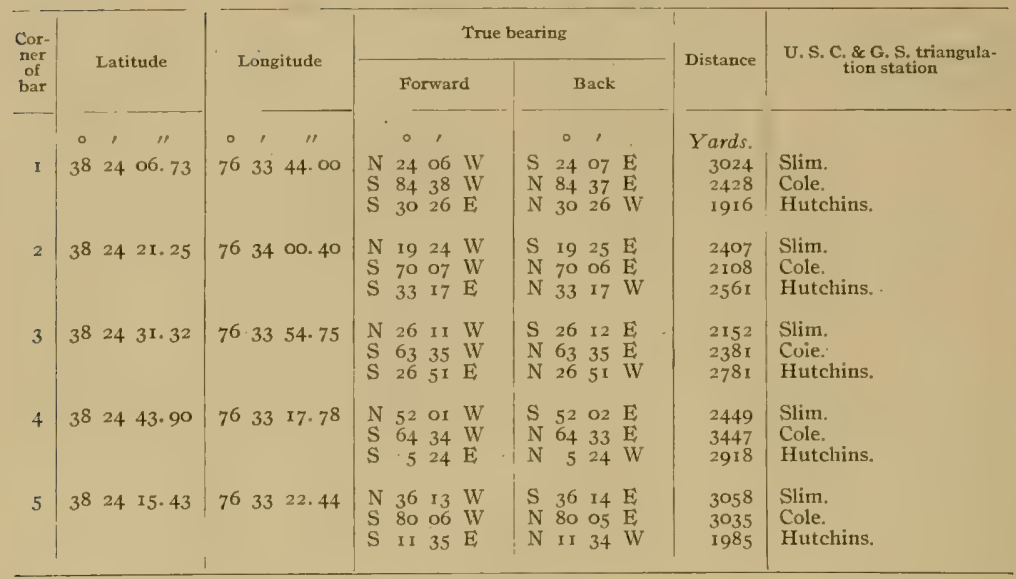

\section{ISLAND CREEK,}

(Midule Patuxent River-Chart No. I9.)

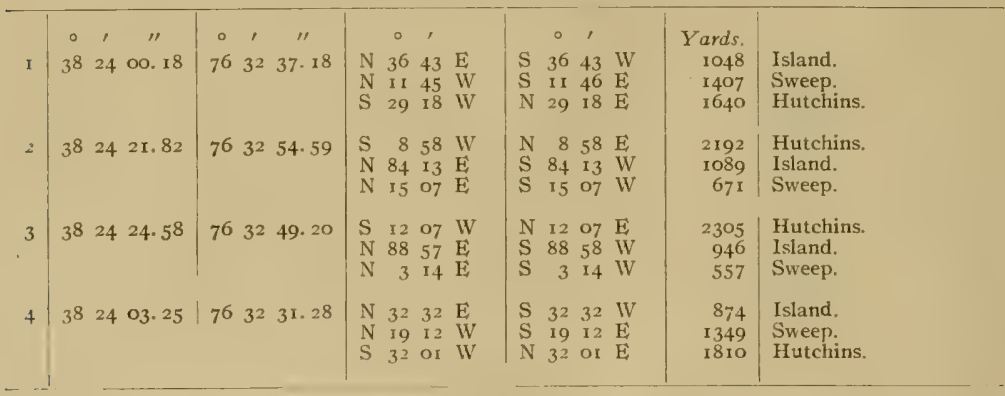


PETERSON (CALVERT COUNTY).

(Middle Patuxent River-Chart No. Ig.)

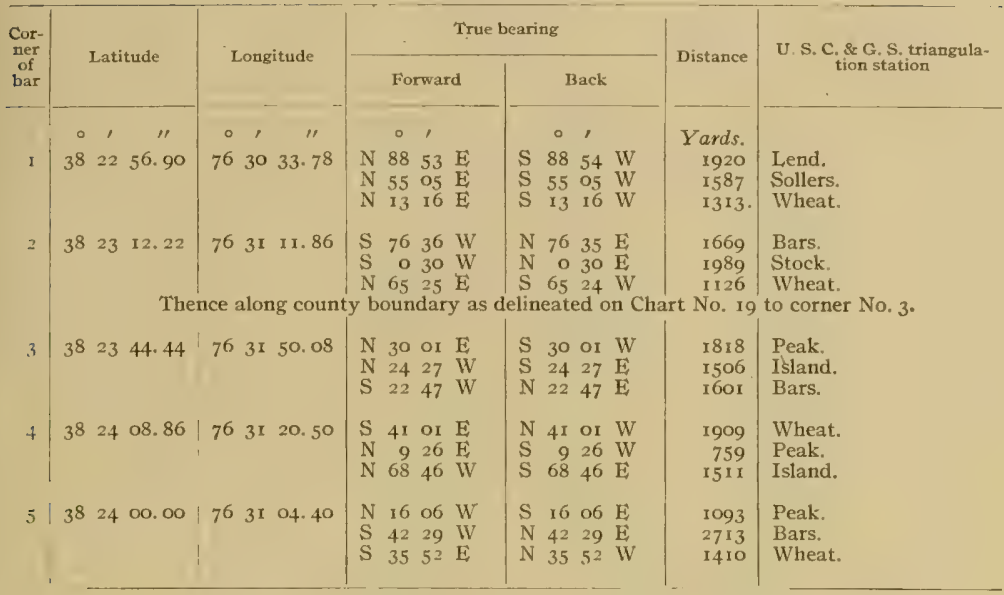

MEARS (CALVERT COUNTY).

(Lower Patuxent River -Chart No. 20.)

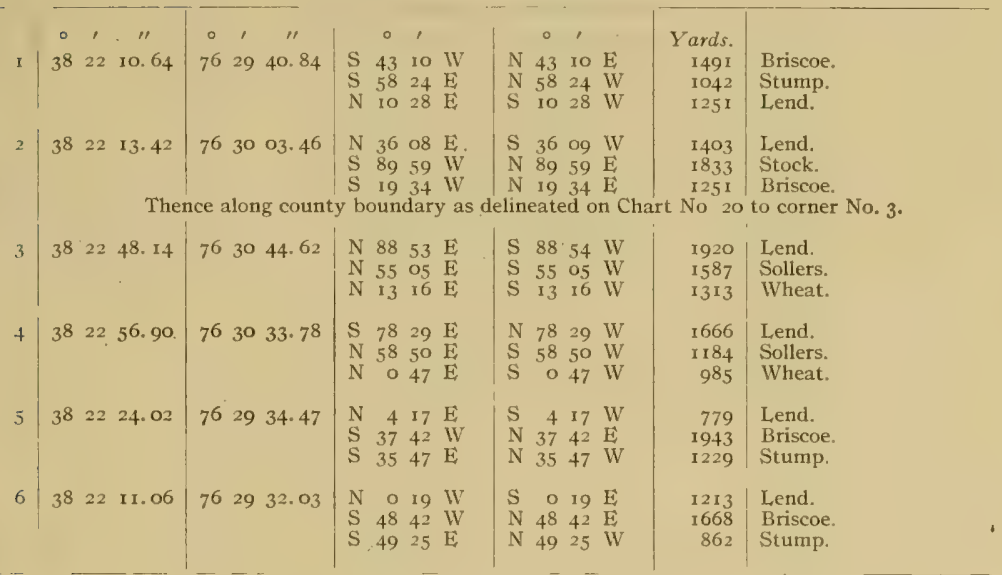


HELI.EN.

(Loxer Patuxent River - Chart No. 20.)

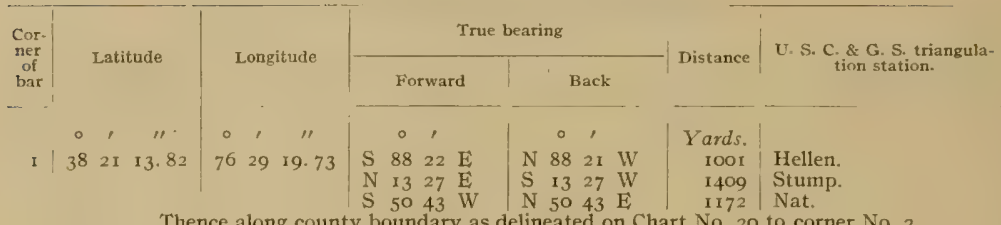

Thence along county boundary as delineated on Chart No. 20 to corner Na. 2.

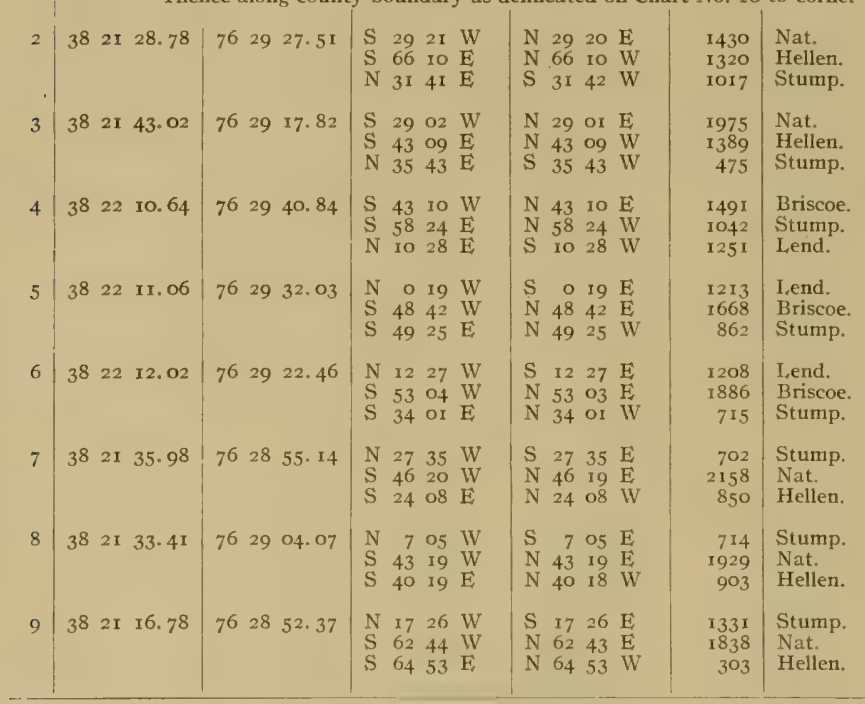

HUNGERFORD HOLLOW.

(Lower Patuxent River-Chart No. 2o.)

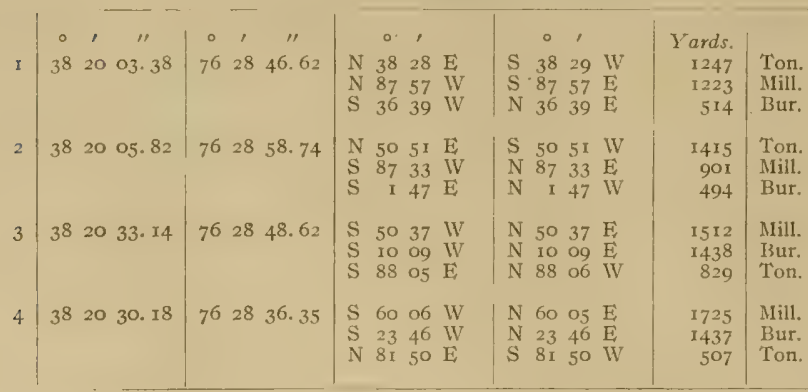


BARN GATES.

(Lower Patuxent River-Charl No. 20.)

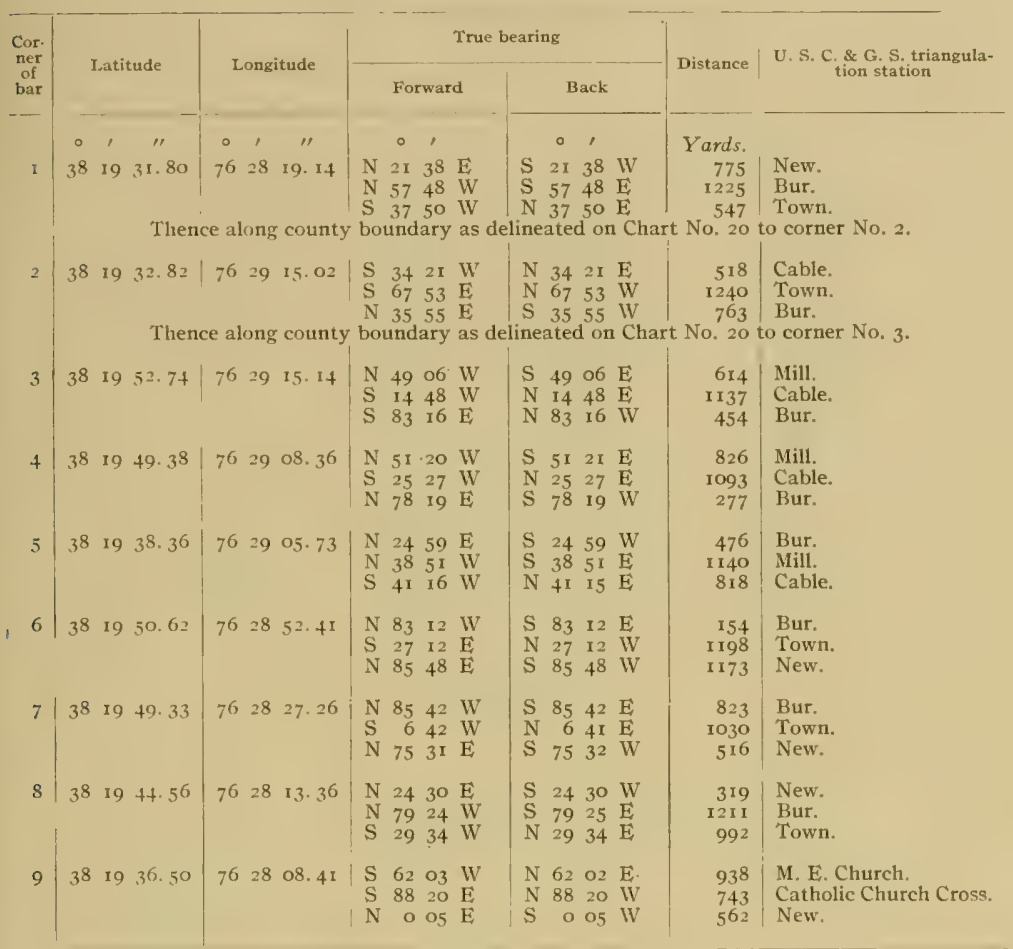


BACK OF ISLAND.

(Lower Patuxent River-Chart No. 20.)

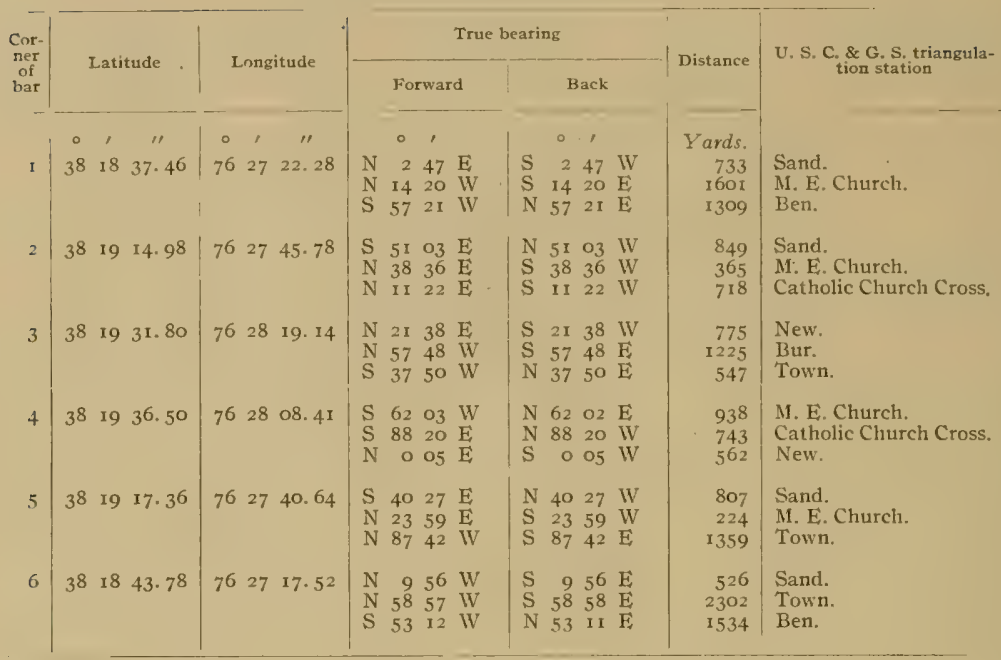

SHELL PILE.

(Lower Paluxent River-Chart No, 20.)

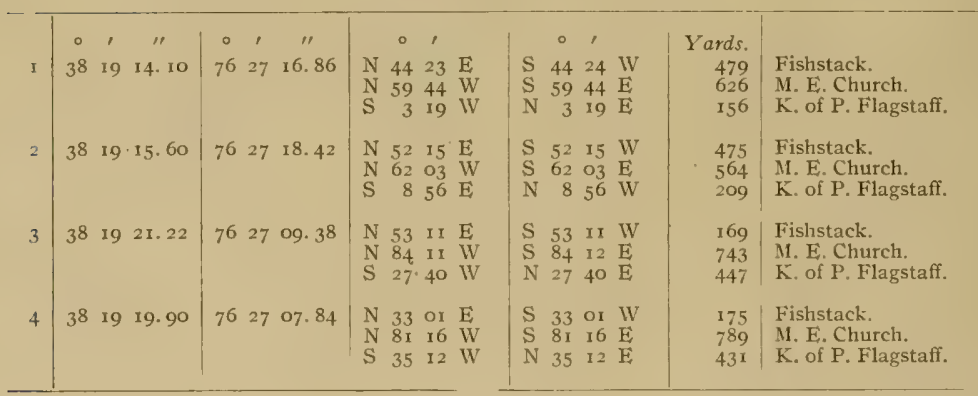


Survey of Oyster Bars, Calvert County, $M d$.

CHERRY TREE.

(Lower Patuxent River-Chart No. 20.)

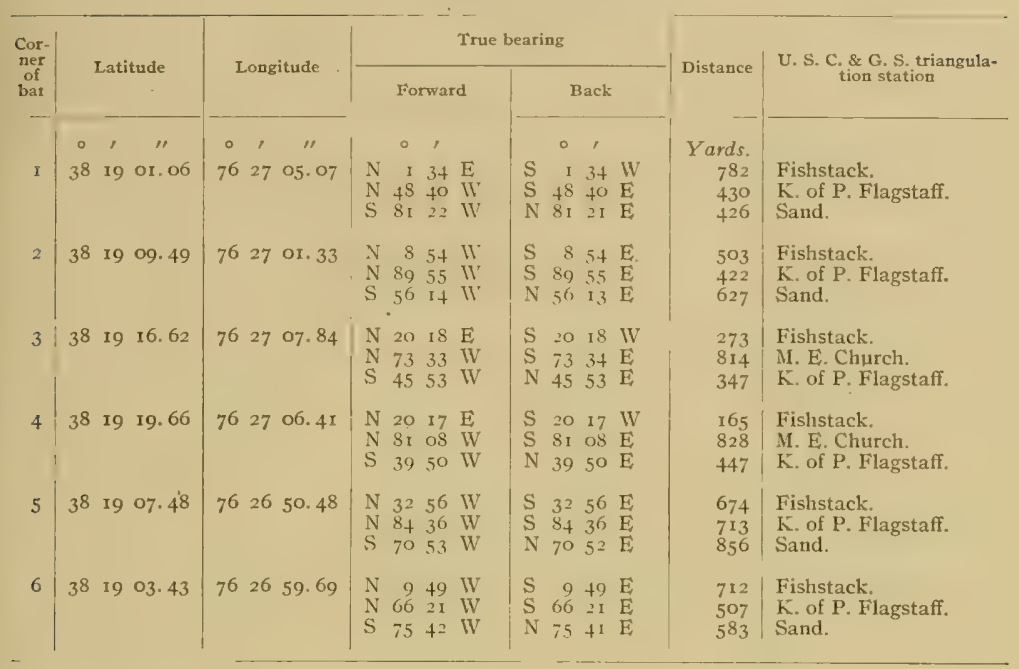


SWASH.

(Lower Paluxent River-Chart No. 20.)

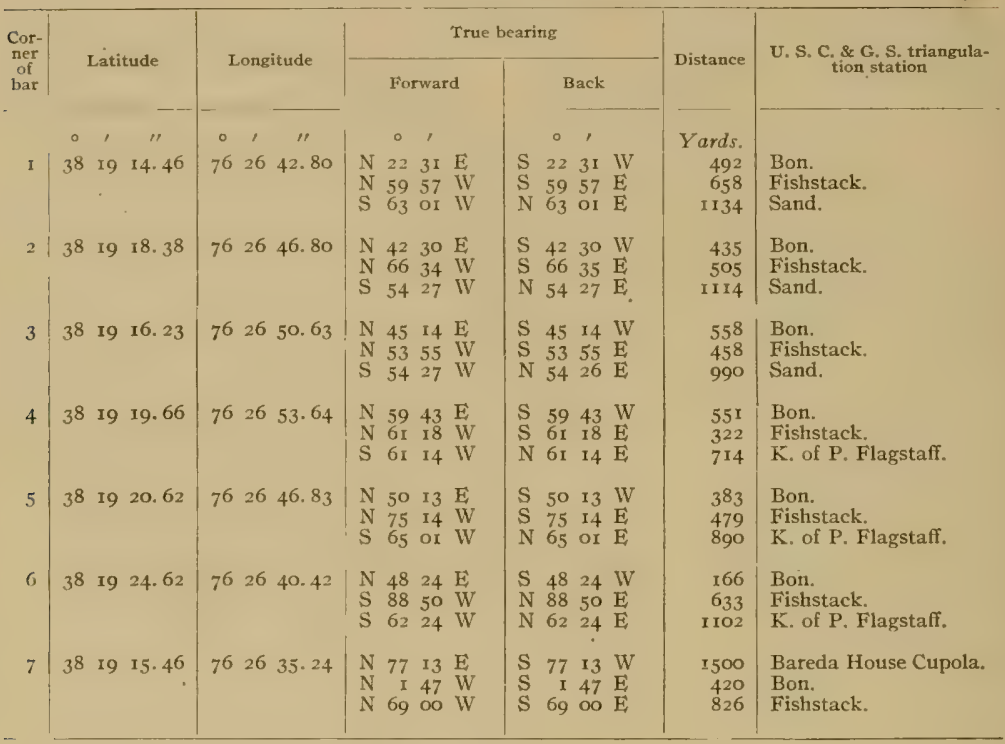

SANDY POINT LUMPS.

(Lower Patuxent River-Chart No. 2o.)

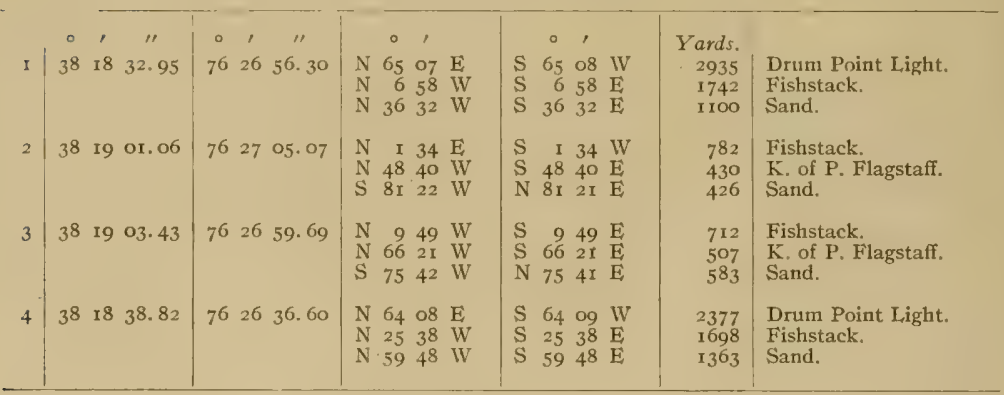


Survey of Oyster Bars, Calvert County, Md.

SOUTHEAST MIDDLE-GROUND.

(Lower Patuxent Rizer-Chat No. 20.)

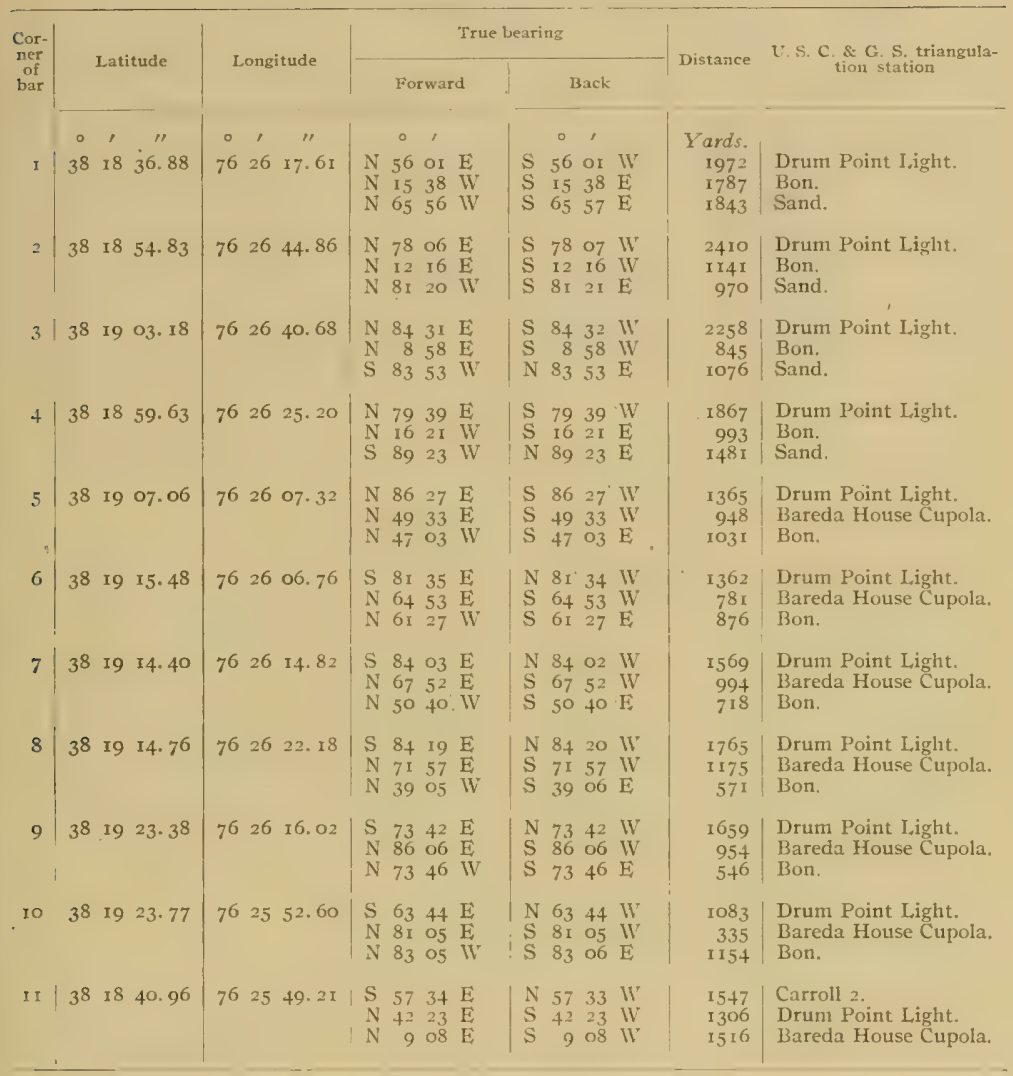

$20908-10-6$ 
I,IGHT HOUSE I,UMP.

(Louer Patuxent River-Chart No, 20.)

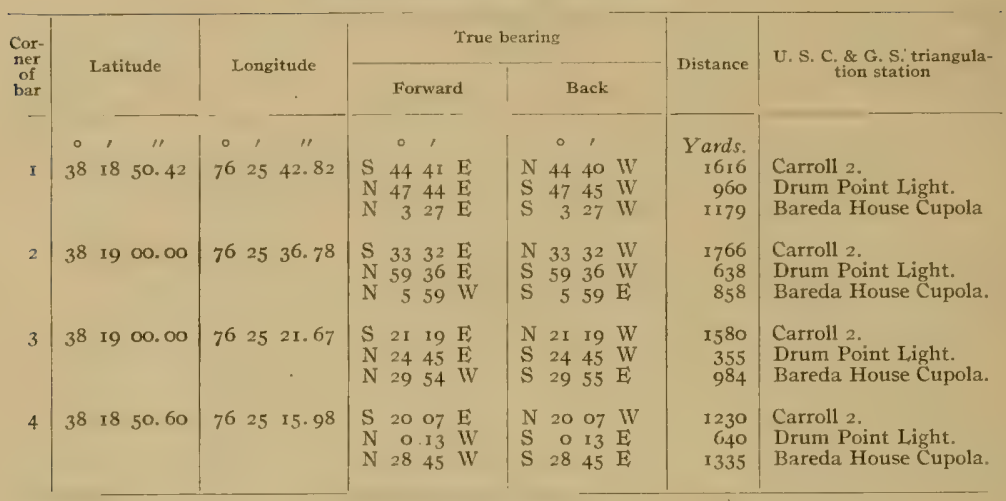

\section{OLD LUMP.}

(Entrance Patuxent River-Chart No. 20.)

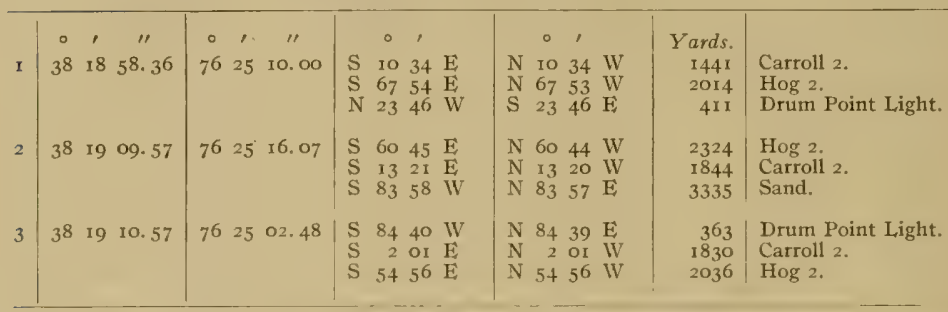

CARROLL MUDS (CALVERT COUNTY).

(Entrance Patuxent River-Chart No. 20.)

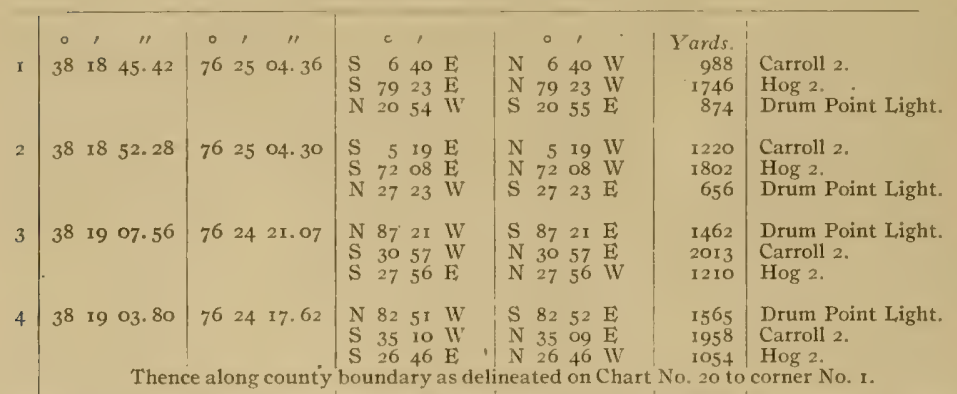




\section{SIMMONS.}

(Entrance Patuxent Rizicr-Chart No. 20.)

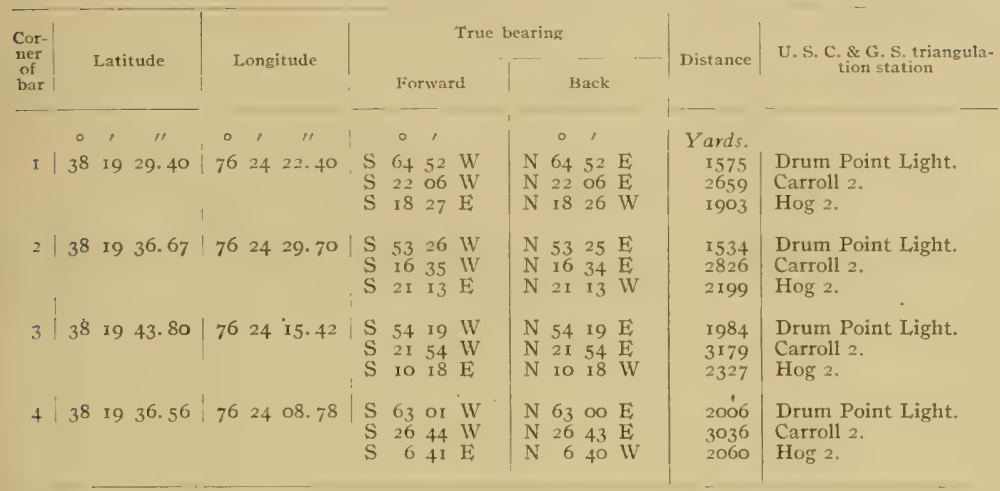

\section{CHINESE MUDS (CALVERT COUNTY).}

(Entrance Patuxent River-Chart No. 20.)

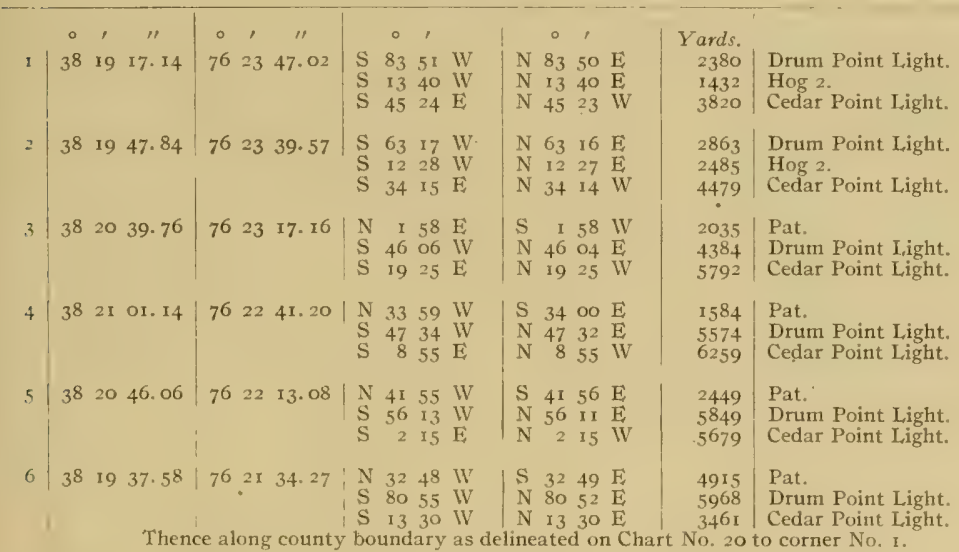


PARKER MOORE.

(Entrance Patuxent Rizer-Chart No. 20.)

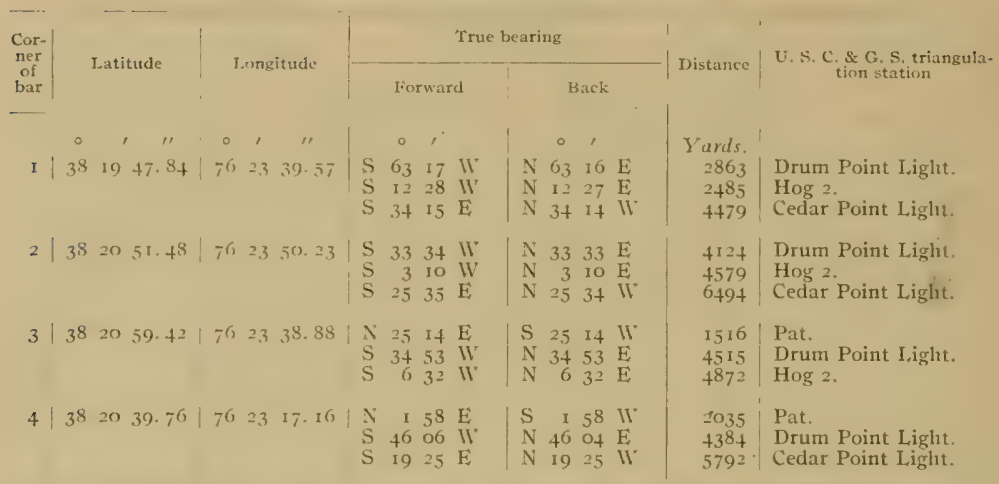

\section{UNDER THE CLIFFS.}

(Entrance Patuxent Rizer-Chant No. 20.)

\begin{tabular}{|c|c|c|c|c|c|c|c|c|c|c|c|c|c|}
\hline & $\circ$ & , & " & $\circ$ & ' & " & & $\circ$ & , & $\circ$ & , & I'arits. & \\
\hline I & 38 & 20 & 11.66 & -6 & 24 & 25.40 & $\begin{array}{l}S \\
S \\
\text { S }\end{array}$ & $\begin{array}{l}32 \\
13 \\
11\end{array}$ & $\begin{array}{l}44 \mathrm{~W}^{\prime} \\
19 \mathrm{~W} \\
55 \mathrm{E}\end{array}$ & $\begin{array}{ll}N & 32 \\
N & 13 \\
N & 11\end{array}$ & $\begin{array}{l}4+\mathrm{E} \\
19 \mathrm{E} \\
55 \mathrm{~W}\end{array}$ & $\begin{array}{l}2489 \\
3996 \\
3300\end{array}$ & $\begin{array}{l}\text { Drum Point Light. } \\
\text { Carroll } 2 . \\
\text { Hog } 2 \text {. }\end{array}$ \\
\hline 2 & 38 & 20 & $13.9^{8}$ & 76 & 24 & $\begin{array}{l}29.06 \\
.\end{array}$ & $\begin{array}{l}S \\
\text { S } \\
\text { S }\end{array}$ & $\begin{array}{l}29 \\
11 \\
13\end{array}$ & $\begin{array}{l}5+\mathrm{W} \\
4+\mathrm{WW} \\
\mathrm{I} 5 \mathrm{E}\end{array}$ & $\begin{array}{ll}N & 29 \\
N & 11 \\
N & 13\end{array}$ & $\begin{array}{ll}54 & \mathrm{E} \\
44 & \mathrm{E} \\
15 & 11\end{array}$ & $\begin{array}{l}2505 \\
4061 \\
3399\end{array}$ & $\begin{array}{l}\text { Drum Point Light. } \\
\text { Carroll } 2 . \\
\text { Hog } 2 .\end{array}$ \\
\hline 3 & 38 & 20 & $53 .+6$ & 76 & 23 & $53.5^{8}$ & $\begin{array}{l}N \\
S \\
S\end{array}$ & $\begin{array}{r}32 \\
2 \\
26\end{array}$ & $\begin{array}{ll}02 & 1 \mathrm{~S} \\
\text { OI } & \mathrm{IV} \\
\mathrm{O} 2 & \mathrm{E}\end{array}$ & $\begin{array}{lr}S & 32 \\
N & 2 \\
N & 26\end{array}$ & $\begin{array}{ll}\text { O2 } & \mathrm{E} \\
\text { OI } & \mathrm{E} \\
\text { or } & \mathrm{IV}\end{array}$ & $\begin{array}{l}+133 \\
4642 \\
6593\end{array}$ & $\begin{array}{l}\text { Drum Point Light. } \\
\text { Hog 2. } \\
\text { Cedar Point Light. }\end{array}$ \\
\hline 4 & 38 & 20 & 51.48 & $7^{6}$ & 23 & 50.23 & $\begin{array}{l}S \\
\text { S } \\
\text { S }\end{array}$ & $\begin{array}{r}33 \\
3 \\
25\end{array}$ & $\begin{array}{ll}3+ & 11 \\
10 & W \\
35 & E\end{array}$ & $\begin{array}{lr}N & 33 \\
N & 3 \\
N & 25\end{array}$ & $\begin{array}{ll}33 & \mathrm{E} \\
10 & \mathrm{E} \\
37 & \mathrm{II}\end{array}$ & $\begin{array}{l}4124 \\
4579 \\
6494\end{array}$ & $\begin{array}{l}\text { Drum Point Light. } \\
\text { Hog } 2 \text {. } \\
\text { Cedar Point Light. }\end{array}$ \\
\hline
\end{tabular}




\section{I.ITTLE COVE: POINT.}

(Entrance Pafuxent Rivr - Chart No. 2o.)

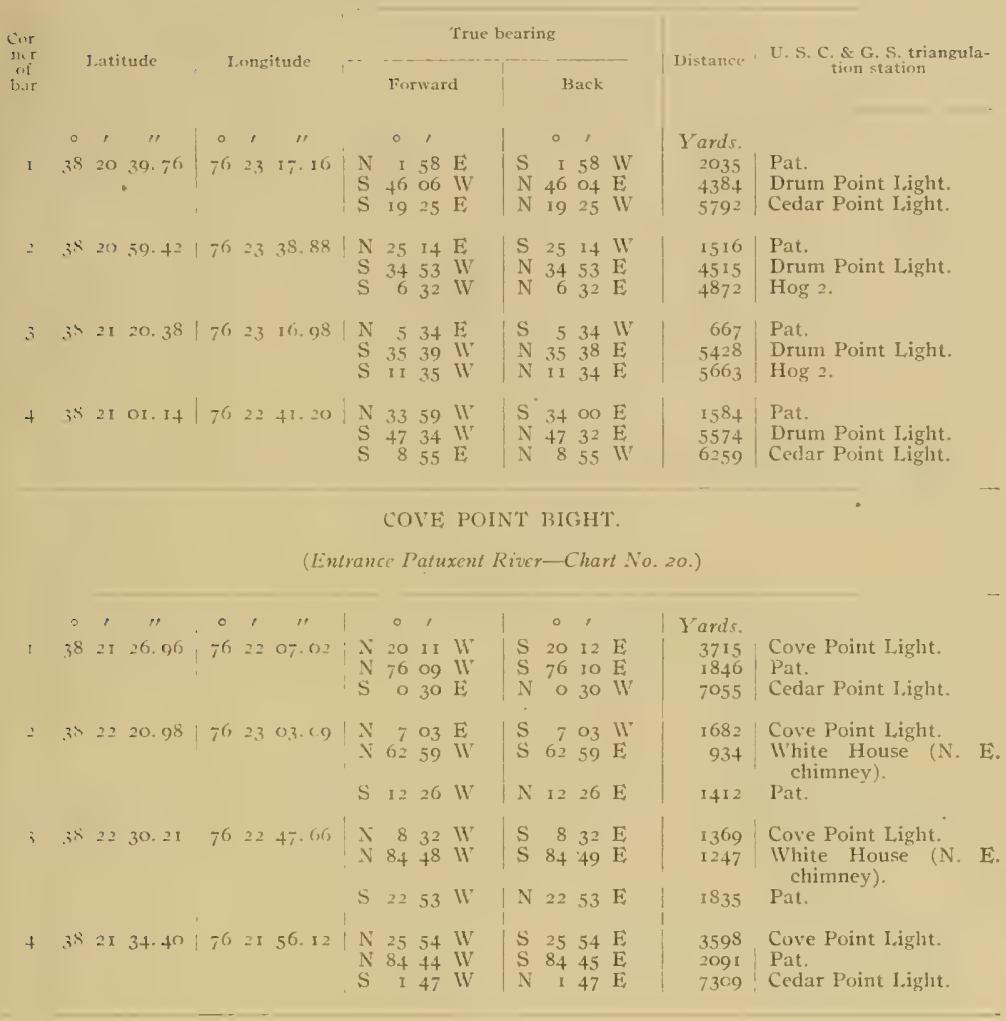





\section{A P PENDIXES.}

\section{APPFNDIX A,-LAWS RELATING TO THE COOPERATION OF THE COAST AND GEODETIC SURVEY AND BUREAU OF FISHERIES WITH THE MARVLAND SHELL FISH COM- MISSION.}

The work of the Coast and Geodetic Survey and of the Bureau of Fisheries, in cooperation with the Maryland Shell Fish Commission, in surveying the oyster bars, establishing permanent landmarks at triangulation stations, and preparing for publication the necessary charts and technical and legal descriptions of boundaries and landmarks shown on these charts, has been executed in compliance with a request from the governor of the State of Maryland to the Secretary of Commerce and Labor, and by the authority of the following laws of the United States and Maryland:

[Act of Congress approved May 26, 1906.]

AN ACY To authorize the Secretary of Commerce and Labor to cooperate, through the Bureau of the Coast and Geodetic Survey and the Bureau of Fisheries, with the sbellish commissioners of the State of Maryland in making surveys of the natural oyster beds, bars, and rocks in the waters within the State of Maryland.

Be it enacted by the Senate and House of Representatives of the United States of America in Congress assembled, That the Secretary of Commerce and Labor be, and he is hereby, authorized and directed, upon the request of the governor of the State of Maryland, to designate stuch officers, experts, and employees of the Bureau of the Coast and Geodetic Survey and of the Bureau of Fisheries as may be necessary to cooperate with the Maryland State board of shellfish commissioners in making a survey of and locating the natural oyster beds, bars, and rocks in the waters within the State of Maryland; and the Secretary of Commerce and Labor is hereby authorized and directed to furnish to the officers, experts, and employees of said Bureaus so detailed as aforesaid such instruments, appliances, and steam launches as may be necessary to make the survey aforesaid; and the Secretary of Commerce and Iabor is hereby authorized to have made in the Bureau of the Coast and Geodetic Survey all the plats necessary to show the results of the aforesaid survey and the locations of the said natural oyster beds, bars, and rocks in the waters within the State of Maryland, and to furnish to the hoard of shellfish commissioners of the State of Maryland such copies as may be necessary, and for this purpose to employ, in the District of Columbia and elsewhere, such technically qualified persons as may be necessary to carry out the purpose of this act.

SEc. 2. That the Secretary of Commerce and Labor is hereby furthier authorized to have erected or constructed by the officers so detailed as aforesaid, while making such survey, such structures as may be necessary to mark the points of triangulation, so that the same may be used for such future work of the Coast and Geodetic Survey as the said Burean may be hereafter required to perform in prosecuting the Government coast survey of the navigable waters of the United States located within the State of Maryland.

SEC. 4 . That this act slrall take effect from the date of its passage.

[Act of Congress approved June $30,1906$.

AN ACT Mlaking appropriations for sundry civil expenses of the Government for the fiscal year ending June thirtieth, nineteen hundred and seven, and for othor purposes,

Be it enacted by the Senate and House of Represcutatives of the Unitcd States of America in Congress assembled, That the following sums be, and the same are hereby, appropriated, for the objects hereinafter expressed, for the fiscal year ending June thirtieth, nineteen hundred and seven, namely: * * * 
CoAst and GeOderic Survey: * * * For any special surveys * * * including the expenditures authorized under Public Act Numbered One hundred and eighty-one, approved May twenty-sixth, nineteen hundred and six, and contingent expenses incident thereto, five thousand dollars, together with the unexpended balance under this appropriation for nineteen hundred and six and prior years which is hereby reappropriated and made available on this account for the fiscal year nineteen hundred and seven. ***

[Act of Congress approved March 4, 1907.]

AN ACT Making appropriations for sundry civil expenses of the Government for the fiscal year ending June thirtieth, nineteen hundred and eight, and for other purposes.

Be it enacted by the Senate and House of Representatives of the United States of America in Congress assembled, That the following sums be, and the same are hereby, appropriated, for the objects hereinafter expressed, for the fiscal year ending June thirtieth, nineteen hundred and eight, namely: ***

COASt ANd GeOdetic Survey: * * * For any special surveys * * * including expenses of surveys in aid cf the shellfish commission of the State of Maryland, to be immediately available and to continue available until expended, twenty-five thousand dollars. * * *

[Act of Congress approved May 27, 1908.]

AN ACT Making appropriations for sundry civil expenses of the Government for the fiscal year ending June thirtieth, nineteen hundred and nine, and for other purposes.

Be it enacted by the Senate and House of Representatives of the United States of America in Congress assembled, That the following sums be, and the same are hereby, appropriated, for the objects hereinafter expressed, for the fiscal year ending June thirtieth, nineteen hundred and nine, namely: * * *

COAST AND GEOdETIC SURvEY: * * * For any special surveys * * * including expenses of surveys in aid of the shellfish commission of the State of Maryland, which expenses, including cost of plats and charts, shall not exceed fifteen thousand dollars in any one year, to be immediately available, twenty thousand dollars.

[Act of Congress approved March 4, 1909.]

AN ACT Making appropriations for sundry civil expenses of the Government for the fiscal year ending June thirtieth. nineteen hundred and ten, and for other purposes.

Be it cnacted by the Senate and House of Representatives of the United States of America in Congress assembled, That the following sums be, and the same are hereby, appropriated, for the objects hereinafter expressed, for the fiscal year ending June thirtieth, nineteen hundred and ten, namely: $* * *$

COAST AnD GeOdetic Survex: * * * For any special surveys * * * including expenses of surveys in aid of the shellish commission of the State of Maryland, which expenses, including cost of plats and charts, shall not exceed fifteen thousand dollars in any one year, to be immediately available, twenty thousand dollars.

[Act of the legislature of Maryland approved April 2, 1906.]

AN ACT To establish and promote the industry of oyster culture in Maryland, to define and mark natural oyster beds. bars and rocks lying under the waters of this State, to prescribe penalties for the infringement of the provisions of this Act, and *** *

Section I. Be it enacted by the General Assembly of Maryland, That the following sections be, and they are hereby, added to Article 72 of the Code of Public General Laws, title "Oysters," * * *

SEC. 86. The Board of Shell Fish Commissioners shall, as soon as practicable after the passage of this Act, cause to be made a true and accurate survey of the natural oyster beds, bars and rocks of this State, said survey to be made with reference to fixed and permanent objects on the shore, giving courses and distances, to be fully described and set out in a written report of said survey, as hereinafter required. A true and accurate delineation of the same shall be made on copies of published maps and 
charts of the United States coast and geodetic survey, which said copies shall be filed in the office of the said commissioners in the city of Annapolis; and the said commissioners shall further cause to be delineated upon copies of the published maps and charts of the United States coast and geodetic survey, of the largest scale, one copy for each of the counties of this State in the waters of which there are natural oyster beds, bars and rocks, all natural beds, bars and rocks lying within the waters of such county, which maps shall be filed in the offices of the clerks of the Circuit Court for the respective counties wherein the grounds so designated may lie. ***

SEC. 87. The Governor of this State is hereby requested to ask the assistance of the United States coast and geodetic survey, and of the United States Fish Commissioner, to aid in the carrying out of the provisions of the preceding section.

SEc. 89. As soon as practicable after the first day of April, 1906, the said commissioners shall organize, and shall at once proceed, with the assistance of such person or persons as may be detailed by the United States coast and geodetic survey, and the United States Fish Commissioner, to aid them in their work, and of such persons as may be appointed under the preceding section, to have laid out, surveyed and designated on the said charts, the natural beds and bars, and shall cause to be narked and defined as accurately as practicable, the limits and boundaries of the natural beds, bars and rocks, as established by said survey, and they shall take true and accurate notes of said survey in writing, and make an accurate report of said survey, setting forth such a description of landmarks as may be necessary to enable the said board, or their successors, to find and ascertain the boundary lines of the said natural oyster heds, bars and rocks, as shown by a delineation on the maps and charts provided in this Act; said report shall be completed and filed in the office of the board in the city of Annapolis within ninety days after the completion of the survey of any county. Said commissioners slall cause the same to be published in pamphlet form, and transmit copies of the same to the clerks of the Circuit Court for the respective counties, where the charts have been filed or directed to be filed as hereinafter provided; the said report to be filed by the clerks of the several counties in a book kept for that purpose. And the said survey and report, when filed, subject to the right of appeal hereafter provided for in this Act, shall be taken in all of the courts of this State as conclusive evidence of the boundaries and limits of all natural oyster beds, bars and rocks, lying within the waters of the county wherein such survey and report are filed, and shall be construed to mean in all of the said courts that there are no natural oyster beds, hars or rocks lying within the waters of the counties wherein such report and survey are filed other than those embraced in the survey authorized by this Act, and that all areas of the Chesapeake Bay and its tributaries within the State of Maryland, not shown in the survey to be natural oyster beds, bars or rocks shall be construed in all the courts of the State to be barren bottoms, and open for disposal by the State for the purpose of private planting or propagation of oysters thereon under the provisions of this Act; provided, that the said survey and report shall not be construed as to affect in any manner the holdings by citizens of this State in any lot which may have been appropriated or taken up under the laws of this State prior to the approval of this Act

The law of the State of Maryland, passed March 9, I842, authorizing officers of the United States Coast and Geodetic Survey to enter upon the lands within the State limits for the purposes of the Survey, is as follows:

AN ACT Concerning the Survey of the Coast of Maryland.

SECTION 1. Be it enacted by the General Assembly of Maryland, That it shall and may be lawful for any person or persons employed under and by virtue of an act of the Congress of the United States, * * * at any time hereafter to enter upon lands within this State for the purpose of exploring, surveying, triangulating, or levelling, or doing any other matter or thing which may be necessary to effect the objects of said act, and to erect any works, stations, buildings, or appendages requisite for that purpose, doing no unnecessary injury to private or other property.

SEc. 2. ${ }^{a}$ And be it enacted, That in case the person or persons employed under the act of Congress aforesaid, can not agree with the owners or possessors of the land so entered upon and used as to the

$a$ Under the rulings of the Comptroller of the Treasury no damages can be collected except through the United States Court of Claims unless an agreement bas been made in advance. 
amount of damage done thereto by reason of the removal of fences, cutting of trees or injury to the crop or crops growing on the same, it shall and may be lawful for the said parties or either of them to apply to the chief justice for the time being or one of the associate judges of the judicial district in which such land may be situated, who shall thereupon appoint three disinterested and judicious freeholders, residents of the same judicial district, to proceed with as much despatch as possible to the examination of the matter in question, and the faithful assessment of the damages sustained by the owners or possessors aforesaid, and the said freeholders or a majority of them, having first taken and subscribed an oath or affirmation before the chief or associate justice aforesaid or other person duly authorized to administer the same, that they will well and truly examine and assess as aforesaid, and having given five days' notice to both parties of the time of their meeting, shall proceed to the spot, and then and there upon their own view and if required, upon the evidence of witnesses, (to be by them sworn or affirmed and examined) shall assess the said damages, and shall afterward make report thereof and of their proceedings in writing under their hands and seals and file the same within five days thereafter in the office of the clerk of the county in which the land aforesaid is situated, subject to an appeal by either party to the county court of the said county within ten days after filing as aforesaid, and the said report so made as aforesaid if no appeal as aforesaid be taken, shall be held to be final and conclusive as between the said parties, and the amount so assessed and reported shall be paid to the said owners or possessors of the land so damaged within twenty days after the filing of said report, and the said chief or associate justice as aforesaid, shall have authority to tax and allow upon the filing of said report, such costs, fees and expenses to the said freeholders for the performance of their duty as he shall think equitable and just, which allowance shall be paid by the person or persons employed under the act of congress aforesaid, within the time last above limited, but if an appeal as aforesaid be taken, the case shall be set down for hearing at the first term of county court aforesaid; ensuing upon and after appeal, and it shall be lawful for either party immediately after the entry of such appeal, to take out summons for such witnesses as may be necessary to be examined upon the hearing aforesaid, and the said court shall have power in its discretion to award costs against which ever the final judgment shall be entered, and such appeal at the option of either party may and shall be heard before and the damage assessed by a jury of twelve men to be taken from the regular panel and elected as in other cases.

SEC. 3. And be it enacted, That if any person or persons shall wilfully injure or deface or remove any signal, monument or building or any appendage thereto, erected, used or constructed under and by virtue of the act of congress aforesaid, such person or persons so offending shall severally forfeit and pay the sum of fifty dollars with costs of suit to be sued for and recovered by any person who shall first prosecute the same before any justice of the peace of the county where the person so offending may reside, and shall also be liable to pay the amount of damages thereby sustained, to be recovered with costs of suit in an action on the case, in the name and for the use of the United States of America, in any court of competent jurisdiction.

\section{APPENDIX B.-THE HAMAN OYSTER CULTURE I,AW.}

[Extract from Second Report of Shell Fish Commission.]

OBJECT.

"The legislature in placing chapter 711 of the acts of 1906 , better known as the Haman Oyster Culture Law, upon the statute books of Maryland had a twofold object in view:

I. To encourage an industry in oyster culture upon the barren bottoms beneath the tidewaters of the State.

2. To prevent the leasing of natural oyster bars for the purpose of oyster culture."

\section{SURVEY.}

"To make the leasing of barren bottoms possible and the leasing of natural bars impossible, provision was made for a survey of the natural bars for the purpose of accurately locating and marking the same. It was definitely provided that no barren bottoms should be leased in any part of the State until the natural bars of that region had been surveyed, charted, and marked with buoys." 
Definition of a Natural OYster Bar.

NATURAL BAR NOT DEFINED.

"The Shell Fish Commission is instructed by section go of the Haman Oyster Culture Law to exercise its judgment liberally in favor of the natural bars when surveying, charting and buoying them, but other than this the Commission is uninstructed in this important matter. The responsibility of defining a natural bar is placed upon the Commission."

\section{DIVERSITY OF OPINION.}

"No definition of a natural oyster bar could be formulated by any man or body of men which would meet with the approval of all parties concerned. Oystermen, as a rule, hold that all bottoms where oysters grow or have grown naturally even though now practically barren of oysters should be considered natural bars. Other citizens of the State who are not directly interested in the oyster business, but interested in the oyster industry from the standpoint of revenue, hold, as a rule, that no bottoms should be excluded from leasing for oyster culture which, by methods known to oyster culturists, may be made to yield a greater number of oysters than they now produce."

"It should be evident to every one that neither of these definitions could be adopted by the Commission as a working basis for determining which of the grounds surveyed are natural oyster bars."

\section{THE GOLDSBOROUGH DEFINITION.}

The definition of a natural oyster bar which very nearly approaches a reasonable and satisfactory compromise between the views of the subject held by oystermen on one hand and by oyster culturists on the other is that contained in an opinion rendered by Judge Charles F. Goldsborough in the circuit court for Dorchester County in the July term, $188 \mathrm{I}$, in the case of William T. Windsor and George R. Todd $v$. Job T. Moore.

This definition has been adopted by the Shell Fish Commission as the basis for the determination of the status of the various oyster bottoms surveyed and is as follows:

What then is a natural bar or bed of oysters? It would be a palpable absurdity for the State to attempt to promote the propagation and growth of oysters and to encourage its citizens, by a grant of land, to engage in their culture, if the lands authorized to be taken up were only those upon which oysters do not and can not be made to grow. That there may be lands covered by water in the State where no oysters can be found, but where, if planted, they could be cultivated successfully, may be possible, but, if so, I imagine that their extent must be too limited for them to be of much practical, general advantage for the purposes of such a law as the one under discussion; but there are thousands of acres of hard and shifting sands where oysters not only are not found, but where it would be folly to plant them; and these latter it can not be supposed that the State intended to offer to give away, for the simple reason that the State could not help knowing that nobody would have them.

Upon the other hand there are large and numerous iracts where oysters of natural growth may be found in moderate numbers, but not in quantities sufficient to make it profitable to catch them, and yet where oysters may be successfully planted and propagated. In my opinion these can not be called natural bars or beds of oysters, within the meaning of the Act of Assembly, and it is just such larids as these that the State meant to allow to be taken up under the provisions of the above-mentioned section of the Act.

But there is still another class of lands where oysters grow naturally and in large quantities and to which the public are now and have been for many years in the habit of resorting with a view to earning a livelihood by catching this natural growth, and here, I think, is the true test of the whole question. Land can not be said to be a natural oyster bar or bed merely because oysters are scattered here and there upon it, and because if planted they will readily live and thrive there; but whenever the natural growth is so thick and abundant that the public resort to it for a livelihood, it is a natural oyster bar or bed and comes within the above-quoted restriction in the law, and can not be located or appropriated by any individual.

\footnotetext{
APPI.ICATION OF DEFINITION.
}

Before this definition may be of use in determining, accurately and scientifically, the status of an oyster ground, its central idea, "livelihood," must be expanded into accurately determinable factors, and these factors must be combined into a practical scheme of investigating the condition of the ground under consideration.

Stated briefly, a livelinood is represented by a sum of money obtained from the sale, at a fixed price, of a certain quantity of oystcrs gathered in a given time from an allotted area of ground. 
Knowing the value of each of these factors it becomes possible to calculate the number of oysters an oyster ground must produce per square yard in order that oystermen may secure a livelihood by working upon it.

NOTE.-The factors into which the Commission resolved the livelihood problem, the value assigned to each factor, and the scheme devised for practical use in examining and applying the definition to oyster bottoms are given in outline in their Second Report under the heading of the preceding extract, and in detail in their First Report on pages 32 to 69.

\section{APPENDIX C.-SUMMARY OF THE PARTICULAR SURVEYING OPERATIONS IVHICH CON- STITUTE AN "OYSTER SURVEY" AS NOW BEING CARRIED ON IN MARYIAAND.}

Explanation.-A brief account of the particular surveying operations which constitute an "oyster survey" as now being carried on in Maryland will assist in the interpretation of records contained in the technical part of this report, and will be of interest to many who may not understand the necessity for the great amount of work being done or its complicated character.

To those familiar with methods used in surveying and charting the characteristic features of large bodies of water there is an evident necessity for the various operations performed, especially when it is known that the boundaries of the public oyster bars and of the private lots leased for purposes of oyster culture must be surveyed and charted with the greatest practical accuracy. To others it will be sufficient to state that the actual experience gained from oyster surveys in other States has proven that in order to avoid endless dissatisfaction and litigation it is necessary to accurately locate and permanently establish oyster boundaries as is now being done in Maryland.

Trianqulation survey.-Such refinement of survey work as that demanded by the conditions of an oyster survey when carried on at considerable distances offshore can only be obtained by the use of a system of triangulation as a frame work or foundation. Therefore, a triangulation survey including the permanent marking of the positions of landmarks with monuments and a record of the descriptions of their locations for future recovery is a necessary operation of a complete oyster survey.

Topographic survey. - The technical records which establish the relation between the offshore oyster boundaries and triangulation landmarks are sufficient for the requirements of engineers in making resurveys, but do not supply the needs of others who are interested in the same boundaries by reason of their occupation as oystermen concerned as to the public oyster bars, or oyster culturists concerned as to the leasable bottoms. For these it is necessary to have the charts of the survey show the relation of the shore line and other topographic features to the boundaries of the public oyster bars and private oyster farms. Therefore, a topographic survey is a necessary operation of a complete oyster survey.

Hydrographic survey.-In the settlement of the important question of what is, or what is not, a natural oyster bar, and in the consideration of bottoms to be selected for purposes of oyster culture, information as to the depth of water and the character of the bottom is required. Therefore, a hydrographic survey is a necessary operation of a complete oyster survey.

Necessary foundation for an oyster survey. - Consequently, the necessary components of a satisfactory foundation for a complete oyster survey are the three classes of survey operations technically named triangulation, topography, and hydrography, or, stated in another way, the foundation of a practical oyster survey includes the surveying operations usually followed by the Coast and Geodetic Survey leading up to the preparation and publication of natitical charts.

Special surveys and investigations pertaining to oysters.-Having obtained this cartographic survey fot a foundation, partly by new work and partly from records of previous work of the Government, the combined operations $a$ making up an "oyster survey" are completed by superimposing on this foundation special surveys and investigations pertaining particularly to oysters or other shell fish.

The special surveys pertaining to oysters furnish information as to the location and outline of oyster-sheil bottoms, and are carried on by the sounding boat party in addition to the usual hydrographic work. $b$ This operation consists of the observation and record of the character of vibration of a wire and chain apparatus which is dragged over the bottom, the vibrations or lack of vibrations indicating the presence and quantity of shells or absence of shells.

$a$ See Appendix D of this publication for "Statistics of results of combined operations of the Government and State."

$b$ See pages 104 to $x 23$ of "First Annual Report of Maryland Shell Fisb Commission." 
The special oyster investigations $a$ consist of the actual determination of the kind and quantity of oysters on the bottom, and such economic and biological studies of the supply of oyster food, density of water, character of the bottom, and other important matters as affect the growth of oysters. In this work the oyster investigation stations are located and buoyed by the hydrographic party while engaged in the survey of the oyster-shell limits. They are selected with the view of obtaining characteristic data which can be used for the interpretation of the recorded vibrations of the chain apparatus at all other points covered by the survey.

Preparation of results. - The actual surveying operations and oyster investigations having been completed for any one county, there still remains technical work of nearly equal magnitude to that described. $b$ This work consists of the preparation of charts and technical descriptions of boundaries and landmarks for publication by the Government, the preparation of that part of the annual report of the Commission covering the special oyster surveys and investigations, the making of the leasing sharts and finished projections, and finally the filing of the oyster charts and records with the courts and the Commission, thus opening a county for oyster culture.

Summary.-From the foregoing account it can be seen that a complete oyster survey properly conducted so as to answer all practical requirements of the present and permanency of results for the future is a very complicated affair, involving many lines of surveying and other scientific work, and requiring the professional services of experts in the various operations of cartographic surveying and shell-fish investigations.

a See pages 30 to 67 and 129 to 199 of "First Annual Report of Maryland Shell Fish Commission."

$b$ No mention is made here of the large amount of administrative work of the Commission, which is greatly complicated and increased by the effect of the oyster-survey operations on many thousands of people whose interests are more or less involved; or of the large amount of survey work involved in the survey and record of the boundaries of oyster lots leased from the State by private individuals for the purposes of oyster culture. 


\section{APPENDIX D.-STATISTICS OF RESULTS OF THE COMBINED OYSTER SURVEY OPERATIONS OF THE GOVERNMENT AND STATE.a}

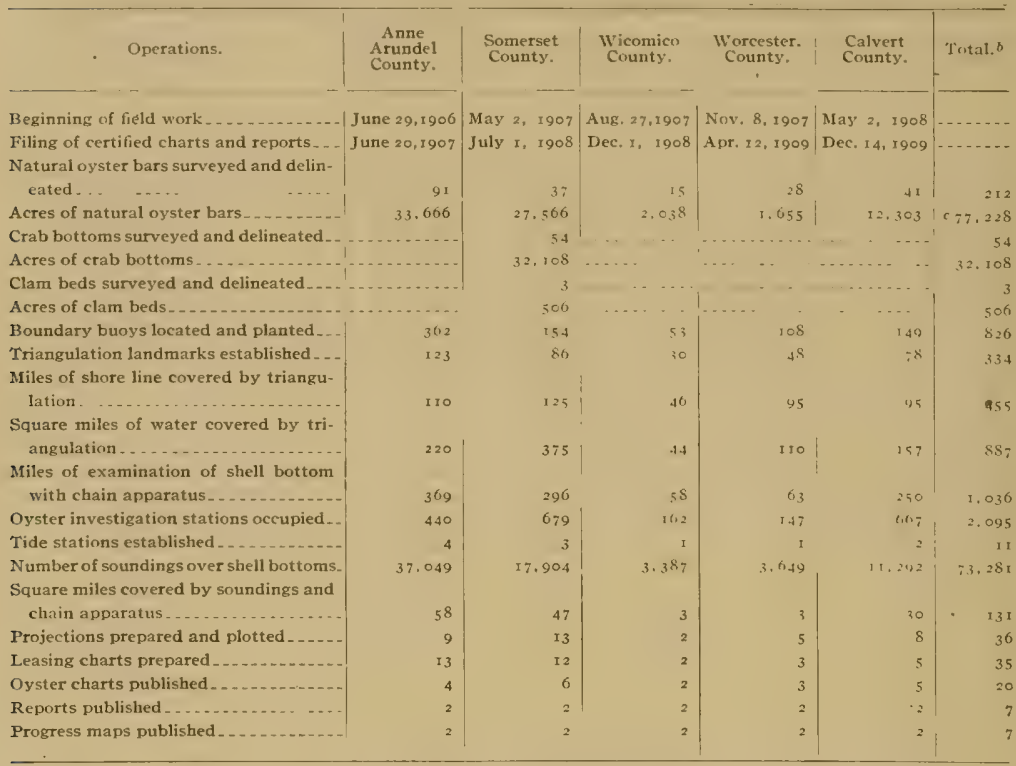

a These statistics do not include the large amount of triangulation, topograpby, and hydrography resultiag from previous work of the Coast and Geodetic Survey, which was utilized in the preparation of the published oyster charts and records. Work in St. Marys and Charles counties has been finished, but fual statistics of results will not be published until these counties are opened for oyster culture.

$b$ Less quantities covered by statistics of more than one county.

c Total area of natural oyster bats of Connecticut is 5,770 acres. 


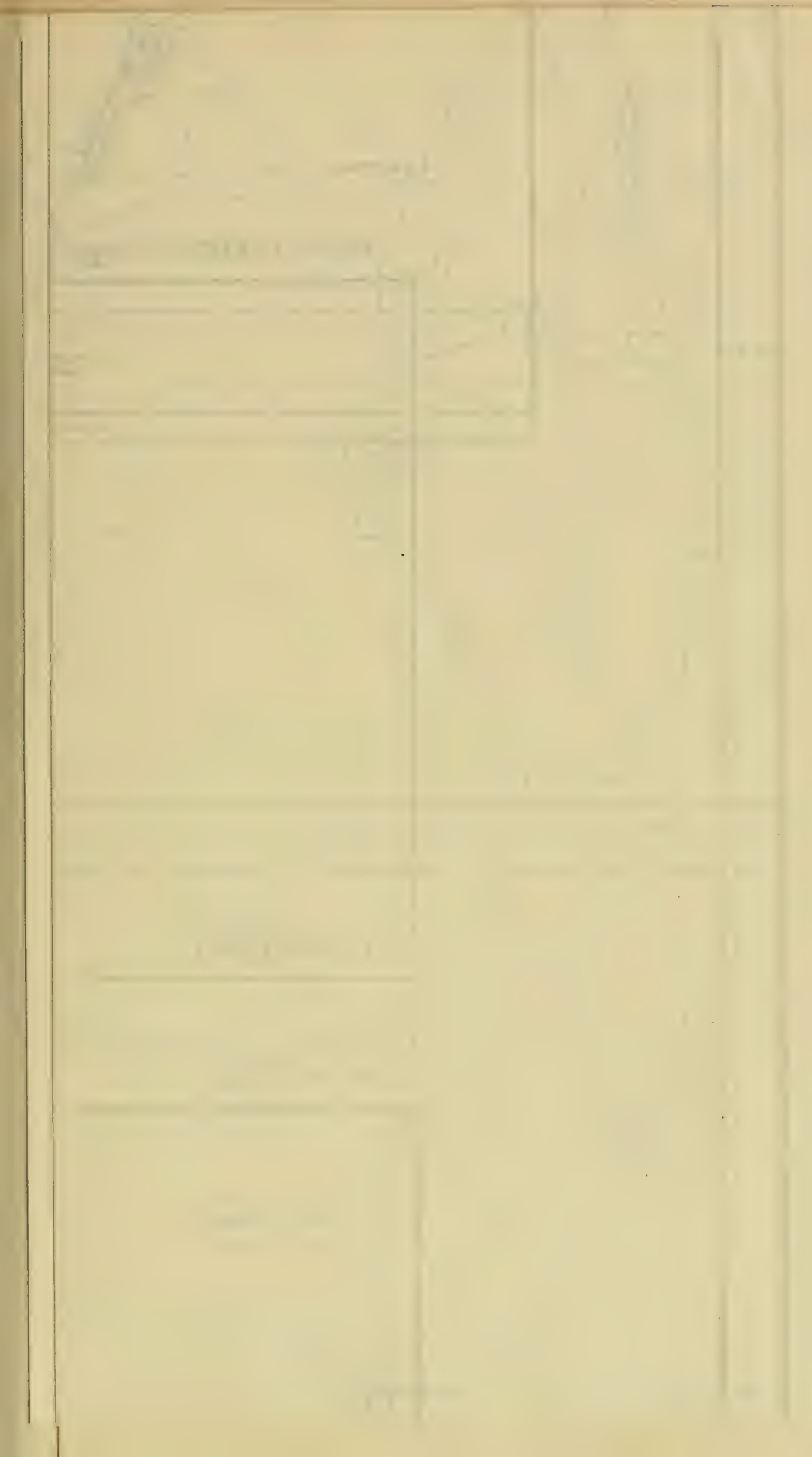





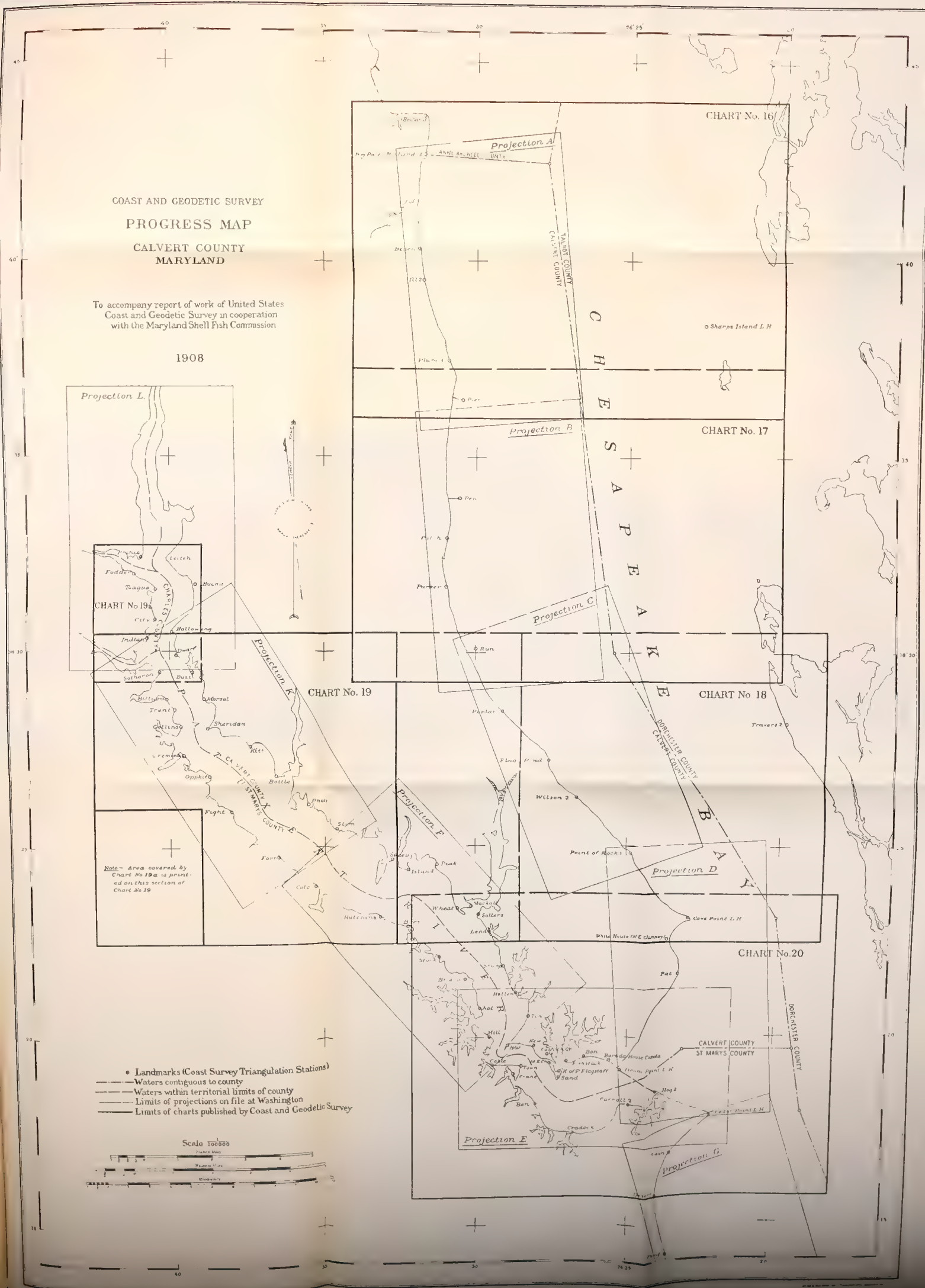




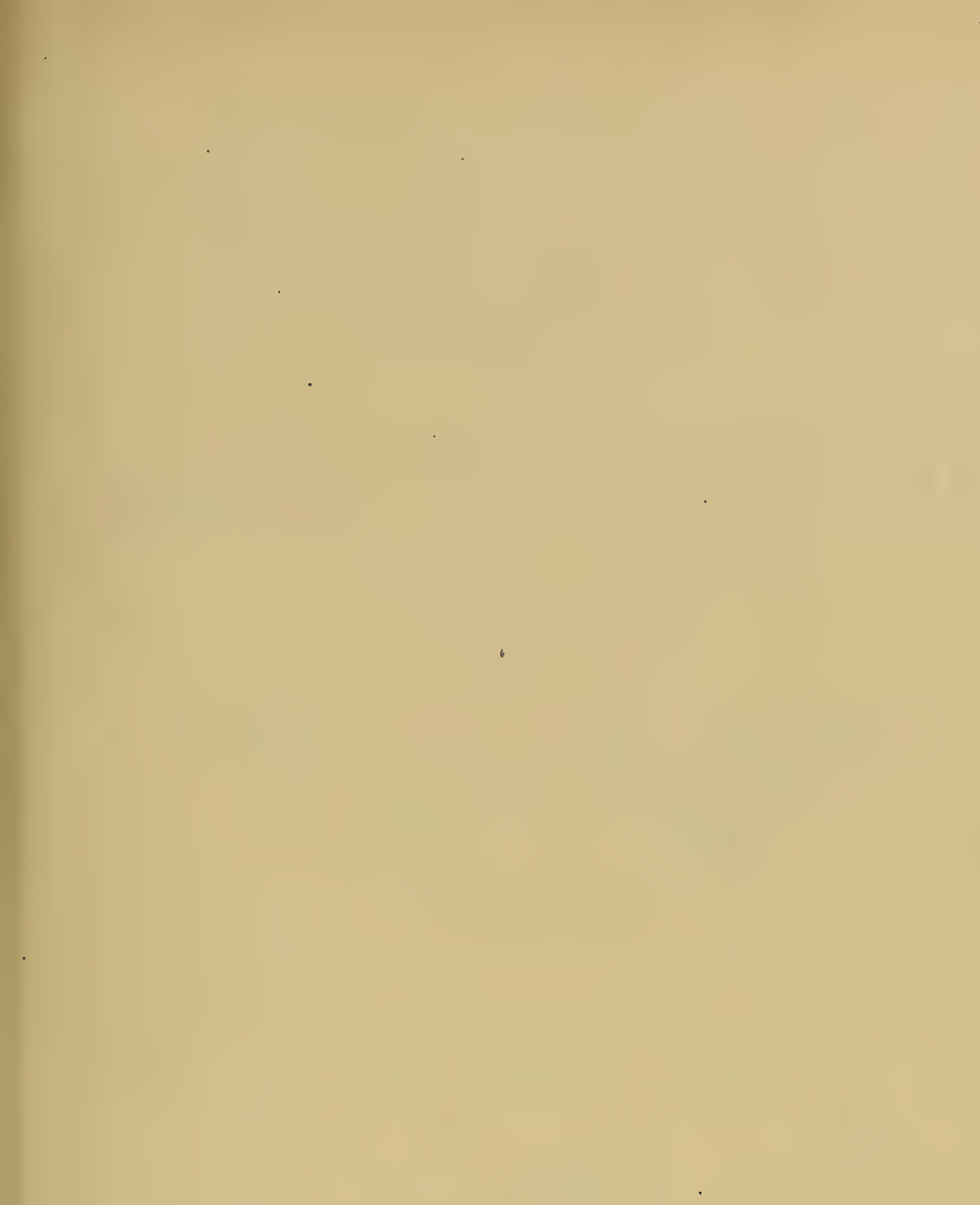



\title{
DEPARTMENT OF COMMERCE AND LABOR
}

COAST AND GEODETIC SURVEY

O. H. TITTMANN, Superintendent

\section{SURVEY OF OYSTER BARS}

\section{CHARLES COUNTY \\ MARYLAND}

\author{
DESCRIPTION OF BOUNDARIES AND LANDMARKS AND \\ REPORT OF WORK OF UNITED STATES COAST \\ AND GEODETIC SURVEY IN COOPERATION \\ WITH UNITED STATES BUREAU OF \\ FISHERIES AND MARYLAND \\ SHELL FISH COMMISSION
}

$$
\text { By C. C. YATES }
$$

CHIEF OF COAST AND GEODETIC SURVEY PARTY ASSISTANT, COAST AND GEODETIC SURVEY

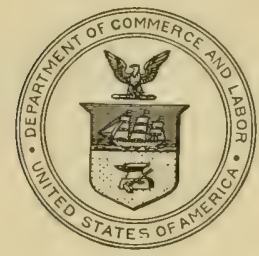

WASHINGTON

GOVERNMENT PRINTING OFFICE.

1911 



\title{
LE'T'TER OF SUBMI'T'TAL.
}

\author{
DEPARTMENT OF COMMERCE AND LABOR, \\ Coast and Geodetic Survey, \\ Washington, January 27, I9II.
}

SIR: I have the honor to transmit herewith a report of the officer detailed from the Coast and Geodetic Survey to cooperate with the Bureau of Fisheries and the Maryland Shell Fish Commission in surveying the oyster bars of the State of Maryland, together with certain technical results which are necessary for the interpretation and use of the plats of the survey made by the Government.

- This work has been done under the provisions of the act of Congress entitled "An act to authorize the Secretary of Commerce and Iabor to cooperate, through the Bureau of the Coast and Geodetic Survey and the Bureau of Fisheries, with the shell fish commissioners of the State of Maryland in making surveys of the natural oyster beds, bars, and rocks in the waters within the State of Maryland," approved May 26, I906, and of the acts of Congress making appropriations for sundry civil expenses of the Government for the fiscal years ending June 30, 1907, 1908; 1909, and 1910 .

Respectfuily,

To Hon. CharLes NAGFL,

O. H. Titrmann, Superintendent.

Secretary of Commerce and Labor. 



\section{E R TIFICA TION.}

BALTIMORE, MD, January 25, rgrt.

The following publication is certified to contain correct technical descriptions of all houndaries and landmarks established in Charles County by the Maryland Shell Fish Commission in cooperation with the United States Coast and Geodetic Survey.

$$
\text { C. C. YATES, }
$$

Chief of Coast and Geodetic Survey Party,

A ssistant, Coast and Geodetic Survey.

Examined and certified to be correct.

BAL,TIMORE, MD., January' 25, I9IT.

$$
\begin{aligned}
& \text { WALTER J. Mitcheli, } \\
& \text { Caswell Grave; } \\
& \text { Beinjamin K. GReEn, } \\
& \text { Maryland Shell Fish Commission. } \\
& \text { SWEPSON EARLE, } \\
& \text { Hydrographic Engineer. }
\end{aligned}
$$

NoTE.-Certified copies of this publication and of the charts of the natural oyster bars of Charles County were filed in the office of the clerk of the circuit court of Charles County and in the office of the Board of Shell Fish Commissioners on January 27, I 911. 



\section{CONTENTS.}

Page.

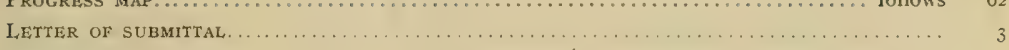

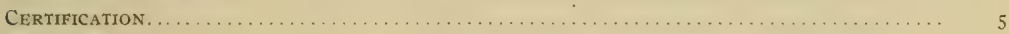

INTRODUCTION:

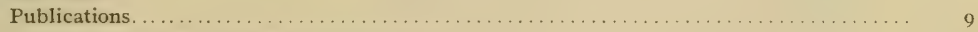

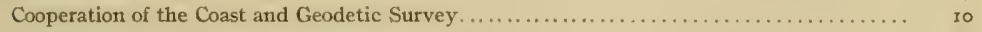

Cooperation of the Bureau of Fisheries. . . . . . . . . . . . . . .

General statement of work of Coast and Geodetic Survey $\ldots \ldots \ldots \ldots \ldots \ldots \ldots \ldots \ldots \ldots$ Io

REPORT OF THE WORK OF THE COAST AND GEODETIC SURVEY:

Instructions. . . . . . . . . . . . . . .

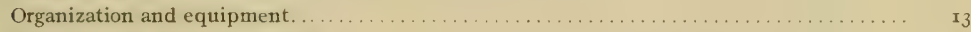

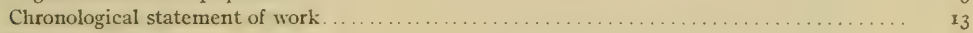

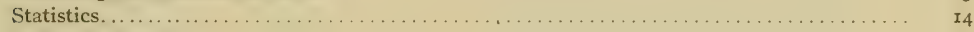

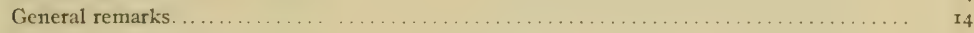

ChARTS AND MAPS:

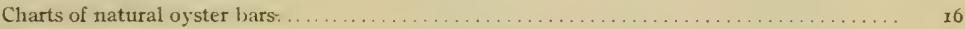

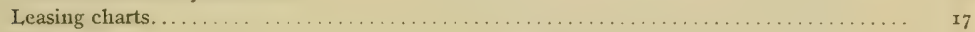

Projections. . . . . . . . . . . . .

Progress maps. . . . . . . . . . . . . . . .

BOUNDARIES OF THE COUNTY WATERS:

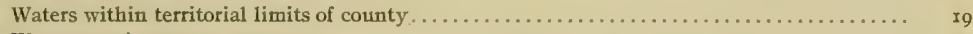

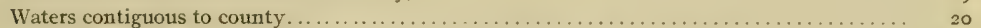

LAandmarks (U. S. CoAst and GeOdetic Survey triangulation stations):

Explanation.

Descriptions of triangulation stations in county and adjacent watersChart No. 26 (Wicomico River)-

Barber.

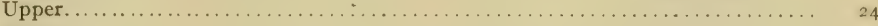

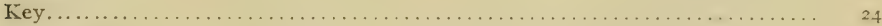

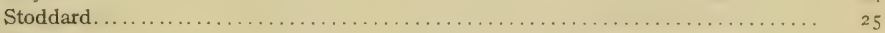

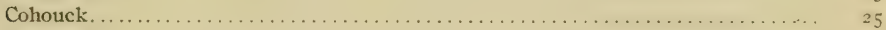

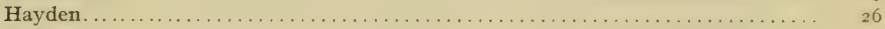

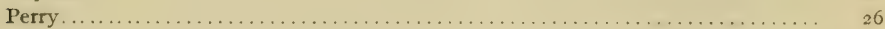

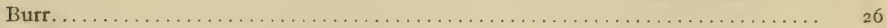

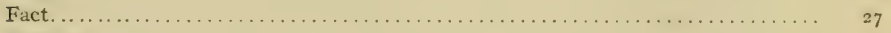

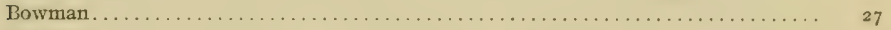

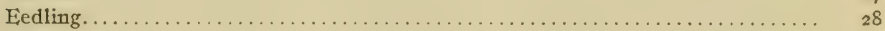

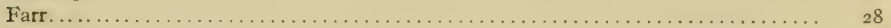

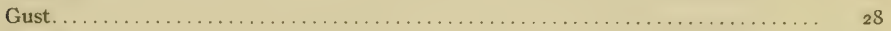

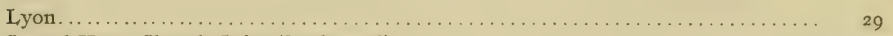

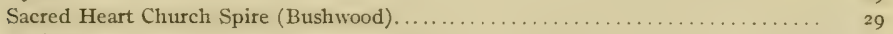

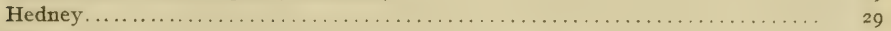

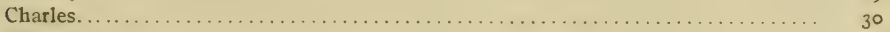

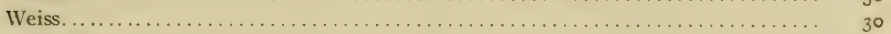

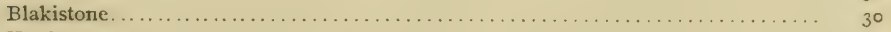

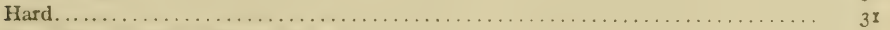

Rock Point Catholic Church Cross....................... 3 I

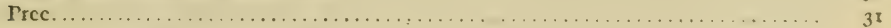


LANDMARKS (U. S. COAST AND GEODETIC SURVEY TRIANGULATION STATIONS)-Continued. Descriptions of triangulation stations in county and adjacent waters-Continued. Chart No. 26 (Wicomico River)-Continued.

Corner

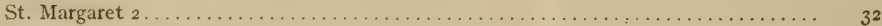

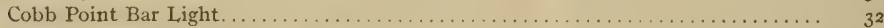

River Springs Catholic Chapel Cross. ......................... 33

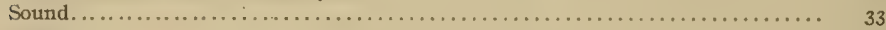

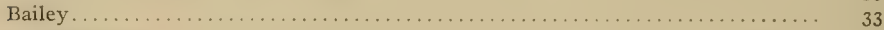

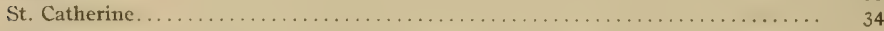

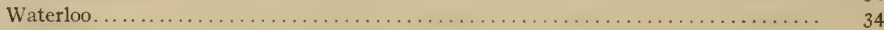

Subchart on Chart No. 26 (Patuxent River) ${ }^{\alpha}$

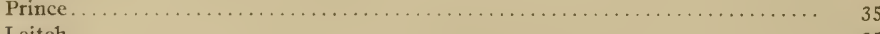

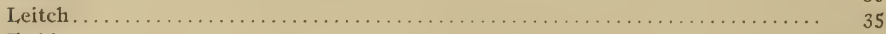

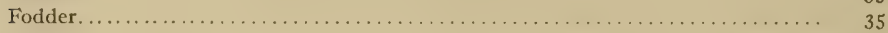

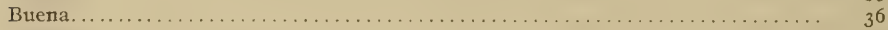

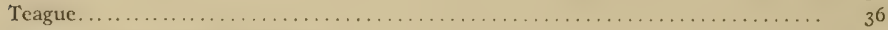

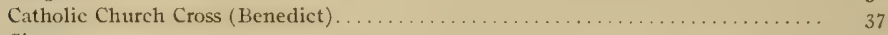

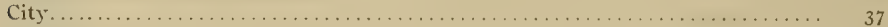

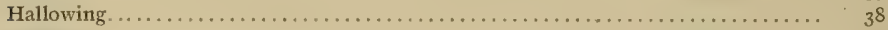

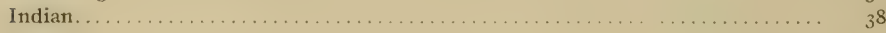

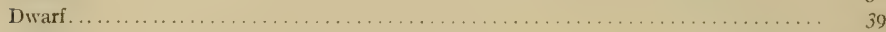

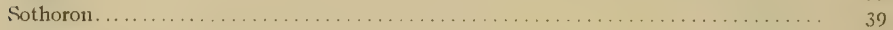

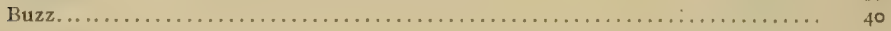

BOUNDARIES OF OYSTER BARS:
Explanation $\ldots \ldots \ldots \ldots \ldots \ldots \ldots \ldots \ldots \ldots \ldots \ldots \ldots \ldots \ldots \ldots \ldots \ldots \ldots \ldots \ldots$

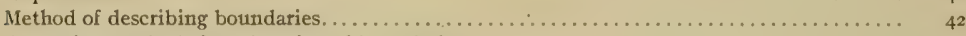

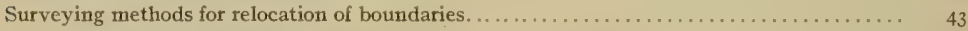

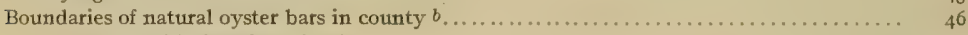

Chart No. 26 (Wicomico River) -

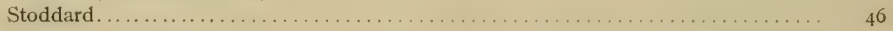

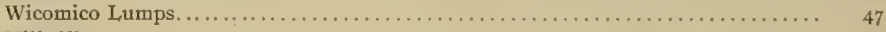

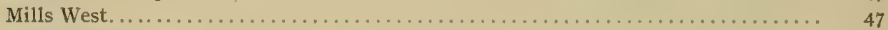

Joes Lumps. . . . . . . . . . . . . . . . . . . . . .

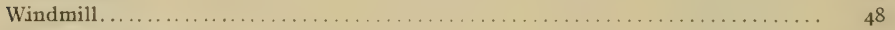

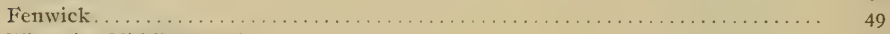

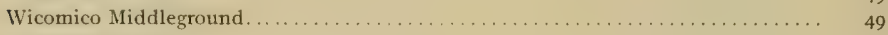

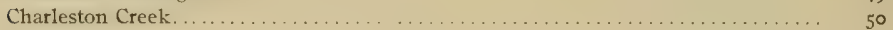

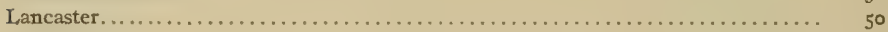

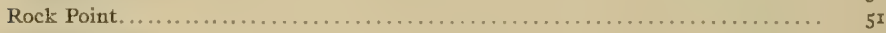

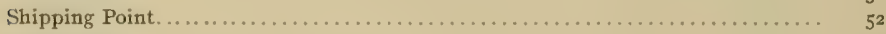

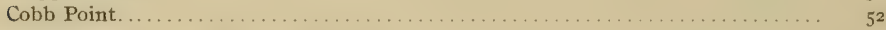

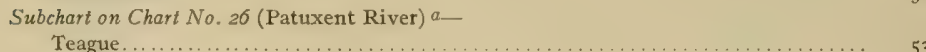

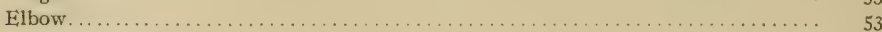

Carpenters Yard . . . . . . . . . . . . . . . . .

APPENDIXES:

Appendix A.-Laws relating to the cooperation of the Coast and Geodetic Survey and

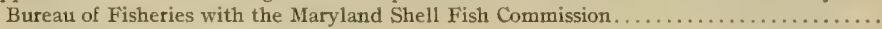

Appendix B.- "The Haman Oyster Culture Law" (extract from Second Report of Shell Fish Commission)

Appendix C.-Summary of the particular surveying operations which constitute an "oyster survey" as now being carried on in Maryland.

Appendix D.-Statistics of results of the combined operations of the Government and State.. 


\section{SURVEY OF OYSTER BARS, CHARLES COUNTY, MD.}

\section{INTRODUCTION.}

PUBLICATIONS.

The preparation of publications relating to the survey of the oyster bars of Maryland has been divided between the Government and the State in accordance with the laws ${ }^{a}$ authorizing the work and the natural division of the surveying operations ${ }^{b}$ of the cooperating forces.

The publications prepared and issued by the Government under the direction of the Superintendent of the Coast and Geodetic Survey consist of a series of charts and a technical report for each county surveyed. ${ }^{c}$ The charts show all legal boundaries of orster bars within the adopted boundaries of the waters opened up for leasing with each county, and the location of all landmarks (Coast and Geodetic Survey triangulation stations) used as a foundation for the delineation of these various boundaries. The technical report gives technical and legal descriptions of all oyster bar and other boundaries, and descriptions of all landmarks shown on the charts, and includes the report of the representative of the Coast and Geodetic Survey in charge of the work of that service in cooperation with the Bureau of Fisheries and the Maryland Shell Fish Commission. These charts and technical reports are prepared and certified for file with the courts and the Commission, as required by the laws of the State, and contain all information necessary to make a permanent record of the work of the Commission and the Government for all future requirements of the courts, or for any resurveys that may become necessary. ${ }^{d}$

The publications prepared and issued by the State under the direction of the Shell Fish Commission consist of annual reports ${ }^{e}$ of all the operations of the Commission

a See Appendix A for laws relating to the cooperation of the Coast and Geodetic Survey and Bureau of Fisheries with the Maryland Shell Fish Commission.

$b$ See Appendix C for a summary of the particular surveying operations which constitute an "oyster survey" as now being carried on in Maryland.

$c$ These charts and technical reports can be obtained by application to the Superintendent of the Coast and Geodetic Survey at Washington, D. C. The publications now ready for issue are those for Anne Arundel, Somerset, Wicomico, Worcester, Calvert, and Charles counties.

$d$ The technical records and charts for each county are published separately on account of the requirements of the oyster-culture laws of the State and the practical considerations which make it desirable to have each county "opened up" for oyster culture as soon as practicable after the completion of its survey. For these reasons and the fact that these reports are each arranged for distribution and use in one county only without reference to other published records, much of the text of this publication is of necessity identical with similar previous publications for other counties.

$e$ These reports can be obtained by application to the Shell Fish Commission, Marine Bank Building, Baltimore, Md. They are issued annually in October, and the first and second reports are now available for distribution. 
performed under the provisions of the laws of Maryland, ${ }^{a}$ including results of biolngical and economic oyster investigations, methods and results of the hydrographic survey of the boundaries of oyster bars and crab bottoms, the administrative report and financial statement of the Commission, information relating to oyster culture, methods of surveying and leasing of oyster lots, and much other important matter of legal and scientific value.

These two sets of publications are planned and arranged to supplement each other without unnecessary duplication, and when combined they form a complete report of operations, methods, and results of the work of both the Government and State. ${ }^{b}$

COOPERATION OF THE COAST AND GEODETIC SURVEY.

The work of the Coast and Geodetic Survey, as the name of the service indicates, includes a survey of the coasts of the United States made on a geodetic basis. This has involved the gradual construction of a great framework of interstate triangulation for use as a foundation for detail hydrographic and topographic surveys, from which there has been compiled and published a complete set of charts of the coasts of the United States, including all waters of Maryland where oysters grow. This existing triangulation, hydrography, and topography is essential as a foundation for a correct and practical survey of natural oyster bars; and it being one of the fundamental functions of the Coast and Geodetic Survey to furnish such data, the cooperation of the Coast and Geodetic Survey with the Bureau of Fisheries and the Maryland Shell Fish Commission is a practical and natural development of Government work leading to the conservation and increase of the supply of food.

\section{COOPERATION OF THE BUREAU OF FISHERIES.}

The Bureau of Fisheries has cooperated with the Coast and Geodetic Survey and the Maryland Shell Fish Commission principally as an adviser in matters relating to the biological and economic survey of oyster bars and the methods to be employed for that purpose. ${ }^{c}$ A steam launch, rowing boat, and certain apparatus have also been furnished.

The primary function of the Bureau of Fisheries is to increase the productiveness of marine and fresh waters by such measures as may be best suited to the purpose, and the services rendered in connection with the survey of the oyster bars of Maryland are strictly in line with the fundamental law under which it acts. In certain States other than Maryland similar work has been conducted by the Bureau acting independently, the same ends being attained at greater expense to the Government.

GENERAL, STATEMENT OF WORK OF COAST AND GEODETIC SURVEX. ${ }^{d}$

The results obtained from the work of the Coast and Geodetic Survey in cooperation with the Bureau of Fisheries and the Maryland Shell Fish Commission need very

a See Appendix B for an extract from the "Second Report of the Maryland Shell Fish Commission," giving a concise summary of the "Haman Oyster Culture Law."

$b$ See Appendix D of this publication for "Statistics of results of combined operations of the. Government and State."

c Hon. George M. Bowers, Commissioner of Fisheries, has detailed for this service Dr. H. F. Moore, Assistant, Bureau of Fisheries.

d For a detail statement of the very large amount of excellent oyster survey work of the Maryland Slicll liish Commission see the "Annual Reports of the Maryland Shell Fish Commission." 
little other summary than is indicated by the published "Charts of Natural Oyster Bars" and the index of hydrographic projections and triangulation stations shown on the county progress maps attached to each report.

The triangulation has been carried on in accordance with the standard methods of the Coast and Geodetic Survey, making this work and that of the "Descriptions of Triangulation Stations" of permanent value, not only to the State of Maryland in the survey of her oyster bars, but also to the Government for any future work it may do in the regions covered by the oyster-survey operations.

The hydrographic projections and published charts are prepared with all the accuracy permitted by their large scale, especially as to the boundaries of the various shell-fish bottoms in relation to landmarks, but this accuracy of location on the charts is further added to and permanently fixed by published technical descriptions which should minimize the probability of any future dispute as to either landmarks or boundaries.

Stated another way, and quoting from the report of the "Survey of Oyster Bars of Anne Arundel County":

The geographic positions of the permanent landmarks and signals have been determined with the usual precision of a trigonometric survey, and their locations at all points necessary to provide ample foundation for the surveying and charting operations permitted great accuracy of definition and location for the natural oyster bar and other boundaries established. At the same time, the very important element of permanency of the positions of boundaries has been secured, as the relocation of geodetic positions can always be accomplished by a competent surveyor, even though the original landmarks and monuments have been washed away, as has been the fate of hundreds of such points established by the Coast and Geodetic Survey on the shores of the Chesapeake Bay during the last $6_{5}$ years. 


\section{REPORT OF THE WORK OF THE COAST AND GEODETIC SURVEY IN CHARLES COUNTY.}

\section{INSTRUCTIONS.}

The following letters, together with the laws ${ }^{a}$ of the United States relating to the subject, constitute the "instructions" received by the chief of the Coast and Geodetic Survey party engaged on work in connection with the Maryland Shell Fish Commission. They are short and definite, but furnish ample authority and leeway for all legitimate development of the cooperation of the Government and the State in the survey of oyster bars. The "free hand" permitted by these orders, together with the aid and many valuahle suggestions received from the officers of the survey at Washington, have proved very beneficial to the work and are greatly appreciated.

\section{DEPARTMENT OF COMMERCE AND LABOR, \\ OFFICE OF THE SECRETARY, Washington, June 2, Igo6.}

SiR: In reply to your letter of May 28 , requesting me to designate officers of the Coast and Geodetic Survey and of the Bureau of Fisheries to cooperate with the State of Maryland in making survey of and locating the natural oyster beds, I have the honor to inform you that Mr. C. C. Yates will be designated to cooperate on the part of the Coast and Geodetic Survey as soon as Congress makes the provisions of the act effective by providing an appropriation for the purpose. Respectfully,

His Excellency Hon. EDWIN WARFIELd, Lawrence O. Murray, Assistant Secretary. Governor of Maryland, Annapolis, Md.

\section{DEPARTMENT OF COMMERCE AND LABOR, Coast and Geodetic Survey, Washington, July 3, I906.}

SIR: Upon the receipt of these instructions you will surrender the command, accounts, etc., of the steamer Endeavor to the Hydrographic Inspector.

As soon as this transfer is completed you will enter upon the duties of Coast Survey representative on the Shell Fish Commission of Maryland.

You will consult the Commissioners, prepare a programme of work, and submit estimates in the usual form.

You are authorized to come to Washington for consultation from time to time as may be necessary.

* Very respectfully,

O. H. TItTmann, Superintendent.

Capt. C. C. YATES,

U. S. C. and G. S. Steamer Endeavor, Baltimore, Md.

a For these laws see Appendix A. 
ORGANIZATION AND EQUIPMENT.

The personnel and occupation of the party of the Coast and fieodetic Survey have remained practically unchanged since the beginning of the "oyster survey." Besides the chief of party, it consists of the necessary triangulators, computers, draftsmen, and temporary employees required to carry on both the surveying operations in the field and the preparation for publication of oyster charts and technical records in the office at Washington.

The equipment for the work of the party has been ample and satisfactory. The large living and office quarters furnished the Government on the Maryland Shell Fish Commission house boat Oyster have been very convenient for the work, besides facilitating efficient cooperation with the surveying and oyster investigation parties of the State. In addition to the accommodations on the Oyster, the Coast and Geodetic Survey party has had the constant use of the large steam launch Inspector and several other boats furnished by its own service, and the occasional use of the Bureau of Fisheries launch Canvasback ${ }^{a}$ and the steamer Governor McLane ${ }^{b}$ of the State fishery force.

The greater part of the equipment of instruments for the operations of both the Government and State has been furnished by the Coast and Geodetic Survey and consists of all necessary theodolites, levels, sextants, drafting instruments, hydrometers, etc., required for all field and office work.

\section{CRONOLOGICAI, STATEMENT OF WORK.}

The field work of the Coast and Geodetic Survey in Charles County ${ }^{\circ}$ dates from August i 8, 1908, when the house boat Oyster was moved from St. Leonards Creek to an anchorage in Battle Creek which is locaterl about 5 miles to the south of that small portion of Charles County bordering on the Patuxent River. The headquarters of the surveying operations remained at this harbor until the completion of that part of the field work which naturally included all of the Patuxent River waters of Calvert and St. Marys counties as well as those of Charles County, although the results are published separately.

On September 3,1908 , the house boat finally left the Patuxent River for a new anchorage in one of the tributaries of Potomac River in St. Marys County, and the field work in Charles County was dropped from that date for a period of nearly two months.

On October 28, 1908, the house boat Oyster was towed by the Governor McLane to an anchorage in the lower part of Wicomico River off Rock Point in Charles County: From this anchorage as a headquarters the surveving operations for the Wicomico waters of both Charles and St. Marys counties were carried on until practically completed on November 25, 1909, when the house boat was towed to Bretons Bay off Leonardtown in St. Marys County.

On December 2, 1909, it was found necessary to obtain additional triangulation information for the publication of the technical report for Calvert County, which inci-

$a$ By courtesy of Dr. H. F. Moore, United States Bureau of Fisheries.

$b$ By courtesy of Capt. James A. Turner, commanding.

c The field work of Charles, Calvert, and St. Marys counties was so intermixed in the Patuxent River that the chronological statement of work for any one of these counties necessarily includes a considerable part of the work of the other counties. 
dentally involved new work required for the report for Charles County, and field work was carried on for that purpose from that date to December 8, I909.

Again from July 20 to August II, I9ro, while the house boat $n y$ ster was anchored in the mouth of the Patuxent River for the purpose of carrying on the oyster survey operations in the bay shore waters of Dorchester County, a number of days when work could not he done in the open bay were employed in checking up deficiencies in the description of stations required for the forthcoming publications of both Charles and St. Marys counties.

The large amount of office work connected with the "oyster survey" of Charles County, including computations and drafting necessary for the preparation for publication of the oyster charts and the technical records, was continued intermittingly with the office work of other counties from the beginning of the field work in Charles County to the time of filing of the certified oyster charts and technical reports in the archives of the Commission and with the clerk of the circuit court of Charles County on January 27, 1911 .

\section{STATISTICS. ${ }^{a}$}

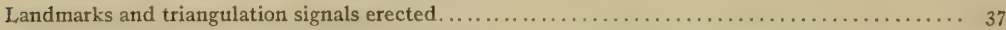

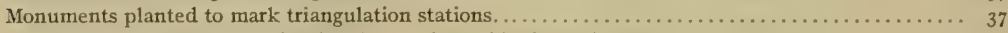

Triangulation stations occupied for observations of horizontal angles $\ldots \ldots \ldots \ldots \ldots \ldots \ldots \ldots \ldots \ldots \ldots \ldots \ldots \ldots \ldots$

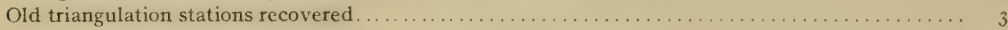

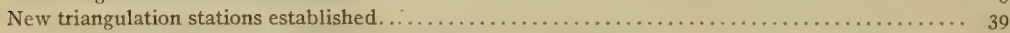

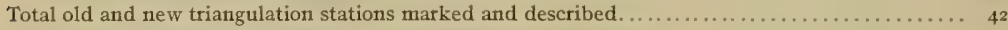

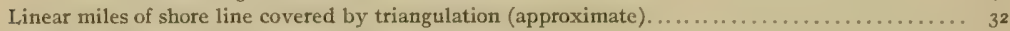

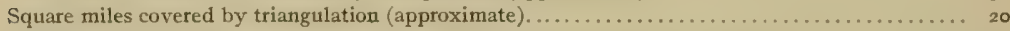

Hydrographic projections prepared and completed as records of oyster boundaries........... 3

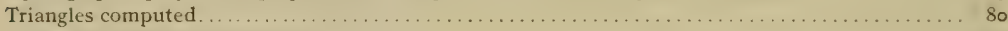

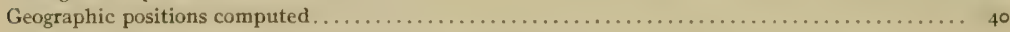

Corners of oyster boundaries established by computation $\ldots \ldots \ldots \ldots \ldots \ldots \ldots \ldots \ldots \ldots \ldots \ldots \ldots \ldots \ldots \ldots \ldots$

Back azimuths and distances computed from corners of boundaries to triangulation stations. ......2234

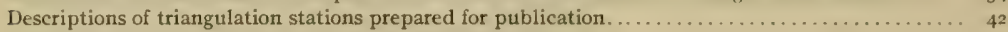

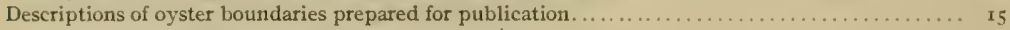

"Charts of Natural Oyster Bars" prepared for publication. ....................... I

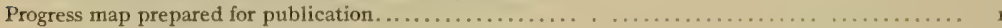

GENERAL REMARKS.

Before ending this report the representative of the Coast and Geodetic Survey wishes to renew his statement of appreciation of the courteous assistance received from various Government and State officials and others interested in the oyster industry of Maryland, especially to the following:

To his colleague from the Department of Commerce and Irabor, Dr. H. F. Moore, of the Bureau of Fisheries, whose well-known scientific knowledge of all matters relating to oysters has been of great value to the work.

a These statistics only include field and office work directly performed by the party of the Coast and Geodetic Survey in connection with the oyster survey of Charies County, and do not include the many thousands of soundings and examinations of the character of the bottom made by the engineers of the Commission, which are of considerable value to the Coast and Geodetic Survey as hydrographic records for future use in connection with the preparation of new editions of charts of the waters of Maryland. See Appendix D of this publication for "Statistics of results of combined operations of the Government and the State." 
To Mr. Walter J. Mitchell, chairman of the Maryland Shell Fish Commission, who, by his administrative ability in carryng out the complicated requirements of the oyster laws and by his unfailing tact, has made the cooperation of the various services engaged on the work both agreeable and effective.

To Dr. Caswell Grave, secretary of the Commission, who, as editor of the Commission's annual report and Commissioner in charge of the biological and economic oyster investigations, has been brought into constant contact with the Government work and aided its operations in every way.

To Mr. Benjamin K. Green, treasurer of the Commission, who has looked after the equipment and commissary of the house boat in such a way as to add greatly to the comfort and convenience of the party of the Coast and Geodetic Survey.

To Mr. Swepson Earle, hydrographic engineer to the Commission, whose knowledge of the work from former service in the Coast and Geodetic Survey has greatly facilitated his practical use of the technical data furnished by the Government.

To Mr. Thomas H. Robinson, counsel to the Commission, for courteously furnishing valuable information relating to county boundaries.

And to the many others connected with the Commission or who as residents in the locality where the work was being carried on have greatly assisted by furnishing important information or willing services. 


\section{CHARTS AND MAPS.}

\section{CIIARTS OF NATURAL OYSTER BARS.}

The charts ${ }^{a}$ of the natural oyster bars of Charles County, published by the Coast and Geodetic Survey from results of surveys of the Government in cooperation with the Maryland Shell Fish Commission, are grouped on one sheet covering a portion of the waters of the upper Patuxent River and all of the waters of the Wicomico River; including all oyster-producing bottoms in Charles County. They are published on a scale of I part in $20,\left(\right.$ )on (approximately $3 \frac{1}{6} 6$ inches to a statute mile) and are constructed on polyconic projections and based on the United States standard datum of the Coast and Creodetic Survey.

These charts show all oyster bars and other boundaries established by the Commission, and are certified for the purpose of filing in the office of the clerk of the Circuit Court of Charles County and in the office of the Commission at Annapolis, as required by the oyster laws of Maryland.

In addition to the oyster bar and other boundaries, the charts show the location and name of all landmarks (U. S. Coast and Geodetic Survey triangulation stations) used in making the survey, together with the hydrography and topography ${ }^{b}$ necessary to make the technical definitions and delineations of boundaries readily understandable both by the people erigaged in the oyster industry and the general public who may become interested through leasing of barren bottoms for oyster culture.

The names of the oyster bars are those used locally, as nearly as could be ascertained by the hydrographic engineer of the Commission. When there was no local name in common use, a name was selected from one of the prominent features of the vicinity. By the use of recognized names or those that would naturally suggest certain sections of water, it is believed that much confusion will be avoided in the location on the charts of the oyster bars, especially by those not familiar with the use of maps.

The corners of the oyster bars are numbered from I to the total number of corners in each area under consideration. Where boundaries adjoin, making one point a corner of two or more oyster bars, these points have two or more numbers, each number corresponding to the bar in which the figure is located. The numbers of the corners correspond with the technical and legal descriptions of this publication under the heading "Boundaries of natural oyster bars."

The landmarks and oyster bars have been grouped in the "Contents" of this publication in accordance with the charts upon which they are shown. To find a particular

a These charts can be obtained by application to the Superintendent of the Coast and Geodetic Survey, at Washington, D. C.

$b$ Much of the detail of the inshore topography was obtained from the excellent map of Charles County, prepared and published by the Maryland Geological Survey under the direction of Dr. William Bullock Clark from surveys of the Maryland Geological Survey in cooperation with the U. S. Geological Survey. 
nyster bar or landmark which is only known by name, consult the "Contents" and the desired chart and general location will be indicated. To find the name of a bar or landmark which is only known by location, consult the progress map at the end of this publication for the number of the chart on which it is to be found, and then examine the known locality on the chart for the name of the bar or landmark in question.

The contours on the charts showing the depth of water at mean low tide have been taken from the hydrographic sheets of former work of the Coast and Geodetic Survey. Four curves were selected as being the most convenient for taking off from the original hydrographic sheets and the ones of greatest value to those interested in shell fish industries. The $\mathrm{I}$-fathom contour ( $6 \mathrm{fect}$ ) and the 5 -fathom curve (3o feet) correspond in a general way to the inner and outer limits of all the oyster bars surveyed. The 3 -fathom contour ( 18 feet) furnishes the curve of about the average depth of water on the oyster bars and the Io-fathom contour ( $60 \mathrm{feet}$ ) serves in a general way to indicate the outer limits of probable oyster culture.

The boundaries of the waters within the "territorial limits of the county" and the boundaries of the "waters contiguous to the county" opened up for the leasing with Charles County are plainly indicated on the charts. A full technical description of these boundaries is given in this publication under the heading "Boundaries of county waters."

The areas in acres of the oyster bars were determined under the direction of the hydrographic engineer of the Commission by two independent planimeter measurements of the areas as delineated on the smooth projections of the Coast and Geodetic Survey. These areas are given in small figures in parentheses on the face of the chart within the boundaries of the different shell fish bottoms.

The symbols used on the charts for the different kinds of boundaries, triangulation stations, contours of depth of water, etc., require no other explanation than that given in the legend and other notes on the face of the charts.

\section{LEASING CHARTS.}

The leasing charts of Charles County, like those for Anne Arundel, Somerset, Wicomico, Worcester, and Calvert counties, have been prepared under the direction of the hydrographic engineer of the Commission. These charts are constructed on polyconic projections and are based on the United States standard datum of the Coast and Geodetic Survey. They are made on the scales of I part in 5,000 or I part in 10,000 , as the needs of oyster culture may require. Anne Arundel County required i 3 leasing charts; Somerset County, 12 charts; Wicomico County, 2 charts; Worcester County, 3 charts; Calvert County, 5 charts; and Charles County, 2 charts, to cover their oyster bottoms.

These charts show all the oyster bars, crab bottoms, and clam beds and other 'boundaries established by the Commission, and also all boundaries of oyster lots leased for the purpose of oyster culture, thus making them comprehensive and valuable records of the results of the operations of the oyster-culture laws.

The lots leased under the provision of the "old 5-acre law" are frequently of irregular shape, but the lots leased under the provision of the new oyster laws must be of rectangular shape by the terms of that act. For this latter purpose the leasing charts 
have been divided by parallels of latitude and meridians of longitude into small rectangles of $I$ acre or 5 acres, as may be best suited to the area under consideration, and prospective leaseholders by the rules of the Commission are compelled to select whole rectangles as far as possible.

For reasons of the present changeable nature of the number of lots leased and the large number of charts required, the leasing charts are not likely to be published for some years, but they can be seen at any time on file at the offices of the Commission, in the Marine Bank Building at Baltimore.

\section{PROJECTIONS.}

The polyconic projections ${ }^{a}$ covering Charles rounty waters are 3 in number and on the scale of I part in 10,000 . They were constructed by draftsmen of the Coast and Geodetic Survey, but the sextant positions which determine the location of the legal boundaries of the oyster bars as delineated by the Shell Fish Commission were plotted by the draftsman of the Commission.

A copy of each of these projections, with all the plotted positions of triangulation stations, shore line, sextant positions, and boundaries of oyster bars, was made under the direction of the hydrographic engineer of the Commission by pricking through with a sharp needle the intersections of the projection lines and all other points as plotted on the original sheets.

These projections (in duplicate) are the original records of all oyster bar and other boundaries established by the Commission, one set being filed in the archives of the Coast and Geodetic Survey, at Washington, and the other set in the archives of the Shell Fish Commission.

PROGRESS MAPS.

The progress map to be found at the end of this publication is on a scale of I part in 100,000 , and shows in outline the work accomplished by the United States Coast and Geodetic Survey in Charles County and contiguous waters. It gives the scheme of all the charts and smooth projections constructed in connection with the survey, the location and names of all triangulation stations used as a basis for the surveying work, and the "boundaries of county waters" established by the Commission for the purpose of carrying out the laws of Maryland relating to oyster culture.

Besides indicating the amount of work done by the Coast and Geodetic Survey in connection with the work of the Shell Fish Commission, this progress map will be of special value for index purposes to engineers and others searching for the particular chart or projection covering the locality of the oyster bars or landmarks that may be under consideration.

The progress maps ${ }^{b}$ accompanying the first and second annual reports of the Maryland Shell Fish Commission were prepared under the direction of the hydrographic engineer of the Commission. They are on the scale of $x$ part in 400,000 , and show the outline of the tide-water counties of Maryland, with shaded areas to indicate the waters already covered by the operations of the oyster survey.

a For the scheme of these projections see the progress map at the end of this publication.

$b$ These maps and reports can be obtained by application to Maryland Shell Fish Commission, Marine Bank Building, Baltimore, Md. 


\title{
BOUNDARIES OF THE COUNTY WATERS. ${ }^{\alpha}$
}

\author{
WATERS WITHIN TERRITORIAL, LIMITS OF COUNTY.
}

The laws of Maryland relating to oyster culture provide that "no person shall be permitted, by lease, assignment, or in any other manner, to acquire a greater amount of land than ten acres situated within the territorial limits of any of the counties, or cne hundred acres in any other place."

The boundary line ${ }^{b}$ between the waters "within the territorial limits" of Charles County and the waters in "any other place," as established by the Shell Fish Commission for the purpose of carrying out the oyster laws, and delineated on the "oyster" charts and the smooth projections of the Coast and Geodetic Survey, is technically described and defined as follows:

Paluxent River waters of Charles County.-Following the boundary line between Charles County and Prince Georges County along the middle of Swanson Creek as laid down on "Chart No. 26, Natural Oyster Bars, Maryland, " to a point defined by the intersection of this boundary line with the boundary line of Calvert County in Patuxent River; thence along the boundary line between Calvert and Charles counties in Patuxent River as laid down on "Chart No. 26, Natural Oyster Bars, Maryland," to a point defined by the intersection of this boundary line with the boundary line between Charles and St. Marys counties off the entrance to Indian Creek: thence along the boundary line between Charles and St. Marys counties in the middle of Indian Creek as laid down on "Chart No. 26, Natural Oyster Bars, Maryland."

Wicomico River waters of Charles County.-Following the boundary line between Charles County and St. Marys County along the middle of Wicomico River as laid down on "Chart No. 26, Natural Oyster Bars, Maryland," from the upper end of Wicomico River, as shown on said chart, to a point at the mouth of Wiconico River defined by the intersection of this boundary line with the straight line between the center point of Cobb Point Bar Light defined by latitude $38^{\circ}$ I $4^{\prime} 33 \cdot 3^{\prime \prime}$ and longitude $76^{\circ}$ $49^{\prime} 36.9^{\prime \prime}$ and a point on the northwest end of St. Catherine Island defined by latitude $38^{\circ} 14^{\prime} 28.9^{\prime \prime}$ and longitude $76^{\circ} 48^{\prime} 10.9^{\prime \prime}$; thence along a straight line dividing the "waters within territorial limits of county" and the "waters of Potomac River under joint jurisdiction of Maryland and Virginia as to fisheries " to the center point of Cobb Point Bar Light defined by latitude $38^{\circ} 14^{\prime} 33 \cdot 3^{\prime \prime}$ and longitude $76^{\circ} 49^{\prime} 36.9^{\prime \prime}$; thence along a line following Cobb Point Bar, as laid down on "Chart No. 26, Natural Oyster Bars, Maryland, " to a point located on Cobb Point defined by latitude $38^{\circ}$ I $5^{\prime} I 7.5^{\prime \prime}$ and longitude $76^{\circ} 50^{\prime} 33 \cdot 4^{\prime \prime}$; thence along the mean low water line of the Maryland shore of Potomac River or a line across the mouth of all inlets less than roo yards in width, as the case may be, and then continuing along the Maryland shore of Potnmac River, crossing the mouth of Potomac River entrances of Neals Sound, around Swan Point, and crossing the mouth of Cuckold Creek and all other creeks, bays, and inlets of Potomac River under the sole jurisdiction of Maryland, to the intersection of this line with the boundary line between Charles County and Prince Georges County.c

a For a complete historical and legal description of the houndaries of the counties of Maryland, the valuable publication entitled "The Counties of Maryland-Their Origin, Boundaries, and Election Districts," prepared by Dr. Edward B. Mathews and published by the Maryland Geological Survey under the direction of Dr. William Bullock Clark, Superintendent, should be consulted, as the boundaries described in this publication have been established and technically defined for the purpose of carrying out the oyster laws of the State, and may or may not be correct for other purposes.

$b$ See "Charts of Natural Oyster Bars," published by the Coast and Geodetic Survey, and the progress map at the end of this publication.

cLatitudes and longitudes based on the United States standard datum of the United States Coast and Geodetic Survey. 


\section{WATERS CONTIGUOUS TO COUNTY.}

The oyster laws of Maryland provide that a true and accurate delineation of all natural oyster bars shall be made on copies of charts of the United States Coast and Geodetic Survey, "which said copies shall be filed in the office of the said Commissioners in the city of Baltimore," and "in the office of the clerks of the circuit courts for the respective counties wherein the grounds so designated may lie."

For the purpose of carrying out the latter part of this section of the law and for the purpose of establishing the limits of the oyster-culture area to be opened up for leasing with each county surveyed, it is necessary for the Shell Fish Commission to establish a houndary line between the. waters contiguous to but not within the territorial limits of each county and the waters contiguous to but not within the territorial limits of adjacent counties.

This boundary line has been delineated on the "Charts of Natural Oyster Bars," published by the Coast and Geodetic Survey, and is technically described and defined as follows:

Commencing at a point located at the mouth and near the middle of Wicomico River defined by the intersection of the boundary line between Charles County and St. Marys County as laid down on "Chart No. 26, Natural Oyster Bars, Maryland," and the straight line between the center point of Cobb Point. Bar Light defined by latitude $38^{\circ} 14^{\prime} 33.3^{\prime \prime}$ and longitude $76^{\circ} 49^{\prime} 36.9^{\prime \prime}$ and a point on the northwest end of St. Catherine Island defined by latitude $38^{\circ} 14^{\prime} 28.9^{\prime \prime}$ and longitude $76^{\circ} 48^{\prime} 10.9^{\prime \prime}$; thence along a straight line dividing the "waters within territorial limits of county" and the "waters of Potomac River under joint jurisdiction of Maryland and Virginia as to fisheries" to the center point of Cobb Point Bar Light defined by latitude $38^{\circ} 14^{\prime} 33 \cdot 3^{\prime \prime}$ and longitude $76^{\circ} 49^{\prime} 36.9^{\prime \prime}$; thence along a line following Cobb Point Bar as laid down on "Chart No. 26, Natural Oyster Bars, Maryland," to a point located on Cobb Point defined by latitude $38^{\circ} 15^{\prime} 17.5^{\prime \prime}$ and longitude $76^{\circ} 50^{\prime} 33.4^{\prime \prime}$; thence along the Maryland shore of the Potomac River across the entrances to Neals Sound, Cuckold Creek, and all other sounds, bays, creeks, or inlets under the sole jurisdiction of Maryland as to fisheries, to the intersection of this line with the boundary line between Charles County and Prince Georges County.c

a Latitudes and longitudes based on the United States standard datum of the United States Coast and Geodetic Survey. 


\section{LANDMARKS (U. S. COAST AND GEODETIC SURVEY TRIANGULATION STATIONS).}

EXPLANATION.

The oyster laws of Maryland authorizing the survey to be made by the Shell Fish Commission provide for "an accurate report of said survey, setting forth such a description of landmarks as may be necessary to enable the said board, or their successors, to find and ascertain the boundary lines of said natural oyster beds, bars, and rocks, as shown by delineation on the maps and charts." The law of the United States authorizing the cooperation of the Department of Commerce and Labor in the survey of natural oyster bars of Maryland provides for the erection of "such structures as may be necessary to mark the points of triangulation, so that the same may be used for such future work of the Coast and Geodetic Survey as the said Bureau may be hereafter required to perform in prosecuting the Government coast survey of the navigable waters of the United States located within the State of Maryland."

Under the provisions of the sections of the laws stated above, the markings and descriptions of landmarks must be sufficient for the present and future needs of both the Government and the State. With this end in view, considerable work has been expended in erecting permanent monuments at the triangulation stations and in the proper description of their location.

An effort has been made to arrange the descriptions of location and character of landmarks in a uniform and logical manner. The descriptions start with the assumption that the individual seeking a landmark has only an indefinite idea of its location. They gradually proceed from description of the general locality of a landmark to the descriptions of its immediate surroundings. "This is followed by specific details of the character of the center and reference marks and a "round" of reference angles and distances which in themselves frequently contain enough information to furnish an independent and reliable location of the triangulation station.

\section{METHOD OF DESCRIBING TRIANGULATION STATIONS.}

The separate descriptions of triangulation stations should not be used without reading the following explanation of the method of describing the triangulation stations, as it contains certain details that are common to all the landmarks described in this publication and which are omitted in the separate descriptions as being needless repetitions:

Name.-The title at the top of each separate description is the name by which the landmark or triangulation station is known and designated in all work and published oyster records or oyster charts of both the Government and State. The selection of the name is usually left to the triangulator establishing the station, and it may or may not have geographic or other significance in reference to the locality. 
General locality.-Under this heading is given the general locality of the landmark in reference to well-known and prominent natural or artificial features, such as the nearest body of water, town, river, steamer wharf, well-defined point of land, church, or any other feature that is likely to remain both permanent and prominent.

This heading also covers a reference to the published chart or map which shows the location of the station most clearly. Nearly all the triangulation stations described in this publication are plainly indicated by name and a triangulation symbol on the published charts of oyster bars of Maryland. In this case they are referred to by serial number only, the words "charts of oyster bars of Maryland" being omitted to avoid needless repetition. These published oyster charts are on the large scale of $\mathrm{I}$ part in 20,000 (approximately $3 \frac{1}{6}$ inches to a statute mile) and show the location of the triangulation stations so clearly that in many cases the written descriptions will not be required to find them.

Immediate locality.-Under this heading is given the description of the "observed station" in reference to its immediate surroundings. This is supposed to include a statement of the station's estimated elevation above high water or some other welldefined level of the locality, such as a road or house; the character of the ground on which it is located, such as marsh land, sand beach, cultivated field, or meadow; estimated bearings in points of the compass and estimated distances in yards from (not to) easily recognized features, such as extreme end of point, edge of bluff, bank of creek, line of telephone poles, shore line, barn, house, fence, ditch, trees, or any other definite detail, such as being on range with the tangent of an island and a church; and so forth.

When a standard monument has been established near the station as a "reference station," this heading also covers a statement of the true bearing of the monument in degrees and minutes and its measured distance in meters, as it is the first object that is likely to eatch the eye when the immediate vicinity of the desired station is reached and might be mistaken for the center mark of the "observed station" unless special attention is called to it.

The distinction between the "observed station" and "reference station" should be carefully noted by anyone making use of the description of stations for any future surveying operations.

The "observed station" is located at the particular triangulation point covered by the description of stations, and is the one whose geographic position is first computed, as it is the point which was "occupied" and "observed on" for horizontal angles. However, in spite of the primary importance of the location of the "observed station," it will be noted from the description of stations that frequently it is not marked as well as the "reference station," and in many instances has only a pine stub to indicate its position. This is the case for the reason that the necessity of intervisibility of landmarks usually made it compulsory to locate "observed stations" on edges of banks and ends of points of land, which in the tide-water section of Maryland generally means they will be washed away in a short period of years. The past experience of the Coast and Geodetic Survey in this region has shown the great need of "reference stations," if the frequent reestablishment of a new framework of triangulation is to be avoided.

The chief reason and need for the establishment of the "reference station," or secondary station, as it might be well named, is explained in the preceding paragraph, but in several instances other reasons, such as the location of the "observed station" 
on an unstable sand dune, in a cultivated field, in front of a residence, or other places objectionable to the landowner, have led to establishment of "reference stations." The location of the "reference station" in relation to the "observed station" is fixed for plotting on charts or for computation of its geographic position by checked measurements of its distances and azimuth from the "observed station." $a$

Marks.-Under this heading is given a description of the character of the permanent monuments or other marks of the location of the "observed station," and of the "reference station" where one has been established.

All the marks designated in the descriptions as "the center point of triangle on standard cement monument" are exactly alike. These monuments are made of cement, sand, and gravel, and are 2 feet long and 8 inches square at top and bottom. Their tops are all marked with the same brass mold and show a center hole surrounded by a triangle, with the letters "M. S. F. C." arranged around the vertex and the letters "U. S. C. S." underneath the base of the triangle. The center hole is always in the center of the top of the monument by construction, and if this is found to have been broken off without disturbing the bottom the center of its square section can be used as the location of the station.

All the "standard cement monuments," whether used for marking the "observed station" or "reference station," have been planted upright in exactly the same manner, with their tops projecting 3 or \& inches above the surface of the ground, unless otherwise stated.

Therefore, as the above facts in reference to the "standard cement monuments" are a constant element in all cases, the repetition of these facts in the description of stations is made needless by this one statement.

References.-Under this heading are given the "rounds" of directions and distances to all objects that might be useful in locating the stations when the surface marks can not be found. It is also contemplated that for general purposes of topography, hydrography, or location of boundaries of oyster bars these references will be sufficient in many cases to relocate the position of an "observed station" or "reference station" when both of them have been destroyed.

The first reference object given in the descriptions is always a triangulation station visible from the station being described, this, if possible, being a light-house, church sp.re, or other permanent and prominent point. Its direction is taken as being $\mathrm{o}^{\circ} \mathrm{OO}^{\prime} \mathrm{OO}^{\prime \prime}$, and the directions of all other objects are measured from it as an initial point, the angles being taken in a clockwise direction (left to right).

The true bearing ${ }^{b}$ of the initial object is always given in parentheses alongside its name. This furnishes means for the calculation of the bearings of any of the other reference objects for the purposes of locating a station by horizontal angles or for the relocation of comer buoys of oyster-bar boundaries by the method of compass directions described $\mathrm{n}$ this publication under the heading of "Boundaries of oyster bars."

a Geographic coordinates (latitude, longitude, distance, and azimuth) relating to any of the "observed stations" or of the "reference stations" described in this publication can be obtained by application to the Superintendent of the Coast and Geodetic Survey, at Washington, D. C.

$b$ The mean magnetic variation for Charles County was $5^{\circ} 20^{\prime}$ west of north in Igro and increasing at the rate of $4^{\prime}$ yearly. 
The distances in the last column under "References" are given in three different units, which vary according to their accuracy. The "miles" are statute miles and may be considered only as rough estimates. The "yards" are more accurate, but must be looked on as results generally obtained by pacing or careful estimating. The "meters," however, are accurate to the degree indicated by their decimals and in every case have been measured with a steel tape. In the same manner the accuracy of the directions are indicated by the refinement of angular measure with which they are recorded.

\section{DESCRIPTIONS OF TRIANGULATION STATIONS.}

\section{BARBER}

General locality.-Northeastern shore of Wicomico River about $3 / 4$ mile north-northeast of Stoddard Point. (See Chart No. 26.)

Immediate locality:-Observed station is on grass land about 2 feet above high-water mark, 3 yards north of shore, 20 yards west of trees which extend inland along creek, 4 yards southwest by west of a corner of a fence and 15 yards southeast of another corner of a fence.

Marks.-Observed station is center point of triangle on standard cement monument.

References.--

"Stoddard" ( $\mathrm{S}_{9}^{\circ} 46^{\prime} \mathrm{WH}$.

Left chimney of Stoddard house............

Near peak of roof between two chimneys.....

Chimney on left end of small house........ 6

Nail in blaze in top fence rail. . . . . . . . . ${ }_{3} 6$

Nail in blaze in cedar tree ( 5 inches diameter). . I55

Nail in blaze in top of chestnut fence post. . . 245

Nail in blaze in persimmon tree ( 5 inches

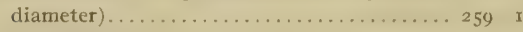

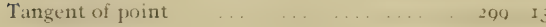

Near large chimney of negro quarters. . . ... $302 \quad 07$

\begin{tabular}{|c|c|c|}
\hline 00 & $\infty$ & ${ }^{\mathrm{I}}{ }^{\mathrm{s}}$ miles. \\
\hline 2 & $\ldots \ldots$ & $11 / 8$ miles. \\
\hline 15 & $\ldots \ldots \ldots$ & I $1 / 2$ miles. \\
\hline & $\ldots \ldots \ldots$ & $\mathrm{I}^{1} / 2$ miles. \\
\hline & .. & I0.62 meters \\
\hline & $\ldots \ldots \ldots$ & 10.75 meters \\
\hline & $\ldots \ldots \ldots$ & 3.43 meters \\
\hline & . & I 3.94 meters \\
\hline & & \\
\hline & . . . . . . & I// miles. \\
\hline
\end{tabular}

\section{UPPER.}

General locality.-Southwestern shore of Wicomico River on Stoddard Point (upper point) about $21 / 4$ miles north-northwest of Mills Point. (See Chart No. 26.)

Immediate locality:-O Observed station is on a long narrow point about 2 feet above high-water mark, 5 yards south of side of point, 8 yards northwest of side of point, 38 yards west of high-water mark on middle of point and ${ }_{3} 8$ yards west by north of high-water mark on extreme end of point.

Marks.-Observed station is center point of triangle on standard cement monument.

References.-

"Stoddard" $\left(\mathrm{S} 2 \mathrm{~T}^{3} 3 \mathrm{~S}^{\prime} \mathrm{E}\right)$

Right chimney of Stoddard house................

Left peak of roof of barn................. 33

L.eft chimney of old house . . . . . . . . + +

Tangent of next point.................... 14

Right chimney of house on ridge........... 17

Chimney outside small house on opposite shore :-.

$28 \quad \ldots \quad \ldots \ldots .1 / 4$ miles.

Near corner post of piazza of large house........ $247 \quad 47 \quad \ldots \ldots \ldots . \quad \ldots 5 / 8$ miles.

Chimney top of Key house................ 206 o. $\ldots \ldots \ldots$ I $1 / 2$ miles.

\section{KEY.}

General locality.-Northeastern shore of Wicomico River on a high bluff about $\mathrm{I}$ mile north of Cohouck Point. (See Chart No. 26.)

Immediate locality.-Observed station is about 30 feet above high-water mark in an orchard, about 24 yards northeast of edge of bank, 49 yards north of edge of bank, I 5 yards east of edge of bank, $x_{30}$ yards south-southwest of negro quarters and 130 yards west of fence which incloses an orchard. 
Marks,-Observed station is center point of triangle on standard cement monument.

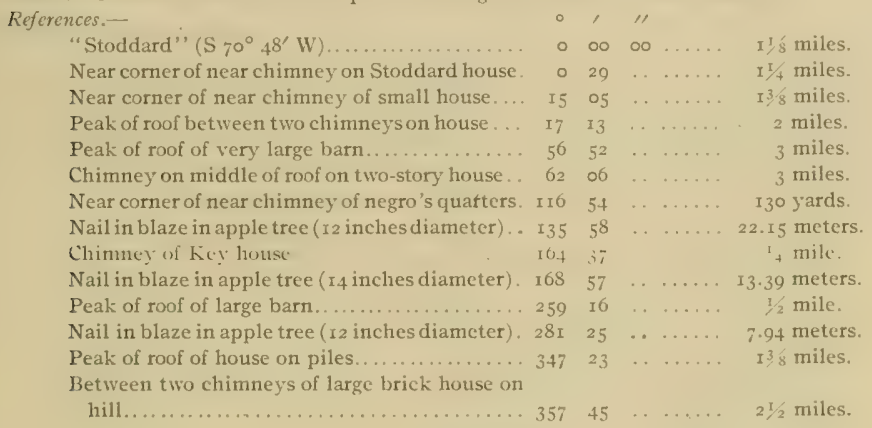

\section{STODDARD.}

General locality'-Western shore of Wicomico River about $1 / 2$ mile south-southeast of Stoddard Point and I mile west-northwest of Cohouck Point. (See Chart No. 26.)

Immediate locality.-Observed station is on gravel, grass, and shell point, near a lone gum tree, about 2 feet above high-water mark, 6 yards south-southwest of side of point, 6 yards north of side of point, io yards west of extreme end of point and 158 yards east-northeast of Stoddard house.

Marks.-Observed station is center point of triangle on standard cement monument.

References.-

\begin{tabular}{|c|c|c|c|c|}
\hline Fune." & & & & \\
\hline ney of small house. & 23 & 08 & . & $1 / 2$ \\
\hline eak of front gable of large house on ridge. & $5^{2}$ & 54 & & $17 \hat{8}$ \\
\hline Key & 94 & 47 & . & $I / / 2$ \\
\hline $\cos ^{2}$ & 153 & $5^{8}$ & & 238 \\
\hline O 1 & 172 & 38 & & le \\
\hline ho & 180 & I9 & & $25 \%$ \\
\hline 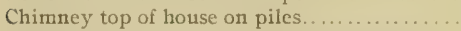 & 228 & 37 & . & $1 / 2 \mathrm{I}$ \\
\hline & 284 & 44 & . & 158 \\
\hline & $3+5$ & 29 & & $.5^{8}$ \\
\hline$(4),-3)$ & & & & \\
\hline
\end{tabular}

\section{COHOUCK.}

General locality.--Eastern shore of Wicomico River on Cohouck Point on the northern side of entrance to Chaptico Bay. (See Chart No. 26.)

Immediate loculity. (Observed station is on Cohouck Point, about t leet above ligh-water mark. 12 yards east of edge of bank, 35 yards south of edge of bank, 85 yards northeast of extreme point and about 25 yards north of marsh.

Marks.-Observed station is center point of triangle on standard cement monument.

References.-

\begin{tabular}{|c|c|c|c|c|}
\hline "Key" (N $\left.3{ }^{\circ} 29^{\prime} \mathrm{E}\right) \ldots \ldots \ldots$ & $\circ$ & $\infty$ & $\infty$ & Iss mile. \\
\hline Nearest chimney on negro quarters..... & $\circ$ & 27 & & nile \\
\hline Near peak of roof of barn.............. & 26 & $3^{8}$ & & mile \\
\hline $\begin{array}{l}\text { Chimney outside near end of two and a half story } \\
\text { house }\end{array}$ & I 28 & $5^{8}$ & & mile \\
\hline Right chimney of Lyon house near Mills Point.... & 171 & 29 & & nile \\
\hline Chimney on tlat roof house near mouth of Bowmans & & & & \\
\hline Creek............ & 226 & 56 & . & aile \\
\hline Chimney on far end of house................. & $26 x$ & 43 & $\cdots$ & aile \\
\hline Chimney on house on piles......... & $27^{\circ}$ & 53 & . & nile \\
\hline Peak of front gable of house on ridge....... & $35^{2}$ & $5^{x}$ & & $1 / 4$ mile \\
\hline
\end{tabular}




\section{HAYDEN.}

General locality:-Western shore of the Wicomico River about 1 1/s miles west of Cohouck Point. (See Chart No. 26.)

Immediate locality,-Observed station is surrounded by water bushes on marshy land, about I foot above high water, 5 yards northwest of shore and 17 yards southeast of line of trees on top of bank. Cement monument marking reference station is 11.50 meters $\mathrm{N} 54^{\circ} 34^{\prime} \mathrm{W}$ of observed station.

Marks.-Observed station is nail in stub with top 3 inches above ground. Reference station is center point of triangle on standard cement monument.

References. -

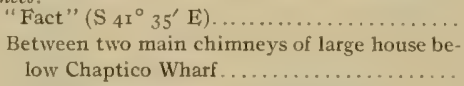

West roof peak of house on Chaptico Wharf....

Chimney on middle of square house.......... 6

Nail in blaze in cedar tree ( 18 inches diameter). 124

Nail in blaze in locust tree ( 8 inches diameter) 155

REFERENCE STATION.................. I67

Nail in blaze in oak tree ( 8 inches diameter). . . 213

Chimney on Key house............... 275

Chimney of Maddox house .............. 344

Right chimney outside of old house......... 354

$\begin{array}{rrrrr}0 & , & & & \\ 0 & 00 & 00 & \ldots \ldots & I 3 / 8 \text { miles. } \\ 5 & 11 & \ldots & \ldots \ldots & 23 / 8 \text { miles. } \\ 6 & 51 & \ldots & \ldots \ldots & 21 / 4 \text { miles. } \\ 65 & 06 & \ldots & \ldots & 5 / 8 \text { mile. } \\ 24 & 14 & \ldots & \ldots \ldots & 23.45 \text { meters. } \\ 55 & 23 & \ldots & \ldots \ldots & 16.55 \text { meters. } \\ 67 & 01 & 20 & \ldots \ldots & 11.51 \text { meters. } \\ 13 & 29 & \ldots & \ldots \ldots & 18.74 \text { meters. } \\ 75 & 45 & \ldots & \ldots \ldots & 13 / 4 \text { miles. } \\ 44 & 28 & \ldots & \ldots \ldots & 31 / 4 \text { miles. } \\ 54 & 31 & \ldots & \ldots \ldots & 15 / 8 \text { miles. }\end{array}$

PERRY.

General locality. - Southeastern shore of Chaptico Bay, about I mile northeast of Mills Point and $5 / \mathrm{s}$ mile southeast of Cohouck Point. (See Chart No. 26.)

Immediate locality.-Observed station is in an open field, about 20 feet above high-water mark, 8 yards northwest of edge of bank, 9 yards south-southwest from edge of gully in bank, 5 yards south of edge of bank of gully, and about I50 yards north-northeast of creek.

Marks.-Observed station is center point of triangle on standard cement monument.

References.-

"Fact" ( $\mathrm{S}_{51}^{\circ}$ I0' W)

Chimney on right end of house .............

Chimney on flat-roof house ..................

Left chimney of Crane house..............

Nail in blaze in locust tree ( 3 inches diameter).
Nearest chimney on larger part of double brick

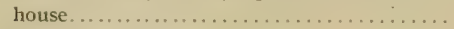

Left chimney of house on piles.............

Near peak of roof on house................

Near corner of near chimney of Stoddard house.

Nail in blaze in locust tree ( 3 inches diameter).

Peak of front gable of house on ridge........ Ix

Nail in blaze in locust tree ( 8 inches diameter). 136

Near chimney of large house on ridge........ I6

Chimney outside of two-and-a-half-story house, 289

\begin{tabular}{|c|c|c|c|}
\hline$\infty$ & oo & $\ldots \ldots$ & I mile. \\
\hline $4^{I}$ & $\cdots$ & $\ldots \ldots$ & 23. 8 miles. \\
\hline 03 & 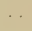 & . & $2^{\prime}=$ miles. \\
\hline 37 & . & $\ldots \ldots$ & 35/8 miles. \\
\hline 34 & . & $\ldots \ldots$ & Io.49 meters. \\
\hline 50 & $\cdots$ & $\ldots \ldots$ & $3^{5 / 8}$ miles. \\
\hline .28 & $\cdots$ & $\ldots \ldots$ & I3/4 miles. \\
\hline 53 & $\cdots$ & $\ldots \ldots$ & 2 miles. \\
\hline 59 & $\cdots$ & $\ldots \ldots$ & 2 miles. \\
\hline 40 & $\cdots$ & $\ldots \ldots$ & 8.44 meters. \\
\hline 5 I & - & $\ldots \ldots$ & 3 to 4 miles. \\
\hline 40 & $\cdots$ & $\ldots \ldots$ & 5.95 meters. \\
\hline o8 & $\cdots$ & $\cdots \cdots$ & I5/8 miles. \\
\hline Is & . & $\ldots \ldots$ & I5o yar \\
\hline
\end{tabular}

BURR.

General locality.-Western shore of Wicomico River directly opposite mouth of Chaptico Bay and 34 mile north of Bowmans Creek. (See Chart No. 26.)

Immediate locality.--Observed station is on hard ground between a sloping bank ro feet high covered with trees and a marshy shore, about 2 feet above high-water mark, 18 yards northwest of extreme point, 23 yards north of shore, 17 yards southwest of shore, and 9 yards southeast of bottom of bank. 
Marks.-Observed station is center point of triangle on standard cement monument.

References.-

"Fact" (S $\left.65^{\circ} 59^{\prime} \mathrm{E}\right)$

Between two chimneys of large house on ridge.

West end of peak of roof of house on Chaptico

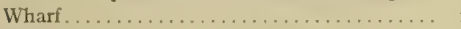

Right chimney of two-and-a-half-story house ...

Chimney in middle of large house .......... 8

Nail in blaze in persimmon tree ( $I$ in inches diameter).

Nail in blaze in persimmon tree (9 inches di-

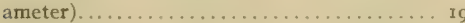

Nail in blaze in persimmon tree (ro inches di-

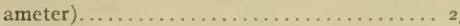

Main chimney of Key house.............20 29

Chimney on Maddox house .............. 35

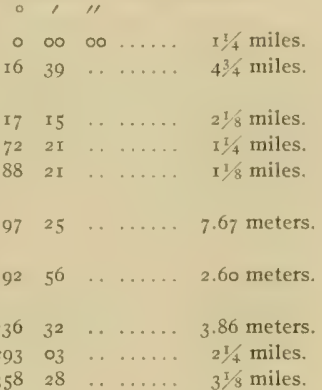

FACT.

General locality,-Eastern shore of Wicomico River on Mills Point on south side of mouth of Chaptico Bay. (See Chart No. 26.)

Immediate locality.-Observed station is on a long point covered on the southern side with gum and cedar trees, about to feet above high-water mark, 23 yards from extreme end of top of bank, 6 yards north of edge of bank, and 8 yards southeast of edge of bank.

Marks.-Observed station is center point of triangle on standard cement monument.

References.-

\begin{tabular}{|c|c|c|c|c|}
\hline & & & & \\
\hline 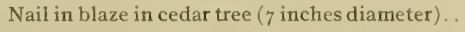 & & 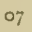 & & ers \\
\hline & 56 & & & 6.3 \\
\hline tey on ell end of Stoddard house. & I 57 & 08 & & $17 / 8$ \\
\hline use. & 199 & 54 & . & $2^{1} s$ \\
\hline ho & 274 & 25 & & \\
\hline ches diame & 301 & 45 & & meters. \\
\hline$-s$ & 3 & 53 & & \\
\hline est end of peak of & 342 & 53 & . & $7 / 8$ mile \\
\hline
\end{tabular}

\section{BOIVMAN.}

General locality. - Western shore of Wicomico River at northeast side of mouth of Bowmans Creek and $I \frac{1}{2}$ miles west by south of Milis Point. (See Chart No. 26.)

Immediate locality. - Observed station is surrounded by water bushes on point of land about $\mathrm{I}^{\mathrm{I}} / 2$ feet above high water, 14 yards east of high-water mark, 16 yards north of extreme end of point, 20 yards northeast of side of point, 20 yards south of several cedar trees, and about 150 yards south of a house.

Marks.-Observed station is center point of triangle on standard cement monument.

References.-

"Sacred Heart Church Spire" (S 62 $\left.{ }^{\circ} 0^{\prime} \mathrm{E}\right)$...

Chimney on end of long house...............

Chimney of Lyon house................. I

Nail in blaze in cedar tree ( 7 inches diameter).

Chimney on square house.............. 76

Crane house. .......................... I68

Nail in blaze in cedar tree ( 6 inches diameter). 21

Nail in blaze in cedar tree ( 7 inches diameter). 23

Chimney on near end of house ........ . 20

Peak of roof between two chimneys....... 357

$\begin{array}{rrrrrr}\circ & 00 & 00 & \ldots & 4^{5 / 8} \text { miles. } \\ \text { I0 } & 37 & \ldots & \ldots & 3^{1 / 4} \text { miles. } \\ 13 & 56 & \ldots & \ldots & 3^{1 / 4} \text { miles. } \\ 59 & 04 & 40 & \ldots & 8.88 \text { meters. } \\ 76 & 25 & \ldots & \ldots & 1 / 4 \text { mile. } \\ 68 & 10 & \ldots & \ldots & 2 \text { miles. } \\ 16 & \text { 10 } & 00 & \ldots \ldots & 18.37 \text { meters. } \\ 32 & 40 & 30 & \ldots & 17.58 \text { meters. } \\ 63 & 10 & \ldots & \ldots & 1 / 2 \text { mile. } \\ 57 & 27 & \ldots & \ldots & 21 / 4 \text { miles. }\end{array}$




\section{EEDLING.}

General locality.-Western shore of Wicomico River about $\mathrm{x}^{1 / 4} / \mathrm{miles}$ southwest of Mills Point and about I mile southeast of mouth of Bowmans Creek. (See Chart No. 26.)

Immediate locality. - Observed station is in a shell-covered cultivated field, about ro feet above high-water mark, 37 yards southwest of shell and gravel beach, 88 yards west-northwest of extreme end of point, and 79 yards north of a ditch in marsh. Cement monument marking reference station is 23.99 meters $\mathrm{N} 89^{\circ} 56^{\prime} \mathrm{W}$ of observed station.

Marks,-Observed and reference stations are marked by the center point of the triangles on standard cement monuments.

References.-

"Fact" ( $\left.39^{\circ} 15^{\prime} \mathrm{W}\right) \ldots \ldots \ldots \ldots \ldots \ldots \ldots \ldots$

Nail in blaze in gum tree ( 20 inches diameter). .

Near peak of roof of house on Chaptico Wharf. .

Chimney outside near end of house on hill.... .

Nail in blaze in cedar tree ( 3 inches diameter). .

REFERENCE STATION.....................

Chimney on right of ell of a house........... 60

Near peak of roof of Eedling house.......... 265 55

Nail in blaze in oak tree (24 inches diameter).. $33 \mathrm{I} \quad 27$

$\begin{array}{rrrrr}0 & \prime & \prime \prime \\ 0 & 00 & 00 & \ldots \ldots & 11 / 4 \text { miles. } \\ 2 & 07 & 50 & \ldots & 26.06 \text { meters. } \\ 42 & 05 & \ldots & \ldots & 13 / 8 \text { miles. } \\ 44 & 24 & \ldots & \ldots & 25 / 8 \text { miles. } \\ 49 & 54 & 40 & \ldots & 25.75 \text { meters. } \\ 50 & 48 & 55 & \ldots & 23.99 \text { meters. } \\ 60 & 12 & \ldots & \ldots & 2 \text { miles. } \\ 265 & 55 & \ldots & \ldots \ldots & 3 / 8 \text { mile. } \\ 331 & 27 & 40 & \ldots \ldots & 33.99 \text { meters. }\end{array}$

FARR.

General locality.-Eastern shore of Wicomico River about $x^{1 / 4}+$ miles south-southeast of Mills Point and $3 / 4$ mile north of the mouth of Manahowick Creek. (See Chart No. 26.)

Immediate locality.-Obscrved station is about ro feet above high-water mark, 5 yards east by south of edge of bank, 32 yards north-northwest of several pine trees at fish shanty near edge of bank, 22 yards south by east of other trees, and 300 yards west by north of a large house.

Marks.-Observed station is center point of triangle on standard cement monument buried I 6 inches below surface of ground with nail in stub at surface.

References.-

"Cobb Point Bar Light" ( $\left.\mathrm{S}_{2}^{\circ} 35^{\prime} \mathrm{E}\right)$.........

"Rock Point Catholic Church Cross"..........

Chimney on left side of house..............

Left peak of house on Chaptico Wharf . I5

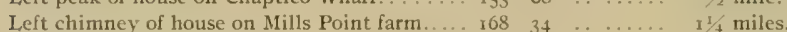

Right chimney on Maddox house $\ldots \ldots \ldots \ldots \ldots 242 \quad 28 \quad \ldots \ldots \ldots .2$ miles.

Right corner of large house............. $292 \quad 33 \quad \ldots \ldots \ldots \quad 1 / 4$ mile.

Near corner of fish shanty. ............. $338 \quad 27 \quad \ldots \ldots \ldots 2.69$ meters.

\section{GUST.}

General locality.-Western shore of Wicomico River on Windmill Point about $3 / 4$ mile north of the mouth of Hedneys Creek and opposite mouth of Manahowic Creek. (See Chart No, 26.)

Immediate locality.-Observed station is on shell and gravel point, bordered by persimmon and cedar trees, about 2 feet above high-water mark, I2 yards northwest of shore, 16 yards south of shore, and 28 yards west-southwest of shore on extreme end of point.

Marks.-Observed station is center point of triangle on standard cement monument.

References.-

"Fact" ( $\left.\mathrm{N}_{20} \circ 0^{\prime} \mathrm{E}\right)$

Nail in blaze in persimmon tree $(8$ inches diameter).

Near peak of roof of house on Chaptico Wharf.

Chimney on left side of large house.........

Chimney on middle of Lyon house.......... IO

Near peak of roof of house with two chimneys. . I7 I 43

Nail in blaze in cedar tree ( 4 inches diameter). . $204 \quad$ I4

Nail in blaze in cedar tree ( 10 inches diameter). 301

$\begin{array}{rcccc}0 & 1 & \prime \prime & & \\ 0 & 00 & 00 & \ldots \ldots & 11 / 2 \text { miles. } \\ 6 & 22 & \ldots & \ldots & 7.95 \text { meters. } \\ 35 & 32 & \ldots & \ldots & 11 / 4 \text { miles. } \\ 58 & 18 & \ldots & \ldots & 13 / 8 \text { miles. } \\ 01 & 24 & \ldots & \ldots & 13 / 4 \text { miles. } \\ 71 & 43 & \ldots & \ldots & 5 / 8 \text { mile. } \\ 04 & 14 & 00 & \ldots \ldots & 5.90 \text { meters. } \\ 301 & 03 & 10 & \ldots \ldots & 16.18 \text { meters. }\end{array}$


LYON.

General locality:-Eastern shore of Wicomico River on a point about $1 / 4$ mile north of Bramlcigh Creck and 2 miles north by east of Rock Point. (See Chart No. 26.)

Immediate locality:-Observed station is on a point of land between the Lyon residence and edge of bark, 10o yards north of small pond which is fringed on river side with cedar trees, about 4 yards north of a bird house on a post, I9 yards east-northeast of most prominent point of bank, I 5 yards eastsoutheast of side of bank, 16 yards north-northeast of another side, and 12 yards south-southwest of a fonce.

Marks.-Observed station is center point of triangle on standard cement monument.

References,-

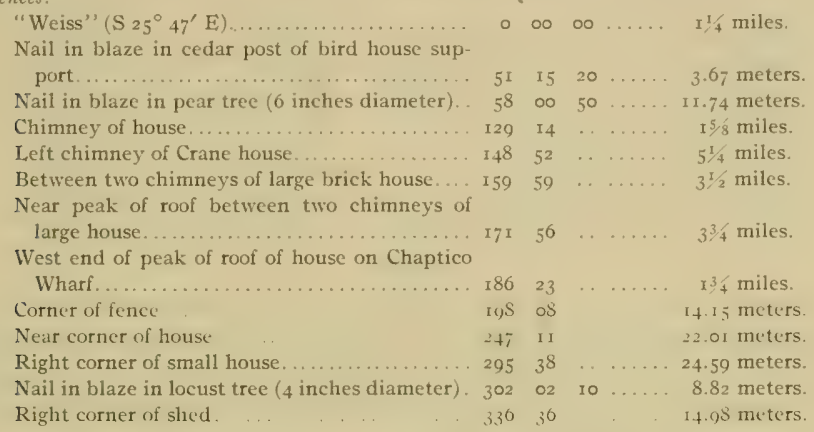

\section{SACRED HEART CHURCH SPIRE (BUSHWOOD).}

General locality.-Easterly side of Wicomico River on high land about $1 \frac{1}{2}$ miles inland, north by east of Bushwood Wharf. (See Chart No. 26.)

Immediate locality.-Observed station is steeple of Sacred Heart Church near Bushwood.

Marks.-Observed station is center of cross on steeple.

References.-None necessary.

\section{HEDNEY.}

General locality.-Westem shore of Wicomico River on first point above mouth of Charleston Creek and about $I 3 / 4$ miles northwest of White Point. (See Chart No. 26.)

Immediate locality.--Observed station is about 25 feet above high-water mark, 16 yards westsouthwest of edge of bank, I39 yards north of large tree at edge of bank, 85 yards north of oak tree at edge of bank, 155 yards east-northeast of gum tree 20 inches diameter on bank of a pond, and about $1 / 8$ mile east-southeast of a house among trees.

Marks.-Observed station is center point of triangle on standard cement monument with top buried I2 inches below the surface of the ground. Surface mark is nail in stub with top 5 inches above surface of ground.

References.-

"Sacred Heart Church Spire" ( $\left.86^{\circ} 3 \mathrm{r}^{\prime} \mathrm{L}\right)$. .

Near comer of nearest chimney of four on a large house on hill

Right chimney of a large house............

Middle of island at end of White Point Bar.

Nail in blaze in oak tree ( 48 inches diameter).

Nail in blaze in walnut tree ( 36 inches diameter).

Middle of gum tree .................... 147

Near peak of roof between two chimneys.....230

Near chimney on large house............. 3I

Chimney of Lyon house............. 352

\begin{tabular}{|c|c|c|}
\hline$\infty$ & $\infty \ldots \ldots$ & $4^{1 / 2}$ miles. \\
\hline II & $\ldots$ & $4^{1 / 2}$ miles. \\
\hline 03 & $\ldots \ldots \ldots$ & 2 miles. \\
\hline 45 & $\therefore \ldots \ldots$ & I7/8 miles. \\
\hline 28 & o. . & 73.16 meters. \\
\hline $5^{2}$ & 30 & I 5.63 meters. \\
\hline 46 & $30 \ldots \ldots$ & I 38.47 meters. \\
\hline 48 & $\ldots \ldots \ldots$ & $3 / 4$ mile. \\
\hline I9 & $\ldots \ldots \ldots$ & I5/8 miles. \\
\hline 40 & $\ldots \ldots \ldots$ & I1/8 miles. \\
\hline
\end{tabular}




\section{CHARLES.}

General locality.-Western shore of Wicomico River on first point south of entrance to Charleston Creek, and I I/4 miles north of Rock Point. (See Chart No. 26.)

Immediale locality.-Observed station is on a small marshy point about 6 inches above high-water mark and 18 yards east of pine woods on a bank to feet above high water. Cement monument marking reference station is $15.5^{6}$ meters $\mathrm{N} 57^{\circ}$ ro' W of observed station.

Marks.-Observed station is nail in stub with top 2 inches above ground. Reference station is center point of triangle on standard cement monument.

References.-

\begin{tabular}{|c|c|c|c|c|c|}
\hline & ○ & & & & \\
\hline 21 & 47 & & & & 2 \\
\hline ze in & 84 & & & & 16. \\
\hline blaze in pine tree ( 7 inches diameter & 134 & & & & 16.8 \\
\hline $\mathrm{CE} S$ & 138 & 28 & 0 & & 15 \\
\hline . & 265 & & & & $x_{1 / 4}^{1}$ \\
\hline Chu & 268 & & $5^{\circ}$ & & $23 / 4$ \\
\hline חת & & & .. & & \\
\hline se on Bushwoo & & & & & niles \\
\hline
\end{tabular}

\section{WEISS.}

General locality.-Eastern shore of Wicomico River on White Point, about 3 miles north by east of Cobb Point Bar Light. (See Chart No. 26.)

Immediate locality.-Observed station is on a bluff near small cedar trees, about 8 feet above highwater mark, $I_{3}$ yards north of and 27 yards south of edges of bluff and 52 yards east of extreme point.

Marks.-Observed station is center point of triangle on standard cement monument.

References.-

"Cobb Point Bar Light" (S II $\left.{ }^{\circ} 43^{\prime} \mathrm{W}\right)$.........

Flagstaff on schoolhouse............... 40

Nail in blaze in cedar tree (Io inches diameter). 54

Left chimney on two-story house.......... I55

Nail in blaze in poplar tree ( 3 inches diameter). 181

"Sacred Heart Church Spire" .............. 216

West chimney of Garner house............ 260

Nail in blaze in poplar tree ( 4 inches diameter), 266

West gable of house on Bushwood Wharf..... 284

Left chimney on two-story house . . . . . . . $34^{2}$

\begin{tabular}{ccccc} 
& \multicolumn{1}{l}{ " } \\
0 & 0 & 00 & $\ldots \ldots$ & $31 / 8$ miles. \\
0 & 41 & 20 & $\ldots$ & $15 / 8$ miles. \\
4 & 03 & 10 & $\ldots$ & 42.29 meters. \\
5 & 26 & $\ldots$ & $\ldots$ & $3 / 4$ mile. \\
1 & 46 & $\ldots$ & $\ldots$ & 6.24 meters. \\
6 & 56 & 30 & $\ldots$ & $13 / 4$ miles. \\
0 & 27 & $\ldots$ & $\ldots$ & $5 / 8$ mile. \\
6 & 27 & 50 & $\ldots$ & 37.80 meters. \\
4 & 26 & $\ldots$ & $\ldots$ & $5 / 8$ mile. \\
& 10 & $\ldots$ & $\ldots$ & $23 / 8$ miles.
\end{tabular}
"I

\section{BLAKISTONE.}

General locality.-Eastem shore of Wicomico River, about $1 / 4$ mile southeast of Plowdens Wharf at Bushwood, and about 3 miles north-northeast of Cobb Point Bar Light. (See Chart No. 26.)

Immediate locality.-Observed station is on second bluff southeast of Bushwood Wharf, I 5 feet above high-water mark, I5 yards southeast of a large dogwood tree, about 6 yards northeast of edge of bluff, 3 yards southwest of rail fence, about I5 yards southwest of an ice house near orchard, and 5 to ro yards south to east of several small cedar trees.

Marks,-Observed station is center point of triangle on standard cement monument.

References.-

"Prec" (S $\left.18^{\circ} 42^{\prime} \mathrm{W}\right)$. .

"Rock Point Catholic Church Cross".......... 5 r

Left peak of roof of wharf house........... 94

Large tree.

Chimney of Blakistone store ............. I2

Near peak of roof of Blakistone house........ I76

Point of cupola on Ranahan house .......... I9I

Near left comer of sill of ice house.......... 233

Right lower cormer.................... 260

Near peak of roof ................... 312

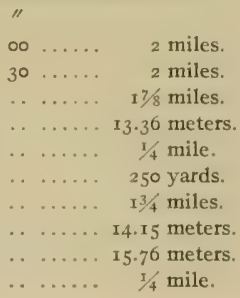


HARD.

General locality.-Western shore of Wicomico River on point of land known as Rock Point about 2 miles north by west of Cobb Point Bar Light. (See Chart No. 26.)

Immediate locality.-Observed station is on low point of land near several small cedar trees about $\mathrm{I}$ - foot above high-water mark, 47 yards west of shore, 16 yards south of shore, 30 yards north of shore, about 80 yards northeast by north of Rock Point Wharf, and 170 yards northeast by east of Lancasters store.

Marks.-Observed station is center point of triangle on standard cement monument.

References.-

"Cobb Point Bar Light" (S $\left.10^{\circ} 17^{\prime} \mathrm{E}\right) \ldots \ldots \ldots . . .2$ miles.

Northeast gable of wharf house............ 4 I $07 \ldots \ldots$. 80 yards.

"Rock Point Catholic Church Cross".......... 70 I6 $20 \ldots \ldots$. $1 / 4$ mile.

South chimney on Lancaster store ........... $88 \quad 53 \quad \ldots \ldots \ldots$ 170 yards.

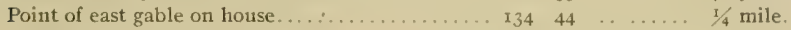

"Sacred Heart Church Spire" .............. $239 \quad 04 \quad 20$..... 3 miles.

Gable of house on wharf at Bushwood.......... $256 \quad 00 \quad \ldots \ldots \ldots$ I $^{3 / 4}+$ miles.

West gable of house.......................... 293 of ...... 2 miles.

West gable on one-story house............... $33_{5}$ I9 $\ldots \ldots 2^{1 / 4}$ miles.

North chimney of two-story house............ 330 I2 $\ldots \ldots 2 \frac{1}{2}$ miles.

\section{ROCK POINT CATHOLIC CHURCH CŔOSS.}

General locality.-Eastern shore of Wicomico River at Rock Point. (See Chart No. 26.)

Immediate locality.-Observed station is in settlement called Rock Point. It is on the larger of two similar buildings, the smaller one being the schoolhouse.

Marks.-Observed station is center point of cross on Rock Point Catholic Church.

References.-None necessary.

\section{PREC.}

General locality.-Eastern shore of Wicomico River on Bluff Point about 2 miles north-northeast of Cobb Point Bar Light. (See Chart No. 26.)

Immediate locality.-Observed station is about ro feet above high-water mark, 34 yards southeast of nearest end of neck of Bluff Point, 29 yards south-southeast of shore, 16 yards northeast of shore, and 88 yards west by southwest of house.

Marks.-Observed station is center point of triangle on standard cement monument.

References.-

"Cobb Point Bar Light" ( $\left.\mathrm{S}_{2} 8^{\circ} 37^{\prime} \mathrm{W}\right) \ldots \ldots$. . .

Tangent of woods on Cobb Point.............

"Rock Point Catholic Church Cross"......... 70

Nail in blaze in locust tree ( 3 inches diameter). . II

Left chimney of Garner house.

Nail in blaze in left one of twin locust trees ( 12 inches diameter $) \ldots \ldots \ldots \ldots \ldots \ldots \ldots \ldots \ldots$ I5 $38 \quad 20 \ldots \ldots . \ldots \ldots$ meters.

"Sacred Heart Church Spire"............ 172 15 10 .... $23 \frac{3}{4}$ miles.

Near chimney of Sherrer house........... $228 \quad 37 \quad \ldots \ldots \ldots 88$ yards.

Nail in blaze in poplar tree ( 6 inches diameter). 243 or $50 \ldots \ldots 33.74$ meters.

Nail in blaze in poplar tree ( 5 inches diameter). 282 o0 $40 \ldots .27 .71$ meters.

L.eft chimney of cottage............... $298 \quad 22 \quad \ldots \ldots \ldots \quad 1 / 8$ mile.

Right chimney of Bailey house on St. Margarets Island. 
General locality. - Western shore of Wicomico River on the eastern side of an island known as Cobb Point Neck about halfway between Cobb Point and the entrance to Neales Sound. (See Chart No. 26.)

Immediate locality.-Observed station is in a cultivated field on a bluff bordered with pine trees about 15 fect above high-lvater mark, 3 yards west of a wire fence running along edge of bluff and 21 yards east-northeast of a wire fence which separates cornfield from pine woods.

Marks.-Observed station is center point of triangle on standard cement monument.

References.-

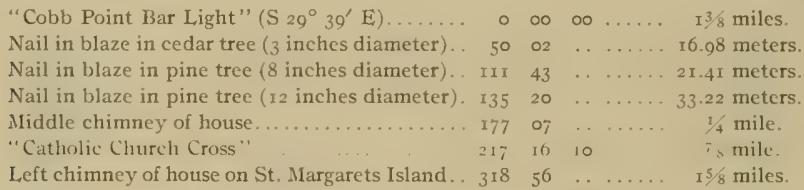

\section{ST. MARGARET 2}

General locality.-Northwestern side of Potomac River on the southwestern side of St. Margarets Island in the mouth of the Wicomico River about I mile northeast of Cobb Point Bar Light. (See Chart No. 26.)

Immediate locality,-Observed station is on a bluff about $\mathrm{r}_{2}$ feet above high-water mark, $\mathrm{x}_{5}$ inches northeast of edge of bluff, 86 yards northwest of cow shed, I29 yards south-southwest of several houses and 154 yards west-southwest of Bailey (large) house. Cement monument marking reference station is 79.19 meters $\mathrm{N} 46^{\circ} 26^{\prime} \mathrm{E}$ of observed station and at corner of cow shed.

Marks. - Observed station is center of a stub in a $2 \frac{1}{2}$-inch tile pipe set in cement with top flush with ground. Reference station is center point of triangle of standard cement monument.

References.-

\begin{tabular}{|c|c|c|c|c|c|}
\hline 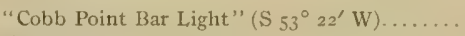 & 0 & 20 & & & \\
\hline Tangent of Cobb Point. & 45 & I3 & & & Is 8 \\
\hline Catholic Church Cross". & 83 & & $5^{\circ}$ & & $I 7 / 8$ \\
\hline left of Garner new house. & 129 & 40 & . & $\ldots \ldots$ & 23,8 \\
\hline 'Sac & $I_{43}$ & 27 & 50 & & es. \\
\hline REFE & 173 & $0.4>>$ & 15 & & 7 \\
\hline 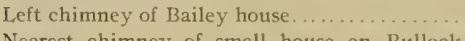 & 194 & $5^{1}$ & & & rids. \\
\hline $\begin{array}{l}\text { chimney of small house on Bullock } \\
1 \ldots \ldots \ldots \ldots \ldots \ldots \ldots \ldots \ldots \ldots \ldots \ldots \ldots \ldots \ldots \ldots \ldots\end{array}$ & 220 & 26 & & & nile. \\
\hline $\begin{array}{l}\text { n St. Catherine } \\
\ldots \ldots \ldots \ldots \ldots\end{array}$ & $25^{8}$ & 32 & & & I $1 / 4$ \\
\hline
\end{tabular}

\section{COBB POINT BAR LIGHT.}

General locality.-Northerly side of Potomac River at mouth of Wicomico River on the southeastern extremity of Cobb Point Bar. (See Chart No. 26.) River.

Immediate locality.--Observed station is on the end of Cobb Point Bar at the mouth of the Wicomico

Marks,-Observed station is center point of black lantern on screw pile structure known as "Cobb Point Bar Light."

References.-

"Blakiston Island Light" (S $\left.61^{\circ} 25^{\prime} \mathrm{E}\right) \ldots \ldots \ldots \ldots .6$......... 5 miles. 


\section{RIVER SPRINGS CATHOLIC CHAPEL, CROSS.}

General locality.-Northern side of Potomac River inland about $3 / 4$ mile north by west of River Springs. (See Chart No. 26.)

Immediate locality.-Observed station is on building known as River Springs Catholic Chapel.

Marks.--Observed station is center of cross on River Springs Catholic Chapel.

References.-None necessary.

\section{SOUND.}

General locality. - Northern shore of St. Catherine Sound about $2 \frac{1}{4}$ miles east by north of Cobb Point Bar Light and $1 / 4$ mile east of Bullock Island. '(See Chart No. 26.)

Immediate locality.-Observed station is about ${ }_{5}$ feet above high-water mark, 35 yards north of edge of bank, 2 yards east of wire fence, 65 yards east of edge of bank, 57 yards south of southeast corner of fence of house yard, and $6_{3}$ yards south by west of telephone pole line which is on the same side of the road.

Marks.-Observed station is center point of triangle on standard cement monument.

References.-.

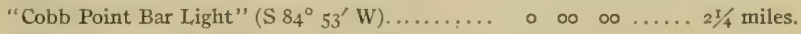

Right chimney of house on Bullock Island.... $8 \quad 24 \quad \ldots \ldots . .1 / 2$ mile.

Near end of small chimney on large house..... 27 I5 $\ldots \ldots \ldots$ I mile.

Left corner post of fence.................... $6_{5} \quad 0_{5} \ldots \ldots \ldots$ Near.

Near corner of chimney of small house......... $86 \quad 25 \quad \ldots \ldots . \quad$ Near.

Near corner post of fence.................. I00 $58 \quad \ldots \ldots \ldots$ Near.

Right peak of roof of barn....................

"River Springs Catholic Chapel Cross"........ I 48 3I Io ..... I mile.

Chimney of Blakistone store.............. 189 I6 ...... $1 / 2$ mile.

Near chimney of Bailey house............... $217 \quad 59 \quad \ldots \ldots .1 / 2$ mile.

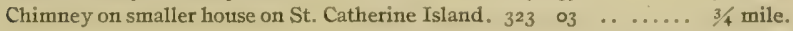

\section{BAILEY.}

General locality.-Northeastern shore of St. Catherine Sound, about $3 / 4$ mile east by north of eastern end of St. Catherine Island and I mile north of the Potomac River. (See Chart No. 26.)

Immediate locality.-Observed station is on shelly ground on Bailey property, about 5 feet above high-water mark, ro yards northeast of high-water mark, 7 yards northeast of a wire fence, 35 yards south-southeast of corner of wire fence, 30 yards north-northwesi of corner of wire and wooden fences, 25 yards north of Bailey house, and 40 yards west by south of comer of wooden fence.

Marks.-Observed station is center point of triangle on standard cement monument.

References.--

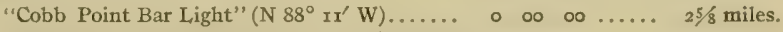

Nail in blaze in one of four cedar trees $(3$ inches diameter $) . \ldots \ldots \ldots \ldots \ldots \ldots \ldots \ldots \ldots \ldots . \ldots \ldots$.

$1329 \quad \ldots \quad \ldots \ldots .12 .37$ meters.

.

Cormer of wire fence..................... $46 \quad 29 \ldots \ldots \ldots 32.06$ meters.

Chimney on house..................... 90 $38 \ldots \ldots$ I 50 yards.

"River Springs Catholic Chapel Cross"....... II3 o6 oo ..... I mile.

Corner of wooden fence............... $75 \quad 52 \quad \ldots \ldots \ldots 37.49$ meters.

Chimney of Bailey house................... $203 \quad 26 \quad \ldots \quad 25$ yards.

Junction of wire and wooden fences........ $254 \quad 35 \quad \ldots \ldots \ldots 26.22$ meters.

Left chimney of house on Waterloo Point.... $277 \quad 43 \quad \ldots \ldots .3 / 4$ mile.

Nail in blaze in first of six cedar trees....... $297 \quad 27 \quad \ldots \ldots .10 .76$ meters.

Right chimney of small house on St. Catherine

Island............................. I mile. 


\section{ST. CATHERINE,}

General locality.-Southem shore of St. Catherine Sound, on the northern side of St. Catherine Island. (See Chart No. 26.)

Immediate locality.-Observed station is about I2 feet above high-water mark, 86 yards south of edge of bank, 49 yards west of line of young cedar trees, 198 yards northeast of a lone mulberry tree 3 feet in diameter, and 207 yards southeast of small house among trees.

Marks.-Observed station is center point of triangle on standard cement monument with top I2 inches below the surface.

0 , I

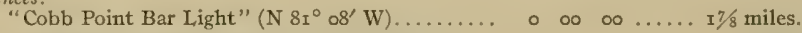

Right side of right chimney on small house...... I3 $04 \ldots \ldots 207$ yards.

Left chimney of large house on St. Margarets Island $\begin{array}{lllll}34 & 42 & \ldots & \ldots & \mathrm{x} 3 / 8 \\ \text { miles. }\end{array}$

Right chimney of house on Bullock Island..... 66 or ..... $1 / 2$ mile.

Chimney of Blackistone house.............. II $39 \ldots \ldots \ldots$. . . $5 / 8$ mile.

"River Springs Catholic Chapel Cross"........ I29 I7 $40 \ldots \ldots$ I5/8 miles.

Left chimney of Bailey house............... I58 ig ...... $7 / 8$ mile.

Right chimney of Young house on Waterloo Point. $207 \quad 48 \quad \ldots \ldots \ldots$. $7 / 8$ mile.

\section{WATERLOO}

General locality.-Southeastern shore of St. Catherine Sound, about 3/4 mile east-southeast of St. Catherine Island and about $1 / 4$ mile north of Potomac River. (See Chart No. 26.)

Immediate locality,-Observed station is at top of rise in field, about 8 feet above high-water mark, 48 yards east by south of shore at a point where several mulberry trees stand, 43 yards south of large sugarberry tree, ig yards south by east of wire-fence post, and 200 yards north of Young house on Water1oo Farm.

Marks,-Observed station is center point of triangle on standard cement monument, with top I2 inches below surface of ground.

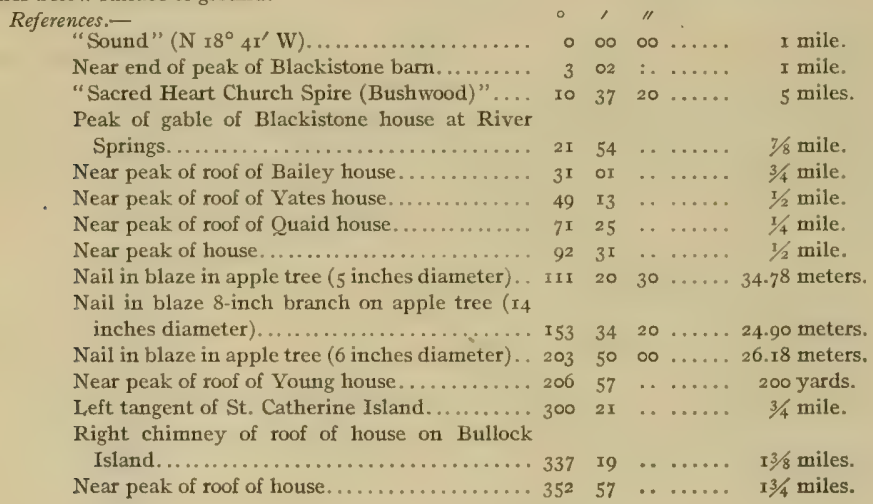


PRINCE.

General locality.-Western shore of Patuxent River, about $1 / 4$ mile north of mouth of Swanson Creek. (See Chart No. 26.)

Immediate locality.-Observed station is in pasture about 20 feet above high water, I5 yards northwest of edge of bank, 75 yards northeast of a grove of trees, and Ioo yards southwest of another grove of trees. Locust trees form a fringe along edge of bank.

Marks.-Observed station is center point of triangle on standard cement monument.

References.-

\begin{tabular}{|c|c|c|c|c|c|}
\hline 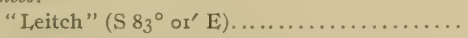 & $\circ$ & $\infty$ & $\infty 0$ & & $3 / 4$ mile. \\
\hline Square chimney on house......... & $\circ$ & 02 & $\ldots$ & & 3/4 mile. \\
\hline Chimney on store at Buena Vista............ & I9 & I5 & . . & & miles. \\
\hline Chimney of Dr. Huggins house at Buena Vista. . & $2 I$ & 07 & & & niles. \\
\hline 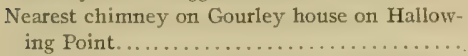 & 55 & I6 & $\cdots$ & & 2I \\
\hline Nail in blaze in locust tree ( 3 inches diameter). . & 79 & $3^{8}$ & 30 & & I5.9 \\
\hline Nail in blaze in locust tree ( 4 inches diameter). . & II0 & $I_{3}$ & 30 & & 14.55 \\
\hline Outside chimney on large house on hill....... & I 50 & 45 & . & & $3 / 4$ mile. \\
\hline 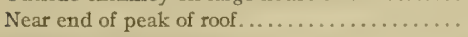 & 226 & 02 & . & & $3 / 4$ mile. \\
\hline Middle of clump of trees... & 273 & $\infty$ & . & & roo yards. \\
\hline Chimney of house .................... & $3 \mathrm{Ir}$ & 04 & . & & miles. \\
\hline n crotch of locust tree $(6$ inches & 350 & 39 & & & \\
\hline
\end{tabular}

\section{LEITCH.}

General locality.-Eastern shore of Patuxent River, on prominent point opposite mouth of Swanson Creek, given on chart as Gods Grace Point, but known locally as Leitchs Point. (See Chart No, 26.)

Immediate locality.-Observed station is on sand and grass land about $x$ foot above high water and 3 yards north of straight line connecting two round points. It is about $x_{3}$ yards northwest of the lower of these two points and 9 yards east of upper point. A creek 3 feet wide has its mouth about Ig yards east by south of the station. There are no permanent objects near station.

Marks.-Observed station is center point of triangle on standard cement monument.

References. -

"Prince" ( $\mathrm{N} 83^{\circ}$ oo' W) - I I"

Near end of comer peak of roof of large house on

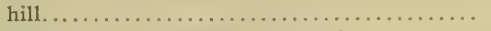

Near end of peak of wharf-house roof .......... 7

Right chimney of house.................. I8

Right chimney of Gourley house............. 253

Canning-house stack......................

"Catholic Church Cross"................. 281

Chimney of small house................... 308

Right outside chimney of old house............. 343 o5 $\ldots \ldots \ldots$ miles.

\section{FODDER.}

General locality.-Western shore of Patuxent River on the southern side of the mouth of Swanson Creek about I mile west-southwest of Leitch Wharf and $3 \frac{4}{4}$ mile west-northwest of Point Judith (locally known as Téague Point). (See Chart No. 26.)

Immediate locality.-Observed station is on the edge of cultivated land about to feet above highwater mark, 4 yards west of edge of bank, and 9 yards north of another edge. Cement monument marking reference station is $15.2 \overline{1}$ meters $\mathrm{S} 60^{\circ} 5^{\prime}$ W $\mathrm{W}$ observed station.

Marks.-Observed station is center point of triangle on standard cement monument with a top 9 inches square and 8 inches above surface of ground. Reference station is center point of triangle on standard cement monument with a top about 8 inches square and 5 inches above surface ground. 


\begin{tabular}{|c|c|c|c|c|c|}
\hline \multicolumn{6}{|l|}{ References.- } \\
\hline "Prince" ( $\mathrm{N}_{25} 5^{\circ}$ oo' E). & 0 & $\infty$ & $\infty$ & & $1 / 2$ mile. \\
\hline Near peak of large house on bluff........... & $x 7$ & 55 & .. & & 2 miles. \\
\hline Right comer of house. ............ & 24 & 08 & . & & $\mathrm{x} 3 / 4$ miles. \\
\hline Near peak of Leitch Wharf house............ & 35 & II & . & *. & $\mathrm{I} / \mathrm{4}$ miles. \\
\hline 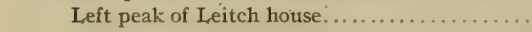 & 48 & 37 & . & ..... & $\mathrm{I} / 4$ miles. \\
\hline Front peak of house at Buena Vista......... & 75 & $\infty$ & $\cdots$ & & $\mathrm{I}^{1} / 4$ miles. \\
\hline Chimney outside left end of house on hill..... & 87 & $x 6$ & .. & & 2 miles. \\
\hline Near peak of smiall house. ................ & IOI & 33 & . & $\ldots \ldots$ & $3 / 8$ mile. \\
\hline Large chimney on small house................ & 174 & 43 & . & $\ldots \ldots$ & I mile. \\
\hline $\begin{array}{c}\text { Left side of left chimney outside Bowling } \\
\text { house } \ldots \ldots \ldots \ldots \ldots \ldots \ldots \ldots \ldots \ldots\end{array}$ & $2 \mathrm{II}$ & 47 & $\ldots$ & & aile. \\
\hline REFERENCE STATION . . . . . . . . . . . . . . & 215 & $5^{2}$ & 30 & $\ldots \ldots$ & I $5.2 x$ meters. \\
\hline Left corner of house on top of hill........... & 318 & 27 & . & $\ldots \ldots$ & I mile. \\
\hline
\end{tabular}

\section{BUENA.}

General locality.-Eastern shore of Patuxent River about $\mathrm{x} 3 / 4$ miles northeast of Benedict at place known as Buena Vista. (See Chart No. 26.)

Immediate locality.-Observed station is in a field on land adjoining house owned by S. V. Smith and occupied by Dr. Huggins. It is about to feet above high water, 8 yards east of edge of bank, and 12 yards south of a rail fence. Cement monument marking reference station is Ix.II meters $\mathrm{N} 5^{\circ} 42^{\prime} \mathrm{E}$ of observed station and near fence.

Marks.-Observed station is nail in stub with top 2 inches above ground. Reference station is center point of triangle on standard cement monument.

References. -

"Hallowing" ( $\left.\mathrm{S}_{27^{\circ}} 22^{\prime} \mathrm{W}\right)$.

Center of red roof on square house near Benedict.

Canning-house stack....................

"Catholic Church Cross"...................

Nail in blaze in locust tree ( 4 inches diameter). .

Left chimney of old house...................

Left chimney of old house ..................

Nail in blaze on cherry tree ( 2 inches diam-

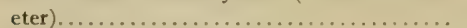

Peak of roof of large house. ......................

Chimney of house near Leitch Wharf.......... I

Nail in blaze on fence post.............. I

REFERENCE STATION. . . . . . . . . . . . . . I5

Near corner of house. .................. I

Cherry tree on fence line ( 15 inches diameter). . 2

Double apple tree ( 30 inches diameter). . . . 290

$$
\begin{aligned}
& \begin{array}{lll}
\circ & \prime \prime \\
0 & 00 & \infty
\end{array} \\
& \text { I8 } 05 \ldots \ldots \ldots \quad 2 \text { miles. } \\
& \text { I } 30 \quad \ldots \quad \ldots \ldots \quad 13 / 4 \text { miles. } \\
& 04 \text { 10 ..... } 13 / 4 \text { miles. } \\
& 48 \quad 40 \ldots .8 .58 \text { meters. } \\
& \text { I5 ..... } 3 \text { miles. } \\
& 52 \ldots \ldots \ldots \quad 3 \text { miles. } \\
& 9905 \quad \ldots \ldots . .9 .70 \text { meters. } \\
& \text { I5 ...... } 4 \text { miles. } \\
& 52 \ldots \ldots \ldots \quad x \text { mile. } \\
& 3350 \ldots \ldots \text { II.I8 meters. } \\
& 2020 \text {..... II.rI meters. } \\
& 44 \quad \ldots \quad \ldots \ldots . \quad 25 \text { yards. } \\
& 25 \quad \ldots \ldots . \quad 35 \text { yards. } \\
& 54 \ldots \ldots . \quad 59 \text { yards. }
\end{aligned}
$$

TEAGUE.

General locality. - Western shore of Patuxent River on point on southern side of entrance to Swanson Creek; locally known as Teague Point, and given on chart as Point Judith. (See Chart No. 26.)

Immediate locality.-Observed station is on gravel and grass land about 3 feet above high water, about II yards from south side, 16 yards from north-northeast side, and 75 yards west by north of extreme end of point. Bushes stand between station and north side of point. There are no permanent reference objects near station.

Marks.-Observed station is center point of triangle on standard cement monument. 


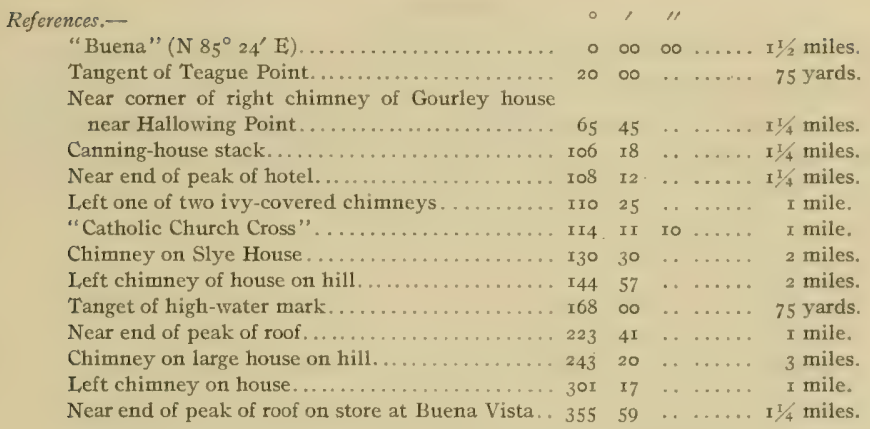

\section{CATHOLIC CHURCH CROSS (BENEDICT).} No. 26.)

General locality.-Western shore of upper Patuxent River in the town of Benedict. (See Chart

Immediate locality.-Observed station is on Catholic Church, located on the main street of the town of Benedict about one-fourth mile from the wharf.

Marks.-Observed station is center point of cross on church.

References.-None necessary.

\section{CITY.}

General locality.-Western shore of Patuxent River on Town Point about one-fourth mile northnortheast of Benedict steamboat wharf. (See Chart No, 26.)

Immediate locality.-Observed station is on gravel and shell point about 4 feet above high water, I2 yards northwest of the shore, 63 yards west-southwest of a shanty, about roo yards west-southwest of extreme end of point, and II yards southeast of a slough. There are no permanent reference objects near station.

Marks.-Observed station is center point of triangle on standard cement monument.

References. -

"Hallowing" ( $\left.\mathrm{S}_{5} \mathrm{I}^{\circ} 2 \mathrm{I}^{\prime} \mathrm{E}\right)$.

Windmill near Sheridan Point. .

Two middle chimneys at Dowells

Left tangent of peak of wharf-house roof......... 8

Center of roof of square house ..............

Canning-house stack. . . . . . . . . . . . . . . .

Nearest ivy-covered chimney of old house....... I30

"Catholic Church Cross" . . . . . . . . . . . . . . . . I I

Left square chimney of house . . . . . . . . . . 24

Near end of peak of roof of Huggins house....... 280

Near corner of shanty..................... 300

Right chimney of Gourley house. .......... 339

Chimney of old building behind wharf........ 352

\begin{tabular}{|c|c|c|}
\hline$\infty$ & $\infty$ & $\ldots \ldots \pi \quad 1 / 2$ mile. \\
\hline 39 & . & ․ $3^{1 / 2}$ \\
\hline 39 & .. & $3^{\pi / 2}$ \\
\hline 34 & . & $\ldots \ldots 1 / 4$ mile. \\
\hline 36 & . & …. $1 / 2$ \\
\hline 22 & . & ... $1 / 4$ \\
\hline$I_{4}$ & .. & $\ldots \ldots$ 1/8 mile. \\
\hline $5^{8}$ & 50 & $\ldots \ldots \quad 3 / 4$ \\
\hline 42 & $\cdots$ & I $3 / 4$ \\
\hline 54 & .. & . $1 / 2$ \\
\hline 44 & . & 63 \\
\hline & $\cdots$ & $3 / 4$ \\
\hline & & \\
\hline
\end{tabular}




\section{HALLOWING.}

General locality.-Eastern shore of Patuxent River on point opposite Benedict, known locally as Holland Point, but given on charts as Hallowing Point. (See Chart No. 26.)

Immediate locality.-Observed station is on a rounded gravel and grass point about 250 yards south of wharf on Holland Point, about 2 feet above high water, ro yards north of shore, 8 yards east of shore, and 15 yards outside of a group of locust trees, sugar-berry trees, and bushes.

Marks.-Observed station is center point of triangle on standard cement monument.

References.-

\begin{tabular}{|c|c|c|c|c|c|}
\hline \multicolumn{6}{|l|}{ "City" $\left(\mathrm{N} 5 \mathrm{I}^{\circ} 2 \mathrm{x}^{\prime} \mathrm{W}\right) \ldots \ldots \ldots \ldots \ldots \ldots \ldots \ldots$} \\
\hline 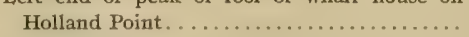 & 23 & I5 & . & & \\
\hline himney of store at Buena Vista. . . . . . . . . & 77 & -3 & & & \\
\hline $\begin{array}{l}1 \text { blaze in neare } \\
\text { r-berry trees (eac }\end{array}$ & 02 & & & & \\
\hline dia & & $5^{8}$ & 50 & & \\
\hline . & 167 & 55 & 40 & & II. \\
\hline mol & 227 & 35 & $\cdots$ & & I \\
\hline oro & & & & & 4. \\
\hline ent & 3 I4 & $x_{5}$ & & & \\
\hline & 333 & 16 & . & & \\
\hline $\mathrm{Ca}$ & 347 & 44 & 20 & $\ldots \ldots$ & $3 / 4$ mile. \\
\hline
\end{tabular}

\section{INDIAN.}

General locality.-Western shore of Patuxent River on north side of entrance to Indian Creek and about one-fourth mile below Benedict steamboat wharf. (See Chart No. 26.)

Immediate locality.-Observed station is about 3 feet above high water, 7 yards west of shore, I6 yards northeast of a fence and a line of trees, 13 yards southwest of a lone locust tree, about 250 yards to the south-southeast of a large square house, and 125 yards east-northeast of another house.

Marks.-Observed station is center point of triangle on standard cement monument.

References:-

"Sothoron" ( $\left.\mathrm{S}_{23}{ }^{\circ} \mathrm{II}^{\prime} \mathrm{E}\right) \ldots \ldots \ldots \ldots \ldots \ldots \ldots$

Nail in blaze in locust tree near fonce ( 5 inches

Nail in blaze in middle branch of locust tree ( 6 inches diameter)..................

Square chimney on old louse............ I3

Right chimney of square house............ I 88

Near end of peak of roof of hotel ...........206

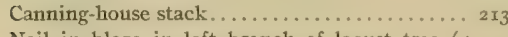

Nail in blaze in left branch of locust tree ( 5 inches diameter $\ldots \ldots \ldots \ldots \ldots \ldots \ldots \ldots . \ldots .225$

Right tangent of Benedict Wharf.......... 228

Chimney of house near "Buena Vista". . . . . 245

Chimney of Gourley house............. 270

Windmill at Dowell's on Sheridan Point. . . . 344

Left of right chimney on Dowell house...... 344

$\circ \infty 00 \ldots . . \quad$ I mile.

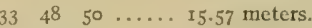

$66 \quad 24 \quad 50 \ldots \ldots .19 .13$ meters.

$23 \ldots \ldots \ldots \quad \mathrm{I} / \mathrm{t} / \mathrm{m}$ miles.

30 $\ldots \ldots \ldots \quad I / 8$ mile.

$26 \quad \ldots \ldots \ldots \quad 1 / 4$ mile.

22 Io $\ldots \ldots$ mile.

$\begin{array}{lll}\ldots & \ldots & 12.90 \text { meters. } \\ \ldots & \ldots & 1 / 2 \text { mile. } \\ \ldots & \ldots & 2^{1} / 4 \text { miles. } \\ \ldots & \ldots & x \text { mile. } \\ \ldots & \ldots & 4^{1} / 4 \text { miles. } \\ \ldots & \ldots & 4^{1 / 4} \text { miles. }\end{array}$




\section{DWARF}

General locality. -Eiastern shore of Patuxent River about 2 miles north-northwest of Sheridan Point and about $x^{1} / 2$ miles southeast of Benedict on a point of land opposite the mouth of Indian Creek. (See Chart No. 26.)

Immediate locality.-Observed station is on sand and grass land about I foot above high-water mark, 6 yards northeast from extreme end of point, 4 yards east of one edge of shore, and 6 yards north of another edge of shore. Point on which station is located has a sugar-berry tree, several small locust trees and water bushes, and a pond behind bushes and trees about roo yards to the east.

Marks.-Observed station is center point of triangle on standard cement monument.

References.-

\begin{tabular}{|c|c|c|c|c|c|}
\hline Sothoron" ( $\left.\mathrm{S}_{42^{\circ}}{ }^{\circ} 5^{\prime} \mathrm{W}\right)$. & 0 & $\infty$ & $\infty$ & & . \\
\hline $\begin{array}{l}\text { Nearest corner of top of nearest chimney on } \\
\text { tenant house } \ldots \ldots \ldots \ldots \ldots \ldots \ldots \ldots \ldots\end{array}$ & 80 & $3 I$ & $\cdots$ & & 2 miles. \\
\hline Center of roof of square house....$\ldots \ldots \ldots$ & 83 & 16 & $\cdots$ & & I mile. \\
\hline Nail in blaze in locust tree ( 4 inches diameter). & 93 & $3^{8}$ & 30 & & 4.22 meters. \\
\hline Canning-house stack. .......... & 95 & 03 & 33 & & I $1 / 4$ miles. \\
\hline "Catholic Church Cross". & 99 & 03 & I0 & & $1 / 4$ miles. \\
\hline Left tangent of wharf.... & I24 & 19 & . & & $3 / 4$ mile. \\
\hline Nail in sugar-berry tree (ro inches diameter). & $15^{2}$ & $3^{8}$ & 30 & & 8.94 meters. \\
\hline Nail in blaze in locust tree ( 3 inches diameter). . & Ig6 & 22 & 20 & & 2.68 meters. \\
\hline Chimney on small house. ............... & $25^{8}$ & $4^{8}$ & .. & & 2 miles. \\
\hline Left point of peak of roof of Dowell's...... & 287 & 30 & .. & & $2 \frac{1}{4}$ miles. \\
\hline Left end of peak of roof of Trent Hall Wharf. & 3 I5 & 35 & .. & & $\mathrm{I} / 2$ miles. \\
\hline ipola on & $32 I$ & 12 & 20 & & $\pi / 2$ miles. \\
\hline ight pillar on Sothoron house po & 359 & $2 I$ & & & $\operatorname{mil}$ \\
\hline
\end{tabular}

\section{SOTHORON.}

General locality.-Western shore of Patuxent River on Long Point between entrances to Indian and Trent Hall creeks. (See Chart No. 26.)

Immediate locality.-Observed station is on sand and grass lowland about $\mathrm{x}$ foot above high-water mark among cedar trees, about 24 yards west by north of extreme end of point, 12 yards north of one edge of shore and 30 yards southwest of another edge of shore.

Marks.-Observed station is center point of triangle on standard cement monument.

References.-

"Hallowing" $\left(\mathrm{N}_{13}{ }^{\circ} 5 \mathrm{I}^{\prime} \mathrm{E}\right) \ldots \ldots \ldots \ldots \ldots \ldots$

Nearest chimney on Gourley house......... 3

Nail in blaze in locust tree ( 4 inches diameter).. 30

Left end of peak of roof of Dowell house....... 120

Middle cupola on Trent Hall stable .......... 150
Point of middle attic window on John Bullinger

house ............................ 187

Left pillar of porch of Sothoron house. ........ 206

Nail in blaze in cedar tree ( 12 inches diameter). 242

Near comer of nearest chimney on Slye house. . 29I

Nail in blaze in locust tree ( 4 inches diameter). . 302

Right one of two outside chimneys on old house

on hill on property of A. B. Slye.......... $307 \quad 3^{\mathrm{I}} \quad \ldots \quad 2$ miles.

Center of roof on square house........... $323 \quad 39 \quad \ldots \ldots . \quad$ I mile.

Nail in blaze in locust tree ( 6 inches diameter).. $350 \quad 24$ 10 .... 12.8I meters. 
BUZZ.

General locality.-Northeast shore of Patuxent River on southwest side of Buzzards Island.near mouth of Buzzards Island Creek. (See Chart No. 26.)

Immediate locality.-Observed station is on marsh, clay, and grass land on wooded island about 2 feet above high water, 5 yards northeast of river shore and 40 yards northwest of extreme point of island. Cement monument marking reference station is 8.97 meters $\mathrm{N}_{42}{ }^{\circ} 3^{\prime} \mathrm{E}$ of observed station.

Marks.-Observed station is nail in stub with top flush with ground. Reference station is center point of triangle on standard cement monument.

References.-

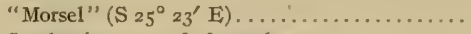

Smokepipe on roof of storehouse.............

Near comer of near chimney . . . . . . . . . . . . .

Chimney of Trent Hall ...............

Nearest of three cupolas on stable............

Left piazzi post at Sothorons............. ro2

Center of roof of square house............. 155

"Catholic Church Cross" ............... 16

Nail in blaze in oak tree ( 18 inches diameter). . $\quad 172$

Nail in blaze in oak tree ( 18 inches diameter).. I9 8

Nail in blaze in oak tree ( 24 inches diameter). . 235

REFERENCE STATION . . . . . . . . . . . . . 252

Nail in blaze in pine tree ( 5 inches diameter). . 255

Chimney on house across creek............ 313

\begin{tabular}{|c|c|c|c|}
\hline$\infty$ & $\infty$ & & $3 / 4$ mile. \\
\hline II & .. & . & es. \\
\hline $3^{6}$ & .. & & 2 miles. \\
\hline 48 & .. & $\ldots \ldots$ & $\mathrm{I}^{1 / 4} / 4$ miles. \\
\hline 36 & 50 & $\ldots \ldots$ & I $1 / 4$ miles. \\
\hline $4 I$ & . & ...... & $I^{1} / 4$ miles. \\
\hline 15. & $\ldots$ & $\ldots \ldots$ & I $3 / 4$ miles. \\
\hline $5^{6}$ & . & $\ldots \ldots$ & 2 miles. \\
\hline I4 & . & & 4.55 meters. \\
\hline 36 & 40 & & 13.16 meters. \\
\hline 08 & 30 & $\ldots \ldots$ & geters. \\
\hline 45 & 45 & $\ldots \ldots$ & 8.9 \\
\hline 43 & . & & aeters. \\
\hline 23 & .. & $\ldots \ldots$ & nile \\
\hline
\end{tabular}




\section{BOUNDARIES OF OYSTER BARS.}

\section{EXPI.ANATION.}

The law of the United States authorizing the cooperation of the Department of Commerce and Labor in the survey of natural oyster bars of Maryland provides for the designation and employment by the Department of Commerce and Labor of such officers, experts, and other technically qualified persons "as may be necessary to cooperate with the Maryland State Board of Shell Fish Commissioners in making a survey of and locating the natural oyster beds, bars, and rocks in the waters within the State of Maryland." The oyster laws of Maryland provide that the Maryland Shell Fish Commissioners, with the aid of such persons as may be designated by the Government, shall proceed "to have laid out, surveyed, and designated on the said charts the natural beds and bars, and shall cause to be marked and defined as accurately as practicable the limits and boundaries of the natural beds, bars, and rocks as established by said survey, and they shall take true and accurate notes of said survey in writing, and make an accurate report of said survey, setting forth such a description of landmarks as may be necessary to enable the said board, or their successors, to find and ascertain the boundary lines of the said natural oyster beds, bars, and rocks, as shown by a delineation on the maps and charts." The oyster laws of Maryland also provide in another section that there shall "be made a true and accurate survey of the natural oyster beds, bars, and rocks *** with reference to fixed and permanent objects on the shore, giving courses and distances, to be fully described and set out in a written report of said survey."

Under the provisions of the laws quoted above the State of Maryland, in cooperation with the Department of Commerce and Labor, must define the boundaries of the natural oyster bars "as accurately as practicable" and also "with reference to fixed and permanent objects on the shore, giving courses and distances." The requirement of "as accurately as practicable" is easily fulfilled by definition of the location of the corners of the oyster bars by latitude and longitude. In fact, this method is probably the most satisfactory and accurate one that could be used for all purposes of legal definition or for relocation of the oyser-bar boundaries by competent engineers. Therefore the additional requirement of "giving courses and distances" is superfluous and is only fulfilled in the published definitions on account of the specific provisions of the law making it compulsory. This part of the description of boundaries has involved an immense amount of extra computations in order to prevent technical discrepancies between the latitude and longitude of a corner of an oyster bar and its distance and bearing from objects on shore of known latitude and longitude without adding anything to the accuracy and very little to the convenience of practical use of the descriptions of the oyser-bar boundaries. 
As provided by law the boundaries of the oyster bars are all straight lines, but in the work already completed they have inclosed areas of all shapes from triangles to complicated I 4 -sided figures, and of all sizes from 4 acres to 7,548 acres. The sides have varied in length from 93 to 7,529 yards, and in some cases the corners of the boundaries have been practically at the triangulation stations from which they are located, while in other instances they were over 13,600 yards from the landmarks most available for the purpose of fixing their position.

The varied characteristics of the legal boundaries of the oyster bars indicated by the above statement, together with the complicated requirements of the law under which the survey has been made and the magnitude of the work with the consequent need of fixed and uniform methods, have made the problem of describing the boundaries one of considerable difficulty and great importance.

The boundaries of the oyster bars of Maryland, as established by the Shell Fish Commission and delineated on the Coast and Geodetic Survey charts and projections and on the leasing charts of the Commission, are technically defined and described by a method somewhat different from that used in other oyster surveys. But it is believed that the forms finally adopted will fulfill all needs of the survey for both the present and the future.

METHOD OF DESCRIBING BOUNDARIES.

The descriptions have been arranged in tabular form, thus avoiding many hundred repetitions of the same words by making one explanation of the tables sufficient for all oyster bars in each county.

Title.-At the top of each tabular form is given the legal name of the oyster bar to be described, and the one by which it is known and designated in the published oyster records and on the oyster charts. The adopted name of the oyster bar is the one used locally, as nearly as could be ascertained by the hydrographic engineer of the Commission; and when there was no local name in common use a name was selected from one of the prominent features of the vicinity that would naturally suggest the section of the waters where the oyster bar was located.

Underneath the name, in parentheses, is given the general locality of the oyster bar and the serial number of the "Maryland Oyster Chart" on which its legal boundaries are shown. ${ }^{a}$

First column.-This column, under the heading of "Corner of bar," gives the number corresponding to the corner of the boundary as shown on the charts and to the number on the buov marking the actual corner of the bar. The numbers of the corners have been assigned by naming the southernmost point No. $\mathrm{I}$, thence proceeding in a clockwise direction around the bar. Where a corner of one oyster bar is identical with the corner of the boundaries of one or more other oyster bars, only the number of the corner of the oyster bar being described in the table is given in this column.

Second and third columns.-These two columns, under the headings of "Latitude" and "Longitude," give the geographic positions of the corners. These positions have been adopted by the Commission as the primary technical definition of the location of the corners, and should be considered as final in case of a dispute arising from discrep-

a These charts can be obtained by application to the Superintendent of the Coast and Geodetic Survey at Washington, D. C. 
ancies caused by other means of location. The latitudes and longitudes given in these columns are based on the United States standard datum of the Coast and Geodetic Survey, and the points thus defined can be relocated from distant triangulation stations of the survey, even though all the landmarks and buoys originally used for their location have been destroyed by natural or other causes.

Fourth and fifth columns.-These two columns, under the general heading of "True bearing" a and the specific headings "Forward" and "Back," give bearings measured from a true north-and-south line. The three "Forward" bearings are from the corner of the boundary designated in the first column to the triangulation stations named on the corresponding lines in the last column, and the three "Back" bearings are from these same stations in the last column to the corresponding corner of boundary in the first column. The difference in minutes of arc between the forward and back bearings shown in some cases is actual and not accidental, and is due to the fact that the computations took into account the spheroidal shape of the earth.

Sixth column.-This column, under the heading of "Distance," gives the three computed distances in yards from the corner of the bar noted in the first column to the three triangulation stations named on the corresponding lines in the last column, and vice versa.

Seventh column.-This column, under the heading of "U. S. C. \& G. S. triangulation station," ${ }^{\prime b}$ gives the names of the landmarks from which were computed the corresponding "Iratitude," "Longitude," "True bearing," and "Distance" of the "Corner of the bar" designated in the first column. A full description of the location and markings of these triangulation stations is given in another part of this publication under the heading of "Descriptions of triangulation stations."

SURVEYING METHODS FOR RELOCATION OF BOUNDARIES.

There are a number of methods that can be used in the relocation of the actual boundaries of the natural oyster bars as technically described in this publication and delineated on the published charts of the Coast and Geodetic Survey and the leasing charts of the Shell Fish Commission.

The following brief descriptions of five of these more or less different methods assume a certain amount of experience and knowledge on the part of the engineer in the particular kind of surveying under consideration, and are only intended as reminders of ways and means that can be used.

There are two problems that are likely to present themselves to those interested in the boundaries of natural oyster bars: one, to determine whether the buoys marking the corners have been dragged or otherwise moved from their correct positions, and the other, to relocate or reestablish a buoy at the point from which it was removed. The different ways of solving these two problems partly depend upon the instruments possessed by the engineer and his assistants and partly on his training and experience.

(I) Triangulation.-This method is the one that will give the greatest accuracy, but on account of its requiring special data and instruments, and being an operation

a The mean magnetic variation for Charles County was $5^{\circ} 20^{\prime}$ west of north in I9ro and increasing at the rate of $4^{\prime}$ yearly.

$b$ Geographic positions of these triangulation stations can be obtained by application to the Superintendent of the Coast and Geodetic Survey, Washington, D. C. 
rarely used by engineers not engaged in geodetic surveying, it is recommended only for cases in dispute that can not be settled satisfactorily by some other method. An explanation of this class of work would be too long for a report of this sort, and those not familiar with this method are referred to the publications on the subject by the Coast and Geodetic Survey.

(2) Hydrographic. - This method is the most simple and satisfactory one that can be adopted if the surveyor can obtain the use of the necessary instruments and assistants. It is the one best suited for the work of the engineers of the Commission in relocating corners of boundaries, as it gives results of the accuracy ordinarily required and is rapid in execution. Besides, it has the advantage of being available whenever three triangulation stations of suitable relative positions are visible from the offshore points needing relocation.

Most navigators and others familiar with the use of a sextant are well acquainted with the graphic three-point method of fixing a position on water, and only a brief description of the operation will be stated.

In the case where there is only one engineer having a single sextant, the three-point method can be used if the two angles determining the position of a buoy are first derived from the "Forward" bearings given in the tabular forms describing the boundaries of the oyster bars. For example, take "Stoddard" oyster bar, which is the first one described in this publication, and assume that "Corner No. 3, " is to be examined as to its position. The angle between the two landmarks "Key" and "Upper" as determined from right to left from the forward bearings from this comer is $122^{\circ} 28^{\prime}$ and the angle between "Upper" and "Stoddard" is $88^{\circ} 43^{\prime}$. Having these two angles, the engineer proceeds to the buoy of doubtful location and measures the actual sextant angles between the landmarks for which the calculations were made. If the measured and calculated angles do not agree the buoy is not in its correct position and the boundary corner must be relocated. This is accomplished by moving the boat about until a point is reached where the angles do agree, and this point being the desired location, the buoy can be placed in its correct position.

If the engineer can obtain the use of both a sextant and a three-arm protractor ("position finder"), the availability of the hydrographic method is increased, as the use of the protractor is essential in case of the washing away or destruction of one or more of the landmarks originally used in describing the boundaries. Under these circumstances, any three landmarks of suitable relative position that are visible from the point to be located can be utilized. For example, the engineer can proceed to the buoy of doubtful position and measure the two adjacent sextant angles between the three landmarks selected. These two angles are set off on the three-arm protractor and the actual position of the buoy plotted on the chart by shifting the protractor about until the edge of each of the three arms passes through the center of the symbols on the cliart marking the position of the three landmarks selected. The center of the hub of the protractor will indicate on the chart the actual position of the buoy, and if the point thus obtained does not coincide with the true position of the corner of the boundary as given on the chart, the surveyor can proceed to locate the buoy correctly by reversing the operation. This is done by placing the center point of the hub of the protractor over the corner of the boundary in question and measuring on the chart the two adjacent protractor angles between the three selected landmarks. One of the 
angles thus obtained is set on the sextant and the boat moved about until the two landmarks are shown by the sextant to subtend the same angle obtained from the protractor. The second angle is then placed on the sextant and the same operation gone through, and so on, first using one angle on the sextant then the other until a point is reached where both observed sextant angles are practically identical with the protractor angles. The point thus located is the desired one and the buoy can be placed to mark the true position of the corner of the boundary in question.

If the engineer possesses two sextants and a protractor, this problem is far easier of solution, as the two angles can be set off on separate sextants and the observer can quickly find the desired point where they agree with the protractor angles by using one sextant after the other without the need of resetting either.

If there are two observers, two sextants, and a protractor, it can be seen that the best conditions for both rapid and accurate hydrographic location of a point is attained. In fact, this is the method by which the buoys at the comers of the boundaries were originally placed by the hydrographic engineer to the Commission.

(3) Magnetic bearings from offishore.- This method of fixing a position on water is a simple and well-known one in navigation. It is available to anyone having a boat compass and will be of special use to the State fishery force in investigating cases where buoys are supposed to have been moved for illegal purposes.

In the case where a buoy is supposed to have been moved from its true position the observer can take compass bearings to the three landmarks given in the last column of the tables opposite the boundary corner in question. These bearings are then corrected for the local declination, ${ }^{a}$ and if the results agree with the published bearings the buoy is correctly located.

In the case where the buoy is not in its correct position, or has disappeared altogether, the desired point can be determined by maneuvering the vessel until the corrected bearings agree with the ones in the tabular descriptions, when the buoy can be anchored in its proper location.

In the case where the landmarks, for which the bearings are published, have been destroyed or washed away, any landmarks whose positions are indicated on the charts can be used. This can be done by getting their bearings directly from the chart by parallel rulers or a protractor and then applying these new bearings in the same manner as the ones published in the tables.

(4) Magnetic bearings from shore. - This method will be of special value to engineers having an ordinary surveyor's compass. The compass can be set over the point marking a "triangulation station" on shore, the name of which is given in the last column opposite the "corner" in question. The instrument is then set at the corresponding "back" bearing (corrected for local magnetic declination) given in the fifth column of the tables opposite the "comer" in question. The direction thus determined will give one range on which the desired point must be located. The compass can then be moved to a second triangulation station and another range located in a similar manner. The intersection of these two range lines will give the desired point; but in general it should be checked by an additional range line determined from a third station.

$a$ 'The mean magnetic variation for Charles County is $5^{\circ} 20^{\prime}$ west of north in rgro and increasing at the rate of $4^{\prime}$ yearly. 
(5) Horizontal angles measured at landmarks. - This process is a modification of the triangulation method, and will be useful to engineers who have a transit and desire considerable accuracy.

The instrument is placed over a "triangulation station," the name of which appears in the last column of the tabular description opposite the "corner" in question. The telescope is then pointed to the landmark indicated in the "Descriptions of landmarks" as having a direction of $\mathrm{O}^{\circ} \mathrm{Oo}^{\prime} \mathrm{OO}^{\prime \prime}$ from the triangulation station being occupied by the transit. The tabular description of the boundaries is next examined and the "back" bearing of the questionable boundary "corner" from the landmark being occupied is taken out. The angle calculated from this "back" bearing and the bearing given in parentheses alongside the zero landmark in the "Descriptions of landmarks" is then set off on the transit and a range line established on which the desired point must be located. A similar process is then carried on at a second station, and so on until the pposition of the buoy is satisfactorily fixed.

BOUNDARIES OF NATURAL OYSTER BARS.

\section{STODDARD.}

(Upper Wicomico River-Chart No. 26.)

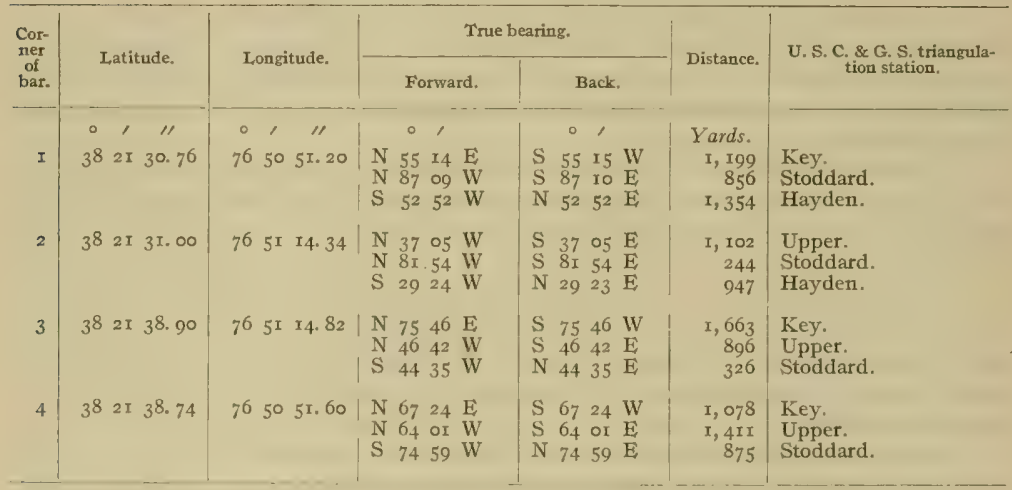




\section{WICOMICO LUMPS}

(Upper Wicomico River-Chart No. 26.)

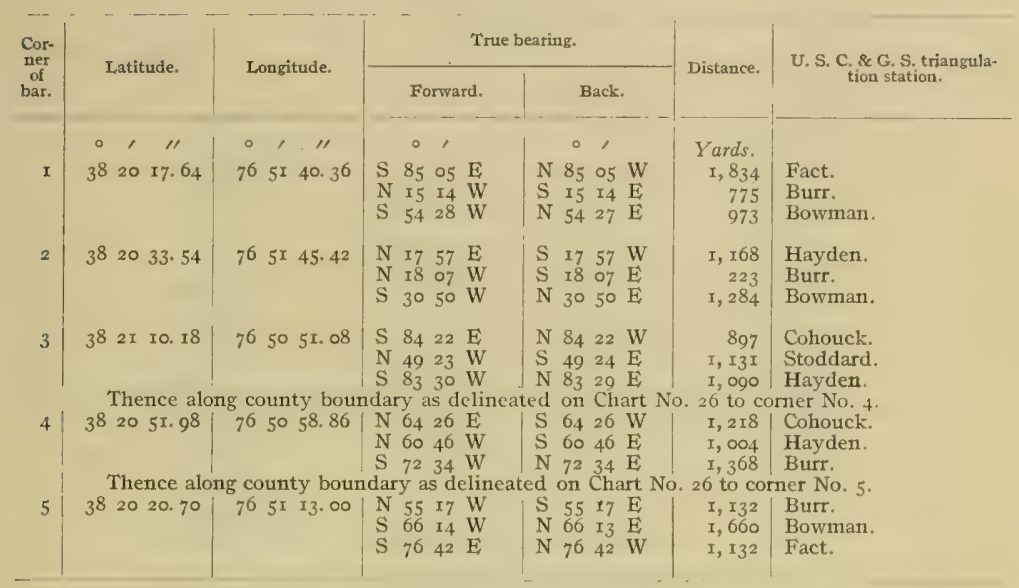

\section{MILLS WEST.}

(Upper Wicomico River-Chart No. 26.)

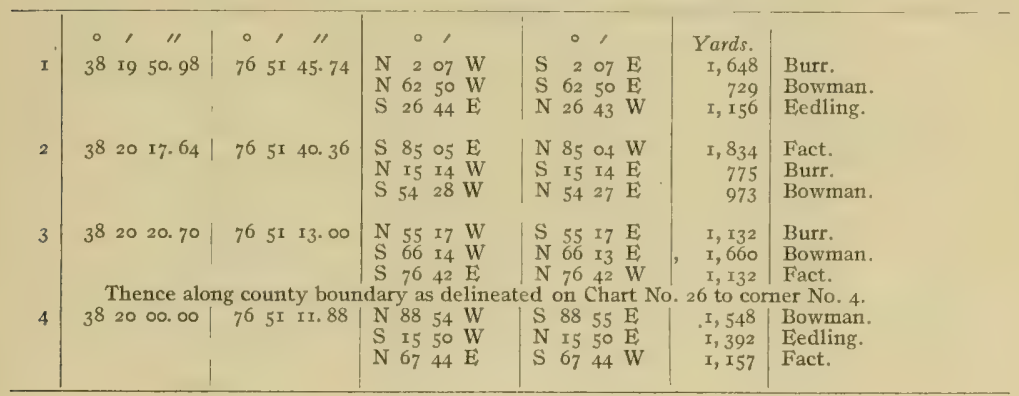


JOES LUMPS.

(Middle Wicomico River-Chart No. 26.)

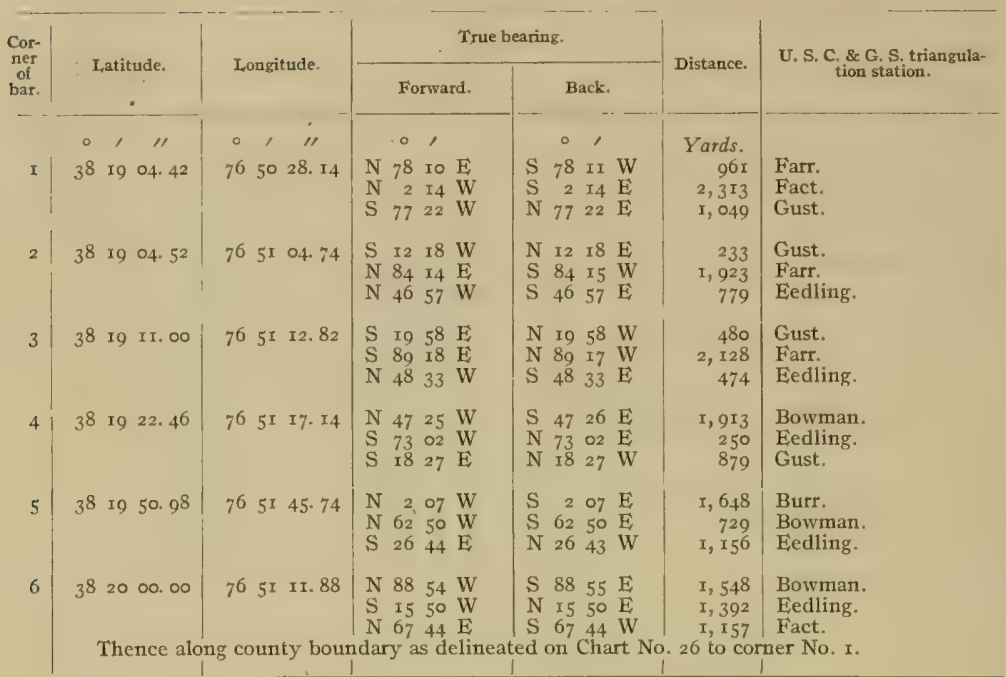

\section{WINDMILL.}

(Middle Wicomico River-Chart No. 26.)

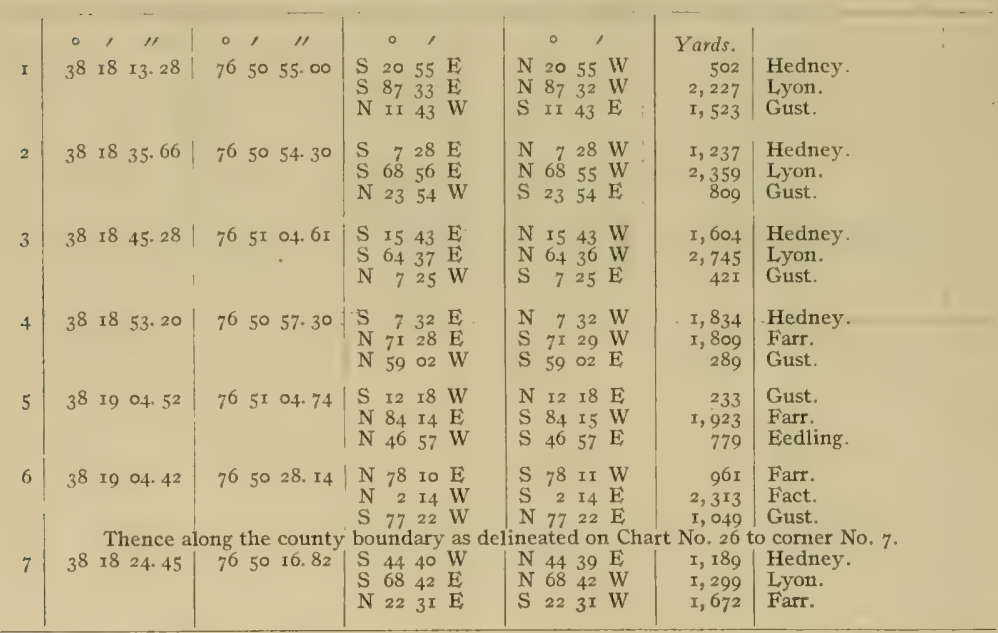


FENWICK.

(Middle Wicomico River-Chart No. 26.)

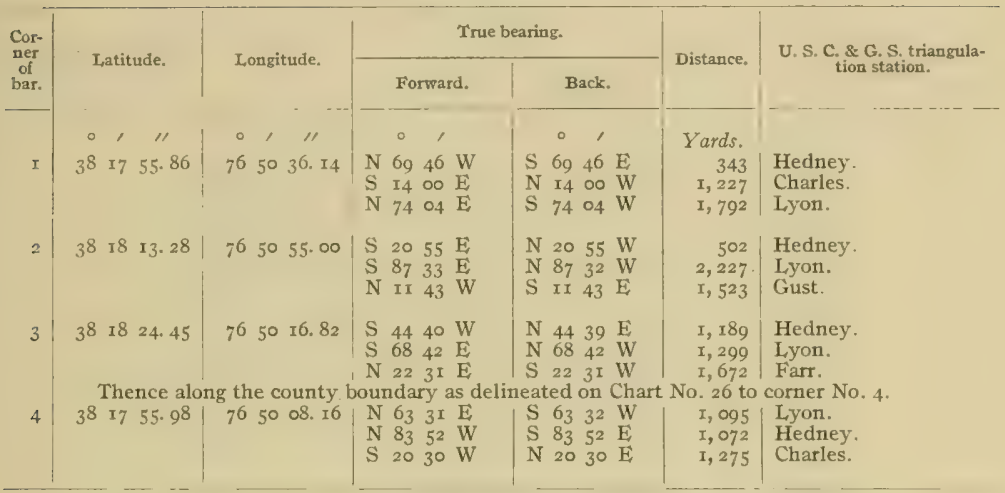

\section{WICOMICO MIDDLE GROUND.}

(Middle Wicomico River-Chan No. 26.)

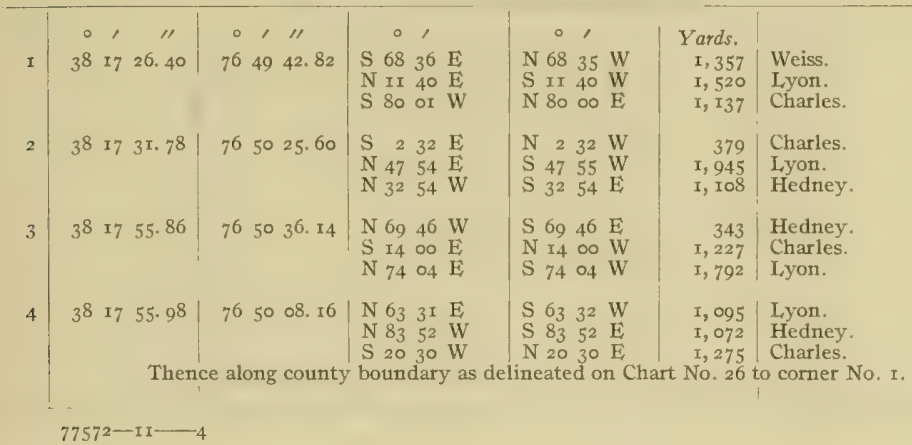

$77572-11-4$ 
CHARLESTON CREEK.

(Middle Wicomico River-Chart No. 26.)

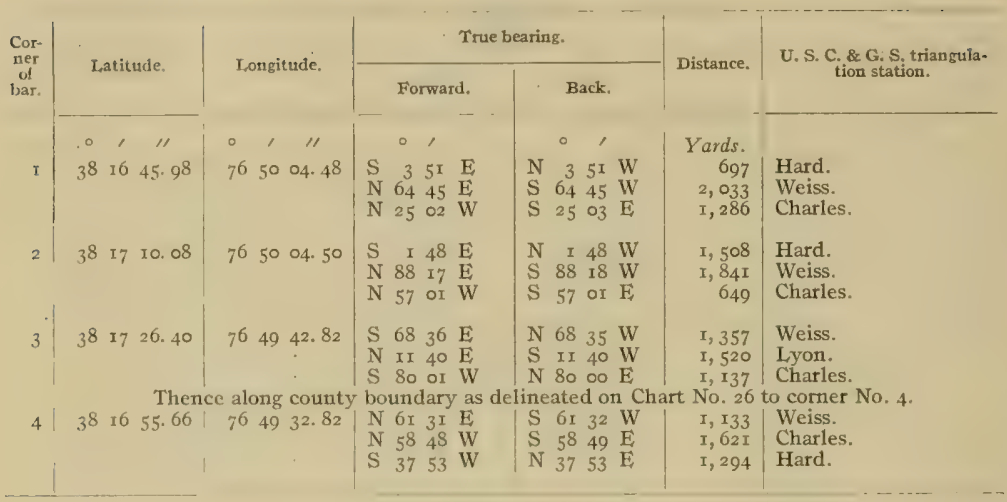

\section{ANCASTER.}

(Lower Wicomico River-Chart No. 26.)

\begin{tabular}{|c|c|c|c|c|c|c|c|c|}
\hline $\mathbf{I}$ & \begin{tabular}{ccc|}
0 & 1 & $\prime \prime$ \\
38 & $x 6$ & 26.20
\end{tabular} & \begin{tabular}{ccc|}
0 & 1 & $\prime \prime$ \\
76 & 49 & 48.82
\end{tabular} & $\begin{array}{lll} & 0 \\
\text { S } & 73 & \\
\text { N } & 42 & 5 \\
\text { S } & 85 & 3\end{array}$ & $\begin{array}{l}\text {, } \\
\text { I9 } \mathrm{E} \\
\text { 50 } \mathrm{E} \\
37 \mathrm{~W}\end{array}$ & $\begin{array}{ll} & 0 \\
N & 73 \\
\text { S } & 42 \\
N & 85\end{array}$ & $\begin{array}{l}18 \mathrm{~W} \\
5 \mathrm{I} \\
37 \mathrm{~W}\end{array}$ & $\begin{array}{r}\text { Yards. } \\
2,146 \\
2,093 \\
37 \mathrm{I}\end{array}$ & $\begin{array}{l}\text { Prec. } \\
\text { Weiss. } \\
\text { Hard. }\end{array}$ \\
\hline 21 & $\begin{array}{llll}38 & 16 & 30.22\end{array}$ & $76 \quad 5004.42$ & $\begin{array}{lll}\mathrm{S} & \mathrm{I}_{5} & 2 \\
\mathrm{~N} & 52 & 4 \\
\mathrm{~N} & 17 & 5\end{array}$ & $\begin{array}{l}25 \mathrm{E} \\
43 \mathrm{E} \\
50 \mathrm{~W}\end{array}$ & $\begin{array}{ll}\text { N } & 15 \\
S & 52 \\
S & x 7\end{array}$ & $\begin{array}{l}25 \mathrm{~W} \\
44 \mathrm{~W} \\
5 \mathrm{E}\end{array}$ & $\begin{array}{r}170 \\
2,310 \\
1,783\end{array}$ & $\begin{array}{l}\text { Hard. } \\
\text { Weiss. } \\
\text { Charles. }\end{array}$ \\
\hline 3 & $\begin{array}{llll}3^{8} & 16 & 45.9^{8}\end{array}$ & $7^{6} 50$ 0.4. $4^{8}$ & $\begin{array}{llll}\mathrm{S} & 3 & 5 \\
\mathrm{~N} & 64 & 4 \\
\mathrm{~N} & 25 & 0\end{array}$ & $\begin{array}{ll}51 & \mathrm{E} \\
45 \mathrm{E} \\
02 \mathrm{~W}\end{array}$ & $\mid \begin{array}{lr}N & 3 \\
\text { S } & 64 \\
\text { S } & 25\end{array}$ & $\begin{array}{l}5 \mathrm{I} W \\
45 \mathrm{~W} \\
\mathrm{O}_{3} \mathrm{E}\end{array}$ & $\begin{array}{r}697 \\
2,033 \\
\mathrm{I}, 286\end{array}$ & $\begin{array}{l}\text { Hard. } \\
\text { Weiss. } \\
\text { Charles. }\end{array}$ \\
\hline 4 & $\begin{array}{llll}3^{8} & 16 & 55.66\end{array}$ & $\begin{array}{llll}76 & 49 & 32.82\end{array}$ & \begin{tabular}{|lll}
$\mathrm{N}$ & $6 \mathrm{r}$ & 3 \\
$\mathrm{~N}$ & $5^{8}$ & 4 \\
$\mathrm{~S}$ & 37 & 5
\end{tabular} & $\begin{array}{ll}3 \mathrm{I} & \mathrm{E} \\
48 & \mathrm{~W} \\
53 & \mathrm{~W}\end{array}$ & $\begin{array}{ll}\mathrm{S} & 6 \mathrm{I} \\
\mathrm{S} & 58 \\
\mathrm{~N} & 37\end{array}$ & $\begin{array}{l}32 \mathrm{~W} \\
49 \mathrm{E} \\
53 \mathrm{E}\end{array}$ & $\begin{array}{l}I, 133 \\
\text { I, 62I } \\
\text { I, 294 }\end{array}$ & $\begin{array}{l}\text { Weiss. } \\
\text { Charles. } \\
\text { Hard. }\end{array}$ \\
\hline 5 & $\begin{array}{l}\text { Thence } \\
\begin{array}{llll} & \text { The } \\
3 & 16 & 34.94\end{array}\end{array}$ & 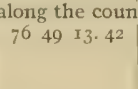 & $\begin{array}{l}\text { ity boun } \\
\text { S } 504 \\
\text { N } 673 \\
\text { N } 21\end{array}$ & $\begin{array}{l}\text { ndary } \\
45 \text { E } \\
32 \mathrm{E} \\
15 \mathrm{E}\end{array}$ & $\begin{array}{l}\text { delineat } \\
\text { N } 50 \\
\text { S } 67 \\
\text { S } \\
21\end{array}$ & $\begin{array}{l}\text { ted in } \\
45 \mathrm{~W} \\
32 \mathrm{~W} \\
{ }_{5} \mathrm{~W}\end{array}$ & \begin{tabular}{|l} 
Tart No. 26 \\
I, 442 \\
I, $79 \mathrm{I}$ \\
I, 330
\end{tabular} & $\begin{array}{l}\text { to corner No. } 5 \\
\text { Prec. } \\
\text { Blakistone. } \\
\text { Weiss. }\end{array}$ \\
\hline
\end{tabular}


ROCK POIN'T.

(Lower Wicomico River-Chart No. 26.)

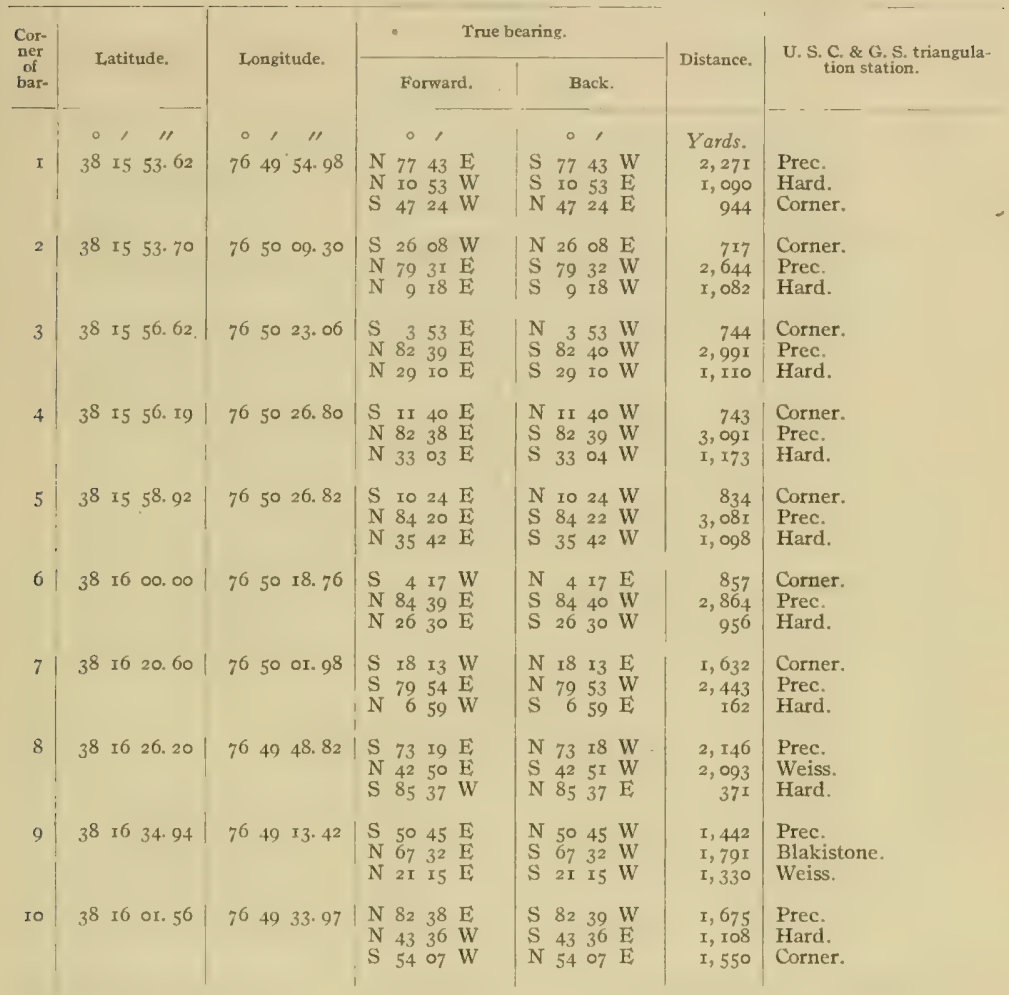




\section{SHIPPING POINT.}

(Lower Wicomico River-Chart No. 26.)

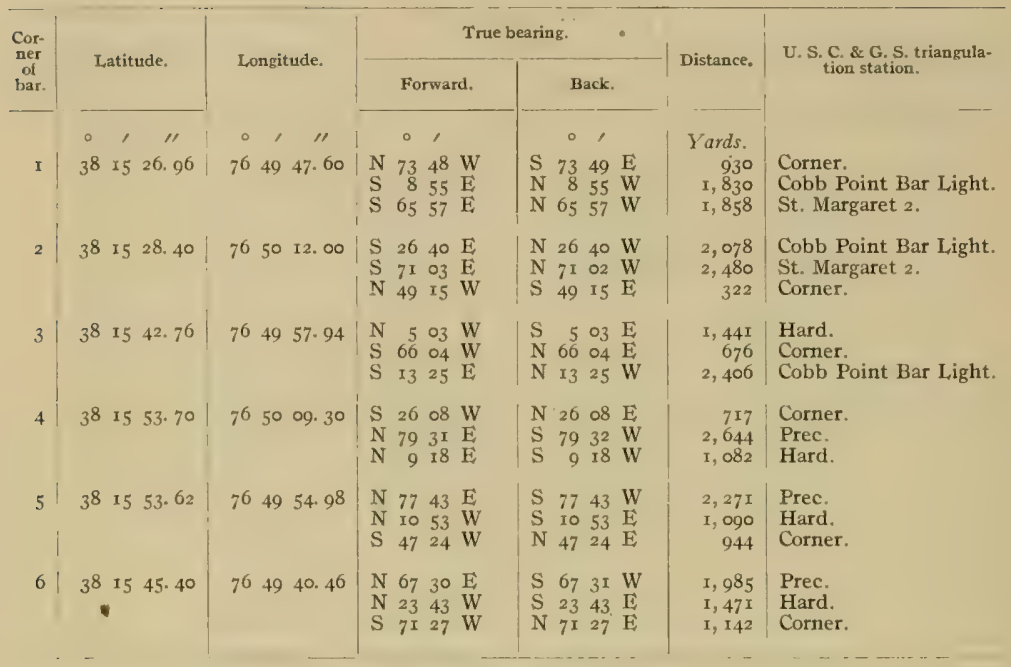

\section{COBB POINT.}

(Lower Wicomico River-Chart No. 26.)

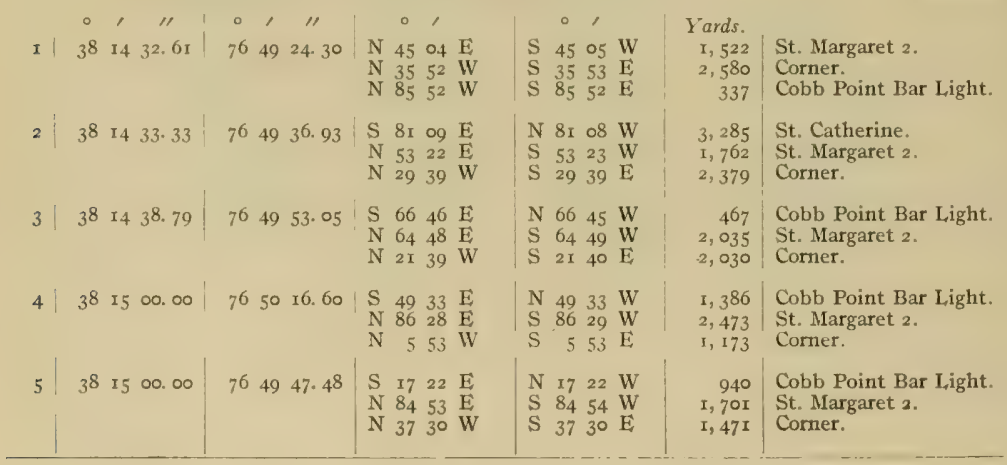




\section{TEAGUE:}

(Upper Patuxent River-Chart No, 26.)

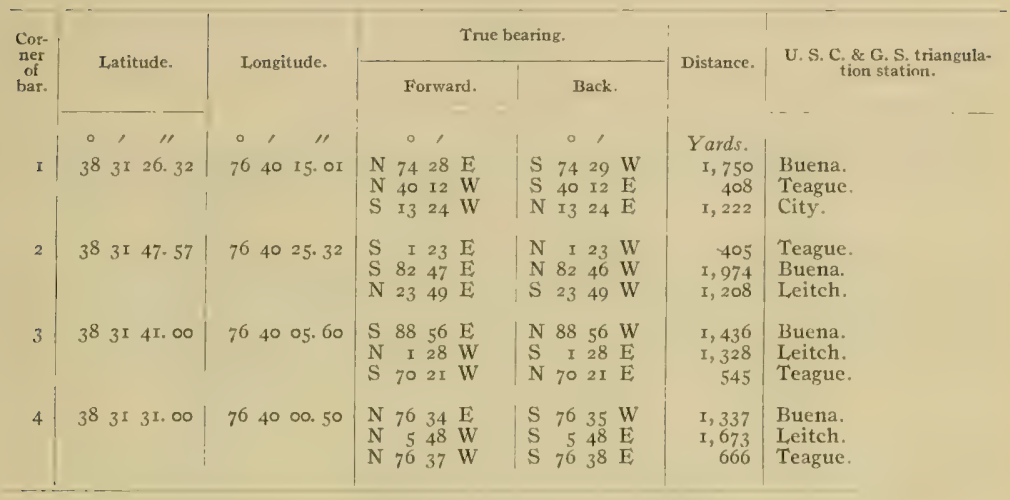

\section{ELBOW.}

(Upper Patuxent River-Chart No. 26.)

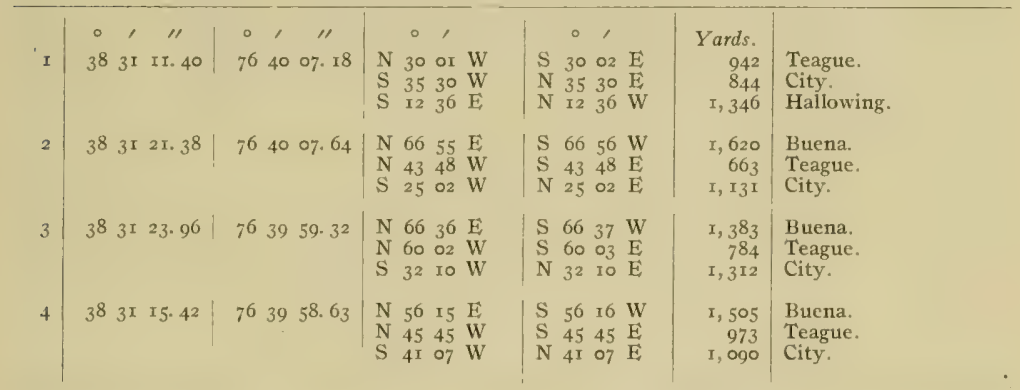


CARPENTERS YARD.

(Upper Patuxent Rizer-Chart No. 26.)

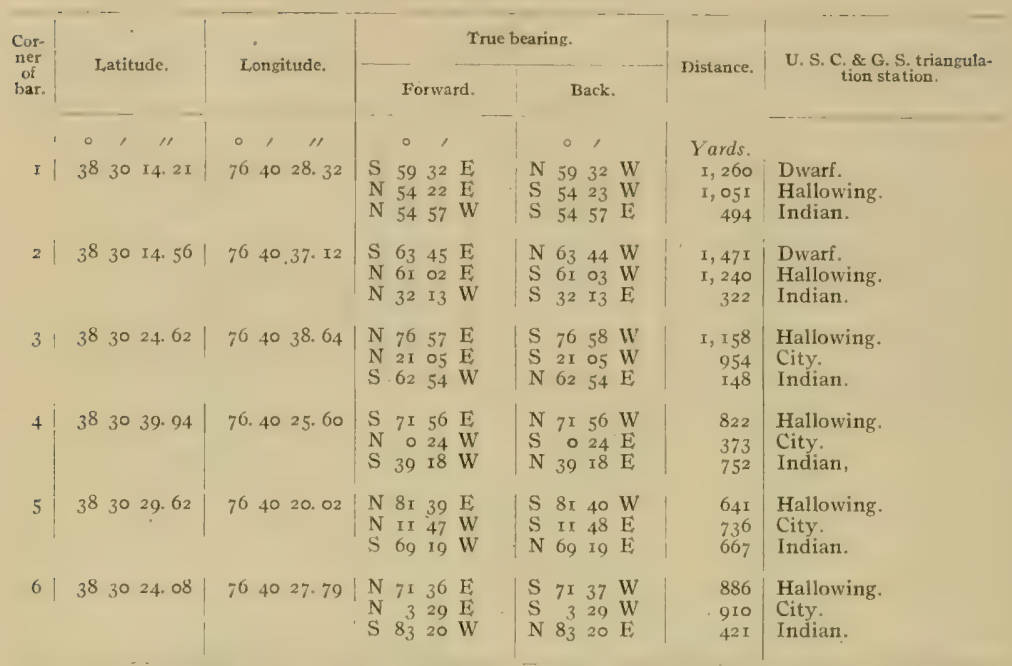




\section{A P P E N I X ES.}

\section{APPENDIX A.-LAWS RELATING TO THE COOPERATION OF THE COAST AND GEODETIC SURVEX AND IBUREAU OF IISHERIES WITH THE MARYLAND SHELL FISH COM- MISSION.}

The work of the Coast and Geodetic Survey and of the Bureau of Fisheries, in cooperation with the Maryland Shell Fish Commission, in surveying the oyster bars, establishing permanent landmarks at triangulation stations, and preparing for publication the necessary charts and technical and legal descriptions of boundaries and landmarks shown on these charts, has been executed in compliance with a request from the governor of the State of Maryland to the Secretary of Commerce and Labor, and by the authority of the following laws of the United States and Maryland:

[Act of Congress approved May 26, 1906.]

AN AC'T To authorize the Secretary of Commerce and Labor to cooperate, through the Bureau of the Coast and Geodetic Survey and the Bureau of Fisheries, with the shellfish commissioners of the State of Maryland in making surveys of the natural oyster beds, bars, and rocks in the waters within the State of Maryland.

Be it enacted by the Senate and House of Representatives of the United States of America in Congress assembled, That the Secretary of Commerce and Labor be, and he is hereby, authorized and directed, upon the request of the govemor of the State of Maryland, to designate such officers, experts, and employees of the Bureau of the Coast and Geodetic Survey and of the Bureau of Fisheries as may be necessary to cooperate with the Maryland State board of shellfish commissioners in making a survey of and locating the natural oyster beds, bars, and rocks in the waters within the State of Maryland; and the Secretary of Commerce and Labor is hereby authorized and directed to fumish to the officers. experts, and employees of said Bureaus so detailed as aforesaid such instruments, appliances, and steam launches as may be necessary to make the survey aforesaid; and the Secretary of Commerce and Labor is hereby authorized to have made in the Bureau of the Coast and Geodetic Survey all the plats necessary to show the results of the aforesaid survey and the locations of the said natural oyster beds, bars, and rocks in the waters within the State of Maryland, and to furnish to the board of shellfish commissioners of the State of Maryland such copies as may be necessary, and for this purpose to employ, in the District of Columbia and elsewhere, such technically qualified persons as may be necessary to carry out the purpose of this act.

SEC. 2. That the Secretary of Commerce and Labor is hereby further authorized to have erected or constructed by the officers so detailed as aforesaid, while making such survey, such structures as may be necessary to mark the points of triangulation, so that the same may be used for such future work of the Coast and Geodetic Survey as the said Bureau may be hereafter required to perform in prosecuting the Government coast survey of the navigable waters of the United States located within the State of Maryland.

SEC. 4. That this act shall take effect from the date of its passage.

[Act of Congress approved June 30, I906.]

AN ACT Making appropriations for sundry civil expenses of the Goyerument for the fiscal year ending Junc thirticth, nineteen hundred and seven, and for other purposes.

Be it enacted by the Senate and House of Representatives of the United Slates of America in Congress assembled, That the following sums be, and the same are hereby, appropriated, for the objects hereinafter expressed, for the fiscal year ending June thirtieth, nineteen hundred and seven, namely: * * * 
Coast and Geoderic Survey: * * * For any special surveys * * * including the expenditures authorized under Public Act Numbered One hundred and eighty-one, approved May twenty-sixth, nineteen hundred and six, and contingent expenses incident thereto, five thousand dollars, together with the unexpended balance under this appropriation for nineteen hundred and six and prior years which is hereby reappropriated and made available on this account for the fiscal year nineteen hundred and seven.

[Act of Congress approved March 4, 1907.]

AN ACT Making appropriations for sundry civil expenses of the Government for the fiscal year ending June thirtieth, nineteen hundred and eight, and for other purposes.

Be it enacted by the Senate and House of Representatives of the United States of America in Congress assembled, That the following sums be, and the same are hereby, appropriated, for the objects hereinafter expressed, for the fiscal year ending June thirtieth, nineteen hundred and eight, namely: * * *

Coast and Geodetic Survey: * * * For any special surveys * * * including expenses of surveys in aid of the shellfish commission of the State of Maryland, to be immediately available and to continue available until expended, twenty-five thousand dollars.

\section{[Act of Congress approved May 27, 1908.]}

AN ACT Making appropriatious for sundry civil expenses of the Government for the fiscal year ending June thirtieth, nineteen hundred and nine, and for other purposes.

Be it enacted by the Senate and House of Representatives of the United States of America in Congress assembled, That the following sums be, and the same are hereby, appropriated, for the objects hereinafter expressed, for the fiscal year ending June thirtieth, nineteen hundred and nine, namely: * * *

CoAst and GeOdetic Survey: * * * For any special surveys * * * including expenses of surveys in aid of the shellfish commission of the State of Maryland, which expenses, including cost of plats and charts, shall not exceed fifteen thousand dollars in any one year, to be immediately available, twenty thousand dollars.

\section{[Act of Congress approved $\left.\mathrm{March}_{4}, 1909.\right]$}

AN ACT Making appropriation for sundry civil expenses of the Government for the fiscal year ending June thirtieth, nineteen hundred and ten, and for other purposes.

Be it enacted by the Senate and House of Representatives of the United States of America in Congress assembled, That the following sums be, and the same are hereby, appropriated, for the objects hereinafter expressed, for the fiscal year ending June thirtieth, nineteen hundred and ten, namely: * * *

Coast and Geodetic Survex: * * * For any special surveys * * * including expenses of surveys in aid of the shellfish commission of the State of Maryland, which expenses, including cost of plats and charts, shall not exceed fifteen thousand dollars in any one year, to be immediately availablé, twenty thousand dollars.

[Act of Congress approved June 25, 3910.$]$

A N ACT Making appropriations for sundry civil expenses of the Government for the fiscal year ending June thirtieth, nineteen hundred and eleven, and for other purposes.

Be it enacted by the Senate and House of Representatives of the United States of America in Congress assembled, That the following sums be, and the same are hereby, appropriated, for the objects hereinafter expressed, for the fiscal year ending June thirtieth, nineteen hundred and eleven, namely: * * *

COAST AND GEODETIC SURVEY: * * * For any special surveys * * * including expenses of surveys in aid of the shellfish commission of the State of Maryland, to be immediately available lifteen thousand dollars. 
[Act of the Legislature of Maryland approved April 2, 5906.]

AN AC'T' To establish and promote the industry of oyster culture in Maryland, to define and mark natural oyster beds, bars and rocks lying under the waters of this State, to prescribe penalties for the infringement of the provisions of this Act, and $* * *$.

Section I. Be it enacted by the General Assembly of Maryland, That the following sections be, and they are hereby, added to article 72 of the Code of Public General Laws, title "Oysters." * * *

SEC. 86. The Board of Shell Fish Commissioners shall, as soon as practicable after the passage of this Act, cause to be made a true and accurate survey of the natural oyster beds, bars and rocks of this State, said survey to be made with reference to fixed and permanent objects on the shore, giving courses and distances, to be fully described and set out in a written report of said survey, as hereinafter required. A true and accurate delineation of the same shall be made on copies of published maps and charts of the United States coast and geodetic survey, which said copies shall be filed in the office of the said commissioners in the city of Annapolis, and the said commissioners shall further cause to be delineated upon copies of the published maps and charts of the United States coast and geodetic survey, of the largest scale, one copy for each of the counties of this State in the waters of which there are natural oyster beds, bars and rocks, all natural beds, bars and rocks lying within the waters of such county, which maps shall be filed in the offices of the clerks of the Circuit Court for the respective counties wherein the grounds so designated may lie. * * *

SEc. 87. The Governor of this State is hereby requested to ask the assistance of the United States coast and geodetic survey, and of the United States Fish Commissioner, to aid in the carrying out of the provisions of the preceding section.

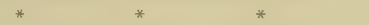

SEC. 89. As soon as practicable after the first day of April, 1906, the said commissioners shall organize, and shall at once proceed, with the assistance of such person or persons as may be detailed by the United States coast and geodetic survey and the United States Fish Commissioner, to aid them in their work, and of such persons as may be appointed under the preceding section, to have laid out, surveyed and designated on the said charts, the natural beds and bars, and shall cause to be marked and defined as accurately as practicable the limits and boundaries of the natural beds, bars, and rocks as established by said survey, and they shall take true and accurate notes of said survey in writing, and make an accurate report of said survey, setting forth such a description of landmarks as may be necessary to enable the said board, or their successors, to find and ascertain the boundary lines of the said natural oyster beds, bars and rocks, as shown by a delineation on the maps and charts provided in this Act; said report shall be completed and filed in the office of the board in the city of Annapolis within ninety days after the completion of the survey of any county. Said commissioners shall cause the same to be published in pamphlet form, and transmit copies of the said to the Clerks of the Circuit court for the respective counties, where the charts have been filed or directed to be filed as hereinafter provided; the said report to be filed by the clerks of the several counties in a book kept for that purpose. And the said survey and report, when filed, subject to the right of appeal hereafter provided for in this Act. shall be taken in all of the courts of this State as conclusive evidence of the boundaries and limits of all natural oyster beds, bars and rocks, lying within the waters of the county wherein such survey and report are filed, and shall be construed to mean in all of the said courts that there are no natural oyster beds, bars or rocks lying within the waters of the counties wherein such report and survey are filed other than those embraced in the survey authorized by this Act, and that all areas of the Chesapeake Bay and its tributaries within the State of Maryland, not shown in the survey to be natural oyster beds, bars or rocks shall be construed in all the courts of the State to be barren bottoms and open for disposal by the State for the purpose of private planting or propagation of oysters thereon under the provisions of this Act; provided, that the said survey and report shall not be construed as to affect in any manner the holdings by citizens of this State in any lot which may have been appropriated or taken up under the laws of this State prior to the approval of this Act. 
The law of the State of Maryland, passed March 9, I842, authorizing officers of the United States Coast and Geodetic Survey to enter upon the lands within the State limits for the purposes of the survey, is as follows:

AN AC'T Concerning the Survey of the Coast of Maryland.

SEctron I. Be it enacted by the General Assembly of Maryland, That it shall and may be lawful for any person or persons employed under and by virtue of an act of the Congress of the United States, * * * at any time hereafter to enter upon lands within this State for the purpose of exploring, surveying, triangulating, or leveling, or doing any other matter or thing which may be necessary to effect the objects of said act, and to erect any works, stations, buildings, or appendages requisite for that purpose, doing no unnecessary injury to private or other property.

SEC. 2.a And be it enacted, That in case the person or persons employed under the act of Congress aforesaid, can not agree with the owners or possessors of the land so entered upon and used as to the amount of damage done thereto by reason of the removal of fences, cutting of trees or injury to the crop or crops growing on the same, it shall and may be lawful for the said parties or either of them to apply to the chief justice for the time being or one of the associate judges of the judicial district in which such land may be situated, who shall thereupon appoint three disinterested and judicious frecholders, residents of the same judicial district, to proceed with as much despatch as possible to the examination of the matter in question, and the faithful assessment of the damages sustained by the owners or possessors aforesaid, and the said freeholders or a majority of them, having first taken and subscribed an oath or affirmation before the chief or associate justice aforesaid or other person duly authorized to administer the same, that they will well and truly examine and assess as aforesaid, and having given five days' notice to both parties of the time of their meeting, shall proceed to the spot, and then and there upon their own view and if required, upon the evidence of witnesses (to be by them sworn or affirmed and examined), shall assess the said damages, and shall afterward make report thereof and of their proceedings in writing under their hands and seals and file the same within five days thereafter in the office of the clerk of the county in which the land aforesaid is situated, subject to an appeal by either party to the county court of the said county within ten days after filing as aforesaid, and the said report so made as aforesaid if no appeal as aforesaid be taken, shall be held to be final and conclusive as between the said parties, and the amount so assessed and reported shall be paid to the said owners or possessors of the land so damaged within twenty days after the filing of said report, and the said chief or associate justice as aforesaid, shall have authority to tax and allow upon the filing of said report, such costs, fees and expenses to the said freeholders for the performance of their duty as he shall think equitable and just, which allowance shall be paid by the person or persons employed under the act of congress aforesaid, within the time last above limited, but if an appeal as aforesaid be taken, the case shall be set down for hearing at the first term of county court aforesaid, ensuing upon and after appeal, and it shall be lawful for either party immediately after the entry of such appeal, to take out summons for such witnesses as may be necessary to be examined upon the hearing aforesaid, and the said court shall have power in its discretion to award costs against which ever the final judgment shall be entered, and such appeal at the option of either party may and shall be heard before and the damage assessed by a jury of twelve men to be taken from the regular panel and elected as in other cases.

SEC. 3. And be it enacted, That if any person or persons shall wilfully injure or deface or remove any signal, monument or building or any appendage thereto, erected, used or constructed under and by virtue of the act of congress aforesaid, such person or persons so offending shall severally forfeit and pay the sum of fifty dollars with costs of suit to be sued for and recovered by any person who shall first prosecute the same before any justice of the peace of the county where the person so offending may reside, and shall also be liable to pay the amount of damages thereby sustained, to be recovered with costs of suit in an action on the case, in the name and for the use of the United States of America, in any court of competent jurisdiction.

$a$ Under the rulings of the Comptroller of the Treasury no damages can be collected except through the United States Court of Claims unless an agreement has been made in advance. 


\section{APPENDIX B.-THE HAMAN OYSTER CUI,TURE I,AW.}

[Extract from Second Report of Shell Fish Commission.]

OBJECT.

"The legislature in placing chapter 7 II of the acts of 1906 , better known as the Haman Oyster Culture Law, upon the statute books of Maryland, had a twofold object in vicw:

r. To encourage an industry in oyster culture upon the barren bottoms beneath the tidewaters of the State.

2. To prevent the leasing of natural oyster bars for the purpose of oyster culturc."

SURVEY.

"To make the leasing of barren bottoms possible and the leasing of natural bars impossible, provision was made for a survey of the natural bars for the purpose of accurately locating and marking the same. It was definitely provided that no barren bottoms should be leased in any part of the State until the natural bars of that region had been surveyed, charted, and marked with buoys."

\section{DEFinition OF A NATURAL OySTER BAR.}

NATURAL BAR NOT DEFINIED.

"The Shell Fish Commission is instructed by section go of the Haman Oyster Culture Law to exercise its judgment liberally in favor of the natural bars when surveying, charting and buoying them, but other than this the Commission is uninstructed in this important matter. The responsibility of defining a natural bar is placed upon the Commission."

\section{DIVERSITY OF OPINION}

"No definition of a natural oyster bar could be formulated by any man or body of men which would . meet with the approval of all parties concerned. Oystermen, as a rule, hold that all bottoms where oysters grow or have grown naturally even though now practically barren of oysters should be considered natural bars. Other citizens of the State who are not directly interested in the oyster business, but interested in the oyster industry from the standpoint of revenue, hold, as a rule, that no bottoms should be excluded from leasing for oyster culture which, by methods known to oyster culturists, may be made to yield a greater number of oysters than they now produce."

"It should be evident to every one that neither of these definitions could be adopted by the Commission as a working basis for determining which of the grounds surveyed are natural oyster bars."

\section{THE GOLDSBOROUGH DEFINITION}

The definition of a natural oyster bar which very nearly approaches a reasonable and satisfactory compromise between the views of the subject held by oystermen on one hand and by oyster culturists on the other is that contained in an opinion rendered by Judge Charles F. Goldsborough in the circuit court for Dorchester County in the July term, $188 \mathrm{r}$, in the case of William T. Windsor and George R. Todd $v$. Job T. Moore,

This definition has been adopted by the Shell Fish Commission as the basis for the determination of the status of the various oyster bottoms surveyed and is as follows:

What then is a natural bar or bed of oysters? It would be a palpable absurdity for the State to attempt to promote the propagation and growth of oysters and to encourage its citizens, by a grant of land, to engage in their culture, if the lands authorized to be taken up were only those upon which oysters do not and can not be made to grow. That there may be lands covered by water in the State where no oysters can be found, but where, if planted, they could be cultivated successfully, may be possible, but, if so, I imagine that their extent must be too limited for them to be of mucli practical, general advantage for the purposes of such a law as the one under discussion; but there are thousands of acres of hard and shifting sands where oysters not only are not found, but where it would be folly to plant them, and these latter it can not be supposed that the State intended to offer to give away, for the simple reason that the State could not help knowing that nobody would have them. 
Upon the other hand there are large and numerous tracts where oysters of natural growth may be found in moderate numbers, but not in quantities sufficient to make it profitable to catch them, and yet where oysters may be successfully planted and propagated. In my opinion these can not be called natural bars or beds of oysters, within the meaning of the Act of Assembly, and it is just such lands as these that the State meant to allow to be taken up under the provisions of the above-mentioned section of the Act.

But there is still another class of lands where oysters grow naturally and in large quantities and to which the public are now and have been for many years in the habit of resorting with a view to earning a livelihood by catching this natural growth, and here, I think, is the true test of the whole question. Land can not be said to be a natural oyster bar or bed merely because oysters are scattered here and there upon it, and because if planted they will readily live and thrive there; but whenever the natural growth is so thick and abundant that the public resort to it for a livelihood, it is a natural oyster bar or bed and comes within the above-quoted restriction in the law, and can not be located or appropriated by any individual.

\section{APPLICATION OF DEFINITION.}

Before this definition may be of use in determining, accurately and scientifically, the status of an oyster ground, its central idea, "livelihood," must be expanded into accurately determinable factors, and these factors must be combined into a practical scheme of investigating the condition of the ground under consideration.

Stated briefly, a livelihood is represented by a sum of money obtained from the sale, at a fixed price, of a certain quantity of oysters gathered in a given time from an allotted area of ground.

Knowing the value of each of these factors it becomes possible to calculate the number of oysters an oyster ground must produce per square yard in order that oystermen may secure a livelihood by working upon it.

Nore.-The factors into which the Commission resolved the livelihood problem, the value assigned to each factor, and the scheme devised for practical use in examining and applying the definition to oyster bottoms are given in outline in their second report under the heading of the preceding extract, and in detail in their first report on pages 32 to 69 .

\section{APPENDIX C.-SUMMARY OF THE PARTICULAR SURVEYING OPERATIONS WHICH CON-} STITUTE AN "OYSTER SURVEY" AS NOW BEING CARRIED ON IN MARYLAND.

Explanation.-A brief account of the particular surveying operations which constitute an "oyster survey" as now being carried on in Maryland will assist in the interpretation of records contained in the technical part of this report, and will be of interest to many who may not understand the necessity for the great amount of work being done or its complicated character.

To those familiar with methods used in surveying and charting the characteristic features of large bodies of water there is an evident necessity for the various operations performed, especially when it is known that the boundaries of the public oyster bars and of the private lots leased for purposes of oyster culture must be surveyed and charted with the greatest practical accuracy. To others it will be sufficient to state that the actual experience gained from oyster surveys in other States has proven that in order to avoid endless dissatisfaction and litigation it is necessary to accurately locate and permanently establish oyster boundaries as is now being done in Maryland.

Triangulation survey.-Such refinement of survey work as that demanded by the conditions of an oyster survey when carried on at considerable distances offshore can only be obtained by the use of a system of triangulation as a framework or foundation. Therefore, a triangulation survey including the permanent marking of the positions of landmarks with monuments and a record of the descriptions of their locations for future recovery is a necessary operation of a complete oyster survey.

Topographic survey. - The technical records which establish the relation between the offshore oyster boundaries and triangulation landmarks are sufficient for the requirements of engineers in making resurveys, but do not supply the needs of others who are interested in the same boundaries by reason of their occupation as oystermen concerned as to the public oyster bars, or oyster culturists concerned as to the leasable bottoms. For these it is necessary to have the charts of the survey show the relation of the shore line and other topographic features to the boundaries of the public oyster bars and private nyster farms. Therefore, a topographic survey is a necessary operation of a complete oyster survey. 
Hydrographic survey.-In the settlement of the important question of what is, or what is not, a natural oyster bar, and in the consideration of bottoms to be selected for purposes of oyster culture, information as to the depth of water and the character of the bottom is required. Therefore, a hydrographic survey is a necessary operation of a complete oyster survey.

Necessary foundation for an oyster survey.-Consequently, the necessary components of a satisfactory foundation for a complete oyster survey are the three classes of survey operations technically named triangulation, topography, and hydrography, or, stated in another way, the foundation of a practical oyster survey includes the surveying operations usually followed by the Coast and Geodetic Survey leading up to the preparation and publication of nautical charts.

Special surveys and investigations pertaining to oysters.-Having obtained this cartographic survey for a foundation, partly by new work and partly from records of previous work of the Government, the combined operations a making up an "oyster survey" are completed by superimposing on this foundation special surveys and investigations pertaining particularly to oysters or other shell fish.

The special surveys pertaining to oysters furnish information as to the location and outline of oystershell bottoms, and are carried on by the sounding boat party in addition to the usual hydrographic work. $b$ This operation consists of the observation and record of the character of vibration of a wire and chain apparatus which is dragged over the bottom, the vibrations or lack of vibrations indicating the presence and quantity of shells or absence of shells.

The' special oyster investigations $c$ consist of the actual determination of the kind and quantity of oysters on the bottom, and such economic and biological studies of the supply of oyster food, density of water, character of the bottom, and other important matters as affect the growth of oysters. In this work the oyster investigation stations are located and buoyed by the hydrographic party while engaged in the survey of the oyster-shell limits. They are selected with the view of obtaining characteristic data which can be used for the interpretation of the recorded vibrations of the chain apparatus at all other points covered by the survey.

Preparation of results. - The actual surveying operations and oyster investigations having been completed for any one county, there still remains technical work of nearly equal magnitude to that described $d$ This work consists of the preparation of charts and technical descriptions of boundaries and landmarks for publication by the Government, the preparation of that part of the annual report of the Commission covering the special oyster surveys and investigations, the making of the leasing charts and finished projections, and finally the filing of the oyster charts and records with the courts and the Commission, thus opening a county for oyster culture.

Summary.-From the foregoing account it can be seen that a complete oyster survey properly conducted so as to answer all practical requirements of the present and permanency of results for the future is a very complicated affair, involving many lines of surveying and other scientific work, and requiring the professional services of experts in the various operations of cartographic surveying and shell-fish investigations.

a See Appendix D of this publication for "Statistics of results of combined operations of the Government and State."

$b$ See pages Iot to 123 of "First Annual Report of Maryland Shell Fish Commission."

$c$ See pages 30 to 67 and 129 to 199 of "First Annual Report of Maryland Shell Fish Commission."

$d$ No mention is made here of the large amount of administrative work of the Commission, which is greatly complicated and increased by the effect of the oyster-survey operations on many thousands of people whose interests are more or less involved; or of the large amount of survey work involved in the survey and record of the boundaries of oyster lots leased from the State by private individuals for the purposes of oyster culture. 


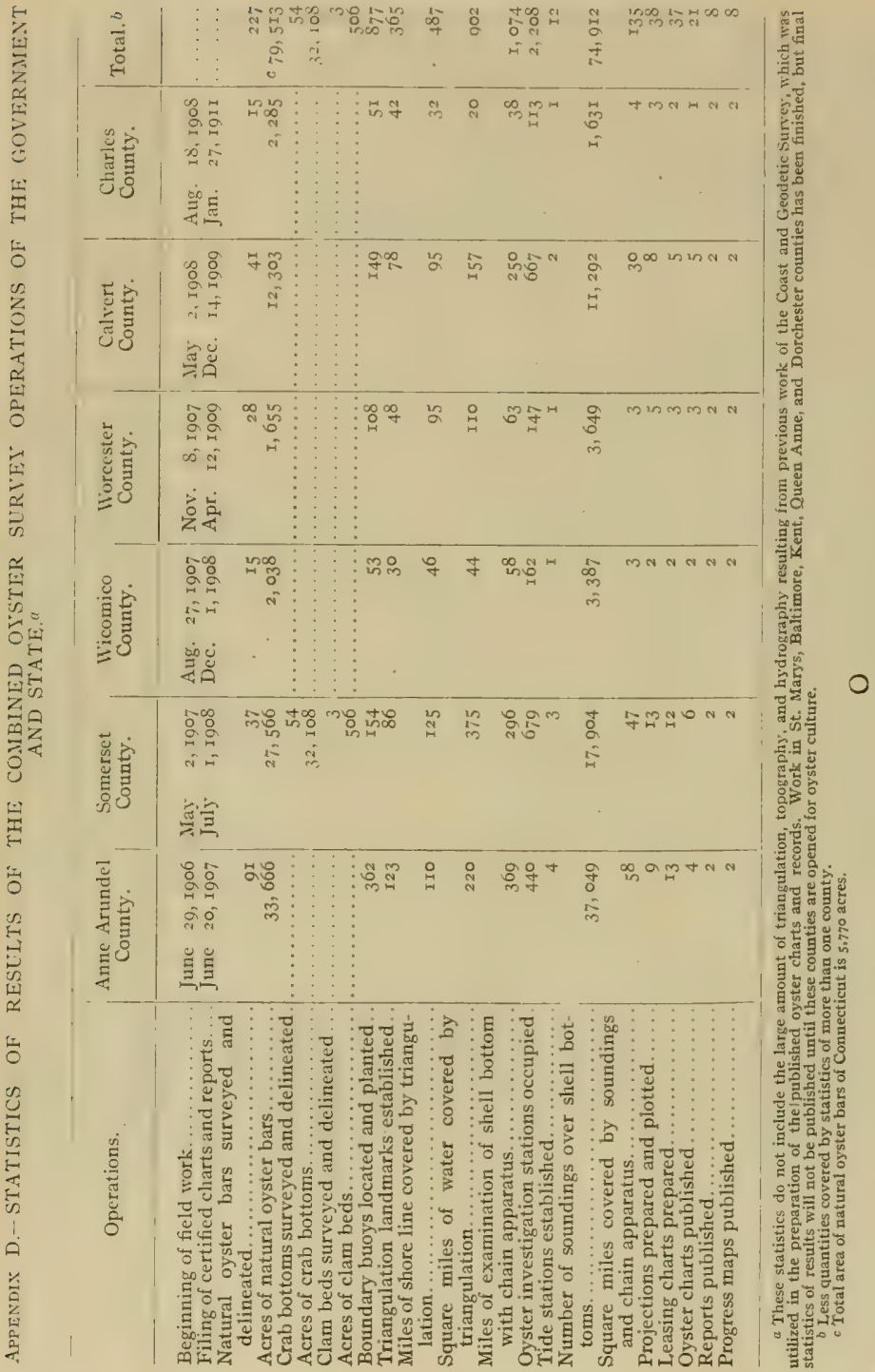







DEPARTMENT OF COMMERCE AND LABOR

COAST AND GEODETIC SURVEY

O. H. TITTMANN Superintendent

\title{
SURVEY OF OYSTER BARS \\ DORCHESTER COUNTY MARYLAND
}

\author{
DESCRIPTION OF BOUNDARIES AND LANDMARKS AND \\ REPORT OF WORK OF UNITED STATES COAST \\ AND GEODETIC SURVEY IN COOPERATION \\ WITH UNITED STATES BUREAU OF \\ FISHERIES AND MARYLAND \\ SHELL FISH COMMISSION
}

By C. C. YATES

CHIEF OF COAST AND GEODETIC SURVEY PARTY

ASSISTANT, COAST AND GEODETIC SURVEY

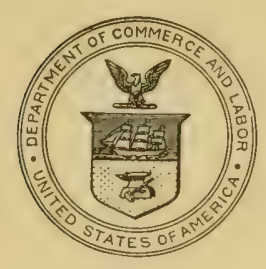

WASHINGTON

GOVERNMENT PRINTING OFFICE

1912 



\section{LETTER OF SUBMIT'TAL.}

\section{Department of COMMERCE AND LABOR, \\ Coast and Geodetic Survey, Washington, August I7, 19I2.}

SIR: I have the honor to transmit herewith a report of the officer detailed from the Coast and Geodetic Survey to cooperate with the Bureau of Fisheries and the Maryland Shell Fish Commission in surveying the oyster bars of the State of Maryland, together with certain technical results which are necessary for the interpretation and use of the plats of the survey made by the Government.

This work has been done under the provisions of the act of Congress entitled "An act to authorize the Secretary of Commerce and Labor to cooperate, through the Bureau of the Coast and Geodetic Survey and the Bureau of Fisheries, with the Shell Fish Commissioners of the State of Maryland in making surveys of the natural oyster beds, bars, and rocks in the waters within the State of Maryland," approved May 26, 1906, and of the acts of Congress making appropriations for sundry civil expenses of the Government for the fiscal years ending June 30, 1907, 1908, 1909, 1910, 1911, and 1912.

Respectfully,

To Hon. Charles Nagel,

O. H. TItTmann, Superintendent.

Secretary of Commerce and Labor. 



\section{CERTIFICA TION.}

BALTIMORE, MD., May 4, I9I2.

The following publication is certified to contain correct technical descriptions of all boundaries and landmarks established in Dorchester County by the Maryland Shell Fish Commission in cooperation with the United States Coast and Geodetic Survey.

C. C. YATES,

Chief of Coast and Goodetic Survey Party, Assistant, Coast and Geodetic Survey.

Examined and certified to be correct.

BALTIMORE, MD., May 4, I9I2.

$$
\begin{aligned}
& \text { WALTER J. Mitchel, } \\
& \text { Caswell, Grave, } \\
& \text { BENJAMin K. GREEN, } \\
& \text { Maryland Shell Fish Commission. } \\
& \text { SWEPSON EARLE, } \\
& \text { Hydrographic Engineer. }
\end{aligned}
$$

NorE.-Certified copies of this publication and of the charts of the natural oyster bars of Dorchester County were filed in the oflice of the clerk of the circuit court of Dorchester County and in the office of the Board of Shell Fish Commissioners on August 17,1912 



\section{CONTENTS.}

PROGRESS M.M...

Page.

LETTER OF ST'BNITTAI.

CERTHFATION. .

INTRODUCTION:

\section{Publications}

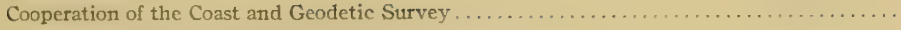

Cooperation of the Bureau of Fisheries.

General statement of work of Coast and Geodetic Survey.

REPORT OF THE WORK OF THE COAST AND GEODETIC SURVEX:

Instructions.

Organization and equipment.

Chronological statement of work.

Statistics

General remarks

CHARTS AND MAPS:

Charts of natural oyster hars . . . . . 25

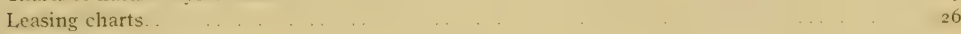

Projections . . . . . . . . . . . . . . . . . . . . . . . . . . .

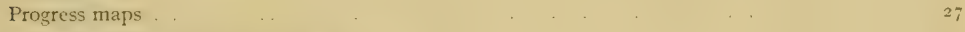

BOUNDARIES OF THE COUNTY WATERS:

Waters within territurial limits of county . . . .

Waters contiguous to county .. . . . 30

Landmarks (U. S. CoASt and Geodetic Survey triangulation Stations):
Explanation.

Method of describing triangulation stations.

Descriptions of triangulation stations in county and adjacent waters-

Chart No. 35 (Upper Choptank River)-

Weather Bureau staff

First . . . . . . . . . . . . . $34 \ldots \ldots \ldots \ldots$

Bach .. . . . . . . . . . . . . . . . . . . 34

Bonne . . . . . . . 35

linter. $\quad 35$

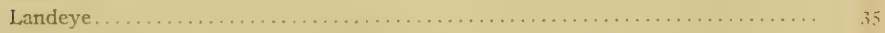

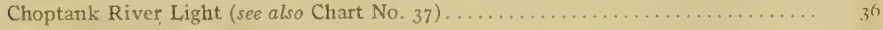

Benoni 2 (sec Progress maj) ... . . . . . . . . 36

Chlora . . . . . . . . . . . 36

Trappe... $\quad \ldots . \quad \ldots \ldots \ldots \ldots \ldots \ldots \ldots \ldots$

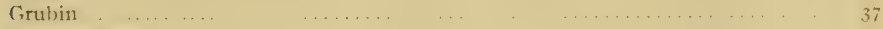

Black Beacon . . . . . . . . . . . . . . . . . . . . . . . . . . 38

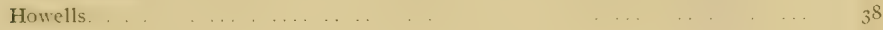

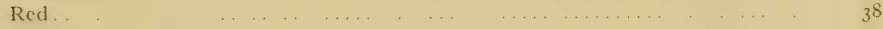

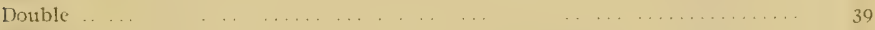

Boling . . . . . . . . . . . . . . . . . . 39

Rear... . . . . . . . . . . . . . . . . . . . . . . . to

Chancellor................ . . . . to 
Landmarks (U. S. Coast and Geodetic Survey triangulation stations)-Continued. Descriptions of triangulation stations in county and adjacent waters-Continued.

Chart No. 35 (Upper Choptank River)-Continued.

Barber.

Duck (Choptank River)

Jam.

Spindle.

Bank.

Raccoon

Page.

Blind.

Up.

Myrtle.

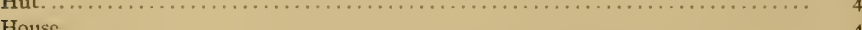

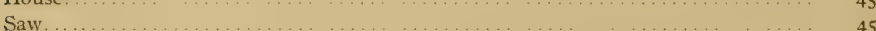

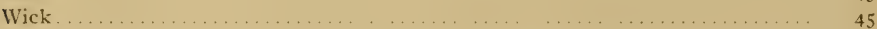

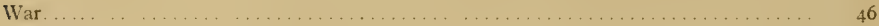

Gander............................................ 47

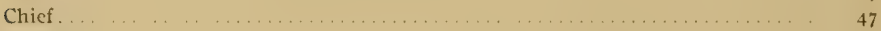

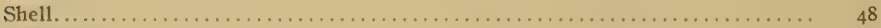

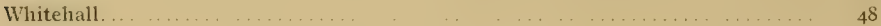

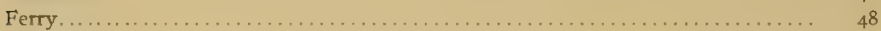

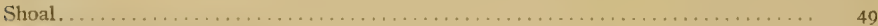

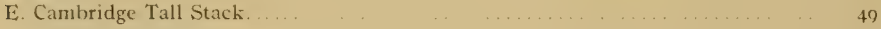

E. Cambridge Spire . . . . . . . . . . . . . . . . . . . .

Cambridge Stand Pipe....................................... 50

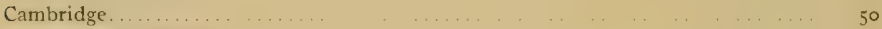

Hambrooks Bar Beacon. . . . . . . . . . . . . . . . . . . . 50

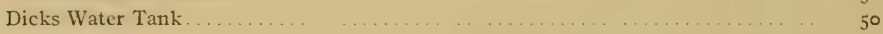

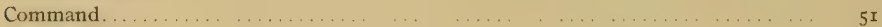

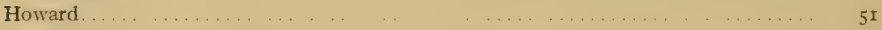

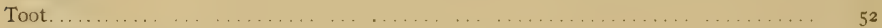

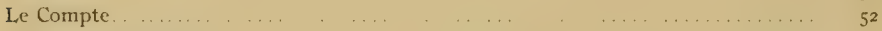

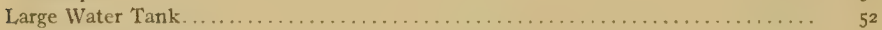

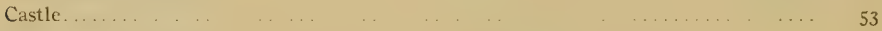

Chart No. 36 (Chesapeake Bay, vicinity of Little Choptank River) -

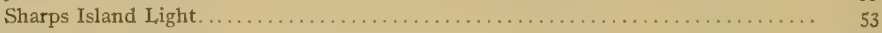

Black....... . . . . . . . . . . . . . . . . 53

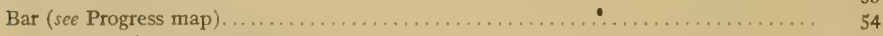

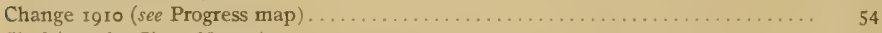

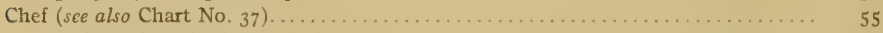

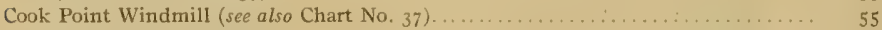

Brannock (see also Chart No. 37 ) ............................. 56

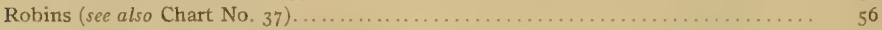

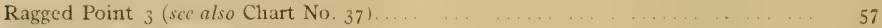

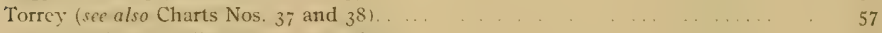

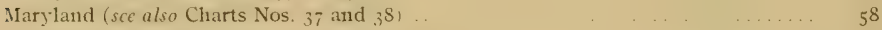

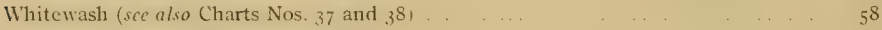

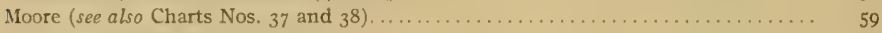

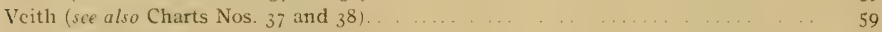

Can (sec also Charts Nos. 37 and 38 )..... . . . . . . . . . . 59

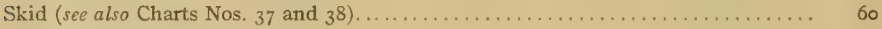

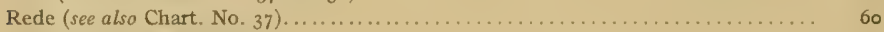

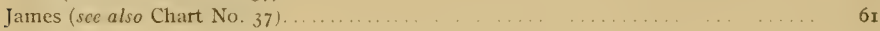


I.andmarks (U. S. Coast and Geodetic Survey triangulation stations)-Continued. Descriptions of triangulation stations in county and adjacent waters-Continued.

Chart No. 37 (Little Choptank River and tributaries)-

Choptank River Light (see also Chart No. 35!

Nelsun 3 ( $\mathrm{sec}$ Progress map).

Annette (sce Progress map).

Peary (set Progress map).

Irish (see Progress map).

Roys (se: Progress map)

Creek (see Progress map)

Corner (Choptank River)

Dot.

Chef (see also Chart No. 36 ).

Cook Point Windmill (ser also Chart No. 30 ,

Brannock (see also Chart No. 36 )

Robins (sec also Chart No. 36 ).

Ragged Point 3 (sce also Chart No. 30) . . . .

Hudson.

Jenifer.

Henry

Mitchell

Fiack

Bayly:

Carric

Louise

Greenwell

Rass

Phil.

Dupont

Beckwith

Cherry Island Water Tank

Lec

Solomon

Seth.

Adam

Laty ton.

David. .

Town

Swep.

Hugh

Eitti:

Mary.

Neil

Kirloy:

Paul (Little Choptank River) (sec Progress map)

Clumrch Creek (No. I West)

Austin

Tom

Brouks.

Ductor

Eleanor

Laney.

Mac

Madison Suthern M. I*. Church Spire

Tolacco Stick 
Landmarks (U. S. Coast and Geodetic Survey triangulation stations)-Continued. Descriptions of triangulation stations in county and adjacent waters-Continued.

Chart No. 37 (Little Choptank River and tributaries)-Continued.

IVool.

Page.

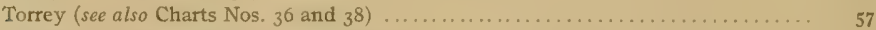

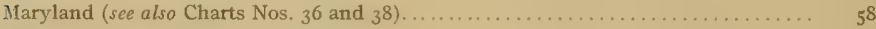

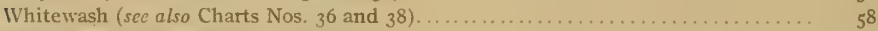

IIonre (sei also Charts Nos. 36 and 38 )... .... 59

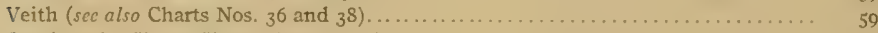

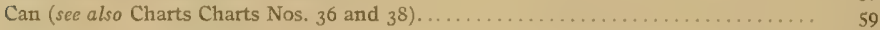

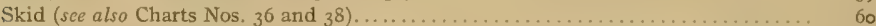

Rede (sce also Cliart No. 36$)$... . . . . . . . 60

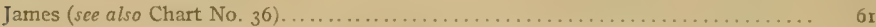

Chart No. 38 (Chesapeake Bay, between James Island and Barren Island)-

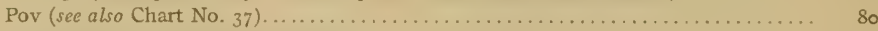

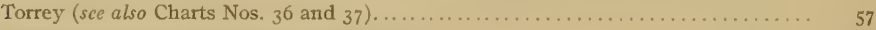

Maryland (sec also Charts Nos. 36 and 37 ) . . . . . . . . . . . . . . . . $5^{8}$

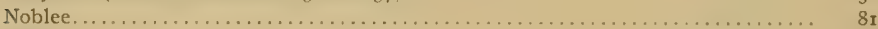

Finish . . . . . . . . . . . . . . . . . . . . . $\quad \mathrm{S}_{\mathrm{I}}$

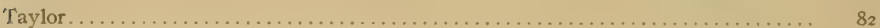

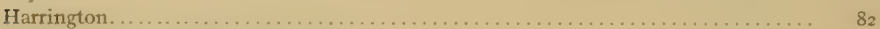

Whitewash (sei ilso Charts Nes. 36 and 37 ) ... 58

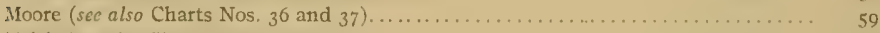

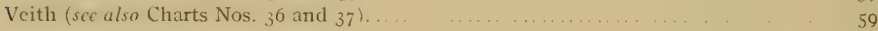

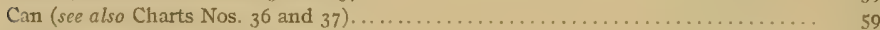

Skid (see also Charts Nos. 36 and $371 \ldots \ldots$. . . . . . . . . 60

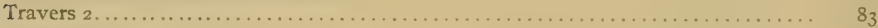

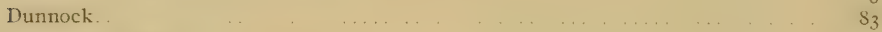

Cove Point Light $\quad \ldots \ldots \ldots \ldots \ldots \ldots \ldots \ldots \ldots$

Point of Rocks. .... . . . . . . . . . . . . . . . $8_{4}$

Chart No. 39 (Chesapeake Bay, vicinity of Barren Island)-
Cedar Point Lirht

Ho.per Island Light. $\quad 8_{4}$

South _ . . . . $\quad 85$

North. ..... ...... . . . . $8_{5}$

Mint $\ldots \ldots \ldots \ldots \ldots \ldots \ldots \ldots \ldots \ldots \ldots$

Kecnes (sec also Chart No. 40)... . . . . . . . . . . . . . . . . 86

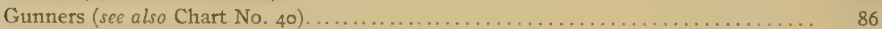

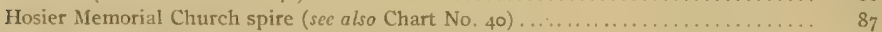

Mount Zion M. E. Church spire (sce also Chart No. 40) ................. 87

Bridge (sec alin Chart No. $401 . \quad 87$

Chart No. 40 (Honga River)-

Applegarth

Hopkins Memorial Church cupola .......................... 88

Hoopersville Methodist Church cupola ......................... 88

Bentley... _... ... $\quad 88$

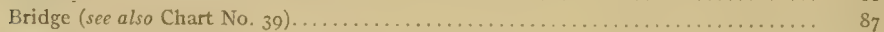

Mount Zion M. E. Church Spire (see also Chart No. 39) ................. 87

Hosier Memorial Church Spire (see also Chart No. 39) ................... 87

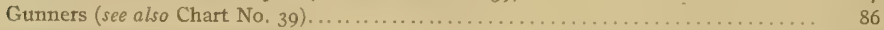

Keenes (sec also Chart No. 39) .............. .... . . 86

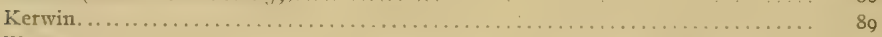

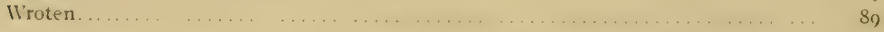


LANDMARKS (U. S. COAST AND GEODETIC SURVEY TRIANGULation STaTIONS)-Continued. Descriptions of triangulation stations in county and adjacent waters-Continued.

Chart No. 40 (Honga River)-Continued.

Charles.

Lakes. .

Asquith.

Windmill 2.

Paul (Honga River)

Tuddville AI. E. Church Spire

Duck (Honga River).

St. Thomas Church Spire

Norman.

Hooper Strait Light.

Chart No. 4 I (Fishing Bay and Nanticoke River)-

Crab.

Head .................................... 93

Croch ... 93

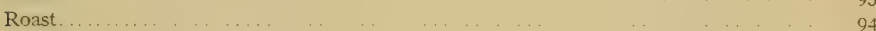

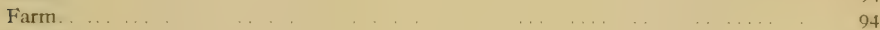

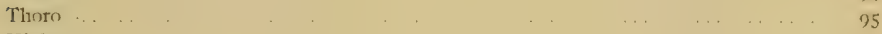

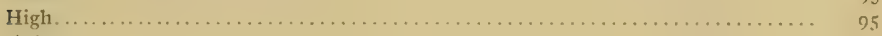

Ellint1 - . 95

liar

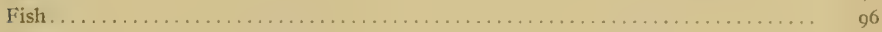

Frog .................. . . . 96

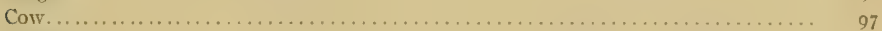

' Okay. ...... ........ . 97

Ar.................... . . . . 98

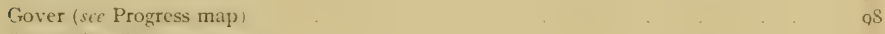

Streett (sec Progress map̣) $\quad$ _. . . . . . 99

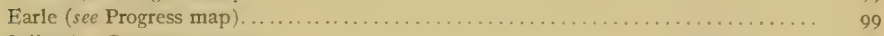

Julict (ree Progress map), 90

Pole. ... . 100

$\begin{array}{ll}\text { Divalve Church } & 100\end{array}$

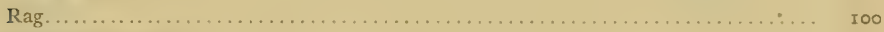

Nanticoke Church...... . Ior

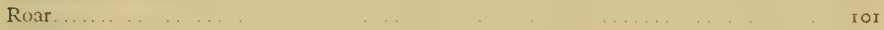

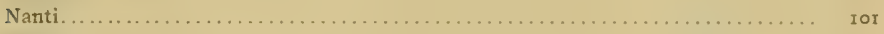

White .......... I02

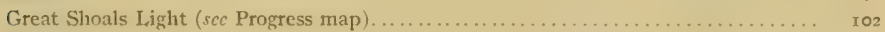

$\begin{array}{ll}\text { Ruom } & 102\end{array}$

Sharkfin Shoal Light. ................................. 10

Haines ... . . . . . . 10,3

1)eal Island Church. $\quad 10,3$

Chart No. 42 (Chesapeake Bay, vicinity of Holland Island)-
Solomons Lump Licht (wec Progress map ........

Holland Island Bar Light............ . . . . . . . 104

Holland Island Cliurch Spire $\quad$. . . . $\quad$ 104

Okahanikan...... . . . . . . . . . 104

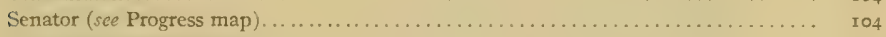

Miles (sec Progress mapl.. . . . . 105

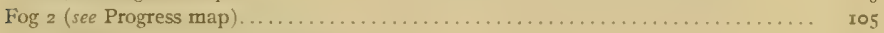

Point No Point Light (see Progress map) . . . . . . . . . . . . . . . . . . . Io5

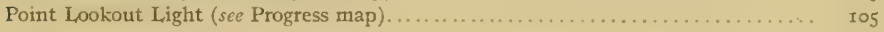


BOUNDARIES OF OYSTER BARS: Page.

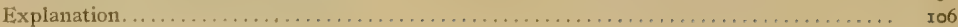

Method of describing boundaries. . . . . . . . .

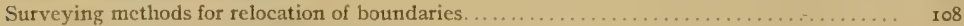

Boundaries of natural oyster bars in county ${ }^{1} \ldots \ldots \ldots \ldots \ldots \ldots \ldots \ldots \ldots \ldots \ldots \ldots \ldots \ldots \ldots$ III

Chart No. 35 (Upper Choptank River)-

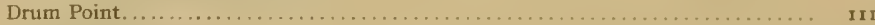

Cabin Creek Entrance. ............................... II

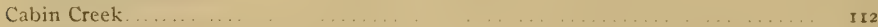

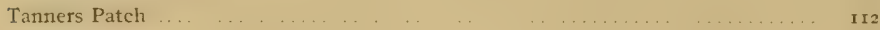

Dixon........................ . . . . . . . . . . . . . .

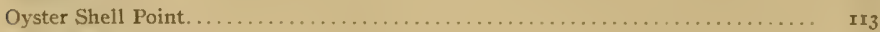

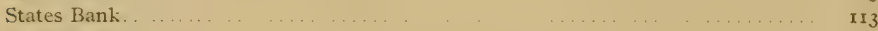

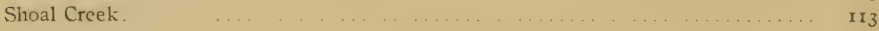

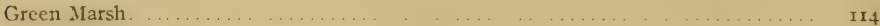

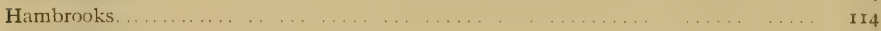

Turtle Back. . . . . . . . . . . . . . . . . . . . . . . . . II

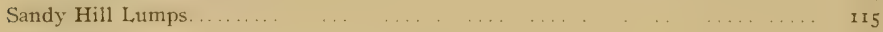

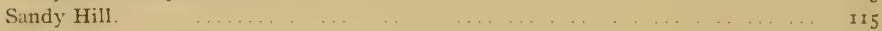

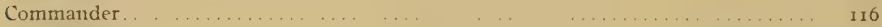

Horn Point. . . . . . . . . . . . . . $\ldots$ I 6

I. Compte _ . . . . . . 117

Castle Haven Creek. .................................. II

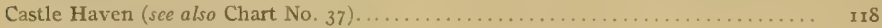

Chart No. 36 (Chesapeake Bay, vicinity of Little Choptank River)-

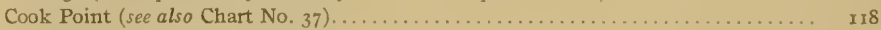

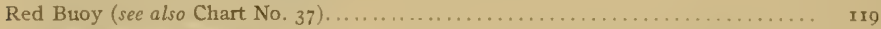

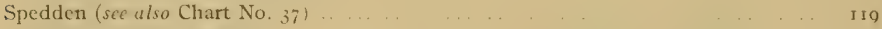

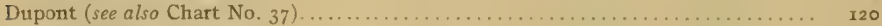

Diamond (sce also Chart No. 37 ) ................. I20

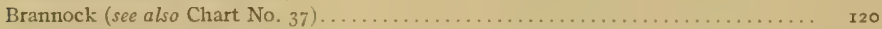

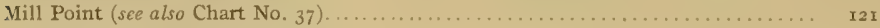

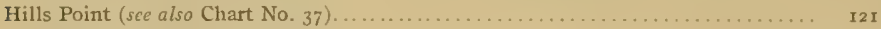

Hills Point North (see also Chart No. 37 ) ....................... I2I

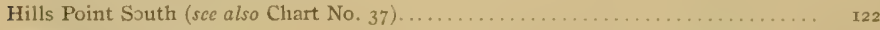

James Point... . . . . . . . 122

Travers (see also Chart No. 381 . … . . . . . . 123

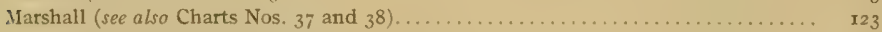

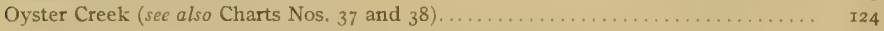

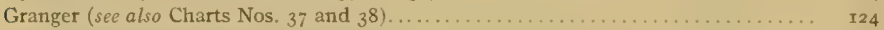

Cators (sec alro Charts Nos. 37 and 38 ). $\quad . \ldots \ldots .124$

Henpeck (see also Charts Nos 37 and 38 i _. . . $\quad$ I25

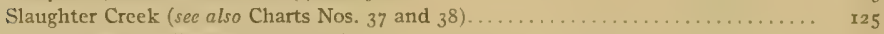

Hooper (see also Charts Nos. 37 and 38 ) ..... . . . . . . . .

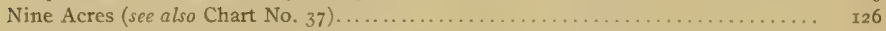

Little Choptank (see also Chart No. 37) ...................... 126

Ragged Point (see also Chart No. 37 ) ......................... 127

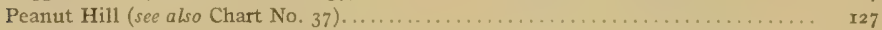

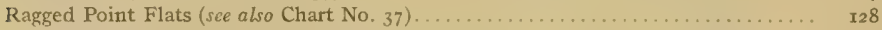

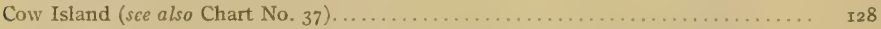

Bald Eagle (sce also Chart No. 37 ) ......... . . . . . . . . I 29

iSee separate publications for boundaries of natural oyster bars in adjacent counties. 
BOUNDARIES OF OYSTER BARS-Continued.

Page.

Boundaries of natural oyster bars in county-Continued.

Chart No. 37 (Little Choptank River and tributaries)-

Castle Haven (sic also Chart No. 35) ... . . Irs

Corners Wharf. ..... . . . . . . . . . . .

Logans Hill . $\quad \ldots \quad \ldots \quad \ldots \quad \ldots \quad \ldots \quad \ldots$

Todd Point . . . . . $\quad$ 130

Cook Point (see alsu Chart Nu. 301

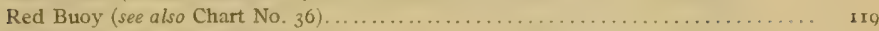

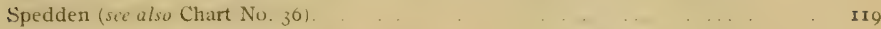

Dupont (see also Chart No. 36$) \ldots \ldots \ldots \ldots \ldots \ldots \ldots \ldots \ldots \ldots \ldots$. . . . 120

Diamond (see also Chart No. 30$)$. ............................. 120

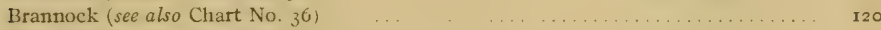

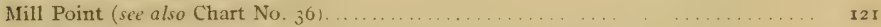

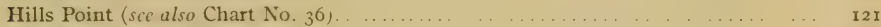

Hills Point North (sce also Chart No. 36$) \ldots \ldots \ldots \ldots \ldots \ldots \ldots \ldots$ r I

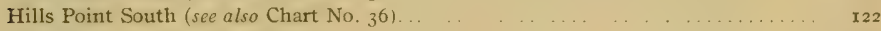

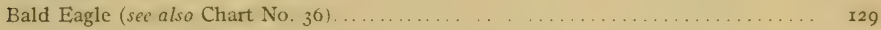

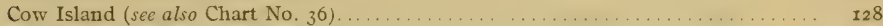

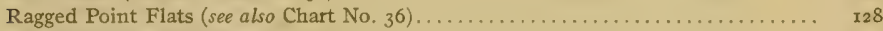

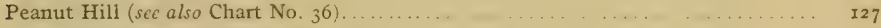

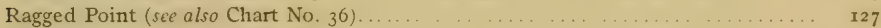

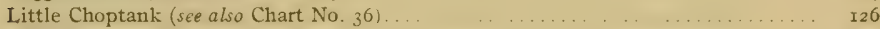

Nine acres (sec also Chart No. $361 \ldots \ldots \ldots \ldots$. . . . . . . . . . . . . . . $\quad$ I26

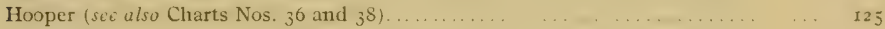

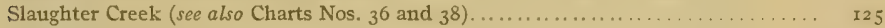

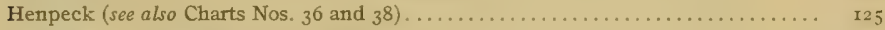

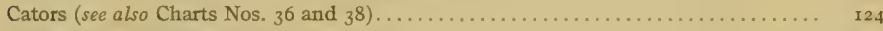

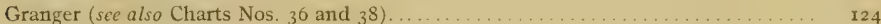

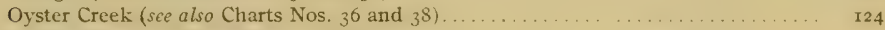

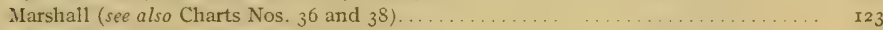

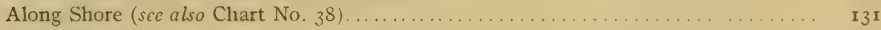

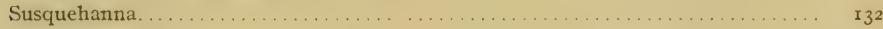

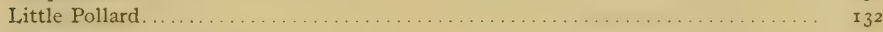

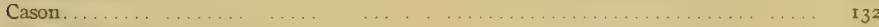

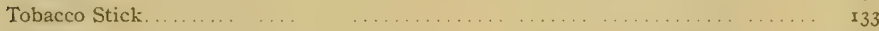

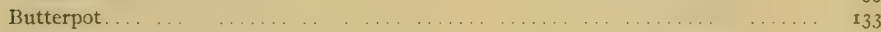

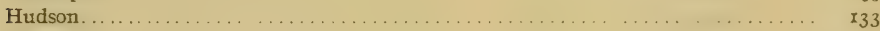

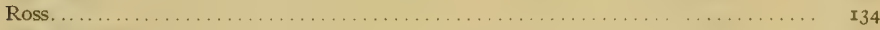

McKeils Point . . . . . . . . . . . .

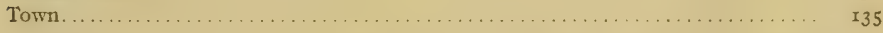

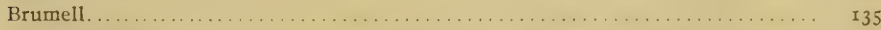

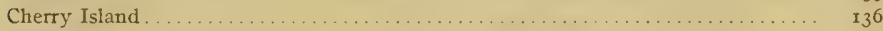

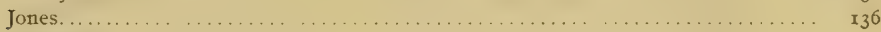

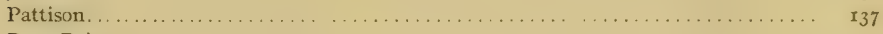

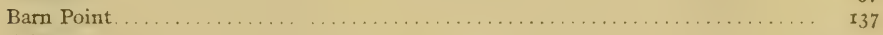

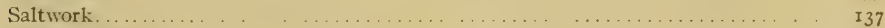

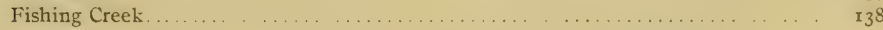

Grapevine............................... $\mathrm{r}_{3} 8$

Chart No. 38 (Chesapeake Bay, between James Island and Barren Island)-

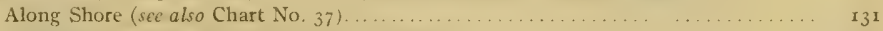

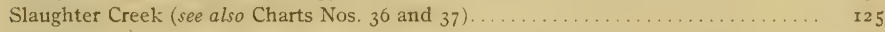

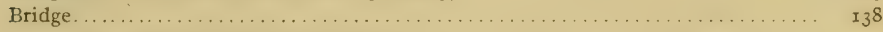

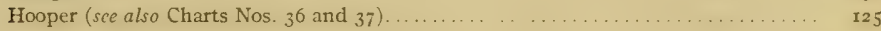


BOUNDARIES OF OYSTER BARS-Continued.

Boundaries of natural oyster bars in county - Continued.

Chart No. 38 (Chesapeake Bay, between James Island and Barren Island)-Continued.

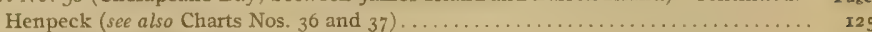

Cators (see also Charts Nos. 30 and 37 ) . . . . . . . . . . . . . . . . 124

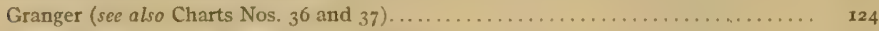

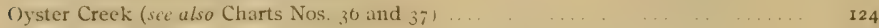

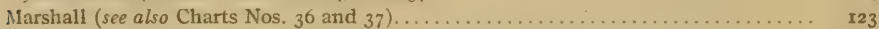

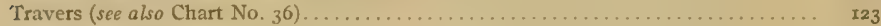

Punch Island Creek . . . . . . . . . . . . . . . . . . . . . . . . . . . . . .

Chart No. 39 (Chesapeake Bay, vicinity of Barren Island)-

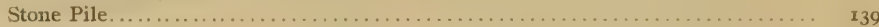

New Discovery....... _ _ _ . . . . . . . . . . . . I39

Horse Point Channel (see also Chart No. 40) ...................... I 40

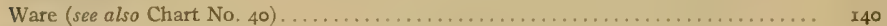

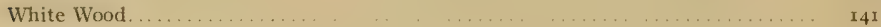

Tar Bay....................................... I

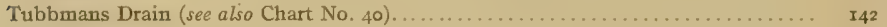

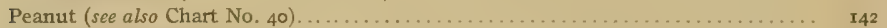

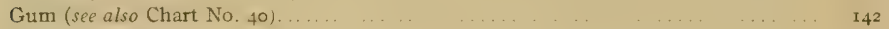

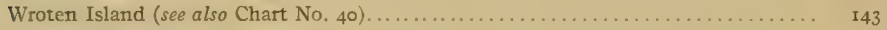

Chart $N o .40$ (Honga River) -
Tubbmans Drain (see also Chart No. 39$) \ldots \ldots \ldots \ldots \ldots \ldots \ldots \ldots \ldots \ldots \ldots \ldots \ldots \ldots \ldots \ldots \ldots \ldots$

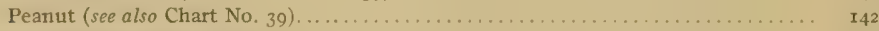

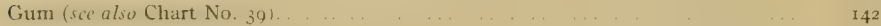

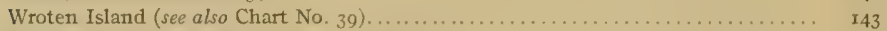

Horse Point Channel (see also Chart No. 39 ) .............. 140

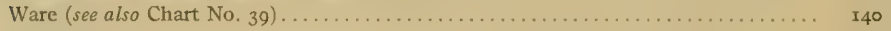

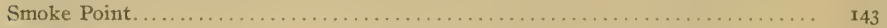

Dark Point ........ . . . . . . . . . . . . . . . . . . . . . . . I44

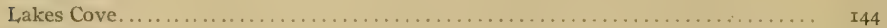

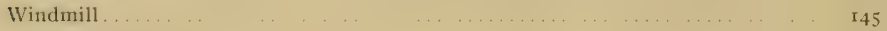

Hickory . . . . . . . . . . . . . . . . . . . . . . . .

Lower Thoroughfire $\quad \ldots \ldots \ldots \ldots . \ldots \ldots$

Paul ... 140

Crab Point . . . . . . . 147

Norman ...... . . . . . . . . . . . . . . . . 147

Applegarth ......................................

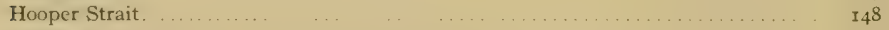

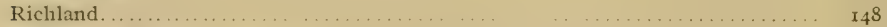

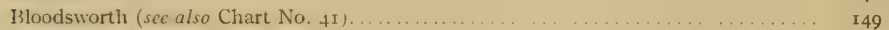

Chart No. $4 \mathrm{I}$ (Fishing Bay and Nanticoke River)
Bloodsworth (see also Chart No. 40 ) $\ldots \ldots \ldots \ldots \ldots \ldots \ldots \ldots \ldots \ldots \ldots \ldots \ldots \ldots \ldots \ldots \ldots$

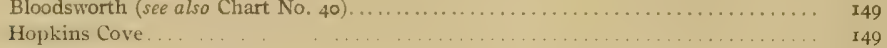

Red Sector. . . . . . . . . . . . . . . . . . .

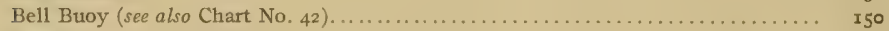

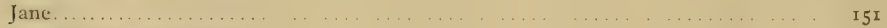

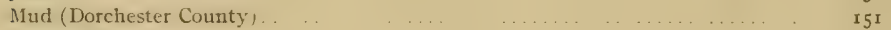

Sharkfin Shoal ....... $\ldots \ldots \ldots \ldots \ldots \ldots \ldots \ldots \ldots$

Ware Sands . . . . . . . . . . . .

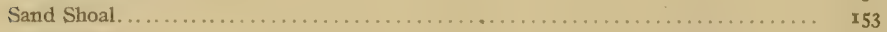

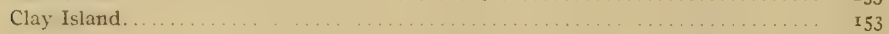

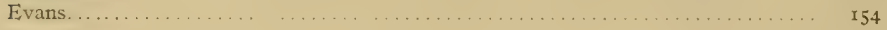

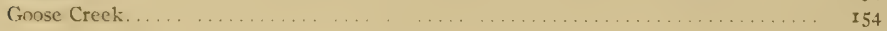


BOUNDARIES OF OYSTER BARS-Continued.

Boundaries of natural oyster bars in county-Continued.

Chart No. 4 I (Fishing Bay and Nanticoke River)-Continued. Puge

Duck Island ........... . . . 155

Bungay..... . . . . . . . . . . . . $\quad$ × 55

Old House. $\quad \ldots \ldots \ldots \ldots$. . . . . . 156

Point . . . . . . . . . . . . . 156

Hill. . . . . ... ... . . 156

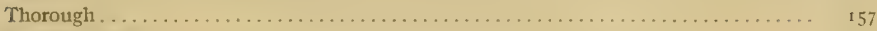

Half Way liark $\quad \ldots \quad 157$

Flat Rock. $\quad 157$

Frug Point. . . . . . . . . . 158

New......... . . . . . . . . . . . . . . . . . $15^{8}$

Hills and Holes... $\ldots \ldots \ldots \ldots \ldots \ldots . . \ldots \ldots$

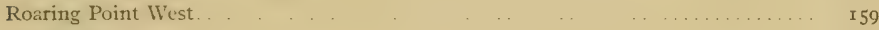

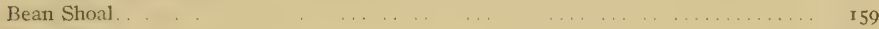

Outer Hole ............ . . ...... $\quad$ r59

Lower Newfoundland . . . . . . . . . . . . . 160

Upper Newfoundland .......... . . . . . . . . . . 160

Chart No. 42 (Chesapeake Bay, vicinity of Holland Island) -
Northrest Middleground . . . . . . . I60

Southeast Middleground .. ... . . . . . . . . . I6 I

Boundary....... . . . . . . . . I6I

Holland straits. ..... . . . . $\quad 162$

Bell Buoy (sct also (hart Nis. +1 ) . . . . . . . . . I50

BOUNDARIES OF CRAB BOTTOMS:

Explanation............ . . . . . . . . . . 163

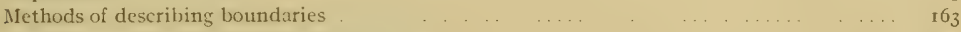

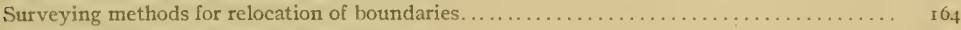

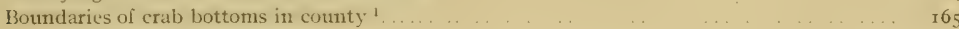

Chart No. 40 (Honga River)-

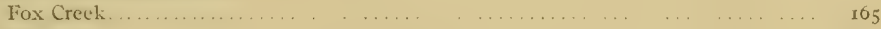

Wingate $\ldots \ldots \ldots \ldots \ldots \ldots \ldots \ldots \ldots \ldots \ldots$

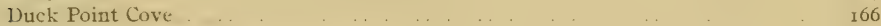

Jenny Island (see also Chart No. $4 \mathrm{r}$ )... I 60

Okahanikan (see also Charts Nos. 4 I and 42$) \ldots \ldots \ldots \ldots \ldots \ldots \ldots \ldots \ldots \ldots \ldots \ldots \ldots \ldots \ldots \ldots$

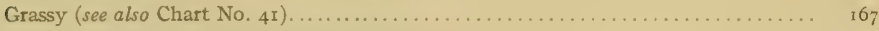

Chart No. 41 . (Fishing Bay and Nanticoke River)
Jenny Island (see also Chart No. 40 ) $\ldots \ldots \ldots \ldots \ldots \ldots \ldots \ldots \ldots \ldots \ldots \ldots \ldots \ldots \ldots \ldots \ldots$

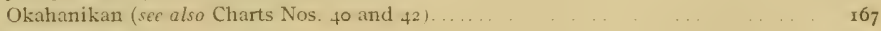

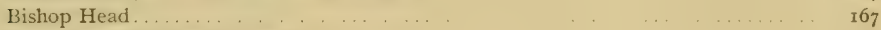

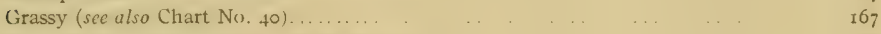

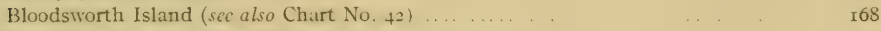

Great Cove $\{$ sec alsu Chart No. 42$) \ldots \ldots \ldots \ldots \ldots \ldots$...... . . . . . . 169

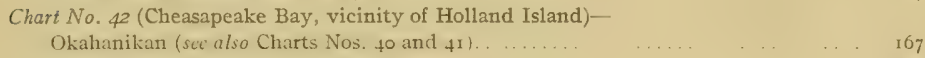

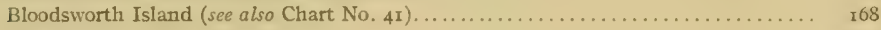

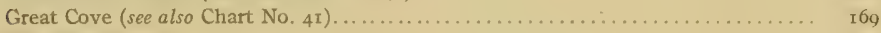

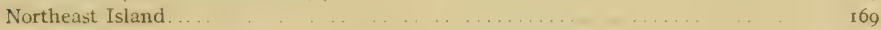

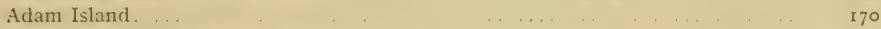

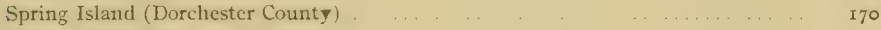

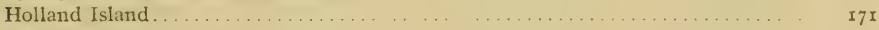

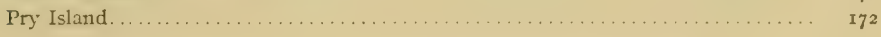

${ }^{1}$ See separate publications for boundaries of crab bottoms in adjacent counties. 
APPENDIXES:

Page.

Appendix A.-Laws relating to the cooperation of the Coast and Geodetic Survey and Bureau of Fisheries with the Maryland Shell Fish Commission .

Appendix B. "The Haman Oyster Culture Law" (extract from Second Report of Shell

Fish Commission) . . . . . . . . . . . . . . . . . . . . . . . . . . . . . . . .

Appendix C.-Summary of the particular surveying operations which constitute an "oyster survey " as now being carried on in Maryland.

Appendix D.-Statistics of results of the combined operations of the Government and State. . 


\section{SURVEY OF OYSTER BARS, DORCHESTER COUNTY, MD.}

\section{INTRODUCTION.}

\section{PUBLICATIONS.}

The preparation of publications relating to the survey of the oyster bars of Maryland has been divided between the Government and the State in accordance with the laws ${ }^{2}$ authorizing the work and the natural division of the surveying operations ${ }^{2}$ of the cooperating forces.

The publications prepared and issued by the Government under the direction of the Superintendent of the Coast and Geodetic Survey consist of a series of charts and a technical report for each county surveyed. ${ }^{3}$ The charts show all legal boundaries of oyster bars within the adopted boundaries of the waters opened up for leasing with each county, and the location of all landmarks (Coast and Geodetic Survey triangulation stations) used as a foundation for the delineation of these various boundaries. The technical report gives technical and legal descriptions of all oyster bar and other boundaries, and descriptions of all landmarks shown on the charts, and includes the report of the representativ - of the Coast and Geodetic Survey in charge of the work of that service in cooperation with the Bureau of Fisheries and the Maryland Shell Fish Commission. These charts and technical reports are prepared and certified for file with the courts and the Commission, as required by the laws of the State, and contain all information necessary to make a permanent record of the work of the Commission and the Government for all future requirements of the courts, or for any resurveys that may become necessary. ${ }^{4}$

The publications prepared and issued by the State under the direction of the Shell Fish Commission consist of annual reports ${ }^{5}$ of all the operations of the Commission performed under the provisions of the laws of Maryland, ${ }^{\circ}$ including results of biological and economic oyster investigations, methods and results of the hydrographic survey of

\footnotetext{
1 See Appendix A for laws relating to the cooperation of the Coast and Geodetic Survey and Bureau of Fisheries with the Maryland Shell Fish Commission.

"See Appendix C for a summary of the particular surveying operations which constitute an "oyster survey" as now being carried on in Maryland.

3 These charts and technical reports can be obtained by application to the Superintendent of the Coast and Geodetic Survey at Washington, D.C. The publications now ready for issue are those for Anne Arundel, Somerset, Wicomico, Worcester, Calvert, Charles, St. Marys, Baltimore, Kent, Queen Annes, Talbot, and Dorchester Counties.

The technical records and charts for each county are published separately on account of the requirements of the oysterculture laws of the State and the practical considerations which make it desirable to have each county "opened up" for oyster culture as soon as practicable after the completion of its survey. For these reasons and the fact that these reports are each arranged for distribution and use in one county only without reference to other published records, much of the text of this publication is of necessity identical with similar previous publications for other counties.

5 These reports can be obtained by application to the Shell Fish Commission, Marine Bank Building, Baltimore, Mrd. They are issued annually in October, and the first, second, third, and fourth reports are now available for distribution.

"See Appendix B for an extract from the "Second Report of the Maryland Shell Fish Commission," giving a concise summary of the "Haman oyster culture law."
}

$$
5^{8} 345-13-2
$$


the boundaries of oyster bars and crab bottoms, the administrative report and financial statement of the Commission, information relating to oyster culture, methods of surveying and leasing of oyster lots, and much other important matter of legal and scientific value.

These two sets of publications are planned and arranged to supplement each other without unnecessary duplication, and when combined they form a complete report of operations, methods, and results of the work of both the Government and State. ${ }^{1}$

\section{COOPERATION OF THE COAST AND GEODETIC SURVEY.}

The work of the Coast and Geodetic Survey, as the name of the service indicates, includes a survey of the coasts of the United States made on a geodetic basis. This has involved the gradual construction of a great framework of interstate triangulation for use as a foundation for detail hydrographic and topographic surveys, from which there has been compiled and published a complete set of charts of the coasts of the United States, including all waters of Maryland where oysters grow. This existing triangulation, hydrography, and topography is essential as a foundation for a correct and practical survey of natural oyster bars; and it being one of the fundamental functions of the Coast and Geodetic Survey to furnish such data, the cooperation of the Coast and Geodetic Survey with the Bureau of Fisheries and the Naryland Shell Fish Commission is a practical and natural development of Government work leading to the conservation and increase of the supply of food.

\section{COOPERATION OF THE BUREAU OF FISHERIES.}

The Bureau of Fisheries has cooperated with the Coast and Geodetic Survey and the Maryland Shell Fish Commission principally as an adviser in matters relating to the biological and economic survey of oyster bars and the methods to be employed for that purpose. $^{2}$ A steam launch, rowing boat, and certain apparatus have also been furnished.

'The primary function of the Bureau of Fisheries is to increase the productiveness of marine and fresh waters by such measures as may be best suited to the purpose, and the services rendered in connection with the survey of the oyster bars of Maryland are strictly in line with the fundamental law under which it acts. In certain States other than Maryland similar work has been conducted by the bureau acting independently, the same ends being attained at greater expense to the Government.

\section{GENERAL STATEMENT OF WORK OF COAST AND GEODETIC SURVEY. ${ }^{3}$}

The results obtained from the work of the Coast and Geodetic Survey in cooperation with the Bureau of Fisheries and the Maryland Shell Fish Commission need very little other summary than is indicated by the published "Charts of Natural Oyster Bars" and the index of hydrographic projections and triangulation stations shown on the county progress maps attached to each report.

\footnotetext{
'See Appendix D of this publication for "Statistics of results of combined operations of the Government and State."

${ }^{2}$ Hon. George M. Bowers, Commissioner of Fisheries, has detailed for this service Dr. H. F. Moore, Assistant, Bureau of Fisheries,

3 For a detail statement of the very large amount of excellent oyster survey work of the Maryland Shell Fish Commission see the "Annual Reports of the Maryland Shell Fish Commission."
} 
The triangulation has been carried on in accordance with the standard methods of the Coast and Geodetic Survey, making this work and that of the "Descriptions of Triangulation Stations" of permanent value, not only to the State of Maryland in the survey of her oyster bars, but also to the Government for any future work it may do in the regions covered by the oyster-survey operations.

The hydrographic projections and published charts are prepared with all the accuracy permitted by their large scale, especially as to the boundaries of the various shell-fish bottoms in relation to landmarks, but this accuracy of location on the charts is further added to and permanently fixed by published technical descriptions, which should minimize the probability of any future dispute as to either landmarks or boundaries.

Stated another way, and quoting from the report of the "Survey of Oyster Bars of Anne Arundel County"':

The geographic positions of the permanent landmarks and signals have been determined with the usual precision of a trigonometric survey, and their locations at all points necessary to provide ample foundation for the surveying and charting operations permitted great accuracy of definition and location for the natural oyster bar and other boundaries established. At the same time, the very important element of permanency of the positions of boundaries has been secured, as the relocation of geodetic positions can always be accomplished by a competent surveyor, even though the original landmarks and monuments have been washed away, as has been the fate of hundreds of such points established by the Coast and Geodetic Survey on the shores of the Chesapeake Bay during the last 65 years. 



\title{
REPORT OF THE WORK OF THE COAST AND GEODETIC SURVEY IN DORCHESTER COUNTY.
}

\author{
INSTRUCTIONS.
}

The following letters, together with the laws ${ }^{1}$ of the United States relating to the subject, constitute the "instructions" received by the chief of the Coast and Geodetic Survey party engaged on work in connection with the Maryland Shell Fish Commission. They are short and definite, but furnish ample authority and leeway for all legitimate development of the cooperation of the Government and the State in the survey of oyster bars. The "free hand" permitted by these orders, together with the aid and many valuable suggestions received from the officers of the survey at Washington, have proved very beneficial to the work and are greatly appreciated.

\section{DEPARTMENT OF COMMERCE AND LABOR, OFFICE OF THE SECRETARY, Washington, June 2, 1906.}

SiR: In reply to your letter of May 28, requesting me to designate officers of the Coast and Geodetic Survey and of the Burcau of Fisheries to cooperate with the State of Maryland in making survey of and locating the natural oyster beds, I have the honor to inform you that Mr. C. C. Yates will be designated to cooperate on the part of the Coast and Geodetic Survey as soon as Congress makes the provisions of the act effective by providing an appropriation for the purpose. Respectfully,

His Excellency Hon. EDWIN WARFIELD,

LAWRENCE O. MURRaY, Assistant Secretary. Governor of Maryland, Annapolis, Md.

\section{DEPARTMENT OF COMMERCE AND LABOR, Coast and Gédedic SuRvey, \\ Washington, July 3, I006.}

SiR: Upon the receipt of these instructions you will surrender the command, accounts, etc., of the steamer Endeavor to the Hydrographic Inspector.

As soon as this transfer is completed you will enter upon the duties of Coast Survey representative on the Shell Fish Commission of Maryland.

You will consult the Commissioners, prepare a program of work, and submit estimates in the usual form.

You are authorized to come to Washington for consultation from time to time as may be necessary. Very respectfully,

Capt, C. C. YATBS,

O. H. Timmann, Superintendent.

U. S. C. and G. S. Steamer Endeavor, Baltimore, Md.

ORGANIZATION AND EQUIPMENT.

The personnel and occupation of the party of the Coast and Geodetic Survey have remained practically unchanged since the beginning of the "oyster survey." Besides 
the chief of party, it consists of the necessary triangulators, computers, draftsmen, and temporary employees required to carry on both the surveying operations in the field and the preparation for publication of oyster charts and technical records in the office at Washington.

The equipment for the work of the party has been ample and satisfactory. The large living and office quarters furnished the Government on the Maryland Shell Fish Commission house boat Oyster have been very convenient for the work, besides facilitating efficient cooperation with the surveying and oyster investigation parties of the State. In addition to the accommodations on the Oyster, the Coast and Geodetic Survey party has had the constant use of the large launch Inspector and several other boats furnished by its own service, and the occasional use of the Bureau of Fisheries launch Canvasback ${ }^{1}$ and the steamer Governor $M c L a n e^{2}$ of the State Fishery Force.

The greater part of the equipment of instruments for the operations of both the Government and State has been furnished by the Coast and Geodetic Survey and consists of all necessary theodolites, levels, sextants, drafting instruments, hydrometers, etc., required for all field and office work.

\section{CHRONOLOGICAL, STATEMENT OF WORK.}

The field work of the Coast and Geodetic Survey in Dorchester County dates from March I4, I9IO, when a subparty was organized and sent out to complete certain unfinished details of triangulation in Talbot County and to take up the overlapping triangulation between Dorchester and Talbot Counties. ${ }^{3}$ This party first went to St. Michaels, then to Cambridge, and finally to Oxford, where the main party on the house boat was joined at the end of April.

On April 30, 1910, the house boat Oyster was towed from Baltimore by the State steamer McLanc to an anchorage in Tar Creek near Bellevue. While at this harbor the house boat was cleaned, painted, and generally overhauled for the season's work, and at the same time triangulation was carried on in Choptank River and its tributaries.

On May 30, 1910, the house boat shifted her anchorage to Tred Avon River off Oxford, from which point a small amount of field work was done in Dorchester County along with the work in Talbot County.

On June 30 , 19ro, the Oyster was towed to an anchorage off Cambridge, where she remained until the completion of the overlapping field work in Choptank River of both Dorchester and Talbot Counties.

On July 20, 1910, the house boat Oyster was towed from Cambridge to an anchorage off Solomons Island in the mouth of the Patuxent River. A greater part of the field work along the Chesapeake Bay shore of Dorchester County was carried on from this harbor. During weather too rough to work in the open Chesapeake Bay, considerable work was also done from this point in checking up descriptions of triangulation stations required for the preparation of the publications covering Calvert, St. Narys, and Charles Counties.

\footnotetext{
1 By courtesy of Dr. H. F. Moore, United States Bureau of Fisheries.

${ }^{2}$ By courtesy of Capt. James A. Turner, commanding.

3 The field work of Dorchester County was so intermixed with that of Talbot County that the chronological statement of the work in one of these counties necessarily includes a considerable part of the work of the other county.
} 
On August I I, 19ro, the Oyster was moved across the Chesapeake Bay to an anchorage in Honga River off Hoopers Island Wharf. A greater part of the oyster-survey work along the lower Chesapeake Bay shore of Dorchester County, as well as that of Honga River and Fishing Bay, was carried on from this point as headquarters.

On September 30, 1910, the field work in the southern half of Dorchester County being completed, the house boat Oyster was towed by the steamer McLanc to the Little Choptank River and anchored off the town of Madison, where she remained for over two months while oyster-survey operations were being carried on in the Little Choptank River and its many tributaries.

On December 4, 19ro, the house boat Oyster was moved to the northern side of Little Choptank River to an anchorage in the mouth of Hudson Creck, where she remained in spite of bad weather and ice until the practical completion of the oyster-survey work in Dorchester County.

On December 15, 1910, the field work of Dorchester County was completed, and as this was the last county to be surveyed, this date also marks the completion of all the field work of the Maryland Oyster Survey, with the exception of the two days, the 20 th and 2 Ist of June, 1912, when a small party, under the charge of Mr. Frank W. Seth, surveyman in the Coast and Geodetic Survey, was put in the field to complete necessary details of triangulation in Talbot and Dorchester Counties.

The office work connected with the oyster survey of Dorchester County, including the computations of geographic information and the drafting necessary for the preparation for publication of the oyster charts and the technical records of that county, was carried on intermittingly with the office work of other counties from the beginning of the field work in Dorchester County on March $1_{4}, 1910$, to the time of filing of the certified oyster charts and technical records in the archives of the Maryland Shell Fish Commission and with the clerk of the circuit court of Dorchester County on August 17, 1912.

STATISTICS, 1

Landmarks and triangulation signals erected

Monuments planted to mark triangulation stations.

356

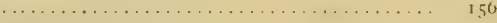

Triangulation stations occupied for observations of horizontal angles............... I6 I

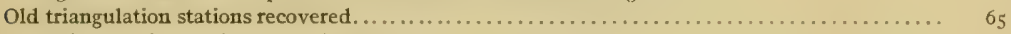

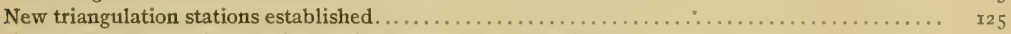

Total old and new triangulation stations marked and described...................... I90

Linear miles of shore line covered by triangulation (approximate) $\ldots \ldots \ldots \ldots \ldots \ldots \ldots \ldots \ldots \ldots \ldots \ldots$

Square miles covered by triangulation (approximate) . . . . . . . . . . . . . . 330

Hydrographic projections prepared and completed as records of oyster boundaries........... 21

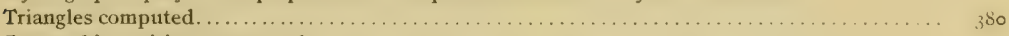

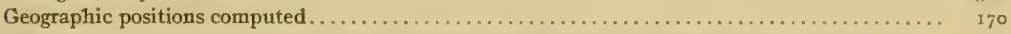

Corners of oyster bar and crab bottom boundaries established by computation.............. 67 I

Back azimuths and distances computed from comers of boundaries to triangulation stations ..... $2,0 x_{3} 3$

Descriptions of triangulation stations prepared for publication. . . . . . . .

Descriptions of oyster bar and crab bottom boundaries prepared for publication............. ${ }^{1} 35$

"Charts of Natural Oyster Bars" prepared for publication....................... 8

Progress map prepared for publication . . . . . . .

1 These statistics only include field and office work directly performed by the party of the Coast and Geodetic Survey in connection with the oyster survey of this county, and do not include the many thousands of soundings and examinations of the character of the bottom made by the engineers of the Commission, which are of considerable value to the Coast and Geodetic Survey as hydrographic records for future use in connection with the preparation of new editions of charts of the waters of Maryland. See Appendix D of this publication for "Statistics of results of combined operations of the Government and the State." 
GENERAL REMARKS.

Before ending this report the representative of the Coast and Geodetic Survey wishes to renew his statement of appreciation of the courteous assistance received from various Government and State officials and others interested in the oyster industry of Maryland, especially to the following:

To his colleague from the Department of Commerce and Labor, Dr, H. F. Moore, of the Bureau of Fisheries, whose well-known scientific knowledge of all matters relating to oysters has been of great value to the work.

To Mr. Walter J. Mitchell, chairman of the Maryland Shell Fish Commission, who, by his administrative ability in carrying out the complicated requirements of the oyster laws and by his unfailing tact, has made the cooperation of the various services engaged on the work both agreeable and effective.

To Dr. Caswell Grave, secretary of the Commission, who, as editor of the Commission's annual report and commissioner in charge of the biological and economic oyster investigations, has been brought into constant contact with the Government work and aided its operations in every way.

To Mr. Benjamin K. Green, treasurer of the Commission, who has looked after the equipment and commissary of the house boat in such a way as to add greatly to the comfort and convenience of the party of the Coast and Geodetic Survey.

To Mr. Swepson Earle, hydrographic engineer to the Commission, whose knowledge of the work from former service in the Coast and Geodetic Survey has greatly facilitated his practical use of the technical data furnished by the Government.

And to the many others connected with the Commission or who as residents in the locality where the work was being carried on have greatly assisted by furnishing important information or willing services. 


\section{CHARTS AND MAPS.}

\section{CHARTS OF NATURAL, OYSTER BARS. ${ }^{1}$}

The charts of the natural oyster bars of Dorchester County published by the Coast and Geodetic Survey from results of the surveys of the Government in cooperation with the Maryland Shell Fish Commission consist of eight sheets covering all the oyster-producing waters of that county. They are published on the large scale of I part in 20,000 (approximately $3 \frac{1}{16}$ inches to a statute mile) and are constructed on polyconic projections; and all information shown on them is based on the United States standard datum of the Coast and Geodetic Survey.

These charts show all oyster bars and other boundaries established by the Commission, and are certified for the purpose of filing in the office of the clerk of the circuit court of Dorchester County and in the office of the Maryland Shell Fish Commission, as required by the oyster laws of Maryland.

In addition to the oyster bar and other boundaries, the charts show the location and name of all landmarks (United States Coast and Geodetic Survey triangulation stations) used in making the survey, together with the hydrography and topography ? necessary to make the technical definitions and delineations of boundaries readily understandable both by the people engaged in the oyster industry and the general public who may become interested through leasing of barren bottoms for oyster culture.

The names of the oyster bars are those used locally, as nearly as could be ascertained by the hydrographic engineer of the Commission. When there was no local name in common use, a name was selected from one of the prominent features of the vicinity. By the use of recognized names or those that would naturally suggest certain sections of water, it is believed that much confusion will be avoided in the location on the charts of the oyster bars, especially by those not familiar with the use of maps.

The corners of the oyster bars are numbered from I to the total number of corners in each area under consideration. Where boundaries adjoin, making one point a corner of two or more oyster bars, these points have two or more numbers, each number corresponding to the bar in which the figure is located. The numbers of the corners correspond with the technical and legal descriptions of this publication under the heading "Boundaries of natural oyster bars."

The landmarks and oyster bars have been grouped in the "Contents" of this publication in accordance with the charts upon which they are shown. To find a particulat oyster bar or landmark which is only known by name, consult the "Contents" and the desired chart and general location will be indicated. To find the name of a bar or landmark which is only known by location, consult the progress map at the end of this publication for the number of the chart on which it is to be found, and then examine the known locality on the chart for the name of the bar or landmark in question.

\footnotetext{
1 These charts can be obtained by application to the Superintendent of the Coast and Geodetic Survey, at TVashington; D. C.

2 Much of the detail of the inshore topography was fobtained from the excellent map of Dorchester County; prepared and published by the Maryland Geological Survey under the direction of Dr. William Bullock Clark from surveys of the Maryland Geological Survey in cooperation with the United States Geological Survey.
} 
The contours on the charts showing the depth of water at mean low tide have been taken from the hydrographic sheets of former work of the Coast and Geodetic Survey. Four curves were selected as being the most convenient for taking off from the original hydrographic sheets and the ones of greatest value to those interested in shell fish industries. The 1 -fathom contour ( 6 feet) and the 5 -fathom curve (30 feet) correspond in a general way to the inner and outer limits of all the oyster bars surveyed. The 3 -fathom contour ( 18 feet) furnishes the curve of about the average depth of water on the oyster bars, and the Io-fathom contour ( 60 feet) serves in a general way to indicate the outer limits of probable oyster culture.

The boundaries of the waters within the "territorial limits of the county" and the boundaries of the "waters contiguous to the county" opened up for the leasing with Dorchester County are plainly indicated on the charts. A full technical description of these boundaries is given in this publication under the heading "Boundaries of county waters."

The areas in acres of the oyster bars were determined under the direction of the hydrographic engineer of the Commission by two independent planimeter measurements of the areas as delineated on the smooth projections of the Coast and Geodetic Survey: These areas are given in small figures in parentheses on the face of the chart within the boundaries of the different shell fish bottoms.

The symbols used on the charts for the different kinds of boundaries, triangulation stations, contours of depth of water, etc., require no other explanation than that given in the legend and other notes on the face of the charts.

LEASING CHARTS.

The leasing charts of Dorchester County, like those for Anne Arundel, Somerset, Wicomico, Worcester, Calvert, Charles, St. Marys, Baltimore, Kent, Queen Annes and Talbot counties, have been prepared under the direction of the hydrographic engineer of the Commission. They are constructed on polyconic projections on the scales of I part in 5,000 or I part in 10,000 as the needs of oyster culture may require, and the information shown on them is based on the United States standard datum of the Coast and Geodetic Survey.

These charts show all the oyster bars, crab bottoms, and clam beds and other boundaries established by the Commission, and also all boundaries of oyster lots leased for the purpose of oyster culture, thus making them comprehensive and valuable records of the results of the operations of the oyster-culture laws.

The lots leased under the provision of the "old 5-acre law" are frequently of irregular shape, but the lots leased under the provision of the new oyster law ; must be of rectangular shape by the terms of that act. For this latter purpose the leasing charts have been divided by parallels of latitude and meridians of longitude into small rectangles of $\mathrm{I}$ acre or 5 acres, as may be best suited to the area under consideration, and prospective leaseholders by the rules of the Commission are compelled to select whole rectangles as far as possible.

For reasons of the present changeable nature of the number of lots leased and the large number of charts required, the leasing charts are not likely to be published for some years, but they can be seen at any time on file at the offices of the Commission, in the Marine Bank Building at Baltimore. 
PROJECTIONS.

The polyconic projections ${ }^{2}$ covering Dorchester County waters are 21 in number and on the scale of I part in ro,ooo. They were constructed by draftsmen of the Coast and Geodetic Survey, but the sextant positions which determine the location of the legal boundaries of the oyster bars as delineated by the Shell Fish Commission were plotted by the draftsman of the Commission.

A copy of each of these projections, with all the plotted positions of triangulation stations, shore line, sextant positions, and boundaries of oyster bars, was made under the direction of the hydrographic engineer of the Commission by pricking through with a sharp needle the intersections of the projection lines and all other points as plotted on the original sheets.

These projections (in duplicate) are the original records of all oyster bar and other boundaries established by the Commission, one set being filed in the archives of the Coast and Geodetic Survey, at Washington, and the other set in the archives of the Shell Fish Commission.

\section{PROGRESS MAPS.}

The progress map to be found at the end of this publication is on a scale of I part in 100,000 , and shows in outline the work accomplished by the United States Coast and Geodetic Survey in Dorchester County and contiguous waters. It gives the scheme of all the charts and smooth projections constructed in connection with the survey, the location and names of all triangulation stations used as a basis for the surveying work. and the "houndaries of county waters" established by the Commission for the purpose of carrying out the laws of Maryland relating to oyster culture.

Besides indicating the amount of work done by the Coast and Geodetic Survey in connection with the work of the Shell Fish Commission, this progress map will be of special value for index purposes to engineers and others searching for the particular chart or projection covering the locality of the oyster bars or landmarks that may be under consideration.

The progress maps ${ }^{2}$ accompanying the first and second annual reports of the Maryland Shell Fish Commission were prepared under the direction of the hydrographic engineer of the Commission. They are on the scale of $\mathrm{I}$ part in 400,000 , and show the outline of the tide-water counties of Maryland, with shaded areas to indicate the waters already covered by the operations of the oyster survey.

\footnotetext{
For the scheme of these projections see the progress map at the end of this publication.

2 These maps and reports can be obtained by application to Maryland Shell Fish Commission, Marine Bank 3uilding, Baltimore, Md,
} 


\section{BOUNDARIES OF 'THE COUNTY WATERS.'}

\section{WATERS WITHIN TERRITORIAL LIMITS OF COUNTY.}

The laws of Maryland relating to oyster culture provide that "no person shall be permitted, by lease, assignment, or in any other manner, to acquire a greater amount of land than ten acres situated within the territorial limits of any of the counties, or one hundred acres in any other place."

The boundary line ${ }^{2}$ between the waters "within the territoriai limits" of Dorchester County and the waters in "any other place," as established by the Shell Fish Commission for the purpose of carrying out the oyster laws, and delineated on the "oyster" charts and the smooth projections of the Coast and Geodetic Survey, is technically described and defined as follows: ${ }^{3}$

Commencing at the head of the oyster-producing waters of Choptank River on the channel boundary line between Dorchester County and Talbot County; thence following the channel boundary line between Talbot County and Dorchester County down the upper Choptank River to a point situated about !nalf way between the town of Choptank and Cabin Creek; thence continuing down the channel boundary line of the upper Choptank River as laid down on "Chart No. 35, Natural Oyster Bars, Maryland" around Chancellors Point and pass the city of Cambridge to the entrance of upper Choptank River between Castle Haven Point and Island Creek; thence along the boundary line between Talbnt Connty and Dorcliester County in the lower Choptank River as laid down on "Charts Nos. 36 and 37 , Natural Oyster Bars, Maryland," to a point in the Chesapeake Bay entrance of the lower Choptank River defined by the intersection of this boundary line with a straight line defined at its northwestern end by a point situated on Blackwalnut Point in latitude $38^{\circ} 40^{\prime} 06.6^{\prime \prime}$ and longitude $76^{\circ} 20^{\prime} 24.7^{\prime \prime}$ and defined at its southeastern end by a point situated on Cook Point in latitude $38^{\circ} 37^{\prime} 55 \cdot 7^{\prime \prime}$ and longitude $76^{\circ} \times 7^{\prime} 28.7^{\prime \prime}$; thence in a straight line across the soutleastern half of the Chesapeake Bay entrance of the lower Choptank River to a point situated on Cook Point defined by latitude $38^{\circ} 37^{\prime} 55.7^{\prime \prime}$ and longitude $76^{\circ} 17^{\prime} 28.7^{\prime \prime}$; thence in a southeasterly direction along the mean low-1vater line or across the mouth of all inlets less than 100 yards in width, as the case may be, of the eastern shore of Chesapeake Jay to a point situated on the northern side of Tripps Bay defined by latitude ${ }_{3} 8^{\circ} 36^{\prime}$ ro. $4^{\prime \prime}$ and longitude $76^{\circ} 16^{\prime} 21.8^{\prime \prime} ;$ thence in a straight line across the eastern end of Tripps Bay to a point situated on the suthem side of the eastem end of Tripps Bay defined by latitude $38^{\circ} 35^{\prime} 5^{2} \cdot 7^{\prime \prime}$ and longitude $76^{\circ}{ }_{1} 6^{\prime}$ $05 . \mathrm{I}^{\prime \prime}$; thence in a southwesterly direction along the mean low-water line or across the mouth of all inlets less than 100 yards in width, as the case may be, of the eastern shore of Chesapeake Bay to a point situated on the northeastern side of the entrance of Brannock Bay defined by latitude $38^{\circ} 35^{\prime} 33.9^{\prime \prime}$ and lingitude $76^{\circ} 16^{\prime} 23.8^{\prime \prime}$; thence in a straight line across the entrance of Brannock Bay to a point situated ')11 Mills Point on the southwestern side of the entrance of Brannock Bay defined by latitude $38^{\circ} 35^{\prime} 07.2^{\prime \prime}$ and longitude $76^{\circ} 17^{\prime} 13.2^{\prime \prime}$; thence in a southwesterly direction along the mean low-water line or across the mouth of all inlets less than 100 yards in width, as the case may be, of the eastern shore of Chesapeake Bay to a point situated on Hills Point on the northern side of the entrance of Little Choptank River defined by latitude $38^{\circ} 33^{\prime} 4^{8} .6^{\prime \prime}$ and longitude $76^{\circ} 18^{\prime} 41.8^{\prime \prime}$; thence in a straight line across the entrance of Little Choptank River to a point situated on James Island on the southern side of I,ittle Choptank River defined by latitude $38^{\circ} 31^{\prime} 44.9^{\prime \prime}$ and longitude $76^{\circ} 20^{\prime}$ or. $9^{\prime \prime}$; thence following the northern and westem side of James Island along the mean low-water line or across the mouth of all inlets less than

1 For a complete historical and legal description of the boundaries of the counties of Maryland, the valuable publication entitled "The Counties of Maryland-Their Origin, Boundaries, and Election Districts," prepared by Dr. Edward B. Mathews and published by the Maryland Geological Survey under the direction of Dr. William Bullock Clark, superintendent, should be consulted, as the boundaries described in this publication have been established and technically defined for the purnose of carrying out the oyster laws of the State, and may or may not be correct for other purposes.

"See "Charts of Natural Oyster Bars," published by the Coast and Geodetic Survey, and the progress map at the end of this publication.

${ }^{3}$ Latitudes and Jongitudes based on the United States standard datum of the United States Coast and Geodetic Survey. 
Ioo yards in width, as the case may be, of the eastern shore of Chesapeake Bay to a point situated on the southern end of James Island defined by latitude $38^{\circ} 30^{\prime} 07.6^{\prime \prime}$ and longitude $76^{\circ} 20^{\prime} 19 \cdot 3^{\prime \prime}$. thence in a straight line across the entrance of Oyster Creek to a point situated on the southern side of the entrance of Oyster Creek defined by latitude $38^{\circ} 29^{\prime} 5 x \cdot 9^{\prime \prime}$ and longitude $76^{\circ} 20^{\prime} 25 \cdot 4^{\prime \prime}$; thence in a southeasterly direction along the mean low-water line across the mouth of all inlets less than roo yards in width, as the case may be, along the eastern shore of Chesapeake Bay across the entrance of Punch Island Creek to a point situated on the northern side of the entrance between two marsh islands into the extreme northen end of Tar Bay defined by latitude $38^{\circ} 22^{\prime} 48.6^{\prime \prime}$ and longitude $76^{\circ} 16^{\prime} 46.7^{\prime \prime}$; thence in a straight line across the entrance of the northern end of Tar Bay to a point situated on the northern end of a marsh island defined by latitude $38^{\circ} 22^{\prime} 33.6^{\prime \prime}$ and longitude $76^{\circ} 16^{\prime} 45-0^{\prime \prime}$; thence in a southerly. direction following the western side of a marsh island along the mean low water line or across the mouth of all inlets less than roo yards in width, as the case may be, of the eastern shore of Chesapeake Bay to a point situated on the southern end of a marsh island on the northern side of the main northern entrance of Tar Bay defined by latitude $38^{\circ} 2 \mathrm{x}^{\prime} 49 \cdot 2^{\prime \prime}$ and longitude $76^{\circ} 16^{\prime} 31.0^{\prime \prime}$; thence in a straight line across the mair northern entrance of Tar Bay to a point situated on the northern end of Barren Island de fined $h$. latitude $38^{\circ} 20^{\prime} 53 \cdot 4^{\prime \prime}$ and longitude $76^{\circ} \mathrm{r} 6^{\prime}$ or $5^{\prime \prime}$; thence following the western and southern side of Barren Island along the mean low-water line or across the mouth of all inlets less than roo yards in width, as the case may be, to a point situated on the southern end of Barren Island defined by latitude $38^{\circ} 18^{\prime} 39.8^{\prime \prime}$ and longitude $76^{\circ} 14^{\prime} 37 \cdot 5^{\prime \prime}$; thence in a straight line across the southern entrance of Tar Bay to a point situated on Pons Point on the western side of Upper Hooper Island defined by latitude $38^{\circ} 18^{\prime} 2.4 .0^{\prime \prime}$ and longitude $; 6^{\circ} 3^{\prime} 27 \cdot 5^{\prime \prime}$; thence in a southeasterly direction following the western side of Upper Hooper Island, Middle Hooper Island, and Lower Hooper Island along the mean low-water line or across the causeways and bridges connecting these islands and the mouths of all inlets less than roo yards in width, as the case may be, of the eastern shore of Chesapeake Bay to a point situated on the southern side of Lower Hooper Island on the northwestem side of the entrance of Hooper Strait defined by latitude $3^{\circ}{ }^{\circ} 3^{\prime} 57.7^{\prime \prime}$ and longitude $76^{\circ} \circ 7^{\prime} 56.5^{\prime \prime}$; thence in a straight line across the Chesapeake Bay entrance of Hooper Strait to a point situated on the northwestern side Bloodsworth Island on the southern side of the entrance of Hooper Strait defined by latitude $38^{\circ} \mathrm{II}^{\prime} 40.6^{\prime \prime}$ and longitude $76^{\circ} 05^{\prime} 25.2^{\prime \prime} ;$ thence in a southerly direction following the western side of Bloodsworth Island along the mean low-11ater line or across the mouth of all inlets less than roo yards in width, as the case may be, to a point situated on the southwestern end of a part of Bloodsworth Island known as Billys Island defined by latitude $38^{\circ}$ o $)^{\prime} 23.3^{\prime \prime}$ and longitude $76^{\circ} \circ 5^{\prime} \circ . \mathrm{x}^{\prime \prime}$; thence in a straight line across the channel between Billys Island and Adam Island to a point situated on the northern end of Adam Island defined by latitude $38^{\circ} \circ g^{\prime}{ }^{1} 4.7^{\prime \prime}$ and longitude $76^{\circ} 05^{\prime} 14.0^{\prime \prime}$; thence following the northern and western side of Adam Island along the mean low-water line or across the mouth of all inlets less than 100 yards in width, as the case may be, of the eastern shore of Chesapeake Bay to a point situated on the southern end of Adam Island defined by latitude $38^{\circ} 08^{\prime} 16.4^{\prime \prime}$ and longitude $76^{\circ} 05^{\prime} \circ 9.0^{\prime \prime}$; thence in a straight line across the channel between Adam Island and Holland Island to a point on the northern end of Holland Island defined by latitude $38^{\circ} 08^{\prime} 06.6^{\prime \prime}$ and longitude $76^{\circ} \circ 5^{\prime} 27.8^{\prime \prime}$; thence in a southerly direction following the western side of Holland Island along the mean low-water line or across the mouth of all inlets less than roo yards in width, as the case may be, to a point on the southern end of Holland Island defined by latitude $38^{\circ}$ o6 $3^{6.4^{\prime \prime}}$; and longitude $76^{\circ} \circ 5^{\prime} 3^{1} \cdot 6^{\prime \prime}$; thence in a straight line to a point situated on the boundary line between Dorchester County and Somerset County on the southern side of the Chesapeake Bay entrance of Holland Straits about $\mathrm{x} / 2$ miles north-northeast of Holland Island Bar L,ight defined by latitude $38^{\circ} 04^{\prime} 40.8^{\prime \prime}$ and longitude $76^{\circ} \circ 4^{\prime} 14.8^{\prime \prime}$; thence in a straight line along the Holland Straits boundary line between Dorchester County and Somerset County to a point on the western side of Pry Island on the east . ern side of Holland Straits defined by latitude $38^{\circ} 05^{\prime} 44 \cdot 1^{\prime \prime}$ and longitude $76^{\circ} 03^{\prime}+4 \cdot 6^{\prime \prime}$; thence in a straight line along the Holland Straits boundary line between Dorchester County and Somerset Count $y$ across the mouth of Pry Cove to a point on the western side of a small marsh island on the eastern side of Holland Straits defined by latitude $38^{\circ} 06^{\prime} 39.9^{\prime \prime}$ and longitude $76^{\circ} \circ 3^{\prime} 17.8^{\prime \prime}$; thence in a straight line diagonally across Holland Straits along the boundary line between Dorchester County and Somerset County to a point on the southeastern side of Bloodsworth Island on the northwestern side of Holland Straits defined by latitude $38^{\circ}$ o $8^{\prime} 50.6^{\prime \prime}$ and longitude $76^{\circ}$ or $53.4^{\prime \prime}$; thence in a straight line across the western half of Upper Tangier Sound along the boundary line between Dorchester County and Somerset County to a point situated in Tangier Sound about $15 / 8$ miles west of upper land end of Deal Island Wharf and $2,3.8$ 
miles south by east of Sharkfin Shoal I,ight defined by latitude $38^{\circ}$ ro' $08.1^{\prime \prime}$ and longitude $76^{\circ} 58^{\prime} 40.6^{\prime \prime}$; thence in a straight line along the Tangier Sound boundary line between Dorchester County and Somerset County to a point in Tangier Sound entrance of Nanticoke and Wicomico Rivers situated about $7 / 8$ mile east-southeast of Sharkfin Shoal Light defined by latitude $38^{\circ} \mathrm{Ix^{ \prime }} 50.3^{\prime \prime}$ and longitude $75^{\circ} 58^{\prime} 20.8^{\prime \prime}$ thence along the boundary line between Dorchester County and Somerset County, up the channel of Nanticoke River, pass Roaring Point and Ragged Point to a point on the channel boundary line between Dorchester County and Somerset County situated about 2 miles north of the town of Bivalve, all as laid down on "Chart No. 4I, Natural Oyster Bars, Maryland," thence continuing up the Nanticoke River along the channel boundary line between Dorchester County and Somerset County to the head of the oyster-producing waters.

\section{WATERS CONTIGUOUS TO COUNTY.}

The oyster laws of Maryland provide that a true and accurate delineation of all natural oyster bars shall be made on copies of charts of the United States Coast and Geodetic Survey, "which said copies shall be filed in the office of the said Commissioners in the city of Baltimore," and "in the office of the clerks of the circuit courts for the respective counties wherein the grounds so designated may lie."

For the purpose of carrying out the latter part of this section of the law and for the purpose of establishing the limits of the oyster-culture area to be opened up for leasing with each county surveyed, it is necessary for the Shell Fish Commission to establish a boundary line between the waters contiguous to but not within the territorial limits of each county and the waters contiguous to but not within the territorial limits of adjacent counties.

This boundary line has been delineated on the "Charts of Natural Oyster Bars," published by the Coast and Geodetic Survey, and is technically described and defined as follows: ${ }^{1}$

Commencing at a point in the Chesapeake Bay entrance of the lower Choptank River defined by the intersection of the boundary line between Dorchester County and Talbot County as laid down on "Charts Nos. 36 and 37 , Natural Oyster Bars, Maryland," with a straight line defined at its northwestern end by a point situated on Blackwalnut Point in latitude $38^{\circ} 40^{\prime} 06.6^{\prime \prime}$ and longitude $76^{\circ} 20^{\prime} 24.7^{\prime \prime}$ and defined at its southeastern end by a point situated on Cook Point in latitude $38^{\circ} 37^{\prime} 55.7^{\prime \prime}$ and longitude $76^{\circ} 17^{\prime} 28.7^{\prime \prime}$; thence along the boundary line between Dorchester County and Talbot County passing into Chesapeake Bay south of Sharps Island as laid down on "Charts Nos. 36 and 37 , Natural Oyster Bars, Maryland," to a point in Chesapeake Bay about $5^{1 / 2}$ miles southwest of Sharps Island Light and $53 / 4$ miles northwest of James Island defined by latitude $38^{\circ} 34^{\prime} 29 \cdot 6^{\prime \prime}$ and longitude $76^{\circ} 26^{\prime} 17 \cdot 0^{\prime \prime} ;$ thence in a straight line in a southerly direction with Chesapeake Bay to a point situated in Chesapeake Bay about $4^{1}{ }_{2}$ miles west of the southern end of James Island defined by latitude $38^{\circ} 30^{\prime} 00.0^{\prime \prime}$ and longitude $76^{\circ} 25^{\prime} 30.0^{\prime \prime}$; thence in a straight line in a southeasterly direction with Chesapeake Bay to a point situated in Chesapeake Bay about $25 / 8$ miles east of Cove Point Light defined by latitude $38^{\circ} 23^{\prime} 10.3^{\prime \prime}$ and longitude $76^{\circ} 20^{\prime} 00.0^{\prime \prime}$; thence in a straight line in a southerly direction with Chesapeake Bay to a point situated in Chesapeake Bay about $3 \div 8$ miles northeast of Cedar Point Light defined by latitude $38^{\circ} 19^{\prime} 37.7^{\prime \prime}$ and longitude $76^{\circ} 19^{\prime} 19.0^{\prime \prime}$; thence in a straight line in a southerly direction with Chesapeake Bay to a point situated in Chesapeake Bay about $23 / 4$ miles east of Cedar Point Light defined by latitude $38^{\circ} 17^{\prime} 58.0^{\prime \prime}$ and longitude $76^{\circ}{ }_{1}^{\prime} 59 \cdot 7^{\prime \prime}$; thence in a straight line in a southeasterly direction with Chesapeake Bay to a point situated in Chesapeake Bay about 5,5 miles west of Holland Island Bar Light in latitude $38^{\circ} 04^{\prime} 34.8^{\prime \prime}$ and longitude $76^{\circ} 12^{\prime}$ or. $0^{\prime \prime}$; thence in a straight line in an easterly direction across the eastern half of Chesapeake Bay to a point situated on Holland Island Bar Light defined by latitude $38^{\circ} 04^{\prime} 07 \cdot 3^{\prime \prime}$ and longitude $76^{\circ} \circ 5^{\prime} 45 \cdot 9^{\prime \prime}$; thence in a straight line in a northeasterly direction toward the entrance of Holland Straits to a point situated about $1_{1}^{1}{ }_{2}$ miles north-northeast of Holland Island Bar Light on the boundary line between Dorchester County and Somerset County on the southern side of the Chesapeake Bay entrance of Holland Straits defined by latitude. $38^{\circ} 04^{\prime}+0.8^{\prime \prime}$ and longitude $76^{\circ} 04^{\prime} \times 4.8^{\prime \prime}$.

\footnotetext{
'Latitudes and longitudes based on the United States standard datum of the United States Const and Geodetic Survey.
} 


\section{LANDMARKS (U. S. COAST AND GEODETIC SURVEY TRIANGUI,ATION STATIONS).}

EXPLANATION.

The oyster laws of Maryland authorizing the survey to be made by the Shell Fish Commission provide for "an accurate report of said survey, setting forth such a description of landmarks as may be necessary to enable the said board, or their successors, to find and ascertain the boundary lines of said natural oyster beds, bars, and rocks, as shown by delineation on the maps and charts." The law of the United States authorizing the cooperation of the Department of Commerce and Labor in the survey of natural oyster bars of Maryland provides for the erection of "such structures as may be necessary to mark the points of triangulation, so that the same may be used for such future work of the Coast and Geodetic Survey as the said bureau may be hereafter required to perform in prosecuting the Government coast survey of the navigable waters of the United States located within the State of Maryland."

Under the provisions of the sections of the laws stated above, the markings and descriptions of landmarks must be sufficient for the present and future needs of both the Government and the State. With this end in view, considerable work has been expended in erecting permanent monuments at the triangulation stations and in the proper description of their location.

An effort has been made to arrange the descriptions of location and character of landmarks in a uniform and logical manner. The descriptions start with the assumption that the individual seeking a landmark has only an indefinite idea of its location. They gradually proceed from description of the general locality of a landmark to the descriptions of its immediate surroundings. This is followed by specific details of the character of the center and reference marks and a "round" of reference angles and distances which in themselves frequently contain enough information to furnish an independent and reliable location of the triangulation station.

\section{METHOD OF DESCRIBING TRIANGULATION STATIONS.}

The separate descriptions of triangulation stations should not be used without reading the following explanation of the method of describing the triangulation stations, as it contains certain details that are common to all the landmarks described in this publication and which are omitted in the separate descriptions as being needless repetitions:

Name.-The title at the top of each separate description is the name by which the landmark or triangulation station is known and designated in all work and published oyster records or oyster charts of both the Government and State. The selection of the name is usually left to the triangulator establishing the station, and it may' or may not have geographic or other significance in reference to the locality.

General locality.-Under this heading is given the general locality of the landmark in reference to well-known and prominent natural or artificial features, such as the nearest body of water, town, river, steamer wharf, well-defined point of land, church, or any other feature that is likely to remain both permanent and prominent. 
This heading also covers a reference to the published chart or map which shows the location of the station most clearly. Nearly all the triangulation stations described in this publication are plainly indicated by name and a triangulation symbol on the published charts of oyster bars of Maryland. In this case they are referred to by serial number only, the words "charts of oyster bars of Maryland" being omitted to avoid needless repetition. These published oyster charts are on the large scale of I part in 20,000 (approximately $3 \frac{1 / 6}{6}$ inches to a statute mile) and show the locations of the triangulation stations so clearly that in many cases the written descriptions will not be required to find them.

Immediate locality.- Under this heading is given the description of the "observed station" in reference to its immediate surroundings. This is supposed to include a statement of the station's estimated elevation above high water or some other welldefined level of the locality, such as a road or house; the character of the grouncl on which it is located, such as marsh land, sand beach, cultivated field, or meadow; estimated bearings in points of the compass and estimated distances in yards from (not to) easily recognized features, such as extreme end of point, edge of bluff, bank of creek, line of telephone poles, shore line, barn, house, fence, ditch, trees, or any other definite detail, such as being on range with the tangent of an island and a church; and so forth.

When a standard monument has been established near the station as a "reference station," this heading also covers a statement of the true bearing of the monument in degrees and minutes and its measured distance in meters, as it is the first object that is likely to catch the eye when the immediate vicinity of the desired station is reached and might be mistaken for the center mark of the "observed station" unless special attention is called to it.

The distinction between the "observed station" and "reference station" should be carefully noted by anyone making use of the description of stations for any future surveying operations.

The "observed station" is located at the particular triangulation point covered by the description of stations and is the one whose geographic position is first computed, as it is the point which was "occupied" and "observed on" for horizontal angles. However, in spite of the primary importance of the location of the "observed station," it will be noted from the description of stations that frequently it is not marked as well as the "reference station," and in some instances has only a pine stub to indicate its position. This is the case for the reason that the necessity of intervisibility of landmarks usually made it compulsory to locate "observed stations" on edges of banks and ends of points of land, which in the tidewater section of Maryland generally means they will be washed away in a short period of years. The past experience of the Coast and Geodetic Survey in this region has shown the great need of "reference stations," if the frequent reestablishment of a new framework of triangulation is to be avoided.

The chief reason and need for the establishment of the "reference station," or secondary station, as it might be well named, is explained in the preceding paragraph, but in several instances other reasons, such as the location of the "observed station" on an unstable sand dune, in a cultivated field, in front of a residence, or other places objectionable to the landowner, have led to establishment of "reference stations." The location of the "reference station" in relation to the "observed station" is fixed 
for plotting on charts or for computation of its geographic position by checked measurements of its distances and azimuth from the "observed station." 1

Marks.- Under this heading is given a description of the character of the permanent monuments or other marks of the location of the "observed station," and of the "reference station" where one has been established.

All the marks designated in the descriptions as "the center point of triangle on standard cement monument" are exactly alike. These monuments are made of cement, sand, and gravel, and are 2 feet long and 8 inches square at top and bottom. Their tops are all marked with the same brass mold and show a center hole surrounded by a triangle, with the letters "M. S. F. C." arranged around the vertex and the letters "U. S. C. S." underneath the base of the triangle. The center hole is always in the center of the top of the monument by construction, and if this is found to have been broken off without disturbing the bottom the center of its square section can be used as the location of the station.

All the "standard cement monuments," whether used for marking the "observed station" or "reference station," have been planted upright in exactly the same manner, with their tops projecting 3 or 4 inches above the surface of the ground, unless otherwise stated.

Therefore, as the above facts in reference tc the "standard cement monuments" are a constant element in all cases, the repetition of these facts in the description of stations is made needless by this one statement.

References.-Under this heading are given the "rounds" of directions and distances to all objects that might be useful in locating the stations when the surface marks can not be found. It is also contemplated that for general purposes of topography, hydrography, or location of boundaries of oyster bars these references will be sufficient in many cases to relocate the position of an "observed station" or "reference station" when both of them have been destroyed.

The first reference object given in the descriptions is always a triangulation station visible from the station being described, this, if possible, being a lighthouse, church spire, or other permanent and prominent point. Its direction is taken as being $\mathrm{O}^{\circ} \mathrm{OO}^{\prime} \mathrm{OO}^{\prime \prime}$, and the directions of all other objects are measured from it as an initial point, the angles being taken in a clockwise direction (left to right).

The true bearing ${ }^{2}$ of the initial object is always given in parentheses alongside its name. This furnishes means for the calculation of the bearings of any of the other reference objects for the purposes of locating a station by horizontal angles or for the relocation of corner buoys of oyster-bar boundaries by the method of compass directions described in this publication under the heading of "Boundaries of oyster bars."

The distances in the last column under "References" are given in three different units, which vary according to their accuracy. The "miles" are statute miles and may be considered only as rough estimates. The "yards" are more accurate, but must be looked on as results generally obtained by pacing or careful estimating. The "meters,"

\footnotetext{
1 Geographic coordinates (latitude, longitude, distance, and azimuth) relating to any of the "observed stations" or of the "reference stations" described in this publication can be obtained by application to the Superintendent of the Coast and Geodetic Survey, at Washington, D. C.

${ }^{2}$ 'The mean magnetic variation for Dorchester County was $6^{\circ} \infty 0^{\prime}$ west of north in Igrr and increasing at the rate of $5^{\prime}$ yearly. $5^{8} 345-13-3$
} 
however, are accurate to the degree indicated by their decimals and in every case have been measured with a steel tape. In the same manner the accuracy of the directions are indicated by the refinement of angular measure with which they are recorded.

\author{
DESCRIPTIONS OF TRIANGULATION STATIONS.
}

WEATHER BURFAU STAFF.

General locality.-E,astern side of Tred Avon River in the town of Oxiord. (See Chart No, 35.)

Immediate locality.-Observed station is in park south of high and primary schools, 55 yards east of shore of Tred Avon River, 55 yards west of Morris Street, and in center of circle of trees.

Marks.--Observed station is center of galvanized iron staff on square galvanized angle-iron tower.

References.-None necessary.

FIRST.

General locality.--Eastern shore of Tred Avon River in town of Oxford ahout T/8 mile north of railroad wharves. (See Chart No. 35.)

Immediate locality.-Observed station is about 8 feet above high water, 2 yards east-southeast of edge of bank, 4 yards east by north of point of bank, 4 yards northeast of edge of bank at small gully, 2 yards south of corner fence post, and 35 yards west of house.

Marks.-Observed station is center point of triangle on standard cement monument projecting 4 inches above surface of ground. Substrface mark is center of 2 -inch tile pipe buried with top 2 inches below base of monument.

References.-

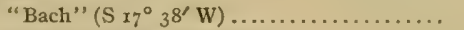

Right peak of small house................

Right peak of modern house............

I.eft peak of small house ............... I28

Nail in blaze in fence post.............. $207 \quad 52 \quad 00 \ldots .4 .98$ meters.

Nail in blaze in apple tree ( 20 inches diam-

eter) ........................ $237 \quad 43 \quad 30 \quad \ldots \ldots$ Ir.94 meters.

Nail in blaze in apple tree ( 12 inches diam-

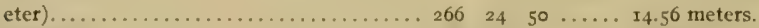

Windmill...................... $34^{6}+3 \ldots \ldots \ldots+$ mile.

BACH.

General locality.-Eastern shore of entrance to Tred Avon River on Bachelor Point about I $3 / 8$ miles north-northeast of Choptank River I,ight. (See Chart No. 35.)

Immediate localily.-Observed station is in cultivated field about 6 feet above high water, 30 yards east of edge of bank, 70 yards north-northeast of edge of bank, on range with Choptank River Light, and roo yards south by west of edge of bank of trees.

Marks.-Observed station is center point of triangle on standard cement monument projecting 5 inches above surface of ground. Subsurface mark is center of 2 -inch tile pipe buried with top 2 inches below base of monument.

References.--

"Choptank River Light" (S I6 $\left.50^{\circ} \mathrm{W}\right)$......

Tangent of Benoni Point............... $55 \quad 39$....... $1^{1 / 4}$ miles.

Left peak of roof of house............. I47 $25 \quad \ldots \ldots \ldots, \mathbf{x} 5 / 8$ miles.

Left comer of burnt house.............. I66 $05 \ldots \ldots \ldots$ I $1 / 3$ miles.

Right comer of house............... 2 II $35 \quad \ldots \ldots \ldots$ mile.

Left corner of left chimney on very large

house............................ $240 \quad 46 \ldots 5 / 8$ mile.

"Large Water Tank"....................... 338 oo $20 \ldots 3 / 4$ miles. 
BOONE.

General locality.-Northeastem shore of Choptank River about $3 / 3$ mile northwest of entrance to Boone Creek, $1 / 2$ mile southeast of Bachelor Point, and I I/s miles northeast of Choptank River Light. (See Chart No. 35.)

Immediate locality.-Observed station is about 5 feet above high water, 13 yards northeast of edge of tree-fringed bank, 60 yards south-southwest of right corner of house, and 50 yards south-southeast of large apple tree.

Marks.-Observed station is center point of triangle on standard cement monument with top 4 inches above surface of ground. Subsurface mark is center of 2 -inch tile pipe buried witl top 2 inches below base of monument.

References.-

"Choptank River Light" ( $33^{\circ} 54^{\prime}$ W) .....

Nail in blaze in locust tree ( 5 inches diameter)................ 2 or $40 \ldots \ldots \ldots \ldots \ldots \ldots$ meters.

Nail in blaze in locust tree (ro inches diam-

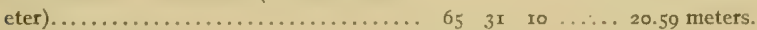

Near peak of house................ $107 \quad 59 \quad \ldots \ldots \ldots 1 / 4$ mile.

Right corner of house................ 159 12 $\ldots \ldots \ldots 57$ yards.

Near peak of house..................

Nail in blaze in locust tree $(4$ inches diameter)........................... 323 14 14.02 meters.

\section{ENTER.}

General locality.-Northern shore of Island Creek on point at east side of entrance to a small cove, about I 8 mile northeast of Choptank River, and $\mathrm{r} 3 / 8$ miles east-northeast of Choptank River Light. (See Chart No. 35.)

Immediate locality.-Observed station is in cultivated land about 6 feet above high water, I 6 yards north of edge of bank of creek, i 8 yards south-southeast of edge of bank of cove, 30 yards east-northeast of outlet of cove, and 250 yards west by south of frame house.

Marks.-Observed station is center point of triangle on standard cement monument projecting 2 inches above surface of ground. Subsurface mark is center of 2 -inch tile pipe buried with top 2 inches below base of monument.

References.-

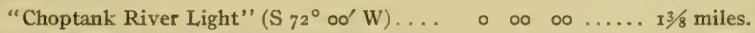

Nail in blaze in locust tree ( 6 inches diameter) $67 \quad 0540 \ldots .39 .96$ meters.

Nail in blaze in cedar tree (ro inches diam. eter)........................ rog $17 \quad 20 \ldots \ldots$ r6.9r meters.

Left corner of left chimney of house..... II $35 \quad \ldots \ldots \ldots 2$ miles.

Left corner of house............. $173 \quad 35 \quad \ldots \ldots \ldots 1 / 8$ mile.

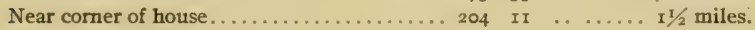

"Large Water Tank" ................. 30I 37 o .... $21 / 2$ miles.

Nail in blaze in locust tree $(4$ inches diameter).......................... 357 I3 $40 \ldots 3$ meters.

\section{LANDEYE.}

General localily.-Northeastern shore of Choptank River on point at south side of entrance to Islana Creek, about $\mathbf{I}^{\mathrm{I} / 2}$ miles east of Choptank River Light. (See Chart No. 35.)

Immediale locality. - Observed station is in cultivated land about 5 feet above high water, 15 yards east-southeast of edge of bank, 50 yards south west of fringe of trees and bushes, 55 yards south-southwest of point of field and end of fringe of trees and bushes.

Marks.-Observed station is center point of triangle on standard cement monument projecting 2 inches above surface of ground. Subsurface mark is center of 2 -inch tile pipe buried with top 2 -inches below base of monument. 


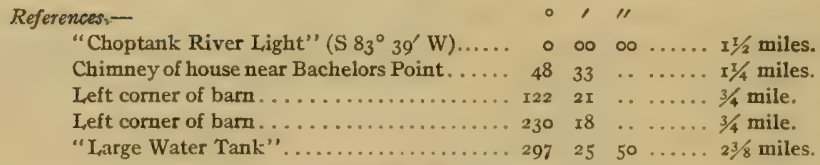

\section{CHOPTANK RIVER LIGHT.}

General locality.-In Choptank River about $\mathrm{I}^{2} / 4$ miles southeast of Benoni Point, I mile south of entrance to Tred Avon River, and $8 \frac{1}{2}$ miles east of Blackwalnut Point. (See Charts Nos. 35 and 37.)

Immediate locality.-Observed station is on hexagonal screw-pile structure known as Choptank River Light House.

Marks.-Observed station is center of lantern on Choptank River Light House.

References.-

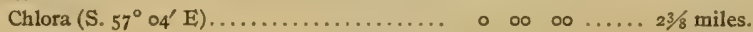

\section{BENONI 2 .}

General locality.-Northern shore of Choptank River on Benoni Point at western side of entrance to Tred Avon River, about I3/8 miles northwest of Choptank River Light. (See Progress map.)

Immediate locality.-Observed station is about 5 feet above high water, 9 yards south-southwest of foot of knoll and edge of marsh, 4 yards northeast of edge of bank, 25 yards east-southeast of point of bank, 30 yards north by west of point of marsh, and 100 yards southwest of a cove. Cement monument marking reference station is 7.45 meters N. $42^{\circ} \mathrm{oz}^{\prime} \mathrm{E}$ of observed station.

Marks.-Observed station is nail in center of 2 by 4 inch stub projecting 4 inches above a 4 -inch tile pipe with top of pipe flush with surface of ground. Reference station is center point of triangle on standard cement monument projecting 4 inches above surface of ground.

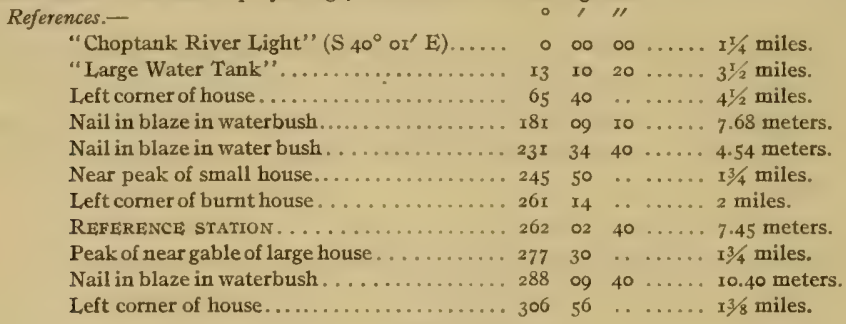

CHLORA.

General locality.-Northeastern shore of Choptank River on Chlora Point about I $1 / 2$ miles southsoutheast of entrance to Island Creek, $1, \frac{1}{2}$ miles northwest of entrance to LaTrappe Creek, and $23 / 3$ miles southeast of Choptank River Light. (See Chart No. 35.)

Immediate locality.--Observed station is about 8 feet above high water, 6 yards east-northeast of edge of bank, 9 yards south of wire fence, and 18 yards north of edge of bank at walnut tree. Cement monument marking reference station is $6.9 \mathrm{r}$ meters $N .78^{\circ} 43^{\prime} \mathrm{E}$ of observed station.

Marks.-Observed station is hole in center of cement filled tile pipe 4 inches diameter, with top about 2 inches below surface of ground. Reference station is center point of triangle on standard cement monument projecting 4 inches above the surface of the ground.

References.-

"Choptank River Light" ( $\left.\mathrm{N}_{57} 0_{3}^{\prime} \mathrm{W}\right)$.......

Nail in blaze in wild cherry tree ( 3 inches diameter) .........................

Nail in blaze in cedar tree ( 4 inches diameter) $\ldots \ldots \ldots \ldots \ldots \ldots \ldots \ldots \ldots \ldots \ldots .129$ 31 $00 \ldots \ldots$ or meters. 


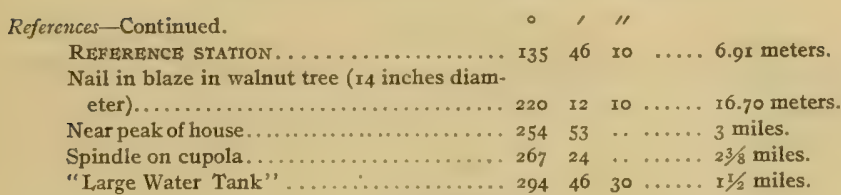

TRAPPE.

General locality.-Northern shore of Choptank River at west side of entrance to La Trappe Creek about $\mathrm{I}^{2} / 2$ miles southeast of Chlora Point. (See Chart No. 35.)

Immediate locality.-Observed station is on grassy gravel point about 3 feet above high water, 4 yards north of shore, 6 yards east-northeast of shore, and 17 yards south by east of large cedar tree. Cement monument marking reference station is 12.62 meters $\mathrm{N} 47^{\circ} 40^{\prime} \mathrm{E}$ of observed station.

Marks.-Observed station is center of 2 -inch tile pipe projecting 2 inches above surface of ground. Subsurface mark is center of 2 -inch tile pipe buried with top 2 inches below base of surface pipe. Reference station is center point of triangle on standard cement monument projecting 2 inches above surface of ground.

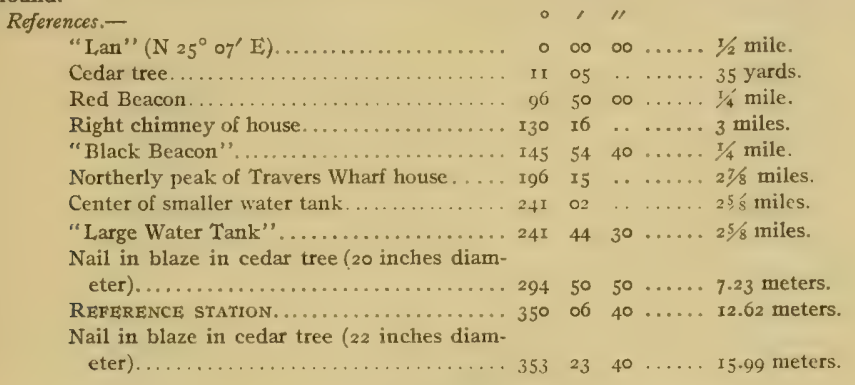

\section{GRUBIN.}

General locality.-Northern shore of Choptank River on east side of entrance to La Trappe Creek. (See Chart No. 35.)

Immediate locality. - Observed station is on grassy marsh back of gravel beach, about I foot above ligh water, 13 yards east of shore, $I_{3}$ yards south of shore, 20 yards southeast of extreme end of point, and 100 yards northwest of pond.

Marks.-Observed station is center point of triangle on standard cement monument projecting 6 inches above surface of ground. Sulssurface mark is center of 2 -inch tile pipe buried with top 2 inches below base of monument.

References.-

"Howard" $\left(\mathrm{S} \mathrm{x}^{\circ} 2 \mathrm{x}^{\prime} \mathrm{W}\right) \ldots \ldots \ldots \ldots \ldots \ldots$

South peak of Travers Wharf house........ 45

"Black Beacon" .....................

"Large Water Tank" . . . . . . . . . . . . . . 8

Red Beacon...................... 90

South peak of shed................. ${ }^{5}$

Near peak of bam.................. 18

Nail in blaze in stump ( 7 inches diameter)... I9

Chimney of house ................... I99

Nail in blaze in cedar tree ( 5 inches diameter)

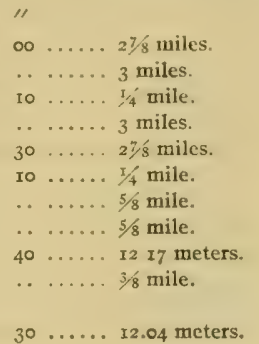




\section{BI,ACK BEACON.}

General locality. - Northeastern shore of Choptank River off entrance to I.a Trappe Creek about $\mathrm{I}^{5}$ \& miles northeast of Horn Point. (See Chart No. 35.)

Immediate locality.--Observed station is on a cylindrical foundation known as La Trappe Creck Outer I,ight.

Marks.--Observed station is center point of lantern on La Trappe Creek Outer Light.

References.-None necessary.

HOWELISS.

General locality.-Northern shore of Choptank River on Howells Point about I $5 / 5$ miles east of Horn Point, 2 miles north of entrance to Jenkins Creek, and 2 miles northwest of Hambrooks Bar Beacon. (See Chart No. 35.)

Immediate locality.-Observed station is on a long grassy gravel point about 3 feet above high water, 50 yards south-southeast of old fish shanty and trees, 25 yards south of highest level part of land, II yards west of shore, 3 yards east of shore, and $1 / 4$ mile north of extreme end of Point. Cement monument marking reference station is 22.82 meters $\mathrm{N} r 7^{\circ} 53^{\prime}$ of observed station.

Marks. - Observed station is nail in center of cedar stub in center of 4 -inch tile pipe with top of pipe 4 inches below surface of ground. Reference station is center point of triangle on standard cement monument projecting 5 inches above surface of ground.

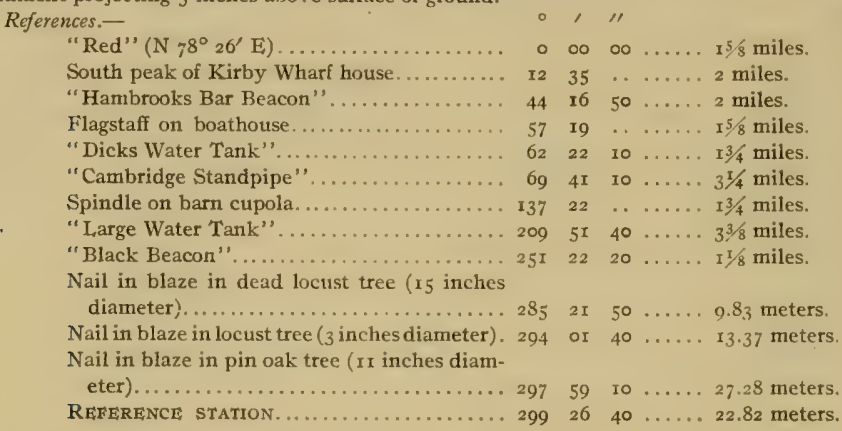

\section{RED}

General locality.-Northern shore of Choptank River at eastern side of Dickinsons Bay about $15 \%$ miles east-northeast of Howells Point and $3 / 4$ mile northwest of Kirby Wharf. (Sec Chart No. 35.)

Immediate locality.--Observed station is on cultivated land on first higl bluff upstream from Howells Point, about i2 feet above high water, 8 yards northeast of edge of bank, ro yards north of edge of bank, ro yards east of edge of bank. Cement monument marking reference station is 23.65 meters $\mathrm{N} 89^{\circ} 58^{\prime}$ F; of observed station and almost on line with east chimney of house.

Marks-Observed station is nail in stub in center of 2 -inch tile pipe with top of pipe 6 inches below surface of ground. Subsurface mark is center of 2 -inch tile pipe buried with top 2 inches below base of surface pipe. Reference station is center noint of triangle on standard cement monument projecting 5 inches above surface of ground.

References.-

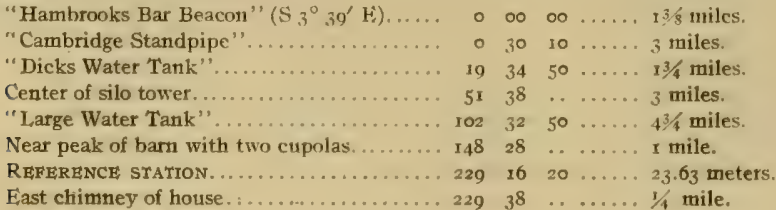


References-Continued.

Near peak of large barn.............. 282 o $7 \ldots \ldots, 4 / 4$ mile.

Right peak of Kirby Wharf house. ........ $308 \quad 26 \quad \ldots \ldots \ldots, 5 / 8$ mile.

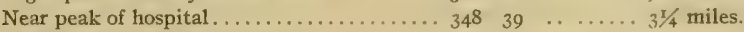

"East Cambridge Tall Stack" ............ 35 $07 \quad 40 \ldots .3$ miles.

\section{DOUBLE.}

General locality.-Northern shore of Choptank River nearly opposite Cambridge, about I mile northwest of entrance to Bolingbroke Creek and $\mathrm{I} / 2$ miles east of Hambrooks Bar Beacon. (See Chart No. 35.)

Immediate locality.-Observed station is on point of marsh separated from field by a row of locust trees about I 2 yards northeast of shore, 20 yards north of shore, 14 yards east of shore, and 30 yards south of a large wild cherry tree.

Marks.-Observed station is center point of triangle on standard cement monument projecting 4 inches above surface of ground. Subsurface mark is center of 2 -inch tile pipe buried with top 2 inches below base of monument.

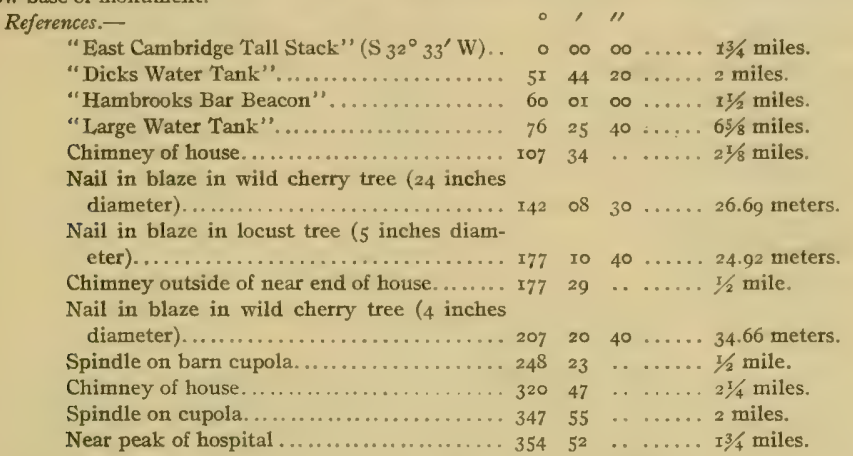

\section{BOLING}

General locality.-Northern shore of Choptank River on an island in entrance to Bolingbroke Creek, about $3 / 4$ mile northwest of Chancellors Point and 2 miles east-northeast of Cambridge. (Sce Chart No. 35.)

Immediate locality.-Observed station is in rushes on a sandy marsh about 3 fcet above high water, 6 yards northeast of shore, 7 yards north of shore, 8 yards east of shore, and 160 yards northwest by north of entrance to Bolingbroke Creek.

Marks.-Observed station is center point of triangle on standard cement monument projecting 5 inches above surface of ground. Subsurface mark is center of 2 -inch tile pipe buried with top 2 inches below base of monument.

References. -

"East Cambridge Tall Stack" (S $60^{\circ} 10^{\prime}$ W). .

Chimney outside of left end of mansard roof house.........................

Flagpole on boat house. .................

"Hambrooks Bar Beacon..................

Nail in blaze in cedar tree ( 8 inches diameter).......................... $\mathbf{r}_{34} 40.30 \ldots 26.5 .3$ meters.

Nail in blaze in old cedar stump ( $1_{3}$ inches

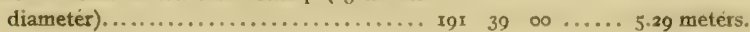

Near peak of barn cupola............. 249 14 $\ldots \ldots \ldots \times 3 / 4$ miles. 


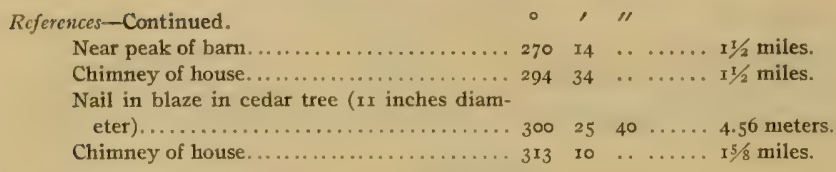

REAR.

General locality.--Northern shore of Choptank River about $1 / 8$ mile northwest of Chancellors Point, and $\pi / 2$ mile southeast of entrance to Bolingbroke Creek. (See Chart No. 35.)

Immediate locality.-Observed station is in cultivated field on bluff about $\mathrm{x} 2$ feet above high water, 65 yards north of edge of bank, I I yards northeast of edge of bank and trees, 160 yards east of edge of bank, and 95 yards northwest of bottom of gully.

Marks.-Observed station is center point of triangle on standard cement monument projecting 6 inches above surface of ground. Subsurface mark is center of 2 -inch tile pipe buried with top 2 inches below base of monument.

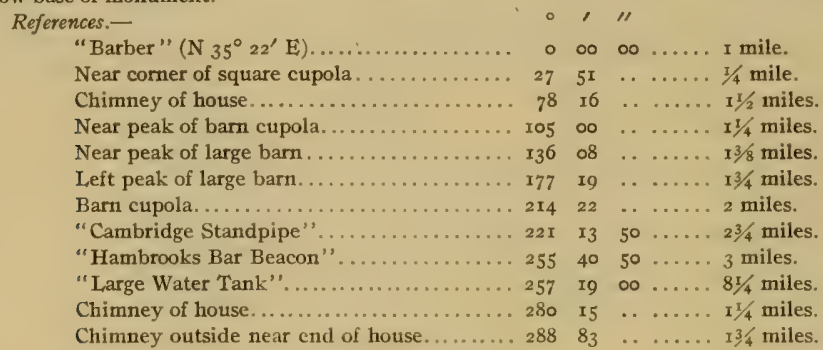

\section{CHANCELLOR.}

General locality.-Northern shore of Choptank River on Chancellors Point about $3 / 4$ mile north of entrance of Hurst Creek, and $3 / 4$ mile southeast of entrance to Bolingbroke Creek. (See Chart No. 35.)

Immediate lacality.-Observed station is on sand and grass point about I foot above high water, 35 yards west of shore, 35 yards northeast of shore, 60 yards north by west of extreme end of point, 13 yards south of line of cedar stumps, 27 yards southeast of large lone pine tree, and almost on range of Cambridge Standpipe and left peak of hospital. Cement monument marking reference station is 4.70 meters $\mathrm{N}, 3 \mathrm{I}^{\circ} 3 \mathrm{I}^{\prime}$ W of observed station and almost on line to large lone pine tree.

Marks.-Observed station is nail in cedar stub in center of 4 -inch tile pipe with top flush with surface of ground. Reference station is center point of triangle on standard cement monument projecting 6 inches above surface of ground.

References.-

"Cambridge Standpipe" (\$ $78^{\circ}$ oo' W) ......

REFHRENCE STATION....................

Nail in blaze in lone pine tree ( 16 inches

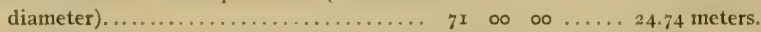

Southeast comer of square cupola........ in $45 \quad \ldots \ldots \ldots 35$ yards.

Nail in blaze in cedar stump ( 16 inches diam-

eter)...................... I22

Chimney of house ................... 216

Near peak of house................... 245

Chimney on left end of house........... 282

Chimney of house................... 328

Nail in blaze in small pine tree. ........... 350

Left peak of hospital................. 359

- $000 \ldots .27 / 8$ miles.

29 10 .... 4.70 meters.

$50 \ldots . . .12 .40$ meters.

...... I I $1 / 4$ miles.

...... II/8 miles.

....... I I miles.

...... I $5 / 8$ miles.

$40 \ldots .23 .26$ meters.

...... $22 / 4$ miles. 
BARBER.

General locality.--Northwestern shore of upper Choptank River about $x$ mile north-northeast of Chancellors Point and about $7 / 8$ mile west-southwest of Goose Point. (See Chart No. 35.)

Immediate locality. - Observed station is on marsh about 2 feet above high water, 12 yards northnorthwest of county road and shore, 45 yards west-southwest of a cabin on the county road, 25 yards west of two cedar trees just across road, and 65 yards south of a wire fence.

Marks.-Observed station is center point of triangle on standard cement monument projecting 5 inches above surface of ground. Subsurface mark is center of 2 -inch tile pipe with top 2 inches below base of monument.

References.-

"Duck" (N $\left.75^{\circ} 49^{\prime} \mathrm{E}\right) \ldots \ldots \ldots \ldots \ldots \ldots \ldots$

Nail in blaze in cedar tree (ro inches diameter $) \ldots \ldots \ldots \ldots \ldots \ldots \ldots \ldots \ldots \ldots \ldots \ldots \ldots$.

Smokepipe on wharf house ................

Near peak of house ...................

Northwest peak of house ............. $9^{2}$

Chimney on left end of house............. I

Near peak of house with square cupola ..... I3

Large lone tree.....................

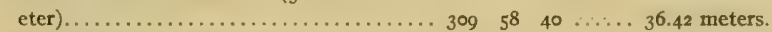

Nail in blaze in persimmon tree ( 5 inches

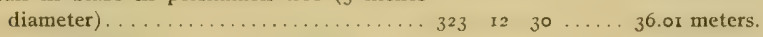

Nesr corner of barn.................... 347 I5 $\ldots \ldots \ldots .21 .96$ meters.

Nail in blaze in cedar tree (Io inches diam-

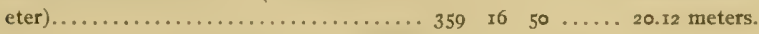

DUCK. (CHOPTANK RIVER.)

General locality.-Northern shore of Choptank River on Goose Point about $3 / 4$ mile north of Oyster Shell Point and $13 / 4$ miles northeast of Chancellors Point. (See Chart No. 35.)

Immediate locality.-Observed station is on edge of sand beach on lower part of point on level with high water, 15 to 20 yards southeast of a group of cedar and persimmon trees. Cement monument marking reference station is $12.6 \mathrm{I}$ meters $\mathrm{N} 28^{\circ} \mathrm{Ig} 9^{\prime} \mathrm{W}$ of observed station.

Marks.-Observed station is center of 2 -inch tile pipe projecting 5 inches above surface of ground. Subsurface mark is center of 2 -inch tile pipe buried with top 2 inches below base of surface pipe. Reference station is center point of triangle on standard cement monument projecting 5 inches above surface of ground.

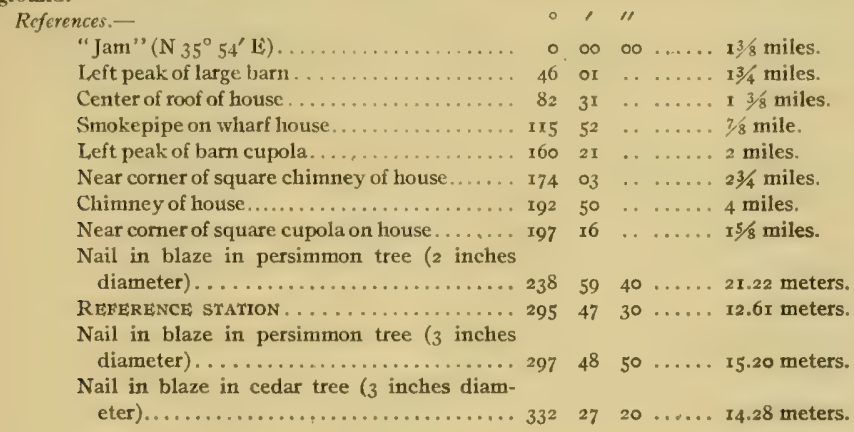


JAM.

Gencral localily. - Western shore of Choptank River on Jamaica Point opposite entrance to Warwick River. (See Chart No. 35.)

Immediate locality.-Observed station is on marsh point about 3 feet above high water, 25 yards west-northwest of end of wharf, 7 yards north of county road, II yards northeast of county road, 13 yards south of shore, 8 yards west-southwest of shore, and 30 yards north by east of shore.

Marks.-Observed station is center point of triangle on standard cement monument projecting 4 inches above surface of ground. Subsurface mark is center of 2 -inch tile pipe buried with top 2 inches below base of monument.

References.-

"Spindle" ( $\left.\mathrm{N} \mathrm{r}_{4}{ }^{\circ} 53^{\prime} \mathrm{W}\right) \ldots \ldots \ldots \ldots \ldots \ldots$

Chimney outside near end of house. .........

Chimney of large house................ I

"Wick"........................ $7_{7}$

Chimney of house ..................

Left chimney of large brick house ........... . 9

Left corner of wharf house. . . . . . . . . . . . 95

Right corner of wharf house........... ro8

Nail in first plank on level part of wharf...... I ro

Near peak of large barn.............. I44

Chimney of house . . . . . . . . . . . . . . . r7x

Near peak of house ................ 202

Near peak of house near wharf. . . . . . . 2Ir

Right peak of bam cupola . . . . . . . . . 218

Near comer of fence.................. . 269

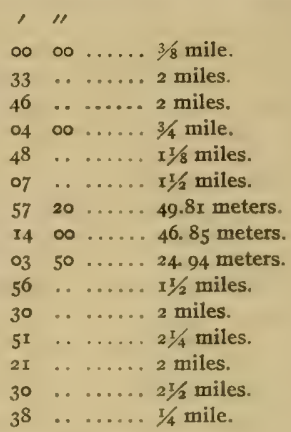

SPINDLE.

General locality. - Western shore of upper Choptank River about $3 / 8$ mile north of Jamaica Point Wharf. (See Chart No. 35.)

NorE.-This triangulation landmark was destroyed before this publication was prepared, and therefore it is not described, although its name and location are shown on Chart No. 35 .

\section{BANK.}

General locality.-Western shore of upper Choptank River about I mile north-northwest of Jamaica Point, and $x^{1 / 4}$ miles southwest of entrance to Cabin Creek. (See Chart No. 35.)

Immediale locality. - Observed station is in a cultivated field on a tree fringed bluff about 20 fect above high water, ro yards northwest of edge of bluff, ro yards west of edge of bluff, and I2 yards north of edge of bluff.

Marks. - Observed station is center point of triangle on standard cement monument projecting 4 inches above surface of ground. Subsurface mark is center of 2 -inch tile pipe buried with top 2 inches below base of monument.

References.-

"Raccoon" (N 19 $\left.26^{\prime} \mathrm{E}\right)$

Left chimney of modern house.

Nail in blaze in branch of double oak tree $(x 2$ and 18 inches diameter $) \ldots \ldots \ldots \ldots \ldots \ldots$

Chimney of house in woods................

Chimney of shanty in woods.............. 86

Chimney of house.................... I0

Nail in blaze in oak tree ( 8 inches diameter)

Nail in blaze in cedar tree ( $y$ inches diam-

eter)............................ 161 oo 10 ..... 21.11 meters.

Front peak of house............... $168 \quad 29 \quad \ldots \ldots \ldots 1 / 8$ mile. 


\section{RACCOON}

Gencral locality. - Westem shore of upper Choptank River about 3\& mile south of entrance to a small creck, I $1 / 2$ miles north of Jamaica Point, and I mile west of entrance to Cabin Creek. (Sce Chart No. 35.)

Immediate locality.-Observed station is between 2 clumps of trees on sandy marsh about 2 feet above high water, 8 yards northwest of shore, 12 yards west of shore, 16 yards north of shore, and 200 yards southeast of woods beyond marsh.

Marks.-Observed station is center point of triangle on standard cement monument projecting 6 inches above surface of ground. Subsurface mark is center of 2 -inch tile pipe buried with top 2 inches below base of monument.

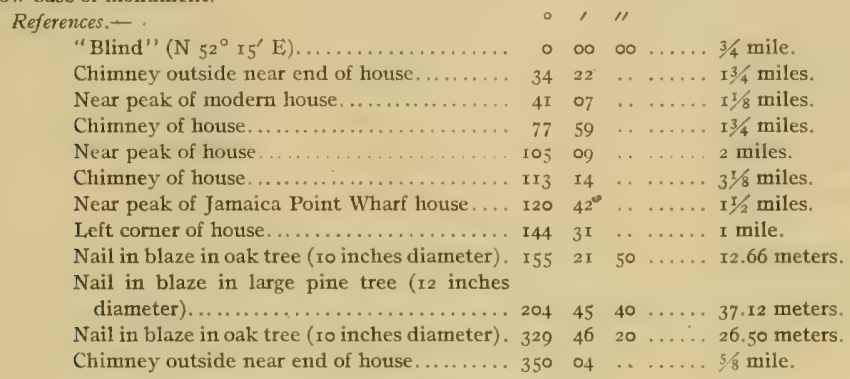

\section{BLIND.}

General locality.-Northwestern shore of Choptank River about $1 / 2$ mile west-northwest of entrance to Cabin Creek, and 2 miles north of Jamaica Point. (See Chart No. 35.)

Immediate locality. - Observed station is on marsh point between river and line of locust tree about I foot above high water, II yards north of shore, I5 yards west of shore, I6 yards northeast of shore at duck blind, and 25 yards east by north of shore.

Marks.-Observed station is center point of triangle on standard cement monument projecting 6 inches above surface of ground. Subsurface mark is center of 2 -inch tile pipe buried with top 2 inches below base of monument.

\section{References.-}

"Up" (N 61 $\left.{ }^{\circ} 44^{\prime} \mathrm{E}\right)$

Chimney outside of near end of old house....

Peak of side gable of modern lousc........ 57

Right peak of Jamaica Point Wharf housc ... I

Chimney on house.................. IO

Nail in blaze in locust tree ( 4 inches diam-

eter).......................

Nail in blaze in locust tree ( 4 inches diam-

cter $) \ldots \ldots \ldots \ldots \ldots \ldots \ldots \ldots \ldots \ldots \ldots 226$

Nail in blaze in locust tree ( 6 inches diam-

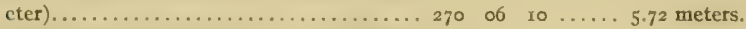

Nail in blaze in locust tree (ro inches diam-

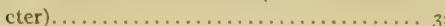

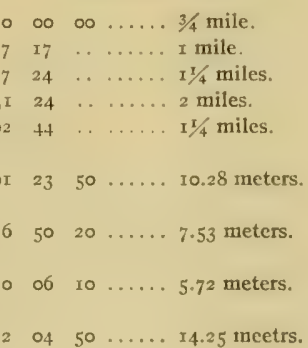


UP.

Gencral locality.-Northwestern shore of upper Choptank River about $3 / 4$ mile north of entrance to Cabin Creek and $2 \frac{1}{2}$ miles north-northeast of Jamaica Point. (See Chart No. 35.)

Immediate locality.-Observed station is on a marsl point about I foot above high water, 55 yards northwest of extreme end of point, 25 yards west of shore, and 20 yards north of shore.

Marks.-Observed station is center point of triangle on standard cement monument projecting 8 inches above surface of marsh. Subsurface mark is center of 2 -inch tile pipe buried with top 2 inches below base of monument.

References.$\circ, 11$

"Myrtle" (S 60"25' E).

Peak of side gable of modern house

Chimney of old house................

Tangent of point....................

House......................... I

Tangent of point................... 122

House....................... 273

Tangent of point.

305

$$
\begin{array}{lllll}
\infty & 00 & \ldots & \ldots & 3 / 8 \text { mile. } \\
14 & \ldots & \ldots & \ldots & 1 \text { mile. } \\
10 & \ldots & \ldots & 5 / 8 \text { mile. } \\
45 & \ldots & \ldots & 1 \text { mile. } \\
45 & \ldots & \ldots & 15 / 8 \text { miles. } \\
02 & \ldots & \ldots & 5 / 8 \text { mile. } \\
00 & \ldots & \ldots & 11 / 2 \text { miles. } \\
15 & \ldots & \ldots & \ldots & 175 \text { yards. }
\end{array}
$$

\section{MYRTLE.}

General locality.-Eastern shore of upper Choptank River about $1 / 2$ mile north of entrance to Cabin Creek. (See Chart No. 35.)

\begin{tabular}{|c|c|c|c|}
\hline Hut'” $\left(\mathrm{S} 7^{\circ} 47^{\prime}\right.$ & $\circ$ & ১o & $\infty$ \\
\hline Left peak of old barn... & 6 & $4 \mathrm{I}$ & aile. \\
\hline Tangent of point. .... & 32 & 14 & aile. \\
\hline Chimney of house..... & 53 & or & \\
\hline Chimney outside east end of house. & 78 & $4^{2}$ & I $1 / 4$ miles. \\
\hline 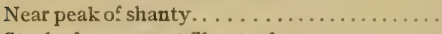 & 157 & 18 & $3 / 4$ mile. \\
\hline annery at Choptank . ............. & 180 & $5^{1}$ & niles. \\
\hline eak of house.... & 194 & 19 & . $2 \frac{1}{4}$ miles. \\
\hline Tangent of point........ & 203 & 56 & nile. \\
\hline Right peak of roof showing over wo & 314 & 37 & $3 / 4$ mile. \\
\hline Large lone pine tree. & 53.5 & II & 300 yard \\
\hline
\end{tabular}

Immediale locality. - Observed station is on a marsh point about I foot above high water, 17 yards east of shore, 20 yards south of extreme end of point, 15 yards southwest of small gut, and 250 yards west of woods.

Marks.-Observed station is center point of triangle on standard cement monument projecting 4 inches above surface of ground. Subsurface mark is center of 2 -inch tile pipe buried with top 2 inches below base of monument.

References.-

HU'T.

General locality._- liastem shorc of upper Choptank River on north side of entrance to Cabin Creek. (See Chart No. 35.)

Immediate locality. - Observed station is on narsh point about I foot above high water, I5 yards east of shore, 50 yards northwest of shore, 20 yards northeast of extreme end of point, 9o yards southwest of at hut, and so yards south-southwest of trees.

Marks,-Observed station is center point of triangle on standard cement monument projecting 6 inches above surface of ground. Subsurface mask is center of 2 -inch tile pipe buried with top 2 inches below base of monument.

References.-

"House" ( $\mathrm{S}_{4} 6{ }^{\circ} 38^{\prime} \mathrm{W}$ )

- 00 oo $\ldots \ldots .3 / 4$ mile.

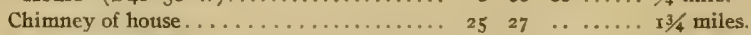

Chimney outside of house............. $60 \quad 33 \ldots \ldots . \ldots .1 / 4$ miles.

Cupola on barn.................. $132 \quad 48 \ldots \ldots \ldots 2 \frac{1}{2}$ miles.

Right comer of hut................. $173 \quad 53 \quad 20 \ldots \ldots$ 90 yards. 


\section{References-Continued. \\ $\circ, 11$ \\ Chimney outside near end of old house . . . . 242 I3 $\quad \ldots \ldots \ldots .1 / 2$ mile. \\ Peak of near gable of modern house....... $28 \mathrm{I} \quad 42 \quad \ldots \ldots \ldots 1 / 2$ mile. \\ Right peak of old barn............... $337 \quad 43 \quad \ldots \ldots .3$ mile.}

\section{HOUSE.}

General locality.-Eastern shore of Choptank River about $1 / 4$ mile south of entrance to Cabin Creek, i mile north of entrance to Warwick River, and on south side of a small cove. (See Chart No. 35.)

Immediate locality. - Observed station is on marsh about $x$ foot above high water, 14 yards south of shore, 26 yards southeast of shore, 35 yards southwest by west of shore and mouth of small creek in marsh and 175 yards north of woods.

Marks.-Observed station is center point of triangle on standard cement monument projecting 3 inches above surface of ground. Subsurface mark is center of 2 -inch tile pipe buried with top 2 inches below base of monument.

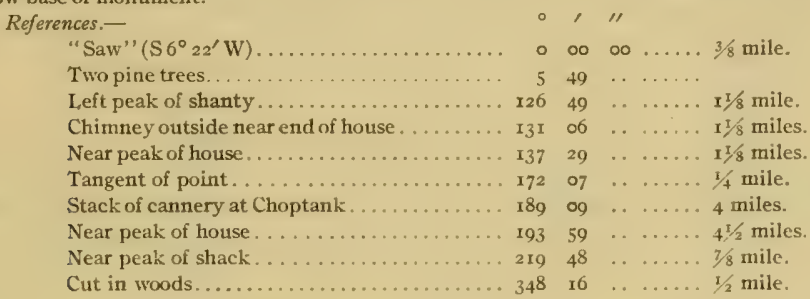

SAW.

General locality. - Eastern shore of Choptank River about $1 / 2$ mile northeast of entrance to Warwick River, and I mile northeast by east of Jamaica Point. (See Chart No. 35.)

Immediale locality.-Ohserved station is on marsh about $\mathrm{x}$ foot above high water, 22 yards east of shore, 26 yards southeast of shore, 37 yards northeast of shore, 200 yards west-northwest of dense woods.

Marks.-Observed station is center point of triangle on standard cement monument projecting 4 inches above surface of ground. Subsurface mark is center of 2 -inch tile pipe buried with top 2 inches below base of monument.

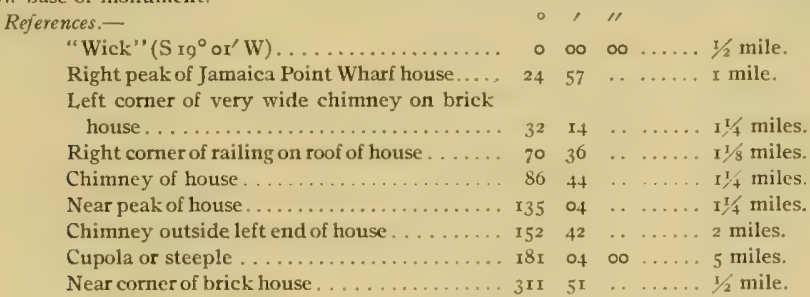

\section{WICK.}

General locality.-Eastern shore of upper Choptank River on northern side of entrance to Warwick River about $3 / 4$ mile northeast of Jamaica Point. (See Chart No. 35.)

Immediate locality.-Observed station is on sandy ridge between beach and marsh about 2 feet above high water, 8 yards northeast of shore, 10 yards north of shore, 9 yards east of shore, 100 yards southeast by east of extreme end of point, and 35 yards northwest of two pine trees. Cement monument marking reference station is 8.26 meters $\mathrm{N} 25^{\circ}$ oo' $\mathrm{E}$ of observed station. 
Marks.-Observed station is nail in cedar stub with top flush with the surface of the ground, Reference station is center point of triangle on standard cement monument projecting 4 inches above surface of ground.
References.-
"War" ( $\mathrm{S}_{2}^{\circ}$ o8' $\left.\mathrm{E}\right)$
Near peak of house in trees...............
Smoke pipe on wharf house................
Tangent of Goose Point................. 4
Right peak of Jamaica Point Whari house...
Right corner of very wide chimney on brick
house .......................... 68
Left comer of cupola on roof ............ I I
Near peak of house.................. 167
REFERENCE STATTON..................207
$\mathrm{Nail}$ in blaze in pine tree ( 12 inches diam-

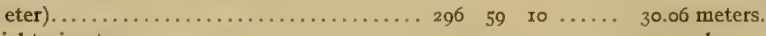
Right pine tree..................... $325 \quad 53 \quad 20 \ldots 400$ yards.
$\infty 00 \ldots .5 / 8$ mile.
2 I $\quad \ldots \quad \ldots .5 / 8$ mile.
$13 \quad \ldots \ldots \ldots 23 / 8$ miles.
$5 \quad 55 \quad \ldots \ldots \ldots \times 17 / 8$ miles.
$29 \quad \ldots \ldots \ldots 5 / 8$ mile.
$68 \quad 42 \quad \ldots \ldots \ldots .7 / 8$ mile.
$10 \quad \ldots \ldots \ldots r \frac{1 / 3}{s}$ miles.
$\infty \ldots \ldots 23 / 8$ miles.
o7 $20 \ldots \ldots 8.26$ meters.

WAR.

General locality.-Eastem shore of upper Choptank River on southern side of entrance to Warwick River about $3 / 4$ mile east-southeast of Jamaica Point. (See Chart No. 35.)

Immediate locality.-Observed station is on northern side of point of marsh about I foot above high water, 45 yards south of shore, 35 yards southeast of shore, 45 yards east of shore, and 35 to 45 yards southwest to west of woods. Cement monument marking reference station is 4.95 meters $\mathrm{S}_{12}{ }^{\circ} 18^{\prime} \mathrm{E}$ of observed station.

Marks.-Observed station is nail in center of cedar stub with top flush with surface of ground. Reference station is center point of triangle on standard cement monument projecting 4 inches above surface of ground.

References.-

"Gander" (S II $\left.{ }^{\circ}{ }_{26} 6^{\prime} \mathrm{W}\right) \ldots \ldots \ldots \ldots \ldots \ldots \ldots$

Chimney of house................... I7

Smoke pipe on wharf house.............. 23

Left chimney of small house............ 26

Square cupola on large house............ 45

Left peak of house. ......................
Right comer of very wide chimney on brick house............................

Left peak of Jamaica Point Wharf house..... ro

Chimney of house .................. $\mathbf{1}_{32}$

Near peak of house.................. $x_{57}$

Nail in blaze in pin oak tree (ro inches diam-

Nail in blaze in pine tree ( $I I$ inches diam-

Nail in blaze in pine tree ( 12 inches diam-

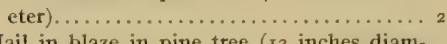

Nail in blaze in pine tree ( 12 inches diamcter) ...................... 267

REFERENCE STATION............... 336

Chimney of house................. 353

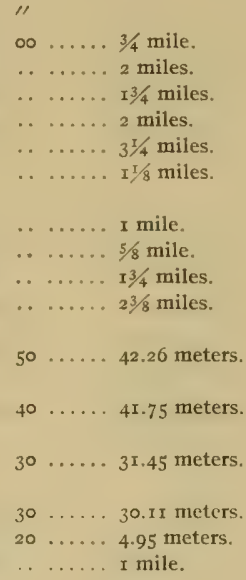




\section{GANDER.}

General locality.-Southeastern shore of Choptank River $3 / 8$ mile southwest of entrance to Goose Creek, about $x 3 / 8$ miles east-northeast of Oystershell Point, and about $x 1 / 8$ miles south-southeast of Jamaica Point. (See Chart No. 35.)

Immediate locality.-Observed station is in an uncultivated field on bank about 6 feet above high water, I9 yards east of edge of bank, 33 yards northeast of edge of bank, 33 yards southeast of edge of bank, and 555 yards west of two large cedar trees at a paling fence.

Marks.-Observed station is center point of triangle on standard cement monument projecting 6 inches above surface of ground. Subsurface mark is center of 2 -inch tile pipe buried with top 2 inches below base of monument.

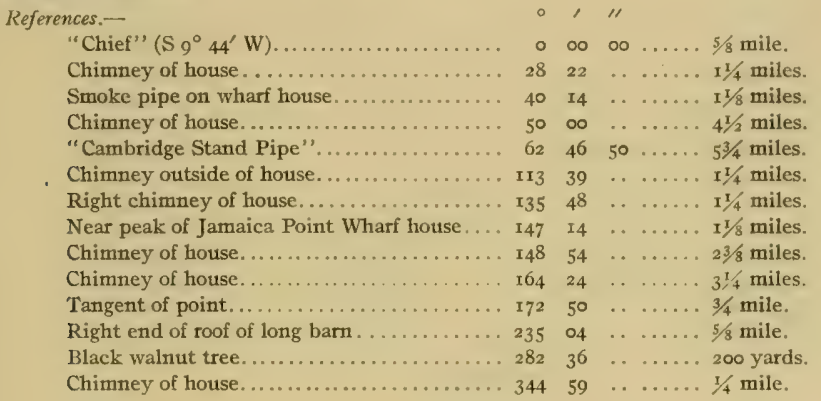

\section{CHIEF.}

General locality.-Southeast shore of Choptank River on a narrow neck of land between Choptank River and Indian Creek, about I mile east of Oystershell Point. (See Chart No. 35.)

Immediate locality.-Observed station is on a grass strip between Choptank River and Indian Creek about 2 feet above high water, 15 yards south of river shore, II yards north of creek shore, 20 yards southeast of river shore, and 25 yards southwest of river shore.

Marks.-Observed station is center point of triangle on standard cement monument projecting. 5 inches above surface of ground. Subsurface mark is center of 2 -inch tile pipe buried with top 2 inches below base of monument.

References. -

"Shell" (S $\left.85^{\circ} \mathrm{II}^{\prime} \mathrm{W}\right)$

Smoke pipe on wharf house

$\mathrm{Nail}$ in blaze in locust tree ( 3 inches diameter).

Right corner of railing on house.......... 7

Near peak of house.................

Right comer of square chimney........... II

Near comer of barn.................. 144

Nail in blaze in cedar tree ( 6 inches diam-

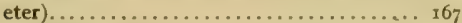

Stack of cannery.................... 208

Peak of house between two chimneys..... 253

$\mathrm{Nail}$ in blaze in cedar tree ( 8 inches diam-

eter).................................. 348

Near peak of cottage................ $35^{8}$ $\circ, 11$

$\circ \infty \infty \ldots . . .1$ mile.

- 42 ...... $3 / 4$ mile.

$3 \quad 37$ 10 .... 11.76 meters.

$32 \ldots \ldots 2$ miles.

$47 \quad \ldots \ldots \ldots 3^{5 / 8}$ miles.

$47 \ldots \ldots \ldots 1 / 2$ mile.

o5 $\ldots \ldots \ldots$. $1 / 4$ mile.

o7 Io ....22.07 meters.

$5^{6} \quad 20 \ldots \ldots 3 / 8$ mile.

$32 \ldots \ldots .1 / 4$ mile.

$0450 \ldots . .513 .8 \mathrm{t}$ meters.

38 ...... I mile. 
SHELI.

General locality.-Southeastern shore of Choptank River on Oyster Shell Point about $3 / 4$ mile south of Goose Point and I $1 / 3$ miles east-northeast of Chancellors Point. (See Chart No. 35.)

Immediate locality. -Observed station is on marsh about I foot above high water, 100 yards north of rail fence, 55 yards southwest of shore, 75 yards south of shore, 400 yards west of a wharf, 250 yards west by north of a small house near the shore, 50 yards west by north of corner of fence. Cement monument marking reference station is 2.27 meters $\mathrm{N} 83^{\circ} \circ 7^{\prime} \mathrm{W}$ of observed station.

Marks.-Observed station is nail in cedar stub flush with surface of ground. Reference station is center point of triangle on standard cement monument projecting 5 inches above the surface of the ground.

References.-

"Whitehall" $\left(\mathrm{S}_{4 \mathrm{I}^{\circ}} 55^{\prime} \mathrm{W}\right) \ldots \ldots \ldots \ldots \ldots$. o

Lone tree........................... 29 I2 ..... 225 yards.

"Cambridge Standpipe" ............. $35 \quad 39$ oo $\ldots \ldots .44^{1 / 2}$ miles.

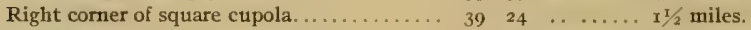

REFERENCE STATION.................. $54 \quad 57 \quad 50 \ldots \ldots .27$ meters.

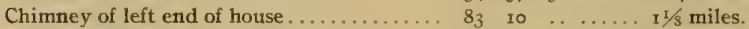

Near peak of large house............. $150 \quad 53 \ldots \ldots \ldots 17 / 8$ miles.

Near peak of Jamaica Point Wharf house... 158 17 $\quad \ldots \ldots \ldots$. $17 / 8$ miles.

Right peak of building............... $177 \quad 29 \quad \ldots \ldots \ldots 25 / 8$ miles.

Chimney on house.................. 205 20 ...... 1,4 miles.

Smoke pipe on wharf house............. 22 I $\quad$ I3 $\ldots \ldots \ldots 1 / 4$ mile.

Near peak of shed....................... $26540 \quad \ldots$ y yards.

Near peak of house................. 280 o6 ..... 300 yards.

\section{WHITEHALI.}

General locality.-Southeastem shore of Choptank River about $5 / 8$ mile southwest of Oystershell Point, and $I / 8$ miles east of Chancellor Point. (See Chart No. 35.)

Immediate locality. - Observed station is on a marsh point among water bushes about i2 yards southsoutheast of shore, $1_{3}$ yards south-southwest of shore, and 15 yards east-southeast of shore.

Marks.--Observed station is center point of triangle on standard cement monument projecting 4 inches above surface of ground. Subsurface mark is center of 2 -inch tile pipe buried with top 2 inches below base of monument.

\begin{tabular}{|c|c|c|c|c|}
\hline eferences.- & 0 & , & $\prime \prime$ & \\
\hline "Ferry" ( $\left.55^{\circ} \circ 8^{\prime} \mathrm{W}\right)$. & 0 & $\infty$ & oo & $\mathrm{I} / 4$ miles. \\
\hline Chimney of house............ & 10 & 50 & . & $23 / 4$ miles \\
\hline "Cambridge Stand Pipe" ................ & 27 & 22 & 40 & 4 miles. \\
\hline Right of square cupola..... & 46 & 16 & .. & I $1 / 8$ miles. \\
\hline L eft chimney on long house $\ldots \ldots \ldots \ldots \ldots$ & 99 & $5^{8}$ & . & $x^{1 /}+4$ miles. \\
\hline Chimney outside near end of house....... & 137 & 20 & .. & $17 / 8$ miles. \\
\hline Near peak of large building..... & 144 & $3 I$ & .. & $23 / 5$ miles. \\
\hline Front peak of Jamaica Point Wharf house. & 150 & ০o & . & ......2 21/2 miles. \\
\hline
\end{tabular}

\section{FERRY.}

General locality.-Southern shore of Choptank near east side of entrance to Hurst Creek about $2^{\mathrm{I}} 2$ miles east of Cambridge. (See Chart. No. 35.)

Immediate locality.-Observed station is on a sand beach about on level with high water, 92 yards east-northeast of Hurst Creek, $x$ yard southeast of shore, and 6 to ro yards northwest to north of several low cedar trees. Cement monument marking reference station is 16.74 meters $\mathrm{S} 50^{\circ} 12^{\prime} \mathrm{E}$ of observed station. 
Marks.-Observed station is nail in pine stub in center of 2 -inch tile pipe with top of pipe 6 inches below surface of ground. Subsurface mark is center of 2 -inch tile pipe buried with top 2 inches below base of surface pipe. Reference station is center point of triangle on standard cement monument.

References.--

"E. Cambridge Tall Stack" (N. $\left.8 \mathrm{I}^{\circ} 2 \mathrm{I}^{\prime} \mathrm{W}\right)$.. 0 o $00 \quad 00 \ldots \ldots 21 / 2$ miles.

"Hambrooks Bar Beacon"............. 24 o5 ro.... 31/3 miles.

Near peak of large house with cupola...... $79 \quad 37 \quad \ldots \ldots$. I mile.

Near peak of barn cupola............. $99 \quad 22 \quad \ldots \ldots .2$ miles.

Near peak of Jamaica Point Wharf house... II6 23 . . . . . 35s miles.

Nail in blaze in cedar tree ( $I$ inches diam-

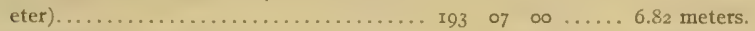

REFERENCE Station..................... 2 II og $00 \ldots .74$ meters.

Nail in blaze in cedar tree $(8$ inches diam-

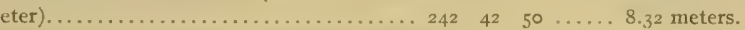

Nail in blaze in cedar tree ( $x 6$ inches diam-

eter)............................ $979 \quad 49 \quad 00 \quad \ldots .76$ meters.

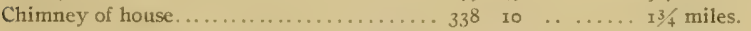

SHOAL.

General localily.-Southern shore of Choptank River near entrance to a small creek about I mile east-southeast of Cambridge $15 / 8$ miles west-southwest of Chancellors Point. (See Chart No. 35.)

Immediale locality.-Observed station is in woods on a point of land about ro feet above high water, 50 yards east of edge of bank, 6 yards southwest of wire fence at edge of high land, 7 yards south of wire fence, $1 \pi$ yards west of wire fence, I3 yards west-southwest of large double oak tree, and 90 yards east of a marsh point at a creek. Cement monument marking reference station is 6.08 meters $\mathrm{S}_{2} 3^{\circ} 44^{\prime} \mathrm{W}$ of observed station.

Marks.-Observed station is center of tile pipe with top 6 inches below surface of ground. Reference station is center point of triangle on standard cement monument projecting 5 inches above surface of ground.
References.-
"Cambridge" ( $\left.\mathrm{N}_{4} 6^{\circ} 3 \mathrm{I}^{\prime} \mathrm{W}\right) \ldots \ldots \ldots \ldots \ldots \ldots$. 0 .
Large chimney of house............... $25 \quad 55 \quad \ldots \ldots \ldots 35 / 8$ miles.

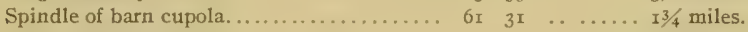

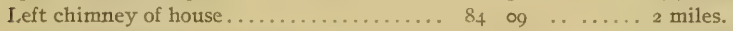
Near peak of barn with cupola............ Io6 II ...... $13 / 4$ miles.
Nail in blaze in large double oak tree..... I20 $03 \quad 20 \ldots$.... Ir.3 I meters.
Nail in blaze in black walnut tree ( $S$ inches

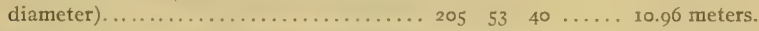
Nail in blaze in cedar tree ( 6 inches diam- eter)........................... $224 \quad 26 \quad 30 \ldots 5$ meters.
REFERIRCE STATION. ................ 250 15 to .... 0.08 meters.
Nail in blaze in hlack walnut tree ( 17 inches

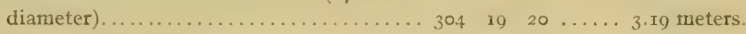
Flagstaff on boathouse............... $35^{8} \quad 43 \quad \ldots \ldots 2 \frac{1}{2}$ miles.

\section{EAST CAMBRIDGE TALL STACK.}

General locality.-Southem shore of Choptank River in the town of Cambridge on the east side of Cambridge Creek. (See Chart No. 35.)

Immediatc locality.-Observed station is tall square brick smokestack at plant of Cambridge Manufacturing Company.

Marks.-Observed station is center of stack.

References.-None necessary.

$5^{8} 345^{-1}-4$ 


\section{EAST CAMBRIDGE SPIRE.}

General locality.-Southern shore of Choptank River in town of Cambridge on the east side of Cambridge Creek and the south side of Maryland Avenue. (See Chart No. 35.)

NoTE.-This triangulation landmark was tom down before this publication was prepared and therefore it is not described, although its name and location are shown on Chart No. 35 .

\section{CAMBRIDGE STANDPIPE,}

General locality.-Southwestern side of Choptank River in the town of Cambridge. (See Chart No. 35.) Street.

Immediate locality.-Observed station is on standpipe on the north side of High Street near Pine

Marks.-Observed station is center of cylindrical water standpipe with ornamental railing on top.

References.-None necessary.

\section{CAMBRIDGE.}

General locality. - Southern shore of Choptank River on a point about $3 / 4$ mile southeast of Hambrooks Bar Beacon and $\mathrm{x} / 2$ mile northwest of Cambridge steamer wharf. (See Chart No. 35.)

Immediate locality.-Observed station is on a marsh point about I foot above high water, 30 yards west of shore, 35 yards south of shore at cut, 40 yards southwest of shore, and 3 yards southwest of barbwire fence running northwest and southeast.

Marks.-Observed station is center point of triangle on standard cement monument projecting 4 inches above surface of ground. Subsurface mark is center of 2 -inch tile pipe buried with top 2 inches below base of monument.

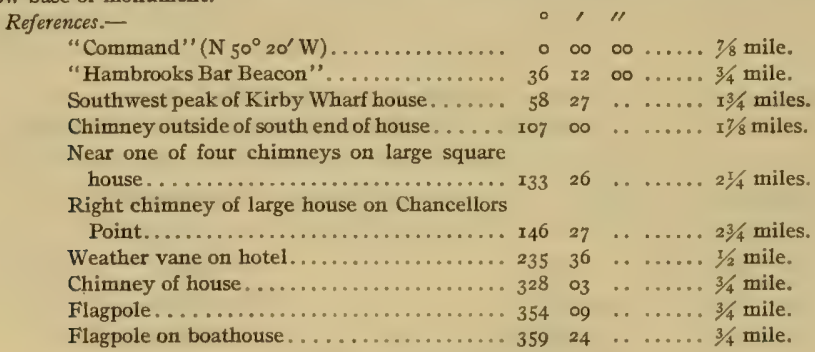

\section{HAMBROOKS BAR BEACON.}

General locality.--Southern side of Choptank River about $1 / 4$ mile offshore from point of land known as Hambrooks Bar, about 2 miles southeast of Howells Point and I, 2 miles northwest of Cambridge. (See Chart No. 35.)

Immediate locality.-Observed station is on a cylindrical foundation known as Hambrooks Bar Beacon.

Marks.-Observed station is center point of lantern on Hambrooks Bar Beacon.

References.-None necessary.

\section{DICKS WATER TANK.}

General locality. - Southern shore of Choptank River near Hambrooks Bar about 5/5 mile southwest of Hambrooks Bar Beacon and 1/2 mile west of extreme end of Hambrooks Bar. (See Chart No. 35.)

Immediate locality.-Observed station is on water tank.

Marks.-Observed station is spindle on top of water tank.

References.-None necessary. 


\section{COMMAND.}

General locality.-Southern shore of Choptank River about 1/2 mile west-southwest of Hambrooks Bar Beacon and about $\mathrm{I}^{1} / 2$ miles northwest of Cambridge Wharf. (See Chart No. 35.)

Immediate locality. - Observed station is on a marsh point inside of a fence line, about 2 feet above high water, 18 yards southeast of shore, 16 yards south of shore, 25 yards southwest of shore, and $15^{\circ}$ yards northwest of a boathouse.

Marks.-Observed station is center point of triangle on standard cement monument projecting 5 inches above surface of ground. Subsurface mark is center of 2 -inch tile pipe buried with top 2 inches below base of monument.

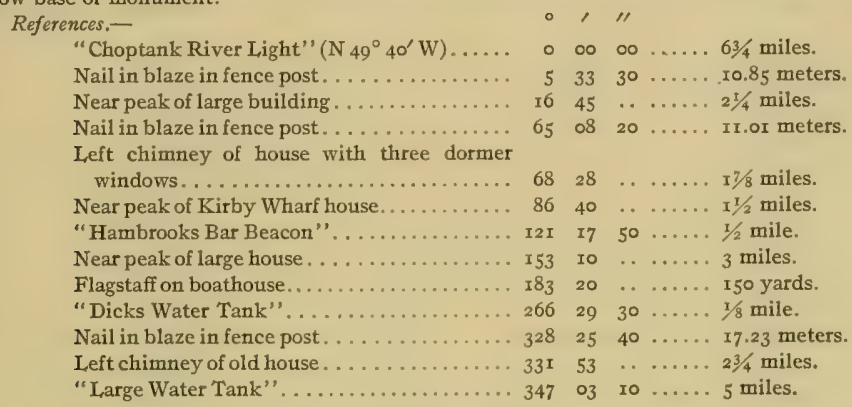

\section{HOWARD.}

General locality.-Southern shore of Choptank River, 2 miles southeast of Horn Point and about $1 / 4$ mile northwest of entrance to Jenkins Creek. (See Chart No. 35.)

Immediate locality.-Observed station is on cultivated land on bluff about iz feet above high water, 25 yards southwest of edge of bluff, 30 yards south of edge of bluff, 35 yards west of edge of bluff, 45 yards west-northwest of comer of fence dividing field from marsh, and 65 yards northeast of the south one of two small poplar trees in field.

Marks.-Observed station is center point of triangle on standard cement monument projecting 4 inches above surface of ground. Subsurface mark is center of 2 -inch tile pipe buried with top 2 inches below base of monument.

References. -

"Choptank River Light" ( $\left.\mathrm{N}_{3} 6^{\circ} \mathrm{r}_{4}^{\prime} \mathrm{W}\right)$.....

Near peak of barn...................

"Black Beacon" .....................

Red Beacon.....................

Near peak of low house in trees........... . 79

Near peak of Kirby Wharf house.......... 9

"Dicks Water Tank" ................. rog

Left chimney of house................. II 5

Nail in blaze in locust tree ( 8 inches diam-

eter).......................... I25

Nail in blaze in locust tree............. I44

Nail in blaze in locust tree.............. I 88

Near peak of barn.................. 245

Right peak of house................. 3 I 7

Right peak of old house .............. $35^{\text {I }}$

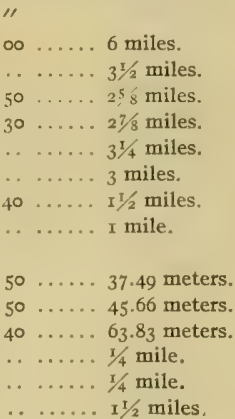


TOOT.

General locality. - Southern shore of Choptank River on Horn Point about 15/8 miles west of Howells Point, and at eastern side of entrance to Lecomptes Bay. (See Chart No. 35.)

Immediate locality. - Observed station is in woods about 7 feet above high water, 5 yards south of shore, 13 yards southwest of shore, and 20 yards west of shore, and near but not on highest point of ground. Cement monument marking reference station is 12.38 meters S $33^{\circ} 34^{\prime}$ W of observed station.

Marks.-Observed station is nail in center of stub in 2-inch tile pipe projecting 2 inches above surface of ground. Subsurface mark is center of 2 -inch tile pipe buried with top 2 inches below base of surface pipe. Reference station is center point of triangle on standard cement monument projecting 4 inches above surface of the ground.

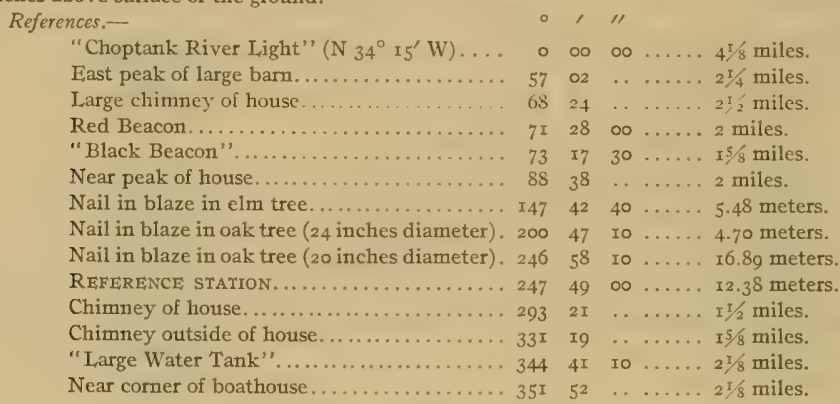

\section{LECOMPTE,}

General locality.-Southern shore of Choptank River on southwestern side of Lecomptes Bay about I $1 / 2$ miles west-southwest of Horn Point, $5 / 8$ mile northwest of Travers Wharf, and $1 / 4$ mile southwest of mouth of Lecomptes Creek. (See Chart No. 35.)

Immediate locality.-Observed station is on marsh about $x$ foot above high water, 18 yards west of point of shore, I4 yards south-southeast of shore, 5 yards east-southeast of turn in shore at beach, 7 yards northeast of a pool, Io yards northwest of cut in shore, and II 5 yards southeast of near one of two large cedar trees.

Marks.-Observed station is center point of triangle on standard cement monument projecting 5 inches above surface of ground. Subsurface mark is center of 2 -inch tile pipe buried with top 2 inches below base of monument.

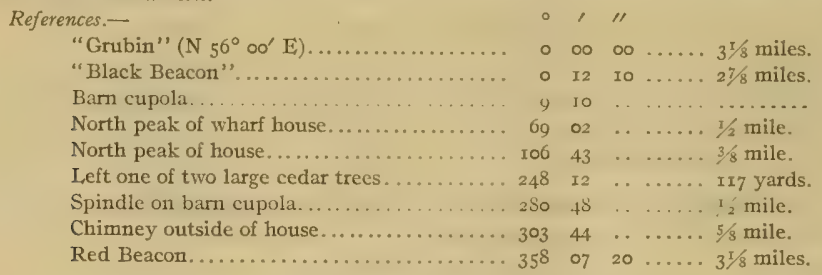

\section{LARGE WATER TANK.}

General locality.-Southwestern shore of Choptank River at Castle Haven, about $21 / 8$ miles south of Choptank River Light. (See Chart No. 35.) Haven.

Immediate locality.-Observed station is on water tank on high steel tower near barns at Castle

Marks,--Observed station is center point of windmill on water tank.

References.-None necessary. 
CASTLE.

Gencral locality.-Southern shore of Choptank River on Castlehaven Point on north side of Castlehaven Creek about 2 miles south-southwest of Choptank River Light. (See Chart No. 35.)

Inmediate locality.-Observed station is on a narrow neck of land, about 25 yards south-southwest of shore of Choptank River, 20 yards north of shore of cove, 22 yards west of bathhouse, and roo yards east-northeast of three poplar trees.

Marks.-Observed station is center point of triangle on standard cement monument projecting 5 inches above surface of ground. Subsurface mark is center of 2 -inch tile pipe buricd with top 2 inches below base of monument.

References. -

\begin{tabular}{|c|c|c|c|}
\hline "Choptank River Light" (N $25^{\circ} 4 \mathrm{I}^{\prime}$ W)...... & $\circ$ & $\infty$ & $\infty{ }^{\circ} \ldots .2$ miles. \\
\hline Right corner of house near Bachelor Point. . & I9 & 27 & 3 miles. \\
\hline 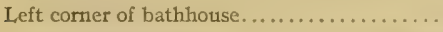 & 95 & $3^{r}$ & 21.42 meters. \\
\hline Near corner of bathhouse................ & 109 & 32 & I 9.83 meters. \\
\hline $\begin{array}{l}\text { Near peak of house ..................... } \\
\text { Right peak of boathouse at Castlehaven }\end{array}$ & 122 & 56 & 3 miles. \\
\hline 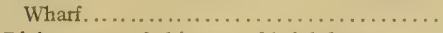 & 215 & 04 & .. $1 / 8$ mile. \\
\hline Right comer of chimney of brick house..... & 254 & $\mathbf{1} 8$ & .. $1 / 8$ mile. \\
\hline
\end{tabular}

JERE.

General locality.-Eastern side of Chesapeake Bay on Sharps Island, about $x^{1} / 2$ miles south-southeast of Sharps Island Light. (See Chart No. 36.)

Immediate locality.-Observed station is on hard ground about 7 feet above high water, 95 yards south-southeast of old hotel building, 95 yards west-southwest of shore, 150 yards southwest of a point and in such a position that Sharps Island Light shows to the right of the old hotel building.

Marks.-Observed station is center point of triangle on standard cement monument projecting 4 inches above surface of ground. Subsurface mark is center of 2 -inch tile pipe buried with top 2 inches below base of monument.

References.-

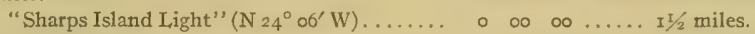

Church cupola.................... $46 \quad 35 \quad 50 \ldots \ldots 5^{1 / 4}$ miles.

Chimney on left end of roof of large house... $47 \quad 44 \quad \ldots \quad \ldots, 5$ miles.

Chimney of large house............... I0 4 . $25 \ldots \ldots .41 / 4$ miles.

L,arge chimney of large house........... II5 $46 \quad \ldots \ldots \ldots 43 / 4$ miles.

Chimney on right end of large house...... I42 2 I $\ldots \ldots .55 \%$ miles.

Near corner of house.................. $346 \quad 59 \quad \ldots . \ldots 9$ yards.

SHARPS ISLAND LIGHT.

General locality.-Eastern side of Chesapeake Bay off entrance to Choptank River, about I mile north-northwest of Sharps Island and $25 / 8$ miles southwest of Blackwalnut Point. (See Chart No. 36 .)

Immediate locality.-Observed station is on structure with a cylindrical foundation known as Sharps Island Light.

Marks.-Observed station is center point of lantern on Sharps Island Light.

References,-

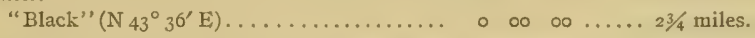

\section{BLACK.}

General locality.-Eastern shore of Chesapeake Bay on Blackwalnut Point at north side of entrance to Choptank River, about $23 / 4$ miles northeast of Sharps Island Light. (See Charts No. 36.)

Immediate locality.-Observed station is in cultivated land about 8 feet above high water, 35 yards east-northeast of edge of bank, 45 yards west of edge of bank, 65 yards northwest of edge of bank, and I3o yards south of a lone apple tree. 
Marks,-Observed station is center point of triangle on standard cement monument projecting 5 inches above surface of ground. Subsurface mark is center of 2 -inch tile pipe buried with top 2 inches below base of monument.

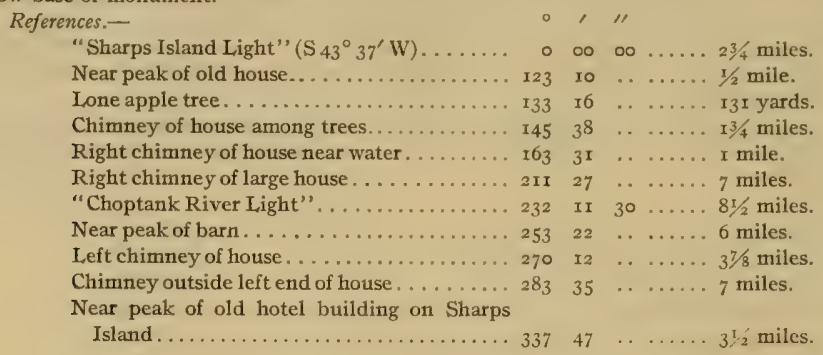

BAR.

General locality.-Western shore of entrance to Harris Creek on Upper Bar Neck Point, about I3/4 miles north-northeast of Blackwalnut Point and $I_{1}^{1} / 2$ miles south-southeast of Tilghman Island Wharf. (See Progress map.)

Immediate locality.-Observed station is in cultivated field about 6 feet above high water, 3 yards west of edge of bank and 60 yards north of line of trees at edge of marsh. Cement monument marking reference station is $45.8 \mathrm{I}$ meters $\mathrm{S} 83^{\circ} \circ \mathrm{o}^{\prime} \mathrm{W}$ of observed station nearly on line to large lone persimmon tree 15 inches diameter.

Marks.-Observed station is center of 4 -inch tile pipe with top about 6 inches below surface of ground. Reference station is center point of triangle on standard cement monument projecting 6 inches above surface of ground.

References.-

"Large Water Tank" (S 6r ${ }^{\circ} 46^{\prime}$ E) . . . . . . . .

Nail in blaze in oak stump............. $6_{3} \quad 18$ o .... 51.17 meters.

Nail in blaze in wild cherry tree.......... $7^{8} \quad 58 \quad 40 \ldots \ldots 46.66$ meters.

Nail in blaze in cedar tree............. $88 \quad 35 \quad 30 \ldots \ldots 47.69$ meters.

Nail in blaze in lone persimmon tree....... r44 33 10 .... 49.48 meters.

REFERENCE STATION.............. I44 46 oo .... 45.81 meters.

Right chimney of first house to right of woods. $205 \quad 39 \quad \ldots \quad \ldots .3 / 8$ mile.

Schoolhouse cupola.................. 213 II $40 \ldots \ldots x^{3 / 8}$ miles.

Stack of cannery.................. 216 I9 $\ldots \ldots \ldots 1 \mathrm{I} / 2$ miles.

Stack of cannery....................... 227 ro $\ldots \ldots$ miles.

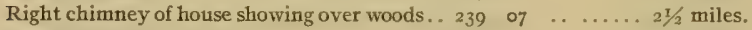

Neavitt schoolhouse cupola............ $26925 \quad \ldots \ldots \ldots 3 \frac{3}{4}$ miles.

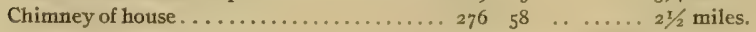

CHANGE (1910).

General locality. -Eastern shore of Harris Creek on Change Point, about $\mathrm{I} / 2$ miles east of Kniapps Narrows. (See Progress map.)

Immediate locality.-Observed station is in cultivated field about 8 feet above high water, 45 yards north-northeast of extreme end of point, 55 yards northwest of edge of bank, 35 yards east of edge of bank, 70 yards southeast by south of corner of wire fence, and 70 yards south-southwest of wire fence.

Marks.-Observed station is center point of triangle on standard cement monument projecting 4 inches above surface of ground. Subsurface mark is center of 2 -inch tile pipe buried with top 2 inches below base of monument. 


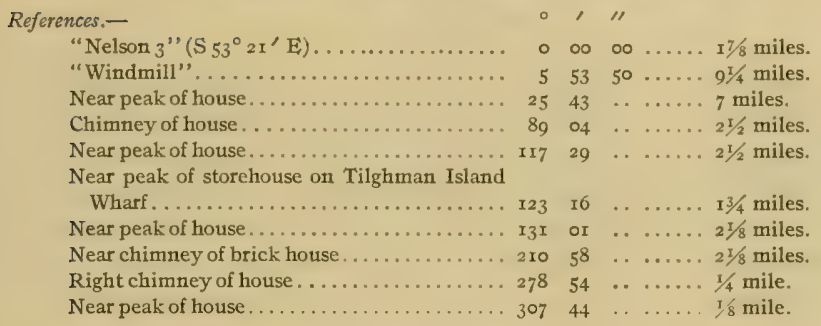

CHEF.

General locality.-Eastern shore of Chesapeake Bay on Cook Point, at southern side of entrance to Choptank River, about 4 miles east of Sharps Island. (See Charts Nos. 36 and 37.)

Immediate locality.-Observed station is in cultivated field about 8 feet above nigh water, 30 yards inside of fringe of trees parallel with shore, 45 yards southwest of eastern end of fringe of trees, 70 yards east of westem end of fringe of trees, and Igo yards northwest by north of gate in fence running east and west.

Marks.-Observed station is center point of triangle on standard cement monument projecting 4 inches above surface of ground. Subsurface mark is center of 2 -inch tile pipe buried with top 2 inches below base of monument.

References.-

"Sharps Island Light" ( $84^{\circ}$ or' W).

$\circ, 11$

Nail in blaze in wild cherry tree ( 4 inches

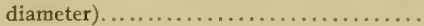

Nail in blaze in locust tree ( 5 inches diam-

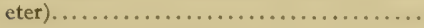

Large chimney of house..................

Nail in blaze in locust tree ( 5 inches diameter)..........

r eft peak of house....................

Near peak of barn......................

Nail in blaze in locust tree ( 5 inches diam-

eter)........................ $99 \quad 50 \quad 30 \ldots 43.16$ meters.

Near chimney on largest building in group .. $127 \quad 24 \quad \ldots \ldots .6$ miles.

Left end of house.................. $150 \quad 48 \quad 30 \ldots \ldots .5 \%$ miles.

"Choptank River Light".............. r $5^{8}$ o2 1o ..... $57 / 8$ miles.

Lone persimmon tree................. $16547 \quad \ldots \ldots \ldots 231$ yards.

"Large water tank"................ 177 43 43 10 ..... $63 / 8$ miles.

Right chimney outside house.......... 194 o2 ...... $2 \frac{1 / 4}{4}$ miles.

Chimney on right one of two houses....... $22237 \quad \ldots \quad \ldots \ldots .1 / 4$ mile.

Right peak of barn................. $25 \mathrm{I}$ is $\ldots \ldots \ldots 1 / 4$ mile.

Right peak of hotel on Sharps Island..... 34 I $27 \quad \ldots \ldots \ldots 4$ miles.

COOK POINT WINDMIIL.

General locality.-Eastern shore of Chesapeake Bay on Cook Point, between Tripps Bay and Cook Point Cove, about $x^{1 / 4}$ miles southeast of end of point. (See Charts Nos. $3^{6}$ and 37.)

Immediate locality.-Observed station is on windmill over smaller and west one of two water tanks west of a barn on Cook Point farm.

Marks.-Observed station is center of windmill over smaller tank.

Reforences.-None necessary. 


\section{BRANNOCK.}

General locality.-Eastern shore of Chesapeake Bay between Choptank River and Little Choptank River, on the southern shore of Brannock Bay, about 7 miles southeast of Sharps Island Light. (See Charts Nos, 36 and 37.)

Immediate locality.-Observed station is on high land about 8 feet above high water, $x$ I yards south of shore, 7 yards south of edge of bluff, 8 yards north of rail fence on far side of county road, 50 yards east of bend where road leaves shore and runs toward farmiho use and 150 yards northeast of a farmhouse.

Marks.-Observed station is center point of triangle on standard cement monument projecting about inches above surface of ground. Subsurface mark is 2 -inch tile pipe buried with top 2 inches below base of monument.

\begin{tabular}{|c|c|c|c|c|}
\hline References.- & 0 & ' & $\prime \prime$ & \\
\hline 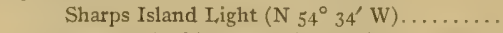 & 0 & 00 & $\infty 0$ & 7 miles. \\
\hline Near peak of house on Cook Point......... & 38 & 18 & . & $3 \frac{1}{2}$ miles. \\
\hline "Cook Point windmill" . .......... & 45 & 33 & 30 & $2, / 2$ miles. \\
\hline Right chimney of house in trees.......... & 83 & I5 & . & 2 miles. \\
\hline Between two chinineys on large part of house. & 104 & $3 I$ & . & .. I mile. \\
\hline Outside chimney on near end of house..... & IoS & 06 & . & ..... t mile. \\
\hline Center one of three chimneys of house....... & $x+2$ & 03 & . & ...... I mile. \\
\hline Tangent of right end of barn roof ........... & I50 & 49 & $\cdots$ & ... I mile. \\
\hline Center one of three chimneys on house. & 163 & I6 & & . 3/4 mile. \\
\hline Right peak of house.............. & 203 & 34 & . & ... 2 miles. \\
\hline Left chimney of $\mathrm{r}^{1 / 2}$-story house across creck. . & 210 & 47 & . & $\ldots \ldots 2$ miles. \\
\hline Near peak of barn....... & 285 & II & . & .... 3/4 mile. \\
\hline Tangent of Mills Point.................... & 343 & 43 & $\cdots$ & . 3/4 mile. \\
\hline Tangent of left end of Sharps Island Hotel.. & $35^{2}$ & I2 & & $5^{1 / 2}$ tuiles. \\
\hline
\end{tabular}

\section{ROBINS}

General locality.-Eastern shore of Chesapeake Bay on Hills Point, at northeast side of entrance to Little Choptank River, about 6 miles southeast of Sharps Island Light. (See Charts Nos. 36 and 37.)

Immediate locality.-Ohserved station is in cultivated field about 8 feet above high water, 40 yards northeast by north of edge of bluff, 45 yards east by north of point of bluff, 65 yards south by east of edge of bluff in range with Sharps Island Light, and r.40 yards north by west of wire fence at bluff.

Marks.-Observed station is center point of triangle on standard cement monument projecting 4 inches above surface of ground. Subsurface mark is center of 2 -inch tile pipe buried with top 2 inches below base of monument.

References.-

"Sharps Island I,ight" ( $\left.\mathrm{N}_{34^{\circ}} \mathrm{II}^{\prime} \mathrm{W}\right) . . . .$. .

Nail in blaze in cedar tree ( 8 inches diam-

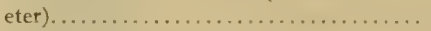

Left chimney of house .................

Near peak of barn.....................

Tallest chimney of house................

Near peak of barn. ................... 222

Tangent of end of woods on Taylor Island . . . 22

Chimney of house on James Point. ........ 24 24

Tangent of James Point.................
Nail in blaze in cedar tree $(8$ inches diam-

Nail in blaze in cedar tree ( 8 inches diameter)........................ $336 \quad 32 \quad 30 \ldots \ldots 28.22$ meters.

Nail in blaze in cedar tree ( 8 inches diam-

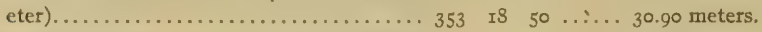

Tangent of right side of hotel on Slarps Island.

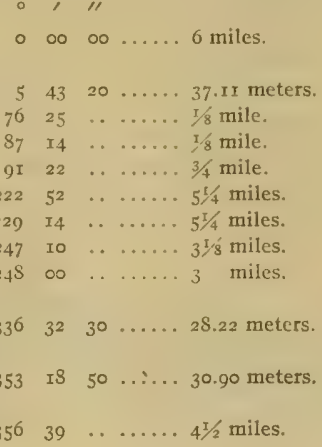


RAGGFD POIN'T 3.

General locality.-Northern shore of Little Choptank River on Ragged Island, about 3 miles cast of the northeast end of James Isiand. (See Charts Nos. 36 and 37.)

Immediate locality.-Observed station is on small marsh point about I foot above high water, 3 yards east of shore, 5 yards northwest of shore, 9 yards north of extreme end of point, and 100 yards east

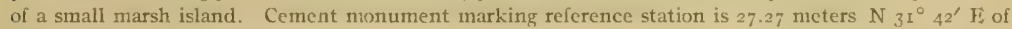
observed station. Tile pipe set in cement marking old reference station is 21.75 meters $\mathrm{N}_{30^{\circ}} 42^{\prime}$ E of observed station.

Marks.-Observed station is nail in cedar stub with top fiush with surface of ground. Reference station is center point of triangle on standard cement monument projecting 4 inches above surface of ground. Old reference station is tile pipe set in cement projecting 2 inches above surface of ground.

References.-

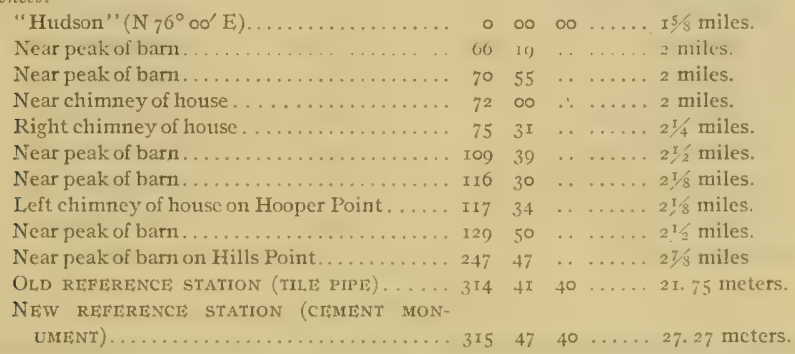

\section{TORREY.}

General locality.-Eastern shore of Slaughter Creek, about I mile southeast of Hooper Point, and $\mathrm{I} / 2$ mile southwest of entrance to Parsons Creck. (See Charts Nos. 36,37 , and 38 .)

Immediate locality. - Observed station is on hard marsh about I foot above high water, 90 yards east northeast of shore, 250 yards south of shore, 50 yards west of young pine thicket, and near several small pine trees.

Marks.-Observed station is center point of triangle on standard cement monument projecting 4 inches above surface of ground. Subsurface mark is center of 2 -inch tile pipe buried with top 2 inclies below base of monument.
References.-
"Maryland" ( $\left.\mathrm{S}_{22}{ }^{\circ} \circ 7^{\prime} \mathrm{W}\right)$
"Peak of barn. .....

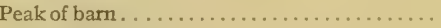

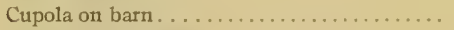
Right chimney of house . . ...............
Left chimney of house. . . . . . . . . . . . .
Right end of ban . . . . . . . . . . . . . . .
Left chimney of house................
Center of old windmill................
Left chimney of house on Hooper Point. .... Iog
Near peak of barn.................. I74
Nail in blaze in pine tree ( 5 inches diam-

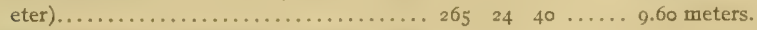
Nail in blaze in pine tree ( 6 inches diam- eter).......................... 28
Nail in blaze in pine tree $(4$ inches diam-

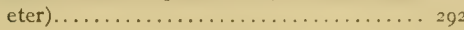

$$
\begin{array}{lllll}
00 & 00 & \ldots & 3 / 4 \text { mile. } \\
25 & \ldots & \ldots & \ldots & \text { m mile. } \\
37 & \ldots & \ldots & 13 / 8 \text { miles. } \\
48 & \ldots & \ldots & 15 / 8 \text { miles. } \\
32 & \ldots & \ldots & 3 / 4 \text { mile. } \\
07 & \ldots & \ldots & 5 & 5 \text { mile. } \\
24 & \ldots & \ldots & 5 / 8 \text { mile. } \\
14 & \ldots & \ldots & 1 \text { mile. } \\
58 & \ldots & \ldots & \text { I mile. } \\
14 & \ldots & \ldots & 4 \text { miles. } \\
24 & 40 & \ldots & 9.60 \text { meters. } \\
& \\
08 & 10 & \ldots & & \\
\end{array}
$$$$
25 \quad \ldots \ldots \text { I mile. }
$$$$
37 \quad \ldots \ldots \ldots, I 3 / 8 \text { miles. }
$$ 


\section{MARYLAND.}

General locality.-Eastern side of Slaughter Creek, about $11 / 4$ miles northeast of Slaughter Creek Bridge, and $1 / 4$ mile southeast of shore. (See Charts Nos. 36,37 , and 38 .)

Immediale locality.-Observed station is in a cultivated field about 35 yards northeast of fence between fields, ro5 yards west-northwest of road from Madison to Taylor Island, II 5 yards northwest of junction of fences at road, and 130 yards west-northwest of house on opposite side of road.

Marks.-Observed station is center point of triangle on standard cement monument projecting 4 inches above surface of ground. Subsurface mark is center of 2 -inch tile pipe buried with top 2 inches below base of monument.

References.-

"Noblee" ( $\mathrm{S}_{29} 9^{\circ} 8^{\prime} \mathrm{W}$ )

0,11

Near peak of canning house . . . . . . . . . . . . .

Spindle on cupola on barn. . . . . . . . . . . . .

Left side of bam . . . . . . . . . . . . . . . .

Right chimney of house . . . . . . . . . . . . .

Near chimney of large house. . . . . . . . . . . .

Near peak of large barn. . . . . . . . . . . . . .

Left chimney of house . . . . . . . . . . . . . I6

Chimney on near end of house ............ 21
Center of front door of house on opposite side

of road........................ 26

Near peak of barn. . . . . . . . . . . . . 353

- $\infty$ $\infty \ldots \ldots .3 / 4$ mile.

$\begin{array}{lllll}2 & 03 & \ldots & \ldots & x^{1} / 8 \\ 8 & \text { miles. }\end{array}$

12 10 .. .....

37 og $\ldots \ldots \ldots 1 / 4$ mile.

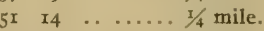

$99 \quad 33 \quad \ldots \quad \ldots .5 .5 / 8$ mile.

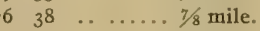

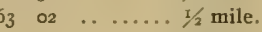

$46 \ldots \ldots .3 / 4$ mile.

\section{WHITEWASH.}

General locality:-Western shore of Slaughter Creek, about I I $/ 4$ miles north of Slaughter Creek Bridge, and $I \frac{5}{2}$ miles southwest of entrance to Parsons Creek. (See Charts Nos. 36,37 , and 38 .)

Immediate locality.-Observed station is on marsh about on level with high water, about 25 yards west-northwest of shore, 50 yards north-northwest of shore, 60 yards southwest of shore, 50 yards eastsoutheast of wire fence, and 300 yards south of farm house.

Marks.-Observed station is center point of triangle on standard cement monument projecting 4 inches above surface of ground. Subsurface mark is center of 2 -inch tile pipe buried with top 2 inches below base of monument.

References, -

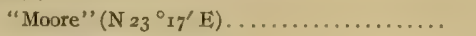

Near chimney of house. . . . . . . . . . . 28

Left chimney of house............... 42

Near peak of barn . . . . . . . . . . . . . . .

Near gable of house. . . . . . . . . . . . . . $9^{2}$

Left chimney of house. . . . . . . . . . . . II5

Cupola on barn ................. $\mathrm{r}_{55}$

Center of canning house ventilators........ I6r

Center of draw of Slaughter Creek Bridge.... r r69

Near peak of large building. . . . . . . . . . 177

Near peak of barn..................... 330

Right chimney of house . . . . . . . . . . . 335

Near peak of barn.

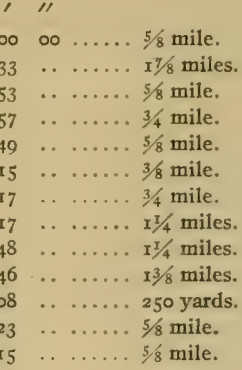


MOORE.

General locality.-Western shore of Slaughter Creek, about 5 s mile south of Hooper Point and 7s's mile west-southwest of entrance to Parsons Creek. (See Charts Nos. 36,37 , and 38 .)

Immediate locality. - Observed station is on sand and shell land near edge of marsh about $\mathrm{r}$ foot above high water, II yards west of shore, 25 yards north of shore, I30 yards south of shore, I40 yards east of near corner of large barn, and 200 yards west-southwest of end of point.

Marks.-Observed station is center point of triangle on standard cement monument projecting 4 inches above surface of ground. Subsurface mark is center of 2 -inch tile pipe buried with top 2 inches below base of monument.

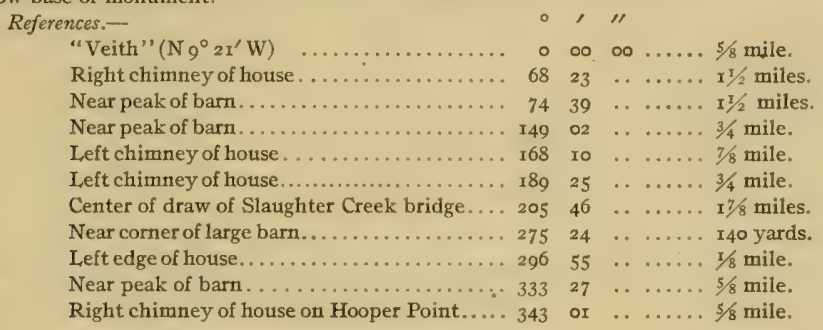

VEITH.

General locality.-Southern shore of Little Choptank River on Hooper Point at western side of entrance to Slaughter Creek about 2 miles south of Ragged Point. (See Charts Nos. 36, 37, and ${ }_{3} 8$.)

Immediate locality.-Observed station is on a marsh about I foot above high water, 25 yards west of shore, 30 yards south of shore, 50 yards northwest of shore, 6 yards east of edge of larger pond in marsh, 25 yards north of edge of smaller pond in marsh, and 125 yards east of an orchard.

Marks.-Observed station is center point of triangle on standard cement monument projecting 4 inches above surface of ground. Subsurface mark is center of 2 -inch tile pipe buried with top 2 inches below base of monument.

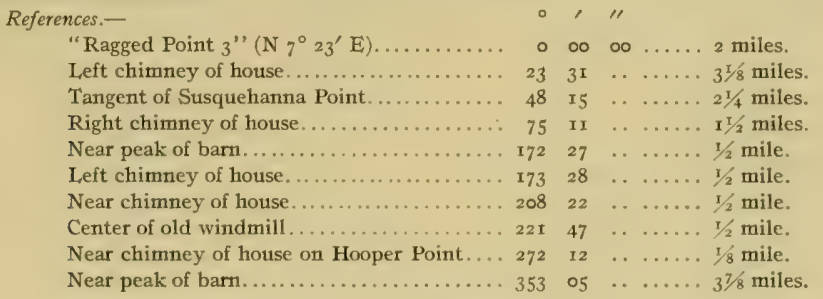

CAN.

General locality. - Southern shore of Little Choptank River on a point about 2 miles east of the southeastern end of James Island, and I mile west of entrance to Slaughter Creek. (See Charts No. ${ }_{36}$, 37 , and 38 .)

Immediate locality.-Observed station is on a marsh point about $\mathrm{I}$ foot above high water, 9 yards southwest of shore, 17 yards southeast of end of point, 20 yards east of shore, and 180 yards north-northwest of a house among trees. Cement monument marking reference station is 9.25 meters S $6^{\circ} 5^{\prime} \mathrm{E}$ of observed station. 
Marks,-Observed station is center of 4 inch tile pipe set in cement and projecting 2 inches above surface of ground. Reference station is center point of triangle on standard cement monument projecting 4 inches above surface of ground.

References.-

"Skid" ( $\mathrm{N} \mathrm{S0}{ }^{\circ} 23^{\prime} \mathrm{W}$ ).

Chimney on near end of old house...........

Chimney on end of small addition to house. . $\begin{array}{llllll}3^{8} & 23 & \ldots & \ldots & 2 \frac{1}{4} \text { miles. }\end{array}$

Near peak of barn on Hills Point........ $8_{3}$ 3I $\ldots \ldots \ldots 41 / 2$ miles.

Near peak of house................. $106 \quad 27 \ldots \ldots .43 / 8$ miles.

Left chimney of house................. $r_{32}$ 18 $\ldots \ldots \ldots 3 \frac{3}{4}$ miles.

Middle chimney of house............. $164 \quad 57 \quad \ldots \ldots \ldots 3 \frac{3 / 4}{4}$ miles.

L.eft chiminey of house.............. $210 \cdot 48 \ldots \ldots$ 180 yards.

REFERENCE STATION..................... $262 \quad 25$ o0 .... 9.25 meters.

Near peak of large barn.................. 328 or $\ldots \ldots \ldots$ miles.

Left chimney of large house on north end of

Taylor Island......................... $345 \quad 56 \quad \ldots \ldots \ldots$ miles.

Tangent to north end of Taylor Island.... 356 20 $\ldots \ldots . \mathrm{r} 3 / 8$ miles.

SKID.

General locality.-Eastern shore of Chesapeake Bay, on extreme southern end of James Island, about $8 \mathrm{I} / 2$ miles north-northeast of Cove Point Light and 4 miles southwest of Ragged Point. (See Charts Nos. 36,37 , and 38 .)

Immediate locality.-Observed station is on land about 5 feet above high water, 33 yards west of shore, 22 yards northeast of shore, and 60 yards northwest of extreme end of point. Four-inch tile pipe marking old reference station is 148.83 meters $\mathrm{N}_{9}^{\circ} 35^{\prime} \mathrm{W}$ of observed station and cement monument marking new reference station is $5^{8} .70$ meters $\mathrm{N} 9^{\circ} 59^{\prime} \mathrm{W}$ of observed station.

Marks.-Observed station is center of 4 -inch tile pipe with top 6 inches below surface of ground. Subsurface mark is center of 4 -inch tile pipe buried with top 2 inches below base of surface pipe. Old reference station is nail in center of 4 -inch tile pipe filled with and set in cement projecting 3 inches above surface of 'ground. New reference station is center point of triangle on standard cement monument projecting 4 inches above surface of ground.

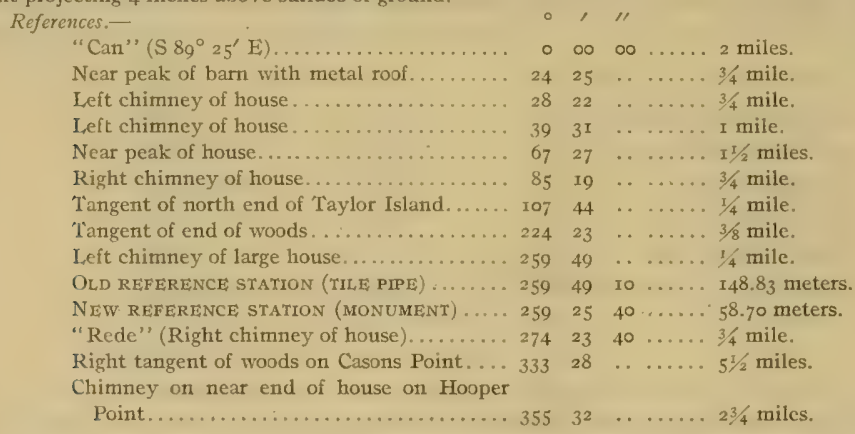

\section{REDE}

General locality,--Southwestern shore of Little Choptank River on James Island about 3 miles west-northwest of Hooper Point. (See Charts Nos. 36 and 37.)

Immediate locality.-Observed station is on two-story house on the east side of James Island and on the south side of Oyster Creek at its mouth.

Marks.-Eastern chimney of two-story house.

References.-None necessary. 
JAMES.

General locality.--Eastern side of Chesapeake Bay on northeast end of James Island at south side of entrance to Little Choptank River. (See Charts Nos. 36 and 37.)

Immediate locality.-Observed station is on marsh about $x$ foot above high water, 8 yards west of shore, II yards northwest of shore, 85 yards south of shore, and 75 yards east of pine woods. Cement monument marking reference station is 19.48 meters $\mathrm{S} 84^{\circ} \mathrm{I} 7^{\prime} \mathrm{W}$ of observed station.

Marks.-Observed station is center of 2 -inch tile pipe projecting 2 inches above surface of ground. Subsurface mark is center of 2 -inch tile pipe buried with top 2 inches below base of surface pipe. Reference station is center point of triangle on standard cement monument.

\begin{tabular}{|c|c|c|c|c|}
\hline References.- & 凷 & , & 11 & \\
\hline "Robins" ( $\left.\mathrm{N}_{23}{ }^{\circ} \mathbf{1 4}^{\prime} \mathrm{E}\right) \ldots \ldots \ldots$ & 0 & $\infty$ & $\infty$ & $\ldots \ldots 23 / 4$ miles. \\
\hline Near peak of house. .............. & 12 & 37 & $\cdots$ & $\ldots \ldots 3 \pi / 2$ miles. \\
\hline Chimney on near end of house..... & $4^{8}$ & $4^{2}$ & $\cdots$ & $\ldots \ldots 3 \mathrm{r} / 4$ miles. \\
\hline 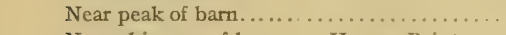 & 89 & or & . & $\ldots \ldots 4^{\mathrm{r}} / 4$ miles. \\
\hline Near chimney of house on Hooper Point. ... & 100 & 36 & $\cdots$ & . 3 miles. \\
\hline Left peak of long barn...... & 107 & 05 & $\cdots$ & . $3 \frac{\pi}{2}$ miles. \\
\hline Near peak of barn.......... & 146 & $\circ$ & $\cdots$ & . $21 / 2$ miles. \\
\hline REFERENCE STATTON...... & $24 \mathrm{I}$ & 03 & $\infty$ & I9.48 meters. \\
\hline "Sharps Island Light" ................. . & 320 & 02 & 40 & $\ldots \ldots 73 / 4$ miles. \\
\hline Right edge of old hotel on Sharps Island. . & 321 & 43 & $\cdots$ & $\ldots \ldots 61 / 4$ miles. \\
\hline Left tangent of woods on Cook Point. ... . . . . . & 357 & 29 & $\cdots$ & ..... 7 miles. \\
\hline
\end{tabular}

\section{NELSON 3 .}

General locality.-Northern shore of Cloptank River on Nelson Island, between the entrance to Harris and Broad Creeks. (See Progress map.)

Immediate locality.-Observed station is on southwest point of island on marsh about 2 feet above high water, 28 yards north-northeast of extreme end of point, 45 yards northwest of edge of marsh, and

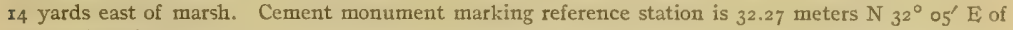
observed station.

Marks.-Observed station is center of nail in 3 -inch square stub in tile pipe flush with ground. Reference station is center point of triangle on standard cement monument projecting 5 inches above surface of ground.

References.-

"Choptank River Light" ( $\left.S_{5} 6^{\circ} \circ 9^{\prime} \mathrm{E}\right)$. . . . . .

"L,arge Water Tank" . . . . . . . . . . . . . I

Right chimney of house...............

Near chimney outside of house........... 45

Near peak of barn on Cook Point........... 6

Left peak of hotel on Sharps Island. . . . . . . .

"Sharps Island Light" . . . . . . . . . . . . . . . I0

Chimney of house . . . . . . . . . . . . . . . I $_{37}$

Stack of cannery at 'Tilghman Island . . . . . I I 53

Windmill at Tilghman Island ........... I 55

Chimney of house on Change Point. . . . . . I I 85

Left peak of house. . . . . . . . . . . . . I97

Chimney of house.................. 254

"St. Michaels Church Spire". . . . . . . . . . 259

REFERENCE STATION................ 268

Left peak of building. . . . . . . . . . . . 293

Near peak of house with three chimneys..... 335

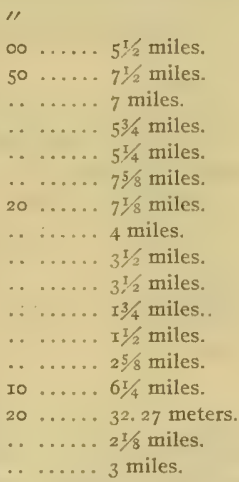

II

$0000 \ldots . .55^{1 / 2}$ miles.

10 og $50 \ldots \ldots 7 \% 7 \frac{1 / 2}{2}$ miles.

$48 \quad \ldots \ldots \ldots, 7$ miles.

$\begin{array}{llllll}5 & 44 & \ldots & \ldots & 5 & 5 \frac{3}{4} 4 \\ \text { miles. }\end{array}$

$7 \quad 40 \quad \ldots \ldots \ldots 5 \frac{1}{1 / 4}$ miles.

o3 $\quad \ldots \ldots \ldots .75 \%$ miles.

of $20 \ldots \ldots 7$. $7 / 8$ miles.

$3^{6} \quad \ldots \quad \ldots .44$ miles.

$43 \quad \ldots \ldots \ldots 3^{1 / 2}$ miles.

$12 \ldots \cdots \cdots 3^{1 / 2}$ miles.

$37 \quad$. : $\ldots \ldots . \quad 13 / 4$ miles.

$50 \quad \ldots \ldots x^{1 / 2}$ miles.

Io $\ldots \ldots \ldots 2^{5} / 8$ miles.

55 10 ..... $6 \frac{1}{1} / 4$ miles.

I3 $20 \ldots \ldots 3^{2.27}$ meters.

I8 ..... 3 miles. 


\section{ANNETTE.}

General locality.-Western shore of Broad Creek about 3/4 mile north of Nelson Point, and on south side of entrance to Balls Creek. (See Progress map.)

Immediate locality. - Observed station is on marsh about I foot above high water, and 4 yards west of shore. Cement monument marking reference station is 9.39 meters $\mathrm{N} 75^{\circ} 59^{\prime} \mathrm{W}$ of observed station.

Marks.-Observed station is center of 2 -inch tile pipe projecting 4 inches above surface of ground. Subsurface mark is center of 2 -inch tile pipe buried with top 2 inches below base of surface pipe. Reference station is center point of triangle on standard cement monument projecting 3 inches above surface of ground.
References.-

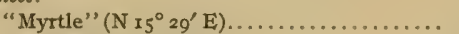
South chimney of house .................
South chimney of house .................
South gable of baru...................
Chimney of house. . . . . . . . . . . . . . 36
South gable of barn................. 7
West chimney of house................ 10
"Choptank River Light" . . . . . . . . . . . . . ri 6
Water tank at Castle Haven. ............. I23
North gable of barn on Todd Point........ 148 3I . . . . . $61 / 2$ miles.
Nail in blaze in cedar tree (ro inches diam.

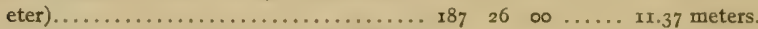
Nail in blaze in cedar tree (ro inches diam- eter) ........................ 235 of $30 \ldots \ldots$ m meters.
REFERENCE $\operatorname{statiON} \ldots \ldots \ldots \ldots \ldots \ldots . .268 \quad 29 \quad 40 \ldots \ldots .39$ meters.

\section{PEARY.}

General locality.-Eastern shore of Broad Creek about I mile north of entrance to Broad Creek, I3/8 miles north of Royston Island and $13 / 4$ miles east-northeast of Nelson Point. (See Progress map.)

Immediate locality.-O Observed station is on wooded shore about 6 feet above high water, 3 yards east of vertical bank which is washed by high water roo yards south of north end of pine woods. Cement monument marking reference station is 20.93 meters $\mathrm{N}_{43^{\circ}} 30^{\prime} \mathrm{E}$ of observed station.

Marks.-Observed station is center of 2 -inch tile pipe projecting 3 inches above surface of ground. Reference station is center point of triangle on standard cement monument.

References:-

"Roys" ( $\left.\mathrm{S}_{17}{ }^{\circ} 35^{\prime} \mathrm{E}\right) \ldots \ldots \ldots \ldots \ldots \ldots \ldots \ldots$

Left tangent of Cook Point...............

Right tangent of Nelson Point. . . . . . . . . 96

East chimney of house................ $x$

East gable of Pariett house............. I3

South gable of barn ................. 168

Nail in blaze in pine tree ( 15 inches diam-

eter)............................ $233 \quad 25 \quad 40 \ldots .49$ meters.

REFERENCE STATION...................24I 04 50.... 93 meters.

Nail in blaze in pine tree ( ${ }_{5}$ inches diam-

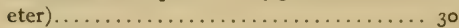

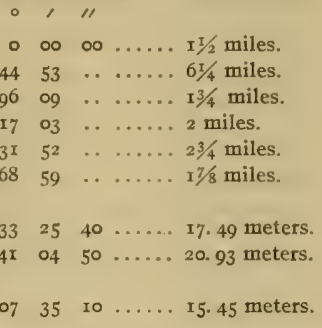

IRISH.

General locality.-Northeastern shore of Choptank River on west side of entrance to Irish Creek about $3 / 8$ mile northeast of Royston Island. (See Progress map.)

Immediate locality.-Observed station is in cultivated land, about 5 feet above high water, I3 yards east-northeast of edge of bank, 5 yards north of foot of bank, 4 yards north of a cedar tree, io yards west of a small cedar tree at west end of line of locust trees, and 23 yards east-southeast of rounded point of bank. 
Marks.-Observed station is center point of triangle on standard cement monument projecting 5 inches above surface of ground. Subsurface mark is center of 2 -inch tile pipe buried with top 2 inches below base of monument.

References.-

"Pont" ( $\mathrm{N}_{13}{ }^{\circ}$ o4' E).

Near peak of building

Nail in blaze in locust tree ( 2 inches diam-

eter) . . . . . . . . . . . . . . . . . . . .

Left peak of house . . . . . . . . . . . . .

Left peak of barn. . . . . . . . . . . . I2

Nail in blaze in cedar tree ( 7 inches diam-

eter $) \ldots \ldots \ldots \ldots \ldots \ldots \ldots \ldots \ldots \ldots \ldots \ldots \ldots$

Near peak of house................... 18

Nail in blaze in cedar tree ( 2 inches diam-

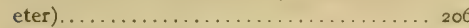

"Sharps Island Light" . . . . . . . . . . . 230

Near peak of house................ 29I

Near peak of barn.................. $34^{8}$

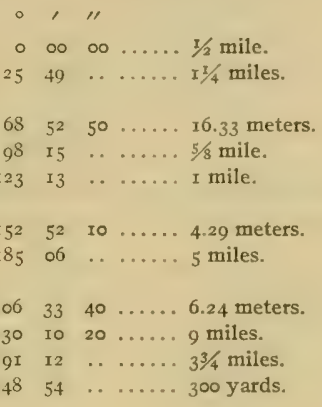

ROYS.

General locality. - Northeastern side of Choptank River on southern end of Royston Island, about $1 / 2$ mile southwest of entrance to Irish Creek. (See Progress map.)

Immediate locality.-Observed station is about 5 feet above high water, $\mathrm{I}_{5}$ yards north of shore, 25 yards east of shore, and 25 yards northeast of extreme end of point.

Marks.-Observed station is center point of triangle on standard cement monument projecting 6 inches above surface of ground. Subsurface mark is center of 2 -inch tile pipe buried with top 2 inches below base of monument.

References.-

"Choptank River Light", (S $44^{\circ} 37^{\prime}$ E) ......

"Large Water Tank" ..................

Right peak of barn............... 7 I os $\ldots \ldots \ldots 5 \frac{3}{3}$ miles.

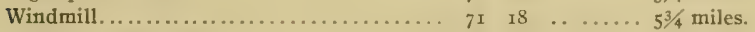

"Sharps Island Light"............... I09 I6 $30 \ldots . .83 / 4$ miles.

Church Spire................... I34 $43 \quad \ldots \ldots \ldots 6$ miles.

Church Spire..................... $134 \quad 47 \quad \ldots \ldots \ldots 6$ miles.

Large spire..................... I34 $57 \quad \ldots \ldots .6$ miles.

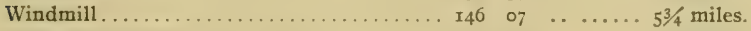

Chimney of house................ I70 $03 \ldots \ldots . . \ldots$ miles.

Near peak of large barn. . . . . . . . . . . . 200 28 . 28 .

Nail in blaze in oak tree ( 3 inches daimeter). 215 t. 10 ..... I0.64 meters.

Nail in blaze in oak tree ( 3 inches diameter). $28 \mathrm{I} \quad 2+20 \ldots \ldots 6.22$ meters.

Nail in blaze in cedar tree ( 5 inches diam-

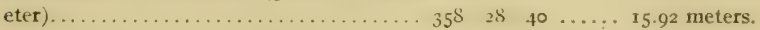

\section{CREEK.}

General locality.-Northeastern shore of Choptank River on east side of entrance to Irish Creek, about $5 / 8$ mile east-northeast of Royston Island. (See Progress map.)

Immediate localily.-Observed station on marsh point about I foot above high water, I y yards southeast of shore, II yards east of shore, 17 yards north-northeast of shore, and 14 yards south of cut in shore.

Marks.-Observed station is center point of triangle on standard cement monument projecting 5 inches above surface of ground. Subsurface mark is center of 2 -inch tile pipe buried with top 2 inches below base of monument. 


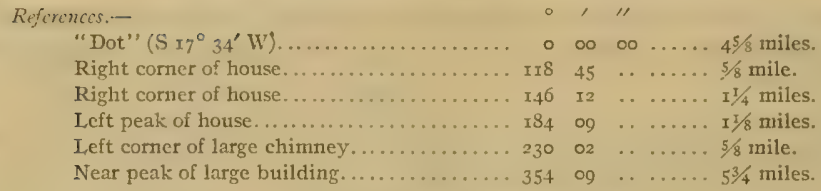

\section{CORNER (CHOPTANK RIVER).}

General locality.-Southern shore of Choptank River on east side of entrance to Chapel Creek, about 2 miles southeast of Todd Point, and 3 miles south-southwest of Choptank River Light. (See Chart No. 37.)

Immediate locality.--Observed station is on grassy land about 3 fect above high water, 30 yards east of shore, 30 yards south of shore, 35 yards southeast of extreme end of point, and west of small clump of small pine trees.

Marks.-Observed station is center point of triangle on standard cement monument projecting 5 inches above surface of ground. Subsurface mark is center of 2 -inch tile pipe buried with top 2 inches below base of monument.

References.-

"Dot" ( $\left.\mathrm{N}_{5} 8^{\circ} 43^{\prime} \mathrm{W}\right)$.

Nail in blaze in holly tree ( 14 inches diam-

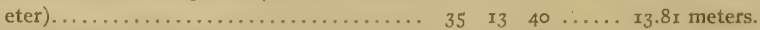

"Choptank River I.ight"................ $75 \quad 55 \quad 20 \ldots \ldots 3$ miles.

Nail in blaze in pine tree ( 4 inches diameter). I05 $0300 \ldots .3 .57$ meters.

Right comer of new house.............. 108 $42 \ldots \ldots \ldots 1 / 2$ mile.

Nail in blaze in pine tree ( 5 inches diameter). $187 \quad 20$ 10 .... 8.21 meters.

Near peak of $21 / 2$-story housc. . . . . . . . $308 \quad 25 \quad \ldots \ldots \ldots 7 / 3$ mile.

Chimney outside right end of house....... $340 \quad 33 \ldots \ldots \ldots 2$ miles.

Chimney outside near end of house........ 356 46 $\quad \ldots \ldots \ldots 21 / 4$ miles.

DOT.

General locnlity.-Southern shote of Choptank River on Todd Point, about 3 miles east of Cook Point, and 3. $1 / 2$ miles southwest of Choptank River Light. (See Chart No. 37.)

Immediate locality.-Observed station is about 4 feet above high water, 55 yards west-sonthwest of shore, 30 yards south-southwest of edge of bank, 40 yards south by east of point where bank meets marsh, 7o yards south by west of extreme end of point, and 200 yards northeast by north of a house.

Marks.-Observed station is center point of triangle on standard cement monument projecting 5 inches above surface of ground. Subsurface mark is center of 2 -inch tile pipe buried with top 2 inches below hase of monument.

References.-

"Choptank River Light" (S $56^{\circ} 26^{\prime}$ E) .....

"Large Water Tank". . ................

Near peak of house.................. 42

Near peak of building................ $7^{2}$

Chimney outside right end of house........ I02

Chimney outside near end of house........ $x_{75}$

Left chimney of house on Cook Point....... 2I2

"Sharps Island Light" ................. 218

Church Spire...................... 250

Left peak of house................... 277

Near peak of harn................... 290

Cupola on house .................... 333

$$
\begin{aligned}
& \infty 00 \ldots . .3 \frac{\pi / 4}{4} \text { miles. } \\
& 36 \quad 00 \ldots \ldots 3^{1 / 2} \text { miles. } \\
& 45 \quad \ldots \quad \ldots .23 / 4 \text { miles. } \\
& 49 \quad \ldots \ldots \ldots 2^{1 / 4} / 4 \text { miles. }
\end{aligned}
$$

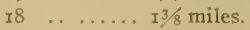

$$
\begin{aligned}
& 25 \ldots \ldots 200 \text { yards. } \\
& 24 \ldots \ldots \ldots 23 / 4 \text { miles. } \\
& 3240 \ldots .7 \pi / 2 \text { miles. } \\
& 04 \quad 40 \ldots \ldots 7^{1 / 4} / 4 \text { miles. } \\
& \text { 10 ....... } 71 / 4 \text { miles. } \\
& \text { o9 ....... } 7 \frac{1 / 2}{2} \text { miles. } \\
& 02 \ldots \ldots .35 \% \text { miles. }
\end{aligned}
$$


HUDSON.

General locality.-Northem shore of Little Choptank River on Casons Point, about I mile north of Susquehanna Point, and I $1 / 2$ miles east-northeast of Ragged Point. (See Chart No. 37.)

Immediale locality.-Observed station is on sand beach about on level with high water, 2 yards south of a rail fence extending along shore, and $\mathrm{I}_{3}$ y y ards west-northwestof end of woods at shore. Cement monument marking reference station is 29.65 meters $\mathrm{N} 8^{\circ} 30^{\prime} \mathrm{W}$ of observed station. Four-inch tile pipe marking old reference station is 3.99 meters $\mathrm{N} 7^{\circ} \mathrm{I}^{\prime}{ }^{\prime} \mathrm{W}$ of observed station.

Marks.-Observed station is center of 4 -inch tile pipe set in centent projecting 3 inches above surface of cement and 6 inches above surface of ground. Reference station is center point of triangle on standard cement monument projecting 4 inches above surface of ground. Old reference station is center of 4 -inch tile pipe projecting 3 inches above surface of ground.

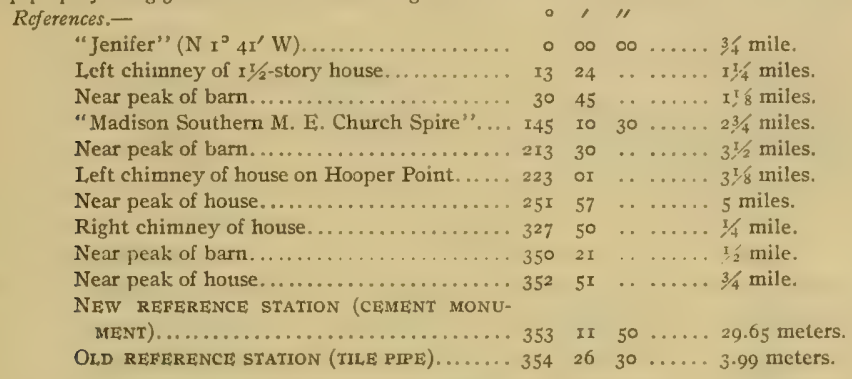

\section{JENIFER.}

General locality.-Western shore of Hudson Creek about 3,8 mile northwest of entrance to Back Creek and $3 / 4$ mile north of Casons Point. (See Chart No. 37.)

Immediate locality.-Observed station is on edge of cultivated field about 2 feet above high water, $\varepsilon$ yards northeast of shore, 9 yards southwest of shore, 55 yards north by west of extreme end of marsh point, and 65 yards southeast of corner of wire fence about in line with a barn.

Marks.-Observed station is center point of triangle on standard cement monument projecting 4 inches above surface of ground. Subsurface mark is center of 2 -inch tile pipe buried with top 2 inches below base of monument.

References.-

"Henry" ( $\left.\mathrm{N} \mathrm{I}^{\circ} 06^{\prime} \mathrm{W}\right) \ldots \ldots \ldots \ldots \ldots \ldots$

Tangent of left end of Ross Wharf...........

Near peak of barn...................

Chimney on left end of house. . . . . . . . . . . .

Near peak of barn.....................

Chimney on near end of house . . . . . . . . . 8

Chimney on near end of house . . . . . . . . . II

"Madison Southern M. E. Church spire" .... I 5

Tangent of Casons Point. .............. I

Chimney on near end of house........... 18

Near peak of house . . . . . . . . . . . . . . 225

Lightning rod on house . . . . . . . . . . 276

Near peak of barn

\begin{tabular}{rcccc}
0 & \multicolumn{1}{c}{$\prime \prime$} \\
0 & 00 & 00 & $\ldots \ldots$ & I/8 mile. \\
8 & 55 & $\ldots$ & $\ldots$ & I mile. \\
20 & 24 & $\ldots$ & $\ldots$ & I mile. \\
32 & 30 & & $\ldots$ & $1 / 2$ mile. \\
64 & 33 & $\ldots$ & $\ldots$ & $5 / 8$ mile. \\
85 & 48 & $\ldots$ & $\ldots$ & I mile. \\
19 & 59 & $\ldots$ & $\ldots$ & 2 miles. \\
51 & 57 & 30 & $\ldots$ & 3 miles. \\
59 & 58 & $\ldots$ & $\ldots$ & $3 / 4$ mile. \\
89 & 26 & $\ldots$ & $\ldots$ & $1 / 2$ mile. \\
225 & 32 & $\ldots$ & $\ldots$ & $1 / 4$ mile. \\
276 & 57 & $\ldots$ & $\ldots$ & 225 yards. \\
304 & 00 & $\ldots$ & $\ldots$ & $1 / 5$ mile.
\end{tabular}

$58345-13-5$ 


\section{HENRY}

General locnlity.-Western shore of Hudson Creek at sauth side of entrance to a cove about I mile north of Casons Point. (See Chart No. 37.)

Immediate locality.-Observed station is about 2 feet above high water, 5 yards south of shore, 5 yards northwest of shore, ro yards west of extreme end of point, and 34 yards north of wire fence at shore.

Marks.--Observed station is center point of triangle on standard cement monument projecting 4 inches above surface of ground. Subsurface mark is center of 2 -inch tile pipe buried with top 2 inches below base of monument.

References.-

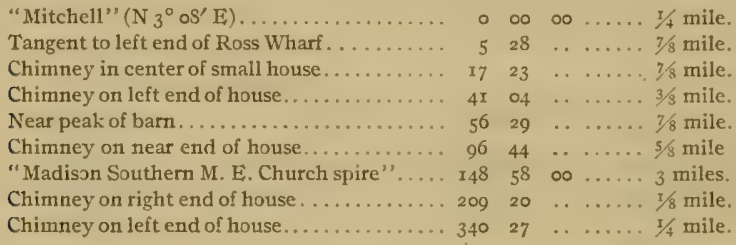

\section{MITCHELL}

General locality.-Western shore of Hudson Creek about $5 / 3$ mile north-northwest of entrance to Back Creek and $\mathrm{x} \frac{1}{4}$ miles north of Casons Point. (See Chart No. 37.)

Immediate locality.-Observed station is in a small grove of oak trees about 2 feet above high water, II yards southwest of shore, I2 yards north of shore, and 29 yards west of extreme end of point.

Marks.-Observed station is center point of triangle on standard cement monument projecting 4 inches above surface of ground. Substurface mark is center of 2 -inch tile pipe buried with top 2 inches below base of monument.

\begin{tabular}{|c|c|c|c|c|}
\hline eferences.- & 0 & , & $\prime \prime$ & \\
\hline "Back" (N $\left.70^{\circ} 5 \mathrm{r}^{\prime} \mathrm{E}\right)$. & 0 & $\infty$ & $\infty$ & $1 / 4$ mile. \\
\hline Chimney on near end of house . . ......... & 23 & 09 & . & 1/4 mile. \\
\hline Chimney on small house................ & 35 & $\circ 9$ & .. & 5/s mile. \\
\hline Chimney on right end of house. .... & $4 \mathrm{I}$ & 36 & . & $3 / 8$ mile. \\
\hline Chimney on right end of house...$\ldots \ldots \ldots$ & 53 & 32 & . & $3 / 8$ mile. \\
\hline 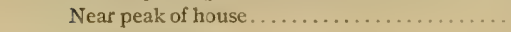 & 122 & $\circ 9$ & .. & $3 / 8$ mile. \\
\hline Near peak of barn . . . . . . . . . . . . . . . . . & I33 & 23 & . & $3 / 8$ mile. \\
\hline Nail in blaze in oak tree ( 18 inches diameter). & 178 & 27 & $\infty$ & 8.72 meters. \\
\hline Nail in blaze in oak tree ( 16 inches diameter). & 194 & $5^{\mathrm{T}}$ & 20 & I4.95 meters. \\
\hline Chimney on left end of house. . . . . . . . . . & 276 & I7 & $\ldots$ & $3 / 4$ mile. \\
\hline Nail in blaze in oak tree ( 12 inches diameter). & $28 \mathrm{I}$ & 12 & 30 & xo.93 mete \\
\hline Near peak of barn... & 321 & 03 & & 5 \& mile. \\
\hline
\end{tabular}

\section{BACK.}

General locality.-Eastern shore of Hudson Creek about 5/s mile north of entrance to Back Creek and $\mathbf{x} 3 / 8$ miles north of Casons Point. (See Chart No. 37.)

Immediate locality.-Observed station is on solid ground at edge of woods about 2 feet above high water, $x 4$ yards east of shore, $x 6$ yards northeast of shore, 45 yards south-southeast of shore, and 175 yards north-northwest of a house.

Marks.-Observed station is center point of triangle on standard cement monument projecting 4 inches above surface of ground. Subsurface mark is center of 2 -inch tile pipe buried with top 2 inches below base of monument. 


\begin{tabular}{|c|c|c|c|c|}
\hline References.- & & , & "I & \\
\hline "Bayly"' (S I $\left.{ }^{\circ} 40^{\prime} \mathrm{E}\right)$ & 0 & $\infty$ & $\infty$ & $3 / 8$ mile. \\
\hline Near chimney of house $\ldots \ldots \ldots \ldots \ldots$. & 29 & 44 & . & $3 / 4$ mile. \\
\hline Near peak of house. . & 33 & 20 & . & $5 / 8$ mile. \\
\hline Near peak of barn. & 42 & 5.3 & & I/2 mile. \\
\hline Chimney on near end of house. . . . . . . . . . & $7^{2}$ & 05 & .. & . $3 / 8$ mile. \\
\hline Left chimney of house. . . . . . . . . . . . . & $r_{5} \mathrm{I}$ & 44 & . & $3 / 4$ mile. \\
\hline Nail in blaze in pine tree ( 12 inclies diameter). & 175 & 02 & 50 & 8.05 meters. \\
\hline Nail in blaze in pinc tree ( $\mathrm{r}_{2}$ inches diameter). & 226 & $I_{4}$ & 50 & II. I9 meters. \\
\hline Nail in blaze in pine tree ( $\mathrm{r}_{2}$ inches diameter). & 305 & 13 & 20 & ..... I6.04 meters. \\
\hline Right chimney of house. ........ & 340 & 53 & .. & $\ldots \ldots 175$ yards. \\
\hline
\end{tabular}

\section{BAYLY.}

General locality.-Eastern shore of Hudson Creek about $3 / 8$ mile north of entrance to Back Creek and I mile north of Casons Point. (See Chart No. 37.)

Immediate locality.-Observed station is on marsh about on level with high water, $\mathrm{xI}$ yards east of shore, 20 yards south of shore, 22 yards northeast of shore, 8 yards west of a bank 3 feet high, and 15 yards southwest of a large dead cherry tree.

Marks.-Observed station is center point of triangle on standard cement monument projecting 4 inches above surface of ground. Subsurface mark is center of 2 -inch tile pipe buried with top 2 inches below base of monument.

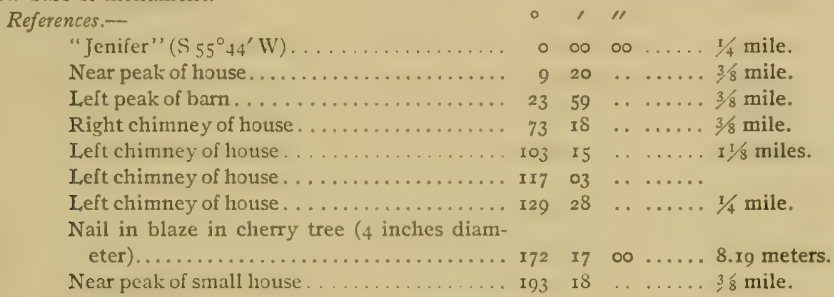

\section{CARRIE,}

General locality.-Eastern shore of Hudson Creek on north side of entrance to Back Creek about $3 / 4$ mile north of Casons Point. (See Chart No. 37.)

Immediate locality.-Observed station is near edge of a cultivated field about 4 feet above high water, I5 yards east of shore, 3 yards east of edge of bank, and I6o yards north of point at north side of entrance to Back Creek.

Marks.-Observed station is center point of triangle on standard cement monument projecting 4 inches above surface of ground. Subsurface mark is center of 2 -inch tile pipe buried with top 2 inches below base of monument.

References.--

"Louise" ( $\left.\mathrm{S}_{2} 8^{\circ}{ }_{5} 6^{\prime} \mathrm{E}\right)$

"Madison Southern M. E. Church Spire"...

Left chimney of house . ............. 74

Chimney in center of house............. Io

Lightning rod on right end of house......... 12

Left dormer window of house............. I74

Left chimney of house.

Nail in blaze in cedar tree (1o inches diam-

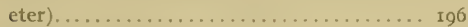

Near peak of barn. .................... 229

Near end of house................... 285 og

Near peak of barn.................. 306 I

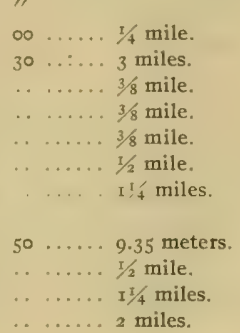




\section{LOUISE.}

General locality.-Eastern shore of Hudson Creek on point at south side of entrance to Back Creek about $1 / 2$ mile north of Casons Point. (See Chart No. 37.)

Immediate locality.-Observed station is on sand and marsh point about $x$ fort above high water, 18 yards north-northeast of shore, 22 yards southeast of shore, 30 yards northwest of shore, and 30 yards east-northeast of extreme end of point.

Marks.-Observed station is center point of triangle on standard cement monument projecting 4 inches above surface of ground. Subsurface mark is center of 2 -inch tile pipe buried with top 2 inches below base of monument.

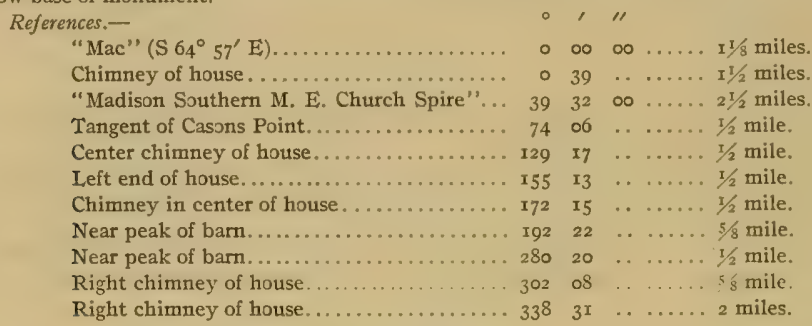

\section{GREENWELL.}

General locality.-Northwestern shore of Little Choptank River on point of land at north side of entrance to a cove between Butter Pot Point and Cedar Point about 3/4 mile northwest of McKeils Point. (See Chart No. 37.)

Immediate locality.-Observed station is on a marsh point about I foot above high water, 5 yards north of shore, 13 yards southwest of shore, and 25 yards northwest of extreme end of point. Cement monument marking reference station is 27.78 meters $\mathrm{N} 35^{\circ} \mathrm{II}$. W of observed station.

Marks.-Observed station is nail in pine stub projecting $\mathrm{I} 2$ inches above surface of ground. Reference station is center point of triangle on standard cement monument projecting 4 inches above surface of ground.

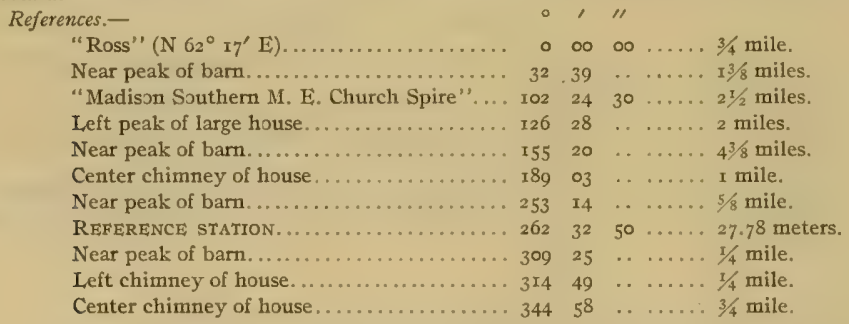

ROSS.

General locality.-Northwestern shore of Little Choptank River on Cedar Point about $3 / 4$ mile north of entrance to Fishing Creek. (See Chart No. 37.)

Immediate locality.-Observed station is on marsh point about I foot above high water, 25 yards southwest of shore, 30 yards west of shore, 60 yards north by west of extreme end of point, and 150 yards east by south of four pine trees.

Marks.-Observed station is center point of triangle on standard cement monument projecting 4 inches above surface of ground. Subsurface mark is center of $z$-inch tile pipe buried with top 2 inches below base of monument. 


\begin{tabular}{|c|c|c|c|}
\hline References.- & 0 & , & $" 1$ \\
\hline "Lee" $\left(\mathrm{N}_{5} \mathrm{I}^{\circ}{ }_{25}{ }^{\prime} \mathrm{E}\right)$. & ○ & $\infty$ & .. 5/8 mile. \\
\hline Chimney on near peak of house........... & $2 \mathrm{I}$ & 43 & .. $23 / 4$ miles. \\
\hline 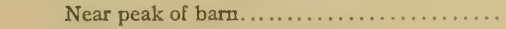 & 23 & ○9 & . $23 / 4$ miles. \\
\hline Chimney on near end of house............ & 43 & 27 & . $7 / 8$ mile. \\
\hline Near peak of barn. .............. & 71 & $3^{2}$ & . I'śs miles. \\
\hline Chimney on left end of house... . & 100 & I3 & .. 2 miles. \\
\hline A cupola...................... & Ior & $\circ 9$ & 2 miles. \\
\hline Left one of four pine trees standing together. . & 233 & I9 & .. I50 yards. \\
\hline Right chimney of $I \frac{\pi}{2}$-story house........... & 272 & 46 & . .... 1/8 mile. \\
\hline 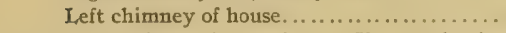 & 292 & II & ....... $13 / 4$ miles. \\
\hline Center of roof of bungalow on Cherry Island. . & $34 \mathrm{I}$ & 28 & . . .... I mile. \\
\hline
\end{tabular}

PHIL.

General locality.-Northwestern shore of entrance to Beckwith and Phillips Creeks on point at west side of entrance to Phillips Creek about $1 / 4$ mile northeast of Cherry Island. (See Chart No. 37.)

Immediate locality.-Observed station is on sand and marsh about I foot above high water, I2 yards southwest of shore, 33 yards north of shore, 25 yards west-northwest of extreme end of point, and 40 yards from trees along edge of cultivated field.

Marks.-Observed station is center point of triangle on standard cement monument projecting 4 inches above surface of ground. Subsurface mark is center of 2 -inch tile pipe buried with top 2 inches below base of monument.

References.-

"Cherry Island Water Tank" (S $\left.72^{\circ} 48^{\prime} \mathrm{E}\right)$.. $\quad 0 \quad 0000 \ldots . .3 / 3$ mile.

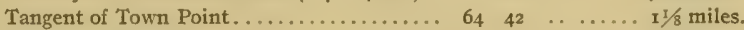

Tangent of McKeils Point............ 82 2r $\ldots \ldots . . .13 / 4$ miles.

Near peak of barn................. roz I5 . . . . $3 / 4$ mile.

Chimney on near end of house.......... 222 r9 $\ldots \ldots \ldots r 1 / 4$ miles.

Chimney on left end of house............ 245 o $\ldots \ldots \ldots 1 / 2$ mile.

Near peak of house.................. 319 $59 \quad \ldots \ldots 3 / 4$ mile.

\section{DUPONT.}

General locality.-Westem shore of Beckwith Creek about I's mile northwest of the northeast end of Cherry Island. (See Chart No. 37.)

Immediate locality. - Observed station is in a grove of small pinc trees about $\mathrm{I}$ foot above high water, I 7 yards west of shore, 25 yards northwest of shore, and 35 yards north of shore.

Marks.-Observed station is center point of triangle on standard cement monument projecting 4 inches above surface of ground. Subsurface mark is center of 2 -inch tile pipe buried with top 2 inches below base of monument.

Refcrences.-

"Cherry Island Water Tank" (S $\left.12{ }^{\circ} 29^{\prime} \mathrm{W}\right)$.. . Center of roof of bungalow on Cherry Island... Chimney on near end of house.

Nail in blaze in holly tree ( 4 inches diameter)...

Near end of $x 1 / 2$-story house. . . . . . . . . . .

Nail in blaze in cedar tree ( 6 inches diameter $). \ldots \ldots \ldots \ldots \ldots \ldots \ldots \ldots$ ro

Near peak of barn. . . . . . . . . . . . 20.20

Near peak of house.................. 24

Between two chimneysi on house . . . . . . 29

Nail in blaze in pine tree ( 6 inches diameter $) . . \ldots \ldots \ldots \ldots \ldots \ldots \ldots \ldots . \ldots \ldots$

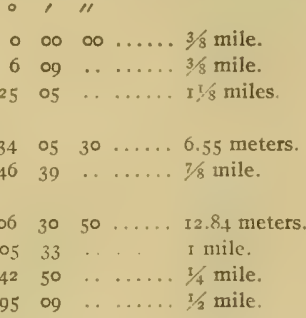

$29740 \ldots \ldots 6.60$ meters 
General locality.-Eastem shore of Beckwith Creek about $1 / 4$ mile northeast of the northeast end of Cherry Island. (See Chart No. 37.)

Immediate locality. - Observed station is near edge of a cultivated ficld about 2 feet above high water, 30 yards northeast of shore, 35 yards east of shore, 35 yards southeast of shore, and about $1 / 8$ mile south by east of small $I \frac{1}{2}$-story house.

Marks.-Observed station is center point of triangle on standard cement monument projecting 4 inches above surface of ground. Subsurface mark is center of 2 -inch tile pipe buried with top 2 inches below base of monument.

References.-

"Cherry Island Water Tank" $\left(\mathrm{S}_{53} 3^{\circ} 40^{\prime} \mathrm{W}\right) \ldots$ o 00 oo $\ldots \ldots 1 / 2$ mile.

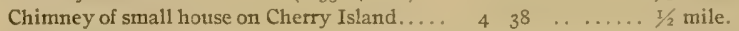

Near peak of bam................... 2I $51 \ldots \ldots$ I/ miles.

Nail in blaze in locust tree (4 inches diameter). 93 og $50 \ldots \ldots 20.32$ meters.

Near peak of barn................. $97 \quad 47 \quad \ldots \ldots .1 / 2$ mile.

Nail in blaze in locust tree ( 3 inches diameter). $102 \quad 49 \quad 30 \ldots \ldots$ 19. 46 meters.

Near peak of barn .................. I $_{5} \quad 55 \ldots \ldots{ }_{2}$ mile.

Left chimey of house.............. $300 \quad 34 \quad \ldots \ldots \ldots$ I/4 mile.

\section{CHERRY ISLAND WATER TANK.}

General locality,-Northeastern side of Little Choptank River on Clierry Island. (See Chart No. $3 \%$.) Immediate locality.-Observed station is on water tower on south end of Cherry Island.

Marks, -Observed station is flagstafi on water tank on Cherry Island.

References.-None necessary.

LEE.

General locality.-North shore of upper Little Choptank River on point between Little Choptank River and Beckwiths Creek. (See Chart No. 37.)

Immediate locality.-Observed station is on a marsh point about I foot above high water, 5 yards northeast of shore, 25 yards south of shore, 60 yards east-southeast of extreme end of point, and 175 yards west-northwest of pine woods at shore. Cement monument marking reference station is II.5I meters $\mathrm{N}_{4}{ }^{\circ} 54^{\prime} \mathrm{E}$ of observed station.

Marks.-Observed station is nail in 3-inch pine stub with top flush with surface of ground. Reference station is center point of triangle on standard cement monument projecting 4 inches above surface of ground.

References.-

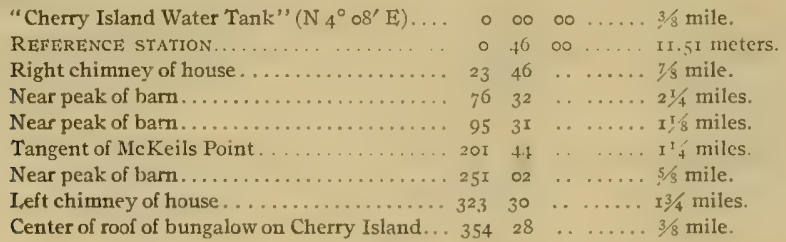

\section{SOLOMON.}

General locality.-Northem shore of upper Little Choptank River on point west at side of entrance to Solomons Cove about $\mathrm{I}^{3} / 8$ miles northeast of Town Point. (See Chart No. 37.)

Immediate locality.-Observed station is on marsh point about on level with high water, I yard east of shore, 3 yards west of shore, and 5 yards north of extreme end of point. Cement monument marking reference station is $\mathrm{r} 4.34$ meters $\mathrm{N}_{2}^{\circ} 39^{\prime} \mathrm{W}$ of observed station.

Marks.-Observed station is nail in cedar stub with top flush with surface of ground. Reference station is center point of triangle on standard cement monument projecting 4 inches above surface of ground. 


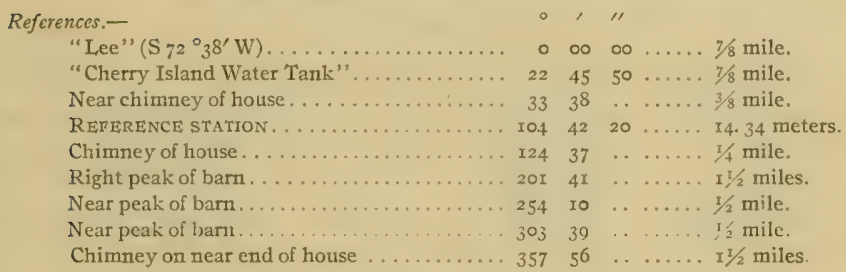

\section{SETH.}

General locality.-Northem shore of upper Little Choptank River opposite' entrance to Smiths Cove, and about $1 / 2$ mile east of Solomons Cove. (See Chart No. 37.)

Immediate locality.-Observed station is on marsh point about on level with high water, 3 yards northwest of shore, 5 yards northeast of shore, and Ioo yards west-southwest of extreme end of point. Cement monument marking reference station is 24.90 meters $\mathrm{N} 26^{\circ} \circ 6^{\prime} \mathrm{W}$ of observed station.

Marks.-Observed station is nail in cedar stub with top flush with surface of ground. Reference station is center point of triangle on standard cement monument projecting 4 inches above surface of ground.

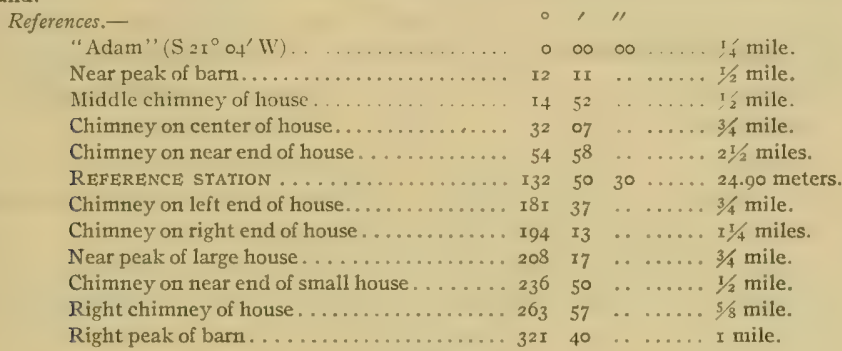

ADAM.

General locality.-Southeastern shore of upper Little Choptank River about $1 / 8$ mile west of entrance to Smith Cove. (See Chart No. 37.)

Immediate locality.-Observed station is on marsh point about on level with high water, 3 yards south of shore, 3 yards southwest of shore, and 6 yards east of shore. Cement monument marking reference station is 27.50 meters $\mathrm{S} 33^{\circ} 3 \mathrm{I}^{\prime} \mathrm{E}$ of observed station.

Marks.-Observed station is nail in cedar stub projecting 5 inches above surface of ground. Reference station is center point of triangle on standard cement monument projecting 4 inches above surface of ground.

References.-

"Seth" ( $\left.\mathrm{N}_{21}^{\circ} 03^{\prime} \mathrm{E}\right)$.

Chimney on $I \frac{1}{2}$-story house

$000 \quad$ '+ mile.

Chimney on right end of house .......... II $50 \ldots$ I $\ldots \ldots$ I $1 / 2$ miles.

Near peak of large house............. If $50 \ldots$. . . I mile.

Chimney on near end of small house...... $42 \quad 36 \ldots \ldots$ imile.

Near peak of barn................ 47 o 7 ...... I mile.

Near peak of barn................. $495^{8} \quad \ldots \ldots \ldots$ I mile.

REFERENCE STATION......... $\quad \ldots . .125 \quad 25 \quad 30 \quad \ldots \quad 27.50$ meters.

Near peak of barn................... $204 \quad 36 \quad \ldots \ldots \ldots 1 / 4$ mile.

Near chimney of house................ 2I I $16 \ldots \ldots \ldots 1 / 4$ mile.

Near peak of barn................... $244 \quad 05 \ldots \ldots 2$ miles. 


\section{LAYTON.}

Gencral locality, - Southeast shore of Little Choptank River about $1 / 2$ mile south of Solomons Cove and $I^{1} / 4$ miles east-northeast of Town Point. (See Chart No. 37.)

Immediate locality.-Observed station is about I foot above high water, 2 yards east of edge of bank I foot high, 23 yards west of shore, 24 yards south-southwest of shore, 30 yards northwest of shore, i8 yards north of a graveyard, and 150 yards northeast of a house. Cement monument marking reference station is 17.13 meters $\mathrm{S} 45^{\circ} \mathrm{oz}^{\prime} \mathrm{E}$ of observed station.

Marks. - Observed station is nail in locust stub with top flush with surface of ground. Reference station is center point of triangle on standard cement monument projecting 4 inches above surface of ground.
References.-
"Lee" (N $\left.79^{\circ} 26^{\prime} \mathrm{W}\right)$
Right chimney of house.....................
"Cherry Island Water Tank"..............
Chimney on center of house...............
Nail in blaze in cedar tree ( 8 inches diam-

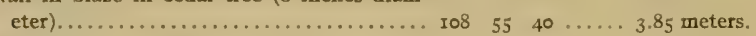

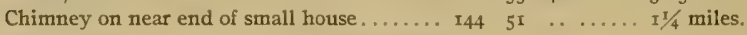
Nail in blaze in cedar tree ( 6 inches diam-

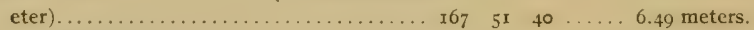
Near chimney of house................ $\mathrm{I}^{2} 2^{2}$ 50 $\ldots \ldots \ldots 1 / 4 \mathrm{mile}$.
REFERENCE STATION............... $2 I_{4} 23 \quad 30 \ldots \ldots$ I7.I3 meters.
Near chimney of house................. $306 \quad 53 \quad \ldots \ldots \ldots$ r50 yards.

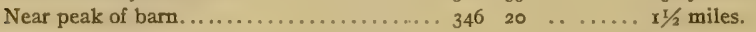

\section{DAVID,}

General locality.-Southern shore of upper Little Choptank River on point about $5 / 3$ mile northeast of Town Point and $3 / 8$ mile southeast of Lee Point. (See Chart No. 37.)

Immediate locality.-Observed station is on a marsh point about on level with high water, 3 yards west of shore, 3 yards east of shore, 3 yards south of extreme end of point, and roo yards north of pine woods. Cement monument marking reference station is 15.24 meters $\mathrm{S}_{2}{ }^{\circ} 58^{\prime} \mathrm{E}$ of observed station.

Marks.-Observed station is a nail in 3 -inch pine stub flush with surface of ground. Reference station is center point of triangle on standard cement monument projecting 4 inches above surface of ground.

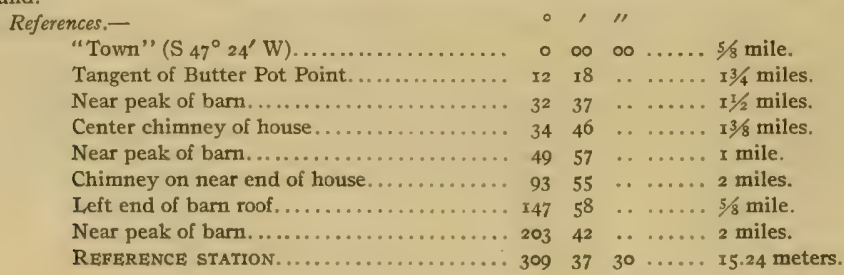

\section{TOWN.}

General locality.--Southeastern shore of Little Choptank River on northeast side of entrance to Fishing Creek on Town Point. (See Chart No. 37.)

Immediate locality.-Observed station is on a small marsh point on the north side of Town Point about I foot above high water, 9 yards east of shore, I 4 yards southwest of shore, I4 yards south-southeast of extreme end of point.

Marks,-O Observed station is center point of triangle on standard cement monument projecting 4 inches above surface of ground. Subsurface mark is center of 2 -inch tile pipe with top 2 inches below base of monument. 


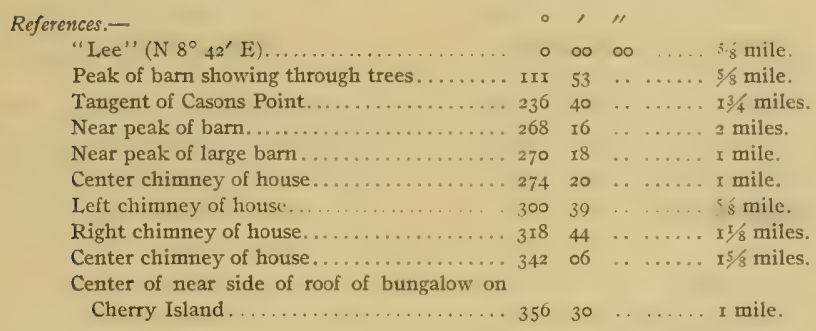

SWEP. .

General locality.-Northeastern shore of Fishing Creek about $3 / 4$ mile east-northeast of McKeils Point and $1 / 4$ mile east-southeast of Town Point. (See Chart No. 37.)

Immediate locality. - Observed station is on firm land about I foxt above high water, 9 yards northeast of shore, ro yards northwest of shore, 7 yards north of extreme end of point, and 30 yards southwest by south of near corner of a dairy.

Marks.-Observed station is center point of triangle on standard cement monument projecting 4 inches above surface of ground. Subsurface mark is center of 2 -inch tile pipe buried with top 2 inches below base of monument.

References.-

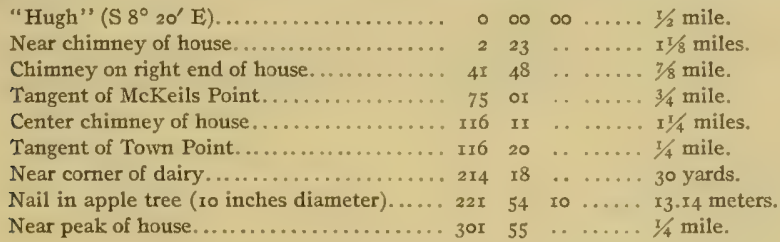

\section{HUGH.}

General locality.-Eastern shore of Fishing Creek about $3 / 4$ mile southeast of Town Point and $3 / 4$ mile northwest of Windmill Point. (See Chart No. 37.)

Immediate locality. - Observed station is on high marsh about 2 feet above high water, xz yards northeast of shore, I3 yards southeast of shore, and 17 yards east of extreme end of point.

Marks.-Observed station is center point of triangle on standard cement monument projecting 4 inches above surface of ground. Subsurface mark is center of 2 -inch tile pipe buried with top 2 inches below base of monument.

\begin{tabular}{|c|c|c|c|c|}
\hline References.- & 。 & & "I & \\
\hline "Etta" (S $\left.64^{\circ} \circ 9^{\prime} \mathrm{E}\right)$. & ○ & $\infty$ & $\infty$ & $1 / 2$ milc. \\
\hline Near peak of barn ....... & 136 & 28 & & 5 s mile. \\
\hline Near chimney of house.... & I38 & 34 & .. & $1 / 2$ mile. \\
\hline Tangent of McKeils Point. . & 168 & 46 & $\ldots$ & . $1 / 2$ mile. \\
\hline Near peak of barn. ........ & I75 & $x_{7}$ & .. & . $2 \frac{1}{2}$ miles. \\
\hline Near peak of barn. . . . . . . . . & 185 & $5^{2}$ & . & . $\mathrm{r}^{5} / 8$ miles. \\
\hline Left chimney of house... & $x 88$ & 25 & .. & ... $\mathbf{I} 5 / 8$ miles. \\
\hline Middle chimney of house.... & 205 & 46 & $\ldots$ & $\ldots \ldots I / 2$ miles. \\
\hline Left chimney of house . . . . . . . . . . & 236 & 05 & $\ldots$ & $\ldots \ldots 1 / 2$ mile. \\
\hline Nail in blaze in twin dead cedar tree. . . . . . . & 252 & 02 & 30 & $\ldots \ldots 13.64$ meters. \\
\hline
\end{tabular}


ETTA.

General locality.-Northeastern shore of Fishing Creek at east side of entrance to a small creek about $1 / 4$ mile north of Windmill Point. (See Chart No. 37.)

Immediate locality.-Observed station is on marsh about I foot above high water, 8 yards east of shore, 9 yards northeast of shore, II yards southeast of shore, and roo yards west of a barn.

Marks.-Observed station is center point of triangle on standard cement monument projecting 4 inches above surface of ground. Subsurface mark is center of 2 -inch tile pipe buried with top 2 inches below base of monument.

\section{References.-}

"Mary" ( $\left.\mathrm{S}_{1}^{\circ} 38^{\prime} \mathrm{E}\right)$ 0,1,

Cupola on Brooks barn............... 28 . 39 .......

Center of cupola on Brooks workshop...... $31 \quad 45 \quad \ldots \ldots .3 / 4$ mile.

Right chimney of house.............. 47 I I $_{3} \ldots \ldots .5 / 8$ mile.

Left peak of house. . . . . . . . . . . . 96 . 59 . . . r mile.

Chimney on near end of house......... 134 o $04 \ldots \ldots \ldots 1 / 8$ mile.

Near peak of house................ I44 II ..... $1 / 8$ mile.

Near peak of large part of house $\ldots \ldots \ldots \ldots \ldots 217 \quad 34 \ldots \ldots \ldots 1 / 8$ mile.

Peak of barn...................... $258 \quad 47 \quad \ldots$ roo yards.

MARY.

Gcneral locality,-Northeastern shore of Fishing Creek on Windmill Point, about $I \frac{1}{2}$ miles southeast of Little Choptank River entrance to Fishing Creek. (See Chart No. 37.)

Immediate locality.-Observed station is on a marsh point about $\mathbf{I}$ foot above high water, II yards northwest of shore, 17 yards southeast of shore, and 18 yards east of shore. Cedar stub marking old station "Windmill Point" is 12.60 meters S $8222^{\prime}$ W of observed station.

Marks.-Observed station is center point of triangle on standard cement monument projecting 4 inches above surface of ground. Subsurface mark is center of 2 -inch tile pipe buried with top 2 inches below base of monument.

References.-

"Neil" (S86 oو' E) ................ o

Near peak of house................... 23 4I ...... $5 / 8$ mile.

Right chimney of house............ 30 x $19 \ldots \ldots$ miles.

Right chimney of house..... . . . . . $47 \quad 26 \quad \ldots \ldots \ldots 5$ mile.

Right chimney of house ............. 100 $37 \ldots \ldots \ldots 1 / 2$ mile.

Left chimney of Brooks house ......... $125 \quad 56 \quad \ldots \ldots 5 / 8$ mile.

Cupola on Brooks workshop............. $x_{32} \quad 58 \quad \ldots \ldots \ldots 5 / 8$ mile.

Right chimney of house............... $15643 \ldots \ldots \ldots$ mile.

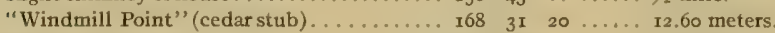

Near peak of barn................ 212 og $\ldots \ldots \ldots 21 / 4$ miles.

NEIL.

General locality.-Northem shore of Fishing Creek about $5 / 8$ mile east of Windmill Point. (See Chart No.37.)

Immediate locality. - Observed station is on third marsh point east of Windmill Point about $\mathrm{I}$ foot above high water, 3 yards north of shore, 5 yards northeast of shore, 5 yards northwest of shore, 70 yards south-southeast of gate to yard of farm house, and II5 yards south of farmhouse. Cement monument marking reference station is 26 . I0 meters $\mathrm{N}_{5}^{\circ} 4 \mathrm{I}^{\prime} \mathrm{E}$ of observed station.

Marks.-Observed station is nail in cedar stub with top flush with surface of ground. Reference station is center point of triangle on standard cement monument projecting 4 inches above surface of ground.
References.-
"Tom" (S $\left.68^{\circ} 55^{\prime} \mathrm{W}\right) \ldots \ldots \ldots \ldots \ldots \ldots \ldots$
Cupola on Brooks barn..................
Center of Brooks workshop cupola............ 
References-Continued.

Near chimney of house. . . . . . . . . . 9.3 9.7

Cupola on barn................... I06 02

REFERENCE STATION................ II6 45

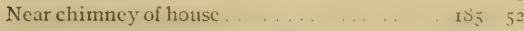

Near peak of house................ I99 48

Lightning rod on right end of house....... $307 \quad 25$

Near peak of house.................. $35^{\mathrm{T}} 38$

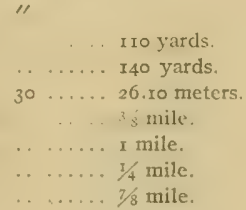

\section{KIRBY.}

General locality.-Northern shore of Fishing Creek opposite entrance to Church Creek about I mile east of Windmill Point. (See Chart No.37.)

Immediate locality.-Observed station is on solid land about I foot above high water, 5 yards north of shore, 6 yards northeast of shore, ro yards east of shore, 45 yards southwest of wire fence, and 125 yards south of a small house. Cement monument marking reference station is 19.99 meters $\mathrm{N} 5^{\circ} 25^{\prime} \mathrm{E}$ of observed station.

Marks.-Observed station is nail in stub with top flush with surface of ground. Reference station is center point of triangle on standard cement monument projecting 4 inches above surface of the ground.

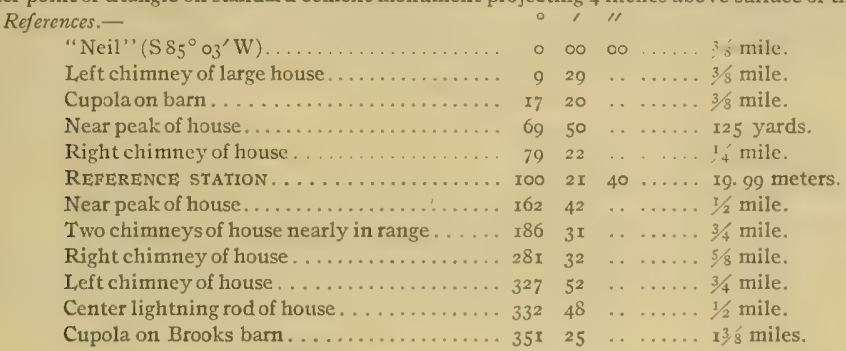

\section{PAUL (LITTLE CHOPTANK RIVER).}

General locality.-Northern shore of Fishing Creek, about I's miles northeast of Deep Water Point. (See Progress map.)

Immediate locality.-Observed station is near edge of a garden about I foot above high water, 8 yards north of shore, xo yards west of shore, 13 yards northeast of shore, and 40 yards southeast of a $I^{1} / 2$-story house. Cement monument marking reference station is 8.53 meters $\mathrm{N} 28^{\circ} 53^{\prime} \mathrm{W}$ of observed station.

Marks.-Observed station is nail in locust stub with top flush with surface of ground. Reference station is center point of triangle on standard cement monument projecting 4 inches above surface of ground.

References.-

"Neil" ( $76^{\circ} 32^{\prime} \mathrm{W}$ ).

pola on barn .......................

Near comer of house...................

RERERENCE STATION..................

Near chimney of house................ I68

Near peak of barn. .................. Igo

Right chimney of house.............. 2

Near peak of barn.................. $25^{8}$

Near peak of barn................. 32 I

Left chimney of house.............. 343

Near peak of house................ 3523

Cupola on Brooks barn................. $35^{8}$

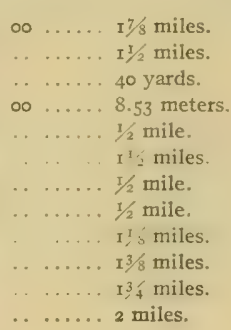




\section{CHURCH CREEK (NO. I WEST).} No. 37.)

General locality.-Western shore of Church Creek, about $3 / 3$ mile south of Fishing Creek. (See Chart

Immediate locality.-Observed station is near edge of cultivated land about 2 feet above high water, 3 yards south of shore, 20 yards northwest of shore, and 30 yards east of extreme end of point. Cement monument marking reference station is 14.60 meters $\mathrm{S}_{4}^{\circ} 47^{\prime} \mathrm{W}$ of observed station.

Marks.-Observed station is nail in stub projecting 2 inches above surface of ground. Reference station is center point of triangle on standard cement monument projecting 4 inches above surface of ground.

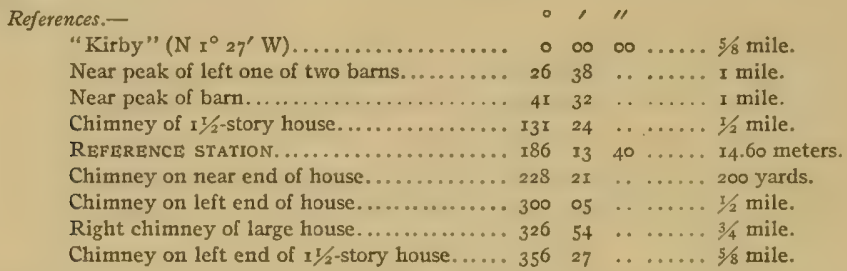

\section{AUSTIN}

General locality._Southern shore of Fishing Creek, on a point about $\$$ s mile east-southeast of Windmill Point. (See Chart No. 37.)

Immediate locality.-Observed station is at edge of young orchard about 3 feet above high water, I8 yards south of shore, 35 yards southwest of shore, 2 yards southwest of edge of bank next to marsh, ro yards east of edge of bank, and 75 yards north-northwest of near corner of a two-story house.

Marks.-Observed station is center point of triangle on standard cement monument projecting 4 inches above surface of ground. Subsurface mark is center of 2 -inch tile pipe buried with top 2 inches below base of monument.

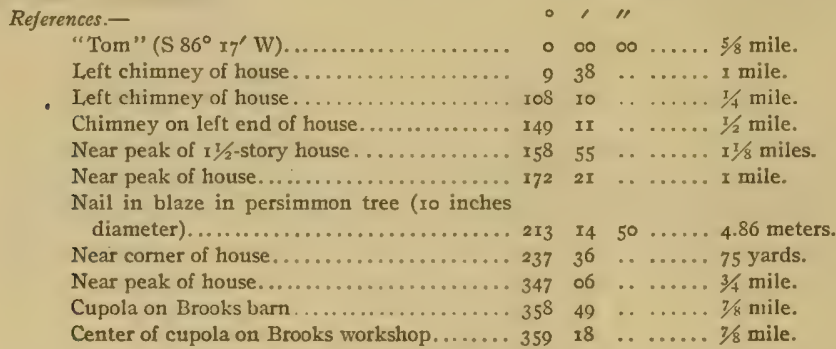

TOM.

General locality.-Southwestern shore of Fishing Creek, on a point of land between two coves, about $1 / 4$ mile south of Windmill Point, and I I/2 miles southeast of Little Choptank River. (See Chart No. 37.)

Immediate locality.-Observed station is on a marsh point about $\mathrm{I}$ foot above high water, 9 yards southwest of end of point, and Io yards southeast of shore.

Marks.-Observed station is center point of triangle on standard cement monument projecting 4 inches above surface of ground. Subsurface mark is center of 2 -inch tile pipe buried with top 2 inches below base of monument. 


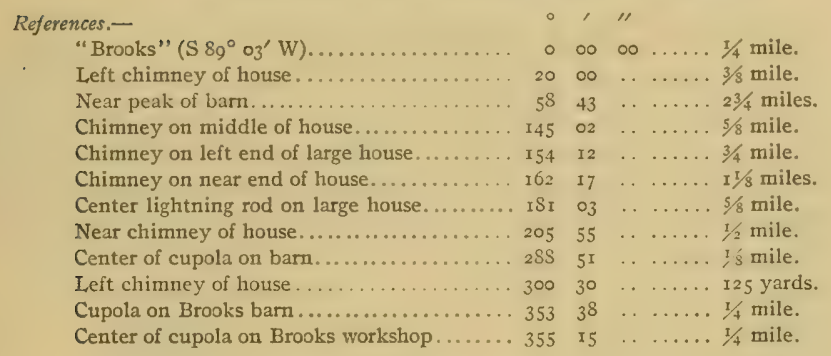

\section{BROOKS.}

General locality.-Southwestern shore of Fishing Creek, near Brooks shipyard, about $1 / 2$ mile south. west of Windmill Point.. (See Chart No. 37.)

Immediate locality. - Observed station is on marsh about 8 yards south of shore, II yards southeast of shore, 15 yards northeast of shore, and 50 yards north by west of northeast end of large workshop.

Marks.-Observed station is center point of triangle on standard cement monument projecting 4 inches above surface of ground. Subsurface mark is center of 2 -inch tile pipe buried with top 2 inches below base of monument.

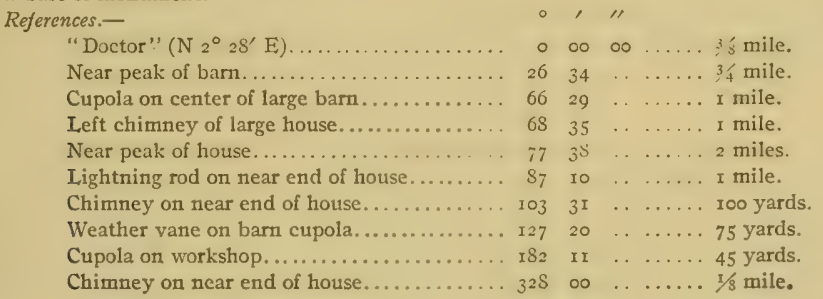

\section{DOCTOR.}

General locality.-Western shore of Fishing Creek on a prominent point about 1 mile southeast of Little Choptank River. (See Chart No. 37.)

Immediate localily. - Observed station is on sand and marsh about I foot above high water, 30 yards southwest of shore, 30 yards northwest of shore, and 25 yards west of extreme end of point.

Marks.-Observed station is center point of triangle on standard cement monument projecting 4 inches above surface of ground. Subsurface mark is center of 2 -inch tile pipe buried with top 2 inches below base of monument.

References.-

\begin{tabular}{|c|c|c|c|c|}
\hline Eleanor"' $\left(\mathrm{N} \mathrm{SI}^{\circ} \circ 4^{\prime}\right.$ & & $\infty$ & & \\
\hline Cangent of McKeils Point. & $3^{2}$ & $5^{\mathrm{I}}$ & . & ${ }_{11}$ \\
\hline iddle dormer window of house. & 34 & 24 & & \\
\hline Jear peak of barn. & 50 & $5^{2}$ & & niles \\
\hline ft chimney of house. . . . . & III & 40 & . & \\
\hline imney of house. & I3I & $2 \mathrm{I}$ & & 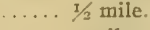 \\
\hline 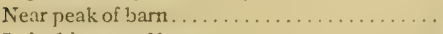 & I93 & $5^{\mathrm{I}}$ & & $m_{4}$ \\
\hline ft chimney of house. . . . . . . & 209 & r6 & & . \\
\hline mney of house.... & $25^{2}$ & $I_{3}$ & $\cdots$ & \\
\hline ane on barn cupola. . . . . . & 257 & 22 & 10 & \\
\hline rkshop........ & 263 & 41 & & \\
\hline
\end{tabular}




\section{FILEANOR.}

General locality.-Southwestern shore of Fishing Creek about $5 / 8$ mile sonth-southeast of McKeils Point, and I mile ssuth of Town Point. (See Chart No. 37.)

Immediate locality.--Observed station is on sandy land at edge of woods about ro yards southwest by south of shore, 15 yards west-northwest of shore, 28 yards west-southwest of extreme end of small marsh point, and 70 yards west-northwest of shore end of fence extending into water at a marsh point.

Marks.-Observed station is center point of triangle on standard cement monument projecting 4 inches above surface of the ground. Subsurface mark is center of 2 -inch tile pipe buried with top 2 inches below base of monument.

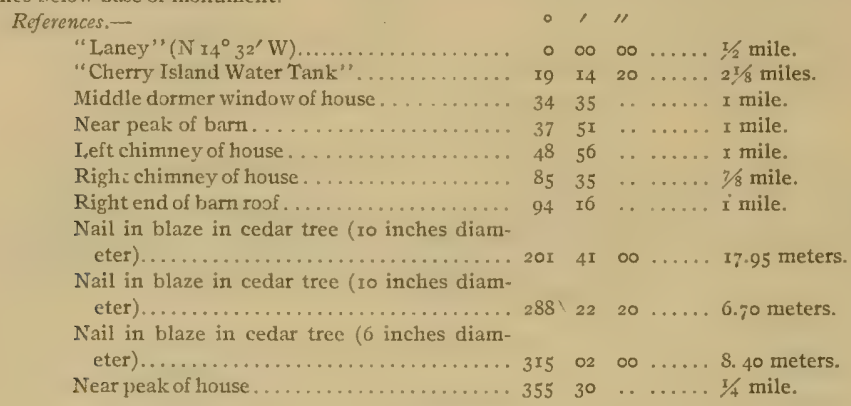

\section{I.ANEY.}

General localily.--Southeastern shore of Little Choptank River on southwestern side of entrance to Fishing Creek on the sortheast end of McKeils Point. (See Chart No. 37.)

Immediate locality.-Observed station is on a marsh point 35 yards southeast of shore, 50 yards northwest of shore, and 35 yards south-southwest of extreme end of point.

Marks.-Observed station is center point of triangle on standard cement monument projecting 4 inches above surface of ground. Subsurface mark is center of 2 -inch tile pipe buried with top 2 inches below base of monument.

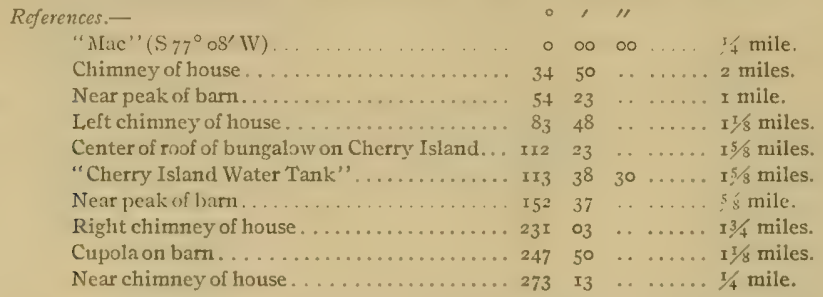

MAC.

Genteral locality.-Southeastern shore of Little Choptank River on northeast side of Tobacco Stick Bay on McKeils Point. (See Chart No. 37.)

Immediate locality.-Observed station is on west side of McKeils Point about 3 feet above high water, I6 yards east of edge of bank, 20 yards southeast of edge of bank, 25 yards northeast of edge of bank, and 150 yards south-southwest of extreme end of point. 
Marks.-Observed station is center point of triangle on standard cement monument projecting 4 inches above surface of ground. Subsurface mark is center of 2 -inch tile pipe buried with top 2 inches below base of montument.

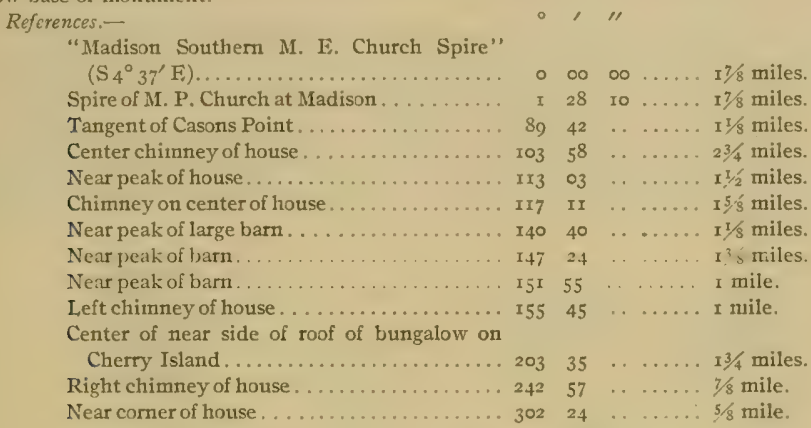

\section{MIADISON SOUTHERN MI, E. CHURCH SPIRE.}

General locality. - Southern shore of I,ittle Choptank River in the town of Madison at the head of Tohacco Stick Bay. (See Chart No. 37.)

Immediate locality.-Observed station is on structure known as Southern M. E. Church, which is the tallest of three spires in the town of Madison.

Marks.-Observed station is spire on Southern M. E. Church.

References,-None necessary.

\section{TOBACCO STICK.}

General locality.-Southem shore of Little Choptank River on the northem end of point between Woolford Creek and Tobacco Stick Bay. (See Chart No. 37.)

Immediate locality.-Observed station is about in the center of a shell pile near end of point about I foot above high water, I 3 yards southeast of shore, 14 yards south of shore, and 30 yards southwest of shore. Cement monument marking reference station is 21.35 meters $\mathrm{S} 29^{\circ} 34^{\prime} \mathrm{E}$ of observed station and about in range with Madison Southern M. E. Church Spire. Four-inch tile pipe marking old reference station is 2.84 meters $\mathrm{N} 76^{\circ} 30^{\prime} \mathrm{E}$ of observed station.

Marks.-Observed station is nail in 6 -inch cedar stub with top flush with surface of ground. Reference station is center point of triangle on standard cement monument projecting 4 inches above surface of ground. Old reference station is 4 -inch tile pipe set in cement.

References.-

"Madison Southern M. E. Church Spire" (S.

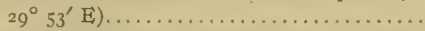

NEW REFERENCE STATION (CEMENT MONUMENT) $\ldots \ldots \ldots \ldots \ldots \ldots \ldots \ldots \ldots \ldots$

Right end of roof of cannery.............

Tangent of James Point................ 122

Chimney on left end of house.............. 16

Chimncy on left end of house ........... is

Near peak of barn.................. $2 \mathrm{xI}$ I6

"Cherry Island Water Tank" ............. $2345^{8}$

Tangent of McKeils Point.............. $240 \quad 46$

OLD REYERFNCE STATION (TILE PIPE) ..... 28622

Near peak of old barn................ 344 5I
- $\infty 00 \ldots . .13 / 4$ miles.

- I8 10 ..... 21.35 meters.

49 ...... I mile.

...... $5 \frac{1}{2}$ miles.

....... $13 / 8$ miles.

3 miles.

...... $15 / 8$ miles.

$50 \ldots \ldots 23 / 4$ miles.

...... r mile.

$50 \ldots .2 .84$ meters.

...... 2 miles. 


\section{WOOL.}

General locality:-Southeastern shore of Little Choptank River on Susquehanna Point 1/4 mile west of entrance to Woolford Creek. (See Chart No. 37.)

Immediate locality.-Observed station is on sand and marsh land about I foot above high water, Io yards south of shore, $1 ;$ yards southwest of shore, and 22 yards cast of shore. Cement monument marking reference station is 24.03 meters $\mathrm{S} 18^{\circ} 12^{\prime} \mathrm{E}$ of observed station. Four-inch tile pipe marking old reference station is 27.12 meters $S 58^{\circ} 3 x^{\prime} W$ of observed station.

Marks.-Observed station is nail in center of 4 -inch tile pipe set in cement with top flush with surface of ground. Reference station is center of point of triangle on standard cement monument projecting 4 inches above surface of ground. Old reference station is nail in center of 4 -inch tile pipe sent in cement projecting about 3 inches above surface of ground.

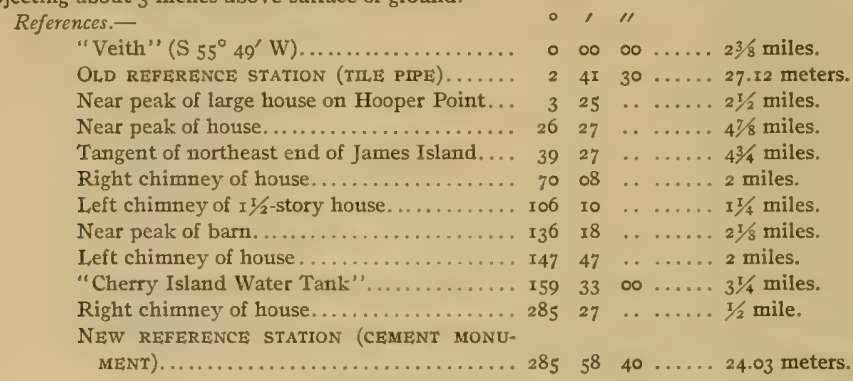

POV.

General localily.-Southern shore of Little Choptank River on extreme end of point about $1 / 4$ mile north of entrance to Parsons Creek about 2 miles south-southeast of Ragged Island, and I I 4 miles east of Hooper Point. (See Charts Nos. 37 and 38. )

Immediate locality.-Observed station is on a marsh point about I foot above high water, 4 yards south of shore, 4 yards southeast of shore, and 8 yards southwest of shore. Tile pipe marking old reference station is 64.66 meters $\mathrm{S} 65^{\circ} \mathrm{I} 7^{\prime} \mathrm{E}$ of observed station. Cement monument marking new reference station is $3 \mathrm{r} .15$ meters $\mathrm{S}_{2} 3^{\circ} 40^{\prime} \mathrm{E}$ of observed station.

Marks.-Observed station is center of 4 -inch tile pipe projecting I2 inches above surface of ground. Old reference station is nail in center of 4 -inch tile pipe set in cement. New reference station is center point of triangle on standard cement monument projecting 4 inches above surface of ground.

References.-

"Hudson" ( $\left.\mathrm{N} 19^{\circ} \mathrm{O4}^{\prime} \mathrm{E}\right)$

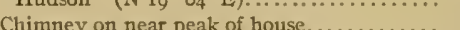

Chimney on right end of same house........

Right chimney of house................. 9

OLD REFERE,NCE STATION (IILE PIPE)...... 95

Near peak of barn................... 100

NEW REFERENCE STATION (MONUMENT) . . . I 137

Near peak of large house. ............. 246

Near peak of house................... 258

Chimney of house................... $26_{3}$

Chimney on left end of house ........... 328

Left side of $x 1 / 2$-story house............ $35^{2}$

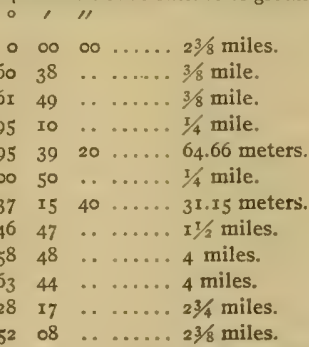


NOBLEE.

General locality.-Eastern side of Slaughter Creek about 1'2 mile northeast of Slaughter Creek Bridge. and $1 / 8$ mile inshore. (See Chart No. 38.)

Immediate locality.--Observed station is in edge of cultivated field on south side of road leading from Madison to Taylor Island, about 250 yards east of shore, 3 yards south of wire fence between field and road, 85 yards west-southwest of farm boundary stone in fence comer near road, and. I35 yards eastnortheast of bam on same side of road as station.

Marks.-Observed station is center point of triangle on standard cement monument projecting 4 inches above surface of ground. Subsurface mark is center of $z$-inch tile pipe buried with top 2 inches below base of monument.

References.-

"Finish" (S $\left.\mathrm{r}_{4}{ }^{\circ} \mathrm{52}^{\prime} \mathrm{W}\right) \ldots \ldots \ldots \ldots \ldots \ldots \ldots$

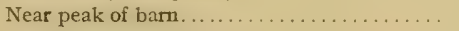

Right chimney of house.............. I

Center of canning house ventilators.........

Center of draw of Slaughter Creek Bridge....

Near peak of Taylor Island wharf house.....

Near peak of store at Taylor Island. . . . . . . .

Near peak of barn.

Nail in blaze in cedar tree ( 4 inches diam-

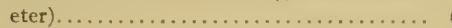

Near chimney of house................

Spindle on barn cupola................ II

Near chimney of house.............. I7

Near peak of house.................. 201

Middle chimney of house.............. 315

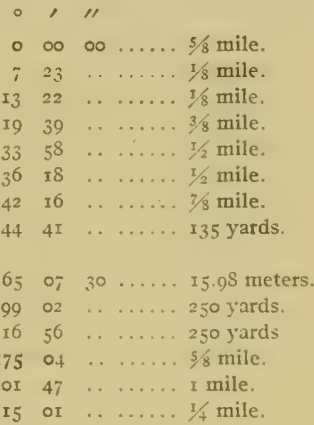

FINISH.

General locality:-Eastern shore of Slaughter Creek about 3's mile southenst of Slaughter Creek Bridge. (See Chart No. 38.)

Immediate locality.-Observed station is in corner of cultivated field, about 50 yards east of shore, I2 yards cast of wire fence between field and marsh, I4 yards north of wire fence between field and woods, and $r 7$ yards northeast of fence corner.

Marks.-Observed station is center point of triangle on standard cement monument projecting 4 inches above surface of ground. Subsurface mark is center of 2 -inch tile pipe buried with top 2 inches below base of monument.

\section{References.-}

"Taylor" ( $87^{\circ} 8^{\prime} \mathrm{W}$ )

Taller stack of canning house at Taylor Island.

Near peak of large dwelling at Taylor Island.

Left chimney of house nearest Slaughter

Creek Bridge......................

Near peak of Taylor Island wharf house.....

Center of draw of Slaughter Creek Bridge. ...

Near peak of old canning house...........

Near peak of barn................... 10

Nail in blaze in pine tree ( 8 inches diameter). 225

Nail in blaze in pine tree ( 12 inches diameter) 246

Nail in blaze in pine tree ( 8 inches diameter). 29

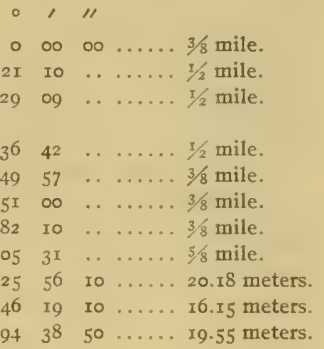
$58345-13-6$ 
TAYLOR.

General locality:- IVestern shore of Slaughter Creek about $1 / 4$ mile south of Slaughter Creek Bridge. (See Chart No. 38.)

Immediate locality.-Observed station is on hard land at edge of marsh about I foot above high water, 22 yards northwest of shore, 28 yards southwest of shore, and 29 yards west of shore.

Marks.-Observed station is center point of triangle on standard cement monument projecting 4 inches above surface of ground. Subsurface mark is center of 2 -inch tile pipe buried with top 2 inches below base of monument.
References.-
"Harrington" ( $\left.\mathrm{N}_{2}{ }^{\circ} 37^{\prime} \mathrm{E}\right)$.

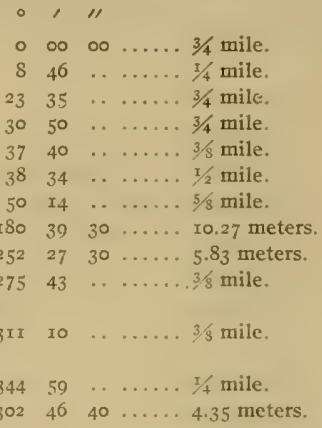
Left side of Taylor Island wharf house ..... $8 \quad 46 \ldots \ldots .1 / 4$ mile.
Spindle on cupola on barn.............. $23 \quad 35 \ldots \ldots .3 / 4$ mile.
Near peak of barn................... 30 , $50 \quad \ldots \ldots \ldots 3 / 4$ mile.
Near peak of old canning house.......... 37 40 . . . . . $3 / 8$ mile.
Left chimney of large house............. $38 \quad 34 \quad \ldots \ldots \ldots 1 / 2$ mile.
Near peak of barn................... $50 \quad r_{4} \ldots \ldots \ldots 5 / 8$ mile.
Nail in blaze in pine tree ( 5 inches diameter). I $80 \quad 3930 \ldots$. ro.27 meters.
Nail in blaze in pine tree ( 5 inches diameter). $\begin{array}{rllll}252 & 27 & 30 & \ldots & 5.83 \\ \text { meters. }\end{array}$
Near peak of house.................. $275 \quad 43 \quad \ldots \ldots \ldots 3 / 8$ mile.
Taller stack of canning house at Taylor
Island ....................
I.eft chimney of house nearest Slaughter
Creek Bridge.................... $344 \quad 59 \quad \ldots \ldots \ldots 1 / 4$ mile.
Nail in blaze in pine tree ( 4 inches diameter). $302 \quad 46 \quad 40 \ldots \ldots 4.35$ meters.

\section{HARRINGTON.}

General locality.-Western shore of Slaughter Creek about 3/8 mile north of Slaughter Creek Bridge. (See Chart No. 38 .)

Immediate locality.-Observed station is on a marsh point at south side of entrance to a creek about on level with high water, 20 yards southwest of shore, 26 yards northwest of shore, 27 yards west of extreme end of point, and 300 yards southeast of a house.

Marks.-Observed station is center point of triangle on standard cement monument projecting 4 inches above surface of ground. Subsurface mark is center of 2 -inch tile pipe buried with top 2 inches below base of monument.

References.-

"Whitewash" ( $\left.\mathrm{N}_{22}{ }^{\circ} 53^{\prime} \mathrm{E}\right) \ldots \ldots \ldots \ldots \ldots$

Chimney on near end of house........... 24

Spindle on cupola on barn............... 6

Near peak of barn................ 8

Near peak of barn................... II

Near peak of old canning house.......... 12

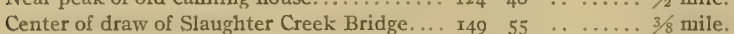

Near gable of house nearest west end of

Slaughter Creek Bridge.............. I6g $26 \ldots \ldots . \ldots 1 / 2$ mile.

Taller stack of canning house at Taylor

Island ..................... 18 I $26 \ldots \ldots \ldots$ mile.

Left chimney of house $\ldots \ldots \ldots \ldots \ldots \ldots \ldots 2 \delta_{2} \quad 29 \quad 20 \ldots \ldots 300$ yards. 


\section{TRAVERS 2 .}

General locality.-Eastern shore of Chesapeake Bay on western side of Taylor Island about 4 miles south of James Point. (See Chart No. $3^{8}$.)

Immediate locality.-Observed station is about 4 feet above high water in a field which was once under cultivation but is now covered with water bushes, about 40 yards east of shore and ${ }_{5} 5$ feet north of a wire fence which starts at the shore and runs east. A stone used as an old reference mark stands 9.4I meters $\mathrm{N} 26^{\circ} 53^{\prime} \mathrm{E}$ of observed station, and the cement monument marking new reference station is $9.5^{2}$ meters $\mathrm{N} 77^{\circ} 20^{\prime} \mathrm{W}$ of observed station.

Marks.-Observed station is a granite post projecting above the ground with crosslines running approximately north to south and east to west. New reference station is center point of triangle on standard cement monument. Old reference station is a cross on a granite post projecting, above the ground with one of the crosslines running in the direction of Cove Point Light.

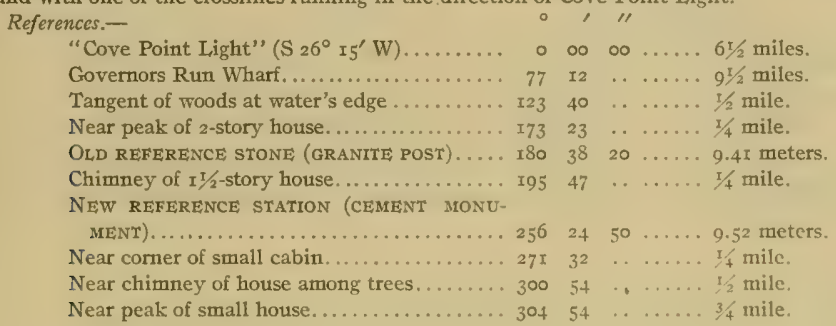

\section{DUNNOCK.}

General locality.-Eastem shore of Chesapeake Bay about $5^{\mathrm{T}} / 4$ miles east of Cove Point Light, and $27 / 8$ miles north-northwest of north end of Barren Island. (See Chart No. $3^{8}$.)

Immediate locality.-Observed station is on a marsh about $x$ foot above high water, 7o yards from shore in line with Cedar Point Light, I08 yards from shore in line with Cove Point Light, and 250 yards from a clump of woods at shore known locally as "Cattle Island Woods." Cement monument marking reference station is 35.18 meters $\mathrm{N} 88^{\circ} 14^{\prime} \mathrm{E}$, of observed station and nearly in line with Cove Point Light.

Marks.-Observed station is center of 2 -inch tile pipe projecting 4 inches above surface of ground. Subsurface mark is center of 2 -inch tile pipe with top 2 inches below base of surface pipe. Reference station is center point of triangle on standard cement monument projecting 6 inches above sturface of ground.

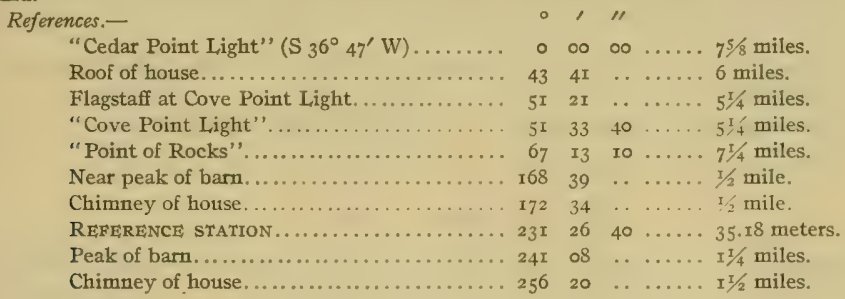




\section{COVE POINT LIGHT.}

General locality.-Western shore of Chesapeake Bay on Cove Point about 5 miles north of entrance to Patuxent River. (See Chart No. 38.)

Immediate locality.-Observed station is on tower known as "Cove Point Light," which is near a detached dwelling and a detached fog-signal house.

Marks.-Observed station is center point of lantern on Cove Point Light.

References.-

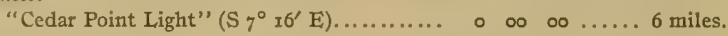

\section{POINT OF ROCKS.}

General locality.-Western shore of Chesapeake Bay on Point of Rocks, about $23 / 4$ miles northwest of Cove Point Light. (See Chart No. $3^{8}$.)

Immediate locality.-Observed station is in dense woods on a bluff about 90 feet high, 5 yards west of edge at extreme point, 8 yards south of edge of bluff, and 5 yards northwest of edge of bluff, Cement monument marking reference station is $9.4^{2}$ meters $\mathrm{S} 66^{\circ} 44^{\prime} \mathrm{W}$ of observed station.

Marks.-Observed station is nail in center of round stake 4 inches in diameter with top flush with surface of ground driven into a 6-inch tile pipe with top 6 inches below surface of ground. Subsurface mark was reported in 1898 as a 6 -inch tile pipe buried with top 2 inches below base of surface pipe. Reference station is center point of triangle on standard cement monument projecting 4 inches above strface of ground.

References.-

"Cove Point Light" ( $\left.\mathrm{S}_{43^{\circ}} 26^{\prime} \mathrm{E}\right) \ldots \ldots \ldots \ldots$.......

Center nail in blaze of tree ( $x_{3}$ inches diam-

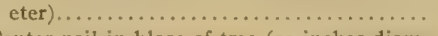

Center nail in blaze of tree ( $\mathrm{I}_{3}$ inches diameter)...................... $90 \quad 0530 \ldots .62$ meters.

REFERENCE STATION............... IIo og $30 \ldots \ldots 9.42$ meters.

Nail in blaze in tree ( 9 inches diameter) ...... I26 $35 \quad 40 \ldots \ldots+4.16$ meters.

Right tangent Governors Run Wharf ...... $186 \quad 20 \quad 20 \ldots \ldots 7 \frac{1}{2} / 2$ miles.

Tangent of main woods............... $249 \quad 57 \quad \ldots \ldots \ldots 81 / 2$ miles.

Left peak of large house ............... $297 \quad 45 \quad 30 \ldots \ldots 6$ miles.

North peak of large house........... 312 17 $30 \ldots \ldots 63 / 4$ miles.

\section{CEDAR POINT LIGHT.}

General locality.-Western shore of Chesapeake Bay on Cedar Point at south side of entrance to Patuxent River, about $3 \frac{1}{4}$ miles east-southeast of Drum Point Light and 6 miles south by east of Cove Point Light. (See Chart No. 39.)

Immediate locality.-Observed station is on a square tower on a square brick dwelling known as Cedar Point Lighthouse.

Marks.-Observed station is center point of lantern on Cedar Point Lighthouse.

References.-

"Cove Point Light" $\left(\mathrm{N} 7^{\circ} \mathrm{I} 6^{\prime} \mathrm{W}\right) \ldots \ldots \ldots$. 0 .

\section{HOOPER ISLAND LIGHT.}

General locality.-Eastern side of Chesapeake Bay offshore about $3^{1 / 2}$ miles west of Hoopers Island, and 4 miles south of Barren Island. (See Chart No. 39.)

Immediate locality.-Observed station is on Hoopers Island Lighthouse.

Maks,-Observed station is center point of lantern on conical tower on cylindrical foundation, known as Hooper Island I,ighthouse.
References.-
"Cedar Point Light" (N $\left.65^{\circ} 04^{\prime} \mathrm{W}\right) \ldots \ldots \ldots$
0 - $00 \ldots . .7$ miles. 


\section{SOUTH.}

General locality.-Eastern side of Chesapeake Bay on western shore of Barren Island, about 43/4 miles north of Hooper Island Light and 6 miles east of Cedar Point Light. (See Chart No. 39.)

Immediate locality.--Observed station is on sandy marsh about i foot above high water and + yards east of rapidly washing shore. Cement monument marking reference station is ror.2I meters N $72^{\circ} 4 \mathrm{O}^{\prime} \mathrm{I}$; of observed station.

Marks.-Observed station is nail in cedar stub about 8 inches in diameter and 4 feet long with top projecting about 20 inches above surface of ground. Reference station is center point of triangle on standard cement monument projecting 6 inches above surface of ground. "South Secondary" is marked the same as the observed station except top was badly bumed, only projecting 3 inches above surface of ground.

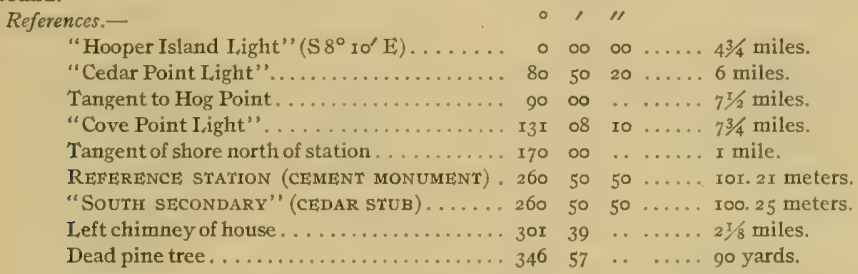

\section{NORTH}

General locality.-Eastem side of Chesapeake Bay on western shore of Barren Island about $3 / 8$ mile south of north end of island and 7 miles east-southeast of Cove Point Light. (See Chart No. 39.)

Immediate locality.-Observed station is on hard land surrounded by water bushes and scrub pines about 2 feet above high water, and 50 yards east-southeast of point where three large pine trees stand near shore. Cement monument marking reference station is $48.7 \mathrm{x}$ meters $\mathrm{N} 72^{\circ} 39^{\prime} \mathrm{F}$ of observed station.

Marks.-Observed station is center one of four nails in cedar stub 8 inches in diameter and 4 feet in length with top projecting about 8 inches above surface of ground. Reference station is center point of triangle on standard cement monument projecting 3 inches above surface of ground. Station called "North Secondary" is marked the same as the observed station except the top of cedar post is about I8 inches above surface of ground.

References.-

"Cove Point Light" ( $\left.\mathrm{N} 64^{\circ} \circ 8^{\prime} \mathrm{W}\right) \ldots . . \ldots$. .

Near peak of house.................. 5

Nail in blaze in pine tree ( 6 inches diameter). $\quad 74$

Nail in blaze in pine tree ( 8 inches diameter). I 6

Nail in blaze in pine tree ( 5 inches diameter). ${ }^{2} 32$

REFERENCE STATION (CEMENT MONUMENT) I I36

NORTH SECONDARY (CEDAR STUB)........ I36

Nail in blaze in pine tree ( 5 inches diameter), 186

"Cedar Point Light". . . . . . . . . . . . . 306

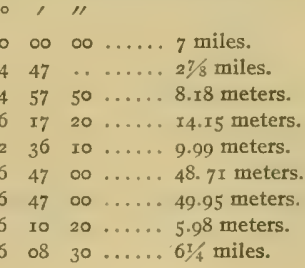

\section{MINT.}

General locality.-Eastern shore of Tar Bay on Charity Point at north side of entrance to Fishing Creek, about $5 / 8$ mile west of Fishing Creek bridge, and $r^{5} s$ miles east of north end of Barren Island. (See Chart No, 39.)

Immediate locality.-Observed station is on shell bank about 4 feet above high water, 2 yards cast of shore, Ir yards southwest of small wild cherry tree, 13 yards west-southwest of another small wild cherry tree, and just west of a dense growth of small trees and brush. Cement monument marking reference

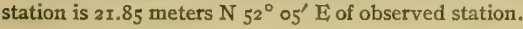


Marks.-Obscrved station is center of 4 -inch tile pipe with top 7 inches below surface of ground. Subsurface mark is center of 4 -inch tile pipe buried with top 2 inches below base of surface pipe. Reference station is center point of triangle on standard cement monument projecting 4 inches above surface of ground.
References.-
"Hosier Memorial Church Spire" ( $\mathrm{S}_{21}{ }^{\circ}$ 24$\left.^{\prime} \mathrm{E}\right)$
"Mt. Zion M. E. Church Spire" . ...........
Chimney on middle of house .............
"Hooper Island Light" . . . . . . . . . . . . . . . .
Chimney on outside of near end of 2-story

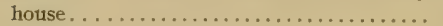
Chimney of shanty. ................
Tangent of north end of Barren Island... . . . . I
Red Beacon...................... 122
Black Beacon . . . . . . . . . . . . . . . . . 123
"Cove Point Light" . . . . . . . . . . . . . . . 130
Left tangent of Cattle Island woods. . . . . . 160 00 $\quad \ldots \ldots . .4$ miles.
Nail in blaze in wild cherry tree $(3$ inches diameter)........................... $233 \quad 20 \quad 00.34$ meters.
REFERENCE StATION.............. $253 \quad 28 \quad 50 \ldots \ldots 21.85$ meters.
Nail in blaze in wild cherry tree ( 5 inches
diameter)........................ 266 Ir. 86 meters.
Left chimney of large 2 -story house..... 356 o7 . . . . $7 / 8$ mile.

\section{KEENES.}

Gcncral locality.-Eastern shore of Honga River on Keenes Point, about $I^{1 / 1} / 4$ miles north-northeast of Fishing Creek Bridge and $3 / 4$ mile east of Cedar Point. (See Charts Nos. 39 and 40.)

Immediate locality.-Observed station is on marsh with dense growth of water bushes alongshore, about I foot above high water, 20 yards north of shore, 30 yards east of shore, and 35 yards south of cultivated land.

Marks.-Observed station is center point of triangle on standard cement monument projecting 4 inches above surface of ground. Subsurface mark is center of 2 -inch tile pipe buried with top 2 inches below base of monument.

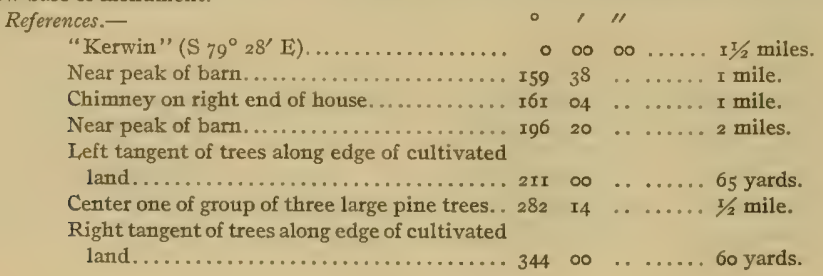

\section{GUNNERS.}

General locality.-Western shore of Honga River on Gunners Island on point at northern side of cntrunce to Gunners Cove, about $5 / 8$ mile north of Long Point and II/s miles southeast of Fishing Creek Bridge. (See Charts Nos. 39 and 40. )

Immcdiate locality.-Observed station is on a marsh with water bushes alongshore, about I foot above high water, 23 yards south west of shore, 28 yards south of shore, 70 yards northwest of extreme end of point, and 170 yards northeast of shore.

Marks.-Observed station is center point of triangle on standard cement monument projecting about 3 inches above surface of ground. Subsurface mark is center of 2 -inch tile pipe buried with top 2 inches below base of monument. 


\begin{tabular}{|c|c|c|c|}
\hline eferences.- & & & \\
\hline "Kerwin" ( $\left.\mathrm{N}_{3} 8^{\circ}{ }_{20}^{\prime} \mathrm{E}\right) \ldots$ & 0 & $\infty$ & .. 2 miles. \\
\hline Near peak of barn............ & 52 & 33 & . $21 / 2$ miles. \\
\hline Chimney on left end of house.............. & 78 & I5 & ..... 2 miles. \\
\hline Right tangent to Wroten Island. . & 112 & 37 & .. I5/8 miles. \\
\hline 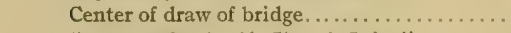 & I34 & 43 & .. $27 / 8$ miles. \\
\hline "Mount Zion M. E. Church Spire" ......... & 170 & 44 & $30 \ldots \ldots . \mathrm{I} 3 / 4$ miles. \\
\hline Left edge of house............... & 239 & 35 & ...... 11/8 miles. \\
\hline Near peak of house .................... & 247 & 12 & ...... I I/8 miles. \\
\hline Center of draw of Fishing Creek Bridge...... & 274 & 40 & ....... II/8 miles. \\
\hline Right edge of old windmill.............. & 275 & $I_{3}$ & ....... $1 \frac{x}{4}$ miles. \\
\hline Near peak of small house........ & 279 & 50 & ...... I1/4 miles. \\
\hline
\end{tabular}

\section{HOSIER MEMORIAL CHURCH SPIRE.}

General locality.-Eastern shore of Tar Bay on Upper Hooper Island, about $5 \frac{3}{8} /$ miles north by east of Hooper Island Light and I mile south of Fishing Creek. (See Charts Nos. 39 and 40.)

Immediate locality.-Observed station is on church known as Hosier Memorial Church.

Marks.-Observed station is center of spire.

References.-None necessary.

\section{MOUNT ZION M. E. CHURCH SPIRE.}

General locality. -Eastern shore of Tar Bay on Upper Hooper Island, about $13 / 4$ miles northwest of Ferry Point and 2 miles south of entrance to Fishing Creek. (See Charts Nos. 39 and 40.)

Immediate locality.-Observed station is on a church known as Mount Zion M. E. Church.

Marks.-Observed station is center of spire on Mount Zion M. E. Church.

References.-None necessary.

\section{BRIDGE.}

General locality-Eastern shore of Chesapeake Bay and western shore of Honga River on Ferry Point at southern end of Upper Hooper Island, about $3 \frac{3}{4}$ miles northeast by north of Hooper Island Light. (See Charts Nos. 39 and 40.)

Immediate locality. - Observed station is on a marsh point, about $\mathrm{I}$ foot above high water, 50 yards west of river shore, 55 yards south of river shore, 85 yards east of shore of bay, 75 yards northeast by north of second telephone pole north of bridge, and 80 yards north-northeast of bridge tender's cabin.

Marks.-Observed station is center point of triangle on standard cement monument projecting 4 inches above surface of ground. Subsurface mark is center of 2 -inch tile pipe buried with top 2 inches below base of monument.

References.-

"Mount Zion M. E. Church Spire" (N $44^{\circ}$ $\left.47^{\prime} \mathrm{W}\right) \ldots \ldots \ldots \ldots \ldots \ldots \ldots \ldots \ldots \ldots \ldots$

Near peak of oyster house................

"Hosier Memorial Church Spire" .......... I4

Left tangent of Wroten Island . . . . . . . . . . 5

Near peak of barn.................. 68

Center of roof of old windmill............ I2

Outside chimney of right end of house...... 164

Chimney in center of large house........... I7 I

Chimney in center of house............. 185 .

"Hooper Island Light" ................ 262

\begin{tabular}{|c|c|c|}
\hline$\infty$ & ০o & ... I5/8 miles. \\
\hline 28 & . & ..... II I $/ 2$ miles. \\
\hline 59 & $\infty$ & $\ldots \ldots 2_{25 / 3}$ miles. \\
\hline $\mathrm{I} 2$ & .. & ..... 2 miles. \\
\hline 33 & .. & ...... II $1 / 2$ miles. \\
\hline 20 & . & $\ldots \ldots, 33 / 4$ miles. \\
\hline$\bullet 3$ & $\cdots$ & ..... I mile. \\
\hline I5 & $\cdots$ & 4 miles. \\
\hline 25 & -. & $\cdots \cdots$ \\
\hline $5^{\mathrm{I}}$ & $5^{\circ}$ & … $33 / 4$ miles. \\
\hline
\end{tabular}

APPLEGARTH.

General locality.-Eastern shore of Chesapeake Bay on south end of Hooper Island, about $3^{1 / 2}$ miles east of Hooper Strait Light. (See Chart No. 40.)

Immediate locality.-Observed station is on marsh, about I foot above high water and I50 yards north of shore. 
Marks.-Observed station is center point of triangle on standard cement monument projecting 3 inches above surface of ground. Subsurface mark is center of 2 -inch tile pipe buried with top 2 inches below base of monument.

References.-

"Hooper Strait Light" ( $\left.88_{3}^{\circ} 45^{\prime} \mathrm{E}\right) \ldots \ldots \ldots$. o 00 o $\ldots \ldots 3 \frac{1}{2}$ miles.

"Point no Point Light"................ I32 34 10 ..... 10 $1 / 2$ miles.

"Hooper Island Light"............... r89 II $30 \ldots \ldots 6$ miles.

Left one of row of large pine trees........ I92 $20 \quad \ldots \ldots \ldots 1 / 8$ mile.

"Hoopersville Methodist Church Cupola"... 214 $53 \quad 30 \ldots \ldots 27 / 8$ miles.

Chimney of house................... 230 o5 $\ldots \ldots \ldots 3 / 4$ mile.

Chimney in middle of house............. $246 \quad 47 \quad \ldots \ldots \ldots, 3 / 4$ mile.

"Hopkins Mcmorial Church Cupola"..... $257 \quad 45$ oo .... $3 / 4$ mile.

Chimney in center of house............. $259 \quad 52 \quad \ldots \ldots \ldots 3 / 4$ mile.

Chimney of abandoned house............ 27 I $25 \ldots \ldots \ldots 1 / 2$ mile.

Near peak of house showing over roof...... 278 of $\ldots \ldots \ldots 1 / 2$ mile.

Right tangent of clump of pine trees. ...... $295 \quad 33 \quad \ldots \ldots .300$ yards.

HOPKINS MEMORIAL, CHURCH CUPOLA.

Gencral locality.-Eastern shore of Chesapeake Bay in small village of Applegarth on Lower Hooper Island, about $2^{3} \mathrm{~s}$ miles southeast by east of Hooper Island Wharf, and $3.4 \%$ miles east-southeast of Hooper Strait Light. (See Chart No. 40.)

Immediate locality.-Observed station is on church known as Hopkins Memorial Church.

Marks.-Observed station is center of bell cupola.

References.-None necessary.

\section{HOOPERSVILLE METHODIST CHURCH CUPOLA.}

Gencral locality.- Eastern shore of Chesapeake Bay in town of Hoopersville on Middle Hooper Island, about $1 / 4$ mile southwest of Hooper Island Wharf. (See Chart No. 40.)

Immediate locality.-Observed station is on church known as Hoopersville Methodist Church.

Marks.-Observed station is center of bell cupola.

References.-None necessary.

\section{BENTLEY.}

General locality.-Southwestern shore of Honga River on the north side of Bentley Point about 2 miles south of Wroten Island, and $I^{1} / 2$ miles east of drawbridge at Ferry Point. (See Chart No. 40.)

Immediate locality.-Observed station is on marsh about I foot above high water, 30 yards southwest of shore, 45 yards east of shore, and 50 yards southeast by south of a small marsh point.

Marks,-Observed station is center point of triangle on standard cement monument projecting 4 inches abuve surface of ground. Subsurface mark is center of 2 -inch tile pipe buried with top 2 inches helow base of monument.

References.-

\begin{tabular}{|c|c|c|c|c|}
\hline $29^{\prime}$ W) $\ldots \ldots \ldots \ldots \ldots \ldots \ldots \ldots \ldots \ldots \ldots \ldots$ & & & & $2 \pi$ \\
\hline Tear peak of house..................... & 9 & 38 & & \\
\hline & 97 & 12 & & \\
\hline & 99 & 26 & & \\
\hline . & 116 & 08 & 50 & \\
\hline & 120 & 37 & & \\
\hline & I25 & 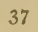 & & \\
\hline & 142 & $\infty$ & & \\
\hline & I5I & 40 & & \\
\hline & $x 7 x$ & $3^{2}$ & & \\
\hline & 236 & 48 & .. & \\
\hline & 326 & 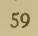 & 40 & \\
\hline ster house at Hooper Island & & & & \\
\hline
\end{tabular}




\section{KERWIN.}

General locality.--Northeastern shore of Honga River about $2 \frac{1}{4}$ miles east-northeast of Fishing Creek Bridge, and $I^{1} / 2$ miles east of Keenes Point. (See Chart No. 40.)

Immediate locality. - Observed station is on marsh about I foot above high water, 60 yards east of shore, 60 yards northwest of shore, and 55 yards north-northeast of end of point.

Marks.-Observed station is center point of triangle on standard cement monument projecting 4 inches above surface of ground. Subsurface mark is center of 2 -inch tile pipe buried with top 2 inches below base of monument.

References.-

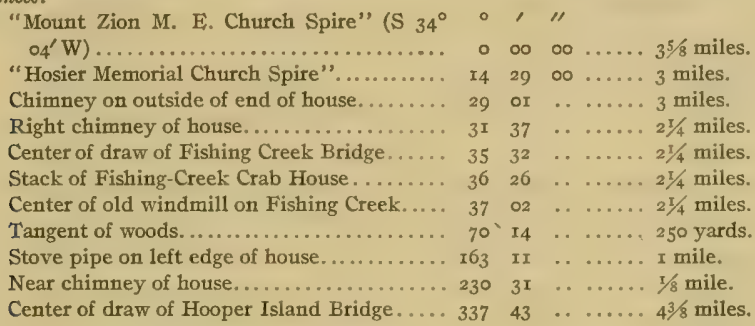

\section{WROTEN.}

General locality.-Northeastern shore of Honga River on southern shore of Wroten Island about $21 / 2$ miles north-northwest of Bentley Point. (See Chart No. 40.)

Immediate locality.-Observed station is on marsh about I foot above high water, 40 yards west of shore, 55 yards northwest of shore, and roo yards north of extreme end of point.

Marks.-Observed station is center point of triangle on standard cement monument projecting 3 inches above surface of ground. Subsurface mark is center of 2 -inch tile pipe buried wtih top 2 inches below base of monument.

References.-

"Charles" ( $\left(\mathrm{S} 65^{\circ} 22^{\prime} \mathrm{E}\right) \ldots \ldots \ldots \ldots \ldots \ldots$. $\ldots \ldots \ldots$.

Chimney on right end of house.......... $7^{8} \quad 32 \ldots \ldots .23 / 8$ miles.

Center of draw of Hooper Island Bridge..... $98 \quad 49 \quad \ldots \ldots \ldots 2$ miles.

"Mount Zion M. E. Church Spire"......... I44 $29 \quad 50 \ldots \ldots .21 / 4$ miles.

Right edge of house in trees............ I6r $54 \ldots \ldots .5 / 8$ mile.

Near peak of barn.................. I74 I3 $\ldots \ldots .3 / 8$ mile.

Near peak of house.................. $2705^{6} \quad \ldots \ldots .3 / 4$ mile.

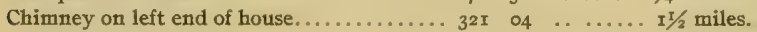

\section{CHARLES.}

General locality.-Northeastern shore of Honga River about $13 / 4$ miles north of Bentley Point, and $2^{\mathrm{T}} / 2$ miles east-northeast of drawbridge at Ferry Point. (See Chart No. 40.)

Immediate locality.-Observed station is on firm land about $\mathrm{I}$ foot above high water, 20 yards eastsoutheast of shore, 30 yards northwest of shore, 50 yards north-northeast of shore, and 40 yards southwest by south of large tree near bend in a rail fence.

Marks.-Observed station is center point of triangle on standard cement monument projecting 4 inches above surface of ground. Subsurface mark is center of 2 -inch tile pipe buried with top 2 inches below base of monument. 


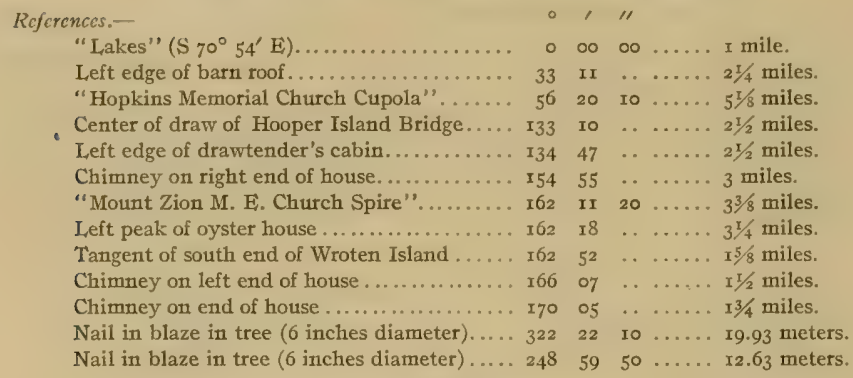

LAKES.

General locality.-Northeastern shore of Honga River on a point at northern side of entrance to Lakes Cove about $I \frac{T}{2} /$ miles north-northeast of Bentley Point. (See Chart No. 40.)

Immediate locality. -Observed station is on marsh about I foot above high water, 26 yards north of shore, 65 yards northeast of shore, and 70 yards east of shore.

Marks.-Observed station is center point of triangle on standard cement monument projecting 3 inches above surface of ground. Subsurface mark is center of 2 -inch tile pipe buried with top 2 inches below base of monument.

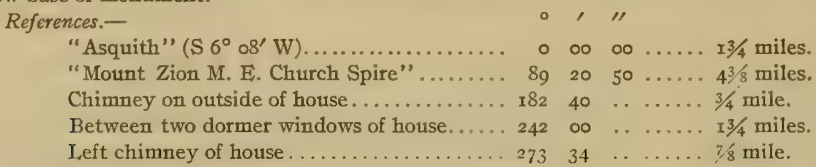

\section{ASQUITH.}

General locality.-Eastem shore of Honga River on Asquith Island, about $21 / 2$ miles northeast of Hoopersville, and $7 / 8$ mile north of Windmill Point. (See Chart No. 40.)

Immediate locality.-Observed station is on strip of sandy marsh between a pond and river about 2 feet above high water, 3 yards west of shore of pond, II yards east of shore of river, and 50 yards south of end of point.

Marks.-Observed station is center point of triangle on standard cement monument projecting 4 inches above surface of ground. Subsurface mark is center of 2 -inch tile pipe with top about 2 inches below base of monument.

References.-

"Hoopersville Methodist Church cupola"

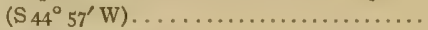

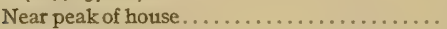

Near peak of barn......................

Near peak of small barn. ................

Nail in blaze in pine tree ( $x_{5}$ inches diam-

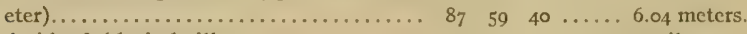

Left side of old windmill.............. I54 5 I ...... 2 miles.

Near peak of house.................. 557 50 $\ldots \ldots \ldots 21 / 8$ miles.

Nail in blaze in pine tree ( 12 inches diam-

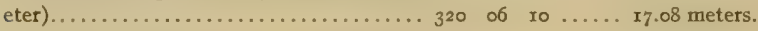

Nail in blaze in pine tree ( 15 inches diam-

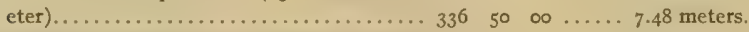

Tangent to outside end of Hooper Island wharf. 
WINDMILI, 2 .

General locality. - Eastem shore of Honga River on Windmill Point, about $17 / 8$ miles east-northeast of Hoopersville. (See Chart No. 40.)

Immediate locality.-Observed station is on marsh about I foot above high water, 25 yards northnortheast of end of point, 35 yards east of shore, and 30 yards northwest of shore. Cement monument marking reference station is 19.78 meters $\mathrm{N}_{3} 6^{\circ} 4 \mathrm{r}^{\prime} \mathrm{E}$ of observed station.

Marks. - Observed station is nail in stub in 4 -inch tile pipe with top of pipe 4 inches below surface of ground. Reference station is center point of triangle on standard cement monument projecting 4 inches above surface of ground.

References.-

"Hoopersville Methodist Church Cupola"

$\left(\mathrm{S} 64^{\circ}{ }_{22}^{\prime} \mathrm{W}\right) \ldots \ldots \ldots \ldots \ldots \ldots \ldots \ldots \ldots \ldots$

Two house chimneys about in line. . . . . . . . .

Center of store doorway in Hoopersville. . . . . .

Near peak of house...................

"Mount Zion M. E. Church spire" . . . . . . . .

"Hosier Memorial Church Spire" . . . . . . . . 68

Tangent to Bentley Point..............

Near gable of house . . . . . . . . . . . r r 49

REFERENCE STATION . . . . . . . . . . . . I52

Near peak of cabin . . . . . . . . . . . . I $8_{3}$

"Toddville M. E. Church Spire" ......... 184

Center gable of house .................. 185

St. Thomas Church Spire" "

St. Thomas Church Spire ............... 2 II $06 \quad 20 \ldots \ldots$ 4 $1 / 8$ miles.

Left tangent Hooper Island Wharf $\ldots \ldots \ldots .35^{6} \quad 25 \quad \ldots \ldots \ldots$ I $\ldots \ldots$ miles.

PAUL, (HONGA RIVER).

General locality.-Eastern shore of Honga River on Paul Point at northwestern side of entrance to Fox Creek, about $\mathrm{I} / 2$ miles east-northeast of Windmill Point, and $3 / 4$ mile southwest of Wingate Point. (See Chart No. 40.)

Immediate locality.-Observed station is on marsh point about I foot above high water, 7 yards west of shore, 13 yards northwest of shore, 25 yards north-northeast of extreme end of point, 50 yards northnorthwest of a small marsh island, and 55 yards east-northeast of a cabin.

Marks.-Observed station is center of triangle on standard cement monument projecting 4 inches above surface of ground. Subsurface mark is center of 2 -inch tile pipe buried with top 2 inches below base of monument.

References.-

"St. Thomas Church Spire" ( $\left.\mathrm{S} 7 \mathrm{I}^{\circ} \mathrm{I} 8^{\prime} \mathrm{E}\right)$....

Left side of small cabin on Crab Point. ..... 3

"Hopkins Memorial Church Cupola"..... 9 I $26 \quad 30 \ldots \ldots 25 / 8$ miles.

Between two stacks on oyster house on

Hooper Island Wharf. . . . . . . . . . . $x_{3} 6 \quad 08 \ldots \ldots .3$ miles.

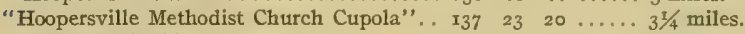

Near corner of cabin................ $x_{50} \quad 0_{5} \ldots \ldots \ldots 53$ yards.

Near peak of house.................. r 95 4r ...... I mile.

Peak of barn........................ 24 I $26 \ldots 2$ miles.

Center one of three chimneys on large house. . $273 \quad 57 \quad \ldots \ldots \ldots 1 \frac{1}{1 / 2}$ miles.

Chimney of Wingate Wharf waiting room.... $304 \quad 38 \quad \ldots \ldots \ldots 5 / 8$ mile.

"Toddville M. E. Church Spire"........ 319 46 o0 .... 31/4 miles.

Flagstaff on hall at Bishop Head ......... $35929 \quad \ldots \ldots \ldots 27 / 8$ miles.

\section{TODDVILLE M. E. CHURCH SPIRE.}

General locality.-On neck of land between Fishing Bay and Honga River in town of Toddville, about $2 \frac{1}{2}$ miles east of Wingate wharf. (See Chart No. 40.)

Immediate locality.-Observed station is on church known as Toddville M. E. Church.

Marks.-Observed station is center of spire.

References.-None necessary. 


\section{DUCK (HONGA RIVER).}

General locality.-Eastern shore of Fox. Creek on Piney Point, at north side of entrance to Duck Point Cove, about $3 / 4$ mile southeast of Wingate Point. (See Chart No. 40.)

Immediate locality.-Observed station is on a marsh point $I$ foot above high water, 50 yards south of shore, 50 yards north of shore, and 65 yards east-northeast of end of point.

Marks.-Observed station is center point of triangle on standard cement monument projecting 4 inches above surface of ground. Subsurface mark is center of 2 -inch tile pipe buried with top 2 inches below base of monument.

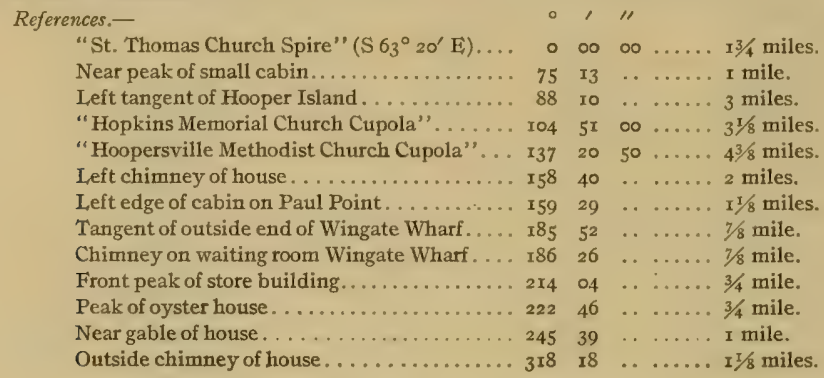

\section{ST. THOMAS CHURCH SPIRE.}

General locality.-Eastern shore of Honga River in town of Bishop Head, about $2 \frac{1}{2}$ miles southeast by east of Wingate Wharf, and $23 / 4$ miles north of Hooper Strait Light. (See Chart No. 40.)

Immediate locality.-Observed station is on church known as St. Thomas Church.

Marks.-Observed station is center of spire.

References.-None necessary.

\section{NORMAN.}

General locality. -Eastern shore of Honga River, about $2 \frac{\pi}{2}$ miles north-northwest of Hooper Strait Light, and $1 / 2$ mile south of Crab Point. (See Chart No. 40.)

Immediate locality.-Observed station is on marsh about I foot above high water, 60 yards east of shore, 70 yards northeast of shore, and 80 yards southeast of shore.

Marks.-Observed station is center point of triangle on standard cement monument projecting 4 inches above surface of ground. Subsurface mark is center of 2 -inch tile pipc buried with top 2 inches below base of monument.

References.-

"Hooper Strait Light" ( $\left.35^{\circ} \mathrm{II}^{\prime} \mathrm{E}\right)$..........

Right tangent of woods................. s

Left edge of small house................ 28

Tangent of lower end of Hooper Island..... .

"Hopkins Memorial Church Cupola" . . . . . .

"Hoopersville M. E. Church Cupola". .... I 27

Between two stacks on oyster house at Hoop-

ers Island Wharf.

Front peak of store building. ............. 205

Near peak of house.................. 216

Left one of two chimneys close together. . . 248

Near peak of canning house............ $250 \quad 36$

Flagstaff on hall at Bishop Head........... 284

"St. Thomas Church Spire".............. 285

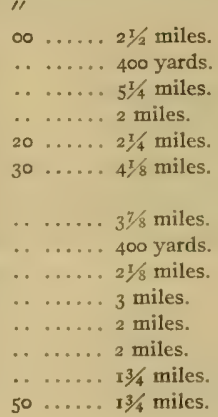




\section{HOOPER STRAIT LIGHT.}

General locality.--Northern side of Hooper Strait at eastern side of entrance to Honga River about $2_{1}{ }^{1}$ i miles ivest-northwest of southern end of Bishop Head, and 3 miles east-southeast of Lower Hooper Island. (See Chart No. 40.)

Light.

Immediate locality.-Observed station is on hexagonal, screw-pile structure known as Hooper Strait

Marks.-Observed station is center of lantern on Hooper Strait Light.

References.-

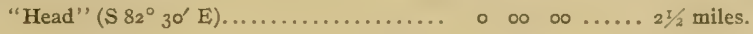

\section{CRAB.}

General locality.-Western shore of upper Tangier Sound on eastern side of Bloodsworth Island, about I mile southeast of entrance to Piney Island Cove, I mile northeast of entrance to Great Cove, and $25 / 3$ miles southwest of Sharkfin Shoal Light. (See Chart No. 4r.)

Immcdiate locality.-Observed station is about I foot above high water, 15 yards southwest of shore, 35 yards west of shore, and I50 yards south-southwest of a crab house.

Marks.-Observed station is center point of triangle on standard cement monument.

References.-

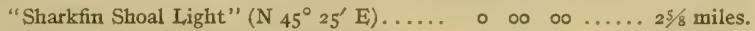

Left end of large house near Stump Point... 6 II $\ldots \ldots, 7 \frac{7}{8}$ miles.

End of roof of house on bluff. .......... $3 x \quad 36 \quad \ldots \ldots .6 \%$ miles.

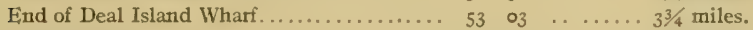

Large house .................... $7^{2} \quad 35 \quad \ldots \ldots \ldots 44^{1 / 4}$ miles.

Aspen tree near "Joshua" ............. 88 o6 ...... 58 miles.

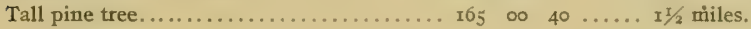

HEAD.

Gencral locality.- Upper end of Tangier Sound, on eastern side of southern part of peninsula known as Bishop Head, situated between Hooper Strait and Fishing Bay. (See Chart No. 4I.)

Immediate locality.-Observed station is on marsh behind water bushes which skirt shore, about I5 yards southwest of shore, and $1 / 2$ mile north of extreme south end of Bishop Head. Cement monument

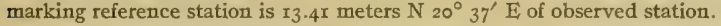

Marks.-Observed station is a nail in a pine stub flush with ground. Reference station is center point of triangle on standard cement monument.

References.-

"Sharkfin Shoal Light" ( $\left.60^{\circ} 4 \mathrm{I}^{\prime} \mathrm{E}\right)$......

Crab-house flagstaff................... 50 $30 \ldots \ldots .31 / 4$ miles.

Large pine tree...................... $97 \quad 42 \ldots \ldots .2$ miles.

REFERENCE STATION................. I3 $_{39} 55 \quad 40 \ldots \ldots$ 13.4I meters.

Near gable of $2 \frac{1}{2}$-story house............. $140 \quad 24 \ldots \ldots \ldots .1 / 4$ mile.

Chimney of house..................... ${ }_{5} 5^{6} \quad 44 \ldots \ldots .1 / 8$ mile.

Chimney of house.................... $208 \quad 28 \quad \ldots \ldots \ldots x$ miles.

Chimney of end of house.............. $238 \quad 53 \quad \ldots \ldots 3$ miles.

Right side of Nanticoke Point woods..... $326 \quad 5^{6} \quad \ldots \ldots 7 \frac{1}{2}$ miles.

\section{CROCH.}

General locality.-Western shore of Fishing Bay about $4 \frac{1}{2}$ miles northwest of Sharkfin Shoal Light, and $1 / 4$ mile north-northeast of entrance to Tedious Creek. (See Chart No. 4r.)

Immediate locality.-Observed station is on marsh about $\mathrm{I}$ foot above high water, 45 yards southwest of shore, 50 yards west of shore, 60 yards northwest of shore, and 150 yards north of a small marsh island covered with water bushes.

Marks.--Observed station is center point of triangle on standard cement monument projecting 4 inches above surface of ground. Subsurface mark is center of 2 -inch tile pipe buried with top 2 inches below base of monument. 


\begin{tabular}{|c|c|c|c|}
\hline eferences.- & - & , & $\prime \prime$ \\
\hline "Sharkfin Shoal Light" ( $\left.\mathrm{S}_{39^{\circ}} \circ 9^{\prime} \mathrm{E}\right) \ldots .$. & $\circ$ & $\infty$ & . $4^{\pi / 2}$ miles. \\
\hline Right chimney of house................ & 36 & 59 & . $2 \frac{1}{8}$ miles. \\
\hline 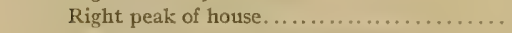 & 59 & 35 & . I $1 / 2$ miles. \\
\hline Chimney in middle of large building. & 79 & 02 & I $5 / 3$ miles. \\
\hline Chimney in middle of house.... & 92 & $5^{I}$ & $I \frac{1}{2}$ miles. \\
\hline Near peak of house. .......... & 120 & II & $5 / 8$ mile. \\
\hline Near peak of house................ & 142 & $4 \mathrm{r}$ & $5 / 8$ mile. \\
\hline Chimney outside of right end of house..... & 197 & 39 & ... $\mathrm{I}^{3} / 8$ miles. \\
\hline Between two chimneys of house nearly in line. & 204 & 40 & ... I I $1 / 4$ miles. \\
\hline Near peak of house. ................... & 219 & 18 & ....... r mile. \\
\hline Chimney outside of right end of house....... & $24 \mathrm{I}$ & 56 & ...... 4 miles. \\
\hline
\end{tabular}

\section{ROAST.}

General locality.-Western shore of Fishing Bay on Roasting Ear Point, about 53/4 miles nortl. northwest of Sharkfin Shoal Light, $4^{\mathrm{T}} / 2$ miles north of Bishop Head, and $3 / 4$ mile rortheast of entrance to Goose Creek. (See Chart No. 4r.)

Immediate locality.-Observed station is on marsh about $\mathrm{x}$ foot above high water, 40 yards northwest of shore, 40 yards west of shore, and 70 yards south by west of shore.

Marks.-Observed station is center point of triangle on standard cement monument projecting 4 inches above surface of ground. Subsurface mark is center of 2 -inch tile pipe buried with top 2 inches helow base of monument.

References.-

"Sharkfin Shoal Light" $\left(S_{2 x^{\circ}} 4 I^{\prime} E\right) \ldots \ldots .00000 \ldots .5 \frac{3}{4}$ miles.

Left chimney of house on Bishop Head.... $30 \quad 05 \ldots \ldots+4 \frac{1}{8}$ miles.

Near peak of house................. $45 \quad 23 \ldots \ldots .3$ miles.

Chimney on left end of house........... 69 15 $\ldots \ldots \ldots 2$ miles.

Smokepipe on near house.............. $733^{36} \ldots \ldots \ldots \mathrm{I}^{3 / 3} / \mathrm{m}$ miles.

Tallest one of five pine trees............. $95 \quad 24 \quad \ldots \ldots$ I mile.

Stack of canning house on Farm Creek..... I I $29 \quad \ldots \ldots \ldots 21 / 2$ miles.

Stack of canning house on Elliott Island . . . 2 $2 x_{9} \quad 33 \quad \ldots \ldots \ldots 2$ miles.

Chimney outside of near end of house . . . . $229 \quad 35 \quad \ldots \ldots \ldots$ I $7 / 8$ miles.

Chimney in middle of house.......... 233 or . . . 2 miles.

Between two gables of large house........ 236 oo ...... 2 miles.

Windmill............................ 240 miles.

FARM.

General locality.-Western shore of Fishing Bay on point at south side of entrance to Cedar Creek, about 15,8 miles west of Fishing Point, and $3 / 4$ mile northeast of entrance to Farm Creek. (See Chart No. 4I.)

Immediate locality.-Observed station is on marsh about I foot above high water, 20 yards south of shore, 60 yards northwest of shore, 45 yards west-southwest of extreme end of point, ro yards east-northeast of a small pond in marsh, and 300 yards south by east of a small oyster watch house on opposite side of Cedar Creek.

Marks.-Observed station is center point of triangle on standard cement monument projecting 4 inches above surface of ground. Subsurface mark is center of 2 -incli tile pipe buried with top 2 inches below base of monument.

References.-

"Toddville M. E. Church Spire" ( $\left.\mathrm{S}_{45}{ }^{\circ} \mathrm{S}^{\prime} \mathrm{W}\right)$.

Chimney in middle of house..............

Stack of canning house on Farm Creek. . .....

Near comer of small shanty. . . . . . . . . . . 5

Smoke pipe on small shanty . . . . . . . . . 8

Left chimney of house............... 20

Stack of canning house at Elliott Island . . . . . 239

Near peak of house.................. 322

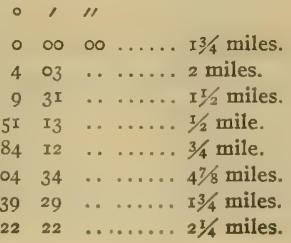


THORO.

General locality.-Western shore of Fishing Bay about $3 / 4$ mile northeast of entrance to Thoroughfarc Creek, and II/2 miles north of Fishing Point on the western end of Elliott Island. (See Chart No. 4I.)

Immediate locality.--Observed station is on marsh about I foot above high water, 40 yards northwest of shore, 50 yards north-northeast of shore, 55 yards northeast by north of shore, and I 30 yards east-northeast of entrance to a small creek.

Marks.-Observed station is center point of triangle on standard cement monument projecting 4 inches above surface of ground. Subsurface mark is center of 2 -inch tile pipe buried with top 2 inches below base of monument.

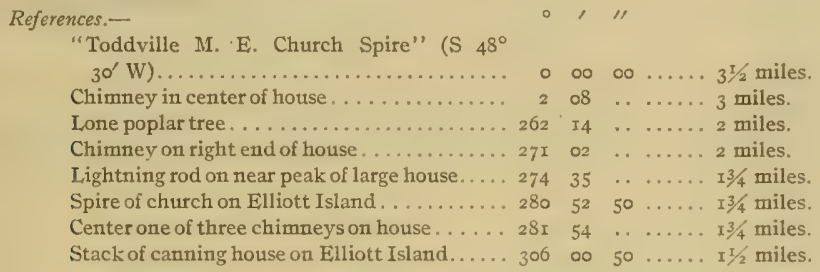

\section{HIGH.}

General locality.-Southeastern shore of Upper Fishing Bay on Elliott Island, about $3 / 3$ mile eastnortheast of extreme end of Fishing Point. (See Chart No. 4r.)

Immediate locality.- Observed station is on high sandy land in a grove of pine trees, about 30 yards east-southeast of edge of bank, and 35 yards west-northwest of near corner of west one of five sheds in a row.

Marks.-Observed station is center point of triangle on standard cement monument projecting 4 inches above surface of ground. Subsurface mark is center of 2 -inch tile pipe buried with top 2 inches below base of monument.

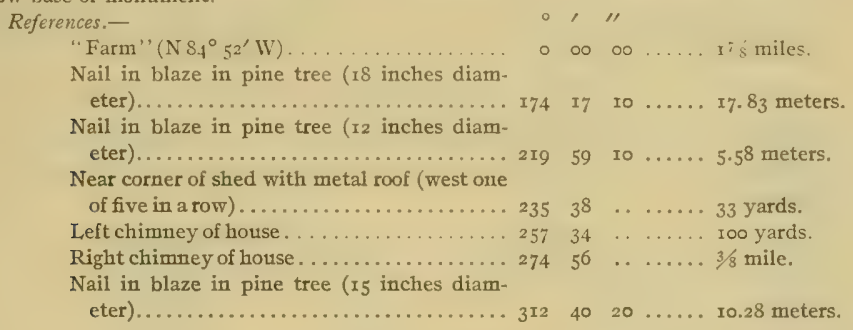

\section{ELLIOTT.}

General locality.-Eastern shore of Fishing Bay on Fishing Point at the extreme western end of Elliott Island about $5 \frac{1}{2}$ miles north-northwest of Clay Island, and opposite entrance to Farm Creek. (See Chart No. 4I.)

Immediate locality.-Observed station is on sandy marsh about I foot above high water, I6 yards south of shore, 20 yards north of shore, 30 yards east-northeast of extreme end of sandy point, 185 yards west-southwest of a sand ridge near trees and brush, and 290 yards northwest of a canning house.

Marks.-Observed station is center point of triangle on standard cement monument projecting 4 inches above surface of ground. Subsurface mark is center of 2 -inch tile pipe buried with top $z$ inches below base of monument. 


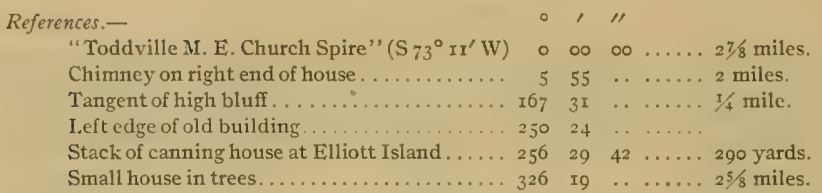

\section{EAR.}

Gencral locality.-Eastem shore of Fishing Bay, about $61 / 8$ miles north of Sharkfin Shoal Light, I3/4 miles east-northeast of Roasting Ear Point, and $\mathrm{I} 3 / 4$ miles southeast of Fishing Point, on Elliott Island. (See Chart No. 4r.)

Immediate locality.-Observed station is on marsh about I foot above high water, 20 yards northeast of shore, 30 yards north by west of shore, and 40 yards east by south of shore.

Marks.-Observed station is center point of triangle on standard cement monument projecting 4 inches above surface of ground. Subsurface mark is center of 2 -inch tile pipe buried with top 2 inches below base of monument.

\begin{tabular}{|c|c|c|c|c|}
\hline References.- & & & & \\
\hline "Sharkfin Shoal Light" (S $5^{\circ} 49^{\prime}$ E) ........ & 0 & $\infty$ & $\infty$ & $61 / 8$ miles. \\
\hline Chimney on left end of house............... & 31 & 23 & .. & $5^{1 / 8}$ miles. \\
\hline Chimney in middle of large building........ & 46 & $2 I$ & . & 5 miles. \\
\hline Near peak of barn............... & 70 & 22 & .. & $21 / 2$ miles. \\
\hline "Toddville M. E. Church Spire" ........... & 102 & I2 & 30 & . $3 \frac{3}{4}$ miles. \\
\hline Stack of canning house at Elliott Island.... & 145 & 59 & .. & . $I / 2$ miles. \\
\hline Chimney on right end of house......... & 151 & 22 & .. & $I \frac{1}{4}$ miles. \\
\hline 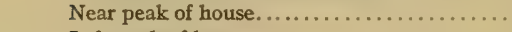 & 164 & 03 & . & $I 1 / 4$ miles. \\
\hline Left peak of barn.................... & 197 & 45 & . & ... I $1 / 4$ miles. \\
\hline "Nanticoke Church". . & $29 I$ & 53 & 50 & - $5^{1 / 8}$ miles. \\
\hline
\end{tabular}

\section{FISH.}

General locality.-Eastern shore of Fishing Bay, about $4 \frac{3}{3} \mathrm{~s}^{-}$miles north of Sharkfin Shoal Light, $3^{1 / 4}$ miles suth -southeast of Elliott Island, and $2 \frac{1}{4}$ miles north-northeast of point of Clay Island. (See Chart No. 4I.)

Immediate locality.-Observed station is on marsh about I foot above high water, 50 yards northeast of shore, 60 yards east of shore, and 85 yards north-northeast of shore.

Marks.-Observed station is center point of triangle on standard cement monument projecting 4 inches above surface of ground. Subsurface mark is center of 2 -inch tile pipe buried with top 2 inches below base of monument.
References.-
"Sharkfin Shoal Light" (S $\left.x^{\circ} 5^{\prime} \mathrm{W}\right) \ldots \ldots$ Center gable of house at Bishop Head.......
Near peak of house....................

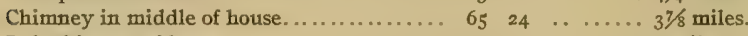
Left chimney of house................ 90 or .....
Near peak of house................. 99 25 . . . . 3 miles.
Stack of canning house on Farm Creek..... I20 $0_{5} \ldots \ldots . \ldots 5$ miles.
Stack of canning house on Elliott Island.... I46 I7 $\ldots \ldots .3 \frac{1}{2}$ miles.
"Nanticoke Church"................ $26_{3} \quad 46 \quad 40 \ldots \ldots 41 / 4$ miles.

\section{FROG.}

General locality.-Western side of entrance to Nanticoke River, on Frog Point, at southeastern end of Clay Island. (See Chart No. 4r.)

Immediate locality.-Observed station is on marsh point about 20 yards west of shore, 25 yards east of shore, 25 yards from extreme end of point, and in front of water bushes. Cement monument marking reference station is $\mathrm{I}_{3} . \mathrm{I0}$ meters $\mathrm{N}_{3}{ }^{\circ} \mathrm{xI}^{\prime} \mathrm{E}$ of observed station. 
Marks.-Observed station is nail in stub flush with ground. Reference station is center point of triangle on standard cement monument.

\begin{tabular}{|c|c|c|c|}
\hline ferences.- & 0 & , & $" \prime$ \\
\hline "Sharkfin Shoal Light" ( $\left.\mathrm{S}_{4 I^{\circ}}{ }_{2} 5^{\prime} \mathrm{W}\right) \ldots .$. & $\circ$ & $\infty$ & $\infty \ldots \ldots 3^{1} / 8$ miles. \\
\hline 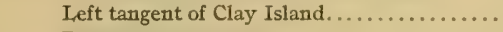 & 35 & 17 & $I I / 4$ miles. \\
\hline 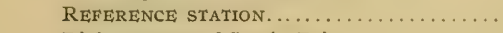 & 141 & 45 & I3.10 meters. \\
\hline Right tangent of Sandy Point. ............ & $\mathbf{x 7 7}$ & $4 \mathrm{I}$ & $3 / 4$ mile. \\
\hline 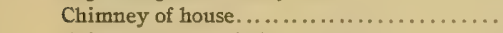 & $\mathbf{1 7 9}$ & 12 & . $2 \frac{1}{2}$ miles. \\
\hline Chimney near end of large house......... & 183 & 02 & .. $21 / 2$ miles. \\
\hline Stack of canning house ................... & 184 & 36 & $21 / 2$ miles. \\
\hline Land end of Nanticoke Wharf............ & 184 & 36 & .. $2 \frac{1}{2}$ miles. \\
\hline End of Nanticoke Wharf house............ & I86 & $\infty$ & $\ldots \ldots \ldots 2 \frac{1}{4}$ miles. \\
\hline 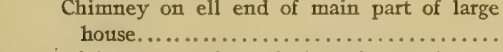 & $2 I I$ & 27 & .. $21 / 4$ miles. \\
\hline $\begin{array}{l}\text { Right tangent of Nanticoke Point woods..... } \\
\text { Large square chimney of house (Dames Quar- }\end{array}$ & 238 & 44 & . $23 / 4$ miles. \\
\hline ter) $\ldots \ldots \ldots \ldots \ldots \ldots \ldots \ldots$ & 204 & 17 & $\cdots \cdots$ \\
\hline Rock Creek poplar tree..................... & 284 & $x_{7}$ & ...... 3 3/2 miles. \\
\hline Flagstaff on Deal Island Wharf............. & 322 & $\circ 9$ & .. ... $43 / 4$ miles. \\
\hline
\end{tabular}

Cow.

General locality.-Western shore of Nanticoke River, on Mink Point, about $3 / 8$ mile east of entrance to Cow Creek and $\mathrm{I} 3 / 8$ miles west of Roaring Point. (See Chart No. 4I.)

Immediate locality.-Observed station is on very soft marsh at edge of water bushes about 5 yards west of shore, ${ }_{5}$ yards northeast of shore, and $x_{5}$ yards northwest of extreme end of point. Cement monument marking reference station is 8.68 meters $\mathrm{N}_{44^{\circ}} 28^{\prime} \mathrm{W}$ of observed station.

Marks.-Observed station is a nail in a pine stub flush with ground. Reference station is center point of triangle on standard cement monument.

References.-

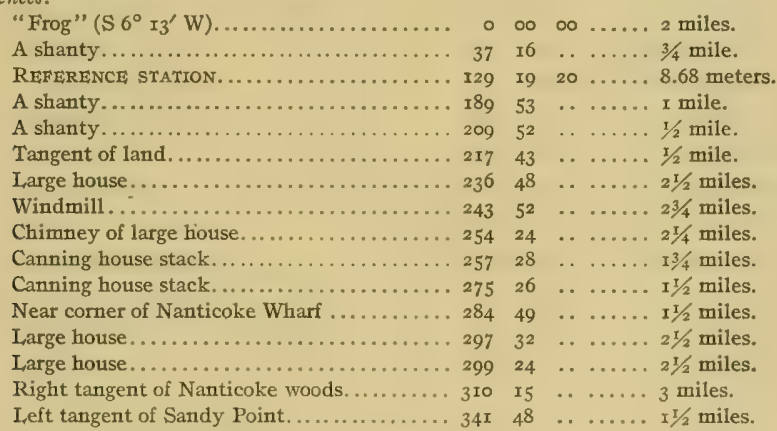

OKAY.

General locality.-Western shore of Nanticoke River, on Marsh Point, about $1 / 3$ mile south of Swan Creek Cove and 2 miles west of Bivalve Wharf. (See Chart No. 4I.)

Immediate locality,-Observed station is on marsh about 2 feet above high water, ro yards back from shore, and 35 yards south of shanty known as Insley's watch house.

Marks.-Observed station is center point of triangle on standard cement monument projecting 4 inches above surface of ground.

$58345-13-7$ 


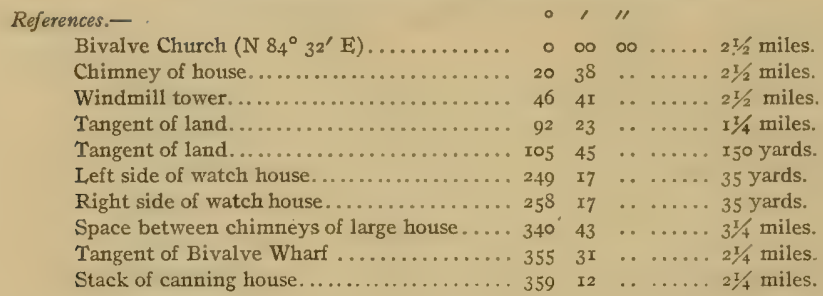

\section{AR.}

General locality. - Western shore of Nanticoke River about $I \frac{1}{2}$ miles northwest of Bivalve Wharf, and $3 / 4$ mile north-northeast of entrance to Longrell Creek. (See Chart No. 4I.)

Immediate locality.-Observed station is on marsh between two small creeks about 40 yards back from shore, 35 yards west-southwest of mouth of one creek, and 45 yards northwest of the mouth of the other creek.

Marks.-Observed station is center point of triangle on standard cement monument, projecting 4 inches above surface of ground.

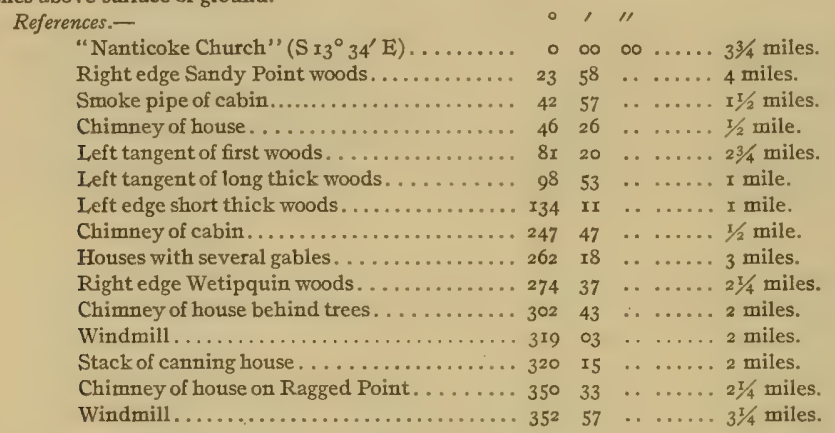

GOVER.

General locality.-Northwestern shore of Nanticoke River about $13 / 4$ miles west-northwest of entrance to Wetipquin Creek and $1 / 8$ mile north of a cove named Perch Haul. (See Progress map.)

Immediate locality.-Observed station is on a point of marsh covered with grass and water bushes, about I 5 yards northwest of extreme end of point, 200 yards cast-northeast of a shanty among bushes and small trees, $1 / 4$ mile east of a clump of about 50 pine trees, and $1 / 4$ mile southeast of another clump of trees.

Marks.-Observed station is center point of triangle on standard cement monument projecting 4 inches above surface of ground.

References.-

Bivalve Church $\left(\mathrm{S}_{21}{ }^{\circ} 30^{\prime} \mathrm{E}\right)$

Tangent of land.

Left side of opening in woods .

Two pine trees together..................

Center of shanty....................

Clump of pine trees. . . . . . . . . . . . . . . . 12

Clump of pine trees.

$\begin{array}{lcllll}\circ & \prime & \prime \prime \\ \circ & 00 & 00 & \ldots & 23 / 4 \text { miles. } \\ 35 & 24 & \ldots & \ldots & x \text { mile. } \\ 72 & 06 & \ldots & \ldots & 2 \text { miles. } \\ 83 & 07 & \ldots & \ldots & 3 / 4 \text { mile. } \\ 98 & 26 & \ldots & \ldots & 200 \text { yards. } \\ 23 & 56 & \ldots & \ldots & 1 / 4 \text { mile. } \\ 76 & 20 & \ldots & \ldots & 1 / 4 \text { mile. }\end{array}$


References-Continued.

Inside edge of cove............... 201 $45 \ldots \ldots$ roo yards.

Clump of small pine trees............. $255 \quad 31 \quad \ldots \ldots \ldots r / 4$ mile.

Tangent to point of land .............. $2696 \quad 35 \quad \ldots \ldots \ldots .1 / 2$ miles.

Left tangent of Sandy Hill Wharf........ ${ }_{276}$ o2 ..... 3 miles.

Large house....................... $286 \quad 27 \quad \ldots \ldots .3 \frac{1}{1 / 4}$ miles.

Left edge of pine woods near Wetipquin

Creek. $\begin{array}{lllll}328 & x_{3} & \ldots & \ldots & 2 \\ & \text { miles. }\end{array}$

\section{STREETT}

General locality.-Northwestern shore of Nanticoke River on point on southwest side of entrance to Jacks Creek. (See Progress map.)

Immediate locality.-Observed station is on a marsh and grass point about 7 yards west from its extreme end and 4 yards from each side of point to north and south. Cement monument marking reference station is $\mathrm{Ir} .89$ meters $\mathrm{N} 60^{\circ} 22^{\prime}$ W of observed station.

Marks.-Observed station is nail in pine stub flush with ground. Reference station is center point of triangle on standard cement monument projecting 4 inches above surface of ground.

References.-

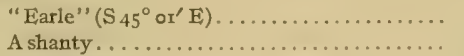

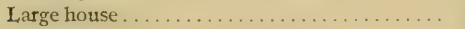

Canning-house stack at Tyaskin . . . . . . . . 33

Large building. . . . . . . . . . . . . . . 36

Point of marsh . . . . . . . . . . . . . . . . 4

First of four trees. . . . . . . . . . . . . . 135

REFERENCE STATION. . . . . . . . . . . . . 164

Point of marsh. .................. 255

House on the other side of Jacks Creek....... $25^{8}$

Left tangent of Sandy Hill Wharf. . . . . . . . . . 309

A house......................... 318 os

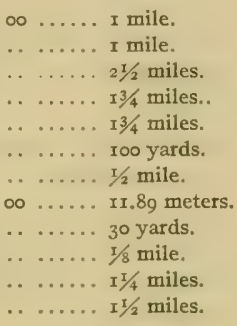

EARLE

General locality.-Southeastern shore of Nanticoke River about I mile below Sandy Hill Wharf. (See Progress map.)

Immediate locality.-Observed station is on sandy and grass land between the river and a pine grove about 5 feet above high water, 80 yards back from shore, 15 yards southeast of a white oak tree, about $2 \frac{1}{2}$ feet in diameter, I 5 yards southwest of another and larger white oak tree, and 20 yards east of a shanty.

Marks.-Observed station is center point of triangle on standard cement monument projecting 4 inches above surface of ground.

References. -

"Juliet" ( $\left.\mathrm{S}_{4 \mathrm{I}^{\circ}} 0^{\prime} \mathrm{W}\right) \ldots \ldots \ldots \ldots \ldots \ldots \ldots$

Nail in blaze in white oak tree $(2 \mathrm{x} / 2$ feet diameter)........................ $88 \quad 44 \quad 30 \ldots \ldots .98$ meters.

Nail in blaze in pine tree.............. $160 \quad 3900 \ldots \ldots 19.05$ meters.

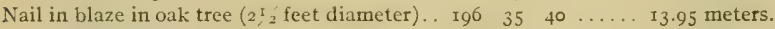

Nail in blaze in pine tree.............. 326 or $00 \ldots \ldots .76$ meters.

Right tangent of woods on other side of Wetipquin Creek................... $35^{8} \quad 5^{2} \quad \ldots \ldots \ldots, 1 \frac{1 / 2}{2}$ miles.

JULIET.

General locality.-Eastern shore of Nanticoke River on point on southwest side of entrance to Wetipquin Creek. (See Progress map.)

Immediate locality,-Observed station is on sand and marsh point about roo yards southwest of entrance to Wetipquin Creek, Io yards back from high water, 5 yards outside of several small pine trees. and roo yards north of dense pine woods. 
Marks.-Observed station is center point of triangle on standard cement monument projecting 4 inches above surface of ground.

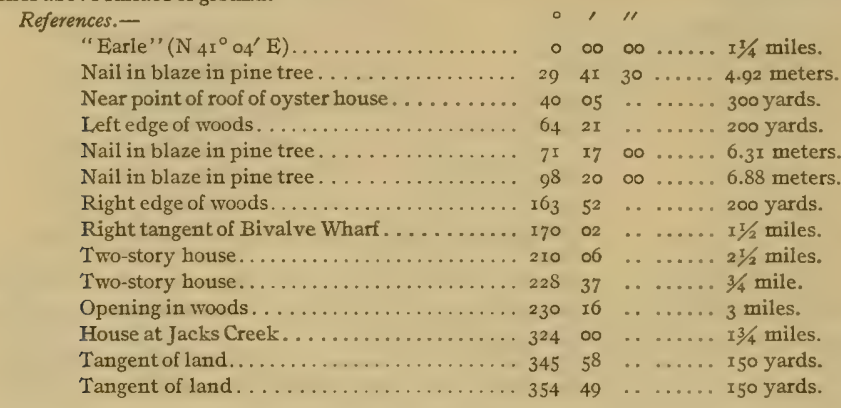

POLE.

General locality. -Eastern shore of Nanticoke River on wharf off town of Bivalve, located about $\mathrm{I} 1 / 4$ miles northeast of Ragged Point. (See Chart No. 4I.)

Immediate locality.-Observed station is on western peak of a house on wharf at Bivalve about 300 yards from shore.

Marks.-Observed station is flagpole on peak of house.

References.-None necessary.

\section{BIVALVE CHURCH.}

General locality.-Eastern shore of Nanticoke River about $3 / 8$ mile back from shore in town of Bivalve on main road leading to the steamer landing. (See Chart No. 4I.)

Immediate locality.-Observed station is on Bivalve Methodist Church.

Marks.-Observed station is center of steeple on Bivalve Methodist Church.

References.-None necessary.

RAG.

General localily.-Eastern shore of Nanticoke River on northern side of Ragged Point, about 2 miles north-northeast of Roaring Point. (See Chart No. 4r.)

Immediate locality. - Observed station is on a sandy point about 25 yards back from shore, roo yards northeast of extreme end of point, 50 yards west of a grove of pine trees, 20 yards southwest of a group of pine trees, 75 yards southwest of another group of pine trees, and 20 yards west of two 15 -inch pine trees $2 \pi / 2$ feet apart.

Marks.-Observed station is center point of triangle on standard cement monument.

References.-

"Nanticoke Church" (S I $\left.{ }^{\circ} 6^{\prime} \mathrm{E}\right)$...........

Left end of Sandy Point.................... 29

Chimney of house.................. 5 II

Large tree at left end of woods............ I30

Left one of two trees (opposite shore)....... 169

Flagpole on Bivalve Wharf .............. 201

Smoke pipe on Bivalve wharf house...... 207

Nail in stump of limb on pine tree......... $21 S$

Nail in baze in double pine tree. . . . . . . . $25^{8}$

Nail in blaze in large pine tree............ 293

Chimney of house................... 303

Windmill near large house.............. 344

Steeple on barn.................... $35^{6}$

Large chimney of large flat-roof house. ..... 357

\begin{tabular}{|c|c|c|}
\hline & & \\
\hline & & \\
\hline & & \\
\hline & & \\
\hline & & \\
\hline & & \\
\hline & & \\
\hline & & \\
\hline & & \\
\hline & & \\
\hline & & \\
\hline & & \\
\hline & & \\
\hline & & \\
\hline$\infty$ & $\infty$ & $\ldots . . . I^{1} / 2$ miles. \\
\hline 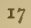 & . & ..... $31 / 2$ miles. \\
\hline $4^{8}$ & . & ..... $2 \frac{1}{2}$ miles. \\
\hline & . & ..... $3 \frac{\pi}{4}$ miles. \\
\hline 56 & . & ..... 31/4 miles. \\
\hline & .. & ...... IJ $3 / 4$ miles. \\
\hline I4 & . & ...... I I $1 / 4$ miles. \\
\hline & $\cdots$ & $\ldots \ldots 3^{2.78}$ meters. \\
\hline & . & ...... I9.66 meters. \\
\hline & . & ..... 43.I9 meters. \\
\hline & $\cdots$ & ...... I35 yards. \\
\hline & . & $\ldots . .3 / 4$ mile \\
\hline & $\cdots$ & $\ldots \ldots x$ \\
\hline & . & $\ldots \ldots I$ \\
\hline
\end{tabular}




\section{NANTICOKE CHURCH.}

General locality.-Eastern shore of Nanticoke River in town of Nanticoke, about $1 / 3$ mile back from river and $3 / 4$ mile northeast of Roaring Point. (See Chart No. $4 \mathrm{r}$.)

Immediate locality.-Observed station is on church known as "Nanticoke Methodist Episcopal Church."

Marks.-Observed station is center of spire on Nanticoke Methodist Episcopal Church.

References.-None necessary.

\section{ROAR.}

General locality.-Eastern shore of Nanticoke River on Roaring Point, about $1 / 4$ mile north from outer end of Roaring Point Wharf. (See Chart No. 4r.)

Immediate locality.- Observed station is on a sandy knoll about 5 feet above high water, 20 yards south of shore, 40 yards north of shore, 30 yards east of extreme end of point, and I 50 yards from pine woods which stand inshore from station.

Marks.-Observed station is center point of triangle on standard cement monument.

References.-

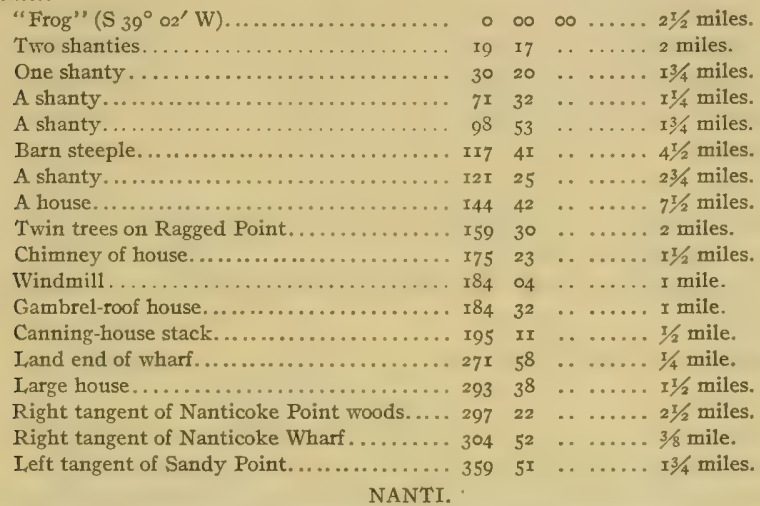

General locality.-Eastern side of Nanticoke River about $1 / 2$ mile northwest of Nanticoke Point, and $I 3 / 4$ miles northwest of Great Shoals Light. (See Chart No. $4 \mathrm{I}$.)

Immediate locality.-Observed station is on grass land about 2 feet above high water, 20 yards back from shore, and about midway between house near poplar trees about $1 / 4$ mile north of station and the edge of woods on Nanticoke Point.

Marks.-Observed station is center point of triangle on standard cement monument.

References.-

"Sharkfin Shoal Light" (S $\left.65^{\circ} \mathrm{x}^{\prime} \mathrm{W}\right)$......

Tangent of Sandy Point................. 5

Left end of Nanticoke Wharf............. 80

Near chimney of house................ $9^{6} \quad 5^{\mathrm{I}} \quad \ldots \ldots \ldots 3 / 4 \mathrm{mile}$.

Chimney of house.................. Ior of ...... I/4 mile.

Near chimney of house nearest woods...... II6 $56 \ldots \ldots \ldots .7 / 4$ mile.

Tree high above woods.............. II9 $53 \ldots \ldots \ldots 21 / 2$ miles.

Right end of heavy woods.............. I34 $03 \quad \ldots \ldots \ldots 1 / 4$ miles.

Right end of scant woods.............. I47 ir ...... $3 / 4$ mile.

Wild cherry tree..................... I78 $24 \quad \ldots \ldots \ldots 50$ yards.

Left end of woods....................

Right end of woods.................... $26945 \quad \ldots \ldots \ldots$ mile.

Poplar tree Dames Quarter.............. $307 \quad 28 \quad \ldots \ldots . .23 / 4$ miles.

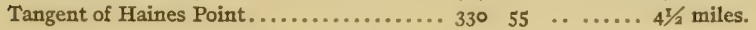


WHITE.

General locality.-Eastern side of entrance to Nanticoke River on Stump Point, about $23 / 4$ miles southeast of Roaring Point and $\mathrm{I} 3 / 8$ miles northwest of Great Shoal Light. (See Chart No. 4I.)

Immediate locality.-Observed station is on sand and grass point about 2 feet above high water, 3 yards east of shore, 20 yards northwest of shore, 15 yards north of extreme end of point, 40 yards west of a cove, roo yards northwest of a point of land, and roo yards southwest of a dense pine woods. Cement monument marking reference station is 16.63 meters $\mathrm{N}_{3}^{\circ} 13^{\prime} \mathrm{E}$ of observed station.

Marks.-Observed station is a nail in a pine stub about 6 inches below surface of ground. Reference station is center point of triangle on standard cement monument.

References.-

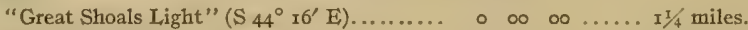

Poplar tree at Dames Quarter............ 65 o 08 ...... $21 / 2$ miles.

Tangent of Hall Point............... 86 o6 ...... $3 \frac{3 / 4}{4}$ miles.

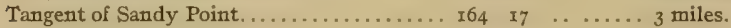

Left end of pine woods............... I72 $27 \ldots \ldots$ roo yards.

Right end of pine woods............... 213 2I $\ldots \ldots \ldots$ r 50 yards.

REFERENCE STATION..................... $227 \quad 2900 \ldots .63$ meters.

Largest one in clump of about 12 pine trees. . $247 \quad 23 \quad \ldots \ldots \ldots 3 / 8$ mile.

Chimney of cabin on Ellis Point.......... 279 o5 $\ldots \ldots \ldots 2$ miles.

A house............................ 31 II $54 \ldots \ldots$ mile.

Point of land ..................... roo yards.

\section{GREAT SHOALS LIGHT.}

General locality. - Entrance to Monie Bay and Wicomico River about halfway between Long Point and Mollies Point. (See Progress map.)

Marks.-Observed station is center of black lantern on square screw pile structure known as "Great Shoals Light."

Reference.-

"Sharkfin Shoal Light" ( $\left.8 \mathrm{I}^{\circ} \mathrm{5}^{\prime} \mathrm{W}\right) \ldots$.

\section{ROOM.}

General locality.-Eastern shore of upper Tangier Sound on Halls Point about II/s miles northeast of , Haines Point, and 25/8 miles east-southeast of Sharkfin Shoal Light. (See Chart No. 4r.)

Immediate locality.-Observed station is on a locust and mulberry fringed bluff about I 5 feet high, 5 yards back from edge of bluff, I 5 yards west-northwest of a barn, 15 yards from a wagon road parallel with shore, and 25 yards east of clump of mulberry trees. Cement monument marking reference station is $2 \mathrm{I} .45$ meters $\mathrm{S} 18^{\circ} 30^{\prime} \mathrm{W}$ of observed station and almost in line with large mulberry tree.

Marks.-Observed station is nail in center of stub with top flush with ground. Reference station is center point of triangle on standard cement monument.

References.-

"Sharkfin Shoal Light" ( $\mathrm{N} 70^{\circ}$ oo' W) ...... Gable on near side of house on Bishop Head. Near end of roof of large $2 \frac{1}{2}$-story house.... Left tangent of Clay Island............... Left side of Sandy Point woods............ Roaring Point Wharf................... $8_{5}$

Near chimney on end of large house....... . 94

Right side of Nanticoke woods............ II

"Mount Vernon Church"............... I27

Near corner of barn................... $\mathrm{x}_{37}$

Right-hand corner of barn............. I5

REFERENCE STATION................. 268

Large cedar tree.................... $276 \quad 30$

Two-inch iron pipe.................. $279 \quad 3^{8}$

\begin{tabular}{|c|c|c|}
\hline & $\prime \prime$ & \\
\hline$\infty$ & $\infty$ & .... $2 \mathrm{r} / 2$ miles. \\
\hline or & . & ...... 5 5 $/ 2$ miles. \\
\hline 53 & . & … $7 \frac{1}{4} / 4$ miles. \\
\hline 18 & . & … $3^{1} / 2$ miles. \\
\hline 08 & . & ....4 4 miles. \\
\hline 22 & . & 5 miles. \\
\hline 36 & . & … $4^{1} \frac{1}{4}$ miles. \\
\hline 28 & . & . $33 / 4$ miles. \\
\hline 18 & $\cdots$ & .. 7 miles. \\
\hline 06 & . & .. I5.96 meters. \\
\hline 08 & $\cdots$ & .. I8. I I meters. \\
\hline 30 & $\infty$ & . 21.45 meters. \\
\hline 30 & . & ..... I00 yards. \\
\hline $3^{8}$ & 30 & ..... $9.2 \times$ meters. \\
\hline
\end{tabular}




\section{SHARKFIN SHOAL, LIGHT.}

General locality.--Northern end of Tangier Sound about equally distant from entrances of Hooper Strait, Fishing Bay, and Nanticoke River. (See Chart No. 4I.)

Immediate locality.-Observed station is on hexagonal, screw-pile structure known as Sharkfin Shoal Lighthouse.

Marks.-Observed station is center point of lantern on Sharkfin Shoal Light.

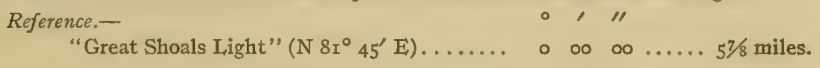

\section{HAINES.}

General locality'- - Eastern shore of upper Tangier Sound on Haines Point about $5 / 3$ mile north of Deal Island Wharf, and $21 / 2$ miles southeast of Sharkfin Shoal Light. . (See Chart No. $4 \mathrm{r}$.)

Immediate locality.--Observed station is on sand and grass point about 5 feet above high water, 20 yards back from shore, 3 yards west of a barb-wire fence, 20 yards south of a clump of locust and water bushes, and about on range with left edge of clump of trees and bushes and Sharkfin Shoal Light. Cement monument marking reference station is 9.64 meters $\mathrm{N} 77^{\circ} 43^{\prime} \mathrm{E}$ of observed station.

Marks.-Observed station is nail in pine stub in center of a drain tile with top broken off below surface. Reference station is center point of triangle on standard cement monument.

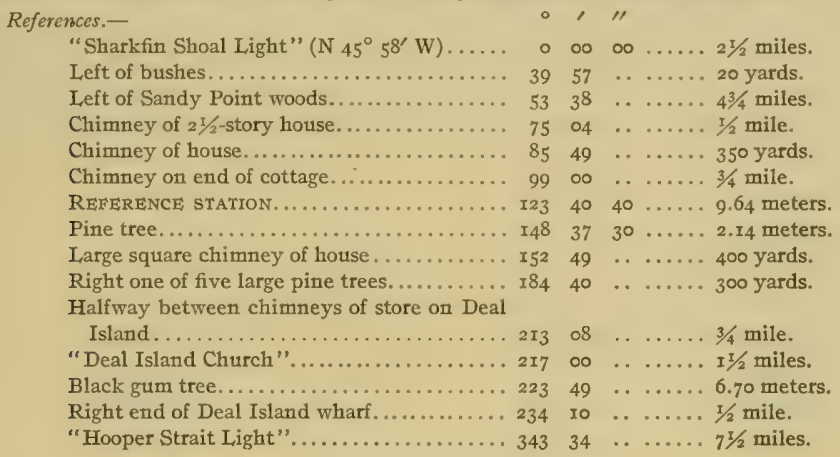

\section{DEAL ISLAND CHURCH.}

General locality. -Western side of upper Tangier Sound on Deal Island on main road about $\pi / 4 \mathrm{mile}$ inshore, and $3 / 4$ mile south of bridge across Laws Thoroughfare. (See Chart No. 4I.)

Immediate locality.-Observed station is on Deal Island Methodist Church.

Marks.-Observed station is center of steeple on Deal Island Methodist Church.

References.-None necessary.

\section{SOLOMONS LUMP LIGHT.}

General locality.--Kedge Straits about $1 / 2$ mile north of Smith Island and about $I / 2$ miles south of South Marsh. (See Progress map.)

Immcdiate locality.-Observed station is on square tower on northerly side of a caisson and octagonal structure known as "Solomons Lump Light."

Marks.-Observed station is center of black lantern on square tower.

References.-

“James Island Light"' $\left(\mathrm{S}_{42^{\circ}} \mathrm{I2}^{\prime} \mathrm{E}\right) \ldots \ldots \ldots \ldots$. 


\section{HOLLAND ISLAND BAR LIGHT.}

General locality. -Easterly side of Chesapeake Bay off entrance to Kedge Straits, about $23 / 4$ miles south of Holland Island, and $3 \frac{3}{4}$ miles northwest of Smith Island. (See Chart No. 42.)

Immediate locality.-Observed station is on hexagonal, screw-pile structure known as Holland Island Bar Light.

Marks.-Observed station is center point of lantern on Holland Island Bar Light.

References.- I II

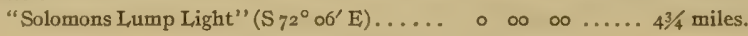

\section{HOLLAND ISLAND CHURCH SPIRE.}

General locality.-Eastern side of Chesapeake Bay on Holland Island about $3^{1 / 2}$ miles north of Holland Island Bar Light. (See Chart No. 42.)

Immediate locality.-Observed station is on church known as Holland Island Church.

Marks.-Observed station is center of spire on Holland Island Church.

References,-None recessary.

\section{OKAHANIKAN.}

General locality.-Eastern shore of Chesapeake Bay on western side of Bloodsworth Island about $3 / 8$ mile south of point at south side of entrance to Okahanikan Cove, and $23 / 4$ miles south-southeast of Hooper Strait Light. (See Chart No. 42.)

Immediate locality.-Observed station is on sandy marsh about 2 feet above high water, 40 yards southeast of shore, 40 yards east of shore, and 35 yards west of water bushes between sand and soft marsh.

Marks.-Observed station is center point of triangle on standard cement monument projecting 4 inches above surface of ground. Subsurface mark is center of 2 -inch tile pipe buried with top 2 inches below base of monument.

References. -

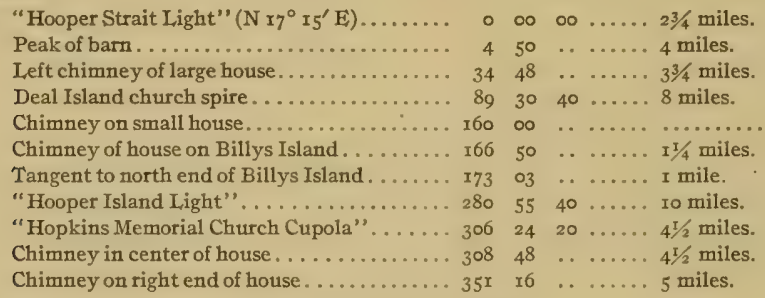

\section{SENATOR.}

General locality.-Western shore of Tangier Sound on southern side of Holland Straits and on extreme northeastem point of South Marsh. (See Progress map.)

Immediate locality.-Observed station is on marshland about 35 yards from north side of point, 30 yards from east side of point, to yards north of a small pool of water, and 5 yards northeast of another small pool of water. No permanent reference points near station.

Marks.-Observed station is center point of triangle on standard cement monument projecting 4 inches above surface of ground.

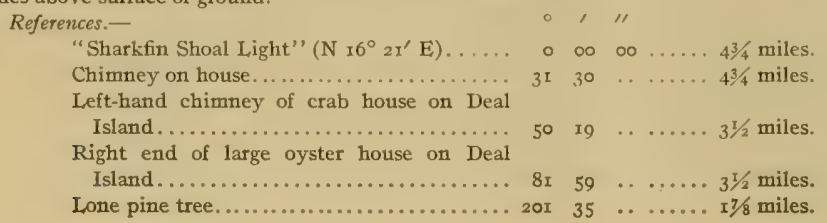


MILES.

General locality.-Western shore of Tangier Sound on eastern side of the lower half of South Marsh just south of the middle one of three creeks on this shore of the island. (See Progress map.)

Immediate locality.-Observed station is on a marsh point about 75 yards south of entrance to a small creek, 50 yards south of the north side of the point, and 60 yards west of its extreme end.

Marks.-Observed station is center point of triangle on standard cement monument projecting 4 inches above surface of ground.

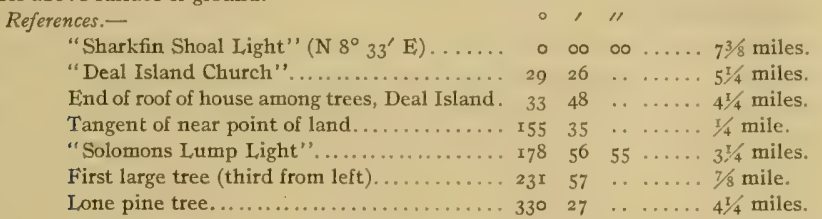

FOG 2.

General locality.-Eastern shore of Chesapeake Bay and southern shore of Kedge Straits on northwest point of Smith Island known as Fog Point. (See Progress map.)

Immediate locality.-Observed station is among myrtle bushes on the north side of a sand and grass point about I foot above high water. 65 yards southwest from extreme end of point, 6 yards south-southeast from shore, and 50 yards east-northeast from the remains of old "Fog Point Lighthouse." Cement monument marking reference station is 15.26 meters $S 0^{\circ} 40^{\prime} \mathrm{W}$ from observed station and about in line with a lone cherry tree one-fourth mile distant.

Marks.-Observed station is nail in center of tile pipe with top flush with surface of ground. Reference station is center point of triangle on standard cement monument projecting 4 inches above surface of ground.

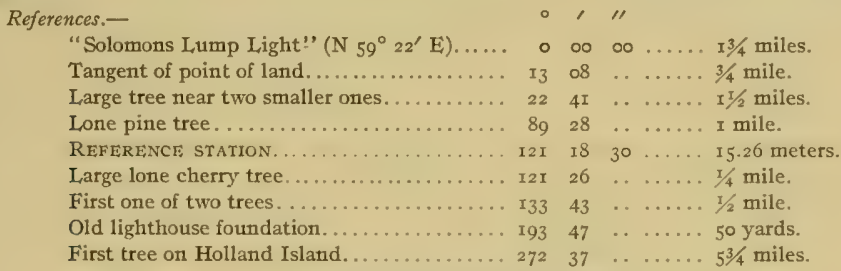

\section{POINT NO POINT LIGHT.}

General locality.-Western side of Chesapeake Bay offshore about $I^{7 / 8}$ miles southeast of Point No Point and $63 / 8$ miles north-northeast of Point Lookout. (See Progress map.)

Immediate locality. - Observed station is on brick dwelling on a cylindrical foundation known as Point No Point Lighthouse.

Marks.-Observed station is center point of lantern on Point No Point Lighthouse.

Referencés. -

$$
\text { "Cedar Point Light" ( } \left.\mathrm{N} 19^{\circ} 35^{\prime} \mathrm{W}\right) \ldots \ldots \ldots \text {..... } 0 \text {, } 00 \ldots \ldots \text { miles. }
$$

\section{POINT LOOKOUT LIGHT.}

General locality.-Westem side of Chesapeake Bay on Point Lookout at northem side of entrance to Potomac River. (See Progress map.)

Immediate locality.-Observed station is on Point Lookout Lighthouse, which is a dweiling on shore near a fog-bell tower. house.

Marks.-Observed station is center point of a lantern on a dwelling known as Point Lookout Light-

$$
\begin{aligned}
& \text { References.- } \\
& \text { "Smith Point Light" ( } \left.\mathrm{S}_{34}{ }^{\circ} 37^{\prime} \mathrm{E}\right) \ldots . . . . \text {... }
\end{aligned}
$$




\section{BOUNDARIES OF OYSTER BARS.}

\section{EXPLANATION.}

The law of the United States authorizing the cooperation of the Department of Commerce and Labor in the survey of natural oyster bars of Maryland provides for the designation and employment by the Department of Commerce and Labor of such officers, experts, and other technically qualified persons "as may be necessary to cooperate with the Maryland State Board of Shell Fish Commissioners in making a survey of and locating the natural oyster beds, bars, and rocks in the waters within the State of Maryland." The oyster laws of Maryland provide that the Maryland Shell Fish Commissioners, with the aid of such persons as may be designated by the Government, shall proceed "to have laid out, surveyed, and designated on the said charts the natural beds and bars, and shall cause to be marked and defined as accurately as practicable the limits and boundaries of the natural beds, bars, and rocks as established by said survey, and they shall take true and accurate notes of said survey in writing, and make an accurate report of said survey, setting forth such a description of landmarks as may be necessary to enable the said board, or their successors, to find and ascertain the boundary lines of the said natural oyster beds, bars, and rocks, as shown by a delineation on the maps and charts." The oyster laws of Maryland also provide in another section that there shall "be made a true and accurate survey of the natural oyster beds, bars, and rocks *** with reference to fixed and permanent objects on the shore, giving courses and distances, to be fully described and set out in a written report of said survey."

Under the provisions of the laws quoted above the State of Maryland, in cooperation with the Department of Commerce and Labor, must define the boundaries of the natural oyster bars "as accurately as practicable" and also "with reference to fixed and permanent objects on the shore, giving courses and distances." The requirement of "as accurately as practicable" is easily fulfilled by definition of the location of the corners of the oyster bars by latitude and longitude. In fact, this method is probably the most satisfactory and accurate one that could be used for all purposes of legal definition or for relocation of the oyster-bar boundaries by competent engineers. Therefore the additional requirement of "giving courses and distances" is superfluous and is only fulfilled in the published definitions on account of the specific provisions of the law making it compulsory. This part of the description of boundaries has involved an immense amount of extra computations in order to prevent technical discrepancies between the latitude and longitude of a corner of an oyster bar and its distance and bearing from objects on shore of known latitude and longitude without adding anything to the accuracy and very little to the convenience of practical use of the descriptions of the oyster-bar boundaries.

As provided by law the boundaries of the oyster bars are all straight lines, but in the work already completed they have inclosed areas of all shapes from triangles to 
complicated I4-sided figures, and of all sizes from 4 acres to 7,548 acres. The sides have varied in length from 93 to 7,529 yards, and in some cases the corners of the boundaries have been practically at the triangulation stations from which they are located, while in other instances they were over 13,600 yards from the landmarks most available for the purpose of fixing their position.

The varied characteristics of the legal boundaries of the oyster bars indicated by the above statement, together with the complicated requirements of the law under which the survey has been made and the magnitude of the work with the consequent need of fixed and uniform methods, have made the problem of describing the boundaries one of considerable difficulty and great importance.

The boundaries of the oyster bars of Maryland, as established by the Shell Fish Commission and delineated on the Coast and Geodetic Survey charts and projections and on the leasing charts of the commission, are technically defined and described by a method somewhat different from that used in other oyster surveys. But it is believed that the forms finally adopted will fulfill all needs of the survey for both the present and the future.

\section{METHOD OF DESCRIBING BOUNDARIES.}

The descriptions have been arranged in tabular form, thus avoiding many liundred repetitions of the same words by making one explanation of the tables sufficient for all oyster bars in each county.

Title.-At the top of each tabular form is given the legal name of the oyster bar to be described, and the one by which it is known and designated in the published oyster records and on the oyster charts. The adopted name of the oyster bar is the one used locally, as nearly as could be ascertained by the hydrographic engineer of the commission; and when there was no local name in common use a name was selected from one of the prominent features of the vicinity that would naturally suggest the section of the waters where the oyster bar was located.

Underneath the name, in parentheses, is given the general locality of the oyster bar and the serial number of the "Maryland Oyster Chart" on which its legal boundaries are shown. ${ }^{1}$

First column.-This column, under the heading of "Corner of bar," gives the number corresponding to the corner of the boundary as shown on the charts and to the number on the buoy marking the actual corner of the bar. The numbers of the corners have been assigned by naming the southernmost point No. I, thence proceeding in a clockwise direction around the bar. Where a corner of one oyster bar is identical with the corner of the boundaries of one or more other oyster bars, only the number of the corner of the oyster bar being described in the table is given in this column.

Second and third columns. - These two columns, under the headings of "Latitude" and "Longitude," give the geographic positions of the corners. These positions have been adopted by the commission as the primary technical definition of the location of the corners, and should be considered as final in case of a dispute arising from discrepancies caused by other means of location. The latitudes and longitudes given in these columns are based on the United States standard datum of the Coast and Geodetic Survey, and the points thus defined can be relocated from distant triangulation stations

\footnotetext{
1 These charts can be obtained by application to the Superintendent of the Coast and Geodetic Survey at Washington, D. C.
} 
of the survey, even though all the landmarks and buoys originally used for their location have been destroyed by natural or other causes.

Fourth and fifth columns. - These two columns, under the general heading of "True bearing" 1 and the specific headings "Forward" and "Back," give bearings measured from a true north-and-south line. The three "Forward" bearings are from the corner of the boundary designated in the first column to the triangulation stations named on the corresponding lines in the last column, and the three "Back" bearings are from these same stations in the last column to the corresponding corner of boundary in the first column. The difference in minutes of arc between the forward and back bearings shown in some cases is actual and not accidental, and is due to the fact that the computations took into account the spheroidal shape of the earth.

Sixth column.-This column, under the heading of "Distance," gives the three computed distances in yards from the corner of the bar noted in the first column to the three triangulation stations named on the corresponding lines in the last column, and vice versa.

Seventh column.-This column, under the heading of "U. S. C. \& G. S. triangulation station," " gives the names of the landmarks from which were computed the corresponding "Latitude," "Longitude," "True bearing," and "Distance" of the "Corner of bar" designated in the first column. A full description of the location and markings of these triangulation stations is given in another part of this publication under the heading of "Descriptions of triangulation stations."

\section{SURVEYING METHODS FOR RELOCATION OF BOUNDARIES.}

There are a number of methods that can be used in the relocation of the actual boundaries of the natural oyster bars as technically described in this publication and delineated on the published charts of the Coast and Geodetic Survey and the leasing charts of the Shell Fish Commission.

The following brief descriptions of five of these more or less different methods assume a certain amount of experience and knowledge on the part of the engineer in the particular kind of surveying under consideration, and are only intended as reminders of ways and means that can be used.

There are two problems that are likely to present themselves to those interested in the boundaries of natural oyster bars: One, to determine whether the buoys marking the corners have been dragged or otherwise moved from their correct positions, and the other, to relocate or reestablish a buoy at the point from which it was removed. The different ways of solving these two problems partly depend upon the instruments possessed by the engineer and his assistants and partly on his training and experience.

(1) Triangulation.-This method is the one that will give the greatest accuracy: but on account of its requiring special data and instruments, and being an operation rarely used by engineers not engaged in geodetic surveying, it is recommended only for cases in dispute that can not be settled satisfactorily by some other method. An explanation of this class of work would be too long for a report of this sort, and those

\footnotetext{
1 The mean magnetic variation for Dorchester County was $6^{\circ} 00^{\prime}$ west of north in IgIx and increasing at the rate of $5^{\prime}$ yearly.

${ }^{2}$ Geographic positions of these triangulation stations can be obtained by application to the Superintendent of the Coast and Geodetic Survey, Washington, D.C.
} 
not familiar with this method are referred to the publications on the subject by the Coast and Geodetic Survey.

(2) Hydrographic.-This method is the most simple and satisfactory one that can be adopted if the surveyor can obtain the use of the necessary instruments and assistants. It is the one best suited for the work of the engineers of the Commission in relocating corners of boundaries, as it gives results of the accuracy ordinarily required and is rapid in execution. Besides, it has the advantage of being available whenever three triangulation stations of suitable relative positions are visible from the offshore points needing relocation.

Most navigators and others familiar with the use of a sextant are well acquainted with the graphic three-point method of fixing a position on water, and only a brief description of the operation will be stated.

In the case where there is only one engineer having a single sextant, the three-point method can be used if the two angles determining the position of a buoy are first derived from the "Forward" bearings given in the tabular forms describing the boundaries of the oyster bars. For example, take "Drum Point" oyster bar, which is the first one described in this publication, and assume that "Corner No. 3 " is to be examined as to its position. The angle between the two landmarks "Up" and "Blind" as determined from right to left from the forward bearings from this corner is $26^{\circ} 36^{\prime}$ and the angle between "Blind" and "Myrtle" is $60^{\circ} 12^{\prime}$. Having these two angles, the engineer proceeds to the buoy of doubtful location and measures the actual sextant angles between the landmarks for which the calculations were made. If the measured and calculated angles do not agree the buoy is not in its correct position and the boundary. corner must be relocated. This is accomplished by moving the boat about until a point is reached where the angles do agree, and this point being the desired location, the buoy can be placed in its correct position.

If the engineer can obtain the use of both a sextant and a three-arm protractor (position finder), the availability of the hydrographic method is increased, as the use of the protractor is essential in case of the washing away or destruction of one or more of the landmarks originally used in describing the boundaries. Under these circumstances, any three landmarks of suitable relative position that are visible from the point to be located can be utilized. For example, the engineer can proceed to the buoy of doubtful position and measure the two adjacent sextant angles between the three landmarks selected. These two angles are set off on the three-arm protractor and the actual position of the buoy plotted on the chart by shifting the protractor about until the edge of each of the three arms passes through the center of the symbols on the chart marking the position of the three landmarks selected. The center of the hub of the protractor will indicate on the chart the actual position of the buoy, and if the point thus obtained does not coincide with the true position of the corner of the boundary as given on the chart, the surveyor can proceed to locate the buoy correctly by reversing the operation. This is done by placing the center point of the hub of the protractor over the comer of the boundary in question and measuring on the chart the two adjacent protractor angles between the three selected landmarks. One of the angles thus obtained is set on the sextant and the boat moved about until the two landmarks are shown by the sextant to subtend the same angle obtained from the protractor. The 
second angle is then placed on the sextant and the same operation gone through, and so on, first using one angle on the sextant, then the other, until a point is reached where both observed sextant angles are practically identical with the protractor angles. The point thus located is the desired one and the buoy can be placed to mark the true position of the corner of the boundary in question.

If the engineer possesses two sextants and a protractor, this problem is far easier of solution, as the two angles can be set off on separate sextants and the observer can quickly find the desired point where they agree with the protractor angles by using one sextant after the other without the need of resetting either.

If there are two observers, two sextants, and a protractor, it can be seen that the best conditions for both rapid and accurate hydrographic location of a point is attained. In fact, this is the method by which the buoys at the corners of the boundaries were originally placed by the hydrographic engineer to the commission.

(3) Magnetic bearings from offshore.-This method of fixing a position on water is a simple and well-known one in navigation. It is available to anyone having a boat compass and will be of special use to the State Fishery Force in investigating cases where buoys are supposed to have been moved for illegal purposes.

In the case where a buoy is supposed to have been moved from its true position the observer can take compass bearings to the three landmarks given in the last column of the tables opposite the boundary corner in question. These bearings are then corrected for the local declination, ${ }^{1}$ and if the results agree with the published bearings the buoy is correctly located.

In the case where the buoy is not in its correct position, or has disappeared altogether, the desired point can be determined by maneuvering the vessel until the corrected bearings agree with the ones in the tabular descriptions, when the buoy can be anchored in its proper location.

In the case where the landmarks, for which the bearings are published, have been destroyed or washed away, any landmarks whose positions are indicated on the charts can be used. This can be done by getting their bearings directly from the chart by parallel rulers or a protractor and then applying these new bearings in the same manner as the ones published in the tables.

(4) Magnetic bearings from shore.-This method will be of special value to engineers having an ordinary surveyor's compass. The compass can be set over the point marking a "triangulation station" on shore, the name of which is given in the last column opposite the "corner" in question. The instrument is then set at the corresponding "back" bearing (corrected for local magnetic declination) given in the fifth column of the tables opposite the "corner" in question. The direction thus determined will give one range on which the desired point must be located. The compass can then be moved to a second triangulation station and another range located in a similar manner. The intersection of these two range lines will give the desired point; but in general it should be checked by an additional range line determined from a third station.

(5) Horizontal angles measured at landmarks.-This process is a modification of the triangulation method, and will be useful to engineers who have a transit and desire considerable accuracy.

1 The mean magnetic variation for Dorchester County was $6^{\circ} \infty 0^{\prime}$ west of north in IgII and increasing at the rate of $5^{\prime}$ yearly. 
The instrument is placed over a "triangulation station," the name of which appears in the last column of the tabular description opposite the "corner" in question. The telescope is then pointed to the landmark indicated in the "Descriptions of landmarks" as having a direction of $\mathrm{O}^{\circ} \mathrm{OO}^{\prime} \mathrm{OO}^{\prime \prime}$ from the triangulation station being occupied by the transit. The tabular description of the boundaries is next examined and the "back" bearing of the questionable boundary "corner" from the landmark being occupied is taken out. The angle calculated from this "back" bearing and the bearing given in parentheses alongside the zero landmark in the "Descriptions of landmarks" is then set off on the transit and a range line established on which the desired point must be located. A similar process is then carried on at a second station, and so on until the position of the buoy is satisfactorily fixed.

BOUNDARIES OF NATURAL OYSTER BARS.

DRUM POINT.

(Upper Choptank River-Chart No. 35.)

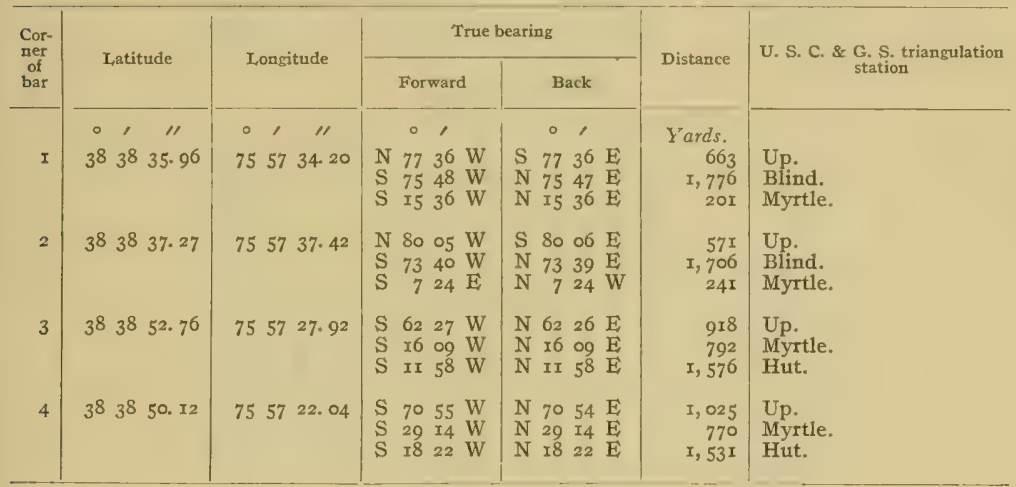

CABIN CREEK ENTRANCE.

(Upper Choptank River-Chart No.35.)

\begin{tabular}{|c|c|c|c|c|c|c|}
\hline I & $3^{8} 3^{8} \quad 02.66$ & $75 \quad 5^{8} \times 3.40$ & $\begin{array}{llll}N & x 7.08 & \mathrm{E}_{\mathbf{F}} \\
\mathrm{N} & 44 & 54 & \mathrm{~W} \\
\mathrm{~S} & 84 & 07 & \mathrm{~W}\end{array}$ & $\begin{array}{llll}\mathrm{S} & \mathrm{I} & 08 & \mathrm{~W} \\
\mathrm{~S} & 44 & 55 & \mathrm{E} \\
\mathrm{N} & 84 & 07 & \mathrm{E}\end{array}$ & $\begin{array}{r}\mathrm{I}, 323 \\
970 \\
\mathrm{x}, 824\end{array}$ & $\begin{array}{l}\text { Up. } \\
\text { Blind. } \\
\text { Raccoon. }\end{array}$ \\
\hline 2 & $3^{8} 3^{8} \quad 07.42$ & $755^{8} \times 7.5^{\circ}$ & $\begin{array}{llll}\mathrm{N} & 24 & 17 & \mathrm{E} \\
\mathrm{N} & 47 & 35 & \mathrm{~W} \\
\mathrm{~S} & 78 & 30 & \mathrm{~W}\end{array}$ & $\begin{array}{llll}\mathrm{S} & 24 & \mathrm{I} & \mathrm{W} \\
\mathrm{S} & 47 & 36 & \mathrm{E} \\
\mathrm{N} & 78 & 29 & \mathrm{E}\end{array}$ & $\begin{array}{r}\mathrm{I}, 215 \\
78 \mathrm{I} \\
\mathrm{I}, 74 \mathrm{I}\end{array}$ & $\begin{array}{l}\text { Up. } \\
\text { Blind. } \\
\text { Raccoon. }\end{array}$ \\
\hline 3 & $3^{8} \quad 3^{8} \times 4.37$ & $755^{8} \quad 05.06$ & $\begin{array}{llll}\mathrm{N} & 11 & 00 & \mathrm{E} \\
\mathrm{N} & 72 & 06 & \mathrm{~W} \\
\mathrm{~S} & 74 & 03 & \mathrm{~W}\end{array}$ & $\begin{array}{llll}\mathrm{S} & \text { II } & 00 & \mathrm{~W} \\
\mathrm{~S} & 72 & 07 & \mathrm{E} \\
\mathrm{N} & 74 & 02 & \mathrm{E}\end{array}$ & $\begin{array}{r}886 \\
951 \\
2,116\end{array}$ & $\begin{array}{l}\text { Up. } \\
\text { Blind. } \\
\text { Raccoon. }\end{array}$ \\
\hline 4 & $3^{8} \quad 3^{8} \quad$ ז0. 08 & $755^{8}$ or. 20 & $\begin{array}{llll}\mathrm{N} & 3 & 47 & \mathrm{E} \\
\mathrm{N} & 66 & 33 & \mathrm{~W} \\
\mathrm{~S} & 78 & 27 & \mathrm{~W}\end{array}$ & $\begin{array}{lrrr}\mathrm{S} & 3 & 47 & \mathrm{~W} \\
\mathrm{~S} & 66 & 34 & \mathrm{E} \\
\mathrm{N} & 78 & 26 & \mathrm{E}\end{array}$ & $\begin{array}{l}\mathrm{I}, \text { or } 7 \\
\mathrm{I}, 098 \\
2, \mathrm{I} 8 \mathrm{I}\end{array}$ & $\begin{array}{l}\text { Up. } \\
\text { Blind, } \\
\text { Raccoon. }\end{array}$ \\
\hline
\end{tabular}


CABIN CREEK.

(Upper Choptank River-Chart No. 35.)

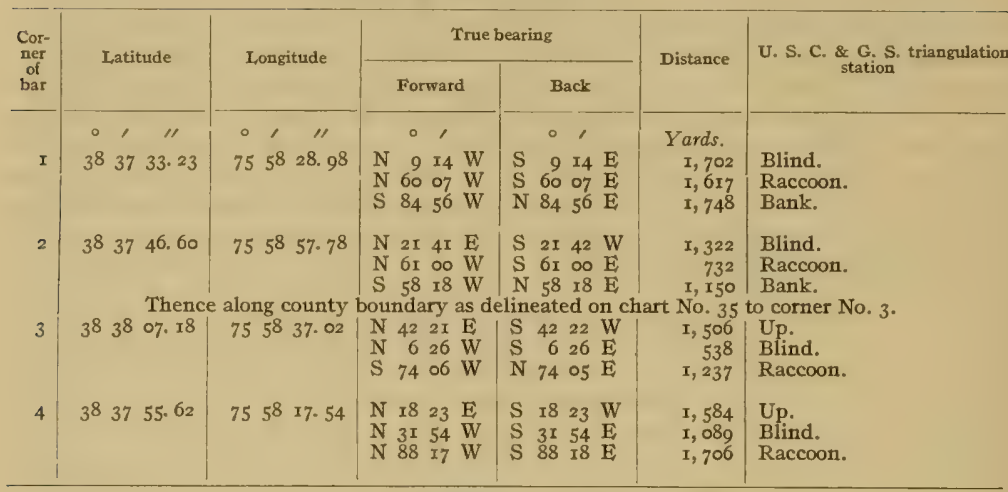

\section{TANNERS PATCH.}

(Upper Choptank River-Chart No. 35.)

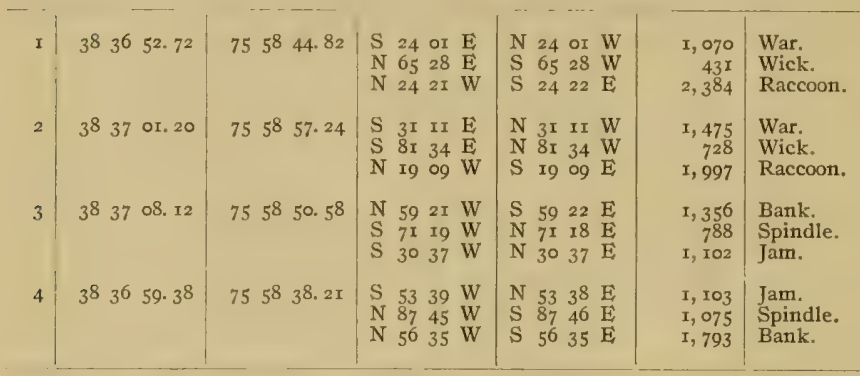

\section{DIXON.}

(Upper Choptank River-Chart No. 35.)

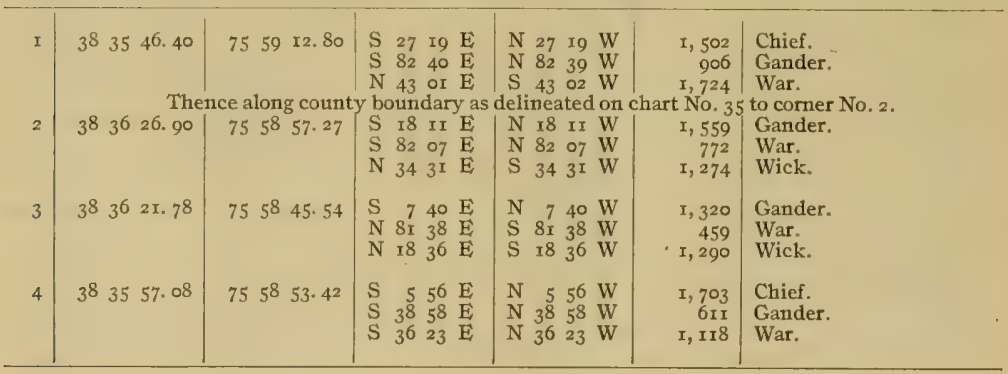


OYSTER SHELL POINT.

(Upper Choplank River-Chart No. 35.)

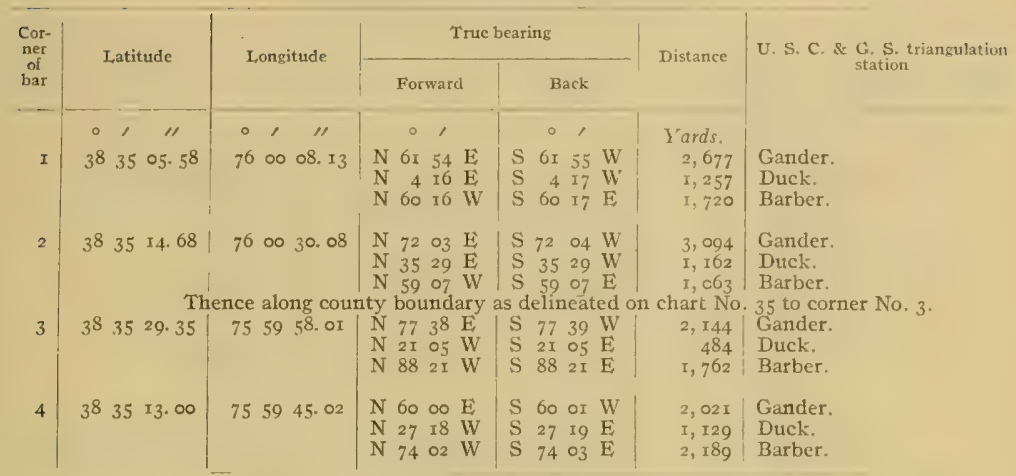

\section{STATES BANK.}

(Middle Choptank River-Chart No. 35.)

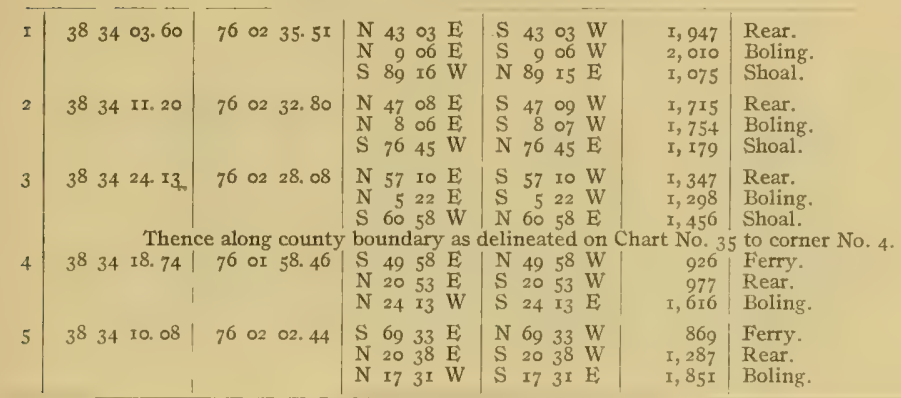

SHOAL, CREEK.

(Middle Choptank River-Chart No. 35.)

\begin{tabular}{|c|c|c|}
\hline $\mathbf{x}$ & $3^{8} 34 \quad 03.60$ & $7^{6}$ o2 $35 \cdot 5^{\mathrm{I}}$ \\
\hline 2 & $3^{8} \quad 34 \quad 26.23$ & $\begin{array}{llll}76 & 03 & 37.80\end{array}$ \\
\hline 3 & $3^{8} 34 \quad 3^{8} .42$ & $\begin{array}{lll}76 & 03 & 29.50\end{array}$ \\
\hline 4 & $3^{8} 34$ Ir. 20 & $\begin{array}{lll}76 & 02 & 32.80\end{array}$ \\
\hline
\end{tabular}

$\begin{array}{lllllll}\mathrm{N}_{4} & \text { O2 } & \mathrm{E} & \mathrm{S} & 43 & 03 & \mathrm{~W}\end{array}$ $\mathrm{N} 906 \mathrm{E} \quad \mathrm{S} 906 \mathrm{~W}$ S 89 16 W \begin{tabular}{llll|lll}
$\mathrm{S}$ & 36 & $26 \mathrm{E}$ & $\mathrm{N}$ & 36 & $26 \mathrm{~W}$
\end{tabular} $\mathrm{N}$ I6 I0 $\mathrm{E}$ : $\mathrm{S}$ I6 II W $\begin{array}{lllllll}N_{5} & 04 & W & S & 5 & \text { o } & E\end{array}$ $\mathrm{N} 845 \mathrm{I}$ $\mathrm{N}$ I3 3 I E $\mathrm{N} 6340 \mathrm{~W}$

$\begin{array}{llll}N & 47 & 08 & \mathrm{E} \\ \mathrm{N} & 8 & 06 & \mathrm{H}\end{array}$ S $7645 \mathrm{~W}$
S $84 \quad 52 \mathrm{~W}$

S I 332 W

$\mathrm{S} 634 \mathrm{I} \mathrm{E}$

$\begin{array}{llll}S & 47 & \circ 9 & W \\ S & 8 & 07 & W\end{array}$

N $76 \quad 45 \mathrm{E}$

\begin{tabular}{r|l} 
I, 947 & Rear. \\
2, 010 & Boling. \\
I, 075 & Shoal. \\
966 & Shoal. \\
2,543 & Double. \\
$2, x 37$ & Cambridge. \\
2,769 & Rear. \\
2,090 & Double. \\
2,100 & Cambridge. \\
1,715 & Rear. \\
1,754 & Boling. \\
1,179 & Shoal.
\end{tabular}

I, 947 Rear.

2, OIO Boling

966 Shoal.

2, 543 Double.

2, $x 37$ Cambridge

2, 100 Cambridge.

5, 754 Boling. 
GREEN MARSH.

(Middle Choptank River-Chart No. 35.)

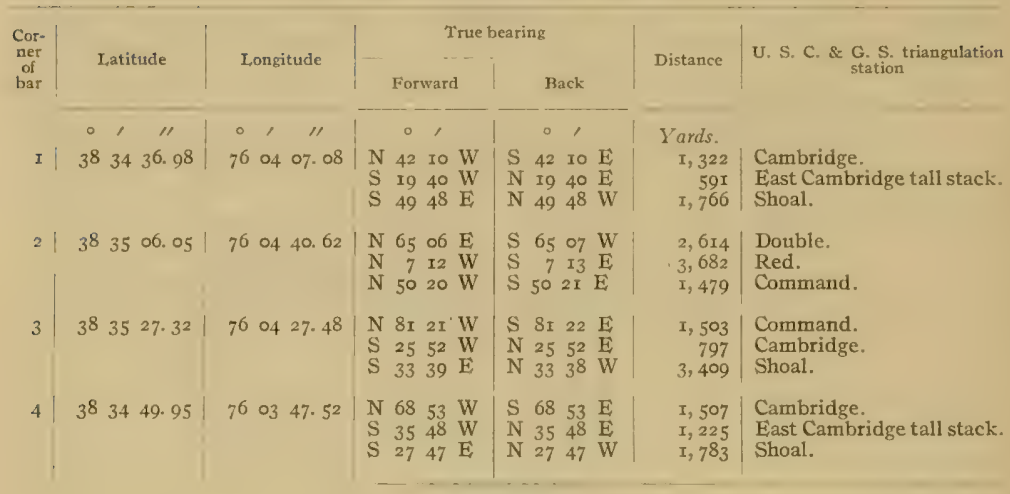

\section{HAMBROOKS.}

(Middle Choptank River-Chart No. 35.)

\begin{tabular}{|c|c|c|c|c|c|c|c|}
\hline$I$ & $3^{8} \quad 35 \quad 36.96$ & $7^{6}$ of & II. 95 & $\begin{array}{llll}\mathrm{S} & 87 & 00 & \mathrm{~W} \\
\mathrm{~S} & 36 & 03 & \mathrm{~W} \\
\mathrm{~N} & 87 & 58 & \mathrm{E}\end{array}$ & $\begin{array}{llll}\mathrm{N} & 86 & 59 & \mathrm{E} \\
\mathrm{N} & 36 & 03 & \mathrm{E} \\
\mathrm{S} & 87 & 58 & \mathrm{~W}\end{array}$ & $\begin{array}{l}\text { I, } 900 \\
\text { I, } 289 \\
\text { I, } 613\end{array}$ & $\begin{array}{l}\text { Command. } \\
\text { Cambridge. } \\
\text { Double. }\end{array}$ \\
\hline 2 & $3^{8} 3551.84$ & $76 \quad 05$ & oI. 66 & $\begin{array}{lrrl}\mathrm{S} & 81 & 22 & \mathrm{E} \\
\mathrm{N} & 2 & 34 & \mathrm{E} \\
\mathrm{N} & 59 & 52 & \mathrm{~W}\end{array}$ & $\begin{array}{lrrr}\mathrm{N} & 8 \mathrm{I} & 2 \mathrm{I} & \mathrm{W} \\
\mathrm{S} & 2 & 34 & \mathrm{~W} \\
\mathrm{~S} & 59 & 53 & \mathrm{E}\end{array}$ & $\begin{array}{l}2,96 \mathrm{I} \\
2, \mathrm{II2} \\
3,077\end{array}$ & $\begin{array}{l}\text { Double. } \\
\text { Red. } \\
\text { Howells. }\end{array}$ \\
\hline 3 & $38 \quad 36 \quad 10.60$ & 7605 & I2. 54 & $\begin{array}{llll}N & 7 I & 30 & E \\
N & I 4 & 32 & E \\
N & 68 & 58 & W\end{array}$ & $\begin{array}{llll}\mathrm{S} & 7 \mathrm{I} & 3 \mathrm{I} & \mathrm{W} \\
\mathrm{S} & \mathrm{I} 4 & 3^{2} & \mathrm{~W} \\
\mathrm{~S} & 68 & 59 & \mathrm{E}\end{array}$ & $\begin{array}{l}3,39 r \\
x, 526 \\
2,544\end{array}$ & $\begin{array}{l}\text { Double. } \\
\text { Red. } \\
\text { Howells. }\end{array}$ \\
\hline
\end{tabular}

Thence along county boundary as delineated on chart No. 35 to comer No. $\mathrm{r}$.

TURTLE BACK.

(Middle Choptank River-Chart No.35-)

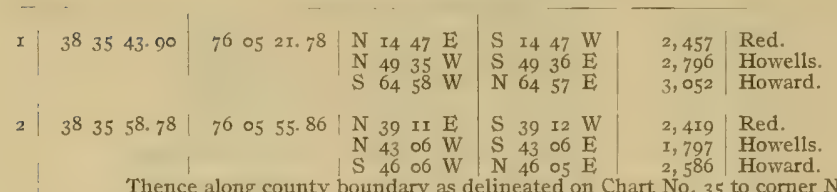

3. Thence along county boundary as delineated on Chart No. 35 to corner No. 3 .

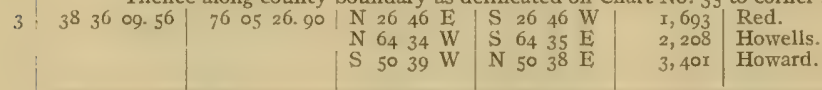


SANDY HILL LUMPS.

(Middle Choptank River-Chart No. 35.)

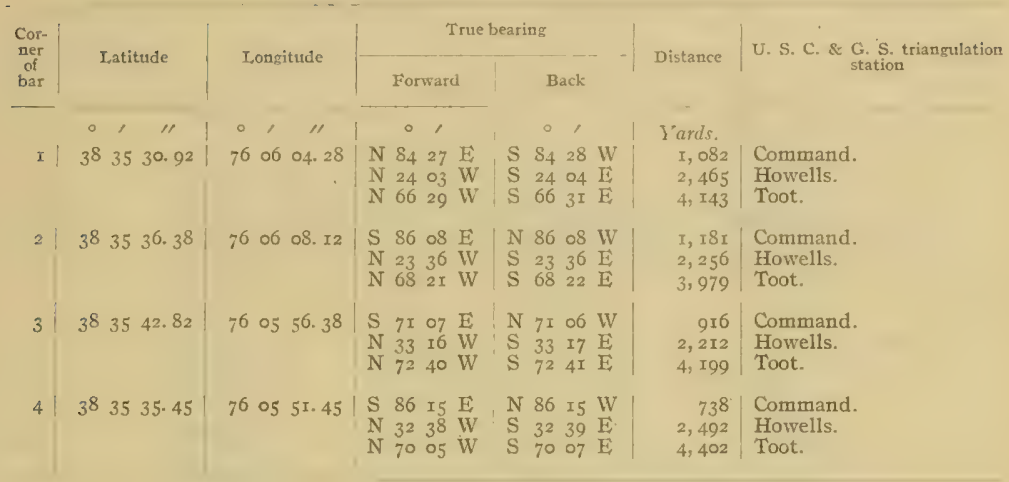

\section{SANDY HILL}

(Middle Choptank River-Chart No. 35.)

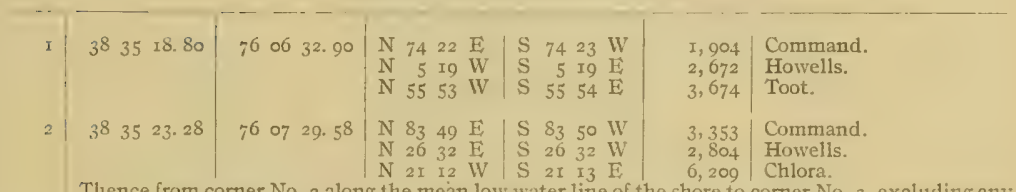

Thence from comer No. 2 along the mean low water line of the shore to comer No. 3 , excluding any. creck, cove, or inlet less than roo yards in widtll at its mouth at low tide.

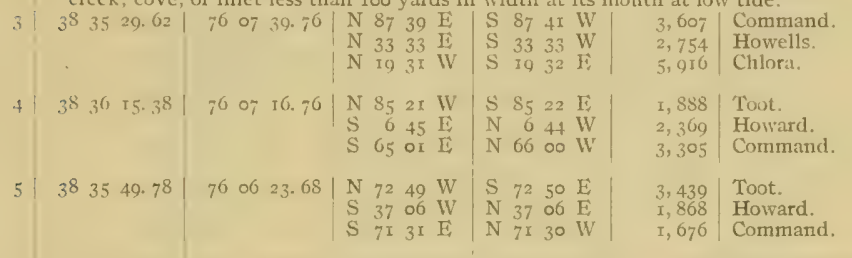




\section{COMMANDER.}

(Middle Choptank River-Chart No. 35.)

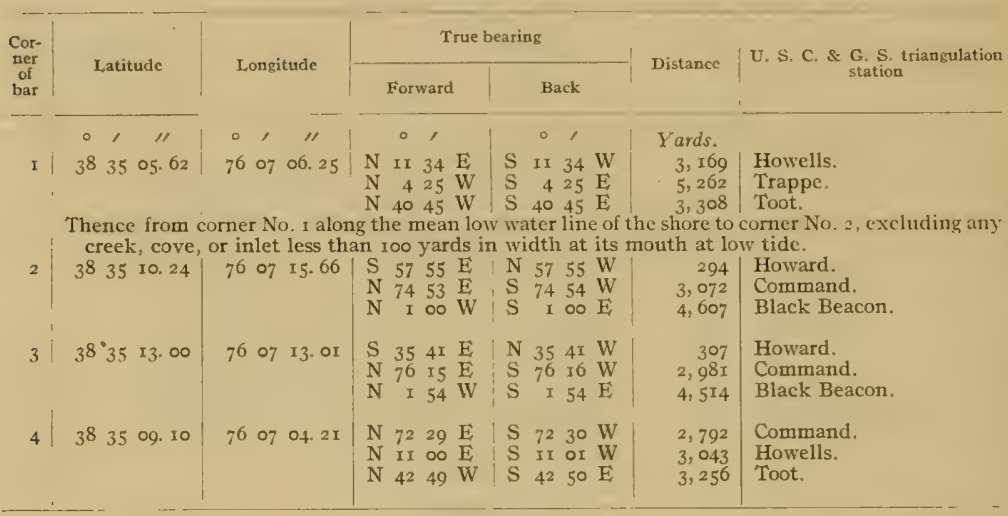

\section{HORN POINT.}

(Middle Choptank River-Chart No. 35.)

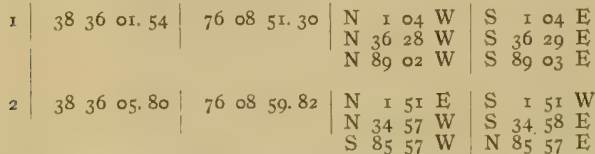

$3 \mid$\begin{tabular}{llll|lll} 
& 8 & 36 & 31.46 & 76 & 08 & 34.36
\end{tabular} $\begin{array}{llllllll}\mathrm{S} & 66 & 39 & \mathrm{~W} & \mathrm{~N} & 66 & 39 & \mathrm{E} \\ \mathrm{S} & 23 & 54 & \mathrm{E} & \mathrm{N} & 23 & 54 & \mathrm{WW}\end{array}$

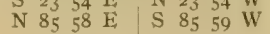

\begin{tabular}{l|lll|lllllll|llll}
4 & 38 & 36 & 46.21 & 76 & 08 & 32.40 & $\mathrm{~S}$ & 57 & 32 & $\mathrm{~W}$ & $\mathrm{~N}$ & 57 & 29 & $\mathrm{E}$ \\
$\mathrm{S}$ & 7 & 44 & $\mathrm{E}$ & $\mathrm{N}$ & 7 & 44 & $\mathrm{~W}$ \\
$\mathrm{~S}$ & 84 & 21 & $\mathrm{E}$ & $\mathrm{N}$ & 8 & 4 & 20 & $\mathrm{~W}$
\end{tabular}

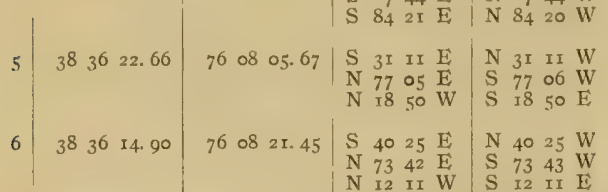

4, 5 or Chlora.

3,859 Large water tank.

I, 8 I9 Le Compte.

4, $35^{8}$ Chlora.

3, 6 II Large water tank.

I, 598 Le Compte.

$2,+69$ Le Compte.

425 Toot

2, 976 Howells.

2, 748 Le Compte.

895 Toot.

2, 929 Howells.

3, 037 Howard.

2, 266 Howells.

4, , 01 Chlora.

3, 070 Howard.

2, 735 Howells.

4, 143 Chlora.

Thence from coner No. 6 along the mean low water line of the shore to conner No. I, exeluding any. creek, cove, or inlet less than roo yards in width at its mouth at low tide. 


\section{LE COMPTE.}

(Middle Choptank River-Chari No. 35.)

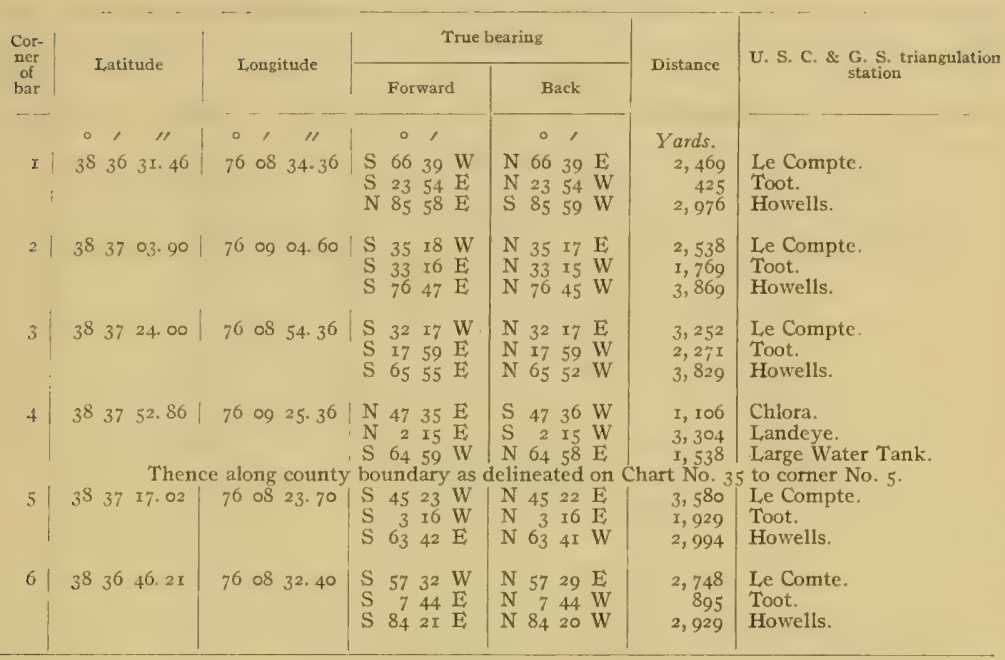

\section{CASTLE HAVEN CREEK.}

(Middle Choptank River-Chart No. 35.)

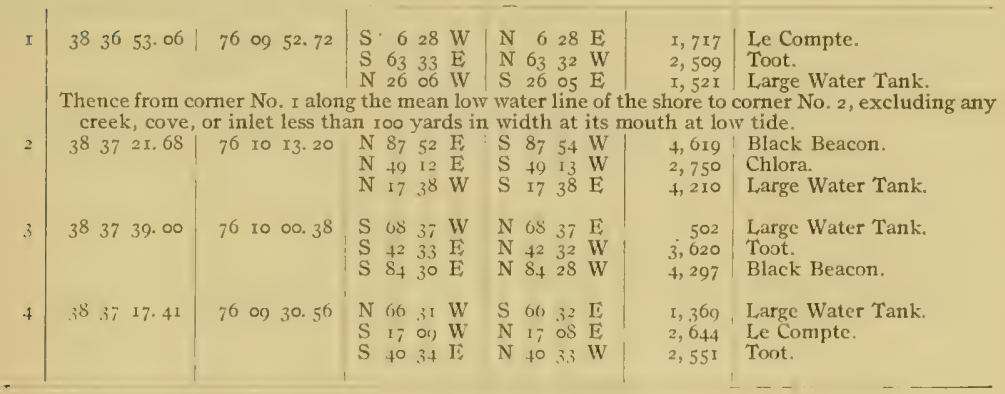




\section{CASTLE HAVEN.}

(Outer Choptank River-Charts Nos. 35 and 37.)

\begin{tabular}{|c|c|c|c|c|c|c|c|c|c|c|c|}
\hline \multirow{3}{*}{$\begin{array}{l}\text { Cor- } \\
\text { ner } \\
\text { of } \\
\text { bar }\end{array}$} & \multirow{2}{*}{ Iatitude } & \multirow{2}{*}{\multicolumn{3}{|c|}{ I,ongitude }} & \multicolumn{5}{|c|}{ True bearing } & \multirow{2}{*}{ Distance } & \multirow{2}{*}{$\begin{array}{c}\text { U.S. C. \& G. S. triangulation } \\
\text { station }\end{array}$} \\
\hline & & & & & \multicolumn{3}{|c|}{ Forward } & \multicolumn{2}{|r|}{ Back } & & \\
\hline & $\begin{array}{ccc}0 & \prime \prime \\
38 & 36 & 51.26\end{array}$ & $\begin{array}{l}0 \\
7^{6}\end{array}$ & I2 & "1. 64 & $\begin{array}{l}\mathrm{N} \\
\mathrm{S} \\
\mathrm{N}\end{array}$ & $\begin{array}{l}0 \\
60 \\
20 \\
63\end{array}$ & $\begin{array}{ll}26 & \mathrm{~W} \\
37 & \mathrm{~W} \\
10 & \mathrm{I}\end{array}$ & $\begin{array}{l}\mathrm{S} \\
\mathrm{N} \\
\mathrm{S}\end{array}$ & $\begin{array}{ccc}0 & 1 & \\
60 & 27 & \mathrm{E} \\
20 & 37 & \vec{E} \\
63 & I I & W\end{array}$ & $\begin{array}{r}\text { Yards. } \\
3,767 \\
\text { II4 } \\
\text { 3, I6I }\end{array}$ & $\begin{array}{l}\text { Dot. } \\
\text { Cormer. } \\
\text { Large Water Tank. }\end{array}$ \\
\hline 2 & $3^{8} \cdot 3^{6} 5^{8} \cdot 5^{0}$ & 76 & I2 & 39.54 & $\begin{array}{l}\mathrm{S} \\
\mathrm{N}\end{array}$ & $\begin{array}{l}68 \\
27 \\
55\end{array}$ & $\begin{array}{ll}22 & \mathrm{E} \\
\text { If } & \mathrm{E} \\
32 & \mathrm{~W}\end{array}$ & $\begin{array}{l}\mathrm{N} \\
\mathrm{S} \\
\mathrm{S}\end{array}$ & $\begin{array}{lll}68 & 22 & \mathrm{~W} \\
27 & 16 & \mathrm{~W} \\
55 & 33 & \mathrm{E}\end{array}$ & $\begin{array}{r}950 \\
5,426 \\
2,855\end{array}$ & $\begin{array}{l}\text { Comer. } \\
\text { Choptank River Light. } \\
\text { Dot. }\end{array}$ \\
\hline 3 & 3837.32 .00 & 76 & I2 & 49.04 & $\begin{array}{l}\mathrm{S} \\
\mathrm{N}\end{array}$ & $\begin{array}{l}37 \\
36 \\
76\end{array}$ & $\begin{array}{l}29 \mathrm{E} \\
32 \mathrm{E} \\
59 \mathrm{~W}\end{array}$ & $\begin{array}{l}\mathrm{N} \\
\mathrm{S} \\
\mathrm{S}\end{array}$ & $\begin{array}{lll}37 & 28 & \mathrm{~W} \\
36 & 33 & \mathrm{~W} \\
77 & 00 & \mathrm{E}\end{array}$ & $\begin{array}{l}1,865 \\
4,597 \\
2,158\end{array}$ & $\begin{array}{l}\text { Comer. } \\
\text { Choptank River Light. } \\
\text { Dot. }\end{array}$ \\
\hline 4 & $3^{8} 3728.60$ & $7^{6}$ & I2 & og. 40 & $\begin{array}{l}\mathrm{N} \\
\mathrm{S} \\
\mathrm{N}\end{array}$ & $\begin{array}{r}79 \\
3 \\
86\end{array}$ & $\begin{array}{ll}I_{3} & W \\
36 & I i \\
45 & E\end{array}$ & $\begin{array}{l}\mathrm{S} \\
\mathrm{N} \\
\mathrm{S}\end{array}$ & $\begin{array}{rrl}79 & 14 & \mathrm{E} \\
3 & 36 & \mathrm{WV} \\
86 & 46 & \mathrm{WV}\end{array}$ & $\begin{array}{l}3,208 \\
1,368 \\
2,952\end{array}$ & $\begin{array}{l}\text { Dot. } \\
\text { Corner. } \\
\text { Large Water Tank. }\end{array}$ \\
\hline 5 & $3^{8} \quad 3^{8} \quad 28.84$ & 76 & Io & $46.4^{8}$ & $\begin{array}{l}S \\
S \\
S\end{array}$ & $\begin{array}{l}3 I \\
35 \\
8 I\end{array}$ & $\begin{array}{ll}49 & W \\
07 & \mathrm{E} \\
02 & \mathrm{E}\end{array}$ & $\begin{array}{l}\mathrm{N} \\
\mathrm{N} \\
\mathrm{N}\end{array}$ & $\begin{array}{lll}3 \mathrm{I} & 48 & \mathrm{E} \\
35 & 07 & \mathrm{WV} \\
81 & 00 & \mathrm{~W}\end{array}$ & $\begin{array}{l}3,998 \\
1,928 \\
2,999\end{array}$ & $\begin{array}{l}\text { Corner. } \\
\text { Castle. } \\
\text { Chlora. }\end{array}$ \\
\hline 6 & $3^{8} \quad 37 \quad 38.70$ & 76 & OQ & 49.62 & $\begin{array}{l}\mathrm{N} \\
\mathrm{N} \\
\mathrm{N}\end{array}$ & $\begin{array}{l}50 \\
30 \\
73\end{array}$ & $\begin{array}{ll}00 & \mathrm{E} \\
04 \mathrm{~W} \\
59 \mathrm{~W}\end{array}$ & $\begin{array}{l}S \\
S \\
S\end{array}$ & $\begin{array}{lll}50 & \text { OI } & W \\
30 & \text { O5 } & \text { E } \\
73 & 59 & \text { E }\end{array}$ & $\begin{array}{r}I, 903 \\
4,008 \\
410\end{array}$ & $\begin{array}{l}\text { Chlora. } \\
\text { Choptank River Light. } \\
\text { Castle. }\end{array}$ \\
\hline
\end{tabular}

Thence from comer No. 6 along the mean low water line of the shore to comer No. $x$, excluding any creek, cove, or inlet less than roo yards in width at its mouth at low tide.

\section{COOK POINT.}

(Outer Choptank River-Charts Nos. 36 and 37.)

\begin{tabular}{|c|c|c|c|c|c|c|c|c|c|c|c|c|}
\hline & $3^{8} 3^{8}$ & 15.20 & 76 & 16 & 26. 68 & $\begin{array}{l}\mathrm{S} \\
\mathrm{S} \\
\mathrm{N}\end{array}$ & $\begin{array}{l}68 \\
75 \\
3 I\end{array}$ & $\begin{array}{ll}\circ \mathrm{W} \\
\text { of } \mathrm{E} \\
\text { I }_{3} \mathrm{E}\end{array}$ & \multicolumn{2}{|c|}{$\begin{array}{llll}\mathrm{N} & 68 & \circ 9 & \mathrm{E} \\
\mathrm{N} & 75 & 06 & \mathrm{WV} \\
\mathrm{S} & 3 \mathrm{I} & x_{5} & \mathrm{~W}\end{array}$} & $\begin{array}{l}\text { I, } 768 \\
3,782 \\
7,853\end{array}$ & $\begin{array}{l}\text { Chef. } \\
\text { Dot. } \\
\text { Roys. }\end{array}$ \\
\hline 2 & $3^{8} 3^{8}$ & 37.80 & 76 & 17 & 47.96 & $\begin{array}{l}\mathrm{S} \\
\mathrm{S} \\
\mathrm{N}\end{array}$ & $\begin{array}{l}\text { I9 } \\
73 \\
23\end{array}$ & $\begin{array}{ll}43 & \mathrm{E} \\
22 & \mathrm{E} \\
34 & \mathrm{WV}\end{array}$ & $\begin{array}{ll}N & 19 \\
N & 73 \\
S & 23\end{array}$ & $\begin{array}{l}42 \mathrm{~W} \\
20 \mathrm{~W} \\
35 \mathrm{~F}\end{array}$ & $\begin{array}{l}r, 508 \\
6,059 \\
6,020\end{array}$ & $\begin{array}{l}\text { Chef. } \\
\text { Dot. } \\
\text { Bar. }\end{array}$ \\
\hline 3 & $3^{8} 3^{8}$ & 48. 40 & 70 & $I_{7}$ & 48. 16 & $\begin{array}{l}\mathrm{S} \\
\mathrm{S} \\
\mathrm{N}\end{array}$ & $\begin{array}{l}16 \\
70 \\
24\end{array}$ & $\begin{array}{ll}\text { os } & \mathrm{E} \\
\mathrm{I} 2 & \mathrm{E} \\
57 & \mathrm{WV}\end{array}$ & $\begin{array}{ll}N & 16 \\
N & 70 \\
S & 24\end{array}$ & $\begin{array}{l}\text { of } \mathrm{W} \\
\text { Io } \mathrm{W} \\
5^{8} \mathrm{E}\end{array}$ & $\begin{array}{l}I, 850 \\
6,174 \\
5,692\end{array}$ & $\begin{array}{l}\text { Chef. } \\
\text { Dot. } \\
\text { Bar. }\end{array}$ \\
\hline 4 & $3^{8} 3^{S}$ & 52.80 & 76 & $I_{7}$ & $30.3^{2}$ & $\begin{array}{l}\mathrm{S} \\
\mathrm{S} \\
\mathrm{N}\end{array}$ & $\begin{array}{r}I \\
07 \\
16\end{array}$ & $\begin{array}{l}\text { I5 E } \\
\text { I. E E } \\
58 \text { E }\end{array}$ & $\begin{array}{lr}N & I \\
N & 67 \\
S & 16\end{array}$ & $\begin{array}{l}\text { I5 } \mathrm{W} \\
\text { I2 } \mathrm{W} \\
59 \mathrm{~W}\end{array}$ & $\begin{array}{l}I, 926 \\
5,788 \\
6,768\end{array}$ & $\begin{array}{l}\text { Chef. } \\
\text { Dot. } \\
\text { Nelson 3 }\end{array}$ \\
\hline 5 & $\begin{array}{lll}38 & 39\end{array}$ & $.17 \cdot 20$ & 76 & 17 & o8. 36 & $\begin{array}{l}\mathrm{N} \\
\mathrm{N} \\
\mathrm{S}\end{array}$ & $\begin{array}{r}16 \\
82 \\
8\end{array}$ & $\begin{array}{l}44 \mathrm{II} \\
5 \mathrm{I} \text { WV } \\
\text { og } \mathrm{IV}\end{array}$ & $\begin{array}{lr}\mathrm{S} & 16 \\
\mathrm{~S} & \mathrm{~S} 2 \\
\mathrm{~N} & 8\end{array}$ & $\begin{array}{ll}45 & W \\
53 & \mathrm{E} \\
09 & \mathrm{I}\end{array}$ & $\begin{array}{l}4,845 \\
5,23.3 \\
3,798\end{array}$ & $\begin{array}{l}\text { Nelson } 3 \\
\text { Black. } \\
\text { Chef. }\end{array}$ \\
\hline 6 & $3^{8} \quad 39$ & 5I. I2 & 76 & 16 & +2.84 & $\begin{array}{l}N \\
N \\
S\end{array}$ & $\begin{array}{l}9 \\
84 \\
17\end{array}$ & $\begin{array}{l}05 \mathrm{E} \\
56 \mathrm{~W} \\
\mathrm{ig} \mathrm{W}\end{array}$ & $\begin{array}{lr}\mathrm{S} & 9 \\
\mathrm{~S} & 84 \\
\mathrm{~N} & \mathbf{1} 7\end{array}$ & $\begin{array}{ll}05 & W \\
.59 & \mathrm{E} \\
\text { I9 } & \mathrm{E}\end{array}$ & $\begin{array}{l}4,564 \\
5,890 \\
4,077\end{array}$ & $\begin{array}{l}\text { Nelson } 3 \\
\text { Black. } \\
\text { Chef. }\end{array}$ \\
\hline 7 & $3^{8} 39$ & 29.28 & $7^{6}$ & 16 & 17.40 & $\begin{array}{l}\mathrm{S} \\
\mathrm{S} \\
\mathrm{N}\end{array}$ & $\begin{array}{l}30 \\
44 \\
42\end{array}$ & $\begin{array}{ll}52 & \mathrm{~W} \\
30 & \mathrm{E} \\
\mathrm{I} 2 & \mathrm{E}\end{array}$ & $\begin{array}{ll}N & 30 \\
N & 44 \\
S & 42\end{array}$ & $\begin{array}{ll}5 \mathrm{I} & \mathrm{E} \\
29 & \mathrm{~W} \\
\text { I3 } & \mathrm{W}\end{array}$ & $\begin{array}{l}3,678 \\
4,863 \\
5,694\end{array}$ & $\begin{array}{l}\text { Chef. } \\
\text { Dot. } \\
\text { Roys. }\end{array}$ \\
\hline
\end{tabular}




\section{RED BUOY.}

(Outer Choptank River-Charts Nos. 36 and 37.)

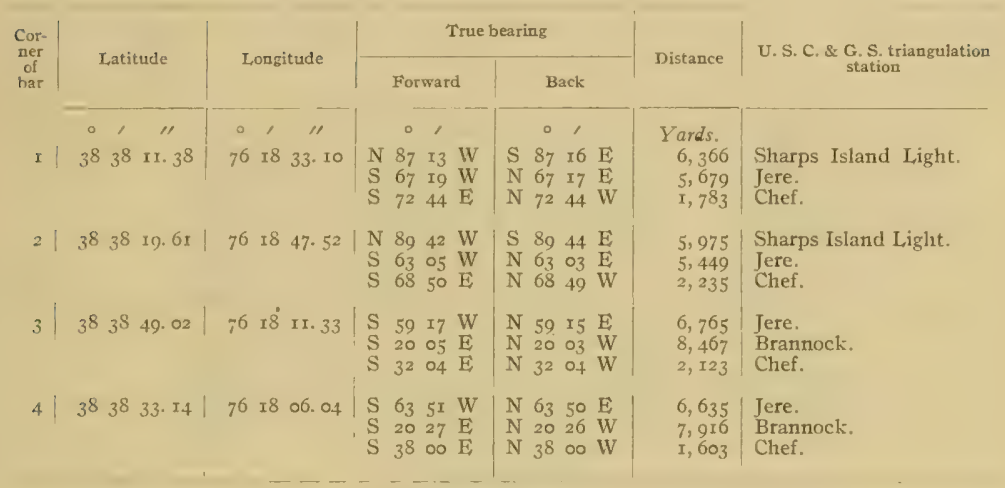

\section{SPEDDEN.}

(Entrance Choptank River-Charts Nos. 36 and 37.)

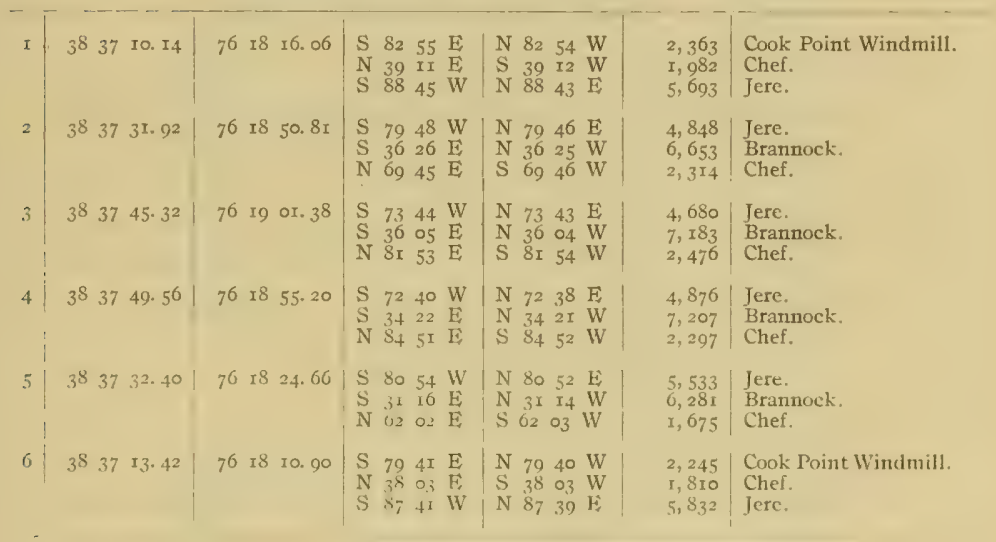




\section{DUPONT.}

(Chesapeake Bay-Off Tripps Bay-Charts Nos. 36 and 37.)

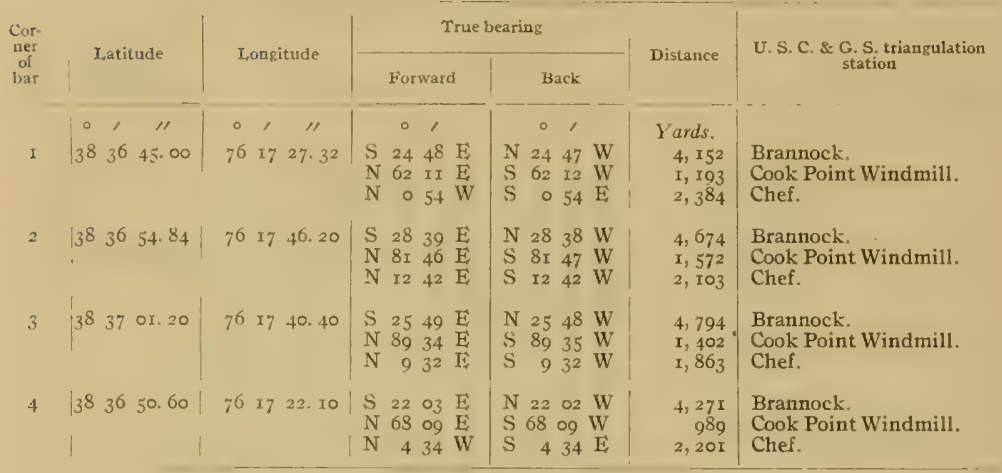

\section{DIAMOND.}

(Chesapeake Bay-Vicinity Sharps Island-Charts Nos, 36 and 37.)

\begin{tabular}{|c|c|c|c|c|c|c|}
\hline$I$ & $3^{8} 3^{6}$ 10. 60 & $\begin{array}{lll}76 & 20 & 02.68\end{array}$ & $\begin{array}{llll}\mathrm{S} & 65 & 58 & \mathrm{E} \\
\mathrm{N} & 48 & 58 & \mathrm{E} \\
N & 56 & 43 & \mathrm{~W}\end{array}$ & $\begin{array}{llll}\mathrm{N} & 65 & 55 & \mathrm{~W} \\
\mathrm{~S} & 49 & 00 & \mathrm{~W} \\
\mathrm{~S} & 56 & 44 & \mathrm{E}\end{array}$ & $\begin{array}{l}6,410 \\
5,398 \\
3,434\end{array}$ & $\begin{array}{l}\text { Brannock. } \\
\text { Chef. } \\
\text { Jere. }\end{array}$ \\
\hline 2 & $3^{8} \quad 3^{6} 39 \cdot 40$ & 762043.16 & $\begin{array}{llll}\mathrm{S} & 62 & 38 & \mathrm{E} \\
\mathrm{N} & 63 & 26 & \mathrm{E} \\
\mathrm{N} & 40 & 3 \mathrm{I} & \mathrm{W}\end{array}$ & $\begin{array}{llll}N & 62 & 36 & W \\
\mathrm{~S} & 63 & 28 & \mathrm{~W} \\
\mathrm{~S} & 40 & 32 & \mathrm{E}\end{array}$ & $\begin{array}{l}7,797 \\
5,750 \\
4,489\end{array}$ & $\begin{array}{l}\text { Brannock. } \\
\text { Chef. } \\
\text { Sharps Island Light. }\end{array}$ \\
\hline 3 & $\begin{array}{l}\text { Thenc } \\
{ }_{3} 83^{6} \quad 58.72\end{array}$ & $\begin{array}{l}\text { along county } \\
7620 \quad 27 \cdot 22\end{array}$ & 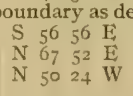 & 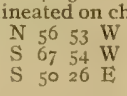 & $\begin{array}{r}\text { Nos. } 36 \\
7,761 \\
5,096 \\
4,332\end{array}$ & $\begin{array}{l}\text { and } 37 \text { to corner No. } 3 \text {. } \\
\text { Brannock. } \\
\text { Chef. } \\
\text { Sharps Island Light. }\end{array}$ \\
\hline 4 & $3^{8} 3^{6} \quad 5^{8} .28$ & $7^{6}$ I8 45.32 & $\begin{array}{llll}N & 88 & 00 & \mathrm{E} \\
N & 6 & 18 & \mathrm{E} \\
N & 65 & 19 & W\end{array}$ & $\begin{array}{llll}\mathrm{S} & 88 & 02 & \mathrm{~W} \\
\mathrm{~S} & 46 & 19 & \mathrm{~W} \\
\mathrm{~S} & 65 & 2 \mathrm{I} & \mathrm{E}\end{array}$ & $\begin{array}{l}3, \mathrm{r} 2 \mathrm{I} \\
2,802 \\
6,64 \mathrm{I}\end{array}$ & $\begin{array}{l}\text { Cook Point Windmill. } \\
\text { Chef. } \\
\text { Sharps Island I.ight. }\end{array}$ \\
\hline 5 & $3^{8} 3^{6}$ 10. 72 & 76 I9 10.96 & $\begin{array}{llll}\mathrm{S} & 59 & 45 & \mathrm{E} \\
\mathrm{N} & 37 & 23 & \mathrm{I} \\
\mathrm{N} & 66 & 05 & \mathrm{~W}\end{array}$ & $\begin{array}{llll}N & 59 & 45 & W \\
S & 37 & 23 & W \\
S & 66 & 06 & F\end{array}$ & $\begin{array}{l}5,191 \\
4,454 \\
4,637\end{array}$ & $\begin{array}{l}\text { Brannock. } \\
\text { Chef. } \\
\text { Jere. }\end{array}$ \\
\hline
\end{tabular}

\section{BRANNOCK.}

(Chesapeake Bay' Off Tripps Bay-Charls Nos. 36 and 37.)

\begin{tabular}{|c|c|c|c|c|c|c|}
\hline I & $\begin{array}{llll}3^{8} & 36 & 0.8 & 83\end{array}$ & 76 I7 22.46 & $\begin{array}{llll}\mathrm{S} & 3 \mathrm{I} & 58 & \mathrm{E} \\
\mathrm{N} & 28 & 00 & \mathrm{E} \\
\mathrm{N} & 74 & 5^{8} & \mathrm{~W}\end{array}$ & $\begin{array}{llll}N & 3 I & 58 & W \\
S & 28 & \text { or } & W \\
S & 75 & \text { or } & \vec{E}\end{array}$ & $\begin{array}{l}3,046 \\
1,974 \\
7,361\end{array}$ & $\begin{array}{l}\text { Brannuck. } \\
\text { Cook Point Windmill. } \\
\text { Jere. }\end{array}$ \\
\hline 2 & $3^{8} \quad 36 \quad 20.52$ & 76 I7 36.43 & $\begin{array}{lrrr}\mathrm{S} & 33 & 57 & \mathrm{E} \\
\mathrm{N} & 43 & 10 & \mathrm{E} \\
\mathrm{N} & 3 & 38 & \mathrm{E}\end{array}$ & $\begin{array}{lccc}\mathrm{N} & 33 & 56 & \mathrm{~W} \\
\mathrm{~S} & 43 & 10 & \mathrm{~W} \\
\mathrm{~S} & 3 & 38 & \mathrm{~W}\end{array}$ & $\begin{array}{l}3,550 \\
I, 895 \\
3,215\end{array}$ & $\begin{array}{l}\text { Brannock. } \\
\text { Cook Point Windmill. } \\
\text { Chef. }\end{array}$ \\
\hline 3 & $38 \quad 36 \quad 33.12$ & 76 I7 29.46 & $\begin{array}{lrrr}\$ & 28 & 05 & \mathrm{E} \\
\mathrm{N} & 49 & 16 & \mathrm{I} \\
\mathrm{N} & 0 & 24 & \mathrm{E}\end{array}$ & $\begin{array}{lrrr}\mathrm{N} & 28 & 05 & \mathrm{~W} \\
\mathrm{~S} & 49 & 17 & \mathrm{~W} \\
\mathrm{~S} & 0 & 24 & \mathrm{~W}\end{array}$ & $\begin{array}{l}3,810 \\
I, 468 \\
2,783\end{array}$ & $\begin{array}{l}\text { Brannock. } \\
\text { Cook Point Windmill. } \\
\text { Chef. }\end{array}$ \\
\hline 4 & $3^{8} \quad 36 \quad$ I 7.62 & $7^{6}$ I & $\begin{array}{llll}\mathrm{S} & 23 & 49 & \mathrm{E} \\
\mathrm{N} & 2 \mathrm{I} & 0.4 & \mathrm{E} \\
\mathrm{N} & 77 & 34 & \mathrm{~W}\end{array}$ & $\begin{array}{cccc}\mathrm{N}_{2} & 23 & 48 & \mathrm{~W} \\
\mathrm{~S} & 2 \mathrm{I} & 04 & \mathrm{~W} \\
\mathrm{~S} & 77 & 37 & \mathrm{E}\end{array}$ & $\begin{array}{l}3, \text { I I I } \\
\text { I, } 586 \\
7,644\end{array}$ & $\begin{array}{l}\text { Brannock. } \\
\text { Cook Point Windmill. } \\
\text { Jere. }\end{array}$ \\
\hline
\end{tabular}


MILL POINT.

(Chesapeake Bay-Off Tripps Bay-Charts Nos. 36 and 37.)

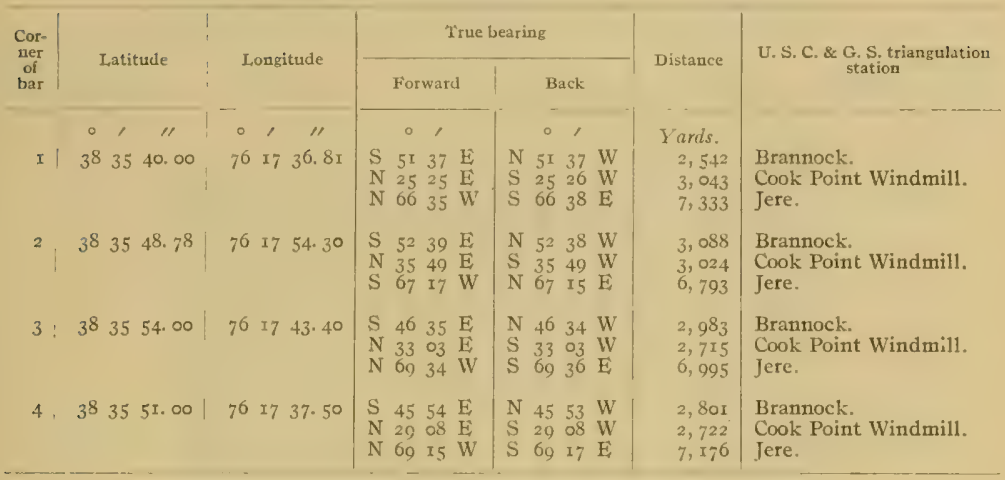

\section{HILLS POIN'T}

(Chesapeake Bay-Off Entrance Litlle Choptank Rizer-Charts Nos. 36 and 37.)

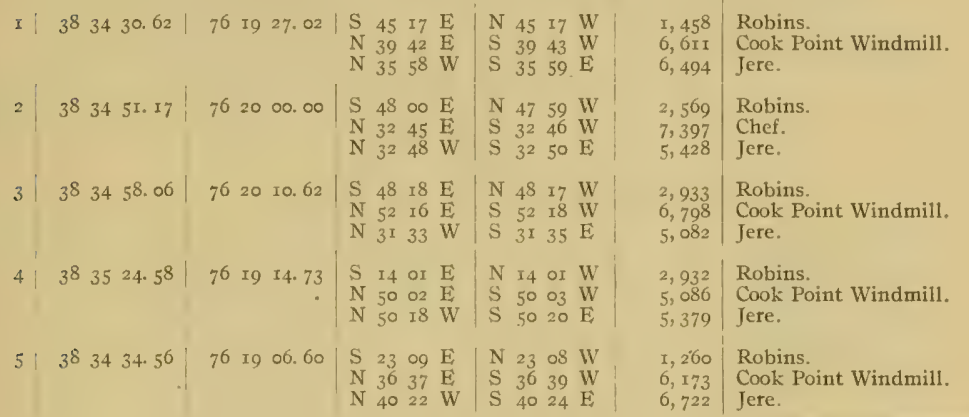

HILLS POINT NORTH.

(Chesapcake Bay-Off Entrance Little Choptank River-Charts Nos. 36 and 37.)

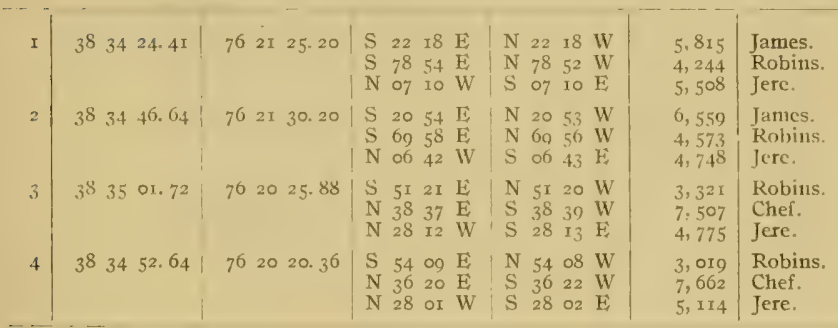




\section{HILLS POINT SOUTH.}

(Chesapeake Bay-Off Entrance Litile Choptank River-Charls Nos. 36 and 37.)

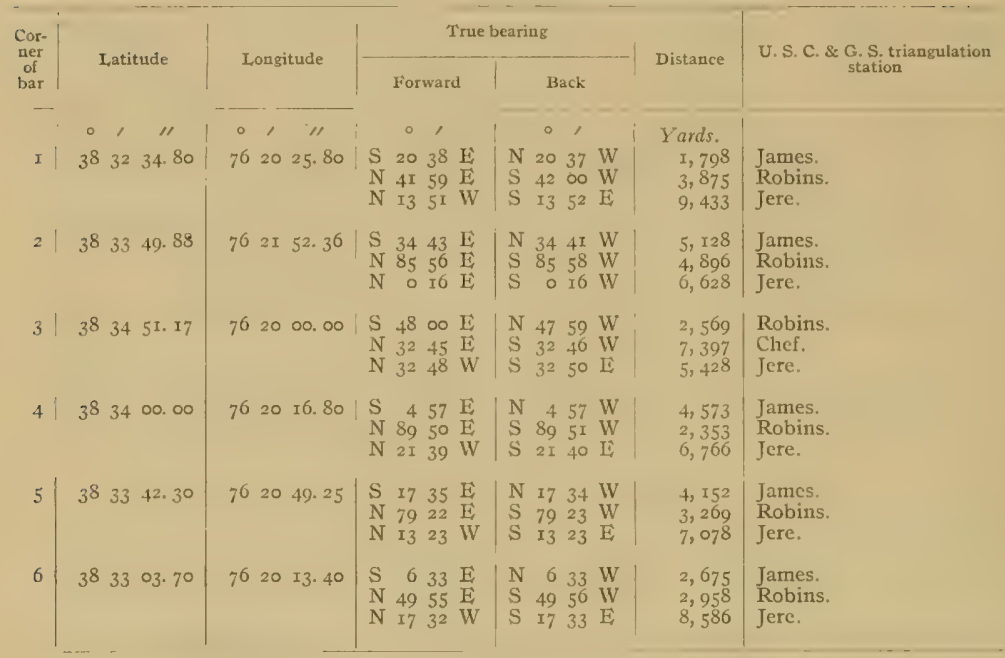

\section{JAMES POINT.}

(Chesapeake Bay-Vicinity James Point-Chart No. 36.)

\begin{tabular}{|c|c|c|c|c|c|c|c|c|c|c|c|c|}
\hline I & 38 & $3 I$ & 4I. 59 & 76 & 22 & oI. $5^{6}$ & $\begin{array}{l}\mathrm{S} \\
\mathrm{N} \\
\mathrm{N}\end{array}$ & $\begin{array}{l}40 \\
88 \\
47\end{array}$ & $\begin{array}{ll}3 I & E \\
00 & E \\
39 & E\end{array}$ & $\begin{array}{llll}\mathrm{N} & 40 & 30 & \mathrm{~W} \\
\mathrm{~S} & 88 & \text { oI } & \mathrm{W} \\
\mathrm{S} & 47 & 4 I & \mathrm{~W}\end{array}$ & $\begin{array}{l}4, I 70 \\
3, I 7 I \\
6,937\end{array}$ & $\begin{array}{l}\text { Skid. } \\
\text { James. } \\
\text { Robins. }\end{array}$ \\
\hline 2 & 38 & $3 I$ & 42.18 & 76 & 22 & 32.00 & $\begin{array}{l}\mathrm{S} \\
\mathrm{N} \\
\mathrm{N}\end{array}$ & $\begin{array}{l}47 \\
88 \\
51\end{array}$ & $\begin{array}{l}47 \mathrm{E} \\
42 \mathrm{E} \\
54 \mathrm{E}\end{array}$ & $\begin{array}{llll}\mathrm{N} & 47 & 46 & \mathrm{~W} \\
\mathrm{~S} & 88 & 43 & \mathrm{~W} \\
\mathrm{~S} & 51 & 56 & \mathrm{~W}\end{array}$ & $\begin{array}{l}4,747 \\
3,977 \\
7,539\end{array}$ & $\begin{array}{l}\text { Skid. } \\
\text { James. } \\
\text { Robins. }\end{array}$ \\
\hline 3 & 38 & $3^{2}$ & 42.94 & 76 & 23 & I0. 08 & $\begin{array}{l}\mathrm{S} \\
\mathrm{S} \\
\mathrm{N}\end{array}$ & $\begin{array}{l}40 \\
68 \\
69\end{array}$ & $\begin{array}{l}49 \vec{E} \\
33 \vec{E} \\
27 \mathrm{E}\end{array}$ & $\begin{array}{llll}\mathrm{N} & 40 & 47 & W \\
\mathrm{~N} & 68 & 3 \mathrm{I} & \mathrm{W} \\
\mathrm{S} & 69 & 29 & \mathrm{~W}\end{array}$ & $\begin{array}{l}6,923 \\
5,355 \\
7,414\end{array}$ & $\begin{array}{l}\text { Skid, } \\
\text { James. } \\
\text { Robins. }\end{array}$ \\
\hline 4 & $3^{8}$ & 3.3 & 25.78 & 76 & 22 & $59 \cdot 76$ & $\begin{array}{l}\mathrm{S} \\
\mathrm{N} \\
\mathrm{N}\end{array}$ & $\begin{array}{r}54 \\
80 \\
4\end{array}$ & $\begin{array}{l}\text { ro } \mathrm{E} \\
\text { on } \mathrm{E} \\
\text { oo } \mathrm{E}\end{array}$ & $\begin{array}{lrrr}N & 54 & 08 & W \\
S & 80 & 11 & W \\
S & 4 & \text { or } & W\end{array}$ & $\begin{array}{l}5,8 I I \\
6,768 \\
9,966\end{array}$ & $\begin{array}{l}\text { James. } \\
\text { Robins. } \\
\text { Sllarps Island I,ight. }\end{array}$ \\
\hline 5 & 38 & 33 & 23.00 & 76 & $2 \Sigma$ & 58. $3^{8}$ & $\begin{array}{l}\mathrm{S} \\
\mathrm{N} \\
\mathrm{N}\end{array}$ & $\begin{array}{r}4.3 \\
76 \\
1\end{array}$ & $\begin{array}{ll}\text { OI } & 1 \mathrm{i} \\
03 & \mathrm{H} \\
27 & \mathrm{li}\end{array}$ & $\begin{array}{lrrr}\mathrm{N} & 43 & 00 & \mathrm{~W} \\
\mathrm{~S} & 76 & 05 & \mathrm{~W} \\
\mathrm{~S} & \mathrm{I} & 27 & \mathrm{~W}\end{array}$ & $\begin{array}{l}4,523 \\
5,197 \\
7,538\end{array}$ & $\begin{array}{l}\text { James. } \\
\text { Robins. } \\
\text { Jere. }\end{array}$ \\
\hline 6 & 38 & 32 & $34 \cdot 3^{0}$ & 76 & $2 I$ & 42.68 & $\begin{array}{l}S \\
N \\
N\end{array}$ & $\begin{array}{r}58 \\
57 \\
I\end{array}$ & $\begin{array}{l}00 \mathrm{Hi} \\
59 \mathrm{H} \\
24 \mathrm{~W}\end{array}$ & $\begin{array}{llll}\mathrm{N} & 57 & 59 & \mathrm{~W} \\
\mathrm{~S} & 58 & \text { ox } & \mathrm{W} \\
\mathrm{S} & \mathrm{I} & 24 & \mathrm{E}\end{array}$ & $\begin{array}{l}3,148 \\
5,457 \\
9,179\end{array}$ & $\begin{array}{l}\text { James. } \\
\text { Robins. } \\
\text { Jerc. }\end{array}$ \\
\hline
\end{tabular}


TRAVERS.

(Chesapeake Bay-Vicinity James Island-Charts Nos. 36 and 38 .)

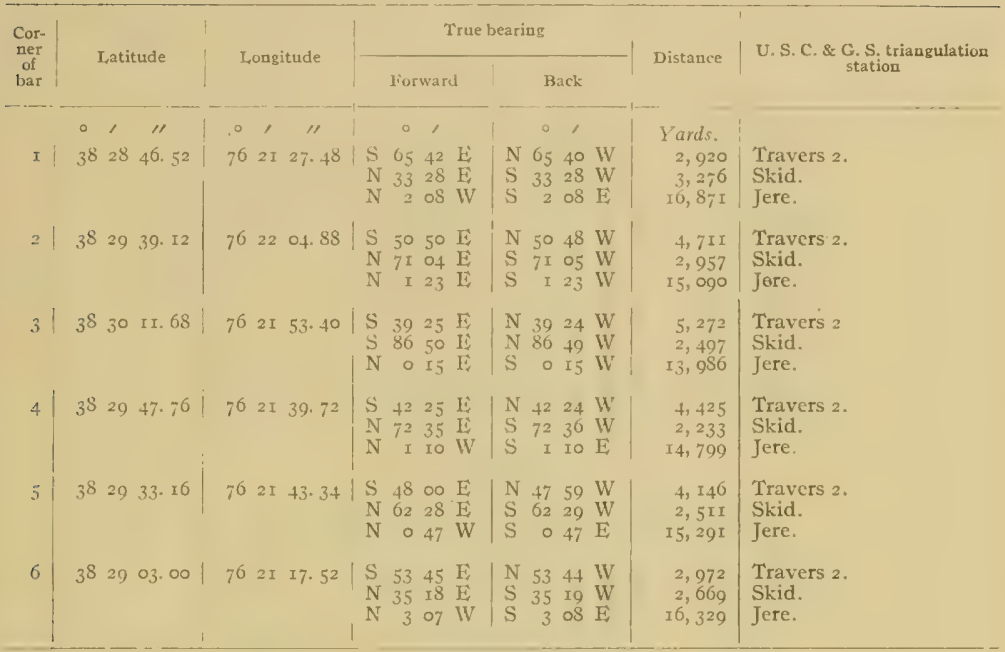

\section{MARSHALI.}

(Oj'ster Creek-Charts Nos. 36, 37, and 38.)

\begin{tabular}{|c|c|c|c|c|c|c|}
\hline & $3^{8} 292$ I. 7 I & 76 I9 59.20 & $\begin{array}{lrrl}N & 44 & \text { 12 } & \mathrm{E} \\
\mathrm{N} & 7 & 40 & \mathrm{WV} \\
\mathrm{N} & \text { in } & 00 & \mathrm{WV}\end{array}$ & $\begin{array}{rrrr}\mathrm{S} & 44 & \text { I4 } & \text { W } \\
\mathrm{S} & 7 & 4 \mathrm{I} & \mathrm{E} \\
\mathrm{S} & \text { I9 } & \text { oI } & \mathrm{E}\end{array}$ & $\begin{array}{l}7,422 \\
3,036 \\
1,636\end{array}$ & $\begin{array}{l}\text { Ragged Point } 3 \text {. } \\
\text { Rede. } \\
\text { Skid. }\end{array}$ \\
\hline & $\begin{array}{llll}38 & 29 & 28.62\end{array}$ & 762007.94 & $\begin{array}{rrrl}N & 46 & 44 & \mathrm{E} \\
\mathrm{N} & 3 & 35 & \mathrm{~W} \\
\mathrm{~N} & 12 & 55 & \mathrm{~W}\end{array}$ & $\begin{array}{rrrr}\mathrm{S} & 46 & 46 & \mathrm{IV} \\
\mathrm{S} & 3 & 35 & \mathrm{E} \\
\mathrm{S} & 12 & 55 & \mathrm{E}\end{array}$ & $\begin{array}{l}7,423 \\
2,78 \mathrm{r} \\
\mathrm{I}, 35 \mathrm{I}\end{array}$ & $\begin{array}{l}\text { Ragged Point } 3 . \\
\text { Rede. } \\
\text { Skid. }\end{array}$ \\
\hline & $3^{8} \quad 2927 \cdot 76$ & $7^{6}$ ig $5^{6} .3^{6}$ & 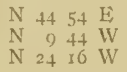 & $\begin{array}{rrrr}\mathrm{S} & +4 & 56 & \mathrm{~W} \\
\mathrm{~S} & 9 & 4+4 & \mathrm{E} \\
\mathrm{S} & 24 & \mathrm{I} 7 & \mathrm{E}\end{array}$ & $\begin{array}{l}7,224 \\
2,8.44 \\
I, 480\end{array}$ & $\begin{array}{l}\text { Ragged Point } 3 \text {. } \\
\text { Rede. } \\
\text { Skid. }\end{array}$ \\
\hline
\end{tabular}




\section{OYSTER CREEK.}

(Litlle Choptank River-Charts Nos. 36, 37, and 38.)

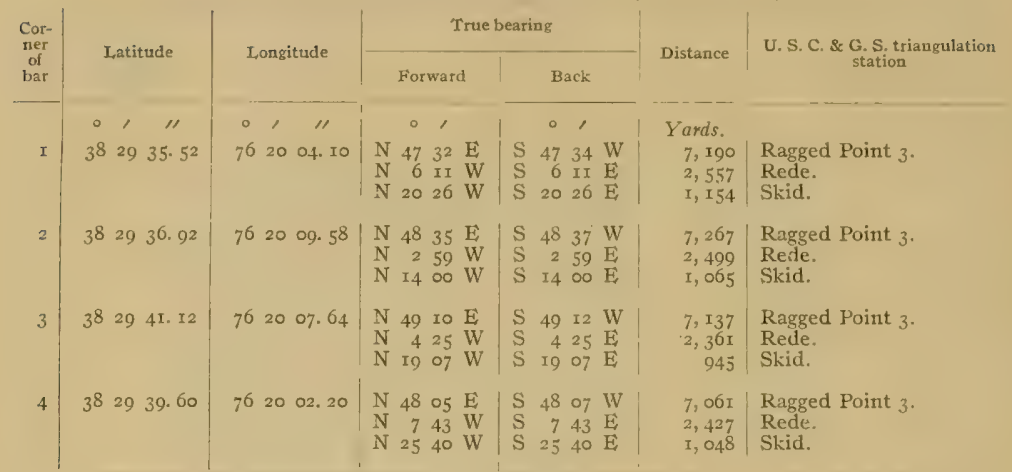

\section{GRANGER.}

(Little Choptank River-Charts Nos, 36, 37, and 38.)

\begin{tabular}{|c|c|c|c|c|c|c|}
\hline I & $3^{8} \quad 3000.84$ & 76 I9 $49 . I_{4}$ & $\begin{array}{llll}\mathrm{N} & 85 & 52 & \mathrm{E} \\
\mathrm{N} & 2 \mathrm{I} & 42 & \mathrm{~W} \\
\mathrm{~N} & 74 & 07 & \mathrm{~W}\end{array}$ & $\begin{array}{llll}\mathrm{S} & \mathrm{S}_{5} & 5 \mathrm{I} & \mathrm{W} \\
\mathrm{S} & 2 \mathrm{I} & 42 & \mathrm{E} \\
\mathrm{S} & 74 & 07 & \mathrm{E}\end{array}$ & $\begin{array}{r}2,653 \\
\mathrm{I}, 8 \mathrm{I} 8 \\
83 \mathrm{r}\end{array}$ & $\begin{array}{l}\text { Can. } \\
\text { Rede. } \\
\text { Skid. }\end{array}$ \\
\hline 2 & $3^{8} \quad 30 \quad 19.44$ & 76 I9 $57 \cdot 5^{6}$ & $\begin{array}{llll}\mathrm{S} & 8 \mathrm{x} & 22 & \mathrm{E} \\
\mathrm{N} & 22 & 55 & \mathrm{~W} \\
\mathrm{~S} & 55 & 16 & \mathrm{~W}\end{array}$ & $\begin{array}{llll}N & 8 I & 23 & W \\
S & 22 & 55 & E \\
N & 55 & 16 & E\end{array}$ & $\begin{array}{r}2,902 \\
I, I 53 \\
702\end{array}$ & $\begin{array}{l}\text { Can. } \\
\text { Rede. } \\
\text { Skid. }\end{array}$ \\
\hline 3 & $3^{8} \quad 30 \quad 22.59$ & 76 I9 46.56 & $\begin{array}{llll}\mathrm{N} & 55 & 58 & \mathrm{E} \\
\mathrm{N} & 37 & 46 & \mathrm{~W} \\
\mathrm{~S} & 59 & 46 & \mathrm{~W}\end{array}$ & $\begin{array}{llll}\mathrm{S} & 56 & 00 & \mathrm{~W} \\
\mathrm{~S} & 37 & 47 & \mathrm{E} \\
\mathrm{N} & 59 & 46 & \mathrm{E}\end{array}$ & $\begin{array}{l}5,840 \\
I, 208 \\
I, 005\end{array}$ & $\begin{array}{l}\text { Ragged Point } 3 . \\
\text { Rede. } \\
\text { Skid. }\end{array}$ \\
\hline 4 & $3^{8} 3004.26$ & $7^{6}$ I9 $38.6 \mathrm{I}$ & $\begin{array}{llll}N & 88 & \text { 10 } & E \\
N & 3 x & \text { o9 } & W \\
N & 84 & 03 & W\end{array}$ & $\begin{array}{llll}\mathrm{S} & 88 & \text { II } & W \\
\mathrm{~S} & 3 \mathrm{I} & \text { o9 } & \mathrm{E} \\
\mathrm{S} & 84 & 04 & \mathrm{E}\end{array}$ & $\begin{array}{l}2,369 \\
1,838 \\
1,085\end{array}$ & $\begin{array}{l}\text { Can. } \\
\text { Rede. } \\
\text { Skid. }\end{array}$ \\
\hline
\end{tabular}

\section{CATORS.}

(Little Choptank River-Charts Nos. 36, 37, and 38.)

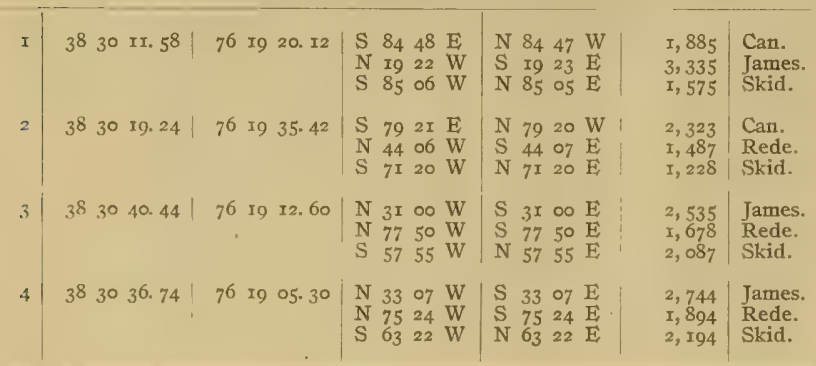


HENPECK.

(Little Choptank River-Charts Nos. 36. 37, and 38.)

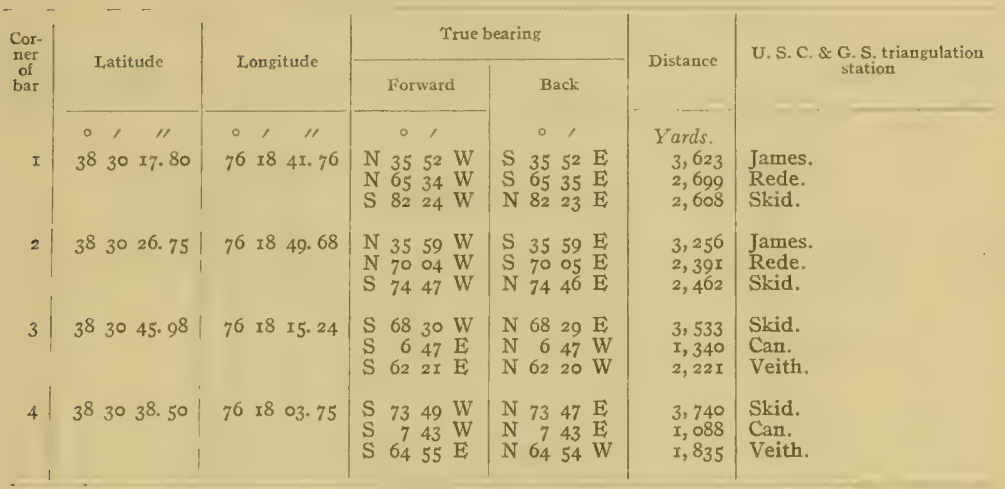

SLAUGHTER CREEK.

(Entrance Slaughter Creek-Charts Nos. 36, 37, and 38.)

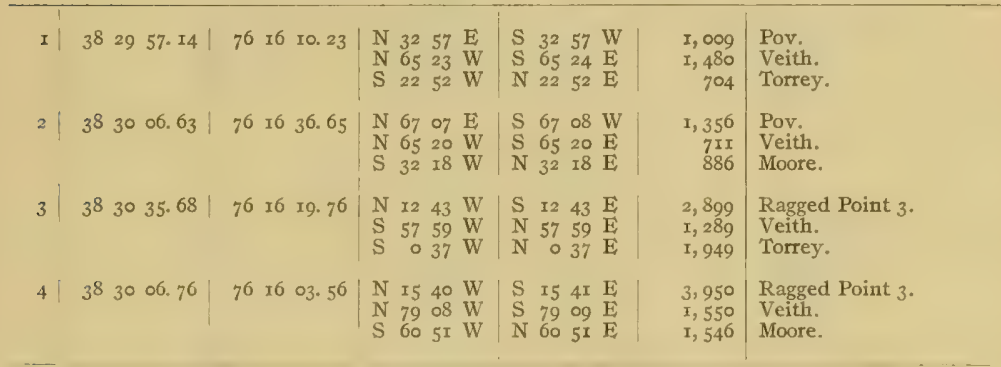

\section{HOOPER}

(Entrance Slaughter Creek-Charts Nos. 36, 37, and 38.)

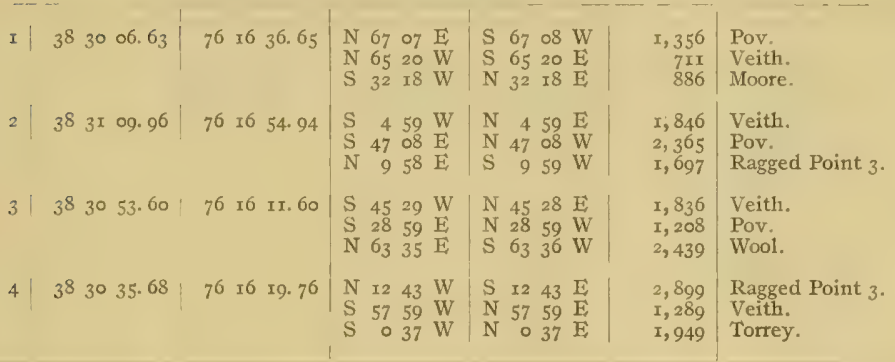




\section{NINE ACRES.}

(Little Choptank River-Charts Nos. 36 and 37.)

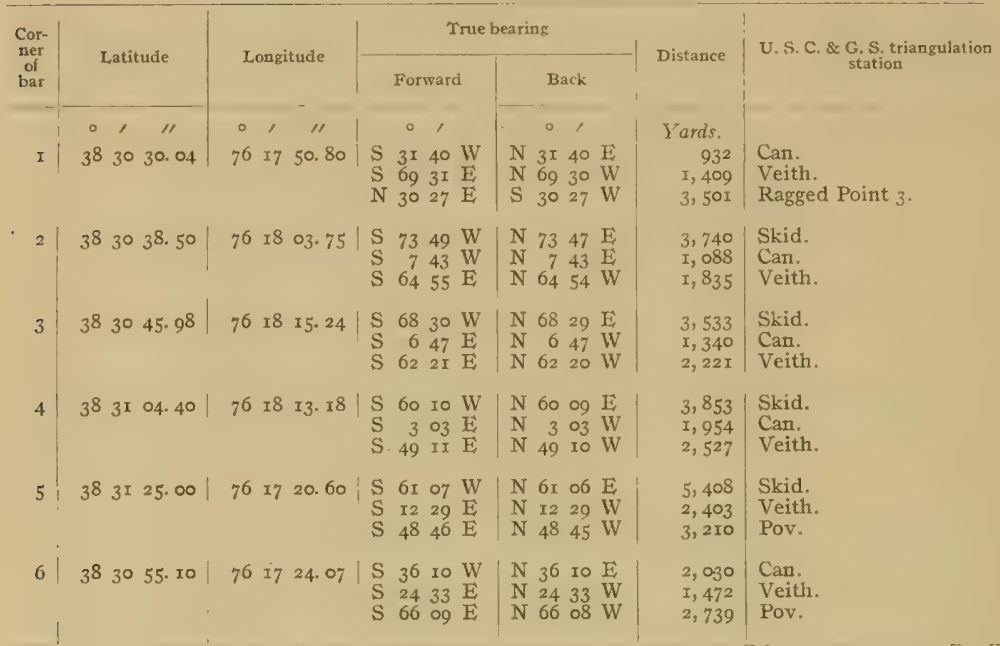

\section{LITTLE CHOPTANK.}

(Little Choptank River-Charts Nos. 36 and 37.)

\begin{tabular}{|c|c|c|c|c|c|c|}
\hline I & $3^{8} 3049 \cdot 5^{8}$ & $7^{6}$ I $8 \quad 43 \cdot 36$ & $\begin{array}{llll}N & 48 & 07 & W \\
N & 88 & 56 & W \\
S & 60 & 53 & W\end{array}$ & $\begin{array}{llll}\mathrm{S} & 48 & \text { os } & \mathrm{E} \\
\mathrm{S} & 88 & 54 & \mathrm{E} \\
\mathrm{N} & 60 & 52 & \mathrm{E}\end{array}$ & $\begin{array}{l}2,794 \\
2,415 \\
2,910\end{array}$ & $\begin{array}{l}\text { James. } \\
\text { Rede. } \\
\text { Skid. }\end{array}$ \\
\hline 2 & ${ }_{3}^{8} 31 \quad 00.84$ & 76 IS 59.66 & $\begin{array}{llll}\mathrm{N} & 47 & 5^{8} & \mathrm{~W} \\
\mathrm{~S} & 80 & 25 & \mathrm{~W} \\
\mathrm{~S} & 49 & 36 & \mathrm{~W}\end{array}$ & $\begin{array}{llll}\mathrm{S} & 47 & 59 & \mathrm{E} \\
\mathrm{N} & 80 & 24 & \mathrm{E} \\
\mathrm{N} & 49 & 36 & \mathrm{E}\end{array}$ & $\begin{array}{l}2,219 \\
2,011 \\
2,771\end{array}$ & $\begin{array}{l}\text { James. } \\
\text { Rede. } \\
\text { Skid. }\end{array}$ \\
\hline 3 & $3^{8} 3^{1} \quad 28.62$ & $7_{6} \mathrm{x} 8 \quad 4 x .03$ & $\begin{array}{llll}\mathrm{S} & 43 & 37 & \mathrm{~W} \\
\mathrm{~S} & \mathrm{I} 6 & 55 & \mathrm{E} \\
\mathrm{S} & 63 & 47 & \mathrm{E}\end{array}$ & $\begin{array}{llll}N & 43 & 36 & \mathrm{E} \\
\mathrm{N} & \mathrm{I} 6 & 55 & \mathrm{~W} \\
\mathrm{~N} & 63 & 45 & \mathrm{~W}\end{array}$ & $\begin{array}{l}3,775 \\
2,894 \\
5,067\end{array}$ & $\begin{array}{l}\text { Skid. } \\
\text { Can. } \\
\text { Pov. }\end{array}$ \\
\hline 4 & $3^{8} 3104.40$ & $7618 \mathrm{I3} .18$ & $\begin{array}{rrrr}\mathrm{S} & 60 & \text { I0 } & \mathrm{W} \\
\mathrm{S} & 3 & 03 & \mathrm{E} \\
\mathrm{S} & 49 & \mathrm{II} & \mathrm{E}\end{array}$ & $\begin{array}{lrrr}N & 60 & \circ 9 & E \\
N & 3 & 03 & W \\
N & 49 & 10 & W\end{array}$ & $\begin{array}{l}3,853 \\
1,954 \\
2,527\end{array}$ & $\begin{array}{l}\text { Skid. } \\
\text { Can. } \\
\text { Veith. }\end{array}$ \\
\hline
\end{tabular}




\section{RAGGED POINT.}

(Little Choptank River-Charts Nos. 36 and 37.)

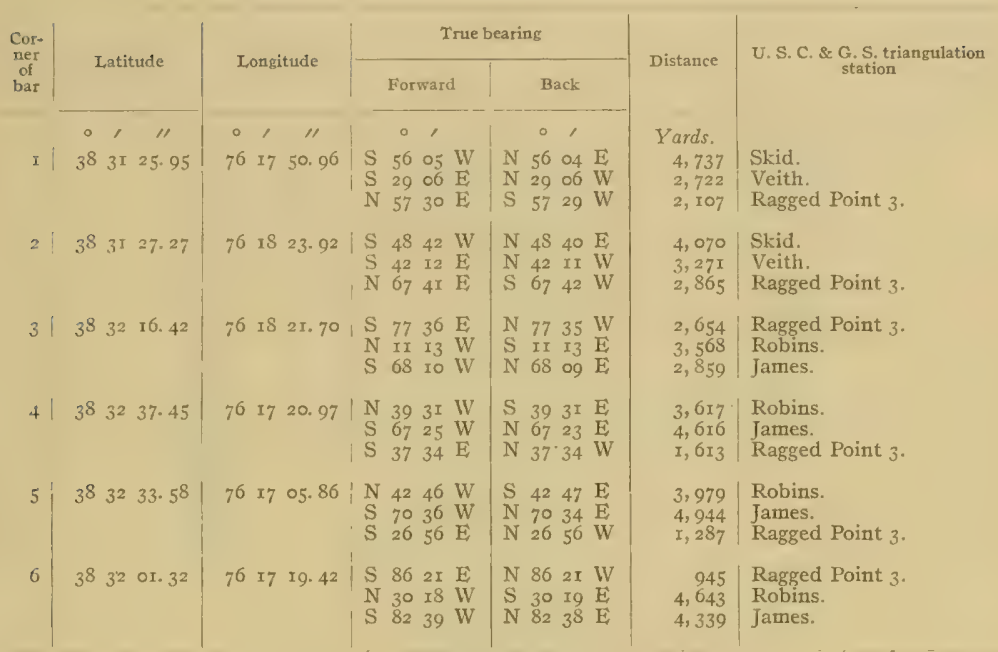

\section{PEANUT HILL.}

(Litle Choptank River-Charts Nos. 36 and 37.)

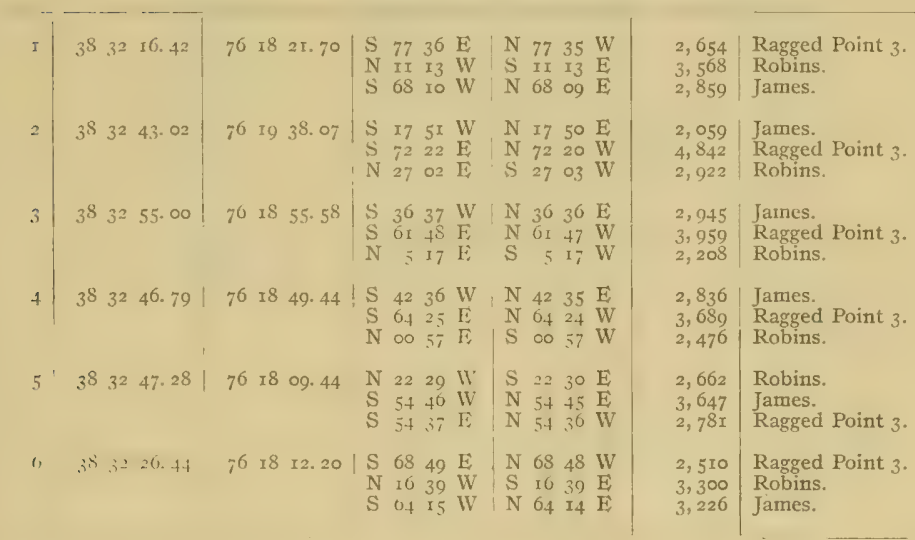




\section{RAGGFD POINT FLATS.}

(Little Choptank River-Charts Nos. 36 and 37.)

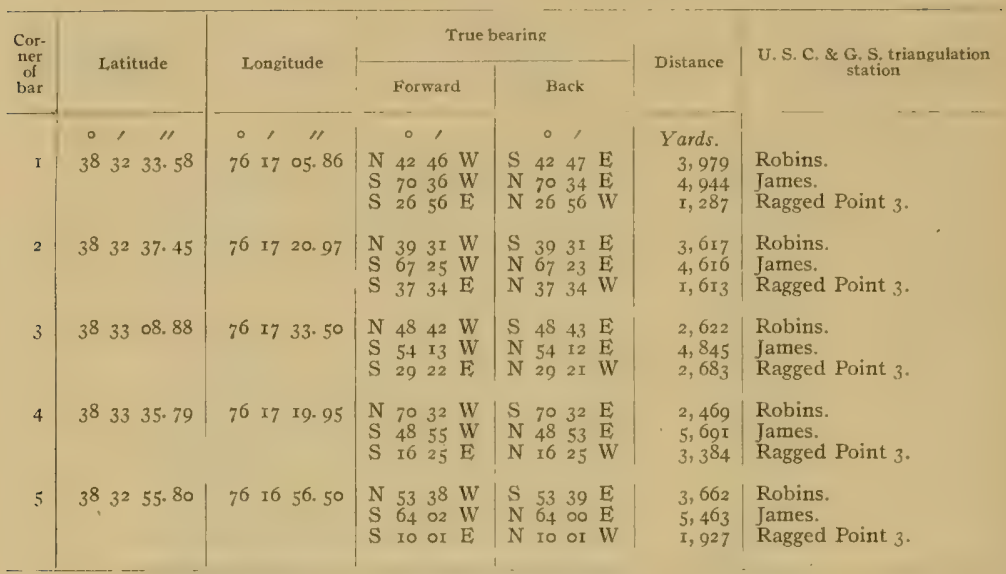

\section{COW ISI.AND.}

(Little Choptank River-Charis Nos. 36 and 37.)

\begin{tabular}{|c|c|c|c|c|c|c|}
\hline I & $\begin{array}{llll}3^{8} & 33 & 0.3 .34\end{array}$ & $\begin{array}{llll}76 & 18 & 15.64\end{array}$ & $\begin{array}{llll}N & 24 & 00 & W \\
S & 46 & 46 & W \\
S & 48 & 30 & E\end{array}$ & $\begin{array}{llll}\mathrm{S} & 24 & \text { OI } & \mathrm{E} \\
\mathrm{N} & 46 & 45 & \mathrm{E} \\
\mathrm{N} & 48 & 29 & \mathrm{~W}\end{array}$ & $\begin{array}{l}2,100 \\
3,863 \\
3,247\end{array}$ & $\begin{array}{l}\text { Robins. } \\
\text { James. } \\
\text { Ragged Point } \hat{3} \text {. }\end{array}$ \\
\hline $2^{\prime}$ & $3^{8} .33 \quad 12.3^{2}$ & 76 I8 $\quad$ I8. 86 & $\begin{array}{llll}N & 25 & 29 & W \\
S & 42 & 47 & W \\
S & 45 & 44 & F\end{array}$ & $\begin{array}{llll}\mathrm{S} & 25 & 3 I & \mathrm{E} \\
\mathrm{N} & 42 & 46 & \mathrm{I} \\
\mathrm{N} & 45 & 43 & \mathrm{~W}\end{array}$ & $\begin{array}{l}1,789 \\
4,018 \\
3,516\end{array}$ & $\begin{array}{l}\text { Rohins, } \\
\text { James. } \\
\text { Ragged Point .3. }\end{array}$ \\
\hline i & $3^{8} 33=2$ r. 90 & $7^{6} \quad 17 \quad 53.22$ & $\begin{array}{llll}N & 49 & 17 & W \\
S & 46 & 37 & W \\
S & 32 & 43 & \text { I }\end{array}$ & $\begin{array}{llll}S & 49 & 17 & \mathrm{I} \\
\mathrm{N} & 46 & 38 & \mathrm{~F} \\
\mathrm{~N} & 32 & 43 & \mathrm{~W}\end{array}$ & $\begin{array}{l}\mathbf{x}, 98 \mathbf{1} \\
4,763 \\
3,207\end{array}$ & $\begin{array}{l}\text { Robins. } \\
\text { James. } \\
\text { Ratgged Point } 3 .\end{array}$ \\
\hline+ & $3^{8} \quad 3.308 .88$ & $7^{6} \quad 17 \quad 35.50$ & $\begin{array}{llll}\mathrm{N} & 48 & -12 & \mathrm{~W} \\
\mathrm{~S} & 54 & \mathrm{I} & \mathrm{W} \\
\mathrm{S} & 29 & 22 & \mathrm{I}\end{array}$ & $\begin{array}{llll}\mathrm{S} & 48 & 43 & \mathrm{I} \\
\mathrm{N} & 54 & \mathrm{I} & \mathrm{E} \\
\mathrm{N} & 29 & 2 \mathrm{I} & \mathrm{W}\end{array}$ & $\begin{array}{l}2,622 \\
4,845 \\
2,683\end{array}$ & $\begin{array}{l}\text { Robins. } \\
\text { James. } \\
\text { Ragged Point } 3 .\end{array}$ \\
\hline
\end{tabular}


BALD EAGLE.

(Litlle Choptank River-Charts Nos. 36 and 37.)

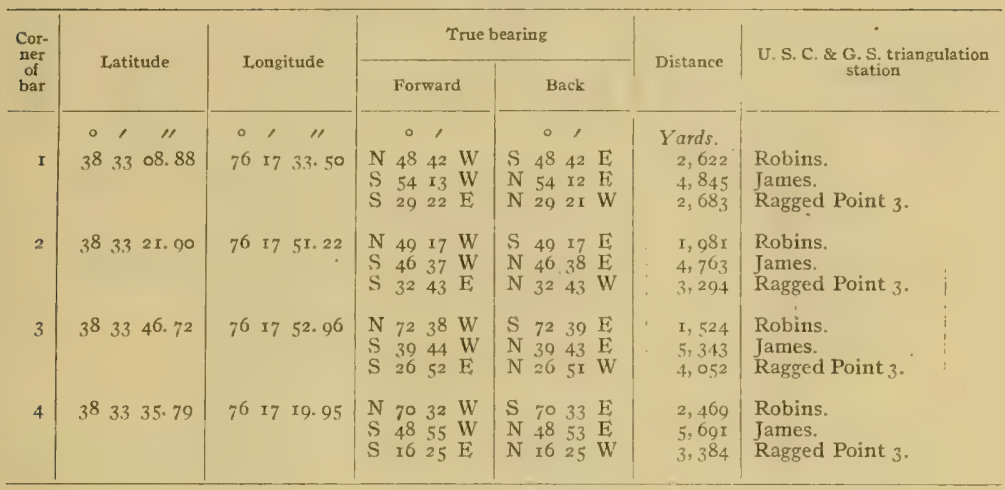

CORNFRS WHART.

(Outer Choptank River-Chart No. 37.)

\begin{tabular}{|c|c|c|c|c|c|c|}
\hline$I$ & $3^{8} 3^{6} 44.62$ & $\begin{array}{lllll}76 & 13 & 08.16\end{array}$ & $\begin{array}{llll}\mathrm{N} & 85 & 54 & \mathrm{E} \\
\mathrm{N} & 69 & 52 & \mathrm{E} \\
\mathrm{N} & 37 & 28 & \mathrm{~W}\end{array}$ & $\begin{array}{llll}\mathrm{S} & 85 & 54 & \mathrm{~W} \\
\mathrm{~S} & 69 & 54 & \mathrm{~W} \\
\mathrm{~S} & 37 & 28 & \mathrm{~F}\end{array}$ & $\begin{array}{l}I, 645 \\
4,794 \\
2,626\end{array}$ & $\begin{array}{l}\text { Corner. } \\
\text { Large Water Tank. } \\
\text { Dot. }\end{array}$ \\
\hline 2 & $3^{8} \quad 3^{6} \quad 55.18$ & $\begin{array}{llll}76 & \text { I3 } & 39.80\end{array}$ & $\begin{array}{llll}\mathrm{S} & 84 & 30 & \mathrm{E} \\
\mathrm{N} & 76 & 23 & \mathrm{E} \\
\mathrm{N} & 23 & 45 & \mathrm{~W}\end{array}$ & $\begin{array}{llll}\mathrm{N} & 84 & 29 & \mathrm{~W} \\
\mathrm{~S} & 76 & 25 & \mathrm{~W} \\
\mathrm{~S} & 23 & 45 & \mathrm{E}\end{array}$ & $\begin{array}{l}2,489 \\
5,492 \\
I, 888\end{array}$ & $\begin{array}{l}\text { Comer. } \\
\text { Large Water Tank. } \\
\text { Dot. }\end{array}$ \\
\hline 3 & $3837 \times 7.05$ & 76 I3 3 I. 38 & $\mid \begin{array}{llll}\mathrm{S} & 66 & 36 & \mathrm{E} \\
\mathrm{N} & 83 & 48 & \mathrm{E} \\
\mathrm{N} & 44 & 47 & \mathrm{~W}\end{array}$ & $\begin{array}{llll}\mathrm{N} & 66 & 35 & \mathrm{~W} \\
\mathrm{~S} & 83 & 50 & \mathrm{~W} \\
\mathrm{~S} & 44 & 47 & \mathrm{~F}\end{array}$ & $\begin{array}{l}2,457 \\
5,145 \\
I, 395\end{array}$ & $\begin{array}{l}\text { Corner. } \\
\text { Large Water Tank. } \\
\text { Dot. }\end{array}$ \\
\hline 4 & $\begin{array}{llll}38 & 37 & 0.99\end{array}$ & $76 \quad$ I2 50.40 & $\begin{array}{llll}\mathrm{S} & 68 & 00 & \mathrm{E} \\
-\mathrm{N} & 77 & 17 & \mathrm{E} \\
\mathrm{N} & 52 & 38 & \mathrm{~W}\end{array}$ & $\begin{array}{llll}\mathrm{N} & 68 & 00 & \mathrm{~W} \\
\mathrm{~S} & 77 & \text { I9 } & \mathrm{W} \\
\mathrm{S} & 5^{2} & 3^{8} & \mathrm{E}\end{array}$ & $\begin{array}{l}1,519 \\
4,377 \\
2.301\end{array}$ & $\begin{array}{l}\text { Corner. } \\
\text { Large Water Tank. } \\
\text { Dot. }\end{array}$ \\
\hline
\end{tabular}

LOGANS HILL.

(Outer Choptank River-Chart No. 37.)

\begin{tabular}{|c|c|c|c|c|c|c|}
\hline I & $\begin{array}{llll}38 & 3^{8} & 19.84\end{array}$ & 76 I2 56.18 & $\begin{array}{llll}\mathrm{S} & 69 & 32 & \mathrm{E} \\
\mathrm{N} & 54 & 34 & \mathrm{E} \\
\mathrm{N} & 20 & 44 & \mathrm{E}\end{array}$ & $\begin{array}{llll}\mathrm{N} & 69 & 3 \mathrm{I} & \mathrm{W} \\
\mathrm{S} & 54 & 35 & \mathrm{~W} \\
\mathrm{~S} & 20 & 44 & \mathrm{~W}\end{array}$ & $\begin{array}{l}4,466 \\
3,590 \\
4,102\end{array}$ & $\begin{array}{l}\text { Large Water Tank. } \\
\text { Choptank River Light. } \\
\text { Benoni } 2 .\end{array}$ \\
\hline 2 & $\begin{array}{r}38 \quad 3905.04 \\
\text { Ther }\end{array}$ & $\begin{array}{l}76 \times 3 \quad 38,98 \\
\text { along county }\end{array}$ & $\begin{array}{llll}\mathrm{S} & 68 & 56 & \mathrm{~W} \\
\mathrm{~S} & 16 & 26 & \mathrm{~W} \\
\mathrm{~N} & 82 & \text { II } & \mathrm{E} \\
\text { boundary as }\end{array}$ & $\begin{array}{llll}\mathrm{N} & 68 & 54 & \mathrm{E} \\
\mathrm{N} & 16 & 25 & \mathrm{E} \\
\mathrm{S} & 82 & \mathrm{I} & \mathrm{WV} \\
\text { lelineated on }\end{array}$ & $\begin{array}{r}6,512 \\
2,764 \\
4,094 \\
\text { Chart No. }\end{array}$ & $\begin{array}{l}\text { Chef. } \\
\text { Dot. } \\
\text { Choptank River Light. } \\
\text { to corner No. }\end{array}$ \\
\hline 3 & $3^{8} 3^{8} 4^{8} .40$ & 76 II 45.22 & $\begin{array}{llll}\mathrm{S} & 49 & 58 & \mathrm{E} \\
\mathrm{N} & 43 & 09 & \mathrm{E} \\
\mathrm{N} & 8 & 24 & \mathrm{~W}\end{array}$ & $\begin{array}{lrrl}\mathrm{N} & 49 & 57 & \mathrm{~W} \\
\mathrm{~S} & 43 & \mathrm{IO} & \mathrm{W} \\
\mathrm{S} & 8 & 24 & \mathrm{E}\end{array}$ & $\begin{array}{l}3,479 \\
1,533 \\
2,905\end{array}$ & $\begin{array}{l}\text { Castle. } \\
\text { Choptank River Light. } \\
\text { Benoni } 2 .\end{array}$ \\
\hline
\end{tabular}

$58345-x_{3}-9$ 
TODD POINT.

(Outer Choptank River-Chart No.37.)

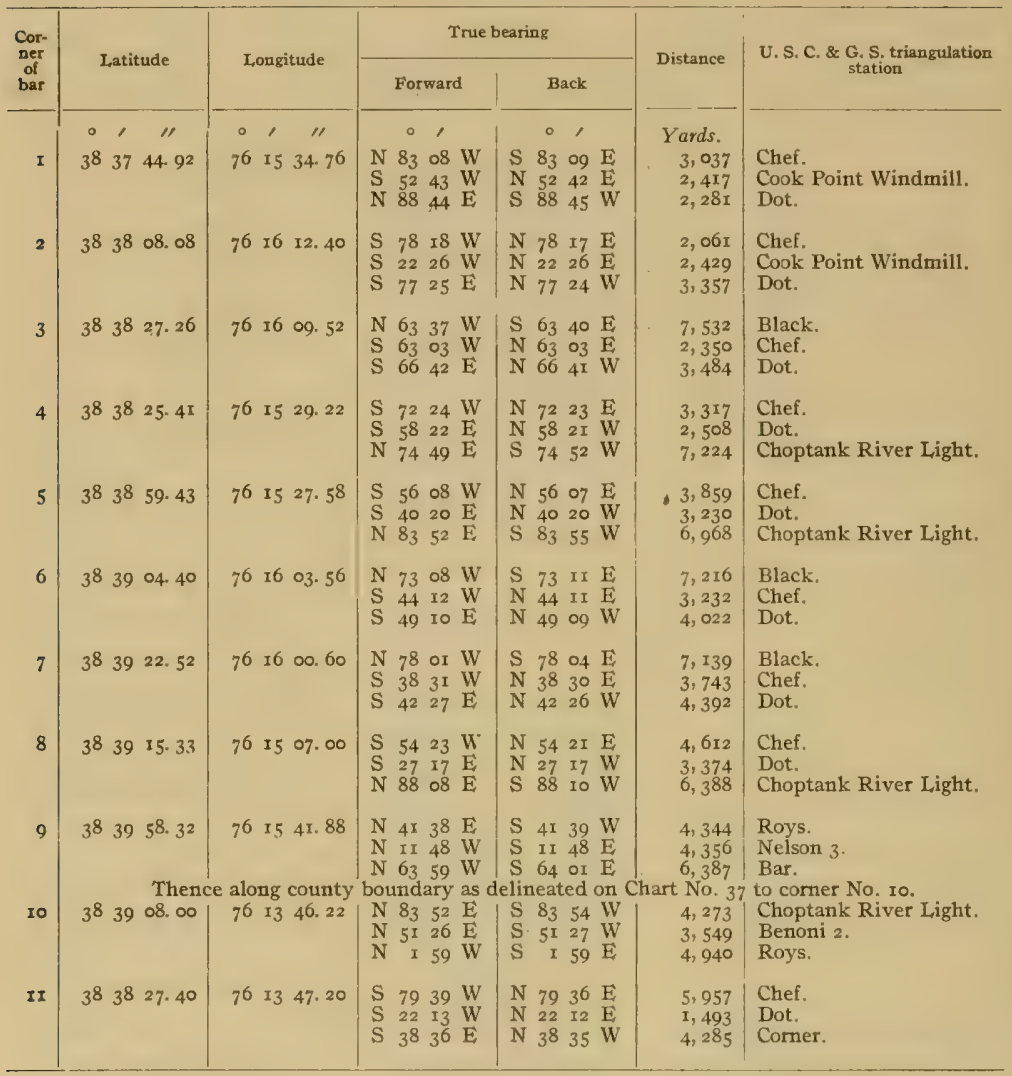


ALONG SHORE.

(Little Choptank River-Charts Nos. 37 and 38.)

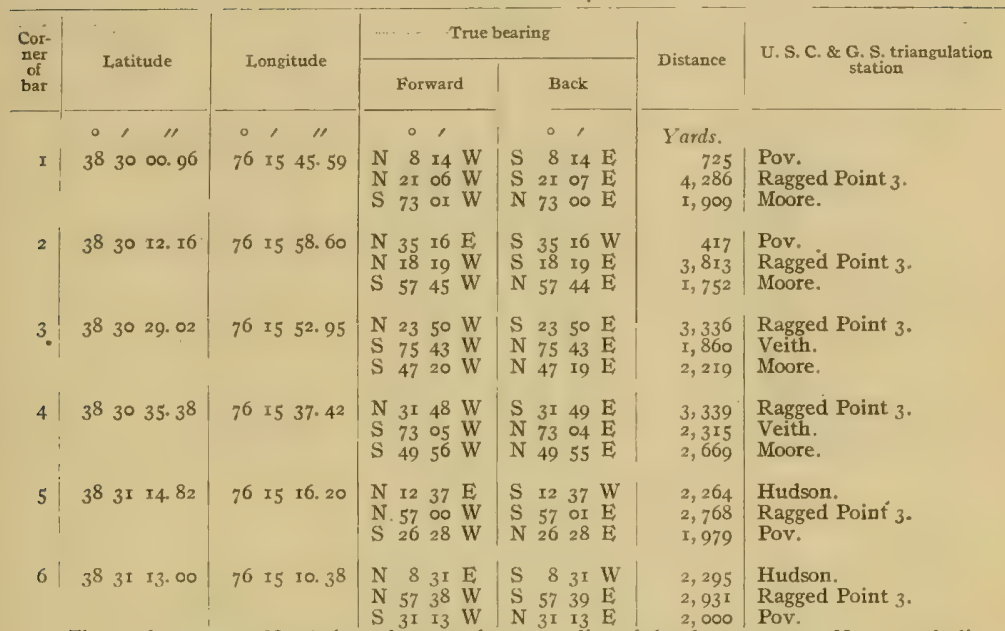

Thence from corner No. 6 along the mean low water line of the shore to comer No, 7 , excluding any creek, cove, or inlet less than roo yards in width at its mouth at low tide.

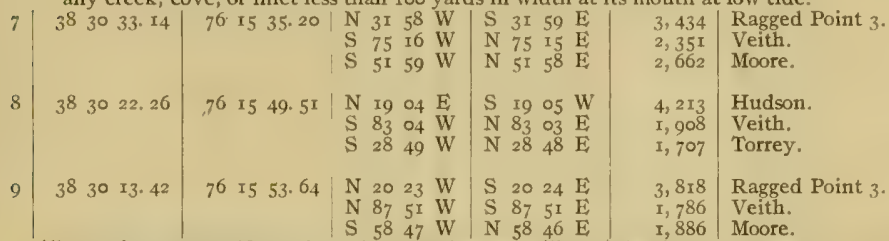

Thence from corner No. 9 along the mean low water line of the shore to corner No. Io, excluding any creek, cove, or inlet less than roo yards in width at its mouth at low tide.

I0 $383005.66 \mid 76$ I5 $45.58 \mid \mathrm{N}$ 10 $32 \mathrm{~W} \mid \mathrm{S}$ 10 $32 \mathrm{E} \mid$

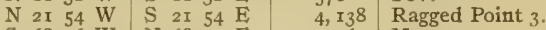

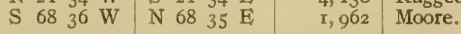




\section{SUSQUEHANNA.}

(Little Choptank River-Chart No. 37.)

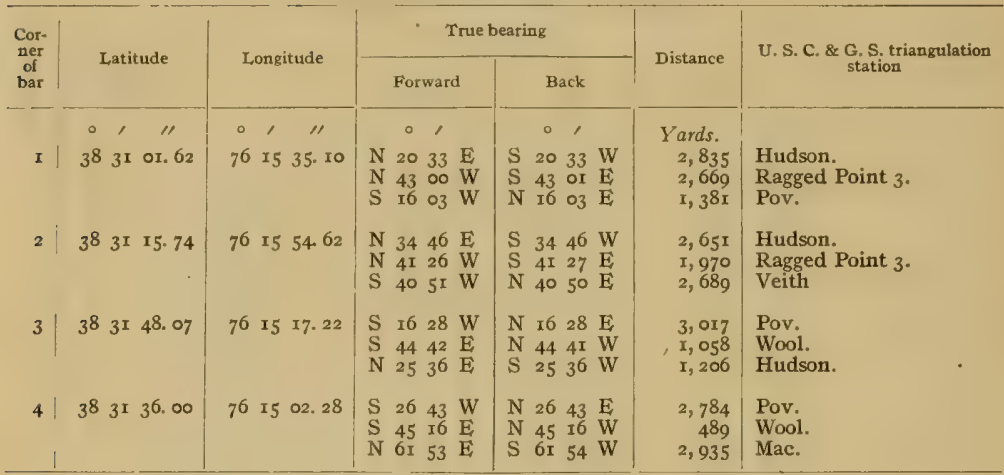

LITTLE POLLARD.

(Little Choptank River-Chart No. 37.)

\begin{tabular}{|c|c|c|c|c|c|c|}
\hline I & $3^{8} 3^{1} 5^{6} .50$ & 76 I6 08.94 & $\begin{array}{llll}\mathrm{S} & 09 & 12 & \mathrm{E} \\
\mathrm{S} & 63 & 53 & \mathrm{E} \\
\mathrm{N} & 66 & 59 & \mathrm{E}\end{array}$ & $\begin{array}{llll}\mathrm{N} & 09 & 12 & \mathrm{~W} \\
\mathrm{~N} & 63 & 52 & \mathrm{~W} \\
\mathrm{~S} & 66 & 59 & \mathrm{~W}\end{array}$ & $\begin{array}{l}3,220 \\
2,353 \\
2,055\end{array}$ & $\begin{array}{l}\text { Pov. } \\
\text { Wool. } \\
\text { Hudson. }\end{array}$ \\
\hline 2 & $3^{8} 3^{2}$ or. 68 & $76 \quad 16 \quad 17.82$ & $\begin{array}{llll}\mathrm{S} & \mathrm{I} 2 & 37 & \mathrm{E} \\
\mathrm{S} & 62 & 44 & \mathrm{E} \\
\mathrm{N} & 73 & 3 \mathrm{I} & \mathrm{E}\end{array}$ & $\begin{array}{llll}\mathrm{N} & 12 & 36 & \mathrm{~W} \\
\mathrm{~N} & 62 & 43 & \mathrm{~W} \\
\mathrm{~S} & 73 & 32 & \mathrm{~W}\end{array}$ & $\begin{array}{l}3,435 \\
2,642 \\
2,217\end{array}$ & $\begin{array}{l}\text { Pov. } \\
\text { Wool. } \\
\text { Hudson. }\end{array}$ \\
\hline 3 & $\begin{array}{llll}3^{8} & 3^{2} & \mathbf{1} 3.23\end{array}$ & $76 \leq 6 \quad 15.16$ & $\begin{array}{llll}\mathrm{S} & \text { 10 } & 18 & \mathrm{~F} \\
\mathrm{~S} & 54 & 55 & \mathrm{E} \\
\mathrm{N} & S_{3} & 2 \mathrm{I} & \mathrm{F}\end{array}$ & $\begin{array}{llll}N & 10 & 17 & W \\
N & 54 & 54 & W \\
S & 83 & 22 & W\end{array}$ & $\begin{array}{l}3,804 \\
2,784 \\
2,070\end{array}$ & $\begin{array}{l}\text { Pov. } \\
\text { Wool. } \\
\text { Hudson. }\end{array}$ \\
\hline 4 & $3^{8} \quad 3^{2} \quad 29.67$ & $76 \times 5 \quad 49.02$ & $\begin{array}{llll}\mathrm{S} & 22 & 35 & \mathrm{~W} \\
\mathrm{~S} & 36 & 46 & \mathrm{E} \\
\mathrm{S} & 57 & 2 \mathrm{I} & \mathrm{E}\end{array}$ & $\begin{array}{llll}\mathrm{N} & 22 & 34 & \mathrm{E} \\
\mathrm{N} & 36 & 45 & \mathrm{~W} \\
\mathrm{~N} & 57 & 20 & \mathrm{~W}\end{array}$ & $\begin{array}{l}4,904 \\
2,689 \\
3,426\end{array}$ & $\begin{array}{l}\text { Veith. } \\
\text { Wool. } \\
\text { Tobacco Stick. }\end{array}$ \\
\hline 5 & $3^{8} 3^{2} \quad 20.5^{2}$ & $7^{6}$ I5 $39.5^{8}$ & $\begin{array}{llll}\mathrm{S} & 67 & 26 & \mathrm{~W} \\
\mathrm{~S} & 35 & 54 & \mathrm{E} \\
\mathrm{S} & 89 & 4 \mathrm{I} & \mathrm{E}\end{array}$ & $\begin{array}{llll}\mathrm{N} & 67 & 25 & \mathrm{E} \\
\mathrm{N} & 35 & 53 & \mathrm{~W} \\
\mathrm{~N} & 89 & 4 \mathrm{I} & \mathrm{W}\end{array}$ & $\begin{array}{l}I, 843 \\
2,278 \\
I, I I_{3}\end{array}$ & $\begin{array}{l}\text { Ragged Point } 3 . \\
\text { Wool. } \\
\text { Hudson. }\end{array}$ \\
\hline
\end{tabular}

\section{CASON.}

(Little Choptank River-Chart No. 37.)

\begin{tabular}{|c|c|c|c|c|c|c|}
\hline I & $3^{8} 3 \mathrm{I} \quad 30.20$ & $\begin{array}{llll}76 & 14 & 38.82\end{array}$ & $\begin{array}{llll}N & 51 & 15 & E \\
N & 16 & 21 & W \\
N & 73 & 23 & W\end{array}$ & $\begin{array}{llll}\mathrm{S} & 5 \mathrm{I} & \mathrm{I} 6 & \mathrm{~W} \\
\mathrm{~S} & \mathrm{I} 6 & 2 \mathrm{I} & \mathrm{E} \\
\mathrm{S} & 73 & 24 & \mathrm{E}\end{array}$ & $\begin{array}{l}2,523 \\
x, 762 \\
3: 456\end{array}$ & $\begin{array}{l}\text { Mac. } \\
\text { Hudson. } \\
\text { Ragged Point } 3 .\end{array}$ \\
\hline 2 & $3^{8} 3^{2}$ or. 19 & \begin{tabular}{llll|}
76 & 15 & 08.99
\end{tabular} & $\begin{array}{llll}\mathrm{S} & 88 & 43 & \mathrm{~W} \\
\mathrm{~S} & 2.3 & 45 & \mathrm{E} \\
\mathrm{S} & 63 & 45 & \mathrm{E}\end{array}$ & $\begin{array}{llll}\mathrm{N} & 88 & 42 & \mathrm{E} \\
\mathrm{N} & 23 & 45 & \mathrm{~W} \\
\mathrm{~N} & 6 & 45 & 45\end{array}$ & $\begin{array}{l}2,513 \\
1,305 \\
2,007\end{array}$ & $\begin{array}{l}\text { Ragged Point } 3 . \\
\text { Wool. } \\
\text { Tobacco Stick. }\end{array}$ \\
\hline 3 & $3^{8} 32 \quad 33.16$ & $7^{6} \quad \begin{array}{rlll}4 & 37 \cdot 54\end{array}$ & $\begin{array}{llll}\mathrm{S} & 10 & 54 & \mathrm{~W} \\
\mathrm{~S} & 36 & 51 & \mathrm{E} \\
\mathrm{N} & 86 & 09 & \mathrm{E}\end{array}$ & $\begin{array}{llll}N & 10 & 54 & \mathrm{E} \\
\mathrm{N} & 36 & 50 & \mathrm{~W} \\
\mathrm{~S} & 86 & \text { I0 } & \mathrm{W}\end{array}$ & $\begin{array}{l}I, 627 \\
1,613 \\
1,938\end{array}$ & $\begin{array}{l}\text { Wool. } \\
\text { Tobacco Stick. } \\
\text { Mac. }\end{array}$ \\
\hline 4 & $3^{8} 3^{1} 5^{0 .} 5^{8}$ & $\begin{array}{llll}76 & 14 & \times 7.50\end{array}$ & $\begin{array}{llll}\mathrm{S} & 45 & 06 & \mathrm{~W} \\
\mathrm{~S} & 39 & 30 & \mathrm{E} \\
\mathrm{N} & 57 & 33 & \mathrm{E}\end{array}$ & $\begin{array}{llll}\text { N } & 45 & 05 & \text { E } \\
\text { N } & 39 & 29 & \text { W } \\
\text { S } & 57 & 34 & \text { W }\end{array}$ & $\begin{array}{r}1,184 \\
686 \\
\mathrm{x}, 662\end{array}$ & $\begin{array}{l}\text { Wool. } \\
\text { Tobacco Stick. } \\
\text { Mac. }\end{array}$ \\
\hline
\end{tabular}


TOBACCO STICK.

(Little Choptonk River-Chart No.37.)

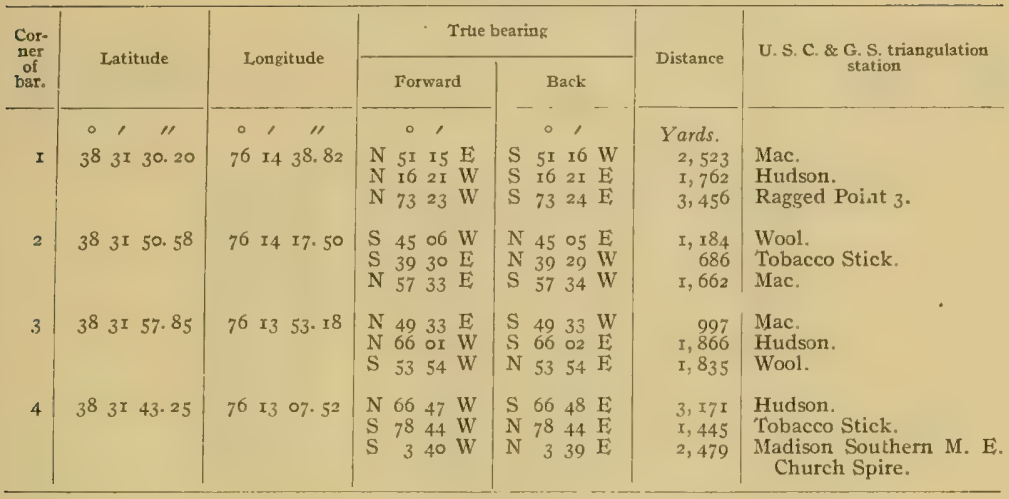

\section{BUTTERPOT.}

(Little Choptank River-Chart No. 37.)

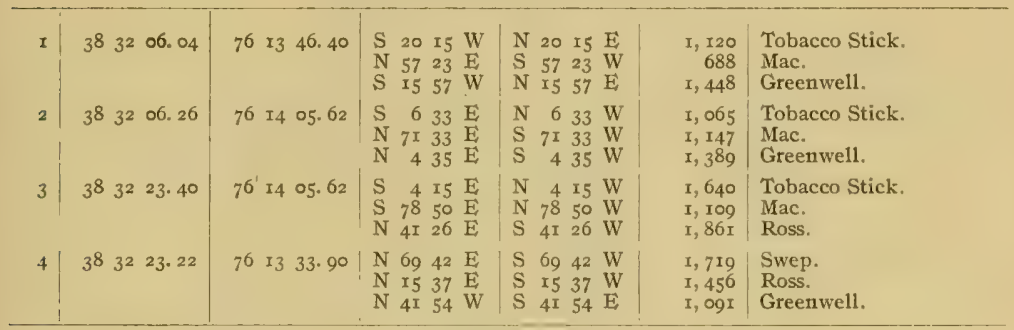

HUDSON.

(Little Choptank River-Hudson Creek-Chart No. 37.)

\begin{tabular}{|c|c|c|c|c|c|c|}
\hline I & $3^{8} 3^{2} \quad 16.77$ & $7^{6} \quad$ I4 22.62 & $\begin{array}{llll}\mathrm{S} & 22 & 15 & \mathrm{~W} \\
\mathrm{~S} & 22 & 03 & \mathrm{E} \\
\mathrm{N} & 89 & 40 & \mathrm{E}\end{array}$ & $\begin{array}{llll}\mathrm{N} & 22 & \mathrm{I} 4 & \mathrm{E} \\
\mathrm{N} & 22 & 02 & \mathrm{~W} \\
\mathrm{~S} & 89 & 4 \mathrm{I} & \mathrm{W}\end{array}$ & $\begin{array}{l}I, 857 \\
I, 524 \\
I, 539\end{array}$ & $\begin{array}{l}\text { Wool. } \\
\text { Tobacco Stick. } \\
\text { Mac. }\end{array}$ \\
\hline 2 & $3^{8} \quad 3^{2} \quad 39.68$ & $76 \quad$ I 456.00 & $\begin{array}{llll}S & 3 & 35 & W \\
N & 8 I & \text { o9 } & E \\
N & 07 & 04 & W\end{array}$ & $\begin{array}{llll}\mathrm{N} & 3 & 35 & \mathrm{E} \\
\mathrm{S} & 8 \mathrm{I} & \text { IO } & \mathrm{W} \\
\mathrm{S} & 07 & 04 & \mathrm{E}\end{array}$ & $\begin{array}{l}654 \\
599 \\
639\end{array}$ & $\begin{array}{l}\text { Hudson. } \\
\text { Lotise. } \\
\text { Jenifer. }\end{array}$ \\
\hline 3 & $3^{8} 3^{2} \cdot 43 \cdot 46$ & 76 I4 $50.6 \mathrm{I}$ & $\begin{array}{llll}\mathrm{S} & I_{3} & \text { IS } & \mathrm{W} \\
\mathrm{S} & 84 & 20 & \mathrm{E} \\
\mathrm{N} & 22 & \text { OI } & \mathrm{E}\end{array}$ & $\begin{array}{llll}N & I_{3} & I_{5} & \mathrm{E} \\
\mathrm{N} & 84 & 20 & W \\
\mathrm{~S} & 22 & \text { or } & W\end{array}$ & $\begin{array}{l}801 \\
452 \\
483\end{array}$ & $\begin{array}{l}\text { Hudson. } \\
\text { Louise. } \\
\text { Carrie. }\end{array}$ \\
\hline 4 & $3^{8} 3^{2} 30.09$ & $7^{6} \quad 14 \quad 3^{2} \cdot 40$ & $\begin{array}{lrrr}S & 76 & 13 & \mathrm{E} \\
\mathrm{N} & 4 & 36 & \mathrm{~W} \\
\mathrm{~S} & 63 & 43 & \mathrm{~W}\end{array}$ & $\begin{array}{lrrr}\mathrm{N} & 76 & \mathrm{I}_{3} & \mathrm{~W} \\
\mathrm{~S} & 4 & 36 & \mathrm{E} \\
\mathrm{N} & 63 & 43 & \mathrm{E}\end{array}$ & $\begin{array}{r}I, 850 \\
417 \\
743\end{array}$ & $\begin{array}{l}\text { Mac. } \\
\text { Louise. } \\
\text { Hudson. }\end{array}$ \\
\hline 5 & $3^{8} 3^{2} 23.40$ & $\begin{array}{llll}76 & 14 & 05.62\end{array}$ & $\begin{array}{lrrr}\mathrm{S} & 4 & 15 & \mathrm{E} \\
\mathrm{S} & 78 & 50 & \mathrm{E} \\
\mathrm{N} & 41 & 26 & \mathrm{E}\end{array}$ & $\begin{array}{lrrr}N & 4 & I 5 & W \\
N & 78 & 50 & W \\
S & 4 I & 26 & W\end{array}$ & $\begin{array}{l}I, 640 \\
I, 109 \\
I, 86 r\end{array}$ & $\begin{array}{l}\text { Tobacco Stick. } \\
\text { Mac. } \\
\text { Ross. }\end{array}$ \\
\hline
\end{tabular}


ROSS.

(Little Choptank River-Hudson Creek-Chart No. 37.)

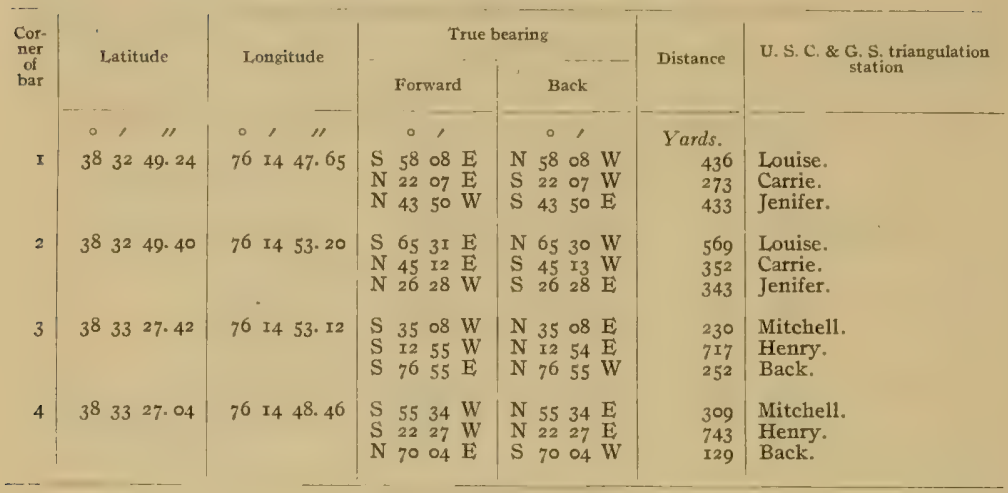

\section{MCKEILS POINT.}

(Litlle Choplank River-Chart No. 37.)

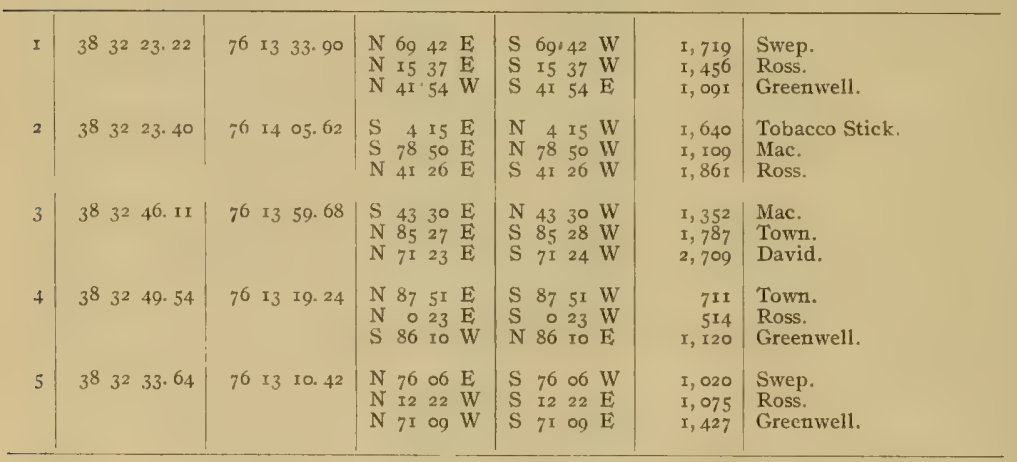


TOWN.

(Little Choptank River-Chart No. 37.)

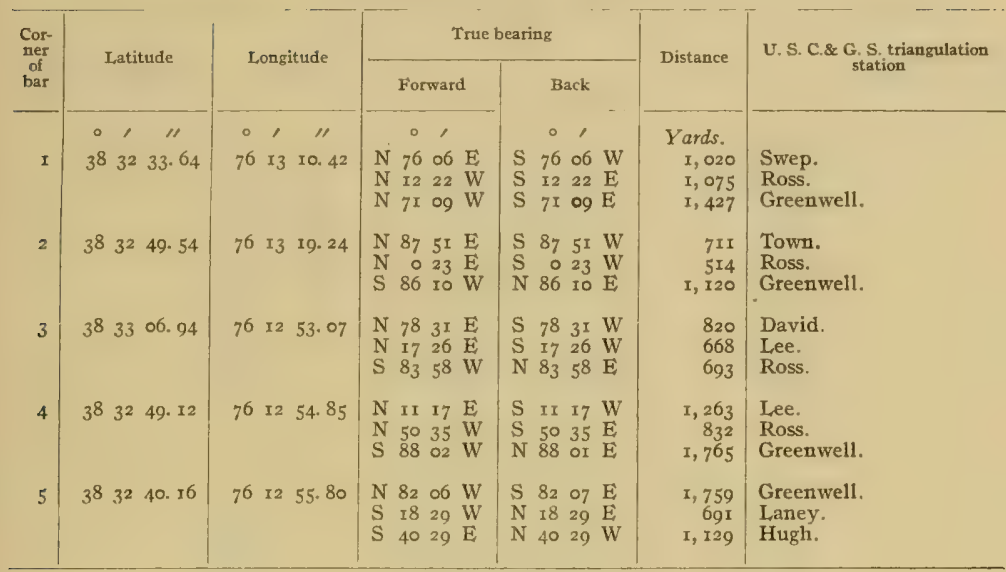

BRUMELL.

(Little Choptank River-Chart No. 37.)

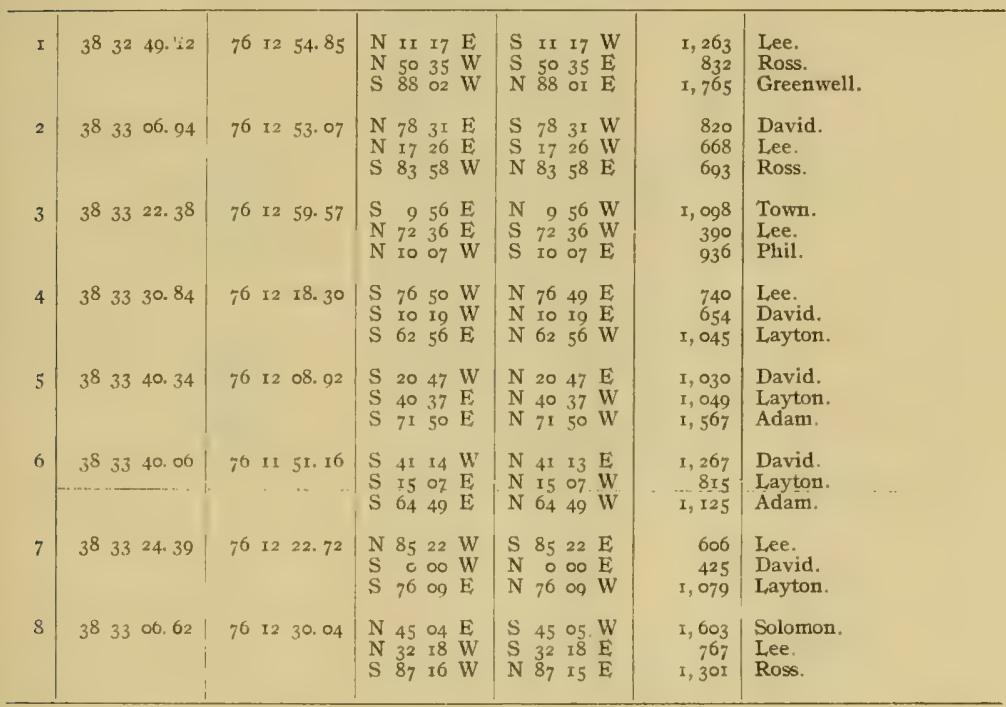


CHERRY ISLAND.

(Little Choptank River-Chart No. 37.)

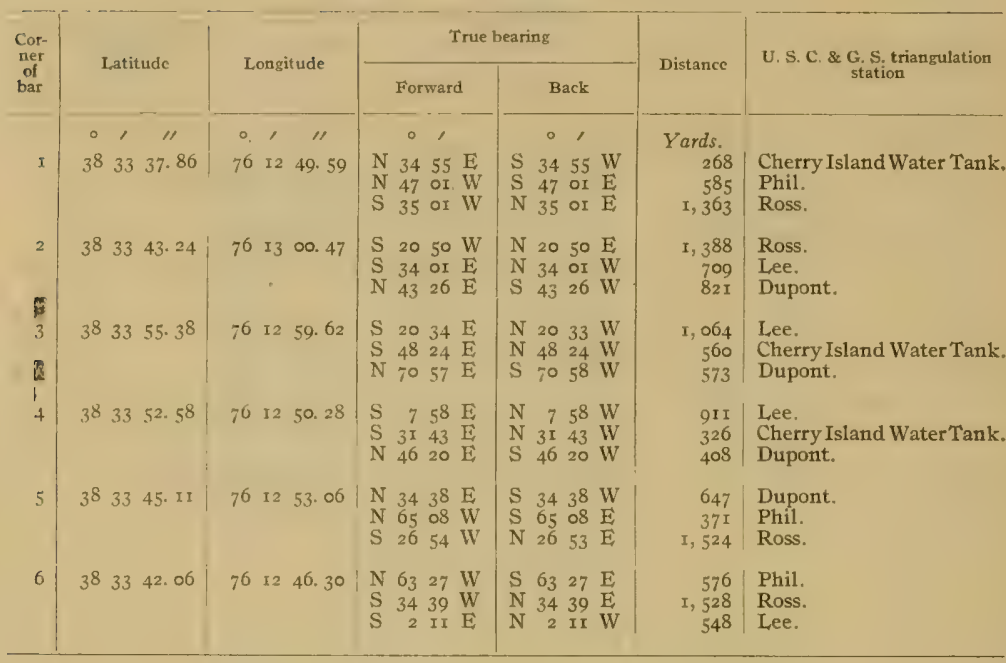

JONES.

(Litle Choptank River-Chart No. 37.)

\begin{tabular}{|c|c|c|c|c|c|c|c|c|c|c|c|}
\hline I & $3^{8} \quad 33$ & I9. 34 & 76 & II & 33.10 & $\begin{array}{l}\mathrm{N} \\
\mathrm{N} \\
\mathrm{N}\end{array}$ & $\begin{array}{l}45 \\
27 \\
83\end{array}$ & $\begin{array}{ll}53 & \mathrm{E} \\
56 & \mathrm{~W} \\
28 & \mathrm{~W}\end{array}$ & $\begin{array}{llll}\mathrm{S} & 45 & 53 & \mathrm{~W} \\
\mathrm{~S} & 27 & 56 & \mathrm{E} \\
\mathrm{S} & 83 & 28 & \mathrm{E}\end{array}$ & $\begin{array}{r}\text { I, OI3 } \\
795 \\
\text { I, } 929\end{array}$ & $\begin{array}{l}\text { Seth. } \\
\text { Solomon. } \\
\text { Lee. }\end{array}$ \\
\hline 2 & $3^{8} 33$ & 28.68 & 76 & I I & 35. I2 & $\begin{array}{l}\mathrm{N} \\
\mathrm{N} \\
\mathrm{S}\end{array}$ & $\begin{array}{l}63 \\
39 \\
65\end{array}$ & $\begin{array}{ll}27 & \mathrm{E} \\
27 & \mathrm{~W} \\
42 & \mathrm{~W}\end{array}$ & $\begin{array}{llll}\mathrm{S} & 63 & 27 & \mathrm{~W} \\
\mathrm{~S} & 39 & 27 & \mathrm{E} \\
\mathrm{N} & 65 & 4 \mathrm{r} & \mathrm{E}\end{array}$ & $\begin{array}{r}873 \\
503 \\
\mathrm{I}, 382\end{array}$ & $\begin{array}{l}\text { Seth. } \\
\text { Solomon. } \\
\text { David. }\end{array}$ \\
\hline 31 & $3^{8} 33$ & 29.68 & 76 & II & 28. 37 & $\begin{array}{l}N \\
N \\
S\end{array}$ & $\begin{array}{l}59 \\
54 \\
41\end{array}$ & $\begin{array}{l}20 \mathrm{~W} \\
36 \mathrm{~W} \\
53 \mathrm{~W}\end{array}$ & $\begin{array}{llll}\mathrm{S} & 59 & 20 & \mathrm{~W} \\
\mathrm{~S} & 54 & 37 & \mathrm{E} \\
\mathrm{N} & 4 \mathrm{I} & 53 & \mathrm{E}\end{array}$ & $\begin{array}{l}699 \\
6 I I \\
586\end{array}$ & $\begin{array}{l}\text { Seth. } \\
\text { Solomon. } \\
\text { Layton. }\end{array}$ \\
\hline 4 & 3833 & 20. $5^{8}$ & 76 & II & 26. 24 & $\begin{array}{l}\mathrm{N} \\
\mathrm{N} \\
\mathrm{S}\end{array}$ & $\begin{array}{l}39 \\
39 \\
73\end{array}$ & $\begin{array}{ll}26 & \mathrm{E} \\
59 \mathrm{~W} \\
49 \mathrm{~W}\end{array}$ & $\begin{array}{llll}\mathrm{S} & 39 & 26 & \mathrm{~W} \\
\mathrm{~S} & 39 & 59 & \mathrm{E} \\
\mathrm{N} & 73 & 49 & \mathrm{E}\end{array}$ & $\begin{array}{l}860 \\
863 \\
466\end{array}$ & $\begin{array}{l}\text { Seth. } \\
\text { Solomon. } \\
\text { Layton. }\end{array}$ \\
\hline
\end{tabular}




\section{PATTISON.}

(Little Choptank River-Chart No. 37.)

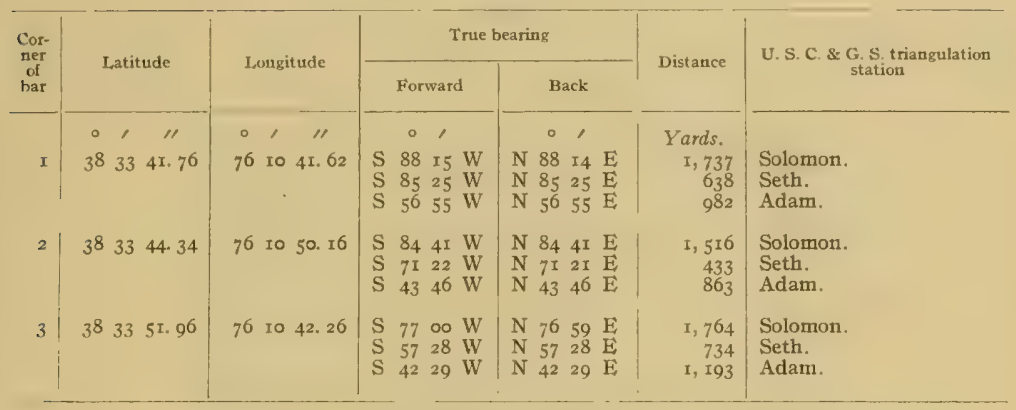

BARN POINT.

(Little Choplank River-Fishing Creek-Chart No. 37.)

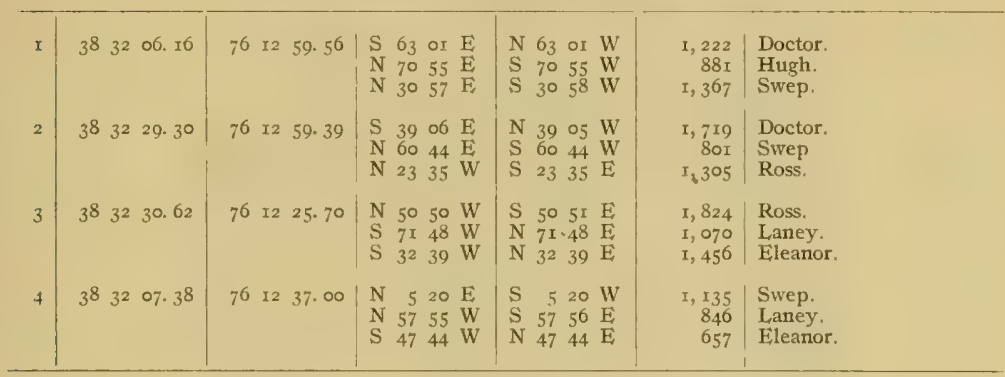

\section{SALTWORK.}

(Little Choptank River-Fishing Creek-Chart No. 37.)

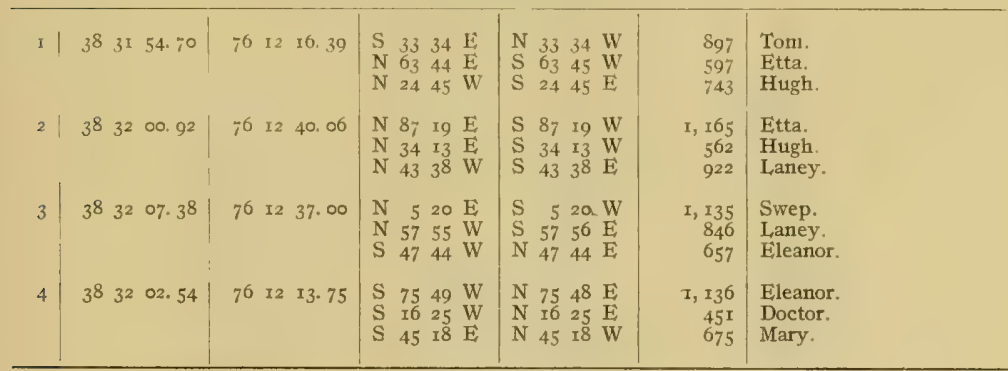


FISHING CREEK.

(Litlle Choptank River-Fishing Creek-Chart No. 37.)

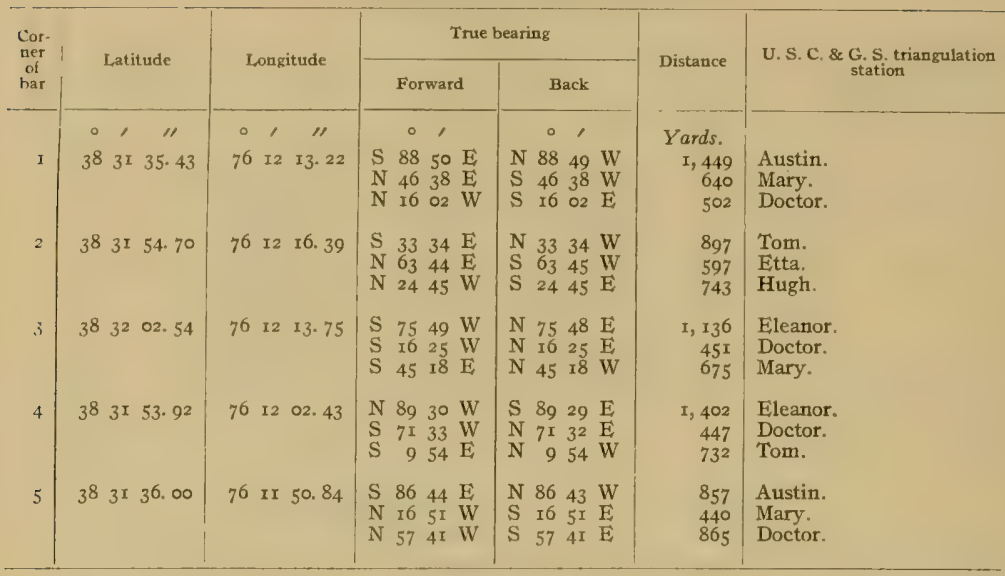

\section{GRAPEVINE.}

(Little Choptank River-Fishing Creek-Chart No. 37.)

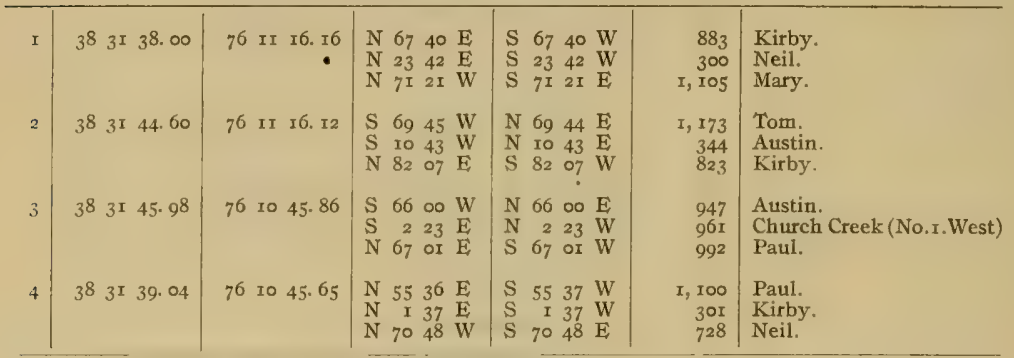

\section{BRIDGE.}

(Slaughter Creek-Chart No. 38.)

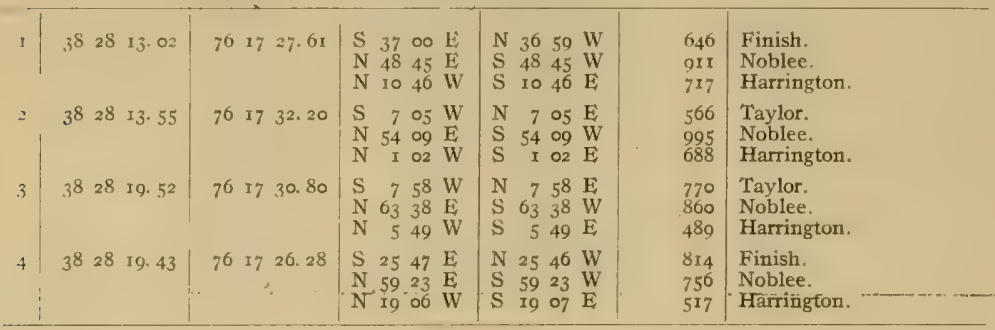




\section{PUNCH ISLAND CREEK.}

(Chesapeake Bay off Punch Island Creck-Chart No. 38.)

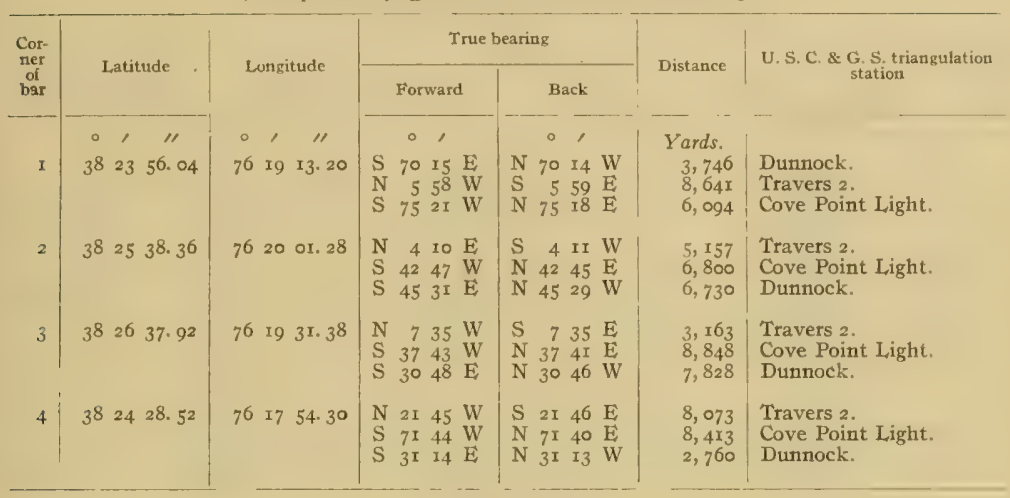

STONF, PILE.

(Chesapeake Bay off Barren Island-Chart No. 39.)

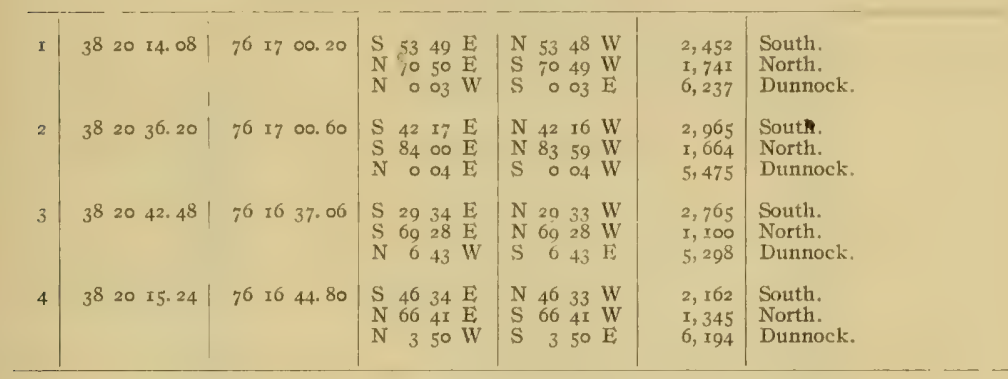

\section{NEW DISCOVERY.}

(Chesapeake Bay off Barren Island-Chart No. 39.)

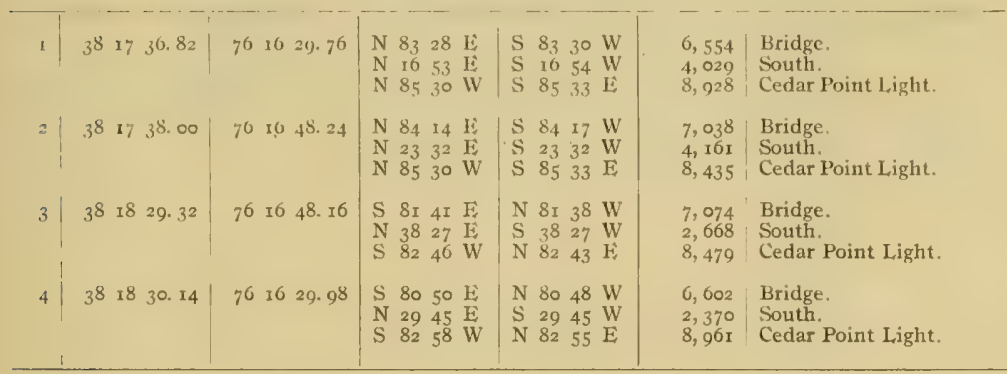


HORSE POINT CHANNEL.

(Tar Bay-Charts Nos. 39 and 40.$)$

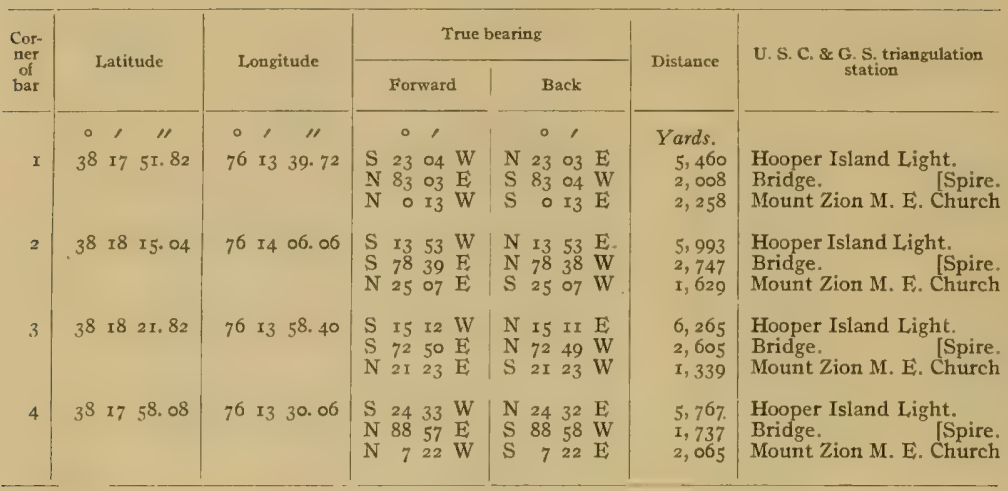

WARE.

(Chesapeake Bay-Off Middle Hooper Island-Charts Nos. 39 and 4o.)

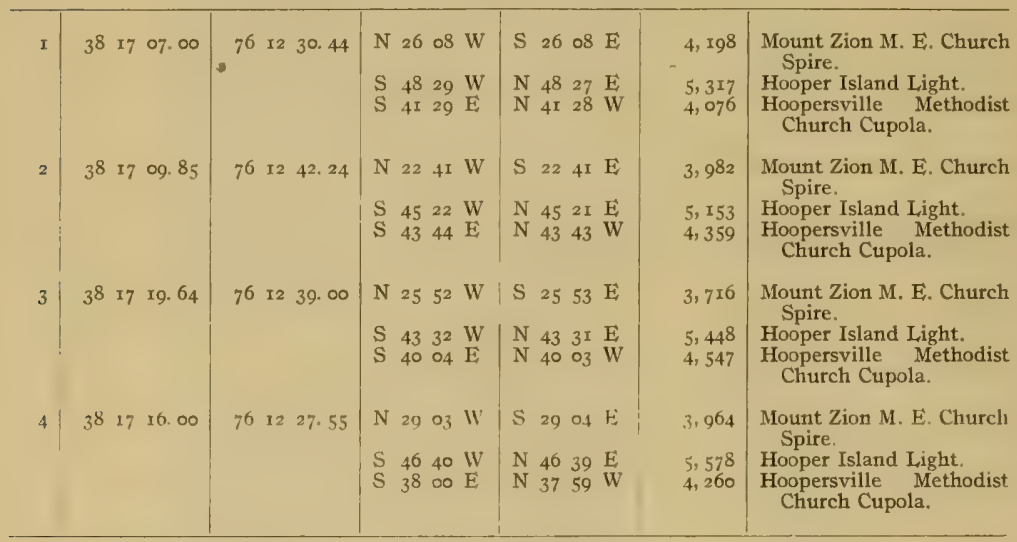


WHITE WOOD.

(Tar Bay-Chart No. 39.)

\begin{tabular}{|c|c|c|c|c|c|c|c|c|c|c|c|c|}
\hline \multirow{3}{*}{$\begin{array}{r}\text { Cor- } \\
\text { ner } \\
\text { of } \\
\text { bar }\end{array}$} & \multirow{2}{*}{\multicolumn{2}{|c|}{ Latitude }} & \multirow{2}{*}{\multicolumn{3}{|c|}{ Longitude }} & \multicolumn{5}{|c|}{ True bearing } & \multirow{2}{*}{ Distance } & \multirow{2}{*}{$\begin{array}{c}\text { U. S. C. \& G. S. triangulation } \\
\text { station }\end{array}$} \\
\hline & & & & & & \multicolumn{3}{|c|}{ Forward } & \multicolumn{2}{|r|}{ Back } & & \\
\hline & $3^{\circ}$ & $\begin{array}{ll}\prime \prime & 42.04\end{array}$ & & & $\begin{array}{c}\prime \prime \\
17.60\end{array}$ & $\begin{array}{l}\mathrm{S} \\
\mathrm{N}\end{array}$ & $\begin{array}{r}0 \\
60 \\
16\end{array}$ & $\begin{array}{ll}33 & \mathrm{~W} \\
29 & \mathrm{E} \\
\text { I3 } & \mathrm{E}\end{array}$ & $\begin{array}{l}\mathrm{N} \\
\mathrm{S} \\
\mathrm{S}\end{array}$ & $\begin{array}{rrrr}9 & 32 & \mathrm{E} \\
60 & 29 & W \\
16 & I_{3} & W\end{array}$ & $\begin{array}{l}\text { Yards, } \\
\text { 6, } 822 \\
\text { I, } 147 \\
2,597\end{array}$ & $\begin{array}{l}\text { Hooper Island Light. } \\
\text { Mount Zion M. E. Church } \\
\text { Spire. } \\
\text { Hosier Memorial Church } \\
\text { Spire. }\end{array}$ \\
\hline 2 & $3^{8}$ & I8 $52.5^{2}$ & 76 & $\mathrm{I}_{4}$ & 23.00 & $\begin{array}{l}\mathrm{S} \\
\mathrm{N}\end{array}$ & $\begin{array}{r}7 \\
79 \\
22\end{array}$ & $\begin{array}{l}57 \mathrm{~W} \\
29 \mathrm{E} \\
05 \mathrm{E}\end{array}$ & $\begin{array}{l}\mathrm{N} \\
\mathrm{S}\end{array}$ & $\begin{array}{rrr}7 & 56 & \mathrm{E} \\
79 & 30 \mathrm{~W} \\
22 & 05 \mathrm{~W}\end{array}$ & $\begin{array}{l}7,150 \\
I, 16 I \\
2,3 I I\end{array}$ & $\begin{array}{l}\text { Hooper Island Light. } \\
\text { Mount Zion M. E. Church } \\
\text { Spire. } \\
\text { Hosier Memorial Church } \\
\text { Spire. }\end{array}$ \\
\hline 3 & $3^{8}$ & 1855.92 & 76 & & I4. 60 & $\begin{array}{l}\mathrm{S} \\
\mathrm{N} \\
\mathrm{N}\end{array}$ & $\begin{array}{r}9 \\
83 \\
17\end{array}$ & $\begin{array}{l}33 \mathrm{~W} \\
58 \mathrm{E} \\
40 \mathrm{E}\end{array}$ & $\begin{array}{l}\mathrm{N} \\
\mathrm{S} \\
\mathrm{S}\end{array}$ & $\begin{array}{lll}9 & 33 & \mathrm{E} \\
83 & 58 & \mathrm{~W} \\
\mathrm{I} & 40 \mathrm{~W}\end{array}$ & $\begin{array}{r}7,298 \\
924 \\
2,127\end{array}$ & $\begin{array}{l}\text { Hooper Island Light. } \\
\text { Mount Zion M. E. Church } \\
\text { Spire. } \\
\text { Hosier Memorial Church } \\
\text { Spire. }\end{array}$ \\
\hline 4 & $3^{8}$ & I8 $45 \cdot 5^{6}$ & 76 & & $08,5^{2}$ & $\begin{array}{l}\mathrm{S} \\
\mathrm{N} \\
\mathrm{N}\end{array}$ & $\begin{array}{l}\text { II } \\
59 \\
\text { II }\end{array}$ & $\begin{array}{ll}20 & W \\
28 & E \\
3 I & E\end{array}$ & $\begin{array}{l}\mathrm{N} \\
\mathrm{S} \\
\mathrm{S}\end{array}$ & $\begin{array}{lll}\text { II } & 20 & \mathrm{E} \\
59 & 28 & \mathrm{~W} \\
\text { II } & 31 & \mathrm{~W}\end{array}$ & $\begin{array}{r}6,983 \\
879 \\
2,425\end{array}$ & $\begin{array}{l}\text { Hooper Island Light. } \\
\text { Mount Zion M. E. Church } \\
\text { Spire. } \\
\text { Hosier Memorial Church } \\
\text { Spire. }\end{array}$ \\
\hline
\end{tabular}

TAR BAY.

(Tar Bay-Chart No. 39.)

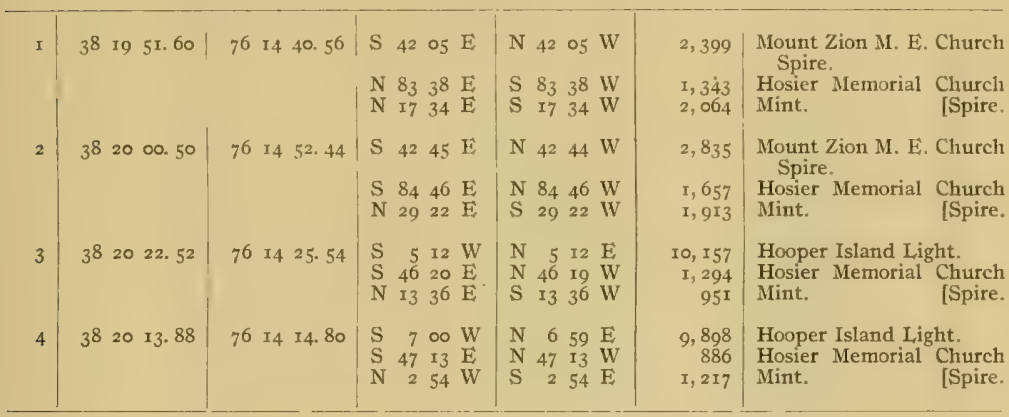


TUBBMANS DRAIN.

(Honga River-Charts Nos. 39 and 40.)

\begin{tabular}{|c|c|c|c|c|c|c|c|c|c|c|c|c|c|}
\hline \multirow{3}{*}{$\begin{array}{l}\text { Cor- } \\
\text { ner } \\
\text { of } \\
\text { bar }\end{array}$} & \multirow{2}{*}{\multicolumn{3}{|c|}{ Latitude }} & \multirow{2}{*}{\multicolumn{3}{|c|}{ Longitude }} & \multicolumn{5}{|c|}{ True bearing } & \multirow{2}{*}{$\begin{array}{l}\text { Distance } \\
\text { Yards. }\end{array}$} & \multirow{2}{*}{ U. S. C. \& G. S. triangulation } \\
\hline & & & & & & & \multicolumn{3}{|c|}{ Forward } & \multicolumn{2}{|r|}{ Back } & & \\
\hline & $\begin{array}{l}0 \\
38\end{array}$ & $\begin{array}{c}1 \\
20\end{array}$ & 4I. 16 & $\begin{array}{c}\circ \\
76\end{array}$ & $\begin{array}{c}1 \\
12\end{array}$ & 40. $5^{2}$ & $\begin{array}{l}\mathrm{S} \\
\mathrm{N} \\
\mathrm{N}\end{array}$ & $\begin{array}{r}0 \\
8 \\
46 \\
14\end{array}$ & $\begin{array}{l}04 \mathrm{~W} \\
46 \mathrm{E} \\
18 \mathrm{~W}\end{array}$ & $\begin{array}{ll}\mathrm{N} & \\
\mathrm{S} & 4 \\
\mathrm{~S} & \mathrm{I}\end{array}$ & $\begin{array}{lll}8 & \\
8 & 04 & \mathrm{E} \\
46 & 47 & \mathrm{~W} \\
4 & 18 & \mathrm{E}\end{array}$ & $\begin{array}{r}\text { Yards. } \\
823 \\
2,825 \\
2,5 \text { II }\end{array}$ & $\begin{array}{l}\text { Gunners. } \\
\text { Kerwin. } \\
\text { Keenes. }\end{array}$ \\
\hline 2 & $3^{8}$ & $2 I$ & 04.94 & 76 & 13 & 32. 18 & $\begin{array}{l}\mathrm{N} \\
\mathrm{S} \\
\mathrm{S}\end{array}$ & $\begin{array}{l}24 \\
67 \\
37\end{array}$ & $\begin{array}{ll}44 & E \\
O 2 & W \\
5 I & E\end{array}$ & $\begin{array}{ll}\mathrm{S} & 2 \\
\mathrm{~N} & 6 \\
\mathrm{~N} & 3\end{array}$ & $\begin{array}{lll}24 & 44 & W \\
67 & \text { OI } & \mathrm{E} \\
37 & 5 \mathrm{I} & \mathrm{W}\end{array}$ & $\begin{array}{l}I, 797 \\
I, 296 \\
2,047\end{array}$ & $\begin{array}{l}\text { Keenes. } \\
\text { Mint. } \\
\text { Gunners. }\end{array}$ \\
\hline 3 & 38 & $2 \pi$ & 32.82 & 76 & I2 & 59. I0 & $\begin{array}{l}\mathrm{S} \\
\mathrm{N}\end{array}$ & $\begin{array}{r}8 \\
85 \\
10\end{array}$ & $\begin{array}{ll}24 & E \\
4 I & E \\
23 & W\end{array}$ & $\begin{array}{ll}\mathrm{N} & \\
\mathrm{S} & 8 \\
\mathrm{~S} & \mathrm{I}\end{array}$ & $\begin{array}{lll}8 & 24 & W \\
85 & 42 & W \\
10 & 23 & E\end{array}$ & $\begin{array}{r}2,585 \\
2,559 \\
703\end{array}$ & $\begin{array}{l}\text { Gunners. } \\
\text { Kerwin. } \\
\text { Keenes. }\end{array}$ \\
\hline 4 & $3^{8}$ & $2 \mathrm{I}$ & 3I. 24 & 76 & I2 & 21. 72 & $\begin{array}{l}\mathrm{S} \\
\mathrm{N} \\
\mathrm{N}\end{array}$ & $\begin{array}{l}I 3 \\
8 I \\
56\end{array}$ & $\begin{array}{ll}48 & W \\
\text { oI } & W \\
2 I & W\end{array}$ & $\begin{array}{ll}N & I \\
S & 8 \\
S & 5\end{array}$ & $\begin{array}{lll}I_{3} & 48 & \mathrm{E} \\
8 \mathrm{I} & 02 & \mathrm{E} \\
56 & 22 & \mathrm{E}\end{array}$ & $\begin{array}{l}2,578 \\
\text { I, } 579 \\
\text { I, } 344\end{array}$ & $\begin{array}{l}\text { Gunners, } \\
\text { Kerwin. } \\
\text { Keenes. }\end{array}$ \\
\hline 5 & $3^{8}$ & 20 & 50.92 & 76 & I2 & 05.68 & $\begin{array}{l}\mathrm{N} \\
\mathrm{N} \\
\mathrm{S}\end{array}$ & $\begin{array}{l}35 \\
36 \\
42\end{array}$ & $\begin{array}{l}13 \mathrm{E} \\
17 \mathrm{~W} \\
18 \mathrm{~W}\end{array}$ & $\begin{array}{ll}\mathrm{S} & 3 \\
\mathrm{~S} & 3 \\
\mathrm{~N} & 4\end{array}$ & $\begin{array}{lll}35 & 13 & W \\
36 & 18 & E \\
42 & 17 & E\end{array}$ & $\begin{array}{l}I, 965 \\
2,610 \\
I, 546\end{array}$ & $\begin{array}{l}\text { Kerwin. } \\
\text { Keenes. } \\
\text { Gunners. }\end{array}$ \\
\hline
\end{tabular}

PEANU'T.

(Honga River-Charts Nos. 39 and 4o.)

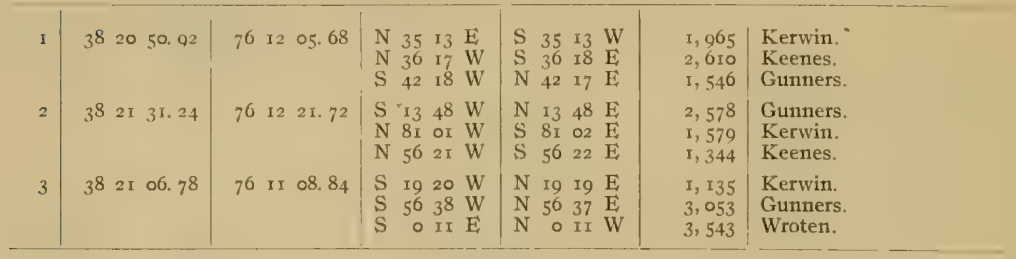

\section{GUM.}

(Honga River-Charts Nos. 39 and 40. )

\begin{tabular}{|c|c|c|c|c|c|c|c|c|c|c|}
\hline$I$ & 3820 & 08.82 & 76 & II & 36. 90 & $\begin{array}{l}\mathrm{N} \\
\mathrm{N} \\
\mathrm{S}\end{array}$ & $\begin{array}{lll}6 & 58 & \mathrm{IE} \\
8 \mathrm{I} & 20 & \mathrm{~W} \\
25 & 29 & \mathrm{E}\end{array}$ & $\begin{array}{lrrl}\mathrm{S} & 6 & 58 & \mathrm{~W} \\
\mathrm{~S} & 8 \mathrm{I} & 2 \mathrm{I} & \mathrm{E} \\
\mathrm{N} & 25 & 29 & \mathrm{~W}\end{array}$ & $\begin{array}{l}3,048 \\
\mathrm{I}, 826 \\
\mathrm{I}, 757\end{array}$ & $\begin{array}{l}\text { Kerwin. } \\
\text { Gunners. } \\
\text { Wroten. }\end{array}$ \\
\hline 2 & $3^{8}=0$ & II. 70 & 76 & II & 54.90 & $\begin{array}{l}\mathrm{S} \\
\mathrm{N} \\
\mathrm{N}\end{array}$ & $\begin{array}{lll}36 & 15 & \mathrm{E} \\
16 & 08 & \mathrm{E} \\
82 & 21 & W\end{array}$ & $\begin{array}{llll}N & 36 & 15 & W \\
\mathrm{~S} & 16 & 08 & W \\
\mathrm{~S} & 82 & 21 & \mathrm{E}\end{array}$ & $\begin{array}{l}2,088 \\
3,049 \\
1,339\end{array}$ & $\begin{array}{l}\text { Wroten. } \\
\text { Kerwin. } \\
\text { Gunners. }\end{array}$ \\
\hline 3 & 3820 & 13.24 & 76 & 12 & 04.30 & $\begin{array}{l}\mathrm{S} \\
\mathrm{N} \\
\mathrm{N}\end{array}$ & $\begin{array}{lll}40 & 32 & \mathrm{E} \\
20 & 52 & \mathrm{E} \\
83 & 18 & \mathrm{~W}\end{array}$ & $\begin{array}{llll}N & 40 & 32 & W \\
S & 20 & 53 & W \\
S & 83 & 19 & E\end{array}$ & $\begin{array}{l}2,283 \\
3,078 \\
1,085\end{array}$ & $\begin{array}{l}\text { Wroten. } \\
\text { Kerwin. } \\
\text { Gunners. }\end{array}$ \\
\hline 4 & $3^{8} 20$ & 50. 92 & 76 & 12 & 05.68 & $\begin{array}{l}\mathrm{N} \\
\mathrm{N} \\
\mathrm{S}\end{array}$ & $\begin{array}{lll}35 & 13 & E \\
36 & 17 & W \\
42 & 18 & W\end{array}$ & $\begin{array}{llll}\mathrm{S} & 35 & 13 & \mathrm{~W} \\
\mathrm{~S} & 36 & 18 & \mathrm{E} \\
\mathrm{N} & 42 & 17 & \mathrm{E}\end{array}$ & $\begin{array}{l}\text { I, } 965 \\
2,610 \\
1,546\end{array}$ & $\begin{array}{l}\text { Kerwin. } \\
\text { Keenes. } \\
\text { Gunners. }\end{array}$ \\
\hline 5 & $3^{8} 2 \mathrm{I}$ & 06. 78 & 76 & II & 08.84 & & $\begin{array}{lll}\text { Ig } & 20 & W \\
56 & 38 & W \\
0 & \text { II } & E\end{array}$ & $\begin{array}{llll}N & 19 & 19 & E \\
N & 56 & 37 & E \\
N & 0 & I I & W\end{array}$ & $\begin{array}{l}I, I 35 \\
3,053 \\
3,543\end{array}$ & $\begin{array}{l}\text { Kerwin. } \\
\text { Gunners. } \\
\text { Wroten. }\end{array}$ \\
\hline 6 & $3^{8} 20$ & 22.66 & 76 & II & 03. 78 & & $\begin{array}{lll}\text { II } & \text { I6 } & W \\
85 & 55 & W \\
3 & 27 & W\end{array}$ & $\begin{array}{lrrr}\mathrm{S} & \text { II } & 17 & \mathrm{E} \\
\mathrm{N} & 85 & 54 & \mathrm{E} \\
\mathrm{N} & 3 & 27 & \mathrm{E}\end{array}$ & $\begin{array}{l}2,609 \\
2,691 \\
2,057\end{array}$ & $\begin{array}{l}\text { Kerwin. } \\
\text { Gunners. } \\
\text { Wroten. }\end{array}$ \\
\hline
\end{tabular}


WROTEN ISLAND.

(Honga River-Charts Nos. 39 and 40.)

\begin{tabular}{|c|c|c|c|c|c|c|c|c|c|c|c|c|c|}
\hline \multirow{2}{*}{$\begin{array}{l}\text { Cor- } \\
\text { net } \\
\text { of } \\
\text { bar }\end{array}$} & \multirow{2}{*}{\multicolumn{3}{|c|}{ Latitude }} & \multirow{2}{*}{\multicolumn{3}{|c|}{ Longitude }} & \multicolumn{5}{|c|}{ True bearing } & \multirow{2}{*}{ Distance } & \multirow{2}{*}{$\begin{array}{l}\text { U. S. C. \& G. S, triangulation } \\
\text { station }\end{array}$} \\
\hline & & & & & & & & Forv & ward & & Back & & \\
\hline & - & , & II & & & & & & , & & 01 & Yards. & \\
\hline I & 38 & I8 & I2. 40 & 76 & I2 & 00.50 & $\begin{array}{l}\mathrm{N} \\
\mathrm{S} \\
\mathrm{S}\end{array}$ & $\begin{array}{l}59 \\
54 \\
6 \mathrm{I}\end{array}$ & $\begin{array}{l}24 \mathrm{~W} \\
59 \mathrm{~W} \\
38 \mathrm{E}\end{array}$ & $\begin{array}{l}\mathrm{S} \\
\mathrm{N} \\
\mathrm{N}\end{array}$ & $\begin{array}{lll}59 & 25 & \mathrm{E} \\
54 & 59 & \mathrm{E} \\
6 \mathrm{I} & 37 & \mathrm{~W}\end{array}$ & $\begin{array}{r}3,072 \\
785 \\
2,445\end{array}$ & $\begin{array}{l}\text { Mount Zion M. E. Church } \\
\text { Bridge. } \\
\text { Bentley. }\end{array}$ \\
\hline 2 & $3^{8}$ & I9 & 20. $3^{2}$ & 76 & 12 & $45 \cdot 56$ & $\begin{array}{l}N \\
S \\
S\end{array}$ & $\begin{array}{l}0 \\
63 \\
\text { II }\end{array}$ & $\begin{array}{ll}33 & \mathrm{E} \\
22 & \mathrm{~W} \\
25 & \mathrm{~F}\end{array}$ & $\begin{array}{l}\mathrm{S} \\
\mathrm{N}\end{array}$ & $\begin{array}{rrr}0 & 33 & W \\
63 & 22 & \mathrm{E} \\
\text { II } & 25 & \mathrm{~W}\end{array}$ & $\begin{array}{l}\text { I, } 912 \\
\text { I, } 619 \\
2,796\end{array}$ & $\begin{array}{l}\text { Gunners. } \\
\text { Mount Zion M. E. Church } \\
\text { Bridge. }\end{array}$ \\
\hline 3 & 38 & 20 & II. 70 & 76 & II & 54.90 & $\begin{array}{l}\mathrm{S} \\
\mathrm{N} \\
\mathrm{N}\end{array}$ & $\begin{array}{l}36 \\
16 \\
82\end{array}$ & $\begin{array}{ll}\text { I5 } & \mathrm{E} \\
\text { o8 } & \mathrm{E} \\
2 \mathrm{I} & \mathrm{W}\end{array}$ & $\begin{array}{l}\mathrm{N} \\
\mathrm{S} \\
\mathrm{S}\end{array}$ & $\begin{array}{ccc}36 & \text { I } 5 & W \\
16 & 08 & W \\
82 & 21 & F\end{array}$ & $\begin{array}{l}2,088 \\
3,049 \\
\mathbf{I}, 339\end{array}$ & $\begin{array}{l}\text { Wroten. } \\
\text { Kerwin. } \\
\text { Gunners. }\end{array}$ \\
\hline 4 & 38 & I9 & 55. I2 & 76 & II & 46.86 & $\begin{array}{l}N \\
S \\
S\end{array}$ & $\begin{array}{l}64 \\
14 \\
42\end{array}$ & $\begin{array}{l}25 \mathrm{~W} \\
25 \mathrm{~W} \\
14 \mathrm{E}\end{array}$ & $\begin{array}{l}\mathrm{S} \\
\mathrm{N} \\
\mathrm{N}\end{array}$ & $\begin{array}{lll}64 & 26 & \mathrm{E} \\
14 & 24 & \mathrm{E} \\
42 & 14 & \mathrm{~W}\end{array}$ & $\begin{array}{l}\text { I, } 708 \\
4,042 \\
\text { I, } 5 \text { I9 }\end{array}$ & $\begin{array}{l}\text { Gunners. } \\
\text { Bridge. } \\
\text { Wroten. }\end{array}$ \\
\hline 5 & $3^{8}$ & 19 & 4 I. 22 & 76 & $x \bar{I}$ & 59.10 & $\begin{array}{l}N \\
\mathrm{~S} \\
\mathrm{~S}\end{array}$ & $\begin{array}{l}45 \\
\mathrm{II} \\
64\end{array}$ & $\begin{array}{ll}\text { I3 } & W \\
\text { II } & W \\
\text { I } & F\end{array}$ & $\begin{array}{l}\mathrm{S} \\
\mathrm{N} \\
\mathrm{N}\end{array}$ & $\begin{array}{lll}45 & \text { I } 4 & \mathrm{E} \\
\text { II } & \text { IO } & \mathrm{E} \\
64 & \text { OI } & W\end{array}$ & $\begin{array}{l}x, 7 I 3 \\
3,513 \\
I, 497\end{array}$ & $\begin{array}{l}\text { Gunners. } \\
\text { Bridge. } \\
\text { Wroten. }\end{array}$ \\
\hline 6 & 38 & 18 & 49.00 & $7^{6}$ & I I & $57 \cdot 96$ & $\begin{array}{l}\mathrm{N} \\
\mathrm{S} \\
\mathrm{S}\end{array}$ & $\begin{array}{l}83 \\
22 \\
+1\end{array}$ & $\begin{array}{ll}0.4 & W \\
53 & W \\
\text { or } & \mathrm{E}\end{array}$ & $\begin{array}{l}\mathrm{S} \\
\mathrm{N} \\
\mathrm{N}\end{array}$ & $\begin{array}{lll}83 & \text { O3 } & \mathrm{E} \\
22 & 53 & \mathrm{E} \\
4 I & \text { OI } & W\end{array}$ & $\begin{array}{l}2,732 \\
1,828 \\
3,175\end{array}$ & $\begin{array}{l}\text { Mount Zion M. E. Church } \\
\text { Bridge. } \\
\text { Bentley. }\end{array}$ \\
\hline 7 & $3^{8}$ & 18 & 42.22 & 76 & Ir & 00.82 & $\begin{array}{l}\mathrm{N} \\
\mathrm{S} \\
\mathrm{S}\end{array}$ & $\begin{array}{r}\mathrm{I} \\
53 \\
20\end{array}$ & $\begin{array}{ll}35 & \mathrm{E} \\
48 & \mathrm{~W} \\
23 & \mathrm{E}\end{array}$ & $\begin{array}{l}\mathrm{S} \\
\mathrm{N}\end{array}$ & $\begin{array}{rrr}1 & 35 & W \\
53 & 47 & \mathrm{E} \\
20 & 22 & \mathrm{~W}\end{array}$ & $\begin{array}{l}\mathrm{I}, 334 \\
2,467 \\
2,3 \mathrm{I} 2\end{array}$ & $\begin{array}{l}\text { Wroten. } \\
\text { Bridge. } \\
\text { Bentley. }\end{array}$ \\
\hline
\end{tabular}

SMOKE POINT.

(Honga River-Chart No. 40.)

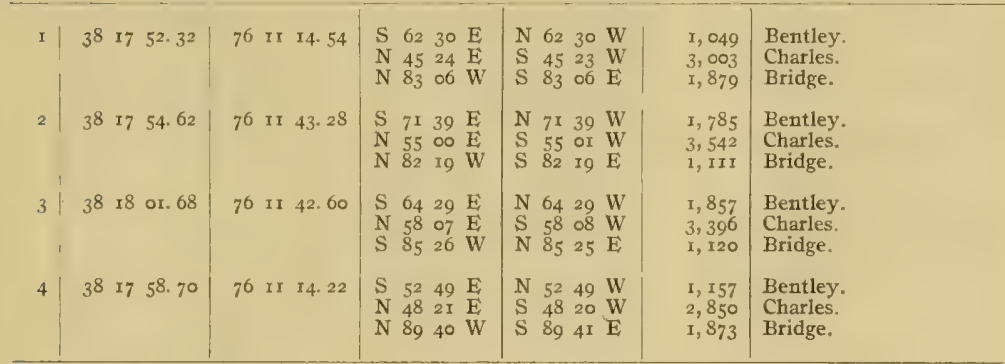


DARK POINT.

(Honga River-Chart No. 40.)

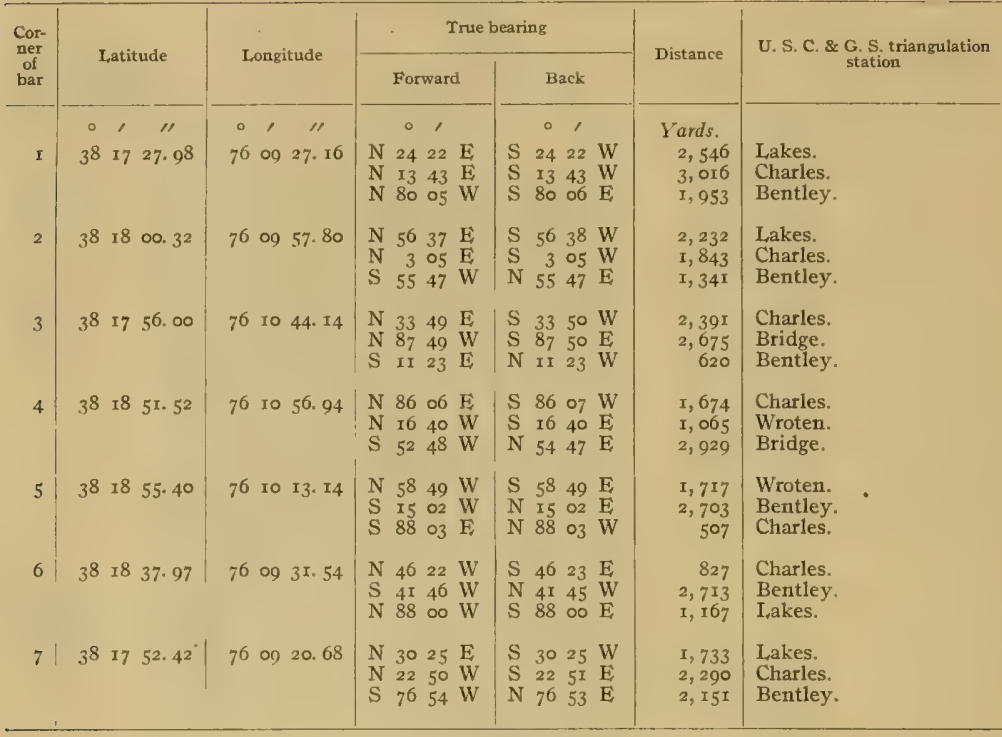

LAKES COVE.

(Honga River-Chart No. 40.)

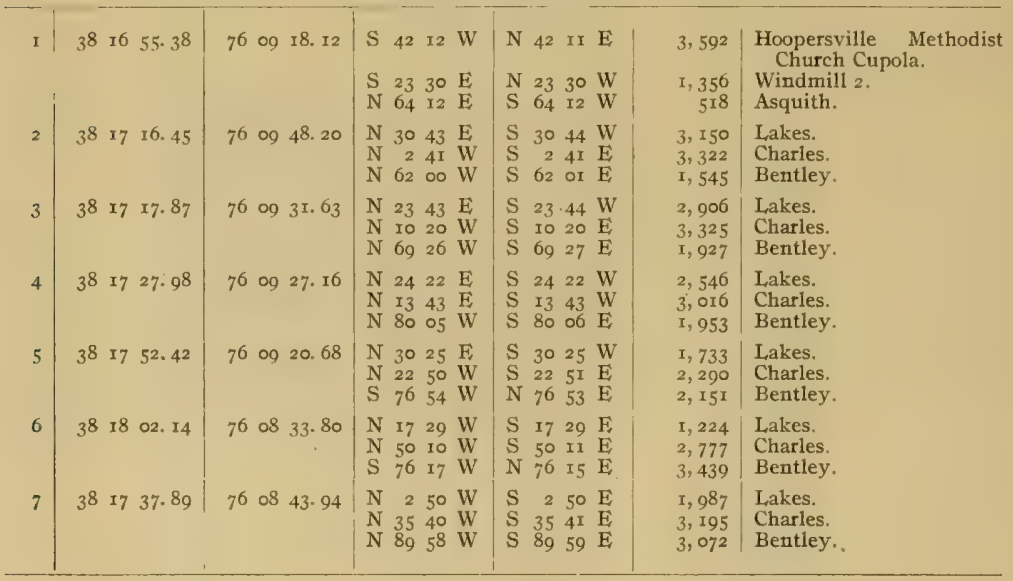


WINDMILI,

(Honga River-Chart No. 40.)

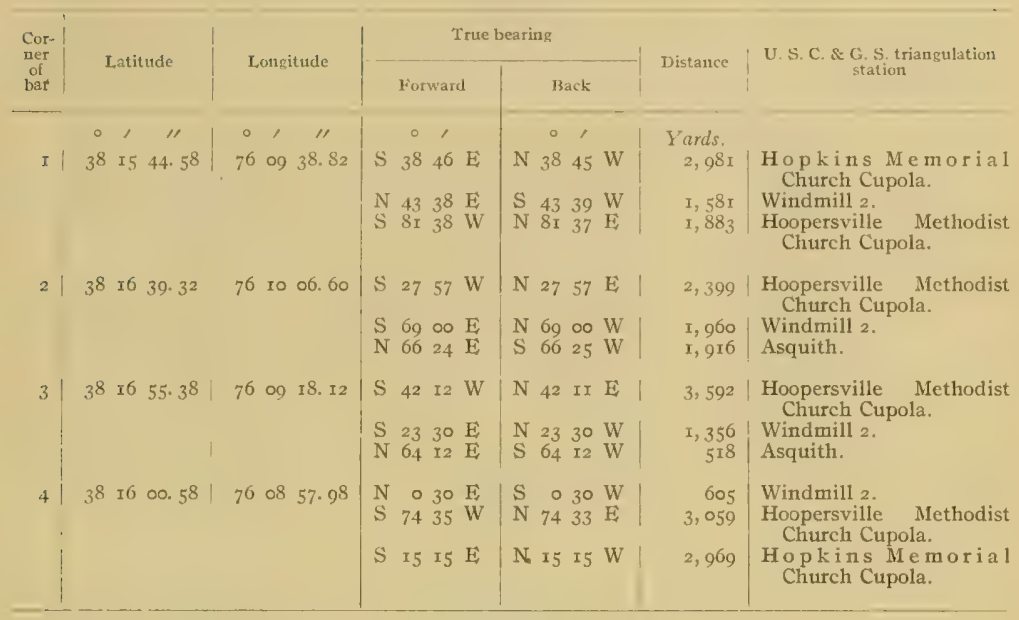

\section{HICKORY}

(Honga River-Chart No. 40.)

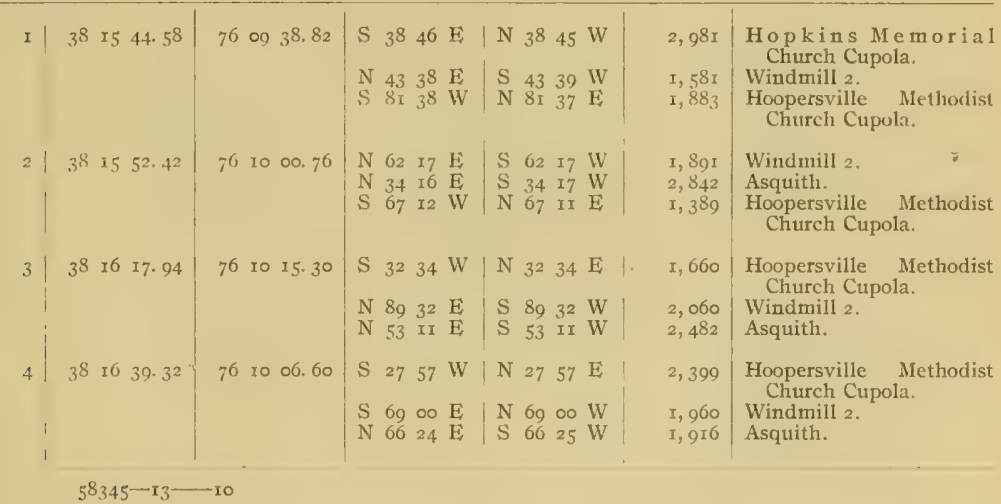


I.OWER THOROUGHFARF;

(Honga River-Chart No. 40.)

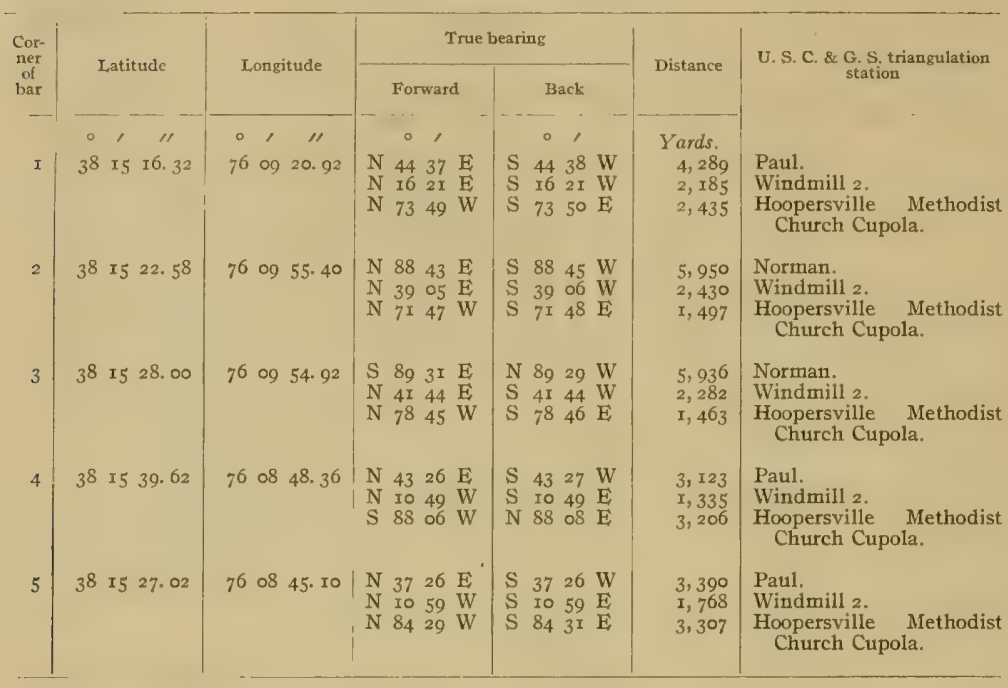

PAUL.

(Honga River-Chart No. 40.)

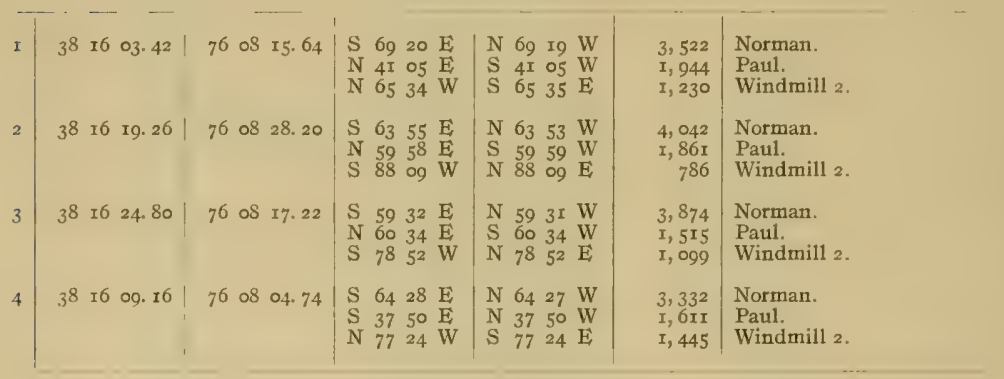


CRAB POINT.

(Honga River-Charl No. 4o.)

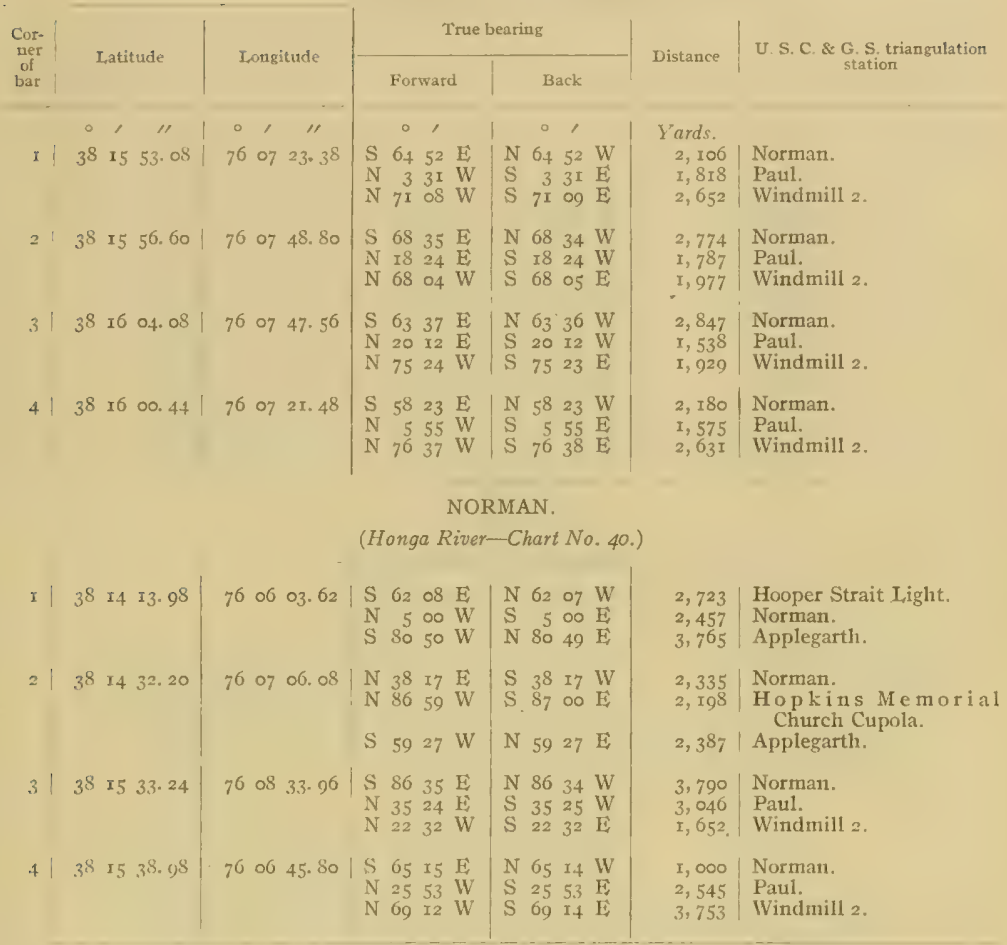

APPLEGARTH.

(Hooper Strait-Chart No. 4o.)

\begin{tabular}{|c|c|c|c|c|c|c|c|c|}
\hline I & $3^{8}$ & 12 & 5I. 50 & 76 o5 47.84 & $\begin{array}{llll}\mathrm{S} & 10 & 27 & \mathrm{E} \\
\mathrm{N} & 52 & 49 & \mathrm{E} \\
\mathrm{N} & 6 & 55 & \mathrm{~W}\end{array}$ & $\begin{array}{lrll}\mathrm{N} & \text { I0 } & 27 & \mathrm{~W} \\
\mathrm{~S} & 52 & 50 & \mathrm{~W} \\
\mathrm{~S} & 6 & 55 & \mathrm{E}\end{array}$ & $\begin{array}{l}3, \text { I } 2 x \\
2,496 \\
5,267\end{array}$ & $\begin{array}{l}\text { Okahanikan. } \\
\text { Hooper Strait Light. } \\
\text { Norman. }\end{array}$ \\
\hline 2 & $3^{S}$ & $x_{3}$ & 49. 00 & 76 o6 46.30 & $\begin{array}{llll}\mathrm{S} & 83 & 04 & \mathrm{E} \\
\mathrm{N} & \mathrm{I} 5 & 38 & \mathrm{E} \\
\mathrm{N} & 84 & 37 & \mathrm{~W}\end{array}$ & $\begin{array}{llll}\mathrm{N} & 83 & 03 & \mathrm{~W} \\
\mathrm{~S} & \mathrm{I} 5 & 38 & \mathrm{~W} \\
\mathrm{~S} & 84 & 38 & \mathrm{E}\end{array}$ & $\begin{array}{l}3,570 \\
3,416 \\
2,593\end{array}$ & $\begin{array}{l}\text { Hooper Strait Liglit. } \\
\text { Norman. } \\
\text { Applegarth. }\end{array}$ \\
\hline 3 & $3^{8}$ & 14 & I.3. 99 & $\begin{array}{llllll}76 & 06 & 03.62\end{array}$ & $\begin{array}{lrll}\mathrm{S} & 62 & 08 & \mathrm{E} \\
\mathrm{N} & 5 & 00 & \mathrm{~W} \\
\mathrm{~S} & 80 & 50 & \mathrm{~W}\end{array}$ & $\begin{array}{llll}\mathrm{N} & 62 & 07 & \mathrm{~W} \\
\mathrm{~S} & 5 & 00 & \mathrm{E} \\
\mathrm{N} & 80 & 49 & \mathrm{E}\end{array}$ & $\begin{array}{l}2,723 \\
2,457 \\
3,765\end{array}$ & $\begin{array}{l}\text { Hooper Strait Light. } \\
\text { Norman. } \\
\text { Applegarth. }\end{array}$ \\
\hline & $3^{8}$ & 13 & I 3.88 & $\begin{array}{llll}76 & 05 & 05.12\end{array}$ & $\begin{array}{llll}\mathrm{N} & 74 & 52 & \mathrm{~W} \\
\mathrm{~N} & 48 & 29 & \mathrm{E} \\
\mathrm{S} & 8 & 30 & \mathrm{~W}\end{array}$ & $\begin{array}{llll}\mathrm{S} & 74 & 54 & \mathrm{E} \\
\mathrm{S} & 48 & 29 & \mathrm{~W} \\
\mathrm{~N} & 8 & 29 & \mathrm{E}\end{array}$ & $\begin{array}{l}5,463 \\
I, I 37 \\
3,866\end{array}$ & $\begin{array}{l}\text { Applegarth. } \\
\text { Hooper Strait Light. } \\
\text { Okahanikan. }\end{array}$ \\
\hline
\end{tabular}


HOOPFIR STRAIT.

(Hooper Strait-Chart No. 40.)

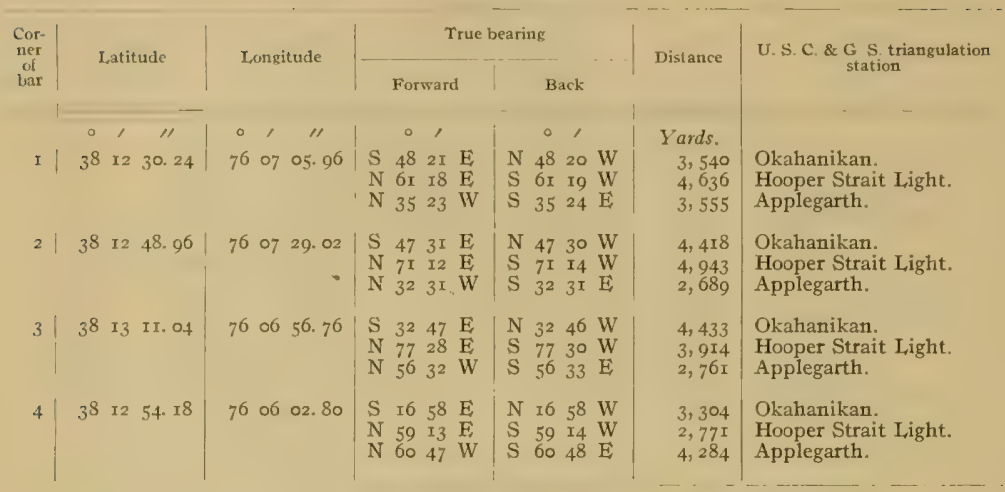

\section{RICHLAND.}

(Hooper Strait-Chart No. 40.)

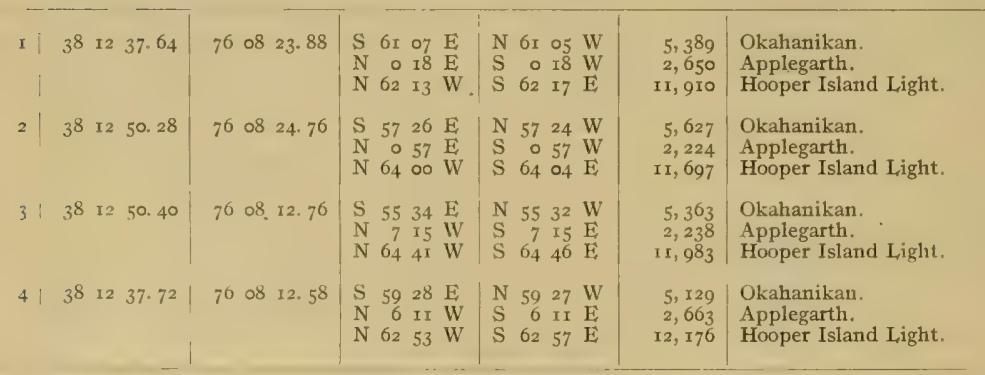




\section{BI.OODSWORTH.}

(Hooper Strait - Charts Nos. fo aud H.)

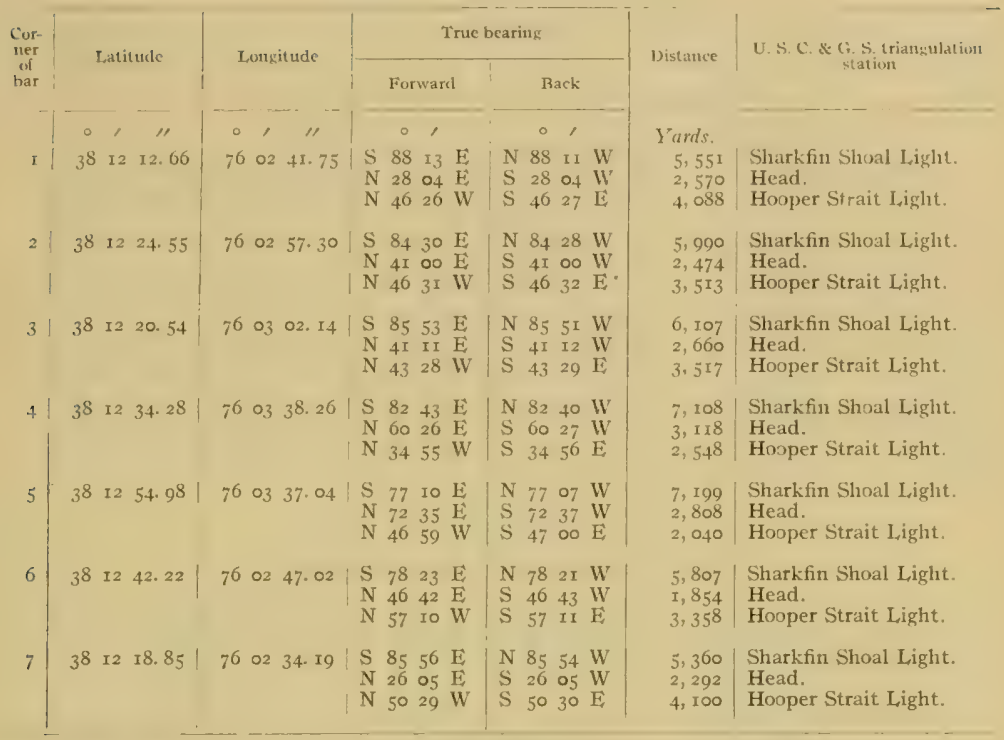

\section{HOPKINS COVF.}

(Hooper Strait-Chart No. $7 I$.)

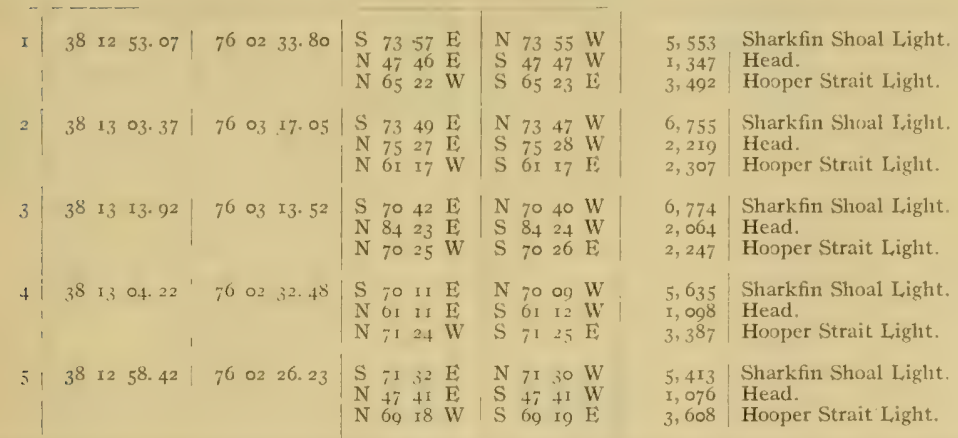


RIII) SHCCTOR,

(Hooper Strait-Chart No. 4I.)

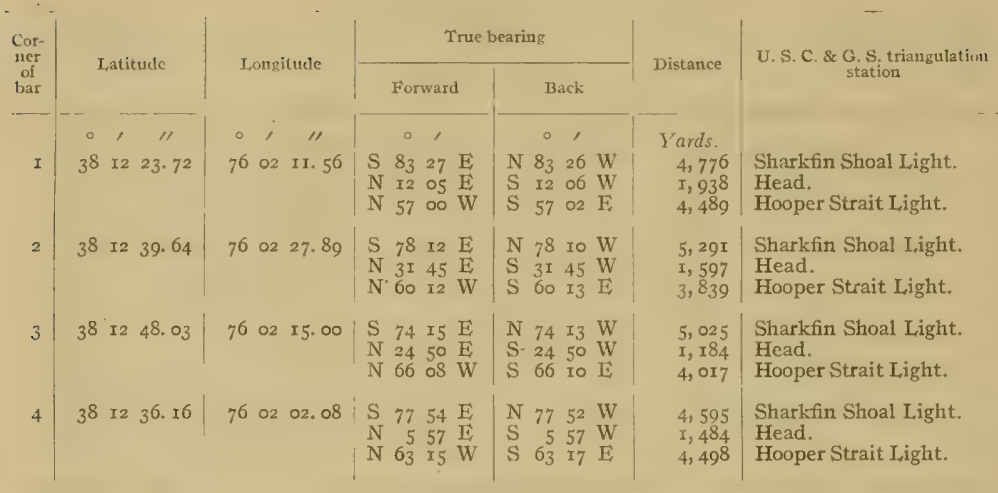

\section{BELI, BUOY.}

(Hooper Strait-Charts Nos. $4 I$ and 42.)

\begin{tabular}{|c|c|c|c|c|c|c|c|}
\hline I & $3^{8}$ II 25.80 & 76 or & 22.21 & $\begin{array}{llll}N & 67 & 4 I & E \\
N & I 3 & I 6 & W \\
N & 49 & 07 & W\end{array}$ & $\begin{array}{llll}\mathrm{S} & 67 & 42 & \mathrm{~W} \\
\mathrm{~S} & \mathrm{I} & \mathrm{I} & \mathrm{E} \\
\mathrm{S} & 49 & 09 & \mathrm{E}\end{array}$ & $\begin{array}{l}3,709 \\
3,953 \\
6,717\end{array}$ & $\begin{array}{l}\text { Sharkfin Shoal Light. } \\
\text { Head. } \\
\text { Hooper Strait Light. }\end{array}$ \\
\hline 2 & $3^{8}$ II 40.82 & 7602 & 00.26 & $\begin{array}{lrll}N & 7^{8} & 3 I & E \\
N & I & 48 & E \\
N & 46 & \text { I } & \text { W }\end{array}$ & $\begin{array}{rrrr}\mathrm{S} & 78 & 33 & \mathrm{~W} \\
\mathrm{~S} & \mathrm{I} & 48 & \mathrm{~W} \\
\mathrm{~S} & 46 & \mathrm{I} & \mathrm{E}\end{array}$ & $\begin{array}{l}4,535 \\
3,343 \\
5,627\end{array}$ & $\begin{array}{l}\text { Sharkfin Shoal Light. } \\
\text { Head. } \\
\text { Hooper Strait Light. }\end{array}$ \\
\hline 3 & $\begin{array}{lll}3^{8} & \text { I2 } & 22.84\end{array}$ & 76 or & 56.04 & $\begin{array}{lrrr}\mathrm{S} & 83 & I_{4} & \mathrm{~W} \\
\mathrm{~N} & 0 & I_{2} & \mathrm{~W} \\
\mathrm{~N} & 59 & 22 & \mathrm{~W}\end{array}$ & $\begin{array}{rrrr}\mathrm{N} & 83 & 12 & \mathrm{E} \\
\mathrm{S} & 0 & 12 & \mathrm{E} \\
\mathrm{S} & 59 & 23 & \mathrm{E}\end{array}$ & $\begin{array}{l}4,362 \\
1,925 \\
4,856\end{array}$ & $\begin{array}{l}\text { Sharkfin Shoal Light. } \\
\text { Head. } \\
\text { Hooper Strait Light. }\end{array}$ \\
\hline 4 & $\begin{array}{llll}38 & \text { I2 } & 24.96\end{array}$ & 76 or & $4^{\text {I. }} 4^{2}$ & $\begin{array}{llll}\mathrm{S} & 8 \mathrm{r} & 33 & \mathrm{E} \\
\mathrm{N} & \mathrm{I} 2 & 03 & \mathrm{~W} \\
\mathrm{~N} & 62 & \mathrm{I} & \mathrm{W}\end{array}$ & $\begin{array}{llll}\mathrm{N} & 8 \mathrm{I} & 32 & \mathrm{IV} \\
\mathrm{S} & \mathrm{I} 2 & 04 & \mathrm{E} \\
\mathrm{S} & 62 & \mathrm{I} & \mathrm{E}\end{array}$ & $\begin{array}{l}3,086 \\
1,895 \\
5,160\end{array}$ & $\begin{array}{l}\text { Sharkfin Shoal Light. } \\
\text { Head. } \\
\text { Hooper Strait Light. }\end{array}$ \\
\hline 5 & $\begin{array}{llll}3^{8} & \text { I2 } & 57.84\end{array}$ & 76 or & 40. $7^{2}$ & $\begin{array}{llll}\mathrm{S} & 66 & 39 & \mathrm{E} \\
\mathrm{N} & 72 & 00 & \mathrm{E} \\
\mathrm{N} & 29 & 06 & \mathrm{~W}\end{array}$ & $\begin{array}{llll}\mathrm{N} & 66 & 37 & \mathrm{~W} \\
\mathrm{~S} & 72 & 03 & \mathrm{~W} \\
\mathrm{~S} & 29 & 06 & \mathrm{E}\end{array}$ & $\begin{array}{r}4,275 \\
7,982 \\
852\end{array}$ & $\begin{array}{l}\text { Sharkfin Shoal Light. } \\
\text { Frog. } \\
\text { Head. }\end{array}$ \\
\hline 6 & $3^{8} x_{3} \quad 04 \cdot 3^{8}$ & 76 or & I9. 76 & $\begin{array}{llll}\mathrm{S} & 60 & 22 & \mathrm{E} \\
\mathrm{N} & 72 & 18 & \mathrm{E} \\
\mathrm{N} & 61 & 40 & \mathrm{~W}\end{array}$ & $\begin{array}{llll}\mathrm{N} & 60 & 21 & \mathrm{~W} \\
\mathrm{~S} & 72 & 20 & \mathrm{~W} \\
\mathrm{~S} & 61 & 4 \mathrm{I} & \mathrm{E}\end{array}$ & $\begin{array}{l}3,874 \\
7,384 \\
\mathrm{r}, 105\end{array}$ & $\begin{array}{l}\text { Sharkfin Shoal Light. } \\
\text { Frog. } \\
\text { Head. }\end{array}$ \\
\hline 7 & $3^{8} \quad 12 \quad 31.84$ & 7600 & II. 98 & $\begin{array}{llll}\mathrm{S} & 62 & 24 & \mathrm{E} \\
\mathrm{N} & 57 & 25 & \mathrm{E} \\
\mathrm{N} & 59 & 43 & \mathrm{~W}\end{array}$ & $\begin{array}{llll}\mathrm{N} & 62 & 24 & \mathrm{~W} \\
\mathrm{~S} & 57 & 27 & \mathrm{~W} \\
\mathrm{~S} & 59 & 44 & \mathrm{E}\end{array}$ & $\begin{array}{l}I, 763 \\
6,209 \\
3,214\end{array}$ & $\begin{array}{l}\text { Sharkfin Shoal I,ight. } \\
\text { Frog. } \\
\text { Head. }\end{array}$ \\
\hline 8 & $3^{8}$ II $5^{8} .90$ & 76 or & 19. 76 & $\begin{array}{llll}N & 85 & 02 & E \\
N & \text { I9 } & 35 & W \\
N & 57 & 08 & W\end{array}$ & $\begin{array}{llll}\mathrm{S} & 85 & 03 & \mathrm{~W} \\
\mathrm{~S} & \mathrm{r} & 36 & \mathrm{E} \\
\mathrm{S} & 57 & 30 & \mathrm{E}\end{array}$ & $\begin{array}{l}3,379 \\
2,899 \\
6,100\end{array}$ & $\begin{array}{l}\text { Sharkfin Shoal Light. } \\
\text { Head, } \\
\text { Hooper Strait Light. }\end{array}$ \\
\hline
\end{tabular}


JANE.

(Upper Tangier Sound-Chart No. $4 T$.)

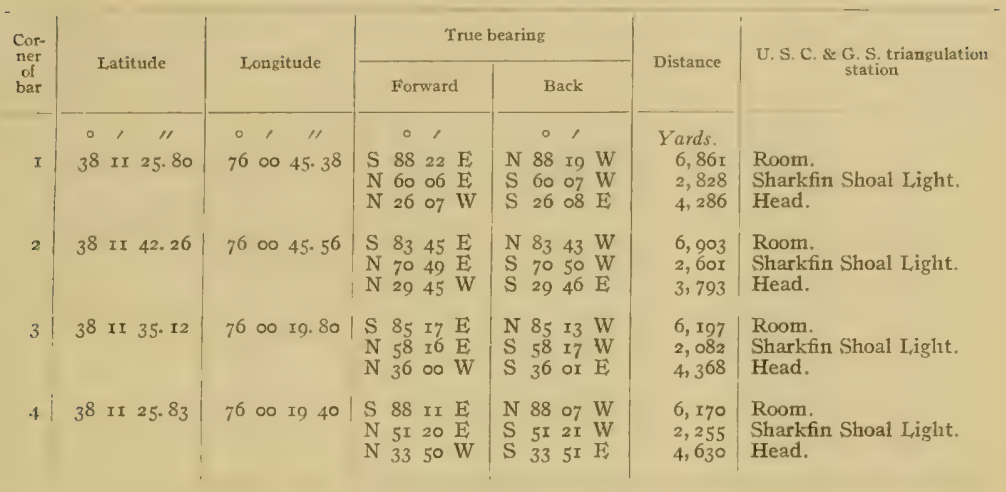

MUD (DORCHESTER COUNTY).

(Upper Tangier Sound-Chart No. 4I.)

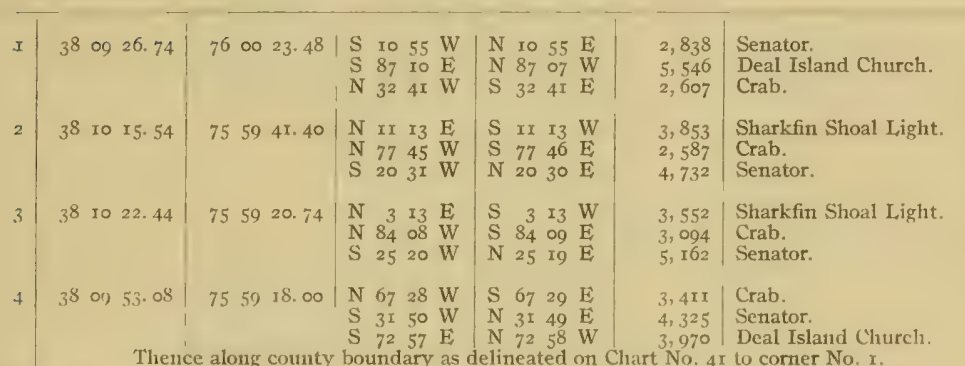

Thence along county boundary as delineated on Chart No. 4 I to comer No. $I$. 


\section{SHARKFIN SHOAL,}

(Upper Tangier Sound-Chait No.41.)

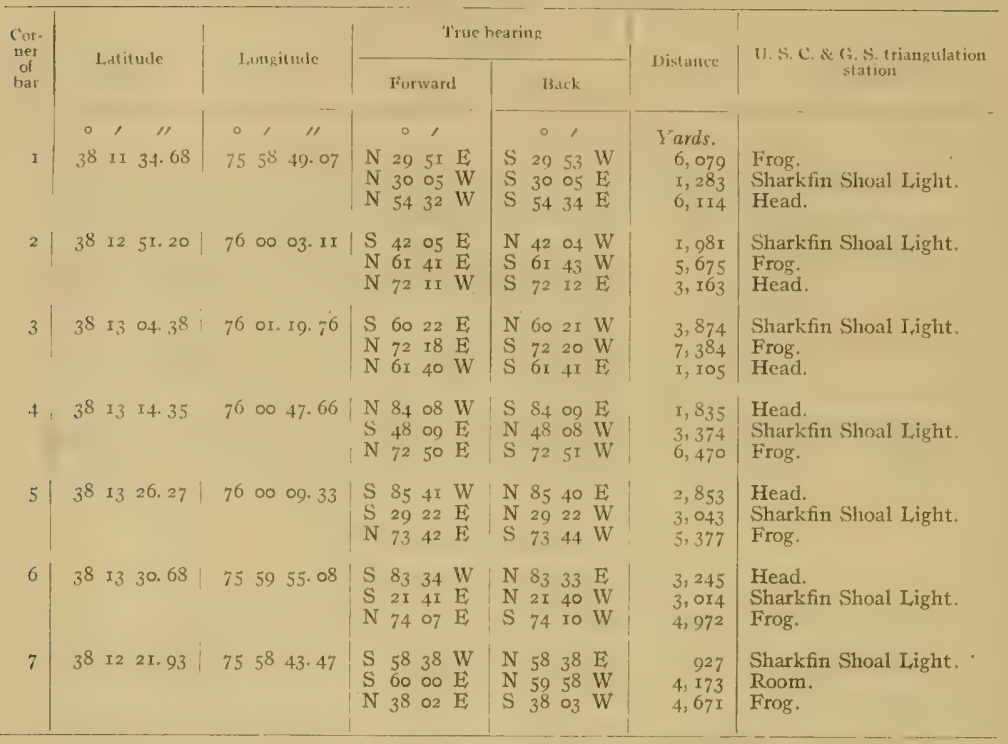

\section{WARE SANDS.}

(Fishing Bay-Chart No, 4 I.)

\begin{tabular}{|c|c|c|c|c|c|c|c|c|c|c|c|c|}
\hline 1 & $3^{8}$ & I2 & $57 \cdot 84$ & 76 & or & 40. $7^{2}$ & $\begin{array}{l}\mathrm{S} \\
\mathrm{N} \\
\mathrm{N}\end{array}$ & $\begin{array}{l}66 \\
72 \\
29\end{array}$ & $\begin{array}{ll}39 & E \\
00 & E \\
06 & \text { IV }\end{array}$ & $\begin{array}{l}N \\
S \\
S\end{array}$ & $\begin{array}{l}66 \\
72 \\
29\end{array}$ & $\begin{array}{ll}37 & W \\
03 & W \\
06 & E\end{array}$ \\
\hline 2 & $3^{8}$ & I3 & $23 \cdot 40$ & 76 & OI & 40.22 & $\begin{array}{l}\mathrm{N} \\
\mathrm{S} \\
\mathrm{S}\end{array}$ & $\begin{array}{l}17 \\
74 \\
56\end{array}$ & $\begin{array}{ll}\text { I2 } & W \\
40 & W \\
50 & E\end{array}$ & $\begin{array}{l}\mathrm{S} \\
\mathrm{N} \\
\mathrm{N}\end{array}$ & $\begin{array}{l}I 7 \\
74 \\
56\end{array}$ & $\begin{array}{ll}\text { I2 } & \mathrm{E} \\
39 & \mathrm{E} \\
48 & \mathrm{~W}\end{array}$ \\
\hline 3 & 38 & I4 & 00.09 & 76 & OI & 56.44 & $\begin{array}{l}S \\
S \\
N\end{array}$ & $\begin{array}{r}0 \\
48 \\
16\end{array}$ & $\begin{array}{l}\text { og } \mathrm{E} \\
52 \mathrm{E} \\
\text { os } \mathrm{W}\end{array}$ & $\begin{array}{l}N \\
N \\
S\end{array}$ & $\begin{array}{r}0 \\
48 \\
16\end{array}$ & $\begin{array}{ll}\circ 9 & W \\
50 & W \\
\circ 8 & E\end{array}$ \\
\hline 4 & $3^{8}$ & I4 & 03.76 & 76 & OI & 49. I2 & $\begin{array}{l}\mathrm{S} \\
\mathrm{S} \\
\mathrm{N}\end{array}$ & $\begin{array}{r}7 \\
46 \\
21\end{array}$ & $\begin{array}{ll}22 & W \\
38 & E \\
2 I & W\end{array}$ & $\begin{array}{l}\mathrm{N} \\
\mathrm{N} \\
\mathrm{S}\end{array}$ & $\begin{array}{r}7 \\
46 \\
21\end{array}$ & $\begin{array}{ll}22 & \mathrm{E} \\
37 & \mathrm{~W} \\
21 & \mathrm{E}\end{array}$ \\
\hline 5 & $3^{8}$ & $I_{3}$ & I4. 35 & 76 & $\infty$ & 47.66 & $\begin{array}{l}\mathrm{N} \\
\mathrm{S} \\
\mathrm{N}\end{array}$ & $\begin{array}{l}84 \\
48 \\
72\end{array}$ & $\begin{array}{ll}08 & W \\
\circ g & E \\
50 & E\end{array}$ & $\begin{array}{l}\mathrm{S} \\
\mathrm{N} \\
\mathrm{S}\end{array}$ & $\begin{array}{l}84 \\
48 \\
72\end{array}$ & $\begin{array}{ll}\circ g & E \\
\circ 8 & W \\
5 I & W\end{array}$ \\
\hline & ${ }_{3} \mathrm{~S}$ & 1.3 & 0.4 .38 & 76 & or & I9. 76 & $\begin{array}{l}\mathrm{S} \\
\mathrm{N} \\
\mathrm{N}\end{array}$ & $\begin{array}{l}60 \\
72 \\
61\end{array}$ & $\begin{array}{ll}22 & \mathbf{E} \\
18 & \mathbf{E} \\
40 & W\end{array}$ & $\begin{array}{l}N \\
S \\
S\end{array}$ & $\begin{array}{l}60 \\
72 \\
6 I\end{array}$ & $\begin{array}{ll}2 \mathrm{I} & \mathrm{WV} \\
20 \mathrm{~W} \\
4 \mathrm{I} & \mathrm{li}\end{array}$ \\
\hline
\end{tabular}

\begin{tabular}{|c|c|}
\hline $\begin{array}{r}4,275 \\
7,982 \\
852\end{array}$ & $\begin{array}{l}\text { Sharkfin Shoal Light. } \\
\text { Frog. } \\
\text { Head. }\end{array}$ \\
\hline $\begin{array}{r}3,799 \\
444 \\
4,672\end{array}$ & $\begin{array}{l}\text { Croch. } \\
\text { Head. } \\
\text { Sharkfin Shoal Light. }\end{array}$ \\
\hline $\begin{array}{l}I, 355 \\
5,767 \\
2,490\end{array}$ & $\begin{array}{l}\text { Head. } \\
\text { Sharkfin Shoal Light. } \\
\text { Croch. }\end{array}$ \\
\hline $\begin{array}{l}\mathbf{I}, 491 \\
5,705 \\
2,435\end{array}$ & $\begin{array}{l}\text { Head. } \\
\text { Sharkfin Shoal Light. } \\
\text { Croch. }\end{array}$ \\
\hline $\begin{array}{l}I, 835 \\
3,374 \\
6,470\end{array}$ & $\begin{array}{l}\text { Head. } \\
\text { Sharkfin Shoal Light. } \\
\text { Frog. }\end{array}$ \\
\hline $\begin{array}{l}3,874 \\
7,384 \\
1,105\end{array}$ & $\begin{array}{l}\text { Sharkfin Shoal Light. } \\
\text { Frog. } \\
\text { Head. }\end{array}$ \\
\hline
\end{tabular}


SAND SHOAI.

(Fishing Bay-Charl No. 4I.)

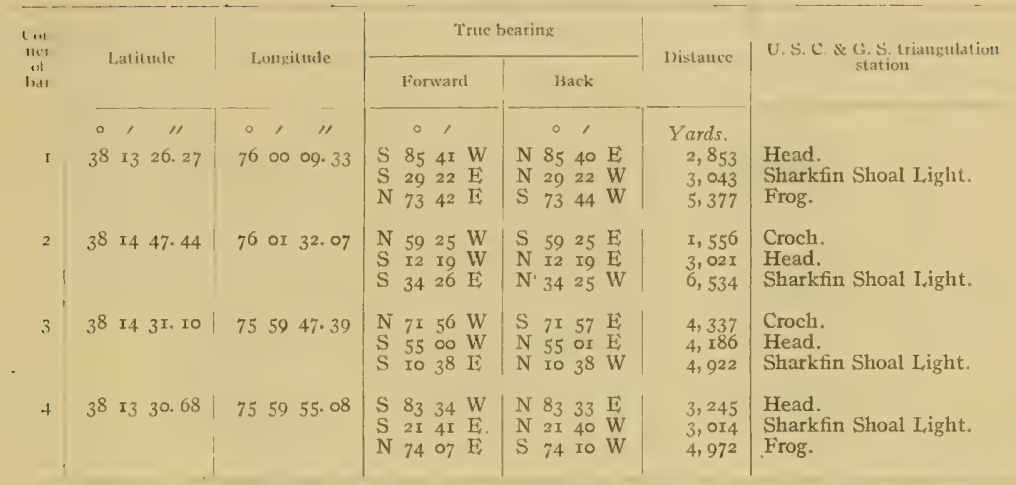

\section{CIAAY ISLAND.}

(Fishing Bay-Chart No. 4I.)

\begin{tabular}{|c|c|c|c|c|c|c|c|c|c|}
\hline I & $3^{8}$ & $I_{3} 38,82$ & $75 \quad 59$ & 28.94 & $\begin{array}{lr}\mathrm{S} & 80 \\
\mathrm{~S} & 7 \\
\mathrm{~N} & 75\end{array}$ & $\begin{array}{l}45 \mathrm{~W} \\
44 \mathrm{E} \\
07 \mathrm{E}\end{array}$ & $\begin{array}{lrrl}\mathrm{N} & 80 & 44 & \mathrm{E} \\
\mathrm{N} & 7 & 44 & \mathrm{~W} \\
\mathrm{~S} & 75 & 09 & \mathrm{~W}\end{array}$ & $\begin{array}{l}3,972 \\
3,104 \\
4,229\end{array}$ & $\begin{array}{l}\text { Head. } \\
\text { Sharkfin Shoal I,ight. } \\
\text { Frog. }\end{array}$ \\
\hline 2 & $3^{8}$ & I4 2 I. 04 & $75 \quad 59$ & $3^{2} \cdot 3^{6}$ & $\begin{array}{lr}S & 6 I \\
S & 6 \\
S & 85\end{array}$ & $\begin{array}{ll}42 & W \\
27 & \mathrm{E} \\
23 & \mathrm{E}\end{array}$ & $\begin{array}{lrll}N & 6 r & 4 I & E \\
N & 6 & 27 & W \\
N & 85 & 2 I & W\end{array}$ & $\begin{array}{l}4,348 \\
4,528 \\
4,192\end{array}$ & $\begin{array}{l}\text { Head. } \\
\text { Sharkfin Shoal I,ight. } \\
\text { Frog. }\end{array}$ \\
\hline 3 & $3^{8}$ & I4 30.64 & $755^{8}$ & I9. I2 & $\begin{array}{ll}\mathrm{S} & 67 \\
\mathrm{~S} & 16 \\
\mathrm{~S} & 73\end{array}$ & $\begin{array}{ll}33 & W \\
38 & W \\
30 & E\end{array}$ & $\begin{array}{llll}\mathrm{N} & 67 & 3 \mathrm{I} & \mathrm{F} \\
\mathrm{N} & 16 & 37 & \mathrm{E} \\
\mathrm{N} & 73 & 29 & \mathrm{~W}\end{array}$ & $\begin{array}{l}6,250 \\
5,03.3 \\
2,326\end{array}$ & $\begin{array}{l}\text { Head. } \\
\text { Sharkfin Shoal I,ight. } \\
\text { Frog. }\end{array}$ \\
\hline 4 & $3^{8}$ & I3 50.82 & $755^{8}$ & 50. 54 & $\begin{array}{lr}\text { S } & 78 \\
\text { S } & 9 \\
N & 77\end{array}$ & $\begin{array}{ll}05 & W \\
5 I & W \\
27 & \mathrm{E}\end{array}$ & $\begin{array}{lrrr}\mathrm{N} & 78 & 03 & \mathrm{E} \\
\mathrm{N} & 9 & 5 \mathrm{x} & \mathrm{E} \\
\mathrm{S} & 77 & 26 & \mathrm{~W}\end{array}$ & $\begin{array}{l}5,050 \\
3,532 \\
3,141\end{array}$ & $\begin{array}{l}\text { Head. } \\
\text { Sharkfin Shoal Light. } \\
\text { Frog. }\end{array}$ \\
\hline
\end{tabular}


EVANS.

(Fishing Bay-Chart No. 4I.)

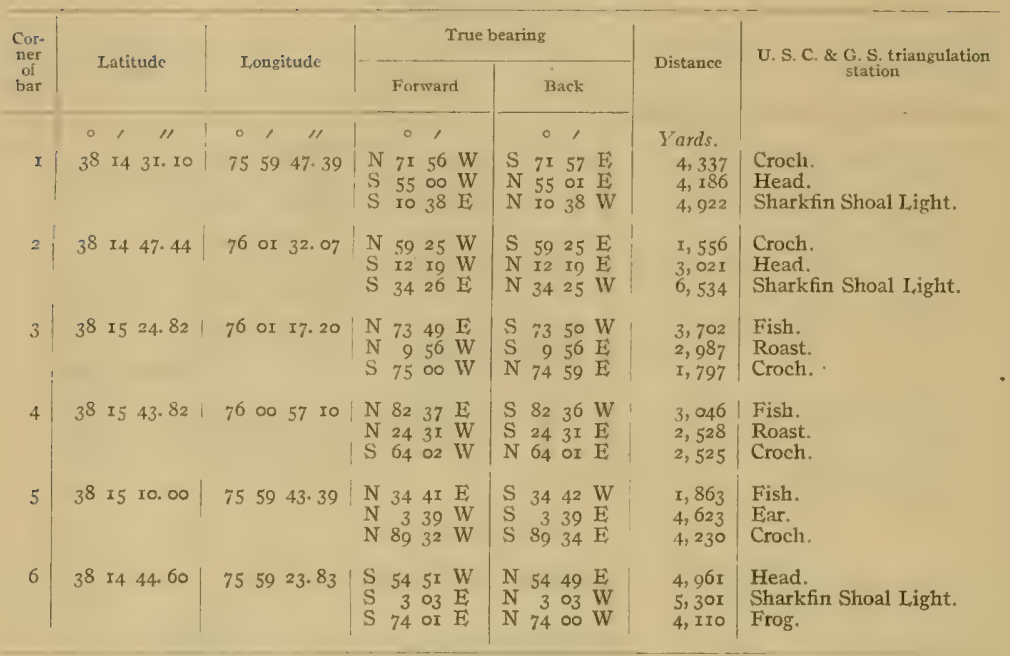

\section{GOOSE CREEK.}

(Fishing Bay-Chart No. 4I.)

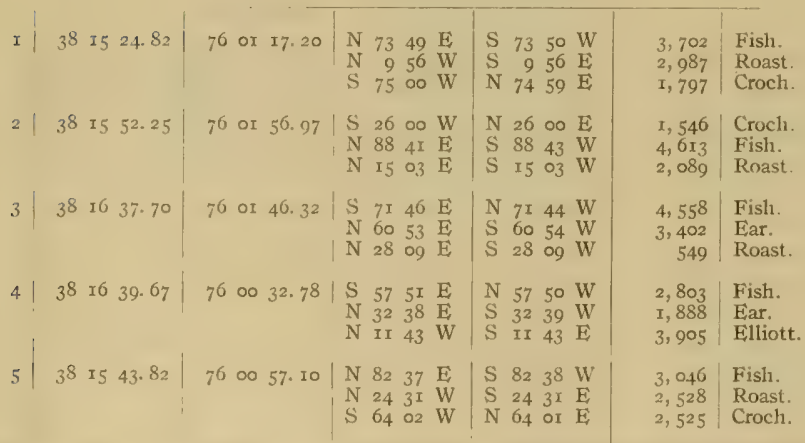




\section{DUCK ISI ANI).}

(Fishing Bay-Chart No. 4t.)

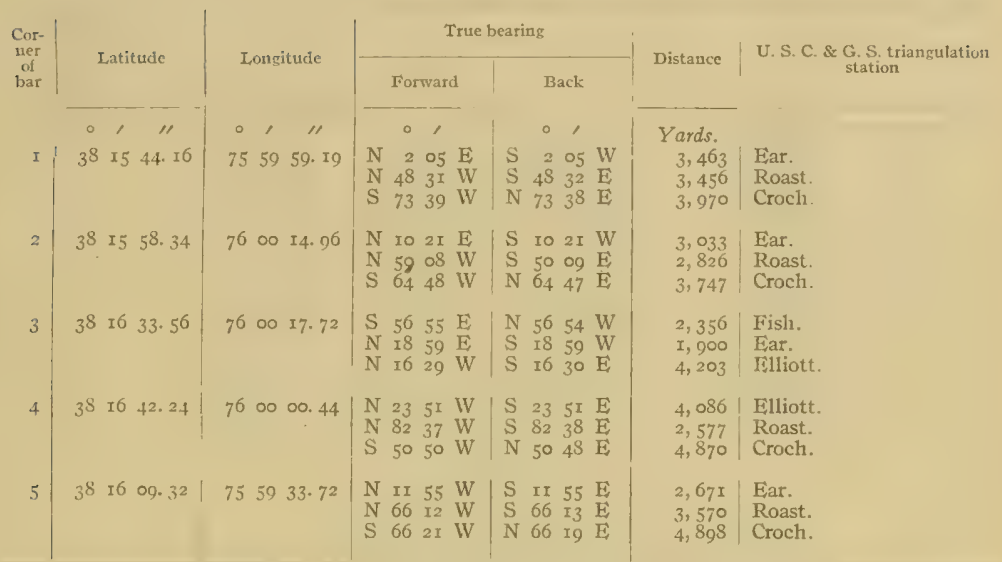

\section{BUNGAY.}

(Fishing Bay-Chart No. 4I.)

\begin{tabular}{|c|c|c|c|c|c|c|}
\hline I & $3^{8} \quad 16 \quad 33 \cdot 5^{6}$ & $7600 \quad 17 \cdot 7^{2}$ & $\begin{array}{llll}\mathrm{S} & 56 & 55 & \mathrm{E} \\
\mathrm{N} & 18 & 59 & \mathrm{E} \\
\mathrm{N} & \mathrm{r} 6 & 29 & \mathrm{~W}\end{array}$ & $\begin{array}{llll}\mathrm{N} & 56 & 54 & \mathrm{~W} \\
\mathrm{~S} & 18 & 59 & \mathrm{~W} \\
\mathrm{~S} & 16 & 30 & \mathrm{E}\end{array}$ & $\begin{array}{l}2,356 \\
1,900 \\
4,203\end{array}$ & $\begin{array}{l}\text { Fish. } \\
\text { Ear. } \\
\text { Elliott. }\end{array}$ \\
\hline 2 & $3^{8}$ I7 $\quad$ IS. 8 I & 76 or 03.08 & $\begin{array}{lrll}\mathrm{S} & 48 & 3 \mathrm{I} & \mathrm{E} \\
\mathrm{N} & 8 \mathrm{r} & 35 & \mathrm{E} \\
\mathrm{N} & 0 & \mathrm{I} & \mathrm{E}\end{array}$ & $\begin{array}{lrrl}\mathrm{N} & 48 & 29 & \mathrm{~W} \\
\mathrm{~S} & 8 \mathrm{r} & 36 & \mathrm{~W} \\
\mathrm{~S} & 0 & 17 & \mathrm{~W}\end{array}$ & $\begin{array}{l}4,2+4 \\
1,844 \\
2,503\end{array}$ & $\begin{array}{l}\text { Fish. } \\
\text { Ear. } \\
\text { Elliott. }\end{array}$ \\
\hline 3 & $\begin{array}{llll}3^{8} & 17 & 48.46\end{array}$ & 76 or $12.5^{8}$ & $\begin{array}{lrrr}\mathrm{S} & 70 & 37 & \mathrm{E} \\
\mathrm{N} & 9 & 59 & \mathrm{E} \\
\mathrm{N} & 50 & \text { o9 } & \mathrm{W}\end{array}$ & $\begin{array}{rrrl}\mathrm{N} & 70 & 37 & \mathrm{~W} \\
\mathrm{~S} & 9 & 59 & \mathrm{~W} \\
\mathrm{~S} & 50 & 10 & \mathrm{E}\end{array}$ & $\begin{array}{l}2,200 \\
I, 528 \\
3,259\end{array}$ & $\begin{array}{l}\text { Fiar. } \\
\text { Elliott. } \\
\text { Farm. }\end{array}$ \\
\hline 4 & $3^{8} I 753.27$ & $7600 \quad 5^{8.09}$ & $\begin{array}{lrll}\mathrm{S} & 62 & \text { II } & \mathrm{E} \\
\mathrm{N} & 5 & \circ 7 & \mathrm{~W} \\
\mathrm{~N} & 56 & 18 & \mathrm{~W}\end{array}$ & $\begin{array}{lrll}\mathrm{N} & 62 & \text { II } & \mathrm{W} \\
\mathrm{S} & 5 & 07 & \mathrm{E} \\
\mathrm{S} & 56 & 19 & \mathrm{E}\end{array}$ & $\begin{array}{l}\mathrm{I}, 9 \mathrm{I} 2 \\
\mathrm{I}, 347 \\
3,47 \mathrm{I}\end{array}$ & $\begin{array}{l}\text { Ear. } \\
\text { Elliott. } \\
\text { Farm. }\end{array}$ \\
\hline 5 & $3^{8} \quad 16 \quad 42.24$ & 760000.44 & $\begin{array}{llll}N & 23 & 51 & W \\
N & 82 & 37 & W \\
\text { S } & 50 & 50 & W\end{array}$ & $\begin{array}{llll}\mathrm{S} & 23 & 5 \mathrm{I} & \mathrm{E} \\
\mathrm{S} & 82 & 38 & \mathbf{E} \\
\mathrm{N} & 50 & 48 & \mathbf{E}\end{array}$ & $\begin{array}{l}4,086 \\
2,577 \\
4,870\end{array}$ & $\begin{array}{l}\text { Elliott. } \\
\text { Roast. } \\
\text { Croch. }\end{array}$ \\
\hline
\end{tabular}


OLD HOUSI:

(Fishing Bay-Chart No. f1.)

\begin{tabular}{|c|c|c|c|c|c|c|c|c|c|c|c|c|c|c|}
\hline \multirow{2}{*}{$\begin{array}{l}\text { Cor- } \\
\text { ney } \\
\text { of } \\
\text { har }\end{array}$} & \multirow{2}{*}{\multicolumn{3}{|c|}{ Talitude }} & \multirow{2}{*}{\multicolumn{3}{|c|}{ I.urgitucle }} & \multicolumn{6}{|c|}{ 'Irue beariug } & \multirow{2}{*}{ Distance } & \multirow{2}{*}{$\underset{\substack{\text { U. S. C. \& } \\
\text { station }}}{\text {. triangulation }}$} \\
\hline & & & & & & & & For & ward & & Back & & & \\
\hline & $\circ$ & , & $\prime \prime$ & 0 & , & "I & & o & 1 & & 0,1 & & Yards. & \\
\hline I & 38 & 17 & 2.4 .57 & 76 & OI & $45 \cdot 8_{3}$ & $\begin{array}{l}N \\
N \\
N\end{array}$ & $\begin{array}{l}88 \\
26 \\
29\end{array}$ & $\begin{array}{ll}32 & \mathrm{E} \\
26 & \mathrm{~F} \\
13 & \mathrm{~W}\end{array}$ & $\begin{array}{ll}S & 88 \\
S & 20 \\
S & 20\end{array}$ & $\begin{array}{ll}38 & 33 \\
6 & 26 \\
9 & 14\end{array}$ & $\begin{array}{l}W \\
W \\
E\end{array}$ & $\begin{array}{l}2,960 \\
2,580 \\
3,316\end{array}$ & $\begin{array}{l}\text { Ear. } \\
\text { Ellliott. } \\
\text { Farm. }\end{array}$ \\
\hline 2 & $3^{8}$ & 17 & 30.80 & 76 & or & 56.02 & $\begin{array}{l}\mathrm{S} \\
\mathrm{N} \\
\mathrm{N}\end{array}$ & $\begin{array}{l}87 \\
34 \\
26\end{array}$ & $\begin{array}{ll}37 & \mathrm{Ii} \\
03 & \mathrm{E} \\
40 & \mathrm{~W}\end{array}$ & $\begin{array}{ll}\mathrm{N} & \mathrm{S} \\
\mathrm{S} & 3 \\
\mathrm{~S} & 2\end{array}$ & $\begin{array}{ll}7 & 35 \\
34 & 03 \\
6 & 4 I\end{array}$ & $\begin{array}{l}W \\
W \\
E\end{array}$ & $\begin{array}{l}3,234 \\
2,535 \\
3,004\end{array}$ & $\begin{array}{l}\text { Ear. } \\
\text { Elliott. } \\
\text { Farm. }\end{array}$ \\
\hline 3 & 38 & 18 & 27.98 & 76 & or & $48 \cdot 36$ & $\begin{array}{l}S \\
N \\
N\end{array}$ & $\begin{array}{l}5 \\
8 r \\
20\end{array}$ & $\begin{array}{ll}32 & \mathrm{E} \\
57 & \mathrm{E} \\
06 & \mathrm{E}\end{array}$ & $\begin{array}{ll}\mathrm{N} & \\
\mathrm{S} & 8 \\
\mathrm{~S} & 20\end{array}$ & $\begin{array}{ll}5 & 32 \\
31 & 57 \\
20 & 07\end{array}$ & $\begin{array}{l}W \\
W \\
W\end{array}$ & $\begin{array}{l}3,249 \\
I, 228 \\
3,08 I\end{array}$ & $\begin{array}{l}\text { Roast. } \\
\text { Elliott. } \\
\text { Thoro. }\end{array}$ \\
\hline+ & 38 & 18 & 26.80 & 76 & OI & 35.94 & $\begin{array}{l}\mathrm{S} \\
\mathrm{N} \\
\mathrm{N}\end{array}$ & $\begin{array}{r}0 \\
76 \\
\times 3\end{array}$ & $\begin{array}{ll}18 & \mathrm{~W} \\
33 & \mathrm{E} \\
58 & \mathrm{E}\end{array}$ & $\begin{array}{ll}\mathrm{N} & \\
\mathrm{S} & 7 \\
\mathrm{~S} & \mathrm{I}\end{array}$ & $\begin{array}{ll}0 & 18 \\
6 & 33 \\
3 & 58\end{array}$ & $\begin{array}{l}\mathrm{E} \\
\mathrm{W} \\
\mathrm{WV}\end{array}$ & $\begin{array}{r}3, \text { I95 } \\
9 \text { II } \\
3, \text { OI } 8\end{array}$ & $\begin{array}{l}\text { Roast. } \\
\text { Elloitt. } \\
\text { Thoro. }\end{array}$ \\
\hline
\end{tabular}

POINT.

(Fishing Bay-Chart No. 7 .)

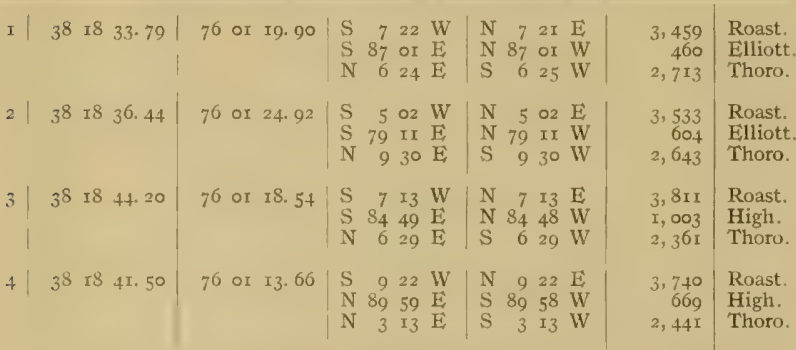

HILL.

(Fishing Bay-Chart No. 4I.)

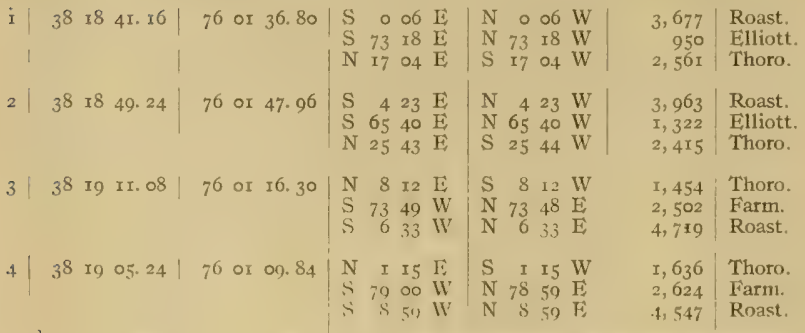




\section{THOROUGH.}

(Fishing Bay-Chart No. fI.)

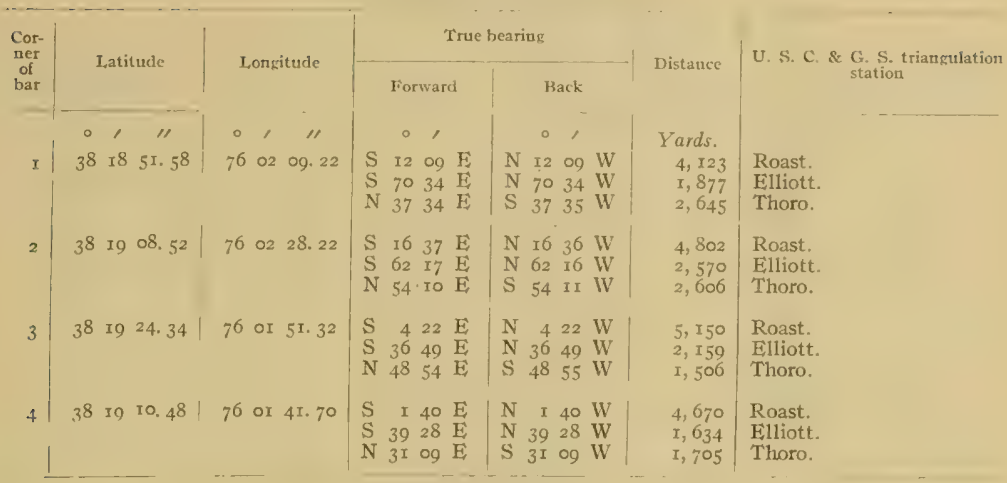

HALF WAY MARK.

(Fishing Bay-Chart No. 4I.)

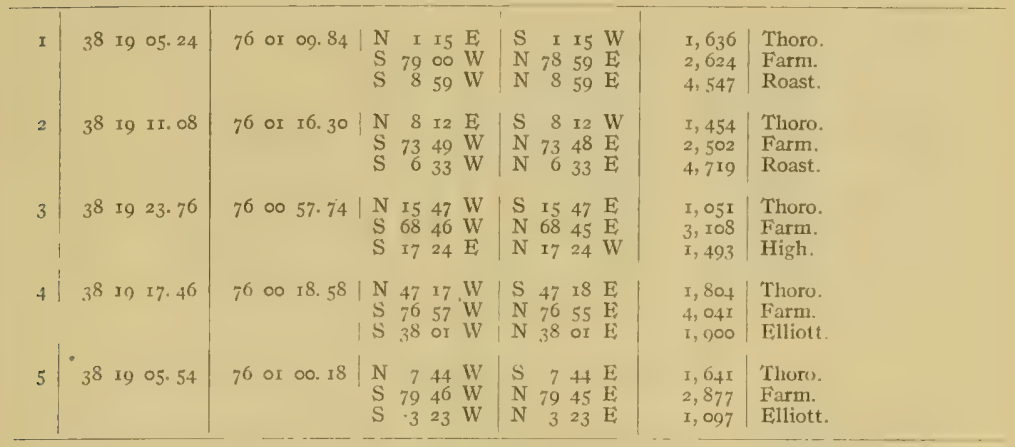

\section{FLAT ROCK.}

(Fishing Bay-Chart No. 4r.)

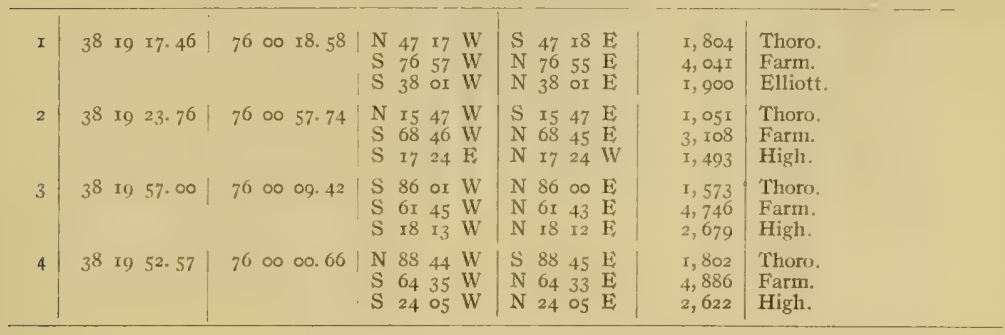




\section{FROG POINT.}

(Upper Tangier Sound-Chart No. 4r.)

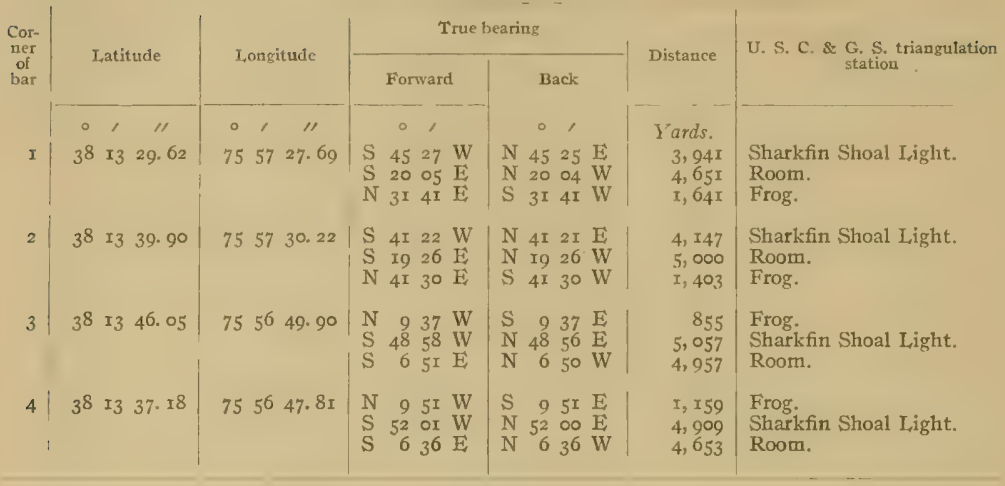

\section{NEW.}

(Nanticoke River-Chart No. 4I.)

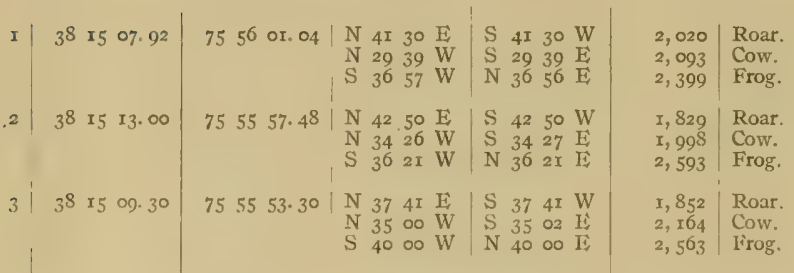

HILLS AND HOLFS.

(Nanticoke River-Chart No. $4 I_{\text {. }}$ )

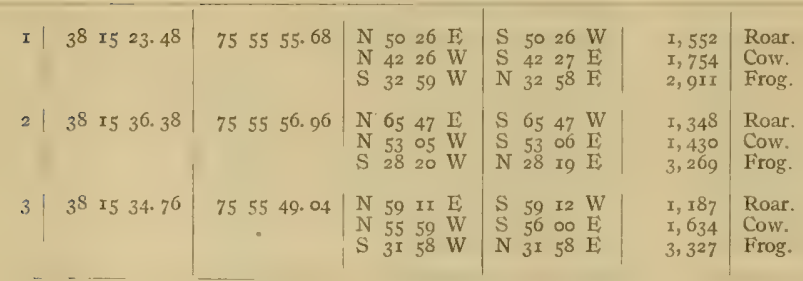


ROARING POINT WFST.

(Nunticoke River-Chart No. 4I.)

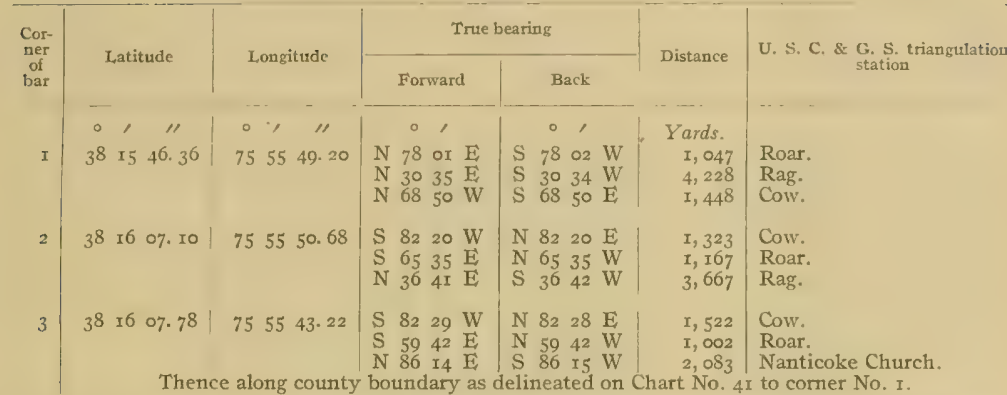

\section{BEAN SHOAL.}

(Nanticoke River-Chart No. 4 I.)

\begin{tabular}{|c|c|c|c|c|c|c|}
\hline I & $3^{8}$ I7 32.06 & $75 \quad 55 \quad 5^{2} .90$ & $\begin{array}{llll}\mathrm{S} & 40 & 49 & \mathrm{E} \\
\mathrm{N} & 88 & 05 & \mathrm{E} \\
\mathrm{N} & 22 & 07 & \mathrm{~W}\end{array}$ & $\begin{array}{llll}N & 40 & 48 & W \\
S & 88 & 05 & W \\
S & 22 & 07 & E\end{array}$ & $\begin{array}{l}3,574 \\
2,25 \mathrm{I} \\
\mathrm{I}, 424\end{array}$ & $\begin{array}{l}\text { Nanticoke Church. } \\
\text { Rag. } \\
\text { Okay. }\end{array}$ \\
\hline 2 & $3^{8}$ I7 $3^{8} .48$ & $755^{6}$ oo. $7^{8}$ & $\begin{array}{llll}\mathrm{S} & 4 \mathrm{I} & 03 & \mathrm{E} \\
\mathrm{S} & 86 & 42 & \mathrm{E} \\
\mathrm{N} & 16 & 30 & \mathrm{~W}\end{array}$ & $\begin{array}{llll}N & 4 I & 03 & W \\
N & 86 & 4 I & W \\
S & I 6 & 30 & E\end{array}$ & $\begin{array}{l}3,876 \\
2,463 \\
\text { I, } 149\end{array}$ & $\begin{array}{l}\text { Nanticoke Church. } \\
\text { Rag. } \\
\text { Okay. }\end{array}$ \\
\hline 3 & $3^{8}$ I7 44.04 & $75 \quad 55 \quad 5^{2} .22$ & $\begin{array}{llll}\mathrm{S} & 36 & 42 & \mathrm{E} \\
\mathrm{S} & 8 \mathrm{I} & 38 & \mathrm{E} \\
\mathrm{N} & 3 \mathrm{I} & \mathrm{I} 2 & \mathrm{~W}\end{array}$ & $\begin{array}{llll}N & 36 & 4 I & W \\
N & 8 I & 37 & W \\
S & 3 I & \text { I2 } & E\end{array}$ & $\begin{array}{l}3,878 \\
2,255 \\
1,070\end{array}$ & $\begin{array}{l}\text { Nanticoke Church. } \\
\text { Rag. } \\
\text { Okay. }\end{array}$ \\
\hline
\end{tabular}

OUTER HOLE.

(Nanticoke River-Chart No. 4I.)

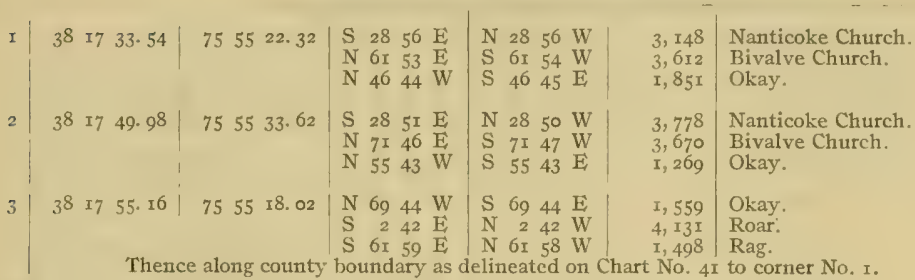




\section{LOWE'R NEWFOUNDLAND.}

(Nanticoke River-Chart No. 4I.)

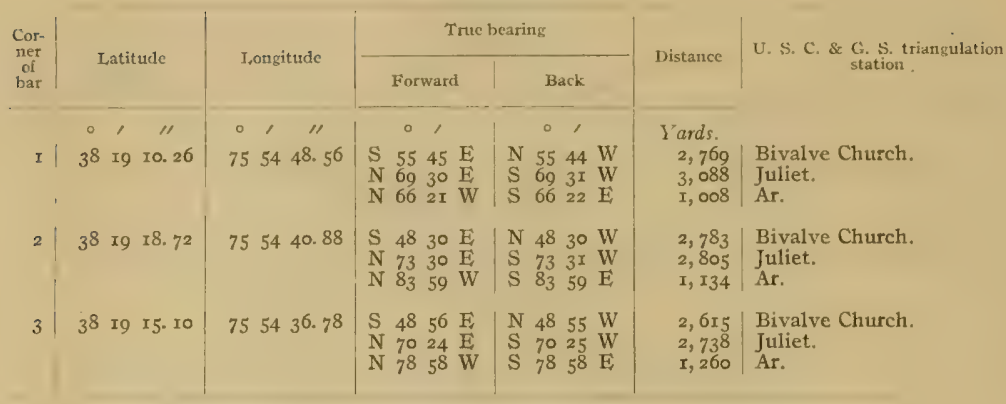

\section{UPPER NEWFOUNDL,AND.}

(Nanticoke River-Chart No. 4I.)

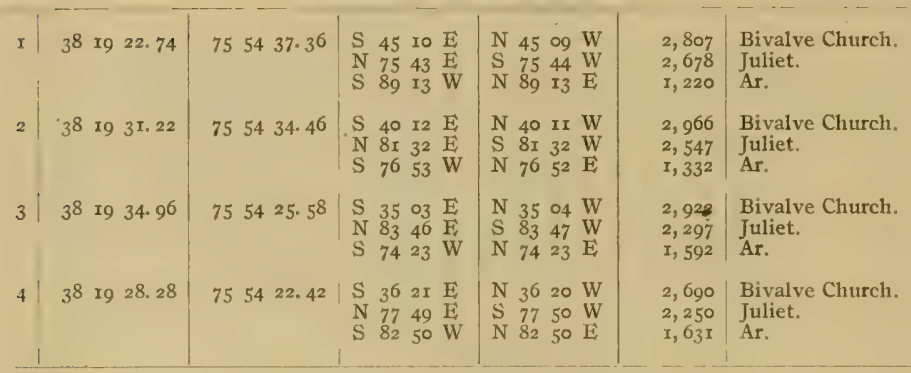

\section{NORTHWEST MIDDLEGROUND.}

(Chesapeake Bay-Off Holland Island-Chart No. 42.)

\begin{tabular}{|c|c|c|c|c|c|c|}
\hline & $3^{8} 06 \quad 15.00$ & 76 I0 I6. 74 & $\begin{array}{llll}\mathrm{S} & 59 & \mathrm{I0} & \mathrm{E} \\
\mathrm{N} & 76 & \mathrm{I} 6 & \mathrm{E} \\
\mathrm{N} & 36 & 52 & \mathrm{E}\end{array}$ & $\begin{array}{llll}\mathrm{N} & 59 & 07 & \mathrm{~W} \\
\mathrm{~S} & 76 & \mathbf{I} & \mathrm{W} \\
\mathrm{S} & 36 & 55 & \mathrm{~W}\end{array}$ & $\begin{array}{r}8,409 \\
8,292 \\
12,872\end{array}$ & $\begin{array}{l}\text { Holland Island Bar I,ight. } \\
\text { Holland Island Church } \\
\text { Okahanikan. [Spire. }\end{array}$ \\
\hline & $\begin{array}{lll}3^{8} \circ 06 & 26.08 \\
& \end{array}$ & $\begin{array}{llll}76 & \text { I2 } & 00.79\end{array}$ & $\begin{array}{llll}\mathrm{S} & 64 & 53 & \mathrm{E} \\
\mathrm{N} & 8 \mathrm{I} & 26 & \mathrm{E} \\
\mathrm{N} & 46 & 34 & \mathrm{E}\end{array}$ & $\begin{array}{llll}N & 64 & 57 & W \\
S & 8 I & 30 & W \\
S & 46 & 38 & W\end{array}$ & $\begin{array}{l}\text { II, O39 } \\
I 0,948 \\
I 4,448\end{array}$ & $\begin{array}{l}\text { Holland Island Bar Iight. } \\
\text { Holland Island Church } \\
\text { Okahanikan. [Spire. }\end{array}$ \\
\hline & $\begin{array}{lllll}3^{8} & 08 & 0.16\end{array}$ & 76 II 24.40 & $\begin{array}{llll}\mathrm{S} & 48 & 36 & \mathrm{E} \\
\mathrm{S} & 80 & 20 & \mathrm{E} \\
\mathrm{N} & 55 & 02 & \mathrm{E}\end{array}$ & $\begin{array}{llll}N & 48 & 32 & W \\
N & 80 & 16 & W \\
\text { S } & 55 & 06 & W\end{array}$ & $\begin{array}{r}12,032 \\
9,999 \\
11,62 I\end{array}$ & $\begin{array}{l}\text { Holland Island Bar Light. } \\
\text { Holland Island Church } \\
\text { Okahanikan. [Spire. }\end{array}$ \\
\hline & $3^{8}$ o7 $3^{8 .} \cdot 7^{8}$ & 76 10 $49 \cdot 45$ & $\begin{array}{llll}\mathrm{S} & 48 & 36 & \mathrm{E} \\
\mathrm{S} & 84 & 3 \mathrm{I} & \mathrm{E} \\
\mathrm{N} & 48 & 58 & \mathrm{E}\end{array}$ & $\begin{array}{llll}N & 48 & 33 & W \\
N & 84 & 28 & W \\
S & 49 & \text { or } & W\end{array}$ & $\begin{array}{r}10,789 \\
8,966 \\
I I, 392\end{array}$ & $\begin{array}{l}\text { Holland Island Bar Liglit. } \\
\text { Holland Island Churcli } \\
\text { Okahanikan. }\end{array}$ \\
\hline
\end{tabular}


Survey of Oyster Bars, Dorchester County, Md.

\section{SOUTHEAST MIDDLEGROUND.}

(Chesapeake Bay-Off Holland Island-Chart No. 42.)

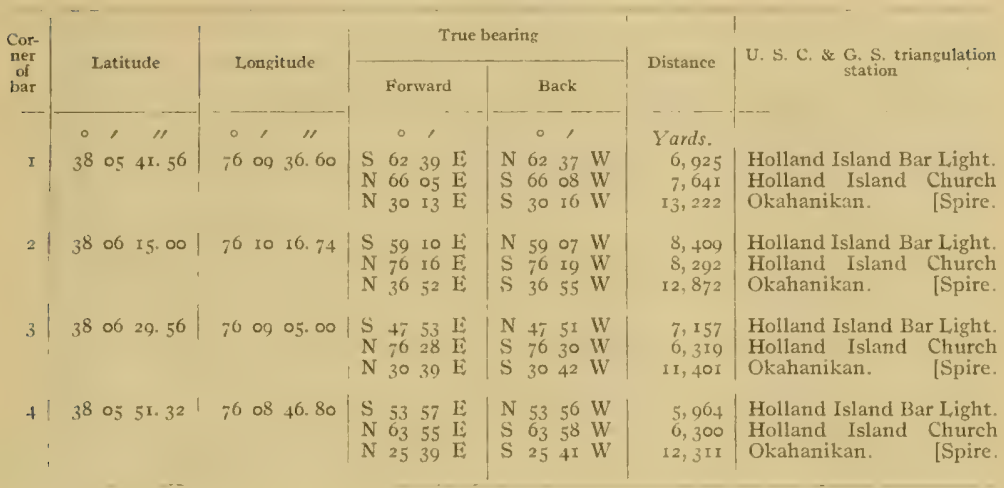

\section{BOUNDARY}

(Entrance to Kedge Straits-Chart No. 42.)

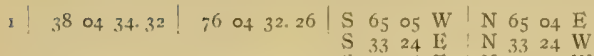
S 5926 II, N 5924 W

\begin{tabular}{l|lll|lll|llll|llll}
2 & 38 & 0.4 & 40.27 & 76 & 04 & 39.44 & $\mathrm{~S}$ & 57 & 52 & $\mathrm{~W}$ & $\mathrm{~N}$ & 57 & 52 & $\mathrm{E}$
\end{tabular} S 3352 li $\mathrm{N} 33$ 50 W $\begin{array}{lllllll}5 & 58 & 49 & \text { li } & N & 58 & 47\end{array}$

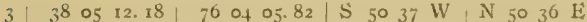
S 22 I 8 E $\quad \mathrm{N} 22$ 17 W S 47 I $\mathrm{E}: \mathrm{N} 47$ I5 W

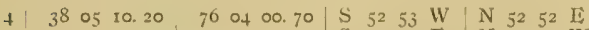
S 2 I 25 E $\quad$ N 2 I 24 W

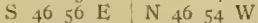

Thenee along comnty boundary as delineated an

$5 \quad 3804+40.76|760414.80| \mathrm{S} 6504 \mathrm{~W} \mid \mathrm{N} 6503 \mathrm{E}$ S 2828 F N 2827 W S $55+$ I I : N 5539 W

Therice along county boundary as delineated on Chart No. 42 to corner No. I.
2, 164 Holland Island Bar Light.

5, 903 Fog 2

6, 730 Solomons Lump Light.

2, ogr Holland Island Bar Light.

6,177 Fog 2

6, 997 Solomons Lump Light.

3, 450 Holland Island Bar Light.

$6,707 \quad$ Forg 2

6, 927 Solomons Lump Light.

3, 516 Holland Island Bar Liglit

6, 593 Fog 2 .

6,780 Solomons Lump Light.

irt No. +2 to conner No. 5 .

2, 677 Holland Island Bar Light.

5,840 Fog 2.

5,840 Fog 2 . 
HOLLAND STRAITS.

(Holland Straits-Chart No. +2.)

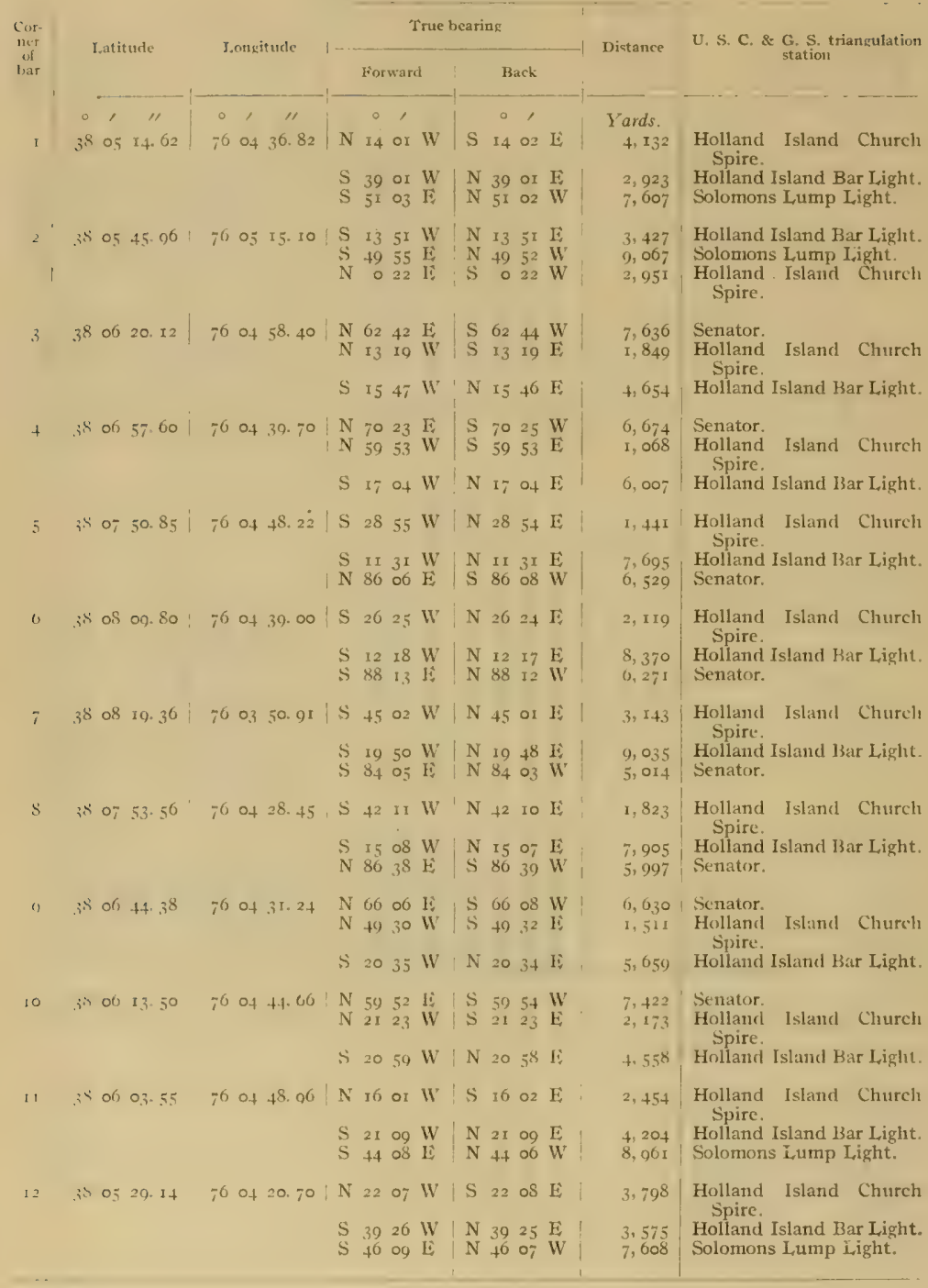




\section{BOUNDARIES OF CRAB BOTTOMS.}

\section{IEXPLANATION.}

The laws providing for the survey of the oyster bars of Maryland also contain a section which requires " an accurate survey of and delineation upon the maps and charts aforesaid of all bottoms of the tributaries of the Chesapeake Bay where grass grows and it is profitable to scrape for soft shell or shedder crabs, and shall have such bottoms properly designated by permanemt objects on the shore, as provided hereinbetore for natural oyster beds, bars, and rocks, which said crabbing sections shall be exempt from leasing for oyster culture."

As far as is known, the crab bottoms of Maryland ${ }^{2}$ were the first of their kind to be surveyed and therefore they presented a new problem, which was found to differ ${ }^{2}$ in many ways from that of a survey of oyster bars.

In a general way, it can be stated that the boundaries of the crab bottoms as established by the Maryland Shell Fish Commission and delineated on the "Maryland Oyster Charts" published by the Coast and Geodetic Survey, are confined to waters between the I-fathom contour ( 6 feet depth of water) and the shore line. Therefore, in most cases the mean low water line of the shore has been adopted as an inner boundary for the crab bottoms, but the same system of straight lines and numbered corners used to delineate the oyster bars has been retained for defining the off-shore water boundaries.

The boundaries of the crab bottoms of Maryland, as established by the Shell Fish Commission and shown on the Coast and Geodetic survey charts and projections and on the "leasing charts" of the Commission, are technically defined and described by a method but little different from that used for the description of the boundaries of oyster bars.

METHOD OF DESCRIBING BOUNDARIES.

The descriptions have been arranged in tabular form, thus avoiding many hundred repetitions of the same words by making one explanation of the tables sufficient for all crab bottoms in each county.

Title.-At the top of each tabular form is given the legal name of the crab bottom to be described, and the one by which it is known and designated in the published records and on the oyster charts. The adopted name of the crab bottom is the one used locally, as nearly as could be ascertained by the hydrographic engineer of the Commission; and when there was no local name in common use, a name was selected from one of the prominent features of the vicinity that would naturally suggest the section of the waters where the crab bottom was located.

Underneath the name, in parentheses, is given the general locality of the crab bottom and the serial number of the "Maryland Oyster Chart," on which its legal boundaries are shown. ${ }^{3}$

First column.- This column, under the heading of "Corner of bottom," gives the number corresponding to the corner of the boundary as shown on the charts and to the

1 Crab bottoms within the meaning of the laws of Maryland were found only in Somerset and Dorchester Counties.

2 See pages 69 to 70 of "First Annual Report of Maryland Shell Fish Commission" for description of "Survey of crabbing grounds,"

s These charts can be obtained by application to the Superintendent of tbe Coast and Geodetic Survey at Washington, D. C. 
number on the buoy marking the actual corner of the bottom. The numbers of the corners have been assigned by maming the southernmost point No. I, thence proceeding in a clockwise direction around the bottom. Where a corner of a crab bottom is identical with the corner of the boundaries of one or more other crab bottoms or oyster bars, only the number of the corner of the crab bottom being described in the table is given in this column.

Second and third columns.- These two columns, under the headings of "Latitude" and "Longitude," give the geographic positions of the corners. These positions have been adopted by the Commission as the primary technical definition of the location of the corners, and should be considered as final in case of a dispute arising from discrepancies caused by other means of location. The latitudes and longitudes given in these columns are based on the United States standard datum of the Coast and Geodetic Survey, and the points thus defined can he relocated from distant triangulation stations of the survey, even though all the landmarks and buoys originally used for their location have been destroyed by natural or other causes.

Fourth and fifth columns. - These two columns, under the general heading of "True bearing" " and the specific headings "Forward" and "Back," give bearings measured from a true north-and-south line. The three "Forward" bearings are from the corner of the boundary designated in the first column to the triangulation stations named on the corresponding lines in the last column, and the three "Back" bearings are from these same stations in the last column to the corresponding corner of boundary in the first column. The difference in minutes or arc between the forward and back bearings shown in some cases is actual and not accidental, and is due to the fact that the computations took into account the spheroidal shape of the earth.

Sixth column.--This column, under the heading of "Distance," gives the three computed distances in yards from the corner of the bottom noted in the first column to the three triangulation stations named on the corresponding lines in the last column, and vice versa.

Seventh column. - This column, under the heading of "U. S. C. \& G. S. triangulation station," " gives the names of the landmarks from which were computed the corresponding "Latitude," "Longitude," "True bearing," and "Distance" of the "Corner of bottom" designated in the first column. A full description of the location and markings of these triangulation stations is given in another part of this publication under the heading of "Descriptions of Triangulation Stations."

Notes.-The descriptive notes relating to the shore line boundaries which appear between the descriptions of corners located on land require no explanation other than the statement that the laws of Maryland reserve to riparian owners all waters of "any. creek, cove, or inlet less than one hundred yards in width at its mouth at low tide."

SURVEYING METHODS FOR RELOCATION OF BOUNDARIES.

There are a number of methods that can be used in the relocation of the actual bomdaries of the crab bottons as technically described in this publication and delineated on the published charts of the Coast and Geodetic Survey, and the "leasing charts" of the Maryland Shell Fish Commission, but as they are practically the same as those

I The mean magnetic variation for Dorchester County was $6^{\circ} \mathrm{oo}^{\prime}$ west of north in $19 x \mathrm{~s}$ and increasing at the rate of $5^{\prime} y^{\text {rearly. }}$

2 Geographic positions of these triangulation stations can be obtained by application to the Superintendent of the Coast and Geodetic Survey, Washiurton, D. C. 
required for the relocation of oyster-bar boundaries, the description of the "Surveying Methods for Relocation of Boundaries" given in this publication under the heading of "Boundaries of Oyster Bars" will be suficient to indicate several metlods that can be used in the relocation of crab-bottom boundaries.

\section{BOUNDARIES OF CRAB BOTTOMS.}

FOX CREEK.

(Honga River-Chart No. 40.)

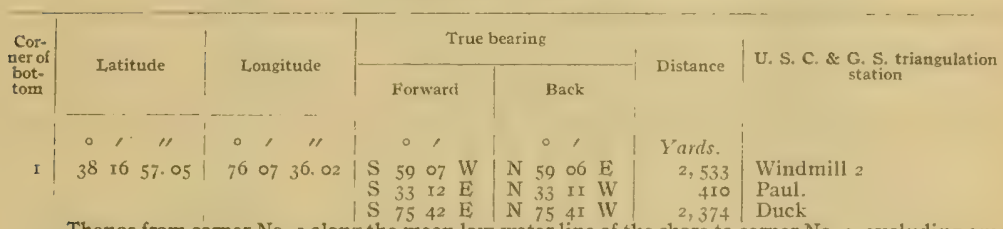

Thence from comer No. 1 along the mean low-water line of the shore to comer No. 2, excluding any creek, cove, or inlet less than roo yards in width at its mouth at low tide.

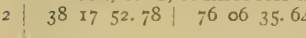
\begin{tabular}{llll|llll}
$\mathrm{S}$ & 49 & 55 & $\mathrm{~W}$ & $\mathrm{~N}$ & 49 & 54 & $\mathrm{E}$ \\
$\mathrm{S}$ & $3 \mathrm{I}$ & $5 \mathrm{I}$ & $\mathrm{W}$ & $\mathrm{N}$ & $3 \mathrm{I}$ & $5 \mathrm{I}$ & $\mathrm{E}$ \\
$\mathrm{S}$ & $\mathrm{x}$ & 46 & $\mathrm{E}$ & $\mathrm{N}$ & $\mathrm{I} 5$ & 46 & $\mathrm{~W}$
\end{tabular}
4, 939 | Windmill 2
3,562
\begin{tabular}{l|lll|lll|llll|llll}
3 & 38 & 17 & 55.54 & 76 & 00 & 27.32 & $\mathrm{~S}$ & 50 & 42 & $\mathrm{~W}$ & $\mathrm{~N}$ & 50 & 41 & $\mathrm{E}$ \\
$\mathrm{S}$ & 34 & $4 \mathrm{I}$ & $\mathrm{W}$ & $\mathrm{N}$ & 34 & 40 & $\mathrm{E}$ \\
$\mathrm{S}$ & 10 & $3 \mathrm{I}$ & $\mathrm{E}$ & $\mathrm{N}$ & $\mathrm{IO}$ & $3 \mathrm{I}$ & $\mathrm{W}$
\end{tabular}
5, $168 \mid$ Windmill 2 .
2,815 Paul.
2, 602 Duck

Thence from corner No. 3 along the mean low-water line of the shore to corner No. 4 , excluding any creek, cove, or inlet less than roo yards in width at its moutn at low tide.

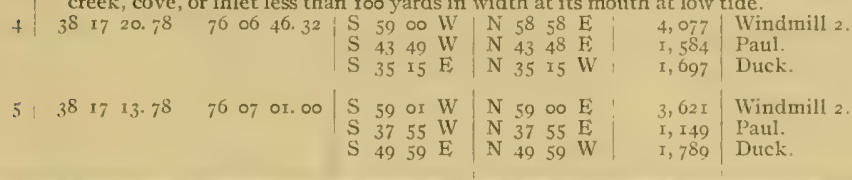

\section{WINGATE.}

(Honga River-Chart No. 40.)

\begin{tabular}{|c|c|c|c|c|c|c|}
\hline I & $\begin{array}{llll}38 & 16 & 28.98\end{array}$ & $7606 \quad 26.00$ & $\begin{array}{llll}\mathrm{S} & 10 & 16 & \mathrm{E} \\
\mathrm{N} & 50 & 39 & \mathrm{E} \\
\mathrm{N} & 69 & 46 & \mathrm{~W}\end{array}$ & $\begin{array}{llll}\mathrm{N} & 10 & 16 & \mathrm{~W} \\
\mathrm{~S} & 50 & 39 & \mathrm{~W} \\
\mathrm{~S} & 69 & 46 & \mathrm{E}\end{array}$ & $\begin{array}{r}2,138 \\
569 \\
\mathrm{I}, 744\end{array}$ & $\begin{array}{l}\text { Norman. } \\
\text { Duck. } \\
\text { Paul. }\end{array}$ \\
\hline 2 & $3^{8} \quad$ I6 48.48 & 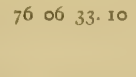 & $\begin{array}{llll}\mathrm{S} & 87 & 52 & \mathrm{~W} \\
\mathrm{~S} & \mathrm{II} & 39 & \mathrm{E} \\
\mathrm{S} & 64 & 42 & \mathrm{E}\end{array}$ & \begin{tabular}{|llll}
$N$ & 87 & 51 & $E$ \\
$N$ & 11 & 39 & $W$ \\
$N$ & 64 & 42 & $W$
\end{tabular} & $\begin{array}{r}x, 449 \\
2,820 \\
696\end{array}$ & $\begin{array}{l}\text { Paul. } \\
\text { Normant. } \\
\text { Duck. }\end{array}$ \\
\hline 3 & $\begin{array}{llll}3^{8} & 17 & 13.78\end{array}$ & 76 o7 or, oo & $\begin{array}{llll}\mathrm{S} & 59 & \text { or } & \mathrm{W} \\
\mathrm{S} & 37 & 55 & \mathrm{~W} \\
\mathrm{~S} & 49 & 59 & \mathrm{E}\end{array}$ & $\begin{array}{llll}\mathrm{N} & 59 & 00 & \mathrm{E} \\
\mathrm{N} & 37 & 55 & \mathrm{E} \\
\mathrm{N} & 49 & 59 & \mathbf{W}\end{array}$ & $\begin{array}{l}3,62 I \\
I, I 49 \\
I, 789\end{array}$ & $\begin{array}{l}\text { Windmill } 2 . \\
\text { Paul. } \\
\text { Duck. }\end{array}$ \\
\hline 4 & $\begin{array}{llll}38 & 17 & 20.78\end{array}$ & 76 o6 46.32 & $\begin{array}{llll}\mathrm{S} & 59 & 00 & \mathrm{~W} \\
\mathrm{~S} & 43 & 49 & \mathrm{~W} \\
\mathrm{~S} & 35 & 15 & \mathrm{E}\end{array}$ & $\begin{array}{llll}\mathrm{N} & 5^{8} & 5^{8} & \mathrm{E} \\
\mathrm{N} & 43 & 48 & \mathrm{E} \\
\mathrm{N} & 35 & 15 & \mathrm{~W}\end{array}$ & $\begin{array}{l}4,077 \\
1,584 \\
1,697\end{array}$ & $\begin{array}{l}\text { Windmill } 2 . \\
\text { Paul. } \\
\text { Duck. }\end{array}$ \\
\hline & $\begin{array}{l}\text { Thence from c } \\
\text { creek, cove, }\end{array}$ & $\begin{array}{l}\text { mer No. } 4 \text { alon } \\
\text { or inlet less th }\end{array}$ & $\begin{array}{l}\text { the mean low } \\
\text { in Ioo yards in }\end{array}$ & $\begin{array}{l}\text {-water line of } t \\
\text { width at its } t\end{array}$ & $\begin{array}{l}\text { thore to } \\
\text { th at lov }\end{array}$ & $\begin{array}{l}\text { comer No. } 5 \text {, excluding any } \\
\text { tide. }\end{array}$ \\
\hline 5 & $\begin{array}{llll}38 & 16 & 39.67\end{array}$ & $7^{6} \circ 609.46$ & $\begin{array}{rrrr}\mathrm{S} & 80 & 57 & \mathrm{~W} \\
\mathrm{~S} & \mathrm{I} & 22 & \mathrm{~W} \\
\mathrm{~S} & 63 & 20 & \mathrm{E}\end{array}$ & $\begin{array}{rrrr}\mathrm{N} & 80 & 55 & \mathrm{E} \\
\mathrm{N} & \mathrm{r} & 22 & \mathrm{E} \\
\mathrm{N} & 63 & 19 & \mathrm{~W}\end{array}$ & $\begin{array}{l}4,531 \\
2,466 \\
3,154\end{array}$ & $\begin{array}{l}\text { Windmill } 2 . \\
\text { Norman. } \\
\text { St. Thomas Church Spire. }\end{array}$ \\
\hline
\end{tabular}


DUCK POINT COVE.

(Honga River-Chart No. 40.)

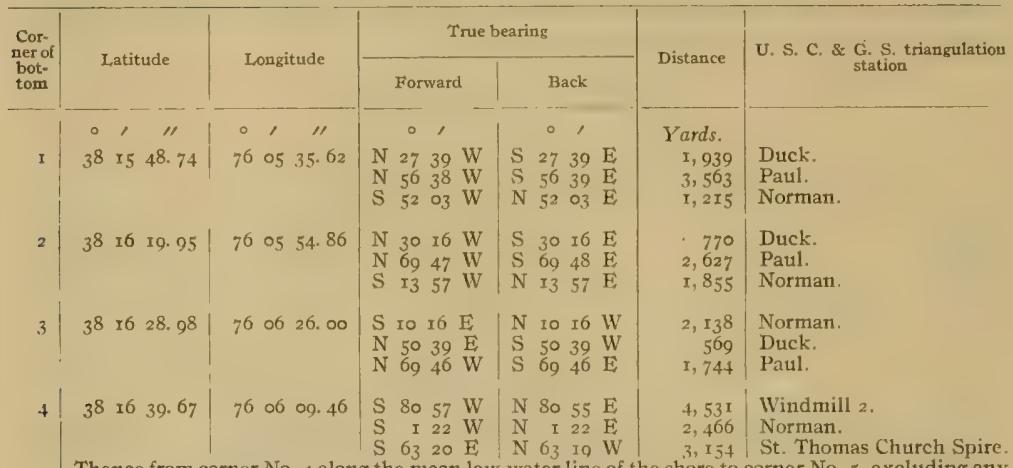

Thence from corner No. 4 along the mean low-water line of the shore to corner No. 5, excluding any creek, cove, or inlet less than roo yards in width at its month at low tide.

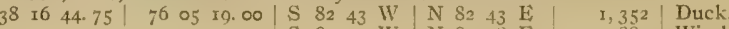

S 8I 20 W N 8 I $18 \mathrm{E} \quad 5,884$. Windmill 2.

\begin{tabular}{|l|l|l|l|l|l}
\hline & 2759 & W & N $2758 \mathrm{E}$ & 2,986 & Norman.
\end{tabular}

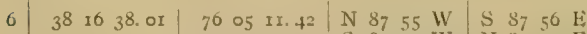

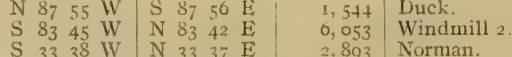

Thence from corner No. 6 along the mean low-water line of the shore to corner No. 7 , excluding any creek, cove, or inlet less than roo yards in width at its mouth at low tide.

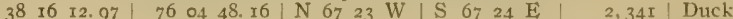

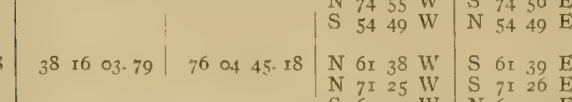

\begin{tabular}{llll|llll|l|l|l}
$\mathrm{N}$ & 67 & 23 & $\mathrm{~W}$ & $\mathrm{~S}$ & 67 & 24 & $\mathrm{E}$ & $2,34 \mathrm{I}$ & Duck. \\
$\mathrm{N}$ & 74 & 55 & $\mathrm{~W}$ & $\mathrm{~S}$ & 74 & 56 & $\mathrm{E}$ & 4,389 & Paul. \\
$\mathrm{S}$ & 54 & 49 & $\mathrm{~W}$ & $\mathrm{~N}$ & 54 & 49 & $\mathrm{E}$ & 2,717 & Norman. \\
& & & & & & & $\mathrm{W}$ & & & \\
$\mathrm{N}$ & $6 \mathrm{I}$ & 38 & $\mathrm{~W}$ & $\mathrm{~S}$ & $6 \mathrm{r}$ & 39 & $\mathrm{E}$ & 2,546 & Duck \\
$\mathrm{N}$ & $7 \mathrm{I}$ & 25 & $\mathrm{~W}$ & $\mathrm{~S}$ & $7 \mathrm{I}$ & 26 & $\mathrm{E}$ & 4,555 & Paul. \\
$\mathrm{S}$ & $6 \mathrm{I}$ & 22 & $\mathrm{~W}$ & $\mathrm{~N}$ & $6 \mathrm{I}$ & $2 \mathrm{I}$ & $\mathrm{E}$ & 2,620 & Norman.
\end{tabular}

Thence from corner $\mathrm{N}$ ). 8 along the mean low-water line of the shore to comer No. 1 , excluding any creek, cove, or inlet less than roo yards in width at its mouth at low tide.

\section{JENNY ISI,AND.}

(Hooper Strait-Charts Nos. 40 and 4 r.)

\begin{tabular}{|c|c|c|c|c|c|c|c|}
\hline I & $\begin{array}{llll}3^{8} & \mathrm{I}_{3} & \mathrm{I}_{3} .92\end{array}$ & 760.3 & $3 \times 3.5^{2}$ & $\begin{array}{llll}\mathrm{S} & 70 & 42 & \mathrm{E} \\
\mathrm{N} & 84 & 23 & \mathrm{E} \\
\mathrm{N} & 70 & 25 & \mathrm{~W}\end{array}$ & $\begin{array}{llll}\mathrm{N} & 70 & 40 & \mathrm{~W} \\
\mathrm{~S} & 94 & 24 & \mathrm{~W} \\
\mathrm{~S} & 70 & 26 & \mathrm{E}\end{array}$ & $\begin{array}{l}6,774 \\
2,064 \\
2,247\end{array}$ & $\begin{array}{l}\text { Sharkfin Shoal Light. } \\
\text { Head. } \\
\text { Hooper Strait Light. }\end{array}$ \\
\hline 2 & $\begin{array}{llll}38 & 13 & 22.80\end{array}$ & 7603 & $35 x .18$ & $\begin{array}{llll}N & 67 & 53 & W \\
N & 8 I & \text { II } & W \\
S & 3 I & 37 & W\end{array}$ & $\begin{array}{llll}\mathrm{S} & 67 & 53 & \mathrm{E} \\
\mathrm{S} & 8 \mathrm{I} & \mathrm{I} & \mathrm{E} \\
\mathrm{N} & 3 \mathrm{I} & 36 & \mathrm{E}\end{array}$ & $\begin{array}{l}I, 204 \\
7,327 \\
4,844\end{array}$ & $\begin{array}{l}\text { Hooper Strait Light. } \\
\text { Applegarth. } \\
\text { Okahanikan. }\end{array}$ \\
\hline 3 & $3^{8} \quad x_{3} 5^{2} \cdot 3^{2}$ & 7604 & $4 \times 4.88$ & $\begin{array}{llll}N & 88 & 53 & W \\
S & 4 I & 48 & W \\
\text { S } & 20 & 26 & W\end{array}$ & $\begin{array}{llll}\mathrm{S} & 88 & 55 & \mathrm{E} \\
\mathrm{N} & 4 \mathrm{I} & 47 & \mathrm{E} \\
\mathrm{N} & 20 & 25 & \mathrm{E}\end{array}$ & $\begin{array}{r}6,611 \\
727 \\
5,464\end{array}$ & $\begin{array}{l}\text { Applegarth. } \\
\text { Hooper Strait Light. } \\
\text { Okahanikan. }\end{array}$ \\
\hline 4 & $3^{8} \quad 14 \quad 06.46$ & 7604 & 402.62 & $\begin{array}{llll}\mathrm{S} & 87 & 08 & \mathrm{~W} \\
\mathrm{~S} & 38 & 31 & \mathrm{~W} \\
\mathrm{~S} & 21 & 46 & \mathrm{~W}\end{array}$ & $\begin{array}{llll}N & 87 & 05 & E \\
N & 38 & 30 & E \\
N & 21 & 45 & E\end{array}$ & $\begin{array}{l}6,944 \\
1,302 \\
6,026\end{array}$ & $\begin{array}{l}\text { Applegarth. } \\
\text { Hooper Strait Light. } \\
\text { Okahanikan. }\end{array}$ \\
\hline 5 & $\begin{array}{l}\text { Thence from c } \\
\text { creek, cove, } \\
\begin{array}{ccc}3^{8} \times 3 & 24.50\end{array}\end{array}$ & $\begin{array}{l}\text { or inle } \\
76 \quad 03\end{array}$ & 300.86 & $\begin{array}{l}\text { g the mear low } \\
\text { in roo yards it } \\
\mathrm{N} 8049 \mathrm{~W} \\
\mathrm{~N} 8255 \mathrm{~W} \\
\mathrm{~S} 4250 \mathrm{~W}\end{array}$ & $\begin{array}{l}\text { water line of } \\
\text { width at its } \\
\text { S } 8050 \text { E } \\
\text { S } 8258 \text { F } \\
\mathrm{N}_{42} 5 \text { r E }\end{array}$ & $\begin{array}{l}\text { hore to } \\
\text { th at lo } \\
2,486 \\
8,644 \\
5,703\end{array}$ & $\begin{array}{l}\text { ormer No. } 5 \text {, excluding } \\
\text { tide. } \\
\text { Hooper Strait Light. } \\
\text { Applegarth. } \\
\text { Okahanikan. }\end{array}$ \\
\hline
\end{tabular}


OKAHANIKAN.

(Hooper Strait-Charts Nos. 40, 4r, and 42.)

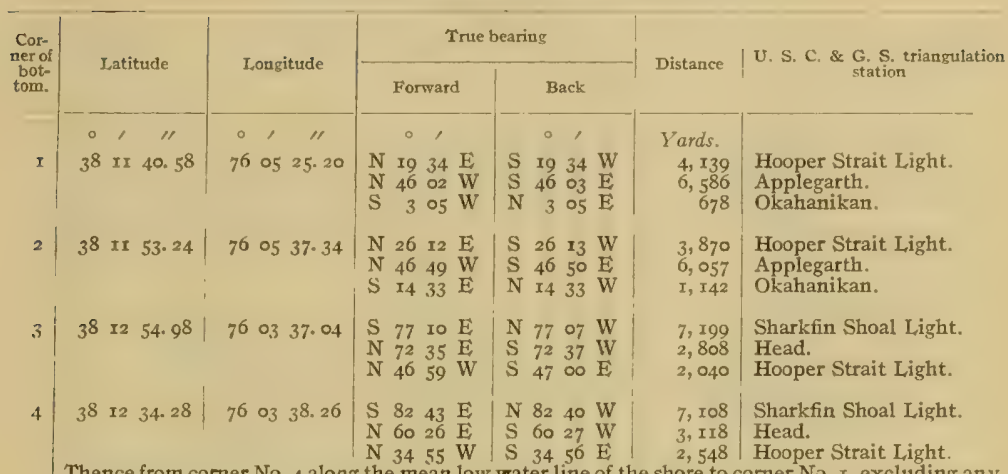

hence from comer No. 4 along the mean low water line of the shore to corner No. I, excluding an creek, cove, or inlet less than roo yards in width at its mouth at low tide.

GRASSY.

(Hooper Strait-Charis Nos. 40 and $4 I$.)

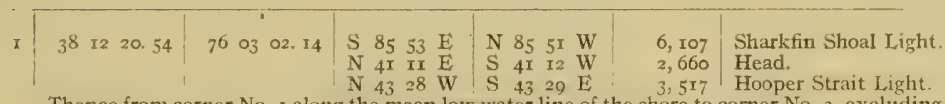

Thence from corner No. I along the mean low water line of the shore to comer No. 2 , excluding any creek, cove, or inlet less than 100 yards in width at its mouth at low tide.

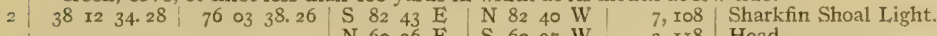

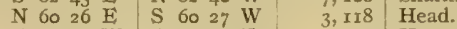 \begin{tabular}{ll|l|l|l} 
N $3455 \mathrm{~W}$ & $\mathrm{~S} 3456 \mathrm{E}$ & 2,548 & Hooper Strait Light.
\end{tabular}

\section{RISHOP HEAD.}

(Hooper Strait-Chart No. 4 r.)

\begin{tabular}{|c|c|c|c|c|c|c|}
\hline I & $\begin{array}{llll}38 & 12 & 22.84\end{array}$ & $7^{6}$ ox $5^{6.04}$ & $\begin{array}{lrrr}\mathrm{S} & 83 & 14 & \mathrm{~W} \\
\mathrm{~N} & 0 & 12 & \mathrm{~W} \\
\mathrm{~N} & 59 & 22 & \mathrm{~W}\end{array}$ & $\begin{array}{rrrr}\mathrm{N} & 83 & \mathrm{I} 2 & \mathrm{E} \\
\mathrm{S} & 0 & \mathrm{I} 2 & \mathrm{E} \\
\mathrm{S} & 59 & 23 & \mathrm{E}\end{array}$ & $\begin{array}{l}4,362 \\
r, 925 \\
4,856\end{array}$ & $\begin{array}{l}\text { Sharkfin Shoal Light. } \\
\text { Head. } \\
\text { Hooper Strait Light. }\end{array}$ \\
\hline 2 & $3^{\mathrm{S}} \quad 1236.16$ & $7^{6} 0202.08$ & $\begin{array}{lrll}\mathrm{S} & 77 & 54 & \mathrm{E} \\
\mathrm{N} & 5 & 57 & \mathrm{E} \\
\mathrm{N} & 63 & \mathbf{1} & \mathrm{W}\end{array}$ & $\begin{array}{lrrl}\mathrm{N} & 77 & 52 & \mathrm{~W} \\
\mathrm{~S} & 5 & 57 & \mathrm{~W} \\
\mathrm{~S} & 63 & 17 & \mathrm{~F}\end{array}$ & $\begin{array}{l}4,595 \\
1,484 \\
4,498\end{array}$ & $\begin{array}{l}\text { Sharkfin Shoal Light. } \\
\text { Head. } \\
\text { Hooper Strait Light. }\end{array}$ \\
\hline 3 & $38 \quad 12 \quad 48.03 i$ & $7602 \quad \times 5.00$ & $\begin{array}{llll}\mathrm{S} & 74 & \mathrm{I} & \mathrm{E} \\
\mathrm{N} & 24 & 50 & \mathrm{E} \\
\mathrm{N} & 66 & 08 & \mathrm{~W}\end{array}$ & $\begin{array}{llll}\mathrm{N} & 74 & \mathrm{I}_{3} & \mathrm{~W} \\
\mathrm{~S} & 24 & 50 & \mathrm{~W} \\
\mathrm{~S} & 66 & \text { 10 } & \mathrm{E}\end{array}$ & $\begin{array}{l}5,025 \\
1,184 \\
4,017\end{array}$ & $\begin{array}{l}\text { Sharkfin Shoal Light: } \\
\text { Head. } \\
\text { Hooper Strait Light. }\end{array}$ \\
\hline 4 & $3^{8} \quad 12 \quad 5^{8}, 4^{2}$ & $7602 \quad 26,23$ & $\begin{array}{llll}\mathrm{S} & 71 & 32 & \mathrm{E} \\
\mathrm{N} & 47 & 4 \mathrm{I} & \mathrm{E} \\
\mathrm{N} & 69 & 18 & \mathrm{~W}\end{array}$ & $\begin{array}{llll}N & 7 I & 30 & W \\
S & 47 & 4 I & W \\
S & 69 & 19 & E\end{array}$ & $\begin{array}{l}5,413 \\
x, 076 \\
3,608\end{array}$ & $\begin{array}{l}\text { Sliarkfin Shoal Light. } \\
\text { Head. } \\
\text { Hooper Strait Light. }\end{array}$ \\
\hline
\end{tabular}


BISHOP HEAD-Continued.

(Hooper Strait-Chart No. 4I)-Continued.

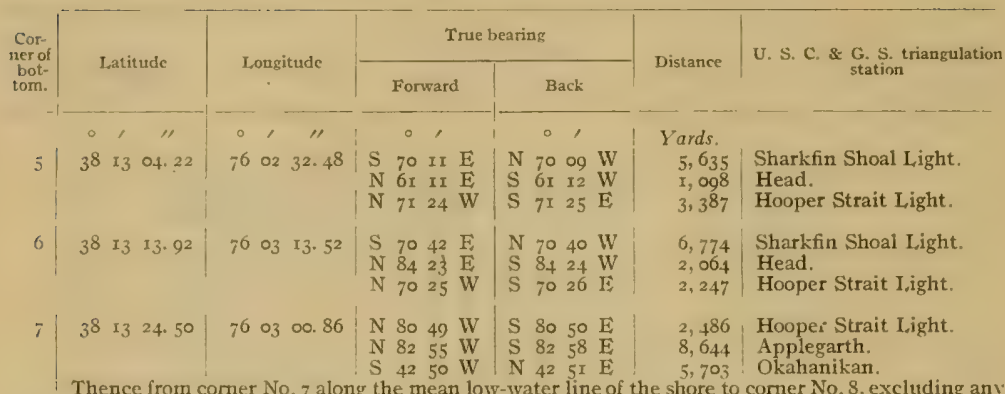

Thence from comer No. 7 along the mean low-water line of the shore to comer No. S, excluding any creek, cove, or inlet less than roo yards in width at its mouth at low tide.

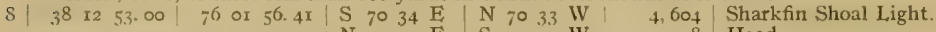
$\mathrm{N} O$ II $\mathrm{E}$ S O II W 908 Head.

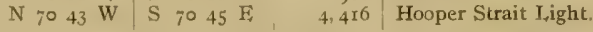

\begin{tabular}{l|lll|lll|lll|lll|l|l|l}
9 & 38 & 12 & 57.84 & 76 & of 40.72 & S 66 & 39 & $\mathrm{E}$ & $\mathrm{N}$ & 66 & $37 \mathrm{~W}$ & 4,275 & Sharkfin Shoal Light.
\end{tabular} \begin{tabular}{ll|llllllll}
$\mathrm{N}$ & 72 & $00 \mathrm{E}$ & $\mathrm{S} 72$ & 03 & $\mathrm{~W}$ & 7,082 & Frog.
\end{tabular}

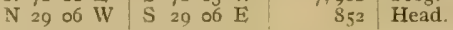

\begin{tabular}{l|lll|llll|llll|llll|} 
& 38 & 12 & 24.96 & 76 & or & 41.42 & S & 81 & 33 & $\mathrm{E}$ & $\mathrm{N}$ & 81 & 32 & $\mathrm{~W}$ \\
$\mathrm{~N}$ & 12 & 03 & $\mathrm{~W}$ & $\mathrm{~S}$ & 12 & 0.4 & $\mathrm{E}$ \\
$\mathrm{N}$ & 62 & 15 & $\mathrm{~W}$ & $\mathrm{~S}$ & 62 & 17 & $\mathrm{E}$
\end{tabular}

3, 986 Sharkfin Shoal Light.

I, 895 Head.

5, I60 Hooper Strait Light.

\section{BLOODSWORTH ISLAND.}

(Hooper Strait-Charts Nos, 4 I and 42. )

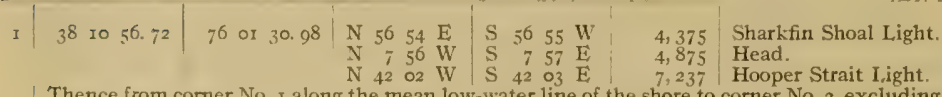

Thence from comer No. I along the mean low-water line of the shore to corner No. 2, excluding any creek, cove, or inlet less than roo yards in width at its mouth at low tide.

\begin{tabular}{|c|c|c|c|c|c|c|}
\hline 2 & $38 \quad 12 \quad 20.54$ & $\begin{array}{llll}76 & 03 & 02 . & 14\end{array}$ & $\begin{array}{llll}\mathrm{S} & 85 & 53 & \mathrm{E} \\
\mathrm{N} & 4 \mathrm{I} & \text { II } & \mathrm{E} \\
\mathrm{N} & 43 & 28 & \mathrm{~W}\end{array}$ & $\begin{array}{llll}N & 85 & 5 I & W \\
S & 4 I & I 2 & W \\
S & 43 & 29 & E\end{array}$ & $\begin{array}{l}6,107 \\
2,660 \\
3.517\end{array}$ & $\begin{array}{l}\text { Sharkfin Shoal Light. } \\
\text { Head. } \\
\text { Hooper Strait Light. }\end{array}$ \\
\hline & $\begin{array}{llll}35 & 12 & 24.55\end{array}$ & $7602 \quad 57.30$ & $\begin{array}{llll}\mathrm{S} & 84 & 30 & \mathrm{E} \\
\mathrm{N} & 4 \mathrm{I} & 00 & \mathrm{E} \\
\mathrm{N} & 46 & 3 \mathrm{I} & \mathrm{W}\end{array}$ & $\begin{array}{llll}\mathrm{N} & 8.4 & 28 & \mathrm{~W} \\
\mathrm{~S} & 4 \mathrm{I} & 00 & \mathrm{~W} \\
\mathrm{~S} & 46 & 32 & \mathrm{E}\end{array}$ & $\begin{array}{l}5,990 \\
2,474 \\
3,5 \times 3\end{array}$ & $\begin{array}{l}\text { Sharkfin Shoal Light. } \\
\text { Head. } \\
\text { Hooper Strait Light. }\end{array}$ \\
\hline 4 & $3^{8} \quad 12 \quad 12.66$ & $76 \quad 02 \quad 4 r .75$ & $\begin{array}{llll}\mathrm{S} & 88 & 13 & \mathrm{E} \\
\mathrm{N} & 28 & 04 & \mathrm{E} \\
\mathrm{N} & 46 & 26 & \mathrm{~W}\end{array}$ & $\begin{array}{llll}N & 88 & \text { II } & W \\
S & 28 & 04 & W \\
S & 46 & 27 & \text { E }\end{array}$ & $\begin{array}{l}5,551 \\
2,570 \\
4,088\end{array}$ & $\begin{array}{l}\text { Sharkfin Shoal Light. } \\
\text { Head. } \\
\text { Hooper Strait Light. }\end{array}$ \\
\hline & $3^{8}$ II 40.82 & 760200.26 & $\begin{array}{lrrl}N & 78 & 3 \mathrm{I} & \mathrm{E} \\
\mathrm{N} & \mathrm{I} & 48 & \mathrm{E} \\
\mathrm{N} & 46 & \mathrm{I}_{5} & \mathrm{~W}\end{array}$ & $\begin{array}{lrrl}\mathrm{S} & 7^{8} & 33 & \mathrm{WV} \\
\mathrm{S} & \mathrm{I} & 4^{8} & \mathrm{~W} \\
\mathrm{~S} & 46 & \mathrm{I} 4 & \mathrm{E}\end{array}$ & $\begin{array}{l}4,535 \\
3,343 \\
5,627\end{array}$ & $\begin{array}{l}\text { Sharkfin Shoal Light. } \\
\text { Head. } \\
\text { Hooper Strait Light. }\end{array}$ \\
\hline & $3^{8} \quad$ II $\quad 25.80$ & 76 or 22.21 & $\begin{array}{llll}N & 67 & 4 I & E \\
N & 13 & 16 & W \\
N & 49 & 07 & W\end{array}$ & $\begin{array}{llll}\mathrm{S} & 67 & 42 & \mathrm{~W} \\
\mathrm{~S} & 13 & \mathrm{x} 6 & \mathrm{E} \\
\mathrm{S} & 49 & 09 & \mathrm{E}\end{array}$ & $\begin{array}{l}3,709 \\
3,953 \\
6,717\end{array}$ & $\begin{array}{l}\text { Sharkfin Shoal Light. } \\
\text { Head. } \\
\text { Hooper Strait Light. }\end{array}$ \\
\hline
\end{tabular}


GREAT COVE,

(Upper Tangier Sound-Charts Nos. 4 I and 42 .)

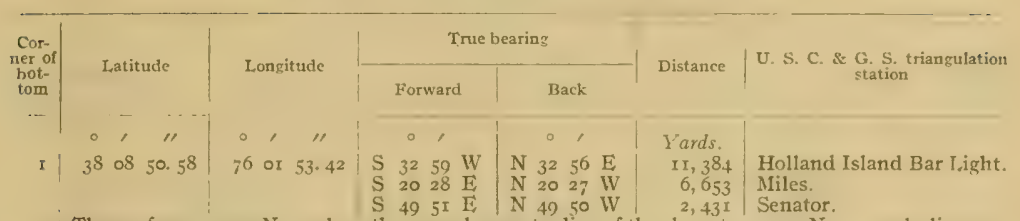

Thence from corner No. I along the mean low-water line of the shore to corner No. 2, excluding any creek, cove, or inlet less than 100 yards in width at its moth at low tide.

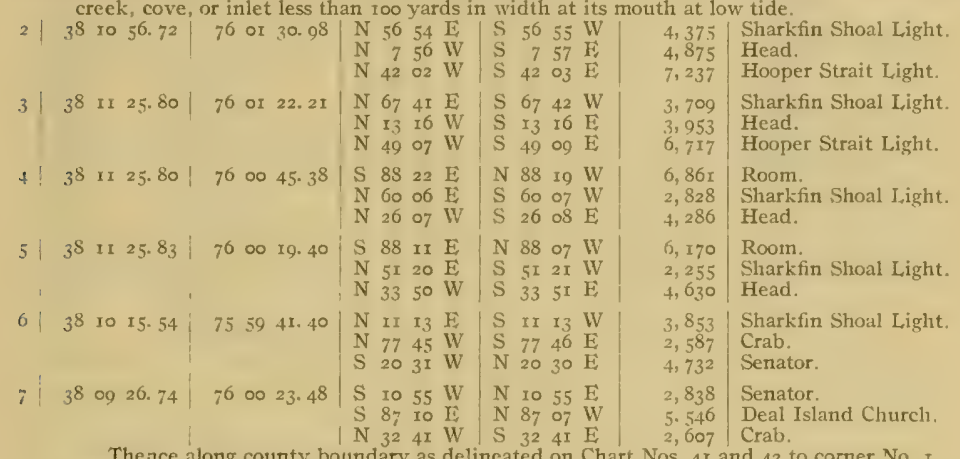

Thence along county boundary as delineated on Chart Nos. $4 \mathrm{r}$ and 42 to corner Nn. I.

\section{NORTHEAST ISLAND}

(Holland Straits-Chart No. f?.)

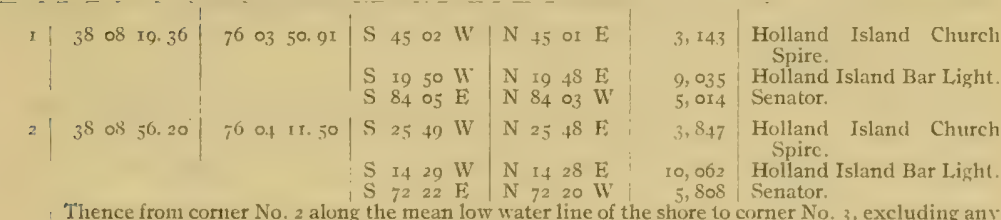
creek, cove, or inlet less than 100 yards in width at its mouth at low tide.

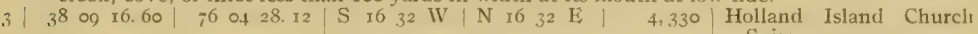

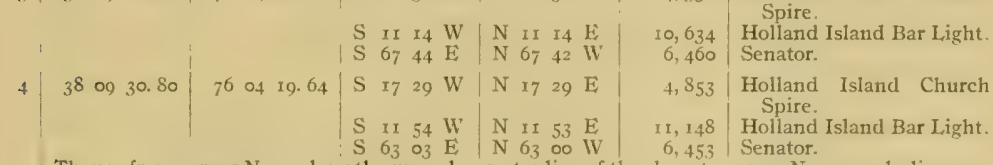

Thence from corner No. 4 along the mean low water line of the shore to corner No. 5, excluding any creek, cove, or inlet less than roo yards in width at its mouth at low tide.

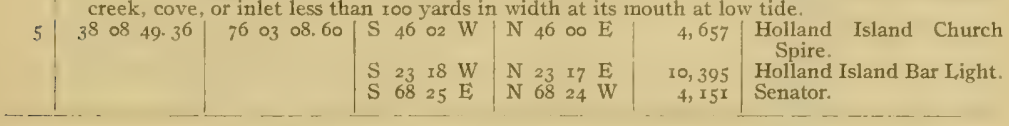


ADAM ISLAND.

(Holland Straits-Chart No. 42.)

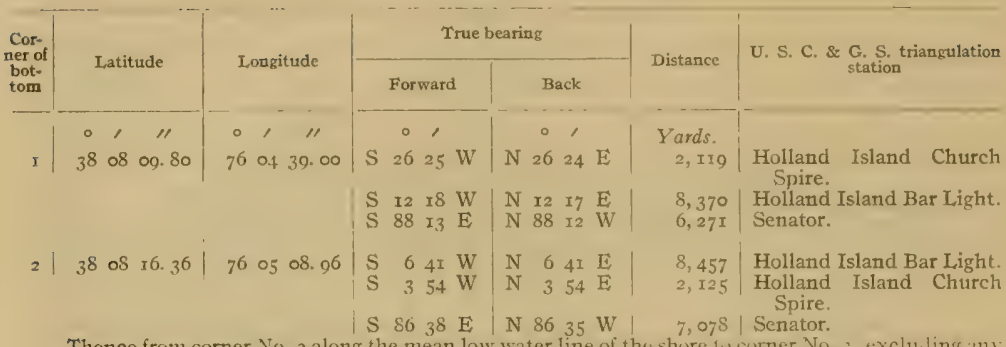

Thence from corner No. 2 along the mean low water line of the shure tw cormer No. 3. cxclun ling any creek, cove, or inlet less than roo yards in width at its mouth at low tide.

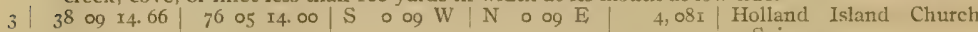

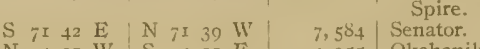

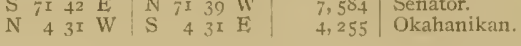

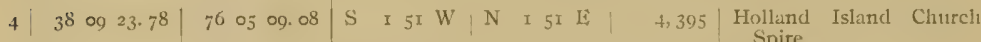
S 69 10 E $\quad \mathrm{N} 6907 \mathrm{~W} / 7,503$ Senator.

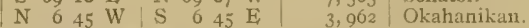

Thence from comer No. 4 along the mean low water line of the shore to comer No. 5 , excluding any creek, cove, or inlet less than too yards in width at its mouth at low tide.

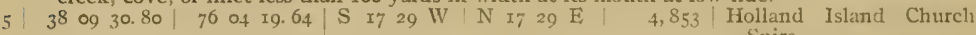

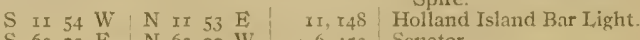

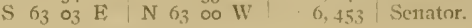

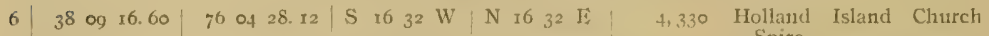
\begin{tabular}{llll|llll|l}
$\mathrm{S}$ & II & I4 & $\mathrm{WV}$ & $\mathrm{N}$ & II & $x_{4}$ & $\mathrm{E}$
\end{tabular} $\mathrm{S} 6744 \mathrm{~F} \mid \mathrm{N} 6742 \mathrm{~W}$ Io, $6_{34}$ Holland Island Bar I,ight. $6,+60$, Senator.

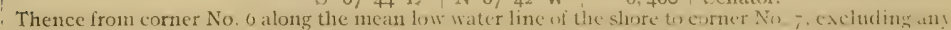
creek, cove, or inlet less than roo yards in width at its mouth at low tide,

$7 \mid 3^{8}$ o8 $56.20 \mid 76$ of II. $50\left|\mathrm{~S}_{25} 49 \mathrm{~W}\right| \mathrm{N}_{25} 48 \mathrm{~F} \mid{ }_{3}, 847$ Holland Island Church

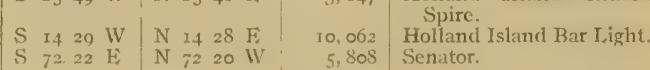

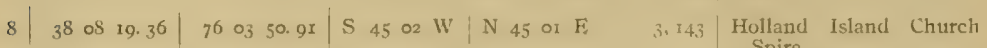
S I9 50 W $\mid \mathrm{N}$ 19 $48 \mathrm{~S}, \quad 9,035$ Holland Island Bar Light. \begin{tabular}{ll|llllll}
$\mathrm{S} 84$ & o5 $\mathrm{E}$ & $\mathrm{N}$ & 84 & 03 & $\mathrm{~W}^{\prime}$ & 5 , OI 4 & Senator.
\end{tabular}

\section{SPRING ISLAND (DORCHESTER COUNTY).}

(Holland Straits-Chart No. 42.)

\begin{tabular}{|c|c|c|c|c|c|c|}
\hline I & $3^{8}$ o6 39.86 & $\begin{array}{llll}76 & 03 & 17.50\end{array}$ & $\begin{array}{llll}\mathrm{S} & 37 & 30 & \mathrm{~W} \\
\mathrm{~S} & 68 & \mathrm{I}_{5} & \mathrm{E} \\
\mathrm{N} & 55 & \text { I9 } & \mathrm{E}\end{array}$ & $\begin{array}{llll}\mathrm{N} & 37 & 28 & \mathrm{E} \\
\mathrm{N} & 68 & 13 & \mathrm{~W} \\
\mathrm{~S} & 55 & 20 & \mathrm{~W}\end{array}$ & $\begin{array}{l}6,484 \\
4,926 \\
4,992\end{array}$ & $\begin{array}{l}\text { Holland Island Bar Light. } \\
\text { Miles. } \\
\text { Senator. }\end{array}$ \\
\hline 2 & $3^{8} \quad 0724.24$ & $\begin{array}{llll}76 & 03 & 49.60\end{array}$ & $\begin{array}{llll}S & 80 & 53 & W \\
S & 25 & \text { or } & W \\
N & 74 & 50 & E\end{array}$ & 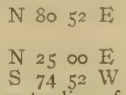 & $\begin{array}{l}2,288 \\
7,329 \\
5,131\end{array}$ & $\begin{array}{l}\text { Holland Island Church } \\
\text { Spire. } \\
\text { Holland Island Bar Light. } \\
\text { Senator. }\end{array}$ \\
\hline
\end{tabular}

hence from corner No, 2 aiong the mean low-water line of the shore to corner No. 3, excluding any creek, cove, or inlet less than 100 yards in width at its mouth at low tide. 
SPRING ISLAND (DORCHESTER COUNTY)-Continued.

(Holland Straits-Chart No.42)-Continued.

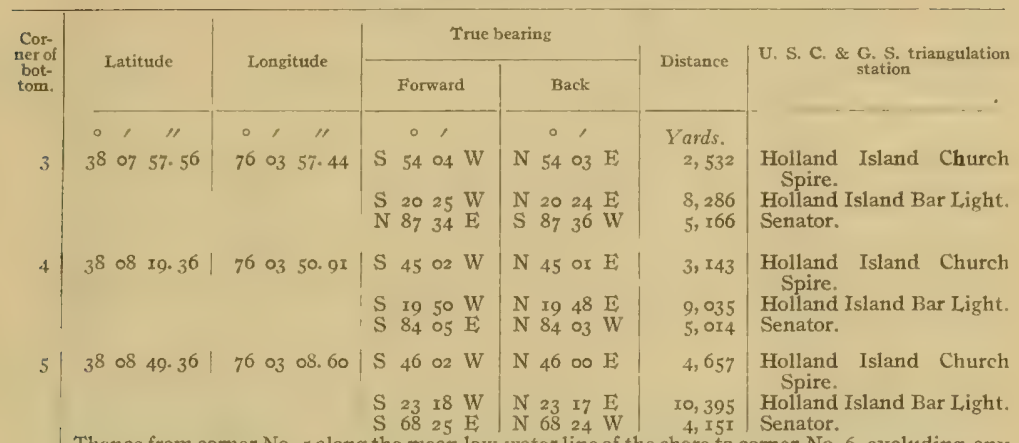

Thence from cormer No. 5 along the mean low-water line of the shore to comer No. 6 , excluding any creek cove, or inlet less than roo yards in width at its mouth at low tide.

$63^{8} 08$ 50. $5^{8} \mid 76$ or $53.42|\mathrm{~S} 3259 \mathrm{~W}| \mathrm{N} 3256 \mathrm{E}|\mathrm{Ir}, 384|$ Holland Island Bar Light.

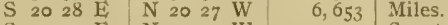

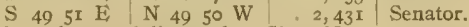

Thence along county boundary as delineated on Chart No. 42 to corner No. I.

HOLLAND ISLAND.

(Holland Straits-Chart No. 42)

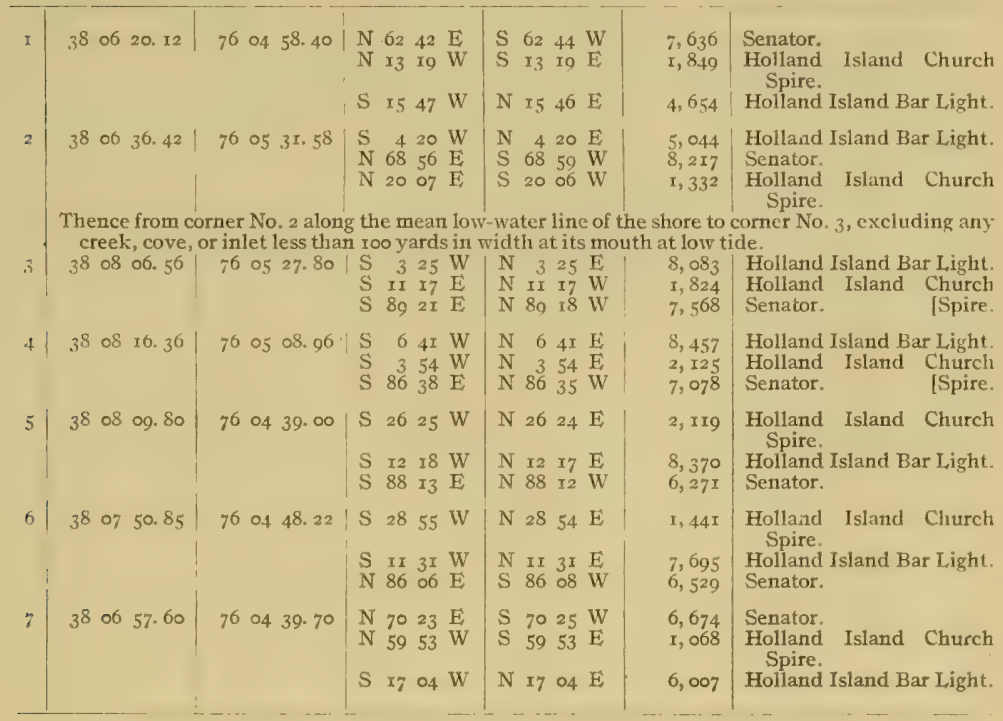


PRY ISLAND.

(Holland Straits-Chart No. 42.)

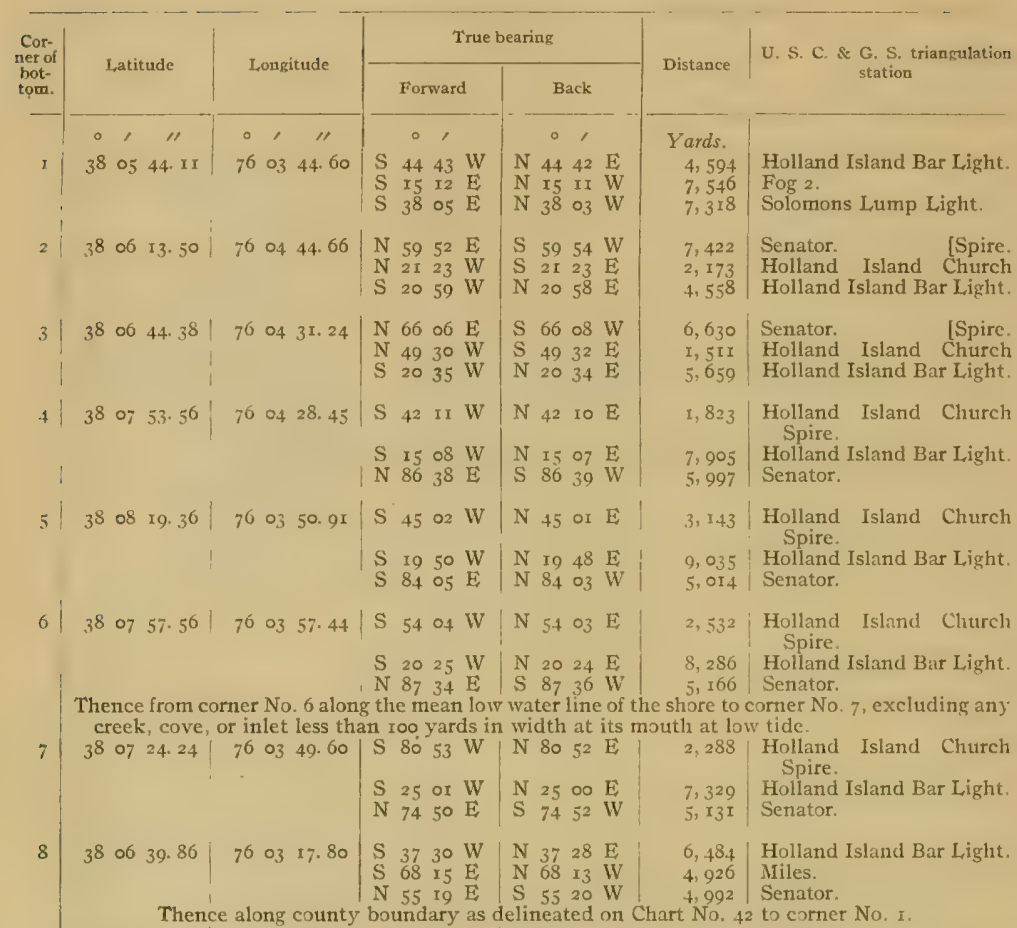

Thence along county boundary as delineated on Chart No, 42 to corner No. I. 


\section{A P P E N D X ES.}

\section{APPLNDIX A.-LAWS RELATING 'TO THE; COOPERATION OH THE COAST AND GEODETIC SURVEY AND BURFAL OF FISHERITS IVITH THE MARYLAND SHELL FISH COM- MISSION.}

The work of the Coast and Geodetic Survey and of the Bureau of Fisheries, in cooperation with the Maryland Shell Fish Commission, in surveying the oyster bars, establishing permanent landmarks at triangulation stations, and preparing for publication the necessary charts and technical and legal descriptions of boundaries and landmarks shown on these charts, has been executed in compliance with a request from the governor of the State of Maryland to the Secretary of Commerce and Labor, and by the authority of the following laws of the United States and Maryland:

[Act of Congress approved May 26, rgo6.]

AN ACT To authorize the Secretary of Commerce and Labor to cooperate, through the Bureau of the Coast and Geadetic Survey and the Bureau of Fisheries, with the shellfish commissioners of the State of Maryland in making surveys of the natural oyster beds, bars, and rocks in the waters within the State of Maryland.

Be it enacted by the Senate and House of Representatives of the United States of America in Congress assembled, That the Secretary of Commerce and Labor be, and he is hereby, authorized and directed, upon the request of the governor of the State of Maryland, to designate such officers, experts, and employees of the Bureau of the Coast and Geodetic Survey and of the Bureau of Fisheries as may be necessary to cooperate with the Maryland State board of shellfish commissioners in making a survey of and locating the natural oyster beds, bars, and rocks in the waters within the State of Maryland; and the Secretary of Commerce and $L_{\text {abor }}$ is hereby authorized and directed to furnish to the ofticers, experts, and employees of said bureaus so detailed as aforesaid such instruments, appliances, and steam launches as may be necessary to make the survey aforesaid; and the Secretary of Commerce and Labor is hereby authorized to have made in the Bureau of the Coast and Geodetic Survey all the plats necessary to show the results of the aforesaid survey and the locations of the said natural oyster beds, bars, and rocks in the waters within the State of Maryland, and to furnish to the board of shellfish commissioners of the State of Maryland such copies as may be necessary, and for this purpose to employ, in the District of Columbia and elsewhere, such technically qualified persons as may be necessary to carry out the purpose of this act.

SEC. 2. That the Secretary of Commerce and Labor is hereby further authorized to have erected or constructed by the officers so detailed as aforesaid, while making such survey, such structures as may be necessary to mark the points of triangulation, so that the same may be used for such future work of the Coast and Geodetic Survey as the said bureau may be hereafter required to perform in prosecuting the Government coast survey of the navigable waters of the United States located within the State of Maryland.

SEC. 4 . That this act shall take effect from the date of its passage. 
[Act of Congress approved June 30, x906.]

AN AC' Making appropriations for suadry civil expenses of the Government for the fiscal year ending June thirtleth, numeteen hundred and seven, and for other purposes.

Be it enacted by the Senate and House of Representatives of the United States of America in Congress asscmblcd, That the following sums be, and the same are hereby, appropriated, for the objects hereinafter expressed, for the fiscal year ending June thirtieth, nineteen hundred and seven, namely: $* * *$

COAST AND GeOdetic SURvey: * * * For any special surveys * * * including the expenditures authorized under Public Act Numbered One hundred and eighty-one, approved May twent $y$-sixth, nineteen hundred and six, and contingent expenses incident thereto, five thousand dollars, together with the unexpended balance under this appropriation for nineteen hundred and six and prior years which is hereby reappropriated and made available on this account for the fiscal year nineteen hundred and seven. ***

\section{[Act of Congress approved March 4, 1907.]}

AN ACT Making appropriations for sundry civil expenses of the Government for the fiscal year ending June tlirtietli, nineteen hundred and eight, and for other purposes.

Be it enacted by the Senate and House of Representatives of the United States of America in Congress assembled. That the following sums be, and the same are hereby, appropriated, for the objects hereinafter expressed, for the fiscal year ending June thirtieth, nineteen hundred and eight, namely: * * *

COAst and Geodetic Survey: * * * For any special surveys * * * including expenses of surveys in aid of the shellfish commission of the State of Maryland, to be immediately available and to continue available until expended, twenty-five thousand dollars. * * *

\section{[Act of Congress approved May 27, 1908.]}

AN ACr Making appropriations for sundry civil expenses of the Government for the fiscal year ending June thirtieth, nineteen hundred and gine, aud for other purposes.

Be it enacted by the Senate and House of Representatives of the United States of America in Congress assembled, That the following sums be, and the same are hereby, appropriated, for the objects hereinafter expressed, for the fiscal year ending June thirtieth, nineteen hundred and nine, namely: * * *

COAST AND GeODETIC SURvey: * * * For any special surveys * * * including expenses of surveys in aid of the shellfish commission of the State of Maryland, which expenses, including cost of plats and charts, shall not exceed fifteen thousand dollars in any one year, to be immediately available, twenty thousand dollars.

[Act of Congress approved March 4, 1909.]

AN ACT Making appropriations for sundry civil cxpenses of the Government for the fiscal year ending June thirtieth, ninctecn hundred and ten, and for other purposes.

Be it enacted by the Senate and House of Representatives of the United States of America in Congress assembled, That the following sums be, and the same are hereby, appropriated, for the objects hereinafter expressed, for the fiscal year ending June thirtieth, nineteen luundred and ten, namely: * * *

COAST AND GEODETIC SURvey: * * * For any special surveys * * * including expenses of surveys in aid of the shellfish commission of the State of Maryland, which expenses, including cost of plats and charts, shall not exceed fifteen thousand dollars in any one year, to be immediately avail. able, twenty thousand dollars

[Act of Congress approved June 25, so10.]

AN ACI Making appropriations for sundry civil expenses of the Government for the fiscal year cnding Jume thirtieth, ninetecn hundred and eleven, and for other purposes.

Be it enacted by the Senate and House of Representatives of the United States of America in Congress assembled, That the following sums be, and the same are hereby, appropriated, for the objects hereinafter expressed, for the fiscal year ending June thirtieth, nineteen hundred and eleven, namely:

Coast and Geoderic Survey: * * * For any special surveys * * * including expenses of surveys in aid of the shellfish commission of the State of Maryland, to be immediately available, fifteen thousand dollars. 
[Act of Congress approved March 4, Igrz.]

AN ACT Making appropriations for sundry civil expenses of the Goverument for the fiscal year ending June thirtieth, nineteen hundred and twelve, and for other purposes.

Be it enacted by the Senate and House of Representatives of the United States of America in Congress assembled, That the following sums be, and the same are hereby, appropriated, for the objects hereinafter expressed, for the fiscal year ending Jure thirtieth, nineteen hundred and twelve, namely: * * *

COAST AND GEODETTC SURVEY: * * * For any special surveys * * * including expenses of surveys in aid of the shellfish commission of the State of Maryland, to be immediately available, thirteen thousand dollars ***

[Act of the Legislature of Maryland approved April 3, rgo6.]

AN ACT To establish and promote the industry of oyster culture in Maryland, to define and mark natural oyster beds, bars and rocks lying under the waters of this State, to prescribe penalties for the infringement of the provisions of this Act, and *** *.

Section x. Be it enacted by the General Assembly of Maryland, That the following sections be, and they are hereby, added to article 72 of the Code of Public General Laws, title "Oysters." * * *

SEC. 86. The Board of Shell Fish Commissioners shall, as soon as practicable after the passage of this act, cause to be made a true and accurate survey of the natural oyster beds, bars and rocks of this State, said survey to be made with reference to fixed and permanent objects on the shore, giving courses and distances, to be fully described and set out in a written report of said survey, as hereinafter required. A true and accurate delineation of the same shall be made on copies of published maps and charts of the United States coast and geodetic survey, which said copies shall be filed in the office of the said commissioners in the city of Annapolis, and the said commissioners shall further cause to be delincated upon copies of the publishcd maps and charts of the United States coast and geodetic survey, of the largest scale, one copy for each of the counties of this State in the waters of which there are natural oyster beds, bars and rocks, all natural beds, bars and rocks lying within the waters of such county, which maps shall be filed in the offices of the clerks of the Circuit Court for the respective counties wherein the grounds so designated may lie ***.

SEC. 87. The governor of this State is hereby requested to ask the assistance of the United States Coast and Geodetic Survey, and of the United States Fish Commissioner, to aid in the carrying out of the provisions of the preceding section.

*

SEC. 89. As soon as practicable after the first day of April, Igo6, the said commissioners shall organize, and shall at once proceed, with the assistance of such person or persons as may be detailed by the United States Coast and Geodetic Survey and the United States Fish Commissioner, to aid them in their work, and of such persons as may be appointed under the preceding section, to have laid out, surveyed and designated on the said charts, the natural beds and bars, and shall cause to be marked and defined as accurately as practicable the limits and boundaries of the natural beds, bars, and rocks as established by said survey, and they shall take true and accurate notes of said survey in writing, and make an accurate report of said survey, setting forth such a description of landmarks as may be necessary to enable the said board, or their successors, to find and ascertain the boundary lines of the said natural oyster beds, bars, and rocks, as shown by a delineation on the maps and charts provided in this act; said report shall be completed and filed in the office of the board in the city of Annapolis within ninety days after the completion of the survey of any county. Said commissioners shall cause the same to be published in pamphlet form, and transmit copies of the same to the clerks of the circuit court for the respective counties, where the charts have been filed or directed to be filed as hereinafter provided; the said report to be filed by the clerks of the several counties in a book kept for that purpose. And the said survey and report, when filed, subject to the right of appeal hereafter provided for in this act, shall be taken in all of the courts of this State as conclusive evidence of the boundaries and limits of all natural oyster beds, bars, and rocks, lying within the waters of the county wherein such survey and report are filed, and shall be construed to mean in all of the said courts that there are no natural oyster beds, bars, or rocks lying within the waters of the counties wherein such report and survey are filed other than those embraced in the survey authorized by this act, and that all areas of the Chesapeake Bay and its tributaries within the State of Maryland, not shown in the survey to be natural 
oyster beds, bars, or rocks shall be construed in all the courts of the State to be barren bottoms and open for disposal by the State for the purpose of private planting or propagation of oysters thereon under the provisions of this act; provided, that the said survey and report shall not be construed as to affect in any manner the holdings by citizens of this State in any lot which may have been appro priated or taken up under the laws of this State prior to the approval of this act.

The law of the State of Maryland, passed March 9, x842, authorizing officers of the United States Coast and Geodetic Survey to enter upon the lands within the State limits for the purposes of the survey, is as follows:

AN ACT Concerning the Survey of the Coast of Maryland.

SECTION I. Be it enacted by the General Assembly of Maryland, That it shall and may be lawful for any person or persons employed under and by virtue of an act of the Congress of the United States, * * * at any time hereafter to enter upon lands within this State for the purpose of exploring, surveying, triangulating, or leveling, or doing any other matter or thing which may be necessary to effect the objects of said act, and to erect any works, stations, buildings, or appendages requisite for that purpose, doing no unnecessary injury to private or other property.

SEC. 2. ${ }^{1}$ And be it enacted, That in case the person or persons employed under the act of Congress aforesaid, can not agree with the owners or possessors of the land so entered upon and used as to the amount of damage done thereto by reason of the removal of fences, cutting of trees or injury to the crop or crops growing on the same, it shall and may be lawful for the said parties or either of them to apply to the chief justice for the time being or one of the associate judges of the judicial district in which such land may be situated, who shall thereupon appoint three disinterested and judicious freeholders, residents of the same judicial district, to proceed with as much dispatch as possible to the examination of the matter in question, and the faithful assessment of the damages sustained by the owners or possessors aforesaid, and the said freeholders or a majority of them, having first taken and subscribed an oath or affirmation before the chief or associate justice aforesaid or other person duly authorized to administer the same, that they will well and truly examine and assess as aforesaid, and having given five days' notice to both parties of the time of their meeting, shall proceed to the spot, and then and there upon their own view and if required, upon the evidence of witnesses (to be by them sworn or affirmed and examined), shall assess the said damages, and shall afterward make report thereof and of their proceedings in writing under their hands and seals and file the same within five days thereafter in the office of the clerk of the county in which the land aforesaid is situated, subject to an appeal by either party to the county court of the said county within ten days after filing as aforesaid, and the said report so made as aforesaid if no appeal as aforesaid be taken, shall be held to be final and conclusive as between the said parties, and the amount so assessed and reported shall be paid to the said owners or possessors of the land so damaged within twenty days after the filing of said report, and the said chief or associate justice as aforesaid, shall have authority to tax and allow upon the filing of said report, such costs, fees, and expenses to the said freeholders for the performance of their duty as he shall think equitable and just, which allowance shall be paid by the person or persons employed under the act of Congress aforesaid, within the time last above limited, but if an appeal as aforesaid be taken, the case shall be set down for hearing at the first term of county court aforesaid, ensuing upon and after appeal, and it shall be lawful for either party immediately after the entry of such appeal, to take out summons for such witnesses as may be necessary to be examined upon the hearing aforesaid, and the said court shall have power in its discretion to award costs against which ever the final judgment shall be entered, and such appeal at the option of either party way and shall be heard before and the damage assessed by a jury of twelve men to be taken from the regular panel and elected as in other cases.

SEC, 3. And be it enacted, That if any person or persons shall wilfully injure or deface or remove any signal, monument, or building or any appendage thereto, erected, used, or constructed under and by virtue of the act of Congress aforesaid, such person or persons so offending shall severally forfeit and pay the sum of fifty dollars with costs of suit to be sued for and recovered by any person who shall first

1 Under the rulings of the Comptroller of the Treasury no damages can be collected except through the United States Court of Clains unless an agreement has been made in advance. 
prosecute the same before any justice of the peace of the county where the person so offending may reside, and shall also be liable to pay the amount of damages thereby sustained, to be recovered with costs of suit in an action on the case, in the name and for the use of the United States of America, in any court of competent jurisdiction.

\section{APPENDIX B.-THE HAMAN OYSTER CULTURE LAW.}

[Extract from Second Report of Shell Fish Commission.]

OBJECT.

"The legislature in placing chapter 711 of the acts of 1906 , better known as the Haman Oyster Culture Law, upon the statute books of Maryland, had a twofold object in view.

r. To encourage an industry in oyster culture upon the barren bottoms beneath the tidewaters of the State.

2. To prevent the leasing of natural oyster bars for the purpose of oyster culture."

\section{SURVEY.}

"To make the leasing of barren bottoms possible and the leasing of natural bars impossible, pro. vision was made for a survey of the natural bars for the purpose of accurately locating and marking the same. It was definitely provided that no barren bottoms should be leased in any part of the State until the natural bars of that region had been surveyed, charted, and marked with buoys."

\section{Definttion of a Natural Oyster Bar.}

\section{NATURAL BAR NOT DEFINED.}

"The Shell Fish Commission is instructed by section go of the Haman Oyster Culture Law to exercise its judgment liberally in favor of the natural bars when surveying, charting and buoying them, but other than this the Commission is uninstructed in this important matter. The responsibility of defining a natural bar is placed upon the Commission."

\section{DIVERSITY OF OPINION.}

"No definition of a natural oyster bar could be formulated by any man or body of men which would meet with the approval of all parties concerned. Oystermen, as a rule, hold that all bottoms where oysters grow or have grown naturally even though now practically barren of oysters should be considered natural bars. Other citizens of the State who are not directly interested in the oyster business, but interested in the oyster industry from the standpoint of revenue, hold, as a rule, that no bottoms should be excluded from leasing for oyster culture which, by methods known to oyster culturists, may be made to yield a greater number of oysters than they now produce."

"It should be evident to every one that neither of these definitions could be adopted by the Com. mission as a working basis for determining which of the grounds surveyed are natural oyster bars."

THF GOLDSBOROUGY DEFINITION.

The definition of a natural oyster bar which very nearly approaches a reasonable and satisfactory compromise between the views of the subject held by oysiermen on one hand and by oyster culturists on the other is that contained in an opinion rendered by Judge Charles F. Goldsborough in the circuit court for Dorchester County in the July term, $188 \mathrm{r}$, in the case of William T. Windsor and George R. Todd v. Job T. Moore.

This definition has been adopted by the Shell Fish Commission as the basis for the determination of the status of the various oyster bottoms surveyed, and is as follows:

What then is a natural bar or bed of oysters? It would be a palpable absurdity for the State to attempt to promote the propagation and growth of oysters and to encourage its citizens, by a grant of land, to engage in their culture, if the lands authorized to he taken up were only those upon which

$$
58345-13-12
$$


oysters do not and can not be made to grow. That there may be lands covered by water in the State where no oysters can be found, but where, if planted, they could be cultivated successfully, may be possible, but, if so, I imagine that their extent must be too limited for them to be of much practical, general advantage for the purposes of such a law as the one under discussion; but there are thousands of acres of hard and shifting sands where oysters not only are not found, but where it would be folly to plant them, and these latter it can not be supposed that the State intended to offer to give away, for the simple reason that the State could not help knowing that nobody would have them.

Upon the other hand there are large and numerous tracts where oysters of natural growth may be found in moderate numbers, but not in quantities sufficient to make it profitable to catch them, and yet where oysters may be successfully planted and propagated. In my opinion these can not be called natural bars or beds of oysters, within the meaning of the act of assembly, and it is just such lands as these that the State meant to allow to be taken up under the provisions of the above-mentioned section of the act.

But there is still another class of lands where oysters grow naturally and in large quantities and to which the public are now and have been for many years in the habit of resorting with a view to earning a livelihood by catching this natural growth, and here, I think, is the true test of the whole question. Land can not be said to be a natural oyster bar or bed merely because oysters are scattered here and there upon it, and because if planted they will readily live and thrive there; but whenever the natural growth is so thick and abundant that the public resort to it for a livelihood, it is a natural oyster bar or bed and comes within the above-quoted restriction in the law, and can not be located or appropriated by any individual.

\section{APPLICATION OF DEFINITION.}

Before this definition may be of use in determining, accurately and scientifically, the status of an oyster ground, its central idea, "livelihood," must be expanded into accurately determinable factors, and these factors must be combined into a practical scheme of investigating the condition of the ground under consideration.

Stated briefly, a livelihood is represented by a sum of money obtained from the sale, at a fixed price, of a certain quantity of oysters gathered in a given time from an allotted area of ground.

Knowing the value of each of these factors it becomes possible to calculate the number of oysters an oyster ground must produce per square yard in order that oystermen may secure a livelihood by working upon it.

Nore.-The factors into which the commission resolved the livelihood problem, the value assigned to each factor, and the scheme devised for practical use in examining and applying the definition to oyster bottoms are given in outline in their second report under the heading of the preceding extract, and in detail in their first report on pages 32 to 69 .

\section{APPENDIX C.-SUMMARY OF THE PARTICULAR SURVEYING OPERATIONS WHICH CON- STITUTE AN "OYSTER SURVEY" AS NOW BEING CARRIED ON IN MARYLAND.}

Explanation.-A brief account of the particular surveying operations which constitute an "oyster survey" as now being carried on in Maryland will assist in the interpretation of records contained in the technical part of this report, and will be of interest to many who may not understand the necessity for the great amount of work being done or its complicated character.

To those familiar with methods used in surveying and charting the characteristic features of large bodies of water tnere is an evident necessity for the various operations performed, especially when it is known that the boundaries of the public oyster bars and of the private lots leased for purposes of oyster culture must be surveyed and charted with the greatest practical accuracy. To others it will be sufficient to state that the actual experience gained from oyster surveys in other States has proven that in order to avoid endless dissatisfaction and litigation it is necessary to accurately locate and permanently establish oyster boundaries as is now being done in Maryland.

Triangulation survey. - Such refinement of survey work as that demanded by the conditions of an oyster survey when carried on at considerable distances offshore can only be obtained by the use of a system of triangulation as a framework or foundation. Therefore, a triangulation survey including the permanent marking of the positions of landmarks with monuments and a record of the descriptions of their locations for future recovery is a necessary operation of a complete oyster survey.

Topographic survey. - The technical records which establish the relation between the offshore ovster boundaries and triangulation landmarks are sufficient for the requirements of engineers in making 
resurveys, but do not supply the needs of others who are interested in the same boundaries by reason of their occupation as oystermen concerned as to the public oyster bars, or oyster culturists concerned as to the leasable bottoms. For these it is necessary to have the charts of the survey show the relation of the shore line and other topographic features to the boundaries of the public oyster bars and private oyster farms. Therefore, a topographic survey is a necessary operation of a complete oyster survey.

Hydrographic survey. - In the settlement of the important question of what is, or what is not, a natural oyster bar, and in the consideration of bottoms to be selected for purposes of oyster culture, information as to the depth of water and the character of the bottom is required. Therefore, a hydrographic survey is a necessary operation of a complete oyster survey.

Necessary foundation for an oyster survey.-Consequently, the necessary components of a satisfactory foundation for a complete oyster survey are the three classes of survey operations technically named triangulation, topography, and hydrography, or, stated in another way, the foundation of a practical oyster survey includes the surveying operations usually followed by the Coast and Geodetic Survey leading up to the preparation and publication of nautical charts.

Special surveys and investigations pertaining to oysters.-Having obtained this cartographic survey: for a foundation, partly by new work and partly from records of previous work of the Government, the combined operations ${ }^{1}$ making up an "oyster survey" are completed by superimposing on this foundation special surveys and investigations pertaining particularly to oysters or other shell fish.

The special surveys pertaining to oysters furnish information as to the location and outline of oystershell bottoms, and are carried on by the sounding boat party in addition to the usual hydrographic work. ${ }^{2}$ This operation consists of the observation and record of the character of vibration of a wire and chain apparatus which is dragged over the bottom, the vibrations or lack of vibrations indicating the presence and quantity of shells or absence of shells.

The special oyster investigations ${ }^{3}$ consist of the actual determination of the kind and quantity of oysters on the bottom, and such economic and biological studies of the supply of oyster food, density of water, character of the bottom, and other important matters as affects the growth of oysters. In this work the oyster investigation stations are located and buoyed by the hydrographic party while engaged. in the survey of the oyster-shell limits. They are selected with the view of obtaining characteristic data which can be used for the interpretation of the recorded vibrations of the chain apparatus at all other points covered by the survey.

Preparation of results.- The actual surveying operations and oyster investigations having been completed for any one county, there still remains technical work of nearly equal magnitude to that described." This work consists of the preparation of charts and technical descriptions of boundaries and landmarks for publication by the Government, the preparation of that part of the annual report of the commission covering the special oyster surveys and investigations, the making of the leasing charts and finished projections, and finally the filing of the oyster charts and records with the courts and the commission, thus opening a county for oyster culture.

Summary.-From the foregoing account it can be seen that a complete oyster survey properly conducted so as to answer all practical requirements of the present and permanency of results for the future is a very complicated afiair, involving many lines of surveying and other scientific work, and requiring the professional services of experts in the various operations of cartographic surveying and shell-fish investigations.

\footnotetext{
I See A ppendix D of this publication for "Statistics of resuits of combined operations of the Government and State."

: See pp. I04 to 123 of First Annual Report of Maryland Shell Fish Commission.

see pp. 30 to 67 and 129 to 199 of First Annual Report of Maryland Shell Fish Commission.

"No mention is made here of the large amout of administrative work of the commission, which is greatly complicated and increased by the effect of the oyster-survey operations on many thousands of people whose interests are more or less involved; or of the large amount of survey work involved in the survey and record of the boundaries of oyster lots leased from the State by private individuais for the purposes of oyster culture.
} 


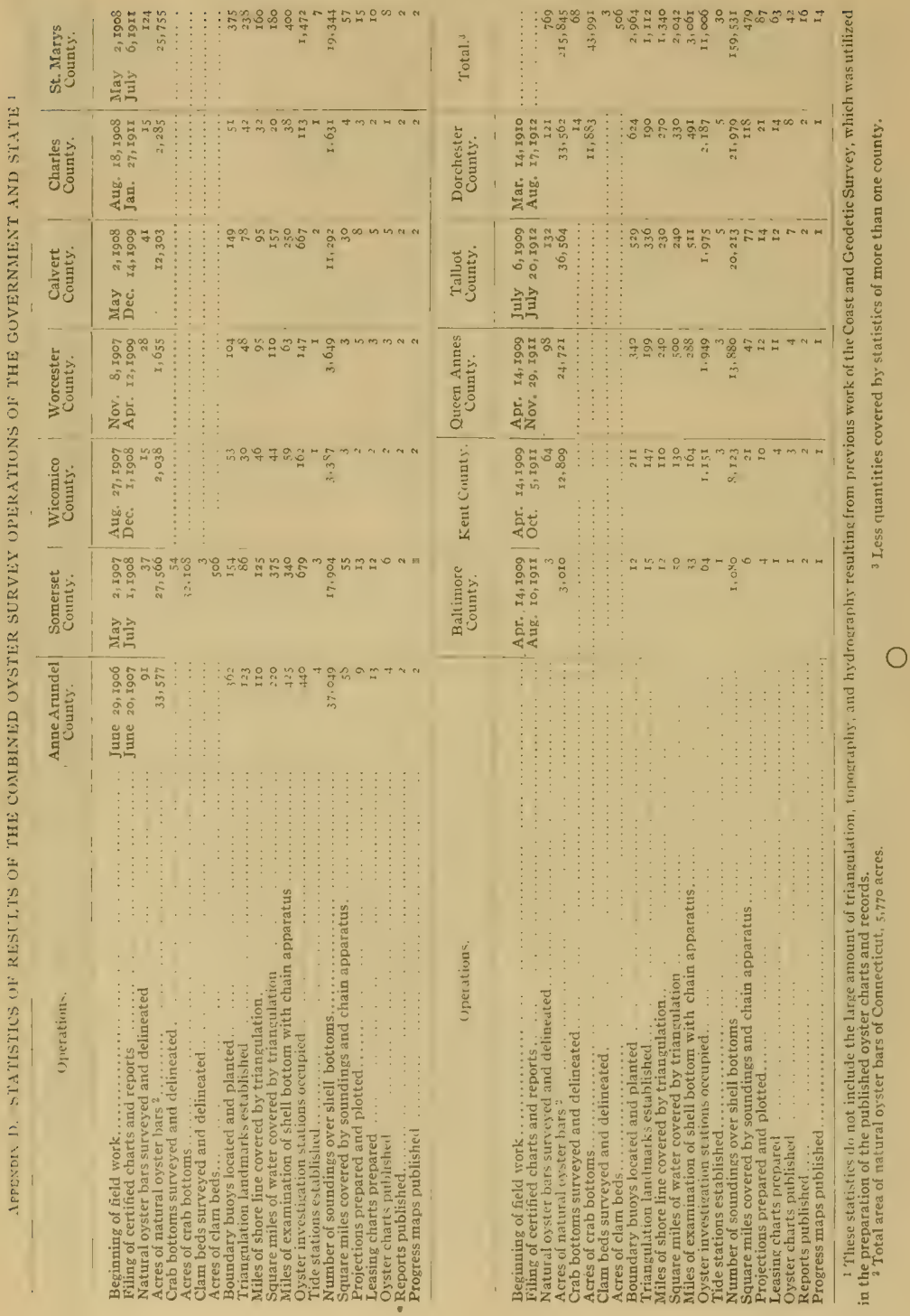






DEPARTMENT OF COMMERCE AND LABOR

COAST AND GEODETIC SURVEY

O. H. TITTMANN, Superintendent

\section{SURVEY OF OYSTER BARS \\ KENT COUNTY MARYLAND}

DESCRIPTION OF BOUNDARIES AND LANDMARKS AND REPORT OF WORK OF UNITED STATES COAST AND GEODETIC SURVEY IN COOPERATION WITH UNITED STATES BUREAU OF

FISHERIES AND MARYLAND

SHELL FISH COMMISSION

By C. C. YATES

CHIEF OF COAST AND GEODETIC SURVEY PARTY ASSISTANT, COAST AND GEODETIC SURVEY

WASHINGTON

GOVERNMENT PRINTING OFFICE:

1912 



\section{LETTER OF SUBMITTAL.}

\section{DEPARTMENT OF COMMERCE AND LABOR, COAST AND GEODETTC SURVEY, Washington, October $5,19 I I$.}

SIR: I have the honor to transmit herewith a report of the officer detailed from the Coast and Geodetic Survey to cooperate with the Bureau of Fisheries and the Maryland Shell Fish Commission in surveying the oyster bars of the State of Maryland, together with certain technical results which are necessary for the interpretation and use of the plats of the survey made by the Government.

This work has been done under the provisions of the act of Congress entitled "An act to authorize the Secretary of Commerce and Labor to cooperate, through the Bureau of the Coast and Geodetic Survey and the Bureau of Fisheries, with the shell fish commissioners of the State of Maryland in making surveys of the natural oyster beds, bars, and rocks in the waters within the State of Maryland," approved May 26, I906, and of the acts of Congress making appropriations for sundry civil expenses of the Government for the fiscal years ending June 30, I907; I908, I909, I9I0, I9II, and 1912. Respectfully,

To Hon. Charles NAgel,

O. H. TitTManN, Superintendent. Secretary of Commerce and Labor. 



\section{CER'TIFICA TION.}

BALTIMORE, MD., October 4, I9II.

The following publication is certified to contain correct technical descriptions of all boundaries and landmarks established in Kent County by the Maryland Shell Fish Commission in cooperation with the United States Coast and Geodetic Survey.

C. C. YATES,

Chief of Coast and Geodetic Survey Party, Assistant, Coast and Geodetic Survey.

Examined and certified to be correct.

BALTIMORE, MD., October 4, I9II.

$$
\begin{aligned}
& \text { WALTER J. Mitchell, } \\
& \text { CASWELl GRAVE, } \\
& \text { BENJAMIN K. GREEN, } \\
& \text { Maryland Shell Fish Commission. } \\
& \text { SwePSON EARLE, } \\
& \text { Hydrographic Engineer. }
\end{aligned}
$$

NorE.-Certified copies of this publication and of the charts of the natural oyster bars of Kent County were filed in the office of the clerk of the circuit contr of Kent County and in the office of the Board of Shell fish Commissioners on Octaber 5, I9II. 



\section{CONTENTS.}

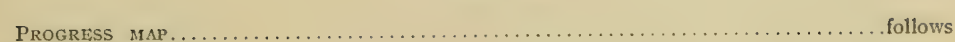

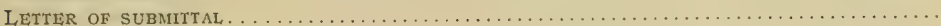

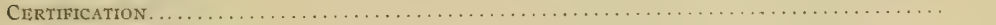

INTRODUCTION:

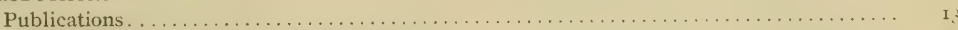

Cooperation of the Coast and Geodetic Survey . . . . . . . . . . .

Cooperation of the Bureau of Fisheries. . . . . . . .

General statement of work of Coast and Geodetic Survey $\ldots \ldots \ldots \ldots \ldots \ldots \ldots \ldots \ldots \ldots$ It

REPORT OF THE WORK OF THE COAST AND GEODETIC SURVEY:

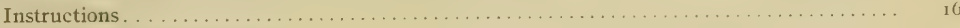

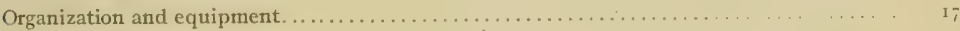

Chronological statement of work . . . . . . . . . . . . . . . . .

Statisties . . . . . . . . . . . . . . . . . .

General remarks. . . . . . . . . . . . . . . . . . .

CHARTS AND MAPS:

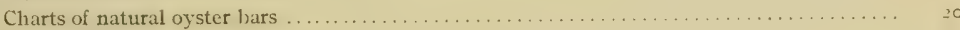

Leasing charts. . . . . . . . . . . . . . . . . .

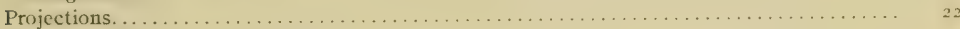

Progress maps. . . . . . . . . . . . . . . . . . . . . . . .

BOUNDARIES OF THE COUNTY WATERS:

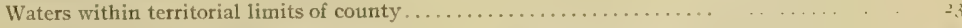

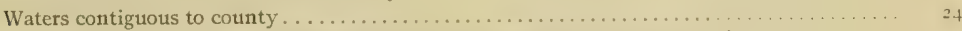

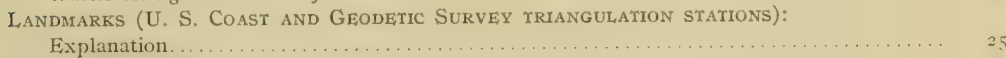

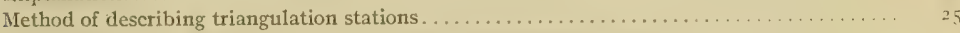

Descriptions of triangulation stations in county and adjacent waters-

Chart No. 28 (Chesapeake Bay, vicinity Tolchester Beach)-

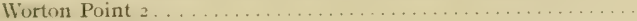

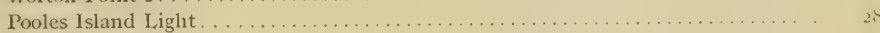

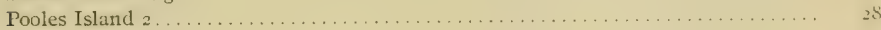

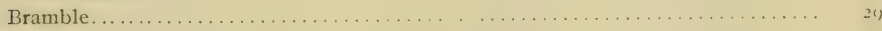

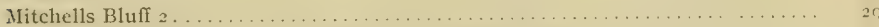

Craighill Channel Light (Front Range) (see progress map) . . . . . . . . . . . . . .30

Craighill Channel Light (Rear Range) (see progress map) . . . . . . . . . . . . . . .30

Fort Howard Taller Water Tank (see progress map) $\ldots \ldots \ldots \ldots \ldots \ldots \ldots \ldots \ldots \ldots$.

Seven Foot Knoll Light (see progress map) ......................... io

Bodkin Point (Old Tower) (see progtess map) . . . . . . . . . . . . . . . . . .

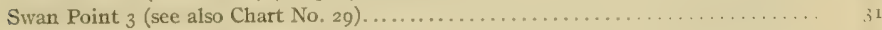

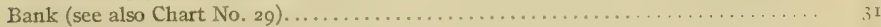

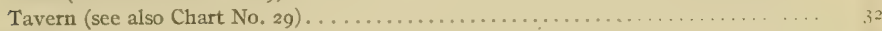

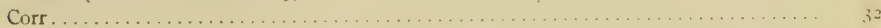

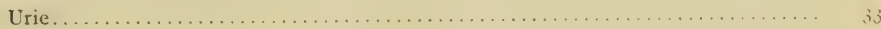




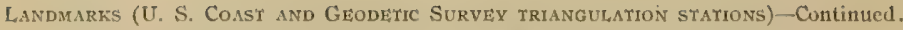
Descriptions of triangulation stations in county and adjacent waters-Continued.

Chart No. 28 (Chesapeake Bay, vicinity Tolchester Beach)-Continued.

Spike.

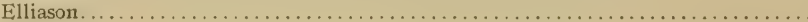

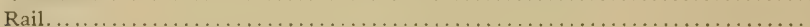

Fork.

Haven (see also Chart No. 29).

Treasure (see also Chart No. 29) .....

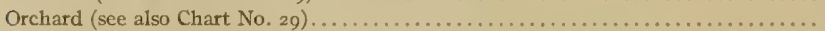

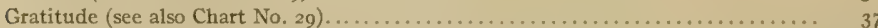

Chart No. 20 (Chesapeake Bay and entrance to Chester River) -

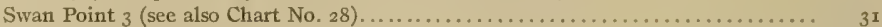

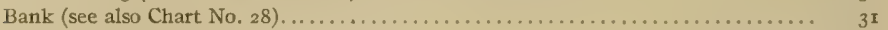

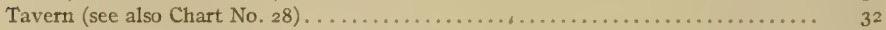

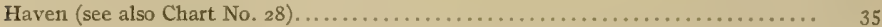

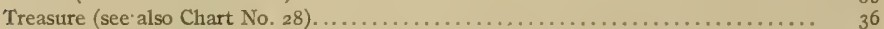

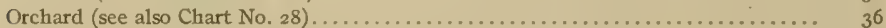

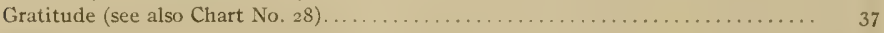

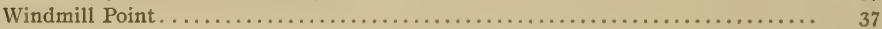

Stevens. . . . . . . . . . . . . . . . . . 38

Baltimore Light (see progress map) . . . . . . . . . . . . . . . . . 38

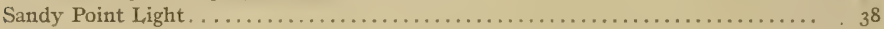

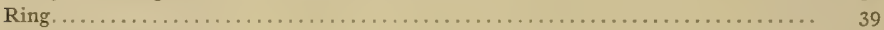

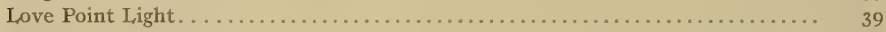

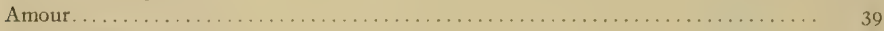

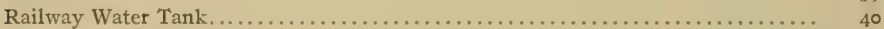

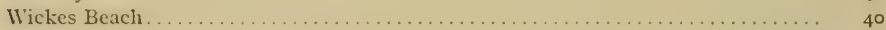

Narrows Point (see also Chart No. 30 ) ......................... 40

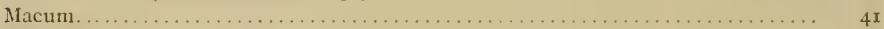

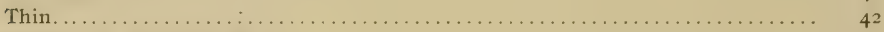

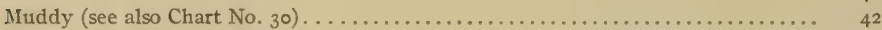

Bridge . . . . . . . . . . . . . . . . . 42

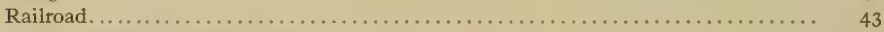

Chart No. 30 (Middle Chester River and tributaries)-

Narrows Point (see also Chart No. 29) ........................ 40

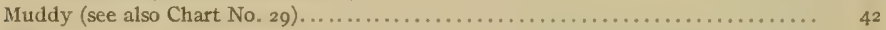

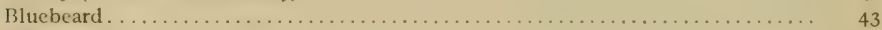

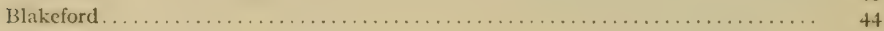

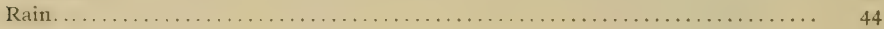

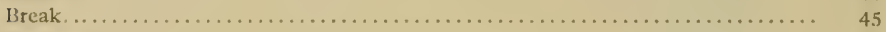

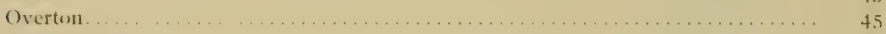

Fir . . . . . . . . . .

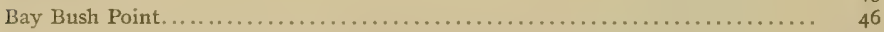

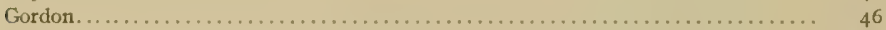

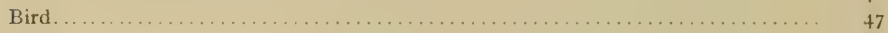

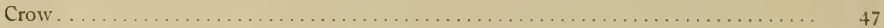

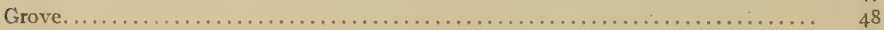

Recds . . . . . . . . . . . . . . . . . . . . . . . . . . . . . . . 48

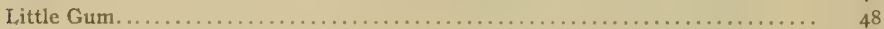

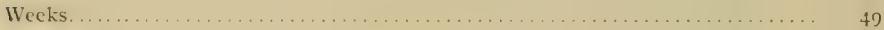

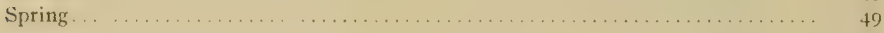

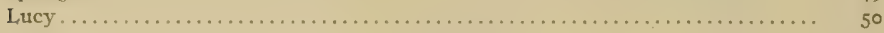

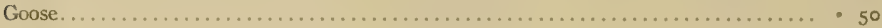


Landmarks (U. S. Coast and Geodetic Survey triangulation stations) - Continucd. Descriptions of triangulation stations in county and adjacent waters-Continued.

Chart No. SO (Middle Chester River and tributaries) - Continued.

Prussian

Page.

Prussian

5 I

Herring.

No Road

Cut.

Fore.

Island

'Tray.

Inn

Holton Point

Earle...

Hydrographic

Ruth .

Melfield.

Bath

Ship. .

Engineer

Swepson

Corsica.

Deep Cove

Snub.

Lawyer .

Drum

Davis.

Isle.

Eagle

Ford.

Kinsley.

Whale.

Bungay

Locust.

Nat.

Mill.

West.

Hornor

King.

Ash.

Noth .

Ixary

Nest.

Woll.

Harp.

Clay.

Lovely.

Gut

Philip.

Ide.

Hoo

Cult.

Wann

Corn.

Neck. 
LANDMARKS (U. S. COAST AND GHODhtic SURVHY TRIANGU ation STATIONS) - Contimer. Descriptions of triangulation stations in county and adjacent waters-Continued.

Chart No. 30 (Middle Chester River and tributaries)-Continued.

Major.

Peach. . . .

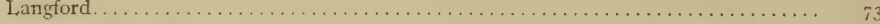

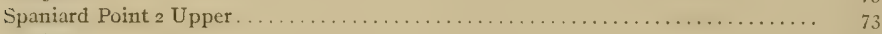

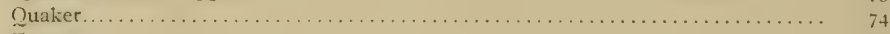

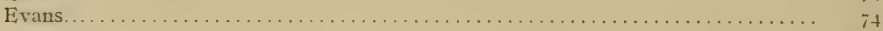

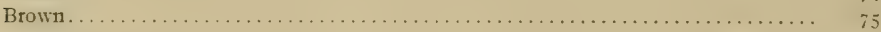

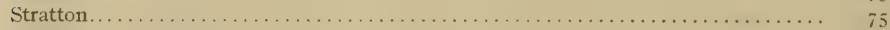

Chester . . . . . . . . . . . . . .

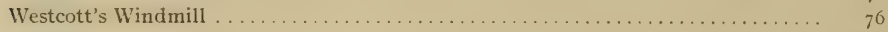

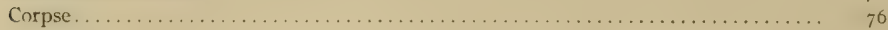

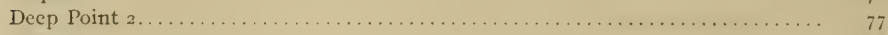

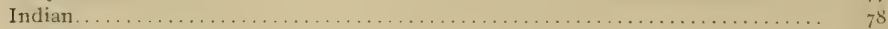

Thom . . . . . . . . . . . . .

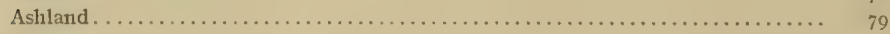

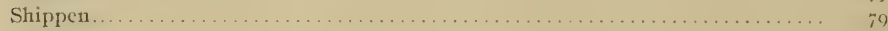

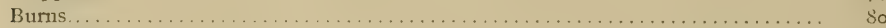

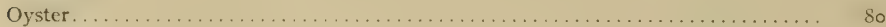

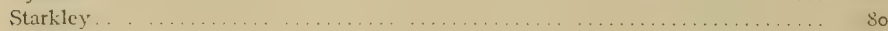

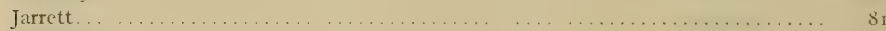

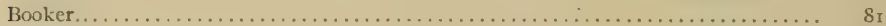

Journey . . . . . . . . . . . . . . . . . . .

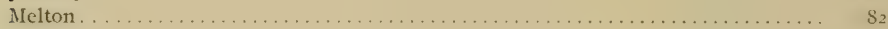

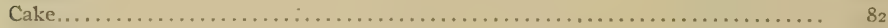

Pomona. . . . . . . . . . . . . . . . . . . . . $s_{3}$

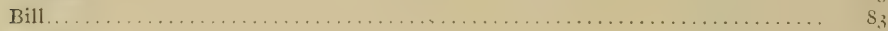

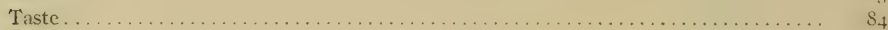

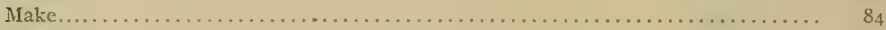

Down . . . . . . . . . . . . . . . . . . . . . . . . . . . . . . $s_{4}$

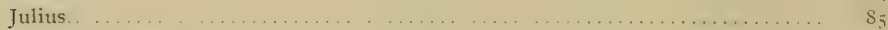

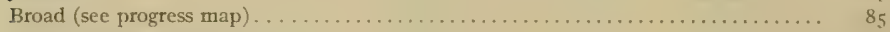

Nils (see progress map) . . . . . . . . . . . . . . . . . . . . . . . 86

Wilmers (see progress map) . . . . . . . . . . . . . . . . . . . . . . . . 86

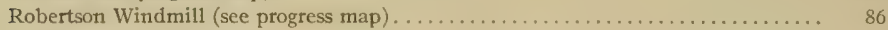

Robertson (sec progress map)..... . . . . . . . . . . . . . . . . . . .

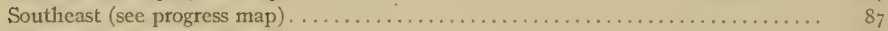

Thursten (see progress mapl $\ldots \ldots \ldots \ldots \ldots \ldots \ldots \ldots \ldots \ldots \ldots \ldots \ldots \ldots \ldots \ldots$

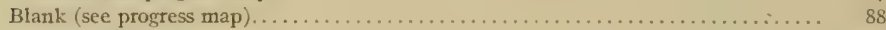

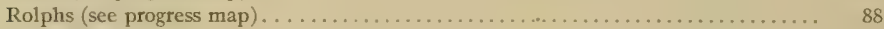

BOUNDARIES OF OYSTER BARS:

Explanation.

Method of describing boundaries.

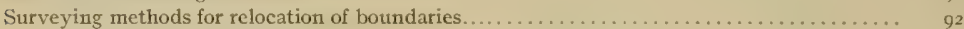

Boundaries of natural oyster bars-

Chart No. 28 (Chesapeake Bay, vicinity of Tolchester Beach)-

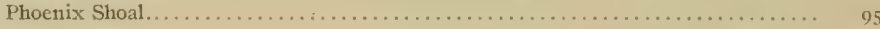

Deep Shoal . . . . . . . . . . . . . . . . . . . . . . . . . . . . . . . .

Coal Lump . . . . . . . . . . . . . . . .

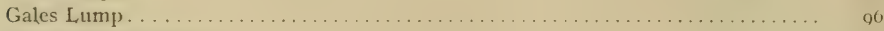

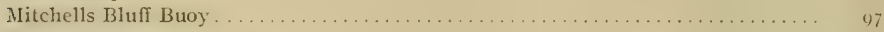

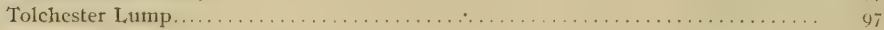

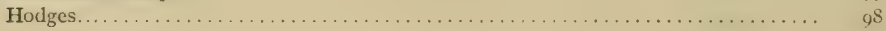


BOUNDARIES OF OYSTYR BARS-COUtinted.

Boundaries of natural oyster bars-Continued.

Chart No. $2 S$ (Chesapeake Bay, vicinity of Tolchester Beach) -Contintued.

Swan Point (sce also Chart No. 20).

Page

Swan Creek

Rockliall (see alsu Chart No. 20)).

White Horse (see also) Chart No. 29)

The Haven (see also Chart No. 29).

Deep Landing Hole (see also Chart No. 29).

Little Neck (sce also Chart No. 29).

Tavern Creek (see also Chart No. 29).

Chart No. 20 (Chesapeake Bay and entrance to Chester River)-

Swan Point (see also Chart No, 28).

Rocklall (see also Chart No. 28) ...

White Horse (see also Chart No. 28)

The Haven (see also Chart No. 28)

Deep Landing Hole (see also Chart No. 28)

Little Neck (see also Chart No. 28).

Tavern Creek (see also Chart No. 28). . .

Windmill Flats

Muddy Drain

Huntingficld

Gum Spring.

White Marsh

Under The Bar

Hickory Thicket.

East Neck Bay.

Entrance Lumps.

Wickes Beach.

Dredge Rock

Side Shoal (see also Chart No. 30)

Mud (see also Chart No. 30)..

Ferry (Kent County)

Buoy Rock (see also Chart No. 30 ).

Charl No. 30 (Middle Chester River and tributaries)-

Side Shoal (sce also Chart No, 29)

Mud (see also Chart No. 29).

Buoy Rock (see also Chart No. 29)

Hail Creek.

Hail Point

Black Buoy.

Durdin

Belts.

Piney Point (Kent County)

Bay Bush Point

Bluff Point.

Chester River IIiddleground.

Limekiln..

Willow Bottom.

Nichols.

Hudson.

Sand Thistle.

Boat House

Drum Point .

Davis Creek. 
BOUNDARINS OF OYSTER BARS-COntimed.

Boundaries of natural oyster bars-Continued.

Chart No. 30 (Middle Chester River and tributaries)-Continued. Page.

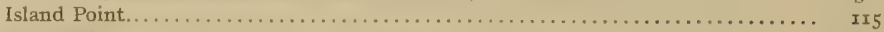

Eagle Point . . . . . . . . . . . . . . . .

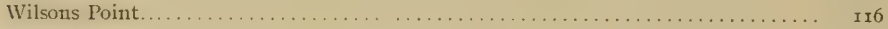

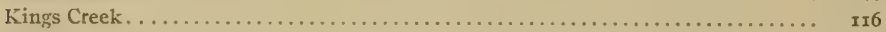

Bailey . . . . . . . . . . . . . .

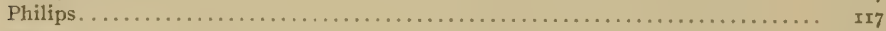

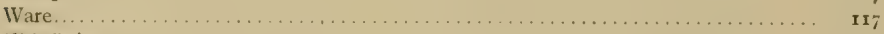

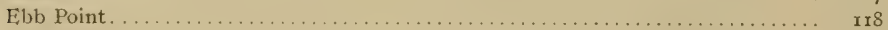

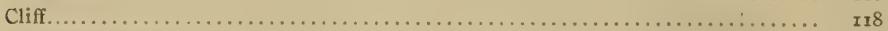

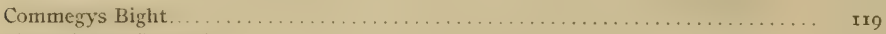

Sheep (Kent County) . . . . . . . . . . . . . . . . . . . . . . . . . . .

Deep Point . . . . . . . . . . . . . . . . . . . . . . . . . .

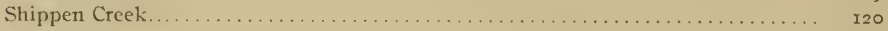

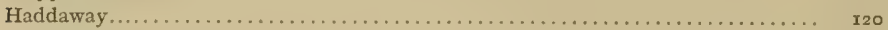

Hollyday $($ Kent County) . . . . . . . . . . . . . . . . . . . . . . . .

Melton Point . . . . . . . . . . . . . . .

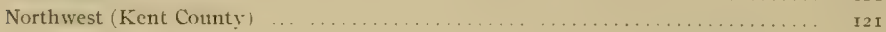

APPENDIXES:

Appendix A.- - Laws relating to the cooperation of the Coast and Geodetic Survey and Bureau

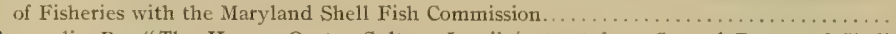

Appendix B.- "The Haman Oyster Culture Law" (extract from Second Report of Shell

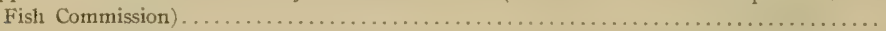

Appendix C.-Summary of the particular surveying operations which constitute an "oyster survey" as now being carried on in Maryland.

Appendix D.-Statistics of results of the combined operations of the Government and State. . 


\title{
SURVEY OF OYSTER BARS, KENT COTNTY, MD.
}

\section{INTRODUCTION.}

\author{
PUBLICATIONS.
}

The preparation of publications relating to the survey of the oyster bars of Maryland has been divided between the Government and the State in accordance with the laws ${ }^{1}$ authorizing the work and the natural division of the surveying operations ${ }^{2}$ of the cooperating forces.

The publications prepared and issued by the Government under the direction of the Superintendent of the Coast and Geodetic Survey consist of a series of charts and a technical report for each county surveyed. ${ }^{3}$ The charts show all-legal boundaries of oyster bars within the adopted houndaries of the waters opened up for leasing with each county, and the location of all landmarks (Coast and Geodetic Survey triangulation stations) used as a foundation for the delineation of these various boundaries. The technical report gives technical and legal descriptions of all oyster bar and other boundaries, and descriptions of all landmarks shown on the charts, and includes the report of the representative of the Coast and Geodetic Survey in charge of the work of that service in cooperation with the Bureau of Fisheries and the Maryland Shell Fish Commission. These charts and technical reports are prepared and certified for file with the courts and the Commission, as required by the laws of the State, and contain all information necessary to make a permanent record of the work of the Commission and the Government for all future requirements of the courts, or for any resurveys that may become necessary.

The publications prepared and issued by the State under the direction of the Shell Fish Commission consist of annual reports ${ }^{5}$ of all the operations of the Commission performed under the provisions of the laws of Maryland, including results of biological

${ }^{1}$ See Appendix A for laws relating to the cooperation of the Coast and Geodetic Survey and Bureau of Fisheries with the Maryland Shell Fish Commission.

¿See Appendix C for a summary of the particular surveying operations which constitute an "oyster survey" as now being carried on in Maryland.

${ }^{3}$ These charts and technical reports can be obtained by application to the Superintendent of the Coast and Geodetic Survey at Washington, D.C. The publications now ready for issue are those for Anne Arundel, Somerset, Wicomico, Worcester, Calvert, Charles, St. Marys, Baltimore, and Kent Counties.

The technical records and charts for each county are published separately, on account of the requirements of the oyster-culture laws of the State and the practical considerations which make it desirable to have each county "opened up "for oyster culture as soon as practicable after the completion of its survey. For these reasons and the fact that these reports are each arranged for distribution and use in one county only without reference to other published records, much of the text of this publication is of necessity identical with similar previous publications for other counties.

${ }_{5}^{5}$ These reports can be obtained by application to the Shell Fish Commission, Marine Bank Building, Baltimore, Md. They are issued annually in October, and the first, second, and third reports are now available for distribution.

"See Appendix B for an extract from the "Second Report of the Maryland Shell Fish Commission," giving a concise summary of the "Hamant Oyster Culture Law." 
and ccononic oyster investigations, methods and results of the hydrographic survey of the boundaries of oyster bars and crab bottoms, the administrative report and financial statement of the Commission, information relating to oyster culture, methods of surreying and leasing of oyster lots, and much other important matter of legal and scientific value.

These two sets of publications are planned and arranged to supplement each other without unnecessary duplication, and when combined they form a complete report of operations, methods, and results of the work of both the Government and State. ${ }^{1}$

\section{COOPERATION OF THE COAST AND GEODETIC SURVEY.}

The work of the Coast and Geodetic Survey, as the name of the service indicates, includes a survey of the coasts of the United States made on a geodetic basis. This has involved the gradual construction of a great framework of interstate triangulation for use as a foundation for detail hydrographic and topographic surveys, from which there has been compiled and published a complete set of charts of the coasts of the United States, including all waters of Maryland where oysters grow. This existing triangulation, hydrography, and topography is essential as a foundation for a correct and practical survey of natural oyster bars; and it being one of the fundamental functions of the Coast and Geodetic Survey to furnish such data, the cooperation of the Coast and Geodetic Survey with the Bureau of Fisheries and the Maryland Shell Fish Commission is a practical and natural development of Government work leading to the conservation and increase of the supply of food.

\section{COOPERATION OF THE BUREAU OF FISHERIES}

The Bureau of Fisheries has cooperated with the Coast and Geodetic Survey and the Maryland Shell Fish Commission principally as an adviser in matters relating to the biological and economic survey of oyster bars and the methods to be employed for that purpose. ${ }^{2}$ A steam launch, rowing boat, and certain apparatus have also been furnished.

The primary function of the Bureau of Fisheries is to increase the productiveness of marine and fresh waters by such measures as may be best suited to the purpose, and the services rendered in connection with the survey of the oyster bars of Maryland are strictly in line with the fundamental law under which it acts. In certain States other than Maryland similar work has been conducted by the Bureau acting independently, the same ends being attained at greater expense to the Government.

\section{GENERAL STATEMENT OF WORK OF COAST AND GEONETIC SURVEY. ${ }^{3}$}

The results obtained from the work of the Coast and Geodetic Survey in cooperation with the Bureau of Fisheries and the Maryland Shell Fish Commission need very little other summary than is indicated by the published "Charts of Natural Oyster Bars" and the index of hydrographic projections and triangulation stations shown on the county progress maps attached to each report.

\footnotetext{
'See Appendix D of this publication for "Statistics of results of combined operations of the Government and State."

${ }^{2}$ Hon. George M. Bowers, Commissioner of Fisheries, has detailed for this service Dr, H. F. Moore, Assistant, Burean of Fisheries.

${ }^{3}$ For a detail statement of the very large amount of excellent oyster-survey work of the Maryland Shell Fish Commission see the "Annual Reports of the Maryland Shell Fish Commission,"
} 
The triangulation has been carried on in accordance with the standard methods of the Coast and Geodetic Survey, making this work and that of the "Descriptions of Triangulation Stations" of permanent value, not only to the State of Maryland in the survey of her oyster bars, but also to the Government for any future work it may do in the regions covered by the oyster-survey operations.

The hydrographic projections and published charts are prepared with all the acçuracy permitted by their large scale, especially as to the boundaries of the various shell-fish bottoms in relation to landmarks, but this accuracy of location on the charts is further added to and permanently fixed by published technical descriptions which should minimize the probability of any future dispute as to either landmarks or boundaries.

Stated another way, and quoting from the report of the "Survey of Oyster Bars of Anne Arundel County":

The geographic positions of the permanent landmarks and signals have been determined with the usual precision of a trigonometric survey, and their locations at all points necessary to provide ample foundation for the surveying and charting operations permitted great accuracy of definition and location for the natural oyster bar and other boundaries established. At the same time, the very important element of permanency of the positions of boundaries has been secured, as the relocation of geodetic positions can always be accomplished by a competent surveyor, even though the original landmarks and monuments have been washed away, as has been the fate of hundreds of such points established by the Coast and Geodetic Survey on the shores of the Chesapeake Bay during the last $6_{5}$ years. 


\title{
REPORT OF THE WORK OF THE COAST AND GEODETIC SURVEY IN KENT COUNTY.
}

\author{
INSTRUCTIONS.
}

The following letters, together with the laws ${ }^{1}$ of the United States relating to the subject, constitute the "instructions" received by the chief of the Coast and Geodetic Survey party engaged on work in connection with the Maryland Shell Fish Commission. They are short and definite, but furnish ample authority and leeway for all legitimate development of the cooperation of the Government and the State in the survey of oyster bars. The "free hand" permitted by these orders, together with the aid and many valuable suggestions received from the officers of the survey at Washington, have proved very beneficial to the work and are greatly appreciated.

\section{DEPARTMENT OF COMMERCE AND LABOR, OFFICE OF THE SECRETARY, Washington, June 2, I006.}

SiR: In reply to your letter of May 28, requesting me to designate officers of the Coast and Geodetic Survey and of the Bureau of Fisheries to cooperate with the State of Maryland in making survey of and locating the natural oyster beds, I have the honor to inform you that Mr. C. C. Yates will be designated to cooperate on the part of the Coast and Geodetic Survey as soon as Congress makes the provisions of the act effective by providing an appropriation for the purpose.

Respectfully,

His Excellency Hon. EDWIN WARFIELD,

LaWrence O. MurRay, Assistant Secretary.

Governor of Maryland, Annapolis, Md.

DEPARTMENT OF COMMERCE AND LABOR, Coast and Geodetic Survey, Vashington, July 3, I906.

SiR: Upon the receipt of these instructions you will surrender the command, accounts, etc, of the steamer Endeavor to the Hydrographic Inspector.

As soon as this transfer is completed you will enter upon the duties of Coast Survey representative on the Shell Fish Commission of Maryland.

You will consult the Commissioners, prepare a programme of work, and submit estimates in the usual form.

You are authorized to come to Washington for consultation from time to time as may be necessary.

* Very respectfully,

O. H. Trmmann, Superintendent.

Capt. C. C. Yates,

U. S. C. and G. S. Steamer Endeavor, Baltimore, Md.

For these laws see Appendix $\mathbf{A}$. 


\section{ORGANIZATION AND EQUIPMENT.}

The personnel and occupation of the party of the Coast and Geodetic Survey have remained practically unchanged since the beginning of the "oyster survey." Besides the chief of pàrty, it consists of the necessary triangulators, computers, draftsmen, and temporary employees required to carry on both the surveying operations in the field and the preparation for publication of oyster charts and technical records in the office at Washington.

The equipment for the work of the party has been ample and satisfactory. The large living and office quarters furnished the Govemment on the Maryland Shell Fish Commission house boat Oyster have been very convenient for the work, besides facilitating efficient cooperation with the surveying and oyster investigation parties of the State. In addition to the accommodations on the Oyster, the Coast and Geodetic Survey party has had the constant use of the large steam launch Inspector and several other boats furnished by its own service, and the occasional use of the Bureau of Fisheries launch Canvasback ${ }^{1}$ and the steamer Governor McLane ${ }^{2}$ of the State fishery force.

The greater part of the equipment of instruments for the operations of both the Government and State has been furnished by the Coast and Geodetic Survey and consists of all necessary theodolites, levels, sextants, drafting instruments, hydrometers, etc., required for all field and office work.

\section{CHRONOLOGICAL STATEMENT OF WORK.}

The field work of the Coast and Geodetic Survey in Kent County ${ }^{3}$ dates from April 14, 1909, when the Maryland Shell Fish Commission house boat Oyster was moved from her winter quarters at Baltimore to an anchorage off Rock Hall Landing in Kent County. The surveying operations carried on from this harbor covered a period of about six weeks in which practically all triangulation was completed on the Chesapeake Bay shores of both Kent and Baltimore Counties as well as a considerable part of the same class of work in the mouth of Chester River in both Kent and Queen Annes counties.

On May 26, 1909, the Oyster was moved from Rock Hall Landing to an anchorage in the upper part of Chester River near Cliffs I anding where she remained for a little over a month.

On June 30, 1909, the house boat was moved to a temporary anchorage off Queenstown in the lower Chester River. This date marked the practical completion of the work in Chester River, the triangulation of which was especially notable for the month of June on account of there having been 92 triangulation stations established which were all marked by monuments and signals, locations described, and then occupied for theodolite observations.

On July x, 1909, the house boat Oyster was towed by the State steamer Governor McLane to Baltimore Harbor, where the following four days, which included a Sunday and a holiday, were spent in taking on coal, water, and other supplies.

\footnotetext{
${ }^{1}$ By courtesy of Dr. H. F. Moore, United States Bureat of Fisheries.

${ }^{2}$ By courtesy of Capt. James A. Turner, commanding.

${ }^{3}$ The field work of Kent, Baltimore, and Queen Annes counties was so intermixed that the chronological statement of the work of one of these counties necessarily includes a considerable part of the work of the other two counties.
}

$14126-12-2$ 
On July 6, rgog, the Governor McLane again moved the Oyster, this time from Baltimore to an anchorage in Queen Annes County in the Eastern Bay entrance of Kent Narrows. From this harbor as headquarters a few additional triangulation observations were made in Kent County although the greater part of work while the house boat was at this anchorage was confined to Queen Annes and 'lalbot counties.

On July 22, 1909, the house boat was again moved to the vicinity of Rock Hall I anding to complete certain oyster survey operations not finished when the Oyster was anchored there in the spring.

On August 5, 1909, the house boat was towed to Worton Creek which is located at the extreme northern limit of oyster growth in Chesapeake Bay. From this harbor all the remaining oyster survey work of the Coast and Geodetic Survey in both Kent and Baltimore counties was completed, although some weeks later a Maryland Shell Fish Commission party returned to these counties to finish certain oyster investigations and hydrographic observations.

The office work connected with the "oyster survey" of Kent County, including compilations of geographic information and drafting necessary for the preparation for publication of the oyster charts and the technical records, was continued intermittingly with the office work of other counties from the beginning of the field work in Kent County to the time of filing of the certified oyster charts and technical reports in the archives of the Shell Fish Commission and with the clerk of the circuit court of Kent County on October 5 , I9xi.

\section{STATISTICS. ${ }^{1}$}

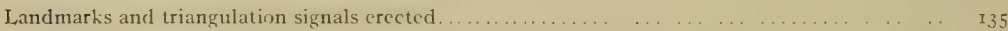

Monuments planted to mark triangulation stations. . . . . . . $\ldots \ldots \ldots \ldots \ldots \ldots \ldots \ldots \ldots \ldots \ldots \ldots \ldots$

Triangulation stations occupied for observations of horizontal angles. . . . . . . . . . . .

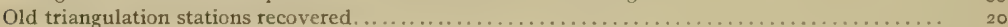

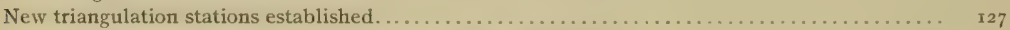

Total old and new triangulation stations marked and described.................... I47

Linear miles of shore line covered by triangulation (approximate) $\ldots \ldots \ldots \ldots \ldots \ldots \ldots \ldots$ IIO

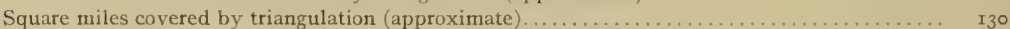

Hydrographic projections prepared and completed as records of oyster boundaries........... Io

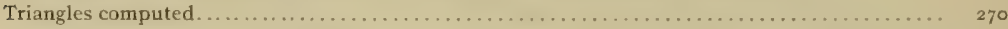

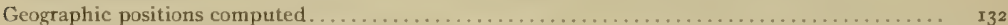

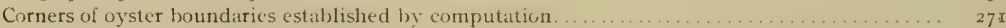

I3ack azimuths and distances computed from cornets of boundaries to triangulation stations..... 8 3

Descriptions of triangulation stations prepared for publication $\ldots \ldots \ldots \ldots \ldots \ldots \ldots \ldots \ldots \ldots . \quad$ I47

Descriptions of oyster boundaries prepared for publication. . . . . . . . . . . . . . . . . . . . 64

"Charts of Natural Oyster Bars" prepared for publication. ......................... 3

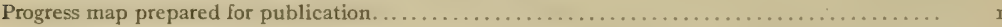

1 These statistics only include field and office work directly performed by the party of the Coast and Geodetic Survey in connection with the oyster survey of Kent County, and do not include the many thousands of soundings and examinations of the character of the bottom made by the engineers of the Commission, which are of considerable value to the Coast and Geodetic Survey as hydrographic records for future use in connection with the preparation of new editions of charts of the waters of Maryland. See Appendix D of this publication for "Statistics of results of combined operations of the Government and the State," 
Before ending this report the representative of the Coast and Geodetic Survey wishes to renew his statement of appreciation of the courteous assistance received from various Government and State officials and others interested in the oyster industry of Maryland, especially to the following:

To his colleague from the Department of Commerce and Labor, Dr. H. F. Moore, of the Burean of Fisheries, whose well-known seientific knowledge of all matters relating to oysters has been of great value to the work.

To Mr. Walter J. Mitchell, chairman of the Maryland Shell Fish Commission, who, by his administrative ability in carrying out the complicated requirements of the oyster laws and by his unfailing tact, has made the cooperation of the various services engaged on the work both agreeable and effective.

To Dr. Caswell Grave, secretary of the Commission, who, as editor of the Commission's annual report and Commissioner in charge of the biological and economic oyster investigations, has been brought into constant contact with the Government work and aided its operations in every way.

To Mr. Benjamin K. Green, treasurer of the Commission, who has looked after the equipment and commissary of the house boat in such a way as to add greatly to the comfort and convenience of the party of the Coast and Geodetic Survey.

To Mr. Swepson Earle, hydrographic engineer to the Commission, whose knowledge of the work from former service in the Coast and Geodetic Survey has greatly facilitated his practical use of the technical data furnished by the Government.

And to the many others connected with the Commission or who as residents in the locality where the work was being carried on have greatly assisted by furnishing important information or willing services. 


\section{CHARTS AND MAPS.}

CHARTS OF NATURAL OYSTER IBARS.

The charts ${ }^{1}$ of the natural oyster bars of Kent County, published by the Coast and Geodetic Survey from results of surveys of the Government in cooperation with the Maryland Shell Fish Commission, consist of three sheets covering a portion of the waters of Chesapeake Bay and all of Chester River, including all oyster-producing bottoms of Kent County. They are published on a scale of I part in 20,000 (approximately $33_{6}^{\prime}$ inch to a statute mile) and are constructed on polyconic projections and based on the United States standard datum of the Coast and Geodetic Survey.

These charts show all oyster bars and other boundaries established by the Commission, and are certified for the purpose of filing in the office of the clerk of the Circuit Court of Kent County and in the office of the Commission, as required by the oyster laws of Maryland.

In addition to the oyster bar and other boundaries, the charts show the location and name of all landmarks (U. S. Coast and Geodetic Survey triangulation stations) used in making the survey, together with the hydrography and topography ${ }^{2}$ necessary to make the technical definitions and delineations of boundaries readily understandable both by the people engaged in the oyster industry and the general public who may become interested through leasing of barren bottoms for oyster culture.

The names of the oyster bars are those used locally, as nearly as could be ascertained by the hydrographic engineer of the Commission. When there was no local name in common use, a name was selected from one of the prominent features of the vicinity. By the use of recognized names or those that would naturally suggest certain sections of water, it is believed that much confusion will be avoided in the location on the charts of the oyster bars, especially by those not familiar with the use of maps.

The corners of the oyster bars are numbered from I to the total number of corners in each area under consideration. Where boundaries adjoin, making one point a corner of two or more oyster bars, these points have two or more numbers, each number corresponding to the bar in which the figure is located. The numbers of the corners correspond with the technical and legal descriptions of this publication under the heading "Boundaries of natural oyster bars."

The landmarks and oyster bars have been grouped in the "Contents" of this publieation in accordance with the charts upon which they are shown. To find a particular oyster bar or landmark which is only known by name, consult the "Contents" and the desired chart and general location will be indicated. To find the name of a bar or landmark which is only known by location, consult the progress map at the end of this publication for the number of the chart on which it is to be found, and then examine the known locality on the chart for the name of the bar or landmark in question.

\footnotetext{
1 These charts can be obtained by application to the Superintendent of the Coast and Geodetic Survey, at WVashington, D. C.

2 Much of the detail of the inshore topography was obtained from the excellent map of Kent County. prepared and published by the Maryland Geological Survey under the direction of Dr. W'illiam Bullock Clark from surveys of the Maryland Geological Survey in cooperation with the U. S. Geological Survey.
} 
The contours on the charts showing the depth of water at mean low tide have been taken from the hydrographic sheets of former work of the Coast and Geodetic Survey. Four curves were selected as being the most convenient for taking of from the original hydrographic sheets and the ones of greatest value to those interested in shell fish industries. The $\mathrm{I}$-fathom contour ( 6 feet) and the 5 -fathom curve (3o feet) correspond in a general way to the inner and outer limits of all the oyster bars surveyed. The 3 -fathom contour ( 8 feet) furnishes the curve of about the average depth of water on the oyster bars and the Io-fathom contour ( 60 feet) serves in a general way to indicate the outer limits of probable oyster culture.

The boundaries of the waters within the "territorial limits of the county" and the boundaries of the "waters contiguous to the county" opened up for the leasing with Kent County are plainly indicated on the charts. A full technical description of these boundaries is given in this publication under the heading "Boundaries of county waters."

The areas in acres of the oyster bars were determined under the direction of the lydrographic engineer of the Commission by two independent planimeter measurements of the areas as delineated on the smooth projections of the Coast and Geodetic Survey. These areas are given in small figures in parentheses on the face of the chart within the boundaries of the different shell fish bottoms.

The symbols used on the charts for the different kinds of boundaries, triangulation stations, contours of depth of water, etc., require no other explanation than that given in the legend and other notes on the face of the charts.

\section{LEASING CHARTS.}

The leasing charts of Kent County, like those for Anne Arundel, Somerset, Wicomico, Worcester, Calvert, Charles, St. Marys, and Baltimore counties, have been prepared under the direction of the hydrographic engineer of the Commission. They are constructed on polyconic projections which are based on the United States standard datum of the Coast and Geodetic Survey, and are made on the scales of I part in 5,000 or I part in 10,000 as the needs of oyster culture may require.

These charts show all the oyster bars, crab bottoms, and clam beds and other boundaries established by the Commission, and also all boundaries of oyster lots leased for the purpose of oyster culture, thus making them comprehensive and valuable records of the results of the operations of the oyster-culture laws.

The lots leased under the provision of the "old 5-acre law" are frequently of irregular shape, but the lots leased under the provision of the new oyster laws must be of rectangular shape by the terms of that act. For this latter purpose the leasing charts have been divided by parallels of latitude and mericlians of longitude into small rectangles of $I$ acre or 5 acres, as may be best suited to the area under consideration, and prospective leaseholders by the rules of the Commission are compelled to select whole rectangles as far as possible.

For reasons of the present changeable nature of the number of lots leased and the large number of charts required, the leasing charts are not likely to be published for some years, but they can be seen at any time on file at the offices of the Commission, in the Marine Bank Building at Baltimore. 


\section{PROJECTIONS.}

The polyconic projections ${ }^{1}$ covering Kent County waters are Io in number and on the scale of I part in ro,ooo. They were constructed by draftsmen of the Coast and Geodetic Survey, but the sextant positions which determine the location of the legal houndaries of the oyster bars as delineated by the Shell Fish Commission were plotted by the draftsman of the Commission.

A copy of each of these projections, with all the plotted positions of triangulation stations, shore lines, sextant positions, and boundaries of oyster bars, was made under the direction of the hydrographic engineer of the Commission by pricking through with a sharp needle the intersections of the projection lines and all other points as plotted on the original sheets.

These projections (in duplicate) are the original records of all oyster-bar and other boundaries established by the Commission, one set being filed in the archives of the Coast and Geodetic Survey, at Washington, and the other set in the archives of the Shell Fish Commission.

\section{PROGRESS MIAPS.}

The progress map to be found at the end of this publication is on a scale of I part in 100,000 , and shows in outline the work accomplished by the United States Coast and Geodetic Survey in Kent County and contiguous waters. It gives the scheme of all the charts and smooth projections constructed in connection with the survey, the location and names of all triangulation stations used as a basis for the surveying work, and the "boundaries of county waters" established by the Commission for the purpose of carrying out the laws of Maryland relating to oyster culture.

Besides indicating the amount of work done by the Coast and Geodetic Survey in connection with the work of the Shell Fish Commission, this progress map will be of special value for index purposes to engineers and others searching for the particular chart or projection covering the locality of the oyster bars or landmarks that may be under consideration.

The progress maps ${ }^{2}$ accompanying the first and second annual reports of the Maryland Shell Fish Commission were prepared under the direction of the hydrographic engineer of the Commission. They are on the scale of 1 part in 400,000 , and show the outline of the tide-water comnties of Maryland, with shaded areas to indicate the waters already covered by the operations of the oyster survey.

1 For the scheme of these projections sec the progress map at the end of this nublication.

2 These maps and renotts can be obtained by application to Maryland Shell Fish Cummission, Marine Bank Building, Baltimore, Md 


\title{
BOUNDARIES OF THE COUN'TY WATERS. ${ }^{1}$
}

\author{
WATERS WITHIN TERRITORIAL, LIMITS OF COUNTY.
}

The laws of Maryland relating to oyster culture provide that "no person shall be permitted, by lease, assignment, or in any other manner, to acquire a greater amount of land than ten acres situated within the territorial limits of any of the counties, or one hundred acres in any other place."

The boundary line 2 between the waters "within the territorial limits" of Kent County and the waters in "any other place," as established by the Shell Fish Commission for the purpose of carrying out the oyster laws, and delineated on the "oyster" charts and the smooth projections of the Coast and Geodetic Survey, is technically described and defined as follows:

Following the boundary line between Kent County and Cecil County along the middle of Sassafras River as laid down on the "Progress map" accompanying the report of "Survey of Oyster Bars, Kent County; Maryland, " to a point defined by the intersection of this boundary line with a straight line across the mouth of Sassafras River defined by a point at its northern extremity situated on the northern side of Sassafras River in latitude $39^{\circ} 23^{\prime} 15^{\prime \prime} .0$ and longitude $76^{\circ} 02^{\prime} 22^{\prime \prime} .5$ and by a point at its southerm extremity situated on the southern side of Sassafras River in latitude $39^{\circ} 22^{\prime}$ I $5^{\prime \prime} .6$ and longitude $76^{\circ} 03^{\prime}$ $24^{\prime \prime} .0$; thence along a straight line across the southern part of the mouth of Sassafras River to a point situated on the southern side of Sassafras River defined by latitude $39^{\circ} 22^{\prime} I_{5}^{\prime \prime} .6$ and longitude $76^{\circ} \circ 3^{\prime}$ $24^{\prime \prime}$. 0 ; thence along the mean low water line or a line across the mouth of all inlets less than roo yards in width, as the case may be, of the southern shore of the entrance to Sassafras River, around Howell Point and along the eastern shore of Chesapeake Bay to a point situated on the northern side of Still Pond defined by latitude $39^{\circ} 20^{\prime} 35^{\prime \prime}$. o and longitude $76^{\circ} 08^{\prime} x \mathrm{I}^{\prime \prime} .8$; thence in a straight line across the entrance to Still Pond to a point situated on the southern side of Still Pond defined by latitude $39^{\circ} 20^{\prime} \mathrm{oz}^{\prime \prime} .0$ and longitude $76^{\circ} 08^{\prime} 46^{\prime \prime} .5$; thence along the mean low water line or across the mouth of all inlets less than roo yards in width, as the case may be, of the eastern shore of Chesapeake Bay around Plum Point and Worton Point to a point situated on the northern side of Worton Creek defined by latitude $39^{\circ} I^{\prime} 7^{\prime} 6^{\prime \prime} \cdot 7$ and Iongitude $76^{\circ} 10^{\prime} 40^{\prime \prime} .8$; thence in a straight line across the entrance of Worton Creek to a point situated on the southern side of Worton Creek defined by latitude $39^{\circ} I 7^{\prime} 28^{\prime \prime} .3$ and longitude $76^{\circ} 10^{\prime}$ $54^{\prime \prime} \cdot 3$; thence along the mean low water line or across the motth of all inlets less than roo yards in width, as the case may be, of the eastern shore of Chesapeake Bay across the mouth of Fairlee Creek past Tolchester Beach to a point situated on Swan Point defined by latitude $39^{\circ} 08^{\prime}$ I $9^{\prime \prime}$. 0 and longitude $76^{\circ} 16^{\prime} 42^{\prime \prime}$. I; thence in a straight line across the entrance to Swan Creek and Rockhall Harbor to a point situated on Huntingfield Point defined by latitude $39^{\circ} \circ 7^{\prime} I 6^{\prime \prime} . \circ$ and longitude $76^{\circ} I 4^{\prime} 57^{\prime \prime} .4$; thence along the mean low water line or across the mouth of all inlets less than roo yards in width, as the case may be, of the eastern shore of Chesapeake Bay to a point situated on Wilson Point defined by latitude $39^{\circ} \mathrm{O} 3^{\prime} \mathrm{II}^{\prime \prime} .2$ and longitude $76^{\circ} \mathrm{I}_{3^{\prime}} 40^{\prime \prime} .0$; thence in a straight line across the mouth of a small bay to a point situated on the eastern side of the entrance to Chester River defined by latitude $39^{\circ} 02^{\prime} 45^{\prime \prime} \cdot 3$ and

\footnotetext{
2 For a complete historical and legal description of the boundaries of the counties of Maryland, the valuable publication entitled "The Counties of Maryland-Their Origin, Boundaries, and Election Districts," prepared by. Dr. Ėdward B. Aathews and published by the Maryland Geolocical Survey under the direction of Dr. William Bullock Clark, Strperintendent, should be consulted, as the boundaries described in this publication have been established and technically defined for the purpose of carrying out the oyster laws of the State, and may or may not be correct for other purposes.

2 See Charts of Natural Oyster Bars, published by the Coast and Geodetic Survey, and the progress map at the end of this publication.
} 
Iongitude $76^{\circ} 14^{\prime} \circ 5^{\prime \prime} \cdot 3$; thence in a straight line ending at a point situated on Love Point on the western side of Chester River defined by latitude $39^{\circ} 02^{\prime} 25^{\prime \prime} .5$ and longitude $76^{\circ} 18^{\prime} 10^{\prime \prime} .0$ to a point on this straight line defined by its intersection with the channel boundary line between Kent County and Queen Annes County as laid down on "Chart No. 29, Natural Oyster Bars, Maryland;" thence up the channel of Chester River following the boundary line between Kent Cointy and Queen Annes County as laid down on "Charts Nos. 29 and 30 , Natural Oyster Bars, Maryland;" thence continuing up the channel of Chester River following the boundary line between Kent County and Queen Annes County to the State boundary line between Maryland and Delaware. ${ }^{1}$

\section{WATERS CONTIGUOUS TO COUNTY.}

The oyster laws of Maryland provide that a true and accurate delineation of all natural oyster bars shall be made on copies of charts of the United States Coast and Geodetic Survey, "which said copies shall be filed in the office of the said Commissioners in the city of Baltimore," and "in the office of the clerks of the circuit courts for the respective counties wherein the grounds so designated may lie."

For the purpose of carrying out the latter part of this section of the law and for the purpose of establishing the limits of the oyster-culture area to be opened up for leasing with each county surreyed, it is necessary for the Shell Fish Commission to establish a boundary line between the waters contiguous to but not within the territorial limits of each county and the waters contiguous to but not within the territorial limits of adjacent counties.

This boundary line has been delineated on "Charts of Natural Oyster Bars," and "Progress Maps" published by the Coast and Geodetic Survey, and is technically described and defined as follows:

Commencing at a point defined by the intersection of a straight line across the mouth of Sassafras River which straight line is defined by a point at its northern extremity situated on the northern side of Sassafras River in latitude $39^{\circ} 23^{\prime} I 5^{\prime \prime}$. 0 and longitude $76^{\circ} 02^{\prime} 22^{\prime \prime} .5$ and by a point at its southern extremity situated on the southern side of Sassafras River in latitude $39^{\circ} 22^{\prime} I 5^{\prime \prime} .6$ and longitude $76^{\circ} \circ 3^{\prime} 24^{\prime \prime} .0$ and the boundary line between Kent County and Cecil County along the middle of Sassafras River as laid down on the "Progress map" accompanying the report of "Survey of Oyster Bars, Kent County, Maryland;" thence in a straight line along the channel of the entrance to Sassafras River and across a part of Chesapeake Bay to a point in Chesapeake Bay about $x^{1 / 2}$ miles northwest by west of Howell Point and $\mathrm{I} 3 / 4$ miles south-southeast of Stony Point defined by latitude $39^{\circ} 22^{\prime} 55^{\prime \prime} .0$ and longitude $76^{\circ} 08^{\prime}$ $05^{\prime \prime} .0$; thence in a straight line with Chesapeake Bay to a point about $22^{3} / 4$ miles west of Worton Point and $2 \frac{1}{2}$ miles northeast of Pooles Island defined by latitude $39^{\circ} 19^{\prime} 00^{\prime \prime} .0$ and longitude $76^{\circ} 13^{\prime} 43^{\prime \prime} \cdot 5$; thence in a straight line with Chesapeake Bay to a point about $x_{16}^{1}$ miles south of Pooles Island and $3^{5 / 3}$ miles west by south of Fairlee Creek defined by latitude $39^{\circ} 15^{\prime} 30^{\prime \prime} .0$ and longitude $76^{\circ}$ I6 $20^{\prime \prime} .4$; thence in a straight line with Chesapeake Bay to a point about 4 miles west by north of Swan Point and $3 \frac{3}{10}$ miles east of Seven Foot Knoll Light defined by latitude $39^{\circ} 09^{\prime} 10^{\prime \prime} .6$ and longitude $76^{\circ} 21^{\prime} 00^{\prime \prime} .0$; thence in a straight line with Chesapeake Bay to a point about $25 / 8$ miles east of Baltimore Light and $3^{5 / 8}$ miles west of I ove Point Light defined by latitude $39^{\circ} 03^{\prime} 30^{\prime \prime} .0$ and longitude $76^{\circ} 21^{\prime} \infty 0^{\prime \prime} .0$; thence along the boundary line between Kent County and Queen Annes County across a part of Chesapeake Bay and along the channel of the entrance of Chester River as laid down on "Chart No. 29, Natural Oyster Bars, Maryland, " to the intersection of this county boundary line with a straight line defined by a point at its eastern extremity situated on the eastern side of the entrance of Chester River in latitude $39^{\circ} \mathrm{o} 2^{\prime}$ $45^{\prime \prime} \cdot 3$ and longitude $76^{\circ} 14^{\prime} \circ 5^{\prime \prime} \cdot 3$ and by a point at its western extremity situated on Love Point on the western side of the entrance to Chester River in latitude $39^{\circ} 02^{\prime} 25^{\prime \prime} \cdot 5$ and longitude $76^{\circ} 18^{\prime} 10^{\prime \prime} .0 .^{1}$

1 Latitudes and longitudes based on the United States standard datum of the United States Coast and Geodetic Survey. 


\section{LANDMARKS (U. S. COAST AND GEODETTIC SURVEY TRIANGULATION STATIONS:}

F.SPI,ANATION.

The oyster laws of Maryland authorizing the survey to be made by the Shell Fish Commission provide for "an accurate report of said survey, setting forth such a description of laridmarks as may be necessary to enable the said hoard, or their successors, to find and ascertain the boundary lines of said natural oyster beds, hars, and rocks, as shown by delineation on the maps and charts." The law of the United States authorizing the cooperation of the Department of Commerce and Labor in the survey of natural oyster bars of Maryland provides for the erection of "such structures as may be necessary to mark the points of triangulation, so that the same may be used for such future work of the Coast and Geodic Survey as the said Bureau may be hereafter required to perform in prosecuting the Government coast survey of the navigable waters of the United States located within the State of Maryland."

Under the provisions of the sections of the laws stated above, the markings and descriptions of landmarks must be sufficient for the present and future needs of both the Government and the State. With this end in view, considerable work has been expended in erecting permanent monuments at the triangulation stations and in the proper description of their location.

An effort has been made to arrange the descriptions of location and character of landmarks in a uniform and logical manner. The descriptions start with the assumption that the individual seeking a landmark has only an indefinite idea of its location. They gradually proceed from description of the general locality of a landmark to the descriptions of its immediate surroundings. This is followed by specific details of the character of the center and reference marks and a "round" of reference angles and distances which in themselves frequently contain enough information to furnish an inclependent and reliable location of the triangulation station.

METHOI OF IOESCRIBING TRIANGULATION STATIONS.

The separate descriptions of triangulation stations should not be uscd without reading the following explanation of the method of describing the trianqulation stations, as it contains certain details that are common to all the landmarks described in this publication and which are omitted in the separate descriptions as heing necdless repetitions:

Name.-The title at the top of each separate description is the name by which the landmark or triangulation station is known and designated in all work and published oyster records or oyster charts of hoth the forernment and State. The selection of the name is usually left to the triangulator establishing the station, and it may or may not have geographic or other significance in reference to the locality.

Gencral locality.-Under this heading is given the general locality of the landmark in reference to well-known and prominent natural or artificial features, such as the 
nearest body of water, town, river, steamer wharf, well-defined point of land, church, or any other feature that is likely to remain both permanent and prominent.

This heading also covers a reference to the published chart or map which shows the location of the station most clearly. Nearly all the triangulation stations described in this publication are plainly indicated by name and a triangulation symbol on the published charts of oyster bars of Maryland. In this case they are referred to by serial number only, the words "charts of oyster bars of Maryland" being omitted to avoid needless repetition. These published oyster charts are on the large scale of I part in 20,000 (approximately $3 \frac{1}{6}$ inches to a statute mile) and show the location of the triangulation stations so clearly that in many cases the written descriptions will not be required to find them.

Immediate locality.--Under this heading is given the description of the "observed station" in reference to its immediate surroundings. This is supposed to include a statement of the station's estimated elevation above high water or some other welldefined level of the locality, such as a road or house; the character of the ground on which it is located, such as marsh land, sand beach, cultivated field, or meadow; estimated bearings in points of the compass and estimated distances in yards from (not to) casily recognized features, such as extreme end of point, edge of bluff, bank of creek, line of telephone poles, shore line, barn, house, fence, ditch, trees, or any other definite detail, such as being on range with the tangent of an island and a church; and so forth.

When a standard monument has been established near the station as a "reference station," this heading also covers a statement of the true bearing of the monument in degrees and minutes and its measured distance in meters, as it is the first object that is likely to catch the eye when the immediate vicinity of the desired station is reached and might be mistaken for the center mark of the "observed station" unless special attention is called to it.

The distinction between the "observed station" and "reference station" should be carefully noted by anyone making use of the description of stations for any future surveving operations.

The "observed station" is located at the particular triangulation point covered by the description of stations, and is the one whose geographic position is first computed, as it is the point which was "occupied" and "observed on" for horizontal angles. However, in spite of the primary importance of the location of the "observed station," it will be noted from the description of stations that frequently it is not marked as well as the "reference station," and in many instances has only a pine stub to indicate its position. This is the case for the reason that the necessity of intervisibility of landmarks usually made it compulsory to locate "observed stations" on edges of banks and ends of points of land, which in the tide-water section of Maryland generally means they will be washed away in a short period of years. The past experience of the Coast and Geodetic Survey in this region has shown the great need of "reference stations," if the frequent reestablishment of a new framework of triangulation is to be avoided.

The chief reason and need for the establishment of the "reference station," or secondary station, as it might be well named, is explained in the preceding paragraph, but in several instances other reasons, such as the location of the "observed station" on an unstable sand dune, in a cultivated field, in front of a residence, or other places objectionable to the landowner, have led to establishment of "reference stations." 
The location of the "reference station" in relation to the "observed station" is fixed for plotting on charts or for computation of its geographic position by checked measurements of its distances and azimuth from the "observed station." I

Marks.-Under this heading is given a description of the character of the permanent monuments or other marks of the location of the "observed station," and of the "refer. ence station". where one has been established.

All the marks designated in the descriptions as "the center point of triangle on standard cement monument" are exactly alike. These monuments are made of cement, sand, and gravel, and are 2 feet long and 8 inches square at top and bottom. Their tops are all marked with the same brass mold and show a center hole surrounded by a triangle, with the letters "M. S. F. C." arranged around the vertex and the letters "U. S. C. S." underneath the base of the triangle. The center hole is always in the center of the top of the monument by construction, and if this is found to have been broken off without disturbing the bottom the center of its square section can be used as the location of the station.

All the "standard cement monuments," whether used for marking the "observed station" or "reference station," have been planted upright in exactly the same manner, with their tops projecting 3 or 4 inches above the surface of the ground, unless otherwise stated.

Therefore, as the above facts in reference to the "standard cement monuments" are a constant element in all cases, the repetition of these facts in the description of stations is made needless by this one statement.

References.--Under this heading are given the "rounds" of directions and distances to all objects that might be useful in locating the stations when the surface marks can not be found. It is also contemplated that for general purposes of topography, hydrography, or location of boundaries of oyster bars these references will be sufficient in many cases to relocate the position of an "observed station" or "reference station" when both of them have been destroyed.

The first reference object given in the descriptions is always a triangulation station visible from the station being described, this, if possible, being a lighthouse, church spire, or other permanent and prominent point. Its direction is taken as being $\mathrm{O}^{\circ} \mathrm{OO}^{\prime} \mathrm{OO}^{\prime \prime}$, and the directions of all other objects are measured from it as an initial point, the angles bcing taken in a clockwise direction (left to right).

The true bearing ${ }^{2}$ of the initial object is always given in parentheses alongside its name. This furnishes means for the calculation of the bearings of any of the other reference objects for the purposes of locating a station by horizontal angles or for the relocation of corner buoys of oyster-bar boundaries by the method of compass directions described in this publication under the heading of "Boundaries of oyster bars."

The distances in the last column under "References" are given in three different units, which vary according to their accuracy. The "miles" are statute miles and may be considered only as rough estimates. The "yards" are more accurate, but must be looked on as results generally obtained by pacing or careful estimating. The "meters,"

\footnotetext{
${ }^{1}$ Geographic coordinates (latitude, longitude, distance, and azimuth) relating to any of the "observed stations" or of the "reference stations" described in this publication can be obtained by application to the Superintendent of the Coast and Geodetic Survey, at Washington, D. C.

${ }^{2}$ The mean magnetic variation for Kent County was $6^{\circ}+5^{\prime}$ west of north in rgar and increasing at the rate of $5^{\prime}$ yearly.
} 
however, are accurate to the degree indicated by their decimals, and in every case have been measured with a steel tape. In the same manner the accuracy of the directions are indicated by the refinement of angular measure with which they are recorded.

\section{DESCRIPTIONS OF TRIANGULATION STATIONS.}

\section{WORTON POINT 2.}

General locality.-Eastern shore of Chesapeake Bay, on Worton Point, about $I 3 / 8$ miles north of mouth of Worton Creek and $4^{\mathrm{T}} / 2$ miles northeast of north end of Pooles Island. (See Chart No. 28.)

Immediate locality.-Observed station is on tree and bush fringed bluff about 30 feet above high water, 2 yards east-southeast of edge of bluff and I yard south-southwest of a very small ravine. Cement monument marking reference station is 14.05 meters $\mathrm{S} 6 \mathrm{I}^{\circ} \mathrm{I} 7^{\prime} \mathrm{E}$ of observed station.

Marks.-Observed station is center of 4 -inch tile pipe with top 6 inches below surface of ground. Subsurface mark is center of 4 -inch tile pipe buried with top 2 inches below base of surface pipe. Reference station is center point of triangle on standard cement monument projecting 4 inches above surface of ground.
References.--
"Pooles Island 2 " (S $\left.62^{\circ} 18^{\prime} \mathrm{W}\right) \ldots \ldots \ldots$
Right tree on Pooles Island. . . . . . . . . . .
South peak of small house.............. 4
Left peak of house ...................
Nail in blaze in ash tree $\left(2 \frac{1}{2}\right.$ inches diameter)
Chimney outside of right end of old house.
Chimney near left end of roof of house with gables......................... Ir6 o4 .......
Nail in blaze in ash tree ( 3 inches diameter). ${ }_{54} \quad 28$ 10 .....

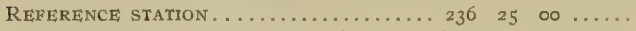
Nail in blaze in locust tree $(5$ inches
diameter) ..................... $310 \quad 4420 \ldots \ldots$

$$
\begin{aligned}
& 4^{5 / 8} \text { miles. } \\
& 4^{1 / 2} \text { miles. } \\
& 4^{\mathrm{T} / 2} \text { miles. } \\
& 4^{\mathrm{T}} / 2 \text { miles. } \\
& \text { I. } 06 \text { meters. } \\
& 3^{\mathrm{T} / 2} \text { miles. } \\
& 4^{\mathrm{T}} / 4 \text { miles. } \\
& 4^{2} 4^{2} \text { meters. }
\end{aligned}
$$$$
\text { I4.05 meters. }
$$
4.6 I meters.

\section{POOLES ISLAND LIGHT.}

General locality.-Upper Chesapeake Bay, on northwest side of Pooles Island. (See Chart No. 28.) Immediate locality.-Observed station is on a detached tower known as Pooles Island Lighthouse. Marks.-Observed station is center point of lantern on tower.

References.-

$$
\begin{aligned}
& \text { "Craighill Channel Light (Front Range)" } \circ \text {, " } \\
& \left(\mathrm{S} 44^{\circ} \mathrm{rg}^{\prime} \mathrm{W}\right) \ldots \ldots \ldots \ldots \ldots \ldots \ldots \ldots \ldots \ldots \\
& \hline
\end{aligned}
$$

\section{POOLES ISI,AND 2.}

General locality - Upper Chesapeake Bay, on Pooles Island, about one-fourth mile southeast of Pooles Island Light and one-fourth mile north by west of Pooles Island Wharf. (See Chart No. 28.)

Immediate locality.-Observed station is in a peach orchard on highest ground on northern part of Pooles Island, about 500 yards southeast of Pooles Island Light and 370 yards north by west of farmhouse. The angle at the southwest corner of the farmhouse between the windmill at the barn and the observed station is $84^{\circ}$, and the angle at the observed station between the light tower and the fog-bell tower is $2^{\circ} 47^{\prime}$.

Marks.-Observed station is center point of triangle on standard cement monument projecting 4 inches above surface of ground. Subsurface mark is center of 2 -inch tile pipe buried with top 2 inches below base of monument. (NotE.-These marks replace old ones of 1896. ) 
References.-

"Pooles Island Light" ( $\left.47^{\circ} 16^{\prime} \mathrm{W}\right) \ldots .$.

Break in bluff on east shore of bay showing

through peach trees .................

dwelling .........................

Center of middle one of three chimneys on

dwelling . . . . . . . . . . . . . . . 218

Center of cupola on small building........ 220

Near gable of barn .................. $23^{8}$

Windmill........................ 241

Center one of four mails in apple tree . . . . . 3360 . 24 ...

Center one of four nails in apple tree.... $336 \quad 24 \quad 10 \quad \ldots \ldots$

$45^{2}$ meters.

$3^{2}+$ miles.

It mile.

$1 / 4$ mile.

$1 / 4$ mile.

$1 / 4$ mile.

$1 / 4$ mile.

33.72 meters.

\section{BRAMBLE.}

General locality.-Eastern shore of Chesapeake Bay, about 3 miles southeast of center of Pooles Island, 3 miles north-northeast of Tolchester Beach, and $1 / 4$ miles southwest of entrance to Fairlec Creek. (See Chart No. 28.)

Immediale locality. - Observed station is on a tree and bush fringed bluff about 30 feet above high water, 3 yards east of edge of bluff, 3 yards west of edge of cultivated field, 35 yards southwest of trees at edge of gully, and 200 yards west of other trees. Cement monument marking reference station is 47 . I6 meters $\mathrm{N} 67^{\circ} 05^{\prime} \mathrm{E}$ of observed station.

Marks.-Observed station is 2 -inch stub projecting 3 inches above surface of ground. Subsurface mark is beer bottle buried below base of stub. Reference station is center point of triangle on standard cement monument projecting 2 inches above surface of ground.

References.-

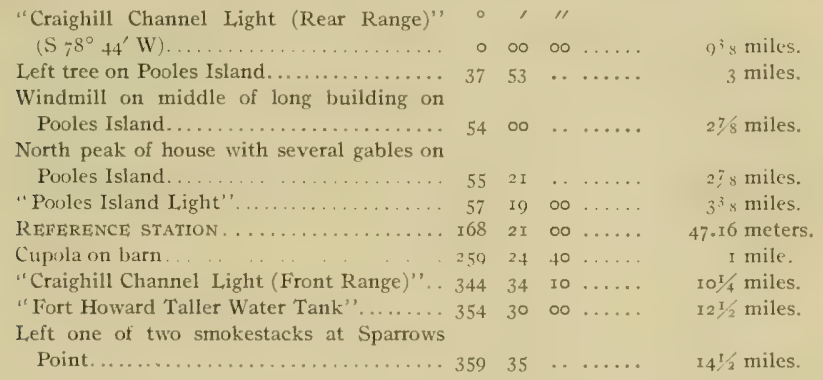

\section{MITCHELLS BLUFF 2 .}

General locality.-Eastern shore of Chesapeake Bay, on Mitchells Bluff, just north of first break in bluff, about five-eighths mile north-northeast of Tolchester Beach Wharf. (See Chart No. 28.)

Immediate locality.-Observed station is in cultivated ground about 30 feet above high water, I3 yards southeast of edge of bluff, 50 yards northeast of point of gully where fishermen haul up gear, 70 yards south of small clump of trees, and one-fourth mile northwest of a large farmhouse.

Marks,-Observed station is center point of triangle on standard cement monument projecting 4 inches above surface of ground. Subsurface mark is wire in center of 2 -inch tile pipe buried with top 2 inches below base of monument. (NorE.-Subsurface mark is either a part or replaces the original one of 1806.$)$ 
References,-

\begin{tabular}{|c|c|c|c|c|c|}
\hline $\begin{array}{l}\text { Craighill Channel Light (Rear Range)" } \\
\left(\mathrm{N} 87^{\circ} 52^{\prime} \mathrm{W}\right) \ldots \ldots \ldots \ldots \ldots \ldots \ldots \ldots \ldots \ldots\end{array}$ & & & 00 & & $83 / 8$ miles \\
\hline 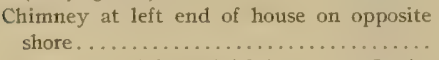 & 7 & & . & & 6 \\
\hline 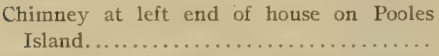 & & II & & & \\
\hline $\begin{array}{l}\text { on middle of roof of building } \\
\text { d trees.............................. }\end{array}$ & & Io & & & \\
\hline $\begin{array}{l}\text { weather vane on middle cupola } \\
\ldots \ldots \ldots \ldots \ldots \ldots \ldots \ldots \ldots \ldots \ldots\end{array}$ & & 28 & 30 & & \\
\hline west chimney of hou & 210 & 54 & . & & \\
\hline & 260 & 07 & $\cdots$ & & \\
\hline & & I8 & 30 & & \\
\hline From & & & 40 & & $83 / 4 \mathrm{~m}$ \\
\hline
\end{tabular}

\section{CRAIGHILI, CHANNEL LIGHT (FRONT RANGE).}

General locality. -Western side of Chesapeake Bay, about 2 miles offshore and about $23 / 4$ miles east of North Point at entrance to Patapsco River. (See progress map.)

Immediate locality.-Observed station is on dwelling on cylindrical foundation known as Craighill Channel Light (Front Range).

Marks.-Observed station is center point of lantern on Craighill Channel Light (Front Range).

References,-

$$
\begin{aligned}
& \text { "Craighill Channel Light (Rear Range)" ० , " }
\end{aligned}
$$

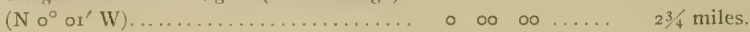

\section{CRAIGHILL CHANNEL LIGHT (REAR RANGE).}

General locality.-Western side of upper Chesapeake Bay about 200 yards offshore from the southwestern end of Hart Island. (See progress map.)

Immediate locality.-Observed station is on a tall square pyramidal skeleton steel frame structure known as Craighill Channel Light (Rear Range).

Marks.-Observed station is center point of lantern on Craighill Channel Light (Rear Range).

References.-

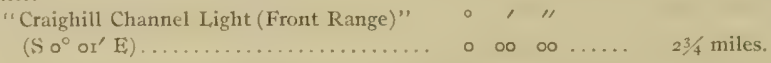

\section{FORT HOWARD TALLER WATER TANK.}

General locality.-Northern side of entrance to Patapsco River about one-half mile north-northwest of North Point. (See progress map.)

Immediate locality.-Observed station is the taller of two steel water tanks on steel towers at Fort - Howard.

Marks.-Obscrved station is center point of pipe attached to center of bottom of tank.

References,--None necessary.

\section{SEVEN FOOT KNOLL, LIGHT.}

General locality.-Western side of Chesapeake Bay off entrance to Patapsco River about $21 / 2$ miles north-northeast of Bodkin Point and $3^{\mathrm{T}} / 4$ miles southeast of North Point. (See progress map.)

Immediate locality.-Observed station is on an octagonal screw pile structure known as Seven Foot Knoll Lighthouse.

Marks.-Observed station is center point of lantern on Seven Foot Knoll Light.

References.-

$$
\text { "Bodkin Point (Old Tower)" ( } \left.\mathrm{S}_{3} 0^{\circ} \mathrm{\circ}^{\prime} \mathrm{W}\right) . . \quad \circ \quad \infty \quad \infty \quad \ldots . . \quad 1 \frac{1 / 2}{2} \text { miles. }
$$




\section{BODKIN POIN'T (OLD 'TOWER).}

(ieneral locality.-Southern side of entrance to Ibodkin Creek on Bodkin Point. (See progress map.) Immediate locality.-Observed station is alout ${ }_{5} 5$ yards east of an old stone dwelling on top of an old tower formerly used as a lighthouse.

Marks.-Observed station is center of drill hole abut 2 inches in diameter and 3 inches deep in stone platform on and near center of top of tower.

Kifounas.

$$
\text { "Sieven Font Knoll Light" ( } \left.30^{\circ} 04^{\prime} \mathrm{E}\right) \ldots \quad 0 \quad 00 \quad 00 \ldots . . . \quad \mathrm{x} \frac{1}{2} \text { miles. }
$$

\section{SWAN POINT 3.}

General locality.-Eastern shore of Chesapeake Bay on Swan Paint about $5^{1 / 2}$ miles south-southwest of Tolchester Beach Wharf and 7 miles north of Love Point. (See Chart No. 28.)

Immediale locality.-Observed station is on sand and marsh point about 2 feet above high water, 5 feet east of shore, 60 yards south-southwest of a fisherman's cabin, and 250 yards from the extreme end of Swan Point. Cement monument marking old reference station is in marsh 21.43 meters N $89^{\circ} \mathrm{I}_{3}^{\prime} \mathrm{E}$ of observed station. Standard cement monument marking new reference station is on line to old reference station 13.26 meters $\mathrm{N} 89^{\circ} \mathrm{I}_{3}^{\prime} \mathrm{E}$ of observed station.

Marks.-Observed station is $1,-$-inch copper rod set in an 8 -inch square cement monument with top alout 5 inches below surface of ground. Subsurface mark is the neck of a flask set in cement about 4 feet below the surface. New reference station is center point of triangle on standard cement monument. Old reference station is eastem one of two , -4 -inch copper rods in an 8 -inch cement monument.

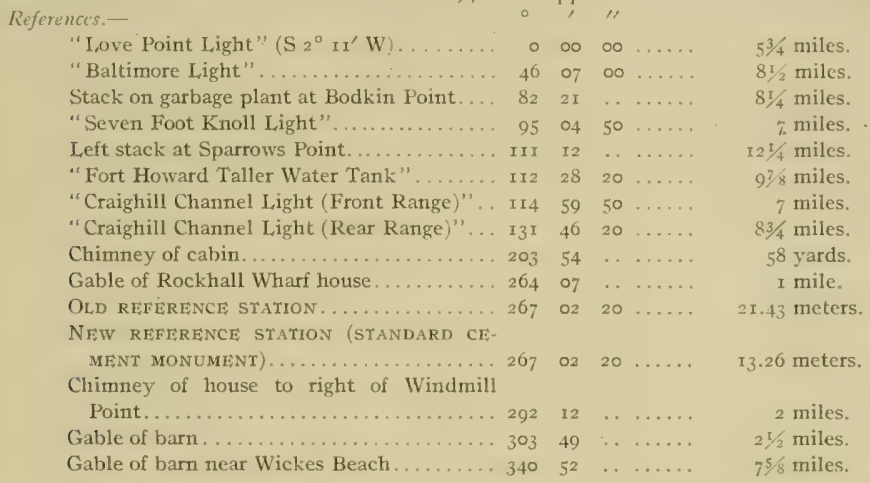

\section{BANK.}

General locality.-Easteru shore of Chesapeake Bay on westem side of entrance to Tavern Creek, about $5 / 8$ mile northeast of Swan Point. (See Charts Nos. 28 and 29-)

Immediate locality. - Observed station is in a cultivated field about 7 feet above high water, I2 yards inshore, and 2 yards from edge of bank.

Marks.-Observed station is center point of triangle on standard cement monument projecting 3 inches above surface of ground. Subsurface mark is center of 2 -inch tile pipe buried with top 2 inches below base of monument. 


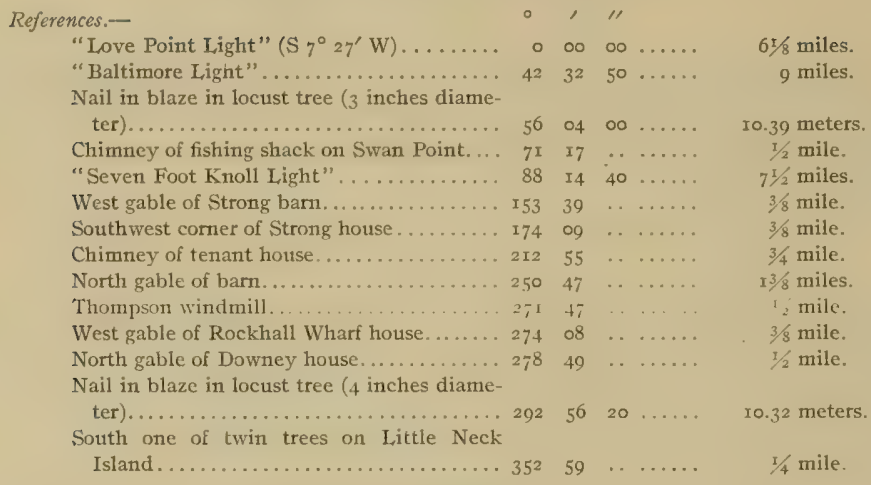

TAVERN.

General locality.-Eastern shore of Chesapeake Bay on western side of Tavern Creek about threeeighths mile north of entrance to creek, I mile northeast of Swan Point and one-half mile northwest of Rockhall Landing. (See Chart No. 28.)

Immediate localily.-Observed station is in the eastern side of peach and apple orchard about I foot above high water, I 52 yards northwest of shore, 165 yards west of shore, 8 yards west of edge of sage land, I 5 yards west of a wire fence, I 8 yards south of another wire fence, 52 yards nortn of still another wire fence, and 125 yards east of a house.

Marks.-Observed station is cenier point of triangle on standard cement monument projecting 2 inches above surface of ground. Subsurface mark is center of 2 -inch tile pipe buried with top 2 inches below base of monument.

References.-

"Orchard" ( $\left.\mathrm{S} 50^{\circ} 3 \mathrm{I}^{\prime} \mathrm{E}\right) \ldots \ldots \ldots \ldots \ldots . . . . . .$.

Gilt ball on lightring rod near left end of house. ................... I $38 \ldots \ldots \ldots$ mile.

Apple tree ( 18 inches diameter) ............ $6.321 \ldots .49$ yards.

Nail in blaze in apple tree (20 inches diame-

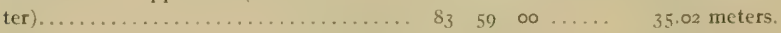

Nail in blaze in apple tree ( 24 inches diame-

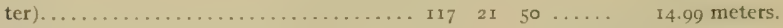

Nail in blaze in peach tree ( 5 inches diame-

ter)........................ $166 \quad 42 \quad 20 \ldots .39$ meters.

Nail in blaze in apple tree ( 18 inches diame-

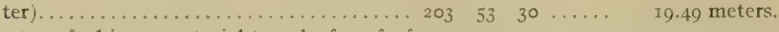

Center of chimney at right end of roof of

house with ell...................

\section{CORR.}

General locality.-Eastem shore of Swan Creek about $\mathrm{I} / 4$ miles north of Rockhall Landing. (See Chart No. 28.)

Immediate locality.-Observed station is about I foot above high water, 6 yards northeast of rounded point of shore, 13 yards northwest of square cut in shore, $1_{3}$ yards southeast of point where wire fence meets shore, and 50 and 65 yards south by west of two large trees.

Marks.-Observed station is center point of triangle on standard cement monument projecting 3 inches above surface of ground. Subsurface mark is center of 2 -inch tile pipe buried with top 2 inches below base of monument. 


\begin{tabular}{|c|c|c|c|c|}
\hline ferences.- & $\circ$ & , & 11 & \\
\hline "Spike" (S $\left.0^{\circ} 49^{\prime} \mathrm{W}\right) \ldots$ & $\circ$ & $\infty$ & $\infty$ & $1 / 4$ mile. \\
\hline Chimney of house . . . . . . . . . . . . . & 14 & $5^{8}$ & $\ldots \ldots \ldots$ & $I^{1} / 8$ miles. \\
\hline Chimney of old house .................. & 35 & 50 & $\ldots \ldots \ldots$ & $3 / 4$ mile. \\
\hline Right chimney of Strong house........... & 48 & 12 & . $\cdots \cdots$ & $x$ mile. \\
\hline Near peak of house between two barns.... & 99 & 35 & . $\cdots$ & $5 / 8$ mile. \\
\hline Large square chimney of large brick house. . & 142 & $5^{2}$ & . $\cdots$ & $1 / 2$ mile. \\
\hline North chimney of brick house ........... & 204 & 34 & . & I 50 yards. \\
\hline East chimney of large house ............. & 245 & $4 \mathrm{I}$ & $\ldots \ldots \ldots$ & $3 / 8$ mile. \\
\hline Chimney of old house. ......... & 311 & 05 & $\ldots \ldots \ldots$ & $1 / 2$ mile. \\
\hline
\end{tabular}

URIE:

General. locality.-Western shore of Swan Creek about I mile north of Rockhall Landing. (See Chart No. 28.)

Immediale locality.-Observed station is on a slight projection of the shore about $\mathrm{I}$ foot above high water and 4 yards west of shore. Cement monument marking reference station is 4.76 meters $\mathrm{S}_{21}{ }^{\circ} 35^{\prime} \mathrm{W}$ of observed station.

Marks.-Observed station is center of 2 -inch tile pipe projecting $\mathrm{I}$ inch above surface of ground. Subsurface mark is center of 2 -inch tile pipe buried with top 2 inches below base of surface mark. Reference station is center point of triangle on standard cement monument projecting 5 inches above surface of ground.

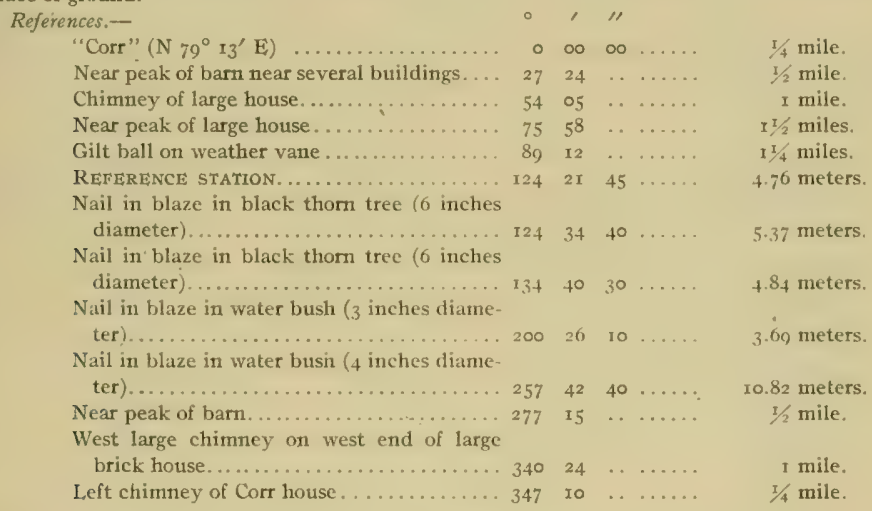

SPIKE.

General locality:-Eastern shore of Swan Creek, about seven-eighths mile north-northeast of Rockhall Landing. (See Chart No. 28.)

Immediate locality.-Observed station is among trees and bushes about 2 feet above high water, 30 yards east of shore, and I yard west of edge of cultivated field.

Marks.-Observed station is center point of triangle on standard cement monument projecting 2 inches above surface of ground. Subsurface mark is center of 2 -inch tile pipe buried with top 2 inches below base of monument.

$14126-12-3$ 


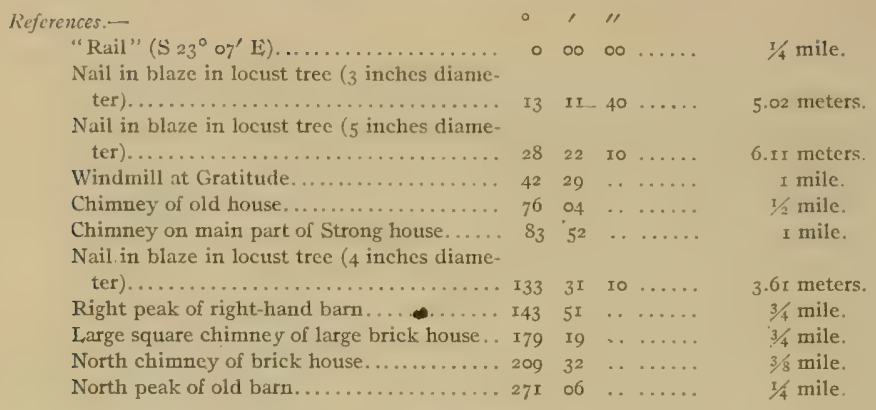

ELLIASON.

General locality.-Western shore of Swan Creek on a point of land at north side of entrance to a small cove about three-fourths mile north of Rockhall Landing. (See Chart No. 28.)

Immediate locality.-Observed station is about 2 feet above high water, 16 yards west by north of shore, 23 yards north-northwest of shore, 30 yards nor theast of shore, and 33 yards north by east of shore.

Marks,-Observed station is center point of triangle on standard cement monument projecting 4 inches above surface of ground. Subsurface mark is center of 2 -inch tile pipe buried with top 2 inches below base of monument.

References.-

"Corr" ( $\left.\mathrm{N} 33^{\circ} 57^{\prime} \mathrm{E}\right)$..

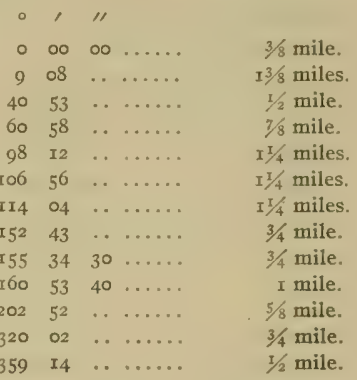

RAII.

General locality.-Eastern shore of Swan Creek about three-fourths mile northeast of Rockhall Landing. (See Chart No. 28.)

Immediate locality. - Observed station is on a low point about 2 feet above high water, 3 yards back from shore, and west of a number of small locust trees.

Marks.-Observed station is center point of triangle on standard cement monument projecting 3 inches above surface of ground. Subsurface mark is center of 2 -inch tile pipe buried with top 2 inches below base of monument. 


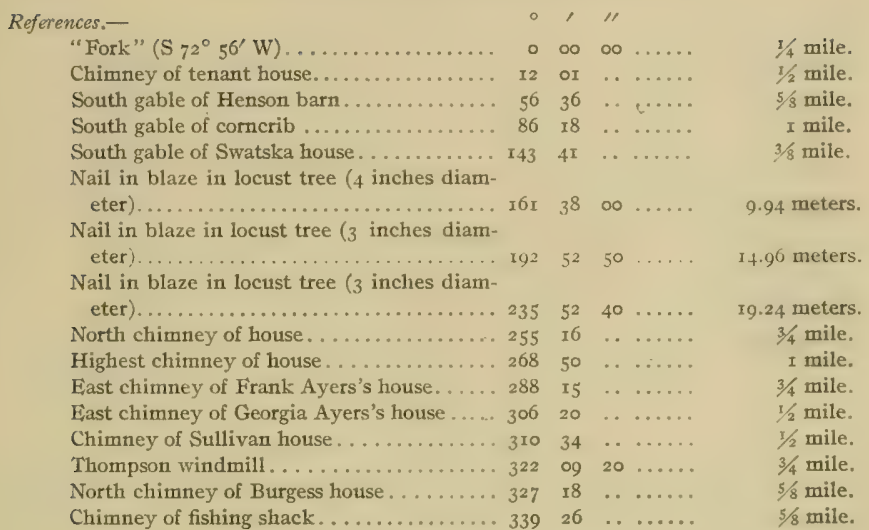

FORK.

General locality.-Western shore of Swan Creek, about one-half mile north-northeast of Rockhall Landing and three-eighths mile northwest of entrance to The Haven.. (See Chart No. 28.)

Immediate locality.-Observed station is on marsh land about 2 feet above high water, 25 yards inshore, and 200 yards from extreme south end of point.

Marks.-Observed station is center point of triangle on standard cement monument projecting 2 inches above surface of ground. Subsurface mark is center of 2 -inch tile pipe buried with top 2 inches below base of monument.

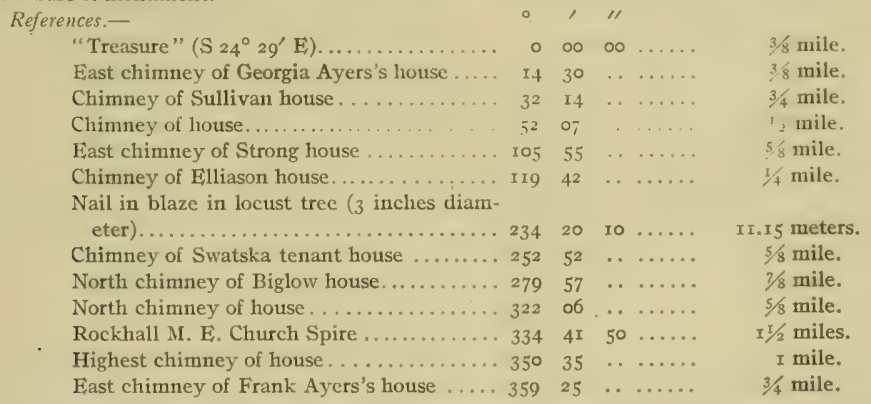

HAVEN.

General locality.-Eastern shore of Swan Creek at northern side of entrance to The Haven about fiveeighths mile east-northeast of Rockhall Landing. (See Charts Nos. 28 and 29.)

Immediate locality.-Observed station is on a long marsh point about 2 feet above high water, 5 yards back from high-water mark, and 7 yards west and 8 yards north of large pine trees.

Marks.-Observed station is center point of triangle on standard cement monument projecting 3 inches above surface of ground. Subsurface mark is center of 2 -inch tile pipe buried with top 2 inches below base of monument. 


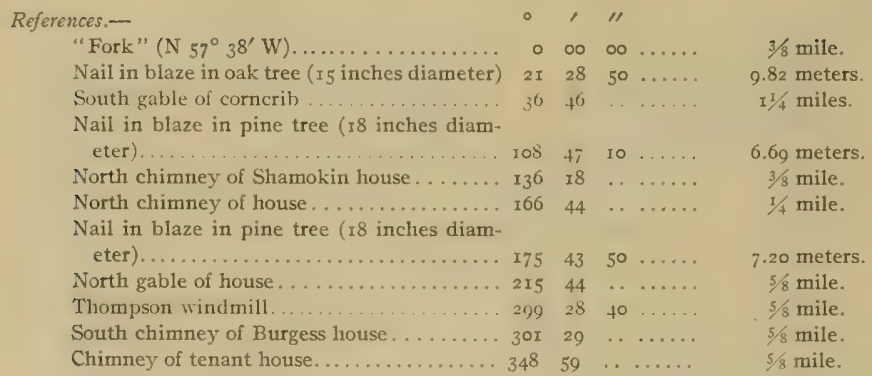

\section{TREASURE.}

General locality,-Eastern and southern shore of Swan Creek on a point at western side of entrance to The Haven, about one-half mile east-northeast of Rockhall Landing. (See Charts Nos. 28 and 29.)

Immediate locality.-Observed station is on a marsh point below high water, about 25 yards inshore, and 300 yards northeast of a house.

Marks.-Observed station is center point of triangle on standard cement monument projecting 6 inches above surface of ground. Subsurface mark is center of 2 -inch tile pipe buried with top 2 inches below base of monument.

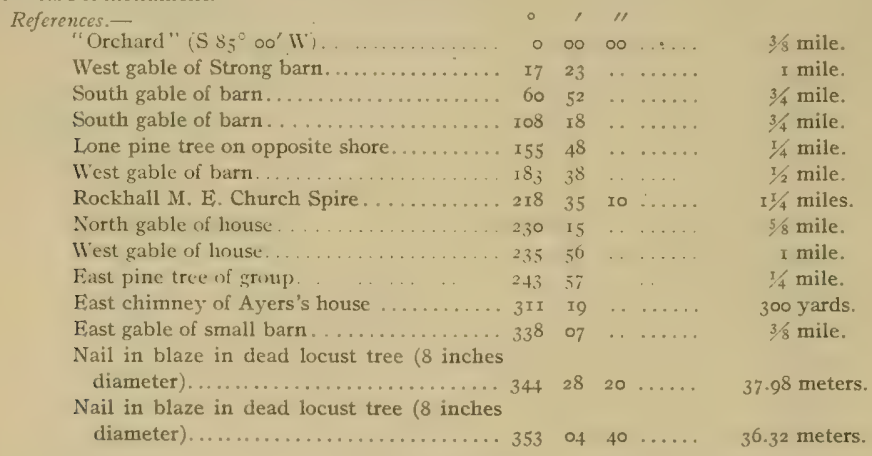

ORCHARD.

General locality.-Eastern and southern shore of Swan Creek on point of land about one-eighth mile north of Rockhall Landing. (See Charts Nos. 28 and 29.)

Immediate locality. - Observed station is on a sand and grass point about 3 feet above high water, 7 yards west of peach orchard, 6 yards east of shore, 33 yards west-southwest of shore, 31 yards south of extreme end of point, 23 yards north of a wire fence, and 53 yards north of a house. Cement monument marking reference station is 9.67 meters $\mathrm{N} 83^{\circ} \circ 4^{\prime \prime} \mathrm{E}$ of observed station.

Marks.-Observed station is center of 2 -inch tile pipe projecting 6 inches above surface of ground. Subsurface mark is center of 2 -inch tile pipe buried with top 2 inches below base of surface mark. Reference station is center point of triangle on standard cement monument projecting 2 inches above surface of ground. 


\begin{tabular}{|c|c|c|c|c|c|}
\hline rerences.- & 。 & , & " & & \\
\hline "Bank" (S $\left.7_{7} 8^{\circ} 45^{\prime} \mathrm{W}\right) \ldots \ldots \ldots \ldots \ldots \ldots$ & $\circ$ & ০o & $\infty$ & - & $3 / 8$ mile. \\
\hline East chimney of house................ & 42 & 23 & . & - & nile. \\
\hline $\begin{array}{l}\text { South peak between two chimneys of large } \\
\text { house } \ldots \ldots \ldots \ldots \ldots \ldots \ldots \ldots \ldots\end{array}$ & 105 & $5 I$ & 0 & & 8 minc \\
\hline Chimney of an old long building........... & 144 & 20 & $\cdots$ & $\ldots \ldots$ & mile. \\
\hline $\begin{array}{l}\text { Nail in blaze in locust tree }(7 \text { inches diam- } \\
\text { eter) } \ldots \ldots \ldots \ldots \ldots \ldots \ldots \ldots \ldots \ldots \ldots \ldots \ldots \ldots \ldots \ldots\end{array}$ & 176 & 02 & 30 & & 21.85 meters. \\
\hline REFERENCE STATION . . . . . . . . . . . . & 184 & 19 & 20 & $\ldots \ldots$ & 9.67 meters. \\
\hline $\begin{array}{l}\text { Nail in blaze in peach tree }(5 \text { inches diam- } \\
\text { eter }) \ldots \ldots \ldots \ldots \ldots \ldots \ldots \ldots \ldots \ldots \ldots \ldots \ldots \ldots\end{array}$ & 226 & $5^{6}$ & 40 & & 8.07 meters. \\
\hline Right corner of $x^{t} / 2$-story building.......... & 229 & 59 & 20 & $\ldots \ldots$ & 32.57 meters. \\
\hline Northwest corner of house. . . . . . . . . & 267 & $2 \mathrm{I}$ & 10 & $\ldots \ldots$ & 53 yards. \\
\hline Nail in blaze in tree ( $I_{3}$ inches diameter). . & 274 & 07 & 20 & . & 21.60 meters. \\
\hline West peak of z-story wharf house. ... & 294. & $5^{6}$ & 40 & ...... & $1 / 8$ mile. \\
\hline Chimney of house on Swan Point.......... & 360 & 00 & .. & $\ldots \ldots$ & I mile. \\
\hline
\end{tabular}

\section{GRATITUDE.}

General locality.-Eastern shore of Chesapeake Bay at eastern side of entrance to Swan Creek, opposite middle of Little Neck Island, and near old Rockhall Wharf. (See Charts Nos. 28 and 29.)

Immediate locality.-Observed station is on a marsh meadow about I foot above high water, i2 yards east of shore, 150 yards southwest of a house, and 400 yards south-southwest of Rockhall Landing.

Marks.-Observed station is center point of triangle on standard cement monument projecting 3 inches above surface of ground. Subsurface mark is center of 2 -inch tile pipe buried with top 2 inches below base of monument.

\begin{tabular}{|c|c|c|c|c|c|}
\hline References.-- & o & , & "I & & \\
\hline "Love Point Light" (S $\left.\mathrm{II}^{\circ}{ }_{4} 6^{\prime} \mathrm{W}\right) \ldots \ldots \ldots$ & 0 & oo & $\infty$ & & $5 / 8$ miles. \\
\hline "Sandy Point Light" ................. & 26 & 05 & ro & ...... & 10 $3 / 4$ miles. \\
\hline "Baltimore Light". & $4^{I}$ & $2 I$ & 20 & $\ldots \ldots$ & 9.3 miles. \\
\hline Chimney of fishing shack on Swan Point.... & 90 & 47 & . & $\cdots \cdots$ & I mile. \\
\hline Left tangent of piles of old Rockhall Wharf. . & 124 & I5 & . & $\ldots \ldots$ & 200 yards \\
\hline $\begin{array}{l}\text { West gable of Strong barn............... } \\
\text { Chimney of tallest wharf house at Rockhall }\end{array}$ & 130 & 49 & . & ...... & $3 / 4$ mile. \\
\hline 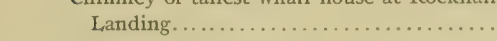 & 162 & I5 & . & & $1 / 4$ mile. \\
\hline Chimney of house. ................... & 166 & 19 & . & . & I mile. \\
\hline $\begin{array}{l}\text { Post on northwest corner of Downey porch.. } \\
\text { Nail in blaze in cedar tree (1o inches diame- }\end{array}$ & I96 & 57 & . & $\ldots \ldots$ & I 50 yards. \\
\hline 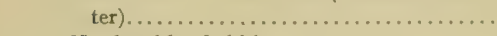 & 273 & 02 & 40 & . & I07 yards. \\
\hline 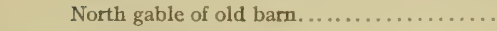 & 276 & 36 & . & ...... & 200 yards. \\
\hline North gable of barn ................... & 309 & 21 & $\cdots$ & $\ldots \ldots$ & $15 / 8$ miles. \\
\hline
\end{tabular}

\section{WINDMILL POINT.}

General locality.-Eastern shore of Chesapeake Bay on Windmill Point at northern side of entrance to Rockhall Harbor. (See Chart No. 29.)

Immediate locality.-Observed station is on low marsh land about level with high water, about 30 yards back from end of point, and 20 yards south of a group of large pine trees. Cemènt monument marking reference station is 24.13 meters $\mathrm{N} 20^{\circ} \mathrm{I} 4^{\prime} \mathrm{E}$ of observed station.

Marks.-Observed station is center point of 2 -inch tile pipe filled with sand with top about flush with surface of ground. Reference station is center point of triangle on standard cement monument. 

References.-
"Love Point Light" (S $\left.17^{\circ} 47^{\prime}\right)$..........
$\circ, 1$
Nail in blaze in pine tree ( 18 inches diame- ter $) \ldots \ldots \ldots \ldots \ldots \ldots \ldots \ldots \ldots \ldots \ldots \ldots$
Nail in blaze in pine tree $(24$ inches diame-
Nail in blaze in pine tree $(24$ inches diame-

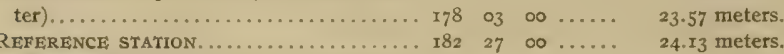
Nail in blaze in pine tree ( 20 inches diame-

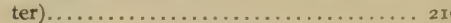
Rockhall M. E. Church Spire............ 238
Highest gable on Sharps Wharf............24
East chimney of house............... 27
Chimney of small house................28
West chimney of small house........... 3 II
$00000 \ldots$.
$5 \frac{\pi}{2}$ miles
$46 \quad 39 \quad 30 \ldots \ldots$
10 $20 \ldots .$.
o5 $40 \ldots$.
I6. 52 meters.
$r$ mile.
$3 / 8$ mile.
$1 / 2$ mile.
$1 / 2$ mile.
I mile.

\section{STEVENS.}

General locality.-Eastern shore of Chesapeake Bay about one-fourth mile south of Huntingfield L'oint at entrance to Huntingfield Creek. (See Chart No. 29.)

Immediate locality. - Observed station is in a cultivated field about 15 feet above high water, 55 yards back from edge of vertical bank 3 feet higher than station, and 450 yards south of the extreme end of Huntingfield Point.

Marks.-Observed station is center point of triangle on standard cement monument projecting 2 inches above surface of ground. Subsurface mark is center of 2 -inch tile pipe buried with top 2 inches below base of monument.

References.--

"Love Point Light" (S $\left.25^{\circ} \mathrm{o}^{\prime} \mathrm{W}\right) \ldots \ldots \ldots$

Right tangent of Love Point..............

Southeast comer of fishing shack on Swan Point........................... III $24 \ldots \ldots$

East gable of Strong barn............. I25 $42 \quad \ldots \ldots \ldots$

Thompson windmill................ $x_{35}$ or $20 \ldots \ldots$

Chimney of house................... $150 \quad 32 \ldots \ldots$.

Nail in blaze in cedar tree (ro inches diame-

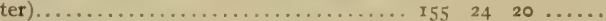

Wicks windmill................... 223 16 $20 \ldots \ldots$

Nail in blaze in locust tree ( 18 inches diame-

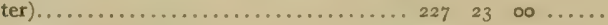

Chimney of small house............... $239 \quad 58 \quad \ldots \ldots \ldots$

Nail in blaze in persimmon tree (ro inches

diameter)...................... $275 \quad 26 \quad 20 \ldots \ldots$

Chimney of Stevens tenant house......... $320 \quad 39 \quad \ldots \ldots \ldots$

$$
\begin{aligned}
& 45 / 8 \text { miles. } \\
& 61 / 2 \text { miles. } \\
& 21 / 2 \text { miles. } \\
& 21 / 2 \text { miles. } \\
& 2 \text { miles. } \\
& \text { I/ } / 4 \text { miles. } \\
& 200 \text { yards. } \\
& \text { I mile. } \\
& \text { I ro yards. } \\
& \text { I mile. } \\
& \text { r } 30 \text { yards. } \\
& \text { I } 2 \text { mile. }
\end{aligned}
$$

\section{BALTIMORE, LIGHT}

General locality.-Western side of Chesapeake Bay offshore about $\mathrm{I}^{1} / 2$ miles east of mouth of Magothy River and one-eighth mile west of entrance to dredged channel leading to Baltimore. . (See progress map.)

Immediate locality.-Observed station is on brick octagonal dwelling on cylindrical foundation known as Baltimore Lighthouse.

Marks.-Observed station is center point of lantern on Baltimore Lighthouse.

References.-None necessary.

\section{SANDY POINT LIGHT}

General locality.-Western side of Chesapeake Bay offshore about one-half mile east of Sandy Point. (See Chart No. 29 and progress map.)

Immediate locality.-Observed station is on brick dwelling on cylindrical foundation known as Sandy Point Lighthouse. 
Marks.-Observed station is center point of lantern on Sandy Point Lighthouse.

References.-
"Bodkin Point (old tower)" ( $\left.\mathrm{N} \mathrm{I4}^{\circ} 35^{\prime} \mathrm{W}\right)$.
○ 00 o......
$8 x / 2$ miles.

RING.

General locality.-Eastern shore of Chesapeake Bay on western side of Kent Island about $2 x / 4$ miles

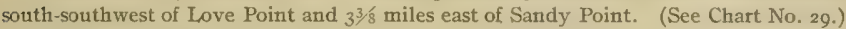

Immediate locality.-Observed station is in a cultivated field about 20 feet above high water, 12 yards inshore, and 2 yards from edge of bank. Cement monument marking reference station is 9.36 meters N $79^{\circ} 2 \mathrm{I}^{\prime} \mathrm{E}$ of observed station.

Marks.-Observed station is center of 4 -inch tile pipe with top 3 inches below surface of ground. Reference station is center point of triangle on standard cement monument projecting 4 inches above surface of ground.

References.-

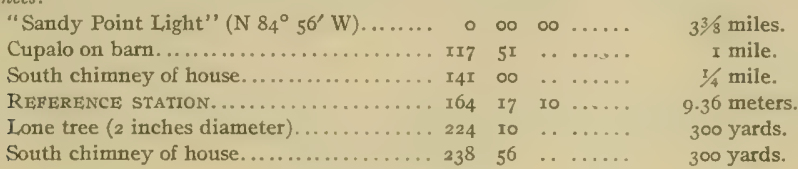

\section{LOVE POINT LIGHT.}

General locality.-Eastern side of Chesapeake Bay at entrance to Chester River offshore about II/2 miles northeast of Love Point. (See Chart No. 29.)

Immediate locality.-Observed station is on hexagonal screw-pile structure known as Love Point Lighthouse.

Marks.-Observed station is center point of lantern on Love Point Lighthouse.

References."Wickes Beach" ( $\left.\mathrm{S}_{47^{\circ}} 55^{\prime} \mathrm{E}\right) \ldots \ldots \ldots \ldots \ldots$....... 00 \%

AMOUR.

General locality.-Northern end of Kent Island at western side of entrance to Chester River, about one-fourth mile southeast of Love Point and three-eighths mile north of Love Point Landing. (See Chart No. 29.)

Immediate locality.-Observed station is on sand and marsh point, about 2 feet above high water, 25 yards inshore, and 55 yards north of fishing shack.

Marks.-Observed station is center point of triangle on standard cement monument projecting 4 inches above surface of ground. Subsurface mark is center of 2 -inch tile pipe buried with top 2 inches below base of monument.

References.-

"Love Point Light" ( $\left.33^{\circ} 42^{\prime} \mathrm{E}\right)$........

Left chimney of house ..................

West gable of house on East Neck. . . . . . . 48

North gable of barn............... 54

North gable of house on Cedar Point...... 76

Gable of barn ......................... 128

Left tangent of Kent Island Landing. . . . . I I32

Northeast corner of fishing shack........ I40

Nail in blaze in cedar tree ( 3 inches diameter) I74

"Railway Water Tank" ............... I99

Nail in blaze in cedar tree ( 4 inches diameter) 206

Nail in blaze in cedar tree ( 6 inches diameter) 295

- 00

........

........

. . . . .

$\ldots \ldots \ldots$

. . . . . .

$\ldots \ldots \ldots$

.......

.......

$50 \ldots \ldots$

........

.......
I5/8 miles.

$43 / 8$ miles.

$33 / 4$ miles.

$3^{T / 4}$ miles.

5 miles.

$4^{1 / 2}$ miles.

$13 / 4$ miles.

57 yards.

12. 46 meters.

$5 / 8$ mile.

I1. 30 meters.

38.88 meters. 


\section{RAILWAY WATHR TANK.}

General locality.-Northern end of Kent Island, about half-way betwcen Chesapeake Bay and Chester River and three-fourths mile south by west of Love Point. (See Chart No. 29.)

Immediate locality.-Observed station is on the only large elevated water tank located just north of the center of the bend of the railway that leaves Love Point Landing.

Marks.-Observed station is center point of top of water tank.

References.-None necessary.

\section{WICKES BEACH.}

General locality. - Eastern shore of mouth of Chester River on western side of East Neck Island near Wickes Beach. (See Chart No. 29.)

Immediate locality.-Observed station is on a narrow sand beach about on level with high water, io yards back from low water, and 2 yards west of swamp which extends back to woods.

Marks.-Observed station is center point of triangle on standard cement monument projecting 4 inches above surface of ground. Subsurface mark is center of 2 -inch tile pipe buried with top 2 inches below base of monument.

\begin{tabular}{|c|c|c|c|c|c|}
\hline \multicolumn{6}{|l|}{ References.- } \\
\hline "Love Point Light" ( $\left.\mathrm{N}_{47}^{\circ} 54^{\prime} \mathrm{W}\right)$. & $\circ$ & $\infty$ & $\infty$ & & 3 miles. \\
\hline Nail in blaze in oak tree ( ${ }_{5}$ inches diameter) & 60 & 45 & 40 & $\ldots$ & 300 yards. \\
\hline $\begin{array}{l}\text { Nail in blaze in gum tree }(12 \text { inches diam- } \\
\text { eter } \ldots\end{array}$ & 70 & 50 & 00 & $\ldots$ & 250 yards. \\
\hline Nail in blaze in oak tree ( 15 inches diameter) & Ir4 & 05 & 50 & ....... & 200 yards. \\
\hline North cupola of barn. & 155 & x 5 & .. & . & $5 / 8$ mile. \\
\hline Lone tree on Cedar Point. ............. & 178 & 23 & . & …. & $17 / 8$ miles. \\
\hline 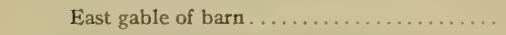 & 200 & $2 I$ & .. & ..... & 4 miles. \\
\hline North gable of Jackson Wharf house....... & 214 & 26 & . & ...... & $4^{1 / 8}$ miles. \\
\hline North gable of barn . . . . . . . . . . . . & 276 & 32 & .. & ...... & 3,8 miles. \\
\hline Cupola on farmhouse...$\ldots \ldots \ldots \ldots \ldots$ & 299 & I6 & .. & ...... & $31 / 8$ miles. \\
\hline "Railway Water Tank". & 321 & 45 & $\infty$ & $\ldots \ldots$ & $35 / 8$ miles. \\
\hline North flagstaff on Love Point Hotel. ....... & 323 & 27 & . & $\ldots \ldots$ & $3 \frac{3}{8}$ miles. \\
\hline
\end{tabular}

\section{NARROWS POINT.}

General locality.-Northern shore of Chester River on southwest end of East Neck Island, about one-eighth mile north of Cockeys Island and three-eighths mile west-northwest of Cedar Point. (See Charts Nos. 29 and 30 .)

Immediate locality, - Observed station is on a low marshy point about level with high water, about 7 yards from low water, and 325 yards west of a fishing shack. Cement monument marking reference station is 12.28 meters $\mathrm{N} 7^{\circ} 5^{\prime} \mathrm{E}$ of observed station.

Marks.-Observed station is center of 3 -inch tile pipe filled with cement with top 4 inclies below surface of ground. Reference station is center point of triangle on standard cement monument projecting 4 inches above surface of ground. 


\section{Riefernecs.}

"Wickes Beach" ( $\left.\mathrm{N}_{4} 6^{\circ} 5^{8} \mathrm{~W}\right) \ldots \ldots \ldots \ldots$. . . $\infty$ o

REEERENCE STATION . . . . . . . . . . . . 64

Chimney of fishing shack. ............ $\Upsilon_{33}$

West gable of Queenstown elevator...... I53

Cupola on barn................... 164 .

North gable of house. . . . . . . . . . . I80 5

North gable of birn. . . . . . . . . . . . . I94 $5 . j$

Cupola on barn .................. 2I6 26

North gable of house . . . . . . . . . . . . . 228 I6

North gable of house on Jackson Creek.... 23 23 47

East gable of Jackson Wharf house....... 233

North gable of barn .... . . . . . . . 254

West chimney of house ............. 285

Chimney of house near Nacum Creek...... 29336

East chimney of house .............. 318 or

"Railway Water Tank" . . . . . . . . . . $\quad .334$

South flagstaff on Love Point Hotel....... 335

Flagstaff on Love Point Wharf . . . . . . 335

Right tangent of Love Point........... 341 . 30

\begin{tabular}{|c|c|c|}
\hline 00 & & 17/8 miles. \\
\hline 0 & $\ldots \ldots$ & 12. 28 meters. \\
\hline & $\ldots \ldots$ & 325 yards. \\
\hline & . & $\begin{array}{l}31 / 4 \text { miles. } \\
25 / 8 \text { miles. }\end{array}$ \\
\hline & & $21 / 2$ miles. \\
\hline & & $21 / 2$ miles. \\
\hline & & $23 / 4$ miles. \\
\hline & $\cdots \cdots$ & 27/8 miles. \\
\hline & $\ldots \ldots$ & $\begin{array}{l}23 / 4 \text { miles. } \\
3 \text { miles. }\end{array}$ \\
\hline & …... & 33\% miles. \\
\hline & $\ldots \ldots$ & $4^{I / 8}$ miles. \\
\hline & $\cdots \cdots$ & $41 / 4$ miles. \\
\hline & $\ldots \ldots$ & $5 \% / 4$ miles. \\
\hline & $\cdots \cdots$ & 5 T/8 miles. \\
\hline & $\cdots \cdots$ & 43/4 miles. \\
\hline & $\cdots \ldots$ & 5 miles \\
\hline
\end{tabular}

MACUM

General locality. - Southern shore of Chester River on Kent Island, about $4^{T / 3}$ miles south of I.ove I'oint Light, 3 miles south-southeast of Love Point Landing, and one-half mile north-northwest of Macum Creek. (See Chart No. 29.)

Immediate locality.-Observed station is in cultivated field, about 7 feet above high water, 25 yards inshore, and 16 yards south of two cedar trees at edge of bank.

Marks.-Observed station is center point of triangle on standard cement monument projecting 3 inches above surface of ground. Subsurface mark is center of 2 -inch tile pipe buried with top 2 inches below base of monument.

References.-

"Love Point Light" ( $\left.\mathrm{N} \circ^{\circ} \mathrm{Ig} \mathbf{g}^{\prime} \mathrm{E}\right) \ldots \ldots \ldots$

North cupola of barn on East Neck Island. .

Chimney of house on East Neck Island.... 5

Nail in blaze in persimmon tree ( 6 inches diameter

South corner of fishing shack on Cedar Point.

West gable of large barn . . . . . . . . . . . . . .

Cupola on small house.

West gable of house

Cupola on barn

- 00

$4 \mathrm{r}$

$52 \quad 13$

it 0

72 os

$89 \quad 48$

$97 \quad 00$

$102 \quad 15$

10820

Gable of house near Jackson Creek. . . . . . II I9

East chimney of brick house............. I9

East chimney of house................ 2 I

Cupola on house ...................... 22

East chimney of house................ 22

North chimney of house. . . . . . . . . . . 25

Lone cedar tree................... 2

Nail in blaze in cedar tree (4 inches diameter)

"Railway Water Tank"

East gable of wharf house on Kent Island

Landing. . .

Flagstaff on wharf house on Love Point

Landing . . . . . . . . . . . . . . . . . .

Chimney of fishing shack........... 343

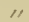

$4^{1 / 2}$ miles.

$33 / 4$ miles

$3^{3 / 4}$ miles.

50

22. 24 meters

4 miles.

5 miles.

5 miles.

$4^{1 / 2}$ miles.

3 miles.

$3^{5}$ \& miles.

${ }^{1} 4$ mile.

I mile.

I3/8 miles.

$5 / 8$ mile.

400 yards.

500 yards.

30. 98 meters

$31 / 8$ miles.

I $1 / 2$ miles.

$31 / 3$ miles.

$31 / 4$ miles. 
THIN.

General locality.-Southern shore of Chester River on western side of entrance to Kent Narrows, about three-fourths mile north of Narrows railway station. (See Chart No. 29.)

Immediate locality.-Observed station is on a marsh poin $i$ about I foot above high water, 55 yards north of shore, and 55 yards west of shore.

Marks.-Observed station is center point of triangle on standard cement monument projecting 5 inches above surface of ground. Subsurface mark is center of 2 -inch tile pipe buried with top 2 inches below base of monument.

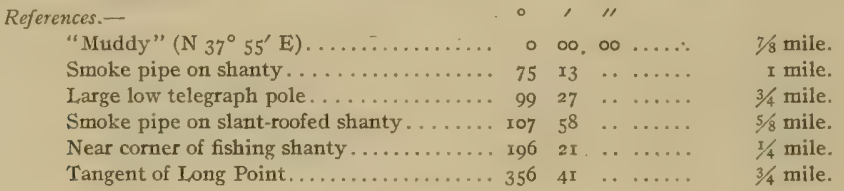

\section{MUDDY.}

Gcneral locality.-Southern shore of Chester River on Long Point, between Muddy Creek and Jackson Creek, about $2^{I} / 4$ miles southwest of Cedar Point and $3 \frac{1}{2}$ miles west of Queenstown. (See Charts Nos. 29 and 30 .)

Immediate locality'.-Observed station is on marsh land covered with myrtle bushes, about 2 feet above high water, 7 yards inshore, 25 yards southwest of extreme end of point, and 70 yards north of group of pine trees.

Marks,-Observed station is center point of triangle, on standard cement monument projecting 3 inches above surface of ground. Subsurface mark is center of 2 -inch tile pipe buried with top 2 inches below base of monument.

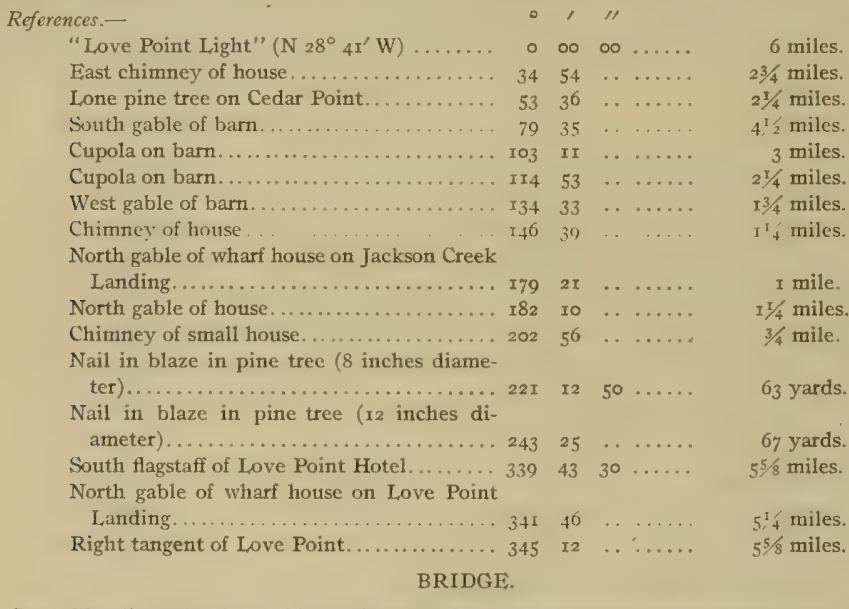

General locality. - Southern side of Chester River on westem shore of Kent Narrows, about oneeighth mile west of Narrows railway station. (See Chart No. 29.)

Immediate locality.-Observed station is on a telegraph pole at a point about 25 feet above high water, 4 yards south of near rail of railroad, 8 yards west of end of railroad bridge, and 7 yards from tie line of bridge.

Marks.-Observed station is a small staff nail sd to telegraph pole.

References.-None necessary. 


\section{RAILROAD.}

General locality.-Southern side of Chester River on eastern shore of Kent Narrows, about threeeighths mile east-southeast of Narrows railway station and one-eighth mile south of railroad. (See Chart No. 29.)

Immediate locality.-Observed station is on cultivated land about 8 feet above high water, 35 yards south by west of telephone line on north side of county road, 75 yards east of shanty, and 80 yards nortineast of shore of small cove.

Marks,-Observed station is center point of triangle on standard cement monument projecting 4 inches above surface of ground. Subsurface mark is center of 2 -inch tile pipe buried with top 2 inches below base of monument.

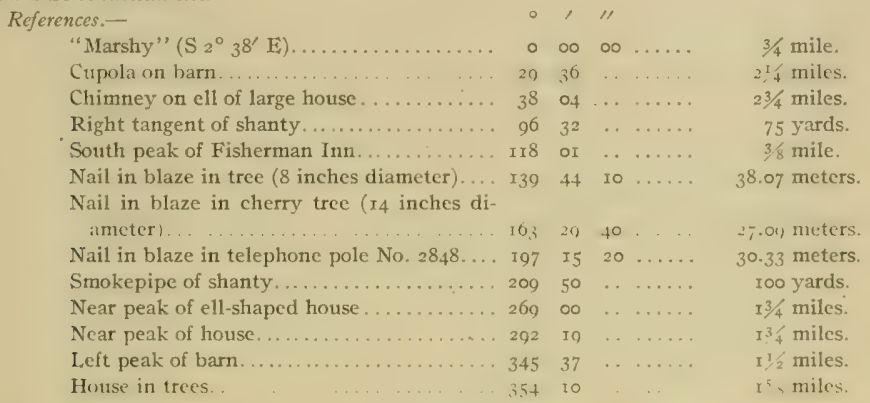

\section{BLUEBEARD.}

General locality:-Eastern shore of Chester River on point at entrance to a small creek, about fiveeighths mile northeast of Blunt Creek and I mile southwest of cntrance to Queenstown Creek. (See Chart No. 30.)

Immediate locality.-Observed station is on a low sand beach about I foot above high water, 5 yards inshore, 2 yards east of small persimmon tree, 55 yards northeast of a small stream, and 200 yards northnortheast of a pond.

Marks-Observed station is center point of triangle on standard cement monument projecting 2 inches above surface of ground. Subsurface mark is center of 2 -inch tile pipe buried with top 2 inches below base of monument.

References.-

"Love Point Light" ( $\left.47^{\circ} 53^{\prime} \mathrm{W}\right) \ldots \ldots$. . .

South gable of house................. I

Right tangent of piles of Bogle Wharf..... 2

Largest of four pine trees on Piney Point...

East chimney of house................

Black beacon at entrance to Queenstown Creek........................

Nail in blaze in swamp-oak tree $(4$ inches diameter $) \ldots \ldots \ldots \ldots \ldots \ldots \ldots \ldots \ldots \ldots \ldots \ldots \ldots \ldots \ldots \ldots$

Nail in blaze in chestnut tree ( 18 inches di-

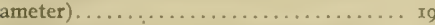

Nail in blaze in oak tree ( 6 inches diameter). 27

Cupola of barn.................. 278

East chimney of house............. 279

North gable of Jackson Creek Landing house......................... 290

East gable of house ................. 329

Gable of Love Point wharf house ........ 344

Right tangent of Love Point............. 347

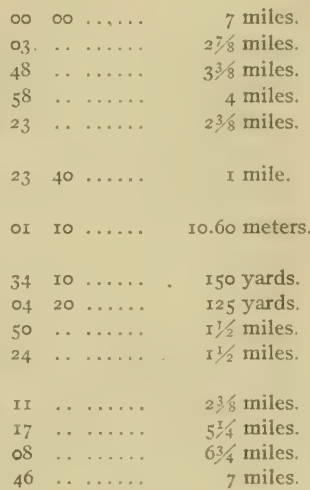




\section{BLAKLFORD.}

General locality.--Eastern shore of Chester River, about three-eighths mile north of Blakeford Point, at entrance to Queenstown Creek. (See Chart No. 3o.)

Immediate locality.-Olsserved station is about $x_{5}$ feet above high water, 8 yards inshore, 2 yards back from top of bank with uniform slope to beach, 25 y'ards north of gully, and 25 yards south of large sycamore tree at foot of slope.

Marks.-Observed station is center point of triangle on standard cement monument projecting 3 inches above surface of ground. Subsurface mark is center of 2 -inch tile pipe buried with top 2 inches below base of monument.

\begin{tabular}{|c|c|c|c|c|}
\hline nces.- & 0 & , & "I & \\
\hline "Rain" ( $\left.\mathrm{N}_{74}{ }^{\circ}{ }_{5} 6^{\prime} \mathrm{W}\right) \ldots \ldots \ldots$ & $\circ$ & oo & $\infty$ & $17 / 8$ miles. \\
\hline Right tangent of piles of Bogle Wharf..... & 27 & 33 & . & 3 miles. \\
\hline 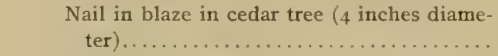 & $8_{3}$ & 12 & I0 & heters. \\
\hline Northwest comer of house in woods........ & I 55 & 39 & .. & 300 yards. \\
\hline West gable of small house . . . . . . . . . . . . & $\mathbf{I} 74$ & 19 & .. & $3 / 8$ mile. \\
\hline West gable of large barn. .................. & 215 & $4 \mathrm{I}$ & .. . & $5 / 8$ mile. \\
\hline West gable of house . . . . . . . . . . . . . . . & 235 & 20 & .. . & $3 / 4$ mile. \\
\hline $\begin{array}{l}\text { Northeast comer of elevator at Queenstown. } \\
\text { Nail in blaze in ash tree (I5 inches diame- }\end{array}$ & 239 & $2 \mathrm{I}$ & . . . & $5 / 8$ mile. \\
\hline First black beacon at entrance to Oueens- & 247 & 00 & 20. & 21. 30 meters. \\
\hline town Creek & 204 & 4) & & \\
\hline Chimney of fishing shack on Cedar Point. . & $35^{2}$ & 26 & & $25 / 8$ miles. \\
\hline
\end{tabular}

\section{RAIN.}

General locality. - Western shore of Chester River on Hail Point, about $x^{5} / 8$ miles south-southeast of Bogle Wharf. (See Chart No. 30.)

Immediate locality.-Observed station is about 5 feet above high water, 3 yards north of shore, and 20 yards northwest of extreme end of point. Cement monument marking reference station is 29.84 meters $\mathrm{N} 65^{\circ} 20^{\prime} \mathrm{W}$ of observed station.

Marks.-Observed station is center of 2 -inch tile pipe projecting 4 inches above surface of ground. Subsurface mark is center of 2 -inch tile pipe buried with top 2 inches below base of surface pipe. Refcrence station is center point of triangle, on standard cement monument projecting 3 inches above surface of ground. Subsurface mark of reference station is center of 2 -inch tile pipe with top 2 inches below base of monument.

References.-

"Bluebeard" ( $\left(\mathrm{S} 21^{\circ} \mathrm{x}^{\prime} \mathrm{E}\right) \ldots \ldots \ldots \ldots \ldots$.

Chimney of house..................

Cupola on barn..................... 33

Chimney of house on Jackson Creek......... 45

Chimney of small house...............

Chimney of fishing shack............. ro

Nail in blaze in pine tree (ro inches diame-

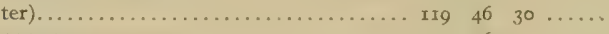

REFERENCE STATION............... I35 $56 \quad 20 \ldots \ldots$

Nail in blaze in pine tree (ro inches diame-

South gable of house.................

Right tangent of piles of Bogle Wharf. . . . I 86

Williams water tank .................. 255

Black beacon at entrance to Queenstown

Creek.......................... 3 r 8 or $\ldots \ldots \ldots$

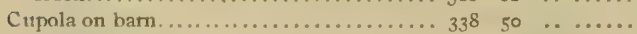

I7/8 miles.

$23 / 4$ miles.

$27 / 8$ miles.

$3 \frac{3}{8}$ miles.

$3^{1} / 2$ miles.

$7 / 8$ mile.

15.45 meters. 29.84 meters.

18.09 meters.

$I \frac{1}{2}$ miles.

I $5 / 8$ miles.

2 miles.

I $1 / 2$ miles.

$\mathrm{I} 3 / 4$ miles. 


\section{BREAK.}

General locality.-Eastern shore of Chester River on Break Point about one-eighth mile north of north side of entrance to Tilghmans Creek. (See Chart No. 30.)

Immediate locality.--Observed station is in a cultivated field about 5 feet above high water, I3 yards inshore, 4 yards from edge of bank, 200 yards north of extreme end of point, and 300 yards west of a house.

Marks.-Observed station is center point of triangle on standard cement monument projecting 5 inches above surface of ground. Subsurface mark is center of 2 -inch tile pipe buried with top 2 inches below base of monument.

References. -

"Blakeford" (S $\left.23^{\circ} 2 \mathrm{I}^{\prime} \mathrm{E}\right)$. .

North chimney of house at Queenstown....

Chimney of house ..................

Cupola on barn near Jackson Creek Landing

Chimney of small house.

Chimney of small house

Chimney of Greens fishing ............. $58 \quad 35$

$84 \quad 38$

South chimney of house............... 103 4

East gable of house ................. r $_{3} \mathrm{r}_{2}$

Right tangent of piles of Bogle Wharf..... r33 30

East chimney of house............... 15 I 35

East chimney of house............... I76 46

Williams water tank................ $200 \quad 5^{8}$

Knob on door of fishing shack. . . . . . . . . 349 5

\begin{tabular}{|c|c|c|c|}
\hline$\infty$ & $\infty$ & $\ldots \ldots$ & I $1 / 2$ miles. \\
\hline & . & ...... & $2 \mathrm{r} / 2$ miles. \\
\hline & .. & ...... & $3^{3 / 8}$ miles. \\
\hline & . & $\ldots \ldots$ & $4^{1 / 8}$ miles. \\
\hline & . & .. & $4^{t} 2$ miles. \\
\hline & . & ..... & $5^{1 / 2}$ miles. \\
\hline & . & $\ldots \ldots$ & $\mathrm{I} / 2$ miles. \\
\hline & .. & $\ldots \ldots$ & $2 \mathrm{I} / 8$ miles. \\
\hline & .. & $\ldots \ldots$ & $2 \mathrm{r} / 8$ miles. \\
\hline & .. & $\ldots \ldots$ & I $5 / 8$ miles. \\
\hline & . & ...... & $21 / 2$ miles. \\
\hline & .. & $\ldots \ldots$ & $33 / 4$ miles. \\
\hline & . & $\ldots \ldots$ & $1 / 4$ mile. \\
\hline & .. & & $1 / 4$ mile. \\
\hline
\end{tabular}

\section{OVERTON}

General locality.-Western shore of Chester River on north side of entrance to Durdin Creek and about Ioo yards south of Bogle Wharf. (See Chart No. 30.)

Immediate locality.-Observed station is on marsh land about $\mathrm{x}$ foot above high water, 4 yards. inshore, roo yards south of Bogle Wharf, 250 yards southeast of Bogle store, and 300 yards west of Bogle Wharf house. 'Cement monument marking reference station is 11.26 meters $\mathrm{S} 73^{\circ} \circ 6^{\prime} \mathrm{W}$ of ob served station.

Marks,-Observed station is center of 2 -inch tile pipe projecting 2 inches above surface of ground. Subsurface mark is center of 2 -inch tile pipe buried with top 2 inches below base of surface pipe. Ref. erence station is center point of triangle on standard cement monument projecting + inches above surface of ground.

\begin{tabular}{|c|c|c|c|c|}
\hline ferences.- & 0 & , & $" \prime$ & \\
\hline "Bay Bush Point" $\left(\mathrm{N}_{3}{ }^{\circ}{ }_{3}{ }^{\prime} \mathrm{W}\right) \ldots$ & o & $\infty$ & $\infty$ & $13 / 4$ miles. \\
\hline 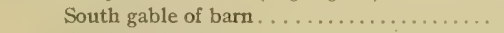 & 4 & I2 & . . & $27 / 8$ miles. \\
\hline South gable of barn. . . . . . . . . . . . . & $x_{7}$ & $2 I$ & . & 3 miles. \\
\hline 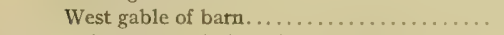 & 39 & 13 & $\ldots \ldots \ldots$ & 5 miles. \\
\hline Left tangent of piles of Bogle Wharf. . . . . . & 73 & 17 & ....... & 300 yards. \\
\hline Chimney of house . . . . . . . . . . . . . & II9 & 25 & . & $2 \frac{1}{2}$ miles. \\
\hline Lower west gable of Queenstown elevator... & 138 & $2 I$ & .. . & $3^{1 / 2}$ miles. \\
\hline North gable of house ................ & 140 & 27 & . . & $3 \frac{3}{4}$ miles. \\
\hline Right tangent of woods on Hail Point...... & I68 & 59 & . . . & $\mathrm{r}^{3} / 8$ miles. \\
\hline REFERENCE STATION . . . . . . . . . & 256 & 18 & 40 & II .26 meters. \\
\hline Chimney of Bogle's store....... & 289 & 17 & .. . & 250 yards. \\
\hline
\end{tabular}

FIR.

General locality.-Eastern shore of Chester River on Piney Point about $\mathbf{1}^{5} / 8$ miles north-northwest of Break Point and one-half mile west of Piney Cove. (See Chart No. 30.)

Immediate locality.-Observed station is on marsh land at the extreme end of Piney Point, about on level with high water, and about 4 yards east of shore. Cement monument marking reference station is 10.45 meters $\mathrm{S} 70^{\circ} 43^{\prime} \mathrm{E}$ of observed station. 
Marks.-Observed station is center of 2 -inch tile pipe with top flush with surface of ground. Subsurface mark is center of 2 -inch tile pipe buried with top 2 inches below base of surface pipe. Reference station is center point of triangle on standard cement monument projecting 4 inches above surface of ground.

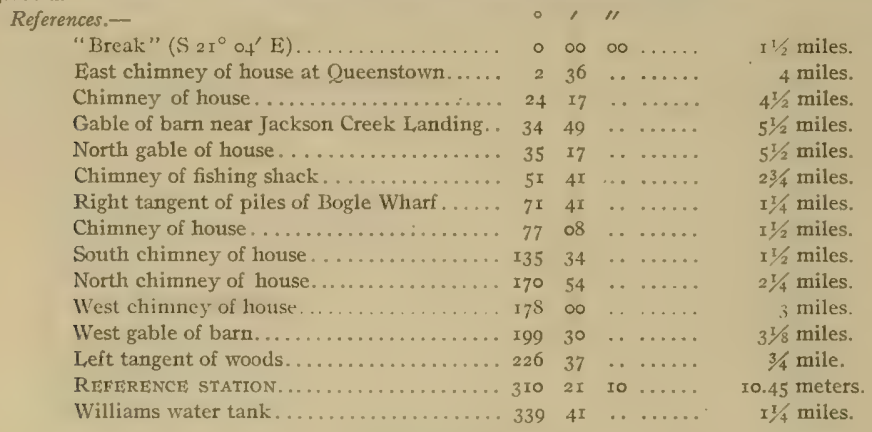

BAY BUSH POINT.

General locality.-Western shore of Chester River on a point about one-fourth mile north of entrance to Fryingpan Cove and Churn Creek. (See Chart No. 30.)

Immediale locality.-Observed station is on a marsh point about I foot above high - water, I5 yards inshore, and in front of several persimmon trees. Cement monument marking reference station is ro. 16 meters $\mathrm{N} 80^{\circ} 13^{\prime}$ W of observed station.

Marks.-Observed station is nail in 3 -inch cement filled tile pipe with top 6 inches below surface of ground incased in cement cake bearing the legend "U.S.C. S.-1896." Reference station is center point of triangle on standard cement monument projecting 4 inches above surface of ground.

References. -

\begin{tabular}{|c|c|c|c|c|}
\hline Wir" (S $\left.57^{\circ} 5^{6^{\prime}} \mathrm{E}\right)$ & 0 & 00 & & $11 / 2$ \\
\hline Williams water tank. . . . . . . . . . . . . & 8 & 22 & .. . & $21 / 2$ miles. \\
\hline Chimney of house at Queenstown.......... & 27 & I7 & .. & les. \\
\hline West gable of birn................ & 35 & 42 & . & 4,3 miles. \\
\hline Left tangent of woods on Hail Point...... & 45 & $5^{8}$ & . & $3 \frac{1}{4}$ \\
\hline Left tangent of piles of Bogle Wharf. . . . . . & 48 & $2 I$ & .. & $x^{1} / 4$ miles. \\
\hline Chimney of Bogle store. . . . . . . . . . . . & $5^{8}$ & $\infty$ & . & I $5 / 8$ miles. \\
\hline $\begin{array}{l}\text { Nail in blaze in persimmon tree }(6 \text { inches } \\
\text { diameter }) \ldots \ldots \ldots \ldots \ldots \ldots \ldots \ldots \ldots \ldots \ldots\end{array}$ & ; & & $\infty$ & \\
\hline REFERENCE STATKON.............. & 157 & 43 & $\infty \ldots \ldots$ & I0.16 meters. \\
\hline immon tree ( 8 inches & & & & \\
\hline & 220 & 45 & $\infty$ & 6.20 meter \\
\hline y of house................. & 244 & 04 & $\ldots \ldots$ & I $1 / 4$ miles. \\
\hline 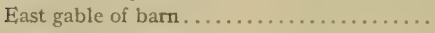 & 262 & Io & .. $\ldots$ & ailes. \\
\hline West gable of barn & 297 & $5^{I}$ & .. $\ldots \ldots$ & $4^{1 / 8}$ miles. \\
\hline West gable of & 316 & 19 & $\ldots \ldots \ldots$ & 3 miles. \\
\hline
\end{tabular}

\section{GORDON.}

General locality.-Eastern side of Chester River about 55 yards off shore, three-fourths mile southwest of entrance to Reeds Creek and seven-eighths mile north-northeast of Piney Point. (See Chart No. 30.)

Immediate locality.-Observed station is in about 3 feet of water at high tide, 55 yards off shore, and 300 yards southwest of end of woods and cultivated field. Cement monument marking reference station is 57.49 meters $\mathrm{S} 71^{\circ} \mathrm{I} 5^{\prime} \mathrm{E}$ of observed station. 
Marks.-Observed station is nail in 2-inch by 4 -inch pine stub driven with top to high water. Reference station is center point of triangle on standard cement monument projecting 4 inches above surface of ground.

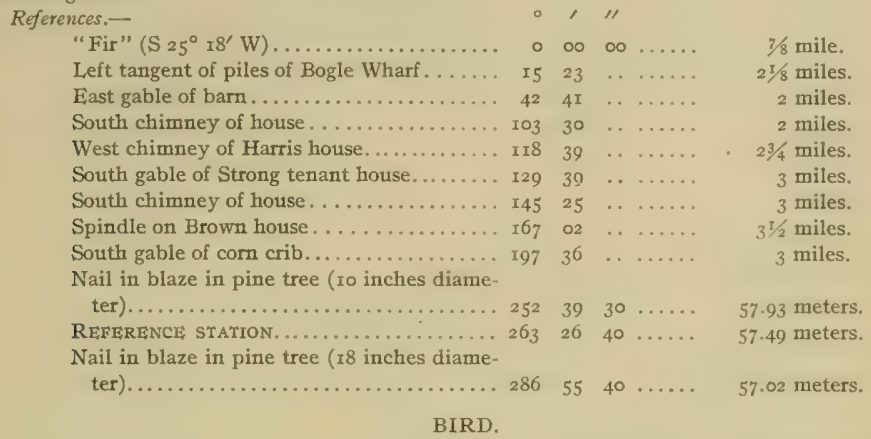

General locality.-Eastern shore of Chester River on Gordon Point at southwest side of entrance to Reeds Creek about I I $/ 2$ miles southwest of Holton Point. (See Chart No. 30.)

Immediate locality. - Observed station is in a marsh meadow about 2 feet above high water, and 75 yards west of shore.

Marks.-Observed station is center point of triangle on standard cement monument projecting 7 inches above surface of ground. Subsurface mark is center of 2 -inch tile pipe buried with top 2 inches below base of monument.

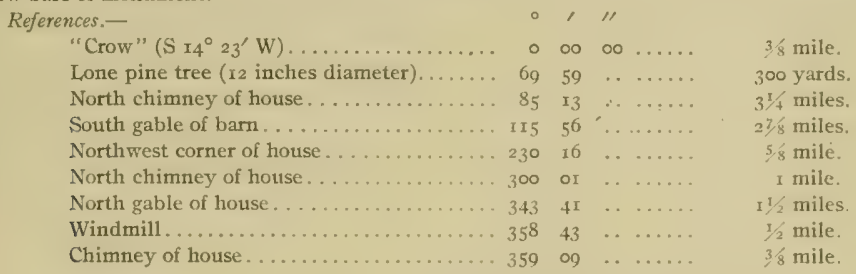

\section{CROW.}

General locality.--Eastern side of Chester River on western shore of Reeds Creek about one-half mile south of extreme end of Gordon Point. (See Chart No. 30.)

Immediate locality.-Observed station is in yard of tenant house about 4 feet above high water, 12 yards west of shore, 5 yards south of a pear orchard, and 7 yards north of a house.

Marks.-Observed station is center point of triangle on standard cement monument projecting 6 inches above surface of ground. Subsurface mark is center of 2 -inch tile pipe buried with top 2 inches below base of monument.

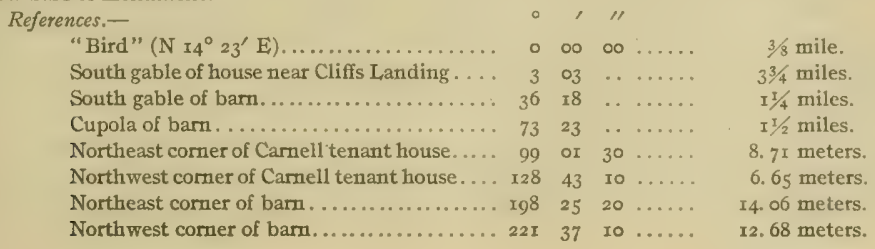


GROVE.

General locality.-Eastern side of Chester River on a point between Reeds Creek and Grove Creek about one-half mile southeast of Gordon Point. (See Chart No. 3o.)

Immediate locality.-Observed station is in a meadow about 2 feet above high water, 26 yards south of shore, 8 yards west of three persimmon trees, and 35 yards west of a pond.

Marks.-Observed station is center point of triangle on standard cement monument projecting 5 inches above surface of ground. Subsurface mark is center of 2 -inch tile pipe buried with top 2 inches below base of monument.

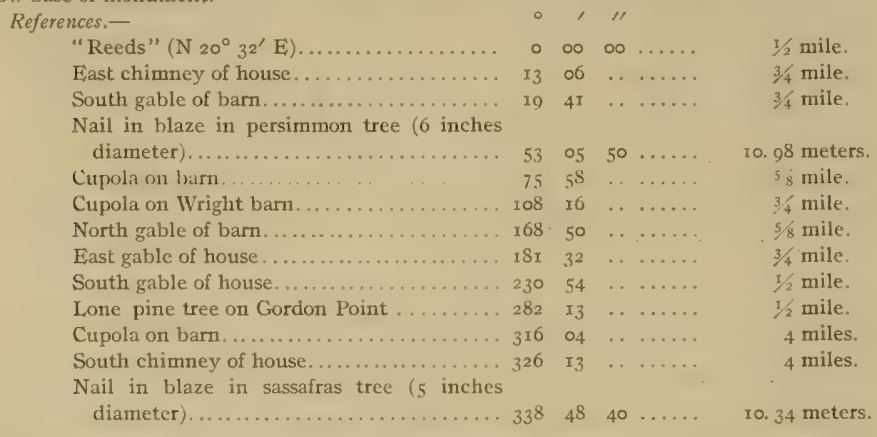

\section{REEDS.}

General locality.-Eastern shore of Chester River at northeast side of entrance to Reeds Creek and about five-eighths mile south of Robins Cove. (See Chart No. 3o.)

Immediate locality.--Observed station is on marsh línd about 2 feet above high water, $3+$ yards east of shore, 9 yards north of ditch draining swamp, and in center of triangle formed by three pine stubs driven flush with marsh to support theodolite.

Marks.-Observed station is center point of triangle on standard cement monument projecting 2 inches above surface of ground. Subsurface mark is center of 2 -inch tile pipe buried with top 2 inches below base of inonument.

References.-

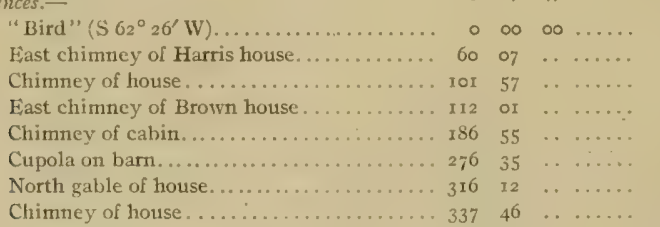

$$
\begin{aligned}
& I / 2 \text { mile. } \\
& 3^{I / 8} \text { miles. } \\
& 31 / 4 \text { miles. } \\
& 3 \text { miles. } \\
& 300 \text { yards } \\
& 11 / 4 \text { miles. } \\
& 13 / 8 \text { miles. } \\
& 7 / 8 \text { mile. }
\end{aligned}
$$

\section{LITTLE GUM.}

General locality.-Westem shore of Chester River on Little Gum Point at southwest side of entrince to Grays Inn Creek. (Sec Chart No. 30.)

Immediale locality,-Observed station is on a marsh point about I foot above high water, 2 yards south of shore; and 12 yards southeast of a 4 -foot ditch. Cement monument marking reference station is 40.97 metcrs $\mathrm{N}_{33^{\circ}} 3 \mathrm{I}^{\prime} \mathrm{W}$ of observed station.

Marks.-Observed station is center of 2 -inch tile pipe with top flush with surface of ground. Subsurface mark is 2 -inch tile pipe buried with top 2 inches below base of surface pipe. Reference station is center point of triangle on standard cement monument projecting 4 inches above surface of ground. 


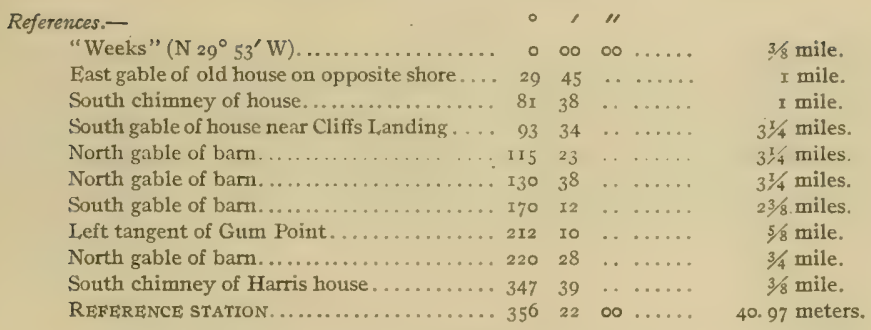

\section{WEEKS.}

General locality.-Western shore of Grays Inn Creek about three-eighths mile northwest of Chester River, and one-eighth mile southeast of Harris Wharf. (See Chart No. 3o.)

Immediate locality.-Observed station is in cultivated field about 7 feet above high water, 6 yards west of shore, 5 yards west of vertical bank 5 feet high, 50 yards northeast of low cedar tree at edge of peach orchard, 250 yards north of a wharf, and 200 yards north-northeast of a house.

Marks.-Observed station is center point of triangle on standard cement monument projecting 4 inches above surface of ground. Subsurface mark is center of 2 -inch tile pipe buried with top 2 inches below base of monument.

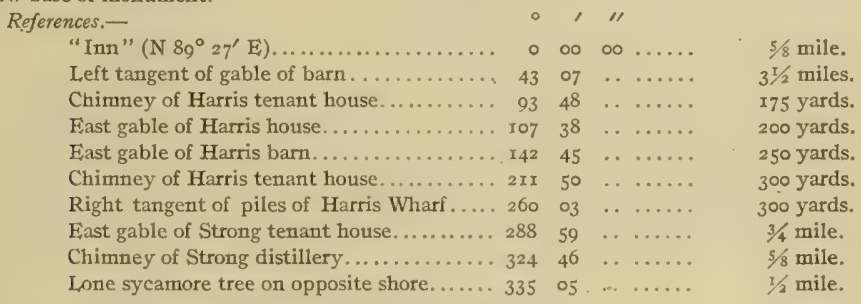

SPRING.

General localily.-Western shore of Grays Inn Creek about one-half mile northwest of Chester River, on Spring Point, near Harris Wharf. (See Chart No. 30.)

Immediate locality. - Observed station is in a cultivated field about io feet above high water, 8 yards southwest of shore, ro yards west of a barn, 4 yards southwest of top of slope, and roo yards southwest of an old wharf.

Marks.-Observed station is center point of triangle on standard cement monument projecting 3 inches above surface of ground. Subsurface mark is center of 2 -inch tile pipe buried with top 2 inches below base of monument.

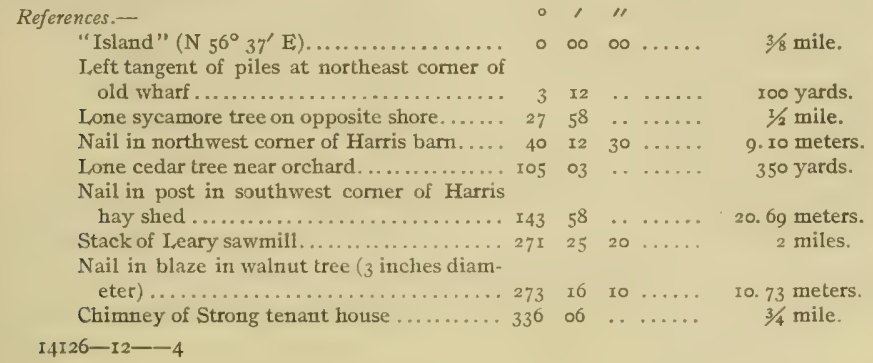




\section{LUCY.}

General locality.-Western shore of Grays Inn Creek abour three-fourths mile nortHwest of Chester River and one-fourth mile northwest of Harris Wharf. (See Chart No. 30.)

Immediate locality. - Observed station is on wooded shore about 5 feet above high water, 5 yards west of shore, 2 yards west of top of vertical bank, and 3 feet north of a stump 4 inches in diameter. Cement monument marking reference station is $x \mathrm{r} .55$ meters $\mathrm{S} 36^{\circ} 59^{\prime} \mathrm{W}$ of observed station.

Marks,-Observed station is center of 2 -inch tile pipe projecting 3 inches above surface of ground. Subsurface mark is center of 2 -inch tile pipe buried with top 2 inches below base of surface pipe. Reference station is center point of triangle on standard cement monument projecting 4 inches above surface of ground.
References:-
"Spring" ( $\left.\mathrm{S}_{4} S^{\circ} 33^{\prime} \mathrm{E}\right)$
Nail in blaze in twin-chestnut tree ( 18
inches diameter $) \ldots \ldots \ldots \ldots \ldots \ldots \ldots$.
REFERENCE STATION...................
Nail in blaze in twin chestnut tree (Io
inches diameter $) \ldots \ldots \ldots \ldots \ldots \ldots \ldots$. III $56 \quad 50 \ldots \ldots$
Stack of Leary sawmill................ Ig8 5 I $20 \ldots \ldots$
East gable of barn................... 2 то $59 \ldots \ldots$
Left tangent of piles of Strong old wharf.... $21_{3} \quad 34 \quad \ldots \ldots \ldots$
Southwest corner of Strong house......... 3 Io $53 \quad \ldots \ldots \ldots$.
Nail in blaze in gum tree ( $1_{5}$ inches diam-

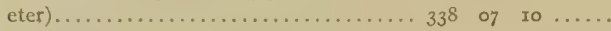
Left tangent of piles of Harris old wharf.... $34548 \quad \ldots \ldots$.
Northeast corner of Harris barn........... 359 r $1_{3} \quad \ldots \ldots \ldots$
$1 / 4$ mile.
9. 54 meters.
II. 55 meters.
8. 31 meters.
I $5 / 8$ miles.
2 miles.
$3 / 4$ mile.
$3 / 4$ mile.
4. 73 meters.
$1 / 4$ mile.
$1 / 4$ mile.

\section{GOOSE.}

General locality. -Western shore of upper Grays Inn Creek about $I^{1 / 3} / 4$ miles northwest of Chester River, on point between Browns Cove and Goose Cove. (See Chart No. 30.)

Immediate lacality. - Observed station is in a cultivated field at edge of.peach orchard about I2 feet above high water, 8 yards southwest of shore, 6 yards southwest of top of vertical bank, and $\mathrm{r}$ yard north of row of peach trees.

Marks.-Observed station is center point of triangle on standard cement monument projecting 5 inches above surface of ground. Subsurface mark is center of 2 -inch tile pipe buried with top 2 inches below base of monument.

References.

"Prussian" ( $\mathrm{N}$ I8 $\left.8^{\circ} 50^{\prime} \mathrm{W}\right) \ldots \ldots \ldots \ldots \ldots$

East gable of house...................

West chimney of house.................

Nail in blaze in locust tree ( 6 inches diam-

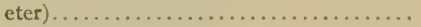

West chimney of house ..............

Left tangent of piles of old wharf ........ 3

West chimney of house. . . . . . . . . . . 87

North post of Harris hay shed.......... ${ }_{5} 6$

Nail in blaze in peach tree ( 6 inches diam-

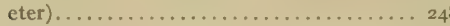

East gable of barn ................. 328

Nail in blaze in locust tree ( 5 inches diam-

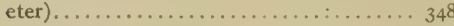

Stack of Learys sawmill. . . . . . . . . 353

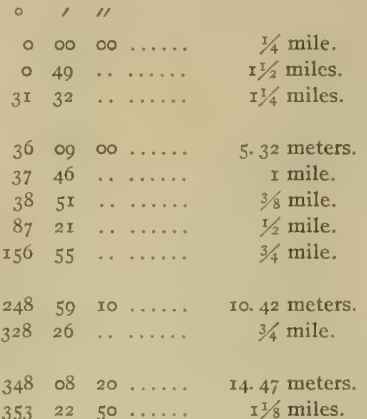




\section{PRUSSIAN.}

General locality.-Western shore of upper Grays Inn Creek about $15 / 8$ miles northwest of Chester River, opposite Strong's old wharf. (See Chart No. 30.)

Immediate locality.-Observed station is in a marsh meadow about I foot above high water, 9 yards southwest of shore, 25 yards west of extreme end of point, and in center of triangle formed by three pine stubs driven flush with marsh to support theodolite.

Marks.-Observed station is center point of triangle on standard cement monument projecting 6 inches above surface of ground. Subsurface mark is center of 2 -inch tile pipe buried with top 2 inches below base of monument.

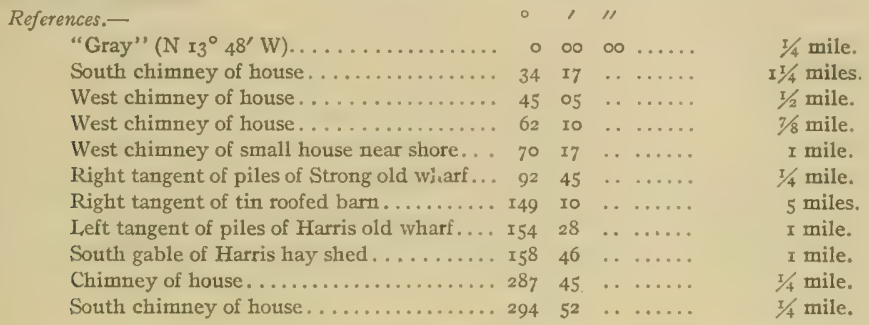

GRAY.

General locality.-Western shore of upper Grays Inn Creek about $13 / 4$ miles northwest of Chester River, 250 yards west of Browns Point, and I mile south-southeast of Learys Mill Wharf. (See Chart No. 30.)

Immediate locality.-Observed station is in a cultivated field about 3 feet above high water, ro yards south of shore, 200 yards north of a group of five pine trees, and about on line with two cedar trees north of station.

Marks.-Observed station is center point of triangle on standard cement monument projecting 3 inches above surface of ground. Subsurface mark is center of 2 -inch tile pipe buried with top 2 inches below base of monument.

References.-

"Herring" ( $\left.\mathrm{N} 44^{\circ} \mathrm{I2}^{\prime} \mathrm{E}\right)$

South gable of barn..................

Nail in blaze in cedar tree ( 3 inches diam-

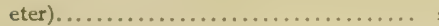

Chimney of Harris house............. ro

West one of group of pine trees ( 12 inches

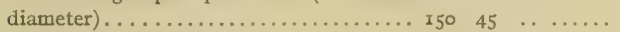

North chimney of house............. I78 $5^{8} \quad \ldots \ldots \ldots$

Stack of Learys sawmill............. $28_{3}$ oو $\ldots \ldots \ldots$

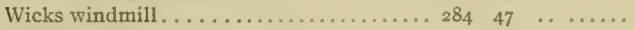

Chimney of small house............. $289 \quad 55 \quad \ldots \ldots \ldots$

Nail in blaze in dead cedar tree (6 inches

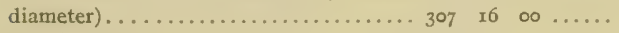

East chimney of house............... $315 \quad 24 \quad \ldots \ldots \ldots$

Lone dead pine tree. . . . . . . . . . $359 \quad 32 \quad \ldots \ldots$.

14 mile.

$3 / 8$ mile.

14. 67 meters.

$\mathrm{I} 3 / 8$ miles.

200 yards

$1 / 4$ mile.

$5 / 8$ mile.

$\mathrm{r} / 2$ miles.

$3 / 4$ mile.

4. 43 meters.

$1 / 2$ mile.

$1 / 4$ mile.

\section{HERRING}

General locality.-Eastern shore of upper Grays Inn Creęk about I7/8 miles northwest of Chester River, at north side of entrance to Herringtown Creek and about five-eighths mile east-southeast of Leary sawmill. (See Chart No. 30.)

Immediate locality. - Observed station is in a marsh meadow about 2 feet above high water, 20 yards north of shore, 5 yards west of a rail fence, 7 yards south of a lone dead pine tree, 75 yards south of a lone cedar tree, and in center of triangle formed by three pine stubs driven flush with marsh to support theodolite. 
Marks.-Observed station is center point of triangle on standard cement monument projecting 6 inches above surface of ground. Subsurface mark is center of 2 -inch tile pipe buried with top 2 inches below base of monument.
References.-

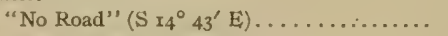
North chimney of house..................
Nail in blaze in dead pine tree (30 inches

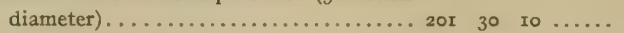
Chimney of house................ 2 I $_{5} \quad 40 \ldots \ldots$
Chimney of house................. $223 \quad 53 \quad \ldots \ldots$
East chimney of house.............. $273 \quad 48 \ldots \ldots$.
West chimney of house.$\ldots \ldots \ldots \ldots \ldots .300$. $02 \ldots \ldots$
$3 / 8$ mile. $1 / 2$ mile.
6. 66 meters. $3 / 8$ mile. $1 / 4$ mile. $\mathrm{I} / 2$ mile. 300 yards.

NO ROAD.

General locality. - Eastern shore of upper Grays Inn Creek about I I $/ 2$ miles northwest of Chester River at south side of entrance to Herringtown Creek, near Strong old wharf. (See Chart No. 3o.)

Immediate locality.-Observed station is on a clay and sand beach on a wooded shore about $\mathbf{I}$ foot above high water, 5 yards east of shore, and 77 yards east of end of piles of an old wharf.

Marks.-Observed station is center point of triangle on standard cement monument projecting 6 inches above surface of ground. Subsurface mark is center of 2 -inch tile pipe buried with top 2 inches below base of monument.

Refercnces.-
"Cut" ( $\left.\mathrm{S} \times 2^{\circ} 0^{\prime} \mathrm{E}\right)$.
$\circ \infty 00 \ldots . .$.
Left targent of piles of Strong old wharf... 87 ro $\ldots \ldots \ldots$
South chimney of house............. I00 $38 \ldots \ldots$. . . .
Stack of Leary sawmill.............. I48 $50 \quad \ldots \ldots \ldots$
Wicks windmill.................. $153 \quad 37 \quad 20 \ldots \ldots$
East chimney of house............... $x_{57} \quad 50 \ldots \ldots$
East gable of barn................. I68 $23 \ldots \ldots$
Nail in blaze in pine tree ( 18 inches diam-
eter).................................

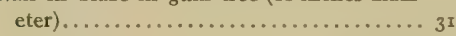
$19925 \quad 50 \ldots \ldots$
$1 / 4$ mile.
100 yards.
$1 / 2$ mile.
I mile.
$2 \pi / 2$ miles.
I $1 / 4$ miles.
$3 / 4$ mile.
24. 75 meters.
8. 16 meters.

\section{CUT.}

General locality.-Eastern shore of upper Grays Inn Creek, on point about $x^{3} / 8$ miles northwest of Chester River, and one-half mile south of Herrington Creek. (See Chart No. 30.)

Immediate locality.-Observed station is on marsh land below high water, about 13 yards north of shore, 60 yards northwest of three large cedar trees, 35 yards southwest of a wire fence at edge of woods, and in center of triangle formed by three pine stubs driven flush with marsh to support theodolite.

Marks,-Observed station is center point of triangle on standard cement monument projecting 5 inches above surface of ground. Subsurface mark is center of 2 -inch tile pipe buried with top 2 inches below base of monument.

References.-

"No road" ( $\left.\mathrm{N} \mathrm{I2}^{\circ} \mathrm{o4}^{\prime} \mathrm{W}\right)$.

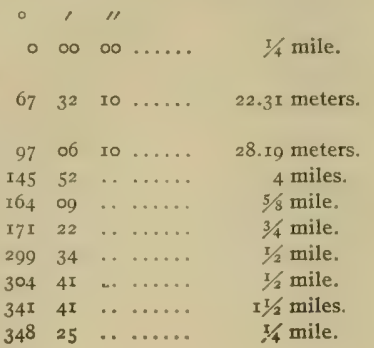

Nail in blaze in pine tree ( 6 inches diame-

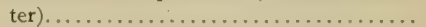

Nail in blaze in cedar tree ( $I_{2}$ inches diameter).......................

West gable of barn................. I

Left tangent of piles of Harris old wharf.... I6

East chimney of Harris house ............ r

East gable of barn.................. 299

. North chimney of house................... 304 4I

South gable of house.................. 34I 4 I

Left tangent of piles of Strong old wharf... $348 \quad 25$ 
FORE.

General locality.-Eastern shore of Grays Inn Creek, on point about 1 mile northwest of Chester River, and three-eighths mile north of Harris Wharf. (See Chart No. 3o.)

Immediate locality. - Observed station is on a marsh point, about I foot above high water, 3 yards northwest of shore, II yards north-northeast of extreme end of point, and in center of triangle formed by three pine stubs driven flush with marsh to support theodolite.

Marks.-Observed station is center point of triangle on standard cement monument projecting $\mathrm{I} 2$ inches above surface of marsh. Subsurface mark is center of 2 -inch tile pipe buried with top 2 inches below base of monument.

\begin{tabular}{|c|c|c|c|c|}
\hline \multicolumn{5}{|l|}{ References.- } \\
\hline "Lucy" $\left(\mathrm{S}_{3} 6^{\circ} \mathrm{Ix}^{\prime} \mathrm{W}\right) \ldots \ldots \ldots \ldots \ldots \ldots$ & 0 & $\infty$ & 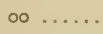 & $3 / 8$ mile. \\
\hline North chimney of house. . . . . . . . . . . & 78 & I7 & $\ldots \ldots \ldots$ & $I / / 4$ miles. \\
\hline East gable of small house. .......... & 80 & 43 & $\ldots \ldots$ & $\mathrm{I} / 4$ miles. \\
\hline Swamp oak tree ( 2 feet diameter)......... & I3I & 28 & . . & 100 yards. \\
\hline Southwest corner of Strong tenant house.... & 234 & 28 & .. . & $3 / 8$ mile. \\
\hline Lone sycamore tree ( 12 inches diameter).... & 274 & $5^{8}$ & $\ldots$. & $3 / 4$ mile. \\
\hline West gable of barn on Grove Creek. ....... & 278 & 30 & $\ldots \ldots \ldots$ & $4 \frac{1}{4}$ miles. \\
\hline North gable of barn with two cupolas...... & 287 & 49 & $\ldots \ldots \ldots$ & $33 / 8$ miles. \\
\hline Chimney of Harris tenant house........... & 319 & 50 & $\ldots \ldots \ldots$ & $5 / 8$ mile. \\
\hline Left tangent of piles of Harris old wharf..... & $32 \mathrm{I}$ & 36 & $\ldots \ldots \ldots$ & $3 / 8$ mile. \\
\hline East gable of Harris barn............... & 328 & 02 & $\ldots \ldots \ldots$ & $3 / 8$ mile. \\
\hline
\end{tabular}

\section{ISLAND.}

General locality.-Eastern shore of Grays Inn Creek, about five-eighths mile northwest of Chester River, on Island Point opposite Harris Wharf. (See Chart No. 30.)

Immediate locality.-Observed station is on marsh land, about I foot above high water, 3 yards northeast of shore, and 400 yards west of a house. Cement monument marking reference station is 9.01 meters $\mathrm{N}_{4} 3^{\circ} 38^{\prime} \mathrm{E}$, of observed station.

Marks.-Observed station is center of 2 -inch tile pipe, with top flush with surface of ground. Subsurface mark is center of 2 -inch tile pipe buried with top 2 inches below base of surface pipe. Reference station is center point of triangle on standard cement monument projecting 6 inches above surface of ground.

\begin{tabular}{|c|c|c|c|c|}
\hline References.- & $\circ$ & ' & $\prime \prime$ & \\
\hline "Tray" $\left(\mathrm{S}_{36} 6^{\circ} 22^{\prime} \mathrm{E}\right)$. & $\circ$ & $\infty$ & $\infty \ldots$ & 3/8 mile. \\
\hline Left tangent of woods on Hail Point........ & 33 & I3 & . . & $5 \frac{3}{4}$ miles. \\
\hline Lone poplar tree. ............... & 65 & 03 & .. & $5 / 8$ mile. \\
\hline East gable of Harris house...$\ldots \ldots \ldots \ldots$ & 68 & 27 & . . . & $1 / 2$ mile. \\
\hline 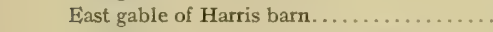 & 73 & 32 & . $\ldots$ & $1 / 2$ mile. \\
\hline Right tangent of piles of old wharf........ & 93 & 29 & . . . & $3 / 8$ mile. \\
\hline Chimney of small house ................. & I53 & 23 & .. $\ldots$ & $1 \frac{\pi}{4}$ miles. \\
\hline East chimney of house $\ldots \ldots \ldots \ldots \ldots \ldots$ & 171 & 07 & . $\cdots$ & $3 / 4$ mile. \\
\hline East gable of Strong tenant housc.......... & 197 & 31 & $\ldots \ldots \ldots$ & $1 / 4$ mile. \\
\hline REFERENCE STATION . . . . . . . . . . . . & 259 & 59 & $50 \ldots \ldots$ & 9.01 meters. \\
\hline Chimney of Strong old distillery .......... & 308 & 33 & . $\cdots \cdots$ & $1 / 4$ mile. \\
\hline Lone cedar tree near shore.............. & 354 & 59 & . $\ldots \ldots$ & 300 yards. \\
\hline
\end{tabular}

TRAY.

General locality.-Eastern shore of Grays Inn Creek, about one-fourth mile northwest of Chester River, three-eighths mile southeast of Island Point, and one-half mile east of Harris Wharf. (Sec Chart No. 30.)

Immediate locality.-Observed station is on a marsl point, about $\mathrm{I}$ foot above high water, 4 yards 11ortheast of shore, ro yards southwest of a small locust stump at foot of bank, and I2 yards southwest of foot of slope. Cement monument marking reference station is 8.86 meters $N 53^{\circ} 42^{\prime} \mathrm{E}$ of observed station. 
Marks.-Observed station is center of 2 -inch tile pipe, with top flush with surface of ground. Subsurface mark is center of 2 -inch tile pipe buried with top 2 inches below base of surface pipe. Reference station is center point of triangle on standard cement monument projecting 7 inches above surface of ground.
References.-
"Island" (N $36^{\circ}$ (
$\begin{array}{cccc}0 & 1 & \\ 0 & 00 & 00 & \ldots . . .\end{array}$
$3 / 8$ mile.
REFERENCE STATION.................. 90 o2 $50 \ldots \ldots$ 8.86 meters.
Nail in blaze in locust tree ( 4 inches diame- ter) $90 \quad 28 \quad 40 \quad \ldots \ldots$ 10.60 meters.
Nail in blaze in persimmon tree $(6$ inches diameter $) \ldots \ldots \ldots \ldots \ldots \ldots \ldots \ldots \ldots \ldots \ldots$ I29 25 10 $\ldots \ldots$
Right tangent of woods on Hail Point. ...... 2I7
Northeast comer of barn. ............. 239
East gable of Harris house............. 287
Chimney of Harris tenant house.......... 30.4
North gable of house near shore.......... 3 I
North gable of barn................... 338
South chimney of house.
........
9.75 meters.
5 miles.
$r$ mile.
$1 / 2$ mile.
$5 / 8$ mile.
$5 / 8$ mile.
$\mathrm{I} / 2$ miles.
$13 / 4$ miles.

INN.

General locality:-Eastern shore of Grays Inn Creek, about one-eighth mile northwest of Chester River and one-half mile southeast of Island Point. (See Chart No. 3o.)

Immediate locality.-Observed station is in a peach orchard, about 4 feet above high water, and 25 yards northeast of shore.

Marks.-Observed station is center point of triangle on standard cement monument projecting 3 inches above surface of ground. Subsurface mark is center of 2 -inch tile pipe buried with top 3 inches below base of monument.

References.-

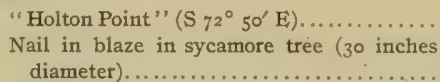

North cupola on barn.

Left tangent of woods on Hail Point. . . . . . 74

East gable of Swatska barn ............ Io

East chimney of house............... I

East gable of Harris house. ............... I50

East gable of small house............ I75

Nail in blaze in peach tree ( 8 inches diame-

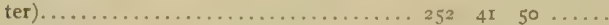

Southwest corner of Earle bathhouse..... $359 \begin{array}{llll}48 & & 28 & \ldots \ldots\end{array}$
$25 / 8$ miles.

4.53 meters.

$21 / 2$ miles,

$4 \frac{\pi}{2}$ miles.

I $1 / 4$ miles.

$1 / 2$ mile.

$5 / 8$ mile.

$5 / 8$ mile.

II.7 I meters.

3 miles.

\section{HOLTON POINT.}

General locality:- Eastem shore of Chester River on Holton Point, at south side of entrance to Corsica River. (See Chart No. 30.)

Immediate locality. - Observed station is on low sand beach, about on level with high water, and onefourth mile west of small bathhouse. Cement monument marking reference station is 5.40 meters $\mathrm{S} 48^{\circ} 06^{\prime} \mathrm{E}$ of observed station.

Marks.-Observed station is nail in 3-inch cement-filled tile pipe, with top about 6 inches below surface of ground, encased in a cement cake bearing the legend "U. S. C. S. I896." Reference station is center point of triangle on standard cement monument projecting 5 inches above surface of ground. 


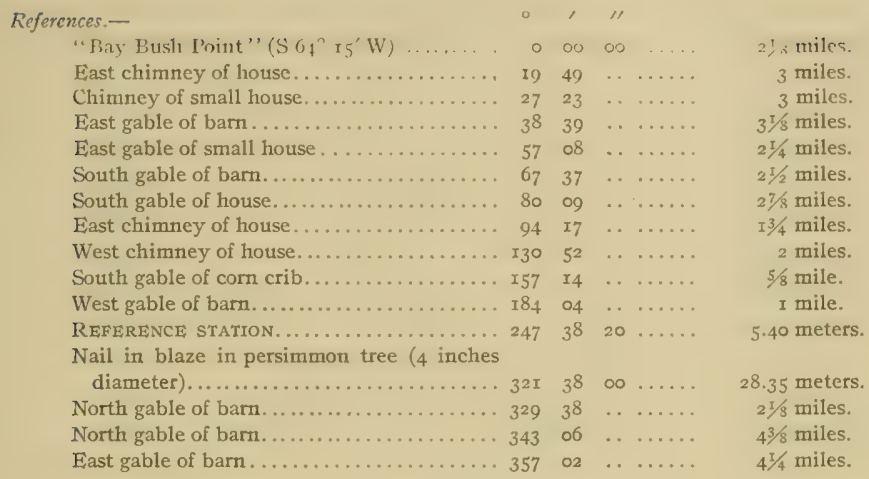

\section{EARLE.}

General locality. - Southern shore of Corsica River on Town Bar Point about one-half mile east of Chester River and 100 yards north of Earle Wharf. (See Chart No. 30.)

Immediate locality.-Ohserved station is on marsh land about I foot above high water, 5 yards soutl of shore, rg yards north of a pond, and roo yards north of Earle Wharf.

Marks.-Observed station is center point of triangle on standard cement montrment projecting 3 inches above surface of ground. Subsurface mark is center of 2 -inch tile pipe buried with top 2 inclies below base of monument.

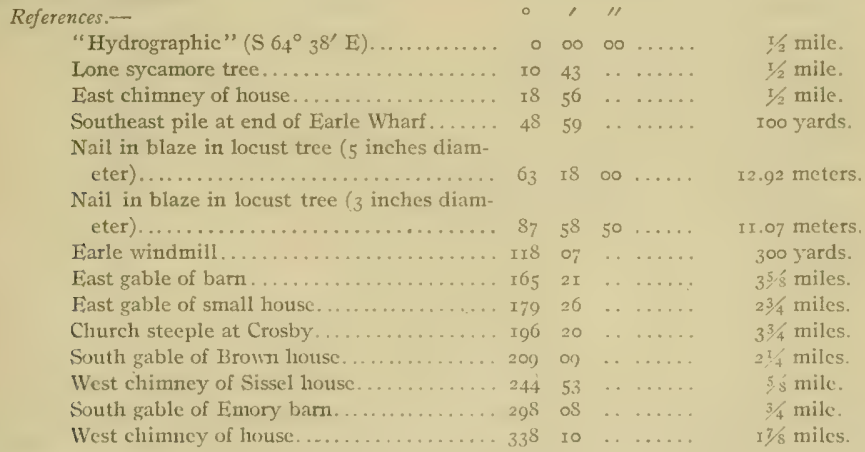

HYDROGRAPHIC.

General locality.-Southern shore of Corsica River about II/s miles cast of Chester River and onehalf mile east of Earle Wharf. (See Chart No. 3o.)

Immediate locality.-Observed station is near edge of ctiltivated field about 3 feet above high water, 20 yards south of shore, 4 yards south of edge of bank 3 feet high, and 400 yards north of lone sycamore tree. 
Marks.-Observed station is center point of triangle on standard cement monument projecting 5 inches above surface of ground. Subsurface mark is center of 2 -inch tile pipe buried with top 2 inches below base of monument.
References.-
"Earle" ( $\left.64^{\circ} 37^{\prime} \mathrm{W}\right)$
$\begin{array}{llll}0 & \prime \prime & \\ 0 & \infty & 0 & \ldots . . .\end{array}$
$5 / 8$ mile.
Church steeple at Crosby............... I4
East gable of barn .................. I9
South gable of Sissel barn............. 33
South gable of Emory barn.............. 73
Southwest corner of Emory Wharf house... 75
West gable of barn.................. I1 4
West gable of barn................... $\mathbf{r}_{35}$
West chimney of house............... I 48
East chimney of house.............. 231
Nail in blaze in apple tree ( 12 inches diam-

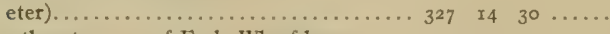
$4 \frac{1}{4}$ miles.
… $\quad 3^{1 / 2}$ miles.
...... $\quad 3 / 4$ mile.
...... $5 / 8$ mile.
$1 / 2$ mile.
$3 / 4$ mile.
I $5 / 8$ miles.
I $1 / 4$ miles.
$3 / 4$ mile.
Southeast corner of Earle Wharf house.... 354
I 6.00 meters.
$1 / 3$ mile.

\section{RUTH.}

General locality.-Southern shore of Corsica River about $I^{I} / 2$ miles east of Chester River and oneeighth mile northwest of entrance to Tilghmans Cove. (See Chart No. 30.)

Immediate locality. -Observed station is in cultivated field about $I_{5}$ feet above high water, ro yards south of shore, 2 yards west of edge of slope, and 6 yards south of edge of slope.

Marks.-Observed station is center point of triangle on standard cement monument projecting 3 inches above surface of ground. Subsurface mark is center of 2 -inch tile pipe buried with top 2 inches below base of monument.

References.-

East chimney of Earle tenant house.....

South gable of Sissel barn.................

Southeast comer of Emory Wharf house....

South gable of Emory barn.............. 60

Chimney of Emory house............. 64

East post of front porch of house.......... I0

Nail in blaze in oak tree ( 24 inches diameter) II

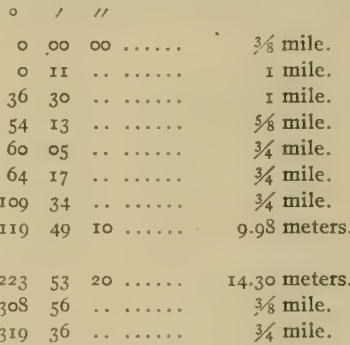

blaze in cedar tree (6 inches diam-

eter)..............................

East gable of small barn............... 308 $56 \quad \ldots \ldots \ldots$

Lone sycamore tree................ 3 I9 $36 \ldots \ldots$

$3 / 4$ mile.

\section{MELFIELD.}

General locality. - Southern shore of Corsica River about $17 / 8$ miles east of Chester River, I mile southeast of Emory Wharf, and one-eighth mile east of entrance to Tilghmans Cove. (See Chart No. 30.)

Immediate locality.-Observed station is in cultivated field about 18 feet above high water, ro yards south of shore, 5 yards south of edge of bluff, and 1o yards west of a ravine.

Marks.-Observed station is center point of triangle on standard cement monument projecting 4 inches above surface of ground. Subsurface mark is center of 2 -inch tile pipe buried with top 2 inches below base of monument. 


\begin{tabular}{|c|c|c|c|c|c|}
\hline rences.- & 0 & , & II & & \\
\hline "Ruth" ( $\left.\mathrm{N}_{7 \mathrm{x}^{\circ}}{ }_{32}^{\prime} \mathrm{W}\right)$.. & 0 & $\infty$ & $\infty 0$ & & $5 / 8$ mile. \\
\hline 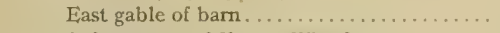 & II & 02 & .. & & 5 miles. \\
\hline Left tangent of Emory Wharf.............. & 29 & 50 & . & . & 7/8 mile. \\
\hline East chimney of Emory house . . . . . . . . . & 38 & ro & - & & I mile. \\
\hline Southwest corner of house............... & 74 & 26 & . & & $3 / 4$ mile. \\
\hline Cupola on Emory Wharf house............ & 96 & 53 & .. & $\ldots \ldots$ & $\mathrm{I} / \mathrm{s}$ miles. \\
\hline 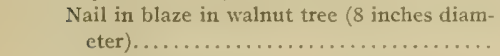 & II 9 & 34 & 10 & & 3.8 i meters. \\
\hline Nail in blaze in gum tree ( 7 inches diameter) & 179 & 56 & Io & & I 6.18 meters. \\
\hline West gable of barn . . . . . . . . . . . . . . . & 195 & 39 & .. & $\ldots \ldots$ & $3 / 8$ mile. \\
\hline $\begin{array}{l}\text { Nail in blaze in locust tree ( } 6 \text { inches diam- } \\
\text { eter) } \ldots \ldots \ldots \ldots \ldots \ldots \ldots \ldots \ldots \ldots \ldots \ldots \ldots \ldots \ldots \ldots \ldots \ldots\end{array}$ & & & Io & & \\
\hline South chimney of Farle house........... & $35^{\circ}$ & & & & mil \\
\hline
\end{tabular}

BATH.

General locality.-Southern shore of Corsica River on Wash Point about 2 miles east of Chester River, one-half mile west of Rocky Point, and one-fourth mile southeast of Ship Point. (See Chart No. 30.)

Immediate locality:-Observed station is on a marsh point about I foot above high water, 15 yards east of shore, 13 yards west of a pond, and surrounded by dense growth of bushes.

Marks.-Observed station is center point of triangle on standard cement monument projecting 8 inches above surface of ground. Subsurface mark is center of 2 -inch tile pipe buried with top 2 inches below base of monument.

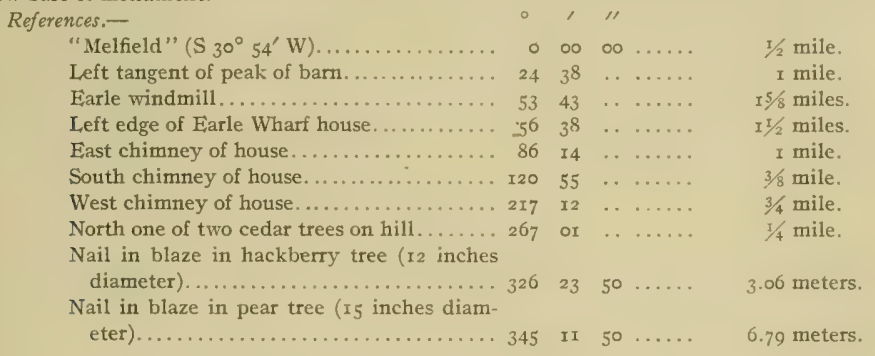

SHIP.

General locality.-Northern shore of Corsica River on Ship Point at west side of entrance to Emorys Creek, about $17 / 8$ miles east of Chester River, and five-eighths mile east of Eimory Wharf. (See Chart No. 30.)

Immedialc locality.-Observed station is on a marsh point covered with bushes about I foot above high water, 6 yards west of shore, and 75 yards south of a cedar tree covered with grape vines.

Marks.-Observed station is center point of triangle on standard cement monument projecting 3 inches above surface of ground. Subsurface mark is center of 2 -inch tile pipe buried with top 2 inches below base of monument. 


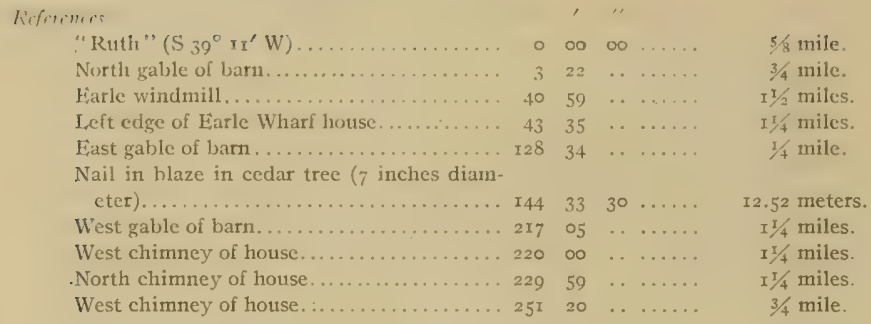

\section{FNGINEER.}

General locality:-Northern shore of Corsica River about I mile east of Chester River, five-eighths mile northeast of Earle Wharf, and 50 yards west of Emory Wharf. (See Chart No. 30.)

Immediate locality.-Observed station is on marshland about $x$ foot above high water, I2 yards north of shore, 50 yards west of Enory Wharf, and 50 yards southeast of a pond.

Marks.-Observed station is center point of triangle on standard cement monument projecting 4 inches above surface of ground. Substuface mark is center of 2 -inch tile pipe buried with top 2 inches below base of monument.

\begin{tabular}{|c|c|c|c|c|}
\hline eferences.- & $\circ$ & & $" \prime$ & \\
\hline "Ruth" (S $\left.20^{\circ} 36^{\prime} \mathrm{E}\right)$. & 0 & $\infty$ & $\infty$ & 5 \& mile. \\
\hline East chimney of house $\ldots \ldots \ldots \ldots \ldots \ldots$ & 29 & $3^{\mathrm{T}}$ & . & $7 / 8$ mile. \\
\hline Nail in blaze in pear tree ( 6 inches diameter) & 70 & 38 & $40 \ldots$ & 99.95 feet. \\
\hline 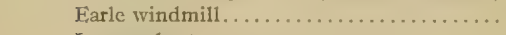 & 90 & I3 & .. & 7/8 mile. \\
\hline Lone cedar tree. ...................... & 165 & 42 & $\ldots \ldots \ldots$ & I25 yards. \\
\hline South gable of Emory barn.............. & 219 & 59 & . $\ldots \ldots$ & 300 yards. \\
\hline East chimney of Emory house....... & 257 & 47 & . $\cdots \cdots$ & 250 yards. \\
\hline West chimney of house ................ & $3 \mathrm{I} 7$ & 59 & $\cdots \cdots \cdots$ & $\mathrm{r} 3 / 8$ miles. \\
\hline Northeast comer of Eimory Wharf house.... & $32 \mathrm{I}$ & 35 & . . . . . & I56.94 feet. \\
\hline
\end{tabular}

\section{SWEPSON.}

General locality.--Northern shore of Corsica River opposite Town Bar Point about one-half mile east of Chester River, three-eighths mile north of Earle Wharf, and three-eighths mile west of Emory Wharf. (See Chart No. 30.)

Immediale locality.-Observed station is on marshland about I foot above high water, I2 yards north of shore, Io yards south of lone cedar tree, and I2 yards east of small ditch draining swamp.

Marks.-Observed station is center point of triangle on standard cement monument projecting 6 inches above surface of ground. Subsurface mark is center of 2 -inch tile pipe buried with top 2 inches below base of monument.

Reforcnes.-.

"Hydrographic" (\$ $32^{\circ}$ o6 $\left.1 \mathrm{li}\right) \ldots \ldots \ldots \ldots \ldots$

East chimncy of house................

Climney of house....................

liarle windmill . . . . . . . . . . . . . . . . . .
Nail in blaze in cedar tree ( 5 inches diameter) ......................... 230

South gable of Emory barn............ 283

West gable of barn. . . . . . . . . . . . . 332

North chimney of small house. .......... 355

Chimney of small house.

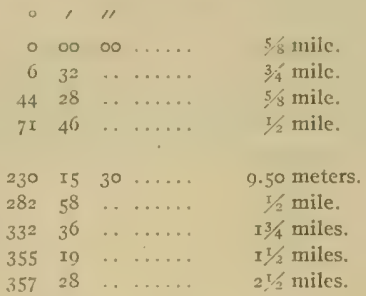




\section{CORSICA.}

General locality:-Eastern shore of Chester River at north side of entrance to Corsica River abont three-eighths mile sonth of Lower Spaniard Point. (Sce Chart No. 3o.)

Immediate localily.-Observed station is in a cullivated field about 7 fect above high water, 16 yards east of shore, II yards east of edge of bank, and 5 yards south of joung peacli orclard.

Marks.-Observed station is center point of triangle on standard cement monument projecting 7 inches above surface of ground. Subsurface mark is center of 2 -inch tile pipe buried with top 2 inches below base of monument.

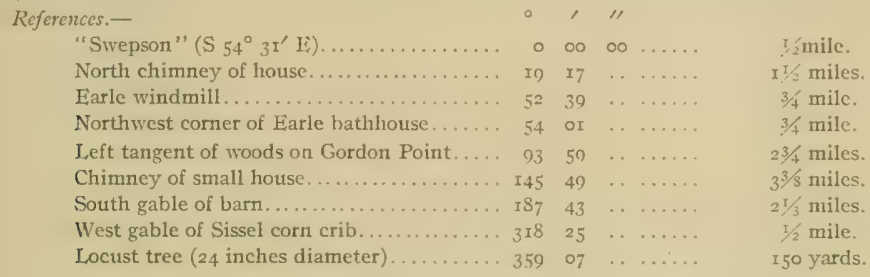

DEEP COVE.

General locality:-Western shore of Chester River on point at west side of entrance to Langford Creek and south side of entrance to Deep Cove. (See Chart No. 30.)

Immediate locality.-Observed station is on marshland about I foot above high water, ro yards inshore, 50 yards east of a dead tree 2 feet in diameter, 80 yards southeast of a tall poplar tree, and 300 yards east of a house.

Marks.-Observed station is center point of triangle on standard cement monument projecting 4 inches ahove surface of ground. Subsurface mark is center of 2 -inch tile pipe buried with top 2 inches below base of monument.

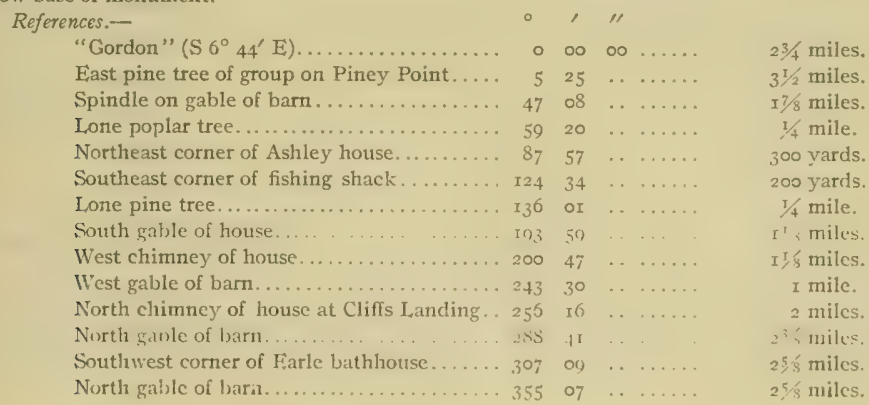

\section{SNUB.}

General locality--Western shore of Langford Creek on prominent point about threc-eighths mile north of Chester River between Deep Cove and Long Cove. (See Chart No. 3o.)

Immediate locality.-Observed station is on a low sand point about 2 feet above high water, 8 yards west of shore, and 75 yards north of cedar trees on shore.

Marks.-Observed station is center point of triangle on standard cement monument projecting 4 inches above surface of ground. Sulssurface mark is center of 2 -inch tile pipe buried with top 2 inches below base of monument. 


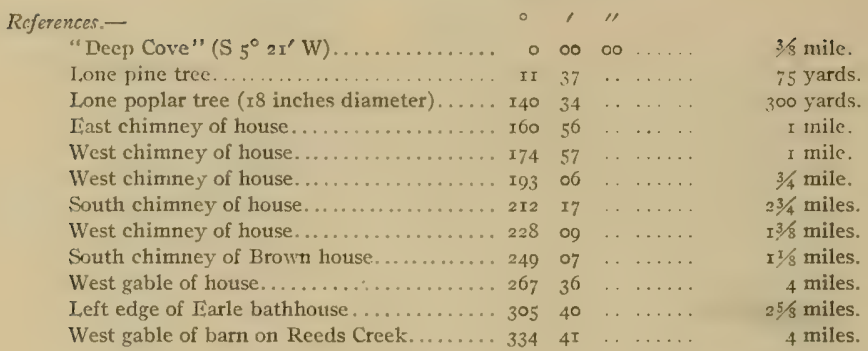

\section{I.AWYER.}

General locality,-Western shote of Langford Creek on Long Point about I mile north of Chester River between Long Cove and I,awyers Cove. (See Chart No. 30.)

Immediate locality.-Observed station is on a low sand point about I foot above high water, 8 yards west of extrente east end of point, and 30 yards east of group of pine trees.

Marks.-Observed station is center point of triangle on standard cement monument projecting 5 inches above surface of ground. Subsurface mark is center of 2 -inch tile pipe buried with top 2 inches below base of monument.

\section{Reforences.-}

"Peach" (S 4I $\left.{ }^{\circ} 4 I^{\prime} \mathrm{E}\right)$

Fast gable of barn

Nail in blaze in twin pine tree ( 18 inches

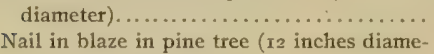
ter $) \ldots \ldots \ldots \ldots \ldots \ldots \ldots \ldots \ldots \ldots \ldots I_{34}$

South chimney of house............... I4I

East chimney of house .............. I70 21

East chimney of house............... I94

West chimney of hiouse.............. 243

West chimney of Brown house ......... 32,345

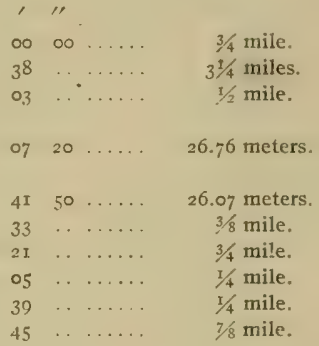

DRUM.

General locality. - Western shore of Langford Creek on Drum Point about II/4 miles north of Chester River, between Lawyers Cove and Davis Creek. (See Chart No. 30.)

Immediate locality.-Observed station is in a marsh meadow, about 2 feet above high water, $\mathrm{I}_{3}$ yards north of shore, I5 yards south of shore, and $\mathrm{I}_{3}$ yards west of extreme end of point.

Marks.-Observed station is center point of triangle. on standard cement monument projecting 5 inches above surface of ground. Subsurface mark is center of 2 -inch tile pipe buried with top 2 inches below base of monument.

References.-

"Major" (S $54^{\circ}+a^{\prime}$ (t)

West gable of Bromn house

Weft gable of Brown house.................

East chimney of Ashley housc...........

I.ast gable of house................... 17 1

Chimney of small house............. 2I

South gable of barn............... 249

West chimney of house................27

West chimney of house................ 305 o

$3 / 8$ mile.

$5 / 8$ mile.

6 miles.

I $1 / 4$ miles.

$1 / 2$ mile.

$3 / 8$ mile.

I $5 / 8$ miles.

I $5 / 8$ miles.

$3 / 4$ mile. 


\section{DAVIS.}

General locality.-Western shore of Langford Creek on point about $17 / 3$ miles north of Chester Rivẹ, one-eighth mile northeast of entrance to Davis Creek, five-eighths mile north of Drum Point, and nearly opposite Orchard Point. (See Chart No. 30.)

Immediate locality.-Observed station is in a cultivated field about ro feet above high water, 20 yards northwest of shore, and ro yards northwest of top of bank.

Marks.-Observed station is center point of triangle on standard cement monument projecting 4 inches above surface of ground. Subsurface mark is center of 2 -inch tile pipe buried with top 2 inches below base of monument.

\begin{tabular}{|c|c|c|c|c|}
\hline \multicolumn{5}{|l|}{ References.- } \\
\hline "Drum" (S I $\left.{ }^{\circ} \circ 7^{\prime} \mathrm{E}\right)$. & 0 & $\infty$ & $\infty$ & $5 / 8$ mile. \\
\hline Nail in blaze in oak tree ( 4 inches diameter). & $2 \mathrm{I}$ & 47 & 30. & I6. 50 meters. \\
\hline Chimney of small house............... & 207 & 06 & .. . & I mile. \\
\hline 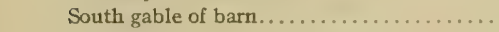 & 234 & II & . . . . . & $I^{I} / 4$ miles. \\
\hline 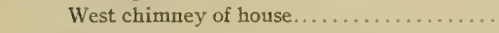 & 267 & 34 & .. $\cdots \cdots$ & I $1 / 8$ miles. \\
\hline West chimney of house................ & 294 & 35 & $\ldots \ldots \ldots$ & mile. \\
\hline Nail in blaze in oak tree ( ${ }_{5}$ inches diameter). & 324 & 22 & 10 $\ldots \ldots$. & I0.46 meters. \\
\hline 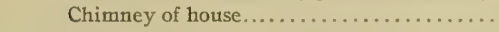 & 337 & 30 & . $\ldots \ldots$ & I $1 / 8$ miles. \\
\hline North gable of house on Reeds Creek..... & 357 & 28 & . . ...... & 6 miles. \\
\hline
\end{tabular}

\section{ISLE:}

General locality.-Western shore of West Fork of Langford Creek, on Island Point, about one-fourth mile north of main body of creek and three-eighths mile northwest of Cacaway Island. (See Chart No. 30.)

Immediate locality._Observed station is on a low sand point about I foot above high water, 5 yards south of shore, 8 yards north of shore, 50 yards west of extreme end of point, and 20 yards east of foot of wooded bluff I5 feet high. Cement monument marking reference station is 5.55 meters $\mathrm{S}_{79^{\circ}} 32^{\prime}$ W of observed station.

Marks.-Observed station is center of 2 -inch tile pipe projecting 3 inches above surface of ground. Subsurface mark is center of 2 -inch tile pipe buried with top 2 inches below base of surface pipe. Reference station is center point of triangle on standard cement monument projecting 4 inches above surface of ground.

\begin{tabular}{|c|c|c|c|c|}
\hline ferences. - & o & , & "I & \\
\hline "Eagle" ( $\left.\mathrm{N}_{43}^{\circ} 25^{\prime} \mathrm{W}\right)$ & $\circ$ & $\infty$ & $\infty$ & I/2 mile. \\
\hline South gable of Leary corncrib............. & I & $4 \mathrm{I}$ & $\cdots \cdots \cdots$ & $x 3 / 4$ miles. \\
\hline 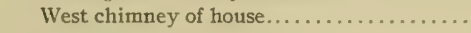 & 47 & 18 & $\ldots \ldots \ldots$ & I $3 / 4$ miles. \\
\hline Chimney of small house................ & 75 & 5 I & $\ldots \ldots \ldots$ & $1 / 2$ mile. \\
\hline North chimney of house................ & 142 & 13 & $\ldots \ldots \ldots$ & $I I / 4$ miles. \\
\hline North gable of barn ................. & $x_{53}$ & $5^{8}$ & ....... & I mile. \\
\hline Lone cedar tree on Drum Point........... & 234 & $5 x$ & .. $\cdots \cdots$ & mile. \\
\hline 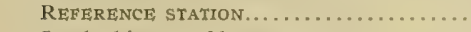 & 302 & 57 & $\infty 0^{\prime} \ldots .$. & 5.55 meters. \\
\hline South chimney of house............... & 355 & 56 & $\ldots \ldots \ldots$ & $1 / 4$ miles. \\
\hline
\end{tabular}

\section{EAGLE.}

General locality.-Western shore of West Fork of Langford Creek, on Eagle Point at south side of entrance to Graveyard Cove, about three-fourths mile northwest of main body of Langford Creek. (See Chart No, 30.)

Immediate locality.-Observed station is on prominent bluff about 20 feet above high water, 26 yards west of extreme end of point, II yards south of top of bank, 8 yards rorth of top of bank, and 2 yards north of small cedar tree.

Marks.-Observed station is center point of triangle on standard cement monument projecting 4 inches above surface of ground. Subsurface mark is center of 2 -inch tile pipe buried with top 2 inches below base of monument. 


\begin{tabular}{|c|c|c|c|c|}
\hline gerences.- & & & 11 & \\
\hline "Hornor" ( $\left.\mathrm{N} 84^{\circ} \circ 9^{\prime} \mathrm{E}\right)$ & $\circ$ & $\infty$ & $\infty$ & $1 / 4$ mile. \\
\hline Left tangent of Cacaway Island............ & 42 & 07 & $\ldots \ldots \ldots$ & $3 / 4$ mile. \\
\hline Nail in blaze in stump near top of bank... & 85 & 52 & $40 \ldots \ldots$ & 9.96 meters. \\
\hline North chimney of house... & $x_{3} \mathrm{I}$ & 49 & $\ldots \ldots \ldots$ & I mile. \\
\hline Lone oak tree ( $x_{2}$ inches diameter)........ & I53 & 29 & $\ldots \ldots$ & $1 / 4$ mile. \\
\hline Nail in blaze in stump ( $x_{5}$ inches diameter). & 202 & 06 & Io $\ldots \ldots$. & 4.54 meters. \\
\hline East chimney of De Ford liouse........... & 216 & 44 & . & 3/8 mile. \\
\hline South chimney of house................ & 224 & 39 & . . . . . & $3 / 4$ mile. \\
\hline Lone cedar tre & 268 & 44 & . $\cdots \cdots$ & $5 / 8$ mile. \\
\hline Chimney of small house............... & 280 & 49 & $\ldots \ldots \ldots$ & $I / 2$ miles. \\
\hline
\end{tabular}

\section{FORD.}

General locality.-Western shore of West Fork of Langford Creek about I mile northwest of main body of Langford Creek, three-eighths mile northwest of Eagle Point, and one-half mile south of Whale Point. (See Chart No. 30.)

Immediate locality.-Observed station is in garden about 20 feet above high water, 9 yards southwest of shore, 7 yards southwest of top of bank, and 80 yards southeast of a house.

Marks.-Observed station is center point of triangle on standard cement monument projecting 4 inches above surface of ground. Subsurface mark is center of 2 -inch tile pipe buried with top 2 inches below base of monument.

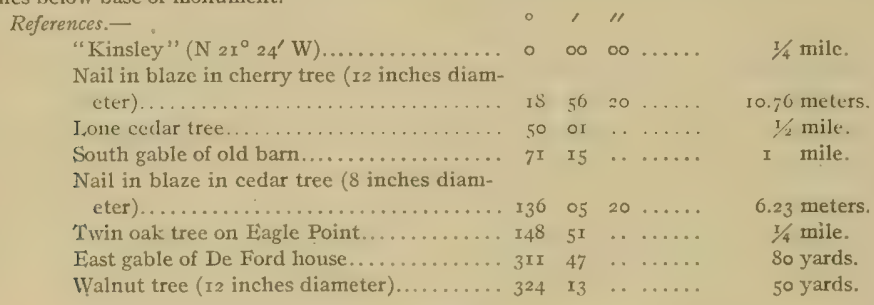

\section{KINSIEY.}

General locality. - Western shore of West Fork of Irangford Creek on Pastor Point about Ix/4 miles northwest of main body of Langford Creek and one-fourth mile south of Whale Point. (See Chart No. 30.)

Immediate locality.-Observed station is about 2 feet above high water, 6 yards west of shore, 200 yards north of a wharf, and at foot of slope rising to an elevation of ro feet.

Marks.-Observed station is center point of triangle on standard cement monument projecting 5 inches above surface of ground. Subsurface mark is center of 2 -inch tile pipe buried with top 2 inches below base of monument.

References.-

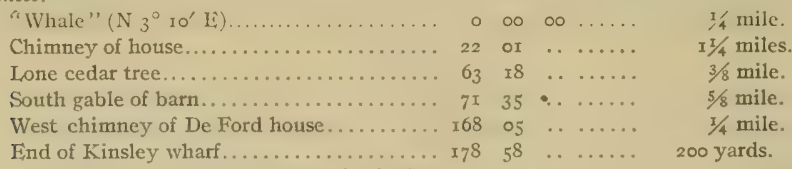

Nail in blaze in wild-cherry tree (I2 inches

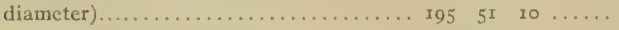

Nail in blaze in twin stump............. $242 \quad 42 \quad 30 \ldots \ldots$

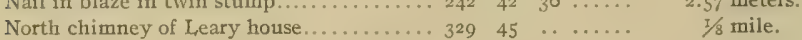

4.or meters.

2.57 meters. 
WHAI,E

General locality.-Western shore of West Fork of Langford Creek, on Whale Point, at south side of entrance to Bungay Creek, about $I^{1} / 2$ miles northwest of main body of Langford Creek, and threeeighths mile southwest of Vickers Wharf. (See Chart No. 30.)

Immediate locality,-Observed station is on a marsh point about 2 feet above high water, 6 yards southwest of shore, and 300 yards northeast of a house. Cement monument marking reference station is 8.75 meters $\mathrm{S} 35^{\circ} 27^{\prime} \mathrm{W}$ of observed station.

Marks.-Observed station is center of 2 -inch tile pipe projecting 3 inches above surface of ground. Subsurface mark is center of 2 -inch tile pipe buried with top 2 inches below base of surface pipe. Reference station is center point of triangle on standard cement monument projecting 4 inches above surface of ground.
References.-
"Nat" (S $\left.76^{\circ} 46^{\prime} \mathrm{E}\right)$
$\begin{array}{rrrrr}0 & 00 & 00 & \ldots \ldots & 1 / 8 \\ 46 & 25 & \ldots & \ldots \ldots & 3 / 4 \text { mile. }\end{array}$
West chimney of De Ford house......... 73 . 51 . . . . .
Nail in blaze in cedar tree ( 6 inches diam-
eter)...................... $82 \quad 53 \quad 50 \ldots \ldots$ meters.
REFERENCE STATION............... II2 I2 ro .... 8.75 meters.
Nail in blaze in cedar tree (I2 inches diam- eter)....................... I30 $49 \quad 20 \ldots \ldots \ldots$ 13.55 meters.
North chimney of house................. $307 \quad 45 \quad \ldots \ldots .3 / 4$ mile.
Leit tangent of piles of Vickers Wharf.... $307 \quad 54 \quad \ldots \ldots \ldots \quad 1 / 4$ mile.
West chimney of house............. 354 ir ..... $3 / 4$ mile.

\section{BUNGAY.}

General locality.-Western shore of West Fork of Langford Creek, on point at north side of entrance to Bungay Creek, about $x 5 / 8$ miles northwest of main body of Langford Creek and one-fourth mile west of Vickers Wharf. (See Chart No, 30.)

Immediate locality.-Olserved station is on a low sand point at north side of entrance to Bungay Creek, about $\mathrm{I}$ foot above high water, and I6 yards west of extreme end of point.

Marks.-Observed station is center point of triangle on standard cement monument projecting 3 inches above surface of ground. Subsurface mark is center of 2 -inch tile pipe buried with top 2 inches below base of monument.

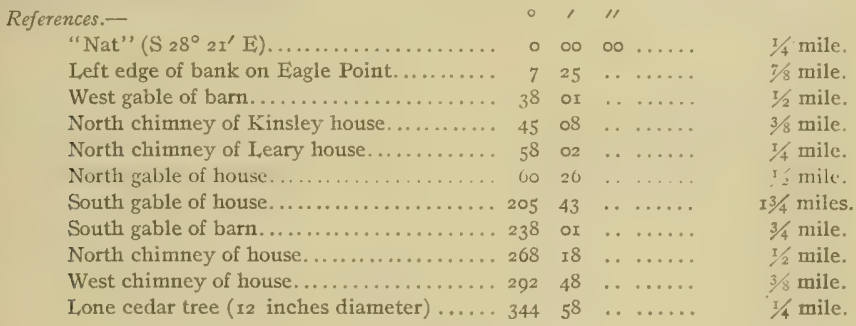

\section{LOCUST.}

General locality.-Eastern shore of West Fork of Langford Creek, near Vickers Wharf, about $\mathrm{x} 5 / 8$ miles northwest of main body of Langford Creek. (See Chart No. 30.)

Immediate locality.-Observed station is in a cultivated field about 2 feet above high water, 5 yards southeast of shore, and immediately back of loading platform on Vickers Wharf.

Marks.-Observed station is nail in root of a leaning locust tree 12 inches in diameter.

References.-

Drift pin in top of pile head at southeast end of Vickers Wharf . . . . 5.78 meters.

Drift pin in top of pile head at northwest end of Vickers Wharf ... 7.78 meters. 


\section{NAT.}

General locality.-Eastern shore of West Fork of Langford Creek, opposite Whale Point, about I3/8 miles northwest of main body of Langford Creek and one-fourth mile south of Vickers Wharf. (See Chart No. 30.)

Immediate locality.-Observed station is on a marsh point about 2 feet above high water, 7 yards south of shore, 8 yards north of shore, 25 yards east of extreme end of point, and in center of triangle formed by three pine stubs driven flush with marsh to support theodolite.

Marks.-Observed station is center point of triangle on standard cement monument projecting 3 inches above surface of ground. Subsurface mark is center of 2 -inch tile pipe buried with top 2 inches below base of monument.
References.-
"Mill" (S $\left.29^{\circ} 19^{\prime} \mathrm{E}\right) \ldots \ldots \ldots \ldots \ldots \ldots \ldots$
Left tangent of Eagle Point..............
West gable of house..................
Left edge of De Ford kitchen.............
North chimney of house................ 7
North gable of barn................ 75
East gable of barn ................. I34
Chimney of house ................. 227
Persimmon tree ( 3 inches diameter).... . . . 266
South gable of barn ................ 302

\begin{tabular}{|c|c|c|}
\hline$\infty$ & $\infty \quad \ldots .$. & $1 / 8$ mile \\
\hline 49 & $\ldots \ldots \ldots$ & $5 / 8$ mile \\
\hline 29 & $\ldots \ldots \ldots$ & I $1 / 2$ miles. \\
\hline 38 & $\ldots \ldots$. & $3 / 8$ mile \\
\hline 35 & $\ldots \ldots \ldots$ & $3 / 8$ mile \\
\hline 40 & . $\ldots \ldots$ & $3 / 8$ mile \\
\hline 57 & . $\ldots . .$. & $1 / 2$ mile \\
\hline $5^{8}$ & $\ldots \ldots \ldots$ & $34 \mathrm{mil}$ \\
\hline or & $\ldots \ldots$ & 70 yards. \\
\hline I5 & $\ldots \ldots \ldots$ & $3 / 8$ mile \\
\hline
\end{tabular}

MILL.

General locality.-Eastern shore of West Fork of Langford Creek, on point at west side of a small cove about II/ miles northwest of main body of Langford Creek and three-eighths mile south of Vickers Wharf. (See Chart No. 30.)

Immediate locality.-Observed station is on a marsh point about 2 feet above high water, 6 yards west of shore, 7 yards east of shore, I5 yards northwest of extreme end of point, and in center of triangle formed by three pine stubs driven flush with marsh to support theodolite. Cement monument marking reference station is 9.48 meters $\mathrm{N}_{2}{ }^{\circ} 57^{\prime} \mathrm{E}$ of observed station.

Marks.-Observed station is center of 2 -inch tile pipe projecting 6 inches above surface of ground. Subsurface mark is center of 2 -inch tile pipe buried with top 2 inches below base of surface pipe, Reference station is center point of triangle on standard cement monument projecting 4 inches above surface of ground.

\begin{tabular}{|c|c|c|c|c|}
\hline \multicolumn{5}{|l|}{ References.- } \\
\hline "Ford" ( $\left.\mathrm{S}_{32^{\circ}} 5 \mathrm{I}^{\prime} \mathrm{W}\right)$. & 0 & $\infty$ & $\infty$ & ${ }^{3}$ s mile. \\
\hline East chimney of De Ford house........... & 9 & 46 & . . & $3 / 8$ mile. \\
\hline South chimney of house.................. & 38 & $\mathrm{I}_{4}$ & $\cdots \cdots \cdots$ & $3 / 8$ mile. \\
\hline North chimney of house..... & 72 & II & . . & $3 / 3$ mile. \\
\hline South chimney of house................. & 142 & 59 & $\therefore \ldots \ldots$ & 2 miles. \\
\hline REFERENCE STATION.................. & I 50 & 06 & $20 \ldots \ldots$ & 9.48 meters. \\
\hline Lone cedar tree $\ldots \ldots \ldots \ldots \ldots \ldots \ldots \ldots$ & $16_{3}$ & 32 & $\cdots \cdots \cdots$ & 300 yards. \\
\hline South gable of barn..................... & $2 r_{3}$ & 2.4 & $\cdots \ldots \ldots$ & $1 / 2$ mile. \\
\hline Chimney of house................ & 343 & 48 & $\cdots \cdots \cdots$ & $3 / 4$ mile. \\
\hline
\end{tabular}

\section{WEST.}

General locality.-Eiastern shore of West Fork of Langford Creek, on Cedar Point, at west side of entrance to Long Cove, about seven-eighths mile north of main body of Langford Creek. (See Chart No. 30.)

Immediate locality.-Observed station is on marsh land about I foot above high water, 5 yards west of shore, 8 yards east of shore, and 25 yards northwest of extreme end of point. Cement monument marking reference station is 21.85 meters $\mathrm{N} 27^{\circ} 40^{\prime} \mathrm{E}$ of observed station. 
Marks.-Observed station is center of 2 -inch tile pipe projecting 3 inches above surface of ground. Subsurface mark is center of 2 -inch tile pipe buried with top 2 inches below base of surface pipe. Reference station is center point of triangle on standard cement monument projecting 4 inches above surface of ground.

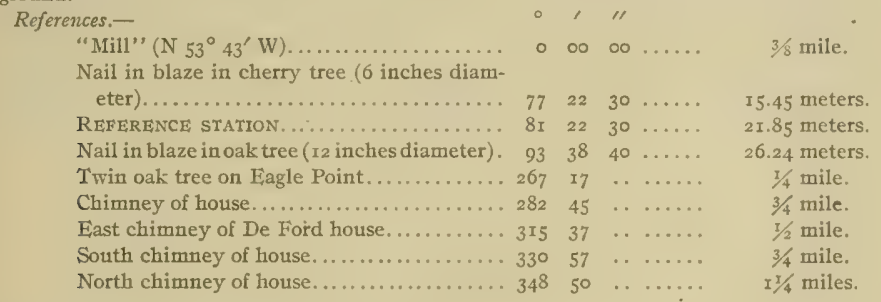

\section{HORNOR.}

General locality.-Eastern shore of West Fork of Langford Creek on point between Iong Cove and Hornors Cove about three-fourths mile north of main body of Langford Creek. (See Chart No. 30.)

Immediate locality.-Observed station is in a marsh meadow about I foot above high water, I5 yards northeast of shore, and 30 yards south of fringe of woods parallel with shore.

Marks.--Observed station is center point of triangle on standard cement monument projecting 6 inches above surface of ground. Subsurface mark is center of 2 -inch tile pipe buried with top 2 inches below base of monument.

\begin{tabular}{|c|c|c|c|c|}
\hline References.- & o & , & $" \prime$ & \\
\hline "Eagle" (S $84^{\circ}$ ro' W).. & 0 & oo & ০o & $3 / 4$ mile. \\
\hline West chimney of De Ford House.......... & 20 & 40 & ....... & $5 / 8$ mile. \\
\hline South chimney of house................ & 29 & 03 & $\ldots \ldots \ldots$ & I $1 / 4$ miles. \\
\hline North chimney of house.............. & 40 & $4 I$ & $\ldots \ldots \ldots$ & $x^{I} / 2$ miles. \\
\hline Leit edge of small house. . . . . . . . . . . . & 242 & 40 & . $\ldots \ldots$ & I mile. \\
\hline Right tangent of Cacaway Island. ........ & 261 & 55 & . $\ldots \ldots$ & $3 / 4$ mile. \\
\hline Chimney of house.................. & 353 & 56 & $\ldots \ldots \ldots$ & $3 / 8$ mile. \\
\hline
\end{tabular}

KING.

General locality.-On point between East Fork and West Fork of Langford Creek about r 50 yards north of Cacaway Island. (See Chart No. 30.)

Immediate locality.-Observed station is on a point about I4 feet high at edge of cultivated field, 3 yards northwest of edge of bank, 3 yards east of edge of bank at gully, and 8 yards east-northeast of point of bank.

Marks.-Observed station is center point of triangle on standard cement monument projecting 6 inches above surface of ground. Subsurface mark is center of 2 -inch tile pipe buried with top 2 inches below base of monument.

\begin{tabular}{|c|c|c|c|c|}
\hline \multicolumn{5}{|l|}{ References.- } \\
\hline "Ash" $\left(\mathrm{N}_{44}^{\circ}{ }^{\circ} 53^{\prime} \mathrm{E}\right) ;$ & ० & $\infty$ & $\infty 0$. & 1/8 mile. \\
\hline Left peak of large house............... & 55 & $5^{2}$ & $\ldots \ldots \ldots$ & $\mathrm{I}^{3} / 4$ miles. \\
\hline Nail in blaze in oak tree ( 8 inches diameter). & 70 & 26 & . . & 6.25 meters. \\
\hline Left chimney of house . . . . . . . . . . . & II3 & IS & $\ldots$. & 3 miles. \\
\hline Nail in blaze in tree ( 4 inches diameter)... & 163 & 48 & ro $\ldots \ldots$. & 8.27 meters. \\
\hline Right peak of barn. . . . . . . . . . . . . & I74 & 35 & . . . . n & 2 miles. \\
\hline Nail in blaze in tree ( 4 inches diameter). . & 246 & 34 & $20 \ldots \ldots$ & 7.49 meters. \\
\hline Left chimney on mansion house.......... & 259 & 16 & $\ldots \ldots \ldots$ & ......... \\
\hline Chimney of house among trees........... & 295 & 12 & $\ldots \ldots \ldots$ & .......... \\
\hline
\end{tabular}

I $4126-12-5$ 
ASH.

General locality.-Western shore of East Fork of Langford Creek about one-half mile north of main body of Langford Creek and one-eighth mile northeast of north end of Cacaway Island. (See Chart No. 30.)

Immediate locality. - Observed station is in cultivated land about io feet above high water, 35 yards northwest of shore, I4 yards northwest of edge of low bank, 20 yards northwest of line of trees along shore, and 36 yards south-southwest of point of trees.

Marks.--Observed station is center point of triangle on standard cement monument projecting 6 inches above surface of ground. Subsurface mark is center of 2 -inch tile pipe buried with top 2 inches below base of montument.
References.-
"Noth" ( $\left.\mathrm{S} 8 \mathrm{I}^{\circ} 4 \mathrm{O}^{\prime} \mathrm{E}\right)$.
"I
Left peak of long barn................
Nail in blaze in oak tree ( 14 inclies diameter)
Nail in blaze in oak tree ( 14 inches diameter)
Left peak of house. . . . . . . . . . . . . . . 12
Chimney of small house . . . . . . . . . 18
Near peak of large house . . . . . . . . . . . . I96
Left chimney of large mansion. . . . . . . 200
Nail in blaze in oak tree ( 5 inches diameter). 324

$\begin{array}{lll}00 & 00 & \ldots \\ 25 & \ldots & \ldots \\ 43 & \text { 10 } & \ldots \\ 49 & 10 & \ldots \\ 38 & \ldots & \ldots \\ 37 & \ldots & \ldots \\ 17 & \ldots & \ldots \\ 11 & \ldots & \ldots \\ 03 & 50 & \ldots \\ \end{array}$
$000 \ldots \ldots$.
3 's mile.
I $1 / 2$ miles.
I9. 55 meters.
27.87 meters.
I mile.
I3/4 miles.
$x 1 / 2$ miles.
$13 / 4$ miles.
21.37 meters.

\section{NOTH.}

General locality.-Western shore of Liast Fork of Langford Creek on point opposite Kings Creek about three-fourths mile northeast of main body of Langford Creek and one-half mile east of north end of Cacaway Island. (See Chart No. 30.)

Immediate locality. - Observed station is in cultivated land about 3 feet above high water, 6 yards west of shore, 23 yards northeast of shore, and 40 yards north of extreme end of point.

Marks.-Observed station is center point of triangle on standard cement monument projecting 6 inches above surface of ground. Subsurface mark is center of 2 -inch tile pipe buried with top 2 inches below base of monument.

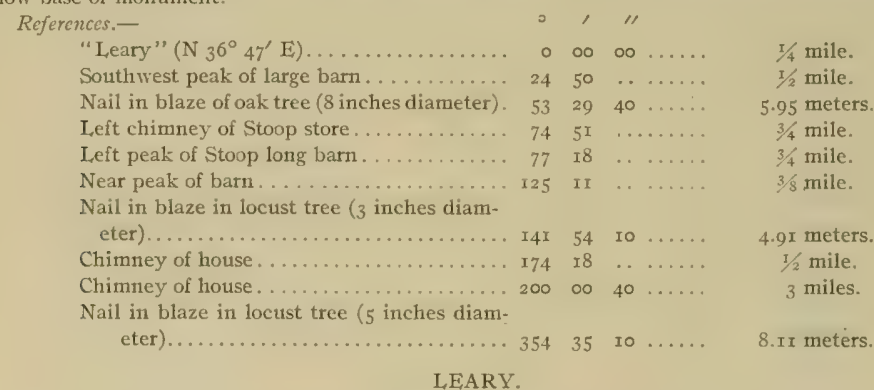

General locality.-Western shore of Fast Fork of Langford Creek about I mile northeast of main body of Langford Creek and three-eighths mile north of Haw Bush Point. (See Chart No. 30.)

Immediate locality.-Observed station is on a marsh point near Leary's old wharf, about I foot above high water, 6 yards west of shore, ro yards northeast of shore, and ro yards north of extreme end of point.

Marks.-Observed station is center point of triangle on standard cement monument projecting 4 inches above surface of ground. Subsurface mark is center of 2 -inch tile pipe buried with top $z$ inches below base of monument. 


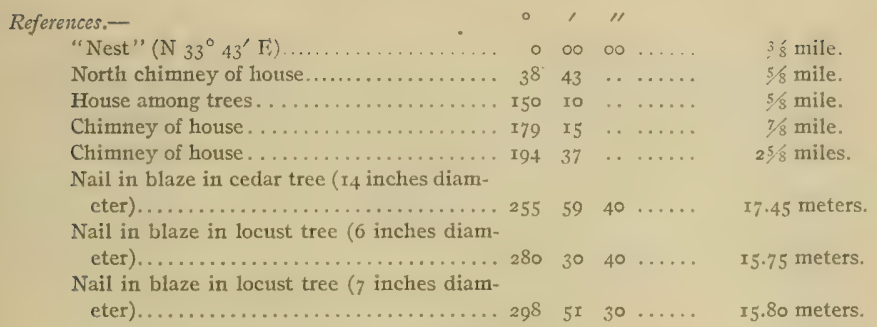

\section{NEST.}

General locality.-Western slore of East Fork of Langford Creek on point about I3/8 miles northeast of main body of Langford Creek and five-eighths mile southwest of entrance to Philips Creek. (See Chart No. 30.)

Immediate locality.-Observed station is in a pasture about to feet above high water, II yards north of edge of bank, I2 yards west of edge of bank, I6 yards west-northwest of point of bank, and I25 yards south of clump of trees.

Marks.-Observed station is center point of triangle on standard cement monument projecting 5 inches above surface of ground. Subsurface mark is center of 2 -inch tile pipe buried with top 2 inclies below base of monument.

\begin{tabular}{|c|c|c|c|c|}
\hline \multicolumn{5}{|l|}{ References.- } \\
\hline "Woll" $\left(\mathrm{N}_{18} 8^{\circ} 22^{\prime} \mathrm{E}\right) \ldots \ldots \ldots \ldots \ldots \ldots$ & $\circ$ & $\infty$ & $\infty$ & $1 / 4$ mile. \\
\hline Large chimney of house. . . . . . . . . . . . & 4 & $4 I$ & . . . . & 3 miles. \\
\hline $\begin{array}{l}\text { Near large chimney of house............ } \\
\text { Nail in blaze in hickory stump (4 inches }\end{array}$ & 62 & $\infty$ & $\ldots \ldots \ldots$ & I mile. \\
\hline diameter $). . . \ldots \ldots \ldots \ldots \ldots \ldots \ldots$ & II5 & o6 & Io $\ldots \ldots$. & ro.07 meters. \\
\hline Chimney of small house...$\ldots \ldots \ldots \ldots \ldots$ & 166 & $2 I$ & $\ldots \ldots \ldots$ & 2 miles. \\
\hline $\begin{array}{l}\text { Chimney of rambling house . . . . . . . . . . . } \\
\text { Nail in blaze in locust tree ( } 4 \text { inches diam- }\end{array}$ & 194 & 49 & $\ldots \ldots \ldots$ & I5 $/ 8$ miles. \\
\hline eter $) \ldots \ldots \ldots \ldots \ldots \ldots \ldots \ldots \ldots \ldots \ldots$ & 212 & I5 & $\cdots \cdots$ & 12.59 meters. \\
\hline $\begin{array}{l}\text { Large tree in small clump............... } \\
\text { Nail in blaze in oak tree ( } 20 \text { inches diam- }\end{array}$ & 275 & 24 & $\ldots \ldots \ldots$ & $\ldots \ldots$ \\
\hline 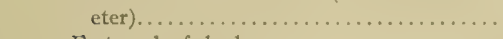 & 334 & 44 & $\infty$ & 38. 40 meters. \\
\hline East peak of shed. . . . . . . . . . . . . . & 346 & I2 & $\ldots \ldots \ldots$ & $\ldots \ldots \ldots \ldots$ \\
\hline
\end{tabular}

\section{WOI,L}

General locality.-Western shore of East Fork of Langford Creek about $\mathrm{I}$ mile north of Haw Bush Point and three-eighths mile southwest of entrance to Philips Creek. (See Chart No. 30.)

Immediate locality.-Observed station is in comer of cultivated field about ro feet above high water, ro yards southwest of edge of bank, I7 yards north of edge of hank, in yards northwest of extreme point of bank, and 125 yards east-northeast of a house,

Marks,-Observed station is center point of triangle on standard cement monument projecting 4 inches above surface of ground. Subsurface mark is center of 2 -inch tile pipe buried with top 2 inches below base of monument. 


\begin{tabular}{|c|c|c|c|c|}
\hline \multicolumn{5}{|l|}{ References:- } \\
\hline "Harp" (N $\left.5{ }^{\circ} 32^{\prime} \mathrm{W}\right)$. & o & $\infty$ & $\infty \ldots$ & $1 / 4$ mile. \\
\hline South peak of barn............... & 8 & $5^{2}$ & .. & $3 / 4$ mile. \\
\hline Large chimney of house............. & 29 & 32 & . $\cdots$ & $2 \mathrm{I} / 8$ miles. \\
\hline Chimney on ell of large house. & 37 & 37 & .. . & I5/8 miles. \\
\hline 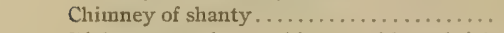 & 56 & 06 & .. . & I mile. \\
\hline Right corner of west chimney of large brick & & & & \\
\hline house..................... & 107 & 59 & . & $3 / 4$ mile. \\
\hline 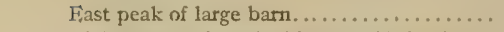 & 151 & I8 & $\cdots \cdots \cdots$ & $1 / 2$ mile. \\
\hline Right corner of north chimney of brick house & 155 & $5^{2}$ & $\ldots \ldots \ldots$ & $3 / 3$ mile. \\
\hline Left tangent of chimney of house........... & 247 & I3 & $\ldots \ldots \ldots$ & 125 yards. \\
\hline
\end{tabular}

\section{HARP.}

Gencral locality.-Western shore of Fiast Fork of Langford Creek on point opposite entrance to Philips Creek. (See Chart No. 30.)

Immediate locality.-Observed station is at southeast end of row of bushes on a marsh point about I foot above high water, 20 yards southwest of edge of marsh, 20 yards west of edge of marsh, 24 yards northwest of edge of marsh, and 40 yards from a tree-fringed bank.

Marks,-Observed station is center point of triangle on standard cement monument projecting 4 inches above surface of ground. Subsurface mark is center of 2 -inch tile pipe buried with top 2 inches below base of monument.

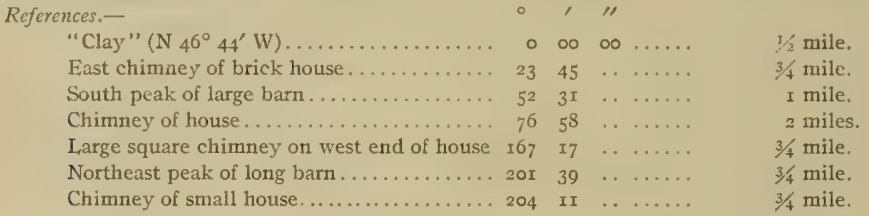

\section{CLAX.}

General locality.-Western shore of East Fork of Langford Creek about one-eighth mile south of Lovely Cove and five-eighths mile northwest of entrance to Philips Creek. (See Chart No. 30.)

Immetiate locality.-Observed station is in woods about 20 feet above high water and 6 yards southwest of edge of bank.

Marks.-Observed station is center point of triangle on standard cement monument projecting 4 inches above surface of ground. Subsurface mark is center of 2 -inch tile pipe buried with top 2 inches below base of monument.

Reforences.-

"Lovely" ( $\left.\mathrm{N} 7^{\circ} \mathrm{Ig}^{\prime} \mathrm{E}\right)$

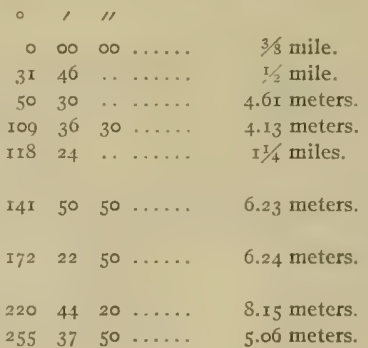

Left tangent of chimney of brick house.... 3 . 3 46 ......

Nail in blaze in oak tree ( 12 inches diameter) $50 \quad 30 \quad \ldots \ldots \ldots$

Nail in blaze in oak tree ( 12 inches diameter) I09 $36 \quad 30 \ldots .$.

West chimney of large brick house........ IIs 24 ......

Nail in blaze in chestnut tree (Io inches di-

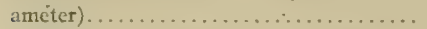

Nail in blaze in chestnut tree (Io inches di-

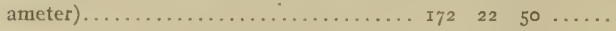

Nail in blaze in chestnut tree ( $\mathrm{I}_{3}$ inches di-

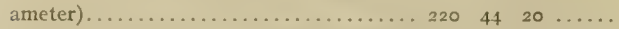

Nail in blaze in oak tree ( 9 inches diameter). $255 \quad 37 \quad 50 \ldots \ldots \quad 5.06$ meters. 


\section{LOVELY.}

Gcneral locality.-Western shore of Fast Fork of Langford Creek on north side of entrance to Lovely Cove and three-fourths mile northwest of entrance to Philips Creek. (See Chart No. 30.)

Immediate locnlity.--Observed station is at edge of cultivated field about 5 feet above higl1 water, I2 yards north of shore, 1 yard north of top of slight slope, and 70 yards east of a cut in shore.

Marks.-Observed station is center point of triangle on standard cement monument projecting 5 inches above surface of ground. Subsurface mark is center of 2 -inch tile pipe buried with top 2 inches below base of monument.

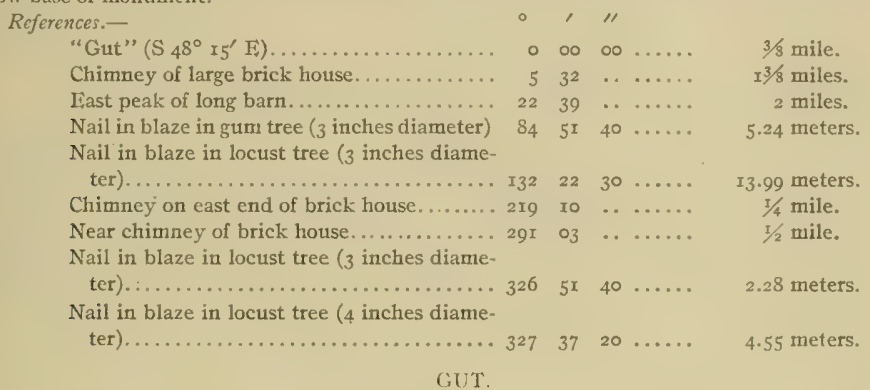

General locality.-Liastern shore of East Fork of Langford Creck on point at north side of entrance to a small cove about one-fourth mile east of entrance to Lovely Cove and one-half mile northwest of entrance to Philips Creek. (See Chart No. 30.)

Immediate locality.-Observed station is on a marsh point about I foot above high water, I5 yards northeast of edge of marsh, 16 yards north of edge of marsh, 21 yards east of edge of marsh, and 65 yards north-northwest of extreme point of marsh.

Marks.-Observed station is center point of triangle on standard cement monument projecting 6 inches above surface of ground. Subsurface mark is center of 2 -inch tile pipe buried with top 2 inches below base of monument.

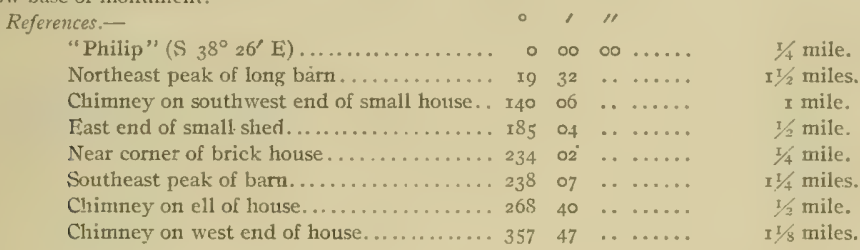

PHILIP.

General locality.-Eastern shore of East Fork of Langford Creek at north side of entrance to Philips Creck and about five-eighths mile southeast of entrance to Lovely Cove. (See Chart No. 3o.)

Immediate locality.-Observed station is on marsh land about I foot above high water, Io yards east of edge of march, I5 yards northeast of edge of marsh, I7 yards southeast of edge of marsh, and southwest of a small group of cedar trees.

Marks.-Observed station is center point of triangle on standard cement monument projecting 3 inches above surface of ground. Subsurface mark is center of 2 -inch tile pipe buried with top 2 inches below base of monument. 


\begin{tabular}{|c|c|c|c|c|}
\hline \multicolumn{5}{|l|}{ Roferences.- } \\
\hline "Ide" (S $\left.33^{\circ} 46^{\prime} \mathrm{E}\right)$ & 0 & $\infty$ & $\infty$. & $1 / 4$ mile. \\
\hline Northeast peak of large barn............. & 22 & 22 & ....... & $x$ mile. \\
\hline Chimney on ell of house................ & 24 & 40 & $\ldots \ldots \ldots$ & $3 / 4$ mile. \\
\hline North peak of building. ................ & IIO & $2 I$ & ....... & $3 / 4$ mile. \\
\hline Southwest chimney of small louse........ & 160 & $3^{8}$ & $\ldots \ldots \ldots$ & $x / 8$ miles. \\
\hline IVast peak of small shed................. & 178 & $2 I$ & .. $\ldots \ldots$ & $I^{1 / 1} / 4$ miles. \\
\hline $\begin{array}{l}\text { Nail in blaze in cedar trec }(4 \text { inches diante- } \\
\text { ter) } \ldots \ldots \ldots \ldots \ldots \ldots \ldots \ldots \ldots \ldots \ldots \ldots \ldots\end{array}$ & $24 I$ & 33 & $20 \ldots \ldots$ & I5.79 meters. \\
\hline 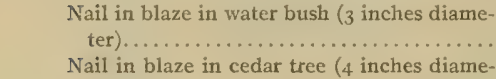 & 272 & 24 & ro & 9.00 meters. \\
\hline ter). & 340 & 46 & $\infty$ & $\mathrm{I}_{3.97}$ meters. \\
\hline
\end{tabular}

IDE.

General locality.-Eastern shore of East Fork of Langford Creek at south side of entrance to Philips Creek about 2 miles northeast of main body of Langford Creek. (See Chart No. 3o.)

Immediate locality.-Observed station is about 2 feet above high water, I 7 yards east of shore, I5 yards southeast of a cut in shore; and 18 yards northeast of another cut in shore.

Marks,-Observed station is center point of triangle on standard cement monument projecting 5 inches above surface of ground. Subsurface mark is center of 2 -inch tile pipe buried with top 2 inches below base of monument.

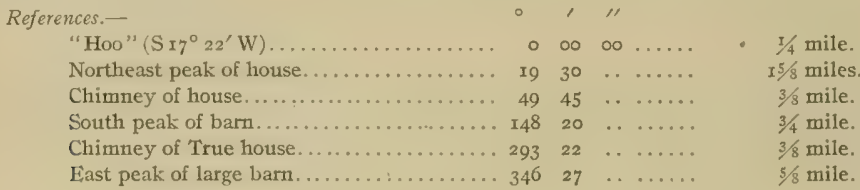

\section{HOO.}

General locality,-Eastem shore of East Fork of Langford Creek about $15 / 8$ miles northeast of main body of Langford Creek, seven-eighths mile north of Haw Bush Point and three-eighths mile south of entrance to Philips Creek. (See Chart No. 30.)

Immediate locality. - Observed station is on marsh land about $I$ foot above high water, 10 yards southeast of shore, 14 yards east of shore, 20 yards north of shore, and in front of water bushes.

Marks.-Observed station is center point of triangle on standard cement monument projecting 7 inches above surface of ground. Subsurface mark is center of 2 -inch tile pipe buried with top 2 inches below base of monument.

References.-

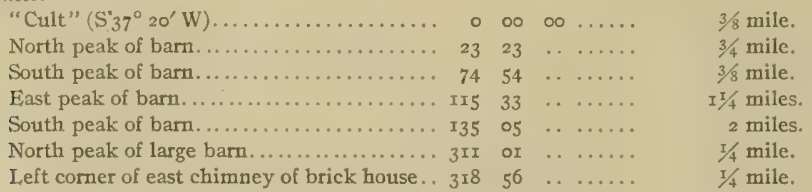

\section{CULT.}

General locality.-Eastern shore of East Fork of Langford Creek on point about $\mathrm{I} / 4$ miles northeast of main body of Langford Creek and one-fourth mile east of Leary's old wharf. (See Chart No. 3o.)

Immediate locality. - Observed station is about 3 feet above high water, I2 yards south-southeast of shore, I6 yards east of shore, 4 yards south-southeast of a road, and 40 yards southeast of a wharf.

Marks.-Observed station is center point of triangle on standard cement monument projecting 4 inches above surface of ground. Subsurface mark is center of 2 -inch tile pipe buried with top 2 inches below base of monument. 


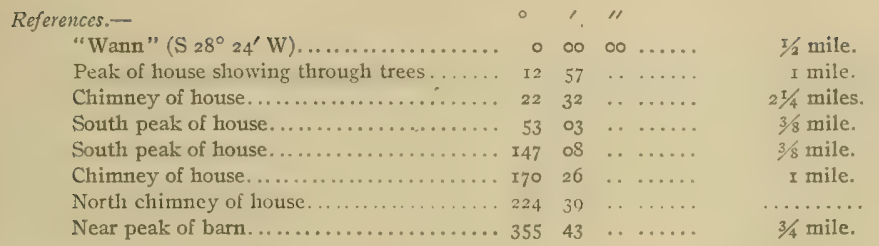

\section{WANN.}

General locality.-Eastern shore of East Fork of Langford Creek on Haw Bush Point at west side of entrance to Kings Creek and Wanns Cove, and about seven-eighths mile northeast of main body of Langford Creek. (See Chart No. 3o.)

Immediate locality.-Observed station is about 3 feet above high water, 2 yards south of shore, 2 yards north of shore, and 16 yards west-southwest of a persimmon tree.

Marks.-Observed station is center point of triangle on standard cement monument projecting 6 inches above surface of ground. Subsurface mark is center of 2 -inch tile pipe buried with top 2 inches below base of monument.

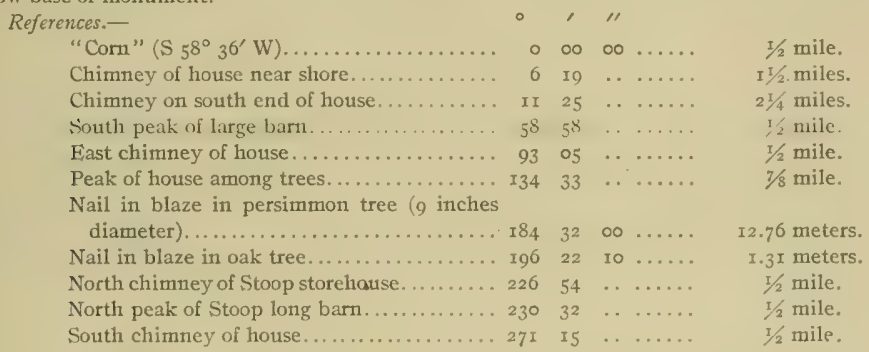

\section{CORN.}

General locality.-Eastern shore of East Fork of Langford Creek on east side of a small cove about three-eighths mile east of main body of Langford Creek, and one-half mile southwest of Haw Bush Point. (See Chart No. 30.)

Immediate locality.-Observed station is in edge of cultivated land about 3 feet above high water, I2 yards east-southeast of shore, and 4 yards east-southeast of line of trees between shore and station.

Marks.-Observed station is center point of triangle on standard cement monument projecting 6 inches above surface of ground. Subsurface mark is center of 2 -inch tile pipe buried with top 2 inches below base of monument.

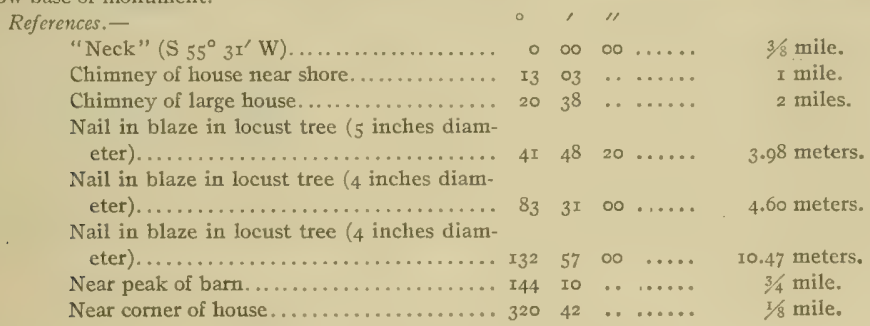


NECK.

Gcneral locality. -Eastern shore of Langford Creek on Orchard Point at south side of entrance to East Fork of Langford Creek about one-fourth mile south of Cacaway Island. (See Chart No. 30.)

Immediate locality.-Observed station is about 6 feet above high water, 6 yards south of shore, I2 $y$ ards east of shore, Io yards east-southeast of point of bank in cultivated field, and 30 yards northwest of corner of peach orchard.

Marks.-Observed station is center point of triangle on standard cement monument projecting 6 inches above surface of ground. Subsurface mark is center of 2 -inch tile pipe buried with top 2 inches below base of monument.

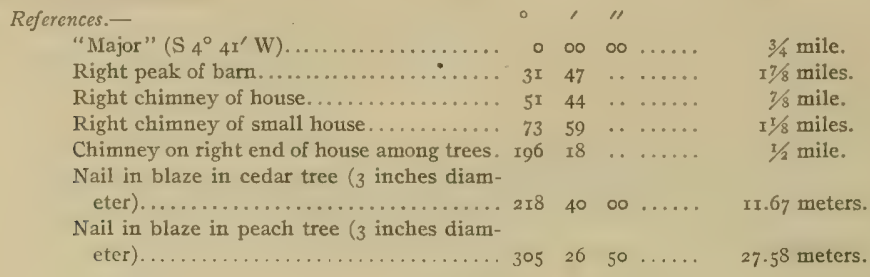

MAJOR.

General locality.-Eastern shore of Langford Creek about II/8 miles north of Chester River, threeeighths mile southeast of Drum Point and three-fourth mile south of Orchard Point. (See Chart No. 30.)

Immediate locality.- Observed station is in a cultivated field about I $_{5}$ feet above high water, 25 yards southeast of shore, $\mathrm{I} 7$ yards southeast of edge of bluff, 9 yards southeast of wire fence, and $x 8$ yards south of locust trees.

Marks,-Observed station is center point of triangle on standard cement monument projecting 5 inches above surface of ground. Subsurface mark is center of 2 -inch tile pipe buricd with top 2 inches below base of monument.

References.-

\begin{tabular}{|c|c|c|c|}
\hline$\left(\mathrm{S} 24^{\circ} \mathrm{O} 2^{\prime} \mathrm{W}\right)$ & & $\circ$ & \\
\hline nimney of house. . . & I9 & 35 & - \\
\hline f house..... & 25 & 54 & \\
\hline Ashley hous & 47 & & \\
\hline e........ & 68 & 2 & \\
\hline e... & 95 & $5^{2}$ & \\
\hline East chimney of house.............. & 103 & 30 & \\
\hline $\begin{array}{l}\text { ail in blaze in locust tree (6 inche } \\
\text { diameter).......................... }\end{array}$ & & & \\
\hline ey of Brown house. & 25 & 20 & \\
\hline
\end{tabular}

$$
\begin{aligned}
& 5 / 8 \text { mile. } \\
& 31 / 4 \text { miles. } \\
& \text { I } / 2 \text { miles. } \\
& \text { I mile. } \\
& \text { I } 1 / 4 \text { miles. } \\
& \text { I mile. } \\
& \text { I mile. }
\end{aligned}
$$

I6.49 meters.

$1 / 4$ mile.

PEACH.

General locality.--Eastern shore of Langford Creek about one-half mile north of Chester River and three-fourths mile south of Drum Point. (See Chart No. 30.)

Inmediate locality.-Observed station is on marsh land about I foot above high water, 4 yards east of shore, 300 yards west of peach orchard, and in center of triangle formed by three pine stubs driven flush with marsh to support theodolite.

Marks -Observed station is center point of triangle on standard cement monument projecting 5 inches above surface of ground. Subsurface mark is center of 2 -inch tile pipe buried with top 2 inches below base of monument. 


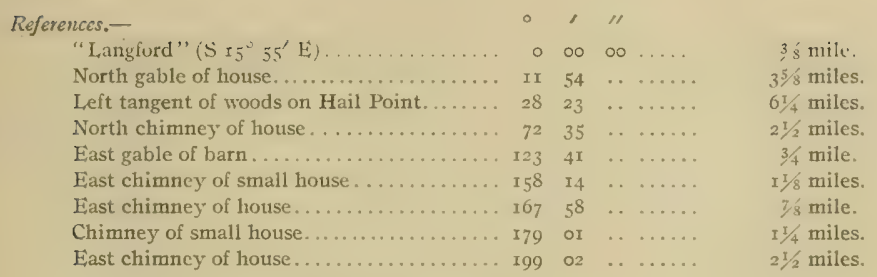

\section{LANGFORD.}

General locality.-Western shore of Chester River, on Nichols Point, at east side of entrance to Langford Creek. (See Chart No. 30.)

Immediate locality.-Observed station is on a sandy point among persimmon trees about 2 feet above high water, 12 yards inshore, and 200 yards south of $\dot{a}$ marsh.

Marks.-Observed station is center point of triangle on standard cement monument projecting 3 inches above surface of ground. Subsurface mark is center of 2 -inch tile pipe buried with top 2 inches below base of monument.

\begin{tabular}{|c|c|c|c|c|}
\hline eferences.- & o & ' & "I & \\
\hline "Gordon" (S $\left.10^{\circ} 42^{\prime} \mathrm{W}\right)$. . & $\circ$ & $\infty$ & $\infty \ldots$ & $25 / 8$ miles. \\
\hline East one of group of four pine trees....... & 2 & $2 I$ & . $\ldots \ldots$ & $31 / 2$ miles. \\
\hline East chimney of house ................ & 45 & 45 & . $\quad \cdots \ldots$ & $21 / 2$ miles. \\
\hline 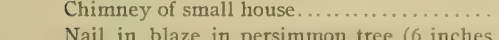 & 56 & 27 & $\ldots \ldots \ldots$ & $2 \frac{1}{4}$ miles. \\
\hline $\begin{array}{l}\text { Nail in blaze in persimmon tree }(6 \text { inches } \\
\text { diameter) } \ldots \ldots \ldots \ldots \ldots \ldots \ldots \ldots \ldots \ldots \ldots\end{array}$ & $7^{2}$ & 02 & $30 \ldots \ldots$ & 4.59 meters. \\
\hline East chimney of house $\ldots \ldots \ldots \ldots \ldots \ldots$ & 87 & 27 & $\ldots \ldots \ldots$ & I mile. \\
\hline 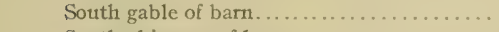 & II 5 & 53 & $\cdots \cdots \cdots$ & I's miles. \\
\hline South chimney of house. .............. & I.4I & 02 & $\cdots \cdots \cdots$ & I $1 / 2$ miles. \\
\hline $\begin{array}{l}\text { Chimney of house. . .................... } \\
\text { Nail in blaze in persimmon tree ( } 6 \text { inches }\end{array}$ & 152 & 40 & $\ldots \ldots \ldots$ & $\mathrm{I} / 2$ miles. \\
\hline $\begin{array}{r}\text { diameter) ............................. } \\
\text { Nail in blaze in persimmon tree }(4 \text { inches }\end{array}$ & 218 & 39 & 20 . & 2.23 meters. \\
\hline diameter $\ldots . . . . \ldots \ldots \ldots$ & $2 \mathrm{Si}$ & I5 & . 10 & 7.63 meters. \\
\hline Northwest corner of Earle bathhouse...... & 299 & 00 & $\cdots \cdots$ & $\mathrm{I} 3 / 4$ miles. \\
\hline 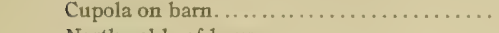 & 332 & 26 & $\ldots \cdots \cdots$ & 2 miles. \\
\hline North gable of house.................... & 346 & 57 & $\ldots \ldots \ldots$ & $21 / 4$ miles. \\
\hline
\end{tabular}

\section{SPANIARD POINT 2 UPPER.}

General locality.--Southeastern shore of Chester River on Lower Spaniard Point about II/4 miles east of Nichols Point, seven-eighths mile south of Cliffs Landing and one-half mile southwest of Spaniard Wharf. (See Cliart No. 30.)

Immediate locality.-Observed station is on a sand beach about I foot above high water, 8 yards southeast of shore, and 300 yards northwest of woods. Cement monument marking reference station is 11.72 meters $S 70^{\circ} 5^{\prime} \mathrm{E}$ of observed station.

Marks.-Observed station is nail in 3 -inch cement-filled tile pipe bearing the legend "U. S. C. S. I896, "with top 6 inches below surface of ground. Reference station is center point of triangle on standard cement monument projecting 6 inches above surface of ground. 


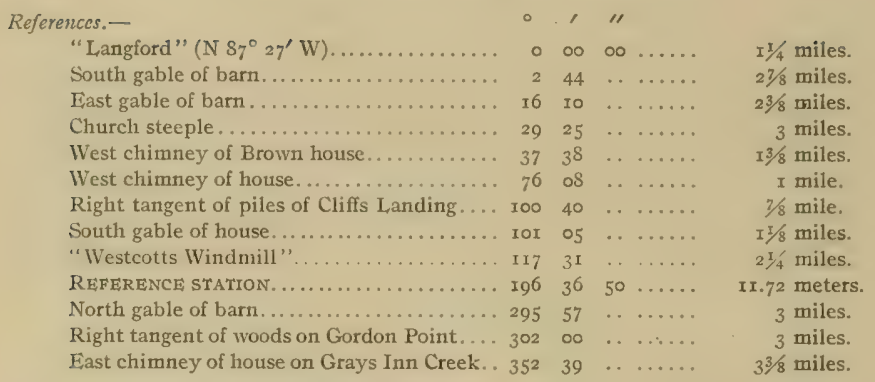

\section{QUAKER.}

General locality.-Western shore of Chester River in Cliff Bight about three-fourths mile north of Nichols Point. (See Chart No. 30.)

Immediate locality. - Observed station is on marsh land about 3 feet above high water, 8 yards northwest of shore, 8 yards southeast of a wire fence and a row of pear trees, and 6 yards south of a group of persimmon trees.

Marks.-Observed station is center point of triangle on standard cement monument projecting 5 inches above surface of ground. Subsurface mark is center of 2 -inch tile pipe buried with top 2 inches below base of monument.

\begin{tabular}{|c|c|c|c|c|}
\hline eferences.- & $\circ$ & , & " & \\
\hline "Brown" ( $\left.\mathrm{N} 80^{\circ} 42^{\prime} \mathrm{E}\right) \ldots \ldots \ldots \ldots \ldots \ldots$ & $\circ$ & $\infty$ & $\infty \ldots$ & $7 / 8$ mile. \\
\hline West gable of barn....... & 15 & 05 & . & $2 \pi / 2$ miles. \\
\hline Left tangent of Spaniard Wharf..... & 24 & I7 & . $\ldots \ldots$ & II/4 miles. \\
\hline Northeast corner of Earle house........... & 70 & 08 & . $\cdots \cdots$ & 2 miles. \\
\hline North gable of house near Reeds Creek...... & 102 & 24 & $\ldots \ldots \ldots$ & $31 / 4$ miles. \\
\hline Right tangent of woods on Gordon Point... & II 4 & 37 & $\ldots \ldots \ldots$ & $3 / 2$ miles. \\
\hline $\begin{array}{l}\text { Lone oak tree ........................... } \\
\text { Nail in blaze in hackberry tree }(6 \text { inches }\end{array}$ & 147 & 43 & ... & I. mile. \\
\hline 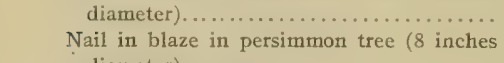 & 203 & o8 & 30. & 4.8I meters. \\
\hline 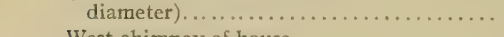 & 319 & I9 & .. & 3.43 meter \\
\hline West chimney of house................ & $35^{1}$ & 40 & $\ldots \ldots \ldots$ & $7 / 8$ inile. \\
\hline
\end{tabular}

EVANS.

General locality.-Southeastern shore of Chester River on Upper Spaniard Point about five-eight11s mile south of Cliffs Landing and one-eighth mile northeast of Spaniard Wharf. (See Chart No, 30.)

Immediate locality.-Observed station is on marsh land about I foot above high water, to yards north of shore, and 200 yards east of end of Spaniard Wharf.

Marks.-Observed station is center point of triangle on standard cement monument projecting 4 inches above surface of ground. Subsurface mark is center of 2 -inch tile pipe buried with top 2 inches below base of monument. 


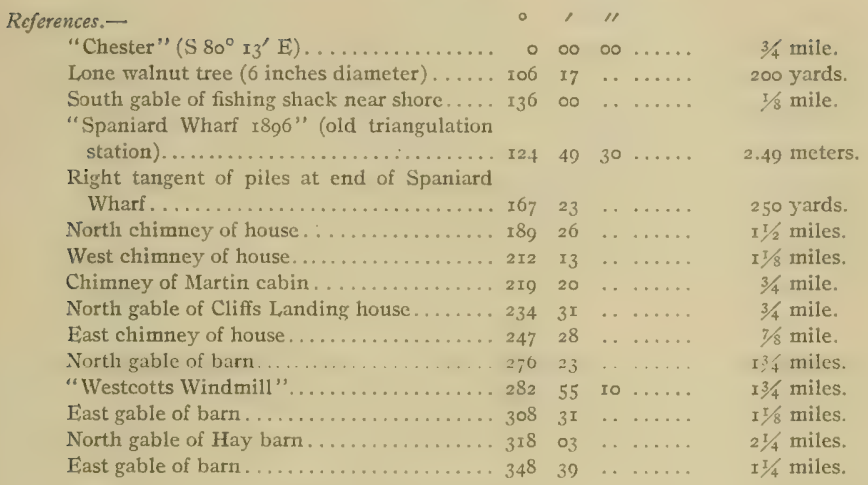

BROWN.

General locality:-Northwestem shore of Chester River on Cliffs Point hetween Cliffs Bight and Conmegys Bight ahout one-fourth mile west of Cliffs Landing. (See Chart No. 30.)

Immediate locality.-Observed station is in a cultivated field about i 2 feet above high water. 25 yards north of shore, 7 yards north of edge of bank, and 45 yards southeast of a large cherry trec.

Marks.-Observed station is center point of triangle on standard cement monument projecting 3 inches above surface of ground. Subsurface mark is center of 2 -inch tile pipe buried with top $a$ inches below base of monument.

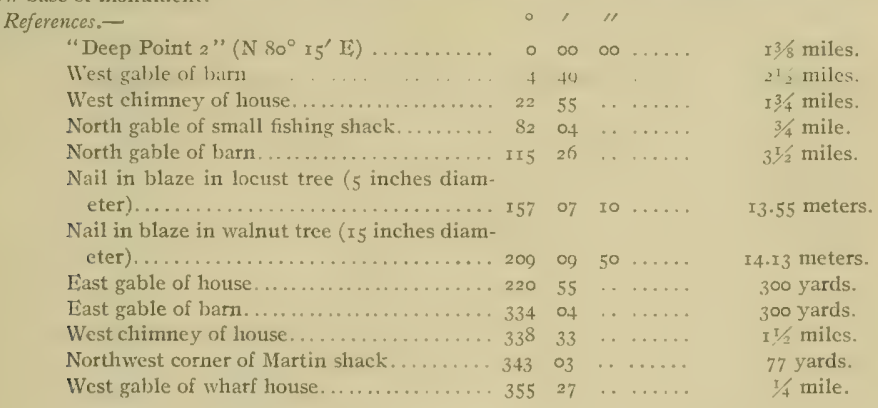

\section{STRATTON.}

General locality.-Northwestem shore of Chester River at west side of entrance to Commegys Bight near Cliffs Landing and about one-fourth mile northeast of Cliffs Point. (See Chart No. 30.)

Immediate locality.-Observed station is on marsh land about on level with high water, 5 feet north of shore, and 21 yards southwest of entrance to a small creek.

Marks.-Observed station is center point of triangle on standard cement monument projecting 6 inches above surface of ground. Subsurface mark is center of 2 -inch tile pipe buried with top 2 inches below base of monument. 


\begin{tabular}{|c|c|c|c|c|c|}
\hline efercnces.- & ० & , & $" \prime$ & & \\
\hline "Deep Point $2 "\left(\mathrm{~N} 83^{\circ} 53^{\prime} \mathrm{E}\right)$. . & 0 & $\infty$ & $\infty$ & . & I $1 / 4$ miles. \\
\hline C'upola on barn.... & 7 & 50 & . & ...... & 2 miles. \\
\hline West gahle of comcrib ............ & 23 & 27 & . & $\ldots \ldots$ & $\mathrm{r} / 2$ miles. \\
\hline Southwest corner of wharf house... & 82 & 0.4 & . & ...... & I00 yards. \\
\hline North gable of house................... & II 4 & 03 & . & .. & 3 miles. \\
\hline Right tangent of woods on Gordon Point .... & 125 & 14 & . & & $37 / 8$ miles. \\
\hline Pine tree on line with bulkhead of wharf.... & I54 & 29 & .. & $\ldots \ldots$ & Ioo yards. \\
\hline North chimney of house . . . . . . . . . . . . & 266 & 37 & .. & $\ldots \ldots$ & 400 yard \\
\hline West gable of Westcott barn ............. & 319 & $5^{8}$ & $\therefore$ & & $x^{2} / 4$ mile \\
\hline 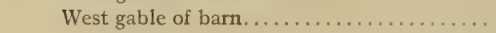 & 340 & 32 & . & $\ldots \ldots$ & I $1 / 4$ miles. \\
\hline
\end{tabular}

\section{CHESTER.}

General locality.-Southeastern shore of Chester River about three-fourths mile east of Upper Spaniard Point and seven-eighths mile south of Deep Point. (See Chart No. 30.)

Immediale locality.-Observed station is in a low meadow about 2 feet above high water, ro yards south of shore, 2 yards south of board and wire fence, 2 yards east of rail fence, and 35 yards northwest of gate to front yard of a house.

Marks.-Observed station is center point of triangle on standard cement monument projecting 5 inches above surface of ground. Subsurface mark is center of 2 -inch tile pipe buried with top 2 inches below base of monument.

References.-

\begin{tabular}{|c|c|c|c|c|}
\hline "Evans" ( $\left.\mathrm{N} 80^{\circ} 12^{\prime} \mathrm{W}\right)$. & 0 & $\infty$ & $\infty$ & 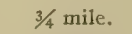 \\
\hline South chimney of house. & 6 & $2 I$ & .. & les. \\
\hline East gable of Clifis Landing house. . & 23 & $3^{8}$ & .. . & les. \\
\hline ble of house.................... & 35 & II & $\ldots \ldots \ldots$ & $\mathrm{I} / 2$ \\
\hline use ..................... & $5^{I}$ & 47 & .. & $I \pi / 2$ \\
\hline of Westcott house. & 76 & 43 & . . . & $I 5 / 8$ \\
\hline f bam .............. & $8_{5}$ & 17 & & I \\
\hline f piles of Indiantown Wharf.. & 136 & $4 \mathrm{I}$ & ... & $\mathrm{r} / 2$ \\
\hline ..... & I39 & 37 & . $\cdots$ & les. \\
\hline y hou & $x^{5} 8$ & 45 & . $\ldots$ & \\
\hline$y$ of Emory tenant house...... & 218 & 16 & . & 100 \\
\hline in persimmon tree $(6$ inches & 247 & 3 & IC & \\
\hline & & 54 & 5 & \\
\hline
\end{tabular}

\section{WESTCOTT'S WINDMILL.}

General locality.-Northwestern side of Chester River about one-eighth mile inshore from northern end of Commegys Bight and $\mathrm{r} 3 / 8$ miles northeast of Cliffs Landing.

Immediate locality.-Observed station is about 35 feet high and on a barn. It is separate from the water tank which is back of the barn.

Marks,-Observed station is center point of windmill.

References.-None necessary.

\section{CORPSE.}

General locality.-Southeastern shore of Chester River about three-eighths mile southeast of Deep Point, $\mathrm{I} / 2$ miles east-northeast of Spaniard Wharf, and five-eighths mile southwest of Indiantown Wharf. (See Chart No. 30.)

Immediate locality.-Observed station is on a sanded marsh strip about I foot above high water, 3 yards east of shore, I 8 yards south-southeast of a point, 43 yards north by east of another point, and oneeighth mile west of a large house. 
Marks.-Observed station is center point of triangle on standard cement monument projecting 3 inches above surface of ground. Subsurface mark is center of 2 -inch tile pipe buried with top 2 inches below base of monument.

\begin{tabular}{|c|c|c|c|c|c|}
\hline References.- & 。 & & "1 & & \\
\hline "Chester" (S $\left.39^{\circ} 24^{\prime} \mathrm{W}\right) \ldots \ldots$. & $\circ$ & $\infty$ & $\infty$ & $\cdots \cdot$ & 7/8 mile. \\
\hline Right tangent of Spaniard Wharf......... & 30 & 29 & .. & ..... & $I^{1} / 2$ miles. \\
\hline Chimney of house near Cliffs Landing..... & 61 & -43 & . & $\cdots \cdots$ & $13 / 4$ miles. \\
\hline Right peak of house on Deep Point......... & $8_{3}$ & 48 & . & . & $1 / 2$ mile. \\
\hline $\begin{array}{l}\text { Left one of two chimneys on south end of } \\
\text { brick house } \ldots \ldots \ldots \ldots \ldots \ldots \ldots \ldots \ldots \ldots\end{array}$ & $1+7$ & 0.3 & .. & & I mile. \\
\hline $\begin{array}{l}\text { Left tangent of Indiantown Wharf........... } \\
\text { Chimney of ell of house near Indiantown }\end{array}$ & 173 & 17 & . & ...... & is mile. \\
\hline 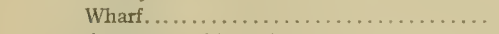 & I8I & 53 & .. & $\ldots \ldots$ & $5 / 8$ mile. \\
\hline Left tangent of large house... & 228 & II & . & $\ldots \ldots$ & $1 / 4$ mil \\
\hline Right chimney of house. ............... & 297 & 55 & . & $\ldots \ldots$ & mile \\
\hline Chimney outside of old house......... & 359 & 07 & . & $\cdots \cdots$ & 8 mile \\
\hline
\end{tabular}

\section{DEEP POINT 2.}

General locality.-Northwestern shorc of Chester River on Deep Point about $\mathrm{I} / 4$ miles east of Cliffs Landing, ${ }^{1}{ }^{1}$, miles northeast of Spaniard Wharf, and three-fourths mile west of Indiantown Wharf. (See Chart No. 30.)

Immediate locality.-Observed station is about I foot above high water, among several cedar and poplar trees on a point, I3 yards northeast of shore, 2I yards southwest by west of shore, 40 yards northwest of extreme end of point, and $I_{2} 0$ yards southeast of a I I/2-story house. Cement monument marking reference station is on line with west end of house $17 . \mathrm{I} 4$ meters $\mathrm{N} 53^{\circ} 5^{\prime} \mathrm{W}$ of observed station.

Marks.-Observed station is nail in center of 2 -inch tile pipe set in cement with top 2 inches below surface of ground. Reference station is center point of triangle on standard cement monument projecting 4 inches above surface of ground.

References.-

"Thorn" (N $\left.40^{\circ} 10^{\prime} \mathrm{E}\right) \ldots \ldots \ldots \ldots \ldots \ldots$

Left chimney of house.................

Left tangent of Ashland Wharf............ I3

Near chimney on west peak of house.......

Southwest peak of house near Indiantown

Wharf . ...............................
Nail in blaze in branch of cedar tree ( 15 inches diameter $) . \ldots \ldots \ldots \ldots \ldots \ldots \ldots . . . \ldots \ldots$

Cupola on barn....................

Nail in blaze in poplar tree (II inches diam-

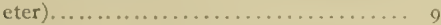

Largest one of three chimneys of housc..... Io

Chimney of brick house.............. r 5

Chimney on near peak of house...........233

REFERENCF STATION................... 265

Nail in blaze in poplar tree (ro inches diam-

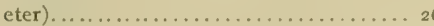

Right tangent of back of Westcott house.... 27
Nail in blaze in branch of double tree ( 8 inches diameter)

$\infty 00$

$43+\cdots$

of $\cdots$

$5^{8} \ldots \ldots$

3 I 23

$5 \quad 2$

r 43

354

07

25

39

$55^{8}$

600

56

$340 \quad 4$ $\infty \ldots \ldots$

$\therefore \ldots . .$.

o $\ldots . .$.

........

. $\ldots \ldots$

. . . . .

$20 \ldots$.

$20 \ldots \ldots$

.......

$\circ$
$3 / 4$ mile.

$3 \frac{3}{4}$ miles.

I $3 / 8$ miles.

$2 \mathrm{r} / 2$ miles.

$7 / 8$ mile.

II. 48 meters.

I mile.

I 5.02 meters.

$\mathrm{I} / 4$ miles.

I mile.

$1 / 4$ miles.

I 7.14 meters.

I 7.78 meters. I20 yards.

I9. 74 meters. 


\section{INDIAN.}

General locality.-Southeastern shore of Chester River near Indiantorn Wharf about three-fourths mile east-northeast of Deep Point. (See Chart No. 30.)

Immediate locality.-Observed station is about 2 feet above high water, Io yards east of shore end of Indiantown Wharf, Io yards southeast of shore, 2I yards north of curved fence of yard of a small house, and 40 yards north by west of a house.

Marks.-Observed station is center point of triangle on standard cement monument projecting 4 inches above surface of ground. Subsurface mark is center of 2 -inch tile pipe buried with top 2 inches below base of monument.

References.-

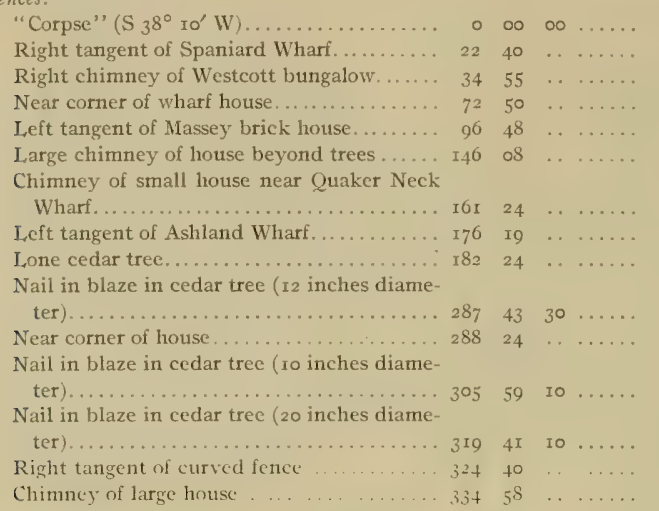

$$
\begin{aligned}
& 5 / 8 \text { mile. } \\
& 2 \text { miles. } \\
& 3 / 4 \text { mile. } \\
& \text { 100 yards. } \\
& 1 / 2 \text { mile. } \\
& \text { I mile. } \\
& \text { I } / 4 \text { miles. } \\
& 5 / 8 \text { mile. } \\
& 120 \text { yards. } \\
& 31.24 \text { meters. } \\
& 5 / 8 \text { mile. }
\end{aligned}
$$

I8.68 meters.

30.92 meters.

to yards.

1 mile.

\section{THORN.}

General locality.-Northwestern shore of upper Chester River opposite White Cove near Westcott Wharf, and about three-fourths mile northeast of Deep Point. (See Chart No. 30.)

Immediate locality.-Observed station is in a cultivated field about 6 feet above high water, I5 yards northwest of shore, 5 yards southwest of corner of board fence, 60 yards south-southeast of a brickhouse, and 42 yards southwest of piles of old wharf at shore line.

Marks.-Observed station is center point of triangle on standard cement monument projecting 4 inches above surface of ground. Subsurface mark is center of 2 -inch tile pipe buried with top 2 inches below base of monument.

References.-

"Shippen" (N $43^{\circ} \mathrm{I}^{\prime}$ ' E) $\ldots \ldots \ldots \ldots \ldots \ldots$

Near peak of large house ..............

Left tangent of Ashland Wharf........... 23

Corner post of fence ( 4 inches diameter)... . 33

Cupola of barn.................... 10

Chimney of small house............... 159

Near corner of Mlassey house............. 208

Nail in blaze in peach tree ( 6 inches diame-

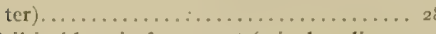

Nail in blaze in fence post ( 3 inches diame-

ter)

$\begin{array}{rccc}0 & 1 & 11 & \\ 0 & 00 & 00 & \ldots \\ 18 & 40 & \ldots & \ldots \\ 23 & 21 & \ldots & \ldots \\ 33 & 23 & 10 & \ldots \\ 104 & 13 & \ldots & \ldots \\ 159 & 09 & \ldots & \ldots \\ 208 & 40 & \ldots & \ldots \\ 28 & \\ 27 & 57 & 22 & \ldots \\ 338 & 27 & 20 & \ldots \ldots\end{array}$

1/2 mile.

$4^{1 / 2}$ miles.

$5 / 8$ mile.

4.33 meters.

7/8 mile.

$\mathrm{x} 3 / 4$ miles.

I/s mile.

I3.74 meters.

5.35 meters. 


\section{ASHLAND.}

General locality,-Southeastern shore of upper Chester River near Ashland Wharf and about onefourth mile northeast of White Cove. (See Chart No. 30.)

Immediate locality.-Observed station is about I foot above high water, 5 yards southeast of shore, 32 yards southwest of fence, and 20 yards west-northwest of persimmon trees.

Marks.-Observed station is center point of triangle on standard cement monument projecting 4 inches above surface of ground. Subsurface mark is center of 2 -inch tile pipe buried with top 2 inches below base of monument.

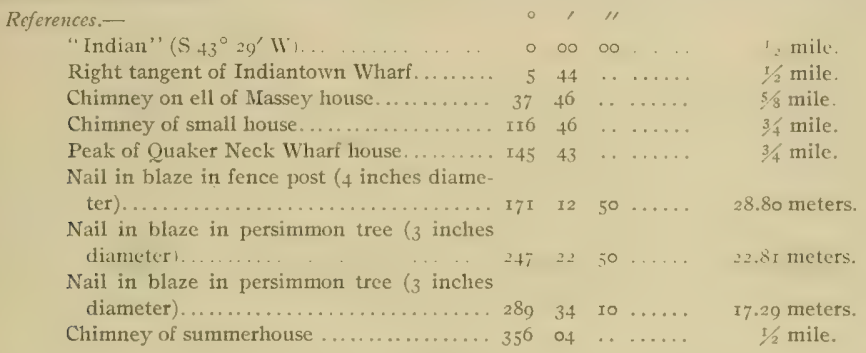

\section{SHIPPEN.}

General locality.-Northwestern shore of upper Chester River opposite Ashland Wharf on point at southern side of entrance to Shippen Creek. (See Chart No. 3o.)

Immediate locality.-Observed station is on sand and marsh point about I foot above high water, 6 yards southwest of shore, I2 yards northeast of shore, 15 yards north of end of sand point, and 25 yards southeast of trees along edge of cultivated field.

Marks.-Observed station is center point of triangle on standard cement monument with top projecting 4 inches above surface of ground. Subsurface mark is center of 2 -inch tile pipe buried with top 2 inclies below base of monument.

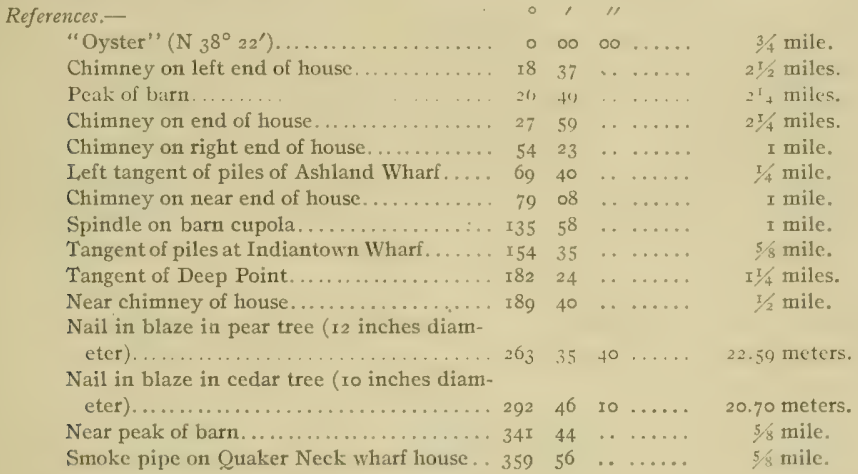




\section{BURNS.}

General locality.-Southeastern slore of upper Chester River opposite Quaker Neck Wharf, about one-Lalf mile northeast of Ashland Wharf. (Sce Chart No. 3o.)

Immediale locality.-Observed station is in meadow land about I foot above ligh water, io yards southeast of shore, 50 yards southwest by south of point, 145 yards northeast by east of a fence, and 200 yards northwest of another fence.

Marks.-Observed station is center point of triangle on standard cement monument projecting 7 inches above surface of ground. Subsurface mark is center of 2 -inch tile pipe buried with top 2 inches helow base of monument.

\begin{tabular}{|c|c|c|c|c|}
\hline \multicolumn{5}{|l|}{ References.- } \\
\hline "Ashland" ( $\left.\mathrm{S}_{45^{\circ}}{ }_{22}^{\prime} \mathrm{W}\right) \ldots \ldots \ldots \ldots \ldots \ldots$ & $\circ$ & $\infty$ & $\infty$ & $5 / 8$ mile. \\
\hline Chimney of house on Westcott Wharf. & 18 & 36 & ... & I $1 / 4$ miles. \\
\hline South peak of large barn............... & 78 & 48 & . & $5 / 8$ mile. \\
\hline Near chimney of Quaker Neck Wharf house. & 89 & 20 & $\cdots$ & $1 / 2$ mile. \\
\hline Left chimney of old house................. & 108 & $4 \mathrm{I}$ & .. & $\ldots \ldots \ldots$ \\
\hline Left tangent $>f$ hook-shaped point of marsh. & $18_{3}$ & 22 & . & $1 / 2$ mile. \\
\hline 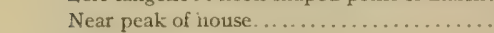 & 196 & 25 & $\ldots \ldots$ & $1 \frac{1}{2}$ miles. \\
\hline Windmill ........... & 234 & 22 & $30 \ldots \ldots$ & $3 / 4$ mile. \\
\hline Chimney of house . . . . . . . . . . . . . . & 280 & 56 & . . ....... & I mile. \\
\hline Left chimney of house on Ashland Road... & 323 & 57 & . . ...... & I mile. \\
\hline
\end{tabular}

\section{OYSTER.}

General locality.-Northwestern shore of upper Chester River about one-eighth mile northeast of Quaker Neck Wharf and one-half mile southwest of entrance to Jarretts Creek. (See Chart No. 30.)

Immediate locality.-Observed station is in a cultivated field about 20 feet above high water, 8 yards west-northwest of edge of bank, 9 yards north-northwest of edge of bank, 25 yards northeast by north of a cedar tree, Ioo yards southwest of low land, and 115 yards east of fence near a house.

Marks.-Observed station is center point of triangle on standard cement monument projecting 5 inches above surface of ground. Subsurface mark is center of 2 -inch tile pipe buried with top 2 inches below base of monument.

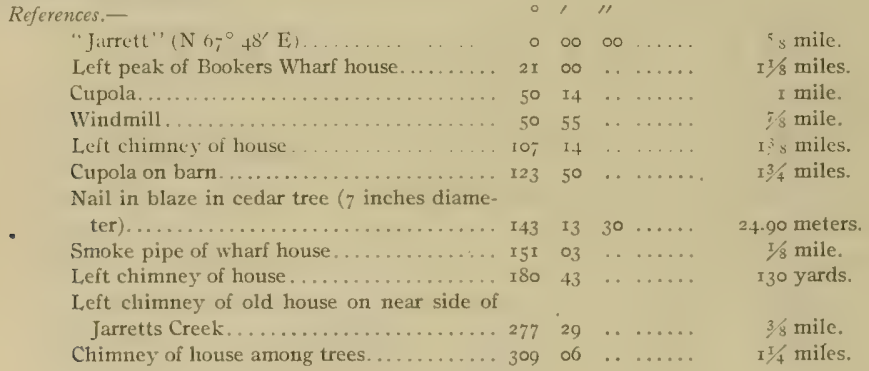

STARKLEY.

Gencral locality.-Southeastern shore of upper Chester River, about three-fourths mile east of Quaker Neck Wharf and one-half mile southwest of Bookers Wharf. (See Chart No. 30.)

Immediate locality.-Observed station is in meadow land about I foot above high water, Io yards east by south of shore, 33 yards south of first cut in shore, I40 yards north by west of a fence, I 45 yards southwest of point where another fence meets shore, and 275 yards south of large cedar tree.

Marks.-Observed station is center point of triangle on standard cement monument projecting 6 inclies above surface of ground. Subsurface mark is center of 2 -inch tile pipe buried with top 2 inches below base of monument. 


\begin{tabular}{|c|c|c|c|c|}
\hline References.- & & & & \\
\hline "Burns" (S $\left.6 \mathrm{r}^{\circ} 34^{\prime} \mathrm{W}\right) \ldots$ & $\circ$ & $\infty$ & $\infty$ & $1 / 2$ mile. \\
\hline Left chimney of Quaker Neck Wharf house. & 39 & 02 & . & 7/8 mile. \\
\hline Right peak of barn. .................. & 66 & 43 & . & $I$ mile. \\
\hline Peak of middle dormer window of large house & $\mathrm{I} I 4$ & 30 & . & $3 / 4$ mile. \\
\hline Left peak of large house............... & 163. & 49 & & $I^{\mathrm{I}} / 4$ miles. \\
\hline Left peak of Bookers Wharf house.......... & 187 & 48 & . & $5 / 2$ mile. \\
\hline Large cedar tree ............ & I9I & II & . $\quad \cdots$ & 275 yards. \\
\hline Spindle on left cupola of bam ........... & 262 & $\infty$ & $20 \ldots \ldots$ & $1 / 2$ mile. \\
\hline Weather vane on barn. ................. & 320 & OI & $50 \ldots \ldots$ & I/2 mile. \\
\hline
\end{tabular}

JARRETT.

General locality.-Northwestern shore of upper Chester River, about five-eighths mile southwest of Melton Point, one-fourth mile east of entrance to Jarretts Creek, and fiye-eighths mile west of Bookers Wharf. (See Chart No. 30.)

Immediate locality.-Observed station is about I foot above high water, I4 yards north of shore, 50 yards from a short fence at shore, 65 yards west of entrance to slough, and 575 vards from another fence.

Marks.-Observed station is center point of triangle on standard cement monument projecting 5 inches above surface of ground. Subsurface mark is center of 2 -inch tile pipe buried with top 2 inches below base of monument.

\begin{tabular}{|c|c|c|c|c|c|}
\hline eferences, $\longrightarrow$ & - & & 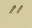 & & \\
\hline "Melton" (N 61 $\left.{ }^{\circ} 34^{\prime} \mathrm{E}\right)$. & 0 & $\infty$ & $\infty$ & & 5/8 mile. \\
\hline Left peak of house on ridge............. & t & 35 & . & & $I^{1} / 2$ miles. \\
\hline Right peak of small house... & 47 & 58 & . & & 34 mile. \\
\hline West peak of Bookers Wharf house... & 48 & 50 & . & $\cdots$ & 5,8 mile. \\
\hline Spindle on left cupola on barn............ & 96 & or & .. & & $3 / 4$ mile. \\
\hline Weather vane on cupola on barn.......... & 125 & 48 & . & & I mile. \\
\hline Chimney of house near Indiantown Wharf. . & I 55 & 29 & $\cdots$ & $\ldots \ldots$ & $x^{7} / 8$ miles. \\
\hline Large chimney of Massey brick house..... & 169 & 16 & $\cdots$ & (2) & I $7 / 8$ miles. \\
\hline Smoke pipe of Quaker Neck Wharf house... & 182 & 50 & $\cdots$ & & 34 mile. \\
\hline Peak of middle dormer window of large house & 299 & 07 & . & $\ldots \ldots$ & $1 / 2$ mile. \\
\hline
\end{tabular}

\section{BOOKFR.}

General locality,- Southeastern shore of upper Chester River, about 175 yards northeast of Bookers Wharf and one-half mile south of Melton Point. (Sce Chart No. 3o.)

Immediate locality.-Observed station is on sanded marsh about I foot above high water, 6 yards southeast of shore, $I_{3}$ yards east by south of a small point, 30 yards southwest by south of locust trees, 125 yards northwest by north of a house on 20 -foot bank, and 140 yards northwest of a creek.

Marks.-Observed station is center point of triangle on standard cement monument projecting 6 inches above surface of ground. Subsurface mark is center of 2 -inch tile pipe buried with top 2 inches below base of monument.

References.-

"Starkley" (S $\left.67^{\circ} 55^{\prime} \mathrm{W}\right)$

Left chimney of Quaker Neck Wharf house

Near peak of house in woods.............

Peak of middle dormer window on left side of house among trees................. 6

Chimney of house.................. II

Nail in blaze in locust tree ( 4 inches diameter) 18

Near peak of house on bank ............ 293

Right peak of Bookers Wharf house....... $35^{\circ}$ $14126-12-6$

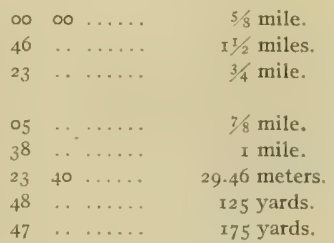




\section{JOURNEY.}

General locality - Fastem shore of upper Chester River, opposite Melton Point, about one-half milé northeast of Bookers Wharf. (See Chart No. 30.)

Immediate locality:- Observed station is in cultivated land about 20 feet above high water, 3 yards southeast by east of edge of bank, south of large elm tree, and northeast of several sycamore and locust trees.

Marks.-Observed station is center point of triangle on standard cement monument projecting 5 inches above surface of ground. Subsurface mark is center of 2 -inch tile pipe buried with top 2 inches below base of monument.

References.-

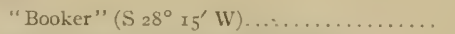

Right peak of Bookers Wharf house.........

Smoke pipe of Quaker Neck Wharf house...

Near peak of house with three dormer windows............................ 77 or $\ldots \ldots \ldots$

Right chimney of $2 \frac{1}{2}$-story house........ $107 \quad 02 \ldots \ldots \ldots$

Nail in blaze in elm tree (ro inches diameter) $\mathrm{I}_{34} \quad 27 \quad 40 \ldots \ldots$

Large cedar tree in yard near fence....... 187 30 $30 . \ldots$

Near peak of old house............... 318 I6 $\ldots \ldots \ldots$

Nail in blaze in sycamore tree ( 8 inches

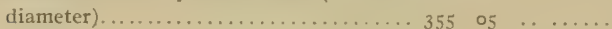

$$
\begin{aligned}
& 1 / 2 \text { mile. } \\
& 1 / 2 \text { mile. } \\
& 15 / 8 \text { miles. } \\
& 7 / 8 \text { mile. } \\
& 11 / 2 \text { miles. } \\
& 22.70 \text { meters. } \\
& 400 \text { yards. } \\
& 200 \text { yards. } \\
& 21.00 \text { meters. }
\end{aligned}
$$

\section{MELTON}

General locality.-Westem shore of upper Chester River, on Melton Point, about one-half mile north of Bookers Wharf. (See Chart No. 30.)

Immediate locality. - Observed station is about 2 feet above high water, 4 yards south of shore, 40 yards north of shore, 32 yards northwest of extreme end of point, 2 yards northeast of marsh, and 125 yards east-southeast of clump of cedar trees.

Marks.-Observed station is center point of triangle on standard cement monument projecting 6 inches above surface of ground. Subsurface mark is center of 2 -inch tile pipe buried with top 2 inches below base of monument.

References.-

"Pomona" ( $N=33^{\circ}, 3 \mathrm{~s}^{\prime} \mathrm{W}$ )

Right chimney of house on knoll........ I $_{7} \quad I_{7} \quad \ldots \ldots \ldots$

Right peak of roof of building.......... 68 o $7 \quad \ldots \ldots \ldots$

Left chimney of house............. II $8 \quad 37 \quad \ldots \ldots \ldots$

Northwest chimney of house on bank near

Bookers Wharf.................... 2I9 $20 \ldots \ldots$

Northwest peak of Bookers Wharf house. ... $226 \quad 3^{8} \quad \ldots \ldots \ldots$

Smoke pipe of Quaker Neck Wharf house. . $296 \quad 46 \quad \ldots \ldots$. .

Near chimney of house with dormer windows $346 \quad 50 \quad \ldots \ldots \ldots$

$$
\begin{aligned}
& 5 \text { mile. } \\
& \text { I } 1 / 2 \text { miles. } \\
& 5 / 8 \text { mile. } \\
& 7 / 8 \text { mile. } \\
& 1 / 2 \text { mile. } \\
& 1 / 2 \text { mile. } \\
& 1 / / 4 \text { miles. } \\
& 5 / 8 \text { mile. }
\end{aligned}
$$

\section{CAKE.}

General locality.-Eastem shore of upper Chester River, about three-eighths mile north of Melton Point and seven-eighths mile north of Bookers Wharf. (See Chart No. 30.)

Immediat lacality.-Ohserved station is in a marsh ahout I foot above ligh water, 13 yards castsoutheast of shore, 35 yards northeast by north of shore, 35 yards northeast of rounded point, 150 yards north-northwest of entrance to a creek, 200 yards south-southwest of buildings, and 300 yards south of a house among trees.

Marks.-Observed station is center point of triangle on standard cement monument projecting 6 inches above surface of ground. Subsurface mark is center of 2 -inch tile pipe buried with top 2 inches below base of monument. 
References.

"Journey" ( $36^{\circ} 20^{\prime} \mathrm{E}$ ) ................ 0000

Chimney on ell of house to left of trees.... 340

Northwest peak of Bookers Wharf house... $3^{8} \quad 53$

South chimney of near one of twin houses.. I $42 \quad 49$

East chimney of brick house among trees on ridge ....................... 160

South peak of building................ 229

Large lone tree on ridge............... 299

Left chimney of large house........... 324

\section{POMONA.}

1/2 mile.

$5 / 8$ mile.

$2 / 8$ mile.

3 ; mile.

I $1 / 2$ miles.

$1 / 4$ mile.

$1 / 4$ mile.

1/4 mile.

General locality.-Western shore of upper Chester River about five-eighths mile northwest of Melton Point and one-half mile south of entrance to Browns Creek. (See Chart No. 3o.)

Immediate locality.-Observed station is among small trees near edge of cultivated field, about 12 feet above high water, 6 yards west of edge of bank, and 8 yards from top of slope to marsh.

Marks.-Observed station is center point of triangle on standard cement monument projecting 4 inches above surface of ground. Subsurface mark is center of 2 -inch tile pipe buried with top 2 inches helow base of monument.

References.-

"Taste" ( $\left.5^{\circ} 30^{\prime} \mathrm{W}\right)$

Nail in blaze in locust tree (3 inches dia. eter) blaze in locust tree ( 3 inches diam

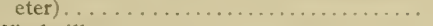
Windmill .....................

Right corner of house............. 7

Large lone tree in field.............. 93

Left chimney of large house. . . . . . . . . 10

Ell of house to left of trees.............
Nail in blaze in locust tree ( 4 inches diam

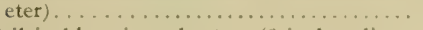

Nail in blaze in cedar tree ( 8 inches diameter) ........................ $196 \quad 39 \quad 40 \ldots \ldots$ meters.

Large cherry tree.................... $277 \quad 32 \quad \ldots 0$ yards.

BII,I.

General locality.-Eiastern shore of upper Chester River about three-fourths mile north of Melton Point and nearly opposite Browns Creek. (See Chart No. 3o.)

Immciliate locality.-Observed station is in grove of $\mathrm{elm}$, ash, and oak trees on north side of a point about 20 feet above high water, 7 yards south-southeast of edge of bank, 30 yards east-northeast of a small house, and 40 yards west-southwest of a fence.

Marks.-Observed station is center point of triangle on standard cement monument projecting 5 inches above surface of ground. Subsurface mark is center of 2 -inch tile pipe buried with top 2 inches below base of monument.

References.-

"Cake" (S $\left.\times 5^{\circ} 4 \mathrm{I}^{\prime} \mathrm{E}\right)$

Right peak of Bookers Wharf house $\ldots . . . . .$.

Nail in blaze in elm tree (10 inches diameter).

Nail in blaze in elm tree ( 9 inches diameter).

Nail in blaze in oak tree (24 inches diameter).

Fast chimney of brick house . . . . . . . . I

Peak of sharp roof . . . . . . . . . I5

"Robertson Windmill". . . . . . . . . . . . . 24

Spindle on peak of house on Rolphs Wharf, 247

Nail in blaze in tree ( 8 inches diameter)... 28

Left chimney of house on ridge ......... 322

Nail in blaze in tree ( ${ }_{5}$ inches diameter) . . 343

Chimney on ell of house

$349 \quad 32$

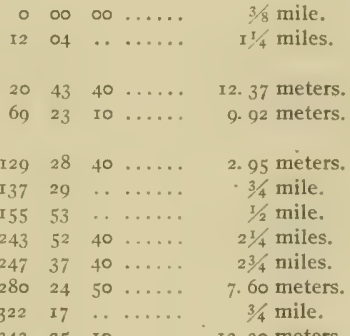

ro ..... I2. 30 meters.

I mile. 
TASTE.

General locality.-Western shore of upper Chester River on point at east side of entrance to Browns Creck, about I mile northwest of Melton Point. (See Chart No. 30.)

Immedinte locality.-Observed station is on a marsh point between Chester River and Browns Creek, about 5 yards north of shore of Chester River, 30 yards south of shore of Browns Creek, 50 yards southwest of point of shore of Browns Creek, and 55 yards west-southwest of cedar trees.

Marks.-Observed station is center point of triangle on standard cement monument projecting 6 inches above surface of ground. Subsurface mark is center of 2 -inch tile pipe buried with top 2 inches below base of monument.

\begin{tabular}{|c|c|c|c|c|}
\hline \multicolumn{5}{|l|}{ References.- } \\
\hline "Make" $\left(\mathrm{N}_{52}{ }^{\circ}{ }_{14}^{\prime} \mathrm{E}\right) \ldots \ldots \ldots \ldots \ldots$ & $\circ$ & $\infty$ & $\infty \ldots \ldots$ & 3/8 mile. \\
\hline 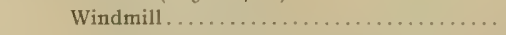 & 7 & II & $30 \ldots \ldots$ & I $3 / 4$ miles. \\
\hline 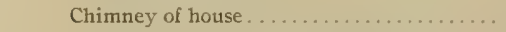 & 25 & 20 & $\ldots \ldots \ldots$ & $\mathrm{r} 3 / 4$ miles. \\
\hline Left chimney of house on ridge.......... & 68 & $5^{8}$ & . & $\mathrm{I}^{1 / 4} / 4$ miles. \\
\hline Chimney on ell of house. ............. & 84 & 20 & . . & $x^{3} / 4$ miles. \\
\hline West chimney of left one of twin houses... & $\mathrm{I}_{42}$ & 19 & .. & 3/8 mile. \\
\hline $\begin{array}{l}\text { Right chimney of brick house............ } \\
\text { Largest cedar tree in clump ( } 5 \text { inches diam- }\end{array}$ & 266 & 13 & $\cdots \cdots \cdots$ & $3 / 4$ mile. \\
\hline eter $\ldots \ldots \ldots \ldots \ldots \ldots \ldots \ldots \ldots \ldots$ & $35^{\circ}$ & 28 & $\cdots \cdots$ & 54 yards. \\
\hline
\end{tabular}

MAKE.

General locality.-Western shore of upper Chester River about II/8 miles north of Melton Point and three-eighths mile northeast of entrance to Browns Creek. (See Chart No. 30.)

Immediate locality.-Observed station is in a pasture land, about 2 feet above high water, Io yards north of shore, ino yards west of tangent of point of curve of shore, and 325 yards southeast of farm buildings behind trees.

Marks.-Observed station is center point of triangle on standard cement monument projecting 4 inches above surface of ground. Subsurface mark is center of 2 -inch tile pipe buried with top 2 inches below base of monument.

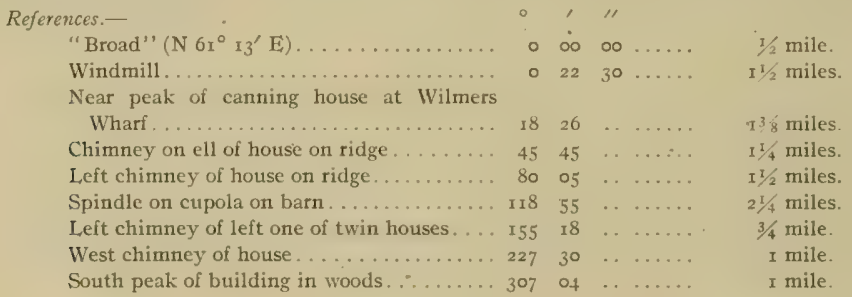

DOWN.

General locality.-Southeastern shore of upper Chester River about 2 miles southwest of entrance to Southeast Creek and I mile east of entrance to Browns Creek. (See Chart No. 30.)

Immediate locality,-Observed station is on a small rounded point of sanded marsh, about I foot above high water, 5 yards south of shore, 40 yards east by south of an inlet, and 95 yards west of a fence beyond trees.

Marks.-Observed station is center point of triangle on standard cement monument projecting 6 inches above surface of ground. Subsurface mark is center of 2 -inch tile pipe buried with top 2 inches below base of monument. 


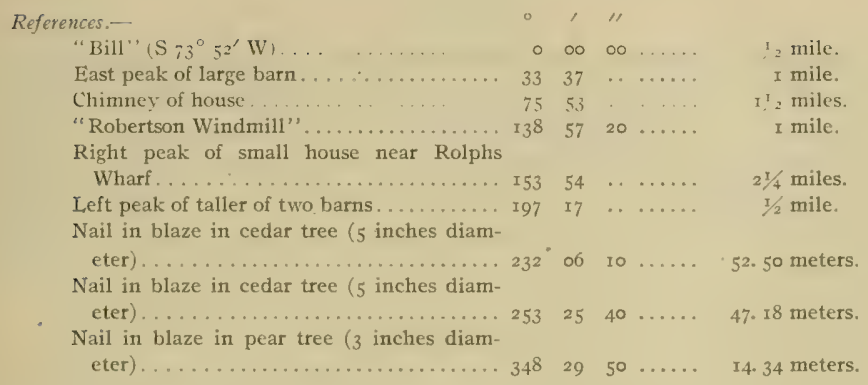

\section{JULIUS.}

General locality.-Southeastern shore of upper Chester River about one-half mile southwest o: Wilmers Wharf. (See Chart No. 3o.)

Immediate locality.-Observed station is on a sanded grass point fringed by cedar trees and about 2 yards south of shore.

Marks.-Observed station is center point of triangle on standard cement monument projecting 5 inches above surface of ground. Subsurface mark is center of 2 -inch tile pipe buried with top 2 inches below base of monument.

References.-

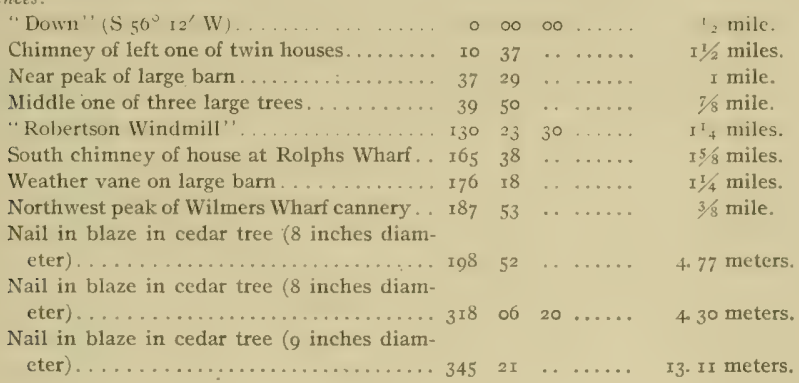

BROAD.

Gencral locality.-Northwestern side of upper Chester River, on an island at entrance to Broad Creek, about I mile northeast of entrance to Browns Creek. (See progress map.)

Immediale locality.-O Observed station is on western end of a marsh island, about 9 yards north of shore, 43 yards south of shore, and 52 yards east-southeast of shore.

Marks.-Observed station is center point of triangle on standard cement monument projecting 6 inches above surface of ground. Subsurface mark is center of 2 -inch tile pipe buried with top 2 inches below base of monumert.

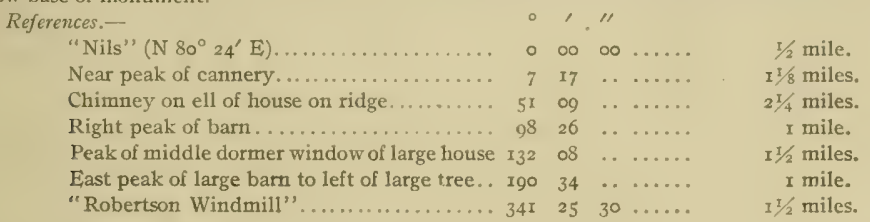




\section{NILS.}

General locality.-Northwestern shore of upper Chester River, about thrce-fourths mile west of entrance to Southeast Creek and one-half mile east of an island at entrance to Broad Creek. (See prog ress map.)

Immediate locality.-Observed station is in edge of cultivated field, about 5 fcet above high water, 4 yards north of shore, i to yards east by south of tangent of point of curve of shore, and 450 yards southwest of a house and windmill.

Marks.-Observed station is center point of triangle on standard cement monument projecting 5 inches above surface of ground. Subsurface mark is center of 2 -inch tile pipe buried with top 2 inches below base of monument.

References.-

\begin{tabular}{|c|c|c|c|c|}
\hline $\begin{array}{l}\text { "Robertson" ( }\left(\mathrm{N} 59^{\circ} \circ 4^{\prime} \mathrm{E}\right) \text {.................. } \\
\text { Weather vane on southwest peak of largest }\end{array}$ & $\circ$ & ০০ & $\infty$ & I/2 mile. \\
\hline barn on ridge. & 10 & 40 & & $I^{1}=$ miles. \\
\hline North peak of Wilmers Wharf cannery..... & 37 & 03 & . $\cdots \cdots \cdot$ & $1 / 2$ mile. \\
\hline Chimney of house near Wilmers Wharf.... . & $4 \mathrm{I}$ & 52 & . . & $1 / 2$ mile. \\
\hline West chimney of large house on ridge...... & 133 & 32 & .. . & s mile. \\
\hline Near peak of roof of house on hill........ & 158 & 22 & . & I mile. \\
\hline "Robertson Windmill" .......... & 336 & 55 & $\ldots \ldots \ldots$ & $1 / 2$ mile. \\
\hline
\end{tabular}

\section{WILMERS.}

General locality.-Southeastern shore of upper Chester River on southwest side of entrance to Southcast Creek, about $\mathbf{x} 75$ yards northeast of Wilmers Wharf. (Sce progress map.)

Immediate locality.-Observed station is on a sanded grass point between river and marsh, about 3 feet above high water, 7 yards east of shore, 5 yards south west of shore, and 6 yards southeast of extreme end of point.

Marks.-Observed station is center point of triangle on standard cement monument projecting 5 inches above surface of ground. Subsurface matk is center of $z$-inch tile pipe buried with top 2 inches below base of monument.

\begin{tabular}{|c|c|c|c|c|}
\hline ferences.- & $\circ$ & ' & " & \\
\hline "Julius" ( $60^{\circ} 34^{\prime} \mathrm{W}$ ). . & $\circ$ & $\infty$ & $\infty \ldots \ldots$ & $1 / 2$ mile. \\
\hline Chimney on near one of twin houses....... & 4 & $5^{8}$ & . . . & $21 / 8$ miles. \\
\hline East peak of large barn................ & 27 & 14 & .. . & $\mathrm{I}^{1} / 3$ miles. \\
\hline "Robertson Windmill" . & it & o) & 30 & ss mile. \\
\hline Cupola on Rohertson barn. & 83 & 23 & . . & $1 / 2$ mile. \\
\hline Flagpole on Rolphs Wharf... & 154 & o6 & $20 \ldots$ & $\mathrm{I}^{1} / 4$ miles. \\
\hline Weather vane on large barn............ & 169 & 23 & . . & $I^{1 / 2}$ miles. \\
\hline Cupola on barn ...................... & 212 & 59 & . $\cdots \cdots$ & 300 yards. \\
\hline Cupola on barn........... & 284 & 57 & $\ldots \ldots \ldots$ & 5 s mile. \\
\hline Right peak of Wilmers Wharf cannery..... & $3+8$ & 26 & $\ldots \ldots \ldots$ & I75 yards. \\
\hline
\end{tabular}

\section{ROBERTSON WINDMILL.}

General locality.-Northwestern side of upper Chester River opposite entrance to Southeast Creek, about $\mathrm{I} 1 / 4$ miles southeast of Rolphs Wharf. (See progress map.)

Immediate locality.-Observed station is on windmill on high tower in rear of house.

Marks.-Observed station is center point of windmill.

References.-None necessary. 


\section{ROBERTSON.}

General locality.-Northwestern shore of upper Chester River near Riverside Wharf opposite entrance to Southeast Creek. (See Progress map.)

Immediate locality.-Observed station is about 2 feet above high water, 5 yards northwest of shore, 45 yards northeast of shore end of a wharf, and roo yards southwest of a point of land.

Marks.-Observed station is center point of triangle on standard cement monument projecting 4 inches above surface of ground. Subsurface mark is center of 2 -inch tile pipe buried with top 2 inches below base of monument.

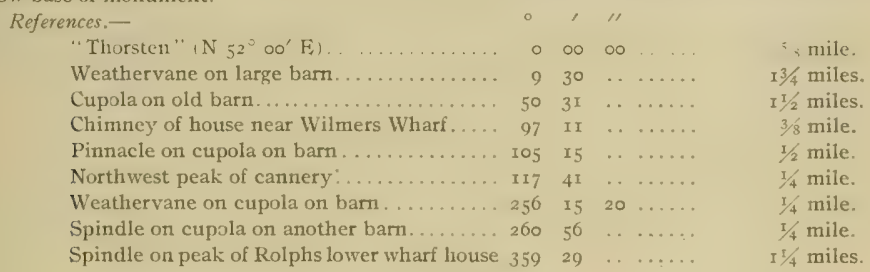

\section{SOUTHEAST.}

General localily.-Southeastern shore of upper Chester River on Deep Point at northeastern side of cntrance to Southeast Creek about three-fourths mile south-southwest of Rolphs Wharf and one-half mile northeast of Wilmers Wharf. (See Prozress map.)

Immediate locality.-Observed station is on cultivated land about ${ }_{5}$ feet above high water, 19 yards south of edge of bank, 2 y yards east by north of edge of bank, and 27 yards east by south of extreme point of bank.

Marks.-Observed station is center point of triangle on standard cement monument projecting 5 inches above surface of ground. Substrface mark is center of 2 -inch tile pipe buried with top 2 inches below base of monument.

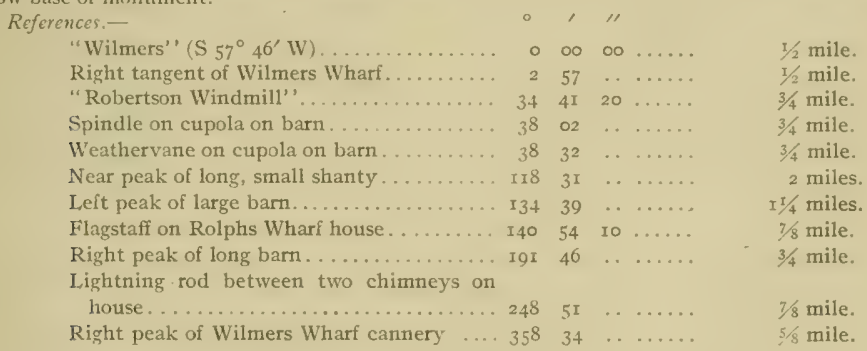

\section{THORSTEN.}

General locality.-Northwestern shore of upper Chester River about three-fourths mile northeast of Wilmers Wharf and one-half mile north of entrance to Southeast Creek. (See Progress map.)

Immediate locality.-Observed station is about 3 feet above high water, 12 yards northwest of shore, ro yards northeast of short fence, and 4 yards southeast of lone cedar tree.

Marks.-Observed station is center point of triangle on standard cement monument projecting 5 inches above surface of ground. Subsurface mark is center of 2 -inch tile pipe buried with top 2 inches below base of monument. 


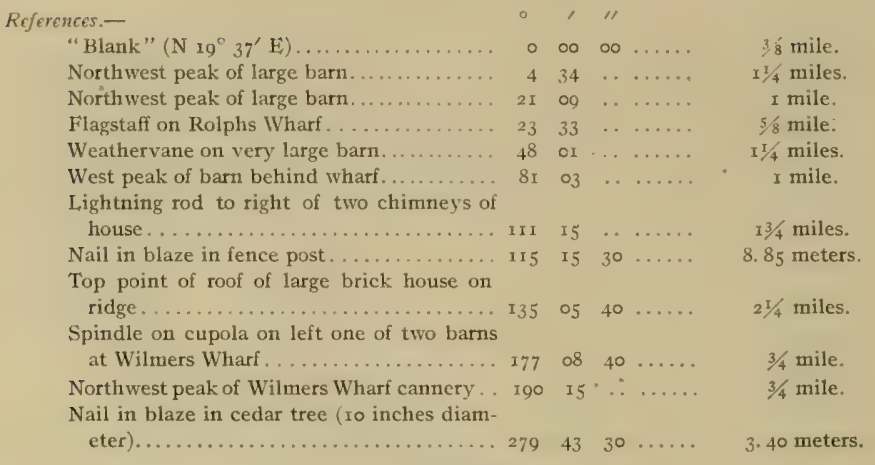

BL, ANK.

General locality.-Northwestern shore of upper Chester River about one-fourth mile west of Rolphs Wharf and three-fourths mile north of entrance to Southeast Creek. (See Progress map.)

Immediate locality.-Observed station is on a grassy point about 2 feet above high water, 7 yards west of shore, 9 yards north of shore, 8 yards northwest of extreme end of point, and 40 yards from a dense clump of trees.

Marks.-Observed station is center point of triangle on standard cement monument projecting 5 inches above surface of ground. Subsurface mark is center of 2 -inch tile pipe buried with top 2 inches below base of monument.

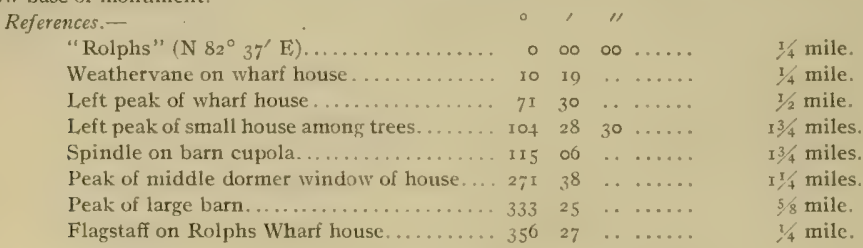

\section{ROLPHS}

General localily,-Fastern shore of upper Chester River about Ioo yards southeast of Rolphs Wharf and three-fourths mile north of entrance to Southeast Creek. (See Progress map.)

Immediate locality.-Observed station is on a grass bank between two large willow trees about 6 feet above high water, 5 yards northeast of shore, I9 yards south-southwest of side gate to yard, and 7 yards southwest of a road 3 feet higher than observed station.

Marks.-Observed station is center point of triangle on standard cement monument projecting 5 inches above surface of ground. Subsurface mark is center of 2 -inch tile pipe buried with top 2 inches helow base of monument. 
K'eferences.-

"Southeast" ( $\left.\mathrm{S}_{22}{ }^{\circ} 53^{\prime} \mathrm{W}\right)$.

Peak of Wilmers What cannery..........

Flagstaff on Rolphs Wharf . .

Nail in blaze in willow tree ( 24 inches diam-

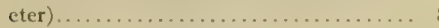

Chimney on ell of Story house. . . . . . . . .

Nail in blaze in willow tree ( 27 inches diam-

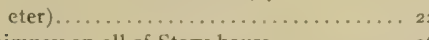

Chimney on ell of Story house........... $261{ }^{2}{ }_{56} \ldots \ldots \ldots$

Nail in blaze in willow tree $(25$ inches diam-

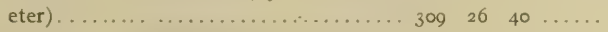

Weathervane on middle of lower wharf house............................ 34

$\begin{array}{rrrrr}\circ & 00 & 00 & \ldots & 3 / 4 \text { mile. } \\ 15 & 06 & \ldots & \ldots \ldots & 11 / 4 \text { miles. } \\ 76 & 59 & \ldots & \ldots & 100 \text { yards. }\end{array}$

88 o6 $20 \ldots \ldots .7 .16$ meters.

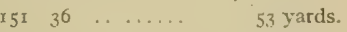

220 3I 10 ..... 13.96 meters. I20 yards.

8. 5 I meters.

100 yards. 


\section{BOUNDARIES OF OYSTER BARS.}

\section{EXPLANATION}

The law of the United States authorizing the cooperation of the Department of Commerce and Labor in the survey of natural oyster bars of Maryland provides for the designation and employment by the Department of Commerce and Labor of such officers, experts, and other technically qualified persons "as may be necessary to cooperate with the Maryland State Board of Shell Fish Commissioners in making a survey of and locating the natural oyster beds, bars, and rocks in the waters within the State of Maryland." The oyster laws of Maryland provide that the Maryland Shell Fish Commissioners, with the aid of such persons as may be designated by the Government, shall proceed "to have laid out, surveyed, and designated on the said charts the natural beds and bars, and shall cause to be marked and defined as accurately as practicable the limits and boundaries of the natural beds, bars, and rocks as established by said survey, and they shall take true and accurate notes of said survey in writing, and make an accurate report of said survey, setting forth such a description of landmarks as may be necessary to enable the said board, or their successors, to find and ascertain the boundary lines of the said natural oyster beds, bars, and rocks, as shown by a delineation on the maps and charts." The oyster laws of Maryland also provide in another section that there shall "be made a true and accurate survey of the natural oyster beds, bars, and rocks *** with reference to fixed and permanent objects on the shore, giving courses and distances, to be fully described and set out in a written report of said survey."

Under the provisions of the laws quoted above the State of Maryland, in cooperation with the Department of Commerce and Labor, must define the boundaries of the natural oyster bars "as accurately as practicable" and also "with reference to fixed and permanent objects on the shore, giving courses and distances." The requirement of "as accurately as practicable" is easily fulfilled by definition of the location of the corners of the oyster bars by latitude and longitude. In fact, this method is probably the most satisfactory and accurate one that could be used for all purposes of legal definition or for relocation of the oyster-bar boundaries by competent engineers. Therefore the additional requirement of "giving courses and distances" is superfluous and is only fulfilled in the published definitions on account of the specific provisions of the law making it compulsory. This part of the description of boundaries has involved an immense amount of extra computations in order to prevent technical discrepancies between the latitude and longitude of a corner of an oyster bar and its distance and bearing from objects on shore of known latitude and longitude without adding anything to the accuracy and very little to the convenience of practical use of the descriptions of the oyster-bar boundaries.

As provided by law the boundaries of the oyster bars are all straight lines, but in the work already completed they have inclosed areas of all shapes from triangles to 
complicated 14 -sided figures, and of all sizes from 4 acres to 7,548 acres. The sizes have varied in length from 93 to 7,529 yards, and in some cases the corners of the boundaries have been practically at the triangulation stations from which they are located, while in other instances they were over 13,600 yards from the landmarks most available for the purpose of fixing their position.

The varied characteristics of the legal boundaries of the oyster bars indicated by the above statement, together with the complicated requirements of the law under which the survey has been made and the magnitude of the work with the consequent need of fixed and uniform methods, have made the problem of describing the boundaries one of considerable difficulty and great importance.

The boundaries of the oyster bars of Maryland, as establisied by the Shell Fish Commission and delineated on the Coast and Geodetic Survey charts and projections and on the leasing charts of the Commission, are technically defined and described by a method somewhat different from that used in other oyster surveys. But it is believed that the forms finally adopted will fulfill all needs of the survey for both the present and the future.

\section{METHOD OF DÉSCRIBING BOUNDARIES.}

The descriptions have been arranged in tabular form, thus avoiding many hundred repetitions of the same words by making one explanation of the tables sulficient for all oyster bars in each county.

Title.-At the top of each tabular form is given the legal name of the oyster bar to be described, and the one by which it is known and designated in the published oyster records and on the oyster charts. The adopted name of the oyster bar is the one used locally, as nearly as could be ascertained by the hydrographic engineer of the Commission; and when there was no local name in common use a name was selected from one of the prominent features of the vicinity that would naturally suggest the section of the waters where the oyster bar was located.

Underneath the name, in parentheses, is given the general locality of the oyster bar and the serial number of the Maryland Oyster Chart on which its legal boundaries are shown. ${ }^{1}$

First column.-This column, under the heading of "Corner of bar," gives the number corresponding to the corner of the boundary as shown on the charts and to the number on the buoy marking the actual corner of the bar. The numbers of the corners have been assigned by naming the southernmost point No. I, thence proceeding in a clockwise direction around the bar. Where a corner of one oyster bar is identical with the corner of the boundaries of one or more other oyster bars, only the number of the corner of the oyster bar being described in the table is given in this column.

Second and third columns. - These two columns, under the headings of "Latitude" and "Longitude," give the geographic positions of the corners. These positions have been adopted by the Commission as the primary technical definition of the location of the corners, and should be considered as final in case of a dispute arising from discrepancies caused by other means of location. The latitudes and longitudes given in these columns are based on the United States standard datum of the Coast and Geodetic surver, and the points thus defined can be relocated from distant triangulation station

1 These charts can be uhtained by anplication to the Superintendent of the Coast aud (Seodetic Survey at Washington, D. C. 
of the survey, even though all the landmarks and buoys originally used for their location have been destroyed by natural or other causes.

Fourth and fifth columns.-These two columns, under the general heading of "True bearing" "and the specific headings "Forward" and "Back," give bearings measured from a true north-and-south line. The three "Forward" bearings are from the corner of the boundary designated in the first column to the triangulation stations named on the corresponding lines in the last column, and the three "Back" bearings are from these same stations in the last column to the corresponding corner of boundary in the first column. The difference in minutes of arc between the forward and back bearings shown in some cases is actual and not accidental, and is due to the fact that the computations took into account the spheroidal shape of the earth.

Sixth column.-This column, under the heading of "Distance," gives the three computed distances in yards from the corner of the bar noted in the first column to the three triangulation stations named on the corresponding lines in the last column, and vice versa.

Seventh column. - This column, under the heading of "U. S. C. \& G. S. triangulation station," " gives the names of the landmarks from which were computed the corresponding "Latitude," "Longitude," "True bearing," and "Distance" of the "Corner the bar" designated in the first column. A full description of the location and markings of these triangulation stations is given in another part of this publication under the heading of "Descriptions of triangulation stations."

\section{SURVEYING METHODS FOR RELOCATION OF BOUNDARIES.}

There are a number of methods that can be used in the relocation of the actual boundaries of the natural oyster bars as technically described in this publication and delineated on the published charts of the Coast and Geodetic Survey and the leasing charts of the Shell Fish Commission.

The following brief descriptions of five of these more or less different methods assume a certain amount of experience and knowledge on the part of the engineer in the particular kind of surveying under consideration, and are only intended as reninders of ways and means that can be used.

There are two problems that are likely to present themselves to those interested in the boundaries of natural oyster bars: one, to determine whether the buoys marking the corners have been dragged or otherwise moved from their correct positions, and the other, to relocate or reestablish a buoy at the point from which it was removed. The different ways of solving these two problems partly depend upon the instruments possessed by the engineer and his assistants and partly on his training and experience.

(I) Triangulation.--This method is the one that will give the greatest accuracy, but on account of its requiring special data and instruments, and being an operation rarely used by engineers not engaged in geodetic surveying, it is recommended only for cases in dispute that can not be settled satisfactorily by some other method. An explanation of this class of work would be too long for a report of this sort, and those not familiar

\footnotetext{
1 The mean magnetic variation for Kent County was $6^{\circ} 15^{\prime}$ west of north in $19 \mathrm{x}$ and increasing at the rate of $5^{\prime}$ yeariy.

2 Geographic positions of these triangulation stations can be ohtained hy application to the Superintendent of the Coast ancl Geodetic Survey, Washington, D. C.
} 
with this method are referred to the publications on the subject by the Coast and Geodetic Survey.

(2) Hydrographic.-This method is the most simple and satisfactory one that can be adopted if the surveyor can obtain the use of the necessary instruments and assistants. It is the one best suited for the work of the engineers of the Commission in relocating corners of boundaries, as it gives results of the accuracy ordinarily required and is rapid in execution. Besides, it has the advantage of being available whenever three triangulation stations of suitable relative positions are visible from the offshore points needing relocation.

Most navigators and others familiar with the use of a sextant are well acquainted with the graphic three-point method of fixing a position on water, and only a brief description of the operation will be stated.

In the case where there is only one engineer having a single sextant, the three-point method can be used if the two angles determining the position of a buoy are first derived from the "Forward" bearings given in the tabular forms describing the boundaries of the oyster bars. For example, take "Phoenix Shoal" oyster bar, which is the first one described in this publication, and assume that "Comer No. 3 ," is to be examined as to its position. The angle between the two landmarks "Worton Point 2 " and "Pooles Island 2 " as determined from right to left from the forward bearings from this corner is $132^{\circ} \mathrm{O}^{\prime}$ " and the angle between "Pooles Island 2" and "Bramble" is $68^{\circ} 13^{\prime}$. Having these two angles, the engineer proceeds to the buoy of doubtful location and measures the actual sextant angles between the landmarks for which the calculations were made. If the measured and calculated angles do not agree the buoy is not in its correct position and the boundary corner must be relocated. This is accomplished by moving the boat about until a point is reached where the angles do agree, and this point being the desired location, the buoy can be placed in its correct position.

If the engineer can obtain the use of both a sextant and $a^{\circ}$ three-arm protractor ("position finder"), the availability of the hydrographic method is increased, as the use of the protractor is essential in case of the washing away or destruction of one or more of the landmarks originally used in describing the boundaries. Under these circum. stances, any three landmarks of suitable relative position that are visible from the point to be located can be utilized. For example, the engineer can proceed to the buoy of doubtful position and measure the two adjacent sextant angles between the three landmarks selected. These two angles are set off on the three-arm protractor and the actual position of the buoy plotted on the chart by shifting the protractor about until the edge of each of the three arms passes through the center of the symbols on the chart marking the position of the three landmarks selected. The center of the hub of the protractor will indicate on the chart the actual position of the buoy, and if the point thus obtained does not coincide with the true position of the corner of the boundary as given on the chart, the surveyor can proceed to locate the buoy correctly by reversing the operation. This is done by placing the center point of the hub of the protractor over the corner of the boundary in question and measuring on the chart the two adjacent protractor angles between the three selected landmarks. One of the angles thus obtained is set on the sextant and the boat moved about until the two landmarks are shown by the sextant to subtend the same angle obtained from the protractor. The 
second angle is then placed on the sextant and the same operation gone through, and so on, first using one angle on the sextant then the other until a point is reached where both observed sextant angles are practically identical with the protractor angles. The point thus located is the desired one and the buoy can be placed to mark the true position of the corner of the boundary in question.

If the engineer possesses two sextants and a protractor, this problem is far easier of solution, as the two angles can be set off on separate sextants and the observer can quickly find the desired point where they agree with the protractor angles by using one sextant after the other without the need of resetting either.

If there are two observers, two sextants, and a protractor, it can be seen that the best conditions for both rapid and accurate hydrographic location of a point is attained. In fact, this is the method by which the buoys at the corners of the boundaries were originally placed by the hydrographic engineer to the Commission.

(3) Magnetic bearings from offshore. - This method of fixing a position on water is a simple and well-known one in navigation. It is available to anyone having a boat compass and will be of special use to the State fishery force in investigating cases where buoys are supposed to have been moved for illegal purposes.

In the case where a buoy is supposed to have been moved from its true position the observer can take compass bearings to the three landmarks given in the last column of the tables opposite the boundary corner in question. These bearings are then corrected for the local declination, ${ }^{1}$ and if the results agree with the published bearings the buoy is correctly located.

In the ease where the buoy is not in its correct position, or has disappeared altogether, the desired point can be determined by maneuvering the vessel until the corrected bearings agree with the ones in the tabular descriptions, when the buoy can be anchored in its proper location.

In the case where the landmarks, for which the bearings are published, have been destroyed or washed away, any landmarks whose positions are indicated on the charts can be used. This can be done by getting their bearings directly from the chart by parallel rulers or a protractor and then applying these new bearings in the same manner as the ones published in the tables.

(4) Magnetic bearings from shore. - This method will be of special value to engineers having an ordinary surveyor's compass. The compass can be set over the point marking a "triangulation station" on shore, the name of which is given in the last column opposite the "corner" in question. The instrument is then set at the corresponding "back" bearing (corrected for local magnetic declination) given in the fifth column of the tables opposite the "corner"-in question. The direction thus determined will give one range on which the desired point must be located. The compass can then be moved to a second triangulation station and another range located in a similar manner. The intersection of these two range lines will give the desired point; but in general it should be checked by an additional range line determined from a third station.

(5) Horizontal angles measured at landmarks. This process is a modification of the triangulation method, and will be useful to engineers who have a transit and desire considerable accuracy.

\footnotetext{
1 The mean maguetic variation for Kent County is $6^{\circ} 5^{\prime}$ ' west of north in $19 \mathrm{I} z$ and increasing'at the rate of $5^{\prime}$ yearly.
} 
The instrument is placed over a "triangulation station," the name of which appears in the last column of the tabular description opposite the "corner" in question. The telescope is then pointed to the landmark indicated in the "Descriptions of landmarks" as having a direction of $\mathrm{O}^{\circ} \mathrm{OO}^{\prime \prime} \mathrm{OO}^{\prime \prime}$ from the triangulation station being occupied by the transit. The tabular description of the boundaries is next examined and the "back" bearing of the questionable boundary "comer" from the landmark being occupied is taken out. The angle calculated from this "back" bearing and the bearing given in parentheses alongside the zero landmark in the "Descriptions of landmarks" is then set off on the transit and a range line established on which the desired point must be located. A similar process is then carried on at a second station, and so on until the position of the buoy is satisfactorily fixed.

BOUNDARIES OF NATURAL OYSTER BARS

PHOENIX SHOAI.

(Chesapeake Ba1-Chart No, 28.)

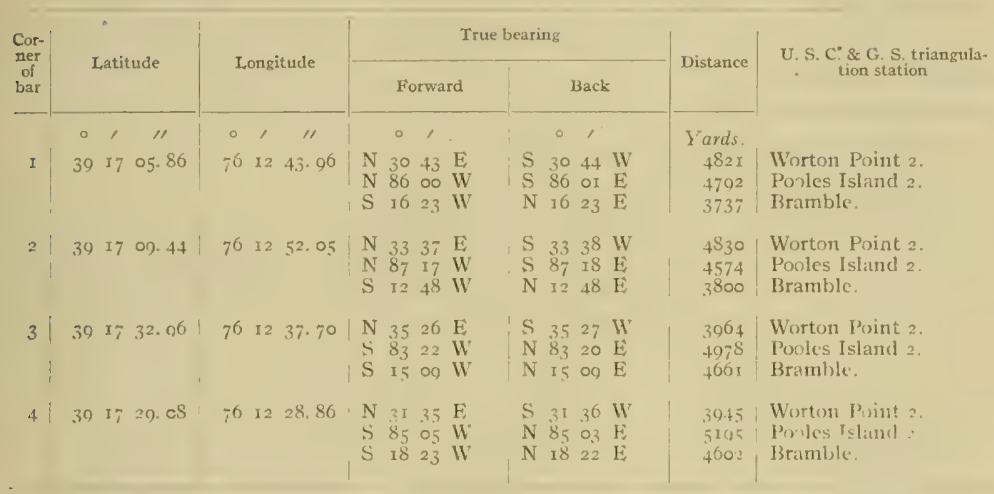

\section{DEEP SHOAL.}

(Chesapeaks Bay-rihart No. 28):

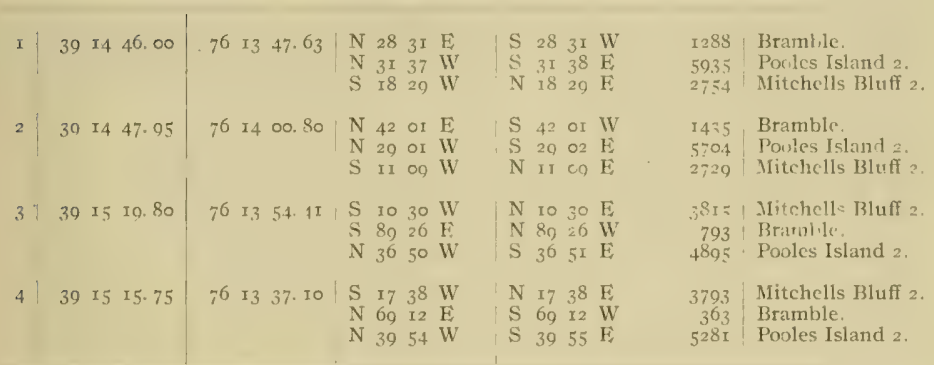


COAL LUMP.

(Chesapeake Bay-Chart No. 28.)

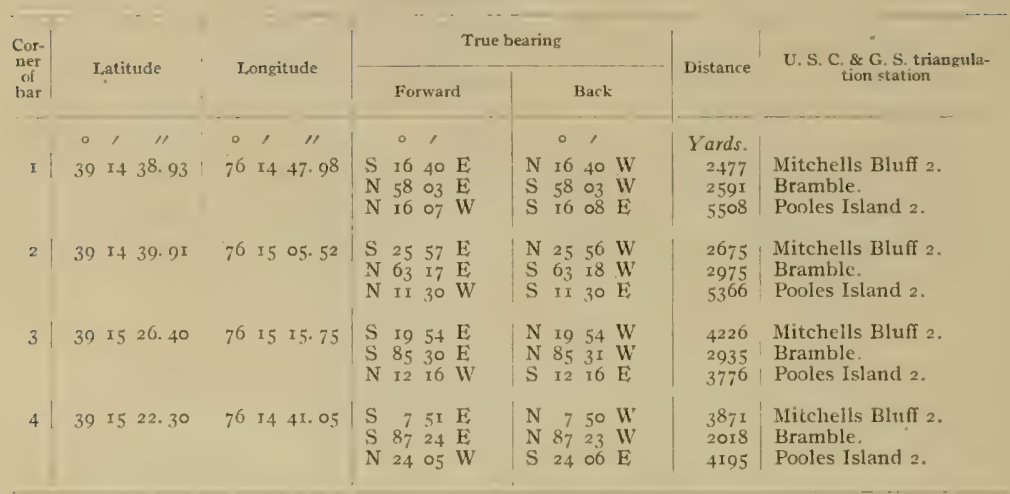

\section{GALES LUMPS.}

(Cheapeake Bay-Chart No. 28.)

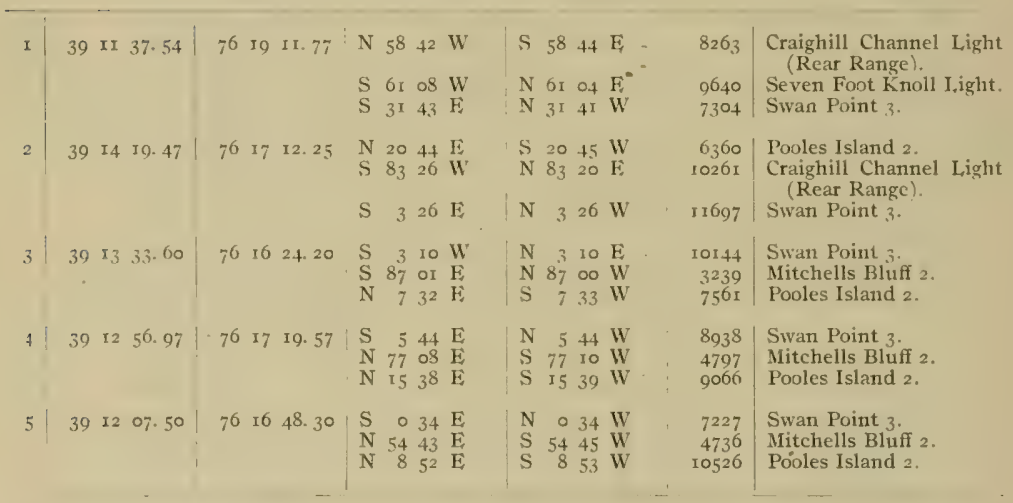


MITCHELLS BLUFF BUOY.

(Chesapeake Bay-Chart No. 28.)

\begin{tabular}{|c|c|c|c|c|c|c|c|c|c|c|c|c|c|c|}
\hline \multirow{2}{*}{$\begin{array}{c}\text { Cor- } \\
\text { ner } \\
\text { of } \\
\text { bar }\end{array}$} & \multirow{2}{*}{\multicolumn{3}{|c|}{ Latitude }} & \multirow{2}{*}{\multicolumn{3}{|c|}{ Longitude }} & \multicolumn{6}{|c|}{ True bearing } & \multirow{2}{*}{ Distance } & \multirow{2}{*}{ U. S. C. \& G.S. triangula- } \\
\hline & & & & & & & & & orward & & & Back & & \\
\hline i & 0 & , & $\prime \prime$ & $\circ$ & , & $\prime \prime$ & & $\circ$ & , & & & , & Yar & \\
\hline$x$ & 39 & 12 & 46.80 & 76 & 16 & 23.97 . & $\begin{array}{l}\mathrm{N} \\
\mathrm{N} \\
\mathrm{S}\end{array}$ & $\begin{array}{r}6 \\
80 \\
75\end{array}$ & $\begin{array}{l}12 \mathrm{E} \\
20 \mathrm{~W} \\
33 . \mathrm{W}\end{array}$ & $\begin{array}{l}\mathrm{S} \\
\mathrm{S} \\
\mathrm{N}\end{array}$ & $\begin{array}{r}6 \\
80 \\
75\end{array}$ & $\begin{array}{l}\text { I2 } \mathrm{W} \\
24 \mathrm{E} \\
29 \mathrm{E}\end{array}$ & $\begin{array}{r}9127 \\
11626 \\
I I 84 I\end{array}$ & $\begin{array}{l}\text { Pooles Island } 2 . \\
\text { Craighill Channel Light } \\
\text { (Rear Range). } \\
\text { Craighill Channel Light } \\
\text { (Front Range). }\end{array}$ \\
\hline 2 & 39 & I2 & $5^{8} \cdot 3^{2}$ & 76. & 16 & 28. 50 & $\begin{array}{l}\mathrm{N} \\
\mathrm{N} \\
\mathrm{S}\end{array}$ & $\begin{array}{r}72 \\
73\end{array}$ & $\begin{array}{l}\text { I } 5 \mathrm{E} \\
\text { og } \mathrm{W} \\
35 \mathrm{~W}\end{array}$ & $\begin{array}{l}\mathrm{S} \\
\mathrm{S} \\
\mathrm{N}\end{array}$ & $\begin{array}{l}7 \\
83\end{array}$ & $\begin{array}{l}\text { I5 } \mathrm{W} \\
\text { I4 } \mathrm{E} \\
3 I \mathrm{E}\end{array}$ & $\begin{array}{r}8755 \\
I 1449 \\
\\
\times 1829\end{array}$ & $\begin{array}{l}\text { Pooles Island } 2 . \\
\text { Craighill Channel Light } \\
\text { (Rear Range). } \\
\text { Craighill Channel Light } \\
\text { (Front Range). }\end{array}$ \\
\hline 3 & 39 & $I_{3}$ & II. 93 & 76 & I 5 & $50.4^{2}$ & $\begin{array}{l}\mathrm{N} \\
\mathrm{N}\end{array}$ & $\begin{array}{r}\circ \\
84 \\
72\end{array}$ & $\begin{array}{l}45 \mathrm{E} \\
53 \mathrm{~W} \\
53 \mathrm{~W}\end{array}$ & $\begin{array}{l}\mathrm{S} \\
\mathrm{S} \\
\mathrm{N}\end{array}$ & $\begin{array}{r}\circ \\
84 \\
72\end{array}$ & $\begin{array}{l}45 \mathrm{~W} \\
57 \mathrm{E} \\
48 \mathrm{E}\end{array}$ & $\begin{array}{r}8226 \\
12390 \\
12918\end{array}$ & $\begin{array}{l}\text { Pooles Island } 2 . \\
\text { Craighill Channel Light } \\
\text { (Rear Range). } \\
\text { Craighill Channel Light } \\
\text { (Front Range). }\end{array}$ \\
\hline+ & 39 & & $\infty . \infty$ & 76 & 15 & $45 \cdot 28$ & $\mathrm{~N}$ & $\begin{array}{r}\circ \\
83 \\
74\end{array}$ & $\begin{array}{l}\text { II } \mathrm{W} \\
\text { o6 W } \\
46 \mathrm{~W}\end{array}$ & $\begin{array}{l}\mathrm{S} \\
\mathrm{S} \\
\mathrm{N}\end{array}$ & $\begin{array}{r}\circ \\
83 \\
74\end{array}$ & $\begin{array}{l}\text { II } \mathrm{E} \\
\text { II } \mathrm{E} \\
4 \text { I } \mathrm{E}\end{array}$ & $\begin{array}{r}8621 \\
12567 \\
12936\end{array}$ & $\begin{array}{l}\text { Pooles Island } 2 \text {. } \\
\text { Craighill Channel Light } \\
\text { (Rear Range). } \\
\text { Craighill Channel Light } \\
\text { (Front Range). }\end{array}$ \\
\hline
\end{tabular}

\section{TOI,CHESTER LUMP.}

(Chesapeake Bay-Chart No. 28.)

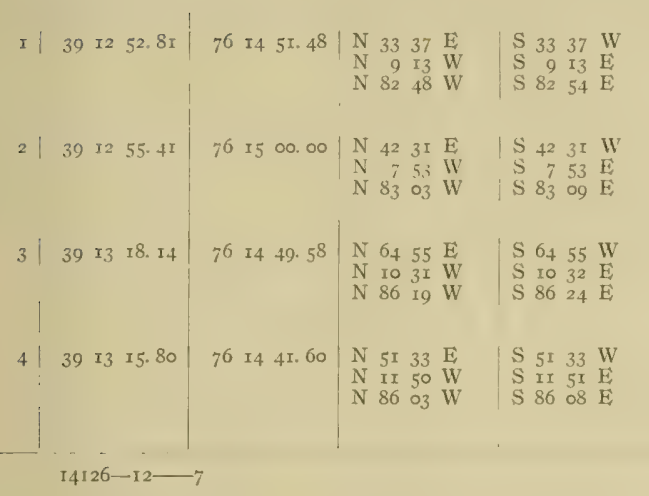

${ }^{1448}$ Mitchells Bluff 2.

S985 Pooles Island 2.

13996 Craighill Channel Light (Rear Range).

1517 Mitchells Bluff 2 .

8865 Pooles Island 2.

${ }_{13764}$ Craighill Channel Light (Rear Range).

830 Mitchells Bluff 2.

8153 Pooles Island 2.

3965
Craighill Channel Light (Rear Range).

603 Mitchells Bluff 2 .

8270 Pooles Island 2.

$1_{4180}$ Craighill Channel Light (Rear Range). 
HODGES.

(Chesapeake Bay-Chart No. 28.)

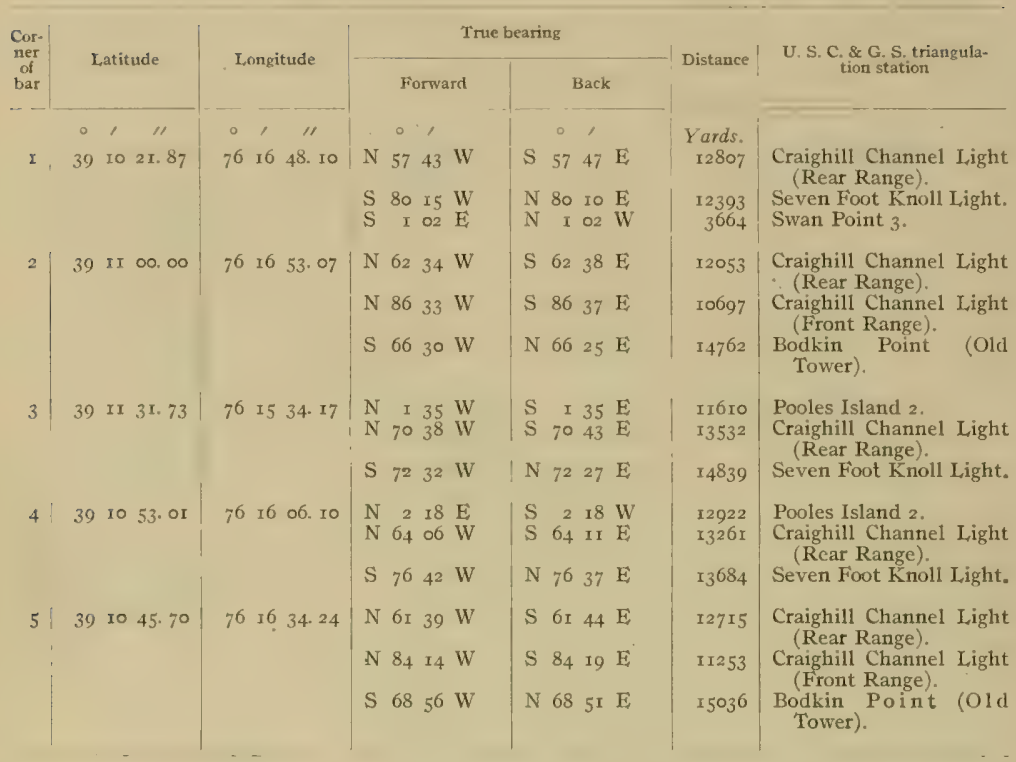


SWAN POINT.

(Chesapeake Bay-Charts Nos. 28 and 20.)

\begin{tabular}{|c|c|c|c|c|c|c|c|c|c|c|c|c|c|c|}
\hline \multirow{3}{*}{$\begin{array}{c}\text { Cor- } \\
\text { zer } \\
\text { of } \\
\text { bax } \\
-\end{array}$} & \multirow{2}{*}{\multicolumn{3}{|c|}{ Latitude }} & \multirow{2}{*}{\multicolumn{3}{|c|}{ Longitude }} & \multicolumn{6}{|c|}{ True bearing } & \multirow[b]{2}{*}{ Distance } & \multirow[b]{2}{*}{$\begin{array}{l}\text { U. S. C. \& G.S. triangula- } \\
\text { tion station }\end{array}$} \\
\hline & & & & & & & & & rwar & & & Back & & \\
\hline & 0 & , & "I & $\circ$ & , & "I & & $\circ$ & , & & $\circ$ & , & Yards. & \\
\hline$x$ & 39 & 05 & 39.09 & $7^{76}$ & I6 & 48.20 & $\begin{array}{l}\mathrm{S} \\
\mathrm{N} \\
\mathrm{N}\end{array}$ & $\begin{array}{r}23 \\
47 \\
0\end{array}$ & & $\begin{array}{l}\mathrm{E} \\
\mathrm{E} \\
\mathrm{E}\end{array}$ & $\begin{array}{rr}\mathrm{N} & 24 \\
\mathrm{~S} & 47 \\
\mathrm{~S} & 0\end{array}$ & $\begin{array}{l}\infty \mathrm{W} \\
49 \mathrm{~W} \\
40 \mathrm{~W}\end{array}$ & $\begin{array}{l}8732 \\
4158 \\
5875\end{array}$ & $\begin{array}{l}\text { Wickes Beach. } \\
\text { Stevens. } \\
\text { Swan Point } 3 \text {. }\end{array}$ \\
\hline 2 & 39 & 07 & 20.67 & $7^{6}$ & I7 & 5r. 73 & $\begin{array}{l}\mathrm{N} \\
\mathrm{N} \\
\mathrm{N}\end{array}$ & $\begin{array}{l}35 \\
48 \\
82\end{array}$ & & $\begin{array}{l}\mathrm{E} \\
\mathrm{W} \\
\mathrm{W}\end{array}$ & $\begin{array}{ll}\text { S } & 35 \\
\text { S } & 48 \\
\text { S } & 82\end{array}$ & $\begin{array}{ll}22 & \mathrm{~W} \\
47 & \mathrm{E} \\
54 \mathrm{E}\end{array}$ & $\begin{array}{r}3002 \\
1219^{2} \\
12102\end{array}$ & $\begin{array}{l}\text { Swan Point } 3 \text {. } \\
\text { Craighill Channel Light } \\
\text { (Front Range). } \\
\text { Bodkin Point (Old } \\
\text { Tower). }\end{array}$ \\
\hline 3 & 39 & 07 & 25. II & $7^{6}$ & I9 & $\infty 0 . \infty$ & $\begin{array}{l}\mathrm{N} \\
\mathrm{N} \\
\mathrm{N}\end{array}$ & $\begin{array}{l}56 \\
43 \\
82\end{array}$ & $\begin{array}{l}55 \\
03 \\
25\end{array}$ & $\begin{array}{l}\mathrm{E} \\
\mathrm{W} \\
\mathrm{W}\end{array}$ & $\begin{array}{ll}S & 56 \\
\text { S } & 43 \\
\text { S } & 82\end{array}$ & $\begin{array}{l}57 \mathrm{~W} \\
06 \mathrm{E} \\
29 \mathrm{E}\end{array}$ & $\begin{array}{r}4213 \\
10797 \\
10293\end{array}$ & $\begin{array}{l}\text { Swan Point } 3 \text {. } \\
\text { Craighill Channel Light } \\
\text { (Front Range). } \\
\text { Bodkin Point (Old } \\
\text { Tower). }\end{array}$ \\
\hline 4 & 39 & 08 & 50.00 & 76 & I9 & $\infty . \infty$ & $\begin{array}{l}\mathrm{N} \\
\mathrm{N} \\
\mathrm{S}\end{array}$ & $\begin{array}{l}36 \\
55 \\
8 I\end{array}$ & $\begin{array}{l}34 \\
42 \\
36\end{array}$ & $\begin{array}{l}\text { W } \\
\text { W } \\
W\end{array}$ & $\begin{array}{l}\text { S } 36 \\
\text { S } 55 \\
\text { N } 8 x\end{array}$ & $\begin{array}{l}37 \mathrm{E} \\
45 \mathrm{E} \\
32 \mathrm{E}\end{array}$ & $\begin{array}{r}12369 \\
8922 \\
10314\end{array}$ & $\begin{array}{l}\text { Craighill Channel Light } \\
\text { (Rear Range). } \\
\text { Craighill Channel Light } \\
\text { (Front Range). } \\
\text { Bodkin Point (Old } \\
\text { Tower). }\end{array}$ \\
\hline 5 & 39 & IO & $25.7^{6}$ & 76 & 17 & or. go & $\begin{array}{l}\mathrm{N} \\
\mathrm{S} \\
\mathrm{S}\end{array}$ & $\begin{array}{r}57 \\
79 \\
6\end{array}$ & $\begin{array}{l}20 \\
2 \mathrm{I} \\
27\end{array}$ & $\begin{array}{l}\text { W } \\
\text { W } \\
\mathrm{E}\end{array}$ & $\begin{array}{lr}S & 57 \\
N & 79 \\
N & 6\end{array}$ & $\begin{array}{l}25 \mathrm{E} \\
16 \mathrm{E} \\
27 \mathrm{~W}\end{array}$ & $\begin{array}{r}12.43 \mathrm{I} \\
\mathbf{1} 2059 \\
3818\end{array}$ & $\begin{array}{l}\text { Craighill Channel Light } \\
\text { (Rear Range). } \\
\text { Seven Foot Knoll Light. } \\
\text { Swan Point } 3 .\end{array}$ \\
\hline 6 & 39 & IO & 21.87 & $7^{6}$ & I6. & 48. 10 & $\begin{array}{l}\mathrm{N} \\
\mathrm{S} \\
\mathrm{S}\end{array}$ & $\begin{array}{l}57 \\
80 \\
I\end{array}$ & $\begin{array}{l}43 \\
\text { I5 } \\
02\end{array}$ & $\begin{array}{l}\text { W } \\
\mathrm{W} \\
\mathrm{E}\end{array}$ & $\begin{array}{lr}\mathrm{S} & 57 \\
\mathrm{~N} & 80 \\
\mathrm{~N} & \mathrm{I}\end{array}$ & $\begin{array}{l}47 \mathrm{E} \\
\text { 10 } \mathrm{E} \\
02 \mathrm{~W}\end{array}$ & $\begin{array}{r}12807 \\
12393 \\
3664\end{array}$ & $\begin{array}{l}\text { Craighill Channel Light } \\
\text { (Rear Range). } \\
\text { Seven Foot Knoll Light. } \\
\text { Swan Point } 3 \text {. }\end{array}$ \\
\hline 7 & 39 & $08=$ & 24. 73 & 76 & 17 & 29. 16 & $\begin{array}{l}\mathrm{N} \\
\mathrm{S} \\
\mathrm{S}\end{array}$ & $\begin{array}{l}42 \\
86 \\
4\end{array}$ & $\begin{array}{l}06 \\
58 \\
15\end{array}$ & $\begin{array}{l}\text { W } \\
\text { W } \\
\text { E }\end{array}$ & $\begin{array}{ll}\mathrm{S} & 42 \\
\mathrm{~N} & 87 \\
\mathrm{~N} & 4\end{array}$ & $\begin{array}{l}10 \mathrm{E} \\
03 \mathrm{E} \\
15 \mathrm{~W}\end{array}$ & $\begin{array}{l}\text { I } 4543 \\
\text { I2607 } \\
\text { I0II6 }\end{array}$ & $\begin{array}{l}\text { Craighili Channel Light } \\
\text { (Rear Range). } \\
\text { Bodkin Point (Old } \\
\text { Tower). } \\
\text { Love Point Light. }\end{array}$ \\
\hline 8 & 39 & 08 & $05 \cdot 3^{6}$ & 76 & $I_{7}$ & 05.35 & $\begin{array}{l}\mathrm{N} \\
\mathrm{N}\end{array}$ & $\begin{array}{l}74 \\
28 \\
89\end{array}$ & $\begin{array}{l}27 \\
53 \\
59\end{array}$ & $\begin{array}{l}\mathrm{E} \\
\mathrm{E} \\
\mathrm{W}\end{array}$ & $\begin{array}{ll}S & 74 \\
S & 28 \\
N & 89\end{array}$ & $\begin{array}{ll}28 \mathrm{~W} \\
53 \mathrm{~W} \\
50 \mathrm{E}\end{array}$ & $\begin{array}{r}2301 \\
1075 \\
\text { I32I } 4\end{array}$ & $\begin{array}{l}\text { Gratitude. } \\
\text { Swan Point } 3 \text {. } \\
\text { Bodkin Point (O1d } \\
\text { Tower). }\end{array}$ \\
\hline 9 & 39 & 075 & 5 x. 73 & 76 & I7 & 20. 18 & $\begin{array}{l}\mathrm{N} \\
\mathrm{N} \\
\mathrm{N}\end{array}$ & $\begin{array}{l}67 \\
32 \\
87\end{array}$ & $\begin{array}{l}33 \\
58 \\
56\end{array}$ & $\begin{array}{l}E \\
E \\
W\end{array}$ & $\mid \begin{array}{ll}\text { S } & 67 \\
\text { S } & 32 \\
\text { S } & 88\end{array}$ & $\begin{array}{l}34 \mathrm{~W} \\
59 \mathrm{~W} \\
\text { or } \mathrm{E}\end{array}$ & $\begin{array}{r}2819 \\
1670 \\
12833\end{array}$ & $\begin{array}{l}\text { Gratitude. } \\
\text { Swan Point } 3 \text {. } \\
\text { Bodkin Point } \quad(01 \mathrm{~d} \\
\text { Tower). }\end{array}$ \\
\hline I0 & 39 & 064 & $46.3^{8}$ & 76 & $I_{7}$ & 02.03 & $\begin{array}{l}\mathrm{S} \\
\mathrm{N} \\
\mathrm{N}\end{array}$ & $\begin{array}{r}0 \\
8 \mathrm{I} \\
6\end{array}$ & $\begin{array}{l}\text { I9 } \\
2 I \\
50\end{array}$ & & $\begin{array}{lr}\mathrm{N} & 0 \\
\mathrm{~S} & 8 \mathrm{r} \\
\mathrm{S} & 6\end{array}$ & $\begin{array}{l}\text { I9 } \mathrm{W} \\
22 \mathrm{~W} \\
50 \mathrm{~W}\end{array}$ & $\begin{array}{l}6756 \\
3483 \\
3631\end{array}$ & $\begin{array}{l}\text { Love Point Light. } \\
\text { Stevens. } \\
\text { Swan Point } 3 \text {. }\end{array}$ \\
\hline II & 39 & 064 & 4 I. 57 & $7^{6}$ & $16=$ & 21.77 & $\begin{array}{l}\mathrm{S} \\
\mathrm{N} \\
\mathrm{N}\end{array}$ & $\begin{array}{r}8 \\
73 \\
9\end{array}$ & $\begin{array}{l}47 \\
58 \\
26\end{array}$ & $\begin{array}{l}\mathrm{W} \\
\mathrm{E} \\
\mathrm{W}\end{array}$ & $\begin{array}{lr}N & 8 \\
\text { S } & 73 \\
\text { S } & 9\end{array}$ & $\begin{array}{l}48 \mathrm{E} \\
59 \mathrm{~W} \\
26 \mathrm{E}\end{array}$ & $\begin{array}{l}6687 \\
2483 \\
3819\end{array}$ & $\begin{array}{l}\text { Love Point Light. } \\
\text { Stevens. } \\
\text { Swan Point } 3 \text {. }\end{array}$ \\
\hline
\end{tabular}


SWAN CREEK.

(Swan Creck-Charl No.28.)

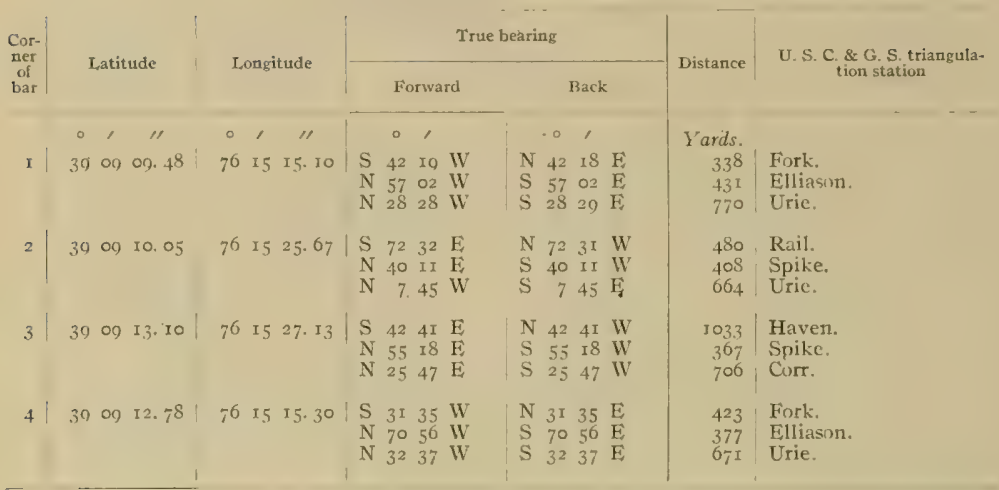

\section{ROCKHALL.}

(Swan Creek-Charts Nos. 28 and 20.)

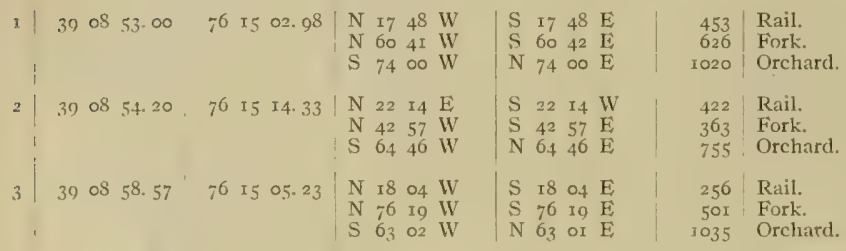

WHITE HORSE.

(Swan Creek-Chart Nos. 28 and 20.)

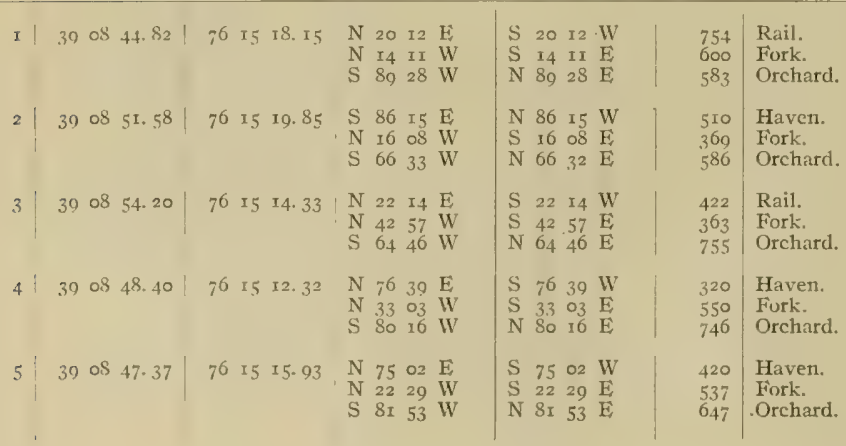


THE HAVEN.

(Swan Creek-Charts Nos. 28 and 29.)

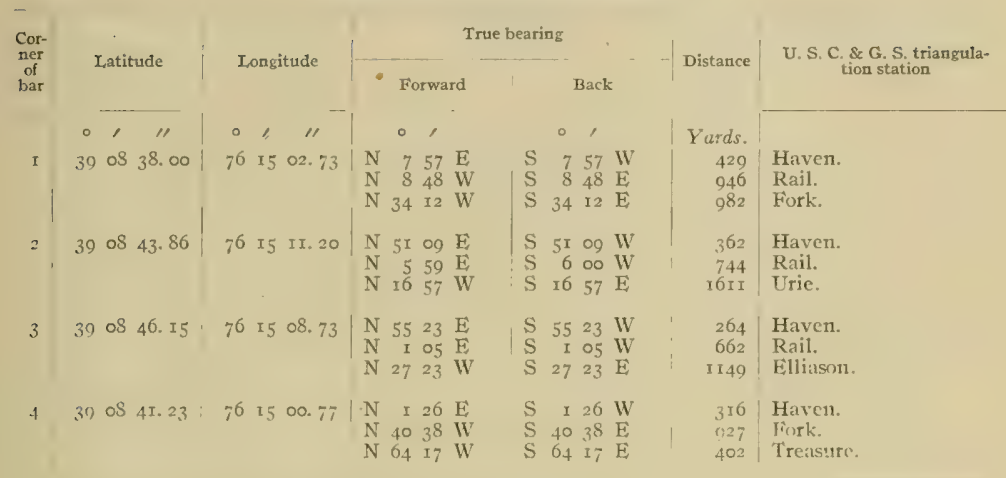

\section{DEEP LANDING HOLE.}

(Swan Creek-Charts Nos, 28 and 20.)

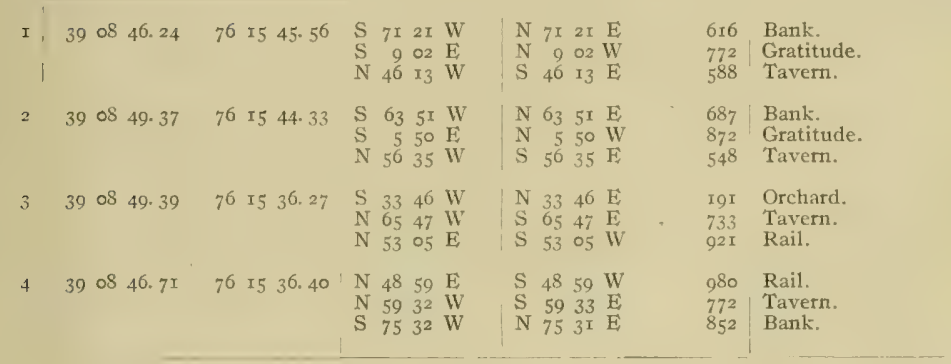

\section{LITTLE NECK.}

(Swan Creek-Charts Nos, 28 and 20.)

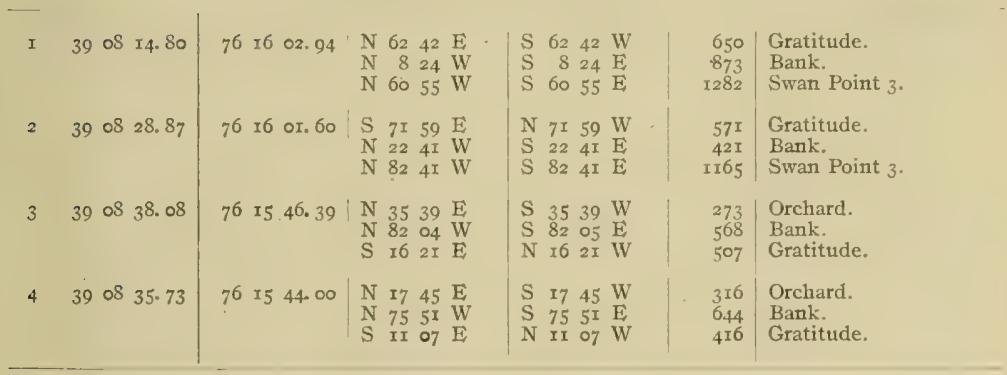


TAVERN CREEK.

(Tavern Creek-Charts Nos. 28 and 20.)

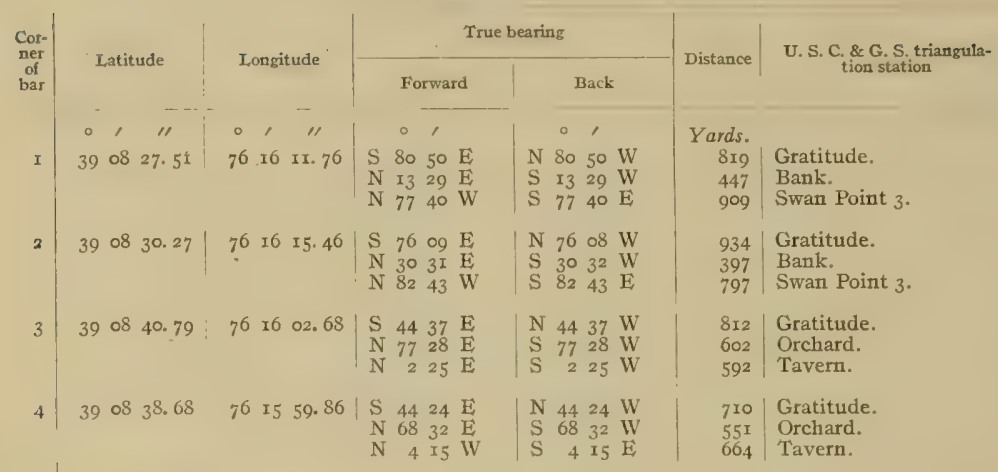

WINDMILL, FLATS.

(Entrance Rockhall Harbor-Chart No. 29.)

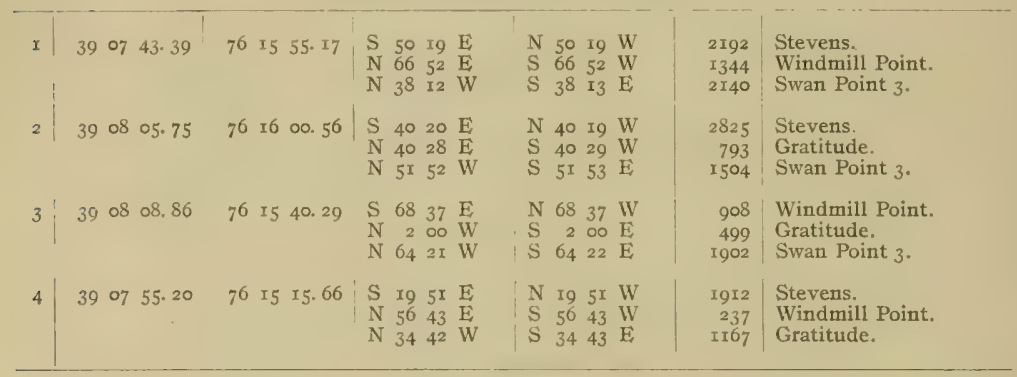

\section{MUDDY DRAIN.}

(Entrance Rockhall Harbor-Chart No. 20.)

\begin{tabular}{|c|c|c|c|c|c|c|c|}
\hline & & & & & & & \\
\hline $\boldsymbol{I}$ & 3907 & II. 20 & 76 I5 $47,3^{8}$ & $\begin{array}{llll}\mathrm{S} & 78 & 02 & \mathrm{E} \\
\mathrm{N} & 32 & 35 & \mathrm{E} \\
\mathrm{N} & 28 & 55 & \mathrm{~W}\end{array}$ & $\begin{array}{llll}\mathrm{N} & 78 & 02 & \mathrm{~W} \\
\mathrm{~S} & 32 & 36 & \mathrm{~W} \\
\mathrm{~S} & 28 & 55 & \mathrm{E}\end{array}$ & $\begin{array}{l}\text { I } 5 \text { I5 } \\
\text { I9I } 5 \\
3162\end{array}$ & $\begin{array}{l}\text { Stevens. } \\
\text { Windmill Point. } \\
\text { Swan Point } 3 .\end{array}$ \\
\hline 2 & 3907 & 20. 43 & $76 \quad 16$ го. $5^{2}$ & $\begin{array}{llll}\mathrm{S} & 73 & 22 & \mathrm{E} \\
\mathrm{N} & 5 \mathrm{I} & 32 & \mathrm{E} \\
\mathrm{N} & 20 & 33 & \mathrm{~W}\end{array}$ & $\begin{array}{llll}\mathrm{N} & 73 & 2 \mathrm{I} & \mathrm{W} \\
\mathrm{S} & 5 \mathrm{I} & 33 & \mathrm{~W} \\
\mathrm{~S} & 20 & 33 & \mathrm{E}\end{array}$ & $\begin{array}{l}2182 \\
2094 \\
2624\end{array}$ & $\begin{array}{l}\text { Stevens, } \\
\text { Windmill Point. } \\
\text { Swan Point } 3 \text {. }\end{array}$ \\
\hline 3 & 39 os & or. 67 & $\begin{array}{llll}76 & \text { I6 } & 23.83\end{array}$ & $\begin{array}{llll}\mathrm{S} & 50 & 26 & \overrightarrow{\mathrm{E}} \\
\mathrm{N} & 56 & 40 & \overrightarrow{\mathrm{E}} \\
\mathrm{N} & 28 & 12 & \mathrm{WV}\end{array}$ & $\begin{array}{llll}N & 50 & 25 & W \\
S & 56 & 40 & W \\
S & 28 & I 2 & E\end{array}$ & $\begin{array}{l}3165 \\
134^{8} \\
1210\end{array}$ & $\begin{array}{l}\text { Stevens. } \\
\text { Gratitude. } \\
\text { Swan Point } 3 .\end{array}$ \\
\hline 4 & 3908 & $05 \cdot 75$ & $76 \times 600.56$ & $\begin{array}{llll}\mathrm{S}_{4} & 40 & 20 & \mathrm{E} \\
\mathrm{N} & 40 & 29 & \overrightarrow{\mathrm{E}} \\
\mathrm{N} & 51 & 52 & \mathrm{WV}\end{array}$ & $\begin{array}{llll}\mathrm{N} & 40 & 19 & \mathrm{~W} \\
\mathrm{~S} & 40 & 29 & \mathrm{WV} \\
\mathrm{S} & 5 \mathrm{I} & 53 & \mathrm{E}\end{array}$ & $\begin{array}{r}2825 \\
793 \\
+504\end{array}$ & $\begin{array}{l}\text { Stevens. } \\
\text { Gratitude. } \\
\text { Swan Point } 3 .\end{array}$ \\
\hline
\end{tabular}




\section{HUNTINGFIELD.}

(Entrance Rockhall Harbor-Charl No. 20.)

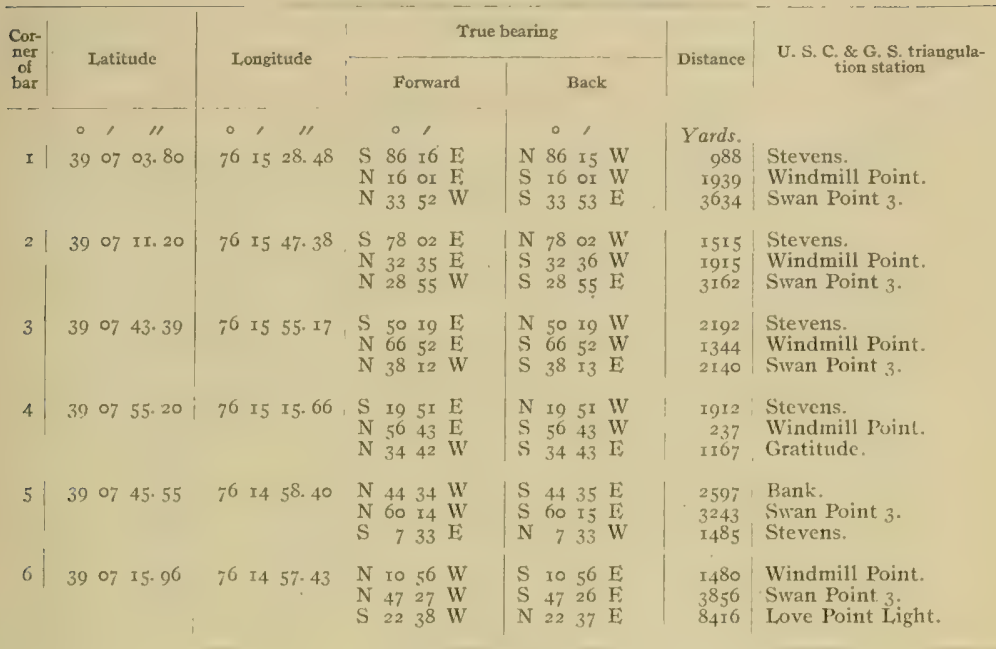

GUM SPRING.

(Entrance Chester River-Chart No. 20.)

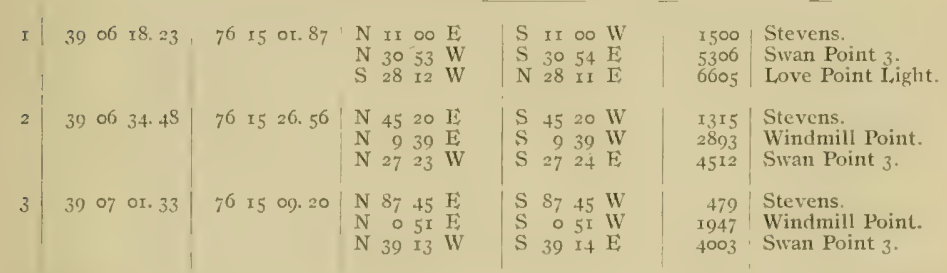


WHITE, MARSH.

(Entrance Chester River-Chart No. 20.)

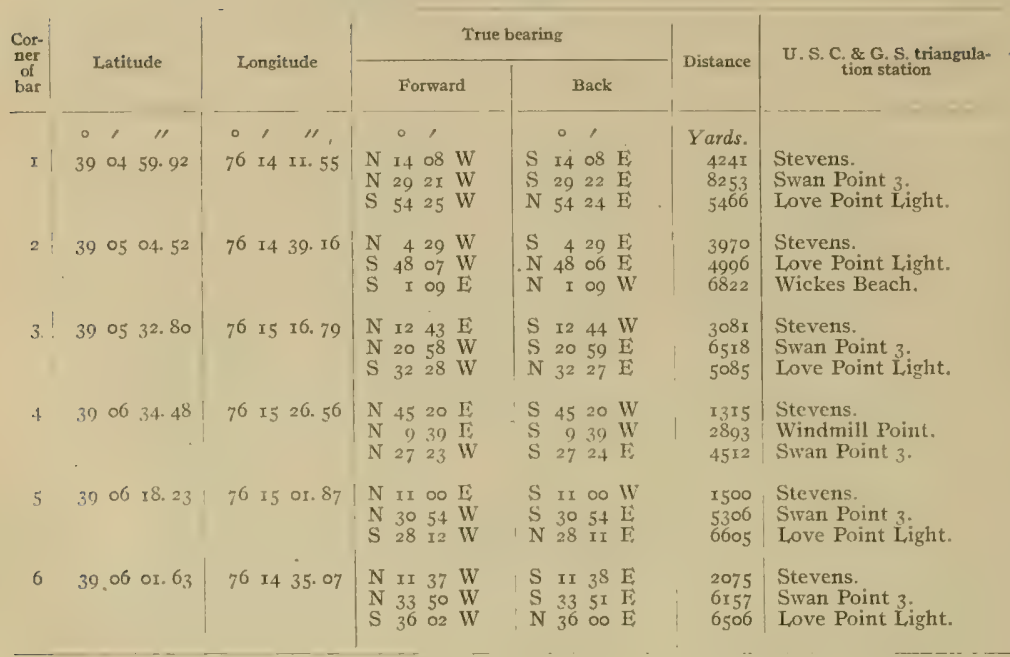

\section{UNDER THE BAR.}

(Entrance Chester River-Chart No. 20.)

\begin{tabular}{|c|c|c|c|c|c|c|}
\hline 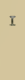 & $\begin{array}{llll}39 & 05 & 32.80\end{array}$ & $76 \quad \mathbf{5} \quad \mathbf{6} .79$ & $\begin{array}{llll}\mathrm{N} & 12 & 43 & \mathrm{E} \\
\mathrm{N} & 20 & 58 & \mathrm{~W} \\
\mathrm{~S} & 32 & 28 & \mathrm{~W}\end{array}$ & $\begin{array}{llll}\mathrm{S} & 12 & 44 & \mathrm{~W} \\
\mathrm{~S} & 20 & 59 & \mathrm{E} \\
\mathrm{N} & 32 & 27 & \mathrm{E}\end{array}$ & $\begin{array}{r}308 r \\
6518 \\
5085\end{array}$ & $\begin{array}{l}\text { Stevens: } \\
\text { Swan Point } 3 \text { : } \\
\text { Love Point Light. }\end{array}$ \\
\hline & $3905 \quad 57.8 \mathrm{I}$ & $76 \quad x_{5} \quad 50.02$ & $\begin{array}{llll}\mathrm{S} & \mathrm{I} 3 & 04 & \mathrm{E} \\
\mathrm{N} & 35 & 40 & \mathrm{E} \\
\mathrm{N} & \mathrm{I} & 33 & \mathrm{~W}\end{array}$ & $\begin{array}{llll}\mathrm{N} & \mathrm{I} & 0.4 & \mathrm{~W} \\
\mathrm{~S} & 35 & 4 \mathrm{r} & \mathrm{W} \\
\mathrm{S} & \mathrm{I} & 34 & 34\end{array}$ & $\begin{array}{l}88+7 \\
2661 \\
544^{2}\end{array}$ & $\begin{array}{l}\text { Wickes Beach. } \\
\text { Stevens. } \\
\text { Swan Point } 3 \text {. }\end{array}$ \\
\hline & 39 o6 34.48 & $7^{6} \quad 1526.5^{6}$ & $\begin{array}{lrll}N & 45 & 20 & \mathrm{E} \\
\mathrm{N} & 9 & 39 & \mathrm{E} \\
\mathrm{N} & 27 & 23 & \mathrm{~W}\end{array}$ & $\begin{array}{lrrr}\mathrm{S} & 45 & 20 & \mathrm{~W} \\
\mathrm{~S} & 9 & 39 & \mathrm{~W} \\
\mathrm{~S} & 27 & 24 & \mathrm{E}\end{array}$ & $\begin{array}{l}13 \times 5 \\
2893 \\
4512\end{array}$ & $\begin{array}{l}\text { Stevens. } \\
\text { Windmill Point. } \\
\text { Swan Point } 3 .\end{array}$ \\
\hline
\end{tabular}




\section{HICKORY THICKET.}

(Entrance Chester River-Chart No. 20.)

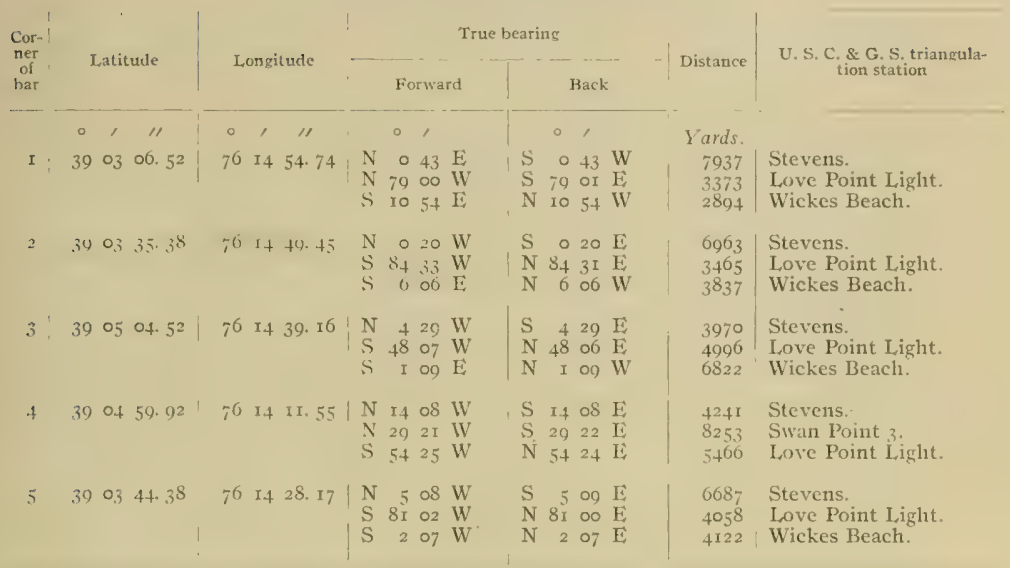

\section{EAST NECK BAY.}

(Enirance Chester Rizer-Chart No. 20.)

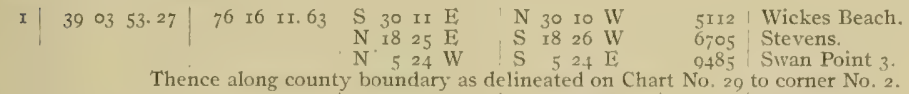

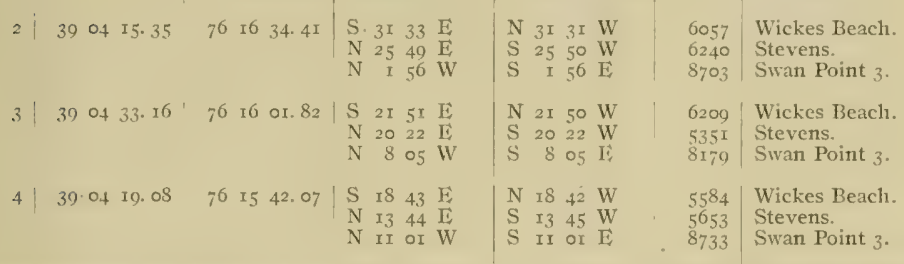


ENTRANCE LUMPS.

(Entrance Chester River-Chart No. 29.)

\begin{tabular}{|c|c|c|c|c|c|c|c|c|c|c|c|c|c|}
\hline \multirow{3}{*}{$\begin{array}{l}\text { Cor- } \\
\text { ner } \\
\text { tof } \\
\text { i bar }\end{array}$} & \multirow{2}{*}{\multicolumn{3}{|c|}{ Latitude }} & \multirow{2}{*}{\multicolumn{3}{|c|}{ Longitude }} & \multicolumn{5}{|c|}{ True bearing } & \multirow{2}{*}{ Distance } & \multirow{2}{*}{$\begin{array}{c}\text { U.S. C. \& G. S. triangula- } \\
\text { tion station }\end{array}$} \\
\hline & & & & & & & & & rward & & Back & & \\
\hline & 0 & , & "I & 0 & 1 & II & & $\circ$ & l & 0 & ' & Yards. & 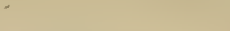 \\
\hline I & 39 & 03 & o6. 52 & 76 & I4 & $54 \cdot 74$ & $\begin{array}{l}\mathrm{N} \\
\mathrm{N} \\
\mathrm{S}\end{array}$ & $\begin{array}{r}0 \\
79 \\
10\end{array}$ & $\begin{array}{l}43 \overrightarrow{\mathrm{E}} \\
00 \mathrm{~W} \\
54 \mathrm{E}\end{array}$ & $\begin{array}{lr}\mathrm{S} & 0 \\
\mathrm{~S} & 79 \\
\mathrm{~N} & 10\end{array}$ & $\begin{array}{ll}43 & W \\
\text { or } & \mathrm{I} \\
54 \mathrm{~W}\end{array}$ & $\begin{array}{l}7937 \\
3373 \\
2894\end{array}$ & $\begin{array}{l}\text { Stevens. } \\
\text { Love Point Light. } \\
\text { Wickes Beach. }\end{array}$ \\
\hline 2 & 39 & 03 & I $3 \cdot 74$ & 76 & I5 & 46.03 & $\begin{array}{l}\mathrm{N} \\
\mathrm{N} \\
\mathrm{S}\end{array}$ & $\begin{array}{l}10 \\
78 \\
60\end{array}$ & $\begin{array}{ll}39 & \mathrm{E} \\
28 & \mathrm{~W} \\
\text { Io } & \mathrm{W}\end{array}$ & $\begin{array}{ll}\mathrm{S} & 10 \\
\mathrm{~S} & 78 \\
\mathrm{~N} & 60\end{array}$ & $\begin{array}{ll}39 & W \\
29 & E \\
08 & E\end{array}$ & $\begin{array}{l}7829 \\
200 x \\
4162\end{array}$ & $\begin{array}{l}\text { Stevens. } \\
\text { Love Point Light. } \\
\text { Amour. }\end{array}$ \\
\hline 3 & 39 & $\mathrm{O}_{3}$ & 34.90 & 76 & I5 & $45 \cdot 98$ & $\begin{array}{l}\mathrm{N} \\
\mathrm{S} \\
\mathrm{S}\end{array}$ & $\begin{array}{l}\text { II } \\
80 \\
26\end{array}$ & $\begin{array}{ll}42 & \mathrm{E} \\
55 & \mathrm{~W} \\
3 \mathrm{I} & \mathrm{E}\end{array}$ & $\begin{array}{ll}S & I I \\
N & 80 \\
-N & 26\end{array}$ & $\begin{array}{ll}42 & W \\
54 & \mathrm{E} \\
30 & \mathrm{~W}\end{array}$ & $\begin{array}{l}7128 \\
1987 \\
4245\end{array}$ & $\begin{array}{l}\text { Stevens. } \\
\text { Love Point Light. } \\
\text { Wickes Beach. }\end{array}$ \\
\hline 4 & 39 & 03 & $35 \cdot 3^{8}$ & 76 & 14 & $49 \cdot 45$ & $\begin{array}{l}\mathrm{N} \\
\mathrm{S} \\
\mathrm{S}\end{array}$ & $\begin{array}{r}0 \\
84 \\
6\end{array}$ & $\begin{array}{l}20 \mathrm{~W} \\
33 \mathrm{~W} \\
06 \mathrm{E}\end{array}$ & $\begin{array}{lr}\mathrm{S} & 0 \\
\mathrm{~N} & 84 \\
\mathrm{~N} & 6\end{array}$ & $\begin{array}{l}20 \mathrm{E} \\
3 \mathrm{I} \\
06 \mathrm{~W}\end{array}$ & $\begin{array}{l}6963 \\
3465 \\
3837\end{array}$ & $\begin{array}{l}\text { Stevens. } \\
\text { Love Point Light. } \\
\text { Wickes Bcach. }\end{array}$ \\
\hline
\end{tabular}

WICKES BEACH.

(Entrance Chester River-Chart No. 20.)

\begin{tabular}{|c|c|c|c|c|c|c|c|c|c|}
\hline I & 39 or & 21.86 & $\begin{array}{lll}76 & 15 & 15 \cdot 70\end{array}$ & $\begin{array}{ll}N & 57 \\
N & 33 \\
N & 77\end{array}$ & $\begin{array}{ll}57 & \mathrm{E} \\
28 \mathrm{~W} \\
57 \mathrm{~W}\end{array}$ & $\begin{array}{lll}\mathrm{S} & 57 & 5 \\
\mathrm{~S} & 33 & 2 \\
\mathrm{~S} & 77 & 5\end{array}$ & $\begin{array}{ll}57 & \mathrm{~W} \\
29 & \mathrm{E} \\
59 & \mathrm{E}\end{array}$ & $\begin{array}{l}1296 \\
5002 \\
5329\end{array}$ & $\begin{array}{l}\text { Wickes Beach } \\
\text { Love Point Light. } \\
\text { Railway Water Tank. }\end{array}$ \\
\hline 2 & 3902 & I3. I8 & $\begin{array}{lll}76 & 16 & 24.02\end{array}$ & $\begin{array}{ll}N & 2 \mathbf{I} \\
\mathrm{S} & 79 \\
\mathrm{~S} & \mathrm{IO}\end{array}$ & $\begin{array}{ll}3 I & W \\
43 & W \\
26 & W\end{array}$ & $\begin{array}{ll}\mathrm{S} & 2 \mathrm{r} \\
\mathrm{N} & 794 \\
\mathrm{~N} & 10\end{array}$ & $\begin{array}{ll}3 x & E \\
42 & F \\
26 & E\end{array}$ & $\begin{array}{l}2625 \\
3470 \\
55^{62}\end{array}$ & $\begin{array}{l}\text { Love Point Light } \\
\text { Railway Water Tank. } \\
\text { Macum. }\end{array}$ \\
\hline 3 & 3902 & 29. 54 , & $\begin{array}{llll}76 & 16 & 03.98\end{array}$ & $\begin{array}{ll}\mathrm{N} & 38 \\
\mathrm{~S} & 73 \\
\mathrm{~S} & \mathrm{I} \\
\end{array}$ & $\begin{array}{ll}\text { I4 } & W \\
27 & W \\
\text { I8 } & W\end{array}$ & $\begin{array}{lll}S & 38 & I \\
N & 73 & 2 \\
N & I 4 & I\end{array}$ & $\begin{array}{ll}\text { I5 } & E \\
26 & E \\
\text { IS } & \text { E }\end{array}$ & $\begin{array}{l}2407 \\
4112 \\
6215\end{array}$ & $\begin{array}{l}\text { Love Point Light. } \\
\text { Railway Water Tank. } \\
\text { Macum. }\end{array}$ \\
\hline 4 & .3902 & 29.16 & 76 I5 I9. 18 & $\begin{array}{ll}\text { N } & 54 \\
\text { S } & 77 \\
\text { S } & 24\end{array}$ & $\begin{array}{ll}30 & W \\
16 & W \\
\text { I9 } & W\end{array}$ & $\begin{array}{lll}\mathrm{S} & 54 & 3 \\
\mathrm{~N} & 77 & \mathrm{I} \\
\mathrm{N} & 24 & \mathrm{I}\end{array}$ & $\begin{array}{ll}3 \mathrm{I} & \mathrm{F} \\
\mathrm{I} 4 & \mathrm{E} \\
\mathrm{I} 8 & \mathrm{~F}\end{array}$ & $\begin{array}{l}3276 \\
5249 \\
6593\end{array}$ & $\begin{array}{l}\text { Love Point Light. } \\
\text { Railway Water Tank, } \\
\text { Macum. }\end{array}$ \\
\hline
\end{tabular}

DRFDGE ROCK.

(Lower Chester River-Chart No. 20.)

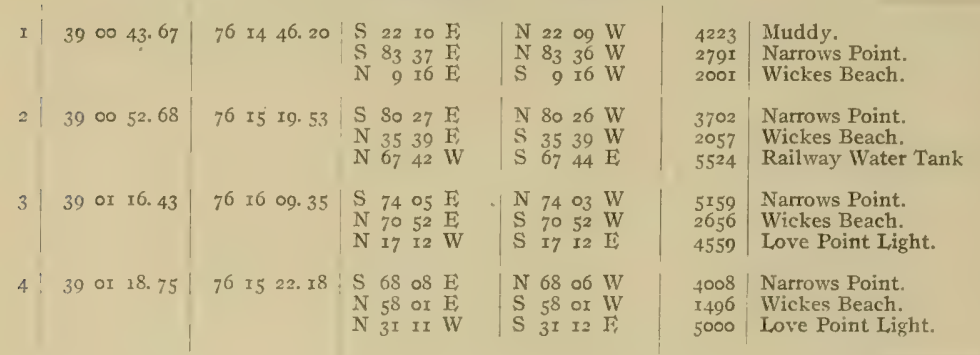


SIDE, SHOAL.

(Lower Chester River-Charts Nos. 29 and 30.)

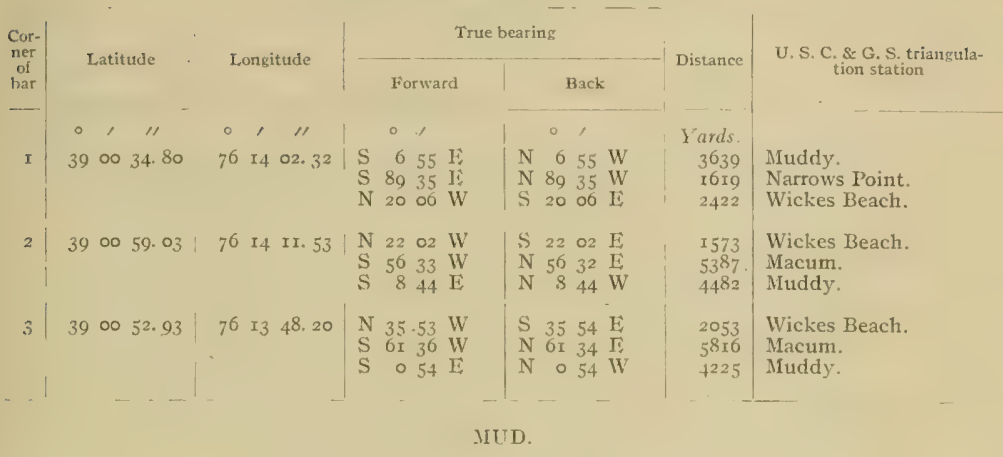

(Lower Chester River-Charls Nos. 2) and 30.)

\begin{tabular}{|c|c|c|c|c|c|c|c|}
\hline I & $39 \cdot 00$ & 10. 92 & $\begin{array}{llll}76 & \text { I4 } & 17.37\end{array}$ & $\begin{array}{lrll}\mathrm{S} & \mathrm{x} 6 & 33 & \mathrm{E} \\
\mathrm{N} & 68 & 30 & \mathrm{E} \\
\mathrm{N} & 8 & 04 & \mathrm{~W}\end{array}$ & $\begin{array}{lrll}N & \text { I6 } & 33 & \text { W } \\
\mathrm{S} & 68 & 3 \mathrm{I} & \mathrm{W} \\
\mathrm{S} & 8 & 04 & \mathrm{Fi}\end{array}$ & $\begin{array}{l}2929 \\
2165 \\
3110\end{array}$ & $\begin{array}{l}\text { Muddy. } \\
\text { Narrows Point. } \\
\text { Wickes Beach. }\end{array}$ \\
\hline 2 & 3900 & 4.3 .67 & $\begin{array}{lll}76 & 14 & 46.20\end{array}$ & $\begin{array}{lrll}\mathrm{S} & 22 & \text { To } & \mathrm{E} \\
\mathrm{S} & 83 & 37 & \mathrm{E} \\
\mathrm{N} & 9 & 16 & \mathrm{E}\end{array}$ & $\begin{array}{lrrr}N & 22 & \text { og } & W \\
N & 83 & 36 & W \\
S & 9 & 16 & W\end{array}$ & $\begin{array}{l}4223 \\
2791 \\
200 I\end{array}$ & $\begin{array}{l}\text { Muddy. } \\
\text { Narrows Point. } \\
\text { Wickes Beach. }\end{array}$ \\
\hline 3 & 3900 & 55.021 & 76 I4 34.42 & $\begin{array}{lrrr}\mathrm{S} & 16 & 38 & \mathrm{E} \\
\mathrm{S} & 74 & \mathrm{I} & \mathrm{E} \\
\mathrm{N} & 0 & 27 & \mathrm{E}\end{array}$ & $\begin{array}{rrrr}N & I 6 & 38 & W \\
N & 74 & I 6 & W \\
S & 0 & 27 & W\end{array}$ & $\begin{array}{l}4482 \\
2559 \\
1592\end{array}$ & $\begin{array}{l}\text { Muddy. } \\
\text { Narrows Point. } \\
\text { Wickes Beach. }\end{array}$ \\
\hline 4 & 3900 & 34. 80 & $7^{6} \mathrm{I} 402.32$ & $\begin{array}{lrrr}\mathrm{S} & 6 & 55 & \mathrm{E} \\
\mathrm{S} & 89 & 35 & \mathrm{E} \\
\mathrm{N} & 20 & 06 & \mathrm{~W}\end{array}$ & $\begin{array}{lrrr}N & 6 & 55 & \mathrm{~W} \\
\mathrm{~N} & 80 & 34 & \mathrm{~W} \\
\mathrm{~S} & 20 & 06 & \mathrm{~F}\end{array}$ & $\begin{array}{l}3639 \\
1619 \\
2422\end{array}$ & $\begin{array}{l}\text { Muddy. } \\
\text { Nartows Point. } \\
\text { Wickes Beach. }\end{array}$ \\
\hline & 3900 & $23.40^{\circ}$ & $.76 \times 3 \quad 40.32$ & $\begin{array}{lrrl}\mathrm{S} & 2 & 30 & \mathrm{~W} \\
\mathrm{~N} & 70 & \mathrm{I} & \mathrm{E} \\
\mathrm{N} & 27 & 57 & \mathrm{~W}\end{array}$ & $\begin{array}{lrrr}\mathrm{N} & 2 & 30 & \mathrm{I} \\
\mathrm{S} & 70 & \mathrm{I} & \mathrm{W} \\
\mathrm{S} & 27 & 57 & \mathrm{~F}\end{array}$ & $\begin{array}{l}323 I \\
1105 \\
3010\end{array}$ & $\begin{array}{l}\text { Muddy. } \\
\text { Narrows Point. } \\
\text { Wickes Beach. }\end{array}$ \\
\hline
\end{tabular}

FERRY (KENT COUNTY).

(Lower Chester River-Chart No. 29.)

\begin{tabular}{|c|c|c|c|c|c|c|c|}
\hline I & 3900 & $\begin{array}{l}04.45 \\
\text { Then }\end{array}$ & $7^{6} \quad$ I4 38.00 & $\begin{array}{l}\mathrm{S} 28 \text { or } \mathrm{E} \\
\mathrm{N} 68 \text { 25 } \mathrm{E} \\
\mathrm{N} \text { I } 5 \mathrm{I} \mathrm{E} \\
\text { boundary as }\end{array}$ & $\begin{array}{lrll}\mathrm{N} & 28 & 00 & \mathrm{~W} \\
\mathrm{~S} & 68 & 26 & \mathrm{~W} \\
\mathrm{~S} & \mathrm{I} & 5 \mathrm{I} & \mathrm{W} \\
\text { lineated on } \mathrm{Cl}\end{array}$ & $\begin{array}{r}2932 \\
2750 \\
3299 \\
N 0.20\end{array}$ & $\begin{array}{l}\text { Muddy. } \\
\text { Narrows Point. } \\
\text { Wickes Beach. }\end{array}$ \\
\hline & 3900 & 29.37 & $76 \times 5 \quad 30.72$ & $\begin{array}{llll}\mathrm{S} & 38 & 53 & \mathrm{E} \\
\mathrm{N} & 87 & 30 & \mathrm{E} \\
\mathrm{N} & 31 & 17 & \mathrm{E}\end{array}$ & $\begin{array}{llll}\mathrm{N} & 38 & 52 & \mathrm{~W} \\
\mathrm{~S} & 87 & 32 & \mathrm{~W} \\
\mathrm{~S} & 3 \mathrm{I} & 18 & \mathrm{~W}\end{array}$ & $\begin{array}{l}4405 \\
3949 \\
2876\end{array}$ & $\begin{array}{l}\text { Muddy. } \\
\text { Narrows Point. } \\
\text { Wickes Beach. }\end{array}$ \\
\hline & 3900 & 44.20 & $7^{6}$ I $_{5} \circ 9.62$ & $\begin{array}{llll}\mathrm{S} & 29 & 21 & \mathrm{E} \\
\mathrm{S} & 84 & 27 & \mathrm{E} \\
\mathrm{N} & 25 & 37 & \mathrm{E}\end{array}$ & $\begin{array}{llll}N & 29 & 20 & W \\
N & 84 & 26 & W \\
S & 25 & 37 & W\end{array}$ & $\begin{array}{l}4507 \\
3398 \\
217 x\end{array}$ & $\begin{array}{l}\text { Muddy. } \\
\text { Narrows Point. } \\
\text { Wickes Beach. }\end{array}$ \\
\hline
\end{tabular}




\section{BUOY ROCK.}

(Lower Chester River-Charts Nos, 29 and 30.)

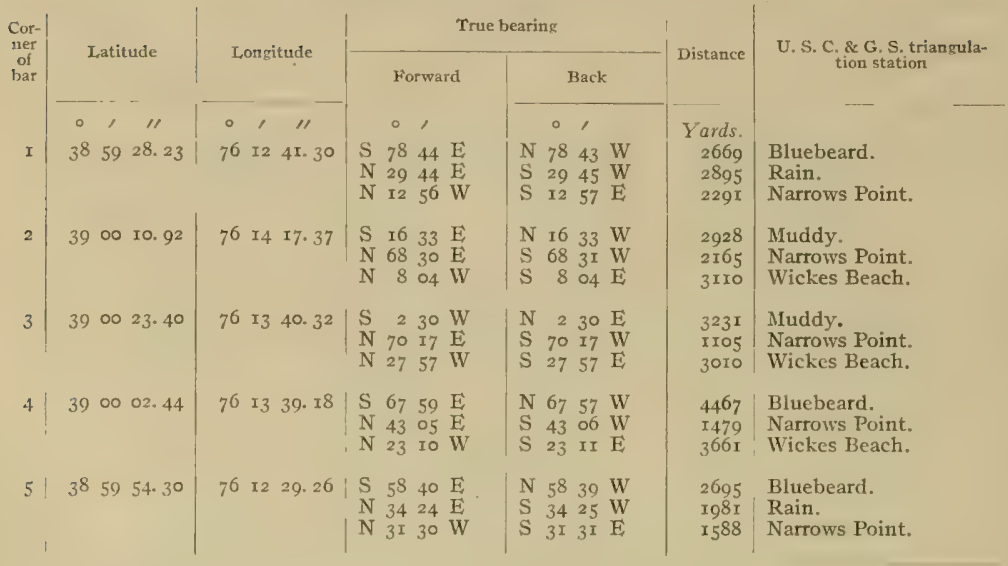

HAIL CREEK.

(Lower Chester River-Chart No. 3o.)

\begin{tabular}{|c|c|c|c|c|c|c|}
\hline I & $3900 \quad 27.60$ & 76 I2 25.07 & $\begin{array}{llll}\mathrm{S} & 32 & \mathrm{I} 2 & \mathrm{~W} \\
\mathrm{~S} & 40 & 57 & \mathrm{E} \\
\mathrm{N} & 63 & 07 & \mathrm{E}\end{array}$ & $\begin{array}{llll}\mathrm{N} & 32 & \text { II } & \mathrm{E} \\
\mathrm{N} & 40 & 57 & \mathrm{~W} \\
\mathrm{~S} & 63 & 08 & \mathrm{~W}\end{array}$ & $\begin{array}{l}3982 \\
3343 \\
\text { I } 13 \text { I }\end{array}$ & $\begin{array}{l}\text { Muddy. } \\
\text { Bluebeard. } \\
\text { Rain. }\end{array}$ \\
\hline & $3900 \quad 33.00$ & $\begin{array}{lll}76 & \text { I2 } & 30.88\end{array}$ & $\begin{array}{llll}\mathrm{S} & 29 & 00 & \mathrm{~W} \\
\mathrm{~S} & 40 & 53 & \mathrm{E} \\
\mathrm{N} & 74 & \mathrm{II} & \mathrm{E}\end{array}$ & $\begin{array}{llll}\mathrm{N} & 29 & 00 & \mathrm{E} \\
\mathrm{N} & 40 & 53 & \mathrm{~W} \\
\mathrm{~S} & 74 & \mathrm{II} & \mathrm{W}\end{array}$ & $\begin{array}{l}406 I \\
3581 \\
I 207\end{array}$ & $\begin{array}{l}\text { Muddy. } \\
\text { Bluebeard. } \\
\text { Rain. }\end{array}$ \\
\hline & $3900 \quad 40.76$ & $\begin{array}{llll}76 & 12 & 17.24\end{array}$ & $\begin{array}{llll}\mathrm{S} & 3 \mathrm{I} & 24 & \mathrm{~W} \\
\mathrm{~S} & 33 & 46 & \mathrm{E} \\
\mathrm{S} & 78 & 5 \mathrm{I} & \mathrm{E}\end{array}$ & $\begin{array}{llll}N & 3 I & 23 & E \\
N & 33 & 45 & W \\
N & 78 & 49 & W\end{array}$ & $\begin{array}{l}4467 \\
3572 \\
4027\end{array}$ & $\begin{array}{l}\text { Muddy. } \\
\text { Bluebeard. } \\
\text { Blakeford. }\end{array}$ \\
\hline & $3900 \quad 37.85$ & 76 I2 06. I0 & $\begin{array}{llll}\mathrm{S} & 35 & \mathrm{I} 2 & \mathrm{~W} \\
\mathrm{~S} & 30 & 3 \mathrm{I} & \mathrm{E} \\
\mathrm{S} & 79 & 27 & \mathrm{E}\end{array}$ & $\begin{array}{llll}N_{3} & \text { II } & E \\
N & 30 & 30 & W \\
N & 79 & 26 & W\end{array}$ & $\begin{array}{l}4546 \\
3332 \\
3720\end{array}$ & $\begin{array}{l}\text { Muddy. } \\
\text { Bluebeard. } \\
\text { Blakeford. }\end{array}$ \\
\hline
\end{tabular}


HAII, POINT.

(Lower Chester River-Chart No. 30.)

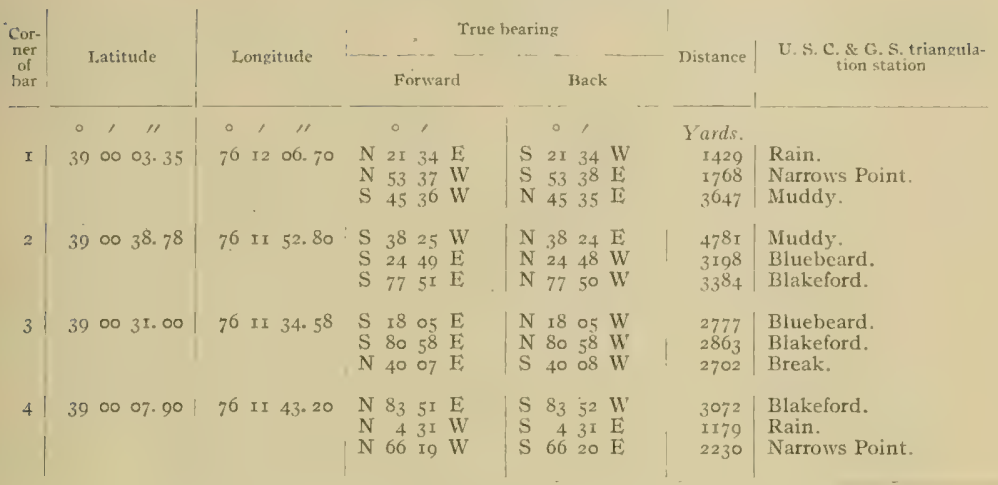

\section{BLACK BUOY.}

(Middle Chester River-Chart No. 30.)

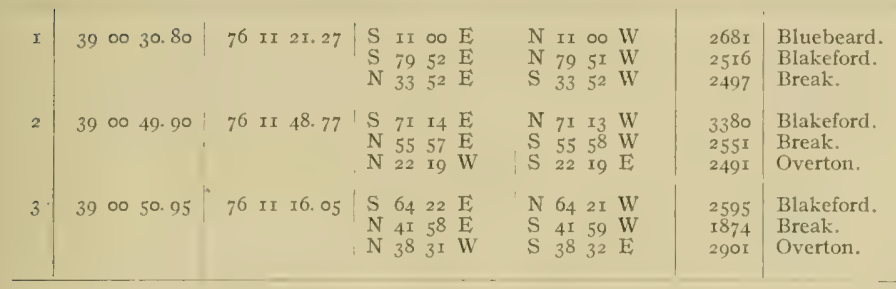

\section{DURDIN.}

(Middle Chester River-Chart No. 30.)

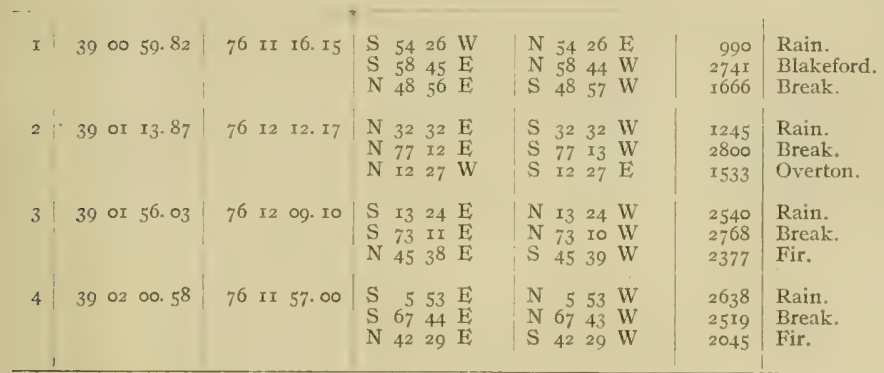


BELTS.

(Middle Chester River-Chart No. 30.)

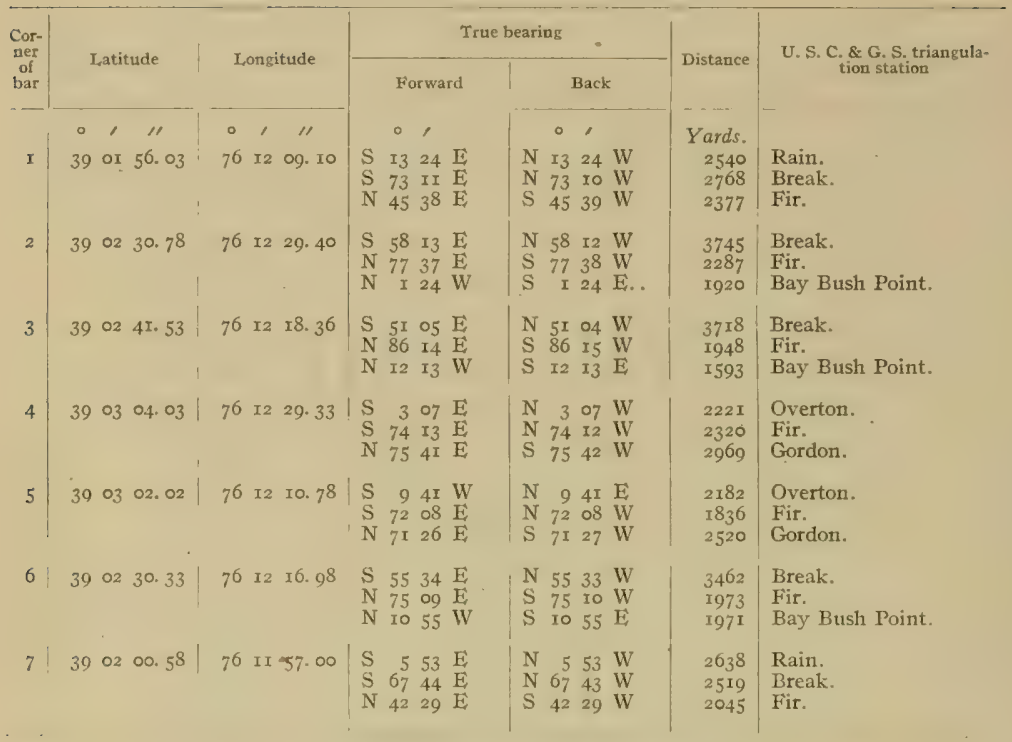

PINEY POINT (KENT COUNTY).

(Middle Chester River-Chart No. 3o.)

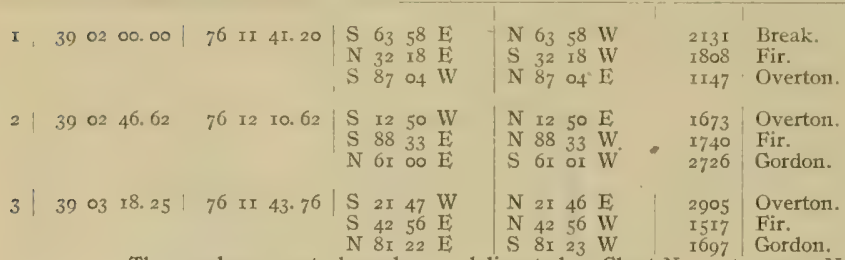

Thence along county boundary as delineated on Chart No. 30 to comer No. $\mathrm{z}$. 


\section{- BAY BUSH POINT.}

(Middle Chester River-Chart No.30.)

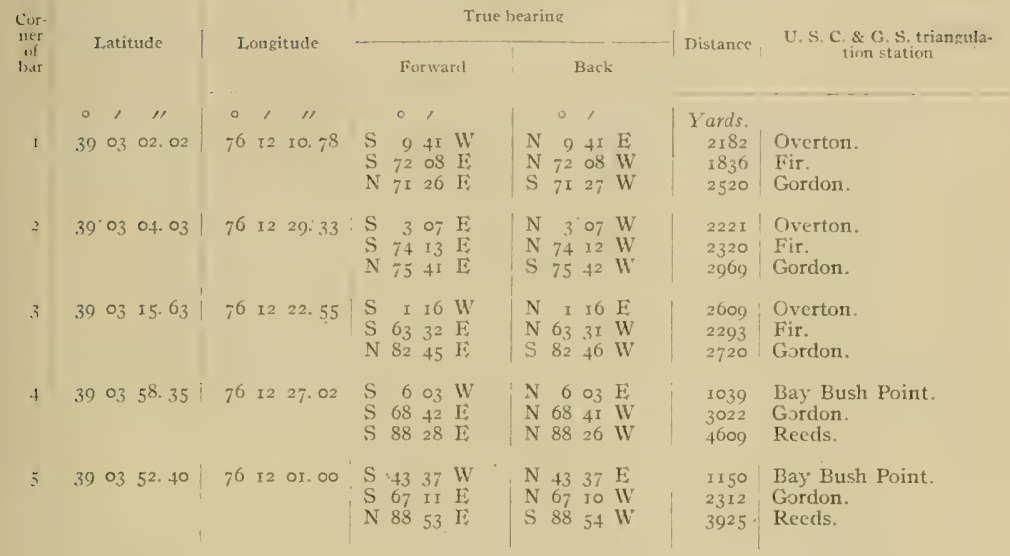

\section{BI,UFF POINT.}

(Middle Chester River-Chart No. 30.)

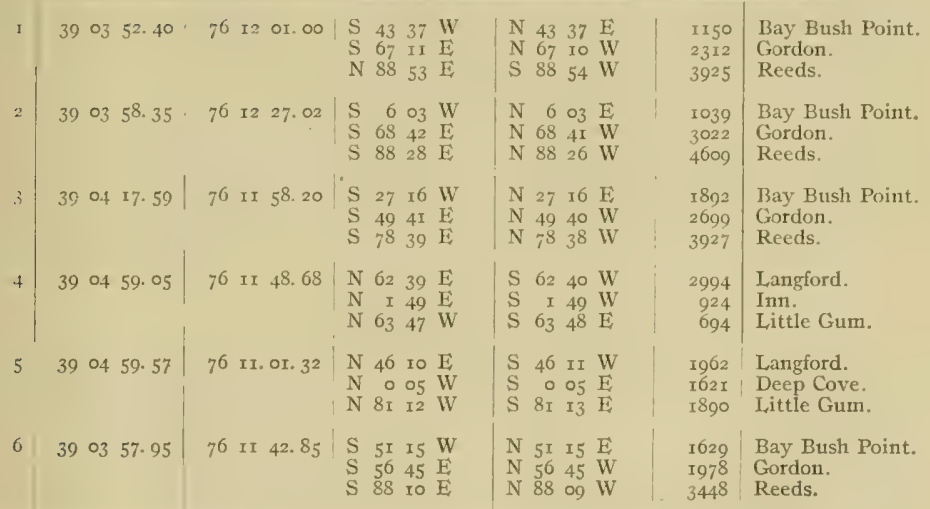




\section{CHESTER RIVER MIDDLEGROUND.}

(Middle Chester River-Chart No. 30.)

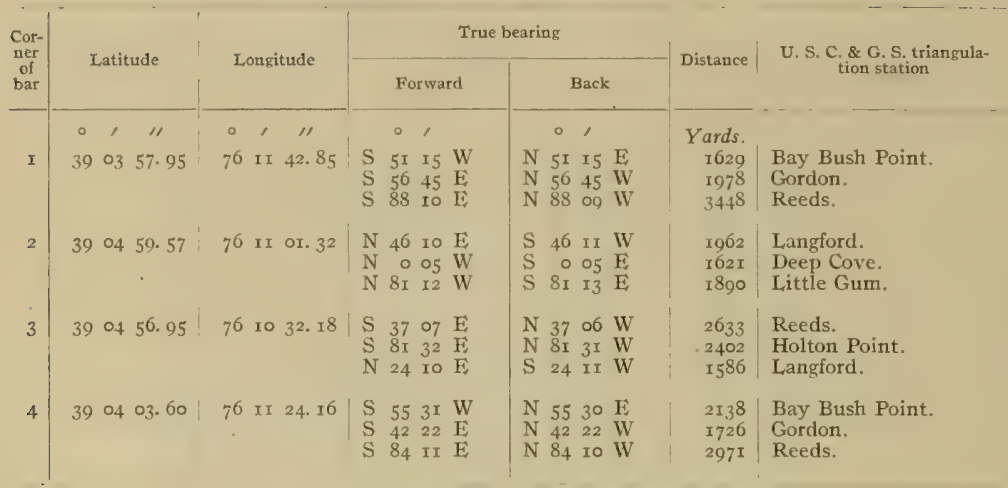

\section{LIMEKILN .}

(Grays Inn Creck Entrance-Chart No. 30.)

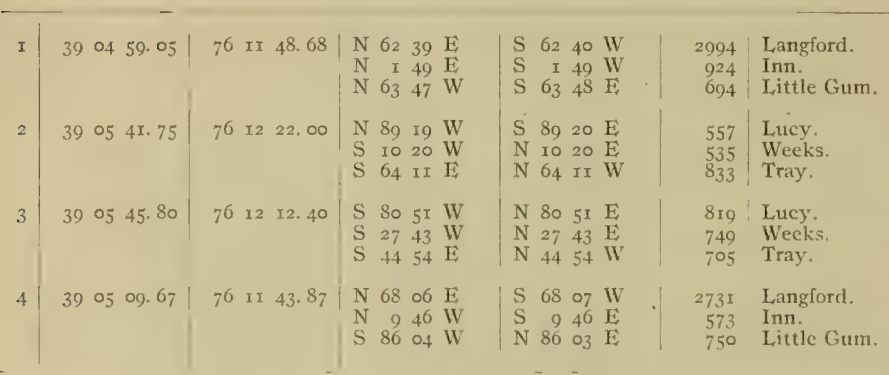

WILIOW BOTTOM.

(Middle Chester River-Chart No. 3o.)

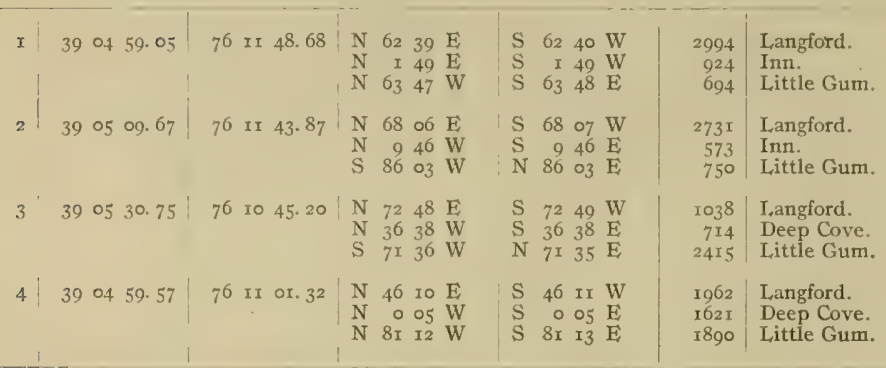


NICHOLS.

(Middle Chester River-Chart No. 30.)

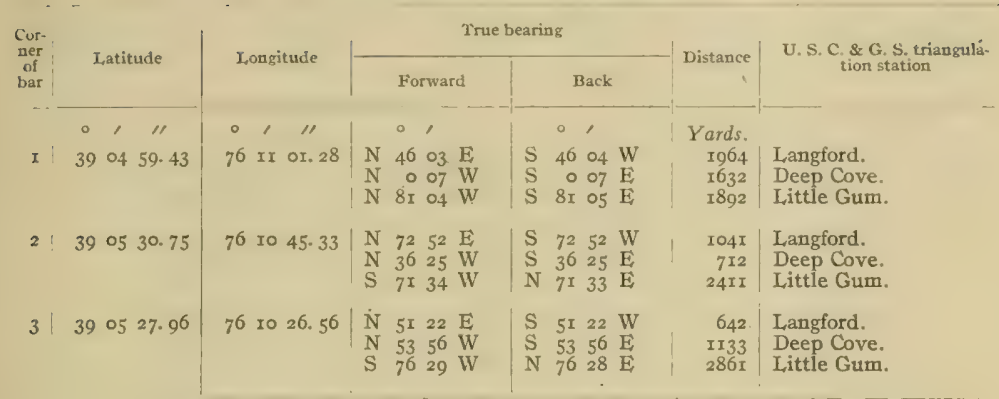

\section{HUDSON.}

(Langford Creek-Chart No. 30.)

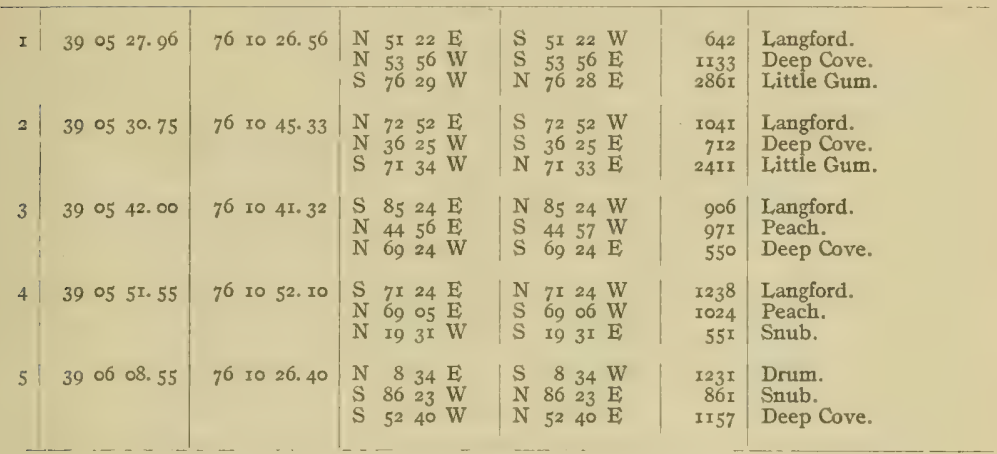

\section{SAND THISTLE,}

(Langford Creek-Chart No. 30.)

\begin{tabular}{|c|c|c|c|c|c|c|}
\hline I & $3905 \quad 5$ I. 55 & $7^{6}$ I0 52.10 & $\begin{array}{llll}\mathrm{S} & 71 & 24 & \mathrm{E} \\
\mathrm{N} & 69 & 05 & \mathrm{E} \\
\mathrm{N} & 19 & 31 & \mathrm{~W}\end{array}$ & $\begin{array}{llll}\mathrm{N} & 7 \mathrm{I} & 24 & \mathrm{~W} \\
\mathrm{~S} & 69 & 06 & \mathrm{~W} \\
\mathrm{~S} & \mathrm{I} & 3 \mathrm{I} & \mathrm{E}\end{array}$ & $\begin{array}{r}1238 \\
\text { I024 } \\
551\end{array}$ & $\begin{array}{l}\text { Langford. } \\
\text { Peach. } \\
\text { Snub. }\end{array}$ \\
\hline & 39 o6 25.20 & 76 I0 43.22 & $\begin{array}{llll}\mathrm{S} & 34 & \text { O } & \mathrm{W} \\
\mathrm{S} & 43 & \mathrm{I} 2 & \mathrm{E} \\
\mathrm{N} & 77 & 31 & \mathrm{E}\end{array}$ & $\begin{array}{llll}\mathrm{N} & 34 & 07 & \mathrm{E} \\
\mathrm{N} & 43 & 12 & \mathrm{~W} \\
\mathrm{~S} & 77 & 32 & \mathrm{~W}\end{array}$ & $\begin{array}{r}744 \\
1055 \\
12 \mathrm{I} 2\end{array}$ & $\begin{array}{l}\text { Snub. } \\
\text { Peach. } \\
\text { Major. }\end{array}$ \\
\hline 3 & 39 o6 08. 55 & 76 10 26.40 & $\begin{array}{lrll}\mathrm{N} & 8 & 34 & \mathrm{E} \\
\mathrm{S} & 86 & 23 & \mathrm{~W} \\
\mathrm{~S} & 52 & 40 & \mathrm{~W}\end{array}$ & $\begin{array}{lrrr}\mathrm{S} & 8 & 34 & \mathrm{~W} \\
\mathrm{~N} & 86 & 23 & \mathrm{E} \\
\mathrm{N} & 52 & 40 & \mathrm{E}\end{array}$ & $\begin{array}{r}123 I \\
861 \\
\text { II } 57\end{array}$ & $\begin{array}{l}\text { Drum. } \\
\text { Snub. } \\
\text { Deep Cove. }\end{array}$ \\
\hline
\end{tabular}

$14126-12-8$ 


\section{BOATHOUSE,}

(Langford Creek-Chart No. 30.)

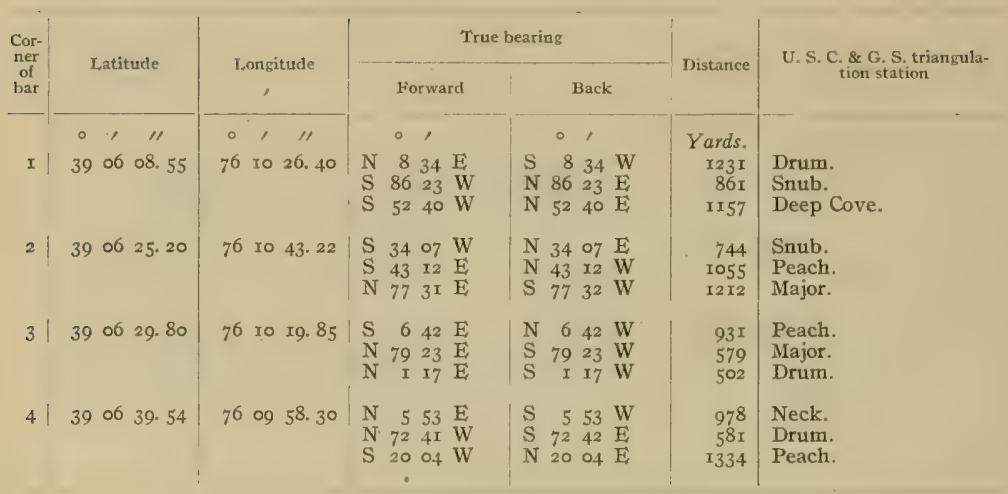

\section{DRUM POINT.}

(Langford Creek-Chart No. 30.)

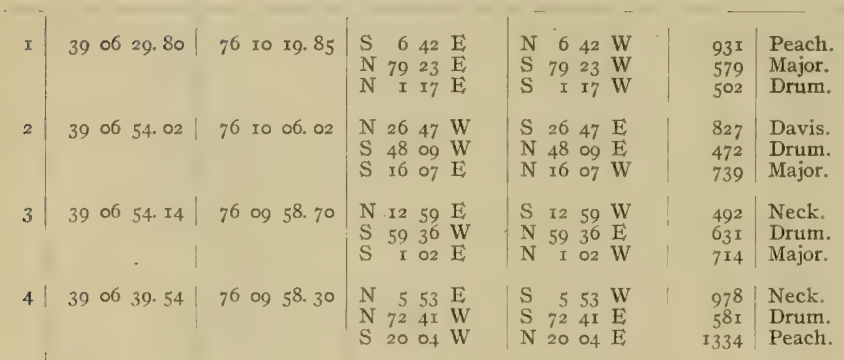


DAVIS CREEK.

(Langford Creek-Chart No. 30.)

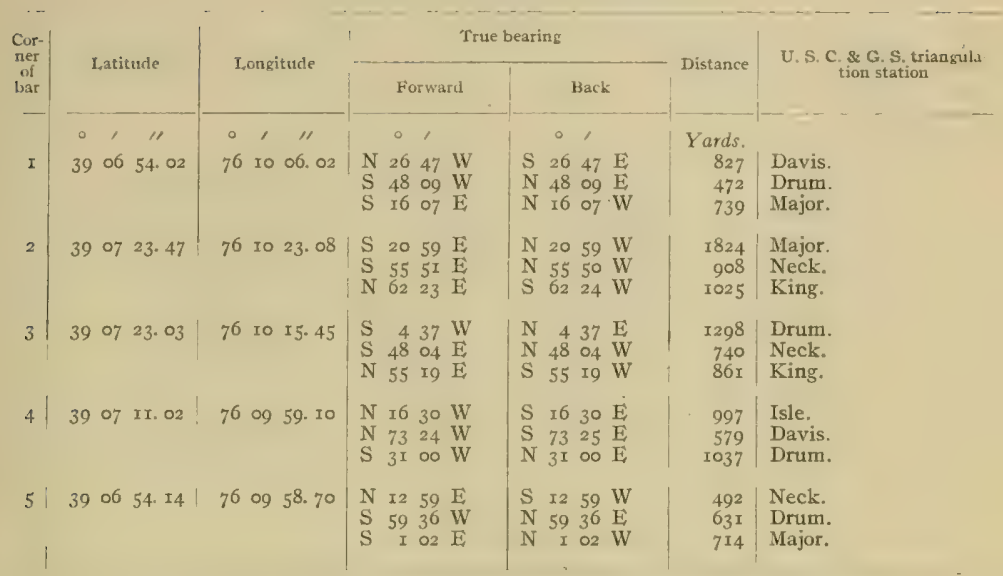

\section{ISLAND POINT.}

(Langford Creek (West Fork)-Chart No. 30.)

\begin{tabular}{|c|c|c|c|c|c|c|c|c|}
\hline I & 39 & ०7 & 29.42 & 76 10 04.32 & $\begin{array}{llll}N & 23 & 33 & W \\
\mathrm{~S} & 42 & 31 & \mathrm{~W} \\
\mathrm{~S} & 19 & 59 & \mathrm{E}\end{array}$ & $\begin{array}{llll}\mathrm{S} & 23 & 33 & \mathrm{E} \\
\mathrm{N} & 42 & 3 \mathrm{I} & \mathrm{E} \\
\mathrm{N} & \mathrm{I} 9 & 59 & \mathrm{~W}\end{array}$ & $\begin{array}{l}365 \\
618 \\
756\end{array}$ & $\begin{array}{l}\text { Isle. } \\
\text { Davis. } \\
\text { Neck. }\end{array}$ \\
\hline 2 & 39 & 07 & 29.93 & $7^{6}$ 10 12.85 & $\begin{array}{llll}\mathrm{S} & 22 & 15 & \mathrm{~W} \\
\mathrm{~S} & 33 & 33 & \mathrm{E} \\
\mathrm{N} & 68 & 06 & \mathrm{E}\end{array}$ & $\begin{array}{llll}\mathrm{N}_{22} & \text { I }_{5} & \mathrm{E} \\
\mathrm{N} & 33 & 33 & \mathrm{~W} \\
\mathrm{~S} & 68 & 06 & \mathrm{~W}\end{array}$ & $\begin{array}{l}511 \\
873 \\
689\end{array}$ & $\begin{array}{l}\text { Davis. } \\
\text { Neck. } \\
\text { King. }\end{array}$ \\
\hline 3 & 39 & 07 & 40. 33 & 76 I0 06.33 & $\begin{array}{llll}\mathrm{S} & 78 & 40 & \mathrm{E} \\
\mathrm{N} & \mathrm{I}_{4} & \mathrm{I}_{3} & \mathrm{~W} \\
\mathrm{~N} & 49 & 05 & \mathrm{~W}\end{array}$ & $\begin{array}{llll}\mathrm{N} & 78 & 40 & \mathrm{~W} \\
\mathrm{~S} & \mathrm{I} 4 & \mathrm{I} & \mathrm{E} \\
\mathrm{S} & 49 & 05 & \mathrm{E}\end{array}$ & $\begin{array}{l}477 \\
673 \\
913\end{array}$ & $\begin{array}{l}\text { King. } \\
\text { Hornor. } \\
\text { Eagle. }\end{array}$ \\
\hline 4 & 39 & 07 & 4 r. 24 & 76 I0 rr. 92 & $\begin{array}{lrrr}\mathrm{S} & 78 & 33 & \mathrm{E} \\
\mathrm{N} & \mathrm{I} & 42 & \mathrm{~W} \\
\mathrm{~N} & 43 & 45 & \mathrm{~W}\end{array}$ & $\begin{array}{lrrl}\mathrm{N} & 78 & 33 & \mathrm{~W} \\
\mathrm{~S} & \mathrm{I} & 42 & \mathrm{E} \\
\mathrm{S} & 43 & 46 & \mathrm{E}\end{array}$ & $\begin{array}{l}628 \\
622 \\
785\end{array}$ & $\begin{array}{l}\text { King. } \\
\text { Hornor. } \\
\text { Eagle. }\end{array}$ \\
\hline 5 & 39 & 07 & 46.05 & 76 Io 10. 35 & $\begin{array}{lrrl}\mathrm{S} & 63 & 26 & \mathrm{E} \\
\mathrm{N} & 7 & 24 & \mathrm{~W} \\
\mathrm{~N} & 55 & 16 & \mathrm{~W}\end{array}$ & $\begin{array}{lrrr}\mathrm{N} & 63 & 26 & \mathrm{~W} \\
\mathrm{~S} & 7 & 24 & \mathrm{E} \\
\mathrm{S} & 55 & 16 & \mathrm{E}\end{array}$ & $\begin{array}{l}641 \\
463 \\
712\end{array}$ & $\begin{array}{l}\text { King. } \\
\text { Hornor. } \\
\text { Eagle. }\end{array}$ \\
\hline 6 & 39 & 07 & 44. 76 & $7^{6}$ 10 $0_{3} .80$ & $\begin{array}{llll}\mathrm{N} & 59 & 20 & \mathrm{~W} \\
\mathrm{~S} & 4 \mathrm{r} & \mathrm{r} & \mathrm{W} \\
\mathrm{S} & 58 & 48 & \mathrm{E}\end{array}$ & $\begin{array}{llll}\mathrm{S} & 59 & 20 & \mathrm{E} \\
\mathrm{N} & 4 \mathrm{I} & 15 & \mathrm{E} \\
\mathrm{N} & 5^{8} & 47 & \mathrm{~W}\end{array}$ & $\begin{array}{l}880 \\
237 \\
469\end{array}$ & $\begin{array}{l}\text { Eagle. } \\
\text { Isle. } \\
\text { King. }\end{array}$ \\
\hline
\end{tabular}


EAGLE POINT.

(Langford Creek (West Fork)-Chart No. 30.)

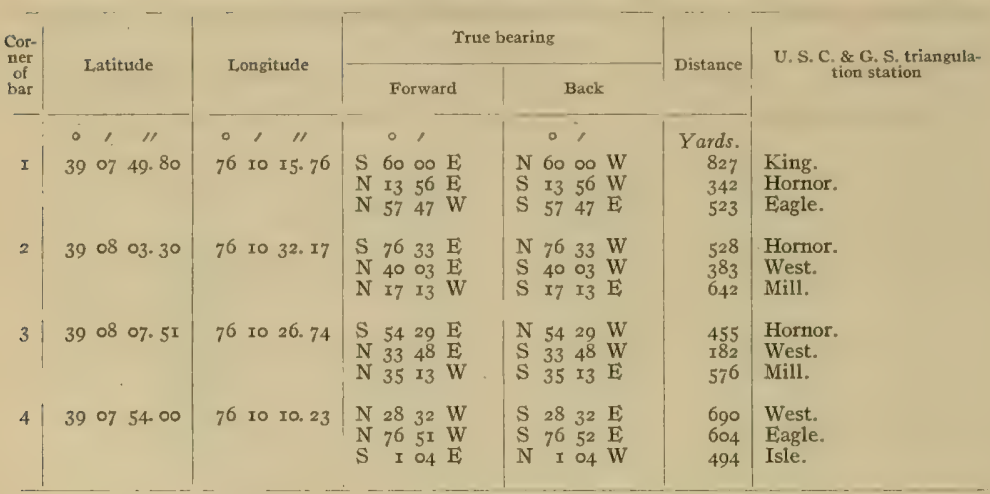

WILSONS POINT.

(Langford Creek (West Fork)-Chart No. 3o.)

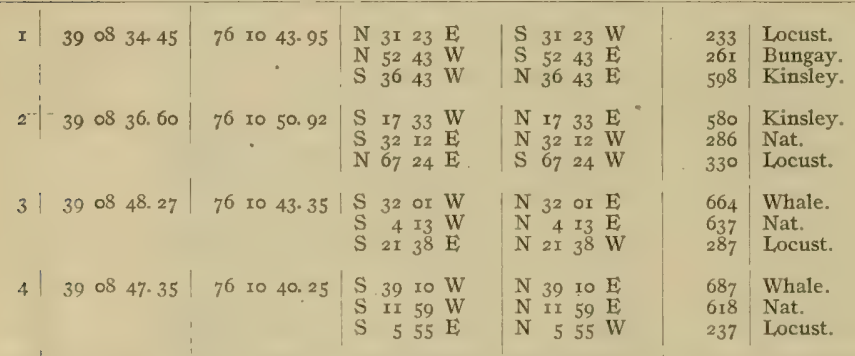

\section{KINGS CREEK.}

(Langford Creek (East Fork)-Chart No. 30.)

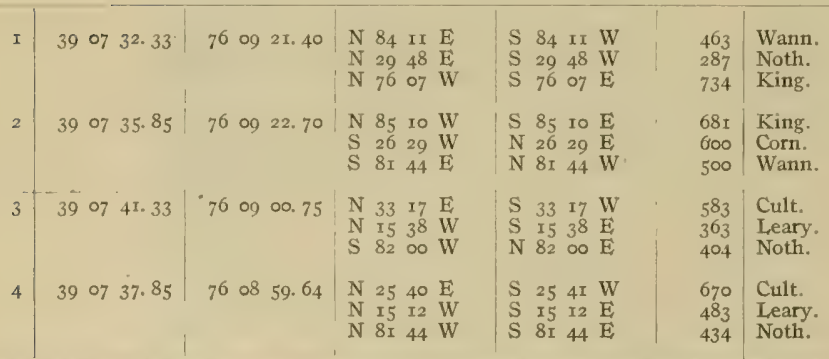


Survey of Oyster Bars, Kent County, Md.

BAILEY.

(Langford Creek (East Fork)-Chart No. 3o.)

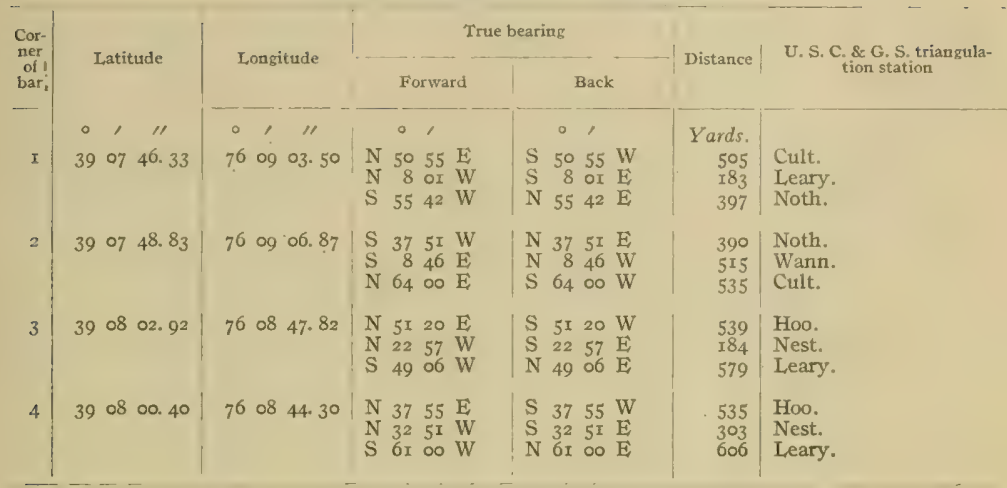

PHILIPS.

(Langford Creek (East Fork)-Chart No. 30.)

\begin{tabular}{|c|c|c|c|c|c|c|c|}
\hline I & $\begin{array}{llll}39 & 08 & 09.97\end{array}$ & 7608 & $43 \cdot 3^{8}$ & $\begin{array}{lrrr}\mathrm{N} & 71 & 58 & \mathrm{E} \\
\mathrm{N} & 9 & 45 & \mathrm{~W} \\
\mathrm{~S} & 70 & \text { OI } & \mathrm{W}\end{array}$ & $\begin{array}{lrrr}\mathrm{S} & 71 & 58 & \mathrm{~W} \\
\mathrm{~S} & 9 & 45 & \mathrm{E} \\
\mathrm{N} & 70 & \text { oI } & \mathrm{E}\end{array}$ & $\begin{array}{l}320 \\
334 \\
200\end{array}$ & $\begin{array}{l}\text { Hoo. } \\
\text { Woll. } \\
\text { Nest. }\end{array}$ \\
\hline 2 & $\begin{array}{llll}39 & 08 & 36.04\end{array}$ & 7608 & 40. $3 \mathrm{I}$ & $\begin{array}{llll}\mathrm{N} & 28 & 27 & \mathrm{~W} \\
\mathrm{~S} & 45 & \mathrm{x} & \mathrm{W} \\
\mathrm{S} & 44 & 45 & \mathrm{E}\end{array}$ & $\begin{array}{llll}\mathrm{S} & 28 & 27 & \mathrm{E} \\
\mathrm{N} & 45 & 19 & \mathrm{E} \\
\mathrm{N} & 44 & 44 & \mathrm{~W}\end{array}$ & $\begin{array}{l}58 \mathrm{I} \\
245 \\
505\end{array}$ & $\begin{array}{l}\text { Gut. } \\
\text { Harp. } \\
\text { Ide. }\end{array}$ \\
\hline 3 . & $\begin{array}{llll}39 & 08 & 35.95\end{array}$ & 7608 & 35.33 & $\begin{array}{llll}\mathrm{N} & 66 & 59 & \mathrm{~W} \\
\mathrm{~S} & 60 & 59 & \mathrm{~W} \\
\mathrm{~S} & 32 & 17 & \mathrm{E}\end{array}$ & $\begin{array}{llll}\mathrm{S} & 67 & 00 & \mathrm{E} \\
\mathrm{N} & 60 & 59 & \mathrm{E} \\
\mathrm{N} & 32 & 17 & \mathrm{~W}\end{array}$ & $\begin{array}{l}959 \\
349 \\
42 \mathrm{I}\end{array}$ & $\begin{array}{l}\text { Clay. } \\
\text { Harp. } \\
\text { Ide. }\end{array}$ \\
\hline 4 & 3908 I0. 16 & 7608 & $37 \cdot 4^{2}$ & $\begin{array}{llll}\mathrm{N} & 57 & 54 & \mathrm{E} \\
\mathrm{N} & 33 & 29 & \mathrm{~W} \\
\mathrm{~S} & 77 & 45 & \mathrm{~W}\end{array}$ & $\begin{array}{llll}\mathrm{S} & 57 & 54 & \mathrm{~W} \\
\mathrm{~S} & 33 & 29 & \mathrm{E} \\
\mathrm{N} & 77 & 45 & \mathrm{E}\end{array}$ & $\begin{array}{l}175 \\
386 \\
353\end{array}$ & $\begin{array}{l}\text { Hoo. } \\
\text { Woll. } \\
\text { Nest. }\end{array}$ \\
\hline
\end{tabular}

WARE,

(Langford Creek (East Fork)-Chart No. 30.

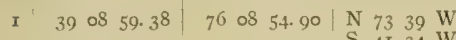

$\begin{array}{lllllllll}2 & 3909 \text { or. } 97 & 760900.33 & \text { N } 89 & 24 & \text { W }\end{array}$

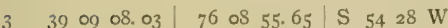
$\begin{array}{llll}\mathrm{S} & 4 \mathrm{I} & 34 & \mathrm{~W} \\ \mathrm{~S} & \mathrm{I} 2 & \mathrm{I} & \mathrm{E}\end{array}$ S 24 II W $\mathrm{S}$ I8 $35 \mathrm{E}$ S 26 I5 W $\mathrm{S}$ ro $23 \mathrm{E}$

S $7339 \mathrm{E}$ N 4 I 34 E $\mathrm{N}$ I2 $10 \mathrm{~W}$

S $8924 \mathrm{E}$ N 24 II E $\mathrm{N}$ I8 $35 \mathrm{~W}$

$\mathrm{N} 5428 \mathrm{E}$ N 26 I5 E $\mathrm{N} 1022 \mathrm{~W}$

S 74 I5 W S $38 \quad 15$ WV S 4 og E
N 74 I5 E $\mathrm{N} 38$ I5 E $\mathrm{N} 400 \mathrm{WW}$
316 Lovely.

556 Clay.

982 Harp.

I6r Lovely.

551 Clay.

II05 Harp.

348 Lovely.

788 Clay.

1272 Harp.

445 Lovely.

706 Clay.

1172 Harp. 
HBB POINT.

(Middle Chester River-Chart No. 30.)

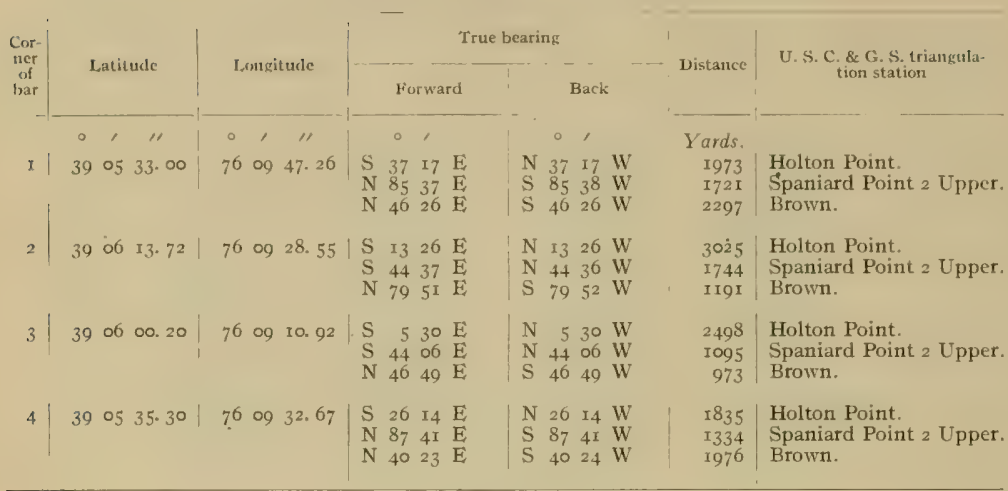

\section{CLIFF.}

(Middle Chester River-Chart No. 30.)

I $390600.20 \mid 76$ og $10.92 \quad \mathrm{~S} \quad \begin{array}{lllll}5 & 30 & \mathrm{E}\end{array}$ N $46 \quad 49 \mathrm{E}$

\begin{tabular}{l|lllllllll}
2 & 3906 & 13.72 & 76 & 09 & 28.55 & $\mathrm{~S}$ & I3 & $26 \mathrm{E}$
\end{tabular} S $4437 \mathrm{E}$ N 795 I E

$3 \mid \begin{array}{lllllllll}39 & 06 & 12.68 & 76 & 08 & 40.08 & \mathrm{~S} & 2 & 19\end{array}$ $\mathrm{S}$ 5I $34 \mathrm{E}$ N $3040 \mathrm{E}$

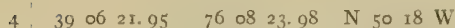
$\begin{array}{lllll}\mathrm{S} & 82 & 38 \mathrm{~W}\end{array}$ S $\begin{array}{lll} & 39 & \mathrm{E}\end{array}$ \begin{tabular}{l|llllllllllll}
5 & 39 & 06 & 12.56 & 76 & 08 & I1. 72 & $\mathrm{~N}$ & 67 & 34 & $\mathrm{E}$ \\
& $\mathrm{N}$ & 47 & 00 & $\mathrm{~W}$
\end{tabular} N $7337 \mathrm{~W}$

$\begin{array}{lrrr}N & 5 & 30 & W \\ N & 44 & 06 & W \\ S & 46 & 49 & W \\ N & 13 & 26 & W \\ N & 44 & 36 & W \\ S & 79 & 52 & W \\ N & 2 & 19 & E \\ N & 51 & 33 & W \\ S & 30 & 40 & W \\ S & 50 & 18 & E \\ N & 82 & 38 & E \\ N & 19 & 39 & W \\ S & 67 & 35 & W \\ S & 47 & 01 & E \\ S & 73 & 37 & E\end{array}$

$249^{8}$ Holton Point.

Io95 Spaniard Point 2 Upper. 973 Brown.

3025 Holton Point.

I744 Spaniard Point 2 Upper. I I I Brown.

I208 Spaniard Point 2 Upper.

953 Evans.

517 Stratton.

207 Stratton

529 Brown.

g6o Evans.

I77 I Deep Point 2.

658 Stratton.

$88_{3}$ Brown. 
COMMEGYS BIGHT.

(Middle Chester River-Chart No. 3o.)

\begin{tabular}{|c|c|c|c|c|c|c|c|c|c|c|c|c|}
\hline \multirow{2}{*}{$\begin{array}{l}\text { Cor- } \\
\text { ner } \\
\text { of } \\
\text { bar }\end{array}$} & \multirow{2}{*}{\multicolumn{2}{|c|}{ Latitude }} & \multirow{2}{*}{\multicolumn{3}{|c|}{ Longitude }} & \multicolumn{5}{|c|}{ True beating } & \multirow{2}{*}{ Distance } & \multirow{2}{*}{$\begin{array}{c}\text { U.S. C. \& G. S. triangula- } \\
\text { tion station }\end{array}$} \\
\hline & & & & & & & For & rward & & Back & & \\
\hline I & $\begin{array}{c}0 \\
39\end{array}$ & $06 \times 12.56$ & $\begin{array}{c}\circ \\
76\end{array}$ & 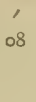 & $\begin{array}{l}\text { II } \\
\text { II. } 72\end{array}$ & $\begin{array}{l}\mathrm{N} \\
\mathrm{N} \\
\mathrm{N}\end{array}$ & $\begin{array}{l}0 \\
673 \\
47 \\
73\end{array}$ & $\begin{array}{ll}34 & E \\
00 & W \\
37 & W\end{array}$ & $\begin{array}{ll}\mathrm{S} & 6 \\
\mathrm{~S} & 4 \\
\mathrm{~S} & 7\end{array}$ & $\begin{array}{lll}0 & \\
67 & 35 & \mathrm{~W} \\
47 & \text { or } & \mathrm{E} \\
73 & 37 & \mathrm{E}\end{array}$ & $\begin{array}{r}\text { Yards. } \\
1771 \\
658 \\
88_{3}\end{array}$ & $\begin{array}{l}\text { Deep Point } 2 \text {, } \\
\text { Stratton. } \\
\text { Brown. }\end{array}$ \\
\hline 2 & 39 & 0621.95 & 76 & 08 & 23.98 & $\begin{array}{l}\mathrm{N} \\
\mathrm{S} \\
\mathrm{S}\end{array}$ & $\begin{array}{l}50 \\
82 \\
19\end{array}$ & $\begin{array}{ll}I 8 & W \\
38 & W \\
39 & \mathrm{E}\end{array}$ & $\begin{array}{l}\mathrm{S} \\
\mathrm{N}\end{array}$ & $\begin{array}{lll}50 & \text { I } & \mathrm{E} \\
82 & 38 & \mathrm{E} \\
\text { I9 } & 39 & \mathrm{~W}\end{array}$ & $\begin{array}{l}207 \\
529 \\
960\end{array}$ & $\begin{array}{l}\text { Stratton. } \\
\text { Brown. } \\
\text { Evans. }\end{array}$ \\
\hline 31 & 39 & o6 38.73 & 76 & 08 & 14.70 & $\begin{array}{l}\mathrm{S} \\
\mathrm{S} \\
\mathrm{S}\end{array}$ & $\begin{array}{r}42 \\
3 \\
83\end{array}$ & $\begin{array}{l}54 \mathrm{~W} \\
05 \mathrm{E} \\
07 \mathrm{E}\end{array}$ & $\begin{array}{l}\mathrm{N} \\
\mathrm{N} \\
\mathrm{N} 8\end{array}$ & $\begin{array}{rrl}42 & 54 & \mathrm{E} \\
3 & 05 & \mathrm{~W} \\
83 & 06 & \mathrm{~W}\end{array}$ & $\begin{array}{r}592 \\
1473 \\
1727\end{array}$ & $\begin{array}{l}\text { Stratton. } \\
\text { Evans. } \\
\text { Deep Point } 2 .\end{array}$ \\
\hline 41 & 39 & 0625.00 & 76 & 07 & I2. 53 & $\begin{array}{l}\mathrm{S} \\
\mathrm{S} \\
\mathrm{N}\end{array}$ & $\begin{array}{l}\text { I I } \\
803 \\
\text { I7 } 3\end{array}$ & $\begin{array}{l}25 \mathrm{~W} \\
30 \mathrm{E} \\
33 \mathrm{E}\end{array}$ & $\begin{array}{l}N \\
N \\
S \\
S\end{array}$ & $\begin{array}{lll}\text { II } & 25 & \mathrm{E} \\
80 & 30 & \mathrm{~W} \\
\text { I7 } & 33 & \mathrm{~W}\end{array}$ & $\begin{array}{r}1258 \\
681 \\
269\end{array}$ & $\begin{array}{l}\text { Chester. } \\
\text { Corpse. } \\
\text { Deep Point } 2 .\end{array}$ \\
\hline
\end{tabular}

SHEEP (KENT COUNTY).

(Middle Chester River-Chart No. 30.)

\begin{tabular}{|c|c|c|c|c|c|c|}
\hline \multirow[b]{2}{*}{ I } & \multirow[b]{2}{*}{$\begin{array}{llll}39 & 06 & 23.28\end{array}$} & \multirow[b]{2}{*}{$7^{6} 0708.8 \mathrm{I}$} & & & & \\
\hline & & & $\begin{array}{llll}\mathrm{S} & 16 & 26 & \mathrm{~W} \\
\mathrm{~S} & 84 & 36 & \mathrm{E} \\
\mathrm{N} & 3 & 04 & \mathrm{~W}\end{array}$ & $\begin{array}{llll}\mathrm{N} & 16 & 26 & \mathrm{E} \\
\mathrm{N} & 84 & 36 & \mathrm{~W} \\
\mathrm{~S} & 3 & 04 & \mathrm{E}\end{array}$ & $\begin{array}{r}1225 \\
576 \\
314\end{array}$ & $\begin{array}{l}\text { Chester. } \\
\text { Corpse. } \\
\text { Deep Point } 2 .\end{array}$ \\
\hline 2 & $3906 \quad 36.86$ & 76 o6 5o. I 3 & $\begin{array}{lrrr}\mathrm{S} & 9 & 12 & \mathrm{E} \\
\mathrm{N} & 65 & 54 & \mathrm{E} \\
\mathrm{N} & 19 & 52 & \mathrm{E}\end{array}$ & $\begin{array}{lrrr}N & 9 & 12 & W \\
S & 65 & 54 & W \\
S & I 9 & 52 & W\end{array}$ & $\begin{array}{l}520 \\
820 \\
851\end{array}$ & $\begin{array}{l}\text { Corpse. } \\
\text { Indian. } \\
\text { Thom. }\end{array}$ \\
\hline 3 & 39 o6 $34 \cdot 74$ & 76 o6 47.60 & $\begin{array}{lrll}\mathrm{S} & 2 & 09 & \mathrm{E} \\
\mathrm{N} & 59 & \mathrm{I}_{3} & \mathrm{E} \\
\mathrm{N} & \mathrm{I}_{4} & \mathbf{1 9} & \mathrm{E}\end{array}$ & $\begin{array}{lrrl}\mathrm{N} & 2 & 09 & \mathrm{~W} \\
\mathrm{~S} & 59 & \mathrm{I}_{3} & \mathrm{~W} \\
\mathrm{~S} & \mathrm{I} 4 & 20 & \mathrm{~W}\end{array}$ & $\begin{array}{l}441 \\
794 \\
900\end{array}$ & $\begin{array}{l}\text { Corpse. } \\
\text { Indian. } \\
\text { Thorn. }\end{array}$ \\
\hline
\end{tabular}

\section{DEEP POINT.}

(Middle Chester River-Chart No. 30.)

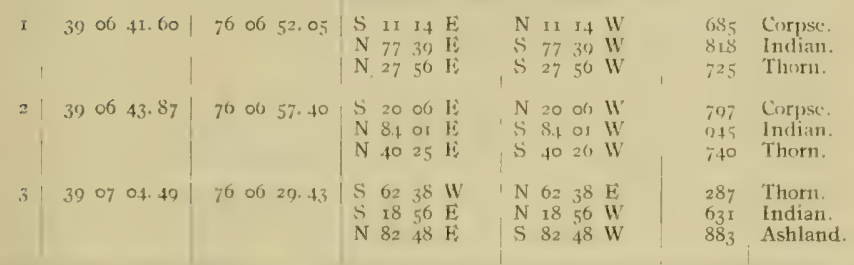


SHIPPEN CREEK.

(Middle Chester River-Chart No. 3o.)

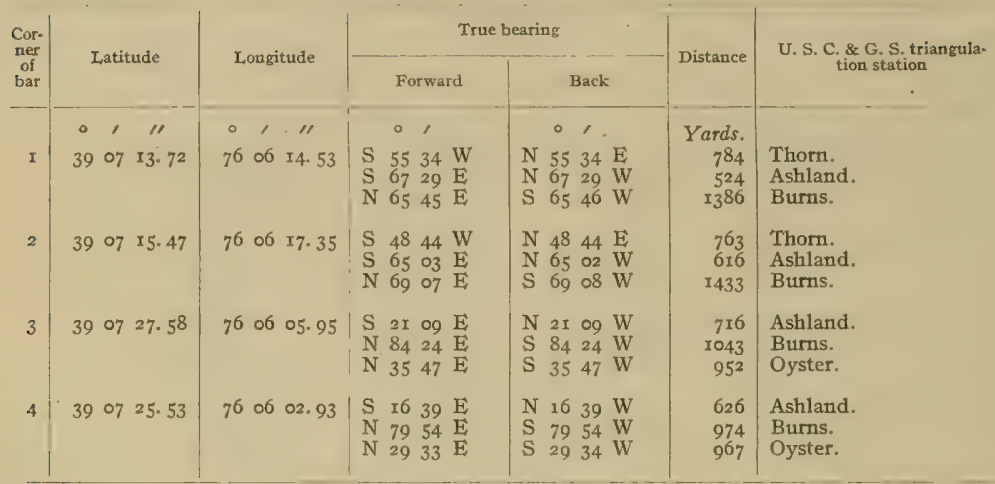

HADDAWAY.

(Middle Chester River-Chart No. 30.)

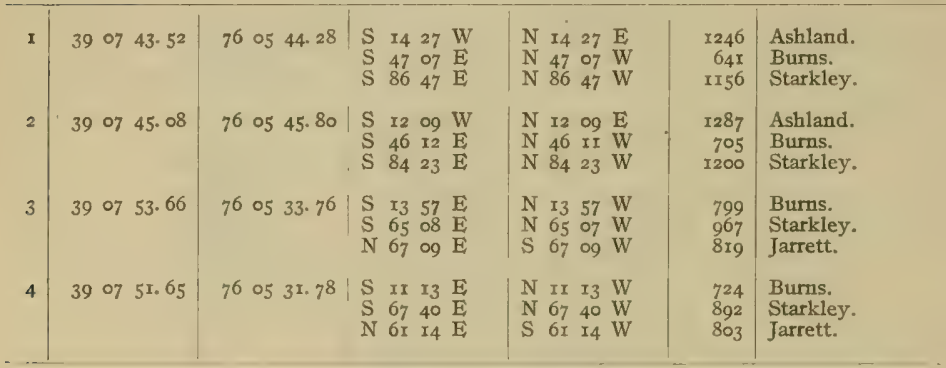

\section{HOLLYDAY (KENT COUNTY).}

(Middle Chester River-Chart No. 30.)

\begin{tabular}{|c|c|c|c|c|c|c|c|}
\hline I & $39 \circ 7$ & $45 \cdot 5^{2}$ & 76 o5 27.55 & $\begin{array}{lrrr}\mathrm{S} & 3 & 23 & \mathrm{E} \\
\mathrm{S} & 79 & 3 \mathrm{I} & \mathrm{E} \\
\mathrm{N} & 44 & 58 & \mathrm{E}\end{array}$ & $\begin{array}{lrrr}N & 3 & 23 & W \\
N & 79 & 3 x & W \\
S & 44 & 59 & W\end{array}$ & $\begin{array}{l}504 \\
726 \\
839\end{array}$ & $\begin{array}{l}\text { Burns. } \\
\text { Starkley. } \\
\text { Jarrett. }\end{array}$ \\
\hline 2 & 3908 & 00.77 & $7^{6} 0500.72$ & $\begin{array}{rrrr}\mathrm{S} & 77 & 5 \mathrm{I} & \mathbf{E} \\
\mathrm{S} & 0 & 50 & \mathrm{E} \\
\mathrm{S} & 33 & 34 & \mathrm{~W}\end{array}$ & $\begin{array}{lrll}N_{7} 77 & 50 & W \\
N & 0 & 50 & W \\
N & 33 & 34 & E\end{array}$ & $\begin{array}{r}1072 \\
646 \\
\times 221\end{array}$ & $\begin{array}{l}\text { Booker. } \\
\text { Starkley. } \\
\text { Burns. }\end{array}$ \\
\hline 3 & 3907 & 53.80 & 760500.86 & $\begin{array}{llll}\mathrm{N} & 89 & 29 & \mathrm{E} \\
\mathrm{N} & 19 & 07 & \mathrm{~W} \\
\mathrm{~S} & 84 & 25 & \mathrm{~W}\end{array}$ & $\begin{array}{llll}\mathrm{S} & 89 & 30 & \mathrm{~W} \\
\mathrm{~S} & 19 & 07 & \mathrm{E} \\
\mathrm{N} & 84 & 25 & \mathrm{E}\end{array}$ & $\begin{array}{r}\text { ro5I } \\
333 \\
\text { I } 59\end{array}$ & $\begin{array}{l}\text { Booker. } \\
\text { Jarrett. } \\
\text { Oyster. }\end{array}$ \\
\hline
\end{tabular}




\section{MELTON POINT.}

(Middle Chester River-Chart No. 30.)

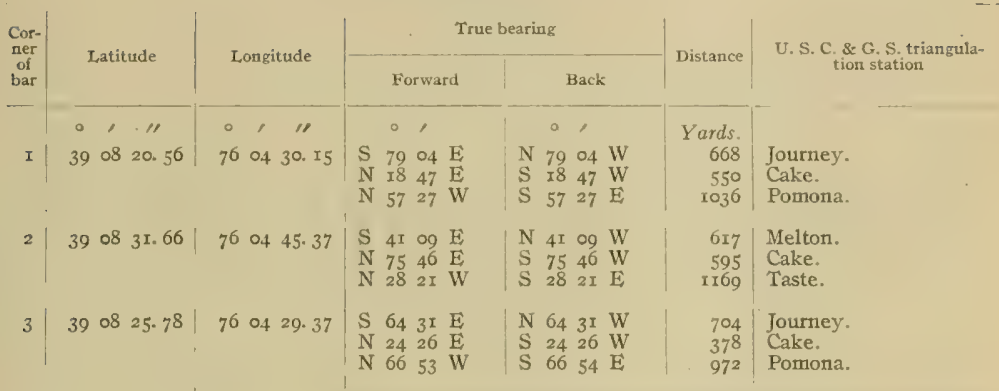

\section{NORTHWEST (KENT COUNTY).}

(Middle Chester River-Chart No. 30.)

\begin{tabular}{|c|c|c|c|c|c|}
\hline $\begin{array}{lll}39 & 08 & 25.78\end{array}$ & $\begin{array}{llll}76 & 04 & 29.37\end{array}$ & $\begin{array}{llll}\mathrm{S} & 64 & 31 & \mathrm{E} \\
\mathrm{N} & 24 & 26 & \mathrm{E} \\
\mathrm{N} & 66 & 53 & \mathrm{~W}\end{array}$ & $\begin{array}{llll}\mathrm{N} & 64 & 3 \mathrm{I} & \mathrm{W} \\
\mathrm{S} & 24 & 26 & \mathrm{~W} \\
\mathrm{~S} & 66 & 54 & \mathrm{E}\end{array}$ & $\begin{array}{l}704 \\
37^{8} \\
97^{2}\end{array}$ & $\begin{array}{l}\text { Journey. } \\
\text { Cake. } \\
\text { Pomona. }\end{array}$ \\
\hline $\begin{array}{llll}39 & 08 & 49.92\end{array}$ & $7604 \quad 53 \cdot 37$ & $\begin{array}{llll}\mathrm{S} & 59 & \mathrm{II} & \mathrm{E} \\
\mathrm{N} & 66 & 46 & \mathrm{E} \\
\mathrm{N} & 39 & 52 & \mathrm{~W}\end{array}$ & $\begin{array}{llll}\mathrm{N} & 59 & 10 & \mathrm{~W} \\
\mathrm{~S} & 66 & 46 & \mathrm{~W} \\
\mathrm{~S} & 39 & 52 & \mathrm{E}\end{array}$ & $\begin{array}{l}916 \\
636 \\
538\end{array}$ & $\begin{array}{l}\text { Cake. } \\
\text { Bill. } \\
\text { Taste. }\end{array}$ \\
\hline $\begin{array}{llll}39 & 08 & 30 . & r_{3}\end{array}$ & $76 \quad 04 \quad 28.43$ & $\begin{array}{llll}\mathrm{S} & 53 & 39 & \mathrm{E} \\
\mathrm{N} & 33 & 40 & \mathrm{E} \\
\mathrm{N} & 75 & 40 & \mathrm{~W}\end{array}$ & $\begin{array}{llll}\mathrm{N} & 53 & 39 & \mathrm{~W} \\
\mathrm{~S} & 33 & 40 & \mathrm{~W} \\
\mathrm{~S} & 75 & 40 & \mathrm{E}\end{array}$ & $\begin{array}{l}759 \\
238 \\
948\end{array}$ & $\begin{array}{l}\text { Journey. } \\
\text { Cake. } \\
\text { Pomona. }\end{array}$ \\
\hline
\end{tabular}





\title{
APPENDIXES.
}

\author{
APPENDIX A.-LAWS RELATING TO THE COOPERATION OF THE COAST AND GEODETIC \\ SURVFY ANI BUREAU OF FISHERIES WITH THE MARYLAND SHELL, FISH COM- \\ MISSION.
}

The work of the Coast and Geodetic Survey and of the Bureau of Fisheries, in cooperation with the Maryland Shell Fish Commission, in surveying the oyster bars, establishing permanent landmarks at triangulation stations, and preparing for publication the necessary charts and technical and legal descriptions of boundaries and landmarks shown on these charts, has been executed in compliance with a request from the governor of the State of Maryland to the Secretary of Commerce and Labor, and by the authority of the following laws of the United States and Maryland:

[Act of Congress approved May 26, x906.]

AN ACT To authorize the Secretary of Commerce and Labor to cooperate, through the Bureau of the Coast and Geodetic Survey and the Bureats of Fisheries, with the shellfish commissioner of the State of Maryland in making surveys of the natural oyster beds, bars, and rocks in the waters within the State of Maryland.

Be it enacted by the Senate and House of Representatives of the United States of America in Congress assembled, That the Secretary of Commerce and Labor be, and he is hereby, authorized and directed, upon the request of the governor of the State of Maryland, to designate such officers, experts, and employees of the Bureau of the Coast and Geodetic Survey and of the Bureau of Fisheries as may be necessary to cooperate with the Maryland State board of shellfish commissioners in making a survey of and locating the natural oyster beds, bars, and rocks in the waters within the State of Maryland; and the Secretary of Commerce and Labor is hereby authorized and directed to furnish to the officers, experts, and employees of said Bureaus so detailed as aforesaid such instruments, appliances, and steam launches as may be necessary to make the survey aforesaid; and the Secretary of Commerce and Labor is hereby authorized to have made in the Bureau of the Coast and Geodetic Survey all the plats necessary to show the results of the aforesaid survey and the locations of the said natural oyster beds, bars; and rocks in the waters within the State of Maryland, and to furnish to the board of shellfish commissioners of the State of Maryland such copies as may be necessary, and for this purpose to employ, in the District of Columbia and elsewhere, such technically qualified persons as may be necessary to carry out the purpose of this act.

SEc. 2. That the Secretary of Commerce and Labor is hereby further authorized to have erected or constructed by the officers so detailed as aforesaid, while making such survey, such structures as may be necessary to mark the points of triangulation, so that the same may be used for such future work of the Coast and Geodetic Survey as the said Bureau may be hereafter required to perform in prosecuting the Government coast survey of the navigable waters of the United States located within the State of Maryland.

SEc. 4. That this act shall take effect from the date of its passage.

[Act of Congress approved June 30, rgo6.]

AN ACT Making appronriations for sundry civil expenses of the Government for the fiscal year ending June thirtieth, nineteen hundred and seven, and for other purnoses.

Be it enacted by the Senate and House of Representatives of the United States of Anerica in Congress assembled, That the following sums be, and the same are hereby, appropriated, for the objects hereinafter expressed, for the fiscal year ending June thirtieth, nineteen hundred and seven, namely: * * *

Coast and Geodetrc Survey: * * * For any special surveys * * * including the expenditures authorized under Public Act Numbered One hundred and eighty-one, approved May twenty-sixth, nincteen hundred and six, and contingent expenses incident thereto, five thousand dollars, 
together with the unexpended balance under this appropriation for nineteen hundred and six and prior years which is hereby reappropriated and made available on this account for the fiscal year nineteen hundred and seven. ***

[Act of Congress approved March 4, r907.]

AN ACT Making appropriations for sundry civil expenses of the Government for the fiscal year ending June thirtieth, nineteen hundred and eight, and for other purposes.

Be it enacted by the Senate and House of Representatives of the United States of America in Congress assembled, That the following sums be, and the same are hereby, appropriated, for the objects hereinafter expressed, for the fiscal year ending June thirtieth, nineteen hundred and eight, namely: * * *

CoAst and Geodetic Survey: * * * For any special surveys * * * including expenses of surveys in aid of the shellfish commission of the State of Maryland, to be immediately available and to continue available until expended, twenty-five thousand dollars. $* * *$

[Act of Congress approved May 27, 1908.]

AN ACT Making appropriations for sundry civil expenses of the Government for the fiscal year ending June thirtieth, nineteen hundred and nine, and for other purposes.

$B e$ it enacted by the Senate and House of Representatives of the United States of America in Congress assembled, That the following sums be, and the same are hereby, appropriated, for the objects hereinafter expressed, for the fiscal year ending June thirtieth, nineteen hundred and nine, namely: * * *

CoAsr ANd Geodetrc Surver: * * * For any special surveys * * * including expenses of surveys in aid of the shellfish commission of the State of Maryland, which expenses, including cost of plats and charts, shall not exceed fifteen thousand dollars in any one year, to be immediately available, twenty thousand dollars.

[Act of Congress approved March 4, rgog.]

AN ACT Making appropriation for sundry civil expenses of the Government for the fiscal year ending June thirtieth, nineteen hundred and ten, and for other purposes.

Be it enacted by the Senate and House of Representatives of the United States of America in Congress assembled, That the following sums be, and the same are hereby, appropriated, for the objects hereinafter expressed, for the fiscal year ending June thirtieth, nineteen hundred and ten, namely: * * *

COAST AND GEOderic Survey: * * * For any special surveys * * * including expenses of surveys in aid of the shellfish commission of the State of Maryland, which expenses, including cost of plats and charts, shall not exceed fifteen thousand dollars in any one year, to be immediately available, twenty thousand dollars.

[Act of Congress approved June 25, r9ro.]

AN ACT Making appropriations for sundry civil expenses of the Government for the fiscal year ending June thirtieth, nineteen hundred and eleven, and for other purposes.

Be it enacted by the Senate and House of Representatives of the United States of America in Congress assembled, That the following sums be, and the same are hereby, appropriated, for the objects hereinafter expressed, for the fiscal year ending June thirtieth, nineteen hundred and eleven, namely: * * *

CoAst ANd GeOdetrc SURvey: * * * For any special surveys * * * including expenses of surveys in aid of the shellifs commission of the State of Maryland, to be immediately available, fifteen thousand dollars.

[Act of Congress approved March 4, 191x.]

AN ACT Making appropriations for sundry civil expenses of the Government for the fiscal year ending June thirtieth, niueteen lundred and twelve, and for other purposes.

Be it enacted by the Senate and House of Representatives of the United States of America in Congress assembled, That the following sums be, and the same are hereby, appropriated, for the objects hereinafter expressed, for the fiscal year ending June thirtieth, nineteen hundred and twelve, namely: * * *

COAST AND GeOdetrc SuRvey: * * * For any special surveys * * * including expenses of surveys in aid of the shellfish commission of the State of Maryland, to be immediately available, thirteen thousand dollars. *** 
[Act of the Legislature of Maryland approved April 2, I906.]

AN ACT To establish and promote the industry of oyster culture in Maryland, to define and mark natural oyster beds, bars and rocks lying under the waters of this State, to prescribe penalties for the infringement of the provisions of this Act, and ****

SEcrion r. Be it enacted by the General Assembly of Maryland, That the following sections be, and they are hereby, added to article 72 of the Code of Public General Laws, title "Oysters." * * *

SEC. 86. The Board of Shell Fish Commissioners shall, as soon as practicable after the passage of this Act, cause to be made a true and accurate survey of the natural oyster beds, bars and rocks of this State, said survey to be made with reference to fixed and permanent objects on the shore, giving courses and distances, to be fully described and set out in a written report of said survey, as hereinafter required. A true and accurate delineation of the same shall be made on copies of published maps and charts of the United States coast and geodetic survey, which said copies shall be filed in the office of the said commissioners in the city of Annapolis, and the said commissioners shall further cause to be delineated upon copies of the published maps and charts of the United States coast and geodetic survey, of the largest scale, one copy for each of the counties of this State in the waters of which there are natural oyster beds, bars and rocks, all natural beds, bars and rocks lying within the waters of such county, which maps shall be filed in the offices of the clerks of the Circuit Court for the respective counties wherein the grounds so designated may lie. * * *

SEC. 87. The Governor of this State is hereby requested to ask the assistance of the United States coast and geodetic survey, and of the United States Fish Commissioner, to aid in the carrying out of the provisions of the preceding section.

*

SEC. 89. As soon as practicable after the first day of April, I906, the said commissioners shall organize, and shall at once proceed, with the assistance of such person or persons as may be detailed by the United States coast and geodetic survey and the United States Fish Commissioner, to aid them in their work, and of such persons as may be appointed under the preceding section, to have laid out, surveyed and designated on the said charts, the natural beds and bars, and shall cause to be marked and defined as accurately as practicable the limits and boundaries of the natural beds, bars, and rocks as established by said survey, and they shall take true and accurate notes of said survey in writing, and make an accurate report of said survey, setting forth such a description of landmarks as may be necessary to enable the said board, or their successors, to find and ascertain the boundary lines of the said natural oyster beds, bars and rocks, as shown by a delineation on the maps and charts provided in this Act; said report shall be completed and filed in the office of the board in the city of Annapolis within ninety days after the completion of the survey of any county. Said commissioners shall cause the same to be published in pamphlet form, and transmit copies of the said to the Clerks of the Circuit court for the respective counties, where the charts have been filed or directed to be filed as hereinafter provided; the said report to be filed by the clerks of the several counties in a book kept for that purpose. And the said survey and report, when filed, subject to the right of appeal hereafter provided for in this Act, shall be taken in all of the courts of this State as conclusive evidence of the boundaries and limits of all natural oyster beds, bars and rocks, lying within the waters of the county wherein such survey and report are filed, and shall be construed to mean in all of the said courts that there are no natural oyster beds, bars or rocks lying within the waters of the counties wherein such report and survey are filed other than those embraced in the survey authorized by this Act, and that all areas of the Chesapeake Bay and its tributaries within the State of Maryland, not shown in the survey to be natural oyster beds, bars or rocks shall be construed in all the courts of the State to be barren bottoms and open for disposal by the State for the purpose of private planting or propagation of oysters thereon under the provisions of this Act; provided, that the said survey and report shall not be construed as to affect in any manner the holdings by citizens of this State in any lot which may have been appropriated or taken up under the laws of this State prior to the approval of this Act.

The law of the State of Maryland, passed March 9, 1842 , authorizing officers of the United States Coast and Geodetic Survey to enter upon the lands within the State limits for the purposes of the survey, is as follows:

AN ACT Concerning the Survey of the Coast of Maryland.

Section I. Be it enacted by the General Assembly of Maryland, That it shall and may be lawful for any person or persons employed under and by virtue of an act of the Congress of the United 
States, * * at any time hereafter to enter upon lands within this State for the purpose of exploring, surveying, triangulating, or leveling, or doing any other matter or thing which may be necessary to effect the objects of said act, and to erect any works, stations, buildings, or appendages requisite for that purpose, doing no unnecessary injury to private or other property.

SEc. $2 .^{1}$ And be it enacted, That in case the person or persons employed under the act of Congress aforesaid, can not agree with the owners or possessors of the land so entered upon and used as to the amount of damage done thereto by reason of the removal of fences, cutting of trees or injury to the crop or crops growing on the same, it shall and may be lawful for the said parties or either of them to apply to the chief justice for the time being or one of the associate judges of the judicial district in which such land may be situated, who shall thereupon appoint three disinterested and judicious frceholders, residents of the same judicial district, to proceed with as much despatch as possible to the examination of the matter in question, and the faithful assessment of the damages sustained by the owners or possessors aforesaid, and the said freeholders or a majority of them, having first taken and subscribed an oath or affirmation before the chief or associate justice aforesaid or other person duly authorized to administer the same, that they will well and truly examine and assess as aforesaid, and having given five days' notice to both parties of the time of their meeting, shall proceed to the spot, and then and there upon their own view and if required, upon the evidence of witnesses (to be by them sworn or affirmed and examined), shall assess the said damages, and shall afterward make report thereof and of their proceedings in writing under their hands and seals and file the same within five days thereafter in the office of the clerk of the connty in which the land aforesaid is situated, subject to an appeal by either party to the county court of the said county within ten days after filing as aforesaid, and the said report so made as aforesaid if no appeal as aforesaid be taken, shall be held to be final and conclusive as between the said parties, and the amount so assessed and reported shall be paid to the said owners or possessors of the land so damaged within twenty days after the filing of said report, and the said chief or associate justice as aforesaid, shall have authority to tax and allow upon the filing of said report, such costs, fees and expenses to the said freeholders for the performance of their duty as he shall think equitable and just, which allowance shall be paid by the person or persons employed under the act of congress aforesaid, within the time last above limited, but if an appeal as aforesaid be taken, the case shall be set down for hearing at the first term of county court aforesaid, ensuing upon and after appeal, and it shall be lawful for either party immediately after the entry of such appeal, to take out summons for such witnesses as may be necessary to be examined upon the hearing aforesaid, and the said court shall have power in its discretion to award costs against which ever the final judgment shall be entered, and such appeal at the option of either party may and shall be heard before and the damage assessed by a jury of twelve men to be taken from the regular panel and elected as in other cases.

SEC. 3. And be it enacted, That if any person or persons shall wilfully injure or deface or remove any signal, monument or building or any appendage thereto, erected, used or constructed under and by virtue of the act of congress aforesaid, such person or persons so offending shall severally forfeit and pay the sum of fifty dollars with costs of suit to be sued for and recovered by any person who shall first prosecute the same before any justice of the peace of the county where the person so offending may reside, and shall also be liable to pay the amount of damages thereby sustained, to be recovered with costs of suit in an action on the case, in the name and for the use of the United States of America, in any court of competent jurisdiction.

\section{APPENDIX B.-THE HAMAN OYSTER CULTURE LAW}

[Fixtract from Second Report of Shell 1ish Commission.]

OBJECT

"The legislature in placing chapter 7 II of the acts of IQ06, better known as the Haman Oyster Culture Law, upon the statute books of Maryland, had a twofold object in view:

"I. To encourage an industry in oyster culture upon the barren bottoms beneath the tidewaters of the State.

"2. To prevent the leasing of natural oyster bars for the purpose of oyster culture."

1 Under the rulings of the Comptroller of the Treasury no damages can be collected except through the United States Court of Claims unless an agreement has been made in advance. 
SURVEY.

"To make the leasing of barren bottoms possible and the leasing of natural bars impossible, provision was made for a survey of the natural bars for the purpose of accurately locating and marking the same. It was definitely provided that no barren bottoms should be leased in any part of the State until the natural bars of that region had been surveyed, charted, and marked with bioys."

\section{DEFINITION OF A NATURAL OYSTER I3AR.}

NATURAL BAR NOT DEFINED.

"The Shell Fish Commission is instructed by section go of the Haman Oyster Culture Law to exercise its judgment liberally in favor of the natural bars when surveying, charting and buoying them, but other than this the Commission is uninstructed in this important matter. The responsibility of defining a natural bar is placed upon the Commission."

\section{DIVERSITY OF OPINION.}

"No definition of a natural oyster bar could be formulated by any man or body of men which would meet with the approval of all parties concerned. Oystermen, as a rule, hold that all bottoms where oysters grow or have grown naturally even though now practically barren of oysters should be considered natural bars. Other citizens of the State who are not directly interested in the oyster business, but interested in the oyster industry from the standpoint of revenue, hold, as a rule, that no bottoms should be excluded from leasing for oyster culture which, by methods known to oyster culturists, may be made to yield a greater number of oysters than they now produce.

"It should be evident to every one that neither of these definitions could be adopted by the Commission as a working basis for determining which of the grounds surveyed are natural oyster bars."

\section{THE GOLDSBOROUGH DEFINITION.}

The definition of a natural oyster bar which very nearly approaches a reasonable and satisfactory compromise between the views of the subject held by oystermen on one hand and by oyster culturists on the other is that contained in an opinion rendered by Judge Charles F. Goldsborough in the circuit court for Dorchester County in the July term, I88x, in the case of William T. Windsor and George $R$. Todd $v$. Job T. Moore.

This definition has been adopted by the Shell Fish Commission as the basis for the determination of the status of the various oyster bottoms surveyed and is as follows:

What then is a natural bar or bed of oysters? It would be a palpable absurdity for the State to attempt to promote the propagation and growth of oysters and to encourage its citizens, by a grant of land, to engage in their culture, if the lands authorized to be taken up were only those upon which oysters do not and can not be made to grow. That there may be lands covered by water in the State where no oysters can be found, but where, if planted, they could be cultivated successfully, may be possible, but, if so, I imagine that their extent must be too limited for them to be of much practical, general advantage for the purposes of such a law as the one under discussion; but there are thousands of acres of hard and shifting sands where oysters not only are not found, but where it would be folly to plant them, and these latter it can not be supposed that the State intended to offer to give away, for the simple reason that the State could not help knowing that nobody would have them.

Upon the other hand there are large and numerous tracts where oysters of natural growth may be found in moderate numbers, but not in quantities sufficient to make it profitable to catch them, and yet where oysters may be successfully planted and propagated. In my opinion these can not be called natural bars or beds of oysters, within the meaning of the Act of Assembly, and it is just such lands as these that the State meant to allow to be taken up under the provisions of the above-mentioned section of the Act.

But there is still another class of lands where oysters grow naturally and in large quantities and to which the public are now and have been for many years in the habit of resorting with a view to earning a livelihood by catching this natural growth, and here, I think, is the true test of the whole question. Land can not be said to be a natural oyster bar or bed merely because oysters are scattered here and there upon it, and because if planted they will readily live and thrive there; but whenever the natural growth is so thick and abundant that the public resort to it for a livelihood, it is a natural oyster bar or bed and comes within the above-quoted restriction in the law, and can not be located or appropriated by any individual. 


\section{APPLICATION OF DEFINIMION.}

Before this definition may be of use in determining, accurately and scientifically, the status of an oyster ground, its central idea, "livelihood," must be expanded into accurately determinable factors, and these facturs must be combined into a practical scheme of investigating the condition of the ground nnder consideration.

Stated briefly, a livelihood is represented by a sum of money obtained from the sale, at a fixed price, of a certain quantily of oysters gathered in a given time from an allotted area of ground.

Knowing the value of each of these factors it becomes possible to calculate the number of oysters an oyster ground must produce per square yard in order that oystermen may secure a livelihood by working upon it.

Norr.-The factors into which the Commission resolved the livelihood problem, the value assigned to each factor, and the scheme devised for practical use in examining and applying the definition to oyster bottoms are given in outline in their second report under the heading of the preceding extract, and in detail in their first report on pages 32 to 69.

\section{APPENDIX C.-SUMMART OF THE PARTICUIAR SURVEYING OPERATIONS WHICH CON-} STITUTE AN "OYSTER SURVEY" AS NOW BEING CARRIED ON IN MARYLAND.

Explanation.-A brief account of the particular surveying operations which constitute an "oyster survey" as now being carried on in Maryland will assist in the interpretation of records contained in the technical part of this report, and will be of interest to many who may not understand the necessity for the great amount of work being done or its complicated character.

To those familiar with methods used in surveying and charting the characteristic features of large bodies of water there is an evident necessity for the various operations performed, especially when it is known that the boundaries of the public oyster bars and of the private lots leased for purposes of oyster culture must be surveyed and charted with the greatest practical accuracy. To others it will be sufficient to state that the actual experience gained from oyster surveys in other States has proven that in order to avoid endless dissatisfaction and litigation it is necessary to accurately locate and permanently establish oyster boundaries as is now being done in Maryland.

Triangulation survey. - Such refinement of survey work as that demanded by the conditions of an oyster survey when carried on at considerable distances offshore can only be obtained by the use of a system of triangulation as a framework or foundation. Therefore, a triangulation survey including the permanent marking of the positions of landmarks with monuments and a record of the descriptions of their locations for future recovery is a necessary operation of a complete oyster survey.

Topographic survey. - The technical records which establish the relation between the offshore oyster boundaries and triangulation landmarks are sufficient for the requirements of engineers in making resurveys, but do not supply the needs of others who are interested in the same boundaries by reason of their occupation as oystermen concerned as to the public oyster bars, or oyster culturists concerned as to the leasable bottoms. For these it is necessary to have the charts of the survey show the relation of the shore line and other topographic features to the boundaries of the public oyster bars and private oyster farms. Therefore, a topographic survey is a necessary operation of a complete oyster survey.

Hydrographic survey. - In the settlement of the important question of what is, or what is not, a natural oyster bar, and in the consideration of bottoms to be selected for purposes of oyster culture, information as to the depth of water and the character of the bottom is required. Therefore, a hydrographic survey is a necessary operation of a complete oyster survey.

Necessary foundation for an oyster survey.-Consequently, the necessary components of a satisfactory foundation for a complete oyster survey are the three classes of survey operations technically named triangulation, topography, and hydrography, or, stated in another way, the foundation of a practical oyster survey includes the surveying operations usually followed by the Coast and Geodetic Survey leading up to the preparation and publication of nautical charts.

Special surveys and investigations pertaining to oysters.-Having obtained this cartographic survey for a foundation, partly by new work and partly from records of previous work of the Government, the combined operations " making up an "oyster survey" are completed by superimposing on this foundation special surveys and investigations pertaining particularly to oysters or other shell fish.

'See Appendix D of this publication for "Statistics of results of combined operations of the Government and State." 
The special surveys pertaining to oysters furnish information as to the location and outline of oystershell bottoms, and are carried on by the sounding boat party in addition to the usual hydrographic work. ${ }^{1}$ This operation consists of the observation and record of the character of vibration of a wire and chain apparatus which is dragged over the bottom, the vibrations or lack of vibrations indicating the presence and quantity of shells or absence of shells.

The special oyster investigations ${ }^{2}$ consist of the actual determination of the kind and quantity of oysters on the bottom, and such economic and biological studies of the supply of oyster food, density of water, character of the bottom, and other important matters as affect the growth of oysters. In this work the oyster investigation stations are located and buoyed by the hydrographic party while engaged in the survey of the oyster-shell limits. They are selected with the view of obtaining characteristic data which can be used for the interpretation of the recorded vibrations of the chain apparatus at all other points covered by the survey.

Preparation of results. - The actual strveying operations and oyster investigations having been completed for any one county, there still remains technical work of nearly" equal magnitude to that described. ${ }^{3}$ This work consists of the preparation of charts and technical descriptions of boundaries and landmarks for publication by the Government, the preparation of that part of the annual report of the Commission covering the special oyster surveys and investigations, the making of the leasing charts and finished projections, and finally the filing of the oyster charts and records with the courts and the Commission, thus opening a county for oyster culture.

Summary.-From the foregoing account it can be seen that a complete oyster survey properly conducted so as to answer all practical requirements of the present and permanency of results for the future is a very complicated affair, involving many lines of surveying and other scientific work, and requiring the professional services of experts in the various operations of cartographic surveying and shell-fish investigations.

1 See pages ro4 to 123 of "First. Annual Report of Maryland Shell Fish Commission."

"See pages 30 to 67 and 129 to 199 of "First Annual Report of Maryland Shell Fish Commission."

a No mention is made here of the large amount of administrative work of the Commission, which is greatly complicated and increased by the effect of the oyster-survey operations on many thousands of people whose interests are more or less involved; or of the large amount of survey work involved in the survey and record of the boundaries of oyster lots leased from the State by private individuals for the purposes of oyster culture.

$14126-12=9$ 


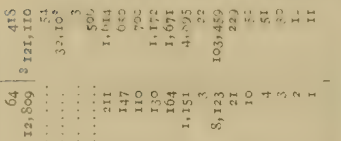

mo : :

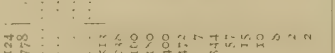

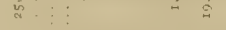

मूल :

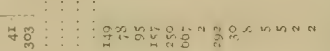

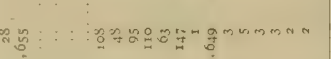
这

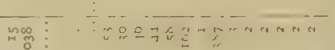

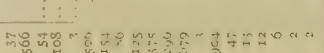
응

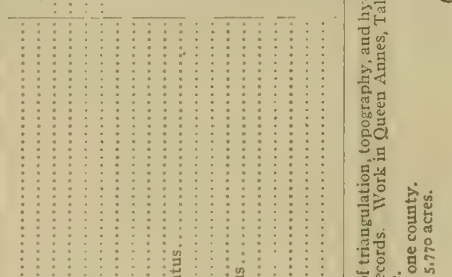

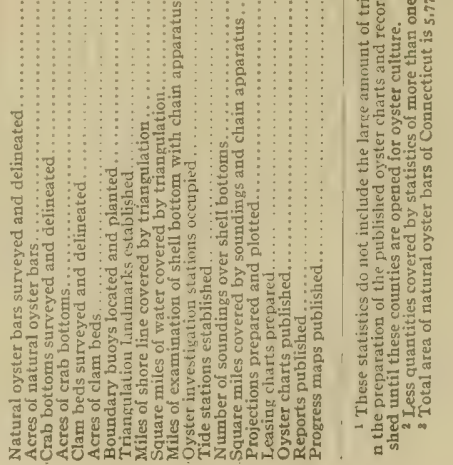








\section{DEPARTMENT OF COMMERCE AND LABOR}

COAST AND GEODETIC SURVEY

O. H. TITTMANN, Superintendent

\section{SURVEY OF OYSTER BARS}

\section{QUEEN ANNES COUNTY MARYLAND}

DESCRIPTION OF BOUNDARIES AND LANDMARKS AND REPORT OF WORK OF UNITED STATES COAST

AND GEODETIC SURVEY IN COOPERATION

WITH UNITED STATES BUREAU OF

FISHERIES AND MARYLAND

SHELL FISH COMMISSION

By C. C. YATES

CHIEF OF COAST AND GEODETIC SURVEY PARTY

ASSISTANT, COAST AND GEODETIC SURVEY

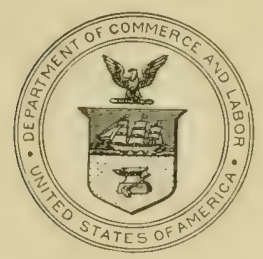

WASHINGTON

GOVERNMENT PRINTING OFFICE

1912 



\section{LETTER OF SUBMI'T'TAL。}

\section{DEPARTMENT OF COMMERCE AND LABOR, Coast and Geodetic Survey, Washington, November 29, 1911 .}

SIR: I have the honor to transmit herewith a report of the officer detailed from the Coast and Geodetic Survey to cooperate with the Bureau of Fisheries and the Maryland Shell Fish Commission in surveying the oyster bars of the State of Maryland, together with certain technical results which are necessary for the interpretation and use of the plats of the survey made by the Government.

This work has been done under the provisions of the act of Congress entitled "An act to authorize the Secretary of Commerce and Labor to cooperate, through the Bureau of the Coast and Geodetic Survey and the Bureau of Fisheries, with the shell fish commissioners of the State of Maryland in making surveys of the natural oyster beds, bars, and rocks in the waters within the State of Maryland," approved May 26, 1906, and of the acts of Congress making appropriations for sundry civil expenses of the Government for the fiscal years ending June $30,1907,1908,1909,1910$, I91 1 , and 1912.

Respectfully,

To Hon. Charles Nagel,

O. H. Titmanan, Superintendent. Secretary of Commerce and Labor. 



\section{CERTIFICATION.}

BALTimok̇e, MD., November $28,19 I 1$.

The following publication is certified to contain correct technical descriptions of all boundaries and landmarks established in Queen Annes County by the Maryland Shell Fish Commission in cooperation with the United States Coast and Geodetic Survey.

C. C. YATES,

Chief of Coast and Geodetic Survey Party, Assistant, Coast and Geodetic Survey.

BALTIMORE, MD., November $28, I 9 I x$.

Examined and certified to be correct.

WALTER J. MITCHELL,

CASWELl, Grave,

BENJAMIN K. GREEN, Maryland Shell Fish Commission.

SWEPSON EARLE,

Hydrographic Engineer.

NoTE.-Certified copies of this publication and of the charts of the natural oyster bars of Queen Annes County were filed in the office of the clerk of the circuit court of Queen Annes County and in the office of the Board of Shell Fish Commissioners on November 29, I9II. 



\section{CONTENTS.}

Page.

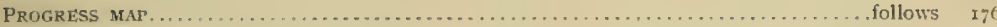

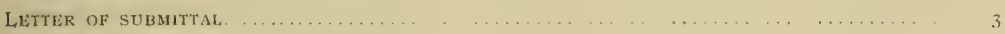

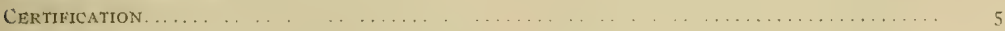

INTRODUCTION:

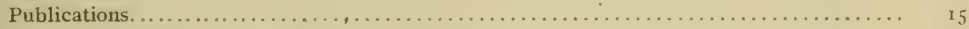

Cooperation of the Coast and Geodetic Survey ........................ I6

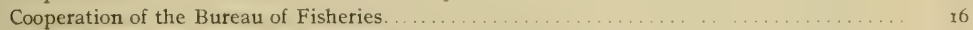

General statement of work of Coast and Geodetic Survey..................... I6

REPORT OF THE WORK OF THE COAST AND GEODETIC SURVEX:

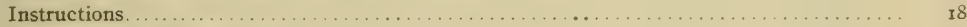

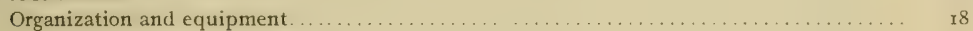

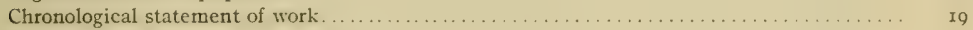

Statistics. . . . . . . . . . . . . . . . . . . . . .

General remarks. . . . . . . . . . . . . . . . . . . . . . .

CHARTS AND MAPS:

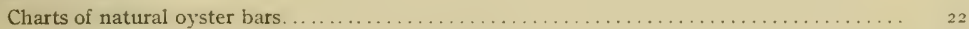

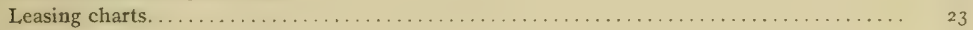

Projections. . . . . . . . . . . . . . . . . . . . . . . . . .

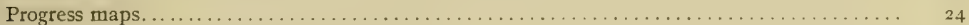

BOUNDARIES OF THE COUNTY WATERS:

Waters within territorial limits of county . . . . . . . . . . . . . . . . . . . 25

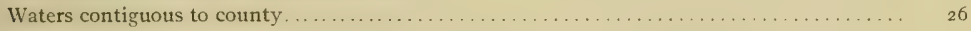

LANDMARKS (U. S. COAST AND GeOdETIC SURVEY TRIANgUlation STaTIONS):

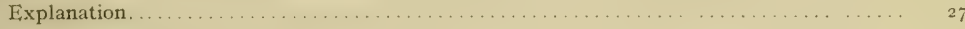

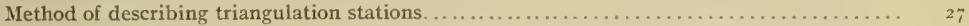

Descriptions of triangulation stations in county and adjacent waters-

Chart No. 29 (Chesapeake Bay and entrance to Chester River)-

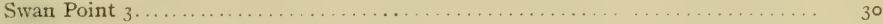

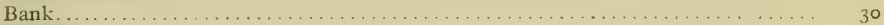

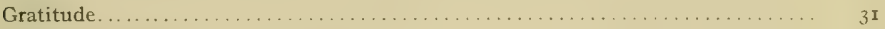

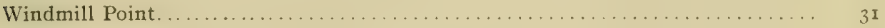

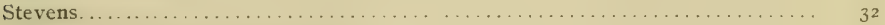

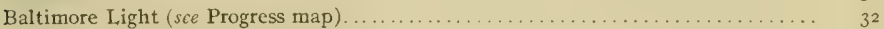

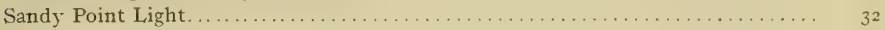

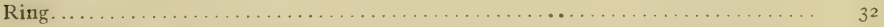

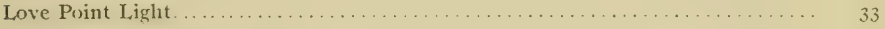

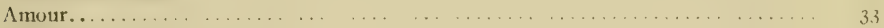

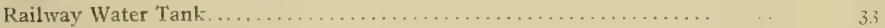

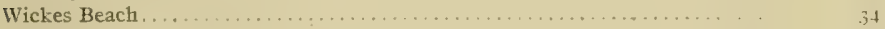

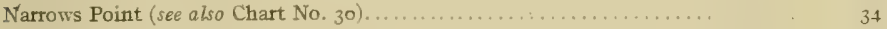

Macum ... .. _ . . . . . . . . . . . . . . . . . . . . . . 35

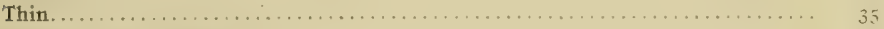

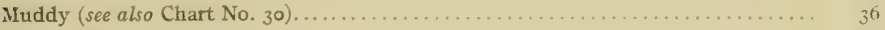

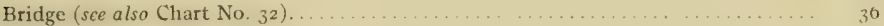

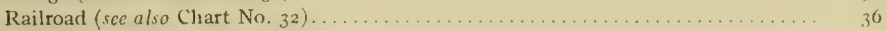


Landararks (U. S. Coast and Geodetic Surveir triangulation statrons)-Continted. Descriptions of triangulation stations in county and adjacent waters-Continued.

Chart No. 30 (Middle Clester River)- Page

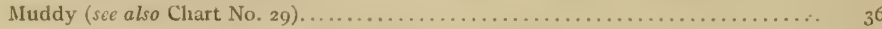

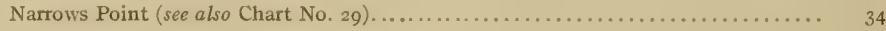

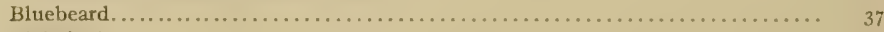

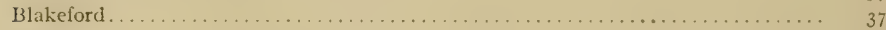

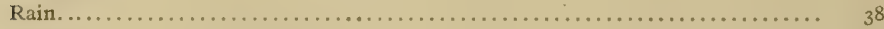

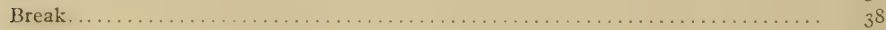

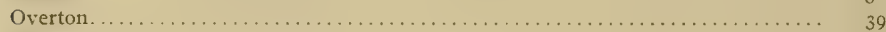

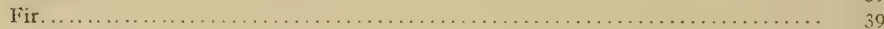

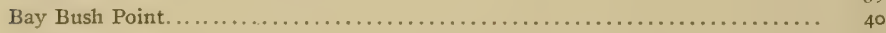

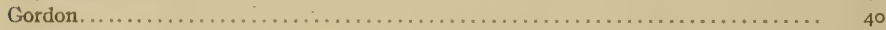

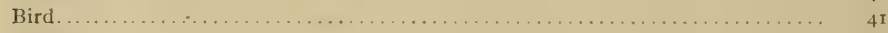

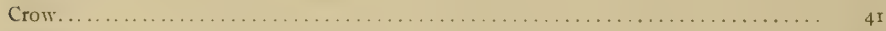

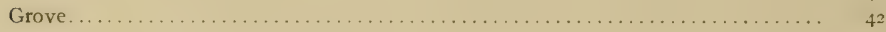

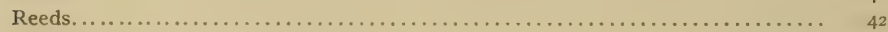

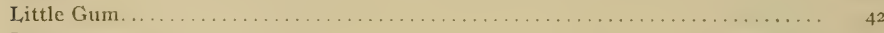

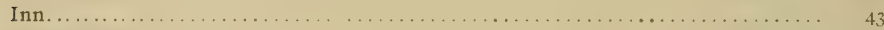

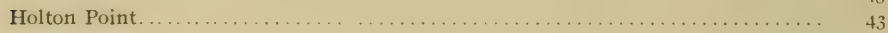

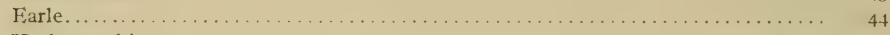

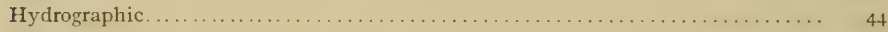

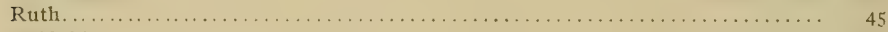

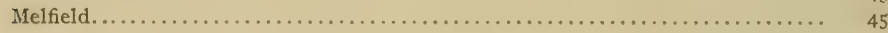

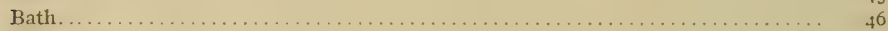

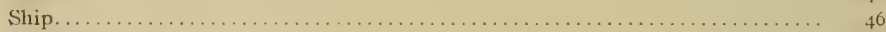

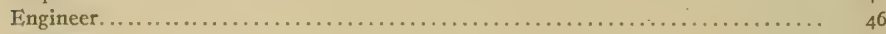

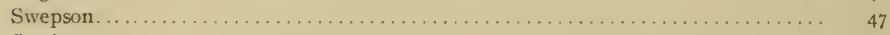

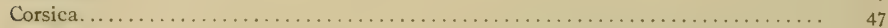

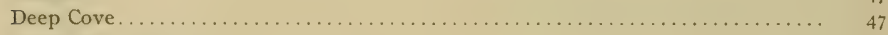

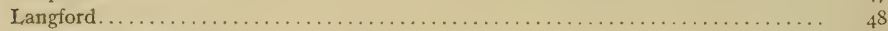

Spaniard Point 2 Upper..................................... ${ }_{4} \delta$

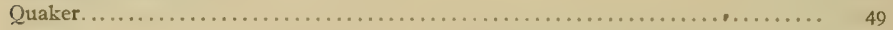

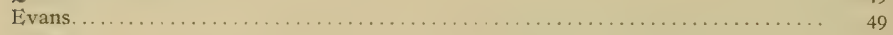

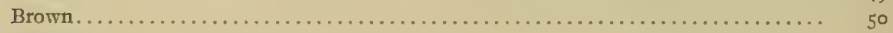

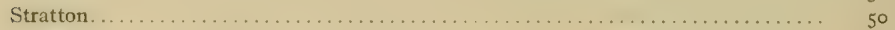

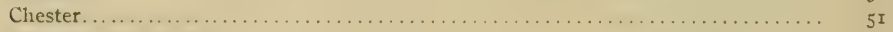

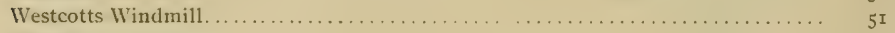

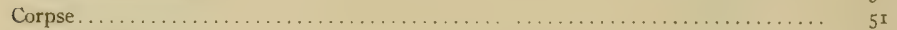

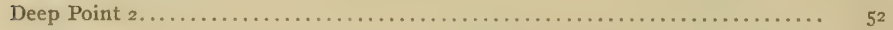

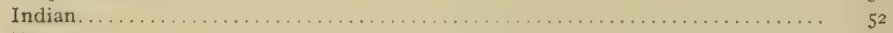

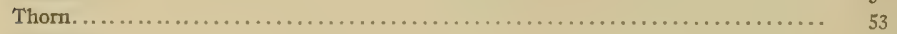

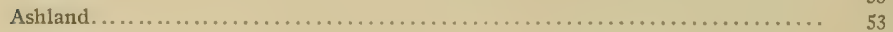

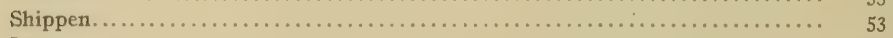

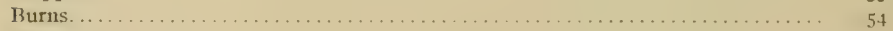

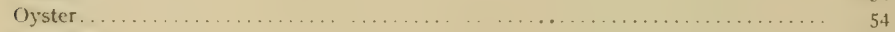

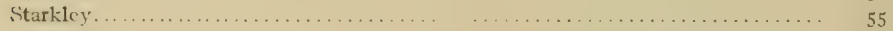

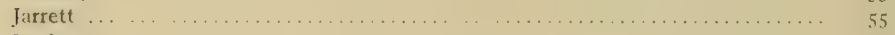

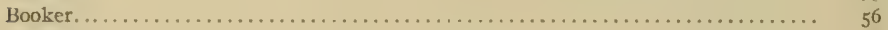

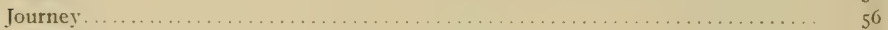

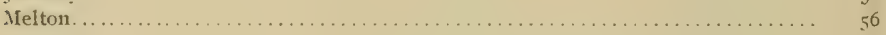

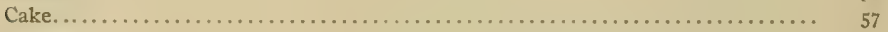

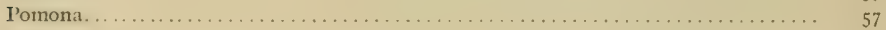

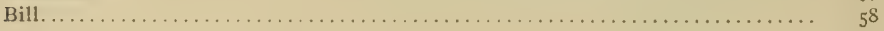

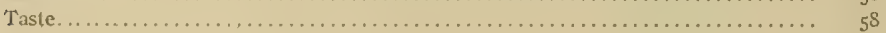


I.andmarks (U. S. Coast and Geonetic Survey triangulation stattons)-Contimued.

Descriptions of triangulation stations in county and adjacent waters-Continued.

Chart No. 30 (Middle Chester River) - Continued.

Make.

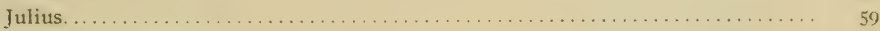

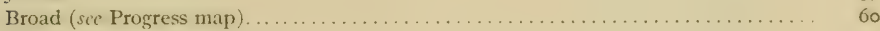

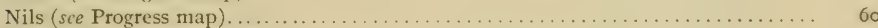

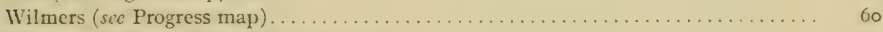

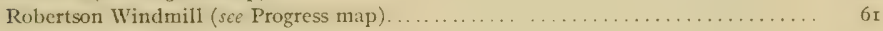

Robertson (see Progress map) . . . . . . . . . . . . . . . . . . . . . . . . . . .

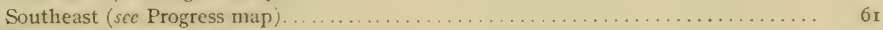

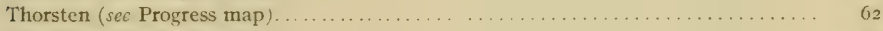

Blank (see Progress map) . . . . . . . . . . . . . . . . . . . . . . . . . . 62

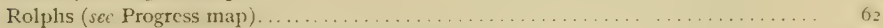

Chart No. $3 I$ (entrance to Eastern Bay and vicinity)-

Craney

Thomas Point Shoal Light.

Bloody: Point Bar Light.

Tenk.

Straight.

Mouth.

Matta.

Then.

Some.

Batts.

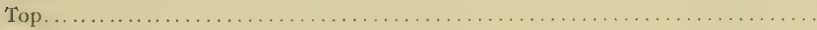

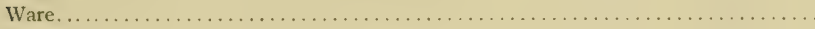

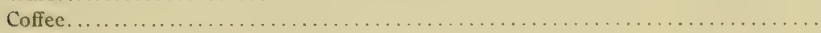

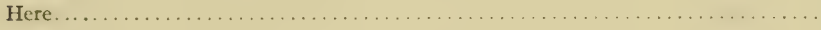

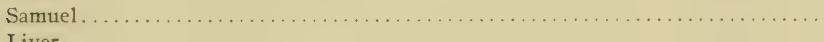

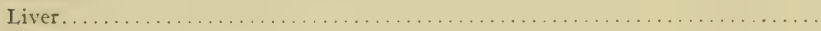

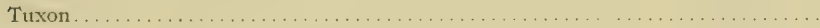

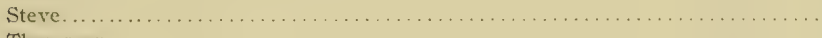

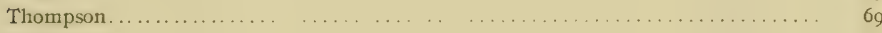

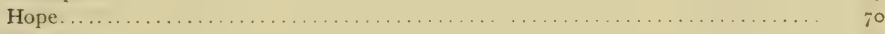

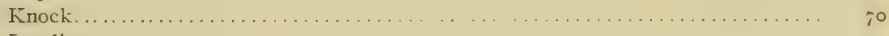

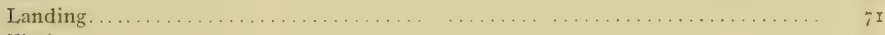

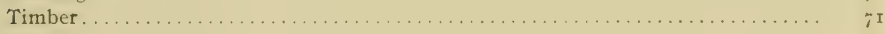

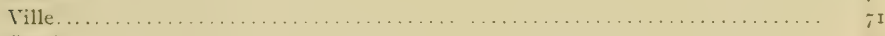

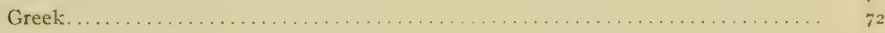

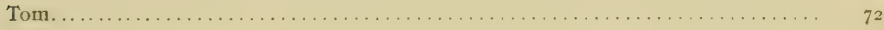

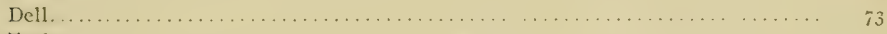

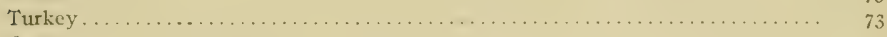

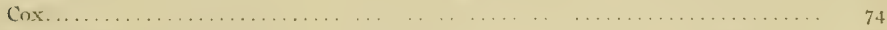

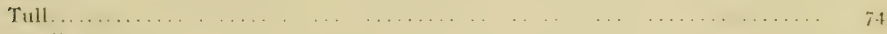

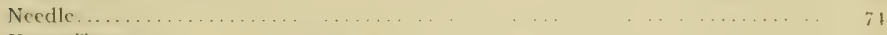

Kemp, Tower.......... . . . . . . . . . . . . . . . . 75

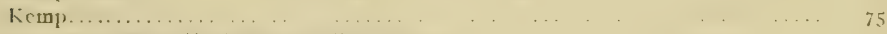

Rich Neck Water Tank (sec also Chart No. 32) .. $\ldots \ldots \ldots \ldots \ldots \ldots \ldots \ldots$. . . . . . .

(Thut . No. 32 (Eastern Bay and tributaries) -

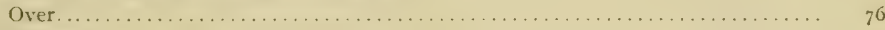

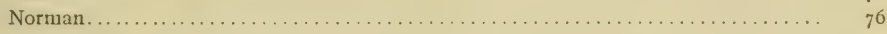

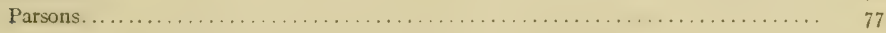


Landmarks (U. S. CoAst AND GEoditic Survey triangulation Statrons)-Continued.

Descriptions of triangulation stations in county and adjacent waters-Continued. Chast No. 32 (Eastern Bay and tributaries)-Continued.

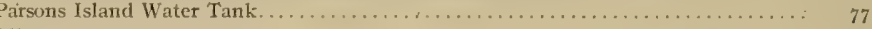

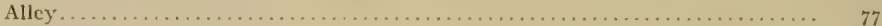

New Jarn Cupola . . . . . . . . . . . . . . . . . . . . $7^{8}$

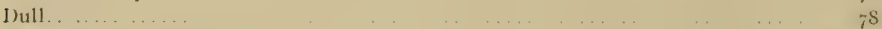

Kirwall . . . . . . . . . . . . . . . . . . . .

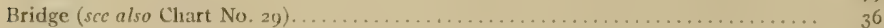

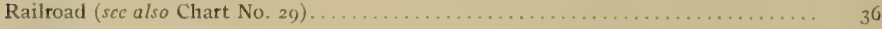

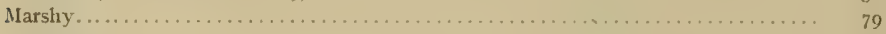

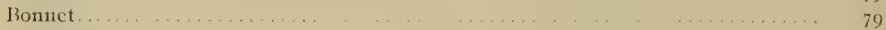

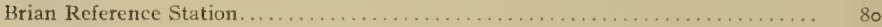

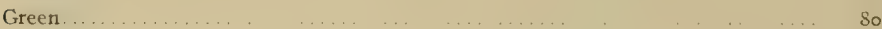

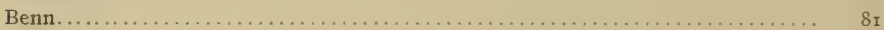

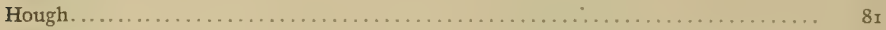

Won $\ldots \ldots \ldots \ldots \ldots \ldots \ldots \ldots \ldots \ldots$

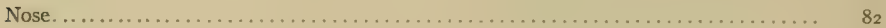

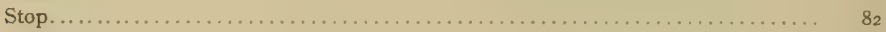

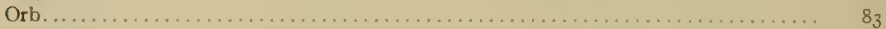

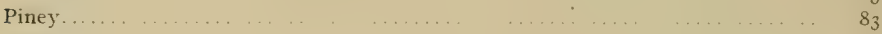

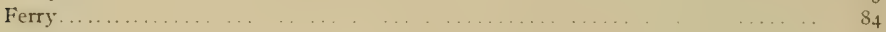

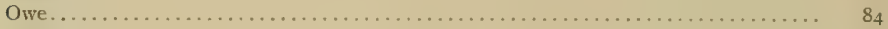

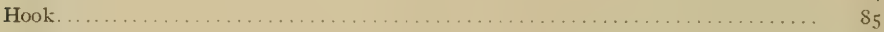

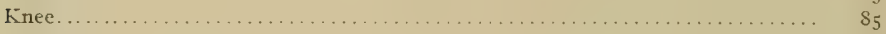

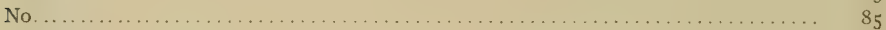

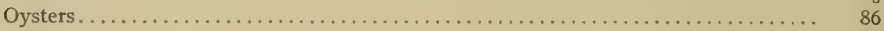

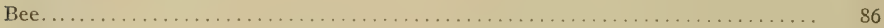

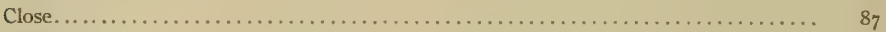

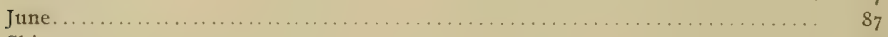

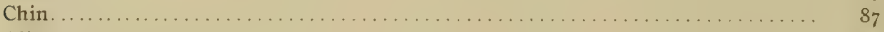

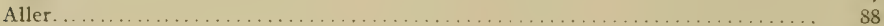

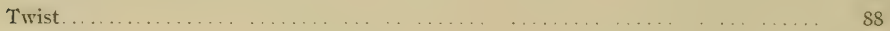

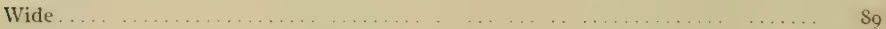

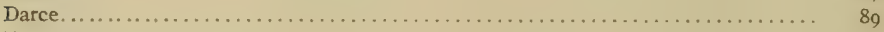

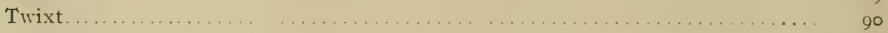

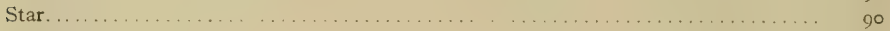

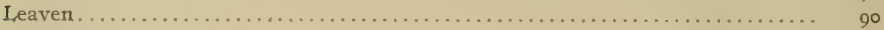

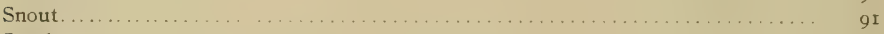

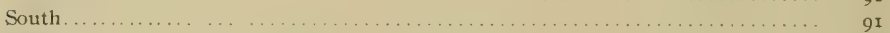

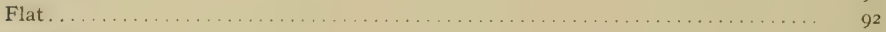

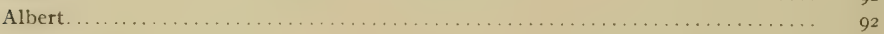

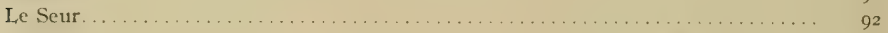

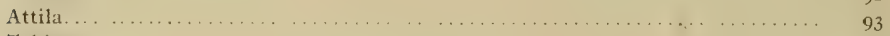

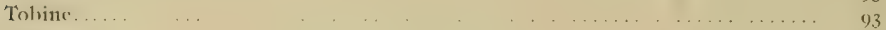

Sians. . . . . . . . 94

Tiurn 94

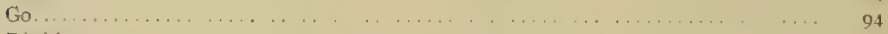

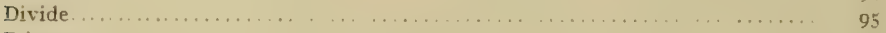

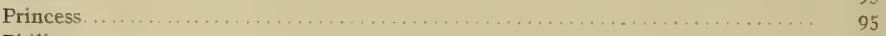

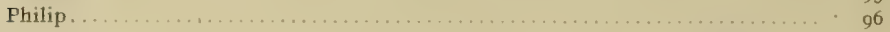

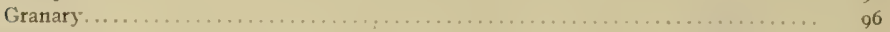

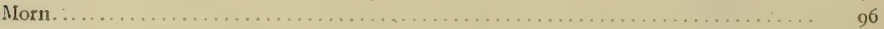

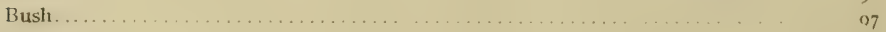

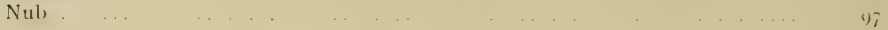


Landmarks (U. S. Coast and Geodetic Survex triangulation stations)-Continued.

Descriptions of triangulation stations in county and adjacent waters-Continued.

Charl No. 32 (Eastem Bay and tributaries)_-Continued.

Whecl.

Jage.

Pick.

Curner

Right.

Chew:

Whale.

Matter

Deck.

()uarter

Nodinı.

Gusta.

Sylvia.

Baldwins.

Cousin.

Lloyd.

Edward

Colonel.

Shaw.

Bruffs.

Law..

Jarues.

Frank

Hood

Herr.

Ollie.

Deewat

Spar.

Sara.

Seth.

Rich Neck Water Tank (sfe also Chart No. 3I). .

Dixon.

Pearson. .

BOUNDARIES OF OYSTER BARS:

Explanation.

Method of deseribing boundaries.

Surveying methods for relocation of houndaries

Boundaries of natural oyster bars in county ${ }^{1}$ -

Chart No. 29 (Chesapeake Bay entrance Chester River)-

Broad Creek.

Lore Point.

Strong I3ay

Carvel.

Fierry (Queen Annes County)

long Point (Chester River) (see also Chart No. 30).

Flood Point

Kent Island Narrows.

Chart No. 30 (Middle Chester River) -

Long Point (Chester River) (see alsa Chart No. 29) In'

Blunt.

Poplar.

1 See separate publications for boundaries of natural bars in adjacent counties. 
BOUNDARIES OF OYSTER BARS-Continued.

Boundaries of natural oyster bars in county-Continued.

Chart No. 30 (Middle Chester River)-Continued.

Carpenter Island.

Page.

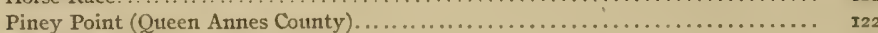

Hells Delight. . . . . . . . . . . . . . . . . . . . . $\ldots \ldots \ldots \ldots \ldots \ldots$

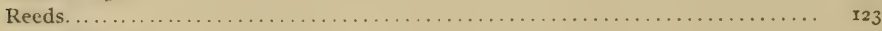

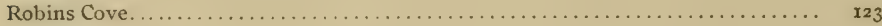

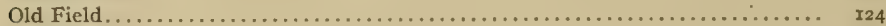

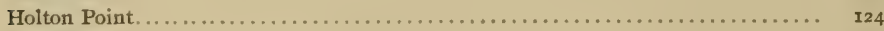

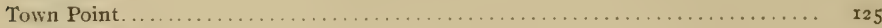

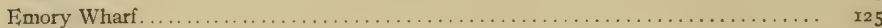

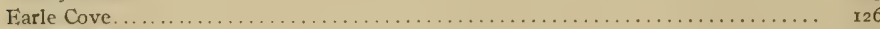

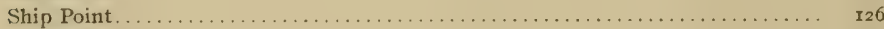

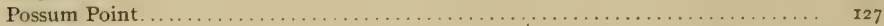

Spaniard Point . . . . . . . . . . . . . . . . . . . . . . . . . . . .

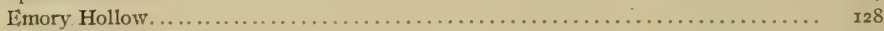

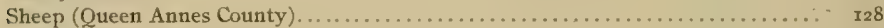

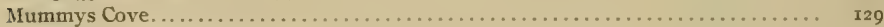

Hollyday (Queen Annes County) . . . . . . . . . . . . . . . . . . . . I 29

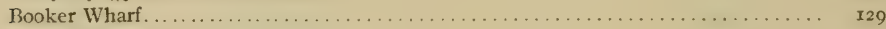

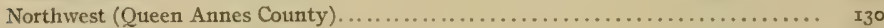

Chart No. $3 I$ (Eastern Bay and tributaries)

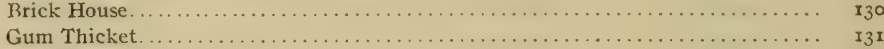

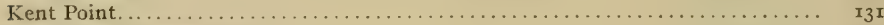

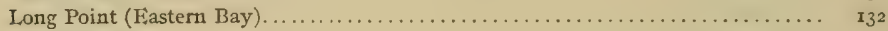

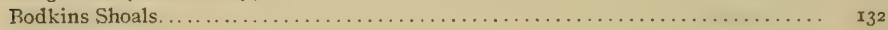

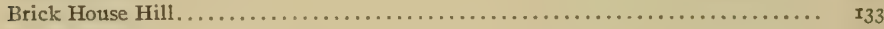

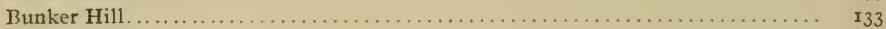

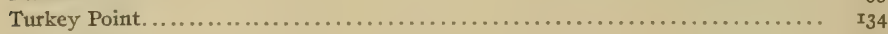

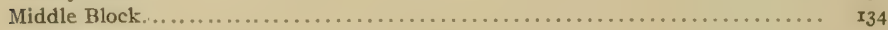

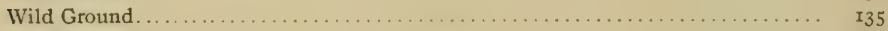

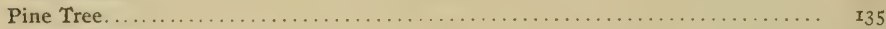

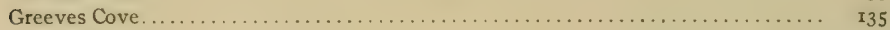

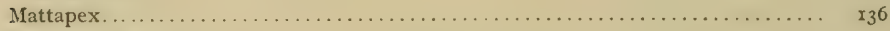

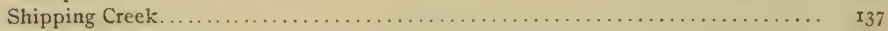

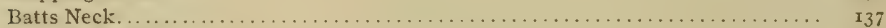

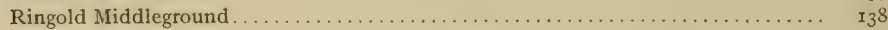

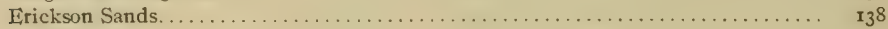

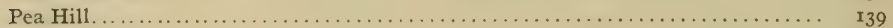

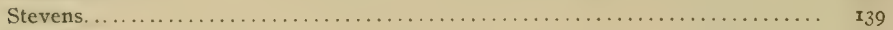

Jones Hole . . . . . . . . . . . . . .

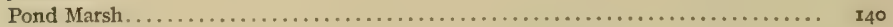

Island Cove . . . . . . . . . . .

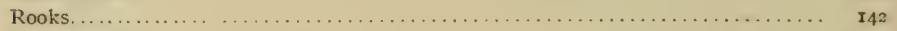

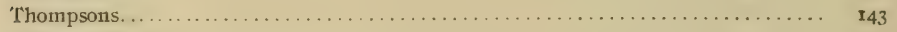

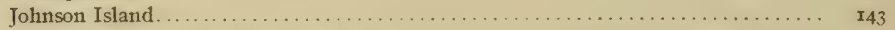

Crab Alley Lumps (see also Chart No. 32$) \ldots \ldots \ldots \ldots \ldots \ldots \ldots \ldots \ldots \ldots \ldots \ldots \ldots \ldots \ldots \ldots$

Cedar Island . . . . . . . . . . . .

Normans Fine Elyes (see also Chart No. 32) ....................... I45

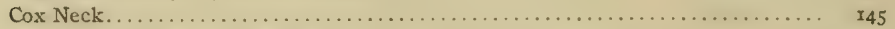

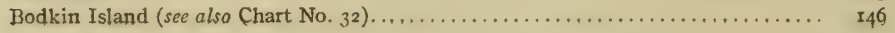


BOUNDARIES OF OYSTER BARS-Continued.

Boundaries of natural oyster bars in county-Continued.

Chart No. 32 (Eastern Bay and tributaries)- $\quad$ Page.

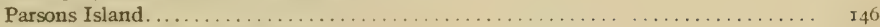

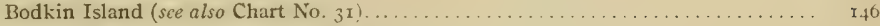

Normans Fine Eyes (sce also Chart No. 31 ) .................... I45

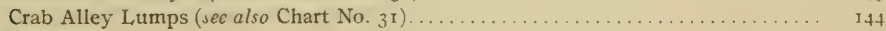

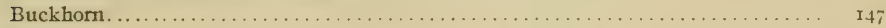

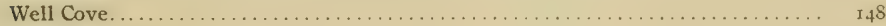

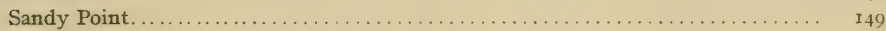

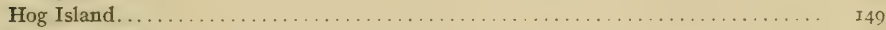

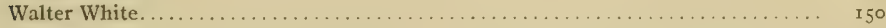

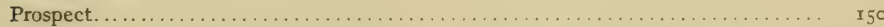

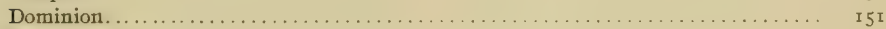

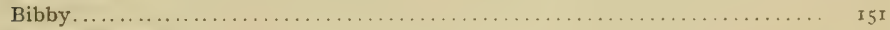

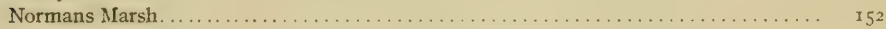

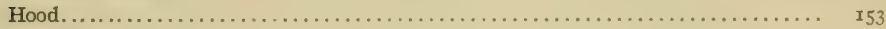

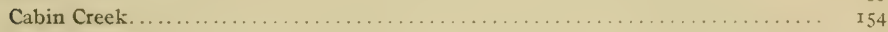

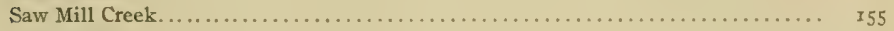

Parsons Island Narrows. ...................................... ${ }_{55}$

Bald Eagle. . . . . . . . . . . . . .

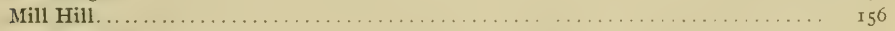

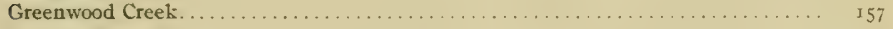

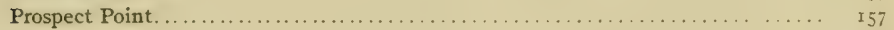

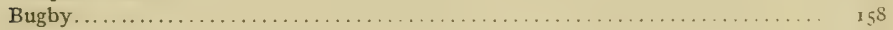

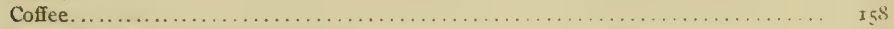

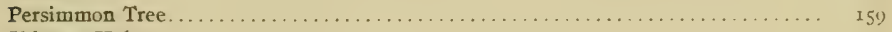

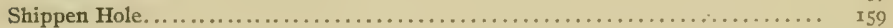

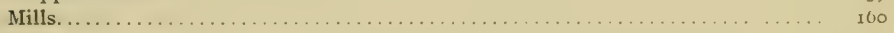

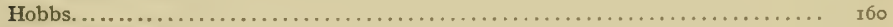

Baxters Hollow. . . . . . . . . . . . . . . . . . . . . . . . . . .

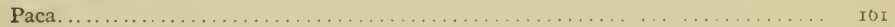

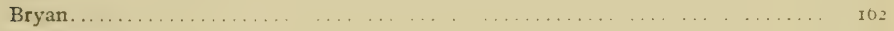

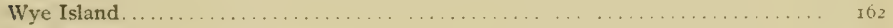

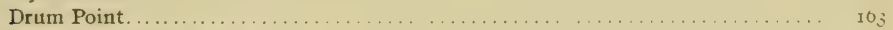

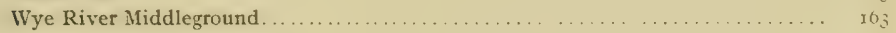

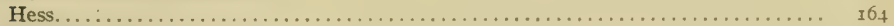

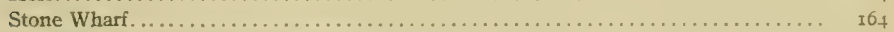

Race Horse (Queen Annes County) . . . . . . . . . . . . . . . . . . . $10_{5}$

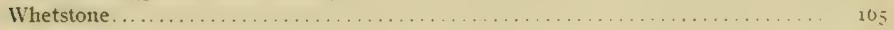

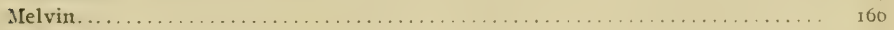

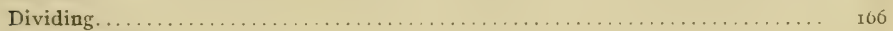

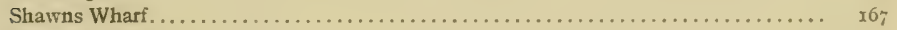

Granary Point.....................................

APPENDIXES:

Appendix A.-Laws relating to the cooperation of the Coast and Geodetic Survey and

Bureau of Fisheries with the Maryland Shell Fish Commission $\ldots \ldots \ldots \ldots \ldots \ldots \ldots \ldots$

Appendix B.-- "The Haman Oyster Culture Law" (extract from Second Report of Shell

Fish Commission).

Appendix C.-Summary of the particular surveying operations which constitute an "oyster survey" as now being carried on in Maryland

Appendix D.-Statistics of results of the combined operations of the Government and State. 



\title{
SURVEY OF OYSTER BARS, QUEEN ANNES COUNTY, MD.
}

\section{INTRODUCTION.}

\author{
PUBLICATIONS.
}

The preparation of publications relating to the survey of the oyster bars of Maryland has been divided between the Government and the State in accordance with the laws ${ }^{1}$ authorizing the work and the natural division of the surveying operations ${ }^{2}$ of the cooperating forces.

The publications prepared and issued by the Government under the direction of the Superintendent of the Coast and Geodetic Survey consist of a series of charts and a technical report for each county surveyed. ${ }^{3}$ The charts show all legal boundaries of oyster bars within the adopted boundaries of the waters opened up for leasing with each county, and the location of all landmarks (Coast and Geodetic Survey triangulation stations) used as a foundation for the delineation of these various boundaries. The technical report gives technical and legal descriptions of all oyster bar and other boundaries, and descriptions of all landmarks shown on the charts, and includes the report of the representative of the Coast and Geodetic Survey in charge of the work of that service in cooperation with the Bureau of Fisheries and the Maryland Shell Fish Commission. These charts and technical reports are prepared and certified for file with the courts and the Commission, as required by the laws of the State, and contain all information necessary to make a permanent record of the work of the Commission and the Government for all future requirements of the courts, or for any resurveys that may become necessary. ${ }^{4}$

The publications prepared and issued by the State under the direction of the Shell Fish Commission consist of annual reports ${ }^{j}$ of all the operations of the Commission performed under the provisions of the laws of Maryland, ${ }^{6}$ including results of biological and economic oyster investigations, methods and restults of the hydrographic survey of

\footnotetext{
ISee Appendix A for laws relating to the cooperation of the Const and Ceodetic Survey and Buteau of Fisheries with the Ifaryland Shell Fish Commission.

"See Appendix C for a summary of the particular surveying uperations which constitnte an "oyster survey" as now being carried on in Maryland.

3 These charts and technical reports can be obtained by application to the Superintendent of the Coast and Ceodetic Survey at Washington, D, C. The publications now ready for issue are those for Anne Arundel, Somerset, Wicomico, Worcester, Calvert, Charles, St. Marys, Baltimore, Kent, and Queen Annes Counties.

1 The technical records and charts for each county are published separately on account of the requirements of the oysterculture laws of the State and the practical considerations which make it desirable to have each county "opened up" for oyster culture as soon as practicable after the completion of its survey. For these reasons and the fact that these reports are each arranged for distribution and use in one county only without reference to other published records, much of the text of this publication is of necessity identical with similar previous publications for other counties.

5 These reports can be obtained by application to the Shell Fish Commission, Marine Bank Building, Baltimore, Md. They. are issued annually in October, and the first, second, and third reports are now available for distribution.

"See Appendix B for an extract from the "Second Report of the Maryland Shell Fish Commission," giving a concise summary of the "Haman cyster culture law:"
} 
the boundaries of oyster bars and crab bottoms, the administrative report and financial statement of the Commission, information relating to oyster culture, methods of surveying and leasing of oyster lots, and much other important matter of legal and scientific value.

These two sets of publications are planned and arranged to supplement each other without unnecessary duplication, and when combined they form a complete report of operations, methods, and results of the work of both the Government and State. ${ }^{1}$

\section{COOPERATION OF THE COAST AND GEODETIC SURVEY.}

The work of the Coast and Geodetic Survey, as the name of the service indicates, includes a survey of the coasts of the United States made on a geodetic basis. This has involved the gradual construction of a great framework of interstate triangulation for use as a foundation for detail hydrographic and topographic surveys, from which there has been compiled and published a complete set of charts of the coasts of the United States, including all waters of Maryland where oysters grow. This existing triangulation, hydrography, and topography is essential as a foundation for a correct and practical survey of natural oyster bars; and it being one of the fundamental functions of the Coast and Geodetic Survey to furnish such data, the cooperation of the Coast and Geodetic Survey with the Bureau of Fisheries and the Maryland Shell Fish Commission is a practical and natural development of Government work leading to the conservation and increase of the supply of food.

\section{COOPERATION OF THE BUREAU OF FISHERIIS.}

The Bureau of Fisheries has cooperated with the Coast and Geodetic Survey and the Maryland Shell Fish Commission principally as an adviser in matters relating to the biological and economic survey of oyster bars and the methods to be employed for that purpose." A steam launch, rowing boat, and certain apparatus have also been furnished.

The primary function of the Bureau of Fisheries is to increase the productiveness of marine and fresh waters by such measures as may be best suited to the purpose, and the services rendered in connection with the survey of the oyster bars of Maryland are strictly in line with the fundamental law under which it acts. In certain States other than Maryland similar work has been conducted by the bureau acting independently, the same ends being attained at greater expense to the Government.

GENERAL, STATEMENT OF WORK OF COAST AND GEODETIC SURVEY: ${ }^{3}$

The results obtained from the work of the Coast and Geodetic Survey in cooperation with the Burcall of Fisheries and the Maryland Shell Fish Commission need very little other summary than is indicated by the published "Charts of Natural Oyster Bars" and the index of hydrographic projections and triangulation stations shown on the county progress maps attached to each report.

\footnotetext{
'See Appendix D of this publication for "Statistics of results of combined operations of the Government and State."

${ }^{2}$ Hon. George M. Bowers, Commissioner of Fisheries, has detailed for this service Dr. H. F. Moore, Assistant, Bureau of Fisheries.

${ }^{3}$ For a detail statement of the very large amount of excellent oyster survey work of the Marylaud Shell Fish Commission see the "Annual Reports of the Maryland Shell Fish Commission."
} 
The triangulation has been carried on in accordance with the standard methods of the Coast and Geodetic Survey, making this work and that of the "Descriptions of Triangulation Stations" of permanent value, not only to the State of Maryland in the survey of her oyster bars, but also to the Government for any future work it may do in the regions covered by the oyster-survey operations.

The hydrographic projections and published charts are prepared with all the accuracy permitted by their large scale, especially as to the boundaries of the various shell-fish bottoms in relation to landmarks, but this accuracy of location on the charts is further added to and permanently fixed by published technical descriptions, which should minimize the probability of any future dispute as to either landmarks or boundaries.

Stated another way, and quoting from the report of the "Survey of Oyster Bars of Anne Arundel County"':

The geographic positions of the permanent landmarks and signals have been determined with the usual precision of a trigonometric survey, and their locations at all points necessary to provide ample foundation for the surveying and charting operations permitted great accuracy of definition and location for the natural oyster bar and other boundaries established. At the same time, the very important element of permanency of the positions of boundaries has been secured, as the relocation of geodetic positions can always be accomplished by a competent surveyor, even though the original landmarks and monuments have been washed away, as has been the fate of hundteds of such points established by the Coast and Geodetic Survey on the shores of the Chesapeake Bay during the last 65 years.

$203 I_{3}-\mathrm{I} 2-2$ 


\section{REPORT OF THE WORK OF THE COAST AND GEODETIC SURVEY IN QUEEN ANNES COUNTY.}

\section{INSTRUCTIONS.}

The following letters, together with the laws ${ }^{1}$ of the United States relating to the subjec , constitute the "instructions" received by the chief of the Coast and Geodetic Survey party ngaged on work in connection with the Maryland Shell Fish Commission. They are short and definite, but furnish ample authority and leeway for all legitimate development of the cooperation of the Government and the State in the survey of oyster bars. The "free hand" permitted by these orders, together with the aid and many valuable suggestions received from the officers of the survey at Washington, have proved very beneficial to the work and are greatly appreciated.

\section{DEPARTMENT OF COMMERCE AND LABOR, OFFICE OF THE SECRETARY, Washington, June 2, I906.}

SIR: In reply to your letter of May 28, requesting me to designate officers of the Coast and Geodetic Survey and of the Bureau of Fisheries to cooperate with the State of Maryland in making survey of and locating the natural oyster beds, I have the honor to inform you that Mr. C. C. Yates will be designated to cooperate on the part of the Coast and Geodetic Survey as soon as Congress makes the provisions of the act effective by providing an appropriation for the purpose.

Respectfully,

His Fixcellency Hon. EDWIN WARFIELD,

\section{LAWRENCE, O. Murray, Assistant Secretary.}

Governor of Maryland, Annapolis, Md.

\section{DEPARTMENT OF COMMERCE AND LABOR, \\ COAST AND GeOdetic SURvey, Washingion, July 3, 1906 .}

SIR: Upon the receipt of these instructions you will surrender the command, accounts, etc., of the steamer Endeavor to the Hydrographic Inspector. * * *

As soon as this transfer is completed you will enter upon the duties of Coast Survey representative on the Shell Fish Commission of Maryland.

You will consult the commissioners, prepare a program of work, and submit estimates in the usual form.

You are authorized to come to Washington for consultation from time to time as may be necessary.

Very respectfully,

O. H. Trtmann, Superintendent.

Capt. C. C. YATES,

U. S. C. and G. S. Steamer Endeavor, Baltimore, Md.

\section{ORGANIZATION AND EQUIPMENT}

The personnel and occupation of the party of the Coast and Geodetic Survey have remained practically unchanged since the beginning of the "oyster survey." Besides 
the chief of party, it consists of the necessary triangulators, computers, draftsmen, and temporary employees required to carry on both the surveying operations in the field and the preparation for publication of oyster charts ancl technical records in the office at Washington.

The equipment for the work of the party has been ample and satisfactory. The large living and oflice quarters furnished the Government on the Maryland Shell Fish Commission house boat $O_{3}$ 'ster have heen very convenient for the work, besides facilitating efficient cooperation with the surveying and oyster investigation parties of the State. In addition to the accommodations on the Oyster, the Coast and Geodetic Survey party has had the constant use of the large steam launch Inspector and several other boats furnished by its own service, and the occasional use of the Bureat of Fisheries launch Canvasback ${ }^{1}$ and the steamer Governor McLanc ${ }^{2}$ of the State fishery force.

The greater part of the equipment of instruments for the operations of both the Government and State has been furnished by the Coast and Geodetic Survey and consists of all necessary theodolites, levels, sextants, drafting instruments, hydrometers, etc., required for all field and office work.

\section{CHRONOLOGICAL STATEMENT OF WORK.}

The field work of the Coast and Geodetic Survey in Queen Annes County ${ }^{3}$ dates from April 14, 1909, when the Maryland Shell Fish Commission house boat Oyster was moved from her winter quarters at Baltimore to an anchorage off Rockhall Landing in Kent County. The surveying operations carried on from this harbor covered a period of about six weeks, in which practically all triangulation was completed on the Chesapeake Bay shores of both Kent and Baltimore counties as well as a considerable part of the same class of work in the mouth of Chester River in both Queen Annes and Kent counties.

On May 26, 1909, the Oyster was moved from Rockhall Landing to an anchorage in the upper part of Chester River near Cliffs Landing, where she was used as the headquarters for all the oyster-surveying operations in that region for a little over a month.

On June 30, 1909, the house boat was moved to a temporary anchorage off Queenstown. This date marked the practical completion of the work in Chester River, the triangulation of which was especially notable for the month of June on account of there having been 92 triangulation stations established, these stations all being marked by monuments and signals and their locations described, besides being oceupied for theodolite observations.

On July I, I909, the house boat Oyster was towed by the State steamer Governor McLanc to Ballimore Harbor, where the following four days, which included a Sunday and a holiday, were spent in taking on coal, water, and other supplies.

On July 6, 1909, the Governor McLane again moved the Oyster, this time from Baltimore to an anchorage in Queen Annes County in the northern part of Prospect Bay and near the southern entrance to Kent Narrows. From this harbor as headquarters a few additional triangulation observations were made in Kent County, although the greater part of the work was confined to Queen Annes and Talbot counties.

1 By courtesy of Dr. H. F. Moore, United States Bureau of Fisheries.

2 By courtesy of Capt. James A. Turner, commanding.

${ }^{3}$ The field work of Queen Annes County was so intermixed with that of Kent and Talbot Counties that the chronological statement of the work in one of these counties necessarily includes a considerable part of the work of the other two counties. 
On July 22, 1909, the house boat was again moved to the vicinity of Rockhall Landing to complete certain oyster-survey operations not finished when the Oyster was there in the spring. And it was not until August I3, 1909, when the house boat was shifted back to Eastern Bay, near the southern entrance to Kent Narrows, that the work in Queen Annes County was resumed. The $O_{y}$ ster remained at this latter anchorage as headquarters for the field work for only two weeks, during which period Governor Crothers, of Maryland, and party visited the house boat and thoroughly examined into the manner and methods by which the work was being conducted.

On August 28, 1909, the Oyster was towed to Haddaway Cove, in Talbot County, and work was not resumed in Queen Annes County until October 16, 1909, when the house boat was towed back to Eastern Bay and tied up at the railway wharf at Claiborne. From this latter point as headquarters the triangulation of Eastern Bay and its northern tributaries to the west of Kent Narrows was practically completed.

On October 29, 1909, the Oyster moved to an anchorage in a branch of lower Miles River called Tilghmans Creek and the next clay completed a month's field work, which was notable as far as triangulation was concerned on account of there having been established, marked, described, and located by theodolite observations over roo tertiary triangulation stations. Two small parties were engaged on this work during this month, one living on the house boat at Claiborne and the other on shore at Cambridge.

On December 1, 1909, the house boat Oyster was moved from Tilghmans Creek to an anchorage off the town of St. Michaels, and from this harbor the remaining triangulation of Wye and Miles rivers was practically completed.

On December 2I, 1909, active field work of the Maryland Shell Fish Commission was closed at St. Michaels, but a triangulation signal building party continued work from quarters on shore at Oxford for two days longer.

On December 24, 1909, the field season for the Coast and Geodetic Survey parties was officially closed, the monthly employees renlaining on the house boat Oyster at Baltimore preparing to lay up the launches and small boats for the winter, and all the officers being on leave from the $25^{\text {th }}$ to 3 ist.

No further field work was done in Queen Annes County until March 14, 1910, when a small party was put in the field to complete certain necessary details of triangulation in Queen Annes and Talbot counties. This party first went to St. Michaels and then to Oxford, where it joined the main party on the house boat about the end of April.

The next and last field work in Queen Annes County covered only a few days' period, commencing November 7 , I9I I, when an officer was detailed to check up and obtain certain details relating to the description of triangulation stations required for the technical publication covering the survey of oyster bars of Queen Annes and Talbot counties.

The office work connected with the oyster survey of Queen Annes County, including compilations of geographic information and drafting necessary for the preparation for publication of the oyster charts and the technical records of that county; was continued intermittingly with the office work of other counties from the beginning of the field work in Queen Annes County to the time of filing of the certified oyster charts and technical publications in the archives of the IIaryland Shell Fish Commission and with the clerk of the circuit court of Queen Annes County on November 28, I9I I. 
Landmarks and triangulation signals erected $\ldots \ldots \ldots \ldots \ldots \ldots \ldots \ldots \ldots \ldots \ldots \ldots \ldots \ldots \ldots \ldots \ldots \ldots \ldots \ldots$

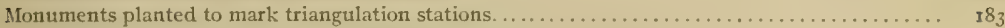

Triangulation stations occupied for observations of horizontal angles. . . . . . . . . . . .

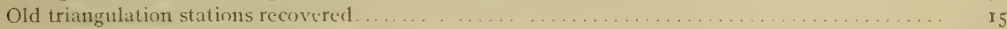

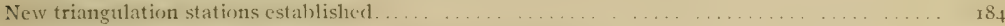

Total old and new triangulation stations marked and described $\ldots \ldots \ldots \ldots \ldots \ldots \ldots \ldots \ldots \ldots \ldots$

Linear miles of shore line covered by triangulation (approximate) $\ldots \ldots \ldots \ldots \ldots \ldots \ldots \ldots \ldots \ldots \ldots$

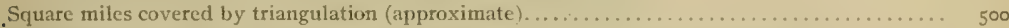

Hydrographic projections prepared and completed as records of oyster boundaries............ 12

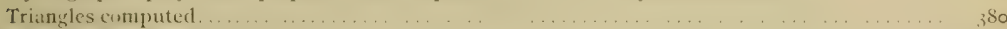

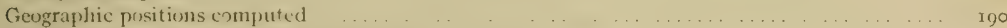

Corners of oyster boundaries established by computation......................... 540

Back azimuths and distances computed from comers of boundaries to triangulation stations..... I, 620

Descriptions of triangulation stations prepared for publication . . . . . . . . . . . . . . 399

Descriptions of oyster boundaries prepared for publication. . . . . . . . . . . . . . . . 98

"Charts of Natural Oyster Bars" prepared for publication. ..................... 4

Progress map prepared for publication. . . . . . . . . . . . . .

GENERAL, REMARKS.

Before ending this report the representative of the Coast and Geodetic Survey wishes to renew his statement of appreciation of the courteous assistance received from various Crovernment and State officials and others interested in the oyster industry of Maryland, especially to the following:

To his colleague from the Department of Commerce and Labor, Dr. H. F. Moore, of the Bureau of Fisheries, whose well-known scientific knowledge of all matters relating to oysters has been of great value to the work.

To Mr. Walter J. Mitchell, chairman of the Maryland Shell Fish Commission, who, by lis administrative ability in carrying out the complicated requirements of the oyster laws and by his unfailing tact, has made the cooperation of the various services engaged on the work both agreeable and effective.

To Dr. Caswell Grave, secretary of the Commission, who, as editor of the Commission's annual report and commissioner in charge of the biological and economic oyster investigations, has been brought into constant contact with the Government work and aided its operations in every way.

To Mr. Benjamin K. Green, treasurer of the Commission, who has looked after the equipment and commissary of, the house boat in such a way as to add greatly to the comfort and convenience of the party of the Coast and Geodetic Survey.

'lo Mr. Swepson Earle, hydrographic engineer to the Commission, whose knowledge of the work from former service in the Coast and Geodetic Survey has greatly facilitated his practical use of the technical data furnished by the Government.

And to the many others connected with the Commission or who as residents in the locality where the work was being carried on have greatly assisted by furnishing important information or willing services.

\footnotetext{
I These statistics only include field and office work directly performed by the party of the Coast and Geodetic Survey in connection with the oyster survey of this county, and do not include the many thousands of soundings and examinations of the character of the bottom made by the engineers of the commission; which are of considerable value to the Coast and Geodetic Survey as hydrographic records for future use in connection with the preparation of new editions of charts of the waters of Maryland. See Appendix D of this publication for "Statistics of results of combined operations of the Government and the State."
} 


\section{CHARTS AND MAPS. ${ }^{1}$}

\section{CHARTS OF-NATURAL OYSTER BARS.}

The charts of the natural oyster bars of Queen Annes County published by the Coast and Geodetic Survey from results of the surveys of the Government in cooperation with the Maryland Shell Fish Commission consist of four sheets covering all the oyster-producing waters of that county. They are published on the large scale of I part in 20,000 (approximately $3 \frac{1}{16}$ inches to a statute mile) and are constructed on polyconic projections; and all information shown on them is based on the United States standard datum of the Coast and Geodetic Survey.

These charts show all oyster bars and other boundaries established by the Commission, and are certified for the purpose of filing in the office of the clerk of the circuit court of Queen Annes County and in the office of the Maryland Shell Fish Commission, as required by the oyster laws of Maryland.

In addition to the oyster bar and other boundaries, the charts show the location and name of all landmarks (United States Coast and Geodetic Survey triangulation stations) used in making the survey, together with the hydrography and topography ? necessary to make the technical definitions and delineations of boundaries readily understandable both by the people engaged in the oyster industry and the general public who may become interested through leasing of barren bottoms for oyster culture.

The names of the oyster bars are those used locally, as nearly as could be ascertained by the hydrographic engineer of the Commission. IIhen there was no local name in common use, a name was selected from one of the prominent features of the vicinity. By the use of recognized names or those that would naturally suggest certain sections of water, it is believed that much confusion will be avoided in the location on the charts of the oyster bars, especially by those not familiar with the use of maps.

The corners of the oyster bars are numbered from I to the total number of conners in each area under consideration. Where boundaries adjoin, making one point a corner of two or more oyster bars, these points have two or more numbers, each number corresponding to the bar in which the figure is located. The numbers of the corners correspond with the technical and legal descriptions of this publication under the heading "Boundaries of natural oyster bars."

The landmarks and oyster bars have been grouped in the "Contents" of this publication in accordance with the charts upon which they are shown. To find a particular oyster bar or landmark which is only known by name, consult the "Contents" and the desired chart and general location will be indicated. To find the name of a bar or

1 These charts can be obtained by application to the Superintendent of the Coast and Geodetic Survey, at Washington, D, C.

2 Much of the detail of the inshore topography was obtained from the excellent map of Queen Annes County, prepared and published by the Maryland Geological Survey under the direction of Dr. William Bullock Clark from surveys of the Mraryland Geological Survey in cooperation with the United States Geological Survey. 
landmark which is only known by location, consult the progress map at the end of this publication for the number of the chart on which it is to be found, and then examine the known locality on the chart for the name of the bar or landmark in question.

The contours on the charts showing the depth of water at mean low tide have been taken from the hydrographic sheets of former work of the Coast and Geodetic Survey. Four curves were selected as being the most convenient for taking off from the original hydrographic sheets and the ones of greatest value to those interested in shell fish industries. The $\mathrm{I}$-fathom contour ( 6 feet) and the 5 -fathom curve (30 feet) correspond in a general way to the inner and outer limits of all the oyster bars surveyed. The 3 -fathom contour ( 8 feet) furnishes the curve of about the average depth of water on the oyster bars, and the ro-fathom contour ( $60 \mathrm{feet})$ serves in a general way to indicate the outer limits of probable oyster culture.

The boundaries of the waters within the "territorial limits of the county" and the boundaries of the "waters contiguous to the county" opened up for the leasing with Queen Annes County are plainly indicated on the charts. A full technical description of these boundaries is given in this publication under the heading "Boundaries of county waters."

The areas in acres of the oyster bars were determined under the direction of the hydrographic engineer of the Commission by two independent planimeter measurements of the areas as delineated on the smooth projections of th Coast and Geodetic Survey. These areas are given in small figures in parentheses on the face of the chart within the boundaries of the different shell fish bottoms.

The symbols used on the charts for the different kinds of boundaries, triangulation stations, contours of depth of water, etc., require no other explanation than that given in the legend and other notes on the face of the charts.

\section{LEASING CHARTS.}

The leasing charts of Queen Annes County, like those for Anne Arundel, Somerset, Wicomico, Worcester, Calvert, Charles, St. Marys, Baltimore, and Kent counties, have been prepared under the direction of the hydrographic engineer of the Commission. They are constructed on polyconic projections on the scales of I part in 5,000 or I part in 10,000 as the needs of oyster culture may require, and the information shown on them is based on the United States standard datum of the Coast and Geodetic Survey.

These charts show all the oyster bars, crab bottoms, and clam beds and other boundaries established by the Commission, and also all boundaries of oyster lots leased for the purpose of oyster culture, thus making them comprehensive and valuable records of the results of the operations of the oyster-culture laws.

The lots leased under the provision of the "old 5-acre law" are frequently of irregular shape, but the lots leased under the provision of the new oyster law s must be of rectangular shape by the terms of that act. For this latter purpose the leasing charts have been divided by parallels of latitude and meridians of longitude into small rectangles of $\mathrm{I}$ acre or 5 acres, as may be best suited to the area under consideration, and prospective leaseholders by the rules of the Commission are compelled to select whole rectangles as far as possible. 
For reasons of the present changeable nature of the number of lots leased and the large number of charts required, the leasing charts are not likely to be published for some years, but they can be seen at any time on file at the offices of the Commission, in the Marine Bank Building at Baltimore.

\section{PROJECTIONS.}

The polyconic projections ${ }^{1}$ covering Queen Annes County waters are 12 in number and on the scale of $x$ part in Io,ooo. They were constructed by draftsmen of the Coast and Geodetic Survey, but the sextant positions which determine the location of the legal boundaries of the oyster bars as delineated by the Shell Fish Commission were plotted by the draftsman of the Commission.

A copy of each of these projections, with all the plotted positions of triangulation stations, shore line, sextant positions, and boundaries of oyster bars, was made under the direction of the hydrographic engineer of the Commission by pricking through with a sharp needle the intersections of the projection lines and all other points as plotted on the original sheets.

These projections (in duplicate) are the original records of all oyster bar and other boundaries established by the Commission, one set being filed in the archives of the Coast and Geodetic Survey, at Washington, and the other set in the archives of the Shell Fish Commission.

\section{PROGRESS MAPS.}

The progress map to be found at the end of this publication is on a scale of I part in 100,000 , and shows in outline the work accomplished by the United States Coast and Geodetic Survey in Queen Annes County and contiguous waters. It gives the scheme of all the charts and smooth projections constructed in connection with the survey, the location and names of all triangulation stations used as a basis for the survering work, and the "boundaries of county waters" established by the Commission for the purpose of carrying out the laws of Maryland relating to oyster culture.

Besides indicating the amount of work done by the Coast and Geodetic Survey in connection with the work of the Shell Fish Commission, this progress map will be of special value for index purposes to engineers and others searching for the particular chart or projection covering the locality of the oyster bars or landmarks that may be under consideration.

The progress maps ${ }^{2}$ accompanying the first and second annual reports of the Maryland Shell Fish Commission were prepared under the direction of the liydrographic engineer of the Commission. They are on the scale of I part in 400,000 , and show the outline of the tide-water comties of Maryland, with shaded areas to indieate the waters alreadly covered by the operations of the oyster survey.

\footnotetext{
t lior the scheme of these projections see the progress map at the end of this publication.

?hese mans and reports can be obtained by application to Maryland Shell Fish Comuission, Mariue 13ank 13uilding, Baltimore, Md.
} 


\title{
BOUNDARIES OF' 'THE COUN'TY WA'TERS.'
}

\author{
WATERS WITHIN TERRITORIAL LIMITS OF COUN'YY.
}

The laws of Maryland relating to oyster culture provide that "no person shall be permitted, by lease, assignment, or in any other manner, to acquire a greater amount of land than to acres situated within the territorial limits of any of the counties, or Ioo acres in any other place."

The boundary line ${ }^{2}$ between the waters "within the territorial limits" of Queen Annes County and the waters in "any. other place," as established by the Shell Fish Commission for the purpose of carrying out the oyster laws, and delineated on the "oyster" charts and the smooth projections of the Coast and Geodetic Survey, is technically described and defined as follows:

Commencing at the intersection of the State houndary line between Maryland and Delaware tvith the boundary line between Queen Annes County and Kent County; thence following tine boundary between Queen Annes and Kent counties and down the channel boundary of the upper part of Chester River; thence continuing down the channel of Chester River following the boundary line between Kent County and Queen Annes County as laid down on "Charts Nos. 29 and 30, Natural Oyster Bars, Maryland, " to a point in the mouth of Clester River defined by the intersection of this channel boundary line with a straight line across the mouth of chester River delined at its western end by a point on I.ove Point on the western side of Chester River in latitude $39^{\circ} \mathrm{o} 2^{\prime} 25 \cdot 5^{\prime \prime}$ and longitude $76^{\circ} 18^{\prime}$ I0.0 $0^{\prime \prime}$, and defined at it $\varsigma^{\circ}$ eastern end by a point on the eastem sirle of Chester River in latitude $34^{\prime \prime} 02^{\prime}+5 \cdot 3^{\prime \prime}$ and longitude $76^{\circ} 14^{\prime} 05.3^{\prime \prime}$; thence in a straight line ending at a point situated on Love Point on the western side of Clrester River defined by latitude $39^{\circ} 02^{\prime} 25.5^{\prime \prime}$ and longitude $76^{\circ} 18^{\prime} 10.0^{\prime \prime}$; thence along the mean low water line or across the mouth of all inlets less than 100 yards in width, as the case may be, of the eastern shore of Chesapeake Bay, around Bloody Point to a point situated on Kent Point on the southern extremity of Kent Island defined by latitude $38^{\circ} 50^{\prime}$ o5. I' and longitude $76^{\circ} 22^{\prime}$ o6. $2^{\prime \prime}$; thence in a straight line ending at a point situated on Wades Point on the eastern side of the entrance of Eastern Bay, defined by latitude $38^{\circ} 49^{\prime} 34 \cdot 2^{\prime \prime}$ and longitude $76^{\circ} 18^{\prime} 04 \cdot 5^{\prime \prime}$ to a point on this straight line defined by its intersection with the boundary line in Eastern Bay between Queen Annes County and Talbot County as laid down on "Chart No. 3I, Natural Oyster Bars, Maryland;" thence along the boundary line between Oueen Annes County and Talbot County in Fastern Bay, around Tilghmans Point, up Miles River, turning between Bennett Point and Herring Island into the mouth of Wye River, and up the clanuel boundary line of that branch of Wye River to the south of Wye Island to tlie point off the castern cod of Wye Island, all as laidl down on "Clarts Nos. 3 and 32 , Natural Oyster Bars, Maryland;" thence continting up the chanuel houndary line of Wye River between Queen Annes County and Talbot County to the head of the oyster-producing watcrs."

1 For a complete historical and legal descrintion of the houndaries of the countics of Maryland, the valuable publicatiun entitles " The Counties of Maryland-Their Origin, 13oundaries, and Eilection Districts," prepared by Dr. Edward ks. Mathews and mublished by the Maryland Geological Survey under the direction of Dr. William Bulkek Clark, Superintendent, shoult! be consulted, as the boundaries described in this mblication have been establisherl and technically delined for the purpose of carrying out the oyster laws of the State, and may or may not be correct for other purpuses.

"See "Charts of Natural Oyster Bars," published by the Coast and Gcodetic Survey, and the progress map at tlie cud of this publication.

Latitudes and longitudes based on the United States standard datum of the United States Coast and Gecdetic Survey. 


\section{WATERS CONTIGUOUS TO COUNTY.}

The oyster laws of Maryland provide that a true and accurate delineation of all natural oyster bars shall be made on copies of charts of the United States Coast and Geodetic Survey, "which said copies shall be filed in the office of the said Commissioners in the city of Baltimore," and "in the office of the clerks of the circuit courts for the respective counties wherein the grounds so designated may lie."

For the purpose of carrying out the latter part of this section of the law and for the purpose of establishing the limits of the oyster-culture area to be opened up for leasing with each county surveyed, it is necessary for the Shell Fish Commission to establish a boundary line between the waters contiguous to but not within the territorial limits of each county and the waters contiguous to but not within the territorial limits of adjacent counties.

This boundary line has been delineated on the "Charts of Natural Oyster Bars," published by the Coast and Geodetic Survey, and is technically described and defined as follows:

Commencing at a point defined by the intersection of the boundary line between Queen Annes County and Kent County as laid down on "Chart No. 29, Natural Oyster Bars, Maryland," with a straight line across the mouth of Chester River, defined at its eastern end by a point on the eastem side of Chester River in latitude $39^{\circ} \mathrm{O}^{\prime}{ }^{\prime} 45 \cdot 3^{\prime \prime}$ and longitude $76^{\circ} 14^{\prime} 05 \cdot 3^{\prime \prime}$, and defined at its western end by a point on Iove Point on the western side of Chester River in latitude $39^{\circ} \mathrm{O}^{\prime} 25 \cdot 5^{\prime \prime}$ and longitude $76^{\circ}$ I $8^{\prime}$ I0.0"; thence following the boundary line between Queen Annes County and Kent County, passing around and about I mile to the northeast of Love Point Light, as laid down on "Chart No. 29, Natural Oyster Bars, Maryland, " to a point in Chesapeake l3ay about $25 / 8$ miles east of Baltimore I,ight and $35 / 3$ miles west of Love Point Light, defined by latitude $39^{\circ} 03^{\prime} 30.0^{\prime \prime}$ and longitude $76^{\circ} 21^{\prime} 00.0^{\prime \prime}$; thence in a straight line with Chesapeake Bay to a point in Chesapeake Bay about $13 / 3$ mileseast of Sandy Point Light and defmed by latitude $39^{\circ} \mathrm{o0^{ \prime }} 57.2^{\prime \prime}$ and longitude $76^{\circ} 21^{\prime} 34.00^{\prime \prime}$; thence in a straight line with Chesapeake Bay to a point in Clesapeake Bay about $I_{16}^{3}$ miles east of Thomas Point Light, defined by latitude $38^{\circ} 53^{\prime} 56.2^{\prime \prime}$ and longitude $76^{\circ} 24^{\prime} 50.2^{\prime \prime}$; thence in a straight line with Chesapeake Bay to a point in Chesapeake Bay about $2 \frac{1}{2}$ miles west of Bloody Point Bar Light defined by latitude $38^{\circ} 50^{\prime}$ or. $I^{\prime \prime}$ and longitude $76^{\circ} 26^{\prime}$ I5. $0^{\prime \prime}$; thence in a straight line with Chesapeake Bay to a point in Chesapeake Bay about $3^{1} / 2$ miles southwest of Bloody Point Bar Light defined by latitude $38^{\circ}$ $4^{\prime}$ 06. $6^{\prime \prime}$ and longitude $76^{\circ} 26^{\prime} 37 \cdot 1^{\prime \prime}$; thence following the boundary line between Queen Annes County and Talbot County passing between Bloody Point Bar L,ight and Poplar Island, as laid down on "Chart No. 3I, Natural Oyster Bars, Maryland, " to a point defined by the intersection of this boundary line with a straight line across the entrance of Fastern Bay defined at its western end by a point situated on Kent Point on the southern extremity of Kent Island in latitude $38^{\circ} 50^{\prime} 05 . \mathbf{I}^{\prime \prime}$ and longitude $76^{\circ}$ $22^{\prime} 06.2^{\prime \prime}$ and defined at its eastern end by a point situated on Wades Point on the eastern side of the entrance of Liastern Bay in latitude $38^{\circ} 49^{\prime} 34.2^{\prime \prime}$ and longitude $76^{\circ} \mathbf{1} 8^{\prime} 0.4 .5^{\prime \prime} .{ }^{\prime}$

\footnotetext{
1 Latitudes and longitudes based on the United States standard datum of the United States Coast and Geodetic Survey.
} 


\section{LANDMARKS (U. S. CUAST AND GEODETIC SURVIV TRIANGULATION STATIONS). \\ EXPLANATION,}

The oyster laws of Maryland authorizing the survey to be made by the Shell Fish Commission provide for "an accurate report of said survey, setting forth such a description of landmarks as may be necessary to enable the said board, or their successors, to find and ascertain the boundary lines of said natural oyster beds, bars, and rocks, as shown by delineation on the maps and charts." The law of the United States authorizing the cooperation of the Department of Commerce and Labor in the survey of natural oyster bars of Maryland provides for the erection of "such structures as may be necessary to mark the points of triangulation, so that the same may be used for such future work of the Coast and Geodetic Survey as the said bureau may be hereafter required to perform in prosecuting the Government coast survey of the navigable waters of the United States located within the State of Maryland."

Under the provisions of the sections of the laws stated above, the markings and descriptions of landmarks must be sufficient for the present and future needs of both the Government and the State. With this end in view, considerable work has been expended in erecting permanent monuments at the triangulation stations and in the proper description of their location.

An effort has been made to arrange the descriptions of location and character of landmarks in a uniform and logical manner. The descriptions start with the assumption that the individual seeking a landmark has only an indefinite idea of its location. They gradually proceed from description of the general locality of a landmark to the descriptions of its inmediate surroundings. This is followed by specific details of the character of the center and reference marks and a "round" of reference angles and distances which in themselves frequently contain enough information to furnish an independent and reliable location of the triangulation station.

\section{METHOD OF DESCRIBING TRIANGULATION STATIONS.}

The separate descriptions of triangulation stations should not be used without reading the following explanation of the method of describing the triangulation stations, as it contains certain details that are common to all the landmarks described in this publication and which are omitted in the separate descriptions as being needless repetitions:

Name.-The title at the top of each separate description is the name by which the landmark or triangulation station is known and designated in all work and published oyster records or oyster charts of both the Government and State. The selection of the name is usually left to the triangulator establishing the station, and it may or may not have geographic or other significance in reference to the locality.

General locality.-Under this heading is given the general locality of the landmark in reference to well-known and prominent natural or artificial features, such as the 
nearest body of water, town, river, steamer wharf, well-defined point of land, church, or any other feature that is likely to remain both permanent and prominent.

This heading also covers a reference to the published chart or map which shows the location of the station most elearly. Nearly all the triangulation stations described in this publication are plainly indicated by name and a triangulation symbol on the published charts of oyster bars of Maryland. In this case they are referred to by serial number only, the words "charts of oyster bars of Maryland" being omitted to avoid needless repetition. These published oyster charts are on the large scale of I part in 20,000 (approximately $3 \frac{1}{6}$ inches to a statute mile) and show the location of the triangulation stations so clearly that in many cases the written descriptions will not be required to find them.

Immetiate locality. - Under this heading is given the description of the "observed station" in reference to its immediate surroundings. This is supposed to include a statement of the station's estimated elevation above high water or some other welldefined level of the locality, such as a road or house; the character of the ground on which it is located, such as marsh land, sand beach, cultivated field, or meadow; estimated bearings in points of the compass and estimated distances in yards from (not to) easily recognized features, such as extreme end of point, edge of bluff, bank of creek, line of telephone poles, shore line, barn, house, fence, ditch, trees, or any other definite detail, such as being on range with the tangent of an island and a church; and so forth.

When a standard monument has been established near the station as a "reference station," this heading also covers a statement of the true bearing of the monument in degrees and minutes and its measured distance in meters, as it is the first object that is likely to catch the eye when the immediate vicinity of the desired station is reached and might be mistaken for the center mark of the "observed station" unless special attention is called to it.

The distinction between the "observed station" and "reference station" should be carefully noted by anyone making use of the description of stations for any future surveying operations.

The "observed station" is located at the particular triangulation point covered by the description of stations and is the one whose geographic position is first computed, as it is the point which was "occupied" and "observed on" for horizontal angles. However, in spite of the primary importance of the location of the "observed station," it will be noted from the description of stations that frequently it is not marked as well as the "reference station," and in many instances has only a pine stub to indicate its position. This is the case for the reason that the necessity of intervisibility of landmarks ustally mate it compulsory to locate "observed stations" on edgres of banks and cnds of points of land, which in the tidewater section of Maryland generally means they will be washed away in a short period of years. The past experience of the Coast and Geodetic Survey in this region has shown the great need of "reference stations," if the frequent reestablishment of a new framework of triangulation is to be avoided.

The chief reason and need for the establishment of the "reference station," or secondary station, as it might be well named, is explained in the preceding paragraph, but in several instances other reasons, such as the location of the "observed station" on an unstable sand dune, in a cultivated field, in front of a residence, or other places objectionable to the landowner, have led to establishment of "reference stations." 
The location of the "reference station" in relation to the "observed station" is fixed for plotting on charts or for computation of its geographic position by checked measurements of its distances and azimuth from the "observed station." 1

Marks.-Under this heading is given a description of the character of the permanent monuments or other marks of the location of the "observed station," and of the "reference station" where one has been established.

All the marks designated in the descriptions as "the center point of triangle on standard cement monument" are exactly alike. These monuments are made of cement, sand, and gravel, and are 2 feet long and 8 inches square at top and bottom. Their tops are all marked with the same brass mold and show a center hole surrounded by a triangle, with the letters "M. S. F. C." arranged around the vertex and the letters "U. S. C. S." underneath the base of the triangle. The center hole is always in the center of the top of the monument by construction, and if this is found to have been broken off without disturbing the bottom the center of its square section can be used as the location of the station.

All the "standard cement monuments," whether used for marking the "observed station" or "reference station," have been planted upright in exactly the same manner, with their tops projecting 3 or 4 inches above the surface of the ground, unless otherwise stated.

Therefore, as the above facts in reference to the "standard cement monuments" are a constant element in all cases, the repetition of these facts in the description of stations is made needless by this one statement.

References.-Under this heading are given the "rounds" of directions and distances to all objects that might be useful in locating the stations when the surface marks can not be found. It is also contemplated that for general purposes of topography, hydrography, or location of boundaries of oyster bars these references will be sufficient in many cases to relocate the position of an "observed station" or "reference station" when both of them have been destroyed.

The first reference object given in the descriptions is always a triangulation station visible from the station being described, this, if possible, being a lighthouse, clunch spire, or other permanent and prominent point. Its direction is taken as being $\mathrm{O}^{\circ} \mathrm{OO}^{\prime} \mathrm{oO}^{\prime \prime}$, and the directions of all other objects are measured from it as an initial point, the angles being taken in a clockwise direction (left to right).

The true bearing ${ }^{2}$ of the initial object is always given in parentheses alongside its name. This furnishes means for the calculation of the bearings of any of the other reference objects for the purposes of locating a station by horizontal angles or for the relocation of corner buoys of oyster-bar boundaries by the method of compass directions described in this publication under the heading of "Boundaries of oyster bars."

The distances in the last column under "References" are given in three different units, which vary according to their accuracy. The "miles" are statute miles and may be considered only as rough estimates. The "yards" are more accurate, but must be looked on as results generally obtained by pacing or careful estimating. The "meters,"

\footnotetext{
1 Geographic coordinates (latitude, longitude, distance, and azimuth) relatins to any of the "observed stations" of of the "reference stations" described in this publication can be obtained by application to the Superintendent of the Coast and Geodetic Survey, at Washington, D.C.

'The mean magnetic variation for Queen Annes County was $6^{\circ} \times 5^{\prime}$ west of north in $x$ rI and increasing at the rate of $5^{\prime} y$ early.
} 
however, are accurate to the degree indicated by their decimals and in exery case have been measured with a steel tape. In the same manner the accuracy of the directions are indicated by the refinement of angular measure with which they are recorded.

\section{DESCRIPTIONS OF TRIANGULATION STATIONS.}

\section{SWAN POINT 3 .}

General locality. - Fastern shore of Chesapeake Bay on Swan Point about $5 \frac{1}{2}$ miles south-southwest of Tolchester Beach Wharf and 7 miles north of I.ove Point. (See Chart No. 29.)

Immediate localily.-Observed station is on sand and marsh point about 2 feet above high water, 5 feet east of shore, 60 yards south southwest of a fisherman's cabin, and 250 yards from the extreme end of Swan Point. Cement monument marking old reference station is in marsh 21.43 meters $\mathrm{N} 89^{\circ}$ ${ } 3^{\prime} \mathrm{E}$ of observed station. Standard cement monument marking new reference station is on line to old reference station $\mathrm{I} 3.26$ meters $\mathrm{N} 89^{\circ} \mathrm{I}_{3^{\prime}} \mathbf{E}$ of observed station.

Marks.-Observed station is $1 / 4$-inch copper rod set in an 8 -inch square cement monument with top about 5 inches below surface of ground. Subsurface mark is the neck of a flask set in cement about 4 feet below the surface. New reference station is center point of triangle on standard cement monument. Old reference station is eastern one of two $1 / 4$-inch copper rods in an 8 -inch cement monument.

References.-

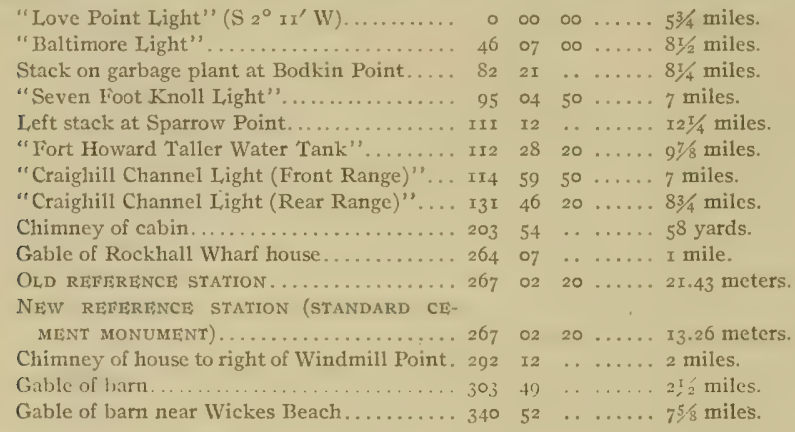

\section{BANK.}

General localily.-Eastern shore of Chesapeake Bay on western side of entrance to Tavern Creek about $5 / 3$ mile northeast of Swan Point. (See Chart No. 29.)

Immediate locality.--Observed station is in a ctiltivated field about 7 feet above high water, I2 yards inshore, and 2 yards from edge of bank.

Marks.-Observed station is center point of triangle on standard cement monument projecting 3 inches above surface of ground. Subsurface nark is center of 2 -inch tile pipe buried with top 2 inches below base of monument.

Reforitics.-

"Love Point Light" (S $\left.7^{\circ} 27^{\prime} \mathrm{W}\right) \ldots \ldots \ldots \ldots$

"Baltimore Light" .....................

Nail in blaze in locust tree ( 3 inches diameter)

$560.400 \ldots \ldots$ ro. 39 meters.

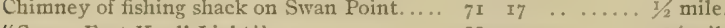

"Sever Foot Knoll Light" .............. 88 I4 $40 \ldots \ldots .7 \%$ miles.

West gable of Strong barn.............. I53 $39 \quad \ldots \ldots \ldots 3 / 8$ mile.

Southwest corner of Strong house........ I74 og ....... $3 / 3$ mile. 
References-Continued.

Chimney of tenant house............. 2 I2 $55 \quad \ldots \ldots \ldots 3 / 4$ mile.

North gable of barn.................. $250 \quad 47 \quad \ldots \ldots \ldots$ I3/8 miles.

Thompson windmill................. $27 \mathrm{I} \quad 47 \ldots \ldots \ldots, 1 / 2$ milc.

West gable of Rockhall Wharf house....... 274 o8 $\ldots \ldots .3 / 8$ mile.

North gable of Downey house............ $278 \quad 49 \quad \ldots \ldots \ldots 1 / 2$ mile.

Nail in blaze in locust tree ( 4 inches diarneter) $292 \quad 56 \quad 20 \ldots \ldots$. 0.32 meters.

South one of twin trees on Little Neck Island. $\begin{array}{rlll}352 & 59 & \ldots \ldots & \ldots\end{array}$

\section{GRATITUDE.}

General locality.-Fiastern shore of Chesapeake Bay at eastern side of entrance to Swan Creek opposite middle of I,ittle Neck Island and near old Rockhall Wharf. (See Chart No. 29.)

Immediale locality.-Observed station is on a marsh meadow about I foot above high water, I2 yards east of shore, 150 yards southwest of a house, and 400 yards south-southwest of Rockhall Landing.

Marks.-Observed station is center point of triangle on standard cement monument projecting 3 inches above surface of ground. Subsurface mark is center of 2 -inch tile pipe buried with top 2 inches below base of monument.

References.-

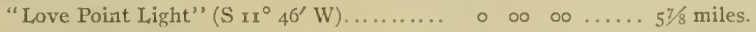

"Sandy Point Light"................ 26 o5 10 ..... 10 $3 / 4$ miles.

"Baltimore Light"............... $4 x \quad 21 \quad 20 \ldots \ldots 93 / 8$ miles.

Chimney of fishing shack on Swan Point.... 90 $47 \quad \ldots$.... I mile.

L,eft tangent of piles of old Rockhall Wharf.. I24 I5 ..... 200 yards.

West gable of Strong barn............. 130 49 $\ldots \ldots \ldots 3 / 4$ milc.

Chimney of tallest wharf house at Rockhall

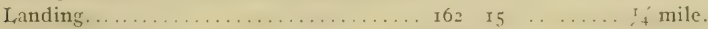

Chimney of house ............... I66 I9 . . ... I mile.

Post on northwest comer of Downey porch... $196 \quad 57 \quad \ldots \quad \ldots \ldots$ r 50 yards.

Nail in blaze in cedar tree (ro inches diameter) $273 \quad 02 \quad 40 \ldots \ldots$ ro7 yards.

North gable of old barn................ $276 \quad 36 \quad \ldots \ldots 200$ yards.

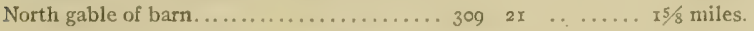

\section{WINDMILL, POINT.}

General locality.-Eastern shore of Chesapeake Bay on Windmill Point at northern side of entrance to Rockhall Harbor. (See Chart No. 29.)

Immediale locality.-Observed station is on low marsh land about level with high water, about 30 yards back from end of point, and 20 yards south of a group of large pine trees. Cement monument

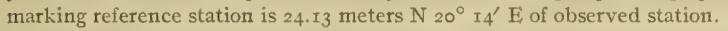

Marks.-Observed station is center point of 2 -inch tile pipe filled with sand with top about flush with surface of ground. Reference station is center point of triangle on standard cement monument.

References.-

"Love Point Light" (S I $7^{\circ} 47^{\prime} \mathrm{W}$ ).

Nail in blaze in pine tree ( 18 inches diam-

eter). ............................... eter)......................... I7

REILRENCE STATION..................... 18
Nail in blaze in pine tree (20 inches diam-

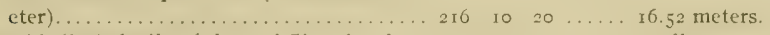

Rockhall Methodist Eipiscopal Church spire.. 238 o5 40 .... I mile.

Highest gable on Sharps Wharf ......... $246 \quad 42 \quad \ldots \ldots 3 / 8$ mile.

East chimney of house.............. 27 I $27 \ldots \ldots \ldots$ mile.

Chimney of small house............... $287 \quad 55 \quad \ldots \ldots .1 / 2$ mile.

West chimney of small house.......... 311 I $04 \ldots \ldots$ I mile. 


\section{STEVENS.}

General locality.-Eastern shore of Chesapeake Bay about $1 / 4$ mile south of Huntingfield Point at entrance to Huntingfield Creck. (See Chart No. 29.)

Immediate locality.-Observed station is in a cultivated field about 15 feet above high water, 55 yards back from edge of vertical bank 3 feet higher than station, and 450 yards south of the extreme end of Funtingfield Point.

Marks.-Observed station is center point of triangle on standard cement monument projecting 2 inches above surface of ground. Stibsurface mark is center of 2 -inch tile pipe buried with top 2 inches below base of monument.

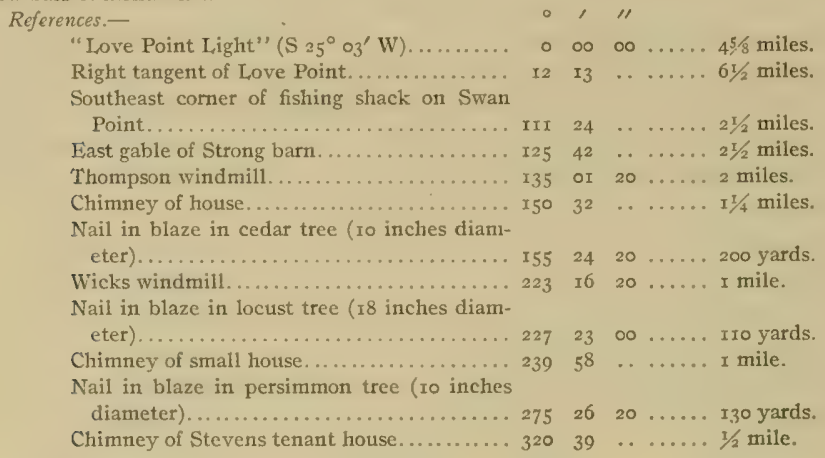

\section{BALTIMORE LIGHT.}

General localify.-Western side of Chesapeake Bay off shore about $x^{1} / 2$ miles east of mouth of Magothy River and $1 / 8$ mile west of entrance to dredged channel leading to Baltimore. (See Progress Map.)

Immediate locality.-Observed station is on brick octagonal dwelling on cylindrical foundation known as Baltimore Lighthouse.

Marks.-Observed station is center point of lantern on Baltimore Lighthouse.

References.-None necessary.

\section{SANDY POINT LIGHT.}

General locality.-Western side of Chesapeake Bay off shore about $1 / 2$ mile east of Sandy Point. (See Chart No, 29.)

Immediate locality,-Observed station is on brick dwelling on cylindrical foundation known as Sandy Point Lighthouse.

Marks.-Observed station is center point of lantern on Sandy Point Lighthouse.

References.-

"Bodkin Point (Old Tower)" ( $\left.\mathrm{N} \mathrm{I4}^{\circ} 35^{\prime} \mathrm{W}\right)$. . $\quad 0$ oo $00 \ldots .8 \mathrm{~s} / 2$ miles.

RING.

General locality. - Eastern shore of Cliesapeake Bay òn western side of Kent Island about $21 / 4$ miles south-southwest of Love Point and $3 \frac{3}{8}$ miles east of Sandy Point. (See Chart No. 29.)

Immediale locality.-Observed station is in a cultivated field about 20 feet above high water, 12 yards inshore, and 2 yards from edge of bank. Cement monument marking reference station is 9.36 meters $\mathrm{N} 79^{\circ} 2 \mathrm{I}^{\prime} \mathrm{E}$, of observed station. 
Marks.-Ohserved station is center of 4 -inch tile pipe with top 3 inches below surface of ground. Reference station is center point of triangle on standard cement monument projecting 4 inches above surface of ground.

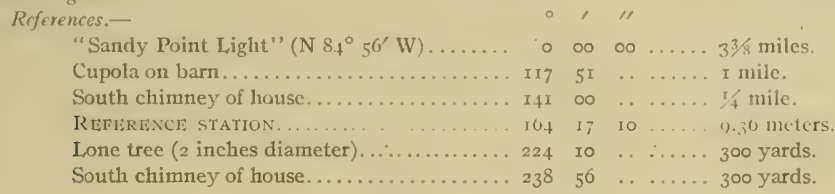

\section{LOVE POINT LIGHT.}

General locality.-Eiastern side of Chesapeake Bay at entrance to Chester River offshore about II/2 miles northeast of Love Point. (See Chart No. 29.)

Immediate locality.-Observed station is on hexagonal screw pile structure known as Love Point Lighthouse.

Marks.-Observed station is center point of lantern on Love Point Lighthouse.

References."Wickes Beach" (S $47^{\circ} 55^{\prime}$ E) $\ldots \ldots \ldots \ldots \ldots$. o

\section{AMOUR.}

General locality.--Northern end of Kent Island at western side of entrance to Chester River ahout I/4 raile southeast of Love Point and 3/8 mile north of Love Point Landing. (See Chart No. 29.)

Immediate localily.-Observed station is on sand and marsh point about 2 feet above high water, 25 yards inshore, and 55 yards north of fishing shack.

Marks.-Observed station is center point of triangle on standard cement monument projecting 4 inches above surface of ground. Subsurface mark is center of 2 -inch tile pipe buried with top 2 inches below base of monument.

References.-

"Love Point Light" ( $\left.333^{\circ} 42^{\prime} \mathrm{E}\right) \ldots \ldots \ldots \ldots$

Left chimney of house................

West gable of house on East Neck.......... 48

North gable of barn................. 5

North gable of house on Cedar Point....... 7

Gable of barn.................... 128

Left tangent of Kent Island Landing....... I3

Northeast corner of fishing shack.......... I4

Nail in blaze in cedar tree $(3$ inches diam-

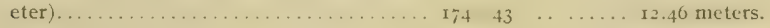

"Railway Water Tank" .............. I99 $53 \quad 50 \ldots \ldots .5 / 8$ mile.

Nail in blaze in cedar tree ( 4 inches diam-

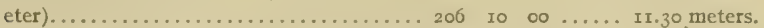

Nail in blaze in cedar tree ( 6 inches diam-

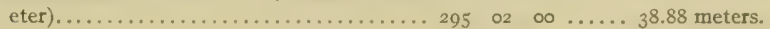

\section{RAII,WAY WATER TANK.}

General locality.-Northern end of Kent Island about halfway between Chesapeake Bay and Chester River and $3 / 4$ mile south by west of Love Point. (See Chart No. 29.)

Immediate locality.-Observed station is on the only large elevated water tank located just north of the center of the bend of the railway that leaves Love Point Landing.

Marks.-Observed station is center point of top of water tank.

References.-None necessary. 


\section{WICKES BEACH.}

General locality.-Eiastern shore of mouth of Chester River on western side of East Neck Island near Wickes Beach. (See Chart No. 29.)

Immediate locality.-Observed station is on a narrow sand beach about on level with high water, Io yards back from low water, and 2 yards west of swamp which extends back to woods.

Marks.-Observed station is center point of triangle on standard cement monument projecting 4 inches above surface of ground. Subsurface mark is center of 2 -inch tile pipe buried with top 2 inches below base of monument.

References.-

"Love Point Light" ( $\left.47^{\circ} 54^{\prime} \mathrm{W}\right) \ldots \ldots \ldots$.... 00 o $00 \ldots .3$ miles.

Nail in blaze in oak tree ( ${ }_{5}$ inches diameter). $604540 \ldots .300$ yards.

Nail in blaze in gum tree ( 12 inches diam-

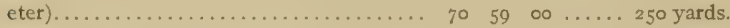

Nail in blaze in oak tree ( 15 inches diameter). II $4550 \ldots \ldots 200$ yards.

North cupola of barn................. I55 $15 \ldots \ldots$. . . . . mile.

Lone tree on Cedar Point............... $178 \quad 23 \quad \ldots \ldots \ldots .77 / 8$ miles.

East gable of barn ................ $200 \quad 21 \quad \ldots \ldots 4$ miles.

North gable of Jackson wharf house........ $2 x_{4} \quad 26 \quad \ldots \ldots \ldots 4$ miles.

North gable of barn.................. $276 \quad 32 \quad \ldots \ldots \ldots 33 / 8$ miles.

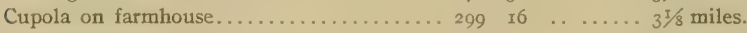

"Railway Water Tank"................ 32 I $45 \quad 0 \quad \ldots \ldots 35 / 8$ miles.

North flagstaff on Love Point Hotel ...... $32327 \quad \ldots \quad \ldots \ldots 33 / 8$ miles.

\section{NARROWS POINT.}

General locality.-Northern shore of Chester River on southwest end of East Neck Island, about I/8 mile north of Cockeys Island and 3/8 mile west-northwest of Cedar Point. (See Charts Nos. 29 and 30. )

Immediate locality.-Observed station is on a low marshy point about level with high water, about 7 yards from low water, and 325 yards west of a fishing shack. Cement monument marking reference station is 12.28 meters $\mathrm{N} 7^{\circ} 5^{8^{\prime}} \mathrm{E}$ of observed station.

Marks.-Observed station is center of 3 -inch tile pipe filled with cement with top 4 inches below surface of ground. Reference station is center point of triangle on standard cement monument projecting 4 inches above surface of ground.

References.-

"Wickes Beach" ( $\left.{ }_{4} 6^{\circ} 5^{8^{\prime}} \mathrm{W}\right) \ldots \ldots \ldots \ldots$. . . .

REFERENCE STATION................. 6

Chimney of fishing shack.............. ${ }_{33}$

West gable of Queenstown elevator........ I53

Cupola on barn.................... I6

North gable of house $\ldots \ldots \ldots \ldots \ldots \ldots \ldots \ldots$ is

North gable of barn. ................. rg.

Cupola on barn..................... 2 I

North gable of house................. 228

North gable of house on Jackson Creek. ...... 23

East gable of Jackson whari house........ 233

North gable of barn ................. 25

West chimney of house ................ 285

Chimney of house near Macum Creek. ...... 293

East chimney of house............... 3 I8

"Railway Water Tank"................ 334

South tlagstaft on Love Point Hotel ....... 335

Flagstaff on Love Point Wharf........... 33

Right tangent of Love Point.............. $34 x$ 30

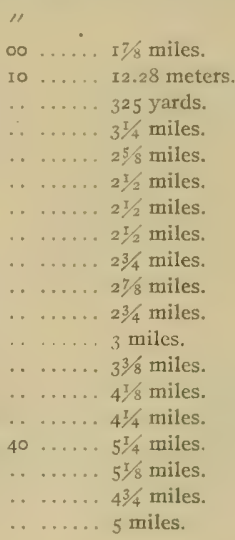


MACUM.

General locality.-Southern shore of Chester River on Kent Island, about $4 \frac{1}{2}$ miles south of Love Point Light, 3 miles south-southeast of Love Point Landing and $1 / 2$ mile north-northwest of Macum Creek. (See Chart No. 29.)

Immediate locality.-Observed station is in cultivated field about 7 feet above high water, 25 yards inshore, and 16 yards south of two cedar trees at edge of bank.

Marks.-Observed station is center point of triangle on standard cement monument projecting 3 inches above surface of ground. Subsurface mark is center of 2 -inch tile pipe buried with top 2 inches below base of monument.

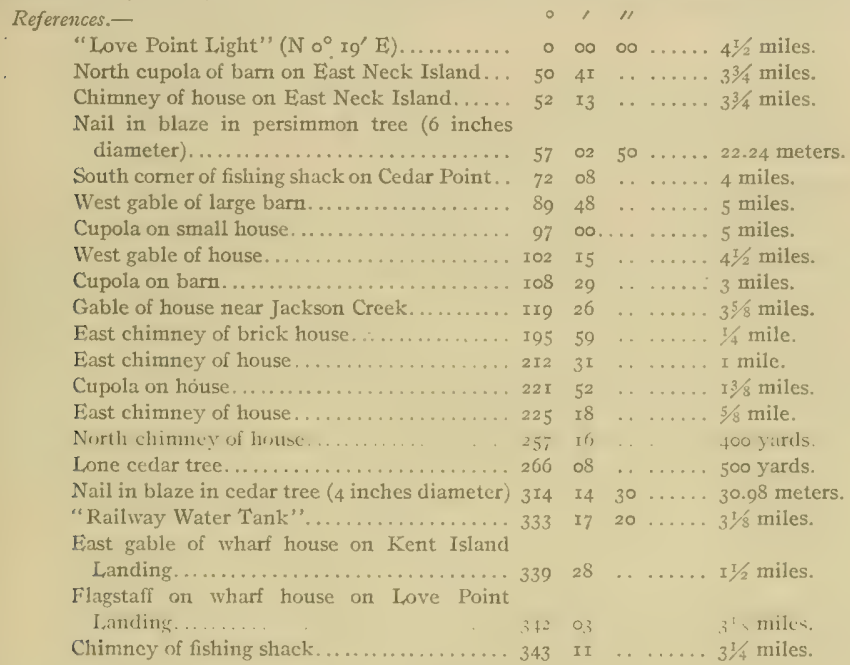

\section{THIN.}

General locality. Southern shore of Chester River on western side of cntrance to Kent Narrows, about $3 / 4$ mile north of Narrows railway station. (See Chart No. 29.)

Immediate locality.-Observed station is on a marsh point about I foot above high water, 55 yards north of shore, and 55 yards west of shore.

Marks.-Observed station is center point of triångle on standard cement monument projecting 5 inches above surface of ground. Subsurface mark is center of 2 -inch tile pipe buried with top 2 inches below base of monument.

References.-

"Muddy" ( $\left.\mathrm{N}_{37^{\circ}} 55^{\prime} \mathrm{E}\right) \ldots \ldots \ldots \ldots \ldots \ldots$..........

Smoke pipe on shanty............... 75 I3 ...... I mile.

Large low telegraph pole.............. $99 \quad 27 \quad \ldots \ldots \ldots 3 / 4$ mile.

Smoke pipe on slant-roofed shanty ......... I07 $5^{8} \ldots \ldots \ldots .5$ mile.

Near corner of fishing shanty............ Ig6 $21 \quad \ldots \ldots \ldots 1 / 4$ mile.

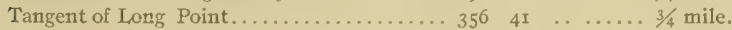




\section{MUDDY.}

General locality.- Southern shore of Chester River on Long Point between Muddy. Creek and Jackson Creek about $2 \frac{1}{4}$ miles southwest of Cedar Point and $3^{1 / 2}$ miles west of Queenstown. (See Charts Nos. 20 and $30 . ;$

Immediate lucality.-Obse:ved station is on marsh land covered with myrtle bushes, about 2 feet above high water. 7 yards inshore, 25 yards southwest of extreme end of point, and 70 yards north of group of pine trees.

Marks.-Observed station is center point of triangle un standard cement monument projecting 3 inches above surface of ground Subsurface mark is center of 2 -inch tile pipe buried with top 2 inches below base of monument.

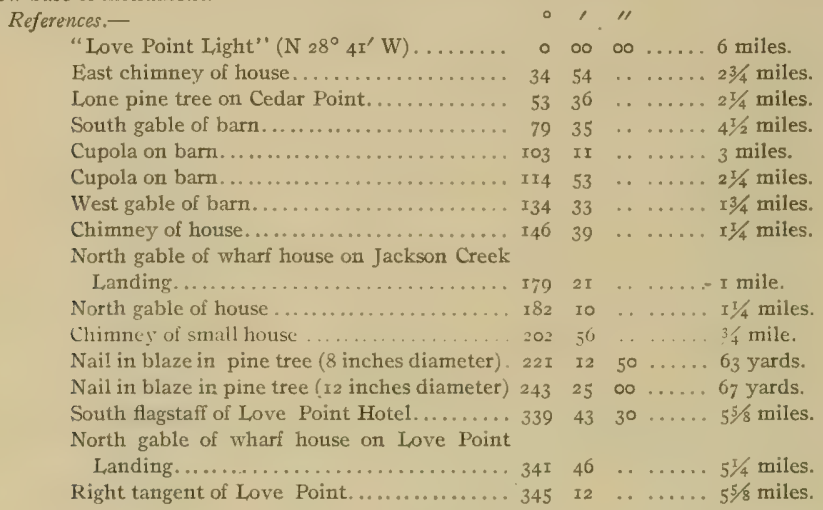

\section{BRIDGE.}

General locality. - Southern side of Chester River on western shore of Kent Narrows about I/8 mile west of Narrows railway station. (See Charts Nos. 29 and 32.)

Immediate locality.-Observed station is on a telegraph pole at a point about 25 feet above high water, 4 yards south of near rail of railroad, 8 yards west of end of railroad bridge, and 7 yards from tie line of bridge.

Marks.-Observed station is a small staff nailed to telegraph pole.

References.-None necessary.

\section{RAILROAD.}

General locality.-Southern side of Chester River on eastern shore of Kent Narrows about $3 / 8$ mile east-southeast of Narrows railway station and $\mathrm{J} / 8$ mile south of railroad. (See Charts Nos. 29 and 32.)

Immediate locality._-Observed station is on cultivated land about 8 feet above high water, 35 yards south by west of telephone line on north side of county road, 75 yards east of shanty, and 8o yards northeast of shore of small cove.

Marks.-Observed station is center point of triangle on standard cement monument projecting 4 inches above surface of ground. Subsurface mark is center of 2 -inch tile pipe buried with top 2 inches below base of monument. 


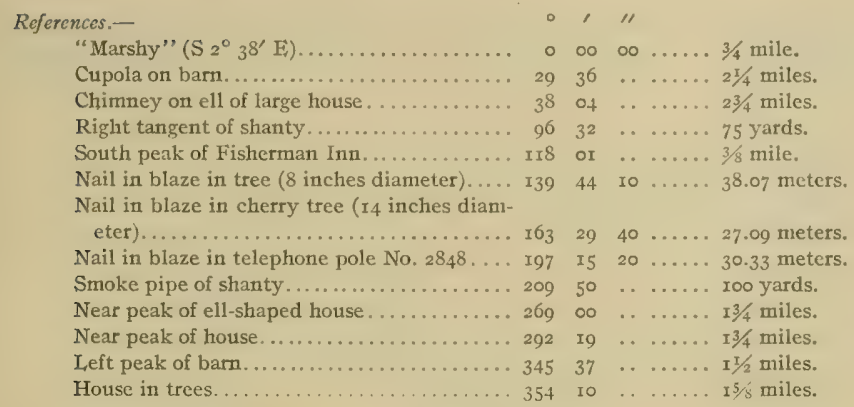

\section{BLUEBEARD.}

General locality.-Eastern shore of Chester River on point at entrance to a small creek about $5 / 8$ mile northeast of Blunt Creek and I mile southwest of entrance to Queenstown Creek. (See Chart No. 30.)

Immediate locality.-Observed station is on a low sand beach about I foot above high water, 5 yards inshore, 2 yards east of small persimmon tree, 55 yards northeast of a small stream, and 200 yards northnortheast of a pond.

Marks.-Observed station is center point of triangle on standard cement monument projecting 2 inches above surface of ground. Subsurface mark is center of 2 -inch tile pipe buried with top 2 inches below base of montument.

References.-

"Love Point Light" ( $\left.\mathrm{N}_{47^{\circ}} 53^{\prime} \mathrm{W}\right) \ldots \ldots \ldots$. 0 , o $00 \ldots \ldots 7$ miles.

South gable of house................. I2 $03 \ldots \ldots$. $\ldots \ldots \ldots$ miles.

Right tangent of piles of Bogle wharf . . . . $29 \quad 48 \quad \ldots \ldots \ldots 33 / 8$ miles.

L,argest of four pine trees on Piney Point... $4^{8} \quad 5^{8} \ldots \ldots \ldots 4$ miles.

East chimney of house.............. $70 \quad 23 \ldots \ldots .23 / 8$ miles.

Black beacon at entrance to Queenstown

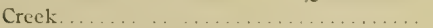

Nail in blaze in swamp-oak tree $(4$ inches . diameter).................... I22 or $10 \ldots \ldots$ 10. (ro meters.

Nail in blaze in chestnut tree ( 18 inches

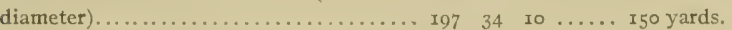

Nail in blaze in oak tree ( 6 inches diameter). $270 \quad 04 \quad 20 \ldots \ldots$ I25 yards.

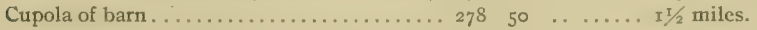

East chimney of house............... $279 \quad 24 \quad \ldots \ldots \ldots$ I $1 / 2$ miles.

North gable of Jackson Creek landing house. 290 ri $\ldots \ldots .23 / 8$ miles.

East gable of house................. 329 I7 $\ldots \ldots .51 / 4$ miles.

Gable of Love Point wharf house....... 344 of . . . . $63 / 4$ miles.

Right tangent of Love Point............ $347 \quad 46 \quad \ldots \ldots 7$ miles.

\section{BLAKEFORD.}

General locality.- Eastern shore of Chester River about $3 / 8$ mile north of Blakeford Point at entrance to Queenstown Creek. (See Chart No. 30.)

Immediate locality.-O Observed station is about $\mathrm{i}_{5}$ feet above high water, 8 yards inshore, 2 yards back from top of bank with uniform slope to beach, 25 yards north of gully, and 25 yards sotith of large sycamore tree at foot of slope. 
Marks.-Observed station is center point of triangle on standard cement monument projecting 3 inches above surface of ground. Subsurface mark is center of 2 -inch pipe buried with top 2 inches below base of monument.
References.-
"Rain" ( $\mathrm{N} 74^{\circ} 5^{6}$ ' W)
Right tangent of piles of Bogle wharf.
Nail in blaze in cedar tree ( 4 inches diam-

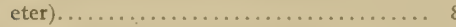
Northwest corner of house in woods. ........
West gable of small house .............. I7
West gable of large barn................ 2 I
West gable of house ................... 235
Northeast corner of elevator at Queenstown. . 239
Nail in blaze in ash tree ( 15 inches diameter). 247
First black beacon at entrance to Queenstown
Creek........................ $294 \quad 49 \quad \ldots \ldots \ldots 1 / 2$ mile.
Chimney of fishing shack on Cedar Point.... 352 26 35 .
$0.0000 \ldots .17 / 8$ miles.
$73 \quad \ldots \quad \ldots \ldots 3$ miles.

$$
\begin{array}{lllll}
\text { I2 } & \text { Io } & \ldots & \ldots & 13.3 \text { m meters. } \\
39 & \ldots & \ldots & \ldots & 300 \text { yards. } \\
\text { I9 } & \ldots & \ldots & 3 / 8 \text { mile. } \\
4 \text { I } & \ldots & \ldots & \ldots & 5 / 8 \text { mile. } \\
20 & \ldots & \ldots & & 3 / 4 \text { mile. } \\
21 & \ldots & \ldots & & 5 / 8 \text { mile. } \\
00 & 20 & \ldots & \ldots & 21.30 \text { meters. }
\end{array}
$$

RAIN.

General locality. -Western shore of Chester River on Hail Point ahout $\mathrm{x} s / 8$ miles south-southeast of Bogle Wharf. (See Cliart No. 30.)

Immediale locality.--Observed station is about 5 feet above high water, 3 yards north of shore, and 20 yards northwest of extreme end of point. Cement monument marking reference station is 29.84 meters $\mathrm{N} 65^{\circ} 20^{\prime}$ W of observed station.

Marks.-Observed station is center of 2 -inch tile pipe projecting 4 inches above surface of ground. Subsurface mark is center of 2 -inch tile pipe buried with top 2 inches below base of surface pipe. Reference station is center point of triangle on standard cement monument projecting 3 inches above surface of ground. Subsurface mark of reference station is center of 2 -inch tile pipe with top 2 inclies below base of monument.

References.-

"Bluebeard" ( $\left.\mathrm{S} 2 \mathrm{r}^{\circ} \mathrm{r} \mathrm{\gamma}^{\prime} \mathrm{E}\right), \ldots \ldots \ldots \ldots \ldots$

Chimney of house ....................

Cupola on barn. ........................

Chimney of house on Jackson Creek.........

Chimney of small house............... 4

Chimney of fishing shack................ Io

Nail in blaze in pine tree (Io inches diam-

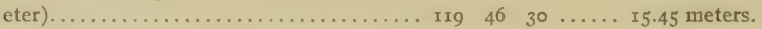

ReTERENCE Station.................. I35 $56 \quad 20 \ldots \ldots 29.84$ meters.

Nail in blaze in pine tree (ro inches diam-

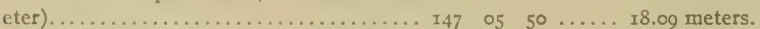

South gable of house................ $173 \quad 28 \quad \ldots \ldots \ldots, \mathbf{I}^{1 / 2}$ miles.

Right tangent of piles of Bogle Wharf . . . . r $86 \quad 59 \quad \ldots \ldots \ldots$ r $5 / 8$ miles.

Williams water tank.................. $255 \quad 59 \quad \ldots \ldots \ldots$ miles.

Black Beacon at entrance to Queenstown

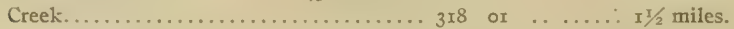

Cupola on bam....................... $33^{8} \quad 5^{3} / 4$ miles.

BREAK.

Gencral locality.-Eastem shore of Chester River on Break Point about 1/3 mile north of north side of entrance to Tilghmans Creek. (See Chart No. 30.)

Immediate locality.-Observed station is in a cultivated field about 5 feet above high water, 13 yards inshore, 4 yards from edge of bank, 200 yards north of extreme end of point, and 300 yards west of a house. 
Marks.-Observed station is center point of triangle on standard cement monument projecting 5 inches above surface of ground. Subsurface mark is center of 2 -inch tile pipe buried with top 2 inches below base of monument.

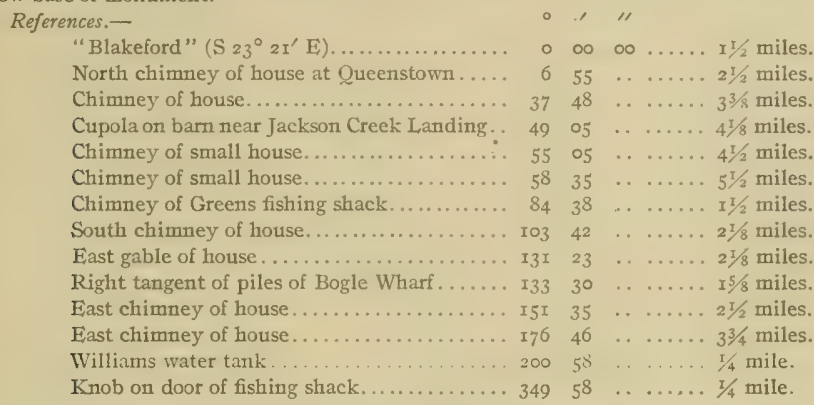

\section{OVERTON.}

General locality.-Western shore of Chester River on north side of entrance to Durdin Creek and about roo yards south of Bogle Wharf. (See Chart No. 30.)

Immediale locality.-Observed station is on marsh land about I foot above high water, 4 yards inshore, 10o yards south of Bogle Wharf, 250 yards southeast of Bogle store, and 300 yards west of Bogle Wharf house. Cement monument marking reference station is 11.26 meters $\mathrm{S} 73^{\circ} \circ 6^{\prime} \mathrm{W}$ of observed station.

Marks.-Observed station is center of 2 -inch tile pipe projecting 2 inches above surface of ground. Subsurface mark is center of 2 -inch tile pipe buried with top 2 inches below base of surface pipe. Reierence station is center point of triangle on standard cement monument projecting 4 inches above surface of ground.

\begin{tabular}{|c|c|c|c|c|}
\hline References.- & 。 & , & "I & \\
\hline "Bay Bush Point" $\left(X j^{0}\right.$ x $\left.j^{\prime} \mathbb{W}\right) \ldots \ldots \ldots$ & $\circ$ & $\infty$ & $\infty 0$ & I +4 miles. \\
\hline 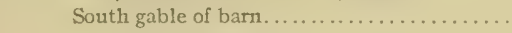 & 4 & 12 & . & $27 / 8$ miles. \\
\hline 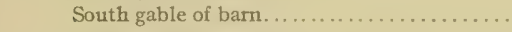 & 17 & $2 I$ & . & .... 3 miles. \\
\hline West gable of barn............... & 39 & 13 & .. & . 5 miles. \\
\hline Left tangent of piles of Bogle Wharf. & 73 & 17 & . & $\ldots .300$ yards. \\
\hline 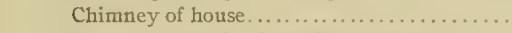 & II9 & 25 & .. & $\ldots \ldots 2 \frac{1}{2}$ miles. \\
\hline Lower west gable of Qucenstown elevator... & 138 & $2 I$ & . & $\ldots \ldots, 3 \frac{T}{2}$ miles. \\
\hline 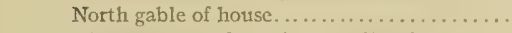 & 140 & 27 & $\ldots$ & ...... $33 / 4$ miles. \\
\hline Right tangent of woods on Hail Point....... & 168 & 59 & .. & ..... I $3 / 8$ miles. \\
\hline REFERENCE STATION.................. & 256 & 19 & 40 & ..... II.26 meters. \\
\hline Chimney of Bogles store.................. & $2 S_{9}$ & $I_{7}$ & .. & $\ldots \ldots 250$ yards. \\
\hline
\end{tabular}

FIR.

General locality.-Eastern shore of Chester River on Piney Point abot1t $15 / 3$ miles north-northwest of Break Point and I/2 mile west of Piney Cove. (See Chart No. 30.)

Immediale locality:-Observed station is on marsh land at the extreme end of Piney Point, about on level with high water, and about 4 yards east of shore. Cement monument marking reference station is 10.45 meters $\$ 70^{\circ} 43^{\prime}$ E of observed station.

Marks.-Observed station is center of 2 -inch tile pipe with top flush with surface of ground. Subsurface mark is center of 2 -inch tile pipe buried with top a inclies below base of surface pipe. Reference station is center point of triangle on standard cement monument projecting 4 inches above surface of ground. 


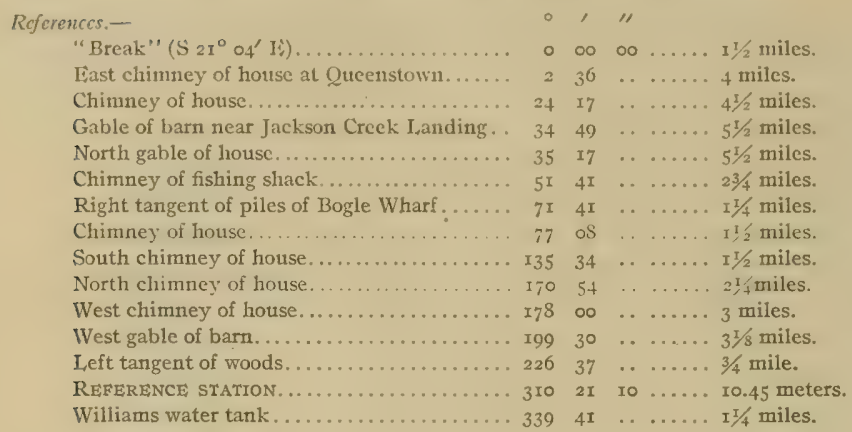

BAY BUSH POINT.

General locality.-Western shore of Chester River on a point about $1 / 4$ mile north of entrance to Fryingpan Cove and Churn Creek. (See Chart No. 30.)

Immediate locality.-Observed station is on a marsh point about I foot above high water, ${ }_{5}$ yards inshore, and in front of several persimmon trees. Cement monument marking reference station is I0.16 meters $\mathrm{N} 80^{\circ}$ I $3^{\prime} \mathrm{W}$ of observed station.

Marks.-Observed station is nail in 3 -inch cement-filled tile pipe with top 6 inches below surface of ground incased in cement cake bearing the legend "U. S. C. S.-I896." Reference station is center point of triangle on standard cement monument projecting 4 inches above surface of ground.

References.-

\begin{tabular}{|c|c|c|c|c|}
\hline "Fir" (S $\left.57^{\circ} 5^{6 \prime} \mathrm{E}\right) \ldots .$. & o & $\infty 0$ & $\infty$ & .. I $1 / 2$ miles. \\
\hline 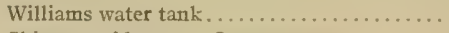 & 8 & 22 & $\cdots$ & $2 \frac{1}{2}$ miles. \\
\hline Chimney of house at Queenstown.......... & 27 & I7 & .. & $5 / / 8$ miles. \\
\hline 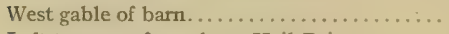 & 35 & 42 & .. & $47 / 8$ miles. \\
\hline Left tangent of woods on Hail Point........ & 45 & $5^{8}$ & . & $3^{1 / 4}$ miles. \\
\hline 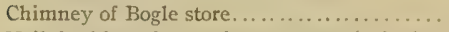 & $5^{8}$ & $\infty$ & & $15 / 8$ miles. \\
\hline 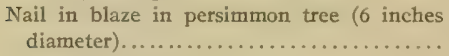 & 69 & 04 & $\infty$ & ers. \\
\hline REFERENCE STATION. & I57 & 43 & $\infty$ & Io. 16 meters. \\
\hline 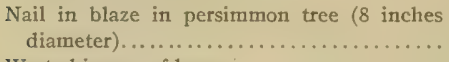 & 220 & 45 & $\infty$ & 6.20 meters. \\
\hline West chimney of house..... & 244 & 04 & .. & I $1 / 4$ miles. \\
\hline East & 262 & Io & .. & les. \\
\hline West gable of bam.......... & 297 & $5 I$ & .. & r/s mile \\
\hline 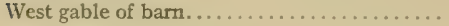 & 316 & I9 & $\ldots$ & ..... \\
\hline
\end{tabular}

\section{GORDON.}

General locality,-Eastern side of Chester River about 55 yards offshore, 3/4 mile southwest of entrance to Reeds Creek and 7/8 mile north-northeast of Piney Point. (See Chart No. 30.)

Immediate locality.-Observed station is in about 3 feet of water at high tide, 55 yards offshore, and 300 yards southwest of end of woods and cultivated field. Cement monument marking reference station is 57.49 meters $\mathrm{S} 7 \mathrm{r}^{\circ} \mathrm{I} 5^{\prime} \mathrm{E}$ of observed station.

Marks.-Observed station is nail in 2 -inch by 4 -inch-pine stub driven with top to high water. Reference station is center point of triangle on standard cement monument projecting 4 inches above surface of ground. 


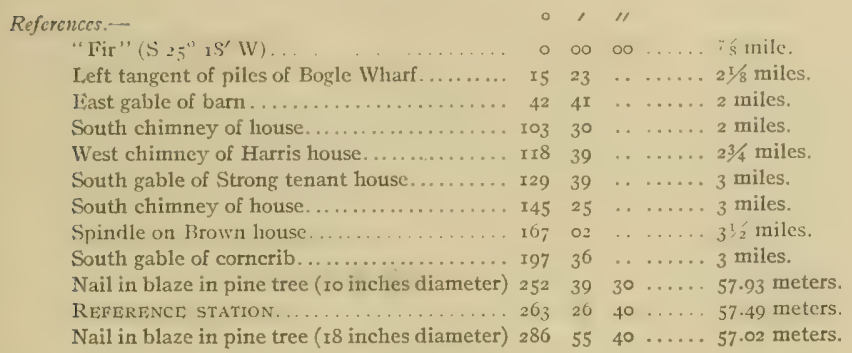

BIRD.

General locality.-Eastern shore of Chester River on Gordon Point at southwest side of entrance to Reeds Creek about $\mathrm{r}^{\mathrm{T}} / 2$ miles southwest of Holton Point. (See Chart No. 30.)

Immediate locality. - Observed station is in a marsh meadow about 2 feet above high water and 75 yards west of shore.

Marks,-Observed station is center point of triangle on standard cement monument projecting 7 inches above surface of ground. Subsurface mark is center of 2 -inch tile pipe buried with top 2 inches below base of monument.

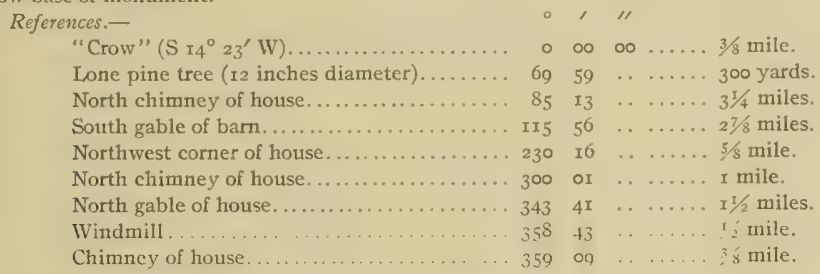

CROW.

General locality.-Eastern side of Chester River on western shore of Reeds Creek about $1 / 2$ mile south of extreme end of Gordon Point. (See Chart No. 30.)

Immediate locality.-Observed station is in yard of tenant house about 4 feet above high water, 12 yards west of shore, 5 yards south of a pear orchard, and 7 yards north of a house.

Marks.-Observed station is center point of triangle on standard cement monument projecting 6 inches above surface of ground. Subsurface mark is center of 2 -inch tile pipe buried with top 2 inches below base of monument.

References.-

"Bird" ( $\left.\mathrm{N} \mathrm{I}_{4}^{\circ}{ }^{2} 3^{\prime} \mathrm{E}\right)$. $\circ, " 1$

South gable of house near Cliffs Landing......

Sotth gable of barn.................. 36

Cupola of barn................... 73

Northeast corner of Carnell tenant house.... 99

Northwest corner of Carnell tenant house.... 128

Northeast corner of barn................ I98

Northwest comer of barn............... 22

$\begin{array}{llll}\infty & 00 & \ldots & 3 / 8 \text { mile. } \\ 03 & \ldots & \ldots & 3 \frac{3}{4} \text { miles. } \\ 18 & \ldots & \ldots & 11 / 4 \text { miles. } \\ 23 & \ldots & \ldots & 11 / 2 \text { miles. } \\ \text { or } & 30 & \ldots & 8.7 \text { meters. } \\ 43 & 10 & \ldots & 6.65 \text { meters. } \\ 25 & 20 & \ldots & 14.06 \text { meters. } \\ 37 & 10 & \ldots & 12.68 \text { meters. }\end{array}$


GROVE.

General locality.-Eastern side of Chester River on a point between Reeds Creek and Grove Creek about $1 / 2$ mile southeast of Gordon Point. (See Chart No. 30.)

Imme iate locality. -Observed station is in a meadow about a feet above high water, 26 yards south of shore, 8 yards west of three persimmon trees, and 35 yards west of a pond.

Marks.-Observed station is center point of triangle on standard cement monument projecting 5 inches above surface of ground. Subsurface mark is center of 2 -inch tile pipe buried with top 2 inches below base of monument.

References.-

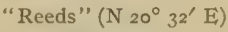

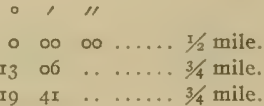

South gable of barn.

I3 of $\ldots \ldots \ldots, 3 / 4$ mile.

Nail in blaze in persimmon tree ( 6 inches diameter $)$.............................

Cupola on barn $\begin{array}{lll}53 & 05\end{array}$

parn........................ $75 \quad 58 \ldots 5 / 8$ mile.

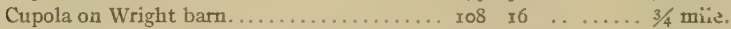

North gable of barn................. r68 $50 \ldots \ldots .5 / 8$ mile.

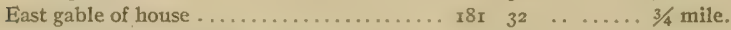

South gable of house ................. $230 \quad 54 \quad \ldots \ldots \ldots 1 / 2$ mile.

Ione pine tree on Gordon Point.......... $282 . \quad r_{3} \ldots \ldots .1 / 2$ mile.

Cupola on barn..................... 316 o. $0 . \ldots \ldots 4$ miles.

South chimney of house................ 326 r $13 \ldots \ldots .4$ miles.

Nail in blaze in sassafras tree ( 5 inches diam-

eter)...............................

\section{REEDS.}

General locality.-Eastern shore of Chester River at northeast side of entrance to Reeds Creck and about $5 / 8$ mile south of Robins Cove. (See Cliart No. 30.)

Immediale locality.-Observed station is on marsh land about 2 feet above high water, 34 yards east of shore, 9 yards north of ditch draining swamp, and in center of triangle formed by three pine stubs driven flush with marsh to support theodolite.

Marks.-Observed station is center point of triangle on standard cement monument projecting 2 inches above surface of ground. Subsurface mark is center of 2 -inch tile pipe buried with top 2 inches below base of monument.

References.-

"Bird" (S 62 $\left.{ }^{\circ} 26^{\prime} \mathrm{IV}\right)$.

"I

East chimney of Harris house...................

Chimney of house....................

East chimney of Brown house ........... II2

Chimney of cabin................. I 86

Cupola on barn...................... 276

North gable of house.................. $3^{16}$

Chimney of house.

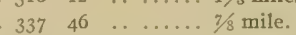

\section{I,ITTLE GUM}

General localify.-Western shore of Chester River on Little Gum Point at southwest side of entrance to Grays Inn Creek. (See Chart No. 30.)

Immediale locality.-Observed station is on a marsli point about I foot above high water, 2 yards south of shore, and 12 yards southeast of a 4 -foot ditch. Cement monument marking reference station is 40.97 meters $\mathrm{N} 33^{\circ} 3 \mathrm{I}^{\prime} \mathrm{W}$ of observed station.

Marks.-Observed station is center of 2 -inch tile pipe with top flush with surface of ground. Subsurface mark is 2 -inch tile pipe buried with top 2 inches below base of surface pipe. Reference station is center point of triangle on standard cement monument projecting 4 inclies above surface of ground. 


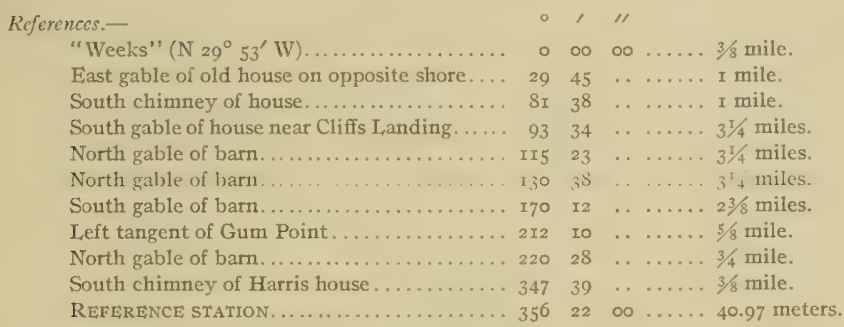

INN.

General locality.-Eastern shore of Grays Inn Creek about $1 / 3$ mile northwest of Chester River and $1 / 2$ mile southeast of Island Point. (See Chart No. 30.)

Immediate locality.-Observed station is in a peach orchard about 4 feet above high water and 25 yards northeast of shore.

Marks,-Observed station is center point of triangle on standard cement monument projecting 3 inches above surface of ground. Subsurface mark is center of 2 -inch tile pipe buried with top 3 inches below base of monument.

References.-

"Holton Point" ( $\$$; $72^{\circ} 50^{\prime}$ li).

Nail in blaze in sycamore tree (30 inches

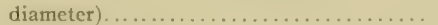

North cupola on barn................

Left tangent of woods on Hail Point........ 7

Liast gable of Swatska barn............. Io

Iiast chimney of house ................ If

East gable of Harris house.............. 150

East gable of small house ................ I

Nail in blaze in peach tree ( 8 inches diam-

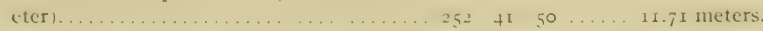

Southwest corner of Earle bathhouse ..... $359 \quad 28 \quad \ldots \ldots \ldots 3$ miles.
0 0 $00 \ldots . . .2^{i}$, miles.

I3 $2430 \ldots \ldots 4.53$ meters.

$54 \ldots \ldots \ldots 4^{1 / 2}$ miles

rg $\ldots \ldots \ldots, I^{1 / 4}$ miles.

53 ..... 5/8 mile.

I5 $\ldots \ldots .5 / 8$ mile.
$8 \quad 57 \quad \ldots \quad \ldots \ldots 2 \frac{1}{1 / 2}$ miles.

02 ..... $1 / 2$ mile.

\section{HOLTON POINT.}

General locality.-Eastern shore of Chester River on Holton Point at south side of entrance to Corsica River. (See Chart No. 30.)

Immediate locality.-Observed station is on low sand beach about on level with high water and $1 / 4$ mile west of small bathhouse. Cement monument marking reference station is 5.40 meters S $48^{\circ} \circ 6^{\prime} \mathrm{E}$ of observed station.

Marks.-Observed station is nail in 3 -inch cement-filled tile pipe with top about 6 inches below surface of ground, incased in cement bearing the legend "U. S. C. S.-1896." Reference station is center point of triangle on standard cement monument projecting 5 inches above surface of ground.

References.-

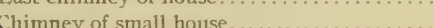

East gable of barn

East gable of small house.................

Sisuth gable of barn................. (a .

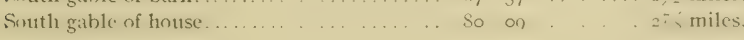


References-Continued.

Liast chimney of house............. 94 I7 $\ldots \ldots \ldots 13 / 4$ miles.

West climney of house............... I30 $52 \ldots \ldots$ miles.

South gable of corncrib............. 157 I4 $\ldots \ldots \ldots 5 / 8$ mile.

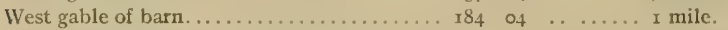

REFERENCE STATION.................. $247 \quad 3^{8} \quad 20 \ldots \ldots 5.40$ meters.

Nail in blaze in persimmon tree $(4$ inches

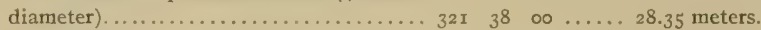

North gable of barn................. $329 \quad 38 \quad \ldots \ldots \ldots 21 / 8$ miles.

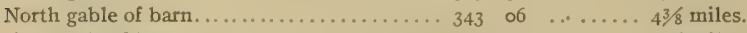

East gable of barn................. 357 o2 $\ldots \ldots 4$ miles.

\section{EARLE}

General locality.-Southern shore of Corsica River on Town Bar Point about $1 / 2$ mile east of Chester River and roo yards north of Earle Wharf. (See Chart No. 30.)

Immediate locality.-Observed station is on marsh land about I foot above high water, 5 yards south of shore, Ig yards north of a pond, and Ioo yards north of Earle Wharf.

Marks.-Observed station is center point of triangle on standard cement monument projecting 3 inches above surface of ground. Subsurface mark is center of 2 -inch tile pipe buried with top 2 inches below base of monument.

References.-

"Hydrographic" (S 64 ${ }_{3}^{\circ} \mathrm{S}^{\prime} \mathrm{F}, \mathrm{L}$.

Lone sycamore tree..................

East climney of house .................

Southeast pile at end of Earle Wharf.......

Nail in blaze in locust tree ( 5 inches diam-

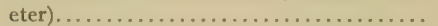

Nail in blaze in locust tree ( 3 inches diam-

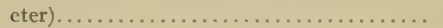

Earle windmill..............................

Eirst mable of born ........ 118 o7

$\ldots \ldots \ldots \ldots \ldots{ }_{16} \quad 2 I$

East gable of small house............... $179 \quad 26$

Church steeple at Crosby............... I96 20

Sotth gable of Brown house..............209 og

West chimney of house................ $244 \quad 53$

South gable of Emory barn............... 298 os

West chimney of house........... 338 io

\section{HYDROGRAPHIC.}

General locality.-Southern shore of Corsica River about $I I / 8$ miles east of Chester River and $1 / 2$ mile east of Earle Wharf. (See Chart No. 30.)

Immediate locality.-Observed station is near edge of cultivated field about 3 feet above high water, 20 yards south of shore, 4 yards south of edge of bank 3 feet high, and 400 yards north of lone sycamore tree.

Marks,-Observed station is center point of triangle on standard cement monument projecting 5 inches above surface of ground. Subsurface mark is center of 2 -inch tile pipe buried with top 2 inches below base of monument.

References.-

"Liarle" ( $\left.\mathrm{N} \mathrm{6}{ }^{\circ} 3 \mathrm{~T}^{\prime} \mathrm{IV}\right)$

Church steeple at Crosby.

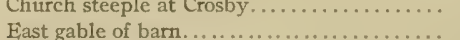

South gable of barn ....................

South gable of Iimory barn. 
References-Continued.

Sonthwest corner of Emory Wharf house $\ldots \ldots 75 \quad 44 \quad \ldots \ldots \ldots .1 / 2$ mile

West gable of barn................. Ir 4 . 5 I $\ldots \ldots .3 / 4$ mile.

West gable of barn............... $135 \quad 37 \quad \ldots \ldots \ldots$ rs'ś miles.

West chimney of house.............. 148 56 $56 \ldots \ldots I^{\mathrm{I}}+$ miles.

Fast chimney of house .............. $2,3 \mathrm{I} \quad 23 \ldots \ldots .3 / 4$ mile.

Nail in blaze in apple tree ( 12 inches diam-

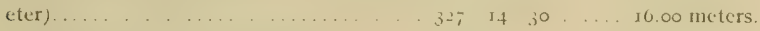

Southeast corner of Earle Wharf house.... 354 5I $\ldots \ldots \ldots 1 / 2$ mile.

\section{RUTH.}

General locality, - Southern shore of Corsica River about $I^{I} / 2$ miles east of Chester River and $1 / 8$ mile northwest of entrance to Tilghmans Cove. (See Chart No. 3o.)

Immediate locality.-Observed station is in cultivated field about I 5 feet above high water, Io yards south of shore, 2 yards west of edge of slope, and 6 yards south of edge of slope.

Marks.--Observed station is center point of triangle on standard cement monument projecting 3 inches above surface of ground. Subsurface mark is center of 2 -inch tile pipe buried with top 2 inches below base of monument.

\begin{tabular}{|c|c|c|c|c|}
\hline References.- & $\circ$ & , & " & \\
\hline "Hydrographic" ( $\left.\mathrm{N} 82^{\circ}{ }^{\circ} 3^{\prime} \mathrm{W}\right) \ldots \ldots \ldots \ldots$ & 0 & $\infty 0$ & $\infty$ & 3/8 mile. \\
\hline East chimney of Earle tenant house........ & $\circ$ & II & .. & . I mile. \\
\hline South gable of Sissel barn. .............. & 36 & 30 & . & I mile. \\
\hline Southeast corner of Emory Wharf house.... & $5+$ & 13 & . & $5 / 8$ mile. \\
\hline South gable of Emory barn................ & 60 & 05 & . & $3 / 4$ mile. \\
\hline Chimney of Emory house................. & 64 & 17 & . & $3 / 4$ mile. \\
\hline East post of front porch of house .......... & $\log$ & 34 & . & $3 / 4$ mile. \\
\hline $\begin{array}{l}\text { Nail in blaze in oak tree ( } 24 \text { inches diameter). } \\
\text { Nail in blaze in cedar tree ( } 6 \text { inches diam- }\end{array}$ & 119 & 49 & 10 & 9.98 meters. \\
\hline & 223 & 53 & 20 & .30 me \\
\hline East gable of small barn................. & 308 & 56 & . & $3 / 8$ mile. \\
\hline Lone sycamore tree. & 319 & 36 & . & . $3 / 4$ mile. \\
\hline
\end{tabular}

\section{MELFIELD.}

General locality.-Southern shore of Corsica River about $17 / 8$ miles east of Chester River, I mile southeast of Emory Wharf, and I/8 mile east of entrance to Tilghmans Cove. (See Chart No. 30.)

Immediate locality.-Observed station is in cultivated field about 18 feet above high water, Io yards south of shore, 5 yards south of edge of bluff, and Io yards west of a ravine.

Marks.-Observed station is center point of triangle on standard cement monument projecting 4 inches above surface of ground. Subsurface mark is center of 2 -inch tile pipe buried with top 2 inches below base of monument.

References.-

"Ruth" ( $\left.\mathrm{N}_{7 x^{\circ}} 3^{\prime} \mathrm{W}\right) \ldots \ldots \ldots \ldots \ldots \ldots \ldots$

East gable of barn....................

Left tangent of Emory Wharf...............

Eiast chimney of Emory house............

Southwest comer of house................

Cupola on Emory Wharf house.............
Nail in blaze in walnut tree $(8$ inches diam.

eter).......................... II9 34 I0 ....

Nail in blaze in gum tree ( 7 inches diameter). I79 56 Io ..... 16.18 meters.

West gable of barn................

Nail in blaze in locust tree ( 6 inches diam-

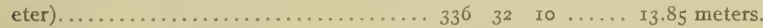

South chimney of Earle house $\ldots \ldots \ldots \ldots \ldots 350 \quad 42 \quad \ldots \ldots \ldots .3 / 8$ miles. 


\section{BATH.}

General locality.-Southern shore of Corsica River on Wash Point about 2 miles east of Chester River, $1 / 2$ mile west of Rocky Point, and $1 / 4$ mile southeast of Ship Point. (See Chart No. 30.)

Immediate locality.-Observed station is on a marsli point about $x$ foot above high water, 15 yards east of shore, I3 yards west of a pond, and surrounded by dense growth of bushes.

Marks.-Observed station is center point of triangle on standard cement monument projecting $\delta$ inches above surface of ground. Subsurface mark is center of 2 -inch tile pipe buried with top 2 inches below base of monument.

References.-

"Melfield" (S $\left.30^{\circ} 54^{\prime} \mathrm{W}\right) . \ldots \ldots \ldots \ldots \ldots \ldots$

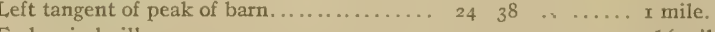

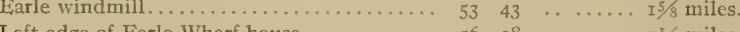

I eft edge of Earle Wharf house........... ${ }_{5}^{6} \quad 3^{8} \quad \ldots \ldots \ldots .1 / 2$ miles.

East chimney of house.............. 86 I4 ..... I mile.

South chimney of house.............. I20 $55 \quad \ldots \ldots \ldots 3 / 8$ mile.

West chimney of house............... 217 I2 $\ldots \ldots .3 / 4$ mile.

North one of two cedar trees on hill....... 267 or ..... $1 / 4$ mile.

Nail in blaze in hackberry tree ( 12 inches

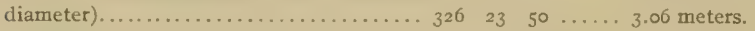

Nail in blaze in pear tree ( 15 inches diam.

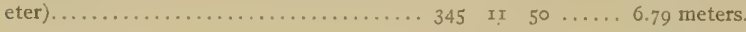

SHIP.

General locality.-Northem shore of Corsica River on Ship Point at west side of entrance to Emorys Creek, about $17 / 8$ miles east of Chester River, and $5 / 8$ mile east of Emory Wharf. (See Chart No. 30.)

Immediate locality.-Observed station is on a marsh point covered with bushes about I foot above high water, 6 yards west of shore, and 75 yards south of a cedar tree covered with grape vines.

Marks.-Observed station is center point of triangle on standard cement monument projecting 3 inches above surface of ground. Subsurface mark is center of 2 -inch tile pipe buried with top 2 inches below base of monument.

References.-

"Ruth" (S $\left.39^{\circ} I I^{\prime} \mathrm{W}\right) \ldots \ldots \ldots \ldots \ldots \ldots \ldots$

North gable of barn...................

Farle windmill .................... 40

Left edge of Earle Wharf house. ............

East gable of barn . . . . . . . . . . . . . I2

Nail in blaze in cedar tree ( 7 inches diam-

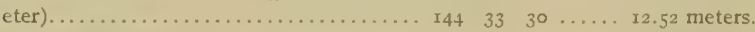

West gable of barn................. $2 I_{7} \quad 0_{5} \ldots \ldots \ldots 1 / 4$ miles.

West chimney of house............... 220 00 ...... $1 \frac{1 / 4}{4}$ miles.

North chimney of house.............. $229 \quad 59 \quad \ldots \ldots \ldots 1 / 4$ miles.

West chimney of house............... 25 I $20 \ldots \ldots, 4$ mile.

\section{ENGINEER.}

General locality.-Northem shore of Corsica River about $x$ mile east of Chester River, $5 / 8$ mile northeast of Earle Wharf, and 50 yards west of Emory Wharf. (See Chart No. 30.)

Immediate locality.--Observed station is on marsh land about I foot above high water, I2 yards north of shore, 50 yards west of Emory Wharf, and 50 yards southeast of a pond.

Marks.-Observed station is center point of triangle on standard cement monument projecting 4 inches above surface of ground. Subsurface mark is center of 2 -inch tile pipe buried with top 2 inches below base of monument. 


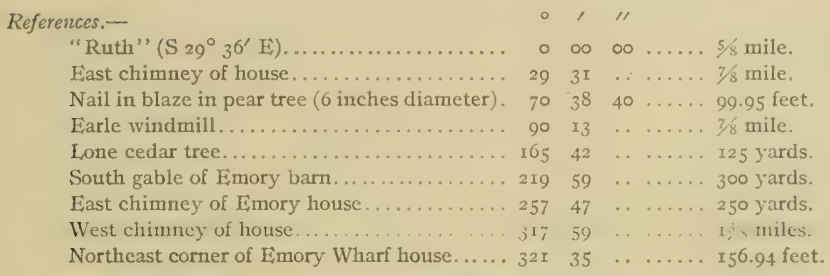

\section{SWEPSON.}

General locality,-Northern shore of Corsica River opposite Town Bar Point about $1 / 2$ mile east of Chester River, $3 / 8$ mile north of Earle Wharf, and 3 's mile west of Emory Wharf. (See Chart No. 30.)

Immediate locality.-Observed station is on marsh land about $I$ foot above high water, 12 yards north of shore, Io yards south of lone cedar tree, and 12 yards east of small ditch draining swamp.

Marks.-Observed station is center point of triangle on standard cement monument projecting 6 inches above surface of ground. Subsurface mark is center of 2 -inch tile pipe buried with top 2 inches below base of monument.

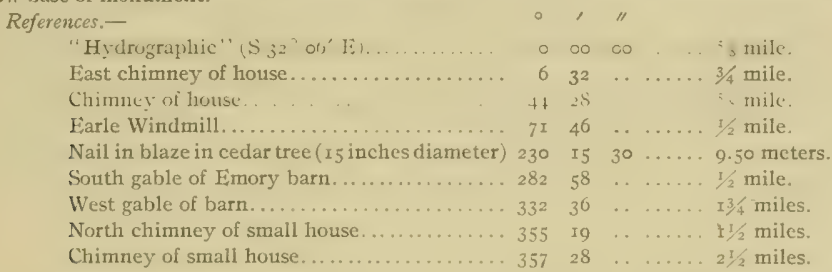

\section{CORSICA.}

General locality.-Eastern shore of Chester River at north side of entrance to Corsica River about 3.8 mile south of Lower Spaniard Point. (See Chart No. 30.)

Immediate locality.-Observed station is in a cultivated field about 7 feet above high water, 16 yards east of shore, II yards east of edge of bank, and 5.yards sotth of young peach orchard.

Marks.-Observed station is center point of triangle on standard cement monument projecting 2 inches above surface of ground. Subsurface mark is center of 2 -inch tile pipe buried with top 2 inches below base of monument.

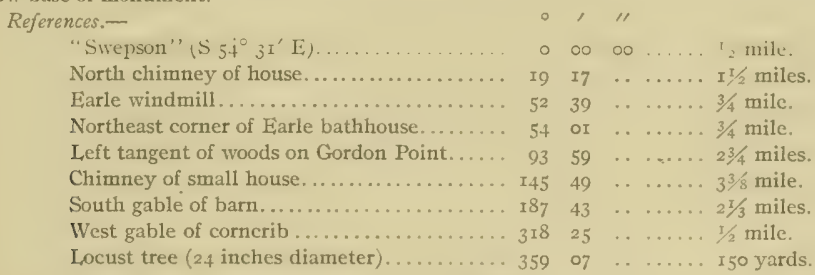

\section{DEEP COVE.}

General locality.-Western shore of Chester River on point at west side of entrance to Langford Creek and south side of entrance to Deep Cove. (See Chart No. 30.)

Immediate locality.-Observed station is on marsh land about I foot above high water, ro yards inshore, 50 yards east of a dead tree 2 feet in diameter, 80 yards southeast of a tall poplar tree, and 300 yards east of a house. 
Marks.-Obscrved station is center point of triangle on standard cement monument projecting 4 inclies above surface of gromnd. Subsurface mark is center of 2 -inch tile pipe buried with top 2 inches helow base of monument.

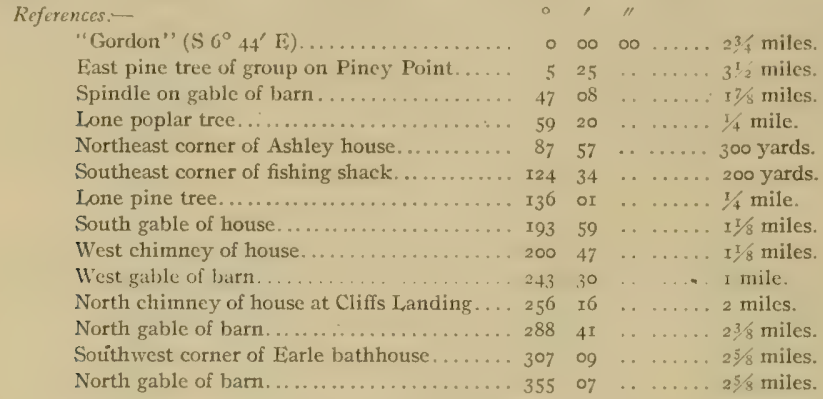

\section{LANGFORD.}

General locality.-Western shore of Chester River on Nichols Point at east side of entrance to Langford Creek. (See Chart No. 30.)

Immediate locality.-Observed station is on a sandy point among persimmon trees about 2 feet above high water, I2 yards inshore, and 200 yards south of a marsh.

Marks.-Observed station is center point of triangle on standard cement monument projecting 3 inches above surface of ground. Subsurface mark is center of 2 -inch tile pipe buried with top 2 inches helow base of monument.

References.--

"Gordon" (S ro $\left.42^{\prime} \mathrm{W}\right)$...

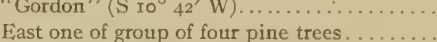

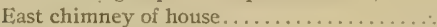

Chimney of small house.................

Nail in blaze in persimmon tree ( 6 inches diameter $) . . . \ldots \ldots \ldots \ldots \ldots \ldots \ldots \ldots \ldots . \ldots \ldots$

East chimney of house................

South gable of barn.................. Iis

South chimney of house ................ If . If

Chimney of house .

Nail in blaze in persimmon tree $(6$ inches diameter)...........................

Nail in blaze in persimmon tree $(4$ inches diameter)...................... 287 I5 $30 \ldots \ldots .63$ meters.

Northwest corner of Earle bathliouse....... 299 00 $\ldots \ldots \ldots .3 / 4$ miles.

Cupola on barn..................... $332 \quad 26 \ldots \ldots 2$ miles.

North gable of house................. $346 \quad 57 \quad \ldots \ldots 2 \frac{21 / 4}{6}$ miles.

SPANIARD POIN'T 2 UPPER.

General locality. - Southeastern shore of Chester River on Lower Spaniard Point about I $1 / 4$ miles east of Nichols Point, $7 / 8$ mile south of Clifis Landing, and $1 / 2$ mile southwest of Spaniard Wharf. (Sec Chart No. 30.)

Immediate locality.-Observed station is on a sand beach about I foot above high water, 8 yards southeast of shore, and 300 yards northwest of woods. Cement monument marking reference station is $\mathrm{II} .72$ meters $\mathrm{S} 70^{\circ} 5^{\prime} \mathrm{E}$ of observed station.

Marks.-Observed station is nail in 3 -inch cement-filled tile pipe bearing the legend "U.S. C. S.1896 ," with top 6 inches below surface of ground. Reference station is center point of triangle on standard cement monument projecting 6 inches above surface of ground. 


\begin{tabular}{|c|c|c|c|c|}
\hline Refcrences.- & 。 & & $" \prime$ & \\
\hline "Langford" (N $\left.87^{\circ} 27^{\prime} \mathrm{W}\right)$. & $\circ$ & $\infty$ & $\infty$ & $\ldots \ldots x^{2} / 4$ miles. \\
\hline South gable of barn........... & 2 & +4 & . & . $2 i$ s miles. \\
\hline Eiast gable of barn .......... & I6 & I0 & - & $23 / 8$ miles. \\
\hline Church steeple. & 20 & 25 & . & 3 miles. \\
\hline West chimney of Brown house............. & 37 & 38 & .. & I $3 / 8$ miles. \\
\hline West chimney of house................. & 76 & 08 & . & I mile. \\
\hline Right tangent of piles of Clifis Landing...... & 100 & 40 & . & . $7 / 8$ mile. \\
\hline South gable of house................... & ror & 05 & $\cdots$ & . I I/8 miles. \\
\hline "Westcotts Windmill". .......... & II 7 & 31 & . & . $2 \frac{1}{4}$ miles. \\
\hline REFERENCE STATION ............. & 196 & $3^{6}$ & 50 & . I1 . 72 meters. \\
\hline 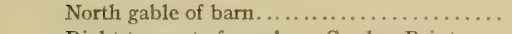 & 295 & 57 & $\cdots$ & . 3 miles. \\
\hline Right tangent of woods on Gordon Point. ... & 302 & $\infty$ & $\cdots$ & .... 3 miles. \\
\hline East chimney of house on Grays Inn Creek. & $35^{2}$ & 39 & $\cdots$ & ..... $33 / 8$ miles. \\
\hline
\end{tabular}

\section{QUAKE,R.}

General locality.-Western shore of Chester River in Cliff Bight about $3 / 4$ mile north of Nichols Point. (See Chart No. 30.)

Immediate locality.-Observed station is on marsh land about 3 feet above high water, 8 yards northwest of shore, 8 yards southeast of a wire fence and a row of pear trees, and 6 yards south of a group of persimmon trees.

Marks.-Observed station is center point of triangle on standard cement monument projecting 5 inches above surface of ground. Subsurface mark is center of 2 -inch tile pipe buried with top 2 inches below base of monument.

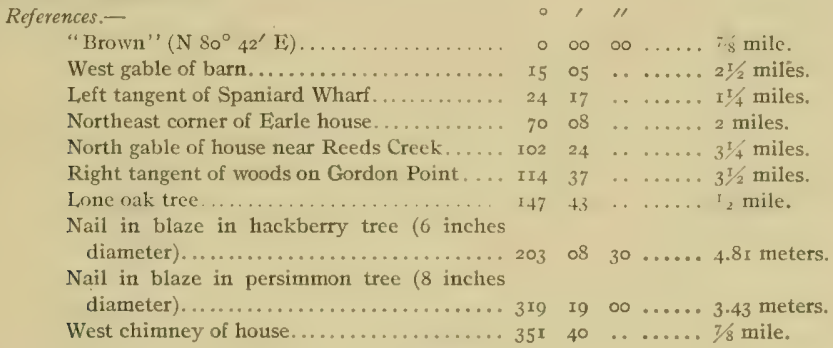

\section{EVANS.}

General locality.-Southeastern shore of Chester River on Upper Spaniard Point about $5 / 8$ mile south of Cliffs Landing and I/8 mile northeast of Spaniard Wharf. (See Chart No. 30.)

Immediate locality.-Observed station is on marsh land about I foot above high water, so yards north of shore, and 200 yards east of end of Spaniard Wharf.

Marks.-Observed station is center point of triangle on standard cement monument projecting 4 inches above surface of ground. Subsurface mark is center of 2 -inch tile pipe buried with top 2 inches below base of monument.

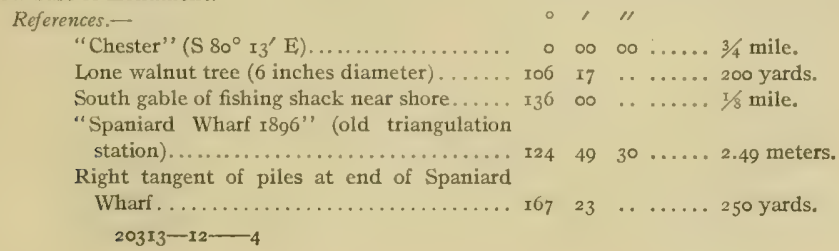


References-Continued.

North chimney of house............... $189 \quad 26$

West chimney of house...............212 $x_{3}$

Chimney of Martin cabin................ 219 20

North gable of Clifts Landing house....... 234 3I

East chimney of house............... $247 \quad 28$

North gable of barn.................. $276 \quad 23$

"Westcott Windmill".................. $282 \quad 55$

East gable of barn. . . . . . . . . . . 308 3I

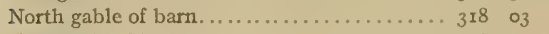

East

BROWN.

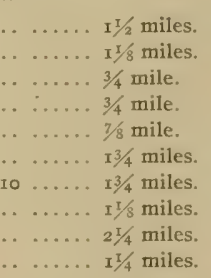

General locality.-Northwestern shore of Chester River on Cliffs Point between Clifis Bight and Commegys Bight about $1 / 4$ mile west of Cliffs Landing. (Sce Chart No. 30.)

Immediate locality.-Observed station is in a cultivated field about 12 feet above high water, 25 yards north of shore, 7 yards north of edge of bank, and 45 yards southeast of a large cherry tree.

Marks.-Observed station is center point of triangle on standard cement monument projecting 3 inches above surface of ground. Subsurface mark is center of 2 -inch tile pipe buried with top 2 inches below base of monument.

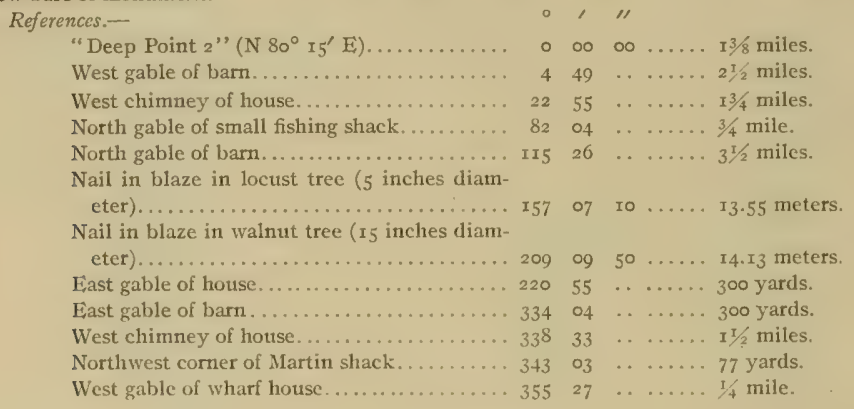

\section{STRATTON.}

General locality.-Northwestern shore of Chester River at west side of entrance to Commegys Bigltt near Clifis Landing and about $1 / 4$ mile northeast of Cliffs Point. (See Chart No. 30.)

Immediate locality.-Observed station is on marsh land about on level with high water, 5 feet north of shore, and 2 I yards southwest of entrance to a small creek.

Marks.-Observed station is center point of triangle on standard cement monument projecting 6 inches above surface of ground. Subsurface mark is center of 2 -inch tile pipe buried with top 2 inches below base of monument.

References.-

"Deep Point 2" ( $\left.\mathrm{N} 83^{\circ} 53^{\prime} \mathrm{E}\right) \ldots \ldots \ldots \ldots \ldots$

Cupola on barn......................

West gable of com crib................ 23

Southwest corner of wharf house......... 8

North gable of house ................. II

Right tangent of woods on Gordon Point... I25 I4

Pine tree on line with bulkhead of wharf.... I54 29

North chimney of house.................. $266 \quad 37$

West gable of Westcott bam............... 319 $5^{8}$

West gable of barn................. $340 \quad 32$

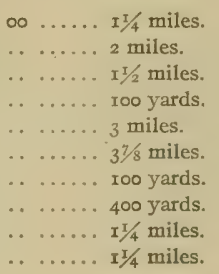




\section{CHESTER.}

General locality. - Southeastern shore of Chester River about $3 / 4$ mile east of Upper Spaniard Point and $7 / 8$ mile south of Deep Point. (See Chart No. 30.)

Immediate locality. - Observed station is in a low meadow about 2 feet above high water, Io yards south of shore, 2 yards south of board and wire fence, 2 yards east of rail fence, and 35 yards northwest of gate to front yard of a house.

Marks.-Observed station is center point of triangle on standard cement monument projecting 5 inches above surface of ground. Subsurface mark is center of 2 -inch tile pipe buried with top 2 inches below base of monument.

References.-

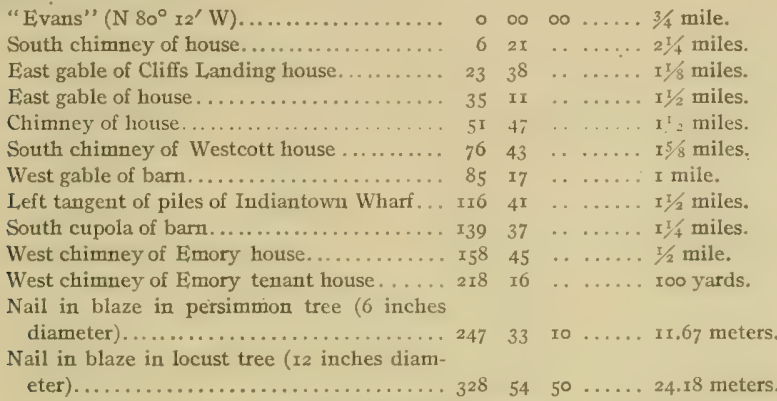

\section{WESTCOTTS WINDMILI.}

General locality.-Northwestem side of Chester River about I/s mile inshore from northem end of Commegys Bight and $I 3 / 8$ miles northeast of Cliffs Landing. (See Chart No. 30.)

Immediate locality.-Observed station is about 35 feet in height on a barn and near a water tank back of barn.

Marks.-Observed station is center point of windmill.

References.--None necessary.

\section{CORPSE,}

General locality. Southeastern shore of Chester River about $3 / 8$ mile southeast of Deep Point, $1 / 2$ miles east-northeast of Spaniard Wharf and 5/8 mile southwest of Indiantown Wharf. (See Chart No. 30.)

Immediate locality. - Observed station is on a sanded marsh strip about I foot above high water, 3 yards east of shore, 18 yards south-southeast of a point, 43 yards north by east of another point, and I/8 mile west of a large house.

Marks.--Observed station is center point of triangle on standard cement monument projecting 3 inches above surface of ground. Subsurface mark is center of 2 -inch tile pipe buried with top 2 inches below base of monument.

References.-

"Chester" (S $\left.39^{\circ} 24^{\prime} \mathrm{WW}^{\mathrm{r}}\right)$.

Right tangent of Spaniard Wharf .

Chimney of house near Cliffs Landing ....

Right peak of house on Deep Point.........

Left one of two chimneys on south end of brick house ..................... I4

Left tangent of Indiantown Wharf.......... I7

Chimney of ell of house near Indiantown

Wharf ....................... I $8 \mathrm{x}$

Left tangent of large house.............228

Right chimney of house............... 297

Chimney outside of old house........... 359

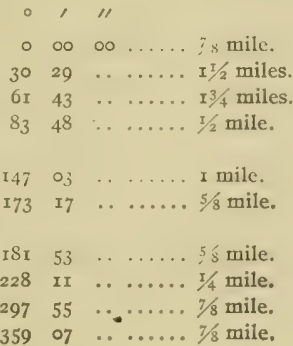




\section{DEEP POINT 2.}

General locality. - Northwestern shore of Chester River on Deep Point about I1/4 miles east of Cliffs Landing, $x \frac{1}{4}$ miles northeast of Spaniard Wharf, and $3 / 4$ mile west of Indiantown Wharf. (See Chart No. 3०.)

Immediate locality.-Observed station is about I foot above high water, among several cedar and poplar trees on a point, I3 yards northeast of shore, 2I yards southwest by west of shore, 40 yards north west of extreme end of point, and 120 yards southeast of a $I^{1 / 2}$-story house. Cement monument marking reference station is on line with west end of house 17 . I4 meters $\mathrm{N} 53^{\circ} 52^{\prime} \mathrm{W}$ of observed station.

Marks. - Observed station is nail in center of 2 -inch tile pipe set in cement with top 2 inches below. surface of ground. Reference station is center point of triangle on standard cement monument projecting 4 inches above surface of ground.

\section{References.-}

"Thorn" (N $\left.40^{\circ} \mathrm{IO}^{\prime} \mathrm{E}\right)$

Left chimney of house............................

Left tangent of Ashland Wharf........... I

Near chimney on west peak of house........

Southwest peak of house near Indiantown

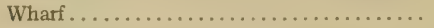

Nail in blaze in branch of cedar tree ( 5 inches diameter $) . . . \ldots \ldots \ldots \ldots \ldots . . . . .$.

Cupola on barn.....................

Nail in blaze in poplar tree ( $\mathrm{II}$ inches diameter)...................... 93

Largest one of three chimneys of house..... I0z

Chimney of brick house................ I5

Chimney on near peak of house.......... 233

REFERENCE STATION...................... 265

Nail in blaze in poplar tree (ro inches diam-

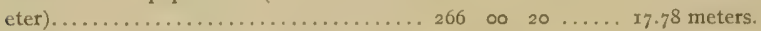

Right tangent of back of Westcott house....279 $56 \quad \ldots \ldots$ I20 yards.

Nail in blaze in branch of double tree ( 8 inches diameter)

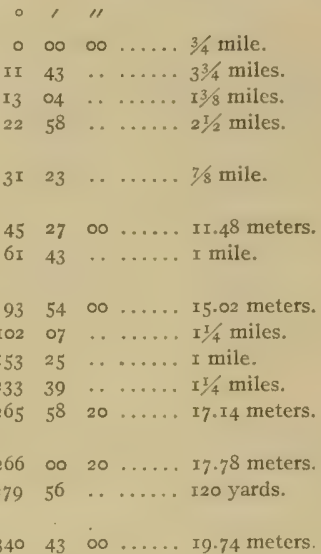

\section{INDIAN.}

General locality. - Southeastern shore of Chester River near Indiantown Wharf about 3/4 mile castnortheast of Deep Point. (See Chart No. 30.)

Immediate locality.-Observed station is about 2 feet above high water, to yards east of shore end of Indiantown Wharf, 10 yards southeast of shore, 21 yards north of curved fence of yard of a small house, and 40 yards north by west of a house.

Marks.-Observed station is center point of triangle on standard cement monument projecting 4 inches above surface of ground. Subsurface mark is center of 2 -inch tile pipe buried with top 2 inches below base of monument.

References.-

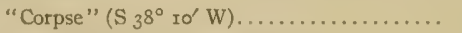

Right tangent of Spaniard Wharf. .........

Right chimney of Westcott bungalow........

Near comer of wharf house................

Left tangent of Massey brick house..........

Large chimney of house beyond trees....... I

Chimney of small house near Quaker Neck Wharf............................ r

Left tangent of Ashland Wharf............ I7

Lone cedar tree.................... I8

Nail in blaze in cedar tree ( 12 inches diameter).

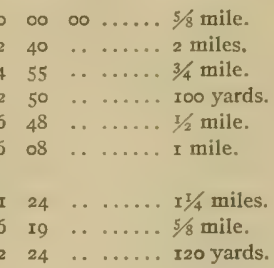


References-Continued.

Near corner of house.

Nail in blaze in cedar tree (ro inches diameter).................... 18.68 meters.

Nail in blaze in cedar tree ( 20 inches diam-

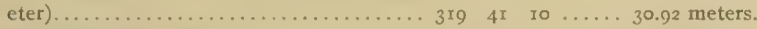

Right tangent of curved fence........... $324 \quad 40 \quad \ldots \ldots .40$ yards.

Chimney of large house................ $334 \quad 5^{8} \quad \ldots \ldots$ t/2 mile.

THORN.

General locality.-Northwestern shore of upper Chester River opposite White Cove near Westcott Wharf and about $3 / 4$ mile northeast of Deep Point. (See Chart No. 3o.)

Immediate locality.-Observed station is in a cultivated field about 6 feet above high water, I5 yards northwest of shore, 5 yards southwest of corner of board fence, 60 yards south-southeast of a brick house, and 42 yards southwest of piles of old wharf at shore line.

Marks.-Observed station is center point of triangle on standard cement monument projecting 4 inches above surface of ground. Subsurface mark is center of 2 -inch tile pipe buried with top 2 inches below base of monument.

References.

"Shippen" ( $\left.\mathrm{N}_{43^{\circ}} \mathrm{x}^{\prime} \mathrm{E}\right) \ldots \ldots \ldots \ldots \ldots \ldots \ldots$

Near peak of large house ..............

Left tangent of Ashland Wharf........... 23

Corner post of fence ( 4 inches diameter).... 33

Cupola of barn....................... I04

Chimney of small house............... I59

Near corner of Massey house............... 208

Nail in blaze in peach tree ( 6 inches diameter) $28_{3}$

Nail in blaze in fence post ( 3 inches diameter) 338

$\begin{array}{lllll}1 & " \\ 00 & \infty & \ldots & \ldots & 1 / 2 \text { mile. } \\ 40 & \ldots & \ldots & 4 / 2 \text { miles. } \\ 21 & \ldots & \ldots & 5 / 8 \text { mile. } \\ 23 & 10 & \ldots & 4.33 \text { meters. } \\ 13 & \ldots & \ldots & 7 / 8 \text { mile. } \\ 09 & \ldots & \ldots & 13 / 4 \text { miles. } \\ 40 & \ldots & \ldots & 1 / 8 \text { mile. } \\ 57 & 22 & \ldots & \ldots & 13.74 \text { meters. } \\ 27 & 20 & \ldots & 5.35 \text { meters. }\end{array}$

ASHLAND.

Gencral locality,-Southeastern shore of upper Chester River near Ashland Wharf and about $1 / 4$ mile northeast of White Cove. (See Chart No, 30.)

Immediate locality:-Observed station is about $\mathrm{I}$ foot above high water, 5 yards southeast of shore, 32 yards south west of a fence, and 20 yards west-northwest of persimmon trees.

Marks.-Observed station is center point of triangle on standard cement monument projecting 4 inches above surface of ground. Subsurface mark is center of 2 -inch tile pipe buried with top 2 inches below base of monument.

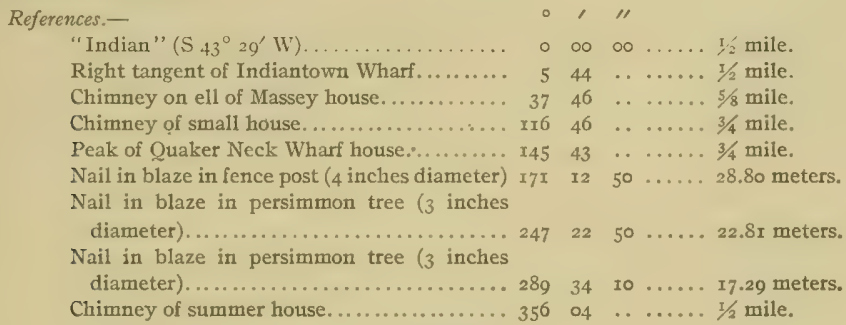

\section{SHIPPEN.}

General locality.-Northwestern shore of Upper Chester River on point at southern side of entrance to Shippen Creek and nearly opposite Ashland Wharf. (See Chart No. 30.)

Immediate locality.-Observed station is on a sand and marsh point about I foot above high water, 6 yards southwest of shore, 12 yards northeast of shore, $1_{5}$ yards north of extreme end of sand point, and 25 yards southeast of trees along edge of cultivated field. 
Marks.-Observed station is center point of triangle on standard cement monument projecting 4 inches above surface of ground. Subsurface mark is ccnter of 2 -inch tile pipe buried with top 2 inches below base of monument.

\begin{tabular}{|c|c|c|c|c|}
\hline References:-- & 。 & , & "I & \\
\hline "Oyster" ( $\left.\mathrm{N}_{3} 8^{\circ} 22^{\prime} \mathrm{E}\right)$. & 0 & $\infty$ & $\infty$ & $\ldots \ldots 3 / 4$ mile. \\
\hline Chimney on left end of house..... & I8 & 37 & . & .. $2 \frac{1}{2}$ miles. \\
\hline Peak of barn................ & 26 & 49 & . & $\ldots \ldots 21 / 4$ miles. \\
\hline Chimney on end of house. ................ & 27 & 59 & . & $\ldots \ldots 21 / 4$ miles. \\
\hline Chimney on right end of house...$\ldots \ldots \ldots$ & 54 & 23 & .. & . $x$ mile. \\
\hline Left tangent of piles of Ashland Wharf...... & 69 & 40 & . & .. $1 / 4$ mile. \\
\hline Chimney on near end of house............ & 79 & 08 & . & ..... x mile. \\
\hline Spindle on barn cupoia............... r & $\mathbf{r}_{35}$ & 58 & . & .. I mile. \\
\hline Tangent of piles at Indiantown Wharf...... I & $x 54$ & 35 & $\cdots$ & . 5/8 mile. \\
\hline Tangent of Deep Point................ I & 182 & 24 & $\cdots$ & .. I $1 / 4$ miles. \\
\hline Near chimney of house ............... I & 189 & 40 & . & .... $1 / 2$ mile. \\
\hline $\begin{array}{l}\text { Nail in blaze in pear tree ( } 12 \text { inches diameter). } 2 \\
\text { Nail in blaze in cedar tree (Io inches diam- }\end{array}$ & 263 & 35 & 40 & .. 22.59 meters. \\
\hline 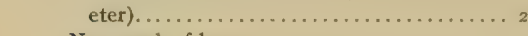 & 292 & 46 & ro & 20.70 mete \\
\hline Near peak of barn.............. & $34 \mathrm{I}$ & 44 & $\cdots$ & . 5/8 mile. \\
\hline Smoke pipe on Quaker Neck Wharf house & 359 & $5^{6}$ & $\cdots$ & ..... 5/8 mile. \\
\hline
\end{tabular}

\section{BURNS.}

General locality.-Southeastern shore of upper Chester River opposite Quaker Neck Wharf, about I/2 mile northeast of Ashland Wharf. (See Chart No. 30.)

Immediate locality.-Observed station is in meadow land about $\mathrm{I}$ foot above high water, ro yards southeast of shore, 50 yards southwest by south of point, $\mathbf{x} 45$ yards northeast by east of a fence, and 200 yards northwest of another fence.

Marks.- Observed station is center point of triangle on standard cement monument projecting 7 inches above surface of ground. Subsurface mark is center of 2 -inch tile pipe buried with top 2 inches below base of monument.

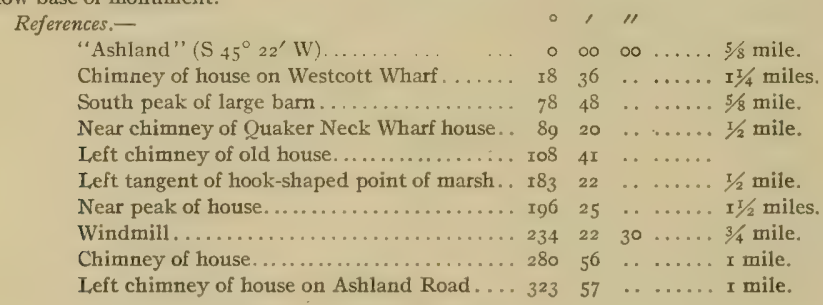

\section{OYSTER.}

General locality.-Northwestern shore of upper Chester River about I/8 mile northeast of Quaker Neck Wharf and $1 / 2$ mile southwest of entrance to Jarretts Creek. (See Chart No. 30.)

Immediate locality.-Ohserved station is in a cultivated field alsout 20 feet above high water, 8 yards west-northwest of edge of bank, 9 yards north-northwest of edge of bank, 25 yards northeast by north of a cedar tree, Ioo yards southwest of lowland, and II5 yards east of fence near a house.

Marks.-Observed station is center point of triangle on standard cement monument projecting 5 inches above surface of ground. Subsurface mark is center of 2 -inch tile pipe buried with top 2 inches below base of monument. 


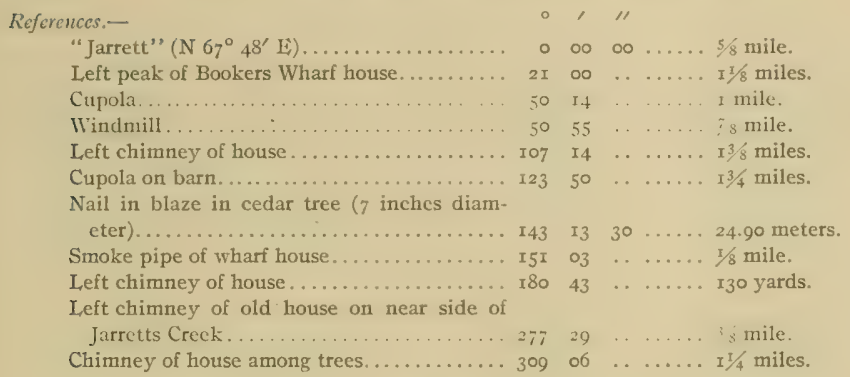

\section{STARKLEY.}

General locality.-Southeastern shore of upper Chester River about 3/4 mile east of Quaker Neck Wharf, and $1 / 2$ mile southwest of Bookers Wharf. (See Chart No. 30.)

Immediate locality. - Observed station is in meadow land about $x$ foot above high water, Io yards east by south of shore, 33 yards south of first cut in shore, I 40 yards north by west of a fence, 145 yards southwest of point where another fence meets shore, and 275 yards south of large cedar tree.

Marks.-Observed station is center point of triangle on standard cement monument projecting 6 inches above surface of ground. Subsurface mark is center of 2 -inch tile pipe buried with top 2 inches below base of monument.

References.-

"Burns" (S $\left.61^{\circ} 34^{\prime} \mathrm{W}\right)$

Left chimney of Quaker Neck Wharf house. . $\begin{array}{lllll}39 & 02 & \ldots & \ldots & 7 / 8\end{array}$

Right peak of barr ................. $66 \quad 43 \quad \ldots \ldots \ldots$ r mile.

Peak of middle dormer window of large house. II4 $30 \quad \ldots \ldots \ldots 3 / 4$ mile,

Left peak of large house.............. $16,349 \quad \ldots \ldots \ldots .1 / 4$ miles.

Left peak of Bookers Wharf house........ $18_{7} \quad 48 \ldots \ldots \ldots 1 / 2$ mile.

Large cedar tree............... I9 I II . . . . . 275 yards.

Spindle on left cupola of barn .......... 262 o0 $20 \ldots \ldots 1 / 2$ mile.

Weathervane on barn............... 320 or $50 \ldots \ldots$ mile.

JARRETT.

General locality.-Northwestern shore of upper Chester River about $5 / 8$ mile southwest of Melton Point, $1 / 4$ mile east of entrance to Jarretts Creek, and $5 / 8$ mile west of Bookers Wharf. (See Chart No. 30.)

Immediate locality.-Observed station is about I foot above high water, I4 yards north of shore, 50 yards from a short fence at shore, 65 yards west of entrance to slough, and 175 yards from another fence.

Marks.--Observed station is center point of triangle on standard cement monument projecting 5 inches above surface of ground. Subsurface mark is center of 2 -inch tile pipe buried with top 2 inches below base of monument.

References.-

"MeIton" ( $\left.\mathrm{N} 6 \mathrm{r}^{\circ} 3 \mathrm{t}^{\prime} \mathrm{E}\right)$.........

Left peak of house on ridge.

Right peak of small house................

West peak of Bookers Wharf house......... + +

Spindle on left cupola on barn............ ?

Weathervane on cupola on barn......... 125

Chimney of house near Indiantown Wharf... I5

Large chimney of Massey brick house...... I69 I6

Smokepipe of Quaker Neck Wharf house.... I $82 \quad 5^{\circ}$

Peak of middle dormer window of large house. 299
00 o $\ldots . .5 / 8$ mile.

$\begin{array}{lllll}35 & \ldots & \ldots & \mathbf{x}^{1 / 2} / 2 \\ \text { miles. }\end{array}$

$5^{8} \ldots \ldots \ldots 3 / 4$ mile.

...... $5 / 8$ mile.

.. .... $3 / 4$ mile.

...... I mile.

....... $17 / 8$ miles.

.. ...... I $1 / 8$ miles.

...... $3 / 4$ mile.

...... $1 / 2$ mile. 


\section{BOOKER.}

General locality,-Southeastern shore of upper Chester River about 175 yards northeast of Bookers Wharf and $1 / 2$ mile south of Melton Point. (See Chart No. 30.)

Immediate locality.-Observed station is on sanded marsh land about I foot above high water, 6 yards southeast of shore, 13 yards east by south of a small point, 30 yards southwest by south of locust trees, 125 yards northwest by north of a house on 20 -foot bank, and I40 yards northwest of a creek.

Marks,--Observed station is center point of triangle on standard cement monument projecting 6 inches above surface of ground. Subsurface mark is center of 2 -inch tile pipe buricd with top 2 inches below base of monument.

References.-

"Starkley" (S $\left.67^{\circ} 55^{\prime} \mathrm{W}\right)$

of Quaker Neck Wharf house. .

Near peak of house in woods................

Peak of middle dormer window on left side of

house among trees............... 68 o5 ..... $7 / 8$ mile.

Chimney of house................... Ir $38 \ldots \ldots$ mile.

Nail in blaze in locust tree ( 4 inches diam-

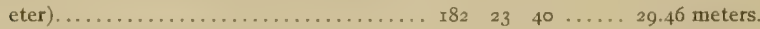

Near peak of house on bank............ $293 \quad 48 \quad \ldots \ldots \ldots$ 125 yards.

Right peak of Bookers Wharf house...... $35047 \quad \ldots \ldots$ I75 yards.

\section{JOURNEY.}

General locality._Eastern shore of upper Chester River opposite Melton Point about $1 / 2$ mile northeast of Bookers Wharf. (See Chart No. 30.)

Immediate locality.-Observed station is in cultivated land about 20 feet above high water, 3 yards southeast by east of edge of bank, south of large elm tree, and northeast of several sycamore and locust trees.

Marks.-Observed station is center point of triangle on standard cement monument projecting 5 inches above surface of ground. Subsurface mark is center of 2 -inch tile pipe buried with top 2 inches below base of monument.

References.-

\begin{tabular}{|c|c|c|c|c|}
\hline "Booker" (S $28^{\circ}$ I $\left.5^{\prime} \mathrm{W}\right)$. & $\circ$ & $\infty$ & & I \\
\hline Right peak of Bookers Wharf house......... & 4 & 24 & . & $1 / 2$ mile. \\
\hline Smokepipe of Quaker Neck Wharf house.... & $4 I$ & 21 & . & $15 / 8$ miles. \\
\hline $\begin{array}{l}\text { Near peak of house with three dormer win- } \\
\text { dows } \ldots \ldots \ldots \ldots \ldots \ldots \ldots \\
\end{array}$ & & or & & \\
\hline Right chimney of $21 / 2$-story house $\ldots \ldots \ldots \ldots$ & 107 & 02 & . & $1 / 2$ miles. \\
\hline Nail in blaze in elm tree ( 10 inches diameter). & I34 & 27 & 40 & 22.70 meters. \\
\hline Large cedar tree in yard near fence......... & 187 & 30 & . & 400 yards. \\
\hline Near peak of old house................... & 318 & 16 & . & 200 yards. \\
\hline $\begin{array}{l}\text { Nail in blaze in sycamore tree ( } 8 \text { inches diam- } \\
\text { eter) } \ldots \ldots \ldots \ldots \ldots \ldots \ldots \ldots \ldots \ldots \ldots \ldots \ldots\end{array}$ & 355 & & & \\
\hline
\end{tabular}

MELTON.

General locality.-Western shore of upper Chester River on Melton Point about $1 / 2$ mile north of Bookers Wharf. (See Chart No. 30.)

Immediate locality.-Observed station is about 2 feet above high water, 4 yards south of shore, 40 yards north of shore, 32 yards northwest of extreme end of point, 2 yards northeast of marsh, and 125 yards east-southeast of clump of cedar trees.

Marks.-Observed station is center point of triangle on standard cement monument projecting 6 inches above surface of ground. Subsurface mark is center of 2 -inch tile pipe buried with top 2 inches below base of monument. 


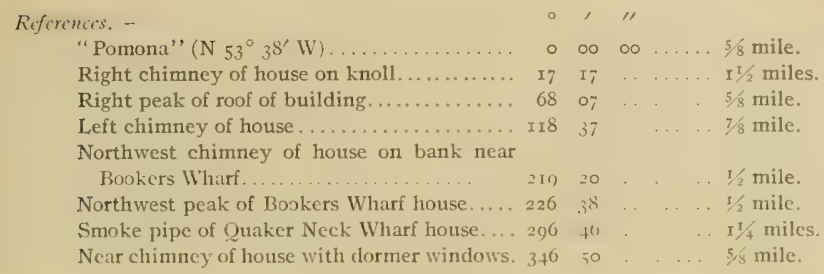

\section{CAKE.}

General locality.- Eastern shore of upper Chester River about $3 / 3$ mile north of Melton Point and $7 / 8$ mile north of Bookers Wharf. (See Chart No. 30.)

Immediate locality -Observed station is in a marsh about I foot above high water, I3 yards eastsoutheast of shore, 35 yards northeast by north of shore, 35 yards northeast of rounded point, 150 yards north-northwest of entrance to a creek, 200 yards south-southwest of buildings, and 300 yards south of a house among trees.

Marks,-Observed station is center point of triangle on standard cement monument projecting 6 inches above surface of ground. Subsurface mark is center of 2 -inch tile pipe buried with top 2 inches below base of monument.

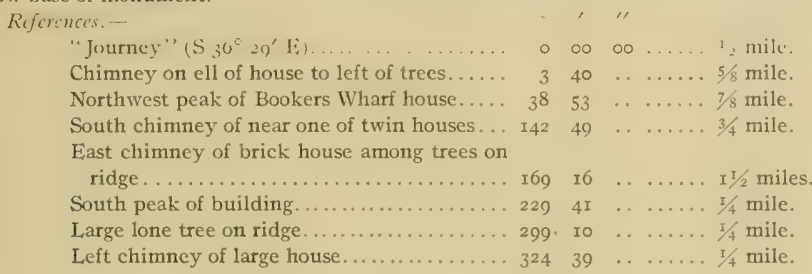

\section{POMONA.}

General locality.-Western shore of upper Chester River about 5.8 mile northwest of Melton Point and $I / 2$ mile south of entrance to Browns Creek. (Sce Chart No. 30.)

Immediate locality.-Observed station is among small trees near edge of cultivated field, about $I_{2}$ feet above high water, 6 yards west of edge of bank, and 8 yards from top of slope to marsh.

Marks.--Observed station is center point of triangle on standard cement monument projecting 4 inches above surface of ground. Subsurface mark is center of 2 -inch tile pipe buried with top 2 inches below base of monument.

\begin{tabular}{|c|c|c|c|c|}
\hline eferences.- & 。 & , & "I & \\
\hline "Taste" ( ${ }^{\circ}{ }^{\circ} 30^{\prime}$ W $) \ldots \ldots \ldots \ldots \ldots \ldots \ldots \ldots$ & $\circ$ & $\infty$ & $\infty$ & I: mile. \\
\hline $\begin{array}{l}\text { Nail in blaze in locust tree ( } 3 \text { inches diam- } \\
\text { eter) } \ldots \ldots \ldots \ldots \ldots \ldots \ldots \ldots \ldots \ldots \ldots \ldots \ldots \ldots\end{array}$ & I.4 & 28 & 20 & leters. \\
\hline 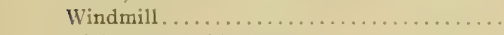 & 52 & 29 & 30 & 2 miles. \\
\hline Right corner of house......... & 71 & 49 & . & . $I / / 4$ miles. \\
\hline Large lone tree in field................ & 9.3 & 20 & .. & $I^{1 / 4}$ miles. \\
\hline Left chimney of large house.............. & IO3 & 47 & .. & I $I / 2$ miles. \\
\hline Ell of house to left of trees. . . . . . . . . . & I 26 & 48 & . & . I $1 / 2$ miles. \\
\hline $\begin{array}{l}\text { Nail in blaze in locust tree ( } 4 \text { inches diam } \\
\text { eter } \ldots \ldots \ldots \ldots \ldots \ldots \ldots \ldots \ldots \ldots \ldots \ldots \\
\text { Nail in blaze in cedar tree ( } 8 \text { inches diam }\end{array}$ & 107 & 10 & 50 & 7.74 meters. \\
\hline 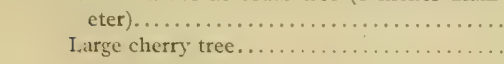 & $\begin{array}{l}196 \\
27 i\end{array}$ & $\begin{array}{l}39 \\
32\end{array}$ & 40 & $\begin{array}{l}\text {. 12.IS meters. } \\
\text {. } 300 \text { yards. }\end{array}$ \\
\hline
\end{tabular}


BII, L .

General locality.-Eastern shore of upper Chester River about 3/4 mile north of Melton Point and nearly opposite Browns Creek. (See Chart No. 30.)

Immediate locality.-Observed station is in grove of elm, ash, and oak trees on north side of a point about 20 feet above high water, 7 yards south-southeast of edge of bank, 30 yards east-northeast of a small house, and 40 yards west-southwest of a fence.

Malks. -Observed station is center point of triangle on standard cement monument projecting 5 inches above surface of ground. Subsurface mark is center of $z$-inch tile pipe buried with top $z$ inches below base of monument.

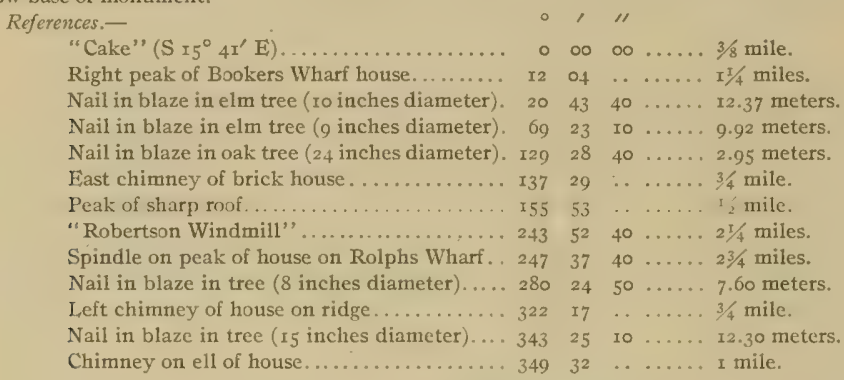

\section{TASTE.}

General locality. - Western shore of upper Chester River on point at east side of entrance to Browns Creek, about I mile northwest of Melton Point. (See Chart No. 3o.)

Immediate locality.--Observed station is on a marsh point between Chester River and Browns Creek, about 5 yards north of shore of Chester River, 30 yards south of shore of Browns Creek, 50 yards southwest of point of shore of Browns Creek, and 55 yards west-southwest of cedar trees.

Marks.-Observed station is center point of triangle on standard cement monument projecting 6 inches above surface of ground. Subsurface mark is center of 2 -inch tile pipe buried with top 2 inches below base of monument.

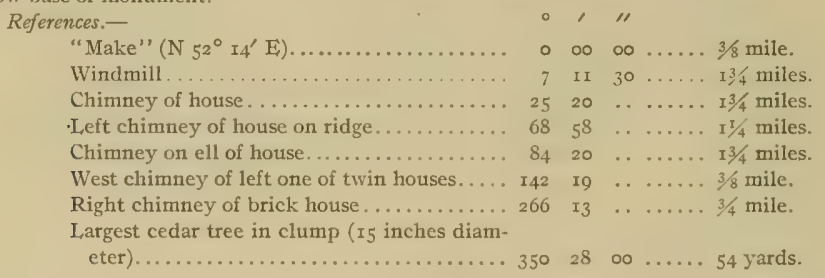

\section{MAKE.}

General locality.-Western shore of upper Chester River about I1/8 miles north of Melton Point and $3 / 8$ mile northeast of entrance to Browns Creek. (See Chart No. 30.)

Immediate locality. - Observed station is in pasture land about 2 feet above high water, ro yards north of shore, IIO yards west of tangent of point of curve of shore, and 325 yards southeast of farm buildings behind trees.

Marks.-Observed station is center point of triangle on staindard cement monument projecting 4 inches above surface of ground. Subsurface mark is center of 2 -inch tile pipe buried with top 2 inches below base of monument. 


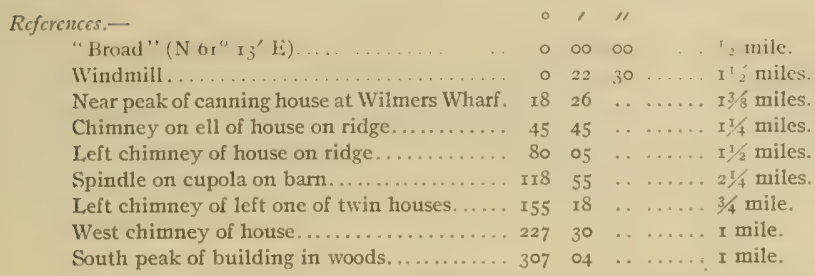

DOWN.

General locality.- Southeastern shore of upper Chester River about a miles southwest of entrance to Southeast Creek and I mile east of entrance to Browns Creek. (See Chart No. 30.)

Immediate locality.-Observed station is on a small rounded point of sanded marsh about I foot above high water, 5 yards south of shore, 40 yards east by south of an inlet, and 95 yards west of a fence beyond trees.

Marks.-Observed station is center point of triangle on standard cement monument projecting 6 inches above surface of ground. Subsurface mark is center of 2 -inch tile pipe buried with top 2 inches below base of monument.

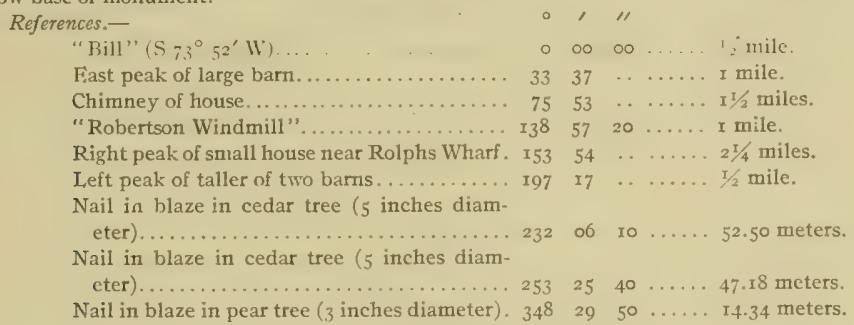

\section{JULIUS.}

General locality.-Southeastern shore of upper Chester River about $1 / 2$ mile southwest of Wilmers Wharf. (See Chart No. 30.)

Immediate locality.--Observed station is on a sanded grass point fringed by cedar trees and about 2 yards south of shore.

Marks.-Obscrved station is center point of triangle on standard cement monument projecting 5 inches above surface of ground. Subsurface mark is center of 2 -inch tile pipe buried with top 2 inches below base of manument.

References.-

"Down" (S $56^{\circ} \mathrm{I2}^{\prime} \mathrm{W}$ )

Chimney of left one of twin houses..........

Near peak of large barn

Middle one of three large trees............

"Robertson Windmill" .................. I3

South chimney of house at Rolphs Wharf. . I6

Weather vane on large barn.............. I7

Northwest peak of Wilmers Wharf cannery... 187

Nail in blaze in cedar tree ( 8 inches diam-

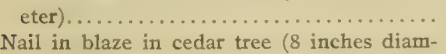
eter) ............................... eter) $\circ, 1$

- $0000 \ldots . .1 / 2$ mile,

$37 \quad \ldots \ldots \ldots \quad \frac{1}{1 / 2}$ miles.

$29 \quad \ldots . \ldots$ I nile.

50 $\ldots \ldots \ldots 7 / 8$ mile.

$23 \quad 30 \ldots \ldots x y x / 4$ miles.

$\begin{array}{lllll}38 & \ldots & \ldots & \mathrm{r} 5 / 8 & \text { miles. }\end{array}$

I8 $\ldots \ldots \ldots \times \quad x 1 / 4$ miles.

$53 \ldots \ldots .36$ mile

$98 \quad 52 \quad 00 \ldots \ldots+4.77$ meters.

318 o6 $20 \ldots .4 .30$ meters.
$2100 \ldots . . .13 .11$ meters. 


\section{BROAD.}

General locality.-Northwestern side of upper Chester River on an island at entrance to Broad Creek about I mile northeast of entrance to Browns Creek. (See Progress map.)

Immediate locality.-Observed station is on western end of a marsh island about 9 yards north of shore, 43 yards south of shore, and $5_{2}^{2}$ yards east-southeast of shore.

Marks.-Observed station is center point of triangle on standard cement monument projecting 6 inches above surface of ground. Substurface mark is center of 2 -inch tile pipe buried with top 2 inches below base of manument.

References.-

"Nils" ( $\mathrm{N}$ So $\left.24^{\prime} \mathrm{E}\right)$

Near peak of cannery.

Chimney on ell of house on ridge................

Right peak of barn................... 9

Peak of middle dormer window of large house. I3

East peak of large barn to left of large tree.... igo

"Robertson Windmill"................. $34 \mathrm{x}$

$$
\begin{aligned}
& \begin{array}{l}
1 " \\
\infty \\
1
\end{array} \\
& \text { I7 } \ldots \ldots \ldots \text { I } 1 / 8 \text { miles. } \\
& \text { og ...... } 21 / 4 \text { miles. } \\
& 26 \text {....... I mile. } \\
& 08 \ldots \ldots \ldots \text { I } 1 / 2 \text { miles. } \\
& 34 \quad \ldots . . . . \text { I mile. } \\
& 2530 \ldots \ldots \ldots .1 / 2 \text { miles. }
\end{aligned}
$$

\section{NILS.}

General locality.-Northwestern shore of upper Chester River about $3 / 4$ mile west of entrance to Southeast Creek and $5 / 2$ mile east of an island at entrance to Broad Creek. (See Progress map.)

Immediate locality. - Observed station is in edge of cultivated field about 5 feet above high water, 4 yards north of shore, I Io yards east by south of tangent of point of curve of shore, and 450 yards southwest of a house and windmill.

Marks.--Observed station is center point of tiangle on standard cement monument projecting 5 inches above surface of ground. Subsurface mark is center of 2 -inch tile pipe buried with top 2 inches below base of monument.

\section{References.-}

"Robertson" (N $\left.59^{\circ} 0^{\prime} \mathrm{E}\right) \ldots \ldots \ldots \ldots \ldots . . . . .$.

Weather vane on southwest peak of largest

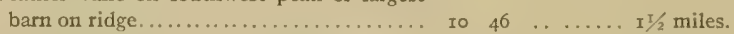

North peak of Wilmers Wharf cannery .... $\quad \begin{array}{llllll}37 & 03 & \ldots & \ldots & 1 / 2 \\ \text { mile. }\end{array}$

Chimney of house near Wilmers Wharf...... 4 I $52 \ldots \ldots .1 / 2$ mile.

West chimney of large house on ridge ..... I I3 $32 \ldots \ldots$ I mile.

Near peak of roof of house on hill......... I $_{5}^{8} \quad 22 \quad \ldots \ldots \ldots$ I mile.

"Robertson Windmill" ............... $336 \quad 55 \quad \ldots \ldots \ldots . / 2$ mile.

\section{WILMERS.}

Gencral locality.-Southeastern shore of upper Chester River on southwest side of entrance to Southeast Creek about 175 yards northeast of Wilmers Wharf. (Sce Progress map.)

Immediate locality.-Observed station is on a sanded grass point between river and marsh about 3 feet above high water, 7 yards east of shore, 5 yards southwest of shore, and 6 yards southeast of extreme end of point.

Marks.-Observed station is center point of triangle on standard cement monument projecting 5 inches above surface of ground. Subsurface mark is center of 2 -inch tile pipe buried with top 2 inches below base of monument.

References.-

"Julius" (S $60^{\circ} 34^{\prime}$ (I) ).

Chimney on near one of twin houses...........

East peak of large barn................

"Robertson Windmill"................. 74

Cupola on Robertson barn............. $8_{3}$

Flagpole on Rolphs Wharf............... I5

Weather vane on large barn ............ I6

Cupola on barn...................... 212

Cupola on barn....................... 284

Right peak of Wilmers Wharf cannery..... 348 


\section{ROBERTSON WINDMILL.}

General locality.--Northwestern side of upper Chester River opposite entrance to Southeast Creek about I I $/ 4$ miles southeast of Rolphs Wharf. (See Progress map.)

Immediate locality.-Observed station is windmill on high towet in rear of house.

Marks.-Observed station is center point of windmill.

References.-None necessary.

\section{ROBERTSON.}

General locality,--Northwestern shore of upper Chester River near Riverside Wharf opposite entrance to Southeast Creek. (See Progress map.)

Immediate locality.-Observed station is about 2 feet above high water, 5 yards northwest of shore, 45 yards northeast of shore end of a wharf, and roo yards southwest of a point of land.

Marks.-Observed station is center point of triangle on standard cement monument projecting 4 inches above surface of ground. Subsurface mark is center of 2 -inch tile pipe buried with top 2 inches below base of monument.

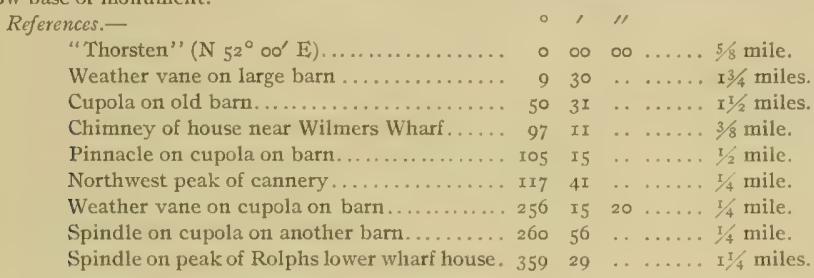

\section{SOUTHEAST.}

General locality.--Southeastern shore of upper Chester River on Deep Point at northeastern side of entrance to Southeast Creek about $3 / 4$ mile south-southwest of Rolphs Wharf and $1 / 2$ mile northeast of Wilmers Wharf. (See Progress map.)

Immediate locality. - Observed station is on cultivated land about I 5 fect above high water, I9 yards south of edge of bank, 2 I yards east by north of edge of bank, and 27 yards east by south of extreme point of bank.

Marks.-Observed station is center point of triangle on standard cement monument projecting 5 inches above surface of ground. Subsurface mark is center of 2 -inch tile pipe buried with top 2 inches below base of monument.

\section{References.-}

"Wilmers" $\left(\mathrm{S} 57^{\circ} 46^{\prime} \mathrm{W}\right)$

Right tangent of Wilmers Wh...............

"Robertson Windmill"......................

Spindle on cupola on barn................. 38

Weather vane on cupola on barn ............. 38

Near peak of long small shanty........... II8

Left peak of large barn.................. I $\mathrm{I}_{34}$

Flagstaff on Rolphs Wharf house.......... I 40

Right peak of long barn................. Ig I

Lightning rod between two chimneys on

house............................. 248 51 $\ldots \ldots \ldots, 7 / 8$ mile.

Right peak of Wilmers Wharf cannery...... $35^{8} \quad 34 \quad \ldots \ldots \ldots 5 / 8$ mile. 


\section{THORSTEN}

General locality, -Northwestern shore of upper Chester River about $3 / 4$ mile northeast of Wilmers Wharf and $I / 2$ mile north of entrance to Southeast Creek. (See Progress map.)

Immediale locality.-Observed station is about 3 feet above high water, I2 yards northwest of shore, 1o yards northeast of short fence, and 4 yards southeast of lone cedar tree.

Marks,-Observed station is center point of triangle on standard cement monument projecting 5 inches above surface of ground. Subsurface mark is center of 2 -inch tile pipe buried with top 2 inches below base of monument.

References.--

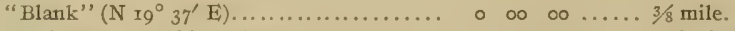

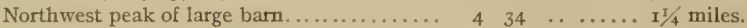

$$
\begin{aligned}
& \text { Northwest peak of large barn........... } 2 \pi \text { o9 } \ldots \ldots \ldots x \text { mile. } \\
& \text { Flagstaff on Rolphs Wharf............. } 23 \quad 33 \ldots \ldots .5 / 8 \text { mile. } \\
& \text { Weather vane on very large barn ......... } 4^{8} \text { or } \ldots \ldots \ldots I^{1 / 4} \text { miles. } \\
& \text { West peak of barn behind wharf.......... } 8_{1} \quad 0_{3} \ldots \ldots \ldots x \text { mile. } \\
& \text { Lightning rod to right of two chimneys of } \\
& \text { house.......................... III } I_{5} \ldots \ldots \ldots I^{3 / 4} \text { miles. } \\
& \text { Nail in blaze in fence post............. II } 5 \text { I5 } 30 \ldots \ldots 8.85 \text { meters. } \\
& \text { Top point of roof of large brick house on ridge. } 135 \quad 05 \quad 40 \ldots \ldots 21 / 4 \text { miles. } \\
& \text { Spindle on cupola on left one of two barns at } \\
& \text { Wilmers Wharf................. } 177 \text { o8 to ... 3/4 mile. } \\
& \text { Northwest peak of Wilmers Wharf cannery . I90 } \text { I5 }^{2} \ldots \ldots .3 / 4 \text { mile. }
\end{aligned}
$$

Nail in blaze in cedar tree (10 inches diam-

\begin{tabular}{|c|c|c|c|c|}
\hline eferences.- & & & $" \prime$ & \\
\hline "Rolplis" ( $\left.\mathrm{N} \mathrm{S2}^{\circ} 37^{\prime} \mathrm{E}\right)$. & 0 & 00 & $\infty$ & t/4 mile, \\
\hline Weather vane on wharf house....... & 10 & 19 & $\cdots$ & $1 / 4$ mile. \\
\hline Left peak of wharf house............... & 71 & 30 & . & $x / 2$ mile. \\
\hline Left peak of small house among trees.. & ro4 & 28 & 30 & $\mathrm{I} 3 / 4$ miles. \\
\hline Spindle on barn cupola ............. & II 5 & o6 & . & .. $13 / 4$ miles. \\
\hline Peak of middle dormer window of house... & 271 & 38 & . & .. I $1 / 4$ miles. \\
\hline Peak of large barn................ & 333 & 25 & .. & $\ldots \ldots 5 / 8$ mile. \\
\hline Flagstaff on Rolphs Wharf house........ & 356 & 27 & .. & $\ldots \ldots$. $1 / 4$ mile. \\
\hline
\end{tabular}

$$
\text { eter } \ldots \ldots \ldots \ldots \ldots \ldots \ldots \ldots \ldots \ldots \ldots \ldots \ldots \ldots \ldots+279 \quad 43 \quad 30 \ldots \ldots \text { meters. }
$$

\section{BLANK.}

General locality.--Northwestern shore of upper Chester River about $1 / 4$ mile west of Rolphs Wharf and $3 / 4$ mile north of entrance to Southeast Creek. (See Progress map.)

Immediale locality.-Observed station is on a grassy point about 2 feet above high water, 7 yards west of shore, 9 yards north of shore, 8 yards northwest of extreme end of point, and 40 yards from a dense clump of trees.

Marks.-Observed station is center point of triangle on standard cement monument projecting 5 inches above surface of ground. Subsurface mark is center of 2 -inch tile pipe buried with top 2 inches below base of monument.

\section{ROLPHS.}

General locality.-Eastern shore of upper Chester River about roo yards southeast of Rolphs Wharf and $3 / 4$ mile north of entrance to Southeast Creek. (See Progress map.)

Immediate locality.-Observed station is on a grass bank between two large willow trees about 6 feet above high water, 5 yards northeast of shore, Ig yards south-southwest of side gate to yard, and 7 yards southwest of a road 3 feet higher than observed station. 
Marks.-Observed station is center point of triangle on standard cement monument projecting 5 inches above surface of ground. Subsurface mark is center of 2 -inch tile pipe buried with top 2 inches below base of monument.
References.-
"Southeast" ( $\mathrm{S} 22^{\circ} 53^{\prime} \mathrm{W}$ )
$\circ \infty 00 \ldots .3 / 4$ mile.

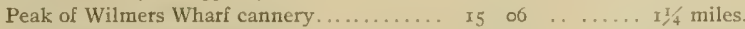
Flagstaff on Rolphs Wharf................ $7^{6} \quad 59 \quad \ldots \ldots$. . I00 yards.
Nail in blaze in willow tree $(24$ inches diam-

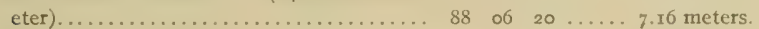
Chimney on ell of Story house........... I5 $5^{1} 3^{6} \ldots \ldots .53$ yards.
Nail in blaze in willow tree ( 27 inches diam-

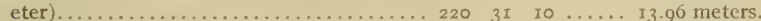
Chimney on ell of Story house........... 26 I $56 \ldots \ldots$ I20 yards.
Nail in blaze in willow tree $(25$ inches diam-
eter)..................... $309 \quad 26 \quad 40 \ldots .51$ meters.
Weather vane on middle of lower whatf house. $\begin{array}{llll}347 & 42 & \ldots\end{array} \ldots$ roo yards.

\section{CRANEY.}

General locality.-Fastern shore of Chesapeake Bay on western shore of Kent Island about $1 / 2$ mile north of Craney Creek and $4 \frac{1}{2}$ miles east of Tolly Point. (See Chatt No. 3 r.)

Immediate locality.-Observed station is about 3 feet above and 30 feet back from high water on a low, sandy, cultivated field. A group of farm buildings stand about $1 / 4$ mile away. Cement monument marking reference station is 4.88 meters $\mathrm{N} 85^{\circ} 36^{\prime} \mathrm{E}$ of observed station.

Marks.--Observed station is a nail in a wooden stub projecting 3 inches above surface of ground. Reference station is center point of triangle on standard cement monument.

References.-

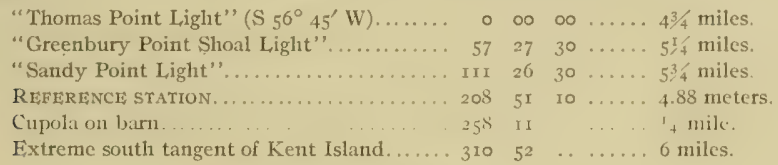

THOMAS POIN'T SHOAL, LIGHT.

General locality.-Western side of Chesapeake Bay offshore about $1^{1 / 4}$ miles southeast of Thomas Point and 3 miles south of entrance to channel to Annapolis. (See Chart No. 3r.)

Immediate locality.-Observed station is on a hexagonal screw-pile structure known as Thomas Point Shoal Lighthouse.

Marks.-Observed station is center point of laptern on Thomas Point Shoal Iighthouse.

Reference.-

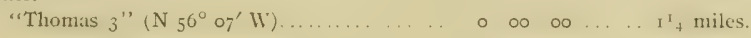

\section{BL,OODY POINT BAR LIGHT.}

General locality.-Offshore of southwestern end of Kent Island on northern side of entrance to Eastern Bay about $\mathrm{I}^{1} / 8$ miles southwest of Bloody Point and I $1 / 4$ miles west of Kent Point. (See Chart No. 3I.)

Immediate locality.-Observed station is on tower on caisson structure known as Bloody Point Bar Lighthouse.

Marks.-Observed station is center point of lantern on Bloody Point Bar Lighthouse.

Reference.-

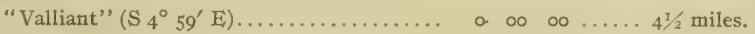


TENK.

General locality. - Northem side of entrance to Eastern Bay on Kent Point about $I \frac{1}{2}$ miles east of Bloody Point Bar Light. (See Chart No. 3x.)

Immediate locality.-Observed station is in about 2 feet of water, 18 yards off shore of Kent Point, 50 yards southwest of point of land, and 65 yards south-southeast of another point of land. Cement

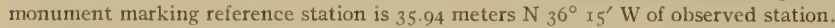

Marks.-Observed station is nail in center of 3 -inch square stub in water with top about on level with high water. Reference station is center point of triangle on standard cement monument projecting 6 inches above surface of ground.
References.-
"Bloody Point Bar Light" (S $86^{\circ} 34^{\prime} \mathrm{W}$ )....
REFERENCE STATION................... 57 II $30 \ldots \ldots 35.94$ meters.

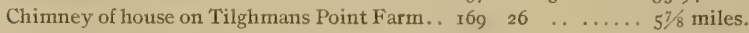
"Rich Neck Water Tank" .............. I75 48 10 ..... 51/4 miles.
Flagpole on Claiborne train shed.......... I 81 I4 $\ldots \ldots \ldots 4^{1 / 3}$ miles.

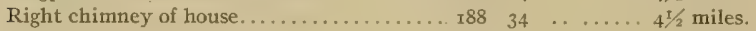
"Kemp Tower"................... I90 $21 \quad 30 \ldots \ldots 3 \% / 8$ miles.
Right chimney of brick house ........... $206 \quad x_{7} \quad \ldots \ldots \ldots 3 \frac{3 / 4}{4}$ miles.
Right chimney of house............. 240 12 $\ldots \ldots \ldots 41 / 2$ miles.
Chimney left of house among trees on Poplar

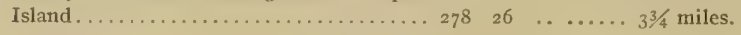

\section{STRAIGHT.}

General locality.-Northern shore of Eastern Bay on Long Point about $2 \frac{1}{4}$ miles northeast of Kent Point, $27 / 8$ miles northwest of Wades Point, and $1 / 8$ mile northeast of entrance to Long Point Creek. (See Chart No. 3i.) ,

Immediate locality.--Observed station is in a cultivated field about 8 feet above high water, 35 yards west of edge of bank, 45 yards northwest of edge of bank near a tree, 80 yards south-southwest of fence corner, 245 yards south-southeast of fence corner at gate, and 175 yards east-southeast of woods.

Marks.-Observed station is center point of triangle on standard cement monument projecting 5 inches above surface of ground. Subsurface mark is center of 2 -inch tile pipe buried with top 2 inches below base of monument.

References.-

"Needle" (N $\left.48^{\circ} \mathrm{I5}^{\prime} \mathrm{E}\right) \ldots \ldots \ldots \ldots \ldots \ldots \ldots$

Left tangent of Tilghmans Point...........

Chimney of house on Tilghmans Point Farm. .

"Kemp Tower".......................

Nail in blaze in red oak tree ( 22 inches diam-

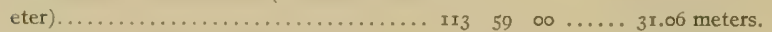

Right tangent of woods on Poplar Island.... I I5 $30 \quad \ldots \ldots \ldots 53 / 4$ miles.

Left tangent of woods on Kent Point....... I79 48 . . . . . 2 miles.

South perak of building............... 264 is $\ldots \ldots \ldots, 2$ mile.

East peak of barn...................

South chimney of house............... 330 Io ...... $1 / 4$ mile.

\section{MOUTH.}

General locality.-Northern shore of Eastern Bay on easten shore of Kent Island about I1/4 miles north of Long Point, $35 / 8$ miles northwest of Claiborne Wharf, and $3 \frac{\mathrm{I} / 4}{4}$ miles southwest of Bodkin Island. (See Chart No. 3r.)

Immediate locality.-Observed station is in a cultivated field about 8 feet above high water, xo yards west of top of a bank with uniform slope to shore, 50 yards south of a small cove, and 20 yards south of a group of cedar trees near shore. 
Marks.-Observed station is center point of triangle on standard cement monument projecting 5 inches above surface of ground. Subsurface mark is center of 2 -inch tile pipe buried with top 2 inches below base of monument.

\begin{tabular}{|c|c|c|c|c|}
\hline References.- & 0 & ' & "I & \\
\hline "Matta" ( $\left.5_{5}^{\circ} 49^{\prime} \mathrm{W}\right)$. & 0 & $\infty 0$ & $\infty$ & $2 !+$ miles. \\
\hline South gable of barn... & 26 & 41 & .. & $4 \frac{1}{4}$ miles. \\
\hline West gable of house & 3,3 & 35 & & $2+$ miles. \\
\hline Right tangent of woods on Turkey Point..... & 50 & 25 & $\cdots$ & 3 miles. \\
\hline "Parsons Island Water Tank" ............. & 66 & 43 & $\infty$ & . $5 \frac{1}{8} / 8$ miles. \\
\hline 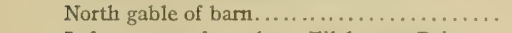 & 74 & 49 & . & . $61 / 4$ miles. \\
\hline Left targent of woods on Tilghmans Point.... & I03 & 05 & . & $4 \frac{\pi}{4}$ miles. \\
\hline South chimney of house on Tilghmans Point & & & & \\
\hline Farm.................. & I12 & I9 & $\cdots$ & 4 miles. \\
\hline "Rich Neck Water Tank". ... . & 124 & 48 & 40 & $37 / 8$ miles. \\
\hline South gable of Claiborne Wharf house....... & I37 & $4 I$ & & $31 / 2$ miles. \\
\hline "Kemp Tower" ... & I 54 & $\circ 9$ & $\infty$ & $3^{\mathrm{T}}-$ miles. \\
\hline East chimney of Legg house............... & 224 & 59 & $\cdots$ & . $3 / 8$ mile. \\
\hline 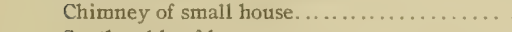 & 286 & 35 & - & I $1 / 2$ miles. \\
\hline 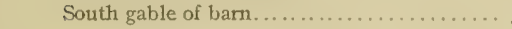 & 342 & 46 & $\because$ & $\mathrm{I}^{3} / 8$ miles. \\
\hline
\end{tabular}

MATTA.

General locality.-Northern shore of Eastern Bay on eastern shore of Kent Island at western side of entrance to Shipping Creek about 2 miles west of Turkey Point. (See Chart No. 3r.)

Immediate locality.-Observed station is in cultivated field about I 5 feet above high water, I25 yards southwest of extreme end of point, 25 yards northwest of dry ditch, and 200 yards northwest of lone cedar tree near shore.

Marks.-Observed station is center point of triangle on standard cement monument projecting 6 inches above surface of ground. Subsurface mark is center of 2 -inch tile pipe buried with top 2 inches below base of monument.

\begin{tabular}{|c|c|c|c|c|}
\hline es.- & & , & "I & \\
\hline "Batts" (N 67 $\left.45^{\prime} \mathrm{E}\right)$. & 0 & $\infty$ & $\infty$ & I mile. \\
\hline North chimney of house... & I7 & 54 & & 2 miles. \\
\hline $\begin{array}{l}\text { Left tangent of woods on Tilghmans Point... } \\
\text { North chimney of house on Tilghmans Point }\end{array}$ & 54 & 30 & & 6 \\
\hline 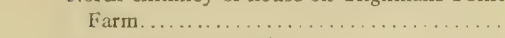 & 62 & 34 & & $5^{3} \mathrm{~s}$ \\
\hline "Rich Neck Water Tank" . . . . . . . . . . . & 71 & $3 \mathrm{I}$ & $\infty$ & \\
\hline Left tangent of woods on Long Point. . . & 105 & 49 & & $21 / 2$ miles \\
\hline Chimney of Greeve house........... & 124 & 53 & .. & $1 / 4$ mile. \\
\hline South chimney of house............ & $23 x$ & I4 & .. & $3 / 4$ mile. \\
\hline South cupola on barn............... & 247 & 39 & & $7 / 8$ mile. \\
\hline East chim & 273 & $5^{8}$ &. & $\mathrm{I} / 2$ mile \\
\hline nall house................ & 296 & I2 & .. & \\
\hline West chimney of house ................ & 305 & 45 & & $1 / 8 \mathrm{mi}$ \\
\hline
\end{tabular}

\section{THEN.}

General locality.-Western shore of small bay at entrance to Shipping Creek about $3 / 4$ mile northwest of Eastern Bay, 3/8 mile northeast of entrance to narrow part of Shipping Creek, and at western side of entrance to a smaller creck. (See Chart No. 3r.)

Immediate locality.-Observed station is on marsh about I foot above high water, 33 yards west of shore, 40 yards south of shore, 50 yards north of shore at line between hard land and marsh, 8 yards east of pasture land, and $1 / 4$ mile east of $21 / 2$-story house.

Marks.-Observed station is center point of triangle on standard cement monument projecting 6 inches above surface of ground. Subsurface mark is center of 2 -inch tile pipe buried with top 2 inches below base of monument.

$$
203 x_{3}-12-5
$$




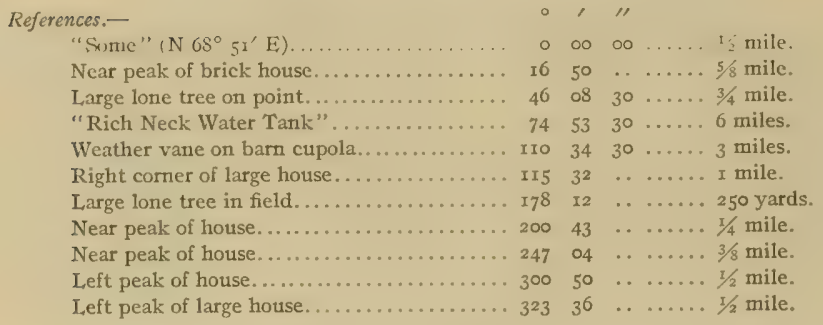

SOME.

General locality. - Northern shore of small bay at entrance to Shipping Creek on a point between two small creeks about $3 / 4$ mile north of Eastern Bay and 2 miles northwest of Turkey Point. (See Chart No. 3I.)

Immediate locality.-Observed station is in a cultivated field about 5 feet above high water, 20 yards northeast of marsh, 30 yards northwest of edge of bank, 28 yards east of edge of bank, 50 yards northeast of shore of Shipping Creek, and 53 yards southwest of shore of small creek.

Marks.-Observed station is center point of triangle on standard cement monument projecting 5 inches alsove surface of ground. Subsurface mark is center of 2 -inch tile pipe buried with top 2 inches below base of monument.

References,-

"Batts" (S $\left.49^{\circ} \mathrm{or}^{\prime} \mathrm{E}\right) \ldots \ldots \ldots \ldots \ldots \ldots \ldots \ldots$

Large lone tree...................... I8

Peak between two chimneys of large house. . 72

Right peak of barn................... ro5

Near peak of house.................. I25

Near peak of large barm............... I7I

Left chimney of old house. ............. 194

Spindle on cupola on barn . . . . . . . . . . . 22I

Large pine tree..................... 307

L.eft corner of large house............... 339

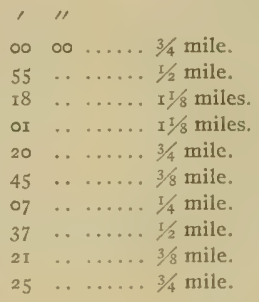

BATTS.

General localily.-Northern shore of Eastern Bay on southern end of Batts Neck between Shipping and Cox Creeks about I I $/ 4$ miles northwest of Turkey Point. (See Chart No. 3r.)

Immediate locality.-Observed station is in cultivated field about 2 feet above high water, $2 \mathrm{I}$ yards north of shore, and Ioo yards west of a wire fence extending roo yards into bay.

Marks.-Observed station is center point of triangle on standard cement monument projecting 6 inches above surface of ground. Subsurface mark is center of 2 -inch tile pipe buried with top 2 inches below base of monument. Station "CoxeS CREEK," 1899 , is 87.70 meters N $72^{\circ} 20^{\prime} \mathrm{E}$ of observed station and is marked by the center of a cross in the top of a granite post about Iz inches square in the rough and about 27 inches long projecting 5 inches above surface of ground. The top of the granite post is dressed to a 6 -inch cube marked with a square cross and the letters "U. S." Subsurface mark is center of neck of a bottle buried with top 3 inches below base of granite post.

References.-

"Turkey" (S $\left.58^{\circ} 24^{\prime} \mathrm{E}\right)$.

North chimney of house on Tilghmans Point I:arm

"Rich Neck Water Tank".

Nail in blaze in one of twin persimmon trees

( 4 inches diameter) .................

Left tangent of woods on Long Point.......

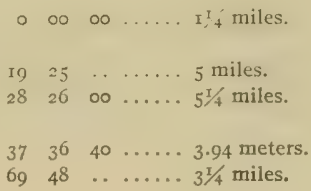


References-Continued.

East gable of house ................ 76 30 $\ldots \ldots \ldots 21 / 2$ miles

Nail in blaze in persimmon tree (6 inches

diameter)...................... gr I3 $_{3} 50 \ldots \ldots$ meters.

South chimney of house............... 202 o8 ...... $3 / 8$ mile.

South chimney of house.............. $242 \quad 32 \quad \ldots \ldots \ldots 3 / 4$ mile.

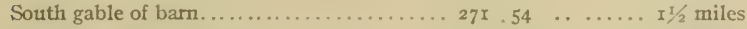

North chimney of house.............. $293 \quad 22 \quad \ldots \ldots \ldots .3 / 8$ miles

"Coxes Creek" IS99 (granite post)........ $310 \quad 44 \quad 20 \ldots \ldots .87 .70$ meters.

North chimney of house............... $34^{\mathrm{r}}$ o7 $\ldots \ldots \ldots \mathrm{r} / \mathrm{s}$ miles.

TOP.

General locality. - Western shore of Cox Creek about I mile north of Eastern Bay and I mile south of

IVarehouse Creek. (See Chart No. 3x.)

Immediate locality.-Observed station is on cupola of a barn about I 50 yards east of shore.

Marks.-Observed station is center point of top of cupola on barn.

References.-None necessary.

WARE.

General locality.-Western shore of Cox Creek about 2 miles north of Eastern Bay and $1 / 4$ mile south of entrance to Warehouse Creek. (See Chart No. 3I.)

Immediate locality.-Observed station is in a cultivated field about I5 feet above high water, 300 yards northwest of end of point, and 90 yards south of wire fence extending east and west.

Marks.-Observed station is center point of triangle on standard cement monument projecting 7 inches above surface of ground. Subsurface mark is center of 2 -inch tile pipe buried with top 2 inches below base of monument.

Riferences.-

\begin{tabular}{|c|c|c|c|}
\hline "Tuxon" $\left(\mathrm{N} I 3^{\circ} 45^{\prime} \mathrm{E}\right) \ldots \ldots \ldots \ldots \ldots \ldots$ & 0 & & \\
\hline South gable of house........ & I & II & $\mathrm{I} / 2$ miles. \\
\hline South chimney of house..... & I9 & 05 & II/4 miles. \\
\hline North chimney of house..... & 34 & 50 & I mile. \\
\hline on barn. & 99 & 46 & $3 / 8$ mile. \\
\hline h chimney of house. . & $I 7 x$ & $4^{8}$ & $\mathrm{I} / 4$ miles. \\
\hline uth chimney of house... & 257 & 55 & 50 yards. \\
\hline uth chimney of house. ...... & 307 & 54 & $\ldots \ldots \ldots$ \\
\hline
\end{tabular}

COFFEE.

General locality. - Southwestern shore of Warehouse Creek on a point about $1 / 2$ mile northwest of Cox Creek. (See Chart No. 3x.)

Immediate locality.-Observed station is on marsh about $\mathbf{I}$ foot above high water, 9 yards south of point of shore, I3 yards southwest of shore, I7 yards west-northwest of shore at fence, I2 yards north of fence, 29 yards east-northeast of comer of fence, and 250 yards north by east of house with two chimneys.

Marks.-Observed station is center point of triangle on standard cement monument projecting 6 inches above surface of ground. Subsurface mark is center of 2 -inch tile pipe buried with top 2 inches below base of monument.

References.-

"Here" ( $\left.\mathrm{N}_{53}{ }^{\circ} 46^{\prime} \mathrm{W}\right)$. $0000 \ldots .3 / 3$ mile.

Left peak of barn..................... $22 \quad 49 \ldots \ldots \ldots .1 / 4$ miles.

Left chimney of brick house............ $5^{I} \quad 40 \ldots \ldots . .1 / 4$ miles.

West chimney of house................. I00 $4 \mathrm{x} \ldots \ldots \ldots$ I $1 / 4$ miles.

Near peak of house................... II3 $46 \ldots \ldots \ldots$ II/4 miles.

Left peak of house................. I36 if . . . . I I $1 / 8$ miles.

Cupola on barn................... I60 $3,3 \ldots \ldots . I^{1}$ miles.

Nail in blaze in fence post............. $x_{73}$ I5 $30 \ldots \ldots .56 .57$ meters.

Nail in blaze in fence post.............. $220 \quad 34 \quad 40 \ldots \ldots .12 .29$ meters.

Near corner of house.................. $226 \quad 02 \quad \ldots \ldots .250$ yards.

Nail in blaze in fence post.................. $245 \quad 5930$. I4.I4 meters. 
HERE.

General locality. - Southwestern shore of Warehouse Creek on a point at northwestern side of entrance to a small cove about 3 - mile northwest of Cox Creek. (See Chart No. 31.)

Immcdiate locality.-Observed station is on marsh about $\mathrm{x}$ foot above high water, 17 yards west of shore, 20 yards southwest of shore, 25 yards northwest of shore, 6o yards north of shore, 3 yards southeast of one-strand barbed-wire fence, and $1 / 4$ mile east to southeast of woods.

Marks.- Observed station is center point of triangle on standard cement monument projecting 5 inches above surface of ground. Subsurface mark is center of 2 -inch tile pipe buried with top 2 inches below base of monument.

References.-

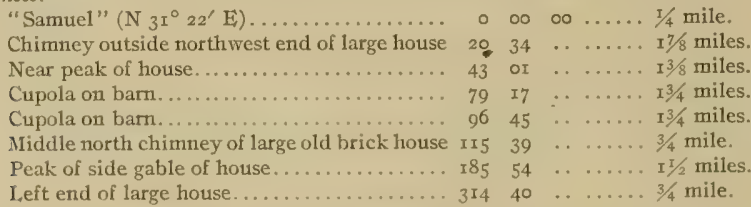

\section{SAMUEL.}

General locality.-Northeastern shore of Warehouse Creek on a point at northwestem side of entrance to a small cove about $3 / 4$ mile northwest of Cox Creek. (See Chart No. 3r.)

Immediate locality. - Observed station is on long marsh point about I foot above high water, 9 yards east of shore of Warehouse Creek, 23 yards west-southwest of shore of small cove, 18 yards north of point, arid 27 yards west of another point.

Marks.-Observed station is center point of triangle on standard cement monument projecting 7 inches above surface of ground. Subsurface mark is center of 2 -inch tile pipe buried with top 2 inches below base of monument.

References.-

"Liver" (S $\left.56^{\circ} 3^{\prime} \mathrm{x}^{\prime} \mathrm{E}\right) \ldots \ldots \ldots \ldots \ldots \ldots \ldots$

Spindle on barn cupola..................

Near peak of small house.............. 34

Left chimney of large house.............. 9

Chimney of house showing through trees... 208

Left comer of large brick house........... 247

Chimney outside of near end of house...... 304

I.elt peak of house................... 339 of

Cupola on barn.................... 353

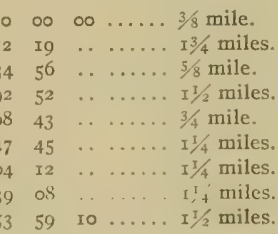

\section{LIVER}

General locality.-Northeastern shore of Warehouse Creek on a point at westem side of entrance to a small cove about $1 / 4$ mile northwest of Cox Creck. (See Chart No. 3I.)

Immediate locality.--Observed station is on a marsh point about $I$ foot above high water, 15 yards northwest of shore, 17 yards southeast of shore, 30 yards north of point of shore, 30 yards northeast of extreme end of point, and 250 yards southwest by south of three large trees.

Marks.-Observed station is center point of triangle on standard cement monument projecting 6 inches above surface of ground. Subsurface mark is center of 2 -inch tile pipe buried with top 2 inches below base of monument.

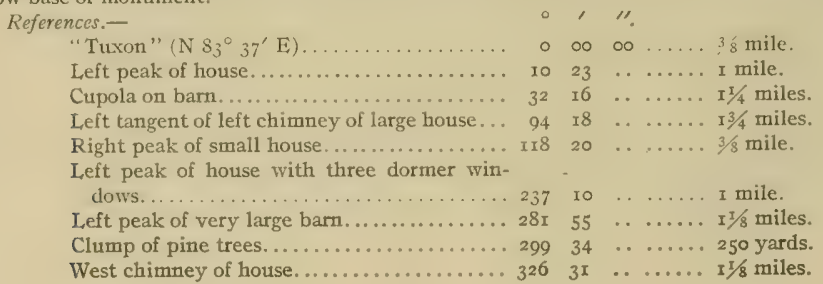




\section{TUXON.}

General locality,-Western shore of Cox Creek on a point about 3 miles north of Eistern Bay, $1 / 2$ mile south of entrance to Thompsons Creek, and $1 / 4$ mile northeast of entrance to Warehouse Creek. (See Chart No. 3I.)

Immediate locality.-Observed station is on marsh about 2 fect above high water and 50 yards west of shore.

Marks.-Observed station is center point of triangle on standard cement monument projecting 8 inches above surface of ground. Subsurface mark is center of 2 -inch tile pipe buried with top 2 inches below base of monument.

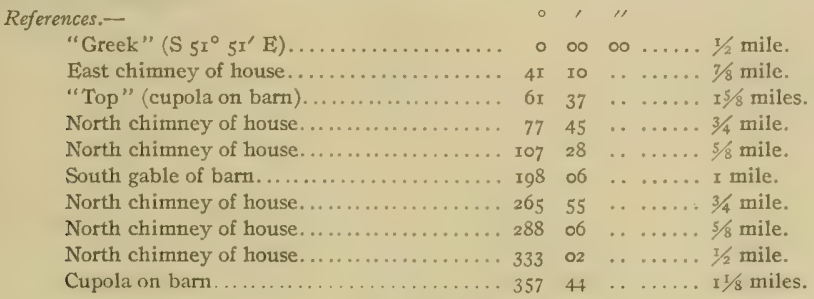

\section{STEVE.}

General locality.-Westem shore of Cox Creek on a point about 3\% miles north of Eastern Bay at southwestern side of entrance to Thompsons Creek and $1 / 2$ mile north of entrance to Warehouse Creek. (See Chart No. 3r.)

Immediate locality.-Observed station is on marsh land about $x$ foot above high water, 27 yards south of shore, 35 yards north of shore, 20 yards west of a point of shore, and 35 yards east of a point of shore.

Marks.-Observed station is center point of triangle on standard cement monument projecting 6 inches above surface of ground. Subsurface mark is center of 2 -inch tile pipe buried with top 2 inches below base of monument.

\begin{tabular}{|c|c|c|c|c|}
\hline References.- & 0 & & "I & \\
\hline 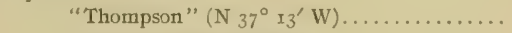 & 0 & $\infty$ & $\infty$ & $3 / 8$ mile. \\
\hline 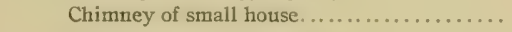 & $\mathbf{r}$ & 03 & . & . $3 / 4$ mile. \\
\hline Right peak of very large house............. & 30 & 08 & . & ... I mile. \\
\hline Near corner of large louse................ & 65 & 50 & . & $\ldots \ldots 3 / 4$ mile. \\
\hline Near comer of large house. .............. & 92 & 28 & . & ..... 5/8 mile. \\
\hline Near peak of house............ & 124 & 07 & . & .. $1 / 2$ mile. \\
\hline 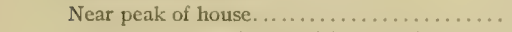 & 164 & $3^{8}$ & . & .. $3 / 4$ mile. \\
\hline Weather vane on house with two chimneys.. & 209 & 03 & . & …. $x^{1 / 4}$ miles. \\
\hline Left chimney of small house.............. & 234 & 45 & . & $\ldots \ldots x 1 / 8$ miles. \\
\hline Right peak of small house............... & 253 & 12 & . & $\ldots \ldots I^{1 / 4} / 4$ miles. \\
\hline 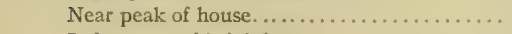 & 329 & 44 & . & ..... r mile. \\
\hline Left comer of brick house................ & 355 & 18 & . & ...... 3/4 mile. \\
\hline
\end{tabular}

\section{THOMPSON.}

General locality.-Western shore of Thompsons Creek about $3 / 8$ mile west of point of land between Thompsons Creek and Cox Creek and I/8 mile northwest of a small cove. (See Chart No. 3I.)

Immediate locality.-Observed station is on marsh about $I$ foot above high water, 30 yards south of shore, 45 yards northwest of shore, 20 yards southwest of point of shore, and 120 yards south-southeast of rail fence. 
Masks,-Obscrved station is center point of triangle on standard cement monument projecting 5 inclies above surface of ground. Subsurface mark is center of 2 -inch tile pipe buried with top 2 inches below base of monument.

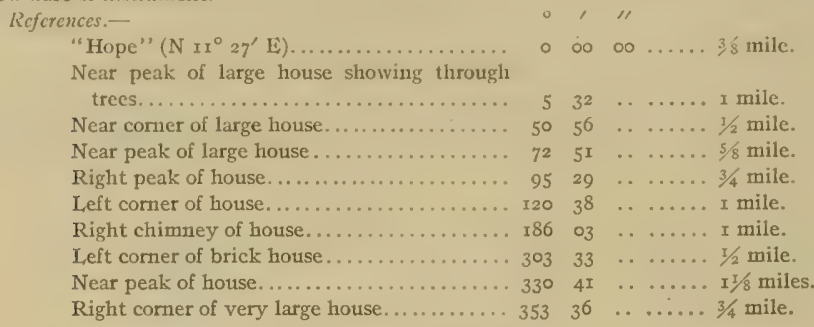

\section{HOPE,}

General locality.-Western shore of Thompsons Creek on a point between Thompsons Creek and a smaller creek about $1 / 2$ mile northwest of Cox Creek. (See Chart No. 3I.)

Immediate locality. - Observed station is on marsh land about I foot above high water, 40 yards west of shore, 90 yards northwest of shore, and 200 yards east-southeast of end of fence.

Marks.-Observed station is center point of triangle on standard cement monument projecting 6 inches above surface of ground. Subsurface mark is center of 2 -inch tile pipe buried with top 2 inches below base of monument.
References.-
"Knock" (S $74^{\circ} 42^{\prime} \mathrm{E}$ ).

$\begin{array}{rccccc}0 & \prime & & & \\ 0 & 00 & 00 & \ldots & \ldots & 1 / 8 \text { mile. } \\ 4 & 07 & \ldots & \ldots & 3 / 8 \text { mile. } \\ 13 & 34 & \ldots & \ldots & 5 / 8 \text { mile. } \\ 42 & 13 & \ldots & \ldots & 11 / 2 \text { miles. } \\ 65 & 46 & 30 & \ldots & 17 / 8 \text { miles. } \\ 150 & 10 & \ldots & \ldots & 7 / 8 \text { mile. } \\ 59 & 59 & \ldots & \ldots & 3 / 8 \text { mile. } \\ 24 & 12 & \ldots & \ldots & 7 / 8 \text { mile. } \\ 53 & 12 & \ldots & \ldots & 3 / 8 \text { mile. }\end{array}$
Right corner of near chimney of house.... 4 o $7 \ldots \ldots .3 / 8$ mile
Right corner of near chimney of house.... $1_{3} 34 \ldots \ldots \ldots 5 / 8$ mile.
Near peak of house................. 42 I3 $\ldots \ldots \ldots 11 / 2$ miles.
Weather vane on house with two chimneys.. $6546 \quad 30 \ldots \ldots .17 / 8$ miles.
Right tangent of near chimney of large house. I50 Io ...... $7 / 8$ mile.
Near peak of large brick house........... I59 $59 \quad \ldots \ldots \ldots 3 / 8$ mile
Near peak of house................. 224 I2 $\ldots \ldots \ldots 7 / 8$ mile
Right peak of large house............. 253 I2 $\ldots \ldots .3 / 8$ mile.

\section{KNOCK.}

General locality.-Eastern shore of Thompsons Creek about $1 / 2$ mile north of Cox Creek and opposite a point of land between Thompsons Creek and a cove. (See Chart No. 3I.)

Immediate locality.-Observed station is in southwest end of point of woods about I foot above high water, 6 yards east of shore, and 60 yards south-southwest of a point of shore.

Marks.-Observed siation is center point of triangle on standard cement monument proiecting 5 inches above surface of ground. Subsurface mark is center of 2 -inch tile pipe buried with top 2 inches below base of monument.
References.-
"Landing" ( $\mathrm{S}_{3}^{\circ}$ o6' E)

$\begin{array}{lccccc}0 & \prime & \prime \prime \\ 0 & 00 & 00 & \ldots \ldots & 1 / 4 \text { mile. } \\ 0 & 08 & 30 & \ldots & 21 / 2 \text { miles. } \\ 8 & 14 & \ldots & \ldots & 11 / 2 \text { miles. } \\ 4 & 16 & \ldots & \ldots & 5 / 8 \text { mile. } \\ 1 & 32 & \ldots & \ldots & 1 / 2 \text { mile. } \\ 8 & 10 & 00 & \ldots & \ldots & 5.50 \text { meters. } \\ 6 & 5^{8} & 30 & \ldots & \ldots & 23.8 \text { I meters } \\ 6 & 49 & 00 & \ldots & 7.15 \text { meters. } \\ 5 & 35 & \ldots & \ldots & 7 / 3 \text { mile. }\end{array}$
"Top" (barn cupola)................. ro of $30 \ldots \ldots 21 / 2$ miles.
Near peak of large house.............. 83 I4 $\ldots \ldots \ldots$ I $8_{3} / 2$ miles.
Near peak of large brick house............ 94 I6 $\ldots \ldots .5 / 8$ mile.
L,eft peak of very large barn............. I5I $32 \ldots \ldots \ldots 1 / 2$ mile.
Nail in blaze in pine tree ( 6 inches diameter). I84 ro $00 \ldots \ldots 5.50$ meters.
Nail in blaze in pine tree ( 8 inches diameter). $226 \quad 5^{8} \quad 30 \ldots .23 .8$ I meters.
Nail in blaze in oak tree (Io inches diameter). $276 \quad 4900 \ldots \ldots 7.15$ meters.
Right corner of near chimney of large house.. $295 \quad 35 \quad \ldots \ldots \ldots$ //s mile. 


\section{LANDING.}

Gencral locality.-Easten shore of Thompsons Creek about 1/8 mile northwest of Cox Creek. (See Chart No. 3r.)

Immediate locality.-. Observed station is on marsh about $\mathrm{x}$ foot above high water, I6 yards northwest of cut in shore, 20 yards north-northwest of point of shore, 14 yards east of point, 12 yards southeast of shore, roo yards west of cultivated land, and 250 yards south of woods.

Marks.--Obscrved station is center point of triangle on standard cement monument projecting 6 inches above surface of ground. Subsurface mark is center of 2 -inch tile pipe buried with top 2 inches below base of monument.

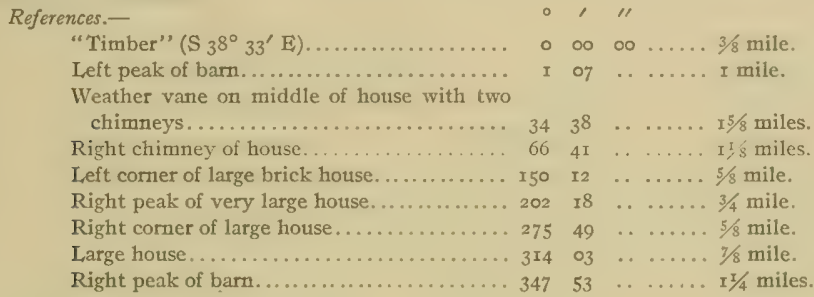

TIMBER.

General locality.-Eastera shore of Cox Creek about $3^{1 / 4}$ miles north of Eastem Bay, $3 / 4$ mile northeast of entrance to Warehouse Creek, and opposite entrance to Thompsons Creek. (See Chart No. 3I.)

Immediate locality.-Observed station is in a pasture between large cherry tree at the edge of the water and four cedar trees at the edge of the bank about 5 feet above high water, 4 yards east of edge of bank, I7 yards east of point, 6 yards southeast of edge of bank, and 12 yards northeast of edge of bank.

Marks.-Observed station is center point of triangle on standard cement monument projecting 6 inches above surface of ground. Subsurface mark is center of 2 -inch tile pipe buried with top 2 inches below base of monument.

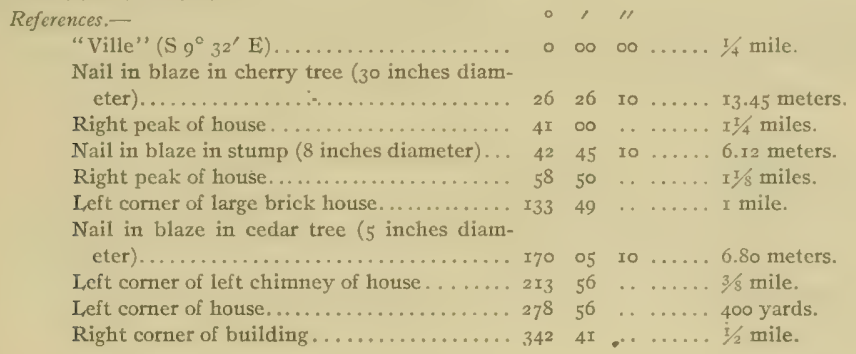

VILI,E.

General localily. - Eastern shore of Cox Creek about 3 miles north of Eastern Bay, 5/8 mile northeast of entrance to Warehouse Creek, and $1_{2}$ mile southeast of entrance to Thompsons Creek. (See Chart No. 3I.)

Immediatc locality.-Observed station is in a pasture about 5 feet above high water, 8 yards east of edge of bank, 33 yards south of tangent of cliff, 60 yards north of small ditch, and II 5 yards north of wire fence. 
Marks.-Observed station is center point of triangle on standard cement monument projecting 5 inches above surface of ground. Subsurface mark is center of 2 -inch tile pipe buricd with top 2 inches below hase of monument.

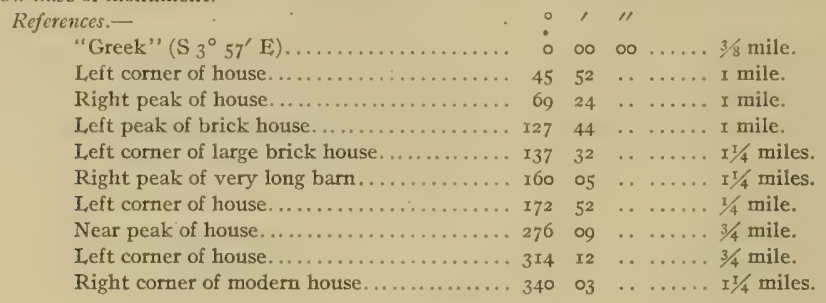

GREEK.

General locality.-Eastern shore of Cox Creek on a point about $23 / 4$ miles north of Eastern Bay and $1 / 2$ mile east of entrance to Warehouse Creek. (See Chart No. 3r.)

Immediate locality. - Observed station is on a marsh point about I foot above high water, 60 yards southwest of extreme end of point, and I25 yards east of a small marsh island.

Marks,-Observed station is center point of triangle on standard cement monument projecting 5 inches above surface of ground. Subsurface mark is center of 2 -inch tile pipe buried with top 2 inches below base of monument.

References.-

"Tuxon" ( $\left.\mathrm{N}_{5} \mathrm{I}^{\circ} \mathrm{5}^{\prime} \mathrm{W}\right) \ldots \ldots \ldots \ldots \ldots \ldots$

East chimney of house.................

South gable of barn...................

Fiast chimney of house ................

East chimney of house..................

North chimney of house ................

Chimney of house .................. I

Cupola on barn................... I

Chimney of small house................ 252

South chiruney of house............... 290

South chimney of house................ 3 IS

TOM.

General locality.-Fastern shore of Cox Creek about 2 miles north of Eastern Bay and $1 / 2$ mile southeast of entrance to Warehouse Creek. (See Chart No. 3I.)

Immediate locality.-Observed station is in a cultivated field about I 2 feet above high water, 300 yards east of shore, 135 yards north of a graveyard, I00 yards southwest of a house, and 40 yards south of driveway beyond wire fence.

Marks.-Observed station is center point of triangle on standard cement monument projecting 6 inches above surface of ground. Subsurface mark is center of 2 -inch tile pipe buried with top 2 inches below base of monument.

References:-

"Ware" ( $\left.67^{\circ} 55^{\prime} \mathrm{W}\right)$

$\begin{array}{rcccc}0 & \prime & & & \\ 0 & 00 & 00 & \ldots & 3 / 8 \text { mile. } \\ 28 & \text { or } & \ldots & \ldots & \text { roo yards. } \\ 61 & 09 & \ldots & \ldots & 21 / 4 \text { miles. } \\ 70 & 29 & \ldots & \ldots & 13 / 4 \text { miles. } \\ 92 & 43 & \ldots & \ldots & 7 / 8 \text { mile. } \\ 176 & 20 & \ldots & \ldots & 3 / 8 \text { mile. } \\ 272 & 59 & \ldots & \ldots & 11 / 4 \text { miles. } \\ 281 & 59 & \ldots & \ldots & 3 / 4 \text { mile. } \\ 336 & 15 & \ldots & \ldots & 3 / 4 \text { mile. }\end{array}$

Southwest corner of east house on road..... 28 or ...... 100 yards.

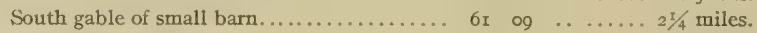

East chimney of house.............. $70 \quad 29 \quad \ldots \ldots .13 / 4$ miles.

Chimney of house................... $9^{2} \quad 43 \quad \ldots \ldots \ldots 7 / 8$ mile.

North chimney of house............... $176 \quad 20 \ldots \ldots .3 / 8$ mile.

North gable of barn................. $272 \quad 59 \quad \ldots \ldots \ldots .1 / 4$ miles.

North chimney of house.............. $28 \mathrm{I} \quad 59 \quad \ldots \ldots .3 / 4$ milc.

Chimney of small house............... 336 I5 $\ldots \ldots .3 / 4$ mile. 
IELI,.

General locality:- Lastern shore of Cox Creek about $1 \frac{1}{2}$ miles north of Liastern Bay and 1 mile south of entrance to Warehouse Creek. (See Cliart iNo, 3r.)

Immediate locality.-Observed station is in a cultivated field about Io feet above high water, 43 yards from shore, 28 yards northeast of top of bank, and 30 yards northeast of a lone cedar tree at edge of bank.

Marks.-Observed station is center point of triangle on standard cement monument projecting 6 inches above surface of ground. Subsurface mark is center of 2 -inch tile pipe buried with top 2 inches below base of monument.

\begin{tabular}{|c|c|c|c|c|}
\hline References.- & 。 & , & " & \\
\hline "Turkey" ( $\left.\mathrm{S}_{7}{ }^{\circ} 22^{\prime} \mathrm{E}\right)$. & 0 & $\infty$ & $\infty 0$ & $15 / 8$ miles. \\
\hline "Rich Neck Water Tank" .............. & I6 & $3 I$ & ০o & $5^{7 / 8}$ miles. \\
\hline Left tangent of woods on Long Point....... & 33 & 36 & . & $41 / 4$ miles. \\
\hline North chimney of house....... & 44 & 07 & $\cdots$ & $3^{1 / 4}$ miles. \\
\hline Left tangent of house.................. & 72 & 56 & . & .. I mile. \\
\hline 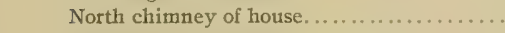 & 88 & 09 & .. & ..... $1 / 2$ mile. \\
\hline Chimney of small house...$\ldots \ldots \ldots \ldots \ldots$ & 136 & I9 & . & ... I $1 / 4$ miles. \\
\hline 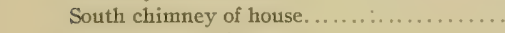 & I54 & 52 & .. & I $1 / 4$ miles. \\
\hline West chimney of house.... . & I88 & I9 & . & .. $1 / 2$ mile. \\
\hline Cupola on barn................. & 230 & 45 & . & It mile. \\
\hline 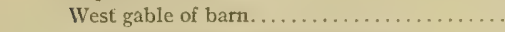 & 303 & 02 & . & ... $1 / 2$ mile. \\
\hline Left tangent of small fishing shack......... & 343 & 03 & .. & $\ldots \ldots 5 / 8$ mile. \\
\hline Right tangent of barn............. & 354 & $3 I$ & .. & ...... I I/4 miles. \\
\hline
\end{tabular}

TURKEY.

General locality.-Northern shore of Eastem Bay on southern end of Cox Neck on Turkey Point about I mile west of the north end of Bodkin Island. (See Chart No. 3r.)

Immediate locality. - Observed station is in marsh meadow about 2 feet above high water, 40 yards northeast of shore, 200 yards south of a group of three pine trees near shore, and in center of triangle formed by three pine stubs driven flush with marsh to support theodolite.

Marks.-Observed station is center point of triangle on standard cement monument projecting 6 inches above surface of ground. Subsurface mark is center of 2 -inch tile pipe buried with top 2 inches below base of monument.

References.-

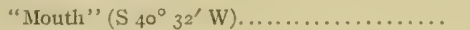

Chimney of house.................... 2

Chimney of Greeve house.............. 4

South cupola on barn................. 6

North chimney of louse............... 7

South chimney of house ............... I03

South chimney of house................. II3

West pine tree of group................. 132

Right tangent of Bodkin Island.......... 25

Left tangent of Tilghmans Point.......... 275
North chimney of house on Tilghmans Point

Farm........................ 286

"Rich Neck Water Tank".............. 297

Left tangent of woods on Long Point. . . . . $35^{2}$

\begin{tabular}{|c|c|}
\hline , & $\infty \ldots \ldots .23 / 4$ miles. \\
\hline Ic & $\ldots \ldots \ldots 23 / 4$ miles. \\
\hline I. & $\ldots \ldots \ldots=21 / 2$ miles. \\
\hline 20 & $\ldots \ldots \ldots 23 / 4$ miles. \\
\hline 36 & $2 \mathrm{I} 2$ miles. \\
\hline 39 & . . .... I $3 / 4$ miles. \\
\hline 22 & $\ldots \ldots \ldots 21 / 2$ miles. \\
\hline 1 & .. .... 200 yards. \\
\hline 4 & .. .... I mile. \\
\hline & . $\cdots \cdots 3^{t} / 2$ miles. \\
\hline $3^{8}$ & .. . . . $33 / 4$ miles. \\
\hline & $41 / 4$ miles. \\
\hline & . \\
\hline
\end{tabular}


$\operatorname{cox}$.

General locality.--Western shore of Crab Alley Bay on Cox Neck about $3 / 8$ mile nortli of Lastern Iay and I mile northwest of Bodkin Island. (Sce Chart No. 3r.)

Immediale locality.-Observed station is at edge of a cultivated ficld on narrow neck of land about 3 feet above ligh water, 16 yards west of shore, 18 yards east of shore, and 80 yards northwest of extreme end of point.

Marks.-Observed station is center point of triangle on standard cement monument projecting 4 inches above surface of ground. Subsurface mark is center of 2 -inch tile pipe buried with top 2 inches below base of monument.

References.-

"Tul1" ( $\left.\mathrm{N} \mathrm{I2}^{\circ} 34^{\prime} \mathrm{E}\right)$

house...................

Cupola on barn.......................... 30

Right corner of old barn...............

East chimney of large brick house........ 54

Right tangent of Normans Point.......... 6

North gable of barn on Parsons Island...... 7

Left tangent of Bodkin Island........... I23

East gable of barn ................. 227

Chimney of house ..................... $23^{2}$

Chimney of house.................... 255

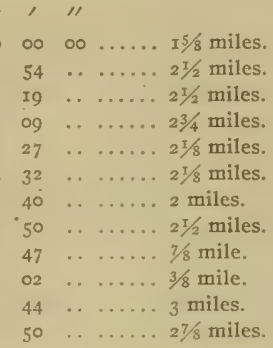

TULL.

General locality.-Eastern side of Kent Island and western side of Crab Alley Bay on northern end of Johnson Island at entrance to Crab Alley Creek about $2 \frac{1}{4}$ miles north of Bodkin Island and $\mathrm{I} / 2$ miles northwest of Normans Point. (See Chart No. 3r.)

Immediate locality.-Observed station is in a marsh meadow about 2 feet above high water, 18 yards south of shore, 53 yards west of extreme northeast end of Johnson Island, and 40 yards north of a group of pine trees.

Marks.--Observed station is center point of triangle on standard cement monument projecting 5 inches above surface of ground. Subsurface mark is center of 2 -inch tile pipe buried with top 2 inches below base of monument.

References.-

\begin{tabular}{|c|c|c|c|}
\hline $\mathrm{Cox}^{\prime \prime}\left(\mathrm{S}_{12}{ }^{\circ} 35^{\prime} \mathrm{W}\right) \ldots \ldots$. & $\circ$ & ০o & $\infty 0$ \\
\hline limney of house.... & 4 & 54 & . \\
\hline st gable of house... & 89 & os & .. \\
\hline imney of house... & I2I & 14 & .. \\
\hline ey on small tenant house & 145 & I2 & .. \\
\hline barn... & 147 & 30 & . . \\
\hline f fishing & 203 & 27 & . . \\
\hline 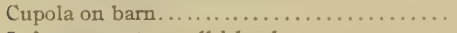 & $25^{8}$ & 23 & $\cdots \ldots \ldots x$ \\
\hline all i & 329 & 35 & .. \\
\hline it tangent to pine woods on Turkey Point & 355 & 24 & \\
\hline
\end{tabular}

\section{NEEDLE.}

General localily. - Northern part of Eastem Bay on Bodkin Island at entrance to Crab Alley Bay about $\mathrm{x} / 2$ miles west of the south end of Parsons Island and $\mathrm{x}$ mile east-southeast of Turkey Point. (See Chart No. 3I.)

Immediate locality.-Observed station is near south end of Bodkin Island about I2 feet above high water, 50 yards north by west of shore, 90 yards northeast by east of shore, Ir 5 yards west-southwest of shore, and in center of radial lines of sight cut in bushes. 
Malks.--Observed station is center point of triangle on standard cement montument projecting 4 inches above surface of ground. Subsurface mark is center of 2 -inch tile pipe buried with top 2 inches below base of monument.

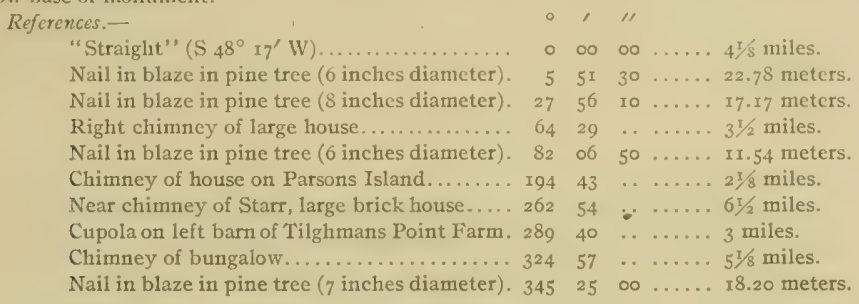

\section{KEMP TOWER.}

General localily.-Southern shore of Eastern Bay on Wades Point about I mile southwest of Claiborne Wharf and 5 I $/ 8$ miles east of Bloody Point Bar Light. (See Chart No. 3I.)

Immediate locality:-Observed station is on tower or cupola of Wades Point Hotel, which is a large square frame structure adjoining a brick house.

Marks.-Observed station is center of top of roof of cupola.

References.-None necéssary.

\section{KEMP.}

General locality.--Southern shore of Eastern Bay on Wades Point about $x^{3} / 8$ miles southwest of Claiborne Wharf and $4 \frac{7}{8}$ miles east by south of Bloody Point Bar Light. (See Chart No. 3I.)

Immediate locality.-Observed station is in cultivated land about 8 feet above high water, 30 yards east by north of a wire fence and several trees, 55 yards south-southeast of edge of bank, 90 yards eastnortheast of a bungalow, I30 yards north by west of a wire and wood fence corner, I30 yards northnorthwest of wooden fence, and $\$ 00$ yards west by south of Wades Point Hotel.

- Marks.-Observed station is center point of triangle on standard cement monument projecting 6 inches above surface of ground. Subsurface mark is center of 2 -inch tile pipe buried with top 2 inclies below base of monument.

References.-

"Bloody Point Bar Light" ( $\left.\mathrm{N} 83^{\circ} 37^{\prime} \mathrm{W}\right)$...

Nail in blaze in locust tree ( 14 inches diam-

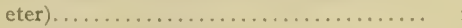

Left tangent of Kent Point..............

Chimney on middle of house............ I

Left peak of barn..................... 25

Clininey of louse. ................ 3

Left chimney of house .............. 4

Peak of main part of house.............. 6

Left tangent of Tilghmans Point.......... I28

"Dixon" (center of house) .............. I30

"Kemp Tower" .................... I39

Fence comer (wood and wire) .......... 244

Near comer of cook house................ 288

Nail in blaze in locust tree ( 7 inches diameter)............................ $300 \quad 2020 \ldots \ldots .27$ meters.

Right corner post of piazza............ $306 \quad 24 \quad \ldots \ldots \ldots$ 90 yards.

Nail in blaze in cedar tree ( 6 inches diam-

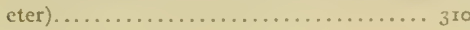
$43 \quad 30 \ldots \ldots 26.97$ meters. 


\section{RICH NECK WA'TER TANK.}

Gencral locality.-On neck of land about halfway between Eastern Bay and Miles River, about $\mathrm{I} 3 / 4$ miles south-southwest of Tilghmans Point. (See Cliarts Nos. 3 I and 32.)

Immediate locality.-Observed station is on large water tank on steel tower on Rich Neck Farm.

Marks.-Observed station is spindle on center of water tank.

References.-None necessary.

\section{OVER.}

General locality.-Eastem shore of Crab Alley Bay on a point about I I $/ 4$ miles north-northwest of Normans Point. (See Chart No. 32.)

Immediate locality.-Observed station is on edge of a cultivated field near a number of locust and wild cherry trees, about 3 feet above high water, II yards northeast of shore, 50 yards southeast of end of a marsh point, and 4 yards north of comer of a rail fence.

Marks.-Observed station is center point of triangle on standard cement monument projecting 3 inches above surface of ground. Subsurface mark is center of 2 -inch tile pipe buried with top 2 inches below base of monument.

References.-

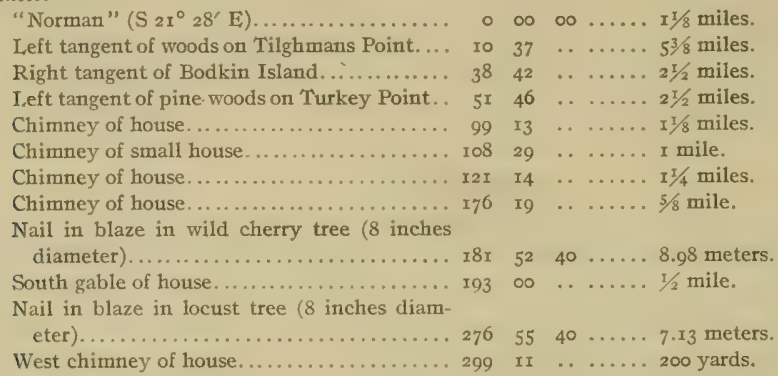

\section{NORMAN}

General locality.-Ejastem shore of Crab Alley Bay on southwestern extremity of Crab Alley Neck about $1 / 4$ mile west of Normans Point, 2 miles northeast of Turkey Point, and 7/8 mile northwest of Parsons Island. (See Chart No. 32.)

Immediate locality.-Observed station is in a cultivated field on a rapidly washing, narrow neck of land, about 6 feet above high water, 20 yards north of vertical bank at shore, 30 yards south of vertical bank at shore, and 40 yards northeast of extreme end of point.

Marks.-Observed station is center point of triangle on standard cement monument projecting 3 inches above surface of ground. Subsurface mark is center of 2 -inch tile pipe buried with top 2 inchics below base of monument.

\section{References, -}

"Parsons" ( $\left.\mathrm{S}_{3} 8^{\circ} 4 \mathrm{O}^{\prime} \mathrm{E}\right) \ldots \ldots \ldots \ldots \ldots \ldots$

Right tangent of Parsons Island............ .

Left tangent of woods on Tilghmans Point...

L.eft tangent of woods on Bodkin Island.....

Right tangent of Bodkin Island............

Right tangent of woods on Turkey Point.....

Nail in blaze of hackberry tree ( 6 inches diameter)

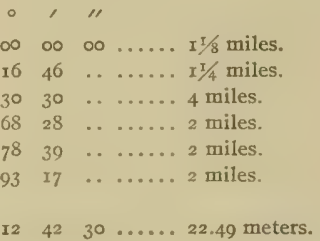


References-Continued.

Chimney of small house............... I54 $22 \ldots \ldots \ldots 13 / 4$ miles.

East chimney of house............... $167 \quad 41 \ldots \ldots \ldots 21 / 4$ miles.

South gable of house................. $205 \quad 38 \quad \ldots \ldots \ldots$ m mile.

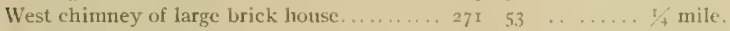

Chimney of small house ................ $292 \quad 22 \quad \ldots \ldots \ldots .3$ miles

"Parsons Island Water Tank" ........... 353 41 to . . . 1 mile.

\section{PARSONS.}

General locality - - In northem side of Eastern Bay on western side of Parsons Island about 3 miles north of Tilghmans Point. (See Chart No. 32.)

Immediate locality.-Observed station is in cultivated land on highest part of island about ${ }_{5}$ feet above high water, I ro yards southeast of shore, 270 yards south-southwest of Parsons Island Water Tank, $35^{\circ}$ yards southwest of a house, 380 yards west-southwest of a large barn, 145 yards northeast of a wire fence, 155 yards northwest of wire fence at farm road, I95 yards southeast of a fence, and on the range of the west edge of the south chimney on the lower gable of the house with the west side of a window in the center of the south side of the house. Cement monument marking reference station is 26 . 10 meters $\mathrm{N} 2 I^{\circ} 43^{\prime} \mathrm{E}$ of observed station.

Marks.-Observed station is center of cross cut on rough granite stone about 35 inches long and 12 inches square with top cut to 6-inch cube and marked " $U$ S" in lower half of cross. Subsurface mark is the mouth of a bottle 3 inches below base of monument. Reference station is center point of triangle on standard cement monument with top 5 inches ahove the surface of the ground.

Reforences.-

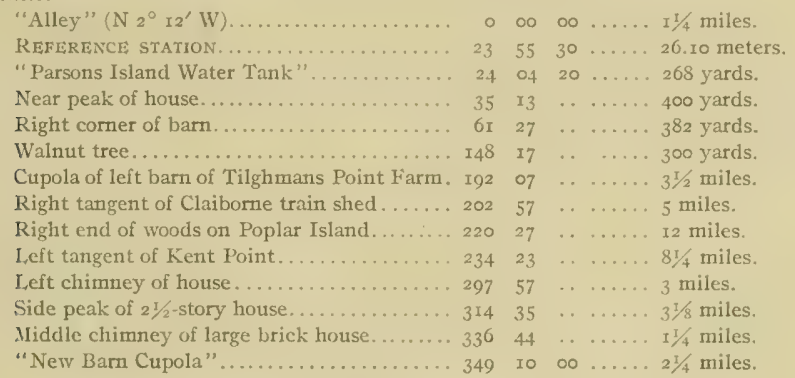

\section{PARSONS ISLAND WATER TANK.}

General localily.-Northern part of Eastern Bay between Crab Alley and Prospect Bays on Parsons Island, about halfway between the north and south end of the island. (See Chart No. 32.)

Immediate locality.-Observed station is on a water tank on wooden structure near a house. Marks.-Observed station is center of spindle on center of water tank.

References.-None necessary.

\section{ALLEY.}

General locality. - Western shore of Prospect Bay on Crab Alley Neck about $3 / 4$ mile north of Parsons Island and $3 / 8$ mile north of Narrows Point. (See Chart No. 32.)

Immediate locality. - Observed station is on hard ground in a marsh at northeast end of clump of 12 persimmon trees about $\mathrm{I}$ foot above high water and 75 yards southwest of point. 
Marks,-Observed station is center point of triangle on standard cement monument projecting 5 inches above surface of ground. Subsufface mark is center of 2 -inch tile pipe buried with top 2 inches below base of monument.

References.-

"Dull" ( $\left.\mathrm{N}_{2}{ }^{\circ} 35^{\prime} \mathrm{W}\right)$

Near peak of "Fishermans Inn".

Nail in blaze in persimmon tree (4 inches diameter)...........................

Left chimney of old house with two dormer windows........................ $48 \quad 29 \quad \ldots \ldots 23 / 8$ miles.

L.eft peak of barn.................... $79 \quad 42 \quad \ldots \ldots \ldots 23 / 4$ miles.

Left chimney of large house............ $1 x_{3} 34 \quad \ldots \ldots \ldots 23 / 4$ miles.

"Parsons Island Water Tank" .......... I77 $35 \quad 30 \ldots \ldots$ I $1 / 8$ miles.

Nail in blaze in persimmon tree $(3$ inches

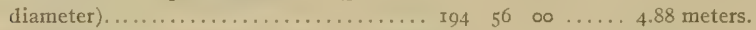

Nail in blaze in persinmon tree $\left(2 \frac{1}{2}\right.$ inches

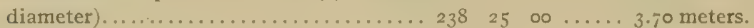

East chimney of brick house.......... 246 o2 $\ldots \ldots \ldots r / 2$ mile.

Nail in blaze in persimmon tree ( 3 inches diameter)........................... 298 2I $30 \ldots 3.29$ meters.

Chimney of house among trees........... 3 II $54 \quad \ldots \ldots \ldots$ I $1 / 2$ miles.

"New Barn Cupola"....................... 335 4I 40 mile.

\section{NEW BARN CUPOLA.}

General locality.-Western shore of Prospect Bay on Crab Alley Neck about I $3 / 4$ miles north-northwest of Parsons Island. (See Chart No. 32.)

Immediate locality.- Observed station is spindle with weather vane on cupola of barn about Ioo yards east-southeast from house on farm belonging to $\mathrm{H}$. C. Norman.

Marks.-Observed station is spindle on cupola.

References.-None necessary.

\section{DUL,L.}

General locality.-Western shore of Prospect Bay on a point at northern side of entrance to a cove about $2 \frac{1}{8}$ miles south of Kent Narrows railroad bridge, $7 / 8$ mile west-southwest of Hoods Point and I I/4 miles north of Narrows Point. (See Chart No. 32.)

Immediate locality.-Observed station is in marsh land about I foot above high water, 30 yards west of shore, 40 yards northeast of shore, and so yards north-northwest of extreme end of point.

Marks.-Observed station is center point of triangle on standard cement monument projecting 4 inches above surface of ground. Subsurface mark is center of 2 -inch tile pipe buried with top 2 inches helow base of monument.

References.-

"Kirwan" ( $\left.\mathrm{N}_{3}^{\circ} \mathrm{oo}^{\prime} \mathrm{W}\right)$.

0 - $00 \ldots \ldots I^{1 / 3}$ miles.

Near peak of "Fishermans Inn" ......... to ox ...... $2^{\mathrm{I}} / 8$ miles.

Chimney of house................... $37 \quad 53 \quad \ldots \ldots \ldots .1 / 2$ miles.

Chimney of house in trees............. 56 og $\ldots \ldots \ldots .1 / 4$ miles.

Chimney of house................. I0.4 $49 \ldots \ldots \ldots 2 \frac{1}{2} / 4$ miles.

Chimney of old wharf house............ I 38 46 $\ldots \ldots .4$ miles.

Between two chimneys of old house...... I $5^{2}$ of $\ldots \ldots \ldots 5^{1 / 4}$ miles.

Left tangent of Parsons Island .......... I69 $4 \mathrm{I} \ldots \ldots \ldots$ I7/8 miles.

"New Barn Cupola"................. 270 $45 \quad 20 \ldots \ldots$ 3/8 mile.

Chimney of ell of house................. 329 o6 ... $3 / 4$ mile. 


\section{KIRWAN.}

General locality.-Westem shore of Prospect Bay on a point about $x^{1 / 4}$ miles south of Kent. Narrows railroad bridge and $1 / 4$ mile southeast of entrance to Kirwans Creek. (Sec Chart No. 32.)

Immediate locality. -Observed station is on a marsh point about I foot above high water, I6 yards southeast of shore, 25 yards northwest of shore, 27 yards west of extreme end of point, and 30 yards south-southeast of shore.

Marks.-Observed station is center point of triangle on standard cement monument projecting 4 inches above surface of ground. Subsurface mark is center of 2 -inch tile pipe buried with top 2 inches below base of monument.

\begin{tabular}{|c|c|c|c|c|}
\hline References.- & $\circ$ & & & \\
\hline "Bridge" (N 8 $\left.4 \mathrm{x}^{\prime} \mathrm{E}\right) \ldots \ldots \ldots \ldots \ldots \ldots \ldots \ldots$ & $\circ$ & $\infty$ & $\infty$ & $\mathrm{I} / \mathrm{s} / \mathrm{miles}$. \\
\hline Near peak of "Fishermans Inn"............ & 9 & $5 I$ & . & I $1 / 8$ miles \\
\hline Chimney of house ..................... & 46 & 45 & .. & II $/ 2$ milc \\
\hline 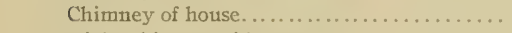 & 53 & 28 & . & I $1 / 2$ milc \\
\hline Right climney of house............... & 64 & 43 & . & $13 / 4 \mathrm{mil}$ \\
\hline Near peak of old house among trees... & 90 & 50 & .. & I mile. \\
\hline Right peak of large barn............... & 129 & 34 & . & $4 / 8 \mathrm{mil}$ \\
\hline "Parsons Island Water Tank" ....... & 167 & 43 & I0 & 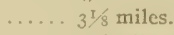 \\
\hline "New Barn Cupola"........... & I88 & 29 & $\ldots$ & I $1 / 8$ mile \\
\hline Right peak of new barn........... & 207 & 22 & . & $5 / 8$ mile. \\
\hline Large chimney near end of old house....... & 263 & 43 & . & ..... I mile. \\
\hline Chimney of house . . . . . . . . . . . . & 308 & $5 \mathrm{I}$ & . & I mile. \\
\hline
\end{tabular}

\section{IIARSHY.}

General locality.-Eastern shore of Prospect Bay about I mile south-southeast of Kent Narrows railroad bridge and $1 / 8$ mile south of entrance to Marshy Creek. (See Chart No. 32.)

Immediate locality.- Observed station is in marsh land about I foot above high water, 25 yards east of shore, 50 yards southeast of shore, 40 yards northeast of extreme end of point, and 4 yards north of a line of four small trees.

Marks.-Observed station is center point of triangle on standard cement monument projecting 4 inches above surface of ground. Subsurface mark is center of 2 -inch tile pipe buried with top 2 inches below base of monument.

References.-

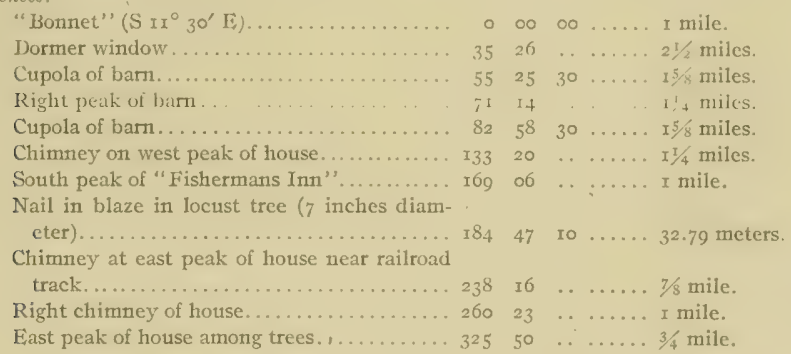

\section{BONNET}

General locality.-Eastern shore of Prospect Bay on Hood Point about I I/2 miles sontheast of Hog Island and $1 / 2$ mile west of Piney Point. (See Chart No. 32.)

Immediate locality.-Observed station is on marsh ground about I foot above high water, $2 \mathrm{x}$ yards west of shore, 12 yards west of inlet, and 55 yards northeast of the extreme end of Hoods Point.

Marks.-Observed station is center point of triangle on standard cement monument projecting 6 inches above surface of ground. Subsurface mark is center of 2 -inch tile pipe buried with top 2 inches below base of monument. 


\begin{tabular}{|c|c|c|c|c|}
\hline eferences.- & & & " & \\
\hline "New Barn Cupola" (S $79^{\circ} 29^{\prime}$ W). & $\circ$ & $\infty$ & $\infty$ & $\mathbf{r}^{1} / 2$ miles. \\
\hline Chimmey of house. . . . . . . . . . . . & 24 & II & .. & $x^{I} / 4$ miles. \\
\hline East gable of barn. ........ & 28 & 24 & $\cdots$ & $11 / 4$ miles \\
\hline North chimney of house... & 64 & 04 & .. & 2 miles. \\
\hline South gable of barn........... & 90 & 43 & .. & 2 Is miles. \\
\hline Chimney on small house... & 137 & 57 & . & $5 / 8$ mile. \\
\hline West gable of house........ & I99 & o6 & . & I5/s mile \\
\hline 1 house..... . & 239 & I3 & .. & $2 \frac{1}{2}$ miles \\
\hline Chimney of s & $25^{8}$ & 39 & . & $4^{3} / 4$ mile \\
\hline South chimney of house on Kent Island. & 323 & 24 & & $\mathbf{1} 3 / 4$ mile \\
\hline 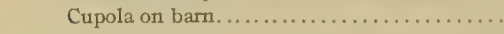 & 353 & 09 & & $\ldots \ldots . \pm 3 / 4$ mile \\
\hline
\end{tabular}

\section{BRIAN REFERENCE STATION.}

General locality.--Eastern shore of Prospect Bay on Brian Point ahout I mile southeast of Piney Point, 2 miles northeast of Parsons Island, and $3 / 8$ mile west of entrance to Hog Hole Creek. (See Chart No. 32.)

Immediate locality.-Observed station is on a marsh point about I foot above high water, I3 yards east of edge of marsh, I4 yards northwest of edge of marsh, I 8 yards north of extreme end of point, and 40 yards southwest of a cultivated field.

Marks.-Observed station is center point of triangle on standard cement monument projecting 4 inches above surface of ground.

Rejerences.-

\begin{tabular}{|c|c|c|c|c|}
\hline $\left.8^{\circ} 55^{\prime} \mathrm{E}\right)$ & $\circ$ & & & \\
\hline eft tangent of woods on Benr & 4 & 55 & . & 4 miles. \\
\hline Right tangent of woods on Parsons Island. & 65 & 33 & . & $21 / 4$ miles. \\
\hline Middle chimney of large brick house........ & 84 & 37 & & $21 / 4$ miles. \\
\hline ola of barn & IO2 & 3 & . & 4 miles. \\
\hline "New Bam Cupola" & 109 & 56 & 20 & iles. \\
\hline eft peak of large house. & II2 & 08 & $\therefore$ & $25 / 8$ miles. \\
\hline ar peak of house & 282 & & . & 2 mile. \\
\hline limney of housc. & 344 & & & I, + miles. \\
\hline
\end{tabular}

\section{GREEN.}

General locality.-Eastern shore of Prospect Bay on point at northern side of entrance to Greenwood Creek about $3^{1 / 4}$ miles northeast of Tilghmans Point and $23 / 4$ miles north of Bennett Point. (See Chart No. 32.)

Immediate locality.-Observed station is on a sanded marsh point about 2 feet above high water, 5 yards northwest of shore, 26 yards northwest of shore, 5.3 yards east by north of a point of shore, 37 yards southeast by east of a point of shore, and 105 yards south-southwest of a point of woods.

Marks.-Observed station is center point of triangle on standard cement monument projecting 5 inches above surface of ground. Subsurface mark is center of 2 -inch tile pipe buried with top 2 inches below base of monument.

References.-

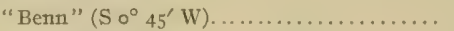

Cupola of barn. ...................

Right tangent of woods on Tilghmans Point.

"Parsons Island Water Tank"........... Ir

East chimney of brick house. .......... I2.

Peak of small house................... I55 o $_{5}$

Chimney outside of house................ $165 \quad 43$

Near peak of barn................... I78 20

Peak of house..................... $235 \quad 45$

Chimney of house behind barn........... 3I6 oI

Square chimney of house.

$$
\begin{aligned}
& \text { II } \\
& \text { o ..... 23/4 miles. } \\
& \text { Io ..... } 6 \text { miles. } \\
& \text {...... } 3 \frac{3}{8} 8 \text { miles. } \\
& 50 \ldots . .2 \frac{1}{1} / 2 \text { miles. } \\
& \text {....... } 3 \frac{1}{2} / 2 \text { miles. } \\
& \text {...... } 4 \text { miles. } \\
& \text {..... } 4 \text { miles. } \\
& \text {..... } 3 \text { miles. } \\
& \text {...... I mile. } \\
& \text {...... } 3 / 8 \text { mile. } \\
& \text {...... } \mathrm{I}^{\mathrm{I} / 2} \mathrm{~m} \text { miles. }
\end{aligned}
$$


BENN.

General locality.-Eastern shore of Miles River on Bennett Point at western side of entrance to Wye River. (See Chart No. 32.)

Immediate locality.-Observed station is on a marsh point about I foot above high water, 75 yards northeast of extreme end of point, 100 yards southwest from edge of wood, and in center of triangle formed by three pine stubs driven flush with marsh to support theodolite.

Marks.-Observed station is center point of triangle on standard cement monument projecting I foot above surface of ground. Subsurface mark is center of 2 -inch tile pipe buried with top 2 inches below base of monument.

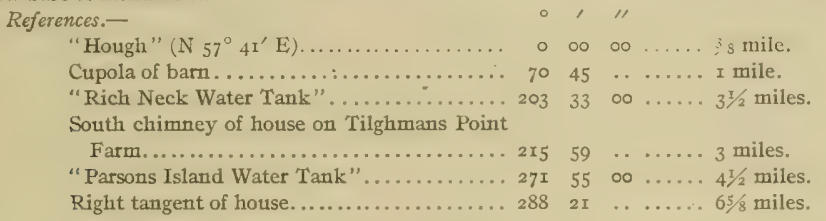

\section{HOUGH.}

General locality.-Northwestern side of entrance to Wye River on a point about $3 / 8$ mile northeast of Miles River and $1 / 2$ mile southwest of north end of Bruffs Island. (See Chart No. 32.)

Immediate locality.-Observed station is on a grass point about I foot above high water, I 6 yards north of shore, 22 yards south of shore, I5 yards west of extreme end of point, in yards east of small pool in marsh, and 200 yards east of woods.

Marks.-Observed station is center point of triangle on standard cement monument projecting 4 inches above surface of ground. Subsurface mark is center of 2 -inch tile pipe buried with top 2 inches below base of monument.
References.-
"Won". (N $\left.09^{\circ} 29^{\prime} \mathrm{E}\right)$
- , I
Near peak of building
Right side of chimney of house............
Near peak of long barn.
Piaza post of house in woods.
Windmill ..........................
Windmill .................... 18 r $48 \ldots \ldots \ldots 4^{1 / 4}$ miles.
Tall, slender tree in woods............ 27 $57 \ldots \ldots$. . 200 yards.
Black walnut tree....................... $33923 \quad 23$. . yards.

WON.

General locality.-Western shore of the branch of Wye River bounding Wye Island on the west about $1 / 2$ mile northwest of northern end of Bruffs Island and $3 / 4$ mile northeast of southern end of Bennett Point. (See Chart No. 32.)

Immediate locality. - Observed station is on small marsh point, about I foot above high water, 4 yards northwest of shore, 4 yards west of shore, 4 yards north of shore, and 40 yards southeast of large lone black-walnut tree. Cement monument marking reference station is 22.80 meters $\mathrm{S} I 5^{\circ} 3 \mathrm{I}^{\prime} \mathrm{W}$ of observed station.

Marks.-Observed station is nail in center of 2 -inch stub projecting 5 inches above 2 -inch tile pipe with top flush with surface of ground. Subsurface mark is center of 2 -inch tile pipe buried with top 2 inches below base of surface pipe. Reference station is center point of triangle on standard cement mon ument projecting 4 inches above surface of ground.

$$
20313-12-6
$$




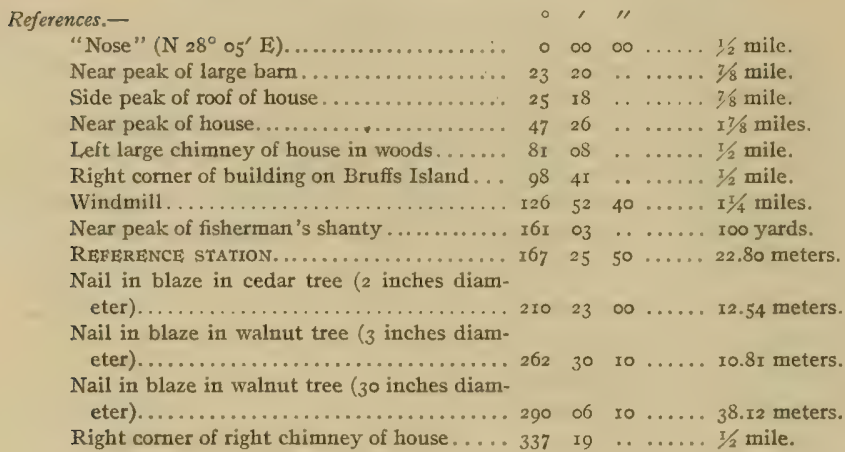

\section{NOSE,}

General locality.-Western shore of the branch of Wye River bounding Wye Island on the west on a point about $5 / 8$ mile north-northwest of Bruffs Island. (See Chart No. 32.)

Immediate locality.-Observed station is on a marsh point about I foot above high water, 4 yards southwest of shore, 6 yards north of shore, I4 yards west-northwest of extreme end of point, and 34 yards east of a row of locust trees.

Marks.-Observed station is center point of triangle on standard cement monument projecting 5 inches above surface of ground. Subsurface mark is center of 2 -inch tile pipe buried with top 2 inches below base of monument.

\begin{tabular}{|c|c|c|c|c|}
\hline References.- & 0 & , & "I & \\
\hline 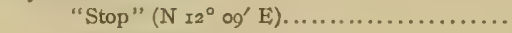 & 0 & $\infty$ & $\infty$ & $3 / 8$ mile. \\
\hline 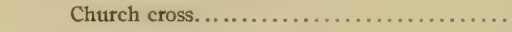 & I & 55 & . & .. 2 miles. \\
\hline Chimney of cottage................... & 3 & 03 & .. & . $13 / 8$ miles. \\
\hline Near peak of house................... & 37 & 22 & $\ldots$ & $5 / 8$ mile. \\
\hline 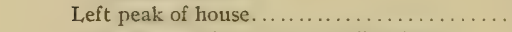 & 67 & 25 & . & $1 / 2$ mile. \\
\hline Right corner of house on Bruffs Island....... & $5^{2}$ & 55 & . & . $3 / 4$ mile. \\
\hline "St. Michaels P. E. Church Spire".... & 183 & 28 & IO & .. $5 \frac{7 / 8}{8}$ miles. \\
\hline "St, Michaels Water Tank" ............. & 184 & 51 & 20 & .. $5 \% / 8$ miles. \\
\hline $\begin{array}{l}\text { Nail in blaze in locust tree }(8 \text { inches diam- } \\
\text { eter) } \ldots \ldots \ldots \ldots \ldots \ldots \ldots \ldots \ldots \ldots \ldots \ldots \ldots\end{array}$ & 237 & $5^{8}$ & 50 & ters. \\
\hline $\begin{array}{l}\text { Nail in blaze in locust tree (9 inches diam- } \\
\text { eter) } \ldots \ldots \ldots \ldots \ldots \ldots \ldots \ldots \ldots \ldots \ldots \ldots \ldots\end{array}$ & $25^{6}$ & $3^{2}$ & Io & I meters. \\
\hline $\begin{array}{l}\text { Near peak of large house, between two chim- } \\
\text { neys. . . } \ldots \ldots \ldots \ldots \ldots \ldots \ldots \ldots \ldots \ldots \ldots \ldots \ldots\end{array}$ & 266 & (9) & & \\
\hline $\begin{array}{l}\text { Nail in blaze in locust tree }(7 \text { inches diam- } \\
\text { eter) } \ldots \ldots \ldots \ldots \ldots \ldots \ldots \ldots \ldots \ldots \ldots \ldots \ldots \\
\text { Tangent of point. . . . }\end{array}$ & $\begin{array}{l}280 \\
316\end{array}$ & $\begin{array}{l}50 \\
16\end{array}$ & 50 & 44 meters. \\
\hline
\end{tabular}

\section{STOP.}

General locality.-Western shore of the branch of Wye River bounding Wye Island on the west on a point about I mile north of Bruffs Island. (See Chart No. 32.)

Immediate locality.-Observed station is on edge of pasture land about 3 feet above high water, 20 yards west of shore, 40 yards north by east of shore, and 50 yards south by west of shore.

Marks.-Observed station is center point of triangle on standard cement monument projecting 4 inches above surface of ground. Subsurface mark is center of 2 -inch tile pipe buried with top 2 inches below base of monument. 


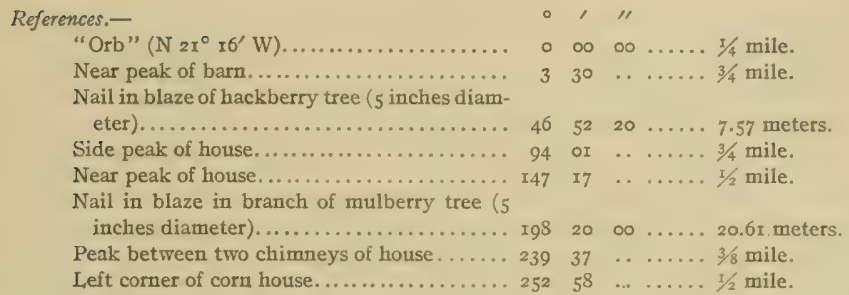

\section{ORB.}

General locality.-Western shore of the branch of Wye River bounding Wye Island on the west on a point about $I 3 / 8$ miles north of Bruffs Island and $5 / 8$ mile southwest of Cedar Point. (See Chart No. 32.)

Immediate locality.-Observed station is on a marsh point about I foot above high water, 6 yards southwest of shore, 7 yards northwest of shore, 6 yards north of shore, and southeast of a point of land 5 feet higher than station.

Marks.-Observed station is center point of triangle on standard cement momument projecting 4 inches above surface of ground. Subsurface mark is center of 2 -inch tile pipe buried with top 2 inches below base of monument.

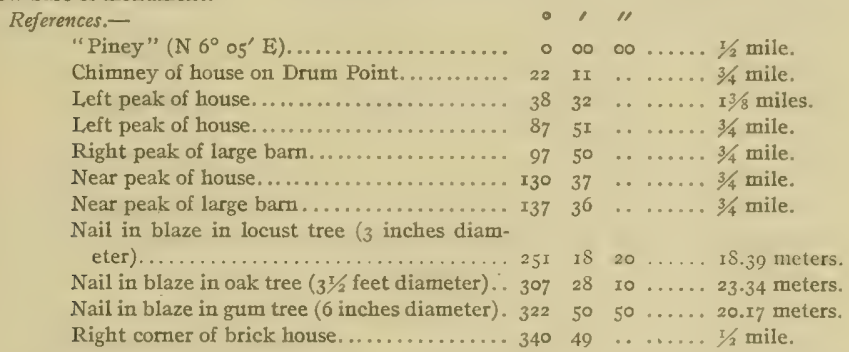

\section{PINEY.}

General locality. -Western shore of the branch of Wye River bounding Wye Island on the west about $3 / 8$ mile southwest of Drum Point and $x_{3}^{3 / 4}$ miles north of Brufis Island. (See Chart No. 32.)

Immediate locality.-Observed station is in a cultivated field about 6 feet above high water, 5 yards northwest of point, 8 yards north of top of bank, 9 yards west of trees at top of bank, and 55 yards northeast of another point.

Marks.-Observed station is center point of triangle on standard cement monument projecting 5 inches above surface of ground. Subsurface mark is center of 2 -inch tile pipe buried with top 2 inches below base of monument.

\section{References.-}

"Ferry" ( $\left.57^{\circ} 08^{\prime} \mathrm{E}\right)$.

Nail in blaze in locust tree (4 inches diam

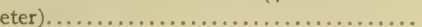

Near peak of house.....................

Near peak of house ....................

Nail in blaze in hackberry tree (5 inches diameter)..........................

Near peak of house.

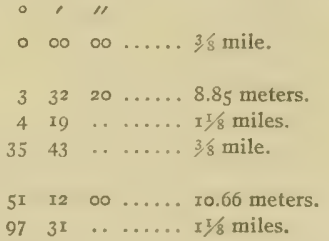




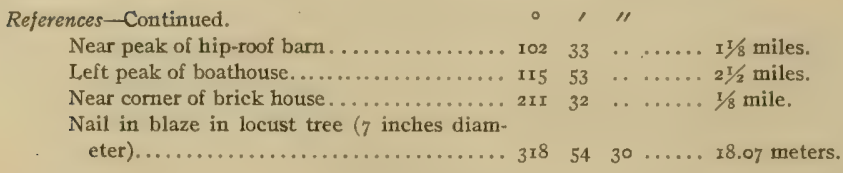

\section{FERRY.}

General locality.-Westem shore of the branch of Wye River bounding Wye Island on the west on Drum Point, about $3 / 8$ mile west of Cedar Point. (See Chart No. 32.)

Immediate locality.-Observed station is in a pasture with paling fence on northwest and westsouthwest sides about 4 feet above high water, 6 yards northwest of shore, to yards west of shore, 20 yards northeast by east of fence at county road, and 40 yards southeast of fence near small house.

Marks.-Observed station is center point of triangle on standard cement monument projecting 8 inches above surface of ground. Subsurface mark is center of 2 -inch tile pipe buried with top 2 inches below base of monument.

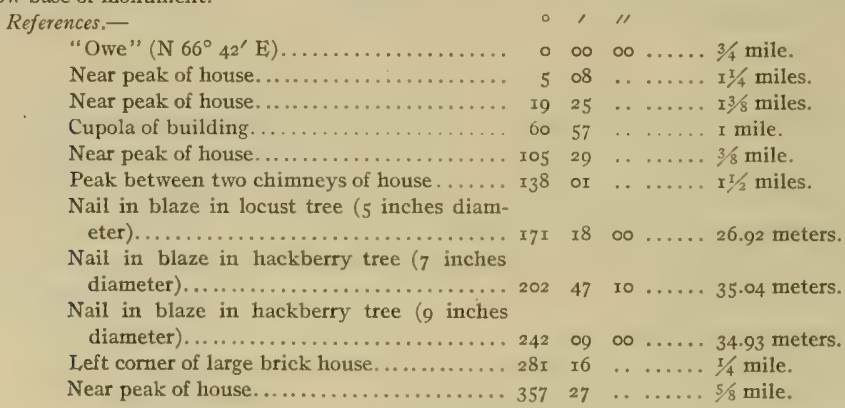

OWE.

General locality. - Western shore of the branch of Wye River bounding Wye Island on the west on a point about $3 / 4$ mile east-northeast of Drum Point and I mile south-southwest of entrance to Wye Narrows. (See Chart No. 32.)

Immediate locality.-Observed station is on a grassy point about 2 feet above high water, 9 yards north of shore, II yards west-southwest of shore, io yards west of extreme end of point, and 75 yards east-southeast of a house I2 feet above high water.

Marks.-Observed station is center point of triangle on standard cement monument projecting 5 inches above surface of ground. Subsurface mark is center of 2 -inch tile pipe buried with top 2 inches below base of monument.

\section{References.-}

"Hook" ( $\left.\mathrm{N}_{7}^{\circ} 36^{\prime} \mathrm{W}\right)$

Peak of near gable of house.

Near comer of house

Right peak of small house. .................. 89

Baldwin windmill. ................... 16

Left peak of house...................... 20

Near corner of chimney outside left end of house......................... 236

Left tangent of large brick house.......... 253

Nail in blaze in black walnut tree $(5$ feet diameter)........................ inches diameter)$$
\text { oo ..... } 1 / 4 \text { mile. }
$$$$
\text { ...... } 2^{\frac{1}{2}} / 2 \text { miles. }
$$$$
\text { ....... } 5 / 8 \text { mile. }
$$$$
\text { ...... } 3 / 4 \text { mile. }
$$$$
40 \ldots \ldots .5 / 8 \text { miles. }
$$$$
\text { ....... } x^{1 / 2} / 8 \text { miles. }
$$$$
39 \quad \ldots \ldots \ldots 7 / 8 \text { mile. }
$$$$
44 \quad \ldots \quad \ldots \ldots .51 / 4 \text { miles. }
$$

02 10 $\ldots \ldots 3$ I. 44 meters.

$331 \quad 5^{8}$ 10 ..... 31.63 meters. 
HOOK.

General locality. - Western shore of the branch of Wye River bounding Wye Island on the west about $3 / 4$ mile southwest of entrance to Wye Narrows and $1 / 4$ mile south of entrance to a cove. (See Chart No. 32.)

Immediale locality. - Observed station is in cultivated land about to feet above high water, 3 yards west of top of bank, 4 yards northeast of top of bank lined with cedars, 7 yards north-northwest of extreme end of point of bank at left of cedars, and north of a long, low peninsula that separates a small pond from river.

Marks.-Observed station is center point of triangle on standard cement monument projecting 5 inches above surface of ground. Subsurface mark is center of 2 -inch tile pipe buried with top 2 inches below base of monument.

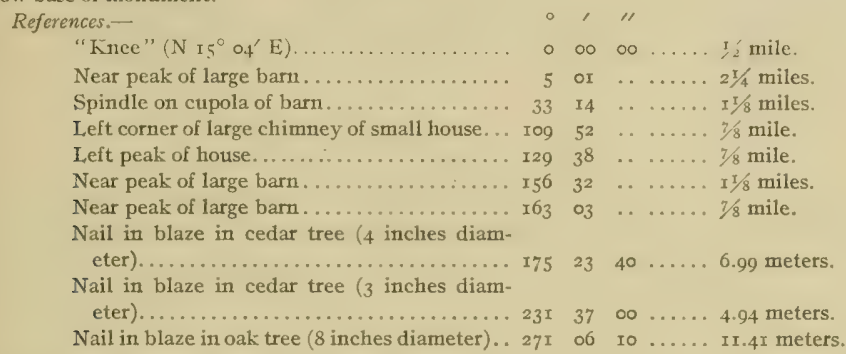

KNEE.

General localily:-Western shore of the branch of Wye River bounding Wye Island on the west about $1 / 2$ mile west-south west of entrance to Wye Narrows. (See Chart No. 32.)

Immediate locality.-Observed station is on a narrow strip of lowland about $\mathrm{I}$ foot above high water, 4 yards west of shore, 12 yards east of cut in bank, and 40 yards south of bank 8 feet high with few trees.

Marks.-Observed station is center point of triangle on standard cement monument projecting 5 inches above surface of ground. Subsurface mark is center of 2 -inch tile pipe buried with top 2 inches below base of monument.

References.-

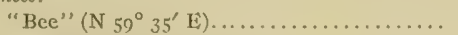

Large pine tree on point................ 26

Smoke pipe on small building........... $84 \quad 59 \ldots \ldots \ldots 1 / 2$ mile

Baldwin windmill................. 108 o8 10 .... $2 \frac{1 / 4}{4}$ miles

Peak of near gable of Baldwin house....... I08 $29 \quad \ldots \ldots \ldots 21 / 4$ miles.

Large chimney of large house........... I20 $43 \quad \ldots \ldots$. . mile.

Lightning rod on Bryan house .......... I29 $59 \quad \ldots \ldots \ldots .3 / 4$ mile.

Nail in blaze in oak tree ( $x 2$ inches diameter). 365 o6 $20 \ldots . .14 .60$ meters.

Nail in blaze in locust tree ( 7 inches diam-

eter $\ldots \ldots \ldots \ldots \ldots \ldots \ldots \ldots \ldots \ldots \ldots \ldots \ldots \ldots \ldots \ldots$ meters.

Nail in blaze in twisted cedar bush ....... $289 \quad 36 \quad$ 10 .... 8.79 meters.

Chimney of house.................... 320 II ...... I 78 miles.

NO.

General locality.-On the westen shore of the continuation of the branch of Wye River bounding Wye Island on the west, about $3 / 8$ mile west-northwest of entrance to Wye Narrows on point at south side of entrance to a small cove. (See Chart No. 32.)

Immediale locality.-Observed station is on a point about I foot above high water, 4 yards southwest of shore, 4 yards north of shore, 5 yards west of extreme end of point, and east of trees on bank 5 feet high. 
Marks.-Observed station is center point of triangle on standard cement monument projecting 5 inches above surface of ground. Subsurface mark is center of $z$-inch tile pipe buried with top 2 inches below base of monument.

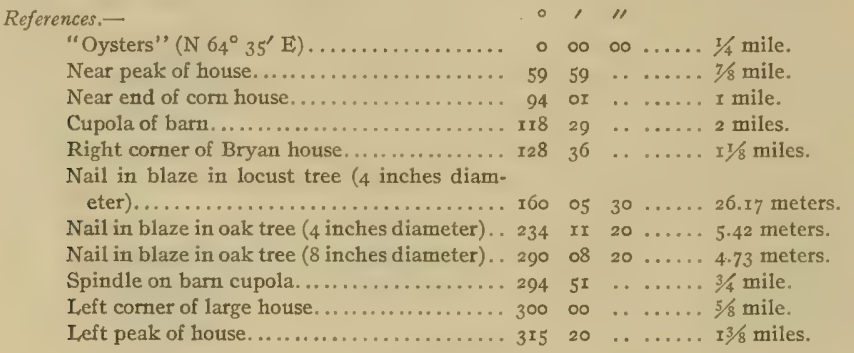

\section{OYSTERS}

General locality.-Eastern shore of the continuation of the branch of Wye River bounding Wye Island on the west about $1 / 4$ mile north of entrance to Wye Narrows on point at south side of entrance to a small cove. (See Chart No. 32.)

Immediate locality.- Observed station is in a clump of small trees on a point about 3 feet above high water, 6 yards south-southeast of edge of bank, 7 yards west of point of bank, and 8 yards east-northeast of edge of bank.

Marks.-Observed station is center point of triangle on standard cement monument projecting 5 inches above surface of ground. Subsurface mark is center of 2 -inch tile pipe buried with top 2 inches below base of monument.

References.-

"June" (S 6 $\left.39^{\prime} \mathrm{W}\right)$

Chimney of large house.

Nail in blaze in oak tree ( 8 inches diameter). $291 \quad 22 \quad 50 \ldots . .4 .7 x$ meters.

Nail in blaze in walnut tree $(7$ inches diam-

eter)............................. 336
Chimney of cabin................... I

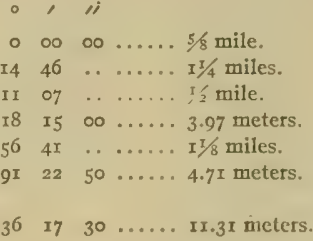

BEE.

General locality.-Northern shore of Wye Narrows at northern side of western entrance to Wye Narrows. (See Chart No. 32.)

Immediate locality.-Observed station is in woods about 4 feet above high water, 7 yards east of edge of bank, II yards northwest of edge of bank, and I3 yards north of point of bank near marsh.

Marks.-Observed station is center point of triangle on standard cement monument projecting 5 inches above surface of ground. Subsurface mark is center of 2 -inch tile pipe buried with top 2 inches below base of monument.

References.-

"Close" ( $\left.\mathrm{S}_{2}{ }^{\circ} 44^{\prime} \mathrm{W}\right)$

Right comer of Bryan house.............. 30

Near peak of house................... 68

Nail in blaze in oak tree ( 4 inches diameter), 201

Nail in blaze in oak tree ( 24 inches diameter). 3 I4

Nail in blaze in oak tree ( 8 inches diameter). 345

$$
\begin{array}{lcccc}
00 & 00 & \ldots & \ldots & 9 / 4 \text { mile. } \\
\text { r5 } & \ldots & \ldots & \ldots & I^{1 / 8} \text { miles. } \\
\text { or } & \ldots & \ldots & \ldots & 7 / 8 \text { mile. } \\
58 & 50 & \ldots & 2.10 \text { meters. } \\
\text { o5 } & 30 & \ldots & 8.64 \text { meters. } \\
50 & 40 & \ldots & 1.86 \text { meters. }
\end{array}
$$


CLOSE.

General locality.-Northern shore of Wye Island at southern side of western entrance to Wye Narrows. (See Chart No. 32.)

Immediale locality.-Observed station is in edge of cultivated land about i2 feet above high water, 3 yards south of edge of bank, 5 yards west-southwest of top of bank, I8 yards west of lone pine tree, and 17 yards east of cut in bank.

Marks.-Observed station is center point of triangle on standard cement monument projecting 5 inches above surface of ground. Subsurface mark is center of 2 -inch tile pipe buried with top 2 inches below base of monument.

References.-

"June" (S $56^{\circ} 2 \mathrm{I}^{\prime} \mathrm{W}$ )

Nail in blaze in

Right comer of large brick house...........

Near peak of house.................... 3

Windmill ...........................

Spindle on barn cupola................. no

Left comer of house.................. I6

Nail in blaze in pine tree ( 2 feet diameter).. $203 \quad 47 \quad 40 \ldots \ldots . \quad 18.28$ meters.

Nail in blaze in black walnut tree (ro inches

diameter $) \ldots \ldots \ldots \ldots \ldots \ldots \ldots \ldots \ldots \ldots \ldots \ldots \ldots \ldots$. 226 I9 $40 \ldots \ldots, 27.00$ meters.

Left peak of large building................. $246 \begin{array}{lllll}35 & \ldots & \ldots & 3 / 4 \\ \text { mile. }\end{array}$

Right peak of com house............... $306 \quad 57 \quad \ldots \ldots \ldots .1 / 2$ mile.

JUNE.

General locality.-On Wye Island on eastern shore of the branch of Wye River bounding Wye Island on the west on a point at northern side of entrance to a cove about $1 / 4$ mile southwest of entrance to Wye Narrows. (See Chart No. 32.)

Immediate locality.-Observed station is on a marsh point about I foot above high water, ro yards south-southeast of shore, 20 yards southwest of lines of trees and marsh, and 50 yards north of twin oak trees.

Marks.-Observed station is center point of triangle on standard cement monument projecting 4 inches above surface of ground. Subsurface mark is center of 2 -inch tile pipe buried with top 2 inches below base of monument.

References.-

"Chin" ( $\left.\mathrm{S}_{24}^{\circ}{ }^{\circ} 00^{\prime} \mathrm{W}\right)$.

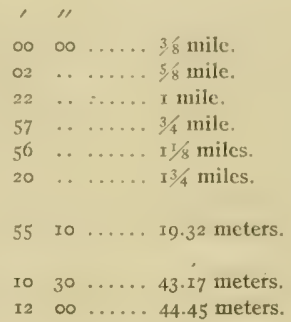

Near peak of Bryan louse.............. Ix $02 \ldots$. . . . $5 / 8$ mile.

Right comer of large house............ $37 \quad 22 \quad \ldots \quad \ldots \ldots$ r mile.

Left comer of near chimney of house...... $\quad \begin{array}{lllll}79 & 57 & \ldots & \ldots & 3 / 4 \\ \text { mile. }\end{array}$

Near comer of house................ $150 \quad 56 \ldots \ldots$ I $\quad \ldots \ldots$ miles.

Spindle on cupola of barn............. I 54 20 ...... $13 / 4$ miles.

Nail in blaze in one of twin oak trees ( 30

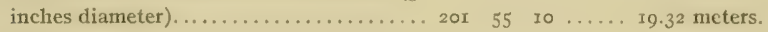

Nail in blaze in one of twin oak trees $(30$ inches diameter $) \ldots \ldots \ldots \ldots \ldots \ldots \ldots .286$ Io $30 \ldots \ldots 43.17$ meters.

Nail in blaze in oak tree ( 15 inches diameter). 325 I2 $00 \ldots .44 .45$ meters.

CHIN.

General locality.-On Wye Island on the eastern shore of the branch of Wye River bounding Wye Island on the west on a point about I mile northeast of Cedar Point and $3 / 4$ mile south-southwest of entrance to Wye Narrows. (See Chart No. 32.)

Immediate locality.-Observed station is on a marsh point about I foot above high water, 6 yards northeast of shore, 20 and 40 yards south of shore, and 7 yards east of extreme end of point. 
Marks.-Observed station is center point of triangle on standard cement monument projecting 6 inches above surface of ground. Subsurface mark is center of 2 -inch tile pipe buried with top 2 inches below base of monument.

References.--
"Aller" (S $43^{\circ}$ o3 $\left.^{\prime} \mathrm{E}\right)$
Near peak of large barn.............. $46 \quad 47 \ldots \ldots . I^{I / 8}$ miles.
Peak between chimneys of house ........ $8 \mathrm{I} \quad 23 \ldots \ldots \ldots$ II/4 miles.
Near peak of Bryan house.............. go $55 \quad \ldots \ldots . .1 / 4$ mile.
Right comer of house in woods...........
Nail in blaze in pine tree (ro inches diam-

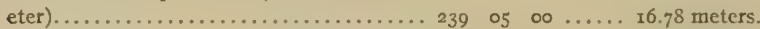
Nail in blaze in pine tree ( 5 inches diameter). 252 I3 $40 \ldots .$. I 9.5 I meters.
Nail in blaze in pine tree ( 6 inches diameter). $319 \quad 42 \quad 50 \ldots \ldots .7 x .68$ meters.

- 00 (1).... 300 yards.

ALLER.

General locality, - On Wye Island on the eastern shore of the branch of Wye River bounding Wye Island on the west about I mile east-northeast of Drum Point and at northern side of entrance to a cove. (See Chart No. 32.)

Immediale locality.-Observed station is on marsh land between two large pine trees about I foot above high water, 17 yards northeast of a small point, I5 yards southeast of a short cut in shore, and 9 yards southwest of edge of cultivated land.

Marks.-Observed station is center point of triangle on standard cement monument projecting 6 inches above surface of ground. Subsurface mark is center of 2 -inch tile pipe buried with top 2 inches below base of monument.

References.-

"Twist" (S $\left.0^{\circ} 2 \mathrm{r}^{\prime} \mathrm{W}\right) \ldots \ldots \ldots \ldots \ldots \ldots \ldots \ldots$

Cupola of building.....................

Left peak of house.....................

Peak between two chimneys of large house. .

Chimney outside left end of house.........

Right comer of house....................
Nail in blaze in pine tree (20 inches diam.

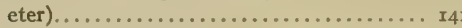

Peak of side gable of house................ 255 o6 $\ldots \ldots . . .1 / 4$ mile.

Nail in blaze in pine tree ( 18 inches diam.

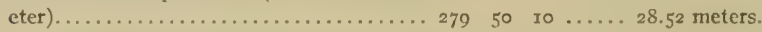

I,eft tangent of large square chimney of house. 3 I3 3 o6 . . . . . 3/8 mile.

TWIST.

Gencral locality.-On Wye Island on the eastern shore of the branch of Wye River bounding Wye Island on the west at northern side of entrance to a small cove about $x$ mile east of Cedar Point. (See Cliart No. 32.)

Immeliale locality.-Observed station is on a marsh point about I foot above high water, In yards southeast of point, 8 yards south of shore at point of higher and solid land with trees, 8 yards west of trees, 18 yards west-southwest of point, and 33 yards north of shore of cove.

Marks.-Observed station is center point of triangle on standard cement monument projecting 7 inclies above surface of ground. Subsurface mark is center of 2 -inch tile pipe buried with top 2 inches below base of monument.

References.-

"Wide" (S $\left.64^{\circ} \mathrm{oo}^{\prime} \mathrm{W}\right) \ldots \ldots \ldots \ldots \ldots \ldots \ldots$

Chimney outside southeast end of house.....

Near corner of brick house...............

Left corner of brick house.

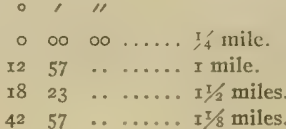




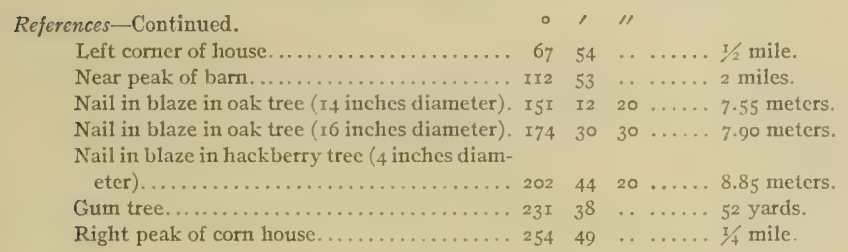

WIDE.

General locality.-On Wye Island on the eastern shore of the branch of Wye River bounding Wyc Island on the west on a point at western side of entrance to a small cove about $3 / 4$ mile east of Cedar Point. (See Chart No. 32.)

Immediate locality. - Observed station is in marsh land surrounded by water bushes about I foot above high water, I2 yards south of shore, I6 yards southeast of shore, 20 yards east of shore, 20 yards northeast of trees, II yards northeast of a wire fence, Ioo yards west of entrance to creek, and near point of higher land and trees.

Marks.-Observed station is center point of triangle on standard cement monument projecting 6 inches above surface of ground. Subsurface mark is center of 2 -inch tile pipe buried with top 2 inches below base of monument.

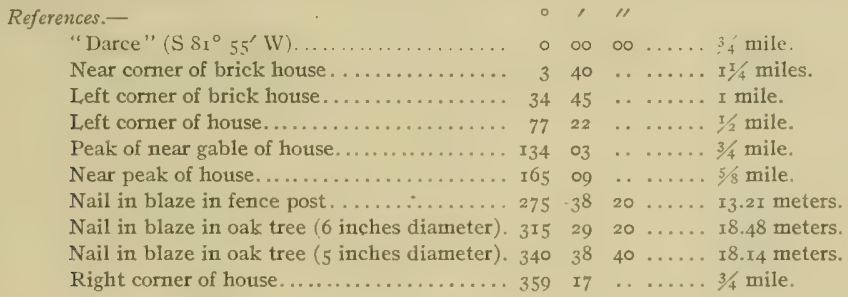

\section{DARCE.}

General localily.-On Wye Island on the eastern shore of the branch of Wye River bounding Wye Island on the west on Cedar Point at ferry landing about $1 / 4$ mile south of Drum Point. (Sec Cliart No. 32.)

Inmediale locality.-Observed station is in cultivated land about ro feet alove ligh water, 8 yards south of point of bank, 23 yards northwest of a house, and 55 yards east-northeast of ferry landing at foot of bank.

Marks.-Observed station is center point of triangle on standard cement monument projecting 5 inclies above surface of ground. Subsurface mark is center of 2 -incli tile pipe buried with top 2 inches below base of monument.

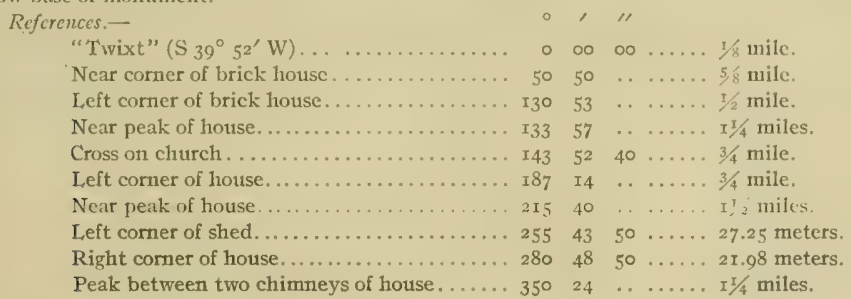


TWIXT.

General locality.-On Wye Island on the eastern shore of the branch of Wye River bounding Wye Island on the west about $1 / 8$ mile southwest of Cedar Point. (See Chart No. 32.)

Immediate locality.-Observed station is on a small marsh island about I foot above high water, 3 yards north of shore, 4 yards east of shore, 7 yards south of shore, 9 yards west of point of shore, and 20 yards west of mainland.

Marks.-Observed station is center point of triangle on standard cement monument projecting 5 inches above surface of ground. Subsurface mark is center of 2 -inch tile pipe buried with top 2 inches below base of monument.

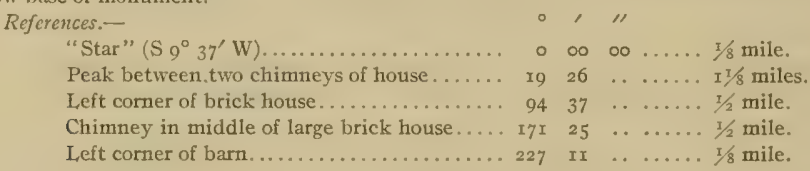

STAR.

General locality.-On Wye Island on the eastern shore of the branch of Wye River bounding Wye Island on the west, about $\mathrm{I} / 2$ miles north of Bruffs Island and $1 / 4$ mile south-southwest of Cedar Point. (See Chart No. 32.)

Immediate locality.-Observed station is on a soft marsh point about I foot above high water, 8 yards north of shore, 9 yards south of shore, and 13 yards east of extreme end of point.

Marks.-Observed station is center point of triangle on standard cement monument projecting 6 inches above surface of ground. Subsurface mark is center of 2 -inch tile pipe buried with top 2 inches below base of monument.

References.-

"Leaver" ( $\left.\mathrm{S}_{15}{ }^{\circ} \circ \mathrm{g}^{\prime} \mathrm{E}\right) \ldots \ldots \ldots \ldots \ldots \ldots . . . . .$.

Near peak of hip roof of large barn...........

"St. Michaels Water Tank"............. $32 \quad 26 \quad 30 \ldots \ldots .67 / 8$ miles

Peak between two chimneys of large house.. $46 \quad 44 \quad \ldots \ldots \ldots$ r mile.

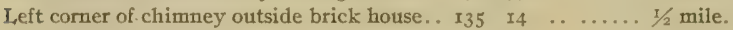

Left corner of large barn................ I36 39 . $39 \ldots \ldots .1 / 2$ mile.

$\begin{array}{llllllll}\text { Chimncy in middle of large brick house.... } & 997 & 42 & \ldots & \ldots & 3 / 4 \\ \text { mile. }\end{array}$

Nail in blaze in locust tree ( 4 inches diam-

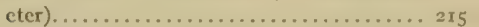

Nail in blaze in gum tree ( 3 inches diameter). 232

Nail in blaze in locust tree ( 8 inclies diam-

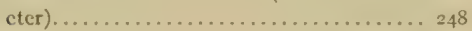

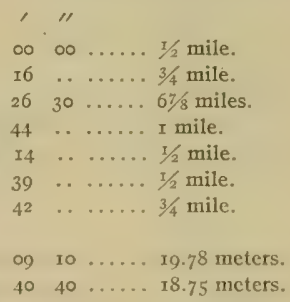

$5930 \ldots . .22 .2 \times$ metcrs.

\section{LEAVEN.}

General locality.-On Wye Island on the eastern shore of the branch of Wye River bounding Wye Island on the west about $\mathrm{I}^{\mathrm{T}} / \mathrm{s}$ miles north-northeast of Bruffs Island and $5 / 3$ mile south of Cedar Point. (See Chart No. 32.)

Immediate locality, - Observed station is in northwest corner of cultivated field about to feet above high water, 4 yards southeast of edge of bank, 5 yards southwest of scant locust woods, and 8 yards eastnortheast of point of bank.

Marks.--Observed station is center point of triangle on standard cement monument projecting 4 inches above surface of ground. Subsurface mark is center of 2 -inch tile pipe buried with top 2 inches below base of monument.

References.-

"Snout" ( $\left.\mathrm{S}_{27} 7^{\circ} 53^{\prime} \mathrm{W}\right) \ldots \ldots \ldots \ldots \ldots \ldots$

Large oak tree........................

Peak between two chimneys of large house...

Left corner of large chimney outside near end of house.......................... $1 x_{3} \quad 37 \quad \ldots \ldots \ldots 7 / 8$ mile. 


\section{References-Continued.}

Chimney outside of house.............. I52 $54 \ldots \ldots .5 / 8$ mile.

Nail in blaze in locust tree ( 12 inches diam-

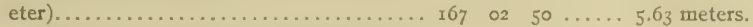

Nail in blaze in locust tree (ro inches diam-

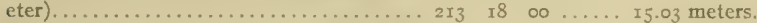

Nail in blaze in locust tree ( 16 inches diam-

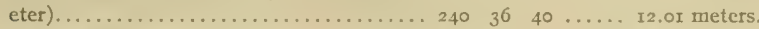

Near peak of house................. 3 I $_{5}$ or $\ldots \ldots \ldots$, mile.

\section{SNOU'T}

General locality.-On Wye Island on the eastern shore of the branch of Wye River bounding Wye Island on the west about $3 / 4$ mile north of Bruffs Island and $1 / 2$ mile north of Bordley Point. (See Chart No. 32.)

Immediate locality.-Observed station is in cuitivated land about I 2 feet above high water, 30 yards east by south of edge of bank, 65 yards south of large cherry tree in side of bank at fence, 65 yards southwest of rail fence, 70 yards northeast of a small clump of trees at edge of bank, and 400 yards west by north of a house.

Marks.-Observed station is center point of triangle on standard cement monument projecting 5 inches above surface of ground. Subsurface mark is center of 2 -inch tile pipe buried with top 2 inches below base of monument.

References.-

"South" (S $\left.20^{\circ} 34^{\prime} \mathrm{E}\right)$

Left peak of boathouse.

"St. Michaels P. E. Church Spire".........

"St. Michaels Water Tank"...............

Nail in blaze in locust tree (ro inches diam-

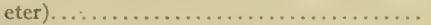

Peak of house between two chimneys.......

Near peak of small house............... II

Nail in blaze in tree ( 8 inches diameter).... I 79

Near peak of barn. .................... I86

Left comer of house.

Nail in blaze in fence post.

Near peak of house.

J.eft peak of house....................296

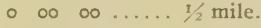

19 $10 \ldots \ldots \ldots 7 / 8$ mile.

$\begin{array}{lllll}38 & 07 & 30 & \ldots & 6 \mathrm{~L} / 4 \mathrm{miles} .\end{array}$

3930 10....6.6 61/8 miles.

$49 \quad 2 \pi \quad 30 \ldots \ldots 66.78$ meters.

$99 \quad 02 \quad \ldots \ldots \ldots .1 / 2$ mile.

.. ..... $1 / 2$ mile.

Io .... 34.39 meters.

....... I I $1 / 4$ miles.

....... $13 / 3$ miles.

Io .... 63.29 meters.

...... $3 / 4$ mile.

$50 \ldots \ldots$ I/4 mile.

\section{SOUTH}

Gencral locality.-On southwestern end of Wye Island on Bordley Point on the northern slore of the junction of the two branches of Wye River bounding Wye Island, about 3 s mile north-northeast of Bruffs Island. (See Chart No. 32.)

Immediate locality.-Observed station is in a pasture on a rounded point about ro fect above high water, IY yards northeast of edge of field, I3 yards north of edge of field, 22 yards northwest of edge of field, 30 yards southeast of cut in cliff, and 50 yards southwest of point of water bushes at gully.

Marks.-Observed station is center point of triangle on standard cement monument projecting 4 inches above surface of ground. Subsurface mark is center of 2 -inch tile pipe buried with top 2 inches below base of monument.

References.-

"Flat" ( $\left.\mathrm{N}_{55^{\circ}} 27^{\prime} \mathrm{E}\right)$.

...............

Windmill .

Spindle on barn cupola................. I3

Left chimney of house in woods........... I53

Left peak of building..................

Peak between two chimneys of house....... 244

Left chimney of house.................. 317

Near peak of house.

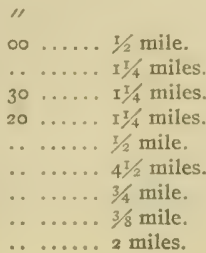

11

- $0000 \ldots . . .1 / 2$ mile,

I9 $30 \ldots \ldots . . . .1 / 4$ miles.

$643430 \ldots \ldots$. I $1 / 4$ miles.

$5520 \ldots \ldots I^{1 / 4} / 4$ miles.

$45 \ldots \ldots \ldots .1 / 2$ mile.

$45 \ldots \ldots 44^{\mathrm{T} / 2}$ miles.

$27 \ldots \ldots .3 / 4$ mile.

$37 \ldots \ldots .3 / 8$ mile

$21 \ldots \ldots \ldots 2$ miles. 
FLAT.

General locality.--On Wye Island on the northern shore of the branch of Wye River bounding Wye Island on the south on a point between two coves about I mile northeast of Bruffs Island and $\pi / 2$ mile northeast of Bordley Point. (See Chart No. 32.)

Immediate locality.-Observed station is on a marsh point about I foot above high water, 8 yards north of shore, 8 yards southwest of shore, 12 yards west of extreme end of point, 17 yards east of south cnd of line of several trees on edge of bank 3 feet high, and 45 yards east of a black gum tree 5 feet in diameter at ground.

Marks.-Observed station is center point of triangle on standard cement monument projecting 5 inches above surface of ground. Subsurface mark is center of 2 -inch tile pipe buried with top 2 inches below base of monument.

\begin{tabular}{|c|c|c|c|}
\hline References.- & $\circ$ & & \\
\hline "Albert" ( $\left(\mathrm{N} 84^{\circ} 3 \mathrm{r}^{\prime} \mathrm{E}\right) \ldots \ldots \ldots \ldots \ldots \ldots$ & $\circ$ & $\infty$ & $1 / 2$ mile. \\
\hline Left comer of tower of house............... & 30 & 33 & $I^{1} / 4$ miles. \\
\hline Windmill . .............. & 62 & 55 & $x / 8$ miles \\
\hline Spindle on barn cupola........ & II9 & 34 & $15 / 8$ miles. \\
\hline Front peak of boathouse........ & I34 & 02 & . I mile. \\
\hline Left tangent of black gum tree....... & 158 & o6 & $40 \ldots$ \\
\hline Near peak of house. ....... & 249 & 34 & $3 / 4$ mile. \\
\hline Spindle on cupola .......... & $35^{I}$ & II & $3 / 4$ mile. \\
\hline Windmill ... & $35^{2}$ & I5 & . $3 / 4$ mile. \\
\hline Near peak of Baldwin house......... & .354 & 50 & $3 / 4$ mile. \\
\hline
\end{tabular}

ALBER'T.

General locality.-On Wye Island on the northwestern shore of the branch of Wye River bounding Wye Island on the south on a point about $I \frac{1}{4}$ miles east-northeast of north end of Bruffs Island, and opposite entrance to Lloyd Creek. (See Chart No. 32.)

Immediate locality.-Observed station is on a marsh point about I foot above high water, I7 yards northwest of shore, 28 yards east of shore, 35 yards south of shore, and 75 yards north-northeast of extreme end of point.

Marks.-Observed station is center point of triangle on standard cement monument projecting 5 inches above surface of ground. Subsurface mark is center of 2 -inch tile pipe buried with top 2 inches below base of monument.

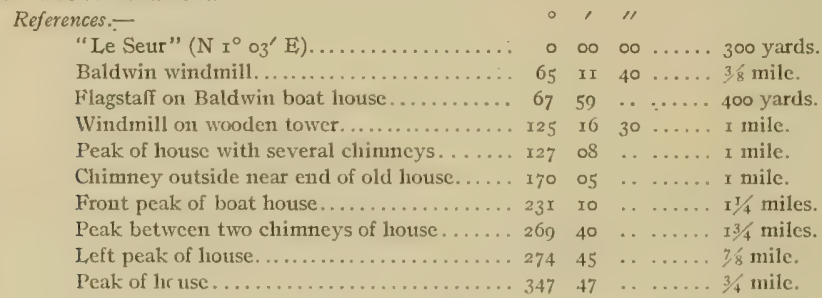

\section{LE: SEUR.}

General locality.-On Wye Island on the northwestern shore of the branch of Wye River bounding Wye Island on the south about $1 / 8$ mile north of a prominent point opposite entrance to Lloyd Creck. (See Cliart No. 32.)

Imnediale locality,-Observed station is in a clump of small trees about 3 feet above high water, II yards east of shore, I2 yards southwest of shore on line to next point, and 12 yards north by east of shore.

Marks.-Observed station is center point of triangle on standard cement monument projecting 5 inches above surface of ground. Subsurface mark is center of 2 -inch tile pipe buried with top 2 inches below base of monument. 


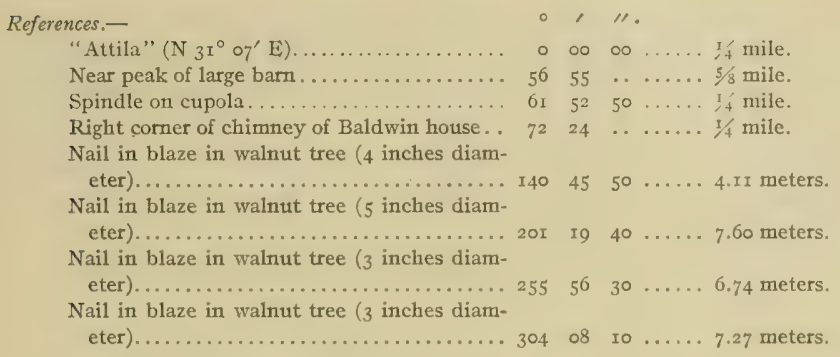

ATTILA.

General locality.-On Wye Island on the northwestem shore of the branch of Wye River bounding Wye Island on the south about $3 / 4$ mile north of entrance to Lloyd Creek at north side of entrance to a small cove. (See Chart No. 32.)

Immediate locality.-Observed station is on slope of a point about 3 feet above high water, ro yards west of shore, Io yards north-northeast of shore, and II yards northwest of shore.

Marks.-Observed station is center point of triangle on standard cement monument projecting 5 inches above-surface of ground. Subsurface mark is center of 2 -inch tile pipe buried with top 2 inches below base of monument.

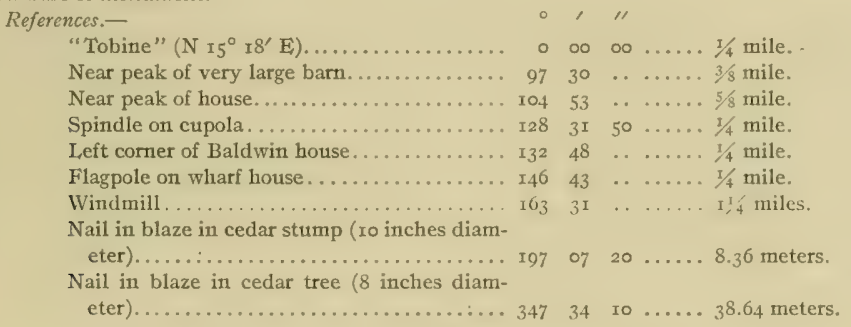

\section{TOBINE.}

General locality.-On Wye Island on the northwestern shore of the branch of Wye River bounding Wye Island on the south about $3 / 4$ mile north of entrance to Lloyd Creek on point at north side of entrance to a small cove. (See Chart No. 32.)

Immediate locality.-Observed station is on point of a cultivated field about 6 feet above high water, 4 yards north of edge of field, 4 yards southwest of edge of field, 5 yards west-northwest of point of field, and $r / 4$ mile east-southeast of a barn with cupola.

Marks.-Observed station is center point of triangle on standard cement monument projecting 5 inches above surface of ground. Subsurface mark is center of 2 -inch tile pipe buried with top 2 inches below base of monument.

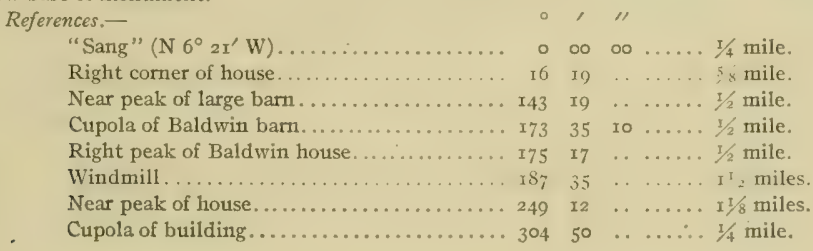


SANG.

General locality.-On Wye Island on the northwestem shore of the branch of Wye River bounding Wye Island on the south about II/7 miles north of entrance to Lloyd Creek and $5 / 8$ mile west of entrance to Dividing Creek. (See Chart No. 32.)

Immediate locality.-Observed station is on bank about i2 feet above high water between two cuts in bank, 2 yards west of edge of bank, 3 yards northwest of edge of bank, 4 yards southwest of edge of bank, $3^{2}$ yards from bottom of northern cut in bank, $5^{2}$ yards from bottom of southern cut in bank, and 95 yards south-southwest of tree-lined gully.

Marks.-Observed station is center point of triangle on standard cement monumient projecting 5 inches above surface of ground. Subsurface matk is center of 2 -inch tile pipe buried with top 2 inches below base of monument.

References.-

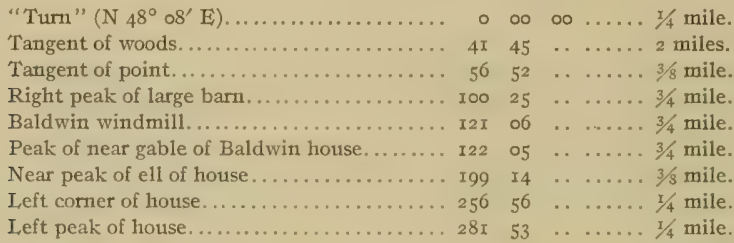

TURN.

General locality.-On Wye Island on the northwestern shore of the branch of Wye River bounding Wye Island on the south, about $1 / 2$ mile west of entrance to Dividing Creek on point at western side of entrance to a small cove. (See Chart No.32.)

-Immediate locality,-Observed station is on bank in a cultivated field, about 8 feet above high water, 5 yards northwest of edge of bank, 6 yards north of edge of bank, 7 yards west of edge of bank, 50 yards south-southwest of entrance to a small creek, and 55 yards east of a dead sycamore tree in field.

Marks,-Observed station is center point of triangle on standard cement monument projecting 5 inches above surface of ground. Subsurface mark is center of 2 -inch tile pipe buried with top 2 inches below base of monument.

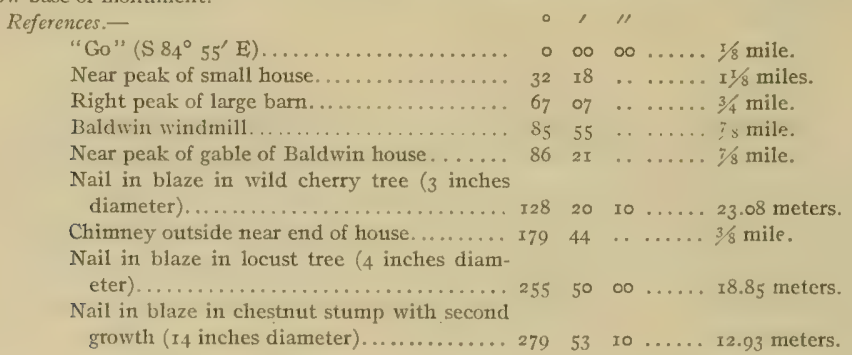

GO.

General locality. - On Wye Island on the northern shore of the branch of Wye River bounding Wye Island on the south, on a point between two coves about $1 / 4$ mile west of entrance to Dividing Creek. (See Chart No. 32.)

Immediate locality.-Observed station is on grassy beach at high water, about 2 yards south of foot of bank 4 feet high covered with dense growth of young trees, and 37 yards from entrance to a small creek. Cement monument marking reference station is r 9.06 meters $\mathrm{N} 22^{\circ} 35^{\prime} \mathrm{E}$ of observed station. 
Marks.-Observed station is nail in center of 2 -inch pine stub projecting 2 inches above 2 -inch tile pipe with top 2 inches below surface of ground. Subsurface mark is center of 2 -inch tile pipe buried with top 2 inches below base of surface pipe. Reference station is center point of triangle on standard cement monument projecting 4 inches above surface of ground.

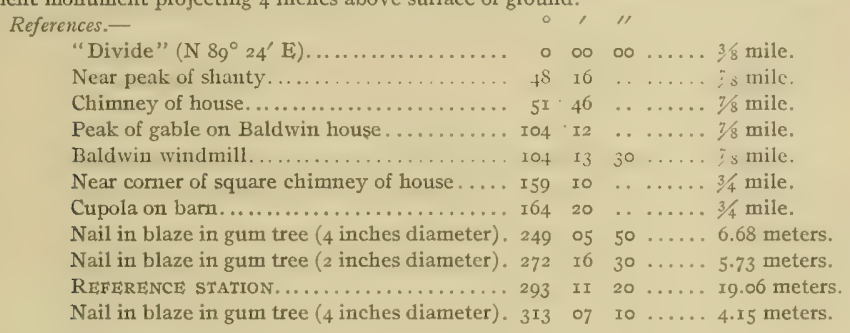

\section{DIVIDE}

General locality.-On Wye Island on the northern shore of the branch of Wye River bounding Wye Island on the south, on point at eastern side of entrance to Dividing Creek. (See Chart No. 32.)

Immediate locality.-Observed station is in point of woods, about 4 feet above high water, 2 yards west-northwest of edge of bank, 8 yards east-northeast of edge of bank, and II yards north-northeast of point of bank.

Marks.-Observed station is center point of triangle on standard cement monument projecting 6 inches above surface of ground. Subsurface mark is center of 2 -incli tile pipe buried with top 2 inches below base of monument.

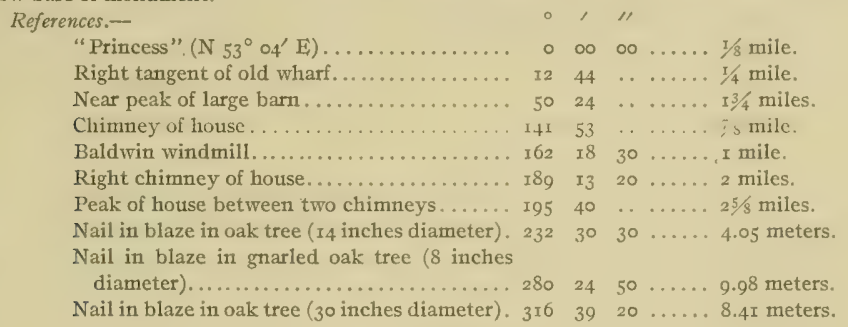

\section{PRINCESS.}

General locality.-On Wye Island on the northern shore of the branch of Wye River bounding Wye Island on the south, about $1 / 8$ mile northeast of entrance to Dividing Creek and $3 / 8$ mile west of entrance to Granary Creek. (See Chart No. 32.)

Immediate locality.-Observed station is in marsh land, about I foot above high water, 4 yards north of shore, 18 yards east by north of a large oak tree at shore, 4 yards south of foot of bank ro feet high covered with vegetation, and Io yards west by south of a white oak tree on bank.

Marks.-Observed station is center point of triangle on standard cement monument projecting 3 inches above surface of ground. Subsurface mark is center of 2 -inch tile pipe buried with top 2 inches below base of monument.

References.-

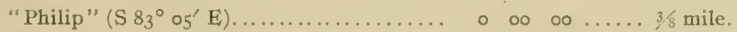

Chimney of house on Pickerings Creek.... I5 $\quad$ i6 $\ldots \ldots \ldots$ I3/4 miles.

Right peak of large barn............... II0 $22 \ldots \ldots$. . . mile.

Baldwin windmill................ 121 or $\ldots \ldots \ldots 1_{1 / 4}^{1}$ miles. 
References-Continued.

$\circ, "$,

Cupola of Baldwin stable............... I2 $40 \ldots \ldots \ldots$ I 40.4 miles.

Nail in blaze in white oak tree (3 inches

diameter $) \ldots \ldots \ldots \ldots \ldots \ldots \ldots \ldots \ldots \ldots . \ldots \ldots 6_{3} \quad 26 \quad 00 \ldots \ldots .65$ meters.

Nail in blaze in cedar tree ( 14 inches diam-

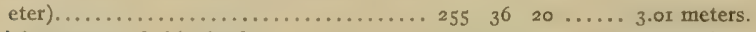

Right tangent of old wharf........... $35^{\mathrm{r}}$ ig $\ldots \ldots \ldots$ i5o yards.

\section{PHILIP.}

General locality.-On Wye Island on the northern shore of the branch of Wye River bounding Wye Island on the south, on western side of entrance to Granary Creek and $1 / 2$ mile east of entrance to Dividing Creek. (See Chart No. 32.)

Immediate locality.-Observed station is about $x$ foot above high water, 3 yards north of shore, 9 yards south-southwest of shore of creek, 9 yards west of extreme end of point, and 6 yards southeast of point of bank 4 feet high. Cement monument marking reference station is 4.62 meters $\mathrm{N} 18^{\circ} \mathrm{r} 2^{\prime} \mathrm{E}$ of observed station.

Marks.-Observed station is nail in center of 2 -inch cedar stub projecting 2 inches above 2 -inch tile pipe with top flush with surface of ground. Subsurface mark is center of 2 -inch tile pipe buried with top 2 inches below base of surface pipe. Reference station is center point of triangle on standard cement monument projecting 4 inches above surface of ground.

References.-

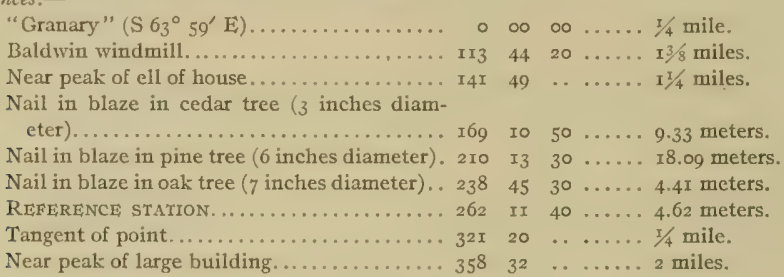

GRANARY.

General locality.--On Wye Island on the northem shore of the branch of Wye River bounding Wye Island on the south on point at eastern side of entrance to Granary Creek, (See Chart No. 32.)

Immediate locality.-Observed station is among water bushes on marsh land about I foot above high water, Io yards northeast of shore, II yards west of shore, I2 yards north by west of extreme end of point, and 50 yards from trees.

Marks. - Observed station is center point of triangle on standard cement monument projecting 4 inches above surface of ground. Subsurface mark is center of 2 -inch tile pipe buried with top 2 inches below base of monument.

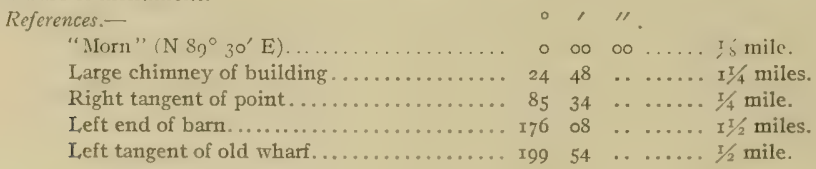

MORN.

General locality.-On Wye Island on the northem shore of the branch of Wye River bounding Wye Island on the south about 300 yards east of entrance to Granary Creek and $3 / 4$ mile northwest of entrance to Pickerings Creek. (See Chart No. 32.)

Immediate locality,-Observed station is about I foot above high water, 4 yards northwest of shore, 4 yards northeast of shore, and 6 yards southeast of foot of wooded slope to field 12 feet above high water. Cement monument marking reference station is 3.82 meters $\mathrm{N} 33^{\circ} 5^{\prime}{ }^{\prime} \mathrm{W}$ of observed station. 
Marks.-Observed station is nail in center of 2 -inch cedar stub projecting 2 inches above 2 -inch tile pipe with top flush with surface of ground. Subsurface mark is center of 2-inch tile pipe buried with top 2 inches below base of surface pipe. Reference station is center point of triangle on standard cerment monument projecting 4 inches above surface of ground.

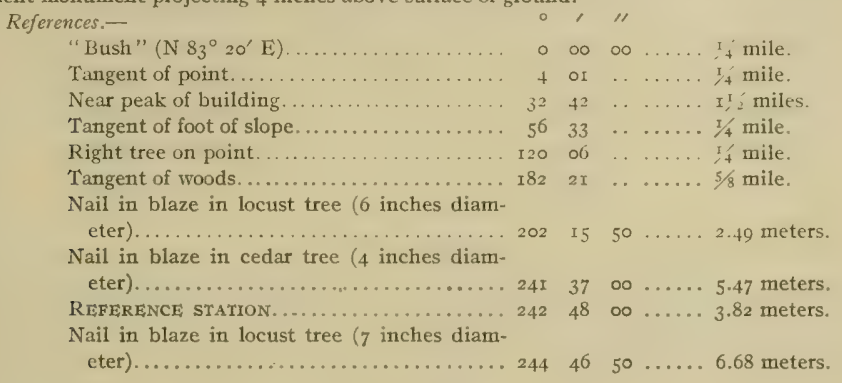

\section{BUSH.}

General locality.-On Wye Island on the northern shore of the branch of Wye River bounding Wye Island on the south on north side of entrance to a small cove about $1 / 2$ mile east of entrance to Granary Creek and 5/8 mile northwest of entrance to Pickerings Creek. (See Chart No. 32.)

Immediate locality.- Observed station is in cultivated land, about 7 feet above high water, 4 yards northeast of edge of bank, 9 yards northwest of point of curve of land, 22 yards west of tangent of land at tree, 30 yards west-northwest of scattering trees, and 50 yards northwest of a point.

Marks.--Observed station is center point of triangle on standard cement monument projecting 5 inches above sutface of ground. Subsurface mark is center of 2 -inch tile pipe buried with top 2 inches helow base of monument.

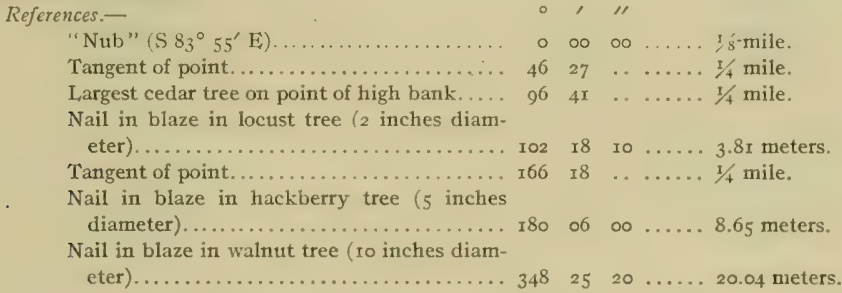

\section{NUB.}

General locality.-On Wye Island on the northern shore of the branch of Wye River bounding Wye Island on the south on eastern side of entrance to a creek about $5 / 8$ mile east of entrance to Granary Creek and $1 / 2$ mile north of entrance to Pickerings Creek." (See Chart No. 32.)

Immediale locality.-Observed station is on a marsh point about I foot above high water, 2 yards east of shore, 20 yards southwest of shore, 45 yards west of shore, 20 yards south of extreme end of point, and 16 yards north-northwest of woods. Cement monument marking reference station is 15 .10 meters $\mathrm{N} 83^{\circ}$ or' $\mathrm{E}$ of observed station.

Marks.-Observed station is nail in center of 2 -inch cedar stub set in 2 -inch tile pipe with top flush with surface of ground. Subsurface mark is center of 2 -inch tile pipe buried with top 2 inches below base of surface pipe. Reference station is center point of triangle on standard cement monument projecting 5 inches above surface of ground.

$$
203{ }^{1} 3-12-7
$$




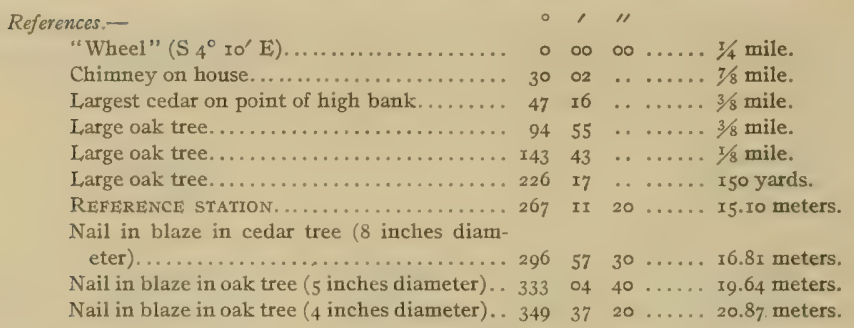

\section{WHEEL.}

General locality.-On Wye Island on the northern shore of the branch of Wye River bounding Wye Island on the south on a point about $5 / 8$ mile southeast by east of entrance to Granary Creek and $\mathrm{I} / 2$ mile northwest of entrance to Pickerings Creek. (See Chart No. 32.)

Immediate locality.-Observed station is on marsh point south of woods about I foot above high water, 2 yards east of shore, 4 yards southeast of point at slight cut in marsh, and 40 yards north of square point of shore. Cement monument marking reference station is 5.26 meters $\mathrm{S} 86^{\circ} 47^{\prime} \mathrm{E}$ of observed station.

Marks.-Observed station is nail in center of 2 -inch cedar stub set in 2 -inch tile pipe projecting 3 inches above surface of ground. Subsurface mark is center of 2 -inch tile pipe buried with top 2 inches below base of surface pipe. Reference station is center point of triangle on standard cement monument projecting 5 inches above surface of ground.

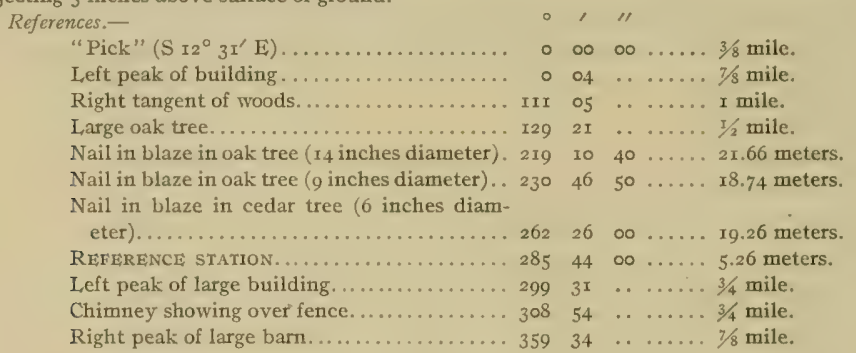

PICK.

General locality. - Southern shore of the branch of Wye River bounding Wye Island on the south on western side of entrance to Pickerings Creek. (See Chart No.32.)

Immediale locality.--Observed station is in cultivated land about $x_{5}$ feet above high water, 25 yards southwest of edge of field at line of cedar trees, 22 yards west of gully, 40 yards south-southeast of a small clump of trees beyond small gully, and 300 yards east-southeast of fringe of cedar trees along edge of field northeast to east of gully.

Marks.-Observed station is center point of triangle on standard cement monument projecting 6 inches above surface of ground. Subsurface mark is center of 2 -inch tile pipe buried with top 2 inches below base of monument.

References.-

"Corner" (N $\left.77^{\circ} 40^{\prime} \mathrm{W}\right)$

in cherry tree (6 inches diam

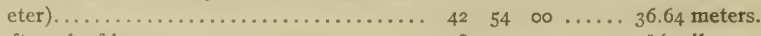

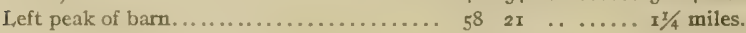


References-Continued.

Front peak of house..............

Nail in blaze in cedar tree $(6$ inches diam-

eter $\ldots \ldots \ldots \ldots \ldots \ldots \ldots \ldots \ldots \ldots \ldots \ldots \ldots \ldots \ldots \ldots \ldots$ IIo II $50 \ldots \ldots .24$ meters.

Nail in blaze in cedar tree ( 6 inches diam-

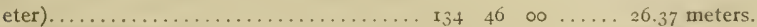

Near peak of house................ I52 in ..... s s mile.

Nail in blaze in hackberry tree ( 5 inches

diameter)........................ $169 \quad 37 \quad 50 \ldots \ldots 23.00$ meters.

Left peak of large barn................ $243 \quad 36 \quad \ldots \ldots \ldots 1 / 4$ mile.

Right peak of house...............

\section{CORNER}

General locality. - Southern shore of the branch of Wye River bounding Wye Island on the south about $1 / 4$ mile west of entrance to Pickerings Creek. (See Chart No. 32.)

Immediate locality.-Observed station is in cultivated land about I 5 feet above high water, 50 yards southwest of edge of bank, 55 yards south of gully, 70 yards north-northwest of trees in depression, and I20 yards west of point of bank.

Marks.-Observed station is center point of triangle on standard cement monument projecting 6 inches above surface of ground. Subsurface mark is center of 2 -inch tile pipe buried with top 2 inches below base of monument.

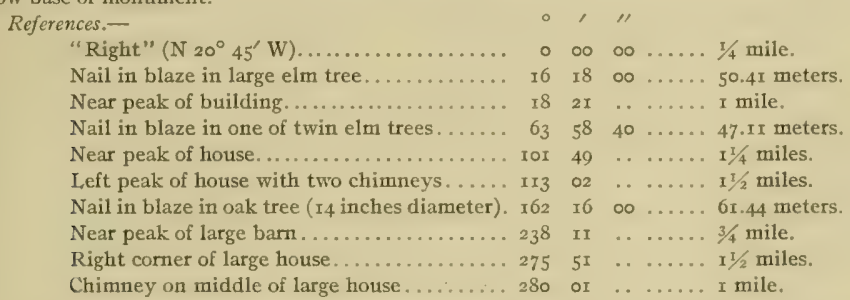

\section{RIGHT.}

General locality.- Southern shore of the branch of Wye River bounding Wye Island on the south on a point about $1 / 2$ mile southeast of entrance to Granary Creek and $1 / 2$ mile northwest of entrance to Pickerings Creek. (See Chart No. 32.)

Immediate locality.-Observed station is in tree-fringed cultivated land about 15 feet above high water, 7 yards south of edge of bank, 9 yards from point of bank at path, 5 yards northwest of edge of bank, and 120 yards east of fence in depression.

Marks.-Observed station is center point of triangle on standard cement monument projecting 5 inches above suriace of ground. Subsurface mark is center of 2 -inch tile pipe buried with top 2 inches helow base of monument.

\section{References.-}

"Cliew" (N $\left.7 x^{\circ}+5^{\prime} \mathrm{W}\right)$.

Left chimney of long house in woods.

Nail in blaze in cedar tree ( 8 inches diameter). .

Left one of two large chimneys showing over the trees.

Left corner of building

Nail in blaze in hickory tree (ro inches diam-

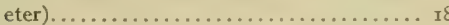

Nail in blaze in elm tree (ro inches diameter). 243

Right peak of house.................. 269

Windmill to right of two large cupolas. . . . 287

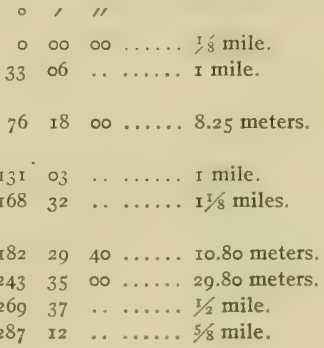




\section{CHEW.}

General locality. - Southern shore of the branch of Wye River bounding Wye Island on the south about $3 / 8$ mile southeast of entrance to Granary Creek and $5 / 8$ mile west-northwest of entrance to Pickerings Creek. (See Chart No. 32.)

Immediate locality.-Observed station is on marsh point about I foot above high water, 6 yards northeast of foot of bank 12 feet high, I2 yards west of point of shore, and Io yards northwest of shore.

Marks.-Observed station is center point of triangle on standard cement monument projecting 2 inches above surface of ground. Subsurface mark is center of 2 -inch tile pipe buried with top 2 inches below base of monument.

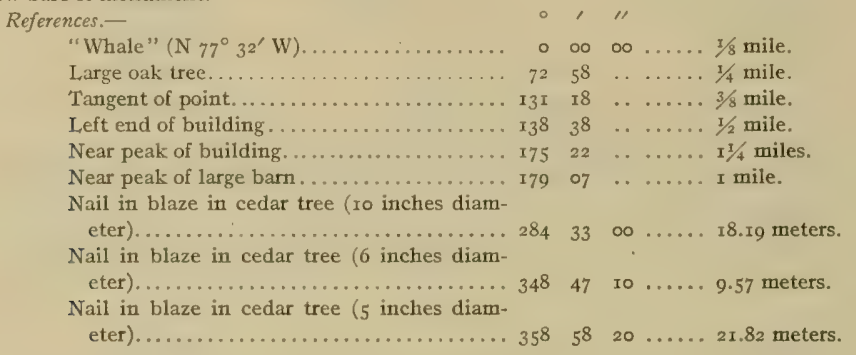

\section{WHALE}

General locality.-Southern shore of the branch of Wye River bounding Wye Island on the south on a point at western side of entrance to a small cove about $1 / 4$ mile south of entrance to Granary Creek. (See Chart No. 32.)

Immediate locality.-Observed station is on a sand-and-grass point about 2 feet above high water, 2 yards south-southeast of shore, 4 yards west-northwest of shore, 9 yards southwest of extreme point, and 7 yards east by north of foot of a terraced bank about ${ }_{5}$ feet high.

Marks.-Observed station is center point of triangle on standard cement monument projecting 5 inches above surface of ground. Subsurface mark is center of 2 -inch tile pipe buried with top 2 inches helow base of monument.

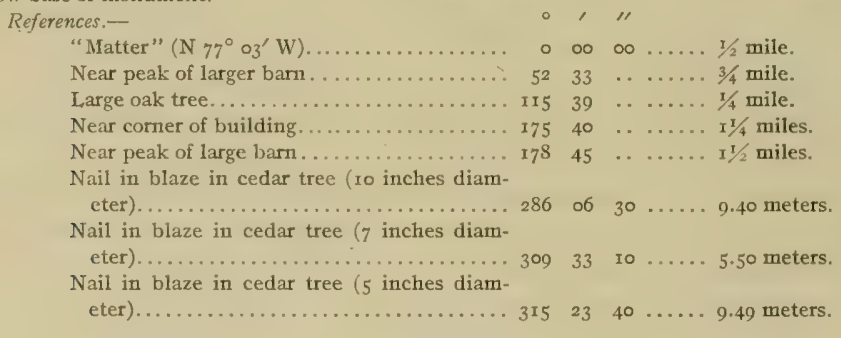

\section{MATTER.}

General locality.-Southern shore of the branch of Wye River bounding Wye Island on the south about $3 / 8$ mile east-southeast of entrance to Dividing Creek and $3 / 8$ mile west-southwest of entrance to Granary Creek. (See Chart No. 32.)

Immediate locality.-Observed station is on small grassy point about $x$ foot above high water, 3 yards south of shore and 2 yards north of foot of tree-fringed bank 5 feet high. Cement monument marking reference station is $8.5^{8}$ meters $\mathrm{S}^{\circ} 32^{\prime} \mathrm{E}$ of observed station. 
Marks.--Observed station is nail in center of 2 -inch cedar stub set in 2 -inch tile pipe with top flush with surface of ground. Subsurface mark is center of 2 -inch tile pipe buried with top 2 inches below base of surface pipe. Reference station is center point of triangle on standard cement monument projecting 5 inches above surface of ground.

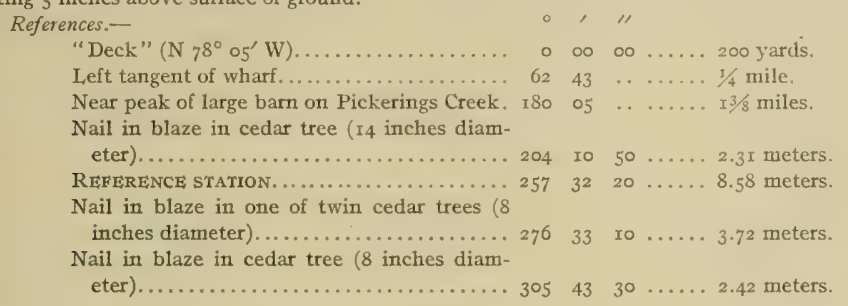

\section{DECK.}

General locality.-Southern shore of the branch of Wye River bounding Wye Island on the south on a point about $1 / 2$ mile southeast of entrance to Dividing Creek. (See Chart No. 32.)

Immediate locality.- Observed station is at edge of water bushes on a grass point about $I$ foot above high water, 4 yards south of shore, Io yards west of a round point, 20 yards east of shore, and 30 yards north of shore.

Marks.-Observed station is center point of triangle on standard cement monument projecting 5 inches above surface of ground. Subsurface mark is center of 2 -inch tile pipe buried with top 2 inches below base of monument.
References.-
"Quarter" $\left(\mathrm{S}_{3} 8^{\circ} \mathrm{r}^{\prime} \mathrm{W}\right) \ldots \ldots \ldots \ldots \ldots \ldots$

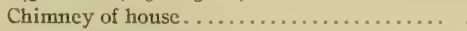

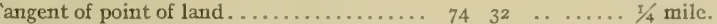
Left tangent of old wharf............... I49 $46 \quad \ldots \ldots \ldots 400$ yards.
South peak of large barn.............. I70 4 I ..... . $3 / 4$ mile.
Tangent of point of land................. $206 \quad 49 \ldots 500$ yards.
Left cedar tree on point...................243 4 I $\ldots 00$ yards.

\section{QUARTER.}

General locality.-Southern shore of the branch of Wye River bounding Wye Island on the soutl: about $3 / 8$ mile south-southeast of entrance to Dividing Creek and at east side of entrance to a cove. (See Chart No. 32.)

Immediate locality.-Observed station is on bank in a cultivated field about 12 fect above high water, 2 yards southeast of edge of bank, Ioo yards south of trees and break in bluff, and I20 yards north of edge of bank at point.

Marks.-Observed station is center point of triangle on standard cement monument projecting 3 inches above surface of ground. Subsurface mark is center of 2 -inch tile pipe buried with top 2 inches below base of monument.

References.-

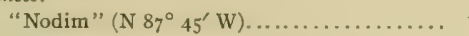

Near peak of barn....................

Chimney outside near end of house........ to

Near corner of barn.................. 53

Right tangent of old wharf.............. II

Right peak of large bam.............. 30.

Baldwin windmill. .................... 3 II $^{7}$

Near peak of house. , ................. 354

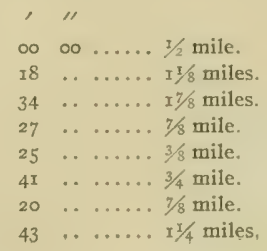




\section{NODIM.}

Gencral locality:- Southeastern shore of the branch of Wye River bounding Wye Island on the south about $3 / 8$ mile south west of entrance to Dividing Creek. (See Chart No. 32.)

Immediate locality.-Observed station is in cultivated land about 4 feet above high water, 4 yards south of shore, 8 yards southeast of shore, 25 yards southwest of shore of marsh, and 13 yards south of corner of marsh.

Marks.-Observed station is center point of triangle on standard cement monument projecting 5 inches above surface of ground. Subsurface mark is center of 2 -inch tile pipe buried with top 2 inclies below base of monument.

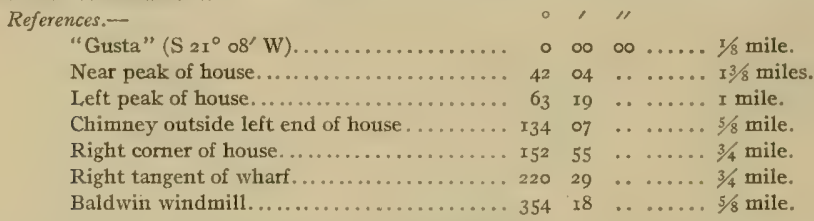

\section{GUSTA}

General locality.--Southeastern shore of the branch of Wye River bounding Wye Island on the south about $7 / 8$ mile north-northeast of entrance to Lloyd Creek. (See Chart No. 32.)

Immediate locality.-Observed station is in a cultivated field about io feet above high water, 8 yards cast of edge of bank, 12 yards southeast of edge of bank, 17 yards northeast of edge of bank, 35 yards north-northeast of a depression, and 65 yards southwest of end of cut in bank.

Marks.-Observed station is center point of triangle on standard cement monument projecting 5 inches above surface of ground. Subsurface mark is center of 2 -inch tile pipe buried with top 2 inches below base of monument.

References.-

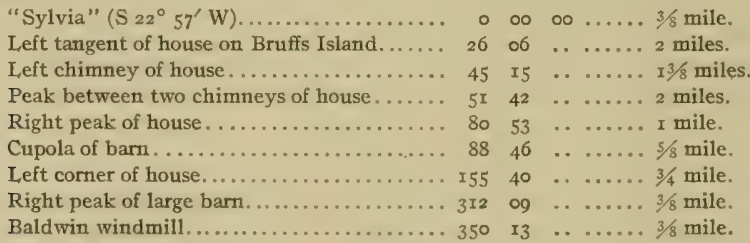

\section{SYLVIA.}

General locality. - Southeastern shore of the branch of Wye River bounding Wye Island on the south on second prominent point north of entrance to Lloyd Creek. (See Chart No. 32.)

Immediale locality.-Observed station is in a cultivated field about Io feet above high water, II yards east by south of edge of bluff, 22 yards northeast of lone locust tree 2 feet in diameter at the edge of the bank, and 400 yards northwest of a large barn.

Marks.-Observed station is center point of triangle on standard cement monument projecting 5 inches above surface of ground. Subsurface mark is center of 2 -inch tile pipe buried with top 2 inches below base of montument.

References.-

"Baldwins" ( $\left.\mathrm{S}_{27}{ }^{\circ} \mathrm{r}_{3}^{\prime} \mathrm{W}\right) \ldots \ldots \ldots \ldots \ldots$.

Nail in blaze in locust tree ( 24 inches diam-

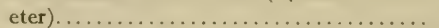

Very large lone tree....................

Nail in blaze in locust tree (6 inches diameter).

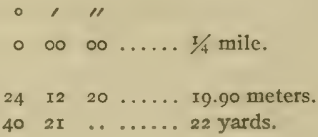




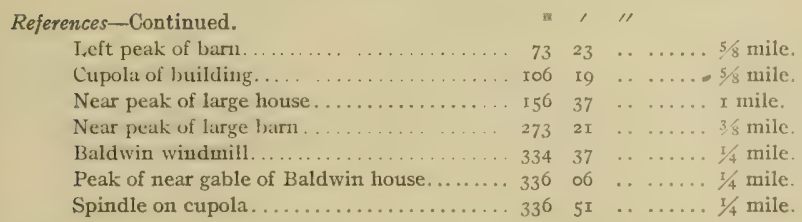

\section{BALDWINS.}

General locality.-Southeastern shore of the branch of Wye River bounding Wye Island on the south on a point about $3 / 8$ mile north of entrance to Lloyd Creek. (See Chart No. 32.)

Immediate locality.-Observed station is on a short, sharp point of marsh about roo yards north of a yacht landing, 7 yards northeast of shore, to yards southeast of shore, 12 yards east of extreme end of point, and 8 yards west of foot of bank 8 feet high.

Marks.-Observed station is center point of triangle on standard cement monument projecting 4 inches above surface of ground. Subsurface mark is center of 2 -inch tile pipe buried with top 2 inches below base of monument.

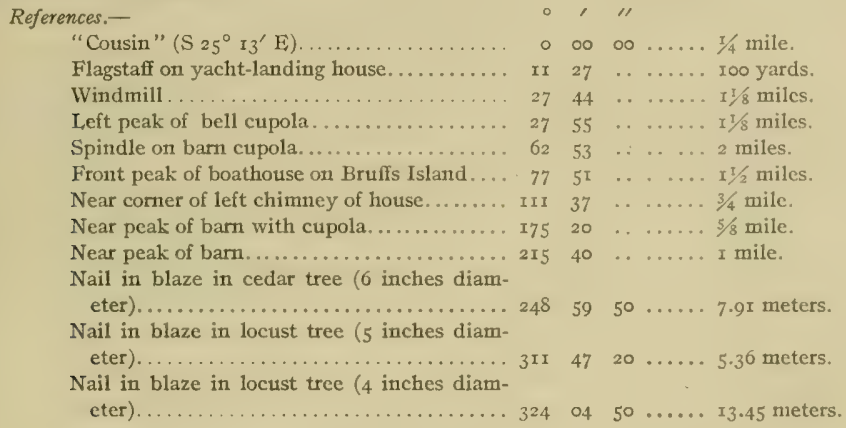

\section{COUSIN.}

General locality.-Southeastern shore of the branch of Wye River bounding Wye Island on the south about $I^{1} / 2$ miles east-northeast of noth end of Bruffs Island and at northern side of entrance to Llyod Creek. (See Chart No. 32.)

Immediate locality.-Observed station is in a pasture about 9 feet above high water, 25 yards east of edge of bank, 65 yards south-southeast of a small clump of trees in bottom land, 65 yards north of trees, 60 yards north of edge of a field, and 200 yards south of a house.

Marks.-Observed station is center point of trangle on standard cement monument projecting 5 inches above surface of ground. Subsurface mark is center of 2 -inch tile pipe buried with top 2 inches below base of monument.

References.-

"Lloyd" (S $\left.36^{\circ} \mathrm{o}^{\prime} \mathrm{W}\right)$...

Spindle on bam cupola

Front peak of boathouse................ 26

Leit peak of house.................. 63

Chimney of house.................... 9

Peak of near gable of Baldwin house........ 135

Windmill on large barn................ $x 87$

Right peak of house.................209

Left peak of bell cupola ............... 333

Windmill. ..................... 334

\begin{tabular}{|c|c|c|}
\hline$\infty$ & $\infty$ & $\mathrm{I} / 2$ mile. \\
\hline 24 & 50 & .. 2 miles. \\
\hline & . & ... I I $/ 2$ miles. \\
\hline & . & .. II/8 miles. \\
\hline & .. & ... 3/4 mile. \\
\hline & . & .....200 yards. \\
\hline & . & ..... $1 / 4$ mile. \\
\hline 44 & . & ..... 350 yards. \\
\hline 34 & . & I mile. \\
\hline & . & ...... \\
\hline
\end{tabular}




\section{LLOYD.}

General locality.-Southern shore of the branch of East Wye River bounding Wye Island on the south at western side of entrance to Lloyd Creek. (See Chart No. 32.)

Immediate locality. - Observed station is in cultivated land about I2 feet above high water, 70 yards southwest of edge of bank, 65 yards south of edge of bank, 65 yards north-northeast of point of woods and bottom land, and 120 yards northwest of an oak tree.

Marks.-Observed station is center point of triangle on standard cement monument projecting 5 inches above surface of ground. Subsurface mark is center of 2 -inch tile pipe buried with top 2 inches below base of monument.

\section{References.-}

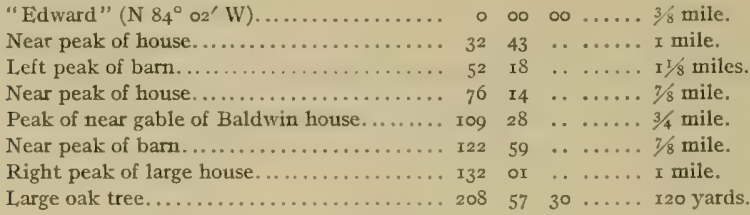

\section{EDWARD.}

General locality.-Southern shore of the branch of Wye River bounding Wye Island on the south on a point at eastern side of entrance to Shaw Bay about $3 / 4$ mile east-northeast of north end of Brufis Island and $3 / 8$ mile west of entrance to Lloyd Creek. (See Chart No. 32.)

Immediale locality.-Observed station is in cultivated land about 8 feet above high water, 8 yards southeast of edge of a bluff which is washing away, and 30 yards southwest of a line of large trees at edge of bank and field.

Marks.-Observed station is center point of triangle on standard cement monument projecting 5 inches above surface of ground. Subsurface mark is center of 2 -inch tile pipe buried with top 2 inches below base of monument.

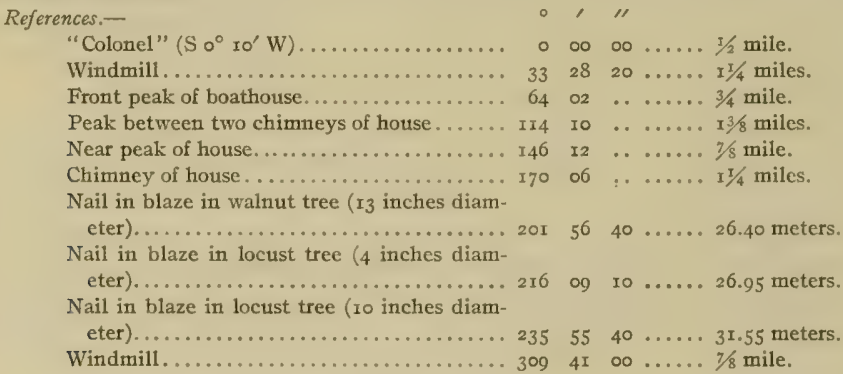

\section{COLONEL.}

General locality. - Southern shore of Shaw Bay on a point at entrance to a small cove about $1 / 2$ mile from the branch of Wye River bounding Wye Island on the south and $5 / 8$ mile east of Brufis Island. (See Chart No. 32.)

Immediate locality.-Observed station is in a field about to feet above high water, 6 yards southeast of edge of bank which is washing away, 9 yards south-southwest of point of bank, and 3 yards west of top of bank lined with cedar, walnut, and oak trees. Cement monument marking reference station is 18.69 meters $\mathrm{S} 24^{\circ} \circ 6^{\prime} \mathrm{E}$ of observed station. 
Marks.-Observed station is nail in center of 2 -inch stub projecting 4 inches above 2 -inch tile pipe with top flush with surface of ground. Subsurface mark is center of 2 -inch tile pipe buried with top 2 inches below base of surface pipe. Reference station is center point of triangle on standard cement monument projecting 4 inches above surface of ground.

References.-

"Shaw" ( N 68 $12^{\prime}$ W)

eak roof between two chimmeys of house.

Near peak of house.................. 48

Peak of near gable of house............. 100

Nail in blaze in oak tree ( 20 inches diameter). II

Nail in blaze in oak tree ( 6 inches diameter). 183

Nail in blaze in oak tree ( 7 inches diameter). 213

REFERENCE STATION.................. 224

Near corner of house on Bruffs Island..... . 355

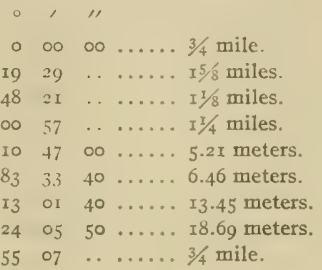

SHAW.

General locality. -Southern shore of entrance to the branch of Wye River bounding Wye Island on the south on northern end of Brufis Island about $3 / 8$ mile southwest of Bordley Point. (See Chart No. 32.)

Immediate loculity.-Observed station is in walnut, pine, and cedar woods, about is feet above high water, 7 yards southwest of edge of bank, and 100 yards north-northwest of a house.

Marks.-Observed station is center point of triangle on standard cement monument projecting 4 inches above surface of ground. Subsurface mark is center of 2 -inch tile pipe buried with top 2 inches below base of monument.

References.-

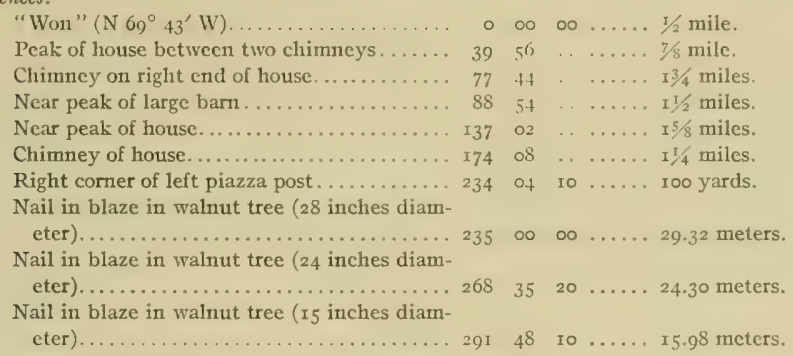

\section{BRUFFS.}

General locality.-Eastern shore of Wye River on northwest point of Bruffs Island about $7 / 8$ mile northeast of Bennett Point and $1 / 2$ mile southwest of Bordley Point. (See Chart No. 32.)

Immediate localily.-Observed station is on a marsh point about I foot above high water, ro yards east of shore, I4 yards southwest of shore, 20 yards southeast of point of marsh, and I 8 yards west of point of woods.

Marks.-Observed station is center point of triangle on standard cement monument projecting 7 inches above surface of ground. Subsurface mark is center of 2 -inch tile pipe buried with top 2 inches below base of monument.

References.-

"Law" ( $\mathrm{S}_{2}^{\circ} \mathrm{o}^{\prime} \mathrm{W}$ ).

$0000 \ldots \ldots 1 / 2$ mile.

"St. Michaels P. E. Church Spire" ...... I7 $35 \quad 20 \ldots \ldots 5 \frac{3}{3 / 8}$ miles.

"St. Michaels Water Tank"........... I7 $5020 \ldots \ldots 5 \frac{1}{4}$ miles.

Cupola of barn....................... $3^{8}$ i5 $00 \ldots \ldots 4^{1 / 8}$ miles.

Near peak of large barn............ $54 \quad 30 \quad \ldots \ldots \ldots 3 \frac{3}{4}$ miles.

Large walnut tree................... $118 \quad 55 \quad \ldots \ldots$. $\ldots \ldots$ mile.

Peak between two chimneys of house...... I56 $15 \ldots \ldots .7 / 8$ mile.

Near corner of house.................. $184{ }_{4} \quad 29 \quad \ldots \ldots 21 / 8$ miles. 


\section{References-Continued.}

Right peak of house................. $208 \quad 24 \quad \ldots \ldots \ldots 7 / 8$ mile.

Nail in blaze in tree ( 4 inches diameter) ... $25720 \quad 30 \ldots . .27 .38$ meters.

Nail in blaze in walnut tree ( 3 inches diam-

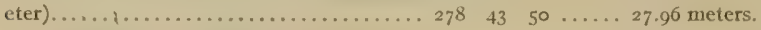

Nail in blaze in cedar tree (4 inches diam-

eter) ........................... 310 49 30 . . 4 I.27 meters.

Smoke pipe of building in woods......... 3I4 28 ..... 200 yards.

LAW.

General locality. - Southeastern shore of Wye River about $3 / 4$ mile east of Bennett Point and $1 / 8$ mile southwest of south end of Bruffs Island. (See Chart No. 32.)

Immediate locality. -Observed station is in cultivated land about ${ }_{5}$ feet above high water, 8 yards southeast of edge of a bluff, 45 yards southwest of a wire fence, Ioo yards northeast of a clump of trees, and 150 yards northwest of a black walnut tree at edge of field.

Marks.-Observed station is center point of triangle on standard cement monument projecting 4 inches above surface of ground. Subsurface mark is center of 2 -inch tile pipe buried with top 2 inches below base of monument.

References...

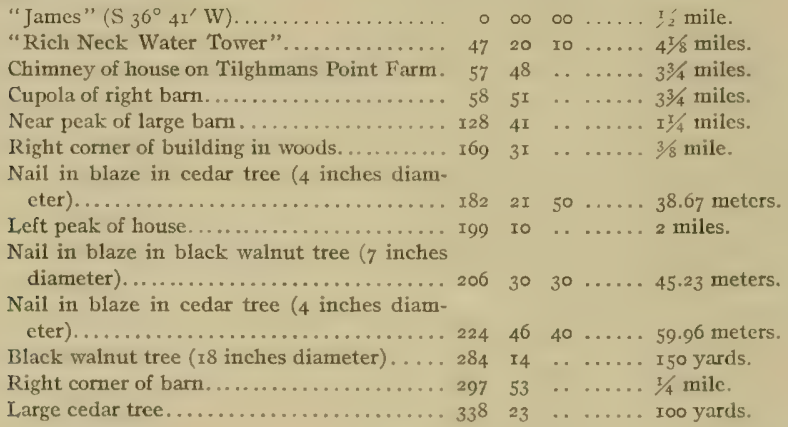

JAMES.

General locality.-Eastern shore of Miles River at southern side of entrance to Wye River about $5 / 8$ mile southwest of Bruffs Island and $5 / 8$ mile southeast of Bennett Point. (See Chart No. 32.)

Immediate locality.-Observed station is in a cultivated field about 20 feet above high water, $x_{7}$ yards east of edge of a bluff at shore, and I4 yards south of edge of a bluff 18 feet high with uniform slope to shore.

Marks.-Observed station is center point of triangle on standard cement monument projecting 6 inches above surface of ground. Subsurface mark is center of 2 -inch tile pipe buried with top 2 inches below base of monument.

\section{References.-}

"Frank" ( $\left.\mathrm{S}_{3}^{\circ} \mathrm{r}^{\prime} \mathrm{W}\right)$.

"St. Michaels P. E. Church Spire"

"St. Michaels Water Tank"..............

South chimney of house..................

South chimney of house on Tilghmans Point

Farm........................... 97 I4 $\ldots 3^{1 / 2}$ miles.

Right tangent of Tilghmans Point....... $109.08 \ldots \ldots 31 / 4$ miles.

Chimney of small cabin............... I74 $03 \ldots \ldots \ldots$ I3/s miles.

West gable of barn.................. 190 $22 \ldots \ldots .23 / 4$ miles.

Cupola of barn........................ $297 \quad 26 \quad \ldots \ldots . .5 / 8$ mile. 


\section{FRANK.}

General locality.-Eastern shore of Miles River about $1 / 2$ mile south of entrance to Wye River and I mile northeast of Herring Island. (See Chart No. 32.)

Immediate locality. - Observed station is in cultivated field about I 8 feet above high water, 8 yards east of a bluff washed by high water, and 225 yards south of a ditch. Cement monument marking reference station is $25.5 \mathrm{I}$ meters $\mathrm{S} 87^{\circ} 47^{\prime} \mathrm{E}$ of observed station.

Marks.-Observed station is center of 2 -inch tile pipe projecting 2 inches above surface of ground. Subsurface mark is center of 2 -inch tile pipe buried with top 2 inches below base of surface pipe. Reference station is center point of triangle on standard cement monument projecting 4 inches above surface of ground.

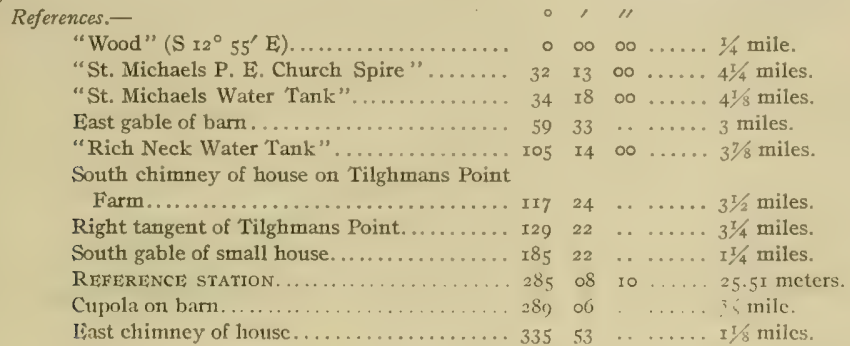

IVOOD

General locality.-Eastern shore of Miles River about $x^{1 / 2}$ miles southeast of Bennett Point, $x^{1 / 4}$ miles east-northeast of Herring Island and $5 / 8$ mile north-northwest of entrance to Woodland Creek. (See Chart No. 32.)

Immediate locality.-Observed station is in a cultivated field about $\mathrm{I} 8$ feet above high water, $\mathrm{r} 8$ yards east of shore and top of vertical bank 18 feet high, and 3 yards south of a wire fence.

Marks.-Observed station is center point of triangle on standard cement monument projecting 5 inches above surface of ground. Subsurface mark is center of 2 -inch tile pipe buried with top 2 inches below base of monument.

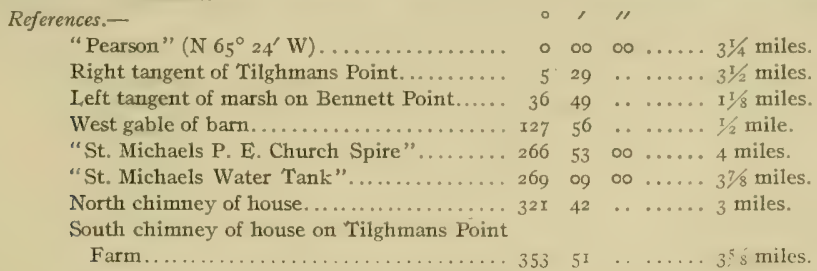

HERR.

General locality,-In Miles River on Herring Island about I I $/ 4$ miles southwest of entrance to Wye River. (See Chart No.32.)

Immediate locality. - Observed station is on sandy ground in the center of Herring Island about 2 feet above high water, 30 yards northeast of shore and 30 yards southwest of shore.

Marks.-Observed station is center point of triangle on standard cement monument projecting 4 inches above surface of ground. Subsurface mark is center of 2 -inch tile pipe buried with top 2 inches below base of monument. 


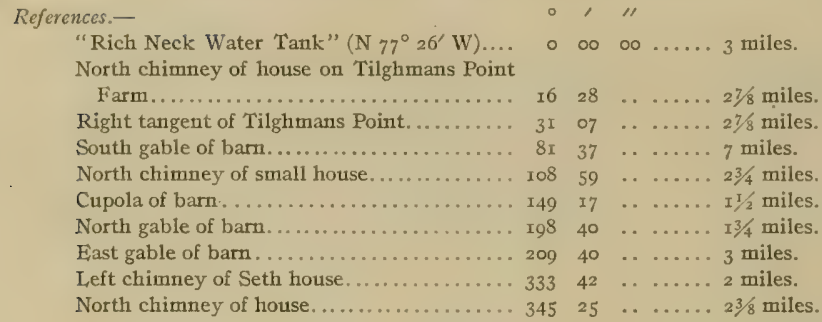

OLI,IE.

General locality.-Eastern shore of Miles River about I mile north of entrance to Leeds Creek and $3 / 4$ mile northeast of Deep Water Point. (See Chart No. 32.)

Immediate locality.-Observed station is in woods about 8 feet above high water, 6 yards west of edge of bank which is washing rapidly, and 8 yards northeast of large pine tree at edge of bank. Cement monument marking reference station is 14.42 meters $N 74^{\circ} \mathrm{I} 5^{\prime} \mathrm{W}$ of observed station.

Marks.-Observed station is center of 2 -inch tile pipe with top flush with surface of ground. Subsurface mark is center of 2 -inch tile pipe buried with top 2 inches below base of surface pipe. Reference station is center point of triangle on standard cement monument projecting 4 inches above surface of the ground.

\begin{tabular}{|c|c|c|c|c|}
\hline \multicolumn{5}{|l|}{ References.- } \\
\hline "Swing" ( $\left.\mathrm{S} \mathrm{I}^{\circ} 20^{\prime} \mathrm{W}\right)$ & 0 & 00 & $\infty$ & $3 / 4$ mile. \\
\hline Nail in blaze in pine tree ( 3 feet diameter). . & 25 & 56 & $\infty$ & 7.62 meters. \\
\hline "St. Michaels Water Tank" ............... & 37 & $5^{8}$ & 20 & $2 \mathrm{~T} / 4$ miles. \\
\hline Weather vane on house on Deep Water Point & & & & \\
\hline 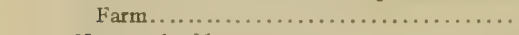 & 57 & Io & .. & ..... I mile. \\
\hline Near peak of house.................... & $9^{\mathrm{I}}$ & 55 & . & $x 5 / 8$ miles. \\
\hline Chimey of house on Tilghmans Point Farm. & 130 & $3^{8}$ & . & . $4^{1 / 2}$ miles. \\
\hline Right tangent of Tilghmans Point.......... & 140 & 03 & .. & $4 \frac{T}{2}$ miles. \\
\hline "Parsons Island Water Tank"............ & x 57 & I9 & 40 & . $7^{1 / 4}$ miles. \\
\hline Left tangent of main woods on Bennett Point. & $x 7^{2}$ & $\infty$ & .. & 3 miles. \\
\hline Chimney on right end of house in woods..... & 180 & $\infty$ & .. & . 4 miles. \\
\hline Nail in blaze in pine tree ( 8 inches diameter). & 240 & 27 & . & .. 0.56 meters. \\
\hline REFERENCE STATION.................... & 284 & 24 & 40 & ..... 14.42 meters. \\
\hline Nail in blaze in pine tree ( 7 inches diameter). & 285 & 22 & 10 & … 10.55 meters. \\
\hline Nail in blaze in pine tree ( 7 inches diameter). & 316 & 39 & . & $\ldots \ldots 12.5^{2}$ meters. \\
\hline
\end{tabular}

\section{DEEWAT.}

General locality.-Western shore of Miles River on Deep Water Point, about 7/8 mile west-northwest of Fairview Point. (See Chart No. 32.)

Immediate locality.-Observed station is on sand and grass point about 2 feet above high water, 8 yards southwest of shore, 7 yards northwest of shore, and io yards west of extreme end of point.

Marks.-Observed station is center point of triangle on standard cement monument projecting 5 inches above surface of ground. Subsurface mark is center of 2 -inch tile pipe buried with top 2 inches below base of monument.

References.-

"St. Michaels Water Tank" (S $\left.33^{\circ} 08^{\prime} \mathrm{W}\right)$... $\quad 0 \quad 00 \quad 00 \ldots \ldots$ I $1 / 2$ miles.

Weather vane on Dodson house.......... $53 \quad 13 \quad \ldots \ldots \ldots .7 / 4$ mile.

Tangent of Tilghmans Point............. II7 $58 \quad \ldots \ldots \ldots 45 / 8$ miles.

Right tangent of Parsons Island.......... I33 $28 \quad \ldots \ldots \ldots 73 / 8$ miles.

Large square chimney of Starr house...... I79 $59 \quad \ldots \ldots \ldots 25 / 8$ miles.

L,arge chimney of house............... 212 o $08 \ldots \ldots \ldots I^{1 / 8}$ miles. 
References-Continued.

Cupola on Rieman house.

Tangent of Long Point .................

Steeple............................. 295

Large chimney of house............... 297

Large chimney of house............... 309

"St. Michaels P. E. Church Spire"....... 353

SPAR.

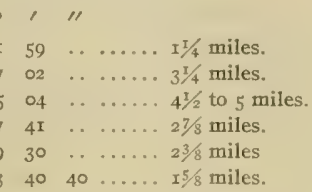

General locality. - Southwestern shore of Miles River about I mile southeast of entrance to Hambleton Creek and $3 / 8$ mile northwest of Deep Water Point. (See Chart No. 32.)

Immediate locality.--Observed station is on cedar-and-locust-fringed shore about 4 feet above high water, II yards west of shore, I2 yards southwest of shore, and 15 yards south of shore.

Marks.-Observed station is center point of triangle on standard cement monument projecting 5 inches above surface of ground. Subsurface mark is center of 2 -inch tile pipe buried with top 2 inches below base of monument.
References.-
"Sara" (N $39^{\circ} \mathrm{Ig}^{\prime} \mathrm{W}$ ).
Chimney of house on Tilghmans Point Farm.
Near peak of barn beyond Herring Island...
Nail in blaze in oak tree ( 3 inches diameter).. 54
Right tangent of chimney............ I2
Tangent of Deep Water Point............ I8
Nail in blaze in locust tree ( 3 inches diam-
$\mathrm{Nail}$ in blaze in locust tree ( 4 inches diam-

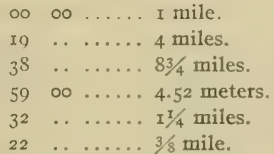

SARA.

General localily. - Southwestern shore of Miles River about $3^{x}+$ miles south-southeast of northern end of Tilghmans Point $I \frac{1}{4}$ miles southwest of Herring Island and on point at eastern side of entrance to Hambleton Creek. (See Chart No. 32.)

Immediate locality.-Observed station is in a cultivated field about 15 feet above high water, I6 yards southwest of a bluff I2 feet high with uniform slope to shore, and 20 yards east of depression 4 feet deep.

Marks.-Observed station is center point of triangle on standard cement monument projecting 6 inches above surface of ground. Subsurface mark is center of 2 -inch tile pipe buried with top 2 inches below base of monument.

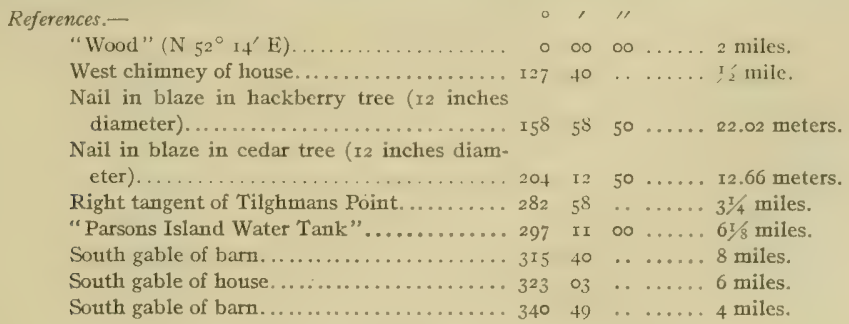

SETH.

General locality.-Southwestern shore of Miles River on a point about $2 \frac{1}{2}$ miles south of northern end of Tilghmans Point and $3 / 4$ mile northwest of entrance to Porters Creek. (See Chart No. 32.)

Immediate locality.-Observed station is in clump of cedar trees about 12 feet above high water, 9 yards southwest of top of vertical bank, washed by high water, 50 yards northwest of extreme end of 
point, and 400 yards northeast of a house. Cement monument marking reference station is $9.5^{6}$ meters $\mathrm{S} 67^{\circ} 4 \mathrm{I}^{\prime} \mathrm{W}$ of observed station.

Marks.-Observed station is center of 2 -inch tile pipe projecting 3 inches above surface of ground. Subsurface mark is center of 2 -inch tile pipe buried with top 2 inches below base of surface pipe. Reference station is center point of triangle on standard cement monument projecting 12 inches above surface of ground.

$$
\begin{aligned}
& \text { References. - } \\
& \text { "Herr" (N } \left.79^{\circ} \circ 7^{\prime} \mathrm{E}\right) \ldots \ldots \ldots \ldots \ldots \ldots \ldots . \quad \circ \infty \ldots \ldots \text { miles. } \\
& \text { Nail in blaze in cedar tree ( } 12 \text { inches diam- } \\
& \text { eter)........................ I45 } 20 \quad 20 \ldots \ldots \text { ro.89 meters. } \\
& \text { REFERENCE STATION................. r68 } 34 \quad 30 \ldots \ldots 9.56 \text { meters. } \\
& \text { Nail in blaze in cedar tree ( } 6 \text { inches diam- }
\end{aligned}
$$

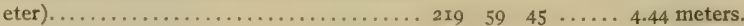

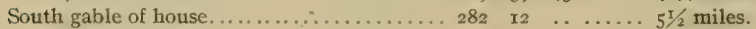

$$
\begin{aligned}
& \text { South gable of barn ................. } 305 \quad 34 \ldots \ldots 6 \text { miles. } \\
& \text { West gable of house............... } 312 \text { 30 } \ldots \ldots 6 \text { miles. } \\
& \text { Cupola on barn..................... } 356 \text {. } 52 \ldots . . .3 \text { miles. }
\end{aligned}
$$

\section{DIXON.}

General locality.-Southeastern side of Eastern Bay on Tilghmans Point about halfway between Eastern Bay and Miles River, 3/4 mile southwest of northern end of point, and $x 5 / 8$ miles northeast of Claiborne Wharf. (See Chart No. 32.) Farm.

Immediate locality.- - Observed station is on top of a 2 -story square frame house on Tilghmans Point

Marks.-Observed station is center of upright staff, 3 inches square, set in the center of trap door at apex of square roof.

References.-None necessary.

\section{PEARSON.}

General locality. - Western shore of Miles River on Tilghmans Point about $3 / 8$ mile south-southenst of northern end of point. (See Chart No. 32.)

Immediate locality.-Observed station is on wooded bluff about 20 feet above high water, 5 yards west of top of vertical bank at shore, and roo yards north of first point south of northern end of Tilghmans Point. Cement monument marking reference station is 12.66 meters $\mathrm{N} 86^{\circ} \circ 3^{\prime} \mathrm{W}$ of observed station.

Marks.-Observed station is center of 2 -inch tile pipe projecting 2 inches above surface of ground. Subsurface mark is center of 2 -inch tile pipe buried with top 2 inches below base of surface pipe. Reference station is center point of triangle on standard cement monument projecting 6 inches above surface of ground.

\section{References.-}

"Green" $\left\langle\mathrm{N}_{\left.45^{\circ} 46^{\prime} \mathrm{E}\right)}\right.$

South gable of barn.

West chimney of house.................

West gable of barn..................

East gable of barn ................. 76

West chimney of house................ II

North chimney of house. ................ 125

Chimney of house................... I

\begin{tabular}{|c|c|c|}
\hline$\infty$ & $\infty$ & … $3^{3 / 8}$ miles. \\
\hline I4 & .. & .... 5 miles. \\
\hline $4^{8}$ & $\cdots$ & … $3 \frac{1}{2} / 2$ miles. \\
\hline $3 I$ & $\cdots$ & .... 27/8 miles. \\
\hline $3 \mathrm{I}$ & . & …. $31 / 2$ miles. \\
\hline 09 & . & .... 4 miles. \\
\hline 30 & $\cdots$ & .... 3 3/4 miles. \\
\hline 20 & $\cdots$ & ..... $31 / 8$ miles. \\
\hline 36 & $\therefore$ & $\ldots \ldots 2^{1} / 2$ miles. \\
\hline$\circ 9$ & 40 & .... 5.3 I meters. \\
\hline II & $\infty$ & .. 12.66 metc \\
\hline 19 & 20 & $\ldots \ldots 9$ \\
\hline$x_{7}$ & - & iles. \\
\hline 02 & .. & $\ldots \ldots$ \\
\hline
\end{tabular}

Nail in blaze in white oak tree ( 8 inches diam-

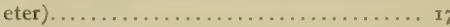

REFERENCE STATION.................. 228

Nail in blaze in white oak tree ( 12 inches

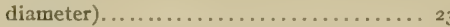

South gable of house on Parsons Island..... 3I7

South gable of barn................. 350 


\section{BOUNDARIES OF OYSTER BARS.}

\section{FXXPI,ANATION.}

The law of the United States authorizing the cooperation of the Department of Commerce and Labor in the survey of natural oyster bars of Maryland provides for the designation and employment by the Department of Commerce and Labor of such officers, experts, and other technically qualified persons "as may be necessary to cooperate with the Maryland State Board of Shell Fish Commissioners in making a survey of and locating the natural oyster beds, bars, and rocks in the waters within the State of Maryland." The oyster laws of Maryland provide that the Maryland Shell Fish Commissioners, with the aid of such persons as may be designated by the Government, shall proceed "to have laid out, surveyed, and designated on the said charts the natural beds and bars, and shall cause to be marked and defined as accurately as practicable the limits and boundaries of the natural beds, bars, and rocks as established by said survey, and they shall take true and accurate notes of said survey in writing, and make an accurate report of said survey, setting forth such a description of landmarks as may be necessary to enable the said board, or their successors, to find and ascertain the boundary lines of the said natural oyster beds, bars, and rocks, as shown by a delineation on the maps and charts." The oyster laws of Maryland also provide in another section that there shall "be made a true and accurate survey of the natural oyster beds, bars, and rocks *** with reference to fixed and permanent objects on the shore, giving courses and distances, to be fully described and set out in a written report of said survey."

Under the provisions of the laws quoted above the State of Maryland, in cooperation with the Department of Commerce and Labor, must define the boundaries of the natural oyster bars "as accurately as practicable" and also "with reference to fixed and permanent objects on the shore, giving courses and distances." The requirement of "as accurately as practicable" is easily fulfilled by definition of the location of the comers of the oyster bars by latitude and longitude. In fact, this method is probably the most satisfactory and accurate one that could be used for all purposes of legal definition or for relocation of the oyster-bar boundaries by competent engineers. Therefore the additional requirement of "giving courses and distances" is supertluous and is only fulfilled in the published definitions on account of the specific provisions of the law making it compulsory. This part of the description of boundaries has involved an immense amount of extra computations in order to prevent technical discrepancies between the latitude and longitude of a corner of an oyster bar and its distance and bearing from objects on shore of known latitude and longitude without adding anything to the accuracy and very little to the convenience of practical use of the descriptions of the oyster-bar boundaries. 
As provided by law the boundaries of the oyster bars are all straight lines, but in the work already completed they have inclosed areas of all shapes from triangles to complicated I4-sided figures, and of all sizes from 4 acres to 7,548 acres. The sides have varied in length from 93 to 7,529 yards, and in some cases the corners of the boundaries have been practically at the triangulation stations from which they are located, while in other instances they were over 13,600 yards from the landmarks most available for the purpose of fixing their position.

The varied characteristics of the legal boundaries of the oyster bars indicated by the above statement, together with the complicated requirements of the law under which the survey has been made and the magnitude of the work with the consequent need of fixed and uniform methods, have made the problem of describing the boundaries one of considerable difficulty and great importance.

The boundaries of the oyster bars of Maryland, as established by the Shell Fish Commission and delineated on the Coast and Geodetic Survey charts and projections and on the leasing charts of the commission, are technically defined and described by a method somewhat different from that used in other oyster surveys. But it is believed that the forms finally adopted will fulfill all needs of the survey for both the present and the future.

\section{METHOD OF DESCRIBING BOUNDARIES.}

The descriptions have been arranged in tabular form, thus avoiding many hundred repetitions of the same words by making one explanation of the tables sufficient for all oyster bars in each county.

Title.-At the top of each tabular form is given the legal name of the oyster bar to be described, and the one by which it is known and designated in the published oyster records and on the oyster charts. The adopted name of the oyster bar is the one used locally, as nearly as could be ascertained by the hydrographic engineer of the commission; and when there was no local name in common use a name was selected from one of the prominent features of the vicinity that would naturally suggest the section of the waters where the oyster bar was located.

Underneath the name, in parentheses, is given the general locality of the oyster bar and the serial number of the "Maryland Oyster Chart" on which its legal boundaries are shown. ${ }^{1}$

First column.-This column, under the heading of "Corner of bar," gives the number corresponding to the corner of the boundary as shown on the charts and to the number on the buoy marking the actual corner of the bar. The numbers of the comers have been assigned by naming the southernmost point No. I, thence proceeding in a clockwise direction around the bar. Where a corner of one oyster bar is identical with the corner of the boundaries of one or more other oyster bars, only the number of the corner of the oyster bar being described in the table is given in this column.

Second and third columns.-These two columns, under the headings of "Latitude" and "Longitude," give the geographic positions of the corners. These positions have been adopted by the commission as the primary technical definition of the location of the corners, and should be considered as final in case of a dispute arising from discrepancies caused by other means of location. The latitudes and longitudes given in these

1 These charts can be obtained by application to the Superintendent of the Coast and Geodetic Survey at Washington, D. C. 
columns are based on the United States standard datum of the Coast and Geodetic Survey, and the points thus defined can be relocated from distant triangulation stations of the survey, even though all the landmarks and buoys originally used for their location have been destroyed by natural or other causes.

Fourth and fifth columns.-These two columns, under the general heading of "True bearing" 1 and the specific headings "Forward" and "Back," give bearings measured from a true north-and-south line. The three "Forward" bearings are from the comer of the boundary designated in the first column to the triangulation stations named on the corresponding lines in the last column, and the three "Back" bearings are from these same stations in the last column to the corresponding corner of boundary in the first column. The difference in minutes of are between the forward and back bearings shown in some cases is actual and not accidental, and is due to the fact that the computations took into account the spheroidal shape of the earth.

Sixth column.-This column, under the heading of "Distance," gives the three computed distances in yards from the corner of the bar noted in the first column to the three triangulation stations named on the corresponding lines in the last column, and vice versa.

Seventh column.-This column, under the heading of "U. S. C. \& G. S. triangulation station," 2 gives the names of the landmarks from which were computed the corresponding "Latitude," "Longitude," "True bearing," and "Distance" of the "Corner of the bar" designated in the first column. A full description of the location and markings of these triangulation stations is given in another part of this publication under the heading of "Descriptions of triangulation stations."

\section{SURVEYING METHODS FOR RELOCATION OF BOUNDARIES.}

There are a number of methods that can be used in the relocation of the actual boundaries of the natural oyster bars as technically described in this publication and delineated on the published charts of the Coast and Geodetic Survey and the leasing charts of the Shell Fish Commission.

The following brief descriptions of five of these more or less different methods assume a certain amount of experience and knowledge on the part of the engineer in the particular kind of surveying under consideration, and are only intended as reminders of ways and means that can be used.

There are two problems that are likely to present themselves to those interested in the boudaries of natural oyster bars: One, to determine whether the buoys marking the corners have been dragged or otherwise moved from their correct positions, and the other, to relocate or reestablish a buoy at the point from which it was removed. The different ways of solving these two problems partly depend upon the instruments possessed by the engineer and his assistants and partly on his training and experience.

(I) Triangulation.-This method is the one that will give the greatest accuracy, but on account of its requiring special data and instruments, and being an operation rarely used by engineers not engaged in geodetic surveying, it is recommended only for

\footnotetext{
1 The mean magnetic variation for Queen Annes County was $6^{\circ}$ I5' west of north in Igri and increasing at the rate of $5^{\prime}$ yearly.

2 Geographic positions of these triangulation stations can be obtained by application to the Superintendent of the Coast and Geodetic Survey, Washington, D. C.
}

$$
203 \mathrm{I}_{3}-\mathrm{I} 2-8
$$


cases in dispute that can not be settled satisfactorily by some other method. An explanation of this class of work would be too long for a report of this sort, and those not familiar with this method are referred to the publications on the subject by the Coast and Geodetic Survey.

(2) Hydrographic. - This method is the most simple and satisfactory one that can be adopted if the surveyor can ohtain the use of the necessary instruments and assistants. It is the one best suited for the work of the engineers of the commission in relocating corners of boundaries, as it gives results of the accuracy ordinarily required and is rapid in execution. Besides, it has the advantage of being available whenever three triangulation stations of suitable relative positions are visible from the offshore points needing relocation.

Most navigators and others familiar with the use of a sextant are well acquainted with the graphic three-point method of fixing a position on water, and only a brief description of the operation will be stated.

In the case where there is only one engineer having a single sextant, the three-point method can be used if the two angles determining the position of a buoy are first derived from the "Forward" bearings given in the tabular forms describing the boundaries of the oyster bars. For example, take "Broad Creek" oyster bar, which is the first one described in this publication, and assume that "Corner No. 3," is to be examined as to its position. The angle between the two landmarks "Sandy Point Light" and "Ring" as determined from right to left from the forward bearings from this corner is $98^{\circ} 09^{\prime}$ and the angle between "Ring" and "Railway Water Tank" is $7 \mathrm{I}^{\circ} 08^{\prime}$. Having these two angles, the engineer procceds to the buoy of doubtful location and measures the actual sextant angles between the landmarks for which the calculations were made. If the measured and calculated angles do not agree the buoy is not in its correct position and the boundary corner must be relocated. This is accomplished by moving the boat about until a point is reached where the angles do agree, and this point being the desired location, the buoy can be placed in its correct position.

If the engineer can obtain the use of both a sextant and a three-arm protractor ("position finder"), the availability of the hydrographic method is increased, as the use of the protractor is essential in case of the washing away or destruction of one or more of the landmarks originally used in describing the boundaries. Under these circumstances, any three landmarks of suitable relative position that are visible from the point to be located can be utilized. For example, the engineer can proceed to the buoy of doubtful position and measure the two adjacent sextant angles between the three landmarks selected. These two angles are set off on the three-arm protractor and the actual position of the buoy plotted on the chart by shifting the protractor about until the edge of each of the three arms passes through the center of the symbols on the chart marking the position of the three landmarks selected. The center of the hub of the protractor will indicate on the chart the actual position of the buoy, and if the point thus obtained does not coincide with the true position of the corner of the boundary as giren on the chart, the surveyor can proceed to locate the buoy correctly by reversing the operation. This is done by placing the center point of the hub of the protractor over the comer of the boundary in question and measuring on the chart the two adjacent protractor angles between the three selected landmarks. One of the angles thus 
obtained is set on the sextant and the boat moved about until the two landmarks are shown by the sextant to subtend the same angle obtained from the protractor. The second angle is then placed on the sextant and the same operation gone through, and so on, first using one angle on the sextant then the other until a point is reached where hoth observed sextant angles are practically identical with the protractor angles. The point thus located is the desired one and the buoy can be placed to mark the true position of the corner of the boundary in question.

If the engineer possesses two sextants and a protractor, this problem is far easier of solution, as the two angles can be set off on separate sextants and the observer can quickly find the desired point where they agree with the protractor angles by using one sextant after the other without the need of resetting either.

If there are two observers, two sextants, and a protractor, it can be seen that the best conditions for both rapid and accurate hydrographic location of a point is attained. In fact, this is the method by which the buoys at the comers of the boundaries were originally placed by the hydrographic engineer to the commission.

(3) Magnetic bearings from offshore.-This method of fixing a position on water is a simple and well-known one in navigation. It is available to anyone having a boat compass and will be of special use to the State fishery force in investigating cases where buoys are supposed to have been moved for illegal purposes.

In the case where a buoy is supposed to have been moved from its true position the ohserver can take compass bearings to the three landmarks given in the last column of the tables opposite the boundary corner in question. These bearings are then corrected for the local declination, ${ }^{1}$ and if the results agree with the published bearings the buoy is correctly located.

In the case where the buoy is not in its correct position, or has disappeared altogether, the desired point can be determined by maneuvering the vessel until the corrected hearings agree with the ones in the tabular descriptions, when the buoy can be anchored in its proper location.

In the case where the landmarks, for which the bearings are published, have been destroyed or washed away, any landmarks whose positions are indicated on the charts can be used. This can be done by getting their bearings directly from the chart by parallel rulers or a protractor and then applying these new bearings in the same manner as the ones published in the tables.

(4) Magnetic bearings from shore.-This method will he of special value to engineers having an ordinary surveyor's compass. The compass can be set over the point marking a "triangulation station" on shore, the name of which is given in the last column opposite the "corner" in question. The instrument is then set at the corresponding "back" bearing (corrected for local magnetic declination) given in the fifth column of the tables opposite the "corner" in question. The direction thus determined will give one range on which the desired point must be located. The compass can then be moved to a second triangulation station and another range located in a similar manner. The intersection of these two range lines will give the desired point; but in general it should be checked by an additional range line determined from a third station.

1 The mean magnetic variation for Queen Annes County is $6^{\circ} 15^{\prime}$ west of north in Igri and increasing at the rate of $5^{\prime}$ yearly 
(5) Horizontal angles measured at landmarks.-This process is a modification of the triangulation method, and will be useful to engineers who have a transit and desire considerable accuracy.

The instrument is placed over a "triangulation station," the name of which appears in the last column of the tabular description opposite the "corner" in question. The telescope is then pointed to the landmark indicated in the "Descriptions of landmarks" as laving a direction of $\mathrm{O}^{\circ} \mathrm{OO}^{\prime} \mathrm{OO}^{\prime \prime}$ from the triangulation station being occupied by the transit. The tabular description of the boundaries is next examined and the "back" bearing of the questionable boundary "corner" from the landmark being occupied is taken out. The angle calculated from this "back" bearing and the bearing given in parentheses alongside the zero landmark in the "Descriptions of landmarks" is then set off on the transit and a range line established on which the clesired point must be located. A similar process is then carried on at a second station, and so on until the position of the butoy is satisfactorily fixed.

BOUNDARIES OF NATURAL OYSTER BARS.

BROAD CREEK.

(Chesapeake Bay-Chart No. 20.)

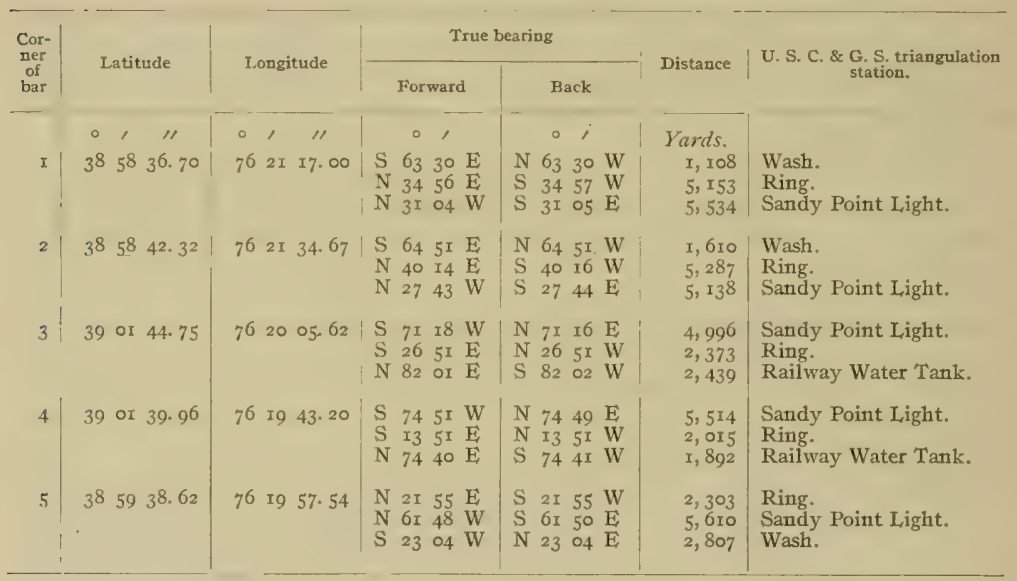


BOUNDARIES OF NATURAL OYSTER BARS-continued.

LOVE POINT.

(Chesapeake Bay off Love Point-Chart No.20.)

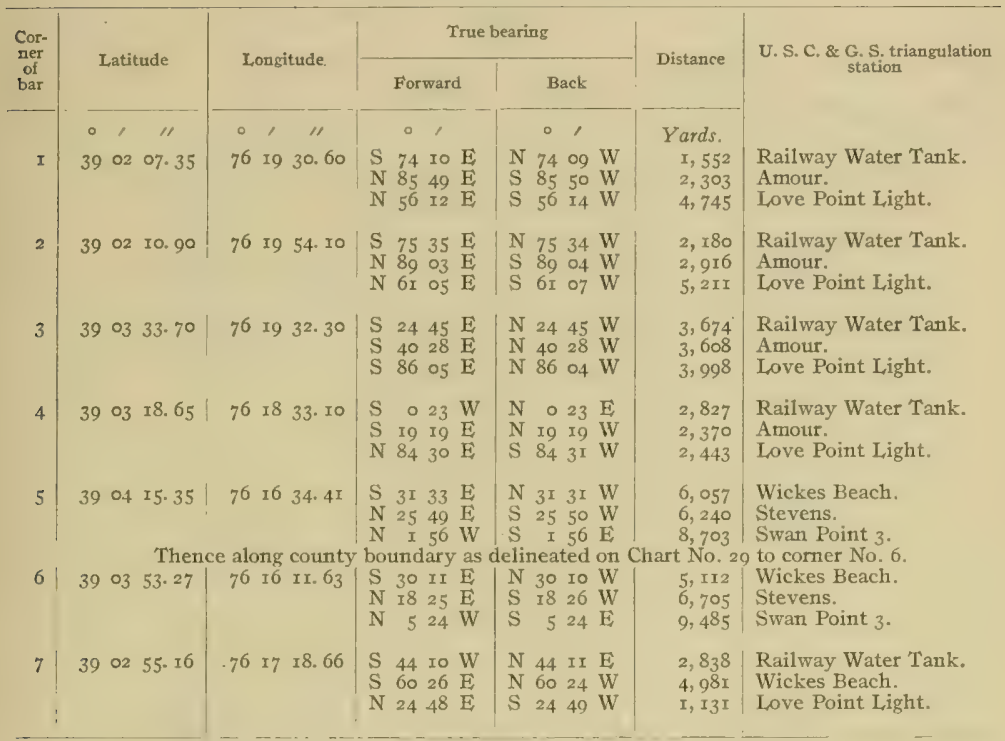

\section{STRONG BAY.}

(Lower Chester River-Chart No. 29.)

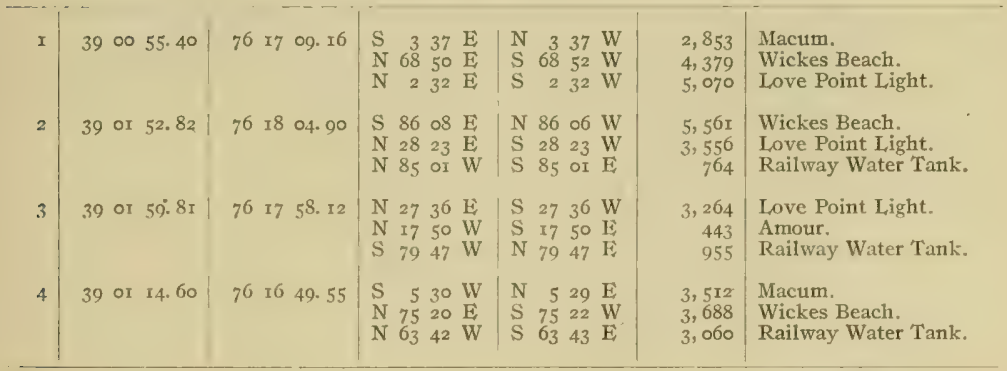


BOUNDARIES OH NATURAI, OYSTLR BARS - continuEd.

\section{CARVEL.}

(Lower Chester River-Chart No. 29.)

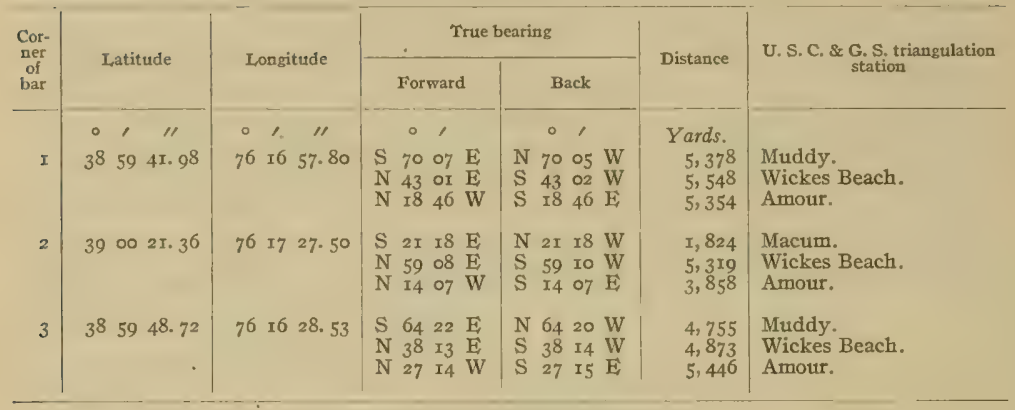

FERRY (QUEEN ANNES COUNTY).

(Lower Chester River-Chart No. 29.)

\begin{tabular}{|c|c|c|c|c|c|c|}
\hline$x$ & $\begin{array}{llll}38 & 59 & 23.94\end{array}$ & $\begin{array}{llll}76 & x_{5} & 34.62\end{array}$ & $\begin{array}{llll}\mathrm{S} & 66 & 55 & \mathrm{E} \\
\mathrm{N} & 59 & 33 & \mathrm{E} \\
\mathrm{N} & \mathrm{I} 8 & 53 & \mathrm{E}\end{array}$ & $\begin{array}{llll}\mathrm{N} & 66 & 54 & \mathrm{~W} \\
\mathrm{~S} & 59 & 35 \mathrm{~W} \\
\mathrm{~S} & \mathrm{I} 8 & 54 & \mathrm{~W}\end{array}$ & $\begin{array}{l}3, \text { II } 8 \\
4,695 \\
4,930\end{array}$ & $\begin{array}{l}\text { Muddy. } \\
\text { Narrows Point. } \\
\text { Wickes Beach. }\end{array}$ \\
\hline 2 & 390009.66 & $\begin{array}{lll}76 & \text { I5 } & 58.46\end{array}$ & $\begin{array}{llll}\mathrm{S} & 52 & \text { 10 } & \mathrm{W} \\
\mathrm{S} & 51 & 40 & \mathrm{E} \\
\mathrm{N} & 35 & 27 & \mathrm{E}\end{array}$ & $\begin{array}{llll}\mathrm{N} & 52 & \text { 10 } & \mathrm{E} \\
\mathrm{N} & 5 \mathrm{I} & 4 \mathrm{I} & \mathrm{W} \\
\mathrm{S} & 35 & 28 & \mathrm{~W}\end{array}$ & $\begin{array}{l}2,128 \\
4,455 \\
3,833\end{array}$ & $\begin{array}{l}\text { Macum. } \\
\text { Muddy. } \\
\text { Wickes Beach. }\end{array}$ \\
\hline 3 & 390029.37 & $\begin{array}{llll}76 & 15 & 30.72\end{array}$ & $\begin{array}{llll}\mathrm{S} & 38 & 53 & \mathrm{E} \\
\mathrm{N} & 87 & 30 & \mathrm{E} \\
\mathrm{N} & 3 \mathrm{I} & \mathrm{I7} & \mathrm{E}\end{array}$ & $\mid \begin{array}{llll}\mathrm{N} & 38 & 52 & \mathrm{~W} \\
\mathrm{~S} & 87 & 32 & \mathrm{~W} \\
\mathrm{~S} & 31 & 18 & \mathrm{~W}\end{array}$ & $\begin{array}{r}4,405 \\
3,949 \\
2,876\end{array}$ & $\begin{array}{l}\text { Muddy. } \\
\text { Narrows Point. } \\
\text { Wickes Beach. }\end{array}$ \\
\hline 4 & $\begin{array}{l}\text { Thenc } \\
39 \text { oo } 0.4 \cdot 45 \text { । }\end{array}$ & $\begin{array}{l}\text { e along county } \\
\begin{array}{ccc}76 & 14 & 38.00\end{array}\end{array}$ & 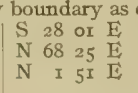 & 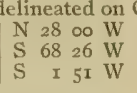 & $\begin{array}{l}\text { Chart No. } 29 \\
2,932 \\
2,750 \\
3,299\end{array}$ & $\begin{array}{l}\text { to corner No. } 4 \text {. } \\
\text { Muddy. } \\
\text { Narrows Point. } \\
\text { Wickes Beach. }\end{array}$ \\
\hline 5 & $3^{8} 5949 \cdot 10$ & $\begin{array}{llll}76 & 14 & 48.4 x\end{array}$ & $\begin{array}{lrrr}\mathrm{S} & 38 & 34 & \mathrm{E} \\
\mathrm{N} & 6 \mathrm{r} & 37 & \mathrm{E} \\
\mathrm{N} & 5 & 42 & \mathrm{E}\end{array}$ & $\mid \begin{array}{rrrr}N & 38 & 33 & W \\
S & 6 r & 38 & W \\
S & 5 & 42 & W\end{array}$ & $\begin{array}{l}2,649 \\
3,218 \\
3,834\end{array}$ & $\begin{array}{l}\text { Muddy. } \\
\text { Narrows Point. } \\
\text { Wickes Beach. }\end{array}$ \\
\hline
\end{tabular}


BOUNDARIES OF NATURAL OYSTLR BARS-cOntinUEd.

LONG POINT (CHESTER RIVER).

(Lower Chester River-Charts Nos. 29 and 30.)

\begin{tabular}{|c|c|c|c|c|c|c|c|c|c|c|c|c|}
\hline \multirow{3}{*}{$\begin{array}{c}\text { Cor- } \\
\text { ner } \\
\text { of } \\
\text { bar } \\
\\
\text { I }\end{array}$} & \multirow{2}{*}{\multicolumn{3}{|c|}{ Latitude }} & \multirow{2}{*}{\multicolumn{3}{|c|}{ Longitude }} & \multicolumn{4}{|c|}{ True bearing } & \multirow{2}{*}{ Distance } & \multirow{2}{*}{$\begin{array}{l}\text { U. S. C. \& G. S. triangulation } \\
\text { station }\end{array}$} \\
\hline & & & & & & & & Forward & & Back & & \\
\hline & $\begin{array}{c}\circ \\
3^{8}\end{array}$ & $\begin{array}{l}\prime \\
59\end{array}$ & $\begin{array}{c}\prime \prime \\
03.26\end{array}$ & & $\mathrm{I}_{3}$ & $\begin{array}{c}11 \\
15 \cdot 32\end{array}$ & $\begin{array}{l}N \\
N \\
S\end{array}$ & $\begin{array}{rcc}0 & 1 \\
84 & 48 & \mathrm{E} \\
7 & \circ 5 & \mathrm{E} \\
56 & 42 & \mathrm{~W}\end{array}$ & $\begin{array}{l}\mathrm{S} \\
\mathrm{S} \\
\mathrm{N}\end{array}$ & $\begin{array}{rcc}0 & 1 \\
84 & 49 & \text { W } \\
7 & 05 & \text { WV } \\
56 & 4 \mathrm{I} & \mathrm{E}\end{array}$ & $\begin{array}{r}\text { Yards. } \\
3,528 \\
3,099 \\
956\end{array}$ & $\begin{array}{l}\text { Bluebeard. } \\
\text { Narrows Point. } \\
\text { Muddy. }\end{array}$ \\
\hline 2 & $3^{8}$ & $59=$ & 28.93 & 76 & 14 & 37.13 & $\begin{array}{l}\mathrm{S} \\
\mathrm{N} \\
\mathrm{N}\end{array}$ & $\begin{array}{rrl}44 & I 4 & \mathrm{E} \\
48 & 55 & \mathrm{E} \\
\mathrm{I} & 04 & \mathrm{E}\end{array}$ & $\begin{array}{l}\mathrm{N} \\
\mathrm{S} \\
\mathrm{S}\end{array}$ & $\begin{array}{rll}44 & \mathrm{I} 4 & \mathrm{~W} \\
48 & 56 & \mathrm{~W} \\
\mathrm{I} & 04 & \mathrm{~W}\end{array}$ & $\begin{array}{l}I, 94 x \\
3,363 \\
4,497\end{array}$ & $\begin{array}{l}\text { Muddy. } \\
\text { Narrows Point. } \\
\text { Wickes Beach. }\end{array}$ \\
\hline 3 & $3^{8}$ & 59 & 49. I0 & 76 & 14 & 48. $4 \mathrm{I}$ & $\begin{array}{l}\mathrm{S} \\
\mathrm{N} \\
\mathrm{N}\end{array}$ & $\begin{array}{rrr}3^{8} & 34 & \mathrm{E} \\
6 \mathrm{I} & 37 & \mathrm{E} \\
5 & 42 & \mathrm{E}\end{array}$ & $\begin{array}{l}\mathrm{N} \\
\mathrm{S} \\
\mathrm{S}\end{array}$ & $\begin{array}{rrr}3^{8} & 33 & W \\
6 r & 38 & W \\
5 & 42 & W\end{array}$ & $\begin{array}{l}2,649 \\
3,218 \\
3,834\end{array}$ & $\begin{array}{l}\text { Muddy. } \\
\text { Narrows Point. } \\
\text { Wickes Beach. }\end{array}$ \\
\hline 4 & 39 & $\infty$ & 04.45 & 76 & 14 & 38.00 & $\stackrel{S}{N}$ & $\begin{array}{rll}28 & \text { or } & \mathrm{E} \\
68 & 25 & \mathrm{E} \\
\text { I } & 51 & \mathrm{E}\end{array}$ & $\begin{array}{l}\mathrm{N} \\
\mathrm{S} \\
\mathrm{S}\end{array}$ & $\begin{array}{rll}28 & 00 & W \\
68 & 26 & W \\
I & 51 & W\end{array}$ & $\begin{array}{l}2,932 \\
2,750 \\
3,299\end{array}$ & $\begin{array}{l}\text { Muddy. } \\
\text { Narrows Point. } \\
\text { Wickes Beach. }\end{array}$ \\
\hline 5 & $3^{8}$ & 592 & 2I. 24 & 76 & $I_{3}$ & I3. 75 & $\begin{array}{l}\mathrm{S} \\
\mathrm{S} \\
\mathrm{N}\end{array}$ & $\begin{array}{rll}36 & 36 & \mathrm{~W} \\
85 & \mathrm{I} 7 & \mathrm{E} \\
7 & 5 \mathrm{I} & \mathrm{E}\end{array}$ & $\begin{array}{l}\mathrm{N} \\
\mathrm{N} \\
\mathrm{S}\end{array}$ & $\begin{array}{rrl}36 & 36 & \mathrm{E} \\
85 & 16 & \mathrm{~W} \\
7 & 52 & \mathrm{~W}\end{array}$ & $\begin{array}{l}I, 410 \\
3,484 \\
2,492\end{array}$ & $\begin{array}{l}\text { Muddy. } \\
\text { Bluebeard. } \\
\text { Narrows Point. }\end{array}$ \\
\hline
\end{tabular}

\section{FLOOD POINT.}

(Chester River Entrance Kent Island Narrows-Chart No. 20.)

\begin{tabular}{|c|c|c|c|c|c|c|}
\hline I & $3^{8} \quad 5^{8} \quad 37.28$ & $76 \quad 14 \quad 44.20$ & $\begin{array}{llll}\mathrm{S} & 20 & 44 & \mathrm{~W} \\
\mathrm{~N} & 77 & 07 & \mathrm{E} \\
\mathrm{N} & 17 & 46 & \mathrm{E}\end{array}$ & $\begin{array}{llll}\mathrm{N} & 20 & 44 & \mathrm{E} \\
\mathrm{S} & 77 & 07 & \mathrm{~W} \\
\mathrm{~S} & \mathrm{I} 7 & 46 & \mathrm{~W}\end{array}$ & $\begin{array}{r}862 \\
I, 581 \\
420\end{array}$ & $\begin{array}{l}\text { Bridge. } \\
\text { Muddy. } \\
\text { Thin. }\end{array}$ \\
\hline 2 & $3^{8} 5^{8} 4^{2} \cdot 5^{2}$ & $76 \quad 14 \quad 47 \cdot 62$ & $\begin{array}{llll}\mathrm{S} & 12 & 20 & \mathrm{~W} \\
\mathrm{~N} & 83 & 50 & \mathrm{E} \\
\mathrm{N} & 44 & 2 \mathrm{I} & \mathrm{E}\end{array}$ & $\begin{array}{llll}\mathrm{N} & \mathrm{I} 2 & 20 & \mathrm{II} \\
\mathrm{S} & 83 & 5 \mathrm{I} & \mathrm{W} \\
\mathrm{S} & 44 & 2 \mathrm{I} & \mathrm{W}\end{array}$ & $\begin{array}{r}\mathrm{I}, 005 \\
\mathrm{I}, 640 \\
3 \mathrm{I} 2\end{array}$ & $\begin{array}{l}\text { Bridge. } \\
\text { Muddy. } \\
\text { Thin. }\end{array}$ \\
\hline & $\begin{array}{l}\text { Thence from } \\
\text { any creek, }\end{array}$ & $\begin{array}{l}\text { mer No. } 2 \text { alo } \\
\text { ve, or inlet le }\end{array}$ & $\begin{array}{l}\text { ng the mean lo } \\
\text { is than roo yar }\end{array}$ & $\begin{array}{l}\text { w-water line } \\
\text { ds in width at }\end{array}$ & $\begin{array}{l}\text { le shore } \\
\text { mouth }\end{array}$ & $\begin{array}{l}\text { to corner No. } 3 \text {, cxcludisig } \\
\text { tow tide. }\end{array}$ \\
\hline 3 & $3^{8} 5^{8} \quad 4^{8} .66$ & 76 I4 37.20 & $\begin{array}{llll}\mathrm{S} & 22 & 22 & \mathrm{~W} \\
\mathrm{~S} & \mathrm{I} & \mathrm{x} & \mathrm{E} \\
\mathrm{S} & 88 & 4 \mathrm{r} & \mathrm{E}\end{array}$ & $\begin{array}{llll}\mathrm{N} & 22 & 2 \mathrm{I} & \mathrm{E} \\
\mathrm{N} & \mathrm{I} & \mathrm{I} & \mathrm{W} \\
\mathrm{N} & 88 & 4 \mathrm{I} & \mathrm{W}\end{array}$ & $\begin{array}{l}I, 286 \\
I, 64 I \\
I, 357\end{array}$ & $\begin{array}{l}\text { Bridge. } \\
\text { Railroad. } \\
\text { Muddy. }\end{array}$ \\
\hline 4 & $3^{8} \quad 5^{8} \quad 4^{6.95}$ & $76 \mathrm{I} 430.6 \mathrm{I}$ & $\begin{array}{lrrr}\mathrm{S} & 30 & 21 & \mathrm{~W} \\
\mathrm{~S} & 7 & 32 & \mathrm{E} \\
\mathrm{N} & 88 & 43 & \mathrm{E}\end{array}$ & $\begin{array}{lrrr}\mathrm{N} & 30 & 21 & \mathrm{E} \\
\mathrm{N} & 7 & 32 & \mathrm{~W} \\
\mathrm{~S} & 88 & 43 & \mathrm{~W}\end{array}$ & $\begin{array}{l}\mathrm{I}, 3 \mathrm{II} \\
\mathrm{I}, 557 \\
\mathrm{I}, \mathrm{I} 84\end{array}$ & $\begin{array}{l}\text { Bridge. } \\
\text { Railroad. } \\
\text { Muddy. }\end{array}$ \\
\hline 5 & $3^{8} \quad 5^{8} \quad 39.02$ & $\begin{array}{llll}76 & 14 & 35.72\end{array}$ & $\begin{array}{llll}\mathrm{S} & 3 \mathbf{I} & 26 & \mathrm{~W} \\
\mathrm{~N} & 77 & 25 & \mathrm{E} \\
\mathrm{N} & \mathbf{1} & 34 & \mathrm{~W}\end{array}$ & $\begin{array}{llll}\mathrm{N} & 3 x & 26 & \mathrm{E} \\
\mathrm{S} & 77 & 26 & \mathrm{~W} \\
\mathrm{~S} & \mathrm{I} & 34 & \mathrm{E}\end{array}$ & $\begin{array}{r}I, \text { OI3 } \\
I, 35 I \\
354\end{array}$ & $\begin{array}{l}\text { Bridge. } \\
\text { Muddy. } \\
\text { Thin. }\end{array}$ \\
\hline
\end{tabular}




\section{BOUNDARIES OF NATURAL OYSTER BARS-continued.}

KEN'T ISLAND NARROWS.

(Kent Island Narrows-Chart No. 29.)

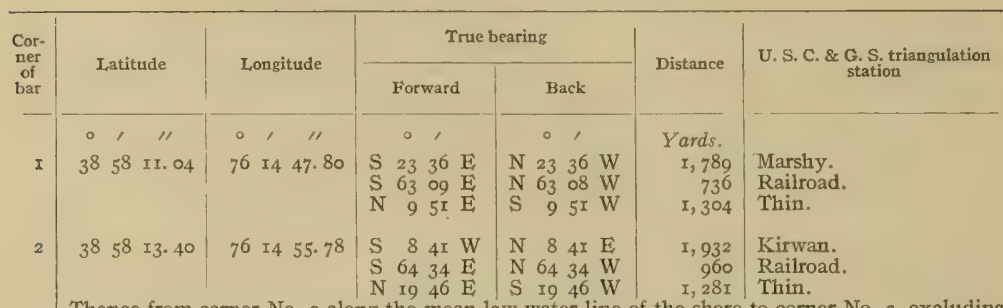

Thence from comer No. 2 along the mean low-water line of the shore to comer No. 3 , excluding any creek, cove, or inlet less than 100 yards in width at its mouth at low tide.

$3\left|3^{8} 5^{8} 4^{2 .} 5^{2}\right| 76 \quad 7447.62|\mathrm{~S} 1220 \mathrm{~W}| \mathrm{N}$ I2 $20 \mathrm{E}|\mathrm{I}, 005|$ Bridge.

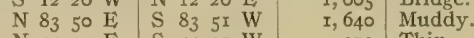

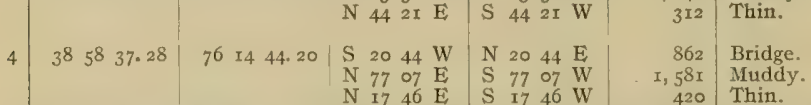

Thence from comer No. + along the mean low-water line of the shore to corner No. 1 , excluding any creek, cove, or inlet less than roo yards in width at its mouth at low tide.

\section{BLUNT.}

(Lower Chester River-Chart No. 3o.)

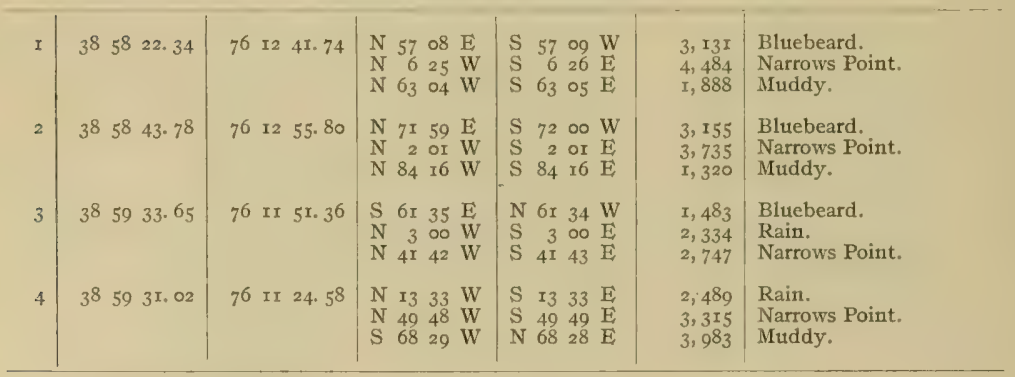


BOUNDARIES OF NATURAL OYSTER BARS-continued.

POPLAR.

(Lower Chester River-Chart No. 30.)

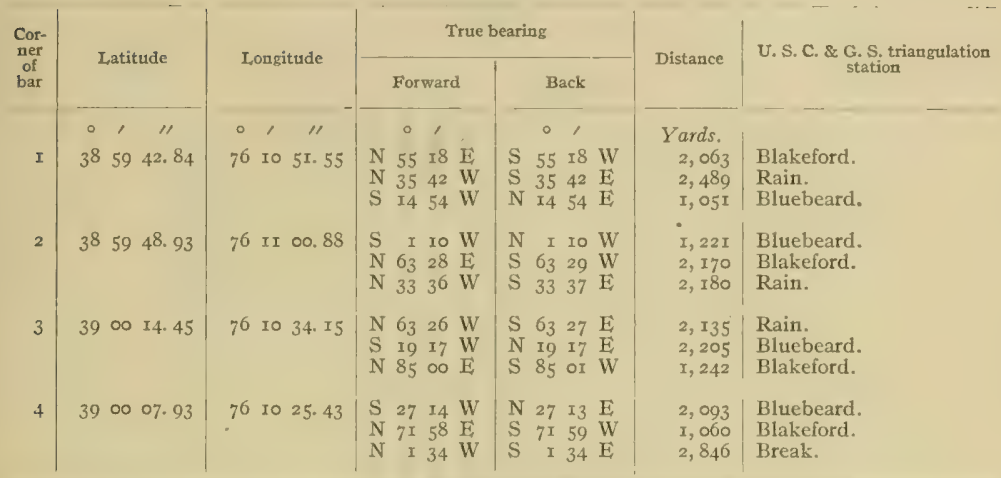

\section{CARPENTER ISIAND.}

(Middle Chester River-Chart No. 30.)

\begin{tabular}{|c|c|c|c|c|c|c|}
\hline I & 390033.76 & 76 xo 47.00 & $\begin{array}{llll}\mathrm{S} & 70 & 59 & \mathrm{E} \\
\mathrm{N} & 1_{3} & 56 & \mathrm{E} \\
\mathrm{N} & 79 & 04 & \mathrm{~W}\end{array}$ & 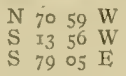 & $\begin{array}{l}I, 667 \\
2,033 \\
I, 600\end{array}$ & $\begin{array}{l}\text { Blakeford. } \\
\text { Break. } \\
\text { Rain. }\end{array}$ \\
\hline 2 & 39 or 12.05 & 76 II 10.98 & $\begin{array}{llll}\mathrm{N} & 51 & 13 & \mathrm{~W} \\
\mathrm{~S} & 43 & 37 & \mathrm{~W} \\
\mathrm{~S} & 50 & \mathrm{I} & \mathrm{E}\end{array}$ & $\begin{array}{llll}\mathrm{S} & 5 \mathrm{I} & \mathrm{I} 4 & \mathrm{E} \\
\mathrm{N} & 43 & 37 & \mathrm{E} \\
\mathrm{N} & 50 & \mathrm{I} & \mathrm{W}\end{array}$ & $\begin{array}{l}2,489 \\
1,365 \\
2,869\end{array}$ & $\begin{array}{l}\text { Overton. } \\
\text { Rain. } \\
\text { Blakeford. }\end{array}$ \\
\hline 3 & 39 or 08.78 & 76 10 30.30 & $\begin{array}{lrll}\mathrm{N} & 3 & 37 & \mathrm{E} \\
\mathrm{S} & 66 & 26 & \mathrm{~W} \\
\mathrm{~S} & 33 & 23 & \mathrm{E}\end{array}$ & $\begin{array}{lrll}\mathrm{S} & 3 & 37 & \mathrm{~W} \\
\mathrm{~N} & 66 & 25 & \mathrm{E} \\
\mathrm{N} & 33 & 23 & \mathrm{~W}\end{array}$ & $\begin{array}{r}794 \\
2,194 \\
2,065\end{array}$ & $\begin{array}{l}\text { Break. } \\
\text { Rain. } \\
\text { Blakeford. }\end{array}$ \\
\hline 4 & 39 or 07.33 & 76 Io II. 84 & $\begin{array}{llll}\mathrm{N} & 27 & 23 & \mathrm{~W} \\
\mathrm{~S} & 7 \mathrm{I} & 39 & \mathrm{~W} \\
\mathrm{~S} & 2 \mathrm{I} & \mathrm{I} & \mathrm{E}\end{array}$ & $\begin{array}{llll}\mathrm{S} & 27 & 23 & \mathrm{E} \\
\mathrm{N} & 7 \mathrm{I} & 38 & \mathrm{E} \\
\mathrm{N} & 2 \mathrm{I} & \mathrm{I}_{3} & \mathrm{~W}\end{array}$ & $\begin{array}{r}947 \\
2,630 \\
\mathrm{I}, 797\end{array}$ & $\begin{array}{l}\text { Break. } \\
\text { Rain. } \\
\text { Blakeford. }\end{array}$ \\
\hline 5 & $39 \infty 0 \quad 36.84$ & 76 10 02.42 & $\begin{array}{llll}\mathrm{N} & 20 & 05 & \mathrm{~W} \\
\mathrm{~N} & 85 & 50 & \mathrm{~W} \\
\mathrm{~S} & 3 \mathrm{I} & 54 & \mathrm{E}\end{array}$ & $\begin{array}{llll}\mathrm{S} & 20 & 05 & \mathrm{E} \\
\mathrm{S} & 85 & 5 \mathrm{I} & \mathrm{E} \\
\mathrm{N} & 3 \mathrm{I} & 54 & \mathrm{~W}\end{array}$ & $\begin{array}{r}1,990 \\
2,752 \\
762\end{array}$ & $\begin{array}{l}\text { Break. } \\
\text { Rain. } \\
\text { Blakeford. }\end{array}$ \\
\hline
\end{tabular}


BOUNDARIES OF NATURAL OYSTER BARS-continUCd.

HORSE RACE.

(Middle Chester River-Chart No, 30.)

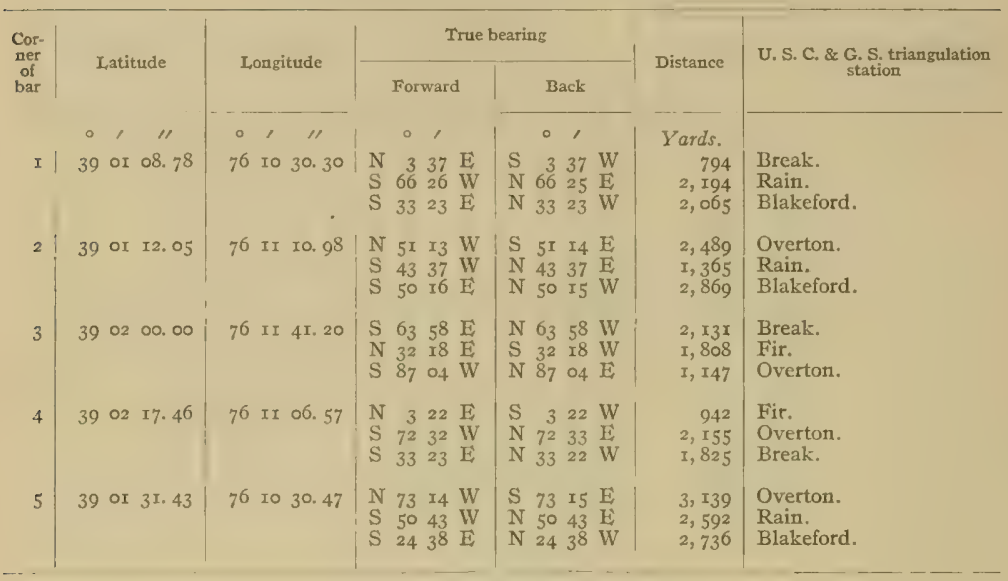

\section{PINEY POINT (QUEEN ANNES COUNTY).}

(Middle Chester River-Chart No. 3o.)

\begin{tabular}{|c|c|c|c|c|c|c|c|c|c|c|c|}
\hline I & 39 & 02 & $\begin{array}{l}00.00 \\
\text { Then }\end{array}$ & $\cdot 76$ & & $\begin{array}{l}\text { 4I. } 20 \\
\text { county }\end{array}$ & $\begin{array}{l}\mathrm{S} \\
\mathrm{N} \\
\mathrm{S} \\
\mathrm{bo}\end{array}$ & $\begin{array}{ccc}63 & 58 & \mathrm{E} \\
32 & \mathrm{I} & \mathrm{E} \\
87 & 04 \mathrm{~W} \\
\text { undary as }\end{array}$ & $\begin{array}{llll}\mathrm{N} 63 & 58 & \mathrm{~W} \\
\mathrm{~S} & 32 & \mathrm{r} 8 & \mathrm{~W} \\
\mathrm{~N} & 8 y & 04 & \mathrm{E} \\
\text { elineated by }\end{array}$ & $\begin{array}{r}\begin{array}{r}2, I 3 I \\
I, 808 \\
I, I 47\end{array} \\
\text { Chart No. 3 }\end{array}$ & $\begin{array}{l}\text { Break. } \\
\text { Fir. } \\
\text { Overton. } \\
\text { to Comer No. } 2 .\end{array}$ \\
\hline 2 & 39 & 03 & I8. 25 & 76 & II & $43.7^{6}$ & $\begin{array}{l}\mathrm{S} \\
\mathrm{S} \\
\mathrm{N}\end{array}$ & $\begin{array}{lll}2 \mathrm{I} & 47 & \mathrm{~W} \\
42 & 56 & \mathrm{E} \\
8 \mathrm{I} & 22 & \mathrm{E}\end{array}$ & $\begin{array}{llll}N & 2 I & 46 & \mathrm{E} \\
\mathrm{N} & 42 & 56 & \mathrm{~W} \\
\mathrm{~S} & 8 \mathrm{I} & 23 & \mathrm{~W}\end{array}$ & $\begin{array}{l}2,905 \\
1,517 \\
1,697\end{array}$ & $\begin{array}{l}\text { Overton. } \\
\text { Fir. } \\
\text { Gordon. }\end{array}$ \\
\hline 3 & 39 & 02 & 59.93 & 76 & II & 14.07 & $\begin{array}{l}\mathrm{S} \\
\mathrm{N} \\
\mathrm{N}\end{array}$ & $\begin{array}{lll}27 & 08 & E \\
45 & 49 & E \\
65 & I 2 & W\end{array}$ & $\begin{array}{llll}N & 27 & 08 & W \\
S & 45 & 49 & W \\
S & 65 & \text { I2 } & E\end{array}$ & $\begin{array}{r}555 \\
I, 25 I \\
2,234\end{array}$ & $\begin{array}{l}\text { Fir. } \\
\text { Gordon. } \\
\text { Bay Bush Point. }\end{array}$ \\
\hline 4 & 39 & $\mathrm{O} 2$ & 4 I. 86 & 76 & I I & $25 \cdot 76$ & $\begin{array}{l}\mathrm{S} \\
\mathrm{N} \\
\mathrm{N}\end{array}$ & $\begin{array}{lll}32 & 45 & \mathrm{E} \\
78 & \mathrm{I} & \mathrm{E} \\
39 & 07 & \mathrm{E}\end{array}$ & $\begin{array}{llll}N & 32 & 44 & W \\
S & 78 & 14 & W \\
S & 39 & 07 & W\end{array}$ & $\begin{array}{r}2,790 \\
572 \\
I, 914\end{array}$ & $\begin{array}{l}\text { Break. } \\
\text { Fir. } \\
\text { Gordon. }\end{array}$ \\
\hline 5 & 39 & 02 & I7. 46 & 76 & II & o6. 57 & $\begin{array}{l}\mathrm{N} \\
\mathrm{S} \\
\mathrm{S}\end{array}$ & $\begin{array}{ccc}3 & 22 & E \\
72 & 32 & W \\
33 & 23 & E\end{array}$ & $\begin{array}{lrrl}\mathrm{S} & 3 & 22 & \mathrm{~W} \\
\mathrm{~N} & 72 & 33 & \mathrm{E} \\
\mathrm{N} & 33 & 22 & \mathrm{~W}\end{array}$ & $\begin{array}{r}942 \\
2,155 \\
1,825\end{array}$ & $\begin{array}{l}\text { Fir. } \\
\text { Overton. } \\
\text { Break. }\end{array}$ \\
\hline
\end{tabular}


BOUNDARIES OF NATURAI, OYSTIGR BARS- contintIEd.

HELLS DELIGH'T.

(Middle Chester River-Chart No. 3o.)

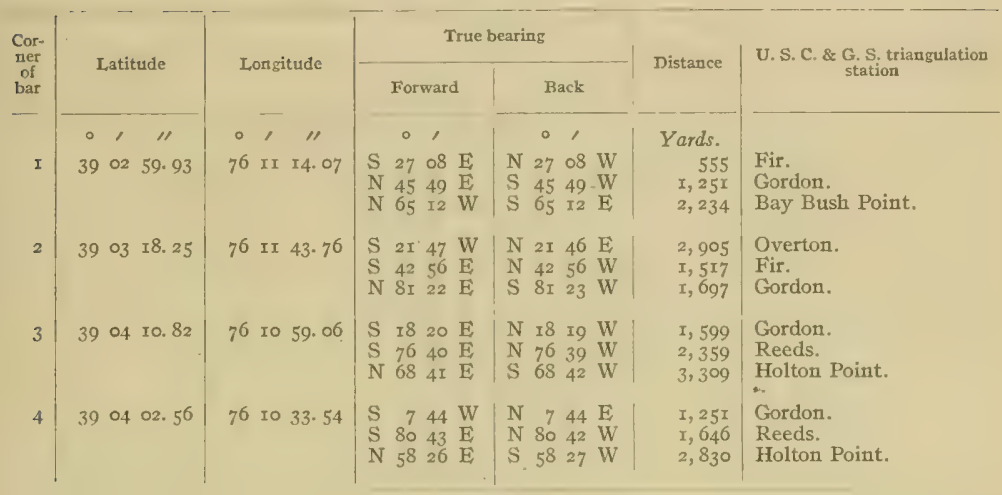

REEDS.

(Reed's Creek-Chart No. 30.)

\begin{tabular}{|c|c|c|c|c|c|c|}
\hline$x$ & $\begin{array}{lll}39 & 03 & 30.37\end{array}$ & 760942.66 & $\begin{array}{llll}\mathrm{N} & \text { ig } & \text { I7 } & \mathrm{E} \\
\mathrm{N} & 48 & 32 & \mathrm{~W} \\
\mathrm{~S} & 31 & 00 & \mathrm{~W}\end{array}$ & $\mid \begin{array}{llll}\mathrm{S} & \text { 19 } & \text { I7 } & \mathrm{W} \\
\mathrm{S} & 48 & 32 & \mathrm{E} \\
\mathrm{N} & 3 \mathrm{I} & 00 & \mathrm{E}\end{array}$ & $\begin{array}{l}868 \\
636 \\
105\end{array}$ & $\begin{array}{l}\text { Reeds. } \\
\text { Bird. } \\
\text { Grove. }\end{array}$ \\
\hline & $\begin{array}{lll}39 & 03 & 36.60\end{array}$ & $76 \circ 99.85$ & $\begin{array}{llll}\mathrm{S} & 24 & \text { I6 } & \mathrm{E} \\
\mathrm{N} & 37 & 58 & \mathrm{E} \\
\mathrm{N} & 53 & 45 & \mathrm{~W}\end{array}$ & $\begin{array}{llll}\mathrm{N} & 24 & 16 & \mathrm{~W} \\
\mathrm{~S} & 37 & 58 & \mathrm{~W} \\
\mathrm{~S} & 53 & 44 & \mathrm{E}\end{array}$ & $\begin{array}{l}328 \\
773 \\
357\end{array}$ & $\begin{array}{l}\text { Grove. } \\
\text { Reeds. } \\
\text { Bird. }\end{array}$ \\
\hline & $3903 \quad 38.95$ & $76 \circ 934.6 x$ & $\begin{array}{lrrr}\mathrm{N} & 8 & \text { o } & \mathrm{E} \\
\mathrm{N} & 79 & \text { og } & \mathrm{W} \\
\mathrm{S} & 35 & \text { or } & \mathrm{W}\end{array}$ & $\begin{array}{rrrr}\mathrm{S} & 8 & \text { o4 } & \mathrm{W} \\
\mathrm{S} & 79 & \text { Io } & \mathrm{E} \\
\mathrm{N} & 35 & \text { or } & \mathrm{E}\end{array}$ & $\begin{array}{l}536 \\
701 \\
463\end{array}$ & $\begin{array}{l}\text { Reeds. } \\
\text { Bird. } \\
\text { Grove. }\end{array}$ \\
\hline
\end{tabular}

\section{ROBINS COVE.}

(Middle Chester River-Chart No. 30.)

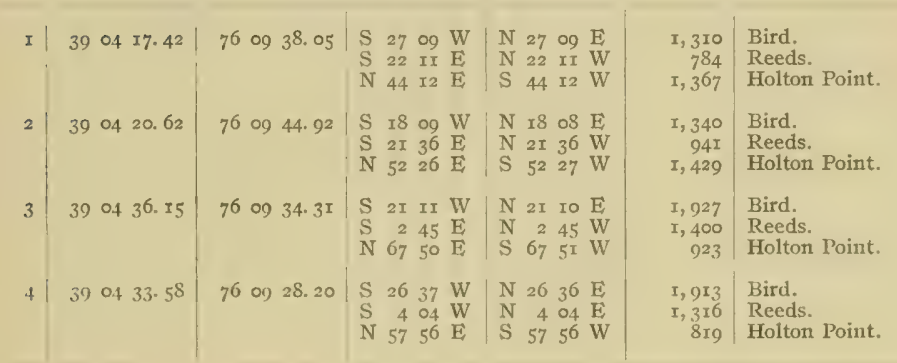


BOUNDARIES OF NATURAL OYSTER BARS-continued.

OLD FIELD.

(Middle Chester River-Chart No. 3o.)

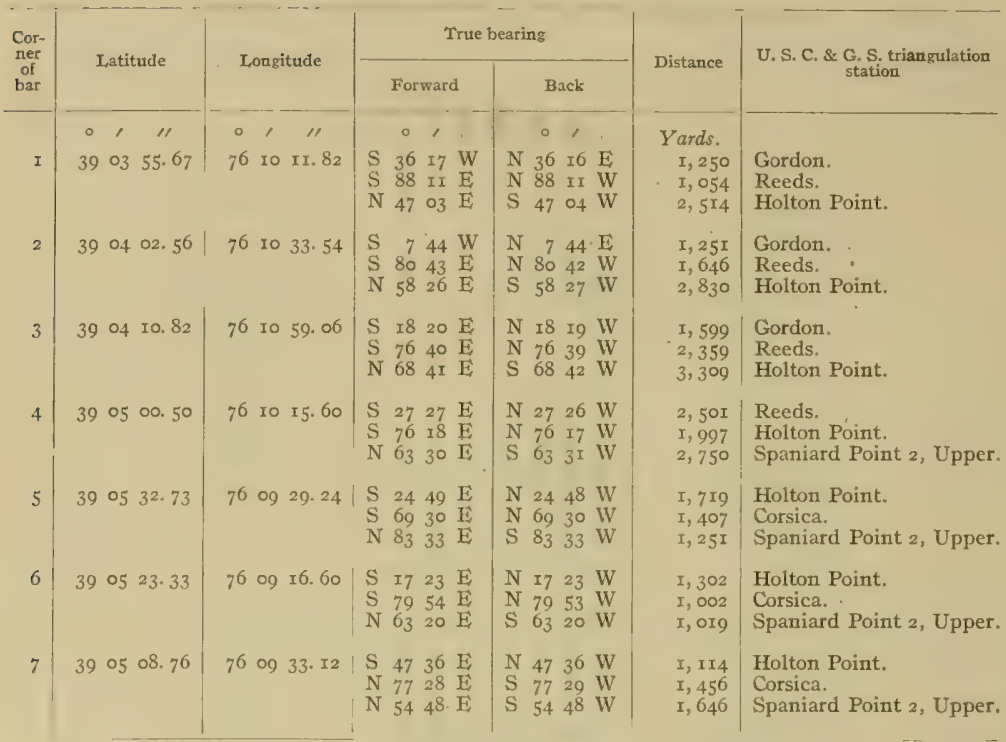

HOLTON POINT.

(Entrance Corsica River-Chart No. 30.)

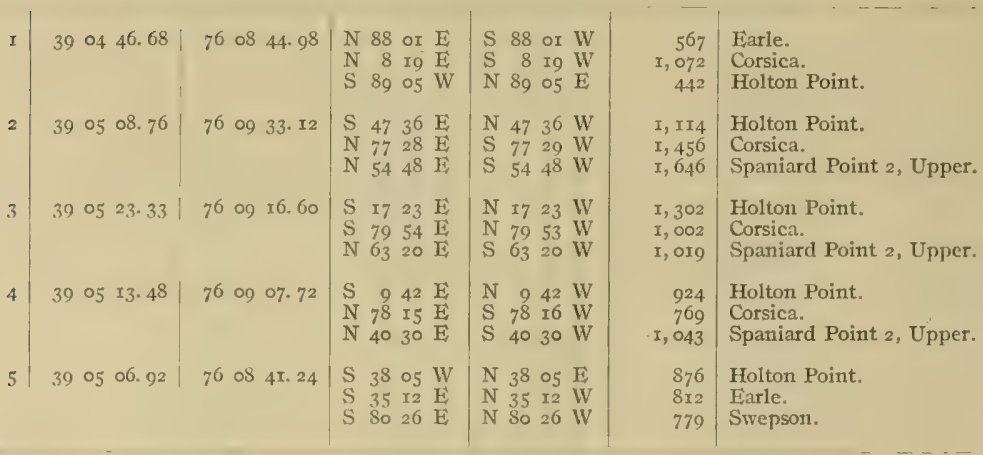


BOUNDARIES OF NATURAL OYSTER BARS-continued.

TOWN POINT.

(Corsica River-Chart No. 30.)

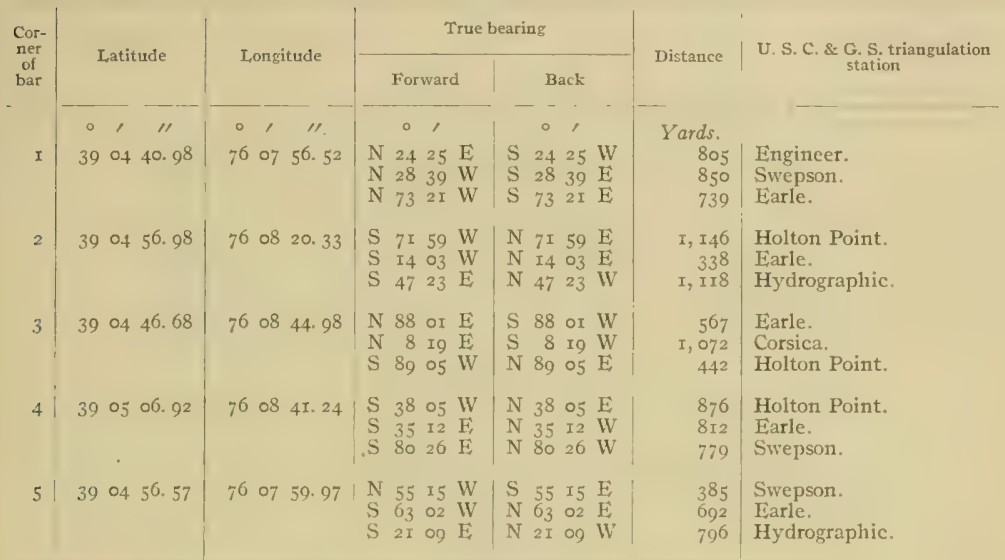

\section{ENIORY WHARF.}

(Corsica River-Chart No. 30.)

\begin{tabular}{|c|c|c|c|c|c|c|}
\hline$I$ & $390.4 \quad 40.98$ & $760756.5^{2}$ & $\begin{array}{llll}\mathrm{N}_{2} & 24 & 25 & \mathrm{E} \\
\mathrm{N} & 28 & 39 & \mathrm{~W} \\
\mathrm{~N} & 73 & 2 \mathrm{I} & \mathrm{W}\end{array}$ & $\begin{array}{llll}\mathrm{S} & 24 & 25 & \mathrm{~W} \\
\mathrm{~S} & 28 & 39 & \mathrm{E} \\
\mathrm{S} & 73 & 2 \mathrm{I} & \mathrm{E}\end{array}$ & $\begin{array}{l}805 \\
850 \\
739\end{array}$ & $\begin{array}{l}\text { Engineer. } \\
\text { Swepson. } \\
\text { Earle. }\end{array}$ \\
\hline & $3904 \quad 56.57$ & 76 o7 59.97 & $\begin{array}{llll}N & 55 & 15 & W \\
\mathrm{~S} & 63 & 02 & W \\
\mathrm{~S} & 2 \mathrm{I} & 09 & \mathrm{E}\end{array}$ & $\mid \begin{array}{llll}\mathrm{S} & 55 & x_{5} & \mathrm{E} \\
\mathrm{N} & 63 & 02 & \mathrm{E} \\
\mathrm{N} & 21 & 99 & \mathrm{~W}\end{array}$ & $\begin{array}{l}385 \\
692 \\
796\end{array}$ & $\begin{array}{l}\text { Swepson. } \\
\text { Earle. } \\
\text { Hydrographic. }\end{array}$ \\
\hline 3 & $390449.4 \mathrm{I}$ & $7^{6}$ o7 31.24 & $\begin{array}{llll}\mathrm{N} & 36 & 29 & \mathrm{~W} \\
\mathrm{~S} & 43 & \text { oI } & \mathrm{W} \\
\mathrm{S} & 23 & 45 & \mathrm{E}\end{array}$ & $\mid \begin{array}{llll}\mathrm{S} & 36 & 29 & \mathrm{E} \\
\mathrm{N} & 43 & \text { oI } & \mathrm{E} \\
\mathrm{N} & 23 & 45 & \mathrm{~W}\end{array}$ & $\begin{array}{l}558 \\
686 \\
657\end{array}$ & $\begin{array}{l}\text { Engineer. } \\
\text { Hydrographic. } \\
\text { Ruth. }\end{array}$ \\
\hline
\end{tabular}


BOUNDARIES OF NATURAI, OYSTER BARS-continUEC.

EARLE COVF.

(Corsica River-Chart No. 3o.)

\begin{tabular}{|c|c|c|c|c|c|c|c|c|c|}
\hline \multirow{2}{*}{$\begin{array}{l}\text { Cor- } \\
\text { ner } \\
\text { of } \\
\text { bar }\end{array}$} & \multirow{2}{*}{\multicolumn{2}{|c|}{ Iatitucle }} & \multirow{2}{*}{ Longitude } & \multicolumn{4}{|c|}{ True bearing } & \multirow{2}{*}{ Distance } & \multirow{2}{*}{$\begin{array}{c}\text { U. S. C. \& G. S. triangulation } \\
\text { station }\end{array}$} \\
\hline & & & & & rwward & & IBack & & \\
\hline$I$ & & $\begin{array}{c}\prime \prime \\
04 \\
29.18\end{array}$ & $\begin{array}{ccc}0 & \prime & \prime \prime \\
76 & 08 & 04.65\end{array}$ & $\begin{array}{lr} & 0 \\
\mathrm{~N} & 66 \\
\mathrm{~N} & 9 \\
\mathrm{~N} & 28\end{array}$ & $\begin{array}{l}\mathrm{I} 4 \mathrm{E} \\
36 \mathrm{~W} \\
44 \mathrm{~W}\end{array}$ & $\begin{array}{lr} & a \\
\text { S } & 66 \\
\text { S } & 9 \\
\text { S } & 28\end{array}$ & $\begin{array}{lll}6 & \text { I4 } & \text { W } \\
9 & 36 & \mathrm{E} \\
8 & 45 & \mathrm{E}\end{array}$ & $\begin{array}{r}\text { Yards. } \\
448 \\
\text { I, I59 } \\
\text { I, } 882\end{array}$ & $\begin{array}{l}\text { Hydrographic. } \\
\text { Swepson. } \\
\text { Corsica. }\end{array}$ \\
\hline 2 & 39 & 0433.48 & $\begin{array}{llll}76 & 08 & \circ & \circ .74\end{array}$ & $\begin{array}{lr}N & 86 \\
N & 3 \\
N & 27\end{array}$ & $\begin{array}{ll}14 & \mathrm{E} \\
25 & \mathrm{~W} \\
04 \mathrm{~W}\end{array}$ & $\begin{array}{lr}\text { S } & 86 \\
\text { S } & 3 \\
\text { S } & 27\end{array}$ & $\begin{array}{lll}6 & x_{5} & \mathrm{~W} \\
3 & 25 & \mathrm{E} \\
7 & 05 & \mathrm{E}\end{array}$ & $\begin{array}{r}545 \\
I, 001 \\
I, 694\end{array}$ & $\begin{array}{l}\text { Hydrographic. } \\
\text { Swepson. } \\
\text { Corsica. }\end{array}$ \\
\hline 3 & 39 & 0437.95 & 76 o8 or. $7^{2}$ & $\begin{array}{ll}N & 29 \\
N & 17 \\
N & 6 I\end{array}$ & $\begin{array}{ll}2 I & \mathrm{E} \\
42 & \mathrm{~W} \\
\text { I2 } & W\end{array}$ & $\begin{array}{ll}\mathrm{S} & 29 \\
\mathrm{~S} & \mathrm{I} 7 \\
\mathrm{~S} & 6 \mathrm{r}\end{array}$ & $\begin{array}{lll}9 & 2 \mathrm{I} & W \\
7 & 42 & \mathrm{E} \\
\mathrm{I} & \mathrm{I} 2 & \mathrm{E}\end{array}$ & $\begin{array}{l}95^{8} \\
889 \\
65^{2}\end{array}$ & $\begin{array}{l}\text { Engineer. } \\
\text { Swepson. } \\
\text { Earle. }\end{array}$ \\
\hline 4 & & 0432.82 & 760758.16 & $\begin{array}{ll}\mathbf{N} & 20 \\
\mathbf{N} & 19 \\
\mathbf{N} & 53\end{array}$ & $\begin{array}{l}27 \mathrm{E} \\
38 \mathrm{~W} \\
47 \mathrm{~W}\end{array}$ & $\begin{array}{ll}\mathrm{S} & 20 \\
\mathrm{~S} & 19 \\
\mathrm{~S} & 53\end{array}$ & $\begin{array}{lll}0 & 27 & \mathrm{~W} \\
9 & 38 & \mathrm{E} \\
3 & 47 & \mathrm{E}\end{array}$ & $\begin{array}{r}x, 075 \\
I, 084 \\
823\end{array}$ & $\begin{array}{l}\text { Engineer. } \\
\text { Swepson. } \\
\text { Earle. }\end{array}$ \\
\hline
\end{tabular}

Thence from corner No. 4 along the mean low water line of the shore to comer No. I, excluding any creek, cove, or inlet less than roo yards in width at its mouth at low tide

\section{SHIP POINT.}

(Corsica River-Chart No. 3o.)

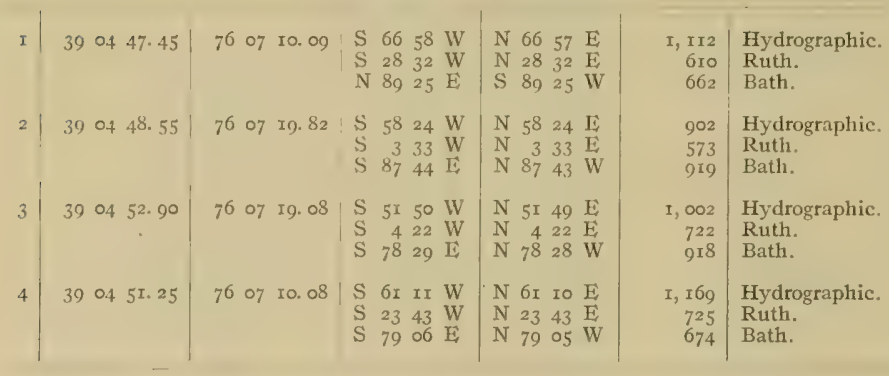


BOUNDARIES OF NATURAT, OYSTER BARS-cOntintIER.

\section{POSSUM POINT.}

(Corsica River-Charl No. 30.)

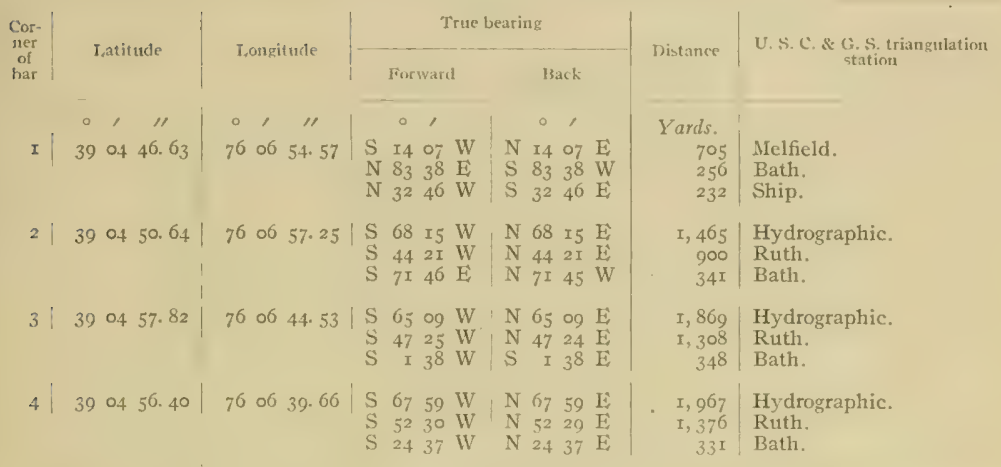

\section{SPANIARD POINT.}

(Middle Chester River-Chart No. 30.)

\begin{tabular}{|c|c|c|c|c|c|c|c|c|c|}
\hline \multirow[b]{2}{*}{ I } & \multirow[b]{2}{*}{$39 \mathrm{c}$} & \multirow[b]{2}{*}{0523.33} & \multirow{2}{*}{\multicolumn{2}{|c|}{76 og 16.60}} & \multirow{2}{*}{\multicolumn{2}{|c|}{$\begin{array}{llll}\mathrm{S} & \mathrm{I} 7 & 23 & \mathrm{E} \\
\mathrm{S} & 79 & 54 & \mathrm{E} \\
\mathrm{N} & 63 & 20 & \mathrm{E}\end{array}$}} & & \multirow[b]{2}{*}{$\begin{array}{l}\text { Holton Point. } \\
\text { Corsica. } \\
\text { Spaniard Point 2, Upper. }\end{array}$} \\
\hline & & & & & & & $\begin{array}{llll}\mathrm{N} & 17 & 23 & \mathrm{~W} \\
\mathrm{~N} & 79 & 53 & \mathrm{~W} \\
\mathrm{~S} & 63 & 20 & \mathrm{~W}\end{array}$ & $\begin{array}{l}I, 302 \\
1,002 \\
I, 019\end{array}$ & \\
\hline 2 & 39 & 0532.73 & 7609 & 29.24 & $\begin{array}{ll}\mathrm{S} & 24 \\
\mathrm{~S} & 60 \\
\mathrm{~N} & 83\end{array}$ & $\begin{array}{ll}49 & \mathrm{E} \\
30 & \mathrm{E} \\
33 \mathrm{E}\end{array}$ & $\begin{array}{llll}\mathrm{N} & 24 & 48 & \mathrm{~W} \\
\mathrm{~N} & 69 & 30 & \mathrm{~W} \\
\mathrm{~S} & 83 & 33 & \mathrm{~W}\end{array}$ & $\begin{array}{l}\mathrm{I}, 719 \\
\mathrm{I}, 407 \\
\mathrm{I}, 25 \mathrm{I}\end{array}$ & $\begin{array}{l}\text { Holton Point. } \\
\text { Corsica. } \\
\text { Spaniard Point 2, Upper. }\end{array}$ \\
\hline 3 & 39 & $0553.20 !$ & 7609 & 05.65 & $\begin{array}{l}\mathrm{S} 30 \\
\mathrm{~S} \\
\mathrm{~N} \\
\mathrm{~N}\end{array}$ & $\begin{array}{l}33 \mathrm{E} \\
35 \mathrm{E} \\
20 \mathrm{E}\end{array}$ & $\begin{array}{llll}\mathrm{N} & 30 & 34 & \mathrm{~W} \\
\mathrm{~N} & 48 & 35 & \mathrm{WV} \\
\mathrm{S} & 32 & 20 & \mathrm{~W}\end{array}$ & $\begin{array}{r}\mathrm{I}, 374 \\
83 \mathrm{I} \\
\mathrm{I}, 067\end{array}$ & ard Point 2, Upper. \\
\hline 4 & 39 & 0605.75 & 76 o8 & I6. 82 & $\begin{array}{ll}\mathrm{S} & 67 \\
\mathrm{~N} & 62 \\
\mathrm{~N} & 56\end{array}$ & $\begin{array}{ll}57 & \mathrm{E} \\
55 & \mathrm{E} \\
06 & \mathrm{~W}\end{array}$ & $\begin{array}{llll}\mathrm{N} & 67 & 56 & \mathrm{~W} \\
\mathrm{~S} & 62 & 56 & \mathrm{~W} \\
\mathrm{~S} & 56 & 07 & \mathrm{E}\end{array}$ & $\begin{array}{l}\mathbf{I}, 554 \\
\mathbf{I} ; 988 \\
857\end{array}$ & Point 2. \\
\hline 5 & 39 & 0600.63 | & 7608 & I4. 36 & $\begin{array}{l}\text { S } 73 \\
\text { N } 57 \\
N \\
\text { No }\end{array}$ & $\begin{array}{ll}22 & \mathrm{E} \\
43 & \mathrm{E} \\
\mathrm{O} 2 & \mathrm{~W}\end{array}$ & $\begin{array}{llll}\mathrm{N} & 73 & 2 \mathrm{I} & \mathrm{W} \\
\mathrm{S} & 57 & 43 & \mathrm{~W} \\
\mathrm{~S} & 50 & 02 & \mathrm{E}\end{array}$ & $\begin{array}{l}\mathrm{I}, 436 \\
2,017 \\
\mathrm{I}, \text { OI } 4\end{array}$ & $\begin{array}{l}\text { Chester. } \\
\text { Deep Point } 2 . \\
\text { Brown. }\end{array}$ \\
\hline 6 & 39 & 0546.26 & 76 o8 & 49.00 & $\begin{array}{lr}\mathrm{S} & 30 \\
\mathrm{~N} & 73 \\
\mathrm{~N} & 6\end{array}$ & $\begin{array}{ll}27 & \mathrm{E} \\
03 & \mathrm{E} \\
4 \mathrm{r} & \mathrm{E}\end{array}$ & $\begin{array}{lrrr}\mathrm{N} & 30 & 27 & \mathrm{~W} \\
\mathrm{~S} & 73 & 04 & \mathrm{~W} \\
\mathrm{~S} & 6 & 4 I & \mathrm{~W}\end{array}$ & $\begin{array}{r}366 \\
\mathrm{I}, 025 \\
\mathrm{I}, \mathrm{I} 44\end{array}$ & $\begin{array}{l}\text { Spaniard Point 2, Upper. } \\
\text { Evans. } \\
\text { Brown. }\end{array}$ \\
\hline
\end{tabular}


BOUNDARIES OF NATURAL OYSTER BARS-continued.

EMORY HOLLOW.

(Middle Chester River-Chart No. 30.)

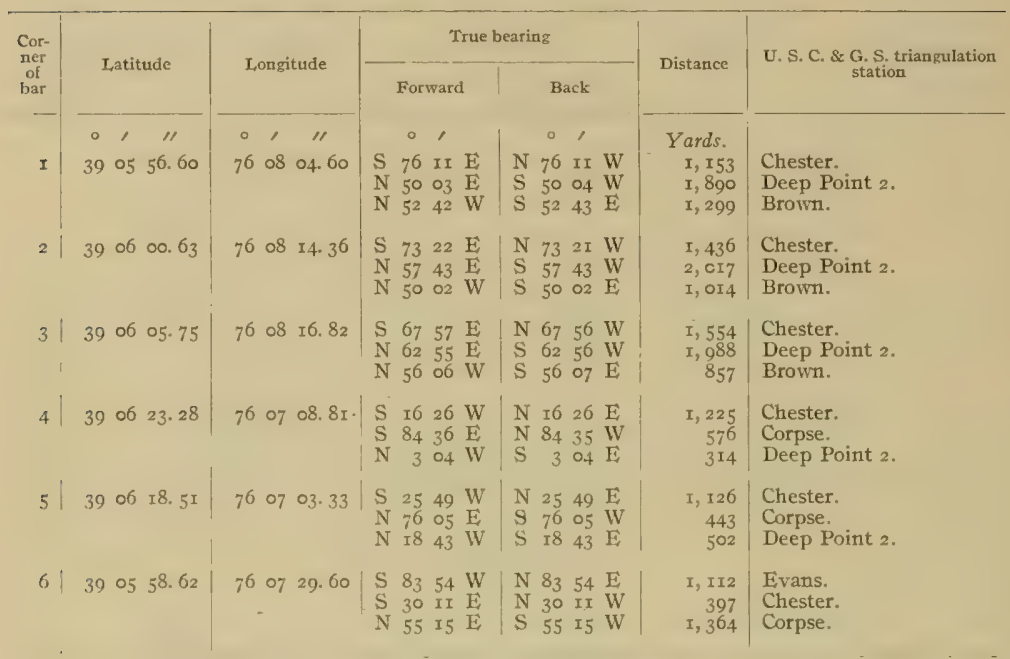

SHEEP (QUEEN ANNES COUNTY).

(Middle Chester River-Chart No. 30.)

\begin{tabular}{|c|c|c|c|c|c|c|}
\hline I & 39 of $18.5^{\mathrm{I}}$ । & $\begin{array}{llll}76 & 07 & 03.33\end{array}$ & $\begin{array}{llll}\mathrm{S} & 25 & 49 & \mathrm{~W} \\
\mathrm{~N} & 76 & 05 & \mathrm{E} \\
\mathrm{N} & \mathbf{1 8} & 43 & \mathrm{~W}\end{array}$ & $\begin{array}{llll}\mathrm{N} & 25 & 49 & \mathrm{E} \\
\mathrm{S} & 76 & 05 & \mathrm{~W} \\
\mathrm{~S} & \mathrm{I} & 43 & \mathrm{E}\end{array}$ & $\begin{array}{r}\text { I, } 126 \\
443 \\
502\end{array}$ & $\begin{array}{l}\text { Chester. } \\
\text { Corpse. } \\
\text { Deep Point } 2 .\end{array}$ \\
\hline 2 & $\begin{array}{llll}39 & 06 & 23.28\end{array}$ & 76 o7 os. $8 \mathrm{r}$ & $\begin{array}{lrrr}\mathrm{S} & \mathbf{1} 6 & 26 \mathrm{~W} \\
\mathrm{~S} & 84 & 36 & \mathrm{E} \\
\mathrm{N} & 3 & 04 & \mathrm{~W}\end{array}$ & $\mid \begin{array}{llll}\mathrm{N} & 16 & 26 & \mathrm{E} \\
\mathrm{N} & 84 & 36 & \mathrm{~W} \\
\mathrm{~S} & 3 & 04 & \mathrm{E}\end{array}$ & $\begin{array}{r}\mathrm{x}, 225 \\
576 \\
314\end{array}$ & $\begin{array}{l}\text { Chester. } \\
\text { Corpse. } \\
\text { Deep Point } 2 .\end{array}$ \\
\hline 3 & $3906 \quad 34.74$ & $7606 \quad 47.60$ & $\begin{array}{llll}\mathrm{S} & 2 & 09 & \mathrm{E} \\
\mathrm{N} & 59 & \mathrm{I}_{3} & \mathrm{E} \\
\mathrm{N} & \mathbf{I} & \mathrm{Ig} & \mathrm{E}\end{array}$ & $\mid \begin{array}{llll}\mathrm{N} & 2 & 09 & \mathrm{~W} \\
\mathrm{~S} & 59 & 13 & \mathrm{~W} \\
\mathrm{~S} & 14 & 20 & \mathrm{~W}\end{array}$ & $\begin{array}{l}44 \mathrm{I} \\
794 \\
900\end{array}$ & $\begin{array}{l}\text { Corpse. } \\
\text { Indian. } \\
\text { Thom. }\end{array}$ \\
\hline 4 & $\begin{array}{llll}39 & 06 & 32.37\end{array}$ & 76 o6 45.00 & $\begin{array}{llll}N & 51 & 37 & E \\
N & 9 & 12 & E \\
N & 89 & 20 & W\end{array}$ & $\begin{array}{llll}\mathrm{S} & 5 \mathrm{I} & 37 & \mathrm{~W} \\
\mathrm{~S} & 9 & \mathrm{I} & \mathrm{W} \\
\mathrm{S} & 89 & 2 \mathrm{I} & \mathrm{E}\end{array}$ & $\begin{array}{l}783 \\
965 \\
643\end{array}$ & $\begin{array}{l}\text { Indian. } \\
\text { Thorn. } \\
\text { Deep Point } 2 .\end{array}$ \\
\hline
\end{tabular}


BOUNDARIES OF NATURAL OYSTER BARS - continued.

MUMMYY COVI:

(Middle Chester River-Chart No. 30.)

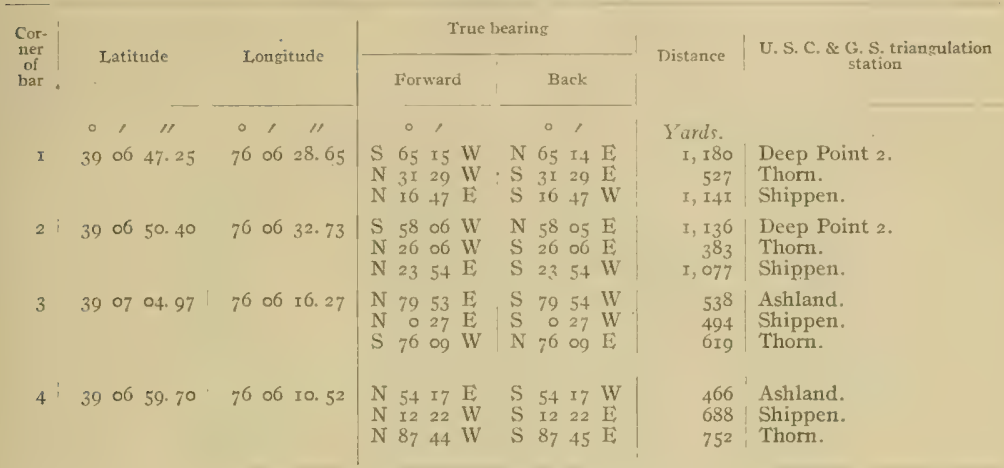

HOLLYDAY (QUEEN ANNES COUNTY).

(Middle Chester River-Chart No. 3o.)

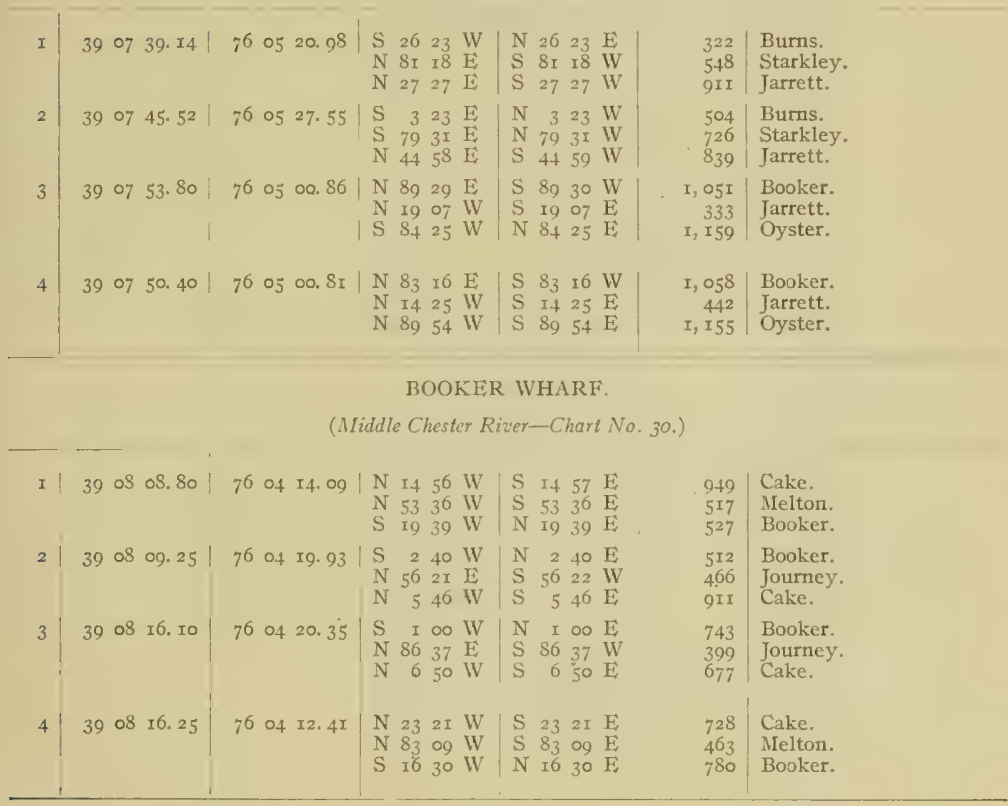

$203 I_{3}-I_{2}-9$ 
BOUNDARIES OF NATURAL OYSTER BARS- continUed.

NORTHWEST (QUEEN ANNES COUNTY).

(Middle Chester River-Chart No. 30.)

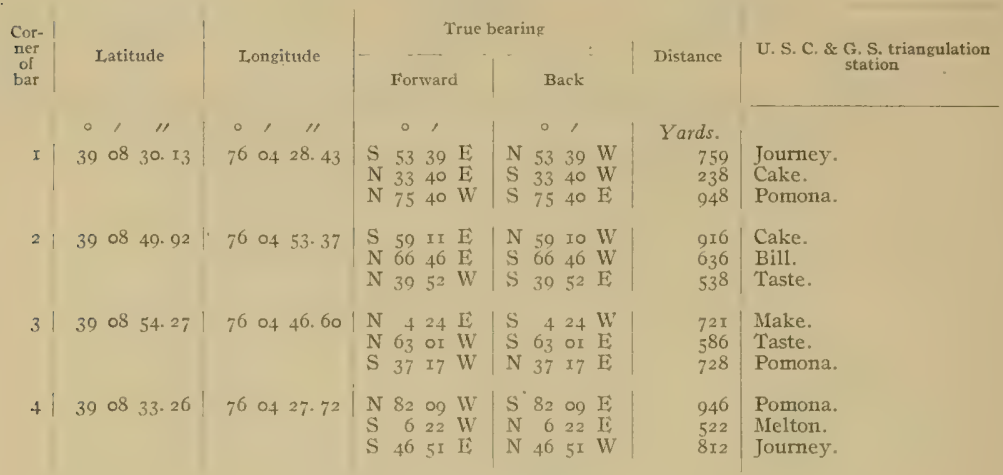

BRICK HOUSE:

(Chesapeake Bay-Off Kent Island-Chart.No. 3I.)

\begin{tabular}{|c|c|c|c|c|c|c|c|c|c|c|c|}
\hline I & $3^{8} \quad 55 \quad 40.93$ & $7^{6} \quad 22$ & 25.00 & $\begin{array}{l}N \\
N \\
S\end{array}$ & $\begin{array}{rr}43 & 59 \\
5 & 42 \\
59 & 16\end{array}$ & $\begin{array}{l}\mathrm{E} \\
\mathrm{W} \\
\mathrm{W}\end{array}$ & $\begin{array}{l}\mathrm{S} \\
\mathrm{S} \\
\mathrm{N}\end{array}$ & $\begin{array}{rrl}44 & 00 & \mathrm{WV} \\
5 & 43 & \mathrm{E} \\
59 & \mathrm{I} & \mathrm{II}\end{array}$ & $\begin{array}{r}\mathrm{I}, 379 \\
10,7 \text { I8 } \\
6,905\end{array}$ & $\begin{array}{l}\text { Craney, } \\
\text { Sandy Point Light. } \\
\text { Thomas Point } \\
\text { Light. }\end{array}$ & Shoal \\
\hline 2 & $3^{8} 55+$ I. 83 & $76 \quad 22$ & $57 \cdot 65$ & $\begin{array}{l}N \\
N \\
S\end{array}$ & $\begin{array}{rr}62 & 07 \\
\text { I } & 07 \\
54 & 57\end{array}$ & $\begin{array}{l}\text { F } \\
\text { W } \\
\text { W }\end{array}$ & $\begin{array}{l}\mathrm{S} \\
\mathrm{S} \\
\mathrm{N}\end{array}$ & $\begin{array}{rrr}62 & 07 & \mathrm{WV} \\
\mathrm{I} & 07 & \mathrm{II} \\
54 & 55 & \mathrm{~F}\end{array}$ & $\begin{array}{r}2,056 \\
10,638 \\
6,200\end{array}$ & $\begin{array}{l}\text { Craney. } \\
\text { Sandy Point Light. } \\
\text { Thomas Point } \\
\text { Light. }\end{array}$ & Shoal \\
\hline 3 & $3^{8} \quad 5^{6}+5 \cdot 73$ & 7622 & 47.84 & $\begin{array}{l}\mathrm{S} \\
\mathrm{N}\end{array}$ & $\begin{array}{rl}52 & 34 \\
46 & 10 \\
3 & 08\end{array}$ & $\begin{array}{l}\mathrm{I} \\
\mathrm{I} \\
\mathrm{IV}\end{array}$ & $\begin{array}{l}\mathrm{N} \\
\mathrm{S} \\
\mathrm{S}\end{array}$ & $\begin{array}{lll}52 & 33 & \mathrm{WV} \\
46 & \text { II } & \mathrm{IW} \\
3 & 08 & \mathrm{IV}\end{array}$ & $\begin{array}{l}I, 963 \\
4,691 \\
8,492\end{array}$ & $\begin{array}{l}\text { Craney. } \\
\text { Wash. } \\
\text { Sandy Point Light. }\end{array}$ & \\
\hline 4 & $3^{8} 5754.10$ & 7621 & 53.66 & $\begin{array}{l}\mathrm{S} \\
\mathrm{N} \\
\mathrm{N}\end{array}$ & $\begin{array}{rl}2 & 10 \\
64 & 17 \\
17 & 01\end{array}$ & $\begin{array}{l}\hat{I i} \\
\mathrm{I} i \\
\mathrm{~W}\end{array}$ & $\begin{array}{l}N \\
S \\
S\end{array}$ & $\begin{array}{rrr}2 & 10 & W \\
64 & 18 & W \\
17 & 02 & I \xi\end{array}$ & $\begin{array}{l}3,502 \\
2,17^{2} \\
0,45^{8}\end{array}$ & $\begin{array}{l}\text { Craney. } \\
\text { Wash. } \\
\text { Sandy Point Light. }\end{array}$ & \\
\hline 5 & $\begin{array}{lllll}3^{8} & 57 & 3^{8} .73\end{array}$ & 7621 & 24.70 & $\begin{array}{l}\mathrm{S} \\
\mathrm{N} \\
\mathrm{N}\end{array}$ & $\begin{array}{ll}11 & 57 \\
39 & 17 \\
21 & 37\end{array}$ & $\begin{array}{l}\text { IV } \\
\text { II } \\
\text { W }\end{array}$ & $\begin{array}{l}N \\
S \\
S\end{array}$ & $\begin{array}{lll}\text { II } & 57 & 1 \xi \\
39 & 17 & W \\
2 \text { I } & 38 & 1 \vdots\end{array}$ & $\begin{array}{l}3,047 \\
I, 887 \\
7,199\end{array}$ & $\begin{array}{l}\text { Craney. } \\
\text { Wash. } \\
\text { Sandy Point Light. }\end{array}$ & \\
\hline 6 & $3^{8} \quad 5^{6} \quad 05.5^{8}$ & $76 \quad 22$ & 28.00 & $\begin{array}{l}N \\
N \\
S\end{array}$ & $\begin{array}{rr}81 & 12 \\
5 & 44 \\
5.3 & 20\end{array}$ & $\begin{array}{l}\text { E } \\
\text { IV } \\
\text { WV }\end{array}$ & $\begin{array}{l}\mathrm{S} \\
\mathrm{S} \\
\mathrm{N}\end{array}$ & $\begin{array}{rrr}8 \text { I } & \text { I } 2 & W \\
5 & 44 & 1 \xi \\
53 & \text { I } 8 & \text { F }\end{array}$ & $\begin{array}{l}1,0.49 \\
9,883 \\
7,302\end{array}$ & $\begin{array}{l}\text { Craney. } \\
\text { Sandy Point Light. } \\
\text { Thomas Point } \\
\text { Light. }\end{array}$ & Shoal \\
\hline
\end{tabular}


BOUNDARIES OF NATURAL OYSTER BARS-continued. GUM THICKET.

(Chesapeake Bay-Off Kent Island-Chart No.3I.)

\begin{tabular}{|c|c|c|c|c|c|c|c|c|c|c|c|c|c|c|}
\hline \multirow{2}{*}{$\begin{array}{l}\text { Cor- } \\
\text { ner } \\
\text { of } \\
\text { bar }\end{array}$} & \multirow{2}{*}{\multicolumn{3}{|c|}{ Latitude }} & \multirow{2}{*}{\multicolumn{3}{|c|}{ I,ongitude }} & \multicolumn{6}{|c|}{ True bearing } & \multirow{2}{*}{ Distance } & \multirow{2}{*}{$\begin{array}{l}\text { U. S. C. \& G. S. triangulation } \\
\text { station }\end{array}$} \\
\hline & & & & & & & & Fotv & ward & & $\mathrm{Ba}$ & ack & & \\
\hline I & $\begin{array}{c}0 \\
3^{8}\end{array}$ & & $\begin{array}{c}\prime \prime \prime \\
08.37\end{array}$ & $\begin{array}{c}0 \\
76\end{array}$ & & $\begin{array}{c}11 \\
45.10\end{array}$ & $\begin{array}{l}\mathrm{N} \\
\mathrm{N} \\
\mathrm{S}\end{array}$ & $\begin{array}{c}0 \\
\text { I0 } \\
56 \\
\text { I5 }\end{array}$ & $\begin{array}{l}1 \\
20 \mathrm{E} \\
03 \mathrm{~W} \\
46 \mathrm{~W}\end{array}$ & $\begin{array}{l}\mathrm{S} \\
\mathrm{S} \\
\mathrm{N}\end{array}$ & $\begin{array}{l}0 \\
\text { I0 } \\
56 \\
\text { I5 }\end{array}$ & $\begin{array}{l}20 \mathrm{~W} \\
05 \mathrm{E} \\
46 \mathrm{E}\end{array}$ & $\begin{array}{r}\text { Yarils. } \\
8,294 \\
6,516 \\
4,459\end{array}$ & $\begin{array}{l}\text { Craney. } \\
\text { Thomas Point Shoal } \\
\text { Light. } \\
\text { Bloody Point Bar Light. }\end{array}$ \\
\hline 2 & $3^{8}$ & $5^{2}$ & 08.42 & 76 & 23 & 02.35 & $\begin{array}{l}\mathrm{N} \\
\mathrm{N} \\
\mathrm{S}\end{array}$ & $\begin{array}{l}\text { I3 } \\
53 \\
\text { I0 }\end{array}$ & $\begin{array}{ll}23 & \mathrm{E} \\
42 & \mathrm{~W} \\
\infty & \mathrm{WV}\end{array}$ & $\begin{array}{l}\mathrm{S} \\
\mathrm{S} \\
\mathrm{N}\end{array}$ & $\begin{array}{l}13 \\
5.3 \\
10\end{array}$ & $\begin{array}{l}24 \mathrm{~W} \\
4+\mathrm{E} \\
00 \mathrm{Ii}\end{array}$ & $\begin{array}{l}8,387 \\
6,144 \\
4,370\end{array}$ & $\begin{array}{l}\text { Craney. } \\
\text { Thomas Point Shoal } \\
\text { Light. } \\
\text { Bloody Point Bar Light. }\end{array}$ \\
\hline 3 & $3^{8}$ & 53 & 02.63 & 76 & 23 & I. 4.86 & $\begin{array}{l}\mathrm{N} \\
\mathrm{N} \\
\mathrm{S}\end{array}$ & $\begin{array}{l}19 \\
68 \\
3\end{array}$ & $\begin{array}{ll}44 & \mathrm{E} \\
38 & \mathrm{~W} \\
59 & \mathrm{~W}\end{array}$ & $\begin{array}{l}\mathrm{S} \\
\mathrm{S} \\
\mathrm{N}\end{array}$ & $\begin{array}{l}\text { I9 } \\
68 \\
3\end{array}$ & $\begin{array}{l}45 \mathrm{~W} \\
40 \mathrm{E} \\
59 \mathrm{E}\end{array}$ & $\begin{array}{l}6,726 \\
4,964 \\
6,136\end{array}$ & $\begin{array}{l}\text { Craney. } \\
\text { Thomas Point Shoal } \\
\text { Light. } \\
\text { Bloody Point Bar Light. }\end{array}$ \\
\hline 4 & $3^{8}$ & 54 & 04.55 & 76 & 22 & 49. 73 & $\begin{array}{l}\mathrm{N} \\
\mathrm{S} \\
\mathrm{S}\end{array}$ & $\begin{array}{l}20 \\
86 \\
7\end{array}$ & $\begin{array}{l}46 \mathrm{E} \\
59 \mathrm{~W} \\
23 \mathrm{WV}\end{array}$ & $\begin{array}{l}\mathrm{S} \\
\mathrm{N} \\
\mathrm{N}\end{array}$ & $\begin{array}{l}20 \\
86 \\
7\end{array}$ & $\begin{array}{l}47 \mathrm{~W} \\
57 \mathrm{E} \\
23 \mathrm{E}\end{array}$ & $\begin{array}{l}4,537 \\
5,292 \\
8,278\end{array}$ & $\begin{array}{l}\text { Craney: } \\
\text { Thomas Point Shoal } \\
\text { Light. } \\
\text { Bloody Point Bar Light. }\end{array}$ \\
\hline 5 & $3^{8}$ & 54 & 05.44 & 76 & 22 & 29.22 & $\begin{array}{l}\mathrm{N} \\
\mathrm{S} \\
\mathrm{S}\end{array}$ & $\begin{array}{l}\text { I4 } \\
86 \\
\text { II }\end{array}$ & $\begin{array}{l}\text { I4 } \mathrm{F}, \\
5^{8} \mathrm{~W} \\
\text { I2 } \mathrm{W}\end{array}$ & $\begin{array}{l}\mathrm{S} \\
\mathrm{N} \\
\mathrm{N}\end{array}$ & $\begin{array}{l}\text { I4 } \\
86 \\
\text { II }\end{array}$ & $\begin{array}{l}\text { I5 W } \\
56 \mathrm{~F} \\
\text { I I } \mathrm{E}\end{array}$ & $\begin{array}{l}4,346 \\
5,833 \\
8,399\end{array}$ & $\begin{array}{l}\text { Craney. } \\
\text { Thomas Point Shoal } \\
\text { Light. } \\
\text { Bloody Point Bar Light. }\end{array}$ \\
\hline
\end{tabular}

\section{KENT POINT.}

(Chesapeake Bay-Off Bloody Point-Chart No. 3I.)

\begin{tabular}{|c|c|c|c|c|c|c|}
\hline I & $3^{8} 50$ or. $x_{3}$ & $7623 \quad 3 x .08$ & $\begin{array}{lrll}\mathrm{S} & +59 & \mathrm{E} \\
\mathrm{S} & 37 & 30 & \mathrm{E} \\
\mathrm{N} & 86 & 33 & \mathrm{E}\end{array}$ & $\begin{array}{lrrr}\mathrm{N} & 4 & 58 & \mathrm{~W} \\
\mathrm{~N} & 37 & 28 & \mathrm{~W} \\
\mathrm{~S} & 86 & 34 & \mathrm{~W}\end{array}$ & $\begin{array}{l}7,688 \\
8,834 \\
2,242\end{array}$ & $\begin{array}{l}\text { Valliant. } \\
\text { Haddaway } \\
\text { Tenk. }\end{array}$ \\
\hline & $\begin{array}{llll}3^{8} & 51 & 05.68\end{array}$ & $76 \quad 23 \quad 37.00$ & $\begin{array}{llll}N & 15 & 3 I & E \\
N & 35 & 04 & W \\
S & 4 & 07 & E\end{array}$ & $\begin{array}{lllll}\mathrm{S} & \mathrm{I} & 5 & 33 & \mathrm{~W} \\
\mathrm{~S} & 35 & 06 & \mathrm{E} \\
\mathrm{N} & 4 & 07 & \mathrm{~W}\end{array}$ & $\begin{array}{r}10,663 \\
7,028 \\
2,183\end{array}$ & $\begin{array}{l}\text { Craney. } \\
\text { Thomas Point Shoal } \\
\text { Light. } \\
\text { Bloody Point Bar Iight. }\end{array}$ \\
\hline & $3^{8} \quad 52$ o8. 42 & $76 \quad 2302.35$ & $\begin{array}{llll}\mathrm{N} & 13 & 23 & \mathrm{E} \\
\mathrm{N} & 53 & 42 & \mathrm{~W} \\
\mathrm{~S} & 10 & 00 & \mathrm{~W}\end{array}$ & $\begin{array}{llll}\mathrm{S} & \mathrm{I}_{3} & 24 & \mathrm{~W} \\
\mathrm{~S} & 53 & 44 & \mathrm{E} \\
\mathrm{N} & \text { 10 } & 00 & \mathrm{E}\end{array}$ & $\begin{array}{l}8,387 \\
6,144 \\
4,370\end{array}$ & $\begin{array}{l}\text { Craney. } \\
\text { Thomas Point Shoal } \\
\text { Light. } \\
\text { Bloody Point Bar Light. }\end{array}$ \\
\hline & $3^{8} 5^{2}$ 08. 37 & $76 \quad 2245 \cdot 10$ & $\begin{array}{llll}\mathrm{N} & \text { 10 } & 20 & \mathrm{E} \\
\mathrm{N} & 56 & 03 & \mathrm{~W} \\
\mathrm{~S} & 15 & 46 & \mathrm{~W}\end{array}$ & $\begin{array}{llll}\mathrm{S} & 10 & 20 \mathrm{~W} \\
\mathrm{~S} & 56 & 05 \mathrm{E} \\
\mathrm{N} & 15 & 46 \mathrm{E}\end{array}$ & $\begin{array}{l}8,294 \\
6,516 \\
4,459\end{array}$ & $\begin{array}{l}\text { Craney. } \\
\text { Thomas Point Shoa } 1 \\
\text { Light. } \\
\text { Bloody Point Bar Light. }\end{array}$ \\
\hline & $3^{8} 5^{\circ} 56.25$ & $\begin{array}{lll}76 & 22 & 54.85\end{array}$ & $\begin{array}{lrrrr}\mathrm{N} & 40 & \text { I } 8 & \mathrm{~W} \\
\mathrm{~S} & 27 & \text { II } & \mathrm{W} \\
\mathrm{S} & \mathrm{I} & 44 & \mathrm{~W}\end{array}$ & $\begin{array}{lrrr}\mathrm{S} & 40 & 20 & \mathrm{E} \\
\mathrm{N} & 27 & \text { II } & \mathrm{E} \\
\mathrm{N} & \mathrm{I} & 44 & \mathrm{E}\end{array}$ & $\begin{array}{l}7,960 \\
2,090 \\
9,522\end{array}$ & $\begin{array}{l}\text { Thomas Point Shoal } \\
\text { Iight. } \\
\text { Bloody Point Bar Light. } \\
\text { Valliant. }\end{array}$ \\
\hline & $3^{8} 5^{\circ} 16.4^{8}$ & $\begin{array}{lll}76 & 22 & 40.82\end{array}$ & $\begin{array}{lrrr}\mathrm{N} & 36 & 40 & \mathrm{~W} \\
\mathrm{~S} & 68 & 39 & \mathrm{~W} \\
\mathrm{~S} & 4 & 37 & \mathrm{~W}\end{array}$ & $\begin{array}{lrrr}\mathrm{S} & 36 & 42 & \mathrm{E} \\
\mathrm{N} & 68 & 38 & \mathrm{E} \\
\mathrm{N} & 4 & 36 & \mathrm{E}\end{array}$ & $\begin{array}{l}9,24 \mathrm{I} \\
\mathrm{I}, 423 \\
8,203\end{array}$ & $\begin{array}{l}\text { Thomas Point Shoal } \\
\text { Light. } \\
\text { Bloody Point Bar Light. } \\
\text { Valliant. }\end{array}$ \\
\hline
\end{tabular}


(Eastern Bay-Chart No. 3T.)

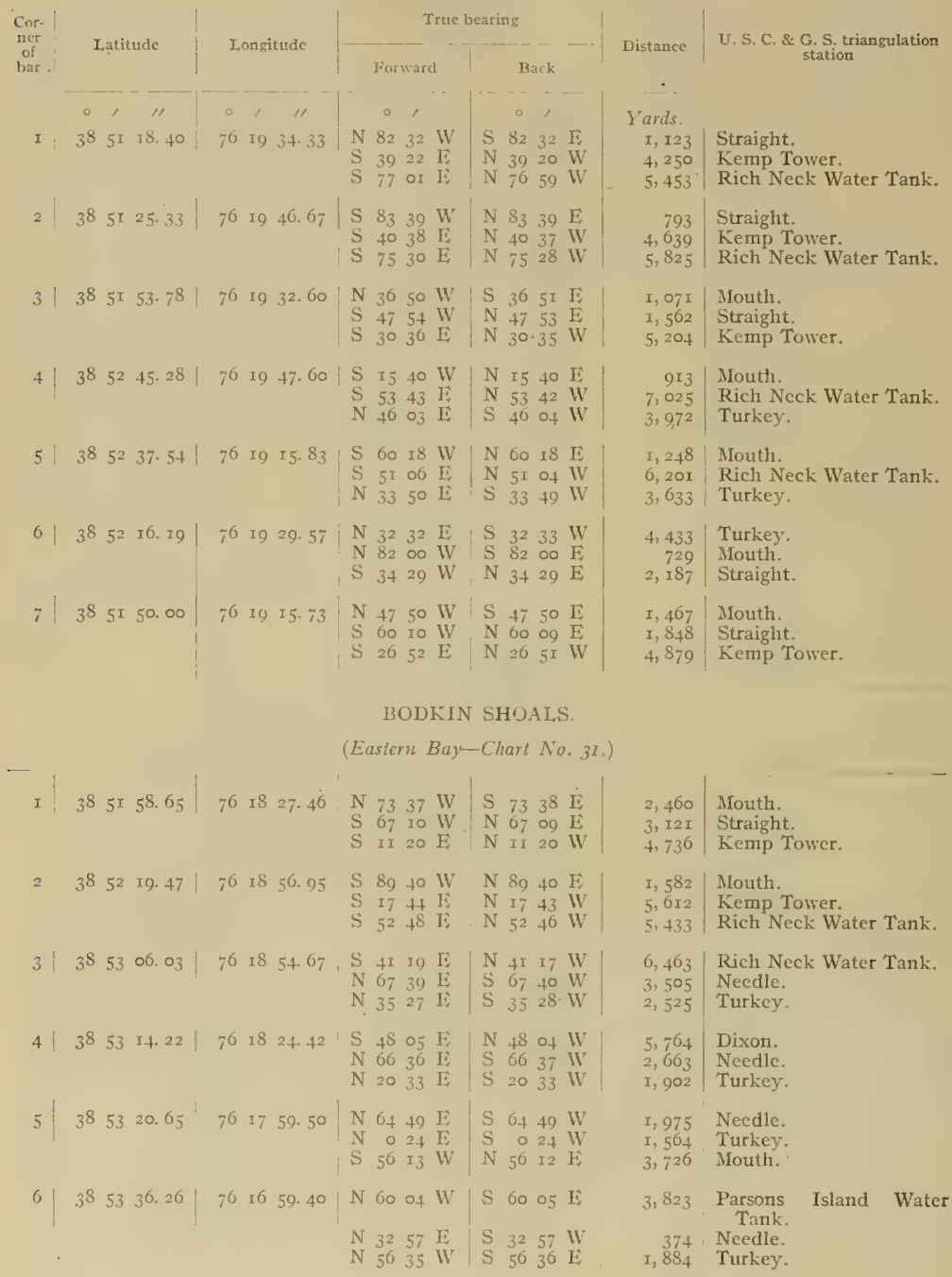


BOUNDARIES OF NATURAL, OYSTER BARS-continUE.

BODKIN SHOALS-Continued.

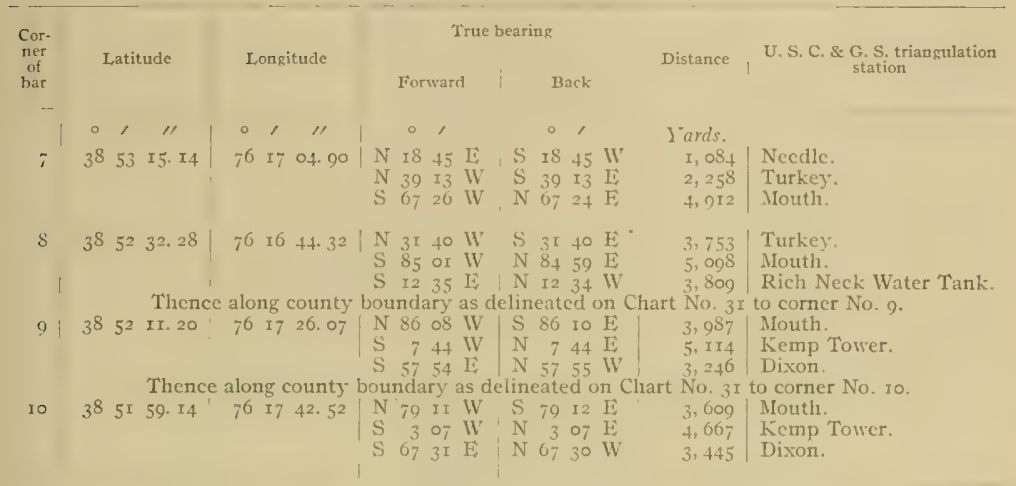

BRICK HOUSE HILL.

(Eastern Baj-Chart No. 3I.)

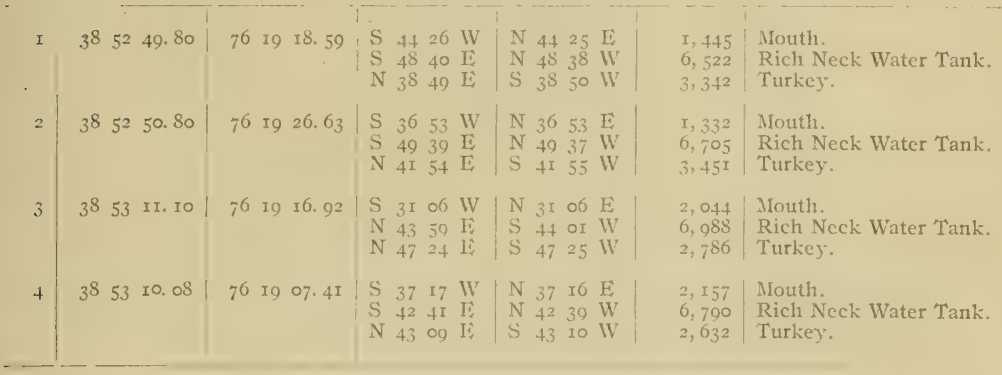

\section{UNKER HILI,}

(Eastcrm Bay-Chart No. 3r.).

$$
\begin{aligned}
& \text { I } \quad 3^{8} 5^{2} 58 . \times 8 \mid 76 \text { I9 } 42.94\left|\mathrm{~S}_{2} 343 \mathrm{E}\right| \mathrm{N} 23.42 \mathrm{~W} \\
& S 5022 \text { E N } 5020 \text { WV } \\
& \mathrm{N} 494 \mathrm{I} \text { E } \mathrm{S} 4942 \mathrm{~W}
\end{aligned}
$$

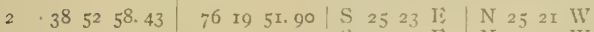

$$
\begin{aligned}
& \text { S } 5129 \text { E } \\
& \text { N } 52 \text { of } 1 \text { is } \quad \text { S } 52 \text { o8 } \mathrm{WV}
\end{aligned}
$$

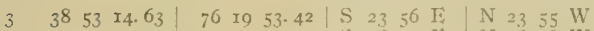

$$
\begin{aligned}
& S 48 \text { I I N } 4828 \mathrm{~W} \\
& \begin{array}{lllllllll}
N & 59 & 36 & \mathrm{~L} & \mathrm{~S} & 59 & 38 \mathrm{~W}
\end{array}
\end{aligned}
$$

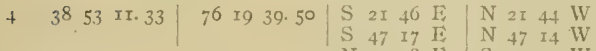

$$
\begin{aligned}
& \begin{array}{llllll}
N & 5438 & \text { Ii } & \text { S } 5439 \text { W }
\end{array}
\end{aligned}
$$

$7,265 \mid$ Kemp Tower.

7, I95 Rich Neck Water Tank

3. 589 Turkey.

$7,370 \mid$ Kemp Tower.

$7,38_{3}$ Rich Neck Water Tank.

3,767 Turkey.

$7,884 \mid$ Kemp Tower.

7, 765 Rich Neck Water Tank.

3, +93 'Turkey.

i, 639 / Kemp Fower.

7,418 Rich Neck Water Tank.

3,246 Turkey. 
BOUNDARIES OF NATURAL OYSTER BARS-continued.

TURKEY POINT.

(Eastern Bay-Chart No. 3I.)

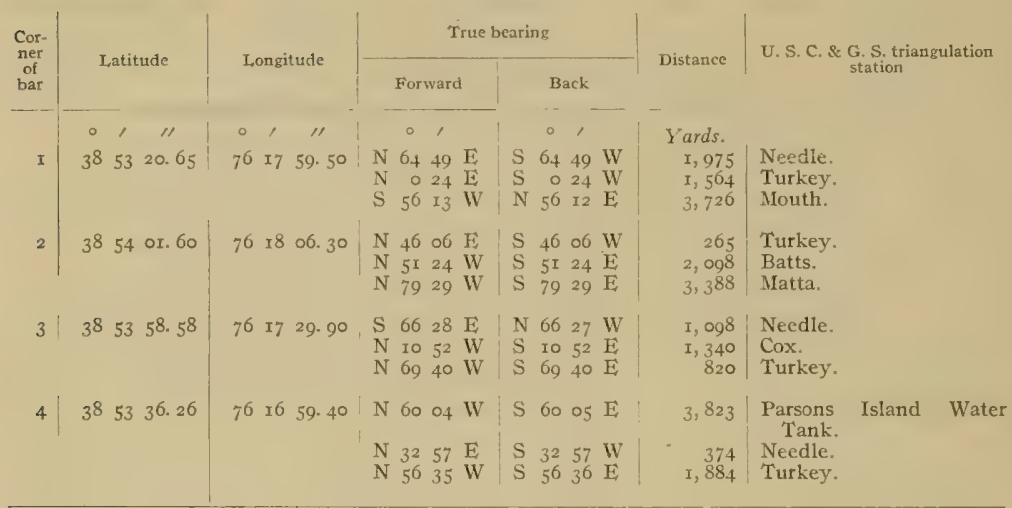

MIDDLE BLOCK.

(Eastern Bay-Chart No. 3I.)

\begin{tabular}{|c|c|c|c|c|c|c|c|}
\hline I & $3^{8} \quad 53 \quad I 4.22$ & 76 I8 24.42 & $\begin{array}{ll}S & 48 \\
N & 66 \\
N & 20\end{array}$ & $\begin{array}{ll}05 \mathrm{E} \\
36 \mathrm{E} \\
33 \mathrm{E}\end{array}$ & $\begin{array}{llll}N & 48 & 0.4 & W \\
S & 66 & 37 & W \\
S & 20 & 33 & W\end{array}$ & $\begin{array}{l}5,764 \\
2,663 \\
1,902\end{array}$ & $\begin{array}{l}\text { Dixon. } \\
\text { Needle. } \\
\text { Turkey. }\end{array}$ \\
\hline 2 & $3^{8} 5351.90$ & $\begin{array}{llll}76 & 18 & 32.00\end{array}$ & $\begin{array}{ll}N & 0 \\
N & 30 \\
N & 70\end{array}$ & $\begin{array}{l}14 \mathrm{E} \\
28 \mathrm{~W} \\
24 \mathrm{~W}\end{array}$ & $\begin{array}{lrrr}\mathrm{S} & 0 & 14 & \mathrm{~W} \\
\mathrm{~S} & 30 & 28 & \mathrm{E} \\
\mathrm{S} & 70 & 25 & \mathrm{E}\end{array}$ & $\begin{array}{l}3,243 \\
1,898 \\
2,817\end{array}$ & $\begin{array}{l}\text { Dell. } \\
\text { Batts. } \\
\text { Matta. }\end{array}$ \\
\hline 3 & $\begin{array}{l}\text { Thence from } \\
\text { any creek, } \\
3^{8} 5357.08\end{array}$ & $\begin{array}{l}\text { rner No. } 2 \text { alo } \\
\text { ve, or inlet le } \\
76 \text { I8 Ix. } 3^{8}\end{array}$ & $\begin{array}{l}\text { ig the } \\
\text { s than } \\
\text { S } 79 \\
\text { N } 43 \\
\text { N } 45\end{array}$ & 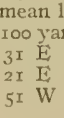 & $\begin{array}{l}\text { W-water line } \\
\text { Is in width at } \\
\mathrm{N} 7930 \mathrm{~W} \\
\mathrm{~S} 432 \mathrm{I} \\
\mathrm{S} 4552 \mathrm{E}\end{array}$ & $\begin{array}{l}\text { shore } \\
\text { mouth } \\
2,136 \\
46 \mathrm{I} \\
2,099\end{array}$ & $\begin{array}{l}\text { to comer No. } 3 \text {, excluding } \\
\text { t low tide. } \\
\text { Necdle. } \\
\text { Turkey. } \\
\text { Batts. }\end{array}$ \\
\hline 4 & $3^{8} 54$ ox. 60 & 76 I8 06.30 & $\begin{array}{ll}N & 46 \\
N & 5 x \\
N & 79\end{array}$ & $\begin{array}{ll}06 \mathrm{E} \\
24 \mathrm{~W} \\
29 \mathrm{~W}\end{array}$ & $\begin{array}{llll}\mathrm{S} & 46 & 06 & \mathrm{~W} \\
\mathrm{~S} & 5 \mathrm{I} & 24 & \mathrm{E} \\
\mathrm{S} & 79 & 29 & \mathrm{E}\end{array}$ & $\begin{array}{r}265 \\
2,098 \\
3,388\end{array}$ & $\begin{array}{l}\text { Turkey. } \\
\text { Batts. } \\
\text { Matta. }\end{array}$ \\
\hline 5 & $3^{8} \quad 5320.65$ & $\begin{array}{llll}76 & 17 & 59.50\end{array}$ & $\begin{array}{lr}\mathrm{N} & 64 \\
\mathrm{~N} & 0 \\
\mathrm{~S} & 56\end{array}$ & $\begin{array}{ll}49 & E \\
24 & E \\
I_{3} & W\end{array}$ & $\begin{array}{lrll}\mathrm{S} & 64 & 49 & \mathrm{~W} \\
\mathrm{~S} & 0 & 24 & \mathrm{~W} \\
\mathrm{~N} & 56 & \mathrm{I} & \mathrm{E}\end{array}$ & $\begin{array}{l}\mathrm{I}, 975 \\
\mathrm{I}, 564 \\
3,726\end{array}$ & $\begin{array}{l}\text { Needle. } \\
\text { Turkey } \\
\text { Mouth. }\end{array}$ \\
\hline
\end{tabular}


BOUNDARIES OF NATURAL OYSTER BARS-continued.

WILD GROUND.

(Eastern Bay-Chart No. 3I.)

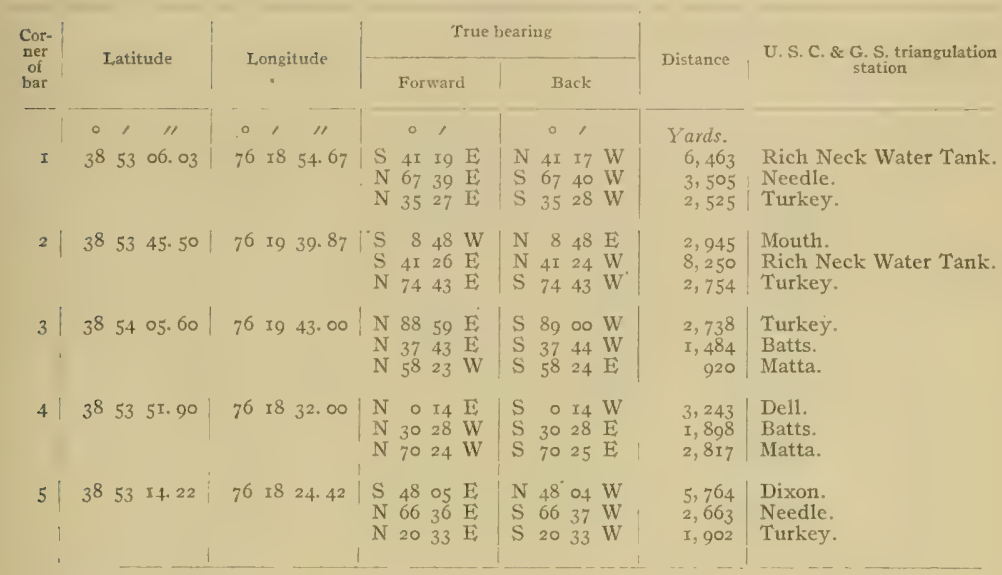

PINE, TREE.

(Eastern Bay-Chart No. 3I.)

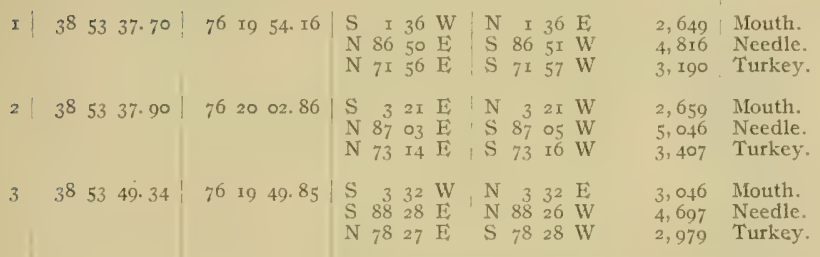

GREEVES COVE.

(Cox Creck-Chart No. 3r.)

\begin{tabular}{|c|c|c|c|c|c|c|}
\hline$I$ & 385428.94 & 762021.80 & $\begin{array}{llll}\mathrm{S} & 78 & 54 & \mathrm{~F} \\
\mathrm{~N} & 78 & 39 & \mathrm{E} \\
\mathrm{N} & \mathbf{I}_{5} & 58 & \mathrm{E}\end{array}$ & $\begin{array}{llll}\mathrm{N} & 78 & 52 & \mathrm{~W} \\
\mathrm{~S} & 78 & 40 & \mathrm{~W} \\
\mathrm{~S} & 15 & 58 & \mathrm{~W}\end{array}$ & $\begin{array}{r}3,833 \\
\mathrm{r}, 970 \\
97 \mathrm{r}\end{array}$ & $\begin{array}{l}\text { Turkey. } \\
\text { Batts. } \\
\text { Then. }\end{array}$ \\
\hline & $3^{8} 5430 \cdot 7^{6}$ & $7620 \quad 33.95$ & $\begin{array}{llll}\mathrm{S} & 78 & 55 & \mathrm{E} \\
\mathrm{N} & 8 \mathrm{I} & 45 & \mathrm{E} \\
\mathrm{N} & 48 & 36 & \mathrm{E}\end{array}$ & $\begin{array}{llll}N & 78 & 54 & W \\
\mathrm{~S} & 8 \mathrm{I} & 46 & \mathrm{~W} \\
\mathrm{~S} & 48 & 36 & \mathrm{~W}\end{array}$ & $\begin{array}{l}4,159 \\
2,275 \\
1,738\end{array}$ & $\begin{array}{l}\text { Turkey. } \\
\text { Batts. } \\
\text { Some. }\end{array}$ \\
\hline 3 & $3^{8} 5434 \cdot 87$ & $7^{6} \quad 20 \quad 36.40$ & $\begin{array}{llll}\mathrm{S} & 77 & 15 & \mathrm{E} \\
\mathrm{N} & 85 & 23 & \mathrm{E} \\
\mathrm{N} & 53 & 33 & \mathrm{E}\end{array}$ & $\begin{array}{llll}\mathrm{N} & 77 & \mathrm{I} 4 & \mathrm{~W} \\
\mathrm{~S} & 85 & 23 & \mathrm{~W} \\
\mathrm{~S} & 53 & 33 & \mathrm{~W}\end{array}$ & $\begin{array}{l}4,250 \\
2,323 \\
x, 701\end{array}$ & $\begin{array}{l}\text { Turkey. } \\
\text { Batts. } \\
\text { Some. }\end{array}$ \\
\hline
\end{tabular}




\section{BOUNDARIES OF NATURAL, OYSTER BARS - continued.}

\section{GREEVES COVE-Continued.}

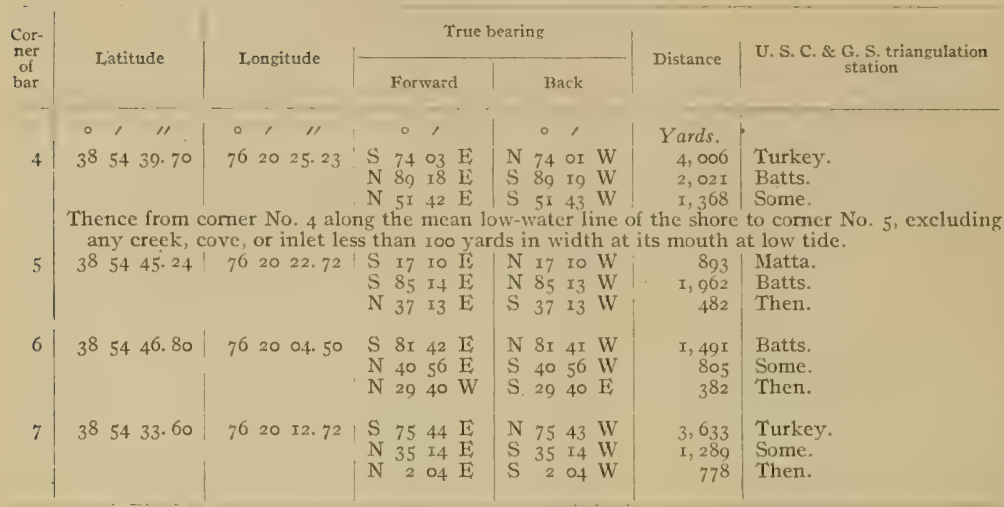

\section{MATTAPEX.}

(Cox Creek-Chart No. 3I.)

\begin{tabular}{|c|c|c|c|c|c|c|}
\hline I & $3^{8} 54 \quad 27 \cdot 39$ & 76 I9 31.84 & $\begin{array}{llll}\mathrm{N} & 54 & 25 & \mathrm{E} \\
\mathrm{N} & 46 & 47 & \mathrm{~W} \\
\mathrm{~S} & 76 & 50 & \mathrm{~W}\end{array}$ & $\begin{array}{llll}\mathrm{S} & 54 & 25 & \mathrm{~W} \\
\mathrm{~S} & 46 & 48 & \mathrm{E} \\
\mathrm{N} & 76 & 50 & \mathrm{E}\end{array}$ & $\begin{array}{r}756 \\
\mathrm{r}, 439 \\
\mathrm{r}, 106\end{array}$ & $\begin{array}{l}\text { Batts. } \\
\text { Then. } \\
\text { Matta. }\end{array}$ \\
\hline 2 & $3^{8} \quad 54 \quad 30.65$ & 76 I9 4 I. 35 & $\begin{array}{lrll}\mathrm{N} & 4 & 06 & \mathrm{~W} \\
\mathrm{~N} & 42 & 22 & \mathrm{~W} \\
\mathrm{~S} & 66 & 2 \mathrm{I} & \mathrm{W}\end{array}$ & $\begin{array}{lrrr}\mathrm{S} & 4 & 06 & \mathrm{E} \\
\mathrm{S} & 42 & 22 & \mathrm{E} \\
\mathrm{N} & 66 & 2 \mathrm{I} & \mathrm{E}\end{array}$ & $\begin{array}{r}\text { I, } \times 55 \\
\text { I, } 185 \\
902\end{array}$ & $\begin{array}{l}\text { Some. } \\
\text { Then. } \\
\text { Matta. }\end{array}$ \\
\hline 3 & $3^{8} 5433.60$ & $7^{6} \quad 20 \quad 12.7^{2}$ & $\begin{array}{lrll}\mathrm{S} & 75 & 44 & \mathrm{E} \\
\mathrm{N} & 35 & \mathrm{I} 4 & \mathrm{E} \\
\mathrm{N} & 2 & 0.4 & \mathrm{E}\end{array}$ & $\begin{array}{rrrr}\mathrm{N} & 75 & 43 & \mathrm{~W} \\
\mathrm{~S} & 35 & \mathrm{I} 4 & \mathrm{~W} \\
\mathrm{~S} & 2 & 04 & \mathrm{~W}\end{array}$ & $\begin{array}{r}3,633 \\
\mathbf{1}, 289 \\
778\end{array}$ & $\begin{array}{l}\text { Turkey. } \\
\text { Some. } \\
\text { Then. }\end{array}$ \\
\hline 4 & $3^{8} 54 \quad 46.80$ & $7^{6} \quad 20 \quad 04 \cdot 50$ & $\begin{array}{llll}\mathrm{S} & 8 \mathrm{I} & 42 & \mathrm{E} \\
\mathrm{N} & 40 & 56 & \mathrm{E} \\
\mathrm{N} & 29 & 40 & \mathrm{~W}\end{array}$ & $\begin{array}{llll}\mathrm{N} & 8 \mathrm{I} & 4 \mathrm{I} & \mathrm{WV} \\
\mathrm{S} & 40 & 56 & \mathrm{~W} \\
\mathrm{~S} & 29 & 40 & \mathrm{~F}\end{array}$ & $\begin{array}{r}\text { I, } 49 \mathrm{I} \\
805 \\
382\end{array}$ & $\begin{array}{l}\text { Batts. } \\
\text { Some. } \\
\text { Then. }\end{array}$ \\
\hline 5 & $3^{8} \quad 54 \quad 5^{8 .} .9^{8}$ & $\begin{array}{lll}76 & 20 & 02 . \\
5^{6}\end{array}$ & $\begin{array}{llll}\mathrm{S} & \text { II } & 29 & \mathrm{~W} \\
\mathrm{~S} & 66 & 16 & \mathrm{E} \\
\mathrm{N} & 67 & 30 & \mathrm{E}\end{array}$ & $\begin{array}{llll}\mathrm{N} & \mathrm{II} & 29 & \mathrm{E} \\
\mathrm{N} & 66 & \mathrm{I} & \mathrm{W} \\
\mathrm{S} & 67 & 30 & \mathrm{~W}\end{array}$ & $\begin{array}{r}I, 344 \\
I, 555 \\
5 \text { I5 }\end{array}$ & $\begin{array}{l}\text { Matta. } \\
\text { Batts. } \\
\text { Some. }\end{array}$ \\
\hline 6 & $3^{8} 545^{6} .33$ & 76 I9 49.20 & $\begin{array}{llll}\mathrm{N} & 23 & 25 & \mathrm{E} \\
\mathrm{N} & 89 & 03 & \mathrm{~W} \\
\mathrm{~S} & 26 & 46 & \mathrm{~W}\end{array}$ & $\begin{array}{llll}\mathrm{S} & 23 & 25 & \mathrm{~W} \\
\mathrm{~S} & 89 & 03 & \mathrm{E} \\
\mathrm{N} & 26 & 46 & \mathrm{E}\end{array}$ & $\begin{array}{r}313 \\
592 \\
1,376\end{array}$ & $\begin{array}{l}\text { Some. } \\
\text { Then. } \\
\text { Matta. }\end{array}$ \\
\hline 7 & $3^{8} 545^{8} .90$ & 76 Ig $39.5^{2}$ & $\begin{array}{llll}\mathrm{N} & 33 & 13 & \mathrm{~W} \\
\mathrm{~S} & 84 & 49 & \mathrm{~W} \\
\mathrm{~S} & 33 & 38 & \mathrm{~W}\end{array}$ & $\begin{array}{llll}\mathrm{S} & 33 & \mathrm{I} & \mathrm{E} \\
\mathrm{N} & 84 & 48 & \mathrm{E} \\
\mathrm{N} & 33 & 38 & \mathrm{E}\end{array}$ & $\begin{array}{r}239 \\
851 \\
\mathbf{I}, 579\end{array}$ & $\begin{array}{l}\text { Some. } \\
\text { Then. } \\
\text { Matta. }\end{array}$ \\
\hline 8 & $3^{8} \quad 54 \quad 43 \cdot 13$ & 76 I9 $41 \cdot 20$ & $\begin{array}{llll}\mathrm{N} & 6 & 45 & \mathrm{~W} \\
\mathrm{~N} & 60 & 27 & \mathrm{~W} \\
\mathrm{~S} & 46 & 4 \mathrm{I} & \mathrm{W}\end{array}$ & $\begin{array}{lrrr}\mathrm{S} & 6 & 45 & \mathrm{E} \\
\mathrm{S} & 60 & 27 & \mathrm{E} \\
\mathrm{N} & 46 & 4 \mathrm{I} & \mathrm{E}\end{array}$ & $\begin{array}{r}737 \\
923 \\
\mathbf{x}, \mathbf{x} 4 \mathrm{x}\end{array}$ & $\begin{array}{l}\text { Some. } \\
\text { Then. } \\
\text { Matta. }\end{array}$ \\
\hline
\end{tabular}


BOUNDARLES OF NATURAL OYSTER BARS - continued.

SHIPPING CREEK:

(Cox Creck-Chart No. 3I.)

\begin{tabular}{|c|c|c|c|c|c|c|c|c|c|c|c|c|c|c|}
\hline \multirow{2}{*}{$\begin{array}{l}\text { Cor- } \\
\text { ner } \\
\text { of } \\
\text { bar }\end{array}$} & \multirow{2}{*}{\multicolumn{2}{|c|}{ Latitude }} & \multirow{2}{*}{\multicolumn{3}{|c|}{ I ongitude }} & \multicolumn{7}{|c|}{ True bearing } & \multirow{2}{*}{ Distance } & \multirow{2}{*}{$\begin{array}{l}\text { U. S. C. \& C. S, triangulation } \\
\text { station. }\end{array}$} \\
\hline & & & & & & & For & ward & & & $\mathrm{Bac}$ & & & \\
\hline$I$ & $\begin{array}{l}0 \\
3^{8}\end{array}$ & $\begin{array}{cc}\prime & \prime \prime \\
54 & 05 \cdot 15\end{array}$ & $\begin{array}{c}\circ \\
76\end{array}$ & $\begin{array}{c}1 \\
\text { ig }\end{array}$ & $5^{\prime \prime} .28$ & $\begin{array}{l}\mathrm{N} \\
\mathrm{N} \\
\mathrm{N}\end{array}$ & $\begin{array}{l}0 \\
88 \\
47 \\
37\end{array}$ & $\begin{array}{l}! \\
50 \\
47 \\
22\end{array}$ & & $\begin{array}{ll}\mathrm{S} & 8 \\
\mathrm{~S} & 4 \\
\mathrm{~S} & 3\end{array}$ & $\begin{array}{l}\circ \\
88 \\
474 \\
372\end{array}$ & $\begin{array}{ll}1 & \\
50 & W \\
47 & W \\
22 & \mathrm{E}\end{array}$ & $\begin{array}{r}\text { Yards. } \\
3,142 \\
, 1,771 \\
627\end{array}$ & $\begin{array}{l}\text { Turkey. } \\
\text { Batts. } \\
\text { Matta. }\end{array}$ \\
\hline 2 & $3^{8}$ & $5420.6 \mathrm{I}$ & 76 & 20 & 08.82 & $\begin{array}{l}\mathrm{S} \\
\mathrm{N} \\
\mathrm{N}\end{array}$ & $\begin{array}{r}82 \\
67 \\
3\end{array}$ & $\begin{array}{l}23 \\
12 \\
32\end{array}$ & $\begin{array}{l}\mathrm{E} \\
\mathrm{E} \\
\mathrm{W}\end{array}$ & $\begin{array}{l}\text { N } 8 \\
\text { S } \\
\text { S }\end{array}$ & $\begin{array}{rr}82 & 2 \\
67 & 1 \\
3 & 3\end{array}$ & $\begin{array}{ll}2 & \mathrm{~W} \\
\text { I2 } & \mathrm{W} \\
32 & \mathrm{E}\end{array}$ & $\begin{array}{l}3,449 \\
1,724 \\
\mathrm{x}, 217\end{array}$ & $\begin{array}{l}\text { Turkey. } \\
\text { Batts. } \\
\text { Then. }\end{array}$ \\
\hline 3 & $3^{8}$ & 5430.65 & 76 & I9 & 4I. 35 & $\begin{array}{l}\mathrm{N} \\
\mathrm{N} \\
\mathrm{S}\end{array}$ & $\begin{array}{r}4 \\
42 \\
66\end{array}$ & $\begin{array}{l}06 \\
22 \\
21\end{array}$ & & $\begin{array}{l}\mathrm{S} \\
\mathrm{S} \\
\mathrm{N}\end{array}$ & $\begin{array}{r}40 \\
42 \\
66\end{array}$ & $\begin{array}{ll}06 \mathrm{E} \\
22 \mathrm{E} \\
2 \mathrm{I}\end{array}$ & $\begin{array}{r}\text { I, I55 } \\
\text { I, I85 } \\
902\end{array}$ & $\begin{array}{l}\text { Some. } \\
\text { Then. } \\
\text { Matta. }\end{array}$ \\
\hline 4 & $3^{8}$ & $54 \quad 27 \cdot 39$ & $7^{6}$ & I9 & 31.84 & $\begin{array}{l}\mathrm{N} \\
\mathrm{N} \\
\mathrm{S}\end{array}$ & $\begin{array}{l}54 \\
46 \\
76\end{array}$ & $\begin{array}{l}25 \\
47 \\
50\end{array}$ & & $\begin{array}{l}\mathrm{S} \\
\mathrm{S} \\
\mathrm{N}\end{array}$ & $\begin{array}{l}542 \\
464 \\
76\end{array}$ & $\begin{array}{ll}25 & \mathrm{~W} \\
48 \mathrm{E} \\
50 \mathrm{E}\end{array}$ & $\begin{array}{r}756 \\
\mathrm{I}, 439 \\
\mathrm{I}, 106\end{array}$ & $\begin{array}{l}\text { Batts. } \\
\text { Then. } \\
\text { Matta. }\end{array}$ \\
\hline 51 & $3^{8}$ & 5405.60 & 76 & I9 & 43.00 & $\begin{array}{l}\mathrm{N} \\
\mathrm{N} \\
\mathrm{N}\end{array}$ & $\begin{array}{l}88 \\
37 \\
5^{8}\end{array}$ & $\begin{array}{l}59 \\
43 \\
23\end{array}$ & $\begin{array}{l}\mathrm{E} \\
\mathrm{E} \\
\mathrm{W}\end{array}$ & $\begin{array}{ll}\mathrm{S} & 8 \\
\mathrm{~S} & 3 \\
\mathrm{~S} & 5\end{array}$ & $\begin{array}{l}89 \\
37 \\
5^{8}\end{array}$ & $\begin{array}{ll}\circ 0 & W \\
44 & W \\
24 & E\end{array}$ & $\begin{array}{r}2,738 \\
1,484 \\
920\end{array}$ & $\begin{array}{l}\text { Turkey. } \\
\text { Batts. } \\
\text { Matta. }\end{array}$ \\
\hline
\end{tabular}

\section{BATTS NECK.}

(Cox Creck-Chart No. 3I.)

\begin{tabular}{|c|c|c|c|c|c|c|c|c|c|}
\hline I & $3^{8} 53$ & 3 5I. 90 & $7^{6} \times 18$ & 32.00 & $\begin{array}{lr}\mathrm{N} & 0 \\
\mathrm{~N} & 30 \\
\mathrm{~N} & 70\end{array}$ & 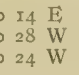 & $\begin{array}{lrrr}\mathrm{S} & 0 & \mathrm{I} 4 & \mathrm{~W} \\
\mathrm{~S} & 30 & 28 & \mathrm{E} \\
\mathrm{S} & 70 & 25 & \mathrm{E}\end{array}$ & $\begin{array}{l}3,243 \\
\mathbf{I}, 898 \\
2,817\end{array}$ & $\begin{array}{l}\text { Dell. } \\
\text { Batts. } \\
\text { Matta. }\end{array}$ \\
\hline 2 & $3^{8} 54$ & 405.60 & $7^{6} 19$ & 43.00 & $\begin{array}{ll}\mathrm{N} & 88 \\
\mathrm{~N} & 37 \\
\mathrm{~N} & 58\end{array}$ & $\begin{array}{ll}59 & \mathrm{E} \\
43 & \mathrm{E} \\
23 & \mathrm{~W}\end{array}$ & $\begin{array}{llll}\mathrm{S} & 89 & 00 & \mathrm{~W} \\
\mathrm{~S} & 37 & 44 & \mathrm{~W} \\
\mathrm{~S} & 58 & 24 & \mathrm{E}\end{array}$ & $\begin{array}{r}2,738 \\
1,484 \\
920\end{array}$ & $\begin{array}{l}\text { Turkey. } \\
\text { Batts. } \\
\text { Matta. }\end{array}$ \\
\hline 31 & $3^{8} 54$ & 427.39 & $76 \quad 19$ & 3 r. 84 & $\begin{array}{ll}\mathrm{N} & 54 \\
\mathrm{~N} & 46 \\
\mathrm{~S} & 76\end{array}$ & $\begin{array}{lll}4 & 25 & E \\
5 & 47 & W \\
5 & 50 & W\end{array}$ & $\begin{array}{llll}\mathrm{S} & 54 & 25 & \mathrm{~W} \\
\mathrm{~S} & 46 & 48 & \mathrm{E} \\
\mathrm{N} & 76 & 50 & \mathrm{E}\end{array}$ & $\begin{array}{r}756 \\
I, 439 \\
\text { I, } 106\end{array}$ & $\begin{array}{l}\text { Batts. } \\
\text { Then. } \\
\text { Matta. }\end{array}$ \\
\hline 4 & $3^{8} 54$ & 434.66 & $7^{6} \quad 18$ & 59.50 & $\begin{array}{ll}\text { N } & 22 \\
N & 50 \\
\text { S } & 75\end{array}$ & 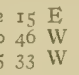 & $\begin{array}{llll}\mathrm{S} & 22 & 16 & \mathrm{~W} \\
\mathrm{~S} & 50 & 46 & \mathrm{E} \\
\mathrm{N} & 75 & 32 & \mathrm{E}\end{array}$ & $\begin{array}{r}\mathrm{I}, 947 \\
307 \\
\mathrm{I}, 993\end{array}$ & $\begin{array}{l}\text { Dell. } \\
\text { Batts. } \\
\text { Matta. }\end{array}$ \\
\hline
\end{tabular}


BOUNDARIES OF NATURAX, OYSTER BARS-continued.

RINGOLD MIDDLEGROUND.

(Cox Creek-Chart No. 3I.)

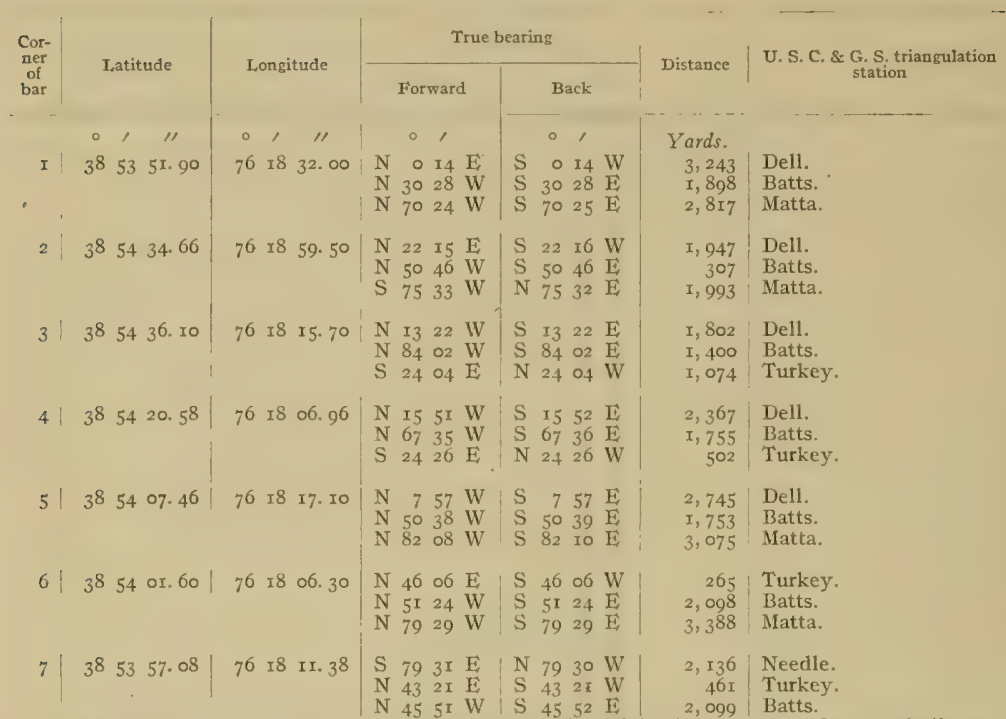

: Thence from comer No. 7 along the mean low-water line of the shore to corner No. I, excluding any creek, cove, or inlet less than 100 yards in width at its mouth at low tide.

\section{ERICKSON SANDS.}

(Cox Creck-Chart No. 3I.)

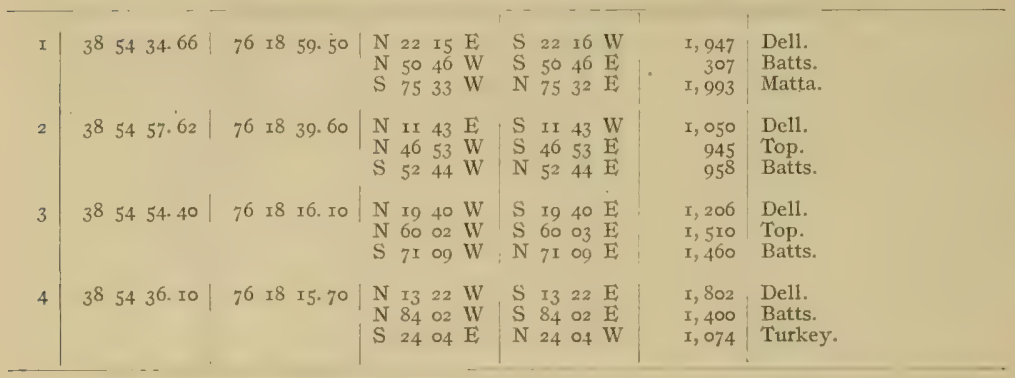


Survey of Oyster Bars, Queen Annes County, $M d$.

BOUNDARIES OF NATURAL, OYSTER BARS-continted.

PEA HILI,

(Cox Creck-Chart No. 3I.)

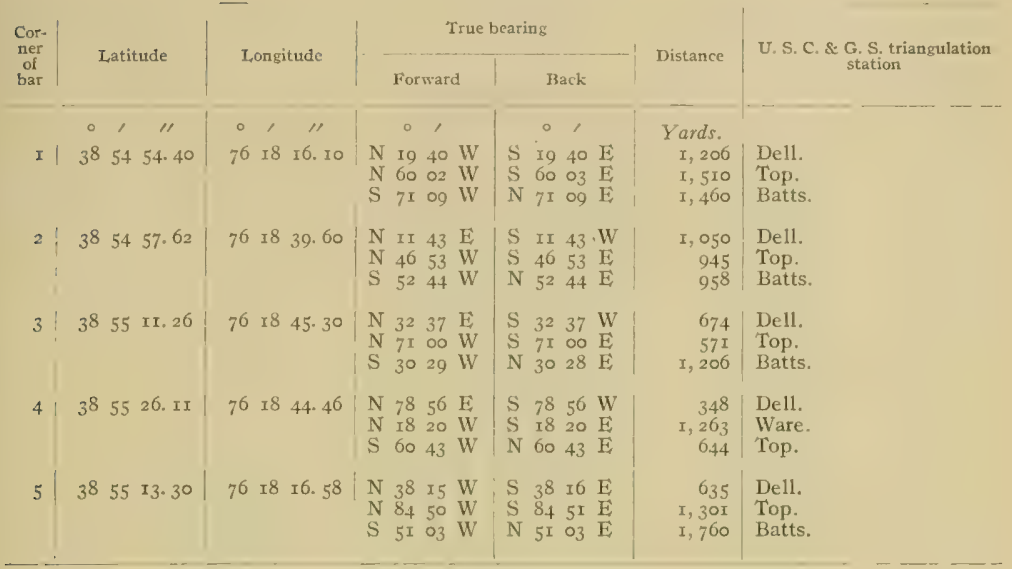

STEVENS.

(Cox Creek-Chart No. 3I.)

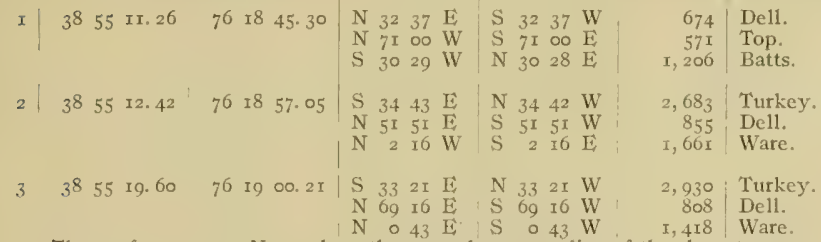

Thence from comer No. 3 along the mean low-water line of the shore to corner No. 4 , excluding any creek, cove, or inlet less than roo yards in width at its mouth at low tide.

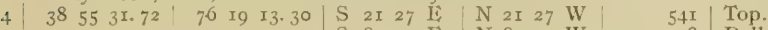

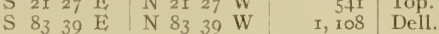

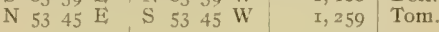

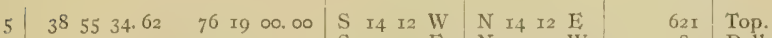

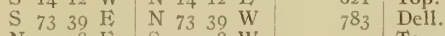

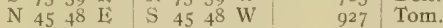

\begin{tabular}{l|lllllllllllll|r|r|r}
6 & 38 & 55 & $26 . \mathrm{II}$ & 76 & $\mathrm{I} 8$ & 44.46 & $\mathrm{~N}$ & 78 & 56 & $\mathrm{E}$ & $\mathrm{S}$ & 78 & 56 & $\mathrm{~W}$ & 348 & Dell. \\
$\mathrm{N}$ & $\mathrm{I} 8$ & 20 & $\mathrm{~W}$ & $\mathrm{~S}$ & $\mathrm{I} 8$ & 20 & $\mathrm{E}$ & $\mathrm{I}, 263$ & Ware.
\end{tabular}

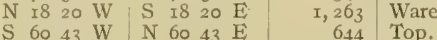
\begin{tabular}{l|ll|l|l}
$6043 \mathrm{~W}$ & $\mathrm{~N} 6043 \mathrm{E}$ & 644 & Top.
\end{tabular} 
BOUNDARIES OF NATURAL OYSTER BARS-continued. JONES HOLE.

(Cox Creck-Chart No. 3I.)

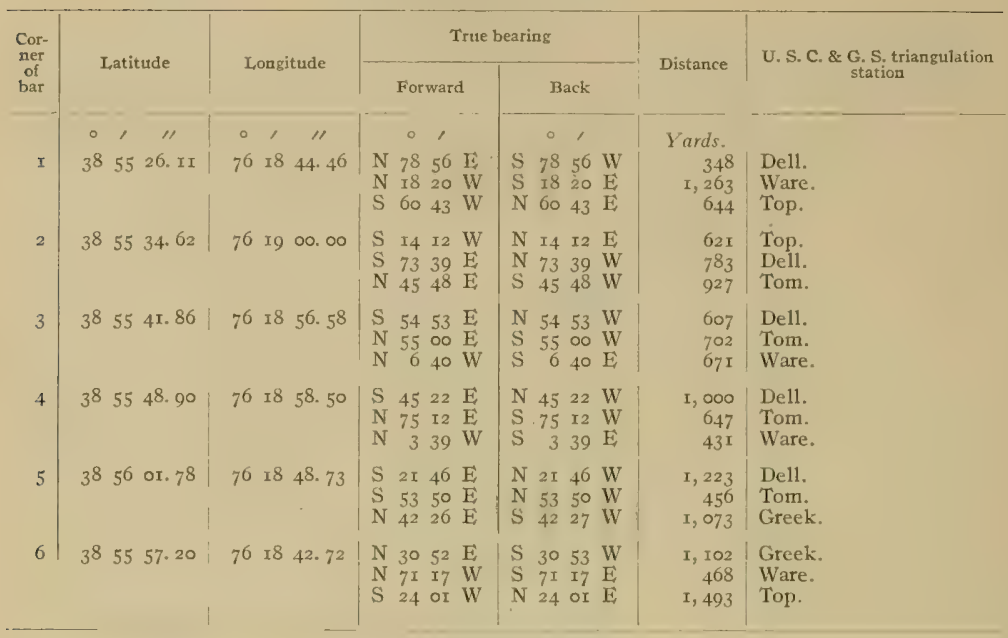

\section{POND MARSH.}

(Cox Creek-Chart No.3I.)

\begin{tabular}{|c|c|c|c|c|c|c|}
\hline$I$ & $\begin{array}{llll}38 & 55 & 57.20\end{array}$ & $\begin{array}{lll}76 & 18 & 42.72\end{array}$ & $\begin{array}{llll}\mathrm{N} & 30 & 52 & \mathrm{E} \\
\mathrm{N} & 7 \mathrm{I} & \mathrm{I} 7 & \mathrm{~W} \\
\mathrm{~S} & 24 & \text { OI } & \mathrm{W}\end{array}$ & $\begin{array}{llll}\mathrm{S} & 30 & 53 & \mathrm{~W} \\
\mathrm{~S} & 7 \mathrm{I} & 17 & \mathrm{E} \\
\mathrm{N} & 24 & \text { OI } & \mathrm{E}\end{array}$ & $\begin{array}{r}I, I 02 \\
468 \\
I, 493\end{array}$ & $\begin{array}{l}\text { Greek. } \\
\text { Ware. } \\
\text { Top. }\end{array}$ \\
\hline 2 & $3^{8} 5^{6}$ or. $7^{8}$ & 76 I8 48.73 & $\begin{array}{llll}\mathrm{S} & 2 \mathrm{I} & 46 & \mathrm{E} \\
\mathrm{S} & 53 & 50 & \mathrm{E} \\
\mathrm{N} & 42 & 26 & \mathrm{E}\end{array}$ & $\begin{array}{llll}N & 2 I & 46 & W \\
N & 53 & 50 & W \\
S & 42 & 27 & W\end{array}$ & $\begin{array}{r}\mathrm{I}, 223 \\
456 \\
\mathrm{I}, 073\end{array}$ & $\begin{array}{l}\text { Dell. } \\
\text { Tom. } \\
\text { Greek. }\end{array}$ \\
\hline 3 & 3856 o6. 34 & $\begin{array}{llll}76 & \text { I } 8 & 5 \text { I. O2 }\end{array}$ & $\begin{array}{lrrr}\mathrm{S} & 45 & 23 & \mathrm{E} \\
\mathrm{N} & 50 & 5^{2} & \mathrm{E} \\
\mathrm{N} & 4 & 58 & \mathrm{E}\end{array}$ & $\begin{array}{lrrl}\mathrm{N} & 45 & 23 & \mathrm{~W} \\
\mathrm{~S} & 50 & 53 & \mathrm{~W} \\
\mathrm{~S} & 4 & 58 & \mathrm{~W}\end{array}$ & $\begin{array}{r}601 \\
r, 012 \\
r, 179\end{array}$ & $\begin{array}{l}\text { Tom. } \\
\text { Greek. } \\
\text { Tuxon. }\end{array}$ \\
\hline 4 & $3^{8} \quad 5^{6} \quad 07.9^{2}$ & $7^{6} \quad 18 \quad 56.05$ & $\mid \begin{array}{llll}\mathrm{S} & 49 & 4 \mathrm{I} & \mathrm{E} \\
\mathrm{N} & 57 & 28 & \mathrm{E} \\
\mathrm{N} & \mathrm{II} & 48 & \mathrm{E}\end{array}$ & $\begin{array}{llll}\mathrm{N} & 49 & 4 \mathrm{I} & \mathrm{W} \\
\mathrm{S} & 57 & 29 & \mathrm{~W} \\
\mathrm{~S} & \mathrm{II} & 49 & \mathrm{~W}\end{array}$ & $\begin{array}{r}736 \\
\text { I, } 087 \\
\text { I, } 146\end{array}$ & $\begin{array}{l}\text { Tom. } \\
\text { Greek. } \\
\text { Tuxon. }\end{array}$ \\
\hline 5 & $38 \quad 56 \quad 26.53$ & $7^{6}$ I9 II. $7^{2}$ & $\begin{array}{lrll}\mathrm{S} & 88 & \circ 9 & \mathrm{E} \\
\mathrm{N} & 4 & 07 & \mathrm{~W} \\
\mathrm{~N} & 78 & 52 & \mathrm{~W}\end{array}$ & $\begin{array}{lrll}N & 88 & \text { og } & W \\
S & 4 & \text { O7 } & \text { E } \\
\text { S } & 78 & 52 & \mathrm{E}\end{array}$ & $\begin{array}{r}I, 331 \\
419 \\
270\end{array}$ & $\begin{array}{l}\text { Greek. } \\
\text { Liver. } \\
\text { Coffee. }\end{array}$ \\
\hline 6 & $\begin{array}{l}3^{8} 5^{6} 3 x \cdot 40 \\
.\end{array}$ & $7^{6}$ I8 $5^{6} .3^{8}$ & $\begin{array}{rrrr}\mathrm{S} & 80 & 30 & \mathrm{~W} \\
\mathrm{~S} & 4 & 45 & \mathrm{~W} \\
\mathrm{~S} & 77 & 23 & \mathrm{E}\end{array}$ & $\begin{array}{lrrr}N & 80 & 30 & \mathrm{E} \\
\mathrm{N} & 4 & 45 & \mathrm{E} \\
\mathrm{N} & 77 & 23 & \mathrm{~W}\end{array}$ & $\begin{array}{r}679 \\
I, 007 \\
948\end{array}$ & $\begin{array}{l}\text { Coffee. } \\
\text { Ware. } \\
\text { Greek. }\end{array}$ \\
\hline 7 & $3^{8} 5^{6} \quad 24 \cdot 24$ & $\begin{array}{llll}76 & \text { I } 8 & 26.8 \mathrm{r}\end{array}$ & $\begin{array}{lrll}N & 8 & 54 & E \\
N & 43 & 10 & W \\
S & 48 & 32 & W\end{array}$ & $\begin{array}{lrrr}\mathrm{S} & 8 & 54 & \mathrm{~W} \\
\mathrm{~S} & 43 & \mathrm{II} & \mathrm{E} \\
\mathrm{N} & 48 & 32 & \mathrm{E}\end{array}$ & $\begin{array}{r}669 \\
783 \\
I, \times 50\end{array}$ & $\begin{array}{l}\text { Ville. } \\
\text { Tuxon. } \\
\text { Ware. }\end{array}$ \\
\hline 8 & $3^{8} 5559 \cdot 52$ & $7^{6}$ I8 $37 \cdot 10$ & $\begin{array}{llll}N & \text { Io } & 40 & W \\
N & 83 & 04 & W \\
S & I 7 & 47 & E\end{array}$ & $\begin{array}{llll}\mathrm{S} & 10 & 40 & \mathrm{E} \\
\mathrm{S} & 83 & 04 & \mathrm{E} \\
\mathrm{N} & 17 & 47 & \mathrm{~W}\end{array}$ & $\begin{array}{r}I, 429 \\
595 \\
202\end{array}$ & $\begin{array}{l}\text { Tuxon. } \\
\text { Ware. } \\
\text { Tom. }\end{array}$ \\
\hline
\end{tabular}


BOUNDARIES OF NATURAL OYSTER BARS-cONTINUEd.

ISLAND COVE.

(Cox Creck-Chart No. 3I.)

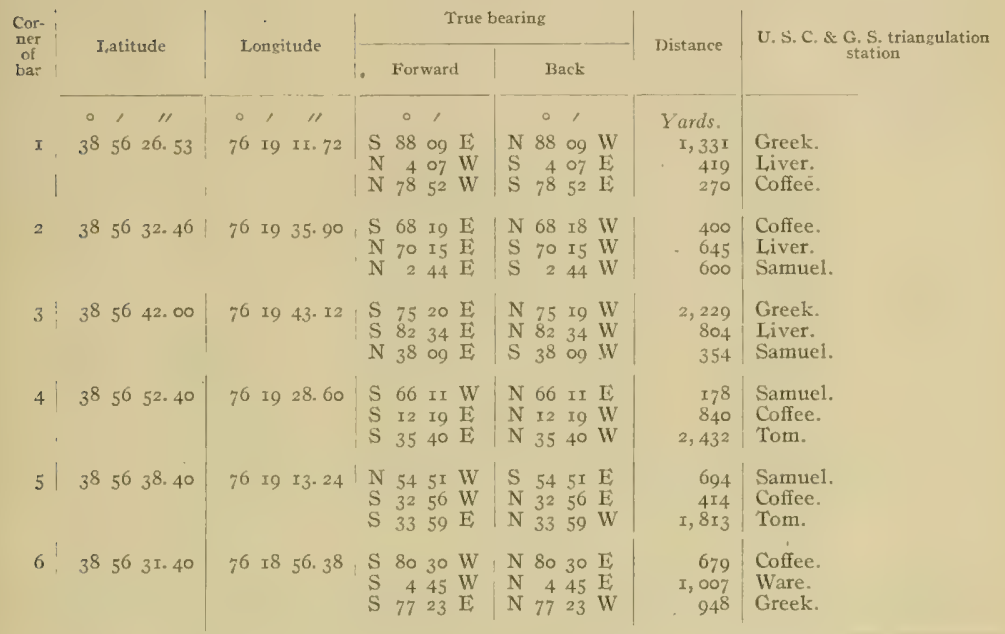


BOUNDARIES OF NATURAL OYSTER BARS-continued.

ROOKS.

(Cox Creek-Chart No. 37.)

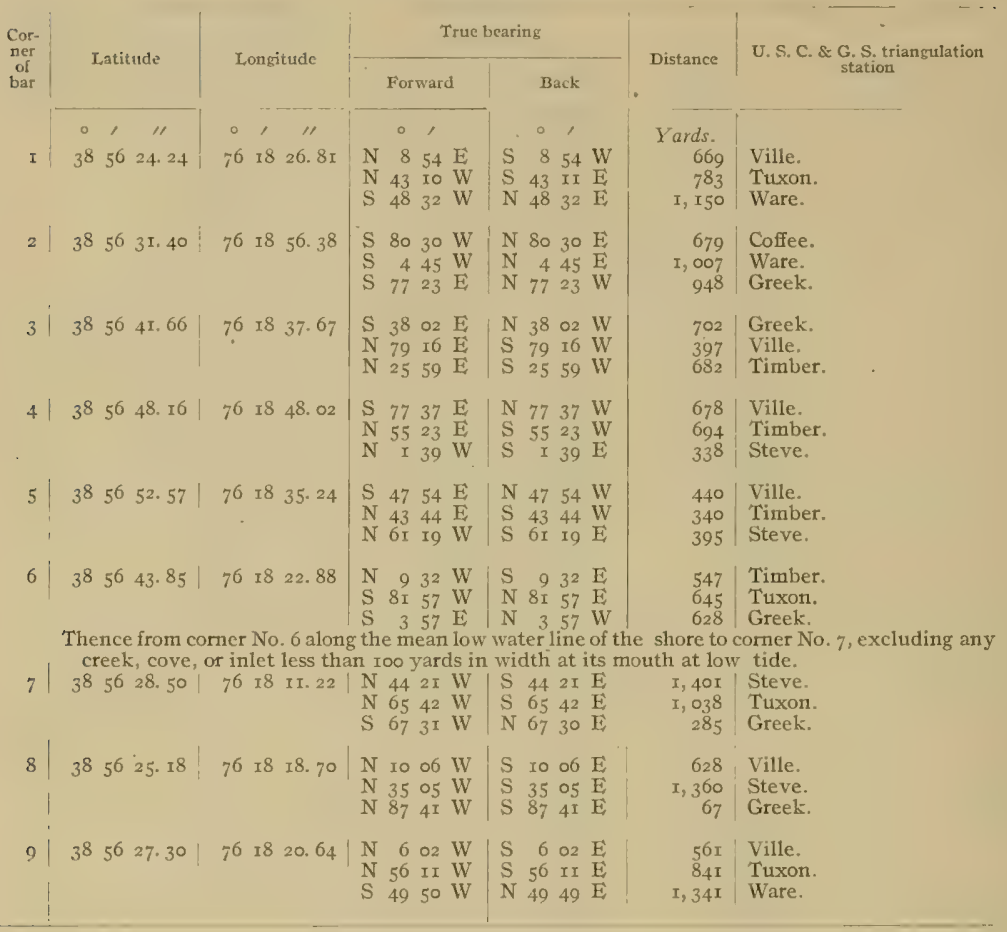


BOUNDARIES OF NATURAL OYSTER BARS-continued.

THOMIPSONS.

(Cox Creek-Chart No. 3r.)

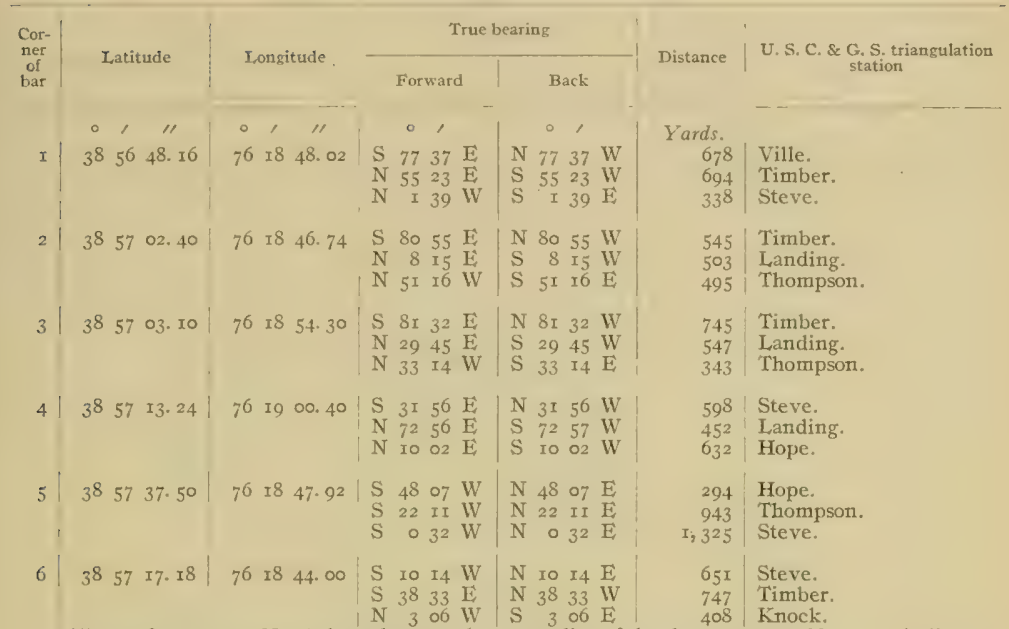

Thence from comer No. 6 along the mean low water line of the shore to comer No. 7 , excluding any creek, cove, or inlet less than roo yards in width at its mouth at low tide.

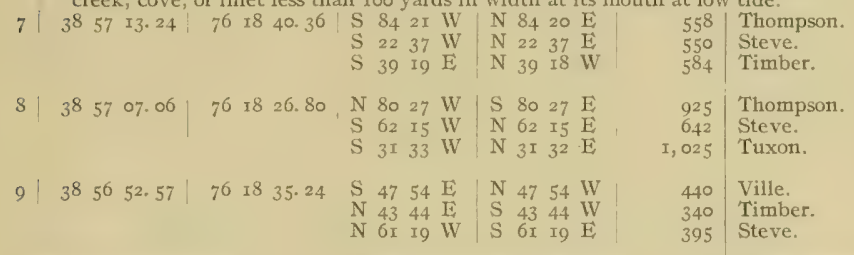

\section{JOHNSON ISLAND.}

(Crab Alley Bay-Chart No. 3T.)

\begin{tabular}{|c|c|c|c|c|c|c|}
\hline$I$ & $3^{8} \quad 55 \quad 24 \cdot 75$ & $76 \quad 1646.80$ & $\begin{array}{llll}\mathrm{S} & 4 \mathrm{I} & 07 & \mathrm{~W} \\
\mathrm{~S} & 75 & 54 & \mathrm{E} \\
\mathrm{N} & 34 & 40 & \mathrm{E}\end{array}$ & $\begin{array}{llll}\mathrm{N} & 4 \mathrm{I} & 07 & \mathrm{E} \\
\mathrm{N} & 75 & 5+ & \mathrm{W} \\
\mathrm{S} & 34 & 40 & \mathrm{~W}\end{array}$ & $\begin{array}{l}\text { 2, III } \\
\text { I, } 696 \\
\text { I, } 662\end{array}$ & $\begin{array}{l}\text { Cox. } \\
\text { Norman. } \\
\text { Over. }\end{array}$ \\
\hline 2 & $3^{8} 5530.85$ & $7^{6} \quad$ I6 58.97 & $\begin{array}{llll}\mathrm{S} & 30 & 4.4 & \mathrm{E} \\
\mathrm{S} & 72 & 32 & \mathrm{E} \\
\mathrm{N} & 20 & 49 & \mathrm{~W}\end{array}$ & $\begin{array}{llll}N & 30 & 44 & W \\
N & 72 & 3 I & W \\
S & 20 & 49 & E\end{array}$ & $\begin{array}{l}2,090 \\
2,061 \\
I, I 82\end{array}$ & $\begin{array}{l}\text { Cox. } \\
\text { Norman. } \\
\text { Tull. }\end{array}$ \\
\hline 3 & 385554.98 & $76 \quad 16 \quad 59 \cdot 34$ & $\begin{array}{llll}S & 54 & 03 & E \\
N & 74 & 46 & E \\
N & 54 & 38 & W\end{array}$ & $\begin{array}{llll}\mathrm{N} & 54 & \text { O2 } & \mathrm{W} \\
\mathrm{S} & 74 & 47 & \mathrm{~W} \\
\mathrm{~S} & 54 & 38 & \mathrm{E}\end{array}$ & $\begin{array}{r}2,44 I \\
I, 322 \\
503\end{array}$ & $\begin{array}{l}\text { Norman. } \\
\text { Over. } \\
\text { Tull. }\end{array}$ \\
\hline 4 & $\begin{array}{llll}3^{8} & 5^{6} & 03.90\end{array}$ & $76 \times 626.66$ & $\begin{array}{llll}\mathrm{S} & 89 & 37 & \mathrm{~W} \\
\mathrm{~S} & 32 & 45 & \mathrm{E} \\
\mathrm{N} & 83 & 36 & \mathrm{E}\end{array}$ & $\begin{array}{llll}\mathrm{N} & 89 & 34 & \mathrm{E} \\
\mathrm{N} & 32 & 46 & \mathrm{~W} \\
\mathrm{~S} & 83 & 36 & \mathrm{~W}\end{array}$ & $\begin{array}{r}I, 27 I \\
2,060 \\
4 I 7\end{array}$ & $\begin{array}{l}\text { Tull. } \\
\text { Norman. } \\
\text { Over. }\end{array}$ \\
\hline
\end{tabular}


BOUNDARIES OF NATURAL OYSTER BARS-continued.

CRAB AI,LEY L,UMPS.

(C iab Alley Bay-Charts Nos. 3 I and 32.)

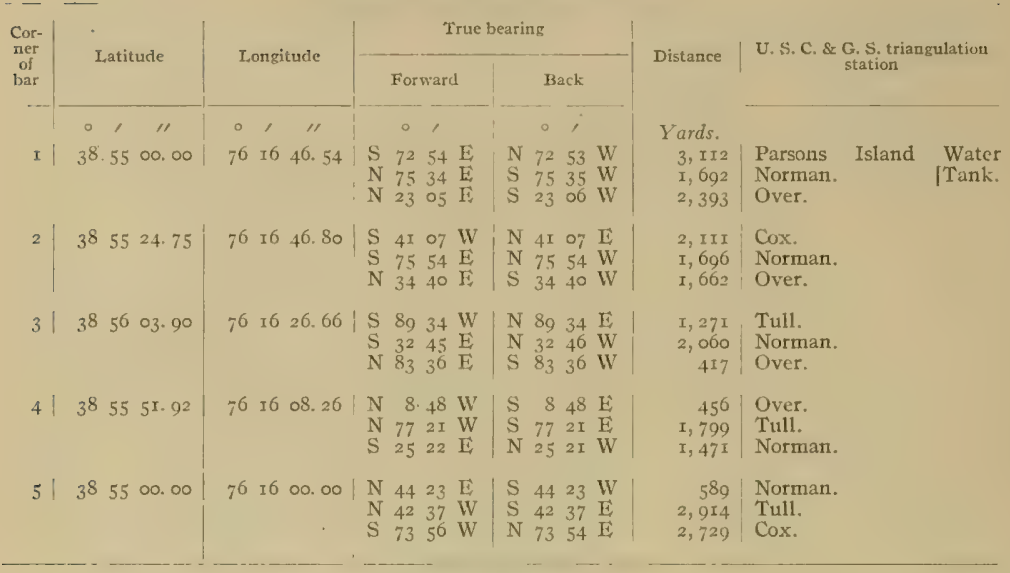

\section{CEDAR ISLAND.}

(Crab Alley Bay-Chart No. 3 II.)

\begin{tabular}{|c|c|c|c|c|c|c|c|}
\hline $3^{8} 544^{6.17}$ & 76 I7 31. 86 & $\begin{array}{llll}\mathrm{S} & 34 & 48 & \mathrm{~W} \\
\mathrm{~S} & 83 & 52 & \mathrm{E} \\
\mathrm{N} & 38 & 38 & \mathrm{E}\end{array}$ & $\begin{array}{lllll}\mathrm{N} & 34 & 47 & \mathrm{E} \\
\mathrm{N} & 8 & 3 & 50 & \mathrm{~W} \\
\mathrm{~S} & 38 & 39 & \mathrm{~W}\end{array}$ & $\begin{array}{r}352 \\
4,193 \\
3,415\end{array}$ & $\begin{array}{l}\text { Cox. } \\
\text { Parsons } \\
\text { Over. }\end{array}$ & Island & $\begin{array}{l}\text { [Tank. } \\
\text { Water }\end{array}$ \\
\hline $3^{8} \quad 55 \quad 00.92$ & 76 I7 50.90 & $\begin{array}{llll}\mathrm{S} & 3 \mathrm{I} & 34 & \mathrm{E} \\
\mathrm{N} & 83 & \mathrm{~T} & \mathrm{E} \\
\mathrm{N} & 50 & 30 & \mathrm{E}\end{array}$ & $\begin{array}{lllll}\mathrm{N} & 3 & \mathrm{I} & 33 & \mathrm{~W} \\
\mathrm{~S} & 8 & 2 \mathrm{~T} & \mathrm{~W} \\
\mathrm{~S} & 50 & 3 \mathrm{I} & \mathrm{W}\end{array}$ & $\begin{array}{l}2,9^{82} \\
3,357 \\
3,413\end{array}$ & $\begin{array}{l}\text { Needle. } \\
\text { Norman. } \\
\text { Over. }\end{array}$ & & \\
\hline $3^{8} \quad 5543 \cdot 39$ & $7_{6}^{6}$ I7 $35 . I_{3}$ & $\begin{array}{lrrr}\mathrm{S} & 2 & 5^{8} & \mathrm{~W} \\
\mathrm{~S} & 70 & 22 & \mathrm{E} \\
\mathrm{N} & 71 & 35 & \mathrm{E}\end{array}$ & $\begin{array}{lrrr}\mathrm{N} & 2 & 58 & \mathrm{E} \\
\mathrm{N} & 70 & 21 & \mathrm{~W} \\
\mathrm{~S} & 71 & 36 & \mathrm{~W}\end{array}$ & $\begin{array}{l}2,222 \\
3,099 \\
2,338\end{array}$ & $\begin{array}{l}\text { Cox. } \\
\text { Norman. } \\
\text { Over. }\end{array}$ & & \\
\hline $3^{8} \quad 55 \quad 39.02$ & 76 I7 21.60 & $\begin{array}{llll}\mathrm{S} & \mathrm{I} 2 & 49 \mathrm{~W} \\
\mathrm{~S} & 70 & 46 & \mathrm{E} \\
\mathrm{N} & \mathrm{II} & 58 & \mathrm{E}\end{array}$ & $\begin{array}{llll}\mathrm{N} & \text { I2 } & 49 & \mathrm{E} \\
\mathrm{N} & 70 & 45 & \mathrm{~W} \\
\mathrm{~S} & \text { II } & 59 & \mathrm{~W}\end{array}$ & $\begin{array}{r}2,125 \\
2,714 \\
848\end{array}$ & $\begin{array}{l}\text { Cox. } \\
\text { Norman. } \\
\text { Tull. }\end{array}$ & & \\
\hline $\begin{array}{llll}3^{8} & 55 & 27.30\end{array}$ & $76 \quad 17 \quad 24.08$ & $\begin{array}{llll}\mathrm{S} & 13 & 37 & \mathrm{~W} \\
\mathrm{~S} & 79 & \mathrm{I} & \mathrm{E} \\
\mathrm{N} & \mathrm{II} & 09 & \mathrm{~W}\end{array}$ & $\begin{array}{llll}\mathrm{N} & 13 & 37 & \mathrm{E} \\
\mathrm{N} & 79 & \mathrm{I} & \mathrm{W} \\
\mathrm{S} & \mathrm{II} & 09 & \mathrm{E}\end{array}$ & $\begin{array}{l}\text { I, } 725 \\
2,675 \\
\mathrm{I}, 249\end{array}$ & $\begin{array}{l}\text { Cox. } \\
\text { Norman. } \\
\text { Tull. }\end{array}$ & & \\
\hline $3^{8} \quad 55 \quad 30.85$ & $7^{6}$ I6 58.97 & $\begin{array}{llll}\mathrm{S} & 30 & 44 & \mathrm{E} \\
\mathrm{S} & 72 & 32 & \mathrm{E} \\
\mathrm{N} & 20 & 49 & \mathrm{~W}\end{array}$ & $\begin{array}{llll}\mathrm{N} & 30 & 44 & \mathrm{~W} \\
\mathrm{~N} & 72 & 3 \mathrm{I} & \mathrm{W} \\
\mathrm{S} & 20 & 49 & \mathrm{E}\end{array}$ & $\begin{array}{l}2,090 \\
2,06 \mathrm{r} \\
\mathrm{I}, 182\end{array}$ & $\begin{array}{l}\text { Cox. } \\
\text { Norman. } \\
\text { Tull. }\end{array}$ & & \\
\hline $3^{8} \quad 55 \quad 24.75$ & $76 \quad I 6 \quad 46.80$ & $\begin{array}{llll}\mathrm{S} & 4 \mathrm{I} & \text { or } & \mathrm{W} \\
\mathrm{S} & 75 & 54 & \mathrm{E} \\
\mathrm{N} & 34 & 40 & \mathrm{E}\end{array}$ & $\begin{array}{llll}\mathrm{N} & 4 \mathrm{I} & 07 & \mathrm{E} \\
\mathrm{N} & 75 & 54 & \mathrm{~W} \\
\mathrm{~S} & 34 & 40 & \mathrm{~W}\end{array}$ & $\begin{array}{l}2, I I I \\
I, 696 \\
I, 662\end{array}$ & $\begin{array}{l}\text { Cox. } \\
\text { Norman. } \\
\text { Over. }\end{array}$ & & \\
\hline $3^{8} 5500.00$ & $7^{6} \quad{ }^{6} 64^{6} .54$ & $\begin{array}{llll}\mathrm{S} & 72 & 54 & \mathrm{E} \\
\mathrm{N} & 75 & 34 & \mathrm{E} \\
\mathrm{N} & 23 & 05 & \mathrm{E}\end{array}$ & $\begin{array}{llll}\mathrm{N} & 72 & 53 & \mathrm{~W} \\
\mathrm{~S} & 75 & 35 & \mathrm{~W} \\
\mathrm{~S} & 23 & 06 & \mathrm{~W}\end{array}$ & $\begin{array}{l}3, x 12 \\
1,692 \\
2,393\end{array}$ & $\begin{array}{l}\text { Parsons } \\
\text { Norman. } \\
\text { Over. }\end{array}$ & Island & $\begin{array}{l}\text { Water } \\
\text { [Tank. }\end{array}$ \\
\hline
\end{tabular}


BOUNDARIES OF NATURAL, OYSTER BARS-continued. NORMANS FINE EYES.

(Eastern Bay-Charts Nos. $3 I$ and 32.)

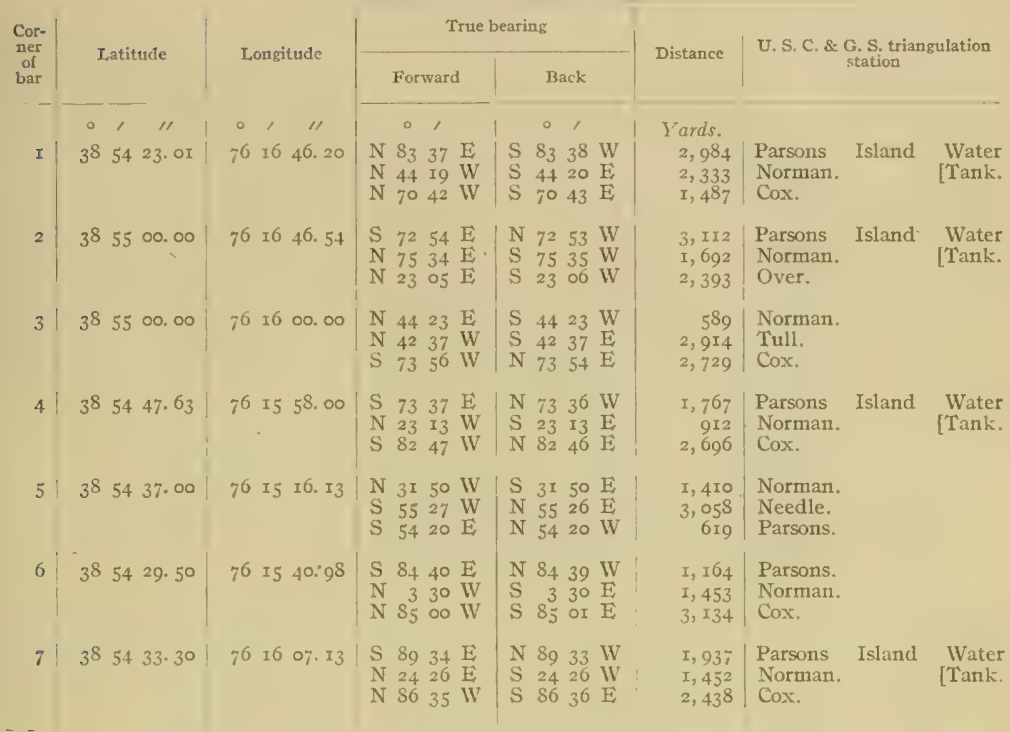

\section{COX NECK.}

(Eastern Baj-Chart No. 3I.)

\begin{tabular}{|c|c|c|c|c|c|c|c|c|}
\hline & $\begin{array}{llll}38 & 54 & 03.40\end{array}$ & 76 I6 57.90 & $\begin{array}{llll}N_{7} & 73 & 07 & \mathrm{E} \\
\mathrm{N} & 39 & 45 & \mathrm{E} \\
\mathrm{N} & 43 & 33 & \mathrm{IV}\end{array}$ & $\begin{array}{llll}\mathrm{S} & 73 & \text { os } & \mathrm{WV} \\
\mathrm{S} & 39 & 45 & \mathrm{WV} \\
\mathrm{S} & 43 & 33 & \mathrm{E}\end{array}$ & $\begin{array}{l}3,42 I \\
3,030 \\
I, 59 I\end{array}$ & $\begin{array}{l}\text { Parsons } \\
\text { Norman. } \\
\text { Cox. }\end{array}$ & Island & $\begin{array}{l}\text { Water } \\
\text { [Tank. }\end{array}$ \\
\hline & ${ }_{3} S 5405.63$ & $76 I_{7} 3 I .13$ & $\begin{array}{llll}\mathrm{N} & \pi i & 3 & \mathrm{E} \\
\mathrm{N} & \mathrm{II} & 33 & \mathrm{~W} \\
\mathrm{~S} & 86 & 20 & \mathrm{~W}\end{array}$ & $\begin{array}{llll}\mathrm{S} & 7 \pi & 32 & \mathrm{~W} \\
\mathrm{~S} & \text { II } & 33 & \mathrm{E} \\
\mathrm{N} & \mathrm{S} 6 & 20 & \mathrm{E}\end{array}$ & $\begin{array}{l}4,250 \\
I, 100 \\
738\end{array}$ & $\begin{array}{l}\text { Parsons } \\
\text { Cox. } \\
\text { Turkey. }\end{array}$ & Island & $\begin{array}{l}\text { Water } \\
\text { [Tanik. }\end{array}$ \\
\hline & $3^{S} 5+$ to. $S_{3}$ & $76 \times 73 \% 30$ & $\begin{array}{llll}\mathrm{S} & \mathrm{S} 6 & 27 & \mathrm{E} \\
\mathrm{N} & 70 & 15 & \mathrm{E} \\
\mathrm{N} & \mathrm{Ix} & 55 & \mathrm{E}\end{array}$ & $\begin{array}{llll}\mathrm{N} & S 6 & 25 & \mathrm{~W} \\
\mathrm{~S} & 70 & 16 & \mathrm{~W} \\
\mathrm{~S} & \mathrm{II} & 56 & \mathrm{~W}\end{array}$ & $\begin{array}{l}4,320 \\
3,162 \\
2,8_{53}\end{array}$ & $\begin{array}{l}\text { Parsous } \\
\text { Norman. } \\
\text { Tull. }\end{array}$ & Island & $\begin{array}{l}\text { Water } \\
\text { [Tank. }\end{array}$ \\
\hline & $3^{S} 5+46.17$ & 76 17 31.86 & $\begin{array}{llll}\mathrm{S} & 34 & 48 & \mathrm{IV} \\
\mathrm{S} & 83 & 52 & \mathrm{E} \\
\mathrm{N} & 38 & 38 & \mathrm{E}\end{array}$ & $\begin{array}{llll}\mathrm{N} & 34 & 47 & \mathrm{E} \\
\mathrm{N} & 83 & 50 & \mathrm{~W} \\
\mathrm{~S} & 38 & 39 & \mathrm{~W}\end{array}$ & $\begin{array}{r}35^{2} \\
4,193 \\
3,415\end{array}$ & $\begin{array}{l}\text { Cox. } \\
\text { Parsons } \\
\text { Over. }\end{array}$ & Island & $\begin{array}{l}\text { Water } \\
\text { [Tank. }\end{array}$ \\
\hline & $3^{8} 5500.00$ & $76 \quad 16 \quad 46.54$ & $\begin{array}{llll}\mathrm{S} & 72 & 54 & \mathrm{E} \\
\mathrm{N} & 75 & 34 & \mathrm{E} \\
\mathrm{N} & 23 & 05 & \mathrm{E}\end{array}$ & $\begin{array}{llll}\mathrm{N} & 7^{2} & 53 & \mathrm{WW} \\
\mathrm{S} & 75 & 35 & \mathrm{~W} \\
\mathrm{~S} & 23 & 06 & \mathrm{~W}\end{array}$ & $\begin{array}{l}3, \text { II } 2 \\
\mathrm{I}, 692 \\
2,393\end{array}$ & $\begin{array}{l}\text { Parsons } \\
\text { Norman. } \\
\text { Over. }\end{array}$ & Island & $\begin{array}{l}\text { Water } \\
\text { [Tank. }\end{array}$ \\
\hline & $3^{S} \quad 54 \quad 23.01$ & $7_{6}^{6} 16 \quad 46.20$ & $\begin{array}{llll}\mathrm{N} & 83 & 37 & \mathrm{E} \\
\mathrm{N} & 44 & 19 & \mathrm{WV} \\
\mathrm{N} & 70 & 42 & \mathrm{WV}\end{array}$ & $\begin{array}{llll}\mathrm{S} & 83 & 38 & \mathrm{~W} \\
\mathrm{~S} & 44 & 20 & \mathrm{E} \\
\mathrm{S} & 70 & 43 & \mathrm{E}\end{array}$ & $\begin{array}{l}2,984 \\
2,333 \\
1,487\end{array}$ & $\begin{array}{l}\text { Parsons } \\
\text { Norman. } \\
\text { Cox. }\end{array}$ & Island & $\begin{array}{l}\text { Water } \\
\text { [Tank. }\end{array}$ \\
\hline
\end{tabular}


BOUNDARIES OF NATURAL, OYSTER BARS-continued.

BODKIN ISLAND.

(Eastern Bay-Charts Nos. 31 and 32.)

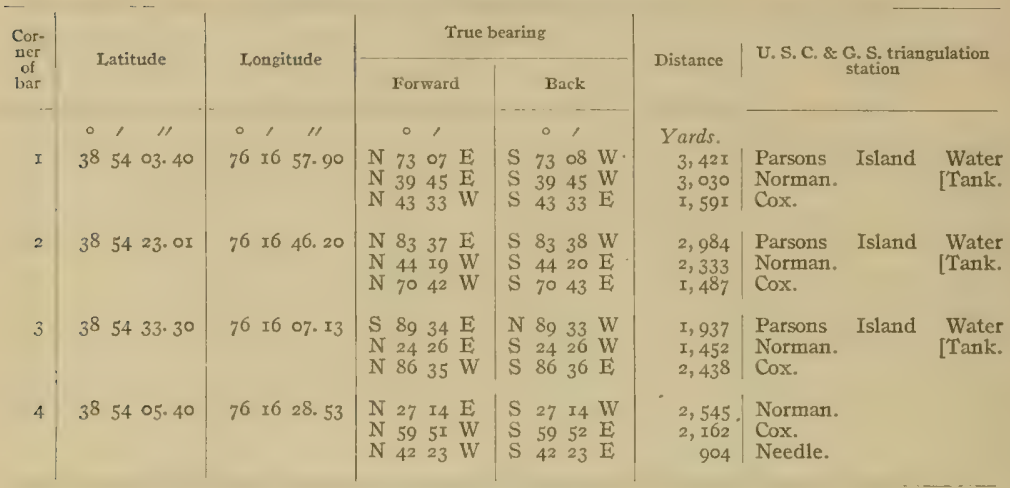

\section{PARSONS ISLAND.}

(Eastern Bay-Chart No. 32.)

\begin{tabular}{|c|c|c|c|c|c|c|c|c|c|}
\hline & $3^{8}$ & $53 \quad 36.00$ & 76 I5 $37.8 z$ & $\begin{array}{lrrr}\mathrm{N} & 3 I & \text { I } 5 & \mathrm{E} \\
\mathrm{N} & 3 & \text { OI } & \mathrm{W} \\
\mathrm{N} & 57 & 03 & \mathrm{~W}\end{array}$ & $\begin{array}{rrrr}\mathrm{S} & 3 I & 16 & \mathrm{~W} \\
\mathrm{~S} & 3 & \text { or } & \mathrm{E} \\
\mathrm{S} & 57 & \text { of } & \mathrm{E}\end{array}$ & $\begin{array}{l}2,242 \\
3,259 \\
3,820\end{array}$ & $\begin{array}{l}\text { Parsons } \\
\text { Norman. } \\
\text { Cox. }\end{array}$ & Island & $\begin{array}{l}\text { Water } \\
\text { [Tank. }\end{array}$ \\
\hline & $3^{S}$ & $535^{8} .40$ । & $76 x 6 \times 6 . \infty 0$ & $\begin{array}{llll}N & 6 I & 50 & E \\
N & I 8 & 28 & E \\
N & 59 & 00 & W\end{array}$ & $\begin{array}{llll}\mathrm{S} & 6 \mathrm{x} & 50 & \mathrm{~W} \\
\mathrm{~S} & \mathrm{I} 8 & 28 & \mathrm{~W} \\
\mathrm{~S} & 59 & \text { oI } & \mathrm{E}\end{array}$ & $\begin{array}{l}2,461 \\
2,634 \\
2,567\end{array}$ & $\begin{array}{l}\text { Parsons } \\
\text { Norman. } \\
\text { Cox. }\end{array}$ & Island & $\begin{array}{l}\text { Water } \\
\text { [Tank. }\end{array}$ \\
\hline & $3^{8}$ & 54 o6. 43 | & $\begin{array}{lll}76 & 16 & 13.60\end{array}$ & $\begin{array}{llll}N & 67 & 04 & E \\
N & 19 & 05 & E \\
N & 65 & 05 & W\end{array}$ & $\begin{array}{llll}\mathrm{S} & 67 & 05 & \mathrm{IV} \\
\mathrm{S} & 19 & 05 & \mathrm{~W} \\
\mathrm{~S} & 65 & 06 & \mathrm{E}\end{array}$ & $\begin{array}{l}2,287 \\
2,358 \\
2,496\end{array}$ & $\begin{array}{l}\text { Parsons } \\
\text { Norman. } \\
\text { Cox. }\end{array}$ & Island & $\begin{array}{l}\text { Water } \\
\text { [Tank. }\end{array}$ \\
\hline & $3^{8}$ & $54 \quad 07: 22$ & 76 I5 49.00 & $\begin{array}{lrll}\mathrm{N}_{5} 59 & 21 & \mathrm{E} \\
\mathrm{N} & 3 & 12 & \mathrm{E} \\
\mathrm{N} & 70 & 37 & \mathrm{~W}\end{array}$ & $\begin{array}{rrrr}\mathrm{S} & 59 & 21 & \mathrm{IV} \\
\mathrm{S} & 3 & 12 & \mathrm{IV} \\
\mathrm{S} & 70 & 3^{8} & \mathrm{E}\end{array}$ & $\begin{array}{l}I, 695 \\
2,205 \\
3,086\end{array}$ & $\begin{array}{l}\text { Parsons } \\
\text { Normant. } \\
\text { Cox. }\end{array}$ & Island & $\begin{array}{l}\text { Water } \\
\text { [Tank. }\end{array}$ \\
\hline & $3^{8}$ & $54=9.50$ & $76 \quad 15 \quad 40.98$ & $\begin{array}{lrrrr}S & 84 & 40 & \mathrm{E} \\
\mathrm{N} & 3 & 30 & \mathrm{WV} \\
\mathrm{N} & 85 & 00 & \mathrm{IV}\end{array}$ & $\begin{array}{llll}\mathrm{N} & 84 & 39 & \mathrm{IV} \\
\mathrm{S} & 3 & 30 & \mathrm{E} \\
\mathrm{S} & 85 & \text { or } & \mathrm{E}\end{array}$ & $\begin{array}{l}1, x 64 \\
I, 453 \\
3,134\end{array}$ & $\begin{array}{l}\text { Parsons. } \\
\text { Norman1. } \\
\text { Cox. }\end{array}$ & & \\
\hline & $3^{S}$ & 5437.001 & 76 I5 $16 . I_{3}$ & $\begin{array}{llll}\mathrm{N} & 3 \mathrm{I} & 50 & \mathrm{~W} \\
\mathrm{~S} & 55 & 27 & \mathrm{~W} \\
\mathrm{~S} & 54 & 20 & \mathrm{E}\end{array}$ & $\begin{array}{llll}\mathrm{S} & 3 I & 50 & \mathrm{E} \\
\mathrm{N} & 55 & 26 & \mathrm{E} \\
\mathrm{N} & 54 & 20 & \mathrm{~W}\end{array}$ & $\begin{array}{r}1,410 \\
3,058 \\
619\end{array}$ & $\begin{array}{l}\text { Norman. } \\
\text { Needle. } \\
\text { Parsons. }\end{array}$ & & \\
\hline & $3^{8}$ & 53 59. Io ! & 76 I5 18.07 & $\begin{array}{lrrr}N & 8 & 32 & E \\
N & 15 & 37 & \text { W } \\
S & 79 & 3 I & \text { WV }\end{array}$ & $\begin{array}{rrrr}\mathrm{S} & 8 & 32 & \mathrm{IV} \\
\mathrm{S} & \mathrm{I} 5 & 38 & \mathrm{E} \\
\mathrm{N} & 79 & 3 \mathrm{I} & \mathrm{E}\end{array}$ & $\begin{array}{l}3,164 \\
2,570 \\
2,509\end{array}$ & $\begin{array}{l}\text { Alley. } \\
\text { Norman. } \\
\text { Needle. }\end{array}$ & & \\
\hline
\end{tabular}


Survey of Oyster Bars, Queen Annes County, $M d$.

BOUNDARIES OF NATURAL OYSTER BARS-continued.

BUCKHORN.

(Prospect Bay-Chart No. 32.)

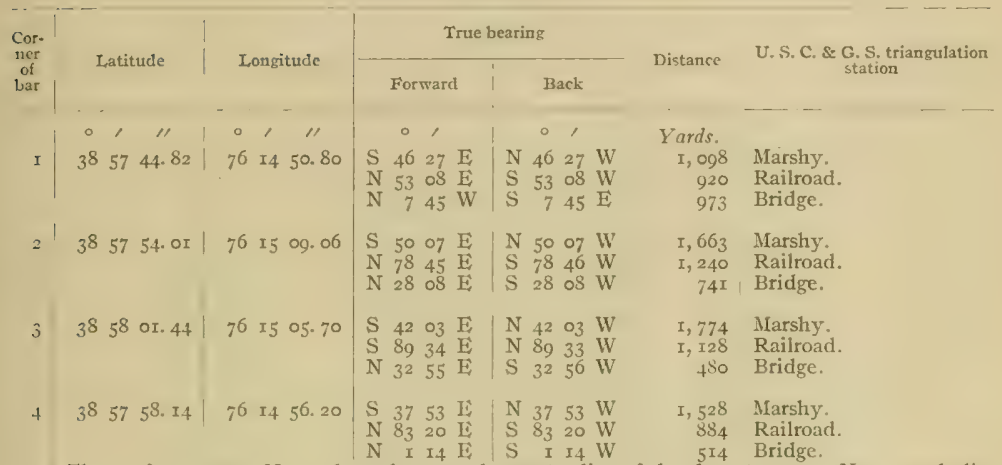

Thence from comer No. 4 along the mean low-water line of the shore to comer No. 5, excluding any creek, cove, or inlct less than 100 yards in width at its mouth at low tide.

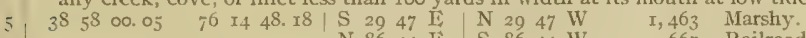

N $8644 \mathrm{Ei} \quad \mathrm{S} 8644 \mathrm{~W} \quad 667$ Railroad.

$\mathrm{N}_{23} 5^{8} \mathrm{~W}$ S $2358 \mathrm{E} \quad 492$ Bridge. 


\section{BOUNDARIES OF NATURAL OYSTER BARS-continUE.}

\section{WELL COVE.}

(Prospect Bay-Chart No. 32.)

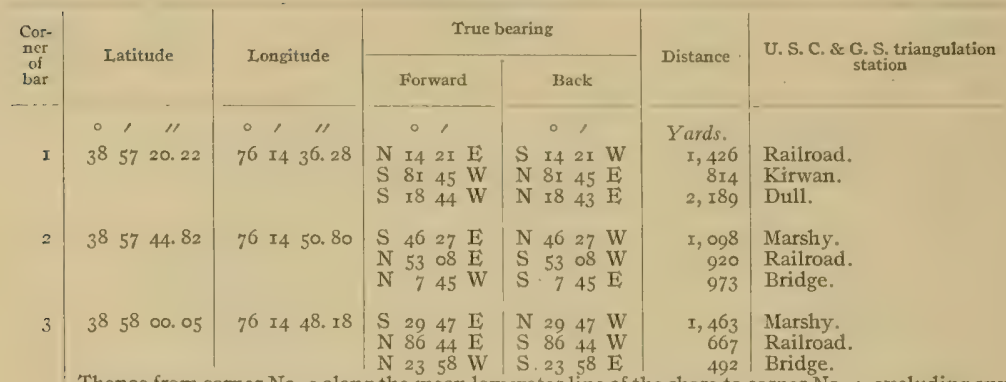

Thence from comer No. 3 along the mean low water line of the shore to corner No. 4, excluding any creek, cove, or inlet less than 100 yards in width at its mouth at low tide.

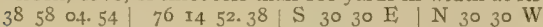

S SI 42 E $\quad$ N SI 42 W

$\mathrm{N} I 2 \quad 52 \mathrm{E} \quad \mathrm{S} I 2 \quad 52 \mathrm{~W}$

I, 650 | Marshy.

785 Railroad.

$\mathrm{S} 2622 \mathrm{E} \quad \mathrm{N} 2622 \mathrm{~W}$

$\mathrm{S} 77$ o4 E N 77 o4 W

\section{S $2730 \mathrm{~W} / \mathrm{N} 2730 \mathrm{E}$}

I, 797 Bridge.

I, $4: 2$ Kirwan.

2, 734 Dull.

Thence from comer No. 8 along the mean low water line of the shore to corner No.9, excluding any creek, cove, or inlet less than roo yards in width at its mouth at low tide.

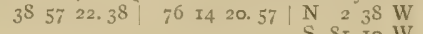
S SI I0 W
$\mathrm{S} 238 \mathrm{E}$
I, 3 I0 | Railroad.
S $2729 \mathrm{~W}$
$\begin{array}{llll}N & 81 & 10 & E \\ N & 27 & 29 & E\end{array}$
$\mathrm{I}, 234$
2,419
Dull. 
BOUNDARIES OF NATURAL OYSTER BARS-CONTIIUEI.

SANDY POIN'T.

(Prospect Bay-Chart No. 32.)

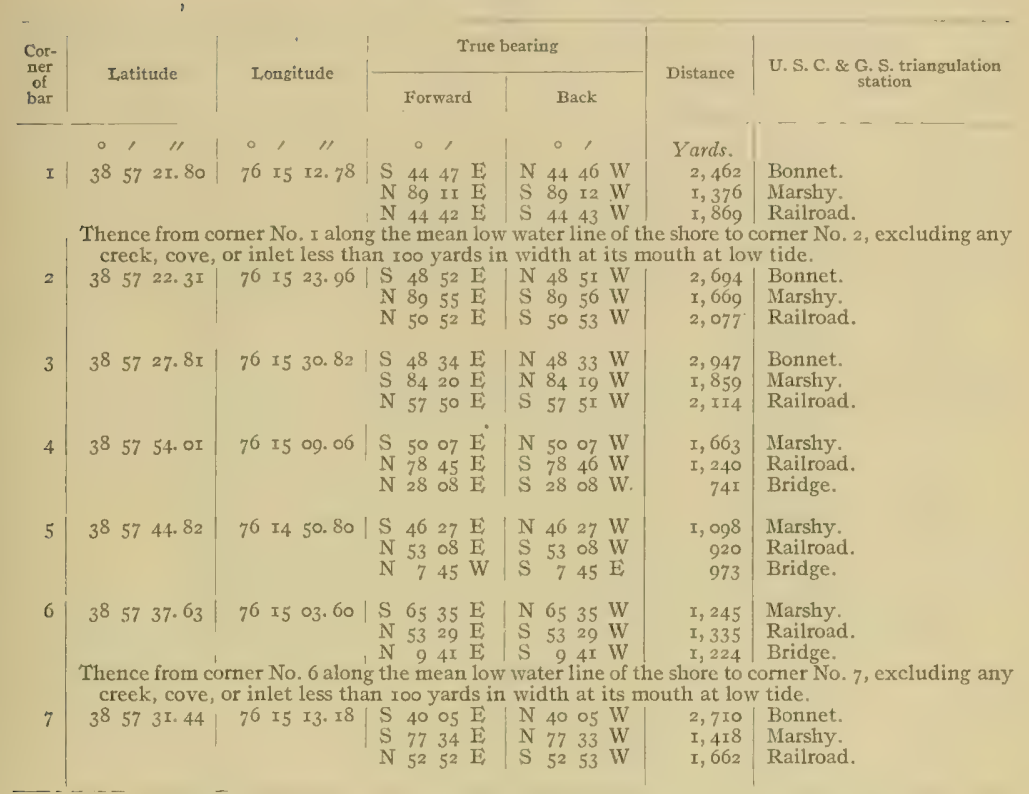

\section{HOG ISLAND.}

(Prospect Bay-Chart No. 32.)

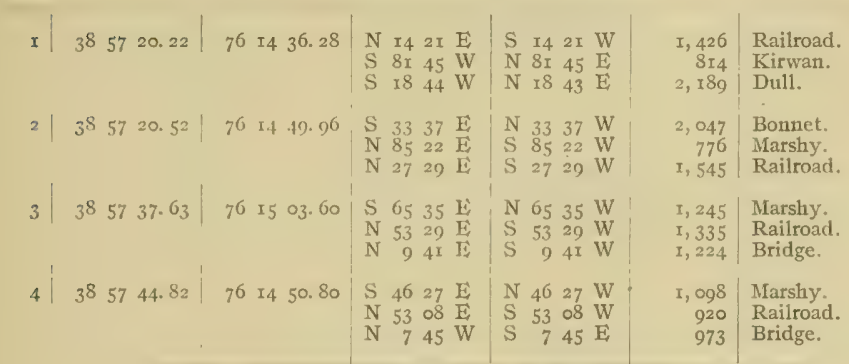


BOUNDARIES OF NATURAL OYSTER BARS-continued.

WALTER WHITE.

(Prospect Bay-Chart No. 32.)

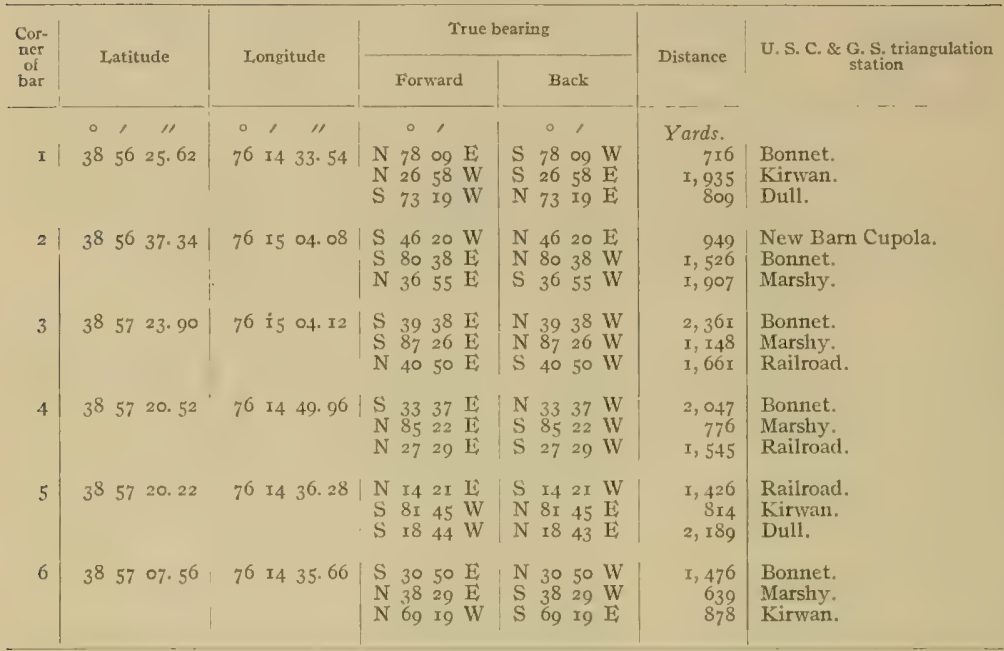

\section{PROSPECT.}

(Prospect Bay-Chart No. 32.)

\begin{tabular}{|c|c|c|c|c|c|c|}
\hline I & $3^{8} \quad 56 \quad 25.62$ & $76 \quad$ I4 $33 \cdot 54$ & $\begin{array}{llll}\mathrm{N} & 78 & 09 & \mathrm{E} \\
\mathrm{N} & 26 & 58 & \mathrm{~W} \\
\mathrm{~S} & 73 & \text { I9 } & \mathrm{W}\end{array}$ & $\begin{array}{llll}\mathrm{S} & 78 & \circ 9 & \mathrm{~W} \\
\mathrm{~S} & 26 & 5^{8} & \mathrm{E} \\
\mathrm{N} & 73 & 19 & \mathrm{E}\end{array}$ & $\begin{array}{r}716 \\
\times, 935 \\
809\end{array}$ & $\begin{array}{l}\text { Bonnet. } \\
\text { Kirwant. } \\
\text { Dull. }\end{array}$ \\
\hline 2 & $3^{8} 5707.56$ & $7^{6} \quad 1435.66$ & $\begin{array}{llll}\mathrm{S} & 30 & 50 & \mathrm{E} \\
\mathrm{N} & 38 & 29 & \mathrm{E} \\
\mathrm{N} & 69 & 19 & \mathrm{~W}\end{array}$ & $\begin{array}{llll}\mathrm{N} & 30 & 50 & \mathrm{~W} \\
\mathrm{~S} & 38 & 29 & \mathrm{~W} \\
\mathrm{~S} & 69 & 19 & \mathrm{E}\end{array}$ & $\begin{array}{r}\mathrm{I}, 476 \\
639 \\
878\end{array}$ & $\begin{array}{l}\text { Bonnet. } \\
\text { Marshy. } \\
\text { Kirwan. }\end{array}$ \\
\hline 3 & $3^{8} 5708.86$ & $7^{6}$ I4 I8. $7^{8}$ & $\begin{array}{llll}\mathrm{N} & 24 & 07 & \mathrm{~W} \\
\mathrm{~N} & 78 & 07 & \mathrm{~W} \\
\mathrm{~S} & 34 & 33 & \mathrm{~W}\end{array}$ & $\begin{array}{llll}\mathrm{S} & 24 & 07 & \mathrm{E} \\
\mathrm{S} & 78 & 08 & \mathrm{E} \\
\mathrm{N} & 34 & 32 & \mathrm{E}\end{array}$ & $\begin{array}{l}2,384 \\
1,294 \\
2,053\end{array}$ & $\begin{array}{l}\text { Bridge, } \\
\text { Kirwan. } \\
\text { Dull. }\end{array}$ \\
\hline & $3^{8} \quad 5^{6} \quad 28,00$ & $\begin{array}{lll}76 & 14 & 19.97\end{array}$ & $\begin{array}{llll}\mathrm{N} & 79 & 00 & \mathrm{E} \\
\mathrm{N} & 36 & 54 & \mathrm{~W} \\
\mathrm{~S} & 74 & 34 & \mathrm{~W}\end{array}$ & $\begin{array}{llll}\mathrm{S} & 79 & 00 & \mathrm{~W} \\
\mathrm{~S} & 36 & 55 & \mathrm{E} \\
\mathrm{N} & 74 & 34 & \mathbf{E}\end{array}$ & $\begin{array}{r}350 \\
2,056 \\
1,175\end{array}$ & $\begin{array}{l}\text { Bonnet. } \\
\text { Kirwan. } \\
\text { Dull. }\end{array}$ \\
\hline
\end{tabular}


BOUNDARIES OF NATURAL OYSTER BARS-continued.

\section{DOMINION.}

(Prospect Bay-Chart No. 32.)

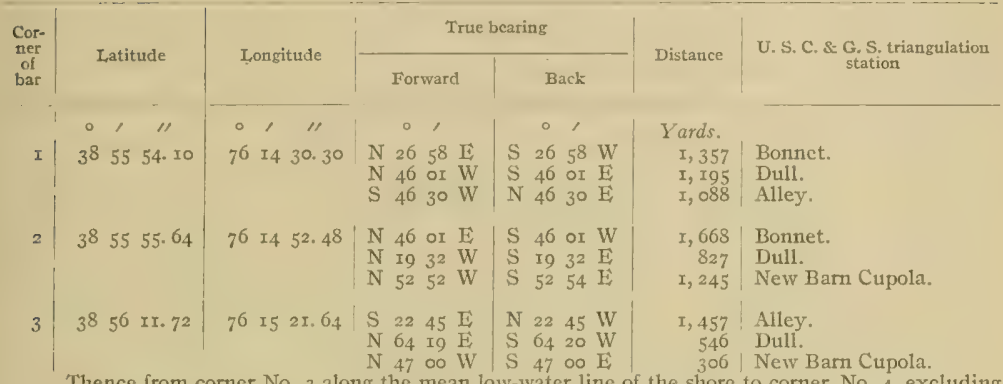

Thence from corner No. 3 along the mean low-water line of the shore to corner No. 4, excluding any creek, cove, or inlet less than Ioo yards in width at its mouth at low tide.

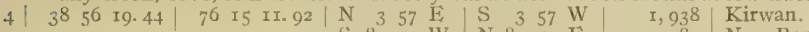

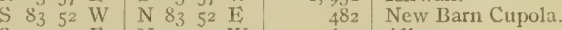

$\mathrm{S}$ I0 $4 \mathrm{I}$ E $\mathrm{N}$ io $40 \mathrm{~W} \quad \mathrm{I}, 633$ Alley.

\begin{tabular}{l|lll|lll|llll|llll}
5 & 38 & 56 & I9. & $4^{8}$ & 76 & 15 & 06.87 & $\mathrm{~N}$ & 0 & $00 \mathrm{I}$ & $\mathrm{S}$ & 0 & $00 \mathrm{~W}$
\end{tabular} \begin{tabular}{lrll|llll}
$\mathrm{S}$ & 85 & 04 & $\mathrm{~W}$ & $\mathrm{~N}$ & 85 & 04 & $\mathrm{E}$ \\
$\mathrm{S}$ & 6 & 12 & $\mathrm{E}$ & $\mathrm{N}$ & 6 & $\mathrm{II}$ & $\mathrm{W}$
\end{tabular}

I, 932 Kirwan.

616 New Barn Cupola. I, 6r.t Alley.

Thence from corner No. 5 along the mean low-water line of the shore to corner No, 6, excluding any creek, cove, or inlet less than roo yards in width at its. mouth at low tide.

6
725 New Bam Cupola.

I, 532 Alley.

I, 528 Bonnet.

7 I6 $\mid$ Bonnet.

I, 935 Kirwan.

809 Dull.

BIBBY.

(Prospect Bay-Chart No. 32.)

\begin{tabular}{|c|c|c|c|c|c|c|}
\hline I & 385540.54 & $\begin{array}{llll}76 & 15 & 05.90\end{array}$ & $\begin{array}{lrll}\mathrm{S} & 26 & 59 & \mathrm{E} \\
\mathrm{N} & 3 & 26 & \mathrm{E} \\
\mathrm{N} & 26 & 52 & \mathrm{~W}\end{array}$ & $\begin{array}{lrll}\mathrm{N} & 26 & 59 & \mathrm{~W} \\
\mathrm{~S} & 3 & 26 & \mathrm{~W} \\
\mathrm{~S} & 26 & 52 & \mathrm{E}\end{array}$ & $\begin{array}{r}327 \\
I, 200 \\
I, 4 I 3\end{array}$ & $\begin{array}{l}\text { Alley. } \\
\text { Dull. } \\
\text { New Barn Cupola. }\end{array}$ \\
\hline$=$ & $3855 \quad 48.28$ & 76 I5 27.44 & $\begin{array}{llll}\mathrm{S} & 52 & 20 & \mathrm{TI} \\
\mathrm{N} & 32 & 07 & \mathrm{E} \\
\mathrm{N} & 4 & 04 & \mathrm{~W}\end{array}$ & $\begin{array}{lrll}\mathrm{N} & 52 & 20 & \mathrm{~W} \\
\mathrm{~S} & 32 & 07 & \mathrm{~W} \\
\mathrm{~S} & 4 & 04 & \mathrm{E}\end{array}$ & $\begin{array}{r}904 \\
I, 2 I 3 \\
I, 002\end{array}$ & $\begin{array}{l}\text { Alley. } \\
\text { Dull. } \\
\text { New Barn Cupola. }\end{array}$ \\
\hline 3 & $3^{8} 5^{6}$ II. 72 & 76 I5 21.64 & $\begin{array}{llll}\mathrm{S} & 22 & 45 & \mathrm{E} \\
\mathrm{N} & 64 & \mathrm{I} 9 & \mathrm{E} \\
\mathrm{N} & 47 & 00 & \mathrm{~W}\end{array}$ & $\begin{array}{llll}\mathrm{N} & 22 & 45 & \mathrm{~W} \\
\mathrm{~S} & 64 & 20 & \mathrm{~W} \\
\mathrm{~S} & 47 & 00 & \mathrm{E}\end{array}$ & $\begin{array}{r}I, 457 \\
546 \\
306\end{array}$ & $\begin{array}{l}\text { Alley. } \\
\text { Dull. } \\
\text { New Barn Cupola. }\end{array}$ \\
\hline 4 & $3^{8} \quad 55 \quad 55.64$ & $76145^{2}, 4^{8}$ & $\begin{array}{llll}N & 46 & \text { or } & E \\
N & \text { If } & 32 & W \\
N & 5^{2} & 5^{2} & W\end{array}$ & $\begin{array}{llll}\mathrm{S} & 46 & \text { or } & \mathrm{W} \\
\mathrm{S} & \text { I9 } & 3^{2} & \mathrm{E} \\
\mathrm{S} & 5^{2} & 54 & \mathrm{E}\end{array}$ & $\begin{array}{r}r, 668 \\
827 \\
r, 245\end{array}$ & $\begin{array}{l}\text { Bonnet. } \\
\text { Dull. } \\
\text { New Barn Cupola. }\end{array}$ \\
\hline 5 & $3^{8} \quad 55 \quad 43.66$ & 76 I5 05. $4^{8}$ & $\begin{array}{lrrr}\mathrm{N} & 44 & 38 & \mathrm{E} \\
\mathrm{N} & 3 & \mathrm{I} 2 & \mathrm{E} \\
\mathrm{N} & 29 & 2 \mathrm{I} & \mathrm{W}\end{array}$ & $\begin{array}{rrrr}\mathrm{S} & 44 & 38 & \mathrm{~W} \\
\mathrm{~S} & 3 & \mathrm{I} 2 & \mathrm{~W} \\
\mathrm{~S} & 29 & 2 \mathrm{I} & \mathrm{E}\end{array}$ & $\begin{array}{l}2, I 05 \\
\mathrm{I}, \mathrm{I} 84 \\
\mathrm{I}, 328\end{array}$ & $\begin{array}{l}\text { Bonnet. } \\
\text { Dull. } \\
\text { New Barn Cupola. }\end{array}$ \\
\hline
\end{tabular}


IBOUNDARIES OF NATURAL, OYSTER BARS-continuEd.

NORMANS MARSH.

(Prospect Bay-Chart No. 32.)

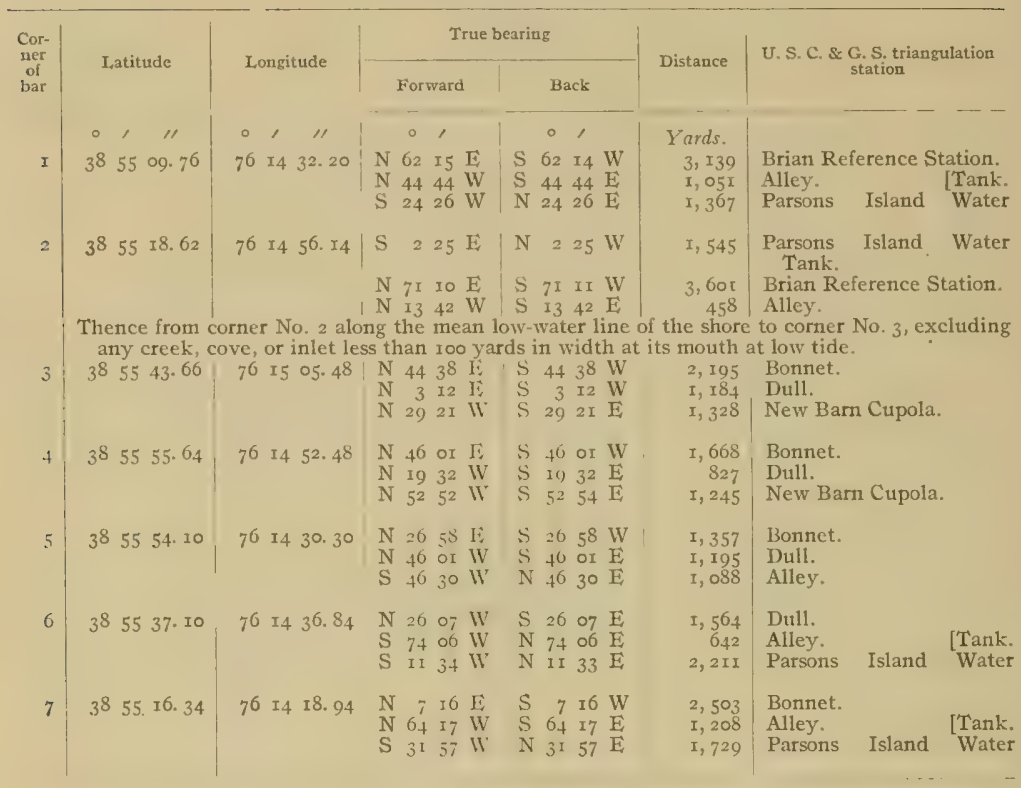


Survey of Oyster Bars, Queen Anvies County, Md.

BOUNDARIISS OF NATURAI, OYSTER BARS-continUed.

HOOD.

(Prospect Bay-Chart No. 32.)

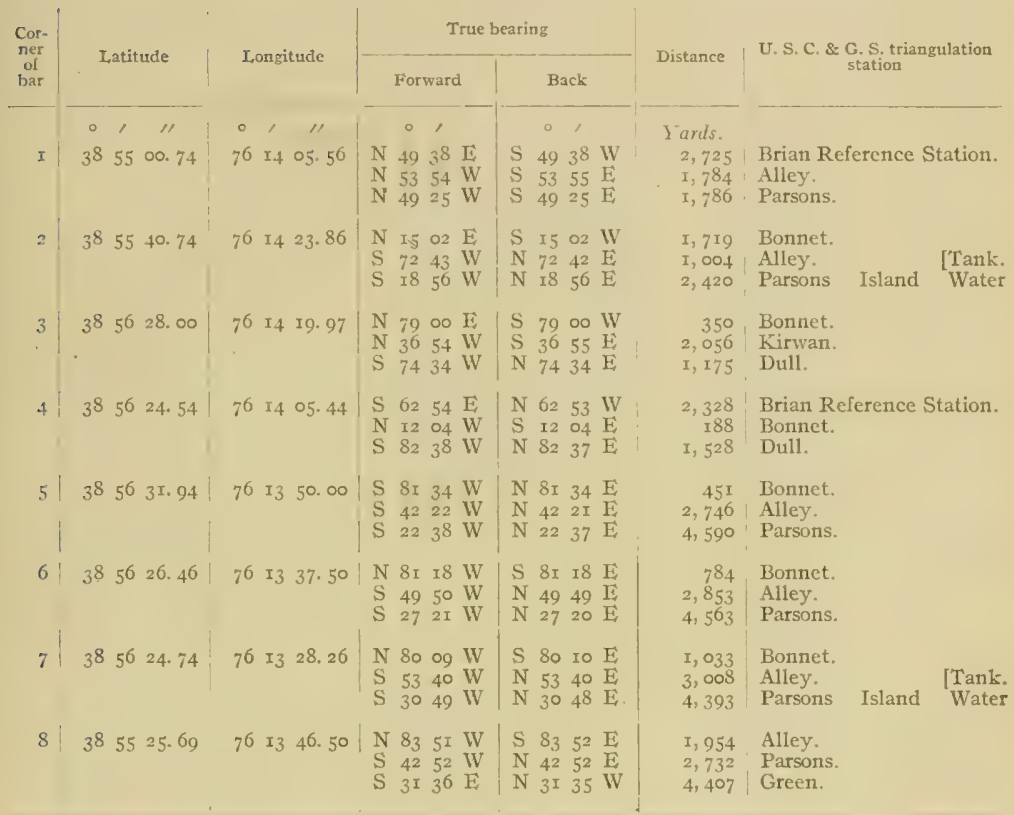


CABIN CREEK.

(Prospect Bay-Chart No. 32.)

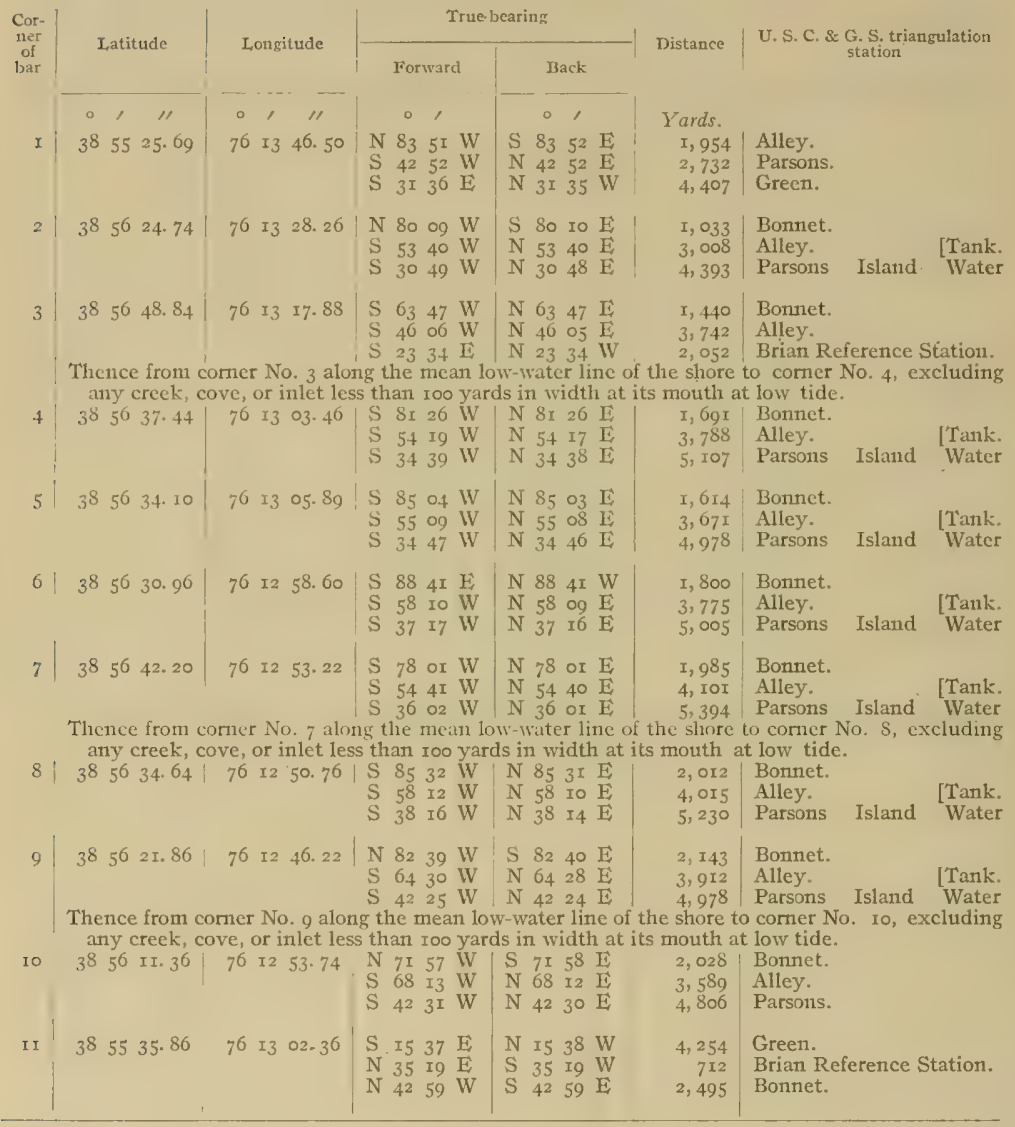


BOUNDARIES OF NATURAL, OYSTER BARS-cOntinUEd.

SAW MILL, CREEK.

(Prospect Bay-Chart No. 32.)

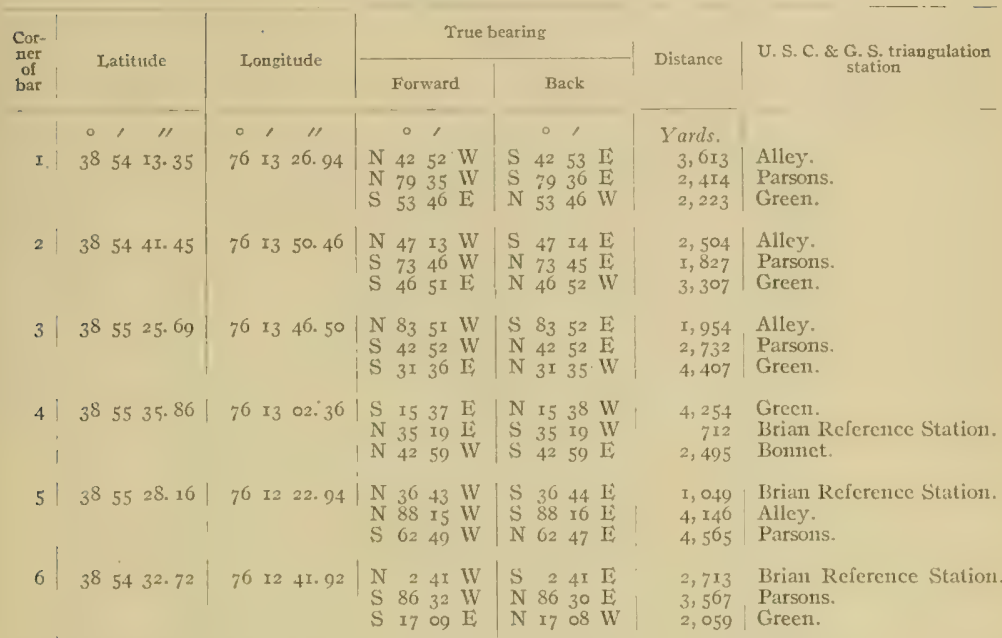

\section{PARSONS ISLAND NARROWS.}

(Eastern Bay-Chart No. 32.)

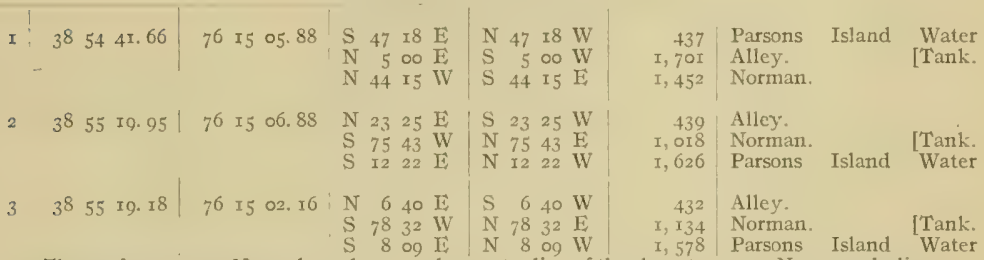
Thence from comer No. 3 along the mean low water line of the shore to corner No. 4 , excluding any creek, cove, or inlet less than 100 yards in width at its mouth at low tide.

\begin{tabular}{l|lll|lll|llll|lll|l|l|l}
4 & $3^{8}$ & 55 & 09.30 & 76 & I4 & 59.22 & $\mathrm{~N}$ & 2 & 04 & $\mathrm{~W}$ & $\mathrm{~S}$ & 2 & 04 & $\mathrm{E}$ & 762 & Alley.
\end{tabular}

$\mathrm{N} 8449 \mathrm{~W} \quad \mathrm{~S} 8.49 \mathrm{E} \quad x$, 893 Norman. [Tank.

\begin{tabular}{ll|l|l|l|l}
$\mathrm{S}$ & $648 \mathrm{E}$ & $\mathrm{N}$ & $648 \mathrm{~W}$ & $\mathrm{I}, 238$ & Parsons Island Water
\end{tabular}

\begin{tabular}{llll|lll|llll|lll}
5 & 38 & 54 & 56.56 & 76 & $x_{4}$ & I8. 6 I & $\mathrm{N}$ & $5 \mathrm{I}$ & $47 \mathrm{IE}$ & $\mathrm{S}$ & $5 \mathrm{I}$ & $48 \mathrm{~W}$
\end{tabular} $\begin{array}{llllllll}\mathrm{N} & 42 & 39 & \mathrm{~W} & \mathrm{~S} & 42 & 39 & \mathrm{E} \\ \mathrm{S} & 49 & 07 & \mathrm{~W} & \mathrm{~N} & 49 & 07 & \mathrm{E}\end{array}$

3, 08r Brian Reference Station.

I, 620 Alley. [Tank.

I, 222 Parsons Island Water

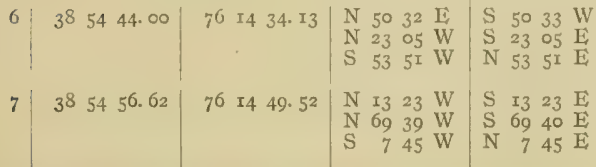

3,666 Brian Reference Station.

I, 755 Alley. [Tank.

638 Parsons Island Water

I, 223 Alley.

$\mathrm{x}, 540$
809 Parsons Island Wank. 
(Easiern Bay-Chart No. 32.)

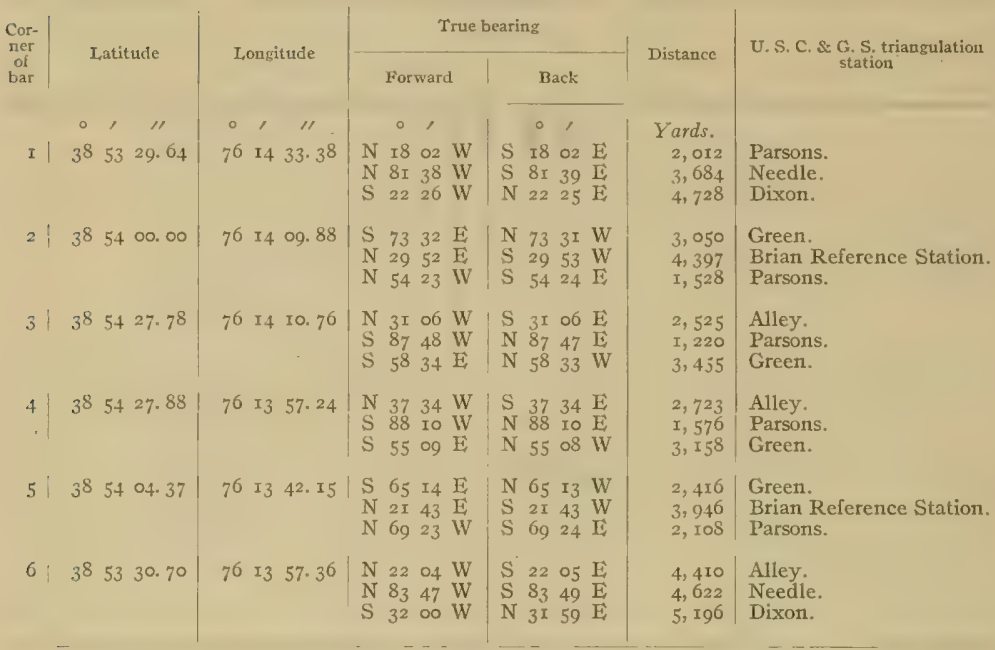

\section{MILL HILL.}

(Eastern Bay-Chart No. 32.)

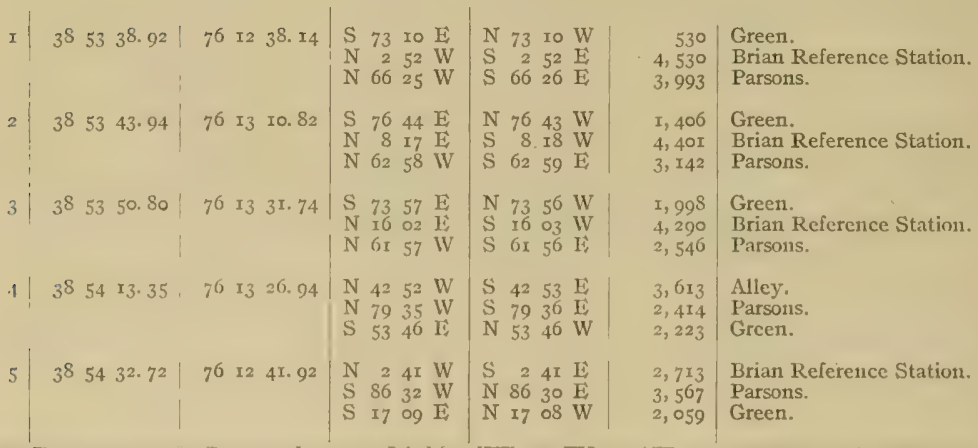


BOUNDARIES OF NATURAL OYSTER BARS-continued.

GREENWOOD CREEK.

(Eastern Bay-Chart No. 32.)

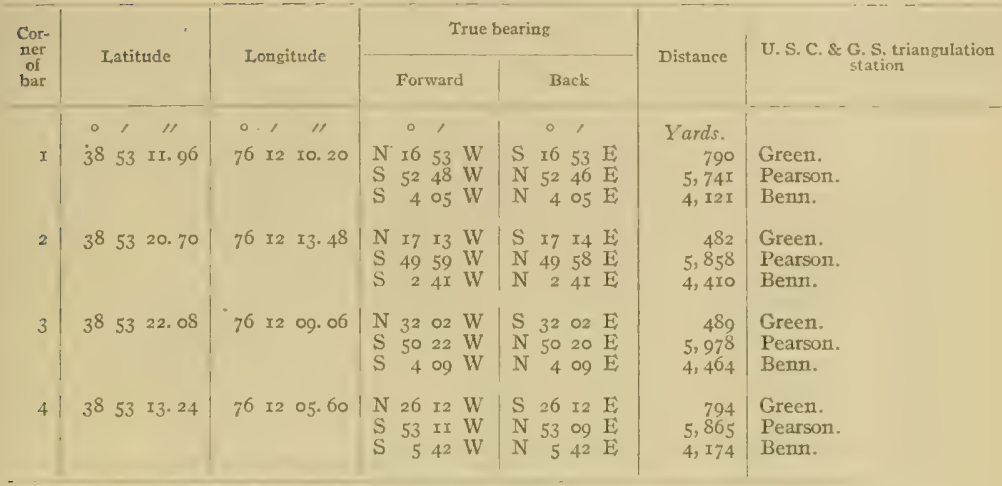

\section{PROSPECT POINT.}

(Eastern Bay-Chart No. 32.)

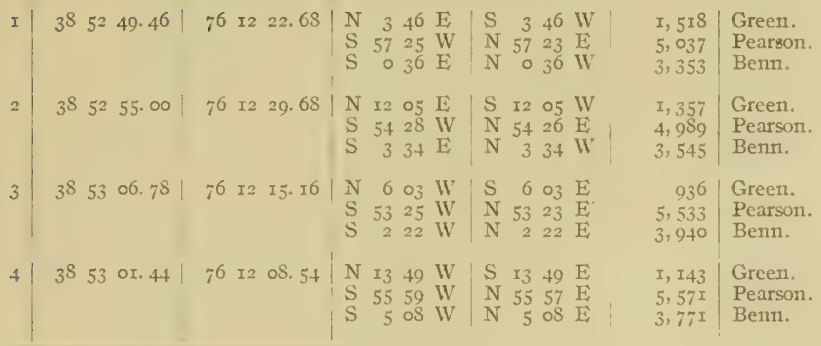


BOUNDARIES OF NATURAL, OYSTER BARS-continUEd.

BUGBY.

(Eastern Bay-Chart No. 32.)

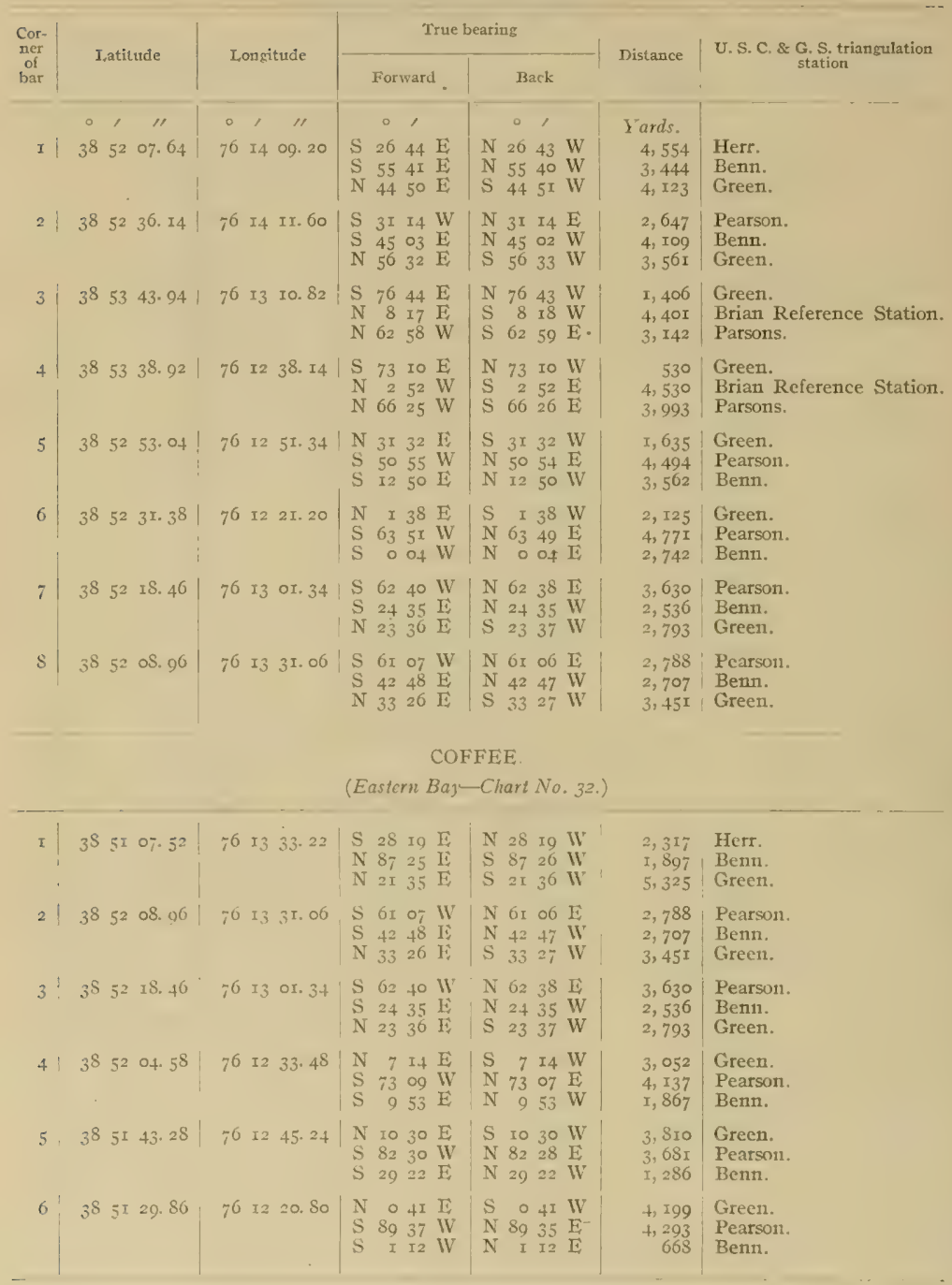


ROUNDARIES OF NATURAL OYSTER BARS-continued.

PERSIMMON TRET.

(Miles River-Chart No. 32.)

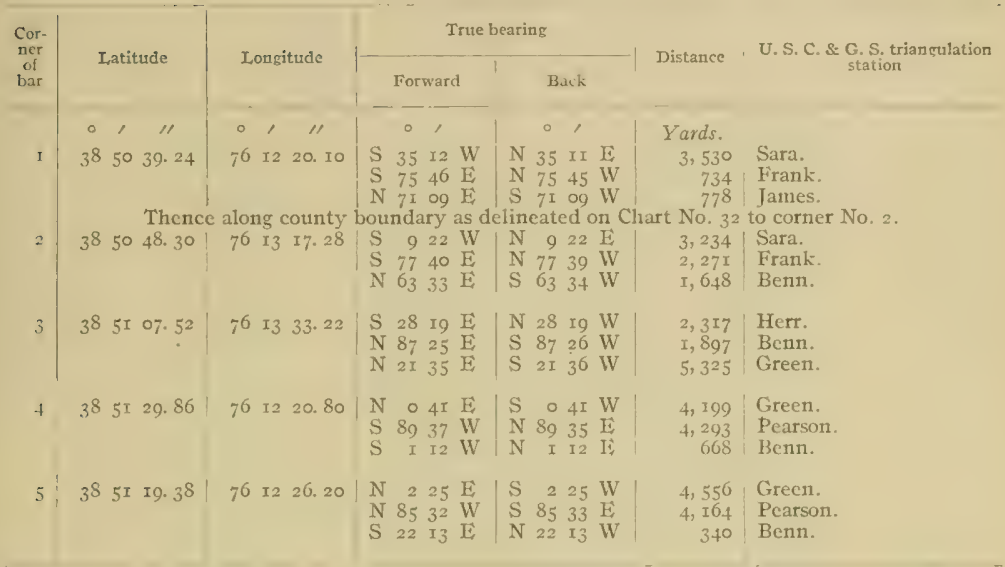

\section{SHIPPEN HOLE}

(II'yc Rizer-Chart No. 32.)

\begin{tabular}{|c|c|c|c|c|c|c|c|c|c|c|}
\hline I & $3^{S} 5$ I or. 04 & 76 & 12 & 07.44 & $\begin{array}{ll}\mathrm{S} & 32 \\
\mathrm{~S} & 39 \\
\mathrm{~N} & +0\end{array}$ & $\begin{array}{l}3+\frac{W}{E} \\
4+\frac{E}{E}\end{array}$ & 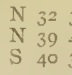 & $\begin{array}{l}33 \mathrm{E} \\
44 \mathrm{~W} \\
35 \mathrm{~W}\end{array}$ & $\begin{array}{r}2,161 \\
629 \\
\text { I, } 374\end{array}$ & $\begin{array}{l}\text { Herr. } \\
\text { James. } \\
\text { Bruffs. }\end{array}$ \\
\hline 2 & $3^{8} 5^{5} 05 \cdot 7^{8}$ & 76 & $x_{2}$ & I4. 70 & $\begin{array}{ll}S & 26 \\
S & 42 \\
N & 50\end{array}$ & $\begin{array}{l}\text { O7 W } \\
4 I \quad E \\
50 ~ E\end{array}$ & $\begin{array}{ll}\mathrm{N} & 26 \\
\mathrm{~N} & 42 \\
\mathrm{~S} & 50\end{array}$ & $\begin{array}{ll}\text { O7 } & \mathrm{E} \\
4 \mathrm{I} & \mathrm{WV} \\
5 \mathrm{I} & \mathrm{WV}\end{array}$ & $\begin{array}{r}2,207 \\
875 \\
\mathrm{I}, 399\end{array}$ & $\begin{array}{l}\text { Herr. } \\
\text { James. } \\
\text { Bruffs. }\end{array}$ \\
\hline 8 & 385 IS. 46 & $7^{6}$ & II & 00.60 & $\begin{array}{ll}\text { S } & 29 \\
\text { S } & 56 \\
N & 57\end{array}$ & $\begin{array}{l}09 \mathrm{WV} \\
06 \mathrm{E} \\
24 \mathrm{E}\end{array}$ & $\begin{array}{l}\text { N } 29 \\
N \quad 56 \\
\text { S } 57\end{array}$ & $\begin{array}{l}\text { OS E } \\
05 \mathrm{IV} \\
24 \mathrm{WV}\end{array}$ & $\begin{array}{r}2,758 \\
\text { Sig } \\
846\end{array}$ & $\begin{array}{l}\text { Herr. } \\
\text { Law: } \\
\text { Brufts. }\end{array}$ \\
\hline 4 & $3^{S} 5^{I} 3^{S} \cdot 8 S$ & 76 & II & $55 \cdot{ }_{3} S$ & $\begin{array}{ll}S & 12 \\
S & 67 \\
N & 10\end{array}$ & $\begin{array}{l}54 \mathrm{~W} \\
59 \mathrm{E} \\
2 \mathrm{~S} W\end{array}$ & $\begin{array}{ll}\mathrm{N} & 12 \\
\mathrm{~N} & 67 \\
\mathrm{~S} & 10\end{array}$ & $\begin{array}{l}5+\mathrm{F} \\
59 \mathrm{~W} \\
28 \mathrm{E}\end{array}$ & $\begin{array}{l}647 \\
620 \\
\text { II } 3\end{array}$ & $\begin{array}{l}\text { Hough. } \\
\text { Bruffs. } \\
\text { WVon. }\end{array}$ \\
\hline 5 & $3^{8} 5140.30$ & 76 & II & 46.76 & $\begin{array}{ll}N & I_{3} \\
N & 75 \\
S & 28\end{array}$ & $\begin{array}{ll}I_{3} & \mathrm{E} \\
39 & \mathrm{~W} \\
43 & \mathrm{~W}\end{array}$ & $\begin{array}{ll}S & 13 \\
S & 75 \\
N & 28\end{array}$ & $\begin{array}{ll}\text { I3 } & \mathrm{W} \\
39 & \mathrm{E} \\
43 & \mathrm{E}\end{array}$ & $\begin{array}{l}969 \\
256 \\
773\end{array}$ & $\begin{array}{l}\text { Nose. } \\
\text { Won. } \\
\text { Hotigh. }\end{array}$ \\
\hline 6 & $3^{S} 5^{I}$ Ix. 30 & 76 & II & $56.3^{8}$ & $\begin{array}{ll}\mathrm{S} & 33 \\
\mathrm{~S} & 69 \\
\mathrm{~N} & 40\end{array}$ & $\begin{array}{l}52 \mathrm{~W} \\
1_{5} \mathrm{E} \\
47 \mathrm{E}\end{array}$ & $\begin{array}{ll}N & 33 \\
N & 69 \\
S & 40\end{array}$ & $\begin{array}{ll}52 & \mathrm{E} \\
\text { I5 } \mathrm{W} \\
48 \\
4\end{array}$ & $\begin{array}{r}2,610 \\
607 \\
921\end{array}$ & $\begin{array}{l}\text { Herr. } \\
\text { Law. } \\
\text { Bruffs. }\end{array}$ \\
\hline
\end{tabular}




\section{BOUNDARIES OF NATURAL OYSTER BARS-continued,}

MILLS.

(Wye River-Chart No. 32.)

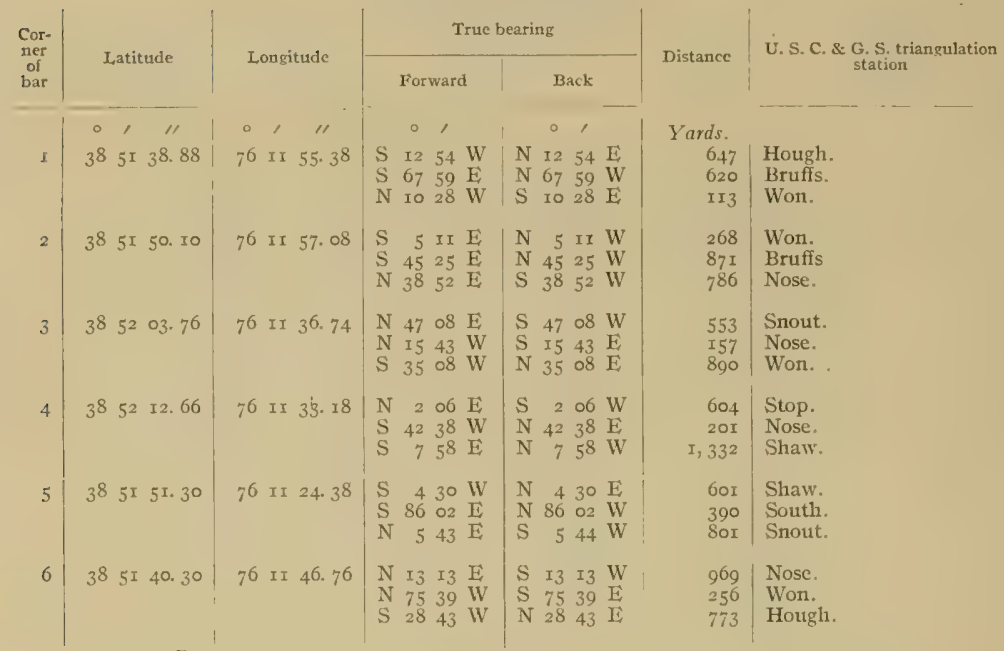

\section{HOBBS.}

(Wye River-Chart No. S2.)

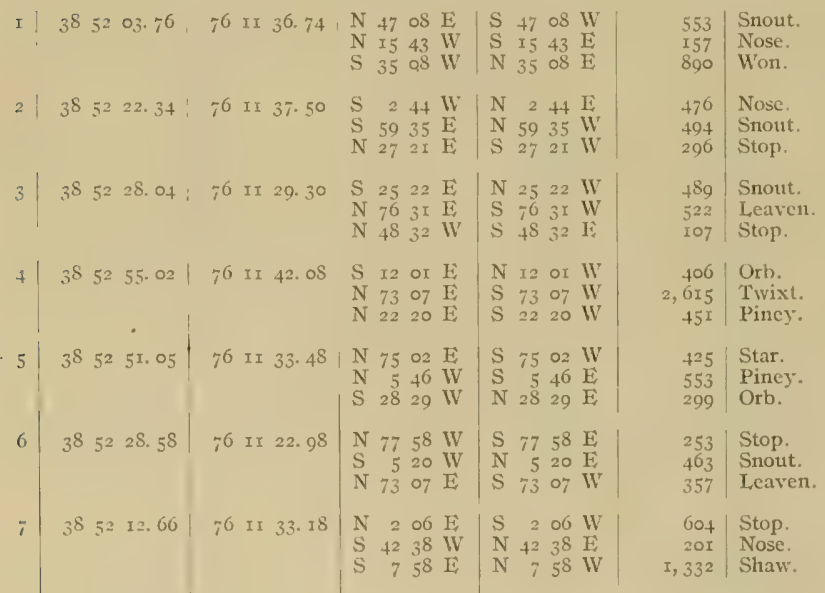


BOUNDARIES OF NATURAL OYSTER BARS-continued.

BAXTERS HOLLOW.

(Wye River-Chart No. 32.)

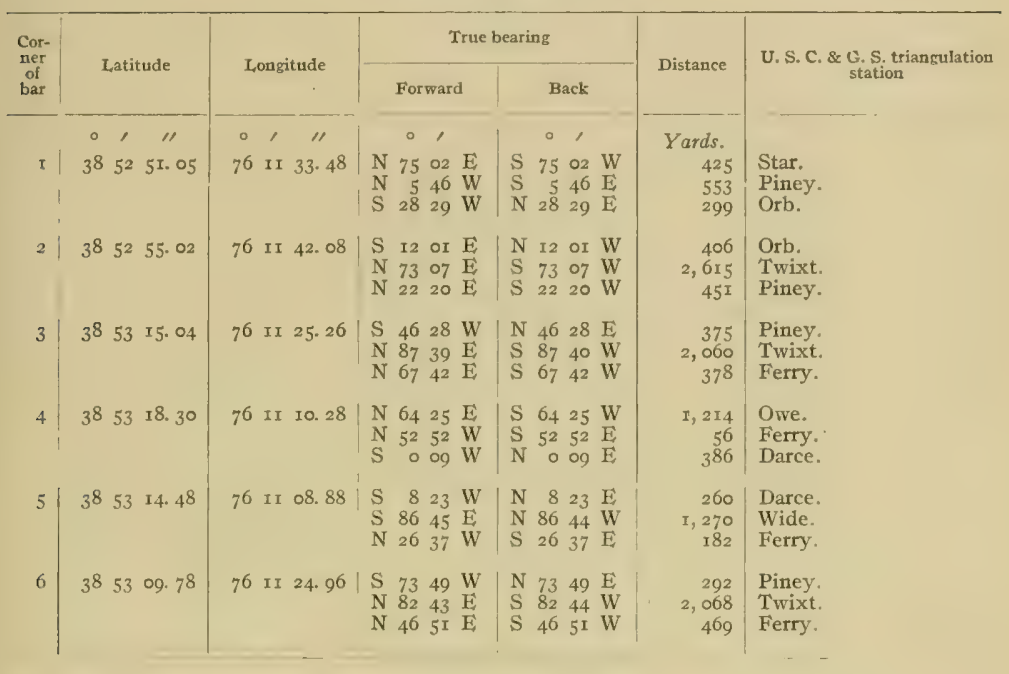

PACA.

(Wye River-Chart No. 32.)

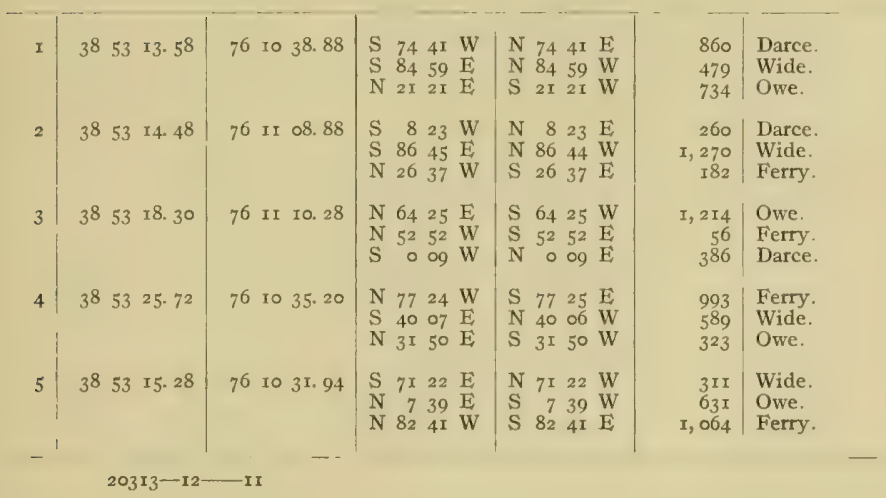


BOUNDARIES OF NATURAL OYSTER BARS-continued.

BRYAN.

(W'e River-Chart No.32.)

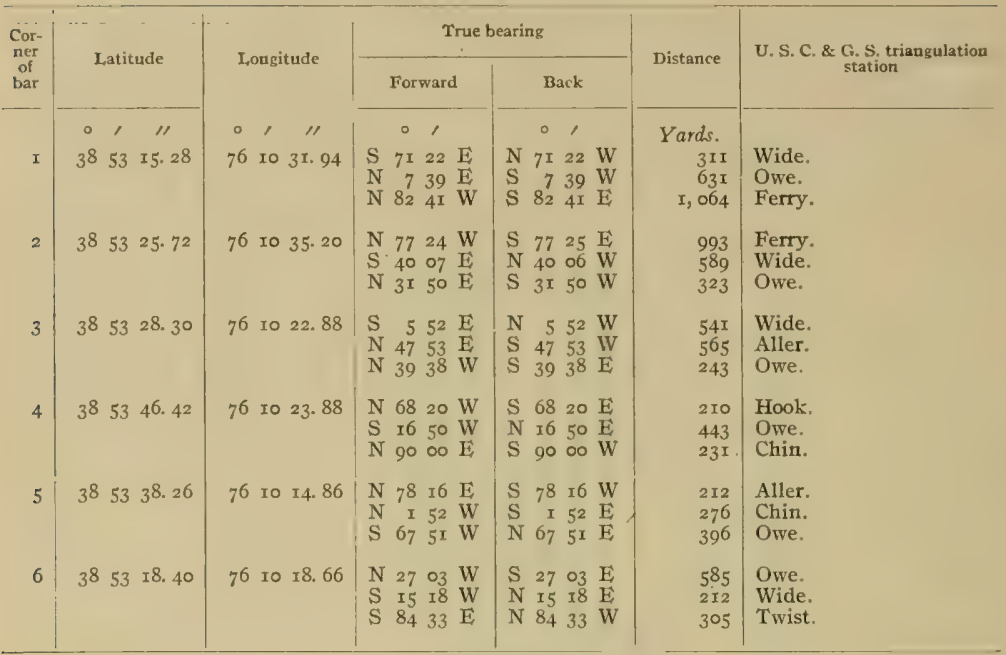

WYE ISLAND.

(Wye River-Chart No.32.)

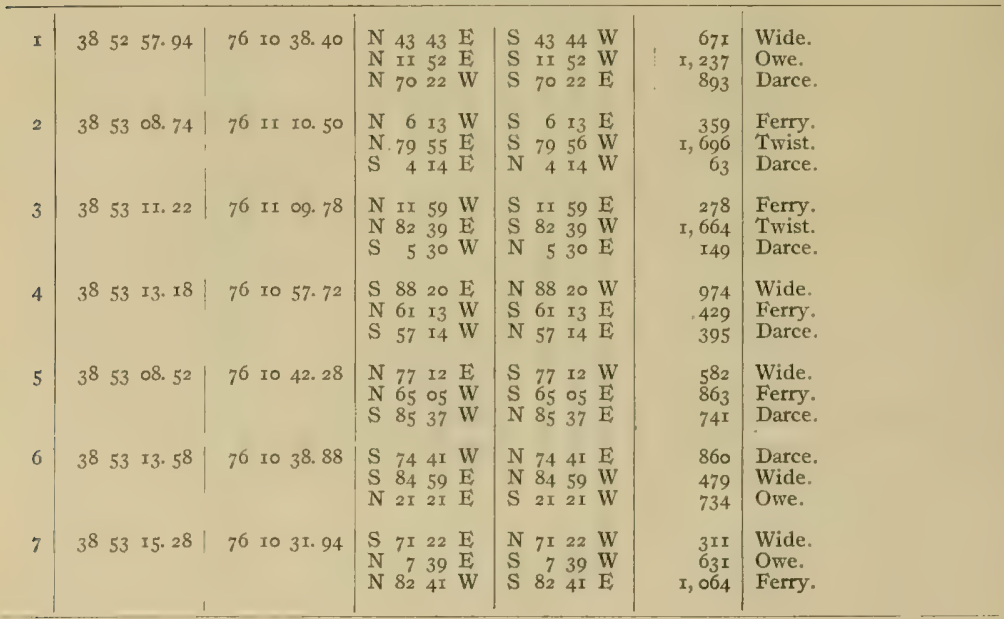


Survey of Oyster Bars, Queen Annes County, $\mathrm{Md}$.

BOUNDARIES OF NATURAL OYSTER BARS- continued.

DRUM POINT.

(IVye River-Chart No.32.)

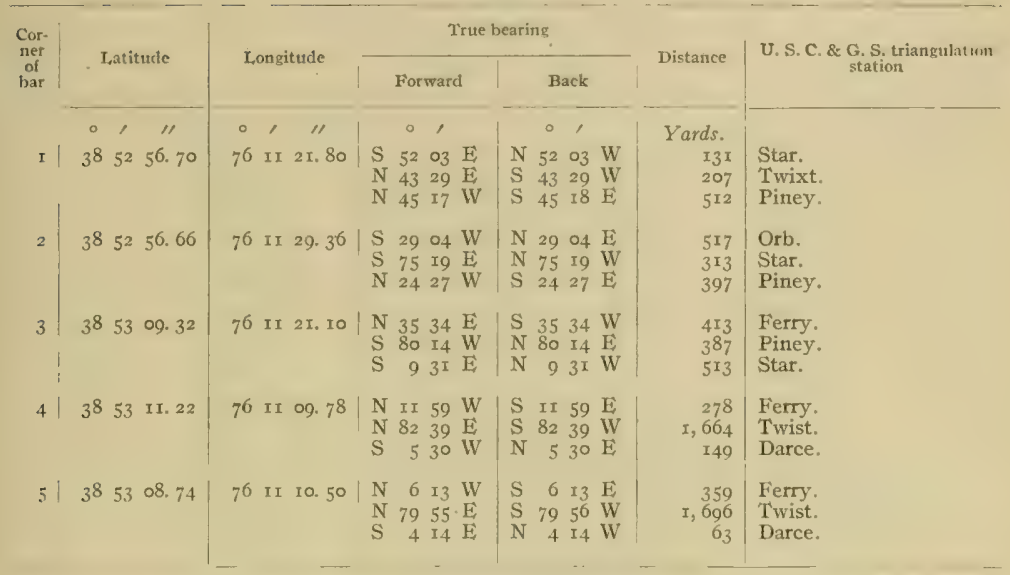

\section{WYE RIVER MIDDLEGROUND.}

(Wye River-Chart No. 32.)

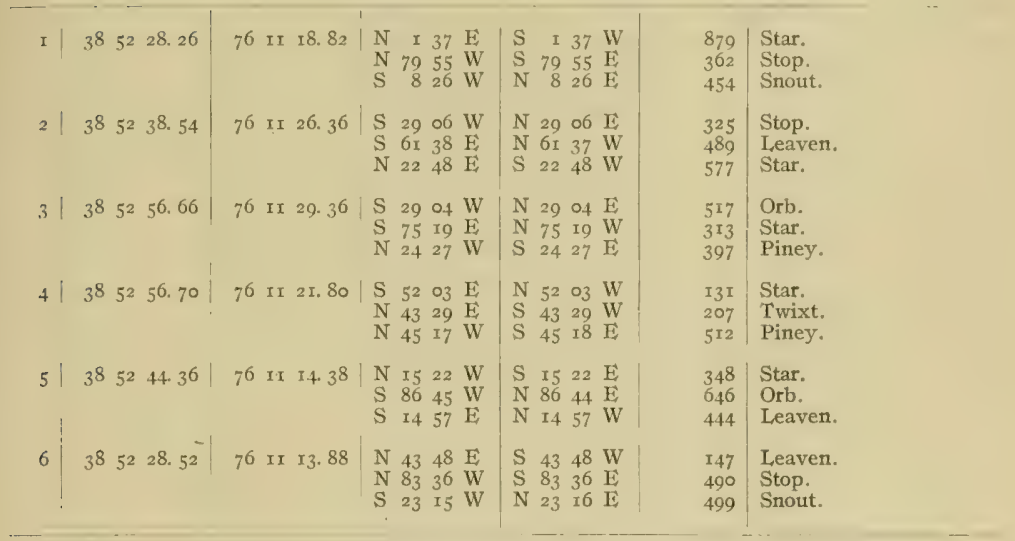


HESS.

(Wye River-Chart No.32.)

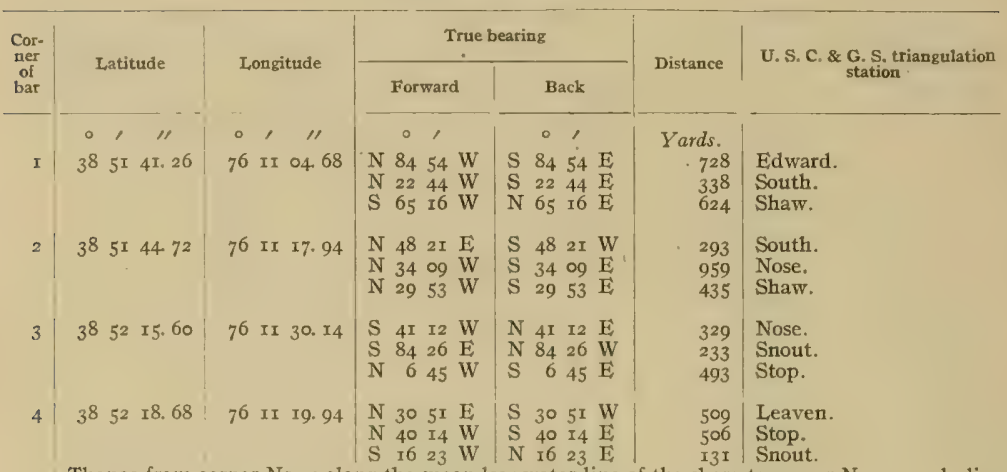

Thence from corner No. 4 along the mean low-water line of the shore to corner No. 5 , excluding any creek, cove, or inlet less than Ioo yards in width at its mouth at low tide.

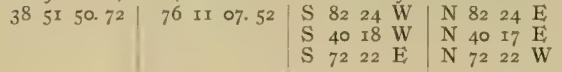

\begin{tabular}{r|l}
57 & South. \\
76 I & Shaw. \\
840 & Edward.
\end{tabular}

\section{STONE WHARF.}

(Wye River-Chart No. 32.)

\begin{tabular}{|c|c|c|c|c|c|c|}
\hline I & $3^{8} 5$ 工 50.80 & $7^{6}$ 10 58.08 & $\begin{array}{llll}\mathrm{N} & 42 & 27 & \mathrm{E} \\
\mathrm{S} & 88 & 06 & \mathrm{~W} \\
\mathrm{~S} & 5 \mathrm{I} & 48 & \mathrm{~W}\end{array}$ & $\begin{array}{llll}\mathrm{S} & 42 & 27 & \mathrm{~W} \\
\mathrm{~N} & 88 & 06 & \mathrm{E} \\
\mathrm{N} & 51 & 48 & \mathrm{E}\end{array}$ & $\begin{array}{l}731 \\
305 \\
943\end{array}$ & $\begin{array}{l}\text { Flat. } \\
\text { South. } \\
\text { Shaw. }\end{array}$ \\
\hline 2 & $3^{8} 5^{1} \quad 53.74$ & 76 II O2. 82 & $\begin{array}{llll}\mathrm{S} & 58 & 4 \mathrm{I} & \mathrm{W} \\
\mathrm{S} & 62 & \mathrm{I}_{3} & \mathrm{E} \\
\mathrm{N} & 54 & 34 & \mathrm{E}\end{array}$ & $\begin{array}{llll}\mathrm{N} & 58 & 41 & \mathrm{E} \\
\mathrm{N} & 62 & 13 & \mathrm{~W} \\
\mathrm{~S} & 54 & 34 & \mathrm{~W}\end{array}$ & $\begin{array}{l}210 \\
764 \\
759\end{array}$ & $\begin{array}{l}\text { South. } \\
\text { Edward. } \\
\text { Flat. }\end{array}$ \\
\hline 3 & $3^{8} \quad 5^{2} 04.80$ & 76 10 53.60 & $\begin{array}{llll}\mathrm{S} & 4 \pi & 14 & \mathrm{~W} \\
\mathrm{~S} & 30 & 42 & \mathrm{E} \\
\mathrm{N} & 79 & 54 & \mathrm{E}\end{array}$ & $\begin{array}{llll}\mathrm{N} & 41 & 14 & \mathrm{E} \\
\mathrm{N} & 30 & 43 & \mathrm{~W} \\
\mathrm{~S} & 79 & 54 & \mathrm{~W}\end{array}$ & $\begin{array}{l}642 \\
849 \\
381\end{array}$ & $\begin{array}{l}\text { South. } \\
\text { Edward. } \\
\text { Flat. }\end{array}$ \\
\hline 4 & $3^{8} \quad 5204.54$ & 76 10 $45 \cdot 7^{8}$ & $\begin{array}{llll}\mathrm{S} & 53 & \text { or } & \mathrm{W} \\
\mathrm{S} & 17 & 28 & \mathrm{E} \\
\mathrm{N} & 65 & 53 & \mathrm{E}\end{array}$ & $\begin{array}{llll}\mathrm{N} & 53 & \text { or } & \mathrm{E} \\
\mathrm{N} & 17 & 28 & \mathrm{~W} \\
\mathrm{~S} & 65 & 53 & \mathrm{~W}\end{array}$ & $\begin{array}{l}787 \\
756 \\
185\end{array}$ & $\begin{array}{l}\text { South, } \\
\text { Edward. } \\
\text { Flat. }\end{array}$ \\
\hline
\end{tabular}


BOUNDARIES OF NATURAL OYSTER BARS-continued.

RACE HORSE (QUEEN ANNES COUNTY).

(Wye River-Chart No. 32.)

\begin{tabular}{|c|c|c|c|c|c|c|c|}
\hline \multirow{2}{*}{$\begin{array}{l}\text { Cor- } \\
\text { ner } \\
\text { of } \\
\text { bat }\end{array}$} & \multirow{2}{*}{\multicolumn{2}{|c|}{ Latitude }} & \multirow{2}{*}{ Longitude } & \multicolumn{2}{|c|}{ True bearing } & \multirow{2}{*}{ Distance } & \multirow{2}{*}{$\begin{array}{l}\text { U.S. C. \& G. S. triangulation } \\
\text { station }\end{array}$} \\
\hline & & & & Forward & Back & & \\
\hline I & $\begin{array}{c}\circ \\
3^{8}\end{array}$ & $\begin{array}{c}\prime \prime \prime \\
5^{I}\end{array}$ & $\begin{array}{ccc}0 & \prime \prime \\
76 & 10 & 59.44\end{array}$ & $\begin{array}{lccc} & 0 & 1 \\
\mathrm{~N} & 82 & 59 & \mathrm{E} \\
\mathrm{N} & 40 & 06 & \mathrm{~W} \\
\mathrm{~S} & 70 & 1_{3} & \mathrm{~W}\end{array}$ & $\begin{array}{lccc} & 0 & 1 & \\
\mathrm{~S} & 83 & 00 & \mathrm{~W} \\
\mathrm{~S} & 40 & 06 & \mathrm{E} \\
\mathrm{N} & 70 & 12 & \mathrm{E}\end{array}$ & $\begin{array}{r}\text { Yards. } \\
592 \\
417 \\
749\end{array}$ & $\begin{array}{l}\text { Edward. } \\
\text { South. } \\
\text { Shaw. }\end{array}$ \\
\hline 2 & $3^{8}$ & $5^{1} 54 \cdot 3^{8}$ & $7^{6}$ 10 5 1. 82 & $\begin{array}{llll}\mathrm{S} & 45 & 39 & \mathrm{E} \\
\mathrm{N} & 38 & 09 & \mathrm{E} \\
\mathrm{S} & 74 & 28 & \mathrm{~W}\end{array}$ & $\begin{array}{llll}\mathrm{N} & 45 & 39 & \mathrm{~W} \\
\mathrm{~S} & 38 & 09 & \mathrm{~W} \\
\mathrm{~N} & 74 & 27 & \mathrm{E}\end{array}$ & $\begin{array}{l}540 \\
53 I \\
488\end{array}$ & $\begin{array}{l}\text { Edward. } \\
\text { Flat. } \\
\text { South. }\end{array}$ \\
\hline 3 & 38 & $5^{1} 5^{8.16}$ & 76 10 41.72 & $\begin{array}{llll}\mathrm{N} & \text { Ir } & 59 & \mathrm{E} \\
\mathrm{S} & 70 & 39 & \mathrm{~W} \\
\mathrm{~S} & 13 & 20 & \mathrm{E}\end{array}$ & $\begin{array}{llll}\mathrm{S} & \text { II } & 59 & \mathrm{~W} \\
\mathrm{~N} & 70 & 39 & \mathrm{E} \\
\mathrm{N} & \text { I3 } & 20 & \mathrm{~W}\end{array}$ & $\begin{array}{l}297 \\
780 \\
519\end{array}$ & $\begin{array}{l}\text { Flat. } \\
\text { South. } \\
\text { Edward. }\end{array}$ \\
\hline 4 & $3^{8}$ & $5^{1} 56.76$ & 76 10 34.74 & $\begin{array}{lrll}S & 8 & \text { oo } & \mathrm{W} \\
\mathrm{N} & 57 & \text { or } & \mathrm{E} \\
\mathrm{N} & 19 & 54 & \mathrm{~W}\end{array}$ & $\begin{array}{lrll}\mathrm{N} & 8 & 00 & \mathrm{E} \\
\mathrm{S} & 57 & 02 & \mathrm{~W} \\
\mathrm{~S} & \mathrm{I} & 54 & \mathrm{E}\end{array}$ & $\begin{array}{l}463 \\
753 \\
360\end{array}$ & $\begin{array}{l}\text { Edward. } \\
\text { Albert. } \\
\text { Flat. }\end{array}$ \\
\hline
\end{tabular}

\section{WHETSTONE.}

(Wye River-Chart No. 32.)

\begin{tabular}{|c|c|c|c|c|c|c|c|}
\hline I & $3^{8} \quad 5^{\text {I }} \quad 55.86$ & 76 & ro 09.00 & $\begin{array}{lrll}\mathrm{S} & 7 & 36 & \mathrm{~W} \\
\mathrm{~N} & 60 & 57 & \mathrm{E} \\
\mathrm{N} & 5 & 59 & \mathrm{~W}\end{array}$ & $\begin{array}{lrll}\mathrm{N} & 7 & 36 & \mathrm{E} \\
\mathrm{S} & 60 & 57 & \mathrm{~W} \\
\mathrm{~S} & 5 & 59 & \mathrm{E}\end{array}$ & $\begin{array}{l}503 \\
572 \\
443\end{array}$ & $\begin{array}{l}\text { Lloyd. } \\
\text { Cousin. } \\
\text { Albert. }\end{array}$ \\
\hline 2 & $3^{8} 5^{2}$ or. 18 & 76 & $1015.5^{8}$ & $\begin{array}{llll}N & 8 I & 42 & E \\
N & 25 & 59 & E \\
N & 73 & \text { I } 5 & \text { W }\end{array}$ & $\begin{array}{llll}\mathrm{S} & 8 \mathrm{I} & 43 & \mathrm{~W} \\
\mathrm{~S} & 25 & 59 & \mathrm{~W} \\
\mathrm{~S} & 73 & \mathrm{I} & \mathrm{E}\end{array}$ & $\begin{array}{l}680 \\
291 \\
655\end{array}$ & $\begin{array}{l}\text { Cousin. } \\
\text { Albert. } \\
\text { Flat. }\end{array}$ \\
\hline 3 & $3852 \quad 06.62$ & 76 & 1007.68 & $\begin{array}{lrll}\mathrm{N} & 39 & 44 & \mathrm{E} \\
\mathrm{N} & 46 & 06 & \mathrm{~W} \\
\mathrm{~S} & 6 & 42 & \mathrm{~W}\end{array}$ & $\begin{array}{lrrr}\mathrm{S} & 39 & 44 & \mathrm{~W} \\
\mathrm{~S} & 46 & 06 & \mathrm{E} \\
\mathrm{N} & 6 & 42 & \mathrm{E}\end{array}$ & $\begin{array}{l}424 \\
113 \\
867\end{array}$ & $\begin{array}{l}\text { Baldwins. } \\
\text { Albert. } \\
\text { Lloyd. }\end{array}$ \\
\hline 4 & $3^{8} 5^{2} \quad 17.26$ & 76 & I0 09. 48 & $\begin{array}{rrrr}\mathrm{N} & 28 & 08 & \mathrm{E} \\
\mathrm{S} & 74 & 46 & \mathrm{~W} \\
\mathrm{~S} & 6 & 48 & \mathrm{~W}\end{array}$ & $\begin{array}{lrrrr}\mathrm{S} & 28 & 08 & \mathrm{~W} \\
\mathrm{~N} & 74 & 46 & \mathrm{E} \\
\mathrm{N} & 6 & 48 & \mathrm{E}\end{array}$ & $\begin{array}{r}396 \\
30 \\
282\end{array}$ & $\begin{array}{l}\text { Attila. } \\
\text { L, Seur. } \\
\text { Albert. }\end{array}$ \\
\hline 5 & $3^{8} .5227 \cdot 7^{2}$ & 76 & 1000.40 & $\begin{array}{lrrr}\mathrm{N} & 7 & 52 & \mathrm{E} \\
\mathrm{S} & 85 & 3^{8} & \mathrm{~W} \\
\mathrm{~S} & 36 & 37 & \mathrm{~W}\end{array}$ & $\begin{array}{lrrr}\mathrm{S} & 7 & 52 & \mathrm{~W} \\
\mathrm{~N} & 85 & 38 & \mathrm{E} \\
\mathrm{N} & 36 & 37 & \mathrm{E}\end{array}$ & $\begin{array}{r}385 \\
52 \\
4+9\end{array}$ & $\begin{array}{l}\text { Tobine. } \\
\text { Attila. } \\
\text { Le Seur. }\end{array}$ \\
\hline 6 & $3^{8} 5^{2} 26.50$ & 76 & og 57.10 & $\begin{array}{lrrr}\mathrm{S} & \mathrm{I} & 19 & \mathrm{~W} \\
\mathrm{~S} & 85 & 52 & \mathrm{E} \\
\mathrm{N} & 4 \mathrm{I} & 24 & \mathrm{~L}\end{array}$ & $\begin{array}{llll}N & I & 19 & \text { I } \\
N & 85 & 52 & W \\
S & 4 I & 24 & W\end{array}$ & $\begin{array}{l}344 \\
163 \\
490\end{array}$ & $\begin{array}{l}\text { Baldwius. } \\
\text { Sylvia. } \\
\text { Gusta. }\end{array}$ \\
\hline
\end{tabular}

Thence along county boundary as delineated on Chart No. 32 to corner No, 7 .

$7 \quad 38 \quad 5220.62 \mid 76$ 10 01. $72|\mathrm{~N} 425 \mathrm{~W}| \mathrm{S} 425 \mathrm{~F}|\mathrm{~S} 36|$ Attila.

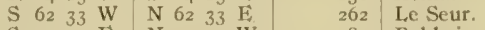

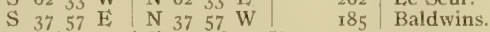

Thence along county boundary as delineated on Chart No. 32 to comer No. 8 ,

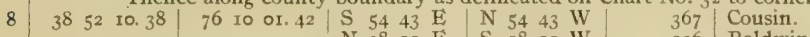

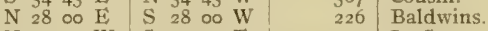

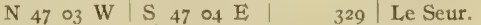

Thence along county boundary as delineated on Chart No. 32 to comer No, I: 
MELVIN.

(Wye River-Chart No. 32.)

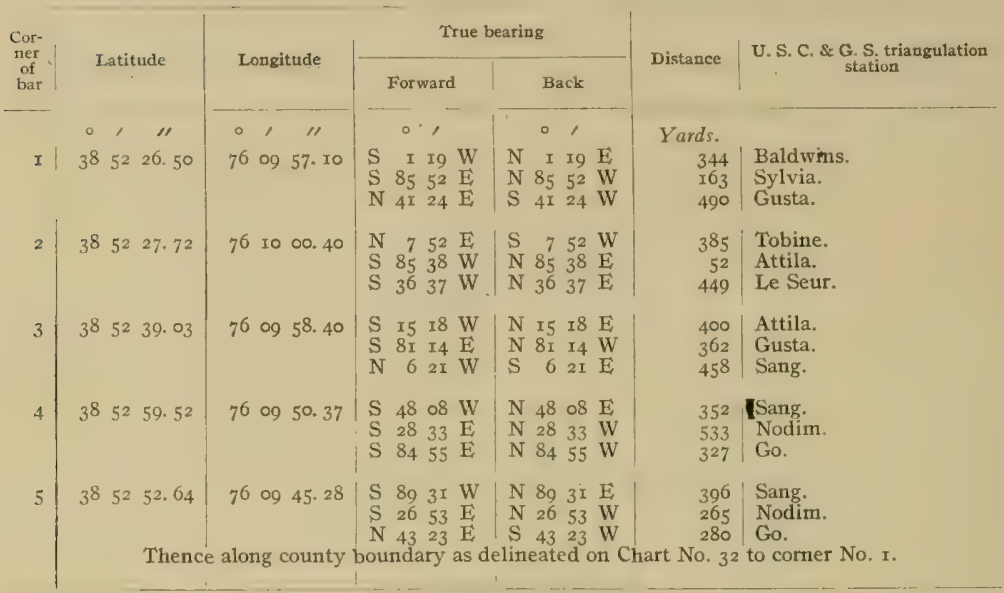

\section{DIVIDING.}

(IVye River-Chart No. 32.)

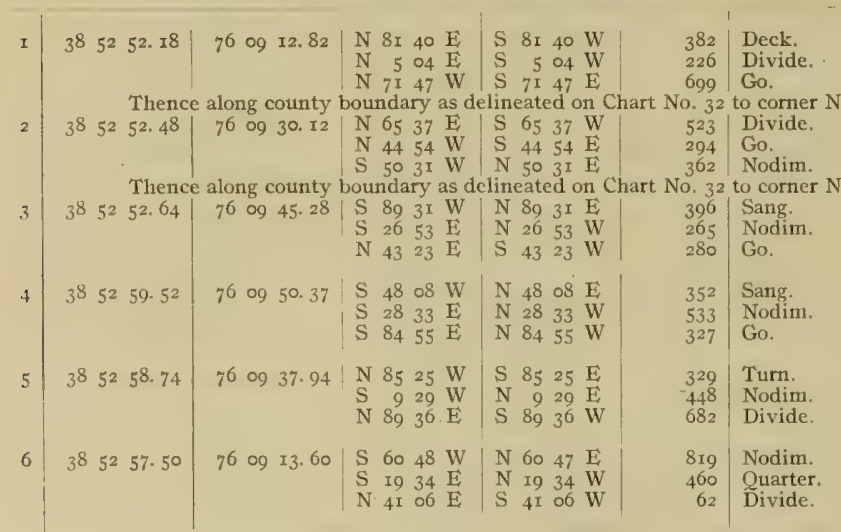


Survey of Oyster Bars, Qucen Annes County, Md.

BOUNDARIES OF NATURAL OYSTER BARS-continued.

SHAWNS WHARF.

(Wye River-Chart No. 32.)

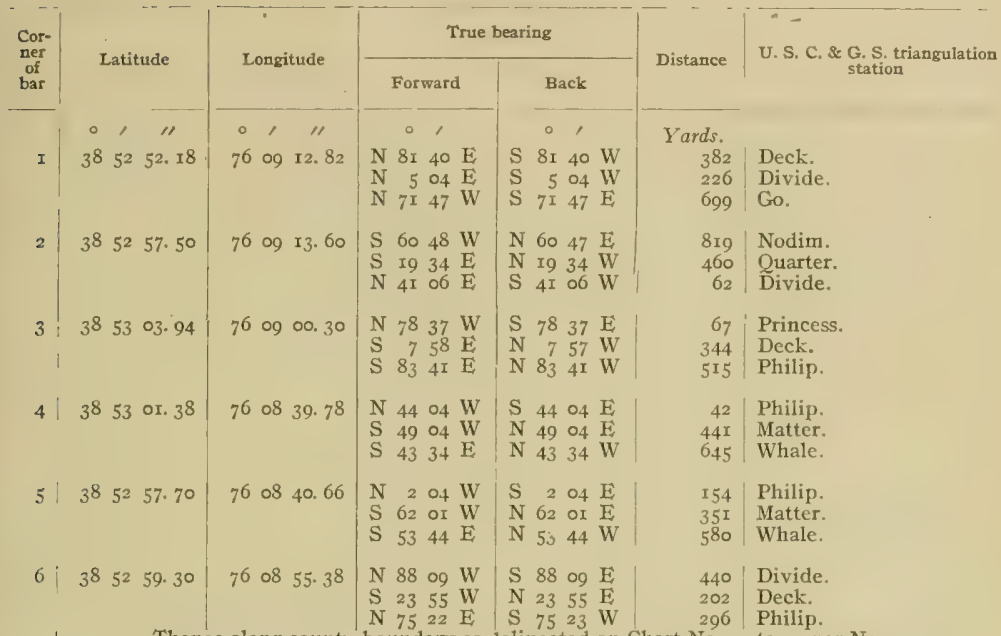

Thence along county boundary as delineated on Chart No. 32 to corner No. I.

\section{GRANARY POINT.}

(Wye River-Chart No. 32.)

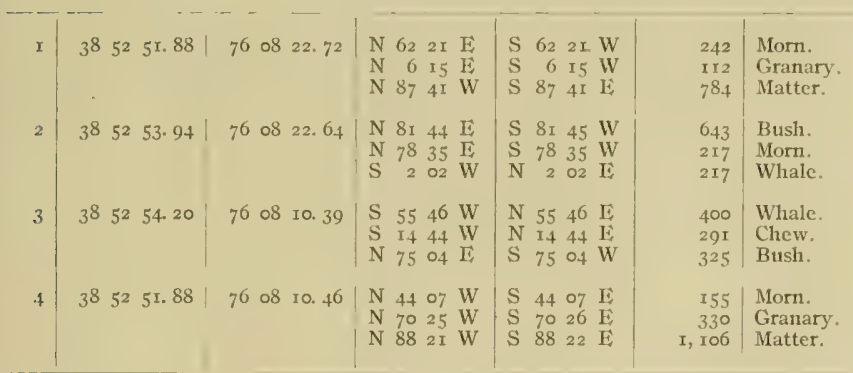





\section{A P P E N I XES.}

\section{APPENDIX A.-LAWS RELATING TO THE COOPERATION OF THE COAST AND GIODETIC SURVEY AND BUREAU OF FISHERIES WITH THE MARYLAND SHELL FISH CON- MISSION.}

The work of the Coast and Geodetic Survey and of the Bureau of Fisheries, in cooperation with the Maryland Shell Fish Commission, in surveying the oyster bars, establishing permanent landmarks at triangulation stations, and preparing for publication the necessary charts and technical and legal descriptions of boundaries and landmarks showri on these charts, has been executed in compliance with a request from the governor of the State of Maryland to the Secretary of Commerce and Labor, and by the authority of the following laws of the United States and Maryland:

[Act of Congress approved May 26, 1906.]

AN ACT To authorize the Secretary of Commerce and Labor to cooperate, through the Bureau of the Coast and Geodetic Survey and the Bureau of Fisheries, with the shellfish commissioners of the State of Maryland irn making surveys of the natural oyster beds, bars, and rocks in the waters within the State of Maryland.

Be it enacted by the Senate and House of Representatives of the United States of America in Congress assembled, That the Secretary of Commerce and Labor be, and he is hereby, authorized and directed, upon the request of the governor of the State of Maryland, to designate such officers, experts, and employees of the Bureau of the Coast and Geodetic Survey and of the Bureau of Fisheries as may be necessary to cooperate with the Maryland State board of shellfish commissioners in making a survey of and locating the natural oyster beds, bars, and rocks in the waters within the State of Maryland; and the Secretary of Commerce and Labor is hereby authorized and directed to furnish to the ofticers, experts, and employees of said Bureaus so detailed as aforesaid such instruments, appliances, and steam launches as may be necessary to make the survey aforesaid; and the Secretary of Commerce and Labor is hereby authorized to have made in the Bureau of the Coast and Geodetic Survey all the plats necessary to show the results of the aforesaid survey and the locations of the said natural oyster beds, bars, and rocks in the waters within the State of Maryland, and to furnish to the board of shellfish commissioners of the State of Maryland such copies as may be necessary, and for this purpose to employ, in the District of Columbia and elsewhere, such technically qualified persons as may be necessary to carry out the purpose of this act.

SEC. 2. That the Secretary of Commerce and Labor is hereby further authorized to have erected or constructed by the officers so detailed as aforesaid, while making such survey; such structures as may be necessary to mark the points of triangulation, so that the same may be used for such future work of the Coast and Geodetic Survey as the said Burcau may be hereafter required to perform in prosecuting the Government coast survey of the navigable waters of the United States located within llie State of Maryland.

Sie. 4. That this act shall take effect from the date of its passage.

[Act of Congress approved June 30, 1906.]

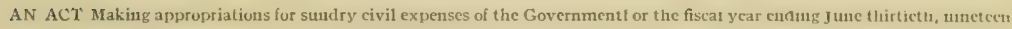
hundred and seven, and for other purposes.

Be it enacted by the Senate and Housc of Representatives of the United States of America in Congress assembled, That the following sums be, and the same are hereby, appropriated, for the objects hereinafter expressed, for the fiscal year ending June thirtieth, nineteen hundred and seven, namely: * * * 
Coast AND GeOdetic Survey: * * * For any special surveys * * * including the expenditures authorized under Public Act Numbered One hundred and eighty-one, approved May twenty-sixth, nineteen hundred and six, and contingent expenses incident thereto, five thousand dollars, together with the unexpended balance under this appropriation for nineteen hundred and six and prior years which is hereby reappropriated and made available on this account for the fiscal year nineteen hundred and seven. ***

\section{[Act of Congress approved March 4, r90\%]}

AN ACT Making appropriations for sundry civil expenses of the Government for the fiscal year ending June thirtieth, nineteen hundred and eight, and for other purposes.

Be it enacted by the Senate and House of Representatives of the United States of America in Congress assembled, That the following sums be, and the same are hereby, appropriated, for the objects hereinafter expressed, for the fiscal year ending June thirticth, nineteen hundred and eight, namely: * * *

COAST AND GEODETIC SURVEY: * * * For any special surveys * * * including expenses of surveys in aid of the shellfish commission of the State of Maryland, to be immediately available and to continue available until expended, twenty-five thousand dollars. * * *

\section{[Act of Congress approved May 27, I908.]}

AN AC'T Making appropriations for sundry civil expenses of the Government for the fiscal year ending June thirtieth, nineteen hundred and nine, and for other purposes.

Be it enacted by the Senate and House of Representatives of the United States of America in Congress assembled, That the following sums be, and the same are hereby, appropriated, for the objects hereinafter expressed, for the fiscal year ending June thirtieth, nineteen hundred and nine, namely: * * *

COAST AND GEOdertc SuRvey: * * * For any special surveys * * * including expenses of surveys in aid of the shellfish commission of the State of Maryland, which expenses, including cost of plats and charts, shall not exceed fifteen thousand dollars in any one year, to be immediately available, twenty thousand dollars.

[Act of Congress approved March 4, I909.]

AN ACT Making appropriations for sundry civil expenses of the Government for the fiscal year ending June thirtieth, nineteen hundred and ten, and for other purposes.

Be it enacted by the Senate and House of Representatives of the United States of America in Congress assembled, That the following sums be, and the same are hereby, appropriated, for the objects hereinafter expressed, for the fiscal year ending June thirtieth, nineteen lundred and ten, namely: * * *

COAST AND GEODETIC SURver: * * * For any special surveys * * * including expenses of surveys in aid of the shellfish commission of the State of Maryland, which expenses, including cost of plats and charts, shall not exceed fifteen thousand dollars in any one year, to be immediately available, twenty thousand dollars.

[Act of Congress approved Jume 25, 1910.]

AN ACT Making appropriations for sundry civil expenses of the Government for the fiscal year cnting June thirticth, uinctecn hundred and eleven, and for other purposes.

Be it enacted by the Senate and House of Representatives of the United States of America in Congress assembled, That the following sums be, and the same are hereby, appropriated, for the objects hereinafter expressed, for the fiscal year ending June thirtieth, nineteen hundred and eleven, namely: * * *

COAST AND GEODETIC SURVEY: * * * For any special surveys * * * including expenses of surveys in aid of the shellfish commission of the State of Maryland, to be immediately available, fifteen thousand dollars. 
[Act of Congress approved March 4, 19rr.]

AN ACT Making appropriation for sundry civil expenses of the Government for the fiscal year ending June thirtieth, nineteen hundred and twelve, and for other purposes.

Be it enacted by the Senate and House of Representatives of the United States of America in Congress assembled, That the following sums be, and the same are hereby, appropriated, for the objects hereinafter expressed, for the fiscal year ending June thirtieth, nineteen hundred and twelve, namely: * * *

COAST AND GeOdetrc SuRvey: * * * For any special surveys * * * including expenses of surveys in aid of the shellfish commission of the State of Maryland, to be immediately available, thirteen thousand dollars.

[Act of the Legislature of Maryland approved April 2, ז906.]

AN ACT To establish and promote the industry of oyster culture in Maryland, to define and mark natural oyster beds, bars and rocks Iying under the waters of this State, to prescribe penalties for the infringement of the provisions of this Act. and ****.

Section r. Be it enacted by the General Assembly of Maryland, That the following sections be, and they are hereby, added to article 72 of the Code of Public General Laws, title "Oysters." * * *

SEC. 86. The Board of Shell Fish Commissioners shall, as soon as practicable after the passage of this Act, cause to be made a true and accurate survey of the natural oyster beds, bars and rocks of this State, said survey to be made with reference to fixed and permanent objects on the shore, giving courses and distances, to be fully described and set out in a written report of said survey, as hereinafter required. A true and accurate delineation of the same shall be made on copies of published maps and charts of the United States coast and geodetic survey, which said copies shall be filed in the office of the said commissioners in the city of Annapolis, and the said commissioners shall further cause to be delineated upon copies of the published maps and charts of the United States coast and geodetic survey, of the largest scale, one copy for each of the counties of this State in the waters of which there are natural oyster beds, bars and rocks, all natural beds, bars and rocks lying within the waters of such county, which maps shall be filed in the oftices of the clerks of the Circuit Court for the respective counties wherein the grounds so designated may lie. * * *

SEC. 87. The Governor of this State is hereby requested to ask the assistance of the United States coast and geodetic survey, and of the United States Fish Commissioner, to aid in the carrying out of the provisions of the preceding section.

SEC. 89. As soon as practicable after the first day of April, I906, the said commissioners shall organize, and shall at once proceed, with the assistance of such person or persons as may be detailed by the United States coast and geodetic survey and the United States Fish Commissioner, to aid them in their work, and of such persons as may be appointed under the preceding section, to have laid out, surveyed and designated on the said charts, the natural beds and bars, and shall cause to be marked and defined as accurately as practicable the limits and boundaries of the natural beds, bars, and rocks as established by said survey, and they shall take true and accurate notes of said survey in writing, and make an accurate report of said survey, setting forth such a description of landmarks as may be necessary to enable the said board, or their successors, to find and ascertain the boundary lines of the said natural oyster beds, bars and rocks, as shown by a delineation on the maps and charts provided in this Act; said report shall be completed and filed in the office of the board in the city of Annapolis within ninety days after the completion of the survey of any county. Said commissioners shall cause the same to be published in pamphlet form, and transmit copies of the same to the Clerks of the Circuit court for the respective counties, where the charts have been filed or directed to be filed as hereinafter provided; the said report to be filed by the clerks of the several counties in a book kept for that purpose. And the said surve $y$ and report, when filed, subject to the right of appeal hereafter provided for in this Act, shall be taken in all of the courts of this State as conclusive evidence of the boundaries and limits of all natural oyster beds, bars and rocks, lying within the waters of the county wherein such survey and report are filed, and shall be construed to mean in all of the said courts that there are no natural oyster beds, hars or rocks lying within the waters of the counties wherein such report and survey are filed other than those embraced in the survey authorized by this Act, and that all areas of the Chesa- 
peake Bay and its tributaries within the State of Maryland, not shown in the survey to be natural oyster beds, bars or rocks shall be construed in all the courts of the State to be barren bottoms and open for disposal by the State for the purpose of private planting or propagation of oysters thereon under the provisions of this Act; provided, that the said survey and report shall not be construed as to affect in any manner the holdings by citizens of this State in any lot which may have been appropriated or taken up under the laws of this State prior to the approval of this Act.

The law of the State of Maryland, passed March 9, I842, authorizing officers of the United States Coast and Geodetic Survey to enter upon the lands within the State limits for the purposes of the survey, is as follows:

AN ACT Concerning the Survey of the Coast of Maryland.

Section r. Be it enacted by the General Assembly of Maryland, That it shall and may be lawful for any person or persons employed under and by virtue of an act of the Congress of the United States, * * * at any time hereafter to enter upon lands within this State for the purpose of exploring, surveying, triangulating, or leveling, or doing any other matter or thing which may be necessary to effect the objects of said act, and to erect any works, stations, buildings, or appendages requisite for that purpose, doing no unnecessary injury to private or other property.

SEc. 2. ${ }^{1}$ And be it enacled. That in case the person or persons employed under the act of Congress aforesaid, can not agree with the owners or possessors of the land so entered upon and used as to the amount of damage done thereto by reason of the removal of fences, cutting of trees or injury to the crop or crops growing on the same, it shall and may be lawful for the said parties or either of them to apply to the chief justice for the time being or one of the associate judges of the judicial district in which such land may be situated, who shall thereupon appoint three disinterested and judicious freeholders, residents of the same judicial district, to proceed with as much despatch as possible to the examination of the matter in question, and the faithful assessment of the damages sustained by the owners or possessors aforesaid, and the said freeholders or a majority of them, having first taken and subscribed an oath or affirmation before the chief or associate justice aforesaid or other person duly authorized to administer the same, that they will well and truly examine and assess as aforesaid, and having given five days' notice to both parties of the time of their meeting, shall proceed to the spot, and then and there upon their own view and if required, upon the evidence of witnesses (to be by them sworn or affirmed and examined), shall assess the said damages, and shall afterward make report thereof and of their proceedings in writing under their hands and seals and file the same within five days thereafter in the office of the clerk of the county in which the land aforesaid is situated, subject to an appeal by either party to the county court of the said county within ten days after filing as aforesaid, and the said report so made as aforesaid if no appeal as aforesaid be taken, shall be held to be final and conclusive as between the said parties, and the amount so assessed and reported shall be paid to the said owners or possessors of the land so damaged within twenty days after the filing of said report, and the said chief or associate justice as aforesaid, shall have authority to tax and allow upon the filing of said report, such costs, fees and expenses to the said freeholders for the performance of their duty as he shall think equitable and just, which allowance shall be paid by the person or persons employed under the act of congress aforesaid, within the time last above limited, but if an appeal as aforesaid be taken, the case slall be set down for hearing at the first term of county court aforesaid, cnsuing upon and after appeal, and it shall be lawful for either party immediately aiter the entry of sucl appeal, to take out summons for such witnesses as may be necessary to be examined upon the licaring aforcsaid, and the said court shall have power in its discretion to award costs against which ever the final judgment shall be entered, and such appeal at the option of either party may and sliall be lieard before and the damage assessed by a jury of twelve men to be taken from the regular panel and elected as in other cases.

SEc. 3. And be it enacted, That if any person or persons shall wilfully injure or deface or remove any signal, monument or building or any appendage thereto, erected, used or constructed under and by virtue of the act of congress aforesaid, such person or persons so offending shall severally forfeit and pay the sum of fifty dollars with costs of suit to be sued for and recovered by any person who shall first

1 Under the rulings of the Comptroller of the Treasury no damages can be collected except through the United States Court of Claims unless an agreement has been made in advance. 
prosecute the same before any justice of the peace of the county where the person so offending may reside, and shall also be liable to pay the amount of damages thereby sustained, to be recovered with costs of suit in an action on the case, in the name and for the use of the United States of America, in any court of competent jurisdiction.

\section{APPENDIX B.-THE HAMAN OYSTER CULTURE LAW.}

[Extract from Second Report of Shell Fish Commission.]

\section{OBJECT.}

"The legislature in placing chapter $7 \mathrm{Ix}$ of the acts of 1906 , better known as the Haman Oyster Culture Law, upon the statute books of Maryland, had a twofold object in view. State.

I. To encourage an industry in oyster culture upon the barren bottoms beneath the tidewaters of the

2. To prevent the leasing of natural oyster bars for the purpose of oyster culture."

SURVEY.

"To make the leasing of barren bottoms possible and the leasing of natural bars impossible, provision was made for a survey of the natural bars for the purpose of accurately locating and marking the same. It was definitely provided that no barren bottoms should be leased in any part of the State until the natural bars of that region had been surveyed, charted, and marked with buoys."

\section{DEFINITION OF A NATURAL OYSTER BAR.}

NATURAL, BAR NOT DEFINED.

"The Shell Fish Commission is instructed by section 90 of the Haman Oyster Culture Law to exercise its judgment liberally in favor of the natural bars when surveying, charting and buoying them, but other than this the Commission is uninstructed in this important matter. The responsibility of defining a natural bar is placed upon the Commission."

\section{DIVERSITY OF OPINION.}

"No definition of a natural oyster bar could be formulated by any man or body of men which would meet with the approval of all parties concerned. Oystermen, as a rule, hold that all bottoms where oysters grow or have grown naturally even though now practically barren of oysters should be considered natural bars. Other citizens of the State who are not directly interested in the oyster business, but interested in the oyster industry from the standpoint of revenue, hold, as a rule, that no bottoms should be excluded from leasing for oyster culture which, by methods known to oyster culturists, may be made to yield a greater number of oysters than they now produce."

"It should be evident to every one that neither of these definitions could be adopted by the Com. mission as a working basis for determining which of the grounds surveyed are natural oyster bars."

\section{THE GOLDSBOROUGH DEFINITION.}

The definition of a natural oyster bar which very nearly approaches a reasonable and satisfactory compromise between the views of the subject held by oystermen on one hand and by oyster culturists on the other is that contained in an opinion rendered by Judge Charles F. Goldsborough in the circuit court for Dorchester County in the July term, $r 88 \mathrm{r}$, in the case of William $\mathrm{T}$. Windsor and George R. Todd $v$. Job T. Moore.

This definition has been adopted by the Shell. Fish Commission as the basis for the determination of the status of the various oyster bottoms surveyed, and is as follows:

What then is a natural bar or bed of oysters? It would be a palpable absurdity for the State to attempt to promote the propagation and growth of oysters and to encourage its citizens, by a grant of land, to engage in their culture, if the lands authorized to be taken up were only those upon which oysters do not and can not be made to grow. That there may be lands covered by water in the State where no oysters can be found, but where, if planted, they could be cultivated successfully, may be 
possible, but, if so, I imagine that their extent must be too limited for them to be of much practical, general advantage for the purposes of such a law as the one under discussion; but there are thousands of acres of hard and shifting sands where oysters not only are not found, but where it would be folly to plant them, and these latter it can not be supposed that the State intended to offer to give away, for the simple reason that the State could not help knowing that nobody would have them.

Upon the other hand there are large and numerous tracts where oysters of natural growth may be found in moderate numbers, but not in quantities sufficient to make it profitable to catch them, and yet where oysters may be successfully planted and propagated. In my opinion these can not be called natural bars or beds of oysters, within the meaning of the act of assembly, and it is just such lands as these that the State meant to allow to be taken up under the provisions of the above-mentioned section of the act.

But there is still another class of lands where oysters grow naturally and in large quantities and to which the public are now and have been for many years in the habit of resorting with a view to earning a livelihood by catching this natural growth, and here, $I$ think, is the true test of the whole question. Land can not be said to be a natural oyster bar or bed merely because oysters are scattered here and there upon it, and because if planted they will readily live and thrive there; but whenever the natural growth is so thick and abundant that the public resort to it for a livelihood, it is a natural oyster bar or bed and comes within the above-quoted restriction in the law, and can not be located or appropriated by any individual.

APPLICATION OF DËFINITION.

Before this definition may be of use in determining, accurately and scientifically, the status of an oyster ground, its central idea, "livelihood," must be expanded into accurately determinable factors, and these factors must be confined into a practical scheme of investigating the condition of the ground under consideration.

Stated briefly, a livelihood is represented by a sum of money obtained from the sale, at a fixed price, of a certain quantity of oysters gathered in a given time from an allotted area of ground.

Knowing the value of each of these factors it becomes possible to calculate the number of oysters an oyster ground must produce per square yard in order that oystermen may secure a livelihood by working upon it.

NoTE.-The factors into which the commission resolved the livelihood problem, the value assigned to each factor, and the scheme devised for practical use in examining and applying the definition to oyster bottoms are given in outline in their second report under the heading of the preceding extract, and in detail in their first report on pages 32 to 69 .

APPINDIX C.-SUMMARI OF THF PARTICULAR SURVEYING OPERATIONS WHICH CONSTITUTE AN "OYSTER SURVEY" AS NOW BEING CARRIED ON IN MARYLAND.

Explanation.-A brief account of the particular surveying operations which constitute an "oyster survey" as now being carried on in Maryland will assist in the interpretation of records contained in the technical part of this report, and will be of interest to many who may not understand the necessity for the great amount of work being done or its complicated character.

To those familiar with methods used in surveying and charting the characteristic features of large bodies of water tnere is an evident necessity for the various operations performed, especially when it is known that the boundaries of the public oyster bars and of the private lots leased for purposes of oyster culture must be surveyed and charted with the greatest practical accuracy. To others it will be sufficient to state that the actual experience gained from oyster surveys in other States has proven that in order to avoid endless dissatisfaction and litigation it is necessary to accurately locate and permanently establish oyster boudaries as is now being done in Maryland.

Triangulation survey.-Such refinement of survey work as that demanded by the conditions of an oyster survey when carried on at considerable distances offshore can only be obtained by the use of a system of triangulation as a framework or foundation. Therefore, a triangulation survey including the permanent marking of the positions of landmarks with monuments and a record of the descriptions of their locations for future recovery is a necessary operation of a complete oyster survey.

Topographic survey.-The technical records which establish the relation between the offshore oyster boundaries and triangulation landmarks are sufficient for the requirements of engineers in making resurveys, but do not supply the needs of others who are interested in the same boundaries by reason of their occupation as oystermen concerned as to the public oyster bars, or oyster culturists concerned 
as to the leasable bottoms. For these it is necessary to have the charts of the survey show the relation of the shore line and other topographic features to the boundaries of the public oyster bars and private oyster farms. Therefore, a topographic survey is a necessary operation of a complete oyster survey.

Hydrographic survey:- In the settlement of the important question of what is, of what is not, a natural oyster bar, and in the consideration of bottoms to be selected for purposes of oyster culture, information as to the depth of water and the character of the bottom is required. Therefore, a hydrographic survey is a necessary operation of a complete oyster survey.

Necessary foundation for an oyster survey.-Consequently, the necessary components of a satisfactory foundation for a complete oyster survey are the three classes of survey operations technically named triangulation, topography, and hydrography, or, stated in another way, the foundation of a practical oyster survey includes the surveying opcrations usually followed by the Coast and Geodetic Survey leading up to the preparation and publication of nautical charts.

Special surveys and investigations pertaining to oysters.- Having obtained this cartographic survey for a foundation, partly by new work and partly from records of previous work of the Government, the combined operations ${ }^{1}$ making up an "oyster survey" are completed by superimposing on this foundation special surveys and investigations pertaining particularly to oysters or other shell fish.

The special surveys pertaining to oysters furnish information as to the location and outline of oystershell bottoms, and are carried on by the sounding boat party in addition to the usual hydrographic work. ${ }^{2}$ This operation consists of the observation and record of the character of vibration of a wire and chain apparatus which is dragged over the bottom, the vibrations or lack of vibrations indicating the presence and quantity of shells or absence of shells.

The special oyster investigations ${ }^{3}$ consist of the actual determination of the kind and quantity of oysters on the bottom, and such economic and biological studies of the supply of oyster food, density of water, character of the bottom, and other important matters as affects the growth of oysters. In this work the oyster investigation stations are located and buoyed by the hydrographic party while engaged in the survey of the oyster-shell limits. They are selected with the view of obtaining characteristic data which can be used for the interpretation of the recorded vibrations of the chain apparatus at all other points covered by the survey.

Preparation of results.-The actual surveying operations and oyster investigations having been completed for any one county, there still remains technical work of nearly equal magnitude to that described. ${ }^{4}$ This work consists of the preparation of charts and technical descriptions of boundaries and landmarks for publication by the Government, the preparation of that part of the annual report of the commission covering the special oyster surveys and investigations, the making of the leasing charts and finished projections, and finally the filing of the oyster charts and records with the courts and the commission, thus opening a county for oyster culture.

Summary.-From the foregoing account it can be seen that a complete oyster survey properly conducted so as to answer all practical requirements of the present and permanency of results for the future is a very complicated affair, involving many lines of surveying and other scientific work, and requiring the professional services of experts in the various operations of cartographic surveying and shell-fish investigations.

1 See Appendix D of this publication for "Statistics of results of combined operations of the Government and State,"

${ }^{2}$ See pp. 104 to 123 of First Annual Report of Maryland Shell Fish Commission.

${ }^{3}$ See pD. 30 to 67 and 129 to r 99 of First Annual Report of Maryland Shell Fish Commission.

- No mention is made here of the large amount of administrative work of the commission, which is greatly complicated and increased by the effect of the oyster-survey operations on many thousands of people whose interests are raore or less involved; or of the large amount of survey work involved in the survey and record of the boundaries of oyster lots leased from the State by private individuals for the purposes of oyster culture. 
APPENDIX D,-STATISTICS OF RESULTS OF THE COMBINED OYSTER SURVEY OPERATIONS OF THE GOVERNMENT AND STATE.

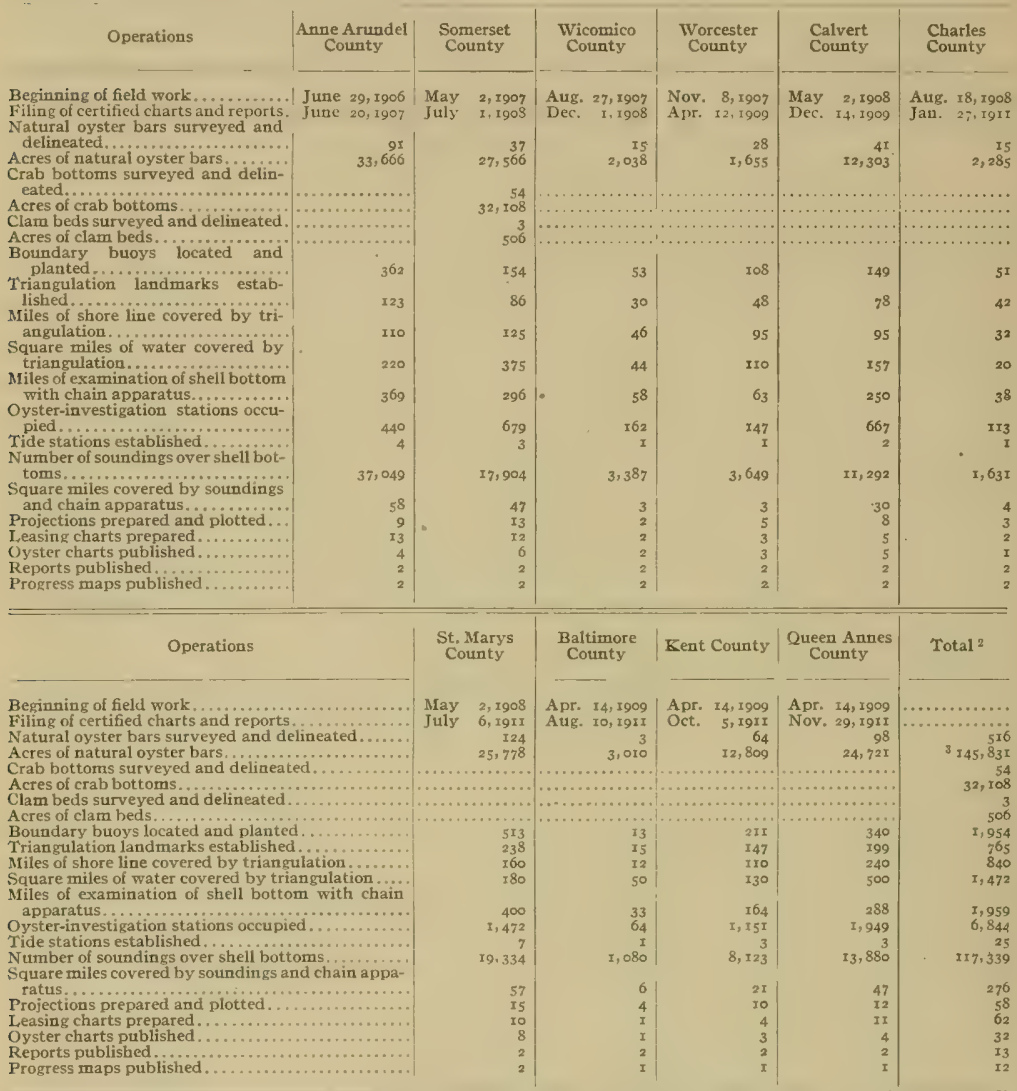

1 These statistics do not include the large amount of triangulation, topography, and hydrography resulting from previous wotk of the Coast and Geodetic Survey, which was utilized in the preparation of the published oyster charts and records. Work in Talbot and Dorchester counties has been finished, but final statistics of results will not be published until these counties Talbot and Dorchester coun

2 Less quantities covered by statistics of more than r county.

a Total area of natural oyster bars of Connerticut is 5.770 acres. 





\title{
DEPARTMENT OF COMMERCE AND LABOR \\ COAST AND GEODETIC SURVEY \\ O. H. TITTMANN, Superintendent
}

\section{SURVEY OF OYSTER BARS ST. MARYS COUNTY MARYLAND}

\author{
DESCRIPTION OF BOUNDARIES AND LANDMARKS AND \\ REPORT OF WORK OF UNITED STATES COAST \\ AND GEODETIC SURVEY IN COOPERATION \\ WITH UNITED STATES BUREAU OF \\ FISHERIES AND MARYLAND \\ SHELL FISH COMMISSION
}

By C. C. YATES

CHIEF OF COAST AND GEODETIC SURVEY PARTY

ASSISTANT, COAST AND GEODETIC SURVEY

WASHINGTON

GOVERNMENT PRINTING OFFICE

1911 



\title{
LE'T'TER OF SUBMITTAL.
}

\author{
DEPARTMENT OF COMMERCE AND LABOR, \\ CoAst and Géodetic Survei, \\ Washington, July 6, I9II.
}

SIR: I have the honor to transmit herewith a report of the officer detailed from the Coast and Geodetic Survey to cooperate with the Bureau of Fisheries and the Maryland Shell Fish Commission in surveying the oyster bars of the State of Maryland, together with certain technical results which are necessary for the interpretation and use of the plats of the survey made by the Government.

This work has been done under the provisions of the act of Congress entitled "An act to authorize the Secretary of Commerce and Labor to cooperate, through the Bureau of the Coast and Geodetic Survey and the Bureau of Fisheries, with the shell fish commissioners of the State of Maryland in making surveys of the natural oyster beds, bars, and rocks in the waters within the State of Maryland," approved May 26, 1906, and of the acts of Congress making appropriations for sundry civil expenses of the Crovernment for the fiscal years ending June $30,1907,1908,1909,1910$, and 1911.

Respectfully,

To Hon. Charles Nagel,

O. H. Titmanan, Superintendent.

Secretary of Commerce and Labor. 



\section{CERTIFICA TION.}

BALTIMORE, MD., July 5, I9II.

The following publication is certified to contain correct technical descriptions of all boundaries and landmarks established in St. Marys County by the Maryland Shell Fish Commission in cooperation with the United States Coast and Geodetic Survey.

$$
\text { C. C. YATES, }
$$

Chief of Coast and Geodetic Survey Party, Assistant, Coast and Geodetic Survey.

Examined and certified to be correct.

BALTIMORE, MD., July 5, I9II.

WALTER J. MITChelL,

CASWELl, Grave,

BENJAMIN K. GREEN,

Maryland Shell Fish Commission.

SWEPSON EARLE,

Hydrographic Engineer.

NoTE.-Certified copies of this publication and of the charts of the natural oyster bars of St. Marys County were filed in the office of the clerk of the circuit court of St. Marys County and in the office of the board of shell fish commissioners on Julv 6, I gr r. 



\section{CONTENTS.}

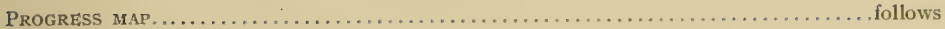

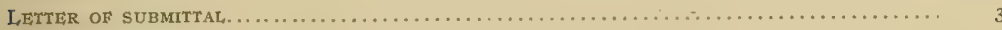

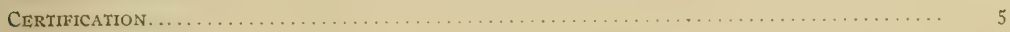

INTRODUCTION:

Publications. . . . . . . . . . . . . . . . . . . . . . . .

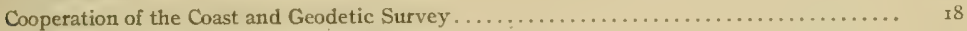

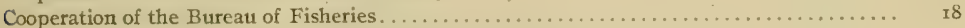

General statement of work of Coast and Geodetic Survey .................... I8

REPORT OF THE WORK OF THE COAST AND GEODETIC SURVEY:

Instructions

Organization and equipment. ...

Chronological statement of work . . . . . . . . . .

Statistics.

General remarks. . . . . . . . . . . . . . . . . . . . . . . . . . . . . . . ${ }^{23}$

CHARTS AND MAPS:

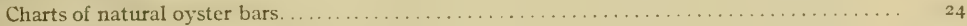

Leasing charts. . . . . . . . . . . . . . . . . . . . . . . . . . . . . . 25

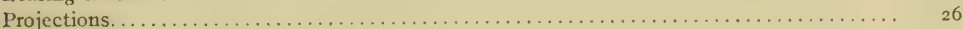

Progress maps. . . . . . . . . . . . . . . . . . . . . . . . . . . . $26 \ldots \ldots \ldots \ldots \ldots$

BOUNDARIES OF THE COUNTY WATERS:

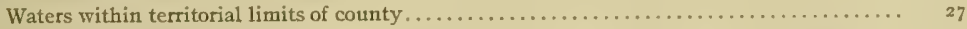

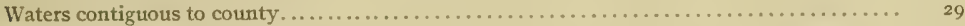

LANDMARKS (UNTTED STATES COAST AND GEOdETIC SURVEY TRIANGUlation STATIONS):

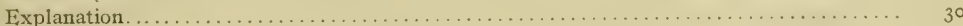

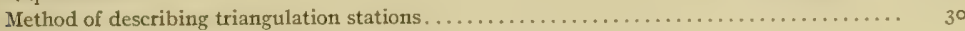

Descriptions of triangulation stations in county and adjacent watersChart No. rg (Upper Patuxent River)-

Prince.

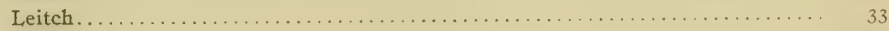

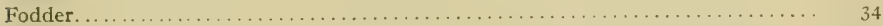

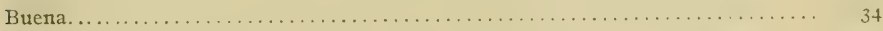

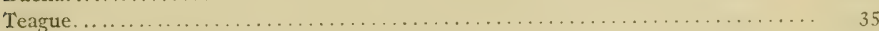

Catholic Church Cross (Benedict) (see also subchart on Chart No. 26) ............ 35

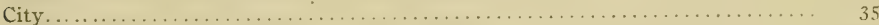

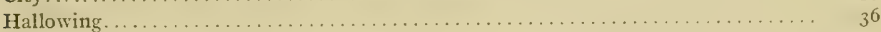

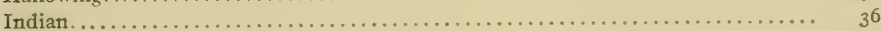

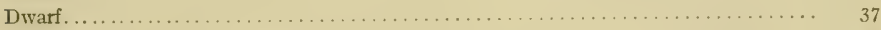

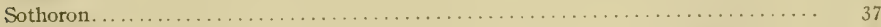

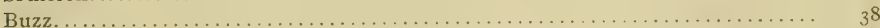

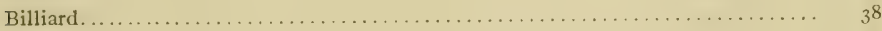

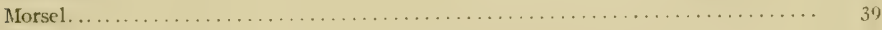

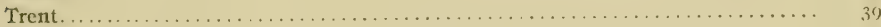

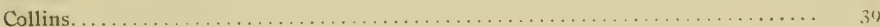

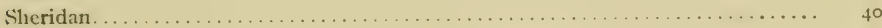

Cremona. 
L.INDMARK: Continued.

Descriptions of triangulation stations in county" and adjacent waters-Continued. Chart No, to-Continued.

Kitt.

(Ippkit

kiatle.

photo.

Fight

Slim

Forr.

Sweep.

Island .

Peak.

Cole. . .

Hutchins

Wheat (see also Chart No. 20).

Mackall (see also Chart No. 20)

Sollers (sie also Chart No. 2o).

Bars.

Lend (see also Chart No, 20).

Chart No. 20 (Lower Patuxent River)-

Wheat (sce also Chart No. Ig)

Mackall (sce also Chart No. Ig)

Page.

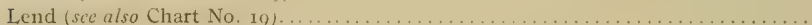

Stock.

Stump.

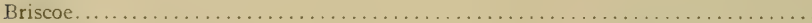

Hellen $\ldots \ldots \ldots \ldots \ldots \ldots \ldots \ldots \ldots \ldots \ldots \ldots \ldots \ldots \ldots \ldots \ldots \ldots \ldots \ldots \ldots \ldots \ldots \ldots$

Nat.$\ldots \ldots \ldots \ldots \ldots \ldots \ldots \ldots \ldots \ldots \ldots \ldots \ldots \ldots \ldots \ldots \ldots \ldots \ldots \ldots \ldots \ldots \ldots \ldots \ldots$

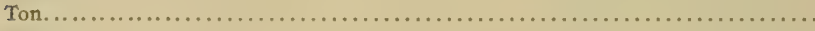

Mtill.

Bur.

New

Catholic Church Cross

Cable

Town

Crane.

Methodist Episcopal Church (Solomons)

Knights of Pythias Flagstaff (Solomons)

Sand.

Fishstack

Bon.

Bareda House Cupola

Drum Point Light.

Ben.

Craddock.

Carroll 2

Hog 2

Pat.

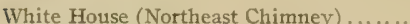

Cove Point Light.

Cedar Point Light.

Cain (see also Chart No. 2x)

Desert (see also Chart No. 2I) 
LANDMARKS-Continucd.

Descriptions of triangulation stations in county and adjacent waters-Continued.

Chart No. 2 (Chesapeake Bay below Cedar Point)-

Cain (sci also Clatart No, zo).

I'aze.

Jesurt (nec ulso (hart No, 2o)

58

Hopper Islatid i,ight.

Find

Reed a mat

Puint Agin

5.

59

59

59

Chart No. 22 (Chesapeake Bay vicinity of Point No Point)-

Point No Point.

Point No Point Light.

St. Jerome

St. Michael Catholic Church Spire

Point Look-in

Potomac (see also Chart N. 23) .

Point Lookout Light (see also Chart No. 23). ...

Hall

Hall House (Middle Chimney)

Sig (sce also Chart No. 24)

Chart No. 23 (mouth of Potomac River)-

Potomac (sec also Chart No. 22).

Point Lookout Light (sce also Chart No. 22)

Smith Point Light

Chart No. 24 (St. Marys River and Smith Creek)-

Sig (sce also Chart No. 22).

Red Beacon (IgoS).

Dago

Tab.

Pier.

Pipe

Enough

Drum.

In.

Oak

60

60

60

$6 \mathrm{I}$

$6 \mathrm{I}$

$6 \mathrm{I}$

62

62

62

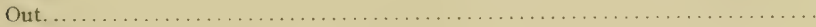

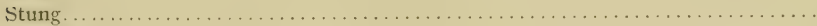

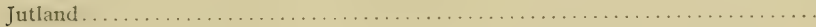

Flat.

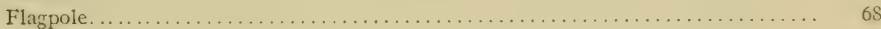

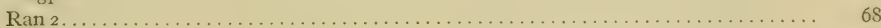

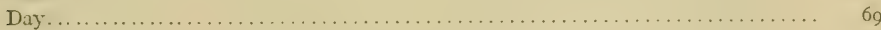

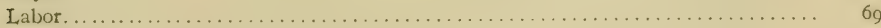

Lynch Point 3 (Virginia) (see Progress map)......................... 70

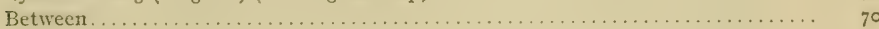

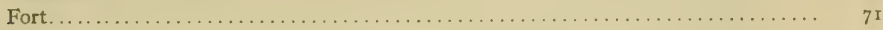

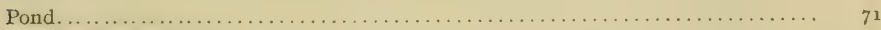

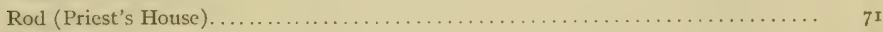

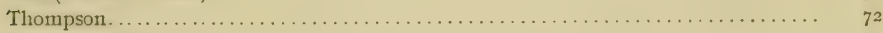

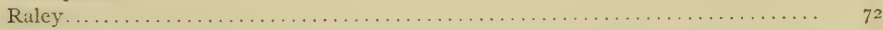

Inigoes. . . . . . . . . . . .

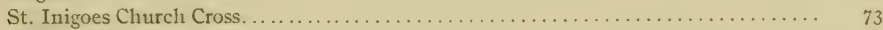

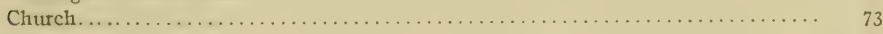

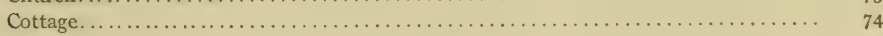

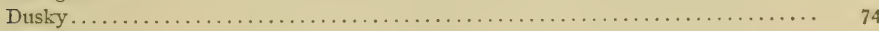


LANDMARKS-Continued.

Descriptions of triangulation stations in county and adjacent waters-Continued.

Chart No.24-Continued.

Page.

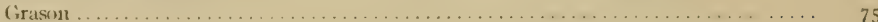

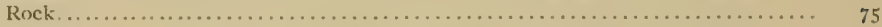

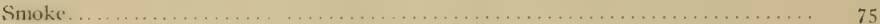

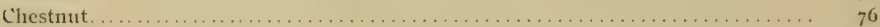

Sleep. ..........................................

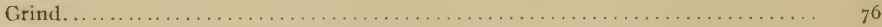

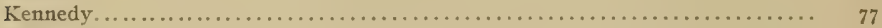

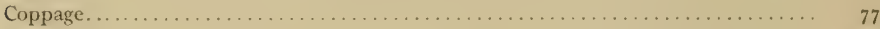

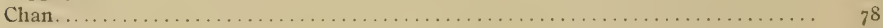

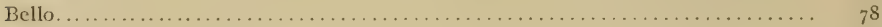

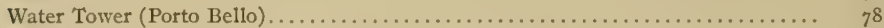

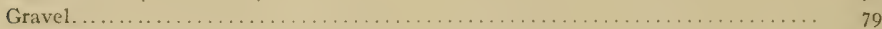

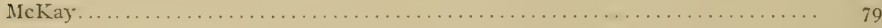

Brome . . . . . . . . . . . . . . . . . . . . . . . . . . . .

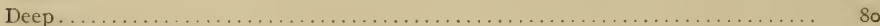

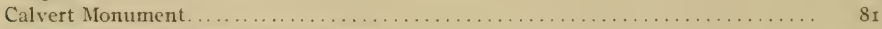

Episcopal Church Cross (Old St. Marys) . . . . . . . . . . . . . . . . . . .

Pagan . . . . . . . . . . . . . . . . . . . . . . . . . . .

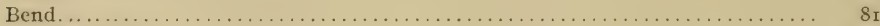

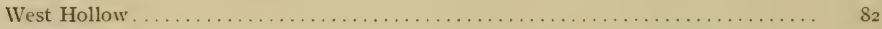

Horseshoe $\ldots \ldots \ldots \ldots \ldots \ldots \ldots \ldots \ldots \ldots \ldots \ldots \ldots \ldots \ldots \ldots \ldots \ldots$

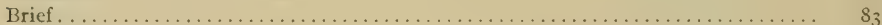

Tenuate. $\ldots \ldots \ldots \ldots \ldots \ldots \ldots \ldots \ldots \ldots \ldots \ldots \ldots \ldots \ldots \ldots \ldots \ldots \ldots \ldots \ldots \ldots$

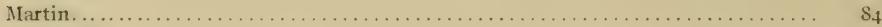

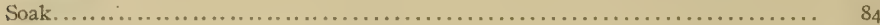

Hammett . . . . . . . . . . . . . . . . . . . . . . . . . . . . $8_{5}$

McCoy ............................................ 85

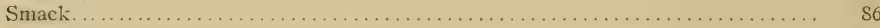

Cherry . . . . . . . . . . . . . . . . . . . . . . . . . .

Price $\ldots \ldots \ldots \ldots \ldots \ldots \ldots \ldots \ldots \ldots \ldots \ldots \ldots \ldots \ldots \ldots \ldots \ldots \ldots$

Adams. . . . . . . . . . . . . . . . . . . . . . . . . . . . . . . . . . . .

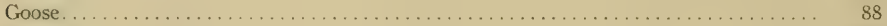

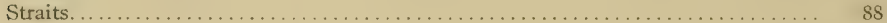

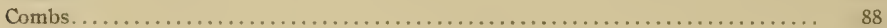

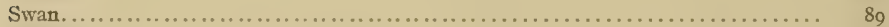

Taylor . . . . . . . . . . . . . . . . . . . . . . . . . . . . . . $8_{9}$

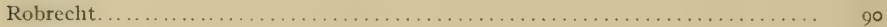

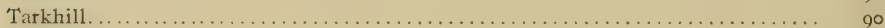

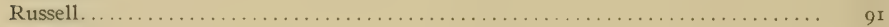

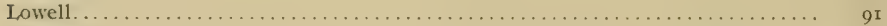

Arbuckle. . . . . . . . . . . . . . . . . . . . . . . . . . . . . .

Wall $\ldots \ldots \ldots \ldots \ldots \ldots \ldots \ldots \ldots \ldots \ldots \ldots \ldots \ldots \ldots \ldots \ldots \ldots \ldots \ldots \ldots \ldots \ldots \ldots \ldots \ldots \ldots \ldots \ldots \ldots$

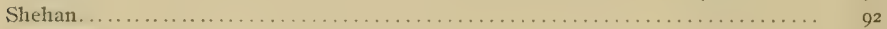

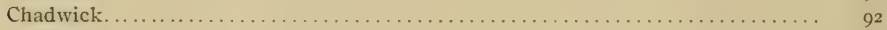

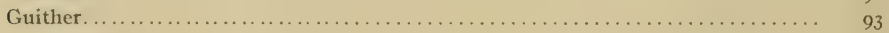

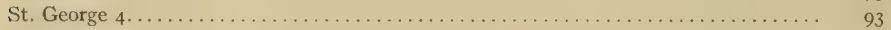

Piney Point Light. . . . . . . . . . . . . . . . . . . . . . . . . . . . . 94

Chart No. 25 (St. Clement Bay and Bretons Bay) -

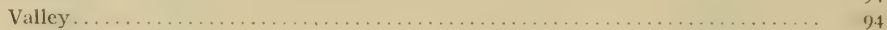

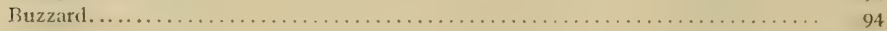


IANDMARKS - Continued.

Descriptions of triangulation stations in county and adjacent waters - Continuect. Chart No.25-Continued.

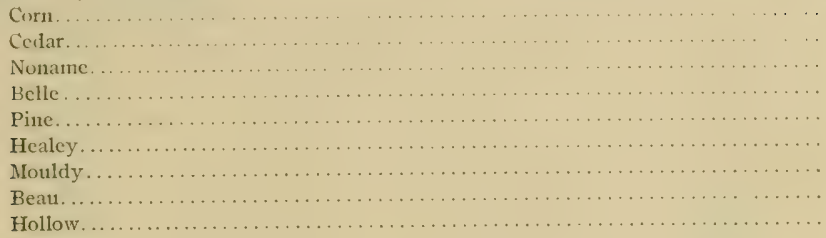

Trees.

Lovers.

Paw.

What.

Cherry Cove.

Protestant

Fence. .

Compton.

Sandbar.

Dune. .

Newtown.

Grove.

Cedoak.

Kaywood.

Heron.

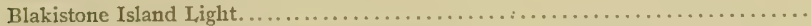

Herring Pond 2 (Virginia) (see Progress map).

St. Clement.

St. Patrick.

Roof. .

Canoe.

Rails. . . .

Woods

Catholic Church Cross (Newton Neck)

Chapel.

Shipping.

Mansion.

Howards.

Mileys.

Bank

Profound.

Cecil.

Radec.

Place.

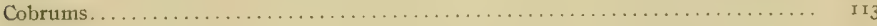

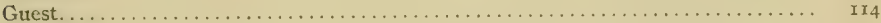

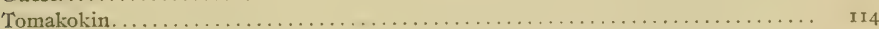

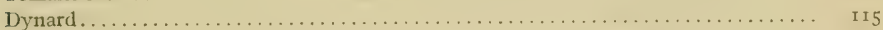

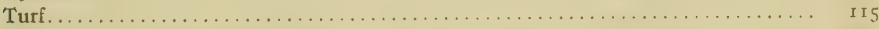

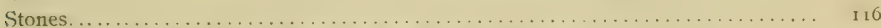

River Springs Catlolic Chapel Cross (sec also Chart No. z6) ................ 126 
LANDMARKS-Continued.

Descriptions of triangulation stations in county and adjacent waters-Continued.

Chart No. 26 (Wicomico River)-

Barber.

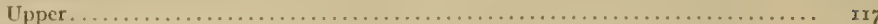

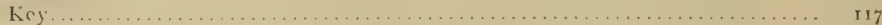

Situldard. . . . . . . . . . . .

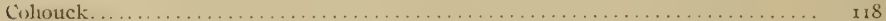

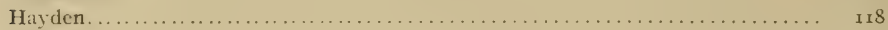

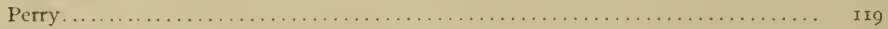

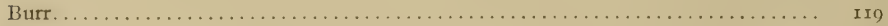

Fact. . . . . . . . . . .

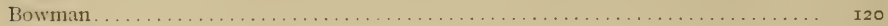

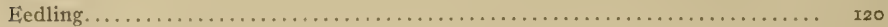

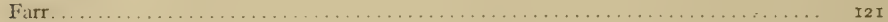

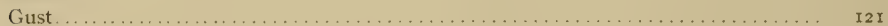

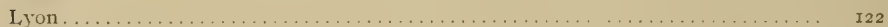

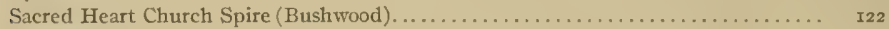

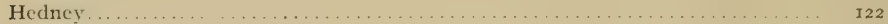

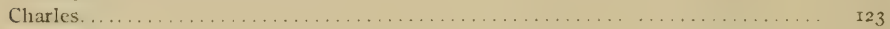

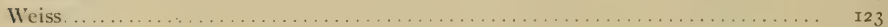

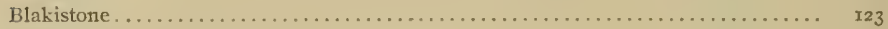

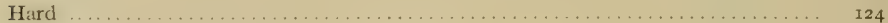

Rock Point Catholic Church Cross. . . . . . . . . . . . . . . . . . . . . . . .

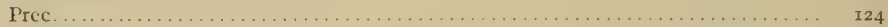

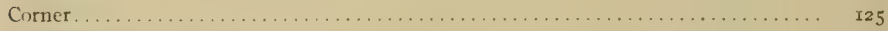

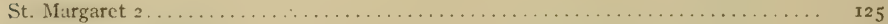

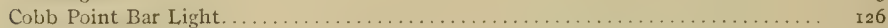

River Springs Catholic Chapel Cross (see also Chart No. 25) ................ I26

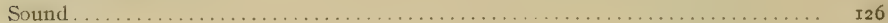

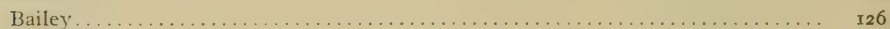

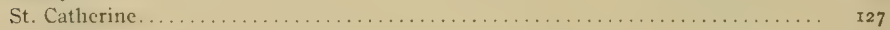

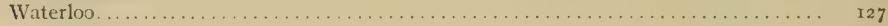

BOUNDARIES OF OYSTER BARS:

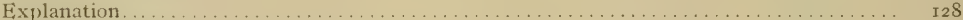

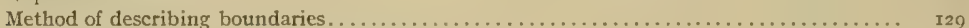

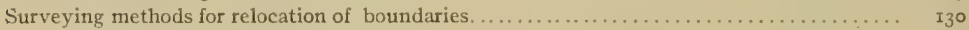

Boundaries of natural oyster bars in county ${ }^{1}$ -

Chart No, Ig (upper Patuxent River)--

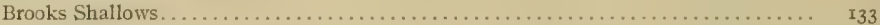

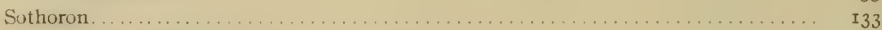

Broad Neck (St. Marys County) ............................... I34

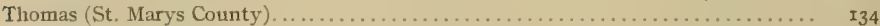

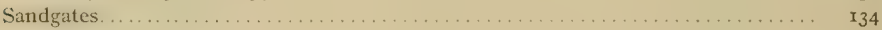

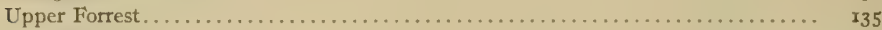

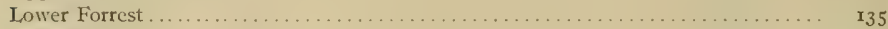

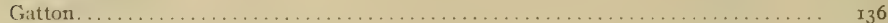

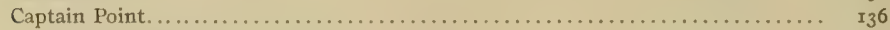

Peterson (St. Marys County) (see also Chart No. 20)..................... I37

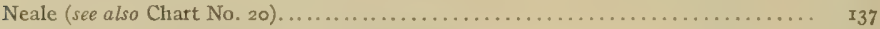

Mears (St. Marys County) (see also Chart No. 20)........................ I37

${ }^{1}$ See separate publications for boundaries of natural bars in adjacent counties. 
BOUNDARIES OF OYSTER BARS-Continued.

Boundaries of natural oyster bars in county-Continued.

Chart No. 20 (Lower Patuxent River)-

Peterson (St, Marys County) (see olso Chart No, rg)..........................

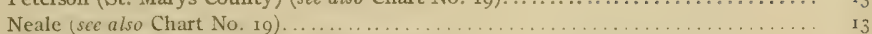

Mears (St. Marys County) (see also (liart No. I0) . . . . . . . . . . . . . . I37

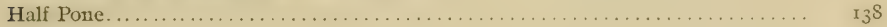

Hawks Nest. . . . . . . . . . . . . . . . . . . . . . . . . . . . . .

Bob Wise . . . . . . . . . . . . . . . . . . . . . . . . . . . . . . . . . . .

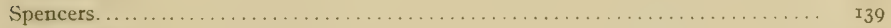

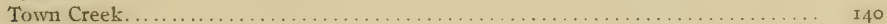

Goodwin. . . . . . . . . . . . . . . . . .

La Grande . . . . . . . . . . . . . . . . . . . . . .

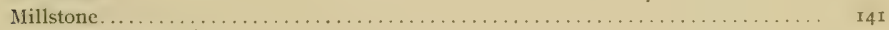

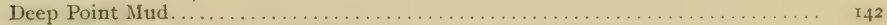

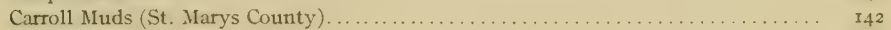

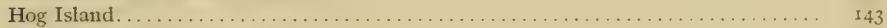

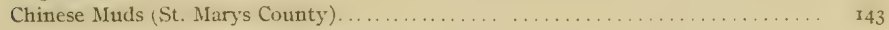

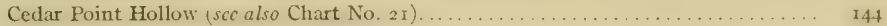

Chart No. 2 (Chesapeake Bay below Cedar Point)-

Cedar Point Hollow see also Chart No, 20) ...................... 144

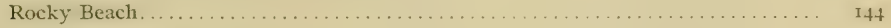

Tenactes............................................ I 45

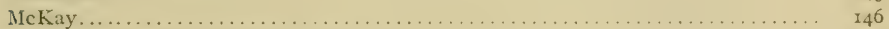

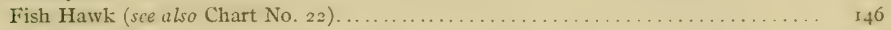

Chart No. 22 (Chesapeake Bay in vicinity of Point No Point)-

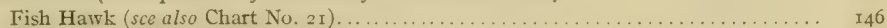

St. Jerome . . . . . . . . . . . . . . . . . .

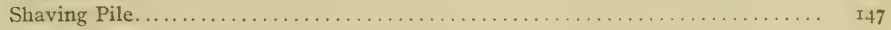

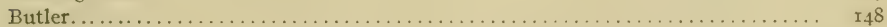

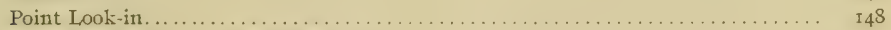

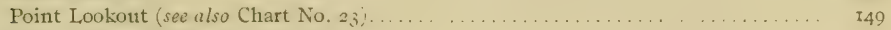

Chart No. 23 (mouth of Potomac River)-

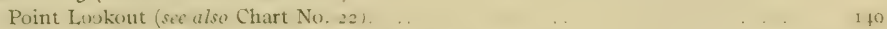

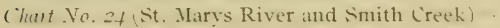

old Hare.

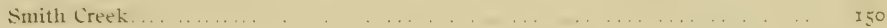

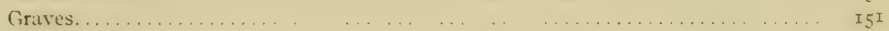

Jutland . . . . . . . . . . . . . . . . . . . . . . .

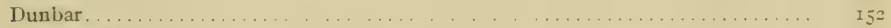

Sedge Point .......... . . . . . . . . . . . . . . . . . . $I_{53}$

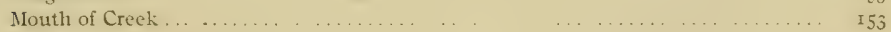

Chicken Cock ... . . . . . . . . . . . . . . . . . . 53

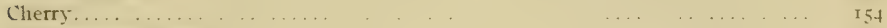

Middleground I

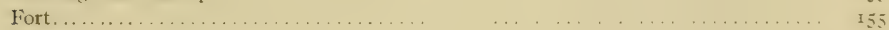

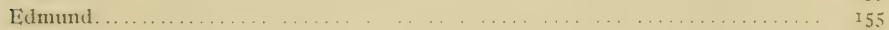

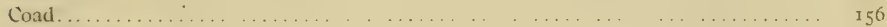

Langley Hollow . . . . . . . . . . . . . . . . . . . . . . . . . . . . 56

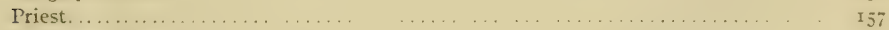

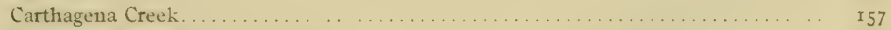

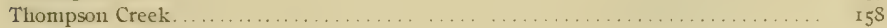

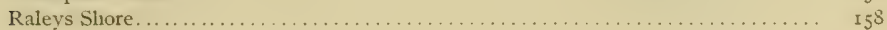


BOUNDARIES OF OYSTER BARS-Continued.

Boundaries of natural oyster bars in county-Continued.

Chart No.24-Continued.

Page.

Kennedy.

Jones.

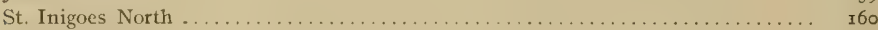

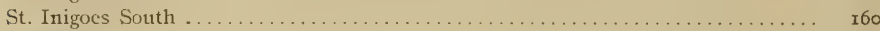

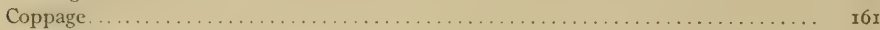

Cooper Creek. . . . . . . . . . . . . . . . . . . .

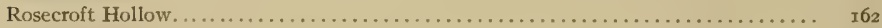

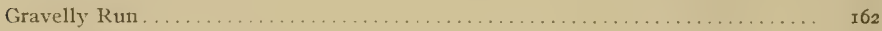

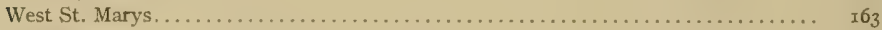

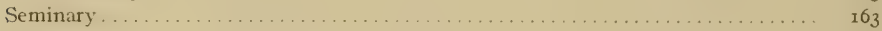

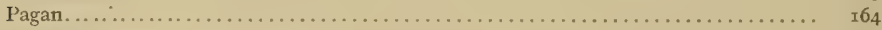

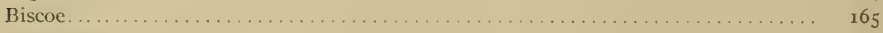

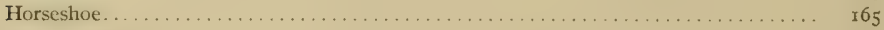

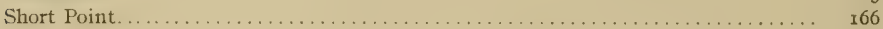

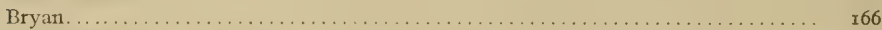

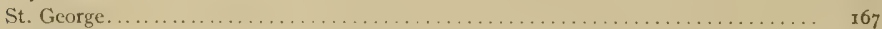

Hurdle................................. $\mathbf{1 6}_{7}$

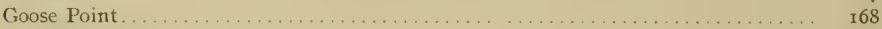

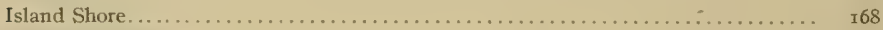

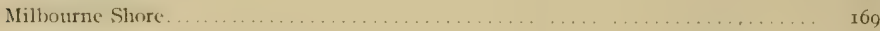

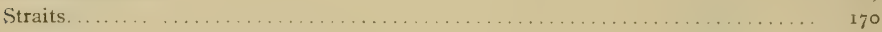

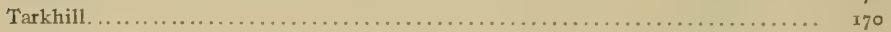

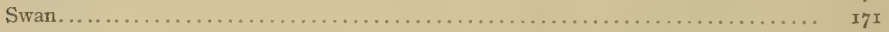

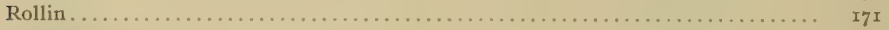

Cedar Point . . . . . . . . . . . . . . . . $\ldots \ldots \ldots \ldots \ldots \ldots \ldots, \ldots \ldots \ldots$

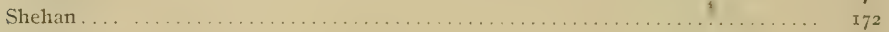

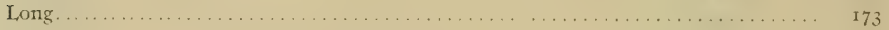

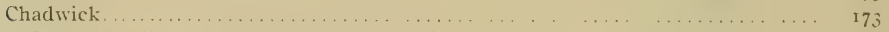

Chart No. 25 (St. Clement Bay and Bretons Bay)-
IIouldy Creek.

Paw Paw Hullow _. _... . . . . . . . . . 175

Lovers Point . . $\quad \ldots \ldots \ldots \ldots \ldots \ldots \ldots \ldots \ldots$

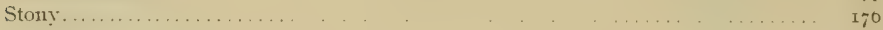

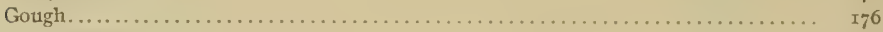

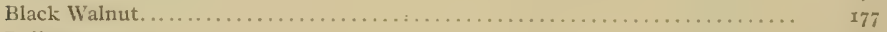

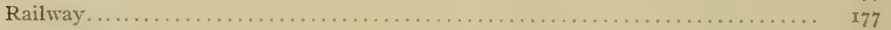

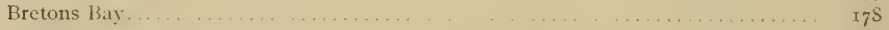

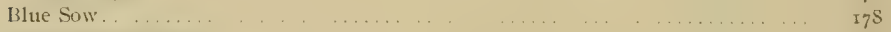

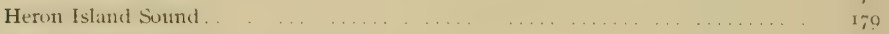

Heron Island Reef . . . . . . . . . . . . . . . . . . .

Dukehart channel . $\ldots \ldots \ldots \ldots \ldots \ldots$

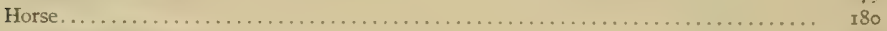

St. Clement lintrance $\ldots \ldots \ldots \ldots \ldots \ldots \ldots \ldots$ iso

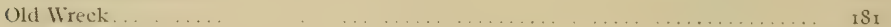

Newtown Flats. . . . . . . . . . . . . . . . . . . . . . . . . . . . .

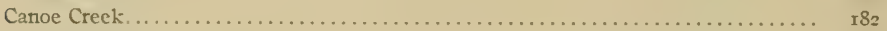

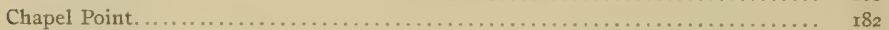

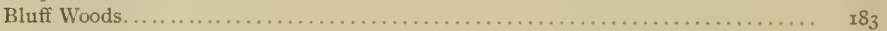

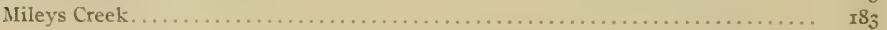

Abell . . . . . . . . . . . . . . . . . . . . 
BOUNDARIES OF OYSTER BARS-Continued.

Boundaries of natural oyster bars in county-Continued.

Chart No. 25-Continued.

Page.

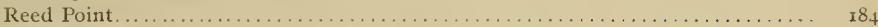

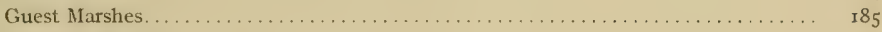

Harry Jacks.................................... ${ }_{186}$

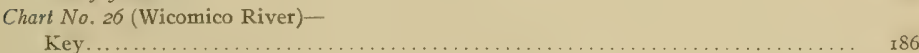

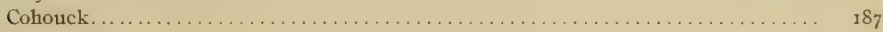

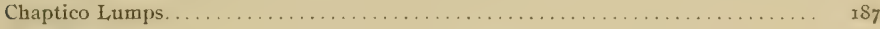

Mills East. . . . . . . . . . . . . . . . . . . . . . . . . . . . . . . . . 88

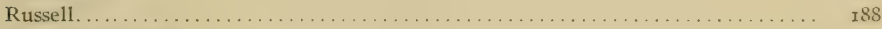

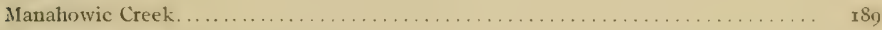

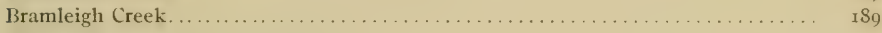

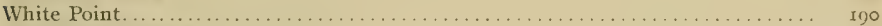

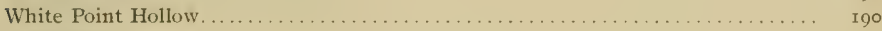

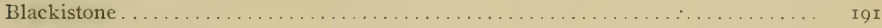

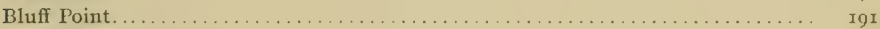

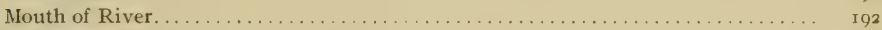

St. Margaret. . . . . . . . . . . . .

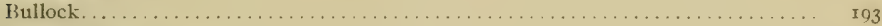

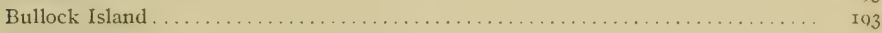

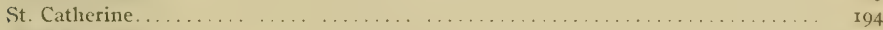

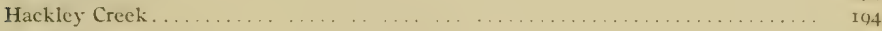

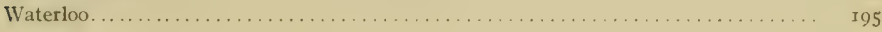

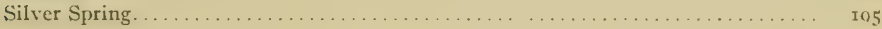

APPENDIXES:

Appendix A.-Laws relating to the cooperation of the Coast and Geodetic Survey and Bureau

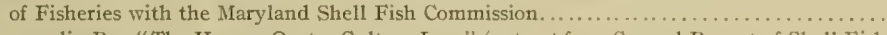

Appendix B.- "The Haman Oyster Culture Law" (extract from Second Report of Shell Fish Commission).

Appendix C.-Summary of the particular surveying operations which constitute an "oyster

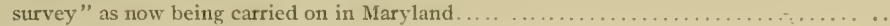

Appendix D.-Statistics of results of the combined operations of the Government and State. . 



\section{SURVEY OF OYSTER BARS, ST. MARYS COUNTY, MD.}

\section{INTRODUCTION.}

PUBLICATIONS.

The preparation of publications relating to the survey of the oyster bars of Maryland has been divided between the Government and the State in accordance with the laws ${ }^{1}$ authorizing the work and the natural division of the surveying operations ${ }^{2}$ of the cooperating forces.

The publications prepared and issued by the Government, under the direction of the Superintendent of the Coast and Geodetic Survey, consist of a series of charts and

- a technical report for each county surveyed. ${ }^{3}$ The charts show all legal boundaries of oyster bars within the adopted boundaries of the waters opened up for leasing with each county, and the location of all landmarks (Coast and Geodetic Survey triangulation stations) used as a foundation for the delineation of these various boundaries. The technical report gives technical and legal descriptions of all oyster bar and other boundaries, and descriptions of all landmarks shown on the charts, and includes the report of the representative of the Coast and Geodetic Survey in charge of the work of that service in cooperation with the Bureau of Fisheries and the Maryland Shell Fish Commission. These charts and technical reports are prepared and certified for file with the courts and the Commission, as required by the laws of the State, and contain all information necessary to make a permanent record of the work of the Commission and the Government for all future requirements of the courts, or for any resurveys that may become necessary.*

The publications prepared and issued by the State under the direction of the Shell Fish Commission consist of annual reports " of all the operations of the Commission performed under the provisions of the laws of Maryland, ${ }^{6}$ including results of biological

\footnotetext{
${ }^{1}$ See Appendix A for laws relating to the cooperation of the Coast and Geodetic Survey and Bureau of Fisheries with the Maryland Shell Fish Commission.

¿See Appendix C for a summary of the particular surveying operations which constitute an "oyster survey" as now being carried on in Maryland.

3 These charts and technical reports can be obtained by application to the Superintendent of the Coast and Geodetic Survey at Washington, D.C. The publications now ready for issue are those for Anne Arundel. Somerset, Wicomico, Worcester, Calvert, Charles, and St. Marys counties.

4 The technical records and charts for each county are published separately on account of the requirements of the oysterculture laws of the State and the practical considerations which raake it desirable to have each county "opened up" for oyster culture as soon as practicable after the completion of its survey. For these reasons and the fact that these reports are each arranged for distribution and use in one county only without reference to other published records, much of the text of this publication is of necessity identical with similar previous publications for other counties.

s These reports can be obtained by application to the shell fish commission, Marine Bank Building, Baltimore, Md. They are issued annually in October, and the first and second reports are now available for distribution.

${ }^{6}$ See Appendix $\mathbf{B}$ for an extract from the Second Report of the Maryland Shell Fish Commission, giving a concise summary of the "Haman Oyster Culture Law."
}

$2606-\mathrm{Ir}-2$ 
and economic oyster investigations, methods and results of the hydrographic survey of the boundaries of oyster bars and crab bottoms, the administrative report and financial statement of the Commission, information relating to oyster culture, methods of surveying and leasing of oyster lots, and much other important matter of legal and scientific value.

These two sets of publications are planned and arranged to supplement each other without unnecessary duplication, and when combined they form a complete report of operations, methods, and results of the work of both the Government and State. ${ }^{1}$

\section{COOPERATION OF THE COAST AND GEODETIC SURVEY.}

The work of the Coast and Geodetic Survey, as the name of the service indicates, includes a survey of the coasts of the United States made on a geodetic basis. This has involved the gradual construction of a great framework of interstate triangulation for use as a foundation for detail hydrographic and topographic surveys, from which there has been compiled and published a complete set of charts of the coasts of the United States, including all waters of Mlaryland where nysters grow. This existing triangulation, hydrography, and topography is essential as a foundation for a correct and practical survey of natural oyster bars; and it being one of the fundamental functions of the Coast and Geodetic Survey to furnish such data, the cooperation of the Coast and Geodetic Survey with the Bureau of Fisheries and the Maryland Shell Fish Commission is a practical and natural development of Government work leading to the conservation and increase of the supply of food.

\section{COOPERATION OF THE BUREAU OF FISHERIES.}

The Bureau of Fisheries has cooperated with the Coast and Geodetic Survey and the Maryland Shell Fish Commission principally as an adviser in matters relating to the biological and economic survey of oyster bars and the methods to be employed for that purpose. ${ }^{2}$ A steam launch, rowing boat, and certain apparatus have also been furnished.

The primary function of the Bureau of Fisheries is to increase the productiveness of marine and fresh waters by such measures as may be best suited to the purpose, and the services rendered in connection with the survey of the oyster bars of Maryland are strictly in line with the fundamental law under which it acts. In certain States other than Maryland similar work has been conducted by the Bureau acting independently, the same ends being attained at greater expense to the Government.

GENERAL STATEMINT OF WORK OF COAST AND GEODETIC SURVEY. ${ }^{3}$

The results obtained from the work of the Coast and Geodetic Survey in cooperation with the Bureat of Fisheries and the Maryland Shell Fish Commission need very little other summary than is indicated by the published Charts of Natural Oyster Bars and the index of hydrographic projections and triangulation stations shown on the county progress maps attached to each report.

1 See Appendix D of this publication for "Statistics of results of combined operations of the Government and State,"

"Hon. George M. Bowers, Commissioner of Fisheries, has detailed for this service Dr. H. F. Moore, assistant, Bureau of Fisheries.

3 For a detail statement of the very large amount of excellent oyster survey work of the Maryland Shell Fish Commission see the annual reports of the Maryland Shell Fish Commission. 
The triangulation has been carried on in accordance with the standard methods of the Coast and Geodetic Survey, making this work and that of the Descriptions of Tringulation Stations of permanent value, not only to the State of Maryland in the survey of her oyster bars, but also to the Government for any future work it may do in the regions covered by the oyster-survey operations.

The hydrographic projections and published charts are prepared with all the accuracy permitted by their large scale, especially as to the boundaries of the various shell-fish bottoms in relation to landmarks, but this accuracy of location on the charts is further added to and permanently fixed by published technical descriptions which should minimize the probability of any future dispute as to either landmarks or boundaries.

Stated another way, and quoting from the report of the "Survey of Oyster Bars of Anne Arundel County."

The geographic positions of the permanent landmarks and signals have been determined with the usual precision of a trigonometric survey, and their locations at all points necessary to provide ample foundation for the surveying and charting operations parmitted great accuracy of definition and location for the natural oyster bar and other boundaries established. At the same time, the very important element of permanency of the positions of boundaries has been secured, as the relocation of geodetic positions can always be accomplished by a competent surveyor, even thoush the original landmarks and monuments have been washed away, as has been the fate of hundreds of such points established by the Coast and Geodetic Survey on the shores of the Chesapeake Bay during the last 65 years. 


\section{REPORT OF THE IVORK OF THE COAST AND GEODETIC SURVEY IN ST. MARYS COUNTY.}

\section{INSTRUC'TIONS.}

The following letters, together with the laws ${ }^{1}$ of the United States relating to the subject, constitute the "instructions" received by the chief of the Coast and Geodetic Survey party engaged on work in connection with the Maryland Shell Fish Commission. They are short and definite, but furnish ample authority and leeway for all legitimate development of the cooperation of the Government and the State in the survey of oyster bars. The "free hand" permitted by these orders, together with the aid and many valuable suggestions received from the officers of the survey at Washington, have proved very beneficial to the work and are greatly appreciated.

\section{DEPARTMENT OF COMMERCE AND LABOR, OFFICE OF THE SECRETARY, Washington, June 2, IDo6.}

SIR: In reply to your letter of May 28, requesting me to designate officers of the Coast and Geodetic Survey and of the Bureau of Fisheries to cooperate with the State of Maryland in making survey of and locating the natural oyster beds, I have the honor to inform you that Mr. C. C. Yates will be designated to cooperate on the part of the Coast and Geodetic Survey as soon as Congress makes the provisions of the act effective by providing an appropriation for the purpose.

Respectfully,

His Excellency Hon. EDWTIN WARFIELD,

\section{Lawrence O. Murray, Assistant Secretary.} Governor of Maryland, Annapolis, MId.

\section{DEPARTMENT OF COMMERCE AND LABOR, CoAst and Geodetic SuRvey, W'ashington, July 3, 1906 .}

SrR: Upon the receipt of these instructions you will surrender the command, accounts, etc., of the steamer Endeavor to the Hydrographic Inspector.

As soon as this transfer is completed you will enter upon the duties of Coast Survey representative on the Shell Fish Commission of Maryland. form.

You will consult the Commissioners, prepare a program of work, and submit estimates in the usual

You are authorized to come to Washington for consultation from time to time as may be necessary.

* Very respectfully,

O. H. Tirmann, Superintendent.

Capt. C. C. YATES,

United States Coast and Geodetic Survey Steamer Endeavor, Baltimore, Md.

ORGANIZATION AND EQUIPMENT.

The personnel and occupation of the party of the Coast and Geodetic Survey have remained practically unchanged since the beginning of the "oyster survey." Besides 
the chief of party, it consists of the necessary triangulators, computers, draftsmen, and temporary employees required to carry on both the surveying operations in the field and the preparation for publication of oyster charts and technical records in the office at Washington.

The equipment for the work of the party has been ample and satisfactory. The large living and office quarters furnished the Government on the Maryland Shell Fish Commission house-boat $O y$ ster have been very convenient for the work, besides facilitating efficient cooperation with the surveying and oyster investigation parties of the State. In addition to the accommodations on the Oyster, the Coast and Geodetic Survey party has had the constant use of the large steam launch Inspector and several other boats furnished by its own service, and the occasional use of the Bureau of Fisheries launch Canvasback ${ }^{1}$ and the steamer Governor Mclane ${ }^{2}$ of the State fishery force.

The greater part of the equipment-of instruments for the operations of both the Government and State has been furnished by the Coast and Geodetic Survey and consists of all necessary theodolites, levels, sextants, drafting instruments, hydrometers, etc., required for all field and office work.

\section{CHRONOLOGICAL STATEMENT OF WORK.}

The field work of the Coast and Geodetic Survey in St. Marys County ${ }^{3}$ dates from May 2, 1908, when the house-boat () ystre left Baltimore for an anchorage in the Patuxent River, inside of Solomons Island. She remained in this harbor for three months, it practically being the only suitable anchorage for the work of the oyster survey for a large part of the Chesapeake Bay shore of both St. Marys and Calvert counties, as well as for the lower Patuxent River. During this period there was a great amount of windy weather and consequent rough seas, which prevented work in the open bay, and in general the triangulation foundation for the oyster survey made very slow progress.

On August 4, 1908, the part of the work necessarily done from the mouth of the Patuxent River was completed, and the Oyster was moved about 7 miles up the river to St. Leonards Creek.

On August 18, 1908, the headquarters for the field work was again changed by moving the house-boat $O_{y}$ ster 8 miles still farther up the river to an anchorage in Battle Creek, where she remained until the completion of that part of the field work which naturally included all the Patuxent River work of Charles and Calvert counties as well as that of St. Marys County, although the results are published separately.

On September 3, 1908, the house-boat finally left the Patuxent River for Smiths Creek, which is one of the tributaries of Potomac River. From this station there was completed all the remaining work of the Chesapeake Bay shore of St. Marys County as well as that of Smiths Creek and the mouth of St. Marys River.

During the stay at Smiths Creek the work was greatly delayed by smoky atmosphere, especially that portion in the open Chesapeake Bay just north of the mouth of Potomac River, where some of the triangulation sides were necessarily comparatively long.

\footnotetext{
1 By courtesy of Dr, H. F. Moore, U. S. Bureau of Fisheries.

2 By courtesy of Capt. James A. Turner, commanding.

2 The field work of St. Marys, Calvert, and Charles counties was so intermixed in the Patuxent River that the chronological statement of work for any one of these counties necessarily includes a considerable part of the work of the other two counties.
} 
On October 7, 1908, the house-boat Oyster was towed to an anchorage at the upper end of St. Marys River off the site of the monument marking Calvert's first settlement in Maryland. From this point the remaining work in St. Marys River, St. Inigoes Creek, and St. Georges River was quickly finished on account of very good weather.

On October 28, 1908, the State steamer Governor Mclane towed the Oyster to an anchorage off Rock Point, in the mouth of Wicomico River. From this location there was done all the oyster survey work of both St. Marys and Clrarles Counties in Wicomico River, St. Catherine Sound, and adjacent waters.

On November 25,1908 , the four launches of the combined oyster-survey parties towed the house-boat $O y^{\prime}$ ster to harbor off the city of Leonardtown, at the head of Breton Bay. From this station all the oyster-survey work was completed in both Bretons Bay and St. Clements Bay.

On December 18 and 19, 1908, the McLane towed the house-boat Oyster and launches to their winter quarters in Baltimore.

On December 2, 1909, it was found necessary to obtain additional triangulation information for the publication of the technical report for Calvert County, which incidentally involved new work required for the report for Charles and St. Marys counties, and field work was carried on for that purpose from that date to December 8, 1909.

Again, from July 20 to August I I, I9IO, while the house-boat Oyster was anchored in the mouth of the Patuxent River for the purpose of carrying on the oyster survey operations in the bay-shore waters of Dorchester County, a number of days when work could not be done in the open bay were employed in checking up deficiencies in the description of stations required for the publications of both Charles and St. Marys Counties.

The large amount of office work connected with the "oyster survey" of St. Marys County, including computations and drafting necessary for the preparation for publication of the oyster charts and the technical records, was continued intermittently with the office work of other counties from the beginning of the fieldwork in St. Marys County to the time of filing of the certified oyster charts and the technical reports in the archives of the Commission and with the clerk of the circuit court of St. Marys County on July $6, x 91$.

\section{STATISTICS. ${ }^{1}$}

Landmarks and triangulation signals erected.

Monuments planted to mark triangulation stations. . . . . . . . . . . . . . . . . . . . 204

Triangulation stations occupied for observations of horizontal angles . . . . . . . . . . . .

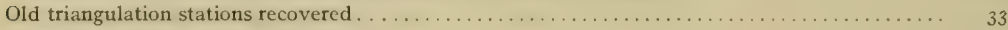

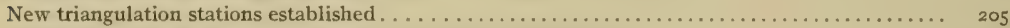

Total old and new triangulation stations marked and described $\ldots \ldots \ldots \ldots \ldots \ldots \ldots \ldots \ldots \ldots \ldots \ldots$

Linear miles of shore line covered by triangulation (approximate) . . . . . . . . . . . . I60

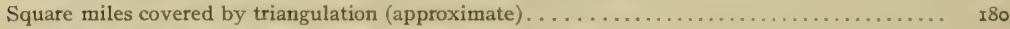

Hydrographic projections prepared and completed as records of oyster boundaries.......... I5

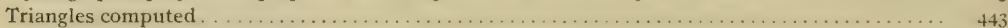

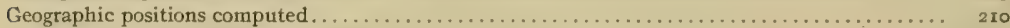

Corners of oyster boundaries established by computation . . . . . . . . . . . . $60_{3}$

1 These statistics only include field and office work directly performed by the party of the Coast and Geodetic Survey in connection with the oyster survey of St. Marys County, and do not include the many thousands of soundings and examinations of the character of the bottom made by the engineers of the Commission, which are of considerable value to the Coast and Geodetic Survey as hydrographic records for future use in connection with the preparation of new editions of charts of the waters of $\mathrm{M}$ aryland. See Appendix D of this publication for "Statistics of results of combined operations of the Government and the State." 
Back azimuths and distances computed from corners of boundaries to triangulation stations. . . . x, 809 Descriptions of triangulation stations prepared for publication . . . . . . . . . . . . . ${ }_{23} 8$

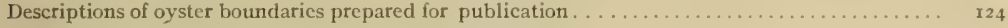
Charts of Natural Oyster Bars prepared for publication . . . . . . . . . . . . . . . . . . 8 Progress map prepared for publication $\ldots \ldots \ldots \ldots \ldots \ldots \ldots \ldots \ldots \ldots \ldots \ldots \ldots \ldots \ldots \ldots \ldots \ldots \ldots \ldots \ldots$

\section{GENERAI，REMARKS.}

Before ending this report the representative of the Coast and Geodetic Survey wishes to renew his statement of appreciation of the courteous assistance received from various Government and State officials and others interested in the oyster industry of Maryland, especially to the following:

To his colleague from the Department of Commerce and Labor, Dr. H. F. Moore, of the Bureau of Fisheries, whose well-known scientific knowledge of all matters relating to oysters has been of great value to the work.

To Mr. Walter J. Mitchell, chairman of the Maryland Shell Fish Commission, who, by his administrative ability in carrying out the complicated requirements of the oyster laws and by his unfailing tact, has made the cooperation of the various services engaged on the work both agreeable and effective.

To Dr. Caswell Grave, secretary of the commission, who, as editor of the commission's annual report and commissioner in charge of the biological and economic oyster investigations, has been brought into constant contact with the Government work and aided its operations in every way.

To Mr. Benjamin K. Green, treasurer of the commission, who has looked after the equipment and commissary of the house-boat in such a way as to add greatly to the comfort and convenience of the party of the Coast and Geodetic Survey.

To Mr. Swepson Earle, hydrographic engineer to the Commission, whose knowledge of the work from former service in the Coast and Geodetic Survey has greatly facilitated his practical use of the technical data furnished by the Government.

- To Mr. Thomas H. Robinson, counsel to the Commission, for courteously furnishing valuable information relating to county boundaries.

And to the many others connected with the Commission or who, as residents in the locality where the work was being carried on, have greatly assisted by furnishing important information or willing services. 


\section{CHARTS AND MAPS.}

CHARTS OF NATURAL OYSTER BARS.

The charts ${ }^{1}$ of the natural oyster bars of St. Marys County, published by the Coast and Geodetic Survey from results of surveys of the Government in cooperation with the Maryland Shell Fish Commission, consist of eight sheets covering all the waters of St. Marys County in Patuxent River, Chesapeake Bay, Smiths Creek, St. Marys River, and tributaries, Bretons Bay, St. Clement Bay, and Wicomico River. ${ }^{2}$ They are published on a scale of I part in 20,000 (approximately $3^{1 / 6}$ inches to a statute mile) and are constructed on polyconic projections and based on the United States standard datum of the Coast and Geodetic Survey.

These charts show all oyster bars and other boundaries established by the Commission and are certified for the purpose of filing in the office of the clerk of the Circuit Court of Charles County and in the office of the Commission at Annapolis, as required by the oyster laws of Maryland.

In addition to the oyster bar and other boundaries, the charts show the location and name of all landmarks (United States Coast and Geodetic Survey triangulation stations) used in making the survey, together with the hydrograply and topography ${ }^{3}$ necessary to make the technicai definitions and delineations of boundaries readily understandable both by the people engaged in the oyster industry and the general public who may become interested through leasing of barren bottoms for oyster culture.

The names of the oyster bars are those used locally, as nearly as could be ascertained by the hydrographic engineer of the Commission. When there was no local name in common use, a name was selected from one of the prominent features of the vicinity. By the use of recognized names or those that would naturally suggest certain sections of water, it is believed that much confusion will be avoided in the location on the charts of the oyster bars, especially by those not familiar with the use of maps.

The corners of the oyster bars are numbered from I to the total number of corners in each area under consideration. Where boundaries adjoin, making one point a corner of two or more oyster bars, these points have two or more numbers, each number corresponding to the bar in which the figure is located. The numbers of the corners correspond with the technical and legal descriptions of this publication under the heading "Boundaries of natural oyster bars."

The landmarks and oyster bars have been grouped in the "Contents" of this publication in accordance with the charts upon which they are shown. To find a particular

\footnotetext{
1 These charts can be obtained by application to the Superintendent of the Coast and Geodetic Survey, at Washington, D. C.

2 The open waters of the Potomac River, although within the accepted boundaries of the State of Maryland, are under the joint jurisdiction of both Maryland and Virginia as to fisheries, and therefore the natural oyster bars of the Potomac River were not surveyed or are they shown in any way on the oyster charts of the adjacent counties of St. Marys and Charles.

${ }^{3}$ Much of the detail of the inshore topography was obtained from the excellent map of St. Marys County, prepared and published by the Maryland Geological Survey tunder the direction of Dr. William Bullock Clark from surveys of the Maryland Geological Survey in cooperation with the U. S. Geological Survey.
} 
oyster bar or landmark which is only known by name, consult the "Contents" and the desired chart and general location will be indicated. To find the name of a bar or landmark which is only known by location, consult the progress map at the end of this publication for the number of the chart on which it is to be found, and then examine the known locality on the chart for the name of the bar or landmark in question.

The contours on the charts showing the depth of water at mean low tide have been taken from the hydrographic sheets of former work of the Coast and Geodetic Survey. Four curves were selected as being the most convenient for taking off from the original hydrographic sheets and the ones of greatest value to those interested in shellfish industries. The $\mathrm{r}$-fathom contour ( $6 \mathrm{feet}$ ) and the 5 -fathom curve ( $30 \mathrm{feet}$ ) correspond in a general way to the inner and outer limits of all the oyster bars surveyed. The 3 -fathom contour (I 8 feet) furnishes the curve of about the average depth of water on the oyster bars and the Io-fathom contour ( 60 feet) serves in a general way to indicate the outer limits of probable oyster culture.

The boundaries of the waters within the "territorial limits of the county" and the boundaries of the "waters contiguous to the county" opened up for the leasing with St. Marys County are plainly indicated on the charts. A full technical description of these boundaries is given in this publication under the heading "Boundaries of county waters."

The areas in acres of the oyster bars were determined under the direction of the hydrographic engineer of the Commission by two independent planimeter measurenents of the areas as delineated on the smooth projections of the Coast and Geodetic Survey. These areas are given in small figures in parentheses on the face of the chart within the boundaries of the different shellfish bottoms.

The symbols used on the charts for the different kinds of boundaries, triangulation stations, contours of depth of water, etc., require no other explanation than that given in the legend and other notes on the face of the charts.

\section{LEASING CHARTS}

The leasing charts of St. Marys County, like those for Anne Arundel, Somerset, Wicomico, Worcester, Calvert, and Charles counties, have been prepared under the direction of the hydrographic engineer of the Commission. These charts are constructed on polyconic projections and are based on the United States standard datum of the Coast and Geodetic Survey. They are made on the scales of I part in 5,000 or I part in 10,000, as the needs of oyster culture may require. Anne Arundel County required 13 leasing charts; Somerset County, 12 charts; Wicomico County, 2 charts; Worcester County, 3 charts; Calvert County, 5 charts; Charles County, 2 charts; and St. Marys County, 8 charts to cover their oyster bottoms.

These charts show all the oyster bars, crab bottoms, and clam beds and other boundaries established by the Commission, and also all boundaries of oyster lots leased for the purpose of oyster culture, thus making them comprehensive and valuable records of the results of the operations of the oyster-culture laws.

The lots leased under the provision of the "old 5-acre law" are frequently of irregular shape, but the lots leased under the provision of the new oyster laws must be of rectangular shape by the terms of that act. For this latter purpose the leasing charts 
have been divicled by parallels of latitude and meridians of longitude into small rectangles of $I$ acre or 5 acres, as may be best suited to the area under consideration, and prospective leaseholders by the rules of the Commission are compelled to select whole rectangles as far as possible.

For reasons of the present changeable nature of the number of lots leased and the large number of charts required, the leasing charts are not likely to be published for some years, but they can be seer at any time on file at the offices of the Commission, in the Marine Bank Building at Baltimore.

\section{PROJECTIONS.}

The polyconic projections ${ }^{1}$ covering St. Marys County waters are 1.5 in number and on the scale of I part in 10,000 . They were constructed by draftsmen of the Coast and Geodetic Survey, but the sextant positions which determine the location of the legal boundaries of the oyster bars as delineated by the Shell Fish Commission were plotted by the draftsman of the Commission.

A copy of each of these projections, with all the plotted positions of triangulation stations, shore line, sextant positions, and boundaries of oyster bars, was made under the direction of the hydrographic engineer of the Commission by pricking through with a sharp needle the intersections of the projection lines and all other points as plotted on the original sheets.

These projections (in duplicate) are the original records of all oyster bar and other boundaries established by the Commission, one set being filed in the archives of the Coast and Geodetic Survey, at Washington, and the other set in the archives of the Shell Fish Commission.

\section{PROGRESS MAPS.}

The progress map to be found at the end of this publication is on a scale of I part in 100,000 , and shows in outline the work accomplished by the United States Coast and Geodetic Survey in St. Marys County and contiguous waters. It gives the scheme of all the charts and smooth projections constructed in connection with the survey, the location and names of all triangulation stations used as a basis for the surveying work, and the "boundaries of county waters" established by the Commission for the purpose of carrying out the laws of Maryland relating to oyster culture.

Besides indicating the amount of work done by the Coast and Geodetic Survey in connection with the work of the Shell Fish Commission, this progress map will be of special value for index purposes to engineers and others searching for the particular chart or projection covering the locality of the oyster bars or landmarks that may be under consideration.

The progress maps ${ }^{2}$ accompanying the first and second annual reports of the Maryland Shell Fish Commission were prepared under the direction of the hydrographic engineer of the Commission. They are on the scale of I part in 400,000 , and show the outline of the tidewater counties of Maryland, with shaded areas to indicate the waters already covered by the operations of the oyster survey.

\footnotetext{
1 For the scheme of these projections see the progress map at the end of this publication.

2 These maps and reports can be obtained by application to Maryland Shell Fish Commission, Marine Bank Building. Baltimore, Md.
} 


\title{
BOUNDARIES OF THE COUNTY WATERS. ${ }^{2}$
}

\author{
WATFRS WITHIN TIERRITORIAI, IIMITS OI: COUNTY.
}

The laws of Naryland relating to oyster culture provide that "no person shall be permitted, by lease, assignment, or in any other manner, to acquire a greater amount of land than ten acres situated within the territorial limits of any of the counties, or one hundred acres in any other place."

The boundary line ${ }^{2}$ between the waters "within the territorial limits" of St. Marys county and the waters in "any other place," as established by the Shell Fish Commission for the purpose of carrying out the oyster laws, and delineated on the "oyster charts" and the smooth projections of the Coast and Geodetic Survey, is technically described and defined as follows:

Patuxent River zaters of St. Marys County.-Following the boundary line between St. Marys County and Charles County along the middle of Indian Creek as laid down on Chart No. 19, Natural Oyster Bars, Maryland, to a point defined by the intersection of this boundary line with the boundary line in the Patuxent River between Calvert County on one side and Charles and St. Marys counties on the other side as laid down on Chart No. rg, Natural Oyster Bars, Maryland; thence down the channel of Patuxent River following the channel boundary line between St. Marys and Calvert counties as laid down on Charts Nos. I9 and 20, Natural Oyster Bars, Maryland, to a point in the mouth of Patuxent River defined by the intersection of this boundary line with a straight line connecting a point defined by latitude $3^{\circ}$ I. $9^{\prime} 09.8^{\prime \prime}$ and longitude $76^{\circ} 25^{\prime} 21.0^{\prime \prime}{ }^{3}$ situated on Drum Point and a point defined by latitude $38^{\circ}$ r $8^{\prime} 35.9^{\prime \prime}$ and longitude $76^{\circ} 23^{\prime} 59.8^{\prime \prime}$ situated on Hog Point; thence along a straight line ending at a point defined by latitude $38^{\circ} 18^{\prime} 35.9^{\prime \prime}$ and longitude $76^{\circ} 23^{\prime} 59.8^{\prime \prime}$ situated on Hog Point on the southern side of the entrance to Patuxent River.

Chesapeake Bay waters of St. Marys County.-Commencing at a point defined by latitude $38^{\circ} 18^{\prime}$ 35. $9^{\prime \prime}$ and longitude $76^{\circ} 23^{\prime} 59.8^{\prime \prime}$ situated on Hog Point on the southern side of the entrance to Patuxent River; thence along the mean low water line of the Chesapeake Bay shore of St. Marys County across the mouth of all inlets less than roo yards in width, around Cedar Point and Point No Point, across the mouth of St. Jerome Creek, and around Point Look-in to a point defined by latitude $38^{\circ} \circ 2^{\prime}$ II. $0^{\prime \prime}$ and longitude $76^{\circ} 19^{\prime} 20.8^{\prime \prime}$ situated on Point Lookout on the northern side of the mouth of Potomac River.

Potomac River waters of St. Marys County. - Commencing at a point defined by latitude $38^{\circ} \mathrm{oz}^{\prime} \mathrm{II} . \mathrm{O}^{\prime \prime}$ and longitude $76^{\circ}$ I $^{\prime} 20.8^{\prime \prime}$ situated on Point Lookout on the northern side of the mouth of Potomac River; thence along the mean low-water line of the Potomac River shore of St. Marys County across the mouth of all inlets less than roo yards in width, around Cornfield Harbor and Cornfield Point to a point defined by latitude $3^{\circ} 04^{\prime} 53.4^{\prime \prime}$ and longitude $76^{\circ} 22^{\prime} 24.2^{\prime \prime}$ situated on a point on the south side of the entrance to Briscoe Creek; thence in a straight line across the mouth of Briscoe Creek to a point defined by latitude $38^{\circ} 05^{\prime} 05 \cdot 4^{\prime \prime}$ and longitude $76^{\circ} 22^{\prime} 35 \cdot 3^{\prime \prime}$ situated on a point on the north side of Briscoe Creek; thence along the mean low-water line of the Potomac River shore of St. Marys County across the mouth of all inlets less than 100 yards in width, to a point defined by latitude $38^{\circ} 05^{\prime} 14.6^{\prime \prime}$ and longitude $76^{\circ} 22^{\prime} 47.8^{\prime \prime}$ situated on the southeastern side of the entrance to Harry James Creek; thence in a straight line across the mouth of Harry James Creek to a point defined by latitude $38^{\circ} 05^{\prime} 27.6^{\prime \prime}$ and longitude $76^{\circ} 23^{\prime} 16.5^{\prime \prime}$ situated on the northwestem side of the entrance to Harry James Creek; thence along the mean low-water line of the Potomac River shore of St. Marys County across the mouth of all inlets less than roo yards in width, to a point defined by latitude $3^{\circ} 05^{\prime} 37.8^{\prime \prime}$ and longitude $76^{\circ} 23^{\prime} 33.2^{\prime \prime}$ situated on Grays Point on the eastern side of Calvert Bay entrance to Smiths Creek;

${ }^{1}$ For a complete historical and legal description of the boundaries of the counties of Maryland, the valuable publication entitled "The Counties of Maryland-Their Origin, Boundaries, and Election Districts," prepared by Dr. Edwatd B. Mathews and published by the Maryland Geological Survey under the direction of Dr. William Bullock Clark; superintendent, should be consulted, as the boundaries described in this publication have been established and technically defined for the purpose of carrying out the oyster laws of the State, and may or may not be correct for other purposes.

2 See Charts of Natural Oyster Bars, published by the Coast and Geodetic Survey, and the progress map at the end of this publication.

${ }^{3}$ Latitudes and longitudes based on the United States standard datum of the U. S. Coast and Geodetic Survey. 
thence in a straight line across the mouth of Smiths Crcek to a point defined by latitude $3^{\circ} 06^{\prime} 12.8^{\prime \prime}$ and longitude $76^{\circ} 25^{\prime} 05.0^{\prime \prime}$ situated on Kitts Point on the western side of the entrance to Smiths Creek; thence along the mean low-water line of the Potomac River shore of St. Marys County across the mouth of all inlets less than 100 yards in width, to a point defined by latitude $38^{\circ} \circ 6^{\prime} 18.0^{\prime \prime}$ and longitude $76^{\circ} 25^{\prime} 18.4^{\prime \prime}$ situated on Kitts Point on the eastern side of the entrance to St. Mary's River; thence in a straight line across the mouth of St. Marys River to a point defined by latitude $38^{\circ} 06^{\prime} 18.8^{\prime \prime}$ and longitude $76^{\circ} 27^{\prime} 53.9^{\prime \prime}$ situated on a point on the southeast side of St. Georges Island on the western side of the entrance to St. Marys River; thence along the mean low-water line of the Potomac River shore of St. Marys County across the mouth of Island Creek and other inlets less than Ino yards in width, to a print defined by latitude $38^{\circ} 08^{\prime} 0.4 \cdot 2^{\prime \prime}$ and longitude $76^{\circ} 29^{\prime} 5^{8.6^{\prime \prime}}$ on the southeastern side of the Potomac River entrance to the straits between St. Georges Island and the mainland leading into St. Georges River; thence in a straight line across the straits separating St. Georges Island from the mainland to a point defined by latitude $38^{\circ} \circ S^{\prime}$ I $5 \cdot 9^{\prime \prime}$ and longitude $76^{\circ} 30^{\prime} \circ 7 \cdot 2^{\prime \prime}$ situated on the northwestern side of the Potomac River entrance to the straits between St. Georges Island and the mainland leading into St. Georges River; thence along the mean low-water line of the Potomac River shore of St. Marys County around Piney Point and across the mouth of Herring Creek, Blake Creek, Poplar Hill Creek, and other inlets less than roo yards in width, to a point defined by latitude $38^{\circ} I_{3}^{\prime} 5^{8} .3^{\prime \prime}$ and longitude $76^{\circ} \mathrm{I}^{\prime} \mathrm{I}_{3} \cdot 3^{\prime \prime}$ situated on Higgins Point on the eastern side of the entrance to Bretons and St. Clement bays; thence in a straight line across the Heron Island Sound entrance to Bretons and St. Clement bays to a point defined by latitude $38^{\circ} 12^{\prime} 54.7^{\prime \prime}$ and longitude $76^{\circ} 43^{\prime} 12.0^{\prime \prime}$ situated on the eastern extremity of the sand bar known as Heron Island; thence in a straight line along the center of Heron Island to a point defined by latitude $3^{\circ}{ }_{1} 3^{\prime} 07.7^{\prime \prime}$ and longitude $76^{\circ} 43^{\prime} 5^{I} \cdot 7^{\prime \prime}$ situated on the westem extremity of the sand bar known as Heron Island; thence in a straight line across the Heron Island Sound entrance to St. Clement and Bretons bays to a point defined by latitude $38^{\circ} 12^{\prime} 30.7^{\prime \prime}$ and longitude $76^{\circ} 44^{\prime} 34.8^{\prime \prime}$ situated on the southeastern end of Blakistone Island; thenee along the mean low-water line of the Potomac River shore of Blakistone Island of St. Marys County around Blakistone Island Light and across all inlets less than roo yards in width to a point defined by latitude $38^{\circ} \mathrm{I2}^{\prime} 50.8^{\prime \prime}$ and longitude $76^{\circ} 44^{\prime} 59.0^{\prime \prime}$ situated on the northwestern end of Blakistone Island on the southeastern side of Dukehart Channel; thence in a straight line across the Dukehart Channel entrance to St. Clement and Bretons bays to a point defined by latitude $38^{\circ}$ i $3^{\prime}$ I $9.8^{\prime \prime}$ and longitude $76^{\circ} 45^{\prime} 09.9^{\prime \prime}$ situated on the mainland on the northwest side of Dukehart Channel; thence along the mean low-water line of the Potomac River shore of St. Marys County across the mouth of Dukehart Creek and other inlets less than 100 yards in width to a point defined by latitude $38^{\circ} \times 3^{\prime} \cdot 39 \cdot 7^{\prime \prime}$ and longitude $76^{\circ} 46^{\prime} 39.9^{\prime \prime}$ situated on the eastern side of the eastern St. Catherine Sound entrance to Wicomico River.

Wicomico River waters of St. Marys County.-Commencing at a point defined by latitude $3^{\circ}{ }^{\circ} 3^{\prime} 39 \cdot 7^{\prime \prime}$ and longitude $76^{\circ} 46^{\prime} 39.9^{\prime \prime}$ situated on the eastern side of the eastern St. Catherine Sound entrance to. Wicomico River; thence in a straight line across the eastern St. Catherine Sound entrance to Wicomico River to a point defined by latitude $38^{\circ}{ }^{\prime} 3^{\prime} 42.2^{\prime \prime}$ and longitude $76^{\circ} 47^{\prime} 17 \cdot 5^{\prime \prime}$ situated on the extreme southeast end of the sand bar making out from the southeast end of St. Catherine Island; thence along a line on the center of the sand bar making out from the southeast end of St. Catherine Island as laid down on Chart No. 26, Natural Oyster Bars, Maryland, to a point defined by latitude $38^{\circ} 14^{\prime} 02.6^{\prime \prime}$ and longitude $76^{\circ} 47^{\prime} 32.6^{\prime \prime}$ situated on the southeastern end of St. Catherine Island; thence along the mean low-water line of the Potomac River shore of St. Catherine Island of St. Marys County across all inlets less than roo yards in width to a point defined by latitude $38^{\circ} 14^{\prime} 28.9^{\prime \prime}$ and longitude $76^{\circ} 48^{\prime} 10.9^{\prime \prime}$ situated on the northwestern end of St. Catherine Island; thence in a straight line to a point in the mouth of Wicomico River defined by the intersection of the boundary line down the middle of Wicomico River between St. Marys and Charles counties as laid down on "Chart No. 26, Natural Oyster Bars, Maryland," and a straight line between a point on the northwestern end of St. Catherine Island defined by latitude $38^{\circ} 14^{\prime} 28.9^{\prime \prime}$ and longitude $76^{\circ} 48^{\prime} 10.9^{\prime \prime}$ and the center point of Cobb Point Bar Light defined by latitude $38^{\circ} 14^{\prime} 33 \cdot 3^{\prime \prime}$ and longitude $76^{\circ} 49^{\prime} 36.9^{\prime \prime}$; thence following the boundary line between St. Marys County and Charles County along the middle of Wicomico River as laid down on "Chart No. 26, Natural Oyster Bars, Maryland," to the end of the water boundary between St. Marys County and Charles County on the northeastern side of the upper Wicomico River as laid down on "Chart No. 26, Natural Oyster Bars, Maryland." 


\section{WATERS CONTIGUOUS TO COUNTX.}

The oyster laws of Maryland provide that a true and accurate delineation of all natural oyster bars shall be made on copies of charts of the United States Coast and Geodetic Survey, "which said copies shall be filed in the office of the said Commissioners," and "in the office of the clerks of the circuit courts for the respective counties wherein the grounds so designated may lie."

For the purpose of carrying out the latter part of this section of the law and for the purpose of establishing the limits of the oyster-culture area to be opened up for leasing with each county surveyed, it is necessary for the Shell Fish Commission to establish a boundary line between the waters contiguous to but not within the territorial limits of each county and the waters contiguous to but not within the territorial limits of adjacent counties.

This boundary line has been delineated on the "Charts of Natural Oyster Bars," published by the Coast and Ceodetic Survey, and is technically described and defined as follows:

Commencing at a point located at the mouth and near the middle of Patuxent River defined by the intersection of Patuxent River channel boundary line between Calvert County and St. Marys County as laid down on Chart No. 20, Natural Oyster Bars, Maryland, and the straight line between a point situated on Hog Point on the southern side of the entrance to Patuxent River defined by latitude $38^{\circ}$ I $8^{\prime} 35.9^{\prime \prime}$ and longitude $76^{\circ} 23^{\prime} 59.8^{\prime \prime} 1$ and a point situated on Drum Point on the northern side of the entrance to Patuxent River defined by -latitude $38^{\circ} 10^{\prime} 09.8^{\prime \prime}$ and longitude $76^{\circ} 25^{\prime} 21.0^{\prime \prime}$; thence along the Chesapeake Bay boundary between Calvert and St. Marys counties as laid down on "Chart No. 20, Natural Oyster Bars, Maryland, " to a point defined by latitude $38^{\circ} I 9^{\prime} 37 \cdot 7^{\prime \prime}$ and longitude $76^{\circ}$ I $9^{\prime}$ I $9.0^{\prime \prime}$ situated about $5^{1 / 4}$ miles southeast of Cove Point Light and $5^{1 / 4}$ miles east by north of Drum Point Light; thence along the Chesapeake Bay boundary between St. Marys and Dorchester counties as laid down on "Chart No. 20, Natural Oyster Bars, Maryland, " to a point defined by latitude $38^{\circ} 17^{\prime} 5^{8} .0^{\prime}$ " and longitude $76^{\circ} 18^{\prime} 59 \cdot 7^{\prime \prime}$ situated about $23 / 4$ miles east of Cedar Point Light; thence along the Chesapeake Bay boumdary between St. Marys and Dorchester counties as laid down on "Charts Nos. 20, 2I, and 22, Natural Oyster Bars, Maryland, "to a point defined by latitude $38^{\circ} 04^{\prime} 34.8^{\prime \prime}$ and longitude $-6^{\circ} I 2^{\prime}$ or. $0^{\prime \prime}$ situated near the middle of Chesapeake Bay near a shoal marked by a red buoy of the U. S. Bureau of

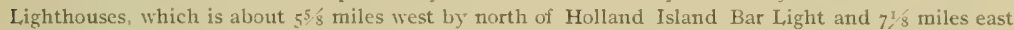
by north of Point Lookout Light; thence with the waters of Chesapeake Bay in a straight line between Somerset County and St. Marys County as laid down on "Charts Nos. 22 and 23, Natural Oyster Bars. Maryland, " to a point on Smith Point defined by the intersection of the straight line Maryland-Virginia boundary across Chesapeake Bay and the mean low-water line of the southern shore of Potomac River; thence in a straight line across the mouth of Potomac River along the line dividing the "waters of the Potomac River under the joint jurisdiction of Maryland and Virginia as to fisheries " from the waters of St. Marys County in Chesapeake Bay, as laid down on "Chart No. 23, Natural Oyster Bars, Maryland," to a point defined by latitude $38^{\circ} 02^{\prime} I I .0^{\prime \prime}$ and longitude $76^{\circ} I 9^{\prime} 20.8^{\prime \prime}$ situated on Point Lookout on the northern side of the mouth of Potomac River."

\footnotetext{
${ }_{1}^{1}$ Latitudes and longitudes based on the United States standard datum of the United States Coast and Geodetic Survey.

2 The waters of the I'otomac River, although belonging to the State of Maryland, are under the joint jurisdiction of Maryland and Virginia as to fisheries, and for this reason the Maryland Shell Fish Commission did not consider it necessary to define the "waters contignous to St. Marys County" lying in the Potomac River.
} 


\section{LANDMARKS (UNITED STATES COAST AND GEODETIC SURVEY TRIAN- GULATION STATIONS).}

\section{EXPLANATION.}

The oyster laws of Maryland authorizing the survey to be made by the Shell Fish Commission provide for "an accurate report of said survey, setting forth such a description of landmarks as may be necessary to enable the said board, or their successors, to find and ascertain the boundary lines of said natural oyster beds, bars, and rocks, as shown by delineation on the maps and charts." The law of the United States authorizing the cooperation of the Department of Commerce and Labor in the survey of natural oyster bars of Maryland provides for the erection of "such structures as may be necessary to mark the points of triangulation, so that the same may be used for such future work of the Coast and Geodetic Survey as the said bureau may be hereafter required to perform in prosecuting the Government coast survey of the navigable waters of the United States located within the State of Maryland."

Under the provisions of the sections of the laws stated above, the markings and descriptions of landmarks must be sufficient for the present and future needs of both the Government and the State. With this end in view, considerable work has been expended in erecting permanent monuments at the triangulation stations and in the proper description of their location.

An effort has been made to arrange the descriptions of location and character of landmarks in a uniform and logical manner. The descriptions start with the assumption that the individual seeking a landmark has only an indefinite idea of its location. They gradully proceed from description of the general locality of a landmark to the descriptions of its immediate surroundings. This is followed by specific details of the character of the center and reference marks and a "round" of reference angles and distances which in themselves frequently contain enough information to furnish an independent and reliable location of the triangulation station.

\section{METHOD OF DESCRIBING TRIANGUI.ATION STATIONS.}

The separate descriptions of triangulation stations should not be used without reading the following explanation of the method of describing the triangulation stations, as it contains certain dctails that are common to all the landmarks described in this publication and which are omitted in the separate descriptions as being needless repetitions:

Name. - The title at the top of each separate description is the name by which the landmark or triangulation station is known and designated in all work and published oyster records or oyster charts of both the Government and State. The selection of the name is usually left to the triangulator establishing the station, and it may or may not have geographic or other significance in reference to the locality.

General locality.-Under this heading is given the general locality of the landmark in reference to well-known and prominent natural or artificial features, such as the 
nearest body of water, town, river, steamer wharf, well-defined point of land, church, or any other feature that is likely to remain both permanent and prominent.

This heading also covers a reference to the published chart or map which shows the location of the station most clearly. Nearly all the triangulation stations described in this publication are plainly indicated by name and a triangulation symbol on the published charts of oyster bars of Maryland. In this case they are referred to by serial number only, the words "charts of oyster bars of Maryland" being omitted to avoid needless repetition. These published oyster charts are on the large scale of I part in 20,000 (approximately $3 \frac{1}{6}$ inches to a statute mile) and show the location of the triangulation stations so clearly that in many cases the written descriptions will not be required to find them.

Immediate locality.-Under this heading is given the description of the "observed station" in reference to its immediate surroundings. This is supposed to include a statement of the station's estimated elevation above high water or some other welldefined level of the locality, such as a road or house; the character of the ground on which it is located, such as marsh land, sand beach, cultivated field, or meadow; estimated bearings in points of the compass and estimated distances in yards from (not to) easily recognized features, such as extreme end of point, edge of bluff, bank of creek, line of telephone poles, shore line, barn, house, fence, ditch, trees, or any other definite detail, such as being on range with the tangent of an island and a church; and so forth.

When a standard monument has been established near the station as a "reference station," this heading also covers a statement of the true bearing of the monument in degrees and minutes and its measured distance in meters, as it is the first object that is likely to catch the eye when the immediate vicinity of the desired station is reached and might be mistaken for the center mark of the "observed station" unless special attention is called to it.

The distinction between the "observed station" and "reference station" should be carefully noted by anyone making use of the description of stations for any future surveying operations.

The "observed station" is located at the particular triangulation point corered by the description of stations, and is the one whose geographic position is first computed, as it is the point which was "occupied" and "observed on" for horizontal angles. However, in spite of the primary importance of the location of the "observed station," it will be noted from the description of stations that frequently it is not marked as well as the "reference station," and in many instances has only a pine stub to indicate its position. This is the case for the reason that the necessity of intervisibility of landmarks usually made it compulsory to locate "observed stations" on edges of banks and ends of points of land, which in the tidewater section of Maryland generally means they will be washed away in a short period of years. The past experience of the Coast and Geodetic Survey in this region has shown the great need of "reference stations," if the frequent reestablishment of a new framework of triangulation is to be avoided.

The chief reason and need for the establishment of the "reference station," or secondary station, as it might be well named, is explained in the preceding paragraph, but in several instances other reasons, such as the location of the "observed station" on an unstable sand dune, in a cultivated field, in front of a residence, or other places 
objectionable to the landowner, have led to establishment of "reference stations." The location of the "reference station" in relation to the "observed station" is fixed for plotting on charts or for computation of its geographic position by checked measurements of its distances and azimuth from the "observed station." 1

Marks.-Under this heading is given a description of the character of the permanent monuments or other marks of the location of the "observed station," and of the "reference station" where one has been established.

All the marks designated in the descriptions as "the center point of triangle on standard cement monument " are exactly alike. These monuments are made of cement, sand, and gravel, and are 2 feet long and 8 inches square at top and bottom. Their tops are all marked with the same brass mold and show a center hole surrounded by a triangle, with the letters "M. S. F. C." arranged around the vertex and the letters "U. S. C. S." underneath the base of the triangle. The center hole is always in the center of the top of the monument by construction, and if this is found to have been broken off without disturbing the bottom the center of its square section can be used as the location of the station.

All the "standard cement monuments," whether used for marking the "observed station" or "reference station," have been planted upright in exactly the same manner, with their tops projecting 3 or 4 inches above the surface of the ground, unless otherwise stated.

Therefore, as the above facts in reference to the "standard cement monuments" are a constant element in all cases, the repetition of these facts in the description of stations is made needless by this one statement.

References.-Under this heading are given the "rounds" of directions and distances to all objects that might be useful in locating the stations when the surface marks can not be found. It is also contemplated that for general purposes of topography, hydrography, or location of boundaries of oyster bars these references will be sufficient in many cases to relocate the position of an "observed station" or "reference station" when both of them have been destroved.

The first reference object given in the descriptions is always a triangulation station visible from the station being described, this, if possible, heing a lighthouse, church spire, or other permanent and prominent point. Its direction is taken as being $\mathrm{o}^{\circ} \mathrm{oo}^{\prime} \mathrm{oo}^{\prime \prime}$, and the directions of all other objects are measured from it as an initial point, the angles being taken in a clockwise direction (left to right).

The true bearing ${ }^{2}$ of the initial object is alway's given in parentheses alongside its name. This furnishes means for the calculation of the bearings of any of the other reference objects for the purposes of locating a station by horizontal angles or for the relocation of corner buoys of oyster-bar boundaries by the method of compass directions described in this publication under the heading of "Boundaries of oyster bars."

The distances in the last column under "References" are given in three different units, which vary according to their accuracy. The "miles" are statute miles and may be considered only as rough estimates. The "yards" are more accurate, but must be

\footnotetext{
1 Geographic coordinates (latitude, longitude, distance, and azimuth) relating to any of the "observed stations" or of the "reference stations" described in this publication can be obtained by application to the Superintendent of the Coast and Gendetic Survey, at Washington, D.C.

2 The mean magnetic variation for St, Marys County was $5^{\circ} 25^{\prime}$ west of north in $x 910$ and increasing at the rate of $4^{\prime}$ yeariy.
} 
looked on as results generally obtained by pacing or careful estimating. The "meters," however, are accurate to the degree indicated by their decimals and in every case have been measured with a steel tape. In the same manner the accuracy of the directions are indicated by the refinement of angular measure with which they are recorded.

\section{DESCRIPTIONS OF TRIANGULATION STATIONS.}

\section{PRINCE.}

General locality,-Western shore of Patuxent River about one-fourth of a mile north of mouth of Swanson Creek. (See chart No. 19.)

Immediate locality.-Observed station is in pasture about 20 feet above high water, I5 yards northwest of edge of bank, 75 yards northeast of a grove of trees and roo yards southwest of another grove of trees. Locust trees form a fringe along edge of bank.

Marks.-Observed station is center point of triangle on standard cement monument.

References.-

\begin{tabular}{|c|c|c|c|c|c|}
\hline (10. & & & & & \\
\hline 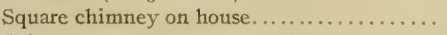 & ○ & 02 & & & le. \\
\hline himney on store at Buena Vista . ......... & I & & & & I \\
\hline 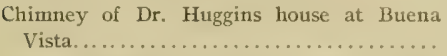 & $2 I$ & 07 & & & $1 \% 4$ intise \\
\hline $\begin{array}{l}\text { earest chimney on Gourley house on Hal- } \\
\text { lowing Point } \ldots \ldots \ldots \ldots \ldots \ldots \ldots \ldots \ldots\end{array}$ & 55 & 10 & & & \\
\hline $\begin{array}{l}\text { ail in blaze in locust tree }(3 \text { inches diam. } \\
\text { eter) } \ldots \ldots \ldots \ldots \ldots \ldots \ldots \ldots \ldots \ldots \ldots \ldots \ldots \ldots \ldots\end{array}$ & 79 & 8 & & & \\
\hline $\begin{array}{l}\text { Tail in blaze in locust tree }(4 \text { inches diam- } \\
\text { eter }) \ldots \ldots \ldots \ldots \ldots \ldots \ldots \ldots \ldots \ldots \ldots \ldots \ldots \ldots \ldots \ldots \ldots\end{array}$ & I IO & I3 & 30 & & \\
\hline$\ldots \ldots$ & I 50 & 45 & . & & \\
\hline$\cdots$ & 226 & 02 & .. & & \\
\hline ..... & 273 & $\infty$ & .. & & 100 \\
\hline$\ldots \ldots \ldots \ldots \ldots$ & $3 I I$ & 04 & .. & ... & $13 / 4$ \\
\hline & & & & & \\
\hline
\end{tabular}

\section{LEITCH.}

General locality.-Eastern shore of Patuxent River on prominent point opposite mouth of Swanson Creek given on chart as Gods Grace Point but known locally as Leitchs Point. (See chart No. 19.)

Immediate locality:-Observed station is on sand and grass land about I foot above high water and 3 yards north of straight line connecting two round points. It is about $I_{3}$ yards northwest of the lower of these two points and 9 yards east of upper point. A creek 3 feet wide has its mouth about 19 yards east by south of the station. There are no permanent objects near station.

Marks.-Observed station is center point of triangle on standard cement monument.

References.

"Prince" (N. $\left.83^{\circ} \infty 0^{\prime} \mathrm{W}.\right) \ldots \ldots \ldots \ldots \ldots \ldots$

Near end of corner peak of roof of large house on hill.

Near end of peak of wharf-house roof . . . . .

Right chimney of house............... 18

Right chimney of Gourley house

Canning-house stack.

"Catholic Church Cross" ................ 28

Chimney of small house............... $308 \quad 52$

Right outside chimney of old house........ $328 \quad 43$

Right outside chimney of old louse........ 343 o5

$$
\begin{aligned}
& \text { } \infty \text {..... } 3 / 4 \text { mile. } \\
& \text {...... } 13 / 4 \text { miles. } \\
& \text {...... } 1 / 4 \text { mile. } \\
& \text {...... I/8 mile. } \\
& \text {...... } 2 \text { miles. } \\
& \text { } \infty \text {..... } 2 \text { miles. } \\
& 30 \ldots \ldots 2 \text { miles. } \\
& \text {...... I mile. } \\
& \text {...... } x^{1 / 4} / 4 \text { miles. } \\
& \text {.. . .... } x \frac{1}{2} / 2 \text { miles. }
\end{aligned}
$$

$2606-\mathrm{II}-3$ 


\section{FODDER.}

General locality,-Western shore of Patuxent River on the southern side of the mouth of Swanson Creek, about I mile west-southwest of Leitch Wharf and three-fourths of a mile west-northwest of Point Judith (loeally known as Teague Point). (See chart No. 19.)

Immediate locality. - Observed station is on the edge of cultivated land about ro feet above highwater mark, 4 yards west of edge of bank, and 9 yards north of another edge. Cenient monument marking reference station is $15.2 \mathrm{I}$ meters $\mathrm{S} 60^{\circ} 52^{\prime} \mathrm{W}$ of observed station.

Marks.-Observed station is center point of triangle on standard cement monument with a top 9 inches square and 8 inches above surface of ground. Reference station is center point of triangle on standard cement monument with a top about 8 inches square and 5 inches above surface of ground.

References.-

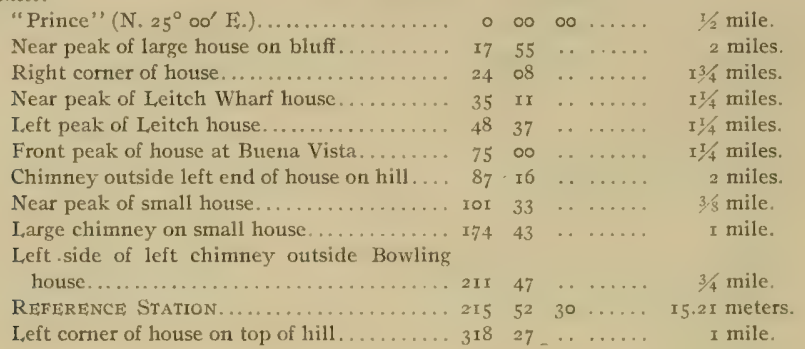

\section{BUFNA.}

General locality.-Fastern shore of Patuxent River, about $x^{3} / 4$ miles northeast of Benedict, at place known as Buena Vista. (See chart No. 19).

Immediate locality.-Observed station is in a field on land adjoining house owned by S. V. Smith and occupied by Dr. Huggins. It is about ro feet above high water, 8 yards east of edge of bank, and I2 yards south of a rail fence. Cement monument marking reference station is II.II meters N. $5^{\circ} 42^{\prime}$ $\mathrm{E}$. of observed station and near fence.

Marks.-Observed station is nail in stub with top 2 inches above ground. Reference station is center point of triangle on standard cement monument.

\section{References.-}

"Hallowing" (S. $27^{\circ} 22^{\prime}$ W.

Center of red roof on square house near

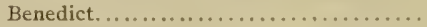

Canning-house stack..................

"Catholic Church Cross" ..................

Nail in blaze in locust tree ( 4 inches diam-

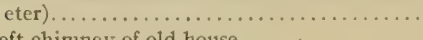

Left chimney of old house................

Left chimney of old house................

Nail in blaze on cherry tree ( 2 inches diam-

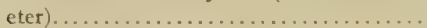

Peak of roof of large house...............

Chimney of house near Leitch Wharf. ...... I

Nail in blaze on fence post............. I

RETERENCE STATION. ............... 15

Near corner of house.................. $1_{59}$

Cherry tree on fence line ( ${ }_{5}$ inches diameter). 221

Double apple tree ( 30 inches diameter)..... 290

\begin{tabular}{|c|c|c|}
\hline 30 & $\ldots \ldots \ldots$ & $\mathrm{I} 3 / 4$ miles. \\
\hline 0.4 & Io $\ldots . .$. & $13 / 4$ miles. \\
\hline 48 & $40 \ldots \ldots$ & $8.5^{8}$ meters. \\
\hline I5 & . $\ldots \ldots$ & 3 miles. \\
\hline $5^{2}$ & . . . . . & 3 miles. \\
\hline 05 & $\ldots \ldots$ & 9.70 meters. \\
\hline I5 & . $\ldots \ldots$ & 4 miles. \\
\hline $5^{2}$ & . $\ldots \ldots$ & x mile. \\
\hline 33 & $50 \ldots \ldots$ & II.I8 meters. \\
\hline 20 & $20 \ldots \ldots$ & If. I I metcrs. \\
\hline 44 & . $\ldots \ldots$ & 25 yards. \\
\hline 25 & $\ldots \ldots$ & 35 yards. \\
\hline 54 & . . . . . & 59 yards. \\
\hline
\end{tabular}


TEAGUE.

General locality.-Western shore of Patuxent River, on point on southern side of entrance to Swanson Creek, locally known as Teague Point, and given on chart as Point Judith. (See chart No. rg.)

Immediate locality.-Observed station is on gravel and grass land about 3 feet above high water, about II yards from south side, I6 yards from north-northeast side, and 75 yards west by north of extreme end of point. Bushes stand between station and north side of point. There are no permanent reference objects near station.

Marks.-Observed station is center point of triangle on standard cement monument.

Refornos.--

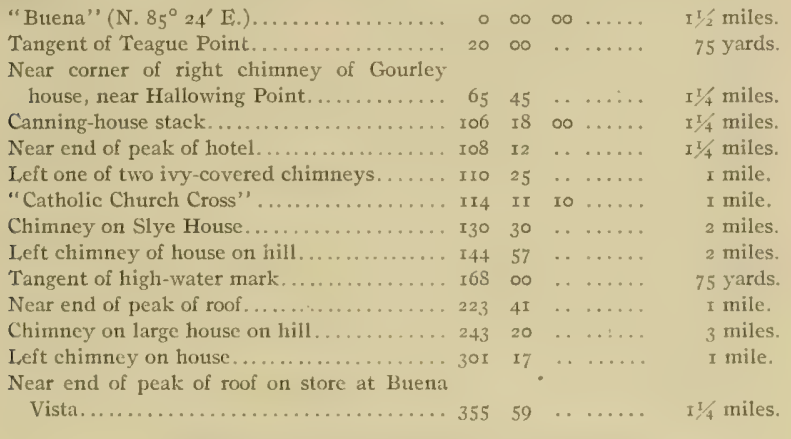

\section{CATHOLIC CHURCH CROSS (BENEDICT)}

General locality.-Western shore of uppe: Pattxent River, in the town of Benedict. (See chart No. I9.)

Immediate locality.-Observed station is on Catholic Church, located on the main street of the town of Benedict, about one-fourth mile from the wharf.

Marks.-Observed station is center point of cross on church.

References.-None necessary.

CITI.

General locality.-Western shore of Patuxent River, on Town Point, about one-fourth mile northnortheast of Benedict steamboat wharf. (See chart No. 19.)

Immediate locality.-Observed station is on gravel and shell point, about 4 fect above high water, I2 yards northwest of the shore, 63 yards west-southwest of a shanty, about roo yards west-southwest of extreme end of point, and is yards southeast of a slough. There are no premanent reference objects near station.

Marks.-Observed station is center point of triangle on standard cement monument.

References.-

"Hallowing" (S. $51^{\circ} 2 \mathrm{I}^{\prime} \mathrm{I}_{\mathrm{*}}$ )

Windmill near Sheridan Point........... 2

Two middle chimneys at Dowells..........

Left tangent of peak of wharf-house roof..... 8

Center of roof of square house.

Canning-house stack. .

00000

I $39 \quad \ldots \ldots \ldots \quad 31 / 2$ miles.

I $39 \quad \ldots \quad \ldots \ldots .31 / 2$ miles.

8 I $34 \ldots \ldots \ldots \quad 1 / 4$ mile.

$84 \quad 36 \quad \ldots \ldots \ldots \quad 1$, mile.

$9522 . \ldots \ldots \ldots$ I/4 milc.

Nearest ivy-covered chimney of old house... I30 I4 $\ldots \ldots \ldots$.... mile.

"Catholic Cnurch Cross" .............. I42 58 . $50 \ldots$.... I/4 mile.

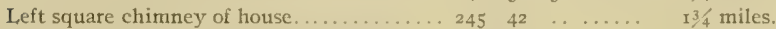

Neat end of peak of roof of Huggins house ... $280 \quad 54 \quad \ldots \quad \ldots \ldots \quad I^{1 / 2}$ niles.

Near corner of shanty .................... $30044 \quad 63$ yards.

Right chimney of Gourley house........ $33920 \quad \ldots \ldots . \ldots \quad 3 / 4$ mile.

Chimney of old building behind wharf ... 352 or $\ldots . . .3 / 4$ mile. 


\section{HALLOWING.}

General locality.-Eastem shore of Patuxent River on point opposite Benedict known locally as Holland Point, but given on charts as Hallowing Point. (See chart No. 19.)

Immediate locality.-Observed station is on a rounded gravel and grass point about 250 yards south of wharf on Holland Point, about 2 feet above high water, Io yards north of shore, 8 yards east of shore, and 15 yards outside of a group of locust trees, sugar-berry trees, and bushes.

Marks.-Observed station is center point of triangle on standard cement monument.

References.-

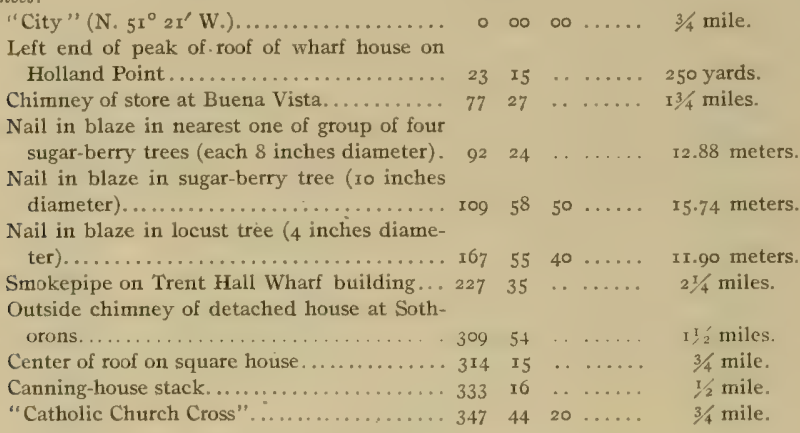

INDIAN.

General locality.-Westem shore of Patuxent River on north side of entrance to Indian Creek and about one-fourth mile below Benedict steamboat wharf. (See chart No. I9.)

Immediate locality.-Observed station is about 3 feet above high water, 7 yards west of shore, z6 yards northeast of a fence and a line of trees, I3 yards southwest of a lone locust tree, about 250 yards to the south-southeast of a large square house, and I.25 yards east-northeast of another house.

Marks.- Observed station is center point of triangle on standard cement monument.

\section{References,-}

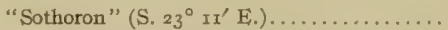

Nail in blaze in locust tree near fence (5

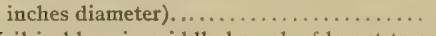

Nail in blaze in middle branch of locust tree (6 inches diameter).................. 6

Square chimney on old house........... 137

Right chimney of square house.......... 188

Near.end of peak of roof of hotel...........206

Canning-house stack. . . . . . . . . . . . . . . $2 I_{3}$

Right tangent of Benedict Wharf ......... 228 I

Chimney of house near "Buena Vista".... $245 \quad 5^{8}$

Chimney of Gourley house............. 270 28

Windmill at Dowell's on Sheridan Point... $344 \quad 48$

Left of right chimney on Dowell house..... $344 \quad 48$

Nail in blaze in left branch of locust tree ( 5 inches diameter) $\circ \infty 0$

3348

624

23

30

26

22

10.

.

.. $\cdots \cdots$

.......

. . . . . .

.......
I mile.

r5. 57 meters.

19. 13 meters.

$\mathrm{I} / \mathrm{t}$ miles.

$1 / 8$ mile.

$1 / 4$ mile.

$1 / 4$ mile.

$1 / 2$ mile.

$2 x / 4$ miles.

$r$ mile.

$4^{1 / 4}$ miles.

$4^{1 / 4}$ miles.

12.90 meters 
DWARF.

General locality-Eastern shore of Patuxent River about 2 miles north-northwest of Sheridan Point and about $I \frac{I}{2}$ miles southeast of Benedict, on a point of land opposite the mouth of Indian Creek. (See chart No. 19.)

Immediate locality.-Observed station is on sand and grass land about I foot above high-water mark, 6 yards northeast from extreme end of point, 4 yards east of one edge of shore and 6 yards north of another edge of shore. Point on which station is located has a sugar-berry tree, several small locust trees and water bushes, and a pond behind bushes and trees about zoo yards to the east.

Marks.-Observed station is center point of triangle on standard cement monument.

References.-

"Sothoron" (S. $42^{\circ} \circ 5^{\prime}$ W.).

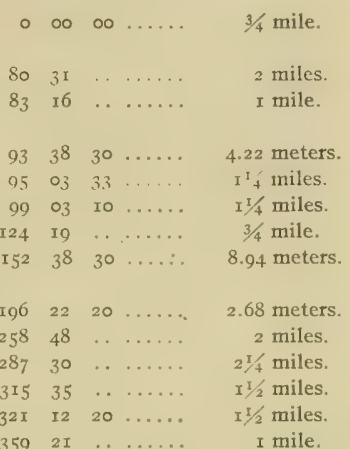

Nearest corner of top of nearest chimney on tenant house.

Center of roof of square house ..............

Nail in blaze in locust tree ( 4 inches diame-

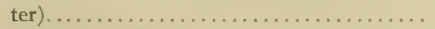

Canning-louse stack. . . . . . . . . . . . . . .

"Catholic Church Cross".................

Left tangent of wharf................... I2

Nail in sugar-berry tree (10 inches diameter). I

Nail in blaze in locust tree ( 3 inches diameter)..................... I96 $22 \quad 20 \ldots \ldots$.

Chimney on small house................ $258 \quad 48 \quad \ldots \ldots \ldots$

Left point of peak of roof of Dowell's..... $287 \quad 30 \quad \ldots \ldots \ldots$

Left end of peak of roof of Trent Hall Wharf. $315 \quad 35 \quad \ldots \ldots \ldots$

Middle cupola on stable.............. 32 I 12 . $20 \ldots \ldots$

Right pillar on Sothoron house porch...... 359 2I ......

I mile.

\section{SOTHORON.}

General locality.-Western shore of Patuxent River on Long Point between entrances to Indian and Trent Hall creeks. (See chart No. I9.)

Immediale locality.-Observed station is on sand and grass lowland about I foot above high-water mark among cedar trees, about 24 yards west by north of extreme end of point, 12 yards north of one edge of shore and 30 yards southwest of another edge of shore.

Marks.-Observed station is center point of triangle on standard cement monument.

References. -

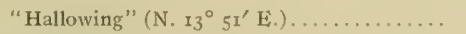

Nearest chimney on Gourley house ..........

Nail in blaze in locust tree ( 4 inches diameter) ....................... 30 . $49 \ldots \ldots \ldots$

Left end of peak of roof of Dowell house.... I20 $35 \quad \ldots \ldots \ldots$

Middle cupola on Trent Hall stable........ I $50 \quad 2500 . .$. .

Point of middle attic window on John Bul-

linger house $\ldots \ldots \ldots \ldots \ldots \ldots \ldots \ldots \ldots \ldots . \ldots \ldots$

Left pillar of porch of Sothoron house...... $206 \quad 23 \quad \ldots \ldots \ldots$

Nail in blaze in cedar tree ( 12 inches diame-

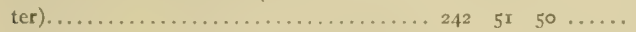

Near comer of nearest chimney on Slye

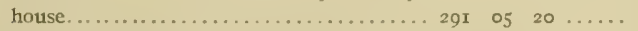

Nail in blaze in locust tree ( 4 inches diameter). $302 \quad 29 \quad 40 \ldots \ldots$

Right one of two outside chimneys on old

house on hill on property of A. B. Slye... $307 \quad 31 \quad \ldots \ldots$.

Center of roof on square house........... $323 \quad 39 \quad \ldots \ldots \ldots$

Nail in blaze in locust tree ( 6 inches diameter). $350 \quad 24$ 10 .....

I $1 / 4$ miles.

$\mathrm{I}^{1 / 4} / 4$ miles.

3. 35 meters

$21 / 4$ miles.

$\mathrm{r} / 4$ miles.

I mile.

$\pi / 2$ mile.

\subsection{2 meters.}

2 miles.

ro.83 meters.

2 miles.

I mile.

I2. 8 I meters. 
BUZZ.

General locality.--Northeast shore of Patuxent River on southwest side of Buzzards Island near mouth of Buzzards Island Creek. (See chart No. 19.)

Immediate locality.-Observed station is on marsh, clay, and grass land on wooded island about 2 feet above high water, 5 yards northeast of river shore and 40 yards northwest of extreme point of island. Cement monument marking reference station is 8.97 meters N. $42^{\circ} 23^{\prime} \mathrm{E}$. of observed station.

Marks.-Observed station is nail in stub with top flush with ground. Reference station is center point of triangle on standard cement monument.

References.-

\begin{tabular}{|c|c|c|c|c|c|}
\hline "Morsel" (S. $25^{\circ} 23^{\prime}$ E.) & 0 & $\infty$ & $\infty 0$ & & ile. \\
\hline Smoke pipe on roof of storehouse. & 39 & II & . & & niles. \\
\hline Near corner of near chimney. & 40 & 36 & . & & 2 miles. \\
\hline Chimney of Trent Hall . . . . . . . & $5^{\circ}$ & 48 & .. & & $I \frac{1}{4}$ miles. \\
\hline Nearest of three cupolas on stable. & 54 & 36 & 50 & & iles. \\
\hline Left piazza post at Sothorons. . & 102 & $4^{I}$ & . & & $I^{I} / 4$ miles. \\
\hline Center of roof of square house. . . . . . . . . . & I55 & I5 & . & & $I 3 / 4$ miles. \\
\hline "Catholic Church Cross" . . . . . . . . . . . . . & 164 & $5^{6}$ & & & 2 miles. \\
\hline Nail in blaze in oak tree ( 18 inches diameter). & 172 & I4 & $\cdots$ & & meters. \\
\hline Nail in blaze in oak tree ( 18 inclies diameter). & 198 & 36 & 40 & & ters. \\
\hline Nail in blaze in oak tree ( 24 inches diameter). & 235 & 08 & 30 & & meters. \\
\hline REFERENCE STATION . . . . . . . . . . & 252 & 45 & 45 & ....... & 8.97 meters. \\
\hline Nail in blaze in pine tree ( 5 inches diameter). & 255 & 43 & . . & $\ldots \ldots$ & neters. \\
\hline Chimney on house across creek . . . . . . . . . . & 313 & 23 & . & $\ldots \ldots$ & $1 / 4$ mile. \\
\hline
\end{tabular}

BILLIARD.

Gencral locality. Southwest shore of Patuxent River about one-fourth of a mile southeast of entrance to 'Trent Hall Creek. (See chart No. I9.)

Immediate locality.-Observed station is on marsh land about x foot above high-water mark, 6 yards west of shore, 70 yards north of curve in shore and about roo to 150 yards north to northwest of a fence which runs to water's edge. No permanent reference objects near station.

Marks.-Observed station is center point of triangle on standard cement monument.

References.-

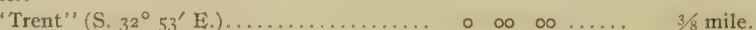

Middle cupola on Trent Hall stable...... $16 \quad 36 \quad \ldots \ldots \ldots \quad 1 / 2$ mile.

Chimney on Trent Hall ............ I8 4 I $\ldots \ldots \ldots$ mile.

Two trees.................. 3 I $47 \quad \ldots \ldots \ldots 200$ yards.

Tangent of curve in water line........ 33 o0 . . . . $\quad 7 x$ yards.

Chimney of $2 \frac{1}{2}$-story house......... $8 \mathrm{r} \quad 59 \ldots \ldots .2$ miles.

Right corner of Sothoron house ........... $16234 \quad \ldots \ldots \ldots \quad 1 / 2$ mile.

Near corner of chimney on Slye house..... I7 I og ....... 2 miles.

Right tangent of wharf............. II $_{3}$ II ..... 2 miles.

Middle of three chimneys on Gourley house.. $228 \quad 53 \quad \ldots \ldots \ldots \quad 2$ miles.

Chimney on house among trees......... $293 \quad 4 T \quad \ldots \ldots \ldots$ I $1 / 2$ miles.

Nearest end of peak roof of Dowell house at

Dukes Wharf ................. $333 \quad 42^{\circ} \ldots \ldots \ldots \quad 13 / 4$ miles.

Right tangent of Sheridan Point......... $34 \sqrt{1} 34 \quad \ldots \ldots \ldots \quad x^{1} / 2$ miles.

Left tangent Trent Hall Wharf . . . . . . . $348 \quad 49 \quad \ldots \ldots \ldots .3 / 8$ mile.

Smoke pipe on house at land end of Trent

Hall Wharf $\ldots \ldots \ldots \ldots \ldots \ldots \ldots \ldots \ldots .356,53 \quad \ldots \ldots \ldots, 3 / 8$ mile. 


\section{MORSEL.}

General locality.-Northeast shore of Patuxent River about $x$ mile north by west of Sheridan Point. (See chart No. Ig.)

Immediate locality.-Observed station is in a wheat field on a cliff about 60 feet above high water, about 5 yards northeast of edge of bank, I10 yards north northwest of rail fence at woods, I03 yards west southwest of woods, and 167 yards west northwest of comer of field at creek and woods. Trees grow out of face of cliff below station.

Marks.-Observed station is center point of triangle on standard cement monument.

References.-

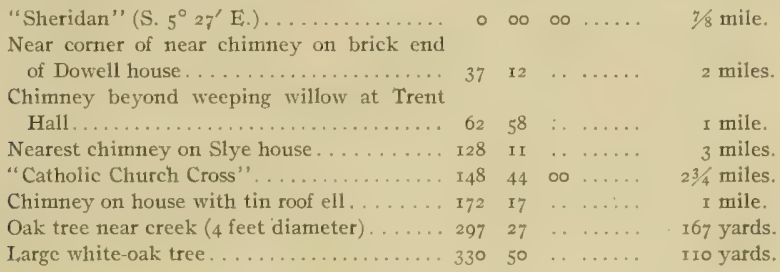

\section{TRENT.}

General locality.-Southwest shore of Patuxent River on White Point about 50 yards west of Trent Hall Wharf. (Sce chart No. I0.)

Immediate locality.-Observed station is I foot above high-water mark on sand and grass land between river and marsh, about 47 yards west of small house on land end of Trent Hall Wharf, about 64 yards northwest of extreme end of White Point, 5 yards southwest of high-water mark, about 428 yards north of Trent Hall and 105 yards south by east of mouth of creck. Cement monument marking reference station is 17.18 meters $\mathrm{S} .69^{\circ} 40^{\prime} \mathrm{W}$. of observed station.

Marks.-Observed station is nail in stub flush with ground. Reference station is center point of triangle on standard cement monument.

References.--

\begin{tabular}{|c|c|c|c|c|}
\hline 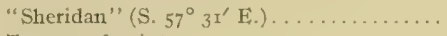 & $\circ$ & $\infty$ & $\infty$ & . \\
\hline Tangent of point. . . . . . . . . . . . . . . . & 32 & $I_{7}$ & .. . & sile. \\
\hline Large lone tree. & 50 & 15 & $\cdots$ & I \\
\hline Right corner of Trent Hall. . & 74 & 08 & . & 428 \\
\hline ight cupola of three on Trent Hall stable.. & 99 & 40 & .. & \\
\hline Garge lone tree . . . . . . . . . . . . . . . & $\mathrm{II}_{3}$ & 5 I & $\cdots \cdots \cdots$ & 13 \\
\hline N & 127 & 10 & $30 \ldots \ldots$ & 7.18 \\
\hline Catholic Church Cross" . . . . . . . . . . . . . & 219 & 22 & $20 \ldots$ & 23, \\
\hline $\begin{array}{l}\text { ight end of peak of roof of Holland Point } \\
\text { Wharf } \ldots \ldots \ldots \ldots \ldots \ldots \ldots \ldots \ldots \ldots \ldots \ldots \ldots\end{array}$ & 233 & 05 & . & $2 \%$ \\
\hline $\begin{array}{l}\text { ight chimney of smaller of two houses among } \\
\text { trees } \ldots \ldots \ldots \ldots \ldots \ldots \ldots \ldots \ldots \ldots \ldots \ldots\end{array}$ & 284 & oI & & \\
\hline .... & 300 & 35 & $\ldots \ldots \ldots$ & $5^{\mathrm{T}}$ \\
\hline ight corner of shan & 300 & 36 & $\cdots$ & yard \\
\hline
\end{tabular}

\section{COLLINS}

General locality.-Southwest shore of Patuxent River about one-fourth of a mile northwest of entrance to Washington Creek on point opposite Sheridan Point. (See chart No. Ig.)

Immediate locality.-Observed station is on marsh land about I foot above high-water mark, 16 yards west of shore, 20 yards northwest of shore, 2I yards southwest of shore, 300 yards northeast of a tall lone tree, and 300 yards southeast of house known as Trent Hall. 
Marks.-Observed station is center point of triangle on standard cement monument. References. -

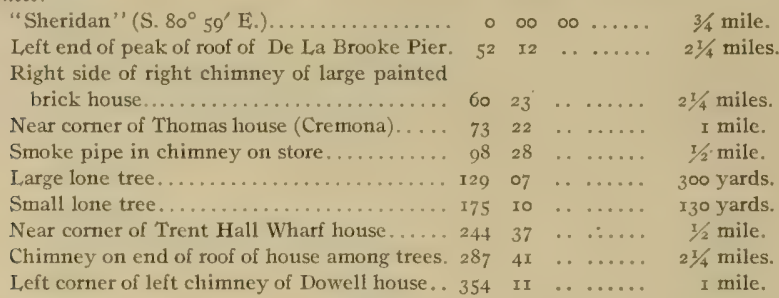

\section{SHERIDAN}

General locality.-Northeast shore of Patuxent River on Sheridan Point. (See chart No. 19.)

Immediate locality.-Observed station is on sand and grass point near edge of the grass, about 2 feet above high-water mark, 6 yards east of extreme edge of grass on point, 8 yards north of grass edge and 7 yards south of grass edge. Cement monument marking reference station is 14.13 meters N. $49^{\circ}$ $56^{\prime} \mathrm{E}$. of observed station.

Marks.-Observed station is nail in stub with top 6 inches above ground. Reference station is center point of triangle on standard cement monument.

References.-

"Kitt" (S. $66^{\circ} 05^{\prime} \mathrm{E}$. .)................

Right tangent of brick house..............

Left end of peak of roof of De La Brooke Pier.

Left comer of left chimney of Thomas house

(Cremona) ........................ I0

Smoke pipe on several gable house ....... I2

Right tangent of Trent Hall Wharf ........ I92

Catholic Church at Benedict............. 216

REFERENCE STATION................ 296

Near chimney of Dowell house.......... 325

\begin{tabular}{|c|c|c|}
\hline ' & $" 1$ & \\
\hline$\infty$ & $\infty \ldots \ldots$ & I $1 / 4$ miles. \\
\hline $4^{I}$ & $\ldots \ldots \ldots$ & 6 miles. \\
\hline$I_{3}$ & $\ldots \ldots \ldots$ & I3/4 miles. \\
\hline $3^{8}$ & .. & $\mathrm{I} / 4$ miles. \\
\hline 25 & . . . . . & 11/4 miles. \\
\hline$\infty$ & $\ldots \ldots \ldots$ & I mile. \\
\hline 56 & $\ldots \ldots \ldots$ & $3^{1} / 2$ miles. \\
\hline or & $\infty$ o..... & I4.I3 meters. \\
\hline 23 & $\ldots \ldots \ldots$ & $I / 4$ mile \\
\hline
\end{tabular}

\section{CREMONA.}

General locality,-Southwest shore of Patuxent River about halfway between Cremona and Persimmon creeks. (See chart No. I9.)

Immediate locality.-Observed station is in orchard on farm known as Cremona, about 6 feet above high-water mark, 10 y ards south of edge of river bank, 7 yards south of rail fence which runs west and east to dooryard fence, 36 yards east of rail fence of cornfield, 75 yards north of rail fence at cornfield, and 53 yards west of picket fence. Several mountain dwarf clierry trees stand between fence and riverbank edge.

Marks.-Observed station is center point of triangle on standard cement monument.

References.-

"Kitt" (N. $84^{\circ} \mathrm{r}^{\prime}$ E. $)$..................

Near end of peak of roof of Young Hance house..............................

Nail in blaze in apple tree ( 24 inches diameter).

Nail in blaze in apple tree ( 16 inches diam-

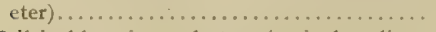

Nail in blaze in apple tree ( 15 inches diameter $\ldots \ldots \ldots \ldots \ldots \ldots \ldots \ldots \ldots \ldots$. . . . . . .

Corner of field..................... I8

Corner of field. . . . . . . . . . . . . . . . . 23
0 00 $00 \ldots . .2$ miles.
I6 $26 \quad \ldots \ldots \ldots . \quad 3$ miles.
$\begin{array}{lllll}37 & 38 & 20 & \ldots & 24.55 \\ & \text { meters. }\end{array}$
$62 \quad 43 \quad 30 \ldots \ldots .13 .12$ meters.
$1003330 \ldots \ldots$ 16.1 I meters.
$55 \quad \ldots \ldots . \quad 87$ yards.
$32 \ldots \ldots . \quad 38$ yards. 
KITT.

General locality,-Northeast shore of Patuxent River on Kitts Marsh Point, which is about halfway between Battle Creek and Sheridan Point. (See chart No. I9.)

Immediate locality.-Observed station is on the point of a long marsh neck, about 15 yards northcast of extreme end of point, $I_{3}$ yards north of edge of marsh, and $\mathrm{I}_{3}$ yards east of edge of marsh. There are no permanent reference objects near station. Cement monument marking reference station is 15.84 meters $\mathrm{N}$. $10^{\circ} 23^{\prime} \mathrm{E}$. of observed station.

Marks.-Observed station is nail in stub flush with surface of marsh. Reference station is center point of triangle on standard cement monument.

References, -

"Battle" (S. $39^{\circ}$ oz' Li.).

$\infty \ldots \ldots . \quad I / 8$ miles.

Right tangent of Long Marsh

Near end of peak of roof of De La Brooke Pier. $\begin{array}{rrrrr}73 & 52 & \ldots & \ldots & I^{I} / 2 \\ \text { miles. }\end{array}$

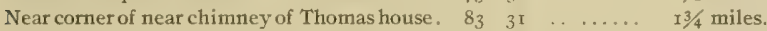

Large house.................... I67 $38 \ldots \ldots$ I mile.

Square chimney of large house $\ldots \ldots \ldots \ldots \ldots . \quad 185 \quad 23 \quad \ldots \ldots \ldots . \quad 1 / 4$ mile.

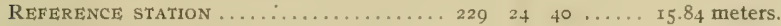

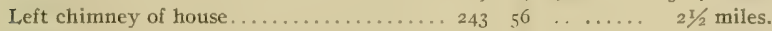

Hance house ................... 299 1.3 . .... 2 miles.

Right chimney of house among trees on hill. $327 \quad 24 \quad \ldots \ldots \ldots+4$ miles.

Left chimney of house.............. 336 59 . . . .

OPPKIT.

General locality.-Southwest shore of Patuxent River on Marsh Point. (See chart No. I9.)

Immediate locality.-Observed station is on sand and grass ridge between sand beach and marsh, about $\mathrm{I}$ foot above high water, 3 yards southwest of high-water mark, 60 yards west-northwest of one point of the beach, 64 yards south of another point of the beach, and 85 yards north-northwest of an oyster watch house on piles. There are no permanent reference objects near station.

Marks.-Observed station is center point of triangle on standard cement monument.

References.-

"Kitt" (N. $\left.56^{\circ} 3 \mathrm{r}^{\prime} \mathrm{E}.\right)$......................
Near end of peak of roof of Williams Wharf

house..........................

Left corner of watch house................ 8

Pier..............................

Right corner of right chimney of brick house. . 126

Chinney on house near trees........... $232 \quad 43$

Highest chimney on Cremona House. . . . . . 25440

Point of roof of Dukes Wharf............ 310

Chimney on house with ell ............ $330 \quad 40$

Large square brick chimney on house with ell. 334

Nearest chimney of pair on end of house.... 353 oo

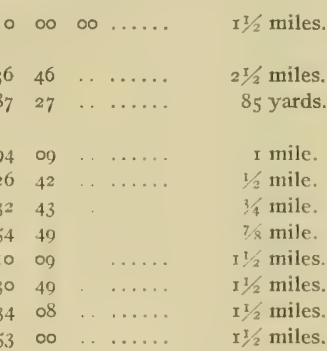




\section{BATTLE.}

General locality.-Northeast shore of Patuxent River on west side of entrance to Battle Creek on Prison Point. (See chart No, 19.)

Immediate locality.-Observed station is on sand and grass land between marsh and river, about I foot above high water, 85 yards south of a field, 6 yards northeast of shore, 20 yards southwest of edge of a pool, Ioo yards southwest by west of a lone tree, 200 yards west of a small house among trees, and Ioo yards west to northwest of several divarf trees between house and beach.

Marks.-Observed station is center point of triangle on standard cement monument.

References.-

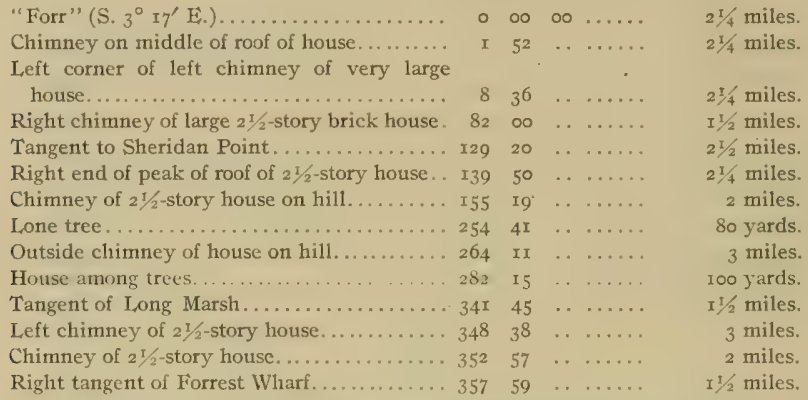

\section{PHOTO.}

General locality.-Northeast side of Patuxent River on east side of entrance to Jacks Bay. (See chart No. 19.)

Immediate locality.-Observed station is in a cultivated field, about 150 yards north-northeast of a marshy point, ro feet above high-water mark, 49 yards east of shore, IIo yards north-northwest of shore, and 68 yards northeast of right end of clump of trees at edge of field and beginning of marsh.point.

Marks.-Observed station is nail in stub with top 2 inches above surface of ground. Subsurface mark is center point of triangle on standard cement monument with top 12 inches below surface.

References.-

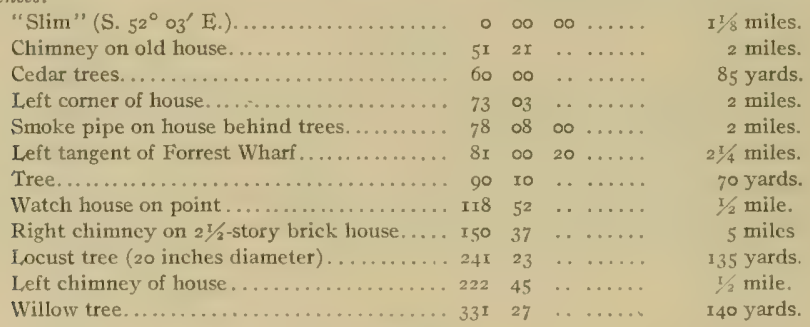

FIGHT.

General locality.-Southwest shore of Patuxent River opposite mouth of Battle Creek on a prominent low point. (See chart No. 19.)

Immediate locality.-Observed station is on land known as Horsehead Marsh, about I foot above ordinary high-water mark, I2 yards south-southwest of extreme end of point, I5 yards west-northwest of shore at small creek, 40 yards northeast of woods, and Iro yards east-southeast of a bluff 50 feet high. 
Marks.-Observed station is center point of triangle on standard cement monument.

References.-

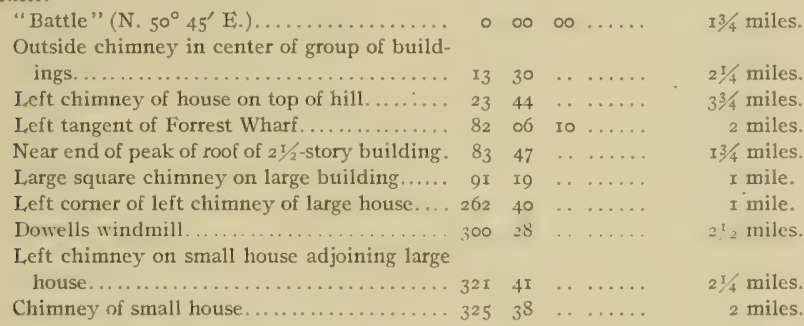

SLIM.

General locality:-Northeast shore of Patuxent River about half way between Battle and Island creeks and one-haif mile west-northwest of Parkers Wharf. (See chart No. I9.)

Immediate locality:-Observed station is in a field on a sand bluff, about 40 feet above high water, I3 yards northeast of edge of bluff, go yards southeast of a point of woods at top of a ravine, about I8o yards southwest of another point of woods, 150 yards west-northwest of a rail fence, and 7 I yards northwest by west of a large sycamore tree.

Marks.-Observed station is nail in round chestnut stub with top ahout 6 inches above the surface of the ground. Subsurface mark is center point of triangle on standard cement monument with top to inches below the surface of the ground.

References.-

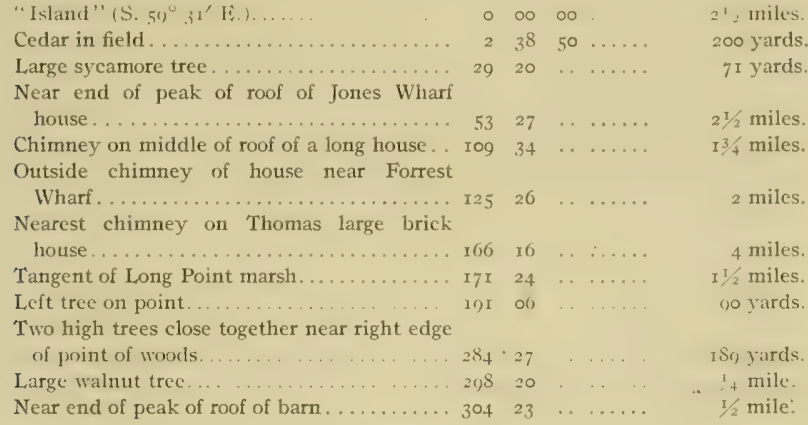

FORR.

General locality.-Southwest shore of Patuxent River just below Forrest Wharf. (See chart No. 19.) Immediate locality. - Observed station is about I foot above high-water nuark on sand and grass land, 7 yards south from extreme high-water mark, 45 yards southeast of land end of Forrest Wharf. 70 yards east by south of an old $2 \frac{1}{2}$-story building, and 65 yards northeast of a saloon.

Marks.-Observed station is center point of triangle on standard cement monument. 


\begin{tabular}{|c|c|c|c|c|c|}
\hline \multicolumn{6}{|l|}{ References.- } \\
\hline "Cole" (S. $50^{\circ}$ or $^{\prime}$ E. $) \ldots \ldots \ldots \ldots \ldots \ldots \ldots$ & $\circ$ & $\infty$ & $\infty$ & & $x^{3} / 8$ miles. \\
\hline Near corner of house on hillside........... & 9 & 59 & . & ... & I8o yards. \\
\hline Near corner of saloon. ................. & IOI & 52 & . & & 65 yards. \\
\hline Outside chimney on house on hill......... & $1 \times 5$ & 22 & . & & 1/8 mile. \\
\hline 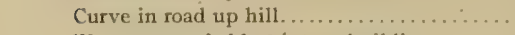 & 131 & 25 & . & $\ldots \ldots$ & 200 yards. \\
\hline West corner of old $21 / 2$-story building. ........ & I39 & $5^{2}$ & . & $\ldots \ldots$ & rds. \\
\hline Land end of wharf. & 169 & 15 & . & & 45 yards. \\
\hline Windmill. & 182 & 59 & 40 & & 2,4 miles. \\
\hline Left corner of left chimney brick house. . . . . & 183 & 05 & .. & $\cdots \cdots$ & 3 miles. \\
\hline Right tangent of Dukes Wharf. ............ & 187 & 07 & . & $\cdots$ & $4 \%$ miles. \\
\hline $\begin{array}{l}\text { Near end of peak of roof of Forrest Wharf } \\
\text { house } \ldots \ldots \ldots \ldots \ldots \ldots \ldots \ldots \ldots \ldots \ldots \ldots\end{array}$ & 257 & I 7 & $\cdots$ & & 1/8 mile. \\
\hline Chimney of house....... & 272 & 35 & .. & $\ldots \ldots$ & 3 or 4 miles. \\
\hline Right & 304 & 23 & . & $\ldots \ldots$ & $2 \mathrm{~T} / 2$ mile \\
\hline Tangent of trees......... & 347 & 46 & . & $\ldots \ldots$ & 3 mile \\
\hline
\end{tabular}

\section{SWEEP.}

General locality:-Northeast shore of Patuxent River on northwest side of mouth of Island Creek near inner end of neck of land joining Broome Island to the mainland. (See chart No. I9.)

Immediate locality.-Observed station is in a field about 4 feet above high water, 4 feet northwest of a wire fence, 24 yards south by west of a stable, 60 yards south-southwest of a house, and 10o yards south-southeast of a pine grove. Cement monument marking reference station is 21.70 meters N. $59^{\circ}$ $39^{\prime}$ E. of station and near fence line.

Marks.-Observed station is the center of an oblong wooden box 4 inches square with top 4 inches above the ground. Reference station is center point of triangle on a standard cement monument.

References.-

\begin{tabular}{|c|c|c|c|c|c|}
\hline "Bars" (S. $15^{\circ}$ Io' E.). & 0 & 00 & $\infty 0$ & & 2 miles. \\
\hline Right chimney of house... & I4 & $4^{8}$ & $\cdots$ & & 3 miles. \\
\hline Peak of roof of Gadden house ............. & 25 & 34 & 20 & & I5/8 miles. \\
\hline Tangent of Broome Island Point........... & 43 & $2 I$ & $\cdots$ & & ile. \\
\hline Chimney on house on hill............... & $5 \mathrm{I}$ & 57 & . & $\ldots \ldots$ & 3 miles. \\
\hline 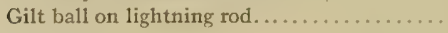 & 62 & 03 & .. & & $3 / 8$ mile. \\
\hline Chimney on house. & 96 & o6 & .. & & aile. \\
\hline Cut in woods. . & $\mathbf{r} 35$ & 40 & .. & & iiles. \\
\hline Chimney of house ................... & 186 & 34 & . & & I50 yards. \\
\hline Tile smoke pipe on house.......... & 203 & 24 & . & & I 40 yards. \\
\hline Neat corne & 230 & 35 & . & & ris. \\
\hline Near corner of barn. & 237 & 32 & . & & 24 yards. \\
\hline REFERENCE STATION. . & 254 & 49 & 20 & & 21.70 meters. \\
\hline Right chimney of four on house. & 279 & 25 & 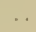 & & $1 / 4$ \\
\hline Top of tower of house. & 301 & 54 & & & nile \\
\hline
\end{tabular}

\section{ISLAND.}

General locality.-Northeast shore of Patuxent River on the extreme southeast point of land about one-nalf mile to the east of the mouth of Island Creek. (See chart No. Ig.)

Immediate locality.-Observed station is on a marshy point at about extreme high-water mark, 30 yards north of extreme end of point, 25 yards east of one side of point, and 20 yards west of another side of point. Old tile pipe used as a reference station is $16.9^{8}$ meters N. $12^{\circ} 39^{\prime} \mathrm{F}$. and cement monument marking new reference station is 30.93 meters $\mathrm{N} .2^{\circ}{ }_{4}^{\prime} \mathrm{E}$. of observed station.

Marks.-Observed station is nail in stub with top flush with marsh. Old reference station is center of 4 -inch tile pipe set in cement with top projecting about to inches above ground. New reference station is center point of triangle on standard cement monument 
References.-

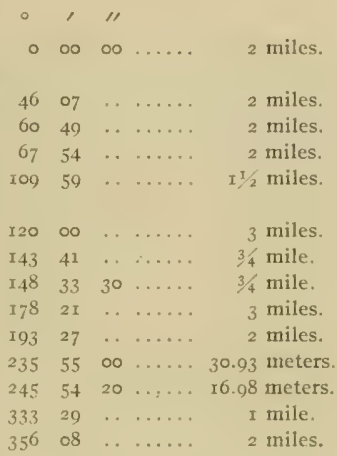

PEAK.

General locality.-Northeast shore of Patuxent River, about in middle of inner shore a large bay between St. Leonard and Island creeks. (See chart No. xg.)

Immediate locality.-Observed station is on Parran house, located near shore at extreme end of a road leading to Wallville.

Marks.-Observed station is ball on tip of tower.

References.- None necessary.

COLE:

General locality.-Southwest shore of Patuxent River, about one-fourth mile northwest of Cole Creek. (See chart No. Ig.)

Immediate locality.- Observed station is about 35 feet above high-water mark on a grass peninsula, 3 yards south-southwest of edge of a bluff which is washing rapidly, 8 yards west of extreme edge of bluff, where it tums inland and is not washing, but slopes gradually to the water, 8 yards north of another edge of the blufi, Io yards northwest of trees on slope of bank, and 20 yards west of a cherry tree 2 feet in diameter. Cement monument marking reference station is 13.53 meters $\mathrm{S} .83^{\circ} \mathrm{Io}^{\prime} \mathrm{W}$. of observed station and nearly on line with large cherry tree.

Marks.-Observed station is nail in stub with top flush with ground. Reference station is center point of triangle on standard cement monument.

References.-

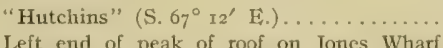

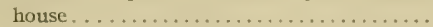

Nail in blaze on limb of oak tree (4 inches diameter).

Screw in blaze in crotch of oak tree ( 15 inches diameter at base $) . \ldots \ldots \ldots \ldots \ldots \ldots \ldots . . \ldots \ldots$

Nail in blaze of cedar tree ( 6 inches diameter).
Nail in blaze on cherry tree $(24$ inches diameter $) \ldots \ldots \ldots \ldots \ldots \ldots \ldots \ldots \ldots \ldots \ldots \ldots$

REFERENCE STATION. .............. I

Right chimney of house.............. I7
Right end of peak of roof of Forrest Whatf house........................ $202 \quad 2$

Right end of house................ 25 I o5

Left end of peak of house............ 280

Gilt ball on Broome house............... 32 I $30 \quad 30 \ldots .$.

Right tangent of Broome Island......... 334 17 $\ldots \ldots \ldots$

2 miles.

$1 \frac{1}{2}$ miles.

10.80 meters

I2.67 meters.

8.43 meters.

I8.65 meters.

13.53 meters.

I/t mile.

I I 2 mile.

3 miles.

3 miles.

2 miles.

$\mathrm{r} 3 / 4$ miles. 


\section{HUTCHINS}

General locality. - Southwest shore of Patuxent River opposite Broome Island on Captain Point, about one-fourth mile northwest of mouth of Cole Creek. (See chart No. Ig.)

Immediate locality. - Observed station is in garden on point of a bluff 50 feet high on Hutchins estate near house occupied by Mr. Gadden, about 6 yards south by east of extreme point of bluff, 2 yards southwest of edge of bluff, 4 yards southeast of edge of bluff, 30 yards north by west from house, 30 yards west of a wire fence running north and south, and I 5 yards east of another north-and-south wire fence. Cement monument marking reference station is 7.57 meters S. $59^{\circ} 39^{\prime} \mathrm{W}$. of observed station. Marks.-Observed station is nail in a stub with top flush with ground. Reference station is center point of triangle on standard cement monument.

References.-

\begin{tabular}{|c|c|c|c|c|}
\hline "Bars" (S. $68^{\circ}$ o $7^{\prime}$ E.). & $\circ$ & $\infty$ & $\infty$ & $7 / 8$ mile. \\
\hline Left corner of extension of Gadden house.... & 58 & 17 & . & leters. \\
\hline Right front corner of Gadden house. & 84 & 56 & . & 28.5 \\
\hline Near corner of well house .......... & 102 & 15 & . & 30.44 \\
\hline Near corner of shed........ & IIg & 43 & . & . \\
\hline NCE STATION . . . . . . . . . . . . & 127 & 46 & . & eter \\
\hline $\begin{array}{l}\text { pple tree }(22 \text { inches diame- } \\
\ldots \ldots \ldots \ldots \ldots \ldots \ldots \ldots \ldots\end{array}$ & 148 & 06 & 20 & \\
\hline Right tangent of Parkers Wharf . . . . . . . & 228 & 12 & . & $2 \pi / 2$ \\
\hline on Broome Island. & 249 & 55 & & iiles. \\
\hline d of peak of house. . & 263 & 17 & $\ldots$ & ailes \\
\hline r on Peterson house & $33^{2}$ & 52 & . & iiles \\
\hline
\end{tabular}

\section{WHEAT.}

General locality.-Northeast shore of Patuxent River on westerly side of mouth of St. Leonard Creek. (See charts Nos. 19 and 20.)

Immediate locality.-Observed station is on a bluff about 40 feet above high water, about 5 yards west of edge of bank, 7 yards south of another edge, and three-eighths mile west of Peterson house. Cement monument marking reference station is 12.80 meters $\mathrm{N}$. $6 \mathrm{I}^{\circ} 55^{\prime} \mathrm{E}$, of observed station and on line to Peterson house.

Marks.-Observed station is center of a 4 -inch tile pipe set in cement with top projecting about 4 inches above ground. Reference station is center point of triangle on standard cement monument with top 6 inches below the surface.

\begin{tabular}{|c|c|c|c|c|c|}
\hline \multicolumn{6}{|l|}{ References.- } \\
\hline "Stump" (S. $36^{\circ} 23^{\prime}$ E.). & o & $\infty 0$ & $\infty$ & & $21 / 4$ miles. \\
\hline Left chimney of Judge Crane house........ & I0 & 07 & & & $43 / 4$ miles. \\
\hline Near end of peak of roof of Marburger house.. & $I_{5}$ & 05 & .. & & $4^{1 / 4}$ miles. \\
\hline Left end of roof of St. Cuthbert Wharf ...... & 24 & 09 & $\ldots$ & & $21 / 4$ miles. \\
\hline Chimney on roof of house . . . . . . . . . . . & 60 & 05 & 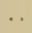 & . & I $1 / 2$ miles. \\
\hline Chimney on store at Sotterly..... & 93 & $4 \mathrm{I}$ & . & & I $1 / 2$ miles. \\
\hline Left end of barn roof. . . . . . & 193 & 27 & . & & 2 miles. \\
\hline REFERENCE STATION. & 278 & 17 & 30 & & I2.80 meters. \\
\hline Center chimney of Peterson house. & $28 \mathrm{r}$ & 22 & 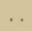 & & $1 / 4$ mile. \\
\hline Chimney of house . .............. & 298 & 03 & $\cdots$ & $\ldots$ & 1/8 mile. \\
\hline Chimney on house on Breeden estate... & 340 & 04 & . & .... & 2 miles. \\
\hline
\end{tabular}

\section{MACKALL.}

General locality.-Northwest shore of Patuxent River on west side of entrance to St. Leonard Creek on first point inside of Peterson Point. (See charts Nos. Ig and 20.)

Immediate locality.-Observed station is about 50 feet above high water, 9 feet northwest of edge of bluff, 7 yards northeast of bushes, and 3 yards southwest of other bushes. Cement monument marking reference station is 3.80 meters N. $35^{\circ} 08^{\prime} \mathrm{W}$, of observed station.

Marks.-Observed station is the center of an oblong wooden box 4 inches square with top 3 inches above the ground. Reference station is center point of triangle on standard cement monument. 


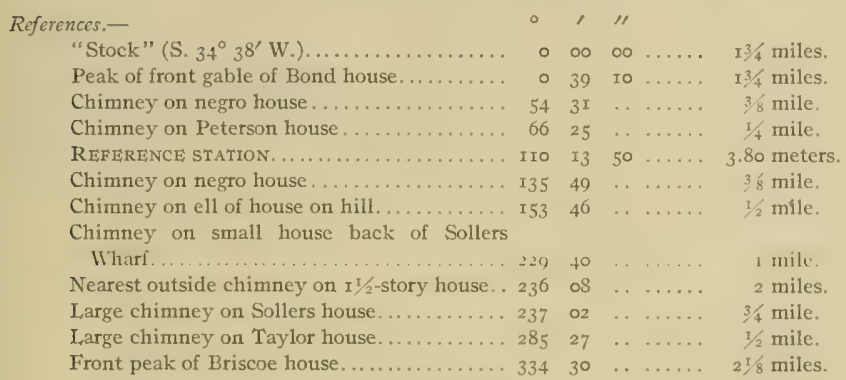

\section{SOLLERS.}

General locality.-Northeast shore of Patuxent River on east side of entrance to St. Leonard Creek. (See charts Nos. I9 and 20.)

Immediate locality.-Observed station is about 50 feet above high water, 6 feet east of edge of bank, 20 yards north-northeast of a clump of trees, I4 yards and 8 yards south-southwest of other trees, and 75 yards north-northwest of a rail fence. Cement monument marking reference station is 13.68 meters S. $44^{\circ} 00^{\prime} \mathrm{E}$. of observed station with top buried $\mathrm{Iz}$ inches below surface.

Marks.-Observed station is the center of an oblong wooden box 5 inches square with top 3 inches above ground. Reference station is center point of triangle on standard cement monument with top I 2 inches below surface.

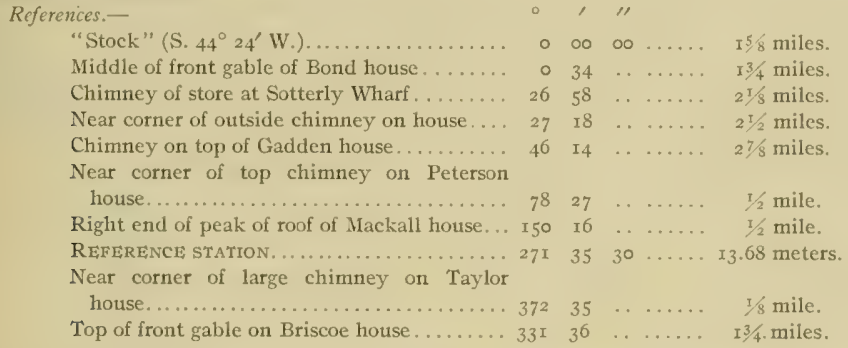

\section{BARS.}

General locality. - Southwest shore of Patuxent River on Sotterly Point about one-fourth mile northwest of Sotterly Wharf. (See chart No. 19.)

Immediale locality.-Observed station is on a blufi about 30 feet above high water, 5 yards south of edge of bank at rail fence, and 2 yards east of this same fence. Cement monument marking reference station is 14.53 meters $\mathrm{S} .9^{\circ} 54^{\prime} \mathrm{W}$. of observed station and near fence line.

Marks.-Observed station is center of a 3 -inch tile pipe set in cement. Reference station is center point of triangle on standard cement monument.

\begin{tabular}{|c|c|c|c|c|}
\hline eferences.- & 。 & ' & $\prime \prime$ & \\
\hline "Wheat" (N. $\left.72^{\circ} \circ 6^{\prime} \mathrm{E}.\right)$. . & $\circ$ & $\infty$ & $\infty$ & $I^{1} / 2$ miles. \\
\hline Chimney on middle of $21 / 2$-story house. . . . . & 17 & 29 & . . & 6 miles. \\
\hline Windmill. & 23 & 23 & .. & 3 miles. \\
\hline Chimney of house. . & $4 I$ & 50 & $\ldots \ldots \ldots$ & 4 miles. \\
\hline REFERENCE STATION . ........ & 117 & $4^{8}$ & $\infty \ldots \ldots$. & 4.53 meters. \\
\hline Smoke pipe on right end of house. & r 57 & 37 & $\ldots \ldots$ & $1 / 4$ mile. \\
\hline Tangent of point of land. & 250 & 47 & $\ldots \ldots \ldots$ & $\mathrm{I}^{1}{ }_{2}$ miles. \\
\hline Peterson house chimney......... & 359 & 22 & & $13 / 4$ miles. \\
\hline
\end{tabular}


LEND.

General locality. - Northeast shore of Patuxent River on a narrow strip of land or peninsula in mouth of Mears Creek about one-half mile southeast of St. Leonard Creek. (See charts Nos, I9 and 20.)

Immediate locality.- Observed station is in the midst of many cherry, oak, and locust trees about I5 feet above high-water mark, I5 yards east-northeast of high ground, 5 yards west of edge and I7 yards north of extreme point of top of peninsula.

Marks.-Observed station is center point of triangle on standard cement monument.

References. -

"Wheat" (N. $50^{\circ} 5 \mathrm{x}^{\prime}$ W.).

Nail in blaze in cherry tree ( 4 inches diam-

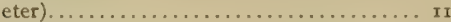

Right chimney of house across creek........ I3

Nail in blaze in oak tree ( 8 inches diameter). . 229

Outside chimney on left end of Briscoe house. 26

Near peak of Bond house............... 297

Chimney on storehouse at Sotterly ........ 318

Near end of peak of roof of Sotterly Wharf house........................... 3 I

Chimney on Gadden house ............. 330

Nail in blaze in cherry tree ( 6 inches diam-

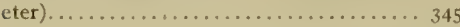

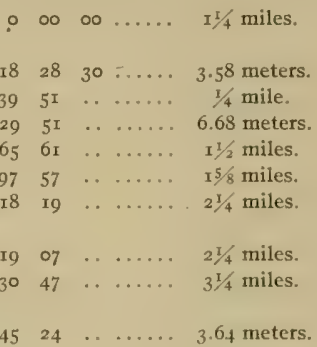

STOCK.

General locality.-Southwest shore of Patuxent River about I mile southeast of Sotterly Point. (See chart No. 20.)

Immediate locality.-Observed station is on a bluff, about 20 feet above high water, 3 yards southwest of edge of bluff, about 50 yards east by north of front door of the house of Mr. Bond, 30 yards west-northwest of extreme end of point of bluff, 35 yards northeast of detached house, and about 43 yards east by south of yard fence at edge of bluff.

Marks.-Observed station is center point of triangle on standard cement monument.

References.-

"Lend" N. $66^{\circ}{ }_{4} 8^{\prime} \mathrm{E}$.

Right chimney of house on Dickson place...

Right chimney of old $x^{T / 2}$-story house.......

Tangent of bluff ...................

Chimney on house on point. .............

Nail in blaze in locust tree (4 inches diameter)......................

Nearest corner of outhouse, corner farthest from house . .................... 16

Left corner of house................ I

Nail in blaze in cherry tree I foot above ground $(4$ feet diameter $) \ldots \ldots \ldots \ldots \ldots .183$

Right corner of house............... $205 \quad 29 \quad 40 \ldots \ldots$

Locust tree ( 4 inches diameter).......... 2 I0 $3 \mathrm{I} \quad 40 \ldots \ldots$

Eind of yard fence................... $230 \quad 31 \quad \ldots \ldots \ldots$

Tree near edge of bank (no nail or blaze)...2 $237 \quad 39 \quad 20 \ldots \ldots$

$$
\begin{aligned}
& 15 \times \text { miles. } \\
& \text { I3/4 miles. } \\
& 2 \text { miles. } \\
& \text { I mile. } \\
& \text { I mile. } \\
& 2.18 \text { meters. } \\
& 34.30 \text { meters. } \\
& 31.13 \text { meters. } \\
& 20.58 \text { meters. } \\
& 45.79 \text { meters. } \\
& 8.83 \text { meters. } \\
& 43 \text { yards. } \\
& 34.27 \text { meters. }
\end{aligned}
$$

\section{STUMP}

General locality.-Northeast shore of Patuxent River about one-half mile northwest of Hellen Creek. (See chart No. 20.) 
Immediate locality.-Observed station is on a bank about 20 feet above high water, Io yards northnortheast of edge of bank at extreme end of point, about 20 yards southeast of edge of bank, and about I 50 yards northwest of a clump of cedar and locust trees at edge of bank. Cement monument marking first reference station is $\mathrm{II} .29$ meters $\mathrm{N}$. $6 \mathrm{I}^{\circ} 5 \mathrm{I}^{\prime} \mathrm{E}$. of observed station with top Io inches below surface of field. Cement monument marking second reference station is 2.62 meters N. $60^{\circ} 42^{\prime} \mathrm{E}$. of observed station about on line with first reference station.

Marks.-Observed station is center of 4 -inch tile pipe set in cement with top flush with ground. First reference station is center point of triangle on standard cement monument with top to inches below the suriace of ground. Second reference station is center point of triangle on standard cement monument with top 6 inches above surface of ground.

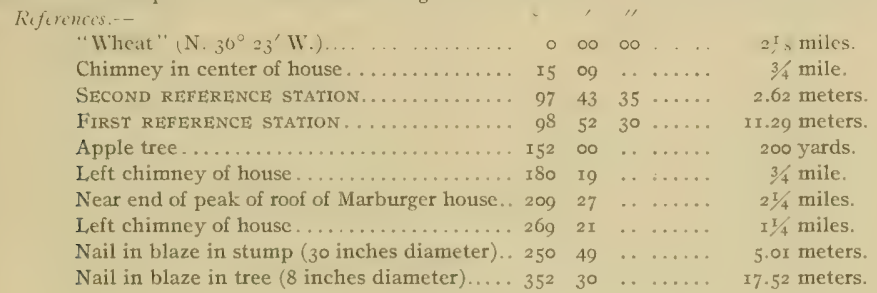

\section{BRISCOE.}

General locality,--Southeast shore of Patuxent River about one-fourth mile northwest of St. Cuthbert Wharf. (See chart No. 20.)

Immediate locality.-Observed station is in a cultivated field, about 20 feet above high water, 80 yards southwest of trees on bank, 50 yards southeast of a creek bed, 46 yards northwest of a clump of trees, ro5 yards east of a corner of fence on road, and about 300 yards northeast of another fence with woods back of it. Cement monument marking reference station is $12.5^{2}$ meters N. $79^{\circ} 35^{\prime} \mathrm{W}$. of observed station.

Marks.-Observed station is a nail in a stub with top flush with ground and a subsurface mark of a standard cement monument with top buried II inches below the surface. Reference station is center of triangle on standard cement monument with top 5 inches above surface of ground.

References.-

\begin{tabular}{|c|c|c|c|c|c|}
\hline Hellen" (S. $7 \mathrm{I}^{\circ} 37^{\prime} \mathrm{E}_{n_{n}}$ ). & 0 & $\infty$ & 00 & & $x^{5}$ \\
\hline Near corner of house.... & 45 & II & . & & \\
\hline peak of roof of barn. . & 57 & I8 & . & . & 3. \\
\hline orked tree.............. & 129 & I7 & . & & 130 \\
\hline nce and $t$ & 136 & 34 & $\cdots$ & . & 10 \\
\hline REI & 172 & OI & 40 & & \\
\hline Lar & 195 & $\infty$ & & & \\
\hline th & & 54 & & & \\
\hline ace & 308 & 59 & $\cdots$ & . & \\
\hline
\end{tabular}

HELLEN.

General locality.-Northeast shore of Patuxent River on east side of mouth of Hellen Creek. (See chart No, 20.)

Immediate locality.-Observed station is at high-water mark on edge of grass and bushes, about I6 yards west-southwest of a bluff ${ }_{5} 5$ feet high, and about 40 yards north-northwest of bluff at edge of water. Cement monument marking reference station is 12.45 meters N. $75^{\circ} \mathrm{I4} 4^{\prime} \mathrm{E}$. of observed station. $2606-\mathrm{rr}-4$ 
Marks.-Observed station was the center of a tile pipe with a subsurface mark of a green yeastpowder bottle, but at date of publication these marks are reported to have been washed away. Reference station is center point of triangle on standard cement monument.

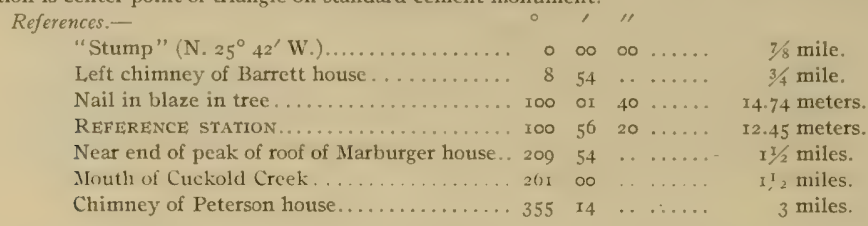

NAT.

General locality.--Southwest shore of Patuxent River about one-half mile above mouth of Cuckold Creek. (See chart No. 20.)

Immediate locality.-Observed station is near edge of a cultivated field on a bluff of sand and gravel about 20 feet above high water, 4 feet east of edge of bluff, and $r 50$ yards north of a rail fence. Cement monument marking reference station is $x 8.44$ meters S. $29^{\circ} 47^{\prime} \mathrm{W}$. of observed station with top 8 inches below surface of ground.

Marks.-Observed station is center of 3 -inch tile pipe embedded in cement. Reference station is center point of triangle on standard cement monument.

References. -

"Hellen" (N. $69^{\circ} 29^{\prime}$ E. $)$ :

Near end of peak of roof of Marburger house on Point Patience................. 68 or $\ldots \ldots \ldots$ I $1 / 2$ miles.

REFERENCE STATION................. I40 I8 $00 \ldots \ldots$ I 8.44 meters.

Large chimney on house.................. 28 I $58 \quad \ldots \ldots$ miles.

Right chimney of house with two gable roofs.......................... 2 miles.

TON.

General locality.-Eastern shore of Patuxent River about I mile northeast of Point Patience. (See chart No. 20.)

Immediate locality.-Observed station is on a bluff about I $_{5}$ feet above high water, Io yards east from edge of bluff, 50 yards south-southwest of edge of a gully and a clump of trees, and about 220 yards west-northwest of a cherry tree $3^{Y}$ feet in diameter. Cement monument marking reference station is $\mathrm{r}_{3} .64$ meters $\mathrm{S} .62^{\circ} 29^{\prime} \mathrm{E}$. of observed station.

Marks.-Observed station is a spike set in cement. Reference station is center point of triangle on standard cement monument buried below surface ro inches.

References.-

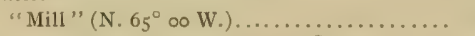

Chimney on far end of Wallace house.......

Chimney on middle of roof on McCorry

store............................. 60 o 09 miles.

Near end of peak of St. Cuthbert Wharf

house........................ 62 miles.

Near end of peak of roof of Parran oyster

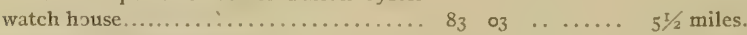

Chimney on Peterson house............. 85 . 39 ...... $3 \frac{33 / 4}{4}$ miles.

Cemented chimney on near end of George old house..................... $94 \quad 59 \ldots \ldots$ I mile.

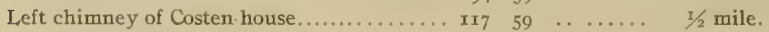

Nail in blaze in tree.................. $137 \quad 35 \quad 20 \ldots \ldots 47.60$ meters.

REFERENCE STATION.................. 232 3I $00 \ldots \ldots .63 .64$ meters.

Left chimney of Marburger house........ 329 II ..... . $3 / 4$ mile. 
MII,

General locality.-Southwest shore of Patuxent River about one-half mile southeast of mouth of Cuckold Creek and one-half mile northwest of Point Patience. (See chart No. 20.)

Immediate locality. - Observed station is on a sand bluff about 20 feet above high water, 7 yards southwest of the edge of the blufi, 40 yards southeast of a fence and a line of cedar trees, and about Ioo yards northwest of another fence at bottom of hill. Cement monument marking reference station is $\mathrm{r}_{3} .76$ meters S. $28^{\circ} \mathrm{r}^{\prime} \mathrm{WV}$. of observed station.

Marks.-Observed station is center point of 3 -inch tile pipe embedded in cement. Reference station is center point of triangle on standard cement monument.

\begin{tabular}{|c|c|c|c|c|c|}
\hline "Ton" (N. $64^{\circ} 59^{\prime}$ E.)... & $\circ$ & $\infty$ & $\infty$ & & $\mathrm{I} / \mathrm{t}$ miles. \\
\hline Nearest chimney of Marburger house on & & & & & \\
\hline 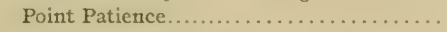 & 39 & or & . & & $3 / 4$ milie. \\
\hline "Catholic Church Cross" ......... & 43 & 03 & 40 & . & 2 miles. \\
\hline "Methodist Episcopal Church Spire"....... & 49 & 23 & 30 & $\ldots \ldots$ & 2 miles. \\
\hline Middle of portico of Judge Crane house..... & 82 & 22 & .. & . & I mile. \\
\hline Windmill near Dent house............... & I36 & 47 & . & & $1 / 2$ mile. \\
\hline 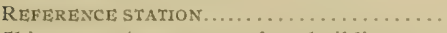 & I 43 & 14 & 40 & & $\times 3.76$ meters \\
\hline Chimney on house among farm buildings... & 293 & 28 & 40 & $\cdots \cdot$ & $4^{1 / 4}$ miles. \\
\hline Left chimney on house with piazza.......... & 304 & 02 & . & $\ldots \ldots$ & $23 / 4$ miles. \\
\hline End of peak of roof of $2 \frac{1}{2} /$-story house........ & 323 & $3^{I}$ & . & ...... & $13 / 4$ miles. \\
\hline Nearest chimney of cottage............. & $33^{8}$ & I7 & . & & 2 miles. \\
\hline Left chimney of house. & 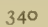 & 19 & & & $2 \mathrm{mil}$ \\
\hline
\end{tabular}

BUR.

General locality.-East shore of Patuxent River, on northwest side of Point Patience, about onefourth mile northeast of its extreme end. (See chart No. 20.)

Immediate locality.-Observed station is on sand and grass land, about I foot above high water, I2 yards southeast of high-water mark on one side of point, 36 yards northwest of high-water mark on other side of point, and about 300 yards northeast of extreme end of point. Cement monument marking reference station is 12.15 meters $\mathrm{N} .85^{\circ} 20^{\prime} \mathrm{E}$. of observed station.

Marks.-Observed station is a 3 -inch tile pipe set in cement with top about $\mathrm{x}$ inch above the surface of the ground. Reference station is center point of triangle on standard cement monument.

References.-

\begin{tabular}{|c|c|c|c|c|c|}
\hline 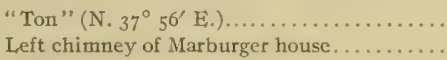 & 16 & $\begin{array}{l}\infty 0 \\
08\end{array}$ & & & $\begin{array}{l}\text { I mile. } \\
x / 4 \text { mile. }\end{array}$ \\
\hline REFERENCE STATION. & 47 & 24 & 30 & & 12.15 \\
\hline "Methodist Episcopal Church Spire" ....... & 75 & 32 & Io & & $13 / 8$ \\
\hline Middle gable of Judge Crane house.......... & 139. & 09 & . & & $1 / 2$ mile. \\
\hline $\begin{array}{l}\text { Nail in blaze in pine tree }(8 \text { inches diam- } \\
\text { eter }) \ldots \ldots \ldots \ldots \ldots \ldots \ldots \ldots \ldots \ldots \ldots \ldots \ldots \ldots \ldots \ldots \ldots \ldots \ldots\end{array}$ & 162 & 4 & 10 & & \\
\hline Square chimney on Dent house........... & 228 & 30 & . & & $3 / 4$ \\
\hline 10urse & 268 & $5^{2}$ & . & & $15 / 8$ \\
\hline 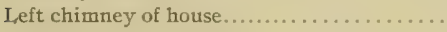 & 346 & 39 & . & & $x^{1} / 2$ \\
\hline Right chimney of house. . & $35^{8}$ & $3 I$ & .. & $\ldots \ldots$ & $x^{3} / 2$ miles. \\
\hline
\end{tabular}

NEW.

General locality.-Northeast sicle of Patuxent River, about three-fourths mile east of Point Patience and about $I \frac{1}{4}$ miles northwest of Sandy Point. (See chart No. 20.)

Immediate locality.-Observed station is about 20 feet above high-water mark in the middle of a cultivated field on Strathmore farm, about 230 yards northeast of shore of Patuxent River, about 82 yards southeast of a creek, about $x_{2} 2$ yards northwest of a small creek or ditch, 230 yards northeast of a large oak tree, and 250 yards north of another large oak tree. 
Marks.-Observed station is center point of triangle on standard cement monument with top is inches below the surface of the ground.

\section{References.-}

"Ben" (S. $2^{\circ}$ Io' E.).

Chimney on flat-roof house

Chimney on main part of a house on Town Creck.

Oak tree about 18 inches diameter on edge of field . . . . . . . . . . . . . . . . . .

Right tangent of Spencers Wharf..........

Corner of field . . . . . . . . . . . . . . . .

Exposed chimney on left of house..........

Left chimney ot house . . . . . . . . . . . . .

Corner of field. . . ................. 20

Corner of field . . . . . . . . . . . . . . . . 25

Silver-tipped tower on Philip Vale house... 30

Oak at edge of field. . . . . . . . . . . . 34

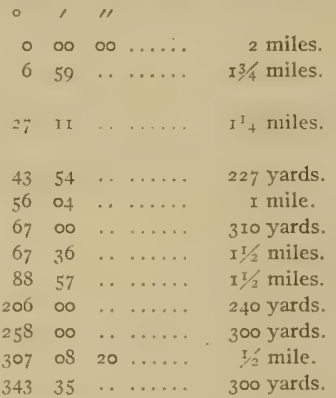

\section{CATHOLIC CHURCH CROSS.}

General locality.-Southeast side of Patuxent River, about halfway to Back Creek and three-fourths mile northwest of Solomons Wharf. (Sec chart. No. 20.)

Immediate locality,-Observed station is on Catholic Church, known as St. Marys Star of the Sea, located in small village of Johnstown, on mainland near Solomons Island, and about 250 yards north of causeway to Solomons Island.

Marks.-Observed station is center of cross on bell cupola.

References.-None necessary.

CABLF

General locality:-Southwest shore of Patuxent River, on east side of entrance to Kings Creek, and about three-fourths mile west of Town Point. (See chart No. 20.)

Immediate locality.-Observed station is on pasture land near the end of high land at the beginning of a long, low peninstila which almost closes the mouth of Kings Creek, about 30 feet above high-water mark, about 20 yards south of edge of bank on river side, about $x 5$ yards east northeast of edge of bank on creek side, 38 yards southeast of extreme edge of top of bank, and 30 yards west of a persimmon tree.

Marks.-Observed station is center point of triangle on standard cement monument buried with top ro inches below the surface of ground.

References.-

"Bur" (N. $35^{\circ}$ I $7^{\prime}$ E.).

Left chimney of Marburger house near Point Patience........................

"Catholic Church Cross" .. . . . . . . . . . .

"Methodist Episcopal Church Spire"......

Left chimney of Judge Crane house........

Nail in blaze of tree ( 18 inches diameter).... 17

Nail in blaze in red cedar tree ( 3 inches diam-

eter) .........................236

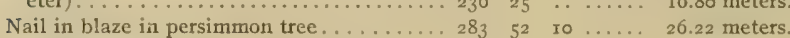

Right chimney on Fenner Lee house...... 284 14 $\ldots . . \ldots .3 / 8$ mile.

I. eft chinmey of house $\ldots \ldots \ldots \ldots \ldots \ldots \ldots, 302 \quad 24 \ldots \ldots \ldots$ mile.

TOWN.

General locality.- Southwestern shore of Patuxent River, on Town Point, about three-fourths mile southeast of Point Patience. (See chart No. 20.)

Immediate locality. - Observed station is about 20 feet above high-water mark, 9 yards west of edge of bluff, 3 yards south of edge of bluff, ro yards southeast of extreme edge of high land, 3 yards south of a rail fence, and 2 yards north of cultivated land. 
Marks.-Observed station is center point of triangle on standard cenent monument. Rejercnees.-

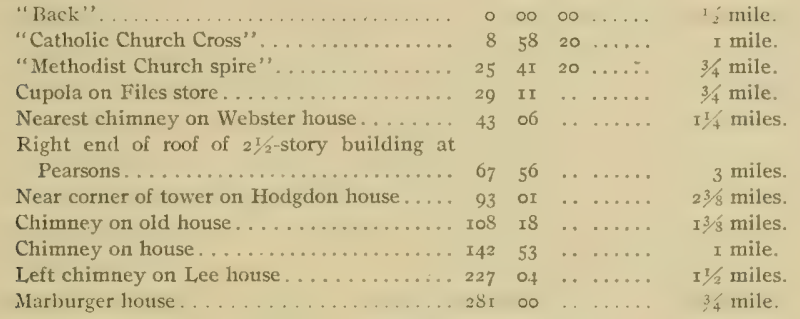

\section{CRANE}

General locality.-Southwest side of Patuxent. River, on northeast side of Town Creck, about onefourth mile southwest of Town Point. (See chart No. 20.)

Immediate locality.-Observed station is in a cultivated field on Judge Crane farm, about 8 feet above high-water mark, $5^{8}$ yards east-northeast of Town Creek, I05 yards west of a fence, II 5 yards westnorthwest of a large cherry tree, 200 yards southeast of several detached buildings, and 20 yards east of top of ravine.

Marks.-Observed station is center point of triangle on standard cement monument with top io inches below ground.

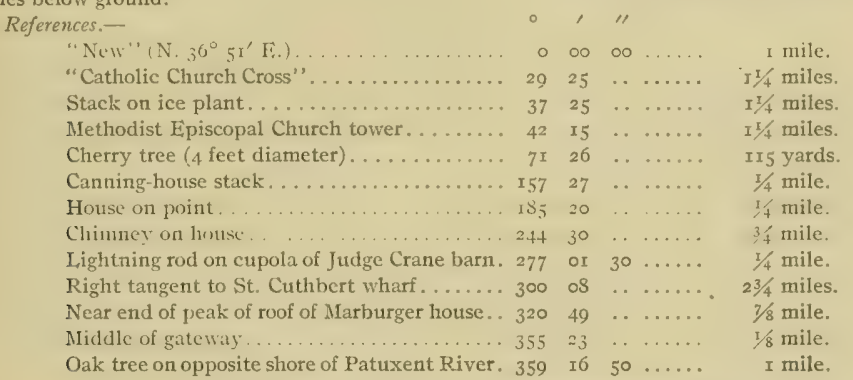

\section{METHODIST EPISCOPAL CHURCH (SOLOMONS).}

General locality.-Northeastern shore of Patuxent River, on upper end of Solomons Island, about one-half mile northwest of Sandy Point. (See chart No. 20.)

Immediate locality.-Observed station is on Methodist Church at upper end of Solonions Island near beginning of causeway to mainland.

Marks.-Observed station is tip of pyramidal tower on Methodist Church.

References.-None necessary.

\section{KNIGHTS OF PYTHIAS FLAGSTAFF (SOLOMONS).}

General locality.-Northeastern side of Patuxent River, on Solomons Island, in the town of Solomons. (See chart No. 20.)

Immediate locality.-Observed station is on flagstaff in front of Knights of Pythias Building.

Marks,-Observed station is center of flagstaff at about the same height as roof of the Knights of Pythias hall.

References.-None necessary. 
SAND.

General locality.-Northeastern side of Patuxent River on Sandy Point on extreme southern point of Solomons Island. (See chart No. 20.)

Immediate locality.-Observed station is on pasture land about 5 feet above high water, 30 yards north of extreme point of planking protecting the shore from washing, I5 yards northeast of the extreme edge of sand and grass line, and about 13 yards east of top of bank. Cement monument marking reference station is 13.64 meters $\mathrm{N} .2^{\circ} \mathrm{Ig}^{\prime} \mathrm{E}$. of observed station.

Marks.-Observed station is nail in southwest side of a 6-inch pile driven into ground with top 6 inches above the surface. Reference station is center point of triangle on standard cement monument.

References.-

"Drum Point Light" (N. $83^{\circ} 57^{\prime}$ E.)........

Right tangent of woods on Hog Point.......

Left end of peak of roof on $2 \frac{1}{2}$-story building at Pearsons.........................

Chimney on storehouse at Millstone.........

Near point of gable of Hodgdon large house with square tower ......................

Near end of peak of roof of Marburger house. . 2

Warren house opposite Johnson store....... 26

REFERENCE STATION.................. 278

"Knights of Pythias flagstaff" "............ 29I

Right chimney of Dr. Marsh house......... 320

"Bareda House Cupola" . ................ 347

\begin{tabular}{|c|c|c|c|}
\hline$\infty$ & $\infty$ & $\ldots \ldots$ & 2 miles. \\
\hline 36 & .. & $\ldots \ldots$ & 3 miles. \\
\hline 03 & .. & $\ldots \ldots \ldots$ & 2 miles. \\
\hline 18 & .. & $\ldots \ldots$ & $\mathrm{I}^{3} / 4$ miles. \\
\hline 54 & . & $\ldots \ldots$ & $\mathrm{r}^{1} / 2$ miles. \\
\hline 22 & . & $\ldots \ldots$ & I $3 / 4$ miles. \\
\hline 22 & $\ldots$ & $\ldots \ldots$ & $1 / 4$ mile. \\
\hline 22 & Io & $\ldots \ldots$ & 13.64 meters \\
\hline $5^{8}$ & . & $\ldots \ldots$ & $1 / 4$ mile. \\
\hline 38 & .. & $\ldots \ldots$ & $1 / 8$ mile. \\
\hline 48 & 30 & $\ldots \ldots$ & $\mathrm{I} / 2$ mile \\
\hline
\end{tabular}

\section{FISHSTACK.}

General locality,-Northeastern side of Patuxent River on northeastern side of entrance to Mill and Back creeks. (See chart No. 20.)

Immediate locality.-Observed station is on mainland on fish fertilizer factory located on opposite side of creek from Solomons Island.

Marks.-Observed station is center of smokestack on fish factory.

References.-None necessary.

\section{BON.}

General locality.-North shore of Patuxent River about II/4 miles west-northwest of Drum Point Light and about I/2 mile east-northeast of Solomons Island. (See chart No. 20.)

Immediate locality.-Observed station is on cultivated land, about 5 feet above high water, about 7 yards north of shore, about 90 yards southeast of a $I^{T} / 2$-story house on land ro feet higher than station, and about 75 yards south of $\mathrm{I}_{\mathrm{I}^{1}}{ }_{2}$-story brick house. Cement monument marking reference station is 0.67 meter N. $45^{\circ} 29^{\prime}$ E. of observed station.

Marks.-Observed station is an inverted nail in center of cement in a 6-inch tile pipe with top flush with surface of ground. Reference station is center point of triangle on standard cement monument.

\section{References.-}

"Drum Point Light" (S. $73^{\circ} 43^{\prime}$ E. . ........

Smoke pipe on oyster watch house...........

L,eft end of peak of roof on $2 \frac{1}{2}$-story building at Pearsons.

\begin{tabular}{|c|c|c|c|}
\hline oo & - & $\ldots \ldots$ & $x 1 / 4$ miles. \\
\hline 32 & . & $\ldots \ldots$ & $I / 2$ mile. \\
\hline 06 & .. & $\ldots \ldots$ & $21 / 4$ miles. \\
\hline 29 & .. & ...... & $2 \frac{1}{2}$ miles. \\
\hline 14 & . & ...... & $21 / 4$ miles. \\
\hline 57 & .. & $\ldots \ldots$ & \\
\hline 37 & . & ...... & I/4 mile. \\
\hline
\end{tabular}

Left end of peak of roof on house with piazza:

Near point of roof of Hodgdon house with square tower.................... 89 I4 $\ldots \ldots . \quad 21 / 4$ miles.

Chimney on end of house.............. $133 \quad 57 \ldots \ldots . \quad 3 / 4$ mile.

Left chimney on Weems house............ $159 \quad 37 \quad \ldots \ldots \ldots . \quad 1 / 4$ mile. 
References-Continued.

Right chimney on wooden house $\ldots \ldots \ldots \ldots 224$ or $\ldots \ldots \ldots$

90 yards.

Left side of chimney on brick house...... $249 \quad 54 \quad \ldots \ldots \ldots$

REFERENCE STATION..................... 299 I2 $00 \ldots \ldots$

75 yards.

Near end of peak of house on bluff between

trees................................... 336 50 $\quad 1 / 2$ mile.

"Bareda House cupola"................ 347 o6 ...... $3 / 4$ mile.

\section{BAREDA HOUSE CUPOLA.}

General locality.-North side of Patuxent River about one-half mile northwest of Drum Point Light. (See chart No. 20.)

Immediate locality.-Observed station is on Bareda House which is a large 3 -story square mansion with square cupola with three windows on each side and a porch all around ground floor, located about Ioo yards back from shore on high land.

Marks.-Observed station is center of ornamental design of four brackets on center of cupola.

References.-None necessary.

\section{DRUM POINT LIGHT.}

General locality.-Northeastem side of entrance of Patuxent River and a short distance off shore from Drum Point. (See chart No. 20.)

Immediate locality.--Observed station is on a screw pile structure known as Drum Point Lighthouse. Marks.-Observed station is center of black lantern on Drum Point Lighthouse.

Reference.-

"Cedar Point Light" (S. $64^{\circ} 33^{\prime}$ E.)....... 0 . 00 o $\ldots . .3 \%$ miles.

BEN.

General locality.-Southwestem shore of Patuxent River about I mile south-southwest of Sandy Point and $I / /+$ miles south-southeast of Town Point. (See chart No. 20.)

Immediate locality.--Observed station is on a clay and sand bluff in a cultivated field, about 20 feet above high-water mark, about Io feet west of edge of bank, 3 feet south of point covered with scrub pines, about 15 yards northeast of one edge of plateau, to yards southeast of another edge of plateau, about 65 yards north of point of woods, and ro yards south of cut in bank which is washing rapidly. Cement monument marking reference station is 8.42 meters S. $56^{\circ} r 5^{\prime} \mathrm{W}$. of station.

Marks.--Observed station is nail in cement in 6-inch tile pipe with top tlush with ground. Reference station is center point of triangle on standard cement monument.

References.-

"Drum Point Light" (N. $68^{\circ}$ o $7^{\prime}$ E. .)........

Left tangent of trees on Hog Point...........

Near end of peak of roof of large $2 \frac{1}{2}$-story building at Pearsons....................

Near piazza post of Millstone Hotel. .........

Chimney of Craddock house ............ 6

Chimney on end of cabin. .............. 97

Tall pine tree..................... $I_{3} 8$

REFERENCE STATION.................. I68

Nail in blaze in pine tree ( 4 inches diameter), 176

Nail in blaze in pine tree ( 4 inches diameter). 223

Nail in blaze in pine tree ( 4 inches diameter). 236

Near end of peak of roof of Marburger house. . 272

"Catholic Church Cross" ................. 304 304

"Bareda House Cupola" . .................. 350

$\begin{array}{rrrrrr}0 & \prime & \prime \prime & & \\ 0 & 00 & 00 & \ldots & 23 / 4 \text { miles. } \\ 16 & 21 & \ldots & \ldots & 3 \frac{3}{4} \text { miles. } \\ 39 & 36 & \ldots & \ldots & 21 / 4 \text { miles. } \\ 56 & 11 & \ldots & \ldots & 13 / 4 \text { miles. } \\ 60 & 28 & \ldots & \ldots & 11 / 4 \text { miles. } \\ 97 & 24 & \ldots & \ldots & 200 \text { yards. } \\ 38 & 35 & \ldots & \ldots & 50 \text { yards. } \\ 68 & 08 & 00 & \ldots & 8.42 \text { meters. } \\ 76 & 33 & 50 & \ldots & 7.79 \text { meters. } \\ 23 & 40 & 40 & \ldots & 8.77 \text { meters. } \\ 36 & 39 & \ldots & \ldots & 2.07 \text { meters. } \\ 72 & 12 & \ldots & \ldots & 2 \text { miles. } \\ 04 & 54 & 40 & \ldots & 11 / 2 \text { miles. } \\ 50 & 34 & 40 & \ldots & 21 / 2 \text { miles. }\end{array}$




\section{CRADDOCK.}

General locality.-Southern shore of Patuxent River, about 23/8 miles south-southeast of Drum Point Light and $1 / 4$ mile west of Millstone Landing. (See chart No. 20.)

Immediate locality.-Observed station is on lawn about I5 feet above high-water mark, about to yards south from top edge of bank, I5 yards from bottom edge of bank and fence, 30 yards east of extreme edge of point, 30 yards northeast of trees along shore of pond, about nio yards northwest of Craddock house and several outbuildings among poplar trees, 50 yards east of fence, and 70 yards west of driveway to house.

Marks.-Observed station is center point of triangle on standard cement monument, with top flush with lawn.

References.-

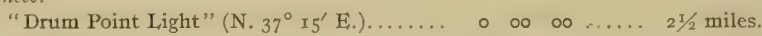

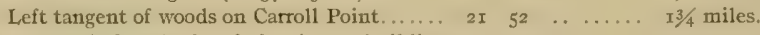

Near end of peak of toof of $2 \frac{1}{2}$-story building

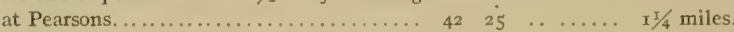

Chimney on hotel at Millstone............ $646_{4} \quad 5^{6} \ldots \ldots \ldots . \quad 1 / 2$ mile.

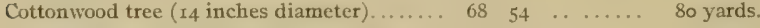

Chimney on roof of Craddock $21 / 2$-story house. $95 \quad 27 \quad \ldots \ldots \ldots$ I Io yards.

Nail in stump ( $\mathrm{I}_{4}$ inches diameter) ......... $309 \quad 25 \quad 50 \ldots \ldots .5 .35$ meters.

"Fishstack"

\section{CARROLL 2 .}

General locality.-South side of Patuxent River, about I mile south-southwest of Hog Point and about I mile south of Drum Point Light. (See chart No. 20.)

Immediate locality. - Observed station is on a sandy clay bluff in a cultivated field, about 50 feet above high-water mark, 4 feet south of top edge of bluff, 180 yards east of trees and ravine beyond cultivated field, 60 yards west of trees and ravine beyond cultivated field, 300 yards north of large square chimney on old-fashioned farmhouse, and 250 yards north of large tree to right of farmhouse. Cement monument marking reference station is 13.32 meters S. $54^{\circ} 30^{\prime} \mathrm{W}$. of observed station. Another reference station is a nail in the east side of cement in a 6 -inch tile pipe 14.64 meters S. $13^{\circ} 20^{\prime} \mathrm{E}$. of observed station and on range with Drum Point Light.

Marks.-Observed station is center of 5 -inch tile pipe with top 8 inches below surface of ground. Reference station is nail in cement on east side of a 6 -inch tile pipe with top 6 inches below surface of ground. Another reference station is center point of triangle on standard cement monument with top 9 inches below surface of ground.

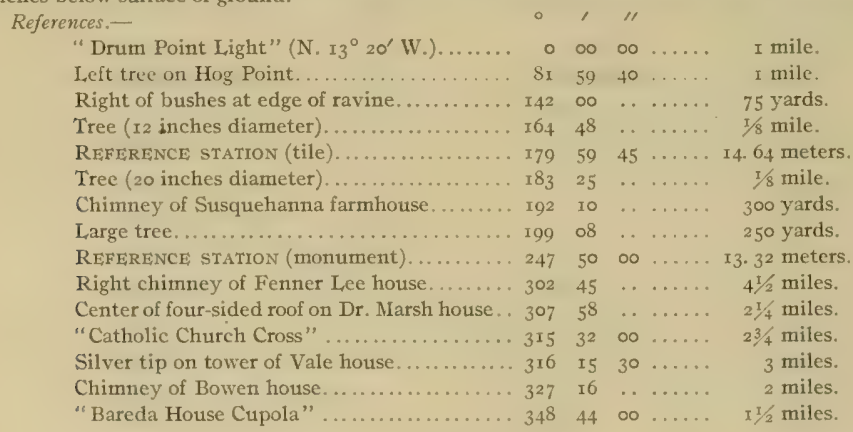

HOG 2.

General locality.-Southern shore of entrance to Patuxent River on Hog Point, about $\mathrm{r}^{7} / 8$ miles west-northwest of Cedar Point Light. (See chart No. 20.) 
Immediate locality.-Observed station is on a sand beach at high-water mark, 30 yards northwest of point of woods, and 200 yards north-northeast of nearest shore of Parsons Creek. Cement monument marking reference station is 33.35 meters $\mathrm{S} .42^{\circ} 22^{\prime} \mathrm{E}$. of observed station on a point of high land.

Marks.-Observed station is nail set in cement in a 6-inch tile pipe, with top I foot below the surface. Reference station is center point of triangle on standard cement monument.

References.-

\begin{tabular}{|c|c|c|c|c|c|}
\hline 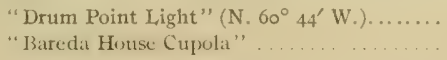 & $\begin{array}{l}0 \\
2\end{array}$ & 44 & 50 & & $\begin{array}{l}I / 4 \text { miles. } \\
I t_{2} \text { miles. }\end{array}$ \\
\hline Chimney of cabin on opposite shore. & 22 & 20 & & & $I / 2$ miles. \\
\hline$t$ of Little Cove Point. & $7 I$ & 56 & . & & ailes. \\
\hline "Cedar Point Light" ....... & 173 & 31 & 40 & & \\
\hline ENCE STATION. & I98 & $2 I$ & 50 & & eters. \\
\hline Nail in blaze in pine tree............... & 201 & 03 & & & 29. $5^{8}$ \\
\hline on opposite side of Parsons Creek..... & 243 & 05 & & & \\
\hline hanna farmhouse. & 301 & 04 & $\cdot$ & & aile. \\
\hline "Methodist Episc & 346 & 16 & 40 & & \\
\hline Steeple of Vale ho & 350 & 55 & & $\ldots \ldots$ & $3 / 2$ miles. \\
\hline
\end{tabular}

\section{PAT.}

General locality:-Western shore of Chesapeake Bay on Little Cove Point, about $13 / 4$ miles south by west of Cove Point Light. (See chart No. 20.)

Immediate locality.-Observed station is on the highest point of a thickly wooded bluff, about 75 feet above high-water mark, 4 yards west of edge of bluff, and I 5 yards southwest of extreme point. Cement monument marking reference station is 24.57 meters S. $71^{\circ} 26^{\prime}$ W. of observed station.

Marks.-Observed station is a 3 -inch round stake set in cement, with top about 4 inches above surface of ground. Reference station is center point of triangle on standard cement monument.

References.-

\begin{tabular}{|c|c|c|c|c|c|}
\hline $0^{\circ}$ & 0 & $\infty$ & & & \\
\hline Near piazza post of house. . . & I4 & $5^{2}$ & & & es. \\
\hline REFERENCE STATION. & 85 & 0 & $\infty$ & & 24. 57 meters. \\
\hline pike in blaze in tree ( 5 inches diameter)... & 94 & $5^{I}$ & . & & 6. 5 \\
\hline Spike in blaze in tree ( 5 inches diameter). . . & II4 & Io & & & $3 \cdot 4$ \\
\hline Spike in blaze in tree ( 17 inches diameter). & $\mathrm{I}_{3} 8$ & 54 & & & 12. 26 \\
\hline ee ( ${ }_{3}$ inches diameter) & 181 & 46 & .. & & \\
\hline ve Poin & 203 & 25 & 30 & & \\
\hline Hoopers Island Light & 327 & 58 & ro & & $10^{x} / 4$ miles \\
\hline
\end{tabular}

\section{WHITE HOUSE (NORTHEAST CHIMNEY).}

General locality.-Western shore of Chesapeake Bay about I mile southwest of Cove Point Light and $1 / 4$ mile southwest of Cove Point Landing. (See chart No. 20.)

Immediale locality.-Observed station is a chimney standing alone about 300 yards southwest of Cove Point Landing which was formerly the more northeasterly of two chimneys on a house that was destroyed by fire. This chimney is near a white house which was built to replace the destroyed house.

Marks.-A chimney standing apart from a small white house owned by Mrs. Hagland.

References.-

$$
\text { "Cove Point Light" (N. } 39^{\circ} 54^{\prime} \text { E.)...... } 0 \text {. } 00 \text { o .... x mile. }
$$

\section{COVE POINT LIGHT.}

General locality.-Western shore of Chesapeake Bay on Cove Point, which is about 5 miles to northward of entrance to Patuxent River. (See chart No. 20.)

Immediate localily.-Observed station is on white tower known as Cove Point Light, which is near white detached dwelling and white detached fog-signal house.

Marks.-Observed station is center point of black lantern on white tower.

References.-

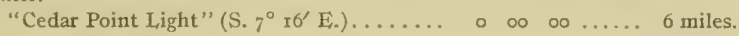




\section{CEDAR POINT LIGHT.}

General locality.-Western shore of Chesapeake Bay on Cedar Point, $3^{x} / 4$ miles east-southeast of Drum Point Light and 6 miles south by east of Cove Point Light. (See chart No. 20.)

Immediate locality.-Observed station is on a brick dwelling known as Cedar Point Lighthouse.

Marks.-Observed station is center point of lantern on Cedar Point Lighthouse.

Reference.-

"Cove Point Light" (N. $7^{\circ} 6^{\prime}$ W. $) \ldots \ldots \ldots$.... $\circ$ o

\section{CAIN.}

General locality. - Western shore of Cheapeake Bay, about $x 5 / 8$ miles southwest of Cedar Point Light. (See charts Nos. 20 and 21.)

Immediate locality.-Observed station is on a bank about 5 feet above high-water mark, about 20 yards northwest of ordinary high water, 5 yards northwest of extreme high water, Ioo. yards southsouthwest of old-fashioned house among several large trees, and about 250 yards below small wharf and canning house. Cement monument marking reference station is 6.45 meters N. $16^{\circ}{ }_{5} 6^{\prime} \mathrm{E}$. of observed station.

Marks.-Observed station is a nail set in cement in a 3 -inch pipe with top about 2 inches above ground. Reference station is center point of triangle on standard cement monument.

References.-

"Cedar Point Light" (N. $46^{\circ} 45^{\prime}$ E. $) \ldots \ldots$.... o o $00 \ldots \ldots$ I $5 / 8$ miles.

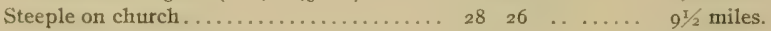

"Hooper Island Light" ............... $56 \quad 28 \quad 40 \ldots \ldots .77^{3 / 4}$ miles.

"Point No Point Light"............... ro6 $05 \ldots$. . . . . $1 x 3 / 4$ miles.

Right chimney on Tarleton house....... 135 I2 $\ldots . \ldots . \quad 3^{1 / 4}$ miles.

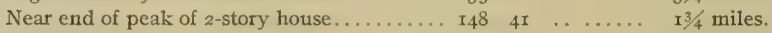

REFERENCE STATION...................... 330 ro $40 \ldots .45$ meters.

Near corner of house................. $335 \quad 13 \quad \ldots \ldots$ I00 yards.

Aspen tree in house yard............... $339 \quad 35 \quad 50 \ldots \ldots$ I00 yards.

\section{DESERT.}

General locality.-Western shore of Chesapeake Bay, about 3 miles south-southwest of Cedar Point Light. (See charts Nos. 20 and 2I.)

Immediate locality,- - Observed station is on sand and grass land, about 25 yards west from ordinary high-water mark, about at level of extreme high-water mark, 40 yards south of a fence, Io yards east of a fence, 45 yards south of a creek, about 50 yards north of point of pine woods, and about 300 yards east of woods across marsh. Cement monument marking reference station is 5.29 meters N. $3 I^{\circ} 24^{\prime}$ W. of observed station.

Marks.-Observed station is a 4 -inch tile pipe projecting about 2 inches above surface of sand Reference station is center point of triangle on standard cement monument.

References. -

"Cedar Point Light" (N. $34^{\circ} 05^{\prime}$ E.).......

Steeple on church.................... 34

"Hooper Island Light" ............... 59

"Point No Point Light". ................ II 3

Near end of peak of roof of Tarleton house... 135

Point of woods..................... 146

Nail in blaze in pine tree ( 14 inches diameter) 294

REFERENCE STATION................. 29430

Chimney on near end of house........... 336

Large square chimney on larger of two houses........................ 34

$\begin{array}{rrrr}00 & 00 & \ldots & 3 \text { miles. } \\ 19 & 40 & \ldots & 102 / 2 \text { miles. } \\ 08 & 40 & \ldots & 8 \text { miles. } \\ 27 & 30 & \ldots & \text { Ir miles. } \\ 09 & \ldots & \ldots & 2 \text { miles. } \\ 00 & \ldots & \ldots & 50 \text { yards. } \\ 30 & 40 & \ldots & 7.62 \text { meters. } \\ 30 & 40 & \ldots & 5.29 \text { meters. } \\ 38 & \ldots & \ldots & 1 / 2 \text { mile. } \\ 48 & \ldots & \ldots & \end{array}$




\section{HOOPER ISLAND LIGHT.}

General locality.-Eastern side of Chesapeake Bay off shore about $3^{1 / 2}$ miles west of Hooper Island and 4 miles south of Barren Island. (See chart No. 21.)

Immediate locality. - Observed station is on Hooper Island Lighthouse.

Marks.-Observed station is center point of lantern on conical tower on cylindrical foundation known as Hooper Island Lighthouse.

References.-

"Cedar Point Light" (N. $65^{\circ}$ of' W. . ..... 0 . 00 oo .... 7 miles.

FORD.

General locality. - Western shore of Chesapeake Bay about $\mathrm{x} 3 / 4$ miles south of entrance to Pine Hill Run and $73 / 4$ miles west of Hooper Island Light. (See chart No. 21.)

Immediate locality. - Observed station is in a garden about 25 feet above high water, 32 yards west of edge of bank, 40 yards northeast of near corner of a house, 4 yards north of a wire fence, 33 yards north of a paling fence, and 38 yards south of another paling fence.

Marks.-Observed station is center point of triangle on standard cement monument.

References. -

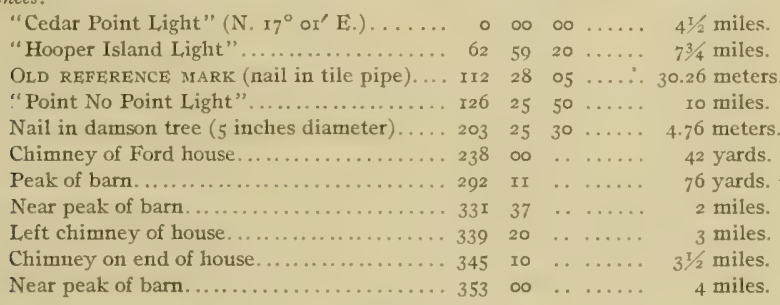

REED.

General locality.-Western shore of Chesapeake Bay about $61 / 2$ miles south of Cedar Point Light; $63 / 4$ miles northwest of Point No Point Light, and $75 / 8$ miles west-southwest of Hooper Island Light. (See chart No. 21.)

Immediate locality.-Observed station is about ro feet above high water, 7 yards west of edge of bluff, 65 yards north-northeast of a house, 35 yards south of a fence, 45 yards north of another fence, 45 yards northwest of a large cedar tree on edge of bluff, and 35 yards north of a line of fruit trees. Cement

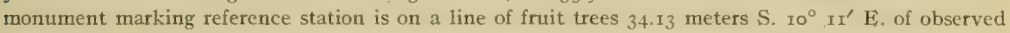
station.

Marks.-Observed station is a cement block with gray iron core and nail in top. Block was formerly square, but has been broken off by plow. Reference station is center point of triangle on standard cement monument.

References.-

"Cedar Point Light" (N. $2^{\circ} 25^{\prime}$ E.).....

"Hooper Island Light"............... 59 is $10 . \ldots . \quad 75 / 8$ miles.

"Point No Point Light"................. 136 59 59 10 ..... $63 / 4$ miles.

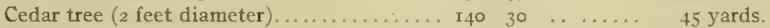

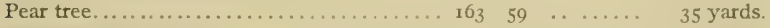

REFERENCE, STATION................. $167 \quad 23 \quad 40 \ldots \ldots .34 .13$ meters.

Cherry tree........................ 202 II ..... 50 yards.

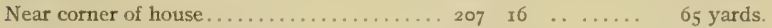

Near peak of roof of house.............. $289 \quad 35 \quad \ldots \ldots \ldots 200$ yards.

Right chimney of Tarleton house......... 33 I 54 . . . . . . $23 / 8$ miles.

Near chimney of $1 \frac{1}{2}$-story house $\ldots \ldots \ldots \ldots .336 \quad 36 \ldots \ldots .4$ miles.

Near peak of Fenwick house................. 347 og ..... $5 \frac{1}{2}$ miles. 
POINT AGIN.

General locality.-Western shore of Chesapeake Bay about $45 / 8$ miles northwest of Point No Point Light, $83 / 4$ miles south of Cedar Point Light, and $73 / 4$ miles southwest of Hooper Island Light. (See chart No. 2I.)

Immediate locality.-Observed station is near edge of dense pine woods about 5 feet above high water, 6 yards southwest of edge of bank, ro yards south of point of curve of bank, 400 yards south of road across marsh, and 425 yards south of mouth of a sand-blocked creek. Cement monument marking reference station is 18.67 meters S. $49^{\circ} 25^{\prime} \mathrm{W}$. of observed station.

Marks.-Observed station is nail in stub with top flush with surface of ground. Reference station is center point of triangle on standard cement monument.

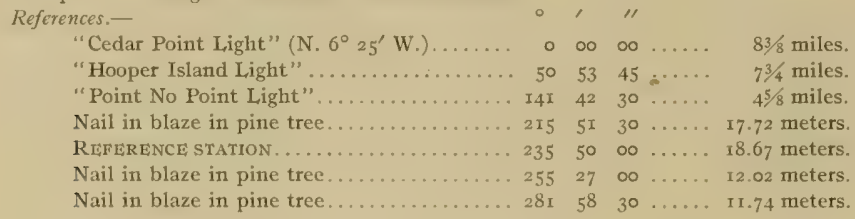

\section{POINT NO POINT.}

General locality.-Westem shore of Chesapeake Bay about one-eighth mile northwest of Point No Point, 2 miles northwest of Point No Point Light, and 2 miles north-northeast of entrance to St. Jerome Creek. (See chart No. 22.)

Immediate locality.-Observed station is partly hidden by pine and cedar trees about to feet above high water, 50 yards west of shore, 65 yards southwest of point where fence and shore meet, 35 yards south of a fence, 30 yards south of edge of a graveyard, and 250 yards south by east of a house. Standard cement monument marking new reference station is 5.17 meters S. $77^{\circ} 43^{\prime} \mathrm{W}$. of observed station. Stone monument marking old reference station is 2.44 meters north of observed station. Stone monument marking old reference station is I.go meters east of observed station. Stone monument marking old reference station is $x .29$ meters south of observed station.

Marks,-Observed station is a stone cone with top 6 inches below surface of ground. Reference station is center point of triangle on standard cement monument. Three other reference stations are square stone pillars with crosses cut in their tops which are just above surface of ground.

References.-

"Point No Point Light" (S. $6 \mathrm{I}^{\circ} 29^{\prime}$ E.)... ○ 00 o0 ......

Nail in blaze in tree.................. $7 \quad 48$ 30....

Nail in blaze in tree (24 inches diameter)... Ir8 03 o0 .....

Chimney of house................ in $_{4}$ i7 $\ldots \ldots$

Near peak of roof on house showing through

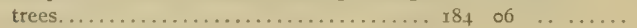

Tangent to fence and graveyard .......... 225 oo ......

Two nails in blaze in cedar trees ( 22 inches

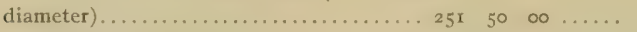

Junction of fence and water................... 279 o

NEW REFERENCE STATION (cement monument) ....................... I 39 if $30 \ldots \ldots$

OrD

OLD REFGRENCE STATION (stone monument) East $\ldots \ldots$ I.90 meters.

OLD REFERENCE STATION (stone monument) South ..... r.29 meters.

\section{POINT NO POINT LIGHT.}

General locality.-Western side of Chesapeake Bay off shore about $x 7 / 8$ miles southeast of Point No Point and $63 / 8$ miles north-northeast of Point Lookout. (See chart No. 22.)

Immediate locality.-Observed station is on Point No Point Lighthouse.
2 miles.

I06 feet.

250 yards.

$1 / 2$ mile.

30 yards.

1.40 meters.

65 yards.

5.17 meters.
2.44 meters.
1.90 meters.
1.29 meters.
0.00 meters. 
Marks-Observed station is center point of lantern on brick dwelling on a cylindrical foundation known as Point No Point Lighthouse.

References.-

"Cedar Point Light" (N. I9 ${ }^{\circ} 35^{\prime}$ W. $) . . . . \quad 0 \quad 00 \quad 00 \ldots \ldots$ I2 miles.

\section{ST. JEROME.}

General locality.-Western shore of Chesapeake Bay on St. Jerome Point at north side of entrance to St. Jerome Creek about $25 / 3$ miles west-southwest of Point No Point Light. (See chart No. 22.)

Immediate localit):- Observed station is about 3 feet above high water, 6 yards northwest by west of shore, 75 yards south of a large pond, and 120 yards north of a house. Cement monument marking reference station is 19.57 meters N. $44^{\circ} 49^{\prime} \mathrm{W}$. of observed station.

Marks.-Observed station is nail in stub with top flush with surface of ground. Reference station is center point of triangle on standard cement monument.

References.-

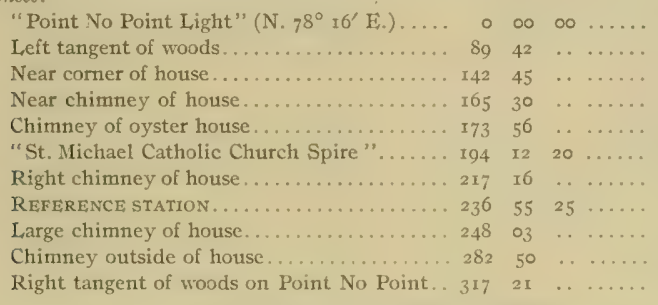
$25 / 8$ miles.
$I^{1} / 8$ miles.
II9 yards.
$1 / 2$ mile.
$1 / 2$ mile.
I $5 / 8$ miles.
$x / 2$ miles.
19. 57 meters.
I 50 yards.
$1 / 2$ milc.
I $1 / 2$ miles.

\section{ST. MICHAEL, CATHOLIC CHURCH SPIRE,}

General locality,-Western shore of Chesapeake Bay about one-half mile west of western and inner shore of St. Jerome Creek. (See chart No. 22.)

Immediate locality.-Observed station is on Catholic Church located on the east side of the main road running to Point Lookout near the village called Ridge or Friendship.

Marks,-Observed station is center point of spire on church.

References.-None necessary.

\section{POINT LOOK-IN.}

General locality.-Western shore of Chesapeake Bay on Point Look-in about $I 3 / 8$ miles south-southeast of entrance to St. Jerome Creek and 3 miles southwest of Point No Point Light. (See chart No. 22.)

Immediate locality,-Observed station is on sand dune about 3 feet above high water, 8 yards west of shore, 4 yards east of slough, 56 yards southeast of point of woods, and 90 yards north of another point of woods. Cement monument marking reference station is in woods across slough 44.04 meters N. $5 I^{\circ}$ $59^{\prime}$ W. of observed station.

Marks.-Observed station is nail in stub with top flush with surface of ground. Reference station is center point of triangle on standard cement monument.

References. -

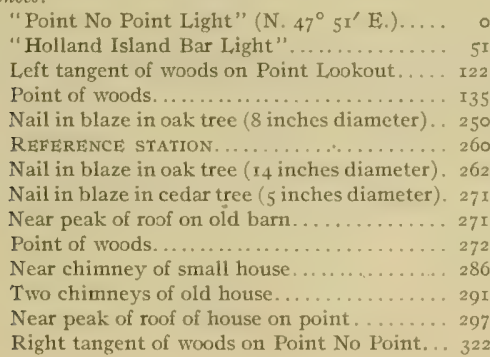

\begin{tabular}{|c|c|c|}
\hline & $\infty$ & 3 \\
\hline & ro ..... & $I_{3}$ miles. \\
\hline & $\ldots \ldots \ldots$ & $3 \frac{5}{8}$ miles. \\
\hline & . $\ldots \ldots$ & 90 yards. \\
\hline & $30 \ldots \ldots$ & 36.68 meters. \\
\hline & $45 \ldots \ldots$ & 44.04 mete \\
\hline & $30 \ldots \ldots$ & 4I.08 meters. \\
\hline & $\infty \ldots .$. & 46.78 meters. \\
\hline & . $\ldots$ & $3 / 8$ mile. \\
\hline & . & 56 yards. \\
\hline & $\ldots \ldots \ldots$ & $7 / 8 \mathrm{mi}$ \\
\hline & $\ldots \ldots \ldots$ & $21 / 8$ miles. \\
\hline & $\ldots \ldots \ldots$ & $1 / 2$ \\
\hline & . . . . . & $23 / 4$ miles. \\
\hline
\end{tabular}




\section{POTOMAC.}

General localily.-Western shore of Chesapeake Bay about three-fourths mile north of extreme end of Point Lookout and one-half mile north-northeast of Point Lookout Light. (See charts Nos. 22 and 23.)

Immediate locality. - Observed station is at upper end of pine woods about a feet above high water, I2 yards west by south of shore, 15 yards east-southeast of woods and edge of marsh, and 100 yards north of large pine trees. Cement monument marking reference station is 10.72 meters S. $23^{\circ} 34^{\prime}$ W. of observed station.

Marks.-Observed station is nail in stub with top flush with surface of ground. Reference station is center point of triangle on standard cement monument.

References.-

\begin{tabular}{|c|c|c|c|c|c|}
\hline "Point No Point Light" (N. $15^{\circ} 30^{\prime}$ E.).... & 0 & $\infty$ & & & $57 / 8$ \\
\hline "Holland Island Bar Light". & 67 & II & 0 & & $121 / 8$ \\
\hline "Sraith Point Light". & I3I & $4 \mathrm{I}$ & 30 & & $13 \frac{1}{2}$ \\
\hline Nail in blaze in pine tree ( 3 inches diameter). & 160 & 10 & 40 & & 6 \\
\hline REF & 188 & 04 & Io & & -1 \\
\hline Chin & 230 & $5^{8}$ & . & & \\
\hline ail & 260 & 21 & I0 & & 0 \\
\hline Firs & 268 & 48 & .. & & \\
\hline Jail & 323 & 22 & $\infty$ & & \\
\hline irs & 334 & 26 & . & & $3^{\mathrm{T}}$ \\
\hline irst & 343 & 30 & . & $\ldots$. & $61 / 4$ \\
\hline 'Hooper Island Light" & 359 & 0.4 & 30 & & $144^{1}$ \\
\hline
\end{tabular}

\section{POINT LOOKOUT LIGHT}

General locality.-Western side of Chesapeake Bay on Point Lookout at northern side of entrance to Potomac River. (See charts Nos. 22 and 23.)

Immediate locality.-Observed station is on Point Lookout Lighthouse, which is a dwelling on shore near a fog-bell tower.

Marks.-Observed station is center point of a lantern on a dwelling known as Point Lookout Lighthouse.

References.-
"Smith Point Light"
(S. $34^{\circ} 37^{\prime}$ E. . .......
- $\infty 00 . . .$. .
I3 miles.

HAI,L.

General locality,-Northeastern shore of Potomac River about five-eighths mile northwest of Cornfield Point and $23 / 4$ miles northwest of Point Lookout. (See chart No. 22.)

Immediate locality.-Observed station is about ${ }_{5}$ feet above high water, 7 yards east of edge of bank, 6 yards south-southeast of a paling fence, and 150 yards south of a large house with two-story porch. Cement monument marking reference station is 17.82 meters $\mathrm{N} .45^{\circ} 59^{\prime} \mathrm{E}$. of observed station. Cemented tile pipe marking another reference station is 23.24 meters $\mathrm{N} .47^{\circ} 55^{\prime} \mathrm{E}$. of observed station.

Marks.-Observed station is nail in 4 -inch cemented tile pipe with top flush with surface of ground. One reference station is center point of triangle on standard cement monument. The other reference station is a tile pipe set in cement with top flush with surface of ground.

References.-
"Day" (N. $46^{\circ} 23^{\prime}$ W.)
- 00 co .......
$4^{\mathrm{T}} / 2$ miles.
Near peak of roof of Hall house......... 40 5 I $30 \ldots \ldots$
REFERENCE STATION (cement monument)... $92 \quad 2250 \ldots \ldots$
I50 yards.
REFERENCE STATION (tile) ............ 94 I7 $40 \ldots \ldots$
Chimney of grain house.............. $96 \quad 24 \ldots \ldots$.
17.82 meters
23.24 meters
70 yards, 


\section{HALL HOUSE (MIDDLE CHIMNEY).}

General locality.-Northeastern shore of Potomac River about five-eighths mile northwest of Comfield Point and $23 / 4$ miles northwest of Point Lookout. (See chart No. 22.)

Immediate locality.-Observed station is on a large wooden house about I50 yards inshore from the bank of river.

Marks.-Observed station is middle point of middle chimney on large house belonging to Mr. Hall. References.-None necessary.

SIG.

General locality -Northeastern shore of Potomac River on eastern side of Calvert Bay on Gray Point. (See charts Nos. 22 and 24.)

Immediate locality.-Observed station is in edge of a scrub growth about ${ }_{5}$ feet above high water, and 3 feet east of edge of bank. Cement monument marking reference station is 12.75 meters N. $58^{\circ} I^{\prime}$ E. of observed station.

Marks.-Observed station is nail in northern one of two stumps $2 \frac{1}{2}$ inches in diameter. Reference station is center point of triangle on standard cement monument.

References.-

"Day" (N. 64 I3' W)

Tall pine tree on Kitts Point

Chimney of house on Kitts Point...........

"Red Beacon".........................

Large chimney of Lewis house.............

Left chimney of Collison house........... 45

Near peak of house..................

Nail in blaze in holly tree ( 3 inches diam-

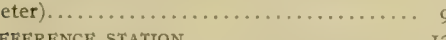

RETERENCE STATION ................. 122

Nail in blaze in gum tree ( 3 inches diameter). $I_{3} 8$

Nail in blaze in pine tree ( 4 inches diameter). I96

Chimney of $\mathrm{I} / 2$-story house............. 353

Near peak of roof of large house........... 357

\begin{tabular}{|c|c|c|c|}
\hline 。 & $\infty$ & . . & $I 3 / 4$ miles. \\
\hline 18 & . & $\ldots \ldots$ & $I 3 / 4$ miles. \\
\hline & .. & $\ldots \ldots$ & I5/8 miles. \\
\hline & 40 & $\ldots \ldots$ & I mile. \\
\hline & $\cdots$ & $\ldots \ldots$ & $I^{1} / 4$ miles. \\
\hline 38 & . & $\ldots \ldots$ & $3 / 4$ mile. \\
\hline & $\therefore$ & $\ldots \ldots$ & I3/4 miles. \\
\hline & 30 & $\ldots \ldots$ & 4.57 meters \\
\hline & 40 & $\ldots \ldots$ & I2.75 meters. \\
\hline & 40 & $\ldots \ldots$ & S.I \\
\hline & 30 & ..... & 6.7 \\
\hline & . & $\ldots \ldots$ & $4^{3}$ \\
\hline & .. & $\ldots \ldots$ & $43 / 4$ miles. \\
\hline
\end{tabular}

\section{SMITH POINT LIGHT}

General locality.-Western side of Chesapeake Bay on southern side of entrance to Potomac River offshore about 3 miles east of Smith Point. (See chart No. 23.)

Immediate locality.--Observed station is on a square brick tower on an octagonal brick building with a cylindrical foundation.

Marks.-Observed station is center point of lantern on structure known as Smith Point Irighthouse.

References."Point Lookout Light" (N. $34^{\circ} 32^{\prime}$ W. .... $\quad 0 \quad$ o $00 \ldots \ldots \ldots$ I3 miles.

RED BEACON (I908).

General locality. - Northeastern side of Potomac River offshore in the mouth of Smiths Creck. (See chart No. 24.)

Immediate locality.-Observed station is on a triangular pile structure.

Marks.-Observed station is center point of a small lantern on pile structure known as Smiths Creek Red Beacon.

References.-None necessary. 
DAGO.

General locality.-Eiastern side of entrance to Smith Creek about one-half mile south-southwest of of Millers Wharf. (See chart No. 24.)

Immediate locality.-Observed station is in a small garden about 6 feet above high water, 40 yards north of an old hotel, 65 yards east of shore, and $6_{5}$ yards southeast of a lumber wharf. Cement monument marking reference station is on a fence line $29.4 \mathrm{I}$ meters $\mathrm{N}$. $78^{\circ}$. I $3^{\prime} \mathrm{W}$. of observed station.

Marks.-Observed station is tile pipe set in cement with top broken off about 9 inches below surface of ground. Reference station is center point of triangle on standard cement monument.

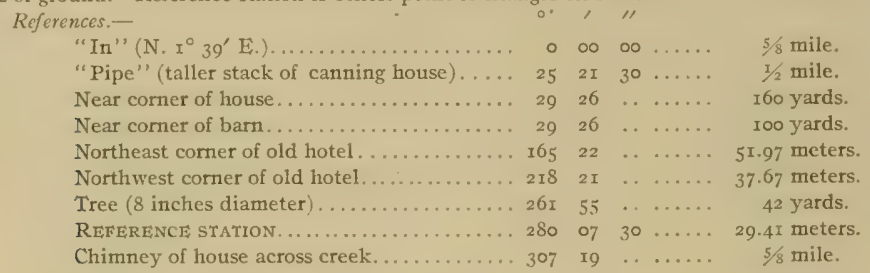

TAB.

General locality.-Western shore of Smith Creek on second prominent point from entrance to creek about three-fourths mile west-southwest of Millers Wharf. (See chart No. 24.)

Immediate locality.-Observed station is about 5 fect above high water, 2 yards north of edge of bank, 5 feet south of edge of bank, 14 yards southwest of a low point, 16 yards north of another low point, 3 I yards southeast of still another point, and $5^{8}$ yards east of a wild-cherry tree. Cement monument marking reference station is 14.53 meters S. $6 x^{\circ}{ }^{\prime} 4^{\prime}$ W. of observed station. Reference tile pipe filled with cement is 47.93 meters S. $61^{\circ} 25^{\prime} \mathrm{W}$. of observed station.

Marks.-Observerl station is center of 4 -inch tile pipe filled with cement with top flush with surface of ground. One reference station is center point of triangle on standard cement monument. Another reference station is center of cemented tile pipe flush with surface of ground.

References.-

\begin{tabular}{|c|c|c|c|c|c|}
\hline "In" (N. $48^{\circ} 08^{\prime}$ E. $) \ldots \ldots \ldots \ldots \ldots \ldots \ldots$ & $\circ$ & ০০ & $\infty$ & $\ldots \ldots$ & $5 / 8$ mile. \\
\hline Near peak of roof of Dunbar house......... & 14 & $\infty$ & . & . & I $1 / 4$ miles. \\
\hline Gilt ball on center of roof of building . . . . . . & 16 & $4 \mathrm{~T}$ & .. & $\ldots$. & $23 / 4$ miles. \\
\hline "Pipe" (taller stack of canning house)...... & 20 & 20 & 40 & $\ldots \ldots$ & $3 / 4$ mile. \\
\hline Left chimney of house with ell ........... & 36 & 27 & .. & $\cdots$ & $1 / 2$ mile. \\
\hline 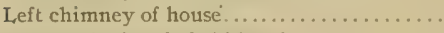 & 55 & 07 & $\cdots$ & $\ldots \ldots$ & $1 / 2$ mile. \\
\hline Near peak of roof of old hotel.............. & 69 & 41 & . & $\ldots \ldots$ & $1 / 2$ mile. \\
\hline "Red Beacon"............. & 105 & 29 & Io & & $5 / 8$ mile. \\
\hline 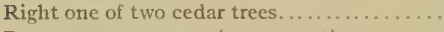 & I 50 & 24 & .. & $\cdots \cdots$ & 55 yards. \\
\hline REFERENCE STATION (MOMUMENT) . . . . . . . & 193 & o6 & Io & $\cdots \cdots$ & I 4.53 meters. \\
\hline REFERENCE STATION (tile) $\ldots \ldots \ldots \ldots \ldots \ldots$ & I93 & 17 & $\infty$ & $\ldots \ldots$ & 47.93 meters. \\
\hline Wild-cherry tree....................... & 235 & 22 & . & ...... & $3 I$ yards. \\
\hline Near peak of large house................ & 300 & or & . & $\ldots \ldots$ & 4 mile. \\
\hline
\end{tabular}

PIE, R

General locality.-Eastern shore of Smith Creck at steamboat landing known as Millers Wharf. (See chart No. 24.)

Immediate locality.-Observed station is on snubbing post on north corner of Millers Whatf, I.46 meters from northeast side of wharf and 0.79 meters from northwest side.

Marks.-Nails mark point where spindle was fastened to snubbing post.

References.-None necessary. 
PIPE,

General locality.-Eastern shore of Smith Creek at Millers Wharf. (See chart No. 24.)

Immediate locality. - Observed station is on a building used for packing oysters and tomatoes near wharf at Wynne.

Marks.-Observed station is center of the taller and more southerly of two smoke pipes on canning hotise at Millers Wharf.

References.-None necessary.

\section{ENOUGH.}

General locality.-Southeastern shore of northeastern branch of Smith Creek about one-fourth mile east-northeast of Millers Wharf. (See chart No. 24.)

Immediate locality.-Observed station is on a lightly wooded bank about 12 feet above high water, 5 yards back from edge of bank, 40 yards south west of a house, and 45 yards northwest of a bam. Cement monument marking reference station is near fence, 19.75 meters $\mathrm{N}$. I9 ${ }^{\circ} 5 \mathrm{I}^{\prime} \mathrm{E}$. of observed station.

Marks.-Observed station is hole in top of a 3 -inch square stub with top about 3 inches above surface of ground. Reference station is center point of triangle on standard cement monument.

\begin{tabular}{|c|c|c|c|c|c|}
\hline References.- & $\circ$ & , & " & & \\
\hline 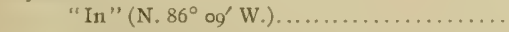 & 0 & Do & oo & $\cdots$ & $1 / 2$ mile. \\
\hline Chimney of house ................... & 105 & 20 & . & $\ldots \ldots$ & $1 / 2$ mile. \\
\hline REFERENCE STATION. $\ldots \ldots \ldots \ldots \ldots \ldots \ldots$ & 106 & $\infty$ & $\infty$ & $\ldots \ldots$ & I 9.75 meters. \\
\hline Near gable of I ogan Dunbar house........ & I 18 & I7 & $\cdots$ & $\cdots$ & 40 yards. \\
\hline West post of small gate............ & 139 & 45 & $\cdots$ & & 28 yards. \\
\hline North gable of barn............. & 215 & 0.4 & $\cdots$ & & 45 yards. \\
\hline North chimney of Fred Dunbar house..... & 234 & 26 & $\cdots$ & & $1 / 4$ mile. \\
\hline Eiast chimney of 2 -story house........... & $25^{2}$ & 32 & $\cdots$ & & $1 / 2$ mile. \\
\hline North gable of store at Wynne........... & 329 & 54 & $\cdots$ & & \\
\hline "Pipe" (taller stack of canning house)...... & $33^{\circ}$ & 33 & $\cdots$ & & $1 / 4$ mile \\
\hline
\end{tabular}

\section{DRUM.}

General locality. - Northwestern shore of northeastern branch of Smith Creek about $1 / 4$ mile northnortheast of Millers Wharf. (See chart No. 24.)

Immediate locality.-Observed station is on marsh land on a point opposite Millers Wharf about 2 I yards north of shore, 22 yards west of shore, 25 yards northeast of shore, and 35 yards southeast of a cultivated field with several cedar trees along its edge.

Marks.-Observed station is center point of triangle on standard cement monument.

References.--

\begin{tabular}{|c|c|c|c|c|}
\hline $\left.77^{\circ} 10^{\prime} \mathrm{W}.\right)$ & $\circ$ & $\infty 0$ & $\infty$ & ${ }_{i}+$ mile. \\
\hline Large chimney of house .............. & I $5 \mathrm{I}$ & 20 & .. . & $1 / 2$ mile. \\
\hline North gable of tobacco barn............. & 152 & I3 & $\ldots \ldots$ & $3 / 4$ mile. \\
\hline Flagstaff on Dumbar pavilion. & 180 & I4 & . . . . & $1 / 4$ mile. \\
\hline North gable of house.... & 195 & $\infty$ & $\cdots$ & I, mile. \\
\hline Left chimney of $2 \frac{1}{2}$-story house... & 212 & 55 & . $\ldots$ & nile. \\
\hline Left chimney of Moore house....... & 215 & 23 & . . . . n & $\mathrm{I} / 4$ mile. \\
\hline North gable of stable............. & 223 & 36 & $\ldots \ldots$ & $1 / 4$ mile. \\
\hline Left chimney of $2 \frac{1}{2}$-story house... & 235 & 05 & . . . & $3 / 8$ mile. \\
\hline Chimney of $1 / 2$-story house... & 246 & 10 & ...... & $1 / 2 \mathrm{mil}$ \\
\hline Cupola of barn. ............ & 272 & $2 I$ & . & It mile. \\
\hline "Pipe" (taller stack of canning house).... & 299 & 56 & $20 \ldots \ldots$ & $3,8 \mathrm{mil}$ \\
\hline West gable of old hotel............... & 307 & 31 & $\ldots \ldots \ldots$ & $1 / 2$ mile \\
\hline
\end{tabular}

$2606-\mathrm{II}-5$ 
IN.

General locality'.-Northern shore of Snith Creek on a point between two main branches of creek about one-fourth mile northwest of Millers Wharf. (See chart No. 24.)

Immediate locality. - Observed station is on a grass point which is surrounded by small bowlders and cobble stones visible at low water about 2 feet above high water, 2 yards east of side of point, 3 yards northwest of side of point, to yards north-northeast of extreme end of point, and near three trees. Cement monument marking reference station is 9.32 meters $\mathrm{N} .7^{\circ} \circ q^{\prime} \mathrm{E}$. of observed station.

Marks.-Observed station is a 2 -inch square stick in center of a 4 -inch tile pipe filled with and set in cement with top about flush with surface of ground. Reference station is center point of triangle on standard cement monument.

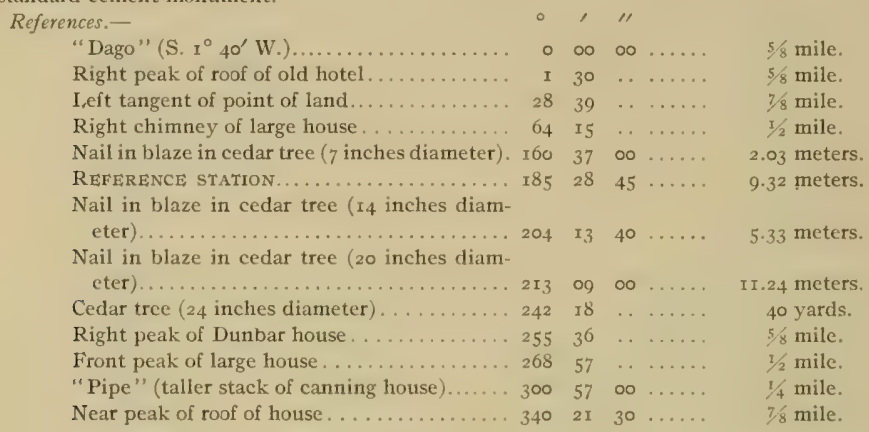

OAK.

General locality.-Western shore of Smith Creek at entrance to northwestern branch of creek about one-half mile west of Millers Wharf. (See chart No. 24.)

Immediate locality.-Observed station is in a pasture about 6 feet ahove high water, I5 yards southsoutheast of center of a clump of trees, 20 yards south of shore, 28 yards north of slore, and 45 yards west of extreme end of point. Cement monument marking reference station is 14.87 meters N. $53^{\circ} 12^{\prime} \mathrm{WV}$. of observed station.

Marks.-Observed station is a syuare hole in cement in 4 -inch tile pipe set in cement. Reference station is center point of triangle on standard cement monument.

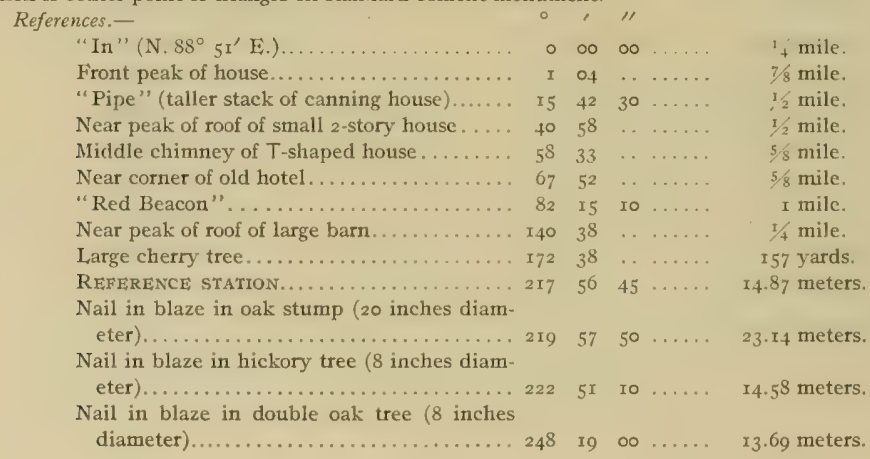




\section{References-Continued.}

Nail in blaze in hickory tree ( 4 inches diam- ${ }^{\circ}$

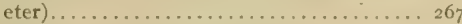

"Flagpole" (on Jutland farmhouse)....... 237

Blaze in oak stump ( 30 inches diameter) ... 340

$\begin{array}{cccc}\text { or } & 00 & \ldots \ldots & 7.37 \text { meters. } \\ \text { o6 } & \ldots & \ldots & 5 / \mathrm{s} \text { mile. } \\ 26 & \ldots & \ldots & 2.04 \text { meters. }\end{array}$

OUT.

General locality.-Eastern shore of northwestern branch of Smith Creek about one-eighth mile north of the main body of Smith Creek. (See chart No. 24.)

Immediate locality.-Observed station is on a sand and marsh point about I foot above high water, 6 yards north of shore, 7 yards southeast of shore, 24 yards east of extreme end of point, and 7 yards west of a cultivated field. Cement monument marking reference station is 6.96 meters N. $82^{\circ} 50^{\prime} \mathrm{E}$. of observed station.

Marks. - Observed station is center of a 2 -inch pine stub set in cement. Reference station is center point of triangle on standard cement monument.

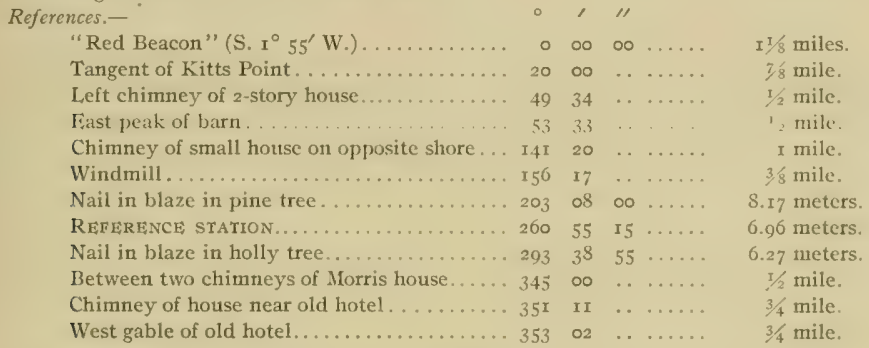

STUNG.

General locality. - Southwestern shore of northwestern branch of Smith Creek about three-fourths mile northwest of Millers Wharf and one-fourth mile northwest of main body of Smith Creek. (See chart No. 24.)

Immediate locality.-Observed sțation is on solid ground on a point making out just above a small cove about 2 feet above high water, 7 yards south of shore, 9 yards northwest of shore, 15 yards southwest of extreme end of point, and 45 yards from a growth of young pine trees.

Marks.-Observed station is center point of triangle on standard cement monument.

References.-

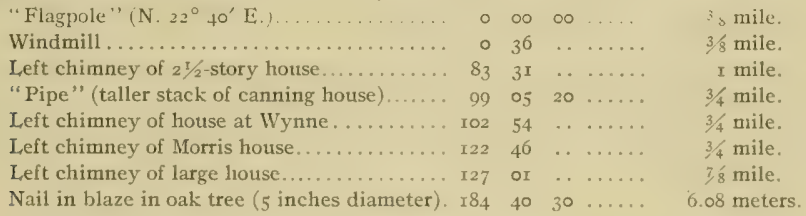

\section{JUTLAND.}

General locality.- Northeastern shore of northwestern branch of Smith Creck about one-half mile north of main body of Smith Creek on a point of land between two coves. (See chart No. 24.)

Immediate locality.-Observed station is on a marsh point about I foot above high water, 2 yards north of shore, 4 yards south of shore, 5 yards east of extreme end of point, and II yards from bank with large cedar trees on its edge with a peach orchard back of them. Cement monument marking reference station is 10.36 meters N. $86^{\circ} 27^{\prime} \mathrm{E}$. of observed station. 
Marks.-Observed station is nail in stub with top flush with surface of ground. Reference station is center point of triangle on standard cement monument.

References. -

\begin{tabular}{|c|c|c|c|c|c|}
\hline "Out" (S. $\left.29^{\circ}{ } \mathrm{r}^{\prime} \mathrm{E}_{.}\right) \ldots \ldots \ldots \ldots \ldots$ & 0 & $\infty$ & $\infty$ & $\ldots \ldots$ & $1 / 4$ mile. \\
\hline Two chimneys of Morris house . . . . . . . . . & ro & $\infty 0$ & . & $\ldots \ldots$ & $3 / 4$ mile. \\
\hline Chimney of house near old hotel........ & I6 & 12 & . & - & I mile. \\
\hline West gable of old hotel........ & I7 & I 7 & . & & I mile. \\
\hline "Red Beacon". & 25 & or & Io & & $I^{3}$ s miles. \\
\hline East gable of barn . . . . . . . . . . . . . . & $5^{6}$ & 18 & • & & $3 / 4$ mile. \\
\hline Southeast gable of small house............ & I 39 & 54 & . & $\ldots$ & $3 / 4 \mathrm{~m}$ \\
\hline Chimney of small house $\ldots \ldots \ldots \ldots \ldots \ldots$ & I69 & 12 & $\ldots$ & & $3 / 4$ mile. \\
\hline Amill ... & 201 & 07 & $\cdots$ & & $1 / 4$ mile. \\
\hline "Flagpole" (on Jutland farmhouse). & 204 & 12 & 55 & & $1 / 4$ mile. \\
\hline CE STATION & 296 & 18 & 35 & & \\
\hline tree................. & 299 & 35 & $\infty$ & $\ldots \ldots$ & $\mathrm{II} .65 \mathrm{~m}$ \\
\hline
\end{tabular}

FLAT.

General locality.-Western shore of northwestern branch of Smith Creek about three-fourths mile north-northwest of main body of Smith Creek on a point of land between two coves. (See chart No. 24.)

Immediate locality.--Observed station is on a marsh point about I foot above high water, 5 yards south of shore, 7 yards north of shore, ro yards west of extreme end of point, and 12 yards from a field 5 feet higher than marsh. Cement monument marking reference station is $10.4 \mathrm{I}$ meters $\mathrm{S} .65^{\circ} \infty 0^{\prime} \mathrm{W}$, of observed station.

Marks.-Observed station is a 2 -inch square pine stub with top about 3 inches above suriace of marsh. Reference station is center point of triangle on standard cement monument.

References.-
"Jutland" (S. $50^{\circ} 36^{\prime}$ E. .)...
$\ldots \ldots \ldots, 00000 . \cdots$
"Pipe" (taller stack of canning house)..... 5 io $\ldots . . .$.
$1 / 4$ mile.
Between two chimneys on Morris house.... $22 \quad 23 \quad \ldots . \ldots$.
Chimney of house near old hotel...........
West gable of old hotel.................
$29 \quad 05 \quad \ldots \ldots \ldots$.
I mile.
I mile.
Blaze in pine tree................. 107 $3730 \ldots \ldots$ 14.12 meters.
REFERENCE STATION................. II5 $35 \quad 40 \ldots \ldots$ I0.4I meters.
Chimney of house.................. I40 $32 \quad \ldots \ldots \ldots . \quad 1 / 4$ mile.
Chimney of small house.............. $200 \quad 4 \mathrm{I} \ldots \ldots \ldots \quad 1 / 4$ mile.
Chimney of house.................. $226 \quad 33 \quad \ldots \ldots \ldots \quad 1 / 2$ mile.
"Flagpole" (on Jutland farmhouse)...... 310 $56 \quad 40 \ldots \ldots$ I/4 mile. $\circ, 11$

\section{FLAGPOLE.}

General locality.-Northeastern shore of northwestern branch of Smith Creek, on a house about threefourths mile north-northwest of main body of Smith Creek. (See chart No. 24.)

Immediate locality.-Observed station is on east gable on the front of a house on Jutland farm.

Marks.-Observed station is flagpole on east gable on the front of residence on Jutland farm.

References.-None necessary.

RAN 2.

General locality.-Eastern shore of northwestern branch of Smith Creek on a point opposite a small cove and about seven-eighths mile north-northwest of main body of Smith Creek. (See clart No. 24.)

Immediate locality.-Observed station is on a narrow sand and marsh point about I foot above high water, 3 yards north of shore, 3 yards south of shore, II yards east of extreme end of point and in front of a bank 8 or 9 feet high covered with honeysuckle and several large trees. Cement monument marking reference station is about Io feet above high water 13.74 meters $\mathrm{N}$. $87^{\circ} 50^{\prime} \mathrm{E}$. of observed station. 
Marks.-Observed station is hole in stub with top about 6 inches above surface of marsh. Reference station is center point of triangle on standard cement monument.

References.-

"Jutland" (S. $25^{\circ}$ o4' E.)

, I

Chimney of Morris house.... . . .

Large chimney of house near old hotel.....

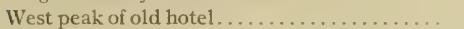

"Red Beacon" ..................... $x_{2}$

East peak of barn.................. 93

Chimney of small house................ I I39

Small blazed apple tree............... 285

REFERENCE STATION ................. 292

"Flagpole" (on Jutland farmhouse) ....... 333

Windmill ............................. 342

0 oo $00 \ldots . .3 \%$ mile.

$\begin{array}{lllll}3 & 33 & \ldots & \ldots \ldots & 1 / 8 \text { miles. }\end{array}$

$8 \quad 29 \quad \ldots \ldots \ldots \quad I 3 / 8$ miles.

I3 $\ldots \ldots \ldots \quad 13 / 8$ miles.

45 Io ..... $x \frac{1}{1 / 2}$ miles.

$05 \ldots \ldots \ldots \quad 1 / 2$ mile.

ro $\ldots \ldots .250$ yards.

$\infty 0 \quad \ldots \ldots \ldots 18.88$ meters.

$5400 \ldots \ldots 13.74$ meters.

59 10 .... $1 / 8$ mile.

$24 \ldots \ldots \ldots \quad 1 / 8$ mile.

DAY.

General locality:- Northeastern shore of Potomac River about one-fourth mile northwest of Kitts Point between entrances to St. Marys River and Smith Creek. (See chart No. 24.)

Immediate locality.-Observed station is on small island of solid ground on a marsh point about 5 feet above high water, 3 yards east of shore, 20 yards northeast of shore, 18 yards north of extreme end of point, and 150 yards south of a large lone dead tree.

Marks.-Observed station is center point of triangle on standard cement monument.

References.-

\begin{tabular}{|c|c|c|c|c|c|}
\hline Labor" $(\mathrm{N}$ & 0 & $\infty$ & $\infty 0$ & & 23 \\
\hline Near peak of roof of $2 \frac{1}{2}$-story house. & 22 & 23 & . & & \\
\hline Near peak of roof of brick house. & 48 & 44 & 30 & & 3 \\
\hline Tall pine on Kitts Point. . & 73 & 48 & 20 & & 50 yal \\
\hline Chimney of old house.... & 118 & I5 & .. & & \\
\hline "Pipe" (taller stack of canning hou & 146 & 59 & ০o & & $1 / 8$ \\
\hline peak of roof of tobacco house.. & r 59 & $5 x$ & $\cdots$ & … & \\
\hline Tear peak of roof between two chim & 181 & $07^{\circ}$ & 20 & & \\
\hline Chimney of Hall house. . & 222 & $4 \mathrm{I}$ & & $\ldots$ & $4^{\pi} / 2 \mathrm{mi}$ \\
\hline
\end{tabular}

LABOR.

General locality.-Northeastern shore of Potomac River on westem side of entrance to St. Marys River on a small island forming the southeastern end of St. George Island. (See chart No. 24.)

Immediate locality.-Observed station is on a marsh grass point about on level with high water, 5 yards north of side of point, 5 yards west of side of point, 8 yards northwest of extreme end of point, 65 yards southwest of another point, 65 yards north-northeast of still another point, and ${ }_{25} 5$ yards southeast of a small pine woods across slough. Cement monument marking reference station is ${ }_{3} .56$ meters N. $64^{\circ} \circ 6^{\prime} \mathrm{W}$. of observed station.

Marks. Observed station is nail in stub with top about flush with surface of ground. Reference station is center point of triangle on standard cement monument.

References.-

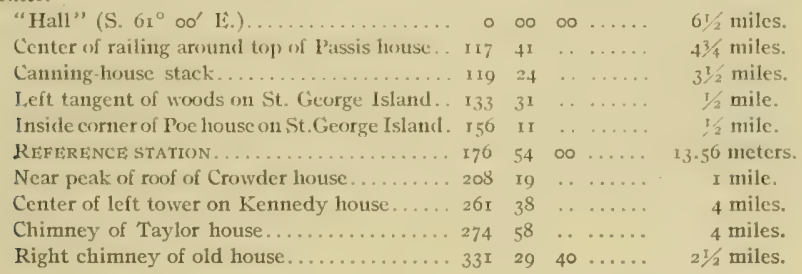




\section{LYNCH POINT 3 (VIRGINIA).}

General locality.-Southwestern shore of Potomac River about three-eighths mile northwest of Lynch Point on northwestern side of entrance to Yeocomico River. (See progress map.)

Immediate locality.-Ohserved station is on sand beach near edge of grass about on level with high water, 50 yards southeast of edge of dense pine woods and a wire fence, 00 yards northwesi of another dense pine woods, and northeast of a slough with about a dozen trees on opposite side. One referenc tile set in cement is at edge of woods 55.68 meters on a continuation inshore of line from Point Lookout Light. Another reference tile set in cement is in woods 85.53 meters in same direction as the nearer reference station.

Marks.-Observed station is center one of four nails in top of a post 5 inches below surface of ground. Reference stations are titles set in cement with tops about 2 inches above surface of ground.

References.-

Stceple on church................. $29 \quad 29 \quad \ldots \ldots \ldots .51 / 4$ miles.

Tall pine tree on Kitts Point............ $5^{8} \quad 30 \quad \ldots \ldots \ldots \quad 67 / 8$ miles.

"St. Michaels Catholic Church Spire"..... $66_{3}$ 4I $30 \ldots . .695 / 8$ miles.

White tower on building............... $80 \quad 54 \ldots \ldots . \quad 85 / 8$ miles.

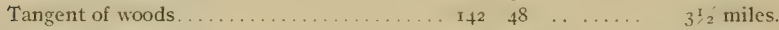

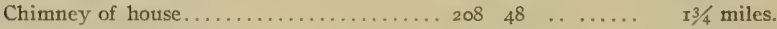

REFERENCE STATION (tile).............. 278 oo $30 \ldots \ldots 5.68$ meters.

REFERENCE STATION (tile) ............... 278 oo $30 \ldots 5.53$ meters.

Near peak of roof between two chimneys... 357 I3 $\ldots \ldots .7$ miles.

\section{BETWEEN.}

General locality.-Eastern shore of St. Marys River about $\mathrm{x}^{2} / 4$ miles northwest of Kitts Point at entrance to river. (See chart No. 24.)

Immediate locality.-Observed station is in a pasture about 3 feet above high water, 5 yards northeast of edge of bank, 5 yards southeast of a rail fence, i2 yards southwest of shore of a creek, and 7 to ro yards west to northwest of persimmon trees. Cement monument marking reference station is at edge of high land 14.42 meters S. $56^{\circ} 22^{\prime} \mathrm{E}$, of observed station.

Marks.-Observed station is nail in stub with top flush with surface of ground. Reference station is center point of triangle on standard cement monument.

References.-

"Day" (S. $27^{\circ}$ or $^{\prime}$ E. . ............... o o o

Chimney of house at edge of woods....... no 45

Chimney of house beyond middle of woods. . $96 \quad 16$

Chimuey of large house with ell ........ 10350

Chimney of $21 / 2$-story house ........... $126 \quad 32$

"Piney Point Light" . . . . . . . . . . . . . . . I

Near peak of roof of brick house between two

Nail in blaze in persimmon tree $(4$ inches

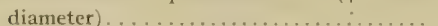

Nail in blaze in persimmon tree (4 inches

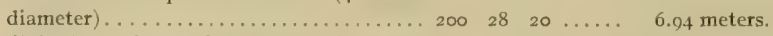

Nail in blaze in persimmon tree $(5$ inches diameter $)$. . . . . . . . . . . . . . . . . . 306

RERERISNCE STATION . . . . . . . . . . . 330

Tall pine on Kitts Point.

$330-30 \quad 00 \ldots .34$ meters

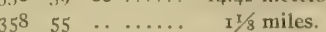

$$
\begin{aligned}
& \text { I } 1 / 8 \text { miles. } \\
& 21 / 8 \text { miles. } \\
& 21 / 4 \text { miles. } \\
& 23 / 8 \text { miles. } \\
& 31 / 8 \text { miles. } \\
& 51 / 2 \text { miles. } \\
& 23, \text { miles. } \\
& 5.87 \text { meters. } \\
& 4 \text { miles. } \\
& 6.94 \text { meters. } \\
& 9.34 \text { meters. } \\
& 14.42 \text { meters. } \\
& x^{1 / 8} \text { miles. }
\end{aligned}
$$


FORT.

General locality.-Eastern shore of St. Marys River on Fort Point about $2 \frac{1}{4}$ miles north of entrance to river and seven-eighths of a mile south of Priests Point. (See chart No. 24.)

Immediale localily.-Observed station is in a cultivated field about ${ }_{5} 5$ feet above high water, I6 yards east of edge of bank, 70 yards west by south of a house, and 34 yards south-southwest of a corner of a fence. Cement monument marking reference station is 32.17 meters N. $22^{\circ} 20^{\prime}$ E. of observed station.

Marks.-Observed station is nail in stub with top flush with surface of ground. Reference station is center point of triangle on standard cement monument.

\begin{tabular}{|c|c|c|c|c|}
\hline \multicolumn{5}{|l|}{ References.- } \\
\hline "Rod" (N. $10^{\circ} 16^{\prime}$ W. $)$. & 0 & $\infty$ & $\infty$ & is mile. \\
\hline REFERENCE STATION . . . . . . & 32 & 35 & $55 \cdots$ & 32.I7 meters. \\
\hline Near chimney of Taylor house. & 78 & 44 & . & 70 yards. \\
\hline Chimney of small building.... & 106 & $3^{8}$ & .. & 250 yards. \\
\hline Chimney of $21 / 2$-story house with ell. & 246 & 30 & . & $21 / 8$ miles. \\
\hline Canning-house stack. . . . . . . . . & 3 I4 & $0_{3}$ & . & $21 / 2$ miles. \\
\hline Near peak of roof of stable. & 342 & 24 & . & $21 / 8$ miles. \\
\hline "Water tower" (near Portobcllo). & $35 \mathrm{I}$ & 03 & Io $\ldots \ldots$. & $23 / 4$ miles. \\
\hline
\end{tabular}

\section{POND}

General locality.-Western shore of St. Marys River on Pond Point about seven-eighths of a mile north-northeast of Cherryfield Point at entrance to St. George River. '(Sec chart No. 24.)

Immediate locality.-Observed station is on marshland at edge of woods about on level with high water, 6 yards west of edge of marsh, 7 yards south of edge of marsh, 25 yards northeast of edge of marsh, and 20 to 30 yards north and east of pine trees. Cement monument marking reference station is 29.59 meters S. $77^{\circ} 29^{\prime} \mathrm{W}$. of observed station.

Marks.-Observed station is nail in stub. Reference station is center point of triangle on standard cement monument.

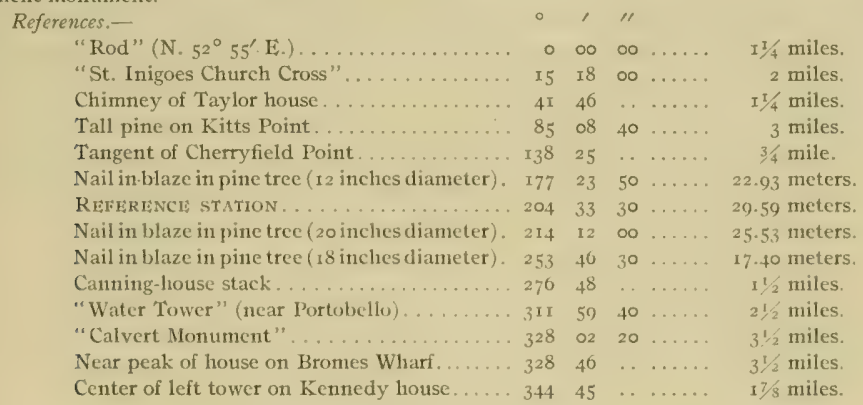

\section{ROD (PRIESTS HOUSE).}

General locality.-Eastern shore of St. Marys River on Priests Point at south side of entrance to St. Inigoes Creek. (See chart No. 24.)

Immediale locality.-Observed station is on a small cupola-shaped centerpiece, or ventilator, on middle of roof of a summer residence of the order of Jesuits, sometimes called Priests Villa.

Marks.-Observed station is a lightning rod on the center ventilator on middle of roof of Priests Villa.

References.-None necessary. 


\section{THOMPSON.}

General locality.-Westem shore of St. Marys River about three-eighths of a mile east-northeast of entrance to Carthagena Creek, five-eighths of a mile southwest of Windmill Point, and $x$ mile north of Pond Point. (Sce chart No. 24.)

Immediate locality.-Observed station is in a cultivated field about 20 feet above high water, 5 yards southwest of edge of bank, 6 yards northeast of edge of bank, and 7 yards west of extreme edge of bank. Cement monument marking reference station is buried with top about ro inches below surface of ground 25.00 meters N. $36^{\circ} 53^{\prime} \mathrm{W}$. of observed station.

Marks.-Observed station is center of a 3 -inch square pine box with top flush with surface of ground. Reference station is center point of triangle on standard cement monument with top about ro inches below surface of ground.

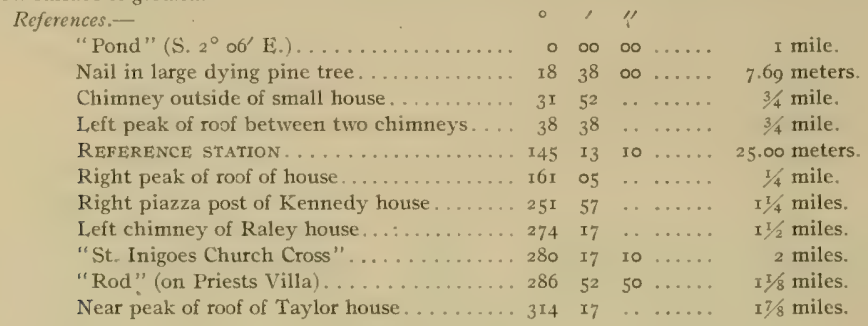

\section{RALEY}

General localily.-Southeastern side of entrance to St. Inigoes Creck about one-half mile northeast of Priests Point and seven-eighths of a mile east-southeast of Windmill Point. (See chart No. 24.)

Immediale locality.-Observed station is in a cultivated field about I5 feet above high water, 40 yards southeast of edge of bank, 40 yards west of edge of ravine, and 135 yards north of a barn.

Marks.--Observed station is center point of triangle on standard cement monument with top about I2 inches below surface of ground. Surface mark is center of a 3 -inch square wooden box.

References.-

\begin{tabular}{|c|c|c|c|c|c|}
\hline "Rod" (S. 5I ${ }^{\circ}$ o3 $^{\prime}$ W.)... & 0 & $\infty$ & $\infty$ & & $1 / 2$ mile. \\
\hline Near corner of near chimney of Raley house. & 8 & $5^{8}$ & - & & Y50 yards. \\
\hline 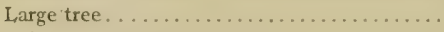 & 32 & $5^{I}$ & . & & I00 yards. \\
\hline Chimney of Kennedy house. . . . . . . . . & IOI & 49 & & & ile. \\
\hline Chimney of small house. & 155 & 22 & $\cdots$ & & $1 / 2$ mile. \\
\hline of of whatr hou & 167 & I6 & . & & ile. \\
\hline Chimney of house among trees... & $\mathrm{x} 77$ & 26 & . & & $5 / 8$ mile. \\
\hline ley of small house. . . . . . . . & 211 & 07 & . & & $1 / 2$ mile. \\
\hline "St. Inigoes Church Cross". & 246 & 43 & $\infty$ & & ile. \\
\hline Right peak of roof of barn... & 315 & I4 & . & ...... & ards. \\
\hline Near peak of corncrib................ & $35 \mathrm{I}$ & 33 & . & ..... & 150 yard \\
\hline
\end{tabular}




\section{INIGOES.}

General locality.-Northern side of entrance to St. Inigoes Creek about five-eighths of a mile north of Priests Point and five-eighths of a mile east of Windmill Point. (See chart No. 24-)

Immediale locality. - Observed station is offshore in about 4 feet of water, $\mathrm{I} / 2$ feet southeast of boat landing, and 45 yards southwest of shore. Cement monument marking reference station is on top of bank about $I_{5}$ feet high, 50.87 meters $N .39^{\circ} 25^{\prime}$ E. of observed station.

Marks.-Observed station is a 3 -inch square stub driven into bottom in about 4 feet of water and standing plumb with top about 2 feet above high water. Reference station is center point of triangle on standard cement monument.

References.--

\begin{tabular}{|c|c|c|c|c|c|}
\hline "Rod"' (S. II ${ }^{\circ} 53^{\prime}$ W.). & 0 & $\infty$ & $\infty$ & & \\
\hline Left tangent of left chimney of brick house. & 49 & 03 & . & & iles. \\
\hline Left peak of roof of carriage house. & 87 & 04 & & & $7 / 8$ \\
\hline house. . & 106 & 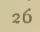 & . & & $13 / 8$ \\
\hline Chis & 139 & 56 & . & & $x^{3} / 4$ \\
\hline of right tow & 168 & 07 & . & & 400 \\
\hline RETERENCE STAT & 207 & $3 r$ & 30 & & 50.87 \\
\hline ney of Tyler house. & 267 & 42 & . & & \\
\hline 01 & 297 & 30 & 40 & $\ldots \ldots$ & \\
\hline arge cli & $33^{\circ}$ & $3^{8}$ & . & $\ldots \ldots$ & 8 InI \\
\hline
\end{tabular}

\section{ST. INIGOES CHURCH CROSS.}

General locality.-Eastern side of St. Marys River inshore about I mile east from Priests Point and three-fourths of a mile south of Grason Wharf on St. Inigoes Creek. (See chart No. 24.)

Immediale locality.-Observed station is on St. Inigoes Catholic Church.

Marks.-Observed station is center of cross on St. Inigoes Catholic Church.

References.-None necessary.

\section{CHURCH.}

General locality.-Southeastern shore of St. Inigoes Creek about five-eighths mile east of St. Marys River and one-fourth mile southwest of Grason Wharf. (See chart No. 24.)

Immediate locality, - Observed station is about 2 feet above high water on a rounded point of land nearly surrounded by water, $x_{3}$ yards southeast of shore, I4 yards south of shore, 24 yards west-southwest of shore, and 35 yards north of inlet and cedar trees.

Marks.-Observed station is center point of triangle on standard cement monument.

References.-

"Grason" ( $\mathrm{N} .34^{\circ}+t^{\prime} \mathrm{E} .1 \ldots \ldots \ldots \ldots \ldots \ldots \ldots$
Near peak of roof of Grason stable..........

Between two chimneys on near end of Grason

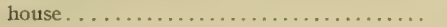

Nail in blaze in cedar tree ( 6 inches diameter), 6

Nail in blaze in cedar tree ( 5 inches diameter). III

Nail in blaze in cedar tree ( 4 inches diameter). I 50

Near peak of roof between two chimneys on

Raley house.................... 280

Chimney of hotise . ................. 3 It

Left chimney on end of house . . . . . . . . 333

Near peak of roof of Grason Wharf house. .... 345

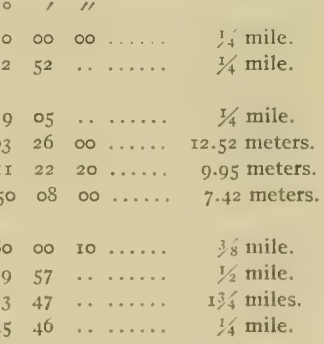




\section{COTTAGE.}

General locality.-Northwestern shore of St. Inigoes Creek about one-half mile east-northeast of St. Marys River and three-eighths mile west-southwest of Grason Wharf. (See chart No. 24.)

Immediate locality.-Ohserved station is on sand about $x$ foot above high water, 2 yards northnorthwest of shore, 20 yards south-southeast of woods, and 120 yards southwest by west of extreme end of point. Cement monument marking reference station is 12.82 meters $\mathrm{N}$. $18^{\circ} 52^{\prime} \mathrm{W}$. of observed station.

Marks. - Observed station is center of 3 -inch square wooden box with top flush with surface of sand. Reference station is center point of triangle on standard cement monument.

References.-

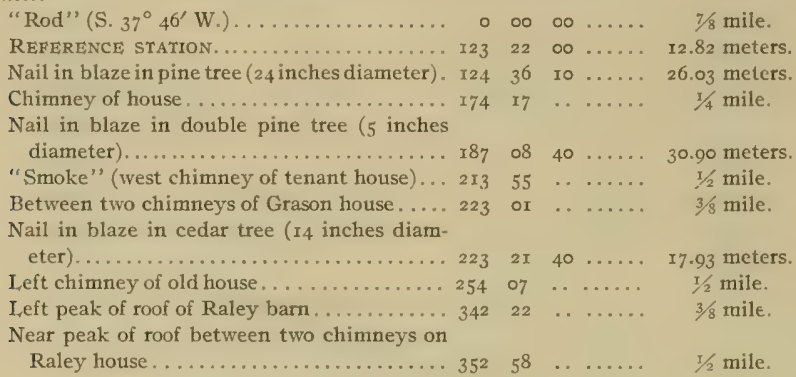

\section{DUSKY.}

General locality.-Northwestern shore of St. Inigoes Creek on a prominent point between creek and a small cove nearly opposite Grason Wharf and about three-fourths mile northeast of St. Marys River. (See chart No. 24.)

Immediate locality.-Observed station is about on level with high water, about 5 yards east of a fence which is on top of a tree-fringed bank I 5 feet high. Cement monument marking reference station is near an old creek bed 25.09 meters N. $2^{\circ} 34^{\prime} \mathrm{E}$. of observed station.

Marks.-Observed station is center of a 3 -inch square wooden box. Reference station is center point of triangle on standard cement monument.

References.-

\begin{tabular}{|c|c|c|c|c|}
\hline$\ldots \ldots \ldots \ldots$ & 0 & $\infty$ & & \\
\hline Near end of Grason Wharf . . . ........ & 32 & 53 & ${ }^{\circ}$ & \\
\hline Right peak of roof of house.... & 70 & 99 & $\cdots$ & \\
\hline himney on outside of small house . . . . . . . & 79 & $\infty$ & . & \\
\hline eft peak of roof of Raley barn..... & 115 & 32 & & \\
\hline rner of Raley house........... & 122 & 40 & & \\
\hline Right.corner of Priest's Villa. . . . . . . . . . . & 128 & 30 & . & \\
\hline 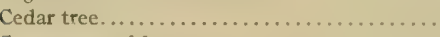 & 139 & 02 & $\cdots$ & \\
\hline orner post of fence & 220 & I5 & . & \\
\hline
\end{tabular}

Nail in blaze in locust tree ( 6 inches diam-

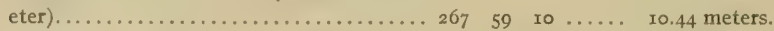

REFERENCE STATION................... 272 51 Io .... 25.09 meters. 
GRASON.

Gencral locality.-Southeastern shore of St. Inigoes Creek near Grason Whatf about 7/8 mile northeast of St. Marys River. (See chart No. 24.)

Immediate locality.-Observed station is about 15 feet above high water, 7 yards southeast of edge of bank, $I_{3}$ yards northwest of a stable, and near three trees.

Marks:-Observed station is center point of triangle on standard cement monument.

References.-

\begin{tabular}{|c|c|c|c|c|c|}
\hline 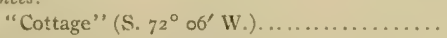 & 0 & 00 & $\infty 0$ & & $3 / 8$ mile. \\
\hline Near corner of wharf house................ & 26 & 39 & . & $\ldots \ldots$ & 130 yards. \\
\hline Chininey of house..................... & 39 & 56 & . & & ile. \\
\hline Nail in blaze in elm tree............. & 93 & $4 \hat{3}$ & $\infty$ & & leters. \\
\hline Chimney of brick house on hill.... & ז 49 & 12 & .. & & illes. \\
\hline "Smoke" (west chimney of tenant house)... & $x 79$ & 03 & 20 & & iile. \\
\hline $\begin{array}{l}\text { Nail in blaze in locust tree }(22 \text { inches diam- } \\
\text { eter }) \ldots \ldots \ldots \ldots \ldots \ldots \ldots \ldots \ldots \ldots \ldots \ldots \ldots \ldots \ldots \ldots \ldots \ldots\end{array}$ & 203 & on & 30 & & ters. \\
\hline Left corner of stable.................... & 254 & 37 & . & & neters. \\
\hline Right corner of stable........... & 303 & 28 & . & & I2.05 meters. \\
\hline Chimney of Raley house................. & 333 & 28 & .. & & $5 / 8$ mile. \\
\hline $\begin{array}{l}\text { Left tangent of Priest's Villa . ............... } \\
\text { Nail in blaze in cherry tree ( } 8 \text { inches diam- }\end{array}$ & 333 & 54 & .. & . & ailes. \\
\hline er) $\ldots \ldots \ldots \ldots \ldots \ldots \ldots$ & & 23 & & & \\
\hline
\end{tabular}

\section{ROCK.}

Gcneral locality:-Northwestem shore of St. Inigoes Creek about one-fourth mile north-northwest of Grason Wharf and seven-eighths mile northeast of St. Marys River. (See chart No. 24.)

Immediate locality.-Observed station is on the western side of entrance to a small creek with a wooded shore, about 2 feet above high water, 4 yards north-northwest of shore, and 8 yards east-southeast of a small pool with trees beyond. Cement monument marking reference station is 17.09 neters N. $85^{\circ}$ $4 \mathrm{I}^{\prime} \mathrm{W}$. of observed station.

Marks.-Observed station is center of 3 -inch square wooden box. Reference station is center point of triangle on standard cement monument.

\begin{tabular}{|c|c|c|c|c|c|}
\hline ferences.- & $\circ$ & , & "1 & & \\
\hline "Smoke" (S. 6r ${ }^{\circ} \mathbf{1 3}^{\prime}$ E. $) \ldots$ & $\circ$ & $\infty$ & $\infty$ & $\ldots$ & $3 / 8$ mile. \\
\hline 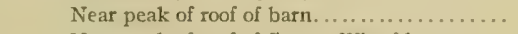 & 1.4 & 37 & . & $\cdots$ & \\
\hline Near peak of roof of Grason Whari house..... & 57 & 35 & $\cdots$ & & 3.s mile. \\
\hline Nail in blaze in pine tree ( 8 inches diameter). & 115 & 28 & $\infty$ & & 9.95 meters. \\
\hline Nail in blaze in pine tree ( 6 inches diameter). & 150 & 23 & 20 & & 17.24 meters. \\
\hline 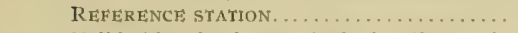 & 155 & 32 & 05 & & 17.09 meters. \\
\hline Nail in blaze in pine tree ( 16 inches diameter). & 207 & $5^{2}$ & 20 & & ters. \\
\hline Chimney on right end of house............ & 250 & 08 & . & & $3 / 4$ mile. \\
\hline 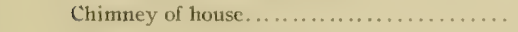 & 333 & $4^{2}$ & .. & $\ldots \ldots$ & $1 / 2$ nile. \\
\hline
\end{tabular}

\section{SMOKE.}

General locality.-Southeastern shore of St. Inigoes Creek about one-fourth mile east of Grason Wharf. (See chart No. 24.)

Immediate locality.-Observed station is on a tenant house which is about ${ }_{5} 5$ feet above high water located about one-fourth mile east of Grason Wharf.

Marks.-Observed station is center of brick chimney on west end of house.

References.-None necessary. 


\section{CHESTNUT.}

General locality, -Southern shore of Upper St. Inigoes Creek about one-half mile east-northeast of Grason Wharf, near the entrance to an eastern branch of creek, and $x^{1 / 4}$ miles northeast of St. Marys River. (See chart No. 24.)

Immediate locality.-Observed station is in a cultivated field fringed by tall trees about 20 feet above high water, is yards south of edge of bank, 70 yards southwest of comer of field, 80 yards west-southwest of edge of bank, 95 yards northeast of trees at hollow, r ro yards southwest of a point, and I50 yards east by north of point where rail fence meets trees.

Marks.-Observed station is center point of triangle on standard cement monument with top about I2 inches below surface of ground. Surface mark is center of 3 -inch square wooden box.

References.-

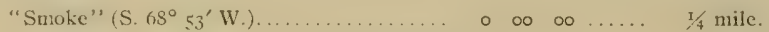

Nail in blaze in pine tree ( 22 inches diameter) 39 o6 $50 \ldots . .18 .5^{8}$ meters.

Nail in blaze in cedar tree ( 18 inches diam-

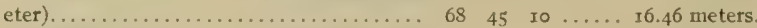

Nail in blaze in pine tree ( 14 inches diameter) I05 $03 \quad 20 \ldots \ldots 2$ I. ro meters.

Tangent of trees..................... 27 I $00 \ldots \ldots$ roo yards.

Junction of fences.................... $318 \quad 47 \quad 50 \ldots \ldots$ r. 50 yards.

\section{SI,FE.P.}

General locality.-Northern shore of Upper St. Inigoes Creek on a point between two forks of creek about $1 / 3$ mile northeast of Grason Wharf and II/4 miles northeast of St. Marys River. (See chart No. 24.)

Immediate locality.-Observed station is about $\mathrm{x}$ foot above high water, 6 yards east of shore, Io yards north of shore, and on line with persimmon trees.

Marks.-Observed station is center point of triangle on standard cement monument.

References.-

\begin{tabular}{|c|c|c|c|c|c|}
\hline "Smoke" (S. II ${ }^{\circ} 24^{\prime}$ W. $)$. . & $\circ$ & $\infty$ & $\infty$ & & aile. \\
\hline Near peak of roof of Grason brick house.. & 21 & 24 & 20 & & $1 / 2$ mile. \\
\hline Left chimney on higher roof of Raley house & 30 & 55 & & & I $1 / 4$ miles. \\
\hline Left peak of roof of wharf hotse........... & 32 & 37 & & & nile. \\
\hline Tangent of point opposite Grason............. & 37 & $5^{2}$ & . & $\ldots$ & ile. \\
\hline Nail in blaze in pine tree ( 2 inches diameter). & 129 & 34 & 00 & & neters. \\
\hline Nail in blaze in pine tree ( 4 inches diameter). & $18 ;$ & $2 S$ & 40 & & I 9.89 meters. \\
\hline $\begin{array}{l}\text { Nail in blaze in persimmon tree (9 inches } \\
\text { dianieter) } \ldots \ldots \ldots \ldots \ldots \ldots \ldots \ldots \ldots \ldots \ldots\end{array}$ & 209 & 56 & Io & & \\
\hline Tangent of marsh poin & 244 & 31 & & 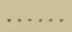 & au \\
\hline Chimney of left ell o & 288 & 26 & & ..... & i \\
\hline
\end{tabular}

\section{GRIND.}

General localily.-Western side of St. Marys River in water just off Windmill Point and opposite entrance to St. Inigoes Creek. (See chart No. 24.)

Immediate localily.-Observed station is in about 4 feet of water, 45 yards east-southeast of extreme end of point and 120 yards northeast of another point. Cement monument marking reference station is among cedar trees $8 \mathrm{r} .36$ meters S. $8 \mathrm{I}^{\circ} 4 \mathrm{O}^{\prime} \mathrm{W}$. of observed station.

Marks.-Observed station is nail in stub in water. Reference station is center point of triangle on standard cement monument.

References,- -

"Rod" (S. $37^{\circ} 47^{\prime}$ E.) . . . . . . . . . . . .

Left peak of roof between two chimneys on brick house. . . . . . . . . . . . . . . . . . .

RLFERENCE $\operatorname{sTATION} \ldots \ldots \ldots \ldots \ldots \ldots \ldots$ I

"Water Tower" (near Portobello) ......... 203

L.eft comer of left chimney on house at Porto-

bello.......................... $208 \quad 26 \quad \ldots \quad 11 / 8$ miles.

$3 / 4$ mile.

I $1 / 2$ miles.

81.36 meters.

$1 \mathrm{~T} / 4$ miles.

1/8 miles. 


\begin{tabular}{|c|c|c|c|c|}
\hline References-Continued. & $\circ$ & , & $\prime \prime$ & \\
\hline "Calvert Monument".. & 237 & 55 & 10.. & $21 / 8$ miles. \\
\hline Near peak of roof of Bromes Wharf house... & 239 & I0 & . . & 2 miles. \\
\hline Right piazza post on Kennedy house...... & 296 & 34 & . & $3 / 4$ mile. \\
\hline "St. Inigoes Church Cross" .............. & $33 I$ & 32 & $30 \ldots \ldots$ & $\mathrm{I} / 2 / 2$ miles. \\
\hline Left peak of roof of Raley house.......... & 334 & 49 & $\ldots \ldots \ldots$ & $7 / 8$ mile. \\
\hline
\end{tabular}

\section{KENNEDY.}

General locality.-Eastern shore of St. Marys River about one-eighth mile north of entrance to St. Inigoes Creek and five-eighths mile east-northeast of Windmill Point. (See chart No. 24.)

Immediale locality. - Observed station is in a garden about 25 feet alove high water, 30 yards northwest of edge of bank at wire fence, 65 yards west-southwest of a house, 18 yards south of a fence, and 52 yards south af a paling fence. Cement monument marking reference station is in a garden 20.25 meters N. $37^{\circ} 05^{\prime} \mathrm{E}$. of observed station.

Marks.--Observed station is center of a 3 -inch square wooden box. Reference station is center point of triangle on standard cement monument.

\begin{tabular}{|c|c|c|c|c|c|}
\hline ences.- - & 0 & 1 & " & & \\
\hline "Rod" (S. $7^{\circ} 45^{\prime}$ W. $) \ldots \ldots \ldots \ldots \ldots \ldots$ & $\circ$ & $\infty$ & $\infty$ & & $3 / 4$ mile. \\
\hline Near peak of roof of barn............... & 86 & 25 & $\cdots$ & & aile. \\
\hline Near peak of roof of building. . . . . . . . . . . & 107 & Io & . & & I $1 / 2$ miles. \\
\hline 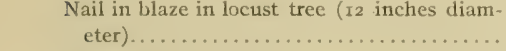 & 137 & 45 & 50 & & $13.2 \mathrm{I}$ meters. \\
\hline REFERENCE STATION . . . . . . . . & 209 & 20 & Io & .. & 20.25 meters. \\
\hline Near corner of shed............. & 209 & 45 & $\cdots$ & $\cdots \cdots$ & ds. \\
\hline Left back piazza post. . . . . . & 250 & $2 I$ & . & $\ldots$ & 60 yards. \\
\hline Chimney of cabin...... & 280 & $\infty$ & .. & $\ldots \ldots$ & I 20 yards. \\
\hline Chimney on top of Raley house. & 334 & 04 & .. & $\ldots \ldots$ & $I / a$ mile. \\
\hline
\end{tabular}

\section{COPPAGE.}

General locality.-Western shore of St. Marys River about one-fourth mile south of entrance to Cooper Creek, and seven-eighths mile northwest of Windmill Point. (See chart No. 24.)

Immediate locality.-Observed station is near densely wooded land about 25 feet above high water, 5 yards southwest of edge of bank, 6 yards south of edge of bank, ro yards west of point with cedar tree, and 200 yards west of remains of a pier. Cement monument marking reference station is II.50 meters S. $83^{\circ} 2 \mathrm{r}^{\prime} \mathrm{W}$. of observed station.

Marks,-Observed station is center of a 3 -inch square wooden box with top flush with surface of ground. Reference station is center point of triangle on standard cement monument.

References.-

"Bello" (N. $42^{\circ}$ II' E.).

Chimney of St. Marys Seminary ............

Near peak of roof of Bromes Wharf house....

Chimney of Brome house . . . . . . . . . . .

Chimney of house ...................

Chimney of Kennedy house . . . . . . . . . . .

Left chimney of Raley house............

Chimney of Priest's villa. . . . . . . . . . . .

Chimney

$\begin{array}{cccccc}0 & 00 & 00 & \ldots & 3 / 4 \text { mile. } \\ 2 & 27 & \ldots & \ldots & 2 \text { miles. } \\ 3 & 14 & \ldots & \ldots & 17 / 8 \text { miles. } \\ 0 & 42 & \ldots & \ldots & 17 / 8 \text { miles. } \\ 4 & 40 & \ldots & \ldots & 7 / 8 \text { mile. } \\ 9 & 22 & \ldots & \ldots & 11 / 4 \text { miles. } \\ 4 & 09 & \ldots & \ldots & 15 / 8 \text { miles. } \\ 3 & 06 & \ldots & \ldots & 15 / 8 \text { miles. } \\ 6 & 45 & \ldots & \ldots & 1 / 2 \text { mile. } \\ 5 & 25 & 20 & \ldots & 7.68 \text { meters. } \\ 6 & 30 & 30 & \ldots & 10.96 \text { meters. } \\ 1 & 09 & 50 & \ldots & 11.50 \text { meters. } \\ 0 & 30 & 30 & \ldots & 7.32 \text { meters. } \\ 4 & 16 & 00 & \ldots & 5 / 8 \text { mile. }\end{array}$

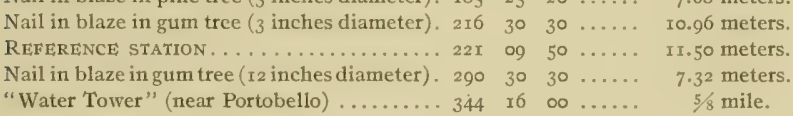


CHAN.

General locality.-Eastern shore of St. Marys River on Chancellor Point about seven-eighths mile north-northwest of entrance to St. Inigoes Creek. (See chart No. 24.)

Immediate locality.-Observed station is on a long point about 3 feet above high water, 10 yards north of side of point, 12 yards south of side of point, 17 yards east of extreme end of point, and near cedar trees. Cement monument marking reference station is 14.14 meters S. $78^{\circ}$ o $9^{\prime} \mathrm{E}$. of observed station.

Marks.-Observed station is center of a 3 -inch square wooden box. Reference station is center point of triangle on standard cement monument.

References.-

\begin{tabular}{|c|c|c|c|c|c|}
\hline 3 & & & & & \\
\hline$y$ of house $\ldots \ldots \ldots \ldots \ldots \ldots \ldots \ldots$ & 9 & $5^{6}$ & .. & & \\
\hline ak of roof between two chimneys.... & 24 & 15 & & ... & les. \\
\hline ney of house on Pagan Point...... & 40 & 35 & . & . & $I^{1} / 2$ \\
\hline onument". & 56 & 56 & 40 & & $I^{3} / 8$ \\
\hline Epi & $5^{8}$ & 39 & 40 & & 178 \\
\hline of roaf of & $5^{8}$ & 47 & . & . & $I^{3} / 8$ \\
\hline $\begin{array}{l}\text { diam- } \\
\ldots \ldots \\
\text { diam- }\end{array}$ & 3 & 55 & 20 & & \\
\hline & I 37 & 32 & 26 & & $31.6 \mathrm{I}$ \\
\hline $\mathrm{REFF}$ & 139 & I9 & 50 & & neters. \\
\hline diam- & & 50 & 20 & & \\
\hline ea & 12 & 54 & . & & \\
\hline 10 & 349 & 29 & & & nile \\
\hline
\end{tabular}

\section{BELLO.}

General locality,-Western shore of St. Marys River on Portobello Point about five-eighths mile north-northwest of Chancellor Point and $I^{I} / 8$ miles north of Windmill Point. (Sce chart No. 24.)

Immediate locality.-Observed station is on northeast peak of roof on wharf house at Portobello Landing.

Marks.-Observed station is a flagpole on northeast peak of wharf house.

References,-None necessary.

\section{WATER TOWER (PORTO BELLO).}

General locality.-Western side of St. Marys River inshore about one-fourth mile west of Portobello Landing. (See chart No. 24.)

Immediate locality.-Observed station is on a detached structure with a water tank on top.

Marks,-Observed station is center of water tank.

References.-None necessary. 


\section{GRAVEL.}

General locality.-Eastern shore of St. Marys River about three-eighths mile north-northeast of Chancellor Point, and five-eighths mile east of Portobello Point. (See chart No. 24.)

Immadiate locality. - Observed station is on gravel washed up between river and slough about on level with high water, 2 yards north of gravel and marsh line, 33 yards east-northeast of outlet of slough, and 65 yards southwest of point where woods and river meet. Cement monument marking reference station is 26.99 meters N. $86^{\circ} \mathrm{O}^{\prime}$ E. of observed station.

Marks.-Observed station is nail in stub. Reference station is center point of triangle on standard cement monument.

References.-

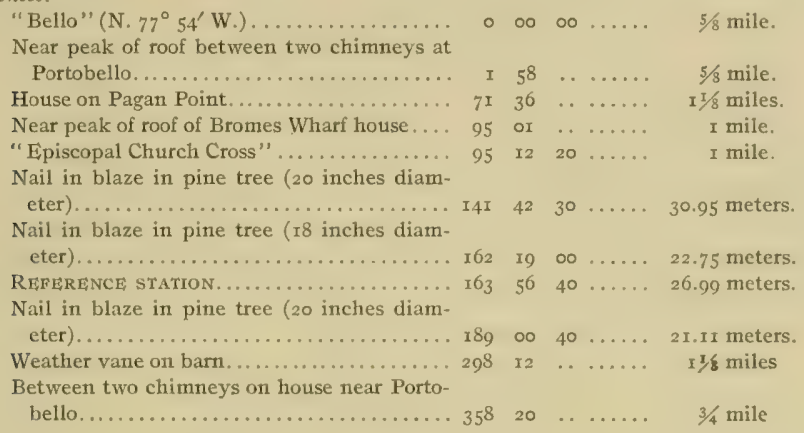

\section{McKAY.}

General locality.-Western shore of St. Marys River about one-half mile north-northeast of Portoballo Point, and five-eighths mile west-southwest of Bromes Wharf. (See chart No. 24.)

Immediate locality. - Observed station is about on level with high water, I4 yards south of a fence extending into water, and at edge of woods. Cement monument marking reference station is 8.12 meters S. $7 \mathrm{I}^{\circ} 35^{\prime} \mathrm{W}$. of observed station.

Marks.-Observed station is center of a 3 -inch square wooden box. Reference station is center point of triangle on standard cement monument.

References.-

"Bello" (S. $23^{\circ}$ I6" W.)

Nail in blaze in locust tree ( 3 inches diam

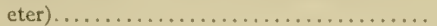

REFERENCE STATION.....................

Nail in blaze in gum tree ( 8 inches diameter) ........................... 3.48 meters.

Nail in blaze in willow tree ( 8 inches diam-

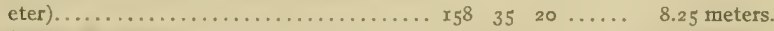

"Calvert MIonument"................ 2 I5 $55^{8} \quad 30 \ldots \ldots . \quad 3 / 4$ mile.

"Ëpiscopal Church Cross" ............ 217 55 10 ..... $3 / 4$ mile.

Near peak of roof on Bromes Wharf house... $22248 \quad \ldots \ldots \ldots \quad 5 / 8$ mile.

Weather vane on barn.................... $350 \quad 55 \quad 40 \ldots \ldots$ I $1 / 2$ miles. 
BROME.

General locality.-Eastern shore of St. Marys River about three-eighths mile south of Bromes Whari at St. Marys. (See chart No. 24.)

Immediate locality.-Observed station is in edge of woods about 6 feet above high water, 2 yards southeast of shore, and 25 yards from foot of a slope. Cement monument marking reference station is in woods 5.65 meters S. $76^{\circ} 12^{\prime} \mathrm{E}$. of observed station.

Marks.-Observed station is center of a 3 -inch square wooden box with top about flush with surface of ground. Reference station is center point of triangle on standard cement monument.

References.-

"McKay" (N. $86^{\circ} 29^{\prime}$ W.)

Peak of roof between two chimneys of McKay

house...........................

Peak of barn........................

Right chimney of two-story house..........

Chimney of small house................

Stovepipe of small cabin.................

Peak of roof of Bromes Wharf house.........

"Episcopal Church Cross" ................

Nail in blaze in chestnut tree........... I5

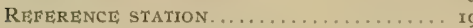

Nail in blaze in cherry tree............. 20

Tangent of Gravelly Point. . . . . . . . . . . . 298

Peak of roof between two chimneys of house

at Portobello.

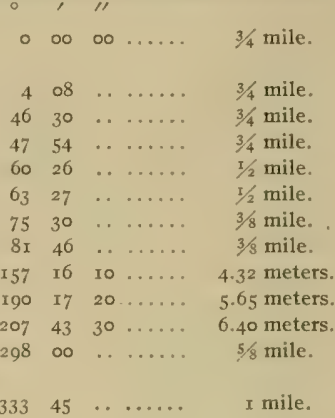

DEEP.

General locality.-Westem shore of St. Marys River opposite Bromes Wharf on first prominent point south of Pagan Point. (See chart No. 24.)

Immediate locality.-Oobserved station is about I foot above high water, II yards southwest of side of point, I2 yards north-northwest of side of point, 17 yards west of extreme end of point, and near several small piles of oyster shells.

Marks.-Observed station is center point of triangle on standard cement monument.

References.-

"Pagan" (N. $0^{\circ} 42^{\prime}$ W. $)$

\begin{tabular}{|c|c|c|c|}
\hline$\infty$ & $\infty$ & $\ldots \ldots$ & $3 / 8$ mile. \\
\hline 05 & . & $\ldots \cdots$ & 3 s mile. \\
\hline 35 & $\therefore$ & $\ldots \ldots$ & $3 / 8$ mile. \\
\hline 06 & $\therefore$ & $\ldots \ldots$ & $1 / 2$ mile. \\
\hline I2 & . & $\cdots \cdots$ & $1 / 2$ mile. \\
\hline$\infty$ & . & $\ldots \ldots$ & $1 / 2$ mile. \\
\hline IO & I5 & $\ldots \ldots$ & $1 / 2$ mile. \\
\hline 12 & $\infty$ & $\ldots \ldots$ & $1 / 2$ mile. \\
\hline 25 & . & ..... & 3/8 mile. \\
\hline 57 & $\cdots$ & $\ldots \ldots$ & $1 / 2$ mile. \\
\hline $5^{8}$ & 35 & $\ldots \ldots$ & 9.01 meters. \\
\hline$\infty$. & $\cdots$ & $\ldots \ldots$ & I $1 / 8$ miles. \\
\hline 08 & $\cdots$ & $\cdots \cdots$ & mile \\
\hline 47 & 20 & & 21. \\
\hline
\end{tabular}

Peak of barn

Chimney of two-story hous

Smoke pipe of cabin near monument. .....

Windmill at St. Marys Seminary ........... 7

"Calvert Monument" ................... 72

"Épiscopal Church Cross" .................

Peak of roof of Bromes Wharf house........ 8

Chimney of small house................ 10

Nail in blaze in cedar tree.............. I4

Tangent of Chancellor Point............ I 83

Peak of roof between two chimneys. . . . . . $2 \times 6$

Nail in blaze in cedar tree.

303 


\section{CALVERT MONUMENT.}

Genoral locality. - Eastern shore of St. Marys River on high prominent point near site of Old St. Marys. (See chart No. 24.)

Immediate locality.-Observed station is a tall granite shaft erected in memory of Calvert who founded the first settlement of Maryland near this point.

Marks.-Observed station is apex of pyramidal top of shaft of Calvert Monument.

References.-None necessary.

\section{EPISCOPAL CHURCH CROSS (OLD ST. MARYS).}

(jeneral locality.-Eastern shore of St. Marys River near site of Old St. Marys. (See chart No. 24.) Immediate locality.-Observed station is on tower of the Episcopal Church at Old St. Marys.

Marks,-Observed station is center of ross on tower of the Episcopal Church.

References - None necessary.

\section{PAGAN.}

General locality.-Western side of upper St. Marys River on Pagan Point opposite site of Old St. Marys. (See chart No. 24.)

Immediate locality.-Observed station is about 30 feet above high water, 120 yards southeast of river, I30 yards southwest of river, 26 yards southwest of a corn crib, 6 yards north of a wire fence, I6 yards south of another wire fence, and I9 yards west of still another wire fence.

Marks,-Observed station is center point of triangle on standard cement monument with top about to inches below surface of ground. Surface mark is nail in stub.

References,-

\begin{tabular}{|c|c|c|c|c|c|}
\hline " & $\circ$ & & Do & & \\
\hline Near peak of roof of wharf house.... & 8 & 12 & .. & & nile. \\
\hline ear peak of roof of Brome house...... & 12 & 03 & & & ile. \\
\hline Left side of left chimney of McKay house... & 96 & $3 I$ & & & $3 / 4$ mile: \\
\hline eft chimney of large house on hill... & IgI & I9 & & & I $1 / 8$ miles. \\
\hline ear corner of corn crib. & 290 & $2 I$ & Io & & 23.II meters. \\
\hline$\ldots \ldots$ & 33 & 33 & 10 & ...... & 27.85 meters. \\
\hline & 348 & 27 & 40 & & 24.9 \\
\hline Episcopal Church Cross" & $35^{8}$ & 26 & 50 & $\ldots$ & I/2 mile. \\
\hline
\end{tabular}

BEND.

General locality.-Eastern shore of Horseshoe Bend in the upper St. Marys River about five-eighths mile north-northeast of Calvert Monument and I mile east of Horseshoe Point. (See chart No. 24.)

Immediate locality. - Observed station is in a clear space about I5 feet above high water, I6 yards east of shore, 6 yards east of edge of bank, 7 yards east of a road, 12 yards south of trees, 12 yards west of bushes, 16 yards north of trees, and 23 yards northwest of trees.

Marks.-Observed station is center point of triangle on standard cement monument.

References.-

"Calvert Monument" (S. $31^{\circ} 22^{\prime}$ W.).......

Near corner of near chimney of McKay house

Chimney on middle of house on Pagan Point.

End of front peak of Brisco house..........

Near chimney of large house ........... 70

$\mathrm{Nail}$ in blaze in pine tree ( 3 inches diameter).

Nail in blaze in gum tree ( 9 inches diameter). 17

Nail in blaze in double cedar tree ( 3 inches diameter)........................ 228

Windmill at St. Marys Seminary........... 35

St. Marys.................... $354 \quad 57 \quad \ldots \ldots \ldots \quad$ 5. 8 mile.

"Ëpiscopal Church Cross" ............. $356 \quad 22$ o0 $\ldots \ldots . \quad 5 / 8$ mile.
$5 / 8$ mile.

$15 / 8$ miles.

$7 / 8$ mile.

I $1 / 2$ miles.

$x 3 / 8$ miles.

I0. 53 meters.

18.70 meters.

22.24 meters

$5 / 8$ mile.

$2606-I x-6$ 


\section{WEST HOLLOW.}

General localily.-Western shore of upper St. Marys River opposite Horseshoe Point and between Pagan Point and Short Point. (See chart No. 24.)

Immediate locality.-Observed station is in a pasture about ${ }_{5}$ feet above high water, 16 yards southwest of edge of bank at shore, 45 yards west by south of extreme end of point, 40 yards northwest of trees in ravine, and ir 5 yards southeast of trees along edge of field and bank of creek.

Marks.-Observed station is center point of triangle on standard cement monument with top about I inch above surface of ground.

References.-

\begin{tabular}{|c|c|c|c|c|c|}
\hline "Brief" (N. 10 ${ }^{\circ} 30^{\prime}$ E. $) \ldots \ldots \ldots \ldots \ldots \ldots$ & 0 & 00 & $\infty 0$ & $\ldots$. & I/2 mile. \\
\hline Right chimney of house on hill........... & I & 48 & . & . & I $1 / 2$ miles. \\
\hline Nail in blaze in oak tree ( 4 inches diameter). & 8 & 42 & 20 & & I8.37 meters. \\
\hline Windmill... & 24 & 49 & . & $\ldots \ldots$ & $x$ mile. \\
\hline Chimney of house. .................... & $26^{\circ}$ & oI & . & $\ldots \ldots$ & I mile. \\
\hline Near corner of chimney of Freeman house... & 36 & 07 & $\cdots$ & $\ldots \ldots$ & I mile. \\
\hline Windmill at St. Marys Seminary........... & 93 & 50 & $\cdots$ & $\cdots$ & $\mathrm{I} / 4$ miles. \\
\hline Near corner of chimney of small house...... & II 2 & 30 & $\cdots$ & & 200 yards. \\
\hline Tile smoke pipe of small house........... & I $7 \mathbf{I}$ & 20 & .. & & $1 / 4$ mile. \\
\hline Nail in blaze in pine tree ( 6 inches diameter). & $28 \mathrm{I}$ & $3^{8}$ & ০o & & 94.40 meters. \\
\hline Nail in blaze in oak tree ( 6 inches diameter). & $3^{24}$ & 17 & 20 & $\ldots \ldots$ & 32.86 meters. \\
\hline
\end{tabular}

\section{HORSESHOE.}

General locality.-Eastern side of upper St. Marys River about three-eighths mile north-northeast of Horseshoe Point, opposite Short Point, and $1 / 1 / 8$ miles north-northwest of Calvert Monument. (See chart No. 24.) -

Immediate locality.-Observed station is in a cultivated field about 25 feet above high water, $x_{75}$ yards east of shore, I20 yards east of edge of bank, 60 yards northwest of a rail fence and a line of trees, and $x_{5}$ yards northeast of corner of fence and bank.

Marks.-Observed station is center point of triangle on standard cement monument with top about I 2 inches below surface of ground. Surface mark is center of 3 -inch square wooden box.

References.-

"Calvert Monument" (S. $28^{\circ} 20^{\prime} \mathrm{E}$.

- 00 00 $\ldots . . .$.

Nail in blaze in oak tree ( $1_{4}$ inches diameter).

Chimney of McCoy house on Lynch Island.. I49 $44 \quad 30 \ldots .$.

Center front peak of Hilton house ........ I66 43 ......

Near end of gable................... $239 \quad 31$

Near corner of near chimney of Freeman house. $\begin{array}{rl}275 & 02\end{array}$

Nail in blaze in cedar tree ( 5 inches diameter). $\begin{array}{llll}306 & 29 & 20 & \ldots .\end{array}$

Nail in blaze in cedar tree ( 4 inches diameter). $354 \quad 3900 \ldots .$.

Right corner of near square pillar at St.

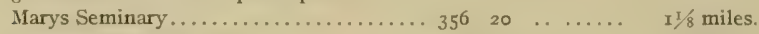

"Episcopal Church Cross"............. 358 of $40 \ldots \ldots$ I's miles. 
BRIEFE.

General locality.-Western shore of upper St. Marys River on Short Point about three-eighths mile northwest of Horseshoe Point and one-half mile south of Martin Point. (See chart No. 24.)

Immediate locality:-Observed station is about Io feet above high water, I 7 yards south-southwest of shore, 30 yards south of edge of bank, 45 yards northwest of shore, and IIo yards west of extreme end of point with four cedar trees.

Marks.-Observed station is center point of triangle on standard cement monument with top about I2 inches below surface of ground. Surface mark is center of a 3 -inch square wooden box.

References. -

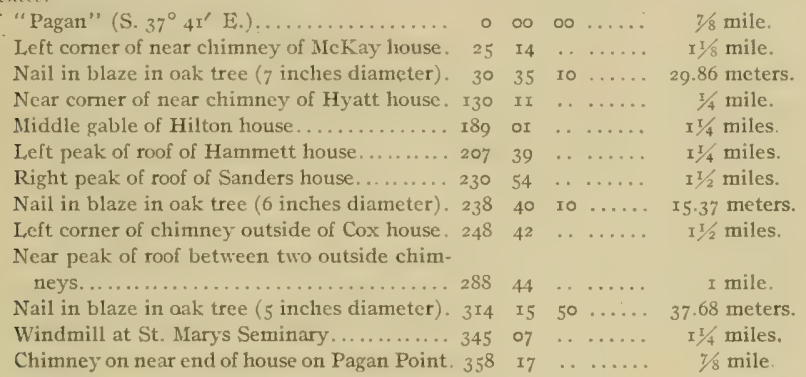

\section{TENUATE:}

General locality.-Western shore of upper St. Marys River on Long Point ahout one-fourth mile northwest of Short Point, three-eighths mile south-southwest of Martin Point, and five-eighths mile northwest of Horseshoe Point. (See chart No. 24.)

Immediate locality. - Observed station is on a point with two cedar trees about 20 feet above high water, 7 yards southeast of edge of bank, ro yards west-southwest of edge of bank, I3 yards south-southwest of extreme point of bank, and 30 yards northeast of a small negro house.

Marks.-Observed station is center point of triangle on standard cement monument.

References.-

"Calvert Monument" (S. $47^{\circ} 35^{\prime}$ E.).......

Outside chimney of Hyatt house............ 26

Nail in blaze in cedar tree (ro inches diameter) ............................ 68

Left comer of negro house.............. 84

Chimney of negro house.............. roo

Right corner of negro house............. I08

Chimney of McCoy house ................ 18

Peak of middle gable of Hilton house ....... 202

Left chimney of Hammett house ............ . 225

Right chimney of Sanders house .......... 254

Windmill............................. 296

I.eft chimney outside of Freeman house... . 3 I.

Windmill at St. Marys Seminary.......... 356 $\infty 00 \ldots \ldots \quad I \frac{1}{2}$ miles.

$27 \quad \ldots \ldots \ldots \quad 1 / 4$ mile.

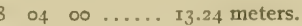

$17 \quad \ldots \ldots \ldots 27.06$ meters.

$5^{8} \quad \ldots \ldots \ldots$ 30 yards.

I2 $20 \ldots \ldots 26.15$ meters.

$49 \quad \ldots \ldots \ldots \quad 7 / 8$ mile.

$03 \ldots \ldots \ldots$ mile.

$37 \ldots \ldots \ldots$ I mile.

27 ...... I mile.

$\infty 30 \ldots . . \times \quad x$ mile.

07 ...... I mile.

o $\ldots \ldots \ldots \quad$ Is/s miles. 


\section{MARTIN.}

General locality.-Fastern shore of upper St. Marys River on Martin Point opposite Long Point about one-half mile north of Short Point, and seven-eighths mile north-northwest of Horseshoe Point. (See chart No. 24.)

Immediate locality.-Ohserved station is on a point of land about 3 feet above high water, 4 yards east of shore, 7 yards northwest of shore, 12 yards north of extreme end of point, and 30 yards north of cedar trees standing in water.

Marks.-Observed station is center point of triangle on standard cement monument.

References.-

"Calvert Monument" (S. $35^{\circ} 2 \mathrm{I}^{\prime}$ E. $)$..........

Nail in blaze in double cedar tree ( $\mathrm{I}_{4}$ inches diameter)

I,eft chimney of Coombs house..............

Chimney of McCoy house on Iynch Island. I49

Nail in blaze in cedar tree ( 9 inclies diam-

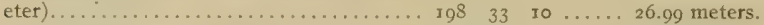

Near side peak of roof on Sanders house..... 244 o6 $\ldots \ldots \ldots . \quad 1 / 2$ mile.

Chimney of house $\ldots \ldots \ldots \ldots \ldots \ldots \ldots \ldots . \ldots \ldots \ldots+5 / 8$ mile.

$\mathrm{Nail}$ in blaze in cedar tree (4 inches diam-

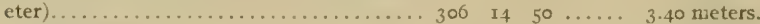

"Episcopal Church Cross" ................ $358 \quad 54$ o0 ..... $13 / 4$ miles.

\section{SOAK.}

Gencral locality.-Western shore of upper St. Marys River about one-half mile southeast of Lynch Island and one-half mile west-northwest of Long Point. (See chart No. 24.)

Immediate locality.-Observed station is about $I$ foot below high water, 3 yards northeast of bank back of which is a dense growth of pine trees, and ro yards west of the first point northwest of Long Point. Cement monument marking reference station is 11.02 meters S. $32^{\circ} 36^{\prime} \mathrm{W}$, of ohserved station.

Marks.-Observed station is nail in stub with top about 6 inches above bottom of river. Reference station is center point of triangle on standard cement nionument.

References.--

\begin{tabular}{|c|c|c|c|c|c|}
\hline "Martin" (N. $78^{\circ}$ s $^{\prime}$ F.). & 0 & $\infty$ & & & \\
\hline Rerrill windmill ........... & 7 & 34 & . & & mes. \\
\hline Near peak of roof of Berrill house. & I0 & 23 & & & iiles. \\
\hline Chimney of house on Long Point.... & 44 & $5^{2}$ & . & & \\
\hline Nail in blaze in pine tree ( 8 inches diameter). & 92 & 50 & 40 & & 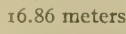 \\
\hline ail in blaze in oak tree ( 20 inches diameter). & 132 & $4 \mathrm{~T}$ & $\infty$ & & 12.0 \\
\hline REFERENCE STATION................... & $x_{34}$ & I9 & $\infty$ & & 11.0 \\
\hline Nail in blaze in oak tree ( ${ }_{5}$ inches diameter). & 187 & 25 & Io & & 17.7 \\
\hline de chimney of Ware house .............. & 2.35 & 18 & . & & niles. \\
\hline Chininey of McCoy house on I,ynch Island. . & 252 & 53 & . & & . \\
\hline Near end of middle gable of Hilton hou & 269 & $\infty$ & $\cdots$ & & \\
\hline of roof between two outside chimneys. . & 302 & 03 & . & & 21 \\
\hline Riglit chimney of Hammett house. & 302 & $5 \mathbf{I}$ & . & & \\
\hline Near peak of si & 334 & $I_{3}$ & . & ....... & \\
\hline
\end{tabular}




\section{HAMMETT.}

General locality.-Fiastern shore of upper St. Marys River on a prominent point about three-eighths of a mile east of Lynch Island and five-eighths of a mile northwest of Martin Point. (See chart No. 24.)

Immediate locality.--Observed station is on edge of cultivated land about 4 feet above high water, 8 yards north of shore, 30 yards east of shore on left line of slough, 7 yards east of a single cedar tree, and 90 yards southeast of trees on other side of point.

Marks.-Observed station is center point of triangle on standard cement monument.

References.-

"Calvert Monument" (S. $41^{\circ} 32^{\prime}$ E.)...... 0 . 00 oo .... $21 / 4$ miles.

Chimney on near end of Garrett house...... 5 . $21 \quad \ldots \ldots . \quad 17 / 8$ miles.

Chimney outside of Hyatt house.......... r t $_{4} 3_{1} \ldots \ldots$ I mile.

Nail in blaze in cedar tree ( 3 inches diam-

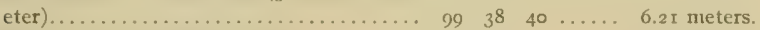

Chimney outside of McCoy house......... I43 $30 \quad \ldots \ldots .3 / 8$ mile.

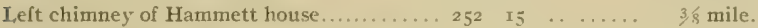

Right peak of roof between two chimneys of

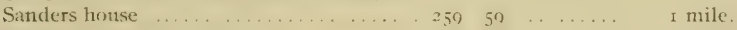

Windmill near Berrill................ $326 \quad 23 \ldots \ldots \ldots . I^{\mathrm{l} / 2}$ miles.

Left chimney of Berrill house............. 329 o8 $\ldots \ldots \ldots$ I $1 / 2$ miles.

Nail in blaze in small persimmon tree.... $335 \quad 20$ 00 .... 8.39 meters.

Near peak of roof between two chimneys of

Freeman house. ... . . . . . 3.36 37 $\quad \ldots \ldots \ldots \quad 1^{1}$. miles.

Windmill at St. Marys Seminary......... 357 i4 $50 \ldots \ldots \quad 2 \frac{1}{4}$ miles.

"Episcopal Church Cross" ............ 359 r 4 50 .... $2 \frac{1}{1 / 4}$ miles.

\section{IICCOY.}

General locality.-Upper St. Marys River on southwestern end of I,ynch Island, about seven-eighths of a mile west-northwest of Martin Point. (See chart No. 24.)

Immediate locality.--Observed station is about ro feet above high water, Io yards east of shore, 30 yards northwest of shore, 45 yaris north of shore at extreme point of island, and I20 yards southwest by south of McCoy camp house.

Marks.- Observed station is center point of triangle on standard cement monument.

References.-

"Calvert Monument" (S. $47^{\circ}$ i $8^{\prime}$ E.).........

Chimney of house on Long Point...........

Left chimney of house on Short Point........
Nail in blaze in walnut tree ( 7 inches diam-

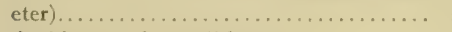

Left chimney of Powell house................

Nail in blaze in walnut tree ( 12 inches diam-

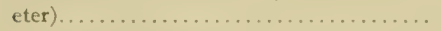

Nail in blaze in walnut tree ( 7 inches diam-

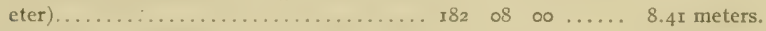

Nail in blaze in walnut tree ( 6 inches diameter)

\begin{tabular}{|c|c|c|}
\hline ০০ & $\infty \ldots \ldots$ & $21 / 2$ miles. \\
\hline $3 I$ & $\ldots \ldots \ldots$ & I mile. \\
\hline 35 & $\ldots \ldots \ldots$ & I $1 / 4$ miles. \\
\hline 49 & $30 \ldots \ldots$ & 5.73 meters. \\
\hline $3^{8}$ & $\ldots \ldots \ldots$ & $3 / 4$ mile. \\
\hline 17 & $20 \ldots \ldots$ & I5.46 meters. \\
\hline 08 & $\infty \ldots \ldots$ & $8.4 \mathrm{I}$ meters. \\
\hline 16 & $40 \ldots$ & 10.34 meters. \\
\hline 14 & $30 \ldots \ldots$ & 120 yards. \\
\hline $\mathrm{O} 2$ & $\ldots \ldots \ldots$ & $13 / 4$ miles. \\
\hline 35 & $20 \ldots \ldots$ & $21 / 2$ \\
\hline 23 & $30 \ldots \ldots$ & $2 \frac{1}{2}$ miles. \\
\hline
\end{tabular}

Right corner of McCoy house............ 283 I4 $30 \ldots \ldots$ 120 yards.

Near peak of roof hetween two chimneys on

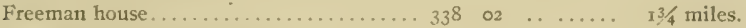

Windmill at St. Marys Seminary......... $357 \quad 35 \quad 20 \ldots \ldots \quad 2 \frac{z^{2} / 2}{2}$ miles.

"Episcopal Church Cross" .............. $35923 \quad 30 \quad \ldots \ldots .2 \frac{21 / 2}{2}$ miles. 
SMACK.

General locality. - Southern side of entrance to St. George River on St. George Island opposite Cherryfield Point. (See chart No. 24.)

Immediate locality.--Observed station is about 3 feet above high water, 8 yards south of shore, 30 yards southwest of extreme end of point, 45 yards west of shore, and 4 yards northeast of fence and orchard. Cement monument marking reference station is 6.20 meters $\mathrm{S}$. $13^{\circ} 27^{\prime} \mathrm{E}$. of observed station.

Marks.-Observed station is nail in stub with top about flush with surface of ground. Reference station is center point of triangle on standard cement monument.

References.-

\begin{tabular}{|c|c|c|c|c|c|}
\hline "Cherry" (N. $3 \mathrm{I}^{\circ} 53^{\prime}$ E. $) \ldots \ldots \ldots \ldots \ldots \ldots$ & $\circ$ & $\infty$ & $\infty$ & $\ldots$ & le. \\
\hline Chimney of Taylor house................ & 27 & 55 & & & $21 / 4$ miles. \\
\hline "St. Michaels Catholic Church Spire" ..... & $5^{8}$ & & 50 & & iles. \\
\hline Tear peak of roof of Lewis Hotel at Smith & & & & & \\
\hline$\ldots \ldots \ldots \ldots \ldots \ldots \ldots \ldots \ldots$ & $7^{2}$ & 05 & 30 & $\cdots \cdot$ & $33 / 4$ miles. \\
\hline Near peak of roof of long barn on Kitts Point. . & 77 & 54 & .. & . & $27 / 81$ \\
\hline Chimney of first house on point of island.... & $1 \times 2$ & 34 & . & ... & $1 / 4$ mile. \\
\hline $\operatorname{atroN} \ldots \ldots \ldots \ldots \ldots \ldots \ldots$ & 134 & 39 & 40 & & 6.20 \\
\hline 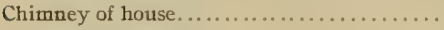 & 137 & 32 & . & & 1/8 mile. \\
\hline puse................. & 170 & $3^{8}$ & . & & 120 yards. \\
\hline 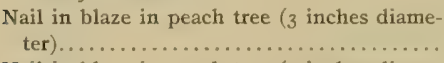 & 177 & 43 & 50 & & 4.7 \\
\hline $\begin{array}{l}\text { Nail in blaze in peach tree }(4 \text { inches diame- } \\
\text { ter } \ldots \ldots \ldots \ldots \ldots \ldots \ldots \ldots \ldots \ldots\end{array}$ & & & & & \\
\hline Ball & 15 & 55 & 0 & . & \\
\hline Chain & $23 I$ & 25 & & 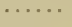 & \\
\hline of house & 254 & & - & & \\
\hline $\begin{array}{l}\text { Near peak of rool. } \\
\text { Chimney of house. }\end{array}$ & 299 & 25 & .. & $\ldots \ldots$ & \\
\hline & & & & ..... & \\
\hline
\end{tabular}

\section{CHERRY}

General locality.-Northern side of entrance to St. George River on Cherryfield Point. (See chart No. 24.)

Immediate locality.-Observed station is about 2 feet above high water, 27 yards east of shore, 30 yards north of shore, 30 yards southwest of pine woods, and near several trees.

Marks.-Observed station is center point of triangle on standard cement monument.

References.-

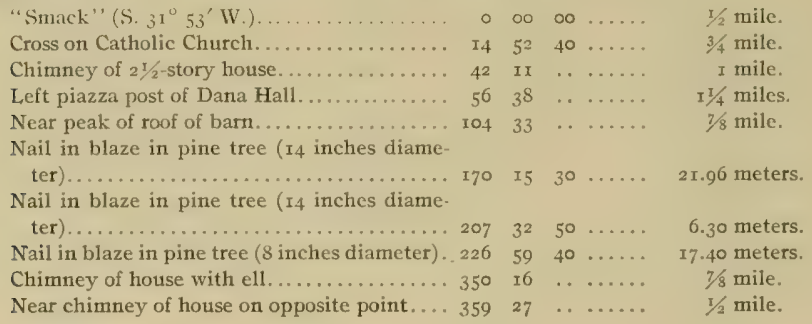




\section{PRICE}

General locality. - Northern shore of St. George River on eastern side of entrance to Price Creek and about one-half mile north of Cherryfield Point. (See chart No. 24.)

Immediale locality.-Observed station is on a marsh point about $I^{1 / 2}$ feet above high water, 9 yards southeast of shore, I 7 yards north-northeast of shore, 2 I yards east-northeast of shore at end of point, and 200 yards west of pine woods on inner edge of marsh.

Marks. - Observed station is center point of triangle on standard cement monument.

References.-

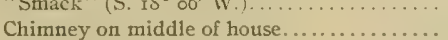

Right chimney of large house.............

Chimney on Adams store............... 46

Near peak of house with no chimney....... 48

Cupola of dance hall................ 5

Chimney of small house................ 53

Chimney of small house. ................

Largest chimney on Milton house......... 86

Peak of Milton barn.................. 92

Chimney of small cabin................ 105

Peak of Thompson hoirse ... . . . . . . . . . 122

\begin{tabular}{|c|c|c|}
\hline D० & $\infty \ldots \ldots$ & I mile. \\
\hline & . $\quad \ldots \ldots$ & $\mathrm{I} 1 / 4$ miles \\
\hline & . . . . . & $13 / 8$ miles \\
\hline & $\ldots \ldots \ldots$ & $13 / 8$ miles \\
\hline 0 & $\ldots \ldots \ldots$ & I $3 / 8$ mile \\
\hline & . . ..... & I $3 / 8$ miles \\
\hline 30 & $\ldots \ldots \ldots$ & $\mathrm{x}^{\mathrm{I} / 2} \mathrm{mi}$ \\
\hline & $\ldots \ldots \ldots$ & $\mathrm{I}^{1} / 2$ mil \\
\hline & . $\ldots . \cdots$ & $3 / 4 \mathrm{milc}$ \\
\hline & $\ldots \ldots \ldots$ & $3 / 4$ mile \\
\hline & $\ldots \ldots \ldots$ & $5 / 8$ mile \\
\hline & $\ldots \ldots \ldots$ & $3 / 4 \mathrm{mil}$ \\
\hline
\end{tabular}

ADAMS.

General locality.-Southwestern shore of St. George River on St. George Island about I mile westsouthwest of Cherry field Point. (See chart No. 24.)

Immediate locality.-Observed station is in chicken yard about I foot above high-water mark, 28 yards southwest of shore, 15 yards southwest of wire fence, 17 yards south of corner of wire fence, $3^{8}$ yards west-northwest of comer of wire fence, 37 yards north of corner of wire fence, and 30 yards east of corner of wire fence. Cement monument marking reference station is 13.63 meters N. $80^{\circ} 35^{\prime} \mathrm{W}$. of observed station.

Marks.-Observed station is nail in tree stump 8 inches in diameter. Reference station is center point of triangle on standard cement monument.

References.-

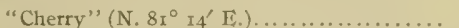

Corner post of wire fence...............

Near peak of rooi of large house............

Left chimney of large house with four gables.

Nail in blaze in pine tree (ro inches diame-

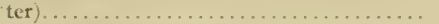

Corner tree of wire fence. ....................

Near edge of peak of gable.

Nail in blaze in pine tree (10 inches diame-

ter $) \ldots \ldots \ldots \ldots \ldots \ldots \ldots \ldots \ldots \ldots$ I 55

Corner tree of wire fence. ....................

Near corner of chicken house........... 189

Nail in blaze in pine tree (ro inches diame-

ter $) \ldots \ldots \ldots \ldots \ldots \ldots \ldots \ldots \ldots \ldots$. . . . . . . . . . . .

REFERENCE STATION ............... IgS

Right chimney of house.................207

Pole on pavilion on wharf............. 228

Corner post of wire fence.............. $28_{3}$

Near peak of roof between chimneys....... 312

$\begin{array}{lll}00 & 00 & \ldots \\ 42 & \ldots & \ldots \\ 03 & \ldots & \ldots \\ 46 & \ldots & \ldots \\ 03 & 20 & \ldots \\ 43 & \ldots & \ldots \\ 2 S & \ldots & \ldots \\ & & \\ 34 & 20 & \ldots \\ 20 & \ldots & \ldots \\ 49 & \ldots & \ldots \\ & & \\ 15 & 10 & \ldots \\ 11 & 30 & \ldots \\ 29 & \ldots & \ldots \\ 02 & \ldots & \ldots \\ 24 & \ldots & \ldots \\ 22 & \ldots & \ldots \\ \end{array}$

I mile.

$3^{S}$ yards.

$1 / 4$ mile.

$1 / 8$ mile,
II.35 meters
37 yards.
Too yards.

21.29 meters.

30 yards.

I2.62 meters

8.89 meters.

I 3.65 meters.

$1 / 8$ mile.

$1 / 4$ mile.

17 yards.

I $3 / 4$ miles. 


\section{GOOSE.}

General locality.-Northeastern shore of St. George River, about three-fourths mile northwest of Cherryfield Point, and one-fourth mile northwest of entrance to Price Creek. (See chart No. 24.)

Immediate locality.-Observed station is about I foot above high-water mark, among cedar, pine, and persimmon trees, 4 yards northeast of edge of lane, 13 yards south of cultivated land beyond trees, and a few yards northwest of four large pine trees at edge of water.

Marks.-Observed station is center point of triangle on standard cement monument.

References.--

"Cherry" (S. $45^{\circ} 49^{\prime}$ E.)..................

Nail in blaze in pine tree ( $I I$ inches diameter $) . \ldots \ldots \ldots \ldots \ldots \ldots \ldots \ldots \ldots . . . \ldots \ldots \ldots$.

Chimney on middle of two and a half story house...........................

Near front peak of two and a half story house. .

Chimney of storehouse ...............

Smokepipe of cottage near high scant woods. . II

High lone pine tree on St. George Island.... I34

Chimney on two and a half story house near

Piney Point......................... I4 45 Nail in blaze in cedar tree $(5$ inches diame
Name

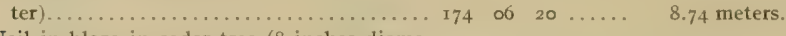

Nail in blaze in cedar tree ( 8 inches diame-

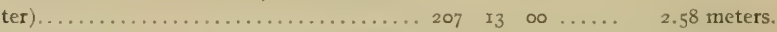

Nail in blaze in cedar tree ( 6 inches diame-

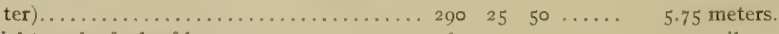

Right peak of wharf house............ 263 or ...... I mile.

Tangent of point..................... 25474 yards.

\section{STRAITS.}

General locality. - Southwestern shore of St. George River on St. George Island about one-fourth of a mile southeast of St. George Island Straits, and about I7/8 miles east of Piney Point Light. (See chart No. 24.)

Immediate locality.-Observed station is on marsh land at about I foot above high-water mark, 3 yards southeast side of point, 5 yards northwest of side of point, and ig yards southwest of extreme end of point.

Marks,-Observed station is center point of triangle on standard cement monument.

References.-

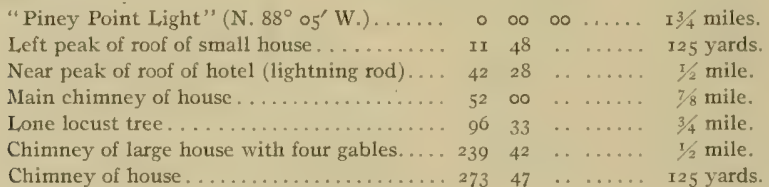

\section{COMBS.}

General locality.- Northeastern side of St. George River on a small island about one-eighth mile off shore and one-half mile east of St. George Island Straits. (See chart No. 24.)

Immediate locality. - Observed station is on marsh land about on level with high water, 7 yards north of extreme end of point, II yards west of shore, and 40 yards east-southeast of another point. Cement monument marking reference station is 13.87 meters $N$. $1^{\circ}{ }^{\prime} 2^{\prime} W$. of observed station. 
Marks.-Observed station is nail in stake. Reference station is center point of triangle on standard cement monument.

References.-

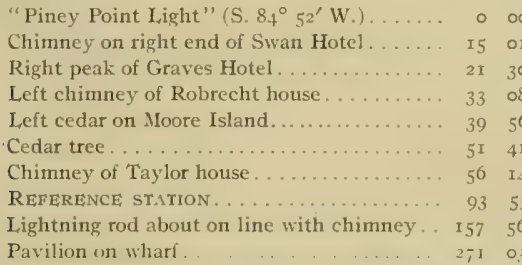

$$
\begin{aligned}
& \text { 2's miles. } \\
& 5.8 \text { mile. } \\
& 3 / 4 \text { mile. } \\
& 7 / 8 \text { mile. } \\
& 3 / 8 \text { mile. } \\
& 3 / 8 \text { mile. } \\
& 1 / 4 \text { mile. } \\
& \text { 30 .... } 13.87 \text { meters. } \\
& 1 / 4 \text { mile. } \\
& 5 / 8 \text { mile. }
\end{aligned}
$$

SWAN.

General locality.--Southwestern shore of St. George River about one-eighth of a mile north of St. George Island Straits and $I / 5$ miles east of Piney Point Light. (See chart No. 24.)

Immediate locality.-Observed station is in a pasture near a locust tree and three small pine trees about 3 feet above high-water mark, 12 yards south-southeast of shore, I4 yards west of shore, 4 yards west of edge of bank, Io yards south-southeast of edge of bank, 12 yards south of extreme point of bank, 30 yards southwest of extreme end of point, and 130 yards northeast of a cross on a grave.

Marks.-Observed station is center point of triangle on standard cement monument.

References.--

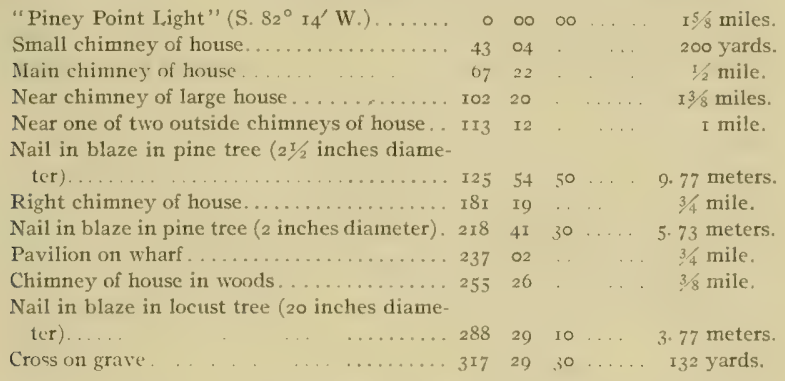

\section{TAYLOR.}

General locality:-Northeastern shore of St. George River about one-half mile northeast of St. George Island Straits. (See chart No. 24.)

Immediate locality.-Observed station is on solid land back of marsh about 4 feet above high water, 37 yards southeast of shore, Io yards south-southeast of fence corner, I00 yards cast-northeast of a clump of trees, and 125 yards northwest of shore.

Marks.-Observed station is center point of triangle on standard cement monument.

References.-

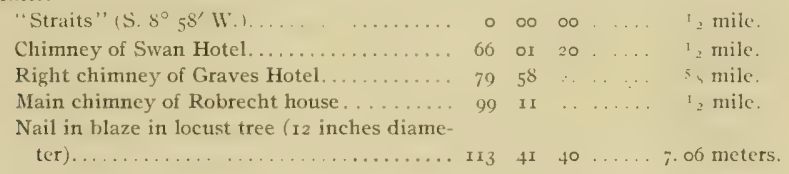


References-Continued.

Right chimney of Adams house......... I23 $58 \ldots \ldots \ldots$ I1/8 miles.

Nail in blaze in cedar fence post ( 4 inches

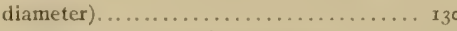

Left chimney of old $21 / 2$-story house....... 134

Chimney of house.................. 285

Chimney of house with four gables behind long building. . . . . . . . . . . . 338

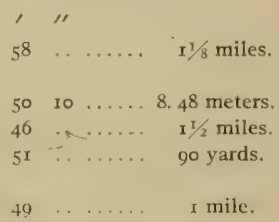

ROBRECHT.

General localily. - Southwestern shore of St. George River on a point of land about five-eighths mile north of St. George Island Straits. (See chart No. 24.)

Immediate localily. - Observed station is in a cultivated field about 4 feet above high water, 6 yards west of edge of bank, 35 yards southeast of edge of bank, 70 yards northwest of edge of bank, and 40 yards south by west of extreme end of point.

Marks.-Observed station is center point of triangle on standard cement monument with top about ro inches below surface of ground. Surface mark is a 3 -inch-square wooden box.

References.-

\begin{tabular}{|c|c|c|c|c|}
\hline 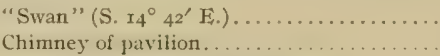 & $\begin{array}{r}0 \\
23\end{array}$ & $\begin{array}{l}\infty \\
29\end{array}$ & $\infty$ & \\
\hline Right chimney of Robrecht house. . & 77 & 03 & . & \\
\hline Chimney of house . .......... & 160 & IO & . & \\
\hline Left chimney of old $21 / 2$-story house. . & 166 & 59 & .. & \\
\hline Left chimney of house......... & 207 & 43 & .. & \\
\hline Near one of two chimneys on house. . & 225 & 28 & & \\
\hline k of roof of house & 312 & 48 & & \\
\hline Chimney of house in woods & 356 & 31 & & $\ldots \ldots$ \\
\hline
\end{tabular}

TARKHILI.

General locality.-Northeastern side of St. George River, a short distance off shore on a small island about three-fourths mile north of St. George Island Straits. (See chart No. 24.)

Immediate locality.-Observed station is on a small marsh island or tump about I foot above high water, 2 yards southwest of edge of island, 3 yards northeast of edge of island, 8 yards northwest of edge of island, and 22 yards southeast of edge of island.

Marks.-Observed station is center point of triangle on standard cement monument.

References.-

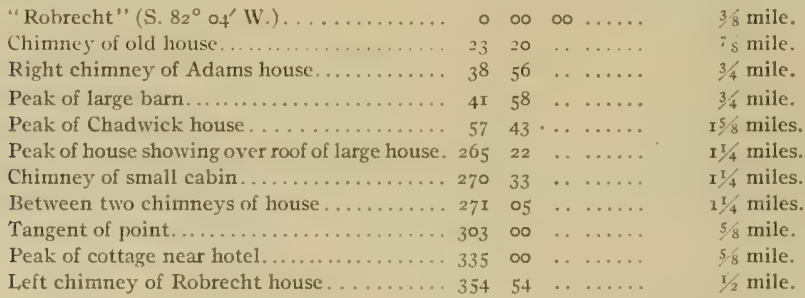


RUSSELL.

General locality. - Southwestern shore of upper St. George River about II/8 miles northwest of St. George Island Straits. (See chart No. 24.)

Immediate locality.-Observed station is on the edge of a cultivated field about $z$ feet above high water, 7 yards northwest of shore, I3 yards west of shore, 40 yards west-northwest of a small marsh point, and 80 yards cast of a comer of a fence around yard of house.

Marks.-Observed station is center point of triangle on standard cement monument.

References.-

\begin{tabular}{|c|c|c|c|c|}
\hline Lowell" (N. 51 ${ }^{\circ}$ o5' E.). & 0 & $\infty$ & $\infty$ & $x^{2}+1$ \\
\hline Between two chimneys of Mac Adams house. & 18 & 20 & & $3+1$ \\
\hline barn. & 23 & 31 & & \\
\hline aze in pine & 75 & +6 & 10 & 6. 45 \\
\hline of To & 223 & 20 & & 90 \\
\hline arn. & 235 & to & & I 50 \\
\hline ea & 257 & 05 & $\ldots$ & \\
\hline & 288 & 53 & 30 & 7.94 \\
\hline ak of large barn. & & +4 & & $3 / 4$ mile. \\
\hline
\end{tabular}

LOWELL.

General locality.--Northeastern shore of upper St. George River about $13 / 4$ miles north of St. George Island Straits. (See chart No. 24.)

Immediate locality.-Observed station is in a field about $\mathrm{x}$ foot above high water, 6 yards northwest of shore, 32 yards northeast of extreme point of shore, and 33 yards east of shore.

Marks.-Observed station is center point of triangle on standard cement monument.

References.-

"Arbuckle" (N. $82^{\circ} 12^{\prime}$ E. .............. o

Peak of barn ......................... 5 is . . . . .

Left chimney of Swan Hotel............ 93 o6 ...... I mile.

Chimney of storehouse............... 95 30 $\ldots \ldots \ldots .3 / 4$ mile.

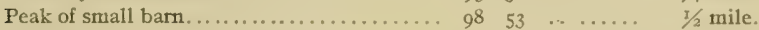

Left chimney of Robrecht house......... $995^{\mathrm{x}} \quad \ldots \ldots \ldots \quad 1 / 2$ mile.

Left lightring rod of Graves house........ ro ro $52 \ldots \ldots$. $\quad \ldots$ mile.

Near chimney of Adams house........... I55 $47 \quad \ldots \ldots \ldots \quad 1 / 4$ mile.

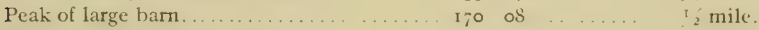

Chimney of Wall house.............. I97 $55 \ldots \ldots \ldots \quad 1 / 2$ mile.

Nail in blaze in persimmon tree..........237 23 10 ...27.58 meters.

\section{ARBUCKLE.}

General locality.- Northeastern side of upper St. George River about $13 / 8$ miles north of St. George Island Straits. (See chart No. 24.)

Immediate locality.-Observed station is in a cultivated field about io feet above high water, roo yards northeast of shore, roo yards north of a ditch, 250 yards west of comer of Adams bam, and 300 yards west by south of Adams house.

Marks.-Observed station is center point of triangle on standard cement monument. (Note: Supposed to be buried with top $x_{2}$ inches below surface of ground.)

References.-

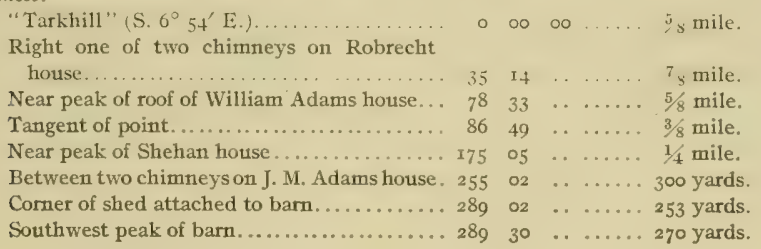


WALL.

General locality.-Southwestem shore of upper St. George River about $\mathbf{I}^{1} / 2$ miles north-northwest of St. George Island Straits. (See chart No. 24.)

Immediute loculity. -Observed station is in a field about 3 feet above high water, 7 yards southwest of shore, 45 yards southeast of shore, 40 yards east of shore of cove, 35 yards east of an oak tree, and 200 yards northwest of a house.

Marks.-Observed station is center point of triangle on standard cement monument.

References.-

\begin{tabular}{|c|c|c|c|c|c|}
\hline Lowell" (S. $76^{\circ} 47^{\prime}$ E. $) \ldots \ldots \ldots \ldots \ldots \ldots$ & 0 & $\infty$ & 0 & & $1 / 2$ mile. \\
\hline Chimney of Wall house. & 9 & 14 & & & 200 \\
\hline eak of barn... & 35 & 48 & & & as \\
\hline utside chimney of house. & I 55 & 40 & . & & \\
\hline y of house... & 189 & $\infty$ & . & & iles. \\
\hline ey of $11 / 2$-story ho & 201 & 44 & & & $I^{1} / 2$ \\
\hline m & 242 & II & & & $13 / 4$ \\
\hline of Chadwick house. & 244 & 24 & $\because$ & & $1 / 2$ \\
\hline ho1 & 257 & 04 & & & e. \\
\hline ). & 261 & 08 & & & 5. 28 \\
\hline across creek. . & 328 & 27 & & & ile \\
\hline uthwest peak of barn. & 352 & $\infty$ & .. & $\ldots \ldots$ & iile. \\
\hline
\end{tabular}

\section{SHEHAN.}

General locality.-Northeastem shore of upper St. George River about $5^{5} / 8$ miles northwest of St. George Island Straits. (See chart No. 24.)

Immediate locality.-Observed station is on solid ground about 2 feet above high water, 8 yards east of shore, 40 yards northwest of shore, 30 yards north-northeast of extreme end of point, 50 yards west of an old rail fence, and north-northwest of marsh between shore and station.

Marks.-Observed station is center point of triangle on standard cement monument.

References.-

\begin{tabular}{|c|c|c|c|c|c|}
\hline 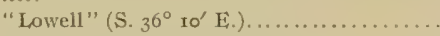 & $\circ$ & $\infty$ & $\infty$ & & $3 / 8$ mile. \\
\hline Chimney of Robrecht house... . & 27 & 34 & & & ailes. \\
\hline Lightning rod of Adams house. & 38 & 32 & . & & $1 / 2$ mile. \\
\hline$y$ of house.....$\ldots \ldots \ldots$ & 44 & $I_{3}$ & . & & $1 / 2$ mile. \\
\hline Peak of Wall house ............... & 62 & 28 & . & & nile. \\
\hline Peak of house........ & 96 & $\infty$ & . & & $3 / 4$ mile. \\
\hline Peak of large barn..... & 121 & 25 & . & & nile. \\
\hline Tangent of point up creek.... & 162 & 50 & . & & ile. \\
\hline Nail in blaze in small pine tree. & 254 & 08 & 50 & & 20. 32 meters \\
\hline
\end{tabular}

\section{CHADWICK.}

General locality.-Northeastern shore of upper St. George River on a prominent point between a cove and creek about 2 miles north-northwest of St. George Island Straits. (See chart No. 24.)

Immediate locality.-Observed station is on edge of an old field about 2 feet above high water, 9 yards northeast of shore, 18 yards northwest of extreme end of point, 80 yards south-southeast of a $21 / 2$ story house, and 75 yards from several apple trees.

Marks.-Observed station is center point of triangle on standard cement monument.

References.-

\begin{tabular}{|c|c|c|c|c|}
\hline Wall" (S. II ${ }^{\circ} 24^{\prime}$ E. .). & ० & $\infty$ & $\infty$ & \\
\hline South peak of barn... & 14 & 24 & . & \\
\hline Chimney of house...... & 27 & 16 & . & \\
\hline $\begin{array}{l}\text { Chimney of house on opposite shore ....... } \\
\text { Chimney of house among trees on opposite }\end{array}$ & 30 & 49 & $\ldots$ & - \\
\hline 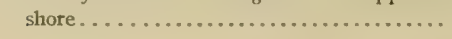 & 36 & o & & \\
\hline
\end{tabular}


References-Continued.

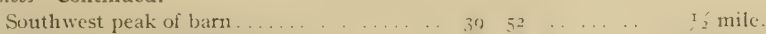

Chimney of house near woods. . . . . . . $8 \begin{array}{llllll}88 & 28 & \ldots & \ldots & 3 / 4 \\ \text { mile. }\end{array}$

Nail in blaze in locust tree........... $137 \quad 55 \quad 50 \ldots \ldots .3 .82$ meters.

Near corner of house............... I I I $46 \ldots \ldots$. 8 I yards.

South corner of house...............

\section{GUITHER.}

General locality.-Southwestern shore of upper St. George River about 2 miles northwest of St. George Island Straits. (See chart No. 24.)

Immediate locality.-Observed station is in a grassy field about 2 feet above high water, directly opposite Chadwick farm house, 12 yards northwest of shore, 18 yards south of shore, and 35 yards southwest of extreme end of point.

Marks.-Observed station is center point of triangle on standard cement monument.

References.-

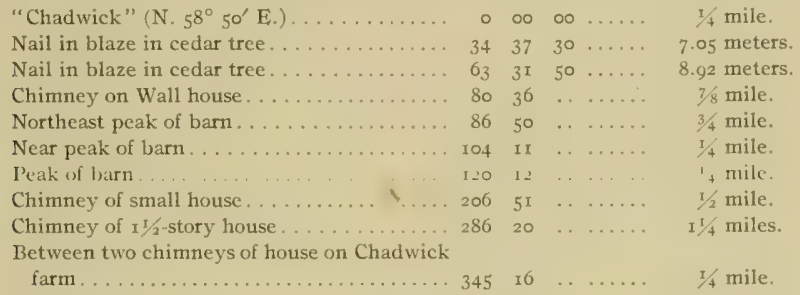

\section{ST. GEORGE 4 .}

General locality.-Northeastern shore of Potomac River about one-eighth mile north of southern end of St. George Island and one-half mile west-southwest of entrance to Island Creek. (See chart No. 24.)

Immediate locality. - Observed station is on grassy sand about 3 feet above high water, I yard northeast of shore, 200 yards northwest by west of extreme end of point, and I50 yards southeast of another point. Standard cement monument marking reference station of 1909 is $26.4 \mathrm{I}$ meters N. $4^{\circ}{ }_{1} 6^{\prime} \mathrm{E}_{\text {; }}$ of observed station. Reference station No. I (tile pipe set in cement) is $3 \mathrm{r} .58$ meters N. $4^{\circ} 30^{\prime} \mathrm{E}$. of observed station. Reference station No. 2 (tile pipe set in cement) is 48.98 meters N. $59^{\circ} 27^{\prime} \mathrm{E}_{\text {. of }}$ observed station.

Marks.-Observed station is $1 / 4$-inch iron pipe in 3 -inch tile pipe set in cement with top about I2 inches below surface of ground. Surface mark is nail in stub. Reference station of 1909 is center point of triangle on standard cement monument. Reference station No. I is center of 3 -inch tile pipe set in cement with top 3 inches above surface of ground. Reference station No. 2 is center of a .3-inch tile pipe set in cement with top about flush with surface of ground.

References.-

"Piney Point Light" (N. $52^{\circ} 48^{\prime}$ W. . ....... Nail in blaze in pine tree ( 4 inches diameter). REFERENCE STATION NO, I (tile) ..........

REFERENCE STATION (cement monument) .. 95

Nail in blaze in pine tree ( 5 inches diameter). to

REFERENCE STATION No. 2 (tile) . . . . . . II

Tall pine tree on Kitts Point.

Left chimney of large colonial house on Vir-

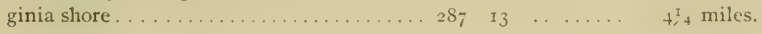

$33 / 4$ miles.

I 9.44 meters.

31.58 meters.

26.41 meters.

26.56 meters.

48.98 meters.

$27 / 8$ miles. 


\section{PINEY POIN'T LIGHT.}

General locality, - Northeastern shore of Potomac River on Piney Point about 5 miles northwest of entrance to St. Marys River. (See chart No. 24.)

Immediate locality.-Observed station is on a tower near a dwelling and a fog-bell tower.

Marks.-Observed station is center point of a lantern on a tower about 30 feet high.

References.-

"Blakistone Island Light" (N. $67^{\circ} \circ 2^{\prime}$ W.).. $\quad \circ \quad 00 \quad 00 \ldots \ldots$... $12 \frac{1}{2}$ miles.

\section{FOXWELLL.}

General locality.-Northeastern shore of upper Bretons Bay about one-half mile east-southeast of Leonardtown Whatf and $1 / 4$ miles north of entrance to Mouldy Creek. (See chart No. 25.)

Immediale locality.-Observed station is about 6 feet above high water, 12 yards northwest of shore, 2 yards from a 3 -foot bank, 12 yards south of an orchard, and 25 yards east of a house.

Marks.-Observed station is center point of triangle on standard cement monument.

References.-

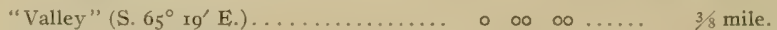

East gable of Duke house............ II4 $28 \ldots \ldots \ldots$ I/2 mile.

Nail in blaze in paulownia stump....... $129 \quad 59 \quad 40 \ldots \ldots$ 8.50 meters.

East gable of Foxwell house........... I49 $24 \quad \ldots \ldots .25$ yards.

Southeast chimney of Key house....... 2II $06 \quad \ldots \ldots \ldots \quad 1 / 2$ mile.

Chimney of small house. ............ $239 \quad 46 \quad \ldots \ldots \ldots \quad 1 / 4$ mile.

South chimney of large 2 -story house..... $27743 \quad \ldots \ldots . \quad 1 / 2$ mile.

Nail in blaze in paulownia tree ( 5 inches

diameter $) \ldots \ldots \ldots \ldots \ldots \ldots \ldots \ldots \ldots .320 \quad$ I7 $30 \ldots \ldots .4 .42$ meters.

Spike in old wharf pile about 6 inches above

ground ....................... $355 \quad 47 \quad 40 \ldots 0$ meters.

\section{VALLEY.}

General locality.-Northeastern shore of bend in upper Bretons Bay about three-fourths mile eastsoutheast of Leonardtown Wharf and $1 \frac{1}{4}$ miles north-northeast of entrance to Mouldy Creek. (See chart No. 25.)

Immediate locality.-Observed station is on a narrow strip of marsh about $\mathbf{I}$ foot above high water, I5 yards east of high water, and roo yards south of a cultivated field.

Marks.-Observed station is center point of triangle on standard cement monument.

References.-

\begin{tabular}{|c|c|c|c|c|}
\hline "Corn" (S. $28^{\circ} \mathrm{oz}^{\prime}$ W.) & 0 & $\infty$ & $\infty$ & \\
\hline 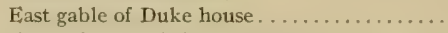 & 50 & 02 & .. & \\
\hline East chimney of Foxwell house....... & 84 & 57 & . & \\
\hline South chimney of large 2 -story house. . & 116 & 27 & . & \\
\hline South gable of house on hill.... & 171 & os & $\cdots$ & \\
\hline Smokestack on sawmill. ............... & 210 & 35 & $\ldots$ & ...... \\
\hline Northwest chimney of old farmhouse...... & 335 & $3^{8}$ & . & ...... \\
\hline
\end{tabular}

\section{BUZZARD.}

General locality.-Western shore of upper Bretons Bay on a prominent point in bend in bay about $1 / 2$ mile southeast of Leonardtown Wharf, and I mile north of entrance to Mouldy Creek. (See chart No. 25.)

Immediate locality.-Observed station is about I foot above high water, 7 yards northwest of shore, ro yards southeast of shore, 80 yards west-northwest of a point, and ro yards east of foot of a slope.

Marks.-Observed station is center point of triangle on standard cement monument. 
References.-

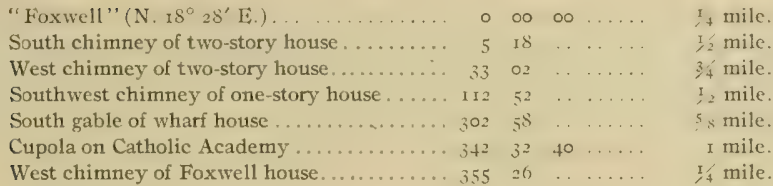

CORN.

General locality.-Eastern shore of upper Bretons Bay on second prominent point riorth of Mouldy Creek about $7 / 8$ mile southeast of Leonardtown Wharf, and II/2 miles northeast of entrance to Mouldy Creek. (See chart No. 25.)

Immediate locality. - Observed station is inside of a rail fence at the edge of a cultivated field about 3 feet above high water, Io yards from shore, and $1 / 4$ mile northwest of a one and one-half story farmhouse.

Marks.-Observed station is center point of triangle on standard cement monument.

References.-

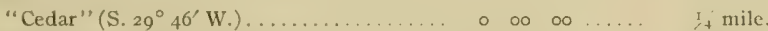

Chimney of small two-story house........ 52 to $\ldots \ldots \ldots$. 1 . mile.

East gable of Duke house............ gI $30 \ldots \ldots$ mile

South gable of wharf house............. I ro to ......

Southwest chimney of Key house......... I2S $3.3 \ldots \ldots$;s mile.

South gable of Foxwell house $\ldots \ldots \ldots \ldots \ldots \ldots$ 1, 30 28 $\ldots \ldots \ldots, 12$ mile.

Cross on Catholic Academ

South gable of house on hill............. $174 \quad 58 \ldots \ldots \ldots .3 \%$ mile.

Smokestack of sawmill.............. I95 39 10 .... I mile.

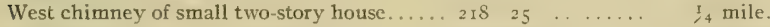

Near chimney of old farmhouse........... 290 o0 ...... I/4 mile.

CEDAR.

General locality.-Eastern shore of upper Bretons Bay on first prominent point north of entrance to Mouldy Creek. (See chart No. 25.)

Immediate locality.-Observed station is on a marsh point about 2 feet above high water, I5 yards east of shore, 5o yards north of a cultivated field bounded by rail fence and small cedar trees, and directly in front of a dense growth of small cedar trees and myrtle bushes.

Marks.-Observed station is center point of triangle on standard cement monument.

References.-

"Pine" (S. $10^{\circ} 40^{\prime} \mathrm{E}$.

1,1

Nail in blaze in cedar tree. ( 6 inches diameter) $\ldots \ldots \ldots \ldots \ldots \ldots \ldots \ldots \ldots \ldots \ldots \ldots \ldots \ldots \ldots \ldots$.

Nail in blaze in cedar tree ( 8 inches diam-

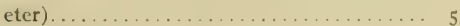

North chimney of small house. ........... 129

South gable of Duke house............... I

Southwest chimney of Key house........... I

Cross on Catholic Academy.............. I

Nail in blaze in cedar tree ( 3 inches diam-

Nail in blaze in cedar tree ( 3 inches diameter).....................

Nail in blaze in cedar tree ( 4 inches diameter)

$\begin{array}{rrrrr}0 & 00 & 00 & \ldots & 1 / 4 \text { mile. } \\ 24 & 41 & 00 & \ldots & 31.91 \text { meters. } \\ 55 & 37 & 10 & \ldots & 21.30 \text { meters. } \\ 129 & 59 & \ldots & \ldots & \frac{3}{8} \text { mile. } \\ 160 & 20 & \ldots & \ldots & 1 / 2 \text { mile. } \\ 180 & 02 & \ldots & \ldots & 11 / 4 \text { miles. } \\ 89 & 02 & 20 & \ldots & 13 / 4 \text { miles. } \\ 25 & 08 & 00 & \ldots & 5.81 \text { meters. } \\ 273 & 57 & 10 & \ldots & 2.47 \text { meters. } \\ 326 & 52 & 00 & \ldots \ldots & 3.45 \text { meters. }\end{array}$




\section{NONAME.}

General locality.-Northwestern shore of upper Bretons IBay on a point about one-half mile northwest of entrance to Mouldy Creek, and I mile northeast of Lovers Point. (See chart No. 25.)

Immediate locality.-Observed station is about 3 feet above high water, near six old piles, I 3 yards northwest of shore, I3 yards southwest of shore, I7 yards northeast of shore, and 80 yards south of a fringe of pine trees.

Marks.-Observed station is center point of triangle on standard cement monument.

References, -

\begin{tabular}{|c|c|c|c|c|c|}
\hline$" B$ Buzzard $\left(\mathrm{N} .3 \mathrm{I}^{\circ}{ }_{23}{ }^{\prime} \mathrm{E}.\right) \ldots \ldots \ldots \ldots \ldots \ldots$ & 0 & $\infty$ & $\infty 0$ & & $1 / 2$ mile. \\
\hline West gable of old farmhouse.... & 45 & 49 & . & & $1 / 2$ mile. \\
\hline Nail in blaze in old pile........ & 82 & 37 & $\infty$ & & I2.70 meters. \\
\hline West gable of two-story house... & 106 & 26 & . & & $5 / 8$ mile. \\
\hline Chimney of two-story house . . . . . . . . . . & 164 & or & $\cdots$ & & $1 / 2$ mile. \\
\hline Nail in blaze in gum tree ( 6 inches diameter). & 200 & 53 & 40 & & 9.72 meters. \\
\hline $\begin{array}{l}\text { West chimney of house....................... } \\
\text { Nail in blaze in locust tree ( } 3 \text { inches diam- }\end{array}$ & 206 & $5 \mathrm{I}$ & $\cdots$ & .. & $1 / 2$ mile. \\
\hline
\end{tabular}

\section{BELLE.}

General locality.-Northwestern shore of upper Bretons Bay about one-half mile north-northeast of Lovers Point, and five-eighth mile west-northwest of entrance to Mouldy Creek. (See chart No. 25.)

Immediate locality. - Observed station is in a cultivated field about 3 feet above high water, 9 yards northwest of shore, 50 yards south by west of a clump of trees, and 65 yards southeast by east and almost in line with northeast side of a house.

Marks.-Observed station is center point of triangle on standard cement monument.

References.-

\begin{tabular}{|c|c|c|c|c|c|}
\hline me" & $\circ$ & $\infty$ & & & le. \\
\hline Left corner of left chimney of house. . . . . & I5 & 22 & . & & aile. \\
\hline Right chimney of house on hill. & 39 & 35 & .. & & ailes. \\
\hline Near peak of roof of house.......... & 53 & 27 & . & & $3 / 4$ mile. \\
\hline Chimney on middle of double house....... & II8 & $x_{4}$ & .. & & $1 / 2$ mile. \\
\hline Right chimney of house........... & $\mathbf{x} 34$ & 26 & .. & & le. \\
\hline Chimney of large house next to wharf. & 147 & 49 & . & $\ldots \ldots$ & \\
\hline mney of Adams ho & 255 & 03 & 40 & $\ldots \ldots$ & \\
\hline Chimney of house. & $3+8$ & $\infty$ & & & $12 \mathrm{mil}$ \\
\hline
\end{tabular}

PINE.

Gensral locality.-Eastern shore of upper Bretons Bay about one-fourth mile north-northeast of entrance to Mouldy Creek. (See chart No. 25.)

Immediate locality.-Observed station is back of a tree-fringed shore in a field about ro feet above high water, 7 yards east of edge of bluff, and 6 yards east of a rail fence.

Marks.-Observed station is center point of triangle on standard cement monument.

References.-

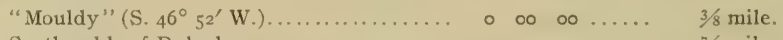

South gable of Duke house............. rog $35 \quad \ldots \ldots \ldots$. $7 / 8$ mile.

Nail in blaze in cedar tree ( 4 inches diam-

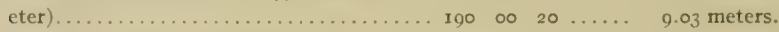

Nail in blaze in persimmon tree ( 4 inches

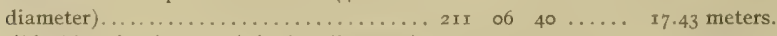

Nail in blaze in pine tree ( 5 inches diameter). $\begin{array}{llll}336 & 04 & 00 . . & 5.72 \\ \end{array}$ 


\section{HEALEY.}

General locality.-Northwestern shore of Bretons Bay on point opposite Abells Wharf and about three-eighths mile north-northeast of Lovers Point. (See chart No. 25.)

Immediate locality', - Observed station is about 12 feet above high water, 6 yards east of edge of bank, 6 yards north of edge of bank, 35 yards west of point where rail fence and water meet, 65 yards southwest of corner of fence, 200 yards southeast of cedar trees, and 250 yards south-southeast of pine trees.

Marks.-Observed station is center point of triangle on standard cement monument.

References.-

\begin{tabular}{|c|c|c|c|c|c|}
\hline 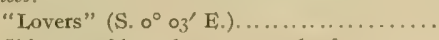 & $\circ$ & $\infty$ & ০০ & & $1 / 2$ \\
\hline Chimney of large house near wharf........ & 7 & 40 & . & . & \\
\hline Near chimney of house................. & $3 \mathrm{I}$ & 42 & $\cdots$ & & $\pi / 8$ \\
\hline Nail in blaze in cedar tree ( 4 inches diameter) & 64 & 46 & 40 & $\ldots$ & 6.02 meters. \\
\hline $\begin{array}{l}\text { blaze in twisted cedar tree }(4 \text { inches } \\
\text { leter }) \ldots \ldots \ldots \ldots \ldots \ldots \ldots \ldots \ldots \ldots\end{array}$ & 105 & 20 & 20 & & IC \\
\hline $\begin{array}{l}\text { Tail in blaze in persimmon tree }(8 \text { inches } \\
\text { diameter) } \ldots \ldots \ldots \ldots \ldots \ldots \ldots \ldots \ldots \ldots\end{array}$ & 129 & 26 & 10 & & ters. \\
\hline Chimney of house on hill............... & 199 & 30 & .. & $\ldots \ldots$ & 400 \\
\hline use on 1 & 234 & 04 & $\cdots$ & .. & rds. \\
\hline Left & 269 & $\infty 9$ & .. & $\ldots \ldots$ & iles. \\
\hline nd of house........... & 305 & I4 & . & $\ldots \ldots$ & le. \\
\hline le house... . & 334 & 39 & . & ... & le. \\
\hline Wi1 & 352 & 59 & . & $\ldots$. & nile. \\
\hline Water & 354 & 12 & . & $\ldots$. & \\
\hline Right chimney of house... & 354 & 35 & . & $\ldots \ldots$ & $5 / 8$ mile. \\
\hline
\end{tabular}

\section{MOULDY.}

General locality.-Southeastern shore of Bretons Bay on a point about too yards west of entrance to Mouldy Creek. (See chart No. 25.)

Immediate locality.-Observed station is about 6 yards south of edge of a 25 -foot bluff, 17 yards from high water, 25 yards north of a cultivated field, 50 yards west of a clump of cedar trees, and roo yards west of entrance to Mouldy Creek.

Marks.-Observed station is center point of triangle on standard cement monument.

References.-

"Beau" (N. $88^{\circ}$ I $^{\prime}$ W. W. . .

\begin{tabular}{|c|c|c|c|c|c|}
\hline $88^{\circ} \mathrm{I}_{3^{\prime}} \mathrm{WW}$.) & 0 & $\infty$ & o & & \\
\hline South chimney of two-story house. & 24 & 30 & . & & $3 / 4$ mile. \\
\hline himney of small two-story house. . & 34 & 13 & . & & $3 / 4$ \\
\hline South gable of Duke house. & $8 \mathrm{I}$ & 33 & . & & ile. \\
\hline Cross on Catholic Church. & $\partial x$ & 14 & 40 & & $2^{\mathrm{T}}+$ \\
\hline Cross on Catholic Academy. & 9 I & 30 & 30 & & $2 \frac{1}{4}$ \\
\hline gable of Foxivell house . . . . . . . . & 96 & o8 & $\therefore$ & & $I / 4$ miles. \\
\hline ey of two-stor & 99 & 56 & . & & $13 / 8$ miles. \\
\hline Nail in blaze in ash tree ( $18 \mathrm{i}$ & 109 & 38 & 30 & & $3 \cdot 32$ \\
\hline farmhouse... & 123 & 57 & . & & ile. \\
\hline Nail in blaze in oak tree ( 2 feet diame & 165 & 53 & 10 & & 52.09 meters. \\
\hline nill. . & 175 & 57 & 30 & & $3 / 8$ mile. \\
\hline h tree $\left(I_{4}\right.$ & $18 \mathrm{I}$ & 24 & 30 & & $54 \cdot 35$ \\
\hline West chimney of large farmhouse... & 248 & 29 & . & & $1 / 2$ mile. \\
\hline Top of windmill. & $32 \mathrm{I}$ & 39 & 30 & & $\mathrm{I}^{\mathrm{I}} 2$ miles. \\
\hline
\end{tabular}

$2606-\mathrm{II}-7$ 
BEAU.

General locality. - Southeastern shore of Bretons Bay on first prominent point northeast of Lovers Point about three-eighths mile west of the entrance to Mouldy Creek. (See chart No. 25.)

Immediale locality.-Observed station is about $\mathrm{I}$ foot above high water, 9 yards south of shore, io yards east of shore, ro yards northwest of a small shanty, and $x$ y yards south-southeast of extreme end of point.

Marks.-Observed station is center point of triangle on standard cement monument.

References.-

"Mouldy" (S. $88^{\circ} \mathrm{I} 4^{\prime}$ E.).

Nail in blaze in double cedar tree (to inches diameter)

Nail in blaze in cedar tree ( 8 inches diameter)

Left corner of shanty.

Nail in blaze in cedar tree (ro inches diameter).

\begin{tabular}{ccccc}
0 & \multicolumn{1}{c}{ " } & & \\
0 & 00 & 00 & $\ldots$ & $3 / 8$ mile. \\
& & & & \\
14 & 05 & 00 & $\ldots$ & 5.24 meters. \\
41 & 48 & 30 & $\ldots$ & 6.20 meters. \\
50 & II & 00 & $\ldots$ & 8.78 meters. \\
& & & & \\
72 & 34 & 10 & $\ldots$ & 5.04 meters. \\
83 & 51 & 10 & $\ldots$ & 9.89 meters. \\
118 & 27 & $\ldots$ & $\ldots$ & $1 / 2$ mile. \\
137 & 20 & $\ldots$ & $\ldots$ & $1 / 2$ mile. \\
229 & 33 & $\ldots$ & $\ldots$ & $1 / 2$ mile. \\
247 & 07 & $\ldots$ & $\ldots$ & $3 / 4$ mile. \\
281 & 13 & $\ldots$ & $\ldots$ & $3 / 4$ mile. \\
302 & 36 & $\ldots$ & $\ldots$ & $17 / 8$ miles. \\
346 & 10 & $\ldots$ & $\ldots$ & $3 / 4$ mile. \\
355 & 55 & $\ldots$ & $\ldots$ & $5 / 8$ mile.
\end{tabular}

Right corner of shanty................ $8_{3}$

Chimney on middle of house ............ II

Chimney on south end of house at wharf .... . 13

Chimney of Adams house. ............... 22

Chimney on middle of house on hill....... 2

Peak of near gable of Duke house.......... 28

Near peak of gable of house............ 302

Left chimney of house . . . . . . . . . . . 346

Near peak of gable of house . . . . . . . . 355

HOLLOW.

General locality.-Western shore of Bretons Bay, about one-half of a mile northwest of Lovers Point and seven-eighths mile northeast of Paw Paw Point. (See chart No. 25.)

Immediate locality.-Observed station is at the side of a ravine about 2 feet above high water, 4 yards northwest of shore, 5 yards southeast of foot of a bank, and northeast of cedar trees.

Marks.-Observed station is center point of triangle on standard cement monument.

References.-

\begin{tabular}{|c|c|c|c|c|c|}
\hline "Healey" (N. $77^{\circ} 52^{\prime}$ E.)... & 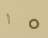 & $\infty 0$ & $\infty$ & & $1 / 2$ \\
\hline Chimney on middle of double house. & 39 & 42 & $\cdots$ & & le. \\
\hline Right chimney of house........ & 55 & 39 & . & & nile. \\
\hline ank. & $5^{6}$ & 14 & . & & \\
\hline y of house. & $7 x$ & 44 & . & & iles. \\
\hline ter) & I53 & 12 & 50 & & ters. \\
\hline Nail in blaze in cedar tree ( 8 inches diameter) & 193 & 43 & $\infty$ & & I9.94 meters. \\
\hline in white-oak stump ( 18 inches & & & & & \\
\hline & & 3 & I0 & & \\
\hline Right chimney of Adams house. & 3 & II & .. & $\ldots \ldots$ & $1 / 2$ mile. \\
\hline
\end{tabular}

\section{TREES.}

General locality.-Western shore of Bretons Bay, about three-eighths of a mile west of Lovers Point and five-eighths mile northeast of Paw Paw Point. (See chart No. 25.)

Immediate locality.-O Observed station is at edge of a cultivated field about 5 feet above high water, I5 yards west of shore, 3 yards back from edge of a bank 3 feet high, and 200 yards from a pine woods Marks.-Observed station is center point of triangle on standard cement monument. 
References.-

"Hollow" (N. $2^{\circ} 5 \mathrm{I}^{\prime} \mathrm{W}$.)..............

West gable of 2 -story house............ 57 21 $\ldots \ldots \ldots, \quad 1 / 2$ mile.

Nail in blaze in cedar tree ( 4 inches diameter) $89 \quad 24 \quad 00 \ldots . . . . .$.

Chimney of 2 -story house............ 10.4 o5 ...... $3 / 4$ mile

Nail in blaze in cedar stump ( 3 inches diam-

eter $) \ldots \ldots \ldots \ldots \ldots \ldots \ldots \ldots \ldots \ldots$ iा 7 is $30 \ldots \ldots \ldots$

Middle chimney on large 2 -story house.... $120 \quad 29 \quad \ldots \ldots \ldots . \quad 5 / 8$ mile.

Nail in blaze in cherry tree (Io inches diam-

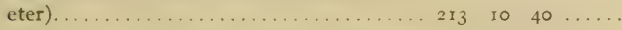

\section{LOVERS.}

General locality.-Southeastern shore of Bretons Bay, about one-eighth of a mile southeast of Lovers Point and I mile east of Paw Paw Point. (See chart No. 25.)

Immediate locality.-Observed station is about 4 feet above high water, 15 yards south of shore, 6 yards north of a road leading to a wharf, 50 yards north-northwest of a $x^{1 / 2} /$-story house, and 100 yards east of small store with an adjoining dwelling.

Marks.-Observed station is center point of triangle on standard cement monument.

References.-

\begin{tabular}{|c|c|c|c|c|c|}
\hline "Trees" (N. $67^{\circ}-47^{\prime}$ W. $) \ldots \ldots \ldots$ & o & oo & $\infty$ & & I/2 mile. \\
\hline North gable of wharf house..... & I7 & $3 \mathrm{I}$ & . & & ards. \\
\hline Near chimney of 2 -story house.. & 77 & 47 & . & . & \\
\hline Chimney of 2-story house.... & $\mathrm{II}_{4}$ & $3 \mathrm{I}$ & . & & iile. \\
\hline 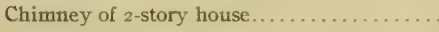 & 144 & II & 40 & & $1 / 4$ mile. \\
\hline Chimney of $\mathrm{I}^{1 / 2}$-story house............ & 162 & 45 & 40 & $\ldots$ & iile. \\
\hline ley of $11 / 2$-story house $\ldots \ldots \ldots$ & 188 & 50 & . & ..... & rds. \\
\hline chimney of large 2 -story house..... & 212 & 30 & . & …… & \\
\hline le of large barn............... & 232 & 59 & ro & ..... & \\
\hline Chimney of store. & 355 & 16 & .. & $\ldots \ldots$ & I00 yards. \\
\hline
\end{tabular}

PAW.

General locality.-Northwestern shore of Bretons Bay on Paw Paw Point, about I mile west-southwest of Lovers Point and three-fourths mile east of Cherry Cove. (See chart No. 25.)

Immediate locality. - Observed station is on marsh land near two cedar trees about 1 foot above high water, 7 yards southeast of shore, 18 yards west by north of extreme end of point, 28 yards northeast of another point, 50 yards south-southwest of several cedar trees, and 75 yards southeast of a cultivated field.

Marks.-Observed station is center point of triangle on standard cement monument.

References.-

Left chimney of house

Right corner of right chimney of priest's house....................... 10 $46 \ldots \ldots$ 17/8 miles.

"Catholic Church Cross (Newtown Neck)". ro r 28 50 ..... I7/8 miles.

Nail in blaze in cedar tree ( 7 inches diamet(r).

Nail in blaze in water bush $(3$ inches diam-
eter $) \ldots \ldots \ldots \ldots \ldots \ldots \ldots \ldots \ldots \ldots \ldots \ldots \ldots \ldots$

Nail in blaze in cedar tree ( 6 inches diameter $\ldots . . . . . . . . . . . . . . . . . . . . . . .220$

Near corner of chimney at Abells Whari.... $279 \quad 42 \quad \ldots \ldots \ldots$

Right chimney of house.............. 286 no . . . .

Water tank. .................. $28-02$

Left peak of roof of large house.......... $3^{\text {Io }} 3^{2}$

$3+$ mile.

\% $/ 8$ mile.

$0.1,3$ meters.

8.79 meters.

4.77 meters.

$27 / 8$ miles.

I mile.

I $1 / 8$ miles.

$\mathrm{I}^{1}{ }_{5}$ miles.

I raile. 


\section{WHAT.}

General locality, - Southeastern shore of Bretons Bay, on first prominent point southwest of Lovers Point, about three-fourths of a mile south-southeast of Paw Paw Point. (See chart No. 25.)

Immediate locality.-Observed station is about 20 feet above high water, 9 yards south of edge of bank, 4 yards east of a fence, 85 yards northeast of a fence at creek, 300 yards northeast of a large barn on other side of creek, and east to northeast of trees.

Marks.-Observed station is center point of triangle on standard cement monument.

References.-

\begin{tabular}{|c|c|c|c|c|c|}
\hline 'Protestant"' (N. $87^{\circ} 05^{\prime}$ W. ...... & 0 & $\infty$ & $\infty 0$ & & ile. \\
\hline Near peak of roof of priest's house.......... & 10 & 30 & .. & & ilies. \\
\hline "Catholic Church Cross (Newtown Neck)" ... & 10 & $5^{2}$ & I0 & & $2 \pi / 4$ miles. \\
\hline $\begin{array}{l}\text { Tear peak of roof between two chimneys of } \\
\text { house } \ldots \ldots \ldots \ldots \ldots \ldots \ldots \ldots \ldots \ldots \ldots \ldots\end{array}$ & 28 & 26 & . & & ilies. \\
\hline $\begin{array}{l}\text { Peak of front gable of Duke house ......... } \\
\text { Jail in blaze in sassafras tree ( } 4 \text { inches }\end{array}$ & 78 & 53 & . & & es. \\
\hline $\begin{array}{l}\text { diameter) } \ldots \ldots \ldots \ldots \ldots \ldots \ldots \ldots \ldots \ldots \ldots \\
\text { ail in blaze in persimmon tree ( } 7 \text { inches }\end{array}$ & 122 & 49 & $\infty 0$ & & 8 \\
\hline diameter) ............................... & I 46 & 12 & 40 & & neters. \\
\hline & 169 & 14 & 50 & & $7.5^{8}$ meters. \\
\hline old house . . . . . . . . . & 270 & I9 & & & 250 yards. \\
\hline 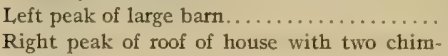 & 289 & Io & . & & yards. \\
\hline & & 38 & & & yards. \\
\hline
\end{tabular}

\section{CHERRY COVE.}

General locality - Northwestern shore of Bretons Bay, about 2 miles north-northeast of Higgins Point and one-eighth mile west-southwest of entrance to Cherry Cove. (See chart No. 25.)

Immediate locality.-Observed station is in a field about 15 feet above high water, 12 yards north of edge of bank, 17 yards west-southwest of near corner of a 2-story house, 23 yards west-northwest of a point, 25 yards west of edge of bank, and 27 yards southwest by south of a wire fence around a garden.

Marks.-Observed station is center point of triangle on standard cement monument.

References.-

\begin{tabular}{|c|c|c|c|c|c|}
\hline "Compton" (S. $73^{\circ} 49^{\prime} \mathrm{W}$.) & $\circ$ & $\infty$ & $\infty$ & $\ldots .$. & $7 / 8$ mile. \\
\hline Peak of tin roof of priest's house. & $\circ$ & 39 & . & & r $1 / 8$ miles. \\
\hline "Catholic Church cross (Newtown Neck)"... & 2 & $\mathrm{I}_{3}$ & 40 & . & I $1 / 8$ miles. \\
\hline Near peak of roof of large house............ & 28 & 46 & 20 & $\ldots \ldots$ & $3 / 8$ mile. \\
\hline Tangent of point of bank on opposite side of & & & & & \\
\hline Cherry Cove.. & I19 & 52 & .. & $\ldots$ & $3 / 8$ mile. \\
\hline 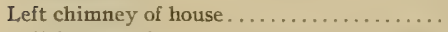 & $13 \mathrm{I}$ & to & .. & $\ldots \ldots$ & $x^{1 / 2} / 8$ miles. \\
\hline Nail in blaze in corner fence post ( 3 inches & & & & & \\
\hline diameter $) \ldots \ldots \ldots \ldots \ldots \ldots \ldots$ & I 45 & I7 & $\infty$ & . & 26.46 meters. \\
\hline Left corner of house............... & $x 66$ & It & 20 & . & 19.95 meters. \\
\hline Near corner of house. & 177 & $5 \mathrm{I}$ & 50 & ...... & $\mathrm{I}_{7.14}$ meters. \\
\hline Right corner of house. & 188 & 05 & 20 & $\ldots \ldots$ & 24.94 meters. \\
\hline Left corner of large house near Abells Wharf. . & 190 & or & & & 2 miles. \\
\hline Water tank... & 196 & $3^{8}$ & & ...... & 2 miles. \\
\hline Chimney of large hous & 228 & I9 & . & $\ldots \ldots$ & 2 miles. \\
\hline Chimney of large house.... & 240 & 39 & & $\ldots \ldots$ & I $3 / 8$ miles. \\
\hline Cupola on building in woods............ & 276 & 42 & & $\ldots \ldots$ & $x / 4$ miles. \\
\hline
\end{tabular}




\section{PROTESTANT.}

General locality.-Southeastern shore of Bretons Bay on Protestant Point opposite Cherry Cove about $17 / 8$ miles east-northeast of Kaywood Point. (See chart No. 25.)

Immediate locality. - Observed station is on a sand bar about 2 feet above high water, 26 yards north of shore, 35 yards east by south of a cedar tree, and 35 yards northwest of entrance to a creek. Cement monument marking reference station is 29.12 meters S. $56^{\circ} 29^{\prime} \mathrm{E}$. of observed station.

Marks.-Observed station is nail in stub with top about $\mathrm{I} 2$ inches above surface of sand. Reference station is center point of triangle on standard cement monument.

References.-

"Cherry Cove" (N. $2 \mathrm{I}^{\circ} 54^{\prime}$ W.).......... ० o

Chimney of house................. o 5

Left chimney of house................

Peak of front gable of Duke house.........

Chimney of Adams house ............. ?

Chimney outside of house at Abells Wharf. .

Water tank..................... 8

Left chimney of house . . . . . . . . . . . . I2 6

REFERENCE STATION................. 145

Nail in blaze in cedar tree ( 7 inches diameter). I45

Nail in blaze in oak tree ( 7 inches diameter).. I73

Nail in blaze in oak tree (20 inches diameter). 204

"Catholic Church Cross (Newtown Neck)" . . 3II

Chimney on middle of roof of house . . . . . 336

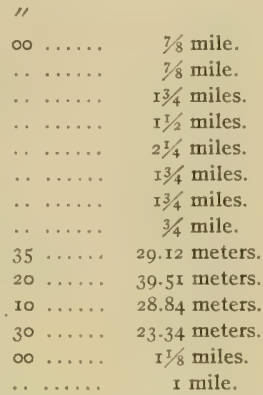

\section{FENCE.}

General locality.-Southeastern shore of Bretons Bay opposite Compton about $15 / 8$ miles northeast of Kaywood Point at entrance to Bay. (See chart No. 25.)

Immediate locality.-Observed station is about 12 feet above high water, 3 yards southeast of edge of bank, 70 yards southwest of locust trees, and in front of cedar and sassafras trees. Cement monument marking reference station is 12.87 meters $\mathrm{S} .25^{\circ} 4 \mathrm{I}^{\prime} \mathrm{E}$. of observed station.

Marks,-Observed station is nail in stub. Reference station is center point of triangle on standard cement monument.

References.-

"Compton" (N. $4 \mathrm{r}^{\circ} 3 \mathrm{O}^{\prime}$ W.)..............

Near corner of large outside chimney of house

Near peak of roof of house. . . . . . . . . . . .

Chimney of house . . . . . . . . . . . . . . .

Largest chimney of Duke house............

Nail in blaze in apple tree ( 16 inches diameter).........................

Large chimney of building among trees...... I86

Nail in blaze in persimmon tree ( 4 inches diameter $). . \ldots \ldots \ldots \ldots \ldots \ldots \ldots \ldots$. 195

REFERENCE STATION................ 195

Nail in blaze in cedar tree ( 2 inches diameter) 232

Chimney on middle of house............. 294

Near end of near chimney of priest's house. . $35^{2}$

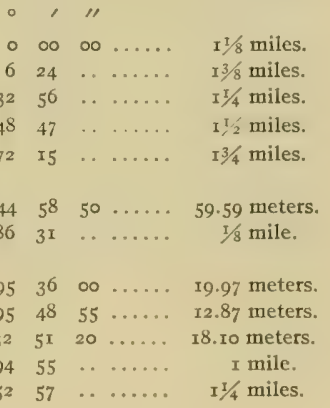




\section{COMPTON}

General locality.-Western shore of Bretons Bay on Newtown Neck about three-eighths mile southsouthwest of entrance to Combs Creek, and $x 5 / 8$ miles north of Kaywood Point. (See chart No. 25.)

Immediale locality.--Observed station is in the corner of a field adjoining a large brick house about 20 feet above high water, 75 yards west of shore, 75 yards south of shore, 2 yards south of a fence, 3 yards west of another fence, and 400 yards east-northeast of a church and a house.

Marks.-Observed station is center point of triangle on standard cement monument.

References.-

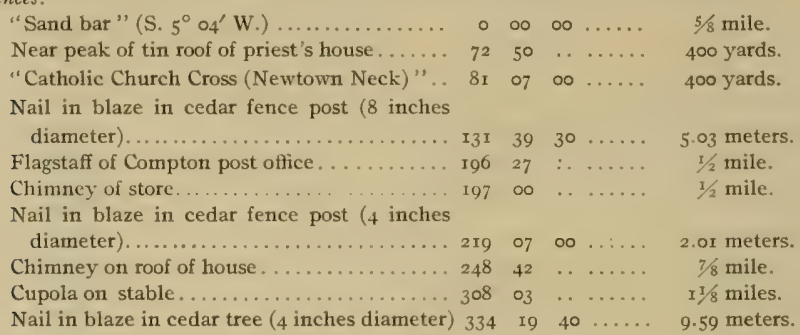

\section{SANDBAR.}

General locality.-Western shore of Bretons Bay on Newtown Neck about $\mathrm{I}^{1} / 8$ miles north of Kaywood Point and II/4 miles south of Combs Creek. (See chart No. 25.)

Immediate locality.-Observed station is on a sand spit between bay and small pond about I foot above high water, 6 yards north of a point of trees, 75 yards west by north of a sand bar visible at low water, and 85 yards south of another point.

Marks.-Observed station is center point of triangle on standard cement monument.

References.-

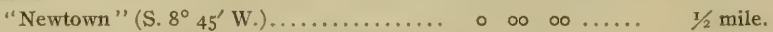

Nail in blaze in holly tree ( 3 inches diameter). I4 o6 $50 \ldots \ldots 7.08$ meters.

Nail in blaze in pine tree ( 7 inches diameter). 36 of $10 . . .5 \quad 5.96$ meters.

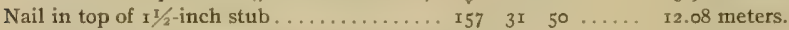

Left comer of left chimney of priest's house. $\begin{array}{rlllll}158 & 57 & \ldots & \ldots & 5 / 8 & \text { mile. }\end{array}$

Flagstaff of Compton post office......... I 8 I $21 \ldots \ldots$ I mile.

Chimney of house with several gables....... I $84 \quad 37 \quad \ldots \ldots \ldots$ I mile.

Left peak of tiri roof................. $20503 \quad \ldots \ldots \ldots$ I mile.

Chimney of house...................

Right chimney of house near Abells Wharf. . $244 \quad 56 \quad \ldots \ldots . .3$ miles.

Water tank at Abells Wharf............. 245 I6 ...... 3 miles.

Nail in blaze in holly tree ( 3 inches diameter). 356 if $00 \ldots . .4 .62$ meters. 


\section{DUNE:}

General locality.-Eastern shore of Bretons Bay about five-eighths mile north of Higgins Point and I I $/ 8$ miles northwest of Kaywood Point. (See chart No. 25.)

Immediate locality. - Observed station is on a sanded grassy knoll about 4 feet above high water, 4 yards southeast of edge of bank, 8 yards northwest of foot of sand slope, 20 yards northeast of first tree in scant woods, 25 yards northwest of edge of woods, 55 yards west-southwest of a large pine tree at point of woods, and 75 yards east-northeast of a mud hole.

Marks.-Observed station is center point of triangle on standard cement monument.

References.-

"Blakistone Island Light" (S. $53^{\circ} 42^{\prime}$ W. $)$...

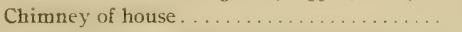

"Catholic Church Cross (Newtown Neck)" ..
Right tangent of right chimney of priest's

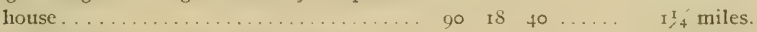

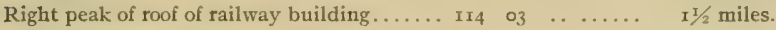

Right peak of roof between two chimneys of

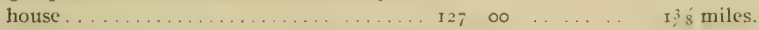

Nail in blaze in pine tree ( 12 inches diameter) $189 \quad 58 \quad 30 \ldots \ldots 47.76$ meters.

Nail in blaze in oak tree ( 6 inches diameter). . $245 \quad 56 \quad 00 \ldots \ldots .9 .79$ meters.

Nail in blaze in oak tree (II inches diameter). 342 Io $20 \ldots \ldots$ I6.78 meters.

\section{NEWTOWN.}

General locality.-Western shore of Bretons Bay about one-half mile north of Kaywood Point and seven-eighths mile northwest of Higgins Point. (See chart No. 25.)

Immediate locality.-Observed station is about $x 2$ feet above high water, surrounded by a fence, 9 yards west-northwest of edge of bank, 9 yards southwest of corner of fence, to yards north-northeast of corner of fence, 13 yards east of corner of fence, 14 yards south-southeast of comer of fence, 30 yards south-southwest of several trees, 60 yards southwest of a ditch, 75 yards south-southeast of a pond, and 85 yards southwest of a point.

Marks.-Observed station is center point of triangle on standard cement monument.

References.-

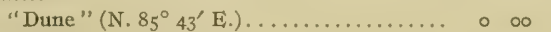

Main chimney of house............... $x_{53} \quad 57$

Nail in blaze in cedar tree ( 3 inches diameter) $24 \pi \quad 26$

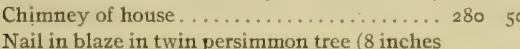

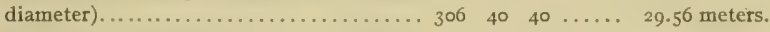

Nail in blaze in sugarberry tree ( 12 inches diameter $) \ldots \ldots \ldots \ldots \ldots \ldots \ldots \ldots \ldots \ldots . \ldots \ldots 23 \quad 04 \quad 20 \ldots \ldots .24 .89$ meters.

Chimney outside of building at Abells Wharf. $\begin{array}{llllll}337 & 37 & \ldots & \ldots & \ldots & 3^{1} / 4 \\ \text { miles. }\end{array}$

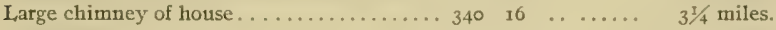

Water tank....................... $340 \quad 35 \quad \ldots \ldots .31 / 4$ miles. 
GROVE:

General locality.-Eastern shore of Bretons Bay about one-half mile north of Higgins Point and seven-eighths mile northeast of Kaywood Point. (See chart No. 25.)

Immediate locality. - Observed station is on sanded grassy land in a grove of trees about 8 feet above high water, 3 yards east of edge of bank, 5 yards south of edge of bank, 23 yards north by cast of a large oak tree, and 30 yards south-southwest of a high sand pile. Cement monument marking reference station is near twin oak trees $2 \mathrm{r} .48$ meters $\mathrm{S} .34^{\circ} 32^{\prime} \mathrm{E}$. of observed station.

Marks.-Observed station is nail in stub with top about flush with surface of ground. Reference station is center point of triangle on standard cement montument.

References.-

"Blakistone Island Light" (S. $54^{\circ} 24^{\prime}$ W.) ..

"Catholic Church Cross (Newtown Neck)" . .

Right tangent of chimney of priest's house...

Tree ( 10 inches diameter) ................ Io

Nail in blaze in persimmon tree (ro inches

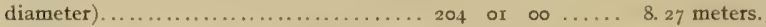

Nail in blaze in forked oak tree ( 12 inches

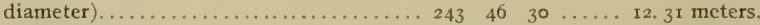

REFERENCE STATION.................. 27 I $03 \quad 45 \ldots \ldots 2$ I. 48 meters

Nail in blaze in right one of twin oak trees

(I2 inches diameter) ................ $272 \quad 35 \quad 50 \ldots \ldots 22.50$ meters

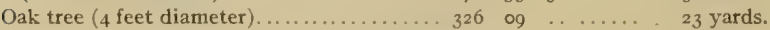

$3 \frac{3}{4}$ miles.

I $1 / 4$ miles.

$1 / 4$ miles.

5 yards.

\section{CEDOAK.}

Generál locality,-Eastern shore of Bretons Bay about one-eighth mile north of Higgins Point and seven-eighths mile east of Kaywood Point. (See chart No. 25.)

Immediate locality.-Observed station is about 8 feet above high water, 2 yards east of edge of bank, II yards north-northwest of edge of bank at cedar woods, 12 yards west-southwest of an oak tree, 30 yards south-southeast of small clump of cedar trees on point, and 40 yards south of edge of clearing. Cement. monument marking reference station is 21 . $9 \mathrm{I}$ meters $\mathrm{N} .76^{\circ} 4 \mathrm{I}^{\prime} \mathrm{E}$. of observed station.

Marks.-Observed station is nail in cedar stub about I inch above surface of ground. Reference station is center point of triangle on standard cement monument.

References.-

"Blakistone Island Light" (S. $5^{8^{\circ}} 45^{\prime}$ W.) ..

Left chimney of Colton Hotel..............

Chimney of house beyond edge of woods ....

Chimney on middle of house...............

Between two chimneys on right of priest's

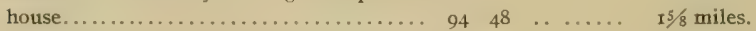

Left peak of roof of railway building........ III $49 \ldots \ldots \ldots$ I $7 / 8$ miles.

Nail in blaze in pine tree ( 13 inches diam-

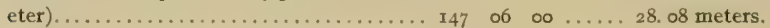

Nail in blaze in oak tree ( 14 inches diameter). I79 $3400 \ldots \ldots$. I0. 22 meters.

REFERENCE STATION.................. I97 56 o5 .... 2I. 9I meters.

Nail in blaze in cedar tree (1o inches diam-

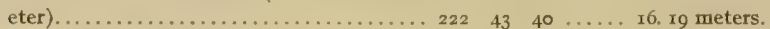

Left tree on Higgins Point............ $290 \quad 59 \quad \ldots \ldots \ldots$ m $1 / 8$ mile.

\section{KAYWOOD.}

General locality. - Northern shore of Heron Island Sound on Kaywood Point. (See chart No. 25.)

Immediate locality.-Observed station is in a clear field about 8 feet above high water, 4 yards westnorthwest of edge of bank, 22 yards northeast of edge of bank, 23 yards north-northeast of extreme point of bank, and 75 yards south-southwest of large gum tree at edge of woods. 
Marks.-Observed station is center point of triangle on standard cement monument.

References.-

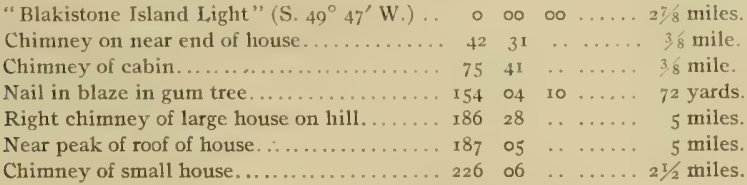

HERON,

General locality. - Northern side of Potomac River on a sand bar called Heron Island at entrances to St. Clement Bay and Bretons Bay and about $1 \frac{1}{2}$ miles east-northeast of Blakistone Island Light. (See chart No. 25.)

Immediate locality.-Observed station is on southeastern end of sand bar remains of Heron Island. Marks.-Observed station is awash except at low water and was not marked.

References,-None necessary.

\section{BLAKISTONE ISLAND LIGHT.}

General locality. - Northern side of Potomac River on southern end of Blakistone Island off entrance to St. Clement Bay and Bretons Bay. (See chart No. 25.)

Immediate locality.-Observed station is on a dwelling near a fog-bell tower.

Marks.-Observed station is center point of lantern on a dwelling known as Blakistone Island Lighthouse.

References.-

"Cobb Point Bar Light" (N. $61^{\circ} 2 z^{\prime}$ W. $) \ldots \quad 00000 \ldots . . .5$ miles.

\section{HERRING POND 2 (VIRGINIA).}

General locality.-Southern shore of Potomac River on a point between Nomini Bay and Machodoc River about three-eighths mile east of Kingcopscio Point. (See progress map.)

Immediate locality. - Observed station is about I foot above high water, 2 feet south of shore, 25 yards west of a round point, 85 yards east-northeast of entrance to Herring Pond Creek, and west-northwest of a grove of cedar trees. Center one of five cedar posts marking reference station is 3 meters S. $5^{\circ} 33^{\prime} \mathrm{E}$. of observed station.

Marks.- Observed station is center of 4 -inch tile pipe set in cement with top about flush with surface of ground. Reference station is center one of four nails in center one of five cedar posts.

References.-

\begin{tabular}{|c|c|c|c|c|c|}
\hline Blakistone Island Light"' & o & & 0 & & \\
\hline Near chimney of Colton Hotel. ........... & 4 & 18 & . & & $5 / 2$ miles. \\
\hline Church Cross on Maryland shore..... ..... & I3 & or & 30 & & es. \\
\hline Right chimney of Yates house............ & 26 & 29 & - & & $5 \frac{3}{4}$ miles. \\
\hline ear corner of large house on hill........... & 108 & 39 & . & & iles. \\
\hline $\begin{array}{l}\text { Top nail in blaze in gnarled cedar tree }(8 \\
\text { inches diameter) } \ldots \ldots \ldots \ldots \ldots \ldots \ldots \ldots \ldots \\
\text {. }\end{array}$ & 160 & 35 & 0 & & \\
\hline $\begin{array}{l}\text { ail in blaze in cedar tree }(5 \text { inches diam- } \\
\text { eter) } \ldots \ldots \ldots \ldots \ldots \ldots \ldots \ldots \ldots \ldots \ldots \ldots \ldots \ldots \ldots\end{array}$ & 220 & 44 & 40 & & \\
\hline N (nail in cedar stub)... & 217 & or & $\infty$ & & $=$ \\
\hline ail in blaze in stump ( 7 inches diameter)... & 227 & 29 & 30 & & $7 \cdot 5^{2}$ meters. \\
\hline 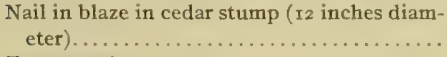 & 288 & 16 & 20 & & \\
\hline onint & 314 & $2 \mathrm{I}$ & . & & . \\
\hline angent of woods.......... & 319 & 13 & .. & ....... & $\mathrm{T} / 2$ mile \\
\hline
\end{tabular}




\section{ST. CLEMENT.}

General locality:-Northern shore of Heron Island Sound on Newton Neck ahout $2 \frac{1}{4}$ miles northeast of Blakistone Island Light. (See chart No. 25.)

Immediate locality.-Observed station is in a cultivated field about io feet above high water, I7 yards northeast of shore, 32 yards east of shore, 32 yards north by west of most prominent point, and 70 yards southeast of another point. Cement monument marking reference station is on line to large nutherry tree 23 , or meters N. $4 \mathrm{I}^{\circ} 29^{\prime} \mathrm{F}$. of observed station.

Marks.-Observed station is nail in stub with top ahout 3 inches above surface of ground. Reference station is center point of triangle on standard cement monument.

References.-

\begin{tabular}{|c|c|c|c|c|c|}
\hline "Blakistone Island I,ight" (S. $37^{\circ} 57^{\prime}$ W.)... & 0 & $\infty$ & $\infty$ & & $21 / 4$ miles. \\
\hline Near comer of left chimney of Colton Hotel. . & 29 & 09 & & & I $7 / 8$ miles. \\
\hline Left comer of left chimney of large house.... & 5.3 & $5^{I}$ & . & & $I \frac{1}{2}$ miles. \\
\hline 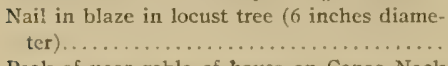 & 57 & 53 & $5 \circ$ & $\cdots$ & $3 x .98$ meters. \\
\hline Peak of near gable of house on Canoc Neck & & & & & \\
\hline Creek............................. & II9 & 23 & . & & $23 / 4$ niles. \\
\hline Left tangent of trees on Long Point........ & 120 & 08 & & & $5 / 8$ mile. \\
\hline $\begin{array}{l}\text { Nail in blaze in mulberry tree }(30 \text { inches } \\
\text { diameter) . . . . . . . . . . . . . . . . }\end{array}$ & 183 & 04 & 40 & & neters. \\
\hline REFERENCE STATION . . . . . & $18_{3}$ & $3 I$ & 40 & ....... & 22.01 meters. \\
\hline Right chimney of house..... & 221 & 59 & . & $\ldots \ldots$ & $3 / 8$ mile. \\
\hline ter)... & & & & & \\
\hline
\end{tabular}

\section{ST. PATRICK.}

General locality,-Western shore of lower St. Clement. Bay about I $T / 2$ miles north of Blakistone Island and one-half mile north-northeast of entrance to St. Patricks Creek. (See chart No. 25.)

Immediate locality._-Observed station is on cultivated land about 8 feet above high water, 26 yards west-northwest of edge of bank, 17 yards east-snutheast of a lone persimmon tree, Ioo yards north-northeast of a rail and wire fence, and 200 yards south of a barn in cornet of field. Cement monument marking reference station is about on line to persimmon tree 15.35 meters N. $59^{\circ} 5 \mathrm{I}^{\prime} \mathrm{W}$. of observed statio.1.

Marks,-Ohserved station is nail in stub with top about fush with surface of ground. Reference station is center point of triangle on standard cement monument.

References.-

"Blakistone Island Light". (S. $10^{\circ} 47^{\prime}$ WV.)... ०

Peak of near gable of large housc........ 55

Chimney of house .................. ror

REFEREACF STATION.............. IO 22

Nail in blaze in persimnon tree ( 12 inches

diameter)...................... 10

Right peak of roof of barn ............. 158

Right tangent of chimney of house....... 175

"Catholic Church Cross (Newtown Neck)" .. 228

Near corner of near chimney of pricst's house. 229

Near chimney of Yates housc........... 255

Chimmey of left house on Blakistone Island. . 357

\begin{tabular}{|c|c|c|}
\hline$\infty 0$ & $\ldots \ldots$ & $2 \frac{x}{8}$ miles. \\
\hline 30 & $\ldots \ldots$ & 1/4 mile. \\
\hline & ..... & $3 / 8$ mile. \\
\hline IC & $\ldots \ldots$ & I5.35 meters. \\
\hline 3 & . & I6.32 meters. \\
\hline & . . . . & 200 yards. \\
\hline & ...... & 200 yards. \\
\hline & $\ldots \ldots$ & $23 / 8$ miles. \\
\hline $4 c$ & $\ldots \ldots$ & 23/8 miles. \\
\hline & $\cdots$ & I mile. \\
\hline & $\ldots \ldots$ & $21 / 8$ miles. \\
\hline
\end{tabular}




\section{$\mathrm{ROOF}$.}

General locality.-Fastern side of St. Clement Bay about one-half mile north-northeast of entrance to bay, and three-eighths mile east-southeast of extreme end of Long Point. (See chart No. 25.)

Immediate locality.-Observed station is on western peak of roof of a barn behind a large house.

Marks.-Observed station is a 3 -inch syuare staff fastened and braced to the westcrn peak of roof of barn.

References.-None necessary.

\section{CANOE}

General locality.-Western shore of lower St. Clement Bay opposite Long Point and about 2 miles north of Blakistone Island. (Sec chart No. 25.)

Immediale locality.-Ohserved station is in a cultivated field about ro feet above high water, 4 yards northwest of edge of bank, 4 yards southwest of a ditch and trees in hollow, and 60 yards south by east of a large apple tree. Cement monument marking reference station is 53.28 meters $\mathrm{N}$. $x 7^{\circ} x 7^{\prime} \mathrm{W}$. of observed station.

Marks.-Observed station is nail in stub with top abont 2 inches above surface of ground. Reference station is center point of triangle on standard cement monument.

References.-

\begin{tabular}{|c|c|c|c|c|c|}
\hline Blakistone Island Light' ' $\left(\mathrm{S} . \mathrm{I}_{4}{ }^{\circ}\right.$ & 0 & & & & $23 / 4$ \\
\hline Chimney of smalt house. . . . . . . . & 19 & 40 & & & $x^{1} / 8$ miles. \\
\hline Near end of roof of house. . . . . . . & 54 & 55 & . & & ile. \\
\hline RETERENCE STATION .... & 148 & & 20 & & ters. \\
\hline 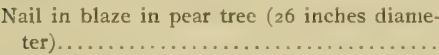 & & & & & \\
\hline Chiminey outside of house . . . . . . . . . . & 150 & 05 & $\cdots$ & $\ldots .$. & $1 / 2$ mile. \\
\hline Left chimney of large hotise & $x ; 8$ & 54 & . & & 1 \\
\hline Chimney of house. & 216 & 23 & 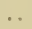 & $\ldots \ldots$ & niles. \\
\hline "Catholic Church Cross (Newtown Neck)". & 233 & 20 & 50 & $\cdots \cdots$ & 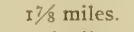 \\
\hline Near peak of roof of barn............... & 257 & 32 & & $\cdots \cdots$ & $1 / 4$ niles. \\
\hline Near chimney of Yates house .... & 283 & 03 & $\cdots$ & $\ldots$. & mil \\
\hline
\end{tabular}

RAIIS.

General locality.--Fiastern shore of St. Clement Bay about three-fourths mile northeast of Long Point and $3 \frac{1}{4}$ miles north-northeast of Blakistone Island Light. (See chart No. 25.)

Immediate locality.-Observed station is about 12 feet above high water, 16 yards southeast of edge of bank, 3 yards northeast of a rail fence, 40 yards northeast of a marshy creek between two fences, and 400 yards west to northwest of woods.

Marks.-Observed station is center point of triangle on standard cement monument.

References,-

"Shipping"' (N. $4^{\circ}$ of' W.)

Chimney of house......................

"Catholic Church Cross (Newtown Neck)"..

Near peak of roof of priest's house..........

Nail in blaze in locust tree ( 5 inclies diame-

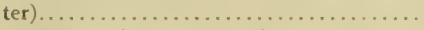

Nail in blaze in cedar tree $(7$ inches diame-

ter) ....................................

ter)........................

Near chimney of house with several gables.. 295 I4 $\quad \ldots \ldots \ldots$

Left chimney of large house $\ldots \ldots \ldots \ldots \ldots 35^{2}$ in $\ldots \ldots \ldots$
I $1 / 4$ miles.

I mile.

$7 / 8$ mile.

$7 / 8$ mile.

5.27 meters.

3.77 meters.

10.24 meters.

I $1 / 2$ miles.

$x y / 4$ miles. 


\section{WOODS.}

General locality.-Western shore of St. Clement Bay ahout I mile north of Long Point and one-half mile northeast of entrance to Canoe Neck Creek. (See chart No. 25.)

Immediate locality. - Observed station is about $\mathrm{I}$ foot above high water, 2 yards northwest of shore, I3 yards southeast of a bank 4 feet high, 75 yards southwest of a shell point, and southeast of a grove of pine, oak, and persimmon trees.

Marks.-Observed station is center point of triangle on standard cement monument.

References:-

"Blackistone Island Light" (S. $21^{\circ} 34^{\prime}$ W.)..

Nail in blaze in pine tree ( 20 inches diam-

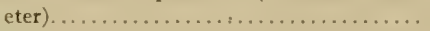

Nail in blaze in pine tree (1o inches diameter).............................

Nail in blaze in pine tree ( $\mathrm{I} 2$ inches diam-

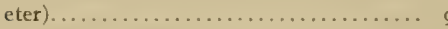

Left chimney of house ............... 2

Chimney of house ...................... 2

"Catholic Church Cross (Newtown Neck)"... $245 \quad 57 \quad 20 \ldots \ldots . \quad$ I $1 / 8$ miles.

Chimney of house................. $299 \quad 42 \quad \ldots \ldots \ldots \quad 7 / 8$ mile.

\section{CATHOLIC CHURCH CROSS (NEWTOWN NECK).}

General locality.-On Newtown Neck about halfway between Bretons Bay and St. Clement Bay and 2 miles north-northeast of Heron Island Sound. (See chart No. 25.)

Immediate locality.-Observed station is on Catholic Church situated on main road on Newtown Neck. Marks.-Observed station is center of cross on Catholic Church.

References.-None necessary.

\section{CHAPEL.}

General locality.-E Eastern shore of St. Clement Bay on a point about five-eighths mile southeast of Shipping Point, and $\mathrm{I} / 2$ miles northeast of Long Point. (See chart No. 25.)

Immediate locality.-Observed station is on southwest slope of a point about I5 feet high, ro feet above high water, 5 yards northeast of edge of bank, 7 yards southeast of edge of bank, 7 yards eastsoutheast of point of bank, 25 yards west-southwest of a cultivated field, and 3 to Io yards west to southwest of a dense growth of young pine trees. Cement monument marking reference station is about 9 - yards from edge of bank on edge of woods and cultivated field 17.12 meters N. $65^{\circ} 49^{\prime}$ E. of observed station.

Marks.-Observed station is nail in stub with top about flush with surface of ground. Reference station is center point of triangle on standard cement monument.

References.-

"Shipping" (N. $34^{\circ} 20^{\prime}$ W.

Chimney on right end of house.............

Peak of front gable of house .............

Near peak of roof on Stones Wharf. .........

Near peak of roof of small house.......... 54

Peak of gable of house................

Nail in blaze in pine tree ( 6 inches diameter). 8

REFERENCE STATION.................. IO

Nail in blaze in pine tree ( 4 inches diameter). II

Nail in blaze in pine tree ( 3 inches diameter). I5

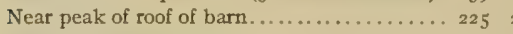

Chimney of Yates house................ 240

Chimney outside of house............... 302

Near peak of gable of house............. 345

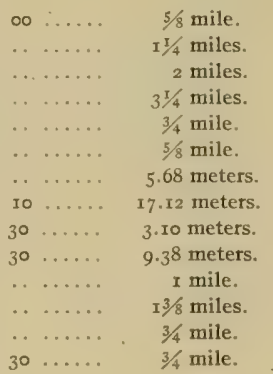




\section{SHIPPING.}

General locality.-Western shore of St. Clement Bay on Shipping Point about three-eighths mile southwest of Howards Wharf and $13 / 4$ miles north-northeast of Long Point. (See chart No. 25.)

Immediate locality.-Observed station is on a sand and grass point about $\mathrm{x}$ foot above high water, 5 yards southwest of shore, 6 yards north of shore, 16 yards west-northwest of extreme end of point, 20 yards east-southeast of woods on point, and 300 yards northeast of a house.

Marks.-Observed station is center point of triangle on standard cement monument.

References.-

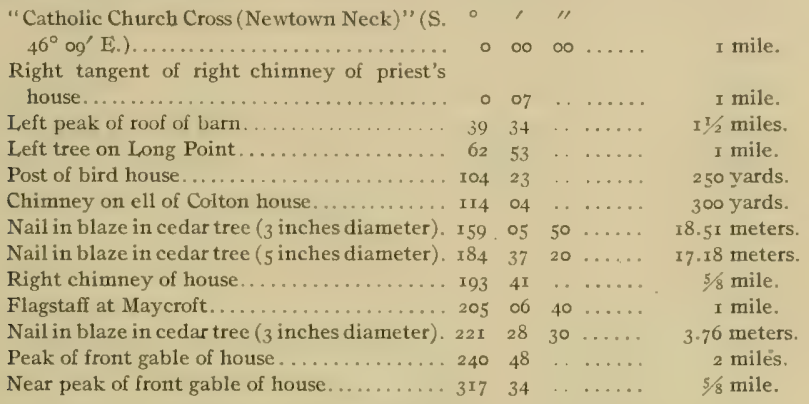

\section{MANSION}

General locality.-Eastern shore of St. Clement Bay about one-half mile southeast of Howards Wharf and 2 miles north-northeast of Long Point. (See chart No. 25.)

Immediate locality. - Observed station is about 20 feet above high water, 6 yards northeast of edge of bank, Ioo yards west by south of a corncrib, 1 10 yards west-northwest of an outbuilding, I25 yards southwest of a house, and 85 yards west of fruit trees. Cement monument marking reference station is 44.26 meters N. $19^{\circ} 04^{\prime} \mathrm{E}$. of observed station.

Marks.-Observed station is nail in stub with top about flush with surface of ground. Reference station is center point of triangle on standard cement monument.

References.-

"Shipping" (N. $84^{\circ} 2 \mathrm{I}^{\prime} \mathrm{W}$. $\circ, 1$,

Right chimney of house ... $\quad 25 \quad 21$

Nail in blaze in cedar tree ( 7 inches diameter). $60 \quad 4$

Nail in blaze in cedar tree ( 7 inches diameter). I02 2 I

REFERENCE STATION................. I03 24

Near corner of house................ I43 38

Near corner of corncrib.................. I6 $6_{3} \quad I_{7}$

Nail in blaze in apple tree ( $\mathrm{I}_{4}$ inches diame-

ter).

$\mathrm{IS}_{2}+5$

Near comer of outbuilding. ............. $203 \quad 42$

"Catholic Church Cross (Newtown Neck)". . 25320

Peak of front gable of Colton house....... 353 in

\begin{tabular}{|c|c|c|}
\hline$\infty$ & $\ldots \ldots$ & $5 / 8$ mile. \\
\hline & $\ldots \ldots$ & I mile. \\
\hline If & $\ldots \ldots$ & 47.34 meters. \\
\hline 10 & ...... & 43.77 meters. \\
\hline 35 & $\ldots \ldots$ & 44.26 meters. \\
\hline & $\ldots \ldots$ & 127 yards. \\
\hline & $\ldots \ldots$ & 99 yards. \\
\hline & $\ldots \ldots$ & 77.64 meters. \\
\hline & $\ldots$ & I I yards. \\
\hline & $\ldots$ & $\begin{array}{l}5 / 8 \text { mile. } \\
7 / 8 \text { mile. }\end{array}$ \\
\hline
\end{tabular}




\section{HOWARDS.}

General locality.-Northeastern shore of St. Clement Bay about $2 \frac{1}{4}$ miles north-northeast of Long Point, one-half mile northeast of Shipping Point and one-eighth mile east of Howards Wharf. (See chart No. 25.)

Immediate locality.-Observed station is in a field about 20 feet above high water, 8 yards north of edge of bank, I6 yards west-northwest of edge of ravine, 18 yards northwest of extreme end of point of bank, 70 yards west of another ravine, roo yards west-northwest of a wire fence, and 250 yards south of a house.

Marks,-Observed station is center point of triangle on standard cement monument.

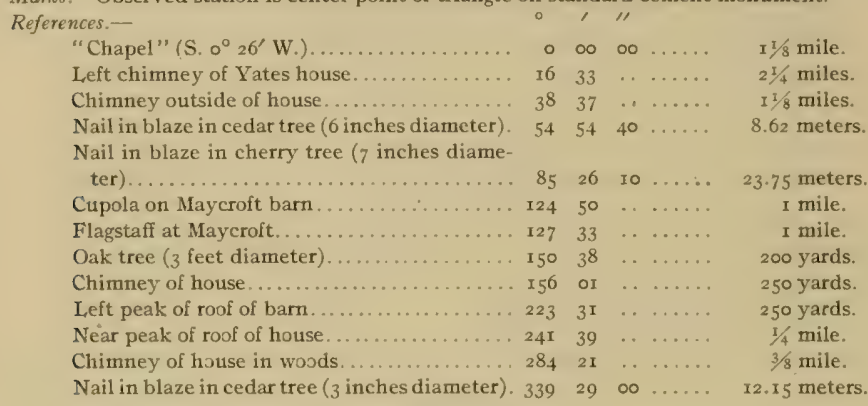

\section{MILEYS.}

General locality.-Western shore of St. Clement Bay about one-half mile west-northwest of Howards Whari, one-half mile northwest of Shipping Point, and one-eighth mile north of entrance to Mileys Creek. (See chart No. 25.)

Immediate locality. - Observed station is among water bushes on marsh land about I foot above high water, I2 yards southwest of shore, 20 yards west of shore, and I50 yards east-southeast of a house.

Marks.-Observed station is center point of triangle on standard cement monument.

References.-

\begin{tabular}{|c|c|c|c|c|c|}
\hline "Shipping" (S. $29^{\circ} 08^{\prime}$ E..). & $\circ$ & $\infty$ & & & $1 / 21$ \\
\hline himney of house & I 44 & 08 & & & 150 \\
\hline orner of chimney of ho & 154 & 56 & & & $150 y$ \\
\hline use.... & 183 & 18 & . & & $x / 4=$ \\
\hline himneys of old & 209 & 36 & . & & \\
\hline of old house. & 247 & 47 & . & & \\
\hline ho & 295 & 02 & & & \\
\hline$y$ of & 348 & 13 & 40 & & \\
\hline Catholic Church Cross (Newtown Neck)" & $3+8$ & 39 & 20 & & miles. \\
\hline
\end{tabular}

BANK.

General locality,-Eastern shore of St. Clement Bay about one-fourth mile north of Howards Wharf, five-eighths mile north-northeast of Shipping Point and five-eighths mile east-northeast of entrance to Mileys Creek. (See chart No. 25.)

Immediale locality.-Observed station is in a field adjoining an orchard back of a tree-fringed shore about 12 feet above high water, 20 yards east of edge of field, I 7 yards south of a small gully, and 50 yards north of a fence dividing orchard and field. Cement monument marking reference station is 18.53 meters N. $42^{\circ} 08^{\prime}$ W. of observed station. 
Marks.-Observed station is nail in stub with top about flush with surface of ground. Reference station is center point of triangle on standard cement monument.

References.-

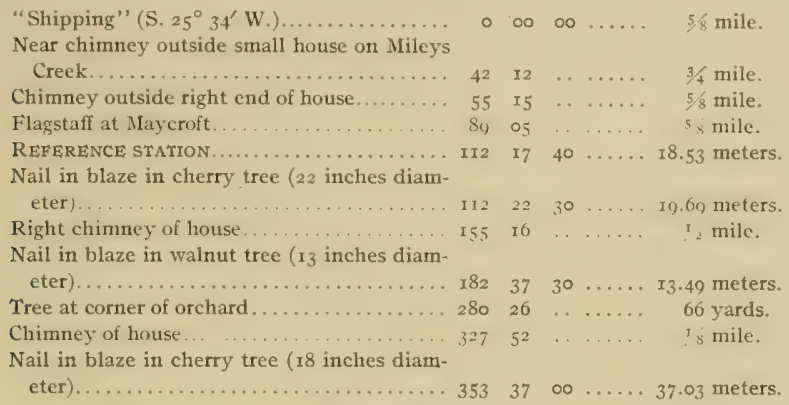

\section{PROFOUND.}

General locality.-Eastern shore of upper St. Clement Bay about one-half mile south of Cedar Point and I mile north of Shipping Point. (See chart No. 25.)

Immediate locality.-Observed station is on the southern side of the point on which the Hudson house is located about 12 feet above high water, 3 yards east-southeast of north corner and 3 yards north-northeast of south corner of a chicken house, 25 yards west of extreme end of point, 16 yards southeast of a well, 5 yards southwest of a drain from well, i6 yards southwest of edge of bank, and 4 yards southeast of top of bank.

Marks.-Obsèrved station is center point of triangle on standard cement monument.

References.-

"Cecil" (N. $70^{\circ}{ }_{5}^{6} \mathrm{E}$. $) \ldots \ldots \ldots \ldots \ldots \ldots \ldots$

Nail in blaze in cherry tree ( 7 inches diameter)..............................

Chimney of house on Howard Point........ 60

"Catholic Church Cross (Newtown Neck)". . 78

Near outside chimney of house........... r20

Left comer of chicken housę............. $1_{32}$

Left side of left chimney of Hudson house... . 20

Right comer of chicken house ............
Nail in blaze in right branch of pear tree $(35$

- $\infty 00 \ldots . .1 / 2$ mile.

Near corner of kitchen ................. . 233

Center of standpipe at well............. 253

Near comer of right chimney of house...... 253

Peak of front gable of house.............. $286 \quad 3$

Nail in blaze in apple tree ( ${ }_{4} 4$ inches diam-

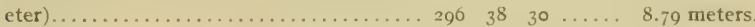

Peak of front gable of house............. $316 \quad 27 \quad \ldots \ldots \ldots 2$ miles.

Near corner of near chimney of house ....... $35^{8} \quad 54 \quad \ldots \ldots \ldots$. $1 / 2$ mile. 
CECIL.

General locality.-Eastern shore of upper St. Clement Bay about one-half mile southeast of Cedar Point and $\mathrm{I}^{1 / 8} \mathrm{~s}$ miles north of Shipping Point. (See chart No. 25.)

Immediate locality.-Observed station is in a field about $\mathrm{I} 2$ feet above high water, I 4 yards northeast of extreme edge of bank, $x_{4}$ yards east of edge of bank, 2 I yards southeast of edge of bank, 25 yards north of a marshy gully, 130 yards west-southwest of a fence surrounding a farmhouse, and 135 yards westsouthwest of a house.

Marks.-Observed station is center point of triangle on standard cement monument.

References.-

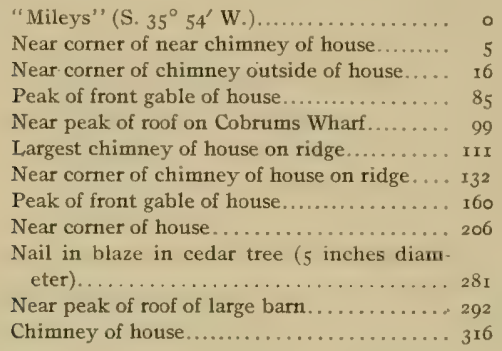

\begin{tabular}{|c|c|c|c|}
\hline$\infty$ & $\infty$ & ....... & $3 / 4$ mile. \\
\hline $4 \mathrm{I}$ & 40 & $\ldots \ldots$ & $3 / 4$ mile. \\
\hline $5^{8}$ & .. & $\ldots \ldots$ & $3 / 4$ mile. \\
\hline $5^{6}$ & $\cdots$ & ..... & $1 / 2$ mile. \\
\hline OI & $\cdots$ & $\ldots \ldots$ & $7 / 8$ mile. \\
\hline 24 & $\cdots$ & $\ldots \ldots$ & $23 / 4$ miles. \\
\hline $3^{8}$ & . & $\cdots \cdots$ & $27 / 2$ miles. \\
\hline $5^{8}$ & $\cdots$ & $\cdots \cdots$ & $\mathrm{x} 3 / 4$ miles. \\
\hline $5^{2}$ & 20 & $\cdots \cdots$ & ${ }^{1} 36$ yards. \\
\hline IO & 20 & $\ldots \ldots$ & 15.07 meters \\
\hline 43 & $\cdots$ & $\cdots \cdots$ & nile. \\
\hline 25 & 20 & $\ldots \ldots$ & \\
\hline
\end{tabular}

\section{RADEC.}

General locality.-Western shore of upper. St. Clement Bay on Cedar Point about three-eighths of a mile southeast of Cobrums Wharf and $I / 4$ miles south of Stones Wharf. (See chart No. 25.)

Immediate locality.-Observed station is on a point about 3 feet above high water, 23 yards northwest of shore, 32 yards south of shore, 75 yards west of extreme end of point, 45 yards northeast of outlet of a small pond, and $\mathrm{r}_{4}$ yards north-northeast of a small cedar tree.

Marks,-Observed station is center point of triangle on standard cement monument.

References. -

"Place" (N. $47^{\circ} 42^{\prime} \mathrm{E}_{\text {. }}$ ).

Nail in blaze in cedar tree $(6$ inches diameter).....

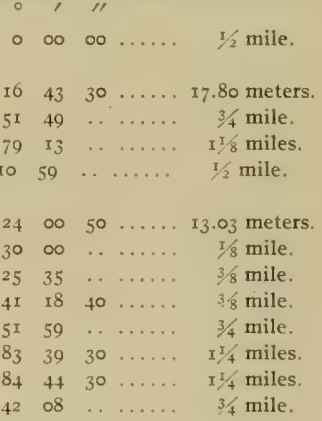

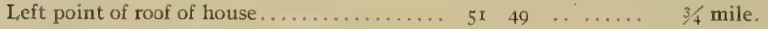

Left chimney of house on Howard Point... 79 I3 $\ldots \ldots \ldots$ I $1 / 8$ miles.

Right side of right chimney of Hudson house. I10 $59 \ldots \ldots \ldots$. $1 / 2$ mile.

Nail in blaze in cedar tree ( 7 inches diam-

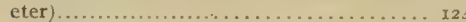

Right tangent of house.................

Peak of front gable of house.............. 225

Near peak of roof of wharf house.......... 24x

Chimney of house................... $25 \mathrm{I}$

Near peak of roof on Stones Wharf........... 283

Left chimney of house ................. 28 .

Left tangent of left chimney of old house... 342

Nail in blaze in cedar tree ( 14 inches diam-

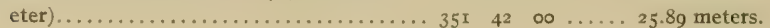


PLACE.

General locality,-Eastem shore of upper St. Clement Bay about three-fourths of a mile east of Cobrums Wharf, five-eighths of a mile southeast of Guest Point and one-half of a mile east-north-east of Cedar Point. (See chart No, 25.)

Immediate locality.-Observed station is on the southern edge of a cultivated field about ro feet above high water, 4 yards north of edge of bank, 20 yards east-southeast of edge of bank, 40 yards east-northeast of extreme end of marsh point, 50 yards north of edge of marsh, and 95 yards west-northwest of a corn crib.

Marks.-Observed station is center point of triangle on standard cement monument.

References.-

"Guest" (N. $4 \mathrm{r}^{\circ} 32^{\prime}$ W. ..............

Left tangent of left chimney of large house.. $57 \quad 46 \quad \ldots \ldots \ldots \quad 3 / 4$ mile.

I.eft tangent of chimney of shack......... I62 $05 \quad \ldots \ldots \ldots$ II2 yards.

Nail in blaze in apple trees ( 5 inches diam-

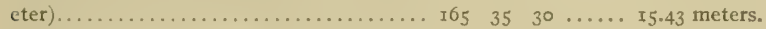

Nail in blaze in old stump ( 5 inches diameter $) \ldots \ldots \ldots \ldots \ldots \ldots \ldots \ldots \ldots \ldots \ldots$ I97 $5 x \quad 40 \ldots \ldots .6 .53$ meters.

Near peak of roof of house on next point... $226 \quad 05 \ldots \ldots .5 / 3$ mile.

Chimney outside near end of house........ 25 I ro ...... I I miles.

Right tangent of right chimney of Hudson

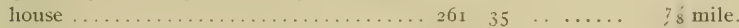

Peak on front gable of house............ 287 x $6 \quad \ldots \ldots \ldots$ s/g mile.

Near peak of roof on Cobrums Wharf..... 3is $05 \ldots . . .3 / 4$ mile.

\section{COBRUMS}

General locality.-Western shore of upper St. Clement Bay on southern side of entrance to Tomakokin Creek, about I mile south-southwest of Stones Wharf and roo yards northwest of Cobrums Wharf. (See chart No. 25.)

Immediate locality.-Observed station is on a marsh point about 2 feet above high water, 65 yards north-northwest of shore end of Cobrums Wharf, 7 yards south of shore, 8 yards southwest of shore, I2 yards west of shore at extreme end of point, and $I 7$ yards east-northeast of a fence.

Marks.-Observed station is center point of triangle on standard cement monument.

References.-

"Tomakokin" (N. $38^{\circ} 47^{\prime}$ W. $) \ldots \ldots \ldots \ldots$. . . .

Chimney on near end of house......... I.

Left tangent of left chimney of house on hill. 4

Near peak of rowf of house on Stones Wharf. . 53

Peak of front gable of house........... 88

Left tangent of left chimncy of old house.... r2I

Left corner of house on Cobrums Wharf.... 177

Right corner of house on Cobrums Wharf.... 184

Right chimney of house............. 190

Nail in blaze in one of several bushes......255

Near peak of roof of barn.............. 264

Nail in blaze in cherry tree ( 3 feet diameter). 306

\begin{tabular}{|c|c|c|}
\hline ১০ & $00 \ldots .$. & 3 s mile. \\
\hline 50 & $\ldots \ldots \ldots$ & 3 s mile. \\
\hline$[7$ & . . . . . & $x / 4 / 4$ miles. \\
\hline & $\ldots \ldots$. & I mile. \\
\hline 50 & $\ldots \ldots \ldots$ & I $1 / 2$ miles. \\
\hline 5. & . . . . . & 7/8 mile. \\
\hline & $30 \ldots \ldots$ & 70 yards. \\
\hline to & . . ..... & 65 yards. \\
\hline & $\ldots \ldots \ldots$ & $1 / 2$ mile. \\
\hline & $50 \ldots \ldots$ & I7.04 meters. \\
\hline & $\ldots \ldots \ldots$ & $1 / 8$ mile \\
\hline & $40 \ldots \ldots$ & 30.28 meters. \\
\hline
\end{tabular}

$2606-\mathrm{II}-8$ 


\section{GUEST.}

General locality.-Eastern shore of upper St. Clement Bay on Guest Point, about one-half mile northeast of Cobrums Wharf and five-eighths mile south-southeast of Stones Wharf. (See chart No. 25:)

Immediate locality.-Observed station is on a marsh point about 3 feet above high water, 32 yards north of shore, 43 yards northeast of shore, 45 yards east of shore, 95 yards west-northwest of south corner of a fence, and 175 yards south-southwest of north corner of a fence at edge of bank.

Marks.-Observed station is center point of triangle on standard cement monument.

References.-

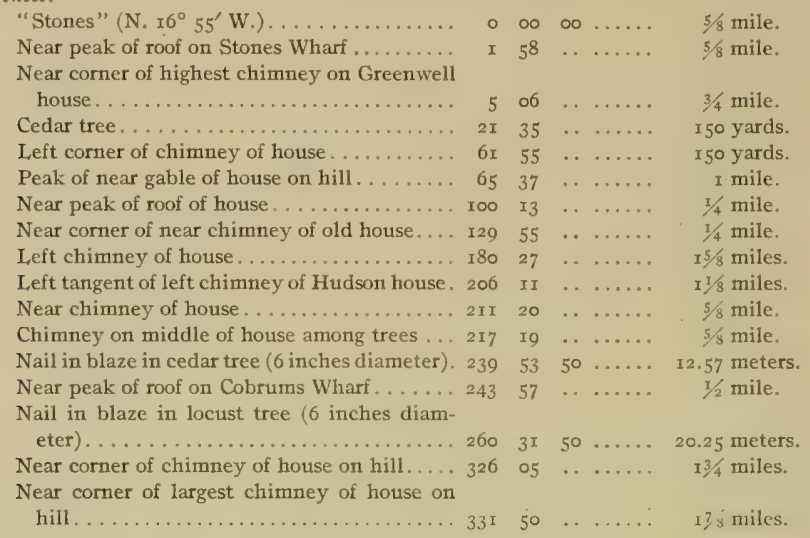

TOMAKOKIN.

General locality.-Western shore of upper St. Clement Bay on northeffr side of entrance to Tomakokin Creek, about three-eighths mile northwest of Cobrums Wharf and three-fourths mile southwest of Stones Wharf. (See chart No. 25.)

Immediate locality.-Observed station is on the edge of a cultivated field about 4 feet above high water, 4 yards west of shore, I2 yards northwest of high water, I4 yards south-southwest of a walnut tree, and 300 yards south-southeast of a barn.

Marks.-Observed station is center point of triangle on standard cement monument.

References.-

"Guest" (N. 84 o oI' E.).

Left corner of left chimney of old house.....

Near peak of roof on Cobrums Wharf . . . . . 5

Right peak of roof of barn.............

Near corner of chimney of house......... 135

Left tangent of left chimney of house....... I I eter) . . . . . . . . . . . . . . . . . . . . I

Nail in blaze. . . . . . . . . . . . . . . . . . 200

Right peak of roof of barn............. 25

Chimney of house showing over barn roof . . . 28

Right chimney of Greenwell house. . . . . . . 30

Near peak of roof on Stones Wharf.........
Nail in blaze in walnut tree ( $I$ inches diameter).

Chimney of old house near Guest Point

\begin{tabular}{|c|c|c|c|}
\hline$\infty$ & $\infty$ & $\ldots \ldots$ & 5 , mile. \\
\hline I5 & . & ...... & I mile. \\
\hline 33 & . & $\ldots \ldots$ & $3 / 8$ mile. \\
\hline $5^{2}$ & . & $\ldots \ldots$ & $1 / 4$ mile. \\
\hline 25 & $\cdots$ & $\cdots \cdots$ & $3 / 8$ mile. \\
\hline $2 I$ & - & $\cdots \cdots$ & $5 / 8$ mile. \\
\hline 46 & 40 & $\ldots \ldots$ & 29.18 meters. \\
\hline 36 & 50 & $\ldots \ldots$ & 40.31 meters. \\
\hline $2 I$ & $\cdots$ & $\ldots \ldots$ & 300 yards. \\
\hline 28 & . & $\ldots \ldots$ & I/8 mile. \\
\hline 49 & $\cdots$ & $\ldots \ldots$ & $7 / 8$ mile. \\
\hline $5^{2}$ & $\cdots$ & $\cdots$ & $3 / 4$ mile. \\
\hline 31 & 30 & $\ldots \ldots$ & I2.7 I meters. \\
\hline $5^{\mathrm{s}}$ & $\cdots$ & $\cdots$ & \\
\hline
\end{tabular}




\section{DYNARD.}

General locality.--Western shore of upper St. Clement Bay about one-half mile southwest of Stones Wharf and one-fourth mile north of Tomakokin Creek. (See chart No. 25.)

Immediate locality.-Observed station is in an angle of rail fence in corner of a cultivated field about 2 feet above high water, 8 yards west of shore, 9 yards west-southwest of shore, and 9 yards northwest of shore.

Marks.-Observed station is center point of triangle on standard cement monument.

References.-

"Turf" (N. $3^{\circ}$ oo' E)

Right chimney of Greenwell house

Near peak of roof on Stones Wharf.

Near corner of chimney of house . . . . . . . 73

Near corner of chimney of house........ 9

Nail in blaze in persimmon tree ( 8 inches diameter)..................... 101

Near corner of chimney of old house...... I07

L.eft cedar tree on Cedar Point. . ........... I5o

Right chimney of house............. I57

Near peak of roof on Cobrums Wharf ...... $16_{3}$

Nail in blaze in cedar fence post........ $18 \mathrm{r}$

Chimney of house .................. 210

Nail in blaze in mulberry tree (10 inches diameter)..................... 325

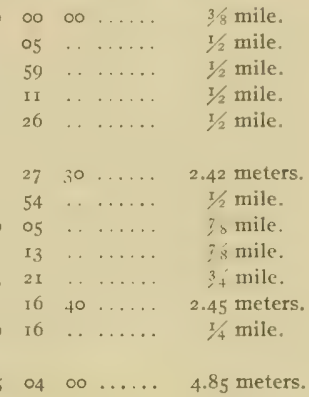

TURF,

General locality.-Western shore of upper St. Clement Bay on a point about three-eighths mile west of Stones Wharf. (See chart No. 25.)

Immediale locality.-Observed station is in a cultivated field about 2 feet above high water, 26 yards south-southwest of shore, 27 yards northwest of shore, 32 yards west of shore, 90 yards north of a point, 300 yards east-northeast of a house, and 200 yards east-northeast of a wire fence.

Marks.-Observed station is center point of triangle on standard cement monument.

References.-

\begin{tabular}{|c|c|c|c|c|}
\hline "Stones" (N. $80^{\circ} 29^{\prime}$ E. .). . & $\circ$ & $\infty$ & $\infty 0$ & $1 / 4$ mile. \\
\hline Right peak of roof on Stones Wharf. . . . . . & 3 & 36 & & ile. \\
\hline 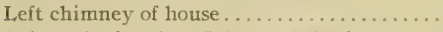 & 86 & 38 & . & I $1 / 4$ miles. \\
\hline Left peak of roof on Cobrums Wharf. ...... & 93 & 17 & & nile. \\
\hline Left tree on print. & 95 & 22 & & 75 yards. \\
\hline Near peak of roof of barn. & $\mathrm{I}_{52}$ & 27 & & 300 \\
\hline Right chimney of house... & 173 & o6 & & 300 yards. \\
\hline Right chimney of house behind trees...... & 226 & 31 & & $1 / 4 \mathrm{mil}$ \\
\hline of house on hill . ........... & $25^{2}$ & 10 & & 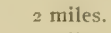 \\
\hline Right chimney of house. . . . . . . . . & 290 & II & & n \\
\hline Right chimney of Greenwell house........ & $35^{2}$ & 57 & . . . . . & nil \\
\hline
\end{tabular}


STONES.

General localily.-Eastern shore of upper St. Clement Bay near Stones Wharf about five-eighths mile north-northwest of Guest Point. (See chart No. 25.)

Immediate locality.-Observed station is on a point about 54 yards west-northwest of northern end of large wharf house, 5 yards northeast of extreme end of point, 5 yards southeast of shore, 30 yards south of a board fence, and 65 yards south-southwest of foot of a hill.

Marks.-Observed station is center point of triangle on standard cement monument.

References. -

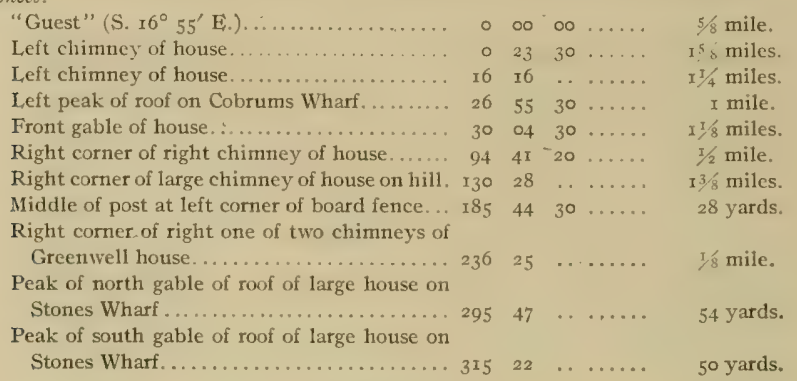

\section{BARBER.}

General locality. -Northeastern shore of Wicomico River about three-fourths mile north-northeast of Stoddard Point. (See chart No. 26.)

Immediate localily.-Observed station is on grass land about 2 feet above high-water mark, 3 yards north of shore, 20 yards west of trees which extend inland along creek, 4 yards southwest by west of a corner of a fence and 15 yards southeast of another corner of a fence.

Marks.-Observed station is center point of triangle on standard cement monument.

References.-

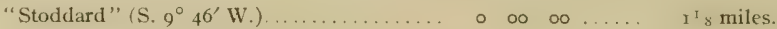

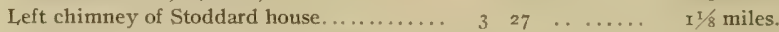

Near peak of roof between two chimneys.... 45 15 $\ldots \ldots \ldots$ I $\quad \ldots$ miles.

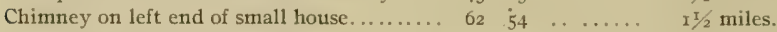

Nail in blaze in top fence rail ............ 136 o6 ...... 10.62 meters.

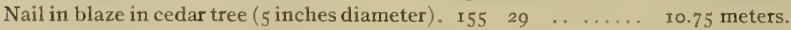

Nail in blaze in top of chestnut fence post... $245 \quad 24 \quad \ldots \ldots . \quad 3.43$ meters.

Nail in blaze in persimmon tree ( 5 inches

diameter $) \ldots \ldots \ldots \ldots \ldots \ldots \ldots \ldots \ldots \ldots .259 \quad 16 \quad \ldots \ldots \ldots . \ldots \ldots+13.94$ meters.

Tangent of point................... 299 I3 . . . . $\quad 1 / 4$ mile.

Near large chimney of negro quarters..... $302 \quad 07 \ldots \ldots . . . \quad$ I $1 / 8$ miles. 


\section{UPPER.}

General locality. - Southwestern shore of Wicomico River on Stoddard Point (upper point) about 21/4 miles north-northwest of Mills Point. (See chart No, 26.)

Immediate locality.-Observed station is on a long narrow point about 2 feet above high-water mark, 5 yards south of side of point, 8 yards northwest of side of point, 38 yards west of high-water mark on middle of point and ${ }_{3} 8$ yards west by north of high-water mark on extreme end of point.

Marks.-Observed station is center point of triangle on standard cement monument.

References.-

Right chimney of Stoddard house.

L.eft peak of roof of barn................

Left chimney of old house..............

Tangent of next point............... I

Right chimney of house on ridge .......... I
Chimney outside small house on opposite

shore....................... $2 \mathbf{I}_{3}$

Near corner post of piazza of large house.... 247

Chimney top of Key house.

\begin{tabular}{|c|c|c|c|}
\hline$\infty$ & $\infty$ & $\ldots \ldots$ & $1 / 2$ mile, \\
\hline 12 & . & ...... & $1 / 2$ mile. \\
\hline 02 & . & ...... & $1 / 2$ mile. \\
\hline 29 & .. & ...... & $1 / 2$ mile. \\
\hline 07 & . & ...... & $5 / 8$ mile. \\
\hline I5 & $\cdots$ & $\ldots \ldots$ & 3 miles. \\
\hline 28 & . & $\ldots \ldots$ & $1 / 4$ miles. \\
\hline 47 & $\cdots$ & ....... & I $5 / 8$ miles. \\
\hline 0.4 & . & $\ldots \ldots$ & I $1 / 2$ miles. \\
\hline
\end{tabular}

KEY.

General locality.-Northeastern shore of Wicomico River on a high bluff about I mile north of Cohouck Point. (See chart No. 26.)

Immediate locality.-Observed station is about 30 feet above high-water mark in an orchard, about 24 yards northeast of edge of bank, 49 yards north of edge of bank, 15 yards east of edge of bank, 130 yards south-southwest of negro quarters and 130 yards west of fence which incloses an orchard.

Marks.-Observed station is center point of triangle on standard cement monument.

References.-

"Stoddard" (S. $70^{\circ} 48^{\prime} \mathrm{W}$.)

Near corner of near chimney on Stoddard

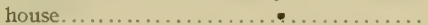

Near corner of near chimney of small house.

Peak of roof between two chimneys on house.

Peak of roof of very large barn............

Chimney on middle of roof on 2-story house. .

Near corner of near chimney of negro's quar-

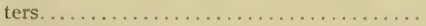

Nail in blaze in apple tree ( 12 inches diameter $) \ldots \ldots \ldots \ldots \ldots \ldots \ldots \ldots \ldots \ldots \ldots \ldots \ldots \ldots \ldots$

Chimney of Key house

$$
\begin{array}{llllll}
164 & 37 & \ldots & \ldots \ldots &
\end{array}
$$

Nail in blaze in apple tree ( 14 inches diameter

Peak of roof of large barm

$\begin{array}{llllll}168 & 57 & \ldots & \ldots & 13.39 \text { meters. } \\ 259 & 16 & \ldots & \ldots & 1 / 2 \text { mile. }\end{array}$

Nail in blaze in apple tree ( 12 inches diameter $\ldots \ldots \ldots \ldots \ldots \ldots \ldots \ldots \ldots . \ldots \ldots$

Between two chimneys of large brick house on hill

$347 \quad 23 \quad \ldots \ldots \ldots$ $357 \quad 45$
I $1 / 8$ miles.

I $3 / 4$ miles.

$\mathrm{I} 3 / 8$ miles.

2 miles.

3 miles.

3 miles.

130 yards.

15 meters.

7.94 meters I $3 / 8$ miles.

$2^{1} 2$ miles 


\section{STODDARD.}

General locality.-Western shore of Wicomico River about one-half mile south-southeast of Stoddard Point and I mile west-northwest of Cohouck Point. (See chart No, 26.)

Immediate locality.-Observed station is on gravel, grass, and shell point, near a lone gum trec, about 2 feet above high-water mark, 6 yards south-southwest of side of point, 6 yards north of side of point, ro yards west of extreme end of point, and I 58 yards east-northeast of Stoddard house.

Marks.-Observed station is center point of triangle on standard cement monument.

References.-

\begin{tabular}{|c|c|c|c|c|c|}
\hline "Upper" (N. $26^{\circ} 37^{\prime}$ W. $) \ldots \ldots \ldots \ldots \ldots \ldots$ & ○ & $\infty$ & 0 & & $1 / 2$ mile. \\
\hline Outside chimney of small house.......... & 23 & 08 & & & iles. \\
\hline Peak of front gable of large house on ridge... & $5^{2}$ & 54 & & & les. \\
\hline Chimney on top of Key house............... & 94 & 47 & & & $I^{2} / 2$ \\
\hline y outside of $2 \frac{r}{2}$ story house. & I53 & $5^{8}$ & . & & 23 \\
\hline Right chimney of large house..... & 172 & 38 & & & les. \\
\hline roof of house on Chaptico Wharf.... & 180 & I9 & .. & & $25 / 8$ \\
\hline top of house on piles........... & 228 & 37 & . & & 1 \\
\hline aer of chimney on Stoddard house. & 284 & 44 & & $\ldots \ldots$ & ards. \\
\hline Nail in blaze in pear tree $(24$ inches & 3 I 5 & 29 & . & & $4.5^{8}$ \\
\hline Nail in blaze in pear tree ( 4 inches diameter). & 349 & 47 & . & & $9 \cdot 4 \pi$ met \\
\hline
\end{tabular}

\section{COHOUCK.}

General locality:-Eastern shore of Wiconico River on Cohouck Point on the northern side of entrance to Chaptico Bay. (See chart No. 26.)

Immediate locality.-Ohserved station is on Cohouck Point, about 6 feet above high-water mark, I2 yards east of edge of bank, 35 yards south of edge of bank, 85 yards northeast of extreme point and about 25 yards north of marsh.

Marks.-Observed station is center point of triangle on standard cement monument.

References.-

\begin{tabular}{|c|c|c|c|c|}
\hline "Key" (N. $3^{\circ} 29^{\prime}$ E.). & o & $\infty$ & $\infty$ & $7 / 8$ mile. \\
\hline Nearest chimney on negro quarters......... & ○ & 27 & & nile. \\
\hline 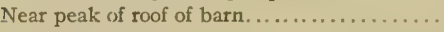 & 26 & $3^{S}$ & $\ldots \ldots$ & mile. \\
\hline Chimney outside near end of $2 \mathrm{r} / 2$-story house. & 128 & $5^{8}$ & $\ldots \ldots$ & mile. \\
\hline 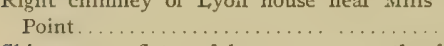 & エフI & 29 & & niles. \\
\hline 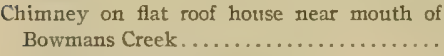 & 226 & $5^{6}$ & & uiles. \\
\hline Chimney on far end of house... & $26 \mathrm{I}$ & 43 & .. & miles. \\
\hline Chimney on house on piles & 270 & 53 & . $\cdots \cdots$ & \\
\hline Peak of front gable of house on ridge....... & $35^{2}$ & $5 I$ & $\ldots \ldots \ldots$ & $21 / 4$ miles. \\
\hline
\end{tabular}

\section{HAYDEN}

General locality.-Westem shore of the Wiconico River about $\mathrm{I} 1 / 8$ miles west of Cohouck Point. (See chart No. 26.)

Immediate locality.-Ohserved station is surrounded by water bushes on marshy land, about I foot above high water, 5 yards northwest of shore and 17 yards southeast of line of trees on top of bank. Cement monument marking reference station is II.50 meters N. $54^{\circ} 34^{\prime} \mathrm{W}$. of observed station.

Marks.-Observed station is nail in stub with top 3 inches above ground. Reference station is center point of triangle on standard cement monument.

References.--

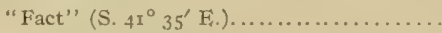

Between two main chimneys of large house below Chaptico Wharf. ...............

West roof peak of house on Chaptico Wharf. .

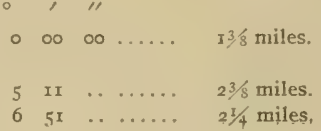


References-Continued.

Chimney on middle of square house........

Nail in blaze in cedar tree ( 18 inches diam-

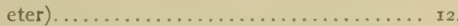

Nail in blaze in locust tree ( 8 inches diameter) I5

RETHRFNCE STATION................. I67

Nail in blaze in oak tree ( 8 inches diameter), 2 I

Chinney on Key house................. 275

Chimney of Maddox house............. 34

Right chimney outside of old house..... 354 $\circ, 11$

65 o6 $\ldots \ldots \ldots .5 / 3$ mile.

I4 . . . . 23.45 meters.

x6. 55 meters.

II. 5 I meters.

58.74 meters.

$13 / 4$ miles.

$31 / 4$ miles.

I5/8 miles.

\section{PERRY.}

Gencral localizy.-Southeastern shore of Chaptico Bay, about I mile northeast of Mills Point and $5 / 8$ mile southeast of Colouck Point. (See chart No, 26.)

Immediale locality.-Observed station is in an open field, about 20 fect above high-water mark, $\$$ yards northwest of edge of bank, 9 yards south-southwest from edge of gully in bank, 5 yards south of edge of bank of gully, and about I 50 yards north-northeast of creek.

Marks.-Observed station is center point of triengle on standard cement monument.

References.-

"Fact" (S. $5 \mathrm{I}^{\circ}$ 10' W.). .

Chimney on right end of house.

Chimney on flat-roof house...............

Left chimney of Crane house..............

Nail in blaze in locust tree ( 3 inches diameter)

Nearest chimney on larger part of double

brick house. .....................

I.eft chimney of house on piles............

Near peak of roof on house................

Near corner of near chimney of Stoddard house.

Nail in blaze in locust tree ( 3 inches diameter) 8

Peak of front gable of house on ridge........ II 3

Nail in blaze in locust tree ( 8 inches diameter) ${ }_{3} 6$

Near chimney of large house on ridge........ I6n

Chimney outside of $21 / 2$-story house ....... 289

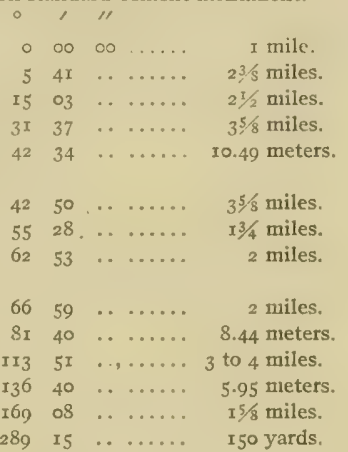

BURR,

General locality.-Western shore of Wicomico River directly opposite mouth of Chaptico Bay and three-fourths mile north of Bowmans Creek. (See chart No. 26.)

Immediate locality.--Observed station is on hard ground between a sloping bank ro feet high covered with trees and a marshy shore, about 2 feet above high-water mark, 18 yards northwest of extreme point 23 yards north of shore, 17 yards southwest of shore, and 9 yards southeast of bottom of bank.

Marks.-Observed station is center point of triangle on standard cement monument.

References.-

"Fact" (S. $65^{\circ} 59^{\prime}$ I:.).

Between two climneys of large house on ridge

West end of peak of roof of house on Chaptico Wharf.

Right chimney of $2 \frac{T}{2}$-story house..........

Chimney in middle of large house..........

Nail in blaze in persimmon tree (II inches diameter).

Nail in blaze in persimmon tree ( 9 inches diameter).

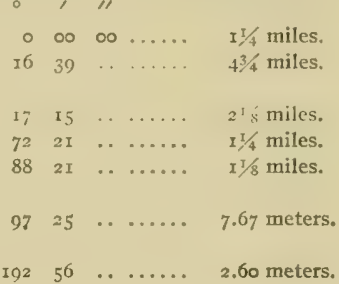


References - Continued.

Nail in blaze in persimmon tree (ro inches diameter)........................ 236 32

Main chimney of Key house............ $293 \quad 03$

Chimney on Maddox house.............. $35^{8} \quad 28$

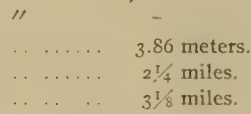

FACT.

Gencral locality.-Eastern shore of Wicomico River on Mills Point on south side of mouth of Chaptico Bay. (See chart No, 26.)

Immediate locality.-Observed station is on a long point covered on the southem side with gum and cedar trees, about io feet above high-water mark, 23 yards from extreme end of top of bank, 6 yards north of edge of bank, and 8 yards southeast of edge of bank.

Marks.-Observed station is center point of triangle on standard cement monument.

References. -

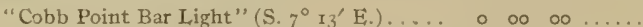

Nail in blaze in cedar tree ( 7 inches diameter). $\begin{array}{lllll}5 & 07 & \ldots & \ldots . & 6.20 \text { meters. }\end{array}$

Nail in blaze in oak tree ( 28 inches diameter). $\begin{array}{rllll}56 & \text { I6 } & \ldots & \ldots & 6.37 \text { meters. }\end{array}$

Chimney on ell end of Stoddard house..... 157 of $\ldots \ldots \ldots \quad$ r $7 / 8$ miles.

Chimney on Key house............... I99 $54 \ldots \ldots \ldots$. $21 / 8$ miles.

Near peak of roof of large house.......... $274 \quad 25 \quad \ldots \ldots \ldots \quad 1 / 4$ mile.

Nail in blaze in cedar tree ( 6 inches diameter). $301 \quad 45 \quad \ldots \ldots \ldots \quad 16.26$ meters.

Near chimney of large house near shore... $317 \quad 53 \quad \ldots \ldots \ldots \quad 5 / 8$ mile.

West end of peak of house on Chaptico Wharf. $342 \quad 53 \quad \ldots \quad \ldots \ldots . \quad 7 / 8$ mile.

\section{BOWMAN.}

General locality.-Western shore of Wicomico River at northeast side of mouth of Bowmans Creek and $I / 2$ miles west by south of Mills Point. (See chart No. 26.)

Immediate locality.-Observed station is surrounded by water bushes on point of land about II/2 feet above high water, I4 yards east of high-water mark, I6 yards north of extreme end of point, 20 yards northeast of side of point, 20 yards south of several cedar trees, and about I50 yards south of a house.

Marks.-Observed station is center point of triangle on standard cement monument.

References.-

"Sacred Heart Church Spire" (S. $62^{\circ} 50^{\prime}$ E.). $00000 .$.

Chimney on end of long house........ Io $37 \ldots \ldots$.... $31 / 4$ miles.

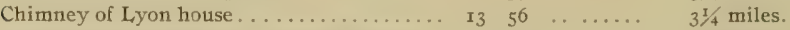

Nail in blaze in cedar tree ( 7 inches diameter). $\begin{array}{lllll}59 & 0.4 & 40 & \ldots . & 8.88 \text { meters. }\end{array}$

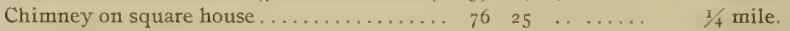

Crane house .................... I68 I0 2 miles.

Nail in blaze in cedar tree ( 6 inches diameter). 216 Io oo .... 18.37 meters.

Nail in blaze in cedar tree ( 7 inches diameter). $232 \quad 40 \quad 30 \ldots \ldots . \quad 17.58$ meters.

Chimney on near end of house........... 263 40 $\quad \ldots \ldots \ldots .21 / 2$ mile.

Peak of roof between two chimneys....... $357 \quad 27 \quad \ldots \ldots \ldots .21 / 4$ miles.

\section{EEDLING.}

General locality:- Western shore of Wicomico River about $I_{1}^{I} / 4$ miles southwest of Mills Point and about I mile southeast of mouth of Bowmans Creek. (See chart No. 26.)

Immediate locality. - Observed station is in a shell-covered cultivated field, about ro feet above high-water mark, 37 yards southwest of shell and gravel beach, 88 yards west-northwest of extreme end of point, and 79 yards north of a ditch in marsh. Cement monument marking reference station is 23.99 meters N. $89^{\circ} 5^{6^{\prime}}$ W. of observed station.

Marks.-Observed and reference stations are marked by the center point of the triangles on standard cement monuments. 


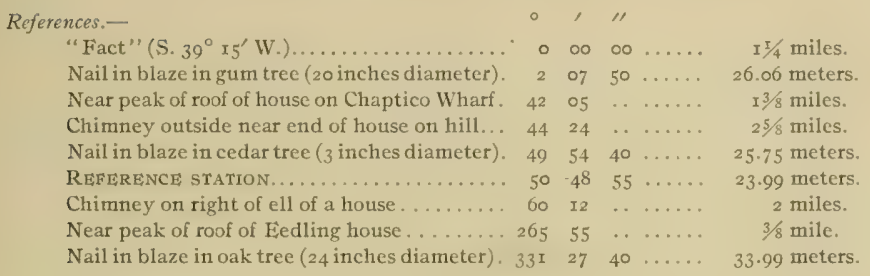

\section{FARR.}

General locality.-Eastem shore of Wicomico River about $1 \frac{1}{4} /$ miles south-southeast of Mills Point and one-fourth mile north of the mouth of Manahowick Creek. (See chatt No. 26.)

I $m$ mediate locality.-Observed station is about ro feet above high-water mark, 5 yards east by south of edge of bank, 32 yards north-northwest of several pine trees at fish shanty near edge of bank, 22 yards south by east of other trees, and 300 yards west by north of a large house.

Marks.-Observed station is center point of triangle on standard cement monument buried 16 inches below surface of ground with nail in stub at surface.

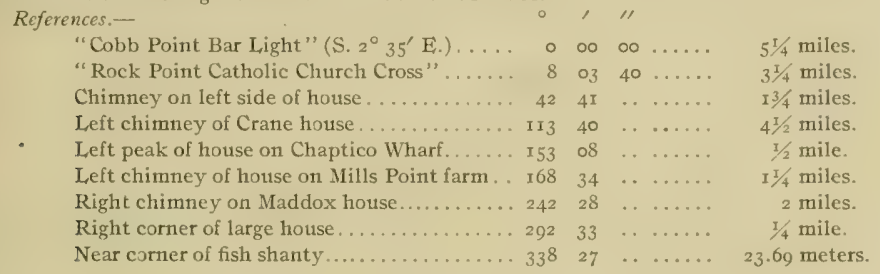

\section{GUST.}

General locality. - Western shore of Wicomico River on Windmill Point about tinree-fourths mile north of the muth of Hedneys Creek and opposite mouth of Manahowic Creek. (See chart No. 26.)

Immediate locality.-Observed station is on shell and gravel point, bordered by persimmon and cedar trees, about 2 feet above high-water mark, I2 yards northwest of shore, i6 yards south of shore, and 28 yards west-southwest of shore on extreme end of point.

Marks.-Observed station is center point of triangle on standard cement monument.

References.-

"Fact" (N. $20^{\circ}$ of' E.) ...

, I I

Nail in blaze in persimmon tree ( 8 inches diameter) $\ldots \ldots \ldots \ldots \ldots \ldots \ldots \ldots \ldots \ldots \ldots \ldots \ldots \ldots \ldots$.

Near peak of roof of house on Chaptico Wharf.

Chimney on left side of large house......... 58

Chimney on middle of Lyon house........ io

Near peak of roof of house with two chimneys. I7

Nail in blaze in cedar tree (4 inches diam-

eter) ............................ 504 It 5.90 meters.

eter) ....................... 
LYON.

General locality.-Eastern shore of Wicomico River on a point about $1 / 4$ mile north of Bramleigh Creek and 2 miles north by east of Rock Point. (See chart No. 26.)

Immediate locality. - Observed station is on a point of land between the Lyon residence and edge of bank, roo yards north of small pond which is fringed on tiver side with cedar trees, about 4 yards north of a bird house on a post, ig yards east-northeast of most prominent point of bank, I5 yards eastsoutheast of side of bank, 16 yards north-northeast of another side, and 12 yards south-southwest of a fence.

Marks - Observed station is center point of triangle on standard cement monument.

References.-

"Weiss" (S. $25^{\circ} 47^{\prime}$ E. $) \ldots \ldots \ldots \ldots \ldots \ldots \ldots$

Nail in blaze in cedar post of bird house support.......................... $5^{I}$ I5 $_{5} 20 \ldots .67$ meters.

Nail in blaze in pear tree ( 6 inches diameter). $5^{8}$ o0 $50 \ldots \ldots$ II.74 meters.

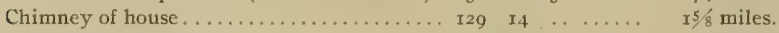

Left chimney of Crane house . . . . . . . . I $4^{8} \quad 5^{2} \ldots \ldots \ldots \quad 5^{1 / 4}$ miles.

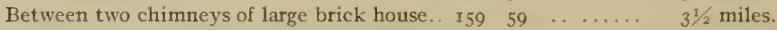

Near peak of roof between two chimneys of

large house..................... I7 $5^{6} \ldots \ldots .3 \frac{3}{4}$ miles.

West end of peak of roof of house on Chaptico

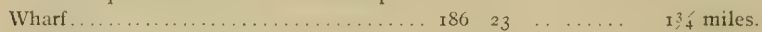

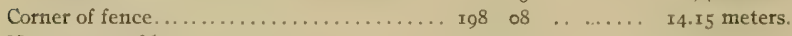

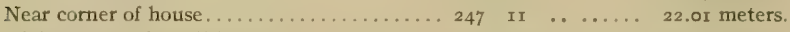

Right corner of small house $\ldots \ldots \ldots \ldots \ldots \ldots .295 \quad 38 \ldots \ldots . \ldots 24.59$ meters.

Nail in blaze in locust tree ( 4 inches diameter). $302 \quad 02 \quad 10 \ldots .8 .82$ meters.

Right corner of shed................ $336 \quad 36 \quad \ldots \ldots .44 .98$ meters.

\section{SACRED HEART CHURCH SPIRE (BUSHWOOD).}

General locality.-Easterly side of Wicomico River on high land about $\mathrm{I}^{\mathrm{T}} / 2$ miles inland, north by east of Bushwood Wharf. (See chart No. 26.)

Immediate localify.-Observed station is steeple of Sacred Heart Church near Bushwood.

Marks.-Observed station is center of cross on steeple.

References.-None necessary.

\section{HEDNEY}

General locality.-Western shore of Wicomico River on first point above mouth of Charleston Creek and about $\mathrm{I} 3 / 4$ miles northwest of White Point. (See chart No. 26.)

Immediate locality.-Observed station is about 25 feet above high-water mark, I6 yards westsouthwest of edge of bank, I39 yards north of large tree at edge of bank, 85 yards north of oak tree at. edge of bank, 155 yards east-northeast of gum tree 20 inches diameter on bank of a pond, and about $1 / 8$ mile east-southeast of a house among trees.

Marks.-Observed station is center point of triangle on standard cement monument with top buried 12 inches below the surface of the ground. Surface mark is nail in stub with top 5 inches above surface of ground.

References.-

"Sacred Heart Church Spire" (N, $86^{\circ} 3 \mathrm{I}^{\prime} \mathrm{E}$.).

Near conner of nearest chimney of four on a large house on hill.

Right chimney of a large house............

Middle of island at end of White Point Bar...

Nail in blaze in oak tree ( 48 inches diameter).

Nail in blaze in walnut tree ( 36 inches diam-

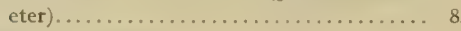

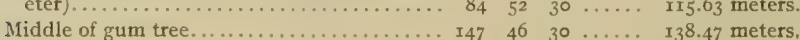


References-Continued.

Near peak of roof between two chimneys.... $239 \quad 48 \quad \ldots \ldots \ldots \quad 3 / 4$ mile.

Near chimney on large house.......... 3I2 I9 ...... I5/8 miles.

Chimney of Lyon house.................. 352 I $40 \ldots$ miles.

CHARLES.

General locality:-Western shore of Wicomico River on first point south of entrance to Charleston Creek, and II/4 miles north of Rock Point. (See chart No, 26.)

Immediate locality.-Observed station is on a small marshy point about 6 inches above high-water mark and 18 yards east of pine woods on a bank to feet above high water. Cement monument marking reference station is 15.56 meters $\mathrm{N}$. $57^{\circ}$ I0' $\mathrm{W}$. of observed station.

Marks.-Observed station is nail in stub with top 2 inches above ground. Reference station is center point of triangle on standard cement monument.

References.-

"Hard" (S. $\mathrm{r}_{7}^{\circ}{ }_{3} \mathrm{~S}^{\prime} \mathrm{E}$. $)$

Nail in blaze in pine tree (Io inches diameter)

Nail in blaze in pine tree ( 12 inches diameter).

Nail in blaze in pine tree ( 7 inches diameter). 134

REFERENCE STATION................... I3 8

West chimney on two-story house......... 265

"Sacred Heart Church Spire (Bushwood)" . . 268

West chimney on Gamer house ........... 293

West gable of house on Bushwood Wharf.... 300

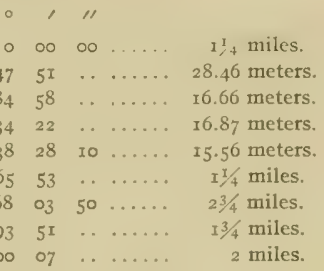

\section{WEISS.}

General locality.-Eastern shore of Wicomico River on White Point, about 3 miles north by east of Cobb Point Bar Light. (See chart No. 26.)

Immediate locality.-Observed station is on a bluff near small cedar trees, about 8 feet above highwater mark, 13 yards north of and 27 yards south of edges of bluff and 52 yards east of extreme point.

Marks.-Observed station is center point of triangle on standard cement monument.

References.-

"Cobb Point Bar Light" (S. $\mathrm{II}^{\circ} 43^{\prime}$ W. $)$....

Flagstaff on schoolhouse.................

Nail in blaze in cedar tree (ro inches diam-

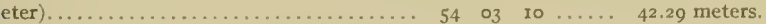

Left chimney on two-story house....... I55 $26 \quad \ldots \ldots \ldots .3 / 4$ mile.

Nail in blaze in poplar tree ( 3 inches diam-

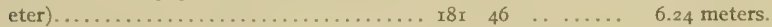

"Sacred Heart Church Spire" .......... 216 56 30 .... I3/4 miles.

West chimney of Gamer house.......... $260 \quad 27 \quad \ldots \ldots \ldots \quad 5 / 8$ mile.

Nail in blaze in poplar tree ( 4 inches diameter)......................... $266 \quad 27 \quad 50 \ldots \ldots$ meters.

West gable of house on Bushwood Wharf.... $2_{2} 84 \quad 26 \quad \ldots \ldots \ldots . \quad 5 / 8$ mile.

Left chimney on two-story house ....... 342 10 . . . $23 / 3$ miles.

\section{BLAKISTONE}

General locality.-Eastern shore of Wicomico River, about one-fourth mile southeast of Plowdens Wharf at Bushwood, and about 3 miles north-northeast of Cobb Point Bar Light. (See chart No. 26.)

Immediate locality.-Observed station is on second bluff southeast of Bushwood Wharf, $\mathrm{I}_{5}$ feet above high-water mark, ${ }_{5}$ yards southeast of a large dogwood tree, about 6 yards northeast of edge of bluff, 3 yards southwest of rail fence, about 15 yards southwest of an ice house near orchard, and 5 to Io yards south to east of several small cedar trees.

Marks.-Observed station is center point of triangle on standard cement monument. 


\begin{tabular}{|c|c|c|c|c|}
\hline eren & & & $\prime \prime$ & \\
\hline "Prec" (S. $18^{\circ} 42^{\prime}$ W.). & 0 & $\infty$ & $\infty$ & 2 miles. \\
\hline "Rock Point Catholic Church Cross" & $5^{I}$ & 28 & 30 & 2 miles. \\
\hline Left peak of roof of wharf housc...... & 94 & I6 & . & I7/8 miles. \\
\hline Large tree. . . . . . . . . . . . . & 117 & 48 & . & I3.36 meters. \\
\hline Chimney of Blakistone store ............. & 125 & 48 & . & $1 / 4$ mile. \\
\hline Near peak of roof of Blakistone house........ & I 76 & 32 & $\ldots \ldots$ & 250 yards. \\
\hline Point of cupola on Ranahan hotise.... & IgI & 45 & $\ldots \ldots$ & $\mathrm{I} 3 / 4$ miles. \\
\hline Near left corner of sill of ice house..... & 233 & 15 & $\ldots \ldots \ldots$ & I4. 15 meters. \\
\hline Right lower corner. . . . . . . . . . . . . . & 260 & 33 & ..... & $x_{5.76}$ meters. \\
\hline Near peak of roof....... & 312 & 54 & $\ldots \ldots$ & $1 / 4$ mile. \\
\hline
\end{tabular}

HARD.

General locality.-Western shore of Wicomico River on point of land known as Rock Point about 2 miles north by west of Cobb Yoint Bar Light. (See chart No. 26.)

Immediate locality.-Observed station is on low point of land near several small cedar trees about I foot above high-water mark, 47 yards west of shore, 16 yards south of shore, 30 yards north of shore, about 80 yards northeast by north of Rock Point Wharf, and $x 70$ yards northeast by east of Lancaster's store.

Marks.-Observed station is center point of triangle on standard cement monument.

References.-

"Cobb Point Bar Light" (S. $10^{\circ} \mathrm{I}^{\prime}$ E.)... ० 0 - $00 \ldots . .2$ miles.

Northeast gable of wharf house........ 4 I $07 \quad \ldots \ldots \ldots$.... 80 yards.

"Rock Point Catholic Church Cross"..... $70 \quad$ I6 $20 \ldots \ldots$ 1/4 mile.

South chimney on Lancaster's store....... $88 \quad 53 \quad \ldots \ldots \ldots$ x $\quad \ldots$ yo yards.

Point of east gable on house.......... $134 \quad 44 \quad \ldots \ldots \ldots \quad 1 / 4$ mile.

"Sacred Heart Church Spire" ......... 239 o4 $20 \ldots \ldots$... 3 miles.

Gable of house on wharf at Bushwood...... 256 oo ....... $13 / 4$ miles.

West gable of house..................... 293 o6 ..... 2 miles.

West gable on one-story house ........ 315 I9 $\ldots \ldots \ldots \quad 21 / 4$ miles.

North chimney of two-story house....... 330 I2 $\ldots \ldots \ldots \quad 21 / 2$ miles.

\section{ROCK POINT CATHOLIC CHURCH CROSS.}

General locality.-Eastern shore of Wicomico River at Rock Point. (See chart No. 26.)

Immediate locality.-Observed station is in settlement called Rock Point. It is on the larger of two similar buildings, the smaller one being the schoolhouse.

Marks.-Observed station is center point of cross on Rock Point Catholic Church.

References.-None necessary.

\section{PREC.}

General locality.-Eastern shore of Wicomico River on Bluff Point about 2 miles north-northeast of Cobb Point Bar Light. (See chart No. 26.)

Immsdiate locality.-Observed station is about ro feet above high-water mark, 34 yards southeast of nearest end of neck of Bluff Point, 29 yards south-southeast of shore, 16 yards northeast of shore, and 88 yards west by southwest of house.

Marks.-Observed station is center point of triangle on standard cement monument.

References,-
"Cobb Point Bar Light" (S. $28^{\circ} 37^{\prime}$ W. . ...
Tangent of woods on Cobb Point............ 34
2 miles.
Rock Point Catholic Church Cross" ...... 70 16 30 ....
2 miles.
Nail in blaze in locust tree ( 3 inches diameter) II6 I4 $40 \ldots \ldots$.
I5/8 miles.
I,eft chimney of Gamer house .
$I 48 \quad 4^{2} \quad \ldots \ldots \ldots$
20.64 meters.
I $1 / 8$ miles. 
References-Continued.

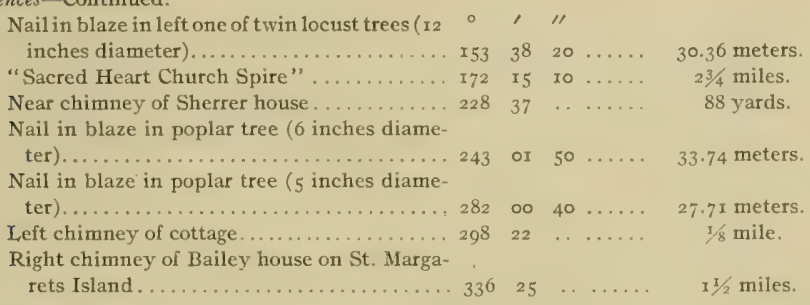

\section{CORNER.}

General locality.-Western shore of Wicomico River on the eastern side of an island known as Cobb Point Neck about halfway between Cobb Point and the entrance to Neales Sound. (See chart No. 26.)

Immediate locality. - Observed station is in a cultivated field on a bluff bordered with pine trees about $I_{5}$ feet above high-water mark, 3 yards west of a wire fence running along edge of bluff and 21 yards east-northeast of a wire fence which separates cornfieid from pine woods.

Marks.-Observed station is center point of triangle on standard cement monument.

References.-

\begin{tabular}{|c|c|c|c|c|c|}
\hline "Cobb Point Bar Light" (S. $29^{\circ} 39^{\prime}$ E.)... & 0 & $\infty$ & $\infty$ & & $I^{3} / 8$ miles. \\
\hline Nail in blaze in cedar tree ( 3 inches diameter) & $5^{\circ}$ & 02 & & & 16.98 meters. \\
\hline Nail in blaze in pine tree ( 8 inches diameter). & III & 43 & $\cdots$ & & neters. \\
\hline Nail in blaze in pine tree ( 12 inches diameter) & 135 & 20 & . & & eters. \\
\hline Middle chimney of house. . & 177 & 07 & $\cdots$ & & nile. \\
\hline "Catholic Church Cross". & 217 & 10 & Io & & nile. \\
\hline Left chimney of house on St. Margarets Island & 318 & $5^{6}$ & & & I5/8 miles. \\
\hline
\end{tabular}

\section{ST. MARGARET 2 .}

General locality.-Northwestern side of Potomac River on the southwestern side of St. Margarets Island in the mouth of the Wicomico River about I mile northeast of Cobb Point Bar Light. (See chart No. 26.)

Immediate locality. - Observed station is on a bluff about iz feet above high-water mark, is inches northeast of edge of bluff, 86 yards northwest of cow shed, I29 yards south-southwest of several houses, and I54 yards west-southwest of Bailey (large) house. Cement monument marking reference station is 79. I9 meters N. $46^{\circ}{ }_{2} 6^{\prime} \mathrm{E}$. of observed station and at corner of cow shed.

Marks.-Observed station is center of a stub in a $2 \frac{1}{2}$-inch tile pipe set in cement with top flush with ground. Reference station is center point of triangle of standard cement monument.

References.-

\begin{tabular}{|c|c|c|c|c|c|}
\hline 'Cobb Point Bar Light & 0 & $\infty$ & & & \\
\hline Tangent of Cobb Point. & 45 & I3 & & & $15 \%$ \\
\hline "Rock Point Catholic Church Cross". & $8_{3}$ & $4^{2}$ & 50 & & iles. \\
\hline ner new house. & 129 & 40 & .. & & $23 / 8$ miles. \\
\hline "Sac & I 43 & 27 & 50 & & $4=$ \\
\hline$\cdots \ldots \ldots \ldots \ldots$ & I73 & 04 & I5 & & neter \\
\hline $\begin{array}{l}\text { ouse.................. } \\
1 \text { house on Bullock }\end{array}$ & I94 & $5^{1}$ & . & & rards. \\
\hline ......... & 220 & 26 & & & nile. \\
\hline of of & & & & & \\
\hline & $25^{8}$ & 3 & & & \\
\hline
\end{tabular}




\section{COBB POINT BAR LIGHT.}

General locality.-Northerly side of Potomac River at mouth of Wicomico River on the southeastern extremity of Cobb Point Bar. (See chart No. 26.) River.

Immediate locality. - Observed station is on the end of Cobb Point Bar at the mouth of the Wicomico

Marks.-Observed station is center point of black lantern on screw pile structure known as "Cobb Point Bar Light."

References.-

"Blakistone Island Light" (S. $6 \mathrm{r}^{\circ} 25^{\prime}$ E.)... $00000 \ldots \ldots .5$ miles.

\section{RIVER SPRINGS CATHOLIC CHAPEI, CROSS.}

General locality.-Northern side of Potomac River inland about three-fourths mile north by west of River Springs. (See charts Nos. 25 and 26.)

Immediate locality.-Observed station is on building known as River Springs Catholic Chapel.

Marks.-Observed station is center of cross on River Springs Catholic Chapel.

References,-None necessary.

SOUND.

General locality.-Northern shore of St. Catherine Sound about $21 / 4$ miles east by north of Cobb Point Bar Light and one-fourth mile east of Bullock Island. (See chart No. 26.)

Immediate locality.-Observed station is about ${ }_{5}$ feet above high-water mark, 35 yards north of edge of bank, 2 yards east of wire fence, 65 yards east of edge of bank, 57 yards south of southeast corner of fence of house yard, and 63 yards south by west of telephone pole line which is on the same side of the road.

Marks,--Observed station is center point of triangle on standard cement monument.

References.-

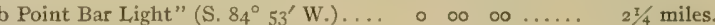

Right chimney of house on Bullock Island.. $\begin{array}{lllll}8 & 24 & \ldots & \ldots & 1 / 2 \text { mile. }\end{array}$

Near end of small chimney on large house... 27 I5 ..... I mile.

Left corner post of fence............... 65 o5 $\quad 0_{5} \ldots \ldots . \quad$ Near.

Near corner of chimney of small house...... $86 \quad 25 \quad \ldots \quad \ldots \ldots . \quad$ Near.

Near corner post of fence............. I00 $5^{8} \ldots \ldots . . . \quad$ Near.

Right peak of roof of barn............. Ir5 $20 \ldots \ldots \ldots$ Near.

"River Springs Catholic Chapel Cross".... r48 31 10 ..... x mile.

Chimney of Blakistone store.......... 189 16 $\ldots \ldots \ldots \quad 1 / 2$ mile.

Near chimney of Bailey house. . . . . . $217 \quad 59 \quad \ldots \ldots \ldots \quad 1 / 2$ mile.

Chimney on smaller house on St. Catherine

Island $\ldots \ldots \ldots \ldots \ldots \ldots \ldots \ldots \ldots \ldots \ldots, 323 \quad 03 \ldots \ldots \ldots$ mile.

BAILEY.

General.localily.-Northeastern shore of St. Catherine Sound, about three-fourths mile east by north of eastern end of St. Catherine Island and I mile north of the Potomac River. (See chart No. 26.)

Immediate locality.-Observed station is on shelly ground on Bailey property, about 5 feet above high-water mark, Io yards northeast of high-water mark, 7 yards northeast of a wire fence, 35 yards south-southeast of corner of wire fence, 30 yards north-northwest of corner of wire and wooden fences, 25 yards north of Bailey house, and 40 yards west by south of corner of wooden fence.

Marks.-Observed station is center point of triangle on standard cement monument.

References. -

"Cobb Point Bar Light" (N. $88^{\circ}$ in $\mathrm{x}^{\prime}$ W.)...

Nail in blaze in one of four cedar trees (3

inches diameter $) \ldots \ldots \ldots \ldots \ldots \ldots \ldots$ I3 $29 \ldots \ldots \ldots . \ldots \ldots$ 12.37 meters.

Nail in blaze in cedar tree ( 8 inches diameter) $44 \quad 59 \quad \ldots \ldots \ldots .27 .82$ meters.

Corner of wire fence................ $46 \quad 29 \quad \ldots \ldots \ldots .32 .06$ meters.

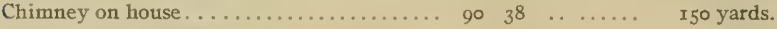

"River Springs Catholic Chapel Cross" .... II3 of $00 . . .$. I mile.

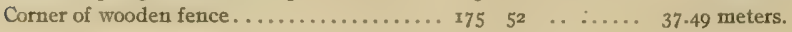


References-Continued.

Chimney of Bailey house . . . . . . . . . . 2032

Junction of wire and wooden fences....... 25435

Left chimney of house on Waterloo Point. . . $277 \quad 43$

Nail in blaze in first of six cedar trees. . . . $297 \quad 27$

Right chimney of small house on St. Catherine

Island ...................... 348

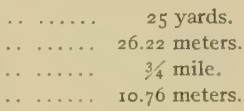

I mile.

\section{ST. CATHERINE.}

General locality.- Southern shore of St. Catherine Sound, on the northern side of St. Catherine Island. (See chart No. 26.)

Immediate locality. - Observed station is about 12 feet above high-water mark, 86 yards south of edge of bank, 49 yards west of line of young cedar trees, 198 yards northeast of a lone mulberry tree 3 feet in diameter, and 207 yards southeast of small house among trees.

Marks.-Observed station is center point of triangle on standard cement monument with top i2 inches below the surface.

References.-

"Cobb Point Bar Light" (N. $8 \mathrm{r}^{\circ} 08^{\prime}$ W.)....

Right side of right chimney on small house. . $\circ, 11$

Left chimney of large house on St. Margarets

Island ..................... $\mathbf{I}^{3 / 8}$ miles.

Right chimney of house on Bullock Island. 66 or ...... $1 / 2$ mile.

Chimney of Blackistone house......... II7 $39 \ldots \ldots \ldots$. $5 / 8$ mile.

"River Springs Catholic Chapel Cross" ... I29 17 40 .... I $5 / \mathrm{s}$ miles.

Left chimney of Bailey house......... I58 ig ..... $7 / 8$ mile.

Right chimney of Young house on Waterloo

Point........................ $207 \quad 48 \ldots \ldots$. $7 / 8$ mile.

WATERLOO.

General locality.-Southeastern shore of St. Catherine Sound, about three-fourths mile east-southeast of St. Catherine Island and about one-fourth mile north of Potomac River. (See chart No. 26.)

Immediate locality.-Observed station is at top of rise in field, about 8 feet above high-water mark, 48 yards east by south of shore at a point where several mulberry trees stand, 43 yards south of large sugarberry tree, I9 yards south by east of wire-fence post, and 200 yards north of Young house on Waterloo Farm.

Marks.-Observed station is center point of triangle on standard cement monument, with top I2 inches below surface of ground.

\section{References.-}

"Sound" (N, $18^{\circ} 4 \mathrm{I}^{\prime}$ W. $)$

Near end of peak of Blackistone barn......

"Sacred Heart Church Spire (Bushwood)" . . r

Peak of gable of Blackistone house at River Springs........................... 2

Near peak of roof of Bailey house........ 3

Near peak of roof of Yates house .......... . 49

Near peak of roof of Quaid house . . . . . . . 7

Near peak of house. . . . . .............. $9^{2}$

Nail in blaze in apple tree ( 5 inches diameter) II

Nail in blaze 8-inch branch on apple tree ( 14 inches diameter). . . . . . . . . . . . 153

Nail in blaze in apple tree ( 6 inches diameter) 203

Near peak of roof of Young house........ 206

Left tangent of St. Catherine Island. . . . . 300

Right chimney of roof of house on Bullock

Island

Near peak of roof of house . . . . . . . . . . $35^{2}$

\begin{tabular}{|c|c|c|}
\hline$\infty$ & $\infty \infty^{\prime} . .$. & I mile. \\
\hline 02 & . $\cdots \cdots$ & I mile. \\
\hline 37 & $20 \ldots \ldots$ & 5 miles. \\
\hline 54 & $\ldots \ldots$ & $7 / 8$ mile. \\
\hline 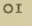 & . $\ldots \ldots$ & $3 / 4$ mile. \\
\hline 13 & $\ldots \ldots \ldots$ & $1 / 2$ mile. \\
\hline 25 & $\ldots \ldots$ & $1 / 4$ mile. \\
\hline $3 I$ & $\ldots \ldots \ldots$ & $1 / 2$ mile. \\
\hline 20 & $30 \ldots \ldots$ & 34.78 meters. \\
\hline 34 & $20 \ldots$ & 24.90 meters. \\
\hline 50 & $\infty \ldots \ldots$ & 26.18 meters. \\
\hline 57 & $\ldots \ldots \ldots$ & 200 yards. \\
\hline & $\cdots \ldots$ & $3 / 4$ mile. \\
\hline rg & . & niles. \\
\hline & . $\ldots \ldots$ & $I 3 / 4$ miles. \\
\hline
\end{tabular}




\section{BOUNDARIES OF OYSTER BARS.}

\section{EXPLANATION.}

The law of the United States authorizing the cooperation of the Department of Commerce and Labor in the survey of natural oyster beds of Maryland provides for the designation and employment by the Department of Commerce and Labor of such officers, experts, and other technically qualified persons "as may be necessary to cooperate with the Maryland State Board of Shell Fish Commissioners in making a survey of and locating the natural oyster beds, bars, and rocks in the waters within the State of Maryland." The oyster laws of Maryland provide that the Maryland Shell Fish Commissioners, with the aid of such persons as may be designated by the Government, shall proceed "to have laid out, surveyed, and designated on the said charts the natural beds and bars, and shall cause to be marked and defined as accurately as practicable the limits and boundaries of the natural beds, hars, and rocks as established by said survey, and they shall take true and accurate notes of said survey in writing, and make an accurate report of said survey, setting forth such a description of landmarks as may be necessary to enable the said board, or their successors, to find and ascertain the boundary lines of the said natural oyster beds, bars, and rocks, as shown by a delineation on the maps and charts." The oyster laws of Maryland also provide in another section that there shall "be made a true and accurate survey of the natural oyster beds, bars, and rocks *** with reference to fixed and permanent objects on the shore, giving courses and distances, to be fully described and set out in a written report of said survey."

Under the provisions of the laws quoted above the State of Maryland, in cooperation with the Department of Commerce and Labor, must define the boundaries of the natural oyster bars "as accurately as practicable" and also "with reference to fixed and permanent objects on the shore, giving courses and distances." The requirement of "as accurately as practicable" is easily fulfilled by definition of the location of the corners of the oyster bars by latitude and longitude. In fact, this method is probably the most satisfactory and accurate one that could be used for all purposes of legal definition or for relocation of the oyster-bar boundaries by competent engineers. Therefore the additional repuirement of "giving courses and distances" is superliuous and is only fulfilled in the published definitions on account of the specific provisions of the law making it compulsory. This part of the description of boundaries has involved an immense amount of extra computations in order to prevent technical discrepancies between the latitude and longitude of a comer of an oyster bar and its distance and bearing from objects on shore of known latitude and longitude without adding anything to the accuracy and very little to the convenience in the practical use of the descriptions of the oyster-bar boundaries.

As provided by law, the boundaries of the oyster bars are all straight lines, but in the work already completed they have inclosed areas of all shapes from triangles to $\mathrm{I}_{2} 8$ 
complicated I4-sided figures and of all sizes from 4 acres to 7,548 acres. The sides have varied in length from 93 to 7.529 yards, and in some cases the corners of the boundaries have been practically at the triangulation stations from which they are located, while in other instances they were over 13,600 yards from the landmarks most available for the purpose of fixing their position.

The varied characteristics of the legal boundaries of the oyster bars indicated by the above statement, together with the complicated requirements of the law under which the survey has been made and the magnitude of the work, with the consequent need of fixed and uniform methods, have made the problem of describing the boundaries one of considerable difficulty and great importance.

The boundaries of the oyster bars of Maryland, as established by the shell fish commission and delineated on the Coast and Geodetic Survey charts and projections and on the leasing charts of the commission, are technically defined and described by a method somewhat different from that used in other oyster surveys. But it is believed that the forms finally adopted will fulfill all needs of the survey for both the present and the future.

\section{METHOD OF DESCRIBING BOUNDARIFS.}

The descriptions have been arranged in tabular form, thus avoiding many hundred repetitions of the same words by making one explanation of the tables sufficient for all oyster bars in each county.

Title-At the top of each tabular form is given the legal name of the oyster bar to be described and the one by which it is known and designated in the published oyster records and on the oyster charts. The adopted name of the oyster bar is the one used locally, as nearly as could be ascertained by the hydrographic engineer of the commission; and when there was no local name in common use a name was selected from one of the prominent features of the vicinity that would naturally suggest the section of the waters where the oyster bar was located.

Undemeath the name in parentheses is given the general locality of the oyster bar and the serial number of the Maryland Oyster Chart on which its legal boundaries are shown. ${ }^{2}$

First column.-This column, under the heading of "Corner of bar," gives the number corresponding to the corner of the boundary as shown on the charts and to the number on the buoy marking the actual corner of the bar. The numbers of the corners have been assigned by naming the southernmost point No. I, thence proceeding in a clockwise direction around the bar. Where the corner of one oyster bar is identical with the corner of the boundaries of one or more other oyster bars, only the number of the corner of the oyster bar being described in the table is given in this column.

Second and third columns.-These two columns, under the headings of "Latitude" and "Longitude," give the geographic positions of the comers. These positions have been adopted by the commission as the primary technical definition of the location of the corners, and should be considered as final in case of a dispute arising from discrepancies caused by other means of location. The latitudes and longitudes given in these columns are based on the United States standard datum of the Coast and Geodetic

1 These charts can be obtained by application to the Superintendent of the Coast and Geodetic Survey at Washington, D. C. $2606-$ II $\longrightarrow 9$ 
Survey, and the points thus defined can be relocated from distant triangulation stations of the survey, even though all the landmarks and buoys originally used for their location have been destroyed by natural or other causes.

Fourth and fifth columns. - These two columns, under the general heading of "True bearing" "and the specific headings "Forward" and "Back," give bearings measured from a true north-and-south line. The three "Forward" bearings are from the corner of the boundary designated in the first column to the triangulation stations named on the corresponding lines in the last column, and the three "Back" bearings are from these same stations in the last column to the corresponding corner of boundary in the first columin. The difference in minutes of arc between the forward and back bearings shown in some cases is actual and not accidental, and is due to the fact that the computations took into account the spheroidal shape of the earth.

Sixth column.-This column, under the heading of "Distance," gives the three computed distances in yards from the corner of the bar noted in the first column to the thiree triangulation stations named on the corresponding lines in the last column, and vice versa.

Seventh column.-This column, under the heading of "U. S. C. \& G. S. triangulation station," 2 gives the names of the landmarks from which were computed the corresponding "Latitude," "Longitude," "True bearing," and "Distance" of the "Corner of the bar" designated in the first column. A full description of the location and markings of these triangulation stations is given in another part of this publication under the heading of "Descriptions of triangulation stations."

\section{SURVEYING METHODS FOR RELOCATION OF BOUNDARIES.}

There are a number of methods that can be used in the relocation of the actual houndaries of the natural oyster bars as technically described in this publication and delineated on the published charts of the Coast and Geodetic Survey and the leasing charts of the shellifish commission.

The following brief descriptions of five of these more or less different methods assume a certain amount of experience and knowledge on the part of the engineer in the particular kind of surveying under consideration, and are only intended as reminders of ways and means that can be used.

There are two problems that are likely to present themselves to those interested in the boundaries of natural oyster bars-one, to determine whether the buoys marking the corners have been dragged or otherwise moved from their correct positions, and the other, to relocate or reestablish a buoy at the point from which it was removed. The different ways of solving these two problems partly depend upon the instruments possessed by the engineer and his assistants and partly on his training and experience.

(I) Triangulation.-This method is the one that will give the greatest accuracy, but on account of its requiring special data and instruments, and being an operation rarely used by engineers not engaged in geodetic surveying, it is recommended only for cases in dispute that can not be settled satisfactorily by some other method. An

\footnotetext{
1 The mean magnetic variation for St. Marys County was $5^{\circ} 25^{\prime}$ west of north in Igro and increasing at the rate of $4^{\prime}$ yearly.

2 Geographic positions of these triangulation stations can be obtained by application to the Superintendent of the Coast and Geodetic Survey, Washington, D. C.
} 
explanation of this class of work would be too long for a report of this sort, and those not familiar with this method are referred to the publications on the subject by the Coast and Geodetic Survey.

(2) Hydrographic.- This method is the most simple and satisfactory one that can be adopted if the surveyor can obtain the use of the necessary instruments and assistants. It is the one best suited for the work of the engineers of the commission in relocating corners of boundaries, as it gives results of the accuracy ordinarily required and is rapid in execution. Besides, it has the advantage of being available whenever three triangulation stations of suitable relative positions are visible fron the offshore points needing relocation.

Most navigators and others familiar with the use of a sextant are well acquainted with the graphic three-point method of fixing a position on water, and only a brief description of the operation will be stated.

In the case where there is only one engineer having a single sextant the three-point method can be used if the two angles deternining the position of a buoy are first derived from the "Forward" bearings given in the tabular forms describing the boundaries of the oyster bars. For example, take "Brooks Shallows" oyster bar, which is the first one described in this publication, and assume that "Corner No. 3 " is to be examined as to its position. The angle between the two landmarks "Dwarf" and "Hallowing" as determined from right to left from the forward bearings from this corner is $54^{\circ} 50^{\prime}$ and the angle between "Hallowing" and "Indian" is $77^{\circ} 10^{\prime}$. Having these two angles, the engineer proceeds to the buoy of doubtful location and measures the actual sextant angles between the landmarks for which the calculations were made. If the measured and calculated angles do not agree the buoy is not in its correct position and the boundary corner must be relocated. This is accomplished by moving the boat about until a point is reached where the angles do agree, and this point being the desired location, the buoy can be placed in its correct position.

If the engineer can obtain the use of both a sextant and a three-arm protractor ("position finder"), the availability of the hydrographic method is increased, as the use of the protractor is essential in case of the washing away or destruction of one or more of the landmarks originally used in describing the boundaries. Under these circumstances, any three landmarks of suitable relative position that are visible from the point to be located can be utilized. For example, the engineer can proceed to the buoy of doubtful position and measure the two adjacent sextant angles between the three landmarks selected. These two angles are set off on the three-arm protractor and the actual position of the buoy plotted on the chart by shifting the protractor about until the edge of each of the three arms passes through the center of the symbols on the chart marking the position of the three landmarks selected. The center of the hub of the protractor will indicate on the chart the actual position of the buoy, and if the point thus obtained does not coincide with the true position of the corner of the boundary as given on the chart the surveyor can proceed to locate the buoy correctly by reversing the operation. This is done by placing the center point of the hub of the protractor over the corner of the boundary in question and measuring on the chart the two adjacent prot ractor angles between the three selected landmarks. One of the angles thus obtained is set on the sextant and the boat moved about until the two landmarks are shown by the 
sextant to subtend the same angle obtained from the protractor. The second angle is then placed on the sextant and the same operation gone through, and so on, first using one angle on the sextant then the other until a point is reached where both observed sextant angles are practically identical with the protractor angles. The point thus located is the desired one and the buoy can be placed to mark the true position of the corner of the boundary in question.

If the engineer possesses two sextants and a protractor, this problem is far easier of solution, as the two angles can be set off on separate sextants and the observer can quickly find the desired point where they agree with the protractor angles by using one sextant after the other without the need of resetting either.

If there are two observers, two sextants, and a protractor, it can be seen that the best conditions for both rapid.and accurate hydrographic location of a point is attained. In fact, this is the method by which the buoys at the corners of the boundaries were originally placed by the hydrographic engineer to the commission.

(3) Magnetic bearings from offshore.-This method of fixing a position on water is a simple and well-known one in navigation. It is available to anyone having a boat compass and will be of special use to the State fishery force in investigating cases where bioys are supposed to have been moved for illegal purposes.

In the case where a buoy is supposed to have been moved from its true position the observer can take compass bearings to the three landmarks given in the last column of the tables opposite the boundary corner in question. These bearings are then corrected for the local declination, ${ }^{1}$ and if the results agree with the published bearings the buoy is correctly located.

In the case where the buoy is not in its correct position, or has disappeared altogether, the desired point can be determined by maneuvering the vessel until the corrected bearings agree with the ones in the tabular descriptions, when the buoy can be anchored in its proper location.

In the case where the landmarks for which the bearings are published have been destroyed or washed away any landmarks whose positions are indicated on the charts can be used. This can be done by getting their bearings directly from the chart by parallel rulers or a protractor and then applying these new bearings in the same manner as the ones published in the tables.

(4) Magnetic bearings from shore.-This method will be of special value to engineers having an ordinary surveyor's compass. The compass can be set over the point marking a "triangulation station" on shore, the name of which is given in the last column opposite the "corner" in question. The instrument is then set at the corresponding "back" bearing (corrected for local magnetic declination) given in the fifth column of the tables opposite the "corner" in question. The direction thus determined will give one range on which the desired point must be located. The compass can then be moved to a second triangulation station and another range located in a similar manner. The intersection of these two range lines will give the desired point, but in general it should be checked by an additional range line determined from a third station.

(5) Horizontal angles measured at landmarks.-This process is a modification of the triangulation method, and will be useful to engineers who have a transit and desire considerable accuracy.

1 The mean maguetic variation for St. Marys County is $5^{\circ} 25^{\prime}$ west of north in rgro and increasing at the rate of $4^{\prime}$ yearly. 
The instrument is placed over a "triangulation station," the name of which appears in the last column of the tabular description opposite the "corner" in question. The telescope is then pointed to the landmark indicated in the "Descriptions of landmarks" as having a direction of $\mathrm{O}^{\circ} \mathrm{oO}^{\prime} \mathrm{o0^{ \prime \prime }}$ from the triangulation station being occupied by the transit. The tabular description of the boundaries is next examined and the "back" bearing of the questionable boundary "corner" from the landmark being occupied is taken out. The angle calculated from this "back" bearing and the bearing given in parentheses alongside the zero landmark in the "Deseriptions of landmarks" is then set of on the transit and a range line established on which the desired point must be located. A similar process is then carried on at a second station, and so on until the position of the buoy is satisfactorily fixed.

BOUNDARIES OF NATURAL OYSTER BARS.

BROOKS SHALLOWS.

(Upper Patuxent River-Chart No. I0.)

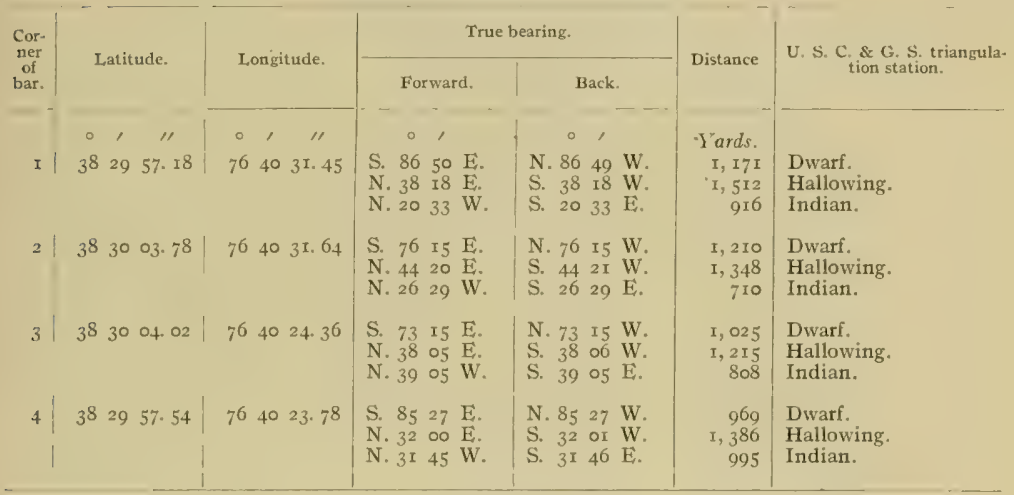

SOTHORON.

(Upper Patuxent River-Chart No. 19.)

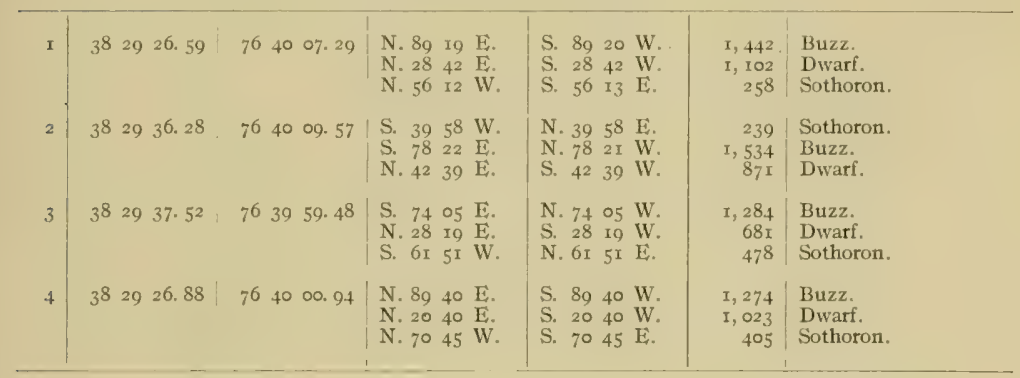


BOUNDARIES OF NATURAL, OYSTIE BARS-conLinUEL. BROAD NECK (ST. MARYS COUNTY).

(Upper Patuxent River-Chart No. Ig.)

\begin{tabular}{|c|c|c|c|c|c|c|c|c|c|}
\hline \multirow{2}{*}{$\begin{array}{l}\text { Cor- } \\
\text { ner } \\
\text { of } \\
\text { bar. }\end{array}$} & \multirow{2}{*}{\multicolumn{2}{|c|}{ Latitude. }} & \multirow{2}{*}{\multicolumn{3}{|c|}{ Longitude. }} & \multicolumn{2}{|c|}{ True bearing. } & \multirow{2}{*}{ Distance. } & \multirow{2}{*}{$\begin{array}{l}\text { U. S. C. \& G. S. trimugula } \\
\text { tion station. }\end{array}$} \\
\hline & & & & & & Forward. & Back. & & \\
\hline I & $\begin{array}{cc}0 & , \\
38 & 27\end{array}$ & 36. I4 & $\begin{array}{c}\circ \\
76\end{array}$ & $\begin{array}{c}1 \\
39\end{array}$ & $\begin{array}{c}\text { "1. } \\
\text { I0. } 54\end{array}$ & $\begin{array}{lccc} & 0 & \\
\text { N. } & 34 & 5^{8} & \mathrm{E} . \\
\text { N. } & 28 & 35 & \mathrm{~W} . \\
\text { S. } & 5^{2} & 54 & \mathrm{~W} .\end{array}$ & $\begin{array}{lccc} & 0 & 1 \\
\text { S. } & 34 & 58 & \text { W. } \\
\text { S. } & 28 & 35 & \mathrm{E} . \\
\text { N. } & 5^{2} & 54 & \mathrm{E} .\end{array}$ & $\begin{array}{r}\text { Yards. } \\
\text { I, I37 } \\
\text { I, } 290 \\
626\end{array}$ & $\begin{array}{l}\text { Sheridan. } \\
\text { Collins. } \\
\text { Cremona. }\end{array}$ \\
\hline 2 & $3^{8} \quad 27$ & $57 \cdot 42$ & 76 & 39 & 27.00 & $\begin{array}{llll}\mathrm{S} . & 3 & 17 & \mathrm{~W} \\
\mathrm{~N} . & 78 & 51 & \mathrm{E} \\
\mathrm{N} . & 23 & 32 & \mathrm{~W} .\end{array}$ & $\begin{array}{llll}\text { N. } & 3 & \text { I7 } & \mathrm{E} . \\
\text { S. } & 78 & 5^{1} & \mathrm{~W} \\
\text { S. } & 23 & 32 & \mathrm{E} .\end{array}$ & $\begin{array}{r}r, \infty 97 \\
I, 109 \\
454\end{array}$ & $\begin{array}{l}\text { Cremona. } \\
\text { Sheridan. } \\
\text { Collins. }\end{array}$ \\
\hline 3 & $3^{8}=28$ & 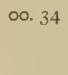 & $7^{6}$ & & 09.64 & $\begin{array}{l}\text { N. } 6340 \mathrm{~W} . \\
\text { S. } 23 \text { 40 W. } \\
\text { N. } 7934 \text { E. }\end{array}$ & $\begin{array}{llll}\text { S. } & 63 & 4 \text { I } & \text { E. } \\
\text { N. } & 23 & 40 & \text { E. } \\
\text { S. } & 79 & 34 & \text { W. }\end{array}$ & $\begin{array}{r}715 \\
1,304 \\
639\end{array}$ & $\begin{array}{l}\text { Collins. } \\
\text { Cremona. } \\
\text { Sheridan. }\end{array}$ \\
\hline
\end{tabular}

Thence along county boundary as delineated on Chart No. Ig to corner No. 4.

\begin{tabular}{|c|c|c|c|c|c|}
\hline $3^{827} 4$ 1. 18 & 763900.00 & $\begin{array}{llll}\text { N. } 26 & 03 & \text { E. } \\
\text { N. } 42 & 57 & \text { W } \\
\text { S. } & 54 & 49 & \text { W. }\end{array}$ & $\begin{array}{llll}\text { S. } & 26 & 03 & \text { IV. } \\
\text { S. } & 42 & 57 & \text { E. } \\
\text { N. } & 54 & 49 & \text { E. }\end{array}$ & $\begin{array}{r}848 \\
\mathbf{I}, 317 \\
95^{2}\end{array}$ & $\begin{array}{l}\text { Sheridan. } \\
\text { Callins. } \\
\text { Cremona. }\end{array}$ \\
\hline
\end{tabular}

\section{THOMAS (ST. MARYS COUNTY).}

(Upper Patuxent River-Chart No. I9.)

\begin{tabular}{|c|c|c|c|c|c|c|}
\hline I & $3^{8} \quad 26 \quad 47 \cdot 4 \mathrm{I}$ & $7^{6} 3^{8}$ 21. 12 & 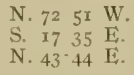 & $\begin{array}{llll}\text { S. } & 72 & 51 & \mathrm{E} \\
\mathrm{N} . & 17 & 34 & \mathrm{~W} \\
\mathrm{~S} . & 43 & 44 & \mathrm{~W}\end{array}$ & $\begin{array}{r}635 \\
\mathrm{r}, 839 \\
2,218\end{array}$ & $\begin{array}{l}\text { Oppkit. } \\
\text { Fight. } \\
\text { Kitt. }\end{array}$ \\
\hline 2 & $3^{8} 274$ 1. 18 & $7^{6} 3900.00$ & $\begin{array}{llll}\text { N. } 26 & 03 & \text { E. } \\
\text { N. } & 42 & 57 & \text { W. } \\
\text { S. } & 54 & 49 & \text { W. }\end{array}$ & $\begin{array}{llll}\text { S. } & 26 & 03 & \text { W. } \\
\text { S. } & 42 & 57 & \mathrm{E} \\
\text { N. } & 54 & 49 & \mathrm{E} .\end{array}$ & $\begin{array}{r}848 \\
\mathrm{I}, 317 \\
952\end{array}$ & $\begin{array}{l}\text { Sheridan. } \\
\text { Collins. } \\
\text { Cremona. }\end{array}$ \\
\hline
\end{tabular}

Thence along county boundary as delineated on Chart No. Ig to corner No. 3 .

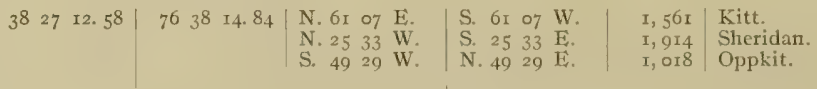

\section{SANDGATES.}

(Middle Patuxent River-Chart No. IO.)

\begin{tabular}{|c|c|c|c|c|c|c|}
\hline I & $3^{8} 25$ or. 66 & $7^{6} 3^{6} 45 \cdot 53$ & $\begin{array}{llll}\text { S. } & 45 & 16 & \mathrm{E} . \\
\mathrm{N} . & 4 \mathrm{I} & 54 & \mathrm{E} . \\
\mathrm{N} . & 47 & 36 & \mathrm{~W} .\end{array}$ & $\begin{array}{llll}\text { N. } 45 & \text { I6 } & \text { W. } \\
\text { S. } 4 \mathrm{I} & 55 & \text { W. } \\
\text { S. } & 47 & 37 & \text { E. }\end{array}$ & $\begin{array}{r}675 \\
2,924 \\
2,688\end{array}$ & $\begin{array}{l}\text { Forr. } \\
\text { Photo. } \\
\text { Fight. }\end{array}$ \\
\hline 2 & $3^{8} \quad 2509.06$ & $7^{6} \quad 36 \quad 57 \cdot 5^{8}$ & $\begin{array}{lll}\text { S. } 47 & 48 & \mathrm{E} . \\
\text { N. } 49 & 42 & \mathrm{E} . \\
\text { N. } 46 & 10 & \mathrm{~W} .\end{array}$ & 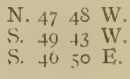 & $\begin{array}{l}1,078 \\
2,980 \\
2,285\end{array}$ & $\begin{array}{l}\text { Forr, } \\
\text { Photo. } \\
\text { Fight. }\end{array}$ \\
\hline 3 & $3^{8} \quad 2528.46$ & $76 \quad 36 \quad 50.40$ & $\begin{array}{llll}\text { S. } 23 & 49 & \mathrm{E} \\
\text { N. } & 58 & 30 & \mathrm{E} \\
\text { N. } 63 & 54 & \text { W. }\end{array}$ & $\begin{array}{llll}\text { N. } 23 & 49 & \text { W. } \\
\text { S. } 58 & 30 & \text { W. } \\
\text { S. } & 03 & 55 & \text { E. }\end{array}$ & $\begin{array}{l}\text { I, } 507 \\
2,437 \\
2,067\end{array}$ & $\begin{array}{l}\text { Forr. } \\
\text { Photo, } \\
\text { Fight. }\end{array}$ \\
\hline
\end{tabular}


IOUNDARIES OF NATURAL OYSTER BARS-continued.

SANDGATES-Continued.

(Middle Patuxent River-Chart No. IQ.)

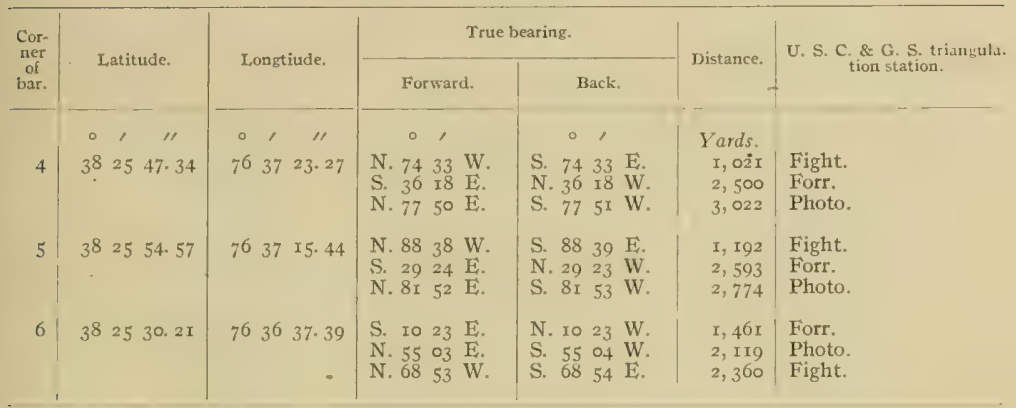

\section{UPPER FORREST.}

(Middle Patuxent River-Chart No. Ig.)

\begin{tabular}{|c|c|c|c|c|c|c|}
\hline I & $\begin{array}{llll}38 & 24 & 45.22\end{array}$ & $\begin{array}{llll}76 & 36 & 02.57\end{array}$ & $\begin{array}{llll}\text { N. } 59 & 04 & \mathbf{E} . \\
\text { N. } & \text { I6 } & 36 & \mathbf{E} . \\
\text { N. } 83 & 08 & \text { W. }\end{array}$ & $\begin{array}{llll}\text { S. } & 59 & 05 & \mathrm{~W} \\
\text { S. } & 16 & 36 & \mathrm{~W} \\
\text { S. } & 83 & 08 & \mathrm{E} .\end{array}$ & $\begin{array}{r}2,846 \\
2,850 \\
666\end{array}$ & $\begin{array}{l}\text { Slim. } \\
\text { Photo. } \\
\text { Forr. }\end{array}$ \\
\hline 2 & $3^{8} \quad 24 \quad 4^{8} .95$ & $763^{6}$ II. 88 & $\begin{array}{llll}\text { N. } 63 & 34 & \mathbf{E} . \\
\text { N. } 22 & 09 & \mathbf{E} \\
\text { S. } & 83 & 38 & \text { W. }\end{array}$ & $\begin{array}{llll}\text { S. } & 63 & 35 & \mathrm{~W} \\
\text { S. } & 22 & \text { 10 } & \text { W. } \\
\text { N. } & 83 & 37 & \mathrm{E} .\end{array}$ & $\begin{array}{r}3,002 \\
2,8 I 3 \\
4 I 7\end{array}$ & $\begin{array}{l}\text { Slim. } \\
\text { Photo. } \\
\text { Forr. }\end{array}$ \\
\hline 3 & $\begin{array}{llll}38 & 25 & \text { I } 5.09\end{array}$ & $\begin{array}{llll}76 & 36 & 13.64\end{array}$ & $\begin{array}{llll}\text { S. } 2 \text { I } & 35 & \mathbf{W} . \\
\text { N. } 80 & 33 & \mathbf{E} \\
\text { N. } & 32 & 43 & \vec{E} .\end{array}$ & $\begin{array}{llll}\text { N. } 2 \text { I } & 35 & \text { E. . } \\
\text { S. } 80 & 34 & \text { W. } \\
\text { S. } & 32 & 43 & \text { W. }\end{array}$ & $\begin{array}{r}997 \\
2,773 \\
2,048\end{array}$ & $\begin{array}{l}\text { Forr. } \\
\text { Slim. } \\
\text { Photo. }\end{array}$ \\
\hline 7 & $\begin{array}{llll}3^{8} & 25 & 09.14\end{array}$ & $\begin{array}{llll}7^{6} & 36 & 05.04\end{array}$ & $\begin{array}{llll}\text { S. } 39 & \text { I8 } & \text { W. } \\
\text { N. } 74 & 59 & \text { E. } \\
\text { N. } 24 & 33 & \text { E. }\end{array}$ & $\begin{array}{llll}\text { N. } 39 & \text { I8 } & \mathrm{E} . \\
\text { S. } & 75 & \text { 00 } & \text { W. } \\
\text { S. } 24 & 34 & \text { W. }\end{array}$ & $\begin{array}{r}939 \\
2,595 \\
2,116\end{array}$ & $\begin{array}{l}\text { Forr. } \\
\text { Slim. } \\
\text { Photo. }\end{array}$ \\
\hline
\end{tabular}

\section{LOWER FORREST.}

(Middle Patuxent River-Chart No. I9.)

\begin{tabular}{|c|c|c|c|c|c|c|}
\hline$I$ & $3^{8} \quad 24 \quad 22 . I 6$ & $7^{6} \quad 3533.18$ & $\begin{array}{llll}\text { S. } & 32 & 4 \mathrm{r} & \mathrm{E} . \\
\text { N. } & 36 & 34 & \mathrm{E} . \\
\text { N. } & 59 & \text { I } 5 & \text { W. }\end{array}$ & $\begin{array}{llll}\text { N. } 32 & 4 \mathrm{I} & \mathrm{W} \\
\text { S. } & 36 & 35 & \mathrm{~W} \\
\text { S. } & 59 & \text { I } 5 & \mathrm{E} .\end{array}$ & $\begin{array}{r}888 \\
2,789 \\
1,676\end{array}$ & $\begin{array}{l}\text { Cole. } \\
\text { Slim. } \\
\text { Forr. }\end{array}$ \\
\hline 2 & 382430.16 & 76354 I. 64 & $\begin{array}{llll}\text { S. } & 34 & 42 & \text { E. } \\
\text { N. } 43 & 45 & \text { E. } \\
\text { N. } & 64 & I_{3} & \text { W. }\end{array}$ & $\begin{array}{llll}\text { N. } 34 & 4 \mathrm{I} & \mathrm{W} \\
\text { S. } & 43 & 45 & \mathrm{~W} \\
\text { S. } 64 & \mathrm{I} 3 & \mathrm{E} .\end{array}$ & $\begin{array}{l}\text { I, } 237 \\
2,727 \\
I, 35 I\end{array}$ & $\begin{array}{l}\text { Sole. } \\
\text { Slim. } \\
\text { Forr. }\end{array}$ \\
\hline 3 & 382436.20 & 763534.00 & $\begin{array}{llll}\text { S. } 22 & 20 & \mathbf{E} . \\
\text { N. } 43 & 37 & \text { E. } \\
\text { N. } 74 & 52 & \text { W. }\end{array}$ & $\begin{array}{llll}\mathrm{N} .22 & 20 & \mathrm{~W} \\
\mathrm{~S} . & 43 & 38 & \mathrm{~W} \\
\mathrm{~S} . & 74 & 53 & \mathrm{E} .\end{array}$ & $\begin{array}{l}x, 320 \\
2,440 \\
I, 470\end{array}$ & $\begin{array}{l}\text { Cole. } \\
\text { Slim. } \\
\text { Fort. }\end{array}$ \\
\hline 4 & $3^{8} 2428.25$ & 763526.00 & $\begin{array}{llll}\text { S. } & 16 & 53 & \vec{E} . \\
\text { N. } & 35 & 56 & \overrightarrow{\mathrm{E}} . \\
\mathrm{N} . & 68 & { }_{3} & \mathrm{~W} .\end{array}$ & $\begin{array}{llll}\text { N. } & 16 & 53 & \mathrm{~W} . \\
\mathrm{S} . & 35 & 56 & \mathrm{~W} . \\
\text { S. } & 68 & \mathrm{I} 4 & \mathrm{E} .\end{array}$ & $\begin{array}{r}996 \\
2,507 \\
1,756\end{array}$ & $\begin{array}{l}\text { Cole. } \\
\text { Slim. } \\
\text { Forr. }\end{array}$ \\
\hline
\end{tabular}


BOUNDARIES OF NATURAL OYSTER BARS-continued.

\section{GATTON.}

(Middle P'atuxent River-Chart No, 19.)

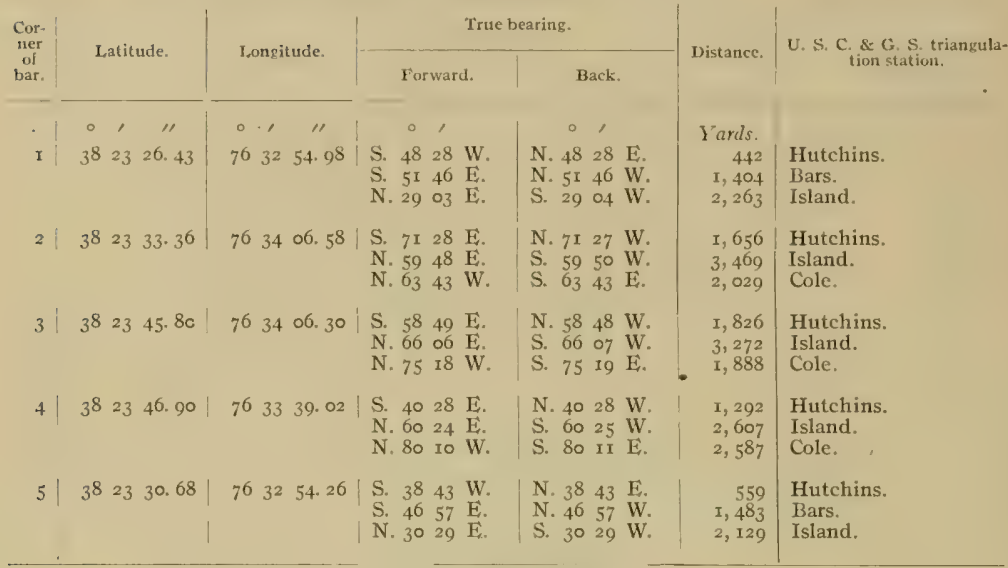

\section{CAPTAIN POINT}

(Middle Paluxent River-Chart No. IO.)

\begin{tabular}{|c|c|c|c|c|c|c|}
\hline I & $3^{8} 23$ or. 40 & $\begin{array}{llll}7^{6} & 32 & 0.4 .82\end{array}$ & $\begin{array}{llll}\text { S. } 83 & 5^{2} & \text { W. } \\
\text { S. } 40 & 3^{2} & \text { E. } \\
\text { N. } 71 & 04 & \text { E. }\end{array}$ & $\begin{array}{llll}\text { N. } 83 & 5 \mathrm{I} & \mathrm{E} . \\
\text { N. } 40 & 3 \mathrm{I} & \mathrm{W} . \\
\text { S. } 7 \mathrm{I} & 04 & \mathrm{~W} .\end{array}$ & $\begin{array}{r}230 \\
2,137 \\
2,569\end{array}$ & $\begin{array}{l}\text { Bars. } \\
\text { Stock. } \\
\text { Wheat. }\end{array}$ \\
\hline 2 & $\begin{array}{lll}3^{8} & 23 & 3\end{array}$ & $76 \quad 32$ II. 74 & $\begin{array}{llll}\text { N. } 75 & \text { I3 } & \text { W. } \\
\text { S. } & \text { I } 3 & 39 & \text { W. } \\
\text { N. } 75 & 34 & \text { E. }\end{array}$ & $\begin{array}{llll}\text { S. } & 75 & \text { I3 } & \text { E. } \\
\text { N. } & 13 & 39 & \text { E. } \\
\text { S. } & 75 & 35 & \text { W. }\end{array}$ & $\begin{array}{r}1,529 \\
191 \\
2,699\end{array}$ & $\begin{array}{l}\text { Hutchins. } \\
\text { Bars. } \\
\text { Wheat. }\end{array}$ \\
\hline 3 & $\begin{array}{lll}3^{8} & 23 & \text { I0. } 34\end{array}$ & $\begin{array}{llll}7^{6} & 32 & 06.79\end{array}$ & $\begin{array}{llll}\text { N. } 8 \text { I } & \text { II } & \text { W. } \\
\text { S. } 28 & 26 & \text { W. } \\
\text { N. } & 77 & 54 & \text { E. }\end{array}$ & $\begin{array}{llll}\text { S. } & 8 \text { I } & \text { II } & \text { E. } \\
\text { N. } & 28 & 26 & \text { E. } \\
\text { S. } & 77 & 55 & \text { W. }\end{array}$ & $\begin{array}{r}I, 628 \\
37 I \\
2,538\end{array}$ & $\begin{array}{l}\text { Hutchins. } \\
\text { Bars. } \\
\text { Wheat }\end{array}$ \\
\hline 4 & $\begin{array}{llll}3^{8} & 23 & 05.78\end{array}$ & $\begin{array}{lll}76 & 32 & \text { 0. } 25\end{array}$ & $\begin{array}{llll}\text { S. } & 63 & 48 & \text { W. } \\
\text { S. } & 35 & 34 & \text { E. } \\
\text { N. } & 73 & 27 & \text { E. }\end{array}$ & $\begin{array}{llll}\text { N. } & 63 & 48 & \text { E. } \\
\text { N. } 35 & 34 & \text { W. } \\
\text { S. } & 73 & 28 & \text { W. }\end{array}$ & $\begin{array}{r}390 \\
2,178 \\
2,408\end{array}$ & $\begin{array}{l}\text { Bars. } \\
\text { Stock. } \\
\text { Wheat. }\end{array}$ \\
\hline
\end{tabular}


I3OUNDARIES OF NATURAL, OYSTER BARS-continued.

PETERSON (ST. MARYS COUNTY).

(Middle Patuxent River-Charts Nos. I9 and 20.)

\begin{tabular}{|c|c|c|c|c|c|c|}
\hline \multirow{2}{*}{$\begin{array}{l}\text { Cor- } \\
\text { ner } \\
\text { of } \\
\text { bar. }\end{array}$} & \multirow{2}{*}{ Latitude. } & \multirow{2}{*}{ Longitude. } & \multicolumn{2}{|c|}{ Truc bearing. } & \multirow{2}{*}{ Distance. } & \multirow{2}{*}{$\begin{array}{c}\text { U. S. C. \& G. S, triansula- } \\
\text { tion station. }\end{array}$} \\
\hline & & & Forward. & Back. & & \\
\hline I & $\begin{array}{ccc}0 & 1 & 11 \\
38 & 23 & 12.22\end{array}$ & $\begin{array}{ccc}0 & \prime \prime \\
76 & 31 & \text { II. } 86\end{array}$ & $\begin{array}{lccc} & 0 & \\
\text { S. } & 76 & 36 & \mathrm{~W} \\
\text { S. } & 0 & 30 & \mathrm{~W} \\
\text { N. } & 65 & 25 & \mathrm{E} .\end{array}$ & \begin{tabular}{lccc} 
& \multicolumn{1}{c}{,} \\
N. 76 & 35 & $\mathrm{E}$. \\
N. 0 & 30 & $\mathrm{E}$. \\
S. 65 & 24 & W.
\end{tabular} & $\begin{array}{r}\text { Yards. } \\
\text { I, } 669 \\
\text { I, } 989 \\
\text { I, } 126\end{array}$ & $\begin{array}{l}\text { Bars. } \\
\text { Stock. } \\
\text { Wheat. }\end{array}$ \\
\hline 2 & $3^{8} 23 \quad 33.08$ & $\begin{array}{llll}76 & 32 & 03.82\end{array}$ & $\begin{array}{lrrr}\text { N. } & 8 & 23 & \text { W. } \\
\text { S. } & 72 & 59 & \text { W. } \\
\text { S. } & 13 & 09 & \text { W. }\end{array}$ & $\begin{array}{lrrr}\text { S. } & 8 & 24 & \mathrm{E} \\
\mathrm{N} . & 72 & 58 & \mathrm{E} \\
\mathrm{N} . & 13 & 09 & \mathrm{E}\end{array}$ & $\begin{array}{l}I, 773 \\
I, 766 \\
I, 122\end{array}$ & $\begin{array}{l}\text { Island. } \\
\text { Hutchins. } \\
\text { Bars. }\end{array}$ \\
\hline 3 & $3^{8} \quad 23 \quad 44 \cdot 44$ & 763150.08 & $\begin{array}{llll}\text { N. } 30 & \text { or } & \mathrm{E} . \\
\text { N. } & 24 & 27 & \text { W. } \\
\text { S. } 22 & 47 & \text { W. }\end{array}$ & $\begin{array}{llll}\text { S. } 30 \text { or } & \text { W. } \\
\text { S. } 24 & 27 & \mathrm{E} \\
\text { N. } 22 & 47 & \mathrm{E} .\end{array}$ & $\begin{array}{l}\mathrm{r}, 8 \mathrm{r} 8 \\
\mathrm{I}, 506 \\
\mathrm{I}, 60 \mathrm{I}\end{array}$ & $\begin{array}{l}\text { Peak. } \\
\text { Island. } \\
\text { Bars. }\end{array}$ \\
\hline
\end{tabular}

Thence along county boundary as delineated on charts Nos. I9 and 20 to corner No. I.

NEALE.

(Lower Patuxent River-Charts Nos. I9 and 20.)

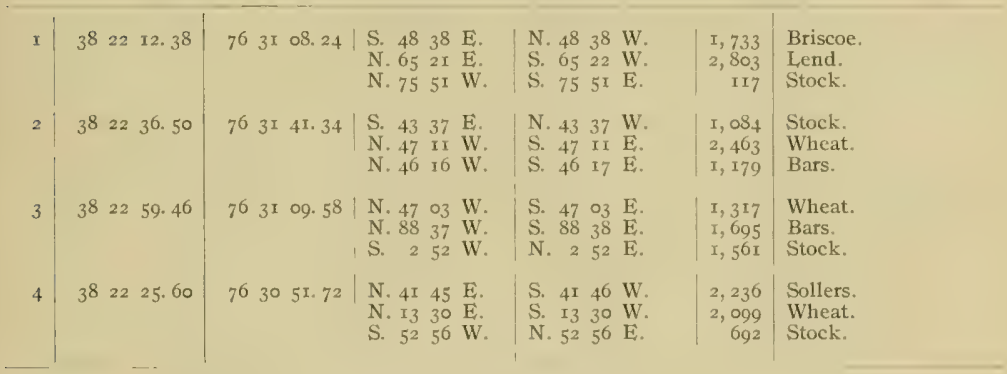

\section{MEARS (ST. MARYS COUNTY).}

(Lower Patuxent River-Charts Nos. I9 and 20.)

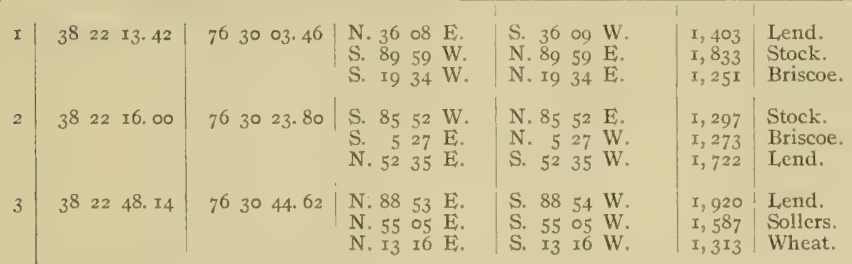

Thence along county boundary as delineated on charts Nos. I9 and 20 to corner No. I. 


\section{HALF PONE.}

(Lower Patuxent River-Chart No. 20.)

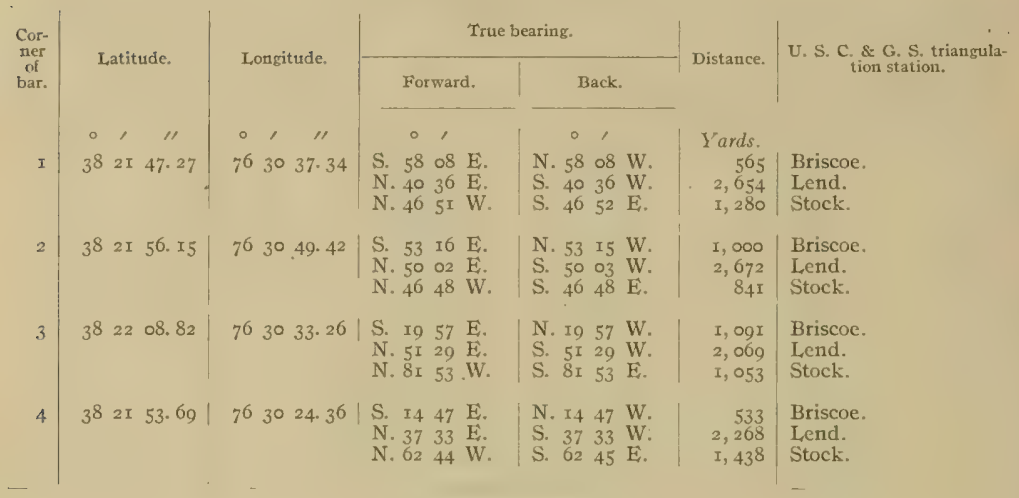

\section{HAWKS NEST.}

(Lozer Patuxent River-Chart No. 2o.)

\begin{tabular}{|c|c|c|c|c|c|c|c|c|}
\hline I & $3^{8}=0$ & 00.53 & 7629 & Ig. I4 & 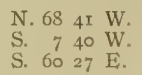 & 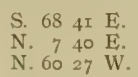 & $\begin{array}{r}385 \\
\mathrm{I}, 375 \\
64 \mathrm{x}\end{array}$ & $\begin{array}{l}\text { Mill. } \\
\text { Cable. } \\
\text { Bur. }\end{array}$ \\
\hline 2 & $3^{8} 20$ & II. 78 & $76 \quad 29$ & 35.80 & $\begin{array}{llll}\text { S. } & \text { I } & 34 & \mathrm{E} . \\
\text { S. } & 55 & \text { II } & \text { E. } \\
\text { N. } & 7 \text { I } & 35 & \text { E. }\end{array}$ & $\begin{array}{l}\text { N. I5 } 34 \text { W. } \\
\text { N. } 55 \text { II } \mathrm{W} . \\
\text { S. } 71 \text {. } 36 \text { W. }\end{array}$ & $\begin{array}{r}248 \\
1,217 \\
2,194\end{array}$ & $\begin{array}{l}\text { Mill. } \\
\text { Bur. } \\
\text { Ton. }\end{array}$ \\
\hline 3 & $3^{8} 20$ & 25.60 & $76 \quad 29$ & 44. 06 & $\begin{array}{llll}\text { S. } 23 & 16 & \mathrm{E} . \\
\text { N. } 84 & 23 & \mathrm{E} . \\
\text { N. } 45 & 52 & \text { E. }\end{array}$ & $\begin{array}{llll}\text { N. } 23 & 16 & \text { W. } \\
\text { S. } 84 & 23 & \text { W. } \\
\text { S. } & 45 & 53 & \text { W. }\end{array}$ & $\begin{array}{r}768 \\
2,312 \\
2,289\end{array}$ & $\begin{array}{l}\text { Mill. } \\
\text { Ton. } \\
\text { Hellen. }\end{array}$ \\
\hline 4 & $3^{8}=0$ & $45 \cdot 5^{6}$ & $76 \quad 29$ & 42.62 & $\begin{array}{llll}\text { S. } & 10 & 53 & \mathrm{E} . \\
\text { N. } 60 & 07 & \mathrm{E} . \\
\text { N. } & 54 & 56 & \mathrm{~W} .\end{array}$ & $\begin{array}{llll}\text { N. } & 10 & 53 & W . \\
\text { S. } 60 & 08 & \text { W. } \\
\text { S. } & 54 & 56 & \text { E. }\end{array}$ & $\begin{array}{r}\text { I, } 403 \\
\text { I, } 855 \\
366\end{array}$ & $\begin{array}{l}\text { Mill. } \\
\text { Hellen. } \\
\text { Nat. }\end{array}$ \\
\hline 5 & $3^{82} 2 \mathrm{I}$ & $15.9^{\circ}$ & 7629 & 58.00 & $\begin{array}{lrrr}\text { S. } & 7 & 37 & \mathrm{E} . \\
\mathrm{S} . & 87 & 08 & \mathrm{E} . \\
\mathrm{N} . & 36 & 37 & \mathrm{~W} .\end{array}$ & $\begin{array}{llll}\text { N. } & 7 & 37 & \text { W. } \\
\text { N. } 87 & 07 & \text { W. } \\
\text { S. } 36 & 37 & \text { E. }\end{array}$ & $\begin{array}{r}821 \\
2,020 \\
945\end{array}$ & $\begin{array}{l}\text { Nat. } \\
\text { Hellen. } \\
\text { Briscoe. }\end{array}$ \\
\hline 6 & $3^{8} 2 \mathrm{x}$ & I 8.88 & $76 \quad 29$ & 48. 21 & $\begin{array}{lrrr}\text { S. } & 9 & 26 & \text { W. } \\
\text { S. } & 83 & 32 & \text { E. } \\
\text { N. } & 51 & 22 & \text { W. }\end{array}$ & $\begin{array}{llll}\text { N. } & 9 & 26 & \text { E. } \\
\text { N. } & 83 & 31 & \text { W. } \\
\text { S. } & 51 & 22 & \text { E. }\end{array}$ & $\begin{array}{r}923 \\
\mathrm{I}, 768 \\
\mathrm{I}, 054\end{array}$ & $\begin{array}{l}\text { Nat. } \\
\text { Hellen. } \\
\text { Briscoe. }\end{array}$ \\
\hline 7 & $3^{8} \quad 20$ & 35.88 & $76 \quad 29$ & 09.36 & $\begin{array}{llll}\text { S. } & 30 & 30 & \mathrm{~W} . \\
\mathrm{S} . & 85 & 02 & \mathrm{E} . \\
\mathrm{N} . & 30 & 06 & \mathrm{E}\end{array}$ & 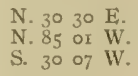 & $\begin{array}{l}x, 218 \\
I, 384 \\
x, 446\end{array}$ & $\begin{array}{l}\text { Mill. } \\
\text { Ton. } \\
\text { Hellen. }\end{array}$ \\
\hline 8 & $3^{8} 20$ & 09.04 & $76 \quad 29$ & 12. 27 & $\begin{array}{llll}\text { S. } & 74 & 48 & \text { W. } \\
\text { S. } & 3 I & 52 & \mathrm{E} . \\
\text { N. } 6 I & 4 I & \mathrm{E}\end{array}$ & 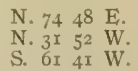 & $\begin{array}{r}561 \\
710 \\
I, 655\end{array}$ & $\begin{array}{l}\text { Mill. } \\
\text { Bur. } \\
\text { Ton. }\end{array}$ \\
\hline
\end{tabular}


BOUNDARIES OF NATURAL, OYSTER BARS-cOntimUEd.

BOB WISE.

(Lower Patuxent River-Chart No. 20.)

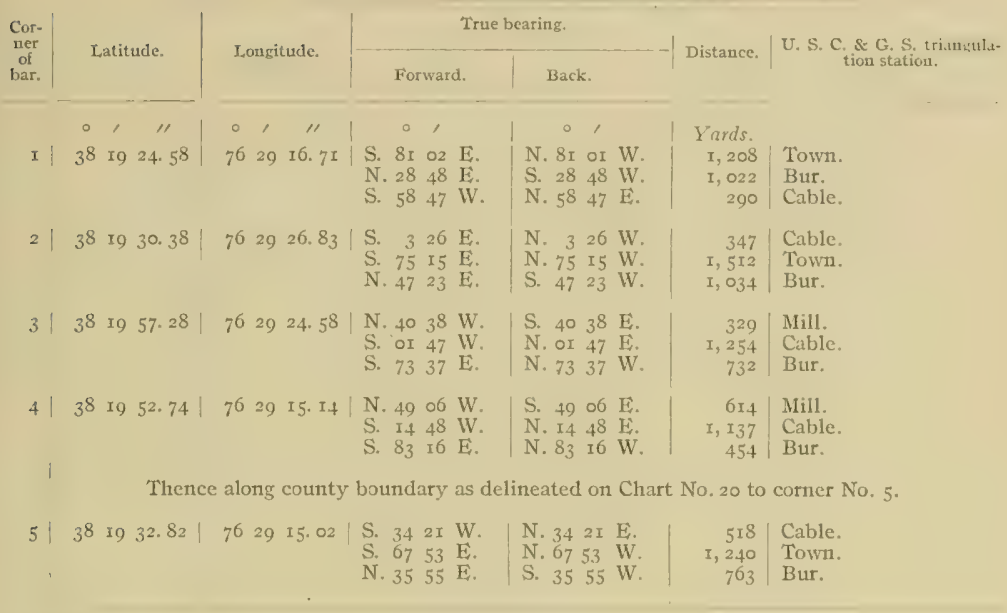

\section{SPENCERS.}

(Lower Patuxent River-Chart No. 20.)
\begin{tabular}{l|lll|lll|l}
$3^{8}$ & I9 22.55 & 76 & 28 & 37.0 .4 & N. 30 & II & W. \\
S. 38 & I6 & W.
\end{tabular}
$\begin{array}{llll}\text { S. } & 38 & \text { I6 } & \text { W. } \\ \text { S. } & 49 & \text { I } & \text { E. }\end{array}$

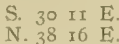
\begin{tabular}{r|l} 
I, II5 & Bur. \\
$43_{3}$ & Crane \\
I85 & Town.
\end{tabular}

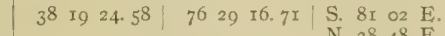
N. 49 I5 W.
$\begin{array}{llll}\text { N. } & 28 & 48 & \text { E. } \\ \text { S. } & 5^{8} & 47 & \text { W. }\end{array}$
N. 8 I or $W$.
I, 208 Town.
S. $2848 \mathrm{~W} . \quad \mathrm{I}, 022$ Bur.
S. $342 \mathrm{x}$ W.
290, Cable.

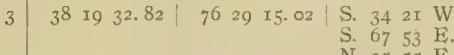
N. $5^{8} 47 \mathrm{E}$.

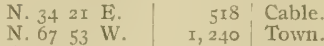
\begin{tabular}{l|l|l|l|l} 
N. $3555 \mathrm{E}$. & S. $3555 \mathrm{~W}$. & 763 & Bur.
\end{tabular}

Thence along county boundary as delineated on Chart No. 20 to corner No. 4 .

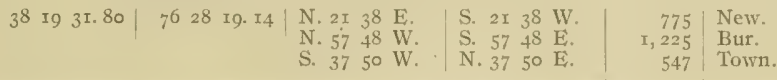


BOUNDARIES OF NATURAL OYSTER BARS-continLEd.

TOWN CREEK.

(Lower Paluxent Rivor-Chart No. 20.)

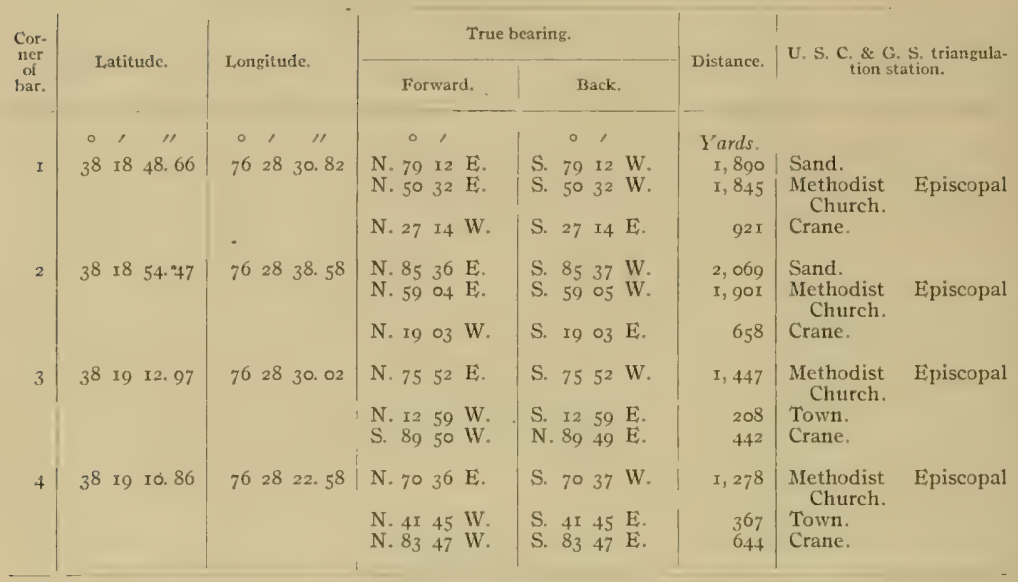

\section{GOODWIN.}

(Lower Patuxent River-Chart No. 20.)

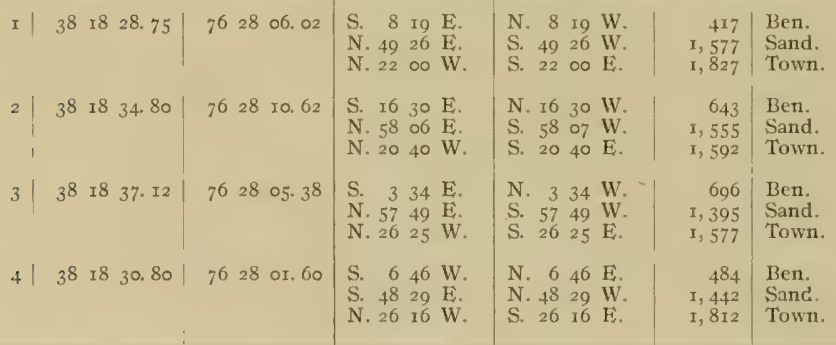


BOUNDARIES OF NATURAL OYSTER BARS-continUEd.

\section{LA GRANDE.}

(Lower Paluxent River-Chart No. 20.)

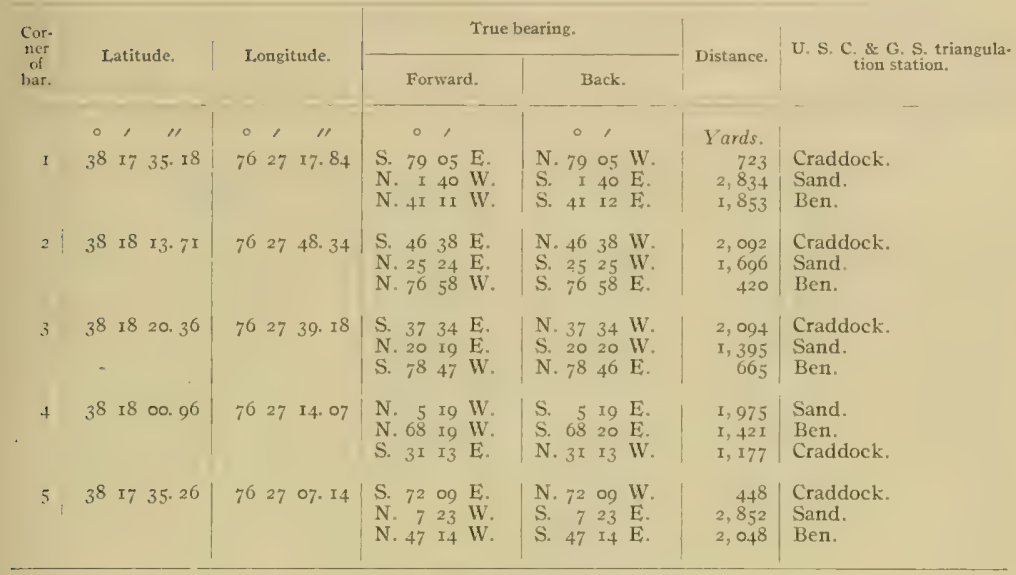

\section{MILLSTONE.}

(Lower Patuxent River-Chart No. 20.)

\begin{tabular}{|c|c|c|c|c|c|c|c|c|}
\hline I & $\begin{array}{lll}38 & 17\end{array}$ & 32.82 & $76 \quad 26$ & 07.63 & $\begin{array}{lll}\text { N. } 22 & 47 & \mathrm{E} \\
\text { N. } 33 & 47 & \mathrm{~W} \\
\text { S. } 87 & \text { I0 } & \mathrm{W}\end{array}$ & $\begin{array}{llll}\text { S. } & 22 & 47 & \text { W. } \\
\text { S. } & 33 & 48 & \mathrm{E} \\
\text { N. } & 87 & 09 & \text { E. }\end{array}$ & $\begin{array}{l}3,538 \\
3,503 \\
\text { I, I } 57\end{array}$ & $\begin{array}{l}\text { Drum Point Light. } \\
\text { Sand. } \\
\text { Craddock. }\end{array}$ \\
\hline 2 & $3^{8} \quad I 7$ & 40. 10 & $76 \quad 26$ & $47 \cdot I 6$ & $\begin{array}{llll}\text { N. } & \text { I8 } & 36 & \mathrm{~W} \\
\text { N. } & 58 & 53 & \mathrm{~W} \\
\text { S. } & \text { I9 } & 08 & \mathrm{~W} .\end{array}$ & $\begin{array}{llll}\text { S. } & \text { I8 } & 37 & \mathrm{E} . \\
\text { S. } & 58 & 54 & \mathrm{E} . \\
\text { N. } & \text { I9 } & 08 & \mathrm{E} .\end{array}$ & $\begin{array}{r}2,813 \\
2,377 \\
322\end{array}$ & $\begin{array}{l}\text { Sand. } \\
\text { Ben. } \\
\text { Craddock. }\end{array}$ \\
\hline 3 & $3^{8}$ I8 & I4. 62 & $76 \quad 26$ & $27 \cdot 79$ & $\begin{array}{llll}\text { N. } 45 & 43 & \mathrm{E} \\
\mathrm{N} . & 43 & 14 & \mathrm{~W} . \\
\mathrm{S} . & 22 & 55 & \mathrm{~W} .\end{array}$ & $\begin{array}{llll}\text { S. } 45 & 44 & \text { W. } \\
\text { S. } & 43 & \text { I } & \text { E. } \\
\text { N. } 22 & 55 & \text { E. }\end{array}$ & $\begin{array}{l}2,654 \\
2,06 I \\
I, 592\end{array}$ & $\begin{array}{l}\text { Drum Point Light. } \\
\text { Sand. } \\
\text { Craddock. }\end{array}$ \\
\hline 4 & $3^{8} \mathrm{I7}$ & 52.60 & $76 \quad 25$ & $45 \cdot 94$ & 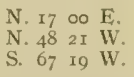 & $\begin{array}{llll}\text { S. } & \text { I7 } & 00 & \mathrm{~W} . \\
\text { S. } 48 & 22 & \mathrm{E} \\
\text { N. } 67 & 18 & \mathrm{E} .\end{array}$ & $\begin{array}{l}2,714 \\
3,377 \\
x, 878\end{array}$ & $\begin{array}{l}\text { Drum Point Light. } \\
\text { Sand. } \\
\text { Craddock. }\end{array}$ \\
\hline
\end{tabular}


BOUNDARIES OF NATURAL OYSTER BARS-continued.

DEEP POINT MUD.

(Lower Patuxent River-Chart No. 20.)

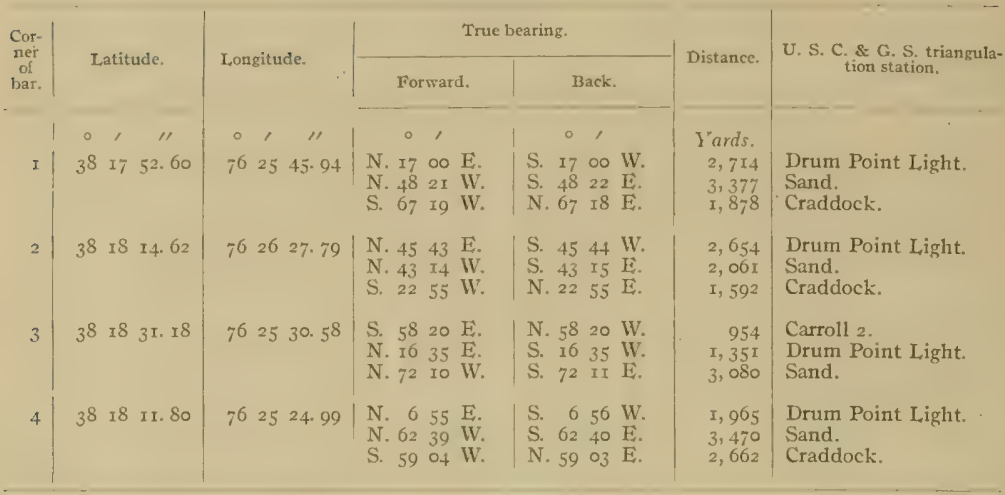

CARROLL MUDS (ST. MARYS COUNTY).

(Lower Patuxent River-Chart No. 20.)

\begin{tabular}{|c|c|c|c|c|c|c|}
\hline I & $3^{8} \quad 18 \quad 16.3^{8}$ & $76 \quad 2444.61$ & 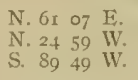 & $\begin{array}{llll}\text { S. } & 61 & \text { o7 } & \text { W. } \\
\text { S. } & 24 & 59 & \text { E. } \\
\text { N. } & 89 & 49 & \text { E. }\end{array}$ & $\begin{array}{r}\mathrm{I}, 362 \\
\mathrm{I}, 978 \\
410\end{array}$ & $\begin{array}{l}\text { Hog } 2 . \\
\text { Drum Point Light. } \\
\text { Carroll } 2 .\end{array}$ \\
\hline & $38 \times 18 \quad 17.00$ & $76 \quad 250.64$ & $\begin{array}{l}\text { S. } 7940 \text { E. } \\
\text { N. } 6946 \text { E. } \\
\text { N. } 9433 \text { W. }\end{array}$ & 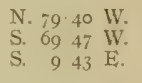 & $\begin{array}{r}124 \\
x, 842 \\
x, 799\end{array}$ & $\begin{array}{l}\text { Carroll } 2 . \\
\text { Hog } 2 . \\
\text { Drum Point Light. }\end{array}$ \\
\hline & ${ }_{3} 8 \quad$ I $8 \quad 45 \cdot 4^{2}$ & $7625^{\circ} 04 \cdot 36$ & $\begin{array}{lrrr}\text { S. } & 6 & 40 & \mathrm{E} . \\
\text { S. } 79 & 23 & \mathrm{E} . \\
\text { N. } 20 & 54 & \mathrm{WV} .\end{array}$ & $\begin{array}{llll}\text { N. } & 6 & 40 & \mathrm{~W} \\
\text { N. } 79 & 23 & \mathrm{~W} . \\
\text { S. } 20 & 55 & \mathrm{E} .\end{array}$ & $\begin{array}{r}988 \\
I, 746 \\
874\end{array}$ & $\begin{array}{l}\text { Carroll } 2 . \\
\text { Hog } 2 . \\
\text { Drum Point Light. }\end{array}$ \\
\hline
\end{tabular}

Thence along county boundary as delineated on Chart No, 20 to corner No. 4 .

\begin{tabular}{|c|c|c|c|c|c|}
\hline $3^{8} \quad$ I9 03.80 & $7624 \quad 17.62$ & $\begin{array}{llll}\text { N. } 82 & 5 \text { I } \mathrm{IV} . \\
\text { S. } 35 & 10 & \mathrm{WV} . \\
\text { S. } 26 & 46 & \mathrm{E} .\end{array}$ & $\begin{array}{llll}\text { S. } & 82 & 52 & \text { E. } \\
\text { N. } & 35 & 09 & \text { E. } \\
\text { N. } 26 & 46 & \text { W. }\end{array}$ & $\begin{array}{l}\mathrm{x}, 565 \\
\mathrm{I}, 95^{8} \\
\mathrm{I}, 054\end{array}$ & $\begin{array}{l}\text { Drum Point Light. } \\
\text { Carroll } 2 . \\
\text { Hog } 2 .\end{array}$ \\
\hline${ }_{3} 8$ I $8 \quad 48.16$ & 762402.46 & 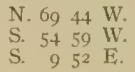 & $\begin{array}{llll}\text { S. } & 69 & 44 & \mathrm{E} . \\
\text { N. } & 54 & 58 & \mathrm{E} . \\
\text { N. } & 9 & 52 & \mathrm{WV} .\end{array}$ & $\begin{array}{r}2,084 \\
1,867 \\
420\end{array}$ & $\begin{array}{l}\text { Drum Point Light. } \\
\text { Carroll } 2 . \\
\text { Hog } 2 .\end{array}$ \\
\hline
\end{tabular}


BOUNDARIISS OF NATURAL, OYSTER BARS-continued,

\section{HOG ISLAND.}

(Entrance Patuxent River-Chart No. 20.)

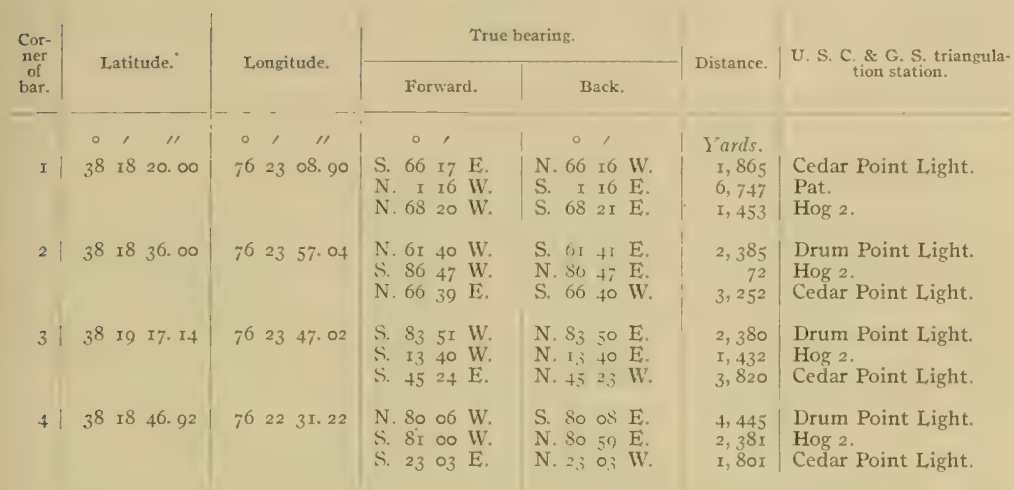

\section{CHINESE MUDS (ST. MARYS COUNTY).}

(Entrance Patuxent River-Chart No. 20.)

\begin{tabular}{|c|c|c|c|c|c|c|c|}
\hline$I$ & $3^{8}$ I8 35.08 & $76 \quad 22$ & oI. $5^{2}$ & $\begin{array}{lrrr}\text { N. } & 77 & 19 & W . \\
\text { N. } 89 & 31 & W . \\
\text { S. } & 3 & 49 & W .\end{array}$ & $\begin{array}{lrrl}\text { S. } & 77 & 21 & \text { E. } \\
\text { S. } & 89 & 32 & \text { E. } \\
\text { N. } & 3 & 49 & \text { E. }\end{array}$ & $\begin{array}{l}5,297 \\
3, \mathrm{I} 42 \\
\mathrm{I}, 26 \mathrm{x}\end{array}$ & $\begin{array}{l}\text { Drum Point Light. } \\
\text { Hog } 2 \text {. } \\
\text { Cedar Point Light. }\end{array}$ \\
\hline 2 & $3^{8}$ I8 $46.9^{2}$ & 7622 & 31.22 & $\begin{array}{l}\text { N. } 80 \text { o6 } \mathrm{W} \text {. } \\
\text { S. } 81 \text { I } 00 \mathrm{~W} . \\
\text { S. } 23 \text { o3 } \mathrm{E} .\end{array}$ & $\begin{array}{llll}\text { S. } 80 & 08 & \text { E. } \\
\text { N. } 80 & 59 & \text { E. } \\
\text { N. } 23 & 03 & \text { W. }\end{array}$ & $\begin{array}{l}4,445 \\
2,381 \\
I, 801\end{array}$ & $\begin{array}{l}\text { Drum Point Light. } \\
\text { Hog } 2 . \\
\text { Cedar Point Light. }\end{array}$ \\
\hline & $3^{8} \quad$ I9 $17 . I_{4}$ & $76 \quad 23$ & 47.02 & $\begin{array}{llll}\text { S. } & 83 & 5 \mathrm{I} & \mathrm{W} . \\
\text { S. } & \mathrm{I}_{3} & 40 & \mathrm{~W} \\
\text { S. } & 45 & 24 & \mathrm{E} .\end{array}$ & 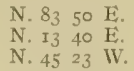 & $\begin{array}{l}2,380 \\
1,432 \\
3,820\end{array}$ & $\begin{array}{l}\text { Drum Point Light. } \\
\text { Hog } 2 \text {. } \\
\text { Cedar Point Light. }\end{array}$ \\
\hline
\end{tabular}

Thence along county boundary as delineated in Chart No. 20 to comer No. 4 .

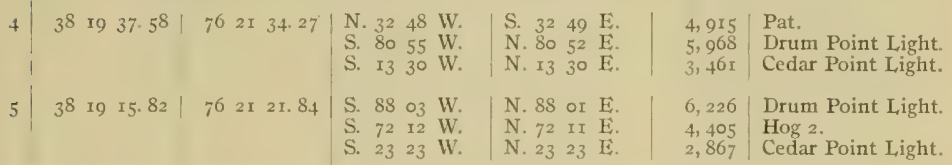


BOUNDARIES OF NATURAL, OYSTER BARS-continued,

CEDAR POINT HOLLOW.

(Chesapeake Bay-Charts Nos. 20 and 2I.)

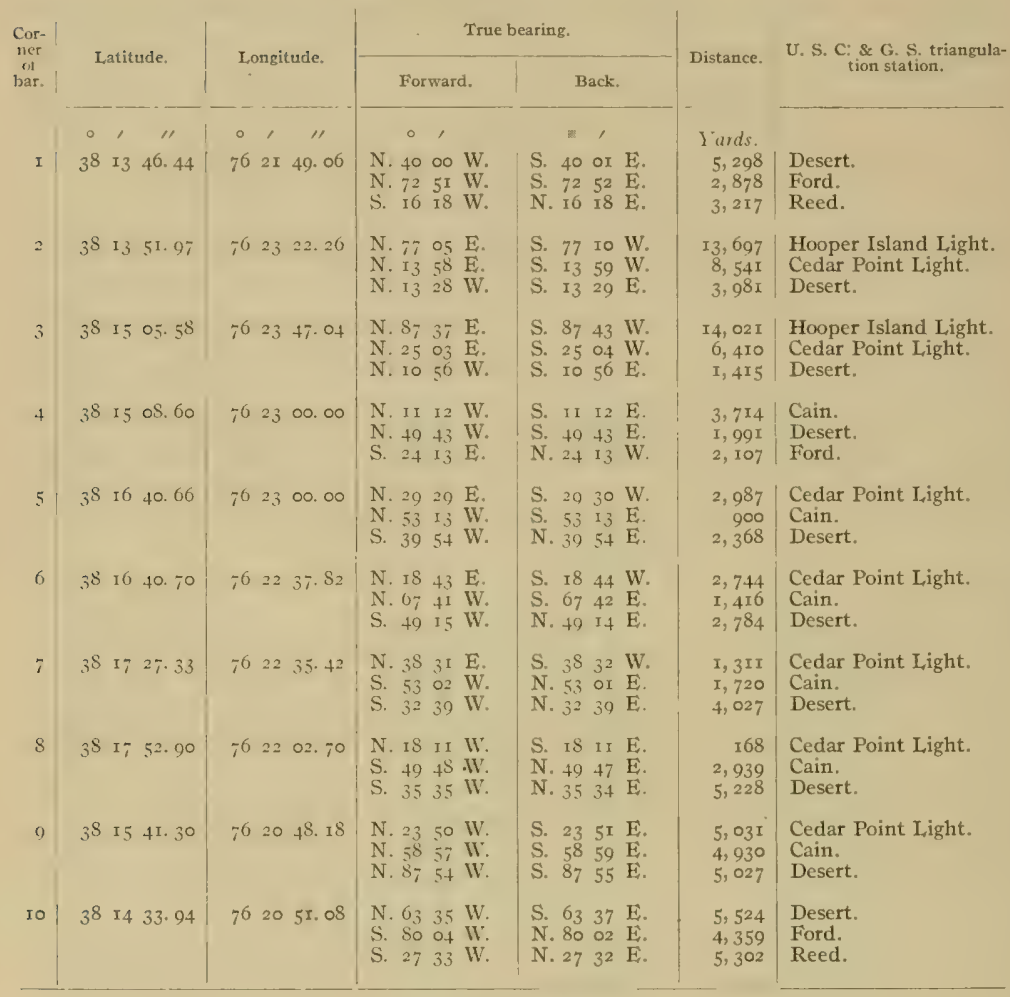

ROCKY BEACH.

(Chesapeake Bay-Chart No. 2I.)

\begin{tabular}{|c|c|c|c|c|c|c|}
\hline I & $3^{8}$ II $37 \cdot 4^{2}$ & $7621 \quad 40.16$ & 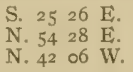 & $\begin{array}{llll}\text { N. } 25 & 26 & \text { W. } \\
\text { S. } & 54 & 32 & \text { W. } \\
\text { S. } & 42 & 06 & \text { E. }\end{array}$ & $\begin{array}{r}2,415 \\
\text { I3, 075 } \\
\text { I, } 7 \text { OI }\end{array}$ & $\begin{array}{l}\text { Point Agin. } \\
\text { Hooper Island Light. } \\
\text { Reed. }\end{array}$ \\
\hline 2 & $3^{8}$ I2 00.00 & $\begin{array}{lll}76 & 22 & 09.62\end{array}$ & $\begin{array}{llll}\text { S. } 3 I & 46 & \mathrm{E} . \\
\text { N. } & 59 & 06 & \mathrm{~W} . \\
\text { N. } 35 & 26 & \mathrm{~W} .\end{array}$ & $\begin{array}{llll}\text { N. } 3 \text { I } & 45 & \text { W. } \\
\text { S. } & 59 & \text { I0 } & \text { E. } \\
\text { S. } & 35 & 26 & \mathrm{E} .\end{array}$ & $\begin{array}{r}3,459 \\
\mathbf{1}, 309 \\
615\end{array}$ & $\begin{array}{l}\text { Point Agin, } \\
\text { Hooper Island Light. } \\
\text { Reed. }\end{array}$ \\
\hline
\end{tabular}


BOUNDARIES OF NATURAL OYSTER BARS-continuEd.

ROCKY BEACH-Continued.

(Chesapeake Bay-Chart No. 2r.)

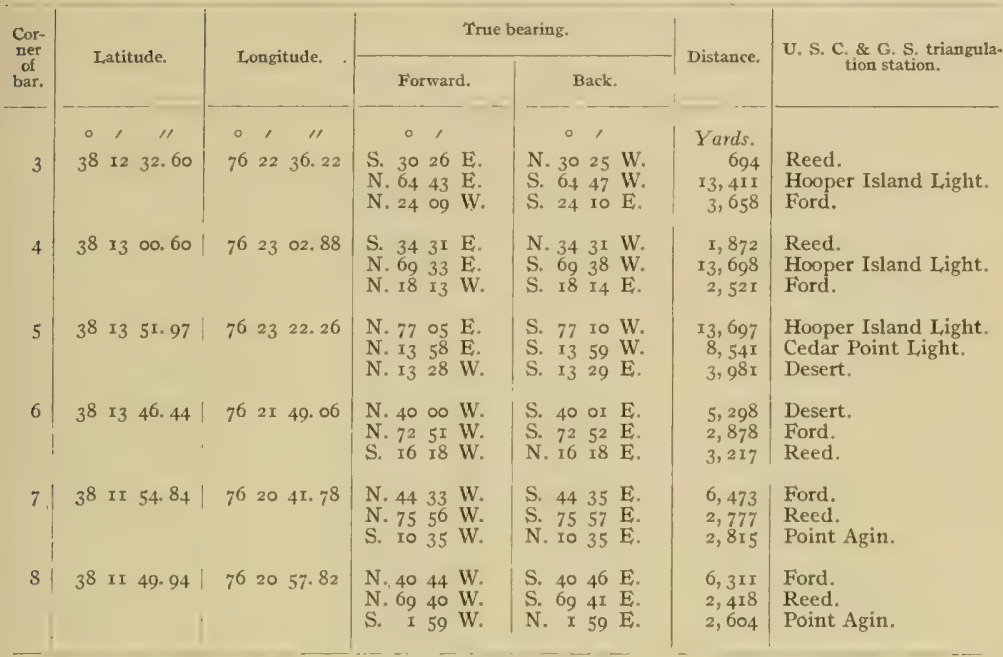

\section{TENACRES.}

(Chesapeake Bay-Chart No.21.)

\begin{tabular}{|c|c|c|c|c|c|c|}
\hline $\mathbf{I}$ & $3^{8} \quad 1022.02$ & $7^{6} \quad 20 \quad 34 \cdot 23$ & 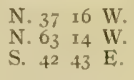 & $\begin{array}{llll}\text { S. } & 37 & \text { I7 } & \mathrm{E} . \\
\text { S. } 63 & \text { I } 5 & \mathrm{E} \\
\text { N. } & 42 & 4 \mathrm{I} & \mathrm{W} .\end{array}$ & $\begin{array}{r}4,78 I \\
805 \\
7,388\end{array}$ & $\begin{array}{l}\text { Reed. } \\
\text { Point Agin. } \\
\text { Point No Point Light. }\end{array}$ \\
\hline 2 & $3^{8}$ II $3 \pi \cdot 42$ & $7621 \quad 40.16$ & 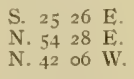 & 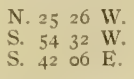 & $\begin{array}{r}2,415 \\
13,075 \\
1,7 \text { O1 }\end{array}$ & $\begin{array}{l}\text { Point Agin. } \\
\text { Hooper Island Light. } \\
\text { Reed. }\end{array}$ \\
\hline 3 & $3^{8}$ II 49.94 & $\begin{array}{lll}76 & 20 & 57.82\end{array}$ & $\begin{array}{lrrr}\text { N. } & 40 & 44 & \text { W. } \\
\text { N. } 69 & 40 & \text { W. } \\
\text { S. } & \text { I } & 59 & \text { W. }\end{array}$ & $\begin{array}{lrrr}\text { S. } & 40 & 46 & \mathrm{E} . \\
\text { S. } & 69 & 4 \mathrm{I} & \mathrm{E} . \\
\text { N. } & \mathrm{I} & 59 & \mathrm{E} .\end{array}$ & $\begin{array}{l}6,311 \\
2,418 \\
2,604\end{array}$ & $\begin{array}{l}\text { Ford. } \\
\text { Reed. } \\
\text { Point Agin. }\end{array}$ \\
\hline & $3^{8}$ 10 40.33 & $76 \quad 2000.73$ & $\begin{array}{llll}\text { N. } & 49 & 50 & \text { W. } \\
\text { S. } 80 & 59 & \text { W. } \\
\text { S. } & 34 & 16 & \text { E. }\end{array}$ & $\begin{array}{llll}\text { S. } & 49 & 52 & \text { E. } \\
\text { N. } 80 & 59 & \text { E. } \\
\text { N. } 34 & 15 & \text { W. }\end{array}$ & $\begin{array}{l}4,942 \\
x, 631 \\
7,316\end{array}$ & $\begin{array}{l}\text { Reed. } \\
\text { Point Agin. } \\
\text { Point No Point Light. }\end{array}$ \\
\hline
\end{tabular}

$2606-\mathrm{II} \longrightarrow \mathrm{IO}$ 
BOUNDARIES OF NATURAL OYSTER BARS- continued.

McKAY.

(Chesapeake Bay-Chart No.2I.)

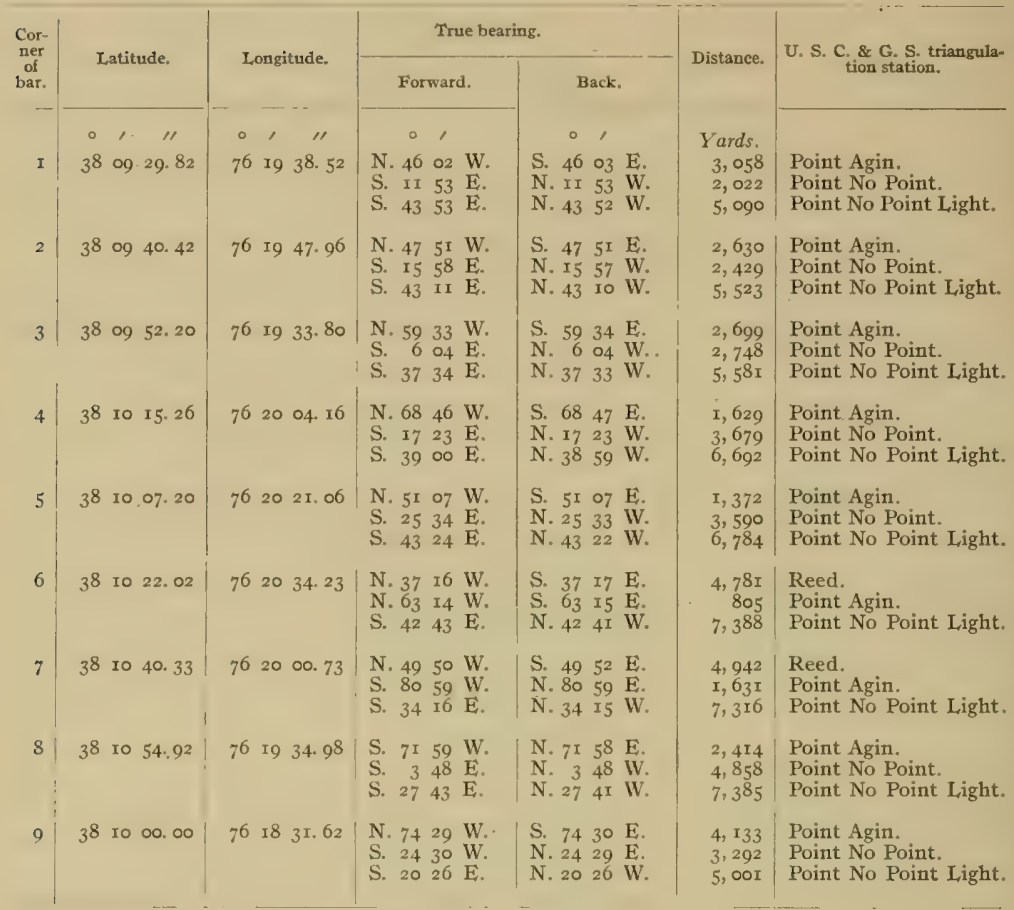

\section{FISH HAWK.}

(Chesapeake Bay-Charts Nos. 21 and 22.)

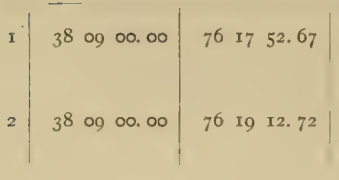

N. $5^{8} \circ_{3} \mathrm{~W}$. S. $6757 \mathrm{~W}$ S. I4 $54 \mathrm{E}$.

N. $42 \quad 43$ W. S. I5 $33 \mathrm{~W}$ S. $4651 \mathrm{E}$.
S. 5805 E.

N. $6756 \mathrm{E}$.

N. I4 $54 \mathrm{~W}$.

S. $4244 \mathrm{E}$.

N. I5 $33 \mathrm{E}$.

N. $4650 \mathrm{~W}$.
5, 914 Point Agin.

2,592 Point No Point.

2, 757 Point No Point Light.

4, 257 Point Agin.

I, 009 Point No Point

3, 894 Point No Point Light. 
BOUNDARIES OF NATURAL OYSTER BARS-continued.

FISH HAWK-Continued.

(Chesapeake Bay-Charts Nos. 21 and 22.)

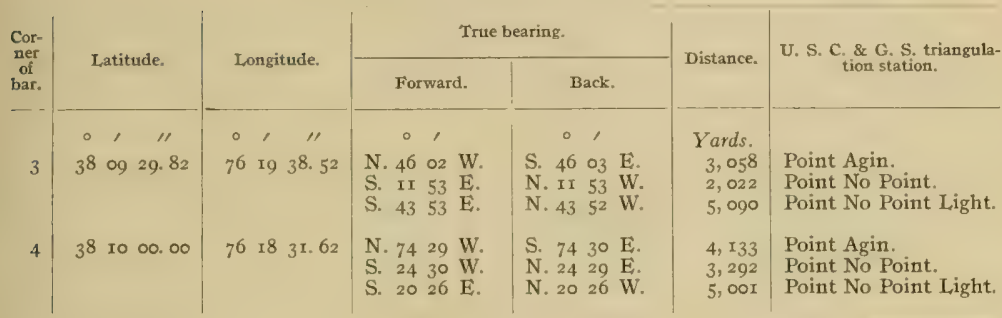

\section{ST. JEROME.}

(Chesapeake Bay-Chart No.22.)

\begin{tabular}{|c|c|c|c|c|c|c|c|c|}
\hline I & $\begin{array}{lll}38 & 07\end{array}$ & I2. 60 & $7^{6}$ I9 & 54. 22 & 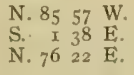 & $\begin{array}{lrrr}\text { S. } & 85 & 57 & \mathrm{E} . \\
\text { N. } & 3 & 38 & \mathrm{~W} \\
\text { S. } & 76 & 23 & \mathrm{~W}\end{array}$ & $\begin{array}{r}501 \\
2,559 \\
4,06 r\end{array}$ & $\begin{array}{l}\text { St. Jerome. } \\
\text { Point Look-in. } \\
\text { Point No Point Light. }\end{array}$ \\
\hline 2 & $\begin{array}{lll}3^{8} & 07\end{array}$ & I3. 74 & $76 \quad 19$ & $57 \cdot 3^{8}$ & $\begin{array}{lrrr}\text { S. } 89 & 35 & \text { W. } \\
\text { S. } & 3 & 28 & \mathrm{E} \\
\text { N. } & 77 & \circ 9 & \mathrm{E} .\end{array}$ & $\begin{array}{l}\text { N. } 8935 \text { E. } \\
\text { N. } 328 \text { W. } \\
\text { S. } 77 \text { II W. }\end{array}$ & $\begin{array}{r}416 \\
2,593 \\
4, \times 25\end{array}$ & $\begin{array}{l}\text { St. Jerome. } \\
\text { Point Look-in. } \\
\text { Point No Point Light. }\end{array}$ \\
\hline 3 & $3^{8} \quad 07$ & $32.5^{8}$ & $7^{6} 19$ & 44.54 & $\begin{array}{lrrl}\text { S. } & 49 & 52 & \text { W. } \\
\text { S. } & 3 & I_{3} & \text { W. } \\
\text { N. } 85 & 36 & \text { E. }\end{array}$ & 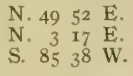 & $\begin{array}{r}991 \\
3,228 \\
3,700\end{array}$ & $\begin{array}{l}\text { St. Jerome. } \\
\text { Point Look-in. } \\
\text { Point No Point Light. }\end{array}$ \\
\hline 4 & $3^{8} 07$ & 20.47 & 76 19 & 36.14 & $\begin{array}{rrrr}\text { S. } 6 I & 28 & \mathrm{~W} \\
\text { S. } & 7 & 28 & \mathrm{~W} \\
\text { N. } & 83 & 36 & \mathrm{E} .\end{array}$ & $\begin{array}{llll}\text { N. } 61 & 27 & \mathrm{E} . \\
\text { N. } & 7 & 28 & \mathrm{E} . \\
\text { S. } 83 & 37 & \mathrm{~W} .\end{array}$ & $\begin{array}{l}\text { I, } 119 \\
3,145 \\
3,487\end{array}$ & $\begin{array}{l}\text { St. Jerome. } \\
\text { Point Look-in. } \\
\text { Point No Point Light. }\end{array}$ \\
\hline
\end{tabular}

\section{SHAVING PILE.}

(Chesapeake Bay-Chart No.22.)

\begin{tabular}{|c|c|c|c|c|c|c|}
\hline I 1 & $3^{8} \circ 6 \quad 4^{2} \cdot 7^{8}$ & $\begin{array}{lll}7^{6} & 18 & 0.4 .96\end{array}$ & $\begin{array}{llll}\text { N. } 27 & 50 & \mathrm{E} . \\
\text { N. } 73 \text { or } & \text { W. } \\
\text { S. } & 6 \text { I } & 28 & \text { W. }\end{array}$ & $\begin{array}{llll}\text { S. } & 27 & 50 & \mathrm{~W} . \\
\text { S. } & 73 & 02 & \mathrm{E} . \\
\text { N. } & 61 & 27 & \mathrm{E} .\end{array}$ & $\begin{array}{l}2,220 \\
3,565 \\
3,232\end{array}$ & $\begin{array}{l}\text { Point No Point Light. } \\
\text { St. Jerome. } \\
\text { Point Look-in. }\end{array}$ \\
\hline 2 & $\begin{array}{llll}38 & 07 & 22.24\end{array}$ & 76 I8 14.40 & $\begin{array}{llll}\text { N. } & 63 & 5 \mathrm{I} & \mathrm{E} \\
\text { S. } & 84 & 46 & \mathrm{~W} \\
\text { S. } & 4 \mathrm{I} & 59 & \mathrm{WV} .\end{array}$ & $\begin{array}{llll}\text { S. } & 63 & 52 & \text { W. } \\
\text { N. } & 84 & 45 & \text { E. } \\
\text { N. } & 41 & 58 & \text { E. }\end{array}$ & $\begin{array}{l}\mathrm{I}, 435 \\
3, \mathrm{I} 73 \\
3,867\end{array}$ & $\begin{array}{l}\text { Point No Point Light, } \\
\text { St. Jerome. } \\
\text { Point Look-in. }\end{array}$ \\
\hline 3 & $3^{8}$ o7 20.54 & $\begin{array}{llll}76 & 17 & 48.04\end{array}$ & $\begin{array}{llll}\text { N. } & 40 & 21 & \mathrm{E} \\
\text { S. } & 86 & 34 & \mathrm{~W} \\
\text { S. } & 49 & 26 & \mathrm{~W} .\end{array}$ & $\begin{array}{llll}\text { S. } 40 & 21 & \text { W. } \\
\text { N. } 86 & 32 & \text { E. } \\
\text { N. } & 49 & 24 & \text { E. }\end{array}$ & $\begin{array}{r}901 \\
3,867 \\
4,331\end{array}$ & $\begin{array}{l}\text { Point No Point Light. } \\
\text { St. Jerome. } \\
\text { Point Look-in. }\end{array}$ \\
\hline
\end{tabular}


BOUNDARIES OF NATURAL OYSTER BARS-continued.

\section{BUTLER.}

(Chesapeake Bay-Chart No. 22.)

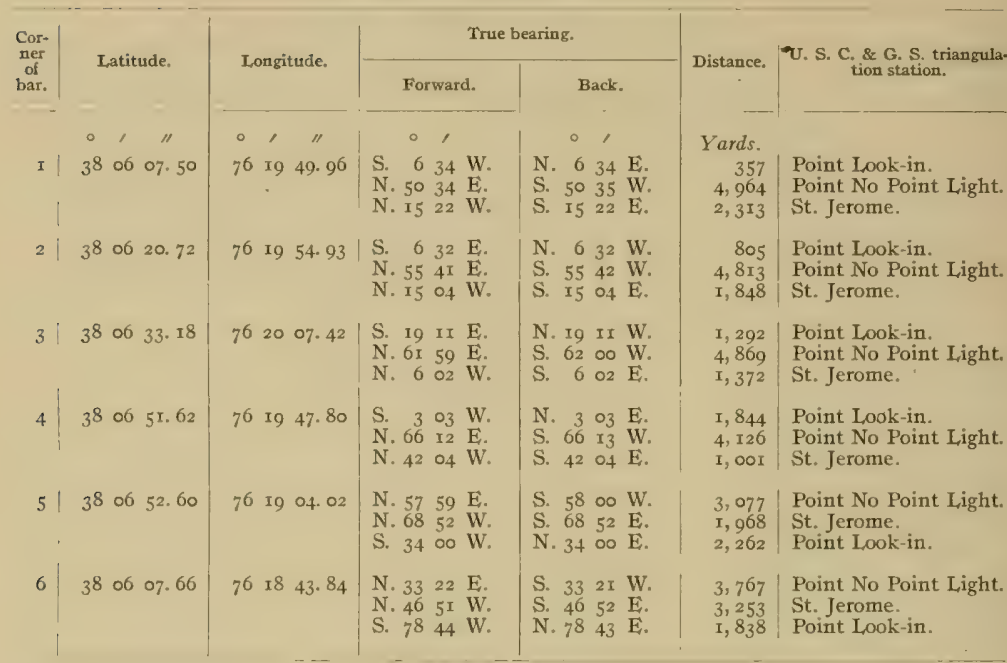

\section{POINT LOOK-IN.}

(Chesapeake Bay-Chart No. 22.)

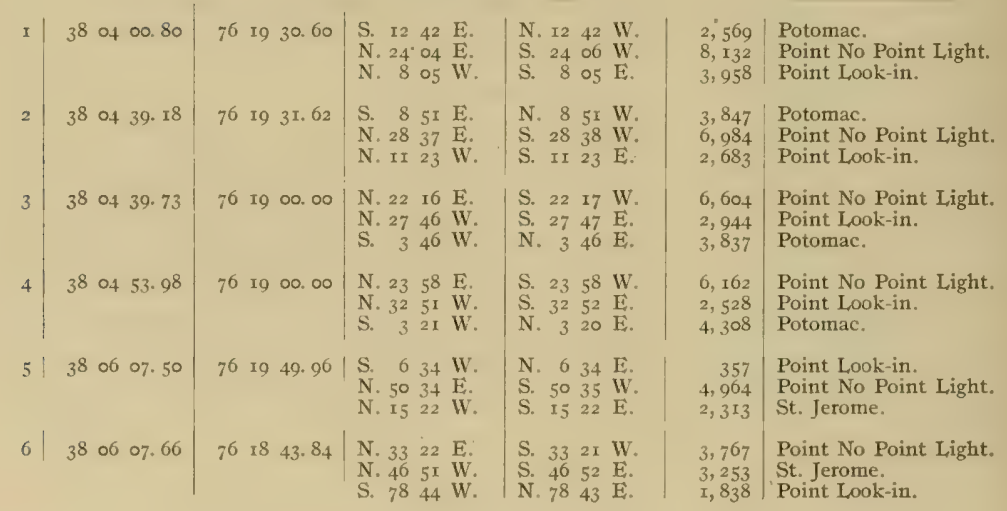


BOUNDARIES OF NATURAL OYSTER BARS-continuEd.

POINT LOOK-IN-Continued.

(Chesapeake Bay-Chart No. 22.)

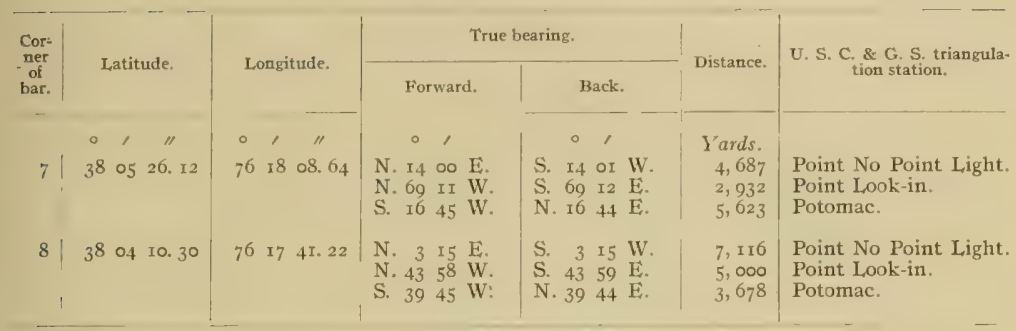

\section{POINT LOOKOUT.}

(Chesapeake Bay-Charts Nos, 22 and 23.)

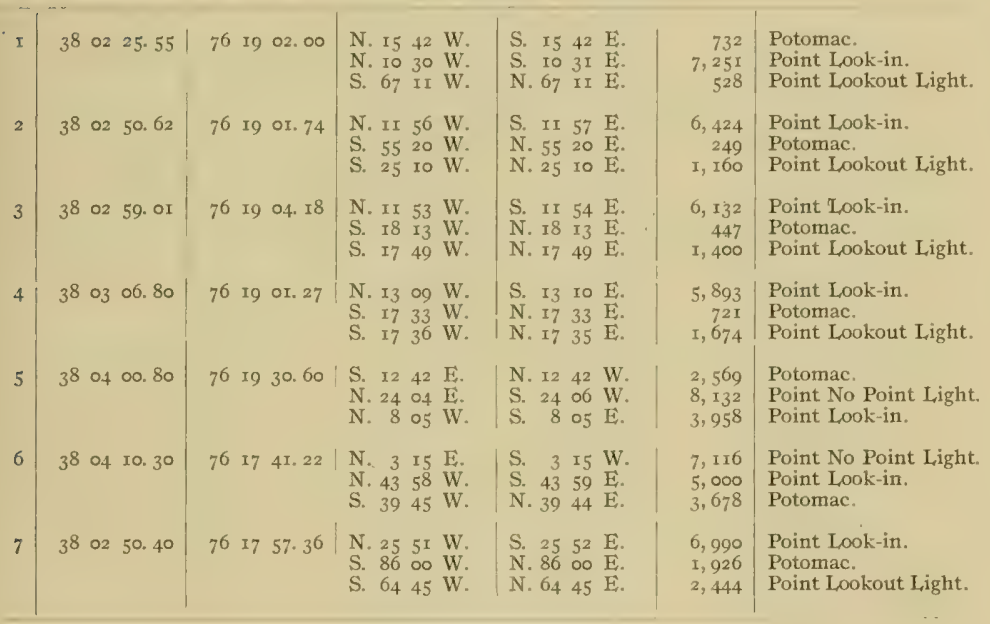

\section{OLD HARE}

(Smith Creck-Chart No. 24.)

\begin{tabular}{|c|c|c|c|c|c|c|}
\hline I & 38 o5 50. $9^{8}$ & $\begin{array}{llll}76 & 24 & 07 \cdot 54\end{array}$ & 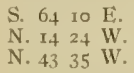 & $\begin{array}{l}\text { N. } 6410 \mathrm{~W} . \\
\text { S. } 1424 \text { E. } \\
\text { S. } 4335 \text { E. }\end{array}$ & $\begin{array}{r}r, 019 \\
I, 389 \\
802\end{array}$ & $\begin{array}{l}\text { Sig. } \\
\text { Dago. } \\
\text { Red Beacon. }\end{array}$ \\
\hline 2 & $3^{8} 06$ 10. 48 & $76245^{8.62}$ & 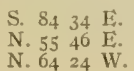 & $\begin{array}{llll}\text { N. } & 84 & 34 & \text { W. } \\
\text { S. } & 55 & 46 & \text { W. } \\
\text { S. } & 64 & 24 & \text { E. }\end{array}$ & $\begin{array}{r}813 \\
I, 228 \\
584\end{array}$ & $\begin{array}{l}\text { Red Beacon. } \\
\text { Dago. } \\
\text { Day. }\end{array}$ \\
\hline
\end{tabular}


BOUNDARIES OF NATURAL OYSTER BARS - continued.

OLD HARE-Continued.

(Chesapeake Bay-Charl No. 24.)

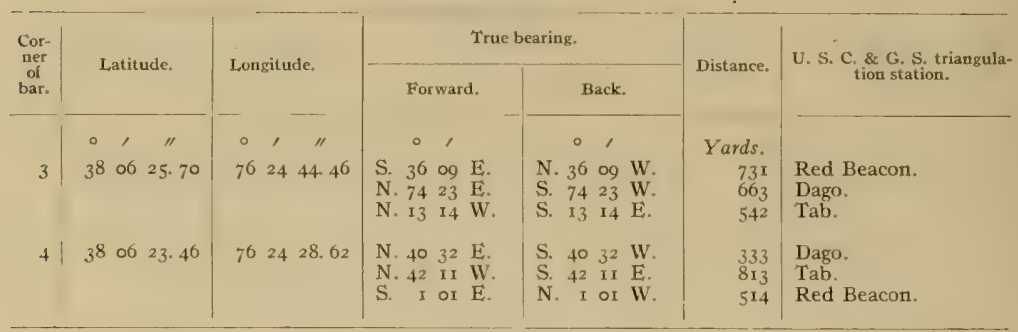

\section{SMITH CREEK.}

(Smith Creek-Chart No. 24.)

\begin{tabular}{|c|c|c|c|c|c|c|}
\hline I & $3^{8} 06 \quad 29.00$ & $76 \quad 24 \quad 46.04$ & $\begin{array}{llll}\text { S. } 34 & 04 & \text { E. } \\
\text { N. } 84 & 24 & \text { E. } \\
\text { N. II } & 06 & \text { W. }\end{array}$ & $\begin{array}{llll}\text { N. } & 34 & 04 & \text { W. } \\
\text { S. } & 84 & 24 & \text { W. } \\
\text { S. } & \text { I I } & 06 & \text { E. }\end{array}$ & $\begin{array}{l}844 \\
684 \\
427\end{array}$ & $\begin{array}{l}\text { Red bes } \\
\text { Dago. } \\
\text { Tab. }\end{array}$ \\
\hline 2 & $3^{8} 06 \quad 41.37$ & $\begin{array}{c}7624 \text { 49. I I } \\
.\end{array}$ & $\begin{array}{llll}\text { S. } & 26 & 23 & \mathrm{E} . \\
\text { S. } & 65 & 19 & \mathrm{E} . \\
\text { N. } & 21 & 08 & \mathrm{E} .\end{array}$ & $\begin{array}{l}\text { N. } 26 \quad 23 \mathrm{~W} . \\
\text { N. } 65 \text { 18 } \\
\text { S. } 21 . \\
\text { S. }\end{array}$ & $\begin{array}{r}I, 249 \\
839 \\
750\end{array}$ & $\begin{array}{l}\text { Red be } \\
\text { Dago. } \\
\text { Oak. }\end{array}$ \\
\hline & $\begin{array}{l}\text { Thence from } \\
\text { any creek, }\end{array}$ & $\begin{array}{l}\text { ner No. } 2 \\
\text { e, or inlet }\end{array}$ & $\begin{array}{l}\text { g the mean } \\
\text { than soo y }\end{array}$ & $\begin{array}{l}\text { vater line of } \\
1 \text { width at i }\end{array}$ & 0 & or \\
\hline 3 & $3^{8} 0702.3^{6}$ & $76 \quad 24 \quad 37.22$ & 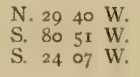 & $\begin{array}{llll}\text { S. } 29 & 40 & \mathrm{E} . \\
\text { N. } 80 & 5 \mathrm{I} & \mathrm{E} . \\
\text { N. } & 24 & 07 & \mathrm{E} .\end{array}$ & $\begin{array}{r}516 \\
47 \\
776\end{array}$ & $\begin{array}{l}\text { Stung. } \\
\text { Oak. } \\
\text { Tab. }\end{array}$ \\
\hline 4 & $3^{8} \quad 0702.5^{6}$ & $\begin{array}{lll}76 & 24 & 33.00\end{array}$ & 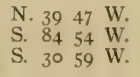 & $\begin{array}{llll}\text { S. } 39 & 48 & \mathrm{E} . \\
\text { N. } & 84 & 54 & \mathrm{E} . \\
\text { N. } 30 & 59 & \mathrm{E} .\end{array}$ & $\begin{array}{l}574 \\
\text { I } 59 \\
834\end{array}$ & $\begin{array}{l}\text { Stung. } \\
\text { Oak. } \\
\text { Tab. }\end{array}$ \\
\hline 5 & $3806 \quad 55.20$ & 762438.39 & 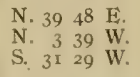 & $\begin{array}{lrrr}\text { S. } & 39 & 48 & \text { W. } \\
\text { S. } & 3 & 39 & \text { E. } \\
\text { N. } & 3 \text { I } & 29 & \text { E. }\end{array}$ & $\begin{array}{l}525 \\
234 \\
547\end{array}$ & $\begin{array}{l}\text { Out. } \\
\text { Oak. } \\
\text { Tab. }\end{array}$ \\
\hline 6 & $3^{8}$ o6 55.02 & $76 \quad 24 \quad 30.62$ & $\begin{array}{llll}\text { N. } 17 & 29 & \text { E. } \\
\text { N. } 42 & 45 & \text { W. } \\
\text { S. } & 46 & 57 & \text { W. }\end{array}$ & $\begin{array}{llll}\text { S. } 17 & 29 & \text { W. } \\
\text { S. } 42 & 45 & \text { E. } \\
\text { N. } & 46 & 57 & \mathrm{E} .\end{array}$ & $\begin{array}{l}429 \\
327 \\
674\end{array}$ & $\begin{array}{l}\text { Out. } \\
\text { Oak. } \\
\text { Tab. }\end{array}$ \\
\hline 7 & $3^{8} \quad 07 \quad 02.61$ & $7^{6} 24^{29} \cdot 5^{8}$ & $\begin{array}{llll}\text { S. } 89 & 53 & \vec{E} . \\
\text { N. } 33 & 25 & \text { E. } \\
\text { S. } 86 & 22 & \text { W. }\end{array}$ & $\begin{array}{llll}\text { N. } 89 & 53 & \text { W. } \\
\text { S. } 33 & 25 & \text { W. } \\
\text { N. } 86 & 22 & \text { E. }\end{array}$ & $\begin{array}{l}273 \\
184 \\
25 \mathrm{I}\end{array}$ & $\begin{array}{l}\text { In. } \\
\text { Out. } \\
\text { Oak. }\end{array}$ \\
\hline 8 & $\begin{array}{llll}38 & 07 & 03.06\end{array}$ & $76 \quad 2422.21$ & $\begin{array}{l}\text { N. } 34 \text { II } \text { W. } \\
\text { S. } 86 \text { oI } \\
\text { S. } 74 \text {. } \\
\text { S. }\end{array}$ & $\begin{array}{llll}\text { S. } 34 & 32 & \mathrm{E} . \\
\text { N. } 86 & \text { OI } & \text { E. } \\
\text { N. } & 74 & 54 & \text { W. }\end{array}$ & $\begin{array}{r}168 \\
447 \\
79\end{array}$ & $\begin{array}{l}\text { Out. } \\
\text { Oak. } \\
\text { In. }\end{array}$ \\
\hline
\end{tabular}


BOUNDARIES OF NATURAL OYSTER IBEDS-continued.

SMITH CREEK-Continued.

(Smith Creek-Chart No, 24.)

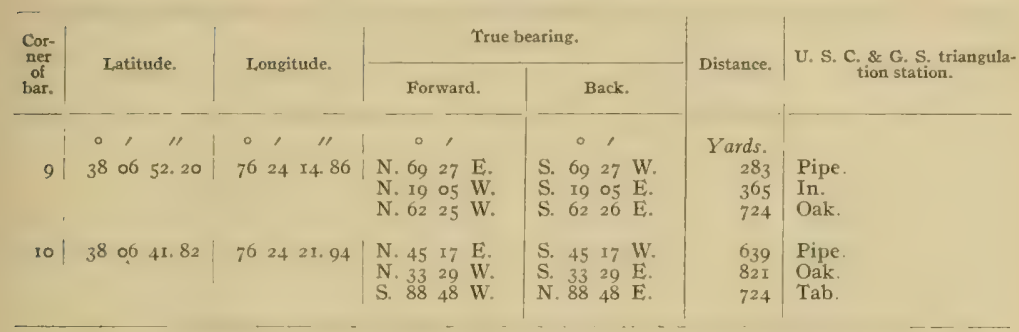

\section{GRAVES.}

(Smith Creek-Chart No. 24.)

\begin{tabular}{|c|c|c|c|c|c|c|}
\hline I & $3^{8}$ o7 02.36 & 762437.22 & $\begin{array}{llll}\text { N. } 29 & 30 & W . \\
\text { S. } & 80 & 5 I & \text { W. } \\
\text { S. } 24 & 07 & \text { W. }\end{array}$ & 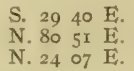 & $\begin{array}{r}5 \times 6 \\
47 \\
776\end{array}$ & $\begin{array}{l}\text { Stung. } \\
\text { Oak. } \\
\text { Tab. }\end{array}$ \\
\hline
\end{tabular}

Thence from corner No. I along the mean low-water line of the shore to corner No. 2, excluding any creek, cove, or inlet less than roo yards in width at its mouth at low tide.

\begin{tabular}{l|lll|lll|}
3 & $3^{8}$ & 97 & 10.60 & 76 & 24 & 45.69 \\
3 & $3^{8}$ & 07 & 15.65 & 76 & 24 & 46.80
\end{tabular}

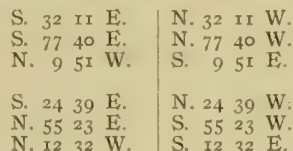

\begin{tabular}{l|l}
337 & Oak. \\
543 & Out. \\
I73 & Stung. \\
& \\
501 & Oak. \\
344 & Jutland. \\
537 & Flat.
\end{tabular}

Thence from corner No. 3 along the mean low-water line of the shore to corner No. 4, excluding any creek, cove, or inlet less than roo yards in width at its mouth at low tide.

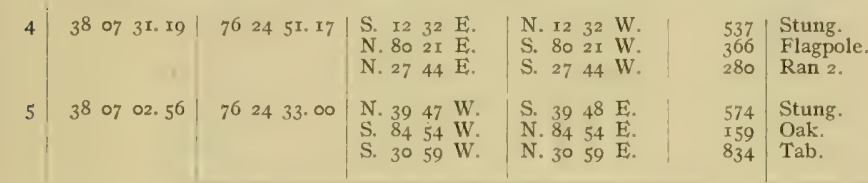

\section{JUTLAND.}

(Smith Creek-Chart No. 24.)

\begin{tabular}{|c|c|c|c|c|c|c|}
\hline I & $3^{8} \circ 0702.61$ & $7^{6} \quad 2429.5^{8}$ & $\begin{array}{llll}\mathrm{S} . & 89 & 53 & \mathrm{E} \\
\mathrm{N} . & 33 & 25 & \mathrm{E} \\
\mathrm{S} . & 86 & 22 & \mathrm{~W}\end{array}$ & $\begin{array}{llll}\text { N. } 89 & 53 & \text { W. } \\
\text { S. } 33 & 25 & \text { W. } \\
\text { N. } 86 & 22 & \text { E. }\end{array}$ & $\begin{array}{l}273 \\
184 \\
251\end{array}$ & $\begin{array}{l}\text { In. } \\
\text { Out, } \\
\text { Oak. }\end{array}$ \\
\hline & $3^{8} \circ 3^{6} .4^{6}$ & $7^{6} 24 \quad 47 \cdot 5^{8}$ & $\begin{array}{llll}\text { S. } 28 \text { I. } & \text { W. } \\
\text { S. } 66 \text { I9 } & \text { E. } \\
\text { N. } 26 \text { I7 } & \text { E. }\end{array}$ & $\begin{array}{llll}\text { N. } 28 & 17 & \mathrm{E} . \\
\text { N. } 66 & 19 & \text { W. } \\
\text { S. } 26 & 17 & \text { W. }\end{array}$ & $\begin{array}{r}203 \\
290 \\
79\end{array}$ & $\begin{array}{l}\text { Flat. } \\
\text { Flagpole. } \\
\text { Ran 2. }\end{array}$ \\
\hline
\end{tabular}


BOUNDARIES OF NATURAL OYSTER BARS-continuEd.

$$
\text { JUTLAND - Continued. }
$$

(Smiths Creek-Chart No. 24.)

\begin{tabular}{|c|c|c|c|c|c|c|c|}
\hline \multirow{2}{*}{$\begin{array}{l}\text { Cor- } \\
\text { ner } \\
\text { of } \\
\text { bar. }\end{array}$} & \multirow{2}{*}{ Latitude. } & \multirow{2}{*}{ Longitude. } & \multicolumn{3}{|c|}{ True bearing. } & \multirow{2}{*}{ Distance. } & \multirow{2}{*}{$\begin{array}{c}\text { U. S. C. \& G. S. triangula- } \\
\text { tion station. }\end{array}$} \\
\hline & & & & Forward. & Back. & & \\
\hline 3 & 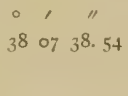 & 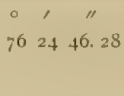 & & $\begin{array}{rll}0 & \\
27 & 44 & \mathrm{~W} \\
\mathrm{I} & \text { OI } \mathrm{W} \\
5 \mathrm{I} & \text { O5 } & \mathrm{E}\end{array}$ & 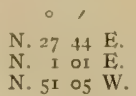 & $\begin{array}{r}\text { Yards. } \\
280 \\
772 \\
296\end{array}$ & $\begin{array}{l}\text { Flat. } \\
\text { Stung. } \\
\text { Flagpole. }\end{array}$ \\
\hline
\end{tabular}

Thence from corner No. 3 along the mean low-water line of the shore to corner No. 4 , excluding any creek, cove, or inlet less than roo yards in width at its mouth at low tide.

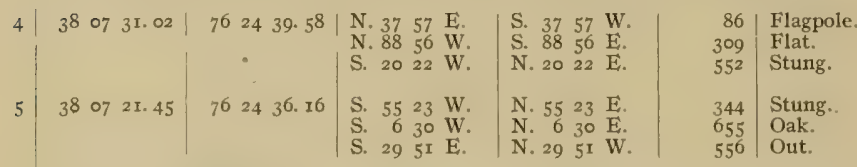

Thence from corner No. 5 along the mean low-water line of the shore to corner No. 6 , excluding any creek, cove, or inlet less than roo yards in width at its mouth at low tide.

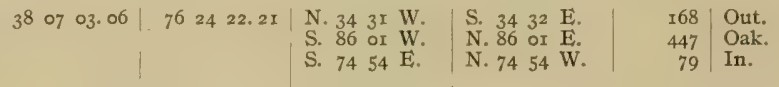

\section{DUNBAR.}

(Smith Creek-Chart No. 24.)

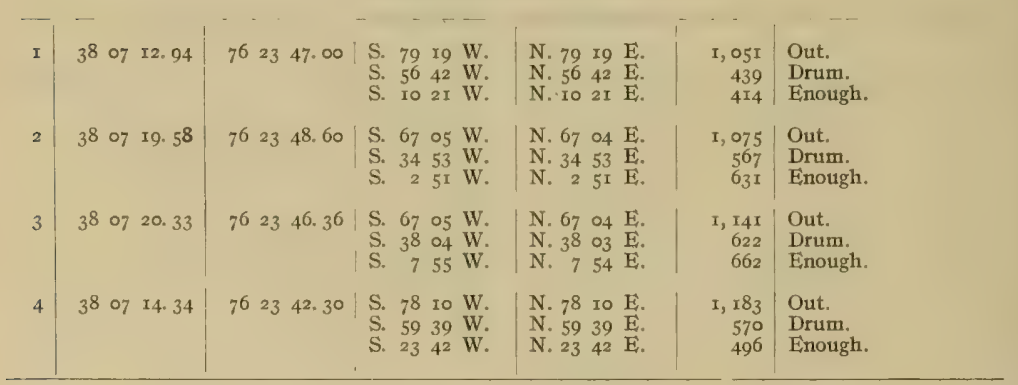


BOUNDARIES OF NATURAL, OYSTER BARS-continued.

SEDGE POINT.

(Lower St. Marys River-Chart No. 24.)

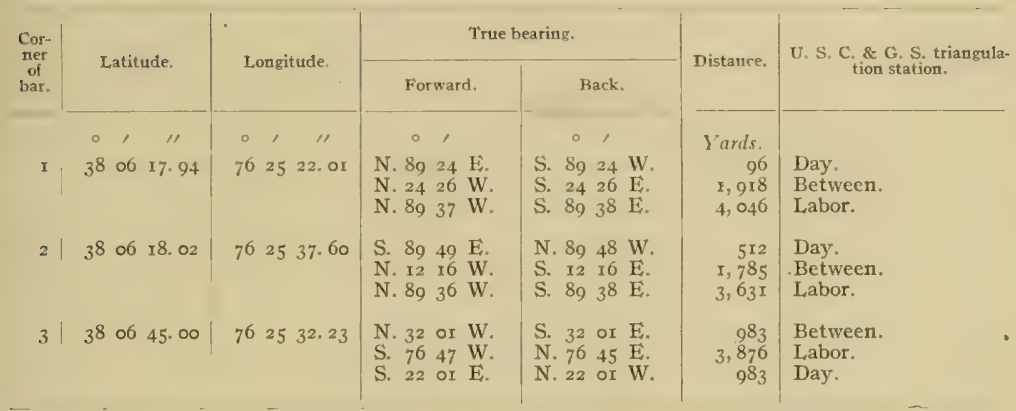

\section{MOUTH OF CREEK.}

(Lower St. Marys River-Chart No. 24.)

\begin{tabular}{|c|c|c|c|c|c|c|}
\hline$I$ & $3^{8} 06 \quad 18.60$ & $\begin{array}{llll}76 & 27 & x 6.76\end{array}$ & $\begin{array}{llll}\text { S. } 89 & 37 & \text { E. } \\
\text { N. } 52 & 43 & \text { E. } \\
\text { N. } 89 & 4 I & \text { W. }\end{array}$ & $\begin{array}{llll}\text { N. } 89 & 36 & \text { W. } \\
\text { S. } & 52 & 44 & \text { W. } \\
\text { S. } & 89 & 42 & \text { E. }\end{array}$ & $\begin{array}{r}3, I 54 \\
2,844 \\
988\end{array}$ & $\begin{array}{l}\text { Day. } \\
\text { Between. } \\
\text { Labor. }\end{array}$ \\
\hline 2 & $3^{8}$ 06 I8. 68 & $\begin{array}{llll}7^{6} & 27 & 27 \cdot 5^{8}\end{array}$ & $\begin{array}{llll}\text { S. } 89 & 36 & \mathrm{E} . \\
\text { N. } & 56 & 00 & \mathrm{E} \\
\text { N. } & 89 & 47 & \text { W. }\end{array}$ & $\begin{array}{llll}\text { N. } 89 & 35 & \text { W. } \\
\text { S. } & 56 & \text { or } & \text { W. } \\
\text { S. } & 89 & 47 & \text { E. }\end{array}$ & $\begin{array}{r}3,44 \mathrm{I} \\
3, \text { O78 } \\
7 \text { OI }\end{array}$ & $\begin{array}{l}\text { Day. } \\
\text { Between. } \\
\text { Labor. }\end{array}$ \\
\hline 3 & 380650.60 & $\begin{array}{llll}76 & 28 & 04.10\end{array}$ & $\begin{array}{llll}\text { S. } & 14 & 17 & \mathrm{E} . \\
\mathrm{N} . & 79 & 38 & \mathrm{E} . \\
\mathrm{N} . & 27 & 13 & \mathrm{~W} .\end{array}$ & $\begin{array}{llll}\text { N. I4 } & \text { I7 } & \text { W. } \\
\text { S. } 79 & 39 & \text { W. } \\
\text { S. } 27 & I_{3} & \text { E. }\end{array}$ & $\begin{array}{l}\text { I, I05 } \\
3,582 \\
\text { I, } 006\end{array}$ & $\begin{array}{l}\text { Labor. } \\
\text { Between. } \\
\text { Smack. }\end{array}$ \\
\hline 4 & $3^{8}$ of II. 80 & 7628 10. 76 & $\begin{array}{llll}\text { N. II } & 4 \mathrm{I} & \mathrm{E} . \\
\mathrm{N} . & 57 & 3 \mathrm{I} & \mathrm{W} \\
\text { S. I4 } & \text { I0 } & \mathrm{E} .\end{array}$ & $\begin{array}{llll}\text { S. II } & 4 I & W . \\
\text { S. } & 57 & 32 & \mathrm{E} . \\
\text { N. } & \text { I4 } & \text { I0 } & \text { W. }\end{array}$ & $\begin{array}{r}970 \\
336 \\
I, 840\end{array}$ & $\begin{array}{l}\text { Cherry. } \\
\text { Smack. } \\
\text { Labor. }\end{array}$ \\
\hline 5 & $\begin{array}{llll}38 & 07 & 04.99\end{array}$ & 762749.02 & $\begin{array}{l}\text { N. } \begin{array}{lll}8 & 00 \\
\text { W. }\end{array} \text {. } 6435 \text { W. } \\
\text { S. } \quad 4 \quad 44 \text { W. }\end{array}$ & $\begin{array}{l}\text { S. } 18 \text { or } \mathrm{E} \text {. } \\
\text { S. } 6435 \text { E. } \\
\text { N. } 444 \text { E. }\end{array}$ & $\begin{array}{r}I, 242 \\
953 \\
I, 564\end{array}$ & $\begin{array}{l}\text { Cherry." } \\
\text { Smack. } \\
\text { Labor. }\end{array}$ \\
\hline
\end{tabular}

\section{CHICKEN COCK.}

(Lower St. Marys River-Chart No. 24.)

\begin{tabular}{|c|c|c|c|c|c|c|}
\hline $\mathbf{I}$ & $3^{8}$ o6 38.30 & $762555 \cdot 4^{6}$ & $\begin{array}{lrrr}\text { S. } & 55 & \text { I4 } & \mathrm{E} . \\
\text { N. } & 5 & \text { I6 } & \mathrm{E} . \\
\text { S. } 78 & 12 & \text { W. }\end{array}$ & 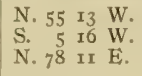 & $\begin{array}{l}\mathrm{I}, 202 \\
\mathrm{I}, 064 \\
3,223\end{array}$ & $\begin{array}{l}\text { Day. } \\
\text { Between. } \\
\text { Labor. }\end{array}$ \\
\hline $\begin{array}{l}2 \\
k \\
k\end{array}$ & $3^{8} 07 \times 18.72$ & $\begin{array}{lll}76 & 26 & 19.44\end{array}$ & $\begin{array}{l}\text { S. } 6737 \mathrm{E} . \\
\text { N. } 228 \mathrm{E} \text {. } \\
\text { S. } \boldsymbol{I}_{5} \mathrm{x}^{2} \mathbf{3} \mathbf{W}:\end{array}$ & $\begin{array}{rrrr}\text { N. } 67 & 36 & \text { W. } \\
\text { S. } 2 & 28 & \text { W. } \\
\text { iN. } 51 & 12 & \text { E. }\end{array}$ & $\begin{array}{r}796 \\
1,899 \\
3,227\end{array}$ & $\begin{array}{l}\text { Between. } \\
\text { Fort. } \\
\text { Labor. }\end{array}$ \\
\hline
\end{tabular}


BOUNDARIES OF NATURAL, OYSTER BARS-continued.

CHICKEN COCK-Continued.

(Lower St. Marys RiverCharl No. 24.)

\begin{tabular}{|c|c|c|c|c|c|c|}
\hline \multirow{2}{*}{$\begin{array}{c}\text { Cor- } \\
\text { ner } \\
\text { of } \\
\text { bar. }\end{array}$} & \multirow{2}{*}{ Latitude. } & \multirow{2}{*}{ Longitude. } & \multicolumn{2}{|c|}{ True bearing. } & \multirow{2}{*}{ Distance. } & \multirow{2}{*}{$\begin{array}{l}\text { U. S. C. \&. G. S. triangula- } \\
\text { tion station. }\end{array}$} \\
\hline & & & Forward. & Back. & & \\
\hline 3 & $\begin{array}{ccc}\circ, 11 \\
3^{8} & 07 & 18.3^{2}\end{array}$ & $\begin{array}{ccc}\circ & \prime \prime \\
76 & 25 & 58.36\end{array}$ & $\begin{array}{lccc} & \circ & \\
\text { N. } & I_{4} & \text { o5 } & \mathrm{E} . \\
\mathrm{S} . & 56 & 52 & \mathrm{~W} \\
\mathrm{~S} . & 3 \mathrm{I} & \text { o7 } & \mathrm{E} .\end{array}$ & \begin{tabular}{lccc} 
& 0 & \multicolumn{1}{c}{} \\
S. & I4 & 05 & W. \\
N. & 56 & $5 \mathrm{I}$ & $\mathrm{E}$. \\
$\mathrm{N}$. & $3 \mathrm{I}$ & 07 & $\mathrm{~W}$.
\end{tabular} & $\begin{array}{r}\text { Yards. } \\
1,970 \\
3,666 \\
339\end{array}$ & $\begin{array}{l}\text { Fort. } \\
\text { Labor. } \\
\text { Between. }\end{array}$ \\
\hline 7 & $3^{8} 0700.00$ & $762545 \cdot 78$ & $\begin{array}{llll}\text { N. } & 26 & 02 & \text { W. } \\
\text { S. } & 67 & 47 & \text { W. } \\
\text { S. } & 27 & \text { I } & \text { E. }\end{array}$ & $\begin{array}{llll}\text { S. } 26 & 02 & \text { E. } \\
\text { N. } 67 & 46 & \text { E. } \\
\text { N. } 27 & \text { I4 } & \text { W. }\end{array}$ & $\begin{array}{r}364 \\
3,686 \\
I, 59.3\end{array}$ & $\begin{array}{l}\text { Between. } \\
\text { Labor. } \\
\text { Day. }\end{array}$ \\
\hline . 5 & $3^{8}$ o6 39.94 & 762545 or & $\begin{array}{llll}\text { N. } 10 & 12 & \text { W. } \\
\text { S. } 78 & 15 & \text { W. } \\
\text { S. } & 43 & 45 & \text { E. }\end{array}$ & $\begin{array}{llll}\text { S. } & 10 & 12 & \text { E. } \\
\text { N. } & 78 & 14 & \text { E. } \\
\text { N. } & 43 & 44 & \text { W. }\end{array}$ & $\begin{array}{l}\mathrm{I}, 023 \\
3,507 \\
\mathrm{I}, 026\end{array}$ & $\begin{array}{l}\text { Between. } \\
\text { Labor. } \\
\text { Day. }\end{array}$ \\
\hline
\end{tabular}

\section{CHERRY.}

(Lower St. Marys River-Chart No. 24.)

\begin{tabular}{|c|c|c|c|c|c|c|}
\hline$x$ & $3^{8} 0706.8 \mathbf{r}$ & $7^{6} \quad 2739 \cdot 46$ & $\begin{array}{llll}\text { N. } 88 & 02 & \text { E. } \\
\text { N. } 29 & 43 & \text { W. } \\
\text { N. } & 72 & 38 & \text { W. }\end{array}$ & $\begin{array}{llll}\text { S. } & 88 & 04 & \text { W. } \\
\text { S. } & 29 & 43 & \text { E. } \\
\text { S. } & 72 & 39 & \text { E. }\end{array}$ & $\begin{array}{l}2,87 x \\
I, 287 \\
x, 170\end{array}$ & $\begin{array}{l}\text { Between. } \\
\text { Cherry. } \\
\text { Smack. }\end{array}$ \\
\hline & $\begin{array}{llll} & 8 & 07 & 23.00\end{array}$ & $\begin{array}{llll}76 & 28 & 15 & 13\end{array}$ & $\begin{array}{llll}\text { N. } 28 & 41 & \mathrm{E} . \\
\text { N. } 77 & 16 & \mathrm{~W} . \\
\text { S. } 40 & 07 & \mathrm{~W} .\end{array}$ & $\begin{array}{llll}\text { S. } & 28 & 41 & \text { W. } \\
\text { S. } & 77 & \text { I } & \text { E. } \\
\text { N. } 40 & 07 & \text { E. }\end{array}$ & $\begin{array}{r}65 I \\
1,413 \\
25^{8}\end{array}$ & $\begin{array}{l}\text { Cherry. } \\
\text { Adams. } \\
\text { Smack. }\end{array}$ \\
\hline & $3^{8}$ o7 39.96 & $\begin{array}{lll}76 & 28 & 03.41\end{array}$ & $\begin{array}{llll}\text { N. } & 45 & 49 & \text { W. } \\
\text { S. } 31 & 53 & \text { W. } \\
\text { S. } & 73 & 48 & \text { E. }\end{array}$ & $\begin{array}{llll}\text { S. } & 45 & 49 & \text { E. } \\
\text { N. } & 31 & 53 & \text { E. } \\
\text { N. } 73 & 47 & \text { W. }\end{array}$ & $\begin{array}{r}\text { I, } 344 \\
906 \\
3,652\end{array}$ & $\begin{array}{l}\text { Goose. } \\
\text { Smack. } \\
\text { Between. }\end{array}$ \\
\hline
\end{tabular}

Thence from comer No. 3 along the mean low-water line of the shore to comer No. 4, excluding any creek, cove, or inlet less than 100 yards in width at its mouth at low tide.
\begin{tabular}{l|lll|lll|llll}
4 & 38 & 07 & 4 I. 20 & 76 & 27 & 49.04 & S. & 46 & 43 & W.
\end{tabular}
N. 4643 E. N. 65 I 33 E
N. 7 I $13 \mathrm{~W}$
$\mathbf{I}, \mathrm{I}_{3} \mid$ Smack.
3, 299 Between

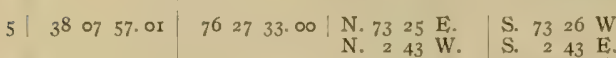
S. $65 \mathrm{I}_{4} \mathrm{~W}$.
2, 7 I9 Fort
S. 4347 W. N. 4347 E.
\begin{tabular}{l|lll|lll|llll}
6 & 38 & 07 & 29.02 & $7^{6}$ & 27 & I9. & 00 & N. I3 I2 W.
\end{tabular}
N. 724 I W.
S. 13 I2 E.
S. $7627 \mathrm{~W}$.
S. $724 \mathrm{I} \mathrm{E}$
N. $7626 \mathrm{E}$.

\begin{tabular}{r|l}
2,129 & Fort. \\
807 & Pond. \\
I, 862 & Smack. \\
& \\
I, 800 & Pond. \\
I, 239 & Cherry. \\
I,709 & Smack.
\end{tabular}


BOUNDARIES OF NATURAL OYSTER BARS-continuEd,

MIDDLEGROUND LUMP.

(Lower St. Marys River-Chart No. 24.)

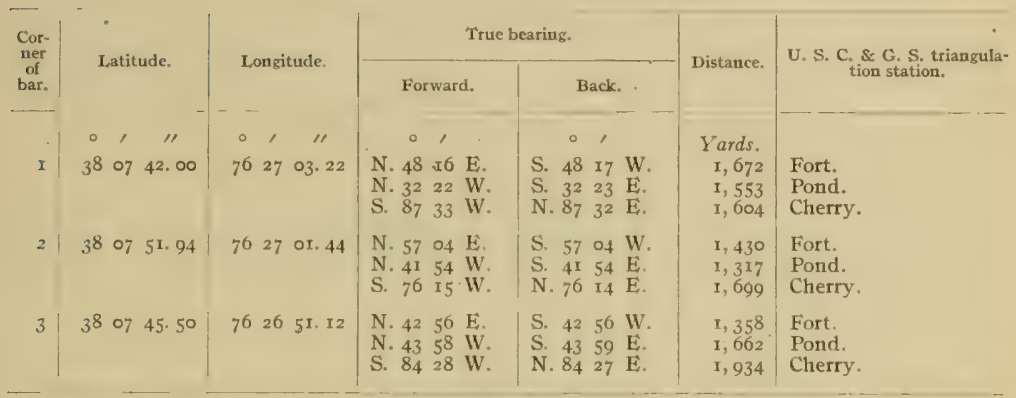

\section{FORT.}

(Lower St. Marys River-Chant No. 24.)

\begin{tabular}{|c|c|c|c|c|c|c|}
\hline I & $3^{8} 07 \quad 36.02$ & $\begin{array}{lll}76 & 25 & 56 . \infty\end{array}$ & $\begin{array}{llll}\text { S. } & 7 & 12 & \text { E. } \\
\text { N. } 87 & 45 & \text { W. } \\
\text { N. } 22 & 26 & \text { W. }\end{array}$ & $\begin{array}{l}\text { N. } \begin{array}{rrl}7 & 12 & \text { W. } \\
\text { S. } 87 & 47 & \text { E. } \\
\text { S. } 22 & 26 & \text { E. }\end{array}\end{array}$ & $\begin{array}{r}893 \\
3,397 \\
1,422\end{array}$ & $\begin{array}{l}\text { Between. } \\
\text { Cherry. } \\
\text { Fort. }\end{array}$ \\
\hline 2 & $3^{8} 0800.00$ & $7^{6} \quad 26 \quad 5^{2} \cdot 5^{2}$ & $\begin{array}{llll}\text { S. } 70 & \text { 19 } & \text { W. } \\
\text { S. } & 43 & 39 & \mathrm{E} . \\
\text { N. } 62 & 17 & \text { E. }\end{array}$ & $\begin{array}{llll}\text { N. } 70 & 18 & \mathrm{E} \\
\text { N. } 43 & 39 & \mathrm{~W} . \\
\text { S. } 62 & 17 & \mathrm{~W} .\end{array}$ & $\begin{array}{l}2,005 \\
2,342 \\
1,087\end{array}$ & $\begin{array}{l}\text { Cherry. } \\
\text { Between. } \\
\text { Fort. }\end{array}$ \\
\hline 3 & $3^{8} 0800.00$ & $\begin{array}{lll}76 & 26 & 13.16\end{array}$ & $\begin{array}{lrrr}\text { N. } & 9 & 36 & \mathrm{~W} . \\
\text { N. } 71 & 54 & \mathrm{~W} . \\
\text { S. } & 18 & 36 & \mathrm{E} .\end{array}$ & $\begin{array}{lrrr}\text { S. } & 9 & 36 & \mathrm{E} . \\
\mathrm{S} . & 71 & 53 & \mathrm{E} \\
\mathrm{N} . & 18 & 36 & \mathrm{~W} .\end{array}$ & $\begin{array}{r}513 \\
2,278 \\
x, 785\end{array}$ & $\begin{array}{l}\text { Fort. } \\
\text { Pond. } \\
\text { Between. }\end{array}$ \\
\hline
\end{tabular}

Thence from corner No. 3 along the mean low-water line of the shore to comer No. 4, excluding any creek, cove, or inlet less than 100 yards in width at its mouth at low tide.
\begin{tabular}{l|l|lll|ll|l}
48 & 38 & 37.98 & 76 & 25 & 54.82 & N. 24 & 42 \\
W.
\end{tabular}
N. $8853 \mathrm{~W}$.
S. $2442 \mathrm{E}$.
I, 373 Fort
S. 8854 E.
\begin{tabular}{l|l} 
1, 373 & Fort. \\
3,426 & Cherry
\end{tabular}
956 Between.

\section{EDMUND}

(Lower St. Marys River-Chart No. 24.)

\begin{tabular}{|c|c|c|c|c|c|c|c|c|c|}
\hline I & $3^{8} 08$ & or, 44 & 76 & 27 & 19. 18 & $\begin{array}{llll}\text { N. } 74 & 4 I & \text { E. } \\
\text { N. } & 3 I & 39 & W . \\
\text { S. } & 58 & 25 & W\end{array}$ & $\begin{array}{llll}\text { S. } 74 & 4 I & \text { W. } \\
\text { S. } & 3 I & 39 & \text { E. } \\
\text { N. } & 5^{8} & 25 & \text { E. }\end{array}$ & $\begin{array}{r}734 \\
774 \\
\text { I, } 382\end{array}$ & $\begin{array}{l}\text { Fort. } \\
\text { Pond. } \\
\text { Cherry. }\end{array}$ \\
\hline 2 & $3^{8} \circ 8$ & 04.62 & 76 & 27 & 32.20 & $\begin{array}{l}\text { N. } 80 \text { 10 } \mathrm{E} . \\
\text { N. } 6 \text { 10 } \mathrm{W} . \\
\text { S. } 45 \text { o0 } \mathrm{W} .\end{array}$ & $\begin{array}{l}\text { S. } 80 \text { II } \text { W. } \\
\text { S. } 6 \text { I0 E. } \\
\text { N. } 44 \text { 59 E. }\end{array}$ & $\begin{array}{r}2,049 \\
555 \\
I, I 73\end{array}$ & $\begin{array}{l}\text { Fort. } \\
\text { Pond. } \\
\text { Cherry. }\end{array}$ \\
\hline 3 & 3808 & 20. 99 & 76 & 27 & $34 \cdot 44$ & $\begin{array}{llll}\text { S. } 48 & 42 & \mathrm{E} . \\
\text { S. } 84 & 28 & \mathrm{E} . \\
\text { N. } & 52 & 55 & \mathrm{E} .\end{array}$ & $\begin{array}{lll}\text { N. } 48 & 41 & \text { W. } \\
\text { N. } 84 & 27 & \text { W. } \\
\text { S. } 52 & 55 & \text { W. }\end{array}$ & $\begin{array}{l}3,64 I \\
2,089 \\
2,252\end{array}$ & $\begin{array}{l}\text { Between. } \\
\text { Fort. } \\
\text { Rod. }\end{array}$ \\
\hline 4 & 3808 & 27.68 & 76 & 27 & 17.64 & $\begin{array}{llll}\text { S. } 63 & 15 & \text { W. } \\
\text { S. } 75 & 17 & \mathrm{E} . \\
\text { N. } 50 & 00 & \mathrm{E} .\end{array}$ & $\begin{array}{l}\mathrm{N} .63 \text { I4 } \mathrm{E} . \\
\mathrm{N} .75 \text { I7 } \mathrm{W} . \\
\text { S. 50 } 00 \mathrm{~W} .\end{array}$ & $\begin{array}{r}50 r \\
I, 687 \\
I, 76 r\end{array}$ & $\begin{array}{l}\text { Pond. } \\
\text { Fort. } \\
\text { Rod. }\end{array}$ \\
\hline
\end{tabular}


BOUNDARIES OF NATURAL, OYSTER BARS-continued.

COAD

(Lower St. Marys River - Chart No. 24.)

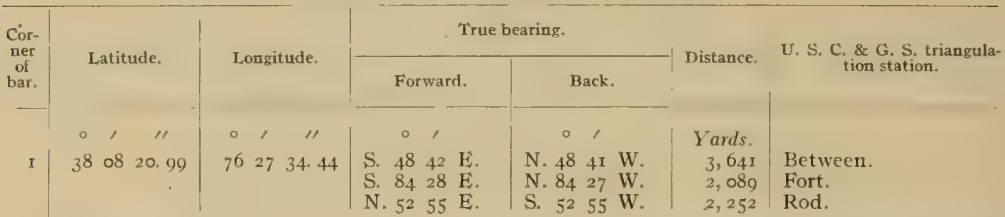

Thence from corner No. I along the mean low-water line of the shore to corner No. 2, excluding any creek, cove, or inlet less than roo yards in width at its mouth at low tide.

\begin{tabular}{|c|c|c|}
\hline $\begin{array}{lll}38 & 08 & 42.80\end{array}$ & $\begin{array}{llll}76 & 27 & 53.82\end{array}$ & $\begin{array}{lll}\text { S. } 7008 & \text { E. } \\
\text { N. } 74 & 54 & \text { E. } \\
\text { N. } 21 & 55 & \text { E. }\end{array}$ \\
\hline $3808 \quad 49.4^{2}$ & $76 \quad 27 \quad 36.62$ & $\begin{array}{lrll}\text { S. } & 3 & 28 & \mathrm{E} \\
\mathrm{N} . & 77 & 49 & \mathrm{E} \\
\mathrm{N} . & 0 & 38 & \mathrm{~W}\end{array}$ \\
\hline
\end{tabular}

N. 70 ० 7 W.

S. $7455 \mathrm{~W}$.

2, 759 Fort.

S. $2155 \mathrm{~W}$.

2, 395

I, 201

Rod.

\begin{tabular}{l|lllllll}
4 & 38 & 08 & 27.68 & 76 & 27 & 17.64
\end{tabular}

N. $038 \mathrm{~W}$.

N. $328 \mathrm{~W}$.

S. $7750 \mathrm{~W}$.

S. $038 \mathrm{E}$.

$\begin{aligned} 960 & \text { Pond. } \\ \text { I, } 897 & \text { Rod. }\end{aligned}$

891 Thompson.

$\mid \begin{array}{llll}\text { S. } & 63 & \text { I } & \text { W. } \\ \text { S. } & 75 & 17 & \text { E. } \\ \text { N. } & 50 & 00 & \text { E. }\end{array}$

N. $63 \quad 14 \mathrm{E}$.

N. 75 I7 W.

S. $5000 \mathrm{~W}$.

$\begin{aligned} 501 & \text { Pond. } \\ x, 687 & \text { Fort. } \\ 1,761 & \text { Rod. }\end{aligned}$

LANGLEY HOLLOW.

(Lower St. Marys River-Chart No. 24.)

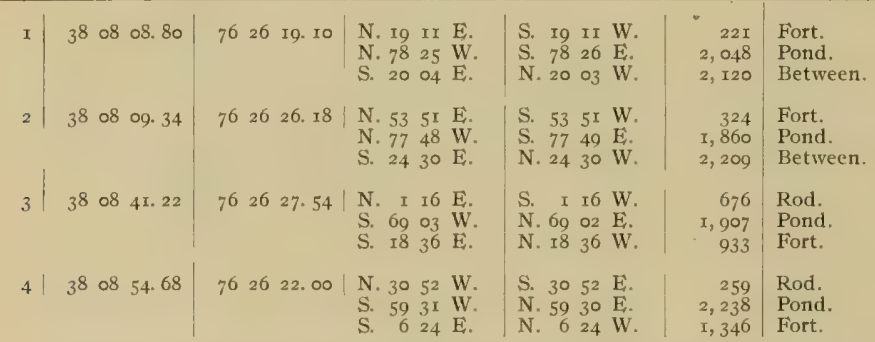

Thence from corner No. 4 along the mean low-water line of the shore to corner No. 5 , excluding any creek, cove, or inlet less than roo yards in width at its mouth at low tide. 
BOUNDARIES OF NATURAL OYSTER BARS-continued.

PRIEST

(Middle St. Marys River-Chart No. 24.)

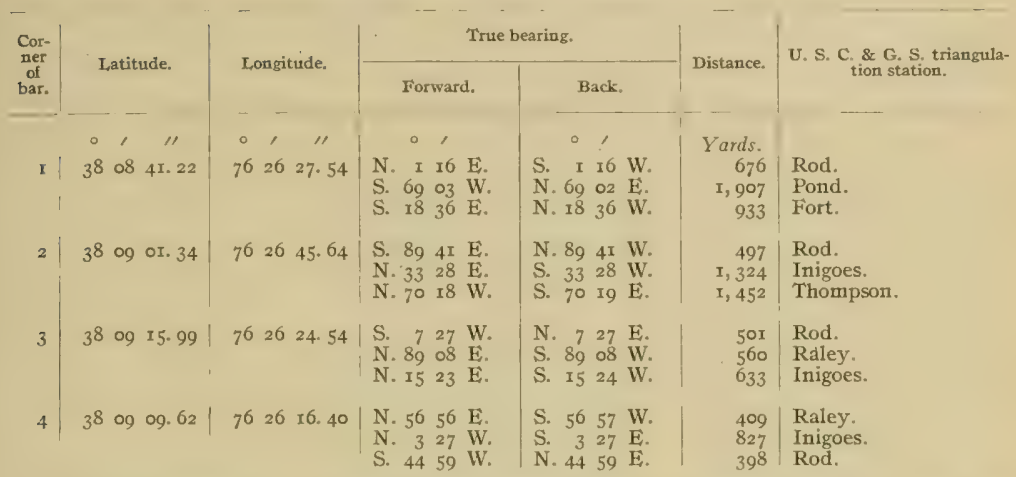

Thence from comer No. 4 along the mean low-water line of the shore to comer No. 5 , excluding any creek, cove, or inlet less than Ioo yards in width at its mouth at low tide.

\begin{tabular}{l|lll|lll}
5 & 380854.68 & 762622.00
\end{tabular}

$\begin{array}{llll}\text { N. } 30 & 52 & W . \\ \text { S. } 59 & 31 & \text { W. } \\ \text { S. } & 6 & 24 & \text { E. }\end{array}$

S. $3052 \mathrm{E}$.

$\begin{array}{llll}\text { N. } & 59 & 30 & \mathrm{E} . \\ \text { N. } & 6 & 24 & \mathrm{~W} .\end{array}$

\begin{tabular}{r|r}
259 & Rod. \\
2,238 & Pond
\end{tabular}

I, 346 Fort.

\section{CARTHAGENA CREEK}

(Middle St. Marys River-Chart No. 24.)

\begin{tabular}{|c|c|c|c|c|c|c|c|c|c|}
\hline$x$ & $3^{8} \circ 9$ & or. 40 & 76 & 27 & 46.92 & $\begin{array}{llll}\text { S. } & 13 & 44 & \text { E. } \\
\text { S. } 89 & 52 & \text { E. } \\
\text { N. } 28 & 31 & \text { E. }\end{array}$ & $\begin{array}{llll}\text { N. } & 13 & 44 & \text { W. } \\
\text { N. } 89 & 52 & \text { W. } \\
\text { S. } & 28 & 31 & \text { W. }\end{array}$ & $\begin{array}{r}\mathrm{I}, 400 \\
2,128 \\
554\end{array}$ & $\begin{array}{l}\text { Pond. } \\
\text { Rod. } \\
\text { Thompson. }\end{array}$ \\
\hline 2 & $3^{8}$ \%9 & II. 20 & 76 & 27 & 53.06 & $\begin{array}{llll}\text { S. } & 16 & 20 & \mathrm{E} \\
\text { S. } 8 \mathrm{r} & 40 & \mathrm{E} \\
\text { N. } 69 & 53 & \mathrm{E}\end{array}$ & $\begin{array}{llll}\text { N. } & \text { I6 } & \text { I9 } & \text { W. } \\
\text { N. } 8 \text { I } & 39 & \text { W. } \\
\text { S. } 69 & 53 & \text { W. }\end{array}$ & $\begin{array}{r}1,764 \\
2,316 \\
456\end{array}$ & $\begin{array}{l}\text { Pond. } \\
\text { Rod. } \\
\text { Thompson. }\end{array}$ \\
\hline 3 & $3^{8} \circ 9$ & I5. 85 & 76 & 27 & 36.98 & 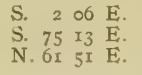 & $\begin{array}{llll}\text { N. } & 2 & 06 & \text { W. } \\
\text { N. } 75 & 12 & \text { W. } \\
\text { S. } 61 & 51 & \text { W. }\end{array}$ & $\begin{array}{l}r, 851 \\
r, 928 \\
r, 188\end{array}$ & $\begin{array}{l}\text { Pond. } \\
\text { Rod. } \\
\text { Grind. }\end{array}$ \\
\hline 4 & $3^{8} \circ 9$ & I 8.75 & 76 & 27 & 32.70 & $\begin{array}{lrrl}\text { S. } & 49 & 22 & \text { W. } \\
\text { S. } & \text { I } & 22 & \text { W. } \\
\text { S. } & 7 \text { I } & 23 & \text { E. }\end{array}$ & $\begin{array}{llll}\text { N. } 49 & 22 & \text { E. } \\
\text { N. } & \text { I } & 22 & \text { E. } \\
\text { N. } 71 & 22 & \text { W. }\end{array}$ & $\begin{array}{r}150 \\
1,948 \\
\text { I, } 847\end{array}$ & $\begin{array}{l}\text { Thompson. } \\
\text { Pond. } \\
\text { Rod. }\end{array}$ \\
\hline 5 & $3^{8} 09$ & $10 . \infty 0$ & 76 & 27 & 22. I8 & $\begin{array}{llll}\text { S. } & 78 & 38 & \text { E. } \\
\text { N. } 40 & 46 & \text { E. } \\
\text { N. } 63 & 25 & \text { W. }\end{array}$ & $\begin{array}{llll}\text { N. } & 78 & 38 & \text { W. } \\
\text { S. } & 40 & 46 & \text { W. } \\
\text { S. } 63 & 25 & \text { E. }\end{array}$ & $\begin{array}{r}x, 499 \\
I, 001 \\
44 \mathrm{I}\end{array}$ & $\begin{array}{l}\text { Rod. } \\
\text { Grind. } \\
\text { Thompson. }\end{array}$ \\
\hline
\end{tabular}




\section{BOUNDARIES OF NATURAL, OYSTER BARS-continued.}

THOMPSON CREEK.

(Middle St. Marys River-Chart No. 24.)

\begin{tabular}{|c|c|c|c|c|c|c|}
\hline \multirow{2}{*}{$\begin{array}{l}\text { Cor- } \\
\text { ner } \\
\text { of } \\
\text { bar. }\end{array}$} & \multirow{2}{*}{ Latitude. } & \multirow{2}{*}{ Longitude. } & \multicolumn{2}{|c|}{ True bearing. } & \multirow{2}{*}{ Distance. } & \multirow{2}{*}{$\begin{array}{l}\text { U. S. C. \& G. S. triangula- } \\
\text { tion station. }\end{array}$} \\
\hline & & & Forward. & Back. & & \\
\hline I & $\begin{array}{ccc}0 & \prime \prime \prime \\
38 & 09 & 10.00\end{array}$ & $\begin{array}{ccc}0 & , \quad 1 \\
76 & 27 & 22.18\end{array}$ & $\begin{array}{cccc} & & \\
\text { S. } & 78 & 38 & \mathrm{E} . \\
\text { N. } 40 & 46 & \mathrm{E} . \\
\text { N. } 63 & 25 & \mathrm{~W}\end{array}$ & $\begin{array}{lccc} & 0 & \\
\text { N. } & 78 & 38 & \text { W. } \\
\text { S. } 40 & 46 & \text { W. } \\
\text { S. } 63 & 25 & \text { E. }\end{array}$ & $\begin{array}{r}\text { Yards. } \\
\text { I, 499 } \\
\text { I, 00I } \\
441\end{array}$ & $\begin{array}{l}\text { Rod. } \\
\text { Grind. } \\
\text { Thompson. }\end{array}$ \\
\hline 2 & 38 ○9 18. 75 & $\begin{array}{llll}76 & 27 & 32.70\end{array}$ & $\begin{array}{rrrr}\text { S. } & 49 & 22 & \text { W. } \\
\text { S. } & \text { I } & 22 & \text { W. } \\
\text { S. } & 71 & 23 & \text { E. }\end{array}$ & $\begin{array}{lrrr}\text { N. } 49 & 22 & \text { E. } \\
\text { N. } & \text { I } & 22 & \text { E. } \\
\text { N. } 7 \text { I } & 22 & \text { W. }\end{array}$ & $\begin{array}{r}\text { I } 50 \\
\text { I, } 948 \\
I, 847\end{array}$ & $\begin{array}{l}\text { Thompson. } \\
\text { Pond. } \\
\text { Rod. }\end{array}$ \\
\hline 3 & $3^{8} \quad 0922.60$ & $76 \quad 27 \quad 28.50$ & $\begin{array}{lrll}\text { S. } & 44 & 46 & \text { W. } \\
\text { S. } & 4 & 2 \mathrm{I} & \mathrm{W} . \\
\text { S. } & 66 & 17 & \mathrm{E} .\end{array}$ & $\begin{array}{l}\text { N. } 4446 \text { E. } \\
\text { N. } 4 \text { 21 } \\
\text { N. } 66 \text { I7. } \\
\text { W. }\end{array}$ & $\begin{array}{r}320 \\
2,083 \\
x, 789\end{array}$ & $\begin{array}{l}\text { Thompson. } \\
\text { Pond. } \\
\text { Rod. }\end{array}$ \\
\hline
\end{tabular}

Thence from corner No. 3 along the mean low-water line of the shore to comer No. 4 , excluding any creek, cove, or inlet less than Ioo yards in width at its mouth at low tide.

\begin{tabular}{|c|c|c|c|c|c|c|}
\hline 4 & $3^{8} \circ 9 \quad 30.77$ & 762700.40 & $\begin{array}{llll}\mathrm{S} . & 41 & 49 & \mathrm{E} . \\
\mathrm{N} . & 51 & 59 & \mathrm{E} . \\
\mathrm{N} . & 23 & 35 & \mathrm{E} .\end{array}$ & $\begin{array}{llll}\text { N. } & 4 \mathrm{I} & 49 & \mathrm{~W} . \\
\text { S. } & 5 \mathrm{I} & 59 & \mathrm{~W} \\
\text { S. } & 23 & 35 & \text { W. }\end{array}$ & $\begin{array}{r}\mathrm{I}, 335 \\
94 \\
\mathrm{I}, 307\end{array}$ & $\begin{array}{l}\text { Rod. } \\
\text { Grind. } \\
\text { Chan. }\end{array}$ \\
\hline & $3^{8} \circ 925.82$ & $76 \quad 26 \quad 45.64$ & $\begin{array}{llll}\text { S. } & 31 & \text { or } & \mathrm{E} \\
\text { N. } & 69 & \text { O3 } & \text { E. } \\
\text { N. } & 54 & 53 & \text { W. }\end{array}$ & $\begin{array}{llll}\text { N. } 3 \text { I } & \text { or } & \text { W. } \\
\text { S. } 69 & \text { o3 } & \text { W. } \\
\text { S. } & 54 & 53 & \text { E. }\end{array}$ & $\begin{array}{l}965 \\
782 \\
389\end{array}$ & $\begin{array}{l}\text { Rod. } \\
\text { Inigoes. } \\
\text { Grind. }\end{array}$ \\
\hline & $3^{8} \circ 9$ I8. 86 & $\begin{array}{llll}76 & 26 & 55.87\end{array}$ & $\begin{array}{lrrr}\text { S. } & 52 & 2 \mathrm{I} & \mathrm{E} . \\
\mathrm{N} . & 62 & 52 & \mathrm{E} . \\
\mathrm{N} . & 5 & 50 & \mathrm{~W} .\end{array}$ & 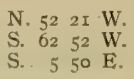 & $\begin{array}{r}972 \\
\mathrm{I}, 126 \\
46 \mathrm{x}\end{array}$ & $\begin{array}{l}\text { Rod. } \\
\text { Inigoes. } \\
\text { Grind. }\end{array}$ \\
\hline
\end{tabular}

\section{RALEYS SHORE,}

(Entrance to St. Inigoes Creek-Chart No, 24.)

\begin{tabular}{|c|c|c|c|c|c|c|}
\hline I & $3^{8} \circ 9 \circ 9.62$ & $7626 \times 6.40$ & $\begin{array}{lrrr}\text { N. } 56 & 56 & \mathrm{E} . \\
\text { N. } & 3 & 27 & \mathrm{~W} \\
\text { S. } & 44 & 59 & \mathrm{WV}\end{array}$ & $\begin{array}{lrrr}\text { S. } & 56 & 57 & \text { W. } \\
\text { S. } & 3 & 27 & \text { E. } \\
\text { N. } 44 & 59 & \text { E. }\end{array}$ & $\begin{array}{l}409 \\
827 \\
398\end{array}$ & $\begin{array}{l}\text { Raley. } \\
\text { Inigoes. } \\
\text { Rod. }\end{array}$ \\
\hline 2 & $3^{8} \circ 9 \quad 15.99$ & $\begin{array}{llll}76 & 26 & 24.54\end{array}$ & $\begin{array}{llll}\text { S. } & 7 & 27 & \text { W. } \\
\text { N. } 89 & 08 & \text { E. } \\
\text { N. } 15 & 23 & \text { E. }\end{array}$ & $\begin{array}{lrrr}\text { N. } & 7 & 27 & \mathrm{E} \\
\text { S. } & 89 & 08 & \mathrm{~W} \\
\text { S. } & 15 & 24 & \mathrm{~W}\end{array}$ & $\begin{array}{l}501 \\
560 \\
633\end{array}$ & $\begin{array}{l}\text { Rod. } \\
\text { Raley. } \\
\text { Inigoes. }\end{array}$ \\
\hline 3 & $3^{8} \circ 926.59$ & $7^{6} \quad 26$ og. 26 & $\begin{array}{llll}\text { S. } & 23 & 39 & \mathrm{E} . \\
\mathrm{N} . & 52 & 44 & \mathrm{E} \\
\mathrm{N} . & 43 & 26 & \mathrm{~W} .\end{array}$ & $\begin{array}{llll}\text { N. } 23 & 39 & \text { W. } \\
\text { S. } & 52 & 44 & \text { W. } \\
\text { S. } & 43 & 26 & \text { E. }\end{array}$ & $\begin{array}{l}380 \\
583 \\
348\end{array}$ & $\begin{array}{l}\text { Raley. } \\
\text { Cottage. } \\
\text { Inigoes. }\end{array}$ \\
\hline 4 & $3^{8} \circ 918.62$ & $\begin{array}{lll}76 & 25 & 59.00\end{array}$ & $\begin{array}{llll}\text { N. } 47 & 12 & \text { E. } \\
\text { N. } & 44 & 28 & \text { W. } \\
\text { S. } & 56 & 18 & \text { W. }\end{array}$ & $\begin{array}{llll}\text { S. } & 47 & \text { I2 } & \text { W. } \\
\text { S. } & 44 & 28 & \mathrm{E} . \\
\text { N. } & 56 & 18 & \mathrm{E} .\end{array}$ & $\begin{array}{l}576 \\
730 \\
144\end{array}$ & $\begin{array}{l}\text { Church. } \\
\text { Inigoes. } \\
\text { Raley. }\end{array}$ \\
\hline
\end{tabular}

Thence from comer No, 4 along the mean low-water line of the shore to comer No. 1 , excluding any creek, cove, or inlet less than roo yards in width at its mouth at low tide. 


\section{BOUNDARIES OF NATURAL OYSTER BARS-continued.}

\section{KENNEDY.}

(St. Inigoes Creek-Chart No. 24.)

\begin{tabular}{|c|c|c|c|c|c|c|}
\hline \multirow{2}{*}{$\begin{array}{l}\text { Cor- } \\
\text { ner } \\
\text { of } \\
\text { bar. }\end{array}$} & \multirow{2}{*}{ Lratitude. } & \multirow{2}{*}{ Longitude. } & \multicolumn{2}{|c|}{ True bearing. } & \multirow{2}{*}{ Distance. } & \multirow{2}{*}{$\begin{array}{c}\text { U. S. C. \& G. S. triangula- } \\
\text { tion station. }\end{array}$} \\
\hline & & & Forward. & Back. & & \\
\hline$I$ & $\begin{array}{ccc}0 & \prime \prime \\
3^{8} \text { og } & 26.00\end{array}$ & $\begin{array}{ccc}0 & \prime & \prime \prime \\
76 & 26 & 04.72\end{array}$ & $\begin{array}{lrrr} & \\
\text { S. } & 5 & 33 & \mathrm{E} \\
\text { N. } & 42 & 36 & \mathrm{E} \\
\text { N. } & 52 & 49 & \text { W. }\end{array}$ & $\begin{array}{lrrr} & 0 & \\
\text { N. } & 5 & 33 & \text { W. } \\
\text { S. } & 42 & 36 & \text { W. } \\
\text { S. } & 52 & 50 & \mathrm{E} .\end{array}$ & $\begin{array}{r}\text { Yards. } \\
330 \\
506 \\
45^{I}\end{array}$ & $\begin{array}{l}\text { Raley. } \\
\text { Cottage. } \\
\text { Inigoes. }\end{array}$ \\
\hline 2 & $3^{8} \circ 935 \cdot 26$ & 7626 II. 26 & $\begin{array}{llll}\text { S. } & 78 & 00 & \mathrm{~W} . \\
\text { S. } & 17 & 49 & \mathrm{E} \\
\mathrm{N} . & 83 & 20 & \mathrm{E}\end{array}$ & $\begin{array}{llll}\text { N. } 78 & 00 & \mathrm{E} \\
\text { N. } & 17 & 49 & \mathrm{~W} \\
\text { S. } 83 & 21 & \text { W. }\end{array}$ & $\begin{array}{l}189 \\
673 \\
520\end{array}$ & $\begin{array}{l}\text { Inigoes. } \\
\text { Raley. } \\
\text { Cottage. }\end{array}$ \\
\hline
\end{tabular}

Thence from corner No. 2 along the mean low-water line of the shore to corner No. 3 , excluding any creek, cove, or inlet less than roo yards in width at its mouth at low tide.

3

4
$38 \circ 95 \cdot 40|762605.82|$

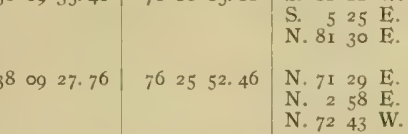

JONES.

(St. Inigoes Creek-Chart No. 24.)

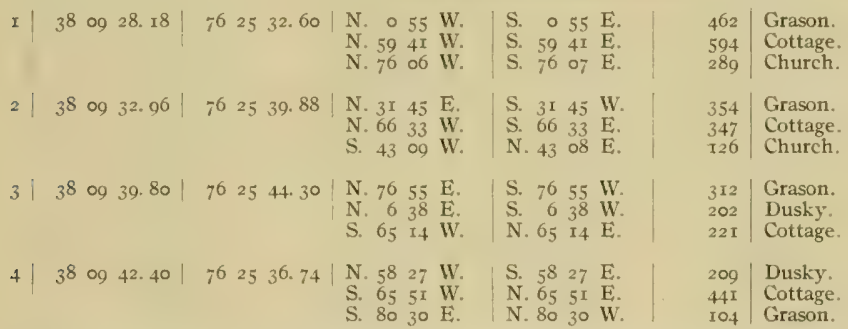

Thence from carner No. 4 along the mean low-water line of the shore to corner No. I, excluding any creek, cove, or inlet less than roo yards in width at its mouth at low tide. 
BOUNDARIES OF NATURAL OYSTER BARS-continued. ST. INIGOES NORTH.

(Si. Inigoes Creek-Chart No. 24.)

\begin{tabular}{|c|c|c|c|c|c|c|}
\hline \multirow{2}{*}{$\begin{array}{l}\text { Cor. } \\
\text { ner } \\
\text { of } \\
\text { bar. }\end{array}$} & \multirow{2}{*}{ Latitude. } & \multirow{2}{*}{ Longitude. } & \multicolumn{2}{|c|}{ True bearing. } & \multirow{2}{*}{ Distance. } & \multirow{2}{*}{$\begin{array}{l}\text { U. S. C. \& G. S. triangula- } \\
\text { tion station. }\end{array}$} \\
\hline & & & Forward. & Back. & & \\
\hline I & $\begin{array}{ccc}\circ & \prime \prime \\
38 & \circ 9 & 54.66\end{array}$ & $\begin{array}{ccc}0 & \prime \prime \\
76 & 25 & 27.3^{8}\end{array}$ & $\begin{array}{lccc} & 0 & \\
\text { S. } & 37 & 57 & \text { E. } \\
\text { N. } & 58 & 04 & \text { E. } \\
\text { S. } & 87 & 54 & \text { W. }\end{array}$ & \begin{tabular}{lccc} 
& \multicolumn{1}{c}{,} \\
N. 37 & 57 & W. \\
S. & 58 & o4 & W. \\
N. 87 & 54 & E.
\end{tabular} & $\begin{array}{r}\text { Yards. } \\
380 \\
397 \\
294\end{array}$ & $\begin{array}{l}\text { Smoke. } \\
\text { Sleep. } \\
\text { Rock. }\end{array}$ \\
\hline 2 & $3^{8}$ ro 03.16 & $\begin{array}{lll}76 & 25 & 29 \cdot 70\end{array}$ & $\begin{array}{llll}\text { S. } & 37 & 59 & \text { W. } \\
\text { S. } & 26 & 47 & \text { E. } \\
\text { S. } & 79 & 07 & \text { E. }\end{array}$ & 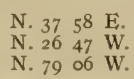 & $\begin{array}{l}377 \\
656 \\
406\end{array}$ & $\begin{array}{l}\text { Rock. } \\
\text { Smoke. } \\
\text { Sleep. }\end{array}$ \\
\hline
\end{tabular}

Thence from comer No. 2 along the mean low-water line of the shore to corner No. 3 , excluding any creek, cove, or inlet less than roo yards in width at its mouth at low tide.

\begin{tabular}{llll|llll|llll}
3 & 38 & 10 & 00.89 & 76 & 25 & 14.72 & S. 70 & 42 & $\mathrm{~W}$. \\
S. II & 24 & $\mathrm{~W}$
\end{tabular}

S. $3029 \mathrm{E}$.

N. $7042 \mathrm{E}$

N. II $24 \mathrm{E}$.

\begin{tabular}{l|llll|llll|lll}
4 & 809 & 58.16 & 76 & 25 & I2. & 42 & N. 33 & 38 & W. \\
S. 21 & 25 & W.
\end{tabular}

\begin{tabular}{l|llll|llll|lll}
4 & 809 & 58.16 & 76 & 25 & I2. & 42 & N. 33 & 38 & W. \\
S. 21 & 25 & W.
\end{tabular}

N. $3029 \mathrm{~W}$.

S. $3338 \mathrm{E}$.

N. $2125 \mathrm{E}$

S. $293 \mathrm{I} \mathrm{E}$. N. $293 \mathrm{I} \mathrm{W}$.

\begin{tabular}{l|l}
668 & Rock. \\
521 & Smoke. \\
445 & Chestnut. \\
& \\
I1 & Sleep. \\
449 & Smoke. \\
335 & Chestnut.
\end{tabular}

ST. INIGOES SOUTH.

(St. Inigoes Creek-Chart No. 24.)

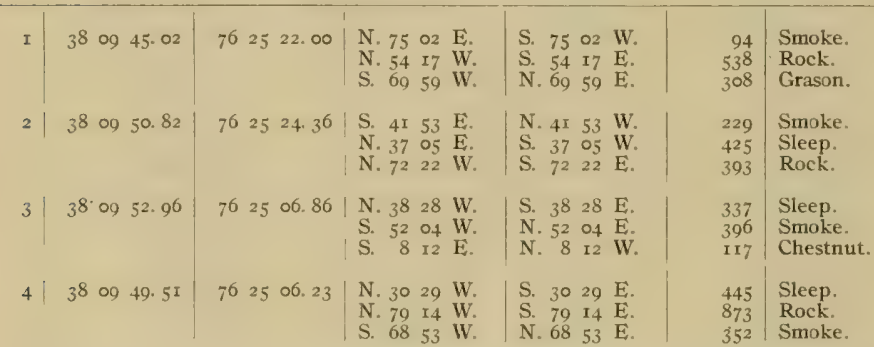

Thence from corner No. 4 along the mean low-water line of the shore to corner No. I, excluding any creek, cove, or inlet less than roo yards in width at its mouth at low tide. 
BOUNDARIES OF NATURAL OYSTER BARS-continued.

COPPAGE.

(Middle St. Marys River-Chart No. 24.)

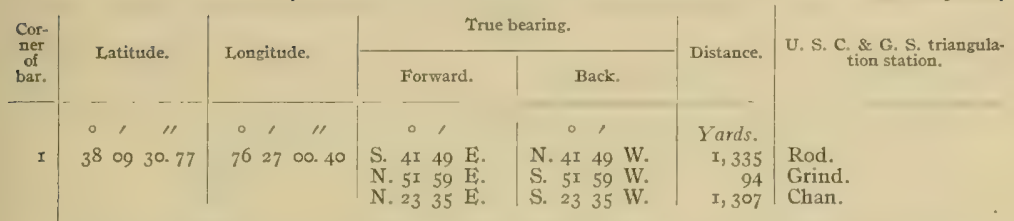

Thence from corner No. I along the mean low-water line of the shore to corner No.2, excluding any creek, cove, or inlet less than roo yards in width at its mouth at low tide.

$3^{8} \circ 4^{8}$. I

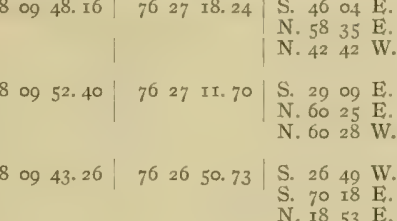

N. 46 o4 W.

S. $5836 \mathrm{~W}$.

S. $4243 \mathrm{E}$.

N. 29 og W.

S. $6026 \mathrm{~W}$.

S. $6028 \mathrm{E}$.

N. $2649 \mathrm{E}$.

N. $7017 \mathrm{~W}$.

S. I8 $53 \mathrm{~W}$.

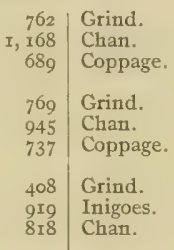

\section{COOPER CREEK.}

(Middle St. Marys River-Chart No. 24.)

\begin{tabular}{|c|c|c|c|c|c|c|}
\hline I & $38 \circ 9 \quad 48$. I6 & $\begin{array}{llll}76 & 27 & 18.24\end{array}$ & $\begin{array}{llll}\text { S. } & 46 & 04 & \mathrm{E} . \\
\text { N. } & 58 & 35 & \mathrm{E} . \\
\text { N. } & 42 & 42 & \mathrm{~W}\end{array}$ & $\begin{array}{llll}\text { N. } & 46 & 04 & \text { W. } \\
\text { S. } & 58 & 36 & \text { W. } \\
\text { S. } & 42 & 43 & \text { E. }\end{array}$ & $\begin{array}{r}762 \\
\text { I, } 168 \\
689\end{array}$ & $\begin{array}{l}\text { Grind. } \\
\text { Chan. } \\
\text { Coppage }\end{array}$ \\
\hline
\end{tabular}

Thence from corner No. I along the mean low-water line of the shore to comer No.2, excluding any creek, cove, or inlet less than 100 yards in width at its mouth at low tide.
$2 \mid 3^{8}$ 10 $06.00|762735.60|$ S. 3 12 W.

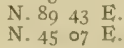
N. 3 I2 E.
S. $8944 \mathrm{~W}$.
95 Coppage.
S. $4507 \mathrm{~W}$.
I, 459 Chan.
\begin{tabular}{lll|llllll}
3 & 38 & 10 06.98 & 76 & 27 & 31.40 & S. 42 & 26 & W.
\end{tabular}
N. 4226 E.
N. $8853 \mathrm{~W}$.
S. $4209 \mathrm{WV}$.
I, I 7 I
Bello.
N. 42 o8 E.
S. $7746 \mathrm{~W}$.
I74 Coppage.
I, 348 Chan.
$4 ! 3^{8} \circ 95^{8.54}\left|7^{6} 2725.5^{8}\right|$ N. 7745 E. $\begin{array}{ll}\text { N. } 27 & 35 \mathrm{E} \text {. } \\ \text { N. } 60 & 06 \mathrm{~W} \text {. }\end{array}$
S. $2735 \mathrm{~W}$.
S. $6006 \mathrm{E}$.
I, o7 I Bello.

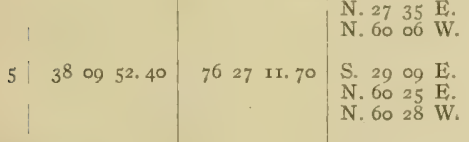
N. 29 og W.
S. $6026 \mathrm{~W}$.
S. $6028 \mathrm{E}$.
I, 220 Chan.
I, 2 I6 Bello.
314 Coppage.
769 Grind.
945 Chan.
737 Coppage.

$2606-I I-I I$ 
BOUNDARIES OF NATURAL OYSTER BARS- continued.

\section{ROSECROFT HOLLOW,}

(Middle St. Marys River-Chart No. 24.)

\begin{tabular}{|c|c|c|c|c|c|c|}
\hline \multirow{3}{*}{$\begin{array}{c}\text { Cor- } \\
\text { ner } \\
\text { of } \\
\text { bar. }\end{array}$} & \multirow{3}{*}{ Latitude. } & & \multirow{3}{*}{ Distance. } & \multirow{3}{*}{$\begin{array}{l}\text { U. S. C. \& G. S. triangula } \\
\text { tion station. }\end{array}$} \\
\hline & & & Tru & earing. & & \\
\hline & & & Forward. & Back. & & \\
\hline I & $\begin{array}{ccc}\circ & , & \prime \prime \\
3^{8} & \circ 9 & 29.88\end{array}$ & $\begin{array}{ccc}0 & 1 \\
76 & 26 & 25.10\end{array}$ & $\begin{array}{lccc} & 0 & \\
\text { N. } 84 & x_{3} & \text { W. } \\
\text { S. } & 5 \text { I } & 20 & \mathrm{E} \\
\text { N. } & 52 \text { II } & \text { E. }\end{array}$ & $\begin{array}{lccc} & 0 & \\
\text { S. } & 84 & \text { I4 } & \text { E. } \\
\text { N. } & 5 \text { I } & \text { I9 } & \text { W. } \\
\text { S. } & 52 & \text { II } & \text { W. }\end{array}$ & $\begin{array}{r}\text { Yards. } \\
870 \\
736 \\
232\end{array}$ & $\begin{array}{l}\text { Grind. } \\
\text { Raley. } \\
\text { Inigoes. }\end{array}$ \\
\hline 2 & $3^{8} \circ 953.02$ & $76 \quad 26 \quad 32.20$ & 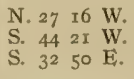 & $\begin{array}{llll}\text { S. } 27 & \text { I6 } & \mathrm{E} \\
\text { N. } & 44 & 21 & \mathrm{E} \\
\text { N. } & 32 & 50 & \text { W. }\end{array}$ & $\begin{array}{l}501 \\
969 \\
573\end{array}$ & $\begin{array}{l}\text { Chan. } \\
\text { Grind. } \\
\text { Kennedy. }\end{array}$ \\
\hline 3 & $\begin{array}{llll}3^{8} & \text { 10 } & 7^{8}\end{array}$ & $\begin{array}{lll}76 & 26 & 45.85\end{array}$ & $\begin{array}{llll}\text { S. } & 36 & 29 & \mathrm{E} . \\
\text { N. } 83 & 50 & \mathrm{E} . \\
\text { N. } & 30 & 39 & \mathbf{W}\end{array}$ & $\begin{array}{llll}\text { N. } & 36 & 28 & \text { W. } \\
\text { S. } 83 & 50 & \text { W. } \\
\text { S. } & 30 & 39 & \text { E. }\end{array}$ & $\begin{array}{r}x, 134 \\
136 \\
970\end{array}$ & $\begin{array}{l}\text { Kennedy. } \\
\text { Chan. } \\
\text { Bello. }\end{array}$ \\
\hline 4 & $3^{8}$ 10 06.21 & $\begin{array}{lll}76 & 26 & 40.81\end{array}$ & $\begin{array}{llll}\text { N. } 37 & 29 & \text { W. } \\
\text { S. } 21 & 30 & \text { W. } \\
\text { S. } 30 & \text { I } 4 & \text { E. }\end{array}$ & $\begin{array}{llll}\text { S. } 37 & 29 & \mathrm{E} . \\
\text { N. } 21 & 30 & \mathrm{E} \\
\text { N. } & 30 & \text { I4 } & \text { W. }\end{array}$ & $\begin{array}{l}x, 032 \\
x, 223 \\
x, 072\end{array}$ & $\begin{array}{l}\text { Bello. } \\
\text { Grind. } \\
\text { Kennedy. }\end{array}$ \\
\hline
\end{tabular}

Thence from comer No. 4 along the mean low-water line of the shore to corner No. 5, excluding any creek, cove, or inlet less than roo yards in width at its mouth at low tide.

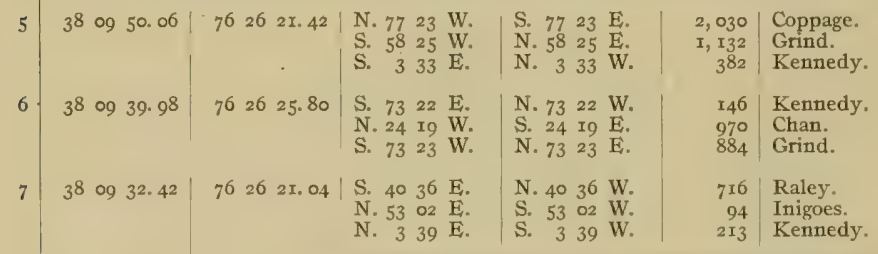

\section{GRAVELLY RUN.}

(Middle St. Marys River-Chart No. 24.)

\begin{tabular}{|c|c|c|c|c|c|c|}
\hline I & $3^{8}$ Io $05.7^{8}$ & $76 \quad 26 \quad 45 \cdot 85$ & $\begin{array}{llll}\text { S. } 36 & 29 & \mathrm{E} . \\
\text { N. } 83 & 50 & \mathrm{E} . \\
\text { N. } & 30 & 39 & \mathrm{~W}\end{array}$ & $\begin{array}{llll}\text { N. } & 36 & 28 & \mathrm{~W} . \\
\text { S. } 83 & 50 & \mathrm{~W} . \\
\text { S. } & 30 & 39 & \mathrm{E} .\end{array}$ & $\begin{array}{r}\mathrm{I}, \mathbf{I} 34 \\
136 \\
970\end{array}$ & $\begin{array}{l}\text { Kennedy. } \\
\text { Chan. } \\
\text { Bello. }\end{array}$ \\
\hline 2 & $3^{8}$ I0 28.46 & $76 \quad 26 \quad 34.00$ & $\begin{array}{llll}\text { N. } 85 & \text { or } & \text { W. } \\
\text { S. } & 13 & 35 & W . \\
\text { S. } & 52 & \text { or } & \text { E. }\end{array}$ & $\begin{array}{llll}\text { S. } 85 \text { o6 } & \text { E. } \\
\text { N. I } & 35 & \text { E. } \\
\text { N. } & 52 & \text { or } & \text { W. }\end{array}$ & $\begin{array}{l}812 \\
772 \\
233\end{array}$ & $\begin{array}{l}\text { Bello. } \\
\text { Chan. } \\
\text { Gravel. }\end{array}$ \\
\hline 3 & $3^{8}$ I0 $3^{8} .22$ & $\begin{array}{lll}76 & 26 & 09.08\end{array}$ & $\begin{array}{llll}\text { N. } & 12 & 06 & \text { E. } \\
\text { N. } & 61 & 06 & \text { W. } \\
\text { S. } & 45 & 24 & \text { W. }\end{array}$ & $\begin{array}{llll}\text { S. } & 12 \text { of } & \text { W. } \\
\text { S. } & 6 \mathrm{r} & 06 & \mathrm{E} \\
\text { N. } & 45 & 24 & \mathrm{E}\end{array}$ & $\begin{array}{r}544 \\
\mathrm{r}, 256 \\
674\end{array}$ & $\begin{array}{l}\text { Brome. } \\
\text { McKay. } \\
\text { Gravel. }\end{array}$ \\
\hline 4 & $3^{8}$ 10 59. I9 & $76 \quad 26$ og. 28 & $\begin{array}{llll}\text { S. } & 34 & 26 & \mathrm{E} . \\
\text { N. I } & 45 & \mathrm{~W} . \\
\text { N. } & 69 & \text { II } & \mathrm{W} .\end{array}$ & 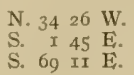 & $\begin{array}{l}211 \\
542 \\
817\end{array}$ & $\begin{array}{l}\text { Brome. } \\
\text { Calvert Monument. } \\
\text { Deep. }\end{array}$ \\
\hline
\end{tabular}


BOUNDARIES OF NATURAL OYSTER BARS- continued.

GRAVELLY RUN-Continued.

(Middle St. Marys River-Chart No. 24.)

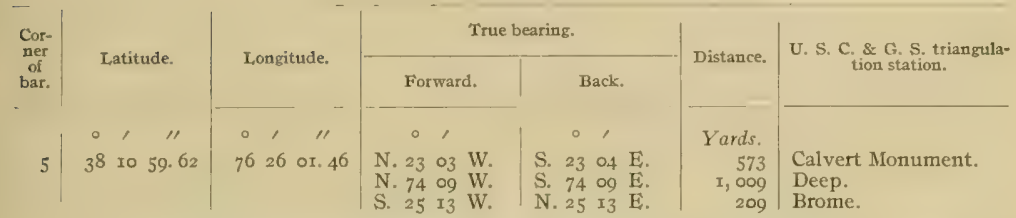

Thence from corner No. 5 along the mean low-water line of the shore to comer No, 6, excluding any creek, cove, or inlet less than Ioo yards in width at its mouth at low tide.

WEST ST. MARYS.

(Middle St. Marys River-Chart No. 24.)

\begin{tabular}{l|ll|lll|} 
& 38 II 07.80 & 76 & 26 & 37.96
\end{tabular}
S. $4022 \mathrm{~W}$.
S. 62 I5 E.
N. 402 I E.
N. 62 I5 W.
\begin{tabular}{l|l}
$5^{12}$ & McKay.
\end{tabular}
N. 7 I 22 E. S. 7 I $23 \mathrm{~W}$
997 Brome.
788 Calvert Monument.

Thence from corner No. I along the mean low-water line of the shore to corner No. 2, excluding any creek, cove, or inlet less than Ioo yards in width at its mouth at low tide.

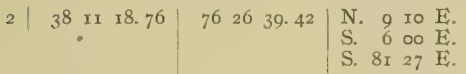
S. 9 10 W
20 | Pagan.
N. $600 \mathrm{~W}$
N. 8127 W

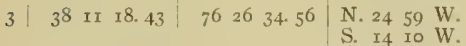
S. $2459 \mathrm{E}$.
N. I4 I0 E,
S. $2924 \mathrm{~W}$.
N. $2924 \mathrm{E}$.
$4 \mid \cdot 38$ II $07.98 \mid 762633.60$
N. I2 2 I W.
S. $8700 \mathrm{~W}$.
S. $I 22 I \mathrm{E}$.
N. $8700 \mathrm{E}$.
372 Deep.
795 Calvert Monument.
S. $4828 \mathrm{~W}$.
N. 4828 E.

\begin{tabular}{l|l}
231 & Pagan. \\
370 & Deep. \\
862 & McKay. \\
& \\
575 & Pagan. \\
116 & Deep. \\
597 & McKay.
\end{tabular}

\section{SEMINARY}

(Upper St. Marys River-Chart No. 24.)

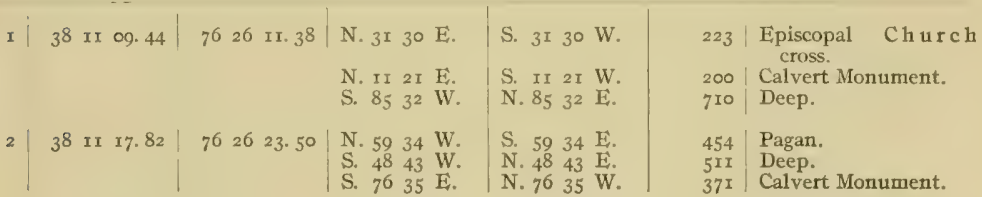


BOUNDARIES OF NATURAL OYSTER BARS-continued.

SEMINARY-Continued.

(Upper St. Marys River-Chart No. 24.)

\begin{tabular}{|c|c|c|c|c|c|c|}
\hline \multirow{2}{*}{$\begin{array}{c}\text { Cor- } \\
\text { ner } \\
\text { of } \\
\text { bar. }\end{array}$} & \multirow{2}{*}{ Latitude. } & \multirow{2}{*}{ Longitude. } & \multicolumn{2}{|c|}{ True bearing. } & \multirow{2}{*}{ Distance. } & \multirow{2}{*}{$\begin{array}{l}\text { U. S. C. \& G. S. triangula- } \\
\text { tion station. }\end{array}$} \\
\hline & & & Forward. & Back. & & \\
\hline 3 & $\begin{array}{ccc}\circ & \prime \prime \\
3^{8} & \text { II } & 25 \times 5^{6}\end{array}$ & $\begin{array}{ccc}0 & 1 & \prime \prime \\
76 & 26 & 03.82\end{array}$ & $\begin{array}{lccc} & 0 & \\
\text { N. } & 34 & 40 & \mathrm{E} . \\
\text { S. } & 88 & 02 & \mathrm{~W} . \\
\text { S. } & 24 & 59 & \mathrm{~W} .\end{array}$ & $\begin{array}{lccc} & 0 & \\
\text { S. } & 34 & 40 & \text { W. } \\
\text { N. } & 88 & \text { 02 } & \text { E. } \\
\text { N. } 24 & 59 & \text { E. }\end{array}$ & $\begin{array}{r}\text { Yards. } \\
744 \\
9 \mathrm{r} 5 \\
383\end{array}$ & $\begin{array}{l}\text { Bend. } \\
\text { Pagan. } \\
\text { Calvert Monument. }\end{array}$ \\
\hline 4 & $3^{8} \times 1 \quad 20.60$ & $\begin{array}{lll}76 & 26 & 00.64\end{array}$ & $\begin{array}{llll}\text { N. } 23 & 28 & \mathrm{E} . \\
\text { N. } 82 & \text { I5 } & \text { W. } \\
\text { S. } & 53 & 5 \mathrm{r} & \mathrm{W} .\end{array}$ & $\begin{array}{llll}\text { S. } & 23 & 29 & \text { W. } \\
\text { S. } 82 & \text { I4 } & \text { E. } \\
\text { N. } & 53 & 51 & \text { E. }\end{array}$ & $\begin{array}{r}849 \\
\mathbf{x}, 009 \\
305\end{array}$ & $\begin{array}{l}\text { Bend. } \\
\text { Pagan. } \\
\text { Calvert Monument. }\end{array}$ \\
\hline
\end{tabular}

Thence from corner No. 4 along the mean low-water line of the shore to corner No. 5 , excluding any creek, cove, or inlet less than 100 yards in width at its mouth at low tide.

\begin{tabular}{|c|c|c|c|c|c|}
\hline $3^{8}$ II 10.80 & $\begin{array}{llll}76 & 26 & 07.96\end{array}$ & 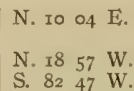 & $\begin{array}{l}\text { S. I0 } 04 \mathrm{~W} \text {. } \\
\text { S. I8 } 57 \mathrm{E} \text {. } \\
\text { N. } 82 \quad 46 \mathrm{E} \text {. }\end{array}$ & $\begin{array}{l}146 \\
15^{8} \\
805\end{array}$ & $\begin{array}{l}\text { Episcopal } \mathrm{Church} \\
\text { cross. } \\
\text { Calvert Monument. } \\
\text { Deep. }\end{array}$ \\
\hline
\end{tabular}

\section{PAGAN.}

(Upper St. Marys River-Chart No. 24.)

\begin{tabular}{|c|c|c|c|c|c|c|}
\hline I & $\begin{array}{llll}38 & \text { II } & 27.28\end{array}$ & $\begin{array}{lll}76 & 26 & 40.00\end{array}$ & $\begin{array}{llll}\text { N. } 79 & 36 & \text { W. } \\
\text { S. } 27 & 56 & \text { E. } \\
\text { N. } 68 & \text { I4 } & \text { E. }\end{array}$ & $\begin{array}{llll}\text { S. } & 79 & 36 & \text { E. } \\
\text { N. } & 27 & 56 & \text { W. } \\
\text { S. } & 68 & \text { 1 } & \text { WV. }\end{array}$ & $\begin{array}{r}\text { I, 069 } \\
\text { I0I } \\
\text { I, } 492\end{array}$ & $\begin{array}{l}\text { West Hollow. } \\
\text { Pagan. } \\
\text { Bend. }\end{array}$ \\
\hline 2 & $3^{8}$ II 33.35 & $76 \quad 26 \quad 4$ T. 14 & $\begin{array}{llll}\text { S. So } & \text { Ig } & \text { W. } \\
\text { S. } 14 & 50 & \text { E. } \\
\text { N. } & 70 \text { I I } & \text { E. }\end{array}$ & $\begin{array}{llll}\text { N. } 89 & \text { 19 } & \text { E. } \\
\text { N. } & 14 & 50 & W \\
\text { S. } 70 & \text { in } & \text { W. }\end{array}$ & $\begin{array}{r}\text { I, 02I } \\
303 \\
\text { I, } 45^{8}\end{array}$ & $\begin{array}{l}\text { West Hollow. } \\
\text { Pagan. } \\
\text { Bend. }\end{array}$ \\
\hline 3 & $3^{8}$ II $34 \cdot 5^{\circ}$ & $\begin{array}{lllll}76 & 26 & 34.24\end{array}$ & $\begin{array}{llll}\text { S. } & 87 & 30 & \text { W. } \\
\text { S. } & 17 & 39 & \text { W. } \\
\text { N. } & 75 & 52 & \text { E. }\end{array}$ & $\begin{array}{llll}\text { N. } & 87 & 35 & \text { E. } \\
\text { N. } & 17 & 39 & \text { E. } \\
\text { S. } & 75 & 52 & \text { W. }\end{array}$ & $\begin{array}{r}I, 206 \\
349 \\
I, 271\end{array}$ & $\begin{array}{l}\text { West Hollow. } \\
\text { Pagan. } \\
\text { Bend. }\end{array}$ \\
\hline+ & $3^{8}$ II 28.18 & $\begin{array}{llll}76 & 26 & 32.54\end{array}$ & 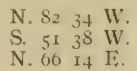 & $\begin{array}{llll}\text { S. } 82 & 35 & \text { E. } \\
\text { N. } & 51 & 37 & \text { E } \\
\text { S. } 66 & \mathrm{I}+ & \text { W. }\end{array}$ & $\begin{array}{r}\mathrm{T}, 260 \\
193 \\
\mathrm{I}, 297\end{array}$ & $\begin{array}{l}\text { West Hollow. } \\
\text { Pagan. } \\
\text { Bend. }\end{array}$ \\
\hline
\end{tabular}

any creek, cove, or inlet less than roo yards in width at its mouth at low tide. 
BOUNDARIES OF NATURAL OYSTER BARS-continUEd.

BISCOE.

(Upper St. Marys River-Chart No. 24.)

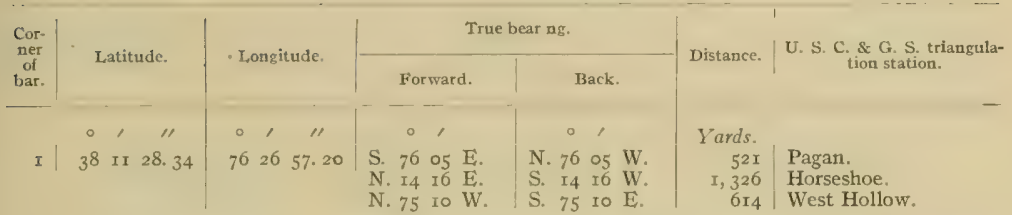

Thence from corner No. I along the mean low-water line of the shore to corner No.2, excluding any creek, cove, or inlet less than roo yards in width at its mouth at low tide.

\begin{tabular}{|c|c|c|c|c|c|c|}
\hline 2 & $3^{8}$ II 28.66 & $\begin{array}{llll}76 & 27 & 02.06\end{array}$ & $\begin{array}{llll}\mathrm{S} . & 77 & 55 & \mathrm{E} \\
\mathrm{N} . & 19 & 39 & \mathrm{E} \\
\mathrm{N} . & 72 & 30 & \mathrm{~W} .\end{array}$ & $\begin{array}{llll}\text { N. } 77 & 54 & \text { W. } \\
\text { S. } & 19 & 39 & \text { W. } \\
\text { S. } & 72 & 30 & \text { E. }\end{array}$ & $\begin{array}{r}649 \\
\mathrm{I}, 356 \\
487\end{array}$ & $\begin{array}{l}\text { Pagan. } \\
\text { Horseshoe. } \\
\text { West Hollow. }\end{array}$ \\
\hline 3 & $3^{8}$ II $33.4^{2}$ & $\begin{array}{llll}76 & 27 & 02.00\end{array}$ & $\begin{array}{llll}\text { S. } & 64 & 54 & \mathrm{E} . \\
\text { N. } 22 & 09 & \mathrm{E} \\
\text { S. } 88 & { }_{3} & \text { W. }\end{array}$ & $\begin{array}{lll}\text { N. } 64 & 54 & \text { W. } \\
\text { S. } 22 & 09 & \text { W. } \\
\text { N. } 88 & x_{3} & \text { E. }\end{array}$ & $\begin{array}{r}699 \\
\text { I, } 205 \\
466\end{array}$ & $\begin{array}{l}\text { Pagan. } \\
\text { Horseshoe. } \\
\text { West Hollow. }\end{array}$ \\
\hline & $3^{8}$ II $33.3^{8}$ & $7^{6} 26 \quad 55 \cdot 5^{8}$ & $\begin{array}{llll}\text { S. } & 57 & 26 & \mathrm{E} \\
\text { N. } & \text { I4 } & \text { I6 } & \mathrm{E} . \\
\text { S. } & 88 & 5 \mathrm{I} & \mathrm{W} .\end{array}$ & $\begin{array}{llll}\text { N. } & 57 & 26 & \text { W. } \\
\text { S. } & \text { I4 } & 16 & \text { W. } \\
\text { N. } 88 & 51 & \text { E. }\end{array}$ & $\begin{array}{r}548 \\
\mathrm{r}, 152 \\
637\end{array}$ & $\begin{array}{l}\text { Pagan. } \\
\text { Horseshoe. } \\
\text { West Hollow. }\end{array}$ \\
\hline
\end{tabular}

HORSESHOE.

(Upper St. Marys River-Chart No. 24.)

\begin{tabular}{|c|c|c|c|c|c|c|}
\hline & $3^{8}$ II 48.18 & $7_{6} \quad 26 \quad 52.00$ & $\begin{array}{llll}\text { N. } 16 & 56 & \mathrm{E} \\
\text { N. } 54 & 00 & \mathrm{~W} \\
\text { S. } & 55 & 02 & \mathrm{~W}\end{array}$ & $\begin{array}{llll}\text { S. } & 16 & 56 & \mathrm{~W} . \\
\mathrm{S} . & 54 & 00 & \mathrm{E} . \\
\mathrm{N} . & 55 & 02 & \mathrm{E}\end{array}$ & $\begin{array}{l}648 \\
694 \\
892\end{array}$ & $\begin{array}{l}\text { Horseshoe, } \\
\text { Brief. } \\
\text { West Hollow. }\end{array}$ \\
\hline & $3^{8}$ II $49 . x 6$ & $7^{6} 26 \quad 56.4^{2}$ & $\begin{array}{llll}\text { N. } 27 & 34 & \mathrm{E} . \\
\text { N. } 49 & 49 & \mathrm{~W} . \\
\text { S. } 48 & 25 & \text { W. }\end{array}$ & $\begin{array}{llll}\text { S. } & 27 & 34 & \text { W. } \\
\text { S. } & 49 & 49 & \mathrm{E} . \\
\text { N. } & 48 & 25 & \text { E. }\end{array}$ & $\begin{array}{l}662 \\
581 \\
819\end{array}$ & $\begin{array}{l}\text { Horseshoe. } \\
\text { Brief. } \\
\text { West Hollow. }\end{array}$ \\
\hline & $3^{8} \times 200.60$ & 762650.46 & $\begin{array}{llll}\text { N. } 36 & 2 \text { I } & \text { E. } \\
\text { S. } 88 & 57 & \text { W. } \\
\text { S. } & 39 & 42 & \text { W. }\end{array}$ & $\begin{array}{llll}\text { S. } & 36 & 21 & \text { W. } \\
\text { N. } 88 & 57 & \text { E. } \\
\text { N. } 39 & 42 & \text { E. }\end{array}$ & $\begin{array}{r}249 \\
602 \\
x, 209\end{array}$ & $\begin{array}{l}\text { Horseshoe. } \\
\text { Brief. } \\
\text { West Hollow. }\end{array}$ \\
\hline
\end{tabular}

Thence from comer No. 3 along the mean low-water line of the shore to comer No. I, excluding any creek, cove, or inlet less than Ioo yards in width at its mouth at low tide. 
BOUNDARIES OF NATURAL, OYSTER BARS-continued.

SHORT POINT.

(Upper St. Marys River-Chart No. 24.)

\begin{tabular}{|c|c|c|c|c|c|c|c|}
\hline \multirow{2}{*}{$\begin{array}{l}\text { Cor- } \\
\text { ner } \\
\text { of } \\
\text { bar }\end{array}$} & \multirow{2}{*}{\multicolumn{2}{|c|}{ Latitude. }} & \multirow{2}{*}{ Longitude. } & \multicolumn{2}{|c|}{ True bear ng. } & \multirow{2}{*}{ Distance, } & \multirow{2}{*}{$\begin{array}{l}\text { U. S. C. \& G. S. triangula- } \\
\text { tion station. }\end{array}$} \\
\hline & & & & Forward. & Back, & & \\
\hline I & $\begin{array}{l}\circ \\
3^{8}\end{array}$ & 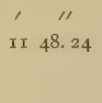 & $\begin{array}{ccc}\circ & \prime & \prime \prime \\
76 & 27 & \times 3.76\end{array}$ & $\begin{array}{llll} & 0 & \\
\text { S. } & 16 & 35 & \text { W. } \\
\text { N. } & 51 & 12 & \mathrm{E} . \\
\text { N. } & 2 & 29 & \mathrm{E} .\end{array}$ & \begin{tabular}{|lrll} 
& \multicolumn{3}{c}{,} \\
N. & 16 & 35 & $\mathrm{E}$. \\
S. & 51 & 12 & $\mathrm{~W}$ \\
S. & 2 & 29 & $\mathrm{~W}$
\end{tabular} & $\begin{array}{r}\text { Yards. } \\
535 \\
984 \\
406\end{array}$ & $\begin{array}{l}\text { West Hollow. } \\
\text { Horseshoe. } \\
\text { Brief. }\end{array}$ \\
\hline 2 & $3^{8}$ & II $49.9^{6}$ & 7627 I8. 60 & $\begin{array}{lrr}\text { S. } 224 & \text { W. } \\
\text { N. } 57 & 59 & \text { E. } \\
\text { N. } 22 & 49 & \text { E. }\end{array}$ & $\begin{array}{lrrr}\text { N. } & 2 & 24 & \mathrm{E} \\
\text { S. } & 57 & 59 & \text { W. } \\
\text { S. } & 22 & 49 & \text { W. }\end{array}$ & $\begin{array}{r}57^{2} \\
\mathrm{x}, 058 \\
377\end{array}$ & $\begin{array}{l}\text { West Hollow. } \\
\text { Horseshoe. } \\
\text { Brief. }\end{array}$ \\
\hline
\end{tabular}

Thence from corner No. 2 along the mean low-water line of the shore to corner No. 3 , excluding any creek, cove, or inlet less than 100 yards in width at its mouth at low tide.

\begin{tabular}{|c|c|c|c|c|c|c|c|c|}
\hline 3 & $3^{8} 12$ & ○. $9^{2}$ & $\begin{array}{ll}76 & 27\end{array}$ & 12. 34 & $\begin{array}{llll}\text { N. } 75 & 26 & \text { E. } \\
\text { N. } 49 & 24 & \text { W. } \\
\text { S. } 43 & 08 & \text { W. }\end{array}$ & $\begin{array}{llll}\text { S. } 75 & 27 & \text { W. } \\
\text { S. } 49 & 24 & \text { E. } \\
\text { N. } 43 & 08 & \text { E. }\end{array}$ & $\begin{array}{r}754 \\
486 \\
30\end{array}$ & $\begin{array}{l}\text { Horseshoe. } \\
\text { Tenuate. } \\
\text { Brief. }\end{array}$ \\
\hline 4 & $3^{8} \quad 12$ & 03.66 & $\begin{array}{lll}76 & 27\end{array}$ & 08.66 & $\begin{array}{lll}\text { N. } 81 & 16 & \mathrm{E} . \\
\text { N. } 64 & 27 & \mathrm{~W} \\
\text { S. } 46 & 02 & \mathrm{~W}\end{array}$ & 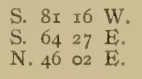 & $\begin{array}{l}639 \\
517 \\
164\end{array}$ & $\begin{array}{l}\text { Horseshoe. } \\
\text { Tenuate. } \\
\text { Brief. }\end{array}$ \\
\hline & $3^{8} \quad 12$ & OI. 82 & $76 \quad 27$ & 04.25 & $\begin{array}{llll}\text { N. } 72 & 48 & \mathrm{E} . \\
\text { N. } 63 & 59 & \mathrm{~W} \\
\text { S. } 77 & 34 & \text { W. }\end{array}$ & $\begin{array}{llll}\text { S. } & 72 & 49 & \text { W. } \\
\text { S. } & 63 & 59 & \mathrm{E} \\
\text { N. } & 77 & 34 & \mathrm{E}\end{array}$ & $\begin{array}{l}539 \\
65 \mathrm{I} \\
24 \mathrm{I}\end{array}$ & $\begin{array}{l}\text { Horseshoe. } \\
\text { Tenuate. } \\
\text { Brief. }\end{array}$ \\
\hline
\end{tabular}

\section{BRYAN}

(Upper St. Marys River-Chart No. 24.)
I $\left|\begin{array}{llll|llll}38 & 12 & 07.80 & 76 & 27 & 15.94\end{array}\right|$

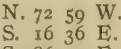
S. $7259 \mathrm{E}$.
S. $8659 \mathrm{E}$.
N. I6 36 .W.
N. $8659 \mathrm{~W}$.
$2\left|\begin{array}{llll|lll}38 & 12 & 09.08 & 76 & 27 & 24.36\end{array}\right|$

\begin{tabular}{l|ll|ll} 
S. 45 I7 E. & N. 45 I7 W. \\
S. 8520 E. & N. 8520 W. \\
N. 50 & 35. W. & S. 50 & 35 & E.
\end{tabular}
285 Tenuate.
265 Brief.
827 Horseshoe.

\begin{tabular}{r|l}
$42 I$ & Brief. \\
I, 053 & Horseshoe. \\
63 & Tenuate.
\end{tabular}
Thence from corner No. 2, along the mean low-water line of the shore to comer No.
any creek, cove, or inlet less than roo yards in width at its mouth at low tide.
N. $8327 \mathrm{~W}$.
S. 233 I W.
S. $5855 \mathrm{E}$.
\begin{tabular}{l|lll|lll|lll|l}
4 & 38 & 12 & 14.96 & 76 & 27 & 25.20 & N. 27 & 41 E.
\end{tabular}
N. 70 or W.
S. $94 I W$.
S. $274 I \mathrm{~W}$.
S. 70 or E.
N. $94 \mathrm{I} \mathrm{E}$.
\begin{tabular}{lllll|llll|lll}
5 & 38 & 12 & 12.86 & 76 & 27 & 14.59 & N. 3 & 58 & W. \\
\hline
\end{tabular}
S. $358 \mathrm{E}$.
N. 74 IS E.
S. $520 \mathrm{E}$.
N. $520 \mathrm{~W}$.
I, ro6 Horseshoe.
68I Martin.
8Ig Soak.
527 Martin.
775 Soak.
I60 Tenuate.
539 Martin.
321 Tenuate.
426 Brief. 
BOUNDARIES OF NATURAL OYSTER IBARS - continuEd.

ST. GEORGE.

(St. George River-Chart No. 24.)

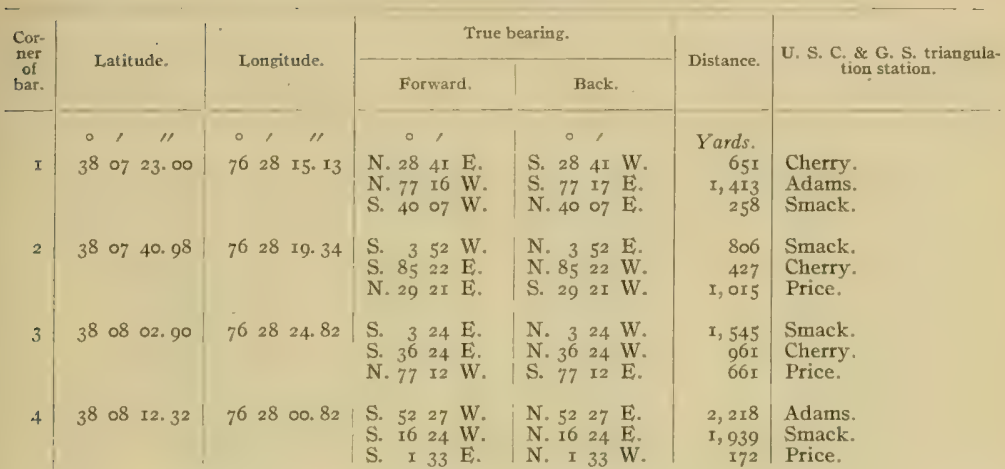

Thence from corner No, 4 along the mean low-water line of the shore to comer No, 5 , excluding any creek, cove, or inlet less than roo yards in width at its mouth at low tide.
$5 \mid$\begin{tabular}{lll|llll} 
& 38 & 07 & 39.96 & 76 & 28 & 03.41
\end{tabular}
\begin{tabular}{llll|lll} 
N. & 45 & 49 & W. & S. 45 & 49 & E. \\
S. $3 I$ & 53 & W. & N. 3 I & 53 & E. \\
S. 73 & 48 & E. & N. 73 & 47 & W.
\end{tabular}
$\mathrm{x}, 344$
906
3,652
Goose.
Smack:
3,652 Between.

\section{HURDLE.}

(St. George River-Chart No. 24.)

\begin{tabular}{|c|c|c|c|c|c|c|c|}
\hline I & $3^{8}$ of 17.82 & 76.28 & $32.9^{8}$ & $\begin{array}{llll}\text { S. } & 85 & 39 & \text { E. } \\
\text { N. } & 46 & 32 & \text { E. } \\
\text { N. } 6 \mathbf{r} & 42 & \text { W. }\end{array}$ & $\begin{array}{llll}\text { N. } & 85 & 39 & \text { W. } \\
\text { S. } 46 & 32 & \text { W. } \\
\text { S. } 61 & 42 & \text { E. }\end{array}$ & $\begin{array}{r}309 \\
I, 085 \\
I, 025\end{array}$ & $\begin{array}{l}\text { Smack. } \\
\text { Cherry. } \\
\text { Adams. }\end{array}$ \\
\hline 2 & $3^{8}$ o7 $3^{8} .80$ & $76 \quad 29$ & 04.22 & $\begin{array}{llll}\text { N. } 33 & 55 & \text { E. } \\
\text { N. } & 5 \text { I } & 43 & \text { W. } \\
\text { S. } & \text { 17 } & 33 & \text { W. }\end{array}$ & $\begin{array}{llll}\text { S. } & 33 & 55 & \text { W. } \\
\text { S. } & 5 \mathrm{I} & 44 & \mathrm{E} \\
\text { N. } & \text { I7 } & 33 & \mathrm{E} .\end{array}$ & $\begin{array}{l}I, x 76 \\
I, 368 \\
233\end{array}$ & $\begin{array}{l}\text { Goose. } \\
\text { Straits. } \\
\text { Adams. }\end{array}$ \\
\hline 3 & $\begin{array}{llll}3^{8} & 07 & 51.97\end{array}$ & $\begin{array}{lll}76 & 28\end{array}$ & 53.00 & 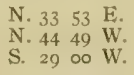 & $\begin{array}{llll}\text { S. } & 33 & 53 & \text { W. } \\
\text { S. } & 44 & 49 & \mathrm{E}\end{array}$ & $\begin{array}{r}64 \mathrm{I} \\
\mathrm{x}, 208 \\
76 \mathrm{I}\end{array}$ & $\begin{array}{l}\text { Goose. } \\
\text { Coombs. } \\
\text { Adams. }\end{array}$ \\
\hline 4 & $3^{8}$ o7 $40.9^{8}$ & 7628 & I9. 34 & $\begin{array}{lrrr}\text { S. } & 3 & 52 & \text { W. } \\
\text { S. } 85 & 22 & \text { E. } \\
\text { N. } 29 & 21 & \text { E. }\end{array}$ & $\begin{array}{llll}\text { N. } & 3 & 52 & \text { E. } \\
\text { N. } 85 & 22 & \text { W. } \\
\text { S. } 29 & 21 & \text { W. }\end{array}$ & $\begin{array}{r}806 \\
427 \\
\mathrm{x}, \text { or } 5\end{array}$ & $\begin{array}{l}\text { Smack. } \\
\text { Cherry. } \\
\text { Price. }\end{array}$ \\
\hline 5 & $3^{8} \quad 07=2 \dot{3} .00$ & $76 \quad 28$ & $I_{5} I_{3}$ & $\begin{array}{llll}\text { N. } 28 & 4 \mathrm{I} & \mathrm{E} \\
\text { N. } 77 & \mathrm{I} 6 & \mathrm{~W} \\
\text { S. } 40 & 07 & \mathrm{~W} .\end{array}$ & $\begin{array}{llll}\text { S. } & 28 & 4 \mathrm{I} & \mathrm{W} . \\
\text { S. } & 77 & 17 & \mathrm{E} . \\
\mathrm{N} . & 40 & 07 & \mathrm{E} .\end{array}$ & $\begin{array}{r}651 \\
\mathrm{r}, 413 \\
258\end{array}$ & $\begin{array}{l}\text { Cherry. } \\
\text { Adams. } \\
\text { Smack. }\end{array}$ \\
\hline
\end{tabular}


BOUNDARIES OF NATURAL, OYSTER BARS - continued.

GOOSE POINT.

(St. George River-Chart No. 24.)

\begin{tabular}{|c|c|c|c|c|c|c|}
\hline \multirow{2}{*}{$\begin{array}{l}\text { Cor- } \\
\text { ner } \\
\text { of } \\
\text { bar. }\end{array}$} & \multirow{2}{*}{ Latitude. } & \multirow{2}{*}{ Longitude. } & \multicolumn{2}{|c|}{ True bearing. } & \multirow{2}{*}{ Distance. } & \multirow{2}{*}{$\begin{array}{l}\text { U. S. C. \& G. S. triangula- } \\
\text { tion station. }\end{array}$} \\
\hline & & & Forward. & Back. & & \\
\hline I & $\begin{array}{ccc}0 & \prime \prime \\
3^{8} & 07 & 40.9^{8}\end{array}$ & $\begin{array}{ccc}0 & 1 & 11 \\
76 & 28 & 19.34\end{array}$ & $\begin{array}{lccc} & 0 & 1 \\
\text { S. } & 3 & 52 & \text { W. } \\
\text { S. } & 85 & 22 & \text { E. } \\
\text { N. } 29 & 2 \text { I } & \text { E. }\end{array}$ & $\begin{array}{lccc} & & \\
\text { N. } & 3 & 52 & \text { E. } \\
\text { N. } 85 & 22 & \text { W. } \\
\text { S. } 29 & 21 & \text { W. }\end{array}$ & $\begin{array}{r}\text { Yards. } \\
806 \\
427 \\
\text { I, OI } 5\end{array}$ & $\begin{array}{l}\text { Smack. } \\
\text { Cherry. } \\
\text { Price. }\end{array}$ \\
\hline 2 & $3^{8} \quad 07 \quad 51.97$ & $7^{6} \quad 28 \quad 53.00$ & $\begin{array}{lll}\text { N. } 33 & 53 & \text { E. } \\
\text { N. } 44 & 49 & \text { W. } \\
\text { S. } 29 & 00 & \text { W. }\end{array}$ & $\begin{array}{llll}\text { S. } & 33 & 53 & \text { W. } \\
\text { S. } & 44 & 49 & \text { E. } \\
\text { N. } 2900 & \text { E. }\end{array}$ & $\begin{array}{r}64 I \\
I, 208 \\
761\end{array}$ & $\begin{array}{l}\text { Goose. } \\
\text { Coombs. } \\
\text { Adams. }\end{array}$ \\
\hline 3 & $\begin{array}{llll}38 & 08 & 07.74\end{array}$ & $\begin{array}{llll}76 & 28 & 39 \cdot 59\end{array}$ & $\begin{array}{llll}\text { S. } & 3 \mathrm{I} & \text { 14 } & \mathrm{W} . \\
\text { S. } & \text { I } & 52 & \mathrm{E} \\
\text { S. } & 45 & 49 & \mathrm{E} .\end{array}$ & $\begin{array}{llll}\text { N. } 3 \text { I } & \text { I4 } & \text { E. } \\
\text { N. } & \text { I } & 52 & \text { W. } \\
\text { N. } & 45 & 49 & \text { W. }\end{array}$ & $\begin{array}{l}I, 400 \\
I, 774 \\
I, 344\end{array}$ & $\begin{array}{l}\text { Adams. } \\
\text { Smack. } \\
\text { Cherry. }\end{array}$ \\
\hline
\end{tabular}

Thence from comer No. 3 along the mean low-water line of the shore to comer No. 4 , excluding any creek, cove, or inlet less than roo yards in width at its mouth at low tide.

\begin{tabular}{|c|c|c|c|c|}
\hline \begin{tabular}{l|lll}
4 & 3808 & 02.90
\end{tabular} & $7^{6} \quad 28 \quad 24.82$ & $\begin{array}{lrrl}\text { S. } & 3 & 24 & \mathrm{E} . \\
\mathrm{S} . & 36 & 24 & \mathrm{E} . \\
\mathrm{N} . & 77 & 12 & \mathrm{~W} .\end{array}$ & $\mid \begin{array}{llll}\text { N. } 3 & 24 & \text { W. } \\
\text { N. } 36 & 24 & \text { W. } \\
\text { S. } 77 & 12 & \text { E. }\end{array}$ & $\begin{array}{r}x, 545 \\
961 \\
66 \mathrm{I}\end{array}$ \\
\hline
\end{tabular}

\section{ISLAND SHORE}

(St. George River-Chart No. 24.)

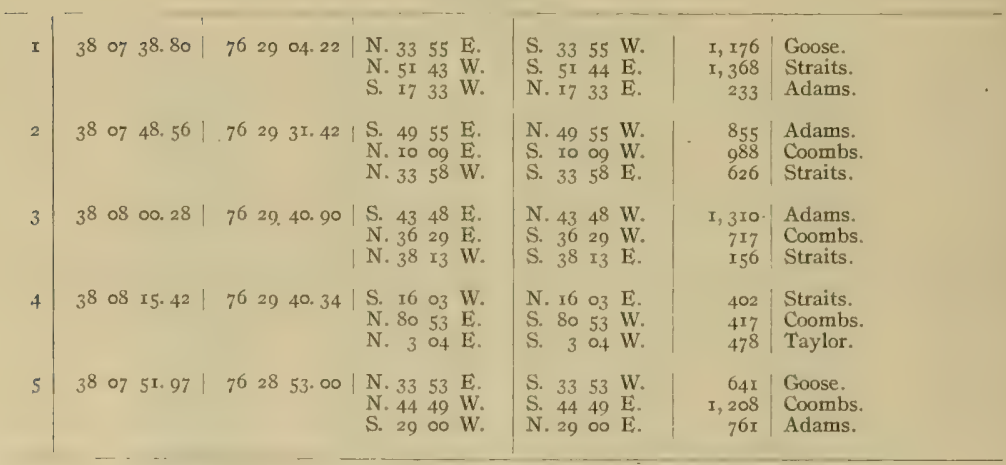


BOUNDARIES OF NATURAL, OYSTER BARS-continued.

MILBOURNE SHORE.

(St. George River-Chart No. 24.)

\begin{tabular}{|c|c|c|c|c|c|c|}
\hline \multirow{2}{*}{$\begin{array}{l}\text { Cor- } \\
\text { ner } \\
\text { of } \\
\text { bar. }\end{array}$} & \multirow{2}{*}{ Latitude. } & \multirow{2}{*}{ Longitude. } & \multicolumn{2}{|c|}{ True bearing. } & \multirow{2}{*}{ Distance. } & \multirow{2}{*}{$\begin{array}{l}\text { U. S. C. \& G. S. triangula } \\
\text { tion station. }\end{array}$} \\
\hline & & & Forward. & Back. & & \\
\hline I & $\begin{array}{ccc}0 & 11 \\
3^{8} & 07 & 51.97\end{array}$ & $\begin{array}{ccc}0 & 1 \\
76 & 28 & 53.00\end{array}$ & 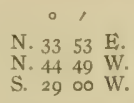 & $\begin{array}{lccc} & \circ & \\
\text { S. } & 33 & 53 & \text { W. } \\
\text { S. } & 44 & 49 & \text { E. } \\
\text { N. } 29 & 00 & \text { E. }\end{array}$ & $\begin{array}{r}\text { Yards. } \\
641 \\
I, 208 \\
761\end{array}$ & $\begin{array}{l}\text { Goose. } \\
\text { Coombs. } \\
\text { Adams. }\end{array}$ \\
\hline 2 & $3^{8} \quad 08 \quad 15.42$ & 762940.34 & $\begin{array}{llll}\text { S. } & 16 & 03 & \text { W. } \\
\text { N. } 80 & 53 & \text { E. } \\
\text { N. } & 3 & 04 & \text { E. }\end{array}$ & $\begin{array}{lrrr}\text { N. } & 16 & 03 & \text { E. } \\
\text { S. } & 80 & 53 & \text { W. } \\
\text { S. } & 3 & 04 & \text { W. }\end{array}$ & $\begin{array}{l}402 \\
417 \\
478\end{array}$ & $\begin{array}{l}\text { Straits. } \\
\text { Coombs. } \\
\text { Taylor. }\end{array}$ \\
\hline 3 & $3^{8}$ 08 21. 42 & $\begin{array}{lll}76 & 29 & 43.00\end{array}$ & $\begin{array}{lrrl}\text { S. } & 3 & 54 & \text { W. } \\
\text { S. } & 74 & \text { I4 } & \mathrm{E} . \\
\text { N. } & \text { I9 } & 15 & \mathrm{E} .\end{array}$ & $\begin{array}{lrrll}\text { N. } & 3 & 54 & \text { F. } \\
\text { N. } 74 & \text { I3 } & \text { W. } \\
\text { S. } & \text { I9 } & \text { I } 5 & \text { W. }\end{array}$ & $\begin{array}{l}595 \\
501 \\
29 I\end{array}$ & $\begin{array}{l}\text { Straits. } \\
\text { Coombs. } \\
\text { Taylor. }\end{array}$ \\
\hline 4 & $3^{8} 08 \quad 27 \cdot 3^{8}$ & $76 \quad 2945 \cdot 70$ & $\begin{array}{llll}\text { S. } & 55 & 3 \mathrm{I} & \mathrm{W} . \\
\text { S. } & 58 & 4 \mathrm{I} & \mathrm{E} . \\
\text { N. } & 66 & 20 & \mathrm{E} .\end{array}$ & $\begin{array}{llll}\text { N. } & 55 & 3 \mathrm{I} & \mathrm{E} . \\
\mathrm{N} . & 58 & 4 \mathrm{I} & \mathrm{W} \\
\text { S. } & 66 & 20 & \mathrm{~W}\end{array}$ & $\begin{array}{l}521 \\
649 \\
184\end{array}$ & $\begin{array}{l}\text { Swan. } \\
\text { Coombs. } \\
\text { Taylor. }\end{array}$ \\
\hline
\end{tabular}

Thence from corner No. 4 along the mean low-water line of the shore to corner No. 5 , excluding any creek, cove, or inlet less than roo yards in width at its mouth at low tide.

$3^{8} 08 \quad 18.06$

$3^{8} \quad 08 \quad 12.16$

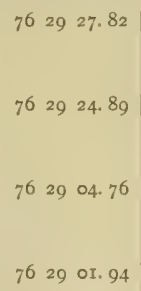

$\begin{array}{llll}76 & 29 & 04.76\end{array}$

$76 \quad 29$ Or. 94

S. $8830 \mathrm{~W}$.

S. $2700 \mathrm{~W}$.

S. $1033 \mathrm{E}$.

S. $4902 \mathrm{~W}$.

S. $1732 \mathrm{E}$.

S. $7455 \mathrm{E}$.

N. 7 I $50 \mathrm{~W}$.

S. $222 \mathrm{~W}$.

S. $7728 \mathrm{E}$.

S. $875 \mathrm{I} \mathrm{W}$.

S. $450 \mathrm{~W}$.

S. $594 \mathrm{I} \mathrm{E}$.
N. $8830 \mathrm{E}$.

N. $2700 \mathrm{E}$.

N. Io $33 \mathrm{~W}$.

N. 49 or E.

N. $1731 \mathrm{~W}$.

N. $7455 \mathrm{~W}$.

S. 7 I $50 \mathrm{E}$.

N. $222 \mathrm{E}$.

N. $7728 \mathrm{~W}$.

N. 875 I

N. $450 \mathrm{E}$.

N. $594 \mathrm{I}$ W.
308 Taylor.

980 Straits.

426 Coombs.

692 Straits.

I, 598 Adams.

I, 250 Goose.

$564 \mid$ Coombs.

I, 348 Adams.

687 Goose.

6 II Coombs.

I, 551 Adams.

690 Groose.

Thence from corner No. 8 along the mean low-water line of the shore to comer No. 9, excluding any creek, cove, or inlet less than Ioo yards in width at its mouth at low tide.

\begin{tabular}{l|lll|lllllll|lll|l|l|l}
98 & 08 & 07.74 & 76 & 28 & 39.59 & S. & 3 I & I4 & W. & N. 3 I & I4 & E. & I, 400 & Adams. \\
& & & & S. & I5 & 52 & E. & N. I5 & 52 & W. & I, 774 & Smack. \\
& & & & & & & 45 & 49 & E. & N. 45 & 49 & W. & I, 344 & Cherry.
\end{tabular}


STRAITS.

(St. George River-Chart No. 24.)

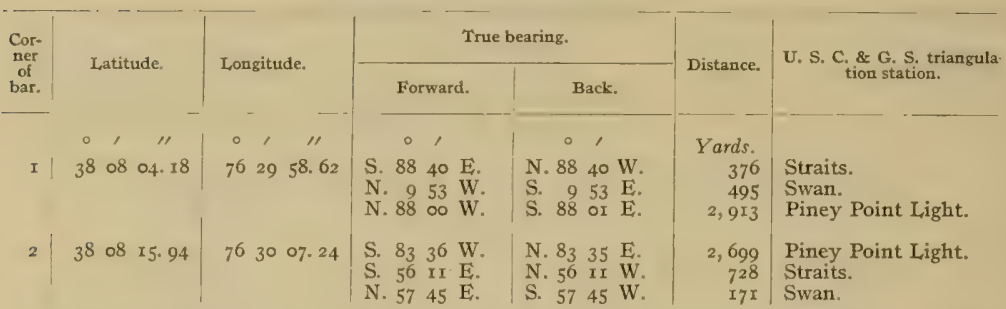

Thence from corner No. 2 along the mean low-water line of the shore to corner No, 3 , excluding any creek, cove, or inlet less than roo yards in width at its mouth at low tide.

\begin{tabular}{|c|c|c|c|c|c|c|}
\hline $3^{8} \circ 8$ & $15 \cdot 32$ & $7^{6} 30$ or. 66 & $\begin{array}{lrll}\text { S. } & 49 & 54 & \text { E. } \\
\text { N. } 85 & 57 & \text { E. } \\
\text { N. } & 2 & 03 & \text { W. }\end{array}$ & $\begin{array}{lrll}\text { N. } & 49 & 54 & \text { W. } \\
\text { S. } 85 & 56 & \text { W. } \\
\text { S. } & 2 & 03 & \text { E. }\end{array}$ & $\begin{array}{l}596 \\
982 \\
\text { x } 5\end{array}$ & $\begin{array}{l}\text { Straits. } \\
\text { Coombs. } \\
\text { Swan. }\end{array}$ \\
\hline 3808 & 13.00 & $7^{6} 2957 \cdot 3^{8}$ & $\begin{array}{llll}\text { S. } & 48 & \text { I2 } & \text { E. } \\
\text { N. } 80 & 19 & \text { E. } \\
\text { N. } & 31 & 49 & \text { W. }\end{array}$ & 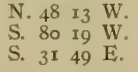 & $\begin{array}{l}459 \\
878 \\
224\end{array}$ & $\begin{array}{l}\text { Straits. } \\
\text { Coombs. } \\
\text { Swan. }\end{array}$ \\
\hline
\end{tabular}

Thence from corner No. 4 along the mean low-water line of the shore to comer No. 1 , excluding any creek, cove, or inlet less than roo yards in width at its mouth at low tide.

\section{TARKHILL,}

(St. George River-Chart No. 24.)

\begin{tabular}{|c|c|c|c|c|c|c|}
\hline & $\begin{array}{llll}38 & 08 & 20.03\end{array}$ & 762958.70 & $\begin{array}{llll}\text { N. } & 57 & 56 & \mathrm{E} . \\
\text { N. } 2 I & 12 & \mathrm{~W} . \\
\text { S. } 60 & 30 & \mathrm{~W} .\end{array}$ & $\begin{array}{llll}\text { S. } & 57 & 56 & \text { W. } \\
\text { S. } & 2 I & 13 & \text { E. } \\
\text { N. } & 60 & 30 & \text { E. }\end{array}$ & $\begin{array}{r}607 \\
8 \mathrm{I} 4 \\
95\end{array}$ & $\begin{array}{l}\text { Taylor. } \\
\text { Robrecht. } \\
\text { Swan. }\end{array}$ \\
\hline & $3^{8} \quad 08 \quad 50.9^{8}$ & $76 \quad 29 \quad 54.84$ & $\begin{array}{llll}\text { N. } & 57 & \text { I2 } & \text { W. } \\
\text { S. } & 54 & \text { 19 } & \text { W. } \\
\text { S. } & 55 & 35 & \text { E. }\end{array}$ & $\begin{array}{llll}\text { S. } & 57 & \text { I } & \mathrm{E} \\
\text { N. } & 54 & \text { I9 } & \mathrm{E} \\
\text { N. } & 55 & 35 & \text { W. }\end{array}$ & $\begin{array}{r}\mathrm{I}, 077 \\
489 \\
337\end{array}$ & $\begin{array}{l}\text { Russell. } \\
\text { Robrecht. } \\
\text { Tarkhill. }\end{array}$ \\
\hline & $38 \circ 903.2 x$ & $\begin{array}{lll}76 & 29 & 50.34\end{array}$ & $\begin{array}{llll}\text { N. } & 80 & 34 & \text { W. } \\
\text { S. } & 36 & 34 & \text { W. } \\
\text { S. } & \text { I } 4 & 42 & \text { E. }\end{array}$ & $\begin{array}{llll}\text { S. } 80 & 35 & \text { E. } \\
\text { N. } 36 & 34 & \text { E. } \\
\text { N. } & \text { I } 4 & 42 & \text { W. }\end{array}$ & $\begin{array}{r}1,040 \\
867 \\
623\end{array}$ & $\begin{array}{l}\text { Russell, } \\
\text { Robrecht. } \\
\text { Tarkhill. }\end{array}$ \\
\hline & $\begin{array}{llll}38 & 08 & 48.22\end{array}$ & $\begin{array}{lll}7^{6} & 29 & 30.20\end{array}$ & $\begin{array}{llll}\text { N. } 66 & 37 & \mathrm{~W} \\
\text { S. } & 75 & 33 & \mathrm{~W} \\
\text { S. } & 2 \mathrm{x} & 17 & \mathrm{~W} .\end{array}$ & $\begin{array}{llll}\text { S. } & 66 & 38 & \mathrm{E} . \\
\text { N. } 75 & 33 & \mathrm{E} . \\
\text { N. } 21 & \mathrm{I} 6 & \mathrm{E} .\end{array}$ & $\begin{array}{r}\mathbf{I}, 702 \\
390 \\
676\end{array}$ & $\begin{array}{l}\text { Russell. } \\
\text { Tarkhill. } \\
\text { Taylor. }\end{array}$ \\
\hline
\end{tabular}

Thence from comer No. 4 along the mean low-water line of the shore to corner No. 5 , excluding any creek, cove, or inlet less than roo yards in width at its mouth at low tide.

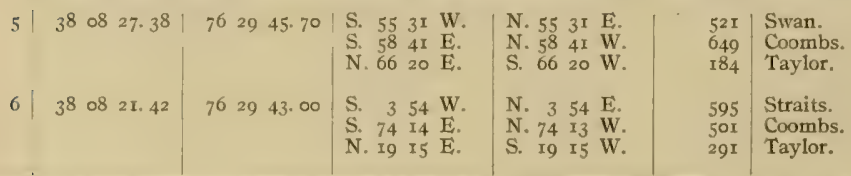


BOUNDARIES OF NATURAL OYSTER BARS - continued.

SWAN.

(Si. George River-Chart No. 24.)

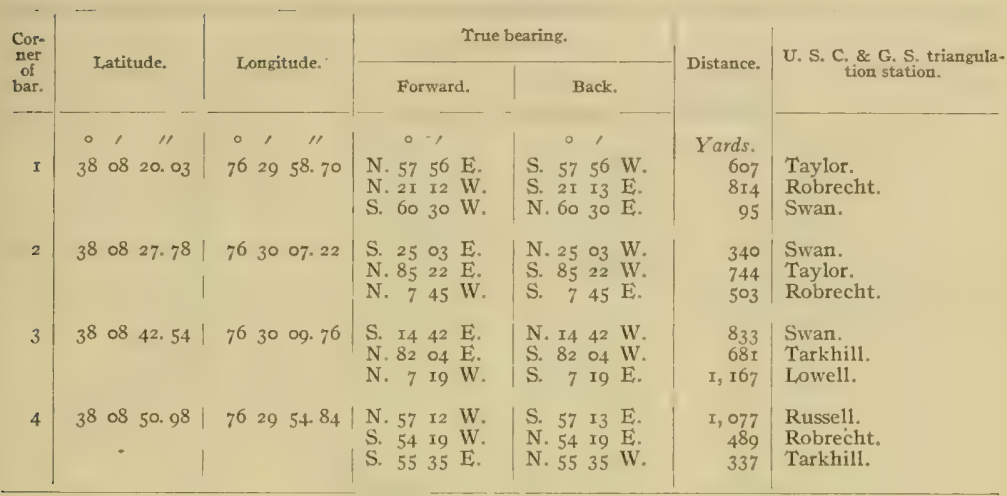

\section{ROLLIN.}

(St. George River-Chart No. 24.)

\begin{tabular}{l|lll|llll|lll|lll} 
I & 3808 & 50.80 & 76 & 30 & 07.82 & N. 43 & 36 & W. & S. 43 & 36 E.
\end{tabular}

S. IO $32 \mathrm{~W}$. N. I0 $32 \mathrm{E}$.

S. $7331 \mathrm{E}$. N. $7331 \mathrm{~W}$

\begin{tabular}{l|ll|lllll|lll}
2 & 3808 & 59.04 & 76 & 30 & 20.32 & S. 26 & 49 & E. & N. 26 & 49 W.
\end{tabular}

N. I2 26 E. S. I2 $26 \mathrm{~W}$.

N. 36 I3 W. S. 36 ×

\begin{tabular}{l|l|l|lll}
3 & $38 \circ 03.57$ & 76 & 30 & I2. 88
\end{tabular}

N. 819 W

N. $6939 \mathrm{~W}$.

S. $64 \mathrm{I} \mathrm{E}$.

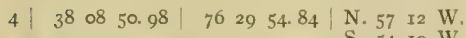

S. $5419 \mathrm{~W}$.

S. $5535 \mathrm{E}$.
S. $8 \mathrm{IO} \mathrm{E}$.

S. $6939 \mathbf{E}$.

N. 64 I W.

S. $57 \mathrm{I} 3 \mathrm{E}$.

N. 54 I9 E.

N. $5535 \mathrm{~W}$
8I3 Russell.

283 Robrecht.

$65 \mathrm{I}$ Tarkhill.

623 Robrecht.

6r6 Lowell.

385 Russell.

453 Lowell.

454 Russell.

7 Robrecht.

I, 077 Russell.

489 Robrecht

337 Tarkhill.

\section{CEDAR POINT.}

(St. George River-Chart No. 24.)

\begin{tabular}{|c|c|c|c|c|c|c|}
\hline I & $\begin{array}{lll}38 & 08 & 50.98\end{array}$ & $\begin{array}{lll}76 & 29 & 54.84\end{array}$ & $\begin{array}{llll}\text { N. } & 57 & 12 & W . \\
\text { S. } & 54 & 19 & \text { W. } \\
\text { S. } & 55 & 35 & \text { E. }\end{array}$ & $\begin{array}{llll}\text { S. } & 57 & \text { I3 } & \text { E. } \\
\text { N. } & 54 & \text { I9 } & \text { E. } \\
\text { N. } & 55 & 35 & \text { W. }\end{array}$ & $\begin{array}{r}1,077 \\
489 \\
337\end{array}$ & $\begin{array}{l}\text { Russell. } \\
\text { Robrecht. } \\
\text { Tarkhill. }\end{array}$ \\
\hline 2 & $\begin{array}{llll}38 & 09 & 03.57\end{array}$ & $\begin{array}{lll}76 & 30 & \text { I } 2.88\end{array}$ & 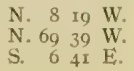 & $\begin{array}{lrrl}\text { S. } & 8 & \text { I9 } & \text { E. } \\
\text { S. } & 69 & 39 & \text { E. } \\
\text { N. } & 6 & 4 I & \text { IV. }\end{array}$ & $\begin{array}{l}453 \\
454 \\
714\end{array}$ & $\begin{array}{l}\text { Lowell. } \\
\text { Russell. } \\
\text { Robrecht. }\end{array}$ \\
\hline
\end{tabular}


CEDAR POINT-Continued.

(St. George River-Chart No. 24.)

\begin{tabular}{|c|c|c|c|c|c|c|}
\hline \multirow{2}{*}{$\begin{array}{l}\text { Cor- } \\
\text { ner } \\
\text { of } \\
\text { bar. }\end{array}$} & \multirow{2}{*}{ Latitude. } & \multirow{2}{*}{ Longitude. } & \multicolumn{2}{|c|}{ True bearing. } & \multirow{2}{*}{ Distance. } & \multirow{2}{*}{$\begin{array}{l}\text { U. S. C. \& G. S., triangula- } \\
\text { tion station. }\end{array}$} \\
\hline & & & Forward. & Back. & & \\
\hline 3 & 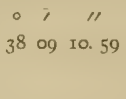 & $\begin{array}{ccc}\circ & 11 \\
76 & 30 & \text { or. } 22\end{array}$ & \begin{tabular}{lccc} 
& 0 & \multicolumn{1}{c}{} & \\
N. & 45 & 13 & E. \\
N. 60 & 37 & W. \\
S. & 83 & 44 & W.
\end{tabular} & \begin{tabular}{lccc} 
& 0 & \multicolumn{1}{c}{} \\
S. & 45 & 13 & W. \\
S. 60 & 37 & E. \\
N. 83 & 44 & E.
\end{tabular} & $\begin{array}{r}\text { Yards. } \\
434 \\
432 \\
740\end{array}$ & $\begin{array}{l}\text { Arbuckle. } \\
\text { Lowell. } \\
\text { Russell. }\end{array}$ \\
\hline
\end{tabular}

Thence from corner No. 3 along the mean low-water line of the shore to corner No. 4 , excluding any creek, cove, or inlet less than roo yards in width at its mouth at low tide.

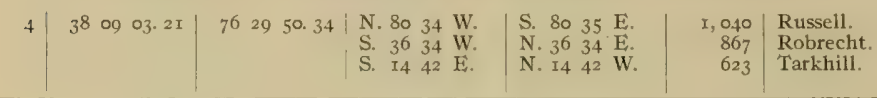

\section{SHEHAN.}

(St. George River-Chart No. 24.)

\begin{tabular}{|c|c|c|c|c|c|c|}
\hline I & $38 \quad 08 \quad 59.04$ & $\begin{array}{llll}76 & 30 & 20 . & 32\end{array}$ & $\begin{array}{llll}\text { S. } 26 & 49 & \text { E. } \\
\text { N. } & 12 & 26 & \text { E. } \\
\text { N. } & 36 & 13 & \text { W. }\end{array}$ & $\begin{array}{llll}\text { N. } & 26 & 49 & \text { W. } \\
\text { S. } & 12 & 26 & \text { W. } \\
\text { S. } & 36 & 13 & \text { E. }\end{array}$ & $\begin{array}{l}623 \\
616 \\
385\end{array}$ & $\begin{array}{l}\text { Robrecht. } \\
\text { Lowell. } \\
\text { Russell. }\end{array}$ \\
\hline & $3^{8}$ o9 04. $5^{6}$ & $\begin{array}{llll}76 & 30 & 28.60\end{array}$ & $\begin{array}{llll}\text { S. } & 34 & 03 & \text { E. } \\
\text { N. } & 40 & 23 & \text { E. } \\
\text { N. } & 3 & \text { II } & \text { W. }\end{array}$ & $\begin{array}{lrrr}\text { N. } & 34 & 03 & \text { W. } \\
\text { S. } & 40 & 23 & \text { W. } \\
\text { S. } & 3 & \text { II } & \text { E. }\end{array}$ & $\begin{array}{l}898 \\
545 \\
125\end{array}$ & $\begin{array}{l}\text { Robrecht. } \\
\text { Lowell. } \\
\text { Russell. }\end{array}$ \\
\hline
\end{tabular}

Thence from corner No. 2 along the mean low-water line of the shore to corner No. 3 , excluding any creek, cove, or inlet less than 100 yards in width at its mouth at low tide.

\begin{tabular}{|c|c|c|c|c|c|c|}
\hline & $3^{8} \circ 008.25$ & $7^{6} \quad 30 \quad 28.86$ & $\begin{array}{llll}\mathrm{S} . & 30 & 25 & \mathrm{E} \\
\mathrm{N} . & 5 \mathrm{I} & 05 & \mathrm{E} \\
\mathrm{N}\end{array}$ & $\begin{array}{llll}\text { N. } & 30 & 24 & W . \\
\text { S. } & 51 & 05 & W .\end{array}$ & $\begin{array}{r}1,005 \\
463 \\
875\end{array}$ & $\begin{array}{l}\text { Robrecht. } \\
\text { Lowell. }\end{array}$ \\
\hline & $3^{8} 0910.60$ & $76 \quad 30 \quad 24.20$ & $\begin{array}{llll}\text { N. } & 48 & 08 & \mathrm{E} \\
\text { N. } & 13 & 26 & \mathrm{~W} \\
\text { S. } & 57 & 26 & \mathrm{~W}\end{array}$ & $\begin{array}{llll}\text { S. } & 48 & 08 & \text { W. } \\
\text { S. } & 13 & 26 & \text { E. } \\
\text { N. } & 57 & 26 & \text { E. }\end{array}$ & $\begin{array}{l}316 \\
816 \\
147\end{array}$ & $\begin{array}{l}\text { Lowell. } \\
\text { Shehan. } \\
\text { Russell. }\end{array}$ \\
\hline & $3^{8}$ o9 15.18 & $7630 \quad 27.62$ & $\begin{array}{lrrr}\text { S. } & 8 & 04 & \text { W. } \\
\text { N. } 80 & 07 & \text { E. } \\
\text { N. } & 8 & 47 & \text { W. }\end{array}$ & $\begin{array}{lrrr}\text { N. } & 8 & 04 & \mathrm{E} \\
\text { S. } & 80 & 07 & \mathrm{~W} . \\
\text { S. } & 8 & 47 & \mathrm{E}\end{array}$ & $\begin{array}{l}235 \\
332 \\
645\end{array}$ & $\begin{array}{l}\text { Russell. } \\
\text { Lowell. } \\
\text { Shelian. }\end{array}$ \\
\hline & $3^{8}$ og 18.67 & $76 \quad 3020.18$ & $\begin{array}{llll}\text { N. } 29 & 42 & \text { W. } \\
\text { S. } 33 & 20 & \text { W. } \\
\text { S. } & 64 & 47 & \text { E. }\end{array}$ & $\begin{array}{llll}\text { S. } & 29 & 42 & \mathrm{E} \\
\text { N. } & 33 & 20 & \mathrm{E} \\
\text { N. } & 64 & 47 & \mathrm{~W}\end{array}$ & $\begin{array}{l}599 \\
421 \\
142\end{array}$ & $\begin{array}{l}\text { Shehan. } \\
\text { Russell. } \\
\text { Loweil. }\end{array}$ \\
\hline
\end{tabular}

Thence from corner No. 6 along the mean low-water line of the shore to corner No. 7 , excluding any creek, cove, or inlet less than 100 yards in width at its mouth at low tide.

7 \begin{tabular}{ll|llll}
38 & 09 & 18.02 & 76 & 30 & 08.56
\end{tabular}

8

\begin{tabular}{|c|c|}
\hline $\begin{array}{rrr}77 & 51 & \text { W. } \\
\text { I } & 32 & \text { W. } \\
83 & 46 & \mathrm{E}\end{array}$ & 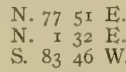 \\
\hline & 8 \\
\hline
\end{tabular}

\begin{tabular}{r|l}
185 & Lowell. \\
1,196 & Robrecht. \\
506 & Arbuckle. \\
296 & Arbuckle. \\
442 & Lowell. \\
827 & Russell.
\end{tabular}


BOUNDARIES OF NATURAL OYSTER BARS-continued.

SHEHAN-Continued.

(St. George River-Chart No. 24.)

\begin{tabular}{|c|c|c|c|c|c|c|}
\hline \multirow{2}{*}{$\begin{array}{l}\text { Cor- } \\
\text { ner } \\
\text { of } \\
\text { bar. }\end{array}$} & \multirow{2}{*}{ Latitude. } & \multirow{2}{*}{ Longitude. } & \multicolumn{2}{|c|}{ True bearing. } & \multirow{2}{*}{ Distance. } & \multirow{2}{*}{$\begin{array}{l}\text { U. S. C. \& G. S. triangula- } \\
\text { tion station. }\end{array}$} \\
\hline & & & Forward. & Back. & & \\
\hline 9 & $\begin{array}{ccc}0 & , & \prime \prime \\
38 & 09 & 10.59\end{array}$ & 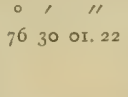 & $\begin{array}{lccc} & 0 & \\
\text { N. } & 45 & \text { I3 } & \text { E. } \\
\text { N. } 60 & 37 & \text { W. } \\
\text { S. } 83 & 44 & \text { W. }\end{array}$ & $\begin{array}{lccc} & 0 & \\
\text { S. } & 45 & 13 & \text { W. } \\
\text { S. } & 60 & 37 & \text { E. } \\
\text { N. } 83 & 44 & \text { E. }\end{array}$ & $\begin{array}{r}\text { Yards. } \\
434 \\
432 \\
740\end{array}$ & $\begin{array}{l}\text { Arbuckle. } \\
\text { Lowell. } \\
\text { Russell. }\end{array}$ \\
\hline IO & $\begin{array}{llll}38 & \circ 9 & 03.57\end{array}$ & $76 \quad 30 \quad 12.88$ & 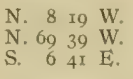 & $\begin{array}{lrrr}\text { S. } & 8 & 19 & \mathrm{E} \\
\text { S. } & 69 & 39 & \mathrm{E} \\
\text { N. } & 6 & 41 & \mathrm{~W}\end{array}$ & $\begin{array}{l}453 \\
454 \\
714\end{array}$ & $\begin{array}{l}\text { Lowell. } \\
\text { Russell. } \\
\text { Robrecht. }\end{array}$ \\
\hline
\end{tabular}

\section{LONG.}

(St. George River-Chart No. 24.)

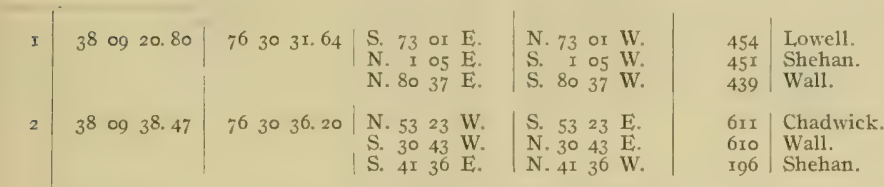

Thence from corner No. 2 along the mean low-water line of the shore to corner No. 3 , excluding any creek, cove, or inlet less than roo yards in width at its mouth at low tide.

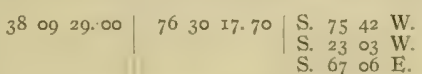

N. 7542 E. N. $2303 \mathrm{E}$. N. $6706 \mathrm{~W}$

$830 \mid$ Wall.

759 Russell.

810 Arbuckle.

\section{CHADWICK.}

(St. George River-Chart No. 24.)

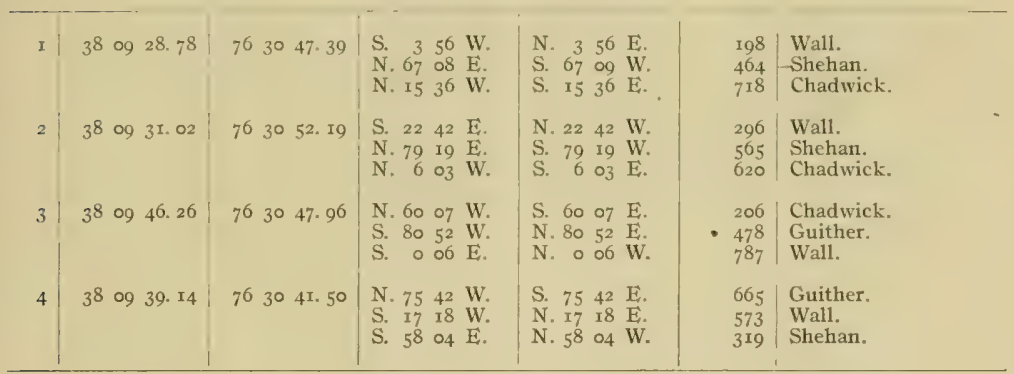


BOUNDARIES OF NATURAL OYSTER BARS - continued.

MOULDY CREEK.

(Upper Bretons Bay-Chart No. 25.)

\begin{tabular}{|c|c|c|c|c|c|c|}
\hline \multirow{2}{*}{$\begin{array}{l}\text { Core } \\
\text { ner } \\
\text { of } \\
\text { bar. }\end{array}$} & \multirow{2}{*}{ Latitude. } & \multirow{2}{*}{ Longitude. } & \multicolumn{2}{|c|}{ True bearing. } & \multirow{2}{*}{ Distance. } & \multirow{2}{*}{$\begin{array}{l}\text { U. S. C. \& G. S. triangula- } \\
\text { tion station. }\end{array}$} \\
\hline & & & Forward. & Back. & & \\
\hline$I$ & $\begin{array}{ccc}0,11 \\
38 & 1600.00\end{array}$ & $\begin{array}{ccc}\circ, & \prime \prime \\
76 & 37 & 51.44\end{array}$ & $\begin{array}{lrrr} & 0 & , \\
\text { N. } & \text { I } & 24 & \text { W. } \\
\text { N. } & 39 & 5^{8} & \text { W. } \\
\text { S. } & 68 & 3 I & \text { W. }\end{array}$ & \begin{tabular}{lccc} 
& 0 &, \\
S. & \multicolumn{1}{c}{24} & $\mathrm{E}$. \\
S. & 39 & $5^{8}$ & $\mathrm{E}$. \\
N. & 68 & 3 & $\mathrm{E}$.
\end{tabular} & $\begin{array}{r}\text { Yards. } \\
782 \\
988 \\
334\end{array}$ & $\begin{array}{l}\text { Cedar. } \\
\text { Noname. } \\
\text { Mouldy. }\end{array}$ \\
\hline 2 & $3^{8} \quad 1600.00$ & $7^{6} \quad 37 \quad 5^{8} \cdot 74$ & 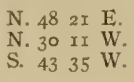 & $\begin{array}{llll}\text { S. } 48 & 2 \text { I } & \text { W. } \\
\text { S. } 30 & \text { II } & \text { E. } \\
\text { N. } & 43 & 35 & \text { E. }\end{array}$ & $\begin{array}{l}370 \\
876 \\
168\end{array}$ & $\begin{array}{l}\text { Pine. } \\
\text { Noname. } \\
\text { Mouldy. }\end{array}$ \\
\hline 3 & $3^{8} \quad 16 \quad 28.70$ & $7^{6} \quad 3^{8} \quad 05 \cdot 44$ & $\begin{array}{llll}\text { S. } & 5 \mathrm{I} & 12 & \mathrm{~W} . \\
\mathrm{S} . & 62 & 17 & \mathrm{E} . \\
\mathrm{N} . & 2 \mathrm{I} & 22 & \mathrm{E} .\end{array}$ & $\begin{array}{llll}\text { N. } & 51 & 12 & \mathrm{E} . \\
\text { N. } 62 & 17 & \mathrm{~W} . \\
\text { S. } 21 & 22 & \mathrm{~W} .\end{array}$ & $\begin{array}{l}336 \\
398 \\
655\end{array}$ & $\begin{array}{l}\text { Noname. } \\
\text { Cedar. } \\
\text { Buzzard. }\end{array}$ \\
\hline 4 & $\begin{array}{llll}38 & 16 & 24.63\end{array}$ & $76 \quad 37 \quad 52.9^{8}$ & $\begin{array}{llll}\text { S. } 82 & 55 & \text { W. } \\
\text { S. } 24 & 20 & \text { E. } \\
\text { N. } 35 & 26 & \text { E. }\end{array}$ & $\begin{array}{lll}\text { N. } 8 z & 55 & \text { E. } \\
\text { N. } 24 & 20 & \text { W. } \\
\text { S. } 35 & 26 & \text { W. }\end{array}$ & $\begin{array}{r}598 \\
52 \\
436\end{array}$ & $\begin{array}{l}\text { Noname. } \\
\text { Cedar. } \\
\text { Corn. }\end{array}$ \\
\hline
\end{tabular}

Thence from corner No. 4 along the mean low-water line of the shore to corner No. I, excluding any creek, cove, or inlet less than roo yards in width at its mouth at low tide.

\section{ISLAND.}

(Upper Bretons Bay-Chart No. 25.)

\begin{tabular}{|c|c|c|c|c|c|c|}
\hline I & $3^{8}$ I5 59.22 & $7_{6}^{6} \quad 3^{8} \quad 50.08$ & $\begin{array}{llll}\text { S. } 83 & \text { 15 } & \text { E. } \\
\text { N. } 23 \text { og } & \text { E. } \\
\text { N. } 84 & 52 & \text { W. }\end{array}$ & $\begin{array}{llll}\text { N. } 83 & \text { I4 } & \text { W. } \\
\text { S. } 23 & \text { og } & \text { W. } \\
\text { S. } & 84 & 53 & \text { E. }\end{array}$ & $\begin{array}{l}656 \\
270 \\
744\end{array}$ & $\begin{array}{l}\text { Beau. } \\
\text { Healey. } \\
\text { Hollow. }\end{array}$ \\
\hline 2 & $3^{8}$ I6 05.53 & $7^{6} 38 \quad 47 \cdot 26$ & $\begin{array}{lrrr}\text { S. } & 55 & 16 & \text { W. } \\
\text { S. } & 2 & 03 & \text { E. } \\
\text { N. } & 41 & 18 & \text { E. }\end{array}$ & 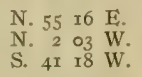 & $\begin{array}{r}967 \\
889 \\
47\end{array}$ & $\begin{array}{l}\text { Trees. } \\
\text { Lovers. } \\
\text { Healey. }\end{array}$ \\
\hline 3 & $3^{8} \quad 16 \quad 04.84$ & $76 \quad 38 \quad 40.20$ & $\begin{array}{llll}\text { S. } & 55 & 35 & \mathrm{E} \\
\text { N. } & 29 & 49 & \mathrm{E} \\
\text { N. } & 69 & 28 & \mathrm{~W}\end{array}$ & 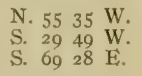 & $\begin{array}{l}471 \\
166 \\
167\end{array}$ & $\begin{array}{l}\text { Beau. } \\
\text { Belle. } \\
\text { Healey. }\end{array}$ \\
\hline 4 & 38 I6 II. 84 & $7^{6} 3^{8}=25 \cdot 3^{6}$ & $\begin{array}{lrrr}\text { N. } & 36 & 47 & \mathrm{E} . \\
\text { S. } & 73 & 37 & \mathrm{~W} . \\
\text { S. } & 0 & 36 & \mathrm{~W} .\end{array}$ & $\begin{array}{llll}\text { S. } 36 & 47 & \text { W. } \\
\text { N. } 73 & 37 & \mathrm{E} \\
\text { N. } & 0 & 36 & \mathrm{E} .\end{array}$ & $\begin{array}{l}447 \\
325 \\
503\end{array}$ & $\begin{array}{l}\text { Noname. } \\
\text { Belle. } \\
\text { Beau. }\end{array}$ \\
\hline 5 & $\begin{array}{llll}3^{8} & 16 & 03.00\end{array}$ & $763^{8} \quad 19.4^{2}$ & $\begin{array}{llll}\text { N. } 66 & 14 & \text { W. } \\
\text { S. } & 38 & 34 & \text { W. } \\
\text { S. } 62 & 46 & \text { E. }\end{array}$ & $\begin{array}{llll}\text { S. } 66 & 14 & \mathrm{E} . \\
\text { N. } & 38 & 34 & \mathrm{E} . \\
\mathrm{N} . & 62 & 45 & \mathrm{~W}\end{array}$ & $\begin{array}{l}513 \\
263 \\
488\end{array}$ & $\begin{array}{l}\text { Belle. } \\
\text { Beau. } \\
\text { Mouldy. }\end{array}$ \\
\hline
\end{tabular}


BOUNDARIES OF NATURAL OYSTER BARS-continued.

PAW PAW HOLLOW.

(Upper Bretons Bay-Chart No. 25.)

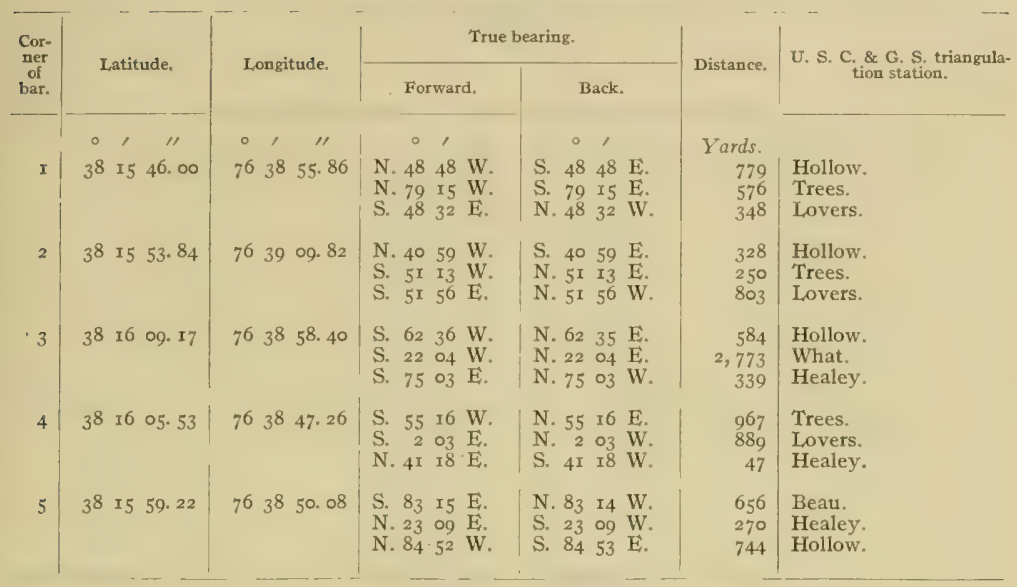

I,OVERS POINT.

(Middle Bretons Bay-Chart No. 25.)

\begin{tabular}{|c|c|c|c|c|c|c|c|c|}
\hline$I$ & $3^{8}$ & I5 $27 \cdot 30$ & $76 \quad 39$ & 0.2. $5^{2}$ & 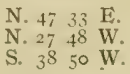 & $\begin{array}{llll}\text { S. } & 47 & 33 & \mathrm{~W} \\
\text { S. } & 27 & 48 & \mathrm{E} \\
\text { N. } & 38 & 50 & \mathrm{E}\end{array}$ & $\begin{array}{r}593 \\
834 \\
r, 486\end{array}$ & $\begin{array}{l}\text { Lovers. } \\
\text { Trees. } \\
\text { What. }\end{array}$ \\
\hline 2 & $3^{8}$ & I5 53.84 & 7639 & 09.82 & $\begin{array}{llll}\text { N. } 40 & 59 & \text { W. } \\
\text { S. } 5 I & 13 & \text { W. } \\
\text { S. } & 5 \text { I } & 56 & \text { E. }\end{array}$ & $\begin{array}{llll}\text { S. } 40 & 59 & \mathrm{E} \\
\text { N. } & 5 \mathrm{I} & \mathrm{I} 3 & \mathrm{E} \\
\text { N. } & 5 \mathrm{I} & 56 & \mathrm{~W}\end{array}$ & $\begin{array}{l}328 \\
250 \\
803\end{array}$ & $\begin{array}{l}\text { Hollow. } \\
\text { Trees. } \\
\text { Lovers. }\end{array}$ \\
\hline 3 & $3^{8}$ & I5 46.00 & $76 \quad 38$ & 55.86 & 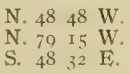 & $\begin{array}{llll}\text { S. } 48 & 48 & \mathrm{E} \\
\text { S. } & 79 & \text { I } 5 & \mathrm{E} \\
\text { N. } & 48 & 32 & \text { W. }\end{array}$ & $\begin{array}{l}779 \\
576 \\
348\end{array}$ & $\begin{array}{l}\text { Hollow. } \\
\text { Trees. } \\
\text { Lovers. }\end{array}$ \\
\hline 4 & $3^{8}$ & I5 27.46 & $76 \quad 38$ & $55 \cdot 38$ & $\begin{array}{llll}\text { N. } 32 & \text { o, } & \mathrm{E} \\
\text { N. } & 38 & 19 & \mathrm{~W} \\
\text { S. } & 43 & 58 & \mathrm{~W} .\end{array}$ & 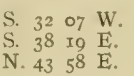 & $\begin{array}{r}466 \\
934 \\
\text { I, } 616\end{array}$ & $\begin{array}{l}\text { Lovers. } \\
\text { Trees. } \\
\text { What. }\end{array}$ \\
\hline
\end{tabular}


BOUNDARIES OF NATURAL OYSTER BARS - continuEd.

STONY

(Middle Bretons Bay-Chart No. 25.)

\begin{tabular}{|c|c|c|c|c|c|c|}
\hline \multirow{2}{*}{$\begin{array}{l}\text { Cor- } \\
\text { ner } \\
\text { of } \\
\text { bar. }\end{array}$} & \multirow{2}{*}{ Latitude. } & \multirow{2}{*}{ Longitude. } & \multicolumn{2}{|c|}{ True bearing. } & \multirow{2}{*}{ Distance. } & \multirow{2}{*}{$\begin{array}{c}\text { U. S. C. \& G. S, triangula } \\
\text { tion station. }\end{array}$} \\
\hline & & & Forward. & Back. & & \\
\hline I & $\begin{array}{ccc}0 & \prime \prime \\
38 & \text { I5 } & \text { ×8. } 94\end{array}$ & $\begin{array}{ccc}0 & \prime & \prime \prime \\
76 & 39 & 49.00\end{array}$ & $\begin{array}{lccc} & 0 & & \\
\text { N. } & 2 I & 58 & \text { W. } \\
\text { S. } & 54 & 43 & \text { W. } \\
\text { S. } & \text { I9 } & 07 & \mathrm{E} .\end{array}$ & $\begin{array}{lccc} & & \\
\text { S. } & 2 I & 58 & \mathrm{E} . \\
\text { N. } & 54 & 43 & \mathrm{E} \\
\text { N. } & \text { I9 } & 07 & \mathrm{~W}\end{array}$ & $\begin{array}{r}\text { Yards. } \\
423 \\
\text { I, } 390 \\
930\end{array}$ & $\begin{array}{l}\text { Paw. } \\
\text { Protestant. } \\
\text { What. }\end{array}$ \\
\hline 2 & $3^{8}$ I5 30.80 & $76 \quad 40 \quad 39.14$ & 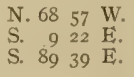 & $\begin{array}{lrrr}\text { S. } 68 & 57 & \text { E } \\
\text { N. } & 9 & 2 I & \text { W. } \\
\text { N. } 89 & 39 & \text { W. }\end{array}$ & $\begin{array}{r}363 \\
I, 219 \\
I, 175\end{array}$ & $\begin{array}{l}\text { Cherry Cove. } \\
\text { Protestant. } \\
\text { Páw. }\end{array}$ \\
\hline 3 & $\begin{array}{lllll}38 & \text { I5 } & 36 . & \text { I } 4\end{array}$ & $764035 \cdot 30$ & $\begin{array}{lrrr}\text { S. } & 83 & 32 & \mathbf{W} . \\
\text { S. } & 3 & 58 & \mathbf{E} . \\
\text { S. } & 46 & 27 & \text { E. }\end{array}$ & 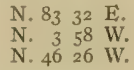 & $\begin{array}{r}443 \\
\text { I, } 387 \\
2, \mathrm{II} 8\end{array}$ & $\begin{array}{l}\text { Cherry Cove. } \\
\text { Protestant. } \\
\text { What. }\end{array}$ \\
\hline
\end{tabular}

Thence from corner No. 3 along the mean low-water line of the shore to corner No. 4, excluding any creek, cove, or inlet less than roo yards in width at its mouth at low tide.

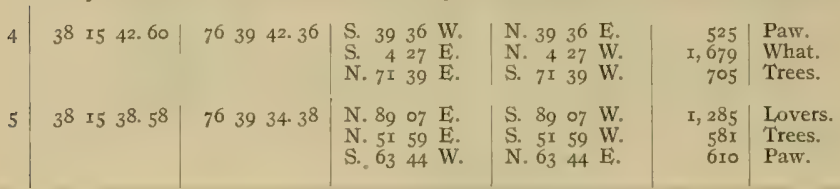

GOUGH.

(Middle Bretons Bay-Chart No. 25.)

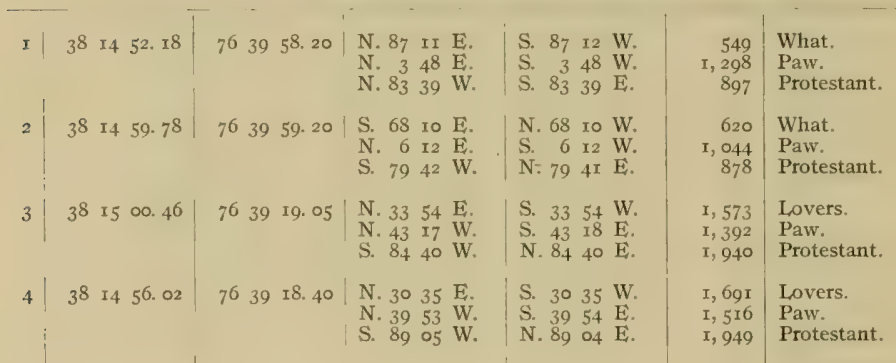


BOUNDARIES OF NATURAL OYSTER BARS-continLed.

\section{BLACK WALNUT.}

(Lower Bretons Bay-Chart No. 25.)

\begin{tabular}{|c|c|c|c|c|c|c|c|c|c|}
\hline \multirow{2}{*}{$\begin{array}{l}\text { Cor- } \\
\text { ner } \\
\text { of } \\
\text { bar. }\end{array}$} & \multirow{2}{*}{\multicolumn{2}{|c|}{ Latitude. }} & \multirow{2}{*}{\multicolumn{3}{|c|}{ Longitude. }} & \multicolumn{2}{|c|}{ True bearing. } & \multirow{2}{*}{ Distance. } & \multirow{2}{*}{$\begin{array}{c}\text { U. S. C. \& G. S. triangula- } \\
\text { tion station. }\end{array}$} \\
\hline & & & & & & Forward. & Back. & & \\
\hline I & $3^{8}$ & I4 3I. O4 & $\begin{array}{c}0 \\
76\end{array}$ & 4I & $\begin{array}{c}\prime \prime \\
12.92\end{array}$ & $\begin{array}{lrrr} & \circ & \\
\text { S. } & 8 I & 47 & \text { W. } \\
\text { S. } & 3 & 33 & \text { E. } \\
\text { N. } & 54 & 56 & \text { E. }\end{array}$ & 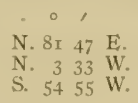 & $\begin{array}{r}\text { Yards. } \\
\text { I, I9I } \\
84 \\
412\end{array}$ & $\begin{array}{l}\text { Newtown. } \\
\text { Dune. } \\
\text { Fence. }\end{array}$ \\
\hline 2 & $3^{8}$ & I4 40.99 & 76 & $4 \mathrm{I}$ & 27.04 & $\begin{array}{llll}\text { N. } 64 & 3 \text { I } & \text { W } \\
\text { S. } 57 & 49 & \text { W. } \\
\text { S. } & 42 & 23 & \text { E. }\end{array}$ & $\begin{array}{llll}\text { S. } 64 & 3 \text { I } & \text { E. } \\
\text { N. } & 57 & 49 & \text { E. } \\
\text { N. } 42 & 23 & \text { W. }\end{array}$ & $\begin{array}{l}749 \\
949 \\
56.4\end{array}$ & $\begin{array}{l}\text { Sandbar. } \\
\text { Newtown. } \\
\text { Dune. }\end{array}$ \\
\hline 3 & $3^{8}$ & I4 53.04 & $7^{6}$ & $4 \mathrm{I}$ & Io. $3 \mathrm{I}$ & $\begin{array}{llll}\text { S. } 85 & 43 & \text { W. } \\
\text { S. } 28 & 06 & \mathrm{E} . \\
\text { N. } 86 & \text { o6 } & \mathrm{E}\end{array}$ & $\begin{array}{lll}\text { N. } 85 & 43 & \text { E. } \\
\text { N. } 28 & 06 & \text { W. } \\
\text { S. } 86 & 06 & \text { W. }\end{array}$ & $\begin{array}{r}\mathbf{I}, \mathbf{I} 25 \\
573 \\
\mathbf{r}, 029\end{array}$ & $\begin{array}{l}\text { Sandbar. } \\
\text { Fence. } \\
\text { Protestant. }\end{array}$ \\
\hline 4 & $3^{8}$ & 1507.04 & 76 & 40 & 27.90 & $\begin{array}{llll}\text { N. } & 47 & 48 & \text { E. } \\
\text { N. } 34 & 22 & \text { W. } \\
\text { S. } & 14 & 06 & \text { W. }\end{array}$ & $\begin{array}{llll}\text { S. } 47 & 48 & \text { W. } \\
\text { S. } 34 & 22 & \text { E. } \\
\text { N. I4 } & \text {. } & \text { E. }\end{array}$ & $\begin{array}{r}1,182 \\
\mathrm{I}, 129 \\
413\end{array}$ & $\begin{array}{l}\text { Paw. } \\
\text { Cherry Cove. } \\
\text { Protestant. }\end{array}$ \\
\hline 5 & $3^{8}$ & $\times 459.78$ & 76 & 39 & 59.20 & $\begin{array}{lrrr}\text { S. } & 68 & \text { 10 } & \text { E. } \\
\text { N. } & 6 & \text { I2 } & \text { E. } \\
\text { S. } & 79 & 42 & \text { W. }\end{array}$ & $\begin{array}{l}\text { N. } 68 \text { 10 } \mathrm{W} . \\
\text { S. } 6 \text { I2 } \\
\text { N. } 79 \text {. } \\
\text { II }\end{array}$ & $\begin{array}{r}620 \\
I, 044 \\
878\end{array}$ & $\begin{array}{l}\text { What. } \\
\text { Paw. } \\
\text { Protestant. }\end{array}$ \\
\hline 6 & $3^{8}$ & I4 52.18 & 76 & 39 & $5^{8.20}$ & $\begin{array}{llll}\text { N. } 87 & \text { II } & \text { E. } \\
\text { N. } & 3 & 48 & \text { E. } \\
\text { N. } 83 & 39 & \text { WV. }\end{array}$ & $\begin{array}{lrrl}\text { S. } 87 & 12 & \text { WV. } \\
\text { S. } & 3 & 48 & \text { W. } \\
\text { S. } & 83 & 39 & \text { E. }\end{array}$ & $\begin{array}{r}549 \\
\mathrm{r}, 298 \\
897\end{array}$ & $\begin{array}{l}\text { What. } \\
\text { Paw. } \\
\text { Protestant. }\end{array}$ \\
\hline 7 & $3^{8}$ & I4 44.29 & 76 & 39 & $57 \cdot 4^{2}$ & $\begin{array}{lll}\text { N. } 26 & 07 & \mathrm{E} \\
\text { N. } 2 & 24 & \mathrm{E} \\
\text { N. } 68 & \text { ro } & \text { W. }\end{array}$ & $\begin{array}{lrrr}\text { S. } & 26 & 07 & \text { W. } \\
\text { S. } & 2 & 24 & \text { W. } \\
\text { S. } & 68 & 10 & \text { E. }\end{array}$ & $\begin{array}{r}2,436 \\
\text { I, } 563 \\
982\end{array}$ & $\begin{array}{l}\text { Trees. } \\
\text { Paw. } \\
\text { Protestant. }\end{array}$ \\
\hline
\end{tabular}

Thence from corner No. 7 along the mean low-water line of the shore to corner No, I, excluding any creek, cove, or inlet less than roo yards in width at its mouth at low tide.

\section{RAILIVAY.}

(Lower Bretons Bay-Chart No. 25.)

\begin{tabular}{|c|c|c|c|c|c|c|c|c|c|}
\hline I & 38 & I4 $53.5^{8}$ & 76 & $4 I$ & 50.42 & $\begin{array}{llll}\text { S. } 28 & 05 & \text { W. } \\
\text { S. } & 68 & 39 & \text { E. } \\
\text { N. } & 2 & 24 & \text { E. }\end{array}$ & 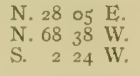 & $\begin{array}{r}\text { I } 6 \\
\text { I, } 434 \\
945\end{array}$ & $\begin{array}{l}\text { Sandbar. } \\
\text { Fence. } \\
\text { Compton. }\end{array}$ \\
\hline 2 & $3^{8}$ & I4 $59 \cdot 46$ & 76 & $4 x$ & $59 \cdot 28$ & $\begin{array}{llll}\text { S. } 3 I & 08 & \mathrm{E} . \\
\text { S. } & 86 & 24 & \mathrm{E} \\
\text { N. } & 20 & 12 & \mathrm{E}\end{array}$ & $\begin{array}{l}\text { N. } 3 I \text { I } 08 \text { W. } \\
\text { N. } 86 \text { 23 } \mathrm{W} . \\
\text { S. } 20 \text { т2 }\end{array}$ & $\begin{array}{r}350 \\
2,334 \\
795\end{array}$ & $\begin{array}{l}\text { Sandbar. } \\
\text { Protestant. } \\
\text { Compton. }\end{array}$ \\
\hline 3 & $3^{8}$ & I5 32.48 & 76 & $4^{r}$ & 36.98 & $\begin{array}{llll}\text { S. } & 40 & 53 & \mathrm{~W} . \\
\text { S. } & 54 & 02 & \mathrm{E} \\
\text { S. } & 88 & 37 & \mathrm{E} .\end{array}$ & $\begin{array}{llll}\text { N. } 40 & 53 & \text { E. } \\
\text { N. } 54 & 02 & \text { W. } \\
\text { N. } 88 & 36 & \text { W. }\end{array}$ & $\begin{array}{r}487 \\
2,145 \\
2,713\end{array}$ & $\begin{array}{l}\text { Compton. } \\
\text { Protestant. } \\
\text { Paw. }\end{array}$ \\
\hline 4 & $3^{8}$ & I5 $29.2 \mathrm{I}$ & 76 & $4 \mathrm{I}$ & 19. 62 & $\begin{array}{llll}\text { S. } 7 \text { I } & 43 & \text { W. } \\
\text { S. } & 47 & 53 & \text { E. } \\
\text { N. } & 76 & 00 & \text { E. }\end{array}$ & $\begin{array}{lll}\text { N. } 71 & 42 & \text { E. } \\
\text { N. } 47 & 53 & \text { W. } \\
\text { S. } 76 & 00 & \text { W. }\end{array}$ & $\begin{array}{r}82 \mathrm{I} \\
\mathrm{I}, 7 \mathrm{I} \\
76 \mathrm{r}\end{array}$ & $\begin{array}{l}\text { Compton. } \\
\text { Protestant. } \\
\text { Cherry Cove. }\end{array}$ \\
\hline 5 & $3^{8}$ & I 526.92 & 76 & 40 & 4I. 23 & $\begin{array}{l}\text { S. I3 } 20 \text { E. } \\
\text { N. } 84 \text { I5 } \\
\text { E. } 47 \text { I5 }\end{array}$ & 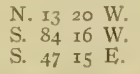 & $\begin{array}{r}I, I O 2 \\
I, 236 \\
384\end{array}$ & $\begin{array}{l}\text { Protestant. } \\
\text { Paw. } \\
\text { Cherry Cove. }\end{array}$ \\
\hline
\end{tabular}


(Lower Bretons Bay-Chart No. 25.)

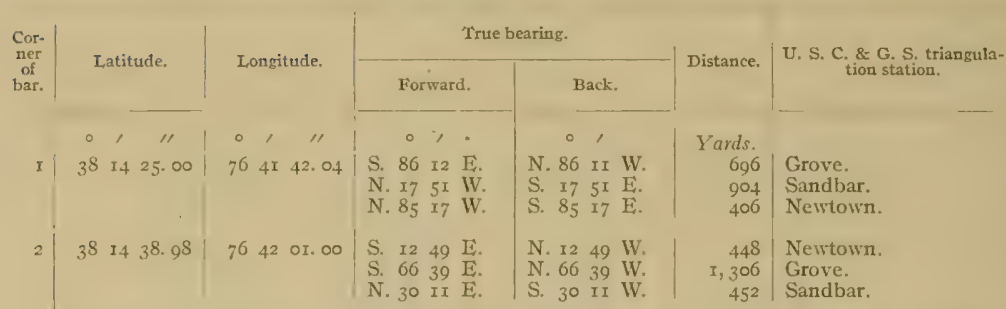

Thence from corner No. 2 along the mean low-water line of the shore to corner No. 3 , excluding any creek, cove, or inlet less than rco yards in width at its mouth at low tide.

\begin{tabular}{|c|c|c|c|c|c|}
\hline $3^{8}$ I 4 48. I2 & $76 \quad 4 \mathrm{x} 54.53$ & $\begin{array}{lrrll}\text { S. } & 5 & 33 & \text { W. } \\
\text { S. } & 51 & 12 & \text { E. } \\
\text { N. } & 33 & 50 & \text { E. }\end{array}$ & $\begin{array}{lrrr}\text { N. } & 5 & 33 & \mathrm{E} . \\
\text { N. } & 5 \text { I } & \text { II } & \text { W. } \\
\text { S. } & 33 & 50 & \text { W. }\end{array}$ & $\begin{array}{r}750 \\
\mathrm{r}, 318 \\
98\end{array}$ & $\begin{array}{l}\text { Newtown. } \\
\text { Grove. } \\
\text { Sandbar. }\end{array}$ \\
\hline $3^{8}$ I4 $49.8 \mathrm{I}$ & $7^{6} 4 \pi \quad 34.62$ & $\begin{array}{llll}\text { S. } & 66 & 36 & \mathrm{E} . \\
\text { S. } & 36 & 5 \mathrm{I} & \mathrm{WV} \\
\text { N. } 86 & 55 & \mathrm{WV} .\end{array}$ & $\begin{array}{lll}\text { N. } 66 & 36 & \text { W. } \\
\text { N. } 36 & 5 \mathrm{I} & \mathrm{E} \\
\text { S. } 86 & 55 & \mathrm{E} .\end{array}$ & $\begin{array}{r}998 \\
\mathrm{I}, 006 \\
476\end{array}$ & $\begin{array}{l}\text { Fence. } \\
\text { Newtown. } \\
\text { Sandbar. }\end{array}$ \\
\hline $3^{8} \quad I 425.80$ & $76 \quad 4$ I 31.20 & $\begin{array}{llll}\text { S. } & 79 & 48 & \text { E. } \\
\text { N. } 34 & 1 \mathrm{I} & \mathrm{W} \\
\text { N. } 89 & 28 & \mathrm{~W}\end{array}$ & $\begin{array}{llll}\text { N. } 79 & 47 & \text { W. } \\
\text { S. } 34 & \text { I2 } & \text { E. } \\
\text { S. } 89 & 28 & \text { E. }\end{array}$ & $\begin{array}{r}413 \\
x, 006 \\
69^{2}\end{array}$ & $\begin{array}{l}\text { Grove. } \\
\text { Sandbar } \\
\text { Newtown. }\end{array}$ \\
\hline
\end{tabular}

BLUE SOW.

(Lower Bretons Bay-Chart No. 25.)

$-$

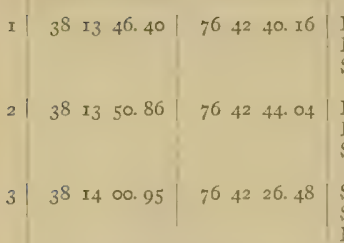

\section{So5 Kaywood. \\ 030 St. Clement.}

I, 938 Heron.

\begin{tabular}{r|l}
795 & Kaywood. \\
769 & St. Clement. \\
2,030 & Heron.
\end{tabular}

I, I68 St. Clement.

2, 540 Heron.

224 Kaywood.

Thence from corner No. 3 along the mean low-water line of the shote to corner No. 4 , excluding any creek, cove, or inlet less than 100 yards in width at its mouth at low tide.
\begin{tabular}{l|lll|llll|llll}
4 & 38 & I. & 08.44 & 76 & 42 & I3.0 & S. & 38 & I9 & W. \\
S. 88 & 02 & E.
\end{tabular}
N. $352 \mathrm{I} \mathrm{E}$.
$\begin{array}{lll}\text { N. } 38 & \text { 19 } & \text { E. } \\ \text { N. } 88 & \text { o3 } & \text { W. }\end{array}$
S. $352 \mathrm{I} \mathrm{W}$
5 $\mid$\begin{tabular}{llll|lll|lll}
$3^{8}$ & 14 & 17.82 & 76 & $4 \pi$ & 56.29 & N. 79 & $3^{8}$ & $\mathrm{E}$.
\end{tabular}
N. 5 2I W.
S. $7939 \mathrm{WV}$
S. 521 E.
S. $4947 \mathrm{~W}$.
N. $4946 \mathrm{E}$.
\begin{tabular}{l|llll|lll|lll}
6 & 38 & 14 & $13.4^{2}$ & 76 & 41 & 52.08 & N. 70 & I 8 E.
\end{tabular}
N. $1800 \mathrm{WV}$.
S. $6328 \mathrm{~W}$.

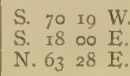
\begin{tabular}{r|l}
233 & Kaywood. \\
I, 574 & Cedoak. \\
725 & Newtown. \\
& \\
I, 991 & Grove. \\
277 & Newtown. \\
772 & Kaywood.
\end{tabular}
I, O2I Grove.
446 Newtown.
$784 \mid$ Kaywood. 
BOUNDARIES OF NATURAL OYSTER BARS-continUEC.

HERON ISLAND SOUND.

(Entrance to Bretons and St. Clement Bajs-Chart No. 25.)

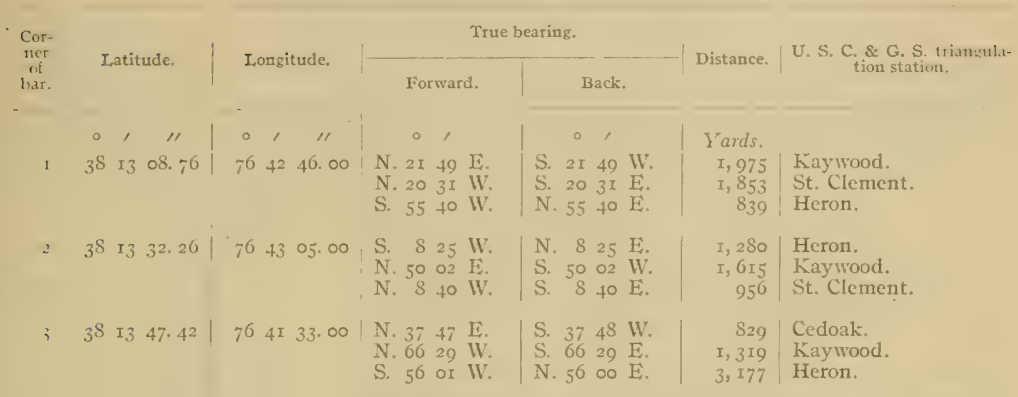

\section{HERON ISLAND REEF.}

(Entrance to Bretons and St. Clement Bays-Chart No. 25.)

I $38 \quad 1254.73 \quad 7643$ I2.04: N. I 08 E. S. I 08 W. N. 3049 W. $\mid$ S. $3050 \mathrm{E}$. S. 68 to W. N. 6839 E.

$=\quad 3^{8} 5307.68 \quad 76435$ I. $7^{2}$ S. $443 \%$ IV.

S. $6732 \mathrm{E}$. N. 3 I 49 E.

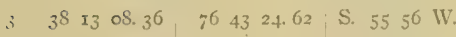

S. 36 of E. N. I2 I4 Ii.

$4 \quad 3^{8} I_{3}$ or. $44 \mid 764306.3^{8}$ N. 3 I 32 E.

N. 3 o5 W. S. 3339 W.
N. $4436 \mathrm{E}$.

N. $673 \mathrm{I} \mathrm{WV}$. S. $3 I 50 \mathrm{~W}$.

N. $5555 \mathrm{E}$.

N. $3^{6} 04 \mathrm{WV}$. S. I2 14 IV.

S. 3 I $33 \mathrm{~W}$. S. 3 O5 E. N. $3339 \mathrm{E}$.
2,209 St. Clement.

3, 305 St. Pattick.

2, 592 Blakistone Island Light.

I, 933 Blakistone Island Light.

I, I42 Heron.

2, ogo St. Clement.

2,510 BIakistone Island Light.

568 Heron.

I, 785 St. Clement.

2, 437 | Kaywood.

I, 98.4 St. Clement.

$27 \mathrm{r}$ Heron.

\section{DUKEHART CHANNEL.}

(Lower St. Clement Bay-Chart No. 25.)

I

$3^{8}$ I2 $55.7^{8}|76+428.62|$ S. 21 o5 W.

S. 89 oo IE.

$\begin{array}{lllllll}2 & 38 & \text { I } 304.56 & 76 & 45 & 04.28\end{array}$

N. +346 E. S. 4346 W.

S. $2414 \mathrm{E}$.

S. $8340 \mathrm{~F}$.

N. $2716 \mathrm{E}$.
| N. 2 I $05 \mathrm{E}$.

N. $89 \infty \mathrm{WV}$.

N. 241.4 W.

N. $8339 \mathrm{WV}$ S. $2717 \mathrm{~W}$.
I, 0.49 | Blakistone Island Light.

2, 037 Heron.

3,008 St. Clement.

I, 398 | Blakistone Island Light.

3, 004 Heron.

2,827 St. Patrick. 
BOUNDARIES OF NATURAL OYSTER BARS-continued.

DUKEHART CHANNEL-Continued.

(Lower St. Clement Bay-Chart No. 25.)

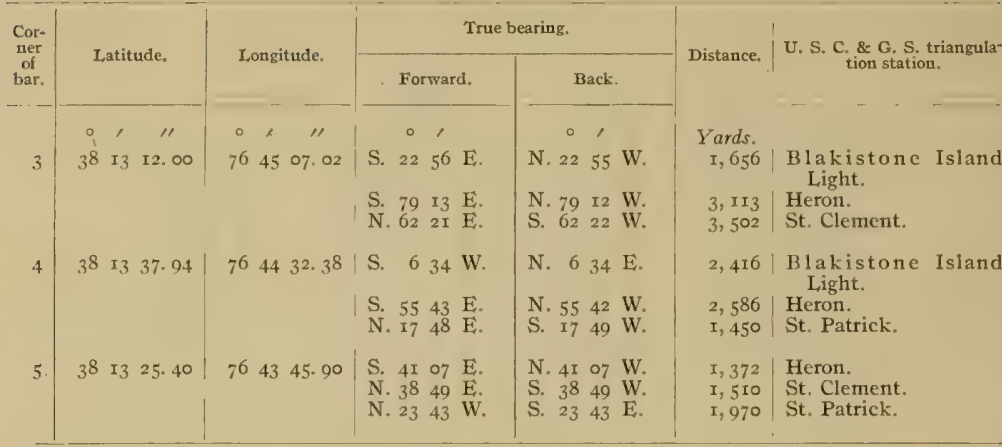

\section{HORSE,}

(Lower St. Clement Bay-Chart No. 25.)

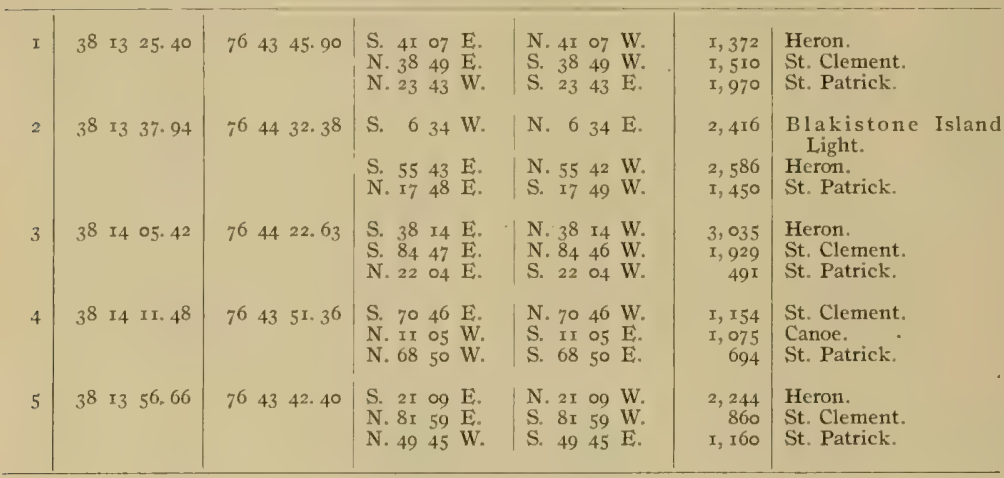

ST. CLEMENT ENTRANCE.

(Lower St. Clement Bay-Chart No. 25.)

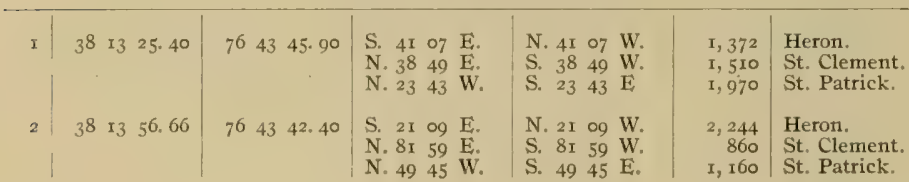


BOUNDARIES OF NATURAL OYSTER BARS-cOntinUEd.

ST. CLEMENT ENTRANCE-Continued.

(Lower St. Clement Bay-Chart No. 25.)

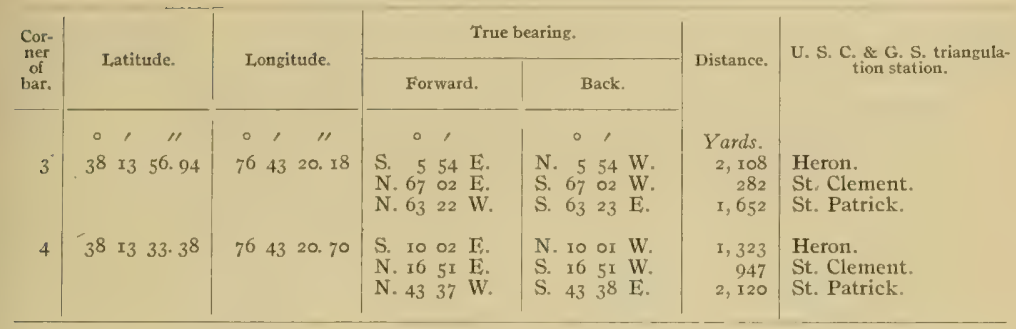

\section{OLD WRECK.}

(Lower St. Clement Bay-Chart No. 25.)

\begin{tabular}{|c|c|c|c|c|c|c|}
\hline I & $3^{8}$ I4 II. 48 & $\begin{array}{lll}76 & 43 & 51 . \\
\text { 1. }\end{array}$ & $\begin{array}{llll}\text { S. } 70 & 46 & \mathrm{E} \\
\text { N. II } & 05 & \mathrm{~W} \\
\text { N. } 68 & 50 & \mathrm{~W}\end{array}$ & $\begin{array}{llll}\text { N. } 70 & 46 & \mathrm{~W} . \\
\text { S. II } & \text { o5 } & \mathrm{E} \\
\text { S. } & 68 & 50 & \mathrm{E} .\end{array}$ & $\begin{array}{r}\text { I, } 154 \\
\text { I, } 075 \\
694\end{array}$ & $\begin{array}{l}\text { St. Clement. } \\
\text { Canoe. } \\
\text { St. Patrick. }\end{array}$ \\
\hline 2 & $38 \quad 1433.42$ & $76 \quad 4407.20$ & $\begin{array}{llll}\text { S. } & 24 & 47 & \text { W. } \\
\text { S. } & 53 & 27 & \mathrm{E} . \\
\text { N. } & 34 & 15 & \mathrm{E} .\end{array}$ & $\begin{array}{llll}\text { N. } 24 & 47 & \mathrm{E} \\
\text { N. } & 53 & 27 & \mathrm{~W} \\
\text { S. } & 34 & I 5 & \mathrm{~W}\end{array}$ & $\begin{array}{r}539 \\
\mathbf{I}, 881 \\
382\end{array}$ & $\begin{array}{l}\text { St. Patrick. } \\
\text { St. Clement. } \\
\text { Canoe. }\end{array}$ \\
\hline 3 & 38 I4 26. 96 & $\begin{array}{lll}76 & 43 & 46.24\end{array}$ & $\begin{array}{llll}\text { S. } 82 & 22 & \mathrm{E} \\
\text { N. } & 32 & 45 & \mathrm{~W} \\
\text { S. } 70 & 52 & \mathrm{~W} .\end{array}$ & $\begin{array}{llll}\text { N. } 82 & 2 I & \text { W. } \\
\text { S. } 32 & 45 & \mathrm{E} \\
\text { N. } 70 & 52 & \mathrm{E}\end{array}$ & $\begin{array}{r}1,124 \\
635 \\
829\end{array}$ & $\begin{array}{l}\text { Roof: } \\
\text { Canoe. } \\
\text { St. Patrick. }\end{array}$ \\
\hline
\end{tabular}

\section{NEWTOWN FLATS.}

(Lower St. Clement Bay-Chart No. 25-)

\begin{tabular}{|c|c|c|c|c|c|c|}
\hline I & $3^{8}$ I. II. 48 & 7643 5I. 36 & $\begin{array}{llll}\text { S. } 70 & 46 & \text { E. } \\
\text { N. II } & 05 & \text { W. } \\
\text { N. } 68 & 50 & \text { W. }\end{array}$ & $\begin{array}{llll}\text { N. } 70 & 46 & \text { W. } \\
\text { S. II } & 05 & \mathrm{E} . \\
\text { S. } & 68 & 50 & \mathrm{E} .\end{array}$ & $\begin{array}{r}\text { I, I 54 } \\
\text { I, } 075 \\
694\end{array}$ & $\begin{array}{l}\text { St. Clement. } \\
\text { Canoe. } \\
\text { St. Patrick. }\end{array}$ \\
\hline 2 & $3^{8} \quad 14 \quad 26.9^{6}$ & $\begin{array}{lll}76 & 43 & 46.24\end{array}$ & $\begin{array}{llll}\text { S. } 82 & 22 & \text { E. } \\
\text { N. } & 32 & 45 & \text { W. } \\
\text { S. } & 70 & 52 & \text { W. }\end{array}$ & $\begin{array}{lll}\text { N. } 82 & 2 \text { I } & \text { W. } \\
\text { S. } 32 & 45 & \text { E. } \\
\text { N. } 70 & 52 & \text { E. }\end{array}$ & $\begin{array}{r}\text { I, } 124 \\
635 \\
829\end{array}$ & $\begin{array}{l}\text { Roof. } \\
\text { Canoe. } \\
\text { St. Patrick. }\end{array}$ \\
\hline 3 & $3^{8} I_{4} 5^{6} .7^{2}$ & $\begin{array}{lll}76 & 43 & 15.80\end{array}$ & $\begin{array}{lrrr}\text { S. } & \text { I4 } & 50 & \mathrm{E} . \\
\mathrm{S} . & 75 & 37 & \mathrm{E} \\
\mathrm{N} . & 2 & 00 & \mathrm{~W} .\end{array}$ & $\begin{array}{l}\text { N. } 14 \text { 50 W. } \\
\text { N. } 75 \text {. } 37 \text { W. } \\
\text { S. } 2 \text { o0 } \mathrm{E} .\end{array}$ & $\begin{array}{r}\mathbf{1}, 190 \\
877 \\
729\end{array}$ & $\begin{array}{l}\text { Roof. } \\
\text { Rails. } \\
\text { Woods. }\end{array}$ \\
\hline 4 & $3^{8} \mathrm{I} 428.4 \mathrm{I}$ & $\begin{array}{lll}76 & 43 & 25 \cdot 92\end{array}$ & $\begin{array}{llll}\text { S. } 70 & 57 & \mathrm{E} . \\
\text { N. } & 56 & 38 & \mathrm{E} \\
\text { N. } 6 \text {. } & \text { I6 } & \text { W. }\end{array}$ & $\begin{array}{llll}\text { N. } 70 & 56 & \mathrm{~W} \\
\text { S. } 56 & 38 & \mathrm{~W} \\
\text { S. } 61 & 16 & \mathrm{E}\end{array}$ & $\begin{array}{r}607 \\
\mathrm{I}, 340 \\
\mathrm{x}, 007\end{array}$ & $\begin{array}{l}\text { Roof. } \\
\text { Rails. } \\
\text { Canoe. }\end{array}$ \\
\hline 5 & $\begin{array}{llll}3^{8} & \text { I } 4 & \text { I9. } & \text { II }\end{array}$ & $\begin{array}{lll}76 & 43 & 20.79\end{array}$ & $\begin{array}{llll}\text { S. } 23 & 07 & \text { E. } \\
\text { N. } & 76 & 27 & \text { E. } \\
\text { N. } & 52 & 19 & \text { W. }\end{array}$ & $\begin{array}{llll}\text { N. } 23 & \circ 7 & \text { W. } \\
\text { S. } 76 & 27 & \text { W. } \\
\text { S. } & 52 & 19 & \text { E. }\end{array}$ & $\begin{array}{r}704 \\
45 \mathrm{I} \\
\mathrm{x}, 288\end{array}$ & $\begin{array}{l}\text { St. Clement. } \\
\text { Roof. } \\
\text { Canoe. }\end{array}$ \\
\hline
\end{tabular}


BOUNIARIISS OI: NATURAL OYSTER IBARS-CONTInUEd:

CANOE CRLEKK.

(Lower St. Clement Bay-Chart No. 25.)

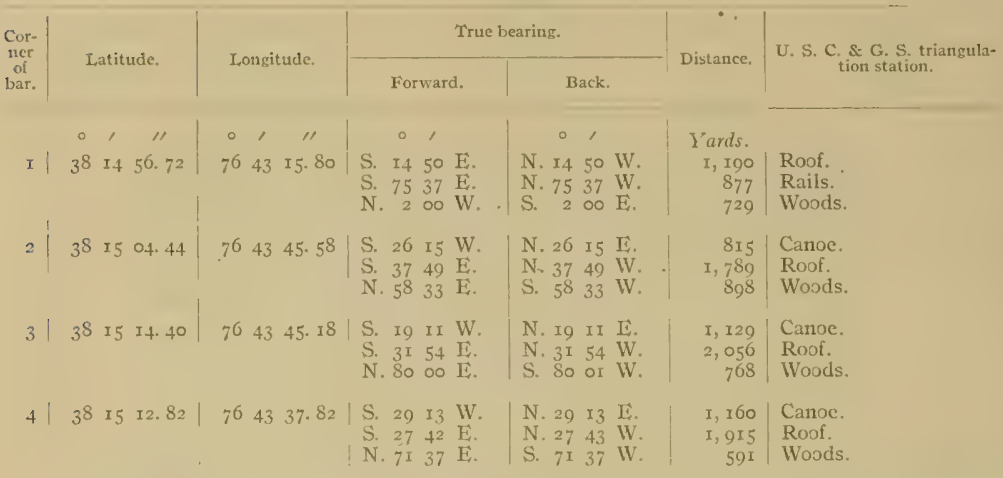

Thence from corner No. 4 along the mean low-water line of the shore to corner No. 5, excluding any creck, cove, or inlet less than roo yards in width at its mouth at low tide.

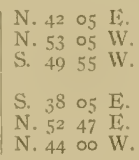

\begin{tabular}{|c|c|c|c|c|c|}
\hline I : $\quad 38 \quad 14 \quad 49.79$ & $\begin{array}{llll}76 & 43 & 04.26\end{array}$ & $\begin{array}{l}\text { S. } 008 \mathrm{~W} \text {. } \\
\text { N. } 88 \text { } 20 \mathrm{E} \text {. } \\
\text { N. } 19 \text { o6 W. }\end{array}$ & $\begin{array}{llll}\text { N. } & 0 & 08 & \mathrm{E} \\
\text { S. } & 88 & 20 & \mathrm{~W} . \\
\text { S. } & 19 & 06 & \mathrm{E} .\end{array}$ & $\begin{array}{r}919 \\
542 \\
1,017\end{array}$ & $\begin{array}{l}\text { Roof. } \\
\text { Rails. } \\
\text { Woods. }\end{array}$ \\
\hline $3^{8} \quad 16 \quad 05.22$ & $76 \quad 42 \quad 2$ I. I 4 & $\begin{array}{llll}\text { N. } 24 & 02 & \text { W. } \\
\text { S. } 70 & 30 & \text { W. } \\
\text { S. } 37 & 37 & \text { E. }\end{array}$ & $\begin{array}{llll}\text { S. } 24 & 02 & \text { E. } \\
\text { N. } & 70 & 30 & \text { E. } \\
\text { N. } 37 & 37 & \text { WV. }\end{array}$ & $\begin{array}{l}325 \\
8 \mathrm{r} 3 \\
474\end{array}$ & $\begin{array}{l}\text { Howards. } \\
\text { Shipping. } \\
\text { Mansion. }\end{array}$ \\
\hline : 38 I6 06. I3 & $76 \quad 4^{2}$ I6. 80 & $\begin{array}{llll}\text { N. } & 42 & 55 & \text { W. } \\
\text { S. } 71 & \text { o6 } & \text { W. } \\
\text { S. } & 23 & 13 & \text { E. }\end{array}$ & \begin{tabular}{|llll} 
S. & 42 & 55 & E \\
N. 71 & 06 & E \\
N. 23 & 13 & W
\end{tabular} & $\begin{array}{l}364 \\
933 \\
443\end{array}$ & $\begin{array}{l}\text { Howards. } \\
\text { Shipping } \\
\text { Mansion. }\end{array}$ \\
\hline
\end{tabular}

\section{CHAPEL POINT.}

(Lower St. Clement Bay-Chart No. 25.)

Thence from corner No. 3 along the mean low-water line of the shore to corner No. 4 , excluding any creek, cove, or inlet less than roo yards in width at its mouth at low tide.

S. 4245 E.

$\mathrm{r}, 280$ Woods

N. $8248 \mathrm{E} . \quad 2,018$ Canoe. 
BOUNDARIES OF NATURAI, OYSTER BARS-continuEd.

BLUFF WOODS.

(Lower St. Clement Bay-Chart No. 25.)

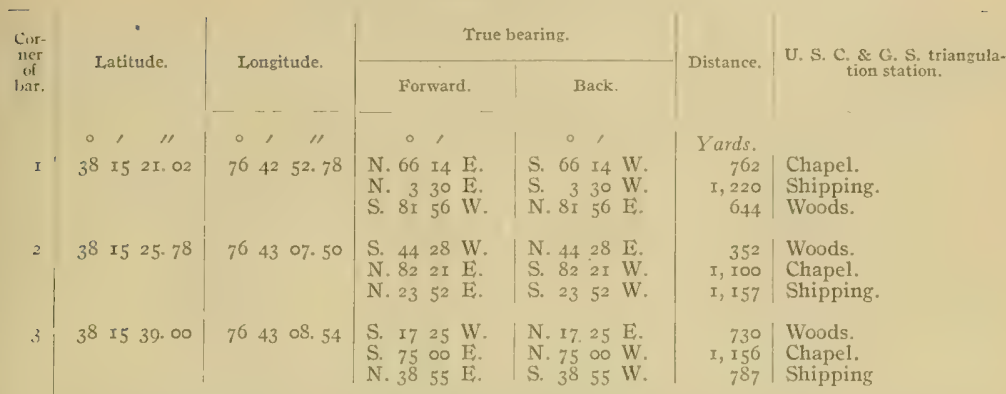

Thenee from corner No. 3 along the mean low-water line of the shore to corner No. 4 , excluding any creek, cove, or inlet less than zoo yards in width at its mouth at low tide.

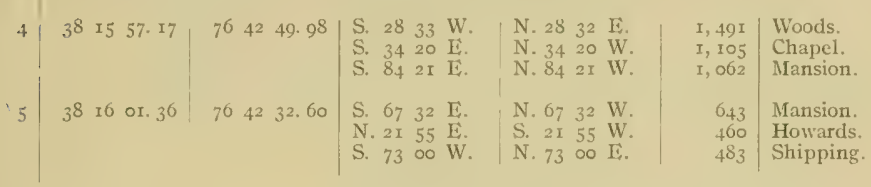

\section{MILEYS CREEK.}

(Lower St. Clement Bay-Chart No. 25.)

\begin{tabular}{|c|c|c|c|c|c|c|}
\hline I & $3^{8}$ I5 $57 \cdot 17$ & $\begin{array}{lll}76 & 42 & 49.98\end{array}$ & $\begin{array}{llll}\text { S. } & 28 & 33 & \text { W. } \\
\text { S. } & 34 & 20 & \text { E. } \\
\text { S. } & 84 & 2 \text { I } & \text { E. }\end{array}$ & $\begin{array}{llll}\text { N. } 28 & 32 & \text { I. } \\
\text { N. } 34 & 20 & \text { W. } \\
\text { N. } 84 & 2 \mathrm{I} & \text { W. }\end{array}$ & $\begin{array}{l}I, 49 I \\
I, 105 \\
I, 062\end{array}$ & $\begin{array}{l}\text { Woods. } \\
\text { Chapel. } \\
\text { Mansion. }\end{array}$ \\
\hline & \multicolumn{6}{|c|}{$\begin{array}{l}\text { Thence from corner No. I along the mean low-water line of th } \\
\text { any ereek, cove, or inlet less than roo yards in width at its }\end{array}$} \\
\hline & 3816 I0. 74 & $\begin{array}{llll}76 & 43 & 07.94\end{array}$ & $\begin{array}{l}\text { S. } 6953 \text { E. } \\
\text { N. } 8+\text { O9 E. } \\
\text { N. } 7 \text { II E. }\end{array}$ & $\begin{array}{l}\text { N. } 6952 \mathrm{~W} . \\
\text { S. } 84 \text { o9 W. } \\
\text { S. } \quad 74 \mathrm{I}\end{array}$ & $\begin{array}{r}\mathrm{I}, 634 \\
\mathrm{I}, \mathrm{II} 8 \\
325\end{array}$ & $\begin{array}{l}\text { Mansion. } \\
\text { Howards. } \\
\text { Mileys. }\end{array}$ \\
\hline & $38 \quad 16 \quad 20.27$ & 7643 o6. 31 & $\begin{array}{l}\text { S. } 2908 \mathrm{E} . \\
\text { N. } 7500 \mathrm{E} \text {. } \\
\text { N. } 35 \quad 54 \mathrm{E} \text {. }\end{array}$ & $\begin{array}{llll}\text { N. } 29 & 07 & \text { W. } \\
\text { S. } 75 & 00 & \text { W. } \\
\text { S. } 35 & 54 & \text { W. }\end{array}$ & $\begin{array}{r}891 \\
95^{8} \\
1,375\end{array}$ & ping. \\
\hline 4 & $3^{8} \quad 16 \quad 30.80$ & $76+3 \quad 12.02$ & 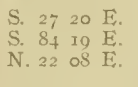 & $\begin{array}{llll}\text { N. } 27 & 19 & W . \\
\text { N. } 84 & 18 & \text { W. } \\
\text { S. } 22 & 08 & \text { W. }\end{array}$ & $\begin{array}{r}x, 276 \\
x, 08_{3} \\
539\end{array}$ & $\begin{array}{l}\text { ping. } \\
\text { lound. }\end{array}$ \\
\hline & $38 \quad 16$ I6. I 4 & $7^{6} 4^{2} \quad 37 \cdot 82$ & $\begin{array}{llll}\text { S. } & 77 & \text { I0 } & \mathrm{E} . \\
\text { N. } & 23 & 26 & \mathrm{E} \\
\text { N. } & 79 & 35 & \mathrm{~W}\end{array}$ & $\begin{array}{llll}\text { N. } 77 & 10 & \text { W. } \\
\text { S. } 23 & 26 & \text { W. } \\
\text { S. } & 79 & 35 & \text { E. }\end{array}$ & $\begin{array}{l}318 \\
422 \\
770\end{array}$ & $\begin{array}{l}\text { ards. } \\
\text { ys. }\end{array}$ \\
\hline & $3^{8}$ I6 or. 36 & $76 \quad 42 \quad 32.60$ & $\begin{array}{llll}\text { S. } & 67 & 32 & \mathrm{EE} . \\
\text { N. } & 21 & 55 & \mathrm{E} . \\
\text { S. } & 73 & 00 & \mathrm{~W} .\end{array}$ & $\begin{array}{lll}\text { N. } 67 & 32 & \text { W. } \\
\text { S. } 2 I & 55 & \text { W. } \\
\text { N. } 73 & 00 & \text { E. }\end{array}$ & $\begin{array}{l}643 \\
460 \\
483\end{array}$ & $\begin{array}{l}\text { Mansion. } \\
\text { Howards. } \\
\text { Shipping. }\end{array}$ \\
\hline
\end{tabular}


BOUNDARIYS OF NATURAL OYSTER IBARS-cOntiHued.

AIBEI,L.

(Upper St. Clement Bay-Chart No. 25.)

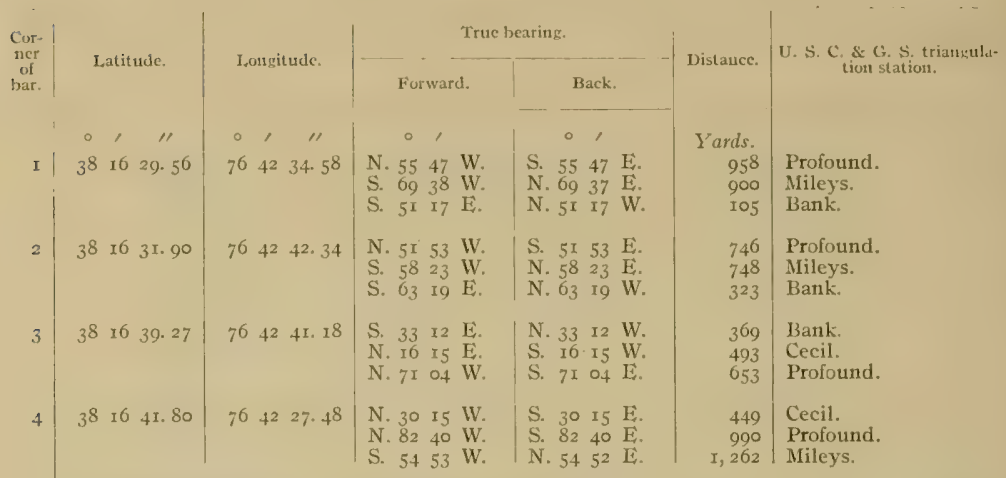

Thence from corner No. 4 along the mean low-water line of the shore to corner No. I, excluding any creek, cove, or inlet less than roo yards in width at its mouth at low tide.

\section{REED POINT.}

(Upper St. Clement Bay-Chart No. 25.)

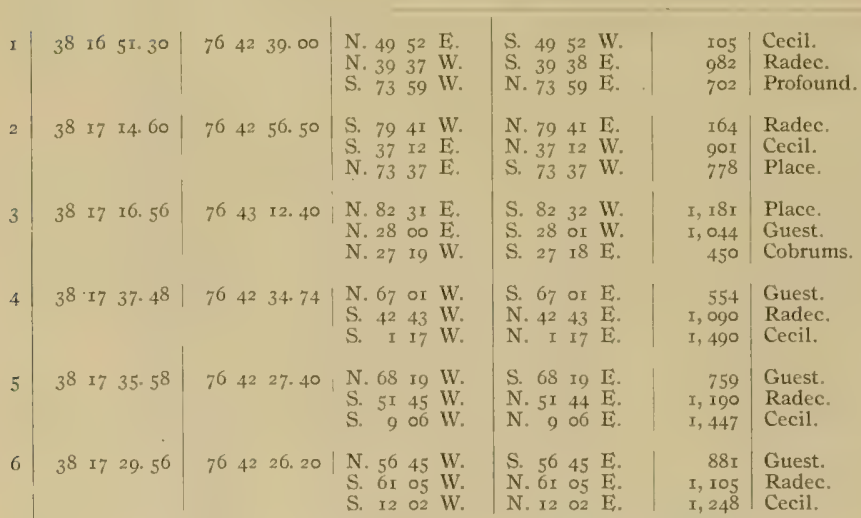

Thence from corner No. 6 along the mean low-water line of the shore to corner No. 7 , excluding any creck, cove, or inlet less than roo yards in width at its mouth at low tide. 
IBOUNDARIES OF NATURAL OYSTER BARS-cOntinUEd. REED POIN'T-Continued.

(Upper St. Clement Bay-Chart No. 25.)

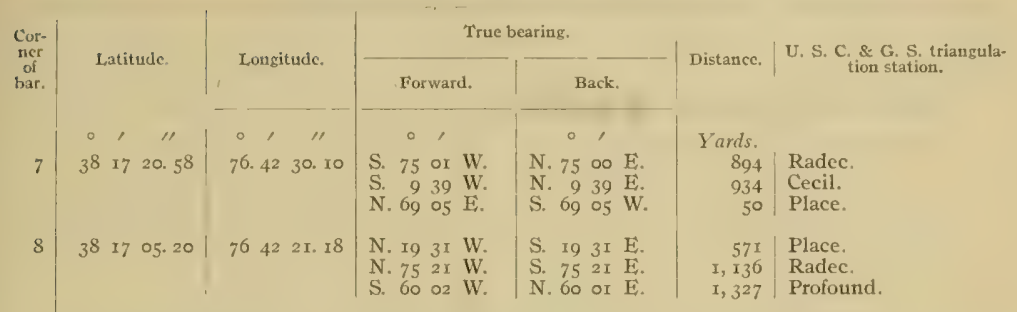

Thence from corner No. 8 along the mean low-water line of the shore to corner No. 1 , excluding any creek, cove, or inlet less than roo yards in width at its mouth at low tide.

\section{GUEST MARSHES.}

(Upper St. Clement Bay-Chart No. 25.)

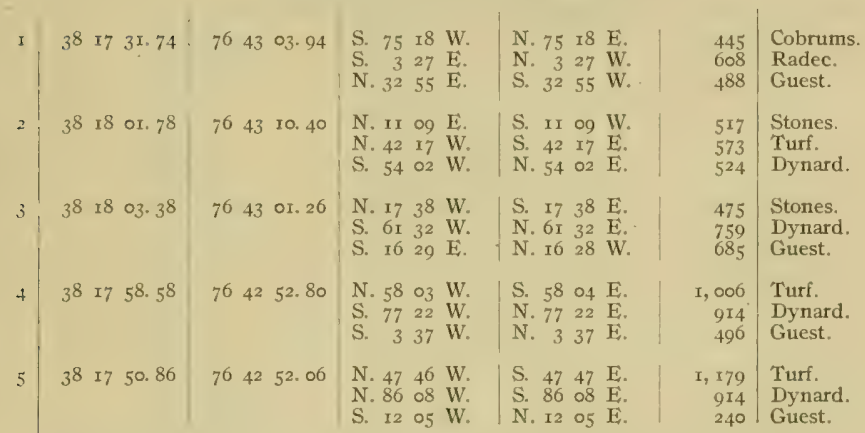

Thence from corner No. 5 along the mean low-water line of the shore to corner No. 6 , excluding any creek, cove, or inlet less than roo yards in width at its mouth at low tide.

6
N. 67 or W.

S. $4243 \mathrm{~W}$. S. I 17 W.

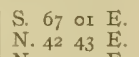

N. I 17 E.
554 Guest.

I, 090 Radec 
BOUNDARIES OF NATURAL OYSTER BARS-continued.

HARRY JACKS.

(Upper St. Clement Bay-Chart No. 25.)

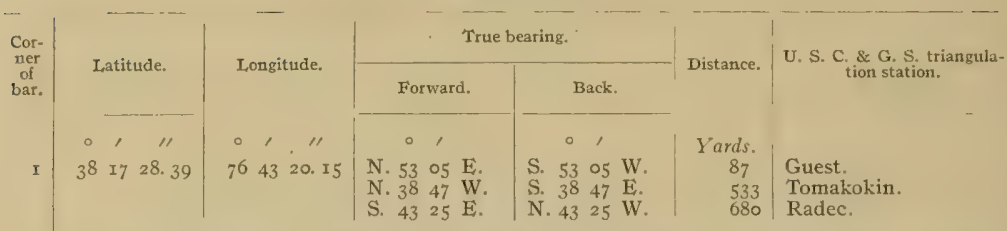

Thence from corner No. I along the mean low-water line of the shore to corner No. 2, excluding any creek, cove, or inlet less than roo yards in width at its mouth at low tide.

\begin{tabular}{lll|lll}
38 & I & 40.70 & 76 & 43 & $32.7 I$
\end{tabular}
S. $7^{8} 34 \mathrm{E}$.

N. 6352 E.

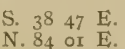

$\begin{array}{lll}\text { N. } 84 \text { OI E. } & \text { N. } 22 \text { II E. }\end{array}$
N. $7834 \mathrm{~W}$

S. $6352 \mathrm{~W}$

S. II IS E.

N. $3^{8} 47 \mathrm{~W}$.

S. 84 or W.

S. $224 \mathrm{I} \mathrm{W}$.

\begin{tabular}{r|l}
267 & Cobrums. \\
I, 067 & Guest. \\
370 & Tomakokin. \\
& \\
533 & Cobrums. \\
I, 036 & Guest. \\
436 & Dynard.
\end{tabular}

Thence from corner No, 3 along the mean low-water line of the shore to corner No. 4, excluding any creek, cove, or inlet less than roo yards in width at its mouth at low tide.

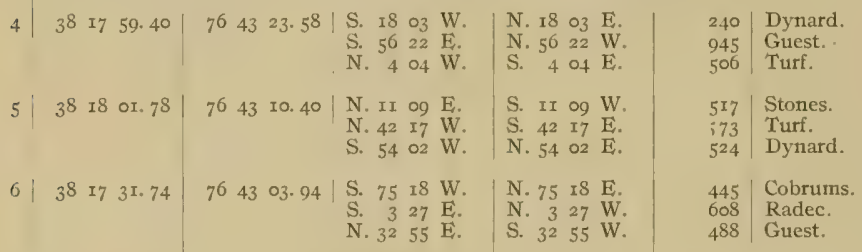

KEY.

(Upper Wicomico River-Chart No. 26.)

\begin{tabular}{|c|c|c|c|c|c|c|}
\hline$I$ & $\begin{array}{llll}3^{8} & 2 I & 49.83\end{array}$ & 76 50 31.02 & $\begin{array}{llll}\text { S. } & 66 & 37 & \mathrm{~W} . \\
\text { S. } & \text { I } 4 & \text { Io } & \mathrm{E} \\
\text { N. } & 84 & 48 & \mathrm{E}\end{array}$ & $\begin{array}{l}\text { N. } 6636 \mathrm{E} \text {. } \\
\text { N. I4 } 10 \mathrm{~W} . \\
\text { S. } 8449 \mathrm{~W} .\end{array}$ & $\begin{array}{r}I, 5 I 6 \\
I, 470 \\
450\end{array}$ & $\begin{array}{l}\text { Stoddard. } \\
\text { Cohouck. } \\
\text { Key. }\end{array}$ \\
\hline 2 & $3^{8} 21 \quad 53.40$ & $7650 \quad 55.74$ & $\begin{array}{llll}\text { N. } 84 & \text { or } & \text { W. } \\
\text { S. } 45 & 34 & \text { W. } \\
\text { S. } 85 & 53 & \text { E. }\end{array}$ & $\begin{array}{llll}\text { S. } 84 & 02 & \mathrm{E} . \\
\text { N. } & 45 & 33 & \mathrm{E} \\
\text { N. } 85 & 53 & \mathrm{~W} .\end{array}$ & $\begin{array}{l}I, I 64 \\
I, 029 \\
I, I 08\end{array}$ & $\begin{array}{l}\text { Upper. } \\
\text { Stoddard. } \\
\text { Key. }\end{array}$ \\
\hline 3 & $\begin{array}{llll}38 & 22 & 08.99\end{array}$ & $7^{6} \quad 5^{x} \quad 08.02$ & $\begin{array}{llll}\text { N. } 3 & \text { or } & \text { W. } \\
\text { S. } 64 & \text { I } 5 & \text { W. } \\
\text { S. } 67 & \text { o5 } & \text { E. }\end{array}$ & $\begin{array}{lrrr}\text { S. } 3 \text { or } & \text { E. } \\
\text { N. } 64 \text { I5 } & \text { E. } \\
\text { N. } 67 & \text { of } & \text { W. }\end{array}$ & $\begin{array}{r}865 \\
9^{24} \\
I, 554\end{array}$ & $\begin{array}{l}\text { Barber. } \\
\text { Upper. } \\
\text { Key. }\end{array}$ \\
\hline 4 & $3^{8} 22 \quad 1418$ & $7650 \quad 40.16$ & $\begin{array}{llll}\text { N. } 48 & 43 & \text { W. } \\
\text { S. } 69 & 52 & \text { W. } \\
\text { S. } 4 x & 33 & \text { E. }\end{array}$ & $\begin{array}{llll}\text { S. } 48 & 44 & \text { E. } \\
\text { N. } 69 & 52 & \text { E. } \\
\text { N. } 4 \text { I } & 33 & \text { W. }\end{array}$ & $\begin{array}{l}I, 042 \\
I, 675 \\
I, 042\end{array}$ & $\begin{array}{l}\text { Barber. } \\
\text { Upper. } \\
\text { Key. }\end{array}$ \\
\hline 5 & $3^{8} 2200.78$ & $7650 \quad 27.60$ & $\begin{array}{llll}\text { N. } 44 & 26 & \text { W. } \\
\text { S. } 86 & \text { I5 } & \text { W. } \\
\text { S. } 47 & 29 & \text { E. }\end{array}$ & $\begin{array}{llll}\text { S. } 44 & 26 & \mathrm{E} \\
\text { N. } & 86 & \text { I5 } & \mathrm{E} \\
\text { N. } & 47 & 29 & \mathrm{~W}\end{array}$ & $\begin{array}{r}I, 598 \\
I, 909 \\
485\end{array}$ & $\begin{array}{l}\text { Barber. } \\
\text { Upper. } \\
\text { Key. }\end{array}$ \\
\hline
\end{tabular}


IBOUNDARIES OF NATURAL OYSTER BARS-cOntinUEI.

\section{COHOUCK.}

(Upper IVicomico River-Chart No. 26.)

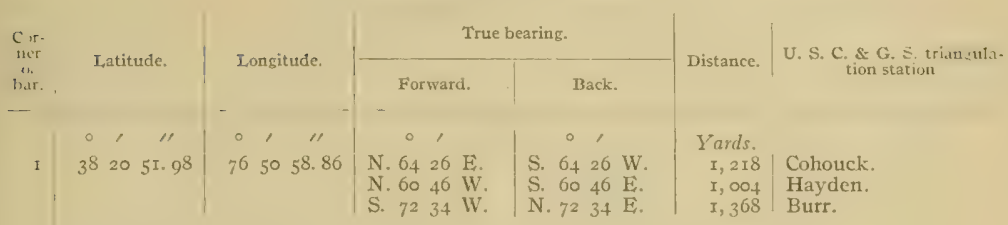

Thence along county boundary, as delineated on chart No. 26 , to corner No. 2.

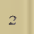

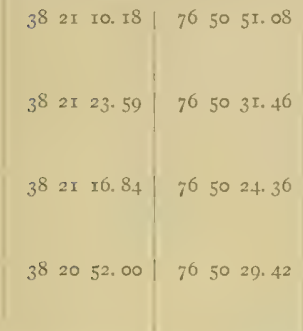

S. 8422 E.

N. $4923 \mathrm{~W}$.

S. $8330 \mathrm{~W}$.

S. $3429 \mathrm{E}$.

N. $2627 \mathrm{E}$.

N. $7822 \mathrm{~W}$.

S. $3018 \mathrm{E}$.

N. 13 I7 E.

N. 7 I $56 \mathrm{~W}$.

N. $3 I$ o $\mathrm{E}$

N. $7333 \mathrm{WV}$

S. $227 \mathrm{~W}$.
N. 8422 W.

S. $4924 \mathrm{E}$.

N. $8329 \mathrm{E}$.

N. 3429 W.

S. $2628 \mathrm{~W}$.

S. $7822 \mathrm{E}$.

N. 30 I 8 W.

S. I3 I7 W.

S. $7 \mathrm{I} 56 \mathrm{E}$.

S. 3 I o8 W.

S. $7333 \mathrm{E}$

N. 227 E.
807 Cohouck.

I, I3I Stoddard.

I, ogo Hayden.

655 Cohouck.

I, 033 Kéy.

I, 409 Stoddard.

362 Cohouck.

I, 187 Key.

I, 649 Stoddard.

6.3 | Cohouck.

I, 728 Hayden.

I, 3I7 Fact.

\section{CHAPTICO LUMPS.}

(Upper Wicomico River-Chart No. 26.)

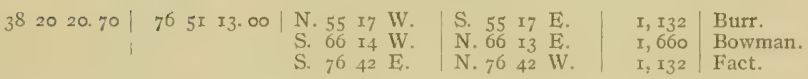

Thence along county boundary, as delineated on chart No. 26 , to comer No. 2 .
$3^{8} 2051.98|765058.86|$ N. 6426 E.
N. 6046 W.
S. $7234 \mathrm{~W}$.
S. $6426 \mathrm{~W}$.
S. $6046 \mathrm{E}$.
I, 2 I8 Cohouck.
N. $7234 \mathrm{E}$.
$\mathrm{I}, 004^{-}$Hayden.

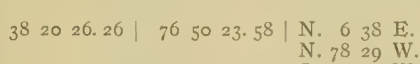
S. $63_{3}^{8} \mathrm{~W}$.
S. $7829 \mathrm{E}$.
I, 368 Burr.
S. 25 I9 W,
N. 25 I9 E.
I, 402 Cohouck.
2, 289 Burr.
494 Fact. 
MILLS EAST.

(Upper Wicomico River-Chart No. 26.)

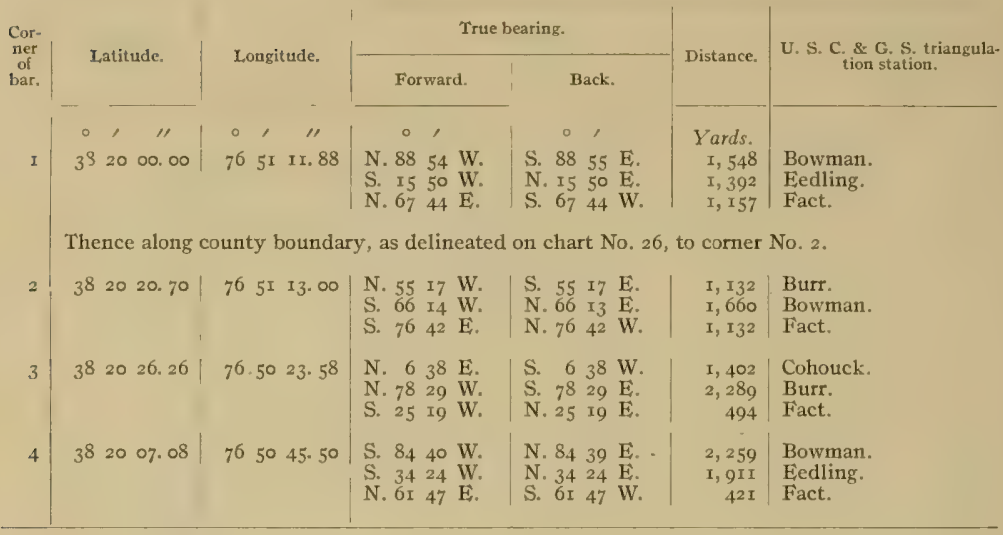

\section{RUSSELL.}

(Middle Wicomico River-Chart No. 26.)

\begin{tabular}{|c|c|c|c|c|c|c|}
\hline $\mathrm{I}$ & $3^{8}$ I9 $04.4^{2}$ & $7^{6} 50 \quad 28.14$ & $\begin{array}{lll}\text { N. } 78 & \text { 10 } & \mathrm{E} . \\
\text { N. } & 2 & \text { I4 } \\
\text { W. } \\
\text { S. } 77 & 22 & \text { W. }\end{array}$ & $\begin{array}{llll}\text { S. } 78 & \text { II } & \text { W. } \\
\text { S. } & 2 & \text { I4 } & \text { E. } \\
\text { N. } 77 & 22 & \text { E. }\end{array}$ & $\begin{array}{r}961 \\
2,313 \\
I, 049\end{array}$ & $\begin{array}{l}\text { Farr. } \\
\text { Fact. } \\
\text { Gust. }\end{array}$ \\
\hline & \multicolumn{6}{|c|}{ Thence along county boundary, as delineated on chart No. 26 , to corrier No. 2 . } \\
\hline 2 & 382000.00 & 76 5I xI. 88 & $\begin{array}{l}\text { N. } 8854 \text { W. } \\
\text { S. } 1550 \text { W. } \\
\text { N. } 6744 \text { E. }\end{array}$ & $\begin{array}{l}\text { S. } 8855 \text { E. } \\
\text { N. } 1550 \text { E. } \\
\text { S. } 6744 \text { W. }\end{array}$ & $\begin{array}{l}\mathrm{I}, 548 \\
\mathrm{I}, 392 \\
\mathrm{I}, \mathrm{x} 57\end{array}$ & $\begin{array}{l}\text { Bowman. } \\
\text { Eedling. } \\
\text { Fact. }\end{array}$ \\
\hline 3 & $3^{8} \quad 20 \quad 07.08$ & $7^{6} 50 \quad 45.50$ & $\begin{array}{l}\text { S. } 8440 \mathrm{~W} \\
\text { S. } 3424 \mathrm{~W} \\
\text { N. } 61 \\
\end{array}$ & $\begin{array}{l}\text { N. } 8439 \text { E. } \\
\text { N. } 3424 \text { E. } \\
\text { S. } 6 \text { I } 47 \text { W. }\end{array}$ & $\begin{array}{r}2,259 \\
\mathrm{I}, 91 \mathrm{II} \\
\quad 42 \mathrm{I}\end{array}$ & $\begin{array}{l}\text { Bowman. } \\
\text { Eedling. } \\
\text { Fact. }\end{array}$ \\
\hline 4 & $3^{8} \quad$ I9 ०9. $7^{6}$ & $7^{6} 49 \quad 56.97$ & $\begin{array}{llll}\text { N. } 8 \mathrm{I} & 38 & \mathrm{E} \\
\text { N. } 23 & \text { I8 } & \text { W. } \\
\text { S. } 77 & 32 & \text { W. }\end{array}$ & $\begin{array}{llll}\text { S. } & 8 \mathrm{I} & 38 & \mathrm{~W} . \\
\text { S. } 23 & \text { I9 } & \mathrm{E} . \\
\text { N. } & 77 & 31 & \mathrm{E} .\end{array}$ & $\begin{array}{r}\text { II4 } \\
2,320 \\
\mathrm{I}, 895\end{array}$ & $\begin{array}{l}\text { Farr. } \\
\text { Fact. } \\
\text { Gust. }\end{array}$ \\
\hline
\end{tabular}




\section{BOUNDARIES OF NATURAL, OYSTER BARS-continued.}

\section{MANAHOWIC CREEK.}

(Middle Wicomico River-Chart No. 26.)

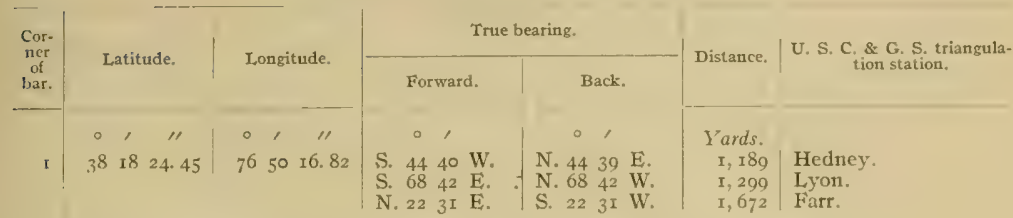

Thence along county boundary; as delineated on chart No. 26 , to comer No. 2.

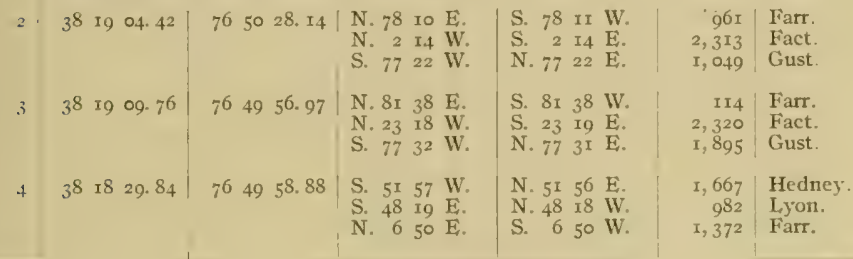

\section{BRAMLEIGH CREEK.}

(Middle IVicomico River-Chart No. 26.)

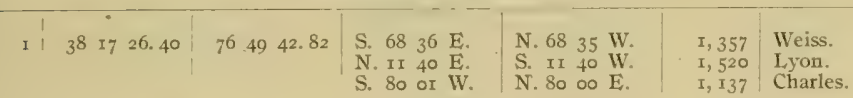

I Thence along county boundary, as delineated on chart No. 26, to comer No. 2.

$=\quad 3^{8} 1755.9^{8} \quad 765008.16$
N. 63 3I E.
S. $6332 \mathrm{~W}$.
I, 095 | Lyon.
N. $83 \quad 52$ W.
S. $8352 \mathrm{E}$.
I, 072 Hedney
S. $2030 \mathrm{~W}$.
N. $2030 \mathrm{E}$.
I, 275 , Charles.

Thence along county boundary, as delineated on chart No. 26 , to comer No. 3 .

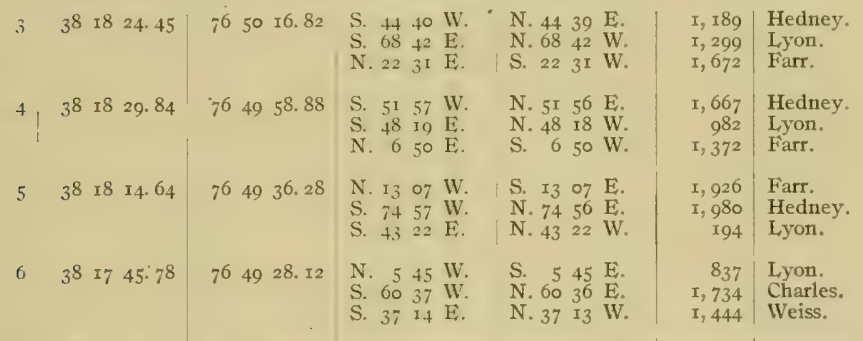


BOUNDARIES OF NATURAL, OYSTER BARS-continUEd,

WHITE POINT.

(Louer Wicomico River-Chart No. 26.)

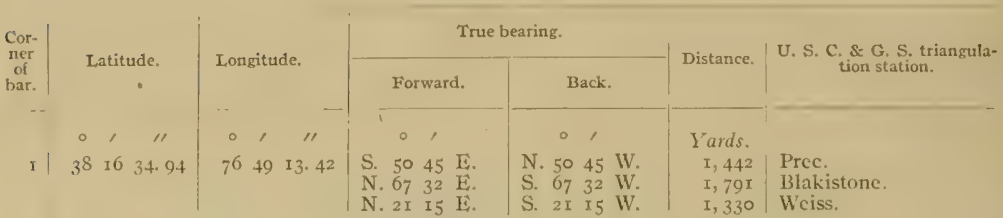

Thence along county boundary, as delineated on chart No. 26 , to comer No. 2 .

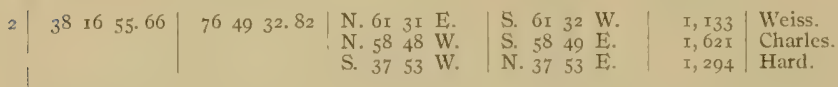

Thence along county boundary, as delineated on chart No. 26, to corner No. 3 .

\begin{tabular}{|c|c|c|c|c|c|c|c|}
\hline \begin{tabular}{l|ll}
3 & 38 & 17
\end{tabular} & 26.40 & $76 \quad 49$ & 42,82 & 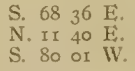 & $\begin{array}{l}\text { N. } 68 \text { 35 W. } \\
\text { S. II } 40 \text { W. } \\
\text { N. } 80 \text { o0 E. }\end{array}$ & $\begin{array}{l}\mathrm{I}, 357 \\
\mathrm{I}, 520 \\
\mathrm{I}, \mathrm{x} 37\end{array}$ & $\begin{array}{l}\text { Weiss. } \\
\text { Lyon. } \\
\text { Charles. }\end{array}$ \\
\hline $3^{8} \quad 17$ & 7 15.96 & $76 \quad 49$ & I2. 16 & $\begin{array}{llll}\text { N. } & 85 & 26 & \mathrm{~W} \\
\text { S. } & 38 & 14 & \mathrm{~W} \\
\text { S. } & 72 & 17 & \mathrm{E} .\end{array}$ & $\begin{array}{llll}\text { S. } & 85 & 26 & \text { E. } \\
\text { N. } & 38 & 13 & \text { E. } \\
\text { N. } & 72 & 17 & \text { W. }\end{array}$ & $\begin{array}{r}I, 94 \mathrm{I} \\
2,172 \\
\quad 47 \mathrm{I}\end{array}$ & $\begin{array}{l}\text { Charles. } \\
\text { Hard. } \\
\text { Weiss. }\end{array}$ \\
\hline $3^{8} \times 6$ & $65^{2 .} 5^{2}$ & 7649 & II. 78 & $\begin{array}{llll}\text { N. } 34 & 11 & \mathrm{E} . \\
\text { N. } 64 & 05 & \mathrm{~W} . \\
\text { S. } & 55 & 52 & \mathrm{~W} .\end{array}$ & $\begin{array}{llll}\text { S. } & 34 & \text { II } & \text { W. } \\
\text { S. } 64 & \text { o6 } & \text { E. } \\
\text { N. } & 55 & 52 & \text { E. }\end{array}$ & $\begin{array}{r}780 \\
2,157 \\
1,636\end{array}$ & $\begin{array}{l}\text { Weiss. } \\
\text { Charles. } \\
\text { Hard. }\end{array}$ \\
\hline 38, I 6 & 6 5 & $7^{6} 48$ & 46.98 & $\begin{array}{llll}\text { S. } & 15 & 44 & \mathrm{E} \\
\text { N. } 82 & 06 & \mathrm{E} \\
\text { N. } & 17 & 47 & \mathrm{~W}\end{array}$ & $\begin{array}{llll}\text { N. } & 15 & 44 & W . \\
\text { S. } 82 & 06 & W \\
\text { S. } & 17 & 47 & \text { E. }\end{array}$ & $\begin{array}{r}\text { I, } 520 \\
96 \mathrm{r} \\
722\end{array}$ & $\begin{array}{l}\text { Prec. } \\
\text { Blakistone. } \\
\text { Weiss. }\end{array}$ \\
\hline
\end{tabular}

\section{WHITE POINT HOLLOW.}

(Lower Wicomico River-Chart No. 26.)

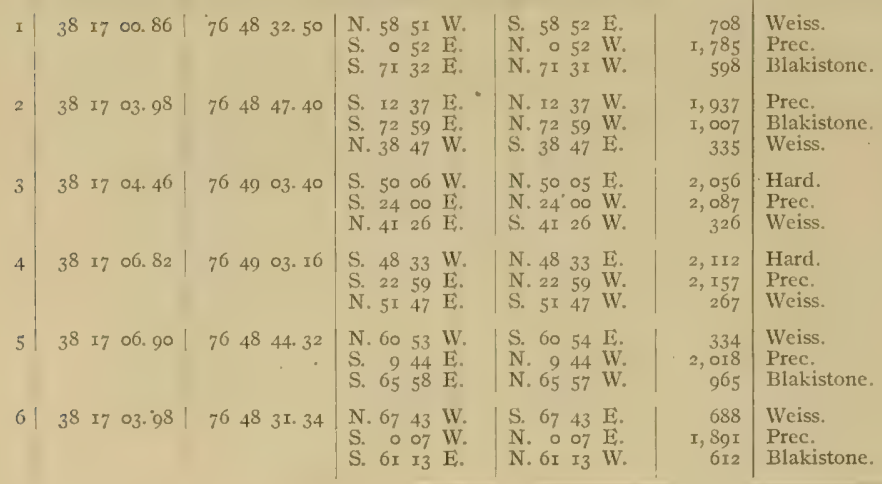


BOUNDARIES OF NATURAL OYSTER BEDS- continued.

BLAKISTONE,

(Lower Wicomico River-Chart No. 26.)

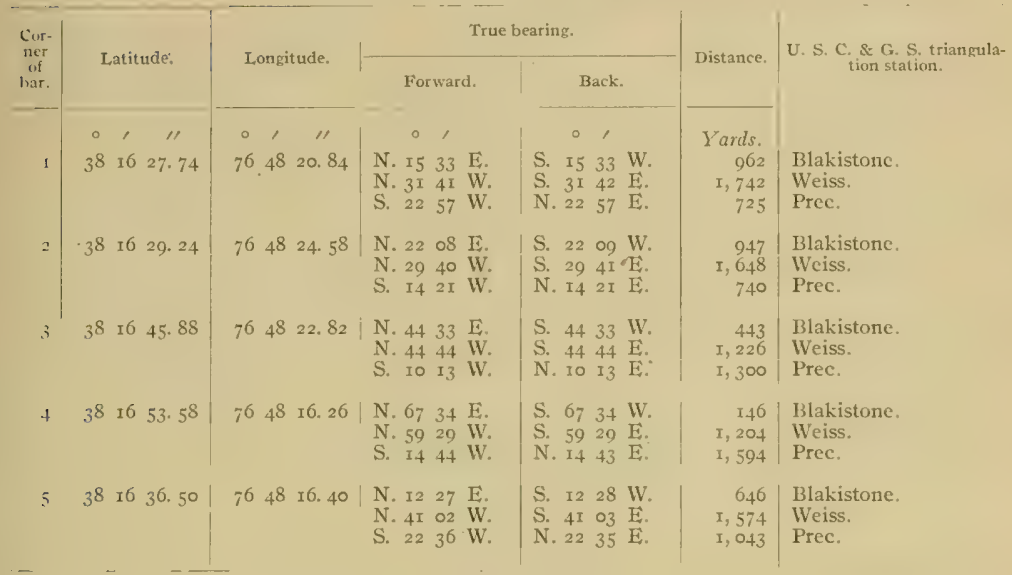

\section{BLUFF POIN'T.}

(Lower Wicomico River-Chart No. 26.)

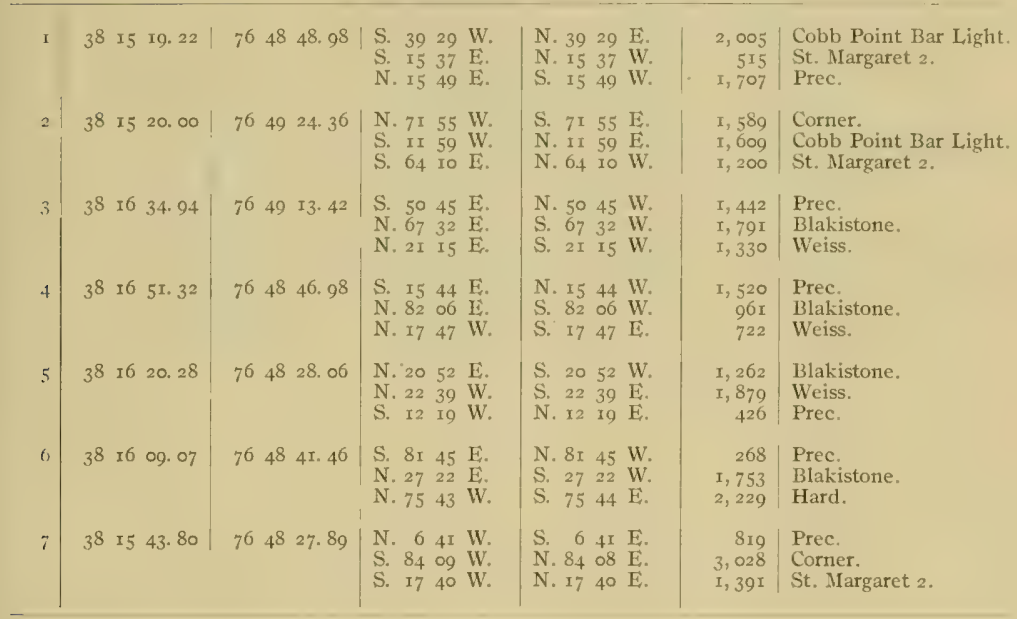


BOUNDARIES OF NATURAL OYSTER BARS-continUE.

MOUTH OF RIVER.

(Lower Wicomico River-Chart No. 26.)

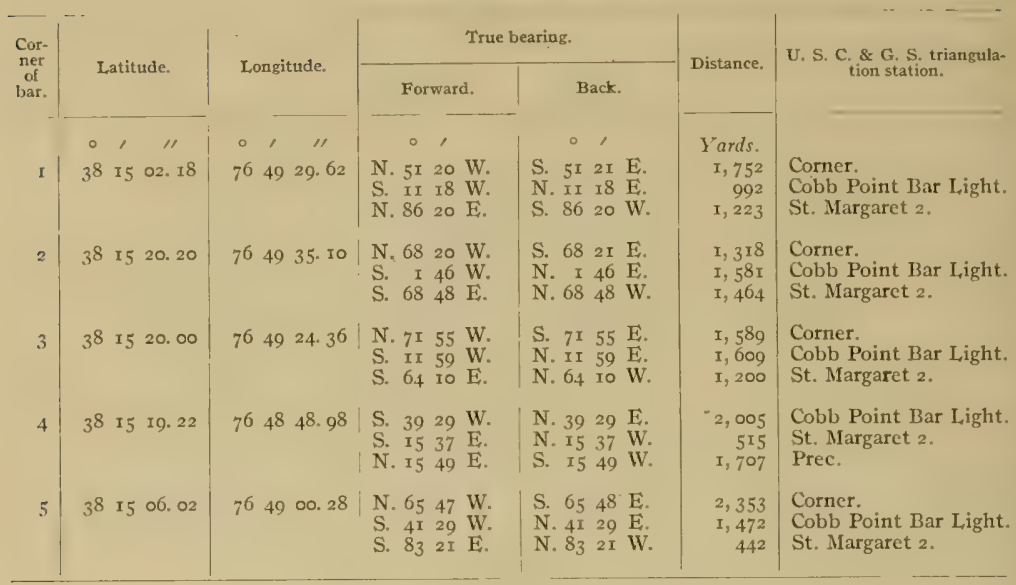

\section{ST. MARGARETT.}

(Lower Wicomico River-Chart No. 26.)

\begin{tabular}{|c|c|c|c|c|c|c|}
\hline I & $3^{8}$ I 5 o8. 20 & $\begin{array}{llll}76 & 4^{8} & 23.66\end{array}$ & $\begin{array}{lrrl}\text { N. } & 5 & 54 & \text { W. } \\
\text { S. } & 76 & 52 & \text { W. } \\
\text { S. } & 37 & 39 & \text { E. }\end{array}$ & $\begin{array}{lrll}\text { S. } & 5 & 54 & \mathrm{E} \\
\text { N. } & 76 & 5 \mathrm{I} & \mathrm{E} \\
\text { N. } & 37 & 38 & \mathrm{~W} .\end{array}$ & $\begin{array}{r}2,024 \\
549 \\
2, \quad 124\end{array}$ & $\begin{array}{l}\text { Prec. } \\
\text { St. Margaret } 2 . \\
\text { St. Catherine. }\end{array}$ \\
\hline 2 & $3^{8}$ I5 I4. I9 & $7^{6} 4^{8} \quad 3^{8} .95$ & $\begin{array}{lrrr}\text { N. } & 6 & \text { I5 } & \text { E. } \\
\text { S. } & 48 & \text { I } 3 & \text { W. } \\
\text { S. } 2 I & 20 & \text { W. }\end{array}$ & $\begin{array}{lrrr}\text { S. } & 6 & \text { I5 } & \text { W. } \\
\text { N. } 48 & \text { I } 3 & \mathrm{E} . \\
\text { N. } 2 \text { I } & 20 & \mathrm{E} .\end{array}$ & $\begin{array}{r}I, 823 \\
2,068 \\
35^{I}\end{array}$ & $\begin{array}{l}\text { Prec. } \\
\text { Cobb Point Bar Light. } \\
\text { St. Margaret } 2 \text {. }\end{array}$ \\
\hline 3 & 38 I5 17.70 & $.764^{8} 3^{6} \cdot 3^{8}$ & $\begin{array}{lrrr}\text { N. } & 4 & 24 & \mathrm{E} \\
\text { S. } & 47 & 06 & \mathrm{~W} . \\
\text { S. } 23 & 48 & \mathrm{~W} .\end{array}$ & 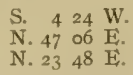 & $\begin{array}{r}\text { I, } 698 \\
2,198 \\
487\end{array}$ & $\begin{array}{l}\text { Prec. } \\
\text { Cobb Point Bar Light. } \\
\text { St. Margaret } 2 \text {. }\end{array}$ \\
\hline 4 & $3^{8}$ I5 II. $3^{6}$ & $7^{6} 4^{8} \quad 2$ I. $7^{6}$ & $\begin{array}{llll}\text { N. } & 7 & 43 & \text { W. } \\
\text { S. } & 68 & 26 & \text { W. } \\
\text { S. } & 34 & 53 & \text { E. }\end{array}$ & 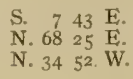 & $\begin{array}{r}I, 925 \\
629 \\
2, \mathrm{I} 8 \mathrm{I}\end{array}$ & $\begin{array}{l}\text { Prec. } \\
\text { St. Margaret } 2 . \\
\text { St. Catherine. }\end{array}$ \\
\hline
\end{tabular}


BOUNDARIES OF NATURAL, OYSTER BARS-continuEd.

\section{BULLOCK.}

(Lower Wicomico River-Chart No. 26.)

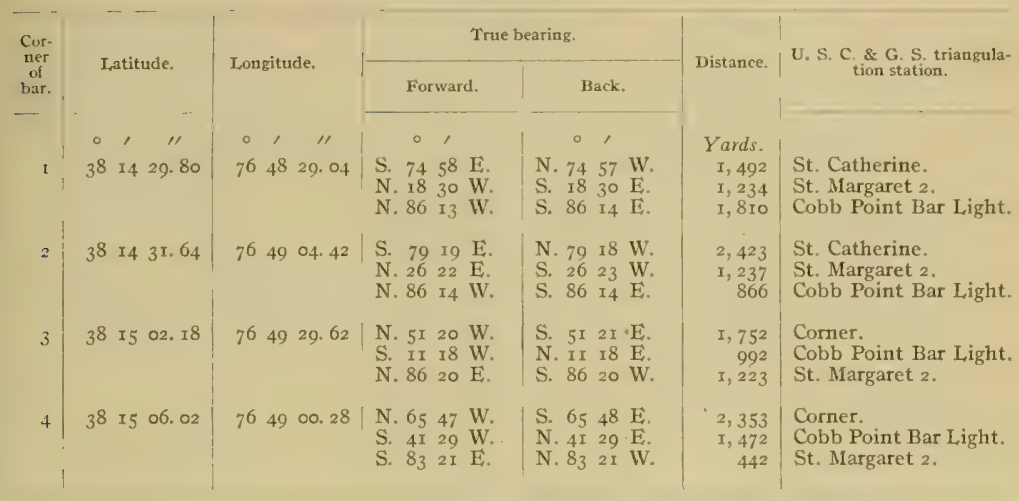

\section{BULLOCK ISLAND.}

(St. Catherine Sound-Chart No.26.)

\begin{tabular}{|c|c|c|c|c|c|c|c|}
\hline I & $3^{8}$ & I4 46.98 & $\begin{array}{lll}76 & 47 & 53.82\end{array}$ & 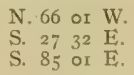 & $\begin{array}{l}\text { S. } 66 \text { o2 } \mathrm{E} . \\
\text { N. } 27 \\
\text { N. } 85 \text { oI } \mathrm{W} .\end{array}$ & $\begin{array}{l}I, 453 \\
I, 089 \\
I, 2 \text { I0 }\end{array}$ & $\begin{array}{l}\text { St. Margaret } 2 . \\
\text { St. Catherine. } \\
\text { Sound. }\end{array}$ \\
\hline 2 & 38 & 1448.06 & $7^{6}+759.66$ & $\begin{array}{llll}\text { N. } 64 & 42 & \text { W. } \\
\text { S. } 33 & \text { I9 } & \text { E. } \\
\text { S. } 84 & \text { O2 } & \text { E. }\end{array}$ & $\begin{array}{lll}\text { S. } 64 & 42 & \mathrm{E} \\
\text { N. } 33 & \text { I9 } & \mathrm{W} . \\
\text { N. } 84 & \text { o1 } & \text { W. }\end{array}$ & $\begin{array}{l}\text { I, } 297 \\
\text { I, } 200 \\
\text { I, } 368\end{array}$ & $\begin{array}{l}\text { St. Margaret } 2 . \\
\text { St. Catherine. } \\
\text { Sound. }\end{array}$ \\
\hline 3 & $3^{8}$ & I4 53.00 & -64758.22 & $\begin{array}{llll}\text { N. } 72 & \text { I } 5 & \text { W. } \\
\text { S. } 27 & 54 & \text { E. } \\
\text { S. } 76 & 5 \text { I } & \text { E. }\end{array}$ & $\begin{array}{llll}\text { S. } 72 & \text { I } & \mathrm{E} \\
\mathrm{N} . & 27 & 54 & \mathrm{~W} . \\
\mathrm{N} . & 76 & 52 & \mathrm{~W} .\end{array}$ & $\begin{array}{l}\text { I, } 272 \\
\text { I, } 323 \\
\text { I, } 357\end{array}$ & $\begin{array}{l}\text { St. Margaret } 2 . \\
\text { St. Catherine. } \\
\text { Sound. }\end{array}$ \\
\hline 4 & $3^{8}$ & I4 52.00 & $764752.5^{6}$ & $\begin{array}{llll}\text { N. } 72 & 48 & \mathrm{WV} \\
\text { S. } 22 & 30 & \mathrm{E} \\
\text { S. } & 76 & 47 & \mathrm{E}\end{array}$ & $\begin{array}{llll}\text { S. } & 72 & 48 & \mathrm{E} \\
\mathrm{N} . & 22 & 29 & \mathrm{~W} \\
\mathrm{~N} . & -6 & 46 & \mathrm{~W}\end{array}$ & $\begin{array}{l}\mathrm{I}, 425 \\
\mathrm{I}, 229 \\
\mathrm{I}, 203\end{array}$ & $\begin{array}{l}\text { St. Margaret } 2 . \\
\text { St. Catherine. } \\
\text { Sound. }\end{array}$ \\
\hline
\end{tabular}

$2606-I_{1}-I_{3}$ 


\section{BOUNDARIES OF NATURAL, OYSTER BARS-continued.}

ST. CATHERINE.

(St. Catherine Sound-Chart No. 26.)

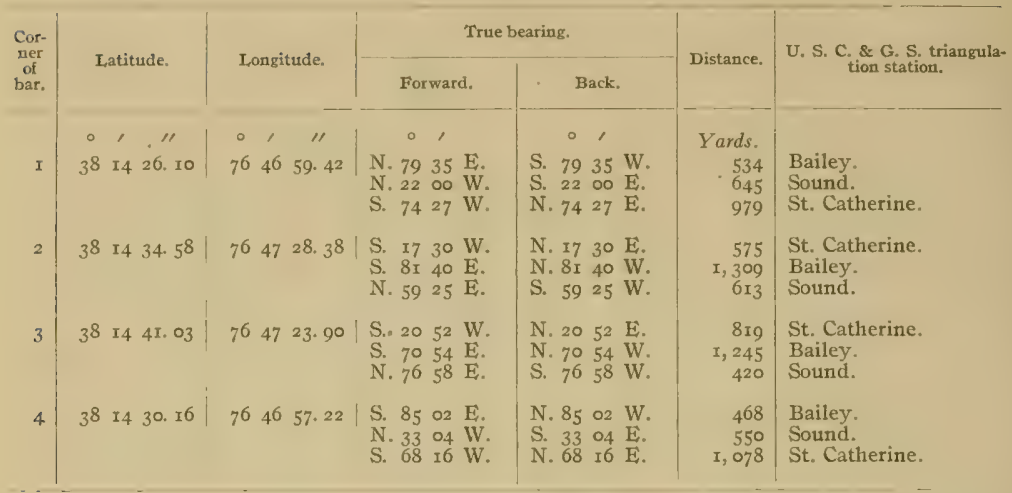

\section{HACKLEY CREEK.}

(St. Catherine Sound-Chart No, 26.)

\begin{tabular}{|c|c|c|c|c|c|c|}
\hline I & $3^{8}$ I. 4 or. 84 & $76 \quad 4706.90$ & $\begin{array}{llll}\text { S. } 64 & 45 & \text { E. } \\
\text { N. } & 3^{8} & 21 & \text { E. } \\
\text { N. } & 53 & \text { I } & \text { WV. }\end{array}$ & $\begin{array}{llll}\text { N. } & 64 & 45 & \text { W. } \\
\text { S. } & 38 & 22 & \text { W. } \\
\text { S. } & 53 & \text { I } & \text { E. }\end{array}$ & $\begin{array}{r}574 \\
\mathbf{1}, 166 \\
928\end{array}$ & $\begin{array}{l}\text { Waterloo. } \\
\text { Bailey. } \\
\text { St. Catherine. }\end{array}$ \\
\hline 2 & $3^{8}$ I4 II. 23 & $7^{6} 47$ I8. 66 & $\begin{array}{llll}\text { S. } & 55 & 59 & \mathrm{E} . \\
\mathrm{N} . & 60 & \text { oI } & \mathrm{E} \\
\mathrm{N} . & 6 \text { I } & \text { oo } & \mathrm{W} .\end{array}$ & $\begin{array}{llll}\text { N. } & 55 & 59 & \text { W. } \\
\text { S. } & 60 & 02 & \text { W. } \\
\text { S. } & 61 & 00 & \mathrm{E} .\end{array}$ & $\begin{array}{r}\text { I, } 004 \\
\text { I, } 196 \\
493\end{array}$ & $\begin{array}{l}\text { Waterloo. } \\
\text { Bailey. } \\
\text { St. Catherine. }\end{array}$ \\
\hline 3 & 381405.18 & 764652.86 & $\begin{array}{llll}\text { S. } & 22 & 09 & \mathrm{E} . \\
\text { N. } & 23 & 36 & \mathrm{E} \\
\text { N. } & 68 & 22 & \mathrm{~W} .\end{array}$ & $\begin{array}{llll}\text { N. } 22 & 09 & \text { W. } \\
\text { S. } 23 & 36 & \text { W. } \\
\text { S. } 68 & 23 & \text { E. }\end{array}$ & $\begin{array}{r}395 \\
875 \\
\mathbf{I}, 202\end{array}$ & $\begin{array}{l}\text { Waterloo. } \\
\text { Bailey. } \\
\text { St. Catherine. }\end{array}$ \\
\hline 4 & $3^{8} 1402.36$ & $76 \quad 4653.36$ & $\begin{array}{llll}\text { S. } 3 & 31 & \text { E. } \\
\text { N. } 22 & \text { o5 } & \text { E. } \\
\text { N. } 64 & \text { oI } & \text { W. }\end{array}$ & 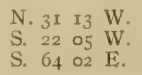 & $\begin{array}{r}306 \\
968 \\
\mathbf{r}, 228\end{array}$ & $\begin{array}{l}\text { Waterloo. } \\
\text { Bailey. } \\
\text { St. Catherine, }\end{array}$ \\
\hline
\end{tabular}


BOUNDARIES OF NATURAL OYSTER BARS-continuEd.

\section{WATERLOO.}

(St. Catherine Sound-Chart No. 26.)

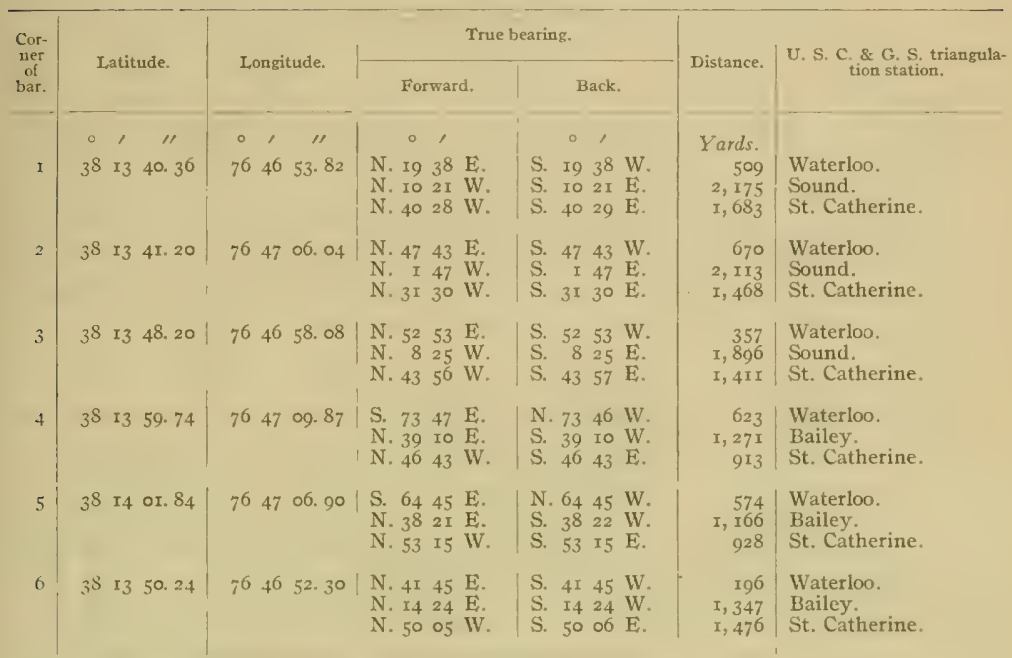

\section{SILVER SPRING.}

(St. Catherine Sound-Chart . Vo. 26.)

\begin{tabular}{|c|c|c|c|c|c|c|}
\hline I & is $x_{3} 50.64$ & $76+7 \times 7.50$ & $\begin{array}{lll}\text { N. } 80 & 35 & \text { E. } \\
\text { N. } 37 & 50 & \text { E. } \\
\text { N. } 26 & 21 & \text { W. }\end{array}$ & $\begin{array}{llll}\text { S. } & 80 & 35 & \mathrm{WV} \\
\text { S. } & 37 & 50 & \mathrm{~W} \\
\text { S. } 26 & 21 & \mathbf{E}\end{array}$ & $\begin{array}{r}8 \mathrm{II} \\
\mathrm{I}, 636 \\
\mathrm{I}, 0.4 \mathrm{I}\end{array}$ & $\begin{array}{l}\text { Waterloo. } \\
\text { Bailey. } \\
\text { St. Catherine, }\end{array}$ \\
\hline 2 & 38 I. $03 \cdot 7^{6}$ & 764722.22 & $\begin{array}{llll}\text { S. } & \text { I } & 31 & \mathrm{E} . \\
\text { N. } & 53 & 05 & \mathrm{E} \\
\text { N. } & 34 & 27 & \mathrm{~W}\end{array}$ & $\begin{array}{l}\text { N. } 7 \text { I } 3 \text { I } \mathrm{W} . \\
\text { S. } 53 \text { o6 } \mathrm{W} . \\
\text { S. } 3+27 \\
\text { E. }\end{array}$ & $\begin{array}{r}977 \\
\mathrm{r}, 415 \\
595\end{array}$ & $\begin{array}{l}\text { Waterloo. } \\
\text { Bailey. } \\
\text { St. Catherine. }\end{array}$ \\
\hline 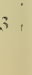 & $38 x_{3} 50.74$ & $76 \quad 4703.7 \mathrm{~S}$ & $\begin{array}{lll}\text { N. } 73 & 27 & \text { E. } \\
\text { N. } 26 & 26 & \text { E. } \\
\text { N. } 41 & 39 & \text { W. }\end{array}$ & $\begin{array}{llll}\text { S. } & 73 & 28 & \text { W. } \\
\text { S. } & 26 & 26 & \text { WV. } \\
\text { S. } & 41 & 39 & \text { E. }\end{array}$ & $\begin{array}{r}455 \\
\mathrm{I}, 439 \\
\mathrm{I}, 245\end{array}$ & $\begin{array}{l}\text { Waterloo. } \\
\text { Bailey. } \\
\text { St. Catherine. }\end{array}$ \\
\hline
\end{tabular}




\section{A P P E N D X ES.}

APPENDIX A.-LAWS RELATING TO THE COOPERATION OF THE COAST AND GEODETIC SURVEY AND BUREAU OF FISHERIES WITH THE MARYLAND SHELL FISH COMMISSION.

The work of the Coast and Geodetic Survey and of the Bureau of Fisheries, in cooperation with the Maryland Shell Fish Commission, in surveying the oyster bars, establishing permanent landmarks at triangulation stations, and preparing for publication the necessary charts and technical and legal descriptions of boundaries and landmarks shown on these charts, has been executed in compliance with a request from the governor of the State of Maryland to the Secretary of Commerce and Labor, and by the authority of the following laws of the United States and Maryland:

[Act of Congress approved May 26, 1906.]

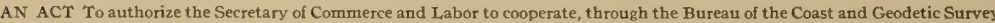
and the Bureau of Fisheries, with the shellfish commissioners of the State of Maryland in making surveys of the natural oyster beds, bars, and rocks in the waters within the State of Maryland.

Be it enacted by the Senate and House of Representatives of the United States of America in Congress assembled, That the Secretary of Commerce and Labor be, and he is hereby, authorized and directed, upon the request of the governor of the State of Maryland, to designate such officers, experts, and employees of the Bureau of the Coast and Geodetic Survey and of the Bureau of Fisheries as may be necessary to cooperate with the Maryland State board of shellfish commissioners in making a survey of and locating the natural oyster beds, bars, and rocks in the waters within the State of Maryland; and the Secretary of Commerce and Labor is hereby authorized and directed to furnish to the officers, experts, and employees of said Bureaus so detailed as aforesaid such instruments, appliances, and steam launches as may be necessary to make the survey aforesaid; and the Secretary of Commerce and Labor is hereby authorized to have made in the Bureau of the Coast and Geodetic Survey all the plats necessary to show the results of the aforesaid survey and the locations of the said natural oyster beds, bars, and rocks in the waters within the State of Maryland, and to furnish to the board of shellfish commissioners of the State of Maryland such copies as may be necessary, and for this purpose to employ, in the District of Columbiz and elsewhere, such technically qualified persons as may be necessary to carry out the purpose of this act.

SEC. 2. That the Secretary of Commerce and Labor is hereby further authorized to have erected or constructed by the officers so detailed as aforesaid, while making such survey, such structures as may be necessary to mark the points of triangulation, so that the same may be used for such future work of the Coast and Geodetic Survey as the said Bureau may be hereafter required to perform in prosecuting the Government coast survey of the navigable waters of the United States located within the State of Maryland.

\footnotetext{
SEC. 4. That this act shall take effect from the date of its passage.
}

[Act of Congress approved June $30, x 906$. ]

AN ACT Making appropriations for sundry civil expenses of the Government for the fiscal year ending June thirtieth, nineteen hundred and seven, and for other purposes.

Be it enacted by the Senate and House of Representatives of the United States of America in Congress assembled, That the following sums be, and the same are hereby, appropriated, for the objects hereinafter expressed, for the fiscal year ending June thirtieth, nineteen hundred and seven, namely: * * * 
COAST AND GEODETIC SURVEY: * * * For any special surveys * * * including the expenditures authorized under Public Act Numbered One hundred and eighty-one, approved May twenty-sixth, nineteen hundred and six, and contingent expenses incident thereto, five thousand dollars, together with the unexpended balance under this appropriation for nineteen hundred and six and prior years which is hereby reappropriated and made available on this account for the fiscal year nineteen hundred and seven. ***

[Act of Congress approved March 4, 1907.]

AN ACT Making appropriations for sundry civil expenses of the Government for the fiscal year ending June thirtieth, nineteen hundred and eight, and for other purposes.

Be it enacted by the Senate and House of Representatives of the United States of America in Congress assembled, That the following sums be, and the same are hereby, appropriated, for the objects hereinafter expressed, for the fiscal year ending June thirtieth, nineteen hundred and eight, namely: * * *

CoAst AND GEODETrC Survey: * * * For any special surveys * * * including expenses of surveys in aid of the shellfish commission of the State of Maryland, to be immediately available and to continue available until expended, twenty-five thousand dollars. * * *

[Act of Congress approved May 27, 1908.]

AN ACT Making appropriations for sundry civil expenses of the Government for the fiscal year ending June thirtieth, nineteen bundred and nine, and for other purposes.

Be it enacted by the Senate and House of Representatives of the United States of America in Congress assembled, That the following sums be, and the same are hereby, appropriated, for the objects hereinafter expressed, for the fiscal year ending june thirtieth, nineteen hundred and nine, namely: * * *

CoAst And Geodetic Survey: * * * For any special surveys * * * including expenses of surveys in aid of the shellfish commission of the State of Maryland, which expenses, including cost of plats and charts, shall not exceed fifteen thousand dollars in any one year, to be immediately available, twenty thousand dollars.

\section{[Act of Congress approved March 4, I909.]}

AN ACT Making appropriation for sundry civil expenses of the Government for the fiscal year ending June thirtieth, nineteen hundred and ten, and for other purposes.

Be it enacted by the Senate and House of Representatives of the United States of America in Congress assembled, That the following sums be, and the same are hereby, appropriated, for the objects hereinafter expressed, for the fiscal year ending June thirtieth, nineteen hundred and ten, namely: * * *

Coast and Geqdetic Survey: * * * For any special surveys * * * including expenses of surveys in aid of the shellish commission of the State of Maryland, which expenses, including cost of plats and charts, shall not exceed fifteen thousand dollars in any one year, to be immediately available, twenty thousand dollars.

[Act of Congress approved June 25, 1930.]

AN ACT Making appropriations for sundry civil expenses of the Government for the fiscal year ending June thirtieth, nineteen hundred and cleven, and for other purposes.

Be it enacted by the Senate and House of Representatives of the United States of America in Congress assembled, That the following sums be, and the same are hereby, appropriated, for the objects hereinafter expressed, for the fiscal year ending June thirticth, nineteen hundred and eleven, namely: * * *

CoAst AND GeOdetrc SURvey: * * * For any special surveys * * * including expenses of surveys in aid of the shellfish commission of the State of Maryland, to be immediately available fifteen thousand dollars. 
[Act of Congress approved March 4, I9ri.]

AN AC'T Making appropriations for sundry civil expenses of the Government for the fiscal year ending June thirtieth, uinetecn hundred and twelve, and for other purposes.

Be il enacted by the Senate and House of Representatives of the United States of America in Congress assembled, That the following sums be, and the same are hereby, appropriated, for the objects hereinafter expressed, for the fiscal year ending June thirtieth, nineteen hundred and twelve, riamely: * * *

Coast and Geodetrc Survey: * * * For any special surveys * * * including expenses of surveys in aid of the shellfish commission of the State of Maryland, to be immediately available, thirteen thousand dollars. * * *

[Act of the Legislature of Maryland approved April 2, rgo6.]

AN ACT To establish and promote the industry of oyster culture in Maryland, to define and mark natural oyster beds, bars, and rocks lying under the waters of this State, to prescribe penalties for the infringement of the provisions of this Act, and ***.

Sectron x. Be it enacted by the General Assembly of Maryland, That the following sections be, and they are hereby, added to article 72 of the Code of Public General Laws, title "Oysters." * * *

SEC. 86. The Board of Shell Fish Commissioners shall, as soon as practicable after the passage of this Act, cause to be made a true and accurate survey of the natural oyster beds, bars and rocks of this State, said survey to be made with reference to fixed and permanent objects on the shore, giving courses and distances, to be fully described and set out in a written report of said survey, as hereinafter required. A true and accurate delineation of the same shall be made on copies of published maps and charts of the United States coast and geodetic survey, which said copies shall be filed in the office of the said commissioners in the city of Annapolis, and the said commissioners shall further cause to be delineated upon copies of the published maps and charts of the United States coast and geodetic survey, of the largest scale, one copy for each of the counties of this State in the waters of which there are natural oyster beds, bars and rocks, all natural beds, bars and rocks lying within the waters of such county, which maps shall be filed in the offices of the clerks of the Circuit Court for the respective counties wherein the grounds so designated may lie. ***

SEC. 87. The Governor of this State is hereby requested to ask the assistance of the United States coast and geodetic survey, and of the United States Fish Commissioner, to aid in the carrying out of the provisions of the preceding section.

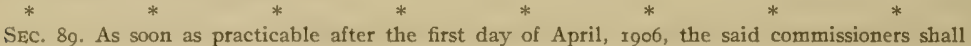
organize, and shall at once proceed, with the assistance of such person or persons as may be detailed by the United States coast and geodetic survey and the United States Fish Commissioner, to aid them in their work, and of such persons as may be appointed under the preceding section, to have laid out, surveyed and designated on the said charts, the natural beds and bars, and shall cause to be marked and defined as accurately as practicable the limits and boundaries of the natural beds, bars, and rocks as established by said survey, and they shall take true and accurate notes of said survey in writing, and make an accurate report of said survey, setting forth such a description of landmarks as may be necessary to enable the said board, or their successors, to find and ascertain the boundary lines of the said natural oyster beds, bars and rocks, as shown by a delineation on the maps and charts provided in this Act; said report shall be completed and filed in the office of the board in the city of Annapolis within ninety days after the completion of the survey of any county. Said commissioners shall cause the same to be published in pamphlet form, and transmit copies of the said to the Clerks of the Circuit court for the respective counties, where the charts have been filed or directed to be filed as hereinafter provided; the said report to be filed by the clerks of the several counties in a book kept for that purpose. And the said survey and report, when filed, subject to the right of appeal hereafter provided for in this Act, shall be taken in all of the courts of this State as conclusive evidence of the boundaries and limits of all natural oyster beds, bars and rocks, lying within the waters of the county wherein such survey and report are filed, and shall be construed to mean in all of the said courts that there are no natural oyster beds, bars or rocks lying within the waters of the counties wherein such report and survey are filed other than those embraced in the survey authorized by this Act, and that all areas of the Chesapeake Bay and its tributaries within the State of Maryland, not shown in the survey to be natural oyster beds, bars or rocks shall be construed in all the courts of the State to be barren bottoms and 
open for disposal by the State for the purpose of private planting or propagation of oysters thereon under the provisions of this Act; provided, that the said survey and report shall not be construed as to affect in any manner the holdings by citizens of this State in any lot which may have been appropriated or taken up under the laws of this State prior to the approval of this Act.

The law of the State of Maryland, passed March 9, 1842, authorizing officers of the United States Coast and Geodetic Survey to enter upon the lands within the State limits for the purposes of the survey, is as follows:

AN ACT Concerning the Survey of the Coast of Maryland.

SECTION I. Be it enacted by the General Assembly of Maryland, That it shall and may be lawful for any person or persons employed under and by virtue of an act of the Congress of the United States, * * * at any time hereafter to enter upon lands within this State for the purpose of exploring, surveying, triangulating, or leveling, or doing any other matter or thing which may be necessary to effect the objects of said act, and to erect any works, stations, buildings, or appendages requisite for that purpose, doing no unnecessary injury to private or other property.

SEC. 2. ${ }^{1}$ And be it enacted, That in case the person or persons employed under the act of Congress aforesaid, can not agree with the owners or possessors of the land so entered upon and used as to the amount of damage done thereto by reason of the removal of fences, cutting of trees or injury to the crop cr crops growing on the same, it shall and may be lawful for the said parties or either of them to apply to the chief justice for the time being or one of the associate judges of the judicial district in which such land may be situated, who shall thereupon appoint three disinterested and judicious freeholders, residents of the same judicial district, to proceed with as much despatch as possible to the examination of the matter in question, and the faithful assessment of the damages sustained by the owners or possessors aforesaid, and the said freeholders or a majority of them, having first taken and subscribed an oath or affirmation before the chief or associate justice aforesaid or other personduly authorized to administer the same, that they will well and truly examine and assess as aforesaid, and having given five days' notice to both parties of the time of their meeting, shall proceed to the spot, and then and there upon their own view and if required, upon the evidence of witnesses (to be by them sworn or affirmed and examined), shall assess the said damages, and shall afterward make report thereof and of their proceedings in writing under their hands and seals and file the same within five days thereafter in the office of the clerk of the county in which the land aforesaid is situated, subject to an appeal by either party to the county court of the said county within ten days after filing as aforesaid, and the said report so made as aforesaid if no appeal as aforesaid be taken, shall be held to be final and conclusive as between the said parties, and the amount so assessed and reported shall be paid to the said owners or possessors of the land so damaged within twenty days after the filing of said report, and the said chief or associate justice as aforesaid, shall have authority to tax and allow upon the filing of said report, such costs, fees and expenses to the said freeholders for the performance of their duty as he shall think equitable and just, which allowance shall be paid by the person or persons employed under the act of congress aforesaid, within the time last above limited, but if an appeal as aforesaid be taken, the case shall be set down for hearing at the first term of county court aforesaid, ensuing upon and after appeal, and it shall be lawful for either party immediately after the entry of such appeal, to take out summons for such witnesses as may be necessary to be examined upon the hearing aforesaid, and the said court shall have power in its discretion to award costs against which ever the final judgment shall be entered, and such appeal at the option of either party may and shall be heard before and the damage assessed by a jury of twelve men to be taken from the regular panel and elected as in other cases.

SEC. 3. And be it enacted, That if any person or persons shall wilfully injure or deface or remove any signal, monument or building or any appendage thereto, erected, used or constructed under and by virtue of the act of congress aforesaid, such person or persons so offending shall severally forfeit and pay the sum of fifty dollars with costs of suit to be sued for and recovered by any person who shall first prosecute the same before any justice of the peace of the county where the person so offending may reside, and shall also be liable to pay the amount of damages thereby. sustained; to be recovered with costs of suit in an action on the case, in the name and for the use of the United States of America, in any court of competent jurisdiction.

Under the rulings of the Comptroller of the Treasury nu damages can be collected except through the United States Court of Claims unless an agreement has been made in advance. 


\section{APPENDIX B.-THE HAMAN OYSTER CULTURE LAW.}

[Exiract from Second Report of Shell Fish Commission.]

OBJECT.

"The legislature in placing chapter $7 x 1$ of the acts of 1906 , better known as the Haman Oyster Culture Law, upon the statute books of Maryland, had a twofold object in view:

1. To encourage an industry in oyster culture upon the barren bottoms beneath the tidewaters of the State.

2. To prevent the leasing of natural oyster bars for the purpose of oyster culture."

\section{SURVEY.}

"To make the leasing of barren bottoms possible and the leasing of natural bars impossible, provision was made for a survey of the natural bars for the purpose of aceurately locating and marking the same. It was definitely provided that no barren bottoms should be leased in any part of the State until the natural bars of that region had been surveyed, chartered, and marked with buoys."

\section{Defintion of a Natural Oyster Bar.}

NATURAL BAR NOT DEFINED.

"The Shell Fish Commission is instructed by section 90 of the Haman Oyster Culture Law to exercise its judgment liberally in favor of the natural bars when surveying, charting and buoying them, but other than this the Commission is uninstructed in this important matter. The responsibility of defining a natural bar is placed upon the commission."

\section{DIVERSITY OF OPINION.}

"No definition of a natural oyster bar could be formulated by any man or body of men which would meet with the approval of all parties concerned. Oystermen, as a rule, hold that all bottoms where oysters grow or have grown naturally even though now practically barren of oysters should be considered natural bars. Other citizens of the State who are not directly interested in the oyster business, but interested in the oyster industry from the standpoint of revenue, hold, as a rule, that no bottoms should be excluded from leasing for oyster culture which, by methods known to oyster culturists, may be made to yield a greater number of oysters than they now produce."

"It should be evident to every one that neither of these definitions could be adopted by the Commission as a working basis for determining which of the grounds surveyed are natural oyster bars."

\section{THE GOLDSBOROUGH DEFINITION.}

The definition of a natural oyster bar which very nearly approaches a reasonable and satisfactory compromise between the views of the subject held by oystermen on one hand and by oyster culturists on the other is that contained in an opinion rendered by Judge Charles F. Goldsborough in the circuit court for Dorchester County in the July term, I88 $\mathrm{x}$, in the case of William $\mathrm{T}$. Windsor and George R. Todd v. Job T. Moore.

This definition has been adopted by the Shell Fish Commission as the basis for the determination of the status of the various oyster bottoms surveyed and is as follows:

What then is a natural bar or bed of oysters? It would be a palpable absurdity for the State to attempt to promote the propagation and growth of oysters and to encourage its citizens, by a grant of land, to engage in their culture, if the lands authorized to be taken up were only those upon which oysters do not and can not be made to grow. That there may be lands covered by water in the State where no oysters can be found, but where, if planted, they could be cultivated successfully, may be possible, but, if so, I imagine that their extent must be too limited for them to be of much practical, general advantage for the purposes of such a law as the one under discussion; but there are thousands of acres of hard and shifting sands where oysters not only are not found, but where it would be folly to plant them, and these latter it can not be supposed that the State intended to offer to give away, for the simple reason that the State could not help knowing that nobody would have them.

Upon the other hand there are large and numerous tracts where oysters of natural growth may be found in moderate numbers, but not in quantities sufficient to make it profitable to catch them, 
and yet where oysters may be successfully planted and propagated. In my opinion these can not be called natural bars or beds of oysters, within the meaning of the Act of Assembly, and it is just such lands as these that the State meant to allow to be taken up under the provisions of the above-mentioned section of the Act.

But there is still another class of lands where oysters grow naturally and in large quantities and to which the public are now and have been for many years in the habit of resorting with a view to carning a livelihood by catching this natural growth, and here, I think, is the true test of the whole question. Land can not be said to be a natural oyster bar or bed merely because oysters are scattered here and there upon it, and because if planted they will readily live and thrive there; but whenever the natural growth is so thick and abundant that the public resort to it for a livelihood, it is a natural oyster bar or bed and comes within the above-quoted restriction in the law, and can not be located or appropriated by any individual.

\section{APPLICATION OF DEFINITION.}

Before this definition may be of use in determining, accurately and scientifically, the status of an oyster ground, its central idea, "livelihood," must be expanded into accurately determinable factors, and these factors must be combined into a practical scheme of investigating the condition of the ground under consideration.

Stated briefly, a livelihood is represented by a sum of money obtained from the sale, at a fixed price, of a certain quantity of oysters gathered in a given time from an allotted area of ground.

Knowing the value of each of these factors, it becomes possible to calculate the number of oysters an oyster ground must produce per square yard in order that oystermen may secure a livelihood by working upon it.

NoTE.-The factors into which the Commission resolved the livelihood problem, the values assigned to each factor, and the scheme devised for practical use in examining and applying the definition to oyster bottoms are given in outline in their second report under the heading of the preceding extract, and in detail in their first report on pages 32 to 69.

\section{APPENDIX C.--SUMMARY OF THE PARTICULAR SURVEYING OPERATIONS WHICH CON- STITUTE AN "OYSTER SURVEY" AS NOW BEING CARRIED ON IN MARYLAND.}

Explanation.-A brief account of the particular surveying operations which constitute an "oyster survey" as now being carried on in Maryland will assist in the interpretation of records contained in the technical part of this report, and will be of interest to many who may not understand the necessity for the great amount of work being done or its complicated character.

To those familiar with methods used in surveying and charting the characteristic features of large bodies of water there is an evident necessity for the various operations performed, especially when it is known that the boundaries of the public oyster bars and of the private lots leased for purposes of oyster culture must be surveyed and charted with the greatest practical accuracy. To others it will be sufficient to state that the actual experience gained from oyster surveys in other States has proven that in order to avoid endless dissatisfaction and litigation it is necessary to accurately locate and permanently establish oyster boundaries as is now being done in Maryland.

Triangulation survey. - Such refinement of survey work as that demanded by the conditions of an oyster survey when carried on at considerable distances offshore can only be obtained by the use of a system of triangulation as a framework or foundation. Therefore, a triangulation survey including the permanent marking of the positions of landmarks with monuments and a record of the descriptions of their locations for future recovery is a necessary operation of a complete oyster survey.

Topographic survey.-The technical records which establish the relation between the offshore oyster boundaries and triangulation landmarks are sufficient for the requirements of enginecrs in making resurveys, but do not supply the needs of others who are interested in the same boundaries by reason of their occupation as oystermen concerned as to the public oyster bars, or oyster culturists concerned as to the leasable bottoms. For these it is necessary to have the charts of the survey show the relation of the shore line and other topographic features to the boundaries of the public oyster bars and private oyster farms. Therefore, a topographic survey is a necessary operation of a complete oyster survey.

Hydrographic survey. - In the settlement of the important question of what is, or what is not, a natural oyster bar, and in the consideration of bottoms to be selected for purposes of oyster culture, 
information as to the depth of water and the character of the bottom is required. Therefore, a hydrographic survey is a necessary operation of a complete oyster survey.

Necessary foundation for an oyster survey. Consequently, the necessary components of a satisfactory foundation for a complete oyster survey are the three classes of survey operations technically named triangulation, topography, and hydrography, or, stated in another way, the foundation of a practical oyster survey includes the surveying operations usually followed by the Coast and Geodetic Survey leading up to the preparation and publication of nautical charts.

Special surveys and investigations pertaining to aysters.-Having obtained this cartographic survey for a foundation, partly by new work and partly from records of previous work of the Government, the combined operations " making up an "oyster survey" are completed by superimposing on this foundation special surveys and investigations pertaining particularly to oysters or other shell fish.

The special surveys pertaining to oysters furnish information as to the location and outline of oystershell bottoms, and are carried on by the sounding boat party in addition to the usual hydrographic work. $^{2}$ This operation consists of the observation and record of the character of vibration of a wire and chain apparatus which is dragged over the bottom, the vibrations or lack of vibrations indicating the presence and quantity of shells or absence of shells.

The special oyster investigations ${ }^{3}$ consist of the actual determination of the kind and quantity of oysters on the bottom, and such economic and biological studies of the supply of oyster food, density of water, character of the bottom, and other important matters as affect the growth of oysters. In this work the oyster investigation stations are located and buoyed by the hydrographic party while engaged in the survey of the oyster-shell limits. They are selected with the view of obtaining characteristic data which can be used for the interpretation of the recorded vibrations of the chain apparatus at all other points covered by the survey.

Preparation of results.- The actual surveying operations and oyster investigations having been completed for any one county, there still remains technical work of nearly equal magnitude to that described.4 This work consists of the preparation of charts and technical descriptions of boundaries and landmarks for publication by the Government, the preparation of that part of the annual report of the Commission covering the special oyster surveys and investigations, the making of the leasing charts and finished projections, and finally the filing of the oyster charts and records with the courts and the Commission, thus opening a county for oyster culture.

Summary.-From the foregoing account it can be seen that a complete oyster survey properly conducted so as to answer all practical requirements of the present and permanency of results for the future is a very complicated affair, involving many lines of surveying and other scientific work, and requiring the professional services of experts in the various operations of cartographic surveying and shell-fish investigations.

\footnotetext{
1 See Appendix D of this publication for "Statistics of results of combined operations of the Government and State."

2 See pages ro $4-123$ of "First Annual Report of Maryland Shell Fish Commission."

3 See pages 30-67 and r29-199 of "First Annual Report of Maryland Shell Fish Commission."

1 No mention is made here of the large amount of administrative work of the commission, which is greatiy complicated and increased by the effect of the oyster-survey operations on many thousands of people whose interests are more or less involved: or of the large amount of survey work involved in the survey and record of the boundaries of oyster lots leased from the State by private individuals for the purposes of oyster culture.
} 
SURVEY OF OYSTER BARS, ST. MARYS COUNTY, MD.

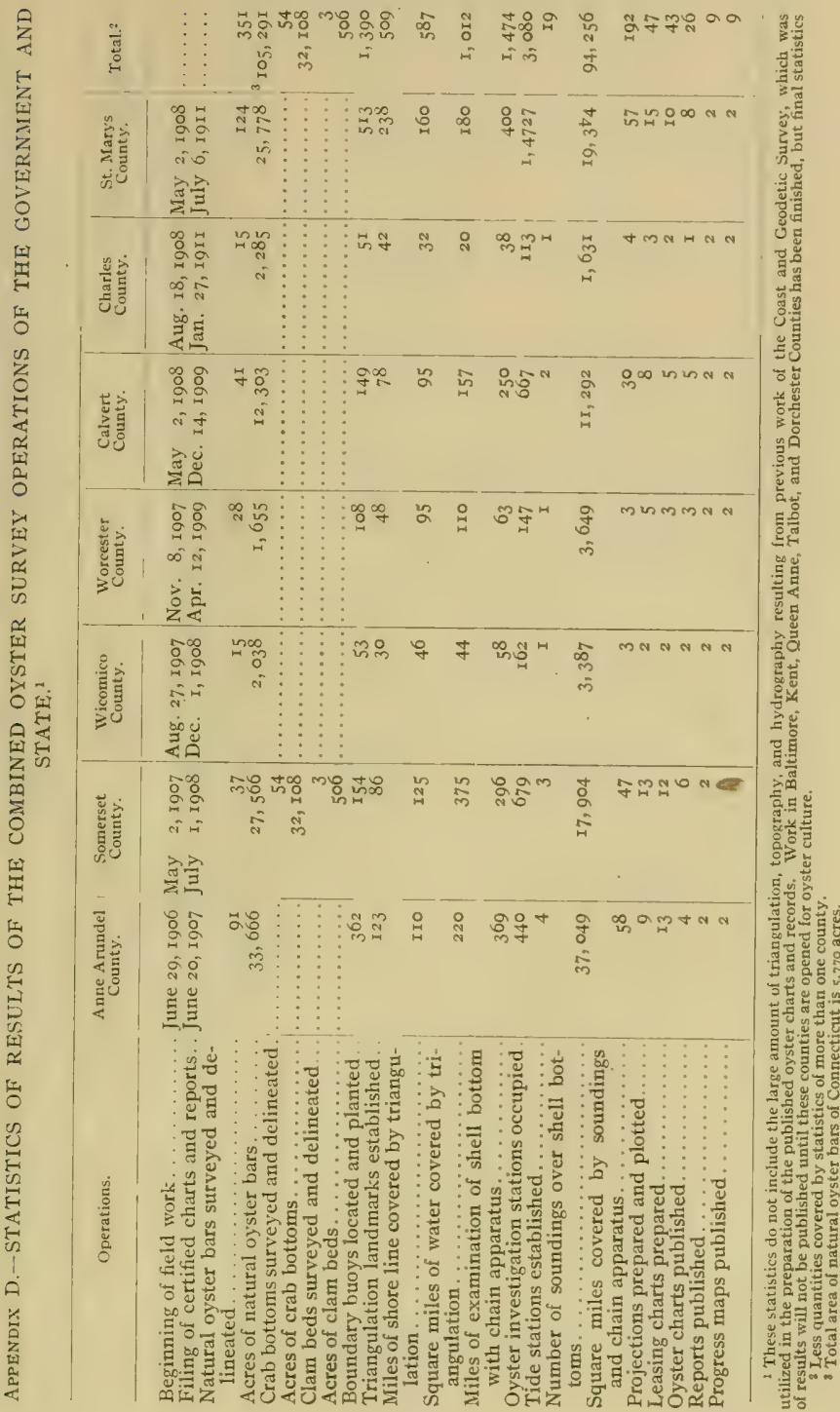





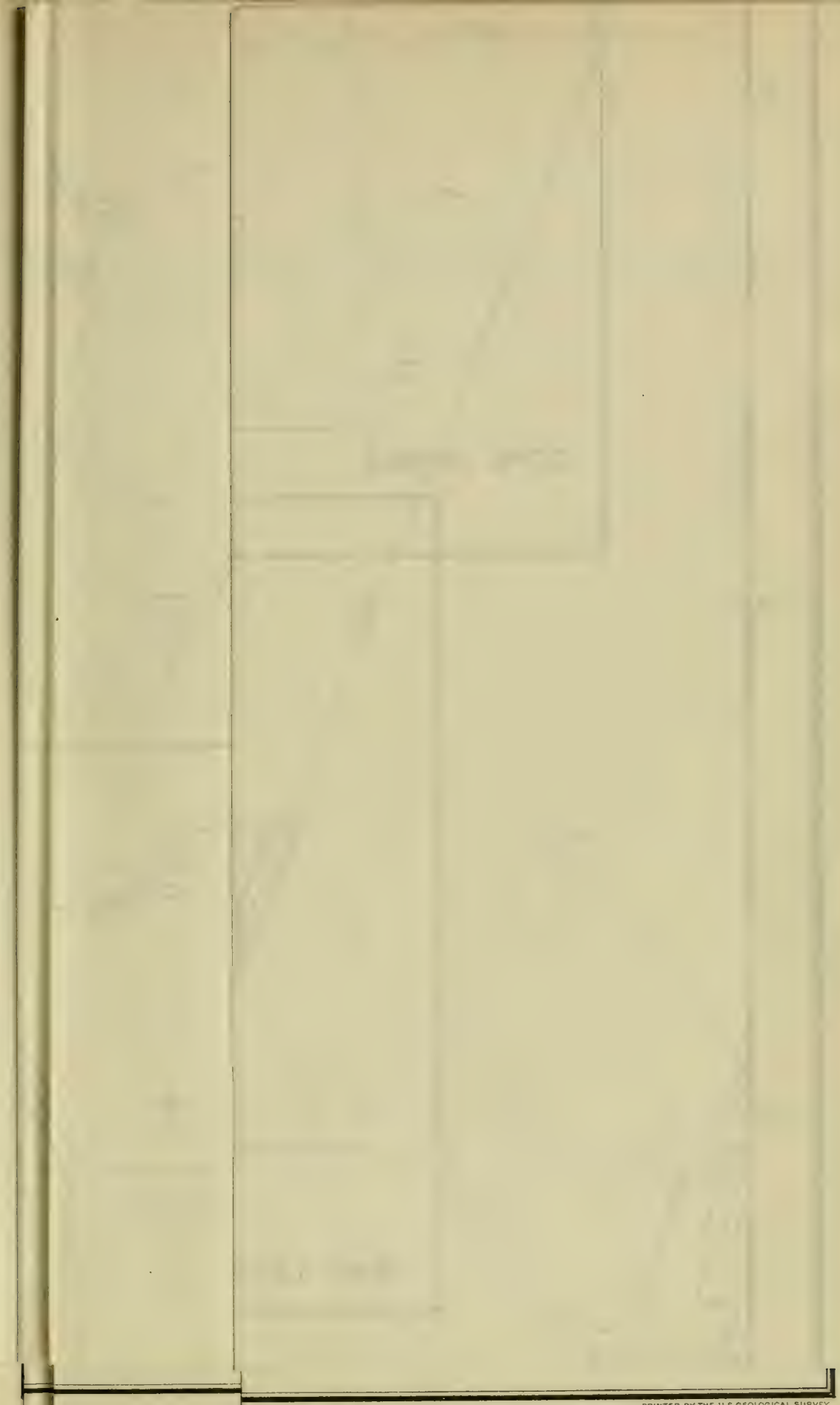




$$
\text { . }
$$ 




\title{
DEPARTMENT OF COMMERCE AND LABOR COAST AND GEODETIC SURVEY \\ O. H. TITTMANN, Superintendent
}

\section{SURVEY OF OYSTER BARS SOMERSET COUNTY MARYLAND}

DESCRIPTION OF BOUNDARIĘS AND LANDMARKS AND REPORT - OF WORK OF UNITED STATES COAST AND GEODETIC SUR-

VEY IN COOPERATION WITH UNITED STATES BUREAU OF FISHERIES AND MARYLAND SHELL FISH COMMISSION

\author{
By C. C. YATES
}

CHIEF OF COAST AND GEODETIC SURVEY PARTY ASSISTANT, COAST AND GEODETIC SURVEY

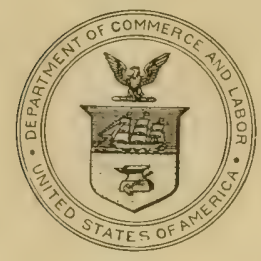

WASHINGTON

GOVERNMENT PRINTING OFFICE 1908 
DEPARTMENT OF COMMERSE AND LABOR

Document No. 94

COAST AND GEODETIC SURVEY 


\title{
LETTTER OF SUBMITTAL.
}

\author{
DEPARTMENT OF COMMERCE AND LABOR, \\ CoAst AND GeOdetic SURVEy, \\ Washington, June 29, 1908 .
}

SIR: I have the honor to transmit herewith the report of the officer detailed from the Coast and Geodetic Survey to cooperate with the Bureau of Fisheries and the Maryland Shell Fish Commission in surveying the oyster bars of the State of Maryland, and certain technical results which are necessary for the interpretation and use of the plats of the survey made by the Government.

This work has been done under the provisions of the act of Congress entitled "An act to authorize the Secretary of Commerce and Labor to cooperate, through the Bureau of the Coast and Geodetic Survey and the Bureau of Fisheries, with the shellfish conmissioners of the State of Maryland in making surveys of the natural oyster beds, bars, and rocks in the waters within the State of Maryland," approved May 26, Igo6, and of the acts of Congress making appropriations for sundry civil expenses of the Government for the fiscal years ending June 30, 1907, 1908, and 1909.

Respectfully,

O. H. Tutrmann, Superintendent.

To Hon. Oscar S. STraus,

Secretary of Commerce and Labor. 



\section{CERTIFIC A T I ON.}

ANNAPOLIS, MD., June 25, I908.

The following publication is certified to contain correct technical descriptions of all boundaries and landmarks established in the waters of Somerset County by the Maryland Shell Fish Commission in cooperation with the United States Coast and Geodetic Survey.

$$
\text { C. C. YATES, }
$$

Chief of Coast and Geodetic Survey Party,

Assistant, Coast and Geodetic Survey.

Examined and certified to be correct.

ANNAPOLIS, MD., June 25, 1908 .

$$
\begin{gathered}
\text { WAlTER J. Mitchell, } \\
\text { CASWELL GRAVE, } \\
\text { BENJAMIN K. GREEN, } \\
\text { Maryland Shell Fish Commissioners. } \\
\text { SWEPSON EARLE, } \\
\text { Hydrographic Engineer. }
\end{gathered}
$$

NorE.-As required by law, certified copies of this publication and of the charts of the natural oyster bars of "Somerset County and adjacent waters" were filed in the oftice of the clerk of the circuit court of Somerset County and in the office of the Board of Shell Fish Commissioners, at Annapolis, on July 1, 1908. 



\section{CONTENTS.}

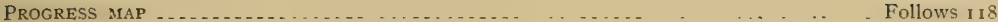

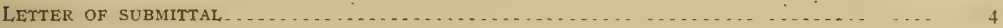

CFRTIFICATION_-_.

INTRODUCTION:

Publications.

Cooperation of the Coast and Geodetic Survey

Cooperation of the Bureau of Fisheries._. 14

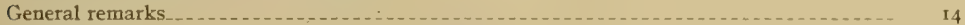

REPORT OF THE WORK OF THE COAST AND GEODETIC SURVEY:

Instructions_._.

Organization_..._- 17

Equipment

Chronological statement of work

Statistics____._.

General statement_-19-_.

CHARTS AND MAPS:

Charts of natural oyster bars_.

Leasing charts_._.

Projections_-_-_-_. 22

Progress maps____._. 23

BOUNDARIES OF COUNTY WATERS:

Waters within territorial limits of county

Waters contiguous to county_..... 24

LANDMARKS (U. S. COAST AND GEODETIC SURVEY TRIANGULATION STATIONS):

Explanation of descriptions of triangulation stations.

Descriptions of triangulation stations-

Chant No. 5 (upper end of Tangier Sound and Wicomico River)-

Senator (see also Charts Nos. 6 and 7)

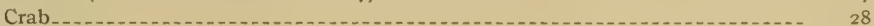

Sharkfin Shoal Light _...

Head

Frog . .

Cow

Nanticoke Church

Roar

Nanti_-___n 30

White

Ella_-

Holland.-_ 32

Child

Creek 
LANDMARKS (U. S. COAST AND GEODETIC SURVEY TRIANGULATION STATIONS)-Continued.

Descriptions of triangulation stations-Continued.

Chart No. 5 (upper end of Tangier Sound and Wicomico River)-Continued.

End

Jones_-1-_

Ivee

Mount Vernon Church._._.

Ball__.

Wind

Little

Dove

Great Shoals Light_-_. 36

Short____

Room_... 37

Haines_____

Deal Island Church

Bar (see also Chart No. 7)

Jean (see also Chart No. 7) ... . . . . . . . . . . . . . .

Sandy (see also Chart No. 7) _...... 39

Chart No. 6 (Chesapeake Bay west of Kedge and Holland straits)--

Holland Island Bar Light.

Senator (see also Charts Nos. 5 and 7)

Solomons Lump Light (see also Chart No. 7)

Fog-_. 39

Joseph (see also Chart No. 8)

Chart No. 7 (Middle Tangier Sound and tributaries)-

Terrapin____.

Solomons Lump Light (see also Chart No. 6)

Miles_.

Senator (see also Charts Nos. 5 and 6)

Bar (see also Chart No, 5)

Joshua

Kelley_._.

Marsh_-....

St. Pierre

Jean (see also Chart No. 5)

Sandy (see also Chart No. 5)

Locust__-__-_.

Fitz (outside limits of chart; see progress map)

Wab (outside limits of chart; see progress map)

Pen (outside limits of chart; see progress map)

Cox__._.

Green. . . . . . . . . . . . . . . . . . . . . . 4.44

Barn

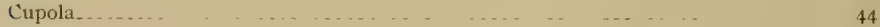

Staff . . . . . . . . . . . . . .

Fairmount Church

Prickly__.

Has_. . . . . . . .

Ford . . .

Moon............ 45

Colburn

Geog-_............................. 46

Flat Cap._. 


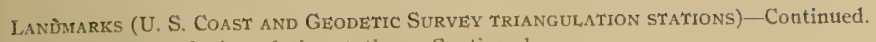

Descriptions of triangulation stations-Continued.

Chart No. 8 (Chesapeake Bay west of Smith Island)-

Smith Point Light.

Joseph (see also Chart No. 6) -

North Church (Smith Island)

Old Church (Smith Island).

Ewell Church (Smith Island)

Shanks Hammock

Chan No. 9 (lower end of Tangier and Pocomoke sounds)-

Reach Hammock

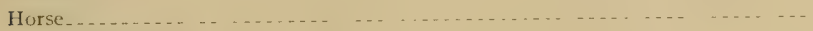

Janes Island Light. . . . . . . . . . . . . . . . . . . . . . . . . . .

Somers Cove Light

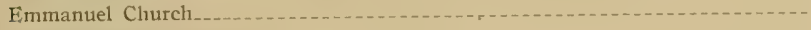

Mount Pleasant Church _... . . . . . . . . . . . . . . . . . . . . . . . .

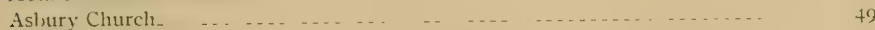

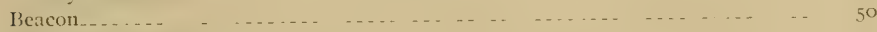

Fox Island Poplar..... . . . . . . . . . . . . . . . . . . . . . . . 5 5

Sim .....

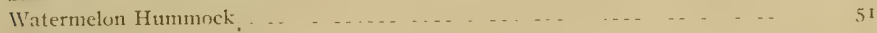

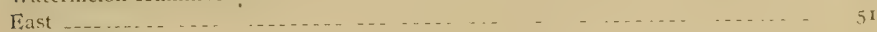

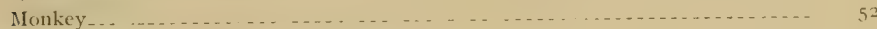

('hall No. Io (upper end of Pocomoke Suund)-

Scot

Old

Will

Cup

Summer -

Oil_... . .

Wharf

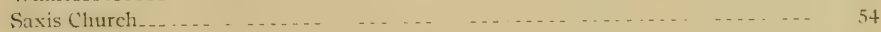

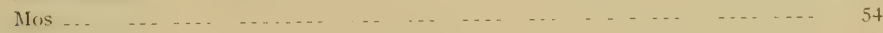

BOUNDARIES OF OYSTER BARS:

Explanation of descriptions of boundaries

Surveying methods for relocation of boundaries_..... 56

Boundaries of natural oyster bars-

Chart No. 5 (Upper Tangier Sound and Wicomico River)-

Turtle Egg Island (see also Chart No. 7)

Hud _...

Old Grchard $\ldots \ldots \ldots \ldots \ldots \ldots \ldots \ldots \ldots$

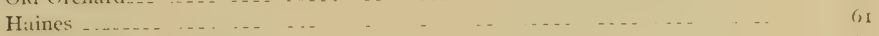

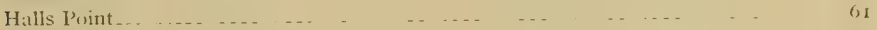

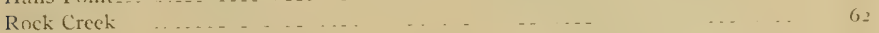

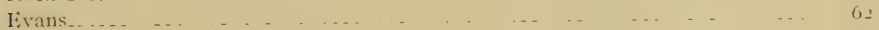

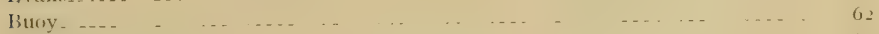

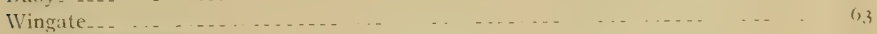

Mount Vermon IVharf .....

Georges (see also Chart No. 7)

Chart No. 6 (Chesapeake Bay west of Kedge and Holland straits)-

Southwest Middleground (see also Cliart No. 8)

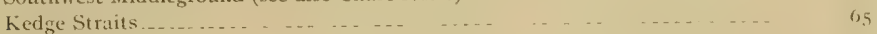

Oyster Creek__.

50095-08 - 2 
BOUNDARTES OF OTSTER BARS-Continted.

Boundaries of natural oyster bars-Continued.

Chart No. 7 (Middle Tangier Sound and tributaries)—

Mussel Hole ... .. . . . . . . . . . . . . . . . . . . . . . 66

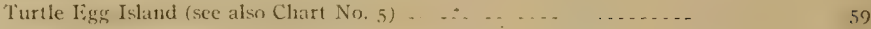

Chain Shoal_..........

Piney Island West_...

P'iney Island Swash_........... 68

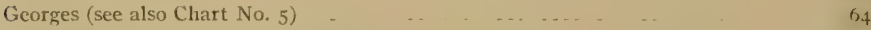

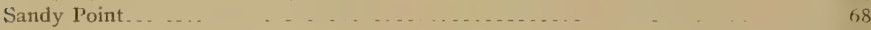

Cormal ... . . 69

Marshy Island

Drum Point

Prickly Point

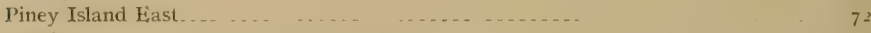

Hurris .......

Big Annemessex _.

Chan No. $\&$ (Chesapeake Bay west of Smith Island)-

Southwest Middleground (see also Chart No. 6)

Church Creek............. . . . . ...

Chart No. 9 (lower end of Tangier and Pocomoke sounds)-

Philibys__._.

Great Rock. . . . . .

Fox Island

Stone-10.1.

Watkins_...

Long Point_... 77

Chart No. Io (upper end of Pocomoke Sound)-

Gunby

Marumsco

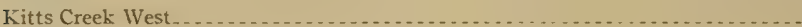

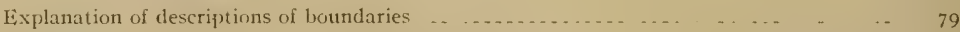

Surveying methods for relocation of boundaries .......... . . $\quad s_{1}$

Boundaries of crab bottoms-

Chart No. 5 (Upper Tangier Sound and Wicomico River)-

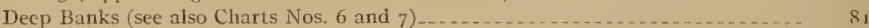

Holland Straits (see also Charts Nos. 6 and 7 ) .................. 82

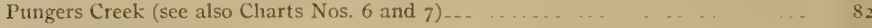

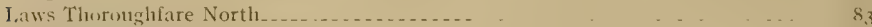

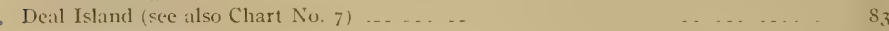

Laws Thoroughfare South (see also Chart No. 7) _. _ . _ _ _ . . . 84

Marsh Island (sce also Chart No. 7) . . . . . . . . . . . . . . . . . 84

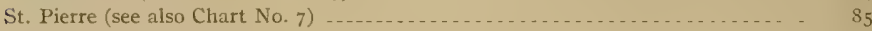

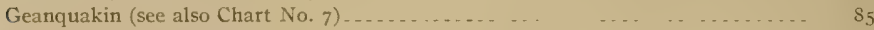

Chart No. 6 (Chesapeake Bay west of Kedge and Holland straits) -

Pungers Creek (see also Charts Nos. 5 and 7 ) _...... . . . . . . . . . . . . . . 82

Holland Straits (see also Charts Nos. 5 and 7 ) . . . . . . . . . . . . . . .

Deep Banks (see also Charts Nos. 5 and 7 ) ..................... SI $_{1}$

Spring Island ... . . . . . . . . . . . . . . . 86

Pry Cove ......

North Kedge Straits_____

Sheepshead (see also Chart No. 7)

Fishing Point (see also Chart No, 7 ) 
BOUNDARIES OF CRAB BOTTOMS-Continued.

Boundaries of crab bottoms-Continued.

Chart No. 6 (Chesapeake Bay west of Kedge and Holland straits)-Continued.

South Kedge Straits.

Smith Island Thoroughfare (see also Charts Nos. 8 and 9)

rage.

Chart No. 7 (Middle Tangier Sound and tributaries)

Terrapin Sand (see also Chart No. 9) .......................

Fishing Point (see also Chart No. 6)

Sheepshead (see also Chart No. 6)

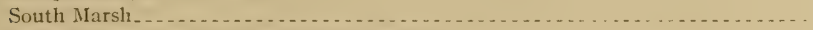

Pungers Creek (see also Charts Nos. 5 and 6 ) ... . . . . . . . . . . . . . . .

Deep Banks (see also Charts Nos. 5 and 6)

Holland Straits (see also Charts Nos, 5 and 6 ) . . .

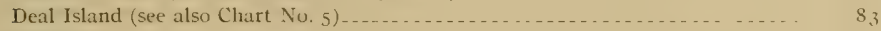

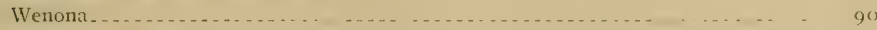

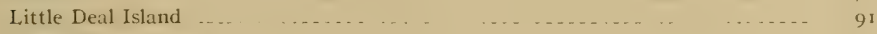

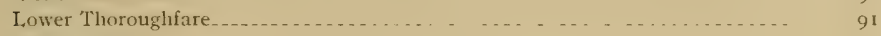

Piney Island.

Laws Thoroughfare South (see also Chart No. 5) _.......................... $8_{4}$

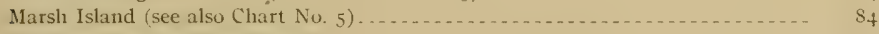

St. Pierre (see also Chart No. 5)

Geanquakin (see also Chart No. 5) . . . . . .

Teague Creck

Goose Creek

Mine Creek_..........

Hazard

Shark Point_-_.

Fords Wharf

Crane Cove

Moon Bay-10.1.

Red Cap Creek ...

Miles....

Colburn____

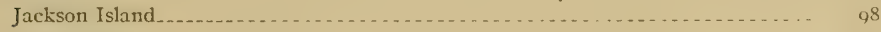

Jones Creek_._.

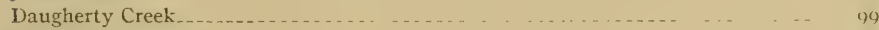

Tenth Point

Chant No. 8 (Chesapeake Bay west of Smith Island)--

Smith Island Thoroughfare (see also Charts Nos. 6 and 9)

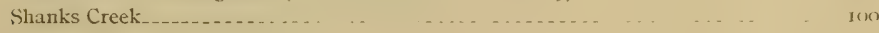

Tylers Creek (see also Chart No. 9)

Chart No. 9 (lower end of Tangier and Pocomoke sounds) -
Tylers Creek (see also Chart No. 8) ........ IOI

Smith Island Thoroughfare (see also Charts Nos. 6 and 8) _...... 89

Big Island ... . . .

Drum

Terrapin Sand (see also Chart No. 7)

Old House

Light House

Cancer_._.

Back Creek

Lavellette___.

Jenkins Creek .

Kings Island_...

Great Point 
BOUNDARIES OF CRAB BOTTOMS-Continued.

Page.

Boundaries of crab bottoms-Continued.

Chart No. 9 (lower end of Tangier and Pocomoke sounds)-Continued.

Fishing Creek

Cedar Straits

Iroad Creek

Ware Point $\ldots \ldots \ldots \ldots$

Apes Hole

Chan No, ro (upper end of Pocomoke Sound). [No crab bottoms.]

BOUNDARIES OF CLAM BEDS:

Explanation of descriptions of boundaries

Surveying methods for relocation of boundaries

Boundaries of clam beds-

Charts Nos. 5, 6, 7, and 8 . [No clam beds on these charts.]

Chart No. 9 (lower end of Tangier and Pocomoke sounds)-

Wate Rock

Gravel Rock

Flat Rock (see also Cliart No, ro)

Chart No. ro (upper end of Pocomoke Sound)-

Flat Rock (seo also Chart No: 9)

APPENDIXES:

Appendix A.-Laws relating to the cooperation of the Coast and Geodetic Survey and Bureau of Fisheries with the Maryland Shell Fish Commission

Appendix B.-Laws relating to survey of clam beds

Appendix C - Statistics of results of the combined operations of the Government and State Appendix D.- "The Haman Oyster Culture Law" (extract from First Report of Shell Fish Commission) 


\section{SURTEY OF OYSTER BARS, SOMERSET COUN'T', MID.}

\section{IN'TRODUCTION.}

\section{PUBLICATIONS.}

The preparation of publications relating to the survey of the oyster bars, crab bottoms, and clam beds of Maryland has been divided between the Government and the State in accordance with the laws ${ }^{a}$ authorizing the work and the natural division of the surveying operations of the cooperating forces.

The publications prepared and issued by the Government under the direction of the Superintendent of the Coast and Geodetic Survey consist of a series of charts and a technical report for each county surveyed. ${ }^{b}$ The charts show all legal boundaries of oyster bars, crab bottoms, and clam beds within the adopted boundaries of the waters opened up for leasing with each county, and the location of all landmarks (Coast and Geodetic Survey triangutation stations) used as a foundation for the delineation of these various boundaries. The technical report gives technical and legal descriptions of all oyster bar and other boundaries, and descriptions of all landnarks shown on the charts, and includes the report ${ }^{c}$ of the representative of the Coast and Geodetic Survey in charge of the work of that Service in cooperation with the Bureau of Fisheries and the Maryland Shell Fish Commission. These charts and technical reports are prepared and certified for file with the courts and the Commission, as required by the laws of the State, and contain all information necessary to make a permanent record of the work of the Commission and the Government for all future requirements of the courts, or for any resurveys that may become necessary.

The part prepared and issued by the State under the direction of the Shell Fish Commission consists of an annual report ${ }^{d}$ of all the operations of the Commission performed under the protisions of the laws of Maryland, e including results of biological and economic oyster investigations, methods and results of the hydrographic survey of the boundaries of oyster bars and crab bottoms, the administrative report and financial statement of the Commission, information relating to oyster culture, methods of sur-

a See Appendix A for laws relating to the cooperation of the Coast and Geodetic Survey and Bureau of Fisheries with the Maryland Shell Fish Commission.

$b$ These charts and technical reports can be obtained by application to the Superintendent of the Coast and Geodetic Survey, at Washington, D. C. The publications ready for issue are those of Anne Arundel and Somerset counties. Those of Wicomico and Worcester counties are now being prepared.

c See page 16 and the progress map attached to this publication.

$d$ These reports can be obtained by application to the Shell Fish Commission, Annapolis, Md. They are issued annually in October, and the first report is now available for distribution.

$\varepsilon$ See Appendix D for an extract from the "First Report of the Maryland Shell Fish Commission," giving a concise summary of the "Haman Oyster Culture Law." 
veying and leasing of oyster lots, and much other important matter of legal and scientific value.

These two sets of publications are planned and arranged to supplement each other without unnecessary duplication, and when combined they form a complete report of operations, methods, and results of the work of both the Government and State.

\section{COOPERATION OF THE COAST AND GEODETIC SURVEY.}

The work of the Coast and Geodetic Survey, as the name of the Service indicates, includes a survey of the coasts of the United States made on a geodetic basis. This has involved the gradual construction of a great framework of interstate triangulation for use as a foundation for detail hydrographic and topographic surveys, from which there has been compiled and published a complete set of charts of the coasts of the United States, including all waters of Maryland where oysters grow. This existing triangulation, hydrography, and topography is essential for a correct and practical survey of natural oyster bars; and it being one of the fundamental functions of the Coast and Geodetic Survey to furnish such data, the cooperation of the Coast and Geodetic Survey with the Bureau of Fisheries and the Maryland Shell Fish Commission is a practical and natural development of Government work leading to the conservation and increase of the supply of food.

\section{COOPERATION OF THE BUREAU OF FISHERIES.}

The Bureau of Fisheries has cooperated with the Coast and Geodetic Survey and the Maryland Shell Fish Commission principally as an advisor in matters relating to the biological and economic survey of oyster bars and the methods to be employed for that purpose. $^{a}$ A steam launch, rowing boat, and certain apparatus have also been furnished.

The primary function of the Bureau of Fisheries is to increase the productiveness of marine and fresh waters by such measures as may be best suited to the purpose, and the services rendered in connection with the survey of the oyster bar of Maryland are strictly in line with the fundamental law under which it acts. In certain States other than Maryland similar work has been conducted by the Bureau acting independently, the same ends being attained at greater expense to the Government.

\section{GENERAL, REMARKS.}

A brief account of the particular surveying operations which constitute an "oyster survey" as now being carricd on in Maryland will assist in the interpretation of records contained in the technical part of this report, and will be of interest to the many who may not understand the necessity for the great amount of work being done or its complicated character.

To those familiar with surveying methods on open waters the necessity for the various operations performed are evident, especially when it is known that the boundaries of the public oyster bars and of the private lots leased for purposes of oyster culture must be surveyed and charted with the greatest attainable accuracy. To others it will be

a Hon. George M. Bowers, Commissioner of Fisheries, has detailed for this service Dr. H. F. Moore, Assistant, Bureau of Fisheries. 
sufficient to state that the actual experience gained from oyster surveys in other States has proven that to accurately locate and permanently establish oyster boundaries as is now being done in Maryland is necessary if endless dissatisfaction and future litigation are to be avoided.

Such refinement of survey work as demanded by the conditions of an oyster survey when carried on at considerable distances offshore can only be obtained by the use of a system of triangulation as a framework or foundation. Therefore, a triangulation survey including the permanent marking of the positions of landmarks with monuments and a record of the descriptions of their locations for future recovery is a necessary operation of a complete oyster survey.

The technical records which established the relation between the offshore oyster boundaries and triangulation landmarks are sufficient for the requirements of engineers in making resurveys, but do not supply the needs of others who are interested in the same boundaries by reason of their occupation as oystermen concerned as to the public oyster bars, or oyster culturists concerned as to the barren bottoms. For these it is necessary to have the charts of the survey show the relation of the shore line and other topographic features to the boundaries of the public oyster bars and private oyster farms. Therefore, a topographic survey is a necessary operation of a complete oyster survey.

In the settlement of the important question of what is, or what is not, a natural oyster bar, and in the consideration of bottoms to be selected for purposes of oyster culture, information as to the depth of water and the character of the bottom is required. Therefore, a hydrographic survey is a necessary operation of a complete oyster survey.

Consequently, the necessary components of a satisfactory foundation for a complete oyster survey are the three classes of survey operations technically named triangulation, topography, and hydrography, or, stated in another way, the foundation of a practical oyster survey includes the surveying operations usually followed by the Coast and Geodetic Survey leading up to the preparation and publication of navigational charts.

Having obtained this cartographic survey for a foundation, partly by new work and partly from records of previous work of the Government, the combined operations " making up an "oyster survey" are completed by superimposing on this foundation special surveys and investigations pertaining particularly to oysters or other shell fish.

The special surveys pertaining to oysters furnish information as to the location and outline of oyster-shell bottoms and are carried on by the sounding boat party in addition to their usual hydrographic work. ${ }^{b}$ This operation consists of a record of the character of vibration of a wire and chain apparatus which drags over the bottom. The vibrations or lack of vibrations indicating the presence or absence of shells.

The special oyster investigations ${ }^{c}$ consist of the actual determination of the kind and quantity of oysters on the bottom, and such economic and biological studies of the supply of oyster food, density of water, character of the bottom, and other important

" See Appendix C of this publication for "Statistics of results of combined operations of the Government and State."

b See pages ro 4 to 23 of "First Annual Report of Maryland Shell Fish Commission."

c See pages 30 to 67 and 129 to 199 of "First Annual Report of Maryland Shell Fish Commission." 
matters as affect the growth of oysters. In this work the oyster investigation stations are located and buoyed by the hydrographic party while engaged in the survey of the oyster-shell limits. They are selected with the view of obtaining characteristic data which can be used for the interpretation of the recorded vibrations of the chain apparatus at all other points covered by the survey.

The actual surveying operations and oyster investigations having been completed for any one county, there still remains technical work of nearly equal magnitude to that described. ${ }^{a}$ This work consists of the preparation of charts and technical descriptions of boundaries and landmarks for record and publication by the Government, the manufacture and planting of the "State buoys" at all corners of the oyster-bar boundaries, the preparation of that part of the annual report of the Commission covering the oyster investigations, the making of the leasing charts and finished projections, and finally the survey and record of the boundaries of oyster lots leased from the State by private individuals for the purposes of oyster culture.

From the foregoing account it can be seen that a complete oyster survey properly conducted so as to answer all practical requirements of the present and permanency of results for the future is a very complicated affair, involving many lines of surveying and other scientific work, and requiring the professional services of experts in the various operations of cartographic surveying and shell-fish investigations.

\section{REPOR'T OF THE WORK OF THE COAST AND GEODETIC SURVEY.}

\section{INSTRUCTIONS.}

The two following letters, together with the laws ${ }^{b}$ of the United States relating to the subject, constitute the "instructions" received by the chief of the Coast and Geodetic Survey party engaged on work in connection with the Maryland Shell Fish Commission. They are short and definite, but furnish ample authority and leeway for all legitimate development of the cooperation of the Government and the State in the survey of oyster bars. The "free hand" permitted by these orders, together with the aid and many valuable suggestions received from the officers of the Survey at Washington, has proved very beneficial to the work, and is greatly appreciated.

$$
\begin{aligned}
& \text { DEPARTMENT OF COMMERCE AND YABOR, } \\
& \text { OFFICE OF THE SECRETARY, } \\
& \text { IVashington, June 2, } 1906 .
\end{aligned}
$$

Sir: In reply to your letter of May 28 , requesting me to designate officers of the Coast and Geodetic Survey and of the Bureau of Fisheries to cooperate with the State of Maryland in making survey of and locating the natural oyster beds, I have the honor to inform you that Mr. C. C. Yates will be designated to cooperate on the part of the Coast and Geodetic Survey as soon as Congress makes the provisions of the act effective by providing an appropriation for the purpose.

Respectfully,

His excellency Hon. EDWIN IVARFIELD,

LAWRENCE O. MURRAY, Assistant Secretary.

Governor of Maryland, Annapolis, MAd.

a No mention is made here of the large amount of administrative work of the Commission, which is greatly complicated and increased by the economic and political effect of the oyster-survey operations on many thousands of people whose interests are more or less involved.

$b$ For these laws see Appendix A. 
DEPARTMENT OF COMMERCE AND LABOR,

Const and Geodetic Surver,

IVashington, July 3, I9o6.

SIR: Upon the receipt of these instructions you will surrender the command, accounts, etc, of the steamer Endeavor to the Hydrographic Inspector.

As soon as this transfer is completed you will enter upon the duties of Coast Survey representative on the Shell Fish Commission of Maryland.

You will consult the commissioners, prepare a programme of work, and submit estimates in the ustral form.

You are authorized to come to Washington for consultation from time to time as may be necessary. Very respectfully,

O. H. Titrmann, Superiutendent.

Capt. C. C. YATES,

U. S. C. and G. S. Stcamer Endeavor, Baltimore, Mil.

ORGANIZATION.

The organization of the party has remained practically unchanged and consists of the chief and the necessary triangulators, computors, and draftsmen.

\section{EQUIPMENT.}

The equipment for the work of the party has been ample and satisfactory. The large living and office quarters furnished the Government on the Maryland Shell Fish Commission house boat Oyster have been very convenient for the work, besides facilitating efficient cooperation with the surveying and oyster investigation parties of the State. In addition to the accommodations on the Oyster the Coast and Geodetic Survey party has had the constant use of the large steam launch Inspector and several other boats furnished by their own Service, and the occasional use of the Bureau of Fisheries launch Canvasback ${ }^{\alpha}$ and the steamer Governor McLane ${ }^{b}$ of the State fishery force.

The greater part of the equipment of instruments for the operations of both the Government and State have been furnished by the Coast and Geodetic Survey and consist of all necessary theodolites, levels, sextants, drafting instruments, hydrometers, etc., required for all field and office work.

\section{CHRONOLOGICAL, STATEMENT OF WORK. ${ }^{c}$}

On June 20, I907, the "Charts of Natural Oyster Bars" and report ${ }^{d}$ of "Survey of Oyster Bars" for Anne Arundel County were issued and filed, and the survey records and reports for that county have been filed in the archives of the Survey at Washington.

In addition to this work, a Coast and Geodetic Survey signal-building party was engaged in the erection of triangulation signals in Somerset County from May 2 to June 25 in cooperation with a signal-building party of the Shell Fish Commission.

$a$ By courtesy of Dr. H. F. Moore, U. S. Bureau of Fisheries.

$b$ By courtesy of Capt. James A. Turner, commanding.

c The field and office work relating to Somerset County is so intermixed with that of Wicomico County that this statement includes part of the work of the latter county.

$d$ See this report for an account of the work from July 3, 1906, to June 20, 1907.

$$
50095-08-3
$$


From June 25 to November 6, when the field work in Somerset and Wicomico counties was practically completed, the usual routine of field and oflice work was followed without material interruption exeept that resulting from the moving of the house boat Oyster from Crisfield to Manokin River on July r 3, then to Piney Island on August 27, and to Wicomico River, on August 30, where she remained until her removal to Nanticoke River on September 30 .

From this latter date the work in Wicomico County predominated, and when the field surveys were practically completed on November 6 the entire party left by rail for Worcester County, it being impracticable to move the house boat to the waters of that locality.

At the close of the survey work in Worcester County in the last part of December, office work relating to Somerset and Wicomico counties was actively commenced at Baltimore $^{a}$ and was continued without material interruption. until March 23, 1908, when a subparty went to Worcester and Somerset counties to finish some details of field work in those sections required for the preparation of the technical reports and oyster charts.

The very large amount of work of computation and drafting necessary to make the results of the survey of the previous season available for publication was nearly completed on May 2, when it was transferred to the Government quarters on the house boat Oyster, which left Baltimore on the same day with the party and outfit for her anchorage off Solomons Island, in the Patuxent River.

The active field work in Calvert County dates from May 2, but from that time until the filing of this report and the oyster charts of Somerset County the chief of party, in addition to his regular field duties, was frequently at Baltimore and Washington to look after their final preparation for publication.

ST.ITISTICS,

Landmarks and triangulation signals erected.

Monuments planted to mark triangulation stations

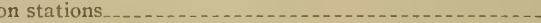

Triangulation stations occupied for observations of horizontal angles

Old triangulation stations recovered.

New triangulation stations established.

Total old and new triangulation stations marked and described

Linear miles of shore line covered by triangulation (approximate)

Square miles covered by triangulation (approximate).

Hydrographic projections prepared and completed as records of oyster, crab, and clam bound

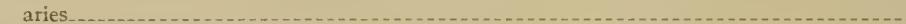

Triangles computed .-

Geographic positions computed.

a Office rooms were furnished for the work of the Government party in the "old court-house" and afterwards in the new custom-house by courtesy of Hon. William F. Stone, collector of customs.

$b$ These statistics only include field and office work directly performed by the party of the Coast and Geodetic Survey in connection with the oyster survey of Somerset County, and do not include the many thousands of soundings and examinations of the character of the bottom made by the engineers of the Commission, which are of considerable value to the Coast and Geodetic Survey as hydrographic records for future use in connection with the preparation of new editions of charts of the waters of Maryland. 
Corners of oyster, crab, and clam boundaries established by computation Back azimuths and distances computed from corners of boundaries to triangulation stations._._ $\mathrm{r}, 5 \mathrm{r} 8$ Descriptions of triangulation stations prepared for publication

Descriptions of oyster, crab, and clam boundaries prepared for publication_._.

Total typewritten pages of manuscript prepared for publication of report_._._._........ 264

"Charts of Natural Oyster Bars" prepared for publication._.

Progress map prepared for publication .... .

\section{GENERAL, STATEMENT.}

The results obtained from the work of the Coast and Geodetic Survey in-Somerset County in cooperation with the Burean of Fisheries and the Naryland Shell Fish Commission need no other summary than is indicated by the published "Charts of Natural Oyster Bars" and the scheme of hydrographic projections and triangulation stations shown on the progress map at the beginning of this report.

The triangulation has been carried on in accordance with the standard methods of the Coast and Geodetic Survey, making this work and that of the "Descriptions of Triangulation Stations" of permanent value, not only to the State of Maryland in the survey of her oyster bars, but also to the Government for any future work it may do in the regions covered by the oyster survey operations.

The hydrographic projections and published charts were prepared with all the accuracy permitted by their large scale, especially as to the boundaries of the various shell-fish bottoms in relation to landmarks, but this accuracy of location on the charts is further added to by published technical descriptions which should minimize the probability of any future dispute as to either landmarks or boundaries.

Stated another way and quoting from the report of the "Survey of Oyster Bars of Anne Arundel County:"

The geographic positions of the permanent landmarks and signals have been determined with the usual precision of a trigonometric survey, and their locations at all points necessary to provide ample foundation for the surveying and charting operations permitted great accuracy of definition and location for the natural oyster bar and other boundaries established. At the same time, the very important element of permanency of the positions of boundaries has been secured, as the relocation of geodetic positions can always be accomplished by a competent surveyor, even though the original landmarks and monuments liave been washed away, as has been the fate of hundreds of such points established by the Coast and Geodetic Survey on the shores of the Chesapeake Bay during the last sixty-five years.

In fact, when the survey of the oyster bars of Maryland is completed, it is believed that it will stand the test of time and practical use as a working foundation for whatever form the oyster legislation of the future may assume; and that the doing of the work systematically and accurately, once for all, not only means a better foundation of a great oyster industry by irradicably locating the natural oyster bars for the use of the public, but also a better and more permanent superstructure of oyster culture for the individual by the reason of the integrity of the foundation on which it stands.

Before ending this report the representative of the Coast and Geodetic Survey wishes to renew his statement of appreciation of the courteous assistance received from various Government and State officials and others interested in the oyster industry of Maryland, especially to the following:

To his colleague from the Department of Commerce and Labor, Dr. H. F. Moore of the Bureau of Fisheries, whose efficient cooperation, well-known experience, and scientific knowledge of all matters relating to oysters have been of great value to the work. 
To Mr. Walter J. Mitchell, chairman of the Maryland Shell Fish Commission, who, by his administrative ability in carrying out the complicated requirements of the oyster laws and by his unfailing tact, has made the cooperation of the various services engaged on the work both agreeable and effective.

To Dr. Caswell Grave, secretary of the Commission, who, as editor of the Commission's annual report and commissioner in charge of the biological and economic oyster investigations, has been brought into constant contact with the Government work and aided its operations in every way.

To Benjamin . K. Green, treasurer of the Commission, who has looked after the equipment and commissary of the house boat in such a way as to add greatly to the comfort and convenience of the party of the Coast and Geodetic Survey.

To Swepson Earle, hydrographic engineer to the Commission, whose knowledge of the work from former service in the Coast and Geodetic Survey has greatly facilitated his practical use of the technical data furnished by the Government.

To Thomas H. Robinson, counsel to the Commission, for courteously furnishing valuable information relating to county boundaries.

And to the many others connected with the Commission or who as residents in the locality where the work was being carried on have greatly assisted by furnishing important information or willing services.

\section{CHARTS AND MAPS.}

CHARTS OF NATURAL OYSTER BARS.

The charts ${ }^{a}$ of the natural oyster bars of "Somerset County and Adjacent Waters," published by the Coast and Geodetic Survey from results of surveys of the Government in cooperation with the Maryland Shell Fish Commission, consist of a series of five sheets covering the eastern shore of Chesapeake Bay from Hooper Strait to the MarylandVirginia boundary, including Tangier and Pocomoke sounds and numerous other tributaries. They are published on a scale of I part in 20,000 (approximately $3 \frac{1}{6}$ inches to a statute mile) and are constructed on polyconic projections and based on the United States standard datum of the Coast and Geodetic Survey.

These charts show all oyster bars, crab bottoms, clam beds, and other boundaries established by the Commission, and are certified for the purpose of filing in the office of the clerk of the circuit court of Somerset County and in the office of the Commission at Annapolis, as required by the oyster laws of Maryland.

In addition to the oyster-bar and other boundaries, the charts show the location and name of all landmarks (U. S. Coast and Geodetic Survey triangulation stations) used in making the survey, together with the hydrography and topography ${ }^{b}$ necessary to make the technical definitions and delineations of boundaries readily understandable

"These charts can he obtained by application to the Superintendent of the Coast and Geodetic Survey, at Washington, D. C.

$b$ Much of the details of the inshore topograply was obtained from the excellent map of Somerset County prepared and published by the Maryland Geological Survey under the direction of Dr. William Bullock Clark from surveys of the Maryland Geological Survey in cooperation with the U. S. Geological Survey. 
both by the people engaged in the oyster industry and the general public who may become interested through leasing of barren bottoms for oyster culture.

The names of the oyster bars, crab bottoms, and clam beds are those used locally, as nearly as could be ascertained by the hydrographic engineer of the Commission. When there was no local name in common use, as was generally the case with the crab bottoms, a name was selected from one of the prominent features of the vicinity. By the use of recognized names or those that would naturally suggest certain sections of water, it is believed that much confusion will be avoided in the location on the charts of the oyster bars and crab bottoms, especially by those not familiar with the use of maps.

The corners of the oyster bars, crab bottoms, and clam beds are numbered from I to the total number of corners in each area under consideration. Where boundaries adjoin, making one point a corner of two or more oyster bars, crab bottoms, or clam beds, as the case may be, these points have two or more numbers, each number corresponding to the bar, bottom, or bed in which the figure is located. The numbers of the corners correspond with the technical and legal descriptions of this publication under the headings of "Boundaries of natural oyster bars," "Boundaries of crab bottoms," and "Boundaries of clam beds."

The landmarks, oyster bars, crab bottoms, and clam beds have been grouped in the "Contents" of this publication in accordance with the charts upon which they are shown. To find a particular bar, bottom, bed, or landmark which is only known by name, consult the "Contents" and the desired chart and general location will be indicated. To find the name of a bar, bottom, bed, or landmark which is only known by location, consult the progress map at the beginning of this publication for the number of the chart on which it is to be found, and then examine the known locality on the chart for the name of the bar, bottom, bed, or landmark in question.

The contours on the charts showing the depth of water at mean low tide have been taken from the hydrographic sheets of former work of the Coast and Geodetic Survey. Four curves were selected as being the most convenient for taking off from the original livdrographic sheets and the ones of greatest value to those interested in shell-fish industries. The I-fathom contour ( 6 feet) corresponds in a general way to the outer limits of the crab bottoms, while the waters outside of this curve and inside the 5 -fathom contour (30 feet) practically include all the oyster bars surveyed. The 3 -fathom contour ( 18 feet) furnishes the curve of about the average depth of water on the oyster bars and the Io-fathom contour (6o feet) serves in a general way to indicate the outer limits of probable oyster culture.

The boundaries of the waters within the "territorial limits of the county" and the boundaries of the "waters contiguous to the county" opened up for the leasing with Somerset County are plainly indicated on the charts. A full technical description of these boundaries is given in this publication under the heading "Boundaries of county waters."

The areas in acres of the oyster bars, crab bottoms, and clam beds were determined under the direction of the hydrographic engineer of the Commission by two independent planimeter measurements of the areas as delineated on the smooth projections of the 
Coast and Geodetic Survey. These areas are given in small figures in parentheses on the face of the chart and are usually located within the boundaries of the different areas.

The symbols used on the charts for the different kinds of boundaries, triangulation stations, contours of depth of water, etc., require no other explanation than that given in the legend and other notes on the face of the charts.

\section{LEASING CHARTS.}

The leasing charts of Somerset County, like those for Anne Arundel County, have been prepared under the direction of the hydrographic engineer of the Commission. These charts are constructed on polyconic projections and based on the United States standard datum of the Coast and Geodetic Survey. They are made on the scales of I part in 5,000 or I part in 10,000 , as the needs of oyster culture may require. Anne Arundel County required 13 leasing charts and Somerset County 12 to cover their oyster bottoms.

These charts show all the oyster bars, crab bottoms, and, clam beds and other boundaries established by the Commission, and also all boundaries of oyster lots leased for the purpose of oyster culture, thus making them comprehensive and valuable records of the results of the operations of the oyster-culture laws.

The lots leased under the provision of the "old 5-acre law" are frequently of irregular slape, but the lots leased under the provision of the new oyster laws must be of rectangular shape by the terms of that act. For this latter purpose the leasing charts have been divided by parallels of latitude and meridians of longitude into small rectangles of $\mathrm{I}$ acre or 5 acres, as may be best suited to area under consideration, and prospective leaseholders by the rules of the Commission are compelled to select whole rectangles as far as practicable.

For reasons of the present changeable nature of the number of lots leased and the large number of charts required, the leasing charts are not likely to be published for some years, but they can be seen at any time on file at the offices of the Commission, in Annapolis.

\section{PROJECTIONS.}

The polyconic projections ${ }^{a}$ covering Somerset County waters are 13 in number and on the scale of I part in I0,000. They were all constructed by draftsmen of the Coast and Geodetic Survey, who also plotted the sextant positions on the smooth projections which determine the location of the legal boundaries of the oyster bars, crab bottoms, or clam beds as delineated by the Shell Fish Commission.

A copy of each of these projections, with all the plotted positions of triangulation stations, shore line, sextant positions, and boundaries of oyster bars, was made under the direction of the hydrographic engineer of the Commission by pricking through with a sharp needle the intersections of the projection lines and all other points as plotted on the original sheets.

These projections (in duplicate) are the original records of all oyster bar and other boundaries established by the Commission, one set being filed in the archives of the Coast and Geodetic Survey, at Washington, and the other set in the office of the Shell Fish Commission at Annapolis.

a For the scheme of these projections see the progress map at the beginning of this publication. 


\section{PROGRESS MAPS.}

The progress map to be found at the beginning of this publication is on a scale of I part in 100,000 , and shows in outline the work accomplished by the U. S. Coast and Gcorletic Survey in Somerset County and contiguous waters. It gives the scheme of all the charts and smooth projections constructed in connection with the survey, the location and names of all triangulation stations used as a basis for the surveying work, and the "boundaries of county waters" established by the Commission for the purpose of carrying out the laws of Maryland relating to oyster culture.

Besides indicating the amount of work done by the Coast and Geodetic Survey in connection with the work of the Shell Fish Commission, this progress map will be of special value for index purposes to engineers and others searching for the particular chart or projection covering the locality of the oyster bars or landmarks that may be under consideration.

The progress map ${ }^{a}$ accompanying the "First Annual Report of the Maryland Shell Fish Commission" was prepared under the direction of the hydrographic engineer of the Commission. It is on the scale of $\mathrm{I}$ part in 400,000 and shows the outline of the tide-water counties of Maryland, with shaded areas to indicate the waters already covered by the operations of the oyster survey of Maryland.

\section{BOUNDARIES OF COUNTY WATERS. ${ }^{b}$}

\section{WATERS WITHIN TERRITORIAL, I,IMITS OF COUNTY.}

The laws of Maryland relating to oyster culture provide that "no person shall be permitted, by lease, assignment, or in any other manner, to acquire a greater amount of land than ten acres situated within the territorial limits of any of the counties, or one hundred acres in any other place."

The boundary line c between the waters "within the territorial limits" of Somerset County and the waters in "any other place," as established by the Shell Fish Commission for the purpose of carrying out the oyster laws, and delineated on the charts and the smooth projections of the Coast and Geodetic Survey, is technically described and defined as follows:

Commencing at a point defined by the intersection of the channels of Wicomico Creek and Wicomico River; thence with the channel of Wicomico River along the boundary line as laid down on Chart No. 5 of the "Natural Oyster Bars" of Maryland, published by the Coast and Geodetic Survey, to a point defined by the intersection of the channel of Nanticoke River with Wicomico River; thence in a straight line to a point defined by $d$ latitude $38^{\circ} \mathrm{II}^{\prime} 50^{\prime \prime} 3$, and longitude $75^{\circ} 58^{\prime} 20, " 8$, situated in upper end of

a This map and report can be obtained by application to Maryland Shell Fish Commission, at Annapolis, Md.

$b$ For a complete historical and legal description of the boundaries of the counties of Maryland, the valuable publication entitled "The Counties of Maryland-Their Origin, Boundaries, and Election Districts," prepared by Dr. Edward B. Mathews and published by the Maryland Geological Survey under the direction of Dr. William Bullock Clark, Superintendent, should be consulted, as the boundaries described in this publication have been established and technically defined for the purpose of carrying out the oyster laws of the State, and may or may not be correct for other purposes.

c See "Charts of Natural Oyster Bars," published by the Coast and Geodetic Survey, and the progress map at the beginning of this publication.

$d$ Latitudes and longitudes based on the United States standard datum of the U. S. Coast and Geodetic Survey. 
Tangier Sound, about $7 / 8$ mile $a$ east-southeast of Sharkfin Shoal Light, $21 / 2$ miles south of western extremity of Clay Island, and $13 / 4$ miles west-northwest of Halls Point; thence in a straight line along the channel of Tangier Sound to a point defined by latitude $38^{\circ} 10^{\prime} 08^{\prime \prime}{ }^{\prime \prime}$, and longitude $75^{\circ} 58^{\prime} 40$. . $^{\prime \prime} 6$, situated about $23 / 8$ miles south by east of Sharkfin Shoal Light and I $5 / 8$ miles west of upper land end of Deal Island; thence in a straight line across 'Tangier Sound to a point defined by latitude $38^{\circ} 08^{\prime} 50 . " 6$, and longitude $76^{\circ} \mathrm{I}^{\prime} 53^{\prime \prime} 4$, situated on a point of land on the southeastern extremity of Bloodworthi Island, which is the north point of the Tangier Sound entrance to Holland Straits; thence in a straight line across Holland Straits to a point defined by latitude $38^{\circ} 06^{\prime} 399^{\prime \prime} 9$, and longitude $76^{\circ} 03^{\prime} 17 . .^{\prime \prime} 8$, situated on northwest extremity of a small island slightly detached from South Marsh and on north side of Holland Straits entrance to Pry Cove; thence in a straight line to a point defined by latitude $38^{\circ} 05^{\prime} 44^{\prime \prime} \mathrm{I}$, and longitude $76^{\circ} 03^{\prime} 44^{\prime \prime} 6$, situated on Pry Island, which is located on south side of Holland Straits entrance to Pry Cove; thence in a straight line to the open waters of the Chesapeake Bay at point defined by latitude $38^{\circ} 04^{\prime} 40 .^{\prime \prime} 8$, and longitude $76^{\circ} 04^{\prime} 14^{\prime \prime} 8$, situated at junction of Holland and Kedge straits; thence in a straight line along the dividing waters of Chesapeake Bay and Kedge Straits to a point defined

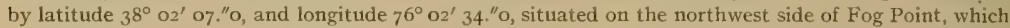
is the south point of the Chesapeake Bay entrance to Kedge Straits; thence along the mean low water line of the Chesapeake Bay shore of Smith Island across the mouth of all inlets less than roo yards in width to a point defined by latitude $38^{\circ} 00^{\prime} 31$. $^{\prime \prime} \mathrm{O}$, and longitude $76^{\circ} 03^{\prime} 08$. $^{\prime \prime} 9$, situated on a point at the extreme northwest entrance to Smith Island Thoroughfare; thence in a straight line across the Chesapeake Bay entrance of Smith Island Thoroughfare and Goose Harbor Cove to a point defined by latitude $37^{\circ} 59^{\prime} 30 .^{\prime \prime} \mathrm{O}$, and longitude $76^{\circ} \mathrm{O} 3^{\prime} 09^{\prime \prime} 6$, situated on a point at the extreme southwest entrance to Goose Harbor Cove; thence along the mean low water line of Chesapeake Bay shore of Smith Island across the mouth of all inlets less than 100 yards in width to the intersection of the mean low water line and the Maryland-Virginia boundary line; thence in a straight line with the Maryland-Virginia boundary across Smith Island and the waters of Smith Gut, Shanks Creek, and Tylers Creek to a point at a corner of the boundary near the Tangier Sound shore of Smith Island situated on land known locally as Horse Hummock; thence in a straight line with the Maryland-Virginia boundary to point at a corner of the boundary in the middle of Tangier Sound, situated about $I 7 / 8$ miles southwest by west of James Island Light, $23 / 4$ miles east by south of Horse Hummock, and $3 \frac{1}{4}$ miles northwest of House Island; thence in a straight line with the Maryland-Virginia boundary to a point at a corner of the boundary in the middle of Tangier Sound, situated about $43 / 8$ miles southwest by south of James Island Light, $37 / 8$ miles southeast by east of Horse Hummock, and $25 / 8$ miles west of House Island; thence in a straight line with the Maryland-Virginia boundary across House Island to a corner of the boundary situated in the water between Watkins Point and Green Harbor Island; thence in a straight line with the Maryland-Virginia boundary to a corner of the boundary situated in the middle of Pocomoke Sound about $4^{1 / 2}$ miles east of Watkins Point and $25 / 8$ miles south of Watkins Island off entrance to Apes Hole Creek; thence in a straight line with the Maryland-Virginia boundary to a corner of the boundary situated in the middle of Pocomoke Sound about $2 \frac{1}{2}$ miles northwest by west of Saxis Church, $2 \frac{1}{2}$ miles east by south of Watkins Island off entrance to Apes Hole, and 2 miles southwest of extreme end of point between East and Marumsco creeks; thence with the Maryland-Virginia boundary as laid down on "Charts of Natural Oyster Bars" No. Io along the middle of Pocomoke Sound and Pocomoke River as far as oysters grow.

\section{WATERS CONTIGUOUS TO COUNTY.}

The oyster laws of Maryland provide that a true and accurate delineation of all natural oyster bars shall be made on copies of charts of the U. S. Coast and Geodetic Survey, "which said copies shall be filed in the office of the said Commissioners in the city of Annapolis," and "in the office of the clerks of the circuit courts for the respective counties wherein the grounds so designated may lie."

For the purpose of carrying out the latter part of this section of the law and for the purpose of establishing the limits of the oyster-culture area to be opened up for the

$a$ Statute miles. 
leasing with Somerset County, a boundary line between the waters contiguous to but not within the territorial limits of Somerset County and the waters contiguous to but not within the territorial limits of adjacent counties has been established by the Shell Fish Commission. This boundary line a has been delineated on the "Charts of Natural Oyster Bars," published by the Coast and Geodetic Survey, and is technicully described and defined as follows:

Commencing at a point defined by latitude $38^{\circ} 04^{\prime} 40^{\prime \prime} .8$, and longitude $76^{\circ} 04^{\prime} 14^{\prime \prime} .8$, situated on line of territorial limits of county at junction of Holland and Kedge straits; thence in as straight line across waters of Chesapeake Bay to Holland Island Bar Light, the location of which is defined by latitude $38^{\circ} 04^{\prime} 07^{\prime \prime} \cdot 3$, and longitude $76^{\circ} 05^{\prime} 45^{\prime \prime} \cdot 9$; thence in a straight line across waters of Chesapeake Bay to a point defined by latitude $38^{\circ} \mathrm{O} 4^{\prime} 34^{\prime \prime} .8$, and longitude $76^{\circ} 12^{\prime} \mathrm{O} 1^{\prime \prime} .0$, sit uated near the middle of Chesapeake Bay, on northwestern end of a shoal marked by a red buoy of the U. S. Light-House Listablishment situated about $5 \% / 8$ miles west by north of Holland Island Bar Light, 7 I/8 miles east by north of Point Lookout Light, and I3 $3 \frac{1}{2}$ miles north of Smith Point Light; thence in a straight line with the waters of Chesapeake Bay to a point on Smith Point defined by the corner of the Maryland-Virginia botundary at the intersection of the straight line boundary across Chesapeake Bay and the low-water line of the southern shore of Potomac River; thence with the Maryland-Virginia boundary in a straight line across Cliesapeake Bay to the point defined by the intersection of the boundary with the mean low-water line of the Chesapeake Bay shore of Smith Island: thence with territorial limits of county along the Chesapeake Bay shore of Smith Island and waters of entrance to Kedge Straits to point of beginning.

\section{LANDMARKS (U. S. COAST AND GLODETIC SURVEI TRIANGULATION STATIONS).}

\section{EXPLANATION OF DESCRIPTIONS OF LANDMARKS.}

The oyster laws of Maryland authorizing the surveys to be made by the Shell Fish Commission provide for "an accurate report of said survey, setting forth such a description of landmarks as may be necessary to enable the said board, or their successors, to find and ascertain the boundary lines of said natural oyster beds, bars, and rocks, as shown by delineation on the maps and charts." The law of the United States authorizing the cooperation of the Department of Commerce and Labor in the survey of - natural oyster bars of Maryland provides for the erection of "such structures as may be necessary to mark the points of triangulation, so that the same may be used for such future work of the Coast and Geodetic Survey as the said Bureau may be hereafter required to perform in prosecuting the Gorernment coast survey of the navigable waters of the United States located within the State of Maryland."

Under the provisions of the sections of the laws stated above, the markings and clescriptions of landmarks must be sufficient for the present and future needs of both the Government and the State. With this end in view, considerable work has been expended in erecting permanent monuments at the triangulation stations and in the proper description of their location.

An effort has been made to arrange the descriptions of locations of landmarks in a uniform and logical manner. The descriptions start with the assumption that the individual seeking to find a landmark has only an indefinite idea of its location. 
They then gradually proceed from general descriptions of the surroundings of a landmark to the specific details of the character of the center and reference markings. An examination of the descriptions themselves will best indicate the method followed.

The heading of each description is the name by which the landmark or triangulation station is known and designated in all work and records of the Government and State.

Under the heading of "Locality" the first paragraph gives a description of the general locality of the landmark and the serial number of the published "Chart of Oyster Bars" of Maryland which best shows its location. The published charts are on the large scale of I part in 20,000 , and show the location of the triangulation stations so clearly that in many cases the written descriptions will not be required to find them.

Under the same heading of "Locality" the second paragraph furnishes the description of the immediate locality of the landmark and refers to the bearing and distance of standard cement monument marking the reference station, as it is the first object that is likely to catch the eye when the immediate vicinity of the desired station is reached.

Under the heading of "Marks" a description is given of the character of the markings of the "observed station" and the reference station. It will be noted that, although the "observed station" is the one "occupied" and "observed on" for horizontal angles, and also the one whose geographic position is computed, frequently it is not marked as well as the reference station, and in many instances has only a pine stub to indicate its position. This is the case for the reason that the necessity of intervisibility of landmarks usually made it compulsory to locate these stations on edges of banks and ends of points of land, which in Chesapeake Bay and tributaries generally means that they will be washed away in a short period of years. The past experience of the Coast and Geodetic Surver in this region has shown the necessity of reference marks, if the frequent reestablishment of a new framework of triangulation is to be avoided.

All the marks designated in the descriptions as "the center point of triangle on standard cement monument" are exactly alike. These monuments are made of cement, sand, and gravel, and are 2 feet long and 8 inches square at top and bottom. Their tops are all marked with the same brass mold and show a center hole surrounded by a triangle, with the letters "M. S. F. C." arranged around the vertex and the letters . "U. S. C. S." underneath the base of the triangle. The center hole is always in the center of the top of the monument by construction, and if this is found to have been broken off without disturbing the bottom, the center of its square section can be used as the location of the station.

All the "standard cement monuments," whether used for marking the "observed station" or "reference station," have been planted upright in exactly the same manner, with their tops projecting 3 or 4 inches above the surface of the ground.

Therefore, as the above facts in reference to the "standard cement monuments" are a constant element in all cases, the repetition of these facts in the description" of stations is made needless by this one statement.

It is the expectation that the reference stations, ${ }^{a}$ the character of which is explained above, will be used in many cases in the near futture in the place of the "observed sta-

"To olbtain the gengraphic positions of any of the "ohserved stations" of of the "reference stations," application should be made to the Superintendent of the Coast and Geodetic Survey at Washington, D. C 
tions." This has been made possible by the careful measurements of direction and distance of these stations from the "observed station," which are recorded under the heading of " References."

Under the heading of "References" are given the directions and distances of all objects that might be useful in locating the stations when the surface marks can not be found. It is also contemplated that for general purposes of topography, hydrography, or location of boundaries of oyster bars these references will be sufficient in many cases to relocate the position of an "observed station" or reference station when both of them have been destroyed.

The first reference object given in the descriptions is always a triangulation station visible from the station being described. Its direction is taken as being $\mathrm{O}^{\circ} \mathrm{OO}^{\prime} \mathrm{OO}^{\prime \prime}$, and the direction of all other objects are measured from it as an initial point, the angles being taken in a clockwise direction (left to right).

The true bearing ${ }^{a}$ of the initial object is always given in parenthesis alongside the name. This furnishes means for the calculation of the bearings of any of the other reference objects for the purposes of locating a station by compass bearings or for the relocation of corner buoys of oyster-bar boundaries by the method of horizontal angles described in this publication under the heading of "Boundaries of oyster bars."

The distances in the last column under "References" are given in three different units, which vary according to their accuracy. The "miles" are statute miles and may be considered only as rough estimates. The "yards" are more accurate, but must be looked on as results generally obtained by pacing or careful estimating. The "meters," however, are accurate to the degree indicated by their decimals and in every case have been measured with a steel tape. In the same manner the accuracy of the directions are indicated by the refinement of direction with which they are recorded.

DESCRIPTIONS OF TRIANGULATION STATIONS.

\section{SENATOR.}

Locality.-Western shore of Tangier Sound, on sonthern side of Holland Straits and on extreme northeast point of South Marsl.. (See Charts Nos. 5, 6, and 7.)

Observed station is on marsh land about 35 yards from north side and about 30 yards from east side of point. Myrtle buslies skirt shore, commencing due north, and two small pools of water are near station, one due south about ro yards and the other southwest about 5 yards. No permanent reference points near station.

Marks.- Observed station is center point of triangle on standard cement monument.

Reforcnces.-

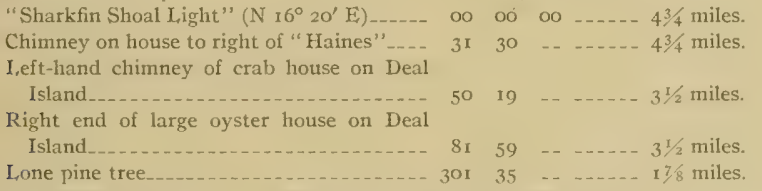

a The mean magnetic variation for Somerset County for 1908 was $5^{\circ} 30^{\prime}$ west of noth and increasing at the rate of $3^{\prime}$ yearly. 
CRAB.

Locality.-Upper end and western shore of Tangier Sound on eastern side of Bloodsworth Island about $25 / 8$ miles southeast of Sharkfin Shoal Light House and about halfway between Piney Island Cove to north and Great Cove to south. (See Chart No. 5.)

Observed station is about ${ }_{5}$ yards from high-water mark to the northeast and about 35 yards from the shore to the east. A small flat-roof crab house stands about 80 yards to the north-northeast and another crab house about twice the distance in the same direction.

Marks.-Observed station is center point of triangle on standard cement monument.

References -

"Sharkfin Shoal Light" ( $\left.\mathrm{N}_{4}^{\circ} 25^{\prime} \mathrm{E}\right) \ldots \ldots$-... 00 oo 00 _..... $25 / 8$ miles.

Left end of large white house near Stump Poin

End of roof of white house on bluff

End of Deal Island wharf

Large white house near red roof one

Aspen tree near "Joshua" .................

Tall pine tree-.

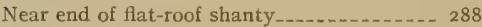

Flag pole on Brown's crab house

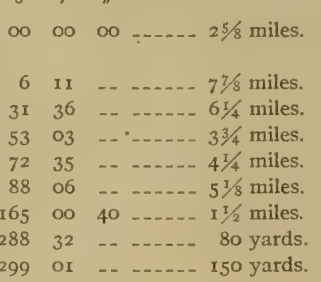

\section{SHARKFIN SHOAL, LIGHT.}

Localizy.-Northern end of Tangier Sound about equally distant from entrances of Hooper Strait, Fishing Bay, and Nanticoke River. (See Chart No. 5.)

Marks,-Observed station is center point of black lantern on hexagonal screw pile known as "Sharkfin Shoal Light."

References.-

"Great Shoals Light" (N $\left.8 \mathrm{I}^{\circ} 45^{\prime} \mathrm{E}\right)$ $\circ, \quad$, oo 00 oo $\ldots . . .5 \%$ miles.

\section{HEAD.}

Locality.-Upper end of Tangier Sound, on southern part of peninsula known as "Bishops Head," sittated between Hooper Strait and Fishing Bay. (See Chart No. 5.)

Observed station is on eastern side marsh land about $1 / 2$ mile north of extreme southerly end of Bishops Head and about 15 yards east of two crab houses. It is about 15 yards southwest of highwater mark, behind water bushes which skirt the shore. Cement monument marking reference station is $3.4 \mathrm{I}$ meters west from observed station.

Marks.-Observed station is a nail in a pine stub flush witl ground. Reference station is center point of triangle on standard cement monument.

References.-

"Sharkfin Shoal Liglit", (S $\left.60^{\circ} 4 \mathrm{I}^{\prime} \mathrm{E}\right)$

Crab-house flagstaff_................ $50 \quad 30 \quad \ldots \ldots$..... $51 / 4$ miles.

Large pine..................... $9742 \ldots \ldots$ miles.

REFERENCE STATION _.............. 13955 40 ..... I3.4I meters.

Near gable of $21 / 2$-story white house $\ldots$ r $140 \quad 24 \quad \ldots \ldots \ldots$..... $1 / 4$ mile.

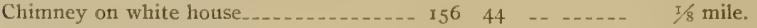

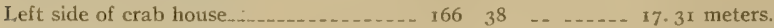

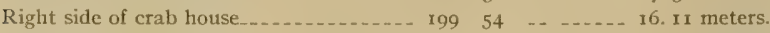

Chimney on yellow house ............ $208 \quad 28 \ldots \ldots \ldots$ I 28 miles.

Chimney on end of white house _........ $238 \quad 53 \ldots \ldots$ miles.

Right side of Nanticoke Point woods__._- $326 \quad 56 \quad \ldots \ldots \ldots$... $\quad 71 / 2$ miles. 
FROG.

Locality.-West shore of mouth of Nanticoke River, on the southeasterly point of Clay Island, known as "Frog Point." (See Chart No. 5.)

Observed station is on a marsh point about 25 yards back from extreme end of point, 20 yards from the east side and 25 yards from the west side. . Water bushes abound back of station. There are no permanent reference objects near station. Cement monument marking reference station is r 3 .ro meters north of observed station.

Marks.-Observeu station is nail in stub flush with ground. Reference station is center point of triangle on standard cement monument.

References.-

"Sharkfin Shoal Light" (S $\left.41^{\circ} 25^{\prime} \mathrm{W}\right)--p^{\circ}$

Left tangent of Clay Island

REFERENCE STATION-................. 141

Right tangent of Sandy Point........... 177

Chimney on white house with black roof _- 179

Chimney on near end of large red-roof white house $183 \quad 02$

Stack on canning house $184 \quad 36$

Land end of Nanticoke wharf $184 \quad 36$

End of Nanticoke wharf house

$86000--\cdots$

Chimney on ell end of main part of large red-roof white house.

Right tangent of Nanticoke Point woods_ 238

Large square chimney on white house (Dames Quarter)

Rock Creek poplar tree................... 284

Flagstaff on Deal Island wharf

27 .......

44 ... - .

$17 \ldots \ldots$

17 ......

09 .......
$31 / 8$ miles. I $1 / 4$ miles.

13. 10 meters.

$3 / 4$ mile.

$21 / 2$ miles.

$2 \frac{1}{2}$ miles.

$2 \pi / 2$ miles.

$21 / 2$ miles.

$21 / 4$ miles.

$21 / 4$ miles.

$23 / 4$ miles.

4 miles.

$31 / 2$ miles.

$4 \frac{3}{4}$ miles.

\section{cow.}

Locality. - Western shore Nanticoke River on Mink Point about $1 / 4$ mile east of entrance to Cow Creek. (See Chart No. 5.)

Observed station is on a very soft marsh point at the outer edge of water bushes about 5 yards back from the shore to the east, $x_{5}$ yards from extreme end of point to the southeast, and 15 yards from the shore to the southwest. No permanent reference objects near station. Cement monument marking reference station is 8.68 meters northwest of observed station.

Marks.-Observed station is a nail in a pine stub flush with ground. Reference station is center point of triangle on standard cement monument.

References. -

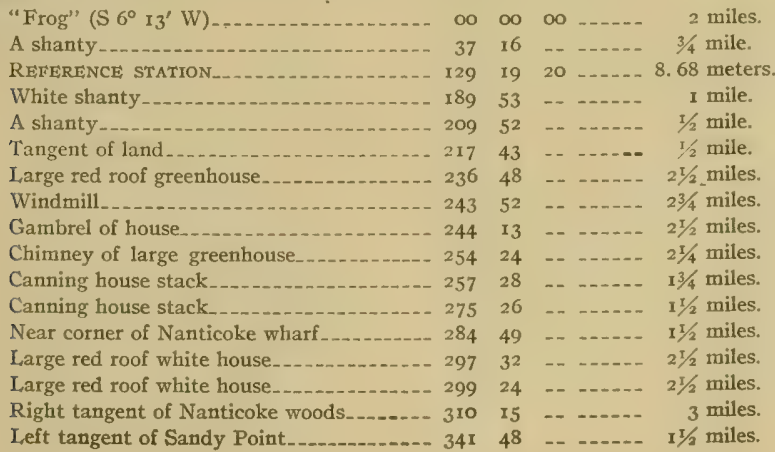




\section{NANTICOKE CHURCH.}

Locality.-Fastern shore of Nanticoke River in town of Nanticoke, about $1 / 4$ mile back from river and $3 / 4$ mile northeast of Roaring Point. (See Chart No. 5.)

Marks.-Observed station is center point of spire of church known as "Nanticoke Methodist Ëpiscopal Church."

References.-None necessary.

\section{ROAR.}

Locality.-Eastern shore of Nanticoke River on point of land known as Roaring Point, and about $1 / 4$ mile north from outer end of Roaring Point wharf. (See Chart No. 5.)

Observed station is 30 yards to the east of the extreme end of the point and on a sandy knoll about 5 feet above high-water mark. It is about 20 yards back from high-water mark on the north side and about 40 yards back from high-water mark on south side of the point. Pine woods stand about $\mathbf{5} 50$ yards inshore from station.

Marks.-Observed station is center point of triangle on standard cement monument.

References.-.

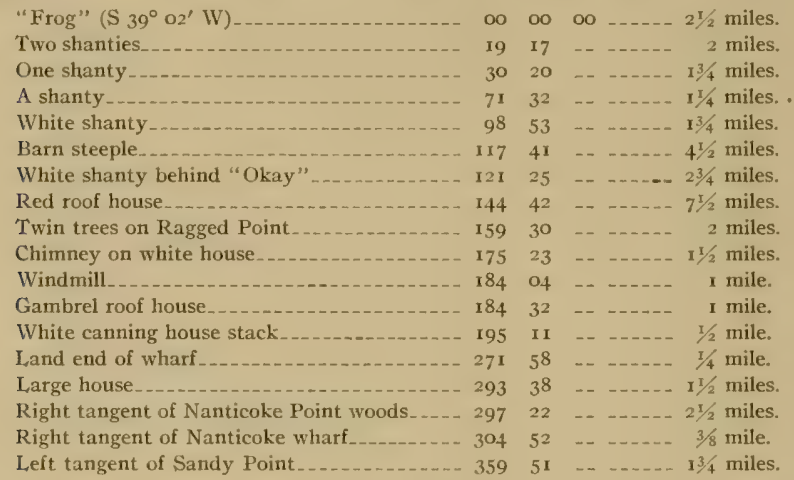

\section{NANTI.}

Locality.-Eastern side of entrance to Nanticoke River about $1 / 2$ mile northwest of Nanticoke Point, (See Chart No. 5.)

Observed station is on grassy land about 2 feet above and 20 yards back from high-water mark. It is about midway between edge of woods on Nanticoke Point and unpainted house near poplars $1 / 4$ mile to the north.

Marks.-Observed station is center point of triangle on standard cement monument.

References.-

"Sharkfin Shoal Light" (S $65^{\circ} 14^{\prime}$ W)

Tangent of Sandy Point

Left end of Nanticoke wharf

Near chimney of red roof house

Chimney of unpainted house

Near chimney of house nearest woods....... I

Tree high above woods.................... II

Right end of heavy woods.............. 134

Right end of scant woods.

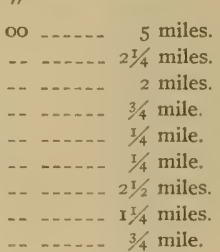




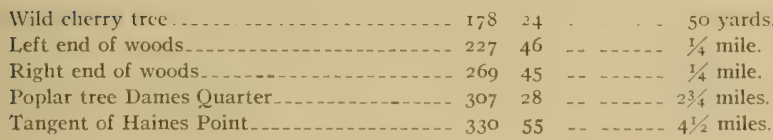

WHITE.

Locality.-Eastern shore of entrance to Nanticoke River on western part of Nanticoke Point. (See Clart No. 5.)

Observed station is on a sand and grass point about 2 feet above high-water mark, 3 yards Irom the west side, 15 yards from the south end, and 20 yards from southeast side. Dense pine woods stand about 100 yards to the northwest, open marsh to the northeast, and a clump of about a dozen pine trees in marsh about $3 / 8$ mile to the northeast. There is a cove about 40 yards east of the station and another point of land about 100 yards to the southeast. Cement monument marking reference station is 16.63 meters north of observed station.

Marks.-Observed station is a nail in a pine stub about 6 inches below surface of ground. Reference station is center point of triangle on standard cement monument.

References.-

"Great Shoals Light" (S $44^{\circ} 16^{\prime} \mathrm{E}$ )

Poplar tree at Dames Quarter

Tangent of Hall Point.

E)

(1)

Tangent of Sandy Point ................ 164

Left end of pine woods................ I

Right end of pine woods _......... 2 I

REFERENCE STATION

Largest tree in clump of about 12 pines... - 2

Chimney on cabin on Ellis Point_........ 279

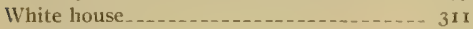

Point of land.

F,L, A.

Locality.-North shore of Wicomico River on point at east side of entrance to Ellis Bay. (See Chart No. 5.)

Observed station is on a marsh point about $\mathrm{r}$ foot above high-water mark. It is about ro yards back from the shore to the west, 20 yards back from the shore to the south, and 20 yards back from the shore to the north. No permanent reference objects near station.

Marks.-Observed station is center point of triangle on standard cement monument.

References.-

"Great Shoals Light" (S 9 $49^{\prime}$ WV)

Tangent of land on Mollies Point.

Watch house.

Left of woods on Nanticoke Point

Chimney of white house

Chimney of gray house

Chimney of white house

Mount Vernon Church________.______ 257

Chimney on middle of white house $\ldots \ldots \ldots \ldots-274$

Chimney on cream and brown house _..... 290

Chimney on brown house.............. 29I

Smoke pipe of watch house

306

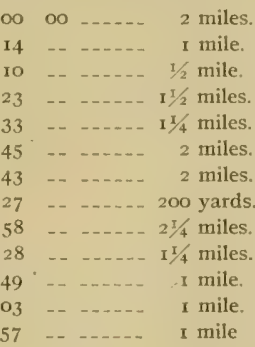




\section{HOLLAND.}

Locality, -North shore of Wicomico River on Holland Point about $1 \mathrm{x} / 4$ miles west of Mount Vernon Church, and $11 / 4$ miles east of Ellis Bay. (See Chart No. 5.)

Observed station is on a marsh point about 20 yards north of high-water mark on its extreme end and about 100 yards west of a creek. A small cabin stands about 200 yards to the west.

Marks.-Observed station is center point of triangle on standard cement monument.

References.-

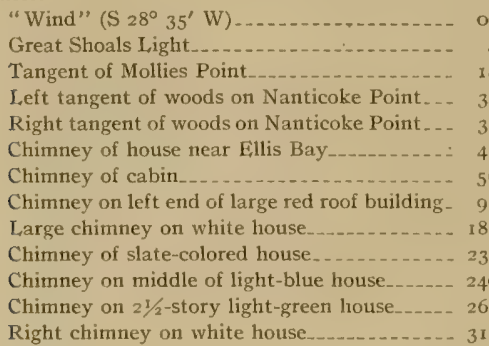

\begin{tabular}{rrrrr}
0 & \multicolumn{1}{c}{ " } & & \\
00 & 00 & 00 & $\ldots \ldots$ & $11 / 4$ miles. \\
4 & 34 & $\ldots$ & $\ldots$ & $23 / 4$ miles. \\
18 & 39 & $\ldots$ & $\ldots$ & 2 miles. \\
34 & 33 & $\ldots$ & $\ldots$ & $23 / 4$ miles. \\
39 & 28 & $\ldots$ & $\ldots$ & $23 / 4$ miles. \\
46 & 19 & $\ldots$ & $\ldots$ & $1 / 4$ miles \\
56 & 14 & $\ldots$ & $\ldots$ & 200 yards. \\
91 & 56 & $\ldots$ & $\ldots$ & 3 miles. \\
88 & 31 & $\ldots$ & $\ldots$ & $1 / 4$ miles. \\
230 & 43 & $\ldots$ & $\ldots \ldots$ & $11 / 4$ miles. \\
240 & 48 & $\ldots$ & $\ldots$ & 1 mile. \\
266 & 41 & $\ldots$ & $\ldots$ & $3 / 4$ mile. \\
317 & 29 & $\ldots$ & $\ldots \ldots$ & $1 / 2$ mile.
\end{tabular}

\section{CHILD.}

Locality.-North shore of Wicomico River about $7 / 8$ mile north of Mount Vernon Church. (See Chart No. 5.)

Observed station is on marsh land about 2 feet above and 15 yards back from high-water mark. There is an old wharf about 300 yards to the east and at a point about roo yards to the north, two creeks join and form a single creek about 20 feet wide which flows into the river at a point about ${ }^{1} 5$ yards west of observed station.

Marks.-Observed station is center point of triangle on standard cement monument.

References.-

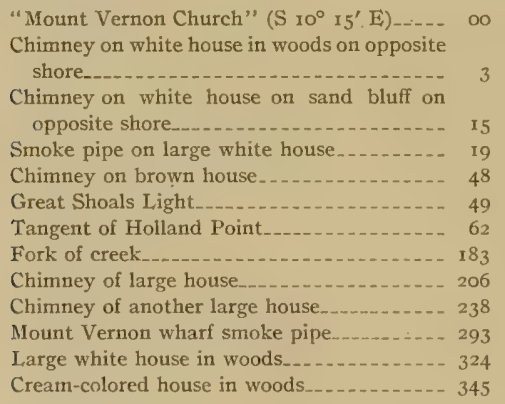

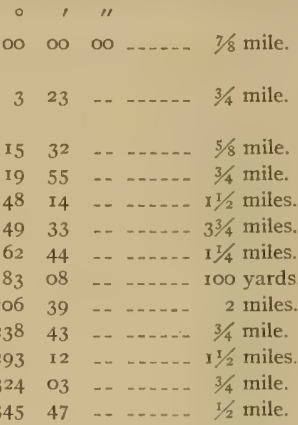

\section{CREEK}

Locality.-North shore of IVicomico River, about $3 / 4$ mile northwest of Mount Vernon whatf and about $\mathbf{1} 3 / 8$ miles northeast of Mount Vernon Church. (See Chart No. 5.)

Observed station is on a marsh grass and sand point making out to the soutl and about 10 yardis from the high-water mark of each of the three sides of the point. About 1o yards west of observed station is the mouth of a creek or drain to feet wide which runs only a short distance inland. There are several unpainted houses within 200 yards of observed station and a lone pear tree stands about 200 
yards to the north. There is a cultivated field about 1,50 yards back of station which cxtends to edge of woods $1 / 4$ mile distant.

Marks.-Observed station is center point of triangle on standard cement monument.

References. -

\begin{tabular}{|c|c|c|c|c|}
\hline Mount Vernon Church (s $30^{\circ} 39^{\prime}$ W) ... & 00 & & & \\
\hline Chimney on light-blue house with red blind & 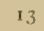 & & & $1 / 4$ \\
\hline e........ & 72 & & & : \\
\hline & 108 & 18 & $\ldots$ & \\
\hline 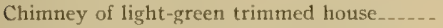 & I 35 & I5 & & \\
\hline ea & & 8 & & \\
\hline 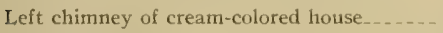 & 218 & 06 & $\cdots$ & \\
\hline Tar & 224 & - & & \\
\hline & 282 & 34 & -- & \\
\hline & 312 & 04 & $\ldots$ & \\
\hline himney on slate-colored $h$ & 352 & 57 &.- & iile. \\
\hline
\end{tabular}

END.

Locality.-North shore of Wicomico River, opposite Mount Vernon wharf. (See Chart No. 5.)

Observed station is on marsh land about. 3 feet above and about roo yards north of high-water mark in river and about 75 yards to the northwest of a large creek which runs about 2 miles inland Water hushes skirt shore around station.

Marks,-Observed station is center point of triangle on standard cement monument.

Reforences.-

"Jones" (S $\left.60^{\circ} 33^{\prime} \mathrm{WV}\right)$ -

Chimney on white house

Tangent of land

Near chimney of cream-colored house ....... 68

Cupola on red barn

Old-style windmill _.............. I63

Chimriey of Whitehaven Hotel........... I7I

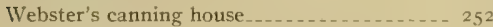

Right hand chimney on gray house_.___._. 273

Left side of Mount Vernon wharf____... 294

Stack of Dashiell's canning house ......... 304

Middle attic window of white house _...... 328

Chimney outside of yellow house_._. . . 35 2

\begin{tabular}{|c|c|c|}
\hline oo & oo. & 3/4 mile \\
\hline 24 & $\ldots$ & I mile. \\
\hline 28 & $\ldots$ & I mile. \\
\hline 25 & $\ldots$ & $1 / 2$ mile. \\
\hline 2 I & . & $3 / 4$ mile. \\
\hline 26 & $\ldots$ & $3 / 4$ mile. \\
\hline 09 & .. & $11 / 4$ miles. \\
\hline 28 & 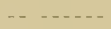 & $\mathrm{r} / 2$ mile. \\
\hline $4^{2}$ & -. & $1 / 2$ mile. \\
\hline 13 & .. - & $1 / 4$ mile \\
\hline 52 & $\ldots$ & $3 / 8$ mile. \\
\hline 54 & $\ldots$ & $1 / 2$ mile \\
\hline 12 & -- & $1 / 2$ mile. \\
\hline
\end{tabular}

WALNUT.

Locality.-South shore of Wicomico River, about 175 yards east of Mount Vernon wliarf. (See Chart No. 5.)

Observed station is on marsh land about 17 feet from shore and so yards west of a small crcek. Several large walnut and locust trees stand about 250 yards south of station and 2 houses and 2 sheds about 250 yards to the southwest.

Marks.-Observed station is center point of triangle on standard cement monument.

References.- -

"Jones" $\left(\mathrm{S} 83^{\circ} 49^{\prime} \mathrm{W}\right.$ )
Right side of Mount Vernon wharf house $\ldots$
Chimney outside of white house
Left chimney of gabled house

$50095-08-5$ 


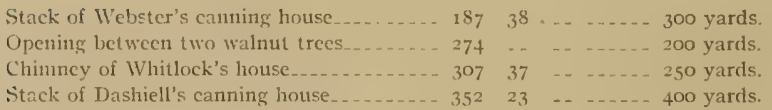

JONES. No. 5.)

Locality.-South shore of Wicomico River about $3 \frac{3}{4}$ mile west of Mount Vernon wharf. (See Chart

Observed station is an a knoll about 25 feet above and 30 yards to south of high-water mark, and about 200 yards to the east of a cove. The knoll on which the station is located is the highest point on the shore in this locality. Several small cahins stand to the northward about 25 yards, and a large lone cedar tree alout 35 yards to the southwest.

Marks.-Observed station is center point of triangle on standard cement monument.

Sicternos.-

"Ivee" (S $\left.78^{\circ} 54^{\prime} \mathrm{W}\right)$
Large square chimney on four-gable house
Cedar tree.
Tangent of point of land
Nail in lilaze in cedar tree.
Chimncy on light-grcen house on opposite
shore

oo 00 oo $\quad 3 / 4$ mile.

I0 05 _..... $1 / 4$ mile.

II $22 \ldots \ldots . .25$ yards.

$34 \quad 54 \ldots 1 / 8$ mile.

$6226 \ldots \ldots 20.30$ meters.

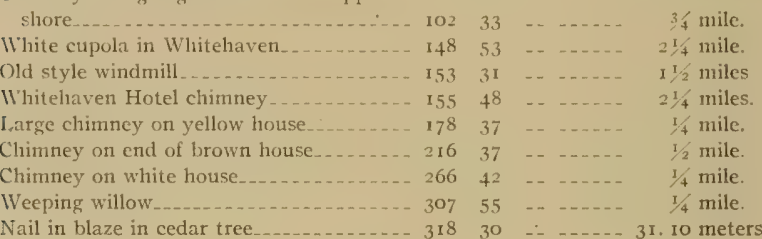

IVEE

Locality - Southeast shore of Wicomico River about 1/4 mile northwest of Mount Vernon Church. (See Clart No. 5.)

Observed station is on grass land ahout $\mathrm{x}$ foot above and ro feet back from high-water mark. A small cove makes in about 100 yards east of station. A small lone pine stands about iro yards to the east-southeast, and a sand blufi with pine trees about 100 yards to the southwest. Beyond the woods along the beach is a bluff 15 feet high upon which are several houses.

Marks.-Observed station is center point of triangle on standard cement monument.

References.-

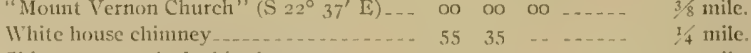

Chinney on end of white housc....... 209 55 ...... 2 miles.

Chimney of green-trimmed lousc near

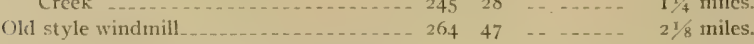

Slate-colored house $\ldots \begin{array}{llll}276 & 22 & \ldots\end{array} \ldots$

Chimney on middle of white house beyond

woods_........... 297 II _.. _... I mile.

Lone pine tree $\ldots \ldots \ldots$ r 


\section{MOUNT VERNON CHURCH.}

Locality.-Southeast side of Wicomico River about $3 / s$ mile back from the shore $x 1 / 2$ miles southwest of Mount Vernon wharf. (See Chart No. 5.)

Observed station is on main road in Mount Vernon and is situated on the highest point in the vicinity.

Marks.-Observed station is center of steeple of Mount Vernon Methodist Church.

References.-None necessary.

$$
\text { I3AL I, }
$$

Locality. - Southeast shore of Wicomico River on a point of land about a mile northeast of W'ingate Point. (See Chart No. 5.)

Observed station is on a sand and grass point making out about 100 yards west of a sand blutf. A small creek enipties into the river about ro yards to the east, and three poplars stand about 100 yards to the south. The extreme northern end of the point is about 35 yards from station and the western side is about to yards.

Marks.-Observed station is center point of triangle on standard cement monument

References.-

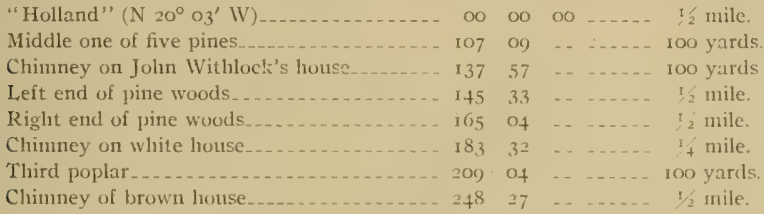

IVIND.

Locality.-Southeast shore of Wicomico River about $1 / 4$ mile north of southern end of Wingate Point. (See Chart No. 5.)

Observed station is about 30 yards from high-water mark of Wicomico River on the north side and 20 yards from the west side. An oyster watchhouse stands about 100 yards to the east of the station

Marks. - Observed station is center point of triangle on stundard cement monument.

References.-

"Great Shoals Light" (S $36^{\circ} 29^{\prime}$ WV)

Tangent of Mullies Puint

Left end of woods

Right end of woods

Tangent of Eillis Point_.................. 10247

White house in woods ............ 157 19

Smoke pipe on watchhouse

Chimney of brown house

Chimney of cream-colored house with brown trimmings . . . . . . 2 2

Watchhouse

Clinney on end of white house Dames

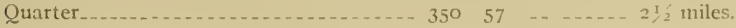

\section{LITTLE.}

Locality.-Southern shore of Monie Bay on second prominent point of marsh about $1 / 4$ mile to the west of entrance to Little Monic Creek. (See Cliart No. 5.)

Observed station is on a marsh point covered with water bushes and reels. It is about I foot above high-water mark, 7 yards from the west side, 10 yards from the east side, and about 50 yards from extreme end of point. No permanent reference objects near station. 
Marks-Observed station is center point of triangle on standard cement monument. References.-

"Great Shoals Light" (S $83^{\circ} 43^{\prime}$ IV)

Left side of woods on Nanticoke Point

Right side of woods on Nanticoke Point ...

Tangent of Wingate Point

\begin{tabular}{|c|c|c|c|}
\hline 00 & Oo & 00 & $\ldots \ldots 21 / 4$ miles \\
\hline 19 & 34 & - & $\ldots \ldots 3^{1 / 4}$ mile \\
\hline 22 & 24 & -. & ... $31 / 2$ miles \\
\hline & 39 & -. & ... I $1 / 2$ mile \\
\hline & 13 & -. & $I^{1} / 2$ miles \\
\hline & $0 z$ & - & $1_{1}{ }_{2}$ mil \\
\hline & 43 & - & .. $11 / 2$ miles \\
\hline & $5^{2}$ & -- & ..... I I/2 miles \\
\hline & -. & -- & - $13 / 4$ mile \\
\hline & 55 & -. & - $\mathrm{I} 3 / 4 \mathrm{mil}$ \\
\hline & 42 & .. & .. $13 / 4$ miles \\
\hline & 47 & $\cdots$ & $\ldots \ldots 1 / 4$ \\
\hline & 16 & - & -75 \\
\hline & 47 & - & $\ldots$ \\
\hline
\end{tabular}

Chimney on red roof white house

Chimney on near end of white house with bruwn trimmings ..................

Chimney on red roof white house with green blinds.

Left chimney of yellow house trimmed white-

Middle of woods. . . . . .

Large brown house .........................

Mount Vernon Church _................ 1

Tangent of point of land _.............. 165

Tangent of point of land $\ldots \ldots \ldots . . . . . . .320$

Tangent of land

346

\section{DOVE.}

Locality.-South shore of Monie Bay and about $1 / 4$ mile east of entrance to Pigeon Creek. (See Chart No. 5.)

Observed station is on marsh land about ro yards back from high-water mark not far from water bushes which stand to the east. Cement monument marking reference station is 13.98 meters southeast from observed station. No permanent reference objects near station.

Marks.--Observed station is a nail in pine stub flush with ground. Reference station is center point of triangle on standard cement monument.

References. -

"Great Shoals Light" (N $57^{\circ} 4 \mathrm{I}^{\prime}$ WV) ......

Left side of Nanticoke Point woods .....

Left side of Roaring Point heavy woods...

High lone pine showing above woods.....

Tangent of Wingate Point_...........

Chimney of red roof house.

roof

Mount Vernon Church

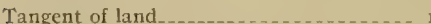

REFERENCE STATION

Chimney of white house with dark red trimmings.

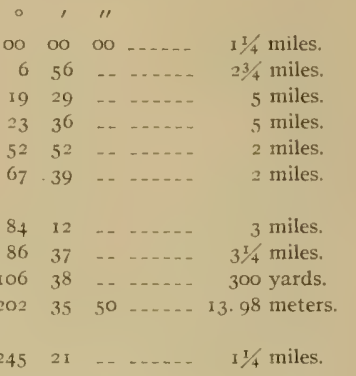

\section{GREAT SHOALS LIGHT.}

Locality.-Middle of entrances to Monie Bay and Wicomico River about halfway between Long Point to the south and Mollies Point to the north. (See Chart No. 5.)

Marks.--Observed station is center of black lantern on square screw pile structure known as "Great Shoals Light."

References.-

"Sharkfin Shoal Light" (S $\left.81^{\circ} 50^{\prime} \mathrm{WV}\right)$ 
SHORT.

Locality. - Southern shote of entrances to Monie Bay and IVicomico River on Long Point and about I mile south-southwest from Great Shoals Light. (See Chart No. 5.)

Observed station is on a sandy knoll on eastern side of entrance to Dames Quarter Creek about 15 feet back from high-water mark on the north side and about 30 feet from east side of point. It is on the highest part of the knoll which is about 5 feet above highl-water mark.

.Marks. - Observed station is center point of triangle on standard cement monument.

References.-

\begin{tabular}{|c|c|c|c|c|}
\hline 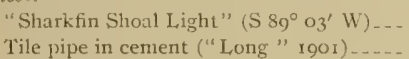 & $\begin{array}{l}00 \\
23\end{array}$ & $\begin{array}{l}00 \\
57\end{array}$ & & $\begin{array}{l}5.38 \text { miles. } \\
63.703 \text { meters. }\end{array}$ \\
\hline Nanticoke wharf & G7 & 57 & 3 & $4^{1} s$ miles. \\
\hline Left side of Nanticoke woods & 69 & 13 & .. & 2 miles. \\
\hline Vellow house with red blinds. & 74 & 53 & .. & $3^{1 / 2}$ miles. \\
\hline Left tangent of Wingate Point. & 124 & 13 & .. & $2^{3 / 3}$ miles. \\
\hline Chimney orr red roof white house. & 132 & 39 & -. & 3 miles. \\
\hline Near chimney of yellow house.. & 136 & 40 & .. & 3 miles. \\
\hline Chimney on red trimmed house. & 212 & 49 & .. & 2 miles. \\
\hline Left tree at Dames Quarter.... & 260 & 37 & -. - & $1 / 4$ mile. \\
\hline Chimney on white barn & 279 & 45 & -. & 300 yards. \\
\hline Left chimney on white house. & 320 & 05 & -. & 200 yards. \\
\hline Chimney on yellow liouse.. & $3+\mathrm{I}$ & 35 & & 200 yards. \\
\hline
\end{tabular}

ROOM.

Locality.-Upper end and eastern shore of Tangier Sound on Halls Point. (See Chart No. 5.)

Observed station is on a bluff 15 feet high about 5 yards back from its edge. It is about 25 yards east of a clump of mulberry trees and about $\mathrm{x} 5$ yards north-northwest of a barn. Locust and mulberry trees stand all about station and locust bushes along the edge of the bluff. A wagon trail runs parallel to the shore about I5 yards back of station. Cement monument marking reference station is 21.4 .5 meters south-southwest of observed station and almost in line with a large mulberry tree.

Marks.-Observed station is nail in center of stub with top flush with ground. Reference station is center point of triangle on standard cement monument.

Rifinna.-

"Sharkfin Shoal Light" (N $70^{\circ} \mathrm{OO}^{\prime}$ (W)

Gable on near side of red roof on white house on Bishop's Head..............

Near end of roof of large $21 / 2$-story house. -

Left tangent of Clay Island..............

Left side of Sandy Point woods...........

Roaring Point wharf

Near chimney on end of large red roof white house _._................. 94

Right side of Nanticoke woods. ......... I10

Mount Vernon Church _..._. _._. 127

Near corner of barn_._._._._._._._. 137

Right hand corner of barn _........... 152

REFERENCE STATION_____.

Large cedar tree ...................... 276

Two-inch iron pipe.............. 279

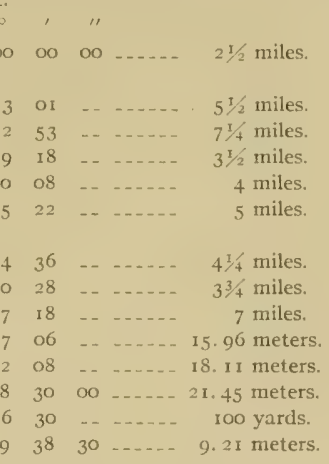

\section{HAINES.}

Locality.-Upper end and eastern shore of Tangier Sound on Haines Point, about $5 / 8$ mile north of Deal Island Wharf, (See Chart No. 5.)

Observed station is on sand and grass point about 20 yards back and 5 feet above high-water mark. Locust and water bushes stand about 20 yards to the north and the left edge of this clump is about on 
line with Sharkfin Shoal Light. A barbwire fence runs 3 yards east of station. Cement monument marking reference station is 9.64 meters east of observed station.

Marks.-Observed station is nail in pine stub in center of a drain tile with top broken off below surface. Reference station is center point of triangle on standard cement monument.

References:-

\begin{tabular}{|c|c|c|c|c|c|}
\hline "Sharkfin Shoal Light" $\left(N_{4} 45^{\circ} 58^{\prime} \mathrm{WV}\right) \ldots$ & $(x)$ & 00 & 00 & & $21 / 2$ miles. \\
\hline Left of buslies. - & 39 & 57 & & & 20 yards. \\
\hline L.eft of Sandy Point woods & 5.3 & 38 & & - & 344 miles. \\
\hline $\begin{array}{l}\text { Chimney of } 21 / 2 \text {-story white house trimmed } \\
\text { with red }\end{array}$ & 75 & 04 & & .. & $1 / 2$ miles. \\
\hline Chimney of unpainted house & 85 & 49 & & . & 350 yards. \\
\hline $\begin{array}{c}\text { Chimney on end of red cottage trimmed } \\
\text { white }\end{array}$ & 99 & $\infty$ & & - & c. \\
\hline REFERENLE STATION & 123 & 40 & to & & 9. $6+$ meters. \\
\hline Pine tree...... $\ldots \ldots \ldots$ & ifs & 37 & 30 & & $2 . t+$ meters. \\
\hline Large square chimnty on red house...... & 152 & +9 & - & & too yards. \\
\hline Right one of ${ }_{5}$ large pines . ........ & 184 & to & - & - & 300 yaris. \\
\hline $\begin{array}{l}\text { Half way between chimneys on store on } \\
\text { Deal Island }\end{array}$ & 21,3 & os & - & & \\
\hline Deal Island Clutrcli_..... & 217 & on & & & I $1 / 2$ miles. \\
\hline Black gum tree. & $\therefore 23$ & (i) & & & 6. 70 meters. \\
\hline 1 of Deal Island wharf & 234 & 10 & & & mile. \\
\hline II(x)per Straits Light & 343 & 34 & . & & $7 \mathrm{I} / 2$ miles \\
\hline
\end{tabular}

\section{DEAI, ISLAND CHURCH.}

Locality,-Deal Island on main road about $1 / 4$ mile from the shore and about $3 / 4$ mile south of Laws Thoroughiare. (See Chart No. 5.)

Marks.-Observed station is center of steeple on Deal Island Methodist Clurcli.

References,-None necessary.

BAR.

Locality,-Eastern shore of Tangier Sound on western side of Deal Island, about I mile northwest of entrance to Lower 'Thoroughfare and $1 / 2$ mile south of Middle Creek. (See Charts Nos. 5 and 7.)

Observed station is about 10 yards east of high-water mark on sand and grass land back of sandy beach. The first of many tree stumps which are submerged at high water commence about roo yards to the north and cat-tails grow abundantly back of station. Cement monument marking reference station is 6.09 meters east of observed station.

Marks.-Observed station is a nail in pine stub flush with ground. Reference station is center point of triangle on standard cement monument.

References. -

"Sharkfin Shoal Light" (N $\left.19^{\circ} 40^{\prime} \mathrm{W}\right)$-..-

' 'angent of Haines Point -

Flag pole on large building on Deal Island wharf

Middle chimney of large gray building-...-

Chimney on white hutise.... ..... .....

Middle chimney on red roof white house _..-

REFERENCE STATION . _. . .

Climney on white house ... . . . . . . . . .

Chimney on dark gray house Right chimney on white four-gabled house with red ruof ...................

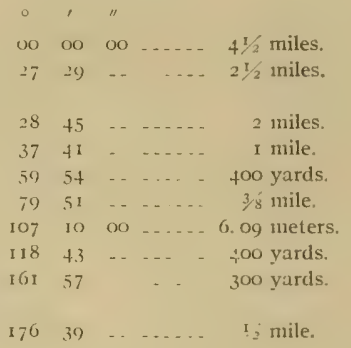


Locality.- Northern shore of Manokin River on a marsh point on the west side of entrance to Geanţuakin Creek. (See Charts Nos. 5 and 7 .)

Observed station is on low marsh land about 35 yards back from extreme end, 30 yards from cast side and 40 yards from north side of point. Pine woods stand about $1 / 8$ mile back from station. There are no permanent reference objects near station.

Marks,-Observed station is center point of triangle on standard cement monument.

References.-

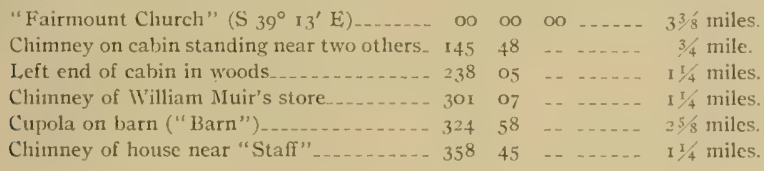

\section{SANDY.}

Locality,-Northern shore of Manokin River on point of land known as Sandy Point opposite Fisling Island. (See Charts Nos. 5 and 7.)

Observed station is on a sandy point about 5 feet above and ro yards back from high-water mark on south side of point and about 75 yards from high-water mark on west side. A sandy beach is building out to southward and a heavy clump of myrtle bushes extends from a point about 25 yards west to a point about 75 yards west.

Marks.-Observed station is center point of triangle on standard cement monument.

References.-

"Fairmount Church" (S $\left.7^{\circ} 54^{\prime} \mathrm{E}\right) \ldots \ldots$
Bell tower on oyster house ("Cupola")

HOLLAND ISLAND BAR LIGHT.

Locality.-Easterly side of Chesapeake Bay off entrance to Kedge Straits, about $23^{\frac{3}{4}}$ miles south of Holland Island, $2 \frac{1}{2}$ miles southwest of South Marsh, and $3 \frac{3}{4}$ miles northwest of Smith Island. (Sce Chart No. 6.)

Marks.-Observed station is center point of black lantern on hexagonal screw pile structure known as "Holland Island Bar Light."

References.-

"Solomons Lump Light" (S $72^{\circ} \mathrm{O} 6^{\prime} \mathrm{E}$ )

\section{SOLOMONS LUMP LIGH'T.}

Locality. - Kedge Straits about $1 / 2$ mile north of Sunith Island and about $1 / 2 / 2$ miles south of South Marsh. (See Charts Nos. 6 and 7.)

Marks.-Observed station is center of black lantern on square tower on northerly side of a caisson and octagonal structure known as "Solomons Lump Light."

Refercnces. -

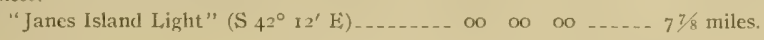

FOG.

Locality-Eastern shore of Chesapeake Bay and southern shore of Kedge Straits on northwest point of Smith Island known as "Fog Point." (See Chart No. 6.)

Observed station is on the north side of a sand and grass point about $x$ foot above high-water and about 65 yards from extreme end of point to northeast and 6 yards souti-southeast from shore. The 
remains of old "log l'oint I, ight House" are ahout 50 yards to west-southwest, and myrtle bushes alound on all sides except on the west side, which is a sandy beach. Cement monument marking reference station is 15.26 meters south from observed station and about in line with a lone clierry tree $1 / 4$ mile distant.

Marks.-Observed station is nail in center of tile pipe with top flush with surface of ground. Reference station is center point of triangle on standard cement monument.

References. -

\begin{tabular}{|c|c|c|c|c|c|}
\hline 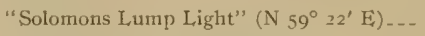 & OO & OO & oo & & $13 / 4$ \\
\hline int of land & 13 & 08 & -- & & \\
\hline 11. & 22 & $4 \mathrm{I}$ & & & I $1 / 2$ miles. \\
\hline ee_-n_... & 89 & 28 & -- & & \\
\hline & 121 & 18 & 30 & & 15.26 \\
\hline & 121 & 26 & -- & & $1 / 4$ \\
\hline & 133 & 43 & -. & & \\
\hline & I9.3 & 47 & $\cdots$ & & 50 \\
\hline st tree on Holland Islar & 272 & 37 & & & $53 / 4$ miles. \\
\hline
\end{tabular}

JOSEPH.

Locality.-Eastern shore of Chesapeake Bay and western side of Snith Island, about 3 miles southwest from Solomons Lump Light and about $1 / 2$ mile north of entrance to. Sinith Island Thoronghfare (See Charts Nos. 6 and 8.)

Observed station is on marsh land about 30 yards back from edge of sandy shore. There is nothing but marsh grass for $1 /+$ mile on all sides except a slough about 30 yards wide, which begins about 60 yards southeast of observed station and runs south to Smith Island Thoroughfare. Cement monument marking reference station is 38.74 meters northeast of station and is nearly on line with Solomons I.ump Light.

Marks.-Observed station is nail in stub flush with ground. Reference station is center point of triangle on standard cement monument.

References.-

\begin{tabular}{|c|c|c|c|c|c|}
\hline "Solomons Lump Light" ( $\left.40^{\circ} 47^{\prime} \mathrm{E}\right)$ - & oo & oo & oo & & les. \\
\hline REFERENCE STATION & oo & $\mathrm{I} 3$ & 55 & & 38. 74 meters. \\
\hline Tall lone tree......... & 20 & $4^{2}$ & - & & $1 \mathrm{I} / 4$ miles. \\
\hline Right-hand one of two pir & 58 & 35 & -. & & $1 / 2$ mile. \\
\hline Right end of slough.... & 69 & +3 & - . & & ards. \\
\hline mith Island North Churc & 103 & 33 & - & -....... & $1 / 2$ miles. \\
\hline able on front of $21 / 2$-story house.. & 109 & 28 & -. & & I $1 / 4$ miles. \\
\hline "Smith Island Old Church" & 128 & DI & -. & & $3 \frac{1}{3}$ miles. \\
\hline
\end{tabular}

\section{TERRAPIN.}

Locality:- Western shore of Tangier Sound on extreme northeast point of Smith Island, known us "Terrapin Sand Point." '(See Chart No. 7.)

Observed station is on the northeast side of a marsh point about 50 yards west of the extreme end and 3.5 yards southwest of high-water mark on northeast side. A clump of myrtle bushes stands on point about 150 yards southwest of the station. There are no permanent reference objects near station.

Marks.-Observed station is center point of triangle on standard cement monument.

References. -

1,eft end of myrtle bushes............... 65 13 _. ..... 150 yards

Smith Island Church................. $80 \quad 25 \ldots \ldots$....... 4 miles.

I. one tree to right of another tree ...... $85 \quad 23 \ldots \ldots 7$ miles.

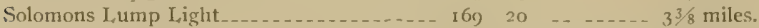

I'oint of this island ................ $21403 \quad \ldots \ldots$..... 150 yards. 


\section{MILES.}

Locality. - Western shore of Tangier Sound on eastern side of the lower half of South Marsh. (See Chart No. 7.)

Observed station is on a marsh point making out about 75 yards south of entrance to small creek, which is middle one of three on this shore of the island. Station is about 50 yards south of the north side and about 60 yards west of extreme end of point. A row of myrtle bushes stands east of the station.

Marks.-Observed station is center point of triangle on standard cement monument.

References.-

"Sharkfin Shoal Light" (N $8^{\circ} 33^{\prime}$ E) …_.. oo oo 00 _..... $73 / 8$ miles.

Deal Island Church . . . . . . . . . . . . $2926 \quad 26 \quad \ldots .51+$ miles.

End of ronf of white house among trees, Deal

Island ........ $33 \quad 48 \ldots \ldots . \ldots 4^{1 / 4}$ miles.

Tangent of near point of land

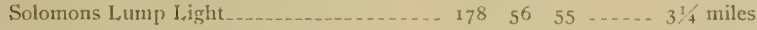

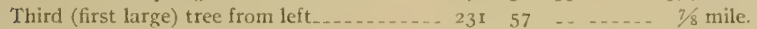

Lone pine tree._.

JOSHUA.

Locality.-Eastern shore of Tangier Sound on western side of Little Island, about 1/8 mile southeast from extreme eastern point of island. (See Chart No. 7.)

Observed station is on northern half of a sand dune about in feet almve and 20 feet back from high-water mark. The southern half of the sand dune is covered with bushes and scrub trees. A large aspen tree stands about $1 / 4$ mile north of the station. Cement monument marking reference station is located on low land 32.06 meters north of observed station, and is nearly on line with large aspen tree.

Marks.-Observed station is a nail in pine stub flush with ground and is likely to be disturbed by shifting of sand dune. Reference station is center point of triangle on standard cement monument.

References.-

\begin{tabular}{|c|c|c|c|c|}
\hline $\begin{array}{l}\text { "Solomons Lump Light" }\left(\mathrm{S}_{37^{\circ}} 4 \mathrm{I}^{\prime} \mathrm{VV}\right) \text {-- } \\
\text { Tall pine tree on opposite shore of Tangier }\end{array}$ & oo & oo & oo - & $5 \frac{7}{8}$ miles. \\
\hline Sound_- & $3 \mathrm{r}$ & 48 & -. & $.51 / 2$ miles. \\
\hline Center point of square roof house on Deal & & & & \\
\hline Island_. & 129 & 32 & & $\mathrm{x} 1 / 4$ miles. \\
\hline Large aspen tree........ & 160 & 08 & $\ldots$ & I mile. \\
\hline REFERENCE STATION_... & 160 & I9 & 20 & 32.06 meters. \\
\hline $\begin{array}{l}\text { Nail in blaze in peach tree }(\mathrm{x} / 2 \text { inches in } \\
\text { diameter) }\end{array}$ & & 40 & & \\
\hline
\end{tabular}

\section{KELLEY.}

Locality,-Northern shore of Manokin River on Kelley Island, which is located off point between Fishing Creek and Iaws Thoroughfare just inside of entrance to Laws Thoroughfare. (See Chart No. 7.)

Observed station is on a small point making off southern side of a marsh island known as "Kelley Island." It is about 8 yards from the east side and about 12 yards from west side of point. Myrtle bushes grow about 5 yards to west and north of observed station and a crab shanty stands on northern end of island about 100 yards north from station. Cement montment marking reference station is 10.44 meters northeast of observed station.

Marks. - Observed station is center of a square wooden box with top just above ground. Reference station is center point of triangle on standard cement monument.

References.--

Pine to leit of two others............ 18 38 ........

Aspen tree near "Joshua"

$61 / 4$ miles.

$33 / 4$ miles.

4 miles.

$50095-08-6$ 


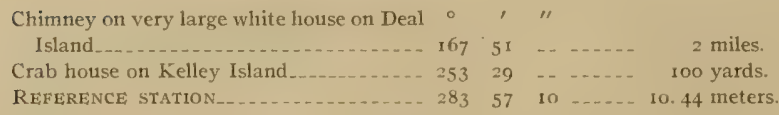

MARSH.

Locality.-Northern shore of Manokin River on a small marshy island on eastern side of entrance to Fishing Creek. (See Chart No. 7.)

Observed station is on southern part of a snall marshy island about 25 feet from the south side, 30 feet from the northeast side, and io feet from west side of the island. Cement monument marking reference station is 24.34 meters northwest of observed station.

Marks.-Observed station is a nail in a pine stub in center of square wooden box. Reference station is center point of triangle on standard cement monument.

References.-

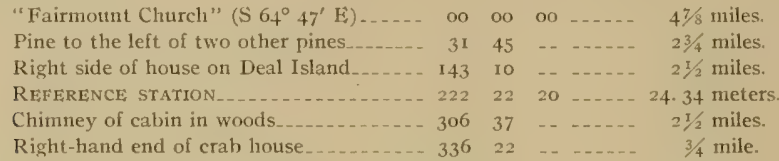

\section{ST. PIERRE.}

Locality.-Manokin River on a small marsh island known as "St. Pierre Island," (See Chart No. 7.)

Observed station is on west side of island about 20 yards from the shore to the west and about 30 yards from the shore to the south. A clump of myrtle bushes stand about 15 yards northwest of station, and the shore of a small bay is about 30 yards to the east. Cement monument marking reference station is 7.97 meters east-southeast of observed station and on line to "Fairmount Church."

Marks.-Observed station is a nail in pine stub in center of square wooden box. Reference station is center point of triangle on standard cement monument.

References.-

REFERENCE STATION

Chimney on house with two ells............ 57

Pine tree to the left of two others........ 58

Left end of roof of white house _._._._._. 6

Left end of crab house near Muddy Cove... 18

Chimney on cabin.................. 258

Chimney on Muir's store _._._._._._. 301

Right-hand chimney on yellow house..... 313

$\begin{array}{rrrrr} & \text {, } & & \\ \text { 00 } & 00 & 00 & \ldots \ldots & 33 / 8 \text { miles. } \\ \text { oo } & 00 & 00 & \ldots \ldots & 7.97 \text { meters. } \\ 57 & 15 & \ldots & \ldots \ldots & 13 / 4 \text { miles. } \\ 58 & 52 & \ldots & \ldots & 2 \text { miles. } \\ 61 & 09 & \ldots & \ldots & 17 / 8 \text { miles. } \\ 88 & 14 & \ldots & \ldots \ldots & 13 / 4 \text { miles. } \\ 58 & 54 & \ldots & \ldots & 1 / 4 \text { miles. } \\ 1 & 22 & \ldots & \ldots & 21 / 4 \text { miles. } \\ 13 & 44 & \ldots & \ldots \ldots & 4 \text { miles. }\end{array}$

\section{LOCUST.}

Locality.-Western shore of upper Manokin River, about $1 / 4$ mile north of Locust Point. (See Chatt No, 7.)

Observed station is on marsh land about 12 yards west from shore of river and about 12 yards north from a small creek. Myrtle bushes extend alongside of river and creek. There are no other permanent reference marks near station.

Marks.-Observed station is center point of triangle on standard cement monument.

Keferences.-

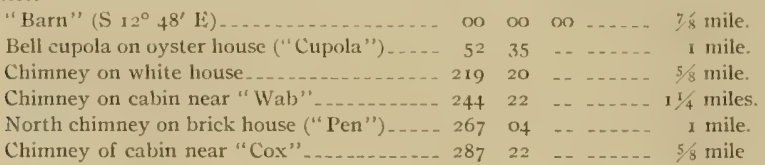


FITZ.

Locality.-Northwestern shore of upper Manokin River, about I mile northeast from Locust Point. (See Progress Map.)

Observed station is on the edge of the lawn of a large old red brick house owned by Mr. Fitzgerald, about 4 yards west of shore and 23 yards southwest of extreme end of point. Four locust trees, each 8 inches in diameter, stand back of station, and there is a cobblestone about 12 inches in diameter about 2 yards to the east. There is a small pond 20 yards to the north of the station.

Marks,-Observed station is center point of triangle on standard cement monument.

References.-

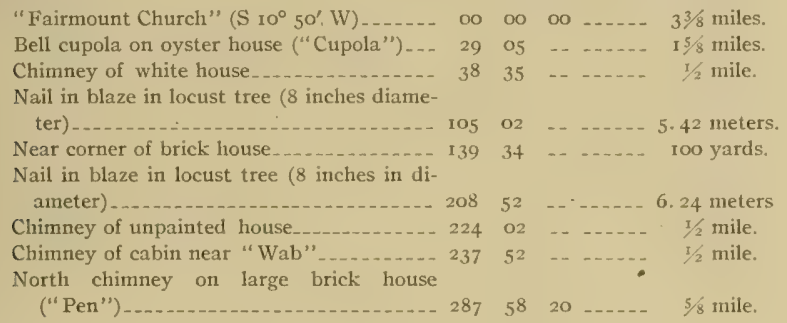

WAB.

Locality.-North shore of upper Manokin River on a point on the western side of entrance to Goose Creek. (See Progress Map.)

Observed station is on a shell and marsh point about ro feet back from both sides of point and about 3 feet above high-water mark. A small shanty stands directly west of station.

Marks.-Observed station is center point of triangle on standard cement monument.

References.-

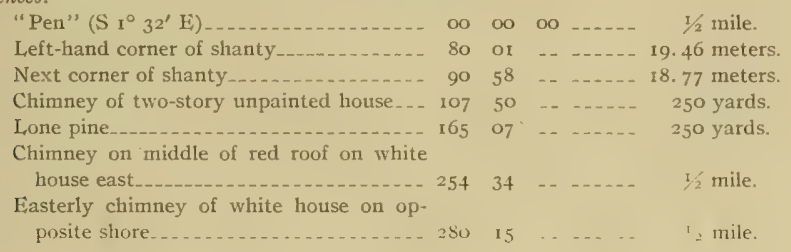

PEN.

Locality.-Southeastern shore of upper Manokin River on Clifton Point. (See Progress Map.) Observed station is northern chimney of a large $2 \frac{1}{2}$ story, 4-gable roof, brick house belonging to KIr. Pendelton. The house is back from the river, and there are trees between it and the shore. Marks.-Observed station is center of northern chimney on house belonging to Mr. Pendelton. References.-None necessary.

\section{COX.}

Locality, -Eastern shore of upper Manokin River on marsh point about $3 / 4$ mile north of entrance to Back Creek. (See Chart No. 7.)

Observed station is about 15 yards east and 10 yards south of high-water mark. A small building stands in the water about 20 feet from bank to the northeast of station, and Bennett's oyster watchhouse is about 15 yards east of station. 
Marks.--Observed station is center point of triangle on standard cement monument. References,-

"Fairmount Church" (S I5 $34^{\prime} \mathrm{W}$ ) --.-

Cupola on barn ("Barn")

10 $37-4 / 8$ mile.

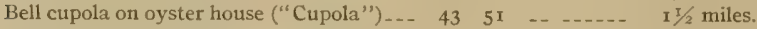

Chimney of white house...... III 27 ...

West corner of roof brick of house on oppo-

site shore near "Fitz"

Cabin near "Wab" ............. $1 / 8$ mile.

Left corner of watchhouse _.......... $266 \quad 45 \quad \ldots \ldots \ldots$ 17.20 meters.

Near corner of watchhouse ............ $274 \quad 58 \quad \ldots \ldots \ldots$ 14. I3 meters.

\section{GREEN.}

Locality.-Upper Manokin River on eastern shore about $\mathrm{g} / 4$ mile north of entrance to Back Creek. (See Chart No. 7.)

Observed station is on grassy land about to yards east of a sandy beacl adjoining a marsh point, and is about 3 yards nortl of curve in road. Two small locust trees stand about 3 yards distant, one to the northwest and the other to the east of station. A cedar tree ro inches in diameter stands about 10 yards to the south.

Marks.-Observed station is center point of triangle on standard cement monument.

References.-

"Fairmount Cliurch" (S $18^{\circ} 53^{\prime} \mathrm{W}$ ) _._._.

Left chimney of white house__._.

Cupola on barn ("Barn") _._...... $25 \quad 23 \quad 50 \ldots 3 / 4$ mile.

Pine tree to the right of two others ....... $35 \quad 50 \ldots \ldots$..... 35 miles.

William Muit's store chimney_____... $84 \quad 55 \quad \ldots \ldots \ldots . .13 / 4$ miles.

Nail in blaze on tree ( 3 inches diameter) _. 107 oI _...... 3.65 meters.

Chimney on white house............ 126 I I _...... $3 / 4$ mile

Tangent of point of land............ I4I I8 _.......

Nail in blaze on tree (ro inches diameter). 342 o9 ...... 8.90 meters.

BARN.

Locality. - South shore of Manokin River on prominent point of land between Wolf Trap and Back creeks. (See Chart No. 7.)

Marks.-Observed station is center point of cupola on a large red frame structure used as a barn on farm of Hershel Ford.

References.-None necessary.

\section{CUPOLA.}

Locality. - South shore of Manokin River on north end of Fishing Island. (See Chart No. 7.)

Marks.-Observed station is center point of top of bell cupola on Bennett's oyster house.

References.-None necessary.

STAFF.

Locality - Southern shore of Manokin River on eastern side of entrance to Broad Creek, aboutt $1 / 4$ mile southeast of Cormal Point. (See Chart No. 7.)

Marks.-Observed station is flagstaff on eastern end of roof of oyster house on Cox's wharf.

References.-None necessary.

$$
\text { . }
$$

\section{FAIRMOUNT CHURCH.}

Locality.-Town of Upper Fairmount about halfway between Manokin and Big Annemessex rivers. (See Chart No. 7.)

Marks.-Observed station is center point of steeple on Fairmount Methodist Church.

References.-None necessary. 
PRICKLY.

Locality.-Eastern shore of Tangier Sound and southeastern side of entrance to Manokin River on a small point $1 / 4$ mile south of Prickly Point. (See Chart No. 7.)

Observed station is on a sandy spot about 5 feet above and 30 yards back from high-water mark on west side and about 35 yards from end of point to northwest. About ro feet southeast of station is a clump of myrtie bushes, and 7 to 18 yards back of these is a small group of pine trees.

Marks,-Observed station is center point of triangle on standard cement monument.

References.-

\begin{tabular}{|c|c|c|c|c|}
\hline Pierre" (N I & $\infty$ & oo & $\infty$ & $31 / 8$ miles. \\
\hline Pine tree to leit of two & 26 & 54 & .- & I $1 / 2$ miles. \\
\hline Chimney of gray house__. & 39 & 22 & -- & iile. \\
\hline Pointed cupola on building through trees. & 49 & 54 & -- & $3 / 4$ mile. \\
\hline Near end of roof of house. & $5^{2}$ & 25 & -- & I mile. \\
\hline Nail in blaze in tree & 68 & 03 & -. & 19. 69 meters. \\
\hline Left end of white house & 93 & 46 & -. & $\mathrm{x} 1 / 4$ miles. \\
\hline Left end of roof of yellow house & IOI & or & $\ldots$ & $3 / 4$ mile. \\
\hline Nail in blaze in tre & I25 & 29 & .. & 23.07 meters. \\
\hline Chimney on gray hous & 163 & 02 & -. & $5 / 8$ mile. \\
\hline Tangent of point of land & 332 & 04 & & $1 / 8$ mile. \\
\hline
\end{tabular}

HAS.

Locality.-Eastern shore of Tangier Sound on point at north side of entrance to Big Annemessex River about halfway between Porpoise Point and Two Mouth Creek. (See Chart No. 7.)

Observed station is on a sand dune about to feet above and 30 yards back from high-water mark to the west. A pool averaging 40 feet by roo feet stands 50 feet east of observed station. Cement monument marking reference station is 5.21 meters east of observed station and about on line to Fords wharf.

Marks.-Observed station is a nail in a pine stub with top flush with ground. Reference station is center point of triangle on standard cement monument.

References.-

"Solomons Lump Light" (S $\left.84^{\circ} 12^{\prime} \mathrm{W}\right)$

co 00 ...... $73 / 4$ miles.

Tangent of point of land........... I2 $02 \quad \ldots \ldots \ldots$..... $1 / 8$ mile.

Chimney of house among trees_........ 92 10 _...... $13 / 3$ miles.

Right end of white house roof ......... 117 I $54 \ldots \ldots$

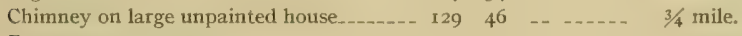

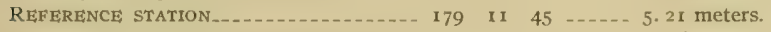

Tower on Odd Fellows Building, Crisfield _ $26550 \quad \ldots \quad \ldots \quad 53 / 8$ miles.

FORD.

Locality.-North shore of Big Annemessex River on south side of Jerico Marshes just east of Muddy Creek. (See Chart No. 7.)

Observed station is chimney on roof of oyster house near Fords wharf. Chimney is a little east of middle of roof.

Marks.-Observed station is center of chimney on roof of oyster house.

References.-None necessary.

MOON.

Locality.-North shore of Big Annemessex River on point between Moon Bay and Crane Cove. (See Cliart No. 7.)

Observed station is on a marsh point about 35 yards from extreme end, 25 yards from east side and 30 yards from south side. A small pool stands about ro yards south of observed station and a crescentshaped pool about ro feet wide and roo feet long extends from a point about 20 yards west to a point about 20 yards north of station. A row of small myrtle bushes begins at a point directly south of 
observed station, extends along shore toward the east, and ends at Moon Bay. Another lot of small myrtle bushes begins at a point about 100 yards west of observed station and extends along the shore to the west. There are no other points of reference near station.

Marks.-Observed station is center point of triangle on standard cement monument.

References.-

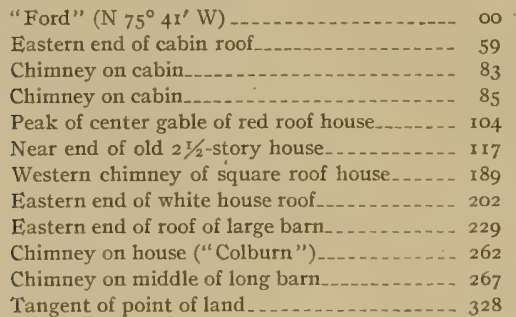

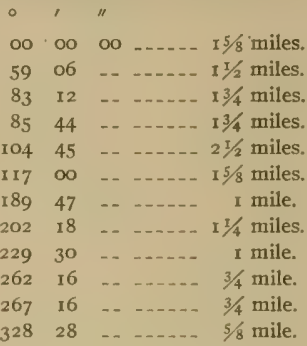

\section{COLBURN.}

Locality.-South shore of Big Annemessex River on southeastern side of entrance to Colburn Creek (See Chart No. 7.)

Observed station is chimney on top of a modern several gable house. House sets alone about halfway between oyster houses to the west and a group of houses to the east.

Marks.-Observed station is center of chimney on top of modern several gabled house.

References.-None necessary.

\section{GEOG.}

Locality. - South shore of Big Annemessex River on point on east side of a square-shaped inlet about $3 / 4$ mile northeast of the entrance to Jones Creek. (See Chart No. 7.)

Observed station is on marsh land about 50 yards back form extreme end of point, about 20 yards from southeast corner of square-shaped bay and about 25 yards from east shore line. Myrtle bushes extend along shore to the east of station for about roo yards, and reeds grow 25 yards to the north.

Marks.-Observed station is center point of triangle on standard cement monument.

References.-

"Has" ( $\left.\mathrm{N} 7 \mathrm{r}^{\circ} 44^{\prime} \mathrm{IV}\right)$

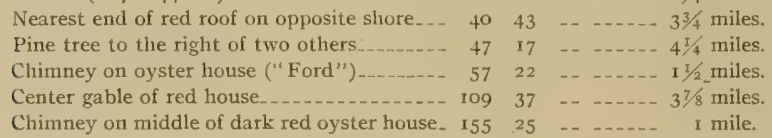

\section{FLAT CAP.}

Locality.-Eastern shore of Tangier Sound and about $1 / 2$ mile south of Flat Cap Point on south side of entrance to Big Annemessex River. (See Chart No. 7.)

Observed station is on a sand dune about Io yards back and io feet above high-water mark. A sandy beach extends along shore for about roo yards in both directions and remainder of land is grassy. A slough begins at a point about 50 yards southeast of observed station and extends south. Cement monument marking reference station is 13.64 meters east of observed station.

Marks.-Observed station is a $\mathrm{r}_{1 / 2}$-inch iron pipe with top flush with the surface of the ground Reference station is center point of triangle on standard cement monument.

References.-

"Solomons Lump Light" ( $81^{\circ} \mathrm{I}^{\prime}$ W) .

Left end of roof of white house near Prickly Point

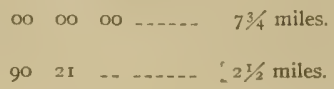




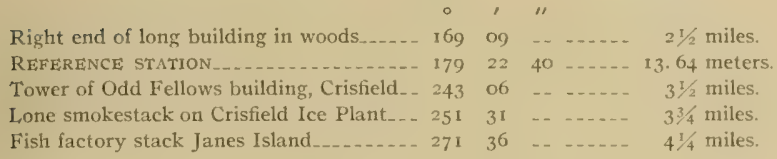

\section{SMITH POINT LIGH'T.}

Locality.-Western side of Chesapeake Bay on southern side of entrance to Potomac River and anout 3 miles east by south of Smith Point. (See Chart No. 8.)

Marks.-Observed station is center point of black lantern on caisson and brick structure known as "Smith Point light."

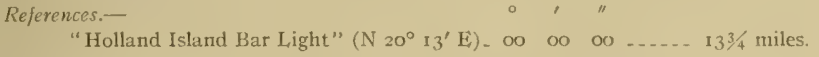

\section{NORTH CHURCH (SMITH ISLAND).}

Locality,-In town of Ëwell on group of marsh islands known as "Sinith Island." (See Chart No. 8.)

Observed station is on solid land on south shore of Smith Island Thoroughfare about I mile from the eastern shore of Chesapeake Bay.

Marks.-Observed station is center point of spire of church known as "Corinth Methodist Eipcopal Church."

References.-None necessary.

\section{OLD CHURCH (SMITH ISLAND).}

Locality.-Western side of the group of marsh islands known as "Smith Island" on solid land about $3 / 8$ mile from the eastern shore of Chesapeake Bay and $1 / 8$ mile east of upper end of Shanks Creek at Rhodes Point. (See Chart No. 8.)

Marks.-Observed station is center point of spire of church known as "Calvary Methodist Ëpiscopal Church."

References.-None necessary.

\section{EWELL CHURCH (SMITH ISLAND).}

Locality. - In town of Tylerton near the center of the group of marsh islands known as "Smith Island" on solid land about $3 / 8$ mile east of the narrowest part of waters joining Tylers Creek and Tylers Ditch. (See Chart No. 8.)

Marks.-Observed station is center point of spire of church known as "Union Methodist Episcopal Church."

References.-None necessary.

\section{SHANKS HAMMOCK.}

Locality.-Eastern shore of Chesapeake Bay on Shanks Island, which is located in Virginia about $3 / 4$ mile east of the southern end of Smith Island. (See Chart No. 8.)

Observed station is on the northeast side of the island, on low ground about $1 / 2$ mile from its northern end about 70 yards back from shore and 1 lo yards from end of point to east. It is near the southern extremity of a hummock covered with a dense growth of scrub trees and bushes and is about 35 yards north of a pile of brick, the ruins of a house. Cement monument marking reference station is $x .+3$ meters southwest of observed station.

Marks.-Observed station is center of a 4 -inch tile pipe with top just below the surface of the ground. Reference station is center point of triangle on standard cement monument.

References.-
"Smith Point Light" (S 69" 16" W)
Smith Island Corinth Church (North Church) 115 50
So - , " 


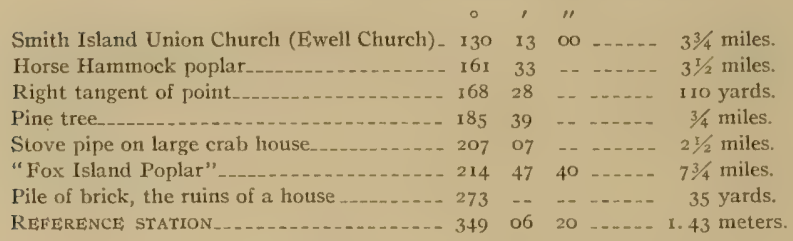

\section{REACH HAMMOCK.}

Locality.-South end and eastern side of Tangier Sound on Reach Hammock Island, which is located between Smith and Tangier islands about I mile east of Fishbone Island. (See Chart No. 9.)

Observed station is on the northeastern end of a small marshy island known as Reach Hammock and is about 5 feet from the present shore line, which is rapidly washing away. It is close to a small fish fertilizer factory which stands on the island. Cement monument marking reference station is 9. ro meters east by south of observed station.

Marks.-Observed station is the center of a 6-inch tile pipe with top flush with surface of the ground. Reference station is center point of triangle on standard cement monument.

References.-

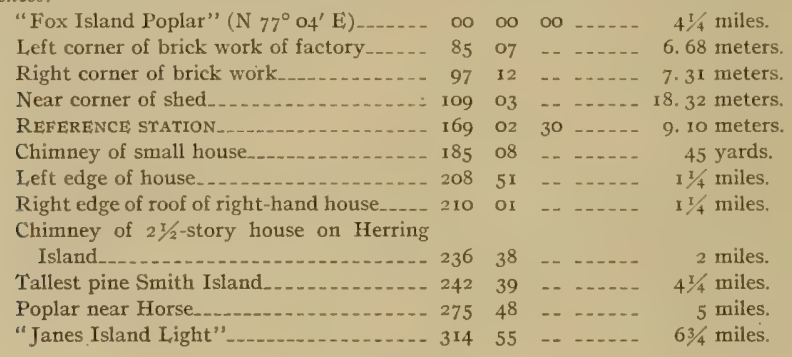

FISHBONE.

Locality.-Dividing waters of Chesapeake Bay and Tangier Sound on western side of Fishbone Island, which is located between Smith and Tangier islands. (See Chart No. 9.)

Observed station is on marsh ground about 15 yards from shore to the west and about halfway between northern and southern extremities of island. The station is about level with high-water mark, but there is a slight elevation between station and shore and a small shanty stands about 20 yards to the southwest. Cement monument marking reference station is 10.08 meters south of observed station and about on line with shanty.

Marks,-Observed station is a nail in stub flush with surface of ground. Reference station is center point of triangle on standard cement monument.

References.-

"Janes Island Light" ( $\left.40^{\circ} 34^{\prime \prime} \mathrm{E}\right)$

"Fox Island Poplar" "_._._. 39

Chimney on house on Reach Hammock_.. 58

REFERENCE STATION__._._.

Near corner of shanty ................. 159

Chimney on $2 \frac{1}{2}$-story house on Herring

Island . . .

Peak of left house

Stove pipe on flat roof shanty ... _... 356

\begin{tabular}{|c|c|c|}
\hline oo & oo _..... & $71 / 4$ miles. \\
\hline 19 & $\ldots$ & $51 / 2$ miles. \\
\hline 49 & $\ldots$ & $1 / 1 / 4$ miles. \\
\hline 30 & $50 \ldots$ & 10. 08 meters. \\
\hline 49 & -- & 17. 44 meters \\
\hline $3^{2}$ & - . . & $11 / 4$ miles. \\
\hline 32 & 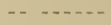 & 200 yards. \\
\hline 41 & - & 200 yards. \\
\hline
\end{tabular}


HORSF.

L.ocality.- West shore of Tangier Sound on east shore of Smith Island at point known as "Horsc IIammock." (See Chart No. 9.)

Observed station is about ro yards off shore in 2 feet of water at low-tide, between shore and northernmost row of piling. Several trees stand on bank near station. Cement monument marking reference station is 27.12 meters west of observed station and 20 yards back from shore.

Marks.--Observed station is stake in water. Reference station is center point of triangle on standard cement monument.

References.-

\begin{tabular}{|c|c|c|c|c|}
\hline "Janes Island Light" & $\infty$ & oo & $\infty$ & $4^{1 / 4}$ miles. \\
\hline omers Cove Light & 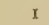 & 30 & oo - & $6 \mathrm{t} / 2$ miles. \\
\hline High pile_.. & 15 & 27 & 30 & 8.41 meters. \\
\hline Fox Island Poplar & 49 & 25 & 50 & $61 / 4$ miles. \\
\hline Left tangent of Smiths Isiand & 106 & 45 & & 150 yards. \\
\hline Near corner of old cedar & 146 & $\mathrm{O} 2$ & -- & 32.42 meters. \\
\hline 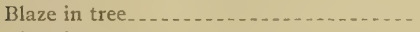 & I55 & $4 \mathrm{I}$ & -- & 14. 2 I meters. \\
\hline Blaze in $\mathrm{tr}$ & 166 & 27 & -. & 25.92 meters. \\
\hline REFERENC & I 74 & 15 & $30-$ & 27. 12 meters. \\
\hline Blaze in popla & 174 & 40 & $30-$ & 45.74 \\
\hline Pile extending above row of piles & 309 & 08 & -. & 16. 66 meters. \\
\hline ligh pile & 333 & 03 & & 9.80 meters. \\
\hline e factory & 355 & 07 & -- & $71 / 4$ miles. \\
\hline & & & & iles. \\
\hline
\end{tabular}

JANES ISLAND LIGHT.

Locality.-Tangier Sound off entrance to Little Annemessex River. (See Chart No. 9.)

Marks.-Observed station is center of black lantern on hexagonal screw pile structure known as "Janes Island Light."

References.-

"Solomons Lump Light" $\left(\mathrm{N}_{42^{\circ}} \mathrm{O}^{\prime} \mathrm{W}\right) \ldots$ oo $\ldots 0$ oo ...... $7 \frac{7 / 8}{8}$ miles.

\section{SOMERS COVE LIGHT.}

Locality.-Little Annemessex River at entrance to Crisfield Harbor. (See Chart No. 9.)

Marks,-Observed station is center of spindle on top of black lantern on square screw pile structurc known as "Somers Cove Light."

References.-

"Janes Island Light" (S $84^{\circ} 4 \mathrm{r}^{\prime} \mathrm{W}$ )

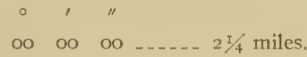

\section{EMMANUEL CHURCH.}

Locality.-City of Crisfield, about $3 / 4$ mile east of Crisfield Harbor. (See Chart No. 9.)

Marks.-Observed station is center of steeple on church known as "Emmanuel Methodist Episcopal church."

References.-None necessary.

\section{MOUNT PLEASANT CHURCH.}

Locality.-City of Crisfield, about I mile from Crisfield Harbor. (See Chart No. 9.)

Marks.-Observed station is center of steeple on brick church on Main street known as "Mount Pleasant Methodist Protestant Church."

References.-None necessary.

\section{ASBURY CHURCH.}

Locality. - In town of Lawsonia, about $\mathrm{I}^{\mathrm{T}} / 2$ miles from Crisfield Harbor, (See Chatt No. 9.) Marks.-Observed station is center of very slender steeple on church known as "Asbury Methodist Eipiscopal Church."

Refercnces.-None necessary.

$50095-0 \mathrm{~S}-7$ 


\section{BEACON.}

Locality.-Between Tangier and Pocomoke sounds, on small island just north of Great Fox Island known as "House Island." (See Chart No. 9.)

Observed station is about roo yards south of extreme northern shore and about 30 yards from west shore of island. The shore of an inlet which makes into eastern side of island is about 15 feet northwest of observed station. Cement monument marking reference station is 4.12 meters west of observed station. A temporary wooden beacon stands 0.70 meters south of observed station.

Marks.-Olsserved station is center of a 6 -inch tile pipe set in cement and projecting above ground about 6 inches. Reference station is center point of triangle on standard cement monument.

Nore.-What was taken to be center mark of old "Beacon" of 1898 is a 2 -inch iron pipe projecting above ground with three stubs projecting 3 feet above ground which were apparently used to support instrument. Wooden sills supported by 10 -inch piles form a square with the 2 -inch pipe in center.

References at obscrved station.-

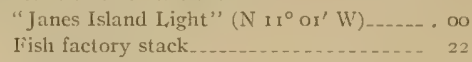

"Asbury Church Spire" _............ $5 \mathrm{I}$

"Sam" "An" Ch

Climney of highest building on Fox Island $17 \mathrm{I}$

"lux Island fuplar".... . . Ii)

2-inch iron pipe ("Beacon I 898 ") _..... 200

Wooden beacon _..._............. 222

REFERENCE STATION (cement monument)- 299

References at 2-inch iron pipe ("Beacon 1898 ").-

"Janes Island I,ight" ( $\left.\mathrm{N} \mathrm{II}^{\circ} \mathrm{OI}^{\prime} \mathrm{W}\right) \ldots$

Fish factory stack

"Ashbury Church Spire"

"Sam"

Chimney on highest building on Fox Island i 7 I

"Fox Island Poplar" ..........._._._._. - 194

RTFERENCE STATION (Cement monument) - 353

"Beacon" (OBSERVED STATION) _-_._._. $20 \quad 35$

Wooden beacon

\begin{tabular}{|c|c|c|}
\hline & Oo - & $3^{3} / 4$ miles. \\
\hline & $\ldots$ & $41 / 4$ miles. \\
\hline & $15 \ldots \ldots$ & 6 miles. \\
\hline & $05 \ldots$ & $11 / 4$ miles. \\
\hline & .. & $x_{1 / 4}$ miles. \\
\hline & 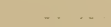 & I milc. \\
\hline & $15 \ldots \ldots$ & 7. 26 meters. \\
\hline & $00 \ldots$ & o. 40 mieters. \\
\hline & to $\ldots$ & 4. I2 meters. \\
\hline & no - & $3 \frac{3}{4}$ miles. \\
\hline & -- & $+1 / 4$ miles. \\
\hline & $\ldots$ & 6 miles. \\
\hline & -. - & I $1 / 4$ miles. \\
\hline & $\cdots$ & I $1 / 4$ miles. \\
\hline & .......... & I mile. \\
\hline & $50 \ldots \ldots$ & 8.875 meters \\
\hline & oo $\ldots \ldots$ & 7.26 meters. \\
\hline & -- & 6.89 meters. \\
\hline
\end{tabular}

\section{FOX ISLAND POI'LAR.}

Locality:-Eastern shore of lower Tangier Sound on western side of Great Fox Island about halfway between the northern and sotuthern ends of the island. (See Clart No. 9.)

Observed station is a very prominent lone Lombardy poplar situated on solid land about is mile inshore from Tangier Sound.

Marks.-Observed station is center of a lone Lombardy poplar tree.

References.-None necessary.

SAMI.

Locality.- Western end and northern siore of Pocomoke Sound on north side of the entrance to Cedar Straits about 1/8 mile north of Green Harbor Island. (See Chart No. 9.)

Observed station is on marsh land between two clumps of water bushes about ro yards hack from extreme high-water mark and 15 yards back from ordinary high-water mark. $\Lambda$ slough passes about roo yards north of station and there are several pools 50 yards north of station. Cement monument marking reference station is $2.8 \mathrm{I}$ meters north of observed station. "Watkins Point" of the MarylandVirginia boundary is in the water between "Sam" and Green Harbor Island.

Marks.-Olsserved station is center of iron pipe projecting 4 inches above ground. Reference station is center point of triangle on standard cement monument. 
Rifirencer-

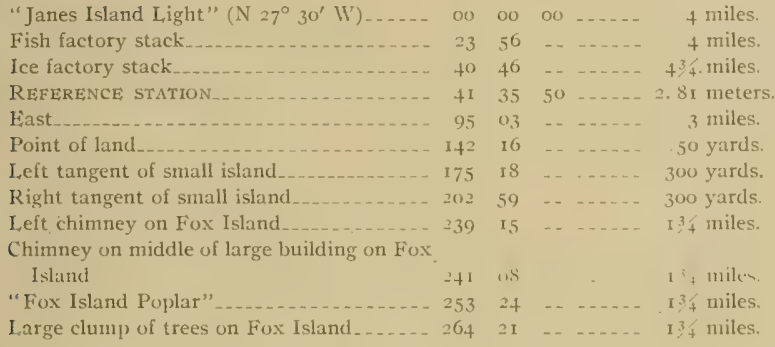

\section{WATERMELON HUMMOCK}

Locality.-Northern shore of Poconoke Sound in midst of a large tract of marsh land lying between Apes Hole Creek and Broad Creek about 23/2 miles southeast of Somers Cove Light. (See Chart No. 9.)

Observed station is in midst of marsh near a clump of trees which stand about 25 yards to the north. It is about 150 yards southwest of a wide part of the upper end of Massey Creek.

Marks.-Observed station is center point of triangle on standard cement monument.

References.-

"Somers Cove Ligltt" (N $\left.51^{\circ} 3 \mathrm{o}^{\prime} \mathrm{W}\right)$

Nail in blaze in pine.

Nail in blaze in pine

Cedar tree

"Fox Island Poplar"

$\begin{array}{rrrrr}\text { oo } & 00 & 00 & \ldots \ldots & 21 / 2 \text { miles. } \\ 46 & 55 & 30 & \ldots \ldots & 21.00 \text { meters. } \\ 83 & 47 & 30 & \ldots \ldots & \text { I r. } 36 \text { meters. } \\ 235 & \text { 19 } & \ldots & \ldots \ldots & 100 \text { yards. } \\ 278 & 51 & \ldots & \ldots \ldots & 434 \text { miles. }\end{array}$

E,AST.

Locality.-North shore of Pocomoke Sound between Apes Hole and Broad creeks on a detached marsh point on east side of entrance to Cow Gap Creek. (See Chart No. 9.)

Observed station is on southerly part of a small marsh island separated about zoo yards from point of mainland. Water bushes cover northerly part of the island. Observed station is about 13 yarts south of shore, $1+$ yards west of shore, 36 yards north of sliure, and 5 yards east of shore. Cement monument marking reference station is 6.38 meters southeast of observed station.

Marks.-Observed station is a spike in a cement filled tile pipe with top even with surface of -marsh. Reference station is center point of triangle on standard cement monument.

References.-

"Janes Island Light" (N 62 $\left.19^{\prime} \mathrm{W}\right) \ldots .$.

Fish factory stack

Somers Cove Light

Tall tree

Point of land east

REFERENCE STATION_..._.

Pole at oyster house $\ldots \ldots \ldots \ldots \ldots$

Right chimney of first house on Fox Island _ 298

Point of land west .................. 305

Cilbin chimney

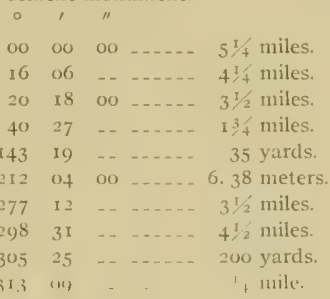




\section{MONKEY.}

Locality.-North side of Pocomoke Sound on a small island known as "Watkins Island" off entrance to Apes Hole Creek. (See Chart No. 9.)

Observed station is in the middle of a small islet about 12 yards by 4 yards which is covered with marsh grass and awash at high water. It is very solid ground on top but soft beneath and island will probably be washed away in a few years.

Marks.-Observed station is center point of triangle on standard cement monument.

References.-

"Scot" (N $\left.77^{\circ} 17^{\prime} \mathrm{E}\right)$
Chimney of Stirling's watch house
Left hand chimney of Matthews red roof
house on Saxis Island.

SCOT.

Locality,-North shore of Pocomoke Sound on extreme southern point of marsh land between East and Marumsco creeks. (See Chart No. 10.)

Observed station is on a marsh point about 25 yards back from extreme end of point, 30 yards back from west side of point, and 20 yards from south side. It is surrounded by a thick and high clump of water bushes which extend along the shore to the eastward. There are no permanent reference objects near station. Cement monument marking reference station is $x \times .66$ meters northeast of observed station.

Marks.-Observed station is an inverted spike in cement which is flush with ground and covers the top of a 6 -inch tile pipe. Reference station is center point of triangle on standard cement monument.

References.-

\begin{tabular}{|c|c|c|c|c|c|}
\hline "Old" (N 83oo' E) & 00 & oo & oo & & $2 \pi / 2$ miles. \\
\hline First red house (near Oil) & 30 & 17 & -- & & $33 / 4$ miles. \\
\hline 2, $1 / 2$-story white house.. & .57 & 17 & & & $2 \frac{1}{4} \cdot$ miles. \\
\hline Chimney on 4 -gable house & 70 & $3 x$ & - & & $21 / 4$ miles. \\
\hline "Saxis Church" ..... & 80 & 59 & 35 & & iles. \\
\hline Chimney of Stirling's watch house & 172 & 55 & -. & & $21 / 2$ miles. \\
\hline Large tree & I 81 & 32 & -. & & $51 / 4$ miles. \\
\hline REFERENCE STATION. & 317 & $3 x$ & 40 & & II. 66 meters. \\
\hline Chimney of brown house & 314 & 56 & -- & -. & $21 / 4$ miles. \\
\hline Chimney of oyster house. & $35^{8}$ & 57 & -- & & $21 / 2$ miles. \\
\hline
\end{tabular}

OLD.

Locality.-North shore of Upper Pocomoke Sound on point of land halfway between Marumsco Creek (called "Old Johns Creek" on navigation charts) and Williams Point. (See Chart No. IO.)

Observed station is about 150 yards east of John T. Handy's wharf and about 15 feet back. It is on a narrow strip of marsh land which is wearing away by wave action, and thick water bushes stand east and west of station. Three large pine trees stand about $\mathrm{I} / 8$ mile north by east and several oyster houses about 200 yards to the west. Cement monument marking reference station is I 1.57 meters north by east of observed station and about on line with largest of three large pines mentioned above.

Marks.-Observed station is spike in cement which is flush with ground and covers the top of a 6 -inch tile pipe. Reference station is center point of triangle on standard cement monument. 


\section{Survey of Oyster Bars, Somerset County, $\mathrm{M} d \mathrm{~d}$.}

Reforences.-

\begin{tabular}{|c|c|c|c|c|c|}
\hline Sicut" (S $\left.83^{\circ} \circ 2^{\prime} \mathrm{IV}^{\prime}\right)$. & $(x)$ & 00 & ou & & $2 \mathrm{I}$ - miles. \\
\hline Chimney of Richardson's oyster house & 12 & 41 & -. & 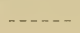 & $13 / 4$ miles. \\
\hline End of wharf ................. & I6 & 41 & -- & & I50 yards. \\
\hline Chimney of dwelling house. & 37 & 53 & -. & & 125 yards. \\
\hline Largest of three pine trees. . & 110 & 40 & - & & 1/4 mile. \\
\hline Tree to right of three pine treses & 112 & $\infty$ & -. & & 1/4 mile. \\
\hline REEERENCE STATION & 112 & 36 & 50 & & I 1.57 meters. \\
\hline Climney of dilapidated white house...... & 162 & 43 & -- & & 250 yards. \\
\hline Nearest gable of first faded red roof house & 250 & 03 & -- & & iles. \\
\hline $\begin{array}{l}\text { Nearest end of peak of Matthew's house on } \\
\text { Saxis Island }\end{array}$ & 310 & 21 & .. & & $21 / 3$ \\
\hline Right tangent of Saxis Island_- & 313 & 21 & -- & & $21 / 2$ nilles. \\
\hline
\end{tabular}

WII, I.

No. 10.)

Locality.-North shore of Pocomoke River on peninsula known as "Williams Point." (See Chart

Observed station is on the highest part of Williams Point about $3 / 8$ mile north of extreme southern end of point and well back from both shores. A clump of bushes and two small cedar trees stand about fo yards to the north and two medium-sized cedar trees about 300 yards to the west. A drainage creek with mouth on easterly side of peninsula runs almost completely around observed station, passing about 50 feet to the south.

Marks.-Observed station is center point of triangle on standard cement monument.

References. -

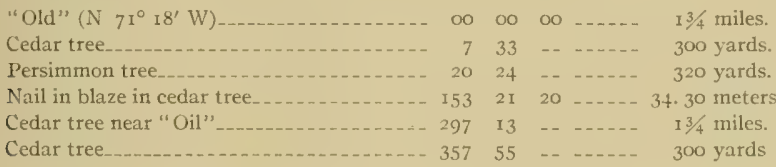

\section{CUP.}

Locality -Virginia side of Pocomoke River on solid land about 1/4 mile back from shore and I/8 nile from nearest bend of Holden Creek. (See Chart No. 10.)

Observed station is octagonal cupola on unpainted barn on land known as "Jolly's Neck Farm." Batm stands mear many cedar trees and south of another large unpainted building.

Marks.-Observed station is center point of top of cupola on barn.

References.-None necessary.

\section{SUMMER.}

Locality. - South and Virginia shore of mouth of Pocomoke River about $3 / 4$ mile south of Williams Point, on point known locally as "Sand Bar Point." (See Chart No. 10.)

Observed station is on sandy part of marsh land about 20 feet back from high-water mark on north and west sides of point. There are no permanent reference marks near station.

Marks.-Observed station is center point of triangle on standard cement monument.

Refercnces.-

"Will" (N $\left.7^{\circ} \mathrm{or}^{\prime} \mathrm{E}\right)$

Chimney of large white house

Large high tree............................. 25

Large ligh tree (opposite shore) _............

Southerly chimney of large house

Chimney on ell of red roof house _._._._._. Ii

First pine tree in half dozen or more........ - I6

Larger chimney of white house near woods . . _ I99

Fiederman's windmill_..................... 24I

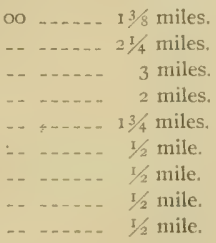




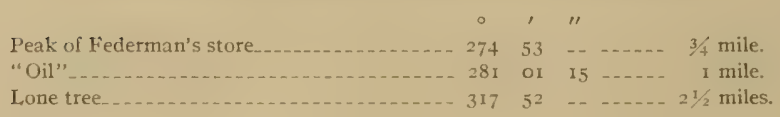

OIL.

Locality.-South and Virginia shore of upper end of Pocomoke Sound on a point of land known as "Pig Point," located about I I/2 miles southwest of IVilliams Ioint. (See Chart No. 10.)

Observed station is on western side of a marsh point covered with sand about 2 feet above and 30 feet east of ordinary ligh-water mark, 5 feet east of extreme high-water mark, soo feet south of ordinary high-water mark, and about 3 feet south of extreme high-water mark. Water bushes skirt shore to east and north and sand beach curves to southwest. On next point about $1 / 4$ mile southwest are two trees. Cement monument marking reference station is 46.18 meters south of observed station.

Marks.-Observed station is spike in center of 6-inch tile pipe filled with cement with top flush with surface. Reference station is center of triangle on standard cement monument.

References.-

"Will" (N+70 IO' $\mathrm{E})$

Large lone tree

Peak of roof of Federman's store

Chimney on oyster house.

Large tree

W'indmill on Federman's barn _..._......

Chimney outside of cabin _.......... I

Persimmon tree.................... I

REFERENCE STATION

Tree

Point of land _....................... 186

"Saxis Church"

Wharf___ _ C

Climney of white house

Highest chinney in group of white houses _ 290

High long leaf pine._. . . . . . . . . . . . . 295

IVesterly end of hurn - $\quad$. $\quad$.. 3.52 +

$$
\begin{array}{cr}
00 \ldots \ldots & 11 / 2 \text { miles. } \\
\ldots \ldots & 21 / 2 \text { miles. } \\
\ldots \ldots & 3 / 8 \text { mile. } \\
\ldots \ldots & 1 / 4 \text { mile. } \\
\ldots & 1 / 4 \text { mile. } \\
40 & 3 / 4 \text { mile. } \\
\ldots \ldots & 1 / 4 \text { mile. } \\
\ldots \ldots & 1 / 4 \text { mile. } \\
\ldots \ldots & 18 \text { meters. } \\
\ldots \ldots & 1 / 4 \text { mile. } \\
\ldots \ldots & 100 \text { yards. } \\
\ldots \ldots & 23 / 4 \text { miles. } \\
\ldots \ldots & 23 / 4 \text { miles. } \\
\ldots \ldots & 21 / 2 \text { miles. } \\
\ldots & 136 \text { miles. } \\
\ldots & 2 \text { miles. } \\
& 2 \text { miles. }
\end{array}
$$$$
40 \ldots . . .46,18 \text { meters. }
$$$$
\text { .. }
$$$$
\text { -..... } 23 / 4 \text { miles. }
$$$$
\text { I } 3 / 4 \text { iniles. }
$$

\section{W'HARF.}

Locality.-Southeast and Virginia side of Pocomoke Sound about $1 / 2$ mile offslonte of Saxis Island and about 3/ mile north-northwest of "Saxis Church." (See Chart No, 1o.)

Observed station is on northwest end of house on detached pile structure called Saxis Pier.

Marks.-Observed station is flag pole on northwest end of peak of pier house on Saxis Island pier Reforences...-

$$
\text { "Saxis Church" (S } \left.26^{\circ} 10^{\prime} \mathrm{E}\right) \ldots \ldots \ldots \text {........ } 00 \text { oo } 00 \ldots 3 / 4 \text { mile. }
$$

\section{SAXIS CHURCH.}

Locality.-Southeast and Virginia shore of Pocomoke Sotınd on solid land known as "Saxis Island" about $3^{1}+$ miles from slore of sound and $1 / 2$ mile northeast of mouth of Starling Creek. (See Chart No. Io.) Church.

Marks.-Observed station is center point of spire on church known as Sonthern Methodist Episcopal

References.-None necessary.

MOS.

Locality.-Eastern extremity of marsh land between Pocomoke Sound and Messongo Creek on a point of land locally called "Fishing Point." (See Chart No. 10.)

Observed station is on the western extremity of marsh point and about 's's mile east of the eastern extremity of a small island. It is about 2 feet above and 8 feet back from ordinary high-water on north 
side and 45 feet from western end of point. $\Lambda$ crab-packing shanty stands about 8 yards to eastward of observed station.

Marks.-Observed station is center point of triangle on standard cement monument.

References.-

"Monkey" $\left(\mathrm{N} 35^{\circ} 23^{\prime} \mathrm{W}^{\prime}\right\rangle$

Point of Island .......................

"Saxis Church" _..................... 82

Right edge of woods on Saxis Island........ 86

Left corner of crab house................. 9

Right corner of crab house $\ldots \ldots \ldots \ldots$

Point of land on Burntwood Island _...... 163

Chimney on shanty.

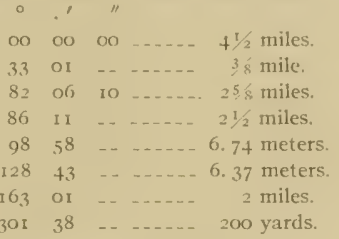

\section{BOUNDARIES OF OYSTER BARS.}

EXPLANATION OF DESCRIPTIONS OF BOUNDARIES.

The oyster bars of Somerset County are 37 in number, and their total area, as marked out by buoys placed by the hydrographic engineer of the Commission, is 27,566 acres. As provided by law, the boundaries of the oyster bars are all straight lines, but they inclose areas of all shapes from triangles to complicated fourteen-sided figures, and of all sizes from 3,083 acres to ro acres. ${ }^{a}$ The sides vary in length from 130 to 6,800 yards, and in some cases the corners of the boundaries are practically at the triangulation stations from which they are located, while in other instances they are over 13,600 yards from the landmarks most available for the purpose of fixing their positions.

The varied characteristics of the legal boundaries of the oyster bars indicated by the above statement, together with the complicated requirements of the law under which the survey has been made, and the magnitude of the work, with the consequent need of fixed and uniform methods, has made the problem of describing the boundaries one of considerable difficulty and importance.

The boundaries of the oyster bars of Maryland, as established by the Shell Fish Commission and delineated on the Coast and Geodetic Survey charts and projections and on the leasing charts of the Commission, are technically defined and described by a method somewhat different from that used in other oyster surveys. But it is believed that the forms finally adopted will fulfill all needs of the survey for both the present and future.

The descriptions have been arranged in tabular form, thus avoiding many hundred repetitions of the same words by making one explanation of the tables sufficient for all oyster bars in the county.

At the top of each tabular form is given the legal name of the oyster bar to be described, its general locality, and the serial number of the "Charts of Oyster Bars" of Maryland on which its legal boundaries are shown.

The first column, under the heading of "Corner of bar," gives the number corresponding to the corner of the boundary as shown on the charts and to the number on the buoy marking the actual corner of the bar. The numbers of the corners have been assigned by naming the southernmost point No. I, thence proceeding in a clockwise direction around the bar; but where a corner of one oyster bar is identical with the

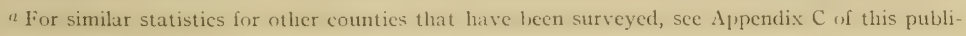
cation. 
corner of the botularies of one or more other oyster bars, crab bottoms, or clam beds, only the number of the corner of the oyster bar being described in the table is given in this column.

The second and third columns, under the headings of "Latitude" and "Longitude," give the geographic positions of the corners. These positions have been adopted by the Commission as the primary technical definition of the corners, and should be considered as final in case of a dispute arising from discrepancies caused by other means of location. The latitudes and longitudes given in these columns are based on the United States standard datum of the Coast and Geodetic Survey, and the points thus defined can be relocated from distant triangulation stations of the Survey, even though all the landmarks and buoys originally used for their location have been destroyed by natural causes or by acts of vandals desiring to defeat the purposes of the oyster laws of Maryland.

The fourth and fifth columns, under the general heading of "True bearing" a and the specific headings "Forward" and "Back," give bearings measured from a true northand-south line. The three "Forward" bearings are from the corner of the boundary designated in the first column to the triangulation stations named on the corresponding lines in the last column, and the three "Back" bearings are from these same stations in the last column to the corresponding corner of boundary in the first column. The difference in minutes of arc between the forward and back bearings shown in some cases is actual and not accidental, and is due to the fact that the computations took into account the spheroidal shape of the earth.

The sixth column, under the heading of "Distance," gives the three computed distances in yards from the corner of the bar noted in the first column to the three triangulation stations named on the corresponding lines in the last column, and vice versa.

The seventh and last column, under the heading of "U. S. C. \& G. S. triangulation station," $b$ gives the names of the landmarks from which were computed the corresponding "Latitude," "Longitude," "True bearing," and "Distance" of the "Corner of the bar" designated in the first column. A full description of the location and markings of these triangulation stations is given in another part of this publication, under the heading of "Description of triangulation stations."

SURVEYING METHODS FOR RELOCATION OF BOUNDARIES.

There are a number of methods that can be used in the relocation of the actual boundaries of the natural oyster bars as technically described in this publication and delineated on the published charts of the Coast and Geodetic Survey and the leasing charts of the Shell Fish Commission.

The following brief descriptions of five of these more or less different methods assume a certain amount of experience and knowledge on the part of the engineer in the particular kind of surveying under consideration, and are only intended as reminders of ways and means that can be used.

There are two problems that are likely to present themselves to those interested in the boundaries of natural oyster bars. One, to determine whether the buoys marking

"The mean magnetic variation of Somerset County for 1908 was $5^{\circ} 30^{\prime}$ west of north, and increasing at the rate of $3^{\prime}$ yearly.

b Geographic positions of these triangulation stations can be obtained by application to the Superintendent of the Coast and Geodetic Survey at Washington. 
the corners have been dragged or otherwise moved from their correct positions, and the other, to relocate or reestablish a buoy at the point from which it was removed. The different ways of solving these two problems partly depend upon the instruments possessed by the engineer and his assistants and partly on his training and experience.

(I) Triangulation.-This method is the one that will give the greatest accuracy, but on account of its requiring special data and instruments, and being an operation rarely used by engineers not engaged in geodetic surveying, it is recommended only for cases in dispute that can not be settled satisfactorily by some other method. An explanation of this class of work would be too long for a report of this sort, and those not familiar with this method are referred to the publications on the subject by the Coast and Geodetic Survey.

(2) Hydrographic.-This method is the most simple and satisfactory one that can be adopted if the surveyor can obtain the use of the necessary instruments and assistants. It is the one best suited for the work of the engineers of the Commission in relocating corners of boundaries, as it gives results of the accuracy ordinarily required and is rapid in execution. Besides, it has the advantage of being available whenever three triangulation stations of suitable relative positions are visible from the offshore points needing relocation.

Most navigators and others familiar with the use of a sextant are well acquainted with the graphic three-point method of fixing a position on water, and only a brief description of the operation will be stated.

In the case where there is only one engineer, having a single sextant, the three-point method can be used, but not until the two angles determining the position of any buoy have been derived from the "Forward bearing" given in the tabular forms describing the boundaries of the oyster bars. For example, take "Turtle Egg Island" bar, which is the first one described in this publication, and assume that "Corner No. 3 ," is to be examined as to its position. The angle between the two landmarks "Senator" and "Deal Island Church" as determined from right to left from the forward bearings from this corner is $128^{\circ} 39^{\prime}$ and the angle between "Deal Island Church" and "Crab" is $99^{\circ} 30^{\prime}$. Having these two angles, the engineer proceeds to the buoy of doubtful location and measures the actual sextant angles between the landmarks for which the calculations were made. If the measured and calculated angles do not agree the buoy is not in its correct position and the boundary corner must be relocated. This is accomplished by moving the boat about until a point is reached where angles do agree, and this point being the desired location, the buoy can be placed in its correct position.

If the engineer can obtain the use of both a sextant and a three-arm protractor ("position finder"), the availability of the hydrographic method is increased, as the use of the protractor is essential in case of the washing away or destruction of one or more of the landmarks originally used in describing the boundaries. Under these circumstances, any three landmarks of suitable relative positions that are visible from the point to be located can be utilized. For example, the engineer can proceed to the buoy of doubtful position and measure the two adjacent sextant angles between the three landmarks selected. These two angles are set off on the three-arm protractor and the actual position of the buoy plotted on the chart by shifting the protractor about until the edge of each of the three arms passes through the center of the symbols on the

$$
50095-0 S-8
$$


chart marking the position of the three landmarks selected. The center of the hub of the protractor will indicate on the chart the actual position of the buoy, and if the point thus obtained does not coincide with the true position of the corner of the boundary as given on the chart, the surveyor can proceed to locate the buoy correctly by reversing the operation. This is done by placing the center point of the hub of the protractor over the corner of the boundary in question and measuring on the chart the two adjacent protractor angles between the three selected landmarks. One of the angles thus obtained is set on the sextant and the boat moved about until the two landmarks are shown by the sextant to subtend the same angle obtained from the protractor. The second angle is then placed on the sextant and the same operation gone through, and so on, first using one angle on the sextant then the other until a point is reached where both observed sextant angles are practically identical with the protractor angles. The point thus located is the desired one and the buoy can be placed to mark the true position of the cornet of the boundary in question.

If the engineer possesses two sextants and a protractor, this problem is far easier of solution, as the two angles car be set off on separate sextants and the observer can quickly find the desired point where they agree with the protractor angles by using one sextant after the other without the need of resetting either.

If there are two observers, two sextants, and a protractor, it can be seen that the hest conditions for hoth rapid and accurate hydrographic locations of points are attained; in fact, this is the method by which the buoys at the corners of the boundaries were originally placed by the hydrographic engineer to the Commission.

(3) Magnetic bearings from offshore.-This method of fixing a position on water is a simple and well-known one in navigation. It is available to anyone having a boat compass and will be of special use to the State fishery force in investigating cases where buoys are supposed to have been moved for illegal purposes.

In the case where a buoy is supposed to have been moved from its true position the observer takes compass bearings to the three landmarks given in the last column of the tables opposite the boundary corner in question. These bearings are then corrected for the local declination, ${ }^{a}$ and if the results agree with the published bearings the buoy is correctly located.

In the case where the buoy is not in its correct position, or has disappeared altogether, the desired point can be determined by maneuvering the vessel until the corrected bearings agree with the ones in the tabular descriptions, when the buoy can be anchored in its proper location.

In the case where the landmarks for which the bearings are published have been destroyed or washed away, any landmarks whose positions are indicated on the charts can be used by getting their bearings directly from the chart by parallel rulers or a protractor and then applying them in the same manner as the ones published in the tables.

(4) Magnetic bcarings from shore.-This method will be of special value to engineers having an ordinary surveyor's compass. The compass can be set over the point mark ing a "triangulation station" on shore, the name of which is given in the last column opposite the "comer" in question. The instrument is then set at the corresponding

"The mean m agnetic variation of Somerset County for 1908 was $5^{\circ} 30^{\prime}$ west of north and increasing at the rate of $3^{\prime}$ yearly. 
"back" bearing (corrected for local magnetic declination), given in the fourth column of the tables opposite the "corner" in question and on line with the name of the "station" being occupied. The direction thus determined will give one range on which the desired point must be located. The compass can then be moved to a second triangulation station and another range located in a similar manner. The intersection of these two range lines will give the desired point; but in general it should be checked by an additional range line determined from a third station.

(5) Horizontal angles measured at landmarks.-This process is a modification of the triangulation method, and will be useful to engineers who have a transit and desire considerable accuracy.

The instrument is placed over a "triangulation station," the name of which appears in the last column of the tabular description opposite the "corner" in question. The telescope is then pointed to the landmark indicated in the "Descriptions of landmarks" as having a direction of $\mathrm{O}^{\circ} \mathrm{OO}^{\prime} \mathrm{OO}^{\prime \prime}$ from the triangulation station being occupied by the transit. The tabular description of the boundaries is next examined and the "back" bearing of the questionable boundary "corner" from the landmark being occupied is taken out. The angle calculated from the "back" bearing and the bearing given in parentheses alongside the zero landmark in the "Descriptions of landmarks" is then set off on the transit, and a range line established on which the desired point must be located. A similar process is then carried on at a second station, and so on until the position of the buoy is satisfactorily fixed.

BOUNDARIES OF NATURAL OYSTER BARS.

TURTLE, EGG.ISLAND.

(Upper Tangier Sound-Charts Nos. 5 and 7 )

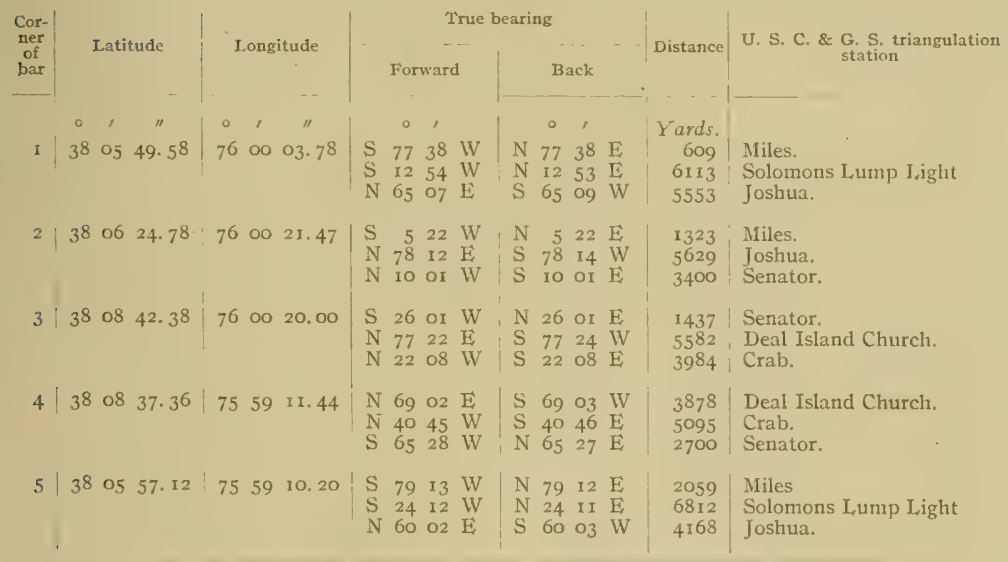




\section{BOUNDARIES OF NATURAL, OYSTER BARS-continued.}

MUD.

(Upper Tangier Sound-Chart No. 5.)

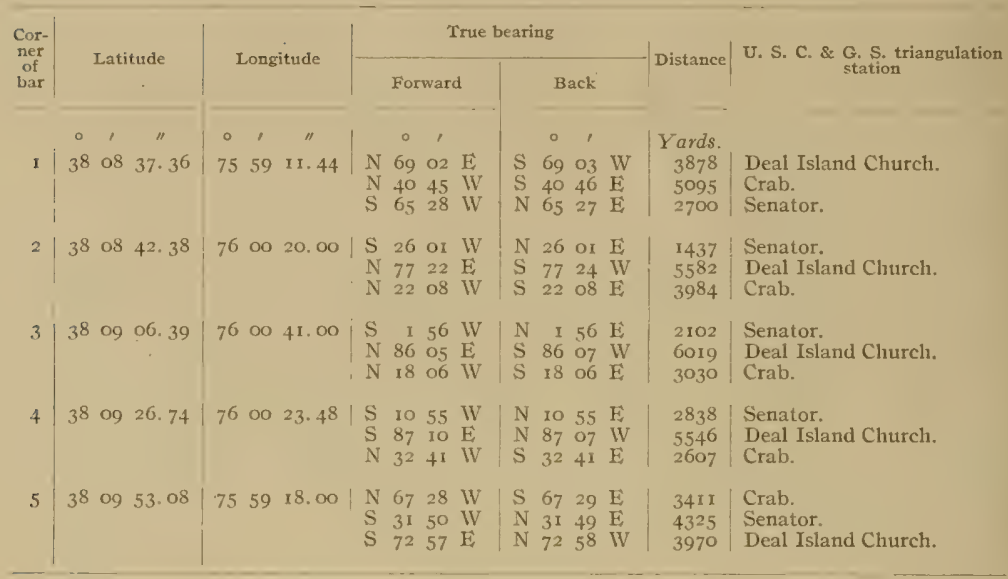

OLD ORCHARD.

(Upper Tangier Sound-Chart No. 5.)

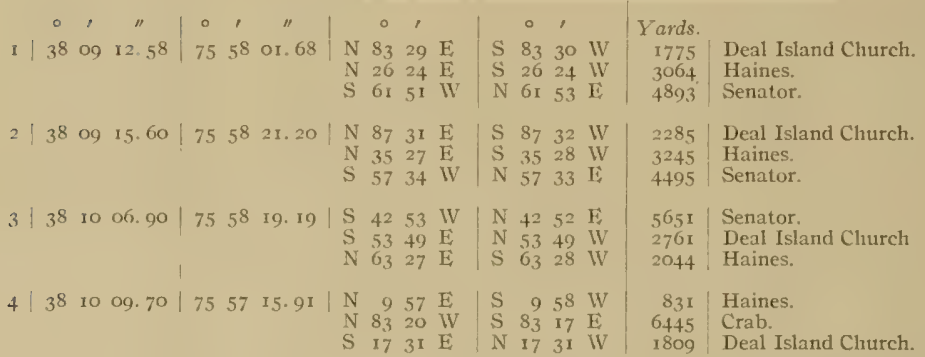




\section{BOUNDARIES OF NATURAI, OYSTER BARS-continued.}

\section{HAINES.}

(Upper Tangier Sound-Chart No. 5.)

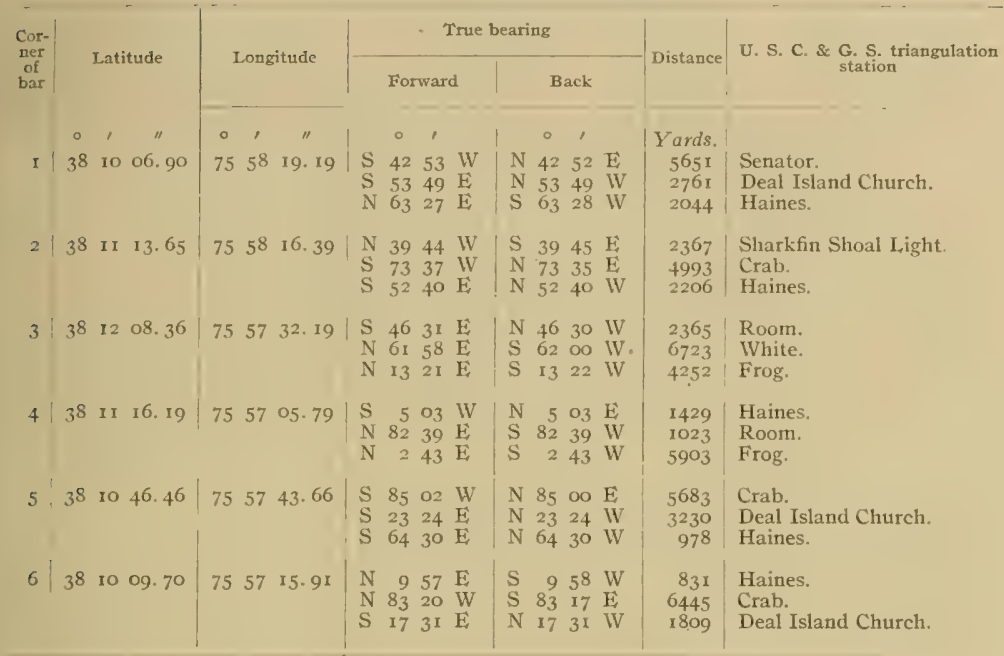

\section{HALLS POINT.}

(Upper Tangier Sound-Chart No. 5.)

\begin{tabular}{|c|c|c|c|c|c|c|c|c|c|c|c|c|c|c|c|}
\hline & $\circ$ & ' & " & 0 & , & " & & 0 & , & & & $\circ$ & , & Yards. & \\
\hline I & $3^{8}$ & II & I6. 19 & 75 & 57 & 05.79 & $\begin{array}{l}\mathrm{S} \\
\mathrm{N} \\
\mathrm{N}\end{array}$ & $\begin{array}{r}5 \\
82 \\
2\end{array}$ & $\begin{array}{l}03 \\
39 \\
43\end{array}$ & $\begin{array}{l}\text { W } \\
\mathrm{E} \\
\mathrm{E}\end{array}$ & $\begin{array}{l}N \\
S \\
S\end{array}$ & $\begin{array}{r}5 \\
82 \\
2\end{array}$ & $\begin{array}{ll}03 & E \\
39 & W \\
43 & W\end{array}$ & $\begin{array}{l}1429 \\
1023 \\
5903\end{array}$ & $\begin{array}{l}\text { Haines. } \\
\text { Room. } \\
\text { Frog. }\end{array}$ \\
\hline 2 & 38 & 12 & 08.36 & 75 & 57 & 32. 19 & $\begin{array}{l}\mathrm{S} \\
\mathrm{N} \\
\mathrm{N}\end{array}$ & $\begin{array}{l}46 \\
61 \\
\times 3\end{array}$ & $\begin{array}{l}31 \\
58 \\
21\end{array}$ & $\begin{array}{l}\mathrm{E} \\
\mathrm{E} \\
\mathrm{E}\end{array}$ & $\begin{array}{l}\mathrm{N} \\
\mathrm{S} \\
\mathrm{S}\end{array}$ & $\begin{array}{l}46 \\
62 \\
\text { I } 3\end{array}$ & $\begin{array}{l}30 \mathrm{~W} \\
\text { oo W } \\
32 \mathrm{~W}\end{array}$ & $\begin{array}{l}2365 \\
6723 \\
4252\end{array}$ & $\begin{array}{l}\text { Room. } \\
\text { White. } \\
\text { Frog. }\end{array}$ \\
\hline 3 & 38 & 12 & 22.96 & 75 & 57 & 04.02 & $\begin{array}{l}\mathrm{S} \\
\mathrm{N} \\
\mathrm{N}\end{array}$ & $\begin{array}{r}24 \\
62 \\
3\end{array}$ & $\begin{array}{l}301 \\
461 \\
39\end{array}$ & $\begin{array}{l}\mathrm{E} \\
\mathrm{E} \\
\mathrm{E}\end{array}$ & $\begin{array}{l}\mathrm{N} \\
\mathrm{S} \\
\mathrm{S}\end{array}$ & $\begin{array}{r}24 \\
62 \\
3\end{array}$ & $\begin{array}{ll}30 & W \\
48 & W \\
39 & W\end{array}$ & $\begin{array}{l}2330 \\
5830 \\
3653\end{array}$ & $\begin{array}{l}\text { Room. } \\
\text { White. } \\
\text { Frog. }\end{array}$ \\
\hline 4 & 38 & 12 & 10. 72 & 75 & 55 & 55.59 & $\begin{array}{l}\mathrm{N} \\
\mathrm{N} \\
\mathrm{S}\end{array}$ & $\begin{array}{l}47 \\
21 \\
26\end{array}$ & $\begin{array}{l}32 \\
22 \\
35\end{array}$ & $\begin{array}{l}\mathrm{E} \\
\mathrm{W} \\
\mathrm{W}\end{array}$ & $\begin{array}{l}\text { S } \\
\text { S } \\
\text { N }\end{array}$ & $\begin{array}{l}47 \\
21 \\
26\end{array}$ & $\begin{array}{l}33 \mathrm{~W} \\
22 \mathrm{E} \\
35 \mathrm{E}\end{array}$ & $\begin{array}{l}4560 \\
4357 \\
1909\end{array}$ & $\begin{array}{l}\text { White. } \\
\text { Frog. } \\
\text { Room. }\end{array}$ \\
\hline 5 & 38 & II & 52.57 & 75 & 55 & 45.84 & $\begin{array}{l}N 4 \\
N \\
\text { S } 4\end{array}$ & $\begin{array}{l}40 \\
21 \\
45\end{array}$ & $\begin{array}{l}04 \\
34 \\
28\end{array}$ & $\begin{array}{l}E \\
W \\
W\end{array}$ & $\begin{array}{l}\mathrm{S} \\
\mathrm{S} \\
\mathrm{N}\end{array}$ & $\begin{array}{l}40 \\
2 \mathrm{I} \\
45\end{array}$ & $\begin{array}{l}05 \mathrm{~W} \\
35 \mathrm{E} \\
28 \mathrm{E}\end{array}$ & $\begin{array}{l}4824 \\
5022 \\
1563\end{array}$ & $\begin{array}{l}\text { White. } \\
\text { Frog. } \\
\text { Room. }\end{array}$ \\
\hline 6 & 38 & II & $47.9^{8}$ & 75 & 56 & 30.40 & $\begin{array}{l}\text { S } \\
N \\
N\end{array}$ & $\begin{array}{r}4 \\
48 \\
7\end{array}$ & $\begin{array}{ll}22 & 1 \\
07 & 1 \\
48 & 1\end{array}$ & $\begin{array}{l}\mathrm{E} \\
\mathrm{E} \\
\mathrm{W}\end{array}$ & $\begin{array}{l}\mathrm{N} \\
\mathrm{S} \\
\mathrm{S}\end{array}$ & $\begin{array}{r}4 \\
48 \\
7\end{array}$ & $\begin{array}{ll}22 & W \\
09 & W \\
49 & E\end{array}$ & $\begin{array}{r}944 \\
5762 \\
4^{870}\end{array}$ & $\begin{array}{l}\text { Room. } \\
\text { White. } \\
\text { Frog. }\end{array}$ \\
\hline
\end{tabular}


BOUNDARIES OF NATURAL, OYSTER BARS-continued.

ROCK CREEK.

(Upper Tangier Sound-Chan No. 5.)

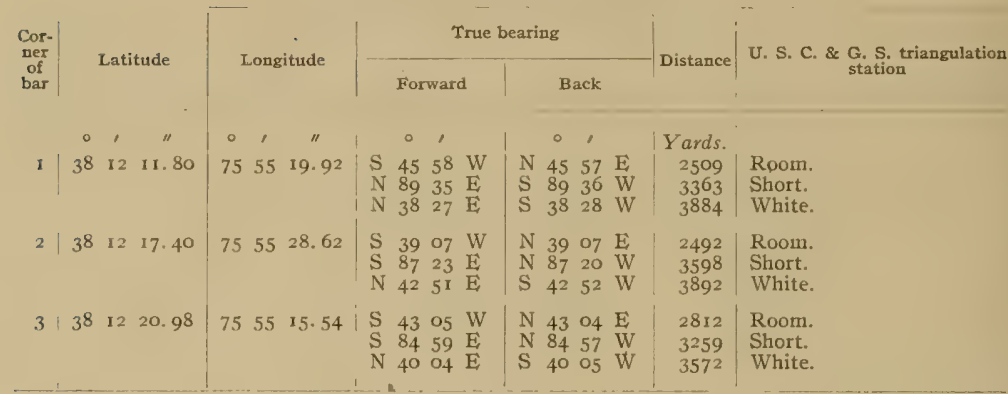

EVANS.

(Entrance to IVicomico River-Chant No. 5.)

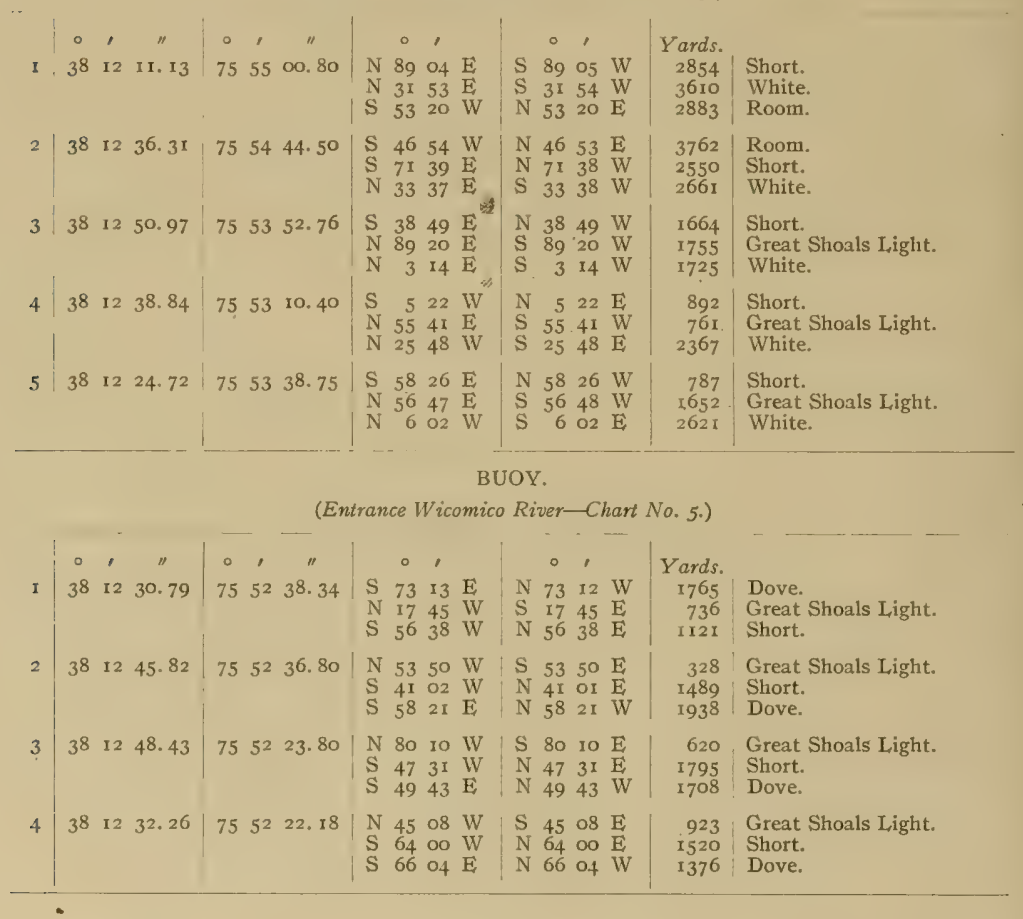


Survey of Oyster Bars, Somerset County, Md.

\section{BOUNDARIES OF NATURAL OYSTER BARS-continued.}

WINGATE.

(Lower Wicomico River-Chart No. 5.)

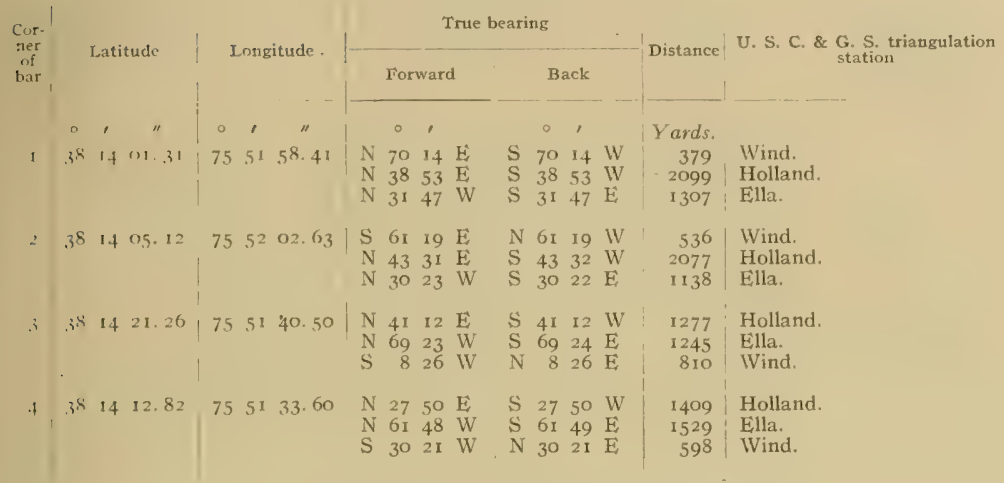

MOUNT VERNON WHARF.

(Middle Wicomico River-Chart No. 5.)

\begin{tabular}{|c|c|c|c|c|c|c|c|c|c|c|c|c|c|c|c|}
\hline & o & 1 & $"$ & $\circ$ & , & $n$ & & 0 & , & & & 0 & , & Yards. & \\
\hline 1 & 38 & 15 & 10. 22 & 75 & 48 & 29.18 & $\begin{array}{l}\mathrm{S} \\
\mathrm{N} \\
\mathrm{S}\end{array}$ & $\begin{array}{r}77 \\
6 \\
81\end{array}$ & $\begin{array}{l}45 \\
\text { OI } \\
\text { O2 }\end{array}$ & $\begin{array}{l}\mathrm{E} \\
\mathrm{W} \\
\mathrm{WW}\end{array}$ & $\begin{array}{l}N \\
S \\
N\end{array}$ & $\begin{array}{r}77 \\
6 \\
81\end{array}$ & $\begin{array}{ll}44 & W \\
O 1 & E \\
O 2 & E\end{array}$ & $\begin{array}{r}175 \\
434 \\
\text { I } 138\end{array}$ & $\begin{array}{l}\text { Walnut. } \\
\text { End. } \\
\text { Jones. }\end{array}$ \\
\hline$=$ & 38 & 15 & $13.7^{6}$ & 75 & $4^{8}$ & 30.30 & $\begin{array}{l}\mathrm{N} \\
\mathrm{S} \\
\mathrm{S}\end{array}$ & $\begin{array}{l}50 \\
74 \\
52\end{array}$ & $\begin{array}{l}26 \\
50 \\
02\end{array}$ & $\begin{array}{l}\text { W } \\
W \\
E\end{array}$ & $\begin{array}{l}\mathrm{S} \\
\mathrm{N} \\
\mathrm{N}\end{array}$ & $\begin{array}{l}50 \\
74 \\
52\end{array}$ & $\begin{array}{ll}26 & \mathrm{E} \\
5 \mathrm{O} & \mathrm{E} \\
\mathrm{O} 2 & \mathrm{~W}\end{array}$ & $\begin{array}{r}1342 \\
\text { I } 34 \\
254\end{array}$ & $\begin{array}{l}\text { Creek. } \\
\text { Jones. } \\
\text { Walnut. }\end{array}$ \\
\hline 3 & $3 S$ & 15 & 15.14 & 75 & $4^{8}$ & 19.08 & $\begin{array}{l}\mathrm{N} \\
\mathrm{S} \\
\mathrm{S}\end{array}$ & $\begin{array}{l}49 \\
76 \\
25\end{array}$ & $\begin{array}{l}44 \\
09 \\
44\end{array}$ & $\begin{array}{l}\text { IV } \\
\text { WV } \\
W\end{array}$ & $\begin{array}{l}\mathrm{S} \\
\mathrm{N} \\
\mathrm{N}\end{array}$ & $\begin{array}{l}49 \\
76 \\
25\end{array}$ & $\begin{array}{l}44 \mathrm{E} \\
09 \mathrm{E} \\
44 \mathrm{E}\end{array}$ & $\begin{array}{r}411 \\
1435 \\
225\end{array}$ & $\begin{array}{l}\text { End. } \\
\text { Jones. } \\
\text { IValnut. }\end{array}$ \\
\hline 4 & $3^{8}$ & I5 & 18.76 & 75 & $4^{8}$ & 09.97 & $\begin{array}{l}\mathrm{N} \\
\mathrm{S} \\
\mathrm{S}\end{array}$ & $\begin{array}{l}75 \\
74 \\
46\end{array}$ & $\begin{array}{l}29 \\
07 \\
18\end{array}$ & $\begin{array}{l}\text { W } \\
\text { W } \\
W\end{array}$ & $\begin{array}{l}\mathrm{S} \\
\mathrm{N} \\
\mathrm{N}\end{array}$ & $\begin{array}{l}75 \\
74 \\
46\end{array}$ & 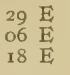 & $\begin{array}{r}574 \\
1701 \\
470\end{array}$ & $\begin{array}{l}\text { End. } \\
\text { Jones. } \\
\text { Walnut. }\end{array}$ \\
\hline & 38 & 15 & 14. I 8 & 75 & $4^{8}$ & $08.5^{6}$ & $\begin{array}{l}\mathrm{N} \\
\mathrm{S} \\
\mathrm{S}\end{array}$ & $\begin{array}{l}63 \\
79 \\
65\end{array}$ & $\begin{array}{l}19 \\
28 \\
41\end{array}$ & $\begin{array}{l}\text { W } \\
W \\
W\end{array}$ & $\begin{array}{l}\mathrm{S} \\
\mathrm{N}\end{array}$ & $\begin{array}{l}63 \\
79 \\
65\end{array}$ & $\begin{array}{ll}19 & \mathrm{E} \\
28 & \mathrm{E} \\
4 \mathrm{I} & \mathrm{E}\end{array}$ & $\begin{array}{r}665 \\
1702 \\
414\end{array}$ & $\begin{array}{l}\text { End. } \\
\text { Jones. } \\
\text { Walnut. }\end{array}$ \\
\hline
\end{tabular}




\section{BOUNDARIES OF NATURAL OYSTER BARS-continued.}

\section{GEORGES.}

(Middle Manokin River-Charts Nos. 5 and 7.)

\begin{tabular}{|c|c|c|c|c|c|c|c|c|c|c|c|c|c|c|}
\hline \multirow{2}{*}{$\begin{array}{l}\text { Cor- } \\
\text { ner } \\
\text { of } \\
\text { bar }\end{array}$} & \multirow{2}{*}{\multicolumn{3}{|c|}{ Latitude }} & \multirow{2}{*}{\multicolumn{3}{|c|}{ Longitude }} & \multicolumn{6}{|c|}{ True bearing } & \multirow{2}{*}{ Distance } & \multirow{2}{*}{ U. S. C. \& G. S. triangulation } \\
\hline & & & & & & & & Forw & ward & & $\mathrm{Bac}$ & ck & & \\
\hline 1 & $\begin{array}{c}\circ \\
38\end{array}$ & , & $\stackrel{n}{34.98}$ & $\begin{array}{c}\circ \\
75\end{array}$ & 50 & 51.58 & $\begin{array}{l}\mathrm{S} \\
\mathrm{N} \\
\mathrm{N}\end{array}$ & $\begin{array}{ll}0 & \\
61 & 0 \\
13 & 4 \\
53 & 5\end{array}$ & $\begin{array}{ll}. & \\
0.4 & \mathrm{E} \\
+2 & \mathrm{E} \\
5^{8} & \mathrm{~W}\end{array}$ & $\begin{array}{ll}\mathrm{N} & 6 \\
\mathrm{~S} & \mathrm{I} \\
\mathrm{S} & 5\end{array}$ & $\begin{array}{ll}0 & 1 \\
61 & 0 \\
13 & 4 \\
53 & 5\end{array}$ & $\begin{array}{ll}1 \\
\mathrm{O}_{2} & \mathrm{WV} \\
42 & \mathrm{WV} \\
5^{8} & \mathrm{E}\end{array}$ & $\left|\begin{array}{r}\text { Yards. } \\
4965 \\
2314 \\
1054\end{array}\right|$ & $\begin{array}{l}\text { Fairmount Church. } \\
\text { Jean. } \\
\text { St. Pierre. }\end{array}$ \\
\hline 2 & 38 & 07 & $37 \cdot 55$ & 75 & 51 & 09.09 & $\begin{array}{l}\mathrm{S} \\
\mathrm{N} \\
\mathrm{N}\end{array}$ & $\begin{array}{ll}62 & 3 \\
35 & 5 \\
68 & 1\end{array}$ & $\begin{array}{l}39 \mathrm{E} \\
54 \mathrm{~W} \\
19 \mathrm{~W}\end{array}$ & $\begin{array}{ll}\mathrm{N} & 6 \\
\mathrm{~S} & 3 \\
\mathrm{~S} & 6\end{array}$ & $\begin{array}{ll}62 & 3 \\
35 & 5 \\
68 & 2\end{array}$ & $\begin{array}{l}37 \mathrm{~W} \\
54 \mathrm{E} \\
20 \mathrm{E}\end{array}$ & $\begin{array}{r}5417 \\
659 \\
3245\end{array}$ & $\begin{array}{l}\text { Fairmount Church. } \\
\text { St. Pierre. } \\
\text { Marsh. }\end{array}$ \\
\hline 3 & 38 & 08 & 15.04 & 75 & 50 & 56.73 & $\begin{array}{l}\mathrm{S} \\
\mathrm{S} \\
\mathrm{N}\end{array}$ & $\begin{array}{ll}44 & 2 \\
71 & 5 \\
37 & 2\end{array}$ & $\begin{array}{ll}25 & \mathrm{WV} \\
55 & \mathrm{E} \\
2 \mathrm{I} & \mathrm{E}\end{array}$ & $\begin{array}{l}\text { N } 4 \\
\text { N } 7 \\
\text { S } 3\end{array}$ & $\begin{array}{ll}44 & 2 \\
71 & 5 \\
37 & 2\end{array}$ & $\begin{array}{ll}25 & \mathrm{E} \\
55 & \mathrm{~W} \\
22 & \mathrm{~W}\end{array}$ & $\begin{array}{l}1023 \\
2350 \\
1130\end{array}$ & $\begin{array}{l}\text { St. Pierre. } \\
\text { Staff. } \\
\text { Jean. }\end{array}$ \\
\hline 4 & 38 & 08 & 41.22 & 75 & 50 & I2. 44 & $\begin{array}{l}\mathrm{N} \\
\mathrm{S} \\
\mathrm{S}\end{array}$ & $\begin{array}{ll}88 & 1 \\
33 & 1 \\
78 & 3\end{array}$ & $\begin{array}{ll}\text { I4 } & W \\
\text { I2 } & \mathrm{E} \\
31 & \mathrm{E}\end{array}$ & $\begin{array}{ll}\mathrm{S} & 8 \\
\mathrm{~N} & 3 \\
\mathrm{~N} & 7\end{array}$ & $\begin{array}{ll}88 & I \\
33 & I \\
78 & 3\end{array}$ & $\begin{array}{ll}\text { I4 } & \mathrm{E} \\
\text { II } & \mathrm{WV} \\
30 & \mathrm{~W}\end{array}$ & $\begin{array}{r}492 \\
\times 927 \\
2791\end{array}$ & $\begin{array}{l}\text { Jean. } \\
\text { Staff. } \\
\text { Sandy. }\end{array}$ \\
\hline 5 & 38 & 08 & 46.80 & 75 & 50 & 02.99 & $\begin{array}{l}\mathrm{S} \\
\mathrm{S} \\
\mathrm{S}\end{array}$ & $\begin{array}{ll}76 & 5 \\
24 & 0 \\
60 & 0\end{array}$ & $\begin{array}{l}56 \mathrm{~W} \\
03 \mathrm{E} \\
07 \mathrm{E}\end{array}$ & $\begin{array}{l}\mathrm{N} \\
\mathrm{N} \\
\mathrm{N}\end{array}$ & $\begin{array}{ll}76 & 5 \\
24 & 0 \\
60 & 0\end{array}$ & $\begin{array}{ll}56 & \mathrm{E} \\
02 & \mathrm{~W} \\
07 & \mathrm{~W}\end{array}$ & $\begin{array}{r}766 \\
1972 \\
2594\end{array}$ & $\begin{array}{l}\text { Jean. } \\
\text { Staff. } \\
\text { Cupola. }\end{array}$ \\
\hline 6 & 38 & 08 & 42.06 & 75 & 49 & 27.21 & $\begin{array}{l}\mathrm{S} \\
\mathrm{S} \\
\mathrm{S}\end{array}$ & $\begin{array}{rl}89 & 3 \\
62 & 0 \\
5 & 1\end{array}$ & $\begin{array}{ll}33 & W \\
07 & W \\
13 & W\end{array}$ & $\begin{array}{l}\mathrm{N} \\
\mathrm{N} \\
\mathrm{N}\end{array}$ & $\begin{array}{rl}89 & 3 \\
62 & 0 \\
5 & 1\end{array}$ & $\begin{array}{ll}33 & \mathrm{E} \\
05 & \mathrm{E} \\
\mathrm{I}_{3} & \mathrm{E}\end{array}$ & $\begin{array}{l}1698 \\
3508 \\
1647\end{array}$ & $\begin{array}{l}\text { Jean. } \\
\text { St. Pierre. } \\
\text { Staft. }\end{array}$ \\
\hline 7 & 38 & os $=$ & 22.52 & 75 & 49 & $17.9^{8}$ & $\begin{array}{l}\mathrm{N} \\
\mathrm{S} \\
\mathrm{S}\end{array}$ & $\begin{array}{ll}7 x & 3 \\
2 I & 5 \\
65 & 4\end{array}$ & $\begin{array}{ll}37 & \mathrm{~W} \\
56 & \mathrm{WV} \\
43 & \mathrm{E}\end{array}$ & $\begin{array}{ll}\mathrm{S} & 7 \\
\mathrm{~N} & 2 \\
\mathrm{~N} & 6\end{array}$ & $\begin{array}{ll}71 & 3 \\
21 & 5 \\
65 & 4\end{array}$ & $\begin{array}{ll}38 & \mathrm{E} \\
56 & \mathrm{E} \\
43 & \mathrm{~W}\end{array}$ & $\begin{array}{l}2054 \\
1059 \\
1153\end{array}$ & $\begin{array}{l}\text { Jean. } \\
\text { Staff. } \\
\text { Cupola. }\end{array}$ \\
\hline 8 & 38 & 08 & 22.89 & 75 & $4^{8}$ & 50.33 & $\begin{array}{l}\mathrm{S} \\
\mathrm{S} \\
\mathrm{N}\end{array}$ & $\begin{array}{ll}48 & 4 \\
32 & 5 \\
83 & 3\end{array}$ & $\begin{array}{ll}42 & \text { WV } \\
5 \mathrm{I} & \mathrm{F} \\
32 & \mathrm{E}\end{array}$ & $\begin{array}{ll}N & 4 \\
N & 3 \\
\text { S } & 8\end{array}$ & $\begin{array}{ll}48 & 4 \\
32 & 5 \\
83 & 3\end{array}$ & $\begin{array}{ll}42 & \mathrm{E} \\
5 \mathrm{I} & \mathrm{W} \\
33 & \mathrm{~W}\end{array}$ & $\begin{array}{r}1507 \\
579 \\
551\end{array}$ & $\begin{array}{l}\text { Staff. } \\
\text { Cupola. } \\
\text { Sandy. }\end{array}$ \\
\hline 9 & 38 & 08 & 18. 77 & 75 & 48 & 36.40 & $\begin{array}{l}\mathrm{S} \\
\mathrm{S} \\
\mathrm{N}\end{array}$ & $\begin{array}{rr}60 & 2 \\
9 & 1 \\
41 & 2\end{array}$ & $\begin{array}{ll}21 & W \\
\text { I9 } & W \\
2 I & E\end{array}$ & $\begin{array}{ll}\mathrm{N} & 6 \\
\mathrm{~N} & \\
\mathrm{~S} & 4\end{array}$ & $\begin{array}{rr}60 & 2 \\
9 & 1 \\
4 & 2\end{array}$ & $\begin{array}{ll}21 & \mathrm{E} \\
19 & \mathrm{E} \\
2 \mathrm{I} & \mathrm{W}\end{array}$ & $\begin{array}{r}729 \\
352 \\
268\end{array}$ & $\begin{array}{l}\text { Staff. } \\
\text { Cupola. } \\
\text { Sandy. }\end{array}$ \\
\hline IO & 38 & 08 & 13.78 & 75 & 48 & 46.70 & $\begin{array}{l}\mathrm{S} \\
\mathrm{S} \\
\mathrm{N}\end{array}$ & $\begin{array}{ll}60 & 4 \\
50 & 3 \\
50 & 4\end{array}$ & $\begin{array}{ll}47 & \mathrm{WV} \\
3 \mathrm{I} & \mathrm{E} \\
42 & \mathrm{E}\end{array}$ & $\begin{array}{ll}\mathrm{N} & 6 \\
\mathrm{~N} & 5 \\
\mathrm{~S} & 5\end{array}$ & $\begin{array}{ll}60 & 4 \\
50 & 3 \\
50 & 4\end{array}$ & $\begin{array}{ll}46 & \mathrm{E} \\
3 \mathrm{I} & \mathrm{W} \\
42 & \mathrm{WV}\end{array}$ & $\begin{array}{r}1407 \\
282 \\
583\end{array}$ & $\begin{array}{l}\text { Staff. } \\
\text { Cupola. } \\
\text { Sandy. }\end{array}$ \\
\hline II & 38 & 08 & 16.22 & 75 & 49 & 44.00 & $\begin{array}{l}\mathrm{N} \\
\mathrm{S} \\
\mathrm{S}\end{array}$ & $\begin{array}{ll}55 & 3 \\
73 & 4 \\
21 & 0\end{array}$ & $\begin{array}{l}34 \mathrm{~W} \\
49 \mathrm{~W} \\
08 \mathrm{E}\end{array}$ & $\begin{array}{l}\mathrm{S} 5 \\
\mathrm{~N} 7 \\
\mathrm{~N}\end{array}$ & $\begin{array}{ll}55 & 3 \\
73 & 4 \\
21 & 0\end{array}$ & $\begin{array}{ll}34 & \mathrm{E} \\
48 & \mathrm{E} \\
08 & \mathrm{WV}\end{array}$ & $\begin{array}{r}1517 \\
2762 \\
825\end{array}$ & $\begin{array}{l}\text { Jean. } \\
\text { St. Pierre. } \\
\text { Staff. }\end{array}$ \\
\hline 12 & 38 & 08 & 07.26 & 75 & 50 & $47 \cdot 14$ & $\begin{array}{l}\mathrm{S} \\
\mathrm{N} \\
\mathrm{S} ?\end{array}$ & $\begin{array}{ll}64 & 1 \\
20 & 2 \\
76 & 4\end{array}$ & $\begin{array}{ll}16 & \mathrm{IV} \\
20 \mathrm{E} \\
43 \mathrm{E}\end{array}$ & $\begin{array}{l}\text { N } 6 \\
\text { S } 2 \\
\text { N } 7\end{array}$ & $\begin{array}{ll}64 & 1 \\
20 & 2 \\
76 & 4\end{array}$ & $\begin{array}{ll}16 & \mathrm{E} \\
20 & \mathrm{WV} \\
43 \mathrm{~W}\end{array}$ & $\begin{array}{l}1078 \\
1237 \\
2034\end{array}$ & $\begin{array}{l}\text { St. Pierre. } \\
\text { Jean. } \\
\text { Staff. }\end{array}$ \\
\hline
\end{tabular}


Survey of Oyster Bars, Somerset County, Md.

\section{BOUNDARIES OF NATURAL OYSTER BARS-continued. \\ SOUTHWEST MIDDLEGROUND.}

(Chesapcake Bay-Off Smith Island-Charts Nos. 6 and 8.)

\begin{tabular}{|c|c|c|c|c|c|c|c|c|c|c|c|c|c|c|}
\hline \multirow{2}{*}{$\begin{array}{l}\text { Cor- } \\
\text { ner } \\
\text { of } \\
\text { bar }\end{array}$} & \multirow{2}{*}{\multicolumn{3}{|c|}{ I.atitude }} & \multirow{2}{*}{\multicolumn{3}{|c|}{ Itringitude }} & \multicolumn{6}{|c|}{ True bearing } & \multirow{2}{*}{ Distunce } & \multirow{2}{*}{ T. S. C. \& G. S. tri.ungutution } \\
\hline & & & & & & & & Forw & vard & & Bac & & & \\
\hline & : & , & $n$ & $\circ$ & , & $"$ & & ○ & , & & $\circ$ & , & Yards. & \\
\hline 1 & 37 & $5^{8}$ & 56.46 & 76 & 10 & or. 95 & $\begin{array}{l}S \\
N \\
N\end{array}$ & $\begin{array}{ll}87 & 3 \\
70 & 2 \\
33 & 0\end{array}$ & $\begin{array}{l}36 \mathrm{E} \\
20 \mathrm{E} \\
04 \mathrm{E}\end{array}$ & $\begin{array}{l}\mathrm{N} \\
\mathrm{S} \\
\mathrm{S}\end{array}$ & $\begin{array}{l}87 \\
70 \\
33\end{array}$ & $\begin{array}{ll}3 \mathrm{I} & \mathrm{WV} \\
24 & \mathrm{WV} \\
07 & \mathrm{WV}\end{array}$ & $\begin{array}{l}\text { I } 2019 \\
\text { I } 802 \\
12510\end{array}$ & $\begin{array}{l}\text { Old Church (Smith Island). } \\
\text { Josepht. } \\
\text { Holland Island Bar Light. }\end{array}$ \\
\hline 2 & $3^{8}$ & oI & 24.82 & 76 & 10 & 20.36 & $\begin{array}{l}\mathrm{S} \\
\mathrm{S} \\
\mathrm{N}\end{array}$ & $\begin{array}{l}66 \\
84 \\
53\end{array}$ & $\begin{array}{ll}I+ & E \\
49 & E \\
\text { Io } & E\end{array}$ & $\mid \begin{array}{l}N \\
N \\
S\end{array}$ & $\begin{array}{l}66 \\
8+ \\
53\end{array}$ & $\begin{array}{ll}09 & \text { WV } \\
44 & \text { WV } \\
\text { r } 3 & \text { W }\end{array}$ & $\begin{array}{r}13658 \\
11653 \\
9142\end{array}$ & $\begin{array}{l}\text { Old Church (Smith Island). } \\
\text { Joseph. } \\
\text { Holland Island Bar Light. }\end{array}$ \\
\hline 3 & $3^{8}$ & 00 & 48.20 & 76 & 08 & 02.85 & $\begin{array}{l}\mathrm{S} \\
\mathrm{N} \\
\mathrm{N}\end{array}$ & $\begin{array}{ll}64 & 1 \\
88 & 4 \\
28 & 3\end{array}$ & $\begin{array}{l}\text { 10 } \mathrm{E} \\
43 \mathrm{E} \\
33 \mathrm{E}\end{array}$ & $\begin{array}{l}\mathrm{N} \\
\mathrm{S} \\
\mathrm{S}\end{array}$ & $\begin{array}{l}6+ \\
88 \\
28\end{array}$ & $\begin{array}{l}07 \mathrm{WV} \\
46 \mathrm{WV} \\
34 \mathrm{WV}\end{array}$ & $\begin{array}{l}9810 \\
7940 \\
7642\end{array}$ & $\begin{array}{l}\text { Old Church (Smith Island). } \\
\text { Joseph. } \\
\text { Holland Island Bar Light. }\end{array}$ \\
\hline 4 & 37 & 59 & $25 \cdot 9^{2}$ & 76 & 07 & $29.6 \mathrm{I}$ & $\begin{array}{l}\mathrm{S} \\
\mathrm{N} \\
\mathrm{N}\end{array}$ & $\begin{array}{l}79 \\
67 \\
16\end{array}$ & $\begin{array}{l}18 \mathrm{E} \\
17 \mathrm{E} \\
15 \mathrm{E}\end{array}$ & $\begin{array}{l}\mathrm{N} \\
\mathrm{S} \\
\mathrm{S}\end{array}$ & $\begin{array}{l}79 \\
67 \\
16\end{array}$ & $\begin{array}{l}15 \mathrm{~W} \\
20 \mathrm{~W} \\
16 \mathrm{WW}\end{array}$ & $\begin{array}{l}8083 \\
7643 \\
9882\end{array}$ & $\begin{array}{l}\text { Old Church (Smith Island). } \\
\text { Joseph. } \\
\text { Holland Island Bar I,ight. }\end{array}$ \\
\hline
\end{tabular}

\section{KEDGE STRAITS.}

(Chesapcake Bay-Off Kedge Siraits-Chart No. 6.)

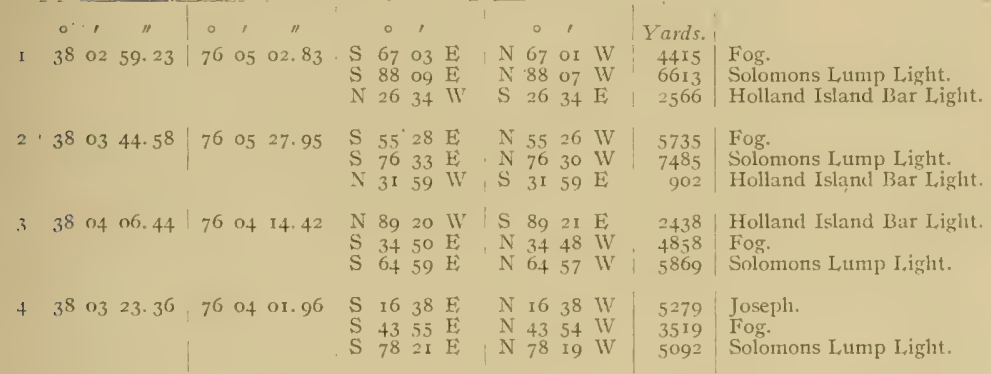

\section{OYSTER CREEK.}

(Outer Kedge Straits-Chart No. 6.)

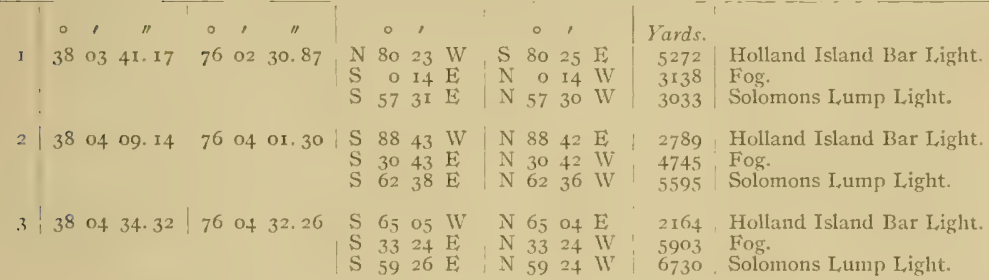
$50095-08 \longrightarrow 9$ 
BOUNDARIISS OF NATURAI, OYSTER BARS-COIIIHUCA.

OYSTYR CREEK-Continued.

\begin{tabular}{|c|c|c|c|c|c|c|c|c|c|c|c|c|c|c|}
\hline \multirow{2}{*}{$\begin{array}{l}\text { Cor- } \\
\text { ner } \\
\text { of } \\
\text { bar }\end{array}$} & \multirow{2}{*}{\multicolumn{3}{|c|}{ Latitude }} & \multirow{2}{*}{\multicolumn{3}{|c|}{ Longitucle }} & \multicolumn{6}{|c|}{ True bearing } & \multirow{2}{*}{ - Distance } & \multirow{2}{*}{$\begin{array}{c}\text { U. S. C. \& G. S. triangulation } \\
\text { station }\end{array}$} \\
\hline & & & & & & & & For & ward & & $\mathrm{Ba}$ & & & \\
\hline 4 & 38 & '́t & 40. 76 & $\begin{array}{c}\circ \\
76\end{array}$ & of & II. 80 & $\begin{array}{l}S \\
S \\
S\end{array}$ & $\begin{array}{l}0 \\
65 \\
28 \\
55\end{array}$ & $\begin{array}{ll}1 \\
04 \\
04 \\
28 \\
4 \mathrm{E} \\
4\end{array}$ & $\begin{array}{l}\mathrm{N} \\
\mathrm{N} \\
\mathrm{N}\end{array}$ & $\begin{array}{l}0 \\
65 \\
28 \\
55\end{array}$ & $\begin{array}{ll}03 \\
03 \\
27 & \mathrm{WV} \\
39 & \mathrm{WV}\end{array}$ & $\begin{array}{r}\text { Yards. } \\
2677 \\
5840 \\
645^{2}\end{array}$ & $\begin{array}{l}\text { Holland Island Bar Light. } \\
\text { Fog. } \\
\text { Solomons Lump Light. }\end{array}$ \\
\hline 5 & 38 & 0.5 & 10. 20 & 76 & of & (H). 70 & $\begin{array}{l}\mathrm{S} \\
\mathrm{S} \\
\mathrm{S}\end{array}$ & $\begin{array}{l}52 \\
21 \\
46\end{array}$ & $\begin{array}{l}53 \mathrm{WV} \\
25 \mathrm{E} \\
56 \mathrm{E}\end{array}$ & $\begin{array}{l}\mathrm{N} \\
\mathrm{N}^{\mathrm{N}} \\
\mathrm{N}\end{array}$ & $\begin{array}{l}52 \\
21 \\
46\end{array}$ & $\begin{array}{l}52 \mathrm{E} \\
24 \mathrm{WV}^{7} \\
54 \mathrm{WV}\end{array}$ & $\begin{array}{l}3516 \\
6593 \\
6780\end{array}$ & $\begin{array}{l}\text { Holland Island Bar Light. } \\
\text { Fog. } \\
\text { Solomons Lump Light. }\end{array}$ \\
\hline 6 & 38 & 05 & 01.98 & 76 & 03 & 411.24 & $\begin{array}{l}\mathrm{S} \\
\mathrm{S} \\
\mathrm{S}\end{array}$ & $\begin{array}{l}61 \\
17 \\
45\end{array}$ & $\begin{array}{ll}\text { 10 } & \mathrm{IV} \\
38 & \mathrm{E} \\
2 \mathrm{I} & \mathrm{E}\end{array}$ & $\begin{array}{l}\mathrm{N} \\
\mathrm{N} \\
\mathrm{N}\end{array}$ & $\begin{array}{l}61 \\
17 \\
45\end{array}$ & $\begin{array}{ll}08 \mathrm{E} \\
37 \mathrm{WV} \\
20 \mathrm{WV}\end{array}$ & $\begin{array}{l}3823 \\
6150 \\
6195\end{array}$ & $\begin{array}{l}\text { Holland Island Bar Light. } \\
\text { Fog. } \\
\text { Solomons Lump Light. }\end{array}$ \\
\hline 7 & 38 & 04 & 29.16 & 76 & 03 & 45.49 & $\begin{array}{l}\mathrm{S} \\
\mathrm{S} \\
\mathrm{S}\end{array}$ & $\begin{array}{l}77 \\
22 \\
54\end{array}$ & $\begin{array}{l}04 \mathrm{~W} \\
50 \mathrm{E} \\
28 \mathrm{E}\end{array}$ & $\stackrel{N}{N}$ & $\begin{array}{l}77 \\
22 \\
54\end{array}$ & $\begin{array}{ll}02 & E \\
50 & I V \\
27 & \mathrm{IV}\end{array}$ & $\begin{array}{l}3293 \\
5160 \\
5587\end{array}$ & $\begin{array}{l}\text { Holland Island Bar Light: } \\
\text { Fog. } \\
\text { Solomons Lump Liglit. }\end{array}$ \\
\hline 8 & 38 & $30_{4}$ & 13. 84 & 76 & 02 & $35 \cdot 49$ & $\begin{array}{l}S \\
S \\
S\end{array}$ & $\begin{array}{r}87 \\
1 \\
44\end{array}$ & $\begin{array}{ll}3 \mathrm{I} & \mathrm{WV} \\
50 & \mathrm{E} \\
28 & \mathrm{E}\end{array}$ & $\begin{array}{l}\mathrm{N} \\
\mathrm{N}\end{array}$ & $\begin{array}{r}87 \\
1 \\
44\end{array}$ & $\begin{array}{ll}29 & \mathrm{E} \\
50 & \mathrm{~W} \\
27 & \mathrm{WV}\end{array}$ & $\begin{array}{l}5080 \\
4241 \\
3826\end{array}$ & $\begin{array}{l}\text { Ifolland Island Bar Light. } \\
\text { Fog. } \\
\text { Solomons Lump Light. }\end{array}$ \\
\hline
\end{tabular}

\section{MUSSEL HOLE.}

(Middle Tangier Sound-Chart No.7.)

\begin{tabular}{|c|c|c|c|c|c|c|c|c|c|c|c|c|c|c|c|c|}
\hline & 0 & ' & " & 0 & , & " & & $\circ$ & , & & & 0 & , & & Yards. & \\
\hline$x$ & 38 & 02 & 36.76 & 75 & 59 & 41.02 & $\begin{array}{l}\mathrm{N} \\
\mathrm{N} \\
\mathrm{S}\end{array}$ & $\begin{array}{l}10 \\
74 \\
35\end{array}$ & $\begin{array}{l}41 \\
37 \\
44\end{array}$ & $\begin{array}{l}W \\
W \\
E\end{array}$ & $\begin{array}{l}\mathrm{S} \\
\mathrm{S} \\
\mathrm{N}\end{array}$ & $\begin{array}{l}\text { 10 } \\
74 \\
35\end{array}$ & $\begin{array}{l}41 \\
38 \\
43\end{array}$ & $\begin{array}{l}\mathrm{E} \\
\mathrm{E} \\
\mathrm{W}\end{array}$ & $\begin{array}{l}6483 \\
2045 \\
4150\end{array}$ & $\begin{array}{l}\text { Miles. } \\
\text { Solomons Lump Light. } \\
\text { Terrapin. }\end{array}$ \\
\hline 2 & 38 & 02 & 44.55 & 76 & oo & 05.88 & $\begin{array}{l}\mathrm{N} \\
\mathrm{N}\end{array}$ & $\begin{array}{r}5 \\
77 \\
40\end{array}$ & $\begin{array}{l}03 \\
56 \\
22\end{array}$ & $\begin{array}{l}\text { W } \\
W \\
\mathrm{E}\end{array}$ & $\begin{array}{l}\mathrm{S} \\
\mathrm{S} \\
\mathrm{N}\end{array}$ & $\begin{array}{r}5 \\
77 \\
40\end{array}$ & $\begin{array}{l}03 \\
57 \\
21\end{array}$ & $\begin{array}{l}\mathrm{E} \\
\mathrm{E} \\
\mathrm{W}\end{array}$ & $\begin{array}{l}8320 \\
1337 \\
4766\end{array}$ & $\begin{array}{l}\text { Miles. } \\
\text { Solomons Lump Light. } \\
\text { Terrapin. }\end{array}$ \\
\hline 3 & 38 & O3 & $07.8 x$ & 75 & 59 & 52.42 & $\begin{array}{l}\mathrm{N} \\
\mathrm{N} \\
\mathrm{S}\end{array}$ & $\begin{array}{r}31 \\
9 \\
73\end{array}$ & $\begin{array}{l}17 \\
34 \\
09\end{array}$ & $\begin{array}{l}\mathrm{E} \\
\text { WV } \\
\text { W }\end{array}$ & $\begin{array}{l}\mathrm{S} \\
\mathrm{S} \\
\mathrm{N}\end{array}$ & $\begin{array}{r}31 \\
9 \\
73\end{array}$ & $\begin{array}{l}19 \\
35 \\
09\end{array}$ & $\begin{array}{l}\mathrm{W} \\
\mathrm{E} \\
\mathrm{E}\end{array}$ & $\begin{array}{l}9118 \\
5399 \\
1742\end{array}$ & $\begin{array}{l}\text { Joshua. } \\
\text { Miles. } \\
\text { Solomons Lump Light. }\end{array}$ \\
\hline 4 & 38 & $\mathrm{O}_{3}$ & 40.94 & 75 & 59 & 32.90 & $\begin{array}{l}\mathrm{N} \\
\mathrm{S} \\
\mathrm{S}\end{array}$ & $\begin{array}{l}18 \\
53 \\
21\end{array}$ & $\begin{array}{l}38 \\
27 \\
45\end{array}$ & $\begin{array}{l}\text { W } \\
\text { W } \\
\mathrm{E}\end{array}$ & $\begin{array}{l}\mathrm{S} \\
\mathrm{N} \\
\mathrm{N}\end{array}$ & $\begin{array}{l}18 \\
53 \\
21\end{array}$ & $\begin{array}{l}38 \\
27 \\
44\end{array}$ & $\begin{array}{l}E \\
E\end{array}$ & $\begin{array}{l}4440 \\
2723 \\
5957\end{array}$ & $\begin{array}{l}\text { Miles. } \\
\text { Solomons L,ump Light. } \\
\text { Terrapin. }\end{array}$ \\
\hline 5 & 38 & 05 & $49 \cdot 5^{8}$ & 76 & oo & $03.7^{8}$ & $\begin{array}{l}\mathrm{S} \\
\mathrm{S} \\
\mathrm{N}\end{array}$ & $\begin{array}{l}77 \\
12 \\
65\end{array}$ & $\begin{array}{l}38 \\
54 \\
07\end{array}$ & $\begin{array}{l}\text { WV } \\
\text { IV } \\
\mathrm{E}\end{array}$ & $\begin{array}{l}\mathrm{N} \\
\mathrm{N} \\
\mathrm{S}\end{array}$ & $\begin{array}{l}77 \\
12 \\
65\end{array}$ & $\begin{array}{l}38 \\
53 \\
09\end{array}$ & $\begin{array}{l}\mathrm{E} \\
\mathrm{E} \\
\mathrm{W}\end{array}$ & $\begin{array}{r}609 \\
6113 \\
5553\end{array}$ & $\begin{array}{l}\text { Miles. } \\
\text { Solomons Lump Light. } \\
\text { Joshua. }\end{array}$ \\
\hline 6 & 38 & $0_{5}$ & $57 \cdot 12$ & 75 & 59 & 10. 20 & $\begin{array}{l}\mathrm{S} \\
\mathrm{S} \\
\mathrm{N}\end{array}$ & $\begin{array}{l}79 \\
24 \\
60\end{array}$ & $\begin{array}{l}13 \\
12 \\
02\end{array}$ & $\begin{array}{l}W \\
W \\
E\end{array}$ & $\begin{array}{l}\mathrm{N} \\
\mathrm{N} \\
\mathrm{S}\end{array}$ & $\begin{array}{l}79 \\
24 \\
60\end{array}$ & $\begin{array}{l}\text { I2 } \\
\text { II } \\
\text { O3 }\end{array}$ & $\begin{array}{l}\mathrm{E} \\
\mathrm{E} \\
\mathrm{W}\end{array}$ & $\begin{array}{l}2059 \\
6812 \\
4168\end{array}$ & $\begin{array}{l}\text { Miles. } \\
\text { Solomons Lump Light. } \\
\text { Joshua. }\end{array}$ \\
\hline 7 & 38 & $\mathrm{O} 2$ & 50.94 & 75 & $5^{8}$ & 34.94 & $\begin{array}{l}N \\
N \\
S\end{array}$ & $\begin{array}{r}26 \\
89 \\
9\end{array}$ & $\begin{array}{l}4 \pi \\
00 \\
44\end{array}$ & $\begin{array}{l}\text { W } \\
\text { W } \\
\mathrm{E}\end{array}$ & $\begin{array}{l}\mathrm{S} \\
\mathrm{S} \\
\mathrm{N}\end{array}$ & $\begin{array}{r}26 \\
89 \\
9\end{array}$ & $\begin{array}{l}42 \\
02 \\
44\end{array}$ & $\begin{array}{l}\mathrm{E} \\
\mathrm{E} \\
\mathrm{W}\end{array}$ & $\begin{array}{l}6596 \\
3734 \\
3904\end{array}$ & $\begin{array}{l}\text { Miles. } \\
\text { Solomons Lump Light. } \\
\text { Terrapin. }\end{array}$ \\
\hline
\end{tabular}


Surey of Ojster Bars, Somerset County, $M$ Id.

BOUNDARIES OF NATURAL OYSTER BARS-continUEd.

CHAIN SHOAL.

(Upper Tangier Sound-Chan No. 7.)

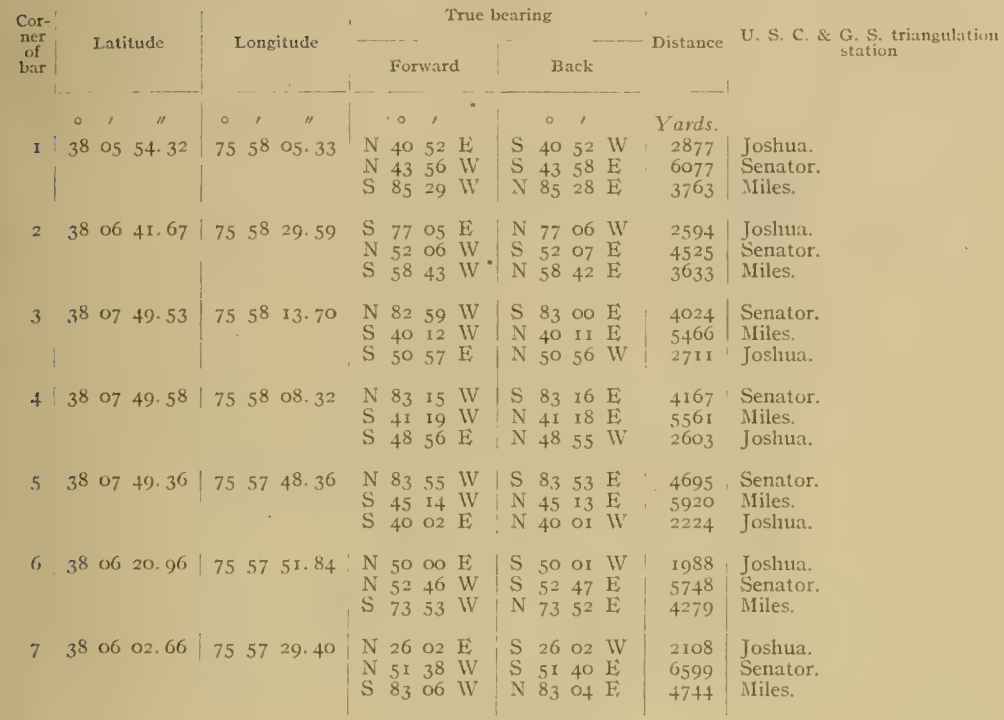

PINEY ISLAND WEST.

(Middle Tangier Sound-Chart No. 7.)

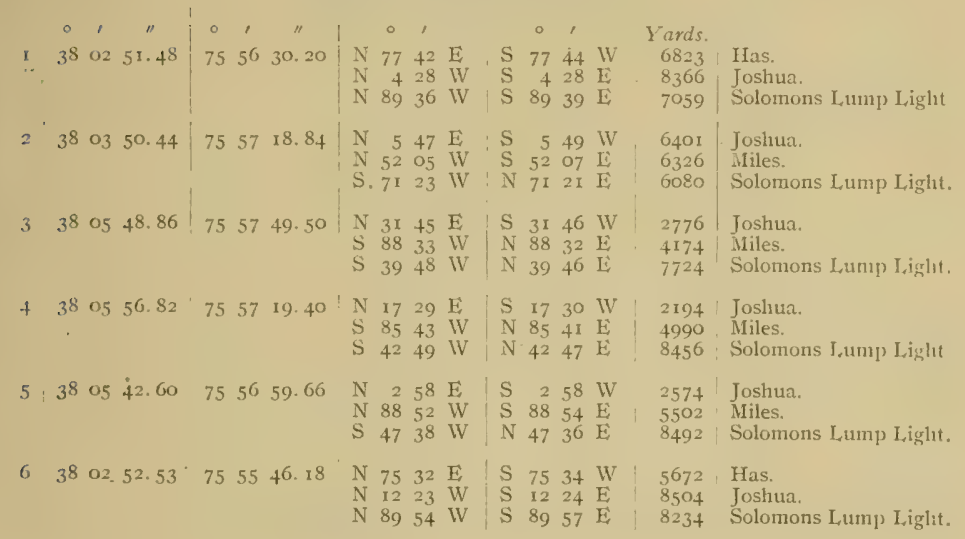




\section{BOUNDARIES OF NATURAL, OYSTER BARS-continuEd.}

PINEY ISLAND SWASH.

(Lower Manokin River-Chart No. 7.)

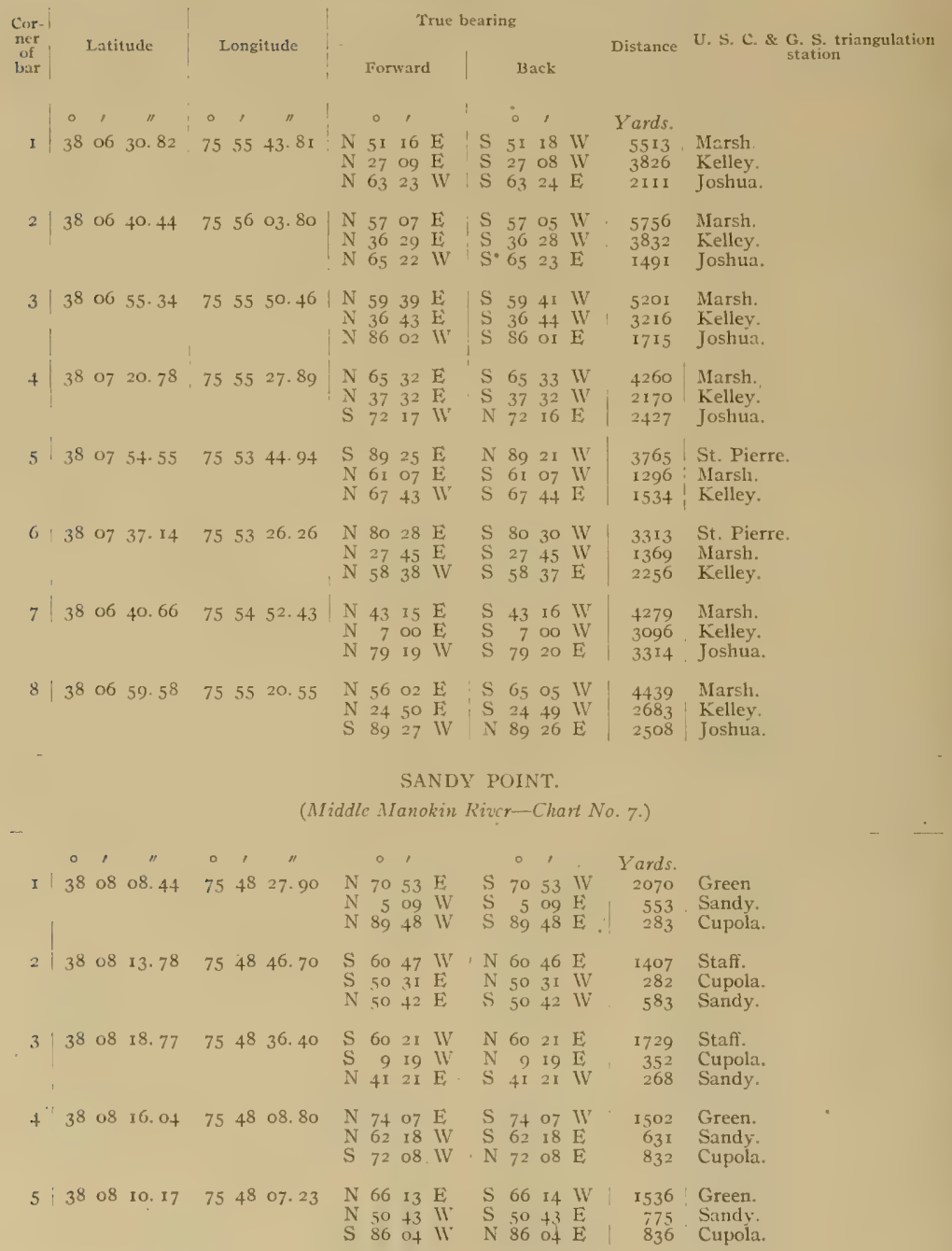


Sura'ey of Oyster Bars, Somerset County, Md.

BOUNDARIES OF NATURAL OYSTER BARS-continued.

CORMAI.

(Middle Manokin River-Chart No. 7.)

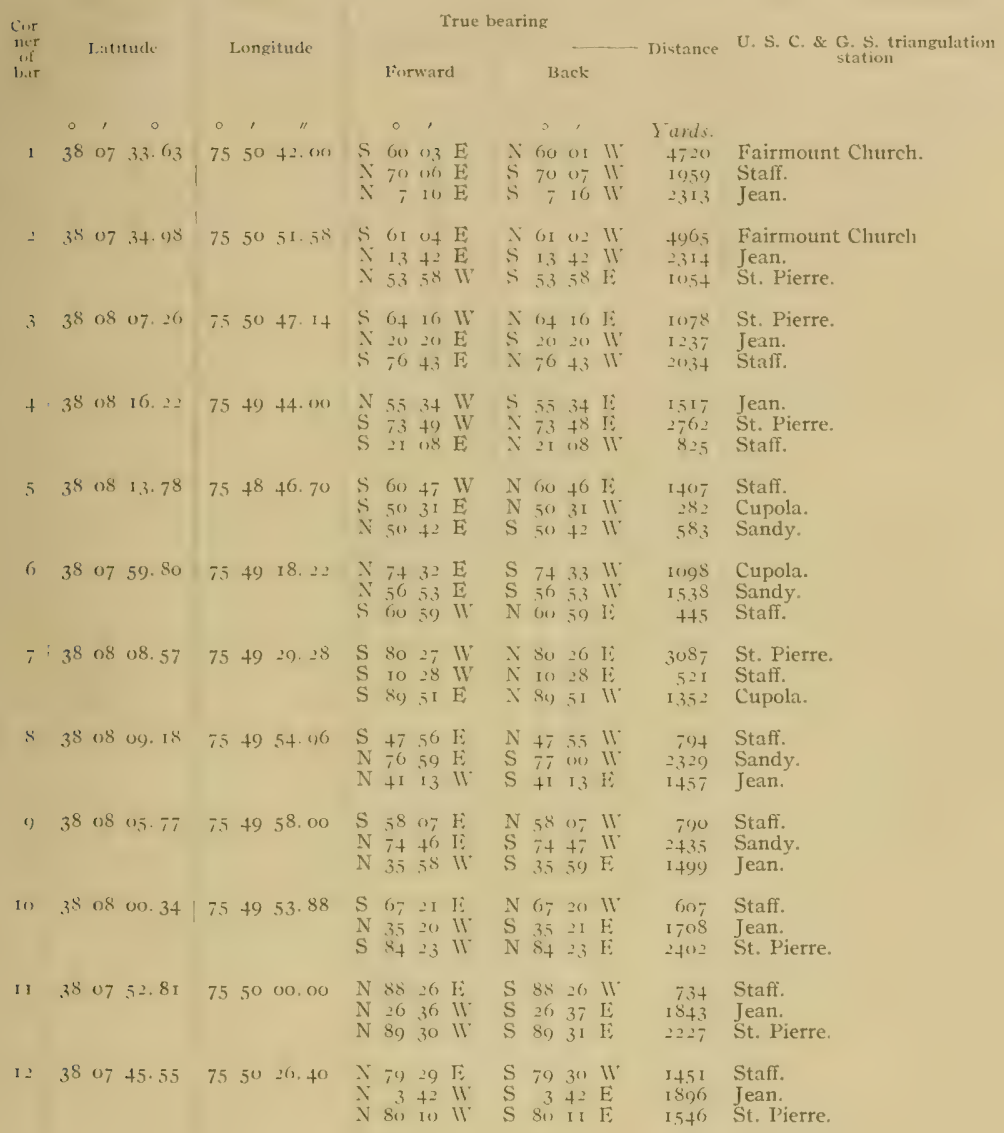


BOUNDARIES OF NATURAL OYSTER BARS - continued.

MARSHY ISLAND.

(Lower Manokin River-Chart No. 7.)

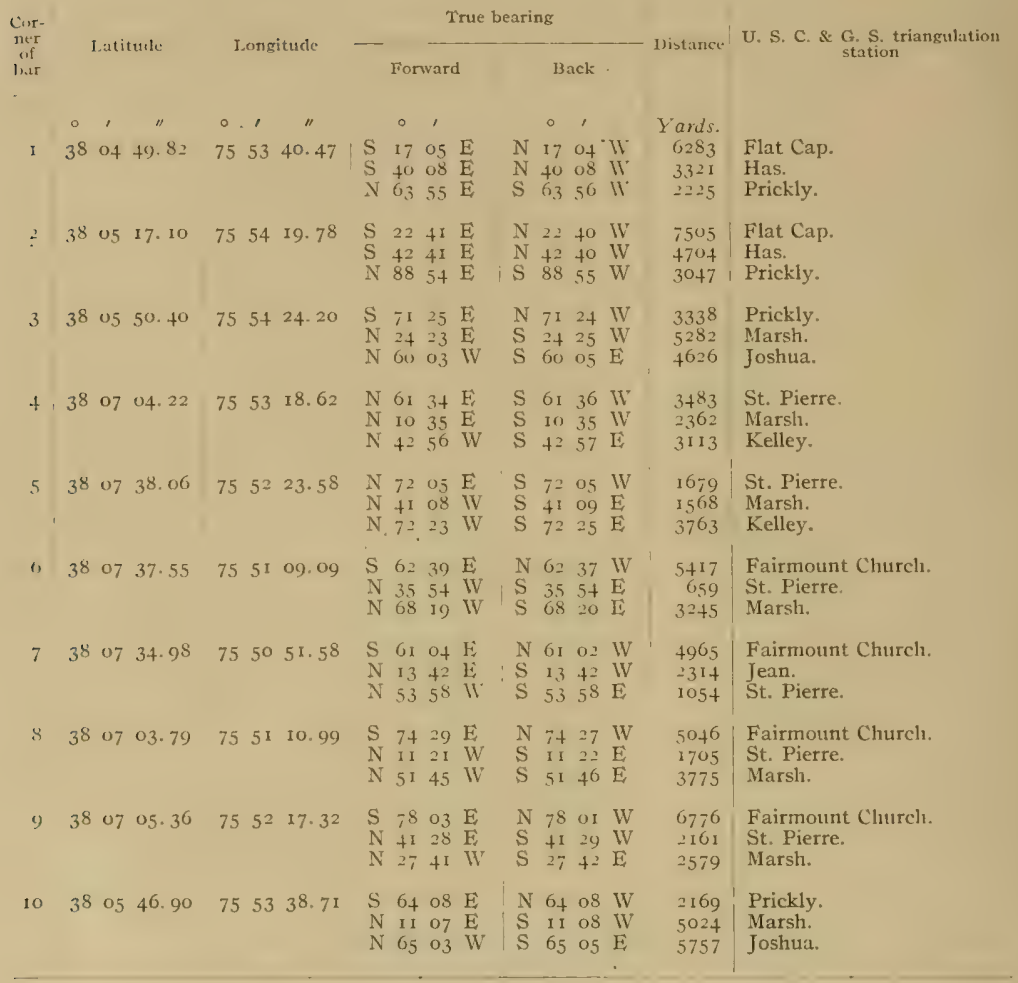


Suréey of Oyster Bars, Somerset Connty, .Md.

BOUNDARIES OF NATURAL OYSTFR BARS-cOntinued.

DRUM POINT.

(Lower Manokin River-Chart No. 7.)

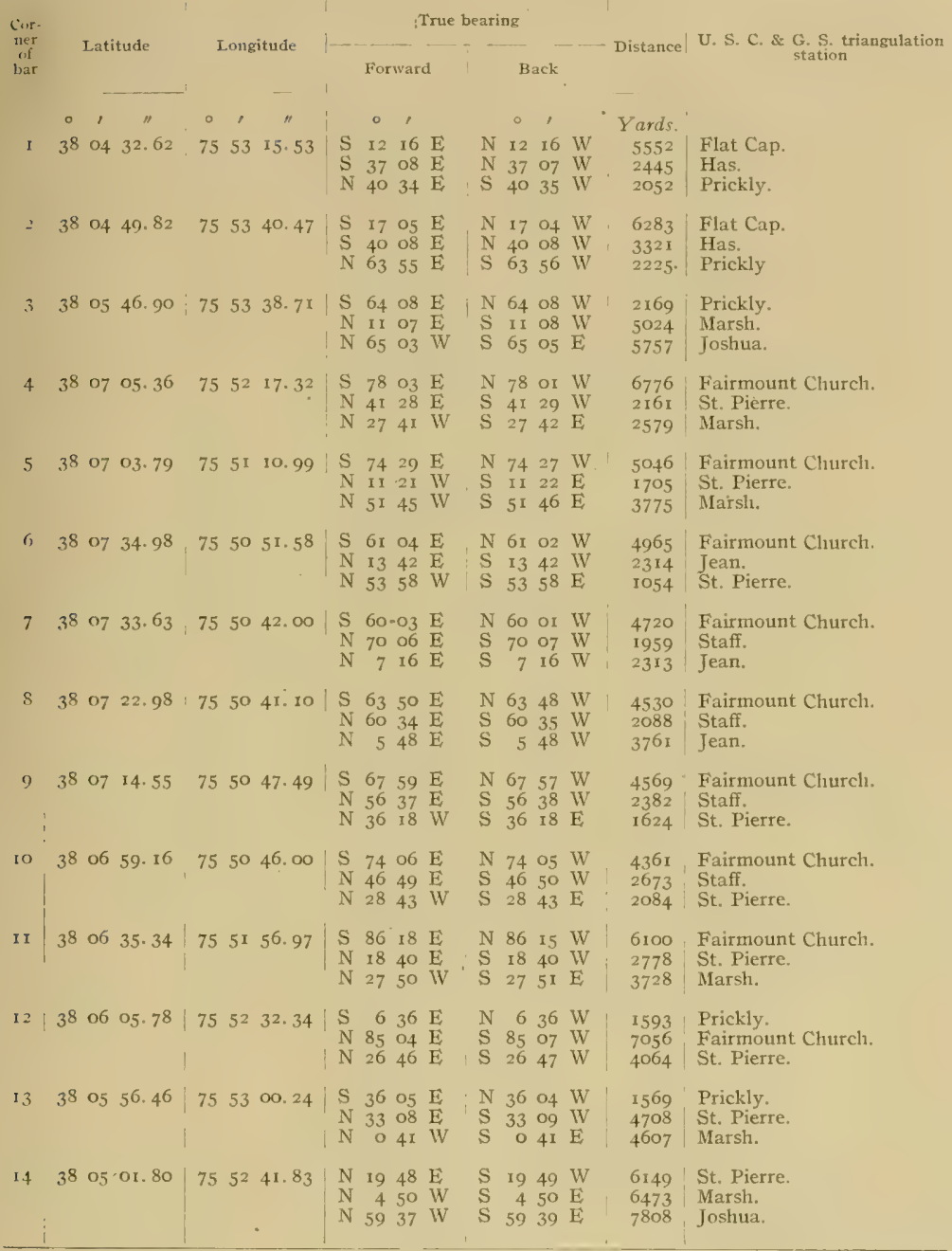


BOUNUARIES OF NATURAL, OYSTER BARS-cONTINUCd.

PRICKLY POINT.

(Mouth Manokin River-Chart No. 7.)

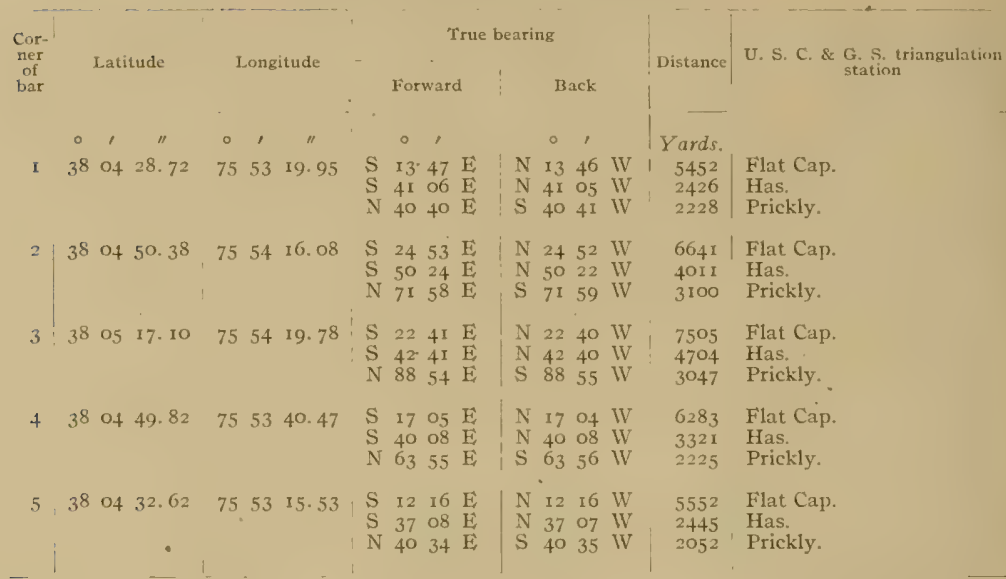

PINEY ISLAND EAST.

(Middle Tangier Sound-Char No. 7.)

\begin{tabular}{|c|c|c|c|c|c|c|c|c|c|c|c|c|c|c|c|}
\hline I & $\begin{array}{c}0 \\
3^{8}\end{array}$ & $\begin{array}{c}, \\
03\end{array}$ & $\begin{array}{c}\prime \prime \\
05.04\end{array}$ & $\begin{array}{c}\circ \\
75\end{array}$ & $\stackrel{,}{54}$ & 16. 59 & $\begin{array}{l}\mathrm{S} \\
\mathrm{N} \\
\mathrm{N}\end{array}$ & $\begin{array}{l}0 \\
48 \\
72 \\
28\end{array}$ & $\begin{array}{l}1 \\
39 \\
\text { I4 } \\
06\end{array}$ & $\begin{array}{l}E \\
E \\
W V\end{array}$ & $\begin{array}{l}N \\
\text { S } \\
\text { S }\end{array}$ & $\begin{array}{l}0 \\
48 \\
72 \\
28\end{array}$ & $\begin{array}{ll} \\
37 \\
\text { I } \\
\text { IV } \\
\text { O8 } \\
\text { E }\end{array}$ & $\begin{array}{r}Y \text { ards. } \\
3742 \\
3260 \\
8939\end{array}$ & $\begin{array}{l}\text { Flat Cap. } \\
\text { Has. } \\
\text { Josluua. }\end{array}$ \\
\hline 2 & 38 & 04 & 19.61 & 75 & 54 & 49.20 & $\begin{array}{l}\mathrm{S} \\
\mathrm{S} \\
\mathrm{N}\end{array}$ & $\begin{array}{l}36 \\
69 \\
62\end{array}$ & $\begin{array}{l}25 \\
05 \\
28\end{array}$ & $\begin{array}{l}\mathrm{E} \\
\mathrm{E} \\
\mathrm{E}\end{array}$ & $\begin{array}{l}N \\
N \\
S\end{array}$ & $\begin{array}{l}36 \\
69 \\
62\end{array}$ & $\begin{array}{ll}23 & W \\
03 & W \\
30 & W\end{array}$ & $\begin{array}{l}6196 \\
4255 \\
4320\end{array}$ & $\begin{array}{l}\text { Flat Cap. } \\
\text { Has. } \\
\text { Prickly. }\end{array}$ \\
\hline 3 & $3^{8}$ & 04 & 12.34 & 75 & 53 & 21.76 & $\begin{array}{l}\mathrm{S} \\
\mathrm{S} \\
\mathrm{N}\end{array}$ & $\begin{array}{l}15 \\
52 \\
33\end{array}$ & $\begin{array}{l}49 \\
10 \\
47\end{array}$ & $\begin{array}{l}\mathrm{E} \\
\mathrm{E} \\
\mathrm{E}\end{array}$ & $\begin{array}{l}N \\
N \\
S\end{array}$ & $\begin{array}{l}\text { I5 } \\
52 \\
33\end{array}$ & $\begin{array}{ll}4^{8} & W \\
\text { IO } & W \\
4^{8} & W\end{array}$ & $\begin{array}{l}4929 \\
2079 \\
2698\end{array}$ & $\begin{array}{l}\text { Flat Cap. } \\
\text { Has. } \\
\text { Prickly. }\end{array}$ \\
\hline 4 & 38 & $\mathrm{O} 3$ & 23.75 & 75 & 53 & 02.85 & $\begin{array}{l}\mathrm{S} \\
\mathrm{N} \\
\mathrm{N}\end{array}$ & $\begin{array}{l}15 \\
72 \\
40\end{array}$ & $\begin{array}{l}\text { II } \\
18 \\
24\end{array}$ & $\begin{array}{l}\mathrm{E} \\
\mathrm{E} \\
\mathrm{W}\end{array}$ & $\begin{array}{l}N \\
S \\
S\end{array}$ & $\begin{array}{l}15 \\
72 \\
40\end{array}$ & $\begin{array}{l}10 \mathrm{~W} \\
19 \mathrm{~W} \\
27 \mathrm{E}\end{array}$ & $\begin{array}{l}3216 \\
1194 \\
9527\end{array}$ & $\begin{array}{l}\text { Flat Cap. } \\
\text { Has. } \\
\text { Joshua. }\end{array}$ \\
\hline
\end{tabular}


Survey of Oyster Bars, Somerset County, Md.

BOUNDARIES OF NATURAL OYSTER BARS-continued.

HARRIS.

(Middle Tangier Sound-Chan No. 7.)

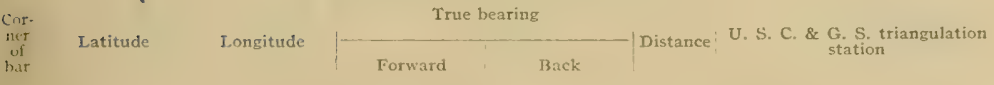

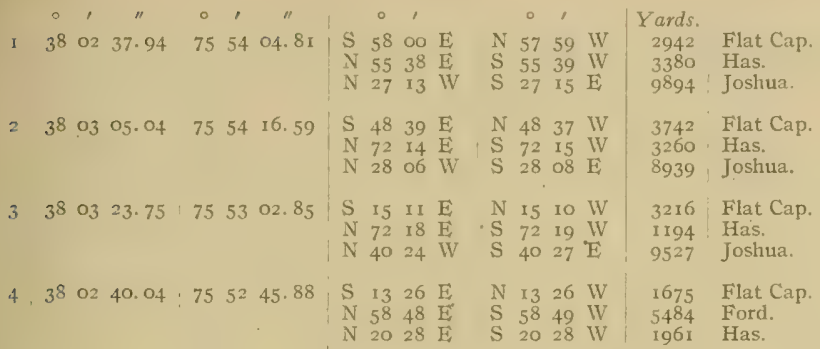

BIG ANNEMESSEX.

(Big Annemessex River-Chart No. 7.)

- , " , "

I $3 \mathrm{~S}_{02} 50.93 \quad 755 \mathrm{I} 45.86 \quad \mathrm{~N} 5 \mathrm{I} 20$ Fi $\quad \mathrm{S} 51$ I I IV $\mathrm{N} 3 \mathrm{I} 53$ II $\quad \mathrm{S} 3153 \mathrm{E}$ $\mathrm{S} 3 \mathrm{I}+\mathrm{II}$ N $31 \mathrm{I}+\mathrm{E}$

$\begin{array}{lllllll}38 & 03 & 16.52 & 75 & 51 & 49.69\end{array}$ $\mathrm{N} 63+\mathrm{E}$ N $531+$ IV S 21 1 $12 \mathrm{WV}$

$\begin{array}{llllllll}3 & 3^{\mathrm{S}} & 03 & 45.06 & 75 & 51 & 07.5^{8}\end{array}$

4 $4 \quad 3 S \quad 03 \quad 51.42 \quad 75 \quad 49 \quad 12.66$

$\begin{array}{llllllll}5 & 38 & 03 & 08,18 & 75 & 48 & 47.60\end{array}$

$\begin{array}{llllllll}6 & 34 & 03 & 03.08 & 75 & 48 & 54.81\end{array}$

$7 \quad 390317.77 \quad 754931.17$

S. $38 \quad 0305.44 \quad 75 \quad 50 \quad 32.58$ $\begin{array}{llllllll}\mathrm{S} & 30 & 17 & \mathrm{WV} & \mathrm{N} & 30 & 17 & \mathrm{E} \\ \mathrm{S} & 55 & 12 & \mathrm{E} & \mathrm{N} & 55 & 1 \mathrm{I} & \mathrm{WV}\end{array}$ $\mathrm{N} 7237 \mathrm{E} \quad \mathrm{S} 7237 \mathrm{~W}$

N $66 \quad 25$ W S 9 I6 $\mathrm{S}+322 \mathrm{E}$

S $7307 \mathrm{E}$ $\mathrm{N}+4.50 \mathrm{E}$

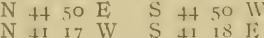

$\mathrm{S} \mathrm{s}_{3}+5 \mathrm{E}$

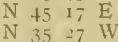

S $6625 \mathrm{E}$ N 916 E: $\mathrm{N}+32 \mathrm{I} \mathrm{IV}^{\circ}$

N 73 of 11 $S+1$ is $\mathrm{E}$

$\mathrm{N} s_{3}+5 \mathrm{IV}$ $\mathrm{S}+517 \mathrm{II}$ S. 3.527 Ii

S $8+7 \mathrm{E}$ $N$ o 5 S E

$\mathrm{N} \&+7 \mathrm{11}$ \& (x) 5911 i 17 in $\mathrm{I}$

$\mathrm{S} 7245 \mathrm{E}$ $\mathrm{N} 2950 \mathrm{E}$ $\mathrm{N} 7 \mathrm{I}$ o $7 \mathrm{~W}$
3959 Ford.

1731 Has.

2336 Flat Cap.

3576 Ford.

1014 Has.

3066 . Flat Cap.

4426 Flat Cap.

3314 Geog.

2170 Ford.

1084 Ford.

2I34 Geog.

2420 Colburn.

1039 Colburn.

1650 Moon.

2517 Ford.

I193 Colburn.

I908 Moon.

2533 Ford.

982 Geug.

2475 Ifwon

1646 Fritd

1872 Geng.11

2287 Ford.

3031 Has. 
BOUNDARIES OF NATURAL, OYSTER BARS-continued.

CHURCH CREEK.

(Chesapeake Bay-Off Smith Island-Chart No. 8.)

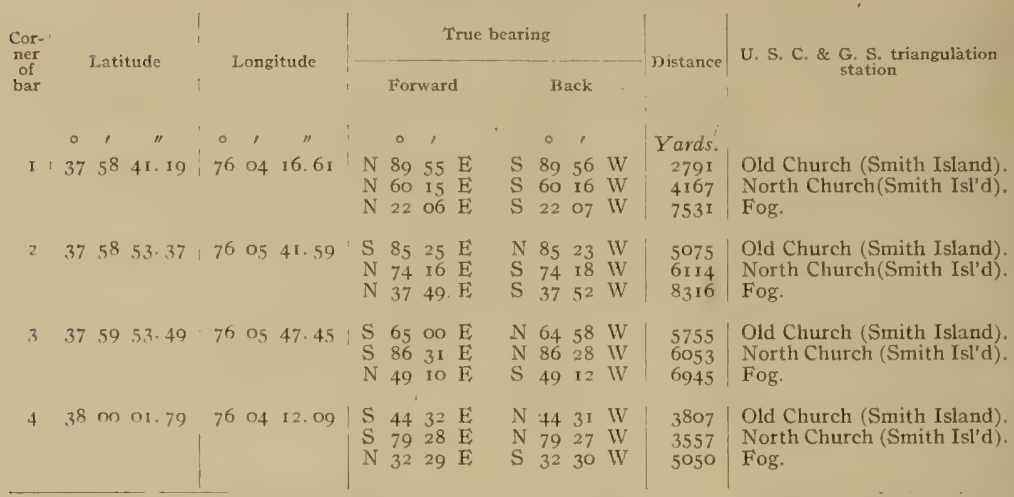

\section{PHILIBYS.}

(Lower Tangier Sound-Chart No. 9.)

\begin{tabular}{|c|c|c|c|c|c|c|c|c|c|c|c|c|c|c|c|}
\hline & 。 & , & " & 。 & , & " & & o & , & & & 。 & , & $a r$ & \\
\hline I & 37 & $5^{6}$ & 57.88 & 75 & 54 & 49.54 & $\begin{array}{l}\mathrm{N} \\
\mathrm{N} \\
\mathrm{N}\end{array}$ & $\begin{array}{l}59 \\
15 \\
86\end{array}$ & $\begin{array}{l}\text { O4 } \\
\text { OI } \\
25\end{array}$ & $\begin{array}{l}\mathrm{E} \\
\mathrm{W} \\
\mathrm{W}\end{array}$ & $\begin{array}{l}S \\
S \\
S\end{array}$ & $\begin{array}{l}59 \\
15 \\
86\end{array}$ & $\begin{array}{ll}O_{5} & \text { IV } \\
\text { OI } & \mathrm{E} \\
28 & \mathrm{E}\end{array}$ & $\begin{array}{l}4041 \\
1771 \\
7711\end{array}$ & $\begin{array}{l}\text { Somers Cove Light } \\
\text { Janes Island Light. } \\
\text { Horse. }\end{array}$ \\
\hline 2 & 37 & 57 & 10. 16 & 75 & 53 & $47.4^{6}$ & $\begin{array}{l}\mathrm{N} \\
\mathrm{N} \\
\mathrm{N}\end{array}$ & $\begin{array}{l}71 \\
39 \\
89\end{array}$ & $\begin{array}{l}38 \\
59 \\
24\end{array}$ & $\begin{array}{l}\mathrm{E} \\
\mathrm{E} \\
\mathrm{W}^{\prime}\end{array}$ & $\begin{array}{l}\mathrm{S} \\
\mathrm{S} \\
\mathrm{S}\end{array}$ & $\begin{array}{l}71 \\
40 \\
89\end{array}$ & $\begin{array}{l}40 \mathrm{~W} \\
00 \mathrm{~W} \\
26 \mathrm{Fi}\end{array}$ & $\begin{array}{l}5281 \\
1692 \\
6149\end{array}$ & $\begin{array}{l}\text { Somers Cove Light } \\
\text { Janes Island Light. } \\
\text { Horse. }\end{array}$ \\
\hline 3 & 37 & 57 & 36.68 & 75 & 54 & $13.9 \mathrm{I}$ & $\begin{array}{l}\mathrm{N} \\
\mathrm{S} \\
\mathrm{N}\end{array}$ & $\begin{array}{r}74 \\
1 \\
73\end{array}$ & $\begin{array}{l}\text { o5 } \\
46 \\
\text { oo }\end{array}$ & $\begin{array}{l}\text { W } \\
\mathrm{W} \\
\mathrm{E}\end{array}$ & $\begin{array}{l}\mathrm{S} \\
\mathrm{N} \\
\mathrm{S}\end{array}$ & $\begin{array}{r}74 \\
1 \\
73\end{array}$ & $\begin{array}{ll}\text { O5 } & \mathrm{E} \\
46 & \mathrm{E} \\
\text { OI } & \mathrm{WV}\end{array}$ & $\begin{array}{l}1467 \\
7833 \\
2629\end{array}$ & $\begin{array}{l}\text { Janes Island Light. } \\
\text { Fox Island Poplar. } \\
\text { Somers Cove Light }\end{array}$ \\
\hline$T$ & 37 & 57 & 06. $7^{6}$ & 75 & 54 & 25.70 & $\begin{array}{l}\mathrm{S} \\
\mathrm{N} \\
\mathrm{N}\end{array}$ & $\begin{array}{r}0 \\
57 \\
37\end{array}$ & $\begin{array}{l}37 \\
52 \\
49\end{array}$ & $\begin{array}{l}\mathrm{E} \\
\mathrm{E} \\
\mathrm{IV}\end{array}$ & $\mid \begin{array}{l}N \\
S \\
S\end{array}$ & $\begin{array}{r}0 \\
57 \\
37\end{array}$ & $\begin{array}{l}37 \mathrm{~W} \\
53 \mathrm{~W} \\
50 \mathrm{E}\end{array}$ & $\begin{array}{l}6821 \\
3341 \\
1786\end{array}$ & $\begin{array}{l}\text { Fox Island Poplar. } \\
\text { Somers Cove Light } \\
\text { Janes Island Light. }\end{array}$ \\
\hline
\end{tabular}


BOUNDARIES OF NATURAL OYSTER BARS - continued.

- GREAT ROCK.

(Lower Tangier Sound-Chart No. 9.)

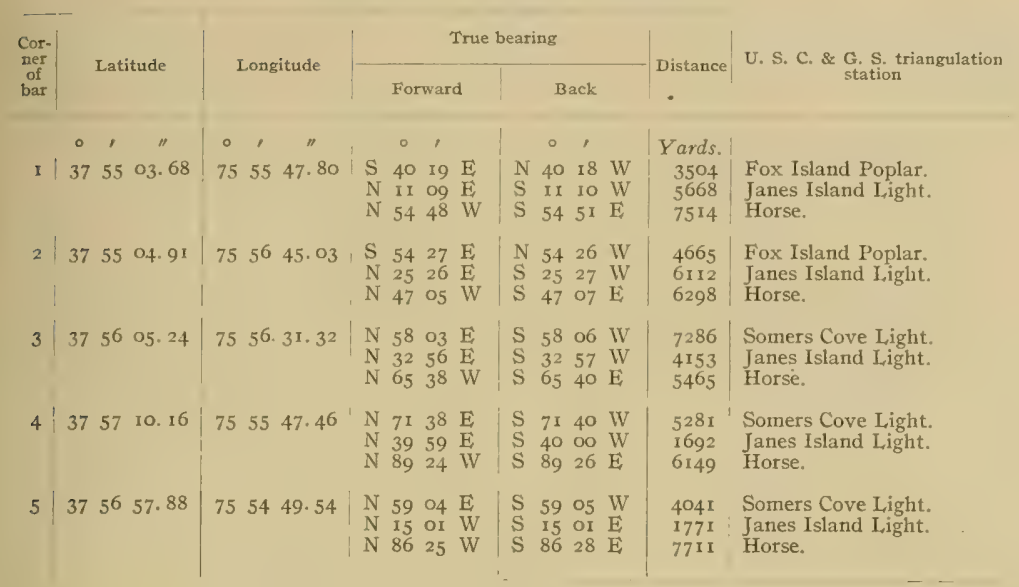

FOX ISLAND.

(Lower Tangier Sound-Chart No. 9.)

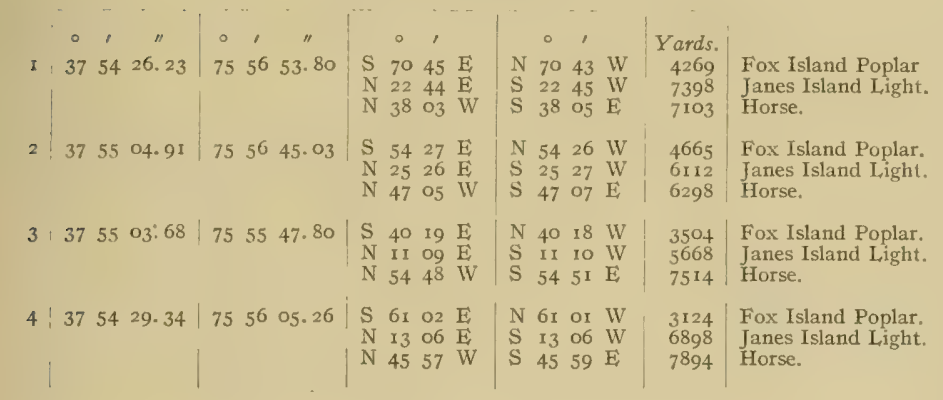


BOUNDARIES OF NATURAL OYSTER BARS-continued.

STONE.

(Northern Pocomoke Sound-Chart No. 9.)

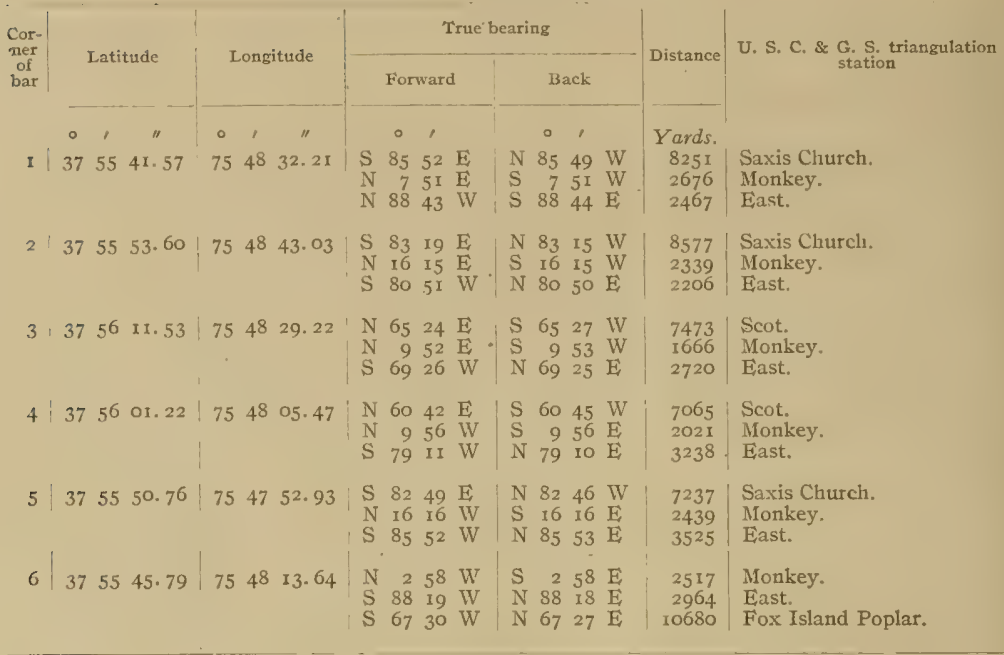

WATKINS.

(Northern Pocomoke Sound-Chart No. 9.)

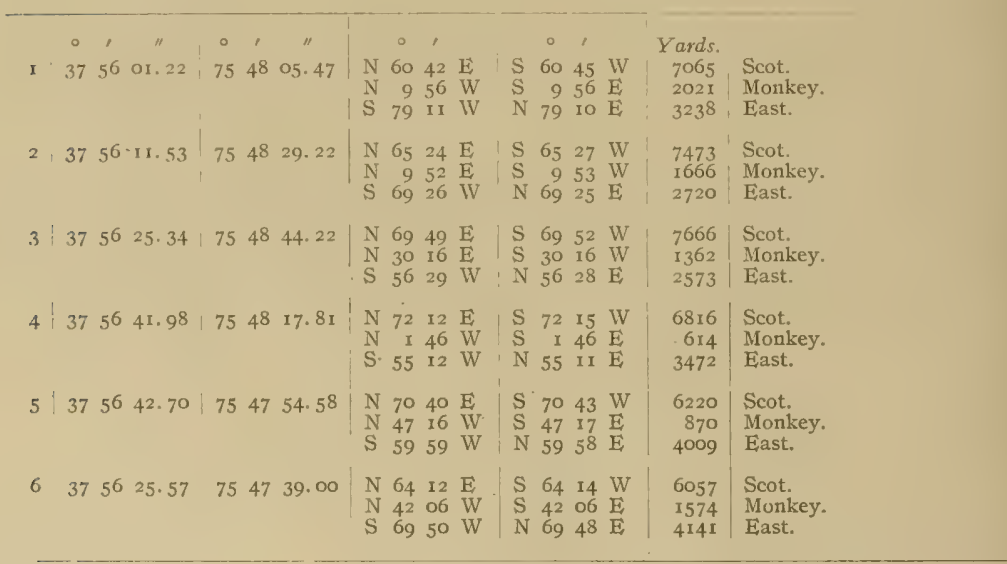


BOUNDARIES OF NATURAL OXSTER BARS - continued.

LONG POINT.

(Northern Pocomoke Sound-Chart No. 9.)

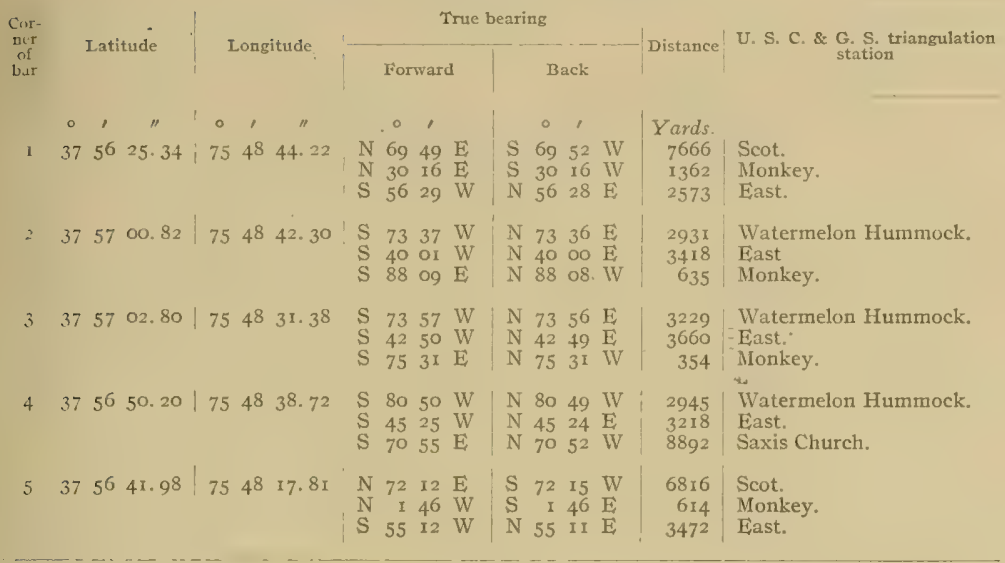

\section{GUNBY. •}

(Middle Pocomoke Sound-Chart No. 1o.)

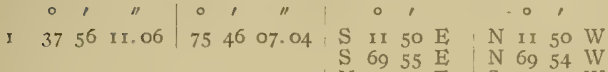
\begin{tabular}{llll|llll}
$\mathrm{S}$ & 69 & 55 & $\mathrm{E}$ & $\mathrm{N}$ & 69 & 54 & $\mathrm{~W}$ \\
$\mathrm{~N}$ & 43 & 49 & $\mathrm{E}$ & $\mathrm{S}$ & 43 & $5 \mathrm{r}$ & $\mathrm{WV}$
\end{tabular}

$2 \quad 375628.98|754640.33| \mathrm{S}$ 19 $31 \mathrm{E}, \mathrm{N}$ 19 31 W $\mathrm{S} 6717 \mathrm{E}, \mathrm{N} 67 \mathrm{I} 5 \mathrm{~W}$ N 57 O3 E 'S 57 O4 W

\begin{tabular}{lllll|lllllll|lll|l}
3 & 37 & 56 & 48.98 & 75 & 46 & 15.36 & $\mathrm{~S}$ & $1 \mathrm{I}$ & $25 \mathrm{E}$ & $\mathrm{N}$ & $\mathrm{II}$ & $24 \mathrm{~W}$
\end{tabular}

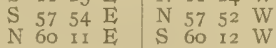

\begin{tabular}{lllll|lllll|llll}
4 & 37 & 56 & 35.02 & 75 & 45 & 34.66 & $\mathrm{~S}$ & I & 10 & $\mathrm{E}$ & $\mathrm{N}$ & I & Io $\mathrm{W}$
\end{tabular} S. 5528 E $\quad \begin{array}{rrrr}5 & 28 & 27 & \text { W }\end{array}$ N $4240 \mathrm{~W} / \mathrm{S} 4241 \mathrm{E}$
Yards.

4762 Mos

4634 Saxis Church.

4330 Scot.

5586 Mos.

5681 Saxis Church.

4632 Scot.

6059 Mos.

5399 Saxis Church.

3712 Scot.

5470 Mos.

423 I Saxis Church.

3 I5O Scot. 
MARUMSCO.

\begin{tabular}{|c|c|c|c|c|c|c|c|c|c|c|c|c|c|}
\hline \multirow{2}{*}{$\begin{array}{c}\text { Cor- } \\
\text { ner } \\
\text { of } \\
\text { bar }\end{array}$} & \multirow{2}{*}{\multicolumn{3}{|c|}{ Latitude }} & \multirow{2}{*}{\multicolumn{3}{|c|}{ Longitude }} & \multicolumn{5}{|c|}{ True bearing } & \multirow{2}{*}{ Distance } & \multirow{2}{*}{$\begin{array}{l}\text { U. S. C. \& G. S. triangulation } \\
\text { station }\end{array}$} \\
\hline & & & & & & & & Forn & vard & & Back & & \\
\hline I & $\begin{array}{c}\circ \\
37\end{array}$ & & $\begin{array}{c}\prime \prime \\
45 \cdot 40\end{array}$ & $\begin{array}{c}\circ \\
75\end{array}$ & & $\begin{array}{c}\prime \prime \\
\text { 30. } 51\end{array}$ & $\begin{array}{l}\mathrm{S} \\
\mathrm{S} \\
\mathrm{N}\end{array}$ & $\begin{array}{c}\circ \\
15 \\
32 \\
62\end{array}$ & $\begin{array}{ll}2 \\
24 \mathrm{~W} \\
50 \mathrm{E} \\
44 \mathrm{E}\end{array}$ & $\mid \begin{array}{cc} & 0 \\
N & 15 \\
N & 32 \\
S & 62\end{array}$ & $\begin{array}{l}23 \mathrm{E} \\
49 \mathrm{~W} \\
46 \mathrm{~W}\end{array}$ & $\begin{array}{c}\text { Yards. } \\
6034 \\
3272 \\
5484\end{array}$ & $\begin{array}{l}\text { Mos. } \\
\text { Saxis Church. } \\
\text { Old. }\end{array}$ \\
\hline 2 & 37 & 57 & 27. 13 & 75 & 45 & 13. 96 & $\begin{array}{l}\mathrm{S} \\
\mathrm{S} \\
\mathrm{N}\end{array}$ & $\begin{array}{r}3 \\
35 \\
70\end{array}$ & $\begin{array}{l}30 \mathrm{~W} \\
13 \mathrm{E} \\
33 \mathrm{E}\end{array}$ & $\begin{array}{lr}\mathrm{N} & 3 \\
\mathrm{~N} & 35 \\
\mathrm{~S} & 70\end{array}$ & $\begin{array}{ll}30 & \mathrm{E} \\
12 & \mathrm{~W} \\
33 & \mathrm{~W}\end{array}$ & $\begin{array}{l}7239 \\
5087 \\
1678\end{array}$ & $\begin{array}{l}\text { Mos. } \\
\text { Saxis Church. } \\
\text { Scot. }\end{array}$ \\
\hline 3 & 37 & & 39.07 & 75 & 43 & 56.62 & $\begin{array}{l}\mathrm{N} \\
\mathrm{S} \\
\mathrm{N}\end{array}$ & $\begin{array}{l}72 \\
10 \\
79\end{array}$ & $\begin{array}{l}05 \mathrm{~W} \\
47 \mathrm{E} \\
58 \mathrm{E}\end{array}$ & \begin{tabular}{|ll}
$S$ & 72 \\
$N$ & 10 \\
S & 79
\end{tabular} & $\begin{array}{l}05 \mathrm{E} \\
47 \mathrm{~W} \\
59 \mathrm{~W}\end{array}$ & $\begin{array}{r}507 \\
4641 \\
4032\end{array}$ & $\begin{array}{l}\text { Scot. } \\
\text { Saxis Church. } \\
\text { Old. }\end{array}$ \\
\hline 4 & 37 & & 55.12 & 75 & 43 & 48.54 & $\begin{array}{l}\mathrm{S} \\
\mathrm{N} \\
\mathrm{N}\end{array}$ & $\begin{array}{l}11 \\
59 \\
23\end{array}$ & $\begin{array}{ll}58 & \mathrm{E} \\
49 & \mathrm{E} \\
\text { II } & \mathrm{W}\end{array}$ & $\begin{array}{ll}\text { N } & \text { II } \\
\text { S } & 59 \\
\text { S } & 23\end{array}$ & $\begin{array}{l}58 \mathrm{~W} \\
50 \mathrm{~W} \\
\text { II } \mathrm{E}\end{array}$ & $\begin{array}{l}3146 \\
4344 \\
1781\end{array}$ & $\begin{array}{l}\text { Saxis Church. } \\
\text { Old. } \\
\text { Scot. }\end{array}$ \\
\hline
\end{tabular}

KITTS CREEK WEST.

(Upper Pocomoke Sound-Chan No. ro.)

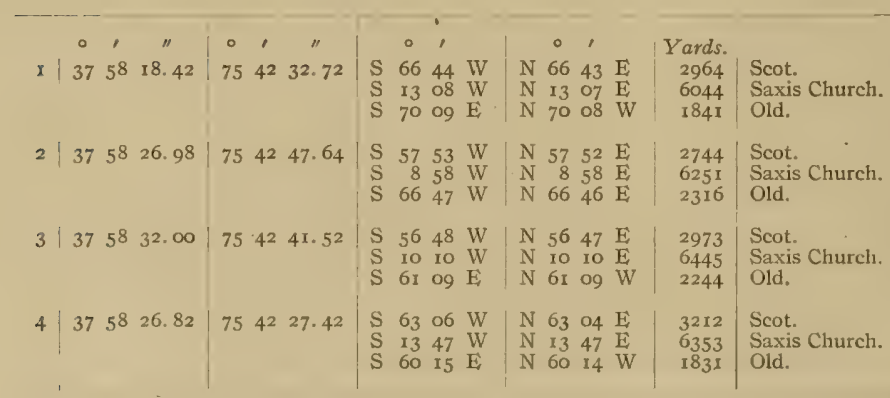


BOUNDARIES OF NATURAL OYSTER BARS-continued.

KITTS CREEK EAST.

(Upper Pocomoke Sound-Chart No. Io.)

\begin{tabular}{|c|c|c|c|c|c|c|c|c|c|c|c|c|c|c|}
\hline \multirow{2}{*}{$\begin{array}{c}\text { Cor- } \\
\text { ner } \\
\text { of } \\
\text { bar }\end{array}$} & \multirow{2}{*}{\multicolumn{3}{|c|}{ Latitude }} & \multirow{2}{*}{\multicolumn{3}{|c|}{ Longitude }} & \multicolumn{6}{|c|}{ True bearing } & \multirow{2}{*}{ Distance } & \multirow{2}{*}{$\begin{array}{l}\text { U. S. C. \& G. S. triangulation } \\
\text { station }\end{array}$} \\
\hline & & & & & & & & Form & rward & & $\mathrm{Bac}$ & ack & & \\
\hline I & $\begin{array}{l}\circ \\
37\end{array}$ & $\begin{array}{l}, \\
57\end{array}$ & 58. 16 & $\begin{array}{c}\circ \\
75\end{array}$ & ' & $47 \cdot 71$ & $\begin{array}{l}\mathrm{S} \\
\mathrm{S} \\
\mathrm{N}\end{array}$ & $\begin{array}{l}\circ \\
82 \\
26 \\
83\end{array}$ & $\begin{array}{ll} \\
56 & W \\
20 & W \\
45 & E\end{array}$ & $\begin{array}{ll}\mathrm{N} & 8 \\
\mathrm{~N} & 2 \\
\mathrm{~S} & 8\end{array}$ & $\begin{array}{ll}\circ & \\
82 & 5 \\
26 & 1 \\
83 & 4\end{array}$ & $\begin{array}{ll}54 & \mathrm{E} \\
19 & \mathrm{E} \\
45 & \mathrm{WV}\end{array}$ & $\left|\begin{array}{r}\text { Yards. } \\
3954 \\
5805 \\
533\end{array}\right|$ & $\begin{array}{l}\text { Scot. } \\
\text { Saxis Church. } \\
\text { Old. }\end{array}$ \\
\hline 2 & 37 & .58 & $15.7^{8}$ & 75 & 42 & 26.14 & $\begin{array}{l}\mathrm{S} \\
\mathrm{S} \\
\mathrm{S}\end{array}$ & $\begin{array}{l}69 \\
145 \\
70\end{array}$ & $\begin{array}{ll}32 & \mathrm{WV} \\
57 & \mathrm{WV} \\
59 & \mathrm{E}\end{array}$ & $\begin{array}{ll}N & 6 \\
N & 1 \\
N & 7\end{array}$ & $\begin{array}{ll}69 & 3 \\
14 & 5 \\
70 & 5\end{array}$ & $\begin{array}{ll}31 & \mathrm{E} \\
57 & \mathrm{E} \\
58 & \mathrm{~W}\end{array}$ & $\begin{array}{l}3093 \\
6001 \\
1645\end{array}$ & $\begin{array}{l}\text { Scot. } \\
\text { Saxis Church. } \\
\text { Old. }\end{array}$ \\
\hline 3 & 37 & $5^{8}$ & 24.01 & 75 & 42 & 20.96 & $\begin{array}{l}S \\
S \\
S\end{array}$ & $\begin{array}{l}655 \\
153 \\
60\end{array}$ & $\begin{array}{ll}54 & \mathrm{WV} \\
3 \mathrm{I} & \mathrm{W} \\
08 \mathrm{E}\end{array}$ & $\begin{array}{ll}N & 6 \\
N & \mathrm{I} \\
\mathrm{N} & 6\end{array}$ & $\begin{array}{ll}65 & 5 \\
15 & 3 \\
60 & 0\end{array}$ & $\begin{array}{ll}52 & \mathrm{E} \\
30 & \mathrm{E} \\
08 & \mathrm{~W}\end{array}$ & $\begin{array}{l}3327 \\
6305 \\
1634\end{array}$ & $\begin{array}{l}\text { Scot. } \\
\text { Saxis Church. } \\
\text { Old. }\end{array}$ \\
\hline 4 & 37 & $5^{8}$ & I6. 70 & 75 & $4^{2}$ & 09.59 & $\begin{array}{l}\mathrm{S} \\
\mathrm{S} \\
\mathrm{S}\end{array}$ & $\begin{array}{l}71 \\
18 \\
63\end{array}$ & $\begin{array}{ll}35 & W \\
5 I & W \\
\text { OO } & E\end{array}$ & $\begin{array}{ll}\mathrm{N} & 7 \\
\mathrm{~N} & \mathrm{I} \\
\mathrm{N} & 6\end{array}$ & $\begin{array}{ll}71 & 3 \\
18 & 5 \\
63 & 0\end{array}$ & $\begin{array}{ll}34 & \mathrm{E} \\
5 \mathrm{I} & \mathrm{E} \\
00 & \mathrm{~W}\end{array}$ & $\begin{array}{l}3520 \\
6158 \\
1249\end{array}$ & $\begin{array}{l}\text { Scot. } \\
\text { Saxis Church } \\
\text { Old. }\end{array}$ \\
\hline 5 & 37 & $5^{8}$ & 06.40 & 75 & 41 & 41.59 & $\begin{array}{l}\mathrm{S} \\
\mathrm{S} \\
\mathrm{S}\end{array}$ & $\begin{array}{ll}79 & 2 \\
26 & 3 \\
59 & \end{array}$ & $\begin{array}{ll}25 & \mathrm{~W} \\
33 & \mathrm{~W} \\
\infty & \mathrm{E}\end{array}$ & $\begin{array}{ll}\mathrm{N} & 7 \\
\mathrm{~N} & 2 \\
\mathrm{~N} & 5\end{array}$ & $\begin{array}{ll}79 & 2 \\
26 & 3 \\
59 & 0\end{array}$ & $\begin{array}{ll}23 & E \\
32 & E \\
00 & W\end{array}$ & $\begin{array}{r}4159 \\
6131 \\
426\end{array}$ & $\begin{array}{l}\text { Scot. } \\
\text { Saxis Church. } \\
\text { Old. }\end{array}$ \\
\hline
\end{tabular}

\section{BOUNDARIES OF CRAB BOTTOMS.}

\section{EXPLANATION OF DESCRIPTIONS OF BOUNDARIES.}

The laws providing for the survey of the oyster bars of Maryland also contain a section which requires "an accurate survey of and delineation upon the maps and charts aforesaid of all bottoms of the tributaries of the Chesapeake Bay where grass grows and it is profitable to scrape for soft shell or shedder crabs, and shall have such bottoms properly designated by permanent objects on the shore, as provided hereinbefore for natural oyster beds, bars, and rocks, which said crabbing sections shall be exempt from leasing for oyster culture.'

The crab bottoms of Somerset County are the first ones to be surveyed in Maryland, ${ }^{\circ}$ and as far as known such a survey is altogether a new problem which differs ${ }^{b}$ in many ways from that of a survey of oyster bars.

In a general way it can be stated that the boundaries of the crab bottoms as established by the Maryland Shell Fish Commission and delineated on the "Charts of Ovster Bars," published by the Coast and Geodetic Survey, are confined to waters between the I-fathon contour ( 6 feet depth of water) and the shore line. Therefore, in most cases the mean low water line of the shore has been adopted as an inner boundary for the

"Anne Arundel County has no crab bottoms within the meaning of the law.

$b$ See pages 69 to 70 of "First Annual Report of Maryland Shell Fish Commission" for description of "Survey of crabbing grounds." 
crab bottoms, but the same system of straight lines and numbered comers used to delineate the oyster bars has been retained for defining the offshore water boundaries.

There are 54 individual "crab bottoms" in Somerset County exempt from leasing for oyster culture which have been surveyed and delineated under separate names by the Commission, and their total area as determined by the hydrographic engineer of the Commission is 32,108 acres. The largest of these bottoms is 2,182 acres and the smallest 23 acres.

The boundaries of the crab bottoms of Somerset County as established by the Shell Fish Commission and shown on the Coast and Geodetic Survey ciarts and projections and on the "leasing charts" of the Commission are technirally defined and described by a method but little different from that used for the description of the boundaries of oyster bars.

The descriptions have been arranged in tabular form, thus avoiding many hundred repetitions of the same words by making one explanation of the tables sufficient for all crabbing bottoms in the county.

At the top of each tabular form is given the legal name of the crab bottom to be described, its general locality, and the serial numbers of the "Charts of Oyster Bars" of Maryland on which its boundaries are shown.

The first column, under the heading of "Corner of bottom," gives the number corresponding to the corner of the boundary as shown on the charts. These numbers have been assigned to the corners of the crab bottoms in a slightly different manner from that used in describing the oyster bars, although both proceed in a clockwise direction around their boundaries. In delineating the crab bottoms it was generally planned to have both the first and last corners fall on land, thus making the mean low-water line of the shore between these two corners form the connecting boundary, as is always stated in such cases in a note at the bottom of the tabular descriptions. Where a corner of one bottom is identical with the corners of one or more other crab bottoms, oyster bars, or clam beds, only the number of the crab bottom being described in the table is given in this column.

The second and third columns, under the headings of "Latitude" and "Longitude," give the geographic positions of the corners. These positions have been adopted by the Commission as the primary technical definitions of the corners, and should be considered as final in case of a dispute arising from discrepancies caused by other means of location. The latitudes and longitudes given in these columns are based on the United States standard datum of the Coast and Geodetic Survey, and the points thus defined can be relocated from distant triangulation stations of the Survey, even though all the landmarks and buoys used for their original location lave been destroyed.

The fourth and fifth columns, under the general heading of "True bearing" "and the specific headings of "Forward" and "Back," give bearings measured from a true north and south line. The three "Forward". bearings are from the corner of the boundary designated in the first column to the triangulation stations named on the corresponding lines in the last column, and the three "Back" bearings are from these same stations in the last column to the corresponding corner of boundary in the first column.

$a$ The mean magnetic variation of Somerset County for 1908 was $5^{\circ} 30^{\prime}$ west of north and increasing at the rate of $3^{\prime}$ yearly. 
The sixtl column, under the heading of "Distance," gives the three computed distances in yards from the corner of the crab bottom noted in the first column to the three triangulation stations named on the corresponding lines in the last column, and vice versa.

The seventh and last column, under the heading of "U. S. C. \& G. S. triangulation station," gives the names of the landmarks from which were computed the corresponding "Latitude," "Longitude," "True bearing," and "Distance" of the "Corner of the bottom" designated in the first column. A full description of the location and markings of these triangulation stations is given in another part of this publication, under the heading of "Descriptions of landmarks."

The descriptive note of the shore line boundary which usually follows the description of the last corner on the tabular form and sometimes between intermediate corners which happen to fall on land requires no explanation, other than to state that the laws of Maryland reserve to riparian owners all waters of "any creek, cove, or inlet less than one hundred yards in width at its mouth at low tide."

\section{SURVEYING METHODS FOR REIOCATION OF IBOUNDARIES.}

There are a number of methods that can be used in the relocation of the actual boundaries of the crab bottoms as technically described in this publication and delineated on the published charts of the Coast and Geodetic Survey, but as they are practically the same as those required for the relocation of oyster-bar boundaries the description of the "Surveying methods for relocation of boundaries" under the heading of "Boundaries of oyster bars" in this publication will be sufficient to indicate several methods that can be used in the relocation of crab-bottom boundaries.

BOUNI)ARIES (OF CRIB BUTTOMS.

DEEP BANKS.

(Inner Ilolland Straits-Charts Nos. 5 and 6.)

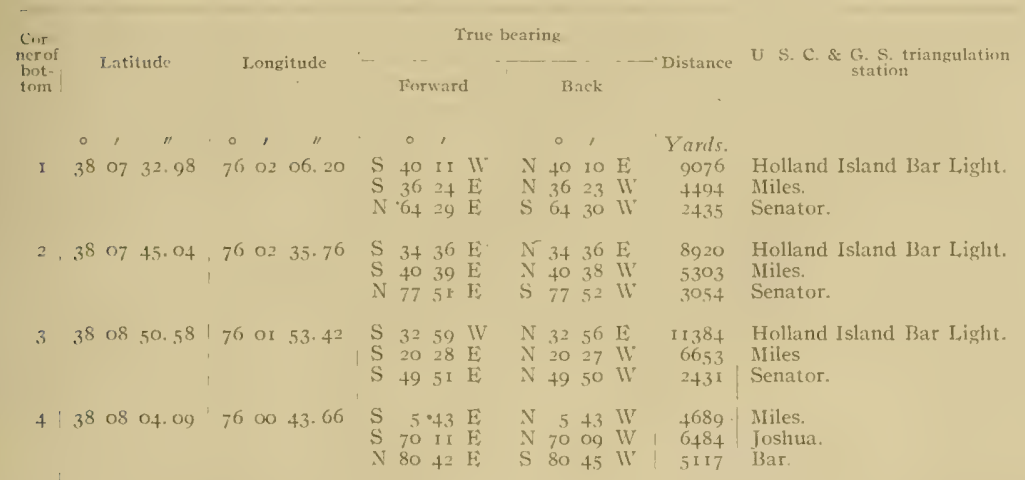

Thence from corner No. 4 along the mean low-water line of the shore to corner No. I, exeluding any creek, cove, or inlet less than roo yards in width at its mouth at low tide. 


\section{BOUNDARIES OF CRAB BOTTOMS-continued.}

\section{HOLLAND STRAITS.}

(IVest Tangier Sound-Charts Nos. 5, 6, and 7.)

\begin{tabular}{|c|c|c|c|c|c|c|c|c|c|c|c|c|c|c|}
\hline \multirow{2}{*}{$\begin{array}{c}\text { Cor- } \\
\text { ner of } \\
\text { bot- } \\
\text { tom }\end{array}$} & \multirow{2}{*}{\multicolumn{3}{|c|}{ Latitude }} & \multirow{2}{*}{\multicolumn{2}{|c|}{ Longitude }} & \multicolumn{7}{|c|}{ True bearing } & \multirow{2}{*}{ Distance } & \multirow{2}{*}{$\begin{array}{l}\text { U. S. C. \& G. S. triangulation } \\
\text { station }\end{array}$} \\
\hline & & & & & & & Forv & ward & & & Back & & & \\
\hline I & $\begin{array}{c}\circ \\
.38\end{array}$ & s os & $\begin{array}{c}\prime \prime \\
04.09\end{array}$ & $\begin{array}{c}\circ \quad, \\
76 \text { oo }\end{array}$ & 43. 66 & $\begin{array}{l}\mathrm{S} \\
\mathrm{S} \\
\mathrm{N}\end{array}$ & $\begin{array}{r}\circ \\
5 \\
70 \\
80\end{array}$ & $\begin{array}{ll}\text { ' } \\
43 \\
\text { II } \\
4^{2} & \mathrm{E} \\
4 & \mathrm{E}\end{array}$ & & $\begin{array}{lr} & 0 \\
N & 5 \\
N & 70 \\
S & 80\end{array}$ & $\begin{array}{l}1 \\
43 \\
09 \\
45\end{array}$ & $\begin{array}{l}\text { IV } \\
\text { WV } \\
\text { WW }\end{array}$ & $\begin{array}{r}\text { Yards. } \\
4689 \\
6484 \\
5117\end{array}$ & $\begin{array}{l}\text { Miles. } \\
\text { Joshua. } \\
\text { Bar. }\end{array}$ \\
\hline 2 & 38 & 8 os & $5^{0 .} .5^{8}$ & 76 or & $53 \cdot+2$ & $\begin{array}{l}\mathrm{S} \\
\mathrm{S} \\
\mathrm{S}\end{array}$ & $\begin{array}{l}32 \\
20 \\
49\end{array}$ & $\begin{array}{ll}59 & \text { UI } \\
28 & \mathrm{E} \\
5 \mathrm{I} & \mathrm{E}\end{array}$ & & $\begin{array}{ll}N & 32 \\
N & 20 \\
N & 49\end{array}$ & $\begin{array}{l}56 \\
27 \\
50\end{array}$ & $\begin{array}{l}\mathrm{E} \\
\mathrm{WV} \\
\mathrm{W}\end{array}$ & $\begin{array}{r}11384 \\
6653 \\
2431\end{array}$ & $\begin{array}{l}\text { Holland Island J3ar I,ight } \\
\text { Miles. } \\
\text { Senator. }\end{array}$ \\
\hline 3 & 38 & 809 & 26.74 & 76 oo & $23 \cdot 4^{8}$ & $\begin{array}{l}\text { S } \\
\text { S } \\
N\end{array}$ & $\begin{array}{l}10 \\
87 \\
32\end{array}$ & $\begin{array}{l}55 \mathrm{H} \\
10 \mathrm{E} \\
4 \mathrm{I} \mathrm{H}\end{array}$ & & $\begin{array}{ll}N & 10 \\
N & 87 \\
\text { S } & 32\end{array}$ & $\begin{array}{l}55 \\
07 \\
41\end{array}$ & $\begin{array}{l}\text { E } \\
\text { W } \\
\text { E }\end{array}$ & $\begin{array}{l}2838 \\
5546 \\
2607\end{array}$ & $\begin{array}{l}\text { Senator. } \\
\text { Deal Island Church. } \\
\text { Crab. }\end{array}$ \\
\hline+ & 38 & 809 & 06. 39 & 7600 & 41.00 & $\begin{array}{l}\mathrm{S} \\
\mathrm{N} \\
\mathrm{N}\end{array}$ & $\begin{array}{r}1 \\
86 \\
18\end{array}$ & $\begin{array}{l}56 \mathrm{Wl} \\
05 \mathrm{~K} \\
\text { o6 } \mathrm{HI}\end{array}$ & & $\begin{array}{lr}N & 1 \\
S & 86 \\
S & 18\end{array}$ & $\begin{array}{l}56 \\
07 \\
06\end{array}$ & $\begin{array}{l}\mathrm{E} \\
\text { IV } \\
\mathrm{E}\end{array}$ & $\begin{array}{l}2102 \\
6019 \\
3030\end{array}$ & $\begin{array}{l}\text { Senator. } \\
\text { Deal Island Churelı. } \\
\text { Crab. }\end{array}$ \\
\hline 5 & 38 & 808 & 42.38 & 7600 & 20.00 & $\begin{array}{l}\mathrm{S} \\
\stackrel{N}{N}\end{array}$ & $\begin{array}{l}26 \\
77 \\
22\end{array}$ & $\begin{array}{ll}\text { OI I } \\
22 & \mathrm{E} \\
\text { O8 } & \mathrm{H}\end{array}$ & & $\begin{array}{ll}\text { N } & 26 \\
\text { S } & 77 \\
\text { S } & 22\end{array}$ & $\begin{array}{l}01 \\
24 \\
08\end{array}$ & $\begin{array}{l}\mathrm{E} \\
\text { IV } \\
\mathrm{E}\end{array}$ & $\begin{array}{l}\text { I }+37 \\
5582 \\
3984\end{array}$ & $\begin{array}{l}\text { Senator. } \\
\text { Deal Island Churcl. } \\
\text { Crab. }\end{array}$ \\
\hline
\end{tabular}

\section{PUNGERS CREEK.}

(West Upper Tangier Sound-Charts Nos. 5, 6, and 7.)

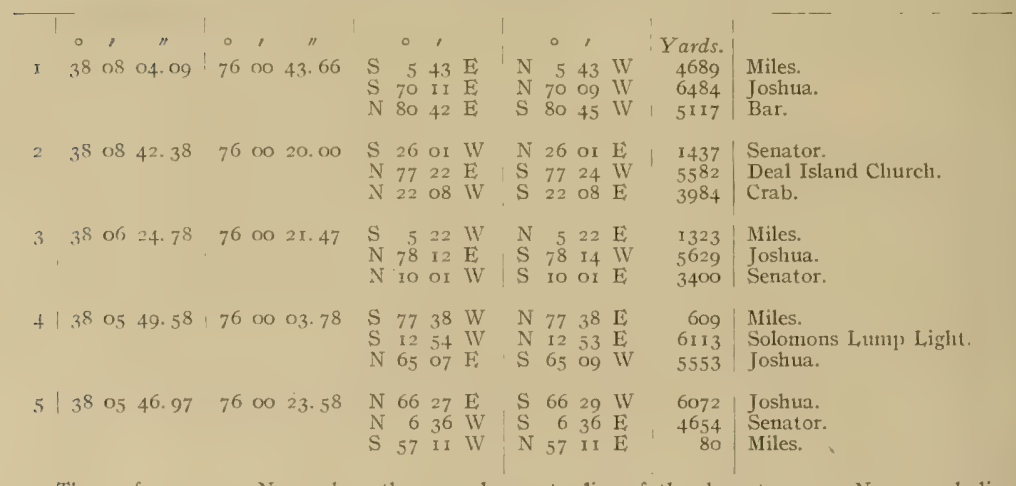

Thence from corner No. 5 along the mean low-water line of the shore to corner No. I, excluding any creek, cove, or inlet less than roo yards in width at its mouth at low tide. 
Survey of Oysler Bars, Somerset County, $1 / d$.

BOUNDARIES OF CRAB BOTTOMS-continued.

\section{LAW'S THOROUGHFARE NORTH.}

(Northeast Tangier Sound-Inside Dcal Island-Chant No. 5.)

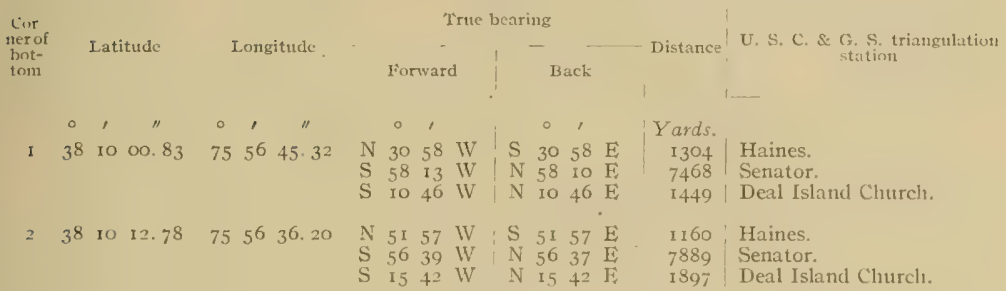

Thence from corner No. 2 along the mean low-water line of the shore to corner No. I, exchulisg any creek, cove, or inlet less than roo yards in width at its mouth at low tide.

DEAL, ISLAND.

(East Upper Tangier Sound-Charls Nos. 5 and 7.)

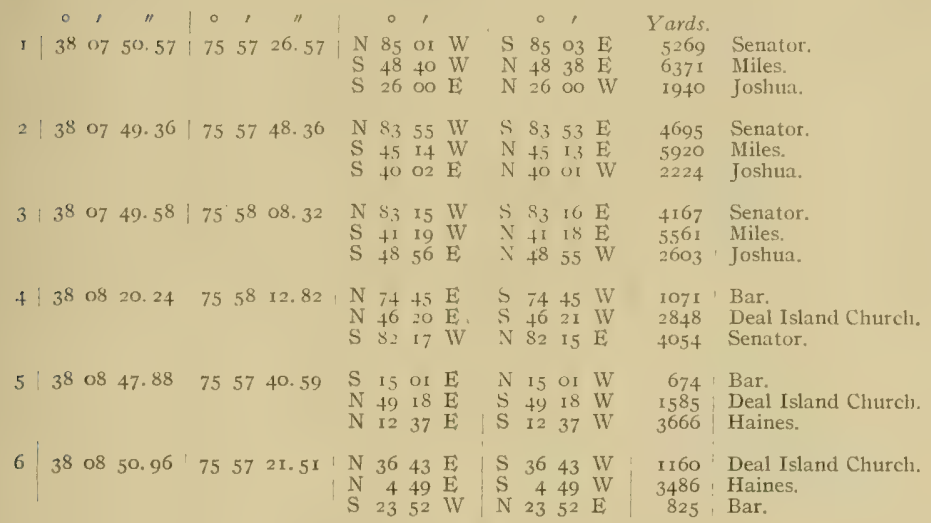

Thence from corner No. 6 along the mean low-water line of the shore to corner No. 1 , excluding any creek, cove, or inlet less than roo yards in width at its mouth at low tide. 
IHOUNDARIES OF CRAB BOTTOMS--continUEA.

\section{LAIVS THOROUGHFARE SOUTH.}

(North Manokin Rizer-Inside of Deal 1stand-Charls Nos, 5 and 7.)

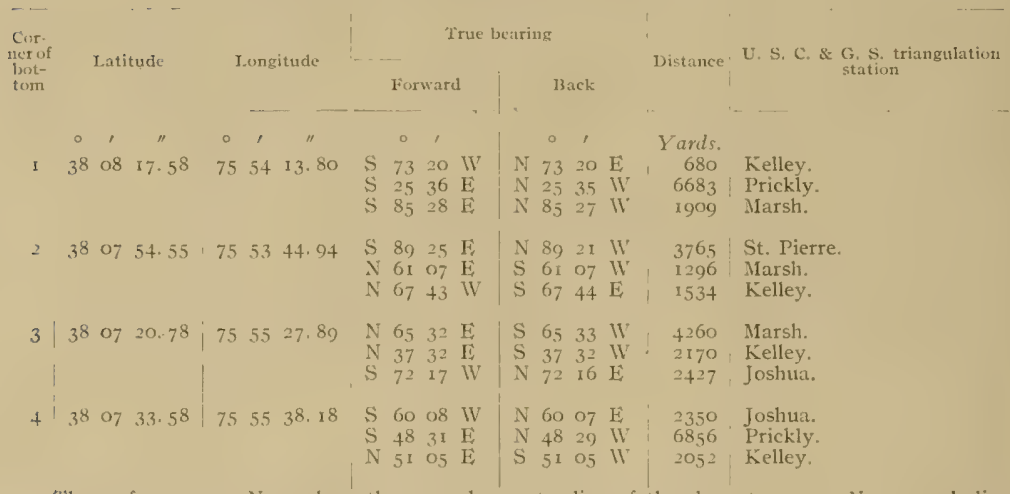

Thence from corner No. 7 along the mean low-water line of the shore to corner Nu. 1, cxcluding any creek, cove, or inlet less than ioo yards in width at its mouth at low tide.

\section{MARSH ISLAND.}

(North Shore Manokin Rizer-Charts Nos. 5 and 7.)

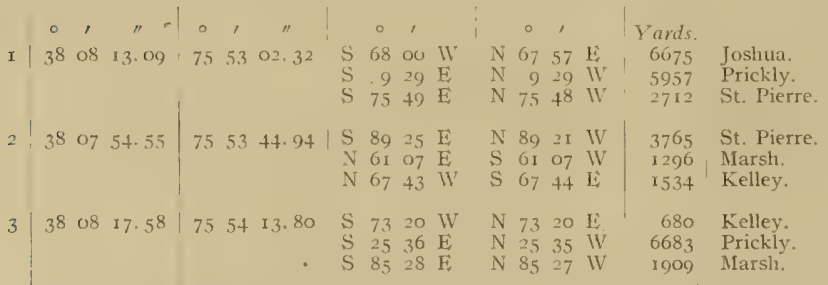

Thence from corner No. 3 along the mean low-water line of the shore to corner No. 1 , excluding any creek, cove, or inlet less than 100 yards in width at its mouth at low tide. 
BOUNDARIES OF CRAB BOTTOMS-continUEd.

S"I. PIERRE.

(Nonth Shore Manokin Rizcr-("harts Nos. 5 and 7 .)

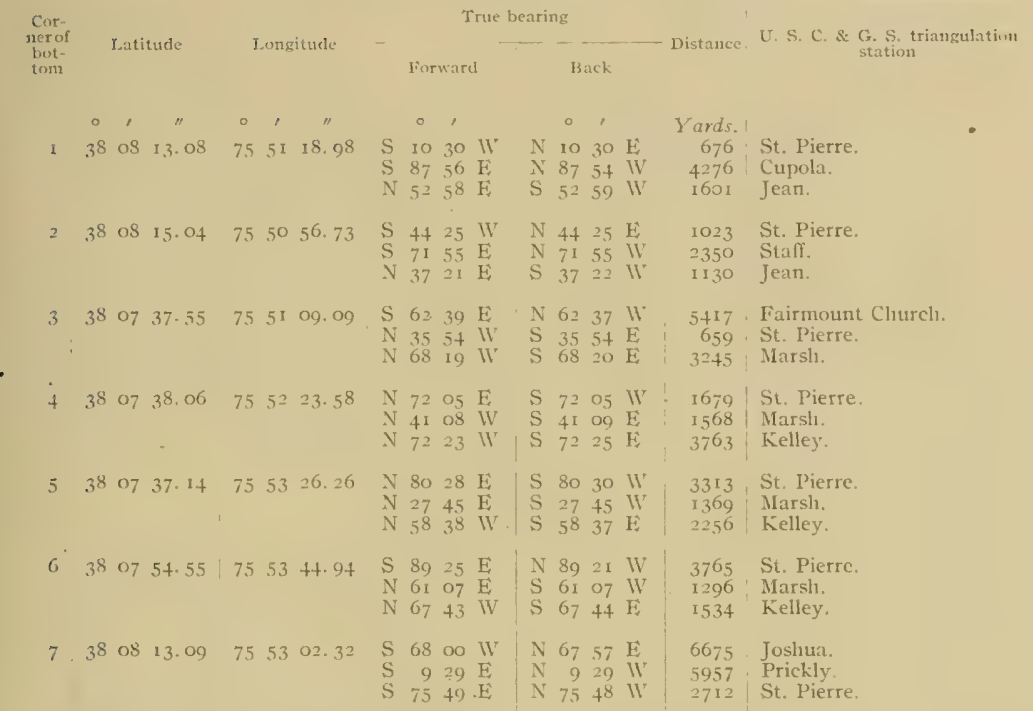

Thence from corner No, 7 along the mean low-water line of the shore to corner No, s, excluding any creek, cove, or inlet less than 100 yards in width at its mouth at low tide.

\section{GEANQUAKIN.}

(Vorth Shore Manokin River-Charts Nos. 5 and 7.)

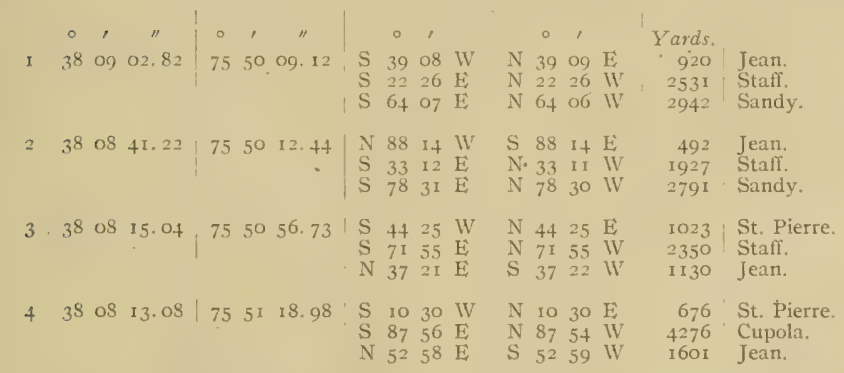

Thence from corner No. 4 along the mean low-water line of the shore to corner No. I, excluding any creek, cove, or inlet less than 100 yards in width at its mouth at low tide. 
BOUNDARIFS OF CRAB BOTTOMS continued.

SPRING ISLAND.

(East Shore Holland Straits-Chart No.6.)

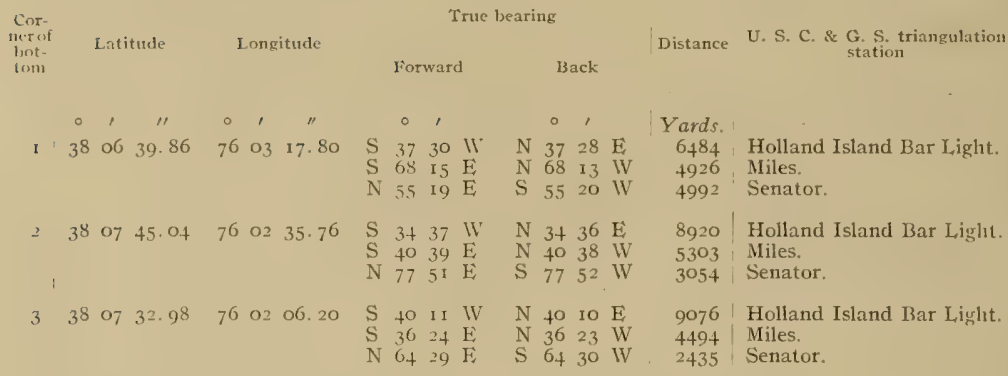

Thence from comer No. 3 along the mean low-water line of the shore to corner No. 1 , excluding any creek, cove, or inlet less than 100 yards in width at its mouth at low tide.

\section{PRY COVE.}

(East Shore Holland Straits-Chart No.6.)

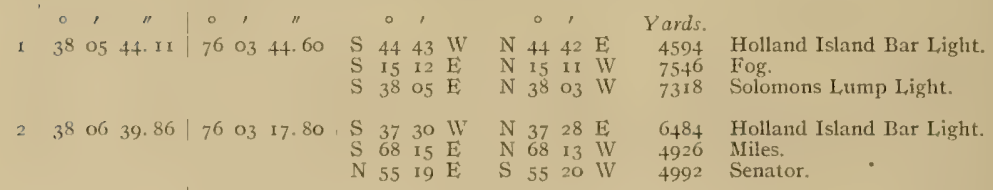

Thence from corner No, 2 along the mean low-water line of the shore to corner No. r, excluding any creek, cove, or inlet less than roo yards in width at its mouth at low tide. 
BOUNDARIES OF CRAB BOTTOMS-continued.

NORTH KEDGE STRAITS.

(Entrance Kedge Straits-Chart No. 6.)

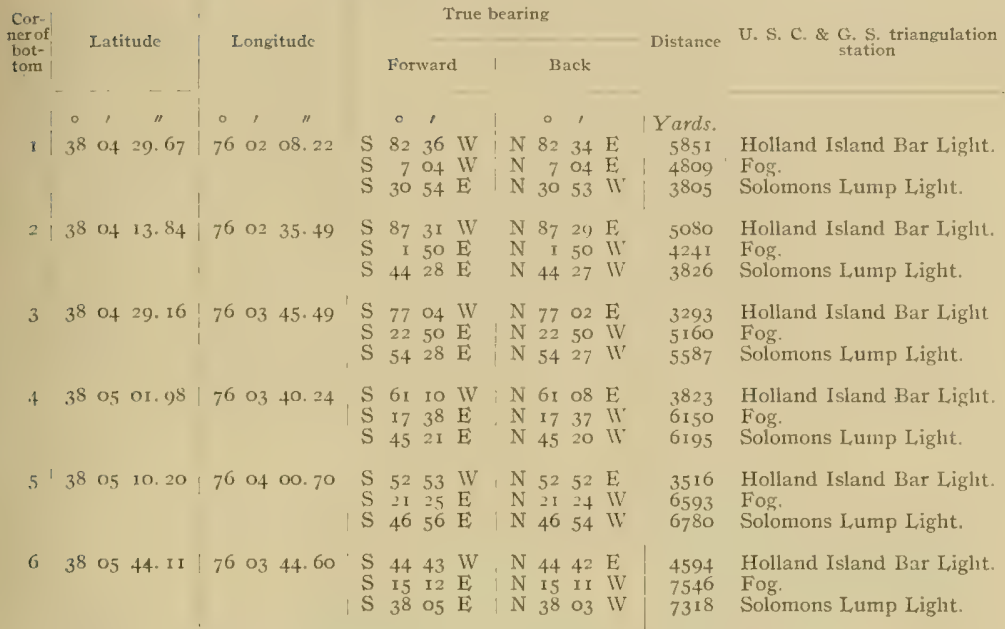

Thence from corner No. 6 along the mean low-water line of the shore to corner No. I, excluding any creek, cove, or inlet less than roo yards in width at its mouth at low tide.

\section{SHEEPSHEAD.}

(North Kedge Straits-Charts Nos. 6 and 7.)

\begin{tabular}{|c|c|c|c|c|c|c|c|c|c|c|c|c|c|}
\hline $\begin{array}{c}0 \\
38\end{array}$ & ' & $\begin{array}{c}\text { " } 4.98 \\
\text { I }\end{array}$ & $\begin{array}{c}0 \\
76\end{array}$ & ' & $\begin{array}{c}\prime \prime \\
+7 \cdot 5^{8}\end{array}$ & $\begin{array}{l}\mathrm{S} \\
\mathrm{N}\end{array}$ & $\begin{array}{r}0 \\
4 \\
48 \\
10\end{array}$ & $\begin{array}{ll}1 \\
04 \\
\text { I } 8 & \mathrm{E} \\
36 & \mathrm{E}\end{array}$ & $\begin{array}{l}N \\
S \\
S\end{array}$ & $\begin{array}{r}0 \\
4 \\
48 \\
10\end{array}$ & $\begin{array}{ll}0 \\
03 \\
21 & 11 \\
36 & 11\end{array}$ & $\begin{array}{l}\text { Yards. } \\
2777 \\
8310 \\
3112\end{array}$ & $\begin{array}{l}\text { Solomons Lump Light. } \\
\text { Joshua. } \\
\text { Iiles. }\end{array}$ \\
\hline 38 & $\mathrm{O}_{3}$ & $07.8 \mathrm{I}$ & 7.5 & 59 & $52+42$ & $\begin{array}{l}\mathrm{N} \\
\mathrm{N} \\
\mathrm{S}\end{array}$ & $\begin{array}{r}31 \\
9 \\
73\end{array}$ & $\begin{array}{ll}17 & \mathrm{E} \\
34 \mathrm{WV} \\
09 \mathrm{~W}\end{array}$ & $\begin{array}{l}\mathrm{S} \\
\mathrm{S} \\
\mathrm{N}\end{array}$ & $\begin{array}{r}31 \\
9 \\
73\end{array}$ & $\begin{array}{l}\text { I9 } \mathrm{II} \\
3.5 \mathrm{E} \\
\text { O9 E }\end{array}$ & $\begin{array}{l}9118 \\
5399 \\
1742\end{array}$ & $\begin{array}{l}\text { Joshua. } \\
\text { Miles. } \\
\text { Solomons Lump Light. }\end{array}$ \\
\hline 38 & 303 & 52.80 & $7^{6}$ & OI & 33.90 & $\begin{array}{l}N \\
\mathrm{~S} \\
\mathrm{~S}\end{array}$ & $\begin{array}{l}85 \\
23 \\
27\end{array}$ & $\begin{array}{ll}49 & W \\
\text { IO } & W \\
\text { II } & \mathrm{E}\end{array}$ & $\begin{array}{l}\mathrm{S} \\
\mathrm{N} \\
\mathrm{N}\end{array}$ & $\begin{array}{l}85 \\
23 \\
27\end{array}$ & $\begin{array}{ll}52 & \mathrm{E} \\
\text { Og } & \mathrm{E} \\
\text { I I } & \mathrm{WV}\end{array}$ & $\begin{array}{l}6734 \\
3837 \\
2272\end{array}$ & $\begin{array}{l}\text { Holland Island Bar Light. } \\
\text { Fog. } \\
\text { Solomons Lump Light. }\end{array}$ \\
\hline 38 & 304 & I3. 84 & 76 & 02 & 35.49 & $\begin{array}{l}\mathrm{S} \\
\mathrm{S} \\
\mathrm{S}\end{array}$ & $\begin{array}{r}87 \\
1 \\
44\end{array}$ & $\begin{array}{ll}3 I & W \\
50 & E \\
28 & E\end{array}$ & $\begin{array}{l}\mathrm{N} \\
\mathrm{N} \\
\mathrm{N}\end{array}$ & $\begin{array}{r}87 \\
1 \\
44\end{array}$ & $\begin{array}{ll}29 \mathrm{E} \\
50 \mathrm{IV} \\
27 \mathrm{WV}\end{array}$ & $\begin{array}{l}5080 \\
424 I \\
3826\end{array}$ & $\begin{array}{l}\text { Holland Island Bar Light. } \\
\text { Fog. } \\
\text { Solomons Lump Light. }\end{array}$ \\
\hline 38 & 3 of & 29.67 & $7^{6}$ & 02 & 08.22 & $\begin{array}{l}\mathrm{S} \\
\mathrm{S} \\
\mathrm{S}\end{array}$ & $\begin{array}{r}82 \\
7 \\
30\end{array}$ & $\begin{array}{ll}36 & W \\
O+ & 11 \\
54 & E\end{array}$ & $\begin{array}{l}\mathrm{N} \\
\mathrm{N} \\
\mathrm{N}\end{array}$ & $\begin{array}{r}82 \\
7 \\
30\end{array}$ & $\begin{array}{ll}34 \mathrm{E} \\
\mathrm{O} 4 \mathrm{~F} \\
53 \mathrm{HI}\end{array}$ & $\begin{array}{l}5851 \\
4809 \\
3805\end{array}$ & $\begin{array}{l}\text { Holland Island Bar Light. } \\
\text { Fog. } \\
\text { Solomons Lump Light. }\end{array}$ \\
\hline
\end{tabular}

'Thence from corner No. 5 along the mean low-water line of the shore to corner No. I, excluding any creek, cove, or inlet less than 100 yards in width at its mouth at low tide. 
BOUNDARIFS OF CRAB BOTTONS-COHTINUEC.

FISHING POIN'T.

(Tangier Sound-Entrance Kedge Straits-Charts Nos. 6 and 7.)

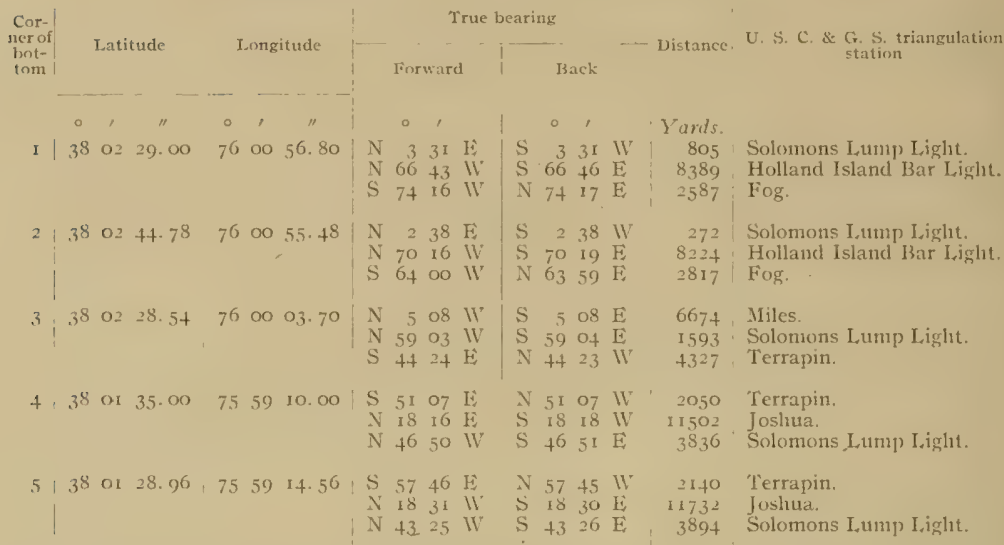

Thence from corner No. 5 along the mean low-water line of the slore to corner No. I, excluding any creek, cove, or inlet less than 100 yards in width at its month at low tide.

\section{SOUTH KEDGE STRAITS.}

(Entrance Kedge Straits-Chart No.6.)

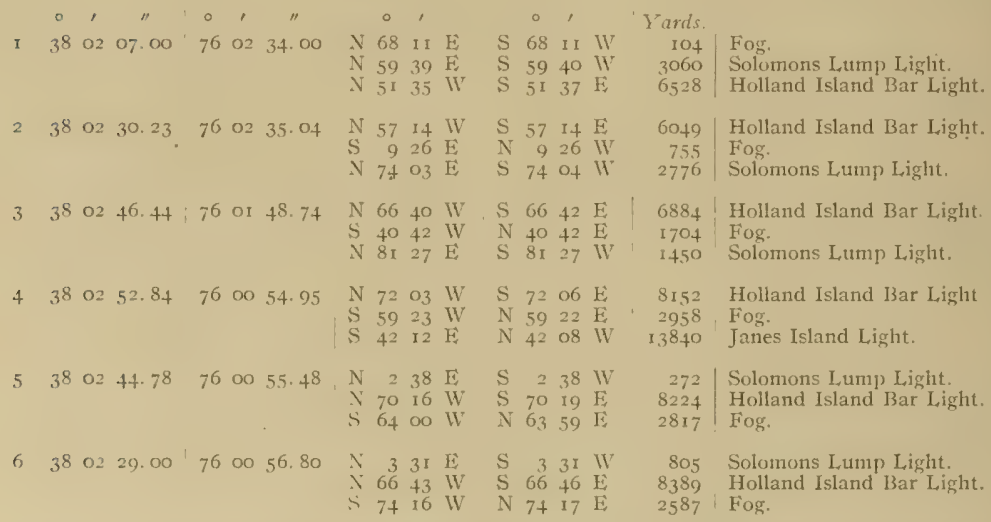

Thence from corner No. 6 along the mean low-water line of the shore to corner No. 1 , excluding any creck, cove, or inlet less than 100 yards in width at its mouth at low tide 
Survey of Oyster Bars, Somerset County', $\mathrm{Md}$.

BOUNDARIES OF CRAB BOTTOMS-continued.

SMITH ISLAND THOROUGHFARE.

(Smith Island-Charts Nos. 6, 8, and 9.)

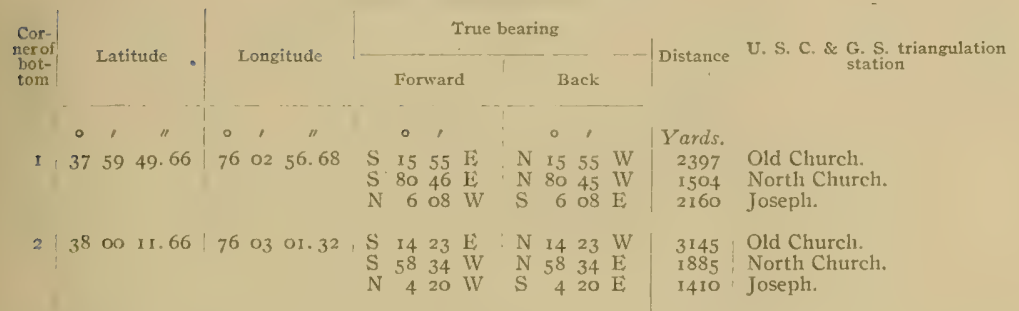

Thence from corner No. 2 along the mean low-water line of the shore to corner No 1, excluding any creek, cove, or inlet less than soo yards in width at its mouth at low tide.

\section{TERRAPIN SAND.}

(Southwest Tangier Sound-Charts Nos. 7 and 9.)

\begin{tabular}{|c|c|c|c|c|c|c|c|c|c|c|c|c|c|c|}
\hline I & $\begin{array}{c}0 \\
38\end{array}$ & or & 28.96 & $\begin{array}{c}0 \\
75\end{array}$ & $\begin{array}{c}1 \\
59\end{array}$ & $\stackrel{\text { I } 4.56}{ }$ & $\begin{array}{ll}\mathrm{S} & 5 \\
\mathrm{~N} & \mathrm{I} \\
\mathrm{N} & 4\end{array}$ & $\begin{array}{r}\circ \\
57 \\
18 \\
43\end{array}$ & $\begin{array}{ll} \\
46 \\
46 \\
3 \mathrm{I} \\
25 & \mathrm{~W}\end{array}$ & $\begin{array}{l}\mathrm{N} \\
\mathrm{S} \\
\mathrm{S}\end{array}$ & $\begin{array}{l}\circ \\
57 \\
18 \\
43\end{array}$ & $\begin{array}{ll} & \\
45 \mathrm{~V} \\
30 \mathrm{E} \\
26 \mathrm{E}\end{array}$ & $\begin{array}{r}\text { Yards. } \\
2140 \\
11732 \\
3894\end{array}$ & $\begin{array}{l}\text { Terrapin. } \\
\text { Joshua. } \\
\text { Solomons Lump Light. }\end{array}$ \\
\hline 2 & 38 & or & 35.00 & 75 & 59 & 10.00 & $\begin{array}{ll}\mathrm{S} & 5 \\
\mathrm{~N} & \mathrm{I} \\
\mathrm{N} & 4\end{array}$ & $\begin{array}{l}51 \\
18 \\
46\end{array}$ & $\begin{array}{ll}07 & \mathrm{E} \\
\text { I6 } & \mathrm{E} \\
50 & \mathrm{WV}\end{array}$ & $\begin{array}{l}\mathrm{N} \\
\mathrm{S} \\
\mathrm{S}\end{array}$ & $\begin{array}{l}51 \\
18 \\
46\end{array}$ & $\begin{array}{ll}07 & \mathrm{~V} \\
\mathrm{I} 8 \mathrm{H} \\
5 \mathrm{I} & \mathrm{E}\end{array}$ & $\begin{array}{r}2050 \\
11502 \\
3836\end{array}$ & $\begin{array}{l}\text { Terrapin. } \\
\text { Joshua. } \\
\text { Solomons Lump Light. }\end{array}$ \\
\hline 3 & $3^{8}$ & or & 01. 70 & 75 & 57 & $33 \cdot 37$ & $\begin{array}{l}\text { S } 8 \\
\text { S } 2 \\
\text { N } 7\end{array}$ & $\begin{array}{l}80 \\
23 \\
78\end{array}$ & $\begin{array}{ll}30 \mathrm{~W} \\
\text { I3 } \mathrm{W} \\
\text { o9 } \mathrm{E}\end{array}$ & $\begin{array}{l}\mathrm{N} \\
\mathrm{N} \\
\mathrm{S}\end{array}$ & $\begin{array}{l}80 \\
23 \\
78\end{array}$ & $\begin{array}{ll}30 & E \\
12 & F \\
14 & V\end{array}$ & $\begin{array}{r}995 \\
8424 \\
8233\end{array}$ & $\begin{array}{l}\text { Terrapin. } \\
\text { Horse. } \\
\text { Flat Cap. }\end{array}$ \\
\hline 4 & 38 & 00 & I5. 12 & 75 & 57 & 10. 17 & $\begin{array}{ll}\text { N } & 4 \\
\text { S } & 3 \\
\text { S } & 3\end{array}$ & $\begin{array}{l}48 \\
32 \\
33\end{array}$ & $\begin{array}{ll}42 & \mathrm{WV} \\
34 & \mathrm{WV} \\
43 & \mathrm{E}\end{array}$ & $\begin{array}{l}\mathrm{S} \\
\mathrm{N} \\
\mathrm{N}\end{array}$ & $\begin{array}{l}48 \\
32 \\
33\end{array}$ & $\begin{array}{ll}43 & \mathrm{E} \\
32 & \mathrm{E} \\
42 & \mathrm{~V}\end{array}$ & $\begin{array}{l}2131 \\
7322 \\
593^{8}\end{array}$ & $\begin{array}{l}\text { Terrapin. } \\
\text { Horse. } \\
\text { Janes Island Light. }\end{array}$ \\
\hline 5 & $3^{8}$ & oo & Io. 56 & 75 & 57 & 23.66 & & $\begin{array}{l}38 \\
30 \\
37\end{array}$ & $\begin{array}{l}30 \mathrm{WV} \\
45 \mathrm{~W} \\
22 \mathrm{E}\end{array}$ & $\begin{array}{l}\mathrm{S} \\
\mathrm{N} \\
\mathrm{N}\end{array}$ & $\begin{array}{l}38 \\
30 \\
37\end{array}$ & $\begin{array}{ll}30 & \mathrm{E} \\
44 & \mathrm{E} \\
2 \mathrm{I} & \mathrm{H}\end{array}$ & $\begin{array}{l}1994 \\
7002 \\
6022\end{array}$ & $\begin{array}{l}\text { Terrapin. } \\
\text { Horse. } \\
\text { Janes Island Light. }\end{array}$ \\
\hline 6 & $3^{8}$ & $\infty 0$ & 18. 54 & 75 & $5^{8}$ & $43 \cdot 3^{8}$ & $\begin{array}{ll}\mathrm{S} & \mathrm{r} \\
\mathrm{S} & 4 \\
\mathrm{~N} & 3\end{array}$ & $\begin{array}{l}13 \\
48 \\
34\end{array}$ & $\begin{array}{ll}\text { oo } & \mathrm{W} \\
5 \mathrm{I} & \mathrm{E} \\
27 & \mathrm{E}\end{array}$ & $\begin{array}{l}\mathrm{N} \\
\mathrm{N} \\
\mathrm{S}\end{array}$ & $\begin{array}{l}13 \\
48 \\
34\end{array}$ & $\begin{array}{ll}00 & F \\
49 & Y \\
27 & V\end{array}$ & $\begin{array}{l}6453 \\
7680 \\
1566\end{array}$ & $\begin{array}{l}\text { Horse. } \\
\text { Janes Island Light. } \\
\text { Terrapin. }\end{array}$ \\
\hline
\end{tabular}

Thence from corner No. 6 along the mean low-water line of the shore to corner No. I, excluding any creek, cove, or inlet less than roo yards in width at its mouth at low tide. 
BOUNDARIFS OF CRAI3 BOTTOMS- continuted. SOUTH MARSH.

(IVest Tangier Sound-Chart No.7.)

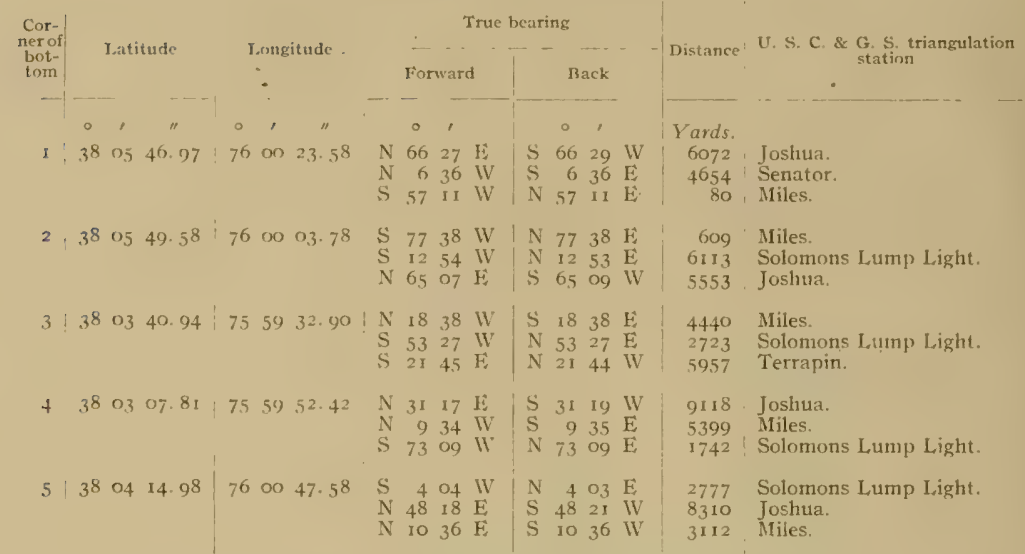

Thence from corner No. 5 along the rmean low-water line of the shore to corner No. I,excluding any creek, cove, or inlet less than roo yards in width at its mouth at low tide.

\section{WENONA.}

(East Upper Tangier Sound-Chart No. 7.)

\begin{tabular}{|c|c|c|c|c|c|c|c|c|c|c|c|c|c|c|c|c|}
\hline$I$ & $\begin{array}{l}0 \\
38\end{array}$ & ' & 07.07 & $\begin{array}{c}0 \\
75\end{array}$ & $\begin{array}{c}1 \\
57\end{array}$ & $\stackrel{n}{\prime \prime}{ }^{8}$ & $\begin{array}{l}\mathrm{N} \\
\mathrm{S} \\
\mathrm{S}\end{array}$ & $\begin{array}{c}0 \\
72 \\
63 \\
30\end{array}$ & $\begin{array}{l}1 \\
\mathrm{O}_{2} \\
23 \\
39\end{array}$ & $\begin{array}{l}\text { IV } \\
\text { W } \\
\mathrm{E}\end{array}$ & $\begin{array}{l}\mathrm{S} \\
\mathrm{N} \\
\mathrm{N}\end{array}$ & $\begin{array}{l}0 \\
72 \\
63 \\
30\end{array}$ & $\begin{array}{l}1 \\
0.4 \\
21 \\
38\end{array}$ & $\begin{array}{l}\mathrm{E} \\
\mathrm{E} \\
\mathrm{W}\end{array}$ & $\begin{array}{c}\text { Yards. } \\
6239 \\
6119 \\
322\end{array}$ & $\begin{array}{l}\text { Senator. } \\
\text { Miles. } \\
\text { Joshua. }\end{array}$ \\
\hline 2 & 38 & 07 & $07.8 \mathrm{I}$ & 75 & 57 & 24.02 & $\begin{array}{l}N \\
S \\
S\end{array}$ & $\begin{array}{l}70 \\
60 \\
68\end{array}$ & $\begin{array}{l}21 \\
18 \\
54\end{array}$ & $\begin{array}{l}\text { WV } \\
\text { WV } \\
\text { E }\end{array}$ & $\begin{array}{l}\mathrm{S} \\
\mathrm{N} \\
\mathrm{N}\end{array}$ & $\begin{array}{l}70 \\
60 \\
68\end{array}$ & $\begin{array}{l}23 \\
17 \\
54\end{array}$ & $\begin{array}{l}\frac{T}{E} \\
\text { IV }\end{array}$ & $\begin{array}{r}56+6 \\
5584 \\
839\end{array}$ & $\begin{array}{l}\text { Senator. } \\
\text { Miles. } \\
\text { Joshua. }\end{array}$ \\
\hline 3 & 38 & 07 & 49.36 & 75 & 57 & $4^{8 .} 36$ & $\begin{array}{l}\mathrm{N} \\
\mathrm{S} \\
\mathrm{S}\end{array}$ & $\begin{array}{l}83 \\
45 \\
40\end{array}$ & $\begin{array}{l}55 \\
14 \\
02\end{array}$ & $\begin{array}{l}\text { W } \\
\text { W } \\
\mathrm{E}\end{array}$ & $\begin{array}{l}S \\
N \\
N\end{array}$ & $\begin{array}{l}83 \\
45 \\
40\end{array}$ & $\begin{array}{l}53 \\
13 \\
\text { OI }\end{array}$ & $\begin{array}{l}E \\
E \\
W\end{array}$ & $\begin{array}{l}+695 \\
5920 \\
2224\end{array}$ & $\begin{array}{l}\text { Senator. } \\
\text { Miles. } \\
\text { Joshua. }\end{array}$ \\
\hline & 38 & 07 & 50.57 & 75 & 57 & 26.57 & $\begin{array}{l}N \\
S \\
S\end{array}$ & $\begin{array}{l}85 \\
48 \\
26\end{array}$ & $\begin{array}{l}\text { or } \\
40 \\
00\end{array}$ & $\begin{array}{l}\text { WV } \\
\text { W } \\
\mathrm{E}\end{array}$ & $\begin{array}{l}\mathrm{S} \\
\mathrm{N} \\
\mathrm{N}\end{array}$ & $\begin{array}{l}85 \\
48 \\
26\end{array}$ & $\begin{array}{l}03 \\
38 \\
00\end{array}$ & $\begin{array}{l}\mathrm{E} \\
\mathrm{E} \\
\mathrm{WV}\end{array}$ & $\begin{array}{l}5269 \\
6371 \\
1940\end{array}$ & $\begin{array}{l}\text { Senator. } \\
\text { Miles. } \\
\text { Joshua. }\end{array}$ \\
\hline
\end{tabular}

Thence from corner No. 4 along the mean low-water line of the shore to corner No. 5 , excluding any creek, cove, or inlet less than roo yards in width at its mouth at low tide

$$
\begin{aligned}
& \begin{array}{l|lll|llll|llll|l|l|l}
5 & 3807 & 37.82 & 75 & 56 & 52.22 & \text { N } 81 & 48 \text { W } & \text { S } 81 & 51 & \text { E } & 6228 & \text { Senator. }
\end{array} \\
& \begin{array}{ll:ll:lll}
\mathrm{S} & 5628 \mathrm{WV} & \mathrm{N} & 56 & 25 \mathrm{E} & 6838 & \text { Miles. }
\end{array} \\
& \mathrm{S} 250 \mathrm{~W} / \mathrm{N} 2 \text { 50 E } 2 \text {. } 3316 \text { Joshua. } \\
& \begin{array}{lllllllllllllllll|l|l}
6 & 38 & 07 & 37.02 & 75 & 56 & 47.46 & \mathrm{~N} & 81 & 43 & \mathrm{~W} & \mathrm{~S} & 81 & 46 & \mathrm{E} & 6357 & \text { Senator. } \\
& \mathrm{S} & 57 & \mathrm{I} & \mathrm{W} & \mathrm{N} & 57 & \mathrm{II} & \mathrm{E} & 6929 & \text { Miles. }
\end{array} \\
& \begin{array}{llll|l|lll|l|l}
\mathrm{S} & 57 & 1+ & \mathrm{W} & \mathrm{N} & 57 & \text { II } & \mathrm{E} & 6929 & \text { Miles. } \\
\mathrm{S} & 8 & 29 & \mathrm{WV} & \mathrm{N} & 8 & 29 & \mathrm{E} & 1301 & \text { Joshur. }
\end{array}
\end{aligned}
$$

Thence from corner No. 6 along the mean low-water line of the shore to corner No. 1, excluding any creek, cove, or inlet less than Ioo yards in width at its mouth at low tide. 
BOUNDARIES OF CRAB BOTTOMS-continued.

L,ITTLE, DEAL, ISLAND.

(North Entrance Manokin River-Chart No. 7.)

\begin{tabular}{|c|c|c|c|c|c|c|c|c|c|c|c|c|c|c|}
\hline \multirow{2}{*}{$\begin{array}{c}\text { Cor- } \\
\text { ner of } \\
\text { bot- } \\
\text { tom }\end{array}$} & \multirow{2}{*}{\multicolumn{3}{|c|}{ Latitude }} & \multirow{2}{*}{\multicolumn{3}{|c|}{ Longitude }} & \multicolumn{6}{|c|}{ True bearing } & \multirow{2}{*}{$\begin{array}{c}\text { Distance } \\
\text { Yards. }\end{array}$} & \multirow{2}{*}{$\begin{array}{l}\text { U. S. C. \& G. S. triangulation } \\
\text { station } \\
\text {. }\end{array}$} \\
\hline & & & & & & & & Forw & ward & & $\mathrm{Bac}$ & & & \\
\hline I & $\begin{array}{c}\circ \\
38\end{array}$ & , & o1. 70 & $\begin{array}{c}\circ \\
7.5\end{array}$ & $\stackrel{1}{56}$ & or. 94 & $\begin{array}{l}\mathrm{N} \\
\mathrm{N} \\
\mathrm{S}\end{array}$ & $\begin{array}{c}\circ \\
63 \\
43 \\
86\end{array}$ & $\begin{array}{ll}1 & \\
\text { I } 7 & \mathrm{E} \\
\text { I9 } & \mathrm{E} \\
\text { O6 } & \mathrm{WV}\end{array}$ & $\begin{array}{l}\mathrm{S} \\
\mathrm{S} \\
\mathrm{N}\end{array}$ & $\begin{array}{ll}\circ & \\
63 & 1 \\
43 & 2 \\
86 & 0\end{array}$ & $\begin{array}{ll}1 & \\
\text { I } 8 & W V \\
20 & W V \\
05 & E\end{array}$ & $\begin{array}{r}\text { Yards. } \\
5355 \\
3249 \\
1407\end{array}$ & $\begin{array}{l}\text { Marsh. } \\
\text { Kelley. } \\
\text { Joshua. }\end{array}$ \\
\hline 2 & 38 & 06 & $55 \cdot 34$ & 75 & 5.5 & $50.4^{6}$ & $\begin{array}{l}\mathrm{N} \\
\mathrm{N} \\
\mathrm{N}\end{array}$ & $\begin{array}{l}59 \\
36 \\
86\end{array}$ & $\begin{array}{ll}39 & \mathrm{E} \\
43 & \mathrm{E} \\
\mathrm{O} 2 & \mathrm{~W}\end{array}$ & $\begin{array}{l}\mathrm{S} \\
\mathrm{S} \\
\mathrm{S}\end{array}$ & $\begin{array}{ll}59 & 4 \\
36 & 4 \\
86 & 0\end{array}$ & $\begin{array}{ll}4 \text { I } & W \\
44 & W \\
\text { OI } & E\end{array}$ & $\begin{array}{l}5201 \\
3216 \\
1715\end{array}$ & $\begin{array}{l}\text { Marsh. } \\
\text { Kelley. } \\
\text { Joshua. }\end{array}$ \\
\hline 3 & 38 & 06 & 40.44 & 75 & 56 & $\mathrm{O}_{3} .8 \mathrm{O}$ & $\begin{array}{l}\mathrm{N} \\
\mathrm{N} \\
\mathrm{N} \\
\mathrm{N}\end{array}$ & $\begin{array}{l}57 \\
36 \\
65\end{array}$ & $\begin{array}{ll}\text { O7 } & \mathrm{E} \\
29 & \mathrm{E} \\
22 & \mathrm{IV}\end{array}$ & $\begin{array}{l}\mathrm{S} \\
\mathrm{S} \\
\mathrm{S}\end{array}$ & $\begin{array}{ll}57 & 0 \\
36 & 2 \\
65 & 2\end{array}$ & $\begin{array}{ll}05 & \text { W } \\
28 & \mathrm{IV} \\
23 & \mathrm{E}\end{array}$ & $\begin{array}{l}5756 \\
3832 \\
1491\end{array}$ & $\begin{array}{l}\text { Marsh. } \\
\text { Kelley. } \\
\text { Joshua. }\end{array}$ \\
\hline 4 & 38 & 06 & 22.24 & 75 & 5.5 & $5^{6 .} 5^{8}$ & $\begin{array}{l}\mathrm{S} \\
\mathrm{S} \\
\mathrm{N}\end{array}$ & $\begin{array}{ll}69 & 1 \\
29 & 2 \\
51 & 2\end{array}$ & $\begin{array}{ll}12 & \mathrm{E} \\
27 & \mathrm{E} \\
25 & \mathrm{WV}\end{array}$ & $\begin{array}{l}\mathrm{N} \\
\mathrm{N} \\
\mathrm{S}\end{array}$ & $\begin{array}{ll}69 & 1 \\
29 & 2 \\
51 & 2\end{array}$ & $\begin{array}{l}10 \mathrm{WV} \\
26 \mathrm{~W} \\
25 \mathrm{Fi}\end{array}$ & $\begin{array}{l}60 \times 8 \\
4243 \\
1979\end{array}$ & $\begin{array}{l}\text { Prickly. } \\
\text { Kelley. } \\
\text { Joshua. }\end{array}$ \\
\hline 5 & 38 & o6 & $22^{\circ} .82$ & 75 & & oo. 64 & $\begin{array}{l}\mathrm{S} \\
\mathrm{N} \\
\mathrm{N}\end{array}$ & $\begin{array}{rr}73 & 3 \\
45 & 5 \\
7 & 2\end{array}$ & $\begin{array}{ll}38 & \mathrm{E} \\
54 & \mathrm{E} \\
28 & \mathrm{E}\end{array}$ & $\begin{array}{l}\mathrm{N} \\
\mathrm{S} \\
\mathrm{S}\end{array}$ & $\begin{array}{rl}73 & 3 \\
45 & 5 \\
7 & 2\end{array}$ & $\begin{array}{ll}36 & \mathrm{~W} \\
55 & \mathrm{~W} \\
28 & \mathrm{~W}\end{array}$ & $\begin{array}{l}7643 \\
5281 \\
1226\end{array}$ & $\begin{array}{l}\text { Prickly. } \\
\text { Kelley. } \\
\text { Joshua. }\end{array}$ \\
\hline 6 & 38 & 06 & 55.00 & 75 & 56 & 48. 50 & $\begin{array}{ll}\mathrm{S} & 6 \\
\mathrm{~N} & 5 \\
\mathrm{~N} & 5\end{array}$ & $\begin{array}{ll}65 & 1 \\
53 & 1 \\
51 & 3\end{array}$ & $\begin{array}{l}12 \mathrm{E} \\
15 \mathrm{E} \\
35 \mathrm{~W}\end{array}$ & $\begin{array}{l}\mathrm{N} \\
\mathrm{S} \\
\mathrm{S}\end{array}$ & $\begin{array}{ll}65 & 1 \\
53 & 1 \\
51 & 3\end{array}$ & $\begin{array}{l}10 \mathrm{~W} \\
16 \mathrm{~W} \\
35 \mathrm{E}\end{array}$ & $\begin{array}{r}7722 \\
4330 \\
210\end{array}$ & $\begin{array}{l}\text { Prickly. } \\
\text { Kelley. } \\
\text { Joshua. }\end{array}$ \\
\hline
\end{tabular}

'Thence from corner No. 6 along the mean low-water line of the shore to corner No. r, excluding any creek, cove, or inlet less than roo yards in width at its mouth at low tide.

LOWER THOROUGHFARE.

(Inside of Little Deal 1sland-Chart No. 7.)

\begin{tabular}{|c|c|c|c|c|c|c|c|c|c|c|c|c|c|}
\hline $\begin{array}{c}0 \\
38\end{array}$ & $\begin{array}{c}, \\
307\end{array}$ & $\begin{array}{c}\prime \prime \\
33 \cdot 5^{8}\end{array}$ & $\begin{array}{c}0 \\
75\end{array}$ & $\begin{array}{c}, \\
55\end{array}$ & 38. 18 & $\begin{array}{l}\mathrm{S} \\
\mathrm{S} \\
\mathrm{N}\end{array}$ & $\begin{array}{l}0 \\
60 \\
48 \\
51\end{array}$ & $\begin{array}{ll}1 & \\
\text { O8 } & \text { W } \\
3 I & \text { E } \\
\text { O. } & \text { E }\end{array}$ & $\begin{array}{l}\stackrel{N}{N} \\
\mathrm{~S}\end{array}$ & $\begin{array}{l}0 \\
60 \\
48 \\
51\end{array}$ & $\begin{array}{ll}, \\
07 \\
29 & \mathrm{~W} \\
05 & \mathrm{~W}\end{array}$ & $\begin{array}{r}\text { Yards. } \\
2350 \\
6856 \\
2052\end{array}$ & $\begin{array}{l}\text { Joshua. } \\
\text { Prickly. } \\
\text { Kelley. }\end{array}$ \\
\hline 38 & 307 & 20. 78 & 7.5 & 5.5 & 27.89 & $\begin{array}{l}\mathrm{N} \\
\mathrm{N} \\
\mathrm{S}\end{array}$ & $\begin{array}{l}65 \\
37 \\
72\end{array}$ & $\begin{array}{ll}3 \div & \mathrm{E} \\
32 & \mathrm{E} \\
17 & \mathrm{WV}\end{array}$ & $\begin{array}{l}\mathrm{S} \\
\mathrm{S} \\
\mathrm{N}\end{array}$ & $\begin{array}{l}65 \\
37 \\
72\end{array}$ & $\begin{array}{ll}33 & \mathrm{WV} \\
32 & \mathrm{~W} \\
16 & \mathrm{E}\end{array}$ & $\begin{array}{l}+260 \\
2170 \\
2427\end{array}$ & $\begin{array}{l}\text { Marsh. } \\
\text { Kelley. } \\
\text { Joshua. }\end{array}$ \\
\hline 38 & 306 & 55.34 & 75 & 55 & $50.4^{6}$ & $\begin{array}{l}\mathrm{N} \\
\mathrm{N} \\
\mathrm{N}\end{array}$ & $\begin{array}{l}59 \\
36 \\
86\end{array}$ & $\begin{array}{ll}\text { 39) } & \mathrm{E} \\
43 & \mathrm{E} \\
\text { o. } & \mathrm{W}\end{array}$ & $\begin{array}{l}S \\
S \\
S\end{array}$ & $\begin{array}{l}59 \\
36 \\
86\end{array}$ & $\begin{array}{ll}4 \text { I } & W \\
44 & W \\
\text { OI } & E\end{array}$ & $\begin{array}{l}5201 \\
3216 \\
1715\end{array}$ & $\begin{array}{l}\text { Marsh. } \\
\text { Kelley } \\
\text { Joshua. }\end{array}$ \\
\hline 38 & 307 & OI. 70 & 75 & 56 & 01. 94 & $\begin{array}{l}\mathrm{N} \\
\mathrm{N} \\
\mathrm{S}\end{array}$ & $\begin{array}{l}6,3 \\
+3 \\
86\end{array}$ & $\begin{array}{ll}17 & \mathrm{E} \\
19 & \mathrm{E} \\
06 & \mathrm{~W}\end{array}$ & $\begin{array}{l}\mathrm{S} \\
\mathrm{S} \\
\mathrm{N}\end{array}$ & $\begin{array}{l}63 \\
43 \\
86\end{array}$ & $\begin{array}{l}18 \mathrm{~W} \\
20 \mathrm{~W} \\
\text { O5 E }\end{array}$ & $\begin{array}{l}5355 \\
3249 \\
1407\end{array}$ & $\begin{array}{l}\text { Marsh. } \\
\text { Kelley. } \\
\text { Joshua. }\end{array}$ \\
\hline 38 & 307 & 37.02 & 75 & $5^{6}$ & $47 \cdot 4^{6}$ & $\begin{array}{l}\mathrm{N} \\
\mathrm{S} \\
\mathrm{S}\end{array}$ & $\begin{array}{r}81 \\
57 \\
8\end{array}$ & $\begin{array}{ll}+3 & \mathrm{~W} \\
14 \mathrm{~W} \\
29 \mathrm{~W}\end{array}$ & $\begin{array}{l}\mathrm{S} \\
N \\
N\end{array}$ & $\begin{array}{r}81 \\
57 \\
8\end{array}$ & $\begin{array}{ll}46 & \mathrm{E} \\
1 \mathrm{I} & \mathrm{E} \\
29 & \mathrm{E}\end{array}$ & $\begin{array}{l}6357 \\
6929 \\
1301\end{array}$ & $\begin{array}{l}\text { Senator. } \\
\text { Miles. } \\
\text { Joshua. }\end{array}$ \\
\hline 38 & 07 & 37.82 & 75 & 56 & $52.2 ?$ & $\begin{array}{l}\mathrm{N} \\
\mathrm{S} \\
\mathrm{S}\end{array}$ & $\begin{array}{r}81 \\
56 \\
2\end{array}$ & $\begin{array}{ll}48 & \mathrm{IV} \\
28 & \mathrm{IV} \\
50 & \mathrm{WW}\end{array}$ & $\begin{array}{l}\mathrm{S} \\
\mathrm{N} \\
\mathrm{N}\end{array}$ & $\begin{array}{r}81 \\
56 \\
2\end{array}$ & $\begin{array}{ll}51 & \mathrm{E} \\
25 & \mathrm{E} \\
50 & \mathrm{E}\end{array}$ & $\begin{array}{l}6228 \\
6838 \\
13 \times 6\end{array}$ & $\begin{array}{l}\text { Senator. } \\
\text { Miles. } \\
\text { Joshua. }\end{array}$ \\
\hline
\end{tabular}

Thence from corner No. 6 along the mean low-water line of the shore to corner No, 1, excluding any creek, cove, or inlet less than roo yards in width at its mouth at low tide. 


\section{BOUNDARIES OF CRAB BOTTOMS-continued.}

\section{PINEY ISLAND.}

(Entrance Manokin River-Chart No. 7.)

\begin{tabular}{|c|c|c|c|c|c|c|c|c|c|c|c|c|c|c|c|}
\hline \multirow{3}{*}{$\begin{array}{c}\text { Cor- } \\
\text { ner of } \\
\text { bot- } \\
\text { tom } \\
\text { I }\end{array}$} & \multirow{2}{*}{\multicolumn{3}{|c|}{ Latitude }} & \multirow{2}{*}{\multicolumn{3}{|c|}{ Longitude }} & \multicolumn{7}{|c|}{ True bearing } & \multirow{2}{*}{ Distance } & \multirow{2}{*}{ U. S. C. \&. G. S. triangulation } \\
\hline & & & & & & & & Forv & ward & & $\mathrm{Bac}$ & ack & & & \\
\hline & $\begin{array}{l}0 \\
38\end{array}$ & $\begin{array}{l}, \\
04\end{array}$ & 50. $3^{\prime \prime}$ & $\begin{array}{c}0 \\
75\end{array}$ & $\frac{1}{54}$ & $\stackrel{1 "}{16,08}$ & $\begin{array}{l}\text { S } \\
\text { S } \\
N\end{array}$ & $\begin{array}{l}0 \\
24 \\
50 \\
71\end{array}$ & $\begin{array}{ll}, \\
53 \mathrm{E} \\
24 \mathrm{E} \\
5^{8} & \mathrm{E}\end{array}$ & $\begin{array}{l}\mathrm{N} \\
\mathrm{N} \\
\mathrm{S}\end{array}$ & $\begin{array}{l}0 \\
245 \\
50 \\
715\end{array}$ & $\begin{array}{l}1 \\
52 \\
22 \\
59\end{array}$ & $\begin{array}{l}\text { W } \\
W \\
W\end{array}$ & $\begin{array}{r}\text { Yards. } \\
664 \mathrm{I} \\
40 \mathrm{II} \\
3 \mathrm{IOO}\end{array}$ & $\begin{array}{l}\text { Flat Cap. } \\
\text { Has. } \\
\text { Prickly. }\end{array}$ \\
\hline 2 & 38 & 05 & 18.04 & 75 & 55 & II. 98 & $\begin{array}{l}\mathrm{N} \\
\mathrm{N} \\
\mathrm{N}\end{array}$ & $\begin{array}{r}89 \\
8 \\
38\end{array}$ & $\begin{array}{l}39 \mathrm{E} \\
43 \mathrm{E} \\
49 \mathrm{~W}\end{array}$ & $\begin{array}{l}\mathrm{S} \\
\mathrm{S} \\
\mathrm{S}\end{array}$ & $\begin{array}{r}89 \\
8 \\
38\end{array}$ & $\begin{array}{l}4 \mathrm{I} \\
43 \\
50\end{array}$ & $\begin{array}{l}W \\
W \\
E\end{array}$ & $\begin{array}{l}4438 \\
5916 \\
4363\end{array}$ & $\begin{array}{l}\text { Prickly. } \\
\text { Kelley. } \\
\text { Joshua. }\end{array}$ \\
\hline 3 & $3^{8}$ & 05 & 53.05 & 75 & 55 & 42.00 & $\begin{array}{l}\mathrm{S} \\
\mathrm{N} \\
\mathrm{N}\end{array}$ & $\begin{array}{l}77 \\
19 \\
41\end{array}$ & $\begin{array}{ll}36 & \mathrm{E} \\
57 & \mathrm{E} \\
\mathrm{O} 2 & \mathrm{~W}\end{array}$ & $\begin{array}{l}\mathrm{N} \\
\mathrm{S} \\
\mathrm{S}\end{array}$ & $\begin{array}{l}77 \\
19 \\
41\end{array}$ & $\begin{array}{l}34 \\
57 \\
02\end{array}$ & $\begin{array}{l}\text { W } \\
\text { W } \\
\mathrm{E}\end{array}$ & $\begin{array}{l}5362 \\
4977 \\
294^{2}\end{array}$ & $\begin{array}{l}\text { Prickly. } \\
\text { Kelley. } \\
\text { Joshua. }\end{array}$ \\
\hline 4 & 38 & 06 & 30.82 & 75 & 55 & $43.8 I$ & $\begin{array}{l}N \\
N \\
N\end{array}$ & $\begin{array}{l}51 \\
27 \\
63\end{array}$ & $\begin{array}{ll}16 & \mathrm{E} \\
09 & \mathrm{E} \\
23 & \mathrm{~W}\end{array}$ & $\mid \begin{array}{l}\mathrm{S} \\
\mathrm{S} \\
\mathrm{S}\end{array}$ & $\begin{array}{l}5 \mathrm{x} \\
27 \\
63\end{array}$ & $\begin{array}{l}18 \\
08 \\
24\end{array}$ & $\begin{array}{l}\text { W } \\
\mathrm{E}\end{array}$ & $\begin{array}{l}5513 \\
3826 \\
2111\end{array}$ & $\begin{array}{l}\text { Marsh. } \\
\text { Kelley. } \\
\text { Joshua. }\end{array}$ \\
\hline 5 & $3^{8}$ & 306 & $59 \cdot 5^{8}$ & 75 & 55 & 20. 55 & $\begin{array}{l}\mathrm{N} \\
\mathrm{N} \\
\mathrm{S}\end{array}$ & $\begin{array}{l}56 \\
24 \\
89\end{array}$ & $\begin{array}{ll}02 & E \\
50 & E \\
27 & W\end{array}$ & $\mid \begin{array}{l}\mathrm{S} \\
\mathrm{S} \\
\mathrm{N}\end{array}$ & $\begin{array}{l}56 \\
24 \\
89\end{array}$ & $\begin{array}{l}05 \\
49 \\
26\end{array}$ & $\begin{array}{l}\text { W } \\
\text { W } \\
\mathrm{E} .\end{array}$ & $\begin{array}{l}4439 \\
2683 \\
2508\end{array}$ & $\begin{array}{l}\text { Marsh. } \\
\text { Kelley. } \\
\text { Joshua. }\end{array}$ \\
\hline 6 & 38 & 306 & 40.66 & 75 & 54 & 52.43 & $\begin{array}{l}\mathrm{N} \\
\mathrm{N} \\
\mathrm{N}\end{array}$ & $\begin{array}{r}43 \\
7 \\
79\end{array}$ & $\begin{array}{ll}15 & \mathrm{E} \\
00 & \mathrm{E} \\
19 & \mathrm{~W}\end{array}$ & $\mid \begin{array}{l}\mathrm{S} \\
\mathrm{S} \\
\mathrm{S}\end{array}$ & $\begin{array}{r}43 \\
7 \\
79\end{array}$ & $\begin{array}{l}16 \\
00 \\
20\end{array}$ & $\begin{array}{l}\text { W } \\
W \\
E\end{array}$ & $\begin{array}{l}4279 \\
3096 \\
3314\end{array}$ & $\begin{array}{l}\text { Marsh. } \\
\text { Kelley. } \\
\text { Joshua. }\end{array}$ \\
\hline 7 & 38 & 307 & $37 \cdot 14$ & 75 & 53 & 26.26 & $\begin{array}{l}\mathrm{N} \\
\mathrm{N} \\
\mathrm{N}\end{array}$ & $\begin{array}{l}80 \\
27 \\
58\end{array}$ & $\begin{array}{ll}28 & \mathbf{E} \\
45 & \mathrm{E} \\
38 & \mathrm{~W}\end{array}$ & $\mid \begin{array}{l}\mathrm{S} \\
\mathrm{S} \\
\mathrm{S}\end{array}$ & $\begin{array}{l}80 \\
27 \\
58\end{array}$ & $\begin{array}{l}30 \\
45 \\
37\end{array}$ & $\begin{array}{l}\text { W } \\
\text { W } \\
\mathrm{E}\end{array}$ & $\begin{array}{l}3313 \\
1369 \\
2256\end{array}$ & $\begin{array}{l}\text { St. Pierre. } \\
\text { Marsh. } \\
\text { Kelley. }\end{array}$ \\
\hline 8 & 38 & 307 & 38.06 & 75 & $5^{2}$ & $23.5^{8}$ & $\begin{array}{l}\mathrm{N} \\
\mathrm{N} \\
\mathrm{N}\end{array}$ & $\begin{array}{l}72 \\
41 \\
72\end{array}$ & $\begin{array}{ll}\text { o5 } & E \\
\text { o8 } & W \\
23 & W\end{array}$ & $\mid \begin{array}{l}\mathrm{S} \\
\mathrm{S} \\
\mathrm{S}\end{array}$ & $\begin{array}{l}72 \\
41 \\
72\end{array}$ & $\begin{array}{l}05 \\
09 \\
25\end{array}$ & $\begin{array}{l}W \\
E \\
E\end{array}$ & $\begin{array}{l}1679 \\
1568 \\
3763\end{array}$ & $\begin{array}{l}\text { St. Pierre. } \\
\text { Marsh. } \\
\text { Kelley. }\end{array}$ \\
\hline 9 & 38 & 07 & 04.22 & 75 & 53 & 18.62 & $\begin{array}{l}\mathrm{N} \\
\mathrm{N} \\
\mathrm{N}\end{array}$ & $\begin{array}{l}61 \\
10 \\
42\end{array}$ & $\begin{array}{ll}34 & \mathrm{E} \\
35 & \mathrm{E} \\
56 & \mathrm{WV}\end{array}$ & $\mid \begin{array}{l}S \\
S \\
S\end{array}$ & $\begin{array}{l}61 \\
10 \\
42\end{array}$ & $\begin{array}{l}36 \\
35 \\
57\end{array}$ & $\begin{array}{l}\text { W } \\
\text { W } \\
E\end{array}$ & $\begin{array}{l}3483 \\
2362 \\
3 \pi 3\end{array}$ & $\begin{array}{l}\text { St. Pierre. } \\
\text { Marsh. } \\
\text { Kelley. }\end{array}$ \\
\hline Io & 38 & 305 & $5^{\circ} .40$ & 75 & 54 & 24.20 & $\begin{array}{l}\mathrm{S} \\
\mathrm{N} \\
\mathrm{N}\end{array}$ & $\begin{array}{l}71 \\
24 \\
60\end{array}$ & $\begin{array}{ll}25 & \mathrm{E} \\
23 & \mathrm{E} \\
\mathrm{O} & \mathrm{W} \\
\mathrm{W}\end{array}$ & $\mid \begin{array}{l}\mathrm{N} \\
\mathrm{S} \\
\mathrm{S}\end{array}$ & $\begin{array}{l}71 \\
24 \\
60\end{array}$ & $\begin{array}{l}24 \\
25 \\
05\end{array}$ & $\begin{array}{l}W \\
W \\
E\end{array}$ & $\begin{array}{l}3338 \\
5282 \\
4626\end{array}$ & $\begin{array}{l}\text { Prickly. } \\
\text { Marsh. } \\
\text { Joshua. }\end{array}$ \\
\hline II & 38 & 305 & 17.10 & 75 & 54 & 19. 78 & $\begin{array}{l}\mathrm{S} \\
\mathrm{S} \\
\mathrm{N}\end{array}$ & $\begin{array}{l}22 \\
42 \\
88\end{array}$ & $\begin{array}{ll}4 \mathrm{I} & \mathrm{E} \\
4 \mathrm{I} & \mathrm{E} \\
54 & \mathrm{E}\end{array}$ & $\mid \begin{array}{l}\mathrm{N} \\
\mathrm{N} \\
\mathrm{S}\end{array}$ & $\begin{array}{l}22 \\
42 \\
88\end{array}$ & $\begin{array}{l}40 \\
40 \\
55\end{array}$ & $\begin{array}{l}\text { W } \\
W \\
W\end{array}$ & $\begin{array}{l}7505 \\
4704 \\
3047\end{array}$ & $\begin{array}{l}\text { Flat Cap. } \\
\text { Has. } \\
\text { Prickly. }\end{array}$ \\
\hline
\end{tabular}


BOUNDARIES OF CRAB BOTTOMS-continued.

TEAGUE, CREEK.

(South Shore Manokin River-Chart No. 7.)

\begin{tabular}{|c|c|c|c|c|c|c|c|c|c|c|c|c|c|}
\hline \multirow{2}{*}{$\begin{array}{l}\text { Cor- } \\
\text { ner of } \\
\text { bot- } \\
\text { tom }\end{array}$} & \multirow{2}{*}{\multicolumn{2}{|c|}{ Latitude }} & \multirow{2}{*}{\multicolumn{3}{|c|}{ Longitude }} & \multicolumn{6}{|c|}{ True bearing } & \multirow{2}{*}{ Distance } & \multirow{2}{*}{$\begin{array}{l}\text { U. S. C. \& G. S. triangulation } \\
\text { station }\end{array}$} \\
\hline & & & & & & & Form & ward & & $\mathrm{Bac}$ & $\mathrm{ck}$ & & \\
\hline I & $3^{8}$ & ' 0648.06 & $\begin{array}{c}\circ \\
75\end{array}$ & $\begin{array}{l}, \\
50\end{array}$ & $\begin{array}{c}\prime \prime \\
19.23\end{array}$ & $\begin{array}{l}\mathrm{S} \\
\mathrm{N} \\
\mathrm{N}\end{array}$ & $\begin{array}{c}0 \\
76 \\
29 \\
37\end{array}$ & $\begin{array}{ll}, & \\
44 & \mathrm{E} \\
12 & \mathrm{E} \\
54 & \mathrm{~W}\end{array}$ & $\begin{array}{l}\mathrm{N} \\
\mathrm{S} \\
\mathrm{S}\end{array}$ & $\begin{array}{cc}0 & 1 \\
76 & 4 \\
29 & 1 \\
37 & 5\end{array}$ & $\begin{array}{ll}1 & \\
44 & W \\
\text { I3 } & W \\
54 & E\end{array}$ & $\begin{array}{r}\text { Yards } \\
3578 \\
2526 \\
2791\end{array}$ & $\begin{array}{l}\text { Fairmount Church. } \\
\text { Staff. } \\
\text { St. Pierre. }\end{array}$ \\
\hline 2 & 38 & 07 ๓о. 26 & 75 & 50 & 28.47 & $\begin{array}{l}\mathrm{S} \\
\mathrm{N} \\
\mathrm{N}\end{array}$ & $\begin{array}{l}71 \\
39 \\
39\end{array}$ & $\begin{array}{ll}43 & E \\
36 & E \\
2 I & W\end{array}$ & $\begin{array}{l}\mathrm{N} \\
\mathrm{S} \\
\mathrm{S}\end{array}$ & $\begin{array}{ll}71 & 4 \\
39 & 3 \\
39 & 2\end{array}$ & $\begin{array}{ll}42 & \text { IV } \\
36 & \text { IV } \\
2 I & E\end{array}$ & $\begin{array}{l}3928 \\
2325 \\
2316\end{array}$ & $\begin{array}{l}\text { Fairmount Church. } \\
\text { Staff. } \\
\text { St. Pierre. }\end{array}$ \\
\hline 3 & $3^{8}$ & 0736.22 & 75 & 50 & 21.92 & $\begin{array}{l}\mathrm{S} \\
\mathrm{N} \\
\mathrm{N}\end{array}$ & $\begin{array}{l}552 \\
66 \\
70\end{array}$ & $\begin{array}{l}29 \mathrm{E} \\
06 \mathrm{E} \\
36 \mathrm{~W}\end{array}$ & $\begin{array}{l}\mathrm{N} \\
\mathrm{S} \\
\mathrm{S}\end{array}$ & $\begin{array}{ll}55 & 2 \\
66 & 0 \\
70 & 3\end{array}$ & $\begin{array}{l}28 \mathrm{~W} \\
07 \mathrm{~W} \\
36 \mathrm{E}\end{array}$ & $\begin{array}{l}4314 \\
1430 \\
1742\end{array}$ & $\begin{array}{l}\text { Fairmount Church. } \\
\text { Staff. } \\
\text { St. Pierre. }\end{array}$ \\
\hline
\end{tabular}

Thence from corner No. 3 along the mean low-water line of the shore to corner No. $\mathbf{r}$, excluding any creek, cove, or inlet less than roo yards in width at its mouth at low tide.

GOOSE CREEK.

(South Shore Manokin River-Chart No. 7.)

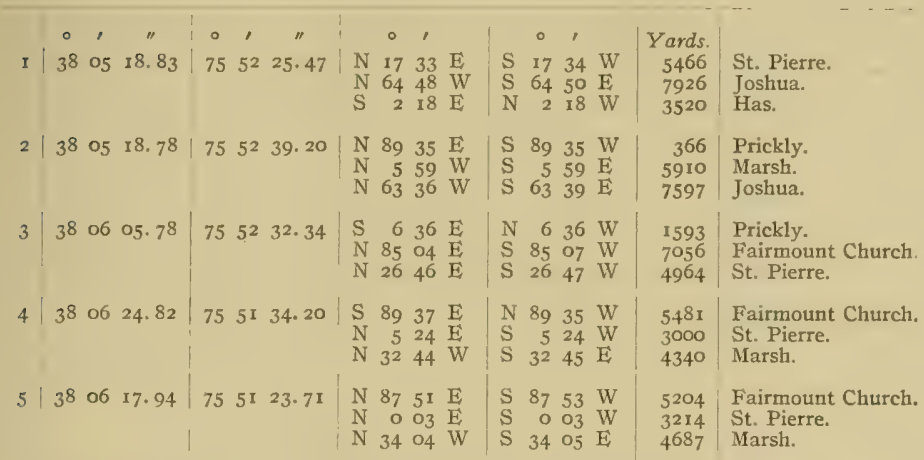

Thence from corner No. 5 along the mean low-water line of the shore to corner No. I, excluding any creek, cove, or inlet less than roo yards in width at its mouth at low tide. 
BOUNDARIES OF CRAB BOTTOMS-continued.

MINE CREEK.

(South Entrance Manokin River-Chart No. 7.)

\begin{tabular}{|c|c|c|c|c|c|c|c|c|c|c|c|c|c|c|}
\hline \multirow{2}{*}{$\begin{array}{c}\text { Cor- } \\
\text { ner of } \\
\text { bot- } \\
\text { tom }\end{array}$} & \multirow{2}{*}{\multicolumn{3}{|c|}{ Latitude }} & \multirow{2}{*}{\multicolumn{3}{|c|}{ Longitude }} & \multicolumn{6}{|c|}{ True bearing } & \multirow{2}{*}{ Distance } & \multirow{2}{*}{$\begin{array}{l}\text { U. S. C. \& G. S. triangulation } \\
\text { station }\end{array}$} \\
\hline & & & & & & & & Fon & ward & & $\mathrm{BaC}$ & ack & & \\
\hline I - . & $3^{\circ}$ & $\begin{array}{c}1 \\
04\end{array}$ & $\begin{array}{c}\text { I } \\
\text { I9. } 88\end{array}$ & $\begin{array}{c}0 \\
75\end{array}$ & $\begin{array}{c}1 \\
52\end{array}$ & 56.22 & $\begin{array}{l}\text { S } \\
\text { S } \\
\text { N }\end{array}$ & $\begin{array}{r}0 \\
7 \\
32 \\
22\end{array}$ & $\begin{array}{ll}\prime \\
35 \\
09 \\
24 \\
24\end{array}$ & $\begin{array}{l}\mathrm{N} \\
\mathrm{N} \\
\mathrm{S}\end{array}$ & $\begin{array}{c}0 \\
7 \\
32 \\
22 \\
22\end{array}$ & $\begin{array}{ll}\text { ' } & \\
35 & W \\
09 & W \\
25 & W\end{array}$ & $\begin{array}{r}\text { Yards. } \\
5040 \\
1807 \\
2150\end{array}$ & $\begin{array}{l}\text { Flat Cap. } \\
\text { Has. } \\
\text { Prickly. }\end{array}$ \\
\hline 2 & $3^{8}$ & 04 & $28 \cdot 7^{2}$ & 75 & 53 & 19.95 & $\begin{array}{l}\mathrm{S} \\
\mathrm{S} \\
\mathrm{N}\end{array}$ & $\begin{array}{l}13 \\
41 \\
40\end{array}$ & $\begin{array}{ll}47 & \mathrm{E} \\
06 & \mathrm{E} \\
40 \mathrm{E}\end{array}$ & $\begin{array}{l}N \\
N \\
S\end{array}$ & $\begin{array}{ll}13 & 4 \\
41 & 0 \\
40 & 4\end{array}$ & $\begin{array}{l}46 \mathrm{~W} \\
\mathrm{O} 5 \mathrm{~W} \\
4 \mathrm{I} . \mathrm{W}\end{array}$ & $\begin{array}{l}5452 \\
2426 \\
2228\end{array}$ & $\begin{array}{l}\text { Flat Cap. } \\
\text { Has. } \\
\text { Prickly. }\end{array}$ \\
\hline 3 & $3^{8}$ & 04 & 32.62 & 75 & 53 & $15 \cdot 53$ & $\begin{array}{l}\mathrm{S} \\
\mathrm{S} \\
\mathrm{N}\end{array}$ & $\begin{array}{l}12 \\
37 \\
40\end{array}$ & $\begin{array}{l}16 \mathrm{E} \\
08 \mathrm{E} \\
34 \mathrm{E}\end{array}$ & $\begin{array}{l}N \\
N \\
S\end{array}$ & $\begin{array}{ll}12 & 1 \\
37 & 0 \\
40 & 3\end{array}$ & $\begin{array}{l}16 \mathrm{~W} \\
07 \mathrm{~W} \\
35 \mathrm{~W}\end{array}$ & $\begin{array}{l}555^{2} \\
2445 \\
205^{2}\end{array}$ & $\begin{array}{l}\text { Flat Cap. } \\
\text { Has. } \\
\text { Prickly. }\end{array}$ \\
\hline 4 & 38 & $0_{5}$ & 01. 80 & 75 & $5^{2}$ & 41.83 & $\begin{array}{l}N \\
N \\
N\end{array}$ & $\begin{array}{r}19 \\
4 \\
59\end{array}$ & $\begin{array}{ll}48 & \mathrm{E} \\
50 & \mathrm{~W} \\
37 & \mathrm{II}\end{array}$ & $\begin{array}{l}\mathrm{S} \\
\mathrm{S} \\
\mathrm{S}\end{array}$ & $\begin{array}{r}194 \\
45 \\
593\end{array}$ & $\begin{array}{l}49 \mathrm{~W} \\
50 \mathrm{E} \\
39 \mathrm{E}\end{array}$ & $\begin{array}{l}6149 \\
6473 \\
7808\end{array}$ & $\begin{array}{l}\text { St. Pierre. } \\
\text { Marsh. } \\
\text { Joshua. }\end{array}$ \\
\hline 5 & 38 & 05 & I 8.78 & 75 & $5^{2}$ & 39.20 & $\begin{array}{l}N \\
N \\
N\end{array}$ & $\begin{array}{r}89 \\
5 \\
63\end{array}$ & $\begin{array}{ll}35 & \mathrm{E} \\
59 & \mathrm{~W} \\
36 & \mathrm{~W}\end{array}$ & $\begin{array}{l}\mathrm{S} \\
\mathrm{S} \\
\mathrm{S}\end{array}$ & $\begin{array}{rr}89 & 3 \\
5 & 5 \\
63 & 3\end{array}$ & $\begin{array}{l}35 \mathrm{~W} \\
59 \mathrm{E} \\
39 \mathrm{E}\end{array}$ & $\begin{array}{r}366 \\
5910 \\
7597\end{array}$ & $\begin{array}{l}\text { Prickly. } \\
\text { Marsh. } \\
\text { Joshua. }\end{array}$ \\
\hline 6 & 38 & 05 & 18.83 & 75 & $5^{2}$ & $25 \cdot 47$ & $\begin{array}{l}\mathrm{N} \\
\mathrm{N} \\
\mathrm{S}\end{array}$ & $\begin{array}{r}17 \\
64 \\
2\end{array}$ & $\begin{array}{ll}33 & \mathrm{E} \\
48 & \mathrm{IV} \\
\mathrm{I} & \mathrm{E}\end{array}$ & $\begin{array}{l}\mathrm{S} \\
\mathrm{S} \\
\mathrm{N}\end{array}$ & $\begin{array}{rl}17 & 3 \\
6+ & 5 \\
2 & 1\end{array}$ & $\begin{array}{l}34 \mathrm{~W} \\
50 \mathrm{E} \\
18 \mathrm{~W}\end{array}$ & $\begin{array}{l}5466 \\
7926 \\
3520\end{array}$ & $\begin{array}{l}\text { St. Pierre. } \\
\text { Joshua. } \\
\text { Has. }\end{array}$ \\
\hline
\end{tabular}

Thence from corner No. 6 along the mean low-water line of the shore to corner No, $x$, excluding any creek, cove, or inlet less than 100 yards in width at its mouth at low tide.

\section{HAZARD.}

(East Tangier Sound-Chart No. 7.)

\begin{tabular}{|c|c|c|c|c|c|c|c|c|c|c|c|c|c|c|c|}
\hline I & $\begin{array}{c}\circ \\
38\end{array}$ & $\begin{array}{c}\text { ' } \\
03\end{array}$ & 34. 52 & $\begin{array}{c}0 \\
75\end{array}$ & $\begin{array}{c}, \\
52\end{array}$ & 20. 16 & $\begin{array}{l}N \\
S \\
S\end{array}$ & $\begin{array}{r}0 \\
2 \\
84 \\
4\end{array}$ & $\begin{array}{ll}\text { L } & \\
\text { I8 } & W \\
12 & W \\
53 & W\end{array}$ & $\begin{array}{l}\mathrm{S} \\
\mathrm{N}\end{array}$ & $\begin{array}{r}0 \\
2 \\
84 \\
4\end{array}$ & $\begin{array}{ll}1 \\
18 \\
18 \\
07 & 1 \\
53 & 1\end{array}$ & $\begin{array}{l}\mathrm{E} \\
\mathrm{E} \\
\mathrm{E}\end{array}$ & $\begin{array}{r}\text { Yards. } \\
3520 \\
13798 \\
3480\end{array}$ & $\begin{array}{l}\text { Prickly. } \\
\text { Solomons Lump Light. } \\
\text { Flat Cap. }\end{array}$ \\
\hline 2 & 38 & 03 & 14. 58 & 75 & 52 & 22.80 & $\begin{array}{l}\mathrm{S} \\
\mathrm{S} \\
\mathrm{N}\end{array}$ & $\begin{array}{r}4 \\
79 \\
5\end{array}$ & $\begin{array}{ll}38 & \mathrm{WV} \\
40 & \mathrm{E} \\
59 & \mathrm{~W}\end{array}$ & $\begin{array}{l}\mathrm{N} \\
\mathrm{N} \\
\mathrm{S}\end{array}$ & $\begin{array}{r}4 \\
79 \\
5\end{array}$ & $\begin{array}{ll}37 & 1 \\
38 & 1 \\
59 & 1\end{array}$ & $\begin{array}{l}\mathrm{E} \\
\mathrm{W} \\
\mathrm{E}\end{array}$ & $\begin{array}{r}2804 \\
4804 \\
676\end{array}$ & $\begin{array}{l}\text { Flat Cap. } \\
\text { Geog. } \\
\text { Has. }\end{array}$ \\
\hline 3 & 38 & 03 & 37.66 & 75 & 53 & 06. 76 & $\begin{array}{l}\mathrm{S} \\
\mathrm{S} \\
\mathrm{N}\end{array}$ & $\begin{array}{l}14 \\
85 \\
17\end{array}$ & $\begin{array}{ll}50 & \mathrm{E} \\
\text { O8 } & \mathrm{E} \\
53 & \mathrm{E}\end{array}$ & $\begin{array}{l}\mathrm{N} \\
\mathrm{N} \\
\mathrm{S}\end{array}$ & $\begin{array}{l}14 \\
85 \\
17\end{array}$ & $\begin{array}{l}50 \\
07 \\
53\end{array}$ & $\begin{array}{l}\text { W } \\
W \\
W\end{array}$ & $\begin{array}{l}3696 \\
1247 \\
3585\end{array}$ & $\begin{array}{l}\text { Flat Cap. } \\
\text { Has. } \\
\text { Prickly. }\end{array}$ \\
\hline 4 & 38 & 04 & 28.72 & 75 & 53 & 19.95 & & $\begin{array}{l}13 \\
41 \\
40\end{array}$ & $\begin{array}{ll}47 & \mathrm{E} \\
06 & \mathrm{E} \\
40 & \mathrm{E}\end{array}$ & $\begin{array}{l}\mathrm{N} \\
\mathrm{N} \\
\mathrm{S}\end{array}$ & $\begin{array}{l}I_{3} \\
41 \\
40\end{array}$ & $\begin{array}{l}46 \\
05 \\
41\end{array}$ & $\begin{array}{l}\text { W } \\
\text { W } \\
\text { W }\end{array}$ & $\begin{array}{l}545^{2} \\
2426 \\
2228\end{array}$ & $\begin{array}{l}\text { Flat Cap. } \\
\text { Has. } \\
\text { Prickly. }\end{array}$ \\
\hline 5 & $3^{8}$ & 04 & 19.88 & 75 & $5^{2}$ & 56.22 & $\begin{array}{l}\mathrm{S} \\
\mathrm{S} \\
\mathrm{N}\end{array}$ & $\begin{array}{r}7 \\
32 \\
22\end{array}$ & $\begin{array}{l}35 \mathrm{E} \\
\mathrm{O} 9 \mathrm{E} \\
24 \mathrm{E}\end{array}$ & $\begin{array}{l}\mathrm{N} \\
\mathrm{N} \\
\mathrm{S}\end{array}$ & $\begin{array}{r}7 \\
32 \\
22\end{array}$ & $\left.\begin{array}{l}35 \\
09 \\
25\end{array}\right\}$ & $\begin{array}{l}W \\
W \\
W\end{array}$ & $\begin{array}{l}5040 \\
1807 \\
2150\end{array}$ & $\begin{array}{l}\text { Flat Cap } \\
\text { Has. } \\
\text { Prickly }\end{array}$ \\
\hline 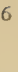 & 38 & $\mathrm{O}_{3}$ & 40.62 & 75 & 52 & $34 \quad 38$ & $\begin{array}{l}\mathrm{S} \\
\mathrm{S} \\
\mathrm{N}\end{array}$ & $\begin{array}{r}1 \\
28 \\
4\end{array}$ & $\begin{array}{l}\text { I7 E } \\
29 \mathrm{E} \\
06 \mathrm{E}\end{array}$ & $\begin{array}{l}\mathrm{N} \\
\mathrm{N} \\
\mathrm{S}\end{array}$ & $\begin{array}{r}\text { I } \\
28 \\
4\end{array}$ & $\begin{array}{l}17 \\
29 \\
06\end{array}$ & $\begin{array}{l}\text { W } \\
\text { W } \\
W\end{array}$ & $\begin{array}{r}3673 \\
431 \\
3320\end{array}$ & $\begin{array}{l}\text { Flat Cap } \\
\text { Has. } \\
\text { Prickly. }\end{array}$ \\
\hline
\end{tabular}

Thence from corner No. 6 along the mean low-water line of the shore to corner No I, excluding any creek, cove, or inlet less than 100 yards in width at its mouth at low tide. 


\section{Surcey of Oyster Bars, Somerset County, Md.}

BOUNDARIES OF CRAB BOTTOMS-continued.

\section{SHARK POINT.}

(North Entrance Big Annemessex River-Chart No. 7.)

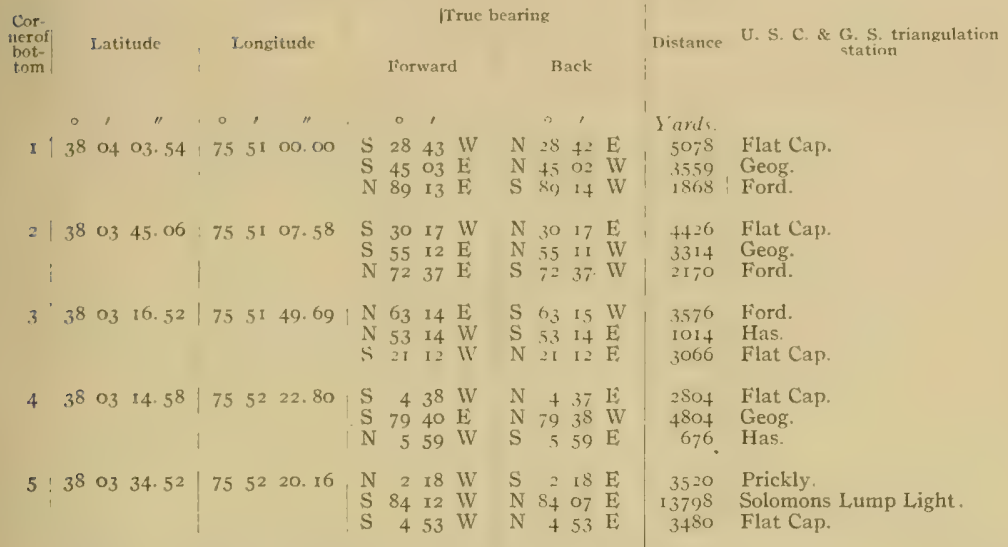

Thence from corner No 5 along the mean low-water line of the shore to corner No. 1 , excluding any creek, cove, or inlet less than Ioo yards in width at its mouth at low tide.

\section{FORDS WHARF.}

(North Shore Big Annemessex River-Chart No. 7.)

\begin{tabular}{|c|c|c|c|c|c|c|c|c|c|c|c|c|c|}
\hline 0. & f & " & 0 & ' & " & & $\circ$ & , & & 。 & , & Yards. & \\
\hline I, 38 & 03 & $59 \cdot 36$ & 75 & 49 & 12.98 & $\begin{array}{l}\mathrm{N} \\
\mathrm{S} \\
\mathrm{S}\end{array}$ & $\begin{array}{r}80 \\
8 \\
73\end{array}$ & $\begin{array}{ll}26 & W \\
02 & W \\
1+4 & E\end{array}$ & $\begin{array}{l}\mathrm{S} \\
\mathrm{N} \\
\mathrm{N}\end{array}$ & $\begin{array}{r}80 \\
8 \\
73\end{array}$ & $\begin{array}{l}26 \\
021 \\
14\end{array}$ & $\begin{array}{r}998 \\
2397 \\
1923\end{array}$ & $\begin{array}{l}\text { Ford. } \\
\text { Geog. } \\
\text { Moon. }\end{array}$ \\
\hline 38 & 03 & 5 1. 42 & 75 & 49 & 12.66 & $\begin{array}{l}\mathrm{N} \\
\mathrm{S} \\
\mathrm{S}\end{array}$ & $\begin{array}{r}66 \\
9 \\
43\end{array}$ & $\begin{array}{ll}25 & W \\
16 & W \\
22 & E\end{array}$ & $\begin{array}{l}\mathrm{S} \\
\mathrm{N} \\
\mathrm{N}\end{array}$ & $\begin{array}{r}66 \\
9 \\
43\end{array}$ & $\begin{array}{l}25 \\
16 \\
21\end{array}$ & $\begin{array}{l}1084 \\
2134 \\
2420\end{array}$ & $\begin{array}{l}\text { Ford. } \\
\text { Geog. } \\
\text { Colburn. }\end{array}$ \\
\hline 38 & 03 & 45.06 & 75 & $5 \mathrm{I}$ & $07 \cdot 5^{8}$ & $\begin{array}{l}\mathrm{S} \\
\mathrm{S} \\
\mathrm{N}\end{array}$ & $\begin{array}{l}30 \\
55 \\
72\end{array}$ & $\begin{array}{ll}17 & \mathrm{IV} \\
12 & \mathrm{E} \\
37 & \mathrm{E}\end{array}$ & $\begin{array}{l}N \\
N \\
S\end{array}$ & $\begin{array}{l}30 \\
55 \\
72\end{array}$ & $\begin{array}{l}17 \\
11 \\
37\end{array}$ & $\begin{array}{l}4426 \\
3314 \\
2170\end{array}$ & $\begin{array}{l}\text { Flat Cap. } \\
\text { Geog. } \\
\text { Ford. }\end{array}$ \\
\hline 38 & 04 & 03.54 & 75 & $5 I$ & 00,00 & $\begin{array}{l}\mathrm{S} \\
\mathrm{S} \\
\mathrm{N}\end{array}$ & $\begin{array}{l}28 \\
45 \\
89\end{array}$ & $\begin{array}{l}43 \mathrm{~W} \\
03 \mathrm{E} \\
13 \mathrm{E}\end{array}$ & $\begin{array}{l}N \\
N \\
\mathrm{~S}\end{array}$ & $\begin{array}{l}28 \\
45 \\
89\end{array}$ & $\begin{array}{l}42 \\
02 \\
1.4\end{array}$ & $\begin{array}{l}5078 \\
3559 \\
\mathbf{1} 868\end{array}$ & $\begin{array}{l}\text { Flat Cap. } \\
\text { Geog. } \\
\text { Ford. }\end{array}$ \\
\hline
\end{tabular}

Thence from corner No, 4 along the mean low-water line of the shore to corner No. .I, excluding any creek, cove, or inlet less than roo yards in width at its mouth at low tide. 
BOUNDARIES OF CRAB BOTTOMS-continued.

CRANE COVE.

(Upper Big Annemessex River-Chart No. 7.)

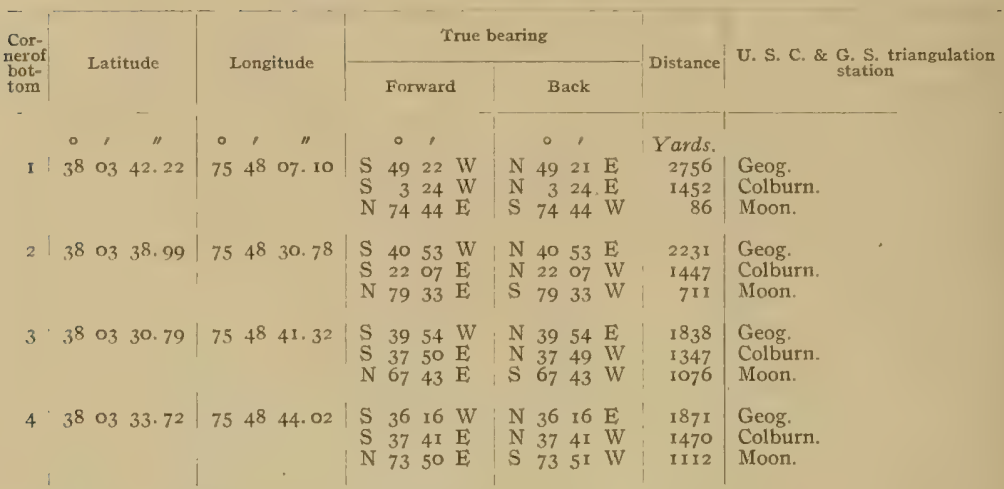

Thence from corner No. 4 along the mean low-water line of the shore to corner No, 1, excluding any creek, cove, or inlet less than roo yards in width at its mouth at low tide.

\section{MOON BAY.}

(Upper Big Annemessex River-Chant No. 7.)

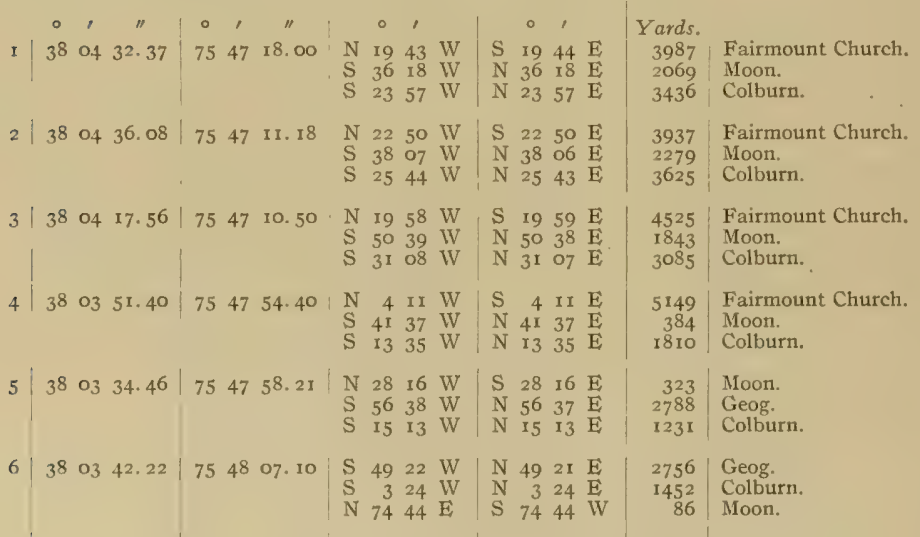

Thence from corner No. 6 along the mean low-water line of the shore to corner No. 1 , excluding any creek, cove, or inlet less than 100 yards in width at its mouth at low tide. 
Survey of Oyster Bars, Somerset County, $M d$.

BOUNDARIES OF CRAB BOTTOMS-continued.

\section{RED CAP CREEK.}

(Upper Big Aninemessex River-Chart No. 7.)

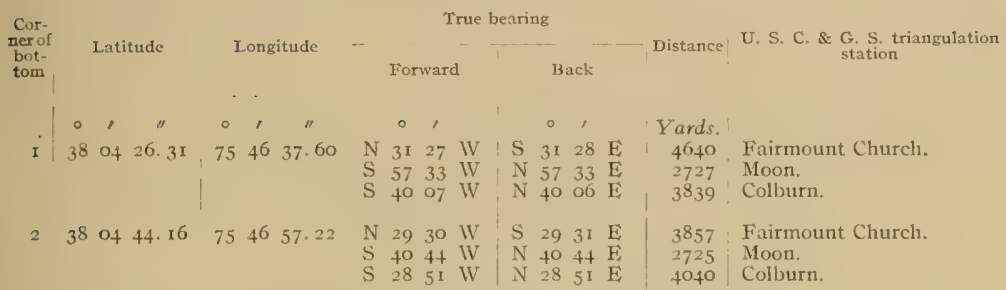

Thence from corner No. 2 along the mean low-water line of the shore to corner No. I, excluding any creek, cove, or inlet less than 100 yards in width at its mouth at low tide.

\section{MILES.}

(Upper Big Annemessex River-Chart No. 7.)

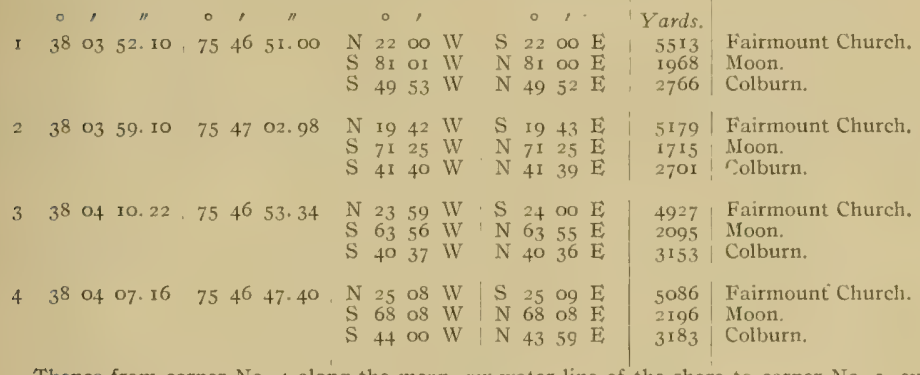

Thence from corner No. 4 along the mean 10 -water line of the shore to corner No. I, excluding any creek, cove, or inlet less than roo yards in width at its mouth at low tide.

$50095-08-13$ 


\section{DOUNDARIESS OF CRAI3 BOTYOMS-continued. COLBURN.}

(Upper Big Annemessex River-Chant No. 7.)

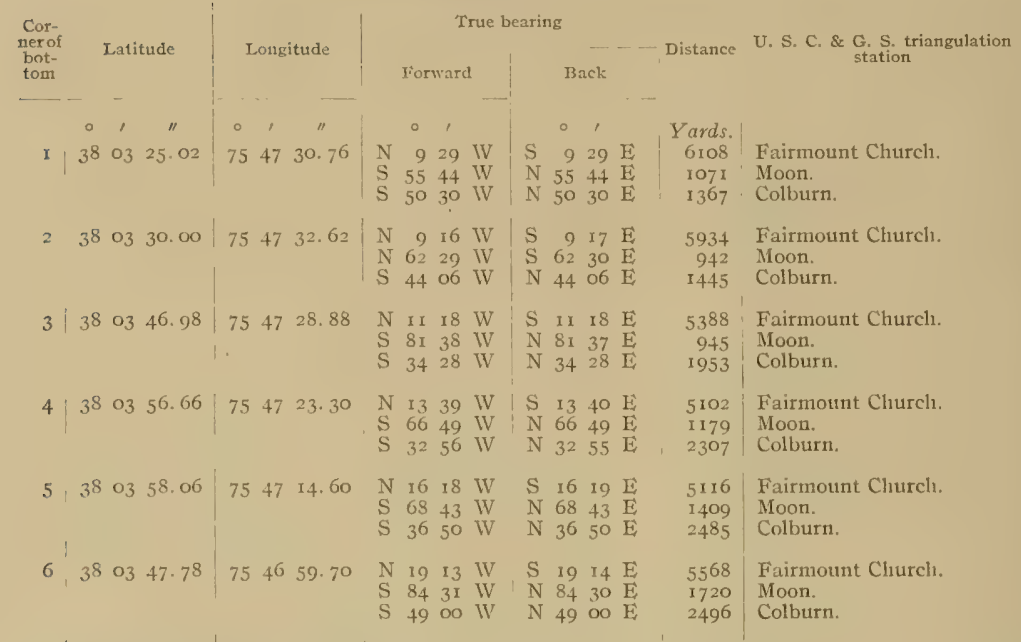

Thence from corner No. 6 along the mean low-water line of the shore to corner No. I, excluding any creek, cove, or inlet less than roo yards in width at its mouth at low tide.

\section{JACKSON ISLAND.}

(South Shore Big Annemessex River-Chart No. 7.)

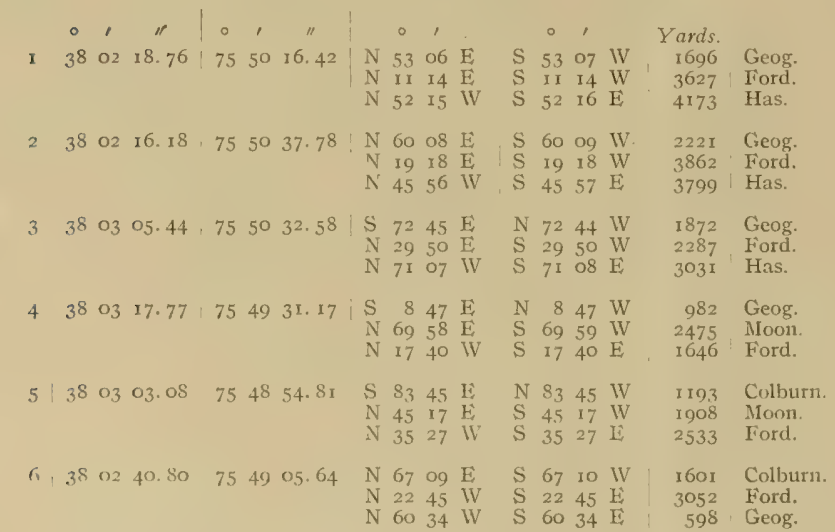

'Thence from corner No. 6 along the mean low-water line of the shore to corner No. I, excluding any creck, cove, or inlet less than Ioo yards in width at its mouth at low tide. 
Survey of Oyster Bars, Somerset Comnty, $\lambda$ d.

BOUNDARIES OF CRAB BOTTOMS-continued.

JONES CREEK.

(South Shove Big Annemessex River-Chart No. 7.)

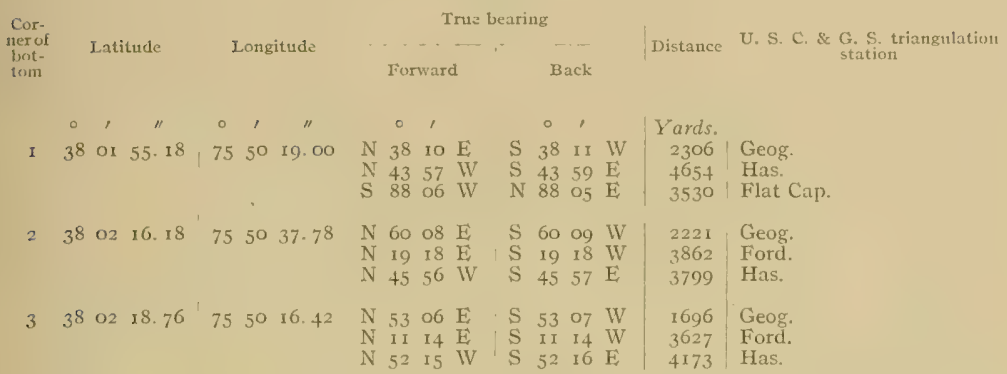

Thence from corner No. 3 along the mean low-water line of the shore to cormer No. 4, exclucling any creek, cove, or inlet less than yoo yards in width at its mouth at low tide.

$+380218.80754956 .98 \quad N 3928 \mathrm{E}$ S 3929 W 1319 Geog.

$\mathrm{N} 56$ 13 IV S 56 I4 E 4593 Has.

S 7730 W N 7728 E 4216 Flat Cap.

$5 \mid 3902$ 06. $75 \quad 7550$ or. $30, \mathrm{~N} 3349 \mathrm{E} \quad \mathrm{S} 3349$ W 1714 Geog,

N 5121 W, S $5123 \mathrm{E} 4740$ Has.

$\mathrm{S} 82+7 \mathrm{~W}, \mathrm{~N} 8246 \mathrm{E}, 4032$ Flat Cap.

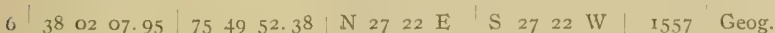

N 5327 IV S $5329 \mathrm{E}$. 4904 Has.

$\mathrm{S} 8239$ W N 8237 E 4273 Flat Cap.

Thence from corner No. 6 along the mean low-water line of the shore to corner No. $x$, excluding any creek, cove, or inlet less than roo yards in width at its moutli at low tide.

\section{DAUGHERTY CREEK.}

(South Shore Big Annemessex River-Chant No. 7.)

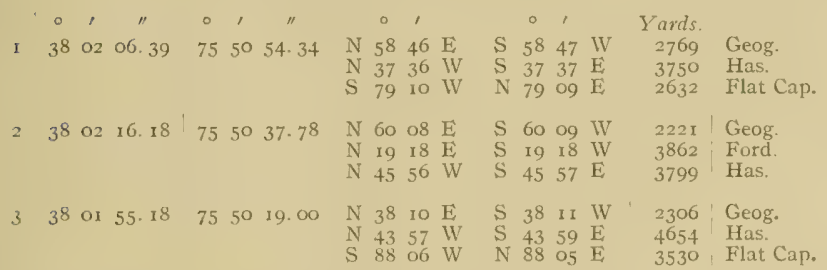

Thence from corner No. 3 along the nean low-water line of the shore to corner No. I, excluding any creek, cove, or inlet less than roo yards in width at its mouth at low tide. 
IHOUNDARIES OF CRAB BOTTOMS-continued.

TENTH DOINT.

(South Shore Big Annemessex River-Chart No.7.)

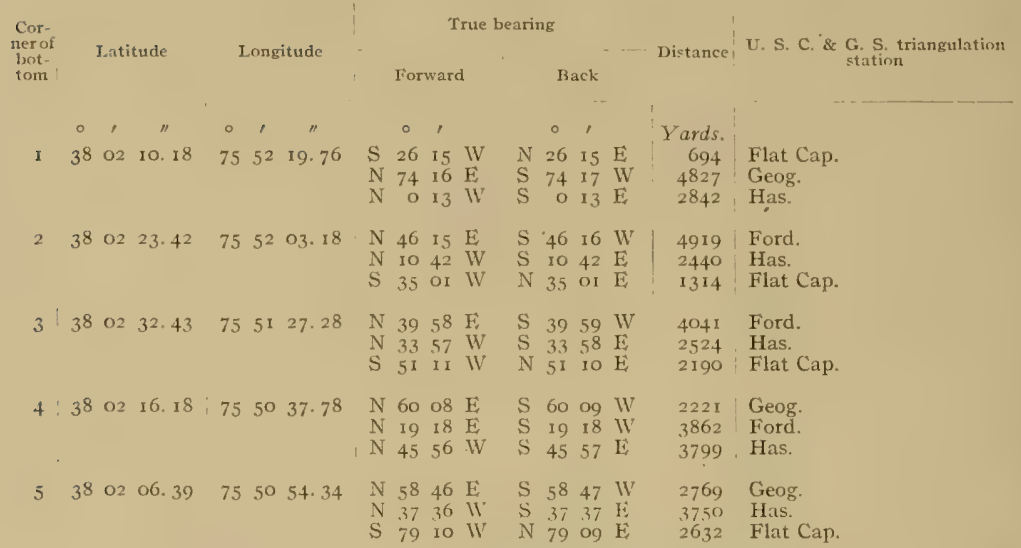

Thence from corner No. 5 along the mean low-water line of the shore to corner No. 1 , excluding any creek, cove, or inlet less than roo yards in width at its mouth at low tide.

\section{SHANKS CREEK.}

(Smith Island-Chant No. 8.)

\begin{tabular}{|c|c|c|c|c|c|c|c|c|c|c|c|c|c|c|}
\hline & 。 & , & $"$ & 0 & , & $"$ & & 0 & , & & 。 & , & Yards. & \\
\hline & 37 & 57 & 15.10 & 76 & or & $47.7^{8}$ & $\begin{array}{l}\mathrm{S} \\
\mathrm{N} \\
\mathrm{N}\end{array}$ & $\begin{array}{l}88 \\
24 \\
22\end{array}$ & $\begin{array}{l}19 \mathrm{E} \\
06 \mathrm{E} \\
07 \mathrm{~W}^{7}\end{array}$ & $\begin{array}{l}\mathrm{N} \\
\mathrm{S} \\
\mathrm{S}\end{array}$ & $\begin{array}{l}88 \\
24 \\
22\end{array}$ & $\begin{array}{l}17 \mathrm{WV} \\
07 \mathrm{~W} \\
07 \mathrm{~F}\end{array}$ & $\begin{array}{l}3472 \\
2535 \\
3138\end{array}$ & $\begin{array}{l}\text { Horse. } \\
\text { Ewell Churcl. } \\
\text { Old Church. }\end{array}$ \\
\hline & 37 & 57 & 15. 78 & 76 & 02 & 17.53 & $\begin{array}{l}\mathrm{S} \\
\mathrm{N} \\
\mathrm{N}\end{array}$ & $\begin{array}{r}88 \\
38 \\
7\end{array}$ & $\begin{array}{ll}20 & \mathrm{E} \\
36 & \mathrm{E} \\
39 & \mathrm{WW}\end{array}$ & $\begin{array}{l}N \\
S \\
S\end{array}$ & $\begin{array}{r}88 \\
38 \\
7\end{array}$ & $\begin{array}{ll}18 & W \\
37 & W \\
39 & E\end{array}$ & $\begin{array}{l}4268 \\
2932 \\
2909\end{array}$ & $\begin{array}{l}\text { Horse. } \\
\text { Ewell Church. } \\
\text { Old Church. }\end{array}$ \\
\hline
\end{tabular}

Thence from corner No. 2 along the mean low-water line of the shore to corner No. I, excluding any creek, cove, or inlet less than 100 yards in width at its mouth at low tide. 
BOUNDARIFS OF CRAB BOTTOMS - continuEd.

TYLERS CREEK.

(Smith 1sland-Charts Nos. 8 and 9.)

\begin{tabular}{|c|c|c|c|c|c|c|c|c|c|c|c|c|c|c|}
\hline \multirow{3}{*}{$\begin{array}{l}\text { Lint- } \\
\text { netof } \\
\text { lint- } \\
\text { loint }\end{array}$} & \multirow{3}{*}{\multicolumn{3}{|c|}{ Latitude }} & \multirow{3}{*}{\multicolumn{3}{|c|}{ Longitude }} & \multicolumn{6}{|c|}{ True bearing } & \multirow{3}{*}{ Distance } & \multirow{3}{*}{ U. S. C. \& $\underset{\text { statinn }}{\text { G. S. triangulation }}$} \\
\hline & & & & & & & & - & 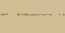 & 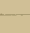 & - & & & \\
\hline & & & & & & & \multicolumn{3}{|c|}{ Forward } & \multicolumn{3}{|c|}{ Back } & & \\
\hline \multirow{3}{*}{ I } & 0 & , & " & $\circ$ & , & " & & $\circ$ & ' & & 0 & , & Yards. & \multirow{3}{*}{$\begin{array}{l}\text { Horse. } \\
\text { Ewell Church. } \\
\text { Old Church. }\end{array}$} \\
\hline & 37 & 57 & 13.20 & 76 & OO & 24. 18 & $S$ & 88 & I4 E & $\mathrm{N}$ & 88 & I4 IV & 1239 & \\
\hline & & & & & & & $N$ & 26 & $42 \mathrm{~W}$ & $\mathrm{~S}$ & 26 & $42 \mathrm{E}$ & 2662 & \\
\hline \multirow[t]{3}{*}{2} & 37 & 57 & I4. 16 & 76 & or & 05.30 & S & 88 & I7 $\mathrm{F}$ & $\mathrm{N}$ & 88 & $16 \mathrm{~W}$ & 2338 & \multirow{3}{*}{$\begin{array}{l}\text { Horse. } \\
\text { Ewell Church. } \\
\text { Old Churcl. }\end{array}$} \\
\hline & & & & & & & N & 2 & $24 \mathrm{~W}$ & $\mathrm{~S}$ & 2 & $2+\mathrm{E}$ & $234^{8}$ & \\
\hline & & & & & & & $N$ & $3^{8}$ & 1611 & $\mathrm{~S}$ & 38 & I $5 \mathrm{~F}$ & 3741 & \\
\hline
\end{tabular}

Thence from corner No. 2 along the mean low-water line of the shore to corner No. I, excluding any creek, cove, or inlet less than roo yards in width at its mouth at low tide.

BIG ISLAND.

(Southwest Tangier:Sound-Chant No. 9.)

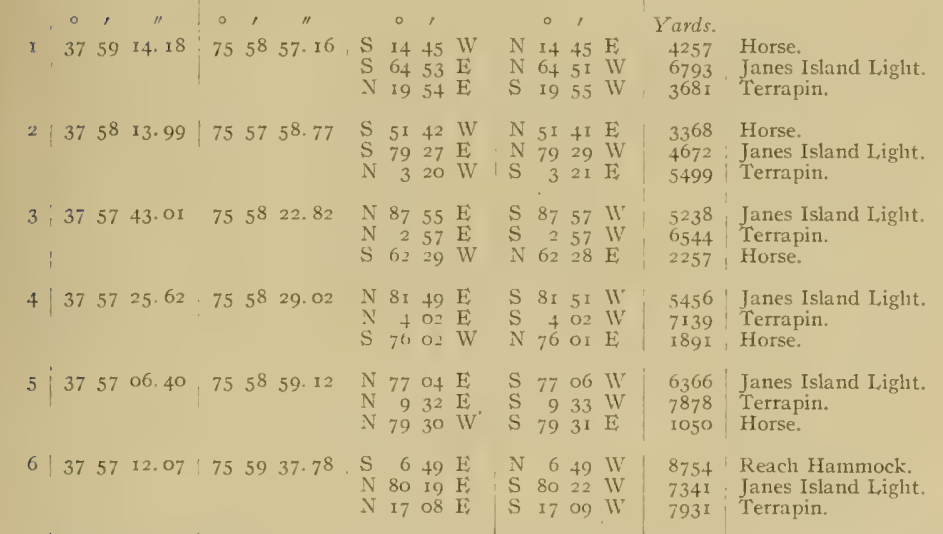

Thence from corner No. 6 along the mean low-water line of the shore to corner No. 1 , excluding any creek, cove, or inlet less than 100 yards in width at its mouth at low tide. 
BOUNDARIF,S OF CRAB BOTTOMS-continued.

\section{DRUM.}

(Southwest Tangier Sound-Chart No. 9.)

\begin{tabular}{|c|c|c|c|c|c|c|c|c|c|c|c|c|c|c|c|c|}
\hline \multirow{2}{*}{$\begin{array}{l}\text { Cor- } \\
\text { nerof } \\
\text { hot- } \\
\text { tom }\end{array}$} & \multirow{2}{*}{\multicolumn{3}{|c|}{ Latitude }} & \multirow{2}{*}{\multicolumn{3}{|c|}{ Longitude }} & \multicolumn{8}{|c|}{ True bearing } & \multirow{2}{*}{ Distance. } & \multirow{2}{*}{ U. S. C. \& G. S. triangulation } \\
\hline & & & & & & & & For & warc & & & & ack & & & \\
\hline I & $\begin{array}{c}\circ \\
3^{8}\end{array}$ & $\begin{array}{c}, \\
\text { oo }\end{array}$ & I 8.54 & $\begin{array}{c}\circ \\
75\end{array}$ & $\begin{array}{l}\prime \\
5^{8}\end{array}$ & $\begin{array}{c}n t \\
43 \cdot 3^{8}\end{array}$ & $\begin{array}{l}\mathrm{S} \\
\mathrm{S} \\
\mathrm{N}\end{array}$ & $\begin{array}{l}0 \\
\text { I } 3 \\
4^{8} \\
34\end{array}$ & $\begin{array}{l}\prime \\
00 \\
51 \\
27\end{array}$ & $\begin{array}{l}\text { W } \\
\mathrm{E} \\
\mathrm{E}\end{array}$ & $\begin{array}{l}N \\
N \\
S\end{array}$ & $\begin{array}{l}0 \\
13 \\
48 \\
34\end{array}$ & $\begin{array}{l}1 \\
00 \\
49 \\
27\end{array}$ & $\begin{array}{l}\mathrm{E} \\
\mathrm{W} \\
\mathrm{WV}\end{array}$ & $\begin{array}{c}\text { Yards. } \\
6453 \\
7680 \\
1566\end{array}$ & $\begin{array}{l}\text { Horse. } \\
\text { Janes Island Light. } \\
\text { Terrapin. }\end{array}$ \\
\hline 2 & $3^{8}$ & $\infty 0$ & 10. $5^{6}$ & 75 & 57 & 23.66 & $\begin{array}{l}N \\
S \\
S\end{array}$ & $\begin{array}{l}38 \\
30 \\
37\end{array}$ & $\begin{array}{l}30 \\
45 \\
22\end{array}$ & $\begin{array}{l}\text { IV } \\
\text { IV } \\
\text { E }\end{array}$ & $\stackrel{S}{N}$ & $\begin{array}{l}38 \\
30 \\
37\end{array}$ & $\begin{array}{l}30 \\
44 \\
21\end{array}$ & $\begin{array}{l}\mathrm{E} \\
\mathrm{E} \\
\mathrm{WW}\end{array}$ & $\begin{array}{l}1994 \\
7002 \\
6022\end{array}$ & $\begin{array}{l}\text { Terrapin. } \\
\text { Horse. } \\
\text { Janes Island Light. }\end{array}$ \\
\hline 3 & 37 & 59 & 33.26 & 75 & 57 & 20.02 & $\begin{array}{l}\mathrm{N} \\
\mathrm{S} \\
\mathrm{S}\end{array}$ & $\begin{array}{l}25 \\
37 \\
45\end{array}$ & $\begin{array}{l}24 \\
42 \\
\text { I5 }\end{array}$ & $\begin{array}{l}\text { WV } \\
\text { WV } \\
\text { E }\end{array}$ & $\begin{array}{l}\mathrm{S} \\
\mathrm{N} \\
\mathrm{N}\end{array}$ & $\begin{array}{l}25 \\
37 \\
45\end{array}$ & $\begin{array}{l}25 \\
40 \\
13\end{array}$ & $\begin{array}{l}\mathrm{E} \\
\mathrm{E} \\
\mathrm{W}\end{array}$ & $\begin{array}{l}3119 \\
6015 \\
5011\end{array}$ & $\begin{array}{l}\text { Terrapin. } \\
\text { Horse. } \\
\text { Janes Island Light. }\end{array}$ \\
\hline+ & 37 & 59 & 12.86 & 75 & $5^{6}$ & $57 \cdot 37$ & $\begin{array}{l}\mathrm{N} \\
\mathrm{S} \\
\mathrm{S}\end{array}$ & $\begin{array}{l}28 \\
46 \\
46\end{array}$ & $\begin{array}{l}59 \\
27 \\
07\end{array}$ & $\begin{array}{l}\text { WV } \\
\text { IV } \\
\text { E }\end{array}$ & $\begin{array}{l}\mathrm{S} \\
\mathrm{N}\end{array}$ & $\begin{array}{l}29 \\
46 \\
46\end{array}$ & $\begin{array}{l}00 \\
26 \\
07\end{array}$ & $\begin{array}{l}\mathrm{E} \\
\mathrm{E} \\
\mathrm{W}\end{array}$ & $\begin{array}{l}4008 \\
5910 \\
4098\end{array}$ & $\begin{array}{l}\text { Terrapin. } \\
\text { Horse. } \\
\text { Janes Island Light. }\end{array}$ \\
\hline 5 & 37 & $5^{8}$ & $47 \cdot 3^{8}$ & 75 & 57 & 15.60 & $\begin{array}{l}N \\
\text { S } \\
S\end{array}$ & $\begin{array}{l}18 \\
49 \\
60\end{array}$ & $\begin{array}{l}27 \\
45 \\
04\end{array}$ & $\begin{array}{l}\text { IV } \\
\text { WV } \\
\text { E }\end{array}$ & $\begin{array}{l}\mathrm{S} \\
\mathrm{N}\end{array}$ & $\begin{array}{l}18 \\
49 \\
60\end{array}$ & $\begin{array}{l}27 \\
44 \\
03\end{array}$ & $\begin{array}{l}\mathrm{E} \\
\mathrm{E} \\
\mathrm{WV}\end{array}$ & $\begin{array}{l}460 x \\
4974 \\
3970\end{array}$ & $\begin{array}{l}\text { Terrapin. } \\
\text { Horse. } \\
\text { Janes Island Light. }\end{array}$ \\
\hline 0 & 37 & $5^{8}$ & 13.99 & 75 & 57 & 58.77 & $\begin{array}{l}\mathrm{S} \\
\mathrm{S} \\
\mathrm{N}\end{array}$ & $\begin{array}{r}51 \\
79 \\
3\end{array}$ & $\begin{array}{l}42 \\
27 \\
20\end{array}$ & $\begin{array}{l}\text { IV } \\
\mathrm{E} \\
\text { WV }\end{array}$ & $\begin{array}{l}N \\
N\end{array}$ & $\begin{array}{r}51 \\
79 \\
3\end{array}$ & $\begin{array}{l}41 \\
29 \\
21\end{array}$ & $\begin{array}{l}\mathrm{E} \\
\mathrm{IV} \\
\mathrm{E}\end{array}$ & $\begin{array}{l}3368 \\
4672 \\
5499\end{array}$ & $\begin{array}{l}\text { Horse. } \\
\text { Janes Island Light. } \\
\text { Terrapin. }\end{array}$ \\
\hline 7 & 37 & 59 & 14.18 & 75 & $5^{8}$ & 57.16 & $\begin{array}{l}\mathrm{S} \\
\mathrm{S} \\
\mathrm{N}\end{array}$ & $\begin{array}{l}\text { I4 } \\
64 \\
\text { I9 }\end{array}$ & $\begin{array}{l}45 \\
53 \\
54\end{array}$ & $\begin{array}{l}\text { W } \\
\mathrm{E} \\
\mathrm{E}\end{array}$ & $\begin{array}{l}N \\
\mathrm{~N}\end{array}$ & $\begin{array}{l}14 \\
64 \\
19\end{array}$ & $\begin{array}{l}45 \\
5 \mathrm{I} \\
55\end{array}$ & $\begin{array}{l}\mathrm{E} \\
\mathrm{W} \\
\mathrm{W}\end{array}$ & $\begin{array}{l}4257 \\
6793 \\
3681\end{array}$ & $\begin{array}{l}\text { Horse. } \\
\text { Janes Island Light. } \\
\text { Terrapin. }\end{array}$ \\
\hline
\end{tabular}

Thence from corner No. 7 along the mean low-water line of the shore to corner No. I, excluding any creek, cove, or inlet less than 100 yards in width at its mouth at low tide.

OLD HOUSF:

(Little Annemessex River-Chart No. 9.)

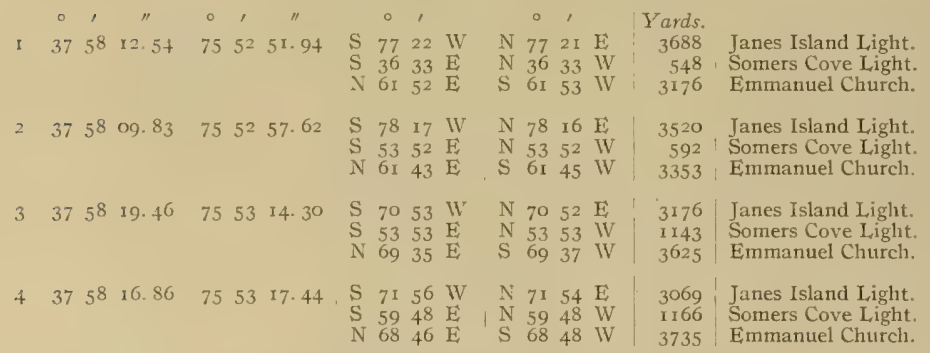

Thence from corner No, 4 along the mean low-water line of the shore to corner No. $I$, excluding any creek, cove, or inlet less than roo yards in width at its mouth at low tide. 
BOUNDARIKS OF CRAB BOTTOMS-continued.

\section{LIGHT HOUSE.}

(Little Annemessex River-Chant No. 9.)

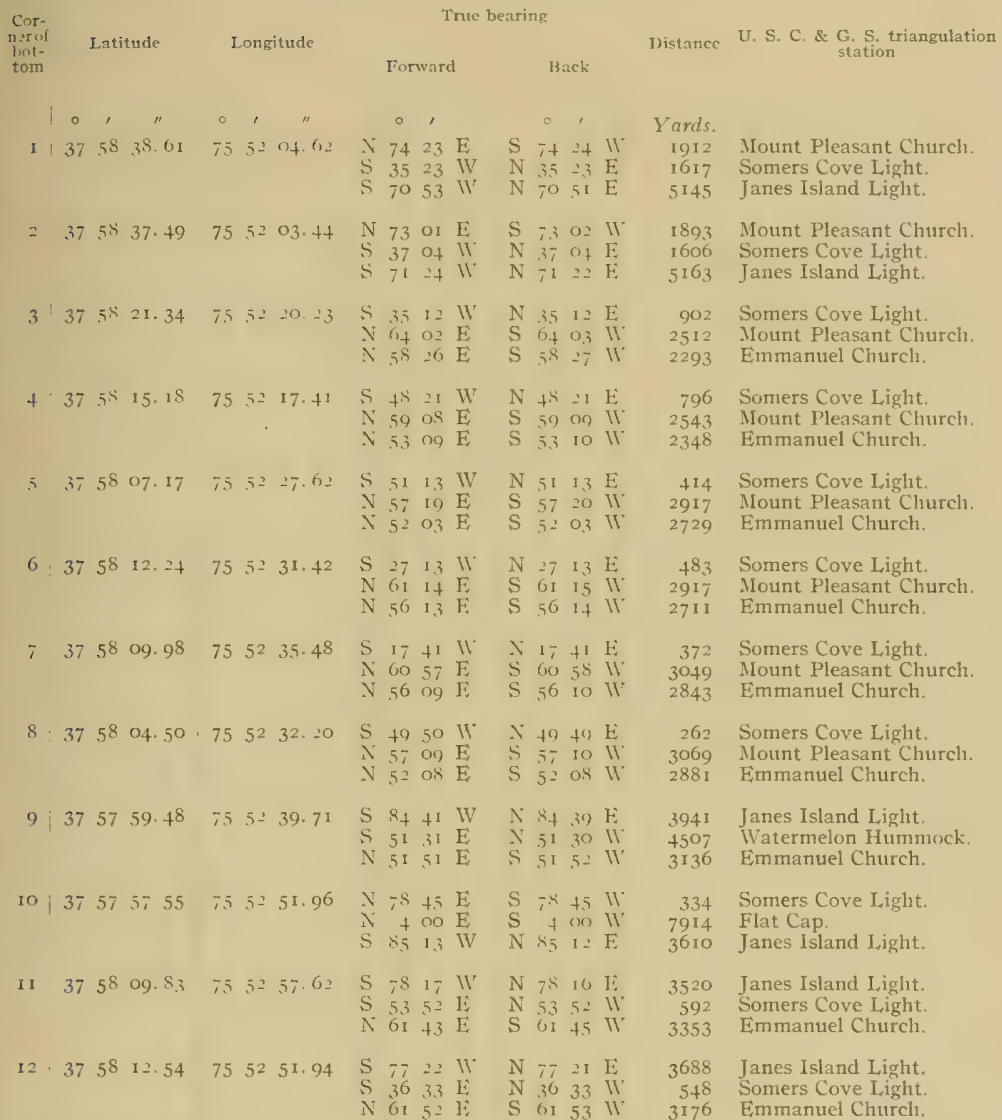

Thence from corner No. 12 along the mean low-water line of the shore to corner No. 1 , excluding any creek, cove, or inlet less than roo yards in width at its mouth at low tide. 
BOUNDARIES OF CRAB BOTTOMS-continued.

\section{CANCER.}

(Little Annemessex River-Chart No. 9.)

\begin{tabular}{|c|c|c|c|c|c|c|c|c|c|c|c|c|c|c|c|}
\hline \multirow{4}{*}{$\begin{array}{l}\text { Cot- } \\
\text { netof } \\
\text { bot- } \\
\text { tom }\end{array}$} & \multirow{3}{*}{\multicolumn{3}{|c|}{ Latitude }} & \multirow{3}{*}{\multicolumn{3}{|c|}{ Longitude }} & \multicolumn{7}{|c|}{ True bearing } & \multirow{3}{*}{ Distance } & \multirow{3}{*}{ U. S. C. \& G. S. triangulation } \\
\hline & & & & & & & & & & & & & & & \\
\hline & & & & & & & & Fior & ward & & & $\mathrm{Bac}$ & ck & & \\
\hline & $\circ$ & , & " & $\circ$ & , & " & & o & , & & & 。 & , & Yards. & \\
\hline I & 37 & 59 & 19.28 & 75 & $5^{2}$ & 02. 18 & $\begin{array}{l}\mathrm{S} \\
\mathrm{S} \\
\mathrm{S}\end{array}$ & $\begin{array}{l}62 \\
20 \\
58\end{array}$ & $\begin{array}{l}55 \\
25 \\
\text { II }\end{array}$ & $\begin{array}{l}\mathrm{E} \\
W \\
W\end{array}$ & $\begin{array}{l}\mathrm{N} \\
\mathrm{N} \\
\mathrm{N}\end{array}$ & $\begin{array}{ll}62 & 5 \\
20 & 2 \\
58 & 0\end{array}$ & $\begin{array}{ll}54 & \text { H } \\
25 & \mathrm{E} \\
09 & \mathrm{E}\end{array}$ & $\begin{array}{l}1655 \\
2871 \\
5797\end{array}$ & $\begin{array}{l}\text { Emmanuel Church. } \\
\text { Somers Cove Light. } \\
\text { Janes Island Light. }\end{array}$ \\
\hline 2 & 37 & 59 & o8. 74 & 75 & 52 & 06. 27 & $\begin{array}{l}\mathrm{S} \\
\mathrm{S} \\
\mathrm{S}\end{array}$ & $\begin{array}{l}75 \\
20 \\
60\end{array}$ & $\begin{array}{l}53 \\
55 \\
44\end{array}$ & $\begin{array}{l}\mathrm{E} \\
\mathrm{WV} \\
\mathrm{W}\end{array}$ & $\begin{array}{l}\mathrm{N} \\
\mathrm{N} \\
\mathrm{N}\end{array}$ & $\begin{array}{l}75 \\
20 \\
60\end{array}$ & $\begin{array}{ll}52 & \mathrm{II} \\
55 & \mathrm{E} \\
42 & \mathrm{E}\end{array}$ & $\begin{array}{l}1631 \\
2500 \\
5523\end{array}$ & $\begin{array}{l}\text { Emmanuel Church. } \\
\text { Somers Cove Light. } \\
\text { Janes Island Light. }\end{array}$ \\
\hline
\end{tabular}

Thence from corner No. 2 along the mean low-water line of the shore to corner No. I, excluding any creek, cove, or inlet less than roo yards in width at its mouth at low tide.

\section{BACK CREEK.}

(Litlle Annemessex River - Chart No. 9.)

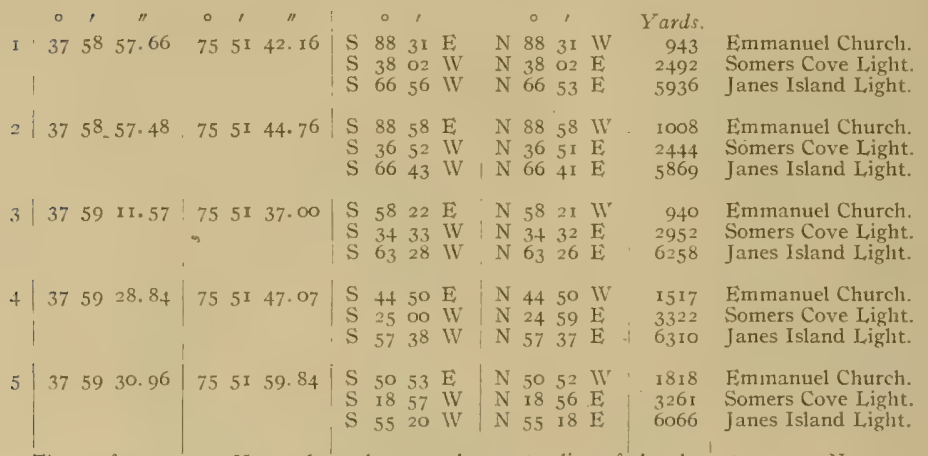

Thence from corner No. 5 along the mean low-water line of the shore to corner No. 1, excluding any creek, cove, or inlet less than 100 yards in width at its mouth at low tide. 
BOUNDARIES OF CRAB BOTTOMS-continued.

LAVELLETTE.

(Little Anremessex River-Chart No. 9.)

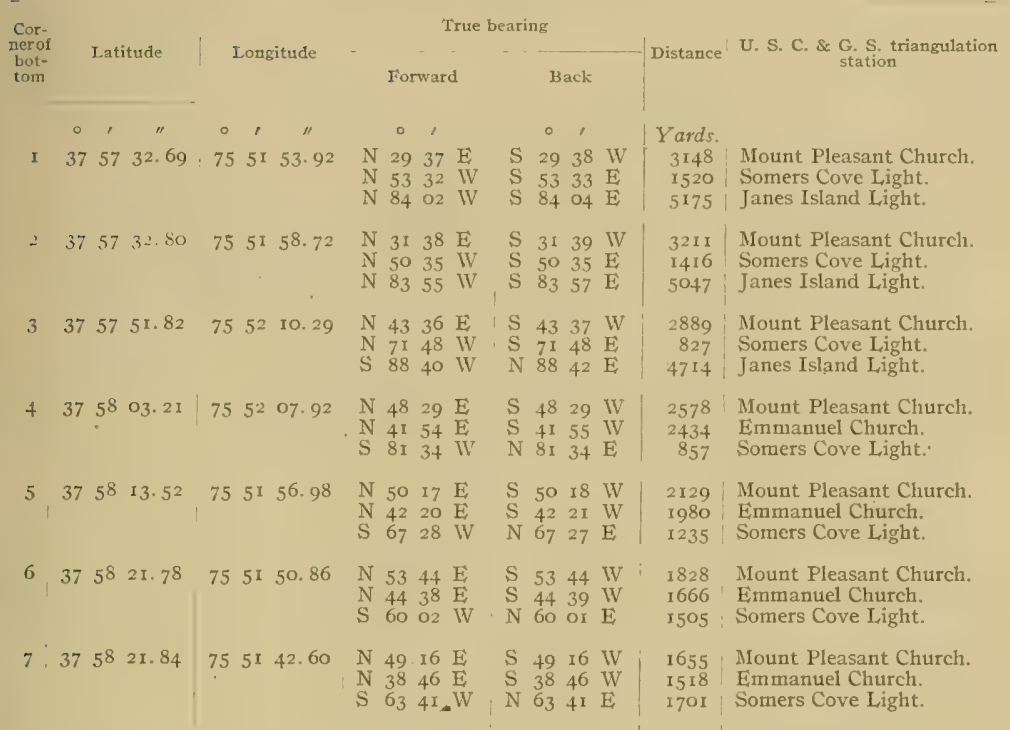

Thence from corner No. 7 along the mean low-water line of the shore to corner No. 1 , excluding any creek, cove, or inlet less than 100 yards in width at its mouth at low tide.

\section{JENKINS CREEK.}

(Little Annemessex River-Chart No. 9.)

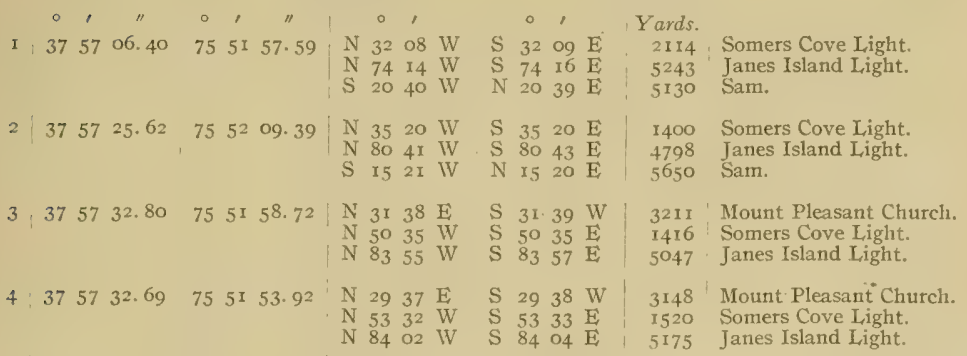

Thence from corner No. 4 along the mean low-water line of the shore to corner No. 5 , excluding any creek, cove, or inlet less than Ioo yards in width at its mouth at low tide.

$$
50095-0 \mathrm{~S}-14
$$


Io6 Suretey of Oyster Bars, Somerset Comnty, Md.

BOUNDARIES OF CRAB IBOTTOMS-continticel.

JENKINS CREEK-Continued.

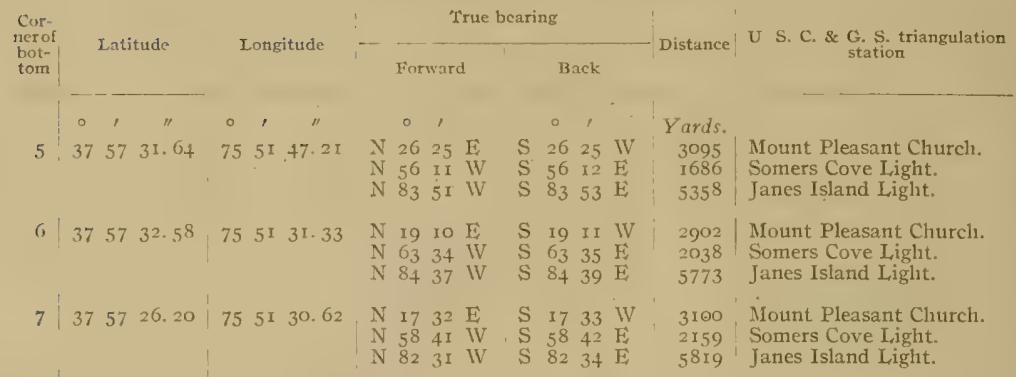

Thence from corner No. 7 along the mean low-water line of the shore to corner No. I, excluding any creek, cove, or inlet less than 100 yards in widtl at its moutls at low tide.

\section{KINGS ISLAND.}

(Little Annemessex River-Chart No. 9.)

\begin{tabular}{|c|c|c|c|c|c|c|c|c|c|c|c|c|c|c|c|c|}
\hline I & $\begin{array}{c}0 \\
37\end{array}$ & $\begin{array}{l}1 \\
57\end{array}$ & 33. 14 & $\begin{array}{c}\circ \\
75\end{array}$ & $\frac{1}{53}$ & $3^{8} \cdot 5^{8}$ & $\begin{array}{l}\mathrm{N} \\
\mathrm{S} \\
\mathrm{N}\end{array}$ & $\begin{array}{c}\circ \\
77 \\
8 \\
60\end{array}$ & $\begin{array}{ll}1 \\
30 & \mathrm{I} \\
5 \mathrm{I} & \mathrm{E} \\
32 & \mathrm{~F}\end{array}$ & $\begin{array}{l}\mathrm{W} \\
\mathrm{E} \\
\mathrm{E}\end{array}$ & $\begin{array}{l}\mathrm{S} \\
\mathrm{N} \\
\mathrm{S}\end{array}$ & $\begin{array}{r}0 \\
77 \\
8 \\
60\end{array}$ & $\begin{array}{l}\prime \\
31 \\
50 \\
32\end{array}$ & & $\begin{array}{l}\text { Yards. } \\
2410 \\
5771 \\
1806\end{array}$ & $\begin{array}{l}\text { Janes Island Light. } \\
\text { Sam. } \\
\text { Somers Cove Light. }\end{array}$ \\
\hline 2 & 37 & 57 & $37 \cdot 36$ & 75 & 53 & 30.06 & $\begin{array}{l}N \\
\mathrm{~S} \\
\mathrm{~N}\end{array}$ & $\begin{array}{r}81 \\
6 \\
60\end{array}$ & $\begin{array}{ll}38 & 1 \\
27 & 1 \\
58 & 1\end{array}$ & $\begin{array}{l}\text { WV } \\
\text { Ii: } \\
\text { Ii }\end{array}$ & $\begin{array}{l}\mathrm{S} \\
\mathrm{N} \\
\mathrm{S}\end{array}$ & $\begin{array}{r}81 \\
6 \\
6\end{array}$ & $\begin{array}{l}39 \\
26 \\
59\end{array}$ & $\begin{array}{l}E \\
\text { IV } \\
W\end{array}$ & $\begin{array}{l}2608 \\
588 \mathrm{y} \\
\text { I } 538\end{array}$ & $\begin{array}{l}\text { Janes Island Light. } \\
\text { Sam. } \\
\text { Somers Cove Light. }\end{array}$ \\
\hline 3 & $\therefore 7$ & 57 & +3117 & 7.5 & 5.3 & $\therefore 7.44$ & $\begin{array}{l}\mathrm{N} \\
\mathrm{S} \\
\mathrm{N}\end{array}$ & $\begin{array}{r}85 \\
56 \\
60\end{array}$ & $\begin{array}{ll}58 & 1 \\
35 & 1 \\
31 & 1\end{array}$ & $\begin{array}{l}\text { II } \\
\text { Ii: } \\
\text { Ii }\end{array}$ & $\begin{array}{l}\mathrm{S} \\
\mathrm{N} \\
\mathrm{S}\end{array}$ & $\begin{array}{r}85 \\
5 \\
6,6\end{array}$ & $\begin{array}{l}59 \\
35 \\
31\end{array}$ & $\begin{array}{l}\mathrm{E} \\
\mathrm{W} \\
\mathrm{W}\end{array}$ & $\begin{array}{l}2657 \\
6065 \\
1389\end{array}$ & $\begin{array}{l}\text { Janes Island Iight. } \\
\text { Sam. } \\
\text { Somers Cove Light. }\end{array}$ \\
\hline 4 & 37 & 57 & $4 \therefore 74$ & 75 & 5.3 & I1). 82 & $\begin{array}{l}\mathrm{N} \\
\mathrm{S} \\
\mathrm{N}\end{array}$ & $\begin{array}{r}86, \\
3 \\
62\end{array}$ & $\begin{array}{ll}n \geq & 1 \\
\text { fo } & 1 \\
1 & =1\end{array}$ & $\begin{array}{l}\text { II } \\
\mathrm{E} \\
\mathrm{I}\end{array}$ & $\begin{array}{l}\mathrm{S} \\
\mathrm{N} \\
\mathrm{S}\end{array}$ & $\begin{array}{r}86 \\
3 \\
62\end{array}$ & $\begin{array}{l}03 \\
40 \\
13\end{array}$ & $\begin{array}{l}\mathrm{E} \\
\mathrm{W} \\
\mathrm{IV}\end{array}$ & $\begin{array}{l}2861 \\
6038 \\
1211\end{array}$ & $\begin{array}{l}\text { Janes Island Light. } \\
\text { Sam. } \\
\text { Somers Cove Light. }\end{array}$ \\
\hline 5 & 37 & 57 & 32.64 & 7.5 & 5.3 & IS. 58 & $\begin{array}{l}N \\
S \\
N\end{array}$ & $\begin{array}{r}79 \\
3 \\
48\end{array}$ & $\begin{array}{ll}26 & 1 \\
33 & 1 \\
54 & 1\end{array}$ & $\begin{array}{l}\text { II } \\
\text { Ii: } \\
\text { li }\end{array}$ & $\begin{array}{l}\mathrm{S} \\
\mathrm{N} \\
\mathrm{S}\end{array}$ & $\begin{array}{r}79 \\
3 \\
48\end{array}$ & $\begin{array}{l}27 \\
33 \\
55\end{array}$ & $\begin{array}{l}\mathrm{E} \\
\mathrm{WV} \\
\mathrm{WV}\end{array}$ & $\begin{array}{l}2937 \\
5695 \\
1377\end{array}$ & $\begin{array}{l}\text { Janes Island Light. } \\
\text { Sam. } \\
\text { Somers Cove Light. }\end{array}$ \\
\hline 6 & 37 & 57 & 32.00 & 7.5 & 5.3 & 12.34 & $\begin{array}{l}N \\
S \\
N\end{array}$ & $\begin{array}{r}43 \\
1 \\
79\end{array}$ & $\begin{array}{ll}14 & 1 \\
53 & 1 \\
36 & 1\end{array}$ & $\begin{array}{l}\mathrm{I} \\
\mathrm{I}: \\
\mathrm{II}^{t}\end{array}$ & $\begin{array}{l}\mathrm{S} \\
\mathrm{N} \\
\mathrm{S}\end{array}$ & $\begin{array}{r}43 \\
1 \\
79\end{array}$ & $\begin{array}{l}15 \\
54 \\
37\end{array}$ & $\begin{array}{l}\text { WV } \\
\text { WV } \\
\mathrm{E}\end{array}$ & $\begin{array}{l}1272 \\
5666 \\
3105\end{array}$ & $\begin{array}{l}\text { Somers Cove Liglit. } \\
\text { Sam. } \\
\text { Janes Island Light. }\end{array}$ \\
\hline 7 & .37 & 57 & $4^{6}, 22$ & 7.5 & 5,3 & $02.9^{8}$ & $\begin{array}{l}\mathrm{N} \\
\mathrm{S} \\
\mathrm{N}\end{array}$ & $\begin{aligned} 85 \\
0 \\
5+\end{aligned}$ & $\begin{array}{l}35 \\
36 \\
5.31\end{array}$ & $\begin{array}{l}11 \\
11 \\
\text { I: }\end{array}$ & $\begin{array}{l}\mathrm{S} \\
\mathrm{N} \\
\mathrm{S}\end{array}$ & $\begin{array}{r}88 \\
0 \\
54\end{array}$ & $\begin{array}{l}37 \\
36 \\
5.3\end{array}$ & $\begin{array}{l}\mathrm{E} \\
\mathrm{E} \\
\mathrm{W}\end{array}$ & $\begin{array}{r}3305 \\
6143 \\
759\end{array}$ & $\begin{array}{l}\text { Janes Island Light. } \\
\text { Sam. } \\
\text { Somers Cove Liglit. }\end{array}$ \\
\hline 8 & 37 & 57 & $44 \cdot 4^{6}$ & 75 & $5^{2}$ & 35.80 & $\begin{array}{l}\mathrm{N} \\
\mathrm{N} \\
\mathrm{S}\end{array}$ & $\begin{array}{l}\text { II } \\
\text { SR } \\
7\end{array}$ & $\begin{array}{l}39 \\
00 \\
24\end{array}$ & $\begin{array}{l}\text { WV } \\
\text { IV } \\
\text { IV }\end{array}$ & $\begin{array}{l}\mathrm{S} \\
\mathrm{S} \\
\mathrm{N}\end{array}$ & $\begin{array}{r}\text { II } \\
88 \\
7\end{array}$ & $\begin{array}{l}39 \\
01 \\
2.3\end{array}$ & $\begin{array}{l}\mathrm{E} \\
\mathrm{E} \\
\mathrm{E}\end{array}$ & $\begin{array}{r}5 \times 7 \\
4032 \\
6 \times 34\end{array}$ & $\begin{array}{l}\text { Somers Cove Light. } \\
\text { Janes Island Light. } \\
\text { Sam. }\end{array}$ \\
\hline 9 & 37 & 57 & 47.00 & 75 & 52 & 22.5 .6 & $\begin{array}{l}N \\
N \\
S\end{array}$ & $\begin{array}{l}+7 \\
89 \\
10\end{array}$ & $\begin{array}{l}25 \\
26 \\
30\end{array}$ & $\begin{array}{l}\text { IV } \\
\text { IV } \\
\text { W }\end{array}$ & $\begin{array}{l}\mathrm{S} \\
\mathrm{S} \\
\mathrm{N}\end{array}$ & $\begin{array}{l}+7 \\
89 \\
10\end{array}$ & $\begin{array}{l}2.5 \\
27 \\
30\end{array}$ & $\begin{array}{l}\mathrm{E} \\
\mathrm{E} \\
\mathrm{E}\end{array}$ & $\begin{array}{r}622 \\
4383 \\
6274\end{array}$ & $\begin{array}{l}\text { Somers Cove Light. } \\
\text { Janes Island Light. } \\
\text { Sam. }\end{array}$ \\
\hline
\end{tabular}


Surecy of Oyster Bars, Somerset County, Md.

BOUNDARIES OF CRAR BOTTOMS-continUEd.

KINGS ISLAND-Continued.

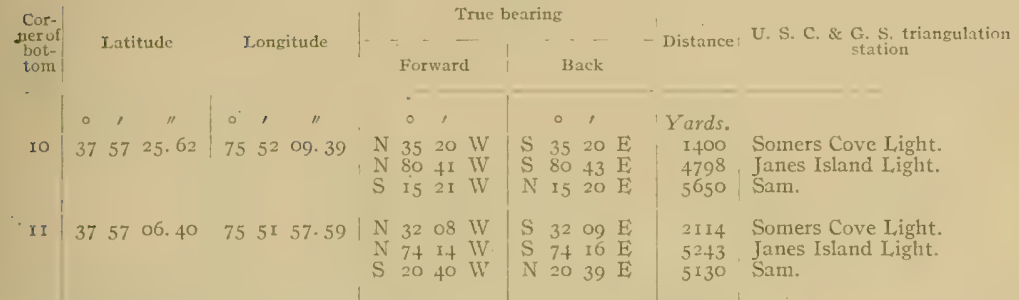

Thence from corner No. Ir along the mean low-water line of the shore to corner No. I, cxcluding any creek, cove, or inlet less than roo yards in width at its mouth at low tide.

GREAT POINT.

(Entrance Little Annemessex River-Chart No. 9.)

\begin{tabular}{|c|c|c|c|c|c|c|c|c|c|c|c|c|c|c|}
\hline$I$ & $\begin{array}{c}\circ \\
37\end{array}$ & $\begin{array}{c}t \\
56\end{array}$ & $58 \cdot 46$ & $\begin{array}{c}\circ \\
75\end{array}$ & $\begin{array}{l}, \\
53\end{array}$ & $\begin{array}{c}\prime \prime \\
32.95\end{array}$ & $\begin{array}{l}\mathrm{S} \\
\mathrm{N} \\
\mathrm{N}\end{array}$ & $\begin{array}{r}0 \\
9 \\
34 \\
55\end{array}$ & $\begin{array}{l}\text { I } \\
\text { I } \mathrm{E} \\
38 \mathrm{E} \\
58 \mathrm{WV}\end{array}$ & $\begin{array}{l}N \\
S \\
S\end{array}$ & $\begin{array}{r}0 \\
9 \\
3+ \\
55\end{array}$ & $\begin{array}{l}\text { I } \\
\text { It W } \\
39 \mathrm{WV} \\
58 \mathrm{E}\end{array}$ & $\begin{array}{r}Y \text { ards. } \\
4592 \\
2494 \\
3022\end{array}$ & $\begin{array}{l}\text { Sam. } \\
\text { Somers Cove Light. } \\
\text { Janes Island I.ight. }\end{array}$ \\
\hline 2 & 37 & 56 & $5^{8.9}$ I & 75 & 53 & 46.39 & $\begin{array}{l}\mathrm{S} \\
\mathrm{N} \\
\mathrm{N}\end{array}$ & $\begin{array}{l}13 \\
41 \\
52\end{array}$ & $\begin{array}{l}33 \mathrm{E} \\
\text { O5 E } \\
\text { Oo W }\end{array}$ & $\begin{array}{l}\mathrm{N} \\
\mathrm{S} \\
\mathrm{S}\end{array}$ & $\begin{array}{l}13 \\
41 \\
52\end{array}$ & $\begin{array}{ll}33 & \mathrm{WV} \\
\text { O5 } & \mathrm{WV} \\
00 & \mathrm{E}\end{array}$ & $\begin{array}{l}4677 \\
2709 \\
2722\end{array}$ & $\begin{array}{l}\text { Sam. } \\
\text { Somers Cuve Light. } \\
\text { Janes Island Light. }\end{array}$ \\
\hline 3 & 37 & 57 & $4^{8.22}$ & 75 & 53 & 58.10 & $\begin{array}{l}\mathrm{N} \\
\mathrm{S} \\
\mathrm{N}\end{array}$ & $\begin{array}{l}89 \\
\mathbf{1} 2 \\
79\end{array}$ & $\begin{array}{ll}35 & W \\
47 & E \\
42 & E\end{array}$ & $\begin{array}{l}\mathrm{S} \\
\mathrm{N} \\
\mathrm{S}\end{array}$ & $\begin{array}{l}89 \\
12 \\
79\end{array}$ & $\begin{array}{ll}35 & \mathrm{E} \\
46 & \mathrm{WV} \\
43 & \mathrm{WV}\end{array}$ & $\begin{array}{l}1832 \\
6367 \\
2127\end{array}$ & $\begin{array}{l}\text { Janes Island Liglit. } \\
\text { Sam. } \\
\text { Somers Cove Liglit. }\end{array}$ \\
\hline 4 & 37 & 57 & $37.3^{6}$ & 75 & 53 & 30.06 & $\begin{array}{l}\mathrm{N} \\
\mathrm{S} \\
\mathrm{N}\end{array}$ & $\begin{array}{r}8 I \\
6 \\
60\end{array}$ & $\begin{array}{ll}38 & \mathrm{WV} \\
27 & \mathrm{E} \\
58 & \mathrm{E}\end{array}$ & $\begin{array}{l}\mathrm{S} \\
\mathrm{N} \\
\mathrm{S}\end{array}$ & $\begin{array}{r}81 \\
6 \\
60\end{array}$ & $\begin{array}{ll}39 & \mathrm{E} \\
26 & \mathrm{IV} \\
59 & \mathrm{WV}\end{array}$ & $\begin{array}{l}2608 \\
5881 \\
1538\end{array}$ & $\begin{array}{l}\text { Janes Island Light. } \\
\text { Sam. } \\
\text { Somers Cove Light. }\end{array}$ \\
\hline 5 & 37 & 57 & 33. 14 & 75 & 53 & $3^{8} .5^{8}$ & $\begin{array}{l}\mathrm{N} \\
\mathrm{S} \\
\mathrm{N}\end{array}$ & $\begin{array}{r}77 \\
8 \\
60\end{array}$ & $\begin{array}{ll}30 & \mathrm{WV} \\
51 & \mathrm{E} \\
32 & \mathrm{E}\end{array}$ & $\begin{array}{l}\mathrm{S} \\
\mathrm{N} \\
\mathrm{S}\end{array}$ & $\begin{array}{r}77 \\
8 \\
60\end{array}$ & $\begin{array}{ll}3 \text { I } & \mathrm{E} \\
50 & \mathrm{IV} \\
32 & \mathrm{~W}\end{array}$ & $\begin{array}{l}2410 \\
5771 \\
1806\end{array}$ & $\begin{array}{l}\text { Janes Island Light. } \\
\text { Sam. } \\
\text { Somers Cove Liglit. }\end{array}$ \\
\hline
\end{tabular}

Thence from corner No. 5 along the mean low-water line of the shore to corner No. I, excluding any creek, cove, or inlet less than roo yards in width at its mouth at low tide.

\section{FISHING CREEK.}

(Southeast Tangier Sound-Chart No. 9.)

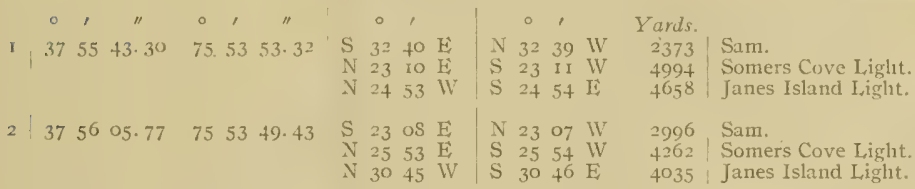

Thence from corner No. 2 along the mean low-water line of the shore to corner No. I, excluding any creek, cove, or inlet less than roo yards in width at its mouth at low tide. 
BOUNDARIES OF CRAB BOTTOMS-continued.

CEDAR STRAITS.

(Cedar Straits-Chart No. 9.)

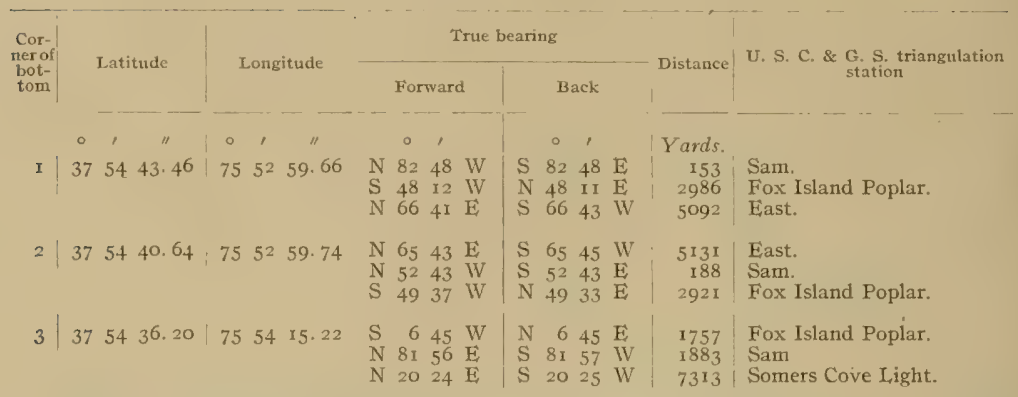

'Thence from corner No. 3 along the mean low-water line of the shore to corner No. 4 , excluding any creek, cove, or inlet less than roo yards in width at its mouth at low tide.

\begin{tabular}{|c|c|c|c|c|c|c|c|c|c|}
\hline 4 & $3754 \quad 41.87$ & $75 \quad 54 \quad 17.75$ & $\begin{array}{lr}\mathrm{S} & 4 \\
\mathrm{~N} & 87 \\
\mathrm{~N} & \mathrm{II}\end{array}$ & $\begin{array}{l}06 \mathrm{~W} \\
50 \mathrm{E} \\
44 \mathrm{~W}\end{array}$ & $\begin{array}{l}\mathrm{N} \\
\mathrm{S}\end{array}$ & $\begin{array}{rr}4 & 0 \\
87 & 5 \\
11 & 4\end{array}$ & $\begin{array}{ll}06 & \mathrm{E} \\
5 \mathrm{I} & \mathrm{IV} \\
44 & \mathrm{E}\end{array}$ & $\begin{array}{l}1941 \\
1933 \\
6430\end{array}$ & $\begin{array}{l}\text { Fox Island Poplar. } \\
\text { Sam. } \\
\text { Janes Island Light. }\end{array}$ \\
\hline & $\begin{array}{lll}37 & 55 & 19.06\end{array}$ & $75 \quad 53 \quad 5^{8.24}$ & $\begin{array}{ll}S & I I \\
S & 50 \\
N & 2 I\end{array}$ & $\begin{array}{ll}42 & W \\
\text { O5 } & \mathrm{E} \\
\text { II } & \mathrm{E}\end{array}$ & $\begin{array}{ll}\mathrm{N} & \mathrm{I} \\
\mathrm{N} & 5 \\
\mathrm{~S} & 2\end{array}$ & $\begin{array}{ll}\text { II } & 4 \\
50 & 0 \\
2 x & 1\end{array}$ & $\begin{array}{ll}4 I & E \\
O_{4} & W \\
\text { I2 } & W\end{array}$ & $\begin{array}{l}3258 \\
1841 \\
5802\end{array}$ & $\begin{array}{l}\text { Fox Island Poplar. } \\
\text { Sam. } \\
\text { Somers Cove Iight. }\end{array}$ \\
\hline & $3755 \quad 33.42$ & $\begin{array}{lll}75 & 53 & 57.33\end{array}$ & $\begin{array}{ll}\text { S } & \text { I0 } \\
\text { S } & 39 \\
\mathrm{~N} & 22\end{array}$ & $\begin{array}{l}33 \mathrm{WV} \\
48 \mathrm{E} \\
49 \mathrm{E}\end{array}$ & $\begin{array}{ll}\mathrm{N} & 1 \\
\mathrm{~N} & 3 \\
\mathrm{~S} & 2\end{array}$ & $\begin{array}{ll}10 & 3 \\
39 & 4 \\
22 & 5\end{array}$ & $\begin{array}{l}33 \mathrm{E} \\
47 \mathrm{~W} \\
50 \mathrm{~W}\end{array}$ & $\begin{array}{l}3738 \\
2168 \\
5343\end{array}$ & $\begin{array}{l}\text { Fox Island Poplar. } \\
\text { Sam. } \\
\text { Somers Cove Light. }\end{array}$ \\
\hline
\end{tabular}

Thence from corner No. 6 along the mean low-water line of the shore to corner No. I, excluding any creek, cove, or inlet less than 100 yards in width at its mouth at low tide.

\section{BROAD CREEK.}

(Western Pocomoke Sound-Chant No. 9.)

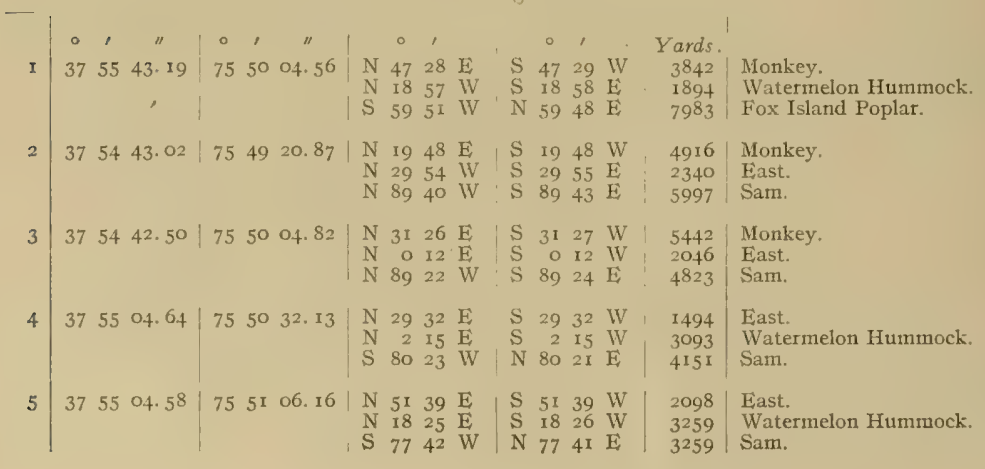


BOUNDARIES OF CRAB BOTTOMS-continued.

BROAD CREEK-Continued.

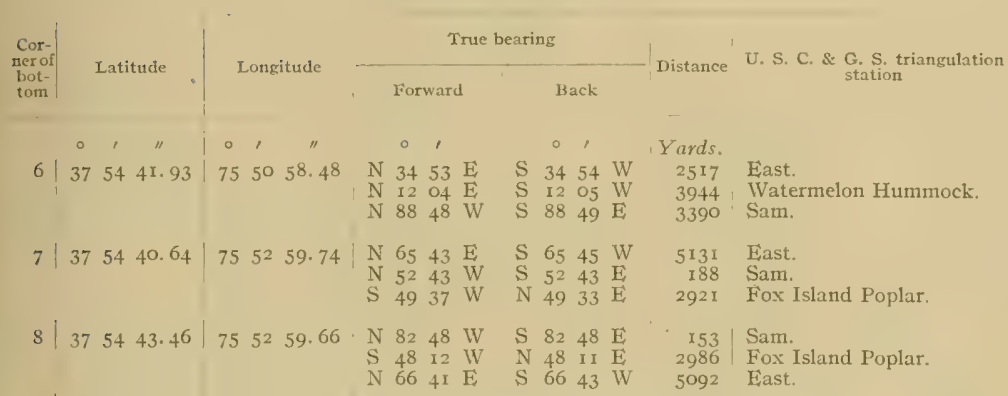

Thence from corner No. 8 along the mean low-water line of the shore to corner No. I, excluding any creek, cove, or inlet less than Ioo yards in width at its mouth at low tide.

\section{WARE POINT.}

(Northern Pocomoke Sound-Chart No. 9.)

\begin{tabular}{|c|c|c|c|c|c|c|c|c|c|c|c|c|c|c|}
\hline I & $\begin{array}{c}0 \\
37\end{array}$ & $\stackrel{1}{57}$ & 02.04 & $\begin{array}{c}\circ \\
75\end{array}$ & $\begin{array}{c}1 \\
49\end{array}$ & 28.14 & $\begin{array}{l}\mathrm{S} \\
\mathrm{S} \\
\mathrm{S}\end{array}$ & $\begin{array}{l}0 \\
6 \mathrm{I} \\
20 \\
88\end{array}$ & $\begin{array}{ll}1 \\
20 \\
06\end{array}$ & $\begin{array}{l}\mathrm{N} \\
\mathrm{N} \\
\mathrm{N}\end{array}$ & $\begin{array}{l}0 \\
6 \mathrm{I} \\
20 \\
88\end{array}$ & $\begin{array}{ll}1 \\
20 & \mathrm{E} \\
05 & \mathrm{E} \\
06 & \mathrm{E}\end{array}$ & \begin{tabular}{|} 
Yards. \\
1810 \\
2830 \\
$x 860$
\end{tabular} & $\begin{array}{l}\text { Watermelon Hummock. } \\
\text { East. } \\
\text { Monkey. }\end{array}$ \\
\hline 2 & 37 & 57 & oo. 82 & 75 & $4^{8}$ & $4^{2} \cdot 30$ & $\begin{array}{l}\mathrm{S} \\
\mathrm{S} \\
\mathrm{S}\end{array}$ & $\begin{array}{l}73 \\
40 \\
88\end{array}$ & $\begin{array}{ll}37 & W \\
\text { OI } & W \\
\text { og } & E\end{array}$ & $\begin{array}{l}\mathrm{N} \\
\mathrm{N} \\
\mathrm{N}\end{array}$ & $\begin{array}{l}73 \\
40 \\
88\end{array}$ & $\begin{array}{ll}36 & \mathrm{E} \\
00 & \mathrm{E} \\
08 & \mathrm{H}\end{array}$ & $\begin{array}{r}2931 \\
3418 \\
635\end{array}$ & $\begin{array}{l}\text { Watermelon Hummock. } \\
\text { East. } \\
\text { Monkey. }\end{array}$ \\
\hline 3 & 37 & 56 & $47 \cdot 45$ & 75 & $4^{8}$ & 49.97 & $\begin{array}{l}\mathrm{N} \\
\mathrm{S} \\
\mathrm{S}\end{array}$ & $\begin{array}{l}62 \\
8 \mathrm{I} \\
42\end{array}$ & $\begin{array}{ll}52 & \mathrm{E} \\
48 & \mathrm{~W} \\
36 & \mathrm{WV}\end{array}$ & $\begin{array}{l}\mathrm{S} \\
\mathrm{N} \\
\mathrm{N}\end{array}$ & $\begin{array}{l}62 \\
8 I \\
42\end{array}$ & $\begin{array}{l}53 \mathrm{~W} \\
47 \mathrm{E} \\
35 \mathrm{E}\end{array}$ & $\begin{array}{r}944 \\
2633 \\
2943\end{array}$ & $\begin{array}{l}\text { Monkey. } \\
\text { Watermelon Hummock. } \\
\text { East. }\end{array}$ \\
\hline 7 & 37 & 55 & 25.60 & 75 & 48 & 51.05 & $\begin{array}{l}\mathrm{N} \\
\mathrm{N} \\
\mathrm{N}\end{array}$ & $\begin{array}{l}15 \\
47 \\
73\end{array}$ & $\begin{array}{ll}\text { I4 } & \mathrm{E} \\
\text { I5 } & \mathrm{W} \\
\text { II } & \mathrm{W}\end{array}$ & $\begin{array}{l}\mathrm{S} \\
\mathrm{S} \\
\mathrm{S}\end{array}$ & $\begin{array}{l}15 \\
47 \\
73\end{array}$ & $\begin{array}{l}14 \mathrm{~W} \\
16 \\
\mathrm{E}\end{array}$ & $\begin{array}{l}3306 \\
3512 \\
2050\end{array}$ & $\begin{array}{l}\text { Monkey. } \\
\text { Watermelon Hummock. } \\
\text { East. }\end{array}$ \\
\hline 5 & 37 & 54 & 43.02 & 75 & 49 & 20. 87 & $\begin{array}{l}\mathrm{N} \\
\mathrm{N} \\
\mathrm{N}\end{array}$ & $\begin{array}{l}19 \\
29 \\
89\end{array}$ & $\begin{array}{ll}48 & \mathrm{E} \\
54 \mathrm{~W} \\
40 \mathrm{~W}\end{array}$ & $\begin{array}{l}\mathrm{S} \\
\mathrm{S} \\
\mathrm{S}\end{array}$ & $\begin{array}{l}19 \\
29 \\
89\end{array}$ & $\begin{array}{ll}48 & \mathrm{II} \\
55 & \mathrm{E} \\
43 & \mathrm{E}\end{array}$ & $\begin{array}{l}4916 \\
2340 \\
5997\end{array}$ & $\begin{array}{l}\text { Monkey. } \\
\text { East. } \\
\text { Sam. }\end{array}$ \\
\hline 6 & 37 & 55 & 43. 19 & 75 & 50 & 04.56 & $\begin{array}{l}\mathrm{N} \\
\mathrm{N} \\
\mathrm{S}\end{array}$ & $\begin{array}{l}47 \\
18 \\
59\end{array}$ & $\begin{array}{ll}28 & \mathrm{E} \\
57 & \mathrm{~W} \\
5 \mathrm{I} & \mathrm{W}\end{array}$ & $\begin{array}{l}\mathrm{S} \\
\mathrm{S} \\
\mathrm{N}\end{array}$ & $\begin{array}{l}47 \\
18 \\
59\end{array}$ & $\begin{array}{ll}29 & \mathrm{II} \\
58 & \mathrm{E} \\
48 & \mathrm{E}\end{array}$ & $\begin{array}{l}3842 \\
1894 \\
7983\end{array}$ & $\begin{array}{l}\text { Monkey. } \\
\text { Watermelon Hummock. } \\
\text { Fox Island Poplar. }\end{array}$ \\
\hline
\end{tabular}

Thence from corner No. 6 along the mean low-water line of the shore to corner No. I, excluding any creek, cove, or inlet less than roo yards in width at its mouth at low tide. 
APES HOLE.

(Northern Pocomoke Sound-Chavt No. 9.)

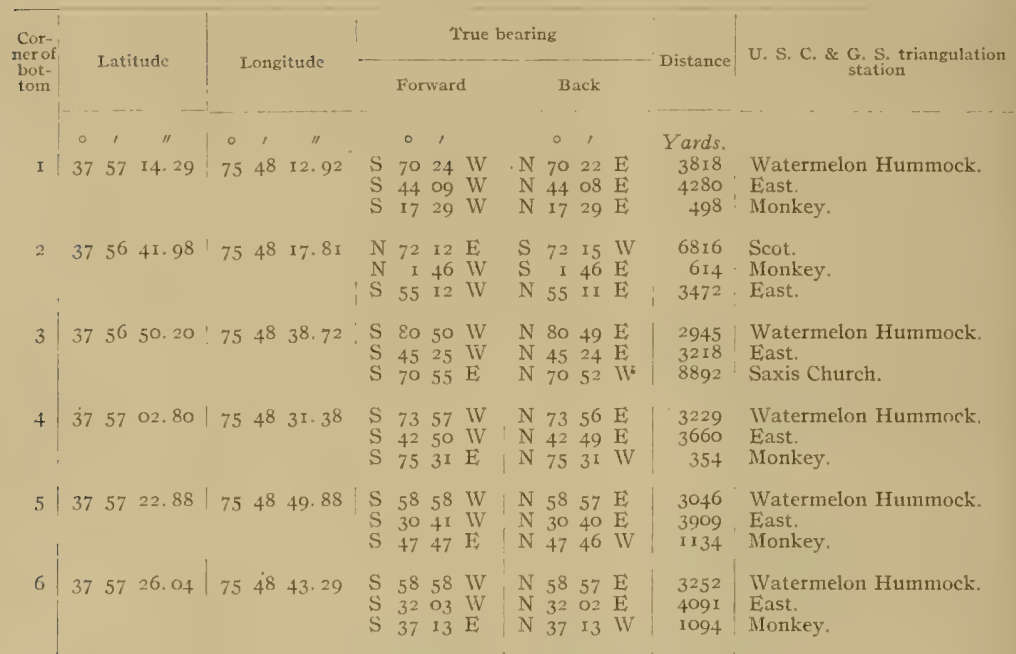

Thence from corner No. 6 along the mean low-water line of the shore to corner No. I, excluding any creek, cove, or inlet less than roo yards in width at its moutl at low tide.

\section{BOUNDARIES OF CLAM BEDS.}

EXIPAANATION OF DESCRIPTIONS OF BOUNDARIES.

The Naryland legislature of 1908 in an act ${ }^{a}$ passed to prescribe additional duties to be performed by the Board of Shell Fish Commissioners provided for the establishment of boundaries of certain clam beds in Pocomoke Sound, which were to be "surveyed and designated on charts" and records prepared and filed in every particular as provided for by the Maryland laws for the survey of natural oyster bars.

The clam beds specified by the law are only 3 in number, with total acreage of 506 acres, the largest bed being 180 acres and the smallest ${ }_{5} 52$ acres.

The boundaries of these clam beds were surveyed and established by the Shell Fish Commission and delineated on the "Charts of Oyster Bars" published by the Coast and Geodetic Survey in a manner identical with that used for the establishment of the oyster bar boundaries. Therefore the "Explanation of descriptions of boundaries," under the heading of "Boundaries of oyster bars," to be found in another part of this publication, will apply to the clam beds.

" For the text of this act see Appendix $B$ of this publication. 
SURVHIING MITIIODS OH RELOCATION OF BOUNDARIES:

For similar reasons to those given under the previous heading, the "Surveying methods of relocation of boundaries," given under the heading of "Boundaries of oyster bres," to be found in another part of this publication, will apply to clam beds.

BOUNDARIES OF CLAM BEDS.

WARE ROCK.

(Pocomoke Sound-Chart No. 9.)

\begin{tabular}{|c|c|c|c|c|c|c|c|c|c|c|c|c|c|c|c|}
\hline Cor- & & & & & & & & & & Crue & iv & & & & \\
\hline bed & & & & & & & & For & ward & & & & ack & & \\
\hline & 0 & 1 & " & 0 & 1 & " & & $\circ$ & ' & & & 0 & , & Yards. & \\
\hline I & 37 & 55 & 13.00 & 75 & $4^{8}$ & og. 78 & $\begin{array}{l}\mathrm{N} \\
\mathrm{N} \\
\mathrm{S}\end{array}$ & $\begin{array}{r}3 \\
71 \\
73\end{array}$ & $\begin{array}{l}42 \\
37 \\
21\end{array}$ & $\begin{array}{l}\text { WV } \\
\text { W }\end{array}$ & $\begin{array}{l}\mathrm{S} \\
\mathrm{S} \\
\mathrm{N}\end{array}$ & $\begin{array}{r}3 \\
71 \\
73\end{array}$ & $\begin{array}{ll}42 & \mathrm{E} \\
38 & \mathrm{E} \\
18 & \mathrm{E}\end{array}$ & $\begin{array}{r}3622 \\
3230 \\
10407\end{array}$ & $\begin{array}{l}\text { Monkey. } \\
\text { East. } \\
\text { Fox. Island Poplar. }\end{array}$ \\
\hline 2 & 37 & 55 & 14.60 & 75 & $4^{8}$ & 46.62 & $\begin{array}{l}\mathrm{N} \\
\mathrm{N} \\
\mathrm{S}\end{array}$ & $\begin{array}{l}11 \\
65 \\
71\end{array}$ & $\begin{array}{l}54 \\
09 \\
20\end{array}$ & $\begin{array}{l}\mathrm{E} \\
\text { IV } \\
\text { WV }\end{array}$ & $\begin{array}{l}\mathrm{S} \\
\mathrm{S} \\
\mathrm{N}\end{array}$ & $\begin{array}{l}11 \\
65 \\
71\end{array}$ & $\begin{array}{l}5+\mathrm{WV} \\
\text { O9 } \mathrm{E} \\
\mathrm{I} 7 \mathrm{E}\end{array}$ & $\begin{array}{l}3640 \\
2294 \\
9486\end{array}$ & $\begin{array}{l}\text { Monkey. } \\
\text { East. } \\
\text { Fox Island Poplar. }\end{array}$ \\
\hline 3 & 37 & 55 & 41.57 & 75 & 48 & $32 \cdot 21$ & $\begin{array}{l}\mathrm{S} \\
\mathrm{N} \\
\mathrm{N}\end{array}$ & $\begin{array}{r}85 \\
7 \\
88\end{array}$ & $\begin{array}{l}52 \\
51 \\
43\end{array}$ & $\begin{array}{l}\mathrm{E} \\
\mathrm{E} \\
\text { IV }\end{array}$ & $\begin{array}{l}\mathrm{N} \\
\mathrm{S} \\
\mathrm{S}\end{array}$ & $\begin{array}{r}85 \\
7 \\
88\end{array}$ & $\begin{array}{l}49 \mathrm{~W} \\
5 \mathrm{I} \\
44 \mathrm{E}\end{array}$ & $\begin{array}{l}8251 \\
2676 \\
2467\end{array}$ & $\begin{array}{l}\text { Saxis Church. } \\
\text { Monkey. } \\
\text { East. }\end{array}$ \\
\hline 4 & 37 & 55 & $45 \cdot 79$ & 75 & 48 & 13.64 & $\begin{array}{l}\mathrm{N} \\
\mathrm{S} \\
\mathrm{S}\end{array}$ & $\begin{array}{r}2 \\
88 \\
67\end{array}$ & $\begin{array}{l}58 \\
19 \\
30\end{array}$ & $\begin{array}{l}\text { W } \\
\text { W }\end{array}$ & $\begin{array}{l}\mathrm{S} \\
\mathrm{N}\end{array}$ & $\begin{array}{r}2 \\
88 \\
67\end{array}$ & $\begin{array}{ll}58 & \mathrm{E} \\
\mathrm{I} 8 & \mathrm{E} \\
30 & \mathrm{WV}\end{array}$ & $\begin{array}{r}2517 \\
2964 \\
10680\end{array}$ & $\begin{array}{l}\text { Monkey. } \\
\text { Eiast. } \\
\text { Fox Island Poplar. }\end{array}$ \\
\hline
\end{tabular}

GRAVEL ROCK.

(Pocomoke Sound-Chant No. 9.)

$\cdot$

\begin{tabular}{|c|c|c|c|c|c|c|c|c|c|c|c|c|c|c|}
\hline 0 & , & $n$ & 0 & ' & " & - & 。 & ' & & & 0 & , & Yards. & \\
\hline 37 & 55 & Ix. 66 & 75 & 47 & $39 \cdot 4^{2}$ & $\begin{array}{l}\mathrm{N} \\
\mathrm{N} \\
\mathrm{S}\end{array}$ & $\begin{array}{l}\text { I5 } \\
74 \\
74\end{array}$ & $\begin{array}{l}55 \\
39 \\
47\end{array}$ & $\begin{array}{l}\text { W } \\
W \\
W\end{array}$ & $\begin{array}{l}\mathrm{S} \\
\mathrm{S} \\
\mathrm{N}\end{array}$ & $\begin{array}{l}\mathbf{5} \\
74 \\
74\end{array}$ & $\begin{array}{l}57 \mathrm{E} \\
4 \mathrm{I} \\
42\end{array}$ & $\begin{array}{r}3808 \\
4020 \\
11174\end{array}$ & $\begin{array}{l}\text { Monkey. } \\
\text { East. } \\
\text { Fox Island Poplar. }\end{array}$ \\
\hline 37 & 55 & 13.00 & 75 & $4^{8}$ & $09 \cdot 78$ & $\begin{array}{l}\mathrm{N} \\
\mathrm{N} \\
\mathrm{S}\end{array}$ & $\begin{array}{r}3 \\
71 \\
73\end{array}$ & $\begin{array}{l}42 \\
37 \\
21\end{array}$ & $\begin{array}{l}\text { W } \\
W \\
W\end{array}$ & $\begin{array}{l}\mathrm{S} \\
\mathrm{S} \\
\mathrm{N}\end{array}$ & $\begin{array}{r}3 \\
71 \\
73\end{array}$ & $\begin{array}{ll}42 & \mathrm{E} \\
38 & \mathrm{E} \\
18 & \mathrm{E}\end{array}$ & $\begin{array}{r}3622 \\
3230 \\
10407\end{array}$ & $\begin{array}{l}\text { Monkey. } \\
\text { East. } \\
\text { Fox Island Poplar. }\end{array}$ \\
\hline 37 & 55 & 45.79 & 75 & $4^{8}$ & 13.64 & $\begin{array}{l}\mathrm{N} \\
\mathrm{S} \\
\mathrm{S}\end{array}$ & $\begin{array}{r}2 \\
88 \\
67\end{array}$ & $\begin{array}{l}58 \\
19 \\
30\end{array}$ & $\begin{array}{l}\text { W } \\
\text { W } \\
\text { W }\end{array}$ & $\begin{array}{l}\mathrm{S} \\
\mathrm{N} \\
\mathrm{N}\end{array}$ & $\begin{array}{r}2 \\
88 \\
67\end{array}$ & $\begin{array}{ll}58 & \mathrm{E} \\
\mathrm{I} 8 & \mathrm{E} \\
27 & \mathrm{E}\end{array}$ & $\begin{array}{r}2517 \\
2964 \\
10680\end{array}$ & $\begin{array}{l}\text { MLonkey. } \\
\text { East. } \\
\text { Fox Island Poplar. }\end{array}$ \\
\hline 37 & 55 & $50.7^{6}$ & 75 & 47 & 52.93 & $\begin{array}{l}\mathrm{S} \\
\mathrm{N}\end{array}$ & $\begin{array}{l}82 \\
16 \\
85\end{array}$ & $\begin{array}{l}49 \\
16 \\
52\end{array}$ & $\begin{array}{l}\mathrm{E} \\
\mathrm{W} \\
\mathrm{W}\end{array}$ & $\begin{array}{l}\mathrm{N} \\
\mathrm{S} \\
\mathrm{N}\end{array}$ & $\begin{array}{l}82 \\
16 \\
85\end{array}$ & $\begin{array}{l}46 \mathrm{~W} \\
16 \\
53\end{array}$ & $\begin{array}{l}7237 \\
2439 \\
3525\end{array}$ & $\begin{array}{l}\text { Saxis Church. } \\
\text { Monkey. } \\
\text { East. }\end{array}$ \\
\hline
\end{tabular}




\section{BOUNDARIES OF CLAM BEDS-continued.}

FLAT ROCK.

(Pocomoke Sound-Charts Nos. 9 and ro.)

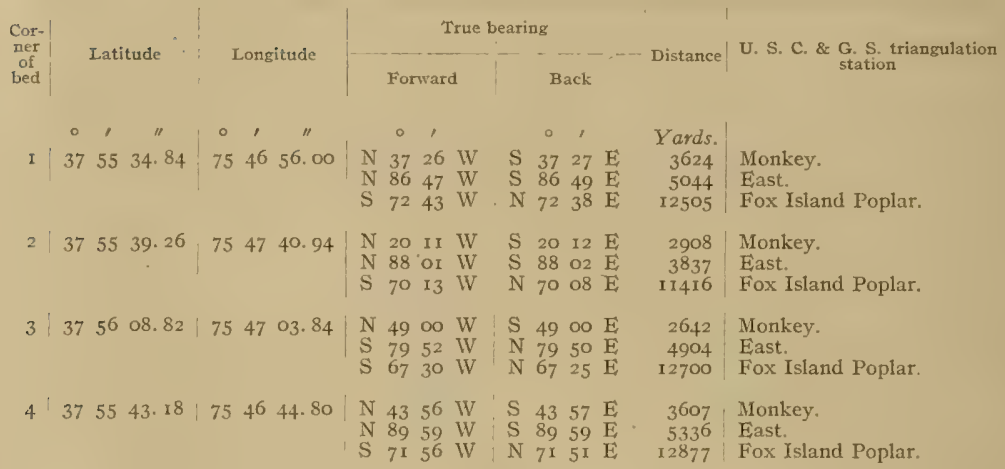




\title{
A P P E N D I E E.
}

\author{
APPENDIX A.-I.AWS RELATING TO THE COOPERATION OH 'THE COAST AND GEODETIC \\ SURVEY AND BUREAU OF FISHERIES WITH THE MARTLAND SHELL FISH COM- \\ MISSION.
}

The work of the Coast and Geodetic Survey and of the Bureau of Fisheries, in cooperation with the Maryland Shell Fish Commission, in surveying the oyster bars, establishing permanent landmarks at triangulation stations, and preparing for publication the necessary charts and technical and legal descriptions of boundaries and landmarks shown on these chatts, has been executed in compliance with a request from the governor of the State of Maryland to the Secretary of Commerce and Labor, and by the authority of the following laws of the United States and Maryland:

[Act of Congress approved May 26, 1906.]

AN ACF To authorize the Secretary of Commerce and Labor to cooperate, through the Bureau of the Coast and Geodetic Survey and the Bureau of Fisheries, with the shellfish commissioners of the State of Maryland in making surveys of the natural oyster beds, bars, and rocks in the waters within the State of Maryland.

Be it enacted by the Senate and House of Representatizes of the Unitcd States of America in Congress assembled, That the Secretary of Commerce and Labor be, and he is hereby, authorized and directed, upon the request of the governor of the State of Maryland, to designate such officers, experts, and employees of the Bureau of the Coast and Geodetic Survey and of the Bureau of Fisheries as may be necessary to cooperate with the Maryland State board of shellish commissioners in making a survey of and locating the natural oyster beds, bars, and rocks in the waters within the State of Maryland; and the Secretary of Commerce and Labor is hereby authorized and directed to furnish to the officers, experts, and employees of said Bureaus so detailed as aforesaid such instruments, appliances, and steam launches as may be necessary to make the survey aforesaid; and the Secretary of Commerce and Labor is lereby authorized to have made in the Bureau of the Coast and Geodetic Survey all the plats necessary to show the results of the aforesaid survey and the locations of the said natural oyster heds, bars, and rocks in the waters within the State of Maryland, and to furnish to the board of shellfish commissioners of the State of Maryland such copies as may be necessary, and for this purpose to employ, in the District of Columbia and elsewhere, such technically qualified persons as may be necessary to carry out the purpose of this act.

SEC. 2. That the Secretary of Commerce and Labor is hereby further authorized to have erected or constructed by the officers so detailed as aforesaid, while making such survey, such structures as may be necessary to mark the points of triangulation, so that the same may be used for such future work of the Coast and Geodetic Survey as the said Bureau may be hereafter required to perform in prosecuting the Government coast survey of the navigable waters of the United States located within the State of Maryland.

SEC. 4. That this act shall take effect from the date of its passage.

[Act of Congress approved June 30, 1906.]

AN ACr Making appropriations for sundry civil expenses of the Government for the fiscal year ending June thirtieth nineteen hundred and seven, and for other purposes.

Be it enacted by the Senate and House of Representatives of the United States of America in Congress assembled, That the following sums be, and the same are hereby, appropriated, for the objects hereinafter expressed, for the fiscal year ending June thirtieth, nineteen hundred and seven, namely: * * * 
Coast and Geodetic Survey: * * * Fior any special surveys * * * inciuding the expenditures authorized under Public Act Numbered One hundred and eighty-one, approved May twenty-sixth, nineteen hundred and six, and contingent expenses incident thereto, five thousand dollars, together with the unexpended balance under this appropriation for nineteen hundred and six and prior years which is hereby reappropriated and made available on this account for the fiscal year nineteen hundred and seven. * * *

\section{[Act of Congress approved March 4, 1907.]}

AN ACT Making appropriations for sundry civil expenses of the Government for the fiscal year ending June thirtieth. nineteen hundred and eight, and for other purposes.

Be ut enacted by the Senate and House of Representatives of the United States of America in Congress assembled, That the following sums be, and the same are hereby, appropriated, for the objects hereinafter expressed, for the fiscal year ending June thirtieth, nineteen hundred and eight, namely: $* * *$

COAST AND GeOdeTIC SuRvey: * * * For any special surveys * * * including expenses of surveys in aid of the shellfish commission of the State of Maryland, to be immediately available and to continue available until expended, twenty-five thousand dollars. * * *

\section{[Act of Congress approved May 27, 1908.]}

AX ACT Making appropriations for sundry civil expenses of the Government for the fiscal year ending June thirtieth, nineteen hundred and nine, and for otber purposes.

Be it enacted by the Senate and House of Representatives of the United States of America in Congress assembled, That the following sums be, and the same are hereby, appropriated, for the objects hereinafter expressed, for the fiscal year ending June thirtieth, nineteen hundred and nine, namely: ***

COAST AND Geodetic SuRvey: * * * For any special surveys * * * including expenses of surveys in aid of the shellish commission of the State of Maryland, which expenses, including cost of plats and charts, shall not exceed fifteen thousand dollars in any one year, to be immediately available, twenty thousand dollars.

[Act of the legislature of Maryland approved April 2, 1906.]

AN AC's to establisi and pronote the industry of oyster culture in Maryland, to define and mark natural oyster beds. lars and rocks lying under the waters of this State, to prescribe penalties for the infringement of the provisions of this Act, and *** * *

Secrron I. Be it enacted by the General Assembly of Maryland, That the following sections be, and they are hereby, added to Article 72 of the Code of Public General Laws, title "Oysters." * * *

SEC. 86. The Board of Shell Fish Commissioners shall, as soon as practicable after the passage of this Act, cause to be made a true and accurate survey of the natural oyster beds, bars and rocks of this State, said survey to be made with reference to fixed and permanent objects on the shore, giving courses and distances, to be fully described and set out in a written report of said survey, as hereinafter required. A true and accurate delineation of the same shall be made on copies of published maps and charts of the United States coast and geodetic survey, which said copies shall be filed in the office of the said commissioners in the city of Annapolis; and the said commissioners shall further cause to be delineated upon copies of the published maps and charts of the United States coast and geodetic survey, of the largest scale, one copy for each of the counties of this State in the waters of which there are natural oyster beds, bars and rocks, all natural beds, bars and rocks lying within the waters of such county, which maps shall be filed in the offices of the clerks of the Circuit Court for the respective counties wherein the grounds so designated may lie.

\footnotetext{
* * * * *
}

SFE. 87. The Governor of this State is hereby requested to ask the assistance of the United States coast and geodetic survey, and of the United States Fish Commissioner, to aid in the carrying out of the provisions of the preceding section. * * * 
SEC. 89. As soon as practicable after the first day of April, 1906, the said commissioners shall organize, and shall at once proceed, with the assistance of such person or persons as may be detailed by the United States coast and geodetic survey, and the United States Fish Commissioner, to aid them in their work, and of such persons as may be appointed under the preceding section, to have laid out, surveyed and designated on the said charts, the natural beds and bars, and shall cause to be marked and defined as accurately as practicable, the limits and boundaries of the natural beds, bars and rocks, as established by said survey, and they shall take true and accurate notes of said survey in writing, and make an accurate report of said survey, setting forth such a description of landmarks as may be necessary to enable the said board, or their successors, to find and ascertain the boundary lines of the said natural oyster beds, bars and rocks, as shown by a delineation on the maps and charts provided in this Act; said report shall be completed and filed in the office of the board in the city of Annapolis within ninety days after the completion of the survey of any county. Said commissioners shall cause the same to be published in pamphlet form, and transmit copies of the same to the clerks of the Circuit Court for the respective counties, where the charts have been filed or directed to be filed as hereinafter provided; the said report to be filed by the clerks of the several counties in a book kept for that purpose. And the said survey and report, when filed, subject to the right of appeal hereafter provided for in this Act, shall be taken in all of the courts of this State as conclusive evidence of the boundaries and limits of all natural oyster beds, bars and rocks, lying within the waters of the county wherein such survey and report are filed, and shall be construed to mean in all of the said courts that there are no natural oyster beds, bars or rocks lying within the waters of the counties wherein such report and survey are filed, other than those embraced in the survey authorized by this Act, and that all areas of the Chesapeake Bay and its tributaries within the State of Maryland, not shown in the survey to be natural oyster beds, bars or rocks, shall be construed in all the courts of the State to be barren bottoms, and open for disposal by the State for the purpose of private planting or propagation of oysters thereon under the provisions of this Act; provided, that the said survey and report shall not be so construed as to afiect in any manner the holdings by citizens of this State in any lot which may have been appropriated or taken up under the laws of this State prior to the approval of this Act. ***

The law of the State of Maryland, passed March 9, 18.12, authorizing officers of the United States Coast and Geodetic Survey to enter upon the lands within the State limits for the purposes of the Survey. is as follows:

An Act Concerning the Survey of the Coast of Maryland.

SECTION I. Be it enacted by the Gencral Assembly of Maryland, That it shall and may be lawful for any person or persons employed under and by virtue of an act of the Congress of the United States, * * * at any time hereafter to enter upon lands within this State for the purpose of exploring, surveying, triangulating, or levelling, or doing any other matter or thing which may be necessary to effect the objects of said act, and to erect any works, stations, buildings, or appendages requisite for that purpose, doing no unnecessary injury to private or other property.

SEC. 2." And be it enacted, That in case the person or persons employed under the act of Congress aforesaid, can not agree with the owners or possessors of the land so entered upon and used as to the amount of damage done thereto by reason of the removal of fences, cutting of trees or injury to the crop or crops growing on the same, it shall and may be lawful for the said parties or either of them to apply to the chief justice for the time being or one of the associate judges of the judicial district in which such land may be situated, who shall thereupon appoint three disinterested and judicious freeholders, residents of the same judicial district, to proceed with as much despatch as possible to the examination of the matter in question, and the faitliful assessment of the damages sustained by the owners or possessors aforesaid, and the said freeholders or a majority of them, having first taken and subscribed an oath or affirmation before the chief or associate justice aforesaid or other person duly authorized to administer the same, that they will well and truly examine and assess as aforesaid, and having given five days' notice to both parties of the time of their meeting, shall proceed to the spot, and then and there upon their own view and if required, upon the evidence of witnesses, (to be by

a Under the rulings of the Comptroller of the Treasury no damages can be collected except through the United States Court of Claims unless an agreement has been made in advance. 
them sworn or affirmed and examined) shall assess the said damages, and shall afterward make report thereof and of their proceedings in writing under their lands and seals and file the same within five days thereafter in the office of the clerk of the county in which the land aforesaid is situated, subject to an appeal by either party to the county court of the said county within ten days after filing as aforesaid, and the said report so made as aforesaid, if no appeal as aforesaid be taken, shall be held to be final and conclusive as between the said parties, and the amount so assessed and reported shail be paid to the said owners or possessors of the land so damaged within twenty days after the filing of said report, and the said chief or associate justice as aforesaid, shall have authority to tax and allow upon the filing of said report, such costs, fees and expenses to the said freeholders for the performance of their duty as he shall think equitable and just, which allowance shall be paid by the person or persons employed under the act of congress aforesaid, within the time last above limited, but if an appeal as aforesaid be taken, the case shall be set down for hearing at the first term of county court aforesaid, ensuing upon and after appeal, and it shall be lawful for either party immediately after the entry of such appeal, to take out summons for such witnesses as may be necessary to be examined upon the hearing aforesaid, and the said court shall have power in its discretion to award costs against which ever the final judgment shall be entered, and such appeal at the option of either party may and shall be heard before and the damages assessed by a jury of twelve men to be taken from the regular panel and elected as in other cases.

SEC. 3. And be it enacted, That if any person or persons shall wilfully injure or deface or remove any signal, monument or building or any appendage thereto, erected, used or constructed under and by virtue of the act of congress aforesaid, such person or persons so offending slall severally forfeit and pay the sum of fifty dollars with costs of suit to be sued for and recovered by any person who shall first prosecute the same before any justice of the peace of the county where the person so offending may reside, and shall also be liable to pay the amount of damages thereby sustained, to be recovered with costs of suit in an action on the case, in the name and for the use of the United States of America, in any court of competent jurisdiction.

\section{APPENDIX B.-LAWS REI,ATING TO SURVEY OF CLAM BEDS.}

[Act of the legislature of Maryland approved April 6, 1908."]]

AN ACI to prescribe additional duties to be performed by the Board of Shell Fish Commissioners, to the duties already prescribed for them by Chapter 7 II of the Acts of the General Assembly of Maryland of 1906.

SECTION r. Be it enacted by the General Assembly of Maryland, That it shall be the duty of the Board of Shell Fish Commissioners, as soon after the passage of this Act as practicable, to have laid out, surveyed and designated on charts provided for such purpose, Gravel Rock, IVare Rock, and Flat Rock, being clam banks located in the waters of Pocomoke Sotnd, in Somerset county, and State of Maryland, and shall cause to be marked and defined as accurately as practicable the limits and boundaries of each of the above named rocks, and they shall take true and accurate notes of said survey and make the report and perform all other duties connected with said survey as said duties are prescribed by Chapter 7 II of the Acts of the General Assembly of Maryland of 1906, pertaining to natural oyster heds and bars.

SEC. 2. And be it enacted by the General Assembly of Maryland, That after said rocks shall have been surveyed as provided in Section I of this Act, no part of them shall be leased to any person or persons for the purpose of planting, bedding or cultivating oysters, thereon, but they shall be reserved to the public in the State of Maryland for the sole purpose of taking clams therefrom, and shall be treated in every particular as are the natural oyster beds or bars which have been or shall be surveyed by the Board of Shell Fish Commissioners under Chapter 711 of the Acts of the General Assembly of Maryland of 1906.

SEC. 3. And be it further enacted, That this Act shall take effect from the date of its passage. 


\section{APPENDIX C-STATISTICS OF RESULTS OF THF COMBINED OPERATIONS OF THE GOVERNMENT AND STATE.}

For a further understanding of the character of the oyster survey work that is being carried on in Maryland the following statistical tabulations of the combined results of the various operations of hoth the Government and State will be of value. In this connection it should be remembered that these statistics only include the new work required to supplement the large amount of existing data obtained from the archives of Coast and Geodetic Survey and utilized in the preparation of the charts and technical records.

\section{Operation.}

\begin{tabular}{l|c|c}
$\begin{array}{c}\text { Anue } \\
\text { Arundel } \\
\text { County. }\end{array}$ & $\begin{array}{c}\text { Somerset } \\
\text { County. }\end{array}$ & Total. $(\alpha)$
\end{tabular}

Natural oyster bars surveyed and delineated.

$91, \quad 37 \mid \quad 128$

Acres of nitural oyster bars.

33,666

Crab bottoms surveyed and delineated...

Acres of crab bottoms. .

Clam beds surveyed and delineated
Acres of clam beds.

Number of oyster lots leased and surveyed $\ldots \ldots \ldots \ldots \ldots$

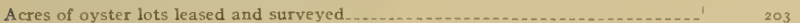

Boundary buoys located and planted. 362

Triangulation landmarks established.

Miles of shore line covered by triangulation .

Square miles of water covered by triangulation

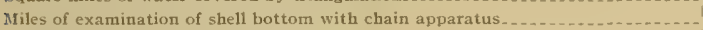

Oyster investigation stations occupied.

Number of soundings over shell bottoms..

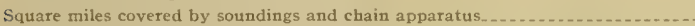

Yrojections prepared and plotted.

Leasing charts prepared.

Oyster charts published.

Reports published.

Progress maps published.

\begin{tabular}{r|r}
37 & 128 \\
27,566 & (b) 61,232 \\
54 & 54 \\
32,108 & 32,108 \\
3 & 3 \\
506 & 506 \\
185 & 223 \\
920 & 1,123 \\
154 & 516 \\
86 & 209 \\
125 & 2.35 \\
375 & 595 \\
296 & 665 \\
679 & 1,119 \\
17904 & 54,953 \\
47 & 105 \\
13 & 22 \\
12 & 25 \\
6 & 10 \\
2 & 3 \\
2 & 3
\end{tabular}

(a) Less' quantities covered by statistics of more than one county.

(b) Total area of natural oyster bars of Connecticut is 5,770 acres.

APPENDIX D.-THE HAMAN OYSTER CULTURE, I,AIV.

[Fxtract from First Report of Shell Fish Commission.]

OBJECT,

"The legislature in placing chapter 7 II of the acts of Igo6, better known as the Haman Oyster Culture Law, upon the statute books of Maryland had a twofold object in view:

1. To encourage an industry in oyster culture upon the barren bottoms beneath the tidewaters of the State.

2. To prevent the leasing of natural oyster bars for the purpose of oyster culture."

SURVEY.

"To make the leasing of barren bottoms possible and the leasing of natural bars impossible, provision was made for a survey of the natural bars for the purpose of accurately locating and marking the same. It was definitely provided that no barren bottoms should be leased in any part of the State until the natural bars of that region had been surveyed, charted, and marked with buoys." 


\section{NATURAL, BAR NOT DEFINED.}

"Ihe Shell Fish Commission is instructed by section 90 of the Haman Oyster Culture Law to exercise its judgment liberally in favor of the natural bars when surveying, charting and buoying them, but other than this the Commission is uninstructed in this important matter. The responsibility of defining a natural bar is placed upon the Commission."

\section{DEFINITION ·F A NATURAL, OYSTER BAR.}

\section{DIVERSITY, OF OPINION.}

"No definition of a natural oyster bar could be formulated by any man or body of men which would meet with the approval of all parties concerned. Oystermen, as a rule, hold that all bottoms where oysters grow or have grown naturally even though now practically barren of oysters should be considered natural bars. Other citizens of the State who are not directly interested in the oyster business, but interested in the oyster industry from the standpoint of revenue, hold, as a rule, that no bottoms should be excluded from leasing for oyster culture which, by methods known to oyster culturalists, may be made to yield a greater number of oysters than they now produce."

"It should be evident to every one that neither of these definitions could be adopted by the Commission as a working basis for determining which of the grounds surveyed are natural oyster bars."

THE GOLDSBOROUGH DEFINITION.

"The definition of a natural bar which very nearly approaches a reasonable and satisfactory compromise between the extreme views given above and which has therefore been adopted by the Commission, is that contained in an opinion rendered by Judge Charles F. Goldsborough in the circuit court for Dorchester County in the July term, $188 \mathrm{I}$, in the case of IVilliam T. Windsor and George R. Tood, v. Job T. Moore. It is as follows:

What then is a natural bar or bed of oysters? It would be a palpable absurdity for the State to attempt to promote the propagation and growth of oysters and to encourage its citizens, by a grant of land, to engage in their culture, if the lands authorized to be taken up were only those upon which oysters do not and can not be made to grow. That there may be lands covered by water in the State where no oysters can be found, but where, if planted, they could be cultivated successfully, may be possible, but, if so, I imagine that their extent must be too limited for them to be of much practical, general advantage for the purposes of such a law as the one under discussion; but there are thousands of acres of hard and shifting sands where oysters not only are not found, but where it would be folly to plant them; and these latter it can not be supposed that the State intended to offer to give away, for the simple reason that the State could not help knowing that nobody would have them.

Upon the other hand there are large and numerous tracts where oysters of natural growth may be found in moderate numbers, but not in quantities sufficient to make it profitable to catch them, and yet where oysters may be successfully planted and propagated. In my opinion these can not be called natural bars or beds of oysters, within the meaning of the Act of Assembly, and it is just such lands as these that the State meant to allow to be taken up under the provisions of the above-mentioned section of the Act.

But there is still another class of lands where oysters grow naturally and in large quantities and to which the public are now and have been for many years in the habit of resorting with a view to earning a livelihood by catching this natural growth, and here, I think, is the true test of the whole question. Land can not be said to be a natural oyster bar or bed merely because oysters are scattered here and there upon it, and because if planted they will readily live and thrive there; but whenever the natural growth is so thick and abundant that the public resort to it for a livelihood, it is a natural oyster bar or bed and comes within the above-quoted restriction in the law, and cannot be located or appropriated by any individual." 




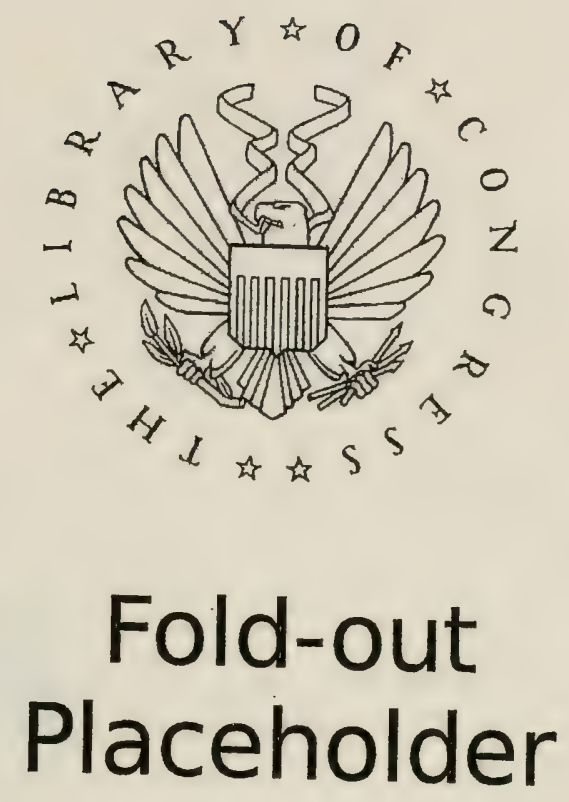

This fold-out is being digitized, and will be inserted at future date. 

DEPARTMENT OF COMMERCE AND LABOR

COAST AND GEODETIC SURVEY

O. H. TITTMANN, Superintendent

\title{
SURVEY OF OYSTER BARS \\ TALBOT COUNTY MARYLAND
}

\author{
DESCRIPTION OF BOUNDARIES AND LANDMARKS AND \\ REPORT OF WORK OF UNITED STATES COAST \\ AND GEODETIC SURVEY IN COOPERATION \\ WITH UNITED STATES BUREAU OF \\ FISHERIES AND MARYLAND \\ SHELL FISH COMMISSION
}

By C. C. YATES

CHIEF OF COAST AND GEODETIC SURVEY PARTY ASSISTANT, COAST AND GEODETIC SURVEY

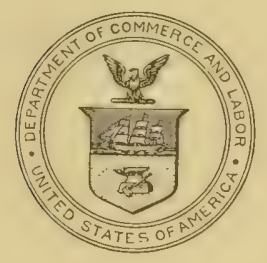

WASHINGTON

GOVERNMENT PRINTING OFFICE 1912 



\section{LETT'TER OF SUBMITTAL.}

\section{DEPARTMENT OF COMMERCE AND LABOR, CoAst and Gejodetic Survey, \\ Washington, July 20, I9r2.}

SIR: I have the honor to transmit herewith a report of the officer detailed from the Coast and Geodetic Survey to cooperate with the Bureau of Fisheries and the Maryland Shell Fish Commission in surveying the oyster bars of the State of Maryland, together with certain technical results which are necessary for the interpretation and use of the plats of the survey made by the Government.

This work has been done under the provisions of the act of Congress entitled "An act to authorize the Secretary of Commerce and Labor to cooperate, through the Bureau of the Coast and Geodetic Survey and the Bureau of Fisheries, with the Shell Fish Commissioners of the State of Maryland in making surveys of the natural oyster beds, bars, and rocks in the waters within the State of Maryland," approved May 26, 1906, and of the acts of Congress making appropriations for sundry civil expenses of the Government for the fiscal years ending June 30, 1907, 1908, 1909, 1910, 1911, and 1912.

Respectfully,

To Hon. Charles NAgEL,

O. H. Trimmann, Superintendent. Secretary of Commerce and Labor. 



\section{CERTIFICATION.}

BAL,TIMORE, MD., May 4, 1912.

The following publication is certified to contain correct technical descriptions of all boundaries and landmarks established in Talbot County by the Maryland Shell Fish Commission in cooperation with the United States Coast and Geodetic Survey.

C. C. YATES,

Chief of Coast and Geodetic Survey Party, Assistant, Coast and Geodetic Survey.

Examined and certified to be correct.

BALTIMORE, MD., May 4, 1912.

$$
\begin{gathered}
\text { WALTER J. MitChili, } \\
\text { CASWELl, GRAVE, } \\
\text { BENJAMin K. GREEN, } \\
\text { Maryland Shell Fish Commission. } \\
\text { SwEPSON EARLE, } \\
\text { Hydrographic Engineer. }
\end{gathered}
$$

NoTE.-Certified copies of this publication and of the charts of the natural oyster bars of Talbot County were filed in the office of the clerk of the circuit court of Talbot County and in the office of the Board of Shell Fish Commissioners on July 20, I 9 r 2. 



\section{CONTENTS.}

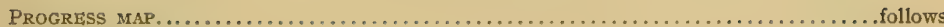

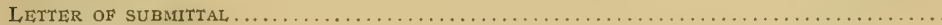

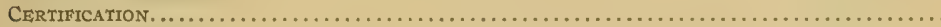

INTRODUCTION.

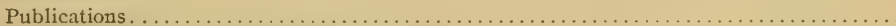

Cooperation of the Coast and Geodetic Survey

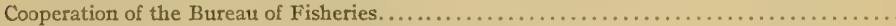

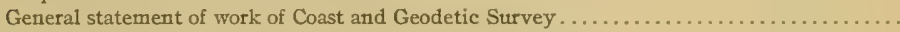

REPORT OF THE WORK OF THE COAST AND GEODETIC SURVEY:

Instructions.

Organization and equipment.

Chronological statement of work

Statistics.

General remarks.

CHARTS AND MAPS.

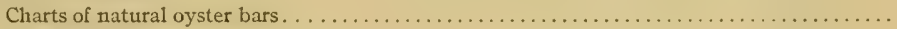

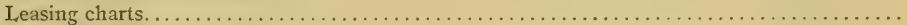

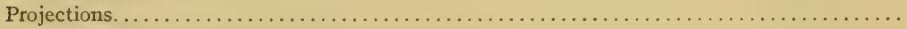

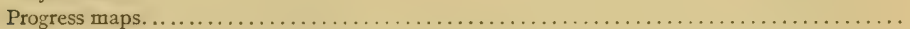

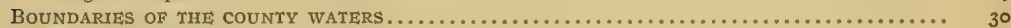

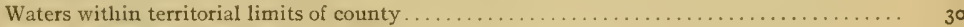

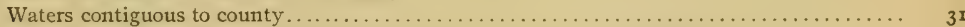

Landmarks (U. S. Coast and Geodetic Survey triangulation stations) ............ 33

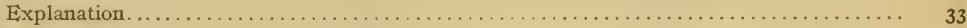

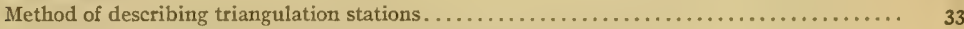

Descriptions of triangulation stations in county and adjacent waters. . . . . . . . . . . 36

Chart No. $3 I$ (entrance to Eastern Bay and vicinity)-

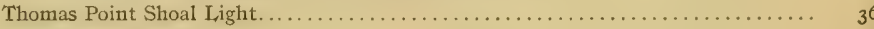

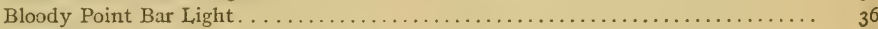

Tenk . . . . . . . . . . . . . . ${ }^{6}$

Straight. . . . . . . . . .

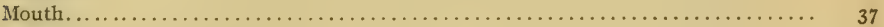

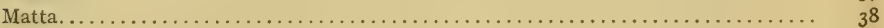

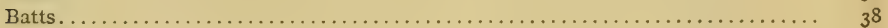

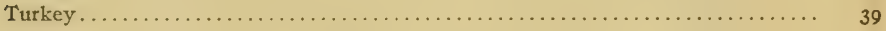

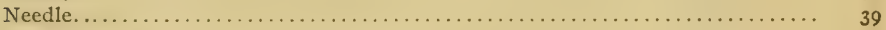

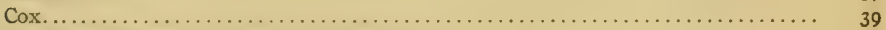

Rich Neck Water Tank (see also Chart No. 32 )..................... 40

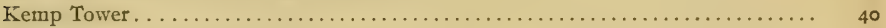

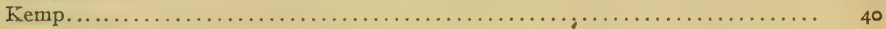

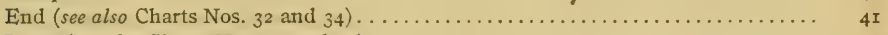

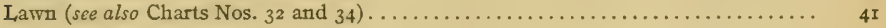




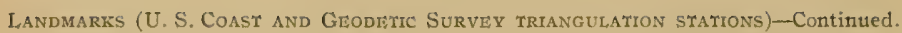

Descriptions of triangulation stations in county and adjacent waters-Continued.

Chart No. 32 (Eastern Bay and tributaries)-

Parsons.

Page.

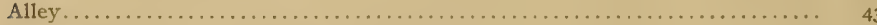

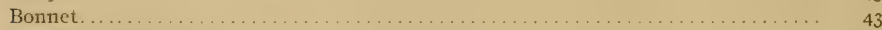

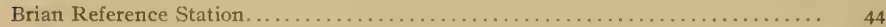

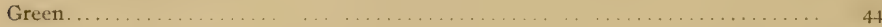

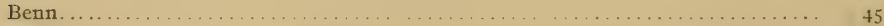

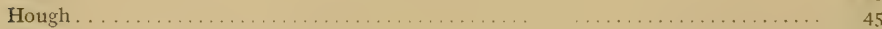

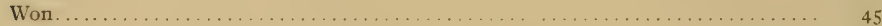

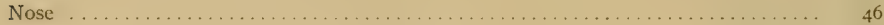

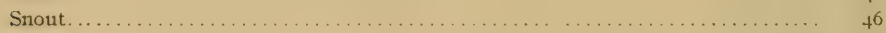

South. ........................................... 47

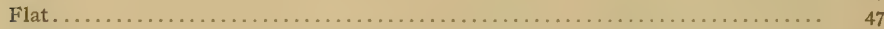

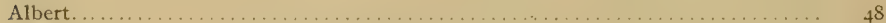

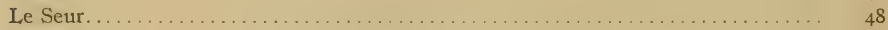

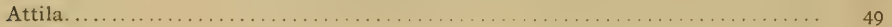

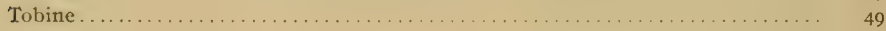

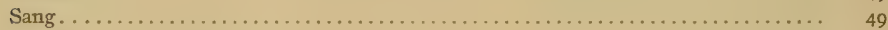

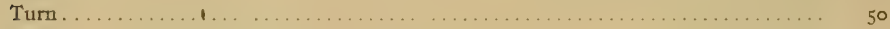

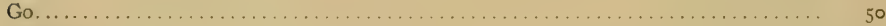

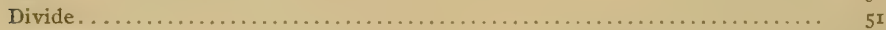

Princess . . . . . . . . . . . . . . . . . . . . . . . . . . . . . .

Philip . . . . . . . . . . . . . . . . . . . . . . . . . . . . .

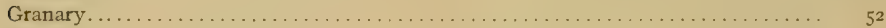

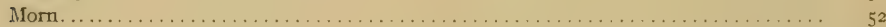

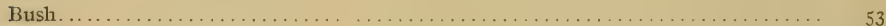

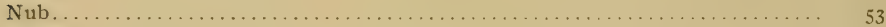

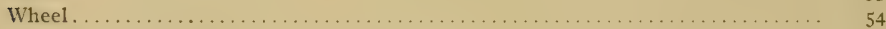

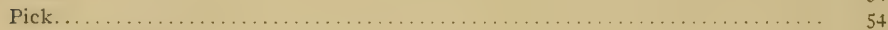

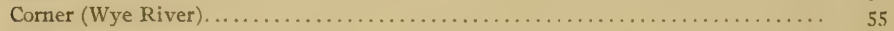

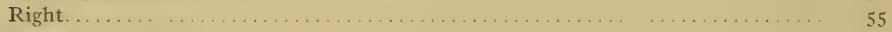

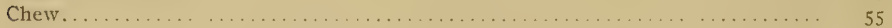

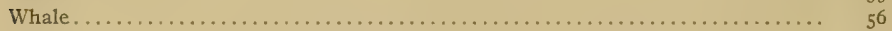

Matter. . . . . . . . . . . . . . . . . . . . . . . . . . . . . . . . . . 56

Deck . . . . . . . . . . . . . . . . . . . . . . . . . . . . . . . . . . . . 57

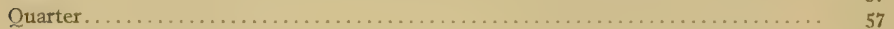

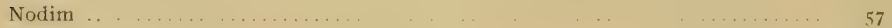

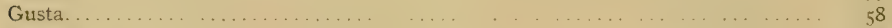

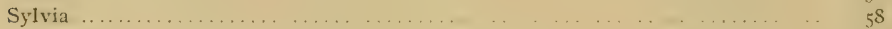

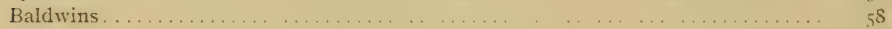

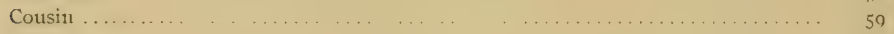

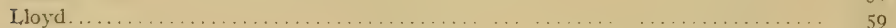

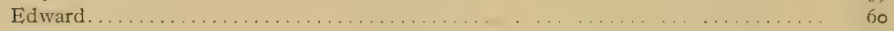

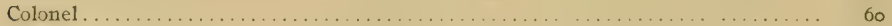

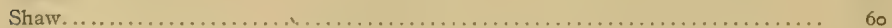

Bruffis. . . . . . . . . . . . . . . . .

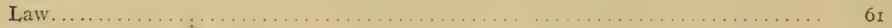

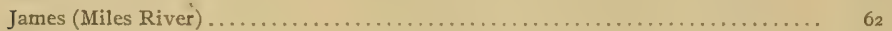

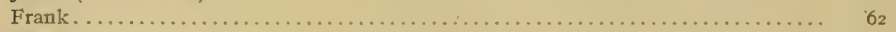

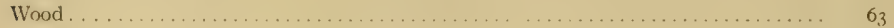




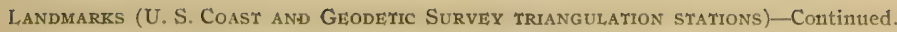
Descriptions of triangulation stations in county and adjacent waters-Continued. Chart No. 32 (Eastern Bay and tributaries)-Continued.

Herr.

Ollie.

Swing.

Fair .

Second

But.

Aber.

Two

Face.

Mais.

Beak.

Rieman.

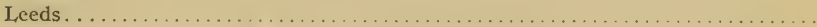

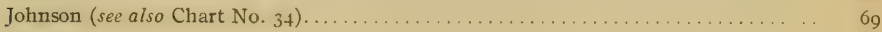

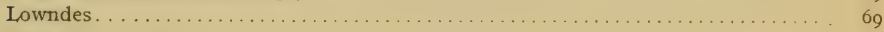

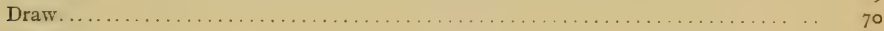

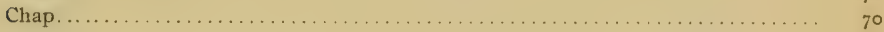

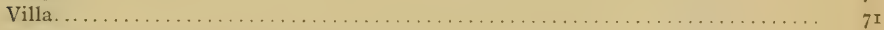

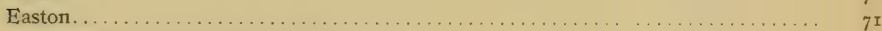

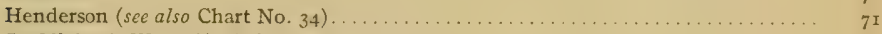

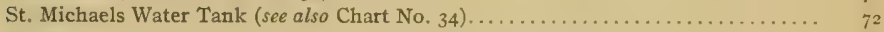

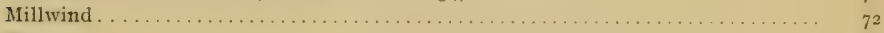

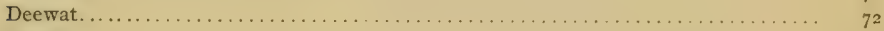

Spar. . . . . . . . . . . . . . . .

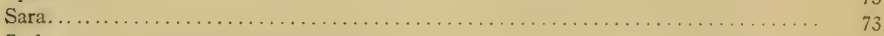

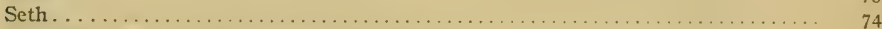

Rich Neck Water Tank (see also Chart No. $3 \mathrm{I}$ ) .................... 40

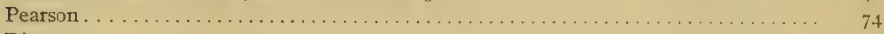

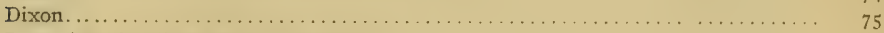

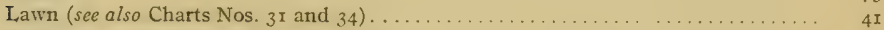

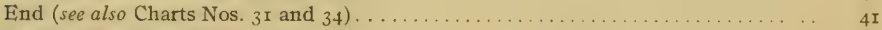

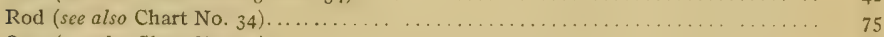

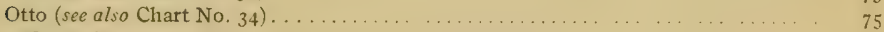

Chart No. 33 (Chesapeake Bay, Poplar Island to Sharps Island)-

Haddaway

Valliant.

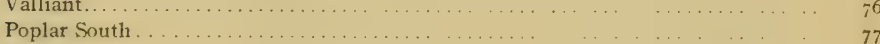

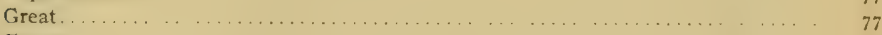

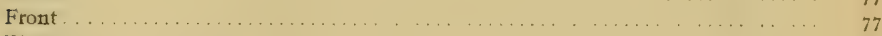

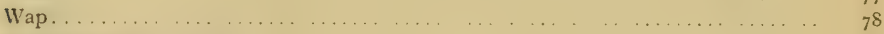

Southern M. E. Church . . . . . . . . . . . . . . . . . . . . . . . . . 78

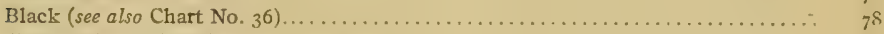

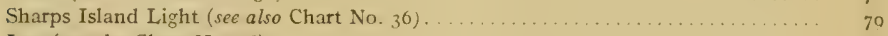

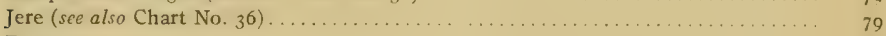

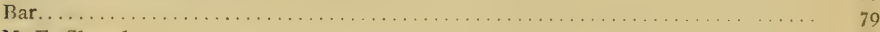

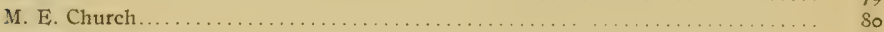

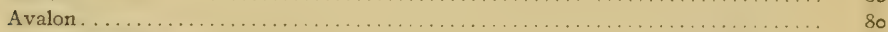

Schoolhouse Cupola . . . . . . . . . . . . . . . . . . . . $\ldots \ldots \ldots \ldots \ldots$

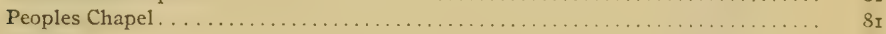

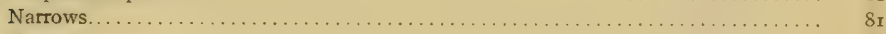

Eagle. . . . . . . . . . 
Landmarks (U. S. Coast and GEOdETic Survey triangulation stations)-Continued. Descriptions of triangulation stations in county and adjacent waters-Continued.

Chart No. 33 (Chesapeake Bay, Poplar Island to Sharps Island)-Continued.

Dunk.

Hawk

Smith

I3riary

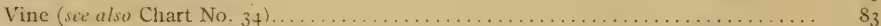

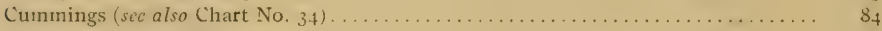

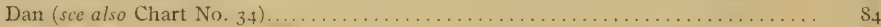

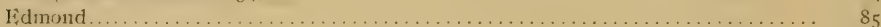

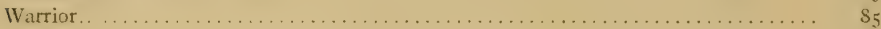

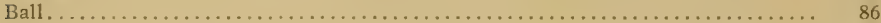

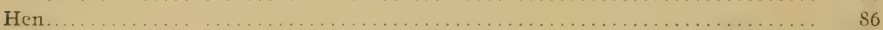

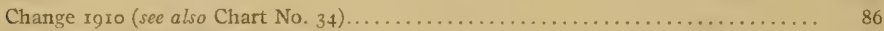

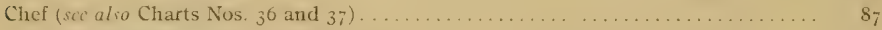

Chart No. 37 (Choptank River and tributaries)-

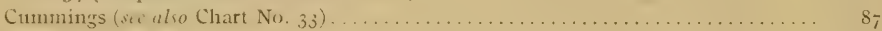

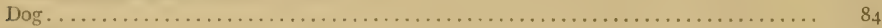

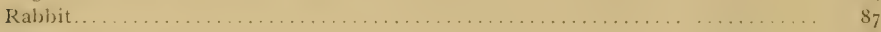

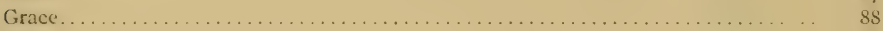

Mink . . . . . . . . . . . . . . .

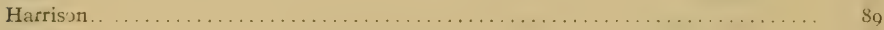

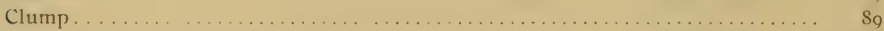

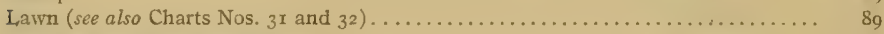

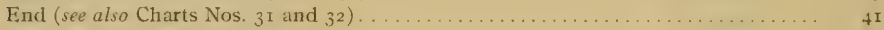

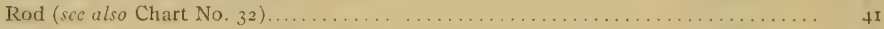

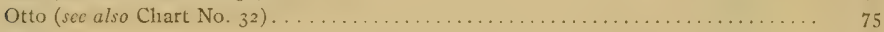

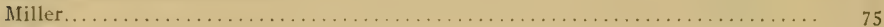

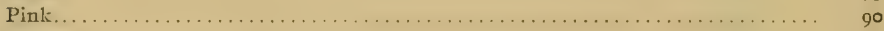

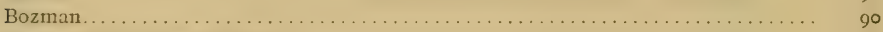

Bozman M. E. Church Spire................................ 9 I

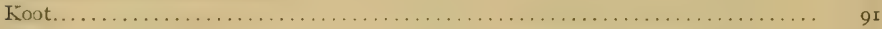

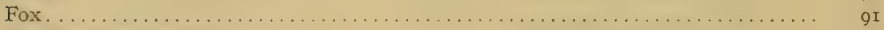

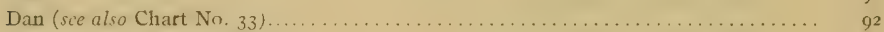

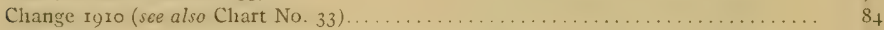

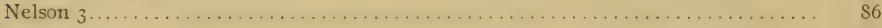

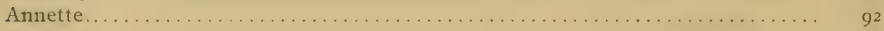

Myrtle . . . . . . . . .

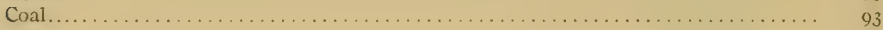

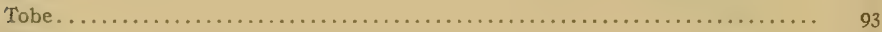

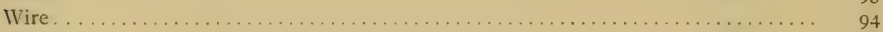

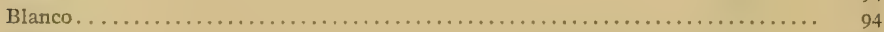

Ned . . . . . . . . . . . . . . . . . . .

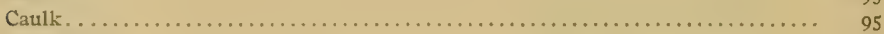

Fairbanks. . . . . . . . . .

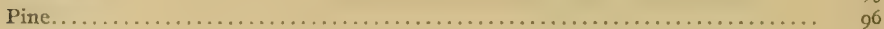

Luna . . . . . . . . . . . . . . . . . . . . .

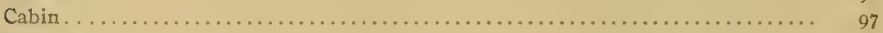

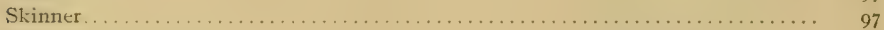

Bald . . . . . . . . . . . . . . . . . . . . .

Rose . . . . . . . . . . . . . . . . . . . . . . . . . .

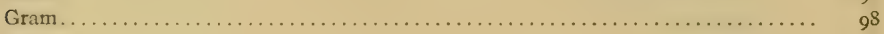

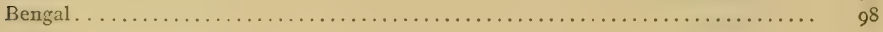


LANDMaRKS (U.S. CoASt AND GeOdetic SuRvey triangulatron stations)-Continued. Descriptions of triangulation stations in county and adjacent waters)-Continued. Chart No. 34 (Choptank River and tributaries)-Continued.

Fiastman

Woodill

Page.

Delta.

\section{Marion}

Willis.

Nilis.

Neptune

Venus

Mars.

Royal

Grave

Ray.

Villey

Judre

Thelmat

Flmore

Beverly

Samuel

Ansley.

Harper

Taft.

Hopkins

spencer

Marsliall

Clark.

Holly.

Marsli

Cedar.

Ross

Cook

Peary.

Irish.

Roys.

Pont .

Sticky

Vue

Ila. .

Creck

Benoni

Mutton

Tred.

Bellevue.

Tar. .

Peck.

Tall.

Plain.

Spin. .

Martin.

Rohertson

Stretch.

May 
Landmarks (U. S. Coast and Geodetic Survey triangulatron statrons) - Continued. Descriptions of triangulation stations in county and adjacent waters - Continued.

Chart No.34-(Choptank River and tributaries)-Continued.

Page.

Peebee.

Neck.

Stab.

Water...

Radcliffe

Bateman.

Melon.

Gash.

Camden

Blossom

Wall.

Aye.

Hunter.

Weave

Twin

Toe.

Trippe.

Venture.

Plow.

Higher.

All.

Cam.

Deux.

Crack.

Mistle.

Layor.

Borough.

Golds.

Mud.

Town.

Riverview (see also Chart No. 35)

Weather Bureau Staff (see also Chart No. 35)

First (sce also Chart No. 35)

Bach (see also Chart No. 35)

Boone (sce also Chart No. 35)

Finter (sce also Chart No. 35)

Straw (see also Chart No. 35).

Delahay (see also Chart No. 35)

Kent (see also Chart No. 35).

Harry (see also Chart No. 35)

Charles (see also Chart No. 35)

Potato (see also Chart No. 35)

Ritter (sce also Chart No. 35)

Show (sce also Chart No. 35 ).

Kit (see also Chart No. 35).

Moke (see also Chart No. 35)

Poco (see also Chart No. 35).

Healey (see also Chart No. 35).

Maslin (see also Chart No. 35)

Mean (sce also Chart No. 35)

Jay (see also Chart No. 35 ). 
Landmarks (U. S. Coast and Geodztic Survery triangulation stations)-Continued. Descriptions of triangulation stations in county and adjacent waters-Continued.

Chart No. 37 (Choptank River and tributaries)-Continued.

Berry (sec also Chart No. 35 ).

Page.

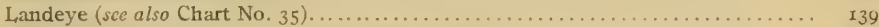

Choptank River Light (see also Charts Nos. 35 and 37 )................

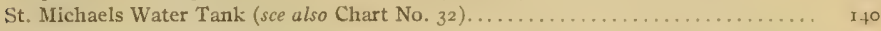

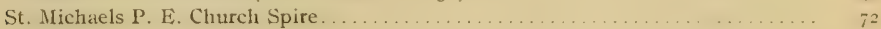

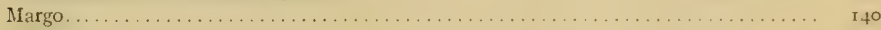

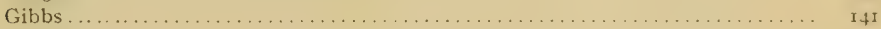

Long . . . . . . . . . . . . .

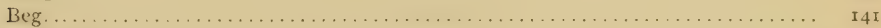

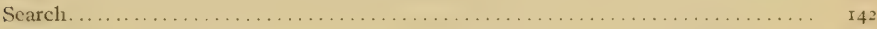

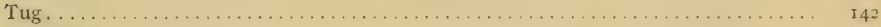

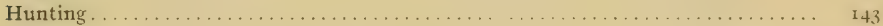

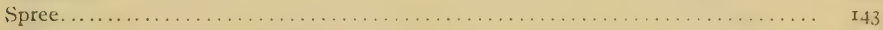

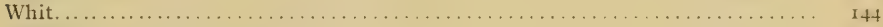

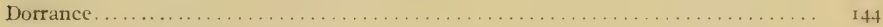

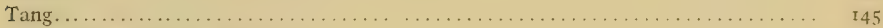

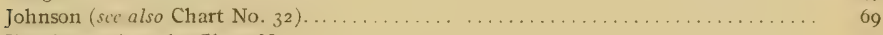

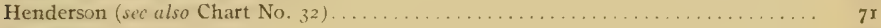

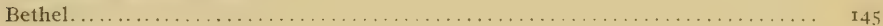

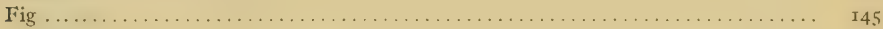

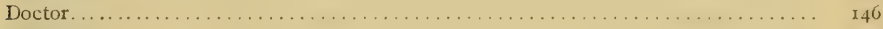

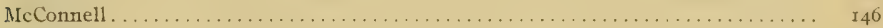

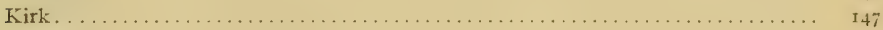

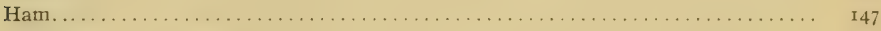

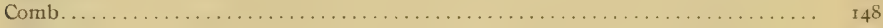

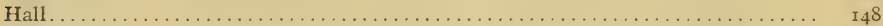

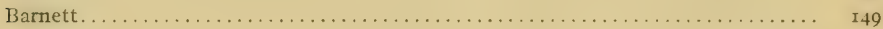

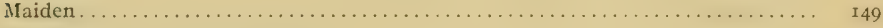

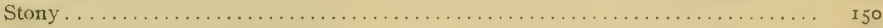

$\begin{aligned} & \text { Chart } \text { No. } 35 \text { (Upper Choptank River) } \\ &\text { Riverview (sce also Chart No. } 34) \ldots \ldots \ldots \ldots \ldots \ldots \ldots \ldots \ldots \ldots \ldots \ldots \ldots \ldots \ldots \ldots \ldots\end{aligned}$

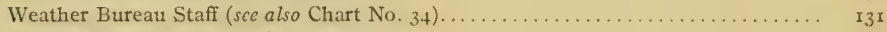

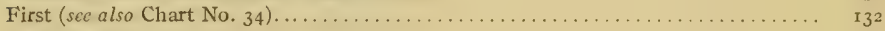

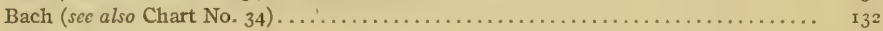

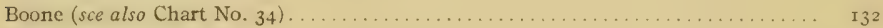

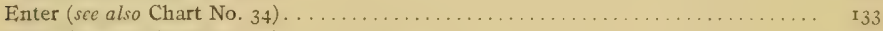

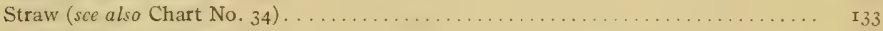

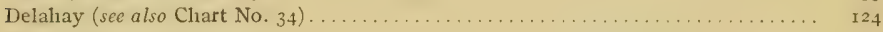

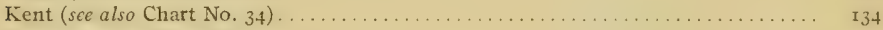

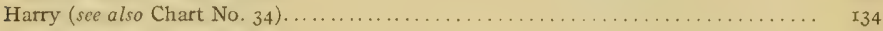

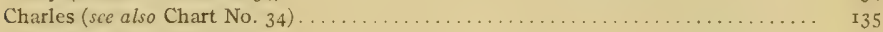

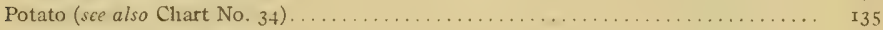

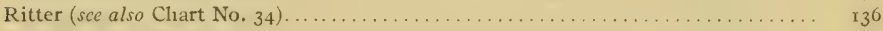

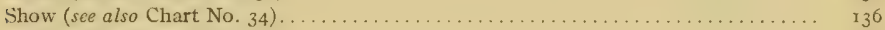

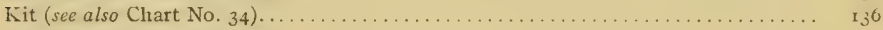

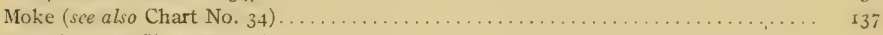

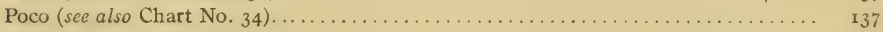

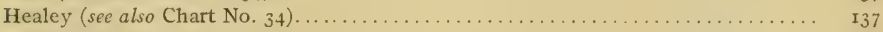

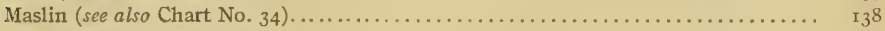

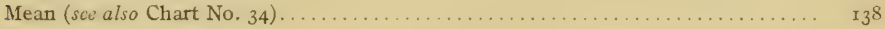

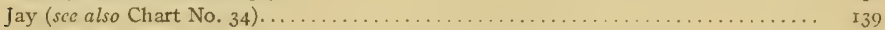


Landmarks (U.S. Coast and GeOdetic Survey triangulation Stations)-Continued. Descriptions of triangulation stations in county and adjacent waters-Continued.

Chart No. 35 (Upper Choptank River)-Continued.

Page

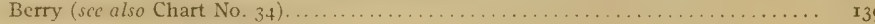

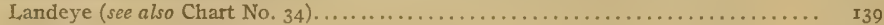

Choptank River Light (sce also Charts Nos. 34 and 37 ).................... I40

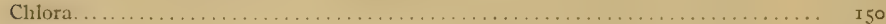

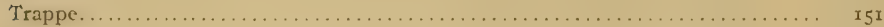

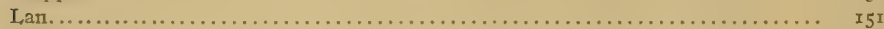

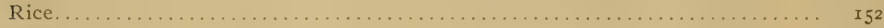

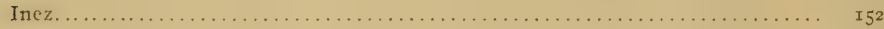

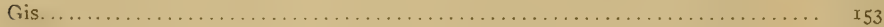

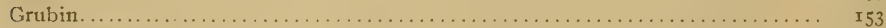

Black Beacon. . . . . . . . . . . . . . . . . . . . . . . . . . . . . . . 53

Howells. . . . . . . . . . . . . . . . . . . . . . . . . . . . . . . . . . . . .

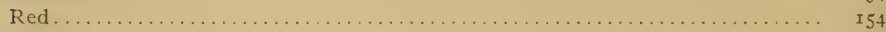

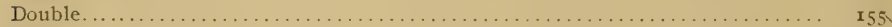

Boling . . . . . . . . . . . . . . . . . . . . . . . . . . . . . . .

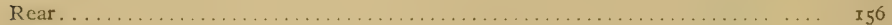

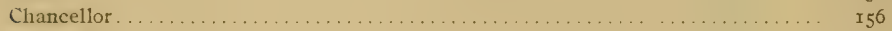

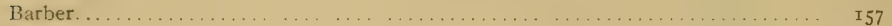

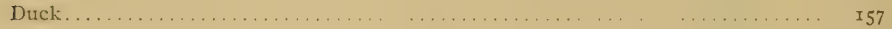

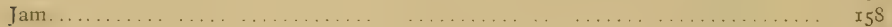

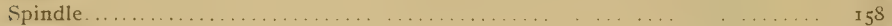

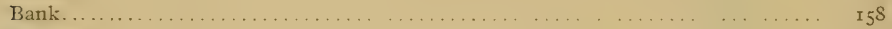

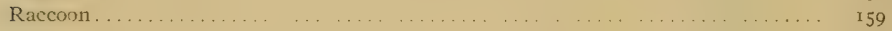

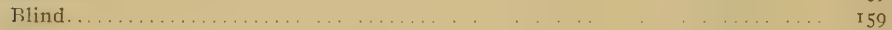

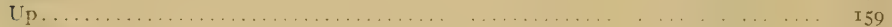

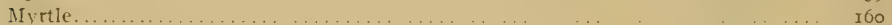

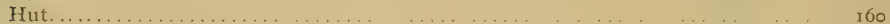

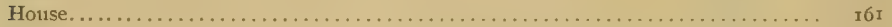

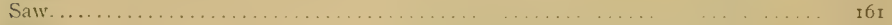

Wick . . . . . . . . . . . . . . . . . . . . . . . . . . . . .

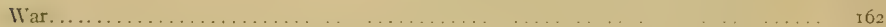

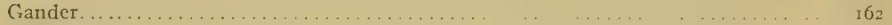

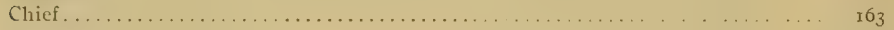

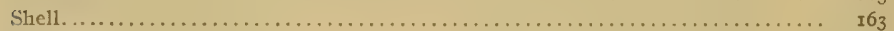

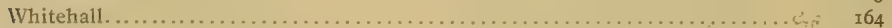

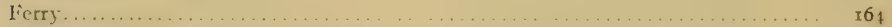

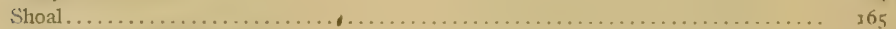

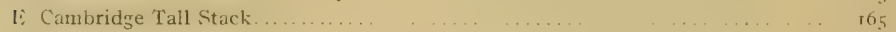

$F_{1}^{*}$ Cambridge Spire $\ldots \ldots \ldots \ldots \ldots \ldots \ldots \ldots \ldots \ldots \ldots \ldots \ldots \ldots \ldots \ldots \ldots \ldots \ldots$

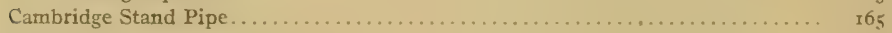

Cambridge $\ldots \ldots \ldots \ldots \ldots \ldots \ldots \ldots \ldots \ldots \ldots \ldots \ldots \ldots \ldots$

Hambrooks Bar Beacor. . . . . . . . . . . . . . . . . . . . . . . . . . . . 66

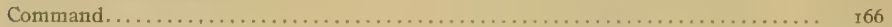

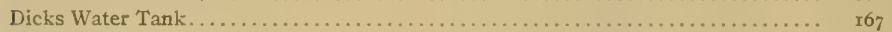

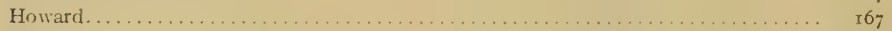

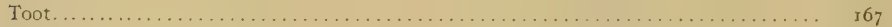

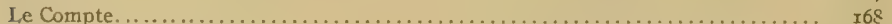

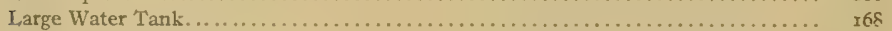

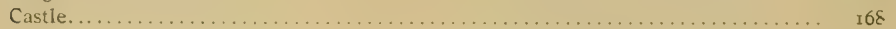




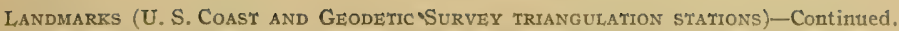

Descriptions of triangulation stations in county and adjacent waters-Continted.

Chart No. 36 (Chesapeake Bay, vicinity of Little Choptank River)-

Sharps Island Light (sce also Chart No, 33) .

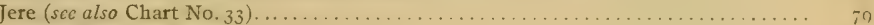

Black (see also Chart No. 33 )...............................

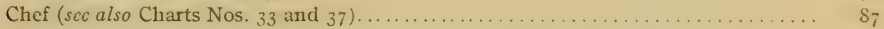

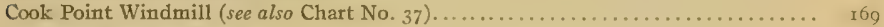

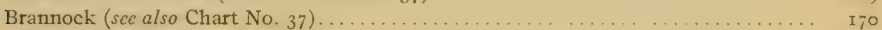

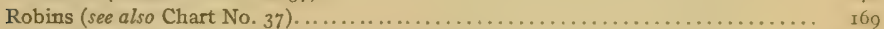

James (Little Choptank River) (see also Chart No. 37) ................. I;0

Chart No. 37 (Little Choptank River and tributaries)-
Choptank River Light (see also Charts Nos. 34 and 35 ).................. I40

Comer (Choptank River) . . . . . . . . . . . . . . . . . . . . .

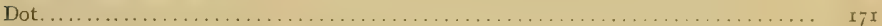

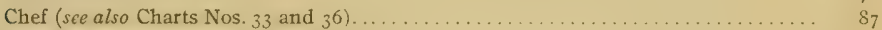

Cook Point Windmill $\left(\right.$ see also Chart No. $\left.{ }_{3} 6\right) \ldots \ldots \ldots \ldots \ldots \ldots \ldots \ldots \ldots \ldots \ldots \ldots \ldots$. . . . . . . . . . .

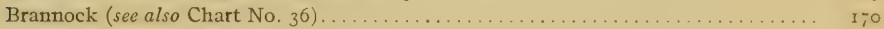

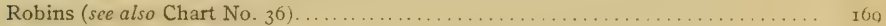

James (Little Choptank River) (see also Chart No. 36$) \ldots \ldots \ldots \ldots \ldots \ldots \ldots \ldots \ldots$ I 70

BOUNDARIES OF OYSTER BARS:

Explanation. . .

Method of describing boundaries.

Surveying methods for relocation of boundaries.

Boundaries of natural oyster bars in county ${ }^{1}$ -

Chart No. 3 I (entrance to Eastern Bay and vicinity)-

Poplar Island (see also Chart No. 33).

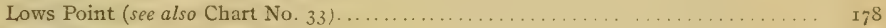

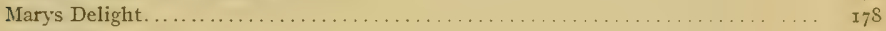

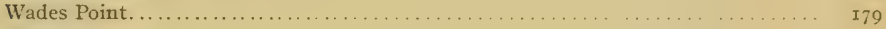

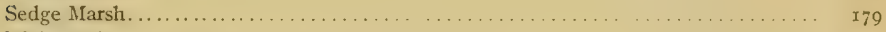

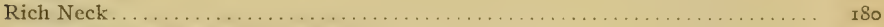

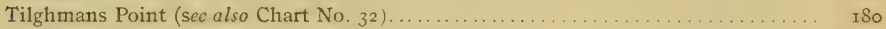

Upper Harris Creek (see also Charts Nos. 32 and 34 )................ I8 I

Chart No. j2 (Eastern Bay and tributaries)-

Tilghmans Point $($ see also Chart No. 3 r) . . . . . . . . . . . . . . . . . . ISo

Upper Hill. . . . . . . . . . . . . . . . . . .

Aldridges Discovery . . . . . . . . . . . . . . . . . . . . . . $I_{2}$

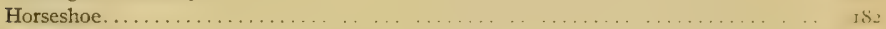

Turtle Back........ . . . . . . . . . . . . . . . . . . . . . . . . . .

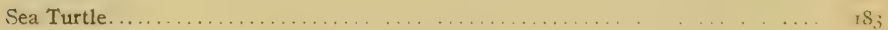

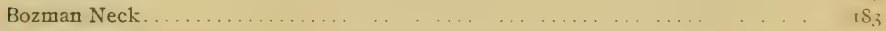

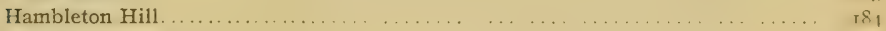

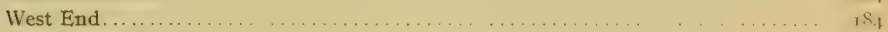

Hambleton .................................. $\mathrm{t}_{5}$

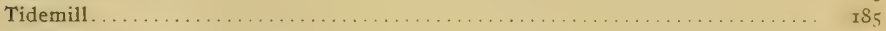

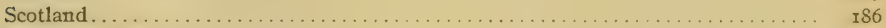

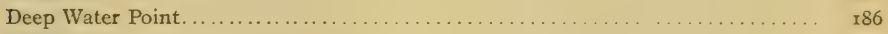

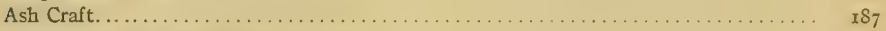

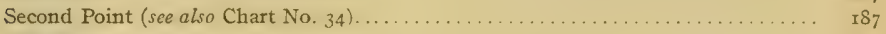

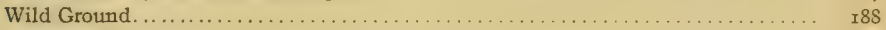

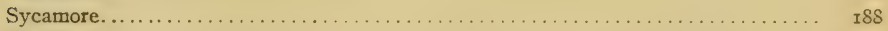

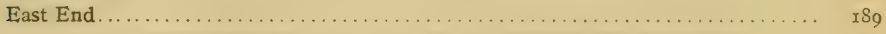

ISee separate cublications fcr boundaries of natural bars in adjacent counties. 
BOUNDARIES OF OYSTER BARS-Continued.

Boundaries of natural oyster bars in county-Continued.

Chart No. 32 (Eastern Bay and tributaries) - Continued.

Herring Island.

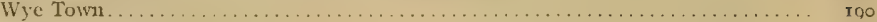

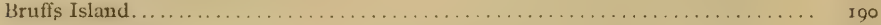

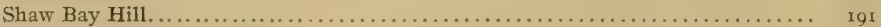

Race Horse (Talbot County) . . . . . . . . . . . . . . . . . . . . . . . . .

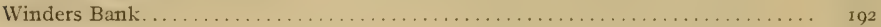

Poplar Point. . . . . . . . . . . . . . . . .

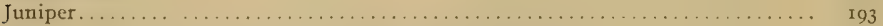

Upper Harris Creek (see also Charts Nos. 3 I and 34 ).................. I 8 I

Chart No. 33 (Chesapeake Bay, Poplar Island to Sharps Island)-

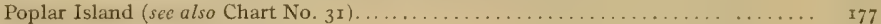

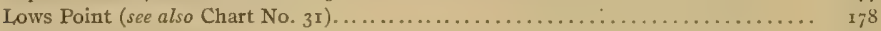

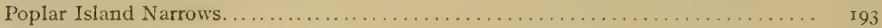

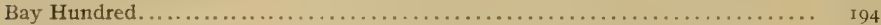

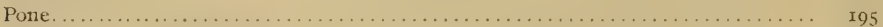

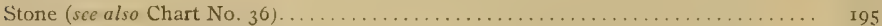

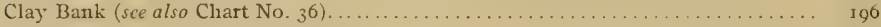

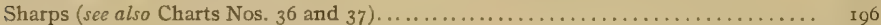

Black Walnut (see also Charts Nos. 36 and 37 ) ..................... I97

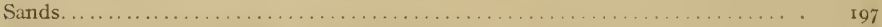

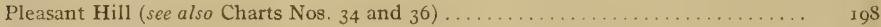

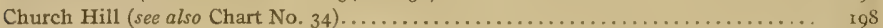

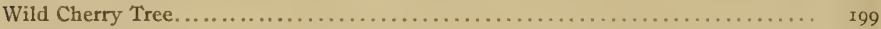

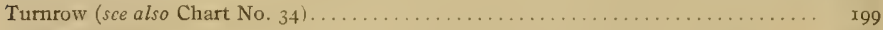

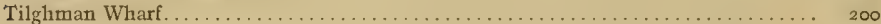

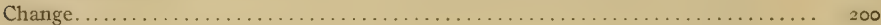

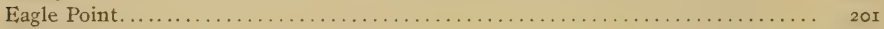

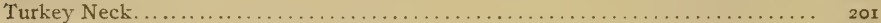

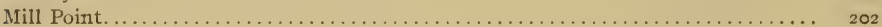

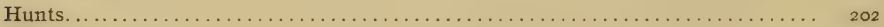

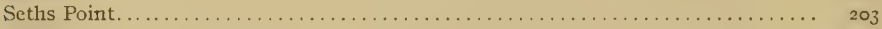

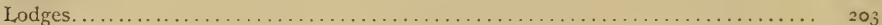

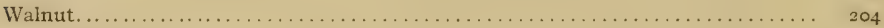

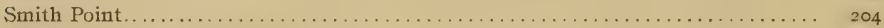

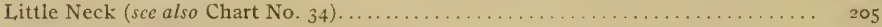

Chart No. 34 (Choptank River and tributaries)-

Little Neck (see also Chart No. 33) ........................... 205

Rabbit Island . . . . . . . . . . . . . . . . . . . . . . . . . . . . .

Upper Harris Creek (see also Charts Nos. $3 \mathrm{I}$ and 32 ).................... $18 \mathrm{I}$

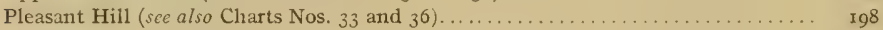

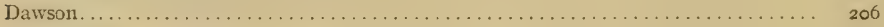

Church Hill (sce also Chart No. 33) ............................. Igs

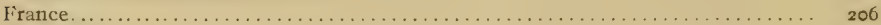

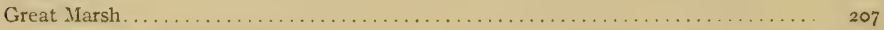

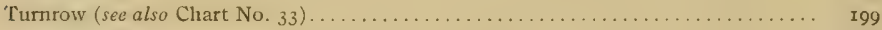

Long Point Woods.......................................... 207

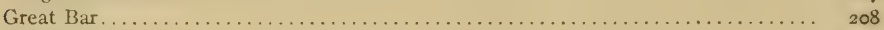

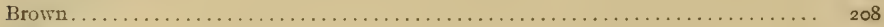

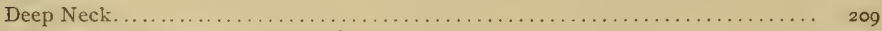

Mulberry Point............................................ 209

Broad Creek Middleground.................................. 2 ro 
BOUNDARIES OF OYSTER BARS-Continued.

Boundaries of natural oyster bars in county-Continued.

Chart No. 34 (Choptank River and tributaries)-Continued. Page.

Well Point ................................ . . 210

Pompes............................ . . $2 \mathrm{II}$

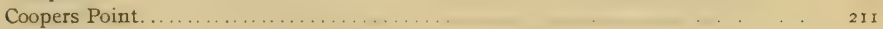

Judys Point. ......... . . . . . . . . . . 212

Brushy Point........ . . . . 2I2

Willeys Island Flats. ... . . . . . . . . . . . . . . . 212

Holland Point..... .......... . . . . . . . . . . 213

Harrison. ......... . . . . . . . . . . . . . . . . $2 \mathrm{I}_{4}$

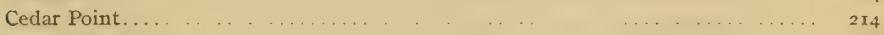

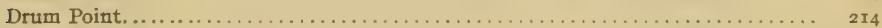

Joe Harris Flats..... . . . . . . . . . . . . . 215

Pin Cushion. ........................ 215

Willeys Island . . . . . . . . . . . . . . . . . . 216

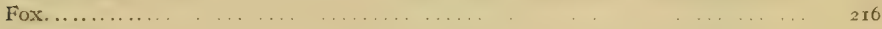

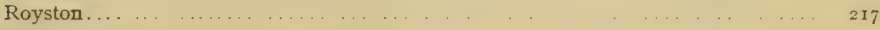

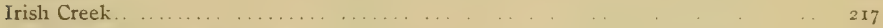

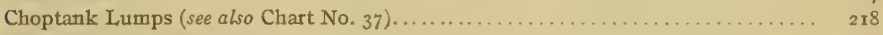

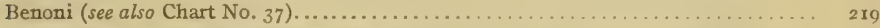

Light House (see also Charts Nos. 35 and 37 )...... . . . 219

Back Shore (see also Charts Nos. 35 and 37 )... . . . . . . 220

Bachelor Point (see also Chart No. 35) ......................... 220

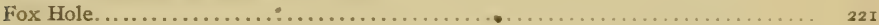

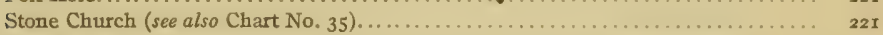

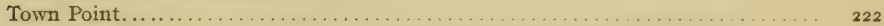

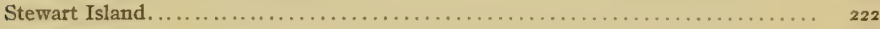

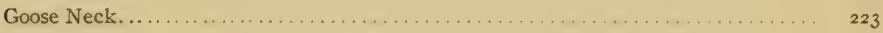

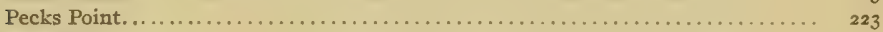

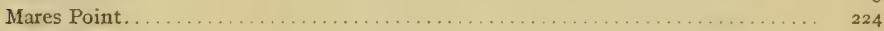

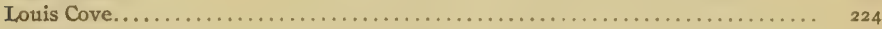

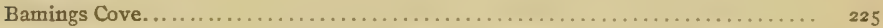

Old House Point. . . . . . . . . . . . . . . . . . . . . . . . 225

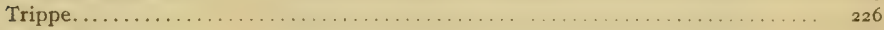

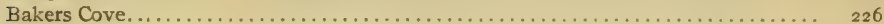

Marshy............................................. 227

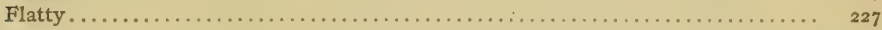

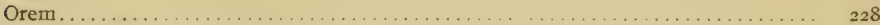

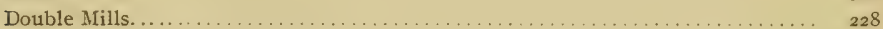

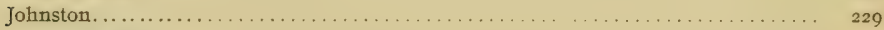

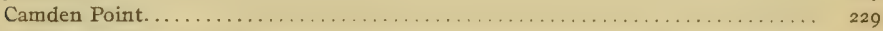

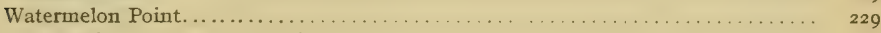

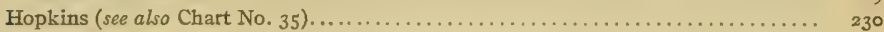

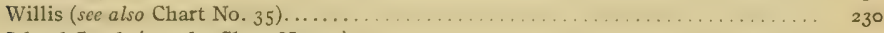

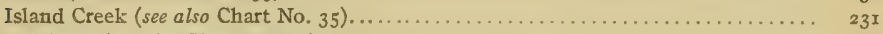

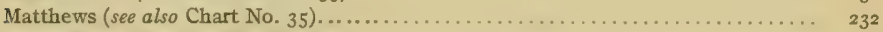

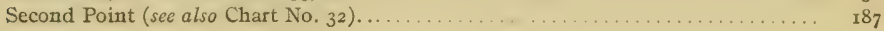

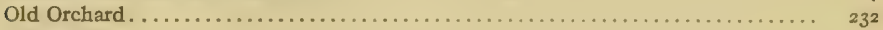

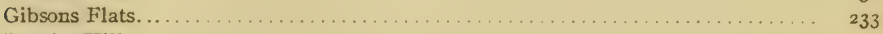

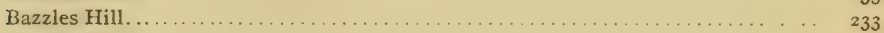

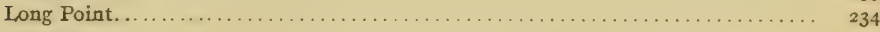

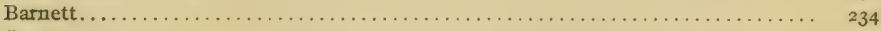

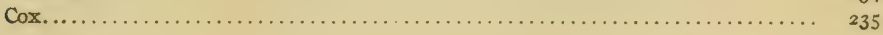


BOUNDARIES OF OYSTER BARS-Continued.

Boundaries of natural oyster bars in county-Continued.

Chart No. 35 (Upper Choptank River)-

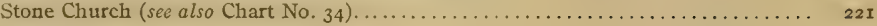

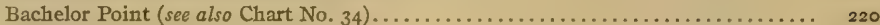

Light House (see also Charts Nos. 34 and 37 )........................ 2 I9

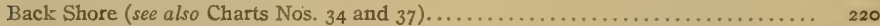

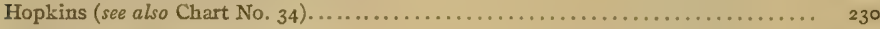

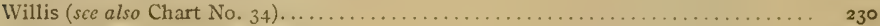

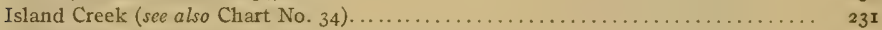

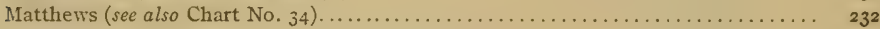

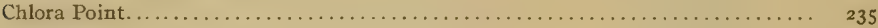

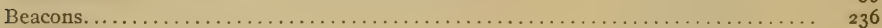

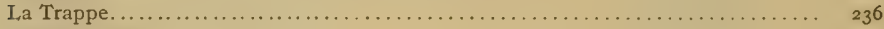

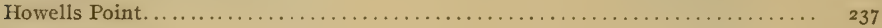

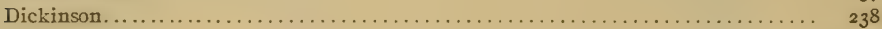

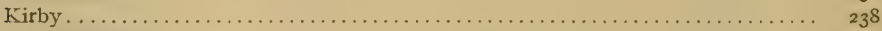

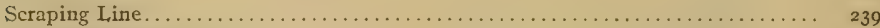

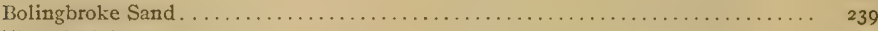

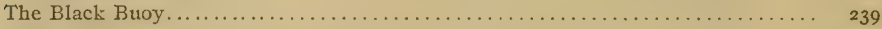

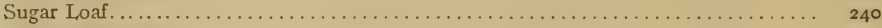

Chancellor Point. . . . . . . . . . . . . . . . . . .

British Harbour . . . . . . . . . . . . .

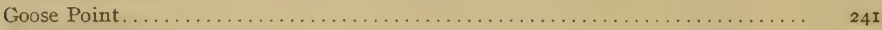

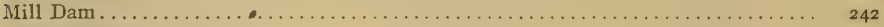

Jamaica Point. . . . . . . . . . . .

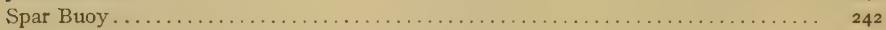

Chart No. 36 (Chesapeake Bay, vicinity of Little Choptank River)-

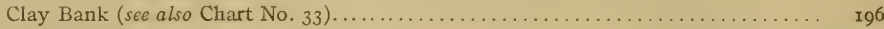

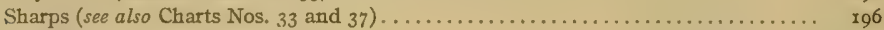

Stone (see also Chart No. 33) ............................. 195

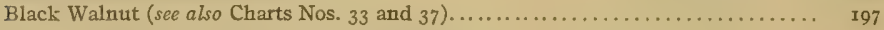

Chart No. 37 (Little Choptank River and tributaries)-

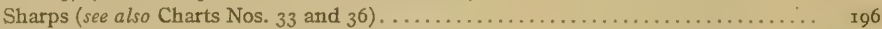

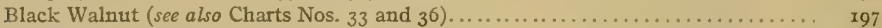

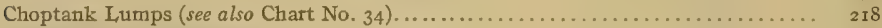

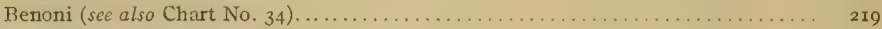

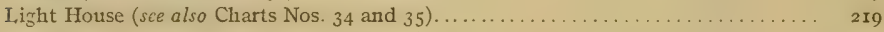

Back Shore (sce also Charts Nos. 34 and 35 ) ........................... 220

APPENDIXES:

Appendix A.- Laws relating to the cooperation of the Coast and Geodetic Survey and Bureau

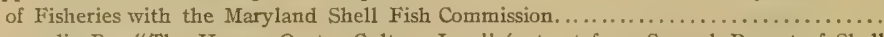

Appendix B.- "The Haman Oyster Culture Law" (extract from Second Report of Shell Fish Commission)

Appendix C.-Summary of the particular surveying operations which constitute an "oyster survey" as now being carried on in Maryland.

Appendix D.-Statistics of results of the combined operations of the Government and State. . 


\section{SURVEY OF OYSTER BARS, TALBOT COUN'TY, MD.}

\section{INTRODUCTION.}

\section{PUBLICATIONS.}

The preparation of publications relating to the survey of the oyster bars of Maryland has been divided between the Government and the State in accordance with the laws ${ }^{1}$ authorizing the work and the natural division of the surveying operations ${ }^{2}$ of the cooperating forces.

The publications prepared and issued by the Government under the direction of the Superintendent of the Coast and Geodetic Survey consist of a series of charts and a technical report for each county surveyed. ${ }^{3}$ The charts show all legal boundaries of oyster bars within the adopted boundaries of the waters opened up for leasing with each county, and the location of all landmarks (Coast and Geodetic Survey triangulation stations) used as a foundation for the delineation of these various boundaries. The technical report gives technical and legal descriptions of all oyster bar and other boundaries, and descriptions of all landmarks shown on the charts, and includes the report of the representative of the Coast and Geodetic Survey in charge of the work of that service in cooperation with the Bureau of Fisheries and the Maryland Shell Fish Commission. These charts and technical reports are prepared and certified for file with the courts and the Commission, as required by the laws of the State, and contain all information necessary to make a permanent record of the work of the Commission and the Government for all future requirements of the courts, or for any resurveys that may become necessary. ${ }^{*}$

The publications prepared and issued by the State under the direction of the Shell Fish Commission consist of annual reports ${ }^{5}$ of all the operations of the Commission performed under the provisions of the laws of Maryland, ${ }^{\circ}$ including results of biological

\footnotetext{
1 See Appendix A for laws relating to the cooperation of the Coast and Geodetic Survey and Bureau of Fisheries with the Maryland Shell Fish Commission.

'See Appendix C for a summary of the particular surveying operations which constitute an "oyster survey" as now being carried on in Maryland.

${ }^{3}$ These charts and technical reports can be obtained by application to the Superintendent of the Coast and Geodetic Survey at Washington, D.C. The publications now ready for issue are those for Anne Arundel, Somerset, Wicomico, Worcester, Calvert, Charles, St. Marys, Baltimore, Kent, Queen Annes, and Talbot Counties.

The technical records and charts for each county are published separately on account of the requirements of the oysterculture laws of the State and the practical considerations which make it desirable to have each county "opened up" for oyster culture as soon as practicable after the completion of its survey. For these reasons and the fact that these reports are each arranged for distribution and use in one county only without reference to other published records, much of the text of this publication is of necessity identical with similar previous publications for other counties.

5 These reports can be obtained by application to the Shell Fish Commission, Marine Bank, Building, Baltimore, Md. They are issued annually in October, and the first, second, third, and fourth reports are now available for distribution.

- See Appendix B for an extract from the "Second Report of the Maryland Shell Fish Commission, " giving a concise summary of the "Haman oyster-culture law."
} 
and economic oyster investigations, methods and results of the hydrographic survey of the boundaries of oyster bars and crab bottoms, the administrative report and financial statement of the Commission, information relating to oyster culture, methods of surveying and leasing of oyster lots, and much other important matter of legal and scientific value.

These two sets of publications are planned and arranged to supplement each other without unnecessary duplication, and when combined they form a complete report of operations, methods, and results of the work of both the Government and State. ${ }^{1}$

\section{COOPERATION OF THE COAST AND GEODETIC SURVEY.}

The work of the Coast and Geodetic Survey, as the name of the service indicates, includes a survey of the coasts of the United States made on a geodetic basis. This has involved the gradual construction of a great framework of interstate triangulation for use as a foundation for detail hydrographic and topographic surveys, from which there has been compiled and published a complete set of charts of the coasts of the United States, including all waters of Maryland where oysters grow. This existing triangulation, hydrography, and topography is essential as a foundation for a correct and practical survey of natural oyster bars; and it being one of the fundamental functions of the Coast and Geodetic Survey to furnish such data, the cooperation of the Coast and Geodetic Survey with the Bureau of Fisheries and the Maryland Shell Fish Commission is a practical and natural development of Government work leading to the conservation and increase of the supply of food.

\section{COOPERATION OF THE BUREAU OF FISHERIES.}

The Bureau of Fisheries has cooperated with the Coast and Geodetic Survey and the Maryland Shell Fish Commission principally as an adviser in matters relating to the biological and economic survey of oyster bars and the methods to be employed for that purpose. $^{2} \quad$ A steam launch, rowing boat, and certain apparatus have also been furnished.

The primary function of the Burcau of Fisheries is to increase the productiveness of marine and fresh waters by such measures as may be best suited to the purpose, and the services rendered in connection with the survey of the oyster bars of Maryland are strictly in line with the fundamental law under which it acts. In certain States other than Maryland similar work has been conducted by the bureau acting independently, the same ends being attained at greater expense to the Government.

\section{GENERAL STATEMENT OF WORK OF COAST AND GEODETIC SURVEY. ${ }^{3}$}

The results obtained from the work of the Coast and Geodetic Survey in cooperation with the Bureau of Fisheries and the Maryland Shell Fish Commission need very little other summary than is indicated by the published "Charts of Natural Oyster Bars" and the index of lydrographic projections and triangulation stations shown on the county progress maps attached to each report.

\footnotetext{
2 See Appendix D of this publication for "Statistics of results of combined operations of the Government and State."

${ }^{2}$ Hon. George M. Bowers, Commissioner of Fisheries, has detailed for this service Dr. H. F. Moore, assistant, Bureau of Fisheries.

s For a detail statement of the very large amount of excellent oyster-survey work of the Maryland Shell Fish Commission see the "Annual Reports of the Maryland Shell Fish Commission."
} 
The triangulation has been carried on in accordance with the standard methods of the Coast and Geodetic Survey, making this work and that of the "Descriptions of Triangulation Stations" of permanent value, not only to the State of Maryland in the survey of her oyster bars but also to the Government for any future work it may do in the regions covered by the oyster-survey operations.

The hydrographic projections and published charts are prepared with all the accuracy permitted by their large scale, especially as to the boundaries of the various shellfish bottoms in relation to landmarks, but this accuracy of location on the charts is further added to and permanently fixed by published technical descriptions which should minimize the probability of any future dispute as to either landmarks or boundaries.

Stated another way, and quoting from the report of the "Survey of Oyster Bars of Anne Arundel County":

The geographic positions of the permanent landmarks and signals have been determined with the usual precision of a trigonometric survey, and their locations at all points necessary to provide ample foundation for the surveying and charting operations permitted great accuracy of definition and location for the natural oyster-bar and other boundaries established. At the same time the very important element of permanency of the positions of boundaries has been secured, as the relocation of geodetic positions can always be accomplished by a competent surveyor, even though the original landmarks and monuments have been washed away, as has been the fate of hundreds of such points established by the Coast and Geodetic Survey on the shores of the Chesapeake Bay during the last 65 years. 


\section{REPORT OF THE WORK OF 'THE COAST AND GEODETIC SURVEY IN TALBOT COUNTY.}

INSTRUCTIONS.

The following letters, together with the laws ${ }^{1}$ of the United States relating to the subject, constitute the "instructions" received by the chief of the Coast and Geodetic Survey party engaged on work in connection with the Maryland Shell Fish Commission. They are short and definite, but furnish ample authority and leeway for all legitimate development of the cooperation of the Government and the State in the survey of oyster bars. The "free hand" permitted by these orders, together with the aid and many valuable suggestions received from the officers of the survey at Washington, have proved very beneficial to the work and are greatly appreciated:

\section{DEPARTMENT OF COMMERCE AND LABOR, OFFICE OF THE SECRETARY, IVashington, June 2, I906.}

Sir: In reply to your letter of May 28 , requesting me to designate officers of the Coast and Geodetic Survey and of the Bureau of Fisheries to cooperate with the State of Maryland in making survey of and locating the natural oyster beds, I have the honor to inform you that Mr. C. C. Yates will be designated to cooperate on the part of the Coast and Geodetic Survey as soon as Congress makes the provisions of the act effective by providing an appropriation for the purpose.

Respectfully,

His Excellency Hon. Edwin WARFIELD,

\section{LaWrence O. Murray, Assistant Secretary.}

Governor of Maryland, Annapolis, Md.

DEPARTMENT OF COMMERCE AND LABOR,

Coast and GeOdetic Survey,

Washington, July 3,1906 .

SIR: Upon the receipt of these instructions you will surrender the command, accounts, etc., of the steamer Endeavor to the Hydrographic Inspector * * *.

As soon as this transfer is completed you will enter upon the duties of Coast Survey representative on the Shell Fish Commission of Maryland. form.

You will consult the Commissioners, prepare a program of work, and submit estimates in the usual

You are authorized to come to Washington for consultation from time to tirne as may be necessary.

Very respectfully,

O. H. Trtmmann, Superintendent.

Capt. C. C. Yares,

U.S. C. \& G. S. Steamer "Endeavor," Baltimore, Md. 


\section{ORGANIZATION AND EQUIPMENT.}

The personnel and occupation of the party of the Coast and Geodetic Survey have remained practically unchanged since the beginning of the "oyster survey." Besides the chief of party, it consists of the necessary triangulators, computers, draftsmen, and temporary employees required to carry on both the surveying operations in the field and the preparation for publication of oyster charts and technical records in the office at Washington.

The equipment for the work of the party has been ample and satisfactory. The large living and office quarters furnished the Government on the Maryland Shell Fish Commission house-boat $O_{y}$ ster have been very convenient for the work, besides facilitating efficient cooperation with the surveying and oyster investigation parties of the State. In addition to the accommodations on the $O_{y} y^{\prime}$ ter , the Coast and Geodetic Survey party has had the constant use of the large launch Inspector and several other boats furnished by its own service, and the occasional use of the Bureau of Fisheries launch Canvasback ${ }^{1}$ and the steamer Governor McLane ${ }^{2}$ of the State Fishery Force.

The greater part of the equipment of instruments for the operations of both the Government and State has been furnished by the Coast and Geodetic Survey, and consists of all necessary theodolites, levels, sextants, drafting instruments, hydrometers, etc., required for all field and office work.

\section{CHRONOLOGICAL STATEMENT OF WORK.}

The field work of the Coast and Geodetic Survey in Talbot County ${ }^{3}$ dates from July 6, 1909, when the Maryland Shell Fish Commission house-boat Oyster was towed by the State Fishery Force steamer Governor McLane to an anchorage in the northern part of Prospect Bay near the southern entrance to Kent Narrows. From this harbor as headquarters a few additional triangulation observations were made in Kent County, although the greater part of the work was confined to Talbot and Queen Annes Counties.

On July 22, 1909, the house-boat was moved to the vicinity of Rockhall, and all field work in Talbot County was discontinued until August r 3, r909, when the Oyster was shifted back to Eastern Bay side of Kent Narrows, where she remained only two weeks. During this period Governor Crothers and party visited the house-boat and thoroughly examined into the manner and methods of the work of the Maryland oyster survey.

On August 28, 1909, the Oyster was towed to Haddaway Cove in Talbot County, where she stayed for only three days on account of the exposed position of the anchorage.

On August 31, 1909, the Oyster changed her anchorage to the very snug harbor inside of Poplar Island, where she remained until all the open Chesapeake Bay work was practically completed as far south as Tilghmans Island. While at this anchorage, one subparty living on shore was engaged on triangulation in Harris Creek with hired boats and an extra party of hands.

\footnotetext{
I By courtesy of Dr. H. F. Moore, United States Bureau of Fisheries.

2 By courtesy of Capt. James A. Turner, commanding.

The field work of Talbot County was so intermixed with that of Queen Annes and Dorchester Counties that the chronological statement of the work in one of these counties necessarily includes a considerable part of the work of the other two counties.
} 


\section{Survey of Oyster Bars, Talbot County, Md.}

O.1 Septenjar 22, r9)9, the house-boat was towed to Du1 Cove in Harris Creek . From this anchorage the triangulation of Harris Creek, as well as a considerable part of Broad Creek, was completed.

On October 16, I909, the house-boat was moved back to Eastern Bay and tied up at the railway wharf at Claiborne. From this point the triangulation of Eastern Bay and its northern tributaries west of Kent Narrows was practically completed.

On October 29, 1909, the Oyster was moved to an anchorage in Tilghmans Creek, which is a branch of the Miles River. The next day completed a month's field work, which was notable as far as triangulation was concerned, on account of the number of stations which were established, marked, described, and located by observations. This number was 108, which is considerably larger than any previous month's record. A good part of this work was carried on by subparty living on shore at Cambridge.

On December I, I909, the house-boat Oyster was moved from Tilghmans Creek, where she had been for over a month, to an anchorage off St. Michaels. From this harbor the remaining triangulation of Wye River and Miles River was practically completed.

On December 2I, 1909, active field work in Talbot County for the calendar year was closed at St. Michaels, but a signal-building subparty continued field work from quarters on shore at Oxford for two days longer.

On December 24, 1909, the field season for the Government parties was officially closed, but the monthly employees remained on the house-boat at Baltimore preparing launches and boats for the winter. All officers were on leave from the $25^{\text {th }}$ to 3 Ist.

On January 3, 19ro, which was the first working day of the year, the winter's office work commenced, and the repairs to launches and construction of triangulation monuments were taken up on the house-boat Oyster by the foreman and two men.

The office work, which consisted of the completion of records, revising descriptions of location of triangulation stations, triangulation computations, oyster-bar computations, preparation of manuscripts of technical publications, drafting and scaling boundaries of oyster bars, etc., continued without a break, except as noted in the following paragraph.

During the period covered by the winter's office work the Maryland Legislature was in session, and as the consideration of oyster legislation formed a very important and prominent part of its proceedings, considerable time of the chief of party and his officers was expended in gathering and imparting information requested by various State officials.

On March 14, I910, a subparty was organized and put in the field to complete certain necessary details of triangulation in Talbot and Dorchester Counties. This party first went to St. Michaels, then to Cambridge, and finally to Oxford, where the 1 main party on the house-boat was joined at the end of April.

On April 30, r9ro, the house-boat Oyster was towed from Baltimore by the State steamer McLane to an anchorage in Tar Creek, near Bellevue. While at this harbor the house-boat was cleaned, painted, and generally overhauled for the season's work, and at the same time triangulation was being carried on to completion in Tred Avon River, Island Creek, and other tributaries of lower Choptank River. 
On May 30, r9ro, the house-boat shifted her anchorage to Tred Avon River off Oxford, where she remained until the practical completion of all the remaining triangulation and other oyster survey work in Talbot County except in the upper Choptank River.

On June 30, 1910, the Oyster was towed to an anchorage off Cambridge, and from this point the oyster survey work of Talbot County in upper Choptank River was carried on to completion, together with that of Dorchester County in the adjacent region.

On July 20, I910, the house-boat Oyster was moved to the Patuxent River off Solomons Island, and no further ficld work was done in Talbot County except from June 20 to June $2 \mathrm{I}$, I9I2, when a small party was put in the field to complete certain necessary details of triangulation in Talbot and Dorchester Counties.

The office work connected with the oyster survey of Talbot County, including the computation of geographic information and the drafting necessary for the preparation for publication of the oyster charts and the technical records of that county, was carried on intermittingly with the office work of other connties from the beginning of the field work in Talbot County on July 6, I909, to the time of filing of the certified oyster charts and technical records in the archives of the Maryland Shell Fish Commission and with the clerk of the circuit court of Talbot County on July $20,1912$.

STATISTICS. ${ }^{1}$

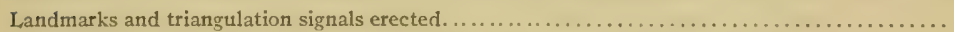

Monuments planted to mark triangulation stations. . . . . . . . . . . .

Triangulation stations occupied for observations of horizontal angles................. 308

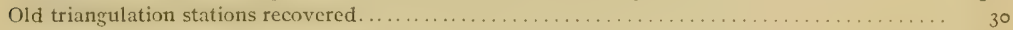

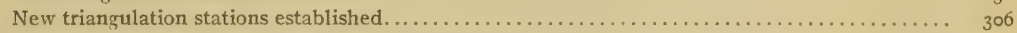

Total old and new triangulation stations marked and described. ...................... 336

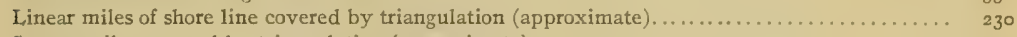

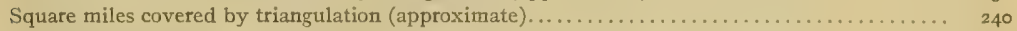

Hydrographic projections prepared and completed as records of oyster boundaries............. I4

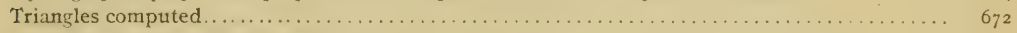

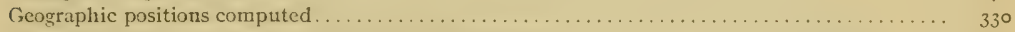

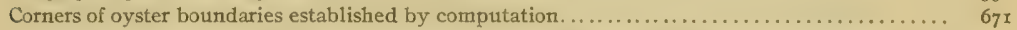

Back azimuths and distances computed from corners of boundaries to triangulation stations..... 2, or 3

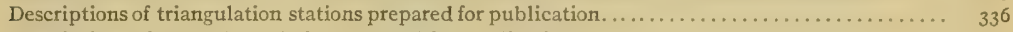

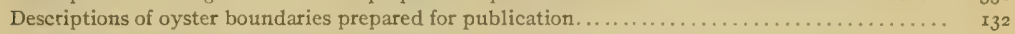

"Charts of Natural Oyster Bars" prepared for publication........................ 7

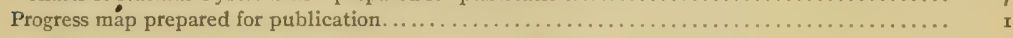

\section{GENERAL REMARKS.}

Before ending this report the representative of the Coast and Geodetic Survey wishes to renew his statement of apprcciation of the courteous assistance received from various Government and State officials and others interested in the oyster industry of Maryland, especially to the following:

\footnotetext{
1 These statistics only include field and office work directly performed by the party of the Coast and Geodetic Survey in connection with the oyster survey of this county, and do not include the many thousands of soundings and examinations of the character of the bottom made by the engineers of the Commission, which are of considerable value to the Coast and Geodetic Survey as hydrographic records for future use in connection with the preparation of new editions of charts of the waters of Maryland. See Appendix D of this publication for "Statistics of results of combined operations of the Government and the State."
} 
To his colleague from the Department of Commerce and Labor, Dr. H. F. Moore, of the Bureau of Fisheries, whose well-known scientific knowledge of all matters relating to oysters has been of great value to the work.

To Mr. Walter J. Mitchell, chairman of the Maryland Shell Fish Commission, who, by his administrative ability in carrying out the complicated requirements of the oyster laws and by his unfailing tact, has made the cooperation of the various services engaged on the work both agreeable and effective.

To Dr. Caswell Grave, secretary of the Commission, who, as editor of the Commission's annual report and commissioner in charge of the biological and economic oyster investigations, has been brought into constant contact with the Government work and aided its operations in every way.

To Mr. Benjamin K. Green, treasurer of the Commission, who has looked after the equipment and commissary of the house-boat in such a way as to add greatly to the comfort and convenience of the party of the Coast and Geodetic Survey.

To Mr. Swepson Earle, hydrographic engineer to the Commission, whose knowledge of the work from former service in the Coast and Geodetic Survey has greatly facilitated his practical use of the technical data furnished by the Government.

And to the many others connected with the Commission or who as residents in the locality where the work was being carried on have greatly assisted by furnishing important information or willing services. 


\section{CHARTS AND MAPS. ${ }^{1}$}

\section{CHARTS OF NATURAL OYSTER BARS.}

The charts of the natural oyster bars of Talbot County published by the Coast and Geodetic Survey from results of the surveys of the Government in cooperation with the Maryland Shell Fish Commission consist of seven sheets covering all the oyster-producing waters of that county. They are published on the large scale of I part in 20,000 (approximately $3 \frac{1}{16}$ inches to a statute mile) and are constructed on polyconic projections; and all information shown on them is based on the United States standard datum of the Coast and Geodetic Survey.

These charts show all oyster hars and other boundaries established by the Commission, and are certified for the purpose of filing in the office of the clerk of the circuit court of Talbot County and in the office of the Maryland Shell Fish Commission, as required by the oyster laws of Maryland.

In addition to the oyster bar and other boundaries, the charts show the location and name of all landmarks (United States Coast and Geodetic Survey triangulation stations) used in making the survey, together with the hydrography and topography ${ }^{2}$ necessary to make the technical definitions and delineations of boundaries readily understandable both by the people engaged in the oyster industry and the general public who may become interested through leasing of barren bottoms for oyster culture.

The names of the oyster bars are those used locally, as nearly as could be ascertained by the hydrographic engineer of the Commission. When there was no local name in common use, a name was selected from one of the prominent features of the vicinity. By the use of recognized names or those that would naturally suggest certain sections of water, it is believed that much confusion will be avoided in the location on the charts of the oyster bars, especially by those not familiar with the use of maps.

The corners of the oyster bars are numbered from I to the total number of corners in each area under consideration. Where boundaries adjoin, making one point a corner of two or more oyster bars, these points have two or more numbers, each number corresponding to the bar in which the figure is located. The numbers of the corners correspond with the technical and legal descriptions of this publication under the heading "Boundaries of natural oyster bars."

The landmarks and oyster bars have been grouped in the "Contents" of this publication in accordance with the charts upon which they are shown. To find a particular oyster bar or landmark which is only known by name, consult the "Contents" and

1 These charts can be obtained by application to the Superintendent of the Coast and Geodetic Survey, at Washington, D. C.

2 Much of the detail of the inshore topography was obtained from the excellent map of Talbot County, prepared and published by the Maryland Geological Survey under the direction of Dr. William Bullock Clark from surveys of the Maryland Geological Survey in cooperation with the United States Geological Survey. 
the desired chart and general location will be indicated. To find the name of a bar or landmark which is only known by location, consult the progress map at the end of this publication for the number of the chart on which it is to be found, and then examine the known locality on the chart for the name of the bar or landmark in question.

The contours on the charts showing the depth of water at mean low tide have been taken from the hydrographic sheets of former work of the Coast and Geodetic Survey. Four curves were selected as being the most convenient for taking off from the original liydrographic sheets and the ones of greatest value to those interested in shell fish industries. The I-fathom contour ( 6 feet) and the 5 -fathom curve (3o feet) correspond in a general way to the inner and outer limits of all the oyster bars surveyed. The 3-fathom contour ( 8 feet) furnishes the curve of about the average depth of water on the oyster bars, and the ro-fathom contour ( 60 feet) serves in a general way to indicate the outer limits of probable oyster culture.

The boundaries of the waters within the "territorial limits of the county" and the boundaries of the "waters contiguous to the county" opened up for the leasing with Talbot County are plainly indicated on the charts. A full technical description of these boundaries is given in this publication under the heading "Boundaries of county waters."

The areas in acres of the oyster bars were determined under the direction of the hydrographic engineer of the Commission by two independent planimeter measurements of the areas as delineated on the smooth projections of the Coast and Geodetic Survey. These areas are given in small figures in parentheses on the face of the chart within the boundaries of the different shell fish bottoms.

The symbols used on the charts for the different kinds of boundaries, triangulation stations, contours of depth of water, etc., require no other explanation than that given in the legend and other notes on the face of the charts.

\section{LEASING CHARTS.}

The leasing charts of Talbot County, like those for Anne Arundel, Somerset, Wicomico, Worcester, Calvert, Charles, St. Marys, Baltimore, Kent, and Queen Annes Counties, have been prepared under the direction of the hydrographic engineer of the Commission. They are constructed on polyconic projections on the scales of I part in 5,000 or I part in 10,000 , as the needs of oyster culture may require, and the information shown on them is based on the United States standard datum of the Coast and Geodetic Survey.

These charts show all the oyster bars, crab bottoms, and clam beds and other boundaries established by the Commission, and also all boundaries of oyster lots leased for the purpose of oyster culture, thus making them comprehensive and valuable records of the results of the operations of the oyster-culture laws.

The lots leased under the provision of the "old 5-acre law" are frequently of irregular shape, but the lots leased under the provision of the new oyster laws must be of rectangular shape by the terms of that act. For this latter purpose the leasing charts have been divided by parallels of latitude and meridians of longitude into small rectangles of $\mathrm{I}$ acre or 5 acres, as may be best suited to the area under consideration, and 
prospective leaseholders by the rules of the Commission are compelled to select whole rectangles as far as possible.

For reasons of the present changeable nature of the number of lots leased and the large number of charts required, the leasing cliarts are not likely to be published for some years, but they can be seen at any time on file at the offices of the Commission, in the Marine Bank Building at Baltimore.

\section{PROJECTIONS.}

The polyconic projections ${ }^{1}$ covering Talbot County waters are 14 in number and on the scale of I part in 10,000 . They were constructed by draftsmen of the Coast and Geodetic Survey, but the sextant positions which determine the location of the legal boundaries of the oyster bars as delineated by the Shell Fish Commission were plotted by the draftsman of the Commission.

A copy of each of these projections, with all the plotted positions of triangulation stations, shore line, sextant positions, and boundaries of oyster bars, was made under the direction of the hydrographic engineer of the Commission by pricking through with a sharp needle the intersections of the projection lines and all other points as plotted on the original sheets.

These projections (in duplicate) are the original records of all oyster bar and other boundaries established by the Commission, one set being filed in the archives of the Coast and Geodetic Survey, at Washington, and the other set in the archives of the Shell Fish Commission.

\section{PROGRESS MAPS.}

The progress map to be found at the end of this publication is on a scale of I part in 100,000 , and shows in outline the work accomplished by the United States Coast and Geodetic Survey in Talbot County and contiguous waters. It gives the scheme of all the charts and smooth projections constructed in connection with the survey, the location and names of all triangulation stations used as a basis for the surveying work, and the "boundaries of county waters" established by the Commission for the purpose of carrying out the laws of Maryland relating to oyster culture.

Besides indicating the amount of work done by the Coast and Geodetic Survey in connection with the work of the Shell Fish Commission, this progress map will be of special value for index purposes to engineers and others searching for the particular chart or projection covering the locality of the oyster bars or landmarks that may be under consideration.

The progress maps ${ }^{2}$ accompanying the first and second annual reports of the Maryland Shell Fish Commission were prepared under the direction of the hydrographic engineer of the Commission. They are on the scale of I part in 400,000, and show the outline of the tide-ivater counties of Maryland, with shaded areas to indicate the waters already covered by the operations of the oyster survey.

1 For the scheme of these projections see the progress map at the end of this publication.

2 These maps and reports can be obtained by application to Maryland Shell Fish Commission, Marine Bank Building, Baltimore, Md. 


\section{BOUNDARIES OF THE COUNTY WATERS. ${ }^{1}$}

\section{WATERS WITHIN TERRITORIAL, LIMITS OF COUNTY.}

The laws of Maryland relating to oyster culture provide that "no person shall be permitted, by lease, assignment, or in any other manner, to acquire a greater amount of land than ten acres situated within the territorial limits of any of the counties, or one hundred acres in any other place."

The boundary line ${ }^{2}$ between the waters "within the territorial limits" of Talbot County and the waters in "any other place," as established by the Shell Fish Commission for the purpose of carrying out the oyster laws, and delineated on the "oyster" charts and the smooth projections of the Coast and Geodetic Survey, is technically described and defined as follows:

Commencing at the head of the oyster-producing waters of Wye River on the channel boundary line between Talbot County and Queen Annes County; thence following the channel boundary line between Talbot County and Queen Annes County down the upper Wye River to a point situated in the vicinity of the eastern end of Wye Island; thence continuing down the channel of the branch of Wye River running south of Wye Island along the boundary line between Talbot County and Queen Annes County, as laid down on "Chart No. 32, Natural Oyster Bars, Maryland," to the mouth of Wye River; thence continuing along the boundary line between Talbot County and Queen Annes County, as laid down on "Chart No. 32, Natural Oyster Bars, Maryland, " passing into Miles River in a curved line about half way between Herring Island and Bennett Point and then down Miles River to a point situated about I $1 / 2$ miles northeast of Tilghmans Point in the Eastern Bay entrance of Miles River; thence continuing on the boundary line between Talbot County and Queen Annes County in Eastern Bay as laid down on "Charts Nos. 3 I and 32, Natural Oyster Bars, Maryland," to a point situated in the Chesapeake Bay entrance of Eastern Bay defined by the intersection of the boundary line between Talbot County and Queen Annes County and a straight line between a point on Fient Point on the southern extremity of Kent Island defined by ${ }^{3}$ latitude $38^{\circ} 50^{\prime} 05 \cdot I^{\prime \prime}$ and longitude $76^{\circ} 22^{\prime} 06.2^{\prime \prime}$ and a point situated on Wades Point on the eastern side of the entrance of Eastern Bay defined by latitude $38^{\circ} 49^{\prime} 34 \cdot 2^{\prime \prime}$ and longitude $76^{\circ} 18^{\prime} 04.5^{\prime \prime}$; thence in a straight line across the eastern half of the Chesapeake Bay entrance of Eastern Bay to a point on Wades Point defined by latitude $38^{\circ} 49^{\prime} 34.2^{\prime \prime}$ and longitude $76^{\circ} 18^{\prime} 04.5^{\prime \prime}$; thence in a southerly direction along the mean low water line or across the mouth of all inlets less than roo yards in width, as the case may be, of the eastern shore of Chesapeake Bay to a point situated on Lows Point defined by latitude $38^{\circ} 46^{\prime} 33.4^{\prime \prime}$ and longitude $76^{\circ} 20^{\prime} 07.4^{\prime \prime}$; thence in a straight line across the notthern entrance of Poplar Island Narrows to a point situated on the northern end of Poplar Island defined by latitude $38^{\circ} 46^{\prime} 42.8^{\prime \prime}$ and longitude $76^{\circ} 22^{\prime} 25.0^{\prime \prime}$; thence along the mean low water line or across the mouth of all inlets less than roo yards in width, as the case may be, of the western shore of

1 For a complete historical and legal description of the boundaries of the counties of Maryland, the valuable publication entitled "The Counties of Maryland-Their Origin, Boundaries, and Election Districts," prepared by Dr. Edward B. MIathews and published by the Maryland Geological Survey under the direction of Dr. William Bullock Clark, superintendent, should be consulted, as the boundaries described in this publication have been established and technically defined for the purpose of carrying out the oyster laws of the State, and may or may not be correct for other purposes.

"See "Charts of Natural Oyster Bars," published by the Coast and Geodetic Survey, and the progress map at the end of this publication.

\& Latitudes and longitudes based on the United States standard datum of the United States Coast and Geodetic Survey. 
Poplar Island to a point situated on the southern end of the main part of Poplar Island defined by latitude $38^{\circ} 45^{\prime} 17.5^{\prime \prime}$ and longitude $76^{\circ} 22^{\prime} 43.6^{\prime \prime}$; thence in a straight line across an inlet into Poplar Island Harbor to a point situated on the western extremity of the detached part of Poplar Island known as Coaches Neck defined by latitude $38^{\circ} 45^{\prime} 08.8^{\prime \prime}$ and longitude $76^{\circ} 22^{\prime} 35 \cdot 3^{\prime \prime}$; thence along the mean Iow water line or across the mouth of all inlets less than roo yards in width, as the case may be, of the western and southern shore of a detached part of Poplar Island known as Coaches Neck to a point situated on its eastern extremity defined by latitude $38^{\circ} 44^{\prime} 59 \cdot 4^{\prime \prime}$ and longitude $76^{\circ} 2 \mathrm{I}^{\prime} 46 \cdot 5^{\prime \prime}$; thence in a straight line across the southern entrance of Poplar Island Narrows to a point situated on the mainland on Great Marsh Point defined by latitude $38^{\circ} 44^{\prime} 56.0^{\prime \prime}$ and longitude $76^{\circ} 20^{\prime} 34.2^{\prime \prime}$; thence in a southerly direction along the mean low water line or across the mouth of all inlets less than 100 yards in width, as the case may be, of the eastern shore of Chesapeake Bay to a point situated on the northern side of the entrance to Front Creek defined by latitude $3^{\circ} 43^{\prime} 47 \cdot 5^{\prime \prime}$ and longitude $76^{\circ} 20^{\prime} 34.0^{\prime \prime}$; thence in a straight line across the Chesapeake Bay entrance of Front Creek and Knapps Narrows to a point situated on the southern side of Chesapeake Bay entrance of Knapps Narrows defined by latitude $38^{\circ} 43^{\prime} \mathrm{I} 4.8^{\prime \prime}$ and longitude $76^{\circ} 20^{\prime} 27.6^{\prime \prime}$; thence in a southerly direction along the mean low water line or across the mouth of all inlets less than 100 yards in width, as the case may be, of the eastern shore of Chesapeake Bay to a point situated on Blackwalnut Point on the northwestern side of the Chesapeake Bay entrance of lower Choptank River defined by latitude $38^{\circ} 40^{\prime}$ o6. $6^{\prime \prime}$ and longitude $76^{\circ} 20^{\prime} 24.7^{\prime \prime}$; thence in a straight line ending at a point situated on Cook Point on the southeastern side of the Chesapeake Bay entrance of lower Choptank River defined by latitude $38^{\circ} 37^{\prime} 55.7^{\prime \prime}$ and longitude $76^{\circ} 17^{\prime} 28.7^{\prime \prime}$ to a point on this line defined by its intersection with boundary line in lower Choptank River between Talbot County and Dorchester County as laid down on "Charts Nos. 33, 36, and 37, Natural Oyster Bars, Maryland;" thence along the boundary line in lower Choptank River between Talbot County and Dorchester County as laid down on "Charts Nos. 33, 34, 36, and 37 , Natural Oyster Bars, Maryland," to the entrance of upper Choptank River between Castle Haven Point and Island Creek; thence continuing along the boundary line between Talbot County and Dorchester County up the channel of upper Choptank River pass the city of Cambridge around Chancellors Point and pass the town of Choptank, all as laid down on "Chart No. 35, Natural Oyster Bars, Maryland;" thence continuing up the channel boundary line of upper Choptank River between Talbot County and Dorchester County to the head of the oyster-producing waters.

\section{WATERS CONTIGUOUS TO COUNTY.}

The oyster laws of Maryland provide that a true and accurate delineation of all natural oyster bars shall be made on copies of charts of the United States Coast and Geodetic Survey, "which said copies shall be filed in the office of the said commissioners in the city of Baltimore," and "in the office of the clerks of the circuit courts for the respective counties wherein the grounds so designated may lie."

For the purpose of carrying out the latter part of this section of the law and for the purpose of establishing the limits of the oyster-culture area to be opened up for leasing with each county surveyed, it is necessary for the Shell Fish Commission to establish a boundary line between the waters contiguous to but not within the territorial limits of each county and the waters contiguous to but not within the territorial limits of adjacent counties.

This boundary line has been delineated on the "Charts of Natural Oyster Bars," published by the Coast and Geodetic Survey, and is technically described and defined as follows:

Commencing at a point in the Chesapeake Bay entrance of Eastem Bay defined by the intersection of the boundary line between Talbot County and Queen Annes County, as laid down on "Chart No. 3 r, Natural Oyster Bars, Maryland, "with a straight line across the Chesapeake Bay entrance of Eastern Bay, 
defined at its western end by a point situated on the southern extremity of Kent Island in latitude $3^{8^{\circ}} 50^{\prime}$ 05. $\mathrm{I}^{\prime \prime}$ and longitude $76^{\circ} 22^{\prime}$ 06. $2^{\prime \prime}$ and defined at its eastern end by a point situated on Wades Point on the eastern side of the entrance of Eastern Bay in latitude $38^{\circ} 49^{\prime} 34.2^{\prime \prime}$ and longitude $76^{\circ} 18^{\prime}$ 0.5.5"; thence along the boundary line between Talbot County and Queen Annes County, passing into Chesapeake Bay between Kent Island and Poplar Island, as laid down on "Chart No.3I, Natural Oyster Bars, Maryland," to a point situated in Chesapeake Bay about $3^{T / 2}$ miles southwest of Bloody Point Bar Light defined by latitude $38^{\circ} 46^{\prime} 06.6^{\prime \prime}$ and longitude $76^{\circ} 26^{\prime} 37 . I^{\prime \prime}$; thence in a straight line in a southerly direction with Chesapeake Bay to a point situated in Chesapeake Bay about $35 / 8$ miles east of Hog Point and $5 \frac{3}{8} 8$ miles southwest of Poplar Island, defined by latitude $3^{\circ} 42^{\prime} 33 \cdot 4^{\prime \prime}$ and longitude $76^{\circ} 27^{\prime} 40.0^{\prime \prime}$; thence in a straight line in a southerly direction witlı Chesapeake Bay to a point situated in Chesapeake Bay about $5^{1 / 2}$ miles southwest of Sharps Island Light and $5 \frac{3}{4}$ miles northwest of James Island, defined by latitude $38^{\circ} 34^{\prime} 29.6^{\prime \prime}$ and longitude $75^{\circ} 26^{\prime} 17.0^{\prime \prime}$; thence along the boundary line between Talbot County and Dorchester County, passing south of Sharps Island into the Chesapeake Bay entrance of the lower Choptank River, as laid down on "Charts Nos. 33, 36, and 37, Natural Oyster Bars, Maryland," to a point defined by the intersection of this boundary line with a straight line across the entrance of lower Choptank River, defined at its northwestern end by a point situated on Blackwalnut Point in latitude $38^{\circ} 40^{\prime} 06.6^{\prime \prime}$ and longitude $76^{\circ} 20^{\prime} 24 \cdot 7^{\prime \prime}$ and defined at its southeastern end by a point situated on Cook Point in latitude $38^{\circ} 37^{\prime} 55.7^{\prime \prime}$ and longitude $76^{\circ} I 7^{\prime} 28.7^{\prime \prime} .{ }^{2}$

I Latitudes and longitudes based on the United States standard datum of the United States Coast and Geodetic Survey. 


\section{LANDMARKS (U. S. COAST AND GEODETIC SURVEY TRIANGULATION STATIONS).}

EXPLANATION.

The oyster laws of Maryland authorizing the survey to be made by the Shell Fish Commission provide for "an accurate report of said survey, setting forth such a description of landmarks as may be necessary to enable the said board, or their successors, to find and ascertain the boundary lines of said natural oyster beds, bars, and rocks, as shown by delineation on the maps and charts." The law of the United States authorizing the cooperation of the Department of Commerce and Labor in the survey of natural oyster bars of Maryland provides for the erection of "such structures as may be necessary to mark the points of triangulation, so that the same may be used for such future work of the Coast and Geodetic Survey as the said bureau may be hereafter required to perform in prosecuting the Government coast survey of the navigable waters of the United States located within the State of Maryland."

Under the provisions of the sections of the laws stated above, the markings and descriptions of landmarks must be sufficient for the present and future needs of both the Government and the State. With this end in view, considerable work has been expended in erecting permanent monuments at the triangulation stations and in the proper description of their location.

An effort has been made to arrange the descriptions of location and character of landmarks in a uniform and logical manner. The descriptions start with the assumption that the individual seeking a landmark has only an indefinite idea of its location. They gradually proceed from description of the general locality of a landmark to the descriptions of its immediate surroundings. This is followed by specific details of the character of the center and reference marks and a "round" of reference angles and distances which in themselves frequently contain enough information to furnish an independent and reliable location of the triangulation station.

\section{METHOD OF DESCRIBING TRIANGULATION STATIONS.}

The separate descriptions of triangulation stations should not be used without reading the following explanation of the method of describing the triangulation stations, as it contains certain details that are common to all the landmarks described in this publication and which are omitted in the separate descriptions as being needless repetitions:

Name.-The title at the top of each separate description is the name by which the landmark or triangulation station is known and designated in all work and published oyster records or oyster charts of both the Government and State. The selection of the name is usually left to the triangulator establishing the station, and it may or may not have geographic or other significance in reference to the locality.

$$
53485-12-3
$$


General locality.-Under this heading is given the general locality of the landmark in reference to well-known and prominent natural or artificial features, such as the nearest body of water, town, river, steamer wharf, well-defined point of land, church, or any other feature that is likely to remain both permanent and prominent.

This heading also covers a reference to the published chart or map which shows the location of the station most clearly. Nearly all the triangulation stations described in this publication are plainly indicated by name and a triangulation symbol on the published charts of oyster bars of Maryland. In this case they are referred to by serial number only, the words "charts of oyster bars of Maryland" being omitted to avoid needless repetition. These published oyster charts are on the large scale of I part in 20,000 (approximately $3 \frac{1}{6}$.inches to a statute mile) and show the locations of the triangulation stations so clearly that in many cases the written descriptions will not be required to find them.

Immediate locality.--Under this heading is given the description of the "observed station" in reference to its immediate surroundings. This is supposed to include a statement of the station's estimated elevation above high water or some other welldefined level of the locality, such as a road or house; the character of the ground on which it is located, such as marsh land, sand beach, cultivated field, or meadow; estimated bearings in points of the compass and estimated distances in yards from (not to) easily recognized features, such as extreme end of point, edge of bluff, bank of creek, line of telephone poles, shore line, barn, house, fence, ditch, trees, or any other definite detail, such as being on range with the tangent of an island and a church, etc.

When a standard monument has been established near the station as a "reference station," this heading also covers a statement of the true bearing of the monument in degrees and minutes and its measured distance in meters, as it is the first object that is likely to catch the eye when the immediate vicinity of the desired station is reached and might be mistaken for the center mark of the "observed station" unless special attention is called to it.

The distinction between the "observed station" and "reference station" should be carefully noted by anyone making use of the description of stations for any future surveying operations.

The "observed station" is located at the particular triangulation point covered by the description of stations, and is the one whose geographic position is first computed, as it is the point which was "occupied" and "observed on" for horizontal angles. However, in spite of the primary importance of the location of the "observed station," it will be noted from the description of stations that frequently it is not marked as well as the "reference station," and in some instances has only a pine stub to indicate its position. This is the case for the reason that the necessity of intervisibility of landmarks usually made it compulsory to locate "observed stations" on edges of banks and ends of points of land, which in the tide-water section of Maryland generally means they will be washed away in a short period of years. The past experience of the Coast and Geodetic Survey in this region has shown the great need of "reference stations," if the frequent reestablishment of a new framework of triangulation is to be avoided.

The chief reason and need for the establishment of the "reference station," or secondary station, as it might be well named, is explained in the preceding paragraph, 
but in several instances other reasons, such as the location of the "observed station" on an unstable sand dune, in a cultivated field, in front of a residence, or other places objectionable to the landowner, have led to establishment of "reference stations." The location of the "reference station" in relation to the "observed station" is fixed for plotting on charts or for computation of its geographic position by checked measurements of its distances and azimuth from the "observed station." 1

Marks.-Under this heading is given a description of the character of the permanent monuments or other marks of the location of the "observed station," and of the "reference station" where one has been established.

All the marks designated in the descriptions as "the center point of triangle on standard cement monument" are exactly alike. These monuments are made of cement, sand, and gravel, and are 2 feet long and 8 inches square at top and bottom. Their tops are all marked with the same brass mold and show a center hole surrounded by a triangle, with the letters "M. S. F. C." arranged around the vertex and the letters "U. S. C. S." underneath the base of the triangle. The center hole is always in the center of the top of the monument by construction, and if this is found to have been broken off without disturbing the bottom, the center of its square section can be used as the location of the station.

All the "standard cement monuments," whether used for marking the "observed station" or "reference station," have been planted upright in exactly the same manner, with their tops projecting 3 or 4 inches above the surface of the ground, unless otherwise stated.

Therefore, as the above facts in reference to the "standard cement monuments" are a constant element in all cases, the repetition of these facts in the description of stations is made needless by this one statement.

References.-Under this heading are given the "rounds" of directions and distances to all objects that might be useful in locating the stations when the surface marks can not be found. It is also contemplated that for general purposes of topography, hydrography, or location of boundaries of oyster bars these references will be sufficient in many cases to relocate the position of an "observed station" or "reference station" when both of them have been destroyed.

The first reference object given in the descriptions is always a triangulation station visible from the station being described, this, if possible, being a lighthouse, church spire, or other permanent and prominent point. Its direction is taken as being $\mathrm{o}^{\circ} \mathrm{oo}^{\prime} \mathrm{oo},{ }^{\prime \prime}$ and the directions of all other objects are measured from it as an initial point, the angles being taken in a clockwise direction (left to right).

The true bearing ${ }^{2}$ of the initial object is always given in parentheses alongside its name. This furnishes means for the calculation of the bearings of any of the other reference objects for the purposes of locating a station by horizontal angles or for the relocation of corner buoys of oyster-bar boundaries by the method of compass directions described in this publication under the heading of "Boundaries of oyster bars."

\footnotetext{
1 Geographic coordinates (latitude, longitude, distance, and azimuth) relating to any of the "observed stations" or of the "reference stations" described in this publication can be obtained by application to the Superintendent of the Coast and Geodetic Survey, at Washington, D. C.

The mean magnetic variation for Talbot County was $6^{\circ}$ ro' west of north in rgrr and increasing at the rate of $5^{\prime}$ yearly.
} 
The distances in the last column under "References" are given in three different units, which vary according to their accuracy. The "miles" are statute miles, and may be considered only as rough estimates. The "yards" are more accurate, but must be looked on as results generally obtained by pacing or careful estimating. The "meters," however, are accurate to the degree indicated by their decimals and in every case have been measured with a steel tape. In the same manner, the accuracy of the directions are indicated by the refinement of angular measure with which they are recorded.

\section{THOMAS POINT SHOAL, LIGHT.}

General locality.-Western side of Chesapeake Bay offshore about II/4 miles southeast of Thomas Point and 3 miles south of entrance to channel to Annapolis. (See Chart No. 3 r.)

Immediate locality.--Observed station is on a hexagonal screw-pile structure known as Thomas Point Shoal Lighthouse.

Marks.-Observed station is center point of lantern on Thomas Point Shoal Lighthouse.

References-

$$
\text { "Thomas } \left.3 \text { " (N } 56^{\circ} \mathrm{o}^{\prime} \mathrm{W}\right) \ldots \ldots \ldots \ldots \ldots \ldots \text {. o }
$$

\section{BLOODY POINT BAR LIGHT.}

General locality.-Offshore of southwestern end of Kent Island on northern side of entrance to Eastern Bay about $\mathrm{I} / \mathrm{s}$ miles southwest of Bloody Point and $\mathrm{I} / 4$ miles west of Kent Point. (See Chart No. $3 \mathrm{I}$.) Immediate locality.-Observed station is on tower on caisson structure known as Bloody Point Bar Lighthouse.

Marks.-Observed station is center point of lantern on Bloody Point Bar Lighthouse.

References.-

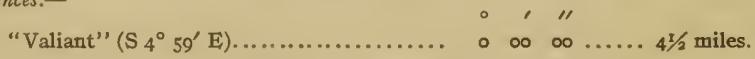

TENK.

General locality. -Northern side of entrance to Eastern Bay on Kent Point about I1/2 miles east of Bloody Point Bar Light. (See Chart No. 3I.)

Immediate locality.-Observed station is in about 2 feet of water 18 yards offshore of Kent Point, 50 yards southwest of point of land, and 65 yards south-southeast of another point of land. Cement

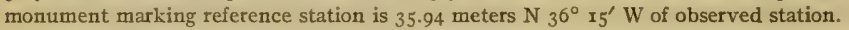

Marks.-Observed station is nail in center of 3 -inch square stub in water with top about on level with high water. Reference station is center point of triangle on standard cement monument projecting

\begin{tabular}{|c|c|c|c|c|}
\hline \multicolumn{5}{|l|}{ References.- } \\
\hline \multicolumn{5}{|l|}{$\begin{array}{r}\text { References.- } \\
\text { "Blood }\end{array}$} \\
\hline REFERENCE STATION....... & 57 & II & 30 & 35.94 meters \\
\hline Chimney of house on Tilghmans Point Farm. . & 169 & 26 . & . & $57 / 8$ miles. \\
\hline "Rich Neck Water Tank". . & 175 & 48 & ro & $5^{1 / 4}$ miles. \\
\hline Flagpole on Claiborne train shed............ & $18 \mathrm{I}$ & $I_{4}$ & . & ..... $4 \mathrm{~T} / 2$ miles. \\
\hline Right chimney of house............... & r88 & 34 & .. & $\ldots . .44^{1} / 2$ miles. \\
\hline "Kemp Tower".......... & x9o & $2 \mathbf{T}$ & 30 & $3 \frac{7}{8}$ miles. \\
\hline Right chimney of brick house............. & 206 & 17 & . & $\ldots . .3 \frac{3}{4}$ miles. \\
\hline Right chimney of house............... & 240 & 12 & .. & ...... $4 \frac{1}{2} / 2$ miles. \\
\hline Chimney left of house among trees on Poplar & & & & \\
\hline Island...$\ldots \ldots \ldots \ldots \ldots \ldots \ldots \ldots \ldots \ldots$ & 278 & 26 & & ..... $33 / 4$ miles. \\
\hline
\end{tabular}
6 inches above surface of ground. 


\section{STRAIGHT.}

General locality. - Northern shore of Eastern Bay on Long Point about 21/4 miles northeast of Kent Point, $27 / 8$ miles northwest of Wades Point and $1 / 8$ mile northeast of entrance to Long Point Creek. (See Chart No. 3r.)

Immediate locality.-Observed station is in a cultivated field about 8 feet above high water, 35 yards west of edge of bank, 45 yards northwest of edge of bank near a tree, 80 yards south-southwest of fence corner, 245 yards south-southeast of fence corner at gate, and 175 yards east-southeast of woods.

Marks.-Observed station is center point of triangle on standard cement monument projecting 5 inches above surface of ground. Subsurface mark is center of 2 -inch tile pipe buried with top 2 inches below base of monument.

References.-

"Needle" ( $\left.\mathrm{N}_{4} 8^{\circ} \mathrm{I}^{\prime} \mathrm{E}\right)$

$\begin{array}{llll}\circ & \prime \prime \\ 0 & 00 & 00 & \ldots . .4 .4 \% \text { miles. }\end{array}$

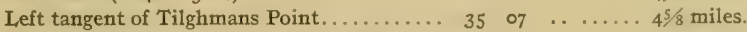

Chimney of house on Tilghmans Point Farm. . $42 \quad 27 \quad \ldots \quad \ldots .44 \frac{1}{8} 8$ miles.

"Kemp Tower"..................... $83 \quad 46 \quad 00 \ldots \ldots 27 / 8$ miles.

Nail in blaze in red oak tree (22 inches diam-

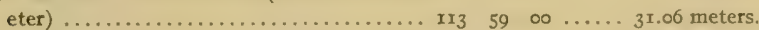

Right tangent of woods on Poplar Island... I I5 $30 \quad \ldots \quad \ldots . .53 \% 4$ miles.

Left tangent of woods on Kent Point........ I79 48 .......

South peak of building.................. 264 mile.

East peak of barn.................. $317 \quad 48 \quad \ldots \ldots \ldots 3 / 4$ mile.

South chimney of house............... 330 Io . . . . $1 / 4$ mile.

\section{MOUTH.}

General locality.-Northern shore of Eastern Bay on eastern shore of Kent Island about I $1 / 4$ miles north of Long Point, $3 \frac{5}{8}$ miles northwest of Claiborne Wharf, and $3 \frac{1}{4}+$ miles southwest of Bodkin Island. (See Chart No. 3r.)

Immediate locality. - Observed station is in a cultivated field about 8 feet above high water, ro yards west of top of a bank with uniform slope to shore, 50 yards south of a small cove, and 20 yards south of a group of cedar trees near shore.

Marks.-Observed station is center point of triangle on standard cement monument projecting 5 inches above surface of ground. Subsurface mark is center of 2 -inch tile pipe buried with top 2 inches below base of monument.

References:-

"Matta" ( $\left.5_{5}^{\circ} 49^{\prime} \mathrm{W}\right)$

South gable of barn.

gable of house ....................

Right tangent of woods on Turkey Point....

"Parsons Island Water Tank"............. 66

North gable of barn................ 74

Left tangent of woods on Tilghmans Point... ro

South chimney of house on Tilghmans

Point Farm.................... I12

"Rich Neck Water Tank" ................ I24

South gable of Claiborne Wharf house...... I37

"Kemp Tower".................... ${ }^{154}$

East chimney of Legg house............. 224

Chimney of small house. .................. 286

South gable of barn................. 342

\begin{tabular}{|c|c|c|}
\hline$\infty$ & $\infty$ & $2,2 / 41$ \\
\hline $4 I$ & . & $\ldots \ldots 4^{T} / 4$ miles \\
\hline 35 & . & $\ldots \ldots 2^{1} / 4$ mile \\
\hline 25 & $\cdots$ & … 3 miles. \\
\hline 43 & . & ..... 5 5 $5 / 8$ miles \\
\hline 49 & . & $61 / 4$ \\
\hline 05 & .. & . $4 \frac{1}{4}$ mile \\
\hline 19 & . & 4 mile \\
\hline 48 & 40 & $31 / 8$ \\
\hline $4 \mathrm{I}$ & . & $3^{T} / 2$ \\
\hline$\circ 9$ & 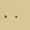 & 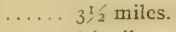 \\
\hline 59 & .. & 6 \\
\hline 35 & .. & \\
\hline & & \\
\hline
\end{tabular}




\section{MATTA.}

General locality.-Northern shore of Eastern Bay on eastern shore of Kent Island at western side of entrance to Shipping Creek about 2 miles west of Turkey Point. (See Chart No. 3r.)

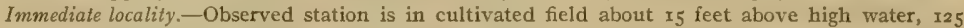
yards southwest of extreme end of point, 25 yards northwest of dry ditch, and 200 yards northwest of lone cedar tree near shore.

Marks.-Observed station is center point of triangle on standard cement monument projecting 6 inches above surface of ground. Subsurface mark is center of 2 -inch tile pipe buried with top 2 inches below base of monument.

References.-

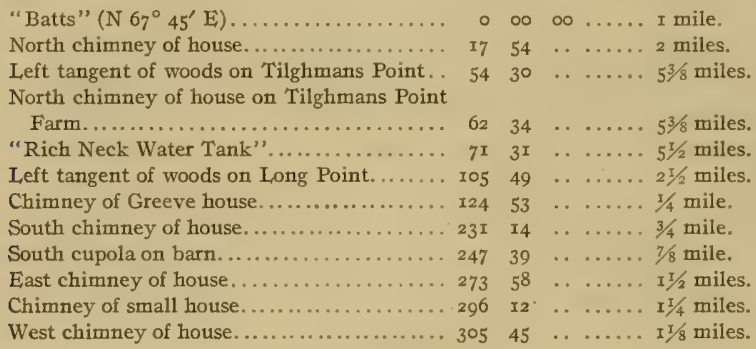

BATTS.

General locality.-Northern shore of Eastern Bay on southern end of Batts Neck between Shipping and Cox Creeks about $\mathrm{I} / 4$ miles northwest of Turkey Point. (See Chart No. $3 \mathrm{x}$.)

Immediate locality.-Observed station is in cultivated field about 2 feet above high water, 2 I yards north of shore, and 100 yards west of a wire fence extending 100 yards into bay.

Marks,-Observed station is center point of triangle on standard cement monument projecting 6 inches above surface of ground. Subsurface mark is center of 2 -inch tile pipe buried with top 2 inches below base of monument. Station "CoXES CREEK," 1899 , is 87.70 meters N $72^{\circ} 20^{\prime} \mathrm{E}$ of observed station and is marked by the center of a cross in the top of a granite post about 12 ,inches square in the rough and about 27 inches long projecting 5 inches above surface of ground. The top of the granite post is dressed to a 6-inch cube marked with a square cross and the letters U. S. Subsurface mark is center of neck of a bottle buried with top 3 inches below base of granite post.

References.--

"Turkey" (S $\left.58^{\circ} 24^{\prime} \mathrm{E}\right)$

North chimney of house on Tilghmans Point

Farm.

"Rich Neck Water Tank"................

Nail in blaze in one of twin persimmon trees

( 4 inches diameter).

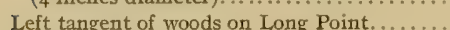

East gable of house.....................

Nail in blaze in persimmon tree ( 6 inches diameter)

South chimney of house................. 202

South chimney of house................ 242

South gable of barn................... 27

North chimney of house................. . 293

"Coxes Creek, I899" (granite post)........ 310

North chimney of house................ 34I

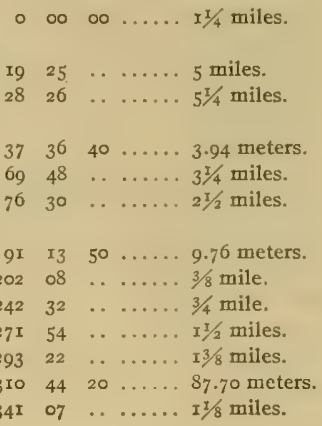




\section{TURKEY.}

General locality. - Northern shore of Eastern Bay on southern end of Cox Neck on Turkey Point about I mile west of the north end of Bodkin Island. (See Chart No. 3I.)

Immediate locality.-Observed station is in marsh meadow about 2 feet above high water, 40 yards northeast of shore, 200 yards south of a group of three pine trees near shore, and in center of triangle formed by three pine stubs driven flush with marsh to support theodolite.

Marks.-Observed station is center point of triangle on standard cement monument projecting 6 inches above surface of ground. Subsurface mark is center of 2 -inch tile pipe buried with top 2 inches below base of monument.
References.-

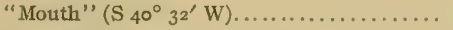
Chimney of house......................
Chimney of Greeve house.................
South cupola on barn...................
North chimney of house.................
South chimney of house................ 10
South chimney of house................. II
West pine tree of group............... I32
Right tangent of Bodkin Island. . . . . . . . 254
Left tangent of Tilghmans Point..........275
North chimney of house on Tilghmans Point

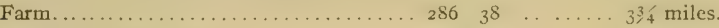
"Rich Neck Water Tank" ............. $297 \quad 25 \quad \ldots \ldots \ldots 4 \%$ miles.
Left tangent of woods on Long Point..... $35^{2} \quad 26 \quad \ldots \ldots 3$ miles.

\section{NEEDLE.}

General locality. -Northern part of Eastern Bay on Bodkin Island at entrance to Crab Alley Bay about $\mathbf{I} / 2$ miles west of the south end of Parsons Island and $\mathrm{I}$ mile east-southeast of Turkey Point. (See Chart No. 3r.)

Immediate locality.-Observed station is near south end of Bodkin Island, about Iz feet above high water, 50 yards north by west of shore, go yards northeast by east of shore, II 5 yards west-southwest of shore, and in center of radial lines of sight cut in bushes.

Marks.-Observed station is center point of triangle on standard cement monument projecting 4 inches above surface of ground. Subsurface mark is center of 2 -inch tile pipe buried with top 2 inches below base of monument.

References.-

"Straight" (S $\left.48^{\circ} \mathrm{I} 7^{\prime} \mathrm{W}\right)$.

Nail in blaze in pine tree ( 6 inches diameter).

Nail in blaze in pine tree ( 8 inches diameter)..

Right chimney of large house...........

Nail in blaze in pine tree ( 6 inches diameter). 8

Chimney of house on Parsons Island . . . . . . I94

Near chimney of Starr, large, brick house... . 262

Cupola on left barn of Tilghmans Point Farm. 289

Chimney of bungalow................ 324

$\mathrm{Nail}$ in blaze in pine tree ( 7 inches diameter). 345

$$
\begin{array}{lllll}
\prime & \prime \prime \\
\infty & \infty & \ldots & 4^{1} / 8 \text { miles. } \\
5^{1} & 30 & \ldots & 22.78 \text { meters. } \\
5^{6} & \text { 10 } & \ldots & \ldots & 17.17 \text { meters. } \\
29 & \ldots & \ldots & 3^{1} / 2 \text { miles. } \\
06 & 50 & \ldots & 11.54 \text { meters. } \\
43 & \ldots & \ldots & 21 / 8 \text { miles. } \\
54 & \ldots & \ldots & 61 / 2 \text { miles. } \\
40 & \ldots & \ldots & 3 \text { miles. } \\
57 & \ldots & \ldots & 5^{\pi} / 8 \text { miles. } \\
25 & 00 & \ldots & 18.20 \text { meters. }
\end{array}
$$

\section{COX.}

General locality.-Western shore of Crab Alley Bay on Cox Neck about 3/8 mile north of Eastern Bay and $x$ mile northwest of Bodkin Island. (See Chart No. $3 I_{1}$ )

Immediate locality.-Observed station is at edge of a cultivated field on narrow neck of land about 3 feet above high water, I6 yards west of shore, IS yards east of shore, and So yards northwest of extreme end of point. 
Marks.-Observed station is center point of triangle on standard cement monument projecting 4 inches above surface of ground. Subsurface mark is center of 2 -inch tile pipe buried with top 2 inches below base of monument.

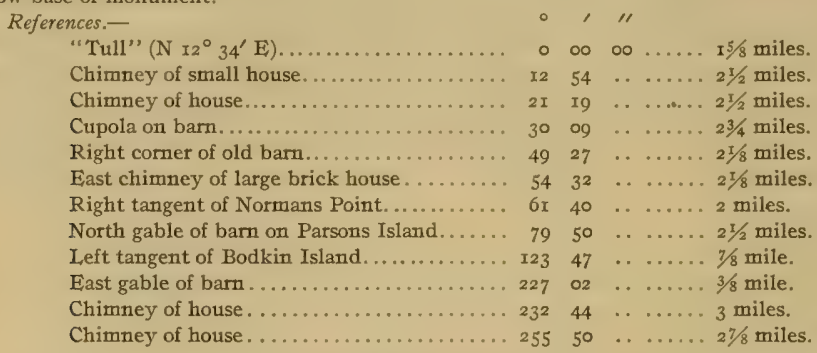

\section{RICH NECK WATER TANK.}

General locality,-On neck of land about halfway between Eastern Bay and Miles River about I3/4 miles south-southwest of Tilghmans Point. (See Charts Nos. 3 and 32.)

Immediate locality.-Observed station is on large water tank on steel tower on Rich Neck Farm. Marks.-Observed station is spindle on center of water tank.

References:-

None necessary.

\section{KEMP TOWER.}

General locality.-Southern shore of Eastern Bay on Wades Point about I mile southwest of Claiborne Wharf and $5^{1 / 8}$ miles east of Bloody Point Bar Light. (See Chart No. 3I.)

Immediate locality.-Observed station is on tower or cupola of Wades Point Hotel, which is a large, square, frame structure adjoining a brick house.

Marks.-Observed station is center of top of roof of cupola.

References.-

None necessary.

\section{KEMP.}

General locality.-Southern shore of Eastern Bay on Wades Point about I $3 / 3$ miles southwest of Claiborne Wharf and $4 \frac{7}{8}$ miles east by south of Bloody Point Bar Light. (See Chart No. 3r.)

Immediate locality.-Observed station is in cultivated land about 8 feet above high water, 30 yards east by north of a wire fence and several trees, 55 yards south-southeast of edge of bank, 90 yards eastnortheast of a bungalow, I30 yards north by west of a wire and wood fence corner, I30 yards northnorthwest of wooden fence, and 400 yards west by south of Wades Point Hotel.

Marks,-Observed station is center point of triangle on standard.cement monument projecting 6 inches above surface of ground. Subsurface mark is center of 2 -inch tile pipe buried with top 2 inches below base of monument.

References.-

"Bloody Point Bar Light" (N $\left.83^{\circ} 37^{\prime} \mathrm{W}\right) \ldots$

Nail in blaze in locust tree ( 14 inches diam.

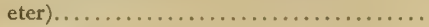

Left tangent of Kent Point..............

Chimney on middle of house.............

Left peak of barn.....................

Chimney of house . ...................

Left chimney of house................

Peak of main part of house..............

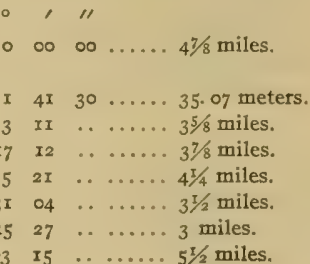


References-Continued.

- , "

Left tangent of Tilghmans Point......... I28 o6 ...... $3 \frac{1 / 2}{2}$ miles.

"Dixon" (center of house)............ $130 \quad 07 \quad 50 \ldots \ldots 27 / 8$ miles.

"Kemp Tower"................... r39 of $40 \ldots \ldots .1 / 4$ mile.

Fence corner (wood and wire) $\ldots \ldots \ldots \ldots .244 \quad 43 \quad \ldots \ldots .132$ yards.

Near corner of cook house.............. 288 40 ....... xro yards.

Nail in blaze in locust tree ( 7 inches diam-

eter).............................. $300 \quad 20 \quad 20 \ldots .23$ meters.

Right comer post of piazza............. $306 \quad 24 \quad \ldots \ldots$ go yards.

Nail in blaze in cedar tree ( 6 inches diameter). $210 \quad 43 \quad 30 \ldots \ldots 26.97$ meters.

END.

General locality.-Western shore of Harris Creek on southwestern side of entrance to Northwest Branch. (See Charts Nos. 31, 32, and 34.)

Immediate locality.--Observed station is in a cultivated field about 5 feet above high water, and 4 yards west of shore. Cement monument marking reference station is 14.76 meters $\mathrm{S} 83^{\circ} 5^{\prime} \mathrm{W}$ of observed station.

Marks.-Observed station is center of 2 -inch tile pipe projecting 5 inches above surface of ground. Reference station is center point of triangle on standard cement monument projecting 3 inches above surface of ground.

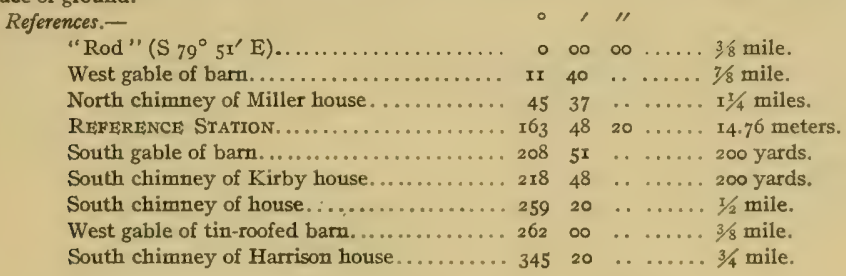

LAWN.

General locality.-Western shore of upper Harris Creek about $1 / 2$ mile south of junction of Northeast Branch and Northwest Branch. (See Charts Nos. 3r, 32, and 34.)

Immediate locality. - Observed station is in northeast corner of a lawn about 5 feet above high water, Io feet southwest of top of vertical bank washed by high water, and I 6 yards northwest of bathhouse and wharf.

Marks.-Observed station is center point of triangle on standard cement monument projecting 6 inches above surface of ground. Subsurface mark is center of 2 -inch tile pipe buried with top 2 inches below base of monument.

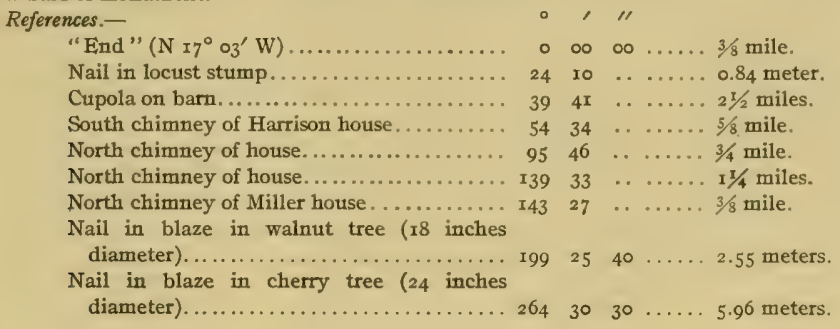




\section{PARSONS.}

General locality. - In northern side of Eastern Bay on western side of Parsons Island about 3 miles north of Tilghmans Point. (See Chart No. 32.)

Immediate locality. - Observed station is in cultivated land on highest part of island about ${ }_{5} 5$ feet above high water, IIo yards southeast of shore, 270 yards south-southwest of Parsons Island water tank, 350 yards southwest of a house, 380 yards west-southwest of a large barn, I45 yards northeast of a wire fence, I55 yards northwest of wire fence at farm road, I95 yards southeast of a fence, and on the range of the west edge of the south chimney on the lower gable of the house with the west side of a window in the center of the south side of the house. Cement monument marking reference station is 26.10 meters $\mathrm{N} 2 \mathrm{x}^{\circ} 43^{\prime} \mathrm{E}$ of observed station.

Marks.-Observed station is center of cross cut on rough granite stone about 35 inches long and 12 inches square with top cut to 6-inch cube and marked "U. S. " in lower half of cross. Subsurface mark is the mouth of a bottle 3 inches below base of monument. Reference station is center point of triangle on standard cement monument with top 5 inches above the surface of the ground.

References.-

\begin{tabular}{|c|c|c|c|c|}
\hline C. & c & 0 & & \\
\hline NCE Station & 23 & 55 & 30 & te \\
\hline ant & 24 & & 20 & \\
\hline house..... & 35 & I3 & .. & ds. \\
\hline it corner of barn... & $6 x$ & 27 & & ds. \\
\hline ee. & 148 & $I_{7}$ & & \\
\hline at farm. & $x 9^{2}$ & 07 & .. & les. \\
\hline$\ldots \ldots$ & 202 & 57 & . & \\
\hline Rig & 220 & 27 & & es. \\
\hline Point..... & 234 & 23 & .. & les. \\
\hline 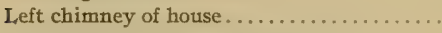 & 297 & 57 & & $\cdot 3$ \\
\hline $\mathrm{r} / 2$-story hous & $3^{14}$ & 35 & & niles. \\
\hline arge brick ho & 336 & 44 & & $\ldots \ldots$ \\
\hline Cupo & 34 & 10 & & $\ldots \ldots 2 y$ \\
\hline
\end{tabular}

\section{PARSONS ISLAND WATER TANK.}

General locality.-Northern part of Eastern Bay between Crab Alley and Prospect bays on Partons Island about half way between the north and south end of the island. (See Chart No. 32 .)

Immediate locality.-Observed station is on a water tank on wooden structure near a house.

Marks.-Observed station is center of spindle on center of water tank.

References.-

None necessary.

\section{NORMAN.}

General locality.-Eastem shore of Crab Alley Bay on southwestem extremity of Crab Alley Neck about $1 / 4$ mile west of Normans Point, 2 miles northeast of Turkey Point, and $7 / 8$ mile northwest of Parsons Island. (See chart No. 32.)

Immediate locality.-Observed station is in a cultivated field on a rapidly washing, narrow neck of land, about 6 feet above high water, 20 yards north of vertical bank at shore, 30 yards south of vertical bank at shore, and 40 yards northeast of extreme end of point.

Marks.-Observed station is center point of triangle on standard cement monument projecting 3 inches above surface of ground. Subsurface mark is center of 2 -inch tile pipe buried with top 2 inches below base of monument. 
References.-

- , I

"Parsons" (S $\left.38^{\circ} 40^{\prime} \mathrm{E}\right) . . . \ldots \ldots \ldots \ldots \ldots$.

Right tangent of Parsons Island.............

Left tangent of woods on Tilghmans Point...

Left tangent of woods on Bodkir Island.....

Right tangent of Bodkin Island .......... 7

Right tangent of woods on Turkey Point.....

Nail in blaze in hackberry tree (6 inches diameter $). . . \ldots \ldots \ldots \ldots \ldots \ldots \ldots \ldots$ II

Chimney of small house................. I5

East chimney of house............... 16

South gable of house................... 205

West chimney of large brick bouse.........271

Chimney of small house................. 292

"Parsons Island Water Tank" ............ 353

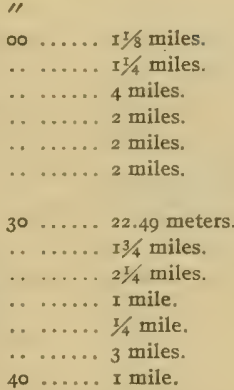

AL,LEY.

General locality.-Western shore of Prospect Bay on Crab Alley Neck, about $3 / 4$ mile north of Parsons Island, and $3 / 8$ mile north of Narrows Point. (See Chart No. 32.)

Immediate locality.- Observed station is on hard ground in a marsh at northeast end of clump of 12 persimmon trees about I foot above high water and 75 yards southwest of point.

Marks.-Observed station is center point of triangle on standard cement monument projecting 5 inches above surface of ground. Subsurface mark is center of 2 -inch tile pipe buried with top 2 inches below base of monument.

References.-

"Dull" ( $\left.\mathrm{N}_{2}^{\circ} 35^{\prime} \mathrm{W}\right)$

$\circ, 11$

Near peak of "Fishermans Inn" ..........

Nail in blaze in persimmon tree (4 inches diameter)...................... 30 4I $20 \ldots 3.99$ meters.

Left chimney of old house with two dormer windows. .................... 48 29 $\ldots \ldots \ldots 23 / 8$ miles.

Left peak of barn ................ $79 \quad 42 \ldots \ldots \ldots 23 / 4$ miles.

Left chimney of large house $\ldots \ldots \ldots \ldots \ldots \ldots x \pm 34 \quad \ldots \ldots \ldots 23 / 4$ miles.

"Parsons Island Water Tank" ......... I77 $35 \quad 30 \quad \ldots \ldots$ I 1/8 miles.

Nail in blaze in persimmon tree (3 inches diameter).................... I94 $56 \quad 00 \ldots \ldots 48$ meters.

Nail in blaze in persimmon tree $\left(2 \frac{1}{2}\right.$ inches

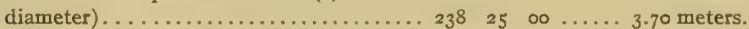

East chimney of brick house.......... 246 o2 ...... $1 / 2$ mile.

Nail in blaze in persimmon tree (3 inches diameter................................. 298 2I $30 \ldots .29$ meters.

Chimney of house among trees........... $3 x_{7} \quad 54 \quad \ldots \ldots \ldots x$ miles.

"New Barn Cupola"................. 335 4I $40 \ldots .$. I mile.

\section{BONNET}

General locality.-Eastern shore of Prospect Bay on Hood Point about I $1 / 2$ miles southeast of Hog Island and $1 / 2$ mile west of Piney Point. (See Chart No. 32.)

Immediate locality.-Observed station is on marsh ground about I foot above high water, 2I yards west of shore, 12 yards west of inlet, and 55 yards northeast of the extreme end of Hoods Point.

Marks.-Observed station is center point of triangle on standard cement monument projecting 6 inches above surface of ground. Subsurface mark is center of 2 -inch tile pipe buried with top 2 inches below base of monument. 


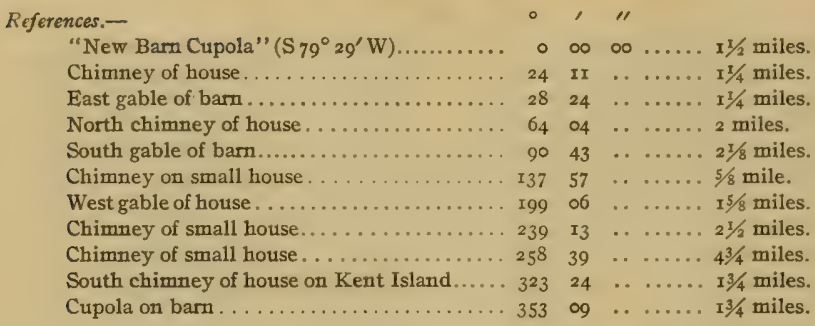

\section{BRIAN REFERENCE STATION.}

General locality.-Eastern shore of Prospect Bay on Brian Point, about I mile southeast of Piney Point, 2 miles northeast of Parsons Island, and $3 / 8$ mile west of entrance to Hog Hole Creek. (See Chart No. 32.)

Immediate locality.-Observed station is on a marsh point about I foot above high water, $\mathrm{I}_{3}$ yards east of edge of marsh, I4 yards northwest of edge of marsh, I8 yards north of extreme end of point, and 40 yards southwest of a cultivated field.

Marks.-Observed station is center point of triangle on standard cement monument projecting 4 inches above surface of ground.

References.-

\begin{tabular}{|c|c|c|c|}
\hline Green" (S $\left.8^{\circ} 55^{\prime} \mathrm{E}\right)$ & $\circ$ & & $\infty$ \\
\hline Left tangent of woods on Bennett Poi & 4 & 55 & 4 miles. \\
\hline Right tangent of woods on Parsons Island.... & 65 & 33 & niles. \\
\hline Middle chimney of large brick house. . & 84 & 37 & $2 \frac{1}{4}$ miles. \\
\hline of barn. & 102 & 34 & ailes. \\
\hline Bam Cupola"' & 109 & 56 & 20 \\
\hline Left peak of large house & 112 & 08 & $25 / 8$ miles. \\
\hline of house & $28_{2}$ & 47 & $1 / 2$ mile \\
\hline Chimney & 344 & 40 & $\ldots \ldots \ldots x x^{1 / 1} / 4$ mile \\
\hline
\end{tabular}

GREEN.

General locality.-Eastem shore of Prospect Bay on point at northern side of entrance to Greenwood Creek, about $3 \frac{1}{4}$ miles northeast of Tilghmans Point, and $23 / 4$ miles north of Bennett Point. (See Chart No. 32.)

Immediate locality. - Observed station is on a sanded marsh point about 2 feet above high water, 5 yards northwest of shore, 26 yards northeast of shore, 53 yards east by north of a point of shore, 37 yards southeast by east of a point of shore, and 105 yards south-southwest of a point of woods.

Marks.-Observed station is center point of triangle on standard cement monument projecting 5 inches above surface of ground. Subsurface mark is center of 2 -inch tile pipe buried with top 2 inches below base of monument.

References.-

\begin{tabular}{|c|c|c|c|}
\hline 'Benn"' (S $\left.0^{\circ} 45^{\prime} \mathrm{W}\right)$. & 0 & $\infty 0$ & \\
\hline of barn...... & I9 & I6 & 10 \\
\hline f wo & 52 & or & . \\
\hline 年 & II5 & 03 & 50 \\
\hline$y$ of $b$ & 124 & 42 & - \\
\hline 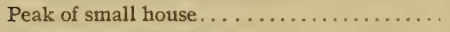 & 155 & 05 & \\
\hline t & 165 & 43 & . \\
\hline barn. & 178 & 20 & \\
\hline & 235 & 45 & \\
\hline & $3^{16}$ & or & . $\cdots$ \\
\hline - & 345 & $4 I$ & $\ldots \ldots$ \\
\hline
\end{tabular}


BENN.

General locality.-Eastern shore of Miles River on Bennett Point at western side of entrance to Wye River. (See Chart No. 32.)

Immediate locality.-Observed station is on a marsh point about $\mathrm{I}$ foot above high water, 75 yards northeast of extreme end of point, roo yards southwest from edge of wood, and in center of triangle formed by three pine stubs driven flush with marsh to support theodolite.

Marks.-Observed station is center point of triangle on standard cement monument projecting I foot above surface of ground. Subsurface mark is center of 2 -inch tile pipe buried with top 2 inches below base of monument.

\section{References.-}

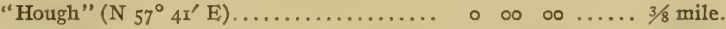

Cupola of barn........................ 70 $45 \ldots$...... I mile.

"Rich Neck Water Tank" .............. $203 \quad 33$.. ... 3 3/2 miles.

South chimney of house on Tilghmans Point

Farm........................... $21_{5} \quad 59 \ldots \ldots$ miles.

"Parsons Island Water Tank"........... 27 I $55 \quad \ldots \ldots .44 \%$ miles,

Right tangent of house.............. 288 21 $\ldots \ldots .65 / 8$ miles.

\section{HOUGH.}

General locality.-Northwestern side of entrance to Wye River on a point about $3 / 8$ mile northeast of Miles River and $1 / 2$ mile southwest of north end of Bruffs Island. (See Chart No. 32.)

Immediate locality.-Observed station is'on a grass point about I foot above high water, I6 yards north of shore, 22 yards south of shore, I 5 yards west of extreme end of point, II yards east of small pool in marsh, and 200 yards east of woods.

Marks.-Observed station is center point of triangle on standard cement monument projecting 4 inches above surface of ground. Subsurface mark is center of 2 -inch tile pipe buried with top 2 inches below base of monument.

References.-

\begin{tabular}{|c|c|c|c|}
\hline & 0 & & \\
\hline ling... & 7 & 22 & \\
\hline ney of house. & 17 & 20 & \\
\hline 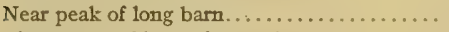 & 28 & 43 & \\
\hline house in woods.............. & 62 & 14 & $1 / 2$ \\
\hline & 128 & 24 & $3 / 4$ \\
\hline & I $8 \mathrm{I}$ & 48 & \\
\hline & & 5 & . \\
\hline$\ldots \ldots$ & 339 & 3 & \\
\hline
\end{tabular}

WON.

General locality.-Westem shore of the branch of Wye River bounding Wye Island on the west about $1 / 2$ mile northwest of northern end of Bruffs Island, and $3 / 4$ mile northeast of southern end of Bennett Point. (See Chart No. 32.)

Immediate locality.-Observed station is on small marsh point, about I foot above high water, 4 yards northwest of shore, 4 yards west of shore, 4 yards north of shore, and 40 yards southeast of large, lone, black walnut tree. Cement monument marking reference station is 22.80 meters $\mathrm{S} I 5^{\circ} 3 \mathrm{I}^{\prime} \mathrm{W}$ of observed station.

Marks,-Observed station is nail in center of 2 -inch stub projecting 5 inches above 2-inch tile pipe with top flush with surface of ground. Subsurface mark is center of 2 -inch tile pipe buried with top 2 inches below base of surface pipe. Reference station is center point of triangle on standard cement monument projecting 4 inches above surface of ground. 


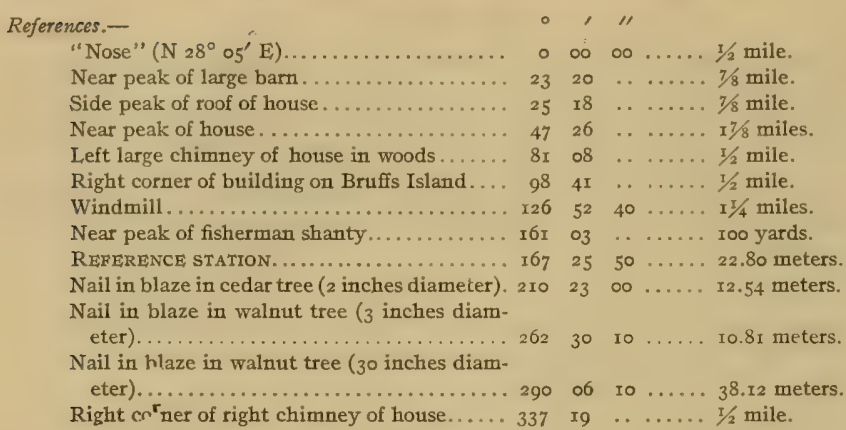

\section{NOSE.}

General locality. - Western shore of the branch of Wye River bounding Wye Island on the west on a point about $5 / 8$ mile north-northwest of Bruffs Island. (See Chart No. 32.)

Immediate locility.-Observed station is on a marsh point about $\mathbf{I}$ foot above high water, 4 yards southwest of shore. 6 yards north of shore, 14 yards west-northwest of extreme end of point, and 34 yards east of a row of lorist trees.

Marks.-Observed station is center point of triangle on standard cement monument projecting 5 inches above surface of ground. Subsurface mark is center of 2 -inch tile pipe buried with top 2 inches below base of mntument.

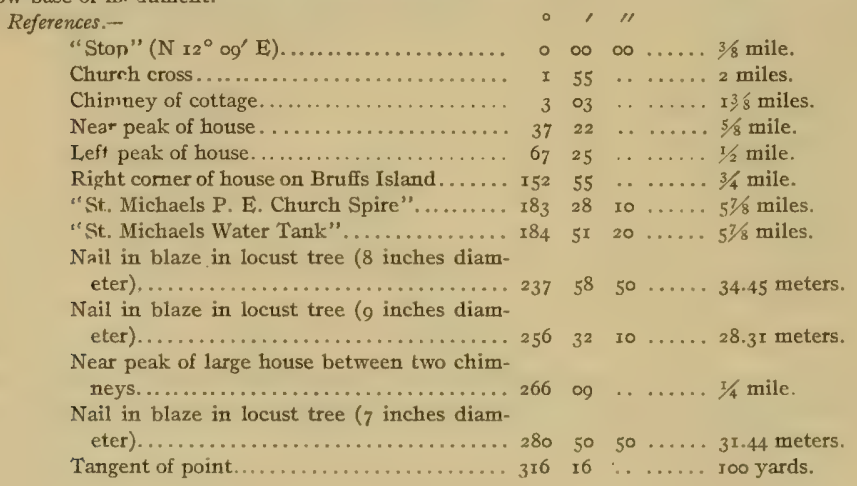

\section{SNOU'T}

General locality.-On Wye Island on the eastern shore of the branch of Wye River, bounding Wye Island on the west about $3 / 4$ mile north of Bruffs Island and $\pi / 2$ mile north of Bordley Point. (See Chart No. 32.)

Immediate locality.-Observed station is in cultivated land about 12 feet above high water, 30 yards east by south of edge of bank, 65 yards south of large cherry tree in side of bank at fence, 65 yards southwest of rail fence, 70 yards northeast of a small clump of trees at edge of bank, and 400 yards west by north of a house. 
Marks.-Observed station is center point of triangle on standard cement monument projecting 5 inches above surface of ground. Subsurface mark is center of 2 -inch tile pipe buried with top 2 inches below base of monument.

\begin{tabular}{|c|c|c|c|c|}
\hline eferences.-- & $\circ$ & & " & \\
\hline "South" (S $\left.20^{\circ} 34^{\prime} \mathrm{E}\right) \ldots \ldots \ldots \ldots \ldots \ldots \ldots \ldots \ldots \ldots \ldots$ & $\circ$ & $\infty$ & $\infty$ & $\ldots \ldots 1 / 2$ mile. \\
\hline Left peak of boat house................. & 19 & Io & .. & ..... $7 / 8$ mile. \\
\hline "St. Michaels P. E. Church Spire" . . . & $3^{8}$ & 07 & 30 & $61 / 4$ miles. \\
\hline "St. Michaels Water Tank" .............. & 39 & 30 & ro & $6 \frac{1}{8}$ miles. \\
\hline 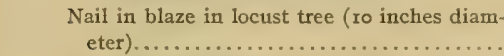 & 49 & $2 \mathrm{I}$ & 30 & 64.78 meters. \\
\hline Peak of house between two chimneys...... & 99 & 02 & . & .. $1 / 2$ mile. \\
\hline Near peak of small house............ & $\operatorname{IrI}$ & 45 & .. & $1 / 2$ mile. \\
\hline Nail in blaze in tree ( 8 inches diameter). & I79 & 42 & Io & . 34.39 mueters. \\
\hline Near peak of barn................ & 186 & 34 & .. & $I^{1 / 4}$ miles. \\
\hline Left corner of house....... & 203 & 36 & . & . I $3 / 8$ miles. \\
\hline Nail in blaze in fence post. . & 246 & 50 & Io & . 63.29 meters. \\
\hline Near peak of house.............. & 249 & $\infty$ & . & $\ldots .3 / 4$ mile. \\
\hline Left peak of house. .................... & 206 & $4 \pi$ & 50 & ..... $1 / 4$ mile. \\
\hline
\end{tabular}

SOUTH.

General locality. - On southwestern end of Wye Island on Bordley Point on the northern shore of the junction of the two branches of Wye River bounding Wye Island about 3.5 mile north-northeast of Bruffs Island. (See Chart No. 32.)

Immediate locality.-Observed station is in a pasture on a rounded point about to feet above high water, II yards northeast of edge of field, I3 yards north of edge of field, 22 yards northwest of edge of field, 30 yards southeast of cut in cliff, and 50 yards southwest of point of water bushes at gully.

Marks.-Observed station is center point of triangle on standard cement monument projecting 4 inches above surface of ground. Subsurface mark is center of 2 -inch tile pipe buried with top 2 inches below base of monument.

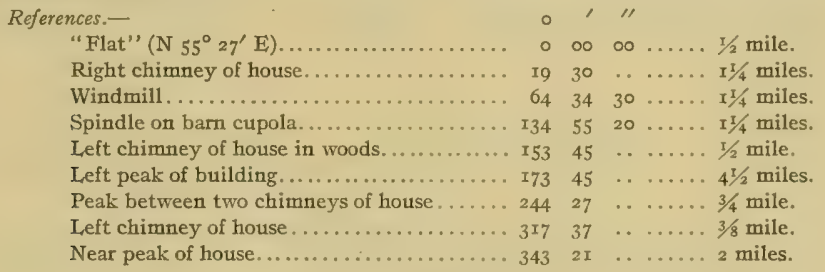

FLAT.

General locality. - On Wye Island on the northern shore of the branch of Wye River bounding Wye Island on the south on a point between two coves about I mile northeast of Bruffs Island and $1 / 2$ mile northeast of Bordley Point. (See Chart No. 32.)

Immediate locality.-Observed station is on a marsh point about I foot above high water, 8 yards north of shore, 8 yards southwest of shore, Iz yards west of extreme end of point, $x 7$ yards east of south end of line of several trees on edge of bank 3 feet high, and 45 yards east of a black gum tree 5 feet in diameter at ground.

Marks.-Observed station is center point of triangle on standard cement monument projecting 5 inches above surface of ground. Subsurface mark is center of 2 -inch tile pipe buried with top 2 inches below base of monument. 


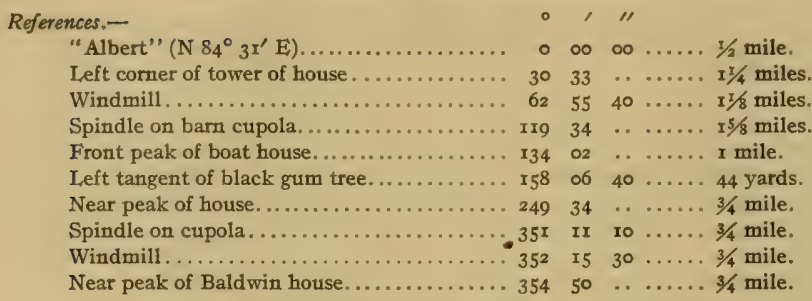

AI,BERT.

General locality.-On Wye Island on the northwestern shore of the branch of Wye River bounding Wye Island on the south on a point about $I 1 / 4$ miles east-northeast of north end of Bruffs Island, and opposite entrance to Lloyd Creek. (See Chart No. 32.)

Immediate locality.-Observed station is on a marsh point about $\mathrm{x}$ foot above high water, $\mathrm{I} 7$ yards northwest of shore, 28 yards east of shore, 35 yards south of shore, and 75 yards north-northeast of extreme end of point.

Marks.-Observed station is center point of triangle on standard cement monument projecting 5 inches above surface of ground. Subsurface mark is center of 2 -inch tile pipe buried with top 2 inches below base of monument.

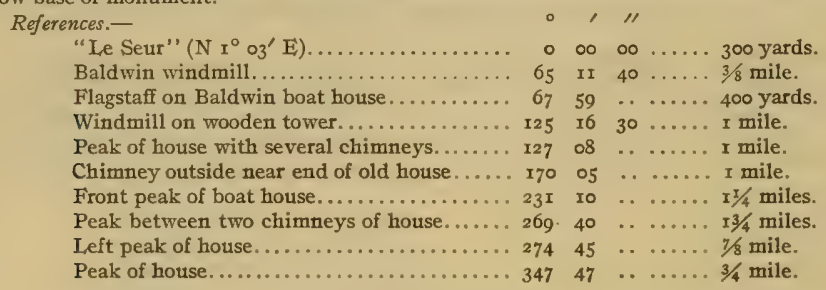

\section{LE, SEUR.}

Gencral locality.-On Wye Island on the northwestern shore of the branch of Wye River bounding Wye Island on the south about 1/8 mile north of a prominent point opposite entrance to Lloyd Creek. (See Chart No. 32.)

Immediate locality.-Observed station is in a clump of small trees about 3 feet above high water, II yards east of shore, I2 yards southwest of shore on line to next point, and 12 yards north by east of shore.

Marks.-Observed station is center point of triangle on standard cement monument projecting 5 inches above surface of ground. Subsurface mark is center of 2 -inch tile pipe buried with top 2 inches below base of monument.

References.-

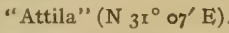

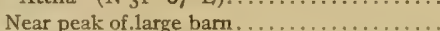

Spindle on cupola.

Right corner of chimney of Baldwin house .

Nail in blaze in walnut tree ( 4 inches diam-

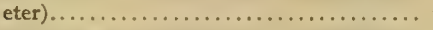

Nail in blaze in walnut tree ( 5 inches diam-

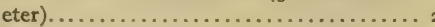

Nail in blaze in walnut tree ( 3 inches diam-

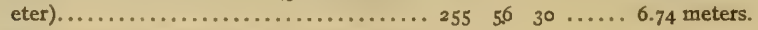

Nail in blaze in walnut tree ( 3 inches diam. eter).

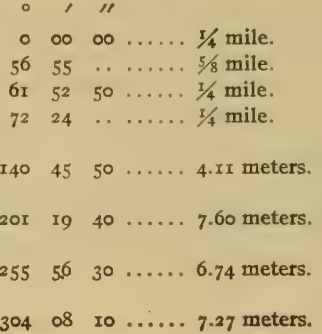




\section{ATTILA.}

General locality. - On Wye Island on the northwestern shore of the branch of Wye River bounding Wye Island on the south about $3 / 4$ mile north of entrance to Lloyd Creek at north side of entrance to a small cove. (See Chart No. 32.)

Immediate locality.-Observed station is on slope of a point about 3 feet above high water, Io yards west of shore, io yards north-northeast of shore, and II yards northwest of shore.

Marks.-Observed station is center point of triangle on standard cement monument projecting 5 inches above surface of ground. Subsurface mark is center of 2 -inch tile pipe buried with top 2 inches below base of montment.

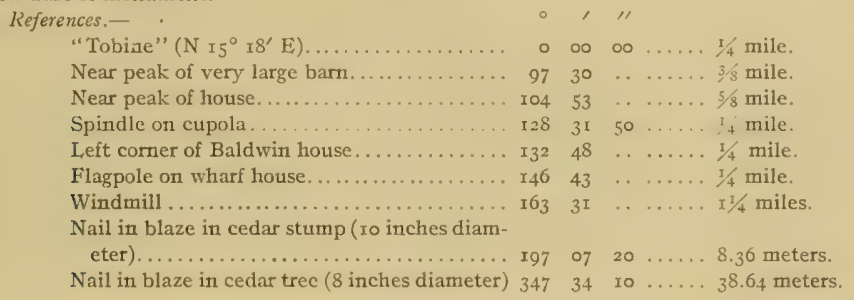

TOBINE.

General locality.--On Wye Island on the northwestern shore of the branch of Wye River bounding Wye Island on the south about $3 / 4$ mile north of entrance to I loyd Creek on point at north side of entrance to a small cove. (See Chart No. 32.)

Immediate locality.-Observed station is on point of a cultivated field about 6 feet above high water, 4 yards north of edge of field, 4 yards southwest of edge of field, 5 yards west-northwest of point of field, and $1 / 4$ mile east-southeast of a barn with cupola.

Marks.-Observed station is center point of triangle on standard cement monument projecting 5 inches above surface of ground. Subsurface mark is center of 2 -inch tile pipe buried with top 2 inches below base of monument.

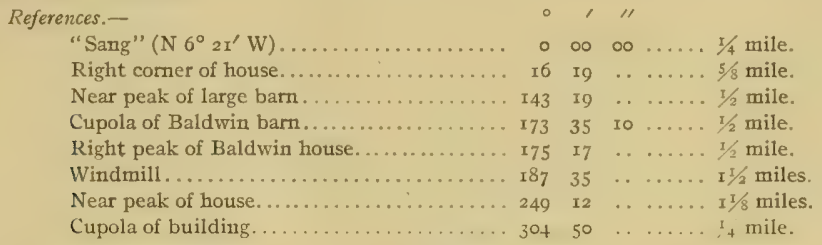

SANG.

General locality.-On Wye Island on the northwestern shore of the branch of Wye River bounding Wye Island on the south about II/4 miles north of entrance to Lloyd Creek and $5 / 8$ mile west of entrance to Dividing Creek. (See Chart No. 32.)

Immediate locality.-Observed station is on bank about $\mathrm{x} 2$ feet above high water between two cuts in bank, 2 yards west of edge of bank, 3 yards northwest of edge of bank, 4 yards southwest of edge of bank, 32 yards from bottom of northern cut in bank, $5^{2}$ yards from bottom of southern cut in bank, and 95 yards south-southwest of tree-lined gully.

Marks.-Observed station is center point of triangle on standard cement monument projecting 5 inches above surface of ground. Subsurface mark is center of 2 -inch tile pipe buried with top 2 inches below base of monument.

$53485-\mathrm{r} 2-4$ 


\begin{tabular}{|c|c|c|c|}
\hline eferences.- & & , & $\prime \prime$ \\
\hline "Turn" (N $\left.48^{\circ} \circ 8^{\prime} \mathrm{E}\right)$. & 0 & $\infty$ & ... $1 / 4$ mile. \\
\hline Tangent of woods.......... & $4 \mathrm{I}$ & 45 & 2 miles. \\
\hline Tangent of point......... & 56 & 52 & 3,8 mile. \\
\hline Right peak of large barn........ & 100 & 25 & 3/4 mile. \\
\hline Baldwin windmill............. & 121 & 06 & . $3 / 4$ mile \\
\hline Peak of near gable of Baldwin house......... & 122 & 05 & 4 mile \\
\hline Near peak of ell of house.... & I99 & 14 & . \\
\hline Left corner of house....... & 256 & $5^{6}$ & ...... mile \\
\hline Left peak of house............. & $28 \mathrm{r}$ & 53 & $\ldots \ldots \ldots r / 4 \mathrm{mil}$ \\
\hline
\end{tabular}

TURN.

General locality.-On Wye Island on the northwestern shore of the branch of Wye River bounding Wye Island on the south about $1 / 2$ mile west of entrance to Dividing Creek on point at western side of entrance to a small cove. (See Chart No. 32.)

Immediate locality.-Observed station is on bank in a cultivated field about 8 feet above high water, 5 yards northwest of edge of bank, 6 yards north of edge of bank, 7 yards west of edge of bank, 50 yards south-southwest of entrance to a small creek, and 55 yards east of a dead sycamore tree in field.

Marks.-Observed station is center point of triangle on standard cement monument projecting 5 inches above surface of ground. Subsurface mark is center of 2 -inch tile pipe buried with top 2 inches below base of monument.

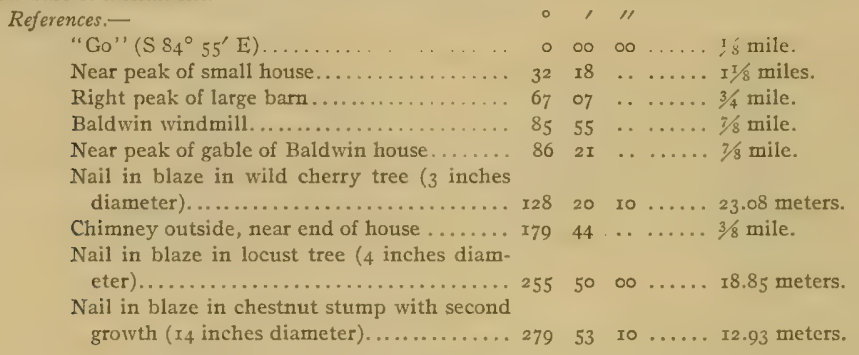

GO.

General locality.-On Wye Island on the northern shore of the branch of Wye River bounding Wye Island on the south on a point between two coves about $1 / 4$ mile west of entrance to Dividing Creek. (See Chart No. 32.)

Immediate locality.-Observed station is on grassy beach at high water, about 2 yards south of foot of bank 4 feet high covered with dense growth of young trees, and 37 yards from entrance to a small creek. Cement monument marking reference station is 19.06 meters $\mathrm{N}_{22}{ }^{\circ} 35^{\prime} \mathrm{E}$ of observed station.

Marks.-Observed station is nail in center of 2 -inch pine stub projecting 2 inches above 2 -inch tile pipe with top 2 inches below surface of ground. Subsurface mark is center of 2 -inch tile pipe buried with top 2 inches below base of surface pipe. Reference station is center point of triangle on standard cement monument projecting 4 inches above surface of ground.
References. -
"Divide" ( $\left.\mathrm{N} 89^{\circ} 24^{\prime} \mathrm{E}\right)$

$\begin{array}{rrrrrr}0 & \prime & \prime \prime & & \\ 0 & 00 & 00 & \ldots & \ldots / 8 \text { mile. } \\ 48 & 16 & \ldots & \ldots & 7 / 8 \text { mile. } \\ 51 & 46 & \ldots & \ldots & 7 / 8 \text { mile. } \\ 104 & 12 & \ldots & \ldots & 7 / 8 \text { mile. } \\ 104 & \text { I3 } & 30 & \ldots & \ldots & 7 / 8 \text { mile. }\end{array}$
Near peak of shanty ................. 48 I6 $\ldots \ldots \ldots 7 / 8$ mile,
Chimney of house................... $5^{I} \quad 46 \ldots \ldots 7 / 8$ mile.
Peak of gable on Baldwin house........ ro4 $12 \ldots \ldots .7 / 8$ mile.
Baldwin windmill.................. I04 I3 $30 \ldots \ldots$. 
References-Continued.

Near corner of square chimney of house.... I59 ro ...... $3 / 4$ mile.

Cupola on barn....................... I6 $20 \ldots \ldots .3 / 4$ mile.

Nail in blaze in gum tree ( 4 inches diameter). $249 \quad 05 \quad 50 \ldots .6 .68$ meters.

Nail in blaze in gum tree ( 2 inches diameter). 272 x6 $30 \ldots \ldots 5.73$ meters.

REFERENCE STATION....................... 293 II $20 \ldots .06$ meters.

Nail in blaze in gum tree ( 4 inches diameter). $3^{13}$ o7 $10 \ldots .4 .15$ meters.

\section{DIVIDE.}

General locality.-On Wye Island on the northern shore of the branch of Wye River bounding Wye Island on the south on point at eastern side of entrance to Dividing Creek. (See Chart No.32.)

Immediate locality.-Observed station is in point of woods about 4 feet above high water, 2 yards west-northwest of edge of bank, 8 yards east-northeast of edge of bank, and II yards north-northeast of point of bank.

Marks.-Observed station is center point of triangle on standard cement monument projecting 6 inches above surface of ground. Subsurface mark is center of 2 -inch tile pipe buried with top 2 inches below base of monument.

References.-

\begin{tabular}{|c|c|c|c|c|}
\hline Princess" & 0 & $\infty$ & 0 & le. \\
\hline Right tangent of old wharf. & I2 & 44 & & $1 / 4$ mile. \\
\hline Near peak of large barn.... & 50 & 24 & & niles. \\
\hline Chimney of house... & IfI & 53 & $\ldots$ & iile. \\
\hline Baldwin windmill.......... & 162 & 18 & 30 & I mile. \\
\hline himney of house...... & 189 & I3 & 20 & niles. \\
\hline Peak of house between two chimneys...... & 195 & 40 & . & $25 / 8$ miles. \\
\hline Nail in blaze in oak tree ( 14 inches diameter). & 232 & 30 & 30 & eter: \\
\hline $\begin{array}{l}\text { Jail in blaze in gnarled oak tree (8 inches } \\
\text { diameter) } \ldots \ldots \ldots \ldots \ldots \ldots \ldots \ldots \ldots \ldots\end{array}$ & So & 24 & 50 & \\
\hline ak tree ( 30 inches diameter). & 31 & 39 & 20 & 8 \\
\hline
\end{tabular}

\section{PRINCESS.}

General locality.-On Wye Island on the northem shore of the branch of Wye River bounding Wye Island on the south about $1 / 8$ mile northeast of entrance to Dividing Creek and $3 / 8$ mile west of entrance to Granary Creek. (See Chart No. 32.)

Immediate locality.-Observed station is in marsh land about I foot above high water, 4 yards north of shore, 18 yards east by north of a large oak tree at shore, 4 yards south of foot of bank ro feet high covered with vegetation, and ro yards west by south of a white oak tree on bank.

Marks.-Observed station is center point of triangle on standard cement monument projecting 3 inches above surface of ground. Subsurface mark is center of 2 -inch tile pipe buried with top 2 inches below base of monument.

References.-

"Philip" ( $\left.\mathrm{S} 83^{\circ} \circ 5^{\prime} \mathrm{E}\right)$

.

Right peak of large barn .............. II0

Baldwin windmill................... I2I

Cupola of Baldwin stable............... I2

Nail in blaze in white oak tree ( 3 inches diam-

eter)........................ $16_{3} \quad 26$ o $\ldots \ldots .65$ meters.

Nail in blaze in cedar tree ( $\mathrm{I}_{4}$ inches diam-

eter).....................

Right tangent of old wharf ............. 35 I I9 . .... $55^{\circ}$ yards. 
PHILIP.

General locality.-On Wye Island on the northern shore of the branch of Wye River bounding Wye Island on the south on western side of entrance to Granary Creek and $1 / 2$ mile east of entrance to Dividing Creek. (See Chart No. 32.)

Immediate locality.-Observed station is about I foot above high water, 3 yards north of shore, 9 yards south-southwest of shore of creek, 9 yards west of extreme end of point, and 6 yards southeast of point of bank 4 feet high. Cement monument marking reference station is 4.62 meters $\mathrm{N} 18^{\circ} 12^{\prime} \mathrm{E}$ of observed station.

Marks.-Observed station is nail in center of 2 -inch cedar stub projecting 2 inches above 2 -inch tile pipe with top flush with surface of ground. Subsurface mark is center of 2 -inch tile pipe buried with top 2 inches below base of surface pipe. Reference station is center point of triangle on standard cement monument projecting 4 inches above surface of ground.

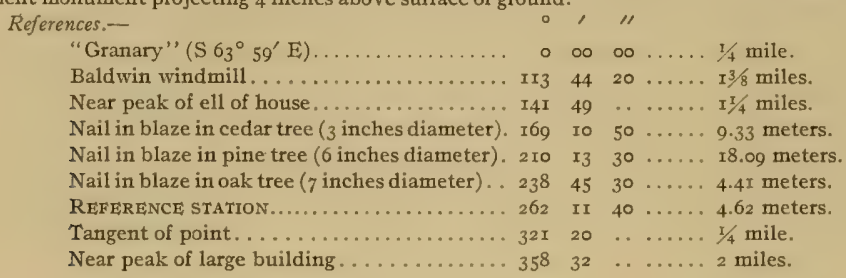

\section{GRANARY.}

General locality.-On Wye Island on the northern shore of the branch of Wye River bounding Wye Island on the south on point at eastern side of entrance to Granary Creek. (See Chart No. 32.)

Immediate locality.-Observed station is among water bushes on marsh land, about I foot above high water, ro yards northeast of shore, II yards west of shore, I2 yards north by west of extreme end of point, and 50 yards from trees.

Marks.-Observed station is center point of triangle on standard cement monument projecting 4 inches above surface of ground. Subsurface mark is center of 2 -inch tile pipe buried with top 2 inches below base of monument.

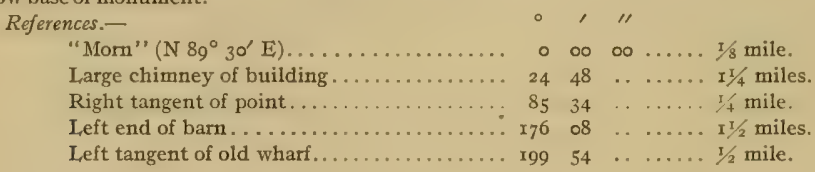

\section{MORN.}

General locality.-On Wye Island on the northern shore of the branch of Wye River bounding Wye Island on the south, about 300 yards east of entrance to Granary Creek and $3 / 4$ mile northwest of entrance to Pickerings Creek. (See Chart No. 32.)

Immediate locality.-Observed station is about I foot above high water, 4 yards northwest of shore, 4 yards northeast of shore, and 6 yards southeast of foot of wooded slope to field 12 feet above high water. Cement monument marking reference station is 3.82 meters $\mathrm{N} 33^{\circ} 52^{\prime} \mathrm{W}$ of observed station.

Marks.-Observed station is nail in center of 2 -inch cedar stub projecting 2 inches above 2 -inch tile pipe with top flush with surface of ground. Subsurface mark is center of 2 -inch tile pipe buried with top 2 -inches below base of surface pipe. Reference station is center point of triangle on standard cement monument projecting 4 inches above surface of ground. 


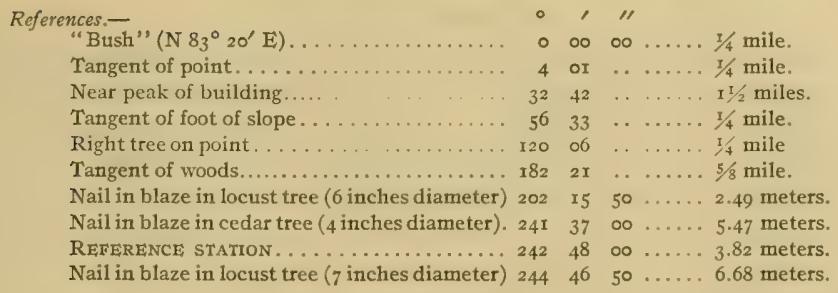

BUSH.

General locality.-On Wye Island on the northern shore of the branch of Wye River bounding Wye Island on the south on north side of entrance to a small cove, about $1 / 2$ mile east of entrance to Granary Creek and $5 / 8$ mile northwest of entrance to Pickerings Creek. (See Chart No. 32.).

Immediate locality.-Observed station is in cultivated land, about 7 feet above high water, 4 yards northeast of edge of bank, 9 yards northwest of point of curve of land, 22 yards west of tangent of land at tree, 30 yards west-northwest of scattering trees, and 50 yards northwest of a point.

Marks.-Observed station is center point of triangle on standard cement monument projecting 5 inches above surface of ground. Subsurface mark is center of 2 -inch tile pipe buried with top 2 inches below base of monument.

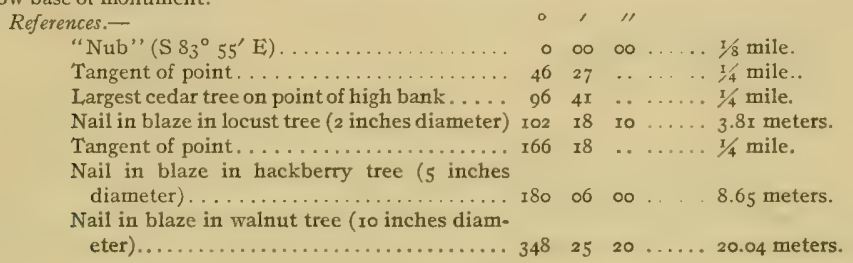

NUB.

General locality.-On Wye Island on the northern shore of the branch of Wye River bounding Wye Island on the south on eastern side of entrance to a creek about $5 / 8$ mile east of entrance to Granary Creek and $1 / 2$ mile north of entrance to Pickerings Creek. (See Chart No. 32.)

Immediate locality.-Observed station is on a marsh point about I foot above high water, 2 yards east of shore, 20 yards southwest of shore, 45 yards west of shore, 20 yards south of extreme end of point, and 16 yards north-northwest of woods. Cement monument marking reference station is 15. Io meters $\mathrm{N} 83^{\circ}$ or $\mathrm{E}$ of observed station.

Marks.-Observed station is nail in center of 2 -inch cedar stub set in 2-inch tile pipe with top flush with surface of ground. Subsurface mark is center of 2 -inch tile pipe buried with top 2 inches below base of surface pipe. Reference station is center point of triangle on standard cement monument projecting 5 inches above surface of ground.

References. -

"Wheel" ( $\left.\mathrm{S}_{4}^{\circ} \mathrm{ro}^{\prime} \mathrm{E}\right)$

Chimney on house.

Largest cedar on point of high bank.

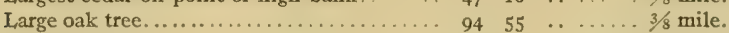

Large oak tree....................... I43 $43 \ldots \ldots . . .1 / 8$ mile.

Large oak tree........................... 226 I7 $\ldots \ldots$ yards.

REFERENCE STATION.................... 267 II $20 \ldots$ I0 meters.

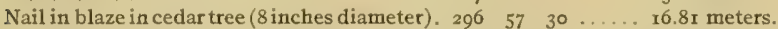

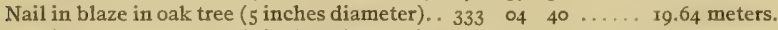

$\mathrm{Nail}$ in blaze in oak tree ( 4 inches diameter). . $\begin{array}{lllll}349 & 37 & 20 & \ldots \ldots & 20.87 \text { meters. }\end{array}$ 


\section{WHEEL.}

General locality.-On Wye Island on the northern shore of the branch of Wye River bounding Wye Island on the south on a point about $5 / 8$ mile southeast by east of entrance to Granary Creek and $1 / 2$ mile northwest of entrance to Pickerings Creek. (See Chart No. 32.)

Immediate locality.-Observed station is on marsh point south of woods, about $\mathrm{I}$ foot above high water, 2 yards east of shore, 4 yards southeast of point at slight cut in marsh, and 40 yards north of square point of shore. Cement monument marking reference station is 5.26 meters $\mathrm{S} 86^{\circ} 47^{\prime} \mathrm{E}$ of observed station.

Marks.-Observed station is nail in center of 2 -inch cedar stub set in 2 -inch tile pipe projecting 3 inches above surface of ground. Subsurface mark is center of 2 -inch tile pipe buried with top 2 inches below base of surface pipe. Reference station is center point of triangle on standard cement monument projecting 5 inches above surface of ground.

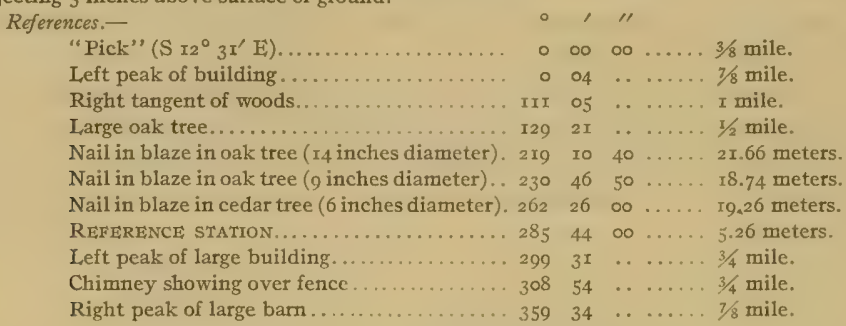

PICK.

General locality.-Southern shore of the branch of Wye River bounding Wye Island on the south on western side of entrance to Pickerings Creek. (See Chart No. 32.)

Immediate locality.-Observed station is in cultivated land about I feet above high water, 25 yards southwest of edge of field at line of cedar trees, 22 yards west of gully, 40 yards south-southeast of a small clump of trees beyond small gully, and 300 yards east-southeast of fringe of cedar trees along edge of field northeast to east of gully.

Marks.-Observed station is center point of triangle on standard cement monument projecting 6 inches above surface of ground. Subsurface mark is center of 2 -inch tile pipe buried with top 2 inches below base of monument.

References.-

"Comer" (N $\left.77^{\circ} 40^{\prime} \mathrm{W}\right)$.

Nail in blaze in cherry tree $(6$ inches diameter)..........................

Left peak of barn.................... ${ }_{58}$

Front peak of housc................. I0

Nail in blaze in cedar tree ( 6 inches diameter). I 10

Nail in blaze in cedar tree ( 6 inches diameter). 134

Near peak of house................. $I_{52}$.

Nail in blaze in hackberry tree ( 5 inches

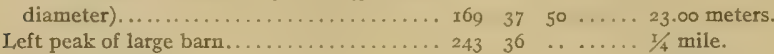

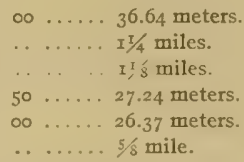




\section{CORNER (Wye River).}

General locality.-Southern shore of the branch of Wye River bounding Wye Island on the south about $I / 4$ mile west of entrance to Pickerings Creek. (See Chart No. 32.)

Immediate locality.-Observed station is in cultivated land about $5_{5}$ feet above high water, 50 yards southwest of edge of bank, 55 yards south of gully, 70 yards north-northwest of trees in depression, and r2o yards west of point of bank.

Marks.-Observed station is center point of triangle on standard cement monument projecting 6 inches above surface of ground. Subsurface mark is center of 2 -inch tile pipe buried with top 2 inches below base of monument.

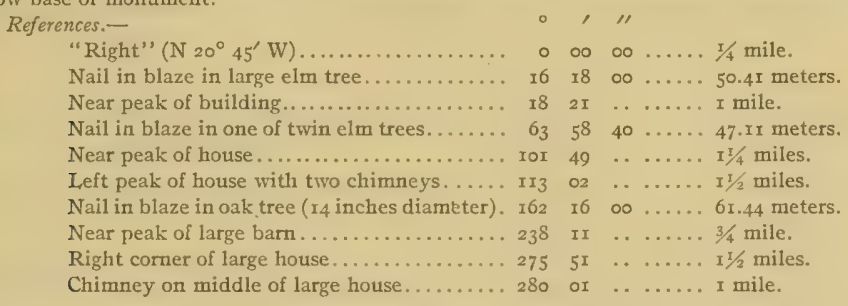

\section{RIGHT.}

General locality.-Southern shore of the branch of Wye River bounding Wye Island on the south on a point about $1 / 2$ mile soutneast of entrance to Granary Creek and $1 / 2$ mile northwest of entrance to Pickerings Creek. (See Chart No. 32.)

Immediate localily.-Observed station is in tree-fringed cultivated land about ${ }_{5}$ feet above high water, 7 yards south of edge of bank, 9 yards from point of bank at path, 5 yards northwest of edge of bank, and 120 yards east of fence in depression.

Marks.-Observed station is center point of triangle on standard cement monument projecting 5 inches above surface of ground. Subsurface mark is center of 2 -inch tile pipe buried with top 2 inches below base of monument.

References.-

"Chew" ( $\left.7 x^{\circ} 45^{\prime} \mathrm{W}\right)$.

Neft chimey of long house in woods........

Nail in blaze in cedar tree ( 8 inches diameter)

Left one of two large chimneys showing over

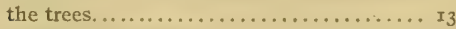

Left corner of building............... I6s ${ }_{32} \ldots \ldots$ I mile.

Nail in blaze in hickory tree (Io inches diameter) $\ldots \ldots \ldots \ldots \ldots \ldots \ldots \ldots \ldots \ldots \ldots \ldots$ I82 $29 \quad 40 \ldots \ldots$ I0.80 meters.

Nail in blaze in elm tree (ro inches diam-

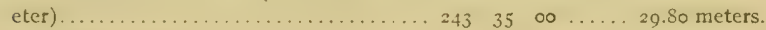

Right peak of house................. $269 \quad 37 \quad \ldots \ldots \ldots .1 / 2$ mile.

Windmill to right of two large cupolas.... 287 I2 $\ldots \ldots .5 / 8$ mile.

CHEW.

General locality. - Suthern shore of the branch of Wye River bounding Wye Island on the south ahout 3 s mile southeast of entrance to Granary Creek and s s mile west-north west of entrance to Pickerings Creek. (See Chart No. 32.)

Immediate locality.-Observed station is on marsh point about $\mathrm{I}$ foot above high water, 6 yards northeast of foot of bank 12 feet high, 12 yards west of point of shore, and Io yards northwest of shore.

Marks.-Observed station is center point of triangle on standard cement monument projecting 2 inches above surface of ground. Subsurface mark is center of 2 -inch tile pipe buried with top 2 inches below base of monument. 


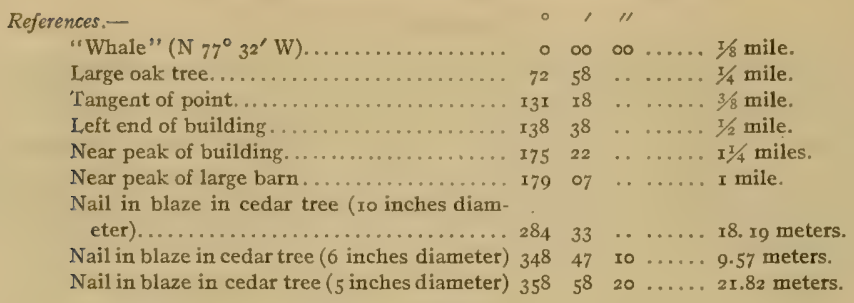

WHALE.

General locality.- Southern shore of the branch of Wye River bounding Wye Island on the south on a point at western side of entrance to a small cove about ' + mile south of entrance to Granary Creek. (See Chart No, 32.)

Immediate locality.-Observed station is on a sand-and-grass point about 2 feet above high water, 2 yards south-southeast of shore, 4 yards west-northwest of shore, 9 yards southwest of extreme end of point, and 7 yards east by north of foot of a terraced bank about I 5 feet high.

Marks.-Observed station is center point of triangle on standard cement monument projecting 5 inches above surface of ground. Subsurface mark is center of 2 -inch tile pipe buried with top 2 inches below base of monument.

References.-

"Matter" (N. $\left.77^{\circ} 0^{\prime} \mathrm{W}\right) \ldots \ldots \ldots \ldots \ldots \ldots$......... 0 . 00 . $00 \ldots$ mile.

Near peak of larger barn............... $52 \quad 33 \quad \ldots \ldots \ldots 3 / 4$ mile.

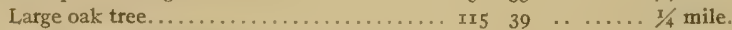

Near corner of building............... I75 $40 \ldots \ldots \ldots$ x $\ldots \ldots$ miles.

Near peak of large barn............... $x_{7} 8 \quad 45 \quad \ldots \ldots \ldots .1 / 2$ miles.

Nail in blaze in cedar tree (Io inches diam-

eter)........................... 286 o6 $30 \ldots .40$ meters.

Nail in blaze in cedar tree ( 7 inches diameter) $309 \quad 33$ Io ....5.50 meters.

Nail in blaze in cedar tree ( 5 inches diameter) $3{ }^{15} \quad 23 \quad 40 \ldots .9949$ meters.

\section{MATTER.}

General locality.- Southem shore of the branch of Wye River bounding Wye Island on the south about $3 / 8$ mile east-southeast of entrance to Dividing Creek and $3 / 8$ mile west-southwest of entrance to Granary Creek. (See Chart No. 32.)

Immediate locality.-Observed station is on small grassy point about I foot above high water, 3 yards south of shore, and 2 yards north of foot of tree-fringed bank 5 feet high. Cement monument marking reference station is 8.58 meters $\mathrm{S} 0^{\circ} 32^{\prime} \mathrm{E}$ of observed station.

Marks.-Observed station is nail in center of 2 -inch cedar stub set in 2 -inch tile pipe with top flush with surface of ground. Subsurface mark is center of 2 -inch tile pipe buried with top 2 inches below base of surface pipe. Reference station is center point of triangle on standard cement monument projecting 5 inches above surface of ground.

References.-

"Deck" (N $78^{\circ}$ o5' W)

Left tangent of wharf................. 6

Nail in blaze in cedar tree ( 14 inches diameter).

204 10 $50 \ldots, 2.3 \times$ meters.

REFERENCE STATION................... $257 \quad 32 \quad 20 \ldots \ldots .58$ meters.

Nail in blaze in one of twin cedar trees ( 8 inches diameter).................... $276 \quad 33$ 10 $\ldots .72$ meters.

Nail in blaze in cedar tree ( 8 inches diameter) $305 \quad 43 \quad 30 \ldots \ldots 2.42$ meters. 


\section{DECK.}

General locality.-Southern shore of the branch of Wye River bounding Wye Island on the south on a point about $1 / 2$ mile southeast of entrance to Dividing Creek. (See Chart No. 32.)

Immediate locality.-Observed station is at edge of water bushes on a grass point about I foot above high water, 4 yards south of shore, ro yards west of a round point, 20 yards east of shore, and 30 yards north of shore.

Marks.-Observed station is center point of triangle on standard cement monument projecting 5 inches above surface of ground. Subsurface mark is center of 2 -inch tile pipe buried with top 2 inches below base of monument.

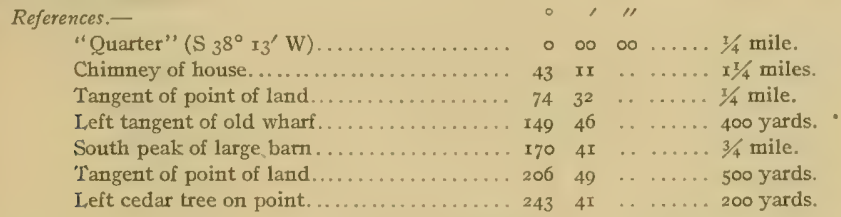

QUARTER.

General locality.-Southern shore of the branch of Wye River bounding Wye Island on the south about $3 / 8$ mile south-southeast of entrance to Dividing Creek and at east side of entrance to a cove. (See Chart No. 32.)

Immediate locality.-Observed station is on bank in a cultivated field about iz feet above high water, 2 yards southeast of edge of bank, roo yards south of trees and break in bluff, and I20 yards north of edge of bank at point.

Marks.-Observed station is center point of triangle on standard cement monument projecting 3 inches above surface of ground. Subsurface mark is center of 2 -inch tile pipe buried with top 2 inches below base of monument.

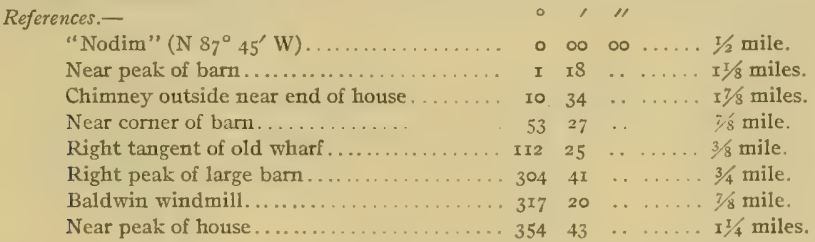

\section{NODIM.}

General locality.-Southeastern shore of the branch of Wye River bounding Wye Island on the south about $3 / 8$ mile southwest of entrance to Dividing Creek. (See Chart No. 32.)

Immediate locality. - Observed station is in cultivated land about 4 feet above high water, 4 yards south of shore, 8 yards southeast of shore, 25 yards southwest of shore of marsh, and 13 yards south of corner of marsh.

Marks.-Observed station is center point of triangle on standard cement monument projecting 5 inches above surface of ground. Subsurface mark is center of $z$-inch tile pipe buried with top $z$ inches below base of monument.

References.-

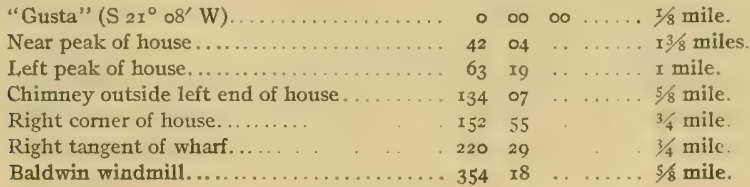




\section{GUSTA.}

General locality. - Southeastern shore of the branch of Wye River bounding Wye Island on the south about $7 / 8$ mile north-northeast of entrance to Lloyd Creek. (See Chart No. 32.)

Immediate locality.-Observed station is in a cultivated field about to feet above high water, 8 yards east of edge of bank, 12 yards southeast of edge of bank, 17 yards northeast of edge of bank, 35 yards north-northeast of a depression, and 65 yards southwest of end of cut in bank.

Marks.-Observed station is center point of triangle on standard cement monument projecting 5 inches above surface of ground. Subsurface mark is center of 2 -inch tile pipe buried with top 2 inches below base of monument.

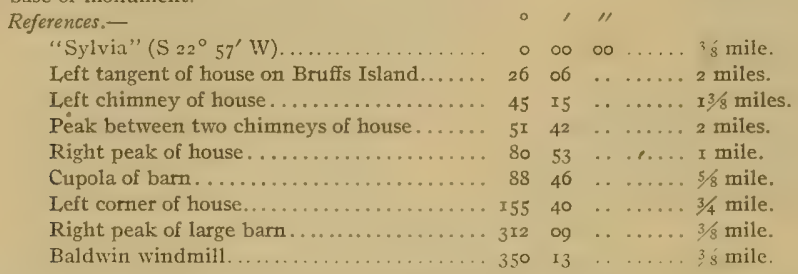

SYLVIA.

General locality.--Southeastern shore of the branch of Wye River bounding Wye Island on the south on second prominent point north of entrance to Lloyd Creek. (See Chart No. 32.)

Immediate locality.-Observed station is in a cultivated field about ro feet above high water, II yards east by south of edge of bluff, 22 yards northeast of lone locust tree 2 feet in diameter at the edge of the bank, and 400 yards northwest of a large barn.

Marks.-Observed station is center point of triangle on standard cement monument projecting 5 inches above surface of ground. Subsurface mark is center of 2 -inch tile pipe buried with top 2 inches below base of monument.

\section{References.-}

"Baldwins" ( $\left.27^{\circ} \mathrm{x}^{\prime} \mathrm{W}\right) \ldots \ldots \ldots \ldots \ldots \ldots$

Nail in blaze in locust tree $(24$ inches diam-

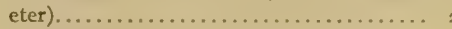

Very large lone tree.................. 4

Nail in blaze in locust tree ( 6 inches diameter)

Left peak of barn..................... 73

Cupola of building.................. 10

Near peak of large house.............. I56

Near peak of large barn............... 273

Baldwin windmill.................. 334

Peak of near gable of Baldwin house ....... 336

Spindle on cupola.................. 336

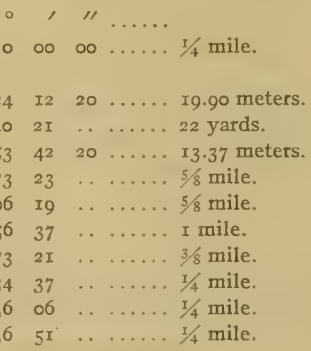

\section{BALDWINS.}

General locality.-Southeastern shore of the branch of Wye River, bounding Wye Island on the south on a point about $3 / 8$ mile north of entrance to Lloyd Creek. (See Chart No. 32.)

Immediate locality.-Observed station is on a short, sharp point of marsh about roo yards north of a yacht landing, 7 yards northeast of shore, 10 yards southeast of shore, 12 yards east of extreme end of point, and 8 yards west of foot of bank 8 feet high.

Marks.-Observed station is center point of triangle on standard cement monument projecting 4 inches above surface of ground. Subsurface mark is center of 2 -inch tile pipe buried with top 2 inches below base of monument. 
References.-

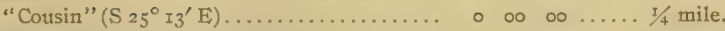

Flagstaff on yacht-landing house . . . . . . . II 27 . . . . . I00 yards.

Windmill . . . . . . . . . . 27 tt . . . I's miles.

Left peak of bell cupola.............. $27 \quad 55 \quad \ldots \ldots \ldots$ I $1 / 3$ miles.

Spindle on barn ctpola. ............. $66_{2} \quad 53 \quad \ldots \ldots \ldots 2$ miles.

Front peak of boathouse on Bruffs Island... 77 5I $\ldots \ldots \ldots x+\ldots$ miles.

Near corner of left chimney of house...... xII $37 \quad \ldots \ldots \ldots 3 / 4$ mile.

Near peak of barn with cupola.......... I75 $20 \quad \ldots \ldots .5 / 8$ mile.

Near peak of barn................... 215 I mile.

Nail in blaze in cedar tree ( 6 inches diam-

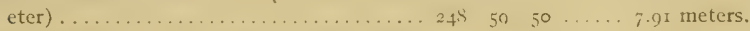

Nail in blaze in locust tree ( 5 inches diam-

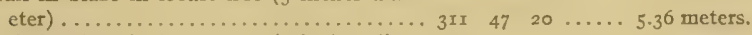

Nail in blaze in locust tree (4 inches diam-

eter).......

.. $32+$ of $50 \ldots \ldots$ I3.45 meters.

\section{COUSIN.}

General locality. - Southeastern shore of the branch of Wye River bounding Wye Island on the south, about $I^{1} / 2$ miles east-northeast of north end of Bruffis Island and at northern side of entrance to Lloyd Creek. (See Chart No. 32.)

Immediale locality.-Observed station is in a pasture about 9 feet above high water, 25 yards east of edge of bank, 65 yards south-southeast of a small clump of trees in bottom land, 65 yards north of trees, 60 yards notth of edge of a field, and 200 yards south of a house.

Marks.- Observed station is center point of triangle on standard cement monument projecting 5 inches above surface of ground. Subsurface mark is center of 2 -inch tile pipe buried with top 2 inches below base of monument.

References.-

"Lloyd" ( $\left.36^{\circ} \mathrm{o}^{\prime} \mathrm{W}\right) \ldots \ldots \ldots \ldots \ldots \ldots \ldots$. o

Spindle on barn cupola.............. 8 . 84 50.... 2 miles.

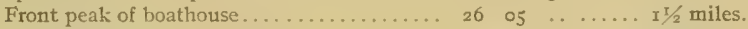

Left peak of house................... $\sigma_{3} \quad I_{3} \ldots \ldots \ldots .1 / 8$ miles.

Chimney of house................. gI $^{I} 3^{I} \ldots \ldots \ldots 3 / 4$ mile.

Peak of near gable of Baldwin house...... I35 $42 \quad \ldots \ldots 200$ yards.

Windmill on large barn............... I87 of $\ldots \ldots \ldots 1 / 4$ mile.

Right peak of house ................. 209 $44 \ldots \ldots 350$ yards.

Left peak of bell cupola.............. $333 \quad 34 \quad \ldots \ldots$ I mile.

Windmill...................... 334 mile.

I,LOYD.

General locality, - Southern shore of the branch of Fast Wye River bounding Wye Island on the south, at westem side of entrance to Lloyd Creek. (See Chart No. 32.)

Immediate locality.-Observed station is in cultivated land about 12 feet above high water, 70 yards southwest of edge of bank, 65 yards south of edge of bank, 65 yards north-northeast of point of woods and bottom land, and I2o yards northwest of an oak tree.

Marks.-Observed station is center point of triangle on standard cement monument projecting 5 inches above surface of ground. Subsurface matk is center of 2 -inch tile pipe buried with top 2 inches below base of monument.

References. -

"Edwards" ( $\left.\mathrm{N} 84^{\circ} \mathrm{o2^{ \prime }} \mathrm{W}\right) \ldots \ldots \ldots \ldots \ldots$

Near peak of house.................

Left peak of barn. . . . . . . . . . . . . . . 5

Near peak of house. ................. 76

Peak of near gable of Baldwin house . . . . . . . Io

Near peak of barn. . . . . . . . . . . . . . . . 122

Right peak of large house . . . . . . . . . . . I32

Large oak tree.................... 208

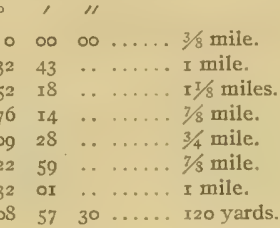




\section{EDWARD.}

General locality.-Southern shore of the branch of Wye River bounding Wye Island on the south on it point at eastern side of entrance to Shaw Bay, about $3 / 4$ mile east-northeast of north end of Bruffs Island and $3 / 3$ mile west of entrance to Lloyd Creek. (See Chart No.32.)

Immediate localily.-Observed station is in cultivated land about 8 feet above high water, 8 yards southeast of edge of a bluff which is washing away, and 30 yards southwest of a line of large trees at edge of bank and field.

Marks.-Observed station is center point of triangle on standard cement monument projecting 5 inches above surface of ground. Subsurface mark is center of 2 -inch tile pipe buried with top 2 inches helow base of monument.

References.-

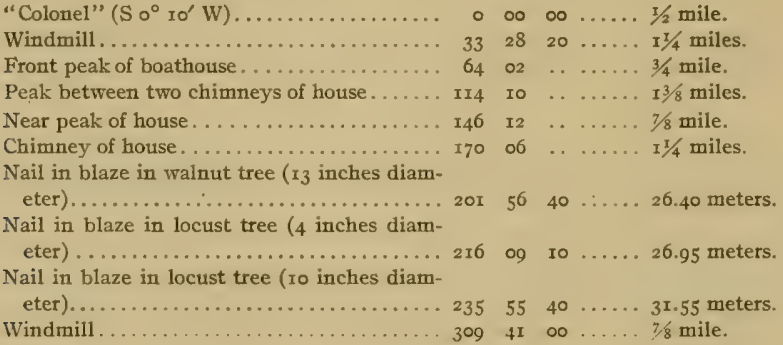

\section{COLONEL.}

General locality. - Southern shore of Shaw Bay on a point at entrance to a small cove about $1 / 2$ mile from the branch of Wye River bounding Wye Island on the south and 5 s mile east of Bruffs Island. (See Chart No. 32.)

Immediate locality.-Observed station is in a field about no feet above high water, 6 yards southeast of edge of bank which is washing away, 9 yards south-southwest of point of bank, and 3 yards west of top of bank lined with cedar, walnut, and oak trees. Cement monument marking reference station is I8.69 meters $\mathrm{S} 24^{\circ} 06^{\prime} \mathrm{E}$ of observed station.

Marks.-Observed station is nail in center of 2 -inch stub projecting 4 inches above 2 -inch tile pipe with top flush with surface of ground. Subsurface mark is center of 2 -inch tile pipe buried with top 2 inches below base of surface pipe. Reference station is center point of triangle on standard cement monument projecting 4 inches above surface of ground.

References.-

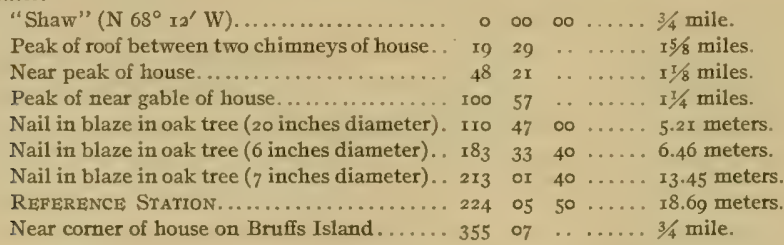

SHAW.

General locality. - Southern shore of entrance to the branch of Wye River bounding Wye Island on the south on norchern end of Bruffs Island about 3 ; mile southwest of Bordley Point. (See Chart No. 32.)

Immediate locality.-Observed station is in walnut, pine, and cedar woods, about I5 feet above high water, 7 yards southwest of edge of bank, and roo yards north-northwest of a house. 
Marks.-Observed station is center point of triangle on standard cement monument projecting 4 inches above surface of ground. Subsurface mark is center of 2 -inch tile pipe buried with top 2 inches below base of monument.

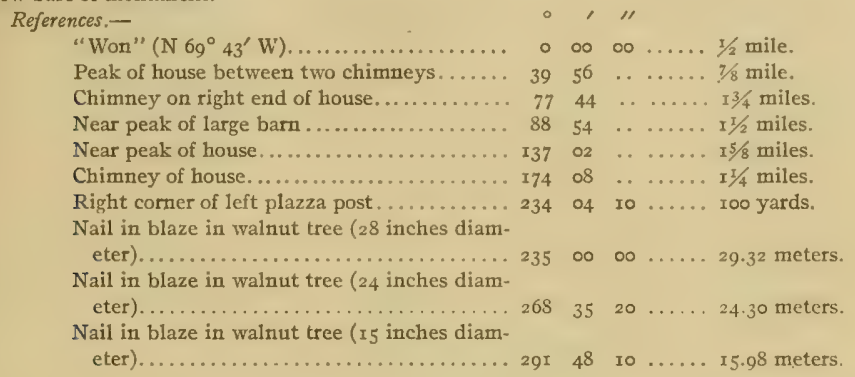

\section{BRUFFS.}

General locality.-Eastern shore of Wye River on norihwest point of Bruffs Island about 7/8 mile northeast of Bennett Point and $1 / 2$ mile southwest of Bordley Point. (See Chart No. 32.)

Immediale locality.-Observed station is on a marsh point about I foot above high water, ro yards east of shore, 14 yards southwest of shore, 20 yards southeast of point of marsh, and 18 yards west of point of woods.

Marks.-Observed station is center point of triangle on standard cement monument projecting 7 inches above surface of ground. Subsurface mark is center of 2 -inch tile pipe buried with top 2 inches below base of monument.

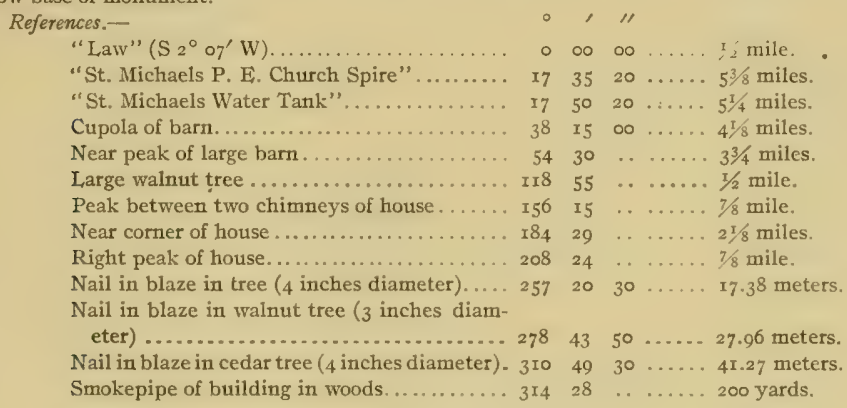

\section{L,AW.}

General locality.-Southeastern shore of Wye River about $3 / 4$ mile east of Bennett Point and $3 / 8$ mile southwest of south end of Bruffs Island. (See Chart No. 32.)

Immediate locality.-Observed station is in cultivated land about is feet above high water, 8 yards southeast of edge of a bluff, 45 yards southwest of a wire fence, roo yards northeast of a clump of trees, and 150 yards northwest of a black walnut tree at edge of field.

Marks.-Observed station is center point of triangle on standard cement monument projecting 4 inches above surface of ground. Subsurface mark is center of 2 -inch tile pipe buried with top 2 inches below base of monument. 


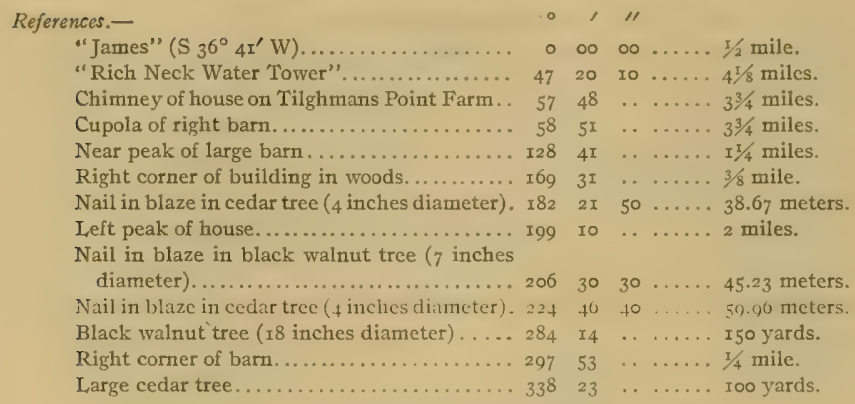

\section{JAMES (MILES RIVER).}

General locality.-Eastem shore of Miles River at southern side of entrance to Wye River, about $5 / 8$ mile southwest of Bruffs Island and $5 / 8$ mile southeast of Bennett Point. (See Chart No. 32.)

Immediate locality.-Observed station is in a cultivated field about 20 feet above high water, I7 yards east of edge of a bluff at shore, and I4 yards south of edge of a bluff I8 feet high, with uniform slope to shore.

Marks.-Observed station is center point of triangle on standard cement monument projecting 6 inches above surface of ground. Subsurface mark is center of 2 -inch tile pipe buried with top 2 inches below base of monument.

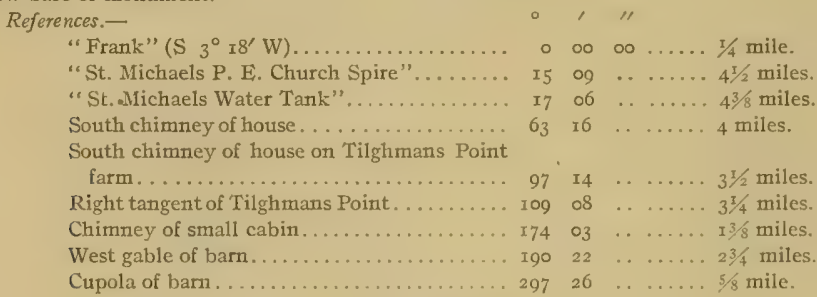

\section{FRANK.}

General locality. - Eastern shore of Miles River about $1 / 2$ mile south of entrance to Wye River and I mile northeast of Herring Island. (See Chart No. 32.)

Immediate locality.-Observed station is in cultivated field about I 8 feet above high water, 8 yards east of a biuff washed by high water, and 125 yards south of a ditch. Cement monument marking reference station is $25.5 \mathrm{x}$ meters $\$ 87^{\circ} 47^{\prime} \mathrm{E}$, of observed station.

Marks.-Observed station is center of 2 -inch tile pipe projecting 2 inches above surface of ground. Subsurface mark is center of 2 -inch tile pipe buried with top 2 inclies below base of surface pipe. Reference station is center point of triangle on standard cement monument projecting 4 inches above surface of ground.

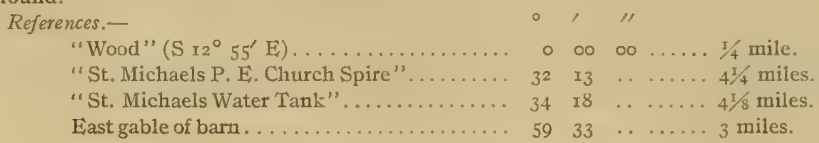




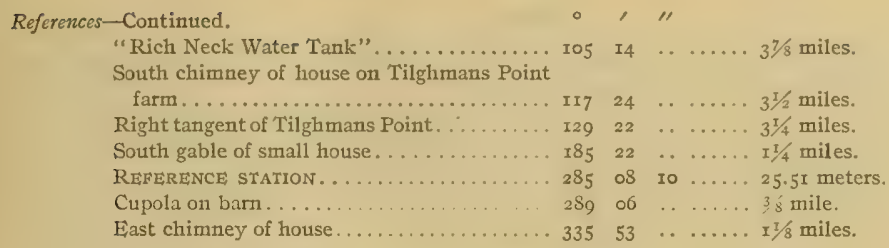

WOOD.

General locality.-Eastern shore of Miles River about I $1 / 2$ miles southeast of Bennett Point, I $1 / 4$ miles east-northeast of Herring Island and $5 / 8$ mile north-northwest of entrance to Woodland Creek. (See Chart No. 32.)

Immediate locality.-Observed station is in a cultivated field about $\mathrm{I} 8$ feet above high water, I 8 yards east of shore and top of vertical bank 18 feet high, and 3 yards south of a wire fence.

Marks.-Observed station is center point of triangle on standard cement monument projecting 5 inches above surface of ground. Subsurface mark is center of 2 -inch tile pipe buried with top 2 inches below base of monument.

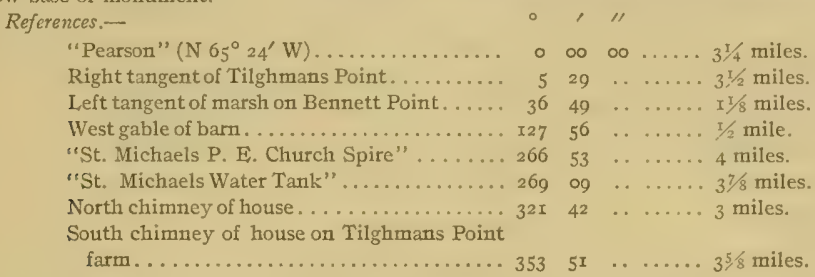

HERR.

General locality. - In Miles River on Herring Island, about $\mathrm{I} / 4$ miles southwest of entrance to Wye River. (See Chart No. 32.)

Immediate locality.-Observed station is on sandy ground in the center of Herring Island, about 2 feet above high water, 30 yards northeast of shore, and 30 yards southwest of shore.

Marks. - Observed station is center point of triangle on standard cement monument projecting 4 inches above surface of ground. Subsurface mark is center of 2 -inch tile pipe buried with top 2 inches below base of monument.

References.-

"Rich Neck Water Tank" ( $77^{\circ} 26^{\prime}$ W) ......

North chimney of house on Tilghmans Point.

farm

Right tangent of Tilghmans Point ........

South gable of barn. ....................

North chimney of small house........... I

Cupola of barn................... I4

North gable of barm. . . . . . . . . . . . . Ig

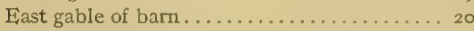

Left chimney of Seth house........... 333

Nortl chimey of house.

$\begin{array}{llllll}0 & 00 & 00 & \ldots & \ldots & 3 \text { miles. } \\ 16 & 28 & \ldots & \ldots & 27 / 5 \text { miles. } \\ 31 & 07 & \ldots & \ldots & 27 / 8 \text { miles. } \\ 81 & 37 & \ldots & \ldots & 7 \text { miles. } \\ 08 & 59 & \ldots & \ldots & 23 / 4 \text { miles. } \\ 49 & 17 & \ldots & \ldots & 1 / 2 \text { miles. } \\ 98 & 40 & \ldots & \ldots & 13 / 4 \text { miles. } \\ 09 & 40 & \ldots & \ldots & 3 \text { miles. } \\ 33 & 42 & \ldots & \ldots & 2 \text { miles. } \\ 45 & 25 & \ldots & \ldots & 2 & 23 \text { miles. }\end{array}$




\section{OLI,IE}

General locality,-Eastern shore of Miles River about I mile north of entrance to Leeds Creek, and $3 / 4$ mile northeast of Deep Water Point. (See Chart No. 32.)

Immediate locality.-Observed station is in woods about 8 feet above high water, 6 yards west of edge of bank which is washing rapidly, and 8 yards northeast of large pine tree at edge of bank. Cement monument marking reference station is 14.42 meters $\mathrm{N} 74^{\circ} \mathrm{I}^{\prime} \mathrm{W}$ of observed station.

Marks.-Observed station is center of 2 -inch tile pipe with top flush with surface of ground. Subsurface mark is center of 2 -inch tile pipe buried with top 2 inches below base of surface pipe. Reference station is center point of triangle on standard cement monument projecting 4 inches above surface of the ground.

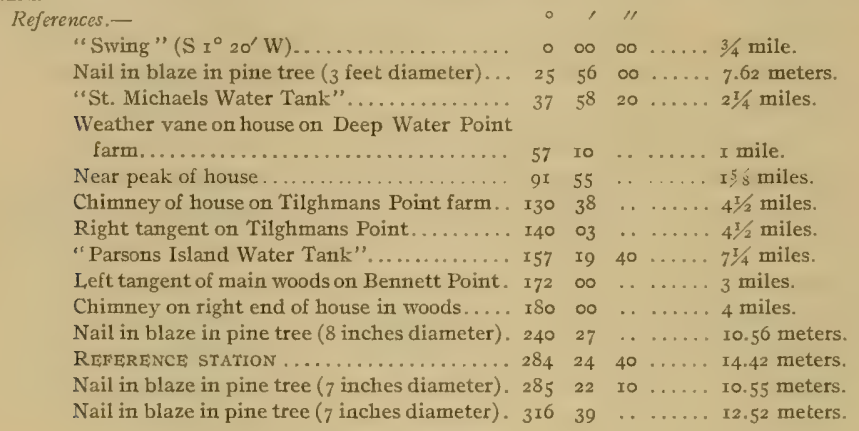

\section{SWING.}

General locality. - Eastern shore of Miles River about $\mathrm{r} / 4$ mile northwest of entrance to L.eeds Creek. (See Chart No. 32.)

Immediate locality.-Observed station is on marsh land between river and small pond about 4 yards east of shore, I8 yards west of pond, I00 yards south of point of woods, and 100 yards northwest of another point of woods. Cement monument marking reference station is 54.35 meters $\mathrm{N} 62^{\circ}$ o $4^{\prime} \mathrm{E}$ of observed station.

Marks.-Observed station is center of 2 -inch tile pipe with top flush with surface of ground, Subsurface mark is center of 2 -inch tile pipe buried with top 2 inches below base of surface pipe. Reference station is center point of triangle on standard cement monument projecting 5 inches above surface of ground.

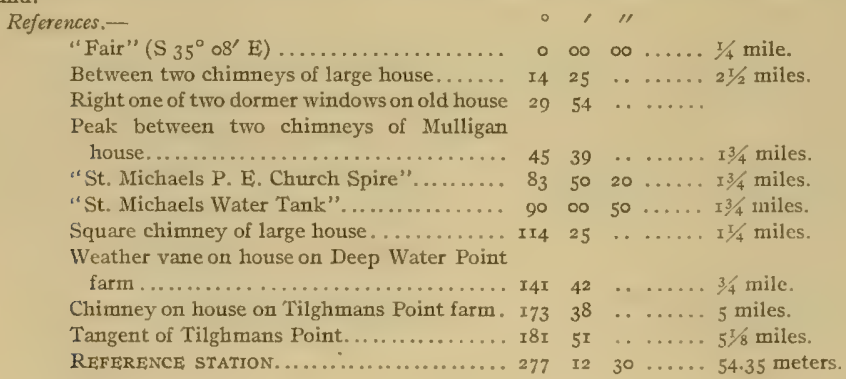




\section{FAIR.}

General locality.--Eastern shore of Miles River on Fairview Point at northrvestern side of entrance to Leeds Creek. (See Chart No. 32.)

Immediate locality.-Observed station is about 2 feet above high water, 9 yards northeast of shore, I6 yards northwest of shore, and I3 yards north of extreme end of point.

Marks.-Observed station is center point of triangle on standard cement monument projecting 4 inches above surface of ground. Subsurface mark is center of 2 -inch tile pipe buried with top 2 inches below base of monument.

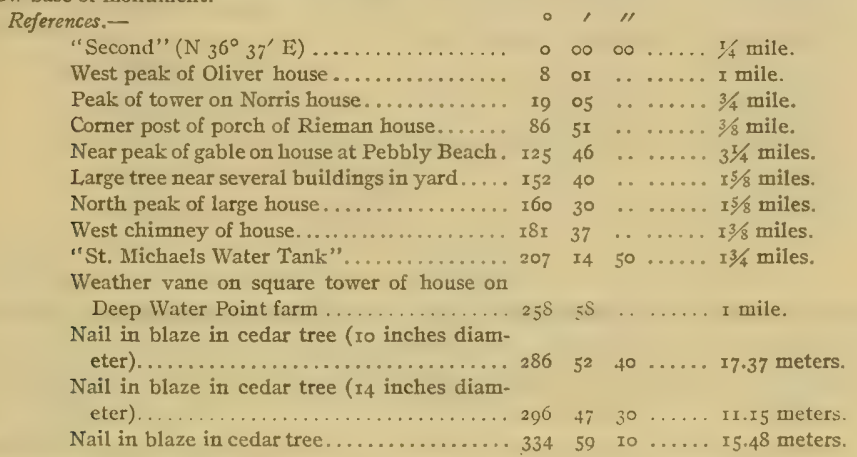

\section{SECOND.}

General locality. - Northwestern shore of Leeds Creek about $1 / 4$ mile northeast of Miles River. (See Chart No. 32.)

Immediate locality. -Observed station is on small marsh point just east of cedar woods about I foot above high water, 5 yards west of shore, I 3 yards north of shore, and 25 yards south of bend in shore.

Marks.-Observed station is center point of triangle on standard cement mointment projecting 5 inches above surface of ground. Subsurface mark is center of 2 -inch tile pipe, buried with top 2 inches below base of monument.

References.-

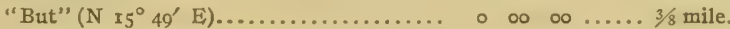

South peak of barn...................... 7 5 50 ....... I mile.

Near corner of house.................. 24 is $\ldots \ldots \ldots$ in miles.

Brick smokestack at Tunis Mills............ $323^{2} \quad 27 \quad \ldots \ldots \ldots .21 / 8$ miles.

Spindle on tower of house............... $46 \quad 46 \ldots \ldots .5 / 8$ mile.

Northeast peak of large building.......... 60 6 $02 \quad . \quad \ldots \ldots .5 / 8$ mile.

Cupola on barn....................... I4I II $\ldots \ldots \ldots$ I $1 / 2$ mile.

Nail in blaze in cedar tree ( 7 inches diameter). 222 ro to ..... 9.3x meters.

Nail in blaze in cedar tree ( 8 inches diameter). $249 \quad 34 \quad 40 \ldots \ldots .78$ meters.

Nail in blaze in cedar tree (ro inches diam-

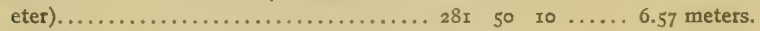

BUT.

General locality.-Northwestern shore of Leeds Creek, about $5 / 8$ mile north of Miles River, and at northeastern side of entrance to a small cove. (See Chart No. 32.)

Immediate locality.-Observed station is on a small marsh point, about I foot above high water, II yards south-south west of shore, 8 yards west of point of shore, 7 yards north of shore, 7 yards east of pasture land, roo yards southwest of a clump of trees, and 6 yards from a line of cedar trees extending north and south.

$53485-12-5$ 
Marks. - Observed station is center point of triangle on standard cement monument projecting 5 inches above surface of ground. Subsurface mark is center of 2 -inch tile pipe buried with top 2 inches below base of monument.

\section{References.-}

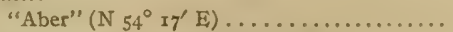

Right comer of large brick house..........

Spindle on tower of house.............. 45

Right peak of house with two chimneys....

Right comer of Rieman house............ II

Nail in blaze in cedar tree (4 inches diam-

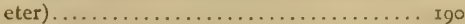

Nail in blaze in hackberry tree ( 3 inches

diameter)..................... II

Nail in blaze in water bush ( 3 inches diam-

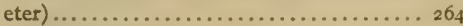

Chimney of house. .................. 305

South peak of large barn.

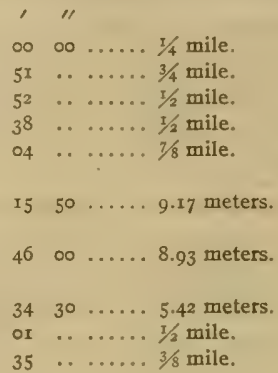

ABER.

General localily.-Northwestern shore of Leeds Creek, about $3 / 4$ mile northeast of Miles River, on point at western side of entrance to a small cove. (See Chart No. 32.)

Immediate locality.-Observed station is on a point covered with cedar trees, about 2 feet above high water, 8 yards southwest of shore, 9 yards north of shore, and 9 yards northwest of extreme end of point.

Marks.-Observed station is center point of triangle on standard cement monument projecting 5 inches above surface of ground. Subsurface mark is center of $z$-inch tile pipe buried with top 2 inches below base of monument.

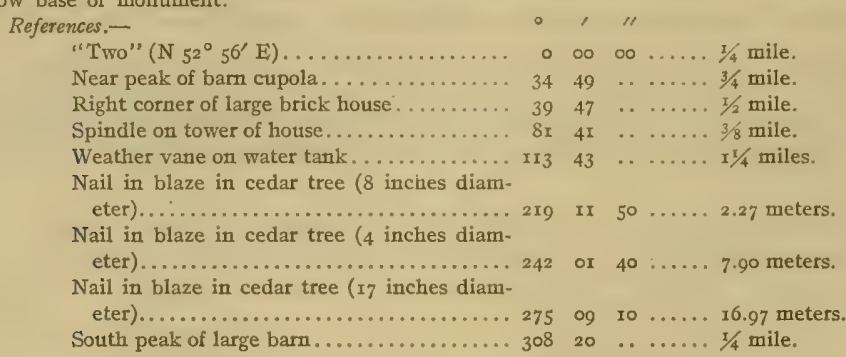

TWO.

General locality.-Northwestern shore of Leeds Creek on a point, about I mile northeast of Miles River, and at southern side of entrance to a small cove. (See Chart No. 32.)

Immediate locality.-Observed station is on marsh point about I foot above high water, 5 yards west of shore, 6 yards northeast of shore, 7 yards north of extreme end of point, and 25 yards southeast of woods.

Marks,-Observed station is center point of triangle on standard cement monument projecting 4 inches above surface of ground. Subsurface mark is center of 2 -inch tile pipe buried with top 2 inches below base of monument. 


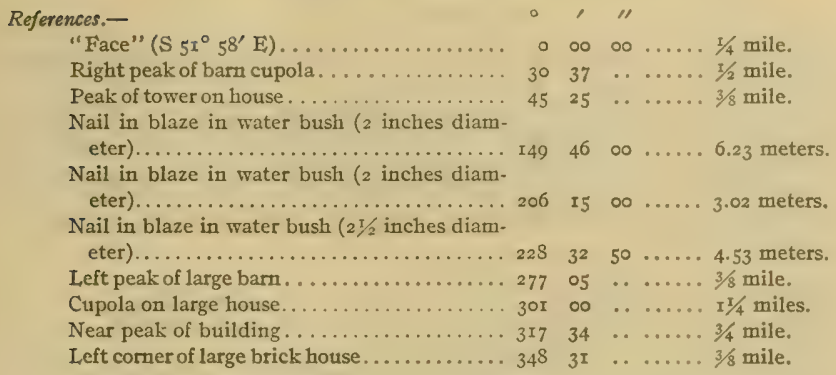

FACE.

General locality.--Southeastern shore of Leeds Creek, about I mile northeast of Miles River, and near northeastern side of entrance to a small cove. (See Chart No. 32.)

Immediate locality. - Observed station is in a field about 5 feet above high water, 130 yards east of bank, I50 yards south of bank, 300 yards west-northwest of large brick house, and IIo yards northnorthwest of two very large cedar trees.

Marks.-Observed station is center point of triangle on standard cement monument projecting 5 inches above surface of ground. Subsurface mark is center of 2 -inch tile pipe buried with top 2 inches below base of monument.

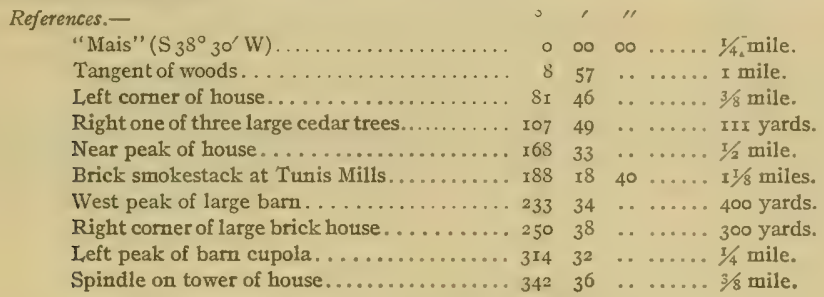

MAIS.

General locality. - Southeastern shore of Leeds Creek about $3 / 4$ mile northeast of Miles River and near point at southwestern side of entrance to a small cove. (See Chart No. 32.)

Immediate locality. - Observed station is in western comer of an orchard about 3 feet above high water, ro yards southeast of top of bank, and $x_{4} 0$ yards northwest of a large house.

Marks.-Observed station is center point of triangle on standard cement monument projecting 5 inches above surface of ground. Subsurface mark is center of 2 -inch tile pipe buried with top 2 inches below base of monument.

References.-

"Beak" (S $40^{\circ} 55^{\prime} \mathrm{W}$ )

Nail in blaze in apple tree ( 6 inches diameter).

South peak of large barn.............. II 5

Nail in blaze in apple tree ( 6 inches diameter). I 55

Nail in blaze in apple tree ( 5 inches diameter). 244

Spizdle on tower of house.............. 264

Nail in blaze in poplar tree ( 8 inches diam.

eter)....................... 302

Weather vane on water tank ............ $3^{13} \quad 5_{2}^{2} \quad 30 \ldots \ldots 3 / 4$ mile. 
BEAK.

General locality. - Southeastern shore of Leeds Creek about 1/2 mile northeast of Miles River at southwestern side of entrance to a small cove. (See Chart No. 32.)

Immediate locality.-Observed station is near edge of pasture land about 3 feet above high water, 6 yards southwest of edge of bank, 12 yards south of point of bank, Io yards southeast of edge of bank, 60 yards west of a small cove, and 25 yards northeast of a line of five poplar trees.

Marks.-Observed station is center point of triangle on standard cement monument projecting 5 inches above surface of ground. Subsurface mark is center of 2 -inch tile pipe buried with top 2 inches below base of monument.

References.-

"Rieman" ( $\left.35^{\circ} \mathrm{5r}^{\prime} \mathrm{W}\right) \ldots \ldots \ldots \ldots \ldots \ldots . . . . .$. Cupola on St. Michaels primary school......
Nail in blaze in poplar tree ( 6 inches diameter $). \ldots \ldots \ldots \ldots \ldots \ldots \ldots \ldots \ldots \ldots \ldots \ldots \ldots \ldots$

Weather vane on water tank............. 123

South peak of large barn.............. I45

Nail in blaze in hackberry tree (5 inches diameter) ......................... I90

Spindle on tower of house.............. 200

Southwest peak of large building......... 227

Nail in blaze in cedar tree ( 4 inches diameter). $24 \mathrm{I}$

Weather vane on tower................ 302

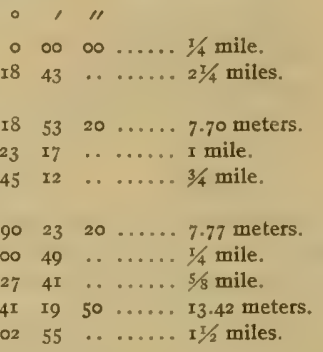

RIEMAN.

General locality. Southeastern shore of Leeds Creek about $1 / 4$ mile northeast of Miles River. (See Chart No. 32.)

Immediate locality.-Observed station is on small marsh point about I foot above high water, 3 yards south of shore, 3 yards northeast of shore, 6 yards east-southeast of extreme end of point, I2 yards west of large cedar tree on point 2 feet higher than station, and I3 yards west-southwest of two large cedar trees.

Marks.-Observed station is center point of triangle on standard cement monument projecting 6 inches above surface of ground. Subsurface mark is center of 2 -inch tile pipe buried with top 2 inches below base of monument.

\section{References.-}

"Leeds" ( $\mathrm{rr}^{\circ} 28^{\prime} \mathrm{W}$ )

"St. Michaels P. E. Church Spire"

"St. Michaels Water Tank" ............ 53

Left piazza post of Fogg cottage.......... 5

Left comer of chimney................. 157

Near corner of house................... 201

Right corner of house................. 2 I

Nail in blaze in cedar tree ( 20 inches diam-

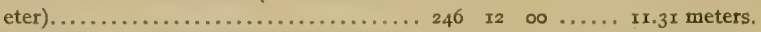

Left comer of Rieman house........... $340 \quad 27 \quad \ldots \ldots \ldots 1 / 4$ mile.

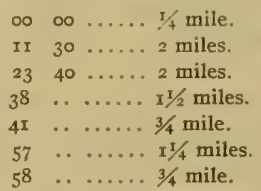

\section{LEEDS}

General locality.-Eastern shore of Miles River at southern side of entrance to Leeds Creek. (See Chart No. 32.)

Immediate locality.-Observed station is on marsh about $\mathrm{x}$ foot above high water, II yards southeast of shore, 23 yards northeast of shore, 27 yards east-northeast of extreme end of point, and 200 yards westnorthwest of a large house.

Marks.-Observed station is center point of triangle on standard cement monument projecting 5 inches above surface of ground. Subsurface mark is center of 2 -inch tile pipe buried with top 2 inches below base of monument. 


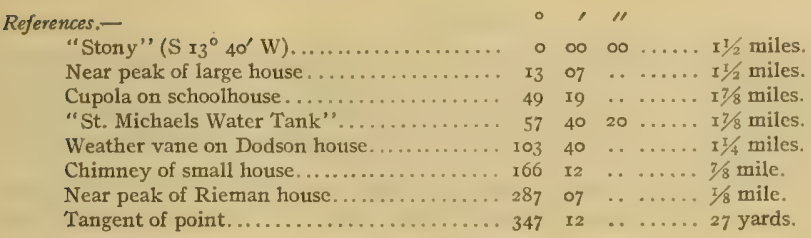

JOHNSON.

General locality.-Northwestem shore of Miles River on a point about $3 / 4$ mile west-southwest of Miles River Bridge. (See Charts Nos. 32 and 34.)

Immediale locality.-Observed station is on a lawn about ro feet above high water, 3 yards northnorthwest of top of bank, 60 yards northeast of cedar tree 20 inches in diameter in clump of six cedar trees near boat landing, and 74 meters southeast of a house.

Marks.-Observed station is center point of triangle on standard cement monument projecting 5 inches above surface of grotind. Subsurface mark is center of 2 -inch tile pipe buried with top 2 inches below base of monument.

References.-

\begin{tabular}{|c|c|c|c|c|}
\hline "Lowndes" ( $\left.\mathrm{N}_{72}{ }^{\circ} \mathrm{oz}^{\prime} \mathrm{E}\right)$.. & 0 & $\infty$ & & $1 / 2$ mile. \\
\hline Windmill on tower. & XI & 40 & & Żśs mile. \\
\hline Left corner of large chimney outside of house. & 35 & 09 & . & $3 / 4$ mile. \\
\hline Nail in blaze in pine tree ( 14 inches diameter). & 48 & $\mathrm{r} 2$ & 30 & II.03 meters. \\
\hline Spindle on left cupola of barn............. & ror & $5^{\mathrm{T}}$ & . & $1 / 2$ mile. \\
\hline Right corner of Mumford house........... & II 4 & 49 & . & $1 / 2$ mile. \\
\hline Nail in blaze in elm tree ( 6 inches diameter). . & $\mathrm{I}_{42}$ & 55 & Io & $10.5^{8}$ meters. \\
\hline Left side of cedar tree ( 20 inches diameter)... & 136 & 40 & & ards. \\
\hline Near peak of Dorrance house............ & I54 & 16 & $\cdots$ & ile \\
\hline Southeast peak of Crown house . .......... & 182 & 45 & . & I/4 mile. \\
\hline Left corner of second story of Lowndes house.. & 226 & 54 & . & 74 meters. \\
\hline Right corner of house.................. & $26_{3}$ & ०9 & .. & \\
\hline Nail in blaze in elm tree ( 5 inches diameter).. & 298 & 45 & 40 & .. I6.II meter \\
\hline 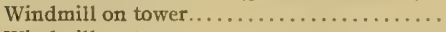 & 340 & $3 \mathrm{I}$ & .. & mile. \\
\hline Windmill or & 346 & 53 & & . \\
\hline
\end{tabular}

LOWNDES.

General locality.--Northwestern shore of Miles River about $1 / 4$ mile southwest of Miles River Bridge. (See Chart No. 32.)

Immediate locality.-Observed station is on a rounded point of marsh about I foot above high water, 7 yards northwest of shore, 8 yards west of shore, 9 yards north of shore, 16 yards east-northeast of shore, and 65 yards east-southeast of small locust trees.

Marks.-Observed station is center point of triangle on standard cement monument projecting 4 inches above surface of ground. Subsurface mark is center of 2 -inch tile pipe buried with top 2 inches below base of monument.

References.-

"Draw" ( N $\left.35^{\circ} 59^{\prime} \mathrm{E}\right)$

o..... $x / 4$ mile

Right corner of Lockwood house.........

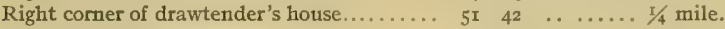

Henderson windmill................. 68 50 ..... $1 / 4$ mile

Near peak of large house............. II6 $5 \mathrm{I} \ldots \ldots . .1 / 2$ mile.

Right corner of large house............ $200 \quad 22 \quad \ldots \ldots 2$ miles.

Nail in blaze in locust tree ( 6 inches diameter) $294 \quad 42 \quad 30 \ldots \ldots$ I9.17.meters.

Windmill at "The Anchorage" .......... $342 \quad 47 \quad \ldots \ldots \ldots 1 / 8$ mile.

Near comer of "The Anchorage"........ 348 50 ...... 1/8 mile.

Left comer of second story of Goldsborough

house......................... $359 \quad 59 \quad \ldots \ldots \ldots 3 / \delta_{\alpha}$ mile. 
DRAW.

General locality. - Northwestern shore of Miles River at northwest end of Miles River Bridge and near old Episcopal Church. (See Chart No. 32.)

Immediale localily.-Observed station is on lawn of "The Anchorage" about 4 feet above high water, $\eta$ yards west of plank sea wall, 40 yards soutliwest of approach to bridge, 60 yards north of corner of plank sea wall, and 85 yards east of a house.

Marks.-Observed station is center point of triangle on standard cement monument with top 5 inches below surface of ground. Subsurface mark is center of 2 -inch tile pipe buried with top 2 inches below base of monument.

References,-

"Chap" ( $\left.59^{\circ} 04^{\prime} \mathrm{E}\right)$

Near peak of Lockwood boat landing..........

Right corner of second story of Lockwood

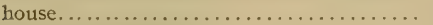

Spindle on barn cupola................

Spike in sea wall post................ 7

Right corner of second story of Henderson house..............................

Nail in blaze in maple tree ( 12 inches diameter $\ldots \ldots \ldots \ldots \ldots \ldots \ldots \ldots \ldots \ldots \ldots \ldots \ldots \ldots$ I $3^{I} \quad 48 \quad 50 \ldots \ldots$ I4.I5 meters.

Left corner of $\log$ cabin................ I93 I8 ...... II2 yards.

Nail in blaze in maple tree ( 12 inches diam-

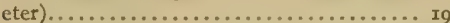

Right corner main house at "The Anchorage" 2 I8

Nail in blaze in pear tree ( 10 inches diameter). 25

Right corner of old Episcopal Clurch...... 302

Spike in sea-wall post................ 325

Windmill on tower................... 33I

Lightring rod on tower of Goldsborough house.................................... $33^{8}$

Comer of stone bridge abutment......... 354

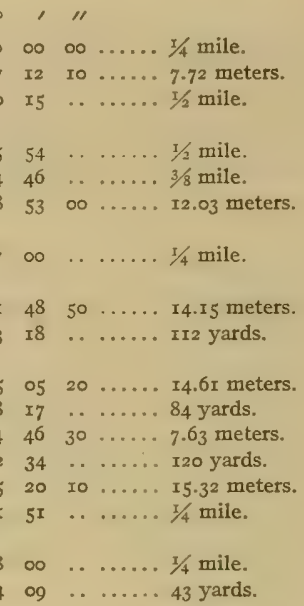

CHAP.

General locality.-Northwestern shore of Miles River opposite point between Glebe Creek and Goldsboro Creek, about I/4 mile northeast of Miles River Bridge. (See Chart No. 32.)

Immediate locality.-Observed station is on point about 2 feet above high water, 5 yards west of shore, 7 yards northeast of shore, and 9 yards north-northwest of extreme end of point.

Marks.-Observed station is center point of triangle on standard cement monument projecting 5 inches above surface of ground. Subsurface mark is center of 2 -inch tile pipe buried with top 2 inches below base of monument.

References.-

"Villa" ( $\left.\mathrm{S} 6 \mathrm{I}^{\circ} \circ 8^{\prime} \mathrm{E}\right)$ "l

Right comer of $2 \mathrm{I} / 2$-story house . "........

Left peak of boathouse at "The Anchorage". II2

Left corner of "The Anchorage" .......... I23

Left corner of old Episcopal Church........ x29

Nail in blaze in locust tree ( 5 inches diameter) I65

Left corner of Goldsborough house........ 203

Nail in blaze in locust tree ( 8 inches diameter) 205

Windmill on tower..................... 210

Nail in blaze in locust tree ( 8 inches diameter) 234

Right peak of brick house............... 275

Near peak of wharf house................ 329

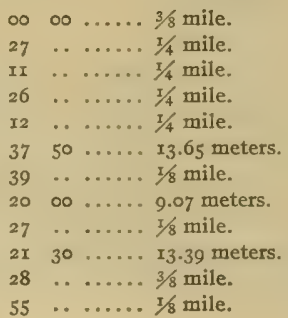


VILLA.

General locality.-Southeastern shore of Miles River at northern side of entrance to Glebe Creek, about $3 / 8$ mile east of Miles River Bridge, (See Chart No. 32.)

Immediate locality.-Observed station is on a marsh point about I foot above high water, II yards northwest of shore, I7 yards southeast of shore, 30 yards west by south of extreme end of point of marsh, 75 yards northeast of shore, and southwest of a few small trees.

Marks.-Observed station is center point of triangle on standard cement monument projecting 4 inches above surface of ground. Subsurface mark is center of 2 -inch tile pipe buried with top 2 inches below base of monument.

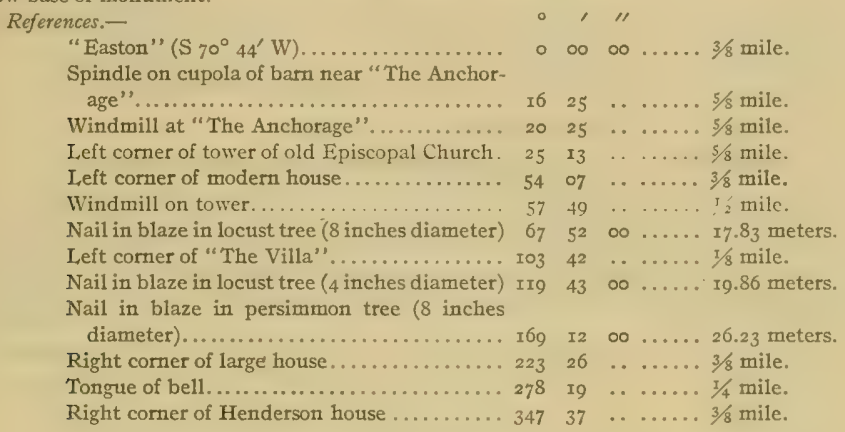

\section{EASTON.}

General locality.-Southeastern side of Miles River on southeastern approach to Miles River Bridge. (See Chart No. 32.)

Immediate localily.-Observed station is on southwest side of cribwork retaining a shell road, 6 inches from downstream edge of cribwork, 7 yards southwest of upstream edge of cribwork, 25 yards southeast of corner of cribwork abutment, 30 yards northwest of extended line of Henderson sea wall, 9 yards southwest by south of nails in side of telephone pole on upstream side of bridge, and 45 yards northwest by west of first telephone pole southeast of bridge on northeastem side of road.

Marks.-Observed station is spindle, I inch diameter, on top of 3 -inch square timber.

References.-None necessary.

\section{HENDERSON.}

General locality. - Southeastem shore of Miles River on a point about $1 / 4$ mile southwest of Miles River Bridge. (See Charts Nos. 32 and 34.)

Immediate locality.-Observed station is on a hard marsh point about I foot above high water, 6 yards southeast of shore, 8 yards south of shore, I3 yards east of shore, 23 yards north-northeast of point of higher land, and I5 yards north of trees along bank.

Marks.-Observed station is center point of triangle on standard cement monument projecting 4 inches above surface of ground. Subsurface mark is center of 2 -inch tile pipe buried with top 2 inches below base of monument.

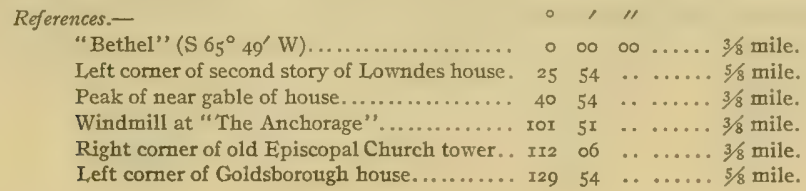


References-Continued.

Henderson windmill................... I74 $47 \ldots \ldots .7 / 8$ mile.

Nail in blaze in wild-cherry tree ( 5 inches

diameter)........................ 258 I7 $30 \ldots \ldots .16 .25$ meters.

Nail in blaze in locust tree ( 5 inches diameter) $306 \quad 43 \quad 40 \ldots \ldots .13 .76$ meters.

Nail in blaze in wild-cherry tree ( 7 inches

diameter).

336 10 10 .....2. I.7 meters.

\section{ST. MICHAELS WATER TANK.}

General locality.-Western side of Miles River in town of St. Michaels, on north side of Railroad Avcnue, near African M. E. Church. (See Charts Nos. 32 and 34.)

Immediate locality.-Observed station is on top of a 60,000 -gallon water tank on a steel tower 90 feet high.

Marks.-Observed station is spindle on center of top of water tank.

References.-None necessary.

\section{MILLWIND.}

General locality.-Westem shore of Miles River at south side of entrance to Long Haul Creek, about 7. ś mile northeast of St. Michaels Water Tank and 5/8 mile south of Deep Water Point. (See Chart No. 32.)

Immediate locality.-Observed station is on edge of cultivated field about 8 feet above high water, 2 yards west of edge of bank, 17 yards south of edge of bluff, and IS yards south by west of junction of bushcovered bank and washed bank.

Marks.-Observed station is center point of triangle on standard cement monument projecting 5 inches above surface of ground. Subsurface mark is center of 2 -inch tile pipe buried with top 2 inches below base of monument.

References.-

"St. Michaels Water Tank" (S $\left.49^{\circ} \mathrm{rg}^{\prime} \mathrm{W}\right)$.... Largest one of group of 3 cherry trees........ Nail in blaze in cedar tree ( 12 inches diameter $) . . \ldots \ldots \ldots \ldots \ldots \ldots \ldots \ldots \ldots \ldots . \ldots \ldots$. Square chimney of Bamard house.........
Weather vane on square tower on house on Deep Water Point farm............... I2

North peak of house................. I68

Left chimney of Rieman house..........221

Right chimney of large modern house on Hunting Creek.................... 246 4I $\ldots \ldots \ldots 21 / 2$ miles.

Steeple on building................ $272 \quad 37 \quad \ldots \ldots, 4$ miles.

Nail in blaze in cedar tree (ro inches diameter).......................... 310 o7 $00 \ldots .28$ meters.

Union M. E. Church spire.............. $35^{8} \quad 26 \quad 20 \ldots \ldots 3 / 4$ mile.

\section{DEEWAT.}

General locality.-Western shore of Miles River on Deep Water Point, about 7/8 mile west-northwest of Fairview Point. (See Chart No. 32.)

Immediate locality.-Observed station is on sand and grass point about 2 feet above high water, $\delta$ yards southwest of shore, 7 yards northwest of shore, and ro yards west of extreme end of point.

Marks.-Observed station is center point of triangle on standard cement monument projecting 5 inches above surface of ground. Subsurface mark is center of 2 -inch tile pipe buried with top 2 inches below base of monument. 


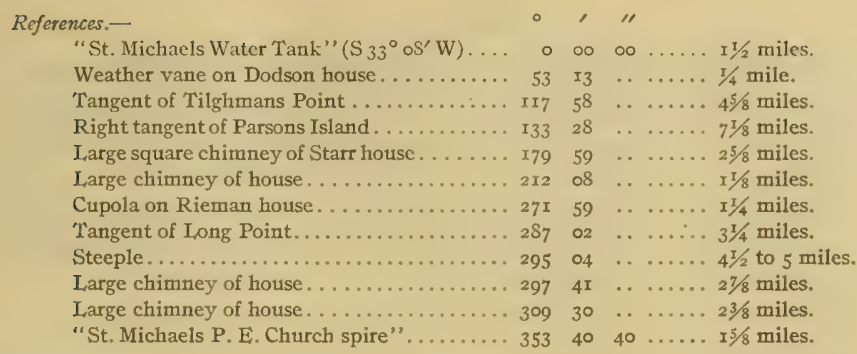

SPAR.

General locality.-Southwestern shore of Miles River, about I mile southeast of entrance to Hambleton Creek and $3 / 8$ mile northwest of Deep Water Point. (See Chart No.32.)

Immediate locality.-Observed station is on cedar and locust fringed shore, about 4 feet above high water, II yards west of shore, I2 yards southwest of shore, and 15 yards south of shore.

Marks.-Observed station is center point of triangle on standard cement monument projecting 5 inches above surface of ground. Subsurface mark is center of 2 -inch tile pipe buried with top 2 inches below base of monument.

\section{References.-}

"Sara" (N $39^{\circ}$ I9' W)

Chimey

Near peak of bam beyond Herring Island...

Nail in blaze in oak tree ( 3 inches diameter). .

Right tangent of chimney............. I2

Tangent of Deep Water Point............ I8

Nail in blaze in locust tree ( 3 inches diam-

eter) ...................................

eter $) \ldots \ldots \ldots \ldots \ldots \ldots \ldots \ldots \ldots \ldots \ldots \ldots \ldots \ldots$

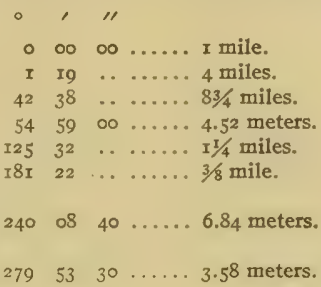

SARA.

Gencral locality.-Southwestern shore of Miles River, about $3^{1 / 4}$ miles south-southeast of northern end of Tilghmans Point, $x^{1 / 4}$ miles southwest of Herring Island, and on point at eastern side of entrance to Hambleton Creek. (See Chart No. 32.)

Immediate locality,-Observed station is in a cultivated field about $\mathrm{I}_{5}$ feet above high water, $x 6$ yards southwest of a bluff $I_{2}$ feet high with uniform slope to shore, and 20 yards east of depression 4 feet deep.

Marks.-Observed station is center point of triangle on standard cement monument projecting 6 inches above surface of ground. Subsurface mark is center of 2 -inch tile pipe buried with top 2 inches below base of monument.

References.-

"Wood" ( $\left.\mathrm{N}_{52}{ }^{\circ} \mathrm{I}_{4}^{\prime} \mathrm{E}\right)$

West chimney of house.................. I2

Nail in blaze in hackberry tree (12 inches diameter) . ...................... I

Nail in blaze in cedar tree ( $\mathrm{r} 2$ inches diameter)........................... 204

Right tangent of Tilghmans Point . . . . . . 282

"Parsons Island Water Tank" . . . . . . . . . 297

South gable of barn..................... 3I5

South gable of house................. 323

South gable of barn................... 340

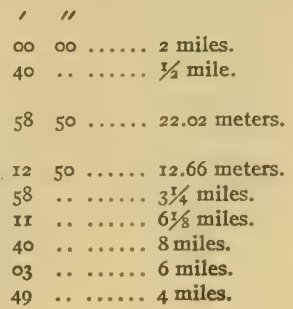




\section{SETH.}

General locality. - Southwestern shore of Miles River, on a point about $2 \frac{1}{2}$ miles south of northern end of Tilghmans Point and $3 / 4$ mile northwest of entrance to Porters Creek. (See Chart No. 32.)

Immediate locality. - Observed station is in clump of cedar trees about 12 feet above high water, 9 yards southwest of top of vertical bank, washed by high water, 50 yards northwest of extreme end of point, and 400 yards northeast of a house. Cement monument marking reference station is 9.56 meters S $67^{\circ} 4 \mathrm{x}^{\prime} \mathrm{W}$ of observed station.

Marks.-Observed station is center of 2 -inch tile pipe projecting 3 inches above surface of ground. Subsurface mark is center of 2 -inch tile pipe buried with top 2 inches below base of surface pipe. Reference station is center point of triangle on standard cement monument projecting 12 inches above surface of ground.

References.-

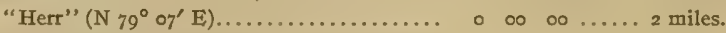

$$
\begin{aligned}
& \text { Nail in blaze in cedar tree ( } \mathrm{x} 2 \text { inches diam- } \\
& \text { eter } \ldots \ldots \ldots \ldots \ldots \ldots \ldots \ldots \ldots \ldots \ldots \text { r................ } 20.89 \text { meters. } \\
& \text { REFERENCE STATION............... I68 } 34 \quad 30 \ldots \ldots 9.56 \text { meters. } \\
& \text { Nail in blaze in cedar tree ( } 6 \text { inches diam- } \\
& \text { eter)......................... 219 } 59 \quad 45 \ldots \ldots 4.44 \text { meters. } \\
& \text { South gable of house................ } 282 \text { 12 } \ldots \ldots \ldots 5 \% \text { miles. } \\
& \text { South gable of barn................ } 305 \quad 34 \quad \ldots \ldots \ldots 6 \text { miles. } \\
& \text { West gable of house.................... } 3^{12} \quad 3^{0} \ldots 6 \text { miles. } \\
& \text { Cupola on barn.................... } 356 \quad 5^{2} \quad \ldots \ldots 3 \text { miles. }
\end{aligned}
$$

\section{PEARSON,}

General locality. -Western shore of Miles River on Tilghmans Point about $3 / 8$ mile south-southeast of northern end of point. (See Chart No. 32.)

Immediate locality.-Observed station is on wooded bluff about 20 feet above high water, 5 yards west of top of vertical bank at shore, and roo yards north of first point south of northern end of Tilghmans Point. Cement monument marking reference station is 12.66 meters $\mathrm{N} 86^{\circ} \circ 3^{\prime} \mathrm{W}$ of observed station.

Marks.-Observed station is center of 2 -inch tile pipe projecting 2 inches above surface of ground. Subsurface mark is center of 2 -inch tile pipe buried with top 2 inches below base of surface pipe. Reference station is center point of triangle on standard cement monument projecting 6 inches above surface of ground.

References.-

"Green" ( $\left.\mathrm{N}^{\mathrm{N}} 45^{\circ} 46^{\prime} \mathrm{E}\right)$.

South gable of barn....................

South chimney of house..................

West chimney of house.................

West gable of barn....................

East gable of barn ................... 7

West chimney of house................. III

North chimney of house................ 12

\begin{tabular}{|c|c|c|}
\hline$\infty$ & $\infty$ & .... $3^{3}$ s miles. \\
\hline I4 & . & .... 5 miles. \\
\hline 48 & . & …… $3^{\pi} / 2$ miles. \\
\hline $3 x$ & . & .... 27/8 miles. \\
\hline $3 \pi$ & . & ...... $3^{\mathrm{T} / 2}$ miles. \\
\hline$\circ 9$ & . & ..... 4 miles. \\
\hline 30 & .. & …... $3^{\mathrm{T}} / 4$ miles. \\
\hline 20 & . & ...... $3^{1 / 8}$ miles. \\
\hline 36 & $\cdots$ & …. $21 / 2$ miles. \\
\hline$\circ$ & 40 & ..... 5.31 meters. \\
\hline II & $\infty$ & ..... 12.66 meters \\
\hline I9 & 20 & ..... 9.99 meters. \\
\hline I7 & . & ...... $3^{1 / 2}$ miles. \\
\hline 02 & . & ..... $43 / 8$ miles. \\
\hline
\end{tabular}

Chimney of house .................. $1_{3}$

Nail in blaze in white oak tree ( 8 inches diaul-

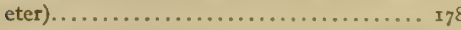

REFERENCE STATION................... 228

Nail in blaze in white oak tree (I2 inches diameter $) \ldots . . . \ldots \ldots \ldots \ldots \ldots \ldots \ldots . . \ldots 239$

South gable of house on Parsons Island..... 3I7

South gable of barn.................. 350 


\section{DIXON.}

General locality.-Southeastern side of Eastern Bay on Tilghmans Point about half way between Eastern Bay and Miles River $3 / 4$ mile southwest of northem end of point and $15 / 8$ miles northeast of Claiborne Wharf. (See Chart No. 32.) farm.

Immediate locality.-Observed station is on top of a 2 -story square frame house on Tilghmans Point

Marks.-Observed station is center of upright staff, 3 inches square, set in the center of trapdoor at apex of square roof.

References.-None necessary.

ROD.

General locality.-Eastern shore of the upper part of Harris Creek on southeastern side of entrance to Northeast Branch. (See Charts Nos. 32 and 34.)

Immediate locality.-Observed station is in a cultivated field about ro feet above high water, 5 yards southeast of shore, and 2 yards southeast of top of bank with uniform slope to shore.

Marks.-Observed station is center point of triangle on standard cement monument projecting 4 inches above surface of ground. Subsurface mark is center of 2 -inch tile pipe buried with top 2 inches below base of monument.

\begin{tabular}{|c|c|c|c|}
\hline References.- & o & & "I \\
\hline "Otto" $\left(\mathrm{S}_{0}^{\circ} 4^{\mathrm{I}^{\prime}} \mathrm{W}\right) \ldots \ldots$ & $\circ$ & $\infty$ & . $3 / 8$ mile. \\
\hline North chimney of house.................. & 5 & $3^{x}$ & $x / 4$ miles. \\
\hline East chimney of house at Bozman......... & 14 & or & .. $2 \pi / 4$ miles. \\
\hline East gable of small barn................ & 92 & I2 & .. 3/4 mile. \\
\hline North chimney of Wamer House............ & 108 & 42 & .. $3 / 4$ mile. \\
\hline Cupola on tin-roofed barn. .............. & I39 & $5^{2}$ & ..... $3 / 4$ mile. \\
\hline Right tangent of barn.................. & 186 & 26 & $\ldots \ldots \ldots$ I $I / 2$ miles. \\
\hline South chimney on Harrison house.......... & 218 & o6 & $\ldots . .250$ yards. \\
\hline 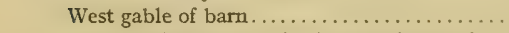 & 300 & 37 & $\ldots \ldots \ldots 3 / 4$ mile. \\
\hline Ione persimmon tree (I2 inches diameter)... & 355 & or & $\ldots \ldots .250$ yards. \\
\hline
\end{tabular}

OTTO.

General locality.-Eastern shore of upper Harris Creek about $1 / 2$ mile south of junction of Northeast Branch and Northwest Branch. (See Charts Nos. 32 and 34.)

Immediate locality.-Observed station is in a cultivated field about $\mathrm{S}$ feet above high water, 18 yards east of top of vertical bank 6 feet high washed by high water, and roo yards north of old fence covcred with vines.

Marks.-Observed station is center point of triangle on standard cement monument projecting 6 inches above surface of ground. Subsurface mark is center of 2 -inch tile pipe buried with top 2 inches below base of monument.

References.-

"Miller" ( $\mathrm{S}$ rI $^{\circ}{ }_{56}$ " E)

Nail in blaze of locust tree ( 4 inches diameter)

North chimney of Bridges house...........

East chimney of Harrison house............

Nail in blaze in one of twin locust trees (I5 inches diameter $) . . . \ldots \ldots \ldots . . . \ldots \ldots .70$

Left tangent of Seth bathhouse.......... 92

South gable of Wamer barn............. I45

East chimney of house................. I58

Cupola on tin-roofed barn................. I66

South chimney of Marion Harrison house... . 204

North chimney of house................. 264

North gable of barn

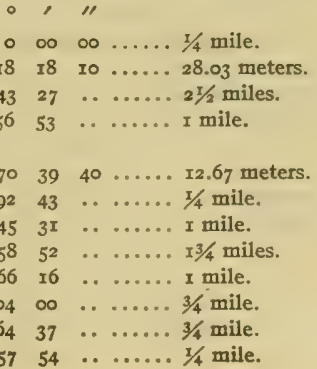




\section{HADDAWAY.}

General locality. - Eastern shore of Chesapeake Bay on Lows Point between Harbor Cove and Haddaway Cove about 2 miles east of north end of Poplar Island. (See chart No. 33.)

Immediate locality. - Observed station is on marsh point about I foot above high water, 65 yards north of shore, Ioo yards south of shore, 140 yards east of shore, and 25 yards west of woods.

Marks.-Observed station is center point of triangle on standard cement monument projecting 6 inches above surface of ground. Subsurface mark is center of 2 -inch tile pipe buried with top 2 inches below base of monument.

References.-

"Valliant" (S $\left.82^{\circ} \circ 8^{\prime} \mathrm{W}\right)$

Left peak of barn on Poplar Island.

"Bloody Point Bar Light"................

I.eft chimney on large house..............

Chimney on middle of large house........ 8

Peak of house between two chimneys...... rog

Chimney of two-story house. ........... 125

"Kemp Tower"................... I27

Nail in blaze in pine tree ( 14 inches diameter) I 39

Nail in blaze in pine tree ( 12 inches diameter) 164

Nail in blaze in pine tree ( 8 inches diameter), 213

Chimney on ell of house............... 275

Chimney of house on Poplar Island. . . . . . . 330

Chimney of house on Poplar Island . . . . . . 359

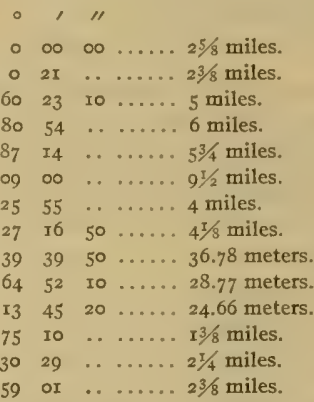

\section{VALIIANT.}

General locality. -Eastern side of Chesapeake Bay on western șore of Poplar Island about $3 / 4$ milc southwest of extreme north end of island. (See Chart No. 33.)

Immediate locality.-Observed station is in cultivated land about 5 feet above high water, $x_{5}$ yards north by east of a line of small trees, 72 yards east by south of shore at end of line of trees, and 2 IO yards south by west of point of woods.

Marks.-Observed station is center point of triangle on standard cement monument projecting 5 inches above surface of ground. Subsurface mark is center of 2 -inch tile pipe buried with top 2 inches below base of monument.

\section{References.-}

"Bloody Point Bar Light" ( $\left.\mathrm{N}_{4}^{\circ} 58^{\prime} \mathrm{W}\right) \ldots$ Near peak of large building.............. r

Near chimney of large house..............

Near comer of shanty in field............ 8

Chimney of house................... 9

Flagstaff on Lowes Wharf................ 100

Chimney of house on point behind trees..... I22

Chimney of small house. ............... I64

Nail in blaze in peach tree ( 4 inches diameter)........................... I diameter)

Nail in blaze in peach tree $\left(2 \frac{\mathrm{T}}{2}\right.$ inches diameter).

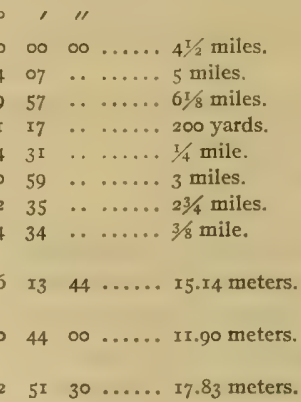


POPLAR SOUTH.

General locality.-Eiastern side of Chesapeake Bay on Poplar Island on a point of land at southern side of Poplar Island Harbor. (See Chart No. 33.)

Immediate locality.-Observed station is on a sandy marsh about I foot above high water, 7 yards west-southwest of shore of harbor, 16 yards' east-northeast of bay shore, 60 yards north-northwest of extreme point of largest one of the group of islands known as Poplar Island, and II yards north of a lone pine tree.

Marks.-Obseved station is center point of triangle on standard cement monument projecting 4 inches above surface of ground. Subsurface mark is center of 2 -inch tile pipe buried with top 2 inches below base of monument.

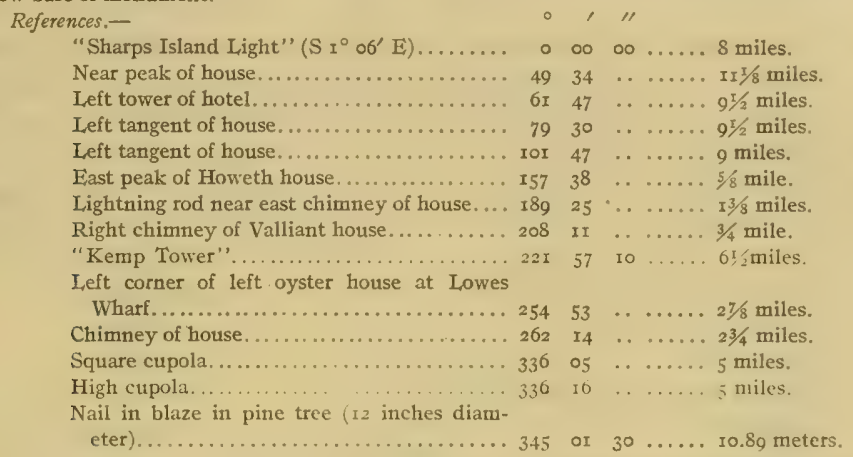

\section{GREAT.}

General locality.-Eastern slore of Chesapeake Bay on Great Marsh Point about I mile east of soutl.east end of Poplar Island. (See Chart No. 33.)

Immediate locality.-Observed station is on marsh point about 2 feet above high water, 40 yards east of shore, 40 yards southeast of shore, 50 yards northeast of shore, and 258 yards from woods.

Marks,-Observed station is center point of triangle on standard cement monument projecting 5 inches above surface of ground. Subsurface mark is center of 2 -inch tile pipe buricd witl top 2 inches below base of monument.

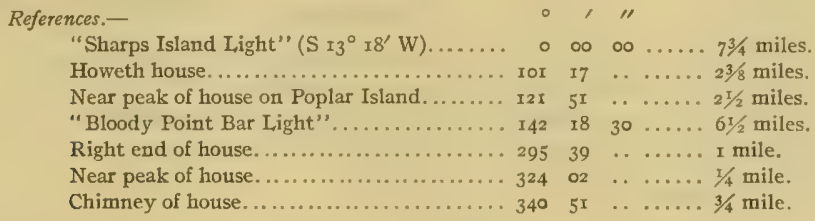

FiRON'T.

General locality.-Eastern shore of Chesapeake Bay about $1 / 4$ mile north of entrance to Front Creek, 7/8 mile north of Knapps Narrows, and $\mathrm{r}^{1} / 2$ miles southeast of southeast end of Poplar Island. (See Chart No. 33.)

Immediate locality.-Observed station is about 3 feet above high water, 13 yards north-northeast of shore, 18 yards southeast of shore, 25 yards east of extreme end of point, and near several dead trees.

Marks.-Observed station is center point of triangle on standard cement monument projecting 5 inches above surface of ground. Subsurface mark is center of 2 -inch tile pipe buried with top 2 inches below base of monument. 


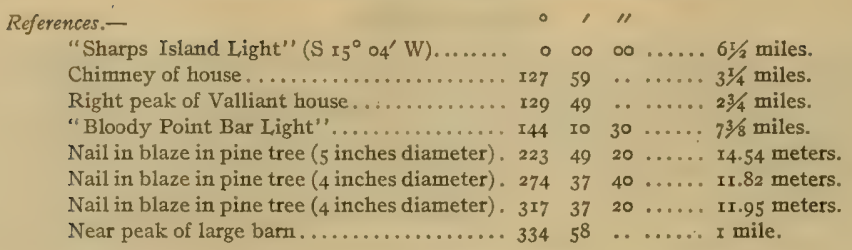

\section{WAP.}

General locality.-Eastern shore of Chesapeake Bay on a point about $43 / 4$ miles north by east of Sharps Island Light and I mile south of Knapps Narrows. (See Chart No. 33.)

Immediate locality.-Observed station is on a point about 3 feet above high water, 56 yards east of extreme end of point, 68 yards north by east of shore, 83 yards south by west of shore, and 3 yards westnorthwest of edge of cultivated land.

Marks.-Observed station is center point of triangle on standard cement monument projecting 4 inches above surface of ground. Subsurface mark is center of 2 -inch tile pipe buried with top 2 inches below base of monument.

References.-

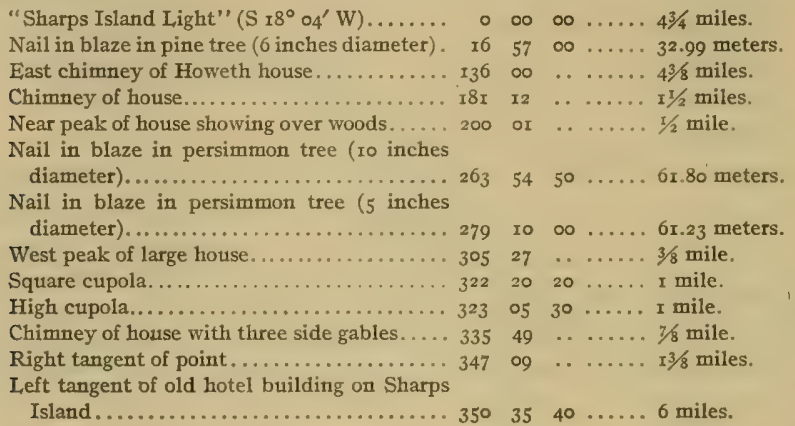

SOUTHERN M. E. CHURCH.

General locality.-Eastern shore of Chesapeake Bay on Tilghman Island about I3/4 miles north of Blackwalnut Point and 2 miles south of Knapps Narrows. (See Chart No. 33.)

Immediate localily... Observed station is about $1 / 4$ mile inshore from Chesapeake Bay on west side of main road on building known as the St. Johns Chapel (Southern M. E. Church).

Marks.-Observed station is center of bell cupola on church.

References,-None necessary.

\section{BLACK.}

General locality.-Eastern shore of Chesapeake Bay on Blackwalnut Point at north side of entrance to Choptank River about $23 / 4$ miles northeast of Sharps Island Light. (See Charts Nos. 33 and 36. )

Immediate locality.-Observed station is in cultivated land about 8 feet above high water, 35 yards east-northeast of edge of bank, 45 yards west of edge of bank, 65 yards northwest of edge of bank, and I30 yards south of a lone apple tree.

Marks.-Observed station is center point of triangle on standard cement monument projecting 5 inches above surface of ground. Subsurface mark is center of 2 -inch tile pipe buried with top 2 inches below base of monument. 


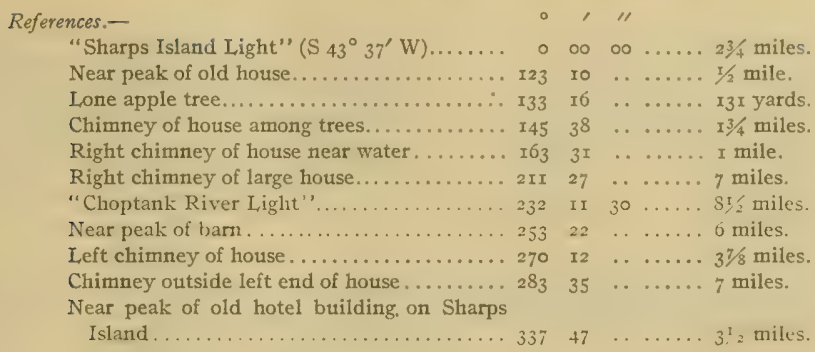

\section{SHARPS ISLAND LIGHT.}

General locality.-Eastern side of Chesapeake Bay off entrance to Choptank River, about I mile north-northwest of Sharps Island and $25 / 8$ miles southwest of Blackwalnut Point. (See Charts Nos. 33 and 36. )

Immediate locality, -Observed station is on structure with a cylindrical foundation known as Sharps Island Light.

Marks.-Observed station is center point of lantern on Sharps Island Light.

References.-

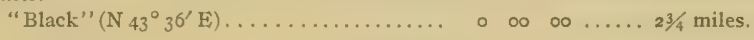

\section{JERE.}

General locality. - Eastern side of Chesapeake Bay on Sharps Island, about I I $/ 2$ miles south-southeast of Sharps Island Light. (See Charts Nos. 33 and 36. )

Immediate locality.-Observed station is on hard ground about 7 feet above high water, 95 yards south-southeast of old hotel building, 95 yards west-southwest of shore, I50 yards southwest of a point, and in such a position that Sharps Island Light shows to the right of the old hotel building.

Marks.-Observed station is center point of triangle on standard cement monument projecting 4 inches above surface of ground. Subsurface mark is center of 2 -inch tile pipe buried with top 2 inches below base of monument.

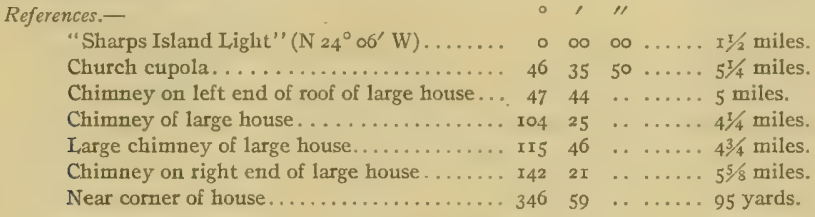

\section{BAR.}

General locality.-Western shore of entrance to Harris Creek on Upper Bar Neck Point about $I 3 / 4$ miles north-northeast of Blackwalnut Point and $I^{x} / 2$ miles south-southeast of Tilghman Island Wharf. (See Chart No. 33.)

Immediate locality.-Observed station is in cultivated field about 6 feet above high water, 3 yards west of edge of bank, and 60 yards north of line of trees at edge of marsh. Cement monument marking reference station is $45.8 \mathrm{I}$ meters $\mathrm{S} 83^{\circ} \mathrm{oo}^{\prime} \mathrm{W}$ of observed station, nearly on line to large lone persimmon tree ${ }_{5}$ inches diameter.

Marks.-Observed station is center of 4 -inch tile pipe with top about 6 inches below surface of ground. Reference station is center point of triangle on standard cement monument projecting 6 inches above surface of ground. 


\begin{tabular}{|c|c|c|c|c|}
\hline References.- & 0 & , & $"$ & \\
\hline "Large Water Tank" (S 6r ${ }^{\circ} 46^{\prime}$ E) . . . . . . . & $\circ$ & $\infty$ & $\infty$ & ..... $9^{1 / 4}$ miles. \\
\hline Nail in blaze in oak stump. . . . . . . . . . . & 63 & I8 & $\infty$ & . 5 x.17 meters: \\
\hline Nail in blaze in wild cherry tree. . . . . . . . & 78 & $5^{8}$ & 40 & 46.66 meters. \\
\hline Nail in blaze in cedar tree. . . . . . . . . . . & 88 & 35 & 30 & 47.69 meters. \\
\hline Nail in blaze in lone persimmon tree. & 144 & 33 & Io & . 49.48 meters. \\
\hline REFERENCE STATION. . . . . . . . . . . & 144 & 46 & $\infty$ & 45.8 I meters. \\
\hline Right chimney of first house to right of woods. & 205 & 39 & . & $3 / 8$ mile. \\
\hline Schoolhouse cupola. & 213 & II & 40 & I3,8 miles. \\
\hline Stack of cannery . . . & 216 & I9 & .. & ..... II/2 miles. \\
\hline Stack of cannery . . . . . . . . . . . . . . . & 227 & to & .. & $\ldots \ldots+13 / 4$ miles. \\
\hline Right chimney of house showing over woods. . & 239 & 07 & .. & $\ldots \ldots 21 / 2$ miles. \\
\hline Neavitt schoolhouse cupola......... & 269 & 25 & . & ..... 33/4 miles. \\
\hline Chimney of house...................... & 276 & $5^{8}$ & .. & $\ldots \ldots 21 / 2$ miles. \\
\hline
\end{tabular}

\section{E. CHURCH.}

General locality.-Eastern shore of Chesapeake Bay on Tilghman Island, about $23 / 4$ miles north of Blackwalnut Point and $3 / 4$ mile south of Knapps Narrows. (See Chart No. 33.)

Immediate locality.-Observed station is on main road about halfway between the shores of Chesapeake Bay and Harris Creek, about $\$ ; \neq$ mile east of Tilghman Island Whari on building known as Tilgh. man Island M. E. Church.

Marks.-Observed station is center of small square cupola on church.

References,-None necessary.

\section{AVALON}

General locality.-Western shore of Harris Creek on Tilghman Island on point about roo yards north of shore end of Tilghman Island Wharf. (See Chart No. 33.)

Immediate locality.-Observed station is on marsh and clay point, about I foot above high water, 9 yards south of shore, I2 yards northwest of shore, 20 yards north-northwest of northeast corner of a house, about I yard east of produced line of end of house, Io yards north of 2 pine trees, and 6 yards north-northwest of bank.

Marks.-Observed station is center point of triangle on standard cement monument projecting 6 inches above surface of ground. Subsurface mark is center of $z$-inch tile pipe buried with top $z$ inches below base of monument.

\section{References.-}

"Narrows" ( $\left.34^{\circ} 29^{\prime} \mathrm{E}\right)$. . . . . . . . . . . .

Near peak of house with 2 chimneys .........

Stack of cannery on wharf . ...............

Near peak of house with 2 chimneys.......

Chimney next to skylight on highest house on Tilghman Island Wharf . . . . . . . . . . .

Stack of cannery ..................... $\times 5^{\circ}$

Nail in blaze in pine tree ( $x_{4}$ inches diameter) $\ldots \ldots \ldots \ldots \ldots \ldots \ldots \ldots \ldots \ldots$ r

Northeast corner of a house .

Nail in blaze in northwest side of pine tree (I5 inches diameter) .............. I8

Nail in blaze in cherry tree ( 12 inches diam-

eter)......................... 224

Lightning rod on east peak of house. . . . . . . 243

Weather, vane on schoolhouse.......... 270

Near peak of house with chimney. . . . . . 322
- $0000 \ldots . .3 / 4$ mile.

$247 \quad \ldots \ldots \ldots 3 \frac{1}{1 / 4}$ miles.

$834 \quad \ldots \ldots \ldots, 1 / 4$ mile.

$\begin{array}{llllll} & 40^{\circ} & \cdots & \ldots & 2^{\mathrm{T}} / 8 & \text { miles. }\end{array}$

$\begin{array}{lllllll} & 38 & \ldots & \ldots & & 1 / 4 \\ \text { mile }\end{array}$

o7 ....... $1 / 4$ mile.

$\infty 030 \ldots .$. I0.2I meters.

It $50 \ldots \ldots$ I7.24 meters.

I4 $00 \ldots . .9 .8$ I meters.

I2 $30 \ldots \ldots$ 10.66 meters.

$47 \quad \ldots \ldots \ldots \times 50$ yards.

59 xo ..... $1 / 4$ mile.

$18 \ldots \ldots .300$ yards. 


\section{SCHOOLHOUSE CUPOLA.}

General locality.-Eastern shore of Chesapeake Bay on Tilghman Island about 3 miles north of Blackwalnut Point and $1 / 2$ mile south of Knapps Narrows. (See Chart No. 33.)

Immediate locality.-Observed station is on main road about halfway between the shores of Chesapeake Bay and Harris Creek about $3 / 8$ mile north west of 'Tilghman Island Wharf on schoolhouse building.

Marks,-Observed station is center of bell cupola on schoolhouse.

References.-None necessary.

\section{PEOPLES CHAPEL.}

General locality.-Eastern shore of Chesapeake Bay on Tilghman Island about $3 \frac{\mathrm{T} / 4}{4}$ miles north of Blackwalnut Point and $1 / 4$ mile south of Knapps Narrows. (See Chart No. 33.)

Immediate locality.-Observed station is in the town of Tilghman about $1 / 2$ mile north of Tilghman Island Wharf on building known as Peoples Chapel.

Marks.-Observed station is center of small square cupola on chapel.

References.-None necessary.

\section{NARROWS.}

General locality. - Western shore of Harris Creek about $1 / 4$ mile northeast of east entrance to Knapps Narrows, and $I \frac{1}{4}$ miles west of Change Point. (See Chart No. 33.)

Immediate locality.-Observed station is in cultivated field back of a fringe of trees about 6 feet above high water, 45 yards west-northwest of shore, I5 yards west-northwest of edge of field, 90 yards south-southwest of corner of field, and 145 yards northeast of a point of bank where wire fence meets trees.

Marks.-Observed station is center point of triangle on standard cement monument projecting 5 inches above surface of ground. Subsurface mark is center of 2 -inch tile pipe buried with top 2 inches below base of monument.

References.-

"Eagle" ( $\left.37^{\circ} 30^{\prime} \mathrm{E}\right)$

Near peak of Morris House with two chimneys

Nail in blaze in wild-cherry tree (6 inches

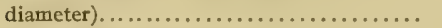

Near peak of Wayman house.............

Nail in blaze in mulberry tree ( $y$ inches diameter $\ldots \ldots \ldots \ldots \ldots \ldots \ldots \ldots \ldots \ldots . . \ldots$

"Choptank River Light"............... $88 \quad 32$ o $38 \ldots .83 / 4$ miles.

Nail in blaze in pine tree ( 12 inches diameter) Iro I5 $_{5}$ oo ..... 17.83 meters.

Near corner peak of house on Tilghman

Island Wharf..................... $x 60$ 59 $59 \ldots \ldots 3 / 4$ mile.

Left stack of cannery................ I72 5 I $\ldots \ldots$ I mile.

Near peak of hotel with chimney almost in

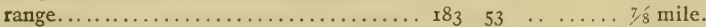

"Peoples Chapel".................. $206 \quad 48$ 40.... śs mile.

Near peak of house with one chimney..... $284 \quad 38 \quad \ldots \ldots \ldots 3 / 8$ mile.

Left peak of house................... $326 \quad 02 \quad \ldots \ldots \ldots 1 / 4$ mile.

\section{EAGLE.}

General locality. -Western shore of Harris Creek on Bald Eagle Point about $3 / 4$ mile west of Turkey Neck Point, and 2 miles north-northeast of Tilghman Island Wharf. (See Chart No. 33.)

Immediate locality.-Observed station is on marsh about $\mathrm{x}$ foot above high water, 2 yards west of shore, 45 yards north by west of point of marsh, I 50 yards south by east of point of marsh, and I20 yards east of woods. Cement monument marking reference station is $15.4 \mathrm{r}$ meters S $88^{\circ} 35^{\prime} \mathrm{W}$ of observed station.

Marks,-Observed station is a nail in a cedar stub 4 inches diameter projecting 2 inches above surface of ground. Reference station is center point of triangle on standard cement monument projecting 6 inches above surface of ground.

$53485-\mathrm{I2}-6$ 


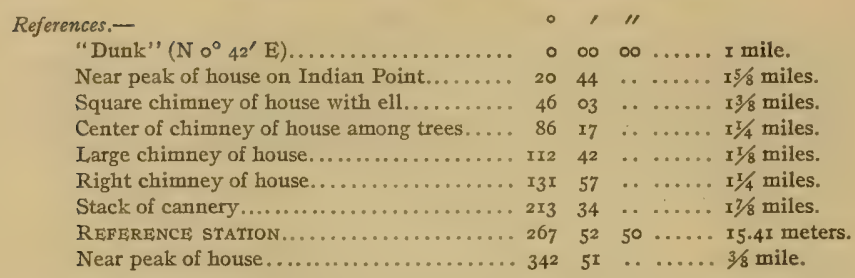

\section{DUNK.}

General locality.-Western shore of Harris Creek on Seths Point at northeast side of entrance to Dun Cove, about 3 miles from the Choptank River. (See Chart No. 33.)

Immediate locality. - Observed station is on marsh about $\mathrm{I}$ foot above high water, 6 yards northwest of shore, 23 yards north-northeast of point, 26 yards northeast of shore of Duns Cove, 12 yards west of shore of Harris Creek, Ioo yards east of bushes extending north and south, and 250 yards east of woods. Cement monument marking reference station is II.22 meters $\mathrm{N} 78^{\circ} 54^{\prime} \mathrm{W}$ of observed station.

Marks.-Observed station is center of 2 -inch tile pipe projecting 4 inches above surface of marsh. Subsurface mark is center of 2 -inch tile pipe buried with top 2 inches below base of surface pipe. Reference station is center point of triangle on standard cement monument projecting 6 inches above surface of ground.

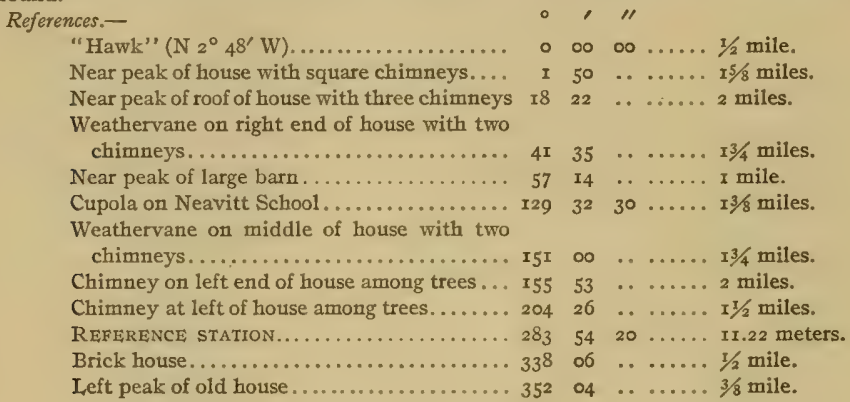

\section{HAWK.}

General locality. - Western shore of Harris Creek about I/2 mile north of Seths Point and 1/2 mile west of Indian Point. (See Chart No. 33.)

Immediate locality.-Observed station is in cultivated field about 4 feet above high water and 22 yards northwest of extreme end of point.

Marks.-Observed station is center point of triangle on standard cement monument projecting 6 inches above surface of ground. Subsurface mark is center of 2 -inch tile pipe buried with top 2 inches below base of monument.

References. -

"Dunk" $\left(\mathrm{S}_{2}{ }^{\circ} 48^{\prime} \mathrm{E}\right) \ldots \ldots \ldots \ldots \ldots \ldots \ldots \ldots$

Nail in blaze in mulberry tree ( 8 inches diam. eter)........................... 2 I 00 . $30 \ldots \ldots .53$ meters.

North chimney of Harrison house....... $47 \quad 04 \quad \ldots \ldots .400$ yards.

Dead pine tree with hawk nest in top...... I4r Ir ...... $1 / 4$ mile.

Cupola on house................... r68 $35 \ldots \ldots$ m . . . miles. 
References-Continued.

South chimney of house................. I 82 46 $46 \ldots \ldots .1 / 8$ miles.

Chimney of Mic Quay oyster house........ $227 \quad 23 \quad \ldots \ldots \ldots x 3 / 8$ miles.

South gable of barn................... $25^{2}$ I2 $\ldots \ldots \ldots 1 / 4$ miles.

North chimney of house.................. $275 \quad 58 \quad \ldots$ mile.

Nail in blaze in hackberry tree (ro inches

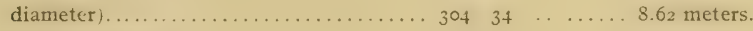

Chimney of house................... $3^{12} \quad 35 \quad \ldots \ldots \ldots I^{1 / 2}$ miles.

North gable of barn................... $330 \quad 40 \quad \ldots 21 / 4$ miles.

SMITH.

General locality.-Eastern shore of Harris Creek on Smith Point between Briary Cove and Waterhole Cove and about $3 / 4$ mile west-southwest of Little Neck Point. (See Chart No. 33.)

Immediate locality.-Observed station is on marsh point, about I foot above high water, and 6 yards west of shore. Cement monument marking reference station is 13.44 meters $\mathrm{N} 62^{\circ} 39^{\prime}$ W of observed station.

Marks.-Observed station is nail in center of 3 -inch stub projecting $\mathrm{x}$ foot above surface of ground. Reference station is center point of triangle on standard cement monument projecting 6 inches above surface of ground.

References.-

"Hawk" (S $12{ }^{\circ} 3 I^{\prime} \mathrm{W}$ ).

Chimney of small house.............. 3 or $\ldots \ldots \ldots .1 / 4$ miles.

North gable of barn................ 2 I $32 \ldots \ldots$ I mile.

North chimney of house............... $26 \quad 39 \quad \ldots \ldots \ldots r / 2$ mile.

North edge of Lamdin house........... $73 \begin{array}{lllll}32 & \ldots & \ldots & 1 / 2 \\ \text { mile. }\end{array}$

REFERENCE STATION ................... I0.4 $4940 \ldots \ldots .13 .44$ meters.

South chimney of house................. I40 $28 \quad \ldots \ldots \ldots 3 / 8$ mile.

East chimney of house ............... I74 $38 \ldots \ldots .4 \%$ mile.

Chimney of house................... $206 \quad 27 \quad \ldots \ldots \ldots 2$ miles.

West gable of McQuay oyster house....... $242 \quad 43 \quad \ldots \ldots \ldots 7 / 8$ mile.

Chimney of McQuay house............ $247 \quad 39 \quad \ldots \ldots \ldots 7 / 3$ mile.

Chimney of small house.............. $270 \quad 46 \quad \ldots \ldots .3 / 4$ mile.

South chimney of Edmonds house........ 288 I3 $\ldots \ldots .3 / 4$ mile.

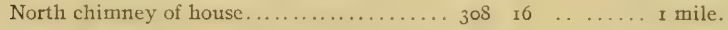

BRIARY.

General locality.-Western shore of Harris Creek, on a point at northeastern side of entrance to Briary Cove, about $3 / 8$ mile west of Little Neck Point. (See Chart No. 33.)

Immediate locality.-Observed station is on a marsh point about to yards from extreme end of point. Marks.-Observed station is center of 3 -inch cedar stub projecting 8 inches above surface of ground. References.-

NoTE.-This station was established in Ig0o and was not reoccupied or re-marked during oyster survey, although relocated by concluded angles.

\section{VINE.}

General locality.-Western shore of Harris Creek about 1/4 mile north-northwest of Little Neck Point. (See Charts Nos. 33 and 34.)

Immediate locality.-Observed station is in cultivated field about 7 feet above high water, 6 yards northwest of shore, and 3 yards northwest of top of vertical bank. Cement monument marking reference station is $x 5.86$ meters $\mathrm{N} 67^{\circ} 54^{\prime} \mathrm{W}$ of observed station.

Marks.-Observed station is center of 2 -inch tile pipe projecting 4 inches above surface of ground. Subsurface mark is center of 2 -inch tile pipe buried with top 2 inches below base of surface pipe. Reference station is center point of triangle on standard cement monument projecting 5 inches above surface of ground. 


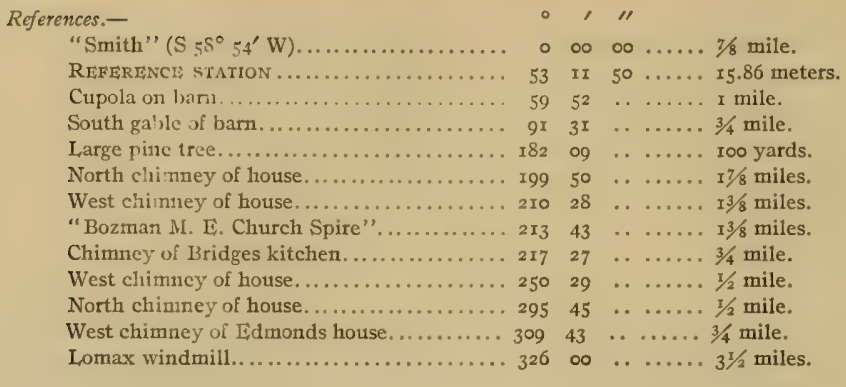

\section{CUMMINGS.}

General locality.-Western shore of Harris Creek, nn point nu western side of entrance to Cummings Creek, about 1/2 mile north-northeast of Little Neck Point. (See Charts Nos. 33 and 34.)

Immediate locality.-Observed station is in a cultivated ficld about ro feet above high water, 70 yards north of extreme end of point, and so yards in w thwest of lone pine tree near shore.

Marks.-Observed station is center p int of tringle on standard cement monument projecting 6 inches above surface of ground. Subsurface mark is center of 2 inch tile pipe buried with top 2 inches below base of monument.

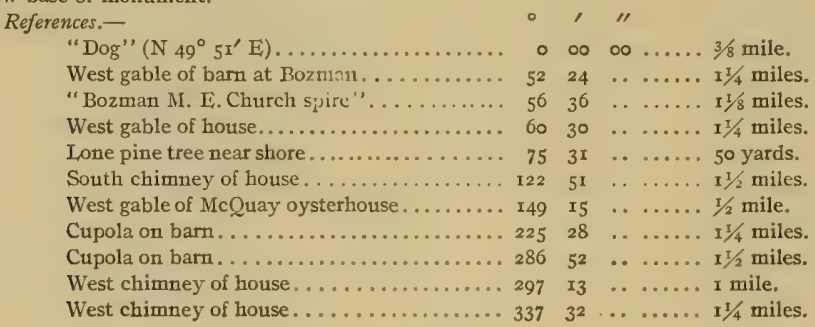

DAN.

General locality.-Eastern shore of Harris Creek on Little Neck Point about $3 / 4$ mile east-northeast of Smith Point. (See Charts Nos. 33 and 34.)

Immediate locality.-Observed station is on narrow neck of oyster shells, about 35 yards east of southwest corner of McQuay's oysterhouse, 60 yards east of the extreme west end of point, 25 yards west of bank at edge of woods, and 3 yards south of shell path to oysterhouse. Cement monument marking reference station is 21.37 meters $\mathrm{S} 69^{\circ} 28^{\prime} \mathrm{E}$ of observed station.

Marks.-Observed station is center of 2 -inch tile pipe projecting 5 inches above surface of ground. Reference station is center point of triangle on standard cement monument projecting 4 inches above surface of ground.

References, -

"Fox" (N 64 $\left.54^{\prime} \mathrm{E}\right) \ldots \ldots \ldots \ldots \ldots \ldots \ldots$

REFERENCE STATION..................

Nail in blaze in persimmon tree ( 4 inches

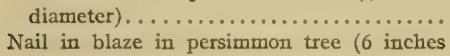
diameter)

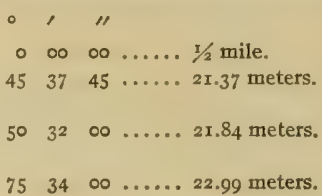


References - Continued.

North chimney of Edmonds house... . . . . . I34

North gable of barn................ 166

Stack of cannery at Sherwood............ Igo

Cupola on house . . ................. 210

Chimney of small house.............. 227

East gable of McQuay oysterhouse . . . . . . 237

Church spire at Wittman . . . . . . . . . . . 292

Chimney of small house.............. 32 I

Chimney of small house.............. 355

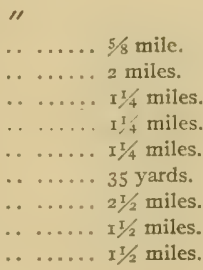

\section{EDMOND.}

General locility.-Eastern shore of Harris Creek, about 5 \& mile south-southwest of Little Neck Point, and $5 / 8$ mile north-northeast of Indian Point. (See Chart No. 33.)

Immediate locality.-Observed station is in southwest corner of yard of a house about is feet above high water, 7 yards southeast of top of bank I $_{5}$ feet high, and nearly on line with south side of house. Cement monument marking reference station is 16.56 meters $\mathrm{S} 59^{\circ} 29^{\prime} \mathrm{E}$ of observed station.

Marks.-Observed station is center of 2 -inch tile pipe projecting 4 inches above surface of ground. Subsurface mark is center of 2 -inch tile pipe buried with top 2 inches below base of surface pipe. Refetence station is center point of triangle on standard cement monument.

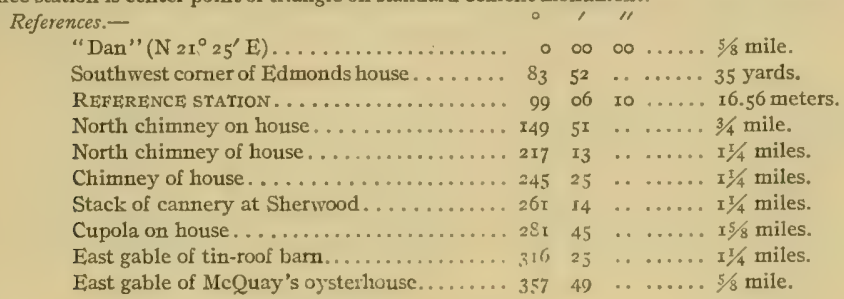

\section{VARRIOA.}

General locality.-Western shore of IIarris Crcck on incins1 Point, about $2 \frac{1}{2}$ miles north of Change Point. (See Chart No. 33.)

Immediate locality. - Observed station is in cultimnted field about 7 feet above high water, 20 yards southeast of shore, $x_{4}$ yards southeast of top of bank with uniform slope to shore, and 40 yards northeast of extreme end of point.

Marks.-Observed station is center point of triangle on standard cement monument projecting 6 inches above surface of ground. Subsurface mark is center of 2 -inch tile pipe buried with top 2 inches below base of monument.

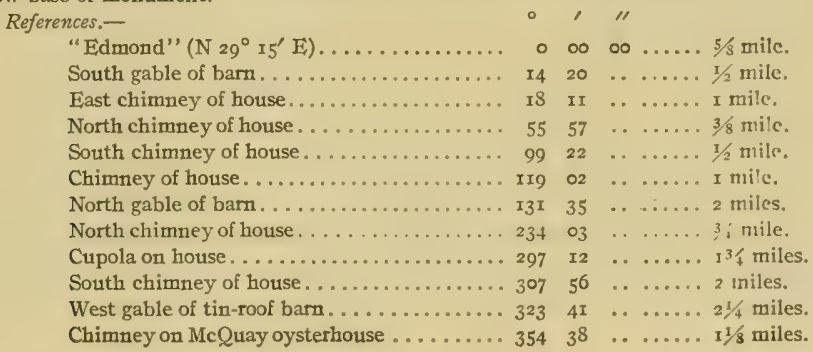


BALL.

General locality.-Eastern shore of Harris Creek about $3 / 4$ mile south-southeast of Indian Point and I mile north of Turkey Neck Point. (See Chart No. 33.)

Immediate locality.-Observed station is in cultivated field about to fect above high water, 15 yards east of shore, 8 yards from top of bank, and 50 yards north of a house.

Marks.-Observed station is center point of triangle on standard cement monument projecting 5 inches above surface of ground. Subsurface mark is center of 2 -inch tile pipe buried with top 2 inches below base of monument.

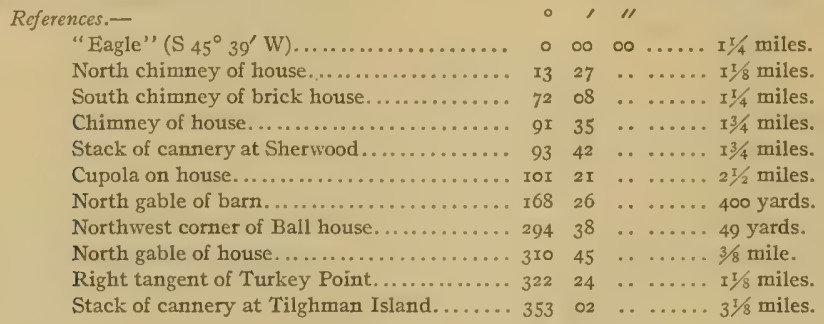

\section{HEN.}

General locality.-Eastern shore of Harris Creek on Turkey Neck Point about $3 / 4$ mile north of Change Point. (See Chart No. 33.)

Immediate locality.-Observed station is in a cultivated field about 8 feet above high water, 9 yards southeast of edge of bank, $x_{7}$ yards east by north of point of bank at line of trees, and 16 yards eastnortheast of edge of bank.

Marks.-Observed station is center point of triangle on standard cement monument projecting 5 inches above surface of ground. Subsurface mark is center of 2 -inch tile pipe buried with top 2 inches below base of monument.

References.-

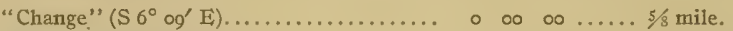

Nail in blaze in cedar tree............... $26 \quad 39$ 10 .... I5.57 meters.

Nail in blaze in cedar tree............. $53 \quad 33 \quad 50 \ldots \ldots .55 .29$ meters.

Stack of cannery.................... $640_{4} \quad \ldots \ldots \ldots 21 / 4$ miles.

Lomax windmill................... $87 \quad 47 \quad 20 \ldots \ldots .1 / 2$ miles.

Left peak of house with two chimneys.... $129 \quad 47 \quad \ldots \ldots$ I mile.

Left chimney of brick house............. I57 $5^{8} \quad \ldots \ldots \ldots .77 / 8$ miles.

Tower of house.................... $x 66 \quad 56 \ldots \ldots .3$ miles.

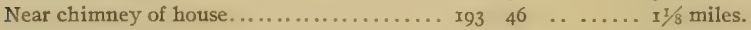

Near peak of house................. $245 \quad 28 \quad \ldots \ldots .3 \%$ mile.

Right peak of house...................... 308 30 mile.

Nail in blaze in locust tree............... $350 \quad 22 \quad 00 \ldots \ldots 22.85$ meters.

CHANGE, rgro.

General locality.-Eastern shore of Harris Creek on Change Point about $x^{1 / 2}$ miles east of Knapps. Narrows. (See Charts Nos. 33 and 34.)

Immediate locality.-Observed station is in cultivated field about 8 feet above high water, 45 yards north-northeast of extreme end of point, 55 yards northwest of edge of bank, 35 yards east of edge of bank, 70 yards southeast by south of corner of wire fence, and 70 yards south-southwest of wire fence.

Marks.-Observed station is center point of triangle on standard cement monument projecting 4 inches above surface of ground. Subsurface mark is center of 2 -inch tile pipe buried with top 2 inches below base of monument. 


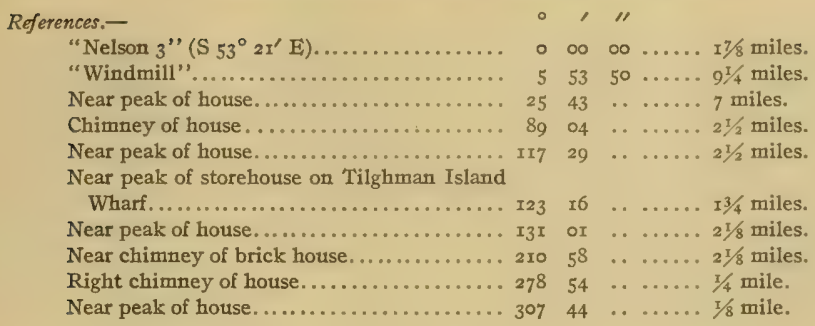

CHEF.

General locality.-Eastern shore of Chesapeake Bay on Cook Point at southern side of entrance to Choptank River about 4 miles east of Sharps Island. (See Charts Nos. 33, 36, and 37.)

Immediate locality.-Observed station is in cultivated field about 8 feet above high water, 30 yards inside of fringe of trees paralleI with shore, 45 yards southwest of eastern end of fringe of trees, 70 yards east of western end of fringe of trees, and rgo yards northwest by north of gate in fence running east and west.

Marks.-Observed station is center point of triangle on standard cement monument projecting 4 inches above surface of ground. Subsurface mark is center of 2 -inch tile pipe buried with top 2 inches below base of monument.

References.-

"Sharps Island Light" ( $84^{\circ}$ or' W)

Nail in blaze in wild-cherry tree (4 inches diameter)...................... I 8 , II Io .... 31.43 meters.

Nail in blaze in locust tree ( 5 inches diameter) 46 of $20 \ldots \ldots 28.53$ meters.

Large chimney of house............... 5 I $57 \ldots \ldots .43 \frac{1}{4}$ miles.

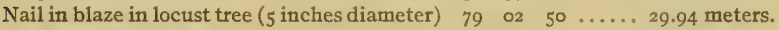

Left peak of house................. 8 I 21 ..... 5 miles.

Near peak of barn................... $9^{8} \quad 22 \quad \ldots \ldots \ldots 7^{1 / 2}$ miles.

Nail in blaze in locust tree ( 6 inches diameter) $99 \quad 50 \quad 30 \ldots \ldots 43.16$ meters.

Near chimney on largest building in group. . $127 \quad 24 \quad \ldots \ldots .66$ miles.

Left end of house................... $x_{50} \quad 48 \quad 30 \ldots \ldots 75 / 8$ miles.

"Choptank River Light"............... I58 02 10 ..... 57/8 miles.

Lone persimmon tree............... 16 $46_{5} \quad 47 \ldots \ldots 23$ yards.

"Large Water Tank"................ I77 43 10 ....6. 63/8 miles.

Right chimney outside house.......... I94 $02 \quad \ldots \ldots \ldots 21 / 4$ miles.

Chimney on right one of two houses....... $22237 \quad \ldots \ldots \ldots .1 / 4$ mile.

Right peak of barn...................... 251 19 ...... $1 / 4$ mile.

Right peak of hotel on Sharps Island.... 34 I $27 \quad \ldots \ldots .4$ miles.

DOG.

General locality.-Eastern shore of Cummings Creek about 3/3 mile north of Harris Creek. (See Chart No. 34.)

Immediate locality.-Observed station is on marsh about on level with high water, and I6 yards west of clump of myrtle bushes. Cement monument marking reference station is 14.43 meters $\mathrm{S} 65^{\circ} 30^{\prime}$ $\mathrm{E}$ of observed station.

Marks.-Observed station is center of 2 -inch tile pipe projecting 3 inches above surface of ground. Subsurface mark is center of 2 -inch tile pipe buried with top 2 inches below base of surface pipe. Reference station is center point of triangle on standard cement monument projecting 5 inches above surface of ground. 


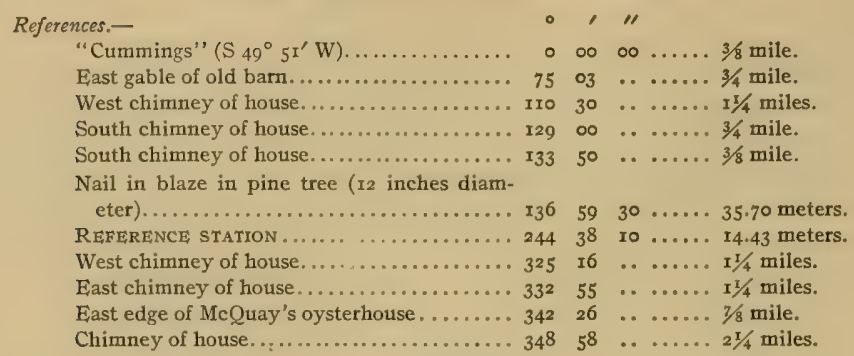

RABBIT.

General locality.-Western shore of Harris Creek on eastern side of entrance to Cummings Creek about $3 / 4$ mile northeast of Little Neck Point. (See Chart No. 34.)

Immediate locality.-Observed station is in cultivated field, about 8 feet above high water, 6 yards north of shore, 2 yards north of top of bank, and 50 yards east of the extreme end of point.

Marks.-Observed station is center point of triangle on standard cement monument projecting 6 inches above surface of ground. Subsurface mark is center of 2 -inch tile pipe buried with top 2 inches below base of monument.

References.-

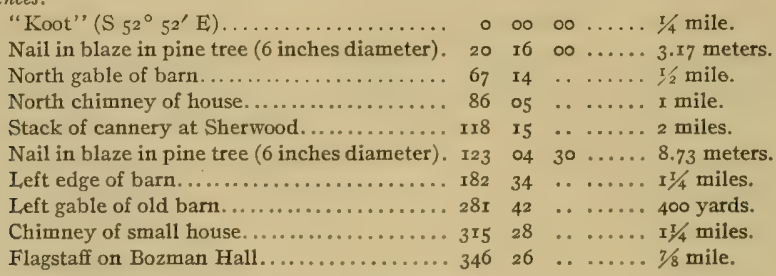

GRACE.

General locality.-Northwestern shore of Harris Creek about $3 / 8$ mile east of entrance to Cummings Creek, and I mile northeast of Little Neck Point. (See Chart No. 34.)

Immediate locality. - Observed station is on marsh point about I foot above high water, and 5 yards north of the extreme end of point.

Marks.-Observed station is center point of triangle on standard cement monument projecting 5 inches above surface of ground. Subsurface mark is center of 2 -inch tile pipe buried with top 2 inches below base of monument.

References.-

"Rabbit" ( $\mathrm{S} 82^{\circ} 20^{\prime} \mathrm{W}$ )

Nail in blaze in locust tree ( 12 inches diameter). ..................... 85

North chimney of Miller house............ I4

Chimney of small house.................. 165

South chimney of house ............. 176

North chimney of house............... $18_{3}$

East chimney of house................220

West chimney of house................ 249

North chimney of Bridges house.......... 295

East gable of McQuay's aysterhouse........ 335

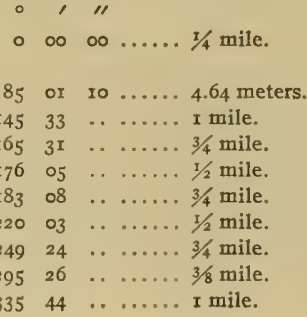




\section{MINK.}

General locality.-Western shore of Harris Creek about $1 / 2$ mile northeast of entrance to Cummings Creek and $1 / 2$ mile northwest of town of Bozman. (See Chart No. 34.)

Immediale locality.--Observed station is on marsh point about $\mathrm{x}$ foot above high water, 2 yards northwest of shore, and 40 yards northeast of wire and board fence. Cement monument marking reference station is 8.73 meters $\mathrm{N} 53^{\circ} 5^{\prime}{ }^{\prime} \mathrm{W}$ of observed station.

Marks.-Observed station is center of 2 -inch tile pipe projecting 3 inches above surface of ground. Subsurface mark is center of 2 -inch tile pipe buried with top 2 inches below base of surface pipe. Reference station is center point of triangle on standard cement monument projecting 6 inches above surface of ground.

References.-

"Harrison" ( $\left.\mathrm{N} \pm 6^{\circ} 5^{8} \mathrm{E}\right)$. - , I

South chimney of Harrison house..........

South chimney of Miller house........... 3

North chimney of house............... . 45

Chimney of house . . . . . . . . . . . . . 8

Flagpole on Bozman Hall............. 135

East chimney of house.............. I55

Chimney of small house............... $18_{2}$

North chimney of Bridges house........... 190

Nail in blaze in locust tree ( 5 inches diameter).......................... $240 \quad 57$ 10... meters.

REFERENCE STATION................... 889 Io $20 \ldots 73$ meters.

Nail in blaze in mulberry tree ( 12 inches

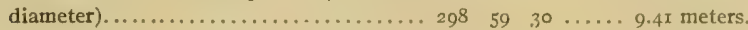

\section{HARRISON.}

General locality.-Western shore of upper Harris Creek about $3 / 4$ mile north-northwest of town of Bozman. (See Chart No. 34.)

Immediate locality.-Observed station is in edge of marsh in northeast comer of old apple orchard about 2 feet above high water, $\mathrm{Ix}$ yards northwest of shore, 23 yards west of extreme end of point, and 80 yards south-southeast of a house.

Marks.-Observed station is center point of triangle on standard cement monument projecting 3 inches above surface of ground. Subsurface mark is center of 2 -inch tile pipe buried with top 2 inches below base of monument.

References.-

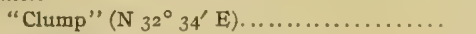

North chimney of Miller house........... 3

South chimney of house..............

North chimney of house.............. $5^{8}$

Chimney of house................. I07

Chimney of small house............... I20

North gable of barn.................. 137

Nail in blaze in apple tree ( 8 inches diameter) ${ }_{7} 73$

Center of old gristmill burr partly embedded

in ground and about 4 feet diameter..... $270 \quad 32 \quad \ldots \ldots .4 .87$ meters.

Northeast corner of Harrison house........ $30 \mathrm{I} \quad 5 \mathbf{I} \ldots \ldots$. . . So yards.

\section{CLUMP.}

General locality.-Western shore of upper Harris Creek on a point about $3 / 4$ mile north of town of Bozman. (See Chart No. 34.)

Immediate locality.-Observed station is on marsh about 2 feet above high water, 6 yards west of shore, and $I_{5}$ yards east of fringe of locust trees and vines. 
Marks.-Observed station is center point of triangle on standard cement monument projecting 3 inches above surface of ground. Subsurface mark is center of 2 -incli tile pipe buried with top 2 inches below base of monument.

References.-

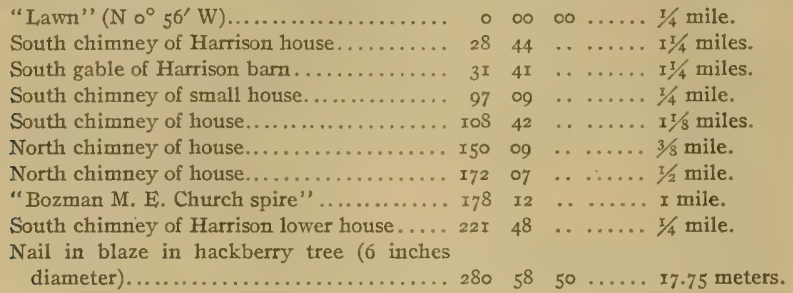

MILLER.

General locality.-Eastern shore of upper Harris Creek about I mile north of town of Bozman. (See Chart No. 34.)

Immediate locality.-Observed station is in cultivated field about I $_{5}$ feet above high water, 65 yards east of shore, and half way between a barn and a house.

Marks,-Observed station is center point of triangle on standard cement monument projecting 5 inches above surface of ground. Subsurface mark is center of 2 -inch tile pipe buried with top 2 inches below base of monument.

References.-

"Pink" ( $\left.30^{\circ} 5^{\prime} \mathrm{W}\right) \ldots \ldots \ldots \ldots \ldots \ldots \ldots$

East gable of barn.................. 50

Left comer of Seth bathhouse........... 92

South chimney of house................ I06

Southwest comer of Miller barn........... ${ }_{5}$ I

West gable of barn.................. 245

South chimney of Harrison house......... 270

Northwest corner of Miller house......... 327

West chimney of house............... 333

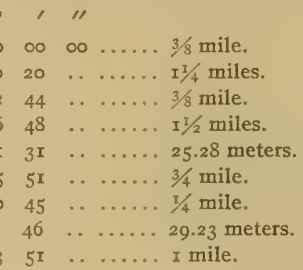

PINK:

General locality.-Eastern shore of upper Harris Creek about $5 / 8$ mile north of town of Bozman. (See Chart No. 34.)

Immediate locality.-Observed station is on a marsh point about I foot above high water, 6 yards southwest of shore, I2 yards southeast of extreme end of point, and 200 yards southwest of a house.

Marks.-Observed station is center point of triangle on standard cement monument projecting 7 inches above surface of ground. Subsurface mark is center of 2 -inch tile pipe buried with top 2 inches below base of monument.

References.-

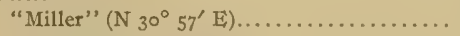

North chimney of Miller house............

Nail in blaze in twin oak tree ( 18 inches diam-

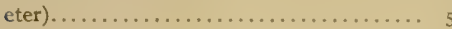

North chimney of Bridges house.......... I

East gable of barn.................. 27

South chimney of house................ 28

Cupola on tin-roof barn................. $3^{\text {rg }}$

South gable of house.................. 335

South chimney of Harrison house........ 342

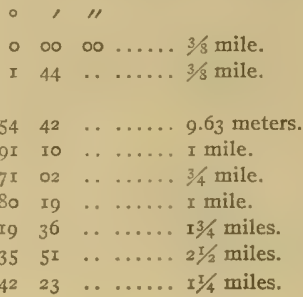


General locality.-Eastern shore of Harris Creek, about $1 / 4$ mile northwest of town of Bozman and $3 / 4$ mile east of entrance to Cummings Creek. (See Chart No. 34.)

Immediate locality.-Observed station is in a cleared space about 8 feet above high water, 25 feet southeast of top of vertical bank 8 feet high, and i 6 yards north of pine woods.

Marks.-Observed station is center point of triangle on standard cement monument projecting 7 inches above surface ground. Subsurface mark is center of 2 -inch tile pipe buried with top 2 inches below base of monument.

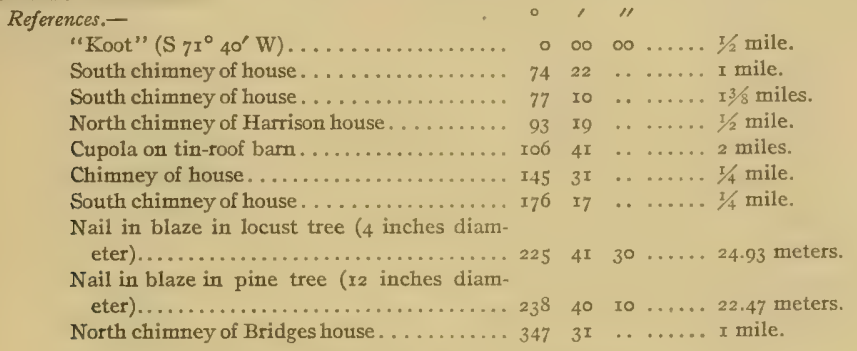

\section{BOZMAN M. E. CHURCH SPIRE.}

General locality. - Southeastern shore of Harris Creek in the town of Bozman, on the northwest side of county road leading to Neavitt. (See Chart No.34.)

Immediate locality.-Observed station is on edifice known as Bozman M. E. Church.

Marks.--Observed station is center of spire on Bozman M. E. Church.

References.-None necessary.

\section{KOOT.}

General locality.-Southeastern shore of Harris Creek on a point of land between two coves, about $3 / 8$ mile southeast of entrance to Cummings Creek, and $I / 2$ mile west of town of Bozman. (See Chart No. 34.)

Immediate locality.-Observed station is in cultivated field about 6 feet above high water, to yards south of shore, 6 yards south of edge of bank 6 feet high, and 200 yards north of a graveyard.

Marks.-Observed station is center point of triangle on standard cement monument projecting 5 inches above surface of ground. Subsurface mark is center of 2 -inch tile pipe buried with top 2 inches below base of monument.

References. -

"Fox" $\left(\mathrm{S}_{71}{ }^{\circ}{ }_{2} 8^{\prime} \mathrm{W}\right)$

Nail in blaze in oak tree ( 6 inches diameter)

North chimney of house. ..............

South gable of old barn...............

South chimney of Miller house.......... I50

Chimney of small house. . . . . . . . . . . . 6 r

West chimney of house............. $x_{7} 8$

Chimney of small house............. I93

Flagstaff on Bozman Hall .............. 2I4

Lone cherry tree in Bridges graveyard . . . . 282

North chimney of Bridges house........ 307

Nail in blaze in locust tree ( 6 inches diam-

eter)............................. $347 \quad 25 \quad 50 \ldots .29$ meters. 
FOX.

General locality.-Southeastern shore of Harris Creek on a point of land between two coves about 3/4 mile south of entrance to Cummings Creek, and I/2 mile northeast of Little Neck Point. (See Chart No. 34.)

Immediate locality.-Observed station is on marsh point about I foot above high water, and 26 yards south of the extreme north end of point.

Marks.-Observed station is center point of triangle on standard cement monument projecting 7 inches above surface of ground. Subsurface mark is center of 2 -inch tile pipe buried with top 2 inches below base of monument.

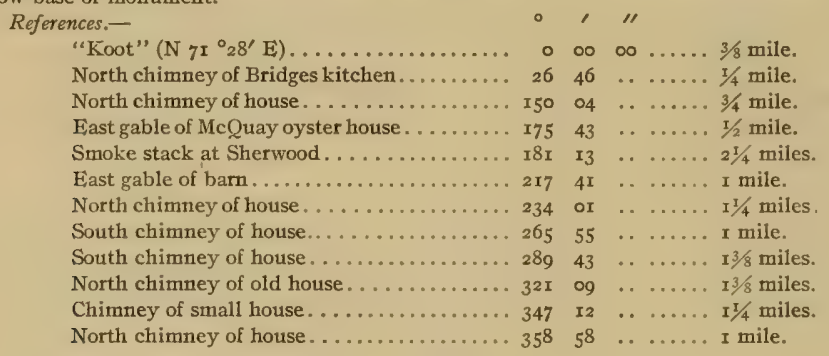

\section{NEISON 3 .}

General locality.-Northern shore of Choptank River on Nelson Island, between the entrances to Harris and Broad Creeks. (See Chart No. 34.)

Immediate locality.-Observed station is on southwest point of island on marsh about 2 feet above high water, 28 yards north-northeast of extreme end of point, 45 yards northwest of edge of marsh, and ${ }_{4}$ yards east of marsh. Cement monument marking reference station is 32.27 meters $\mathrm{N}_{32^{\circ}} \circ 5^{\prime} \mathrm{E}$ of observed station.

Marks.-Observed station is center of nail in 3-inch square stub in tile pipe flush with ground. Reference station is center point of triangle on standard cement monument projecting 6 inches above surface of ground.

References.-

"Choptank River Light" (S $\left.56^{\circ} \circ 9^{\prime} \mathrm{E}\right)$......

"Large Water Tank" ................... I

Right chimney of house ................. 3

Near chimney outside of house............ 45

Near peak of barn on Cook Point.......... . 67

Left peak of hotel on Sharps Island . . . . . . . 98

"Sharps Island Light" . . . . . . . . . . . . . . . to9

Chimney of house.................. I37

Stack of cannery at Tilghman Island . . . . . . I 53

Windmill at Tilghman Island. . . . . . . . 155

Chimney of house on Change Point....... 185

Left peak of house................ 197

Chimney of house .................. 254

"St. Michaels Church Spire" . . . . . . . . . . 259

REFERENCE STATION................. 268

Left peak of building . . . . . . . . . . . . 293

Near peak of house with three chimneys. . . . 335

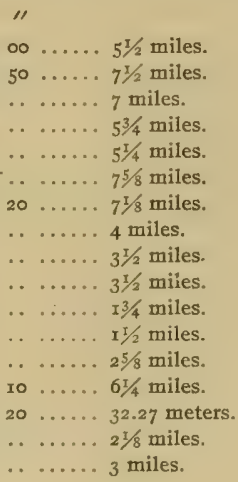




\section{ANNETTE.}

General locality.-Western shore of Broad Creek about $3 / 4$ mile north of Nelson Point, and on south side of entrance to Balls Creek. (See Chart No. 34.)

Immediate locality.-Observed station is on marsh about $\mathrm{I}$ foot above high water, and 4 yards west of shore. Cement monument marking reference station is 9.39 meters $\mathrm{N} 75^{\circ} 59^{\prime} \mathrm{W}$ of observed station.

Marks.-Observed station is center of 2 -inch tile pipe projecting 4 inches above surface of ground. Subsurface mark is center of 2 -inch tile pipe buried with top 2 inches below base of surface pipe. Reference station is center point of triangle on standard cement monument projecting 3 inches above surface of ground.
References.-
"Myrtle" ( $\mathrm{N}$ I5 $\left.29^{\prime} \mathrm{E}\right)$
"
South chimney of house.............. I8 $39 \ldots \ldots \ldots 35 \%$ miles.
South chimney of house............... $29 \quad 53 \quad \ldots \ldots \ldots 33 / 4$ miles.

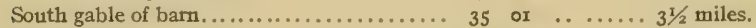
Chimney of house. .................. $3^{6} \quad 35 \quad \ldots \ldots \ldots 3 \frac{1}{1} / 2$ miles.
South gable of barn.................. $7^{2} \quad 54 \quad \ldots \ldots \ldots 2$ miles.
West chimney of house.............. 102 I9 $\ldots \ldots .3 \frac{3}{8}$ miles.
"Choptank River Light"................ II6 $34 \quad 40 \ldots \ldots$.... 61/4 miles.
Water tank at Castle Haven............. I23 54 ....... $81 / 4$ miles.
North gable of barn on Todd Point........ I48 31 .....6. $6 \mathrm{I} / 2$ miles.
Nail in blaze in cedar tree (Io inches diameter) I87 $26 \quad 00 \ldots .$. II.37 meters.
Nail in blaze in cedar tree (ro inches diameter) 235 o6 $30 \ldots \ldots .86 .8 \mathrm{r}$ meters.
REFERENCE STATION...................... $268 \quad 29 \quad 40.39$ meters.

\section{MYRTLE.}

General locality. - Western shore of Broad Creek about I1/4 miles north of Nelson Point and $1 / 4$ mile north of Balls Creek. (See Chart No. 34.)

Immediale locality. - Observed station is on marsh point about I foot above high water and 4 yards northwest of shore.

Marks.-Observed station is center point of triangle on standard cement monument projecting 5 inches above surface of ground. Subsurface mark is center of 2 -inch tile pipe buried with top 2 inches below base of monument.

References. -

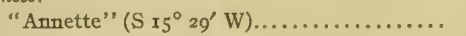

Elast gable of house...................

Nail in blaze in pine tree ( 4 inches diameter).

Nail in blaze in locust tree (4 inches diam-

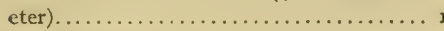

South chimney of house................. $2 x_{5} \quad 04 \ldots \ldots \ldots 3^{T / 4}$ miles.

Chimney of house............... 225 2I $\ldots \ldots .31 / 8$ miles.

Chimney of house................... 24I $26 \ldots \ldots 2$ miles.

West gable on barn.................. $255 \quad 40 \ldots 2 \frac{1}{8}$ miles.

North chimney of house............. $268 \quad 45 \quad \ldots \ldots 21 / 2$ miles.

I argest tree on Royston Island ........... $300 \quad 4 \mathrm{I} \quad \ldots \ldots 27 / 8$ miles.

Water tank at Castle Haven............. 307 og ...... $81 / 2$ miles.

\section{COAL.}

General locality.-Western shore of Broad Creek about 2 miles north of Nelson Point and I mile west of Deep Neck Point. (See Chart No. 34.)

Immediate locality.-Observed station is in cultivated field about ${ }_{4}$ feet above high water, I2 yards northwest of shore, 4 yards north of small lone cedar tree, and 200 yards north of pine woods.

Marks,-Observed station is center point of triangle on standard cement monument projecting 3 inches above surface of ground. Subsurface mark is center of 2 -inch tile pipe buried with top 2 inches helow base of monument. 


\begin{tabular}{|c|c|c|c|}
\hline eferences.- & 。 & , & " \\
\hline "Myrtle" ( $\left.44^{\circ}{ }_{2} 3^{\prime} \mathrm{W}\right)$. . & 0 & $\infty$ & 7/8 mile. \\
\hline South gable of Bridges barn............ & ${ }^{136}$ & 22 & $1 / 4$ mile. \\
\hline South chimney of Bridges house.......... & I 52 & 03 & $\pi / 4$ mile. \\
\hline North chimney of house.......... & $x 67$ & r8 & . $I / 2$ miles. \\
\hline South chimney of house..... & I 70 & $3 I$ & $2 \frac{x}{4}$ miles. \\
\hline Chimney of small house.............. & 203 & 48 & . $23 / 8$ miles. \\
\hline 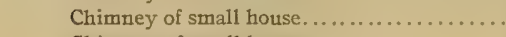 & 209 & $5^{2}$ & $23 / 8$ miles. \\
\hline Chimney of small house....... & 272 & 47 & ....... I $1 / 2$ miles. \\
\hline Largest tree on Royston Island......... & 288 & 22 & ..... 3 miles. \\
\hline Left tangent of Nelson Island............. & $33^{\mathbf{I}}$ & $4 \mathrm{I}$ & .....2. $23 / 8$ miles. \\
\hline
\end{tabular}

TOBE.

General locality.-Western shore of Broad Creek on point at southern side of entrance to Leadenham Creek. (See Chart No. 34.)

Immediate locality.-Observed station is in edge of cultivated field about 2 feet above high water, rg yards south of shore, and back of a fringe of myrtle bushes.

Marks.-Observed station is center point of triangle on standard cement monument projecting 3 inches above surface of ground. Subsurface mark is center of 2 -inch tile pipe buried with top 2 inches below base of monument.

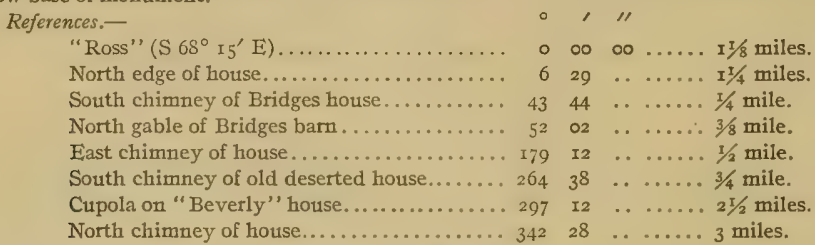

WIRE.

General locality. - Southern shore of Leadenham Creek about I mile southwest of Mulberry Point, and $1 / 4$ mile southwest of Broad Creek. (See Chart No. 34.)

Immediate locality.-Observed station is in cultivated field about 5 feet above high water, 4 yards southeast of shore at top of a vertical bank 5 feet high, and 125 yards west of board fence and row of cedar trees. Cement monument marking reference station is 18.90 meters S $23^{\circ} 36^{\prime} \mathrm{E}$ of observed station.

Marks.-Observed station is center of 2 -inch tile pipe projecting 4 inches above surface of ground. Subsurface mark is center of 2 -inch tile pipe buried with top 2 inches below base of surface pipe. Reference station is center point of triangle on standard cement monument projecting 6 inches above surface of ground.
References.-
"Tobe" (N 64 $\left.26^{\prime} \mathrm{E}\right)$

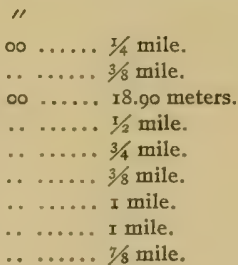
South chimney of Bridges house........ 55 3I $\ldots \ldots \ldots 3 / 8$ mile.
REFERENCE STATION.................. gI $5^{8}$ co .... 18.90 meters.
North gable of barn................. I60 $4 \mathrm{x} \ldots \ldots . . .1 / 2$ mile.
Chimney of house................... 238 Ig $\ldots \ldots 3 / 4$ mile.
North chimney of Fairbank house........ 249 og ...... $3 / 8$ mile.
South chimney of house................... 256 of mile.
South chimney of house............. $320 \quad 50 \quad \ldots \ldots$ I mile.
Chimney of small cabin............. $343 \quad 22 \quad \ldots \ldots .7 / 8$ mile. 


\section{BLANCO.}

General locality.-Sotithern shore of Leadenham Creek about $5 / 8$ mile west of Broad Creek entrance to creek and $3 / 4$ mile southwest of entrance to Grace Creek. (See Chart No. 34-)

Immediate locality. - Observed station is in a cultivated field about 9 feet above high water and $x_{3}$ yards south of edge of vertical bank at shore.

Marks,-Observed station is center point of triangle on standard cement monument projecting 4 inches above surface of ground. Subsurface matk is center of 2 -inch tile pipe buried with top 2 inches below base of monument.

Rejerences.-

"Fairbanks" ( $\left.\mathrm{N}_{30} 0^{\circ} 8^{\prime} \mathrm{E}\right) \ldots \ldots \ldots \ldots \ldots \ldots$. 0 ,

West chimney of house................. 28 oo ...... $x^{1 / 4}$ miles.

West gable of house................ 37 o $37 \ldots \ldots .3$ miles.

North gable of barn.................. 136 $_{3} 49 \quad \ldots \ldots \ldots 1 / 4$ mile.

South chimney of house.................. 308 5I . . . . mile.

East chimney of house.................. 322 o7 $\ldots \ldots 3 / 4$ mile.

Chimney of house...................... 328 ig mile.

West chimney of house................ $356 \quad 26 \quad \ldots \ldots 3 / 8$ mile.

NED.

General locality.-Southern shore of Leadenham Creek about II/8 miles west of Broad Creek entrance to creek and opposite entrance to Caulk Cove. (See Chart No. 34.)

Immediate locality.-Observed station is on marsh point about I foot above high water, 5 yards east of shore, ig yards south of the extreme end of marsh point, and north of a heavy pine woods.

Marks.-Observed station is center point of triangle on standard cement monument projecting 5 inches above surface of ground. Subsurface mark is center of 2 -inch tile pipe buried with top 2 inches below base of monument.

References.-

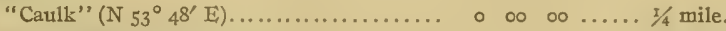

West chimney of house............... I5 $23 \ldots \ldots . . .5 / 8$ mile.

Nail in blaze in pine tree ( 12 inches diameter). I23 o6 $50 \ldots \ldots$ I0.47 meters

Nail in blaze in pine tree ( 12 inches diameter), 177 59 10 ..... 7.52 meters.

East chimney of house................ $226 \quad 43 \quad \ldots \ldots .3 / 8$ mile.

Chimney of small house............... 262 ro ..... $1 / 2$ mile.

East chimney of house................ $286 \quad 20 \quad \ldots \ldots 3 / 4$ mile.

\section{CAULK.}

General locality.-Northern shore of Leadenham Creek about $3 / 4$ mile west of Broad Creek entrance to creek and $1 / 4$ mile east-southeast of entrance to Caulk Cove. (See Chart No. 34.)

Immediate locality.-Observed station is on marsh on a wooded shore about I foot above high water and 3 yards north of shore.

Marks.-Observed station is center point of triangle on standard cement monument projecting 2 inches above surface of ground. Subsurface mark is center of 2 -inch tile pipe buried with top 2 inches below base of monument.

References.-

"Fairbanks" ( $\left.84^{\circ} 28^{\prime} \mathrm{E}\right) \ldots \ldots \ldots \ldots \ldots \ldots$

North gable of Bridges barn .............. 28

West chimney of house................ I25

East chimney of house................ I72

Nail in blaze in pine tree ( 5 inches diameter). 2 I6

Nail in blaze in pine tree ( 6 inches diameter). 339

West chimney of house.

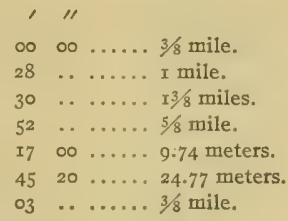




\section{FAIRBANKS.}

General locality.-Northern shore of Leadenham Creek about $1 / 2$ mile west of Broad Creek entrance to creek and on first point southwest of entrance to Grace Creek. (See Chart No. 34.)

Immediate locality.-Observed station is on marsh point about 75 yards south of a house and $I_{3}$ yards north of extreme end of point.

Marks.-Observed station is center point of triangle on standard cement monument projecting 3 inches above surface of ground. Subsurface mark is cement of 2 -inch tile pipe buried with top 2 inches below base of monument.
References.-
"Pine" (N $\left.50^{\circ} 00^{\prime} \mathrm{E}\right)$
$\begin{array}{lll}\circ & \prime \prime \\ 0 & 0 & 0\end{array} \ldots . .3 / 8$ mile.
South comer of small house.............. $33 \quad 48 \quad \ldots \ldots .3$ miles.
West gable of Bridges barn............. $80 \quad 22 \quad \ldots \ldots 3 / 4$ mile.
West chimney of house............... $138 \quad 27 \quad \ldots \ldots \ldots 1 / 2$ mile.
South gable of corn crib.............. 257 o4 ...... I0o yards.
Elast chimney of house.............. $300 \quad 34 \quad \ldots \ldots 75$ yards.
South gable of barn..................... 317 I9 $\ldots 00$ yards.

PINE.

General locality.-Northern shore of Leadenham Creek on point between entrances to Leadenham Creek and Grace Creek, and about $1 / 2$ mile west of Broad Creek. (See Chart No. 34.)

Immediate locality.-Observed station is on wooded shore about 5 feet above high water, 5 yards west of shore, 60 yards north of the extreme end of point, and at intersection of two lanes cut through woods. Cement monument marking reference station is $9.5^{2}$ meters $\mathrm{N} 67^{\circ} 25^{\prime} \mathrm{W}$ of observed station. Marks.-Observed station is center of 2 -inch tile pipe projecting 3 inches above surface of ground. Subsurface mark is center of 2 -inch tile pipe buried with top 2 inches below base of surface pipe. Reference station is center point of triangle on standard cement monument.

References.-

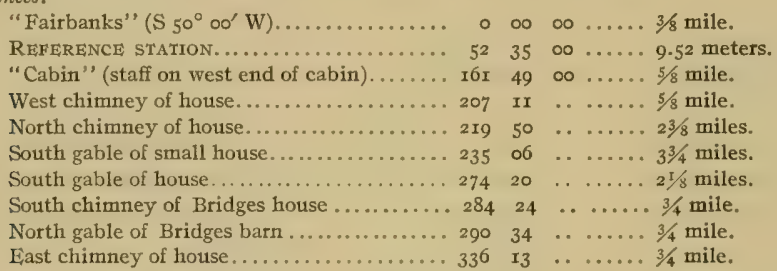

\section{LUNA.}

General locality.-Western shore of Grace Creek on a prominent point about $1 / 2$ mile northwest of Broad Creek entrance to creek. (See Chart No. 34.)

Immediate locality.-Observed station is about 5 feet above high water, 5 yards north of shore, II yards west of the extreme end of point, and 3 yards east of a dense growth of small pine trees.

Marks.-Observed station is center point of triangle on standard cement monument projecting 4 inches above surface of ground. Subsurface mark is center of 2 -inch tile pipe buried with top 2 inches below base of monument.

References.-

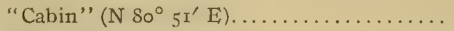

North chimney of house..................

South gable of barn..................

North gable of Bridges barn ............ 92

Nail in blaze in pine tree ( 5 inches diameter). 188

Nail in blaze in pine tree ( 5 inches diameter). 256

West chimney of house.

\begin{tabular}{|c|c|c|}
\hline$\infty$ & $\infty$ & ..... I/4 mile. \\
\hline 07 & . & .... 3/8 mile. \\
\hline 30 & . & .. 3/8 mile. \\
\hline ro & . & ..... r mile. \\
\hline 48 & Io & … 3.29 meters. \\
\hline & $\infty$ & 2.6 m meters. \\
\hline & .. & ..... I/4 mile. \\
\hline
\end{tabular}




\section{CABIN.}

General locality.-Eastern shore of Grace Creek about $1 / 2$ mile north of Broad Creek entrance to creek. (See Chart No. 34.)

Immediate locality.-Observed station is on west gable of deserted cabin about io feet above high water, and 17 yards east of shore.

Marks.-Observed station is a twenty-penny wire nail driven 2 feet below the peak of west gable of a deserted cabin, and surmounted by a staff etected over nail.

References.- None necessary.

\section{SKINNER}

General locality.-Western shore of Broad Creek at eastern side of entrance to Grace Creek, about $5 / 8$ mile west of Mulberry Point. (See Chart No. 34.)

Immediate locality.- Observed station is on marsh point about I foot above high water, 3 yards north east of shore, 42 yards east of the extreme end of point, and 40 yards southwest of a small clump of trees.

Marks.-Observed station is center point of triangle on standard cement monument projecting 4 inches above surface of ground. Subsurface mark is center of 2 -inch tile pipe buried with top 2 inches below hase of monument.

References.--

"Ross" ( $\left.\mathrm{S}+5^{\circ} 32^{\prime} \mathrm{E}\right)$.

$\begin{array}{rcccc}0 & \prime & \prime \prime & & \\ 0 & 00 & 0 & \ldots & I^{\mathrm{I}}+\text { miles. } \\ 5 & 48 & \ldots & \ldots & 21 / 4 \text { miles. } \\ 21 & 10 & \ldots & \ldots & 21 / 4 \text { miles. } \\ 45 & 46 & \ldots & \ldots & 3 / 4 \text { mile. } \\ 51 & 32 & \ldots & \ldots & 3 / 4 \text { mile. } \\ 108 & 33 & \ldots & \ldots & 5 / 8 \text { mile. } \\ 103 & 55 & \ldots & \ldots & 1 / 2 \text { mile. } \\ 212 & 06 & \ldots & \ldots & 3 / 4 \text { mile. } \\ 228 & 36 & \ldots & \ldots & 1 / 2 \text { mile. } \\ 272 & 26 & \ldots & \ldots & 1 / 4 \text { mile. } \\ 318 & 07 & \ldots & \ldots & 2 \text { miles }\end{array}$

BALD.

General locality.-Western shore of Broad Creek on Mulberry Point on northern side of entrance to Leadenham Creek. (See Chart No. 34.)

Inmediate locality.-Observed station is on marsh point about $\mathrm{I}$ foot above high water, 2 yards north of shore, 50 yards west of extreme east end of point, and 40 yards southeast of a rail fence. Cement

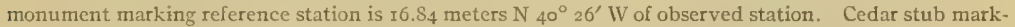
ing old triangulation station "Mulberry" is 22.46 meters $\mathrm{N} 52^{\circ} 57^{\prime} \mathrm{E}$ of observed station.

Marks,-Observerl station is center of 2 -inch tile pipe projecting 7 inches above surface of ground. Subsurface mark is center of 2 -inch tile pipe buried with top 2 inches below base of surface pipe. Reference station is center point of triangle on standard cement monument projecting 4 inches above surface of ground. Old triangulation station "Mulberry" is nail in 2 -inch cedar stub projecting 2 inches above surface of ground.

References.--

"Tobe" (S $\left.57^{\circ} \circ 9^{\prime} \mathrm{W}\right)$

East gable of house.....................

East chimney of house................

REFERENCE STATION ................ I

South chimney of Willey house........... I5

Cupola on "Bcverly" house. .............. 166

OLD TRIANGULATION STATION MUIBERRY... I 175

Right tangent of north end of Willey Island. . 2 I5

Right tangent of marsh at Deep Neck Point. . 286

North gable of Bridges barn............. 344 $53485-12-7$

$\begin{array}{llllll}0 & 00 & 00 & \ldots \ldots & 7 / 8 \text { mile. } \\ 9 & 19 & \ldots & \ldots & 11 / 4 \text { miles. } \\ 4 & 05 & \ldots & \ldots & 1 / 4 \text { mile. } \\ 8 & 25 & 00 & \ldots & 16.84 \text { meters. } \\ 8 & 43 & \ldots & \ldots & 11 / 8 \text { miles. } \\ 6 & 28 & \ldots & \ldots & 11 / 4 \text { miles. } \\ 5 & 48 & 40 & \ldots & 22.46 \text { meters. } \\ 5 & 38 & \ldots & \ldots & 3 / 4 \text { mile. } \\ 6 & 05 & \ldots & \ldots \ldots & 11 / 8 \text { miles. } \\ 4 & 46 & \ldots & \ldots & \text { I mile. }\end{array}$


ROSE

General locality.-Western shore of upper Broad Creek on a very prominent point about $3 / 8$ mile north-northeast of Mulberry Point and 5/8 mile west-northwest of the south end of Hambleton Island. (Sce Chart No. 34.)

Immediate locality.-Observed station is on marsh point about a feet above high water, 4 yards west of end of point, and zo yards east of point of pine woods.

Marks-Observed station is center point of triangle on standard cement monument projecting 6 inches above surface of ground. Subsurface mark is center of 2 -inch tile pipe buried with top 2 inches helow base of monument.

\section{References.-}

"Gram" ( $\left.5^{\circ} 29^{\prime} \mathrm{W}\right)$

South chimney of house..................

South climncy of Willis house.......... $42 \quad 53 \ldots \ldots \ldots 3 / 4$ mile.

Cupola on "Beverly" house............ 53 . $0_{3} \ldots \ldots . .$. I mile.

West chimney of "Beverly" tenant house... 66 59 $6 . . . \ldots \times 1 / 2$ miles.

West gable of house................. III $08 \ldots \ldots \ldots$ I $3 / 8$ miles.

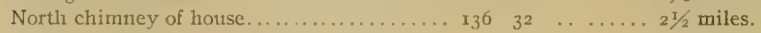

Right tangent of woods on Deep Neck Point. . I79 32 ...... I I $1 / 8$ miles.

Left tangent of Nelson Island............

West gable on Bridges barn............ $225 \quad 04 \ldots \ldots \ldots x^{3} / 8$ miles.

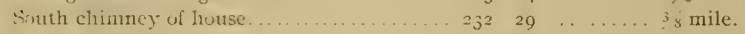

North chimney of house............... 259 o6 $\ldots \ldots .3 / 8$ mile.

Cuppla on barn ................... 359 2I $\ldots \ldots \ldots$ It/4 miles.

\section{GRAM.}

General locality.-Western shore of upper Broad Creek about $3 / 4$ mile north of Mulberry Point and about $1 / 2$ mile west of upper end of Hambleton Island. (See Chart No. 34.)

Immediate locality.-Observed station is on marsh point about 2 feet above high water, ro yards west of extreme east end of point, and about $\mathrm{T} / 4$ mile northeast of a house.

Marks,-Observed station is center point of triangle on standard cement monument projecting 6 inches above surface of ground. Subsurface mark is center of 2 -inch tile pipe buried with top 2 inches below base of monument.
References.-
"Royal" ( $\left.8^{\circ} 49^{\prime} \mathrm{E}\right)$
North ching
North chimney of house ................
North chimney of Price house............
South chimney of Willey house........... 6
Cupola on "Beverly" house............... 6
West chimney of house............... g6
Right tangent of woods on Deep Neck Point. 165
North chimney of house............... 23I
South gable of Miller barn.............. $3 I_{3}$
South chimney of Harrison house......... 316
Cupola on barn...................... 344
South chimney of louse.............. 353

$\begin{array}{ccccc}\prime \prime & \prime \prime & & \\ 00 & 0 & \ldots & \ldots & 3 / 8 \text { mile. } \\ 31 & \ldots & \ldots & 5 / 8 \text { mile. } \\ 36 & \ldots & \ldots & 3 / 4 \text { mile. } \\ 08 & \ldots & \ldots & 1 / 2 \text { mile. } \\ 45 & \ldots & \ldots & 3 / 4 \text { mile. } \\ 11 & \ldots & \ldots & 15 / 8 \text { miles. } \\ 22 & \ldots & \ldots & 15 / 3 \text { miles. } \\ 02 & \ldots & \ldots & 1 / 4 \text { mile. } \\ 28 & \ldots & \ldots & 2 & 2 \text { miles. } \\ 54 & \ldots & \ldots & 17 / 8 \text { miles. } \\ 46 & \ldots & \ldots & 3 / 4 \text { mile. } \\ 26 & \ldots & \ldots & 3 / 4 \text { mile. }\end{array}$

\section{BENGAL.}

General locality.-Western shore of upper Broad Creek about $3 / 4$ mile west of north end of Hambleton Island. (See Chart No. 34.)

Immediate locality.-Observed station is on narrow marsh point about I foot above high water, 4 yards south of shore, 55 yards west of extreme end of point, and north of a fringe of pine and cedar trees along bank. Cement monument marking reference station is $8.8 \mathrm{I}$ meters $\mathrm{S} 52^{\circ} 34^{\prime} \mathrm{W}$ of observed station. 
Marks.-Observed station is center of 2 -inch tile pipe projecting 3 inches above surface of ground. Subsurface mark is center of 2 -incli tile pipe buried with top 2 inches below base of surface pipe. Reference station is center point of triangle on standard cement monument projecting 5 inches above surface of ground.

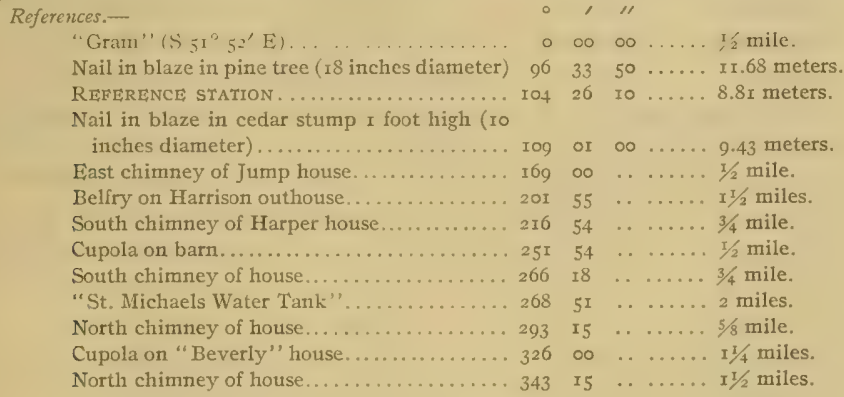

\section{EASTMAN}

General locality. -Westem shore of upper Broad Creek about II/4 miles west-northwest of north end of Hambleton Island. (See Chart No. 34.)

Immediate locality.-Observed station is on marsh point about 2 feet above high water, I2 yards south of extreme end of point, 3 yards northeast of clump of myrtle bushes, and 200 yards east of a house.

Marks,-Observed station is center point of triangle on standard cement monument projecting 4 inches above surface of ground. Subsurface mark is center of 2 -inch tile pipe buried with top 2 inches below base of monument.

\begin{tabular}{|c|c|c|c|c|}
\hline References.- & & & & \\
\hline "Woodill" ( $\left.\mathrm{N}_{23} 3^{\circ} 46^{\prime} \mathrm{W}\right)$ & o & $\infty$ & $\infty$ & 8 mile. \\
\hline Belfry on Harrison outhouse............. & 4 & 06 & 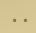 & mile. \\
\hline South gable of barn............. & I2 & 36 & . & 2 miles. \\
\hline South chimney of Willis house...... & 18 & $3^{1}$ & & II/4 miles. \\
\hline Chimney of Burke house.......... & 22 & 59 & . & $3 / 4$ mile. \\
\hline North chimney of Harper house. ....... & 38 & 29 & . & . $1 / 2$ mile. \\
\hline North chimney of house.......... & $\mathrm{S}_{2}$ & 43 & . & I mile. \\
\hline North chimney of house...$\ldots \ldots \ldots \ldots$. & 124 & 09 & $\cdots$ & I $1 / 8$ miles. \\
\hline suse.............. & 297 & I3 & . & 200 yard \\
\hline East chimney of Jump house............. & 327 & 23 & & .... $\pi / 2$ mile. \\
\hline
\end{tabular}

WOODILL.

General locality.-Western shore of upper Broad Creek about $3 / 4$ mile east of Bozman and I $1 / 2$ miles northwest of Hambleton Island. (See Chart No. 34.)

Immediate locality.-Observed station is on wooded sliore about 6 feet above high water, 8 yards southwest of shore, and 5 yards north of a pile of oyster shells.

Marks.-Observed station is center point of triangle on standard cement monument projecting 4 inches above surface of ground. Subsurface mark is center of 2 -inch tile pipe buried with top 2 inches below base of monument.

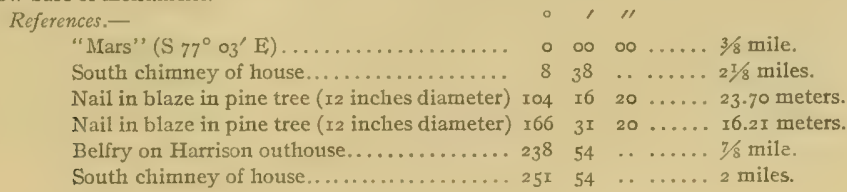




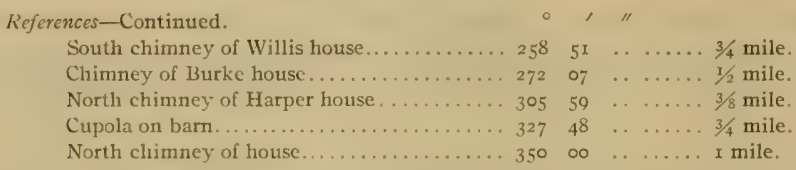

DELTA.

General locality. - Western shore of upper Broad Crcek about $3 / 4$ mile northeast of Bozman, and I3/4 miles northwest of Hambleton Island. (Sce Chart No. 34.)

Immediate locality.-Observed station is on marsh about I foot above high water, ro yards west of shore, and about 100 yards east of an orchard.

Marks.-Observed station is center point of triangle on standard cement montument projecting 7 inches above surface of ground. Subsurface mark is center of 2 -inch tile pipe buried with top 2 inches below base of monument.

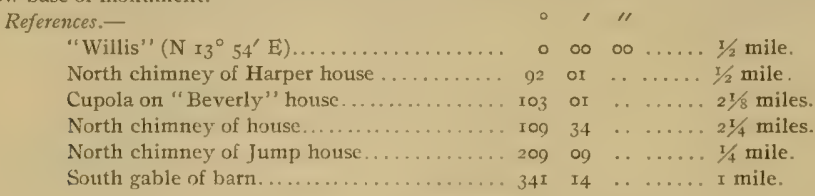

\section{MARION.}

General localily.-Western shore of upper Broad Creek about $2 \frac{1}{2}$ miles northwest of Hambleton Island. (See Chart No. 34.)

Immediate locality.-Observed station is on cast side of a tenant house in a cultivated field about 8 feet above high water, $x_{2}$ yards south of shore, and I2 yards northwest of old open well.

Marks, - Observed station is center of hole drilled in east face of center one of three posts supporting east front of a tenant house, and surmounted by spindle erected over hole.

References.-None necessary.

\section{WILIIS.}

General locality.-Eastern shore of upper Broad Creek, on a point at northern side of entrance to a small crcek about $2 \frac{1}{2}$ miles west of St. Michaels. (See Chart No. 34.)

Immeliate locality.-Observed station is on maish point at west edge of yard of a house about I foot above high water, 8 yards east of shore, 5 yards west of top of slope, about 4 feet higher than station, and 65 yards southwest of the southwest corner of a house.

Marks.-Observed station is center of 2 -inch tile pipe projecting 6 inches above surface of ground. Subsurface mark is center of 2 -inch tile pipe buried with top 2 inches below basc of surface pipe.

References.-

"Neptune" ( $\mathrm{S}_{15}{ }^{\circ} 36^{\prime} \mathrm{E}$

North chimney of houre.

North chimney of house ................

North gable of house.

"Marion" (staff on cast side of house)

Chinıney on Harrison tenant housc

South chimney of $\mathrm{H}$ arrison house. . . . . . . . .

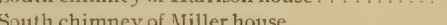

South chimney of Harrison house

Nail in blaze in cedar tree (I5 inches diameter).

Southwest comer of Willis house.

Nail in blaze in cedar tree ( 5 inches diameter

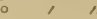

$\begin{array}{rrrrrr}0 & 00 & 00 & \ldots & 3 / 8 \text { mile. } \\ 37 & 51 & \ldots & \ldots & 1 / 2 \text { mile. } \\ 41 & 18 & \ldots & \ldots & 1 / 2 \text { mile. } \\ 70 & 53 & 10 & \ldots & 1 / 4 \text { mile. } \\ 70 & 55 & \ldots & \ldots & 1 / 4 \text { mile. } \\ 113 & 36 & \ldots & \ldots & 1 / 4 \text { mile. } \\ 125 & 01 & \ldots & \ldots & 5 / 8 \text { mile. } \\ 165 & 07 & \ldots & \ldots & 11 / 4 \text { miles. } \\ & & & & \\ 74 & 34 & 50 & \ldots & 16.59 \text { meters. } \\ 82 & 18 & \ldots & \ldots & 1 / 2 \text { mile. } \\ 246 & 43 & \ldots & \ldots & 63 \text { yards. } \\ 302 & 55 & 50 & \ldots & 11.8 \text { r meters. } \\ 356 & 35 & \ldots & \ldots & 3 / 8 \text { mile. }\end{array}$

Chimney of house . . . . . . . . . . . $356 \quad 35 \quad \ldots \ldots \ldots 3 / 8$ mile. 


\section{NEPTUNE.}

General locality.-Eastem shore of upper Broad Creek about 2 miles north of Mulberry Point and 2 miles west of St. Michaels. (See Chart No. 34.)

Immediate locality.-Observed station is in cultivated garden about $\eta$ feet above high water, Io yards north of shore, 20 yards east of the extreme end of point, 2 yards north of top of bank with uniform slope to shore, and 40 yards west of a house.

Marks.-Observed station is center point of triangle on standard cement monument projecting 5 inches above surface of ground. Subsurface mark is center of 2 -inch tile pipe buried with top 2 inches below base of monument.

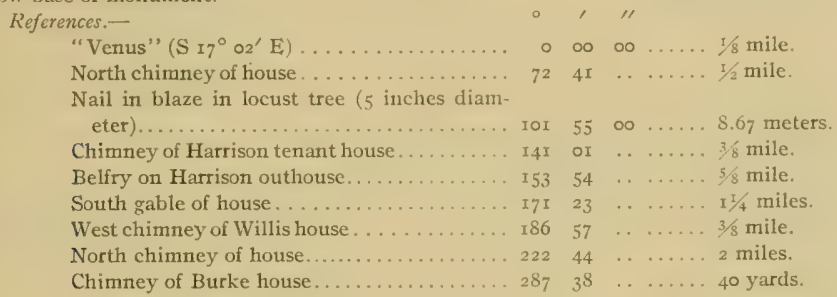

\section{VENUS.}

General locality.-Eastern shore of upper Broad Creek about $1 / 2$ mile north of entrance to Edgar Cove. (See Chart No. 34.)

Immediate locality.-Observed station is on wooded point about 6 feet above high water and 3 yards northeast of edge of a vertical bank 6 feet high. Cement monument marking reference station is 13.28 meters $\mathrm{S} 79^{\circ} 28^{\prime} \mathrm{E}$ of observed station.

Marks.-Observed station is center of 2 -inch tile pipe projecting 4 inches above surface of ground. Subsurface mark is center of 2 -inch tile pipe buried with top 2 inches below base of surface pipe. Reference station is center point of triangle on standard cement monument.

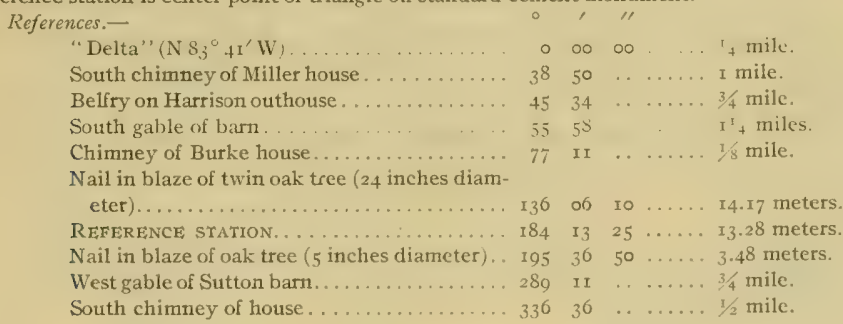

\section{MARS.}

General locality.-Eastern shore of upper Broad Creek about $x$ mile northwest of north end of Hambleton Island. (See Chart No. 34.)

Immediate locality._Observed station is on marsh about 2 feet above high water and 7 yards east of shore.

Marks.-Observed station is center point of triangle on standard cement monument projecting 5 inches above surface of ground. Subsurface mark is center of 2 -inch tile pipe butried with top 2 inches below base of monument. 


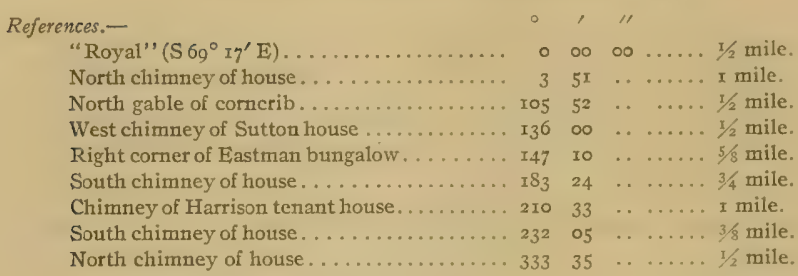

\section{ROYAL.}

General locality.-Eastern shore of upper Broad Creek about I/2 mile northwest of north end 01 Hambleton Island. (See Chart No. 34.)

Immediate locality.-Observed station is on marsh point about I foot above high water, 5 yards northeast of shore, 45 yards south of a lone leaning cedar tree.

Marks.-Observed station is center point of triangle on standard cement monument projecting 5 inches above surface of ground. Subsurface mark is center of 2 -inch tile pipe buried with top 2 inches below base of monument.

References.-

\begin{tabular}{|c|c|c|c|c|}
\hline t & $\circ$ & $\infty$ & & \\
\hline North chimney of house. ......... & I & 57 & & ailes. \\
\hline Tail in blaze in red oak tree ( 3 feet dian & $9^{2}$ & $3 I$ & 0 & . \\
\hline West chimney of house. ........ & $\mathrm{II}_{3}$ & 59 & & ine. \\
\hline South chimney of "Beverly" house. . & 178 & 12 & & \\
\hline Right tangent of woods on Deep Neck & 247 & 53 & & les. \\
\hline aney of house. . & 273 & 53 & & mile. \\
\hline 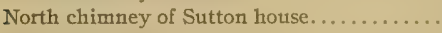 & $33^{8}$ & 34 & . & . \\
\hline ey of Jump house... & 348 & I8 & & mile. \\
\hline
\end{tabular}

\section{GRAVE.}

General locality.-Eastern shore of upper Broad Creek on point of mainland between Broad Creek and Back Creek about $1 / 8$ mile west of north end of Hambleton Island. (Sce Chart No. 34.)

Immediate locality.-Observed station is on marsh point about 2 feet above high water, II yards northeast of shore, and about $1 / 4$ mile southwest of a house.

Marks.-Observed station is center point of triangle on standard cement monument projecting 6 inches above surface of ground. Subsurface mark is center of 2 -inch tile pipe buried with top 2 inches below base of monument.

References.-

"Ray" (S $\left.26^{\circ} 20^{\prime} \mathrm{E}\right)$

Right tangent of woods Deep Neck Point

North chimney of house.................

South gable of barn................. I

North chimney of Jump house............ I3

South chimney of house.................. I

South chimney of Price house............ 249

Cupola on "Beverly" house............... 300

North chimney of Willey house......... 309

\section{RAY.}

General locality.-Eastern shore of Broad Creek on western side of Hambleton Island about $1 / 2$ mile north of the south end of island, and 7/8 mile northeast of Mulberry Point. (See Chart No. 34.)

Immediate locality.-Observed station is on marsh about I foot above high water, 4 yards east of shore, and 13 yards west of fringe of small trees at top of bank near edge of cultivated field. 
Marks.-Observed station is center point of triangle on standard cement monument projecting 6 inches above surface of marsh. Subsurface mark is center of a 2 -inch tile pipe buried with top 2 inches below base of monument.

References.-

"Willey" (S $\left.7^{\circ} \mathrm{I} 5^{\prime} \mathrm{E}\right)$

Right

Right tangent of woods Deep Neck Point.... 23

West gable of Bridges barn..............

East chimney of house.............. 73

North chimney of house................ ro

North chimney of house............... I20

South chimney of house............... 159

Nail in blaze in cedar tree ( 6 inches diameter). $245 \quad 5$

Nail in blaze in wild cherry tree ( 7 inches

diameter).

\section{WILLEY.}

General locality,-Eastern shore of Broad Creek on southern end of Hambleton Island about $5 / 8$ mile north of Cedar Point. (See Chart No. 34.)

Immediate locality.-Observed station is in cultivated field about ${ }_{5}$ feet above high water, and 50 yards north of shore.

Marks.-Observed station is center point of triangle on standard cement monument projecting 5 inches above surface of ground. Subsurface mark is center of 2 -inch tile pipe buried with top 2 inches below base of monument.

References.-

"Bald". $\left(\mathrm{S} 87^{\circ}+\mathrm{S}^{\prime} \mathrm{W}\right)$. .

North chimney of house................

Chimney of house.....................

South chimney of house................

Chimney of "Beverly" tenant house....... x . I

Cupola on outhouse. ................. I8

Chimney of house.................... In

West chimney of house................. 208

North gable of barn.................. 230

Left tangent of Nelson Island............. 304

East chimney of house

$\begin{array}{lllll}303 & 17 & 50 & \ldots & 20.5^{2} \\ \text { meters. }\end{array}$

$0000 \ldots .3 / 8$ mile.

$27 \quad \ldots \ldots \ldots 13 / 8$ miles.

$34 \ldots \ldots \ldots 2$ miles.

...... I mile.

...... $3 / 4$ mile.

....... $13 / 4$ miles.

....... II/4 miles.

ro ..... II.08 meters.

\section{JUDGE.}

Gencral locality.-Western shore of Back Creek on a prominent point on eastern side of Hambleton Island about $1 / 2$ mile north of Edge Creek. (See Chart No. 34.)

Immediale locality.-Observed station is on marsh point about 2 feet above high water, 7 yards west of the extreme end of point, and 8 yards east of a cut inshore.

Marks.-Observed station is center point of triangle on standard cement monument projecting 0 inches above surface of ground. Subsurface mark is center of 2 -inch tile pipe buried with top 2 inches below base of monument.

References.-

"Willey" (S I $\left.4^{\circ} 4 i^{\prime} \mathrm{W}\right) \ldots \ldots \ldots \ldots \ldots \ldots \ldots$

Lone cedar tree..................... 5

South chimney of Willey house.......... 136

North chimney of house................ I4t

West chimney of "Beverly" house......... I6

East chimney of "Beverly" tenant house... 20.4

Chimney of house.

East chimney of house................ 265

North chimney of house ............... 299

Right edge of small house.............. 328

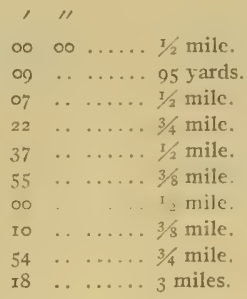


THELMA.

General locality.-Western shore of Back Creek on northern part of Hambleton Island, about I mile north of Edge Creek. (See Chart No. 34.)

Immediate locality.-Observed station is in front yard of a house about 6 feet above high water, 3 yards west of shore, 20 yards southeast of a house, and nearly on line with south side of a house.

Marks.-Observed station is center point of triangle on standard cement monument projecting 4 inches above surface of ground. Subsurface mark is center of 2 -inch tile pipe buried with top 2 inches below base of monument.

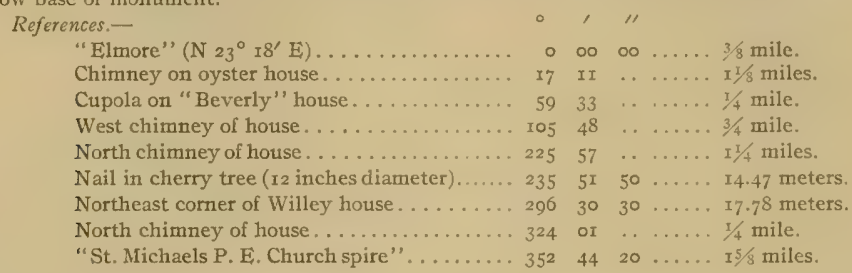

\section{ELMORE.}

General locality. - Western shore of Back Creek, about $3 / 8$ mile north of north end of Hambleton Island and $I / 4$ miles south of St. Michaels. (See Chart No. 34.)

Immediate locality.-Observed station is near edge of a cultivated field, about 6 feet above high water, 5 yards south of edge of vertical bank at shore, and 20 yards west of extreme end of point of marsh.

Marks.-Observed station is center point of triangle on standard cement monument projecting 5 inches above surface of ground. Subsurface mark is center of 2 -inch tile pipe buried with top 2 inches below base of monument.

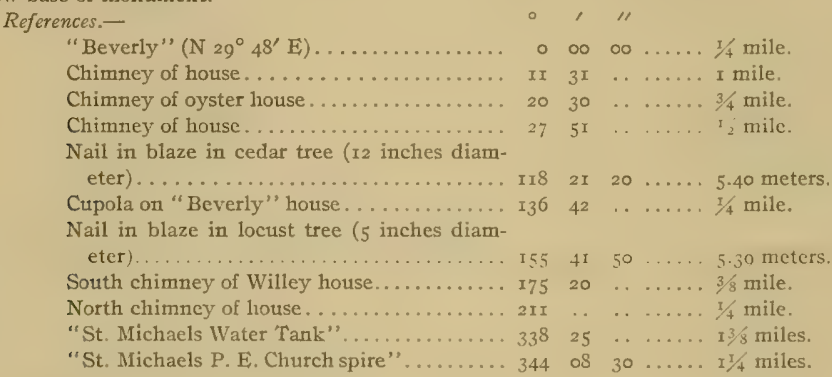

\section{BEVERLY.}

General locality.-Eastern shore of Back Creek, about 3/4 mile south of St. Michaels, and 5/3 mile nortin of north end of Hambleton Island. (See Chart No. 34.)

Immediale locality.-Observed station is on sandy marsh point about $\mathrm{I}$ foot above high water, 8 yards northeast of shore and south of a heavy growth of small pine trees.

Marks.-Observed station is center point of triangle on standard cement monument projecting 4 inches above surface of ground. Subsurface mark is center of 2 -inch tile pipe buried with top 2 inches below base of monument. 


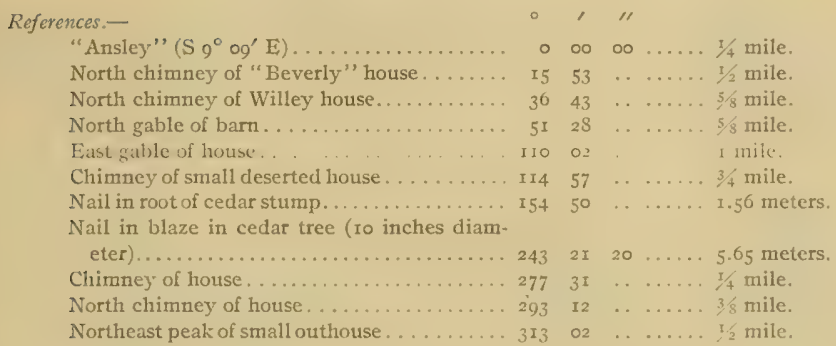

\section{SAMUEL,}

General locality.-Eastern side of Back Creek on northern side of small creek, about I mile south of St. Michaels and $3 / 4$ mile northeast of north end of Hambleton Island. (See Cliart No. 34.)

Immediate locality.-Observed station is on point near edge of cultivated field, about 6 feet above high water, 15 yards north of shell covered shore, and 30 yards northwest of extreme end of marsh point, and near a number of small cedar and locust trees.

Marks,-Observed station is center point of triangle on standard cement monument projecting 2 inches above surface of ground. Subsurface mark is center of 2 -inch tile pipe buried with top 2 inches below base of monument.

References.-

"Ansley" (S $20^{\circ}$ 10' W)

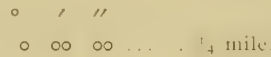

West chimney of "Beverly" kitchen........

North chimney of Willey house............

North chimney of house

Nail in blaze in locust tree ( 5 inches diameter $) \ldots \ldots \ldots \ldots \ldots \ldots \ldots \ldots \ldots \ldots \ldots \ldots \ldots \ldots$.

Nail in blaze in cedar tree ( 12 inches diameter)...

Chimney of small house............. I I

Chimney of oyster house . . . . . . . . . . . . 252

North chimney of house.............. 276

Chimney of old deserted house . . . . . . . 317 ... ISS

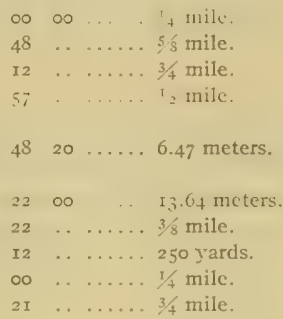

ANSLEY.

Gencral localily,-Eastern shore of Back Creek, about I mile south of St. Michaels, 1' milc northeast of north end of Hambleton Island, and $1 / 8$ mile south of entrance to a small creek. (See Chart No. 3.4.)

Immediate locality.-Observed station is on marsh point about $\mathrm{x}$ foot above high water, 3 yards south of shore and in center of triangle formed by three pine stubs driven flush with marsh to support theodolite. Cement monument marking reference station is $2 \mathrm{I} .25$ meters $\mathrm{N} 7 \mathrm{I}^{\circ} \mathrm{I} \mathrm{3}^{\prime} \mathrm{E}$ of observed station.

Marks.-Observed station is center of 2 -inch tile pipe projecting 4 inches above surface of ground. Subsurface mark is center of 2 -inch tile pipe buried with top 2 inches below base of surface pipe. Reference station is center point of triangle on standard cement monument.

References.-

"Samuel" ( $\mathrm{N} 20^{\circ}$ 10' E).

Nail in blaze in pine tree ( 12 inches diam.

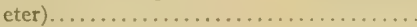

REFERENCE STATION................

Nail in blaze in pine tree ( 18 inches diam-

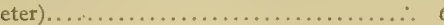

$\circ \infty \infty \ldots . .1 / 4$ mile.

$\begin{array}{llllll}35 & 3.3 & 50 & \ldots \ldots & 18.74 & \text { meters }\end{array}$

$51 \quad 02 \quad 40 \ldots \ldots 21.25$ meters.

$66 \quad 1200 \ldots \ldots \times 12.72$ meters. 
References-Continued.

Cupola on "Beverly" house........... I79 $34 \ldots \ldots . \ldots 1 / 4$ mile

North chimney of Willey house......... $205 \quad 52 \quad \ldots \ldots \ldots .1 / 2$ mile.

North chimney of house............. 253 I9 $\ldots \ldots .3 / 8$ mile.

South gable of barn. . . . . . . . . . . 323 5 $55 \quad \ldots \ldots 5 / 8$ mile.

\section{HARPER。}

General locality.-Eastern shore of Back Creek on a prominent point opposite north end of Hambieton Island about I I/2 miles south of St. Michaels. (See Chart No. 34.)

Immediate locality.-Observed station is in the northwest corner of yard of a house about 4 feet above high water, I $_{3}$ yards south of edge of a stone sea wall, and 55 yards northwest of a house.

Marks.-Observed station is center point of triangle on standard cement monument projecting 4 inches above surface of ground. Subsurface mark is center of 2 -inch tile pipe buried with top 2 inches below base of monument.

\section{References.-}

"Judge" ( $\left.\mathrm{S}_{3}^{\circ} \circ 5^{\prime} \mathrm{E}\right)$

Left tangent of Nelson Point.

Left tangent of Nelson Point. .................

North chimney of Willey house............

East chimney of house................ I

South chimney of house ............... I

South gable of barn................. I8

"St. Michaels Water Tank". ............. I88

Nail in pecan tree (24 inches diameter)..... 237

Northwest comer of "Beverly" kitchen... . 315

Nail in leaning locust tree.

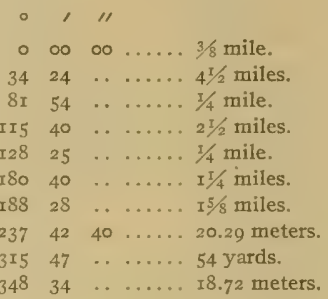

TAFT.

General locality.-Eastern shore of Back Creek about 2 miles south of St. Michaels, I/2 mile north of Edge Creek, and nearly opposite extreme eastern point of Hambleton Island. (See Chart No. 34.)

Immediate localify.-Observed station is in cultivated field about 7 feet above high water, 12 yards east of shore, $I_{5}$ yards north of edge of a bank 6 feet above marsh, and 5 yards east of edge of bank.

Marks.-Observed station is center point of triangle on standard cement monument projecting 6 inches above surface of ground. Subsurface mark is center of 2 -inch tile pipe buried with top 2 inches below base of monument.

\section{References.-}

"Hopkins" ( $\left.\mathrm{S} 9^{\circ} \circ \mathrm{oO}^{\prime} \mathrm{E}\right)$

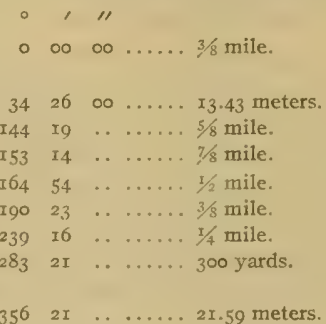

\section{HOPKINS.}

General locality.-Northern shore of Edge Creek on eastern side of entrance to Back Creek about $3 / 4$ mile north-northeast of Cedar Point. (See Chart No. 34.)

Immediate locality.-Observed station is in cultivated field about 8 feet above high water, $x_{5}$ yards north of shore, 20 yards from three small cedar trees near shore. 
Marks.-Observed station is center point of triangle on standard cement monument projecting 5 inches above surface of ground. Subsurface mark is center of 2 -inch tile pipe buried with top 2 inches below base of monument.

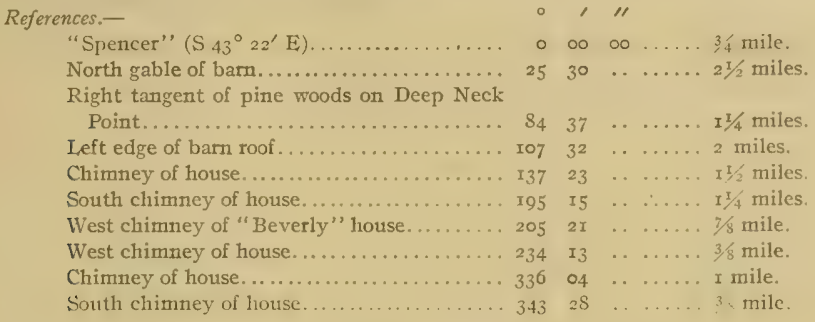

\section{SPENCER.}

General locality.-Northem shore of Edge Creek at westem side of entrance to Solitude Creek about I mile east of Broad Creek. (See Chart No. 34.)

Immediate locality.-Observed station is on marsh point about $\mathrm{I}$ foot above high water, 4 yards northeast of shore, and $2 x$ yards northwest of extreme end of point, with a long bar of oyster shells extending 65 yards into creek. Cement monument marking reference station is 11.22 meters $\mathrm{N} \mathrm{S}^{\circ} 44^{\prime} \mathrm{E}$ of observed station.

Marks.-Observed station is nail in 3 -inch cedar stub projecting 4 inches above surface of marsh. Reference station is center point of triangle on standard cement monument projecting 5 inches above surface of ground.

References.-

\begin{tabular}{|c|c|c|c|c|}
\hline 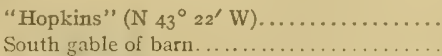 & $\begin{array}{r}0 \\
36\end{array}$ & OI & & $\begin{array}{l}3 / 4 \text { mile. } \\
\ldots .1+\text { mile. }\end{array}$ \\
\hline EFERENCE STATION .... & 52 & 05 & Io & II.22 metc \\
\hline imney of house........ & 96 & 18 & & $3 / 8$ mile. \\
\hline himney of house......... & Iro & $5 \mathbf{I}$ & & ile. \\
\hline chimney of house........... & ISo & 45 & $\ldots$ & $I / 2$ miles. \\
\hline st chimney of house... & 201 & 47 & . & $I \pi / 4$ miles. \\
\hline all house. ....... & 243 & I9 & . & $I^{2} / 2$ \\
\hline mney of house......... & 306 & 49 & $\cdots$ & $21 / 4$ miles. \\
\hline e of house.............. & 316 & 57 & . & $23 / 4$ miles. \\
\hline ath chimney of house................ & 345 & 29 & & miles. \\
\hline
\end{tabular}

\section{MARSHALL.}

General locality.-Northern shore of Edge Creek opposite Elberts Cove about I $1 / 4$ miles east of Cedar Point at Broad Creek entrance to creek. (See Chart No. 34.)

Immediate locality.-Observed station is in cultivated field about 6 feet above high water, 16 yards northeast of shore, 3 yards northeast of an old row of fence posts, 13 yards northwest of wire fence and line of cedar trees, and 125 yards west of an old deserted house.

Marks.-Observed station is center point of triangle on standard cement monument projecting $i$ inches above surface of ground. Subsurface mark is center of 2 -inch tile pipe buried with top 2 inches below base of monument.

References.-

"Holly" ( $\left.\mathrm{S}_{13}{ }^{\circ} 25^{\prime} \mathrm{E}\right) \ldots \ldots \ldots \ldots \ldots \ldots \ldots$

West chimney of house.............. 21

North gable of house................... 62

North gable of barn................ $75 \quad 45 \quad \ldots \ldots \ldots$ I $1 / 4$ miles. 
References-Continued.

East chimney of house $\ldots \ldots \ldots \ldots \ldots \ldots \ldots$ I20 $35 \quad \ldots \ldots \ldots 21 / 4$ miles.

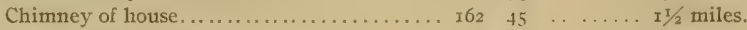

Eiast chimney of house ................ I76 $04 \ldots \ldots \ldots 3 / 8$ mile.

Lone dead tree ( 18 inches diameter)....... $206 \quad 48 \quad \ldots \ldots .125$ yards.

West chimney of old deserted house....... 288 I7 $\ldots \ldots \ldots$ 125 yards.

Nail in blaze in cedar tree ( 5 inches diameter). 2 I4 43 Io . . . I2.55 meters.

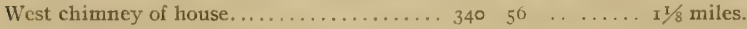

CLARK.

General locality.-Northern shore of Edge Creek on western side of entrance to Spencer Creek about I5/8 miles east of Cedar Point. (See Chart No. 34.)

Immediate locality.--Observed station is in cultivated field behind a fringe of locust and cedar trees about 6 feet above high water, 17 yards north of shore, and 35 yards northwest of extreme end of point.

Marks.-Observed station is center point of triangle on standard cement monument projecting 5 inches above surface of ground. Subsurface mark is center of 2 -inch tile pipe buried with top 2 inches below base of monument.

References.-

"Holly" (S $20^{\circ} \mathrm{I2}^{\prime} \mathrm{W}$ )

East chimney of house.

$\circ$ oo $00 \ldots . .3,3$ mile.

Nail in blaze in locust tree ( 7 inches diameter) $7^{2}$ if $\ldots \ldots \ldots 7.5^{8}$ meters.

East chimney of deserted house.......... $97 \quad 34 \quad \ldots \ldots \ldots .1 / 4$ mile.

South chimney of house............... I4/2 $23 \ldots \ldots \ldots 1 / 2$ mile.

West gable of Hammond wharf house...... I80 $40 \quad \ldots \ldots . . .3 / 3$ mile.

North chimney of house............. $216 \quad 23 \ldots \ldots .3 / 4$ mile.

South gable of house.................. $255 \quad 52 \quad \ldots \ldots \ldots 5 / 8$ mile.

North chimney of house............... $276 \quad 48 \quad \ldots \ldots \ldots$ I mile.

West chimney of house............... 295 o5 $\ldots \ldots .3 / 4$ mile.

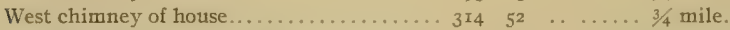

Nail in blaze in cedar tree ( 6 inches diameter). $\begin{array}{lllll}323 & 03 & 40 & \ldots & 3.67\end{array}$ meters.

\section{HOLLY.}

General locality.-Southern shore of Edge Creek about 2 miles east of Broad Creek and nearly opposite entrance to Spencer Creek. (See Chart No. 34.)

Immediate locality.-Observed station is on marsh point about on level with high water, I3 yards north of a fringe of cedar trees and roo yards west of a cove. Cement monument marking reference station is II.68 meters $\mathrm{S} 14^{\circ} 24^{\prime} \mathrm{W}$ of observed station.

Marks.-Observed station is center of 2 -inch tile pipe projecting 4 inches above surface of ground. Subsurface mark is center of 2 -inch tile pipe buried with top 2 inches below base of surface pipe. Reference station is center point of triangle on standard cement monument projecting 5 inches above surface of ground.

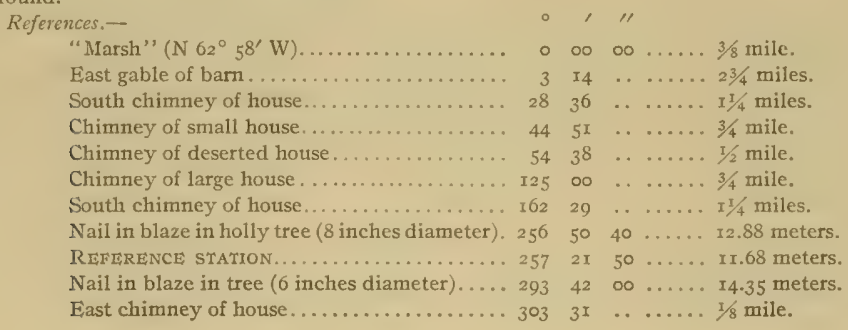




\section{MARSH.}

General locality.-Southem shore of Edge Creek at eastern side of entrance to Elbert Cove about $I^{1} / 2$ miles east of Broad Creek. (See Chart No. 34.)

Immediate localify:-Observed station is on marsh point about I foot above high water, I 8 yards west of shore, 27 yards south of extreme north end of point, and 35 yards north of an old fence line with a row of cedars. Cement monument marking reference station is $x 3.5^{8}$ meters S $14^{\circ} 47^{\prime} \mathrm{W}$ of observed station.

Marks.-Observed station is nail in 3 -inch cedar stub projecting 5 inches above surface of ground. Reference station is center point of triangle on standard cement monument projecting 4 inches above surface of ground.

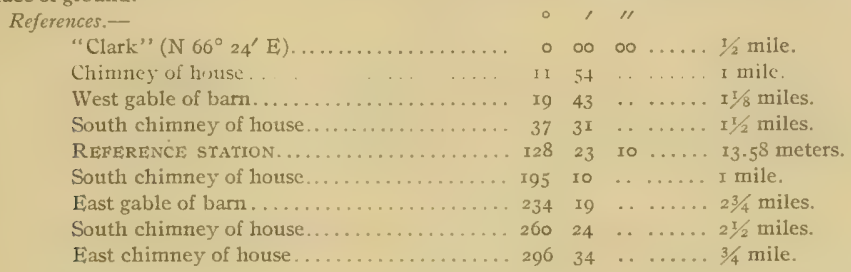

CEDAR.

General locality.-Eastern shore of Broad Creek on Cedar Point at southern side of entrance to Edge Creek about $5 / 8$ mile south of south end of Hambleton Island and $1 / 2$ mile east-northeast of Deep Neck Point. (See Chart No. 34.)

Immediate locality. -Observed station is on a hard oyster shell bank about 3 feet above high water, 3 yards south of shore, and in front of a thicket of cedar and oak trees. Cement monument marking reference station is II.I 6 meters $\mathrm{S} 27^{\circ} 55^{\prime} \mathrm{E}$ of observed station.

Marks..-Observed station is nail in center of 2 -inch cedar stub projecting 2 inches above surface of ground. Reference station is center point of triangle on standard cement monument projecting 5 inches above surface of ground.

References.-

"Willey" (N $\left.4^{\circ} 24^{\prime} \mathrm{W}\right)$

Michaels Water Tank" ...............

West chimney on house ................

Cupola on house.....................

East chimney of house ..............

North chimmey of house...............

REFERENCE $\operatorname{sTATION} \ldots \ldots \ldots \ldots \ldots \ldots \ldots$ I

Nail in blaze in twin oak tree ( 12 inches diameter $) \ldots \ldots \ldots \ldots \ldots \ldots \ldots \ldots \ldots . \ldots \ldots$

Nail in blaze in elm tree ( 12 inches diameter). $2 \mathrm{I}_{3}$

North chimney of house.............. 270

East gable of house.................. 28

East chimney of house............... 308

East chimney of house................ 330

South chimney of house.............. $35^{1}$

\begin{tabular}{|c|c|c|}
\hline 1 & "I & \\
\hline$\infty$ & $\infty$ & .... 5/8 mile. \\
\hline 03 & . & $\ldots \ldots 3^{1 / 4}$ miles. \\
\hline 29 & . & ..... $I 1 / 8$ miles. \\
\hline I0 & . & ..... I mile. \\
\hline 03 & . & ..... II/4 miles. \\
\hline 29 & . & ..... I I $1 / 2$ miles. \\
\hline 28 & Io & ..... II.I6 meters \\
\hline 20 & $\infty$ & .... 6.I4 meters. \\
\hline$\$ 9$ & 50 & ...... 4.13 meters \\
\hline 59 & . & ..... $13 / 8$ miles. \\
\hline 43 & . & ...... I I $1 / 2$ miles. \\
\hline II & . & ..... $\mathrm{r}^{\mathrm{I} / 4}$ miles. \\
\hline $3^{8}$ & $\cdots$ & ..... I $7 / 8$ miles. \\
\hline $5^{I}$ & . & ..... 2 miles. \\
\hline
\end{tabular}

ROSS.

General locality.-Eastern shore of Broad Creek on Deep Neck Point about I mile south-southeast of Mulberry Point and $1 / 2$ mile west-southwest of Cedar Point. (See Chart No. 34.)

Immediate locality. - Observed station is on wooded shore about ro feet above high water, and 6 yards southeast of top of vertical bank which is washing rapidly. Cement monument marking reference station is $\mathrm{I} 4.94$ meters S $6 \mathrm{x}^{\circ} 43^{\prime} \mathrm{E}$ of observed station. 
Marks.-Observed station is center of 2 -inch tile pipe projecting 4 inches above surface of ground. Subsurface mark is center of 2 -inch tile pipe buried with top 2 inches below bottom of surface pipe. Reference station is center point of triangle on standard cement monument.

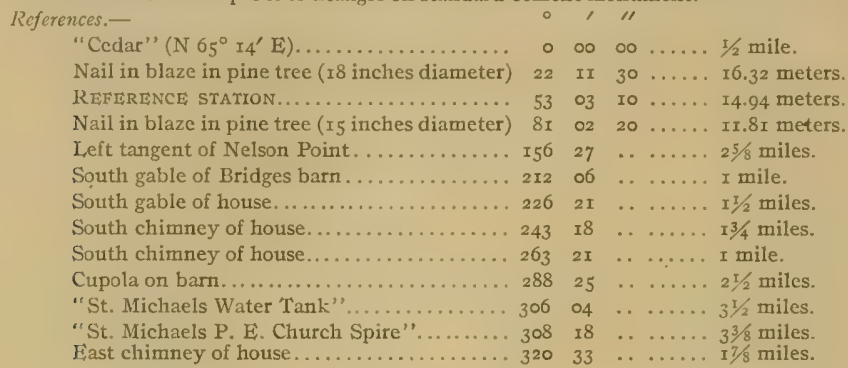

COOK.

General locality, -Eastern shore of Broad Creek about I $3 / 4$ miles north of Choptank River and $1 / 2$ mile south of entrance to Bridge Creek. (See Chart No.34.)

Immediate locality.-Observed station is on point of marsh about $\mathrm{I}$ foot above high water and 2 yards east of shore. Cement monument marking reference station is 11.63 meters $\mathrm{N} 61^{\circ} 29^{\prime} \mathrm{E}$ of observed station.

Marks.-Observed station is center of $z$-inch tile pipe projecting 4 inches above surface of ground. Subsurface mark is center of 2 -inch tile pipe buried with top 2 inches below base of surface pipe. Reference station is center point of triangle on standard cement monument projecting 6 inches above surface of ground.

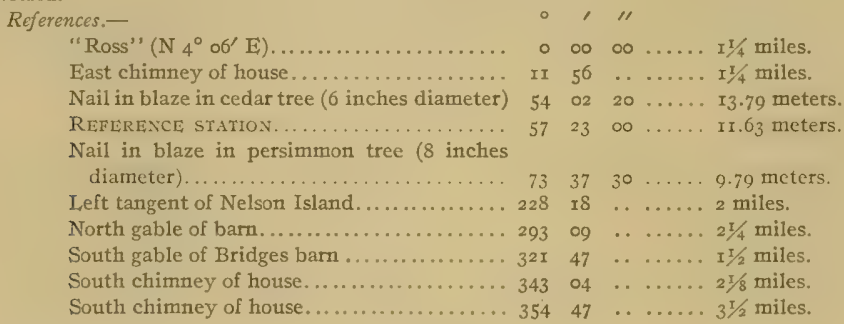

\section{PEARY.}

General locality.-Eastern shore of Broad Creek about I mile north of entrance to Broad Creek, $\mathbf{1} 3 / 8$ miles north of Royston Island, and I3/4 miles east-northeast of Nelson Point. (See Chart No. 34.)

Immediate locality._-Observed station is on wooded shore about 6 feet above high water, 3 yards east of vertical bank, which is washed by high water, roo yards south of north end of pine woods. Cement monument marking reference station is 20.93 meters $\mathrm{N}_{4} 3^{\circ} 3 \mathrm{~d} \mathrm{E}$ of observed station.

Marks.-Observed station is center of 2 -inch tile pipe projecting 3 inches above surface of ground. Reference station is center point of triangle on standard cement monument. 


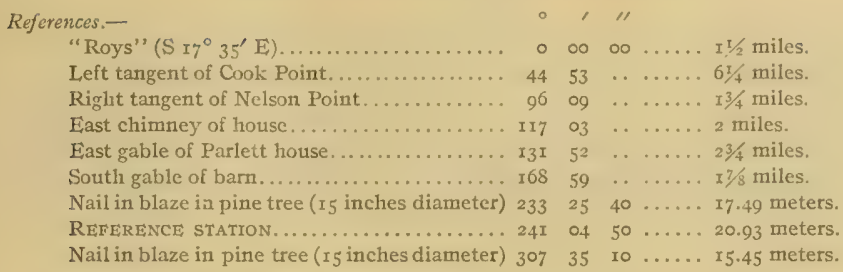

\section{IRISH.}

General locality.-Northeastem shore of Choptank River on west side of entrance to Irish Creek, about $3 / 8$ mile northeast of Royston Island. (See Chart No. 34.)

Immediate locality.-Observed station is in cultivated land, about 5 feet above high water, I3 yards east-northeast of edge of bank, 5 yards north of foot of bank, 4 yards north of a cedar tree, 10 yards west of a small cedar tree at west end of line of locust trees, and 23 yards east-southeast of rounded point of bank.

Marks.-Observed station is center point of triangle on standard cement monument projecting 5 inches above surface of ground. Subsurface mark is center of 2 -inch tile pipe buried with top 2 inches below base of monument.

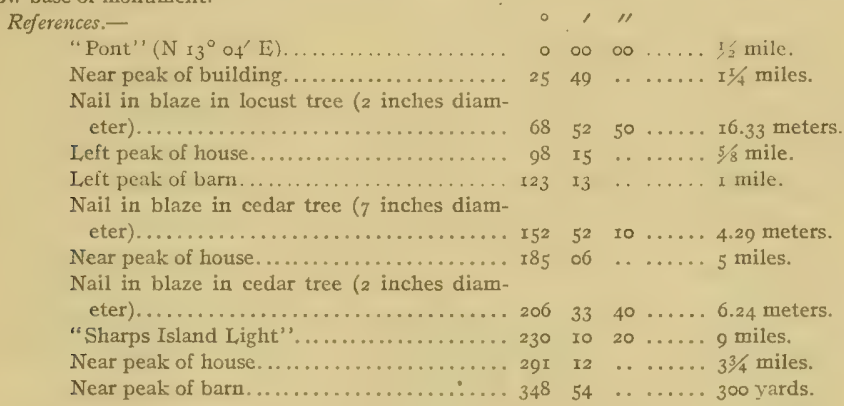

\section{ROYS.}

General locality.-Northeastern side of Choptank River on southern end of Royston Island, about $1 / 2$ mile southwest of entrance to Irish Creek. (See Chart No. 34.)

Immediate locality... Observed station is about 5 feet above high water, I5 yards north of shore, 25 yards east of shore, and 25 yards northeast of extreme end of point.

Marks.-Observed station is center point of triangle on standard cement monument projecting 6 inches above surface of ground. Subsurface mark is center of 2 -inch tile pipe buried with top 2 inches below base of monument.

References.-

\begin{tabular}{|c|c|c|c|}
\hline "Choptank River Light"" ( $\left.\mathrm{S}_{44^{\circ}} 37^{\prime} \mathrm{E}\right)$...... & 0 & $\infty$ & \\
\hline "Large Water Tank" ...................... & 9 & 09 & $\infty$ \\
\hline Peak of large barn........ & 49 & 44 & .. \\
\hline Right peak of barn... & 71 & 08 & $\cdots$ \\
\hline Windmill. ............. & 71 & 16 & $\cdots$ \\
\hline "Sharps Island Light" ..... & 109 & I6 & 30 \\
\hline Church spire........... & 134 & 43 & \\
\hline
\end{tabular}




\section{References-Continued.}

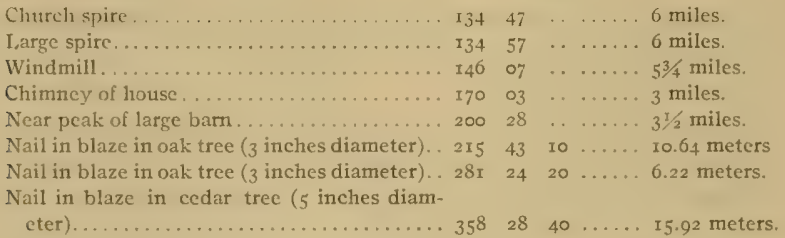

\section{PONT.}

General locality.-Western shore of Irish Creek on point about $1 / 2$ mile north of Choptank River cntrance to creek. (See Chart No. 34.)

Immediate locality:- Observed station is in pasture land, about 5 feet above high water, 3 yards west of edge of bank, 30 yards south-southwest of point of bank, 35 yards north by west of point of bank. and $\mathrm{T} / \mathrm{s}$ mile northeast of $2 \mathrm{~T} / 2$-story frame house.

Marks.-Observed station is center point of triangle on standard cement monument projecting 3 inches above surface of ground. Subsurface mark is center of 2 -inch tile pipe buried with top 2 inches below base of monument.

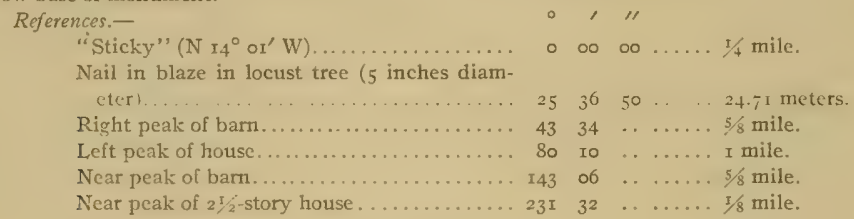

\section{STICKY}

General locality,-Western shore of Irish Creek about $3 / 4$ mile from Choptank River entrance to creek. (See Chart No. 34.)

Immediate locality.-Observed station is on small marsh point about I foot above high water, 8 yards east of shore, 8 yards west of shore, 4 yards south of a 3 -foot terrace covered with small cedar and pine trees, and 23 yards north-northeast of extreme end of point.

Marks.-Observed station is center point of triangle on standard cement monument projecting 5 inches above surface of ground. Subsurface mark is center of 2 -inch tile pipe buried with top 2 inches below base of monument.

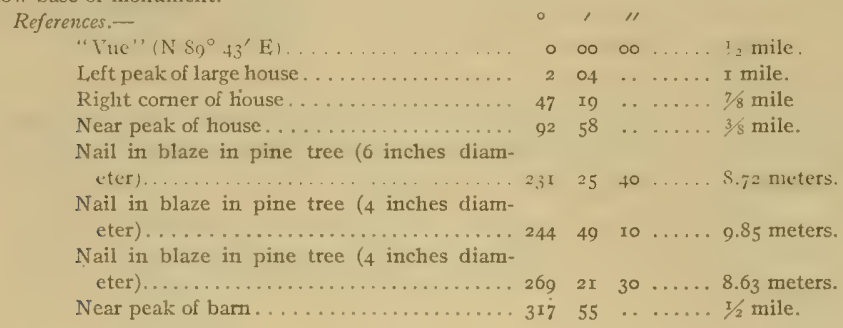


VUE.

General locality.-Northern shore of Irish Creek, about $3 / 4$ mile from Choptank River entrance to creek. (See Chart No. 34.)

Immediate locality.-Observed station is on a marsh point about I foot above high water, 4 yards west-northwest of shore, 5 yards northeast of shore, and 8 yards north of extreme end of point.

Marks.-Observed station is center point of triangle on standard cement monument projecting 6 inches above surface of ground. Subsurface mark is center of 2 -inch tile pipe buried with top 2 inches below base of monument.

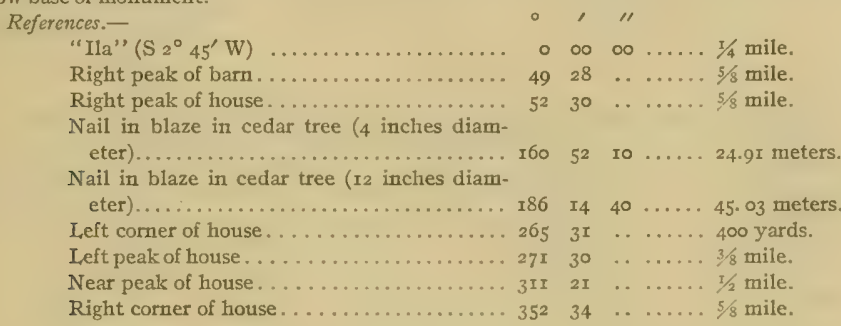

ILA.

General locality.-Eastern shore of Irish Creek, about $1 / 2$ mile from Choptank River entrance to creek, on a point at north side of entrance to a cove. (See Chart No. 34.)

Immediate locality.-Observed station is in cultivated land about 5 feet above high water, 3 yards south-southwest of edge of bank, 20 yards northeast of edge of bank at trees, I 7 yards southeast of point of bank, and 23 yards east by north of point of bank.

Marks.-Observed station is center point of triangle on standard cement monument projecting 3 inches above surface of ground. Subsurface mark is center of 2 -inch tile pipe buried with top 2 inches below base of monument.

References.-

"Creek" (S $\left.16^{\circ} 5^{\prime} 1^{\prime} \mathrm{W}\right) \ldots \ldots \ldots \ldots \ldots \ldots . . . \ldots \ldots$

Nail in blaze in locust tree (3 inches diam-

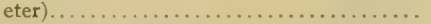

Nail in blaze in locust tree ( 4 inches diam-

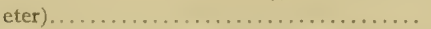

Nail in blaze in locust tree ( 3 inches diam-

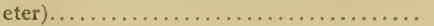

Left corner of barn. . . . . . . . . . . . . . . . .

Near peak of barn................. $\mathbf{r}_{3}$

Left corner of left chimney of house......... I55

Left peak of house. . . . . . . . . . . . . . . I I I

Left peak of house. . . . . . . . . . . . . . 222

Left corner of left chimney of large house..... 265

Right peak of house ................ 334

$\begin{array}{lcccc}0 & \prime & \prime \prime \\ 0 & 00 & 00 & \ldots \ldots & 1 / 2 \text { mile. } \\ 13 & 57 & 30 & \ldots & 16.07 \text { meters. } \\ 28 & 06 & 10 & \ldots & 19.32 \text { meters. } \\ 53 & 06 & 20 & \ldots & 21.36 \text { meters. } \\ 59 & 17 & \ldots & \ldots & 1 / 2 \text { mile. } \\ 30 & 36 & \ldots & \ldots & 3 / 4 \text { mile. } \\ 55 & 18 & \ldots & \ldots & 5 / 8 \text { mile. } \\ 91 & 36 & \ldots & \ldots & 5 / 8 \text { mile. } \\ 22 & \text { or } & \ldots & \ldots & 1 / 2 \text { mile. } \\ 65 & 09 & \ldots & \ldots & 3 / 8 \text { mile. } \\ 34 & 56 & \ldots & \ldots & 5 / 8 \text { mile. }\end{array}$

CREEK.

General locality.-Northeastern shore of Choptank River on east side of entrance to Irish Creek, about 5/8 mile east-northeast of Royston Island. (See Chart No. 34.)

Immediate locality.-Observed station on marsh point about $x$ foot above high water, II yards south. east of shore, II yards east of shore, I7 yards north-northeast of shore and If yards south of cut in shore.

$53485-x_{2}-8$ 
Marks,-Observed station is center point of triangle on standard cement monument projecting 5 inches above surface of ground. Subsurface mark is center of 2 -inch tile pipe buried with top 2 inches below base of monument.

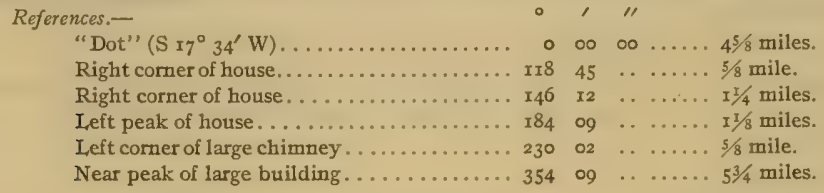

\section{BENONI 2.}

General locality.-Northern shore of Choptank River on Benoni Point at western side of entrance to Tred Avon River, about $\mathrm{x} 3 / 8$ miles northwest of Choptank River Light. (See Chart No. 34.)

Immediate locality.- Observed station is about 5 feet above high water, 9 yards south-southwest of foot of knoll and edge of marsh, 4 yards northeast of edge of bank, 25 yards east-southeast of point of bank, 30 yards north by west of point of marsh, and roo yards southwest of a cove. Cement monument

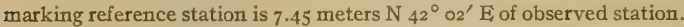

Marks.-Observed station is nail in center of stub projecting 4 inches above a 4 -inch tile pipe with top of pipe flush with surface of ground. Reference station is center point of triangle on standard cement monument projecting 4 inches above surface of ground.

References.-

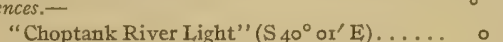

"Large Water Tank" ................. I3 ro

Left comer of house.

Nail in blaze in water bush............ I8I of $10 \ldots \ldots 7.68$ meters.

Nail in blaze in water bush ............ 23I $34 \quad 40 \ldots .4 .54$ meters.

Near peak of small house.............. $245 \quad 50 \quad \ldots \ldots \ldots r 3 / 4$ miles.

Left corner of bumt house. ......... 26 I $14 \quad \ldots \ldots \ldots 2$ miles.

REFERENCE STATION............... 262 o2 $40 \ldots \ldots 7.45$ meters.

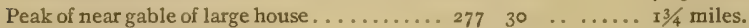

Nail in blaze in water bush............ 288 og $40 \ldots \ldots 10.40$ meters

Left corner of house................... $306 \quad 5^{6} \quad \ldots \ldots \ldots$

\section{MUTTON.}

General locality.-Western shore of Tred Avon River opposite town of Oxford, about $\mathrm{I}^{1} / 4$ miles northnortheast of Benoni Point. (See Chart No. 34.)

Immediate locality.-Observed station is in cultivated land about 5 feet above high water, I3 yards west of edge of tree-fringed bank at edge of strip of marsh, 20 yards southwest of edge of bank, and 25 yards northeast of edge of bank at bend.

Marks.-Observed station is center point of triangle on standard cement monument projecting 5 inches above surface of ground. Subsurface mark is center of 2 -inch tile pipe buried with top 2 inches below base of monument.

References.-

"Choptank River Light" (S $\left.6^{\circ} 44^{\prime} \mathrm{E}\right)$.......

Right corner of barn ................ 70

Near corner of barn.................. 108

Center of chimney outside of house......... I6

Near corner of house................ $2 \mathrm{I}_{4}$

Nail in blaze in persimmon tree ( 12 inches diameter) ...................... 22

Nail in blaze in cedar tree ( 8 inches diameter) 242

Nail in blaze in cedar tree ( 10 inches diameter) 279

Nail in blaze in locust tree ( 6 inches diameter) 354

0,11

$\infty \quad \infty \ldots \ldots .2 \pi / 4$ miles.

$54 \ldots \ldots .1 / 4$ mile.

$44 \ldots . . .660$ yards.

....... $1 / 4$ mile.

...... 1/2 mile.

$20 \ldots . .18 .44$ meters.

$30 \ldots . .13 .48$ meters.

40 ...... II.80 meters.

20 ..... I7.18 meters. 
TRED. No. 34.)

General locality.-Western shore of Tred Avon River about $3 / 2$ mile west of Oxford. (See Chart

Immediate locality.-Observed station is about on level with high water, 2 yards west of shore of marsh strip, 6 yards east of foot of a bank, 6 feet high, 30 yards south by east of small house among trees, I3 yards south by east of end of fence, and 20 yards north of small point of marsh strip. Cement monument marking reference station is $4.9^{8}$ meters $\mathrm{N} 68^{\circ} 24^{\prime} \mathrm{W}$ of observed station and at foot of bank.

Marks.-Observed station is nail in center of cypress stub projecting 5 inches above 4 -inch tile pipe with top of pipe flush with surface of ground. Reference station is center point of triangle on standard cement monument projecting 5 inches above surface of ground.

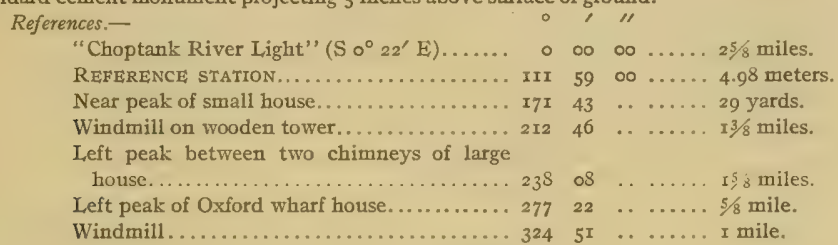

BELLEVUE.

General locality.-Western shore of Tred Avon River at Bellevue steamboat landing about $3 / 4$ mile northwest of Oxford steamboat landing. (See Chart No. 34.)

Immediate locality.-Observed station is on south side of roadway pier to Bellevue wharf, about I6 yards south by west of a crab house, and 25 yards west of wharf house.

Marks.-Observed station is center of 3 -inch square staff 12 feet high.

References.-

Right corner of storehouse............. N. E. . .... 16.00 meters.

Left cornier of wharf house.............. E. by $\mathrm{N} . \ldots \ldots 24.25$ meters.

Right corner of wharf house............. E. by S. .... 24.18 meters.

Center one of four nails in plank............. by $\mathrm{E}, \ldots \ldots 3.42$ meters.

Center one of four nails in plank........... E. by S. .....73 meters.

Center one of four nails in plank............. by $\mathrm{N} . \ldots .82$ meters.

TAR.

General localily.-Westem shore of Tred Avon River on point between 'Tar Creek and Plaindealing Creek about $1 / 1 / 8$ miles north of Oxford steamboat wharf. (See Chart No. 34.)

Immediate locality.-Observed station is on a long point about 4 feet above high water, Io yards eastnortheast of Tar Creek, 9 yards north by west of point of bank, ro yards northwest by west of edge of bank, 6 yards west-southwest of edge of bank, and 60 yards west by north of extreme end of point of shore.

Marks.-Observed station is center point of triangle on standard cement monument projecting 5 inches above surface of ground. Subsurface mark is center of 2 -inch tile pipe buried with top 2 inches below base of monument.

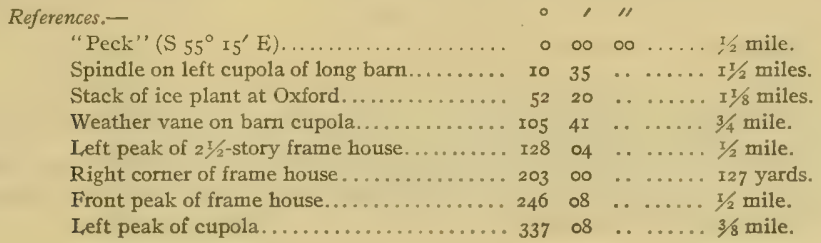


PECK.

General locality.-Northeastern shore of Tred Avon River on Peck Point about I mile northeast of Oxford Steamboat wharf. (See Chart No. 34.)

Immediate locality.--Observed station is in woods about 8 feet above high water, 4 yards north of edge of bank, 4 yards northwest of edge of bank, and 8 yards east of edge of bank.

Marks.-Observed station is center point of triangle on standard cement monument projecting 3 inches above surface of ground. Subsurface mark is center of 2 -inch tile pipe buried with top 2 inches below base of monument.

References. -

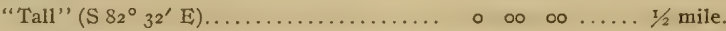

Spindle on left cupola on long barn......... 4 I 55 ...... $13 / 4$ miles.

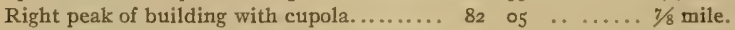

Nail in blaze in locust tree ( 6 inches diameter) $8_{3} \quad 59$ xo $\ldots . .2 .80$ meters.

Left comer of large $2 \frac{x}{2}$-story house......... $150 \quad 40 \ldots \ldots \ldots .1 / 4$ miles.

Spindle on barn cupola................. 160 $35 \quad \ldots \ldots \ldots .1 / 4$ miles.

Nail in blaze in cherry tree ( 4 inches diameter) $200 \quad 5920 \ldots .55 .65$ meters.

Nail in blaze in persimmon tree (3 inches

diameter)....................... $314 \quad 22 \quad 30 \ldots 3$ meters.

\section{TALL.}

General locality.-Northwestem shore of Tred Avon River on a prominent point $I 3 / 8$ miles northeast of Oxford steamboat wharf. (See Chart No. 34.)

Immediate locality.-Observed station is among cedar and wild pear trees about 2 feet above high water 7 yards north west of, shore, 40 yards east by north of shore, and 50 yards north-northeast of extreme end of point.

Marks.-Observed station is center point of triangle on standard cement monument projecting 4 inches above surface of the ground. Subsurface mark is center of 2 -inch tile pipe buried with top 2 inches below base of monument.

References,-

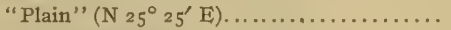

Right peak of house.....................

Top of roof of tower.....................

Nail in blaze in cedar tree $(6$ inches diam-

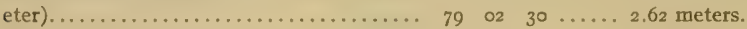

Spindle on barn cupola................ I05 I5 ...... II/4 miles.

Spindle on left cupola of large barn........ 135 o4 $\quad$...... I mile.

Nail in blaze in cedar tree ( 5 inches diam-

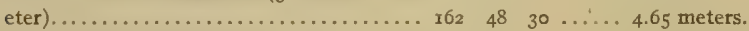

Right peak of Oxford wharf house ....... 211 o8 $\ldots \ldots \ldots$ I3/8 miles.

Nail in blaze in cedar tree (5 inches diam-

eter)............................ $218 \quad 45 \quad 30 \ldots$ meters.

Spindle on top of water tank........... $240 \quad 35 \quad \ldots \ldots \ldots r 1 / 2$ miles.

Nail in blaze in cedar tree $(8$ inches diam-

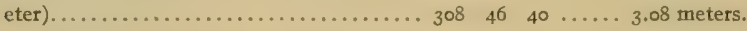

PLAIN.

General locality.-Western shore of Tred Avon River about $1 / 2$ mile west of north side of entrance to Trippe Creek, and $x 3 / 8$ miles south-southwest of Double Mills wharf. (See Chart No. 34.)

Immediate locality.-Observed station is in cultivated land about 3 feet above high water, 5 yards southwest of shore, Io yards west of shore at first water bush, and 150 yards northwest of point of shore. Cement monument marking reference station is 17.90 meters $\mathrm{S} 55^{\circ} \mathrm{I} 6^{\prime} \mathrm{E}$ of observed station. 
Marks:-Observed station is nail in center of 2 -inch stub in center of 2 -inch tile pipe with top of stub projecting $\mathrm{I} 2$ inches above surface of ground. Subsurface mark is another 2 -inch tile pipe buried with top 2 inches below base of surface pipe. Reference station is center point of triangle on standard cement monument projecting 2 inches above surface of ground.

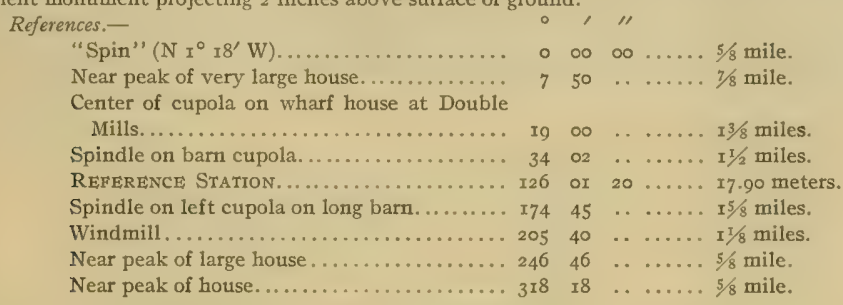

SPIN.

General locality.-Western shore of Tred Avon River on a point of land between two small creeks about $3 / 4$ mile north west of entrance to Trippe Creek, and 7/8 mile south-south west of Double Mills wharf. (See Chart No. 34.)

Immediate locality.-Observed station is in pasture land near 4 large trees about to feet above high water, 20 yards north by west of bank edge, 30 yards west by north of point of bank and go yards northeast of a slight cut in the bank.

Marks.-Observed station is center point of triangle on standard cement monument projecting 4 inches above surface of ground. Subsurface mark is center of 2 -inch tile pipe buried with top 2 inches below base of monument.

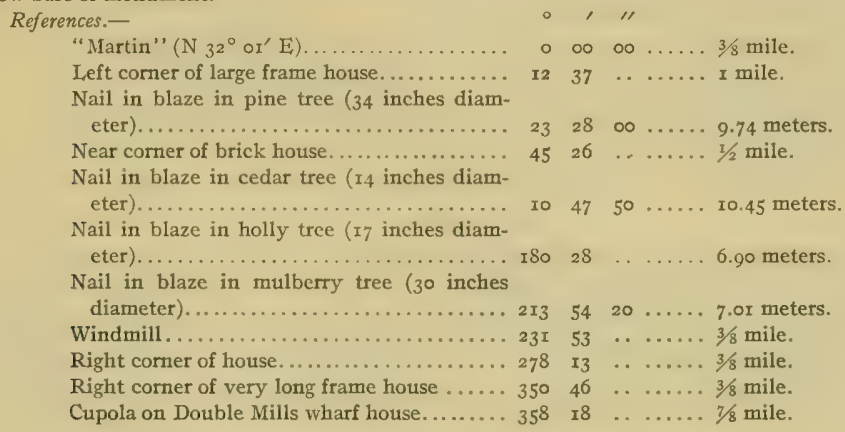

\section{MARTIN.}

General locality.-Western shore of Tred Avon River about x mile north-northwest of entrance to Trippe Creek, and I/2 mile southwest of Double Mills wharf. (See Chart No. 34.)

Immediate locality:- - Observed station is on a long narrow point about 2 feet above high water, 8 yards southwest of shore, II yards north of piling protecting shore, 30 yards northwest of extreme end of point, and I4 yards east of middle one of three apple trees.

Marks.-Observed station is center point of triangle on standard cement monument projecting 3 inches above surface of ground. Subsurface mark is center point of 2 -inch tile pipe buried with top 2 inches below base of monument. 


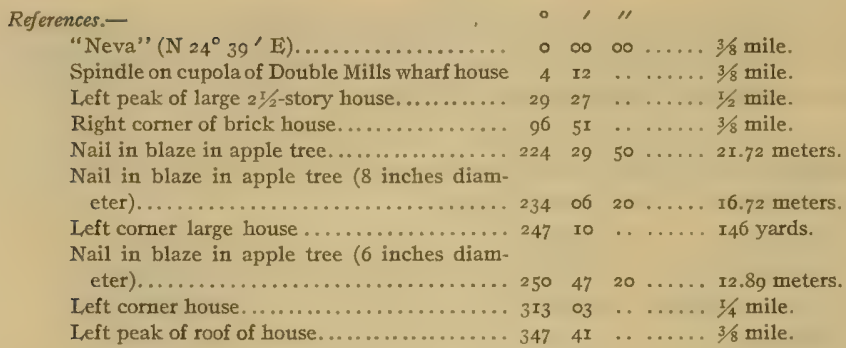

\section{NEVA.}

General locality.-Western shore of Tred Avon River at Double Mills wharf about $13 / 8$ miles north of entrance to Trippe Creek. (See Chart No. 34.)

Immediate locality.-Observed station is in southeast corner of a pasture about 3 feet above high water roo yards west-southwest of Double Mills wharf 5 yards west-southwest of wire and lath fence at road, 44 yards north of bank I foot high at river, and I4 yards northwest of comer post of fence.

Marks.-Observed station is center of triangle on standard cement monument projecting 4 inches above surface of ground. Subsurface mark is center of 2 -inch tile pipe buried with top 2 inches below base of monument.

References.-

"Robertson" ( $\left.\mathrm{N} I x^{\circ} 57^{\prime} \mathrm{E}\right)$.

Spindle on cupola on Double Mills wharf house............................

Nail in blaze in horse chestnut tree ( 8 inches diameter).

Right comer of right chimney outside of house.

Right corner of brick house............ I5

Spindle on left cupola on long barn....... I7

Right corner of house................. 26

Nail in blaze in linden tree (Io inches diameter)............................... $33^{15} \quad 5^{8} \quad 30 \ldots$ meters.

\section{ROBERTSON.}

General locality.-Northwestern shore of Tred Avon River about s s mile north of Double Mills Wharf and $3 / 8$ mile west of end of Long Point. (See Chart No. 34.)

Immediate locality.-Observed station is on grassy land about 2 feet above high water, 7 yards north of shore, 2 yards south of fence, 3 yards east of a few very small cedar trees, and 40 yards west of cedar trees on high land beyond gully.

Marks.-Observed station is center point of triangle on standard cement monument projecting 5 inches above surface of ground. Subsurface mark is center of 2 -inch tile pipe buried with top 2 inches below base of monument.

References.-

"Stretch" (S $\left.88^{\circ} 57^{\prime} \mathrm{E}\right)$... $\circ, 11$

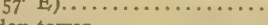

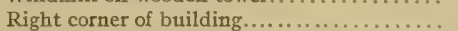

"Aye" (weather vane on largest barn cupola)

Right corner of house...................

Weather vane on Double Mills Wharf house. .

Right peak of large house.............. II

Nail in blaze in fence post............... $x 75$

Nail in blaze in fence post. ............ 2I

Nail in blaze in fence post............... 30

$00,00 \ldots .1 / 4$ mile.

$47 \quad \ldots . . . . x$ mile.

$\begin{array}{ccccc}90 & 22 & \ldots & \ldots & 5 / 8 \\ 8 & \text { mile. }\end{array}$

46 I8 $26 \quad \ldots \ldots \pi / 2$ mile.

$60 \quad 22 \quad \ldots \quad \ldots \ldots .1 / 2$ mile.

$\begin{array}{llll}3 & 29 & \ldots & \ldots \\ 3 / 8 & \text { mile. }\end{array}$

$33 \ldots \ldots .3 / 8$ mile.

o5 1o ....4 4.47 meters.

r5 $20 \quad \ldots 2.27$ meters.

$0450 \ldots . .1 .80$ meters. 
STRETCH.

General locality.-Western shore of upper Tred Avon River on Long Point at south side of entrance to Maxmore Creek about $1 / 2$ mile northeast of Double Mills Wharf. (See Chart No. 34.)

Immediate locality.-Observed station is on a rounded marsh point about I foot above high water, 16 yards west-northwest of shore, and 22 yards west-southwest of shore.

Marks.-Observed station is center point of triangle on standard cement monument projecting 4 inches above surface of ground. Subsurface mark is center of 2 -inch tile pipe buried with top 2 inches below base of monument.

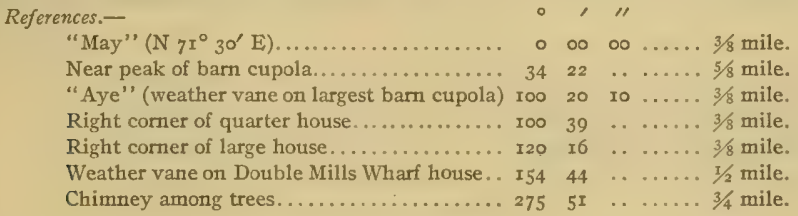

\section{MAY.}

General locality.-Northwestern shore of upper Tred Avon River about $3 / 5$ mile east of entrance to Maxmore Creek and $7 / 8$ mile northeast of Double Mills wharf. (See Chart No. 34.)

Immediate locality.-Observed station is at point of woods on marsh about I foot above high water, Io yards west-northwest of shore, Ix yards north of shore, and 20 yards east of shore.

Marks.-Observed station is center point of triangle on standard cement monument projecting 4 inches above surface of ground. Subsurface mark is center of 2 -inch tile pipe buried with top 2 inches below base of monument.

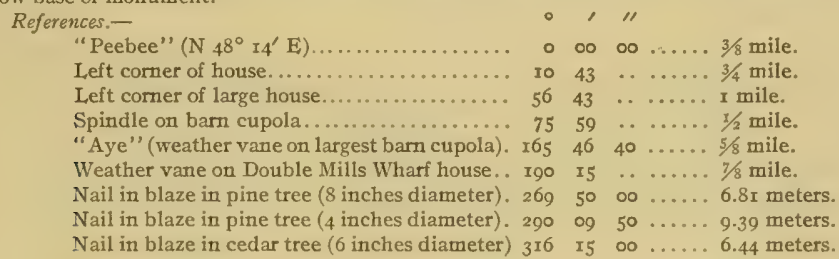

\section{PEEBEE.}

Gencral locality.-Western shore of upper Tred Avon about $\mathrm{r} 1 / 4$ miles northeast of Double Mills Wharf and $3 / 8$ mile northwest of entrance to Peachblossom Creek. (See Chart No. 34.)

Immediate locality.-Observed station is in cultivated land about 4 feet above high water, 6 yards southwest of edge of bank, I4 yards west-northwest of edge of bank, i6 yards northwest of extreme point of bank, 50 yards northeast of a clump of cedar trees, and 400 yards east of dense woods.

Marks.-Observed station is center point of triangle on standard cement monument projecting 5 inches above surface of ground. Subsurface mark is center of 2 -inch tile pipe buried with top 2 inches below base of monument.

\section{References.-}

"Neck" ( $\left.\mathrm{N}_{2} 8^{\circ} 5^{\prime} \mathrm{E}\right)$

Spindle on bam cupola

Nail in blaze in cedar tree ( 16 inches diameter) 68 50 10 .... 9.08 meters.

Left corner of house among trees........... $x_{14} 40 \quad \ldots \ldots .3 / 4$ mile.

Left comer of frame building showing through

cedar trees....................... I93 $46 \ldots \ldots \ldots$ I mile.

Nail in blaze in cedar tree ( 7 inches diameter). $305 \quad 5400 \quad \ldots . .56 .90$ meters.

Nail in blaze in cedar tree ( 12 inches diam-

eter)................................... $328 \quad 43 \quad 00 \quad 8_{3}$ meters.

Peak of building.......................... $35^{8}$ is $\ldots 2$ miles. 


\section{NECK.}

General locality.-Western shore of upper Tred Avon River on Neck Point opposite Camden Point and about $1 / 2$ mile north-northwest of entrance to Peachblossom Creek. (See Chart No. 34.)

Immediate locality. - Observed station is about I foot above high water, 5 yards west-southwest of shore, $x_{2}$ yards north of shore, and 8 yards northwest of extreme end of point.

Marks.-Observed station is center point of triangle on standard cement monument projecting 5 inches above surface of ground. Subsurface mark is center of 2 -inch tile pipe buried with top 2 inches below base of monument.
References.-
"Stab" ( $\left.\mathrm{N} \mathrm{II} 49^{\prime} \mathrm{W}\right)$
0 oo $00 \ldots \ldots, 3 / 8$ mile.
Near peak of barn................... I4 $33 \ldots \ldots$. $\ldots \ldots \ldots$ mile.
Near peak of large house.............. 66 o6 . . . . . $3 / 4$ mile.
Right peak of large house............... roo $\mathrm{r}_{3} \ldots \ldots \ldots, \frac{1}{2}$ mile.
Left comer of large house among trees........
Windmill on wooden tower............. I75 $32 \ldots \ldots \ldots .3 / 4$ mile.

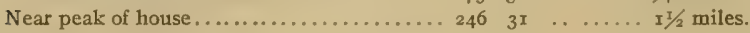

STAB.

General locality.-Westem shore of upper Tred Avon River, on first point north of Neck Point, about 7/8 mile north-northwest of entrance to Peachblossom Creek. (See Chart No. 34.)

Immediate locality.-Observed station is in cultivated land, about 8 feet above high water, 3 yards northwest of edge of bank, 25 yards northeast of an oak tree at ravine, and 6 yards west of point of bank.

Marks.-Observed station is center point of triangle on standard cement monument projecting 4 inches above surface of ground. Subsurface mark is center of 2 -inch tile pipe buried with top 2 inches below base of monument.

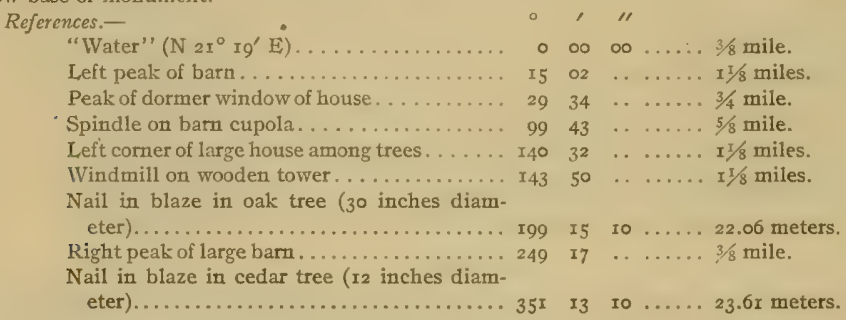

\section{WATER.}

General locality.-Western shore of upper Tred Avon River, opposite Watermelon Point, about $3 / 4$ mile north of Neck Point, and I I/4 miles north of entrance to Peachblossom Creek. (See Chart No. 34.)

Immediate locality.-Observed station is in cultivated field west of a broad marsh about 6 feet above high water, 2 yards west of edge of bank, 35 yards north-northwest of point of bark, 20 yards south of point of bank, and 45 yards east-northeast of inside curve of cut.

Marks.-Observed station is center point of triangle on standard cement monument projecting 3 inches above surface of ground. Subsurface is center of 2 -inch tile pipe buried witl top 2 inches below base of monument.

References,-

"Melon" ( $\left.83^{\circ} 37^{\prime} \mathrm{E}\right) \ldots \ldots \ldots \ldots \ldots \ldots \ldots$

Left large chimney of house............ 59

Spindle on barn cupola. ............... 6

Center of cedar tree..................... I9

Left corner of house................. 25

Right corner of house. . . . . . . . . . . . . . 293

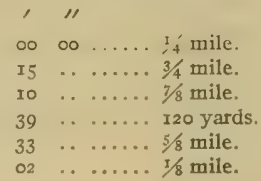




\section{RADCLIFFE.}

General locality.-Northwestern shore of Tred Avon River, on point of land between. Dixon Creek and Tred Avon River. (See Chart No. 34.)

Immediate locality.-Observed station is on small piece of fast land at end of marsh point, about 2 feet above high water, II yards northeast by north of shore, I5 yards north of shore, 40 yards southeast of shore, and among several pine and oak trees.

Marks.-Observed station is center point of triangle on standard cement monument projecting 2 inches above surface of ground. Substrface mark is center of 2 -inch tile pipe buried with top 2 inches below base of monument.

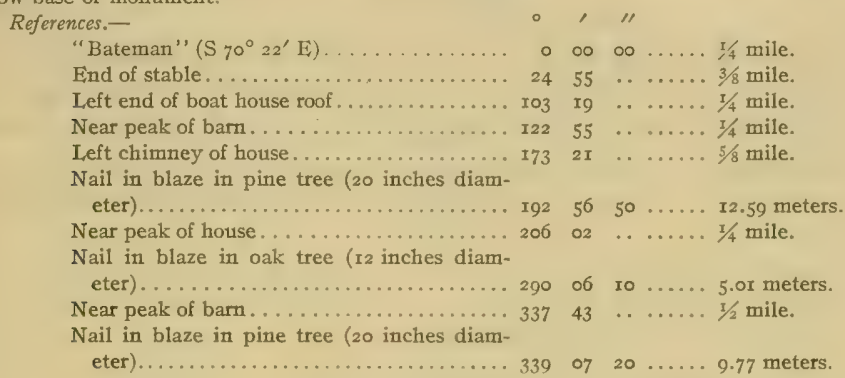

\section{BATEMAN.}

General locality. - Southeastern shore of upper Tred Avon River, about $3 / 8$ mile east of entrance to Dixon Creek, and I1/8 miles southwest of Easton Point Wharf. (See Chart No. 34.)

Immediate locality.-Observed station is on marsh about $\mathrm{I}$ foot above high water, 5 yards southeast of shore, I2 yards southwest of shore, and 20 yards northeast of high land.

Marks.-Observed station is center point of triangle on standard cement monument projecting 2 inches above surface of ground. Subsurface mark is center of 2 -inch tile pipe buried with top 2 -inches below base of monument.

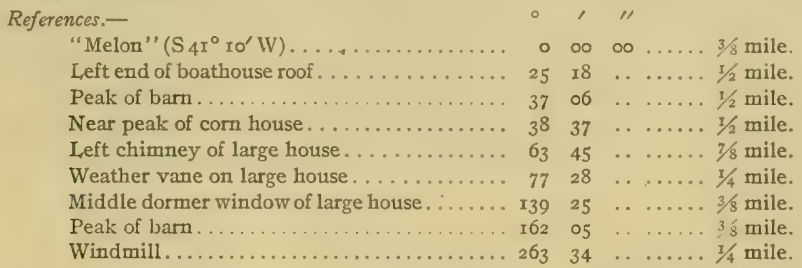

\section{MELON.}

General locality.-Eastern shore of upper Tred Avon River, on Watermelon Point, about 1/2 mile south of entrance to Dixon Creek, 3/4 mile north of Camden Point, and I I/ 8 miles north of entrance to Peachblossom Creek. (See Chart No. 34.)

Immediate locality,-Observed station is about 9 feet above high water, 30 yards south-southeast of edge of bank, 60 yards east by south of point of bank at large cedar tree, 35 yards east of edge of bank, I 50 yards northwest of a cove, and Ioo yards west by south of small cedar tree at cut in bank.

Marks.-Observed station is center point of triangle on standard cement monument projecting 4 inches above surface of ground. Subsurface mark is center of 2 -inch tile pipe buried with top 2 inches below base of monument. 


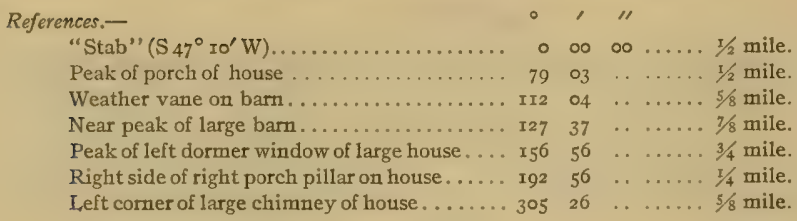

\section{GASH.}

Gencral locality.-Eastern shore of upper Tred Avon River on point of land between Camden Point and Watermelon Point, about $3 / 4$ mile north of entrance to Peachblossom Creek. (See Chart No. 34.)

Immediate localily.-Observed station is about 5 feet above high water, 16 yards north of shore, 25 yards east-northeast of point of shore, 18 yards east-southeast of bank, ro yards west of field, and near several large pine trees.

Marks.-Observed station is center point of triangle on standard cement monument projecting 4 inches above surface of ground. Subsurface mark is center of 2 -inch tile pipe buried with top 2 inches below base of monument.

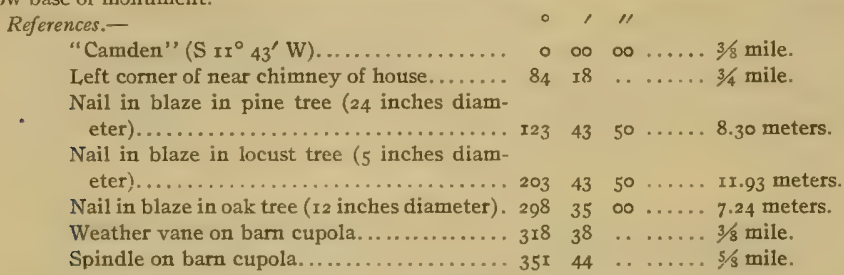

\section{CAMDEN.}

General locality.-Eastern shore of upper Tred Avon River on Camden Point at north side of entrance to a small cove, and about $3 / 8$ mile north of entrance to Peachblossom Creek. (See Chart No. 34.)

Immediate locality.-Observed station is on sandy grass land about 2 feet above high water, 8 yards north-northeast of sandy shore, 22 yards south-southeast of shore of Tred Avon River, 30 yards east of extreme end of point, ro yards southeast of a mudhole, and 30 yards southwest of clump of cedar and hackberry trees.

Marks.-Observed station is center point of triangle on standard cement monument projecting 5 inches above surface of ground. Subsurface mark is center of 2 -inch tile pipe buried with top 2 inches below base of monument.

References.-

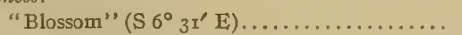

Windmill on wooden tower................

Left peak of long building...............

Near peak of barn.................

Nail in blaze in cedar tree ( 7 inches diameter)........................... $212 \quad 39 \quad 20 \ldots 27.27$ meters.

Nail in blaze in hackberry tree (3 inches diameter) ....................... $224 \quad 0300 \ldots \ldots .26 .84$ meters.

Nail in blaze in cedar tree ( 14 inches diameter)............................... $239 \quad 40 \quad 40 \ldots .87$ meters.

Left corner of roof of house............. 329 I4 $\quad \ldots \ldots \ldots 3 / 4$ mile. 


\section{BLOSSOM}

General locality.-Eastern shore of Tred Avon River at north side of entrance to Peachblossom Creek. (See Chart No. 34.)

Immediate locality.-Observed station is on a marsh point about I foot above high water, I4 yards east by south of shore of river, I2 yards west-northwest of shore of small elliptical cove, and 40 yards north by west of entrance to cove.

Marks.-Observed station is center point of triangle on standard cement monument with top projecting 4 inches above the surface of the ground. Subsurface mark is center of 2 -inch tile pipe 24 inches long buried with top 2 inches below hase of monument.

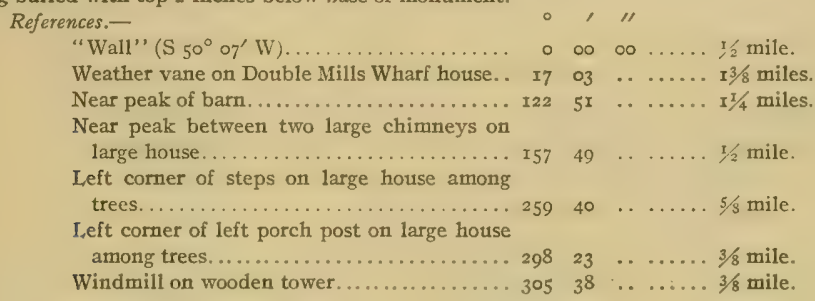

\section{WALL.}

General locality, - Southeastern shore of Tred Avon River on a point of land at west side of entrance to a small creek about I mile east-northeast of Double Mills Wharf. (See Chart No. 34.)

Immediate locality.-Observed station is in pasture land about 5 feet above high water, 20 yards south of extreme edge of bank, 4 yards west of terrace, 20 yards west of shore, 18 yards south-southeast of edge of bank, and 20 yards east of gully.

Marks.-Observed station is center point of triangle on standard cement monument projecting 4 inches above surface of ground. Subsurface mark is center of 2 -inch tile pipe buried with top 2 inches below base of monument.

References.-

\begin{tabular}{|c|c|c|c|c|}
\hline $\begin{array}{l}\text { "Aye" (weather vane on largest barn cupola) } \\
\left(\mathrm{S} 6 \mathrm{I}^{\circ} \mathrm{oo}^{\prime} \mathrm{W}\right) \ldots \ldots \ldots \ldots \ldots \ldots \ldots \ldots \ldots \ldots\end{array}$ & $\circ$ & $\infty$ & $\infty$ & - $5 / 8$ mile. \\
\hline Right corner of house ................. & 7 & 59 & 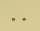 & $5 / 8$ mile \\
\hline Weather vane on Double Mills Wharf house.. & I4 & 49 & . & I mile. \\
\hline eter)................................. & 37 & 36 & 50 & 17.37 meters. \\
\hline diameter) $\ldots \ldots \ldots \ldots \ldots \ldots \ldots \ldots \ldots \ldots \ldots \ldots \ldots$ & I54 & 55 & 20 & 5.03 meters. \\
\hline $\begin{array}{l}\text { Windmill on wooden tower................ } \\
\text { Nail in blaze in cedar tree }(28 \text { inches diam- }\end{array}$ & 231 & og & . & aile. \\
\hline & 255 & $3 I$ & & \\
\hline Nail in blaze in oak tree ( 30 inches diameter). & 340 & 33 & $40^{\circ}$ & 96 meters. \\
\hline
\end{tabular}

AYE.

General locality. - Southeastern shore of Tred Avon River about 1/2 mile east of Double Mills Wharf. (See Chart No. 34.)

Immediale locality.-Observed station is on cupola on largest barn.

Marks.-Observed station is spindle on cupola.

References.-None necessary. 


\section{HUNTER}

General locality.--Eastern shore of Tred Avon River at south side of entrance to a cove about $1 / 2 \mathrm{mile}$ south-southeast of Double Mills Wharf, and I mile north of entrance to Trippe Creek. (See Chart No. 34.)

Immediate locality.--Observed station is on a marsh point about $x$ foot above high water, 3 yards southwest of shore, 5 yards east-northeast of shore, 6 yards southeast of point of marsh, and Io yards west of a clump of wild cherry, hackberry, and cedar trees.

Marks.-Observed station is center point of triangle on standard cement monument projecting 5 inches above surface of ground. Subsurface mark is center of 2 -inch tile pipe buried with top 2 inches below base of monument.
References.-
"Weave" ( $\left.\mathrm{S}_{27} 7^{\circ} 35^{\prime} \mathrm{W}\right)$
$\circ$ o $00 \ldots . .1 / 2$ mile.
Near peak between two chimneys of large house...........................
Near peak of cupola on building......... 35
Right peak of large house...............
Weather vane on wharf house at Double Mills. I28

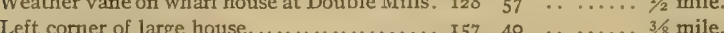
"Aye" (weather vane on largest barn copola). I75 I8 $20 \ldots . . .3 / 8$ mile.
Nail in blaze in wild-cherry tree ( 5 inches

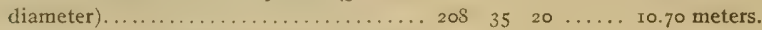
Nail in blaze in hackberry tree (6 inches diameter $) \ldots \ldots \ldots \ldots \ldots \ldots \ldots \ldots \ldots \ldots, 232, x_{4} 00 \ldots \ldots \pm 1.18$ meters.
Nail in blaze in leaning cedar tree ( 8 inches diameter $) \ldots \ldots \ldots \ldots \ldots \ldots \ldots \ldots \ldots . \ldots \ldots 6_{3} \quad 50 \quad 50 \ldots \ldots .02$ meters.
Nail in blaze in cedar tree ( 20 inches diam-

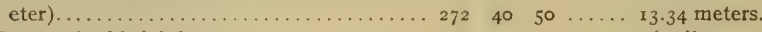
Near peak of brick house............. 352 45 $\quad \ldots \ldots \ldots 1 / 4$ mile.

\section{WEAVE,}

General locality.-Eastern shore of Tred Avon River about $1 / 2$ mile north of entrance to Trippe Creek, and $x$ mile south of Double Mills Wharf. (See Chart No. 34.)

Immediate locality.-Observed station is on marsh about I foot above high water, 20 yards east of shore, I6 yards south of shore at small inlet, 6 yards west of small point on inlet, and 20 yards northeast of shore.

Marks.--Observed station is center point of triangle on standard cement monument projecting 5 inches above surface of ground. Subsurface mark is center of 2 -inch tile pipe buried with top 2 inches below base of monument.

References.-

"Twin" $\left(\mathrm{S} 7^{\circ}{ }_{2} 3^{\prime} \mathrm{E}\right) \ldots \ldots \ldots \ldots \ldots \ldots \ldots \ldots$

Spindle on left cupola on long barn.........

Stack of ice plant at Oxford.

Near peak between two chimneys of large

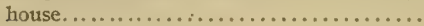

Left comer of chimney outside left end of

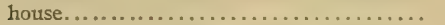

Left comer of large house.............. I57

Peak of near gable of large house........... I8I

Weather vane on wharf house at Double Mills. 189

Left comer of large house............... 20526

Left peak of house.................. $237 \quad 5^{8}$

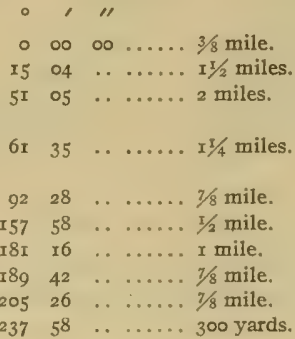


TWIN.

General locality,-Eastern shore of Tred Avon River on point of land on north side of entrance to Trippe Creek. (See Chart No. 34.)

Immediate locality.-Observed station is in cultivated land about 4 feet above high water, 45 yards east-southeast of shore of Tred Avon River, and Iro yards northwest of shore of Trippe Creek.

Marks.-Observed station is center point of triangle on standard cement monument projecting 5 inches above surface of ground. Subsurface mark is center of 2 -inch tile pipe buried with top 2 inches below base of monument.

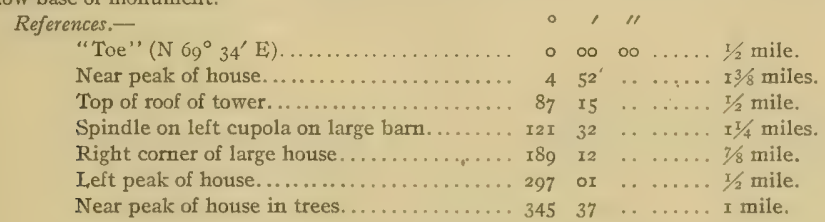

TOE.

General locality.-Northern shore of Trippe Creek on a point of land about $1 / 2$ mile northeast of point at notth side of entrance to Trippe Creek. (See Chart No. 34, )

Immediate locality.-Observed station is on a marsh point about I foot above high water, ro yards northwest of shore, I4 yards southwest of shore, I2 yards north of round point of shore, I2 yards west of round point of shore, and 30 yards southeast of cedar and persimmon trees.

Marks.-Observed station is center point of triangle on standard cement monument projecting 4 inches above surface of ground. Subsurface mark is center of 2 -inch tile pipe buried with top 2 inches below base of monument.

References.-

\begin{tabular}{|c|c|c|c|c|}
\hline 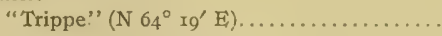 & $\circ$ & o & oo & $\ldots .1 / 4$ mile. \\
\hline Near peak of house...$\ldots \ldots \ldots \ldots \ldots \ldots$ & 16 & 03 & . & . $15 / 4$ miles. \\
\hline Near peak of house.............. & 33 & 06 & $\because$ & .. $x 3 / 8$ miles. \\
\hline 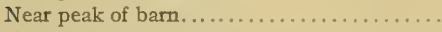 & 126 & 49 & . & .. I mile. \\
\hline 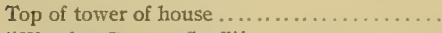 & 137 & $5^{2}$ & . & $5 / 8$ mile. \\
\hline "Weather Bureau Staff" . . . . . . . . . . . . & 166 & 59 & 50 & $23 / 4$ miles. \\
\hline 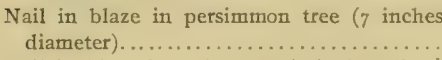 & 227 & $2 I$ & 20 & 4 meters. \\
\hline 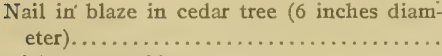 & 250 & 42 & 30 & \\
\hline 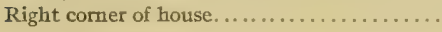 & 327 & 07 & . & $\ldots \ldots$ \\
\hline
\end{tabular}

\section{TRIPPE.}

General locality.-Northem shore of Trippe Creek about $5 / 8$ mile east of Tred Avon River and $1 / 8$ mile east of entrance to a small creek. (See Chart No. 34.)

Immediate locality.-Observed station is on a marsh point about I foot above high water, 23 yards northwest of shore at entrance to slough, 30 yards east-northeast of shore, and 50 yards north by east of extreme end of point.

Marks.-Observed station is center point of triangle on standard cement monument projecting 3 inches above surface of ground. Subsurface mark is center of 2 -inch tile pipe buried with top 2 inches below base of monument. 


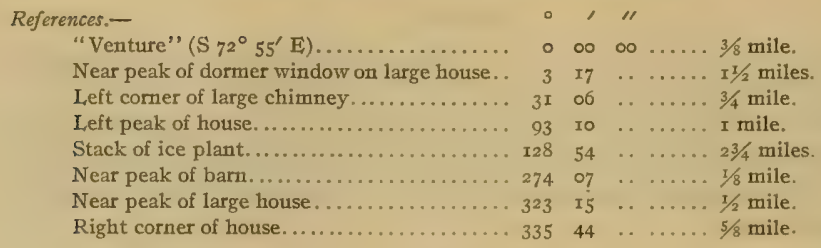

\section{VENTURE.}

General locality.-Northern shore of Trippe Creek on a point on the west side of a cove about I mile east of Tred Avon River. (See Chart No. 34.)

Immediate locality.-Observed station is about $\mathrm{I}$ foot above high water on the inner edge of a strip of marsh at bottom of a bank 4 feet high, 4 yards north of shore of marsh, 8 yards north-northwest of point of marsh, 3 yards south by west of top of bank, 7 yards west of point of bank, and 6 yards west of a lone cedar tree.

Marks.-Observed station is center point of triangle on standard cement monument projecting 4 inches above surface of ground. Subsurface mark is center of 2 -inch tile pipe buried with top 2 inches below base of monument.

References.-

"Plow" ( $\left.87^{\circ} 47^{\prime} \mathrm{E}\right)$.

Nail in blaze in cedar

eter)

Peak of dormer window of large house.......

Right peak of right barn............... 5

Left corner of left chimney of house.........

Left peak of barn.................... 246

Spindle on right cupola of bam

\section{PLOW.}

General locality. - Northern shore of Trippe Creek on a point of land between two coves about $x^{1} / 4$ miles from Tred Avon River. (See Chart No. 34.)

Immediate locality.--Observed station is on a marsh point about I foot above high water, 15 yards west-northwest of shore, 25 yards north of shore, 20 yards east of extreme end of point, and 5 yards south of foot of bank 7 feet high.

Marks.-Observed station is center point of triangle on standard cement monument projecting 4 inches above surface of ground. Subsurface mark is center of 2 -inch tile pipe buried with top 2 inches below base of monument.

References.-

"Higher" (N $\left.79^{\circ} \mathrm{I}_{4}^{\prime} \mathrm{E}\right)$

Right comer of porch underpinning.........

Left peak of barn...................... 54

Near peak of barn . ................. ro

Left corner of large chimney.............. II

Nail in blaze in persimmon tree $\left(2 \frac{1}{2}\right.$ inches

diameter)........................... $257 \quad 46 \quad 40 \ldots \ldots .72 .76$ meters.

Nail in blaze in oak tree ( 5 inches diameter). . $267 \quad 47$ ro ..... 44.53 meters.

Nail in blaze in persimmon tree $\left(2 \frac{1}{2}\right.$ inches

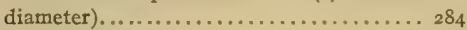

Near peak of barn ..................... 345

$\begin{array}{lllll}57 & 00 & \ldots & 1_{5} .85 & \text { meters. }\end{array}$

of ....... $5 / 8$ mile. 


\section{HIGHER}

General locality.--Northern shore of Trippe Creek at east side of entrance to a cove about $x^{3} / 4$ miles from Tred Avon River entrance to Trippe Creek. (See Chart No. 34.)

Immediale locality.-Observed station is in cultivated land about 8 feet above high water, 30 yards northeast of edge of bank, 35 yards southeast by east of row of trees, 50 yards east-southeast of point of bank and trees.

Marks.-Observed station is center point of triangle on standard cement monument projecting 4 inches above surface of ground. Subsurface mark is center of 2 -inch tile pipe buried with top 2 inches below base of monument.

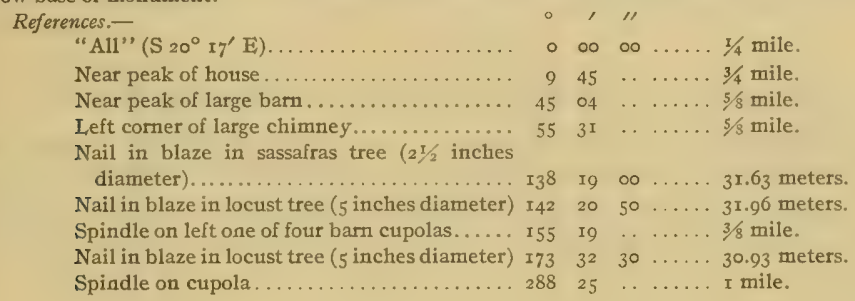

ALL.

General locality.-Northern shore of Trippe Creek about $53 / 4$ miles from Tred Avon River entrance to Trippe Creek, and 300 yards west by north of a colonial house. (See Chart No. 34.)

Immediate locality.-Observed station is about I foot above high water, 35 yards southeast of shore, 35 yards east of round point of shore, 80 yards northwest of cut in shore, and 40 yards south by east of left one of nine large pine trees.

Marks.-Observed station is center point of triangle on standard cement monument projecting 4 inches above surface of ground. Subsurface mark is center of 2 -inch tile pipe buried with top 2 inches below base of monument.

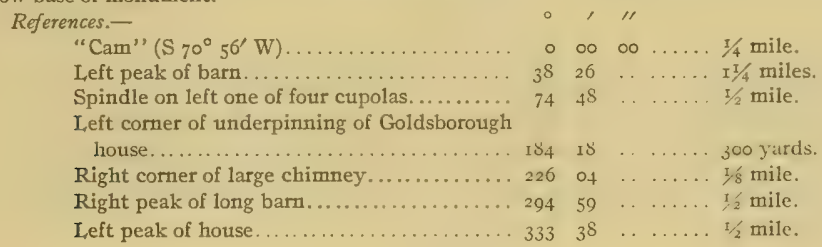

\section{CAM.}

General locality,-Southern shore of Trippe Creek on a prominent point about $\mathrm{I}^{\mathrm{I}} / 2$ miles from Tred Avon River entrance to Creek. (See Chart No. 34.)

General locality.-Observed station is on marsh point about ro yards southeast of shore, 20 yards south-southwest of point of shore, and $x 5$ yards northeast by east of point of bank at marsh.

Marks.-Observed station is center point of triangle on standard cement monument projecting 5 inches above surface of ground. Subsurface mark is center of 2 -inch tile pipe buried with top 2 inches below base of monument.

References.-

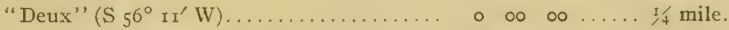

Left peak of barn showing through trees..... ${ }_{5} \& \quad 53 \quad \ldots \ldots \ldots 7 / 8$ mile.

"Aye" (weather vane on large barn cupola).. $8_{3}$ or $20 \ldots \ldots$ I $3 / 4$ miles.

Right peak of barn with cupola............ II2 $5^{6} \ldots \ldots \ldots .1 / 2$ mile. 


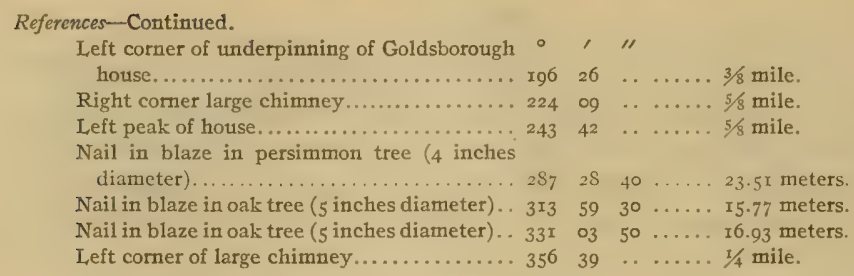

\section{DEUX.}

General locality.-Southern shore of Trippe Creek about $I^{I} / 2$ miles from Tred Avon River. (See Chart No. 34.)

Immediate locality.-Observed station is in an orchard about 8 feet above high water, 50 yards north-. northeast of rambling house, 20 yards southeast of top of bank, I4 yards southwest of top of bank, I 3 yards south of point of bank at ditch, and 3 yards east of a drainage ditch.

Marks.-Observed station is center point of triangle on standard cement monument projecting 5 inches above surface of ground. Subsurface mark is center of 2 -inch tile pipe buried with top 2 inches below base of monument.

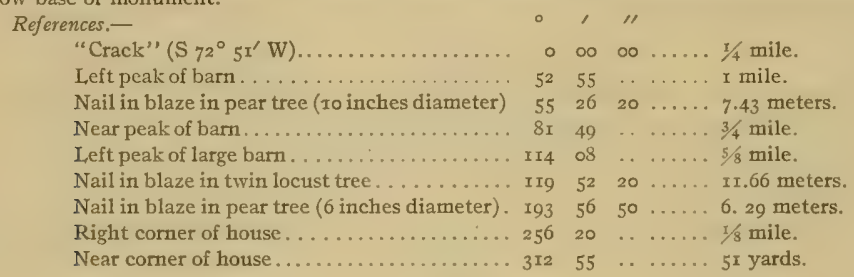

\section{CRACK.}

General locality. Southern shore of Trippe Creek on point at west side of entrance to a small creek, about $I_{1}^{1} / 4$ miles from Tred Avon River entrance to creek. (Sce Chart No. 34.)

Immediate locality.-Observed station is about 3 feet above high water, 13 yards south of edge of bank I5 yards northeast of shore, 40 yards east of extreme end of point, and among scattering locust trees.

Marks,-Observed station is center point of triangle on standard cement monument projecting 5 inches above surface of ground. Subsurface mark is center of 2 -inch tile pipe buried with top 2 inches below base of monument.

\section{References.-}

"Mistle" ( $\left.\mathrm{N}_{3} \mathrm{x}^{\circ} 34^{\prime} \mathrm{W}\right) \ldots \ldots \ldots \ldots \ldots \ldots$.

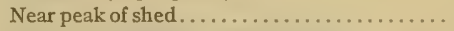

Spindle on right one of four cupolas. . . . . . .

Near peak between two chimneys on large house.....................

Left corner of house. . . . . . . . . . . . . . . x

Right peak of barn .................. I3

Near peak of barn. .................. I $8 \mathrm{I}$

Nail in blaze in cedar tree ( 3 inches diam-

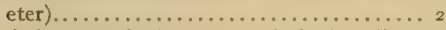

Nail in blaze in locust tree ( 3 inches diameter)............................... eter).

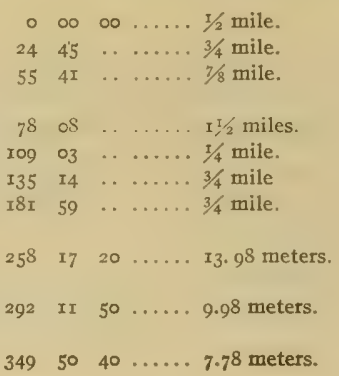


MISTLE.

General locality. - Southern shore of Trippe Creek on a very long point, about $1 / 2$ mile east-northeast of Tred Avon River. (See Chart No. 34.)

Immediate locality.-Observed station is on marsh point about I foot above high water, Io yards southsoutheast of shore, 14 yards west by north of shore, 24 yards southwest of extreme end of point, 4 yards south of a cedar tree, and 12 yards north of a cedar tree.

Marks.-Observed station is center point of triangle on standard cement monument projecting 4 inches above surface of ground. Subsurface mark is center of 2 -inch tile pipe buried with top 2 inches below base of monument.

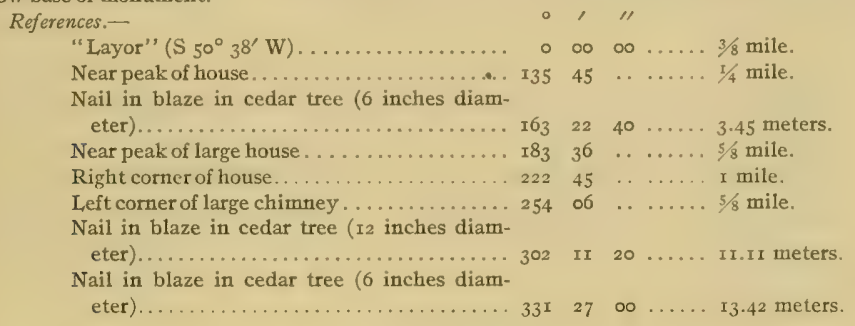

\section{LAYOR.}

General locality.-Southern shore of Trippe Creek, about $1 / 4$ mile east of Tred Avon River. (See Chart No. 34.)

Immediate locality.-Observed station is in edge of cultivated land about 5 feet above high water, 50 yards south of shore, 17 yards east of bank, 2 yards south-southwest of water bushes, and 200 yards wes of large lone tree.

Marks.-Observed station is center point of triangle on standard cement monument projecting 5 inches above surface of ground. Subsurface mark is center of 2 -inch tile pipe buried with top 2 inches below base of monument.

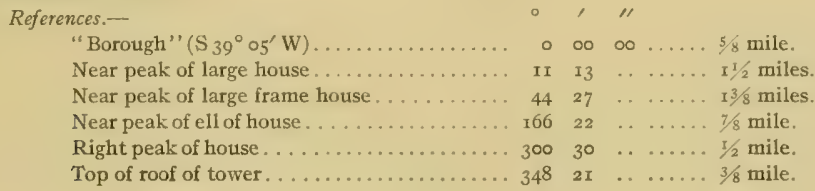

\section{BOROUGH.}

General locality.-Southeastem shore of Tred Avon River, about $1 / 4$ mile north-northeast of entrance to Goldsboro Creek, and $1 / 2$ mile south-southwest of entrance to Trippe Creek. (See Chart No. 34.)

Immediate locality.-Observed station is about 3 feet above high water in cultivated land, I7 yards east-southeast of shore, 25 yards south of shore, 30 yards southwest of shore, $t / 8$ mile northwest of house in trees, and $1 / 8$ mile west-southwest of large lone tree.

Marks.-Observed station is center point of triangle on standard cement monument projecting 4 inches above surface of ground. Subsurface mark is center of 2 -inch tile pipe buried with top 2 inches below base of monument.

$$
534^{85}-\mathrm{I} 2-9
$$




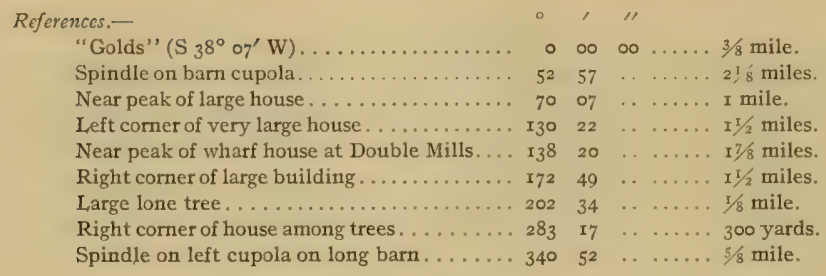

\section{GOLDS.}

General locality.-Eastern shore of Tred Avon River on a point of land between Goldsboro Creek and Mud Creek. (See Chart No. 34.)

Immediate locality.-Observed station is on hard marsh about I foot above high water, zo yards south of shore, 60 yards west-southwest of shore, and 60 yards south-southeast of point of shore.

Marks.-Observed station is center point of triangle on standard cement monument projecting 6 inches above surface of ground. Subsurface mark is center of 2 -inch tile pipe buried with top 2 inches below base of monument.

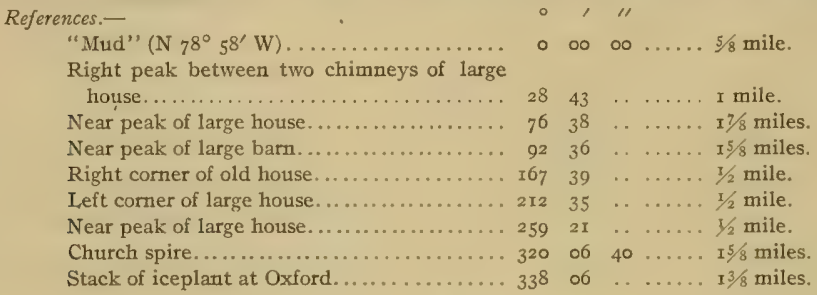

MUD.

General locality.-Southeastern shore of Tred Avon River at western side of entrance to Mud Creek. (See Chart No. 34.)

Immediate locality.-Observed station is among trees on northeast point of a pasture about 4 feet above high water, 13 yards southwest of shore of pond on point, 20 yards north of end of pond, 25 yards northwest of shore of pond, and 45 yards south-southeast of a lone tree at shore of river.

Marks.-Observed station is center point of triangle on standard cement monument projecting 4 inches above surface of ground. Subsurface mark is center of 2 -inch tile pipe buried with top 2 inches below base of monument.

References.-

"Town" (N $\left.85^{\circ} 59^{\prime} \mathrm{W}\right) \ldots \ldots \ldots \ldots \ldots \ldots$

Spindle on barn cupola.

0 oo $00 \ldots \ldots .1 / 4$ mile.

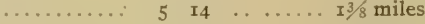

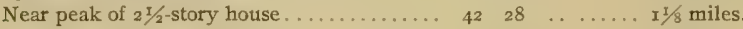

Right corner of $21 / 2$-story house ......... $7^{1} \quad 42 \ldots \ldots \ldots 1 / 2$ mile.

Nail in blaze in hackberry tree $(24$ inches

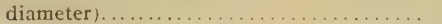

Center of roof of tower................ $x_{5}$

Nail in blaze in twin elm tree.......... 216

Spindle on cupola of long barn .......... 220

Nail in blaze in elm tree ( 7 inches diameter). . 249

"Weather Bureau Staff".............. 315

87 of $10 \ldots . .5 .5^{1}$ meters.

$45 \quad \ldots \ldots \ldots . .2 \mathrm{x} / 8$ miles.

59 Io ..... 8.98 meters.

....... $7 / 8$ mile.

$20 \ldots \ldots .13 .44$ meters.

$40 \ldots \ldots$ I $1 / 8$ miles. 
TOWN.

General locality. Southeastern shore of Tred Avon River about 1/4 mile northeast of east side of entrance to Town Creek, and $3 / 4$ mile northeast of Oxford steamboat wharf. (See Chart No. 34.)

Immediate locality.-Observed station is in northwest corner of a cultivated field about 6 feet above high water, ro yards south of edge of bank, I2 yards east-southeast of point of bank, 25 yards west-southwest of edge of bank, 3 yards northeast of a fence, and 4 yards northeast of gully.

Marks.-Observed station is center point of triangle on standard cement monument projecting 4 inches above surface of ground. Subsurface mark is center of 2 -inch tile pipe buried with top 2 inches below base of monument.

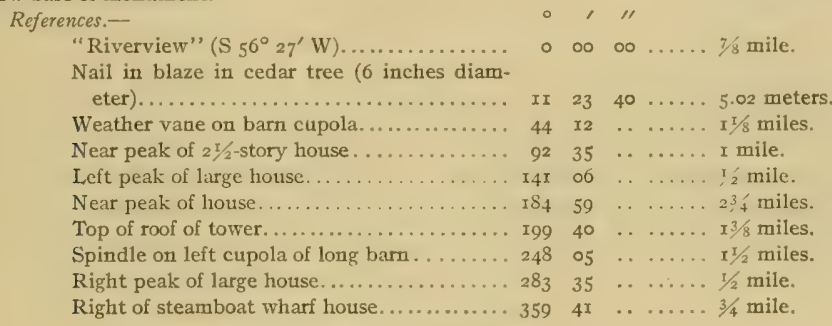

\section{RIVERVIEW.}

General locality.-Eastern shore of Tred Avon River about I/8 mile west by south of Oxford steamboat wharf. (See Charts Nos. 34 and 35 .)

Immediate locality.-Observed station is about 3 feet above high water, 3 yards east of shore, 23 yards south-southwest of a fisherman's shanty, and 50 yards north by west of west end of "Lovers Lane."

Marks.-Observed station is center of triangle on standard cement monument projecting 5 inches above surface of ground. Subsurface mark is center of 2 -inch tile pipe buried with top 2 inches below base of monument.

References.-

\begin{tabular}{|c|c|c|c|c|}
\hline 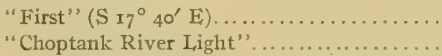 & 27 & 00 & $\begin{array}{l}\infty 0 \\
20\end{array}$ & $\begin{array}{l}1 / 2 \text { mile. } \\
21 / 2 \text { miles. }\end{array}$ \\
\hline Left peak of building........ & 82 & 54 & & $3 / 4$ mile. \\
\hline Spindle on barn cupola. & I $7 \mathrm{I}$ & $I_{7}$ & $\ldots$ & 7/8 mile. \\
\hline Left corner of fisherman's shanty... & 206 & 21 & 50 & 5.82 meters. \\
\hline Right corner of fisherman's shanty... & 224 & I2 & 40 & $6 \mathrm{r}$ meters. \\
\hline Left peak of large house................. & 239 & 57 & .. & $1 / 4$ miles. \\
\hline Right corner of steamboat wharf house..... & 263 & 06 & . & $1 / 8$ mile. \\
\hline Stack of iceplant. .................... & 273 & $\infty$ & . & $3 / 8$ mile. \\
\hline Nail in blaze in oak tree ( 18 inches diameter). & 342 & 44 & 40 & .25 meters. \\
\hline
\end{tabular}

WEATHER BUREAU STAFF.

General locality.-Eastern side of Tred Avon River in the town of Oxford. (See Charts Nos. 34 and 35 .)

Immediate locality.--Observed station is in park south of High and Primary Schools, 55 yards east of shore of Tred Avon River, 55 yards west of Morris Street, and in center of circle of trees.

Marks.-Observed station is center of galvanized iron staff on square galvanized angle-iron tower.

References.-None necessary. 


\section{FIRST.}

General locality.-Eastern shore of Tred Avon River in town of Oxford about $5 / 8$ mile north of railroad wharves. (See Charts Nos. 34 and 35 .)

Immediate locality.-Observed station is about 8 feet above high water, 2 yards east-southeast of edge of bank, 4 yards east by north of point of bank, 4 yards northeast of edge of bank at small gully, 2 yards south of corner fence post, and 35 yards west of house.

Marks.-Observed station is center point of triangle on standard cement monument projecting 4 inches above surface of ground. Subsurface mark is center of 2 -inch tile pipe buried with top 2 inches below base of monument.

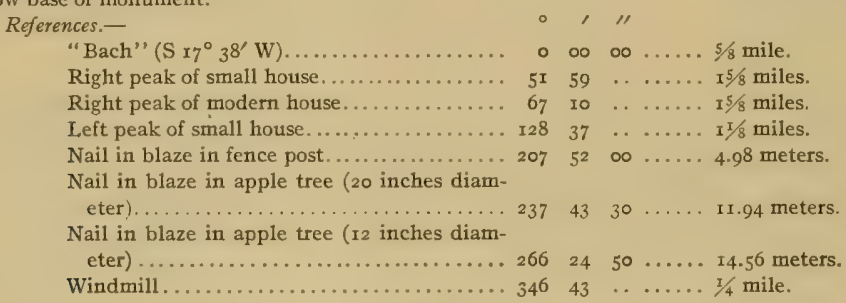

\section{$\mathrm{BACH}$.}

General locality.-Eastern shore of entrance to Tred Avon River on Bachelor Point about I $3 / 8$ miles north-northeast of Choptank River Light. (See Charts Nos. 34 and 35.)

Immediate locality. - Observed station is in cultivated field about 6 feet above high water, 30 yards east of edge of bank, 70 yards north-northeast of edge of bank on range with Choptank River Light, and Ioo yards south by west of edge of bank of trees.

Marks.-Observed station is center point of triangle on standard cement monument projecting 5 inches above surface of ground. Subsurface mark is center of 2 -inch tile pipe buried with top 2 inches below base of monument.

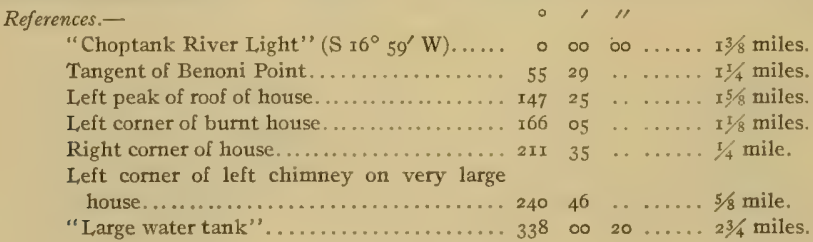

BOONE.

General locality.-Northeastern shore of Choptank River about $3 / 8$ mile northwest of entrance to Boone Creek, $1 / 2$ mile southeast of Bachelor Point, and II/8 miles northeast of Choptank River Light. (See Charts Nos. 34 and 35.)

Immediate locality.-Observed station is about 5 feet above high water, $I_{3}$ yards northeast of edge of tree-fringed bank, 60 yards south-southwest of right corner of house, and 50 yards south-southeast of large apple tree.

Marks.- Observed station is center point of triangle on standard cement monument with top 4 inches above surface of ground. Subsurface mark is center of 2 -inch tile pipe buried with top 2 inches below base of monument. 
References.-

"Choptank River Light" (S $\left.33^{\circ} 54^{\prime} \mathrm{W}\right)$......

Nail in blaze in locust tree ( 5 inches diam-

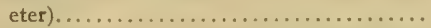

Nail in blaze in locust tree (Io inches diam-

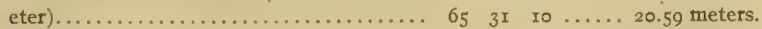

Near peak of house................. I07 $59 \ldots \ldots \ldots$ mile.

Right comer of house............... I59 $12 \ldots \ldots \ldots 57$ yards.

Near peak of house................. $195 \quad 28 \ldots \ldots .3 / 4$ mile.

Nail in blaze in locust tree (4 inches diam-

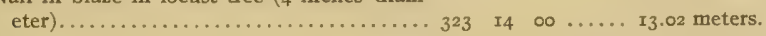

\section{ENTER.}

General locality.-Northern shore of Island Creek on point at east side of entrance to a small cove, about Iśs mile northeast of Choptank River and I 3 ; 8 miles east-northeast of Choptank River Light. (See Charts Nos. 34 and 35 .)

Immediate locality.-Observed station is in cultivated land about 6 feet above high water, I 6 yards north of edge of bank of creek, 18 yards south-southeast of edge of bank of cove, 30 yards east-northeast of outlet of cove, and 250 yards west by south of frame house.

Marks,-Observed station is center point of triangle on standard cement monument projecting 2 inches above surface of ground. Subsurface mark is center of 2 -inch tile pipe buried with top 2 inches below base of monument.

References.-

"Choptank River Light" (S $72^{\circ}$ oo' $\left.^{\prime} \mathrm{W}\right)$...... Nail in blaze in locust tree ( 6 inches diameter) $\ldots \ldots \ldots \ldots \ldots \ldots \ldots \ldots \ldots \ldots \ldots \ldots \ldots \ldots \ldots \ldots \ldots$.

Nail in blaze in cedar tree (ro inches diam-

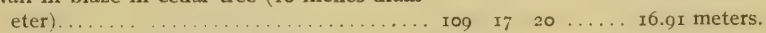

Left corner of left chimney of house. . . . II $\begin{array}{lllll}35 & \ldots \ldots & \ldots & \text { miles. }\end{array}$

Left corner of house....................

Near comer of house................... 204 II ..... $1 / 2$ miles.

"Large water tark"................. 30r 37 00 .... $2 \frac{1}{2}$ miles.

Nail in blaze in locust tree $(4$ inches diam-

eter)........................... 357 I3 $40 \ldots 3$ meters.

STRAW.

General locality.-Northern shore of Island Creek s/8 mile east-northeast of Choptank River entrance to creek. (See Charts Nos. 34 and 35 .)

Immediate locality.-Observed station is about 6 feet above high water, 3 yards northeast of edge of bank, I 8 yards east of bank, 4 yards west of wire fence, 8 yards northwest by west of point where bank meets fence, and 5 yards south of southeast comer of a small house.

Marks.-Observed station is center point of triangle on standard cement monument projecting 2 'nches above surface of ground. Subsurface mark is center of 2 -inch tile pipe buried with top 2 inches elow base of monument.

References,-

"Delahay" (N 66 ro' E).

Nail in blaze in locust tree ( 4 inches diam-

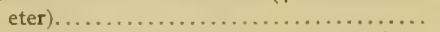

Nail in blaze in locust tree ( 14 inches diameter)....................................

Nail in blaze in locust tree ( 8 inches diam-

Nail in blaze in locust tree ( 8 inches diam-

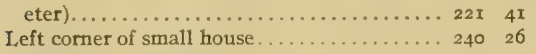

Near corner of small house .............. $287 \quad$ I6

Spindle on barn cupola. ................ $349 \quad 22$ $\circ, 11$

- $\infty$ oo ..... 1/4 mile.

I5 $4300 \ldots .4 .33$ meters.

7208 10 $\ldots \ldots .7 .89$ meters.

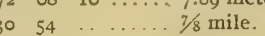

ro ..... I4.86 meters.

. . ... 5.94 meters.

...... 4.04 meters.

. ...... ' '́ mile. 


\section{DELAHAY.}

General locality.-Northern shore of Island Creek about $\mathrm{I}$ mile east-northeast of Choptank River entrance to creek. (See Charts Nos. 34 and 35.)

Immediate locality. - Observed station is in cultivated land about 5 feet above high water, 2 yards northwest of edge of bank, 100 yards east of edge of bank of inlet, 27 yards northeast of point of bank, and 75 yards southwest of farm buildings.

Marks.-Observed station is center point of triangle on standard cement monument projecting 3 inches above surface of ground. Subsurface mark is center of 2 -inch tile pipe buried with top 2 inches below base of monument.

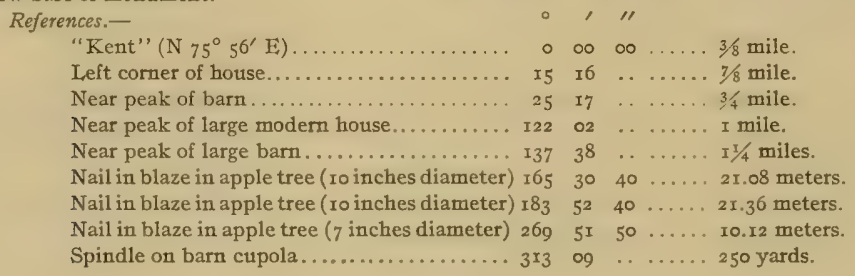

\section{KENT.}

General locality.-Northern shore of Island Creek on a point about I1/4 miles northeast of Choptank River entrance to creek. (See Charts Nos. 34 and 35.)

Immediate locality._-Observed station is in a cultivated field about 5 feet above high water, 50 yards northwest of top of bank, 8o yards east of bank, 75 yards north-northeast of point and i 10 yards east-southeast of point.

Marks.-Observed station is center point of triangle on standard cement monument projecting 3 inches above surface of ground. Subsurface mark is center of 2 -inch tile pipe buried with top 2 inches below base of monument.
References.-
"Harry" $\left(\mathrm{N} 36^{\circ} 27^{\prime} \mathrm{E}\right) \ldots \ldots \ldots \ldots \ldots \ldots . \ldots$
Left corner of chimney outside left end of
house............................. 4

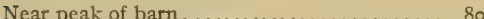

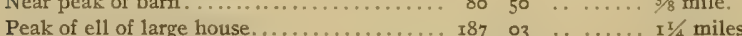
Near peak of building.................. $217 \quad 54 \quad \ldots \ldots \ldots 5 / 8$ mile.
Spindle on barn cupola ................. 240 4I $\ldots \ldots \ldots .1 / 4$ mile.
Near peak of large house............. 309 12 $\ldots \ldots \ldots .7 / 2$ mile.

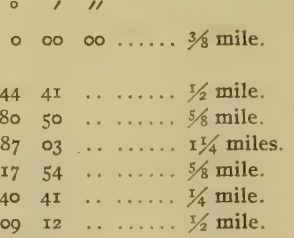

\section{HARRY.}

General locality.-Northern shore of Island Creek about $\mathrm{x}^{1} / 2$ miles from Choptank River. (See Charts Nos. 34 and 35.)

Immediate locality.-Observed station is about 6 feet above high water, 9 yards northwest of edge of bank at cedar trees, 20 yards northeast of cut in bank, and 50 yards south-southwest of bank at cut in shore.

Marks.-Observed station is center point of triangle on standard cement monument projecting 4 inches above surface of ground. Subsurface mark is center of 2 -inch tile pipe buried with top 2 inches below base of monument. 


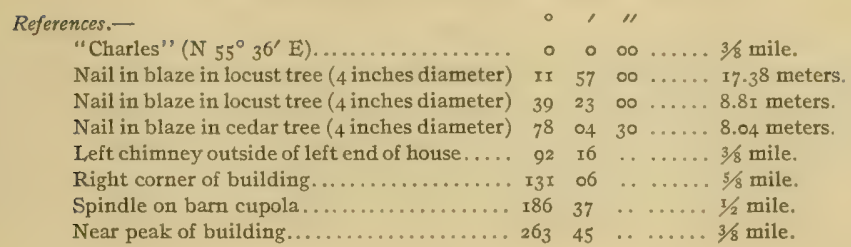

CHARLES.

General locality.-Northern shore of Island Creek about 2 miles from Choptank River. (See Charts Nos. 34 and 35 .)

Immediate locality.-Observed station is in southwest corner of truck garden about 6 feet above high water, 6 yards north of edge of bank, 25 yards west of top of bank near locust tree, and 3 yards east of edge of a r 2 -foot hole 6 feet deep.

Marks.-Observed station is center point of triangle on standard cement monument projecting 3 inches above surface of ground. Subsurface mark is center of 2 -inch tile pipe buried with top 2 inches below base of monument.

References.-

"Potato" ( $\mathrm{N} 78^{\circ}$ or' $\left.\mathrm{E}\right)$

$\mathrm{Nail}$ in blaze in locust tree ( 4 inches diameter)

Nail in blaze in locust tree ( 4 inches diameter)

Near peak of small building...............

Nail in blaze in cherry tree ( 12 inches diam.

eter $\ldots \ldots \ldots \ldots \ldots \ldots \ldots \ldots \ldots \ldots \ldots$ II2 $20 \quad 20 \ldots \ldots 4.17$ meters.

Right corner of chimney on quarter house... $125 \quad 27 \quad \ldots \ldots \ldots 1 / 2$ mile.

Near peak of large barn.............. 213 $02 \quad \ldots \ldots 5 / 8$ mile.

Left corner of barn.................. 265

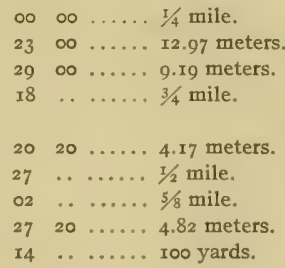

\section{POTATO.}

General locality.-Northern shore of Island Creek about 2\%/4 miles northeast of Choptank River entrance to creek. (See Charts Nos. 34 and 35.)

Immediate locality.- Observed station is in cultivated land about 8 feet above high water, 50 yards northwest of edge of bank, 70 yards west of shore at lowest point of bank, 70 yards north of edge of bank and 400 yards south of woods.

Marks.-Observed station is center point of triangle on standard cement monument projecting 4 inches above surface of ground. Subsurface mark is center of 2 -inch tile pipe buried with top 2 inches below base of monument.

References.-

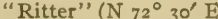

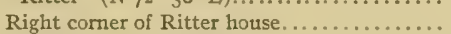

Right peak of large barn................

Near peak of large barn ............. 134

Near peak of house. ................... I62

Right comer of chimney of house.......... I9

Left peak of outhouse.

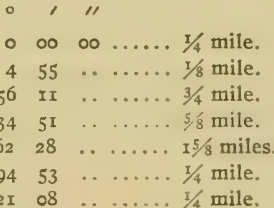


RITTER.

General locality.-Northern side of Island Creek about $2 \frac{1}{2}$ miles from Choptank River entrance to creek. (See Charts Nos. 34 and 35 .)

Immediate locality. - Observed station is in cultivated land about 8 feet above high water, I2o yards north-northwest of nearest point of shore, 160 yards southwest by west of shore of small creek at lowest part of bank, 50 yards east of a wire fence, and 120 yards south of a fence.

Marks.-Observed station is center point of triangle on standard cement monument projecting 3 inches above surface of ground. Subsurface mark is center of 2 -inch tile pipe buried with top 2 inches below base of monument.
References.-
"Show" ( $\left.\mathrm{N}_{50}^{\circ} 4 \mathrm{I}^{\prime} \mathrm{E}\right)$
$0000 . \ldots .1 / 4$ mile.
Near peak of barn.................... I7 $51 \ldots \ldots, \ldots, \ldots$ mile.
Left corner of large chimney of house...... $22 \quad 44 \quad \ldots \ldots \ldots 1 / 2$ mile.
Right corner of vine-covered chimney..... $66 \quad 25 \quad \ldots \ldots .5 / 8$ mile.
Left side of tall chimney............ $779 \quad 43 \ldots \ldots$. . mile.
Near peak of large barn.............. $236 \quad 48 \quad \ldots \ldots 350$ yards.
Left peak of long barn................ $31743 \ldots \ldots 3 / 4$ mile.

\section{SHOW.}

General locality.-Northern shore of upper Island Creek on a point of land between two coves about $23 / 4$ miles east of Choptank River entrance to creek. (See Charts Nos. 34 and 35 .)

Immediate locality.-Observed station is about 9 feet above high water, 6 yards northwest of top of bank, and 35 yards east by north of a large cherry tree in clump of large trees.

Marks.-Observed station is center point of triangle on standard cement monument projecting 3 inches above surface of ground. Subsurface mark is center of 2 -inch tile pipe buried with top 2 inches below base of monument.

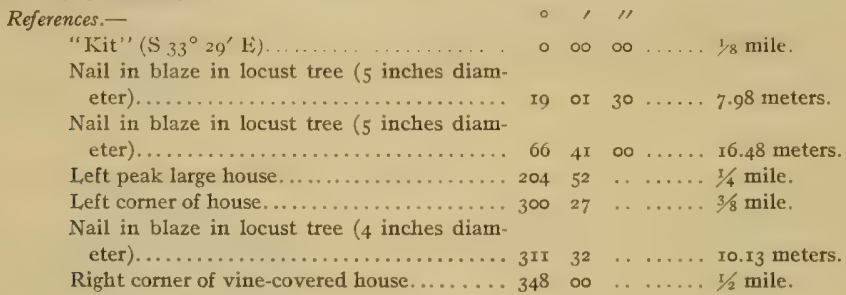

\section{KIT.}

General locality.-Southeastern shore of Island Creek on a prominent point extending into a bend in the creek about $23 / 4$ miles from Choptank River entrance to creek. (See Charts Nos. 34 and 35 .)

Immediate locality.-Observed station is in cultivated land about 8 feet above high water, I3 yards east of top of bank at trees, 20 yards southeast of point of bank, and 30 yards south of top of bank.

Marks.-Observed station is center point of triangle on standard cement monument projecting 4 inches above surface of ground. Subsurface mark is center of 2 -inch tile pipe buried with top 2 inches below base of monument.

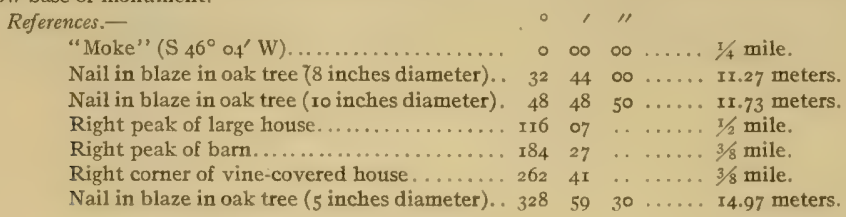


MOKE

General locality.-Northern shore of Island Creek on a prominent point extending into a bend in the creek, about $2 \frac{1}{2}$ miles from Choptank River entrance to creek. (See Charts Nos. 34 and 35.)

Immediate locality.-Observed station is in a pasture about 8 feet above high water, 23 yards northnorthwest of edge of bank, I0o yards northeast of edge of bank at point, and roo yards southeast of edge of bank at cedar tree.

Marks.--Observed station is center point of triangle on standard cement monument projecting 3 inches above surface of ground. Subsurface mark is center of 2 -inch tile pipe buried with top 2 inches below base of monument.

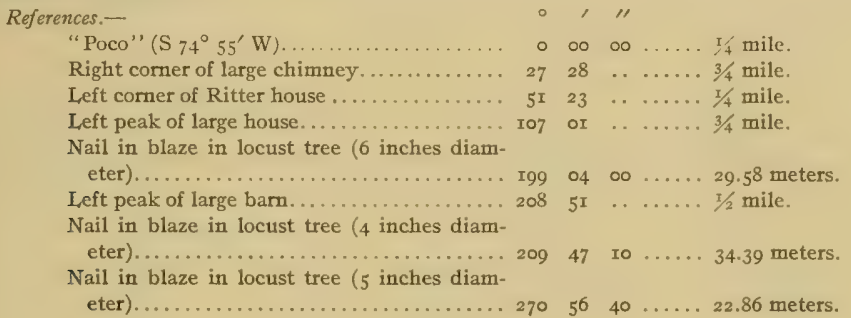

POCO.

General locality.-Southem shore of upper Island Creek on point about $2 \frac{1}{4}$ miles from Choptank River entrance to creek. (See Charts Nos. 34 and 35 .)

Immediate locality.-Observed station is in cultivated field about 9 feet above high water, 70 yards east-southeast of shore at low bank, 80 yards south by east of edge of bark, Ioo yards west of a point of bank, and 130 yards south by west of a point of bank.

Marks.-Observed station is center point of triangle on standard cement monument projecting 5 inches above surface of ground. Subsurface mark is center of 2 -inch tile pipe buried with top 2 inches below base of monument.

References. -

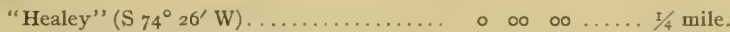

Windmill on wooden tower............... $35 \quad 36 \ldots \ldots .7 / 8$ mile.

Left corner of chimney at left end of house.. 246 15 $\ldots \ldots \ldots 1 / 2$ mile.

Peak of ell of house................... 318 o $8 \ldots \ldots 5$ mile.

Left peak of bam.................. 33 r $48 \ldots \ldots$ mile.

Left peak of building.................. $346 \quad 40 \quad \ldots \ldots 5 / 8$ mile.

\section{HEALEY.}

General locality. - Southern shore of Island Creek at west side of entrance to a cove, about $x 7 / 8$ miles from Choptank River. (See Charts Nos. 34 and 35.)

- Immediate locality.--Observed station is in cultivated field about ro feet above high water, II yards west-southwest of bank fringed with trees, and I50 yards south of a point.

Marks.-Observed station is center point of triangle on standard cement monument projecting 3 inches above surface of ground. Subsurface mark is center of tile pipe buried with top 2 inches below base of monument. 


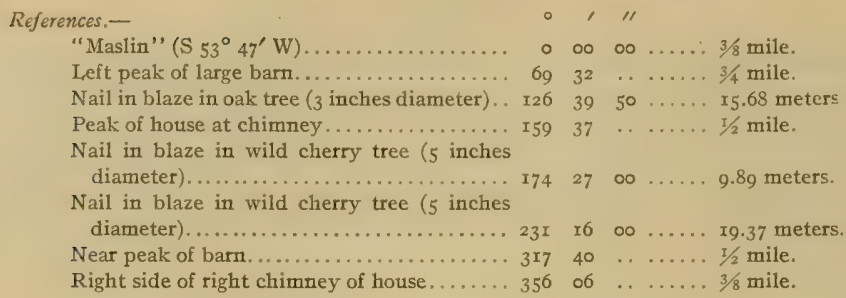

\section{MASLIN.}

General locality. - Southeastern side of Island Creek about $I \frac{1}{2}$ miles northeast of Choptank River entrance to creek. (See Charts No. 34 and 35 .)

Immediate locality.-Observed station is about 8 feet above high water, 95 yards southeast of shore near rail fence, 30 yards north by west of quarter buildings, 9 yards west of fence corner, 6 yards northwest by west of wire fence, 7 yards southwest by west of wire fence, and 25 yards northwest by north of a graveyard.

Marks.-Observed station is center point of triangle on standard cement monument projecting 4 inches above surface of ground. Subsurface mark is center of 2 -inch tile pipe buried with top 2 inches below base of monument.

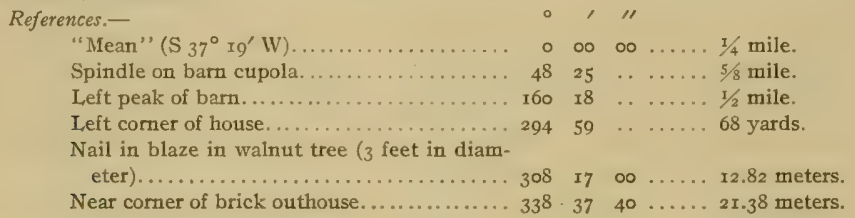

\section{MEAN.}

General locality.- Southern shore of Island Creek on a point at north side of entrance to a south fork of creek, about II/4 miles east-northeast of Choptank River entrance to creek. (See Charts Nos. 34 and 35 .)

Immediate locality.-Observed station is in cultivated land about 5 feet above high water, I3 yards east of edge of bank, Io yards north of line of trees at edge of bank, and I2 yards northeast of point of trees.

Marks,-Observed station is center point of triangle on standard cement monument projecting 3 inches above surface of ground. Subsurface mark is center of 2 -inch tile pipe buried with top 2 inches below base of monument.

References.-

"Choptank River Light" (S $\left.77^{\circ} \circ 7^{\prime} \mathrm{W}\right)$......

Spindle on barn cupola...................

Near peak of house................... 80

Near peak of barn..................... $206 \quad 4$ I $\ldots \ldots .3 / 8$ mile.

Nail in blaze in cherry tree ( 3 inches diam-

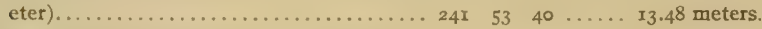

Nail in blaze in locust tree ( 3 inches diameter)......................... 286 I6 $40 \ldots .12$ meters.

Nail in blaze in locust tree ( 3 inches diam-

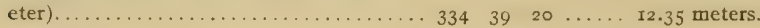


JAY.

General locality.-Southern shore of Island Creek about I mile east of Choptank River entrance to creek. (See Charts Nos. 34 and 35.)

Immediate locality.-Observed station is in northeast comer of cultivated field about 5 feet above high water, 3 yards southwest of point of bank, 3 yards south-southeast of edge of bank, 3 yards westsouthwest of edge of bank, and 30 yards east-northeast of scattering trees.

Marks.-Observed station is center point of triangle on standard cement monument projecting 2 inches above surface of ground. Strbsutface mark is center of 2 -inch tile pipe buried with top 2 inches below base of monument.

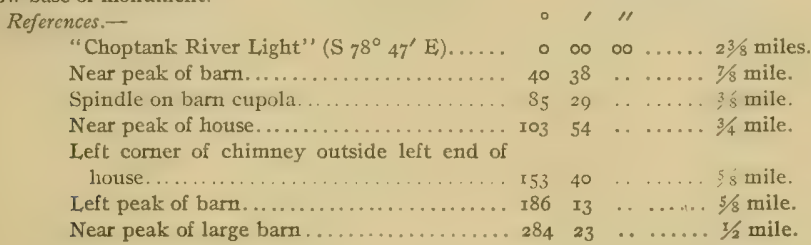

\section{BERRY.}

General locality. Southern shore of Island Creek on a prominent point about $1 / 2$ mile east of Choptank River entrance to creek. (See Charts Nos. 34 and 35.)

Immediate locality.-Observed station is in cultivated land about 6 feet above high water, I 7 yards south-southwest of edge of bank, 17 yards west-southwest of edge of bank, $2 x$ yards southeast of edge of bank, 20 yards southeast of a small house, and 3 yards west of a line of four trees.

Marks.-Observed station is center point of triangle on standard cement monument projecting 3 inches above surface of ground. Subsurface mark is center of 2 -inch tile pipe buried with top $z$ inches below base of monument.

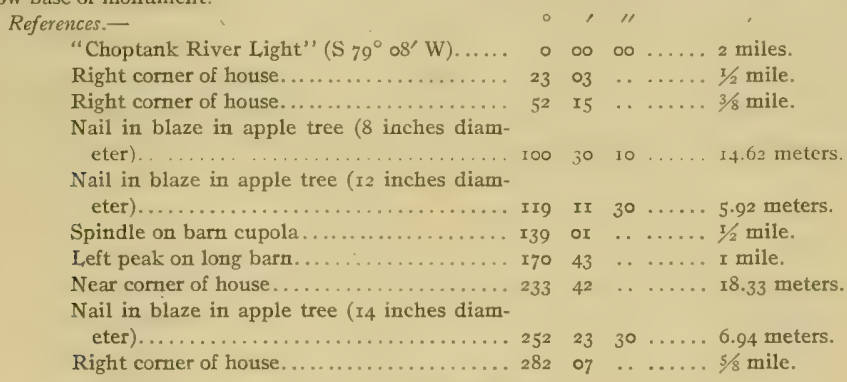

\section{I.ANDEYE.}

General locality.-Northeastern shore of Choptank River on point at south side of entrance to Island Creek, about I I/2 miles east of Choptank River I,ight. (See Charts Nos. 34 and 35.)

Immediate locality.-Observed station is in cultivated land about 5 feet above high water, I 5 yards east-southeast of edge of bank, 50 yards southwest of fringe of trees and bushes, 55 yards south-southwest of point of field and end of fringe of trees and bushes.

Marks.-Observed station is center point of triangle on standard cement monument projecting 2 inches above surface of ground. Subsurface mark is center of 2 -inch tile pipe buried with top 2 inches below base of monument. 


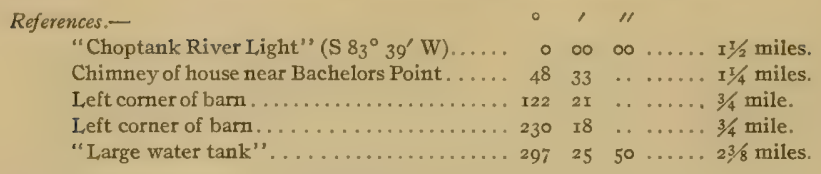

CHOPTANK RIVER LIGHT.

General locality.-In Choptank River about $\mathrm{x}^{2} / 4$ miles southeast of Benoni Point, I mile south of entrance to Tred Avon River, and $81 / 2$ miles east of Blackwalnut Point. (See Charts Nos. 34, 35, and 37.)

Immediate locality.-Observed station is on hexagonal screw-pile structure known as Choptank River Lighthouse.

Marks.-Observed station is center of lantern on Choptank River Lighthouse.

References.-

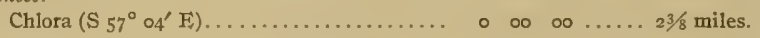

\section{ST. MICHAELS P. F. CHURCH SPIRF,}

General locality.-Western side of Miles River in town of St. Michaels at southeast corner of Talbot and Mill Streets. (See Chart No. 34.)

Immediale locality.-Observed station is on stone edifice known as St. Michacls Protestant Episcopal Church.

Marks.-Observed station is center point of steeple on St. Michaels Protestant Episcopal Church.

References.-None necessary.

\section{MARGO.}

General locality.-Northeastern shore of Miles River, about II/4 miles north-northwest of Long Point and $z$ miles east of St. Michaels. (See Chart No. 34.)

Immediate locality._-Observed station is on a marsh point about I foot above high water, 30 yards north of edge of marsh, 35 yards east of extreme point, and 55 yards west of bushes at edge of marsh. Cedar stub marking old triangulation station "Marengo $1899^{\prime \prime}$ 'is at edge of marsh, 29.61 meters S $57^{\circ}$ II $^{\prime}$ W of observed station.

Marks.-Observed station is center point of triangle on standard cement monument projecting 6 inches above surface of ground. Subsurface mark is center of 2 -inch tile pipe buried with top 2 inches below base of monument. Reference station "Marengo $I 899$ " is center of five copper nails in top of 5 -inch cedar stub 5 feet long with top flush with the surface of the ground.

References.-

"St. Michaels Water Tank" ( $\left.86^{\circ} \mathrm{oz}^{\prime} \mathrm{W}\right)$....

Right chimney of Fogg house.............

Peak of near gable of house...............

Weather vane on square tower on Dodson house...........................

Right tangent of point............... 4

Persimmon tree.................... $7^{2}$

Near peak of large house with large square chimney........................ $288 \quad 29 \quad \ldots \ldots \ldots I^{1 / 4}$ miles.

Large square chimney on Dodson tenant house....................... 298 mile.

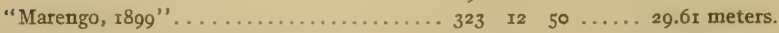

Spindle on M. E. Church cupola........ $354 \quad 51 \quad \ldots \ldots 2$ miles.

"St. Michaels P. E. Church spire" ....... $355 \quad 53 \quad 20 \ldots \ldots 2$ miles. 
GIBBS.

General locality. -Northeastem shore of Miles River about $1 / 2$ mile northwest of extreme end of Long Point, and $\mathrm{x} / 2$ miles south-southeast of entrance to Leeds Creek. (See Chart No. 34.)

Immediate locality.-Observed station is on marsh about $\mathrm{I}$ foot above high water, I7 yards north of shore, 25 yards east of shore, 20 yards northeast of extreme end of point, 35 yards west-northwest of point of woods, and 35 yards southwest of woods.

- Marks.-Observed station is center point of triangle on standard cement monument projecting 5 inches above surface of ground. Subsurface mark is center of 2 -inch tile pipe buried with top 2 inches below base of monument.

\begin{tabular}{|c|c|c|c|c|}
\hline References.- & 0 & 1 & "I & \\
\hline "Long" ( $\left.\mathrm{S}_{44}{ }^{\circ} 29^{\prime} \mathrm{E}\right)$. . & 0 & $\infty$ & $\infty$ & ..... $1 / 2$ mile. \\
\hline Chimney on side of roof of large building.... & $2 I$ & 03 & .. & ..... $13 / 4$ miles. \\
\hline West peak of long building............. & 33 & 20 & .. & .. I $3 / 4$ miles. \\
\hline Southeast chimney of house . . . . . . . . . . & $6 x$ & 44 & .. & ..... I mile. \\
\hline Chimney outside of northeast end of Slater & & & & \\
\hline 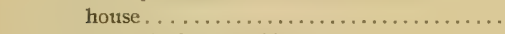 & 102 & 28 & . & ..... I mile. \\
\hline Near peak of Leonard house. . . . . . . . . . . . & 134 & $3 I$ & .. & $\ldots \ldots x^{1} / 2$ miles. \\
\hline "St. Michaels Water Tank" ........ & $15 \mathrm{I}$ & 57 & 40 & .. $25 / 8$ miles. \\
\hline Right chimney of house . . . . . . . . . . . . & $17 \mathrm{I}$ & 17 & .. & $\ldots \ldots .3$ miles. \\
\hline Weather vane on Dodson house.......... & I8I & ro & .. & $\ldots \ldots 23 / 4$ miles. \\
\hline Right tangent of Tilghman Point. ......... & I9I & $4 \mathrm{I}$ & . & .. $7 \frac{1}{4} /$ miles. \\
\hline Left tangent of Fairview Point. . . . . . . . . & 192 & 55 & $\ldots$ & ..... 2 miles. \\
\hline Nail in blaze in pine tree. . . . . . . . . & 265 & 45 & 40 & .... 44.35 meters. \\
\hline Nail in blaze in pine tree. . . . . . . . . . . . & $30 I$ & $3^{8}$ & 50 & ....29. 29 meters. \\
\hline Nail in blaze in pine tree. . . . . . . . . . . & 327 & $5^{8}$ & 40 & .... 30.44 meters. \\
\hline
\end{tabular}

LONG.

General locality:- Northern shore of Miles River on Long Point about 1/8 mile southwest of entrance to Hunting Creek, and $\mathrm{I} / 4$ miles north of railroad bridge across entrance to Oak Creek. (See Chart No. 34.)

Immediate locality.-Observed station is in cedar and pine woods about 6 feet above high water, Io yards east-southeast of edge of bank protected by log breakwater, Ir yards northeast of point of bank, 4 yards northwest of edge of bank, and 30 yards northwest of point of sandy marsh.

Marks.-Observed station is center point of triangle on standard cement monument projecting 4 inches above surface of ground. Subsurface mark is center of 2 -inch tile pipe buried with top 2 inches below base of monument.

References,-

"Hunting" ( $\left.\mathrm{N}_{5} 6^{\circ} 23^{\prime} \mathrm{E}\right)$...

Nail in blaze in cedar tree ( 8 inches diameter)

Left peak of roof of house............... 23 2 $2 \mathrm{x} \quad \ldots \ldots \ldots . \mathrm{I} 3 / 8$ miles.

Spindle on barn cupola............... I03 $47 \ldots \ldots$. . . . $1 / 8$ miles.

Smoke pipe of Royal Oak railroad station... I I I $37 \quad \ldots \ldots \ldots$ I $3 / 8$ miles.

Nail in blaze in cedar tree ( 6 inches diameter) $18 \mathrm{x} \quad 35$ Io $\ldots \ldots 2.53$ meters.

"St. Michaels Water Tank"............. $235 \quad 36 \quad 40 \ldots \ldots .3$ miles.

Nail in blaze in twin cedar tree ( 16 inches

diameter $) \ldots \ldots \ldots \ldots \ldots \ldots \ldots \ldots \ldots \ldots .286$ I5 $30 \ldots \ldots .47$ meters.

Left comer of roof of house............

BEG.

General locality.- Southwestern shore of Hunting Creek on first prominent point north of Miles River entrance to Hunting Creek. (See Chart No. 34.)

Immediate locality.-Observed station is in scant pine woods about 5 feet above high water, 3 yards south of bank, 9 yards northwest of bank, and II yards west of point of bank. 
Marks.-Observed station is center point of triangle on standard cement monument projecting 5 inches above surface of ground. Subsurface mark is 2 -inch tile pipe buried with top 2 inches below base of monument.

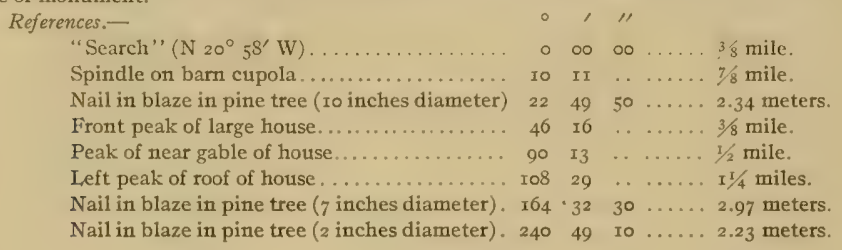

\section{SEARCH.}

General locality. - Western shore of Hunting Creek about $1 / 2$ mile north of Miles River. (See Chart No. 34.)

Immediate locality.-Observed station is on marsh about I foot above high water, II yards northwest of shore, 40 yards south-southwest of shore, 35 yards west-southwest of point of shore, 3 yards east of water bushes, 20 yards south of bushes, and 25 yards southwest of water bushes.

Marks.-Observed station is center point of triangle on standard cement monument projecting 5 inches above surface of ground. Subsurface mark is center of 2 -inch tile pipe buried with top 2 inches below base of monument.

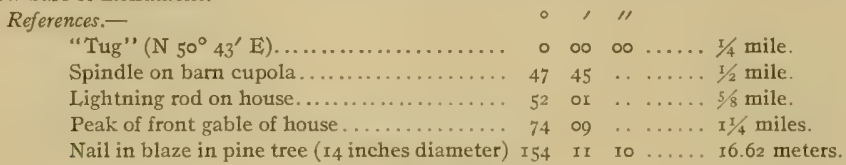

TUG.

General locality.-Eastern shore of Hunting Creek about $1 / 2$ mile north of Miles River. (See Chart No. 34.)

Immediate locality.-Observed station is in cultivated land about 6 feet above high water, ro yards east of edge of bank, 32 yards north of extreme point of shore, 7 yards northeast of a shanty, 14 yards northwest of shore, and trees along shore.

Marks.-Observed station is center point of triangle on standard cement monument projecting 4 inches above surface of ground. Subsurface mark is center of 2 -inch tile pipe buried with top 2 inches below base of monument.

References.-

"Hunting" (S $\left.33^{\circ} 40^{\prime} \mathrm{E}\right)$

Nail in blaze in cedar tree ( 4 inches diameter)

Left corner of shanty................ 53

Right corner of shanty................ 83

- "St. Michaels Water Tank" ............ 132

Left corner of house behind very large oak tree 185

Left peak of ell of house.............. 272

Nail in blaze in birch tree ( 5 inches diameter) 288

Nail in blaze in birch tree ( 9 inches diameter) 304

Right peak of barn with cupola.......... $35^{\circ}$

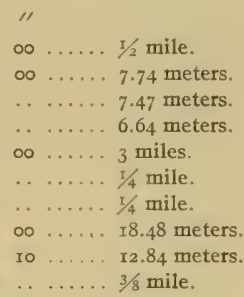




\section{HUNTING.}

General locality.-Northwestern shore of Miles River on east side of entrance to Hunting Creek and $1 / 2$ mile northeast of Long Point. (See Chart No. 34.)

Immediate locality.-Observed station is in south comer of cultivated field, about 5 feet above high water, 2 yards northwest of edge of bank with bushes, 6 yards west of edge of bank, 7 yards northeast of point of bank, 50 yards north of edge of lower land, and 200 yards south of a large barn with a cupola.

Marks:-Observed station is center point of triangle on standard cement ground projecting 5 inches above surface of ground. Subsurface mark is center of 2 -inch tile pipe buried with top 2 inches below base of monument.

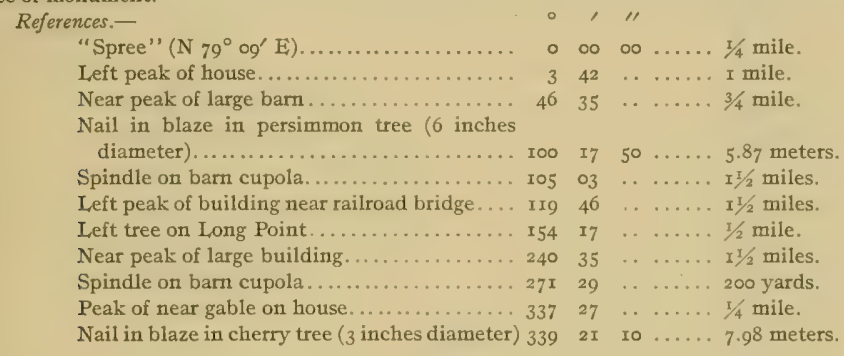

SPREE.

General locality.-Northwestern shore of Miles River, about $1 / 2$ mile east of entrance to Hunting Creek, and $3 / 4$ mile northeast of Iong Point. (See Chart No. 34.)

Immediate locality.-Observed station is on marsh about I foot above high water, 2 yards north of shore, 15 yards west-southwest of wire fence, and 25 yards south of trees. Cement monument marking reference station is 10.57 meters $\mathrm{N}_{2}{ }^{\circ}{ }_{1} 8^{\prime}$ E of observed station and on line with cherry tree.

Marks.-Observed station is center of 2 -inch tile pipe with top flush with surface of gtound. Subsurface mark is center of 2 -inch tile pipe buried with top $z$ inches below base of surface pipe. Reference station is center point of triangle on standard cement monument projecting 4 inches above surface of ground.

\begin{tabular}{|c|c|c|c|c|}
\hline ces.- & $\circ$ & 1 & 11 & \\
\hline "Whit" (N $\left.60^{\circ} 48^{\prime} \mathrm{E}\right)$. & 0 & 00 & $\infty$ & $1 / 2$ \\
\hline Left comer of boathouse ................ & I & 07 & . & $1 / 4$ mile. \\
\hline Near corner of large house. .............. & 3 & 50 & .. & . \\
\hline Left peak of roof of house. . . . . & 38 & I7 & . & $5 / 8$ mile. \\
\hline Spindle on barn cupola................. & II5 & 26 & .. & $3 / 4$ mile. \\
\hline 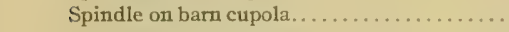 & 135 & 22 & .. & $7 / 8$ mile. \\
\hline Left corner of roof of house . . . . . . . . . . . . & 166 & 42 & .. & iles. \\
\hline $\begin{array}{l}\text { Nail in blaze in hackberry tree }(5 \text { inches } \\
\text { diameter }) \ldots \ldots \ldots \ldots \ldots \ldots \ldots \ldots \ldots \ldots\end{array}$ & 265 & 58 & $\infty$ & \\
\hline 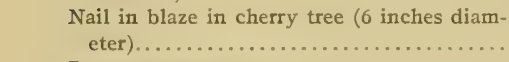 & 300 & 33 & . & \\
\hline REF & 301 & 30 & 30 & .57 meters. \\
\hline Right peak of colonial house & 354 & I5 & . & mile. \\
\hline Nail in blaze in fence bost. . . . . . & $35^{8}$ & $5^{2}$ & 30 & 5.04 meters. \\
\hline
\end{tabular}




\section{WHIT.}

General locality,-Northwestem shore of Miles River on east side of entrance to a small cove about I $1 / 4$ miles northeast of Long Point. (See Chart No. 34.)

Immediate locality.-Observed station is on a small marsh point near a small clump of cedar and hackberry trees about I foot above high water, 5 yards northwest of shore, 4 yards northeast of shore, and 6 yards north of extreme end of point.

Marks.-Observed station is center point of triangle on standard cement monument projecting 5 inches above surface of ground. Subsurface mark is center of 2 -inch tile pipe buried with top 2 inches below base of monument.

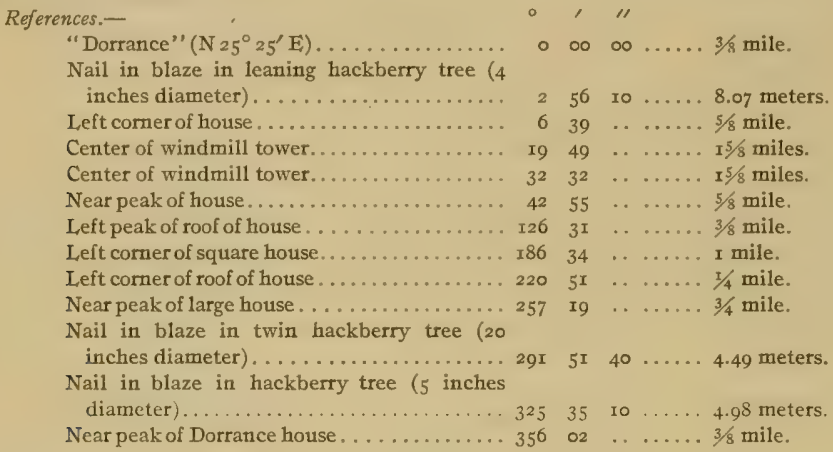

\section{DORRANCE}

General locality. -Northwestem shore of Miles River about I $3 / 8$ miles southwest of Miles River bridge and $I 5 / 8$ miles northeast of Long Point. (See Chart No. 34.)

Immediate locality. - Observed station is about 5 feet above high water, 2 yards northwest of edge of bank, 9 yards west-southwest of a large tree on point of bank, II yards west of point of bank, and I2 yards southwest of edge of bank.

Marks.-Observed station is center point of triangle on standard cement monument projecting 5 inches above surface of ground. Subsurface mark is center of 2 -inch tile pipe, buried with top 2 inches below base of monument.

References.-

"Tang" ( $\left.\mathrm{N}_{40} 0^{\circ} 0^{\prime} \mathrm{E}\right)$.

Center of windmill tower.

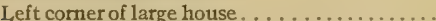

Near corner of Henderson house ............

Center of windmill on tower...............

Nail in blaze in hickory tree ( 20 inches diameter) ................

Spindle on barn cupola................

Right peak of house................

Near peak of house. ................ I36

Nail in blaze in hickory tree ( 18 inches diam-

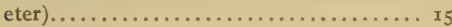

Right corner of house................... 20

Left peak of small tenant house. . . . . . . . . 259

Near comer of Dorrance house. . . . . . . . . . . . 328

Right corner of house................. 355

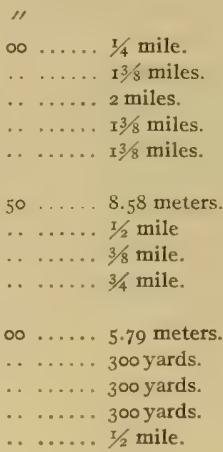


TANG.

General locality.-Northwestern shore of Miles River at south side of entrance to a cove, about Ir/8 miles southwest of Miles River bridge. (See Chart No. 34.)

Immediate locality.-Observed station is on marsh point about $\mathrm{I}$ foot above high water, 20 yards northwest of shore, 25 yards north of point of shore, 35 yards west-southwest of another point of shore, and I5O yards southeast of wire fence.

Marks.-Observed station is center point of triangle on standard cement monument projecting 5 inches above surface of ground. Subsurface mark is center of 2 -inch tile pipe buried with top 2 inches below base of monument.

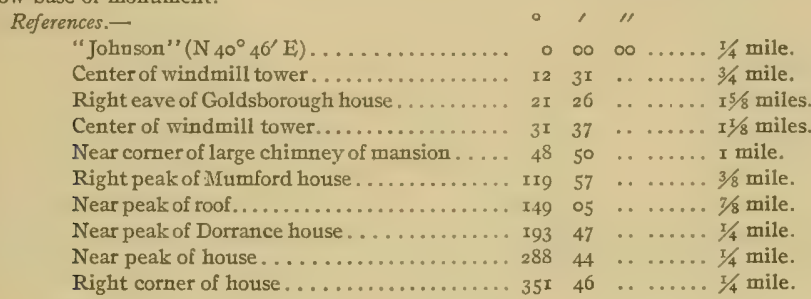

BETHEL

General locality. - Southeastern shore of Miles River at north side of entrance to a small creek, about $3 / 4$ mile southwest of Miles River bridge. (See Chart No. 34.)

Immediate locality.-Observed station is in a clump of pine trees about 3 feet above high water, 9 yards south of shore of rounded point, and 20 yards east of shore.

Marks.-Observed station is center point of triangle on standard cement monument projecting 4 inches above surface of ground. Subsurface mark is center of 2 -inch tile pipe buried with top 2 inches below base of monument.

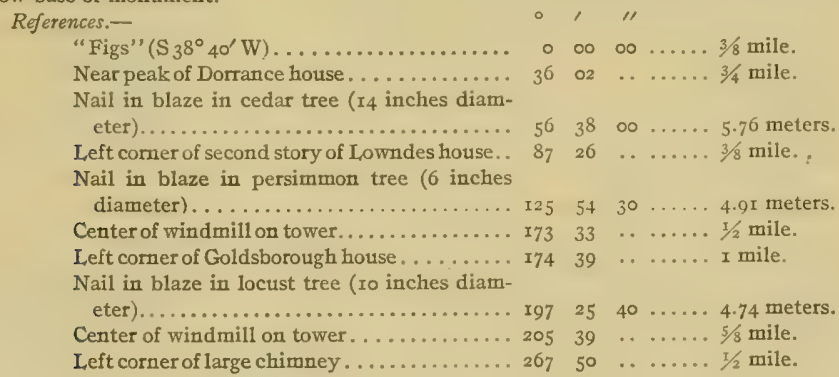

FIG.

General locality!-Southeastern shore of Miles River, about I mile southwest of Miles River bridge. (See Chart No. 34.)

Immediate locality.-Observed station is in cultivated land about $\mathrm{i} 2$ feet above high water, 4 yards southeast of edge of tree-covered bank, and I50 yards north-northwest of large bam with two cupolas.

Marks.-Observed station is center point of triangle on standard cement monument projecting 5 inches above surface of ground. Subsurface mark is center of 2 -inch tile pipe buried with top 2 inches below base of monument.

$53485-12-10$ 


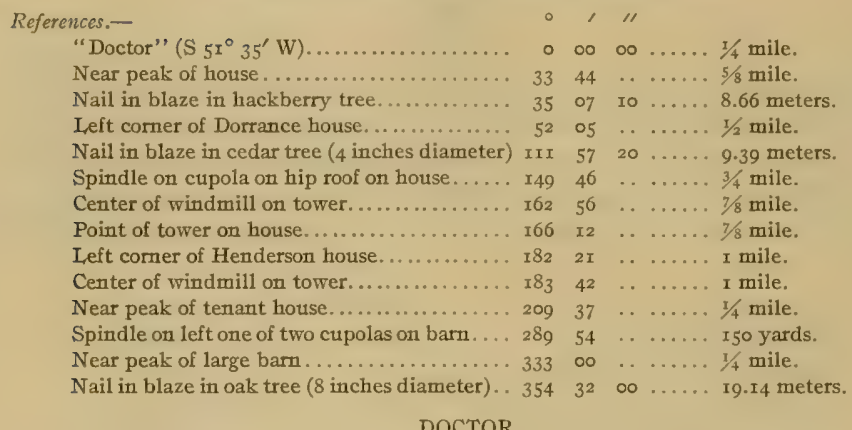

General locality. - Southeastern shore of Miles River, about I I $/ 4$ miles west-southwest of Miles River bridge and $x 3 / 4$ miles northeast by east of Long Point. (See Chart No. 34.)

Immediate locality.-Observed station is in cultivated land back of bushes about 4 feet above high water, 4 yards southeast of edge of bank, 55 yards southwest of a wire fence, 80 yards west of corner of wire fence, I00 yards west by south of a house, and roo yards west-southwest of a marsh point.

Marks.-Observed station is center point of triangle on standard cement monument projecting 5 inches above surface of ground. Subsurface mark is center of 2 -inch tile pipe buried with top 2 inches below base of monument.

References.-

"McConnell" (S $\left.3 \mathrm{I}^{\circ} \mathrm{I}^{\prime} \mathrm{W}\right) \ldots \ldots \ldots \ldots \ldots$

Spindle on barn cupola..................

Near peak of house................. 36

Peak of house $\ldots \ldots \ldots \ldots \ldots \ldots \ldots \ldots \ldots$ II

Nail in blaze in bush ( 3 inches diameter).... $\mathrm{I}_{3} 6$

Nail in blaze in apple tree ( 8 inches diameter) 154

Left corner of house.................. $\mathbf{r}_{5}$

Center of tower..................... 180

Left corner of shed.................. $2 \mathbf{r}_{3}$

Nail in blaze in fence post. . . . . . . . . . . 228

Right peak of large barn ............... 344

Near peak of roof of house.............. 350

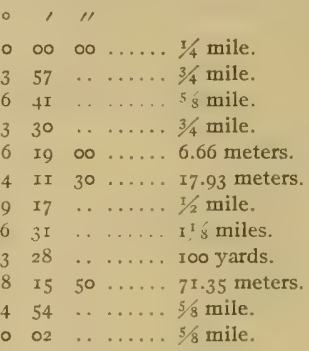

\section{MCCONNELL.}

General locality.-Southeastern shore of Miles River, near west side of entrance to a small cove about I I/2 miles east-northeast of Long Point and I5/8 miles southwest of Miles River bridge. (See Chart No. 34.)

Immediate locality.-Observed station is in cultivated land about 6 feet above high water, I5 yards southeast of edge of bank, 20 yards south of point of bank, and 40 yards west of edge of field at trees.

Marks.-Observed station is center point of triangle on standard cement monument projecting 4 inches above surface of ground. Subsurface mark is center of 2 -inch tile pipe buried with top 2 inches below base of monument.

References.-

"Kirk" (S $\left.5 \mathrm{x}^{\circ} 55^{\prime} \mathrm{W}\right) \ldots$

Left peak of roof of house.................

Left peak of large house..................

Front peak of house...................

"St. Michaels Water Tank" ............. 4

Spindle on barn cupola.

$\begin{array}{rrccc}0 & \prime & \prime \prime \\ 0 & 00 & 00 & \ldots & 5 / 5 \text { mile. } \\ 3 & 39 & \ldots & \ldots & 25 / 2 \text { miles. } \\ 28 & 52 & \ldots & \ldots & 3 / 4 \text { mile. } \\ 45 & 04 & \ldots & \ldots & 1 / 2 \text { mile. } \\ 46 & 40 & 20 & \ldots & 41 / 4 \text { miles. } \\ 114 & 02 & \ldots & \ldots & 1 / 2 \text { mile. }\end{array}$


References-Coritinued.

Left corner of plastered house............ 120 $37 \quad \ldots \ldots \ldots .1 / 2$ mile.

Right corner of large house............ I45 I6 $\quad \ldots \ldots \ldots 5 / 8$ mile.

Right corner of house................. I69 $12 \ldots \ldots \ldots 7 / 8$ mile.

Nail in blaze in cherry tree ( 5 inches diameter).................... I90 $40 \quad 30 \ldots \ldots 39.78$ meters,

Nail in blaze in cherry tree ( 8 inches diam-

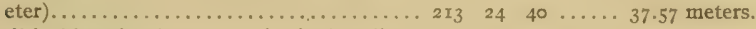

Nail in blaze in cherry tree (Io inches diameter)........................... $237 \quad 57$ o $\ldots \ldots 2$ meters.

Right peak of barn.................. 31 II $22 \ldots \ldots \ldots$ mile.

\section{KIRK.}

General locality.-Southeastern shore of Miles River, between two creeks about $\mathrm{x}$ mile east of Long Point. (See Chart No. 34.)

Immediate locality.-Observed station is in cultivated field, 7 feet above high water, I5 yards southeast of edge of bank, 35 yards west-southwest of point of bank covered with trees, and 40 yards westnorthwest of a large sycamore tree.

Marks.-Observed station is center point of triangle on standard cement monument projecting 5 inches above surface of ground. Subsurface mark is center of 2 -inch tile pipe buried with top 2 inches below base of monument.

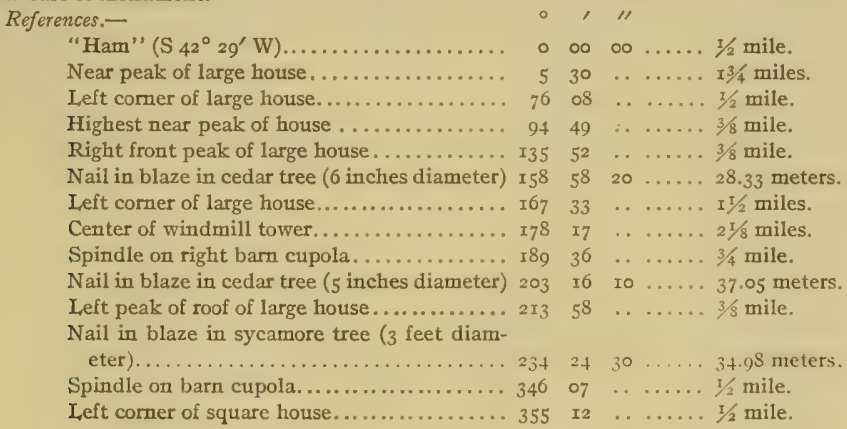

HAM.

General locality,-Southeastern shore of Miles River, about $5 / 8$ mile east-southeast of Long Point, $1 / 2$ mile southeast of entrance to Hunting Creek, and 1/2 mile northeast of entrance to Newcomb Creek. (See Chart No. 34.)

Immediate locality.-Observed station is in cultivated land about 6 feet above high water, I2 yards south-southeast of edge of bank, 20 yards west-southwest of wooden fence at orchard, 65 yards northnorthwest of fence at road, 70 yards west-northwest of large, square house, and 70 yards north west of corner of fence.

Marks,-Observed station is center point of triangle on standard cement monument projecting 4 inches above surface of ground. Subsurface mark is center of 2 -inch tile pipe buried with top $z$ inches below base of monument. 


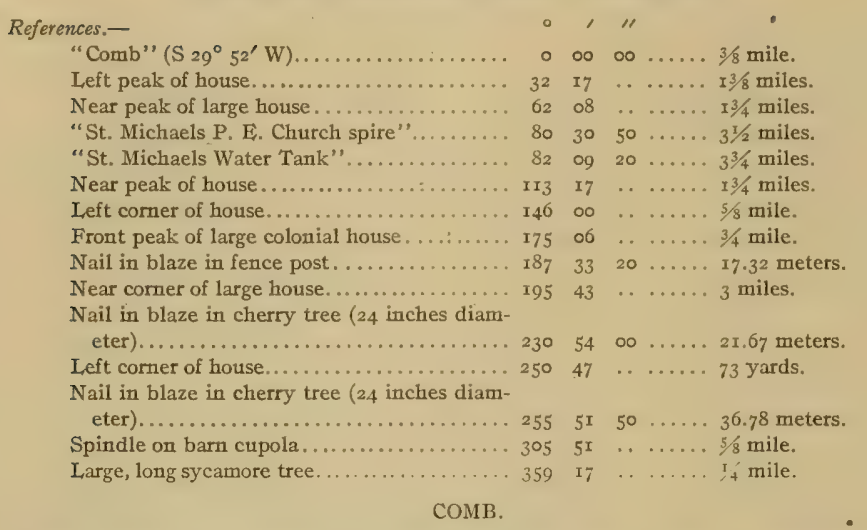

General locality.-Southeastern shore of Miles River about 1/8 mile north of entrance to Newcomb Creek and 3/4 mile northeast of railroad bridge across entrance to Oak Creek. (See Chart No. 34.)

Immediate locality.-O Observed station is in cultivated field about 6 feet above high water, 35 yards southeast of edge of bank, 30 yards east of edge of bank, 45 yards north of edge of bank on range with point, and 300 yards southwest of large lone sycamore tree.

Marks.-Observed station is center point of triangle on standard cement monument projecting 3 inches above the surface of the ground. Subsurface mark is center of 2 -inch tile pipe buried with top 2 inches below base of monument.

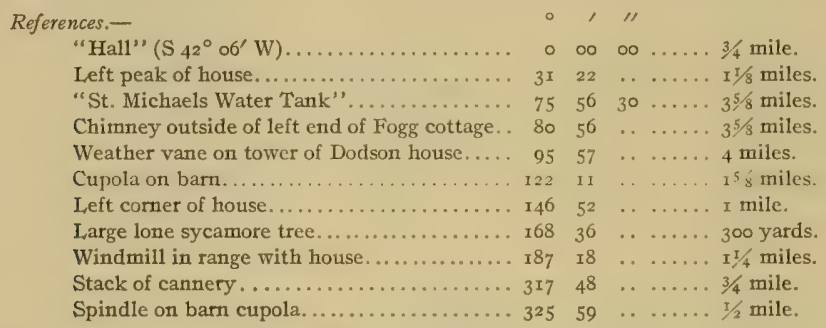

HAIL

General locality. - Southern shore of Miles River about Ioo yards west of west end of railroad trestle across entrance to Oak Creek, and roo yards east of Royal Oak railway station. (See Chart No. 34.)

Immediate locality. - Observed station is in marsh about $x$ foot above high water, 30 yards southwest of shore, 40 yards south of shore, 85 yards west-northwest of shore at corner of shed, and 35 yards northnortheast of near rail of railway track.

Marks.-Observed station is center point of triangle on staxdard cement monument projecting 3 inches above the surface of the ground. Subsurface mark is center of 2 -inch tile pipe buried with top 2 inches below base of monument. 


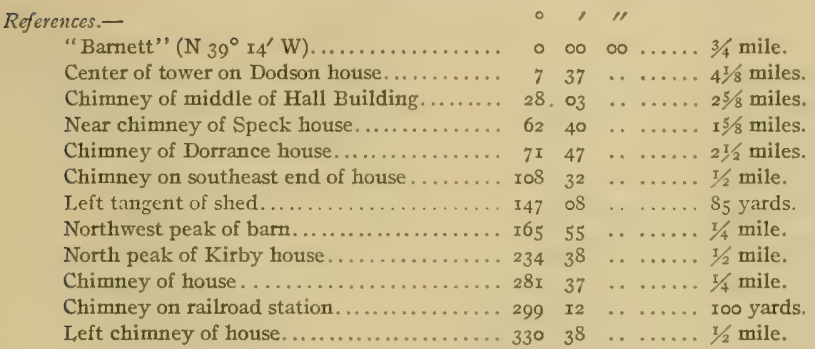

\section{BARNETT.}

General locality. - Southern shore of Miles River about 3/4 mile northwest of entrance to Oak Creek, and $7 / 8$ mile southeast of entrance to Spencers Cove. (See Chart No. 34.)

Immediate locality.-Observed station is on marsh about I foot above high water, 9 yards southwest of shore, I2 yards northwest of shore, 18 yards west-northwest of extreme end of point, and 8 yards northeast of foot of a bank 6 feet high.

Marks.-Observed station is center point of triangle on standard cement monument projecting 5 inches above surface of ground. Subsurface mark is center of 2 -inch tile pipe buried with top 2 inches below base of monument.

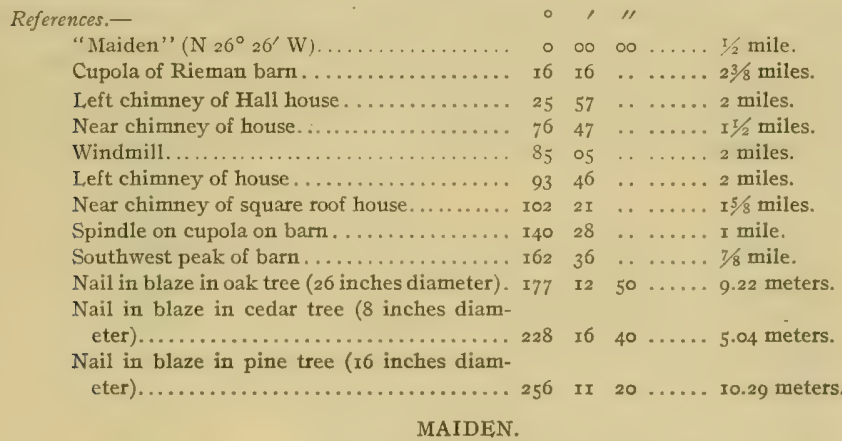

General locality. - Southwestern shore of Miles River about $1 / 2$ mile west of Long Point and $21 / 3$ miles southeast of St. Michaels. (See Chart No. 34.)

Immediate locality. - Observed station is just outside of a fringe of trees near a small marsh skirting the shore on a point about 3 feet above high water, 3 yards south of shore, 5 yards northeast of foot of bank, 7 yards east of point of bank. Cement monument marking reference station is 4.34 meters S $16^{\circ}$ $57^{\prime}$ W of observed station. Stone monument marking "Miles River" (I899) is 38.22 meters S $48^{\circ} 29^{\prime}$ E of observed station.

Marks.-Observed station is center of 2 -inch tile pipe 3 inches above surface of ground. Subsurface mark is center of 2 -inch tile pipe buried with top 2 inches below base of surface pipe. New reference station is center point of triangle on standard cement monument projecting 4 inches above surface of ground. Old triangulation station (Miles River, 1899 ) is center of cross lines on 6-inch square top stone monument. 


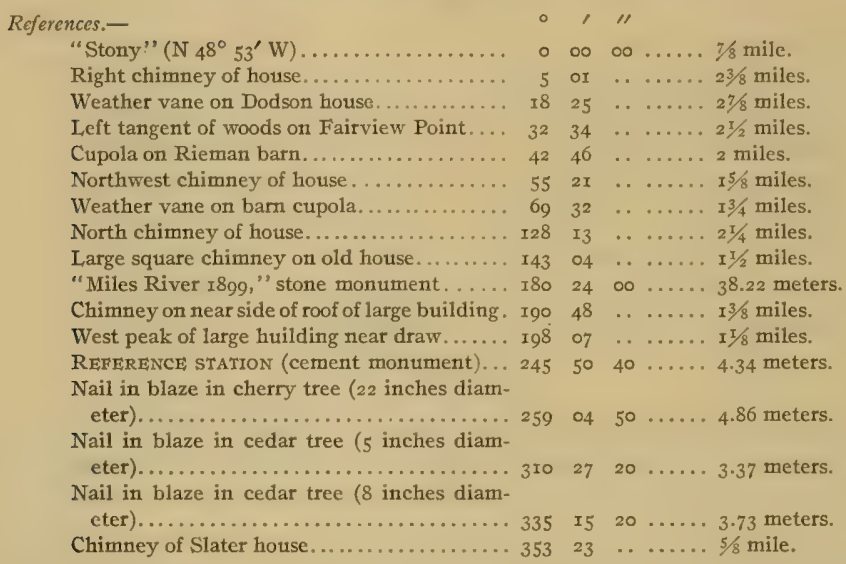

\section{STONY.}

General locality.-Southwestern shore of Miles River on point at east side of entrance to Spencer Cove about $I \frac{1}{4}$ miles southeast of St. Michaels. (See Chart No. 34.)

Immediate locality.-Observed station is in clump of large oak and birch trees about 8 feet above high water, i 4 yards south of shore, 16 yards south-southwest of a point and 12 yards west of another point.

Marks.-Observed station is center point of triangle on standard cement monument projecting 6 inches above surface of ground. Subsurface mark is center of 2 -inch tile pipe with top 2 inches below base of monument.

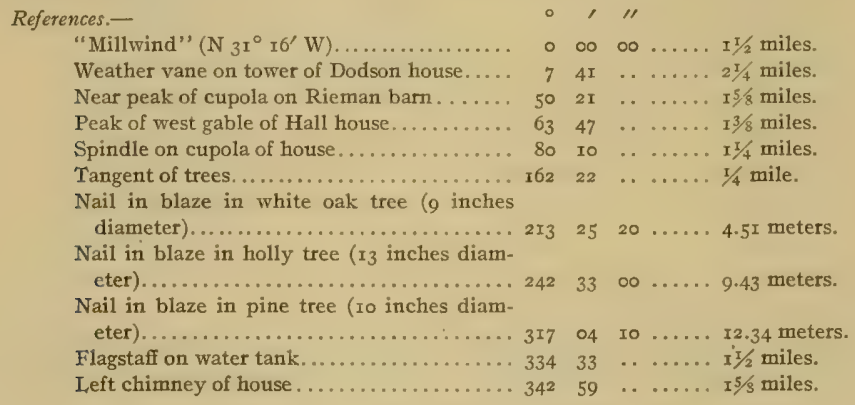

CHIORA.

General locality.-Northeastern shore of Choptank River, on Chlora Point, about $I \frac{1}{2}$ miles southsoutheast of entrance to Island Creek, I I $/ 2$ miles northwest of entrance to La Trappe Creek, and $23 / 8$ miles southeast of Choptank River Light. (See Chart No. 35.)

Immediate locality.-Observed station is about 8 feet above high water, 6 yards east-northeast of edge of bank, 9 yards south of wire fence, and is yards north of edge of bank at walnut tree. Cement monument marking reference station is 6.9 I meters $\mathrm{N} 78^{\circ} 43^{\prime} \mathrm{E}$ of observed station. 
Marks.-Observed station is hole in center of cement-filled tile pipe 4 inches diameter with top about 2 inches below surface of ground. Reference station is center point of triangle on standard cement. monument projecting 4 inches above the surface of the ground.

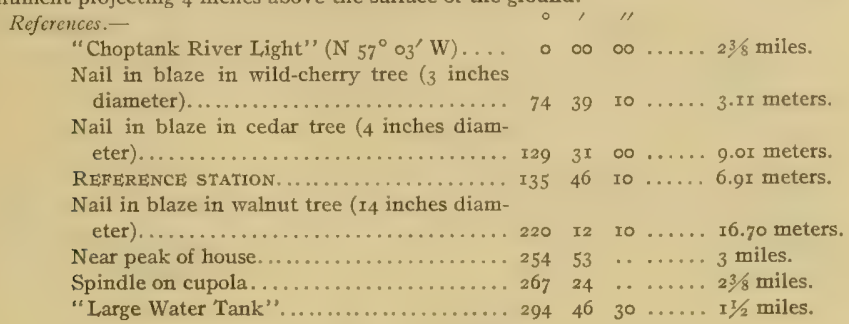

TRAPPE.

General locality.-Northern shore of Choptank River, at west side of entrance to L,a Trappe Creek, about I $1 / 2$ miles southeast of Chlora Point. (See Chart No. 35.)

Immediate locality.-Observed station is on grassy gravel point about 3 feet above high water, 4 yards north of shore, 6 yards east-northeast of shore, and 17 yards south by east of large cedar tree. Cement monument marking reference station is 12.62 meters $\mathrm{N}_{47^{\circ}} 40^{\prime} \mathrm{E}$ of observed station.

Marks.-Observed station is center of 2 -inch tile pipe projecting 2 inches above surface of ground. Subsurface mark is center of 2 -inch tile pipe buried with top 2 inches below base of surface pipe. Reference station is center point of triangle on standard cement monument projecting 2 inches above surface of ground.

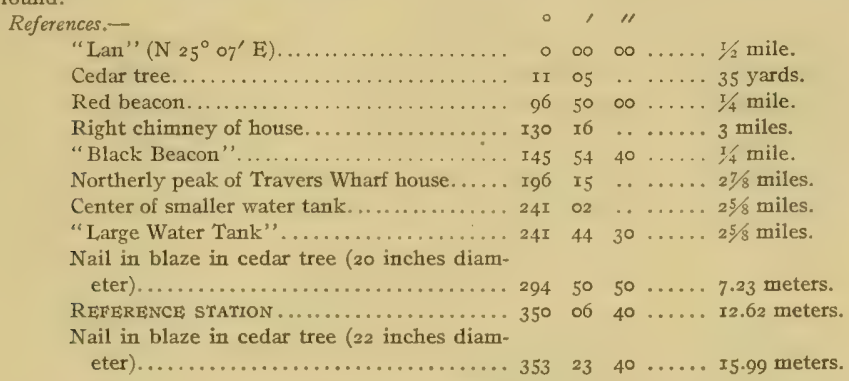

LAN.

General localily.-Northwestern shore of $\mathrm{L}_{\text {a }}$ Trappe Creek, about $3 / 4$ mile north of Choptank River. (See Chart No. 35.)

Immediate locality.-Observed station is on tree-fringed high land about ro feet above high water, 8 yards southeast of shore, 85 yards north of shore, and ro5 yards northeast of extreme end of point.

Marks.-Observed station is center point of triangle on standard cement monument projecting 4 inches above surface $f$ ground. Subsurface mark is center of 2 -inch tile pipe buried with top 2 inches below base of monument. 
References.-

\begin{tabular}{|c|c|c|c|c|}
\hline "Rice" ( $\left(\mathrm{N} 60^{\circ}\right.$ o $\left.0^{\prime} \mathrm{E}\right), \ldots \ldots \ldots \ldots \ldots \ldots \ldots$ & $\circ$ & $\infty$ & $\infty$ & le. \\
\hline Near peak of barn................... & 16 & I3 & . & $3 / 4$ mile. \\
\hline Chimney of abandoned house.............. & $4 \mathrm{I}$ & 40 & . & ile. \\
\hline 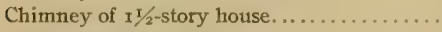 & 47 & 44 & . & mile. \\
\hline Peak of metal-roofed barn............... & 62 & $5^{8}$ & - & . $1 / 2$ mile. \\
\hline Chimney of house in trees............ & 69 & o6 & & I/2 mile. \\
\hline 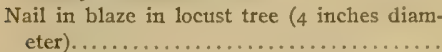 & 185 & 07 & 30 & \\
\hline "Large Water Tank" (Castlehaven)....... & I98 & 49 & $\infty$ & $27 / 8$ miles. \\
\hline Chimney on small house.............. & 235 & $5^{2}$ & . & $\pi / 4$ mile. \\
\hline 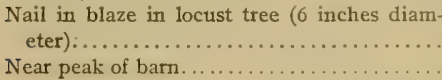 & 92 & & $\infty$ & \\
\hline
\end{tabular}

\section{RICE.}

General locality. - Northwestern shore of La Trappe Creek, about I/8 mile northeast of a wharf and 3/4 mile north-northeast of Choptank River. (See Chart No. 35.)

Immediate locality.-Observed station is on tree-fringed cultivated land, about 3 feet above high water, 28 yards south of shore, 15 yards south of edge of marsh and cultivated land, and 50 yards west of a small creek.

Marks.-Observed station is center point of triangle on standard cement monument projecting 2 inches above surface of ground. Subsurface mark is center of 2 -inch tile pipe buried with top 2 inches below base of monument.

References.-

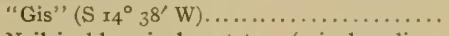

Nail in blaze in locust tree ( 5 inches diam-

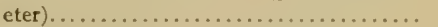

Chimney between two I-story houses........

Near peak of barn......................

Chimney of small house............... 205

Near peak of barn.................... $25434 \quad \ldots \ldots \ldots 3 / 8$ mile.

Nail in blaze in locust tree ( 5 inches diam-

eter).........................

Nail in blaze in locust tree ( 3 inches diam-

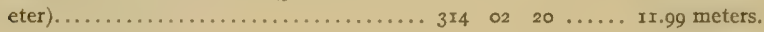

INEZ.

General locality.-Eastern shore of La Trappe Creek, on southwestern shore of a small cove about $3 / 4$ mile northeast of Choptank River. (See Chart No. 35.)

Immediate locality. - Observed station is on high land in pasture field about ro feet above high water 3 yards south of edge of tree-fringed bank, and 125 yards northeast of small house.

Marks.-Observed station is center point of triangle on standard cement monument projecting 2 inches above surface of ground. Subsurface mark is center of 2 -inch tile pipe buried with top about 2 inches below base of monument.

References.-

"Gis" (S $60^{\circ} 27^{\prime} \mathrm{W}$ )

Chimney of I $1 / 2$-story house.

Near peak of abandoned house.............

Nail in blaze in hackberry tree (3 inches

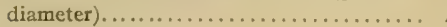

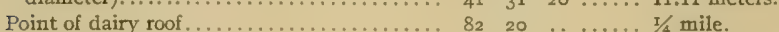

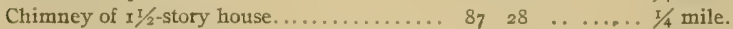

Peak of roof of small house........... I22 $59 \quad \ldots \ldots \ldots 1 / 4$ mile. 
References-Continued.

Peak of barn...................... I30 oo . . . ; mile.

Nail in blaze in locust tree (4 inches diameter)................. I5I I9 $40 \ldots \ldots 3.44$ meters,

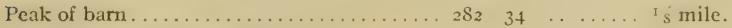

Right chimney of house in trees........ 302 19 $\ldots \ldots \ldots 1 / 4$ mile.

"Black Beacon". .......................... 339 \% mile.

GIS.

General locality. - Southeastern shore of LaTrappe Creek, about $1 / 4$ mile south of a wharf, and $1 / 2$ mile northeast of Choptank River. (See Chart No. 35.)

Immediate locality.-Observed station is on sand and marsh point about I foot above high water, II yards southeast of shore, 13 yards north of shore, 20 yards northeast of shore, and 30 yards north of high cultivated land.

Marks.-Observed station is center point of triangle on standard cement monument projecting 4 inclies above surface of ground. Subsurface mark is center of 2 -inch tile pipe buried with top 2 inches below base of monument.

References.-

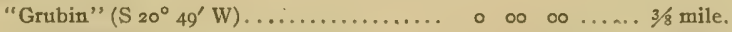

"Black Beacon"................... x4 $34 \quad 50 \ldots \ldots .5 / 8$ mile.

Red Beacon...................... 20 of $30 \ldots \ldots 5$ mile.

Chimney of house ................. 93 o9 ....... $1 / 2$ mile.

Left chimney on house............. I49 $29 \quad \ldots \ldots \ldots .3 / 8$ mile.

Chimney between two small houses........

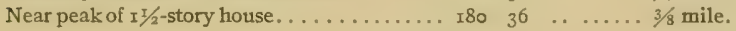

\section{GRUBIN.}

General locality.-Northern shore of Choptank River on east side of entrance to La Trappe Creek. (See Chart No. 35.)

Immediate locality.-Observed station is on grassy marsh back of gravel beach, about I foot above high water, I3 yards east of shore, I3 yards south of shore, 20 yards southeast of extreme end of point, and roo yards northwest of pond.

Marks.-Observed station is center point of triangle on standard cement monument projecting 6 inches above surface of ground. Subsurface mark is center of 2 -inch tile pipe buried with top 2 inches below base of monument.

References. -

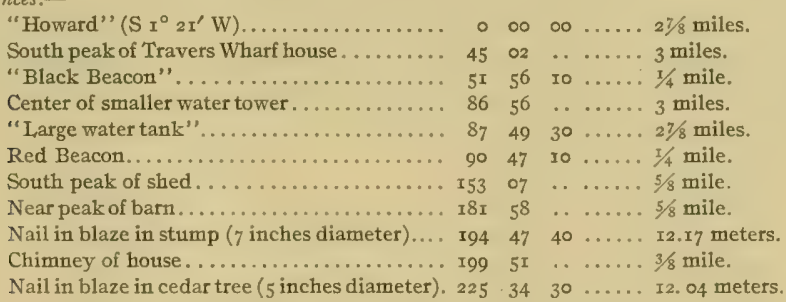

BLACK BEACON.

General locality.-Northeastern shore of Choptank River off entrance to LaTrappe Creek, about I5/8 miles northeast of Horn Point. (See Chart No. 35.) light.

Immediate locality.-Observed station is on a cylindrical foundation known as LaTrappe Creek outer

Marks.-Observed station is center point of lantern on LaTrappe Creek outer light.

References,-None necessary. 


\section{HOWELIS.}

General locality.-Northern shore of Choptank River on Howells Point about $15 / 8$ miles east of Horn Point, 2 miles north of entrance to Jenkins Creek, and 2 miles northwest of Hambrooks Bar Beacon. (See Chart No. 35.)

Immediate locality.-Observed station is on a long grassy gravel point about 3 feet above high water, 50 yards south-southeast of old fish shanty and trees, 25 yards south of highest level part of land, II yards west of shore, 3 yards east of shore, and $1 / 4$ mile north of extreme end of point. Cement monument marking reference station is 22.82 meters $\mathrm{N} 17^{\circ} 53^{\prime} \mathrm{E}$ of observed station.

Marks.-Observed station is nail in center of cedar stub in center of 4 -inch tile pipe with top of pipe 4 inches below surface of ground. Reference station is center point of triangle on standard cement monument projecting 5 inches above surface of ground.

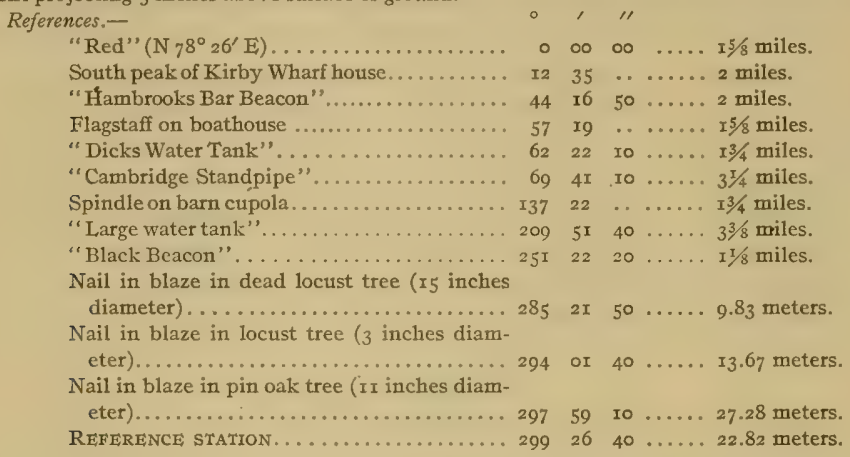

\section{RED.}

General locality.-Northern shore of Choptank River at eastern side of Dickinsons Bay, about $\mathrm{x} 5 / 8$ miles east-northeast of Howells Point and $3 / 4$ mile northwest of Kirby Wharf. (See Chart No. 35.)

Immediate locality. - Observed station is on cultivated land on first high bluff upstream from Howells Point, about I2 feet above high water, 8 yards northeast of edge of bank, Io yards north of edge of bank, and ro yards east of edge of bank. Cement monument marking reference station is 23.65 meters N $89^{\circ}$ $5^{8^{\prime}} \mathrm{E}$ of observed station and almost on line with east chimney of house.

Marks.-Observed station is nail in stub in center of 2 -inch tile pipe with top of pipe 6 inches below surface of ground. Subsurface mark is center of 2 -inch tile pipe buried with top 2 inches below base of surface pipe. Reference station is center point of triangle on standard cement monument projecting 5 inches above surface of ground.

References.-

"Hambrooks Bar Beacon" ( $\left.\mathrm{S}_{3}^{\circ} 39^{\prime} \mathrm{E}\right)$......

"Cambridge Standpipe" ................

"Dicks Water Tank" "................... r.

Center of silo tower................... 5

"Large Water Tank". ... . . . . . . . . . . . . roz

Near peak of barn with two cupolas........ I4

REFERENCE STATION............... 229

East chimney of house . . . . . . . . . . . 229

Near peak of large barn. . . . . . . . . . 282

Right peak of Kirby Wharf house : . . . . . . 308

Near peak of hospital ................ 348

"East Cambridge Tall Stack" ........... 35I

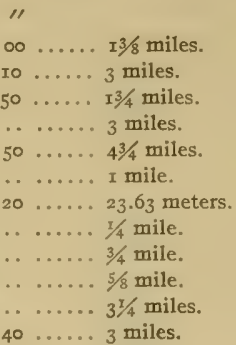


DOUBL,E.

General localily. - Northern shore of Choptank River nearly opposite Cambridge about I mile north. west of entrance to Bolingbroke Creek and $I^{1} / 2$ miles east of Hambrooks Bar Beacon. (See Chart No. 35.)

Immediate locality.-Observed station is on point of marsh separated from field by a row of locust trees about 12 yards northeast of shore, 20 yards north of shore, 14 yards east of shore, and 30 yards south of a large wild-cherry tree.

Marks.-Observed station is center point of triangle on standard cement monument projecting 4 inches above surface of ground. Subsurface mark is center of 2 -inch tile pipe buried with top 2 inches below base of monument.
References.--
"East Cambridge tall stack" ( $\left.\mathrm{S}_{32}{ }^{\circ} 33^{\prime} \mathrm{W}\right) \ldots$
"Dicks Water Tank"....................
"Hambrooks Bar Beacon" ............ 6o or $00 . . . .11 / 2$ miles.
"Large Water Tank" .................. $76 \quad 25 \quad 40 \ldots \ldots 65 / 8$ miles.
Chimney of house ................. ro $34 \ldots \ldots 2 \frac{1}{8}$ miles.
Nail in blaze in wild-cherry tree $(24$ inches

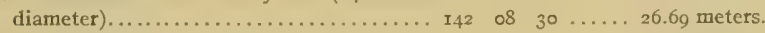
Nail in blaze in locust tree ( 5 inches diameter) I 77 ro $40 \ldots \ldots 24.9^{2}$ meters.
Chimney outside of near end of house...... $177 \quad 29 \quad \ldots \ldots \ldots 1 / 2$ mile.
Nail in blaze in wild-cherry tree ( 4 inches

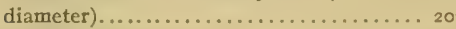
Spindle on barn cupola. ...................248 2430.34 .66 meters
Chimney of house................. 320 +7 $\ldots \ldots \ldots 2 \frac{1}{4} 4$ miles.
Spindle on cupola................. $347 \quad 55 \quad \ldots \ldots .2$ miles.
Near peak of hospital................. $354 \quad 52 \quad \ldots \ldots \ldots .3 / 4$ miles.

BOLING.

General locality.-Northern shore of Choptank River on an island in cntrance to Bolingbroke Creek about $3 / 4$ mile northwest of Chancellors Point and 2 miles east-northeast of Cambridge. (See Chart No. 35.)

Immediate locality.-Observed station is in rushes on a sandy marsh about 3 feet above high water, 6 yards northeast of shore, 7 yards north of shore, 8 yards east of shore, and r6o yards northwest by north of entrance to Bolingbroke Creek.

Marks.-Observed station is center point of triangle on standard cement monument projecting 5 inches above surface of ground. Subsurface mark is center of 2 -inch tile pipe buried with top 2 inches below base of monument.

References.-

"East Cambridge Tall Stack" (S $\left.60^{\circ} \mathrm{I} 9^{\prime} \mathrm{W}\right)$..

Chimney outside of left end of mansard-roof

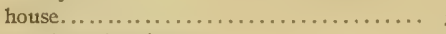

Flagpole on boathouse................

"Hambrooks Bar Beacon" ............. 44

Nail in blaze in old cedar stump ( $I_{3}$ inches diameter $). . . \ldots \ldots \ldots \ldots \ldots \ldots \ldots \ldots$. 19

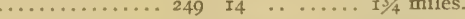

........ $\mathrm{r}^{\mathrm{r}} \mathrm{z}$ miles.

Nail in blaze in cedar tree ( $1 \mathrm{I}$ inches diameter) $300 \quad 25 \quad 40 \ldots \ldots .4 .56$ meters.

Chimney of house................... $3^{1} 3$ so $\ldots \ldots / 8$ miles. 


\section{REAR.}

General locality.-Northem shore of Choptank River about I/8 mile northwest of Chancellors Point and $1 / 2$ mile southeast of entrance to Bolingbroke Creek. (See Chart No. 35.)

Immediate locality.-Observed station is in cultivated field on bluff about $x_{2}$ feet above high water, 65 yards north of edge of bank, r ro yards northeast of edge of bank and trees, I60 yards east of edge of bank, and 95 yards northwest of bottom of gully.

Marks.-Observed station is center point of triangle on standard cement monument projecting 6 inches above surface of ground. Subsurface mark is center of 2 -inch tile pipe buried with top 2 inches below base of monument.

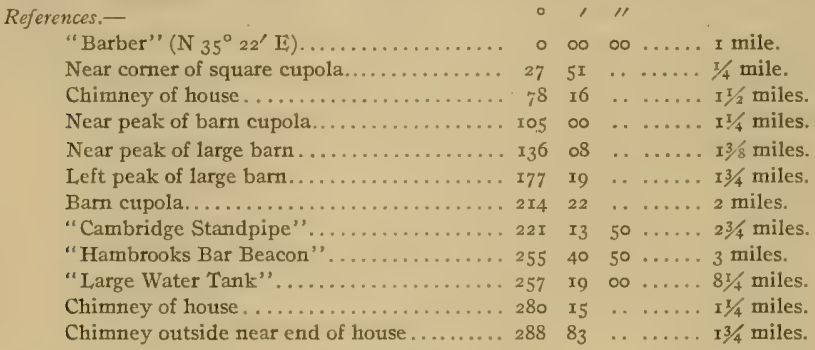

\section{CHANCEI,I,OR.}

General locality.-Northem shore of Choptank River on Chancellors Point about $3 / 4$ mile north of entrance to Hurst Creek and $3 / 4$ mile southeast of entrance to Bolinghroke Creek. (See Chart No. 35.)

Immediate locality.-Observed station is on sand and grass point about $x$ foot above high water, 35 yards west of shore, 35 yards northeast of shore, 60 yards north by west of extreme end of point, $\mathrm{r}_{3}$ yards south of line of cedar stumps, 27 yards southeast of large lone pine tree, and almost on range of Cambridge Standpipe and left peak of hospital. Cement monument marking reference station is 4.70 meters $\mathrm{N}_{3 \mathrm{I}^{\circ}} 3 \mathrm{I}^{\prime} \mathrm{W}$ of observed station and almost on line to large lone pine tree.

Marks.-Observed station is nail in cedar stub in center of 4 -inch tile pipe with top flush with surface of ground. Reference station is center point of triangle on standard cement monument projecting 6 inches above surface of ground.

References.-

"Cambridge Standpipe" (S $78^{\circ} \circ$ W) .....

REFEREACE STATION ...................

Nail in blaze in lone pine tree ( 16 inches diam-

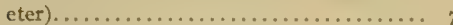

Southeast corner of square cupola........... II
Nail in blaze in cedar stump (I6 inches diam-

eter).

Chimney of house....................216

Near peak of house.................. 245

Chimney on left end of house............ 282

Chimney of house................... 328

Nail in blaze in small pine tree........... $35^{\circ}$

Left peak of hospital................ 359 $\circ, 11$

0 $00 \ldots .27 / 8$ miles.

29 I0 .... 4.70 meters.

$0000 \ldots 24.74$ meters.

$45 \quad \ldots \ldots 350$ yards.

$3250 \ldots \ldots$. I2.40 meters.

$3^{8} \ldots \ldots \ldots$ I $1 / 4$ miles.

$53 \ldots \ldots \ldots I^{1 / 8}$ miles.

$44 \ldots \ldots \ldots .1 / 4$ miles.

$52 \quad \ldots . . .15 / 8$ miles.

$0440 \ldots \ldots 23.26$ meters.

o6 ....... $2^{1} / 4$ miles. 
BARBER.

General locality.-Northwestern shore of upper Choptank River about I mile north-northeast of Chancellors Point and about 7/8 mile west-southwest of Goose Point. (See Chart No. 35.)

Immediate locality.-Observed station is on marsh about 2 feet above high water, 12 yards northnorthwest of county road and shore, 45 yards west-southwest of a cabin on the county road, 25 yards west of two cedar trees just across toad, and 65 yards south of a wire fence.

Marks.-Observed station is center point of triangle on standard cement monument projecting 5 inches above surface of ground. Subsurface mark is center of 2 -inch tile pipe with top 2 inches below base of monument.

References.-

"Duck" (N $\left.75^{\circ} 49^{\prime} \mathrm{E}\right)$...................

Nail in blaze in cedar tree (10 inches diam-

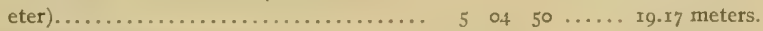

Smokepipe on wharf house............... $354^{8} \quad \ldots \ldots \ldots .1 / 2$ miles.

Near peak of house .................... 57 o6 $\ldots \ldots \ldots$. $1 / 2$ miles.

Northwest peak of house................ $9^{2} \quad 22 \quad \ldots \ldots \ldots .13 / 4$ miles.

Chimney on left end of house............ II6 4 II $\ldots \ldots \ldots .2^{1 / 4}$ miles.

Near peak of house with square cupola ...... $1333 \quad 33 \quad \ldots \ldots \ldots .7 / 8$ mile.

Large lone tree....................... $208 \quad 40 \quad \ldots \ldots . .350$ yards.

Nail in blaze in cedar tree ( 5 inches diameter $) 209 \quad 5^{8} \quad 40 \ldots \ldots .36 .42$ meters.

Nail in blaze in persimmon tree $(5$ inches

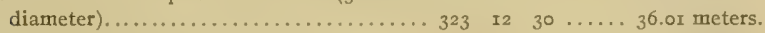

Near corner of barn ................... 347 I5 $\ldots \ldots \ldots .21 .96$ meters.

Nail in blaze in cedar tree (ro inches diam-

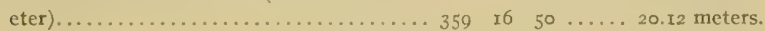

DUCK.

General locality.-Northern shore of Choptank River on Goose Point $3 / 4$ mile north of Oyster Shell Point and $I 3 / 4$ miles northeast of Chancellors Point. (See Chart No. 35.)

Immediale locality.-Observed station is on edge of sand beach on lower part of point about on level with high water, 15 to 20 yards southeast of a group of cedar and persimmon trees. Cement monument marking reference station is $\mathrm{x} 2.6 \mathrm{r}$ meters $\mathrm{N} 28^{\circ} \mathrm{Ig} 9^{\prime} \mathrm{W}$ of observed station.

Marks.-Observed station is center of 2 -inch tile pipe projecting 5 inches above surface of ground. Subsurface mark is center of 2 -inch tile pipe buried with top 2 inches below base of surface pipe. Reference station is center point of triangle on standard cement monument projecting 5 inches above surface of ground.

References.-

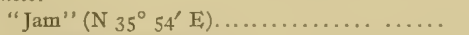

Left peak of large barn................ 46

Center of roof of house................ 8

Smoke pipe on wharf house ............ II

Left peak of barn cupola................ I6

Near corner of square chimney of house..... I74

Chimney of house . . . . . . . . . . . . . 192

Near comer of square cupola on house..... I97

Nail in blaze in persimmon tree ( 2 inches diameter $\ldots \ldots \ldots \ldots \ldots \ldots \ldots \ldots \ldots .238 \quad 59 \quad 40 \ldots \ldots 21.22$ meters.

REFERENCE STATION........................ $295 \quad 47$ 30.6r meters.

Nail in blaze in persimmon tree $(3$ inches diameter $) \ldots \ldots \ldots \ldots \ldots \ldots \ldots \ldots \ldots .297 \quad 48 \quad 50 \ldots \ldots . \ldots \ldots$ I5.20 meters.

Nail in blaze in cedar tree ( 3 inches diam-

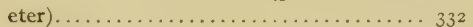
$27 \quad 20 \ldots \ldots .14 .28$ meters. 
JAM.

General locality.-Western shore of Choptank River on Jamaica Point opposite cntrance to Warwick River. (See Chart No. 35.)

Immediate locality,-Observed station is on marsh point about 3 feet above high water, 25 yards west-northwest of end of wharf, 7 yards north of county road, II yards northeast of county road, I3 yards south of shore, 8 yards west-southwest of shore, and 30 yards north by east of shore.

Marks,-Observed station is center point of triangle on standard cement monument projecting 4 inches above surface of ground. Subsurface mark is center of 2 -inch tile pipe buried with top 2 inches below base of monument.

References.-

"Spindle" ( $\mathrm{N} \mathrm{I4}^{\circ} 53^{\prime} \mathrm{W}$ ).

mey outside near end of house.........

Chimney of large house.................

"Wick" ...........................

Chimney of hotise . . . . . . . . . . . . . . .

Left chimney of large brick house ..........

Left comer of wharf house...............

Right comer of wharf house........... 108

Nail in first plank on level part of wharf..... II

Near peak of large barn ............... 144

Chimney of house ................. I $7 x$

Near peak of house. .................. 202

Near peak of house near wharf.......... 211

Right peak of barn cupola............... 2Is 30

Near corner of fence. ................. $269 \quad 3^{8}$

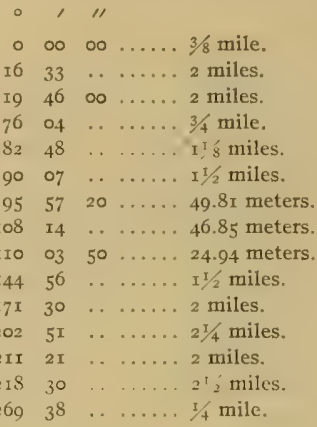

SPINDLE.

General locality.-Western shore of upper Choptank River about $3 / 8$ mile north of Jamaica Point Wharf. (See Chart No. 35.)

NoTE.-This triangulation landmark was destroyed before this publication was prepared, and therefore it is not described, although its name and location are shown on Chart No. 35 .

BANK,

General locality.-Western shore of upper Choptank River about I mile north-northwest of Jamaica Point and II/4 miles southwest of entrance to Cabin Creek. (See Chart No. 35.)

Immediate locality.-Observed station is in a cultivated field on a tree-fringed bluff about 20 feet above high water, yo yards northwest of edge of bluff, Io yards west of edge of bluff, and I2 yards north of edge of bluff.

Marks,-Observed station is center point of triangle on standard cement monument projecting 4 inches above surface of ground. Subsurface mark is center of 2 -inch tile pipe buried with top 2 inches below base of monument.

References.-

"Raccoon" ( $\left.\mathrm{N} 19^{\circ} 26^{\prime} \mathrm{E}\right) \ldots \ldots \ldots \ldots \ldots \ldots$

Left chimney of modern house............

Nail in blaze in branch of double oak tree ( 12 and 18 inches diameter $). . \ldots \ldots \ldots \ldots \ldots$.

Chimney of house in woods................

Chimney of shanty in woods...............

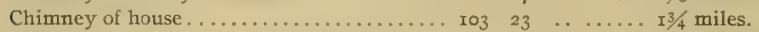

Nail in blaze in oak tree ( 8 inches diameter).. I24 13 Io $\ldots . .8 .55$ meters.

Nail in blaze in cedar tree ( 7 inches diasn-

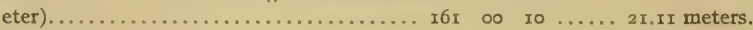

Front peak of house.................. I68 $29 \ldots \ldots \ldots 1 / 8$ mile. 


\section{RACCOON.}

General locality.-Westem shore of upper Choptank about 3/8 mile south of entrance to a small creek, I $1 / 2$ miles north of Jamaica Point, and I mile west of entrance to Cabin Creek. (See Chart No. 35.)

Immediate locality. -Observed station is between 2 clumps of trees on sandy marsh about 2 fect above high water, 8 yards northwest of shore, I2 yards west of shore, I6 yards north of shore; and 200 yards southwest of woods beyond marsh.

Marks.-Observed station is center point of triangle on standard cement monument projecting 6 inches above surface of ground. Subsurface mark is center of 2 -inch tile pipe buried with top 2 inches below base of monument.

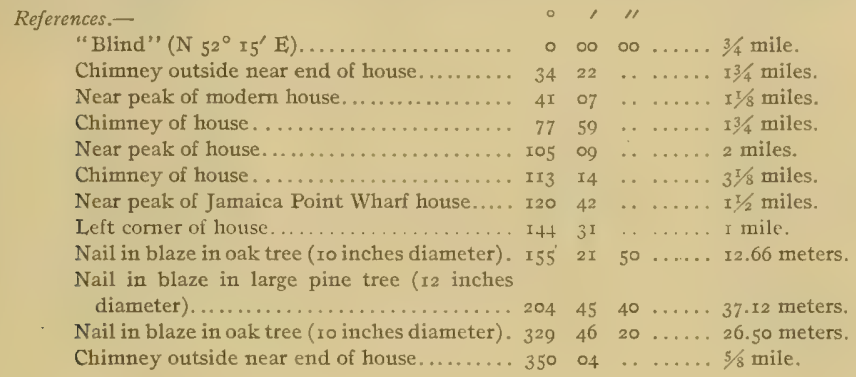

\section{BLIND.}

General locality.-Northwestem shore of Choptank River about $1 / 2$ mile west-north west of entrance to Cabin Creek, and 2 miles north of Jamaica Point. (See Chart No. 35.)

Immediate locality.-Observed station is on a marsh point between river and line of locust trees about I foot above high water, II yards north of shore, I5 yards west of shore, i6 yards northeast of shore at duck blind, and 25 yards east by north of shore.

Marks.-Observed station is center point of triangle on standard cement monument projecting 6 inches above surface of ground. Subsurface mark is center of 2 -inch tile pipe buried with top 2 inches below base of monument.

References.-

"Up" (N 61 $\left.{ }^{\circ} 44^{\prime} \mathrm{E}\right)$

Chimney outside of near end of old house....

Peak of side gable of modern house........ 5

Right peak of Jamaica Point wharf house. . . I 31

Chimney on house ................. I6

Nail in blaze in locust tree $(4$ inches diam-

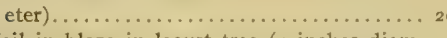

Nail in blaze in locust tree (4 inches diam-

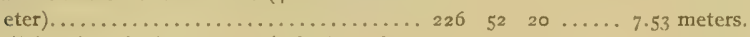

Nail in blaze in locust tree ( 6 inches diam-

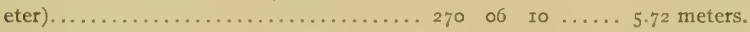

Nail in blaze in locust tree (ro inches diam-

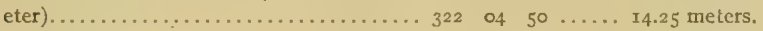

\section{UP.}

General locality.-Northwestern shore of upper Choptank River about $3 / 4$ mile north of entrance to Cabin Creek and $2 \frac{1}{2}$ miles north-northeast of Jamaica Point. (See Chart No. 35 .)

Immediate locality.-Observed station is on a marsh point about I foot above high water, 55 yards northwest of extreme end of point, 25 yards west of shore, and 20 yards north of shore. 
Marks.-Observed station is center point of triangle on standard cement monument projecting $\delta$ inches above surface of marsh. Subsurface mark is center of 2 -inch tile pipe buried with top 2 inches below base of monument.

\begin{tabular}{|c|c|c|c|c|}
\hline References.- & & & & \\
\hline "Myrtle" (S $\left.60^{\circ} 25^{\prime} \mathrm{E}\right)$. & $\circ$ & $\infty$ & $\infty$ & ${ }^{3}$ s mile. \\
\hline Peak of side gable of modern house......... & 34 & 14 & . & I mile. \\
\hline 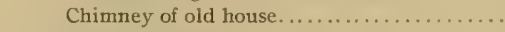 & 36 & IO & . & $5 / 3$ mile. \\
\hline Tangent of point......... & 77 & 45 & .. & I mile. \\
\hline House............ & III & 45 & . & I $7 / 8$ mile \\
\hline Tangent of point. . & 122 & 02 & . & s s mile. \\
\hline House. . & 273 & $\infty$ & & $\therefore x x^{1 / 2}$ mile \\
\hline Tangent of point........ & 305 & I5 & & I $75 \mathrm{ya}$ \\
\hline
\end{tabular}

\section{MYRTLE.}

General locality.-Eastern shore of upper Choptank River about 1/2 mile north of entrance to Cabin Creek. (See Chart No. 35.)

Immediate locality.-Observed station is on a marsh point about I foot above high water, I7 yards east of shore, 20 yards south of extreme end of point, 15 yards southwest of small gut, and 250 yards west. of woods.

Marks.-Observed station is center point of triangle on standard cement monument projecting 4 inches above surface of ground. Subsurface maxk is center of 2 -inch tile pipe buried with top 2 inches below base of monument.

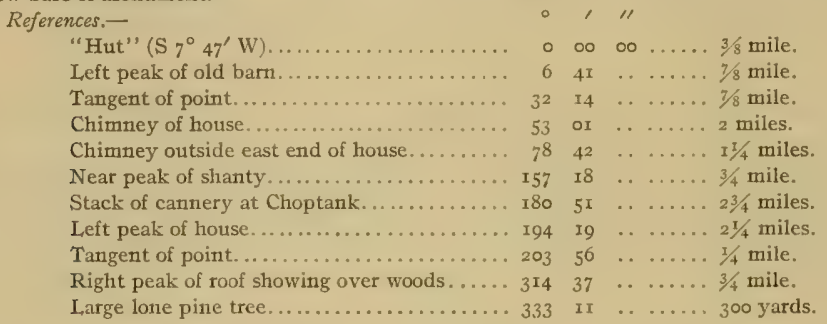

\section{HUT.}

General locality.-Fastern shore of upper Choptank River on north side of entrance to Cabin Creek. (See Chart No. 35.)

Immediate locality. - Observed station is on a marsh point about I foot above high water, 15 yards east of shore, 50 yards northwest of shore, 20 yards northeast of extreme end of point, 90 yards southwest of a hut, and 80 yards south-southwest of trees.

Marks.-Observed station is center point of triangle on standard cement monument projecting 6 inches above surface of ground. Subsurface mark is center of 2 -inch tile pipe buried with top 2 inches below base of monument.

References.-

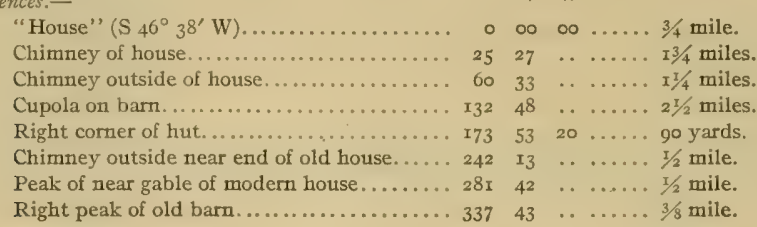




\section{HOUSE.}

General locality. -Eastern shore of Choptank River about $x / 4$ mile south of entrance to Cabin Creek. I mile north of entrance to Warwick River, and on south side of a small cove. (See Chart No. 35.)

Immcdiate locality.-Observed station is on marsh about I foot above high water, 14 yards south of shore, 26 yards southeast of shore, 35 yards southwest by west of shore and mouth of small creek in marsh and 175 yards north of woods.

Marks.-Observed station is center point of triangle on standard cement monument projecting 3 inches above surface of ground. Subsurface mark is center of 2 -inch tile pipe buried with top 2 inches below base of monument.

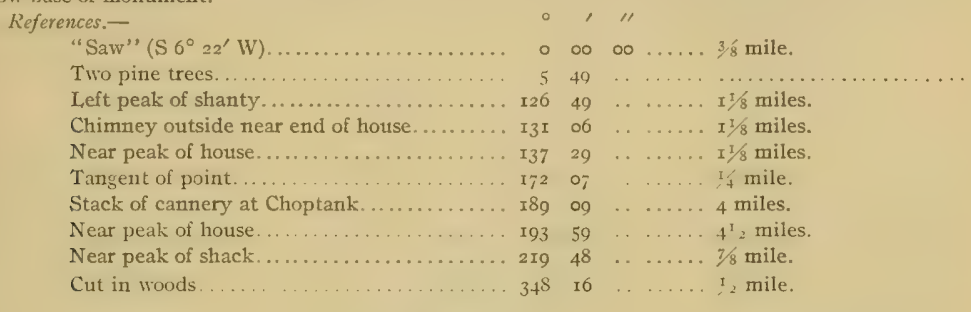

SAW.

General locality.-Eastem shore of Choptank River about 1/2 mile northeast of entrance to Warwick River, and I mile northeast by east of Jamaica Point. (See Chart No. 35.)

Immediate locality.-Observed station is on marsh about $\mathrm{I}$ foot above high water, 22 yards east of shore, 26 yards southeast of shore, 37 yards northeast of shore, 200 yards west-northwest of dense woods.

Marks.-Observed station is center point of triangle on standard cement monument projecting 4 inches above surface of ground. Subsurface mark is center of 2 -inch tile pipe, buried with top 2 inches below base of monument.

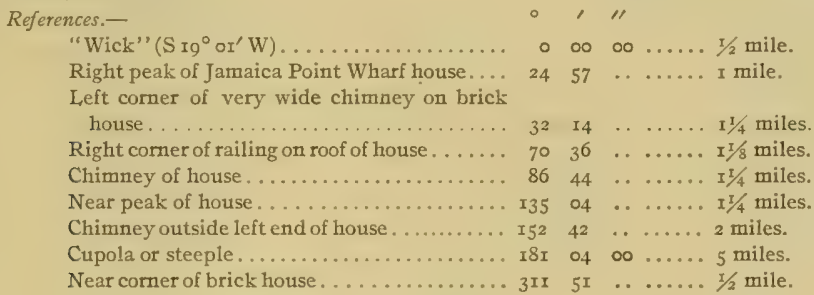

\section{WICK.}

General locality.-Eastern shore of upper Choptank River on northern side of entrance to Warwick River, about $3 / 4$ mile northeast of Jamaica Point. (See Chart No. 35.)

Immediate locality.-Observed station is on sandy ridge between beach and marsh, about 2 feet above high water, 8 yards northeast of shore, to yards north of shore, 9 yards east of shore, Ioo yards southeast by east of extreme end of point, and 35 yards northwest of two pine trees. Cement monument marking reference station is 8.26 meters $\mathrm{N} 25^{\circ}$ oo' $\mathrm{F}$, of observed station.

Marks.-Observed station is nail in cedar stub with top flush with the surface of the ground. Reference station is center point of triangle on standard cement monument projecting 4 inches above surface of ground.

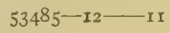




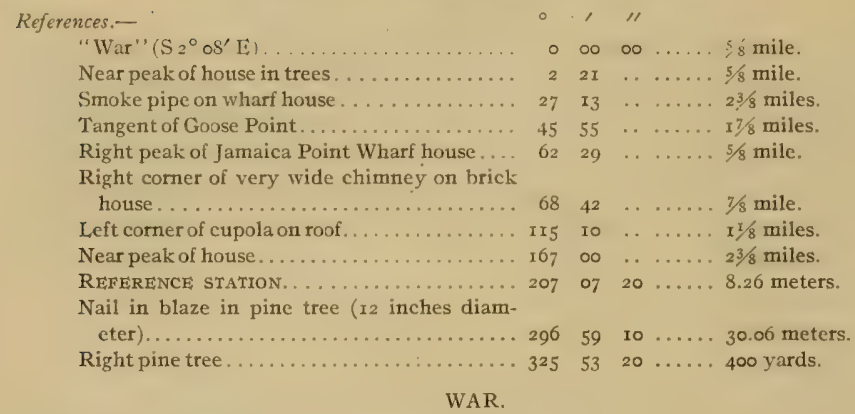

General locality.-Eastern shore of upper Choptank River on southern side of entrance to Warwick River, about $3 / 4$ mile east-southeast of Jamaica Point. (See Chart No. 35.)

Immediate locality. - Observed station is on northern side of point of marsh about I foot above high water, 45 yards south of shore, 35 yards southeast of shore, 45 yards east of shore, and 35 to 45 yards southwest to west of woods. Cement monument marking reference station is 4.95 meters $\mathrm{S} 12^{\circ} 18^{\prime} \mathrm{E}$ of observed station.

Marks.-Observed station is nail in center of cedar stub with top flush with surface of ground. Reference station is center point of triangle on standard monument projecting 4 inches above surface of ground,

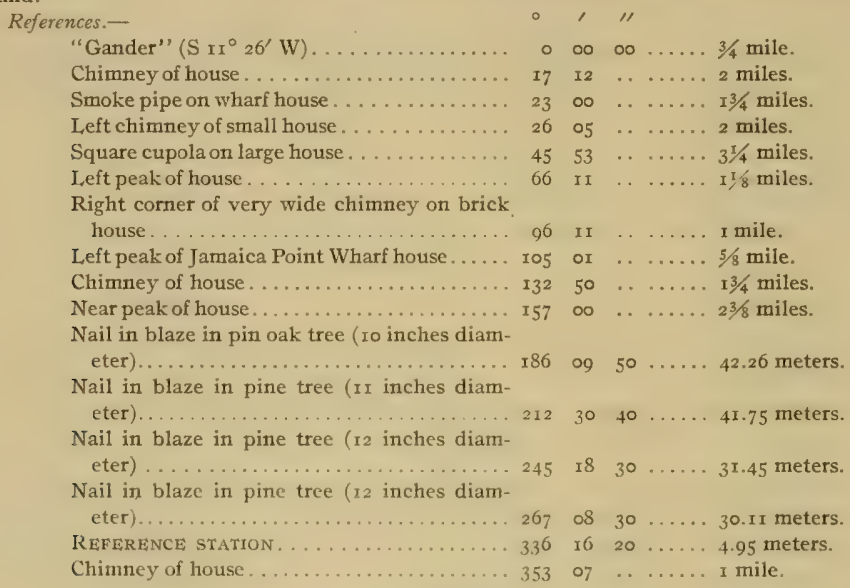

\section{GANDER.}

General locality.--Southeastern shore of Choptank River $3 / 8$ mile southwest of entrance to Goose Creek about $I^{3 / 3}$ miles east-northeast of Oystershell Point and about $I^{1 / 3} / 8$ miles south-southeast of Jamaica Point. (See Chart No. 35.)

Immediate locality.-Observed station is in an uncultivated field on bank about 6 feet above high water, 99 yards east of edge of bank, 33 yards northeast of edge of bank, 33 yards southeast of edge of bank, and 55 yards west of two large cedar trees at a paling fence. 
Marks.-Observed station is center point of triangle on standard cement monument projecting 6 inches above surface of ground. Subsurface mark is center of 2 -inch tile pipe buried with top $z$ inches below base of monument.

\begin{tabular}{|c|c|c|c|c|}
\hline eferences.- & o & , & $" \prime$ & \\
\hline "Chief" $\left(\mathrm{S}_{9}{ }^{\circ} 44^{\prime} \mathrm{W}\right) \ldots \ldots \ldots \ldots \ldots \ldots \ldots$ & $\circ$ & $\infty 0$ & $\infty$ & ... s/8 mile. \\
\hline Chimney of house . . . . . . . . . . . . . . . & 28 & 22 & .. & .. $x 1 / 4$ miles. \\
\hline Smokepipe on wharf house.... & 40 . & I4 & . & . I I $1 / 8$ miles. \\
\hline 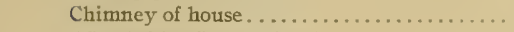 & 50 & $\infty$ & .. & $\ldots \ldots 4^{1 / 2}$ miles. \\
\hline "Cambridge Stand Pipe" ................ & 62 & 46 & 50 & ..... 53/4 miles. \\
\hline Chimney outside of house . . . . . . . . . . . . & II 3 & 39 & . & $\ldots \ldots$ I $1 / 4$ miles. \\
\hline Right chimney of house . . . . . . . . . . . . & I35 & 48 & .. & $\ldots \ldots .1 / 4$ miles. \\
\hline Near peak of Jamaica Point Wharf house..... & 147 & 14 & .. & ....... I $1 / 8$ miles. \\
\hline Chimney of house . . . . . . . . . . . . . & 148 & 54 & . & $\ldots \ldots 23 / 8$ miles. \\
\hline Chimney of house... . & 164 & 24 & . & $\ldots \ldots 31 / 4$ miles. \\
\hline Tangent of point. & 172 & 50 & . & . . $3 f$ mile. \\
\hline Right end of roof of long barn.... & 235 & 04 & . & ..... 5/8 mile. \\
\hline Black walnut tree. . . . . . . . . . . & 282 & 36 & .. & $\ldots .200$ yard \\
\hline Chimney of house. . . . . . . . & 344 & 59 & .. & ..... $1 / 4$ mile. \\
\hline
\end{tabular}

CHIFF.

General locality,--Southeast shore of Choptank River on a narrow neck of land between Choptank River and Indian Creek, about 1 mile east of Oystershell Point. (See Chart No. 35.)

Immediate locality.-Observed station is on a grass strip between Choptank River and Indian Creek about 2 feet above high water, I 5 yards south of river shore, II yards north of creek shore, 20 yards southeast of river shore, and 25 yards southwest of river shore.

Marks.-Observed station is center point of triangle on standard cement monument projecting 5 inches above surface of ground. Subsurface mark is center of 2 -inch tile pipe buried with top 2 inches below base of monument.

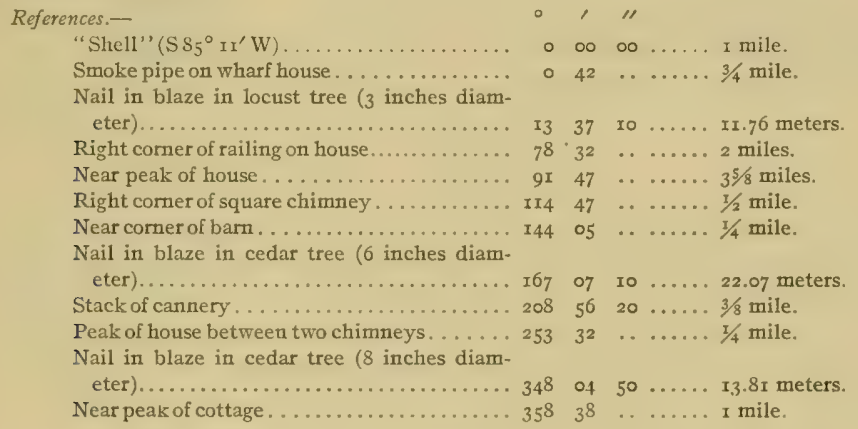

SHELL.

General locality. - Southeastern shore of Choptank River on Oyster Shell Point about $3 / 4$ mile south of Goose Point and $\mathrm{I}^{1} / 2$ miles east-northeast of Chancellors Point. (See Chart No. 35.)

Immediate locality.-Observed station is on marsh about $i$ foot above high water, roo yards north of rail fence, 55 yards southwest of shore, 75 yards south of shore, 400 yards west of a wharf, 250 yards west by north of a small house near the shore, 50 yards west by north of corner of fence. Cement monument marking reference station is 2.27 meters $\mathrm{N} 83^{\circ} \circ 7^{\prime} \mathrm{W}$ of observed station.

Marks.-Observed station is nail in cedar stub flush with surface of ground. Reference station is center point of triangle on standard cement monument projecting 5 inches above the surface of the ground. 


\begin{tabular}{|c|c|c|c|c|}
\hline rerences.- & $\circ$ & & $\|$ & \\
\hline "Whitehall" (S $\left.+1^{\circ} 55^{\prime} \mathrm{W}\right) \ldots \ldots \ldots \ldots \ldots$ & 0 & $\infty$ & $\infty$ & śs mile. \\
\hline 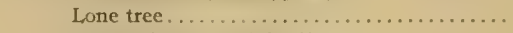 & 29 & 12 & . & 225 yards. \\
\hline "Cambridge Standpipe"........ & 35 & 39 & $\infty$ & $4 \frac{1}{2}$ miles. \\
\hline Right corner of square cupola............ & 39 & 24 & . & I $1 / 2$ miles. \\
\hline RFHERENCE STATION. & 54 & 57 & 50 & 2.27 meters \\
\hline Chimney on left end of house & 83 & ro & .. & .. I I/8 miles. \\
\hline Near peak of large house.... & 150 & 53 & .. & ... I $7 / 8$ miles. \\
\hline Near peak of Jamaica Point Wharf house.... & $15^{8}$ & 17 & . & I7/8 miles. \\
\hline 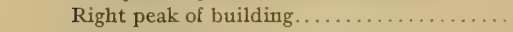 & 177 & 29 & $\cdots$ & $25 / 8$ miles. \\
\hline 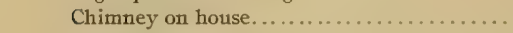 & 205 & 20 & . & $\ldots \ldots I^{I} / 4$ miles. \\
\hline Smoke pipe on wharf house. ............ & 221 & 13 & .. & $\ldots \ldots 1 / 4$ mile. \\
\hline Near peak of shed........... & 265 & 40 & . & I50 yards. \\
\hline Near peak of house. & 280 & 06 & & $\ldots .300$ yards. \\
\hline
\end{tabular}

WHITEHALL.

General locality.-Southeastern shore of Choptank River about $5 / 8$ mile southwest of Oystershe: Point, and $\mathrm{I} / \mathrm{s}$ miles east of Chancellor Point. (See Chart No. 35.)

Immediate locality.-Observed station is on a marsh point among water bushes about I2 yards southsoutheast of shore, $x_{3}$ yards south-southwest of shore, and I5 yards east-southeast of shore.

Marks.-Observed station is center point of triangle on standard cement monument projecting 4 inches above surface of ground. Subsurface mark is center of 2 -inch tile pipe buried with top 2 inches below base of monument.

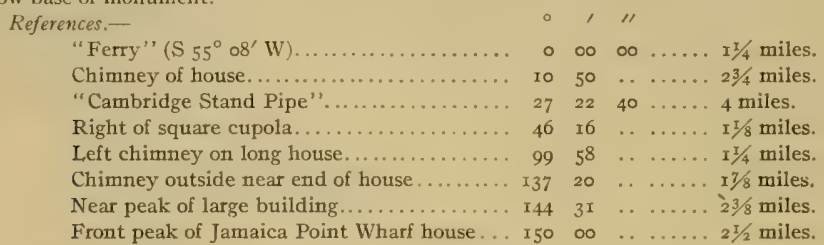

\section{FERRY.}

General locality. - Southern shore of Choptank River near east side of entrance to Hurst Creek about ${ }_{2} \mathrm{~T} / 2$ miles east of Cambridge. (See Chart No. 35.)

Immediate locality. - Observed station is on a sand beach about on level with high water, 92 yards cast-northeast of Hurst Creek, I yard southeast of shore, and 6 to Io yards northwest to north of several low cedar trees. Cement monument marking reference station is 16.74 meters $\mathrm{S} 50^{\circ} \mathrm{I2} 2^{\prime} \mathrm{E}$ of observed station.

Marks.-Observed station is nail in pine stub in center of 2 -inch tile pipe with top of pipe 6 inches below surface of ground. Subsurface mark is center of 2 -inch tile pipe buried with top 2 inches below base of surface pipe. Reference station is center point of triangle on standard cement monument.

References.-

"E. Cambridge Tall Stack" (N $\left.8 \mathrm{I}^{\circ} 2 \mathrm{I}^{\prime} \mathrm{W}\right)$..

"Hambrooks Bar Beacon" . ..............

Near peak of large house with cupola....... 79

Near peak of barn cupola................

Near peak of Jamaica Point Wharf house.... II

Nail in blaze in cedar tree ( $1 \mathrm{I}$ inches diameter) I9

REFERENCE STATION................ 2 IX

Nail in blaze in cedar tree ( 8 inches diameter) 242

Nail in blaze in cedar tree ( 16 inches diameter) 279

Chimney of house................ $33^{8}$

\begin{tabular}{|c|c|c|}
\hline 00 & $\infty$ & .. $2 \mathrm{~T} / 2$ miles. \\
\hline 05 & 10 & ..... $3^{1} / 2$ miles. \\
\hline & $\cdots$ & .. 1 mile. \\
\hline & .. & 2 miles. \\
\hline & . . & $3 \frac{5}{8}$ miles. \\
\hline & $\infty$ & 6.82 meters. \\
\hline & $\infty$ & .. 16.74 meters. \\
\hline & 50 & 8.32 meters. \\
\hline & $\infty$ & .. 9.76 meters. \\
\hline & . & .. I $3 / 4$ miles. \\
\hline
\end{tabular}


SHOAL.

General locality, - Southern shore of Choptank River near entrance to a small creek about $x$ mile east-southeast of Cambridge and $15 / 8$ miles west-southwest of Chancellors Point. (See Chart No. 35.)

Immediate locality. - Observed station is in woods on a point of land about to feet above high water, 50 yards east of edge of bank, 6 yards south west of wire fence at edge of high land, 7 yards south of wire fence, II yards west of wire fence, ${ }_{3} 3$ yards west-southwest of large double oak tree, and go yards east of a marsh point at a creek. Cement monument marking reference station is 6.08 meters $\mathrm{S}_{23}{ }^{\circ} 44^{\prime} \mathrm{W}$ of observed station.

Marks.-Observed station is center of tile pipe with top 6 inches below surface of ground. Reference station is center point of triangle on standard cement monument projecting 5 inches above surface of ground.

\begin{tabular}{|c|c|c|c|c|}
\hline References.- & 0 & , & "I & \\
\hline "Cambridge" $\left(\mathrm{N}_{4} 6^{\circ}{ }_{3} \mathrm{r}^{\prime} \mathrm{W}\right) \ldots \ldots \ldots \ldots \ldots$ & $\circ$ & $\infty$ & $\infty$ & $\ldots \ldots I 3 / 4$ miles. \\
\hline Large chimney of house ................. & 25 & 55 & . & - $3 \frac{5}{8}$ miles. \\
\hline Spindle on barn cupola. . & $6 x$ & $3 \mathbf{I}$ & . & . I $3 / 4$ miles. \\
\hline Left chimney of house . . . . . . . . . . . . & 84 & $\circ 9$ & .. & ..... 2 miles. \\
\hline Near peak of barn with cupola............ & 106 & II & .. & $\ldots \ldots .13 / 4$ miles. \\
\hline $\begin{array}{l}\text { Nail in blaze in large double oak tree....... } \\
\text { Nail in blaze in black walnut tree ( } 8 \text { inches }\end{array}$ & 120 & 03 & 20 & II. 3 I meters. \\
\hline 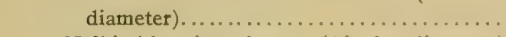 & 205 & 53 & 40 & $\therefore \quad$ ro.96 meters. \\
\hline Nail in blaze in cedar tree ( 6 inches diameter) & 224 & 26 & 30 & . 8.05 meters. \\
\hline $\begin{array}{l}\text { REFERENCE STATION. . . . . . . . . . . . . . } \\
\text { Nail in blaze in black walnut tree ( } 7 \text { inches }\end{array}$ & 250 & I5 & 40 & ..... 6.08 meters. \\
\hline 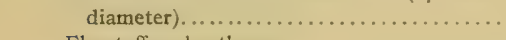 & 304 & 19 & 20 & 3.19 meters. \\
\hline Flagstaff on boathouse......... & $35^{8}$ & 43 & $\cdots$ & $\ldots \ldots 2^{1} 2$ miles. \\
\hline
\end{tabular}

\section{E. CAMBRIDGE TALL STACK.}

General locality.-Southern shore of Choptank River in the town of Cambridge on the east side of Cambridge Creek. (See Chart No. 35.)

Immediate locality.-Observed station is tall square brick smokestack at plant of Cambridge Manufacturing Co.

Marks.-Observed station is center of stack.

References.-None necessary.

\section{E. CAMBRIDGE SPIRE.}

General locality. - Southern shore of Choptank River in town of Cambridge on the east side of Cambridge Creek and the south side of Maryland Avenue. (See Chart No. 35.)

NorE.-This triangulation landmark was tom down before this publication was prepared and therefore it is not described, although its name and location are shown on Chart No. 35 .

\section{CAMBRIDGE STAND PIPE.} 35.)

General locality.-Southwestern side of Choptank River in the town of Cambridge. (See Chart No.

Immediate locality.-Observed station is on standpipe on the north side of High Street near Pine Street.

Marks.-Observed station is center of cylindrical water standpipe with ornamental railing on top. References.-None necessary.

\section{CAMBRIDGE.}

General locality.-Southern shore of Choptank River on a point about $3 / 4$ mile southeast of Hambrooks Bar Beacon and $1 / 2$ mile northwest of Cambridge steamer wharf. (See Chart No. 35.)

Immediate locality. - Observed station is on a marsh point about I foot above above high water, 30 yards west of shore, 35 yards south of shore at cut, 40 yards southwest of shore, and 3 yards southwest of barbed-wire fence running northwest and southeast. 
Marks.-Observed station is center point of triangle on standard cement monument projecting 4 inches above surface of ground. Subsurface mark is center of 2 -inch tile pipe buried with top 2 inches below base of monument.

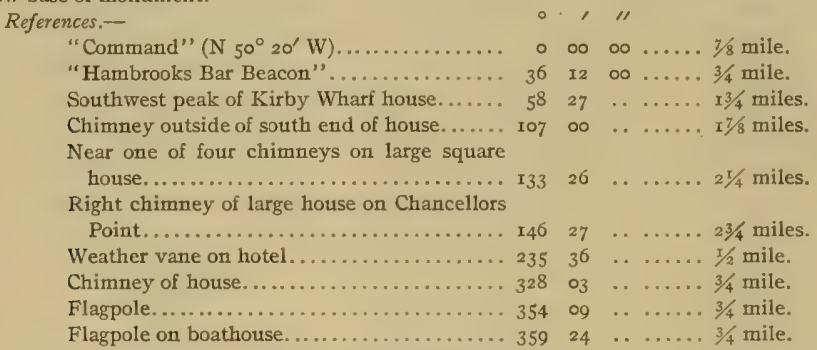

\section{HAMBROOKS BAR BEACON.}

General locality.--Southern side of Choptank River about $1 / 4$ mile offshore from point of land known as Hambrooks Bar, about 2 miles southeast of Howells Point, and $\mathrm{I}^{1 / 2}$ miles northwest of Cambridge. (See Chart No. 35.)

Immediate locality.-Observed station is on a cylindrical foundation known as Hambrooks Bar Beacon.

Marks.-Observed station is center point of lantern on Hambrooks Bar Beacon.

References.-None necessary.

\section{COMMAND.}

General locality.-Southern shore of Choptank River about $1 / 2$ mile west-southwest of Hambrooks Bar Beacon and about $I^{1 / 2}$ miles northwest of Cambridge Wharf. (See Chart 35.)

Immediate locality.-Observed station is on a marsh point inside of a fence line about 2 feet above high water, I 8 yards southeast of shore, I6 yards south of shore, 25 yards southwest of shore, and I50 yards northwest of a boathouse.

Marks,-Observed station is center point of triangle on standard cement monument projecting 5 inches above surface of ground. Subsurface mark is center of 2 -inch tile pipe buried with top 2 inches below base of monument.

References.-

"Choptank River Light" ( $\left.49^{\circ} 40^{\prime} \mathrm{W}\right)$....

Nail in blaze in fence post.................

Near peak of large building...............

Nail in blaze in fence post..................

Left chimney of house with three dormer windows......................

Near peak of Kirby Wharf house..........

"Hambrooks Bar Beacon". .............. I2

Near peak of large house............. I5

Flagstaff on boathouse............... r 8

"Dicks Water Tank" .................... 266

Nail in blaze in fence post............... 328

Left chimney of old house............. 33

"Large Water Tank" . ............... 347

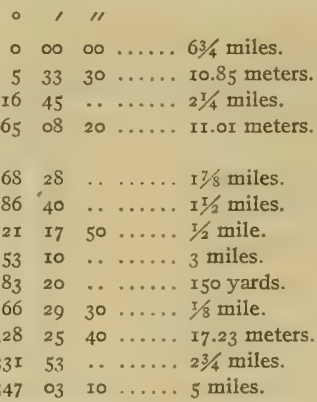




\section{DICKS WATER TANK.}

General locality.-Southern shore of Choptank River near Hambrooks Bar about $5 / 8$ mile southwest of Hambrooks Bar Beacon, and $\pi / 2$ mile west of extreme end of Hambrooks Bar. (See Chart No. 35.)

Immediate locality. -Observed station is on water tank.

Marks.-Observed station is spindle on top of water tank.

References.-None necessary.

\section{HOWARD.}

General locality.-Southern shore of Choptank River, 2 miles southeast of Horn Point, and about I/ mile northwest of entrance to Jenkins Creek. (See Chart No. 35.)

Immediate locality.-Observed station is on cultivated land on bluff about I2 feet above high water, 25 yards southwest of edge of bluff, 30 yards south of edge of bluff, 35 yards west of edge of bluff, 45 yards west-northwest of corner of fence dividing field from marsh, and 65 yards northeast of the south one of two small poplar trees in field.

Marks.-Observed station is center point of triangle on standard cement monument projecting 4 inches above surface of ground. Subsurface mark is center of 2 -inch tile pipe buried with top 2 inches below base of monument.

\begin{tabular}{|c|c|c|c|c|}
\hline \\
\hline "Choptank River Light"' (N $36^{\circ} \mathrm{I}^{\prime}$ W) . . . & 0 & $\infty 0$ & $\infty 0$ & 6 miles. \\
\hline 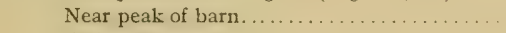 & 30 & 20 & . & $3 ! 2 ́ 2$ miles. \\
\hline "Black Beacon". & 32 & I 6 & 50 & 25.5 miles. \\
\hline Red Beacon....................... & 34 & II & 30 & . $27 / 8$ miles. \\
\hline Near peak of low house in trees........... & 79 & $5^{2}$ & .. & . $3^{1 / 4}$ miles. \\
\hline Near peak of Kirby Wharf house........... & 90 & 53 & .. & . 3 miles. \\
\hline "Dicks Water Tank" ........... & 109 & 57 & 40 & I $1 / 2$ miles. \\
\hline Left chimney of house ................ & II 5 & $\infty$ & . & ..... I mile. \\
\hline $\begin{array}{l}\text { Nail in blaze in locust tree }(8 \text { inches diam- } \\
\text { eter) } \ldots \ldots \ldots \ldots \ldots \ldots \ldots \ldots \ldots \ldots \ldots \ldots\end{array}$ & 125 & $5 \pi$ & 50 & $9 \mathrm{met}$ \\
\hline Nail in blaze in locust tree............... & 144 & 34 & 50 & 5.66 meter \\
\hline Nail in blaze in locust tree. ............ & I 88 & 22 & 40 & 63.83 meter \\
\hline Near peak of barn.............. & 245 & 03 & $\ldots$ & $1 / 4$ mile. \\
\hline Right peak of house. & 317 & 02 & . & $1 / 4$ mile. \\
\hline Right peak of old house.... & $35 \mathrm{I}$ & 02 & & ..... $1 / 2$ miles. \\
\hline
\end{tabular}

TOOT.

General locality, -Southern shore of Choptank River on Horn Point about I $5 / 8$ miles west of Howells Point, and at eastern side of entrance to Lecomptes Bay. (See Chart No. 35.)

Immediate locality.-Observed station is in woods about 7 feet above high water, I5 yards south of shore, 13 yards southwest of shore, and 20 yards west of shore, and near but not on highest point of ground. Cement monument marking reference station is $12.3^{8}$ meters $\mathrm{S}_{33^{\circ}} 34^{\prime} \mathrm{W}$ of observed station.

Marks.-Observed station is nail in center of stub in 2 -inch tile pipe projecting 2 inches above surface of ground. Subsurface mark is center of 2 -inch tile pipe buried with top 2 inches below base of surface pipe. Reference station is center point of triangle on standard cement monument projecting 4 inches above the surface of the ground.

References.-

"Choptank River Light" ( $\mathrm{N}_{34}{ }^{\circ} \mathrm{I}^{\prime} \mathrm{W}$ ) ...

East peak of large barn...................

Large chimney of house..................

Red Beacon......................

"Black Beacon". ........................ 7

Near peak of house................... 88

Nail in blaze in elm tree................ I47

Nail in blaze in oak tree ( 24 inches diameter). 200

Nail in blaze in oak tree ( 20 inches diameter). 246

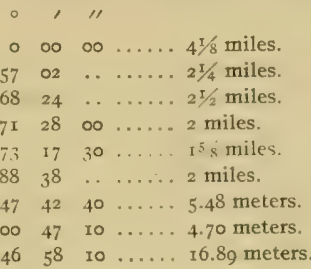




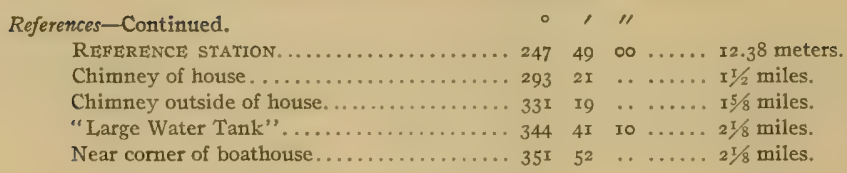

\section{LE COMPTE}

General locality.-Southern shore of Choptank River on southwestern side of Lecomptes Bay about I I $/ 2$ miles west-southrvest of Horn Point, $5 / 8$ mile northwest of Travers Wharf, and $1 / 4$ mile southwest of mouth of Lecomptes Creek. (See Chart No. 35.)

Immediate locality.-Observed station is on marsh about I foot above high water, I8 yards west of point of shore, 14 yards south-southeast of shore, 5 yards east-southeast of turn in shore at beach, 7 yards northeast of a pool, ro yards northwest of cut in shore, and II 5 yards southeast of near one of two large cedar trees.

Marks.-Observed station is center point of triangle on standard cement monument projecting 5 inches above surface of ground. Subsurface mark is center of 2 -inch tile pipe buried with top 2 inches below base of monument.

\begin{tabular}{|c|c|c|c|c|}
\hline References.- & 。 & & "I & \\
\hline "Grubin" (W $\left.56^{\circ} \mathrm{oo}^{\prime} \mathrm{E}\right) \ldots$ & 0 & $\infty$ & $\infty$ & $31 / 8$ miles. \\
\hline "Black Beacon" "........................ & 0 & 12 & ro & $27 / 8$ miles. \\
\hline Barn cupola.................. & 9 & I0 & . & \\
\hline North peak of wharf house... & 69 & 02 & .. & $1 / 2$ mile. \\
\hline North peak of house............. & 106 & 43 & .. & $3 / 8$ mile. \\
\hline Left one of two large cedar trees... & 248 & 12 & .. & II7 yards. \\
\hline Spindle on barn cupola ........... & 280 & 48 & .. & I's mile. \\
\hline Chimney outside of house......... & 303 & 44 & . & ..... 5/s mile, \\
\hline Red Beacon.................... & $35^{8}$ & 07 & 20 & $\ldots \ldots 3 \mathrm{I} / 8$ miles. \\
\hline
\end{tabular}

\section{LARGE WATER TANK.}

General locality. - Southwestern shore of Choptank River at Castle Haven about $2 \frac{x}{8}$ miles south of Choptank River Light. (See Chart No. 35.) Haven.

Immediate locality.-Observed station is on water tank on high steel tower near barns at Castle

Marks.-Observed station is center point of windmill on water tank.

References.-None necessary.

\section{CASTLE.}

General locality. - Southern shore of Choptank River on Castle Haven Point on north side of Castle Haven Creek about 2 miles south-southwest of Choptank River Light. (See Chart No. 35.)

Immediate locality.-Observed station is on a narrow neck of land, about 25 yards south-southwest of shore of Choptank River, 20 yards north of shore of cove, 22 yards west of bathhouse, and I0o yards east-northeast of three poplar trees.

Marks.-Observed station is center point of triangle on standard cement monument projecting 5 inches above surface of ground. Subsurface mark is center of 2 -inch tile pipe buried with top 2 inches below base of monument.

References.-

"Choptank River Light" ( $\left.\mathrm{N}_{25} 5^{\circ} \mathrm{r}^{\prime} \mathrm{W}\right) \ldots$. Right corner of house near Bachelor Point...

Left corner of bathhouse.............. 95

Near corner of bathhouse............... I0

Near peak of house................... I22

Right peak of boathouse at Castle Haven Wharf.

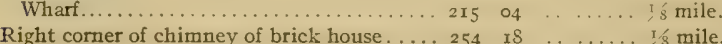




\section{COOK POINT WINDMILL.}

General locality.-Eastern shore of Chesapeake Bay on Cook Point between Tripps Bay and Cook Point Cove about $r^{1 / 4}$ miles southeast of end of point. (See Charts Nos. 36 and 37.)

Immediate locality.-Observed station is on windmill over smaller and west one of two water tanks west of a bam on Cook Point farm.

Marks.-Observed station is center of windmill over smaller tank.

References.-None necessary.

\section{BRANNOCK.}

General locality.-Eastern shore of Chesapeake Bay between Choptank River and Little Choptank River on the southern shore of Brannock Bay about 7 miles southeast of Sharps Island Light. (See Charts Nos. 36 and 37.$)$

Immediate locality.-Observed station is on high land about 8 feet above high water, II yards south of shote, 7 yards south of edge of bluff, 8 yards north of rail fence on far side of county road, 50 yards east of bend where road leaves shore and runs toward farmhouse and 150 yards northeast of a farmhouse.

Marks,-Observed station is center point of triangle on standard cement monument with top projecting about 4 inches above surface of ground. Subsurface mark is 2 -inch tile pipe buried witl top) 2 inches below base of monument.

References.-

Sharps Island Light ( $\left.54^{\circ} 34^{\prime} \mathrm{W}\right) \ldots \ldots \ldots$.

Near peak of house on Cook Point. . . . . . . .

"Cook Point Windmill" .................

Right chimney of house in trees.

Between two chimneys on large part of house. 104 3I $\ldots . \ldots$. I mile.

Outside chimney on near end of house..... 108 of $\ldots \ldots \ldots$ I mile.

Center one of three chimneys of house..... $142 \quad 03^{\prime} \ldots \ldots . .$. I mile.

Tangent of right end of barn roof.......... I50 49 ....... I mile.

Center one of three chimneys on house.... I6 $6_{3}$ I6 $\quad \therefore \ldots \ldots 3 / 4$ mile.

Right peak of house................. $203 \quad 34 \quad \ldots \ldots 2$ miles.

Left chimney of $x^{1} / 2$-story house across creek. $210 \quad 47 \quad \ldots \ldots .2$ miles.

Near peak of barn.................... 285 if . . . $3 / 4$ mile.

Tangent of Mills Point................ $343433 \quad \ldots \ldots .3 / 4$ mile.

Tangent of left end of Sharps Island Hotel... $35^{2}$ I2 $\ldots \ldots .5 \frac{1}{2}$ miles.

ROBINS.

General locality.-Eastern shore of Chesapeake Bay on Hills Point at northeast side of entrance to Little Choptank River about 6 miles south-southeast of Sharps Island Light. (See Charts Nos. 36 and 37.)

Immediate locality.-Observed station is in cultivated field about 8 feet above high water, 40 yards northeast by north of edge of bluff, 45 yards east by north of point of bluff, 65 yards south by east of edge of hluff in range with Sharps Island Light, and $\mathbf{I} 40$ yards north by west of wire fence at bluff.

Marks.-Observed station is center point of triangle on standard cement monument projecting 4 inches above surface of ground. Subsurface mark is center of $z$-inch tile pipe buried with top 2 inches helow base of monument.

References.-

"Sharps Island Light" ( $\left.\mathrm{N}_{34^{\circ}} \mathrm{II}^{\prime} \mathrm{W}\right)$........ Nail in blaze in cedar tree ( 8 inches diam-

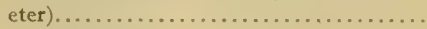

Left chimney of house .................

Tallest chimney of house...............

Near peak of barn.................... 222

Tangent of end of woods on Taylor Island .. 229

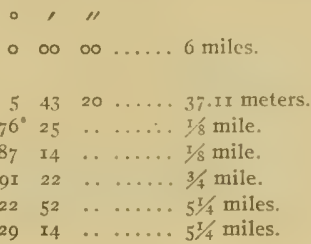


References-Continued.

Chimney of house on James Point....... 247 ro $\ldots \ldots 3 \frac{1}{1 / 8}$ miles.

Tangent of James Point................

Nail in blaze in cedar tree ( 8 inches diam-

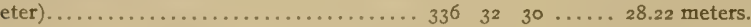

Nail in blaze in cedar tree ( 8 inches diam-

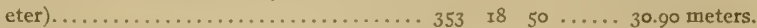

Tangent of right side of hotel on Sharps

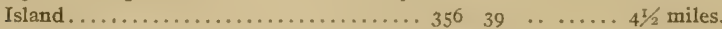

\section{JAMES (LITTLE CHOPTANK RIVER).}

General locality.--Eastern side of Chesapeake Bay on northeast end of James Island at south side of entrance to Little Choptank River. (See Charts Nos. 36 and 37 .)

Immediate locality,--Observed station is on marsh about I foot above high water, 8 yards west of shore, Ir yards northwest of shore, 85 yards south of shore, and 75 yards east of pine woods. Cement monument marking reference station is 19.48 meters S $84^{\circ} \mathrm{I} 7^{\prime} \mathrm{W}$ of observed station.

Marks.-Observed station is center of 2 -inch tile pipe profecting 2 inches above surface of ground. Subsurface mark is center of 2 -inch tile pipe buried with top 2 inches below base of surface pipe. Reference station is center point of triangle on standard cement monument.

References.-

\begin{tabular}{|c|c|c|c|}
\hline "Rohins" (N 00 , F & & & \\
\hline Near peak of house. & I 2 & 37 & $3 \frac{1}{2}$ miles. \\
\hline Chimney on near end of house. & $4^{8}$ & 4 & $3^{1 / 4}$ miles. \\
\hline Jear peak of barn.......... & Sq & or & $41 / 4$ miles. \\
\hline imney of house on Hooper Point. & 100 & 36 & $3 \mathrm{~m}$ \\
\hline Left peak of long barn.................... & 107 & 05 & $31 / 2$ miles. \\
\hline 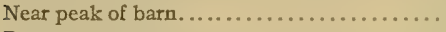 & $\mathbf{1 4 6}$ & 09 & $2 \frac{1}{2}$ miles. \\
\hline TION & $24 I$ & 03 & $\infty$ \\
\hline 1 Light" ......... & 320 & 02 & $40 \ldots$ \\
\hline old hotel on Sharps Island & $32 I$ & 43 & . \\
\hline oint........ & 357 & 29 & les. \\
\hline
\end{tabular}

\section{CORNER (Choptank River).}

General locality. - Southern shore of Choptank River on east side of entrance to Chapel Creek about 2 miles southeast of Todd Point, and 3 miles south-southwest of Choptank River Light, (See Chart No. 37.)

Immediate locality.-Observed station is on grassy land about 3 feet above high water, 30 yards east of shore, 30 yards south of shore, 35 yards southeast of extreme end of point, and west of small clump of small pine trees.

Marks.-Observed station is center point of triangle on standard cement monument projecting 5 inches above surface of ground. Subsurface mark is center of 2 -inch tile pipe buried with top 2 inches below base of monument.

References.-

"Dot" (N $\left.58^{\circ} 43^{\prime} \mathrm{W}\right)$

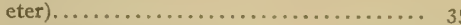

"Choptank River Light"............... 75

Nail in blaze in plne tree ( 4 inches diameter). 105

Right corner of new house............... I08

Nail in blaze in pine tree ( 5 inches diameter). 187

Near peak of $21 / 2$-story house.............. 308

Chimney outside right end of house....... 340

Chimney outside near end of house........ $35^{6}$ $\circ, 11$

$0000 \ldots .21 / 8$ miles.

$\mathrm{r}_{3} 40 \ldots \ldots \times \mathrm{r}_{3} .8 \mathrm{x}$ meters.

$20 \ldots .3$ miles.

$\infty \ldots \ldots 3.57$ meters.

...... $1 / 2$ mile.

I0 .... 8.21 meters.

...... $7 / 8$ mile.

.. ..... 2 miles.

....... $2 \frac{x}{4}$ miles. 
DOT.

General locality. - Southern shore of Choptank River on Todd Point about 3 miles east of Cook Point and $3 \frac{1}{2}$ miles southwest of Choptank River Light. (See Chart No. 37.)

Immediate locality. - Observed station is about 4 feet above high water, 55 yards west-southwest of shore, 30 yards south-southwest of edge of bank, 40 yards south by east of point where bank meets marsh, 70 yards south by west of extreme end of point, and 200 yards northeast by north of a house.

Marks.-Observed station is center point of triangle on standard cement monument projecting 5 inches above surface of ground. Subsurface mark is center of 2 -inch tile pipe buried with top 2 inches below base of monument.

References.-

"Choptank River Light" ( $\left.\mathrm{N}_{56} 6_{26} \mathrm{E}\right) \ldots .$.

"Large Water Tank" .................

Near peak of house................... 4

Near peak of building................. $7^{2}$

Chimney outside right end of house . . . . . 102

Chimney outside near end of house........ I75

Left chimney of house on Cook Point........ 2I

"Sharps Island Light" ................. 2I

Church spire . . . . . . . . . . . . . . . . . 25

Left peak of house................... 277

Near peak of barn..................... 290

" Cupola on house.

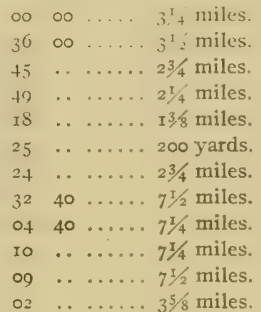




\section{BOUNDARIES OF OYSTER BARS.}

\section{EXPLANATION.}

The law of the United States authorizing the cooperation of the Department of Commerce and Labor in the survey of natural oyster bars of Maryland provides for the designation and employment by the Department of Commerce and Labor of such officers, experts, and other technically qualified persons "as may be necessary to cooperate with the Maryland State Board of Shell Fish Commissioners in making a survey of and locating the natural oyster beds, bars, and rocks in the waters within the State of Maryland." The oyster laws of Maryland provide that the Maryland Shell Fish Commissioners, with the aid of such persons as may be designated by the Government, shall proceed "to have laid out, surveyed, and designated on the said charts the natural beds and bars, and shall cause to be marked and defined as accurately as practicable the limits and boundaries of the natural beds, bars, and rocks as established by said survey, and they shall take true and accurate notes of said survey in writing, and make an accurate report of said survey, setting forth such a description of landmarks as may be necessary to enable the said board, or their successors, to find and ascertain the boundary lines of the said natural oyster beds, bars, and rocks, as shown by a delineation on the maps and charts." The oyster laws of Maryland also provide in another section that there shall "be made a true and accurate survey of the natural oyster beds, bars, and rocks *** with reference to fixed and permanent objects on the shore, giving courses and distances, to be fully described and set out in a written report of said survey."

Under the provisions of the laws quoted above the State of Maryland, in cooperation with the Department of Commerce and Labor, must define the boundaries of the natural oyster bars "as accurately as practicable" and also "with reference to fixed and permanent objects on the shore, giving courses and distances." The requirement of "as accurately as practicable" is easily fulfilled by definition of the location of the corners of the oyster bars by latitude and longitude. In fact, this method is probably the most satisfactory and accurate one that could be used for all purposes of legal definition or for relocation of the oyster-bar boundaries by competent engineers. Therefore the additional requirement of "giving courses and distances" is superfluous and is only fulfilled in the published definitions on account of the specific provisions of the law making it compulsory. This part of the description of boundaries has involved an immense amount of extra computations in order to prevent technical discrepancies between the latitude and longitude of a corner of an oyster bar and its distance and bearing from objects on shore of known latitude and longitude without adding anything to the accuracy and very little to the convenience of practical use of the descriptions of the oyster-bar boundaries. 
As provided by law the boundaries of the oyster bars are all straight lines, but in the work already completed they have inclosed areas of all shapes from triangles to complicated I4-sided figures, and of all sizes from 4 acres to 7,548 acres. The sides have varied in length from 93 to 7,529 yards, and in some cases the corners of the boundaries have been practically at the triangulation stations from which they arf located, while in other instances they were over 13,600 yards from the landmarks most available for the purpose of fixing their position.

The varied characteristics of the legal boundaries of the oyster bars indicated by the above statement, together with the complicated requirements of the law under which the survey has been made, and the magnitude of the work with the consequent need of fixed and uniform methods, have made the problem of describing the boundaries one of considerable difficulty and great importance.

The boundaries of the oyster bars of Maryland, as established by the Shell Fish Commission and delineated on the Coast and Geodetic Survey charts and projections and on the leasing charts of the Commission, are technically defined and described by a method somewhat different from that used in other oyster surveys. But it is believed that the forms finally adopted will fulfill all needs of the survey for both the present and the future.

METHOD OF DESCRIBING BOUNDARIES.

The descriptions have been arranged in tabular form, thus avoiding many hundred repetitions of the same words by making one explanation of the tables sufficient for all oyster bars in each county.

Title.-At the top of each tabular form is given the legal name of the oyster bar to be described, and the one by which it is known and designated in the published oyster records and on the oyster charts. The adopted name of the oyster bar is the one used locally, as nearly as could be ascertained by the hydrographic engineer of the Commission; and when there was no local name in common use a name was selected from one of the prominent features of the vicinity that would naturally suggest the section of the waters where the oyster bar was located.

Underneath the name, in parentheses, is given the general locality of the oyster bar and the serial number of the "Maryland Oyster Chart" on which its legal boundaries are shown. ${ }^{1}$

First column,--This column, under the heading of "Corner of bar," gives the number corresponding to the corner of the boundary as shown on the charts and to the number on the buoy marking the actual corner of the bar. The numbers of the corners have been assigned by naming the southernmost point No. $I$, thence proceeding in a clockwise direction around the bar. Where a corner of one oyster bar is identical with the corner of the boundaries of one or more other oyster bars, only the number of the corner of the oyster bar being described in the table is given in this column.

Second and third columns.--These two columns, under the headings of "Latitude" and "Longitude," give the geographic positions of the corners. These positions have been adopted by the Commission as the primary technical definition of the location of

I These charts can be obtained by application to the Superintendent of the Coast and Geodetic Survey, at Washington, D. C. 
the corners, and should be considered as final in case of a dispute arising from discrepancies caused by other means of location. The latitudes and longitudes given in these columns are based on the United States standard datum of the Coast and Geodetic Survey, and the points thus defined can be relocated from distant triangulation stations of the survey, even though all the landmarks and buoys originally used for their location have been destroyed by natural or other causes.

Fourth and fifth columns.-These two columns, under the general heading of "True bearing" "and the specific headings "Forward" and "Back," give bearings measured from a true north-and-south line. The three "Forward" bearings are from the corner of the boundary designated in the first column to the triangulation stations named on the corresponding lines in the last column, and the three "Back" bearings are from these same stations in the last column to the corresponding corner of boundary in the first column. The difference in minutes of arc between the forward and back bearings shown in some cases is actual and not accidental, and is due to the fact that the computations took into account the spheroidal shape of the earth.

Sixth column.-This column, under the heading of "Distance," gives the three computed distances in yards from the corner of the bar noted in the first column to the three triangulation stations named on the corresponding lines in the last column, and vice versa.

Seventh column.-This column, under the heading of "U.S. C. \& G. S. triangulation station," 2 gives the names of the landmarks from which were computed the corresponding "Latitude," "Longitude," "True bearing" and "Distance" of the "Corner of bar" designated in the first column. A full description of the location and markings of these triangulation stations is given in another part of this publication under the heading of "Descriptions of triangulation stations."

\section{SURVEYING METHODS FOR RELOCATION OF BOUNDARIES.}

There are a number of methods that can be used in the relocation of the actual boundaries of the natural oyster bars as technically described in this publication and delineated on the published charts of the Coast and Geodetic Survey and the leasing charts of the Shell Fish Commission.

The following brief descriptions of five of these more or less different methods assume a certain amount of experience and knowledge on the part of the engineer in the particular kind of surveying under consideration, and are only intended as reminders of ways and means that can be used.

There are two problems that are likely to present themselves to those interested in the boundaries of natural oyster bars: one, to determine whether the buoys marking the corners have been dragged or otherwise moved from their correct positions, and the other, to relocate or reestablish a buoy at the point from which it was removed. The different ways of solving these two problems partly depend upon the instruments possessed by the engineer and his assistants and partly on his training and experience.

\footnotetext{
1 'The mean magnetic variation for Talbot County was $6^{\circ}$ ro' west of north in Igri and increasing at the rate of $5^{\prime}$ yearly.

2 Geographic positions of these triangulation stations can be obtained by application to the Superintendent of the Coast and Geodetic Survey. Washington, D, C.
} 
(I) Triangulation.-This method is the one that will give the greatest accuracy, but on account of its requiring special data and instruments, and being an operation rarely used by engineers not engaged in geodetic surveying, it is recommended only for cases in dispute that can not be settled satisfactorily by some other method. An explanation of this class of work would be too long for a report of this sort, and those not familiar with this method are referred to the publications on the subject by the Coast and Geodetic Survey.

(2) Hydrographic. - This method is the most simple and satisfactory one that can be adopted if the surveyor can obtain the use of the necessary instruments and assistants. It is the one best suited for the work of the engineers of the Commission in relocating corners of boundaries, as it gives results of the accuracy ordinarily required and is rapid in execution. Besides, it has the advantage of being available whenever three triangulation stations of suitable relative positions are visible from the offshore points needing relocation.

Most navigators and others familiar with the use of a sextant are well acquainted with the graphic three-point method of fixing a position on water, and only a brief description of the operation will be stated.

In the case where there is only one engineer having a single sextant, the three-point method can be used if the tivo angles determining the position of a buoy are first derived from the "Forward" bearings given in the tabular forms describing the boundaries of the oyster bars. For example, take "Poplar Island" oyster bar, which is the first one described in this publication, and assume that "Corner No. 3 ," is to be examined as to its position. The angle between the two landmarks "Valliant" and "Haddaway," as determined from right to left from the forward bearings from this corner, is $58^{\circ} 17^{\prime}$, and the angle between "Haddaway" and "Bloody Point Bar Light" is $\mathrm{I} 20^{\circ} 05^{\prime}$. Having these two angles, the engineer proceeds to the buoy of doubtful location and measures the actual sextant angles between the landmarks for which the calculations were made. If the measured and calculated angles do not agree, the broy is not in its correct position and the boundary corner must be relocated. This is accomplished by moving the boat about until a point is reached where the angles do agree, and this point being the desired location, the buoy can be placed in its correct position.

If the engineer can obtain the use of both a sextant and a three-arm protractor (position finder), the availability of the hydrographic method is increased, as the use of the protractor is essential in case of the washing away or destruction of one or more of the landmarks originally used in describing the boundaries. Under these circumstances any three landmatks of suitable relative position that are visible from the point to be located can be utilized. For example, the engineer can proceed to the buoy of doubtful position and measure the two adjacent sextant angles between the three landmarks selected. These two angles are set off on the three-arm protractor and the actual position of the buoy plotted on the chart by shifting the protractor about until the edge of each of the three arms passes through the center of the symbols on the chart marking the position of the three landmarks selected. The center of the hub of the protractor will indicate on the chart the actual position of the buoy, and if the point thus obtained does not coincide with the true position of the corner of the boundary as given on the chart, the surveyor can proceed to locate the buoy correctly by reversing the operation. 
This is done by placing the center point of the hub of the protractor over the corner of the boundary in question and measuring on the chart the two adjacent protractor angles between the three selected landmarks. One of the angles thus obtained is set on the sextant and the boat moved about until the two landmarks are shown by the sextant to subtend the same angle obtained from the protractor. The second angle is then placed on the sextant and the same operation gone through, and so on, first using one angle on the sextant, then the other, until a point is reached where both observed sextant angles are practically identical with the protractor angles. The point thus located is the desired one and the buoy can be placed to mark the true position of the corner of the boundary in question.

If the engineer possesses two sextants and a protractor, this problem is far easier of solution, as the two angles can be set of on separate sextants and the observer can quickly find the desired point where they agree, with the protractor angles by using one sextant after the other without the need of resetting either.

If there are two observers, two sextants, and a protractor, it can be seen that the best conditions for both rapid and accurate hydrographic location of a point is attained. In fact, this is the method by which the buoys at the corners of the boundaries were originally placed by the hydrographic engineer to the Commission.

(3) Magnetic bearings from offshore. - This method of fixing a position on water is a simple and well-known one in navigation. It is available to anyone having a boat compass and will be of special use to the State Fishery Force in investigating cases where buoys are supposed to have been moved for illegal purposes.

In the case where a buoy is supposed to have been moved from its true position the observer can take compass bearings to the three landmarks given in the last column of the tables opposite the boundary corner in question. These bearings are then corrected for the local declination, ${ }^{1}$ and if the results agree with the published bearings the buoy is correctly located.

In the case where the buoy is not in its correct position, or has disappeared altogether; the desired point can be determined by maneuvering the vessel until the corrected bearings agree with the ones in the tabular descriptions, when the buoy can be anchored in its proper location.

In the case where the landmarks for which the bearings are published have been destroyed or washed away, any landmarks whose positions are indicated on the charts can be used. This can be done by getting their bearings directly from the chart by parallel rulers or a protractor and then applying these new bearings in the same manner as the ones published in the tables.

(4) Magnetic bearings from shore.-This method will be of special value to engineers having an ordinary surveyor's compass. The compass can be set over the point marking a "triangulation station" on shore, the name of which is given in the last column opposite the "corner" in question. The instrument is then set at the corresponding "back" bearing (corrected for local magnetic declination) given in the fifth column of the tables opposite the "comer" in question. The direction thus determined will give one range on which the desired point must be located. The compass can then be moved to a

1 The mean magnetic variation for Talbot County is $6^{\circ}$ ro' west of north in rgr and increasing at the rate of $5^{\prime}$ yearly. 
second triangulation station and another range located in a similar manner. The intersection of these two range lines will give the desired point; but in general it should be checked by an additional range line determined from a third station.

(5) Horizontal angles measured at landmarks.-This process is a modification of the triangulation method, and will be useful to engineers who have a transit and desire considerable accuracy.

The instrument is placed over a "triangulation station," the name of which appears in the last column of the tabular description opposite the "corner" in question. The telescope is then pointed to the landmark indicated in the "Descriptions of landmarks" as having a direction of $\mathrm{O}^{\circ} \mathrm{OO}^{\prime} \mathrm{OO}^{\prime \prime}$ from the triangulation station being occupied by the transit. The tabular description of the boundaries is next examined and the "back" bearing of the questionable boundary "corner" from the landmark being occupied is taken out. The angle calculated from this "back" bearing and the bearing given in parentheses alongside the zero landmark in the "Descriptions of landmarks" is then set off on the transit and a range line established on which the desired point must be located. A similar process is then carried on at a second station, and so on until the position of the buoy is satisfactorily fixed.

BOUNDARIES OF NATURAL OYSTER BARS.

POPLAR ISLAND.

(Chesapeake Bay-Off Poplar Island-Charts Nos. 31 and 33.)

\begin{tabular}{|c|c|c|c|c|c|c|c|c|c|c|}
\hline \multirow{2}{*}{$\begin{array}{l}\text { Cor- } \\
\text { ner } \\
\text { of } \\
\text { bar }\end{array}$} & \multirow{2}{*}{\multicolumn{2}{|c|}{ Latitude }} & \multirow{2}{*}{\multicolumn{2}{|c|}{ Longitude }} & \multicolumn{4}{|c|}{ True bearing } & \multirow{2}{*}{ Distance } & \multirow{2}{*}{$\begin{array}{l}\text { U. S. C. \& } \text { G. S. triangulation } \\
\text { station }\end{array}$} \\
\hline & & & & & & rward & & Back & & \\
\hline I 1 & & $\begin{array}{c}\prime \prime \prime \\
4543 \cdot 5^{2}\end{array}$ & & 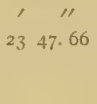 & $\begin{array}{lr} & 0 \\
\mathrm{~S} & 62 \\
\mathrm{~N} & 47 \\
\mathrm{~N} & 2\end{array}$ & $\begin{array}{ll}30 \mathrm{E} \\
\mathrm{O}_{3} & \mathrm{E} \\
53 & \mathrm{E}\end{array}$ & $\begin{array}{lr} & 0 \\
N & 62 \\
\mathrm{~S} & 47 \\
\mathrm{~S} & 2\end{array}$ & $\begin{array}{lll}0 & 1 & \\
2 & 29 & W \\
7 & 03 & W \\
2 & 53 & W\end{array}$ & $\begin{array}{l}\text { Yards. } \\
\text { I, } 902 \\
\text { I, } 510 \\
8,697\end{array}$ & $\begin{array}{l}\text { Poplar South. } \\
\text { Valliant. } \\
\text { Bloody Point Bar Light. }\end{array}$ \\
\hline 2 & $3^{8}$ & 4553.47 & 76 & 24 I9. 45 & $\begin{array}{lr}\mathrm{S} & 64 \\
\mathrm{~N} & 70 \\
\mathrm{~N} & 8\end{array}$ & $\begin{array}{ll}20 \mathrm{E} \\
22 & \mathrm{E} \\
4 \mathrm{E} & \mathrm{E}\end{array}$ & $\begin{array}{lr}N & 64 \\
\text { S } & 70 \\
\text { S } & 8\end{array}$ & $\begin{array}{lll}4 & 19 & W \\
0 & 23 & W \\
8 & 42 & W\end{array}$ & $\begin{array}{l}2,801 \\
2,065 \\
8,448\end{array}$ & $\begin{array}{l}\text { Poplar South. } \\
\text { Valliant. } \\
\text { Bloody Point Bar Light. }\end{array}$ \\
\hline 3 & $3^{8}$ & $47 \quad 45 \cdot 44$ & 76 & 2317.97 & $\begin{array}{lr}\mathrm{S} & 5 \\
\mathrm{~S} & 64 \\
\mathrm{~N} & 4\end{array}$ & $\begin{array}{ll}57 & \mathrm{E} \\
\mathrm{I} 4 & \mathrm{E} \\
\mathrm{I} 9 \mathrm{~W}\end{array}$ & $\begin{array}{lr}N & 5 \\
N & 64 \\
\text { S } & 4\end{array}$ & $\begin{array}{lll}5 & 57 & W \\
4 & \text { I2 } & W \\
4 & \text { I9 } & E\end{array}$ & $\begin{array}{l}3,099 \\
5,587 \\
4,589\end{array}$ & $\begin{array}{l}\text { Valliant. } \\
\text { Haddaway; } \\
\text { Bloody Point Bar Light. }\end{array}$ \\
\hline 4 & 38 & 4732.65 & 76 & $22 \times 3.67$ & $\begin{array}{ll}\mathrm{S} & 26 \\
\mathrm{~S} & 59 \\
\mathrm{~N} & 22\end{array}$ & $\begin{array}{ll}26 \mathrm{E} \\
04 \mathrm{E} \\
\text { II W }\end{array}$ & $\begin{array}{ll}\mathrm{N} & 26 \\
\mathrm{~N} & 59 \\
\mathrm{~S} & 22\end{array}$ & $\begin{array}{lll}6 & 26 & \mathrm{~W} \\
9 & 04 & \mathrm{~W} \\
2 & 12 & \mathrm{E}\end{array}$ & $\begin{array}{l}5,807 \\
3,888 \\
5,408\end{array}$ & $\begin{array}{l}\text { Great. } \\
\text { Haddaway. } \\
\text { Bloody Point Bar Light. }\end{array}$ \\
\hline
\end{tabular}

$53485-12-12$ 
BOUNDARIES OF NATURAL, OYSTER BARS-continUEd.

LOWS POINT.

(Eastern Bay-Charts Nos, $3 I$ and 33.)

\begin{tabular}{|c|c|c|c|c|c|c|c|c|c|}
\hline \multirow{2}{*}{$\begin{array}{l}\text { Cor- } \\
\text { ner } \\
\text { of } \\
\text { bar }\end{array}$} & \multirow{2}{*}{ Iatitude } & \multirow{2}{*}{ Longitude } & \multicolumn{5}{|c|}{ Truc bearing } & \multirow{2}{*}{ Distance } & \multirow{2}{*}{$\begin{array}{l}\text { U. S. C. \& G. S. triangulation } \\
\text { station }\end{array}$} \\
\hline & & & & Forwa & ard & & Back & & \\
\hline I & $\begin{array}{ccc}\circ & , \quad 11 \\
38 & 47 & \circ 9.33\end{array}$ & $\begin{array}{ccc}\circ & 1 & 11 \\
76 & 21 & 37.76\end{array}$ & $\begin{array}{l}\mathrm{S} \\
\mathrm{S} \\
\mathrm{N}\end{array}$ & $\begin{array}{ll}0 & 1 \\
14 & 2 \\
56 & 5 \\
46 & 4\end{array}$ & $\begin{array}{ll}1 & \\
20 & \mathrm{E} \\
52 & \mathrm{E} \\
4 \mathrm{I} & \mathrm{E}\end{array}$ & $\begin{array}{l}\mathrm{N} \\
\mathrm{N} \\
\mathrm{S}\end{array}$ & $\begin{array}{lll}0 & 1 \\
14 & 20 & W \\
56 & 52 & W \\
46 & 43 & W\end{array}$ & $\begin{array}{r}\text { Yards. } \\
4,639 \\
2,219 \\
7,455\end{array}$ & $\begin{array}{l}\text { Great. } \\
\text { Haddaway. } \\
\text { Kemp Tower. }\end{array}$ \\
\hline 2 & 38474 I. 86 & 7621216.85 & $\begin{array}{l}\mathrm{S} \\
\mathrm{N} \\
\mathrm{N}\end{array}$ & $\begin{array}{ll}38 & 2 \\
53 & 1 \\
37 & 0\end{array}$ & $\begin{array}{l}27 \mathrm{E} \\
15 \mathrm{E} \\
00 \mathrm{~W}\end{array}$ & $\begin{array}{l}\mathrm{N} \\
\mathrm{S} \\
\mathrm{S}\end{array}$ & $\begin{array}{lll}38 & 27 & W \\
53 & 16 & W \\
37 & 02 & E\end{array}$ & $\begin{array}{l}2,949 \\
6,332 \\
5,882\end{array}$ & $\begin{array}{l}\text { Haddaway. } \\
\text { Kemp. } \\
\text { Bloody Point Bar Light. }\end{array}$ \\
\hline 3 & $3^{8}+8 \quad 26.00$ & 76 Ig 35.90 & $\begin{array}{l}\mathrm{N} \\
\mathrm{N} \\
\mathrm{S}\end{array}$ & $\begin{array}{ll}46 & 2 \\
62 & 3 \\
12 & 2\end{array}$ & $\begin{array}{ll}20 & \mathrm{E} \\
38 & \mathrm{~W} \\
20 & \mathrm{~W}\end{array}$ & $\begin{array}{l}\mathrm{S} \\
\mathrm{S} \\
\mathrm{N}\end{array}$ & $\begin{array}{lll}46 & 2 I & W \\
62 & 4 I & E \\
I 2 & 20 & E\end{array}$ & $\begin{array}{l}3,331 \\
6,984 \\
3,888\end{array}$ & $\begin{array}{l}\text { Kemp. } \\
\text { Bloody Point Bar Light. } \\
\text { Haddaway. }\end{array}$ \\
\hline 4 & $3^{8} \quad 4807.05$ & 76 I8 50.23 & $\begin{array}{l}\mathrm{N} \\
\mathrm{N} \\
\mathrm{S}\end{array}$ & $\begin{array}{ll}19 & 0 \\
62 & 3 \\
32 & 4\end{array}$ & $\begin{array}{ll}02 & \mathrm{WV} \\
32 & \mathrm{~W}^{7} \\
48 & \mathrm{WV}\end{array}$ & $\begin{array}{l}S \\
\mathrm{~S} \\
\mathrm{~N}\end{array}$ & $\begin{array}{lll}19 & 03 & \mathrm{E} \\
62 & 35 & \mathrm{E} \\
32 & 47 & \mathrm{E}\end{array}$ & $\begin{array}{l}6,979 \\
8,349 \\
3,759\end{array}$ & $\begin{array}{l}\text { Straight. } \\
\text { Bloody Point Bar Light. } \\
\text { Haddaway }\end{array}$ \\
\hline 5 & $\begin{array}{llll}38 & 47 & 16.801\end{array}$ & $7620 \quad 36.40$ & $\begin{array}{l}\mathrm{S} \\
\mathrm{N} \\
\mathrm{N}\end{array}$ & $\begin{array}{ll}27 & 3 \\
4 \mathrm{x} & 4 \\
30 & 4\end{array}$ & $\begin{array}{l}37 \mathrm{E} \\
42 \mathrm{E} \\
44 \mathrm{~W}^{\prime}\end{array}$ & $\begin{array}{l}N \\
\text { S } \\
\text { S }\end{array}$ & $\begin{array}{lll}27 & 37 \mathrm{~W} \\
41 & 44 \mathrm{~W} \\
30 & 40 \mathrm{E}\end{array}$ & $\begin{array}{l}7,654 \\
6,497 \\
7: 802\end{array}$ & $\begin{array}{l}\text { Haddaway. } \\
\text { Kemp Tower. } \\
\text { Bloody Point Bar Light. }\end{array}$ \\
\hline
\end{tabular}

MARYS DELIGHT.

(Eastern Bay-Chart No. 3I.)

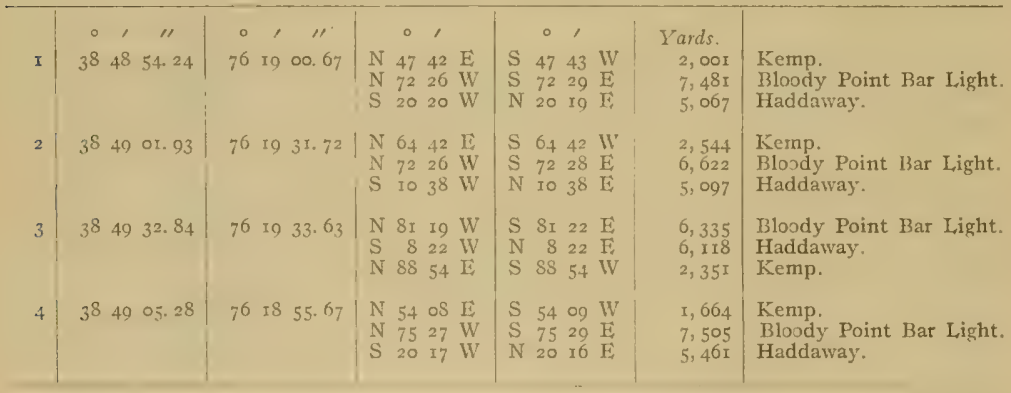


Survey of Oyster Bars, Talbot County, Md.

BOUNDARIES OF NATURAL OYSTER BARS-continued.

WADES POINT.

(Eastern Bay-Chart No. 3I.)

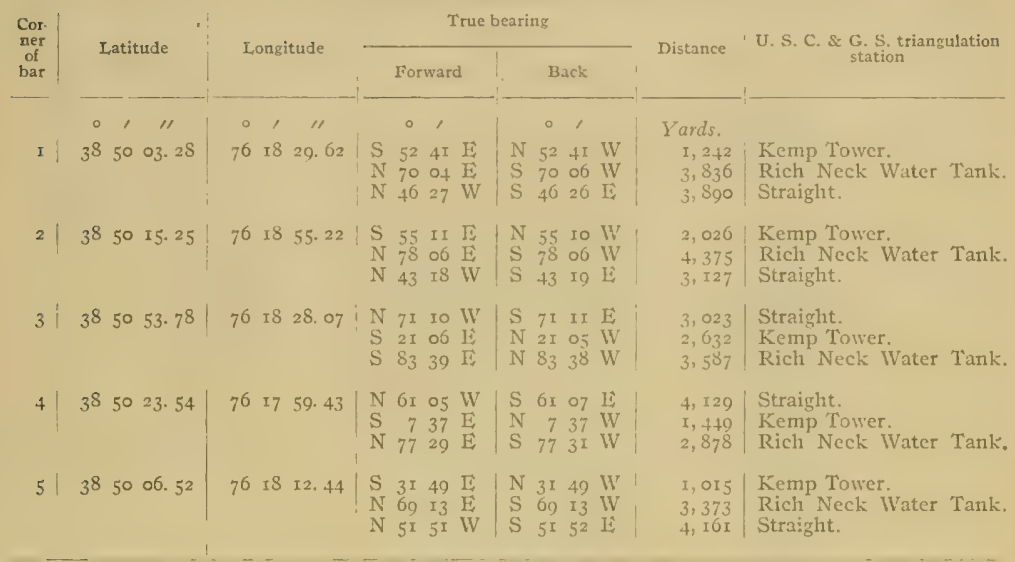

\section{SEDGE MARSH.}

(Eastem Bay-Chart.No. 3I.)

\begin{tabular}{|c|c|c|c|c|c|c|c|c|c|c|c|c|}
\hline I & $3^{8}$ & $\begin{array}{r}\prime \\
50\end{array}$ & $\begin{array}{c}\prime \prime \\
45.88\end{array}$ & $\begin{array}{r}0 \\
76\end{array}$ & I & $\begin{array}{c}\prime \prime \\
35.05\end{array}$ & $\begin{array}{ll} & 0 \\
N & 73 \\
\text { S } & I I \\
\text { S } & 86\end{array}$ & $\begin{array}{ll}1 \\
43 \mathrm{~W} \\
38 \mathrm{~W} \\
34 \mathrm{~F}\end{array}$ & $\begin{array}{ll} & 0 \\
\mathrm{~S} & 73 \\
\mathrm{~N} & \mathrm{II} \\
\mathrm{N} & 86\end{array}$ & $\begin{array}{ll} \\
45 \\
3 \mathrm{~S} & \mathrm{E} \\
33 & \mathrm{~W}\end{array}$ & $\begin{array}{r}\text { Yards } \\
4,436 \\
2,235 \\
2,166\end{array}$ & $\begin{array}{l}\text { Straight. } \\
\text { Kemp Tower. } \\
\text { Rich Neck Water Tank. }\end{array}$ \\
\hline 2 & $3^{8}$ & 50 & 50. 10 & ${ }_{7}^{6}$ & I7 & 5 t. 70 & $\begin{array}{lr}N & 73 \\
S & 0 \\
S & 84\end{array}$ & $\begin{array}{l}55 \mathrm{~W} \\
18 \mathrm{~W} \\
\text { O2 E }\end{array}$ & $\begin{array}{lr}\mathrm{S} & 73 \\
\mathrm{~N} & 0 \\
\mathrm{~N} & 84\end{array}$ & $\begin{array}{ll}57 & \mathrm{E} \\
18 & \mathrm{E} \\
\text { or } & \mathrm{W}\end{array}$ & $\begin{array}{l}3,975 \\
2,332 \\
2,615\end{array}$ & $\begin{array}{l}\text { Straight. } \\
\text { Kemp Tower. } \\
\text { Ricl Neck Water Tank. }\end{array}$ \\
\hline 3 & $3^{8}$ & 5 I & og. 90 & 76 & $\mathrm{I}_{i}$ & 29. $3^{8}$ & $\begin{array}{ll}N & 84 \\
S & I_{1} \\
S & 65\end{array}$ & $\begin{array}{ll}23 & W \\
\text { I9 } & W^{r} \\
\text { oI } & \mathrm{E}\end{array}$ & $\begin{array}{ll}S & 84 \\
N & \text { II } \\
N & 65\end{array}$ & $\begin{array}{l}25 \mathrm{E} \\
\text { I9 } \mathrm{E} \\
\text { OI } \mathrm{W}\end{array}$ & $\begin{array}{l}4,429 \\
3,059 \\
2,225\end{array}$ & $\begin{array}{l}\text { Straight. } \\
\text { Kemp Tower. } \\
\text { Rich Neck Water Tank. }\end{array}$ \\
\hline 4 & $3^{8}$ & $5 \mathrm{I}$ & 04.26 & 76 & 17 & 20. $\mathrm{x} 7$ & $\begin{array}{ll}N & 8_{2} \\
S & 16 \\
S & 67\end{array}$ & $\begin{array}{ll}22 & W \\
43 & W \\
06 & E\end{array}$ & $\begin{array}{ll}\mathrm{S} & 82 \\
\mathrm{~N} & 16 \\
\mathrm{~N} & 67\end{array}$ & $\begin{array}{ll}23 & E \\
42 & E \\
0.4 & W\end{array}$ & $\begin{array}{l}4,693 \\
2,934 \\
1,927\end{array}$ & $\begin{array}{l}\text { Straight. } \\
\text { Kemp Tower. } \\
\text { Rich Neck Water Tank. }\end{array}$ \\
\hline
\end{tabular}


BOUNDARIFS OF NATURAL OYSTER BARS-continuEd.

RICH NECK.

(Eastern Bay-Chart No. 3I.)

\begin{tabular}{|c|c|c|c|c|c|c|c|c|c|c|c|c|c|}
\hline \multirow{2}{*}{$\begin{array}{l}\text { Cor- } \\
\text { ner } \\
\text { of } \\
\text { bar }\end{array}$} & \multirow{2}{*}{\multicolumn{3}{|c|}{ Latitude }} & \multirow{2}{*}{\multicolumn{3}{|c|}{ Longitude }} & \multicolumn{5}{|c|}{ True bearing } & \multirow{2}{*}{ Distance } & \multirow{2}{*}{$\begin{array}{l}\text { U. S. C. \& G. S. triangulation } \\
\text { station }\end{array}$} \\
\hline & & & & & & & & For & ward & & Back & & \\
\hline I & 38 & ' & $\begin{array}{c}\prime \prime \\
32.93\end{array}$ & $\begin{array}{r}\circ \\
76\end{array}$ & I & 0.3 .04 & $\begin{array}{l}\mathrm{N} \\
\mathrm{S} \\
\mathrm{S}\end{array}$ & $\begin{array}{l}0 \\
71 \\
18 \\
37\end{array}$ & $\begin{array}{l}\text { I2 } \\
\text { I } \\
56 \mathrm{~W} \\
38 \mathrm{E}\end{array}$ & $\begin{array}{ll}\mathrm{S} & 7 \\
\mathrm{~N} & 7 \\
\mathrm{~N} & 3\end{array}$ & $\begin{array}{lll}0 & , & \\
7 \mathrm{I} & \mathrm{I} & \mathrm{E} \\
\mathrm{I} & 55 & \mathrm{E} \\
37 & 38 & \mathrm{~W}\end{array}$ & $\begin{array}{l}\text { Yards. } \\
4,844 \\
3,993 \\
2,166\end{array}$ & $\begin{array}{l}\text { Mouth. } \\
\text { Kemp Tower. } \\
\text { Rich Neck Water Tank. }\end{array}$ \\
\hline 2 & 38 & $5 \mathrm{I}$ & 59. 14 & 76 & & $4^{2} \cdot 5^{2}$ & $\begin{array}{l}\mathrm{N} \\
\mathrm{S} \\
\mathrm{S}\end{array}$ & $\begin{array}{r}79 \\
3 \\
67\end{array}$ & $\begin{array}{ll}\text { II } \mathrm{W} \\
\text { o7 } \mathrm{W} \\
\text { 3I } \mathrm{E}\end{array}$ & $\mid \begin{array}{ll}\mathrm{S} & 7 \\
\mathrm{~N} & \\
\mathrm{~N} & 6\end{array}$ & $\begin{array}{lll}79 & \text { I2 } & \mathrm{E} \\
3 & 07 & \mathrm{E} \\
67 & 30 & \mathrm{WW}\end{array}$ & $\begin{array}{l}3,609 \\
4,667 \\
3,445\end{array}$ & $\begin{array}{l}\text { Mouth. } \\
\text { Kemp Tower. } \\
\text { Dixon. }\end{array}$ \\
\hline 3 & 38. & $5^{2}$ & $\begin{array}{l}\text { Then } \\
\text { II. } 20\end{array}$ & & & $\begin{array}{l}\text { county } \\
26.07\end{array}$ & $\begin{array}{l}\text { bo } \\
N \\
S \\
S\end{array}$ & $\begin{array}{r}86 \\
7 \\
77\end{array}$ & $\begin{array}{l}\text { dary as } \\
\text { OS WV } \\
44 \text { W } \\
54 \text { IE }\end{array}$ & $\begin{array}{l}\text { deline } \\
\text { S } 8 \\
\text { N }\end{array}$ & 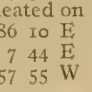 & $\begin{array}{l}\text { Chart No. } 3 \\
\qquad \begin{array}{r}3,987 \\
5, \text { II } 4 \\
3,246\end{array}\end{array}$ & $\begin{array}{l}\text { If to corner No. } 3 \text {. } \\
\text { Kemp Tower. } \\
\text { Dixon. }\end{array}$ \\
\hline 4 & 38 & $5 I$ & 46.33 & 76 & 16 & 48.83 & $\begin{array}{l}\mathrm{N} \\
\mathrm{S} \\
\mathrm{S}\end{array}$ & $\begin{array}{l}77 \\
21 \\
23\end{array}$ & $\begin{array}{ll}24 & W \\
33 & W \\
38 & E\end{array}$ & $\begin{array}{ll}\mathrm{S} & 7 \\
\mathrm{~N} & 2 \\
\mathrm{~N} & 2\end{array}$ & $\begin{array}{lll}77 & 26 & \mathrm{E} \\
2 \mathrm{I} & 32 & \mathrm{E} \\
23 & 38 & \mathrm{~W}\end{array}$ & $\begin{array}{l}5,083 \\
4,546 \\
2,367\end{array}$ & $\begin{array}{l}\text { Mouth, } \\
\text { Kemp Tower. } \\
\text { Rich Neck Water Tank. }\end{array}$ \\
\hline
\end{tabular}

TILGHMANS POINT.

(Eastern Bay-Charts Nos. $3^{I}$ and 32.)

\begin{tabular}{|c|c|c|c|c|c|c|c|c|c|c|c|c|c|c|}
\hline & 0 & , & 11 & 0 & 1 & "I & & 0 & , & & 0 & 1 & 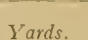 & \\
\hline I & $3^{8}$ & 51 & 30.20 & 76 & 16 & I 5.27 & $\begin{array}{l}\mathrm{S} \\
\mathrm{S} \\
\mathrm{S}\end{array}$ & $\begin{array}{r}34 \\
2 \\
68\end{array}$ & $\begin{array}{ll}45 & \text { W } \\
\text { I } 4 & \mathrm{E} \\
50 & \mathrm{E}\end{array}$ & $\begin{array}{l}\mathrm{N} \\
\mathrm{N} \\
\mathrm{N}\end{array}$ & $\begin{array}{r}34 \\
2 \\
6 S\end{array}$ & $\begin{array}{l}44 \mathrm{E} \\
I_{4} \mathrm{~W} \\
49 \mathrm{~W}\end{array}$ & $\begin{array}{r}4,484 \\
I, 625 \\
947\end{array}$ & $\begin{array}{l}\text { Kemp Tower. } \\
\text { Rich Neck Water Tank. } \\
\text { Dixon. }\end{array}$ \\
\hline 2 & $3^{8}$ & $5 \mathrm{I}$ & 45.94 & 76 & 16 & 26. I0 & $\begin{array}{l}\mathrm{S} \\
\mathrm{S} \\
\mathrm{S}\end{array}$ & $\begin{array}{r}28 \\
9 \\
53\end{array}$ & $\begin{array}{ll}\text { I8 } & \mathrm{W} \\
\text { I2 } & \mathrm{E} \\
\text { I5 } & \mathrm{F}\end{array}$ & $\begin{array}{l}\mathrm{N} \\
\mathrm{N}\end{array}$ & $\begin{array}{r}28 \\
9 \\
53\end{array}$ & $\begin{array}{ll}\text { I7 } & \mathrm{E} \\
\text { I2 } & \mathrm{WV} \\
\text { I4 } & \mathrm{WV}\end{array}$ & $\begin{array}{l}4,788 \\
2,183 \\
\text { I, } 459\end{array}$ & $\begin{array}{l}\text { Kemp Tower. } \\
\text { Rich Neck Water Tank. } \\
\text { Dixon. }\end{array}$ \\
\hline 3 & $\cdot 38$ & 52 & I2. 40 & 76 & 15 & 41.00 & $\begin{array}{l}N \\
N \\
S\end{array}$ & $\begin{array}{l}14 \\
30 \\
\text { I5 }\end{array}$ & $\begin{array}{l}45 \mathrm{E} \\
40 \mathrm{WV} \\
25 \mathrm{~W}\end{array}$ & $\begin{array}{l}\mathrm{S} \\
\mathrm{S} \\
\mathrm{N}\end{array}$ & $\begin{array}{l}\text { It } \\
30 \\
\text { I5 }\end{array}$ & $\begin{array}{l}46 \mathrm{~W} \\
4 \mathrm{IH} \\
25 \mathrm{E}\end{array}$ & $\begin{array}{l}4,898 \\
3,653 \\
3,16 x\end{array}$ & $\begin{array}{l}\text { Parsons Island Water } \\
\text { Tank. } \\
\text { Needle. } \\
\text { Rich Neck Water Tank. }\end{array}$ \\
\hline 4 & $3^{8}$ & 52 & 39.22 & 76 & I5 & 25.84 & $\begin{array}{l}\mathrm{N} \\
\mathrm{N} \\
\mathrm{S}\end{array}$ & $\begin{array}{l}x x \\
45 \\
8\end{array}$ & $\begin{array}{ll}52 & \mathrm{E} \\
19 & \mathrm{~W} \\
57 & \mathrm{~W}\end{array}$ & $\begin{array}{l}S \\
S \\
N\end{array}$ & $\begin{array}{l}\text { II } \\
45 \\
8\end{array}$ & $\begin{array}{ll}52 & \mathrm{~W} \\
20 & \mathrm{E} \\
57 & \mathrm{E}\end{array}$ & $\begin{array}{l}3,693 \\
3,181 \\
2,702\end{array}$ & $\begin{array}{l}\text { Parsons. } \\
\text { Needle. } \\
\text { Dixon. }\end{array}$ \\
\hline 5 & $3^{8}$ & $5^{2}$ & 31. 74 & 76 & $x_{5}$ & 11. $3^{8}$ & $\begin{array}{l}N \\
N \\
S\end{array}$ & $\begin{array}{r}5 \\
46 \\
18\end{array}$ & $\begin{array}{ll}35 & \mathrm{E} \\
43 & \mathrm{~W} \\
2 \mathrm{I} & \mathrm{WV}\end{array}$ & $\begin{array}{l}\mathrm{S} \\
\mathrm{S} \\
\mathrm{N}\end{array}$ & $\begin{array}{r}5 \\
46 \\
18\end{array}$ & $\begin{array}{ll}35 & \mathrm{~W} \\
44 & \mathrm{E} \\
2 \mathrm{I} & \mathrm{E}\end{array}$ & $\begin{array}{l}3,884 \\
3,63 x \\
2,547\end{array}$ & $\begin{array}{l}\text { Parsons. } \\
\text { Needle. } \\
\text { Dixon. }\end{array}$ \\
\hline 6 & $3^{8}$ & $5^{2}$ & II. 48 & 76 & 15 & 19. 40 & $\begin{array}{l}\mathrm{N} \\
\mathrm{N} \\
\mathrm{S}\end{array}$ & $\begin{array}{r}7 \\
37 \\
18\end{array}$ & $\begin{array}{ll}23 & \overrightarrow{\mathrm{E}} \\
28 & \mathrm{~W} \\
48 & \mathrm{~W}\end{array}$ & $\begin{array}{l}\mathrm{S} \\
\mathrm{S} \\
\mathrm{N}\end{array}$ & $\begin{array}{r}7 \\
37 \\
18\end{array}$ & $\begin{array}{ll}23 & \mathrm{~W} \\
29 & \mathrm{E} \\
48 & \mathrm{E}\end{array}$ & $\begin{array}{l}4,588 \\
3,997 \\
I, 832\end{array}$ & $\begin{array}{l}\text { Parsons. } \\
\text { Needle. } \\
\text { Dixon. }\end{array}$ \\
\hline
\end{tabular}


Survey of Oyster Bars, Talbot County, Md.

BOUNDARIES OF NATURAL OYSTER BARS-continued.

UPPER HARRIS CREEK.

(Harris Creck-Charts Nos. 3I, 32, and 34.)

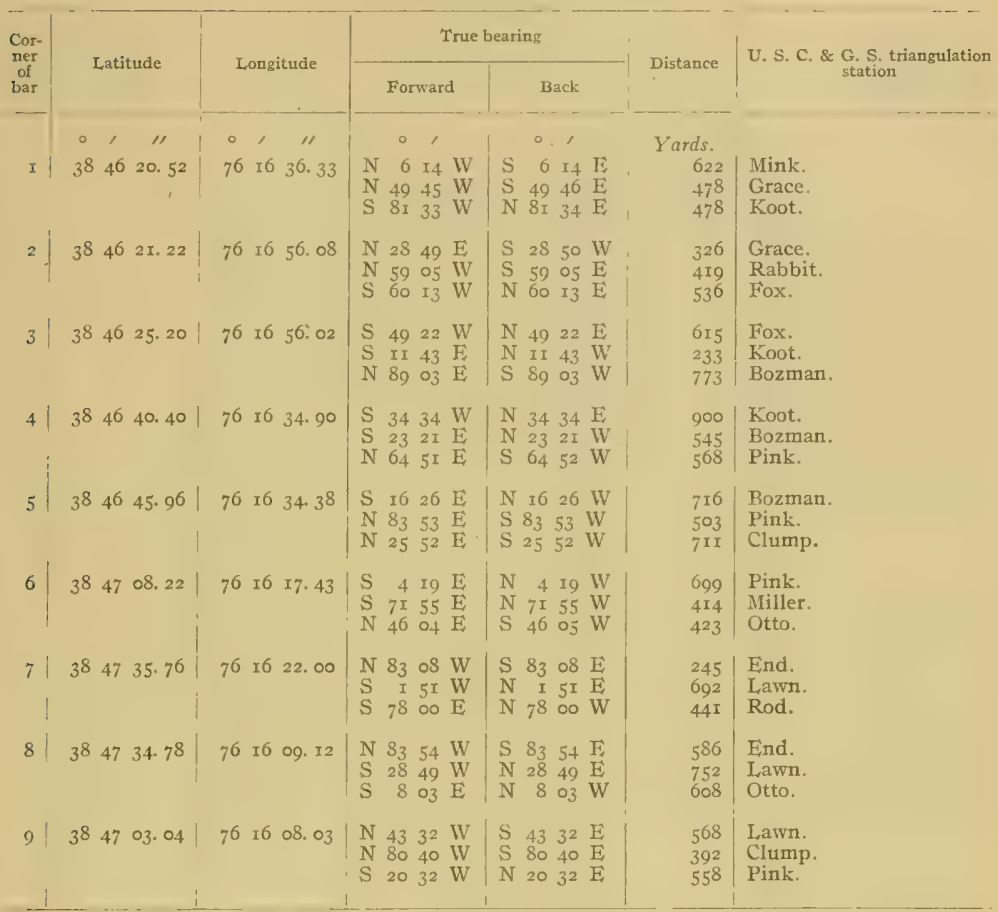

\section{UPPER HILL.}

(Eastern Bay-Chart No. 32.)

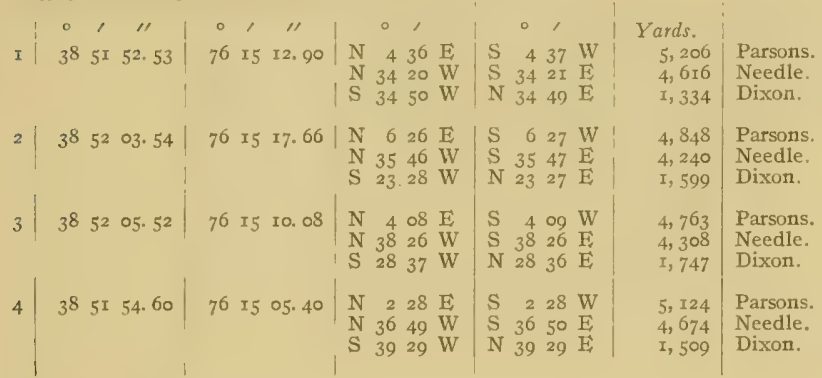


BOUNDARIES OF NATURAL OYSTER IBARS-continuEd.

AI,DRIDGES DISCOVERY.

(Miles River-Chart No. 32.)

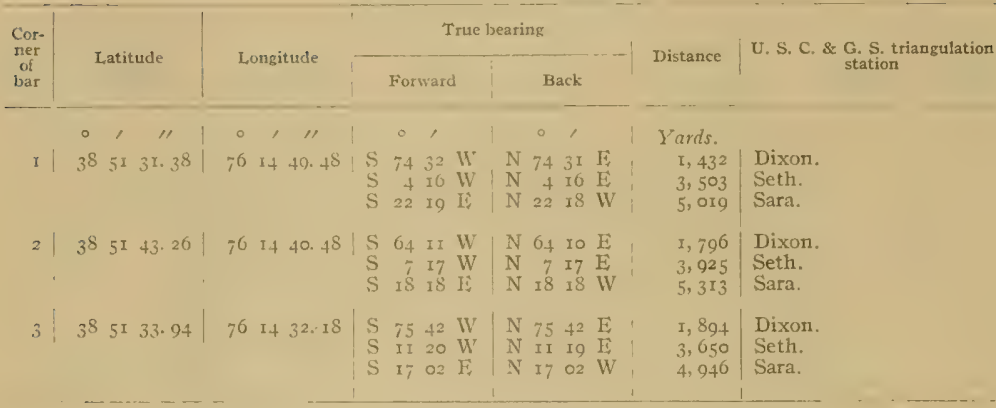

\section{HORSESHOE}

(Miles River-Chart No, 32.)

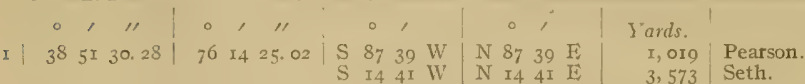

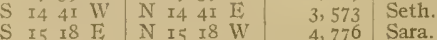

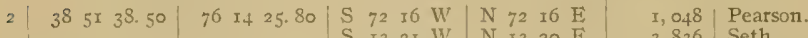

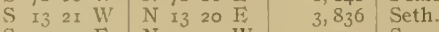

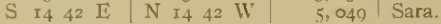

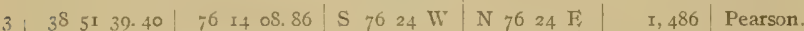

S I0 30 W N I9 29 E $\quad 3,992$ Seth.

\begin{tabular}{ll|lll|l|l}
$\mathrm{S} 9$ & $38 \mathrm{H}$ & $\mathrm{N}$ & 9 & $38 \mathrm{~W}$ & 4,985 & Sara.
\end{tabular}

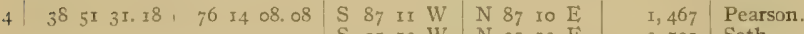

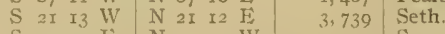

\begin{tabular}{ll|lll|l}
$\mathrm{S} 957 \mathrm{I}$ & $\mathrm{N} 957 \mathrm{~W}$ & 4,707 & Sara.
\end{tabular}

TURTLE PACK.

(Miles River-Chart No. 32.)

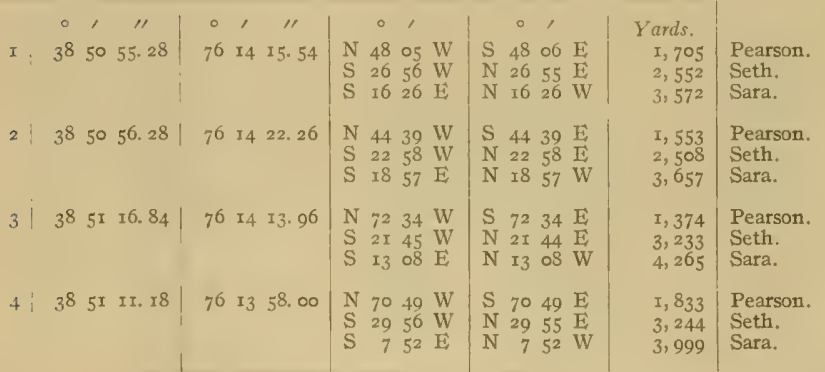


Survey of Oyster Bars, Talbot County, $M d$.

BOUNDARIES OF NATURAL, OYSTER BARS-continued.

SEA TURTLE.

(Miles River-Chart No. 32.)

\begin{tabular}{|c|c|c|c|c|c|c|c|c|}
\hline \multirow{2}{*}{$\begin{array}{l}\text { Cor- } \\
\text { ner } \\
\text { of } \\
\text { bar }\end{array}$} & \multirow{2}{*}{ Latitude } & \multirow{2}{*}{ Longitude } & \multicolumn{4}{|c|}{ True bearing } & \multirow{2}{*}{ Distance } & \multirow{2}{*}{ 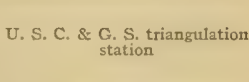 } \\
\hline & & & For & ward & $\mathrm{Ba}$ & ack & & \\
\hline I & $\begin{array}{ccc}0 & , \quad 11 \\
3^{8} & 5^{1} & \text { 02. } \\
5^{8}\end{array}$ & $\begin{array}{c}0,11 \\
76 \text { I5 } 23.66\end{array}$ & $\begin{array}{lc} & 0 \\
N & 30 \\
N & 39 \\
\text { S } & 61\end{array}$ & $\begin{array}{ll}1 \\
37 \\
\text { O } \\
\text { E } \\
55 \\
\mathrm{~W}\end{array}$ & $\begin{array}{lc} & 0 \\
S & 30 \\
S & 39 \\
N & 6 \pi\end{array}$ & $\begin{array}{ll}37 & \mathrm{WV} \\
03 & \mathrm{E} \\
54 & \mathrm{E}\end{array}$ & $\begin{array}{r}\text { Yards. } \\
\mathbf{1}, 037 \\
759 \\
\text { I. } 47 \mathbf{I}\end{array}$ & $\begin{array}{l}\text { Pearson. } \\
\text { Dixon. } \\
\text { Rich Neck Water Tank. }\end{array}$ \\
\hline 2 & $3^{8} \quad 5^{1} \quad 07.98$ & $\begin{array}{llll}76 & 15 & 26.28\end{array}$ & $\begin{array}{ll}N & 40 \\
N & 45 \\
\text { S } & 54\end{array}$ & $\begin{array}{ll}03 & W \\
07 & W \\
33 & W\end{array}$ & $\begin{array}{ll}\mathrm{S} & 40 \\
\mathrm{~S} & 45 \\
\mathrm{~N} & 54\end{array}$ & $\begin{array}{ll}03 & \mathrm{E} \\
07 & \mathrm{E} \\
33 \mathrm{E}\end{array}$ & $\begin{array}{r}927 \\
577 \\
\text { I, } 508\end{array}$ & $\begin{array}{l}\text { Pearson. } \\
\text { Dixon. } \\
\text { Rich Neck Water Tank. }\end{array}$ \\
\hline 3 & $3^{8} \quad 5^{1} \quad I_{3} .84$ & 76 I5 06.67 & $\begin{array}{lr}N & 8 \\
N & 77 \\
\text { S } & 58\end{array}$ & $\begin{array}{l}52 \mathrm{E} \\
14 \mathrm{WV} \\
27 \mathrm{WW}\end{array}$ & $\begin{array}{lr}\mathrm{S} & 8 \\
\mathrm{~S} & 77 \\
\mathrm{~N} & 5^{8}\end{array}$ & $\begin{array}{l}52 \mathrm{~W} \\
\text { I5 } \mathrm{E} \\
26 \mathrm{E}\end{array}$ & $\begin{array}{r}519 \\
949 \\
2,048\end{array}$ & $\begin{array}{l}\text { Pearson. } \\
\text { Dixon. } \\
\text { Rich Neck Water Tank. }\end{array}$ \\
\hline 4 & $3^{8} \quad 5^{1}$ o8. $5^{8}$ & $7^{6} \quad \mathrm{I} 5$ 03. 15 & $\begin{array}{lr}N & \text { I } \\
N & 69 \\
\text { S } & 64\end{array}$ & $\begin{array}{ll}04 & W \\
12 & W \\
03 & W\end{array}$ & $\begin{array}{lr}S & I \\
S & 69 \\
N & 64\end{array}$ & $\begin{array}{ll}\text { O4 } & \mathrm{E} \\
\text { I2 } & \mathrm{E} \\
\text { O3 } & \mathrm{LE}\end{array}$ & $\begin{array}{r}690 \\
1,089 \\
2,045\end{array}$ & $\begin{array}{l}\text { Pearson. } \\
\text { Dixon. } \\
\text { Rich Neck Water Tank. }\end{array}$ \\
\hline
\end{tabular}

\section{BOZMAN NECK.}

(Miles River-Chart No. 32.)

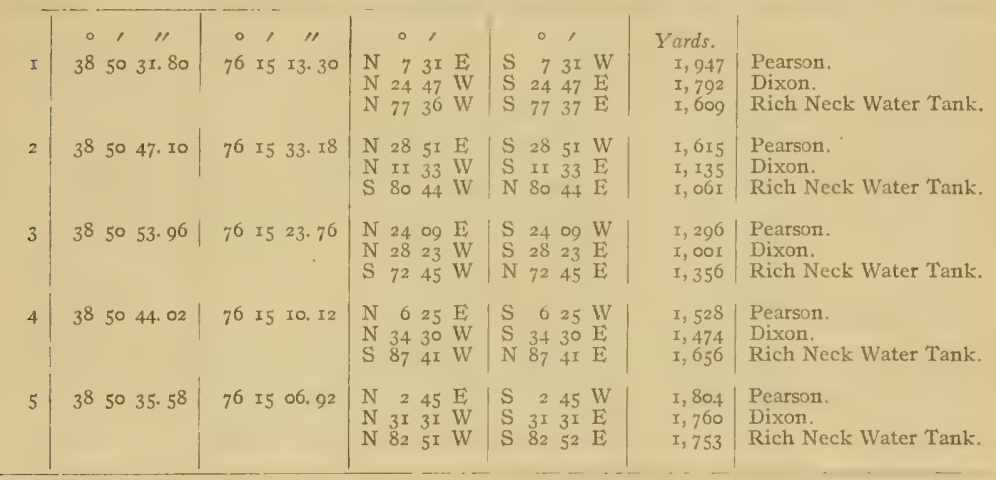


BOUNDARIES OF NATURAL OYSTER BARS-continuEd.

HAMBLETON HILL.

(Miles River-Chart No. 32.)

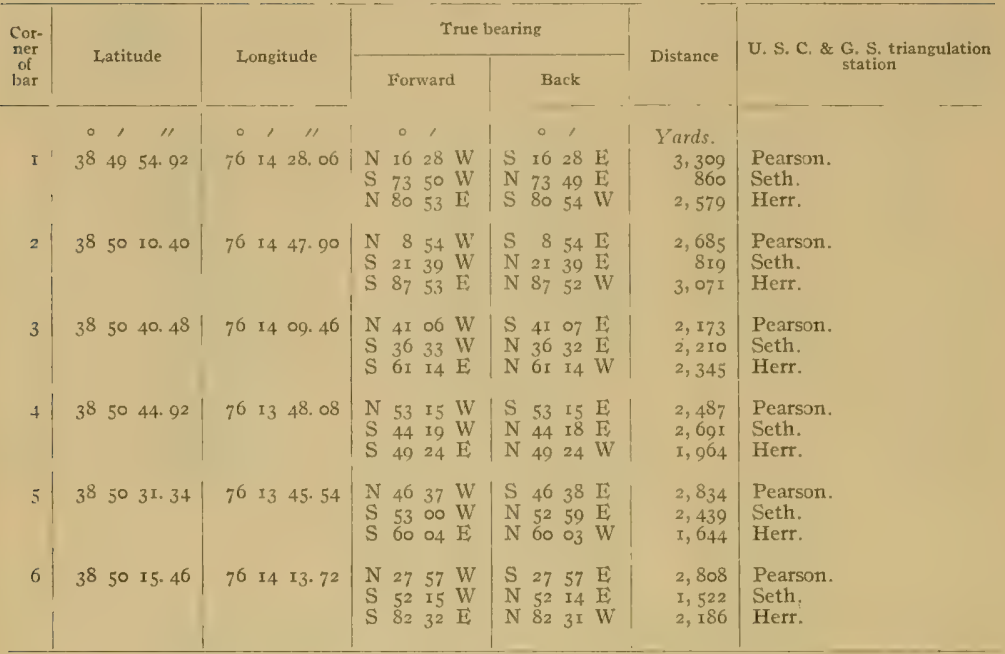

\section{WEST END.}

(Miles River-Chart No. 32.)

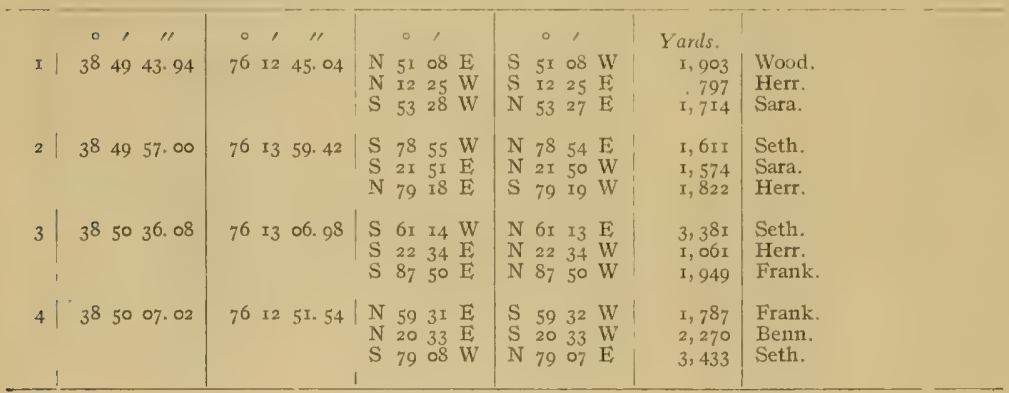


Survey of Oyster Bars, Talbot County, $M d$.

BOUNDARIES OF NATURAL OYSTER BARS-continuEd.

HAMBLETON.

(Miles River-Chart No. 32.)

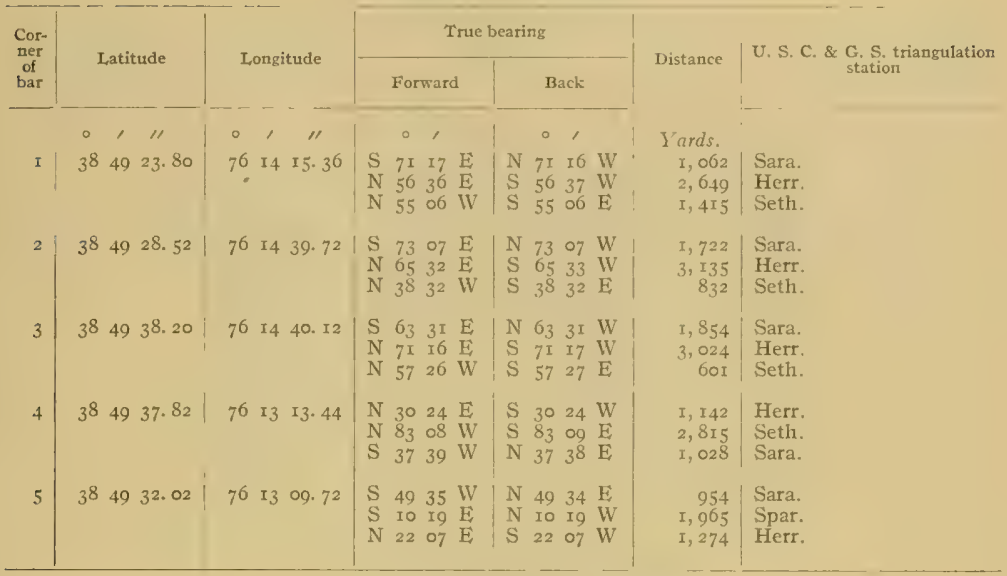

\section{TIDEMILL.}

(Miles River-Chart No. 32.)
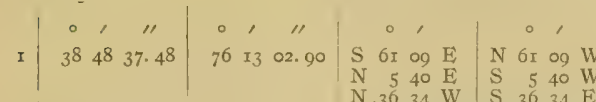

Yards.

\begin{tabular}{r|r}
197 & Spar. \\
3,035 & Herr.
\end{tabular}

Thence from comer No. I along the mean low-water line of the shore to corner No. 2, excluding any creek, cove, or inlet less than roo yards in width at its mouth at low tide.

2

3

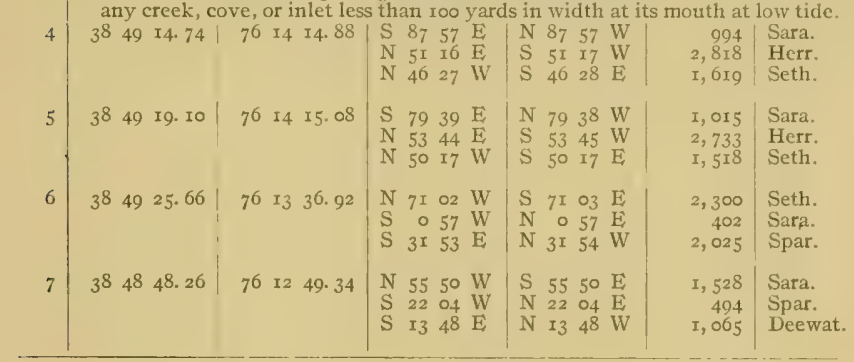
S 59 o8 W $\mathrm{W} 59$ o8 $\mathrm{E}$
S $3735 \mathrm{E} \quad \mathrm{N} 3735 \mathrm{~W}$
\begin{tabular}{llll|llll}
$\mathrm{S}$ & 33 & 36 & $\mathrm{E}$ & $\mathrm{N}$ & 33 & 36 & $\mathrm{~W}$ \\
$\mathrm{~N}$ & 38 & 42 & $\mathrm{E}$ & $\mathrm{S}$ & 38 & 43 & $\mathrm{~W}$
\end{tabular}
2,480 | Seth.
5 I Sara.
I, 694 Spar.
$194 \mid$ Sara.
2, 099 Herr.
2, 286 Seth.

the shore to corner No. 4, excluding Thence from comer No. 3 along the mean low-water line of the shore to corne 
BOUNDARIES OF NATURAL OYSTER BARS-continUEd.

SCOTLAND.

(Miles River-Chart No. 32.)

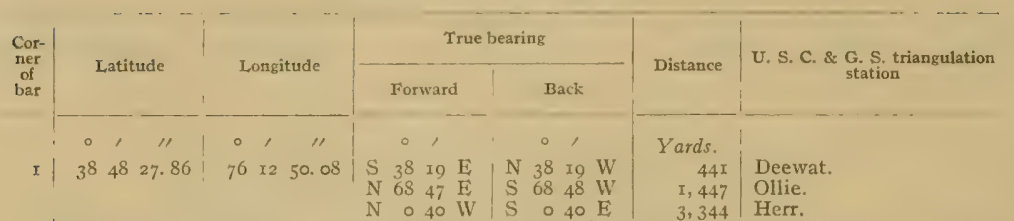

Thence from corner No. I along the mean low-water line of the shore to corner No. 2, excluding any creek, cove, or inlet less than Ioo yards in width at its mouth at low tide.

2

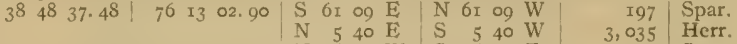

\begin{tabular}{lrrr|rrrr|r|r}
$\mathrm{N}$ & 5 & 40 & $\mathrm{E}$ & $\mathrm{S}$ & 5 & 40 & $\mathrm{~W}$ & 3,035 & Herr. \\
$\mathrm{N}$ & 36 & 34 & $\mathrm{~W}$ & $\mathrm{~S}$ & 36 & 34 & $\mathrm{E}$ & $\mathrm{I}, 520$ & Sara.
\end{tabular}

$3\left|3^{8} 4^{8} \quad 4^{8.26}\right| 76$ I2 $49.34 \mid$ \begin{tabular}{llll|llll}
$N$ & 55 & 50 & $W$ & $S$ & 55 & 50 & $E$ \\
$S$ & 22 & 04 & $W$ & $N$ & 22 & 04 & $E$
\end{tabular} \begin{tabular}{llll|lllll}
$\mathrm{S}$ & $I_{3}$ & 48 & $\mathrm{E}$ & $\mathrm{N}$ & $\mathrm{I}_{3}$ & 48 & $\mathrm{~W}$
\end{tabular}

\begin{tabular}{l|llll|llll}
4 & 38 & 48 & 41.30 & 76 & I2 & 31.26
\end{tabular}
ז, $528 \mid$ Sara.

494 Spar.

r, 065 Deewat.

2, 055 Sara.

700 Spar

830 Deewat.

\section{DEEP WATER POINT.}

(Miles River-Chart No. 32.)

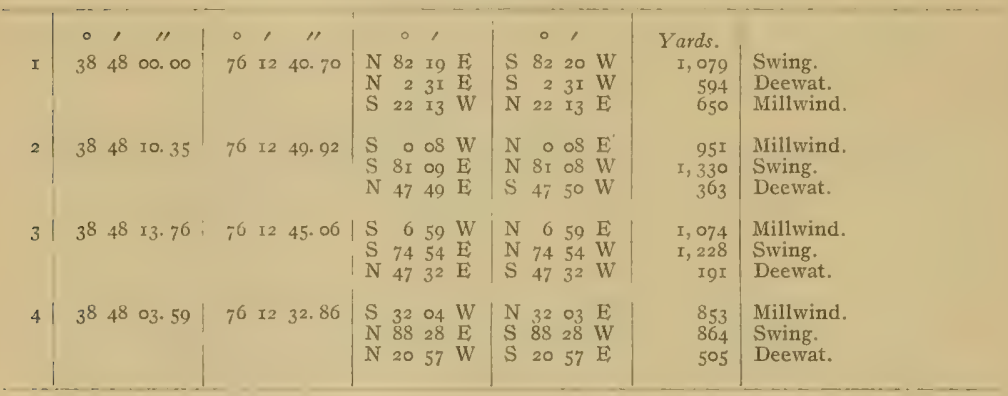


BOUNDARIES OF NATURAL OYSTER BARS-continued.

ASH CRAFT.

(Miles River-Chart No. 32.)

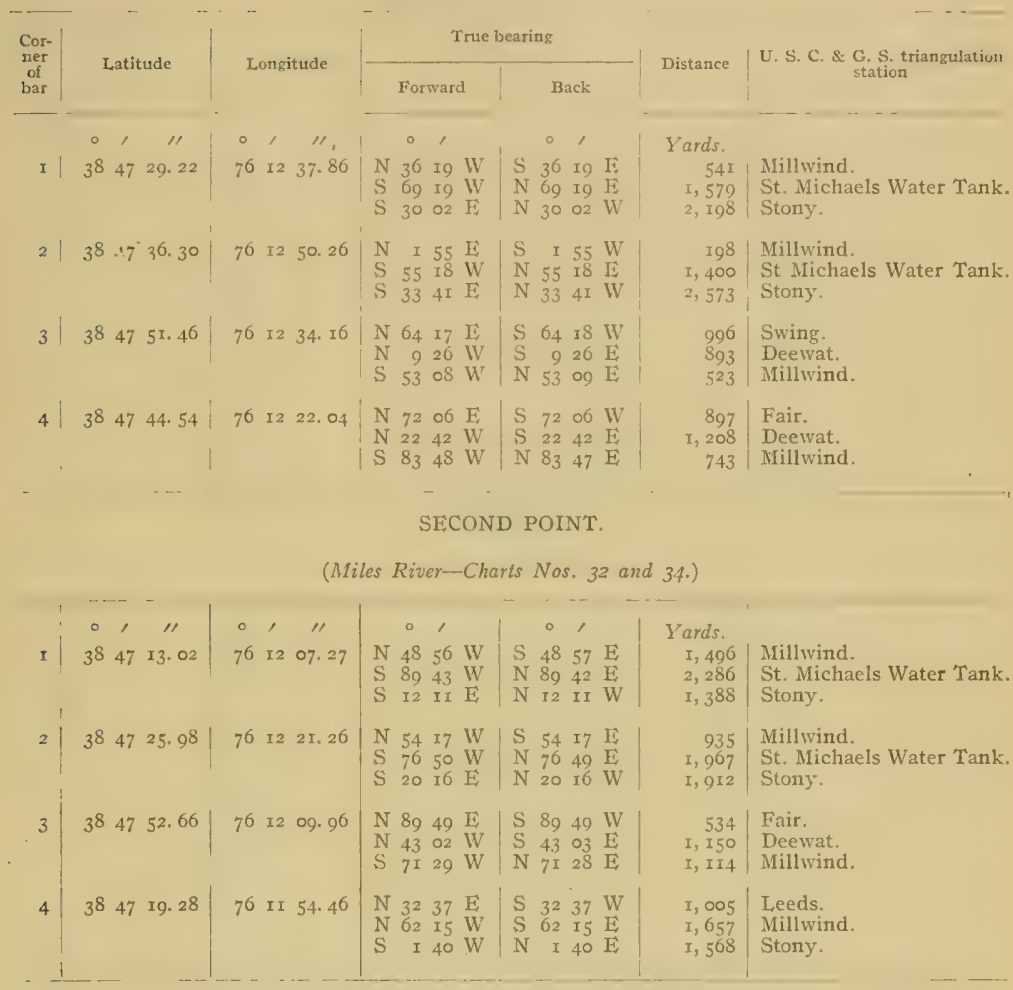


BOUNDARIES OF NATURAL, OYSTER BARS-continued.

WILD GROUND.

(Miles River-Chart No. 32.)

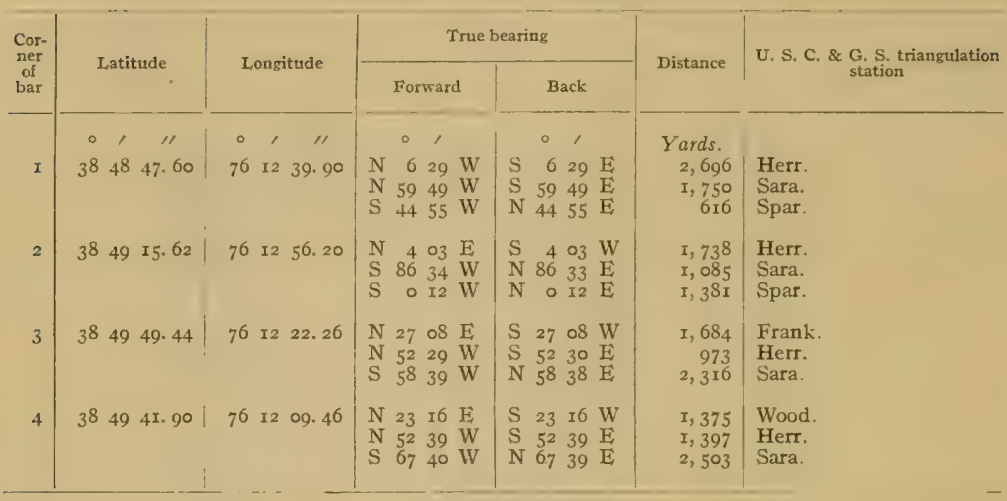

\section{SYCAMORE.}

(Miles River-Chart No. 32.)

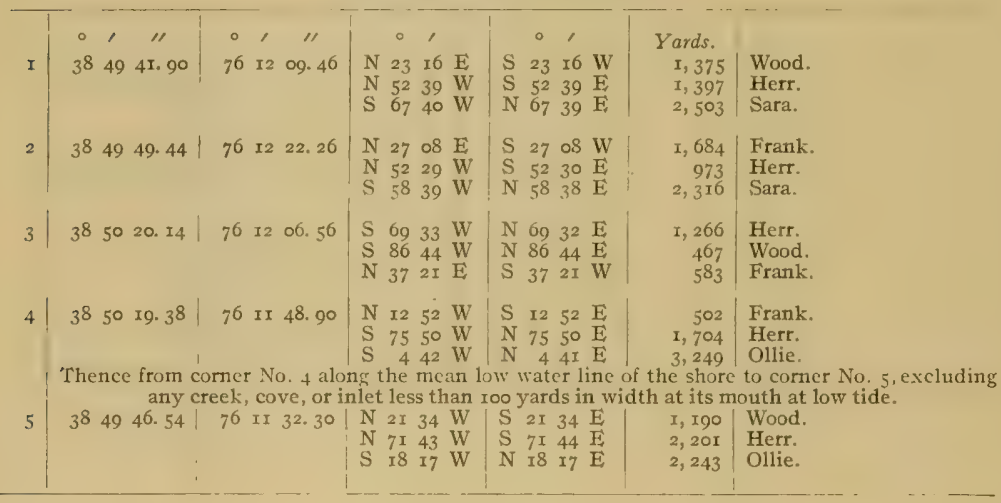


Survey of Oyster Bars, Talbot County, Md.

BOUNDARIES OF NATURAL OYSTER BARS-continued.

EAST END.

(Miles River-Chart No. 32.)

\begin{tabular}{|c|c|c|c|c|c|c|c|c|c|c|c|c|c|c|}
\hline \multirow{2}{*}{$\begin{array}{l}\text { Cor- } \\
\text { ner } \\
\text { of } \\
\text { bar }\end{array}$} & \multirow{2}{*}{\multicolumn{2}{|c|}{ Latitude }} & \multirow{2}{*}{\multicolumn{3}{|c|}{ Longitude }} & \multicolumn{7}{|c|}{ True bearing } & \multirow{2}{*}{ Distance } & \multirow{2}{*}{$\begin{array}{c}\text { U. S. C. \& G. S. triangulation } \\
\text { station }\end{array}$} \\
\hline & & & & & & & For & rward & & & $\mathrm{Ba}$ & & & \\
\hline I & & $\begin{array}{cc}\prime \prime \prime \\
49 & 43.94\end{array}$ & $\stackrel{\circ}{76}$ & $\begin{array}{l}1 \\
12\end{array}$ & $\begin{array}{c}\prime \prime \\
45.04\end{array}$ & $\begin{array}{l}\mathrm{N} \\
\mathrm{N} \\
\mathrm{S}\end{array}$ & $\begin{array}{l}0 \\
51 \\
12 \\
53\end{array}$ & $\begin{array}{l}1 \\
08 \\
25 \\
28\end{array}$ & $\begin{array}{l}\mathrm{E} \\
\mathrm{W} \\
\mathrm{W}\end{array}$ & $\begin{array}{l}\mathrm{S} \\
\mathrm{S} \\
\mathrm{N}\end{array}$ & $\begin{array}{l}\circ \\
51 \\
12 \\
53\end{array}$ & $\begin{array}{ll}\text { O8 } \\
25 \\
27 & \mathrm{E} \\
27 & \end{array}$ & $\begin{array}{r}\text { Yards. } \\
\text { I, 903 } \\
797 \\
\text { I, } 714\end{array}$ & $\begin{array}{l}\text { Wood. } \\
\text { Herr. } \\
\text { Sara. }\end{array}$ \\
\hline$=1$ & $3^{5}$ & $50 \quad 07.02$ & 76 & 12 & 5I. 54 & $\begin{array}{l}\mathrm{N} \\
\mathrm{N} \\
\mathrm{S}\end{array}$ & $\begin{array}{l}59 \\
20 \\
79\end{array}$ & $\begin{array}{l}31 \\
33 \\
08\end{array}$ & $\begin{array}{l}E \\
E \\
W\end{array}$ & $\begin{array}{l}\mathrm{S} \\
\mathrm{S} \\
\mathrm{N}\end{array}$ & $\begin{array}{l}59 \\
20 \\
79\end{array}$ & $\begin{array}{ll}32 & W \\
33 & W \\
07 & E\end{array}$ & $\begin{array}{l}1,787 \\
2,270 \\
3,43.3\end{array}$ & $\begin{array}{l}\text { Frank. } \\
\text { Benn. } \\
\text { Seth. }\end{array}$ \\
\hline 3 & 38 & $50 \mathrm{r} 3.5^{8}$ & 76 & 12 & 35.30 & $\begin{array}{l}\mathrm{N} \\
\mathrm{S} \\
\mathrm{S}\end{array}$ & $\begin{array}{l}10 \\
62 \\
17\end{array}$ & $\begin{array}{l}57 \\
41 \\
29\end{array}$ & & $\begin{array}{l}\mathrm{S} \\
\mathrm{N} \\
\mathrm{N}\end{array}$ & $\begin{array}{l}10 \\
62 \\
17\end{array}$ & $\begin{array}{ll}57 & \mathrm{~W} \\
4 \mathrm{I} & \mathrm{E} \\
29 & \mathrm{~W}\end{array}$ & $\begin{array}{r}\mathrm{I}, 940 \\
482 \\
3,189\end{array}$ & $\begin{array}{l}\text { Benr } \\
\text { Herr. } \\
\text { Ollic. }\end{array}$ \\
\hline 4 & $3^{8}$ & 4957.98 & 76 & 12 & 30. 18 & $\begin{array}{l}\mathrm{S} \\
\mathrm{N} \\
\mathrm{N}\end{array}$ & $\begin{array}{r}13 \\
56 \\
5\end{array}$ & $\begin{array}{l}49 \\
3 I \\
29\end{array}$ & $\begin{array}{l}\text { W } \\
\text { E } \\
\text { E }\end{array}$ & $\begin{array}{l}\mathrm{N} \\
\mathrm{S} \\
\mathrm{S}\end{array}$ & $\begin{array}{r}{ }_{1} 3 \\
56 \\
5\end{array}$ & $\begin{array}{ll}49 & \mathrm{E} \\
3 \mathrm{I} & \mathrm{W} \\
29 & \mathrm{~W}\end{array}$ & $\begin{array}{l}2,894 \\
1,306 \\
2,442\end{array}$ & $\begin{array}{l}\text { Spar. } \\
\text { Wood. } \\
\text { Benn. }\end{array}$ \\
\hline
\end{tabular}

\section{HERRING ISLAND.}

(Miles River-Chart No. 32.)

\begin{tabular}{|c|c|c|c|c|c|c|c|c|c|c|c|c|c|c|}
\hline I & $\begin{array}{l}0 \\
38\end{array}$ & 50 & $\begin{array}{c}\prime \prime \\
07.02\end{array}$ & $\begin{array}{l}0 \\
76\end{array}$ & I & 51. 54 & $\begin{array}{l}N \\
N \\
S\end{array}$ & $\begin{array}{l}0 \\
59 \\
20 \\
79\end{array}$ & $\begin{array}{ll}3 \mathrm{I} & \mathrm{F} \\
33 & \mathrm{E} \\
08 & \mathrm{~W}\end{array}$ & $\begin{array}{l}\mathrm{S} \\
\mathrm{S} \\
\mathrm{N}\end{array}$ & $\begin{array}{l}2 \\
59 \\
20 \\
79\end{array}$ & $\begin{array}{ll}32 & W \\
33 & W \\
07 & \mathrm{E}\end{array}$ & $\begin{array}{l}\text { Yards. } \\
\begin{array}{r}\text { I, } 787 \\
2,270 \\
3,433\end{array}\end{array}$ & $\begin{array}{l}\text { Frank. } \\
\text { Benn. } \\
\text { Seth. }\end{array}$ \\
\hline 2 & $3^{8}$ & 50 & 36. o8 & 76 & 13 & 06. 98 & $\begin{array}{l}\mathrm{S} \\
\mathrm{S} \\
\mathrm{S}\end{array}$ & $\begin{array}{l}61 \\
22 \\
87\end{array}$ & $\begin{array}{ll}\mathrm{I} 4 & \mathrm{~W} \\
34 \mathrm{E} \\
50 & \mathrm{E}\end{array}$ & $\begin{array}{l}\mathrm{N} \\
\mathrm{N} \\
\mathrm{N}\end{array}$ & $\begin{array}{l}61 \\
22 \\
87\end{array}$ & $\begin{array}{ll}\text { I3 } & \mathrm{E} \\
34 & \mathrm{~W} \\
50 & \mathrm{~W}\end{array}$ & $\begin{array}{l}3,38 I \\
I, 06 I \\
I, 949\end{array}$ & $\begin{array}{l}\text { Seth. } \\
\text { Herr. } \\
\text { Frank. }\end{array}$ \\
\hline 3 & 38 & $5^{\circ}$ & 48.30 & 76 & 13 & I7. 28 & $\begin{array}{l}\mathrm{S} \\
\mathrm{S} \\
\mathrm{N}\end{array}$ & $\begin{array}{r}9 \\
77 \\
63\end{array}$ & $\begin{array}{l}22 \mathrm{~W} \\
40 \mathrm{~F} \\
33 \mathrm{E}\end{array}$ & $\begin{array}{l}\mathrm{N} \\
\mathrm{N} \\
\mathrm{S}\end{array}$ & $\begin{array}{r}92 \\
773 \\
633\end{array}$ & $\begin{array}{ll}22 & \mathrm{E} \\
39 & \mathrm{~W} \\
34 & \mathrm{~W}\end{array}$ & $\begin{array}{l}3,234 \\
2,271 \\
1,648\end{array}$ & $\begin{array}{l}\text { Sara. } \\
\text { Frank. } \\
\text { Benn. }\end{array}$ \\
\hline 4 & 38 & $\begin{array}{l}\text { Th } \\
50\end{array}$ & $\begin{array}{c}\text { hence a } \\
39.24\end{array}$ & $\begin{array}{l}n g \\
76\end{array}$ & $\begin{array}{l}\text { cout } \\
\text { I2 }\end{array}$ & & $\begin{array}{l}\text { inda } \\
\mathrm{S} \\
\mathrm{S} \\
\mathrm{N}\end{array}$ & $\begin{array}{l}\text { ary } \\
35 \\
75 \\
71\end{array}$ & $\begin{array}{l}\text { as delir } \\
\text { I2 W } \\
46 \mathrm{E} \\
09 \mathrm{E}\end{array}$ & $\begin{array}{l}\text { eate } \\
\mathrm{N} \\
\mathrm{N} \\
\mathrm{S}\end{array}$ & $\begin{array}{l}\text { d or } \\
35 \\
75 \\
71\end{array}$ & $\begin{array}{l}\text { n Char } \\
\text { I I E } \\
45 \mathrm{~W} \\
\text { og W }\end{array}$ & $\begin{array}{r}\text { No. } 32 \text { to } \\
3,530 \\
734 \\
778\end{array}$ & $\begin{array}{l}\text { orner No. } 4 . \\
\text { Sara. } \\
\text { Frank. } \\
\text { James. }\end{array}$ \\
\hline 5 & 38 & 50 & I $3.5^{8}$ i & 76 & I2 & 35.30 & $\begin{array}{l}\mathrm{N} \\
\mathrm{S} \\
\mathrm{S}\end{array}$ & $\begin{array}{l}10 \\
62 \\
17\end{array}$ & $\begin{array}{ll}57 & \mathrm{E} \\
4 \mathrm{I} & \mathrm{W} \\
29 & \mathrm{E}\end{array}$ & $\begin{array}{l}\mathrm{S} \\
\mathrm{N} \\
\mathrm{N}\end{array}$ & $\begin{array}{l}\text { I0 } \\
624 \\
172\end{array}$ & $\begin{array}{ll}57 & W \\
4 I & E \\
29 & W\end{array}$ & $\begin{array}{r}1,940 \\
482 \\
3,189\end{array}$ & $\begin{array}{l}\text { Benn. } \\
\text { Herr. } \\
\text { Ollie. }\end{array}$ \\
\hline
\end{tabular}


BOUNDARIES OF NATURAL OYSTER BARS-continued.

WYE TOWN.

(Wye River-Chart No. 32.)

\begin{tabular}{|c|c|c|c|c|c|c|c|c|c|c|c|c|c|}
\hline \multirow{3}{*}{$\begin{array}{c}\text { Cor- } \\
\text { ner } \\
\text { of } \\
\text { bar }\end{array}$} & \multirow{2}{*}{\multicolumn{3}{|c|}{ Latitude }} & \multirow{2}{*}{\multicolumn{3}{|c|}{ Longitude }} & \multicolumn{5}{|c|}{ 'True bearing } & \multirow{2}{*}{$\frac{\text { Distance }}{\text { Yards }}$} & \multirow{2}{*}{$\begin{array}{c}\text { U. S. C. \& G. S. triangulation } \\
\text { station }\end{array}$} \\
\hline & & & & & & & \multicolumn{3}{|c|}{ Forward } & \multicolumn{2}{|r|}{ Back } & & \\
\hline & $3^{\circ}$ & 50 & Ig. 38 & 76 & II & 48. 90 & $\begin{array}{l}N \\
S \\
S\end{array}$ & $\begin{array}{c}0 \\
12 \\
75 \\
4\end{array}$ & $\begin{array}{ll}52 & W \\
50 & W \\
42 & W\end{array}$ & $\begin{array}{l}\mathrm{S} \\
\mathrm{N} \\
\mathrm{N}\end{array}$ & $\begin{array}{ccc}0 & \ell \\
\text { I2 } & 52 & \mathrm{E} \\
75 & 50 & \mathrm{E} \\
4 & 4 \mathrm{r} & \mathrm{E}\end{array}$ & $\begin{array}{r}\text { Yards. } \\
502 \\
1,704 \\
3,249\end{array}$ & $\begin{array}{l}\text { Frank. } \\
\text { Herr. } \\
\text { Ollie. }\end{array}$ \\
\hline 2 & $3^{8}$ & 50 & 20. 14 & 76 & 12 & o6. 56 & $\begin{array}{l}\mathrm{S} \\
\mathrm{S} \\
\mathrm{N}\end{array}$ & $\begin{array}{l}69 \\
86 \\
37\end{array}$ & $\begin{array}{ll}33 & \mathrm{WV} \\
44 & \mathrm{~W} \\
2 \mathrm{I} & \mathrm{E}\end{array}$ & $\begin{array}{l}\mathrm{N} \\
\mathrm{N} \\
\mathrm{S}\end{array}$ & $\begin{array}{lll}69 & 32 & \mathrm{E} \\
86 & 44 & \mathrm{E} \\
37 & 2 \mathrm{I} & \mathrm{W}\end{array}$ & $\begin{array}{r}I, 266 \\
467 \\
583\end{array}$ & $\begin{array}{l}\text { Hert. } \\
\text { Wood. } \\
\text { Frank. }\end{array}$ \\
\hline 3 & 38 & 50 & 42.68 & 76 & 12 & 10. 64 & $\begin{array}{l}\mathrm{S} \\
\mathrm{N} \\
\mathrm{N}\end{array}$ & $\begin{array}{l}57 \\
742 \\
16\end{array}$ & $\begin{array}{ll}I 7 & \mathrm{E} \\
25 & \mathrm{E} \\
59 & \mathrm{WV}\end{array}$ & $\begin{array}{l}\mathrm{N} \\
\mathrm{S} \\
\mathrm{S}\end{array}$ & $\begin{array}{lll}57 & \text { I8 } & W \\
74 & 26 & W \\
16 & 59 & \text { E }\end{array}$ & $\begin{array}{l}549 \\
505 \\
966\end{array}$ & $\begin{array}{l}\text { Frank. } \\
\text { James. } \\
\text { Benn. }\end{array}$ \\
\hline $4 i$ & $3^{8}$ & $5 \mathrm{I}$ & 07.40 & 76 & II & 52.90 & $\begin{array}{l}\mathrm{S} \\
\mathrm{N} \\
\mathrm{N}\end{array}$ & $\begin{array}{ll}80 & c \\
3 I & 3 \\
8 & \end{array}$ & $\begin{array}{ll}02 & \mathrm{E} \\
36 & \overrightarrow{\mathrm{E}} \\
\text { II } & \mathrm{W}\end{array}$ & $\begin{array}{l}\mathrm{N} \\
\mathrm{S} \\
\mathrm{S}\end{array}$ & $\begin{array}{lll}80 & 02 & W \\
3 & 36 & W \\
83 & I I & E_{1}\end{array}$ & $\begin{array}{l}483 \\
973 \\
755\end{array}$ & $\begin{array}{l}\text { Law. } \\
\text { Brufis. } \\
\text { Benn. }\end{array}$ \\
\hline 5 & $3^{8}$ & $5 \mathrm{I}$ & 02.72 & $7^{6}$ & II & $45 \cdot 5^{8}$ & $\begin{array}{l}\mathrm{N} \\
\mathrm{N} \\
\mathrm{N}\end{array}$ & $\begin{array}{l}75 \\
174 \\
75\end{array}$ & $\begin{array}{ll}\text { I0 } & \mathrm{E} \\
48 & \mathrm{E} \\
17 & \mathrm{~W}\end{array}$ & $\begin{array}{l}\mathrm{S} \\
\mathrm{S} \\
\mathrm{S}\end{array}$ & $\begin{array}{lll}75 & \text { I9 } & \mathrm{W} \\
\text { I7 } & 49 & \mathrm{~W} \\
75 & \text { I8 } & \mathrm{E}\end{array}$ & $\begin{array}{r}293 \\
\mathrm{I}, 037 \\
975\end{array}$ & $\begin{array}{l}\text { Law. } \\
\text { Bruffs. } \\
\text { Benn. }\end{array}$ \\
\hline 6 & $3^{8}$ & 50 & 46. 70 & 76 & II & 52.20 & $\begin{array}{l}\mathrm{N} \\
\mathrm{N} \\
\mathrm{S}\end{array}$ & $\begin{array}{l}36 \\
44 \\
49\end{array}$ & $\begin{array}{ll}4 I & \mathrm{E} \\
\text { I7 } & \mathrm{W} \\
29 & \mathrm{~W}\end{array}$ & $\begin{array}{l}\mathrm{S} \\
\mathrm{S} \\
\mathrm{N}\end{array}$ & $\begin{array}{lll}36 & 4 I & \text { WV } \\
44 & \text { I7 } & \mathrm{E} \\
49 & 28 & \mathrm{E}\end{array}$ & $\begin{array}{r}767 \\
1,100 \\
2,059\end{array}$ & $\begin{array}{l}\text { Law. } \\
\text { Benn. } \\
\text { Herr. }\end{array}$ \\
\hline
\end{tabular}

Thence from comer No. 6 along the mean low water line of the shore to comer No. 1 , excluding any creek, cove, or inlet less than roo yards in width at its mouth at low tide:

\section{BRUFFS ISLAND.}

(Wye River-Chart No. 32.)

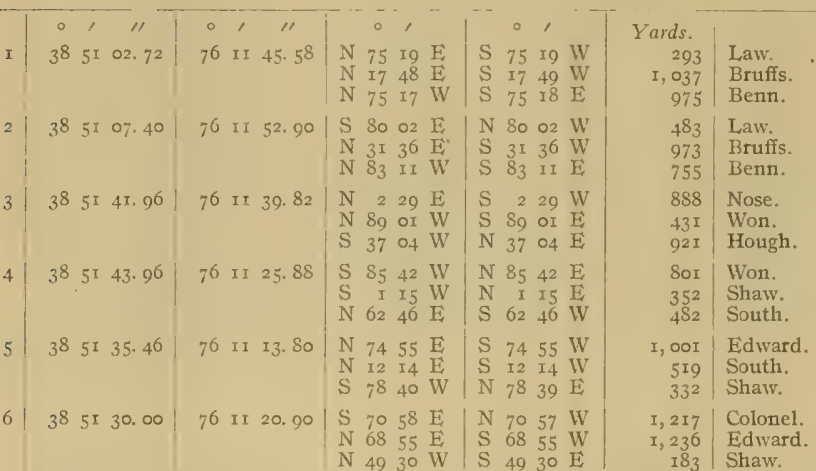

Thence from corner No. 6 along the mean low water line of the shore to corner No.7, excluding any creck, cove, or inlet less than roo yards in width at its mouth at low tide. 
BOUNDARIES OF NATURAL, OYSTER BARS-continued.

SHAW BAY HILL.

(Wye River-Chart No. 32.)

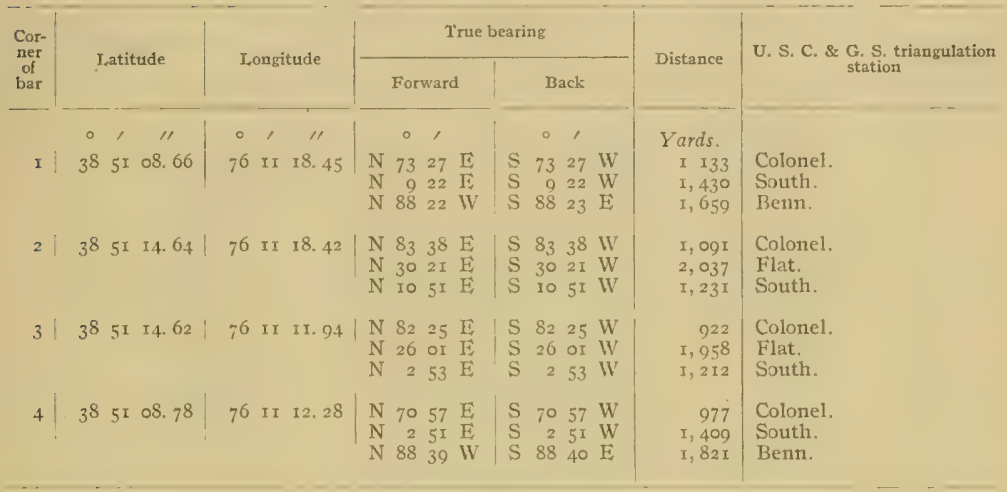

RACE HORSE ('Talbot County).

(W) R Rizer-Chart No. 32.)

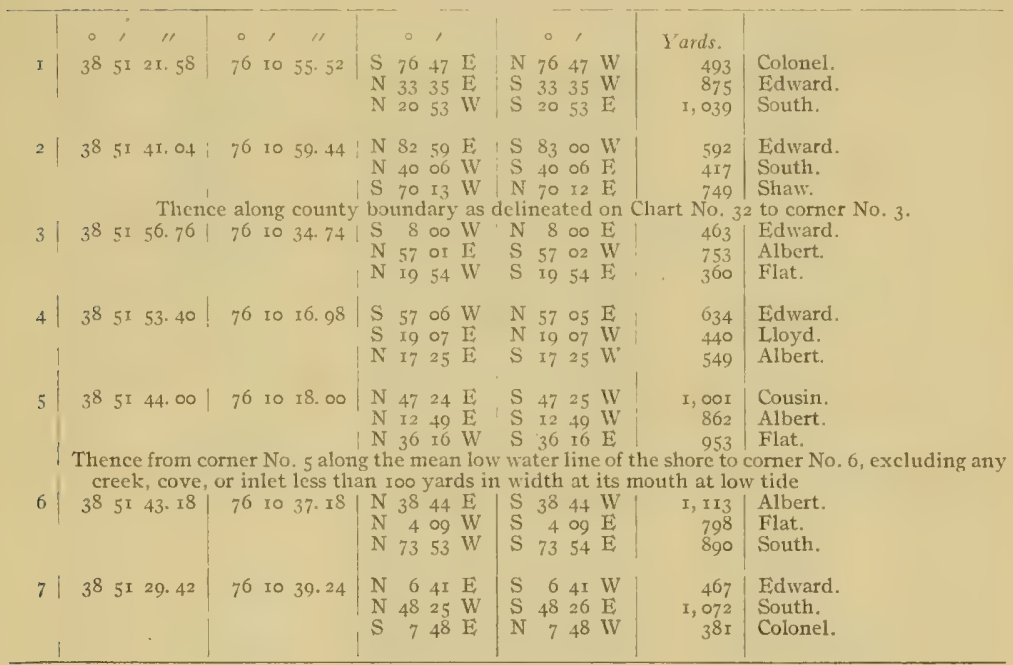


BOUNDARIES OF NATURAL OYSTER BARS-continued.

WINDERS BANK.

(Wye River-Chart No. 32.)

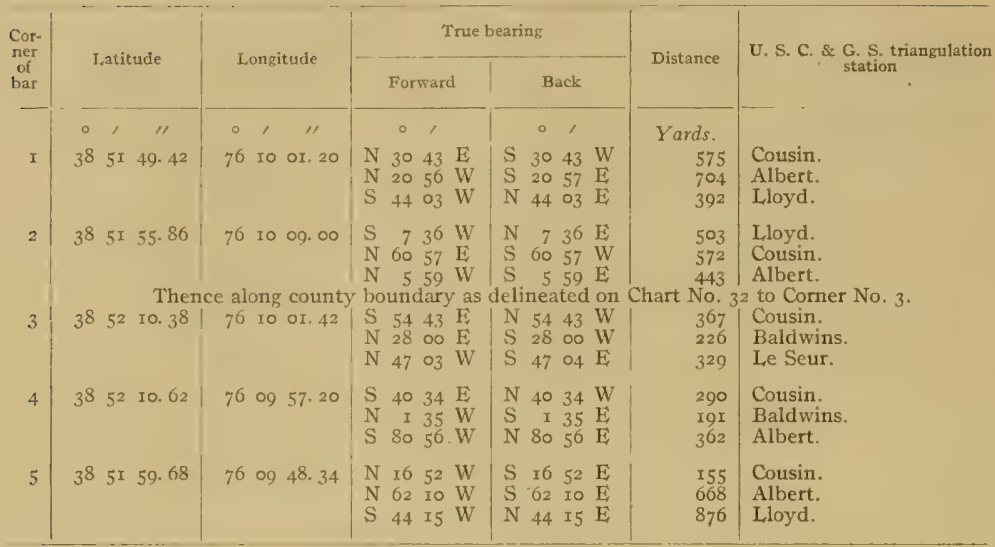

\section{POPLAR POINT.}

(Wye River-Chart No. 32.)

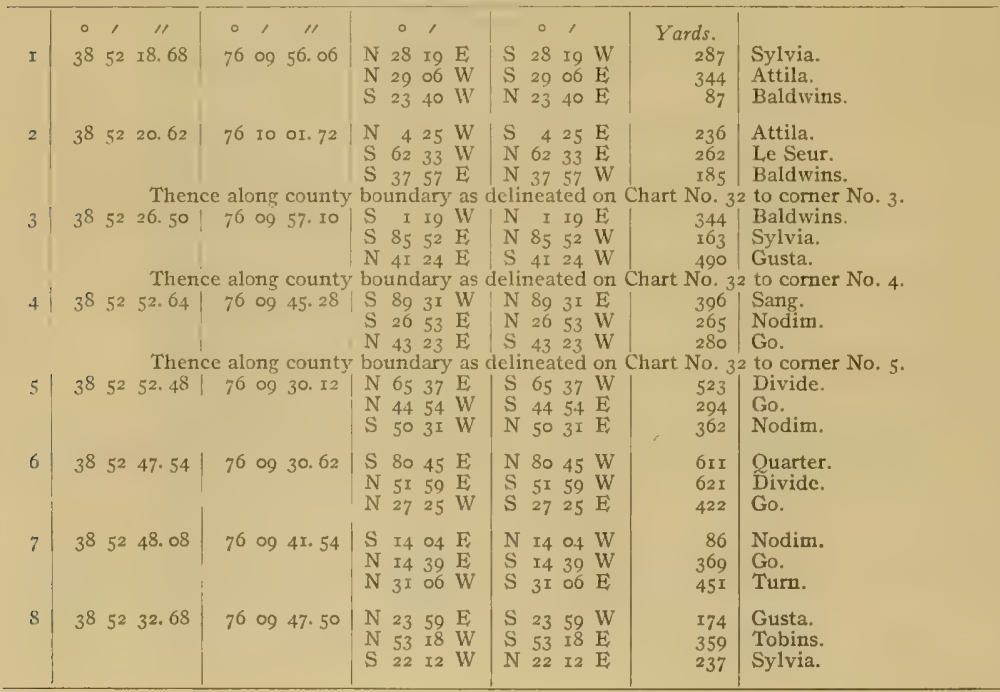


Survey of Oyster Bars, Talbot County, Md.

BOUNDARIES OF NATURAL, OYSTER BARS-continued.

JUNIPER.

(Wye River-Chart No. 33.)

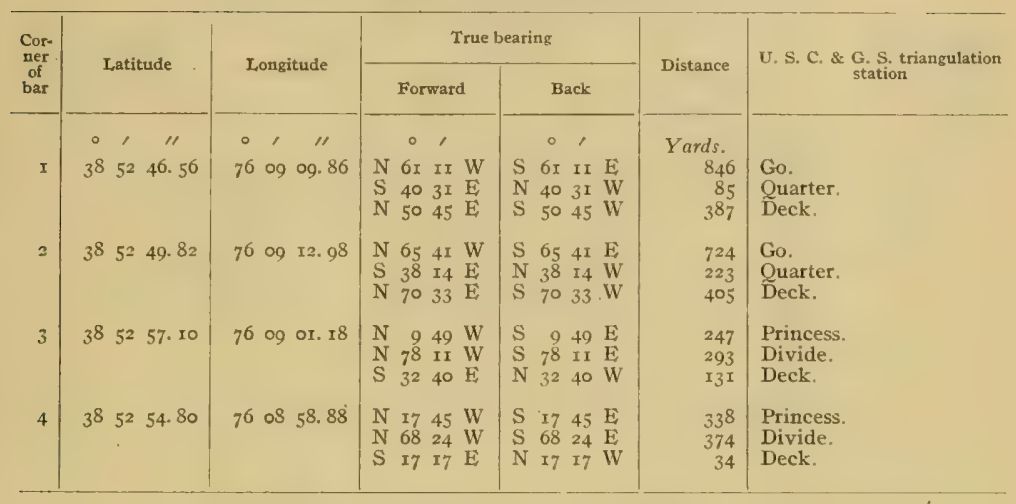

POPLAR ISLAND NARROWS.

(Chesapeake Bay-Vicinity Poplar Island-Chart No. 33.)

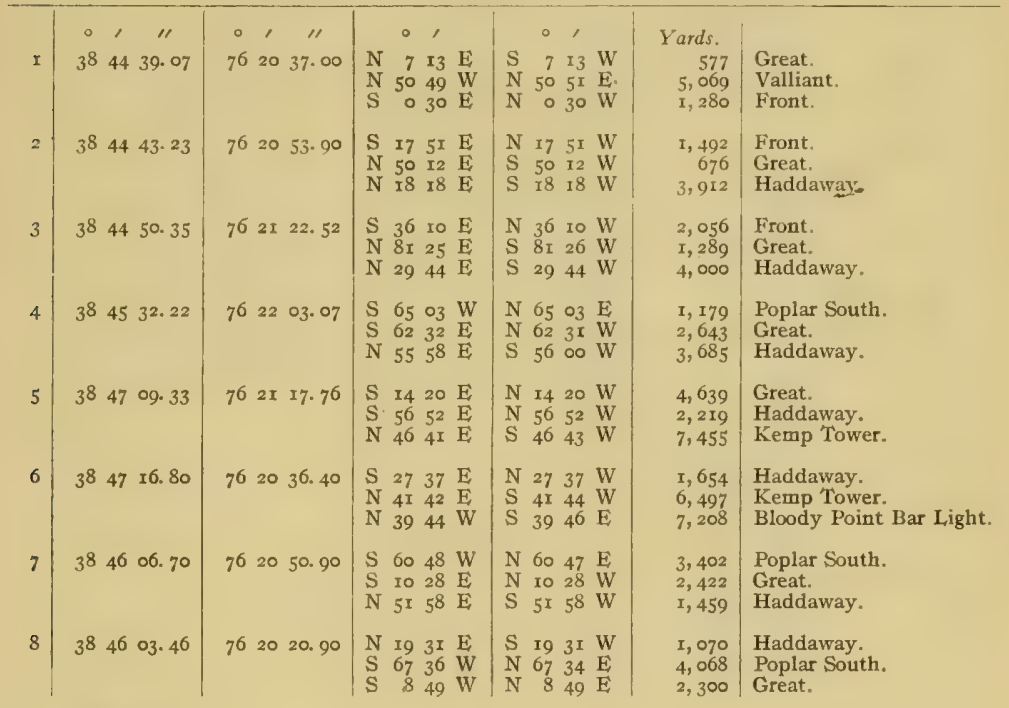

$53485-I_{2}-I_{3}$ 
BOUNDARIES OF NATURAL, OYSTER BARS-continued.

POPLAR ISLAND NARROWS-Continued.

(Chesapeake Bay-Vicinity Poplar Island-Chart No. 33)-Continued.

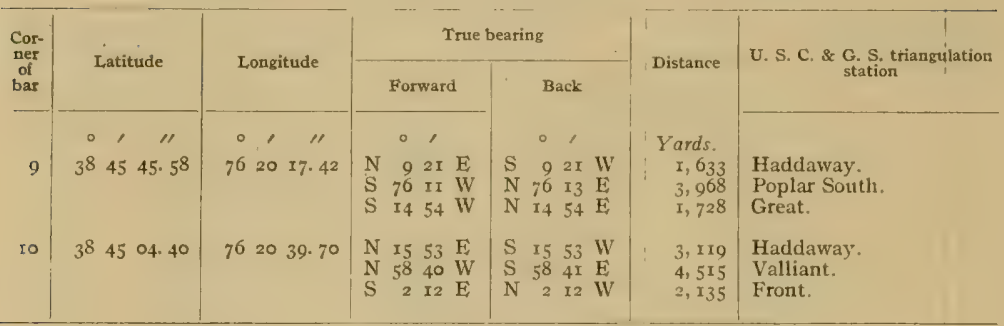

\section{BAY HUNDRED}

(Chesapeake Bay-Vicinity Poplar Island-Chart No. 33.)

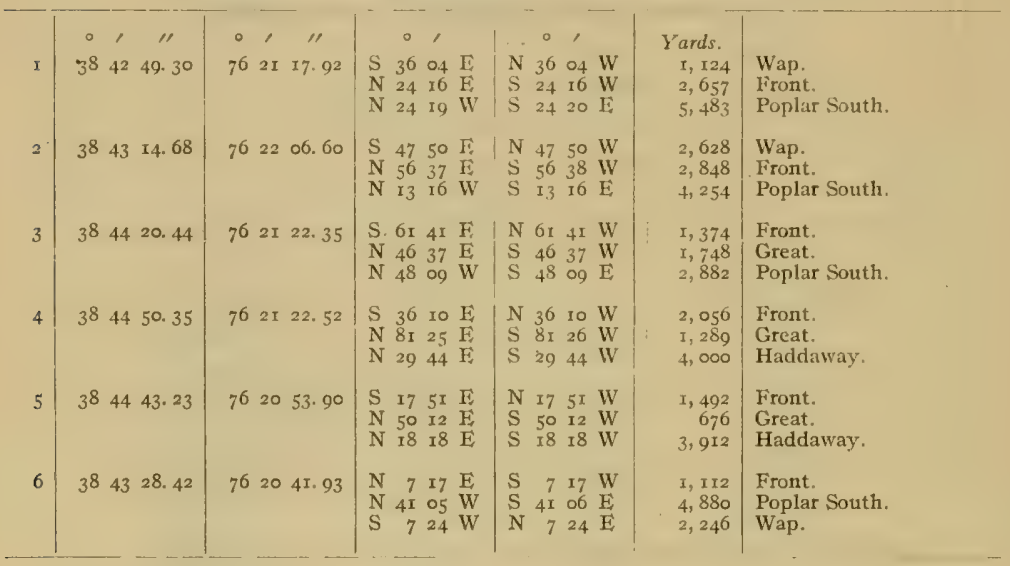


BOUNDARIES OF NATURAL OYSTER BARS-continued.

PONE.

(Chesapeake Bay-Off Tilghman Island-Chart No.33.)

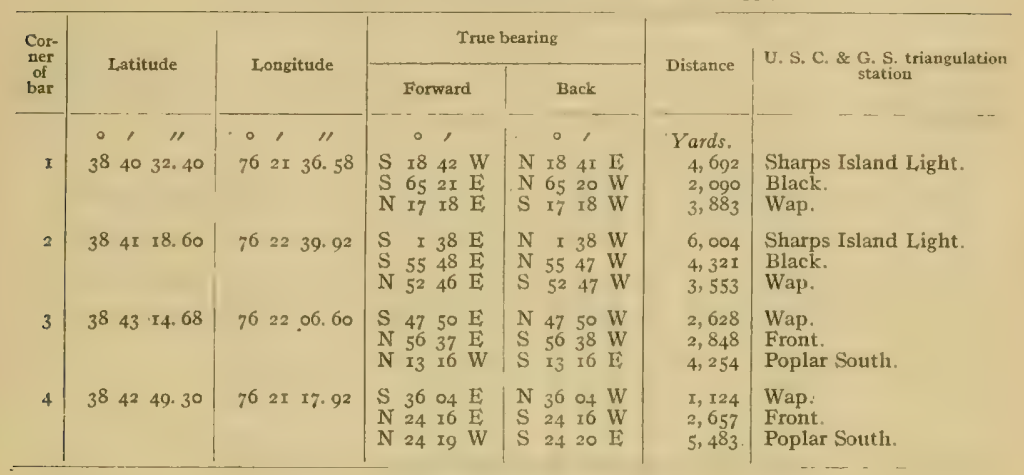

STONE:

(Chesapeake Bay-Vicinity Sharps Island-Charts Nos. 33 and 36.)

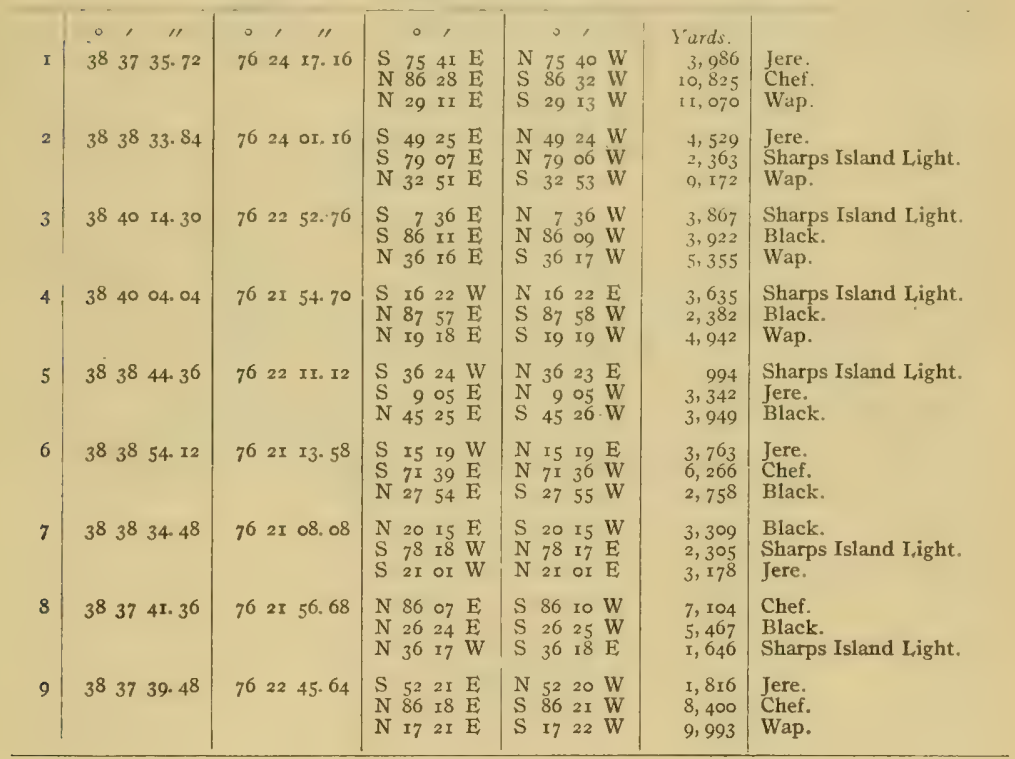


BOUNDARIES OF NATURAL OYSTER BARS-continued.

CLAY BANK.

(Chesapeake Bay-Vicinity Sharps Island-Charts Nos. 33 and 36.$)$

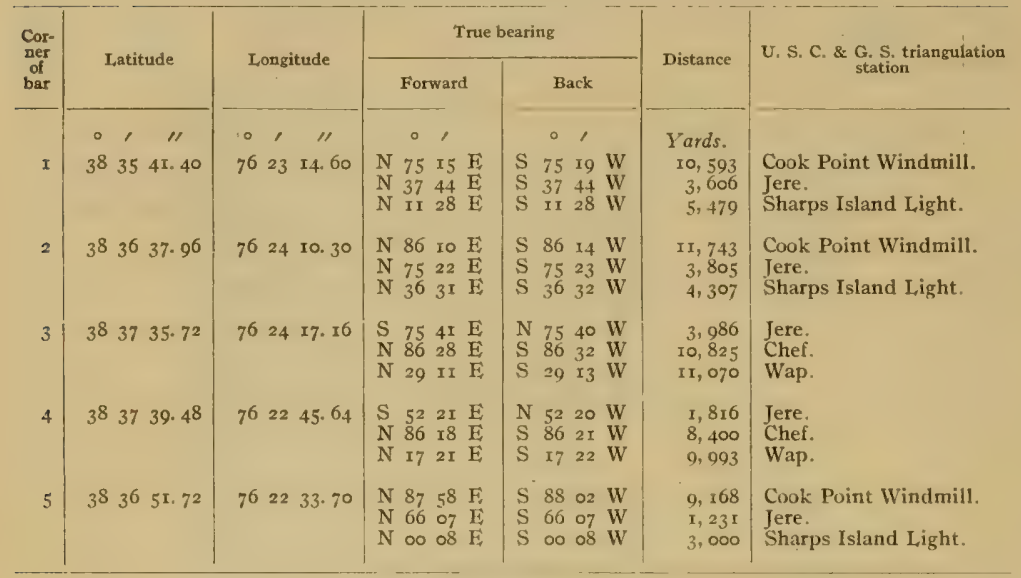

\section{SHARPS.}

(Outer Choptank River-Charts Nos. 33, 36, and 37.)

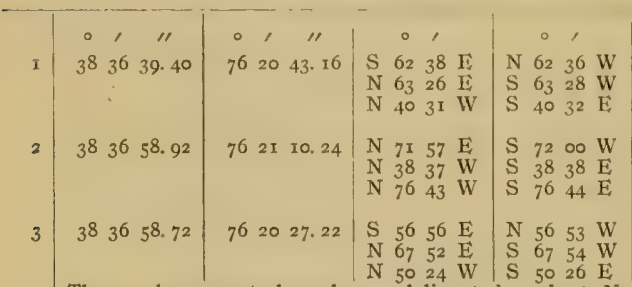

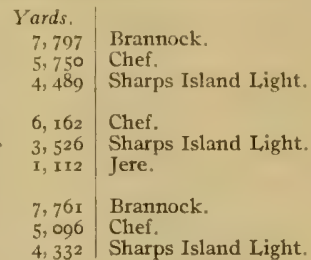

Thence along county boundary as delineated on charts Nos. 33,36 , and 37 to comer No. I. 
Survey of Oyster Bars, Talbot Counly, Md.

BOUNDARIES OF NATURAL OYSTER BARS-continued.

\section{BI,ACK WALNUT.}

(Outer Choptank River-Charts Nos. 33, 36, and 37.)

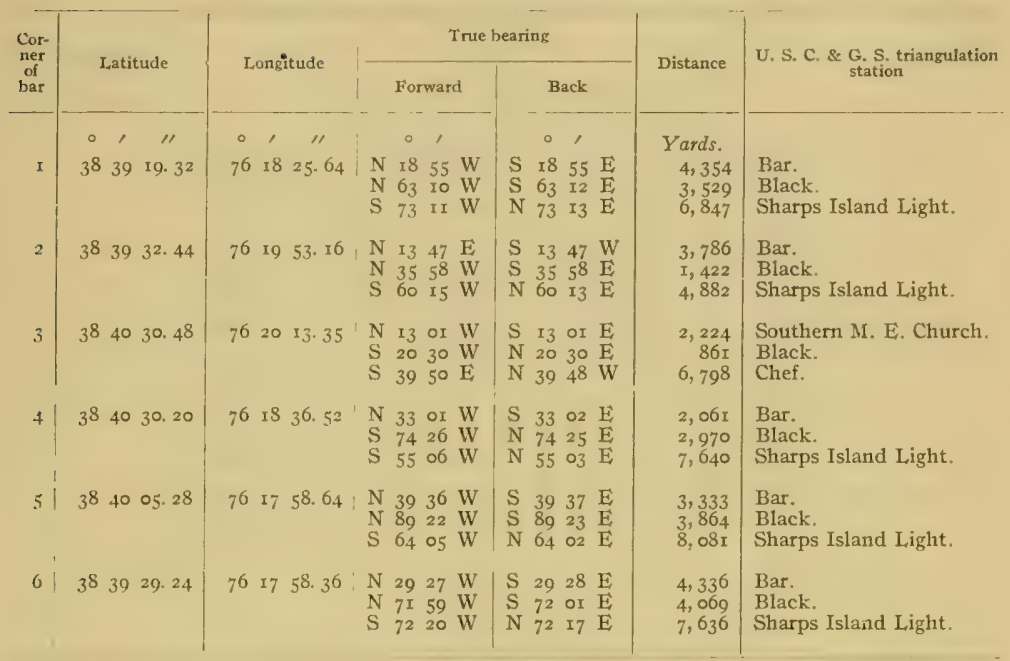

SANDS.

(Outer Choptank River-Chart No. 33.)

\begin{tabular}{|c|c|c|c|c|c|c|c|c|c|c|c|c|c|}
\hline & $\circ$ & , & $\prime \prime$ & $\circ$ & , & "I & & 0 & , & 0 & , & Yards. & \\
\hline I & $3^{8}$ & 40 & 05.28 & 76 & I7 & $5^{8} .64$ & $\begin{array}{l}\mathrm{N} \\
\mathrm{N} \\
\mathrm{S}\end{array}$ & $\begin{array}{l}39 \\
89 \\
64\end{array}$ & $\begin{array}{ll}36 & \mathrm{WV} \\
22 & \mathrm{~W} \\
05 & \mathrm{~W}\end{array}$ & $\begin{array}{ll}\mathrm{S} & 39 \\
\mathrm{~S} & 89 \\
\mathrm{~N} & 64\end{array}$ & $\begin{array}{ll}37 & \mathrm{E} \\
23 & \mathrm{E} \\
02 & \mathrm{E}\end{array}$ & $\begin{array}{l}3,333 \\
3,864 \\
8,081\end{array}$ & $\begin{array}{l}\text { Bar. } \\
\text { Black. } \\
\text { Sharps Island Light. }\end{array}$ \\
\hline 2 & $3^{8}$ & 40 & 30.20 & 76 & I8 & $36.5^{2}$ & $\begin{array}{l}\mathrm{N} \\
\mathrm{S} \\
\mathrm{S}\end{array}$ & $\begin{array}{l}33 \\
74 \\
55\end{array}$ & $\begin{array}{l}\text { or W } \\
26 \mathrm{~W} \\
06 \mathrm{~W}\end{array}$ & $\begin{array}{l}\mathrm{S} \\
\mathrm{N} \\
\mathrm{N} \\
\mathrm{N} \\
55\end{array}$ & $\begin{array}{l}02 \mathrm{E} \\
25 \mathrm{E} \\
03\end{array}$ & $\begin{array}{l}2,061 \\
2,970 \\
7,640\end{array}$ & $\begin{array}{l}\text { Bar. } \\
\text { Black. } \\
\text { Sharps Island Light. }\end{array}$ \\
\hline 3 & $3^{8}$ & $4 \mathrm{I}$ & 30,48 & 76 & 18 & 56.80 & $\begin{array}{l}\mathrm{N} \\
\mathrm{N} \\
\mathrm{S}\end{array}$ & $\begin{array}{l}28 \\
37 \\
62\end{array}$ & $\begin{array}{l}\text { I0 } \mathrm{E} \\
16 \mathrm{~W} \\
38 \mathrm{~W}\end{array}$ & $\begin{array}{ll}\mathrm{S} & 28 \\
\mathrm{~S} & 37 \\
\mathrm{~N} & 62\end{array}$ & $\begin{array}{l}\text { II } \mathrm{W} \\
\text { I7 } \mathrm{E} \\
38 \mathrm{E}\end{array}$ & $\begin{array}{r}3,509 \\
2,709 \\
662\end{array}$ & $\begin{array}{l}\text { Change igro. } \\
\text { Avalon. } \\
\text { Bar. }\end{array}$ \\
\hline 4 & $3^{8}$ & $4 \mathrm{I}$ & 48.84 & 76 & 17 & 50.20 & $\begin{array}{l}\mathrm{N} \\
\mathrm{N} \\
\mathrm{S}\end{array}$ & $\begin{array}{r}78 \\
3 \\
66\end{array}$ & $\begin{array}{l}54 \mathrm{H} \\
07 \mathrm{E} \\
20 \mathrm{~W}\end{array}$ & $\begin{array}{lr}S & 78 \\
S & 3 \\
N & 66\end{array}$ & $\begin{array}{ll}56 & \mathrm{~W} \\
07 & \mathrm{~W} \\
20 & \mathrm{E}\end{array}$ & $\begin{array}{l}2,791 \\
2,478 \\
2,304\end{array}$ & $\begin{array}{l}\text { Nelson } 3 . \\
\text { Change Igro. } \\
\text { Bar. }\end{array}$ \\
\hline 5 & $3^{8}$ & 40 & $5^{6.9} .92$ & 76 & 17 & 58.88 & $\begin{array}{l}\mathrm{N} \\
\mathrm{N} \\
\mathrm{S}\end{array}$ & $\begin{array}{r}I \\
68 \\
66\end{array}$ & $\begin{array}{ll}43 & \mathrm{E} \\
40 & \mathrm{~W} \\
I_{4} & \mathrm{~W}\end{array}$ & $\begin{array}{lr}S & I \\
S & 68 \\
N & 66\end{array}$ & $\begin{array}{ll}43 & W \\
4 I & \vec{E} \\
\text { I } 2 & E\end{array}$ & $\begin{array}{l}4,227 \\
2,274 \\
4,214\end{array}$ & $\begin{array}{l}\text { Change rgro. } \\
\text { Bar. } \\
\text { Black. }\end{array}$ \\
\hline
\end{tabular}


BOUNDARIES OF NATURAL OYSTER BARS-continued.

PLEASAN'T HILL.

(Outer Choptank River-Charts Nos. 33, 34, and 36.)

\begin{tabular}{|c|c|c|c|c|c|c|}
\hline \multirow{2}{*}{$\begin{array}{l}\text { Cor- } \\
\text { neer } \\
\text { of } \\
\text { bar }\end{array}$} & \multirow{2}{*}{ Latitude } & \multirow{2}{*}{ Longitude } & \multicolumn{2}{|c|}{ True bearing } & \multirow{2}{*}{ Distance" } & \multirow{2}{*}{ 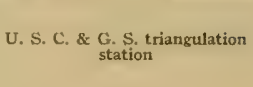 } \\
\hline & & & Forward & Back & & \\
\hline$I$ & $\begin{array}{ccc}0 & 1 \\
38 & 40 & 04.20\end{array}$ & $\begin{array}{ccc}\circ & \prime \prime \prime \\
76 & 17 & \text { or. } 08\end{array}$ & $\begin{array}{cccc} & 0 & 1 \\
N & 16 & 28 & \mathrm{E} \\
\mathrm{N} & 54 & 28 & \mathrm{~W} \\
\mathrm{~N} & 89 & 10 & \mathrm{~W}\end{array}$ & $\begin{array}{lccc} & 0 & , \\
\text { S } & 16 & 29 & \text { W } \\
\text { S } & 54 & 29 & \mathrm{E} \\
\text { S } & 89 & \text { II } & \mathrm{E}\end{array}$ & $\begin{array}{r}\text { Yards. } \\
4,24 \circ \\
4,480 \\
5,385\end{array}$ & $\begin{array}{l}\text { Nelson } 3 . \\
\text { Bar. } \\
\text { Black. }\end{array}$ \\
\hline 2 & $\begin{array}{llll}38 & 40 & 05.28\end{array}$ & 76 I7 58.64 & $\begin{array}{llll}\mathrm{N} & 39 & 36 & \mathrm{~W} \\
\mathrm{~N} & 89 & 22 & \mathrm{~W} \\
\mathrm{~S} & 64 & 05 & \mathrm{~W}\end{array}$ & $\begin{array}{llll}\mathrm{S} & 39 & 37 & \mathrm{E} \\
\mathrm{S} & 89 & 23 & \mathrm{E} \\
\mathrm{N} & 64 & 02 & \mathrm{E}\end{array}$ & $\begin{array}{l}3,333 \\
3,864 \\
8,08 \mathrm{I}\end{array}$ & $\begin{array}{l}\text { Bar. } \\
\text { Black. } \\
\text { Sharps Island Light. }\end{array}$ \\
\hline 3 & $\begin{array}{llll}3^{8} & 40 & 56.92\end{array}$ & $\begin{array}{llll}76 & 17 & 58.88\end{array}$ & $\begin{array}{llll}N & I & 43 & \mathrm{E} \\
N & 68 & 40 & \mathrm{~W} \\
\mathrm{~S} & 66 & \mathrm{I} & \mathrm{W}\end{array}$ & $\begin{array}{lrrr}\mathrm{S} & \mathrm{I} & 43 & \mathrm{~W} \\
\mathrm{~S} & 68 & 4 \mathrm{I} & \mathrm{E} \\
\mathrm{N} & 66 & \mathrm{I} & \mathrm{E}\end{array}$ & $\begin{array}{l}4,227 \\
2,274 \\
4,214\end{array}$ & $\begin{array}{l}\text { Change Igio. } \\
\text { Bar. } \\
\text { Black. }\end{array}$ \\
\hline 4 & $3^{8} \quad 40 \quad 57.06$ & $\begin{array}{llll}76 & \text { I7 } & 00.88\end{array}$ & $\begin{array}{llll}\mathrm{N} & 27 & 40 & \mathrm{E} \\
\mathrm{N} & 77 & 19 & \mathrm{~W} \\
\mathrm{~S} & 72 & 27 & \mathrm{~W}\end{array}$ & $\begin{array}{llll}\mathrm{S} & 27 & 4 \mathrm{I} & \mathrm{W} \\
\mathrm{S} & 77 & 20 & \mathrm{E} \\
\mathrm{N} & 72 & 25 & \mathrm{E}\end{array}$ & $\begin{array}{l}2,578 \\
3,743 \\
5,653\end{array}$ & $\begin{array}{l}\text { Nelson } 3 . \\
\text { Bar. } \\
\text { Black. }\end{array}$ \\
\hline 5 & $3^{8} \quad 40 \times 4.76$ & 76 I7 & $\begin{array}{llll}N & 17 & 56 & \mathrm{E} \\
N & 58 & 21 & \mathrm{~W} \\
\mathrm{~S} & 87 & 03 & \mathrm{~W}\end{array}$ & $\begin{array}{llll}\mathrm{S} & 17 & 56 & \mathrm{~W} \\
\mathrm{~S} & 58 & 23 & \mathrm{E} \\
\mathrm{N} & 87 & \text { or } & \mathrm{E}\end{array}$ & $\begin{array}{l}3,899 \\
4,286 \\
5,394\end{array}$ & $\begin{array}{l}\text { Nelson } 3 . \\
\text { Bar. } \\
\text { Black. }\end{array}$ \\
\hline
\end{tabular}

\section{CHURCH HILI.}

(Outer Choptank River-Charts Nos, 33 and 34.)

\begin{tabular}{|c|c|c|c|c|c|c|c|c|c|c|c|c|c|}
\hline & $\circ$ & , & 11 & $\circ$ & 1 & "I & o & , & 。 & , & & Yards. & \\
\hline & 38 & 40 & $5^{6 .} 9^{2}$ & 76 & I7 & $5^{8} .88$ & $\begin{array}{lr}\mathbf{N} & \mathbf{I} \\
\mathbf{N} & 68 \\
\mathrm{~S} & 66\end{array}$ & $\begin{array}{l}43 \mathrm{E} \\
40 \mathrm{~W} \\
14 \mathrm{~W}\end{array}$ & $\begin{array}{ll}S & I \\
S & 68 \\
N & 66\end{array}$ & $\begin{array}{l}43 \\
4 \mathrm{I} \\
\mathrm{I} 2\end{array}$ & $\begin{array}{l}\mathrm{W} \\
\mathrm{E} \\
\mathrm{E}\end{array}$ & $\begin{array}{l}4,227 \\
2,274 \\
4,214\end{array}$ & $\begin{array}{l}\text { Change Igıo. } \\
\text { Bar. } \\
\text { Black. }\end{array}$ \\
\hline & $3^{8}$ & $4 I$ & 48. 84 & 76 & $I_{7}$ & 59.20 & $\begin{array}{lr}\mathrm{N} & 78 \\
\mathrm{~N} & 3 \\
\mathrm{~S} & 66\end{array}$ & $\begin{array}{ll}54 & \mathrm{E} \\
07 & \mathrm{E} \\
20 \mathrm{~W}\end{array}$ & $\begin{array}{lr}\mathrm{S} & 78 \\
\mathrm{~S} & 3 \\
\mathrm{~N} & 66\end{array}$ & $\begin{array}{l}56 \\
07 \\
20\end{array}$ & $\begin{array}{l}\text { W } \\
\text { W } \\
\text { E }\end{array}$ & $\begin{array}{l}2,791 \\
2,478 \\
2,304\end{array}$ & $\begin{array}{l}\text { Nelson } 3 . \\
\text { Change I9Io. } \\
\text { Bar. }\end{array}$ \\
\hline 3 & $3^{8}$ & $4 I$ & 54.74 & 76 & I7 & ○., $7^{2}$ & $\begin{array}{ll}N & 74 \\
N & 3 I \\
S & 72\end{array}$ & $\begin{array}{ll}\text { Io } & \mathrm{E} \\
48 & \mathrm{~W} \\
55 & \mathrm{~W}\end{array}$ & $\begin{array}{ll}\mathrm{S} & 74 \\
\mathrm{~S} & 3 \mathrm{I} \\
\mathrm{N} & 72\end{array}$ & $\begin{array}{l}\text { II } \\
48 \\
54\end{array}$ & $\begin{array}{l}\text { W } \\
\mathrm{E} \\
\mathrm{E}\end{array}$ & $\begin{array}{l}1,240 \\
2,677 \\
3,824\end{array}$ & $\begin{array}{l}\text { Nelson } 3 . \\
\text { Change I9Io. } \\
\text { Bar. }\end{array}$ \\
\hline & $3^{8}$ & 40 & 57.06 & 76 & I7 & oo. 88 & $\begin{array}{ll}\mathrm{N} & 27 \\
\mathrm{~N} & 77 \\
\mathrm{~S} & 72\end{array}$ & $\begin{array}{ll}40 & \mathrm{E} \\
\text { I9 } & \mathrm{W} \\
27 & \mathrm{~W}\end{array}$ & $\begin{array}{ll}\mathrm{S} & 27 \\
\mathrm{~S} & 77 \\
\mathrm{~N} & 72\end{array}$ & $\begin{array}{l}4 I \\
20 \\
25\end{array}$ & $\begin{array}{l}\text { W } \\
\mathrm{E} \\
\mathrm{E}\end{array}$ & $\begin{array}{l}2,578 \\
3,743 \\
5,653\end{array}$ & $\begin{array}{l}\text { Nelson } 3 . \\
\text { Bar. } \\
\text { Black. }\end{array}$ \\
\hline
\end{tabular}


Survey of Oyster Bars, Talbot Couniy, $M d$.

BOUNDARIES OF NATURAI, OYSTER BARS-continuEd.

WILD CHERRY TREE.

(Entrance Harris Creek-Chart No. 33.)

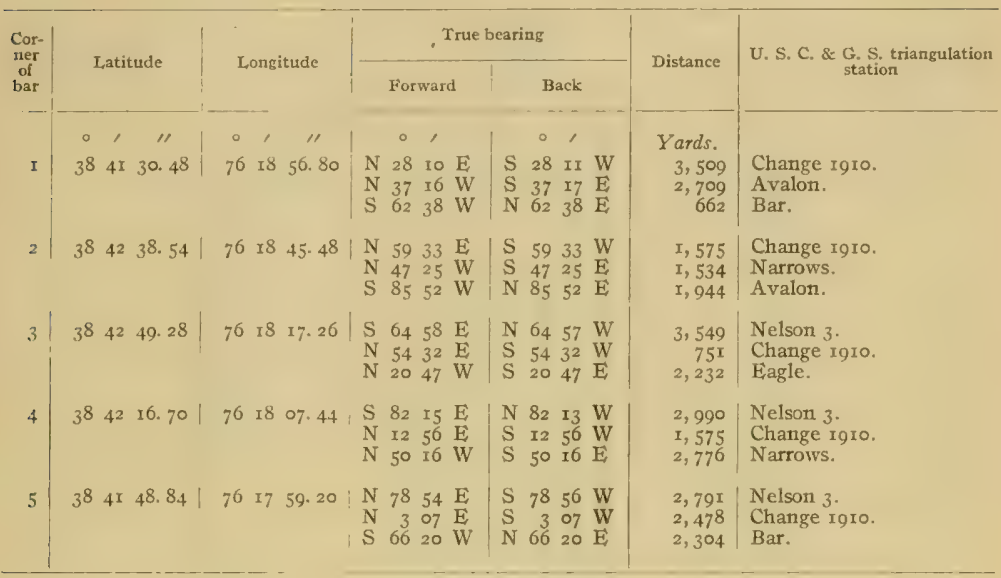

TURNROW.

(Entrance Harris Creek-Charts Nos. 33 and 34.)

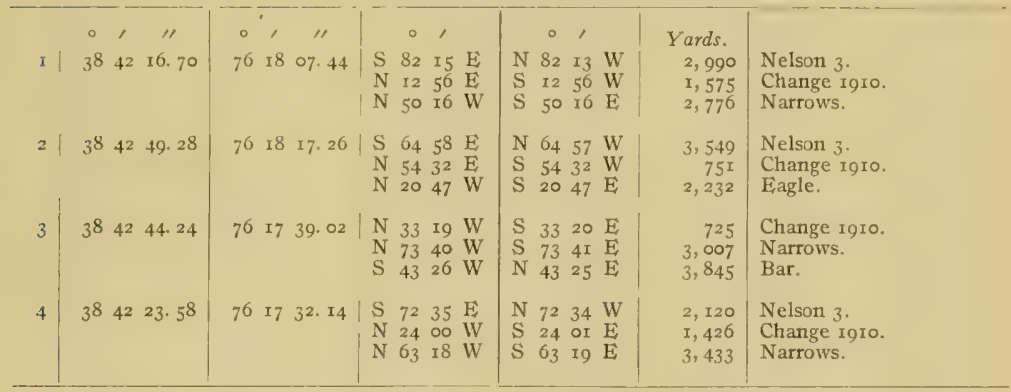


BOUNDARIES OF NATURAL OYSTER BARS-cONTINUEd.

TILGHMAN WHARH.

(Entrance Harris Creek-Chart No. 33.)

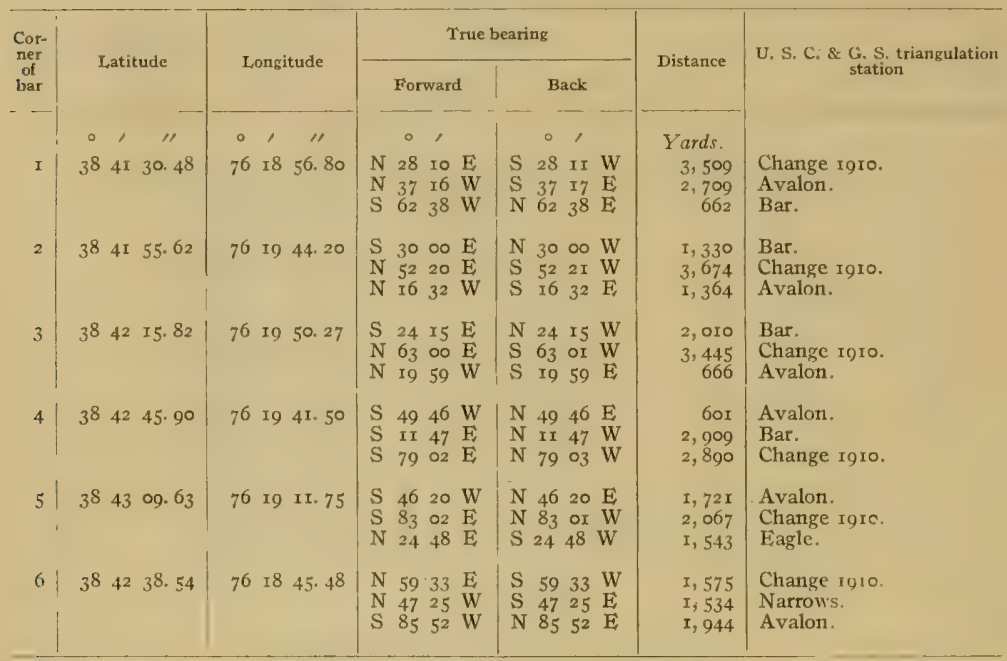

\section{CHANGE.}

(Harris Creek-Chart No. 33.)

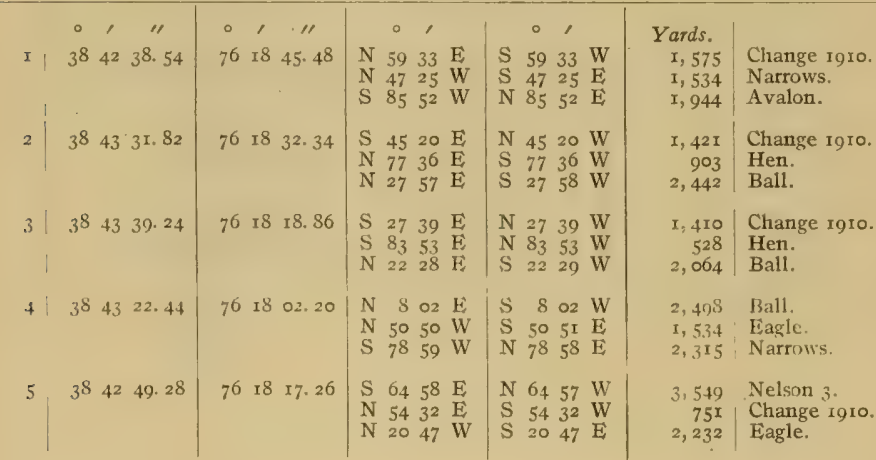


BOUNDARIES OF NATURAL, OYSTER BARS-continued.

\section{FAGLE POINT.}

(Harris Creek-Chart No. 33.)

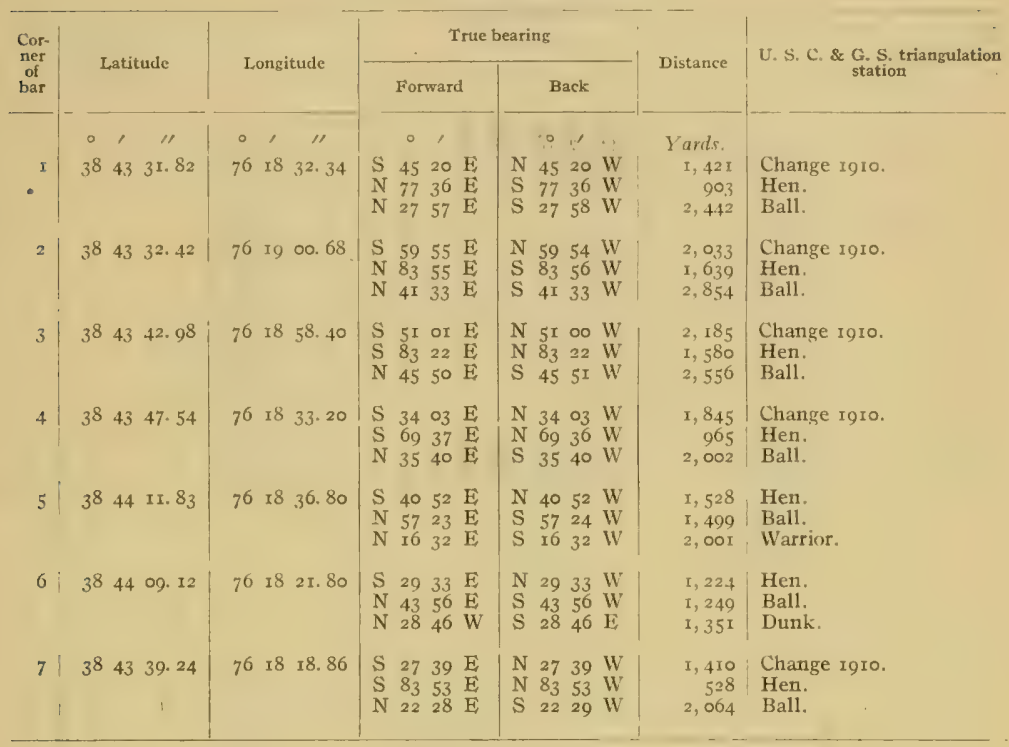

TURKEY NECK.

(Harris Creek-Chart No. 33.)

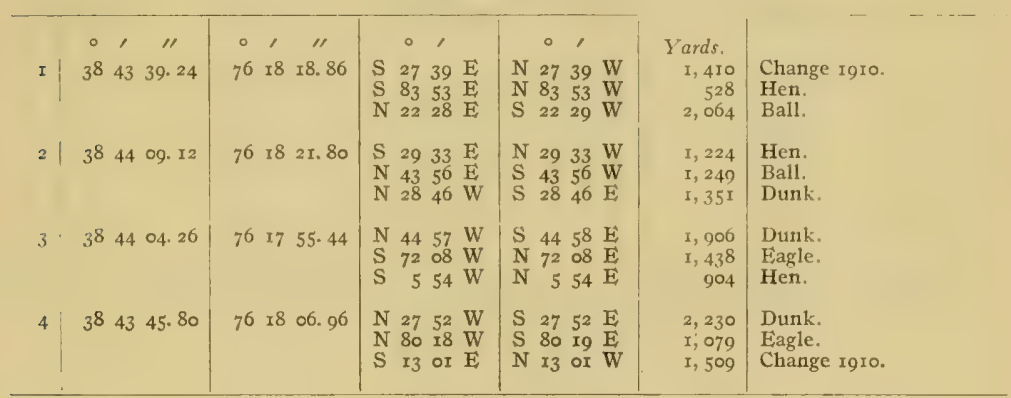


BOUNDARIES OF NATURAL, OYSTER BARS-continued.

MILL POINT.

(Harris Creek-Chart No. 33.)

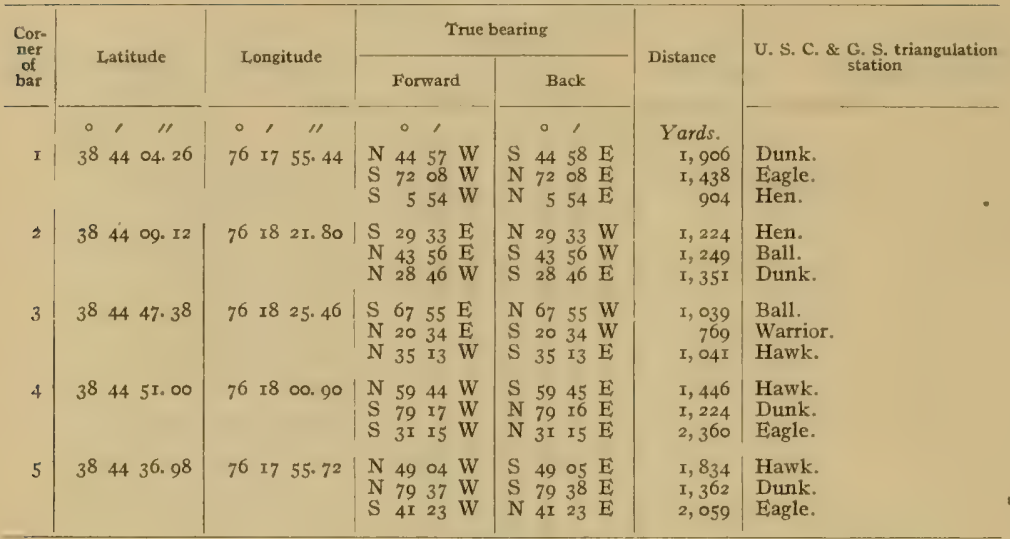

\section{HUNTS.}

(Harris Creek-Chart No. 33.)

\begin{tabular}{|c|c|c|c|c|c|c|c|c|c|c|c|c|c|c|}
\hline I & $\begin{array}{c}0 \\
38\end{array}$ & $\begin{array}{l}\prime \\
44\end{array}$ & $\begin{array}{c}\text { "I } \\
\text { Og. I2 }\end{array}$ & $\begin{array}{c}\circ \\
76\end{array}$ & 18 & 21.80 & $\begin{array}{l}\mathrm{S} \\
\mathrm{N} \\
\mathrm{N}\end{array}$ & $\begin{array}{c}0 \\
29 \\
43 \\
28\end{array}$ & $\begin{array}{ll}33 & \mathrm{E} \\
56 & \mathrm{E} \\
46 & \mathrm{~W}\end{array}$ & $\begin{array}{l}\mathrm{N} \\
\mathrm{S} \\
\mathrm{S}\end{array}$ & $\begin{array}{c}0 \\
29 \\
43 \\
28\end{array}$ & $\begin{array}{ll}33 & \mathrm{~W} \\
56 & \mathrm{~W} \\
46 & \mathrm{E}\end{array}$ & $\begin{array}{l}\text { Yards. } \\
\qquad \text { I, } 224 \\
\text { I, } 249 \\
\text { I, } 35 \text { I }\end{array}$ & $\begin{array}{l}\text { Hen. } \\
\text { Ball. } \\
\text { Dunk. }\end{array}$ \\
\hline 2 & $3^{8}$ & 44 & Ir. $8 \dot{3}$ & 76 & I 8 & 36.80 & $\begin{array}{l}\mathrm{S} \\
\mathrm{N} \\
\mathrm{N}\end{array}$ & $\begin{array}{l}40 \\
57 \\
16\end{array}$ & $\begin{array}{ll}52 & \mathrm{E} \\
23 & \mathrm{E} \\
32 & \mathrm{E}\end{array}$ & $\begin{array}{l}\mathrm{N} \\
\mathrm{S} \\
\mathrm{S}\end{array}$ & $\begin{array}{l}40 \\
57 \\
16\end{array}$ & $\begin{array}{ll}52 & W \\
24 & W \\
32 & W\end{array}$ & $\begin{array}{l}\text { I, } 528 \\
\text { I, } 499 \\
2, \text { oor }\end{array}$ & $\begin{array}{l}\text { Hen. } \\
\text { Ball. } \\
\text { Warrior. }\end{array}$ \\
\hline 3 & $3^{8}$ & 44 & $x 9.42$ & 76 & 18 & 54,98 & $\begin{array}{l}\mathrm{S} \\
\mathrm{N} \\
\mathrm{N}\end{array}$ & $\begin{array}{l}46 \\
72 \\
32\end{array}$ & $\begin{array}{ll}22 & \mathrm{E} \\
26 & \mathrm{E} \\
\mathrm{I} 6 & \mathrm{E}\end{array}$ & $\begin{array}{l}N \\
S \\
S\end{array}$ & $\begin{array}{l}46 \\
72 \\
32\end{array}$ & $\begin{array}{ll}2 I & W \\
27 & W \\
\text { I } 6 & W\end{array}$ & $\begin{array}{l}2,045 \\
I, 828 \\
I, 966\end{array}$ & $\begin{array}{l}\text { Hen. } \\
\text { Ball. } \\
\text { Wartior. }\end{array}$ \\
\hline 4 & $3^{8}$ & 44 & 25.50 & 76 & 18 & 42.80 & $\begin{array}{l}\mathrm{S} \\
\mathrm{N} \\
\mathrm{N}\end{array}$ & $\begin{array}{l}35 \\
76 \\
26\end{array}$ & $\begin{array}{ll}37 & \mathrm{E} \\
\mathrm{x} & \mathrm{E} \\
32 & \mathrm{E}\end{array}$ & $\begin{array}{l}\mathrm{N} \\
\mathrm{S} \\
\mathrm{S}\end{array}$ & $\begin{array}{l}35 \\
76 \\
26\end{array}$ & $\begin{array}{ll}37 & W \\
I_{7} & W \\
32 & W\end{array}$ & $\begin{array}{l}\text { I, } 988 \\
\text { I, } 463 \\
\text { I, } 629\end{array}$ & $\begin{array}{l}\text { Hen. } \\
\text { Ball. } \\
\text { Warrior. }\end{array}$ \\
\hline 5 & $3^{8}$ & 44 & $33 \cdot 24$ & 76 & 18 & 44.02 & $\begin{array}{l}\mathrm{S} \\
\mathrm{N} \\
\mathrm{N}\end{array}$ & $\begin{array}{l}32 \\
86 \\
32\end{array}$ & $\begin{array}{ll}23 & \mathrm{E} \\
37 & \mathrm{E} \\
26 & \mathrm{E}\end{array}$ & $\begin{array}{l}\mathrm{N} \\
\mathrm{S} \\
\mathrm{S}\end{array}$ & $\begin{array}{l}32 \\
86 \\
32\end{array}$ & $\begin{array}{ll}22 & W \\
37 & W \\
26 & W\end{array}$ & $\begin{array}{l}2,223 \\
1,456 \\
1,417\end{array}$ & $\begin{array}{l}\text { Hetl. } \\
\text { Ball. } \\
\text { Warrior. }\end{array}$ \\
\hline 6 & $3^{8}$ & 44 & 38.50 & 76 & 18 & 55.12 & $\begin{array}{l}\mathrm{S} \\
\mathrm{S} \\
\mathrm{N}\end{array}$ & $\begin{array}{l}35 \\
87 \\
45\end{array}$ & $\begin{array}{ll}50 & \vec{F} \\
00 & E \\
57 & E\end{array}$ & $\begin{array}{l}\mathrm{N} \\
\mathrm{N} \\
\mathrm{S}\end{array}$ & $\begin{array}{l}35 \\
86 \\
45\end{array}$ & $\begin{array}{ll}49 & W \\
59 & W \\
57 & W\end{array}$ & $\begin{array}{l}2,534 \\
\text { I, } 749 \\
\text { I, } 465\end{array}$ & $\begin{array}{l}\text { Hén. } \\
\text { Ball. } \\
\text { Warrior. }\end{array}$ \\
\hline & $\begin{array}{l}\text { The } \\
\text { ar }\end{array}$ & $\begin{array}{l}\text { ence } \\
\text { ny c }\end{array}$ & $\begin{array}{l}\text { frow } \\
\text { creek, }\end{array}$ & $\begin{array}{l}\text { mer } \\
\text { ve, }\end{array}$ & $\begin{array}{l}\text { No } \\
\text { or ir }\end{array}$ & $\begin{array}{l}\text { o. } 6 \text { alo } \\
\text { nlet les }\end{array}$ & & $\begin{array}{l}\text { the } \\
\text { han }\end{array}$ & $\begin{array}{l}\text { mean ic } \\
\text { roo yar }\end{array}$ & $\begin{array}{l}\text { W- } \\
\text { ds in }\end{array}$ & wate & $\begin{array}{l}\text { er line } \\
\text { idth at }\end{array}$ & $\begin{array}{l}\text { the shore } \\
\text { s mouth a }\end{array}$ & $\begin{array}{l}\text { to corner } \\
\text { low tide. }\end{array}$ \\
\hline 7 & $3^{8}$ & 44 & 44.25 & 76 & 18 & 46.42 & $\begin{array}{l}\mathrm{S} \\
\mathrm{N} \\
\mathrm{N}\end{array}$ & $\begin{array}{r}79 \\
44 \\
2\end{array}$ & $\begin{array}{ll}2 \mathrm{I} & \mathrm{E} \\
57 & \mathrm{E} \\
48 & \mathrm{~W}\end{array}$ & $\begin{array}{l}\mathrm{N} \\
\mathrm{S} \\
\mathrm{S}\end{array}$ & $\begin{array}{r}79 \\
44 \\
2\end{array}$ & $\begin{array}{l}20 \mathrm{~W} \\
57 \mathrm{~W} \\
48 \\
\mathrm{E}\end{array}$ & $\begin{array}{r}\text { I, } 543 \\
\text { I, } 166 \\
95^{8}\end{array}$ & $\begin{array}{l}\text { Ball. } \\
\text { Warrior. } \\
\text { Hawk. }\end{array}$ \\
\hline 8 & $3^{8}$ & 44 & $47 \cdot 38$ & 76 & I 8 & 25.46 & $\begin{array}{l}\mathrm{S} \\
\mathrm{N} \\
\mathrm{N}\end{array}$ & $\begin{array}{l}67 \\
20 \\
35\end{array}$ & $\begin{array}{ll}55 & \mathrm{E} \\
34 & \mathrm{E} \\
\mathrm{r}_{3} & \mathrm{~W}\end{array}$ & $\begin{array}{l}\mathrm{N} \\
\mathrm{S} \\
\mathrm{S}\end{array}$ & $\begin{array}{l}67 \\
20 \\
35\end{array}$ & $\begin{array}{ll}55 & W \\
34 & W \\
\text { I3 } & E\end{array}$ & $\begin{array}{r}x, 039 \\
769 \\
x, 041\end{array}$ & $\begin{array}{l}\text { Ball. } \\
\text { Warrior. } \\
\text { Hawk. }\end{array}$ \\
\hline
\end{tabular}


BOUNDARIES OF NATURAL OYSTER BARS-cOIIInUEd.

SETHS POINT.

(Harris Creek-Chart No. 33.)

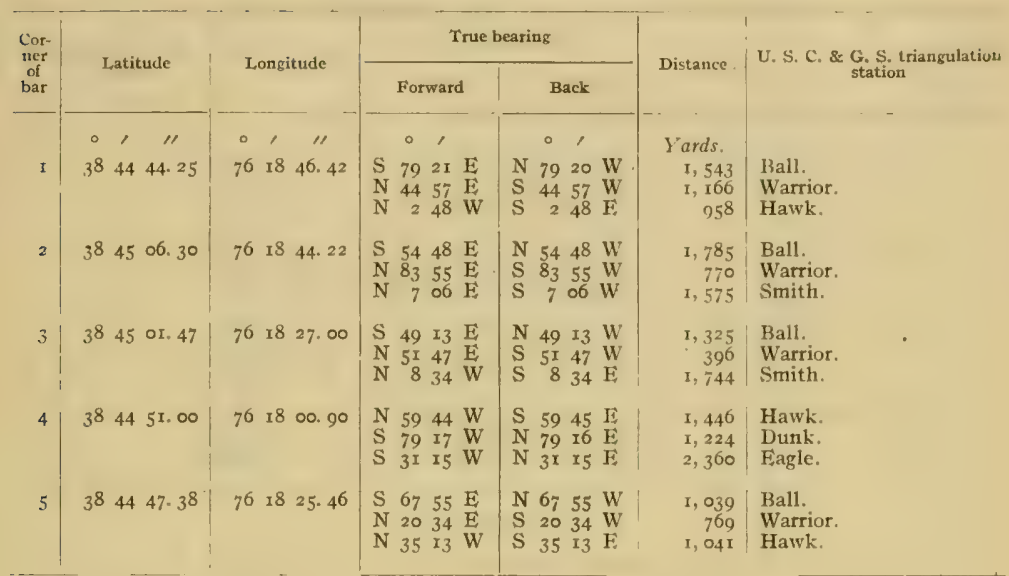

\section{LODGES.}

(Harris Creek-Chart No. 33.)

\begin{tabular}{|c|c|c|c|c|c|c|c|c|c|c|c|c|c|c|}
\hline I & $3^{8}$ & $\begin{array}{c}1 \\
45\end{array}$ & $\begin{array}{c}\text { "I } \\
\text { or. } 47\end{array}$ & $\begin{array}{c}0 \\
76\end{array}$ & 18 & 27.00 & $\begin{array}{l}\mathrm{S} \\
\mathrm{N} \\
\mathrm{N}\end{array}$ & $\begin{array}{c}0 \\
49 \\
51 \\
8\end{array}$ & $\begin{array}{ll}I_{3} & \mathrm{E} \\
47 & \mathrm{E} \\
34 & \mathrm{~W}\end{array}$ & $\begin{array}{l}\mathrm{N} \\
\mathrm{S} \\
\mathrm{S}\end{array}$ & $\begin{array}{c}0 \\
49 \\
51 \\
8\end{array}$ & $\begin{array}{l}\text { I3 W } \\
47 \mathrm{~W} \\
34 \mathrm{E}\end{array}$ & $\begin{array}{r}\text { Yards. } \\
x, 325 \\
396 \\
I, 744\end{array}$ & $\begin{array}{l}\text { Ball. } \\
\text { Warrior. } \\
\text { Smith. }\end{array}$ \\
\hline 2 & $3^{8}$ & 45 & o6. 30 & 76 & 18 & 44. 22 & $\begin{array}{l}\mathrm{S} \\
\mathrm{N} \\
\mathrm{N}\end{array}$ & $\begin{array}{r}54 \\
83 \\
7\end{array}$ & $\begin{array}{ll}48 & \mathrm{E} \\
55 & \mathrm{E} \\
06 & \mathrm{E}\end{array}$ & $\begin{array}{l}\mathrm{N} \\
\mathrm{S} \\
\mathrm{S}\end{array}$ & $\begin{array}{r}54 \\
83 \\
7\end{array}$ & $\begin{array}{ll}48 & W \\
55 & W \\
06 & W\end{array}$ & $\begin{array}{r}\text { I, } 785 \\
770 \\
I, 575\end{array}$ & $\begin{array}{l}\text { Ball. } \\
\text { Warrior. } \\
\text { Smith. }\end{array}$ \\
\hline 3 & $3^{8}$ & 45 & 39.46 & 76 & 18 & 54.80 & $\begin{array}{l}\mathrm{S} \\
\mathrm{S} \\
\mathrm{N}\end{array}$ & $\begin{array}{l}45 \\
82 \\
67\end{array}$ & $\begin{array}{ll}\text { I3 } & \mathrm{E} \\
54 & \mathrm{E} \\
38 & \mathrm{E}\end{array}$ & $\begin{array}{l}\mathrm{N} \\
\mathrm{N} \\
\mathrm{S}\end{array}$ & $\begin{array}{l}45 \\
82 \\
67\end{array}$ & $\begin{array}{ll}I_{3} & W \\
54 & W \\
39 & W\end{array}$ & $\begin{array}{l}I, 472 \\
I, 53 I \\
2,054\end{array}$ & $\begin{array}{l}\text { Warrior. } \\
\text { Edmond. } \\
\text { Dan. }\end{array}$ \\
\hline 4 & $3^{8}$ & 45 & $20: 25$ & 76 & r8 & 10. 74 & $\begin{array}{l}\mathrm{N} \\
\mathrm{S} \\
\mathrm{S}\end{array}$ & $\begin{array}{l}32 \\
75 \\
37\end{array}$ & $\begin{array}{ll}\text { I2 } & W \\
22 & W \\
49 & W\end{array}$ & $\begin{array}{l}\mathrm{S} \\
\mathrm{N}\end{array}$ & $\begin{array}{l}32 \\
75 \\
37\end{array}$ & $\begin{array}{ll}12 & E \\
22 & E \\
49 & E\end{array}$ & $\begin{array}{l}\mathrm{I}, 292 \\
\mathrm{I}, 020 \\
\mathrm{I}, 537\end{array}$ & $\begin{array}{l}\text { Smith. } \\
\text { Hawk. } \\
\text { Dunk. }\end{array}$ \\
\hline
\end{tabular}


BOUNDARIES OF NATURAL, OYSTER BARS-continUEd.

WALNUT.

(Harris Creck-Chart No. 33.)

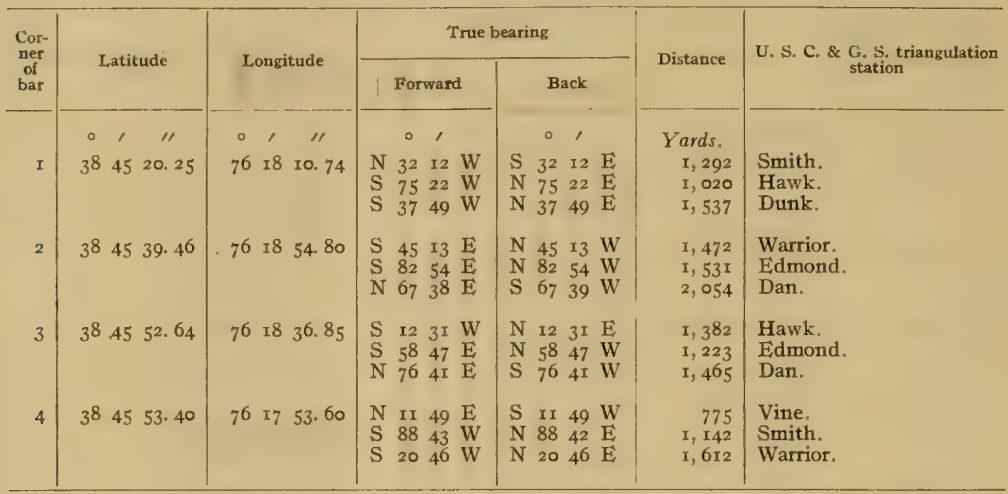

\section{SMITH POINT.}

(Harris Creek-Chart No. 33.)

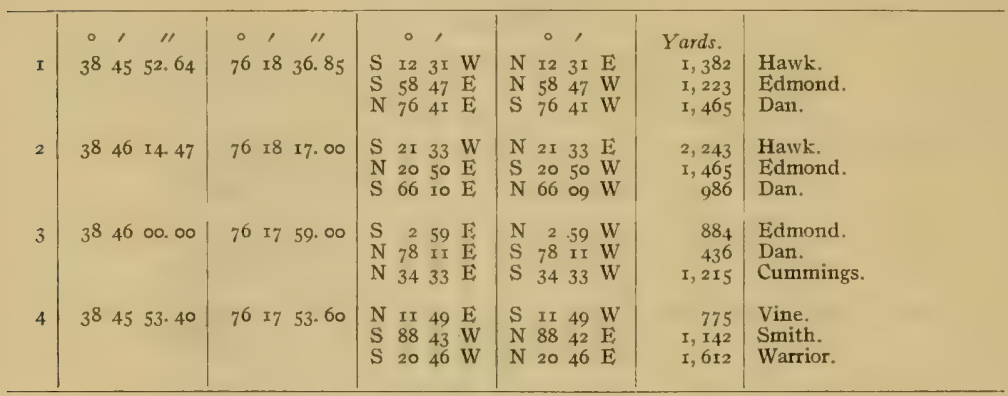


BOUNDARIES OF NATURAL OYSTER BARS-continted.

LITTLF NECK.

(Harris Creek-Charts Nos. 33 and 34.)

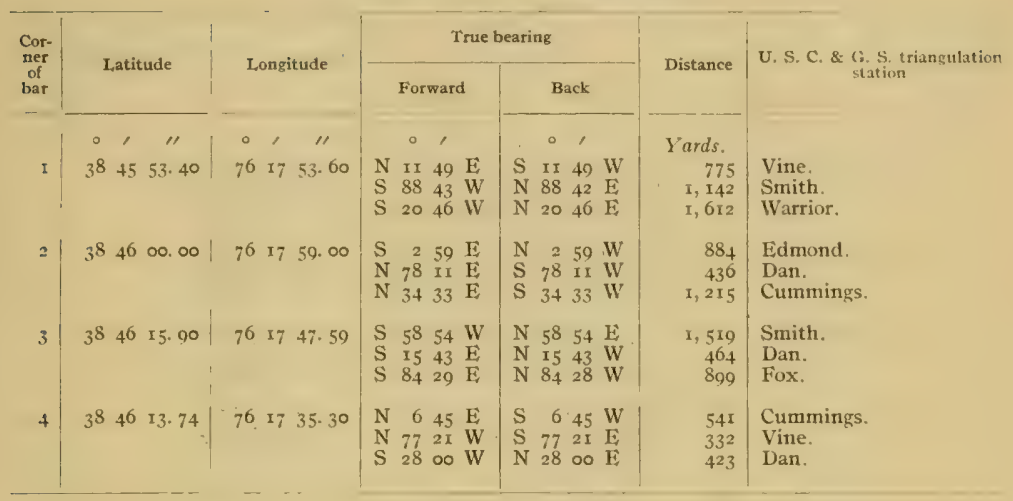

\section{RABBIT ISLAND.}

(Harris Creck-Chart No. 34.)

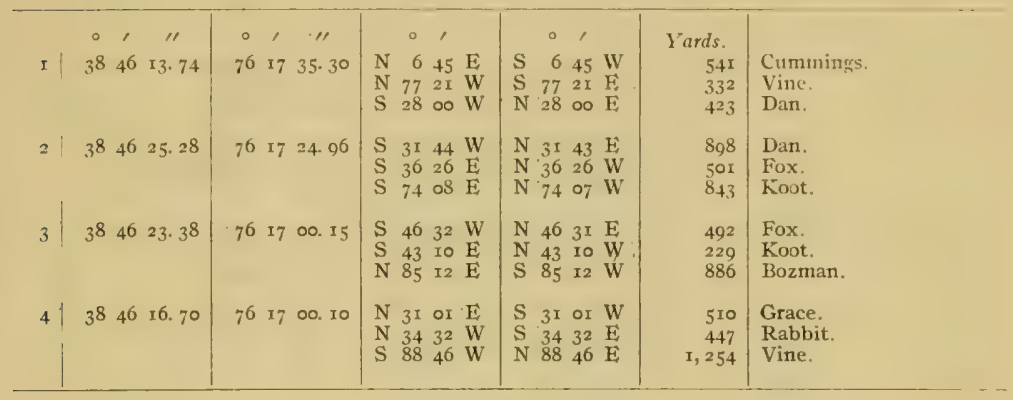


BOUNDARIES OF NATURAL OYSTER BARS - continued.

DAWSON.

(Outer Choptank River-Chart No. 37.)

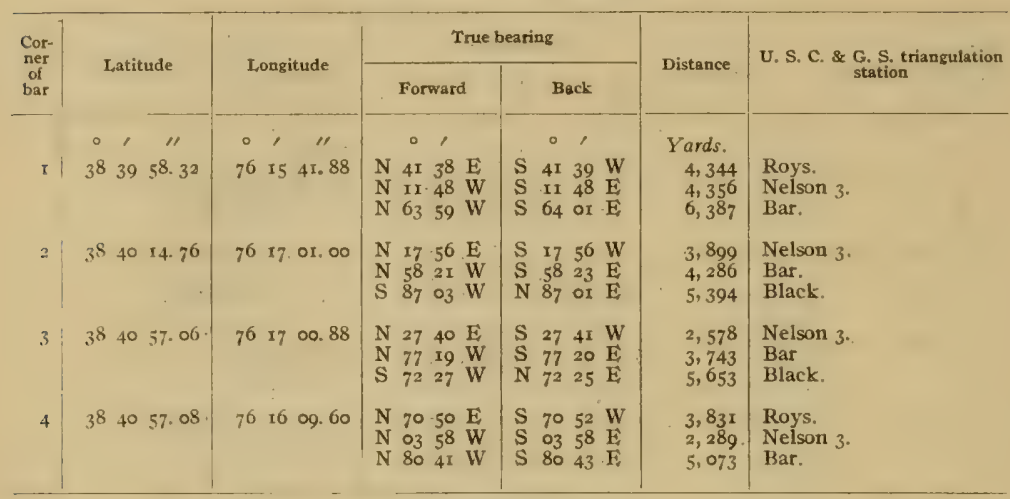

FRANCE.

(Outer (hoptank River-Chart No. 34.)

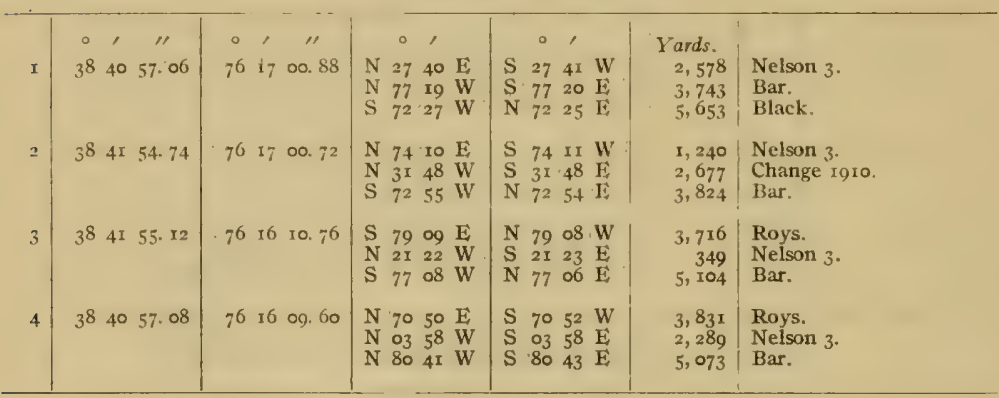


Survey of Oyster Bars, Talbot Couniy, Md.

BOUNDARIES OF NATURAL OYSTER BARS - continued.

GREAT MARSH.

(Outer Choptank River-Chart No. 34.)

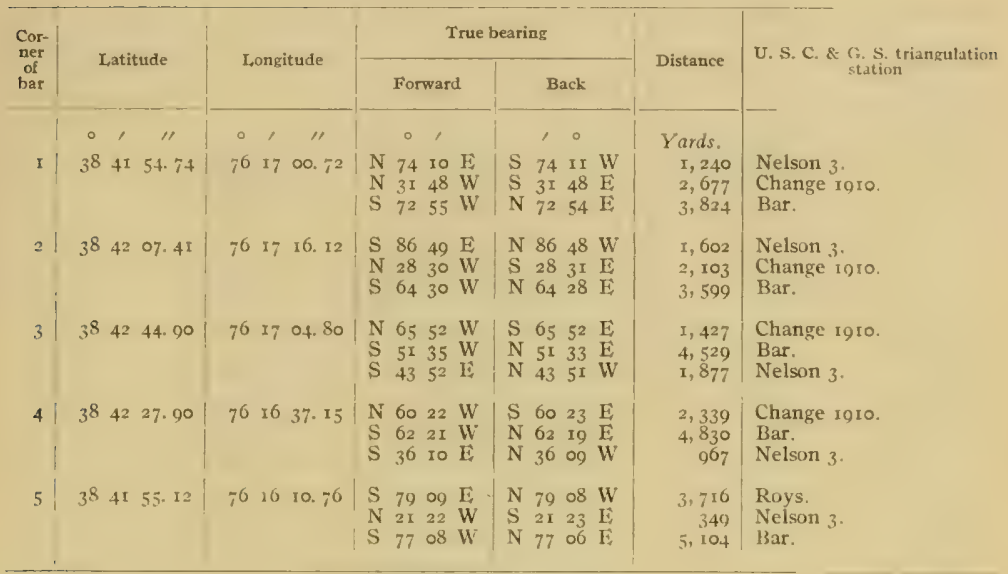

\section{LONG POINT WOODS.}

(Broad Creek-Chart No. 34.)

\begin{tabular}{|c|c|c|c|c|c|c|c|c|c|c|c|c|}
\hline I i & $\begin{array}{c}\circ \\
3^{8}\end{array}$ & $\begin{array}{l}1 \\
4 \mathrm{~T}\end{array}$ & $\begin{array}{c}\prime \prime \\
44.94\end{array}$ & $\begin{array}{c}\circ \\
76\end{array}$ & ' & $\begin{array}{c}11 \\
29.7^{6}\end{array}$ & $\begin{array}{lc} & 0 \\
S & 82 \\
N & 41 \\
N & 61\end{array}$ & $\begin{array}{ll}\prime \\
06 & \mathrm{E} \\
I_{7} & \mathrm{E} \\
05 & W\end{array}$ & $\begin{array}{ll} & 0 \\
N & 82 \\
\text { S } & 41 \\
\text { S } & 61\end{array}$ & $\begin{array}{ll}1 \\
\text { o5 } \mathrm{W} \\
\text { I7 } \mathrm{W} \\
\text { o6 } \mathrm{E}\end{array}$ & $\begin{array}{l}\text { Yards. } \\
2,591 \\
2,732 \\
1,383\end{array}$ & $\begin{array}{l}\text { Roy's. } \\
\text { Peary. } \\
\text { Nelson } 3 .\end{array}$ \\
\hline 2 & $3^{8}$ & 42 & 29. 78 & 76 & 16 & 05.00 & $\begin{array}{ll}S & 61 \\
N & 78 \\
N & 16\end{array}$ & $\begin{array}{l}53 \mathrm{E} \\
48 \mathrm{~F} \\
07 \mathrm{~W}\end{array}$ & $\begin{array}{ll}\text { N } & 6 \mathrm{r} \\
\mathrm{S} & 78 \\
\mathrm{~S} & 16\end{array}$ & $\begin{array}{ll}52 & W \\
49 & W \\
07 & E\end{array}$ & $\begin{array}{l}3,965 \\
2,786 \\
1,130\end{array}$ & $\begin{array}{l}\text { Roys. } \\
\text { Peary. } \\
\text { Annette. }\end{array}$ \\
\hline 31 & $3^{8}$ & 42 & 57.80 & 76 & 16 & 04.68 & $\begin{array}{lr}\mathrm{S} & 9 \\
\mathrm{~N} & 8 \mathrm{I} \\
\mathrm{N} & 2\end{array}$ & $\begin{array}{l}09 \mathrm{~W} \\
55 \mathrm{E} \\
20 \mathrm{~W}\end{array}$ & $\begin{array}{lr}\text { N } & 9 \\
\text { S } & 8 \mathrm{r} \\
\mathrm{S} & 2\end{array}$ & $\begin{array}{l}09 \mathrm{E} \\
56 \mathrm{~W} \\
20 \mathrm{E}\end{array}$ & $\begin{array}{l}\mathrm{I}, 8 \mathrm{II} \\
2,633 \\
\mathrm{I}, 140\end{array}$ & $\begin{array}{l}\text { Nelson } 3 . \\
\text { Cook. } \\
\text { Myrtle. }\end{array}$ \\
\hline 4 & $3^{8}$ & 42 & 38,10 & 76 & 15 & 4I. 50 & $\begin{array}{ll}\text { N } & 62 \\
N & 49 \\
\text { S } & 38\end{array}$ & $\begin{array}{ll}35 & \mathrm{E} \\
\mathrm{I}_{5} & \mathrm{~W} \\
42 & W\end{array}$ & $\begin{array}{ll}\text { S } & 62 \\
\text { S } & 49 \\
\text { N } & 38\end{array}$ & $\begin{array}{ll}35 & W \\
\mathrm{I} 6 & \mathrm{E} \\
42 & \mathrm{E}\end{array}$ & $\begin{array}{l}2,247 \\
1,234 \\
r, 440\end{array}$ & $\begin{array}{l}\text { Cook. } \\
\text { Annette. } \\
\text { Nelson } 3 .\end{array}$ \\
\hline 5 & $3^{8}$ & $4 I$ & 54.64 & 76 & I 5 & 07.08 & $\begin{array}{ll}\mathrm{S} & 70 \\
\mathrm{~N} & 34 \\
\mathrm{~N} & 79\end{array}$ & $\begin{array}{ll}5 \text { I } & \mathrm{E} \\
52 & \mathrm{E} \\
\text { I9 } & \mathrm{W}\end{array}$ & $\begin{array}{ll}\text { N } & 70 \\
\text { S } & 34 \\
\text { S } & 79\end{array}$ & $\begin{array}{ll}50 & W \\
53 & W \\
20 & E\end{array}$ & $\begin{array}{l}2,082 \\
2,104 \\
1,843\end{array}$ & $\begin{array}{l}\text { Roys. } \\
\text { Peary. } \\
\text { Nelson } 3 .\end{array}$ \\
\hline
\end{tabular}


BOUNDARIES OF NATURAL OYSTER BARS-continued.

GREAT BAR.

(Broad Creek-Chart No. 34.)

\begin{tabular}{|c|c|c|c|c|c|c|c|c|}
\hline \multirow{2}{*}{$\begin{array}{l}\text { Cor- } \\
\text { ner } \\
\text { of } \\
\text { bar }\end{array}$} & \multirow{2}{*}{ Latitude } & \multirow{2}{*}{ Longitude } & \multicolumn{4}{|c|}{ True beating } & \multirow{2}{*}{ Distance } & \multirow{2}{*}{$\begin{array}{c}\text { U. S. C. \& G. S, triangulation } \\
\text { station }\end{array}$} \\
\hline & & & & orward & & Back & & \\
\hline I & $\begin{array}{ccc}\circ & \prime \prime \\
3^{8} & 42 & 16.56\end{array}$ & 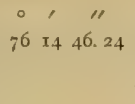 & $\begin{array}{lc} & 0 \\
\mathrm{~S} & 44 \\
\mathrm{~N} & 33 \\
\mathrm{~N} & 57\end{array}$ & $\begin{array}{lll}4 & 53 & \mathrm{E} \\
3 & 28 & \mathrm{E} \\
7 & 24 & \mathrm{~W}\end{array}$ & $\begin{array}{ll} & \circ \\
\text { N } & 44 \\
\text { S } & 33 \\
\text { S } & 57\end{array}$ & $\begin{array}{ccc}0 & 1 & \\
44 & 52 & W \\
33 & 28 & W \\
57 & 25 & \mathrm{E}\end{array}$ & $\begin{array}{r}\text { Yards. } \\
2,007 \\
1,183 \\
2,842\end{array}$ & $\begin{array}{l}\text { Roys. } \\
\text { Peary. } \\
\text { Annette. }\end{array}$ \\
\hline 2 & $3^{8}+2 \quad 3^{8} .10$ & 76 I5 4I. 50 & $\begin{array}{ll}\mathrm{N} & 62 \\
\mathrm{~N} & 49 \\
\mathrm{~S} & 38\end{array}$ & $\begin{array}{lll}2 & 35 & \mathrm{E} \\
9 & \mathrm{I} & \mathrm{W} \\
3 & 42 & W\end{array}$ & $\begin{array}{ll}\mathrm{S} & 62 \\
\mathrm{~S} & 49 \\
\mathrm{~N} & 38\end{array}$ & $\begin{array}{lll}52 & 35 & W \\
49 & 16 & E \\
38 & 42 & E\end{array}$ & $\begin{array}{l}2,247 \\
\mathrm{I}, 234 \\
\mathrm{I}, 440\end{array}$ & $\begin{array}{l}\text { Cook. } \\
\text { Annette. } \\
\text { Nelson } 3 .\end{array}$ \\
\hline 3 & $\begin{array}{llll}38 & 43 & 23.66\end{array}$ & $7^{6}$ I.4 $5^{8} .4^{2}$ & $\begin{array}{ll}N & 27 \\
N & 81 \\
\text { S } & 70\end{array}$ & $\begin{array}{lll}7 & 22 & W \\
35 & W \\
34 & W\end{array}$ & $\begin{array}{ll}S & 27 \\
S & 8 I \\
N & 70\end{array}$ & $\begin{array}{lll}27 & 23 & \mathrm{E} \\
8 \mathrm{I} & 36 & \mathrm{E} \\
70 & 33 & \mathrm{E}\end{array}$ & $\begin{array}{l}\text { I, } 547 \\
\text { I, } 816 \\
2,198\end{array}$ & $\begin{array}{l}\text { Coal. } \\
\text { Myrtle. } \\
\text { Annette. }\end{array}$ \\
\hline 4 & $38 \quad 43 \quad 26.45$ & $\begin{array}{llll}76 & 14 & 27.40\end{array}$ & $\begin{array}{ll}\mathrm{N} & 50 \\
\mathrm{~N} & 86 \\
\mathrm{~S} & 46\end{array}$ & $\begin{array}{lll}0 & 06 & W \\
6 & \text { I5 } & W \\
6 & 0.4 & W\end{array}$ & $\begin{array}{ll}\mathrm{S} & 50 \\
\mathrm{~S} & 86 \\
\mathrm{~N} & 46\end{array}$ & $\begin{array}{lll}50 & 06 & \mathrm{E} \\
36 & 16 & \mathrm{E} \\
6 & 03 & \mathrm{E}\end{array}$ & $\begin{array}{l}1,996 \\
2,621 \\
3,970\end{array}$ & $\begin{array}{l}\text { Coal. } \\
\text { Myrtle. } \\
\text { Nelson } 3 .\end{array}$ \\
\hline 5 & $3^{8}+2 \quad 40.56$ & $76 \quad 14+5.00$ & $\begin{array}{ll}S & 31 \\
N & 74 \\
N & 27\end{array}$ & $\begin{array}{lll}\mathrm{I} & 48 & \mathrm{E} \\
+ & 00 & \mathrm{IE} \\
4 & 48 & \mathrm{E}\end{array}$ & $\begin{array}{ll}\mathrm{N} & 3 \mathrm{I} \\
\mathrm{S} & 74 \\
\mathrm{~S} & 27\end{array}$ & $\begin{array}{lll}\text { I } & 47 & W \\
4 & 00 & W \\
7 & 48 & W\end{array}$ & $\begin{array}{r}2,625 \\
645 \\
x, 076\end{array}$ & $\begin{array}{l}\text { Roys. } \\
\text { Peary. } \\
\text { Cook. }\end{array}$ \\
\hline 6 & $3^{8}+2 \quad 25.02$ & 761437.76 & $\begin{array}{ll}S & 54 \\
N & 3 I \\
N & 64\end{array}$ & $\begin{array}{lll}4 & 40 & E \\
I & 24 & E \\
4 & 33 & W\end{array}$ & $\begin{array}{ll}\mathrm{N} & 54 \\
\mathrm{~S} & 3 \mathrm{I} \\
\mathrm{S} & 64\end{array}$ & $\begin{array}{lll}4 & 39 & W \\
\pi & 24 & W \\
4 & 34 & \text { E }\end{array}$ & $\begin{array}{r}1,908 \\
822 \\
2,900\end{array}$ & $\begin{array}{l}\text { Irish. } \\
\text { Peary. } \\
\text { Annette. }\end{array}$ \\
\hline
\end{tabular}

\section{BROWN}

(Broad Creek-Chart No. 37.)

\begin{tabular}{|c|c|c|c|c|c|c|c|c|c|c|c|}
\hline & & & & \multirow{2}{*}{\multicolumn{2}{|c|}{, II }} & \\
\hline & 0,1 & "I & 。 & & & 。 & , & $\circ$ & , & Yards. & \\
\hline 1 & 3843 & 06. 34 & 76 & 15 & 50.75 & $\begin{array}{ll}\mathrm{N} & 25 \\
\mathrm{~S} & 77 \\
\mathrm{~S} & \mathbf{1} 7\end{array}$ & $\begin{array}{ll}59 & W \\
59 & W \\
32 & W\end{array}$ & $\begin{array}{ll}\mathrm{S} & 25 \\
\mathrm{~N} & 77 \\
\mathrm{~N} & \mathbf{1} 7\end{array}$ & $\begin{array}{ll}59 & \mathrm{E} \\
58 & \mathrm{E} \\
32 & \mathrm{E}\end{array}$ & $\begin{array}{r}945 \\
705 \\
2,177\end{array}$ & $\begin{array}{l}\text { Myrtle. } \\
\text { Annette. } \\
\text { Nelson } 3 .\end{array}$ \\
\hline 2 & $\begin{array}{lll}38 & 43\end{array}$ & 2 I. 80 & 76 & 16 & I 5.06 & $\begin{array}{ll}\text { S } & 46 \\
\text { S } & 81 \\
\text { N } & 6 r\end{array}$ & $\begin{array}{l}06 \mathrm{E} \\
21 \mathrm{E} \\
28 \mathrm{E}\end{array}$ & $\begin{array}{l}N \quad 46 \\
N \text { I } \\
\text { S } 6 r\end{array}$ & $\begin{array}{l}04 \mathrm{~W} \\
20 \mathrm{~W} \\
30 \mathrm{~W}\end{array}$ & $\begin{array}{l}5,223 \\
2,914 \\
3,449\end{array}$ & $\begin{array}{l}\text { Roys. } \\
\text { Cook. } \\
\text { Ross. }\end{array}$ \\
\hline 3 & $3^{8} \quad 43$ & 57.80 & 76 & $x_{5}$ & 12.66 & $\begin{array}{ll}\mathrm{S} & 36 \\
\mathrm{~N} & 72 \\
\mathrm{~N} & 23\end{array}$ & $\begin{array}{l}43 \mathrm{E} \\
35 \mathrm{E} \\
04 \mathrm{E}\end{array}$ & $\begin{array}{lll}\mathrm{N} & 36 & 4 \\
\mathrm{~S} & 72 & 3 \\
\mathrm{~S} & 23\end{array}$ & $\begin{array}{l}43 \mathrm{~W} \\
36 \mathrm{~W} \\
04 \mathrm{~W}\end{array}$ & $\begin{array}{l}2,06 I \\
I, 448 \\
2,122\end{array}$ & $\begin{array}{l}\text { Cook. } \\
\text { Ross. } \\
\text { Bald. }\end{array}$ \\
\hline 4 & $3^{8} 43$ & 37.40 & 76 & $I_{5}$ & I7. 94 & $\begin{array}{ll}N & 12 \\
S & 8 I \\
S & 52\end{array}$ & $\begin{array}{ll}08 & W \\
\text { I } & W \\
3 & W\end{array}$ & $\begin{array}{lll}\mathrm{S} & \mathrm{I} 2 & \\
\mathrm{~N} & 8 \mathrm{r} & 1 \\
\mathrm{~N} & 5^{2} & 3\end{array}$ & $\begin{array}{ll}08 & \mathrm{E} \\
\mathrm{r} 4 & \mathrm{E} \\
30 & \mathrm{E}\end{array}$ & $\begin{array}{r}932 \\
\mathrm{I}, 296 \\
\mathrm{I}, 962\end{array}$ & $\begin{array}{l}\text { Coal. } \\
\text { Myrtle. } \\
\text { Annette. }\end{array}$ \\
\hline
\end{tabular}


Survey of Oyster Bars, Talbot County, Md.

BOUNDARIES OF NATURAL OYSTER BARS-continued.

DEEP NECK.

(Broad Creek-Chart No. 34.)

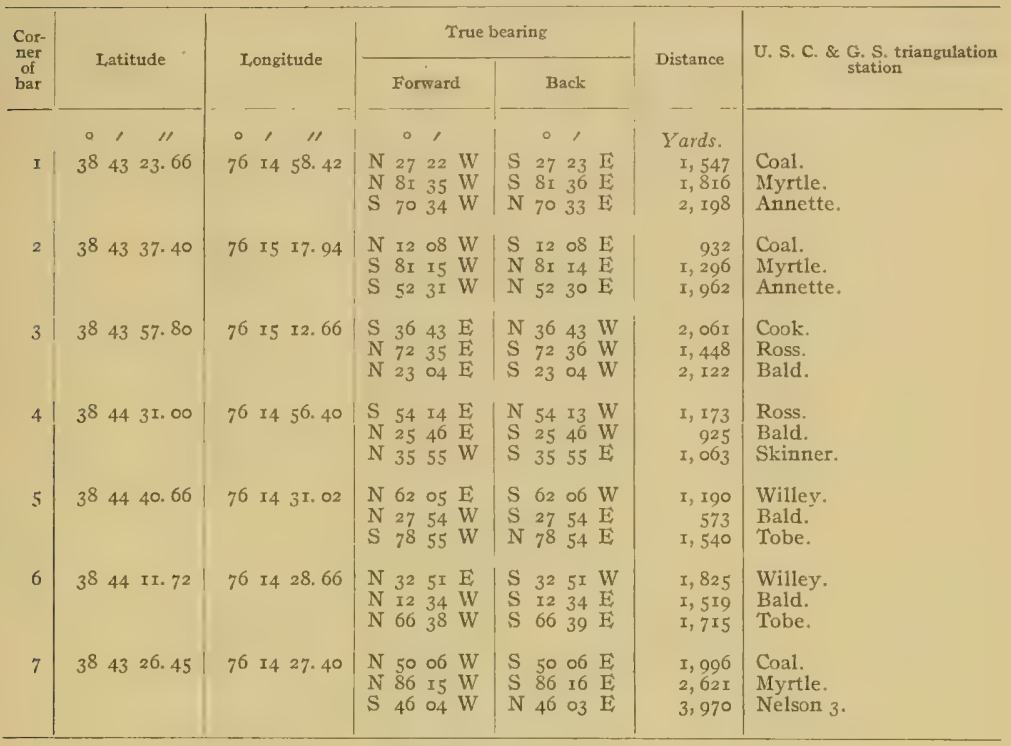

MULBERRY POINT.

(Broad Creek-Chart No. 34.)

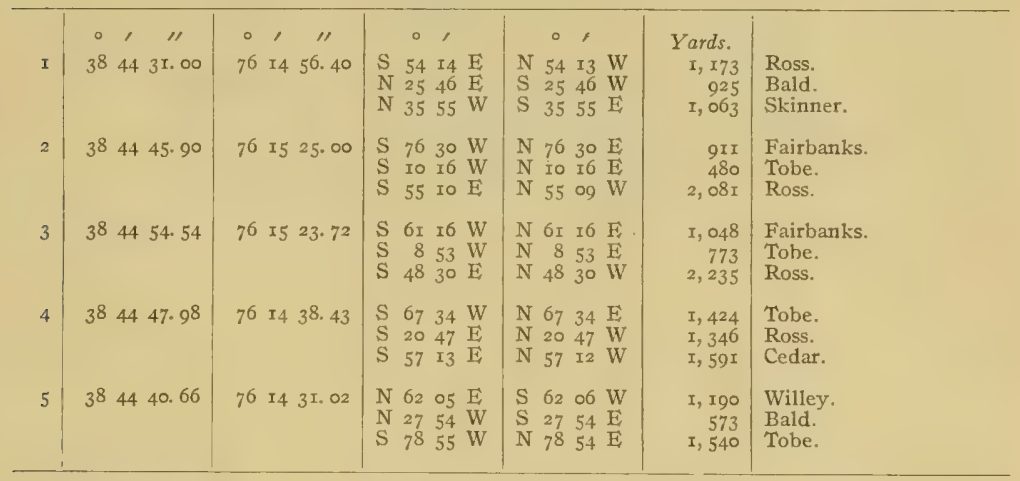

$53485-12-14$ 
BOUNDARIES OF NATURAL, OXSTER BARS-continuEd.

BROAD CREEK MIDDLEGROUND.

(Broad Creek-Chart No. 34.)

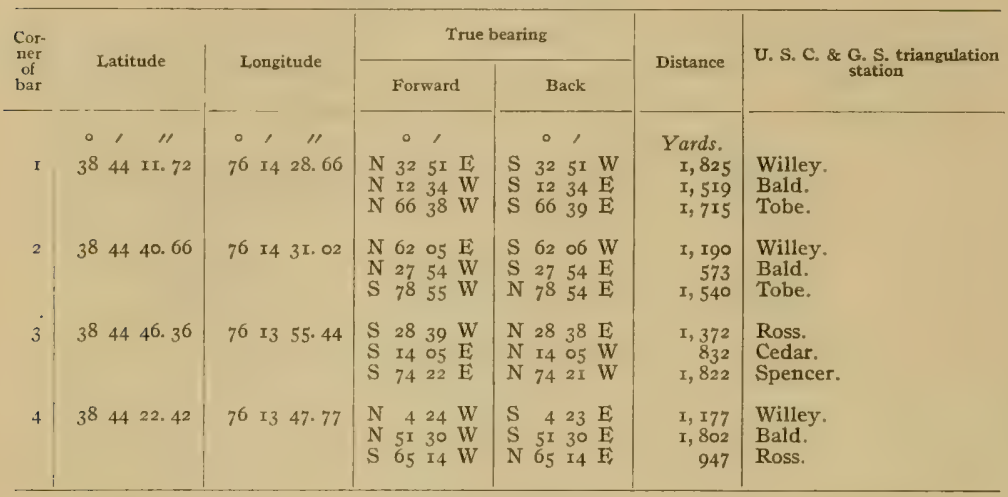

WELL POINT.

(Broad Creek-Chart No. 34.)

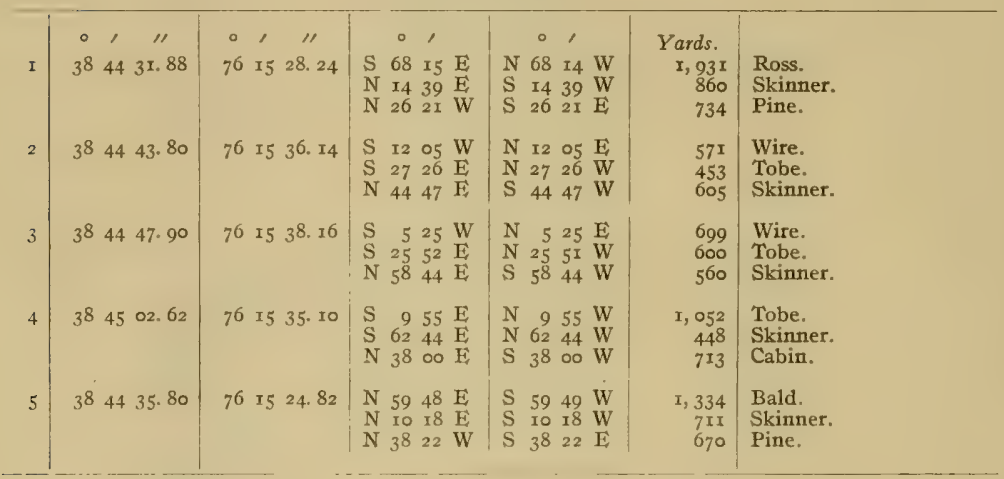


BOUNDARIES OF NATURAL, OYSTER BARS-continued.

POMPES.

(Broad Creek-Chart No. 34.)

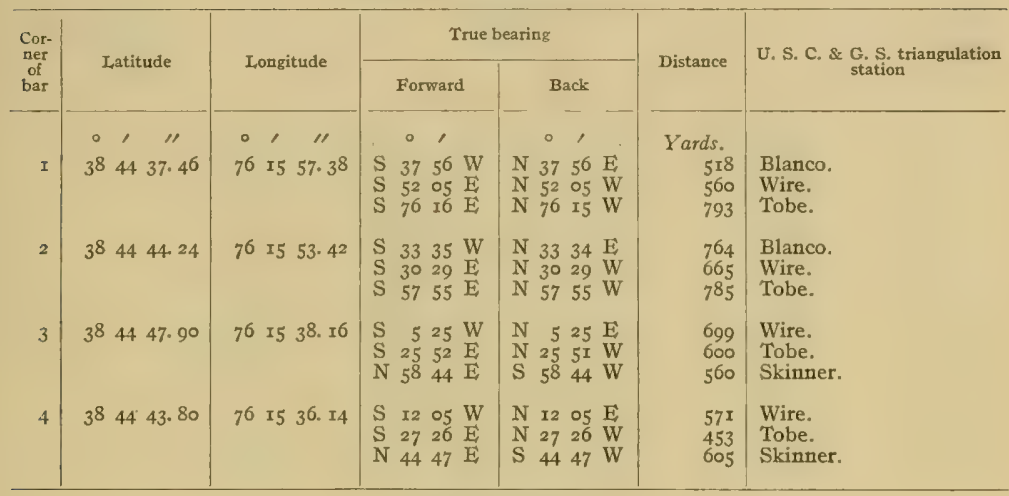

COOPERS POINT.

(Broad Creek-Chart No. 34.)

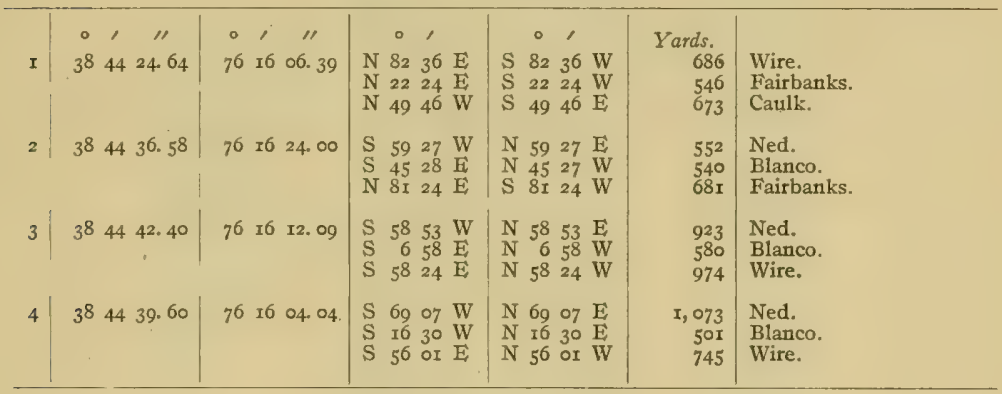


BOUNDARIES OF NATURAL OYSTER BARS-continued.

JUDYS POINT.

(Broad Creek-Chart No. 34.)

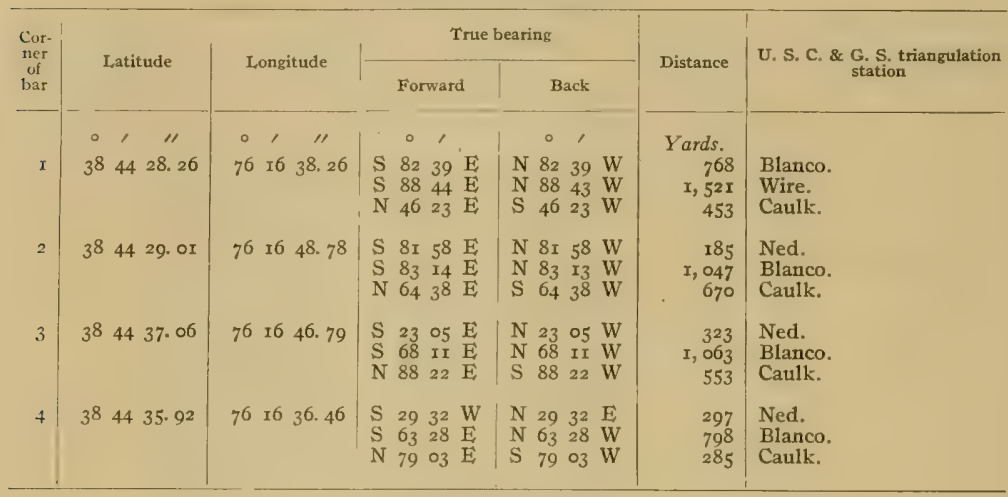

\section{BRUSHY POINT.}

(Broad Creek-Chart No.34)

\begin{tabular}{|c|c|c|c|c|c|c|c|c|c|c|c|c|c|}
\hline$I$ & $\begin{array}{c}0 \\
3^{8}\end{array}$ & ' & $\begin{array}{c}\prime \prime \prime \\
02.62\end{array}$ & $\begin{array}{c}\circ \\
76\end{array}$ & $\frac{1}{\mathbf{r}_{5}}$ & 35. 10 & $\begin{array}{l}\mathrm{S} \\
\mathrm{S} \\
\mathrm{N}\end{array}$ & $\begin{array}{cc}0 \\
9 & 5 \\
62 & 4 \\
38 & 0\end{array}$ & $\begin{array}{ll} \\
55 & \mathrm{E} \\
44 & \mathrm{E} \\
00 & \mathrm{E}\end{array}$ & $\begin{array}{lr} & 0 \\
N & 9 \\
N & 62 \\
\text { S } & 38\end{array}$ & $\begin{array}{ll}55 \\
55 \\
44 & W \\
00 & W\end{array}$ & $\begin{array}{r}\text { Yards. } \\
\mathbf{I}, 052 \\
448 \\
713\end{array}$ & $\begin{array}{l}\text { Tobe. } \\
\text { Skinner. } \\
\text { Cabin. }\end{array}$ \\
\hline 2 & $3^{8}$ & 45 & 03.90 & 76 & I5 & 42.63 & $\begin{array}{ll}\mathrm{S} & \mathrm{I} \\
\mathrm{S} & 6 \\
\mathrm{~N} & 5\end{array}$ & $\begin{array}{ll}19 & 2 \\
67 & 2 \\
50 & 5\end{array}$ & $\begin{array}{ll}23 & \mathrm{E} \\
25 & \mathrm{E} \\
53 & \mathrm{E}\end{array}$ & $\begin{array}{ll}\mathrm{N} & 19 \\
\mathrm{~N} & 67 \\
\mathrm{~S} & 50\end{array}$ & $\begin{array}{ll}23 & W \\
24 & W \\
53 & W\end{array}$ & $\begin{array}{r}\text { I, I45 } \\
647 \\
822\end{array}$ & $\begin{array}{l}\text { Tobe. } \\
\text { Skinner. } \\
\text { Cabin. }\end{array}$ \\
\hline 3 & $3^{8}$ & 45 & 12. 80 & 76 & 15 & 36.64 & $\begin{array}{l}\text { S } \\
\text { S } 3 \\
N\end{array}$ & $\begin{array}{rr}9 & 0 \\
38 & 4 \\
65 & 3\end{array}$ & $\begin{array}{ll}08 & E \\
4 I & E \\
32 & E\end{array}$ & $\begin{array}{lr}\mathrm{N} & 9 \\
\mathrm{~N} & 38 \\
\mathrm{~S} & 65\end{array}$ & $\begin{array}{l}08 \mathrm{~W} \\
40 \mathrm{~W} \\
32 \mathrm{~W}\end{array}$ & $\begin{array}{r}\text { I, } 398 \\
702 \\
5^{27}\end{array}$ & $\begin{array}{l}\text { Tobe. } \\
\text { Skinner. } \\
\text { Cabin. }\end{array}$ \\
\hline 4 & $3^{8}$ & 45 & I4. 68 & 76 & 15 & 28.24 & $\begin{array}{ll}\mathrm{S} & 2 \\
\mathrm{~S} & \mathrm{I} \\
\mathrm{N} & 5\end{array}$ & $\begin{array}{ll}22 & 3 \\
\text { 19 } & 3 \\
5^{8} & 5\end{array}$ & $\begin{array}{ll}32 & \mathrm{~W} \\
33 & \mathrm{E} \\
57 & \mathrm{E}\end{array}$ & $\begin{array}{ll}N & 22 \\
N & 19 \\
S & 58\end{array}$ & $\begin{array}{ll}32 & \mathrm{E} \\
33 & \mathrm{~W} \\
58 & \mathrm{~W}\end{array}$ & $\begin{array}{l}851 \\
650 \\
301\end{array}$ & $\begin{array}{l}\text { Pine. } \\
\text { Skinner. } \\
\text { Cabin. }\end{array}$ \\
\hline
\end{tabular}

\section{WILLEYS ISLAND FLATS.}

(Broad Creek-Chart No. 34.)

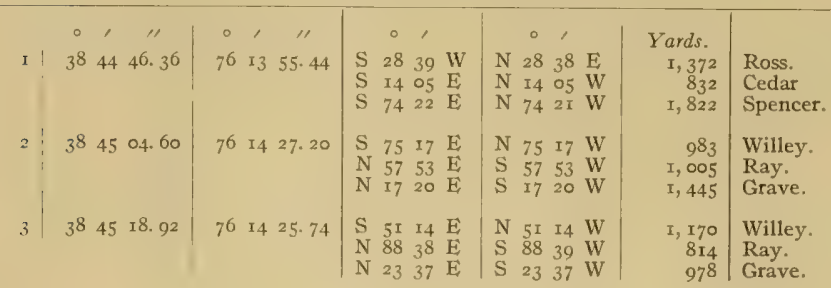


Survey of Oyster Bars, Talbot County, Md.

BOUNDARIES OF NATURAL OYSTER BARS - continued.

WILLEYS ISLAND FLATS-Continued.

(Broad Creck-Chart No.34)-Continued.

\begin{tabular}{|c|c|c|c|c|c|c|c|c|c|c|c|c|c|}
\hline \multirow{3}{*}{$\begin{array}{c}\text { Cor- } \\
\text { ner } \\
\text { of } \\
\text { bar }\end{array}$} & \multirow{2}{*}{\multicolumn{3}{|c|}{ Latitude }} & \multirow{2}{*}{\multicolumn{3}{|c|}{ Longitude }} & \multicolumn{5}{|c|}{ True bearing } & \multirow{3}{*}{$\begin{array}{l}\text { Distance } \\
\text { Yards. } \\
\text { I, 452 } \\
\text { I, I4I } \\
\text { I, I } 32\end{array}$} & \multirow{2}{*}{$\begin{array}{l}\text { U. S. C. \& G. S. triangulation } \\
\text { station }\end{array}$} \\
\hline & & & & & & & \multicolumn{3}{|c|}{ Forward } & \multicolumn{2}{|r|}{ Back } & & \\
\hline & & 45 & $\begin{array}{l}\text { II } 58 \\
\text { 19. }\end{array}$ & $\begin{array}{l}\circ \\
76\end{array}$ & I4 & 38. I4 & $\begin{array}{l}\mathrm{S} \\
\mathrm{N} \\
\mathrm{N}\end{array}$ & $\begin{array}{c}\circ \\
58 \\
88 \\
39\end{array}$ & $\begin{array}{ll}40 & \mathrm{E} \\
32 & \mathrm{E} \\
27 & \mathrm{E}\end{array}$ & $\begin{array}{l}\mathrm{N} \\
\mathrm{S} \\
\mathrm{S}\end{array}$ & $\begin{array}{ccc}\circ & 1 & \\
58 & 39 & W \\
88 & 32 & W \\
39 & 27 & W\end{array}$ & & $\begin{array}{l}\text { Willey. } \\
\text { Ray. } \\
\text { Grave. }\end{array}$ \\
\hline 5 & $3^{8}$ & 45 & 34.03 & 76 & $\mathrm{r}_{4}$ & 32. I4 & $\begin{array}{l}\mathrm{S} \\
\mathrm{S} \\
\mathrm{N}\end{array}$ & $\begin{array}{r}5 \\
64 \\
55\end{array}$ & $\begin{array}{ll}29 & \mathrm{E} \\
59 & \mathrm{E} \\
26 & \mathrm{E}\end{array}$ & $\begin{array}{l}\mathrm{N} \\
\mathrm{N} \\
\mathrm{S}\end{array}$ & $\begin{array}{rrr}5 & 29 & W \\
64 & 59 & W \\
55 & 26 & W\end{array}$ & $\begin{array}{r}798 \\
1,084 \\
68 I\end{array}$ & $\begin{array}{l}\text { Rose. } \\
\text { Ray. } \\
\text { Grave. }\end{array}$ \\
\hline 6 & $3^{8}$ & 45 & 40.86 & 76 & 14 & 39. Io & $\begin{array}{l}\mathrm{N} \\
\mathrm{N} \\
\mathrm{N}\end{array}$ & $\begin{array}{l}7^{8} \\
30 \\
33\end{array}$ & $\begin{array}{l}08 \mathrm{E} \\
24 \mathrm{E} \\
48 \mathrm{~W}\end{array}$ & $\begin{array}{ll}\mathrm{S} & 7 \\
\mathrm{~S} & 3 \\
\mathrm{~S} & 3\end{array}$ & $\begin{array}{lll}78 & 08 & W \\
30 & 24 & W \\
33 & 48 & \mathrm{E}\end{array}$ & $\begin{array}{r}76 r \\
589 \\
I, 00 I\end{array}$ & $\begin{array}{l}\text { Grave. } \\
\text { Royal. } \\
\text { Mars. }\end{array}$ \\
\hline 7 & $3^{8}$ & 45 & 54.63 & 76 & 14 & 37.10 & $\begin{array}{l}\mathrm{N} \\
\mathrm{S} \\
\mathrm{S}\end{array}$ & $\begin{array}{l}58 \\
65 \\
10\end{array}$ & $\begin{array}{ll}55 & W \\
37 & W \\
41 & E\end{array}$ & $\begin{array}{l}\mathrm{S} \\
\mathrm{N} \\
\mathrm{N}\end{array}$ & $\begin{array}{lll}58 & 55 & \mathrm{E} \\
65 & 37 & \mathrm{~F} \\
10 & 41 & W\end{array}$ & $\begin{array}{l}712 \\
524 \\
706\end{array}$ & $\begin{array}{l}\text { Mars. } \\
\text { Bengal. } \\
\text { Gram. }\end{array}$ \\
\hline 8 & 38 & 45 & $45 \cdot 50$ & 76 & 14 & 10. 90 & $\begin{array}{l}\mathrm{N} \\
\mathrm{S} \\
\mathrm{S}\end{array}$ & $\begin{array}{l}51 \\
55 \\
26\end{array}$ & $\begin{array}{ll}44 & W \\
26 & W \\
29 & \mathrm{E}\end{array}$ & $\begin{array}{ll}\mathrm{S} & 5 \\
\mathrm{~N} & 5 \\
\mathrm{~N} & 2\end{array}$ & $\begin{array}{lll}5 I & 44 & E \\
55 & 26 & E \\
26 & 29 & W\end{array}$ & $\begin{array}{l}569 \\
68 I \\
944\end{array}$ & $\begin{array}{l}\text { Royal. } \\
\text { Gram. } \\
\text { Ray. }\end{array}$ \\
\hline 9 & $3^{8}$ & 45 & I. $3^{8}$ & 76 & I3 & 58.24 & $\begin{array}{l}N \\
S \\
S\end{array}$ & $\begin{array}{l}53 \\
80 \\
15\end{array}$ & $\begin{array}{ll}29 & W \\
5 \text { I } & W \\
\text { Io } & W\end{array}$ & $\begin{array}{ll}\mathrm{S} & 5 \\
\mathrm{~N} & 8 \\
\mathrm{~N} & \mathrm{I}\end{array}$ & $\begin{array}{lll}53 & 30 & E \\
80 & 5 I & E \\
I 5 & 09 & E\end{array}$ & $\begin{array}{r}I_{1} I_{3} \\
827 \\
2,227\end{array}$ & $\begin{array}{l}\text { Gram. } \\
\text { Rose. } \\
\text { Ross. }\end{array}$ \\
\hline
\end{tabular}

HOL, I.AND POINT.

(Broad Creek-Chart No. 34.)

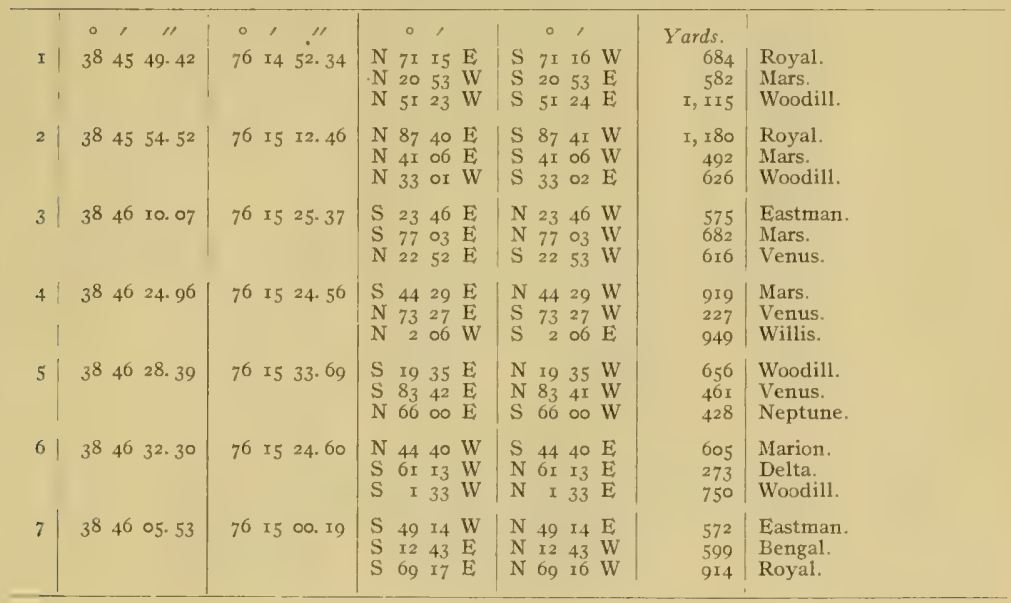


BOUNDARIES OF NATURAL OYSTER BARS-continued.

HARRISON.

(Broad Creek-Chart No. 34.)

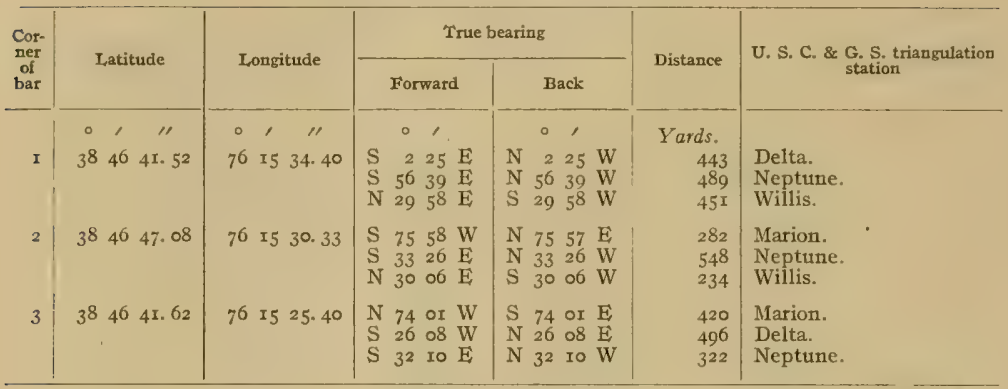

CEDAR POINT.

(Broad Creek-Chart No. 34.)

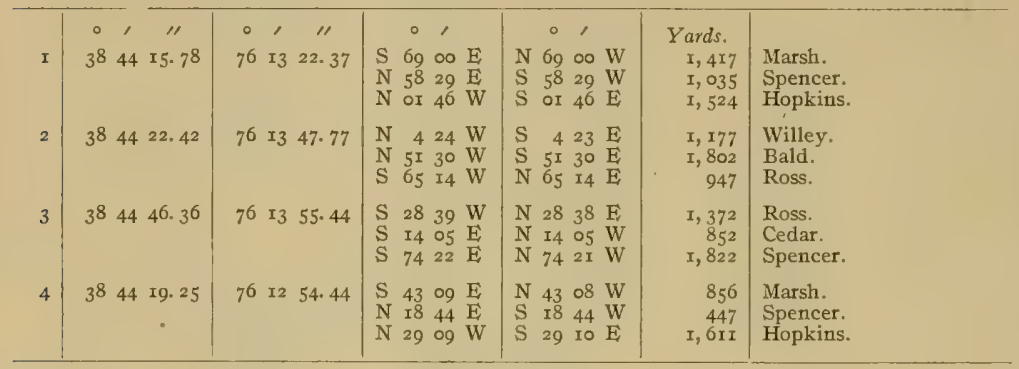

\section{DRUM POINT.}

(Broad Creek-Chart No. 34.)

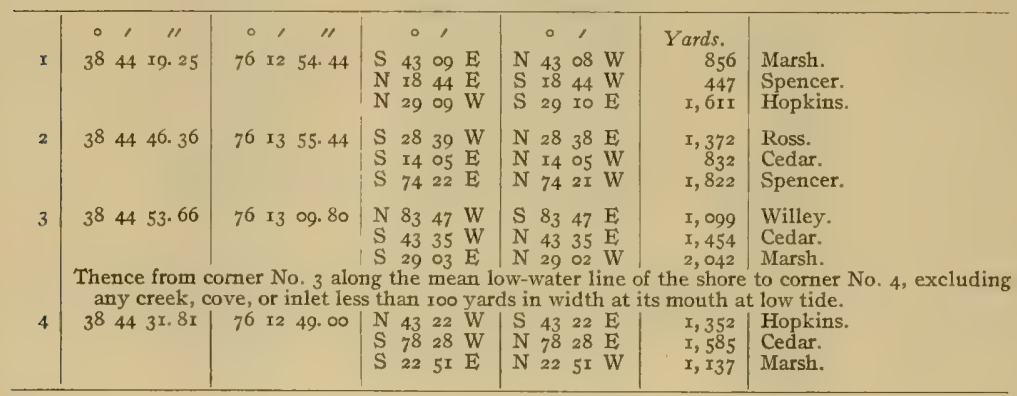


BOUNDARIES OF NATURAL OYSTER BARS-continued.

\section{JOE HARRIS FLATS.}

(Broad Creek-Chart No. 34.)

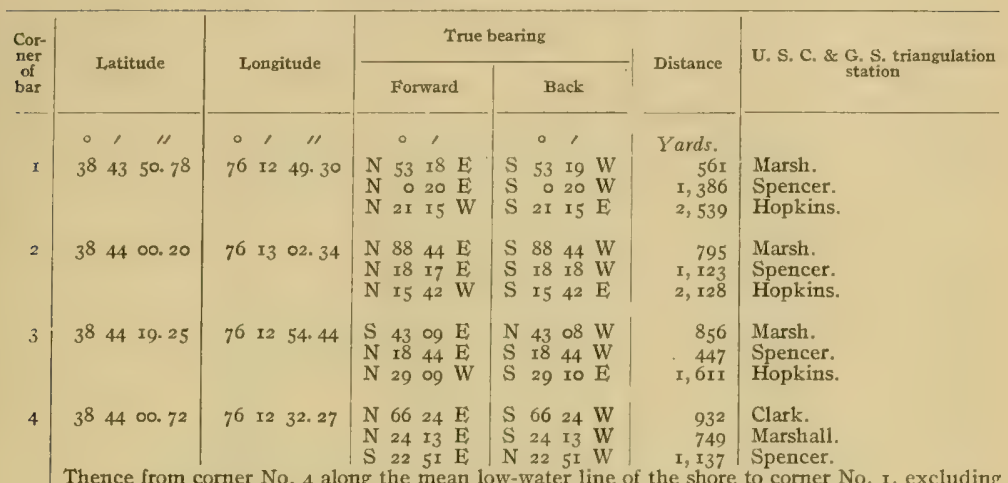
any creek, cove, or inlet less than 100 yards in width at its mouth at low tide.

PIN CUSHION.

(Broad Creek-Chart No. 34 .

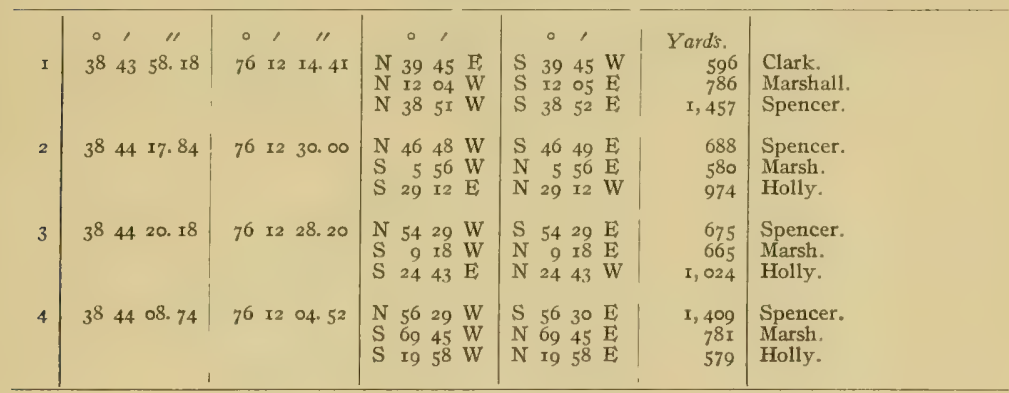


BOUNDARIES OF NATURAL, OYSTER BARS--continued.

WILLEYS ISLAND.

(Broad Creek-Chart No. 34.)

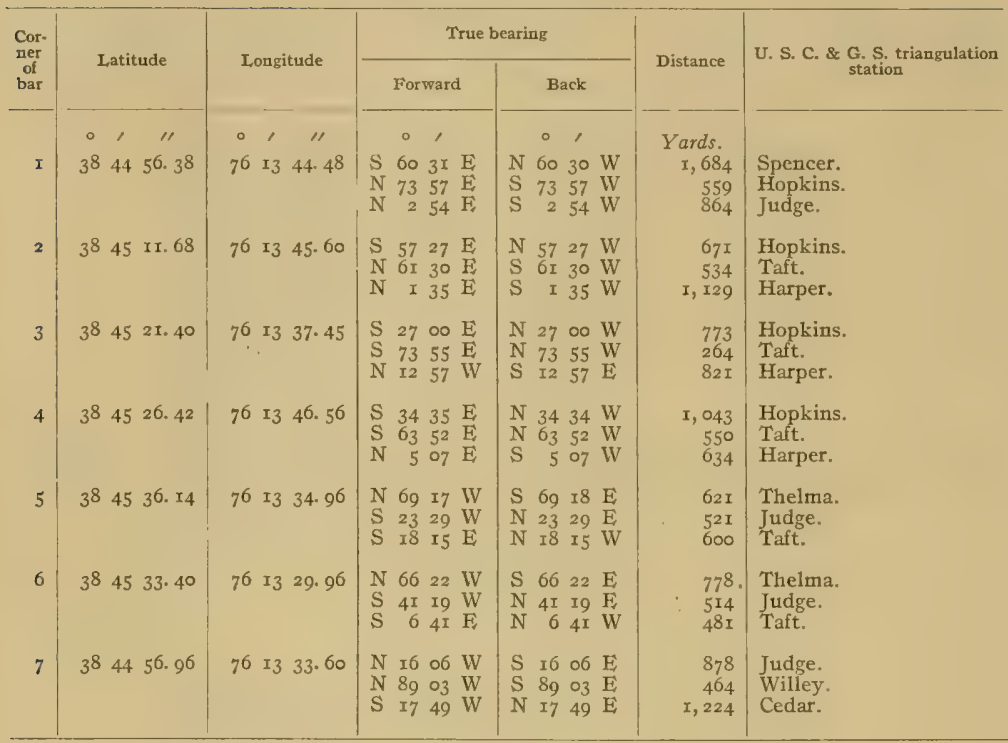

FOX.

(Broad Creek-Chart No. 34.)

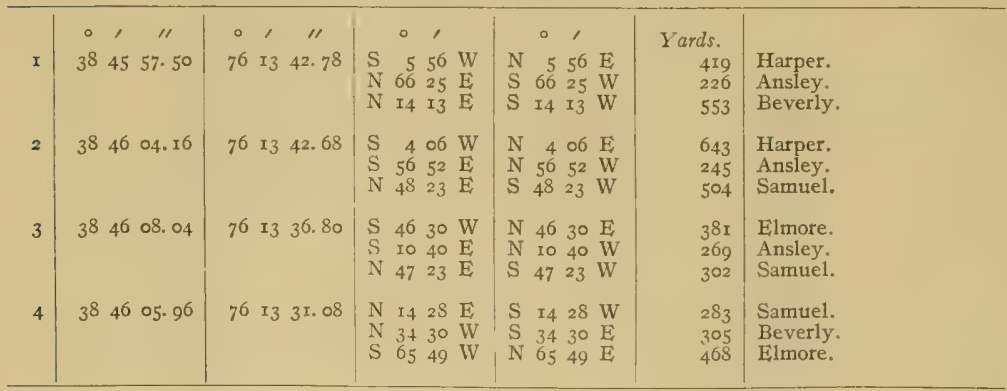


Survey of Oyster Bars, Talbot County, Md.

BOUNDARIES OF NATURAL OYSTER BARS-continued.

ROYSTON.

(Outer Choptank River-Chart No. 34.)

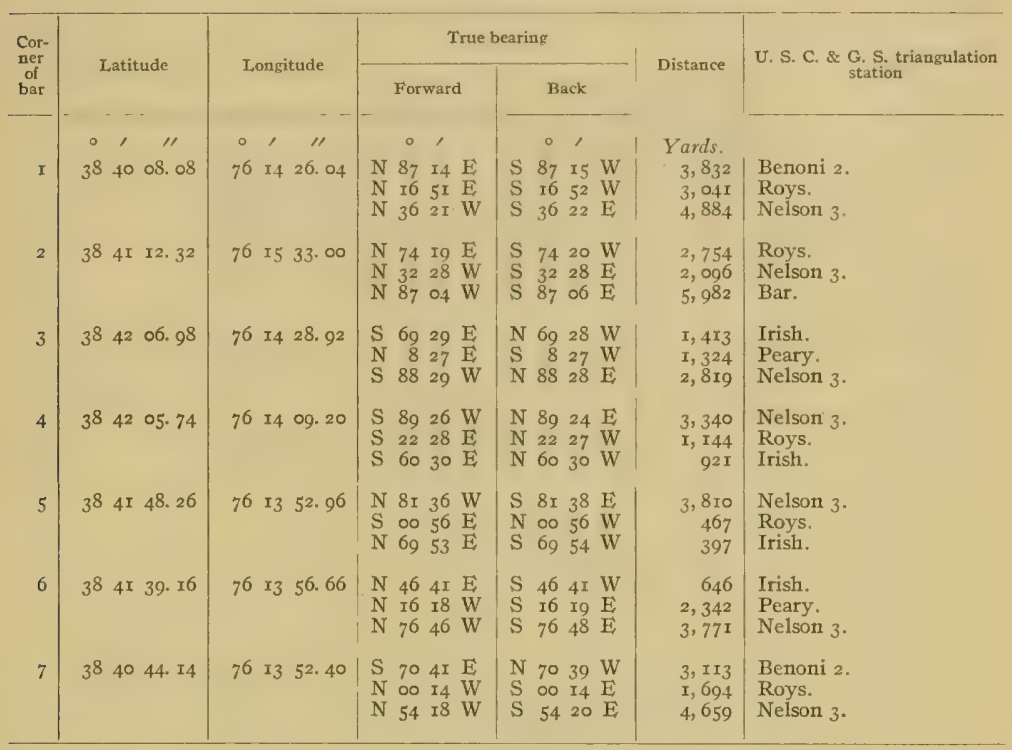

IRISH CREEK.

(Outer Choptank River-Chart No. 34.)

\begin{tabular}{|c|c|c|c|c|c|c|c|c|c|c|c|c|}
\hline$I$ & $\begin{array}{c}\circ \\
3^{8}\end{array}$ & $\begin{array}{c}1 \\
39\end{array}$ & $\begin{array}{c}\text { "I } \\
466\end{array}$ & $\begin{array}{c}0 \\
76\end{array}$ & I & $\begin{array}{c}\text { "I } \\
\text { II. IO }\end{array}$ & $\begin{array}{cc} & 0 \\
S & 76 \\
N & 62 \\
N & I 6\end{array}$ & $\begin{array}{ll}23 & \mathrm{E} \\
23 & \mathrm{E} \\
35 & \mathrm{~W}\end{array}$ & $\begin{array}{cc} & 0 \\
N & 76 \\
S & 62 \\
S & 16\end{array}$ & $\begin{array}{l}23 \mathrm{~W} \\
23 \mathrm{~W} \\
35 \mathrm{E}\end{array}$ & $\begin{array}{l}\text { Yards. } \\
\qquad \begin{array}{l}3,4 \mathrm{I} 2 \\
2,083 \\
3,85 \mathrm{I}\end{array}\end{array}$ & $\begin{array}{l}\text { Choptank River Light. } \\
\text { Benoni 2. } \\
\text { Roys. }\end{array}$ \\
\hline 2 & $3^{8}$ & 40 & 26. 10 & 76 & 13 & 50. $3^{8}$ & $\begin{array}{lr}S & 8 I \\
N & I \\
N & 49\end{array}$ & $\begin{array}{ll}4 I & E \\
30 & W \\
05 & W\end{array}$ & $\begin{array}{lr}N & 8 r \\
S & r \\
S & 49\end{array}$ & $\begin{array}{l}40 \mathrm{~W} \\
30 \mathrm{E} \\
06 \mathrm{E}\end{array}$ & $\begin{array}{l}2,916 \\
2,304 \\
5,079\end{array}$ & $\begin{array}{l}\text { Benoni } 2 . \\
\text { Roys. } \\
\text { Nelson } 3 .\end{array}$ \\
\hline 3 & $3^{8}$ & 40 & 44. I4 & 76 & I3 & 52.40 & $\begin{array}{l}\mathrm{S} 70 \\
\mathrm{~N} \\
\mathrm{~N} \\
54\end{array}$ & $\begin{array}{ll}4 I & E \\
\text { I4 } & W \\
\text { I8 } & W\end{array}$ & $\begin{array}{ll}N & 70 \\
\text { S } & 00 \\
\text { S } & 54\end{array}$ & $\begin{array}{l}39 \mathrm{~W} \\
\mathrm{I} 4 \mathrm{E} \\
20 \mathrm{E}\end{array}$ & $\begin{array}{l}3, \mathbf{I}_{3} \\
\mathrm{r}, 694 \\
4,659\end{array}$ & $\begin{array}{l}\text { Benoni } 2 . \\
\text { Roys. } \\
\text { Nelson } 3 .\end{array}$ \\
\hline 4 & 38 & $4 I$ & 16.80 & $7^{6}$ & $I_{3}$ & 2r. 94 & $\begin{array}{ll}N & I I \\
N & 53 \\
N & 70\end{array}$ & $\begin{array}{ll}24 & \mathrm{E} \\
5 \mathrm{I} & \mathrm{W} \\
36 & \mathrm{~W}\end{array}$ & $\begin{array}{ll}\text { S } & \text { II } \\
\text { S } & 53 \\
\text { S } & 70\end{array}$ & $\begin{array}{l}24 \mathrm{~W} \\
5 \mathrm{I} \mathrm{E} \\
37 \mathrm{E}\end{array}$ & $\begin{array}{l}\text { I, I42 } \\
\text { I, } 006 \\
4,865\end{array}$ & $\begin{array}{l}\text { Creek. } \\
\text { Roys. } \\
\text { Nelson } 3\end{array}$ \\
\hline 5 & $3^{8}$ & $4 I$ & 52.04 & 76 & 13 & I6. 44 & $\begin{array}{l}\mathrm{N} 24 \\
\mathrm{~N} \\
\mathrm{~S} \\
\mathrm{~S}\end{array}$ & $\begin{array}{l}\text { o4 } \mathrm{E} \\
\text { og W } \\
\text { og W }\end{array}$ & $\begin{array}{ll}\mathrm{S} & 24 \\
\mathrm{~S} & 89 \\
\mathrm{~N} & 58\end{array}$ & $\begin{array}{l}\text { of W } \\
\text { og } \mathrm{E} \\
\text { og E }\end{array}$ & $\begin{array}{r}772 \\
593 \\
\mathrm{I}, \mathbf{1 2 8}\end{array}$ & $\begin{array}{l}\text { Ila. } \\
\text { Irish. } \\
\text { Roys. }\end{array}$ \\
\hline
\end{tabular}


Survey of Oyster Bars, Talbot County, Md.

BOUNDARIES OF NATURAL OYSTER BARS-continued.

IRISH CREEK-Continued.

(Outer Choplank River-Chart No. 34)-Continued.

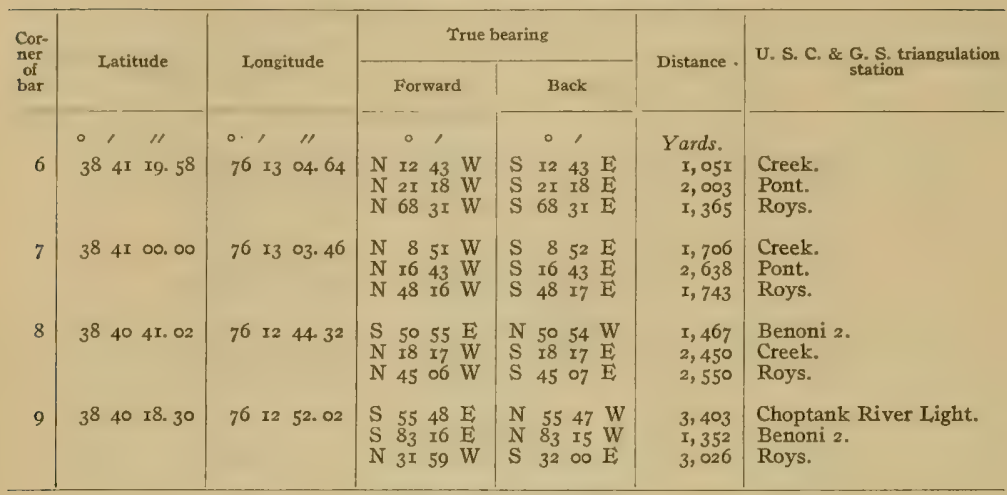

CHOPTANK LUMPS.

(Outer Choptank River-Charts Nos. 34 and 37.)

\begin{tabular}{|c|c|c|c|c|c|c|}
\hline I & $\begin{array}{ccc}0 & 1 & \prime \prime \\
38 & 39 & 08 . \infty\end{array}$ & $\begin{array}{ccc}\circ & \prime \prime \\
76 & 13 & 46.22\end{array}$ & 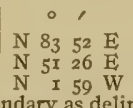 & 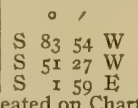 & $\begin{array}{r}\text { Yards. } \\
4,273 \\
3,549 \\
4,940\end{array}$ & $\begin{array}{l}\text { Choptank River Light. } \\
\text { Benoni } 2 \text {. }\end{array}$ \\
\hline 2 & $\begin{array}{lll}3^{8} & 39 & 5^{8} .3^{2}\end{array}$ & $\begin{array}{cccc}76 & 15 & 4 \mathrm{I} .88\end{array}$ & 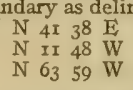 & $\begin{array}{l}\text { eated on Cha } \\
\text { S } 4 \text { I } 39 \text { W } \\
\text { S II } 48 \text { E } \\
\text { S } 64 \text { oI E E }\end{array}$ & $\begin{array}{l}\text { Nos. } 34 \\
4,344 \\
4,356 \\
6,387\end{array}$ & $\begin{array}{l}\text { nd } 37 \text { to comer No. } 2 . \\
\text { Roys. } \\
\text { Nelson } 3 . \\
\text { Bar. }\end{array}$ \\
\hline 3 & $3^{8} 3943.3^{\circ}$ & $\begin{array}{lll}76 & x_{3} & 45.60\end{array}$ & $\begin{array}{lrll}S & 80 & \text { I0 } & \mathrm{E} \\
\mathrm{N} & 69 & 4 \mathrm{I} & \mathrm{E} \\
\mathrm{N} & 2 & 5 \mathrm{I} & \mathrm{W}\end{array}$ & $\begin{array}{lrrr}\mathrm{N} & 80 & 08 & \mathrm{~W} \\
\mathrm{~S} & 69 & 42 & \mathrm{~W} \\
\mathrm{~S} & 2 & 5 \mathrm{II} & \mathrm{E}\end{array}$ & $\begin{array}{l}4,295 \\
2,941 \\
3,751\end{array}$ & $\begin{array}{l}\text { Choptank River Light. } \\
\text { Benoni } 2 . \\
\text { Roys. }\end{array}$ \\
\hline
\end{tabular}


Survey of Oyster Bars, Talbot County, Md.

BOUNDARIES OF NATURAL OYSTER BARS-continued.

BENONI.

(Outer Choptank River-Charts Nos. 34 and 37.)

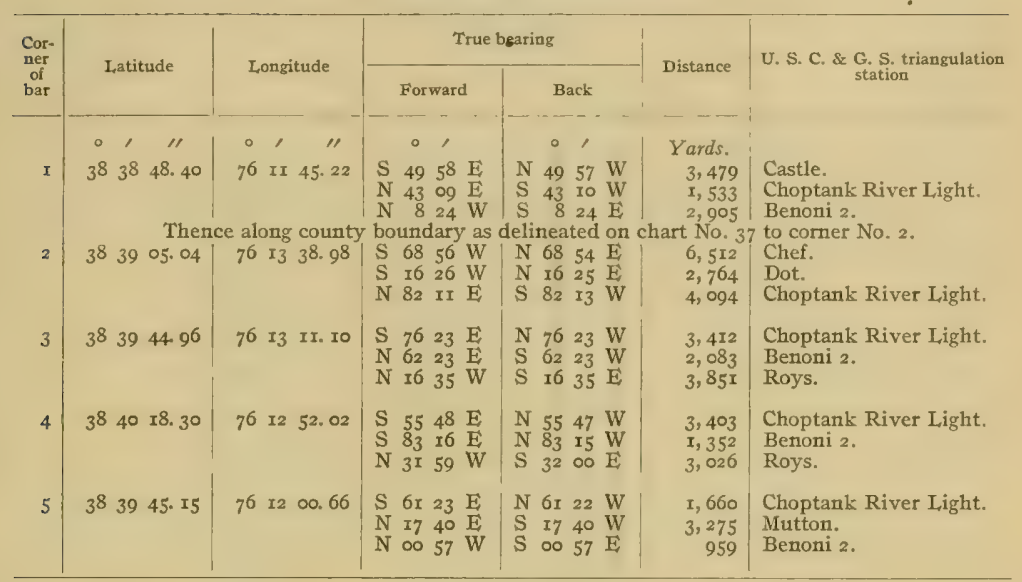

\section{LIGHTHOUSE.}

(Outer Choptank River-Charts Nos. 34, 35, and 37.)

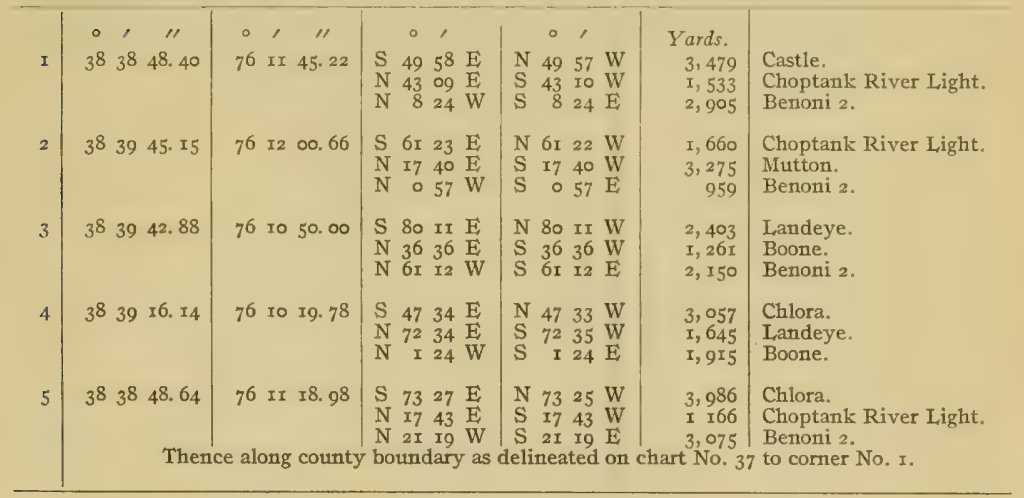


BOUNDARIES OF NATURAL OYSTER BARS-continued.

BACK SHORE.

(Outer Choptank River-Charts Nos. 34, 35, and 37.)

\begin{tabular}{|c|c|c|c|c|c|c|}
\hline \multirow{2}{*}{$\begin{array}{l}\text { Cor- } \\
\text { ner } \\
\text { of } \\
\text { bar }\end{array}$} & \multirow{2}{*}{ L,atitude } & \multirow{2}{*}{ Longitude } & \multicolumn{2}{|c|}{ True bearing } & \multirow{2}{*}{ Distance } & \multirow{2}{*}{$\begin{array}{c}\text { U. S. C. \& G. S. triangulation } \\
\text { station }\end{array}$} \\
\hline & & & Forward & Back & & \\
\hline I & $\begin{array}{ccc}0 & \prime \prime \\
38 & 37 & 52.86\end{array}$ & $\begin{array}{ccc}0 & 1 & 11 \\
76 & \circ 9 & 25.36\end{array}$ & $\begin{array}{rrrr} & 0 & \\
\mathrm{~N} & 47 & 35 & \mathrm{E} \\
\mathrm{N} & 2 & \text { I5 } & \mathrm{E} \\
\mathrm{S} & 64 & 59 & \mathrm{~W}\end{array}$ & $\begin{array}{lrrrr} & 0 & 1 \\
\mathrm{~S} & 47 & 36 & \mathrm{~W} \\
\mathrm{~S} & 2 & \mathrm{I} 5 & \mathrm{~W} \\
\mathrm{~N} & 64 & 58 & \mathrm{E}\end{array}$ & $\begin{array}{r}\text { Yards. } \\
\text { I, I06 } \\
3,304 \\
\text { I, } 538\end{array}$ & $\begin{array}{l}\text { Chlora. } \\
\text { Landeye. } \\
\text { Large Water Tank. }\end{array}$ \\
\hline
\end{tabular}

Thence along county boundary as delineated on charts Nos. 34 and 35 to comer No. 2.

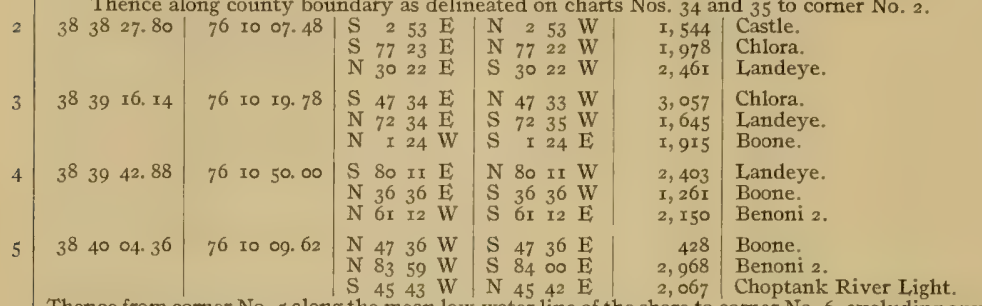

Thence from comer No. 5 along the mean low-water line of the shore to corner No. 6 , excluding any creek, cove, or inlet less than roo yards in width at its mouth at low tide.

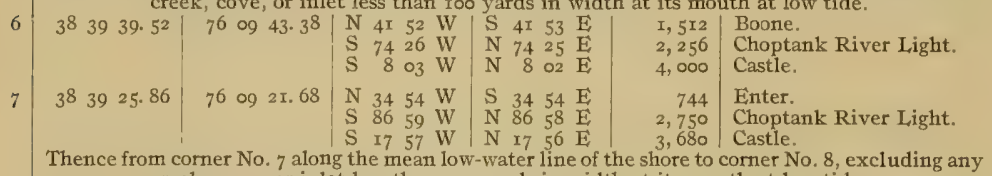
creek, cove, or inlet less than roo yards in width at its mouth at low tide.

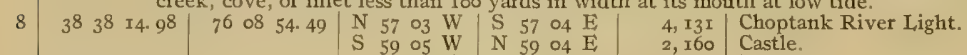

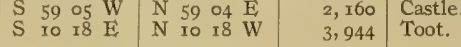

\section{BACHELOR POINT.}

(Entrance Tred Avon River-Charts Nos. 34 and 35.)

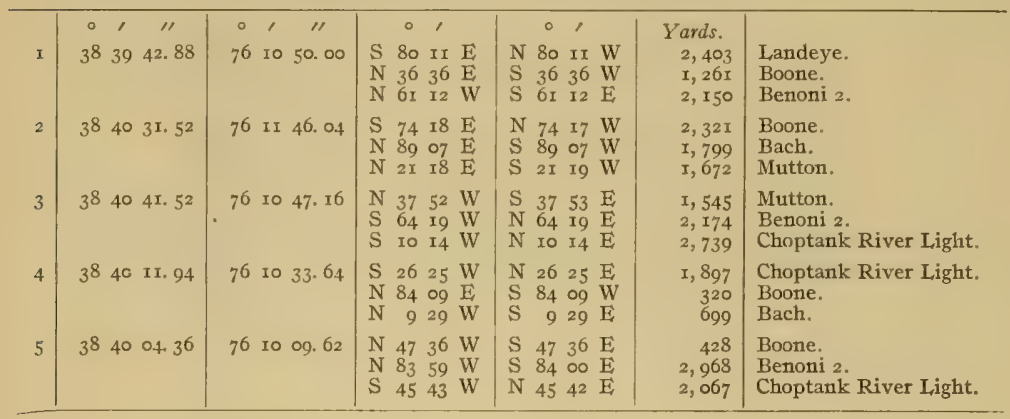


BOUNDARIES OF NATURAL, OYSTER BARS-continued.

FOX HOLE.

(Tred Avon River-Chart No. 34.)

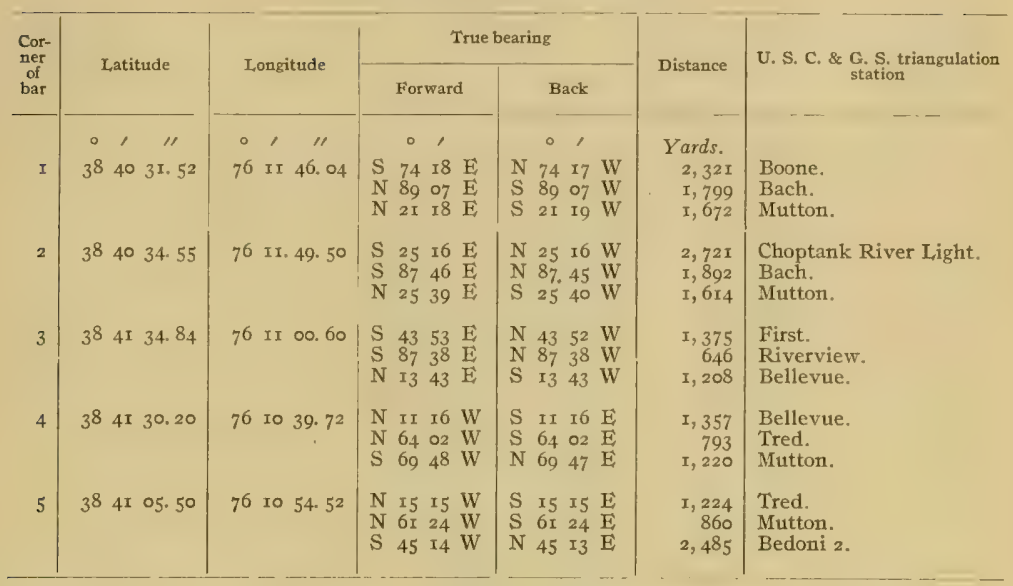

STONE CHURCH.

(Tred Avon River-Charts Nos. 34 and 35.)

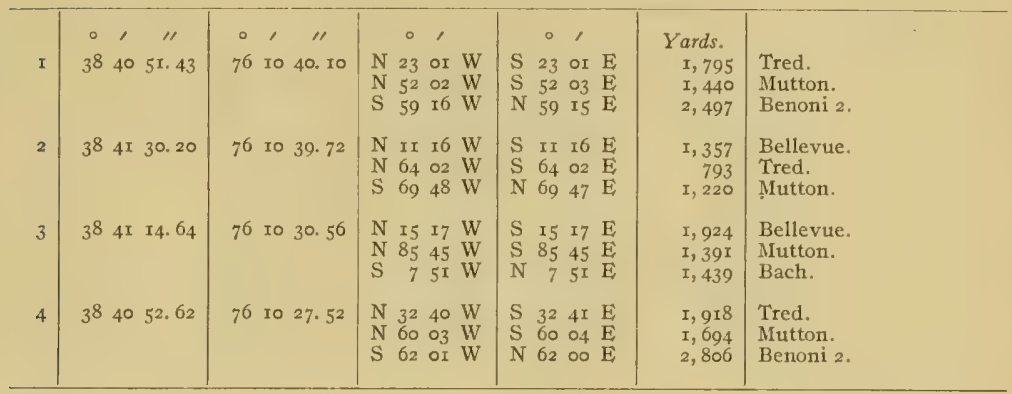


BOUNDARIES OF NATURAL OYSTER BARS-continLed.

TOWN POINT.

(Tred Avon River-Chart No. 34.)

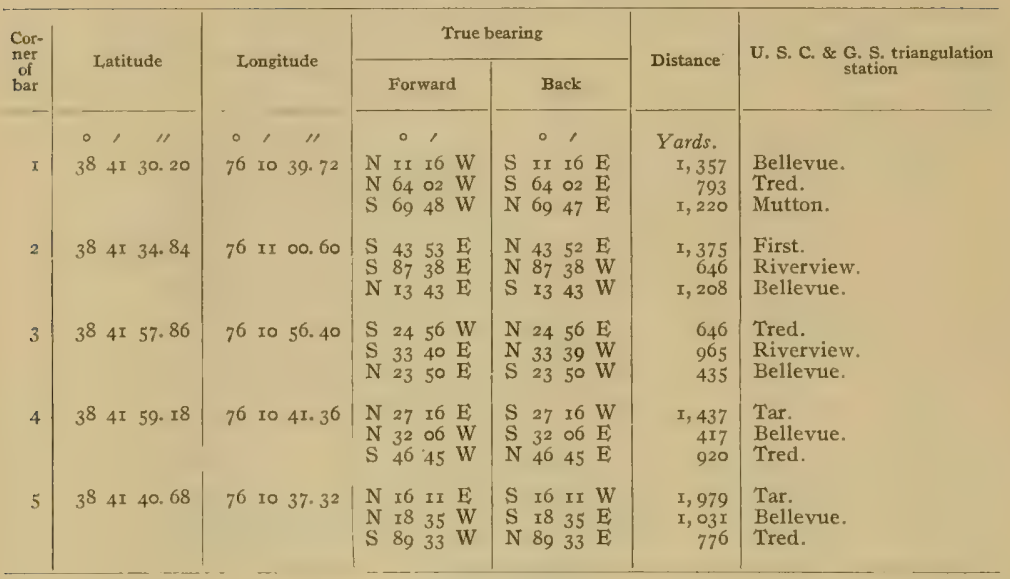

STEWART ISLAND.

(Tred Avon River-Chart No. 34.)

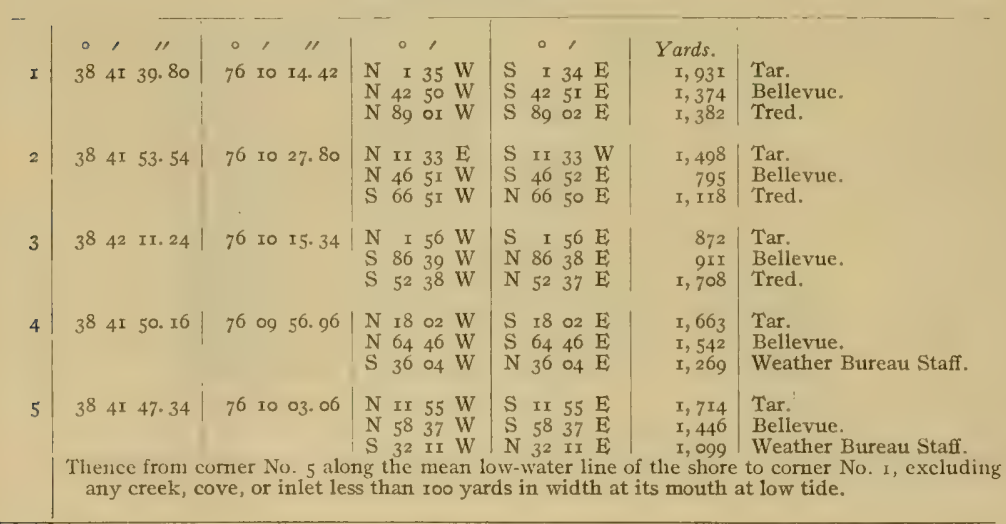


Survey of Oysier Bars, Talbot County, $M d$.

BOUNDARIES OF NATURAL OYSTER BARS-continued.

GOOSE NECK.

(Tred Avon River-Chart No. 34.)

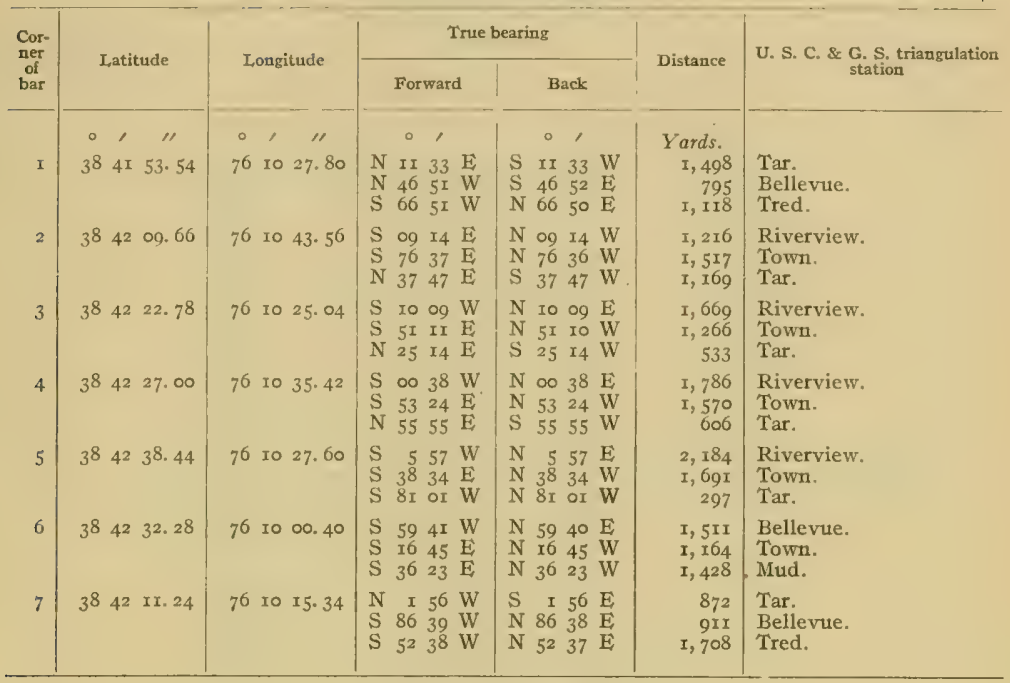

PECKS POINT.

(Tred Avon River-Chart No. 34.)

\begin{tabular}{|c|c|c|c|c|c|c|c|c|c|c|c|}
\hline I & $\begin{array}{c}0 \\
3^{8}\end{array}$ & $\begin{array}{c}\prime \\
4 I\end{array}$ & $\begin{array}{c}\prime \prime \\
50.16\end{array}$ & $\begin{array}{c}\circ \\
76\end{array}$ & $\begin{array}{l}1 \\
09\end{array}$ & $5^{\prime \prime \prime}{ }^{\prime \prime}$ & $\begin{array}{lc} & 0 \\
N & 18 \\
N & 64 \\
\mathrm{~S} & 36\end{array}$ & $\begin{array}{ll}1 \\
02 \\
46 & W \\
04 & W\end{array}$ & $\begin{array}{lccc} & 0 & 1 \\
\mathrm{~S} & \mathrm{I} 8 & 02 & \mathrm{E} \\
\mathrm{S} & 64 & 46 & \mathrm{E} \\
\mathrm{N} & 36 & 04 & \mathrm{E}\end{array}$ & $\begin{array}{l}\text { Yards. } \\
\text { I, } 66_{3} \\
\text { I, } 542 \\
\text { I, } 269\end{array}$ & $\begin{array}{l}\text { Tar. } \\
\text { Bellevue. } \\
\text { Weather Bureau Staff. }\end{array}$ \\
\hline 2 & $3^{8}$ & 42 & II. 24 & 76 & 10 & 15.34 & $\begin{array}{lr}\mathrm{N} & \mathrm{I} \\
\mathrm{S} & 86 \\
\mathrm{~S} & 52\end{array}$ & $\begin{array}{ll}56 & W \\
39 & W \\
38 & W\end{array}$ & $\begin{array}{lrll}\mathrm{S} & \mathrm{I} & 56 & \mathrm{E} \\
\mathrm{N} & 86 & 38 & \mathrm{E} \\
\mathrm{N} & 52 & 37 & \mathrm{E}\end{array}$ & $\begin{array}{r}872 \\
91 x \\
\text { I, } 708\end{array}$ & $\begin{array}{l}\text { Tar. } \\
\text { Bellevue. } \\
\text { Tred. }\end{array}$ \\
\hline 3 & $3^{8}$ & 42 & 32.28 & 76 & 10 & ○. 40 & $\begin{array}{ll}\text { S } & 59 \\
\text { S } & 16 \\
\text { S } & 36\end{array}$ & $\begin{array}{l}4 \mathrm{I} W \\
45 \mathrm{E} \\
23 \mathrm{E}\end{array}$ & $\begin{array}{llll}\mathrm{N} & 59 & 40 & \mathrm{E} \\
\mathrm{N} & \mathbf{1 6} & 45 & \mathrm{~W} \\
\mathrm{~N} & 36 & 23 & \mathrm{~W}\end{array}$ & $\begin{array}{l}I, 5 I I \\
I, I 64 \\
I, 428\end{array}$ & $\begin{array}{l}\text { Bellevue. } \\
\text { Town. } \\
\text { Mud. }\end{array}$ \\
\hline 4 & $3^{8}$ & $4^{2}$ & x8. $3^{8}$ & 76 & oو & 47.40 & $\begin{array}{ll}\mathrm{S} & 79 \\
\mathrm{~S} & 00 \\
\mathrm{~S} & 36\end{array}$ & $\begin{array}{ll}52 & \mathrm{~W} \\
37 & \mathrm{~W} \\
33 & \mathrm{E}\end{array}$ & $\begin{array}{llll}\mathrm{N} & 79 & 52 & \mathrm{E} \\
\mathrm{N} & 00 & 37 & \mathrm{E} \\
\mathrm{N} & 36 & 33 & \mathrm{~W}\end{array}$ & $\begin{array}{r}x, 672 \\
645 \\
848\end{array}$ & $\begin{array}{l}\text { Bellevue. } \\
\text { Town. } \\
\text { Mud. }\end{array}$ \\
\hline 5 & $3^{8}$ & 42 & I9. 34 & 76 & 99 & 34.80 & $\begin{array}{ll}\mathrm{S} & 26 \\
\mathrm{~S} & 13 \\
\mathrm{~S} & 53\end{array}$ & $\begin{array}{ll}43 & W \\
27 & \mathrm{E} \\
53 & \mathrm{E}\end{array}$ & $\begin{array}{llll}\mathrm{N} & 26 & 43 & \mathrm{E} \\
\mathrm{N} & \mathbf{1} 3 & 27 & \mathrm{~W} \\
\mathrm{~N} & 53 & 52 & \mathrm{~W}\end{array}$ & $\begin{array}{r}759 \\
734 \\
\mathrm{I}, 575\end{array}$ & $\begin{array}{l}\text { Town. } \\
\text { Mud. } \\
\text { Golds. }\end{array}$ \\
\hline 6 & $3^{8}$ & $4 I$ & 59.24 & 76 & $\circ 9$ & $47.7 \mathrm{I}$ & $\begin{array}{lr}N & 0 \\
N & 77 \\
S & 56\end{array}$ & $\begin{array}{ll}07 & W \\
54 & W \\
27 & W\end{array}$ & $\begin{array}{lrrr}\mathrm{S} & 0 & 07 & \mathrm{E} \\
\mathrm{S} & 77 & 55 & \mathrm{E} \\
\mathrm{N} & 56 & 26 & \mathrm{E}\end{array}$ & $\begin{array}{r}749 \\
\mathrm{r}, 676 \\
\mathrm{I}, 537\end{array}$ & $\begin{array}{l}\text { Peck. } \\
\text { Bellevue. } \\
\text { Riverview. }\end{array}$ \\
\hline
\end{tabular}

Thence from corner No. 6 along the mean low-water line of the shore to corner No. $r$, excluding any creek, cove, or inlet less than Ioo yards in width at its mouth at low tide. 
BOUNDARIES OF NATURAL, OYSTER BARS-continued.

MARES POINT.

(Tred Avon River-Chart No. 34.)

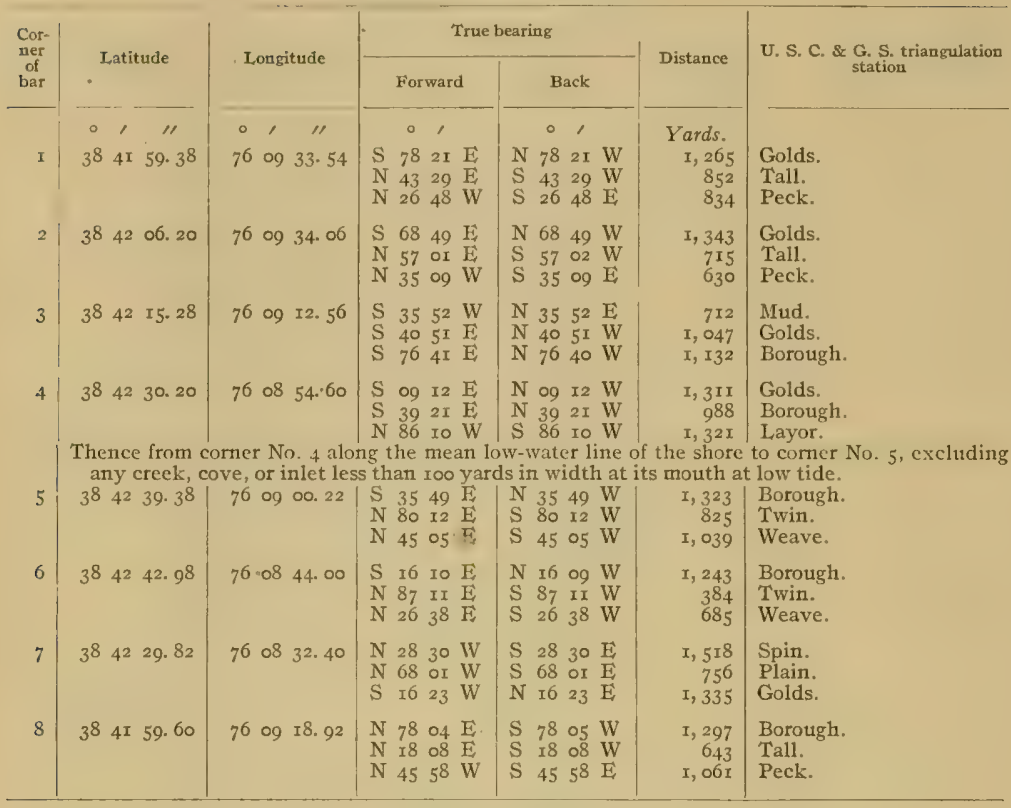

\section{LOUIS COVE.}

(Tred Avon River-Chart No. 34.)

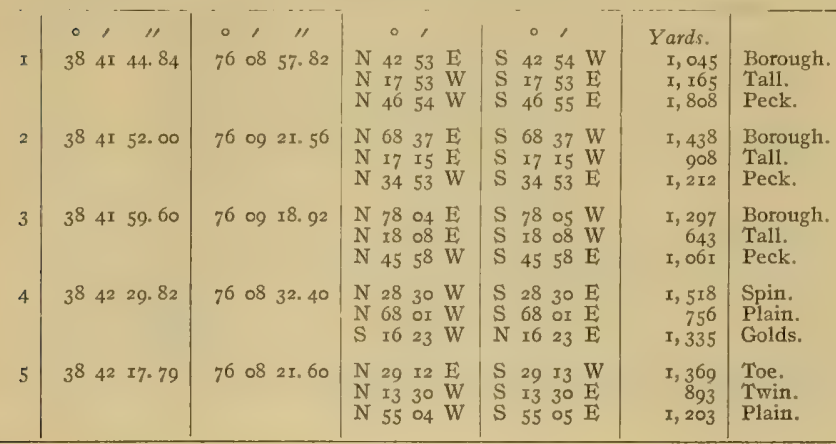


BOUNDARIES OF NATURAL OYSTER BARS-continued.

BAMINGS COVE.

(Tred Avon River-Chart No. 34.)

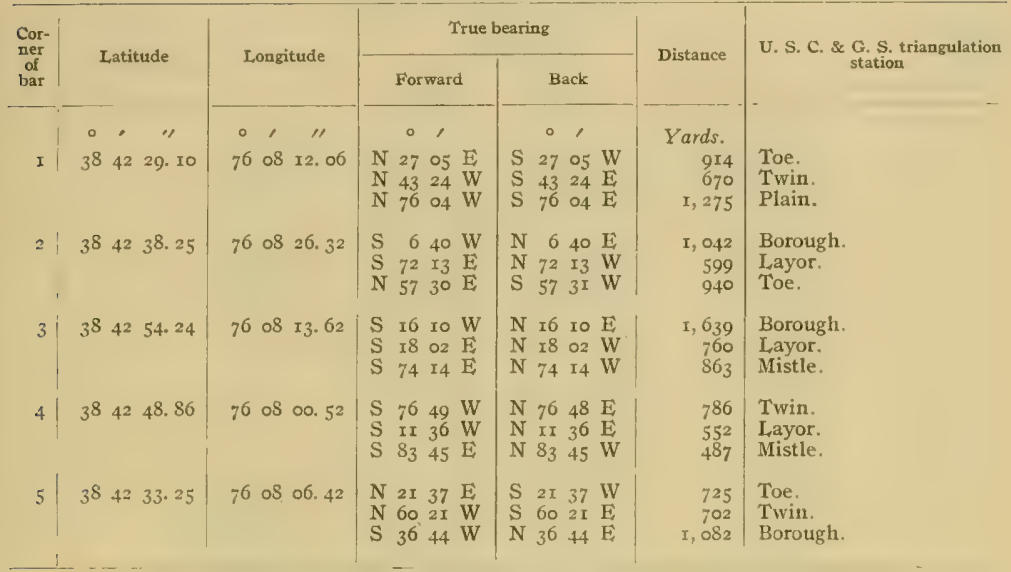

OLD HOUSE POIN'T.

(Tred Avon River-Chart No. 34.)

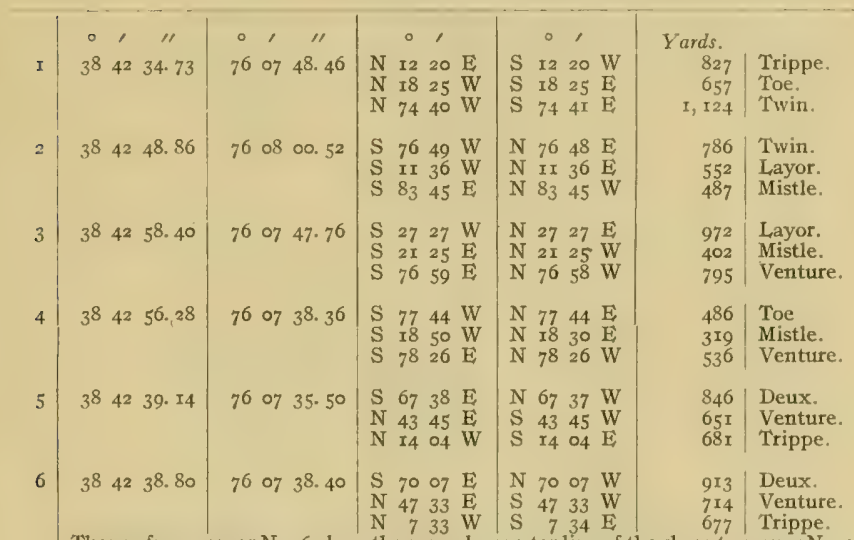

Thence from corner No. 6 along the mean low water line of the shore to comer No. 7 , excluding any creek, cove, or inlet less than roo yards in width at its mouth at low tide. 
Survey of Oyster Bars, Talbot County, Md.

BOUNDARIES OF NATURAL OYSTER BARS - contintIed.

OLD HOUSE POINT-Continued.

(Tred Avon River-Chart No. 34)-Continued.

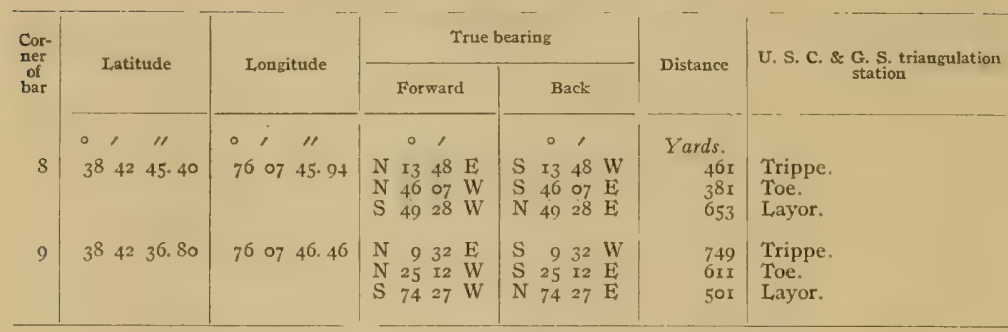

TRIPPE.

(Tred Avon River-Chart No. 34.)

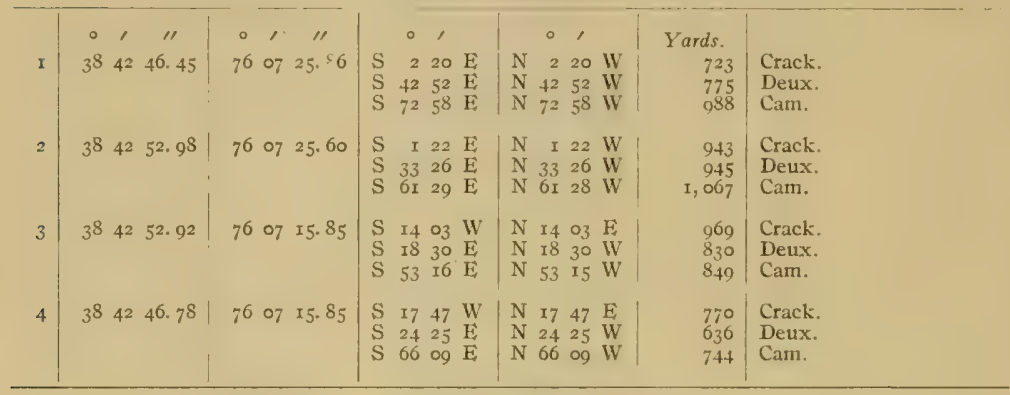

\section{BAKERS COVE.}

(Tred Avon River-Chart No. 34.)

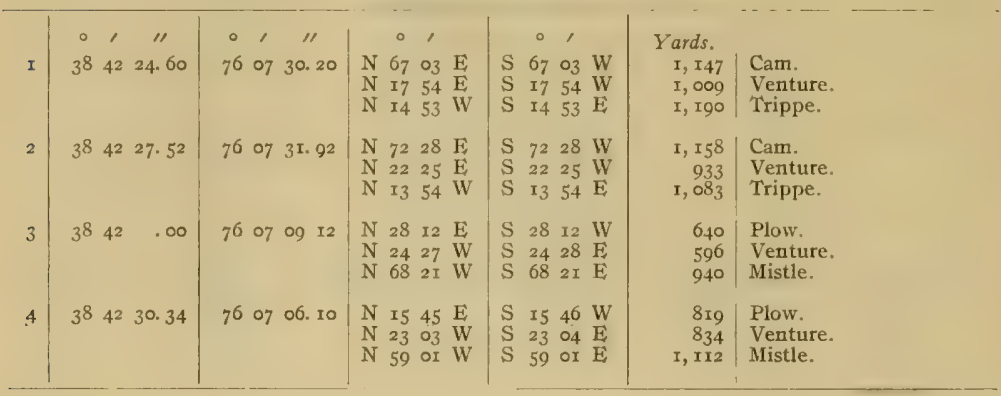


Survey of Oyster Bars, Talbot County, $M d$.

BOUNDARIES OF NATURAL, OXSTER BARS-continued.

MARSHY.

(Tred Avon River-Chart No. 34.)

\begin{tabular}{|c|c|c|c|c|c|c|c|c|c|c|c|c|c|c|}
\hline \multirow{3}{*}{$\begin{array}{l}\begin{array}{l}\text { Cor- } \\
\text { ner } \\
\text { of } \\
\text { bar }\end{array} \\
\end{array}$} & \multirow{2}{*}{\multicolumn{3}{|c|}{ Latitude }} & \multirow{2}{*}{\multicolumn{2}{|c|}{ Longitude }} & \multicolumn{7}{|c|}{ True bearing } & \multirow{3}{*}{$\begin{array}{l}\text { Distance } \\
\\
\text { Yards. } \\
\text { r, } 243 \\
384 \\
685\end{array}$} & \multirow{2}{*}{$\begin{array}{c}\text { U. S. C. \& G. S. triangulation } \\
\text { station }\end{array}$} \\
\hline & & & & & & & For & ward & & $\mathrm{Bac}$ & act: & & & \\
\hline & & $\begin{array}{c}1 \\
42 .\end{array}$ & $\begin{array}{c}\prime \prime \prime \\
42.98\end{array}$ & $\begin{array}{c}\circ \quad 1 \\
7^{6} \text { os }\end{array}$ & 44.00 & $\begin{array}{l}\mathrm{S} \\
\mathrm{N} \\
\mathrm{N}\end{array}$ & $\begin{array}{c}0 \\
16 \\
87 \\
26\end{array}$ & $\begin{array}{ll}\text { IO } & \mathrm{E} \\
\text { II } & \mathrm{E} \\
3^{8} & \mathrm{E}\end{array}$ & $\begin{array}{l}\mathrm{N} \\
\mathrm{S} 8 \\
\mathrm{~S}\end{array}$ & $\begin{array}{c}0 \\
16 \\
87 \\
26 \\
26\end{array}$ & $\begin{array}{l}1 \\
\circ 9 \\
\text { Ir } \\
38\end{array}$ & & & $\begin{array}{l}\text { Borough. } \\
\text { Twin. } \\
\text { Weave. }\end{array}$ \\
\hline 2 & $3^{8}$ & 43 & ○. $7^{8}$ & 76 os & $46.5^{8}$ & $\begin{array}{l}\mathrm{S} \\
\mathrm{N} \\
\mathrm{N}\end{array}$ & $\begin{array}{r}37 \\
88 \\
2\end{array}$ & $\begin{array}{ll}50 & \mathrm{E} \\
\mathrm{I}_{5} & \mathrm{E} \\
25 & \mathrm{E}\end{array}$ & $\begin{array}{l}N \\
S \\
S\end{array}$ & $\begin{array}{l}37 \\
88 \\
2\end{array}$ & $\begin{array}{l}50 \\
15 \\
25\end{array}$ & & $\begin{array}{l}736 \\
375 \\
911\end{array}$ & $\begin{array}{l}\text { Twin. } \\
\text { Weave. } \\
\text { Martin. }\end{array}$ \\
\hline 3 & $3^{8}$ & 43 & 03.12 & 76 os & 58.00 & $\begin{array}{l}\mathrm{S} \\
\mathrm{S} \\
\mathrm{N}\end{array}$ & $\begin{array}{l}48 \\
84 \\
22\end{array}$ & $\begin{array}{ll}46 & E \\
\text { IS } & E \\
\text { I } & E\end{array}$ & $\begin{array}{ll}\mathrm{N} & 4 \\
\mathrm{~N} & 8 \\
\mathrm{~S} & 2\end{array}$ & $\begin{array}{l}48 \\
84 \\
22\end{array}$ & $\begin{array}{l}46 \\
17 \\
14\end{array}$ & & $\begin{array}{r}\text { I, } 002 \\
680 \\
899\end{array}$ & $\begin{array}{l}\text { Twin. } \\
\text { Weave. } \\
\text { Martin. }\end{array}$ \\
\hline 4 & $3^{8}$ & 43 & II. 90 & 76 os & $57 \cdot 40$ & $\begin{array}{l}S \\
S \\
N\end{array}$ & $\begin{array}{l}37 \\
61 \\
31\end{array}$ & $\begin{array}{ll}38 & \mathrm{E} \\
\text { os } & \mathrm{E} \\
\text { Io } & \mathrm{E}\end{array}$ & $\begin{array}{ll}N & 3 \\
N & 6 \\
S & 3\end{array}$ & $\begin{array}{l}37 \\
61 \\
31\end{array}$ & $\begin{array}{l}3^{8} \\
07 \\
\text { Io }\end{array}$ & & $\begin{array}{r}\mathrm{r}, 207 \\
752 \\
626\end{array}$ & $\begin{array}{l}\text { Twin. } \\
\text { Weave. } \\
\text { Martin. }\end{array}$ \\
\hline 5 & $3^{S}$ & 43 & 09.80 & 7608 & $37 \cdot 38$ & $\begin{array}{l}\mathrm{N} \\
\mathrm{S} \\
\mathrm{S}\end{array}$ & $\begin{array}{l}18 \\
88 \\
28\end{array}$ & $\begin{array}{l}39 \mathrm{~W} \\
38 \mathrm{~W} \\
\text { o7 W }\end{array}$ & $\begin{array}{ll}\mathrm{S} & \mathrm{I} \\
\mathrm{N} & 8 \\
\mathrm{~N} & 2\end{array}$ & $\begin{array}{l}18 \\
88 \\
28\end{array}$ & $\begin{array}{l}39 \\
38 \\
07\end{array}$ & & $\begin{array}{r}641 \\
594 \\
\mathrm{r}, 208\end{array}$ & $\begin{array}{l}\text { Martin. } \\
\text { Spin. } \\
\text { Plain. }\end{array}$ \\
\hline 6 & $3^{S}$ & 42 & 52.44 & 76 os & 32. $5^{6}$ & $\begin{array}{l}\mathrm{N} \\
\mathrm{N} \\
\mathrm{S}\end{array}$ & $\begin{array}{l}\text { I5 } \\
51 \\
55\end{array}$ & $\begin{array}{ll}34 & W \\
35 & W \\
26 & W\end{array}$ & $\begin{array}{ll}\mathrm{S} & 1 \\
\mathrm{~S} & 5 \\
\mathrm{~N} & 5\end{array}$ & $\begin{array}{l}15 \\
51 \\
55\end{array}$ & $\begin{array}{l}34 \\
35 \\
26\end{array}$ & & $\begin{array}{r}r, 238 \\
920 \\
845\end{array}$ & $\begin{array}{l}\text { Martin. } \\
\text { Spin. } \\
\text { Plain. }\end{array}$ \\
\hline 7 & $3^{8}$ & 42 & 44. 64 & 76 os & 36.46 & $\begin{array}{l}\mathrm{N} \\
\mathrm{S} \\
\mathrm{S}\end{array}$ & $\begin{array}{r}36 \\
69 \\
6\end{array}$ & $\begin{array}{l}30 \mathrm{~W} \\
56 \mathrm{~W} \\
42 \mathrm{E}\end{array}$ & $\begin{array}{l}\mathrm{S} \\
\mathrm{N} \\
\mathrm{N}\end{array}$ & $\begin{array}{r}36 \\
69 \\
6\end{array}$ & $\begin{array}{l}30 \\
56 \\
42\end{array}$ & $\begin{array}{l}E \\
E \\
W\end{array}$ & $\begin{array}{r}\text { I, } 038 \\
632 \\
r, 259\end{array}$ & $\begin{array}{l}\text { Spin. } \\
\text { Plain. } \\
\text { Borough. }\end{array}$ \\
\hline
\end{tabular}

FLATTY.

(Tred Avon River-Chart No. 34.)

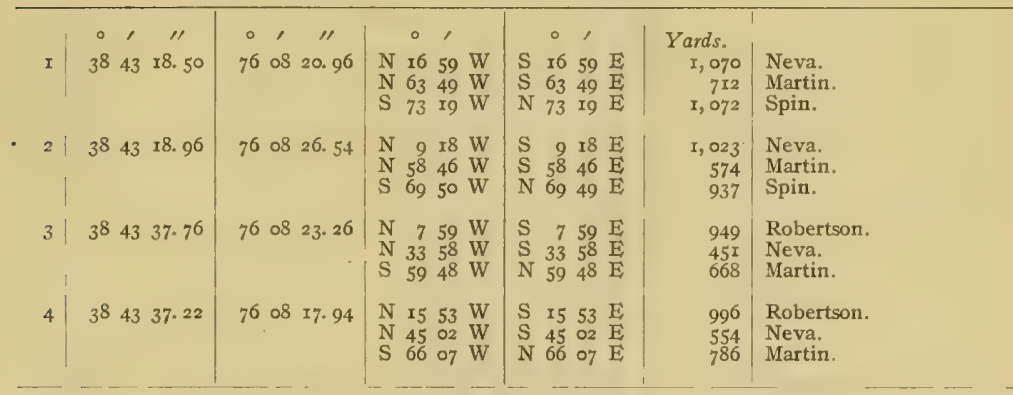


BOUNDARIES OF NATURAL OYSTER BARS-continUEd,

OREM.

(Tred Avon River-Chari No. 34.)

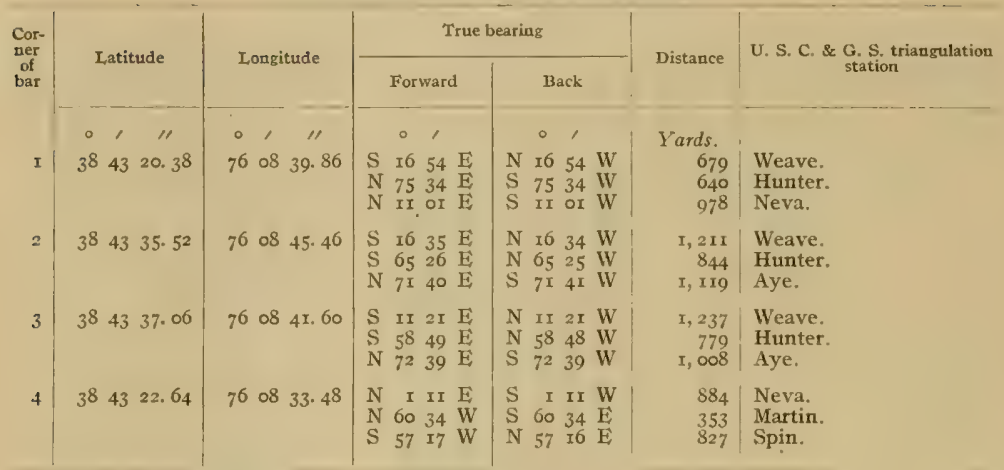

\section{DOUBLE MILLS.}

(Tred Avon River-Chart No. 34.)

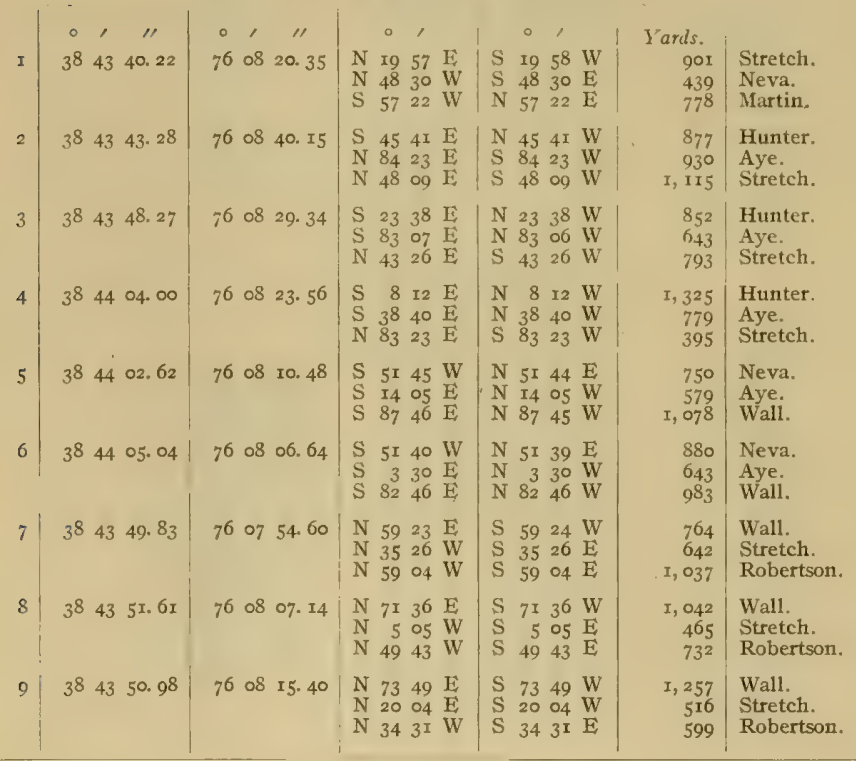


BOUNDARIES OF NATURAL OYSTER BARS-continued.

\section{JOHNSTON.}

(Tred Avon River-Chart No.34.)

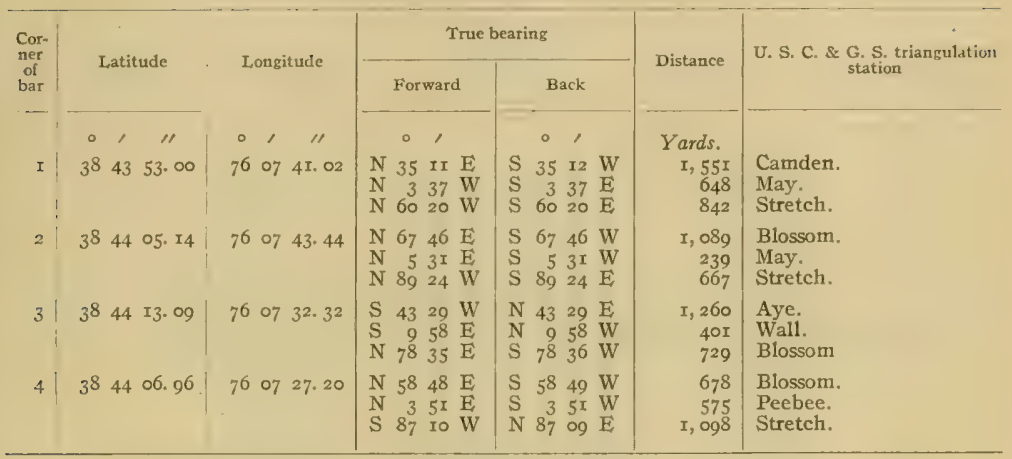

\section{CAMDEN POINT.}

(Tred Avon River-Chart No. 34.)

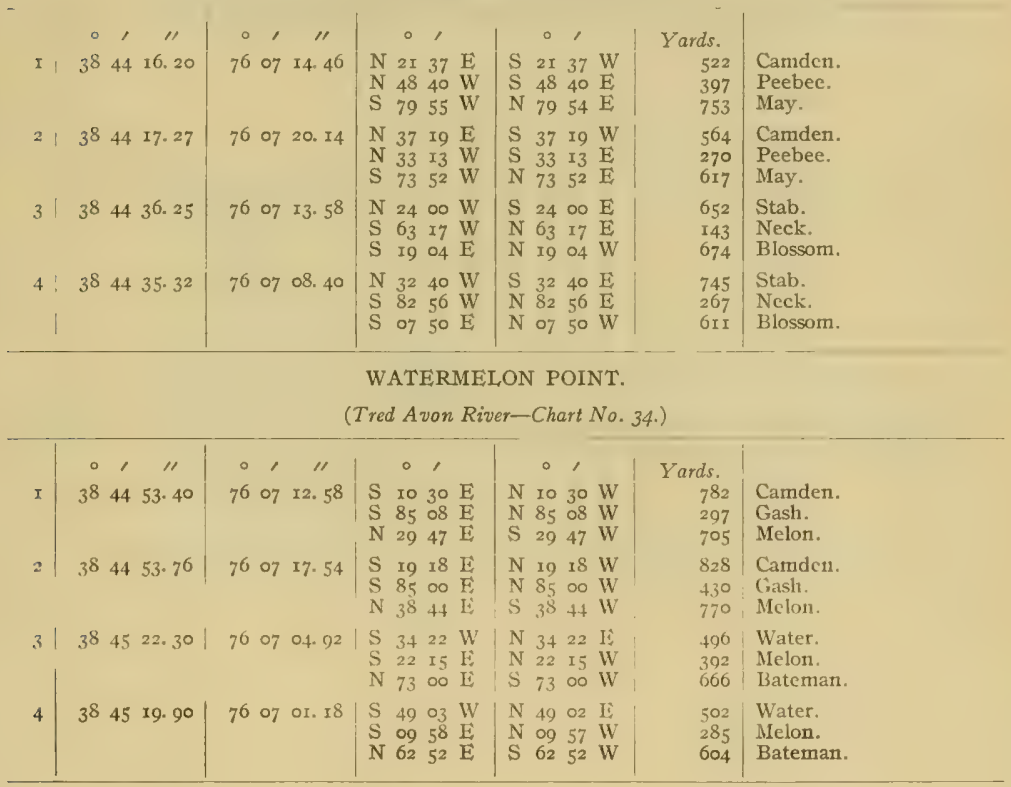


BOUNDARIES OF NATURAL, OYSTER BARS - continued.

HOPKINS.

(Island Creek-Charts Nos. 34 and 35.)

\begin{tabular}{|c|c|c|c|c|c|c|}
\hline \multirow{2}{*}{$\begin{array}{c}\text { Cor- } \\
\text { ner } \\
\text { of } \\
\text { bar }\end{array}$} & \multirow{2}{*}{ Latitudc } & \multirow{2}{*}{ Longitude } & \multicolumn{2}{|c|}{ True bearing } & \multirow{2}{*}{ Distance } & \multirow{2}{*}{$\begin{array}{l}\text { U. S. C. \& G. S. triangulation } \\
\text { station }\end{array}$} \\
\hline & & & Forward & Back & & \\
\hline I & $\begin{array}{ccc}0 & \prime \prime \\
38 & 39 & 25.86\end{array}$ & $\begin{array}{ccc}0 & 1 & \prime \prime \\
76 & 09 & 2 x .68\end{array}$ & $\begin{array}{ccccc} & 0 & l & \\
\mathrm{~N} & 34 & 54 & \mathrm{~W} \\
\mathrm{~S} & 86 & 59 & \mathrm{~W} \\
\mathrm{~S} & \mathrm{r} & 57 & \mathrm{~W}\end{array}$ & $\begin{array}{lccc} & 0 & \\
\mathrm{~S} & 34 & 54 & \mathrm{E} \\
\mathrm{N} & 86 & 58 & \mathrm{E} \\
\mathrm{N} & 17 & 56 & \mathrm{E}\end{array}$ & $\begin{array}{r}\text { Yards. } \\
744 \\
2,750 \\
3,680\end{array}$ & $\begin{array}{l}\text { Enter. } \\
\text { Choptank River Light. } \\
\text { Castle. }\end{array}$ \\
\hline 2 & $3^{8} 3939 \cdot 5^{2}$ & $76 \circ 943 \cdot 3^{8}$ & $\begin{array}{lrll}\mathrm{N} & 4 \mathrm{x} & 52 & \mathrm{~W} \\
\mathrm{~S} & 74 & 26 & \mathrm{~W} \\
\mathrm{~S} & 8 & 03 & \mathrm{~W}\end{array}$ & $\begin{array}{lrll}\mathrm{S} & 4 \mathrm{I} & 53 & \mathrm{E} \\
\mathrm{N} & 74 & 25 & \mathrm{E} \\
\mathrm{N} & 8 & 02 & \mathrm{E}\end{array}$ & $\begin{array}{l}1,512 \\
2,256 \\
4,000\end{array}$ & $\begin{array}{l}\text { Boone. } \\
\text { Choptank River Light. } \\
\text { Castle. }\end{array}$ \\
\hline
\end{tabular}

Thence from comer No. 2 along the mean low-water line of the shore to comer No. 3 , excluding any creek, cove, or inlet less than roo yards in width at its mouth at low tide.

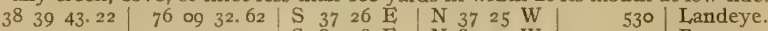

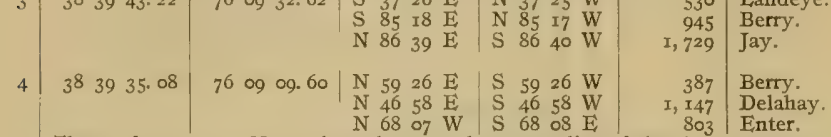

Thence from corner No. 4 along the mean low-water line of the shore to corner No. I, excluding any creek, cove, or inlet less than roo yards in width at its mouth at low tide.

\section{WILLIS.}

(Island Creek-Charts No. 34 and 35.)

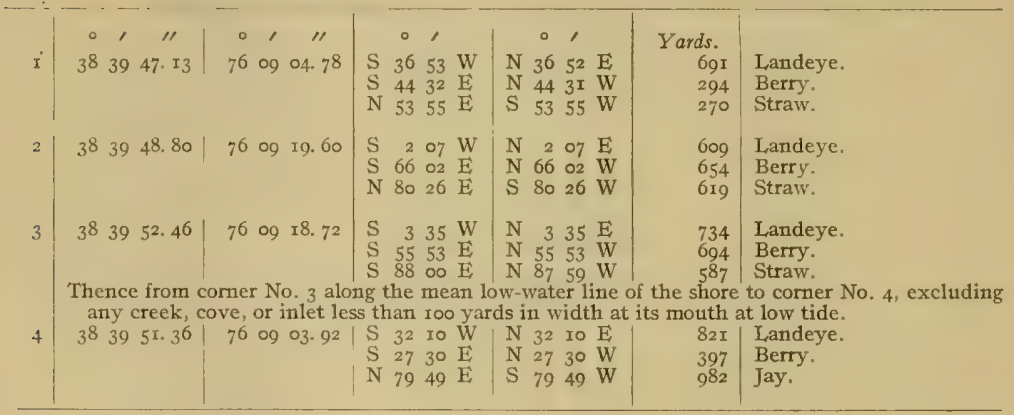


BOUNDARYES OF NATURAL, OXSTER BARS--continued.

ISI,AND CREEK.

(Island Creek-Charts Nos. 34 and 35.)

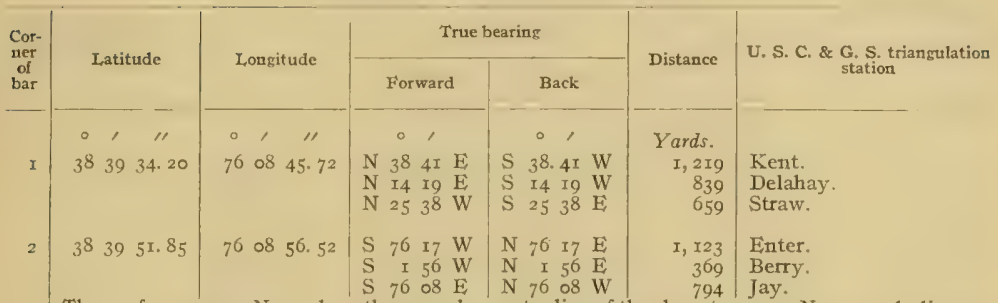

Thence from comer No. 2 along the mean low water line of the shore to corner No. 3, excluding any creek, cove, or inlet less than roo yards in width at its mouth at low tide.

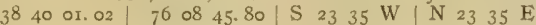

S 44 I9 E $\quad$ N 44 I8 W

739 | Berry

$\begin{array}{lllllll} & 76 & 15 & \mathrm{E} & \mathrm{N} & 76 & \text { I4 }\end{array}$

$4|384000.84| 760839.00$

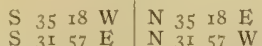

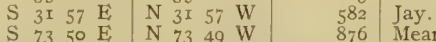

698 Jay.

r, 05 I Mean.

Thence from corner No. 4 along the mean low water line of the shore to comer No. 5 , excluding any creek, cove, or inlet less than roo yards in width at its mouth at low tide.

\begin{tabular}{|c|c|c|c|c|}
\hline 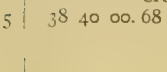 & $\begin{array}{llll}76 & 08 & 28.02\end{array}$ & $\begin{array}{llll}\mathrm{S} & 48 & 59 & \mathrm{~W} \\
\mathrm{~S} & 02 & 03 & \mathrm{E} \\
\mathrm{S} & 66 & 35 & \mathrm{E}\end{array}$ & $\begin{array}{llll}N & 48 & 58 & \mathrm{E} \\
\mathrm{N} & 02 & 03 & \mathrm{~W} \\
\mathrm{~N} & 66 & 35 & \mathrm{~W}\end{array}$ & $\begin{array}{r}I, 05 x \\
488 \\
600\end{array}$ \\
\hline $3^{8} \quad 40 \quad 02.45$ & $\begin{array}{llll}76 & 08 & 2 x & 56\end{array}$ & $\begin{array}{llll}\mathrm{S} & 52 & \text { I3 } & \mathrm{W} \\
\mathrm{S} & \mathrm{I}_{5} & 39 & \mathrm{~W} \\
\mathrm{~S} & 5 \mathrm{I} & 52 & \mathrm{E}\end{array}$ & $\begin{array}{llll}N & 52 & 13 & E \\
N & 15 & 39 & E \\
N & 51 & 52 & W\end{array}$ & $\begin{array}{r}I, I 84 \\
570 \\
482\end{array}$ \\
\hline
\end{tabular}

Thence from corner No. 6 along the mean low water line of the shore to corner No. 7 , excluding any creek, cove, or inlet less than roo yards in width at its mouth at low tide.

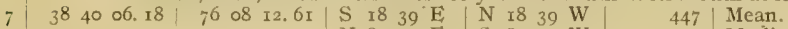

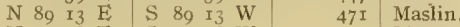

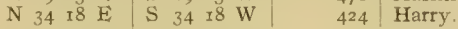

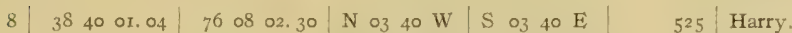

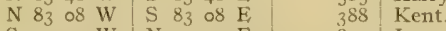

S 5257 W N 5257 E 830 Jay.

Thence from comer No. 8 along the mean low water line of the shore to corner No. 9, excluding any creek, cove, or inlet less than roo yards in width at its mouth at low tide.

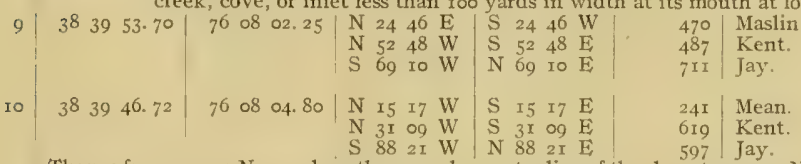

Thence from corner No. Io along the mean low water line of the shore to comer No. I, excluding any creek, cove, or inlet less than roo yards in width at its mouth at low tide. 
BOUNDARIES OF NATURAL OYSTER BARS-continued.

\section{MATTHEWS.}

(Island Crcck-Charts Nos. 34 and 35.)

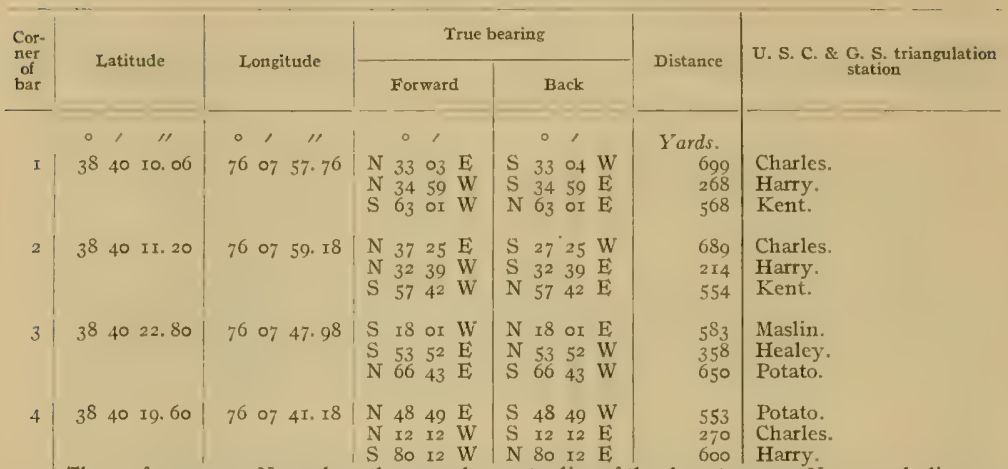

Thence from comer No. 4 along the mean low water line of the shore to comer No. 1 , excluding any creek, cove, or inlet less than 100 yards in width at its mouth at low tide.

\section{OLD ORCHARD.}

(Miles River-Chart No. 34.)

\begin{tabular}{|c|c|c|c|c|c|c|c|c|c|c|c|}
\hline & 0 , & II & $c$ & , & "I & o & , & 。 & , & Yards. & \\
\hline I & $3^{8}+6$ & 44.981 & 76 & I 2 & 09.46 & $\begin{array}{ll}\mathrm{S} & 40 \\
\mathrm{~S} & 78 \\
\mathrm{~N} & 29\end{array}$ & $\begin{array}{ll}29 & \mathrm{E} \\
19 & \mathrm{E} \\
02 & \mathrm{~W}\end{array}$ & $\begin{array}{l}\text { N } 40 \\
N \quad 78 \\
\text { S } 29\end{array}$ & $\begin{array}{l}29 \mathrm{~W} \\
18 \mathrm{~W} \\
02 \mathrm{E}\end{array}$ & $\begin{array}{r}540 \\
2,200 \\
2,206\end{array}$ & $\begin{array}{l}\text { Stony. } \\
\text { Gibbs. } \\
\text { Millwind. }\end{array}$ \\
\hline 2 & $38+7$ & or). $58^{\circ}$ & 76 & 12 & $3+.28$ & $\begin{array}{ll}\text { N } & 20 . \\
N & 86 \\
\text { S } & 39\end{array}$ & $\begin{array}{ll}42 & W \\
\text { I2 } & W \\
\text { O2 } & E\end{array}$ & $\begin{array}{ll}\mathrm{S} & 20 \\
\mathrm{~S} & 86 \\
\mathrm{~N} & 39\end{array}$ & $\begin{array}{ll}42 & E \\
I_{2} & E \\
\text { O2 } & W\end{array}$ & $\begin{array}{l}I, 175 \\
I, 576 \\
I, 597\end{array}$ & $\begin{array}{l}\text { Millwind. } \\
\text { St. Michaels Water Tank. } \\
\text { Stony. }\end{array}$ \\
\hline 3) & $3^{8}+7$ & $1_{3} .60$ & 70 & 12 & 26.40 & $\begin{array}{ll}N & 32 \\
\text { S } & 88 \\
\text { S } & 30\end{array}$ & $\begin{array}{ll}54 & W \\
59 & W \\
06 & E\end{array}$ & $\begin{array}{ll}\mathrm{S} & 32 \\
\mathrm{~N} & 88 \\
\mathrm{~N} & 30\end{array}$ & $\begin{array}{l}54 \mathrm{E} \\
59 \mathrm{E} \\
06 \mathrm{~W}\end{array}$ & $\begin{array}{l}\text { I, } 147 \\
\text { I, } 780 \\
\text { I, } 590\end{array}$ & $\begin{array}{l}\text { Millwind. } \\
\text { St. Michaels Water Tank. } \\
\text { Stony. }\end{array}$ \\
\hline 4 & $3^{8} 4^{6}$ & 50.94 & $7^{6}$ & II & 53.28 & $\begin{array}{lr}\mathrm{S} & 7 \\
\mathrm{~S} & 69 \\
\mathrm{~N} & 2\end{array}$ & $\begin{array}{ll}08 & \mathrm{~W} \\
3 \mathrm{I} & \mathrm{E} \\
35 \mathrm{E}\end{array}$ & $\begin{array}{lr}\mathrm{N} & 7 \\
\mathrm{~N} & 69 \\
\mathrm{~S} & 2\end{array}$ & $\begin{array}{l}\text { o8 } \mathrm{E} \\
3 \mathrm{I} \\
35 \mathrm{~W}\end{array}$ & $\begin{array}{r}617 \\
1,855 \\
2,085\end{array}$ & $\begin{array}{l}\text { Stony. } \\
\text { Gibbs. } \\
\text { Fair. }\end{array}$ \\
\hline
\end{tabular}


BOUNDARIES OF NATURAL OYSTER BARS-continued.

GIBSONS FLATS.

(Miles River-Chart No. 34).

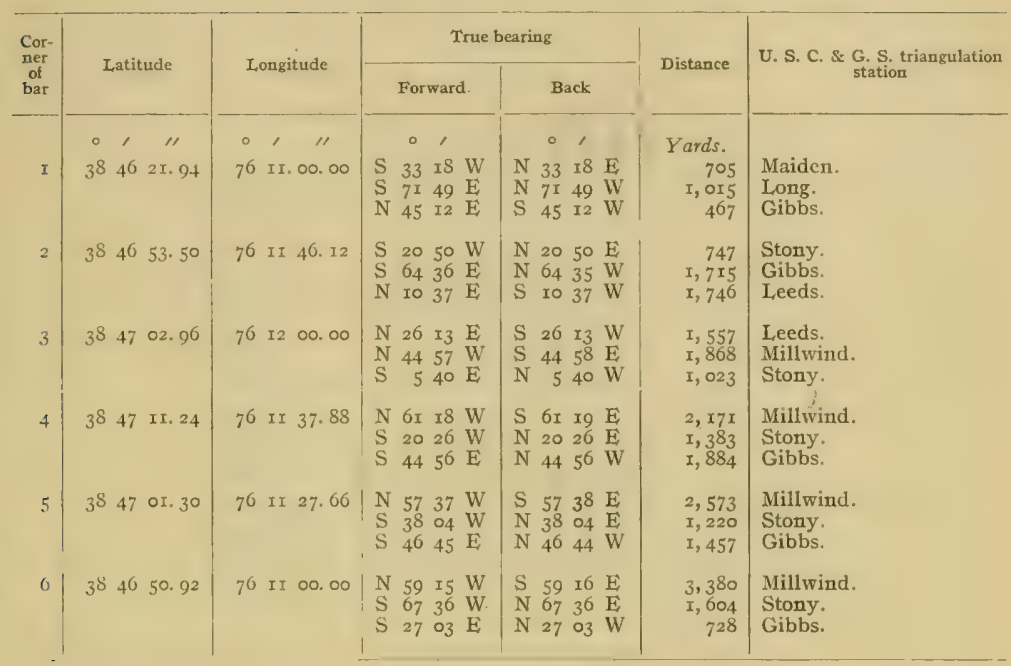

BAZZLES HILL.

(Miles River-Chart No. 34.)

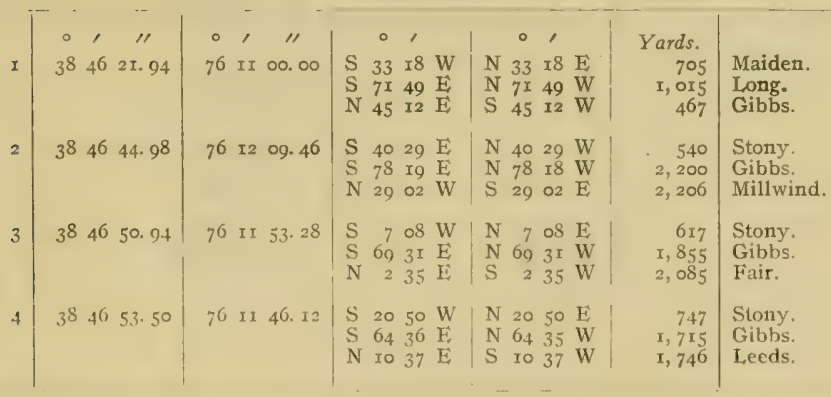


BOUNDARIES OF NATURAL, OYSTER BARS-continued.

LONG POINT.

(Miles River-Chart No. 34.)

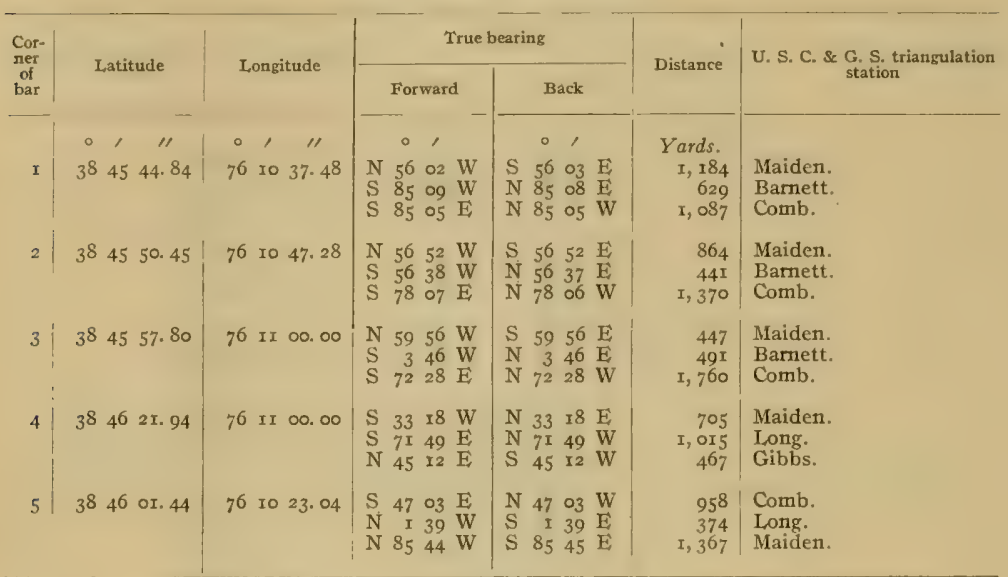

\section{BARNETT.}

(Miles River-Chart No. 34.)

\begin{tabular}{|c|c|c|c|c|c|c|}
\hline I & $\begin{array}{ccc}0 & \prime & \prime \prime \\
38 & 45 & 40.04\end{array}$ & $\begin{array}{ccc}\circ & \prime \prime \prime \\
76 & 10 & 57.24\end{array}$ & $\begin{array}{cccc} & 0 & \\
& & \\
\mathrm{~S} & 38 & 36 & \mathrm{E} \\
\mathrm{N} & 87 & 33 & \mathrm{E} \\
\mathrm{N} & 44 & 04 & \mathrm{~W}\end{array}$ & \begin{tabular}{cccc} 
& 0 & \multicolumn{1}{c}{} \\
$\mathrm{N}$ & 38 & 36 & $\mathrm{~W}$ \\
$\mathrm{~S}$ & 87 & 33 & $\mathrm{~W}$ \\
$\mathrm{~S}$ & 44 & 04 & $\mathrm{E}$
\end{tabular} & $\begin{array}{l}\text { Yards. } \\
\mathrm{I}, \mathrm{r} 59 \\
\mathrm{I}, 605 \\
\mathrm{r} 5 \mathrm{I}\end{array}$ & $\begin{array}{l}\text { Hall. } \\
\text { Comb. } \\
\text { Barnett. }\end{array}$ \\
\hline 2 & $3^{8} \quad 45 \quad 46.02$ & $\begin{array}{llll}76 & 11 & 03.90\end{array}$ & $\begin{array}{llll}\mathrm{S} & 37 & 15 & \mathrm{E} \\
\mathrm{N} & 50 & 03 & \mathrm{E} \\
\mathrm{N} & 24 & 35 & \mathrm{~W}\end{array}$ & $\begin{array}{llll}N & 37 & \text { I } & \text { W } \\
\text { S } & 50 & 04 & \text { W } \\
\text { S } & 24 & 35 & E\end{array}$ & $\begin{array}{r}117 \\
\text { I, } 393 \\
684\end{array}$ & $\begin{array}{l}\text { Barnett. } \\
\text { Long. } \\
\text { Maiden. }\end{array}$ \\
\hline 3 & $\begin{array}{lll}38 & 45 & 57.80\end{array}$ & 76 II 00.00 & $\begin{array}{lrrr}\mathrm{N} & 59 & 56 & \mathrm{~W} \\
\mathrm{~S} & 3 & 46 & \mathrm{~W} \\
\mathrm{~S} & 72 & 28 & \mathrm{E}\end{array}$ & $\begin{array}{lrrr}\mathrm{S} & 59 & 56 & \mathrm{E} \\
\mathrm{N} & 3 & 46 & \mathrm{E} \\
\mathrm{N} & 72 & 28 & \mathrm{~W}\end{array}$ & $\begin{array}{r}447 \\
491 \\
I, 760\end{array}$ & $\begin{array}{l}\text { Maiden. } \\
\text { Barnett. } \\
\text { Comb. }\end{array}$ \\
\hline 4 & $3^{8} 45 \quad 50.45$ & 76 I0 47.28 & $\begin{array}{llll}\mathrm{N} & 56 & 52 & \mathrm{~W} \\
\mathrm{~S} & 56 & 38 & \mathrm{~W} \\
\mathrm{~S} & 78 & 07 & \mathrm{E}\end{array}$ & $\begin{array}{llll}\mathrm{S} & 56 & 52 & \mathrm{E} \\
\mathrm{N} & 56 & 37 & \mathrm{E} \\
\mathrm{N} & 78 & 06 & \mathrm{~W}\end{array}$ & $\begin{array}{r}864 \\
441 \\
r, 370\end{array}$ & $\begin{array}{l}\text { Maiden. } \\
\text { Bamett. } \\
\text { Comb. }\end{array}$ \\
\hline
\end{tabular}


BOUNDARIES OF NATURAL OYSTER BARS-continued.

$\operatorname{cox}$.

(Miles River-Chart No. 34.)

\begin{tabular}{|c|c|c|c|c|c|c|}
\hline \multirow{2}{*}{$\begin{array}{l}\text { Cor- } \\
\text { ner } \\
\text { of } \\
\text { bar }\end{array}$} & \multirow{2}{*}{ Latitude } & \multirow{2}{*}{ Longitude } & \multicolumn{2}{|c|}{ True bearing } & \multirow{2}{*}{ Distance } & \multirow{2}{*}{$\begin{array}{c}\text { U. S. C. \& G. S. triangulation } \\
\text { station }\end{array}$} \\
\hline & & & Forward & Back & & \\
\hline I & $\begin{array}{ccc}0 & 11 \\
38 & 46 \text { I6. I } 3\end{array}$ & $\begin{array}{ccc}0 & \prime & 11 \\
76 & 09 & 22.88\end{array}$ & $\begin{array}{cccc} & 0 & 1 \\
N & 27 & \text { I0 } & \mathrm{E} \\
\mathrm{N} & 64 & \mathrm{I} 2 & \mathrm{~W} \\
\mathrm{~S} & 85 & 40 & \mathrm{~W}\end{array}$ & $\begin{array}{lccc} & 0 & \prime \\
\mathrm{S} & 27 & 10 & \mathrm{~W} \\
\mathrm{~S} & 64 & \mathrm{I}_{3} & \mathrm{E} \\
\mathrm{N} & 85 & 40 & \mathrm{E}\end{array}$ & $\begin{array}{l}\text { Yards. } \\
1,05^{2} \\
911 \\
x, 603\end{array}$ & $\begin{array}{l}\text { Whit. } \\
\text { Hunting. } \\
\text { Long. }\end{array}$ \\
\hline 2 & $3^{8} \quad 46=28.88$ & $76 \circ 926.79$ & $\begin{array}{llll}\mathrm{S} & 24 & \text { II } & \mathrm{W} \\
\mathrm{S} & 33 & 37 & \mathrm{E} \\
\mathrm{N} & 7 \mathrm{I} & 02 & \mathrm{E}\end{array}$ & $\begin{array}{llll}N & 24 & \text { II } & \mathrm{E} \\
\mathrm{N} & 33 & 37 & \mathrm{~W} \\
\mathrm{~S} & 7 \mathrm{I} & 03 & \mathrm{~W}\end{array}$ & $\begin{array}{r}I, 074 \\
347 \\
I, 056\end{array}$ & $\begin{array}{l}\text { Ham. } \\
\text { Kitk. } \\
\text { McConnell. }\end{array}$ \\
\hline 3 & $3^{8} 46 \quad 30.98$ & $7609 \mathrm{Ig} .6 \mathrm{I}$ & $\begin{array}{llll}\mathrm{S} & 30 & 56 & \mathrm{~W} \\
\mathrm{~S} & 00 & 25 & \mathrm{E} \\
\mathrm{N} & 71 & 24 & \mathrm{E}\end{array}$ & $\begin{array}{llll}N & 30 & 56 & \mathrm{E} \\
N & 00 & 25 & W \\
\mathrm{~S} & 7 \mathrm{I} & 24 & \mathrm{~W}\end{array}$ & $\begin{array}{r}I, 225 \\
360 \\
854\end{array}$ & $\begin{array}{l}\text { Ham. } \\
\text { Kirk. } \\
\text { McConnell. }\end{array}$ \\
\hline 4 & $3^{8} 4^{6} \quad 24 \cdot 46$ & $76 \circ 907.19$ & $\begin{array}{lrll}N & 5 & 46 & E \\
N & 73 & 35 & W \\
S & 88 & 03 & W\end{array}$ & $\begin{array}{lrll}\mathrm{S} & 5 & 46 & \mathrm{~W} \\
\mathrm{~S} & 73 & 35 & \mathrm{E} \\
\mathrm{N} & 88 & 02 & \mathrm{E}\end{array}$ & $\begin{array}{r}658 \\
756 \\
I, 857\end{array}$ & $\begin{array}{l}\text { Whit. } \\
\text { Spree. } \\
\text { Beg. }\end{array}$ \\
\hline 5 & $\begin{array}{l}3^{8} 4620.94 \\
\text { Thence from } \\
\text { any creek, }\end{array}$ & $\begin{array}{l}76 \text { og } 14.50 \\
\text { mer No. } 5 \text { alo } \\
\text { ve, or inlet le }\end{array}$ & $\begin{array}{l}\mathrm{N} 47 \text { 50 } \mathrm{E} \\
\mathrm{N} \text { I8 } 3 \mathrm{I} \text { E } \\
\mathrm{N} 57 \text {. W } \\
\text { ng the mean } \\
\text { s than soo ya }\end{array}$ & $\begin{array}{l}\text { S } 47 \text { 50 W } \\
\text { S } 18 \text { II W } \\
\text { S } 57 \text {. } 59 \text { E } \\
\text { w-water line } \\
\text { ds in width at }\end{array}$ & $\begin{array}{r}911 \\
816 \\
627 \\
\text { the shore }\end{array}$ & $\begin{array}{l}\text { McConnell. } \\
\text { Whit. } \\
\text { Spree. } \\
\text { to corner No. r, excluding } \\
\text { low tide. }\end{array}$ \\
\hline
\end{tabular}

CHLORA POINT.

(Middle Choptank River-Chart No. 35.)

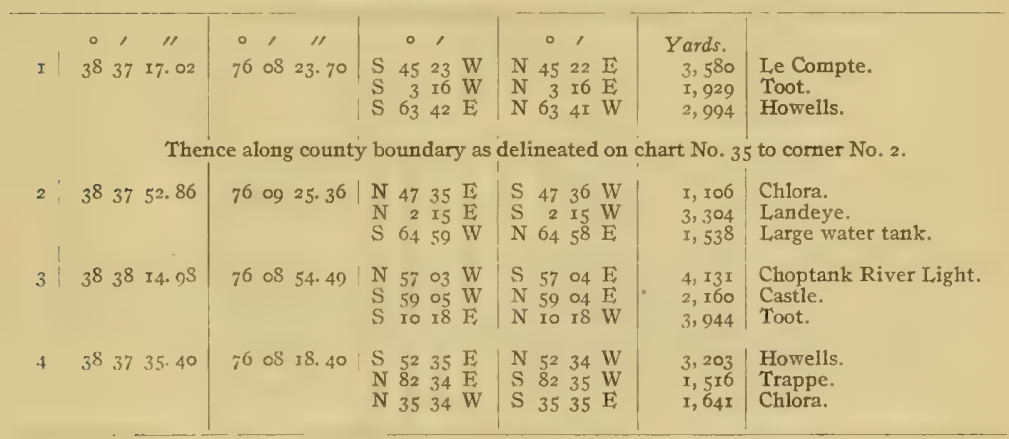


BOUNDARIES OF NATURAL OYSTER BARS-continued.

BEACONS.

(Middle Choptank River-Chart No. 35.)

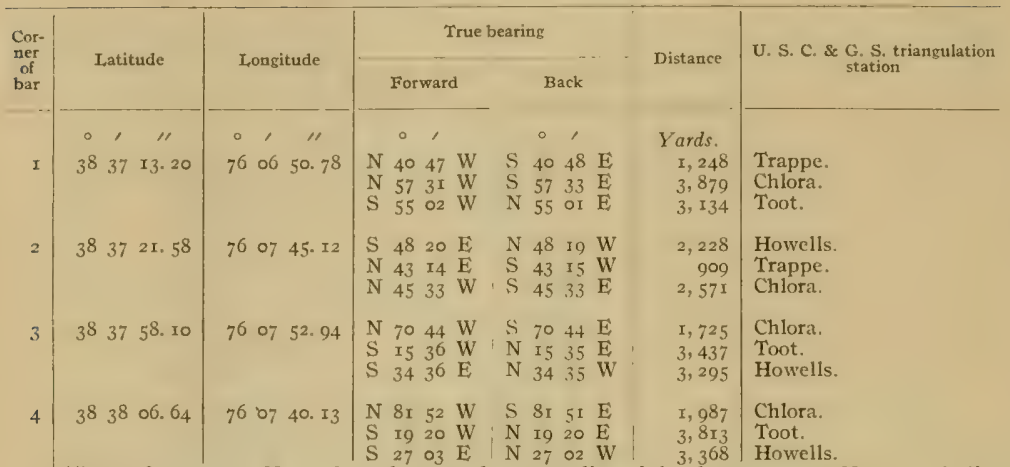

Thence from corner No. 4 along the mean low-water line of the shore to corner No. 5 , excluding any creek, cove, or inlet less than 100 yards in width at its mouth at low tide.

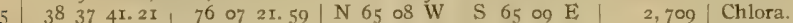

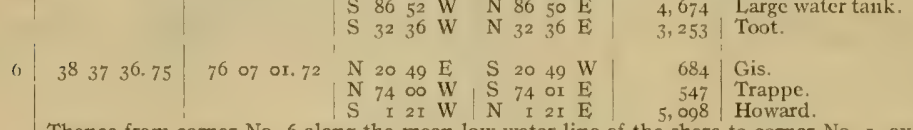

Thence from corner No. 6 along the mean low-water line of the shore to comer No. I, excluding any creek, cove, or inlet less than 100 yards in width at its mouth at low tide.

\section{LA TRAPPE.}

(La Trappe Creek-Chart No. 35.)

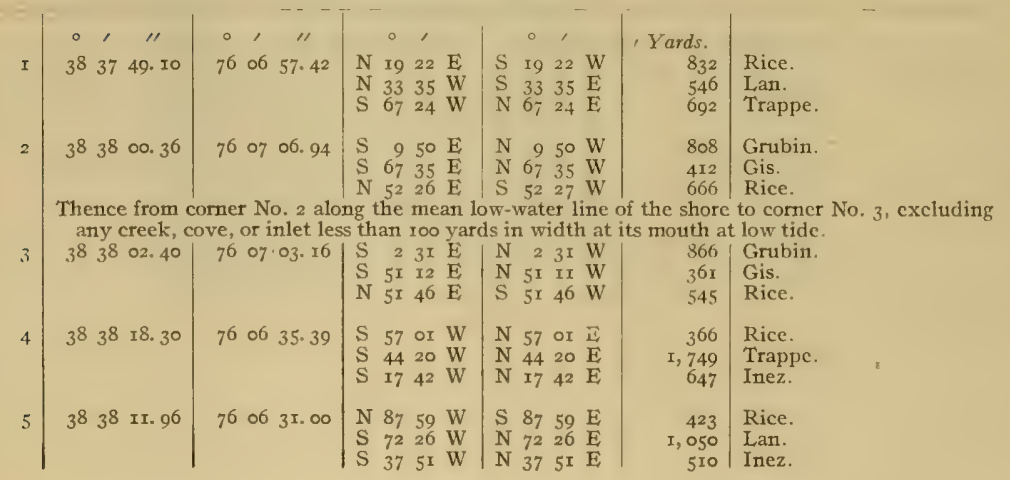


Survey of Oyster Bars, Talbot County, Md.

BOUNDARIES OF NATURAL OYSTER BARS-continued.

\section{LA TRAPPE-Continued.}

(La Trappe Creek-Chart No. 35)-Continued.

\begin{tabular}{|c|c|c|c|c|c|c|c|c|c|c|c|c|c|c|}
\hline \multirow{2}{*}{$\begin{array}{l}\text { Cor- } \\
\text { ner } \\
\text { of } \\
\text { bar }\end{array}$} & \multirow{2}{*}{\multicolumn{3}{|c|}{ Latitude }} & \multirow{2}{*}{\multicolumn{3}{|c|}{ L,ongitude }} & \multicolumn{6}{|c|}{ True bearing } & \multirow{2}{*}{ Distance } & \multirow{2}{*}{$\begin{array}{l}\text { U. S. C. \& G. S. triangulation } \\
\text { station }\end{array}$} \\
\hline & & & & & & & & Forw & Nard & & Bac & ck & & \\
\hline 6 & $\begin{array}{l}\circ \\
3^{8}\end{array}$ & 38 & $\begin{array}{l}\prime \prime \\
\infty 0.08\end{array}$ & $\begin{array}{l}0 \\
76\end{array}$ & 06 & $\begin{array}{c}\prime \prime \\
53.96\end{array}$ & $\begin{array}{l}N \\
N \\
S\end{array}$ & $\begin{array}{c}0 \\
23 \\
77 \\
14\end{array}$ & $\begin{array}{ll}58 \\
58 & \mathrm{E} \\
56 & \mathrm{~W} \\
37 & \mathrm{~W}\end{array}$ & $\begin{array}{l}\mathrm{S} \\
\mathrm{S} \\
\mathrm{N}\end{array}$ & $\begin{array}{cc}0 & \\
23 & 5 \\
77 & 5 \\
14 & 3\end{array}$ & $\begin{array}{ll}58 \\
58 \\
57 & \mathrm{E} \\
37 & \mathrm{E}\end{array}$ & $\begin{array}{r}\text { Yards. } \\
455 \\
402 \\
814\end{array}$ & $\begin{array}{l}\text { Rice. } \\
\text { Lan. } \\
\text { Grubin. }\end{array}$ \\
\hline $\bar{i}$ & 38 & 37 & 49.40 & $7^{6}$ & 06 & 52.64 & $\begin{array}{l}\mathrm{N} \\
\mathrm{N} \\
\mathrm{S}\end{array}$ & $\begin{array}{l}10 \\
43 \\
70\end{array}$ & $\begin{array}{ll}56 & \mathrm{E} \\
56 & \mathrm{~W} \\
\text { I0 } & \mathrm{W}\end{array}$ & $\begin{array}{l}\mathrm{S} \\
\mathrm{S} \\
\mathrm{N}\end{array}$ & $\begin{array}{ll}10 & 5 \\
43 & 5 \\
70 & 1\end{array}$ & $\begin{array}{ll}56 & \mathrm{WV} \\
57 & \mathrm{E} \\
\text { IO } & \mathrm{E}\end{array}$ & $\begin{array}{l}790 \\
617 \\
815\end{array}$ & $\begin{array}{l}\text { Rice. } \\
\text { Lran. } \\
\text { Trappe. }\end{array}$ \\
\hline
\end{tabular}

\section{HOWELLS POINT}

(.iddle Choptank River-Chart No. 35.)

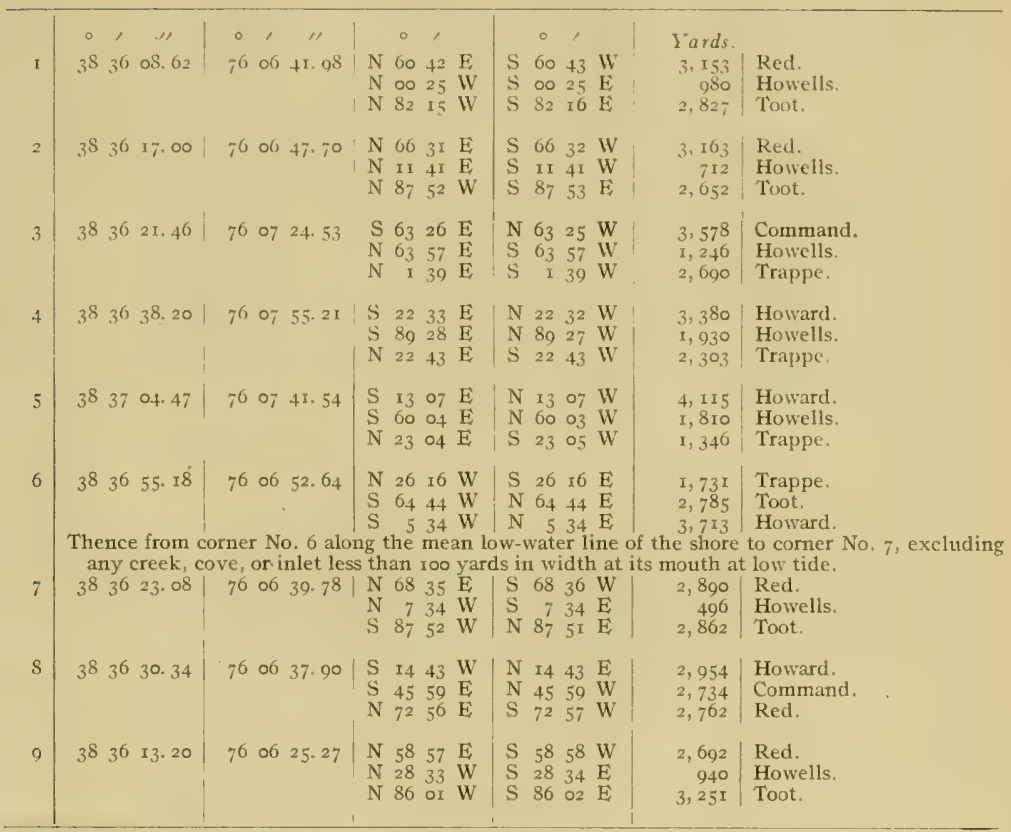


BOUNDARIES OF NATURAL OYSTER BARS-continUEd.

DICKINSON.

(Middle Choptank River-Chart No. 35.)

\begin{tabular}{|c|c|c|c|c|c|c|c|c|}
\hline \multirow{2}{*}{$\begin{array}{l}\text { Cot- } \\
\text { ner } \\
\text { of } \\
\text { bar }\end{array}$} & \multirow{2}{*}{ Latitude } & \multirow{2}{*}{ Longitude } & \multicolumn{4}{|c|}{ True bearing } & \multirow{2}{*}{ Distance } & \multirow{2}{*}{$\begin{array}{l}\text { U. S. C. \& G. S. triangulation } \\
\text { station }\end{array}$} \\
\hline & & & For & rward & $\mathrm{Ba}$ & & & \\
\hline I & $\begin{array}{ccc}\circ & \prime \prime \\
3^{8} & 35 & 58.78\end{array}$ & $\begin{array}{ccc}\circ & \prime \prime & \prime \prime \\
76 & 05 & 55.86\end{array}$ & $\begin{array}{lc} & 0 \\
N & 39 \\
N & 43 \\
\text { S } & 46\end{array}$ & $\begin{array}{l}\text { II } \\
\text { If } \\
\text { of } \mathrm{W} \\
\text { of } \mathrm{W}\end{array}$ & \begin{tabular}{|cc} 
& 0 \\
S & 39 \\
S & 43 \\
N & 46
\end{tabular} & $\begin{array}{l}1 \\
\text { I2 } \mathrm{V} \\
06 \mathrm{E} \\
05 \mathrm{E}\end{array}$ & $\begin{array}{l}\text { Yards. } \\
2,419 \\
1,797 \\
2,586\end{array}$ & $\begin{array}{l}\text { Red. } \\
\text { Howells. } \\
\text { Howard. }\end{array}$ \\
\hline 2 & ${ }_{3} 83_{3} 64^{6.24}$ & $7606 \quad 33.60$ & $\begin{array}{ll}\mathrm{S} & 38 \\
\mathrm{~S} & \mathrm{I} 4 \\
\mathrm{~N} & 83\end{array}$ & $\begin{array}{l}25 \mathrm{~W} \\
17 \mathrm{~W} \\
48 \mathrm{E}\end{array}$ & $\begin{array}{ll}\mathrm{N} & 38 \\
\mathrm{~N} & \mathrm{I} 4 \\
\mathrm{~S} & 83\end{array}$ & $\begin{array}{l}25 \mathrm{E} \\
\mathrm{I} 7 \mathrm{E} \\
49 \mathrm{~V}\end{array}$ & $\begin{array}{r}369 \\
3,502 \\
2,543\end{array}$ & $\begin{array}{l}\text { Howells. } \\
\text { Howard. } \\
\text { Red. }\end{array}$ \\
\hline 3 & $3^{8} 3^{6} \quad 55.65$ & 76 o6 3r.08 & $\begin{array}{ll}\mathrm{S} & 26 \\
\mathrm{~S} & 14 \\
\mathrm{~S} & 89\end{array}$ & $\begin{array}{l}00 \mathrm{~W} \\
05 \mathrm{~W} \\
00 \mathrm{E}\end{array}$ & $\begin{array}{ll}N & 26 \\
N & 14 \\
N & 88\end{array}$ & $\begin{array}{l}00 \mathrm{~B} \\
05 \mathrm{E} \\
59 \mathrm{~V}\end{array}$ & $\begin{array}{r}675 \\
3,825 \\
2,461\end{array}$ & $\begin{array}{l}\text { Howells. } \\
\text { Howard. } \\
\text { Red. }\end{array}$ \\
\hline 4 & $\begin{array}{llll}3^{8} & 36 & 29.84\end{array}$ & 760541.78 & $\begin{array}{ll}N & 54 \\
N & 80 \\
S & 38\end{array}$ & $\begin{array}{ll}24 & \mathrm{E} \\
37 & \mathrm{~W} \\
12 & \mathrm{~W}\end{array}$ & $\begin{array}{ll}\mathrm{S} & 54 \\
\mathrm{~S} & 80 \\
\mathrm{~N} & 38\end{array}$ & $\begin{array}{ll}24 & \mathrm{~V} \\
38 & \mathrm{~F} \\
\text { II } & \mathrm{I}\end{array}$ & $\begin{array}{l}\mathrm{I}, 422 \\
\mathrm{I}, 622 \\
3,615\end{array}$ & $\begin{array}{l}\text { Red. } \\
\text { Howells. } \\
\text { Howard. }\end{array}$ \\
\hline 5 & $3^{8} \quad 3^{6} \quad 40.84$ & 760.443 .15 & $\begin{array}{ll}\text { S } & 88 \\
\text { S } & 25 \\
\text { S } & 49\end{array}$ & $\begin{array}{ll}03 & \mathrm{~W} \\
25 & \mathrm{~W} \\
18 & \mathrm{E}\end{array}$ & $\begin{array}{ll}N & 38 \\
N & 25 \\
N & 49\end{array}$ & $\begin{array}{ll}02 & \mathrm{H} \\
25 & \mathrm{H} \\
\times 7 & \mathrm{~V}\end{array}$ & $\begin{array}{l}3,153 \\
2,495 \\
3,215\end{array}$ & $\begin{array}{l}\text { Howells. } \\
\text { Command. } \\
\text { Double. }\end{array}$ \\
\hline 6 & $3^{8} 3^{6} 24.3^{8}$ & 760453.36 & $\begin{array}{ll}N & 8 \mathrm{I} \\
\mathrm{S} & 25 \\
\mathrm{~S} & 60\end{array}$ & $\begin{array}{l}10 \mathrm{WV} \\
14 \mathrm{~W} \\
20 \mathrm{E}\end{array}$ & $\begin{array}{ll}\mathrm{S} & 8 \mathrm{r} \\
\mathrm{N} & 25 \\
\mathrm{~N} & 60\end{array}$ & $\begin{array}{ll}\text { II } & \mathrm{B} \\
\text { I4 } & \mathrm{H} \\
\text { I9 } & \mathrm{V}\end{array}$ & $\begin{array}{l}2,916 \\
1,878 \\
3,117\end{array}$ & $\begin{array}{l}\text { Howells. } \\
\text { Command. } \\
\text { Double. }\end{array}$ \\
\hline 7 & $3^{8} 36 \quad 10.60$ & $76 \quad 0_{5} \quad$ I2. 54 & $\begin{array}{ll}N & 71 \\
N & 14 \\
N & 68\end{array}$ & $\begin{array}{ll}30 \mathrm{E} \\
32 & \mathrm{E} \\
58 & \mathrm{~W}\end{array}$ & $\begin{array}{ll}\mathrm{S} & 71 \\
\mathrm{~S} & 14 \\
\mathrm{~S} & 68\end{array}$ & $\begin{array}{ll}31 & V \\
32 & Y \\
59 & H\end{array}$ & $\begin{array}{l}3,39 I \\
I, 526 \\
2,544\end{array}$ & $\begin{array}{l}\text { Double. } \\
\text { Red. } \\
\text { Howells. }\end{array}$ \\
\hline 8 & $3^{8} 3^{6} \circ 9.5^{6}$ & $\begin{array}{llll}76 & 05 & 26.90\end{array}$ & $\begin{array}{ll}y & \text { boun } \\
N & 26 \\
N & 64 \\
\text { S } & 50\end{array}$ & $\begin{array}{l}46 \mathrm{E} \\
34 \mathrm{~W} \\
39 \mathrm{~W}\end{array}$ & $\begin{array}{l}\text { delineat } \\
\text { S } 26 \\
\text { S } 64 \\
\text { N } 50\end{array}$ & $\begin{array}{l}4 \text { ated o } \\
46 \mathrm{~V} \\
35 \mathrm{H} \\
38 \mathrm{E}\end{array}$ & $\begin{array}{r}\text { hart No. } 35 \\
\text { I, } 693 \\
2,208 \\
3,401\end{array}$ & $\begin{array}{l}\text { to corner No. } 8 \text {. } \\
\text { Red. } \\
\text { Howells. } \\
\text { Howard. }\end{array}$ \\
\hline
\end{tabular}

\section{KIRBY.}

(Middle Choptank River-Chart No. 35.)

\begin{tabular}{|c|c|c|c|c|c|c|c|c|c|c|c|}
\hline I & $\begin{array}{cc}\circ & 1 \\
38 & 35\end{array}$ & 36.96 & $\begin{array}{c}\circ \\
76\end{array}$ & $\begin{array}{c}1 \\
04\end{array}$ & $\begin{array}{c}\prime \prime \\
\text { Ix. } 95\end{array}$ & $\begin{array}{lc} & 0 \\
S & 87 \\
\text { S } & 36 \\
N & 87\end{array}$ & $\begin{array}{l}1 \\
00 \mathrm{~W} \\
03 \mathrm{~W} \\
58 \mathrm{E}\end{array}$ & $\begin{array}{lc} & 0 \\
N & 86 \\
N & 36 \\
\text { S } & 87\end{array}$ & $\begin{array}{ll} \\
59 & \mathrm{~F} \\
\mathrm{O}_{3} & \mathrm{E} \\
5^{8} & \mathrm{~W}\end{array}$ & $\begin{array}{r}\text { Yards. } \\
\mathrm{I}, 900 \\
\mathrm{I}, 289 \\
\mathrm{I}, 6 \mathrm{r} 3\end{array}$ & $\begin{array}{l}\text { Command. } \\
\text { Cambridge. } \\
\text { Double. }\end{array}$ \\
\hline 2 & $3^{8} 3^{6}$ & $\begin{array}{l}\text { Then } \\
\text { I0. } 60\end{array}$ & $\begin{array}{c}\text { e alo } \\
76\end{array}$ & & $\begin{array}{l}\text { county } \\
\text { 12. } 54\end{array}$ & $\begin{array}{l}\text { bound } \\
N 71 \\
N \text { I } \\
N 68\end{array}$ & $\begin{array}{l}\text { lary as } \\
30 \mathrm{E} \\
32 \mathrm{E} \\
58 \mathrm{~W}\end{array}$ & $\begin{array}{ll}\text { lelinea } \\
\text { S } & 7 x \\
\text { S } & \text { I4 } \\
\text { S } & 68\end{array}$ & $\begin{array}{ll}3 & \text { ted on } \\
32 & W \\
32 & W \\
59 & E\end{array}$ & $\begin{array}{r}\text { Chart No. } \\
3,391 \\
1,526 \\
2,544\end{array}$ & $\begin{array}{l}5 \text { to corner No. } 2 . \\
\text { Double. } \\
\text { Red. } \\
\text { Howells. }\end{array}$ \\
\hline 3 & $3^{8} 3^{6}$ & $24 \cdot 3^{8}$ & 76 & 04 & $53 \cdot 3^{6}$ & $\begin{array}{ll}N & 8 I \\
S & 25 \\
S & 60\end{array}$ & $\begin{array}{l}\text { Io } \mathrm{W} \\
14 \mathrm{~W} \\
20 \mathrm{E}\end{array}$ & $\begin{array}{ll}S & 8 I \\
N & 25 \\
N & 60\end{array}$ & $\begin{array}{ll}\text { II } & \mathrm{E} \\
\text { I4 } & \mathrm{E} \\
\text { I9 } & \mathrm{W}\end{array}$ & $\begin{array}{l}2,916 \\
1,878 \\
3, \text { Ix7 }\end{array}$ & $\begin{array}{l}\text { Howells. } \\
\text { Command. } \\
\text { Double. }\end{array}$ \\
\hline 4 & $3^{8} 35$ & $53.9^{8}$ & 76 & 03 & 49.22 & $\begin{array}{ll}\mathrm{N} & 4 \mathrm{I} \\
\mathrm{S} & 76 \\
\mathrm{~S} & 40\end{array}$ & $\begin{array}{l}49 \mathrm{~W} \\
36 \mathrm{~W} \\
\text { o5 W }\end{array}$ & $\begin{array}{l}\text { S } 4 \mathrm{I} \\
\mathrm{N} \\
76 \\
\mathrm{~N} \\
40\end{array}$ & $\begin{array}{l}48 \mathrm{E} \\
35 \mathrm{E} \\
05 \mathrm{E}\end{array}$ & $\begin{array}{l}2,708 \\
\mathrm{I}, 7 \mathrm{I4} \\
2, \mathrm{II} 3\end{array}$ & $\begin{array}{l}\text { Red, } \\
\text { Hambrooks Bar Beacon. } \\
\text { Cambridge. }\end{array}$ \\
\hline
\end{tabular}


BOUNDARIES OF NATURAL OYSTER BARS-contintIed.

SCRAPING LINE.

(Middle Choptank River-Chart No. 35.)

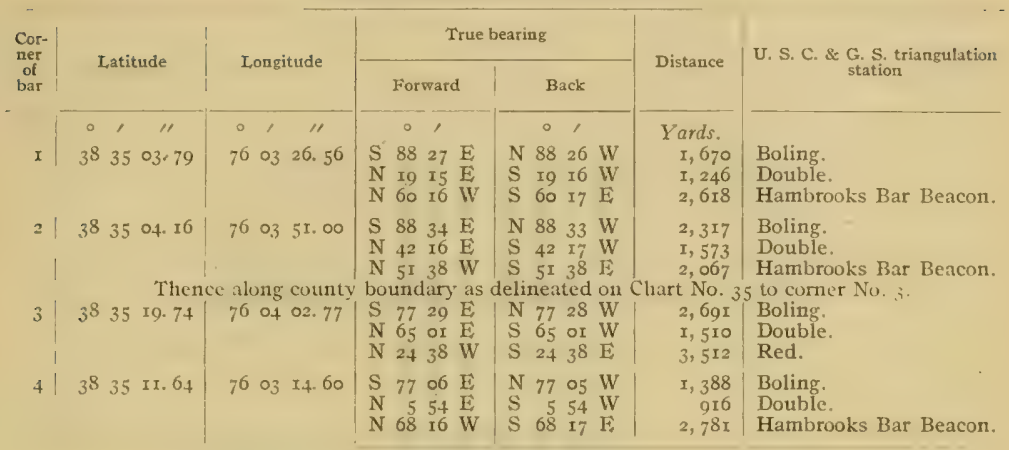

BOLINGBROKE, SAND.

(Middle Choptank River-Chart No. 35.)

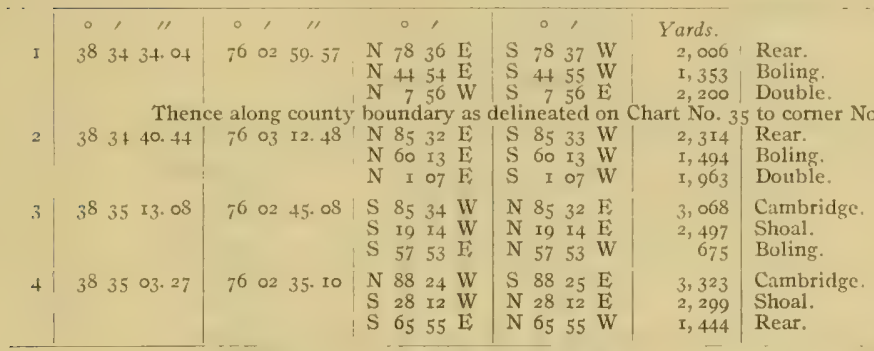

THE BLACK BUOY.

(Middle Choptank River-Chart No. 35.)

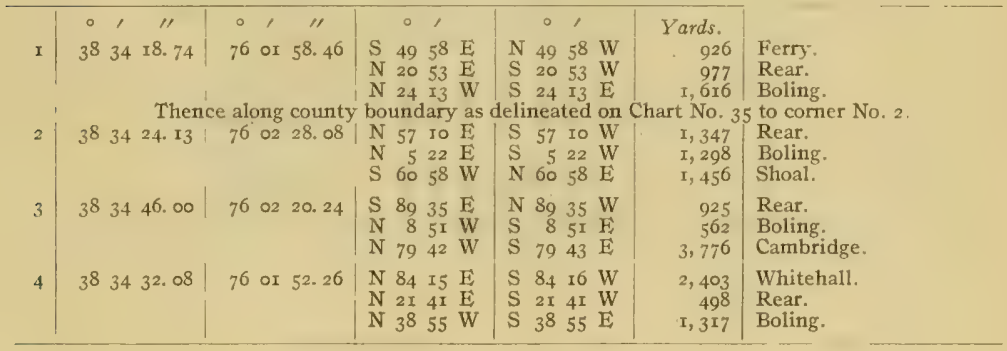


BOUNDARIES OF NATURAL OYSTER BARS-continued.

SUGAR LOAF.

(Middle Choptank River-Chart No. 35.)

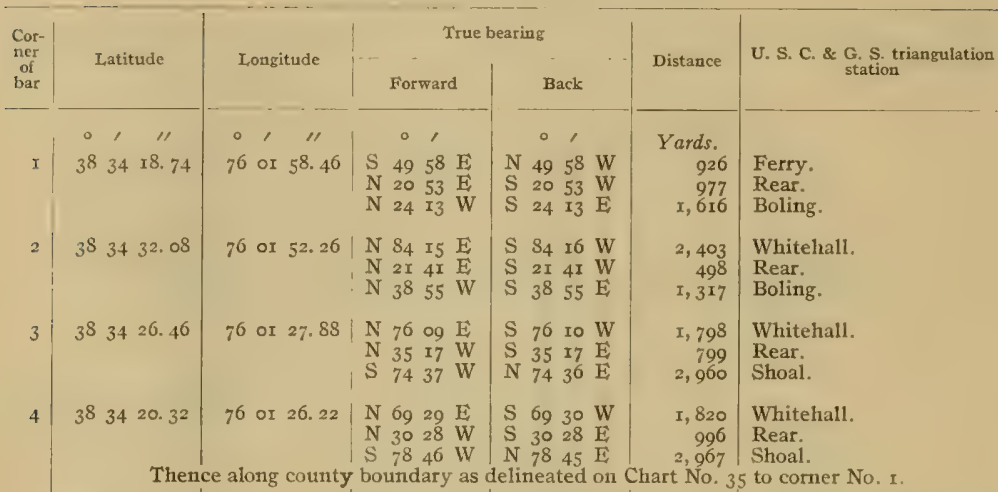

\section{CHANCELLOR POINT.}

(Upper Choptank River-Chart No. 35.)

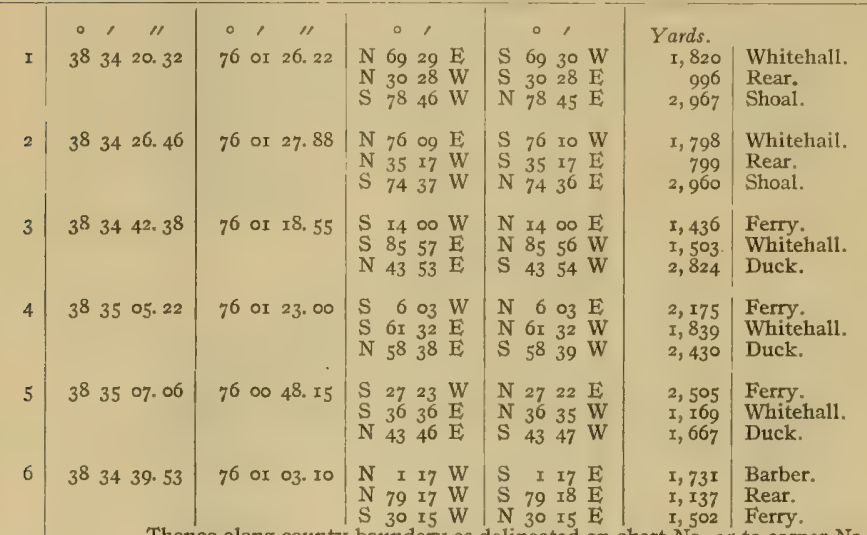

Thence along county boundary as delineated on chart No. 35 to corner No. I. 
Survey of Oyster Bars, Talbot County, $M d$.

BOUNDARIES OF NATURAL OYSTER BARS-continuEd.

BRITISH HARBOR.

(Upper Choptank River-Chart No. 35.)

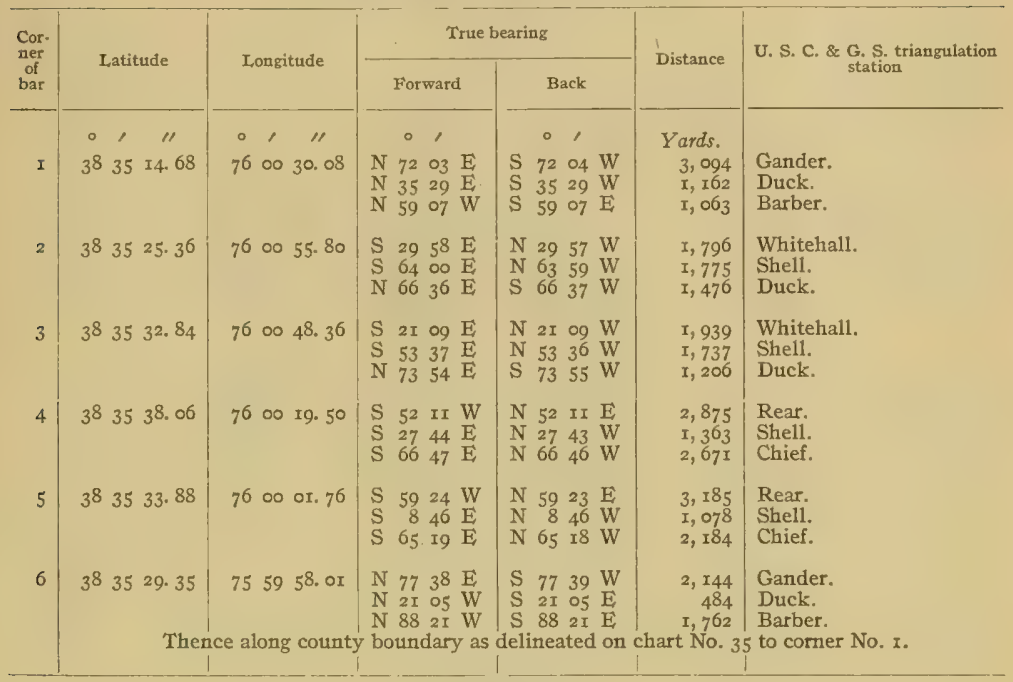

\section{GOOSE POINT}

(Upper Choptank River-Chart No. 35.)

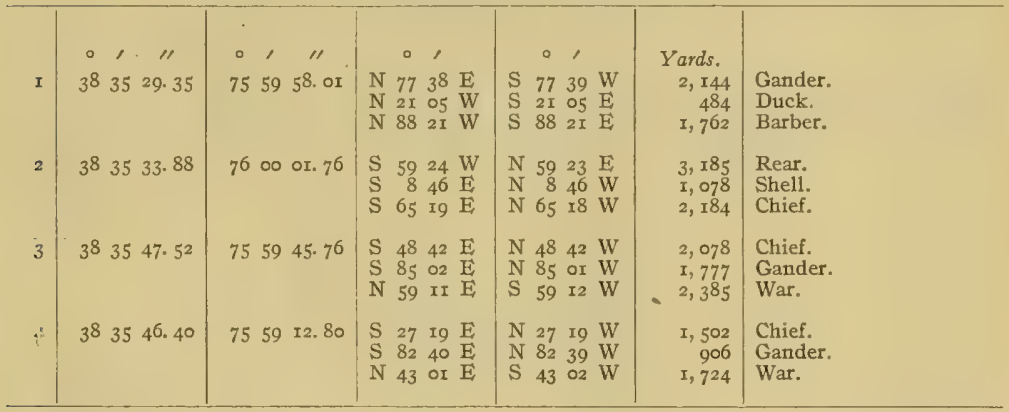

$53485-12-16$ 
Survey of Oyster Bars, Talbot County, $M d$.

BOUNDARIES OF NATURAL OYSTER BARS-continuEd.

MILL DAM.

(Upper Choptank River-Chart No. 35.)

\begin{tabular}{|c|c|c|c|c|c|c|}
\hline \multirow{2}{*}{$\begin{array}{c}\text { Cor- } \\
\text { ner } \\
\text { of } \\
\text { bar }\end{array}$} & \multirow{2}{*}{ Latitude } & \multirow{2}{*}{ Longitude } & \multicolumn{2}{|c|}{ True bearing } & \multirow{2}{*}{ Distance } & \multirow{2}{*}{ 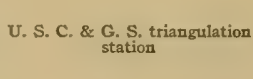 } \\
\hline & & & Forward & Back & & \\
\hline I & $\begin{array}{llll}38 & 35 & 46.40\end{array}$ & $\begin{array}{ccc}0 & 11 \\
75 & 59 & 12.80\end{array}$ & $\begin{array}{cccc} & 0 & \\
S & 27 & \text { IO } & \mathrm{E} \\
\mathrm{S} & 82 & 40 & \mathrm{E} \\
\mathrm{N} & 43 & \text { OI } & \mathrm{E}\end{array}$ & $\begin{array}{cccc} & 0 & \prime & \\
N & 27 & \text { I9 } & W \\
N & 82 & 39 & W \\
S & 43 & 02 & W\end{array}$ & $\begin{array}{r}\text { Yards. } \\
\text { I, } 502 \\
906 \\
\text { I, } 724\end{array}$ & $\begin{array}{l}\text { Chief. } \\
\text { Gander. } \\
\text { War. }\end{array}$ \\
\hline 2 & $3^{8} 3^{6}$ oo. $5^{8}$ & $755935 \cdot 54$ & $\begin{array}{llll}S & 35 & 28 & E \\
S & 68 & 24 & E \\
N & 66 & 16 & E\end{array}$ & $\begin{array}{llll}\mathrm{N} & 35 & 28 & \mathrm{~W} \\
\mathrm{~N} & 68 & 23 & \mathrm{~W} \\
\mathrm{~S} & 66 & \mathrm{r} & \mathrm{W}\end{array}$ & $\begin{array}{l}2,224 \\
I, 6 I_{3} \\
I, 94 I\end{array}$ & $\begin{array}{l}\text { Chief. } \\
\text { Gander. } \\
\text { War. }\end{array}$ \\
\hline 3 & $3^{8} 3^{6}$ I9. 46 & $75 \quad 5925.95$ & $\begin{array}{llll}\mathrm{S} & 45 & 2 \mathrm{I} & \mathrm{E} \\
\mathrm{N} & 84 & 34 & \mathrm{E} \\
\mathrm{N} & 48 & 42 & \mathrm{E}\end{array}$ & $\begin{array}{llll}\mathrm{N} & 45 & 2 \mathrm{I} & \mathrm{W} \\
\mathrm{S} & 84 & 34 & \mathrm{~W} \\
\mathrm{~S} & 48 & 43 & \mathrm{~W}\end{array}$ & $\begin{array}{l}I, 75 I \\
I, 530 \\
I, 97 I\end{array}$ & $\begin{array}{l}\text { Gander. } \\
\text { War. } \\
\text { Wick. }\end{array}$ \\
\hline 4 & $\begin{array}{llll}3^{8} & 36 & 29.37\end{array}$ & $\begin{array}{llll}75 & 59 & 02.88\end{array}$ & $\begin{array}{llll}\mathrm{S} & 22 & 06 & \mathrm{E} \\
\mathrm{S} & 78 & \mathrm{I} 8 & \mathrm{E} \\
\mathrm{N} & 42 & 00 & \mathrm{E}\end{array}$ & $\begin{array}{llll}\mathrm{N} & 22 & 05 & \mathrm{~W} \\
\mathrm{~N} & 78 & \mathrm{I7} & \mathrm{W} \\
\mathrm{S} & 42 & 00 & \mathrm{~W}\end{array}$ & $\begin{array}{r}I, 689 \\
933 \\
I, 300\end{array}$ & $\begin{array}{l}\text { Gander. } \\
\text { War. } \\
\text { Wick. }\end{array}$ \\
\hline 5 & $\begin{array}{r}383626.90 \\
\text { Ther }\end{array}$ & $\begin{array}{l}75585.27 \\
\text { e along county }\end{array}$ & $\begin{array}{llll}\mathrm{S} & \text { I8 } & \text { Ir } & \mathrm{E} \\
\mathrm{S} & 82 & \text { or } & \mathrm{E} \\
\mathrm{N} & 34 & \mathrm{I} & \mathrm{E} \\
\text { boundary as }\end{array}$ & $\begin{array}{llll}N & 18 & 11 & W \\
N & 82 & 07 & W \\
S & 34 & 3 x & W \\
\text { delineated on }\end{array}$ & $\begin{array}{r}\text { I, } 559 \\
772 \\
\text { r, } 274 \\
\text { art No. } 3 \\
\end{array}$ & $\begin{array}{l}\text { Gander. } \\
\text { War. } \\
\text { Wick. } \\
\text { to corner No. I. }\end{array}$ \\
\hline
\end{tabular}

JAMAICA POINT.

(Upper Choptank River-Chart No. 35.)

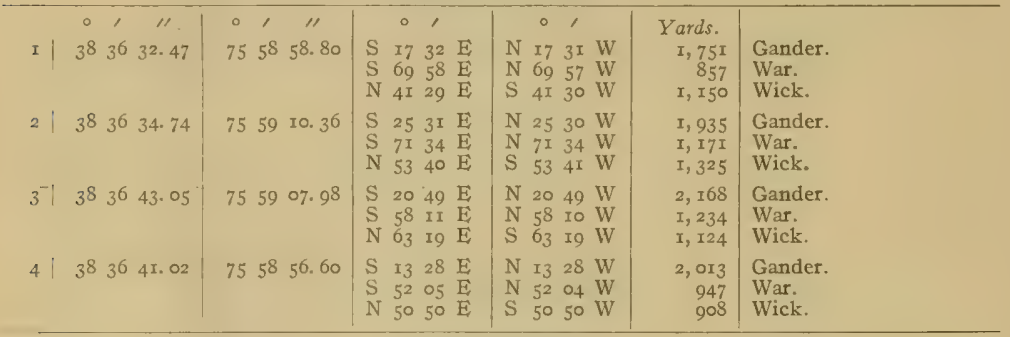

SPAR BUOY.

(Upper Choptank River-Chart No. 35.)

\begin{tabular}{|c|c|c|c|c|c|c|}
\hline I & 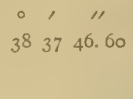 & $\begin{array}{ccc}0 & 1 & \prime \prime \\
75 & 5^{8} & 57.7^{8}\end{array}$ & \begin{tabular}{|cccc} 
& 0 & 1 \\
$N$ & 21 & $4 \mathrm{r}$ & $\mathrm{E}$ \\
$\mathrm{N}$ & $6 \mathrm{I}$ & 00 & $\mathrm{~W}$ \\
$\mathrm{~S}$ & 58 & $\mathrm{r}$ & $\mathrm{W}$
\end{tabular} & \begin{tabular}{|cccc} 
& 0 & \multicolumn{1}{c}{} \\
$\mathrm{S}$ & 21 & 42 & $\mathrm{~W}$ \\
$\mathrm{~S}$ & $6 \mathrm{I}$ & 00 & $\mathrm{E}$ \\
$\mathrm{N}$ & 58 & 18 & $\mathrm{E}$
\end{tabular} & $\begin{array}{r}\text { Yards. } \\
\mathrm{I}, 3^{22} \\
732 \\
\mathrm{I}, \mathrm{I} 50\end{array}$ & $\begin{array}{l}\text { Blind. } \\
\text { Raccoon. } \\
\text { Bank. }\end{array}$ \\
\hline$=$ & $\begin{array}{llll}3^{8} & 3^{8} & 03.9^{2}\end{array}$ & $\begin{array}{lll}75 & 5^{8} & 55.44\end{array}$ & $\begin{array}{llll}S & 41 & 13 & W \\
S & 50 & 52 & E \\
N & 86 & 59 & E\end{array}$ & $\begin{array}{llll}\mathrm{N} & 41 & \text { I2 } & \mathrm{E} \\
\mathrm{N} & 50 & 52 & \mathrm{~W} \\
\mathrm{~S} & 87 & 00 & \mathrm{~W}\end{array}$ & $\begin{array}{l}\mathrm{I}, 580 \\
\mathrm{I}, 300 \\
\mathrm{I}, 990\end{array}$ & $\begin{array}{l}\text { Bank. } \\
\text { House. } \\
\text { Hut. }\end{array}$ \\
\hline 3 & $3^{8} \quad 38$ o7. Is & $\begin{array}{lll}75 & 58 \quad 37.02 \\
& & \end{array}$ & 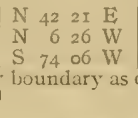 & $\begin{array}{llll}\mathrm{S} & 42 & 22 & \mathrm{~W} \\
\mathrm{~S} & 6 & 26 & \mathrm{E} \\
\mathrm{N} & 74 & 05 & \mathrm{E} \\
\text { delineated on } \\
\text { I }\end{array}$ & $\begin{array}{r}\text { I, } 506 \\
538 \\
\text { I, 237 } \\
\text { art No. 3 }\end{array}$ & $\begin{array}{l}\text { Up. } \\
\text { Blind. } \\
\text { Raccoon. } \\
5 \text { to corner No. r. }\end{array}$ \\
\hline
\end{tabular}




\section{A P PENDIXES.}

\section{APPENDIX A.-LAIVS RELATING TO THE COOPERATION OF THE COAST AND GEODETIC SURVEY AND BUREAU OF FISHERIES WITH THE MARYLAND SHELL FISH COM- MISSION.}

The work of the Coast and Geodetic Survey and of the Bureau of Fisheries, in cooperation with the Maryland Shell Fish Commission, in surveying the oyster bars, establishing permanent landmarks at triangulation stations, and preparing for publication the necessary charts and technical and legal descriptions of boundaries and landmarks shown on these charts, has been executed in compliance with a request from the governor of the State of Maryland to the Secretary of Commerce and Labor, and by the authority of the following laws of the United States and Maryland:

[Act of Congress approved May 26, 1906.]

AN ACT To authorize the Secretary of Commerce and Labor to cooperate, through the Bureau of the Coast and Geodetic Survey and the Bureau of Fisheries, with the shellish commissioners of the State of Maryland in making surveys of the natural oyster beds, bars, and rocks in the waters within the State of $\lambda$ aryland.

Be it enacted by the Senate and House of Representatives of the United States of America in Congress assembled, That the Secretary of Commerce and Labor be, and he is hereby, authorized and directed, upon the request of the governor of the State of Maryland, to designate such officers, experts, and employees of the Bureau of the Coast and Geodetic Survey and of the Bureau of Fisheries as may be necessary to cooperate with the Maryland State board of shellfish commissioners in making a survey of and locating the natural oyster beds, bars, and rocks in the waters within the State of Maryland; and the Secretary of Commerce and Labor is hereby authorized and directed to fumish to the officers, experts, and employees of said Bureaus so detailed as aforesaid such instruments, appliances, and steam launches as may be necessary to make the survey aforesaid; and the Secretary of Commerce and Labor is hereby authorized to have made in the Bureau of the Coast and Geodetic Survey all the plats necessary to show the results of the aforesaid survey and the locations of the said natural oyster beds, bars, and rocks in the waters within the State of Maryland, and to furnish to the board of shellfish commissioners of the State of Maryland such copies as may be necessary, and for this purpose to employ, in the District of Columbia and elsewhere, such technically qualified persons as may be necessary to carry out the purpose of this act.

SEC. 2. That the Secretary of Commerce and Labor is hereby further authorized to have erected or constructed by the officers so detailed as aforesaid, while making such survey, such structures as may be necessary to mark the points of triangulation, so that the same may be used for such future work of the Coast and Geodetic Survey as the said Bureau may be hereafter required to perform in prosecuting the Government coast survey of the navigable waters of the United States located within the State of Maryland.

SEC. 4. That this act shall take effect from the date of its passage.

[Act of Congress approved June 30, rgo6.]

AN ACT Making appropriations for sundry civil expenses of the Government for the fiscal year ending June thirtieth, nineteen huadred and seven, and for other purposes,

Be it enacted by' the Senate and House of Representatives of the United States of America in Congress assembled, That the following sums be, and the same are hereby, appropriated, for the objects hereinafter expressed, for the fiscal year ending June thirtieth, nineteen hundred and seven, namely: * * * 
Coast and Geodetic Surver: * * * For any special surveys * * * including the expenditures authorized under Public Act Numbered One hundred and eighty-one, approved May twenty-six, nineteen hundred and six, and contingent expenses incident thereto, five thousand dollars, together with the unexpended balance under this appropriation for nineteen hundred and six and prior years which is hereby reappropriated and made available on this account for the fiscal year nineteen hundred and seven $* * *$.

[Act of Congress approved March 4, 1907.]

AN ACT Making appropriations for sundry civil expenses of the Government for the fiscal year ending June thirtieth, nineteen hundred and eight, and for other purposes.

Be it enacted by the Senate and House of Representatives of the United States of America in Congress assembled, That the following sums be, and the same are hereby, appropriated, for the objects hereinafter expressed, for the fiscal year ending June thirtieth, nineteen hundred and eight, namely:

COAST AND GEODETIC SURVEY: * * * For any special surveys * * * including expenses of surveys in aid of the shellfish commission of the State of Maryland, to be immediately available and to continue available until expended, twenty-five thousand dollars * * *.

[Act of Congress approved May 27, rgo8.]

AN ACT Making appropriations for sundry civil expenses of the Government for the fiscal yeat ending June thirtieth, nineteen hundred and nine, and for other purposes.

Be it enacted by the Senate and House of Representatives of the United States of America in Congress assembled, That the following sums be, and the same are hereby, appropriated, for the objects hereinafter expressed, for the fiscal year ending June thirtieth, nineteen hundred and nine, namely: * * *

COAST AND GEOdETIC SURvey: * * * For any special surveys * * * including expenses of strveys in aid of the shellfish commission of the State of Maryland, which expenses, including cost of plats and charts, shall not exceed fifteen thousand dollars in any one year, to be immediately available, twenty thousand dollars.

[Act of Congress approved March 4, rgog.]

AN ACT Making appropriation for sundry civil expenses of the Government for the fiscal year ending June thirtieth, nineteen hundred and ten, and for other purposes.

Be it enacted by the Senate and House of Representatives of the United States of America in Congress assembled, That the following sums be, and the same are hereby, appropriated, for the objects hereinafter expressed, for the fiscal year ending June thirtieth, nineteen hundred and ten, namely: * * *

Const And Geodetic Survey: * * * For any special surveys * * * including expenses of surveys in aid of the shellfish commission of the State of Maryland, which expenses, including cost of plats and charts, shall not exceed fifteen thousand dollars in any one year, to be immediately available, twenty thousand dollars.

[Act of Congress approved June 25, 1910.]

AN ACT Making appropriations for sundry civil expenses of the Government for the fiscal year ending June thirtieth, nineteen hundred and eleven, and for other purposes.

Be it enacled by the Senate and House of Representatives of the United States of America in Congress assembled, That the following sums be, and the same are hereby, appropriated, for the objects hereinafter expressed, for the fiscal year ending June thirtieth, nineteen hundred and eleven, namely: * * *

Coast and Geodetic Survey: * * * For any special surveys, * * * including expenses of surveys in aid of the shellfish commission of the State of Maryland, to be immediately available fifteen thousand dollars. 
[Act of Congress approved Mrarch 4, xgrr.]

AN ACT Making appropriation for sundry civil expenses of the Govermment for the fiscal year ending June thirtieth, nineteen hundred and twelve, and for other purposes.

Be it enacted by the Senate and House of Representatives of the United States of America in Congress assembled, That the following sums be, and the same are hereby, appropriated, for the objects hereinafter expressed, for the fiscal year ending June thirtieth, ninetecr hundred and twelve, namely: * * *

COAST AND GEOdETIC SURvey: * * * For any special surveys * * * including expenses of surveys in aid of the shellfish commission of the State of Maryland, to be immediately available, thirteen thousand dollars.

[Act of the Legislature of Maryland approved April 2, 1906.]

AN AC'T To establish and promote the industry of oyster culture in Maryland, to define and mark natural oyster beds, bars and rocks lying under the waters of this State, to prescribe penalties for the infringement of the provisions of this Act, and ****.

SEcrron r. Be it enacted by the General Assembly of Maryland, That the following sections be, and they are hereby, added to article 72 of the Code of Public General Laws, title "Oysters." * * *

SEC. 86. The Board of Shell Fish Commissioners shall, as soon as practicable after the passage of this Act, cause to be made a true and accurate survey of the natural oyster beds, bars and rocks of this State, said survey to be made with reference to fixed and permanent objects on the shore, giving courses and distances, to be fully described and set out in a written report of said survey, as hereinafter required. A true and accurate delineation of the same shall be made on copies of published maps and charts of the United States coast and geodetic survey, which said copies shall be filed in the office of the said commissioners in the city of Annapolis, and the said commissioners shall further cause to be delineated upon copies of the published maps and charts of the United States coast and geodetic survey, of the largest scale, one copy for each of the counties of this State in the waters of which there are natural oyster beds, bars and rocks, all natural beds, bars and rocks lying within the waters of such county, which maps shall be filed in the offices of the clerks of the Circuit Court for the respective counties wherein the grounds so designated may lie. * * *

SEC. 87. The Governor of this State is hereby requested to ask the assistance of the United States coast and geodetic survey, and of the United States Fish Commissioner, to aid in the carrying out of the provisions of the preceding section.

* * * $\quad$ *

SEC, 89. As soon as practicable after the first day of April, Ino6, the said commissioners shall organize, and shall at once proceed, with the assistance of such person or persons as may be detailed by the United States coast and geodetic survey and the United States Fish Commissioner, to aid them in their work, and of such persons as may be appointed under the preceding section, to have laid out, surveyed and designated on the said charts, the natural beds and bars, and shall cause to be marked and defined as accurately as practicable the limits and boundaries of the natural beds, bars, and rocks as established by said survey, and they shall take true and accurate notes of said survey in writing, and make an accurate report of said survey, setting forth such a description of landmarks as may be necessary to enable the said board, or their successors, to find and ascertain the boundary lines of the said natural oyster beds, bars and rocks, as shown by a delineation on the maps and charts provided in this Act; said report shall be completed and filed in the office of the board in the city of Annapolis within ninety days after the completion of the survey of any county. Said commissioners shall cause the same to be published in pamphlet form, and transmit copies of the same to the Clerks of the Circuit court for the respective counties, where the charts have been filed or directed to be filed as hereinafter provided; the said report to be filed by the clerks of the several counties in a book kept for that purpose. And the said survey and report, when filed, subject to the right of appeal herearter provided for in this Act, shall be taken in all of the courts of this State as conclusive evidence of the boundaries and limits of all natural oyster beds, bars and rocks, lying within the waters of the county wherein such survey and report are filed, and shall be construed to mean in all of the said courts that there are no natural oyster beds, bars or rocks lying within the waters of the counties wherein such report and survey are filed other than those embraced in the survey authorized by this Act, and that all areas of the Chesapeake Bay and its tributaries within the State of Maryland, not shown in the survey to be natural 
oyster beds, bars or rocks shall be construed in all the courts of the State to be barren bottoms and open for disposal by the State for the purpose of private planting or propagation of oysters thereon under the provisions of this Act, provided, that the said survey and report shall not be construed as to affect in any manner the holdings by citizens of this State in any lot which may have been appropriated or taken up under the laws of this State prior to the approval of this Act.

The law of the State of Maryland, passed March 9, I 842 , authorizing officers of the United States Coast and Geodetic Survey to enter upon the lands within the State limits for the purposes of the survey, is as follows:

AN ACT Conceraing the Survey of the Coast of Maryland.

Section I. Be it enacted by the General Assembly of Maryland, That it shall and may be lawful for any person or persons employed under and by virtue of an act of the Congress of the United States, * * * at any time hereafter to enter upon lands within this State for the purpose of exploring, surveying, triangulating, or leveling, or doing any other matter or thing which may be necessary to effect the objects of said act, and to erect any works, stations, buildings, or appendages requisite for that purpose, doing no unnecessary injury to private or other property.

SEC. $2{ }^{1}$ And be it enacted, That in case the person or persons employed under the act of Congress aforesaid, can not agree with the owners or possessors of the land so entered upon and used as to the amount of damage done thereto by reason of the removal of fences, cutting of trees or injury to the crop or crops growing on the same, it shall and may be lawful for the said parties or either of them to apply to the chief justice for the time being or one of the associate judges of the judicial district in which such land may be situated, who shall thereupon appoint three disinterested and judicious freeholders, residents of the same judicial district, to proceed with as much despatch as possible to the examination of the nuatter in question, and the faithful assessment of the damages sustained by the owners or possessors aforesaid, and the said freeholders or a majority of them, having first taken and subscribed an oath or affirmation before the chief or associate justice aforesaid or other person duly authorized to administer the same, that they will well and truly examine and assess as aforesaid, and having given five days' notice to both parties of the time of their meeting, shall proceed to the spot, and then and there upon their own view and if required, upon the evidence of witnesses (to be by them sworn or affirmed and examined), shall assess the said damages, and shall afterward make report thereof and of their proceedings in writing under their hands and seals and file the same within five days thereafter in the office of the clerk of the county in which the land aforesaid is situated, subject to an appeal by either party to the county court of the said county within ten days after filing as aforesaid, and the said report so made as aforesaid if no appeal as aforesaid be taken, shall be held to be final and conclusive as between the said parties, and the amount so assessed and reported shall be paid to the said owners or possessors of the land so damaged within twenty days after the filing of said report, and the said chief or associate justice as aforesaid, shall have authority to tax and allow upon the filing of said report, such costs, fees and expenses to the said freeholders for the performance of their duty as he shall think equitable and just, which allowance shall be paid by the person or persons employed under the act of congress aforesaid, within the time last above limited, but if an appeal as aforesaid be taken, the case shall be set down for hearing at the first term of county court aforesaid, ensuing upon and after appeal, and it shall be lawiul for either party immediately after the entry of such appeal, to take out summons for such witnesses as may be necessary to be examined upon the hearing aforesaid, and the said court shall have power in its discretion to award costs against which ever the final judgment shall be entered, and such appeal at the option of either party may and shall be heard before and the damage assessed by a jury of twelve men to be taken from the regular panel and elected as in other cases.

SEc. 3. And be it enacted, That if any person or persons shall wilfully injure or deface or remove any signal, monument or building or any appendage thereto, erected, used or constructed under and by virtue of the act of congress aforesaid, such person or persons so offending shall severally forfeit and pay the sum of fifty dollars with costs of suit to be sued for and recovered by any person who shall first

1 Under the rulings of the Comptroller of the Treasury no damages can be collected except through the United States Court of Claims unless an agreement has been made in advance. 
prosecute the same before any justice of the peace of the county where the person so offending may reside, and shall also be liable to pay the amount of damages thereby sustained, to be recovered with costs of suit in an action on the case, in the name and for the use of the United States of America, in any court of competent jurisdiction.

\section{APPENDIX B.-THE HAMAN OYSTER CULTURE LAW.}

[Extract from Second Report of Shell Fish Commission.]

$$
\text { OBJECT. }
$$

"The legislature in placing chapter $7 \mathrm{Ir}$ of the acts of $I 906$, better known as the Haman oyster culture law, upon the statute books of Maryland, had a twofold object in view:

"I. To encourage an industry in oyster culture upon the barren bottoms berieath the tidewaters of the State.

"2. To prevent the leasing of natural oyster bars for the purpose of oyster culture."

\section{SURVEY.}

"To make the leasing of barren bottoms possible and the leasing of natural bars impossible, provision was made for a survey of the natural bars for the purpose of accurately locating and marking the same. It was definitely provided that no barren bottoms should be leased in any part of the State until the natural bars of that region had been surveyed, charted, and marked with buoys."

DEFINition OF a NATURAL OYSTER BAR.

NATURAL BAR NOT DEFINED.

"The Shell Fish Commission is instructed by section 90 of the Haman oyster culture law to exercise its judgment liberally in favor of the natural bars when surveying, charting, and buoying them, but other than this the commission is uninstructed in this important matter. The responsibility of defining a natural bar is placed upon the commission.

\section{DIVERSITY OF OPINION.}

"No definition of a natural oyster bar could be formulated by any man or body of men which would meet with the approval of all parties concemed. Oystermen, as a rule, hold that all bottoms where oysters grow or have grown naturally, even though now practically barren of oysters, should be considered natural bars. Other citizens of the State, who are not directly interested in the oyster business but interested in the oyster industry from the standpoint of revenue, hold, as a rule, that no bottoms should be excluded from leasing for oyster culture which by methods known to oyster culturists may be made to yield a greater number of oysters than they now produce.

"It should be evident to everyone that neither of these definitions could be adopted by the commission as a working basis for determining which of the grounds surveyed are natural oyster bars."

\section{THE GOLDSBOROUGH DEFINITION.}

The definition of a natural oyster bar which very nearly approaches a reasonable and satisfactory. compromise between the views of the subject held by oystermen on one hand and by oyster culturists on the other is that contained in an opinion rendered by Judge Charles F. Goldsborough in the circuit court for Dorchester County in the July term, I88I, in the case of William T. Windsor and George R. Todd $v$. Job T. Moore.

This definition has been adopted by the Shell Fish Commission as the basis for the determination of the status of the various oyster bottoms surveyed, and is as follows:

What, then, is a natural bar or bed of oysters? It would be a palpable absurdity for the State to attempt to promote the propagation and growth of oysters and to encourage its citizens, by a grant of land, to engage in their culture, if the lands authorized to be taken up were only those upon which oysters do not and can not be made to grow. That there may be lands covered by water in the State 
where no oysters can be found, but where, if planted, they could be cultivated successfully, may be possible; but if so, I imagine that their extent must be too limited for them to be of much practical general advantage for the purposes of such a law as the one under discussion; but there are thousands of acres of hard and shifting sands where oysters not only are not found, but where it would be folly to plant them, and these latter it can not be supposed that the State intended to offer to give away, for the simple reason that the State could not help knowing that nobody would have them.

Upon the other hand there are large and numerous tracts where oysters of natural growth may be found in moderate numbers, but not in quantities sufficient to make it profitable to catch them, and yet where oysters may be successfully plarited and propagated. In my opinion these can not be called natural bars or beds of oysters within the meaning of the act of assembly, and it is just such lands as these that the State meant to allow to be taken up under the provisions of the above-mentioned section of the act.

But there is still another class of lands where oysters grow naturally and in large quantities and to which the public are now and have been for many years in the habit of resorting with a view to earning a livelihood by catching this natural growth, and here, $I$ think, is the true test of the whole question. Land can not be said to be a natural oyster bar or bed merely because oysters are scattered here and there upon it and because if planted they will readily live and thrive there; but whenever the natural growth is so thick and abundant that the public resort to it for a livelihood, it is a natural oyster bar or bed and comes within the above-quoted restriction in the law, and can not be located or appropriated by any individual.

APPLICATION OF DEFINITION.

Before this definition may be of use in determining accurately and scientifically the status of an oyster ground, its central idea, "livelihood," must be expanded into accurately determinable factors, and these factors must be combined into a practical scheme of investigating the condition of the ground under consideration.

Stated briefly, a livelihood is represented by a sum of money obtained from the sale, at a fixed price, of a certain quantity of oysters gathered in a given time from an allotted area of ground.

Knowing the value of each of these factors, it becomes possible to calculate the number of oysters an oyster ground must produce per square yard in order that oystermen may secure a livelihood by working upon it.

NOTE.-The factors into which the commission resolved the livelihood problem, the value assigned to each factor, and the scheme devised for practical use in examining and applying the definition to oyster bottoms are given in outline in their second report under the heading of the preceding extract, and in detail in their first report on pages 32 to 69 .

\section{APPENDIX C.-SUMMARY OF THE PARTICULAR SURVEYING OPERATIONS WHICH CON- STITUTE AN "OYSTER SURVEY" AS NOW BEING CARRIED ON IN MARYLAND.}

Explanation,-A brief account of the particular surveying operations which constitute an "oyster survey" as now being carried on in Maryland, will assist in the interpretation of records contained in the technical part of this report, and will be of interest to many who may not understand the necessity for the great amount of work being done or its complicated character.

To those familiar with methods used in surveying and charting the characteristic features of large bodies of water there is an evident necessity for the various operations performed, especially when it is known that the boundaries of the public oyster bars and of the private lots leased for purposes of oyster culture must be surveyed and charted with the greatest practical accuracy. To others it will be sufficient to state that the actual experience gained from oyster surveys in other States has proven that in order to avoid endless dissatisfaction and litigation it is necessary to accurately locate and permanently establish oyster boundaries as is now being done in Maryland.

Triangulation survey:-Such refinement of survey work as that demanded by the conditions of an oyster survey when carried on at considerable distances offshore can only be obtained by the use of a system of triangulation as a framework or foundation. Therefore, a triangulation survey, including the permanent marking of the positions of landmarks with monuments, and a record of the descriptions of their locations for future recovery is a necessary operation of a complete oyster survey. 
Topographic survey. -The technical records which establish the relation between the offshore oyster boundaries and triangulation landmarks are sufficient for the requirements of engineers in making resurveys, but do not supply the needs of others who are interested in the same boundaries by reason of their occupation as oystermen concerned as to the public oyster bars, or oyster culturists concerned as to the leasable bottoms. For these it is necessary to have the charts of the survey show the relation of the shore line and other topographic features to the boundaries of the public oyster bars and private oyster farms. Therefore a topographic survey is a necessary operation of a complete oyster survey.

Hydrographic survey,--In the settlement of the important question of what is or what is not a natural oyster bar, and in the considetation of bottoms to be selected for purposes of oyster culture, information as to the depth of water and the character of the bottom is required. Therefore a hydrographic survey is a necessary operation of a complete oyster survey.

Necessary foundation for an oyster survey.-Consequently, the necessary components of a satisfactory foundation for a complete oyster survey are the three classes of survey operations technically named triangulation, topography, and hydrography, or, stated in another way, the foundation of a practical oyster survey includes the surveying operations usually followed by the Coast and Geodetic Survey leading up to the preparation and publication of nautical charts.

Special survey's and investigations pertaining to oysters.-Having obtained this cartographic survey for a foundation, partly by new work and partly from records of previous work of the Government, the combined operations ${ }^{1}$ making up an "oyster survey" are completed by superimposing on this foundation special survey's and investigations pertaining particularly to oysters or other shell fish.

The special surveys pertaining to oysters furnish information as to the location and outline of oystershell bottoms, and are carried on by the sounding-boat party in addition to the usual hydrographic work. ${ }^{2}$ This operation consists of the observation and record of the character of vibration of a wire and chain apparatus which is dragged over the bottom, the vibrations or lack of vibrations indicating the presence and quantity of shells or absence of shells.

The special oyster investigations ${ }^{3}$ consist of the actual determination of the kind and quantity of oysters on the bottom, and such ecoromic and biological studics of the supply of oyster food, density of water, character of the bottom, and other important matters as affect the growth of oysters. In this work the oyster investigation stations are located and buoyed by the hydrographic party while engaged in the survey of the oyster-shell limits. They are selected with the view of obtaining characteristic data which can be used for the interpretation of the recorded vibrations of the chain apparatus at all other points covered by the survey.

Preparation of results. - The actual surveying operations and oyster investigations having been completed for any one county, there still remains technical work of nearly equal magnitude to that described. 4 This work consists of the preparation of charts and technical descriptions of boundaries and landmarks for publication by the Government, the preparation of that part of the annual report of the commission covering the special oyster surveys and investigations, the making of the leasing charts and finished projections, and finally the filing of the oyster charts and records with the courts and the commission, thus opening a county for oyster cuiture.

Summary.-From the foregoing account it can be seen that a complete oyster survey properly conducted so as to answer all practical requirements of the present and permanency of results for the future is a very complicated affair, involving many lines of surveying and other scientific work, and requiring the professional services of experts in the various operations of cartographic surveying and shell-fish investigations.

'See Appendix D of this publication for "Statistics of results of combined operations of the Government and State."

2 See pp. ro 4 to 123 of "First Annual Report of Maryland Shell Fish Commission."

"See pp. 30 to 67 and $x 29$ to I 99 of "First Annual Report of Mtaryland Shell Fish Commission"

1 No mention is made here of the large amount of administrative work of the commission, which is greatly complicated and increased by the effect of the oyster-survey operations on many thousands of people whose interests are more or less involved; or of the large amount of survey work involved in the survey and record of the boundaries of oyster lots leased from the State by private individuals for the purposes of oyster culture. 


\section{APPENDIX D-STATISTICS OF RESULTS OF THE COMBINED OYSTER SURVEY OPERATIONS OF THE} GOVERNMENT AND STATE.

\begin{tabular}{|c|c|c|c|c|c|c|}
\hline Operations & $\begin{array}{l}\text { Anne Arun- } \\
\text { del County }\end{array}$ & $\begin{array}{l}\text { Somerset } \\
\text { County }\end{array}$ & $\begin{array}{l}\text { Wicomico } \\
\text { County }\end{array}$ & $\begin{array}{l}\text { Worcester } \\
\text { County }\end{array}$ & $\begin{array}{l}\text { Calvert } \\
\text { County }\end{array}$ & $\begin{array}{l}\text { Charles } \\
\text { County }\end{array}$ \\
\hline Beginning of field work............... & $\mid$ June 29, rgos | & May 2,190\%. & Aug. 27, 2907 & Nov, 8, IgO7 & May 2,1908 & Aug. ${ }_{x} 8, x 908$ \\
\hline $\begin{array}{l}\text { Filing of certified charts and reports...... } \\
\text { Natural oyster bars surveyed and de- }\end{array}$ & June 20,1907 & July 1,1908 & Dec. $x_{1}, 1908$ & Apr. 12,1909 & Dec. 14,1909 & Jan. 27,1912 \\
\hline $\begin{array}{l}\text { lineated } \\
\text { Acres of natural oyster bars . . . . . . . . . }\end{array}$ & $\begin{array}{r}91 \\
33,577\end{array}$ & $\begin{array}{r}37 \\
27,560\end{array}$ & $\begin{array}{r}15 \\
2,038\end{array}$ & $\begin{array}{r}2 S \\
1,655\end{array}$ & $\begin{array}{r}4 I \\
12,303\end{array}$ & 2,285 \\
\hline Crab bottoms surveyed and delineated... & .............. & & ......... & .......... & & ....... \\
\hline Acres of crab bottoms... & ...... & 32,108 & …... & $\ldots \ldots$. & & ...... \\
\hline 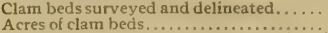 & ..... & $\begin{array}{r}3 \\
506\end{array}$ & an. & W... & & w....... \\
\hline Boundary buoys located and planted .... & 362 & 154 & 53 & 104 & 149 & 57 \\
\hline $\begin{array}{l}\text { Triangulation landmarks established.... } \\
\text { Miles of shore line covered by triangula- }\end{array}$ & 123 & S6 & 30 & $4^{8}$ & 78 & 42 \\
\hline $\begin{array}{l}\text { tion...................................... } \\
\text { Square miles of water covered by trian- }\end{array}$ & Iro & 125 & 46 & 95 & 95 & 32 \\
\hline $\begin{array}{l}\text { gulation............................... } \\
\text { Miles of examination of shell bottom with }\end{array}$ & 220 & 375 & 44 & Iro & 157 & 20 \\
\hline 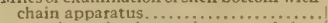 & 425 & 340 & 59 & 63 & 250 & 38 \\
\hline Oyster investigation stations occupied... . & 440 & 679 & 162 & 147 & 667 & $x_{3}$ \\
\hline Tide stations establis & 4 & 3 & 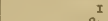 & I & 2 & \\
\hline $\begin{array}{l}\text { Number of soundings over shell bottoms. } \\
\text { Square miles covered by soundings and }\end{array}$ & 37,049 & 17,904 & 3,387 & 3,649 & $I \mathrm{I}, 292$ & $x, 63 I$ \\
\hline 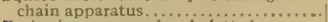 & $5^{8}$ & 55 & 3 & 3 & 30 & \\
\hline Projections prepared and & 9 & 13 & 2 & 5 & 8 & \\
\hline L,easing charts pres & 13 & 12 & 2 & 3 & 5 & \\
\hline Oyster charts published. & 4 & 6 & 2 & 3 & 5 & \\
\hline Reports published. & 2 & 2 & 2 & 2 & 2 & \\
\hline Progress maps published. & 2 & 2 & 2 & 2 & 2 & 2 \\
\hline Operations & $\begin{array}{l}\text { St. Marys } \\
\text { County }\end{array}$ & $\begin{array}{c}\text { Baltimore } \\
\text { County }\end{array}$ & $\begin{array}{c}\text { Kent } \\
\text { County }\end{array}$ & $\begin{array}{l}\text { Queen Annes } \\
\text { County }\end{array}$ & $\begin{array}{l}\text { Talbot } \\
\text { County }\end{array}$ & Total ${ }^{2}$ \\
\hline Beginning of field work. . & May 2, rgos & Apr. 14,1909 & Apr. 24,7909 & Apr. 14,1909 & July 6,1909 & \\
\hline $\begin{array}{l}\text { Filing of certified charts and reports ..... } \\
\text { Natural oyster bars surveyed and de- }\end{array}$ & July $6, x 911$ & Aug. 10, 191I & Oct. 5, Ig: II & Nov. 29, I911 & Juiy $20,19 \mathrm{Iz}$ & \\
\hline lineated $3 . .$. & 124 & & & 98 & 132 & 648 \\
\hline Acres of natural oy: & 25,755 & 3,010 & 12,809 & $24,72 I$ & $36,5^{64}$ & $I 82,283$ \\
\hline $\begin{array}{l}\text { Crab bottoms surveyed and delineated.... } \\
\text { Acres of crab bottoms................... }\end{array}$ & ;... & & & & & $\begin{array}{r}54 \\
32,108\end{array}$ \\
\hline $\begin{array}{l}\text { Clam beds surveyed and delineated } . . . . \\
\text { Acres of clam beds. }\end{array}$ & & & & & & $\begin{array}{r}3 \\
506\end{array}$ \\
\hline Boundary busoys located and planted ..... & 375 & 12 & $21 \mathrm{I}$ & $340^{\circ}$ & 529 & 2,340 \\
\hline $\begin{array}{l}\text { Triangulation landmarks established..... } \\
\text { Miles of shore line covered by triangula- }\end{array}$ & 238 & is & 147 & 199 & 336 & 1,022 \\
\hline $\begin{array}{l}\text { tion, ......................................... } \\
\text { Square miles of water covered by trian- }\end{array}$ & 160 & 12 & 110 & 240 & 230 & $\mathrm{I}, 070$ \\
\hline 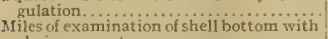 & 180 & 50 & 130 & 500 & 240 & 1,710 \\
\hline chain apparatus. & 400 & 33 & $x 64$ & 288 & 511 & 2,571 \\
\hline Oyster investigatio & 1,472 & 64 & I, 151 & $x, 949$ & 1,975 & 8,819 \\
\hline Tide stations established... & 7 & $I$ & & & 5 & 26 \\
\hline $\begin{array}{l}\text { Number of soundings over shell bottoms. } \\
\text { Square miles covered by soundings and }\end{array}$ & I9, 344 & $\mathrm{I}, 080$ & 8,123 & $\mathrm{I}_{3}, 880$ & 20,213 & 137,552 \\
\hline chain & 57 & 6 & $2 \pi$ & 47 & 77 & 361 \\
\hline Projections prepared and plotte & I5 & 4 & xo & 12 & 14 & 69 \\
\hline Leasing charts $p$ & Io & $\mathbf{I}$ & 4 & II & I2 & 53 \\
\hline Oyster charts publishe & 8 & I & 3 & 4 & 7 & 35 \\
\hline Reports published. & 2 & 2 & 2 & 2 & 2 & I5 \\
\hline Progress maps published... & 2 & I & I & I & I & $I_{3}$ \\
\hline
\end{tabular}

1 These statistics do not include the large amount of triangulation, topography, and hydrography resulting from previous work of the Coast and Geodetic Survey, which was utilized in the preparation of the published oyster charts and records. Work in Kent, Queen Annes, Talbot, and Dorchester Counties has been finished, but final statistics of results will not be published until these counties are opened for oyster culture.

2 Less quantities covered by statistics of more than one county.

Total area of natural oyster bars of Connecticut, 5,770 acres. 




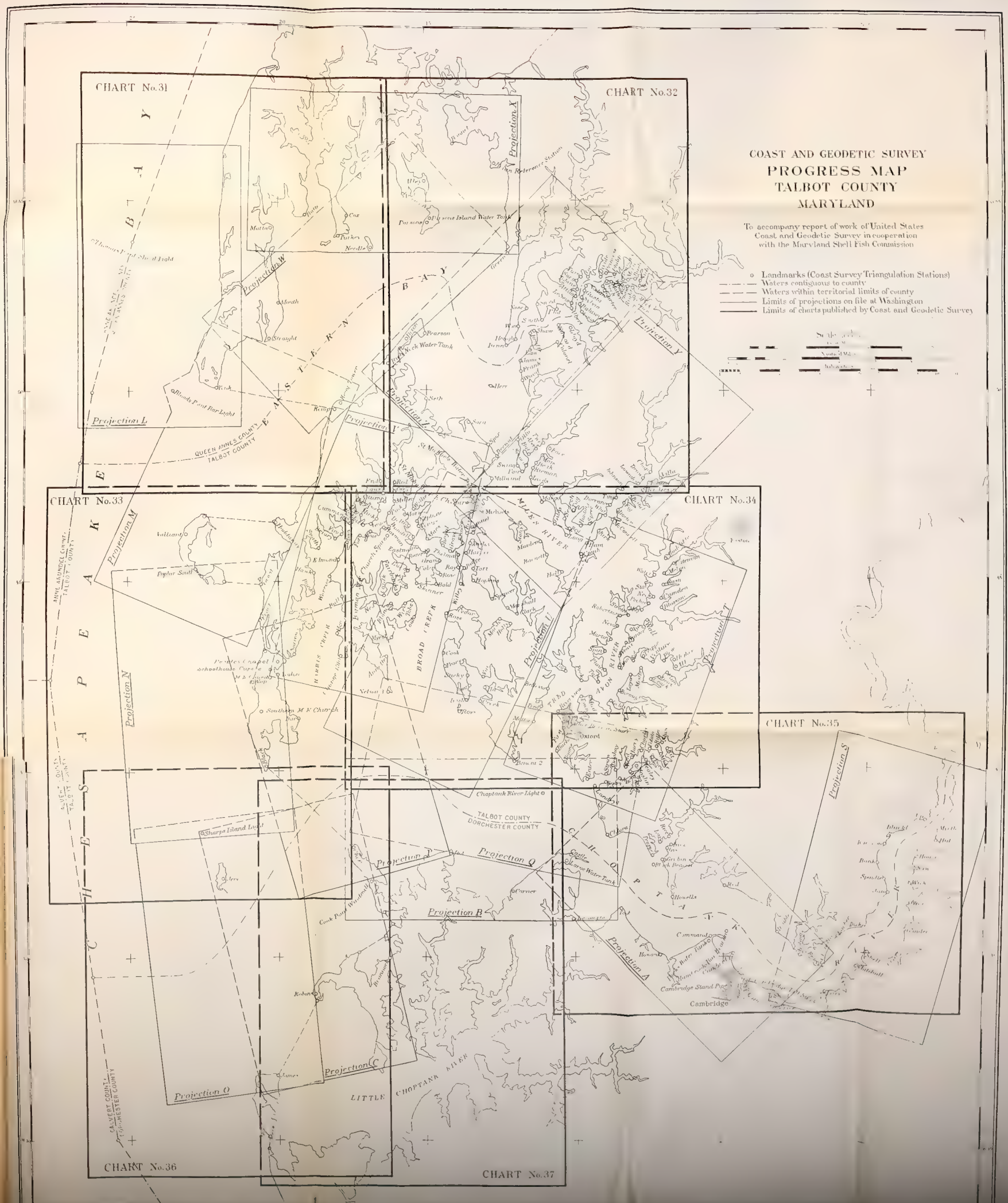











\title{
DEPARTMENT OF COMMERCE AND LABOR COAST AND GEODETIC SURVEY \\ O. H. TITTMANN, Superintendent
}

\section{SURVEY OF OYSTER BARS WICOMICO COUNTY MARYLAND}

DESCRIPTION OF BOUNDARIES AND LANDMARKS AND REPORT OF WORK OF UNITED STATES COAST AND GEODETIC SURVEY IN COOPERATION WITH UNITED STATES BUREAU OF FISHERIES AND MARYLAND SHELL FISH COMMISSION

\author{
By C. C. YATES
}

CHIEF OF COAST AND GEODETIC SURVEY PARTY ASSISTANT, COAST AND GEODETIC SURVEY

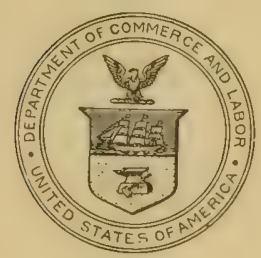

WASHINGTON

GOVERNMENT PRINTING OFFICE

1909 



\section{IET'TER OF SUBMITTAL.}

\section{DEPARTMENT OF COMMERCE AND LABOR, COAST AND GEODETTC SURVEY, \\ Washington, November 12,1908 .}

SIR: I have the honor to transmit herewith a report of the officer detailed from the Coast and Geodetic Survey to cooperate with the Bureau of Fisheries and the Mary land Shell Fish Commission in surveying the oyster bars of the State of Maryland, and certain technical results which are necessary for the interpretation and use of the plats of the survey made by the Government.

This work has been done under the provisions of the act of Congress entitled "An act to authorize the Secretary of Commerce and Labor to cooperate, through the Bureau of the Coast and Geodetic Survey and the Bureau of Fisheries, with the shell fish commissioners of the State of Maryland in making surveys of the natural oyster beds, bars. and rocks in the waters within the State of Naryland," approved May 26, 1906, and of the acts of Congress making appropriations for sundry civil expenses of the Government for the fiscal years ending June 30, 1907, 1908 , and 1909.

Respectfully,

To Hon. Oscar S. Straus,

O. H. Timtmann, Superintendent.

Secretary of Commerce and Labor. 



\title{
CERT I Fi I I A T ION.
}

ANNAPOLIS, MD., November ro, 1908 .

The following publication is certified to contain correct technical descriptions of all boundaries and landmarks established in the waters of Wicomico County by the Maryland Shell Fish Commission in cooperation with the United States Coast and Geodetic Survey.

C. C. YATES,

Chief of Coast and Geodetic Survey Party, Assistant, Coast and Geodetic Survey.

Examined and certified to be correct.

ANNAPOLIS, MD., November Io, Igo8.

\author{
WALTER J. MTTCHELL, \\ Caswell Grave, \\ BENJAMIN K. GREEN, \\ Maryland Shell Fish Commission. \\ SWEFSON EARLE, \\ Hydrographic Engineer.
}

NoTE. - As required by law, certified copies of this publication and of the charts of the natural oyster bars of "Wicomico County and Adjacent Waters" were filed in the office of the clerk of the circuit court of Wicomico County and in the office of the Board of Shell Fish Commissioners, at Annapolis, on December I, 1908. 



\section{CONTENTS.}

Page.

PROGRESS MAP.

LETTER OF SUBMITTAL.

CERTIFICATION

INTRODUCTION:

Publications

9

Cooperation of the Coast and Geodetic Survey

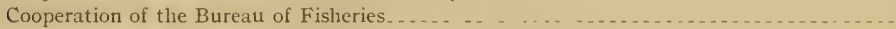

General remarks

REPORT OF THE WORK OF'THE COAST AND GEODETIC SURVEY:

Instructions

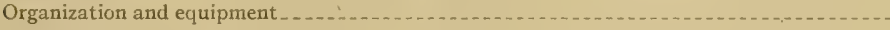

Chronological statement of work

Statistics

General statement.

Charts AND MAPS:

Charts of natural oyster bars.

Leasing charts

Projections

Progress maps

BOUNDARIES OF THE COUNTY WATERS:

Waters within territorial limits of county

Waters contiguous to county

LANDMARKS (U. S. COAST AND GEODETIC SURVEY TRIANGULATION STATIONS):

Explanation of descriptions of landmarks

Descriptions of triangulation stations-

Chart No. II (Middle Nanticoke River)-

Cow (see also Chart No. 12)

Okay -

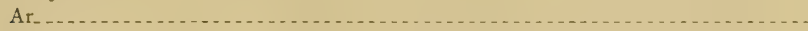

Gover-1.0

Streett_-1-1-1

Earle _.

Juliet

Pole

Bivalve Church $\ldots \ldots \ldots$

Rag - .

Nanticoke Church (see also Chart No, 12)

Chart No. 12 (Nanticoke and Wicomico rivers)-

Cow (see also Chart No. II)

Nanticoke Church (see also Chart No. I I)

Crab_ _..

Sharkfin Shoal Light . .

Head

Frog 
Landmarks (U. S. COAST and GeOdetic Survey triangulation statrons)-Continued.

Descriptions of triangulation stations-Continued.

Chart No. 12 (Nanticoke and Wicomico rivers)-Continued.

Page.

Roar_...

Nanti_. 2 . 2 .

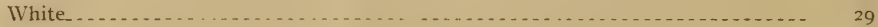

Ella_...

Holland . . . .

Child .

Creek 1. . . . . . . .

End

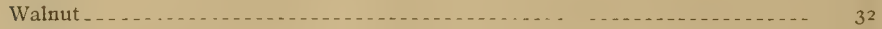

Jones. . . . . . . . . 32

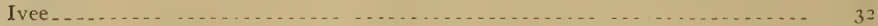

Mount Vernon Church. . ... ... .

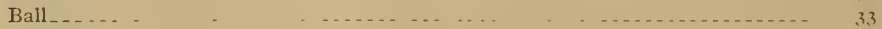

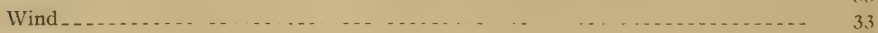

Little

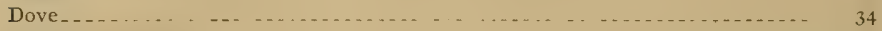

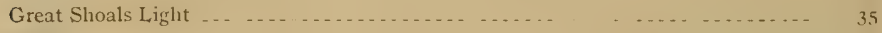

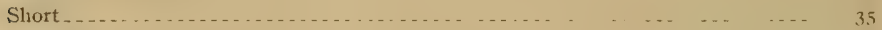

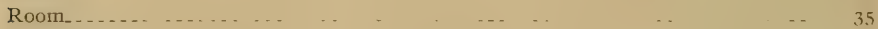

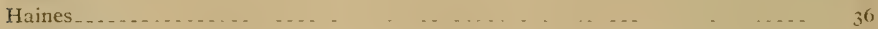

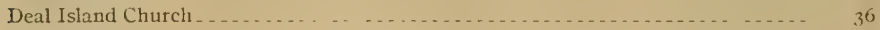

Bar_........ 36

BOUNDARIES OF OYSTER BARS:

Explanation of descriptions of boundaries. 38

Surveying methods for relocation of boundaries_. 39

Boundaries of natural oyster bars-

Chart No. II (Middle Nanticoke River)-

Upper Stake_.

Wetipquin . . . .

Sand Lump

Hickory Nut _...

Old Womans Patch

Cedar Shoal_...

Long Shoal _...

Charry Tree .............

Wilson Shoals. . . . . . . . . .

Roaring Point East (see also Chart No. 12) _....... 45

Chart No. I2 $_{2}$ (Nanticoke and Wicomico rivers)-

Roaring Point East (see also Chart No. II)

Niddleground ...

Big Hill__.

Great Shoals

Ingram Shoal . . . . . . . . . . . . . . .

Holland _.......

APPENDIXES:

Appendix A.-Laws relating to the cooperation of the Coast and Geodetic Survey and Bureau of Fisheries with the Maryland Shell Fish Commission....................... Appendix B.- "The Haman Oyster Culture Law" (extract from First Report of Shell Fish Commission).

Appendix C.-Statistics of results of the combined operations of the Government and State. 


\title{
SURVEY OF OYSTER BARS, WICOMICO COUNTY, MD.
}

\section{INTRODUCTION.}

\author{
PUBLICATIONS.
}

The preparation of publications relating to the survey of the oyster bars of Maryland has been divided between the Government and the State in accordance with the laws ${ }^{\circ}$ authorizing the work and the natural division of the surveying operations of the cooperating forces.

The publications prepared and issued by the Government under the direction of the Superintendent of the Coast and Geodetic Survey consist of a series of charts and a technical report for each county surveyed. ${ }^{b}$ The charts show all legal boundaries of oyster bars within the adopted boundaries of the waters opened up for leasing with each county, and the location of all landmarks (Coast and Geodetic Survey triangulation stations) used as a foundation for the delineation of these various boundaries. The technical report gives technical and legal descriptions of all oyster bar and other boundaries, and descriptions of all landmarks shown on the charts, and includes the reportc of the representative of the Coast and Geodetic Survey in charge of the work of that Service in cooperation with the Bureau of Fisheries and the Maryland Shell Fish Commission. These charts and technical reports are prepared and certified for file with the courts and the Commission, as required by the laws of the State, and contain all information necessary to make a permanent record of the work of the Commission and the Government for all future requirements of the courts, or for any resurveys that may become necessary.

The part prepared and issued by the State under the direction of the Shell Fish Commission consists of an annual report ${ }^{d}$ of all the operations of the Commission performed under the provisions of the laws of Maryland, ${ }^{e}$ including results of biological

"See Appendix A for laws relating to the cooperation of the Coast and Geodetic Survey and Bureau of Fisheries with the Maryland Shell Fish Commission.

$b$ These charts and technical reports can be obtained by application to the Superintendent of the Coast and Geodetic Survey, at Washington, D. C. The publications ready for issue are those for Anne Arundel, Somerset, and Wicomicn counties. Those for Worcester, Calvert, St. Marys, and Charles counties are now being prepared.

- See page 13 and the progress map attached to this publication.

¿These reports can be obtained by application to the Shell Fish Commission, Annapolis, Md. They are issued annually in October, and the first report is now available for distribution.

e See Appendix B for an extract from the "First Report of the Maryland Shell Fish Commission," giving a concise summary of the "Haman Oyster Culture Law."

$61807 \rightarrow 09-2$ 
and economic oyster investigations, methods and results of the hydrographic survey of the boundaries of oyster bars and crab bottoms, the adninistrative report and financial statement of the Commission, information relating to oyster culture, methods of sur veying and leasing of oyster lots, and much other important matter of legal and scientific value.

These two sets of publications are planned and arranged to supplenent each other without unnecessary duplication, and when combined they form a complete report of operations, methods, and results of the work of both the Government and State.

\section{COOPERATION OF THE COAST AND GEODFTIC SURVEY.}

The work of the Coast and Geodetic Survey, as the name of the Service indicates, includes a survey of the coasts of the United States made on a geodetic basis. This has involved the gradual construction of a great framework of interstate triangulation for use as a foundation for detail hydrographic and topographic surveys, from which there has been compiled and published a complete set of charts of the coasts of the United States, including all waters of Maryland where oysters grow. This existing triangulation, hydrography, and topography is essential for a correct and practical survey of natural oyster bars; and it being one of the fundamental functions of the Coast and Geodetic Survey to furnish such data, the cooperation of the Coast and Geodetic Survey with the Bureau of Fisheries and the Maryland Shell Fish Commission is a practical and natural development of Govermment work leading to the conservation and increase of the supply of food.

\section{COOPERATION OF THE BUREAU OF FISHERIES.}

The Bureau of Fisheries has cooperated with the Coast and Geodetic Survey and the Maryland Shell Fish Commission principally as an adviser in matters relating to the biological and economic survey of oyster bars and the methods to be employed for that purpose. $^{a}$ A steam launch, rowing boat, and certain apparat us have also been furnished.

The primary function of the Burean of Fisheries is to increase the productiveness of marine and fresh waters by such measures as may be best suited to the purpose, and the services rendered in connection with the survey of the oyster bars of Maryland are strictly in line with the fundamental law under which it acts. In certain States other than Maryland similar work has been conducted by the Bureau acting independently, the same ends being attained at greater expense to the Government.

\section{GENERAL REMARKS.}

A brief account of the particular surveying operations which constitute an "oyster survey" as now being carried on in Maryland will assist in the interpretation of records contained in the technical part of this report, and will be of interest to many who may not understand the necessity for the great amount of work being done or its complicated character.

To thoce familiar with methods used in surveying and charting the characteristic features of large bodies of water there is an evident necessity for the various operations

"Hon. George M. Bowers, Commissioner of Fisheries, has detailed for this service Dr. H. F. Moore, Assistant, Bureau of Fisheries. 
performed, especially when it is known that the boundaries of the public oyster bars and of the private lots leased for purposes of oyster culture must be surveyed and charted with the greatest attainable accuracy. To others it will be sufficient to state that the actual experience gained from oyster surveys in other States has proven that in order to avoid endless dissatisfaction and litigation, it is necessary to accurately locate and permanently establish oyster houndaries as is now being done in Maryland.

Such refinement of survey work as that demanded by the conditions of an oyster survey when carried on at considerable distances offshore can only be obtained by the use of a system of triangulation as a frame work or foundation. Therefore, a triangulation survey including the permanent marking of the positions of landmarks with monuments and a record of the descriptions of their locations for future recovery is a necessary operation of a complete oyster survey.

The technical records which established the relation between the offshore oyster boundaries and triangulation landmarks are sufficient for the requirements of engineers in making resurveys, but do not supply the needs of others who are interested in the same boundaries by reason of their occupation, as oystermen concerned as to the public oyster bars, or oyster culturists concerned as to the barren bottoms. For these it is necessary to have the charts of the survey show the relation of the shore line and other topographic features to the boundaries of the public oyster bars and private oyster farms. Therefore, a topographic survey is a necessary operation of a complete oyster survey.

In the settlement of the important question of what is, or what is not, a natural oyster bar, and in the consideration of bottoms to be selected for purposes of oyster culture, information as to the depth of water and the character of the bottom is required. Therefore, a hydrographic survey is a necessary operation of a complete oyster survey.

Consequently, the necessary components of a satisfactory foundation for a complete oyster survey are the three classes of survey operations technically named triangulation, topography, and hydrography, or, stated in another way, the foundation of a practical oyster survey includes the surveying operations usually followed by the Coast and Geodetic Survey leading up to the preparation and publication of nautical charts.

Having obtained this cartographic survey for a foundation, partly by new work and partly from records of previous work of the Government, the combined operations ${ }^{a}$ making up an "oyster survey" are completed by superimposing on this foundation special surveys and investigations pertaining particularly to oysters or other shell fish.

The special surveys pertaining to oysters furnish information as to the location and outline of oyster-shell bottoms, and are carried on by the sounding boat party in addition to the usual hydrographic work. ${ }^{b}$ This operation consists of the observation and record of the character of vibration of a wire and chain apparatus which is dragged over the bottom, the vibrations or lack of vibrations indicating the presence and quantity of shells or absence of shells.

"See Appendix C of this puhlication for "Statistics of results of combined operations of the Government and State."

$b$ See pages 104 to 123 of "First Anuual Report of Maryland Shell Fish Commission." 
The special oyster investigations ${ }^{a}$ consist of the actual determination of the kind and quantity of oysters on the bottom, and such economic and biological studies of the supply of oyster food, density of water, character of the bottom, and other important matters as affect the growth of oysters. In this work the oyster investigation stations are located and buoyed by the hydrographic party while engaged in the survey of the oyster-shell limits. They are selected with the view of obtaining characteristic data which can be used for the interpretation of the recorded vibrations of the chain apparatus at all other points covered by the survey.

The actual surveying operations and oyster investigations having been completed for any one county, there still remains technical work of nearly equal magnitude in that described. ${ }^{b}$ This work consists of the preparation of charts and technical descrip. tions of boundaries and landmarks for record and publication by the Government, the manufacture and planting of "State buoys" at all corners of the oyster-bar boundaries, the preparation of that part of the annual report of the Commission covering the oyster investigations, the making of the leasing charts and finished projections, and finally the survey and record of the boundaries of oyster lots leased from the State by private individuals for the purposes of oyster culture.

From the foregoing account it can be seen that a complete oyster survey properly conducted so as to answer all practical requirements of the present and permanency of results for the future is a very complicated affair, involving many lines of surveying and other scientific work, and requiring the professional services of experts in the various operations of cartographic surveying and shell-fish investigations.

$a$ See pages 30 to 67 and 129 to 199 of "First Annual Report of Maryland Shell Fish Commission."

$b$ No mention is made here of the large amount of administrative work of the Commission, which is greatly complicated and increased by the economic and political effect of the oyster-survey operations on many thousands of people whose interests are more or less involved. 


\section{REPORT OF THE WORK OF THE COAST AND GEODETIC SURVEY.}

\section{INSTRUCTIONS.}

The two following letters, together with the laws ${ }^{a}$ of the United States relating to the subject, constitute the "instructions" received by the chief of the Coast and Geodetic Survey party engaged on work in connection with the Maryland Shell Fish Commission. They are short and definite, but furnish ample authority and leeway for all legitimate development of the cooperation of the Government and the State in the survey of oyster bars. The "free hand" permitted by these orders, together with the aid and many valuable suggestions received from the officers of the Survey at Washington, has proved very beneficial to the work, and is greatly appreciated.

\section{DEPARTMENT OF COMMERCE AND I,ABOR, OFFICE OF THE SECRETARY, Washington, June 2, 1906.}

SiR: In reply to your letter of May 28, requesting me to designate officers of the Coast and Geodetic Survey and of the Bureau of Fisheries to cooperate with the State of Maryland in making survey of and locating the natural oyster beds, I have the honor to inform you that Mr. C. C. Yates will be designated to cooperate on the part of the Coast and Geodetic Survey as soon as Congress makes the provisions of the act effective by providing an appropriation for the purpose. Respectfully,

His excellency Hon. EDWIN WARFIELD,

LA IWRENCE O. MurRax, Assistant Secretary.

Governor of Maryland, Annapolis, $M d$.

\section{DEPARTMENT OF COMMERCE AND LABOR, Coast and Geodetrc Survey, Washington, July 3, I906.}

SiR: Upon the receipt of these instructions you will surrender the command, accounts, etc., of the steamer Endeavor to the Hydrographic Inspector.

As soon as this transfer is completed you will enter upon the duties of Coast Survey representative on the Shell Fish Commission of Maryland.

You will consult the commissioners, prepare a programme of work, and submit estimates in the usual form.

You are authorized to come to Washington for consultation from time to time as may be necessary.

*

Very respectfully,

O. H. Trrmann, Superintendent.

Capt. C. C. YATES,

U. S. C. and G. S. Steamer Endeavor, Baltimore, $M d$.

ORGANIZATION AND EQUIPMENT.

The personnel and occupation of the party of the Coast and Geodetic Survey have remained practically unchanged since the beginning of the "oyster survey." Besides the chief of party, it consists of the necessary triangulators, computers, draftsmen, and temporary employees required to carry on both the surveying operations in the 
field and the preparation for publication of charts and technical records in the Office at Washington.

The equipment for the work of the party has been ample and satisfactory. The large living and office quarters furnished the Government on the Maryland Shell Fish Commission house boat Oyster have been very convenient for the work, besides facilitating efficient cooperation with the surveying and oyster investigation parties of the State. In addition to the accommodations on the Oyster, the Coast and Geodetic Survey party has had the constant use of the large steam launch Inspector and several other boats furnished by its own Service, and the occasional use of the Bureau of Fisheries launch Canvasback ${ }^{a}$ and the steamer Governor McLane ${ }^{b}$ of the State fishery force.

The greater part of the equipment of instruments for the operations of both the Government and State has been furnished by the Coast and Geodetic Survey and consists of all necessary theodolites, levels, sextants, drafting instruments, hydrometers, etc., required for all field and office work.

\section{CHRONOLOGICAL STATEMENT OF WORK.}

On June 20,1907 , the work in connection with the publication of the "Charts of Natural Oyster Bars" and report ${ }^{d}$ of "Survey of Oyster Bars" for Anne Arundel County was finally completed and the survey records and reports for that county were ready for filing in the archives of the Survey at Washington.

In addition to this work, a Coast and Geodetic Survey signal-building party was engaged in the erection of triangulation signals in Somerset County from May 2 to June 25 in cooperation with a signal-building party of the Shell Fish Commission.

From June 25 until the practical completion of the field work in Somerset and Wicomico counties on November 6, the usual routine of field and office work was followed without material interruption except that resulting from the moving of the house boat Oyster from Crisfield to Manokin River on July 13, then to Piney Island on August 27, and to Wicomico River on August 30, where she remained until her removal to Nanticoke River on September 30, I907.

From this latter date the work in IVicomico County predominated until the field surveys of that county were completed, when the entire party left by rail for Worcester County, it being impracticable to move the house boat to the waters of that locality.

At the close of the survey work in Worcester County in the last part of December, office work relating to Somerset and Wicomico counties was begun at Baltimore, ${ }^{e}$ and was continued without material interruption until March 23 , I9o8, when a subparty went to Worcester and Somerset counties to finish some details of field work in those sections required for the preparation of the technical reports and oyster charts.

a By courtesy of Dr. H. F. Moore, U. S. Bureau of Fisheries.

$b$ By courtesy of Capt. James A. Turner, commanding.

$c$ The field and office work relating to Somerset County is so intermixed with that of Wicomico County that this statement includes the work of both counties.

$d$ See that report for'an account of the work from July 3, 1906, to June 20, 1907.

e Office rooms were furnished for the work of the Government party in the "old court-house" and afterwards in the new custom-house by courtesy of Hon. William F. Stone, collector of customs. 
The very large amount of work of computation and drafting necessary to make the results of the survey of the previous season available for publication was nearly completed on May 2, 1908, when it was transferred to the Government quarters on the house boat Oyster, which left Baltimore on the same day with the party and outfit for her anchorage off Solomons Island, in the Patuxent River.

On July I, I908, certified copies of the technical report and oyster charts of Somerset County were filed in the office of the clerk of the circuit court of Somerset County and in the office of the Board of the Shell Fish Commissioners, at Annapolis, thus opening that county for oyster culture on that date.

\section{sTATISTICS. ${ }^{a}$}

Landmarks and triangulation signals erected

Monuments planted to mark triangulation stations

Triangulation stations occupied for observatious of horizontal angles _...

Old triangulation stations recovered.

New triangulation stations established

Total old and new triangulation stations marked and described

Linear miles of shore line covered by triangulation (approximate)

Square miles covered by triangulation (approximate) _...

Hydrographic projections prepared and completed as records of oyster boundaries ........... 2

Triangles computed

Geographic positions computed

Corners of oyster botndaries established by computation

Back azimuths and distances computed from comers of boundaries to triangulation stations_.... 168

Descriptions of triangulation stations prepared for publication _... 37

Descriptions of oyster boundaries prepared for publication

Total typewritten pages of manuscript prepared for publication of report_.................. 115

"Charts of Natural Oyster Bars" prepared for publication

Progress map prepared for publication . . .

\section{GENERAL STATEMENT.}

The results obtained from the work of the Coast and Geodetic Survey in Wicomico County in cooperation with the Bureau of Fisheries and the Maryland Shell Fish Commission need no other summary than is indicated by the published "Charts of Natural Uyster Bars" and the scheme of hydrographic projections and triangulation stations shown on the progress map at the end of this report.

The triangulation has been carried on in accordance with the standard methods of the Coast and Geodetic Survey, making this work and that of the "Descriptions of Triangulation Stations" of permanent value, not only to the State of Maryland in the survey of her oyster bars, but also to the Government for any future work it may do in the regions covered by the oyster survey operations.

The hydrographic projections and published charts were prepared with all the accuracy permitted by their large scale, especially as to the boundaries of the various

a These statistics only include field and oflice work directly performed by the party of the. Coast and Geodetic Survey in connection with the oyster survey of Wicomico County, and do not include the many thousands of 6oundings and examinations of the character of the bottom made by the engineers of the Commission, which are of considerable value to the Coast and Geodetic Survey as hydrographic records for future use in connection with the preparation of new editions of charts of the waters of Maryland. 
shell-fish bottoms in relation to landmarks, but this accuracy of location on the charts is further added to by published technical descriptions which should minimize the probability of any future dispute as to either landmarks or boundaries.

Stated another way and quoting from the report of the "Survey of Oyster Bars of Anne Arundel County:"

The geographic positions of the permanent landmarks and signals have been determined with the usual precision of a trigonometric survey, and their locations at all points necessary to provide ample foundation for the surveying and charting operations permitted great accuracy of definition and location for the natural oyster bar and other boundaries established. At the same time, the very important element of permanency of the positions of boundaries has been secured, as the relocation of geodetic positions can always be accomplished by a competent surveyor, even though the original landmarks and monuments have been washed away, as has been the fate of hundreds of such points established by the Coast and Geodetic Survey on the shores of the Chesapeake Bay during the last sixty-five years.

In fact, when the survey of the oyster bars of Maryland is completed, it is believed that it will stand the test of time and practical use as a working foundation for whatever form the oyster legislation of the future may assume, and that the doing of the work systematically and accurately, once for all, not only means a better foundation of a great oyster industry by irradicably locating the natural oyster bars for the use of the public, but also a better and more permanent superstructure of oyster culture for the individual by the reason of the integrity of the foundation on which it stands.

Before ending this report the representative of the Coast and Geodetic Survey wishes to renew his statement of appreciation of the courteous assistance received from various Government and State officials and others interested in the oyster industry of Maryland, especially to the following:

To his colleague from the Department of Commerce and Labor, Dr. H. F. Moore of the Bureau of Fisheries, whose well-known scientific knowledge of all matters relating to oysters has been of great value to the work.

To Mr. Walter J. Mitchell, chairman of the Maryland Shell Fish Commission, who, by his administrative ability in carrying out the complicated requirements of the oyster laws and by his unfailing tact, has made the cooperation of the various services engaged on the work both agreeable and effective.

To Dr. Caswell Grave, secretary of the Commission, who, as editor of the Commission's annual report and commissioner in charge of the biological and economic oyster investigations, has been brought into constant contact with the Government work and aided its operations in every way.

To Benjamin K. Green, treasurer of the Commission, who has looked after the equipment and commissary of the house boat in such a way as to add greatly to the comfort and convenience of the party of the Coast and Geodetic Survey.

To Swepson Earle, hydrograplic engineer to the Commission, whose knowledge of the work from former service in the Coast and Geodetic Survey has greatly facilitated his practical use of the technical data furnished by the Government.

To Thomas H. Robinson, counsel to the Commission, for courteously furnishing valuable information relating to county boundaries.

And to the many others connected with the Commission or who as residents in the locality where the work was being carried on have greatly assisted by furnishing important information or willing services. 


\section{CHARTS AND MAPS.}

\section{CHARTS OF NATURAL OYSTER BARS.}

The charts ${ }^{a}$ of the natural oyster bars of "Wicomico County and Adjacent Waters," published by the Coast and Geodetic Survey from results of surveys of the Government in cooperation with the Maryland Shell Fish Commission, consist of two sheets covering the eastern shore of Nanticoke River and the northern shore of Wicomico River, including all oyster-producing bottoms of IIicomico County. They are published on a scale of $x$ part in 20,000 (approximately $3 \frac{1}{6}$ inches to a statute mile) and are constructed on polyconic projections and based on the United States standard datum of the Coast and Geodetic Survey.

These charts show all oyster bars and other boundaries established by the Commission, and are certified for the purpose of filing in the office of the clerk of the circuit court of Wicomico County and in the office of the Commission at Annapolis, as required by the oyster laws of Maryland.

In addition to the oyster-bar and other boundaries, the charts show the location and name of all landmarks (U. S. Coast and Geodetic Survey triangulation stations) used in making the survey, together with the hydrography and topography ${ }^{b}$ necessary to make the technical definitions and delineations of boundaries readily understandable both by the people engaged in the oyster industry and the general public who may become interested through leasing of barren. bottoms for oyster culture.

The names of the oyster bars are those used locally, as nearly as could be ascertained by the hydrographic engineer of the Commission. When there was no local name in common use, a name was selected from one of the prominent features of the vicinity. By the use of recognized names or those that would naturally suggest certain sections of water, it is believed that much confusion will be avoided in the location on the charts of the oyster bars, especially by those not familiar with the use of maps.

The corners of the oyster bars are numbered from I to the total number of corners in each area under consideration. Where boundaries adjoin, making one point a corner of two or more oyster bars, these points have two or more numbers, each number corresponding to the bar in which the figure is located. The numbers of the corners correspond with the technical and legal descriptions of this publication under the headings of "Boundaries of natural oyster bars."

The landmarks and oyster bars have been grouped in the "Contents" of this publication in accordance with the charts upon which they are shown. To find a

" These charts can be obtained by application to the Superintendent of the Coast and Geodetic Survey, at Washington, D. C.

$b$ Much of the details of the inshore topography was obtained from the excellent map of Wicomico County prepared and published by the Maryland Geological Survey under the direction of Dr. William Bullock Clark from surveys of the Maryland Geological Survey in cooperation with the U. S. Geological Survey. 
particular oyster bar or landmark which is only known by name, consult the "Contents" and the desired chart and general location will be indicated. To find the name of a bar or landmark which is only known by location, consult the progress map at the end of this publication for the number of the chart on which it is to be found, and then examine the known locality on the chart for the name of the bar or landmark in question.

The contours on the charts showing the depth of water at mean low tide have been taken from the hydrographic sheets of former work of the Coast and Geodetic Survey. Four curves were selected as being the most convenient for taking off from the original hydrographic sheets and the ones of greatest value to those interested in shell-fish industries. The $\mathrm{I}$-fathom contour ( 6 feet) corresponds in a general way to the outer limits of the crab bottoms, while the waters outside of this curve and inside the 5 -fathom contour (3o feet) practically include all the oyster bars surveyed. The 3 -fathom contour ( 8 feet) furnishes the curve of about the average depth of water on the oyster bars and the ro-fathom contour (6o feet) serves in a general way to indicate the outer limits of probable oyster culture.

The boundaries of the waters within the "territorial limits of the county" opened up for the leasing with Wicomico County are plainly indicated on the charts. A description of this houndary is given in this publication under the heading "Boundaries of the county waters."

The areas in acres of the oyster bars were determined under the direction of the hydrographic engineer of the Commission by two independent planimeter measurements of the areas as delineated on the smooth projections of the Coast and Geodetic Survey. These areas are given in small figures in parentheses on the face of the chart and are usually located within the boundaries of the different areas.

The symbols used on the charts for the different kinds of boundaries, triangulation stations, contours of depth of water, etc., require no other explanation than that given in the legend and other notes on the face of the charts.

\section{LEASING CHARTS.}

The leasing charts of Wicomico County, like those for Anne Arundel and Somerset counties, have been prepared under the direction of the hydrographic engineer of the Commission. These charts are constructed on polyconic projections and based on the United States standard datum of the Coast and Geodetic Survey. They are made on the scales of I part in 5,000 or I part in 10,000 , as the needs of oyster culture may require. Anne Arundel County required I 3 leasing charts, Somerset County I2, and Wicomico County 2 to cover their oyster bottoms.

These charts show all the oyster bars, crab bottoms, and clam beds and other boundaries established by the Commission, and also all boundaries of oyster lots leased for the purpose of oyster culture, thus making them comprehensive and valuable records of the results of the operations of the oyster-culture laws.

The lots leased under the provision of the "old 5 -acre law" are frequently of irregular shape, but the lots leased under the provision of the new oyster laws must be of rectangular shape by the terms of that act. For this latter purpose the leasing charts have been divided by parallels of latitude and meridians of longitude into small 
rectangles of $\mathrm{I}$ acre or 5 acres, as may be best suited to area under consideration, and prospective leaseholders by the rules of the Commission are compelled to select whole rectangles as far as practicable.

For reasons of the present changeable nature of the number of lots leased and the large number of charts required, the leasing charts are not likely to be published for some years, but they can be seen at any time on file at the offices of the Commission, in Annapolis.

\section{PROJECTIONS.}

The polyconic projections ${ }^{a}$ covering Wicomico County waters are 2 in number and on the scale of $\mathrm{I}$ part in 10,000. They were constructed by draftsmen of the Coast and Geodetic Survey, who also plotted the sextant positions which determine the location of the legal boundaries of the oyster bars as delineated by the Shell Fish Commission.

A copy of each of these projections, with all the plotted positions of triangulation stations, shore line, sextant positions, and boundaries of oyster bars, was made under the direction of the hydrographic engineer of the Commission by pricking through with a sharp needle the intersections of the projection lines and all other points as plotted on the original sheets.

These projections (in duplicate) are the original records of all oyster bar and other boundaries established by the Commission, one set being filed in the archives of the Coast and Geodetic Survey, at Washington, and the other set in the office of the Shell Fish Commission at Annapolis.

PROGRESS MAPS.

The progress map to be found at the end of this publication is on a scale of $I$ part in I0O,000, and shows in outline the work accomplished by the U. S. Coast and Geodetic Survey in Wicomico County and contiguous waters. It gives the scheme of all the charts and smooth projections constructed in connection with the survey, the location and names of all triangulation stations used as a basis for the surveying work, and the "boundaries of county waters" established by the Commission for the purpose of carrying out the laws of Maryland relating to oyster culture.

Besides indicating the amount of work done by the Coast and Geodetic Survey in connection with the work of the Shell Fish Commission, this progress map will be of special value for index purposes to engineers and others searching for the particular chart or projection covering the locality of the oyster bars or landmarks that may be under consideration.

The progress map" accompanying the "First Annual Report of the Maryland Shell Fish Commission" was prepared under the direction of the hydrographic engineer of the Commission. It is on the scale of I part in 400,000 and shows the outline of the tide-water counties of Maryland, with shaded areas to indicate the waters already covered by the operations of the oyster survey of Maryland.

$a$ For the scheme of these projections see the progress map at the end of this publication.

$b$ This map and report can be obtained by application to Maryland Shell Fish Commission, at Annapolis, Md. 


\title{
BOUNDARIES OF THE COUNTY WATERS. ${ }^{a}$
}

\author{
WATERS WITHIN TERRITORIAL LIMITS OF COUNTY.
}

The laws of Maryland relating to oyster culture provide that "no person shall be permitted, by lease, assignment, or in any other manner, to acquire a greater amount of land than ten acres situated within the territorial limits of any of the counties, or one hundred acres in any other place."

The boundary line ${ }^{b}$ between the waters "within the territorial limits" of Wicomico County and the waters in "any other place," as established by the Shell Fish Commission for the purpose of carrying out the oyster laws, and delineated on the charts and the smooth projections of the Coast and Geodetic Survey, is identical with the boundary line between Wicomico County and the adjacent counties of Dorchester and Somerset; therefore technically all waters opened up for leasing with Wicomico County are within the "territorial limits" of that county.

\section{WATERS CONTIGUOUS TO COUNTY.}

The oyster laws of Maryland provide that a true and accurate delineation of all natural oyster bars shall be made on copies of charts of the U. S. Coast and Geodetic Survey, "which said copies shall be filed in the office of the said Commissioners in the city of Annapolis," and "in the office of the clerks of the circuit courts for the respective counties wherein the grounds so designated may lie."

For the purpose of carrying out the latter part of this section of the law and for the purpose of establishing the limits of the oyster-culture area to be opened up for leasing with each county surveyed, it is necessary for the Shell Fish Commission to establish a boundary line between the waters contiguous to but not within the territorial limits of each county, and the waters contiguous to but not within the territorial limits of adjacent counties. But technically, as explained under the preceding heading of "Waters within territorial limits of county," there are no "waters contiguous to the county" in Wicomico County; and therefore there are no waters opened up for leasing with that county in which a person can lease "a greater amount than ten acres."

a For a complete historical and legal description of the boundaries of the counties of Maryland, the valuable publication entitled "The Counties of Maryland-Their Origin, Boundaries, and Election Districts," prepared by Dr. Edward B. Mathews and published by the Maryland Geological Survey under the direction of Dr. William Bullock Clark, Superintendent, should be consulted, as the boundaries described in this publication have been established and technically defined for the purpose of carrying out the oyster laws of the State, and may or may not be correct for other purposes.

$b$ See "Charts of Natural Oyster Bars," published by the Coast and Geodetic Survey, and the progress map at the end of this publication. 


\section{LANDMARKS (U. S. COAST AND GEODITIC SURVLY TRIANGULATION STATIONS).}

FAPLANATION OF DESCRIPTIONS OF IAANDMARKS.

The oyster laws of Maryland authorizing the surveys to be made by the Shell Fish Commission provide for " an accurate report of said survey, setting forth such a description of landmarks as may be necessary to enable the said board, or their successors, to find and ascertain the boundary lines of said natural oyster beds, bars, and rocks, as shown by delineation on the maps and charts." The law of the United States authorizing the cooperation of the Department of Commerce and Labor in the survey of natural oyster bars of Maryland provides for the erection of "such structures as may be necessary to mark the points of triangulation, so that the same may be used for such future work of the Coast and Geodetic Survey as the said Bureau may be hereafter required to perform in prosecuting the Government coast survey of the navigable waters of the United States located within the State of Maryland."

Under the provisions of the sections of the laws stated above, the markings and descriptions of landmarks must be sulficient for the present and future needs of both the Government and the State. With this end in view, considerable work has been expended in erecting permanent monuments at the triangulation stations and in the proper description of their location.

An efiort has been made to arrange the descriptions of locations of landmarks in a uniform and logical manner. The descriptions start with the assumption that the individual seeking to find a landmark has only an indefinite idea of its location. They then gradually proceed from general descriptions of the surroundings of a landmark to the specific details of the character of the center and reference markings. An examination of the descriptions themselves will best indicate the method followed.

The heading of each description is the name by which the landmark or triangulation station is known and designated in all work and records of the Government and State.

Under the heading of "Locality" the first paragraph gives a description of the general locality of the landmark and the serial number of the published "Chart of Oyster Bars" of Maryland which best shows its location. The published charts are on the large scale of 1 part in 20,000 , and show the location of the triangulation stations so clearly that in many cases the written descriptions will not be required to find them.

Under the same heading of "Locality" the second paragraph furnishes the description of the immediate locality of the landmark and refers to the bearing and distance of standard cement monument marking the reference station, as it is the first object that is likely to catch the eye when the immediate vicinity of the clesired station is reached.

Under the heading of "Marks" a description is given of the character of the markings of the "observed station" and the reference station. It will be noted that, although 
the "observed station" is the one "occupied" and "observed on" for horizontal angles, and also the one whose geographic position is computed, frequently it is not marked as well as the reference station, and in many instances has only a pine stub to indicate its position. This is the case for the reason that the necessity of intervisibility of landmarks usually made it compulsory to locate these stations on edges of banks and ends of points of land, which in Chesapeake Bay and tributaries generally means that they will be washed away in a short period of years. The past experience of the Coast and Geodetic Survey in this region has shown the necessity of reference marks, if the frequent reestablishment of a new framework of triangulation is to be avoided.

All the marks designated in the descriptions as "the center point of triangle on standard cement monument" are exactly alike. These monuments are made of cement, sand, and gravel. and are 2 feet long and 8 inches square at top and bottom. Their tops are all marked with the same brass mold and show a center hole surrounded by a triangle, with the letters "M. S. F. C." arranged around the vertex and the letters "U. S. C. S." underneath the base of the triangle. The center hole is always in the center of the top of the monument by construction, and if this is found to have been broken off without disturbing the bottom, the center of its square section can be used as the location of the station.

All the "standard cement monuments," whether used for marking the "observed station" or "reference station," have been planted upright in exactly the same manner, with their tops projecting 3 or 4 inches above the surface of the ground.

Therefore, as the above facts in reference to the "standard cement monuments" are a constant element in all cases, the repetition of these facts in the description of stations is made needless by this one statement.

It is the expectation that the reference stations, ${ }^{a}$ the character of which is explained above, will be used in many cases in the near future in the place of the "observed stations." This has been made possible by the careful measurements of direction and distance of these stations from the "observed station," which are recorded under the heading of "References."

Under the heading of "References" are given the directions and distances of all objects that might be useful in locating the stations when the surface marks can not be found. It is also contemplated that for general purposes of topography, hydrography, or location of boundaries of oyster bars these references will be sufficient in many cases to relocate the position of an "observed station" or "reference station" when both of them have been destroyed.

The first reference object given in the descriptions is always a triangulation station visible from the station being described. Its direction is taken as being $\mathrm{O}^{\circ} \mathrm{OO}^{\prime} \mathrm{OO}^{\prime \prime}$, and the directions of all other objects are measured from it as an initial point, the angles being taken in a clockwise direction (left to right).

The true bearing ${ }^{b}$ of the initial object is always given in parenthesis alongside the name. This furnishes means for the calculation of the bearings of any of the other

$n$ To obtain the geographic positions of any of the "observed stations" or of the "reference stations," application should be made to the Superintendent of the Coast and Geodetic Survey at Washington, D. C.

$b$ The mean magnetic variation for IVicomico County is $5^{\circ} 45^{\prime}$ west of north 1908 ) and is increasing at the rate of $3^{\prime}$ yearly. 
reference objects for the purposes of locating a station by compass bearings or for the relocation of corner buoys of oyster-bar boundaries by the method of horizontal angles described in this publication under the heading of "Boundaries of oyster bars."

The distances in the last column under "References" are given in three different units, which vary according to their accuracy. The "miles" are statute miles and may be considered only as rough estimates. The "yards" are more accurate, but must be looked on as results generally obtained by pacing or careful estimating. The "meters," however, are accurate to the degree indicated by their decimals and in every case have been measured with a steel tape. In the same manner the accuracy of the directions are indicated by the refinement of direction with which they are recorded.

DESCRIPTIONS OF TRIANGULATION STATIONS.

COIV.

Locality.-IVestern shore Nanticoke River on Mink Point about $1 / 4$ mile east of entrance to Cow Creek. See Charts Nos. Ix and 12.)

Observed station is on a very soft marsh point at the outer edge of water bushes about 5 yards back from the shore to the east, 15 yards from extreme end of point to the southeast, and 15 yards from the shore to the southwest. No permanent reference objects near station. Cement monument marking reference station is 8.68 meters northwest of observed station.

Marks.-Observed station is a nail in a pine stub flush with ground. Reference station is center point of triangle on standard cement monument.

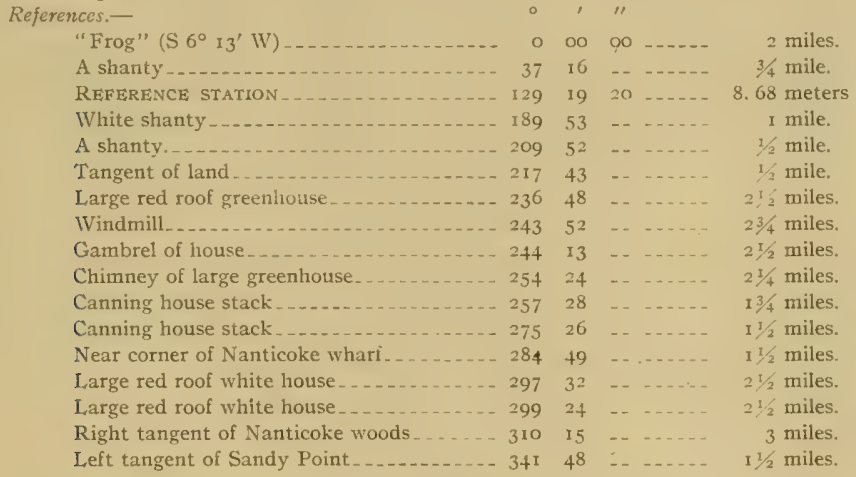

OKAY.

Locality.-Western shore of Nanticoke River about $\mathrm{I} / \mathrm{s}$ mile south of Swan Creek Cove on Marsh Point. (See Chart No. ri.)

Observed station is on marsh land about 2 feet above and 10 yards back from high-water mark. A shanty known as Insleys watch house stands about 35 yards north of observed station. No other permanent reference objects near station.

Marks.-Observed station is center point of triangle on standard cement monument.

References.-

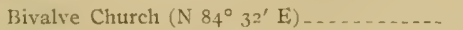

Chimney of red roof house................

Windmill tower.........................

$\begin{array}{rrrrr}0 & 00 & 00 & \ldots \ldots & 21 / 2 \text { miles. } \\ 20 & 38 & \ldots & \ldots \ldots & 21 / 2 \text { miles. } \\ 46 & 41 & \ldots & \ldots \ldots & 21 / 2 \text { miles. } \\ 92 & 23 & \ldots & \ldots \ldots & 11 / 4 \text { miles. }\end{array}$

'langent of land ................. 
References-Continued.

Tangent of land

- , 1

Left side of watch house

105

Right side of watch house

Space between chimneys of large white

house

Tangent of Bivalve wharf

$340 \quad 43 \quad \ldots-\ldots-1$

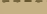

150 yards.

$17 \ldots \ldots$...... 35 yards.

$17 \ldots \ldots$..... 35 yards.

$355 \quad 31 \quad \ldots \ldots . . . .$.

$3 \frac{1}{4}$ miles.

$21 / 4$ miles.

Stack of cant

AR.

Locality. - Western shore of Nanticoke River about $1 \frac{1}{2}$ miles northwest by west of Bivalve wharf. (See Chart No. II.)

Observed station is on marsh land between two small creeks about 40 yards back from high-water mark. It is about 43 yards northwest of the mouth of one creek, and 35 yards west-southwest of mouth of the other creek. No permanent objects near station.

Marks,-Observed station is center point of triangle on standard cement monument.

References.-

"Nanticoke Church" (S $13^{\circ} 34^{\prime} \mathrm{E}$ ) - 000 oo

Right edge Sandy Point woods _........... $23 \quad 58$

Smoke pipe of cabin near "Okay".........

Chimney on house ............................

Left tangent of first woods ............... 81

Left tangent of long thick woods .......... 98

Left edge short thick woods . . . . . . . _... _ 134

Chimney of red roof cabin ............. 247

Houses with several gables_................ 262

Right edge Wetipquin woods . . . ......... 274

Chimney of house behind trees _._._._. 302

Windmill _............ 319

Stack of canning house .............. 320

Chimney of house on Ragged Point ..... 350

Windmill

oo -1..-...

8 -.....

- - - - - -

- $-1 . . . .$.

(-

-........

- - - - - n

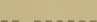

- - - - n

- - - - - n

- - - - - -

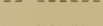

- - - - - n

-......

-. - - - -
$3 \frac{3 / 4}{4}$ miles.

4 miles.

$1 \frac{1}{2}$ miles.

$1 / 2$ mile.

$23 / 4$ miles.

I mile.

$x$ mile.

$1 / 2$ mile.

3 miles.

$21 / 4$ miles.

2 miles.

2 miles.

2 miles.

$21 / 4$ miles.

$3 \frac{1}{4}$ miles.

GOVER

Locality.-Northwestern shore of Nanticoke River $x 3 / 4$ miles west-northwest of entrance to Wetipquin Creek and I/8 mile north of cove named Perch Haul. See Chart No. Ir.)

Observed station is on a point of marsh covered with grass and water bushes, and is about ${ }_{15}$ yards northwest from extreme end of point. A shanty stands among the bushes and small trees about 200 yards to the west-southwest. A clump of about 50 pine trees stands about $1 / 4$ mile west and another clump stands about $1 / 4$ mile northwest.

Marks,-Observed station is center point of triangle on standard cement monument.

References.-

Bivalve Church $\left(\mathrm{S}_{21} \mathrm{I}^{\circ} 3 \mathrm{O}^{\prime} \mathrm{E}\right)$............

Tangent of land

Left side of opening in woods

Two pine trees together.................. 83

Center of shanty .......................... 98

Clump of pine trees.................... 123

Clump of pine trees........................ 176

Inside edge of cove........... 201

Clump of small pine trees................ 255

Tangent to point of land . . .

Left tangent of Sandy Hill wharf ............ 276

Large house . . . . . . . . . . . . . . . .

Left edge of pine woods near Wetipquin Creek:-

$$
\begin{array}{rrrr}
00 & 00 \ldots \ldots & \ldots 3 / 4 & \text { miles. } \\
24 & \ldots & \ldots \ldots & \text { I mile. } \\
06 & \ldots & \ldots \ldots & 2 \text { miles. } \\
07 & \ldots & \ldots \ldots & 3 / 4 \text { mile. } \\
26 & \ldots & \ldots & 200 \text { yards. } \\
56 & \ldots & \ldots \ldots & 1 / 4 \text { mile. } \\
20 & \ldots & \ldots & 1 / 4 \text { mile. } \\
45 & \ldots & \ldots & \text { 100 yards. } \\
31 & \ldots & \ldots \ldots & 1 / 4 \text { mile. } \\
35 & \ldots & \ldots \ldots & 1 / 2 \text { miles. } \\
02 & \ldots & \ldots \ldots & 3 \text { miles. } \\
27 & \ldots & \ldots \ldots & 314 \text { miles. }
\end{array}
$$$$
\text { . }
$$

2 miles. 


\section{Survey of Oyster Bars, Wicomico County, Md.}

\section{STREETT.}

Locality.-Northwestern shore of Nanticoke River on point on southwest side of entrance to Jacks Creek. (See Chart No. II.)

Observed station is on a marsh and grass point 7 yards west from its extreme end and about 4 yards from each side of point to north and south. Cement monument marking reference station is $x .89$ meters west of observed station.

Marks.-Observed station is nail in pine stub flush with ground. Reference station is center point of triangle on standard cement monument.

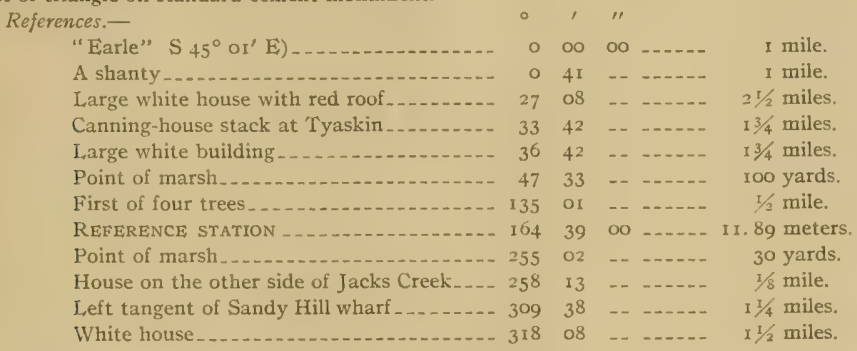

\section{EARLE.}

Locality.-Southeast shore of Nanticoke River about one mile below Sandy Hill wharf. (See Chart No. Ix.)

Observed station is on sand and grass land between river and pine grove, and about 80 yards back and 5 feet above high-water mark. A white oak tree about $21 / 2$ feet in diameter stands between station and river and another and larger white oak tree stands about 15 yards to the northeast. There is a shanty about 20 yards to the west and a sand beach northwest of the station.

Marks.-Observed station is center point of triangle on standard cement monument.

References.-

"Juliet" (S $4 \mathrm{r}^{\circ} \mathrm{o5}^{\prime} \mathrm{W}$ )

Nail in blaze in white oak tree $(2 \pi / 2$ feet in diameter) _............................

Nail in blaze in oak tree $\left(2 \frac{1}{2}\right.$ feet in diameter) _............. 196 $35 \quad 40 \ldots 5$ meters.

Nail in blaze in pine tree............ 326 or oo _..... 15.76 meters.

Right tangent of woods on other side of Wetipquin Creek $35^{8} \quad 5^{2} \quad \ldots \ldots \ldots+1 / 2$ miles.

\section{JULIETT.}

Locality.-Eastern shore of Nanticoke River on point on southwest side of entrance to Wetipquin Creek. (See Chart No. II.)

Observed station is on sand and marsh point about roo yards southwest of entrance to Wetipquin Creek. It is about ro yards back from high-water mark and about 5 yards outside of several small pine trees. Very dense pine woods stand about roo yards to the south of the station.

Marks.-Observed station is center point of triangle on standard cement monument.

References.--

"Earle" ( $\left.\mathrm{N}_{4}^{\circ} \mathrm{n} 4^{\prime} \mathrm{E}\right)$.

Nail in blaze in pine tree

ster house

$61807-09-4$

$\begin{array}{rrrrr}0 & 00 & 00 & \ldots \ldots & 1,4 \text { miles. } \\ 29 & 41 & 30 & \ldots \ldots & 4.92 \text { meters. } \\ 40 & 05 & \ldots & \ldots \ldots & 300 \text { yards. } \\ 64 & 21 & \ldots & \ldots \ldots & 200 \text { yards. }\end{array}$


References-Continued.

Nail in blaze in pine tree.............

Nail in blaze in pine tree............. 98

Right edge of woods__._._.

Right tangent of Bivalve wharf_........ 170

Two-story white house............. 210

Two-story white house with red roof....... 228

Opening in woods.

Gray house at Jacks Creek _..._._._._. 324

Tangent of land .

Tangent of land.
"

$1700 \ldots . .$.

$00 \ldots . . .$.

- - - n....

-. - . - .

-. -....

- n- - n

- - - - - n

- - - - - -

-......

-. -....
6. 3 I meters.

6. 88 meters.

200 yards.

$11 / 2$ miles.

$21 / 2$ miles.

$3 / 4$ mile.

3 miles.

$13 / 4$ miles.

I50 yards.

150 yards.

POLE.

Locality.-Eastern shore of Nanticoke River on wharf off town of Bivalve, located about $1 \mathrm{I} / 4 \mathrm{miles}$ northeast of Ragged Point. (See Chart No. II.)

Marks.-Observed station is flagpole on western peak of a house on wharf at Bivalve about 300 yards from shore.

References.-None necessary.

\section{BIVALVE CHURCH.}

Locality.-Eastern shore of Nanticoke River about $3 / 8$ mile back from shore in town of Bivalve on main road leading to the steamer landing. (See Chart No. II.)

Marks.-Observed station s center of steeple on Bivalve Methodist Church.

References.-None necessary.

\section{RAG.}

Locality.-Eastern shore of Nanticoke River on northern side Ragged Point. (See Chart No. Ir.)

Observed station is on a sandy point about 25 yards back from high-water mark and roo yards northeast from extreme end of point. A grove of pine trees stands about 50 yards to the east and two groups of pine trees about 20 and 75 yards to the northeast. Two pine trees each 15 inches in diameter and $2 \frac{T}{2}$ feet apart stand about 20 yards to the east of the station.

Marks.-Observed station is center point of triangle on standard cement monument.

References.-

Nanticoke Church (S I0

Left end of Sandy Point........... 29 I7 _...... $3 \frac{1}{2}$ miles.

Climney on house near "Cow" ........ $5148 \ldots 21 / 2$ miles.

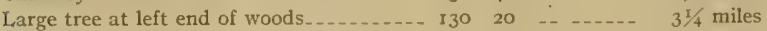

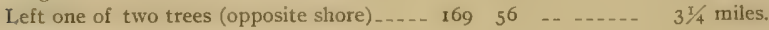

Flag pole on Bivalve wharf ........... 201 II _...... $I \frac{I}{4}$ miles.

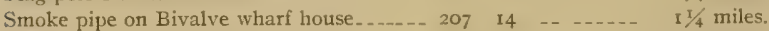

Nail in stump of limb on pine tree...... $218 \quad 35 \ldots \ldots \ldots 32.78$ meters.

Nail in blaze in double pine tree _....... 258 or _.. ..... 19.66 meters.

Nail in blaze in large pine tree ........ $29326 \ldots \ldots$ _..... 43. I9 meters.

Chimney on a white house............ $303 \quad 29 \ldots \ldots$...... 135 yards.

Windmill near large house ........... $344 \quad 13 \quad \ldots \ldots . . .3 / 4$ mile.

Steeple on a barn................. 1 mile.

Large chimney on large flat-roof house.... 357. Io ....... I mile.

\section{NANTICOKE: CHURCH.}

Locality.-Eastern shore of Nanticoke River in town of Nanticoke, about $1 / 4$ mile back from river and $3 / 4$ mile northeast of Roaring Point. (See Charts Nos. II and I2.)

Marks.-Observed station is center point of spire of church known as "Nanticoke Methodist Episcopal Church."

References,-None necessary. 
CRAB.

Locality.-Upper end and western shore of Tangier Sound on eastern side of Bloodsworth Island about $25 / 8$ miles southeast of Sharkfin Shoal Light and about halfway between Piney Island Cove to north and Great Cove to south. (See Chart No. 12.)

Observed station is about 15 yards from high-water mark to the northeast and about 35 yards from the shore to the east. A small flat-roof crab house stands about 80 yards to the north-northeast and another crab house about twice the distance in the same direction.

Marks.-Observed station is center point of triangle on standard cement monument.

References.-

"Sharkfin Shoal Light" ( $\left.45^{\circ} 25^{\prime} \mathrm{E}\right) \ldots \ldots . . .000000 .25 / 8$ miles.

Left end of large white house near Stump Point_. 6 II _..

End of roof of white house on bluff......... $31 \quad 36 \ldots \ldots$ miles.

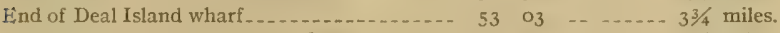

Large white house near red roof house _....... $72 \quad 35 \ldots \ldots \ldots$..... $41 / 4$ miles.

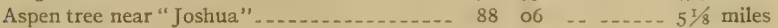

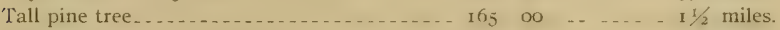

Near end of flat-roof shanty__._._._.

Flag pole on Brown's crab house_.._._._. 299 or _._ _.... 150 yards.

\section{SHARKFIN SHOAL LIGHT.}

Locality. - Northern end of Tangier Sound about equally distant from entrances of Hooper Strait, Fishing Bay, and Nanticoke River. (See Chart No. 12.)

Marks.-Observed station is center point of black lantern on hexagonal serew pile known as "Sharkfin Shoal Light."

References.-

"Great Shoals Light" ( $\left.8 \mathrm{r}^{\circ} 45^{\prime} \mathrm{E}\right) \ldots \ldots \ldots \ldots \ldots \ldots \ldots \ldots$ miles.

HEAD.

Locality.-Upper end of Tangier Sound, on southern part of peninsula known as "Bishops Head," situated between Hooper Strait and Fishing Bay. (See Chart No. r2.)

Observed station is on eastern side of marsh land about $T / 2$ mile northjof extreme southerly end of Bishops Head and about $1_{5}$ yards east of two crab houses. It is about ${ }_{5}$ yards southwest of highwater mark, behind water bushes which skirt the shore. Cement monument marking reference station is 13.41 meters west from observed station.

Marks.-Observed station is a nail in a pine stub flush with ground. Reference station is center point of triangle on standard cement monument.

References.-

"Sharkfin Shoal Light" (S $\left.60^{\circ} 4 \mathrm{I}^{\prime} \mathrm{E}\right)$-....

Crab-house flagstaff........... 5

Large pine........................ 97

REFERENCE STATION _...

Near gable of $2 \frac{1}{2}$-story white house_.... I 40

Chimney on white house ................ ${ }_{5} 6$

Left side of crab house................. 166

Right side of crab house._._._._. . . 199

Chimney on yellow house............... 208

Chimney on end of white house......... 238

Right side of Nanticoke Point woods. ..... 326

\begin{tabular}{|c|c|c|}
\hline ০০ & o & $23 / 4$ miles. \\
\hline 30 & $--\ldots$ & $31 / 4$ miles. \\
\hline 2 & $\ldots$ & 2 miles. \\
\hline 5 & $40 \ldots$ & 13. 41 meters. \\
\hline 2. & - & $1 / 4$ mile. \\
\hline 44 & $\ldots$ & $1 / 8$ mile. \\
\hline 3 & - - - & I 7.31 meters. \\
\hline & n. & 16. I I meters. \\
\hline & - & I $1 / 2$ miles. \\
\hline & - & 3 miles. \\
\hline & - & $71 / 2$ miles. \\
\hline
\end{tabular}


FROG.

Locality. -West shore of mouth of Nanticoke River, on the southeasterly point of Clay Island. known as "Frog Point." (See Chart No. 12.)

Observed station is on a marsh point about 25 yards back from extreme end of point, 20 yards from the east side and 25 yards from the west side. Water bushes abound back of station. There are no permanent reference objects near station. Cement monument marking reference station is 13. ro meters north of observed station.

Marks. - Observed station is nail in stub flush with ground. Reference station is center point of triangle on standard cement monument.

References.-

"Sharkfin Shoal Light" (S 4 $\mathrm{I}^{\circ}{ }_{25}$ ' W)

Left tangent of Clay Island...........

REFERENCE STATION

Right tarigent of Sandy Point.......... $\mathrm{x} 7 \mathrm{7}$

Chimney on white house with black roof.... I
Chimney on near end of large red-roof white house

Land end of Nanticoke wharf

End of Nanticoke wharf house _.......... 18

Chimney on ell end of main part of large redroof white house

Right tangent of Nanticoke Point woods.... 238
Large square chimney on white house

(Dames Quarter) -.................... 264

Rock Creek poplar tree
Flagstaff on Deal Island wharf $\ldots \ldots \ldots$

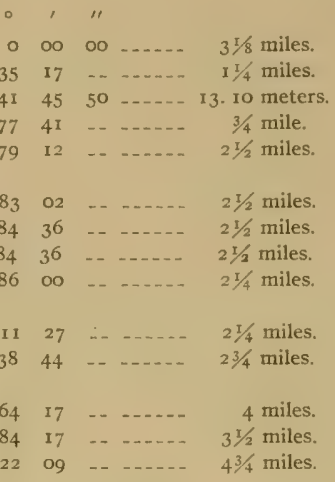

ROAR.

Locality.-Eastern shore of Nanticoke River on point of land known as Roaring Point, and about $1 / 4$ mile north from outer end of Roaring Point wharf. (See Chart No. 12.)

Observed station is 30 yards to the east of the extreme end of the point and on a sandy knoll about 5 feet above high-water mark. It is about 20 yards back from high-water mark on the north side and about 40 yards back from high-water mark on south side of the point. Pine woods stand about 150 yards inshore from station.

Marks.--Observed station is center point of triangle on standard cement monument.

References,-

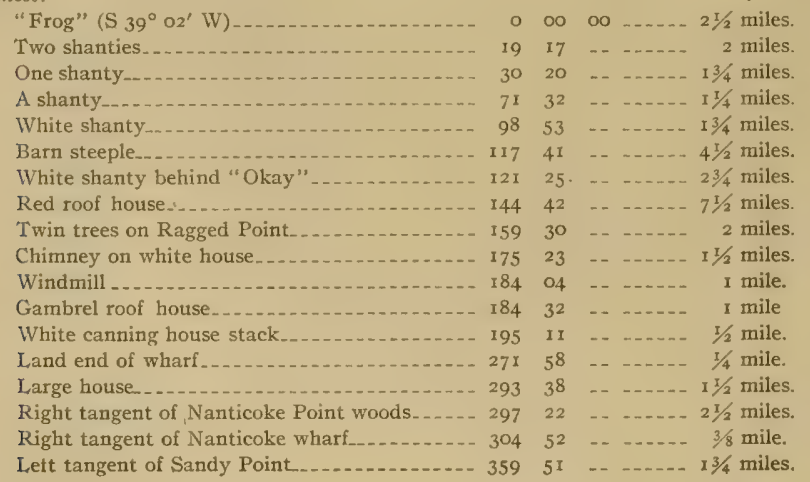




\section{Survey' of Oyster Bars, Wicomico Connty; $M$ N.}

\section{NANTI.}

Locality.-Eastern side of entrance to Nanticoke River about $1 / 2$ mile northwest of Nanticoke Point.

(See Chart No. 12.)

Observed station is on grassy land about 2 feet above and 20 yards back from high-water mark. It is about midway between edge of woods on Nanticoke Point and unpainted house near poplars $1 / 4$ mile to the north.

Marks.-Observed station is center point of triangle on standard cement monument.

References.-

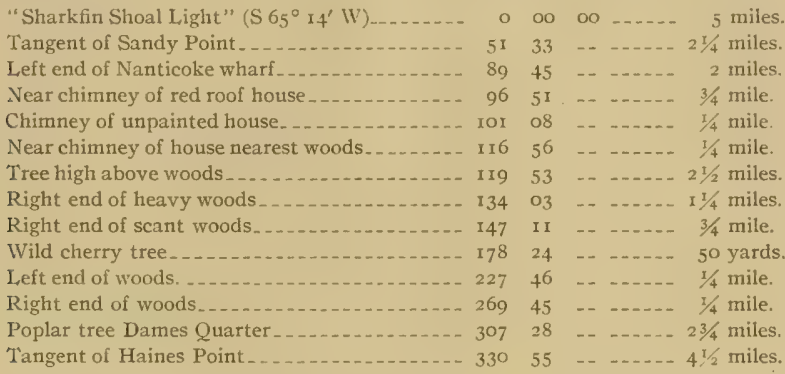

\section{WHITE.}

Locality.-Eastern shore of entrance to Nanticoke River on western part of Nanticoke Point. (See Chart No. 12.)

Observed station is on a sand and grass point about 2 feet above high-water mark, 3 yards from the west side, 15 yards from the south end, and 20 yards from southeast side. Dense pine woods stand about 100 yards to the northwest, open marsh to the northeast, and a clump of about a dozen pine trees in marsh about $3 / 8$ mile to the northeast. There is a cove about 40 yards east of the station and another point of land about 100 yards to the southeast. Cement monument marking reference station is 16.63 meters north of observed station.

Marks.-Observed station is a nail in a pine stub about 6 inches below surface or ground. Reference station is center point of triangle on standard cement monument.

References.-

\begin{tabular}{|c|c|c|c|c|c|}
\hline "Great Shoals Light" & o & $\infty$ & oo & & I $1 / 4$ miles. \\
\hline Poplar tree at Dames Quarter & 65 & o8 & $\ldots$ & & $2 \pi / 2$ miles. \\
\hline Tangent of Hall Point & 86 & 06 & -. & & $3 \frac{3}{4}$ miles. \\
\hline Tangent of Sandy Point. ... & 164 & 17 & -- & & 3 miles. \\
\hline Left end of pine woods..... & 172 & 27 & - & & 100 yards. \\
\hline Right end of pine woods ..... & 213 & $2 \mathrm{I}$ & -- & & I50 yards. \\
\hline REFERENCE STATION & 227 & 29 & oo & & 16. 63 \\
\hline Largest tree in clump of about 12 pines..... & 247 & 23 & -- & & $3 / 8$ mile. \\
\hline Chimney on cabin on Ellis Point & 279 & 05 & -- & $\cdots$ & 2 miles. \\
\hline White house & $3 I I$ & 54 & - & & nile. \\
\hline Point of land ...... & 3.35 & 02 & - & & 10o yards. \\
\hline
\end{tabular}

ELLA.

Locality.-North shore of Wicomico River on point at east side of entrance to Ellis Bay. (See Chart No. 12.)

Observed station is on a marsh point alout $\mathrm{x}$ foot above high-water mark. It is about io yards back from the shore to the west, 20 yards back from the shore to the south, and 20 yards back from the shore to the north. No permanent reference objects near station. 
Marks,-Observed station is center point of triangle on standard cement monument. References.-

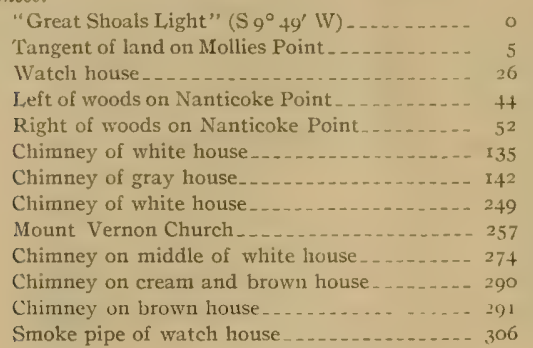

$\begin{array}{rrrrr}0 & 00 & 00 & \ldots \ldots & 2 \text { miles. } \\ 5 & 14 & \ldots & \ldots & \text { I mile. } \\ 26 & 10 & \ldots & \ldots & 1 / 2 \text { mile. } \\ 4+ & 23 & \ldots & \ldots & 11 / 2 \text { miles. } \\ 52 & 33 & \ldots & \ldots & 11 / 4 \text { miles. } \\ 35 & 45 & \ldots & \ldots & 2 \text { miles. } \\ 42 & 43 & \ldots & \ldots & 2 \text { miles. } \\ 49 & 27 & \ldots & \ldots & 200 \text { yards. } \\ 257 & 58 & \ldots & \ldots \ldots & 21 / 4 \text { miles. } \\ 74 & 28 & \ldots & \ldots & 1 / 4 \text { miles. } \\ 90 & 49 & \ldots & \ldots \ldots & 1 \text { mile. } \\ 91 & 03 & \ldots & \ldots \ldots & 1 \text { mile. } \\ 306 & 57 & \ldots & \ldots & 1 \text { mile. }\end{array}$

\section{HOLLAND.}

Locality. - North shore of Wicomico River on Holland Point about $\mathrm{I} / \mathrm{t}$ miles west of Mount Vernon Church, and I $1 / 4$ miles east of Ellis Bay. (See Chart No. 12.)

Observed station is on a marsh point about 20 yards north of high-water mark on its extreme end and about 100 yards west of a creek. A small cabin stands about 200 yards to the west.

Marks.-Observed station is center point of triangle on standard cement monument.

References. -

"Wind" (S $280^{\circ} 35^{\prime}$ "W) - -

Great Shoals Light.

Tangent of Mollies Point

Left tangent of woods on Nanticoke Point

Right tangent of woods on Nanticoke Point ....

Chimney of house near Ellis Bay .............

Chimney of cabin ....................... 56

Chimney on left end of large red roof building - -

Large chimney on white house _............ 188

Chimney of slate-colored house........... 230

Chimney on middle of light-blue house....... $2+0$

Chimney on $21 / 2$-story light-green house _._._. 266

Right chimney on white house........... 317

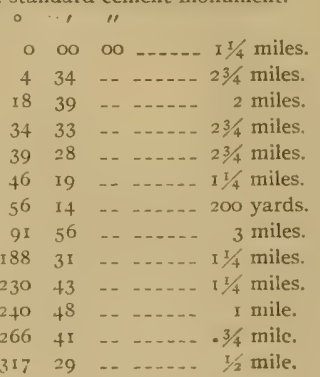

CHILD.

Locality. -North shore of Vicomico River about $7 / 8$ mile north of Mount Vernon Church. (See Chart No. I2.)

Observed station is on marsh land about 2 feet above and I5 yards back from high-water mark.

. There is an old wharf about 300 yards to the east and at a point about roo yards to the north, two creeks join and form a single creek about 20 feet wide which flows into the river at a point about 1.5 yards west of observed station.

Marks.-Observed station is center point of triangle on standard cement monument.

References.-

"Mount Vernon Church" (S $10^{\circ}$ I5' E) .......

Chimney on white house in woods on opposite

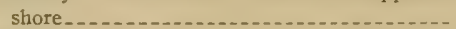

Chimney on white house on sand bluff on opposite shore..................

Smoke pipe on large white house

Chimney on brown house

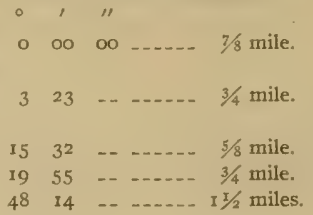




\section{Survey of Oyster Bars, Wicomico County, Md.}

References-Continued.

Great Shoals Light _................. $49 \quad 33 . \ldots 3 \frac{3}{4}$ miles.

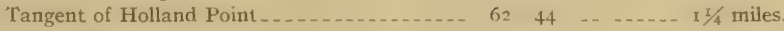

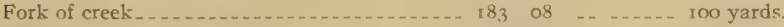

Chimney of large house............... $206 \quad 39$.. ..... 2 miles,

Chimney of another large house ........... $238 \quad 43 \quad \ldots \ldots \ldots$.... $3 / 4$ mile.

Mount Vernon wharf smoke pipe _........ 293 I2 _...... I I/2 miles.

Large white house in woods _........ $324 \quad 03 \ldots \ldots$ mile.

Cream-colored house in woods _............ $345 \quad 47 \ldots \ldots$ mile.

\section{. CREEK.}

Locality. - North shore of Wicomico River about $3 / 4$ mile northwest of Mount Vernon wharf and about $x \frac{3}{8}$ miles northeast of Mount Vernon Church. (See Chart No. 12.)

Observed station is on a marsh grass and sand point making out to the south and about ro yards from the high-water mark of each of the three sides of the point. About ro yards west of observed station is the mouth of a creek or drain ro feet wide which runs only a short distance inland. There are several unpainted houses within 200 yards of observed station and a lone pear tree stands about 200 yards to the north. There is a cultivated field about 150 yards back of station which extends to edge of woods $1 / 4$ mile distant.

Marks.--Observed station is center point of triangle on standard cement monument.

References.-

"Mount Vernon Church" (S $30^{\circ} 39^{\prime} \mathrm{W}$ ) .....

Chimney on light-blue house with red blinds

Chimney of old unpainted house

Chimney of light-green trimmed house _....- ${ }_{3} 35$ I5 _.. _.... 200 yards.

Pear tree . . . . .

Left chimney of cream-colored house _...... 218 o6 ...... 300 yards.

Tangent of cove_._.

Smoke pipe on Mount Vernon wharf _._._._ $282 \quad 34 \quad \ldots \ldots \ldots$ mile.

Chimney outside yellow house_..._._... 312 o4 _.. _.... $5 / 3$ mile.

Chimney on slate-colored house._._.

END.

Locality.-North shore of Wicomico River opposite Mount Vernon wharf. (See Chart No. 12.)

Observed station is on marsh land about 3 feet above and about roo yards north of high-water mark in river and about 75 yards to the northwest of a large creek which runs about 2 miles inland. Water bushes skirt shore around station.

Marks.-Observed station is center point of triangle on standard cement monument.

References.-

"Jones" ( $\left.\mathrm{S} 60^{\circ} 33^{\prime} \mathrm{W}\right)$

Chimney on white house

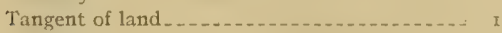

Near chimney of cream-colored house_._._._. 68

Cupola on red barn _.

Old-style windmill _._._._._. 163

Chimney of Whitehaven Hotel _..._....... I7I

Webster's canning house _... _. _ _ _ _ _ 252

Right-hand chimney on gray house _._._._. 273

Left side of Mount Vernon wharf _._._........ 294

Stack of Dashiell's canning house._........ 304

Middle attic window of white house $\ldots . \ldots \ldots$

Chimney outside of yellow house

\begin{tabular}{|c|c|c|c|}
\hline 00 & oo & - & $3 / 4$ mile. \\
\hline 24 & .- & _..... & I mile. \\
\hline 28 & -- & -..... & I mile. \\
\hline 25 & .. & ...... & $1 / 2$ mile. \\
\hline 21 & -- & $\ldots$ & $3 / 4$ mile. \\
\hline 26 & -- & -- & $3 / 4$ mile. \\
\hline 09 & -- & & I $1 / 4$ miles. \\
\hline 28 & -- & & $1 / 2$ mile. \\
\hline 42 & -- & & $\pi / 2$ mile. \\
\hline 13 & -- & $\ldots$ & $1 / 4$ mile. \\
\hline 52 & -- & $\ldots$ & $3 / 8 \mathrm{mi}$ \\
\hline 54 & -- & & $1 / 2$ mile. \\
\hline & -- & $\therefore$ & $\pi / 2$ mile. \\
\hline
\end{tabular}




\section{WALNUT:}

Locality.-South shore of Wicomico River about 175 yards east of Mount Vernon wharf. (See Chart No. 12.)

Observed station is on marsh land about 17 feet from shore and 50 yards west of a small creek. Several large walnut and locust trees stand about 250 yards south of station and 2 houses and 2 sheds about 250 yards to the southwest.

Marks.-Observed station is center point of triangle on standard cement monument.

References.-

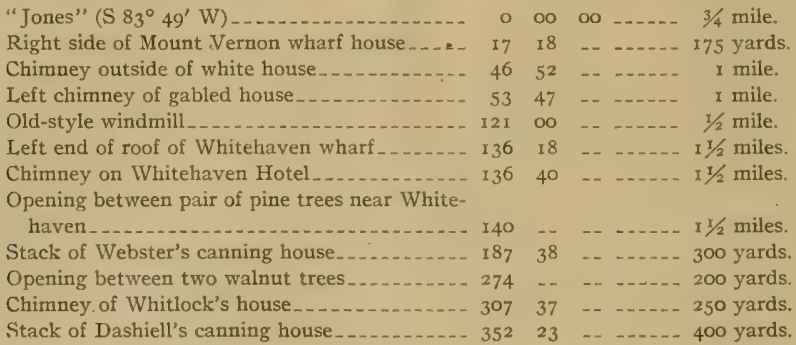

JONES.

Locality.-South shore of Wicomico River about 3/4 mile west of Mount Vernon wharf. (See Chart No. 12.)

Observed station is on a knoll about 25 feet above and 30 yards to south of high-water mark, and about 200 yards to the east of a cove. The knoll on which the station is located is the highest point on the shore in this locality. Several small cabins stand to the northward about 25 yards, and a large lone cedar tree about 35 yards to the southwest.

Marks,-Observed station is center point of triangle on standard cement monument.

References.-

\begin{tabular}{|c|c|c|c|c|c|}
\hline "Ivee" (S $\left.78^{\circ} 54^{\prime} \mathrm{W}\right) \ldots$ & 0 & oo & oo & & $3 / 4 x$ \\
\hline Large square chimney on four-gable house & ro & 05 & $\cdots$ & & aile. \\
\hline Cedar tree & II & 22 & 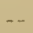 & & ards. \\
\hline Tangent of point of land & 34 & 54 & -- & & tile. \\
\hline Nail in blaze in cedar tree & 62 & 26 & - & & meters. \\
\hline himney on light-green house on opposite & $\mathrm{o}_{2}$ & 33 & - & & e. \\
\hline White cupola in Whitehaven & 148 & 53 & -- & & niles. \\
\hline Old-style windmill ..... & I 53 & 31 & -. & & I $1 / 2$ miles. \\
\hline Whitehaven Hotel chimney & 155 & 48 & - & & $21 / 4$ miles. \\
\hline Large chimney on yellow house ...... & 178 & 37 & -- & & $1 / 4$ mile. \\
\hline a end of brown house & 216 & 37 & -- & $\ldots . .-100$ & nile. \\
\hline Chimney on white house & 266 & 42 & -- & & nile. \\
\hline Weeping willow & 307 & 5.5 & - & & mile. \\
\hline Nail in blaze in cedar tree & 318 & 30 & -- & & meters. \\
\hline
\end{tabular}

IVEE.

Locality.-Southeast shore of Wicomico River about $1 / 4$ mile northwest of Mount Vernon Church. (See Chart No. 12.)

Observed station is on grass land about I foot above and ro feet back from high-water mark. A small cove makes in about 100 yards east of station. A small lone pine stands about Iro yards to 


\section{Survey of Oyster Bars, Wicomico Connty, Md.}

the east-southeast, and a sand bluff with pine trees about Ioo yards to the southwest. Beyond the woods along the beach is a bluff ${ }_{15}$ feet high upon which are several houses.

Marks.-Observed station is center point of triangle on standard cement monument.

References.-

"Mount Vernon Church" ( $\left.22^{\circ} 37^{\prime} \mathrm{E}\right)$ _..... 0 oo

White house chimney_......... $55 \quad 35 \quad \ldots \ldots$ mile.

Chimney on end of white house ........... $20955 \quad \ldots \ldots$ miles.

Chimney of green-trimmed house near "Creek" - $245 \quad 28 \quad \ldots \ldots \ldots$ I $1 / 4$ miles.

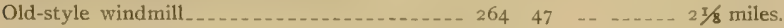

Slate-colored house ................ $276 \quad 22 \ldots 1 / 2$ mile.

Chimney on middle of white house beyond

woods _.... I mile.

Lone pine tree

\section{MOUNT VERNON CHURCH.}

Locality--Southeast side of Wicomico River about 3/8 mile back from the shore $\mathrm{I}^{\mathrm{y} / 2}$ miles southwest of Mount Vernon wharf. (See Chart No. 12.)

Observed station is on main road in Mount Vernon and is situated on the highest point in the vicinity.

Marks.-Observed station is center of steeple of Mount Vernon Methodist Church.

References.-None necessary.

BALL.

Locality,-Southeast shore of Wicomico River on a point of land about I mile northeast of Wingate Point. (See Chart No. 12.)

Observed station is on a sand and grass point making out about 10o yards west of a sand bluff. A small creek empties into the river about ro yards to the east, and three poplars stand about roo yards to the south. The extreme northern end of the point is about 35 yards from station and the western side is about ro yards.

Marks.-Observed station is center point of triangle on standard cement monument.

References.-

"Holland" $\mathrm{N} 20^{\circ} \mathrm{O}^{\prime}$ (W) "

Middle one of five pines $\ldots \ldots \ldots \ldots$

Chimney on John Withlock's house _.......... 137

Left end of pine woods................... 145

Right end of pine woods.

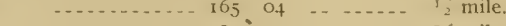

Third poplar

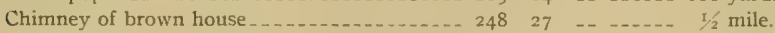

\section{WIND.}

Locality.-Southeast shore of Wicomico River about $1 / 4$ mile north of southern end of Wingate loint. (See Chart No. 12.)

Observed station is about 30 yards from high-water mark of Wicomico River on the north side and 20 yards from the west side. An oyster watchhouse stands about roo yards to the east of the station.

Marks.-Observed station is center point of triangle on standard cement monument.

References....

Tangent of Mollies Point

Left end of woods

Right end of woods....... 5 I

Tangent of Ellis Point____._._._._. 102

White house in woods _................ 157

Smoke pipe on watchhouse _._._._._._. 185

Chimney of brown house.

$$
\begin{aligned}
& \text { oo ....... I I } 1 / 2 \text { miles. } \\
& \text {.. -..... I mile. } \\
& \text { _. ....... } 13 / 4 \text { miles. } \\
& \text { _. _..... } 13 / 4 \text { miles. } \\
& \text {-. -.... } 1 \text { mile. } \\
& \text {-. ..... } 3 \text { miles. } \\
& \text {.. ...... too yards. } \\
& \text {........ } T / 2 \text { mile. }
\end{aligned}
$$


References-Continued.

Chimney of cream-colored house with brown trimmings . . .

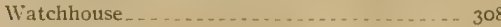

Chimney on $21 / 2$-story house _........... 342 I8 _. .... 3 miles

Chimney on end of white house Dames Quarter.

$350 \quad 57 \quad \ldots \ldots . \quad 2{ }^{1} 2$ miles.

\section{LITTLE.}

Locality.-Southern shore of Monie Bay on second prominent point of marsh about $1 / 4$ mile to the west entrance to Little Monie Creek. (See Chart No. 12.)

Observed station is on a marsh point covered with water bushes and reeds. It is about I foot above high-water mark, 7 yards from the west side, 10 yards from the east side, and about 50 yards from extreme end of point. No permanent reference objects near station.

Marks.-Observed station is center point of triangle on standard cement monument.

References.-

"Great Shoals Light" (S $83^{\circ} 43^{\prime} \mathrm{W}$ ) .........

Left side of woods on Nanticoke Point .......

Right side of woods on Nanticoke Point......

Tangent of Vingate Point_.................

Chimney on red roof white house ...........

Chimney on near end of white house with brown trimmings

Chimney on red roof white house with green blinds

Left chimney of yellow house trimmed white.

Middle of woods.

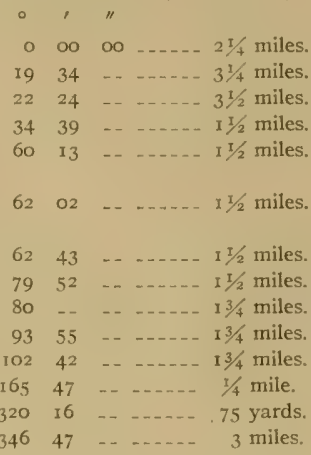

Large brown house..............

Mount Vernon Church......................

Tangent of point of land................. I6

Tangent of point of land................. 32

Tangent of land ....................... 34

47 ....... 3 miles

DOVE.

Locality.-South shore of Monie Bay and about $1 / 4$ mile east of entrance to Pigeon Creek. (Sec Chart No. I2.)

Observed station is on marsh land about to yards back from high-water mark not far from water bushes which stand to the east. Cement monument marking reference station is 13.98 meters southeast from observed station. No permanent reference objects near station.

Marks.-Observed station is a nail in pine stub flush with ground. Reference station is center point of triangle on standard cement monument.

References.-

"Great Shoals Light" (N $\left.57^{\circ} 4 \mathrm{x}^{\prime} \mathrm{W}\right)$-..Left side of Nanticoke Point woods ........ Left side of Roaring Point heavy woods. ..

High lone pine showing above woods......

Tangent of Wingate Point ................

Chimney of red roof house. .............

Chimney on yellow house with red gable roof _ . _ . . . .

Mount Vernun Church _................

Tangent of land ......................

REFERENCE STATION _..........

Chimney of white house with dark red trimmings

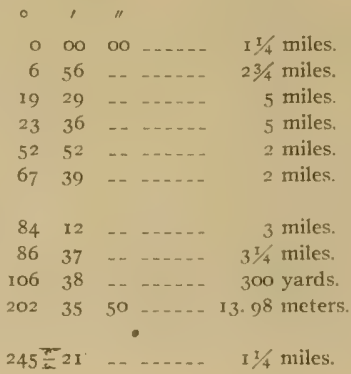




\section{GREAT SHOALS LIGHT.}

Locality.-Middle of entrances to Monie Bay and Wicomico River about halfway between Long Point to the south and Mollies Point to the north. (See Chart No. 12.)

Marks.-Observed station is center of black lantern on square screw pile structure known as "Great Shoals Light."

References.-

"Sharkfin Shoal Light" (S $\left.8 x^{\circ} 50^{\prime} \mathrm{IV}\right) \ldots \ldots \ldots \ldots \ldots \ldots$ miles.

\section{SHOR'r.}

Locality.-Southern shore of entrances to Monie Bay and Wicomico River on Long Point and about I mile south-southwest from Great Shoals Light. (See Chatt No. 12.)

Observed station is on a sandy knoll on eastern side of entrance to Dames Quarter Creek about $x_{5}$ feet back from high-water mark on the north side and about 30 feet from east side of point It is on the highest part of the knoll which is about 5 feet above high-water mark.

Marks.-Observed station is center point of triangle on standard cement monument.

References.-

\begin{tabular}{|c|c|c|c|c|c|}
\hline $\begin{array}{l}\text { "Sharkfin Shoal Light"" (S } 89^{\circ} \circ 3^{\prime} \text { W) } \\
\text { Tile pipe in cement ("Long'" } 190 \mathrm{I})\end{array}$ & 23 & 57 & $\begin{array}{l}00 \\
45\end{array}$ & & $\begin{array}{c}53 / 8 \text { miles. } \\
63.703 \text { meters }\end{array}$ \\
\hline Nanticoke wharf $\ldots . .$. & 67 & 57 & & & $4 \frac{1}{8}$ miles. \\
\hline eft side of Nanticoke woods. & 69 & 13 & - & & es. \\
\hline Tellow house with red blinds & 74 & 53 & -. & & $31 / 2$ miles. \\
\hline tangent of Wingate Point & I 24 & 13 & $\cdots$ & & $23 / 3$ \\
\hline ley on red roof white hor & 132 & 39 & 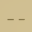 & & 3 miles. \\
\hline ar chimney of yellow house & I 36 & 40 & -. & & 3 miles. \\
\hline drimmed hou & 212 & 49 & - & - & iiles. \\
\hline Quarter & 260 & 37 & - & - & $1 / 4$ mile. \\
\hline ney on & 279 & 45 & - & ...... & ards. \\
\hline & 320 & 05 & - & ...... & rds. \\
\hline mney on yellow house & $34 \mathrm{I}$ & 35 & & & yards. \\
\hline
\end{tabular}

ROOM.

Locality.-Upper end and eastern shore of Tangier Sound on Halls Point. (See Chart No. 12.)

Observed station is on a bluff ${ }_{5} 5$ feet high about 5 yards back from its edge. It is about 25 yards east of a clump of mulberry trees and about 15 yards north-northwest of a barn. Locust and mulberry trees stand all about station and locust bushes along the edge of the bluff. A wagon trail runs parallel to the shore about 15 yards back of station. Cement monument marking reference station is 21.45 meters south-southwest of observed station and almost in line with a large mulberry tree.

Marks.-Observed station is nail in center of stub with top flush with ground. Reference station is center point of triangle on standard cement monument.

References.-

"Sharkfin Shoal Light" (N $70^{\circ} \mathrm{oo}^{\prime} \mathrm{W}$ ) -...

Gable on near side of red roof on white house on Bishops Head.

Near end of roof of large $2 \frac{\pi}{2}$-story house -

Left tangent of Clay Island ............... 39

Left side of Sandy Point woods..........

Roaring Point wharf

Near chimney on end of large red roof white house _._.

Right side of Nanticoke woods ........... x I0

Mount Vernon Church _................ I 127 I

Near corner of barn _................. I37 of
$21 / 2$ miles.

$5 \frac{1}{2}$ miles.

$7 \frac{1}{4}$ miles.

$3 \pi / 2$ miles.

4 miles.

5 miles.

$4 \frac{1}{4}$ iniles.

$33 / 4$ miles.

7 miles.

15. 96 meters. 
References-Continued.

Right-hand corner of barn.

REFERENCE STATION

Large cedar tree ... _............. 276

Two-inch iron pipe
- , "

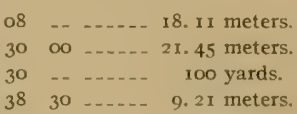

\section{HAINES.}

Locality.-Upper end and eastern shore of Tangier Sound on Haines Point, about $5 / 8$ mile north of Deal Island wharf. (See Chart No. 12.)

Observed station is on sand and grass point about 20 yards back and 5 feet above high-water mark. Locust and water bushes stand about 20 yards to the north and the left edge of this clump is about on line with Sharkfin Shoal Light. A barbwire fence runs 3 yards east of station. Cement monument marking reference station is $9.6+$ meters east of observed station.

Marks.-Observed station is nail in pine stub in center of a drain tile with top broken off below surface. Reference station is center point of triangle on standard cement monument.

References.-

\begin{tabular}{|c|c|c|c|c|c|}
\hline "Sharkfin Shoal Light" $\left.\left(\mathrm{N}_{4} 5^{\circ} 58^{\prime} \mathrm{W}\right)^{\prime}\right)_{\ldots}$ & 0 & Do & $\mathrm{OO}$ & & $21 /$ \\
\hline Left of bushes. & 39 & 57 & . & & 20 yards. \\
\hline Left of Sandy Point woods & 53 & 38 & .. & & $3 / 4$ miles. \\
\hline $\begin{array}{l}\text { Chimney of } 21 / 2 \text {-story white house trimmed } \\
\text { with red }\end{array}$ & 75 & 04 & 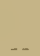 & & mile. \\
\hline Chimney of unpainted house & 85 & 49 & -- & & 350 yards. \\
\hline $\begin{array}{l}\text { Chimney on end of red cottage trimmed } \\
\text { white }\end{array}$ & 99 & oo & -- & & iile. \\
\hline REFERENCE STATION & 123 & 40 & 40 & & 9.64 meters. \\
\hline Pine tree $\ldots \ldots \ldots$ & $1+8$ & 37 & 30 & $\ldots$ & 2 It meters. \\
\hline Large square chimney on red house ........ & 152 & 49 & .. & $\ldots$ & 400 yards. \\
\hline Right one of 5 large pines & $x 84$ & 40 & -- & & 300 yards. \\
\hline $\begin{array}{l}\text { Half way between chimneys on store on } \\
\text { Deal Island. }\end{array}$ & 213 & 08 & - & & \\
\hline Deal Island Church & 217 & oo & -. & & $1 \mathrm{~s} / 2$ miles. \\
\hline Black gum tree .- & 223 & 49 & -- & & meters. \\
\hline Right end of Deal Island & 234 & 10 & - - & & aile. \\
\hline Hooper Straits Light _. . . & $3+3$ & 34 & -. & & $7 \frac{1}{2}$ miles. \\
\hline
\end{tabular}

\section{DEAL, ISLAND CHURCH.}

Locality.-Deal Island on main road about $1 / 4$ mile from the shore and about $3 / 4$ mile south of Laws Thoroughfare. (See Chart No, 12.)

Marks.-Observed station is center of steeple on Deal Island Methodist Church.

References.-None necessary.

BAR.

Locality.-Eastern shore of Tangier Sound on western side of Deal Island, about I mile northwest of entrance to Lower Thoroughfare and $1 / 2$ mile south of Middle Creek, (See Cliart No. 12.)

Observed station is about Io yards east of high-water mark on sand and grass land back of sandy beach. The first of many tree stumps which are submerged at high water commence about roo yards to the north and cat-tails grow abundantly back of station. Cement monument marking reference station is 6. o9 meters east of observed station.

Marks.-Observed station is a nail in pine stub flush with ground. Reference station is center point of triangle on standard cement monument.

References.-

"Sharkfin Shoal Light" ( $\left.19^{\circ} 40^{\prime} \mathrm{W}\right)$...Tangent of Haines Point
000 oo - . - $41 / 2$ miles.

$2729 \quad \ldots-\ldots 2 \frac{1}{2}$ miles. 
Survey of Oyster Bars, Wicomico County, Md.

References-Continued.

Flag pole on large building on Deal Island wharf ...........................

Middle chimney of large gray building - ...-

Chimney on white house

Middle chimney on red roof white house....

REFERENCE STATION

$\circ$, ,

Chimney on white house

$28 \quad 45 \quad \ldots \ldots \ldots .2$ miles.

$37 \quad 41 \quad \ldots \ldots$ I mile.

$59 \quad 54 \quad \ldots \ldots \ldots 4$..... 400 yards.

$5 x+\ldots \quad+3 / 8$ mile.

Chinuney on dark gray house 43 ...... 400 yards.

Right chimney on white four-gabled house

$176 \quad 39 \quad 1 / 2$ mile. 


\section{BOUNDARIES OF OYSTER BARS.}

\section{EXPLANATION OF DESCRIPTION OF BOUNDARIES.}

The oyster bars of Wicomico County are I 5 in number, and their total area, as marked out by buoys placed by the hydrographic engineer of the Commission, is 1,638 acres. As provided by law, the boundaries of the oyster bars are all straight lines, but they inclose areas of all shapes from triangles to complicated eight-sided figures, and of all sizes from $\mathrm{I}, \mathrm{I} 23$ acres to 4 acres. $^{a}$. The sides vary in length from 120 to 3,800 yards, and in some caśes the corners of the boundaries are practically at the triangulation stations from which they are located, while in other instances they are over 7,500 yards from the landmarks most available for the purpose of fixing their positions.

The varied characteristics of the legal boundaries of the oyster bars indicated by the above statement, together with the complicated requirements of the law under which the survey has been made and the magnitude of the work with the consequent need of fixed and uniform methods, have made the problem of describing the boundaries one of considerable difficulty and importance.

The boundaries of the oyster bars of Maryland, as established by the Shell Fish Commission and delineated on the Coast and Geodetic Survey charts and projections and on the leasing charts of the Commission, are technically defined and described by a method somewhat different from that used in other oyster surveys. But it is believed that the forms finally adopted will fulfill all needs of the survey for both the present and future.

The descriptions have been arranged in tabular form, thus avoiding many hundred repetitions of the same words by making one explanation of the tables sufficient for all oyster bars in the county.

At the top of each tabular form is given the legal name of the oyster bar to be described, its general locality, and the serial number of the "Charts of Oyster Bars" of Maryland on which its legal boundaries are shown.

The first column, under the heading of "Corner of bar," gives the number corresponding to the corner of the boundary as shown on the charts and to the number on the buoy marking the actual corner of the bar. The numbers of the corners have been assigned by naming the southernmost point No. I, thence proceeding in a clockwise direction around the bar; but where a corner of one oyster bar is identical with the corner of the boundaries of one or more other oyster bars only the number of the corner of the oyster bar being described in the table is given in this column.

The second and third columns, under the headings of "Latitude" and "Longitude," give the geographic positions of the corners. These positions have been adopted by the cation.

"For similar statistics for other counties that have been surveyed, see Appendix C of this publi- 
Commission as the primary technical definition of the corners, and slould be considered as final in case of a disputc arising from discrepancies caused by other means of location. The latitudes and longitudes given in these columns are based on the United States standard datum of the Coast and Geodetic Survey, and the points thus defined can be relocated from distant triangulation stations of the Survey, even though all the landmarks and buoys originally used for their location have been destroyed by natural causes or by acts of vandals desiring to defeat the purposes of the oyster laws of Maryland.

The fourth and fifth columns, under the general heading of "True bearing" $a$ and the specific headings "Forward" and "Back," give bearings measured from a true northand-south line. The three "Forward" bearings are from the comer of the boundary designated in the first column to the triangulation stations named on the corresponding lines in the last column, and the three "Back" bearings are from these same stations in the last column to the corresponding corner of. boundary in the first column. The difference in minutes of are between the forward and back bearings shown in some cases is actual and not accidental, and is due to the fact that the computations took into account the spheroidal shape of the earth.

The sixth column, under the heading of "Distance," gives the three computed distances in yards from the corner of the bar noted in the first column to the three triangulation stations named on the corresponding lines in the last column, and vice versa.

The seventh and last column, under the heading of "U. S. C. \& G. S. triangulation station," "bives the names of the landmarks from which were computed the correspond ing "Latitude," "Longitude," "True bearing," and "Distance" of the "Corner of the bar" designated in the first column. A full description of the location and markings of these triangulation stations is given in another part of this publication, under the heading of "Descriptions of triangulation stations."

\section{SURVEYING METHODS FOR RELOCATION OF BOUNDARIES.}

There are a number of methods that can be used in the relocation of the actual boundaries of the natural oyster bars as technically described in this publication and delineated on the published charts of the Coast and Geodetic Survey and the leasing charts of the Shell Fish Commission.

The following brief descriptions of five of these more or less different methods assume a certain amount of experience and knowledge on the part of the engineer in the particular kind of surveying under consideration, and are only intended as reminders of ways and means that can be used.

There are two problems that are likely to present themselves to those interested in the boundaries of natural oyster bars. One, to determine whether the buoys marking the corners have been dragged or otherwise moved from their correct positions, and the other, to relocate or reestablish a buoy at the point from which it was removed. The different ways of solving these two problems partly depend upon the instruments possessed by the engineer and his assistants and partly on his training and experience.

a The mean magnetic variation for Wicomico County is $5^{\circ} 45^{\prime}$ west of north (1908), and is increasing at the rate of $3^{\prime}$ yearly.

$b$ Geographic positions of these triangulation stations can be obtained by application to the Superintendent of the Coast and Geodetic Survev at Washington. 
(x) Triangulation.-This method is the one that will give the greatest accuracy, but on account of its requiring special data and instruments, and being an operation rarely used by engineers not engaged in geodetic surveying, it is recommended only for cases in dispute that can not be settled satisfactorily by some other method. An explanation of this class of work would be too long for a report of this sort, and those not familiar with this method are referred to the publications on the subject by the Coast and Geodetic Survey.

(2) Hydrographic.-This method is the most simple and satisfactory one that can be adopted if the surveyor can obtain the use of the necessary instruments and assistants. It is the one best suited for the work of the engineers of the Commission in relocating corners of boundaries, as it gives results of the accuracy ordinarily required and is rapid in execution. Besides, it has the advantage of being available whenever three triangulation stations of suitable relative positions are visible from the offshore points needing relocation.

Most navigators and others familiar with the use of a sextant are well acquainted with the graphic three-point method of fixing a position on water, and only a brief description of the operation will be stated.

In the case where there is only one engineer having a single sextant, the three-point method can be used if the two angles determining the position of a buoy are first derived from the "Forward" bearings given in the tabular forms describing the boundaries of the oyster bars. For example, take "Upper "Stake" bar, which is the first one described in this publication, and assume that "Corner No 3 ," is to be examined as to its position. The angle between the two landmarks "Juliet" and "Earle" as determined from right to left from the forward bearings from this corner is $92^{\circ} 57^{\prime}$ and the angle between "Earle" and "Streett" is $66^{\circ} 5 \mathrm{I}^{\prime}$. Having these two angles, the engineer proceeds to the buoy of doubtful location and measures the actual sextant angles between the landmarks for which the calculations were made. If the measured and calculated angles do not agree the buoy is not in its correct position and the boundary corner must be relocated. This is accomplished by moving the boat about until a point is reached where the angles do agree, and this point being the desired location, the buoy can be placed in its correct position.

If the engineer can obtain the use of both a sextant and a three-arm protractor ("position finder"), the availability of the hydrographic method is increased, as the use of the protractor is essential in case of the washing away or destruction of one or more of the landmarks originally used in describing the boundaries. Under these circumstances, any three landmarks of suitable relative position that are visible from the point to be located can be utilized. For example, the engineer can proceed to the buoy of doubtful position and measure the two adjacent sextant angles between the three landmarks selected. These two angles are set off on the three-arm protractor and the actual position of the buoy plotted on the chart by shifting the protractor about until the edge of each of the three arms passes through the center of the symbols on the chart marking the position of the three landmarks selected. The center of the hub of the protractor will indicate on the chart the actual position of the buoy, and if the point thus obtained does not coincide with the true position of the corner of the boundary as given on the chart, the surveyor can proceed to locate the buoy correctly by reversing the operation. This is done by placing the center point of the hub of the 
protractor over the corner of the boundary in question and measuring on the chart the two adjacent protractor angles between the three selected landmarks. One of the angles thus obtained is set on the sextant and the boat moved about until the two landmarks are shown by the sextant to subtend the same angle obtained from the protractor. The second angle is then placed on the sextant and the same operation gone through, and so on, first using one angle on the sextant then the other until a point is reached where both observed sextant angles are practically identical with the protractor angles. The point thus located is the desired one and the buoy can be placed to mark the true position of the corner of the boundary in question.

If the engineer possesses two sextants and a protractor, this problem is far easier of solution, as the two angles can be set off on separate sextants and the observer can quickly find the desired point where they agree with the protractor angles by using one sextant after the other without the need of resetting either.

If there are two observers; two sextants, and a protractor, it can be seen that the best conditions for both rapid and accurate hydrographic locations of points are attained; in fact, this is the method by which the buoys at the corners of the boundaries were originally placed by the hydrographic engineer to the Commission.

(3) Magnetic bearings from offshore, - This method of fixing a position on water is a simple and well-known one in navigation. It is available to anyone having a boat compass and will be of special use to the State fishery force in investigating cases where buoys are supposed to have been moved for illegal purposes.

In the case where a buoy is supposed to have been moved from its true position the observer takes compass bearings to the three landmarks given in the last column of the tables opposite the boundary corner in question. These bearings are then corrected for the local declination, ${ }^{a}$ and if the results agree with the published bearings the buoy is correctly located.

In the case where the buoy is not in its correct position, or has disappeared altogether, the desired point can be determined by maneuvering the vessel until the corrected bearings agree with the ones in the tabular descriptions, when the buoy can be anchored in its proper location.

In the case where the landmarks for which the bearings are published have been destroyed or washed away, any landmarks whose positions are indicated on the charts can be used by getting their bearings directly from the chart by parallel rulers or a protractor and then applying them in the same manner as the ones published in the tables.

(4) Magnetic bearings from shore.-This method will be of special value to engineers having an ordinary surveyor's compass. The compass can be set over the point marking a "triangulation station" on shore, the name of which is given in the last column opposite the "corner" in question. The instrument is then set at the corresponding "back" bearing (corrected for local magnetic declination) given in the fourth column of the tables opposite the "corner" in question, and the direction thus determined will give one range on which the desired point must be located. The compass can then be moved to a second triangulation station and another range located in a similar manner. The intersection of these two range lines will give the desired point; but in general it should be checked by an. additional range line determined from a third station.

" The mean magnetic variation for Wicomico County is $5^{\circ} 45^{\prime}$ west of north (Igo8) and is increasing at the rate of $3^{\prime}$ yearly. 
(5) Horizontal angles measured at landmarks.-This process is a modification of the triangulation method, and will be useful to engineers who have a transit and desire considerable accuracy.

The instrument is placed over a "triangulation station," the name of which appears in the last column of the tabular description opposite the "corner" in question. The telescope is then pointed to the landmark indicated in the "Descriptions of landmarks" as having a direction of $\mathrm{o}^{\circ} \mathrm{oo}^{\prime} \mathrm{oo}^{\prime \prime}$ from the triangulation station being occupied by the transit. The tabular description of the boundaries is next examined and the "back" bearing of the questionable boundary "corner" from the landmark being occupied is taken out. The angle calculated from this "back" bearing and the bearing given in parentheses alongside the zero landmark in the "Descriptions of landmarks" is then set off on the transit, and a range line established on which the desired point must be located. A similar process is then carried on at a second station, and so on until the position of the buoy is satisfactorily fixed.

BOUNDARIES OF NATURAL OYSTER BARS.

UPPER STAKE.

(Nanticoke River-Chart No. II.)

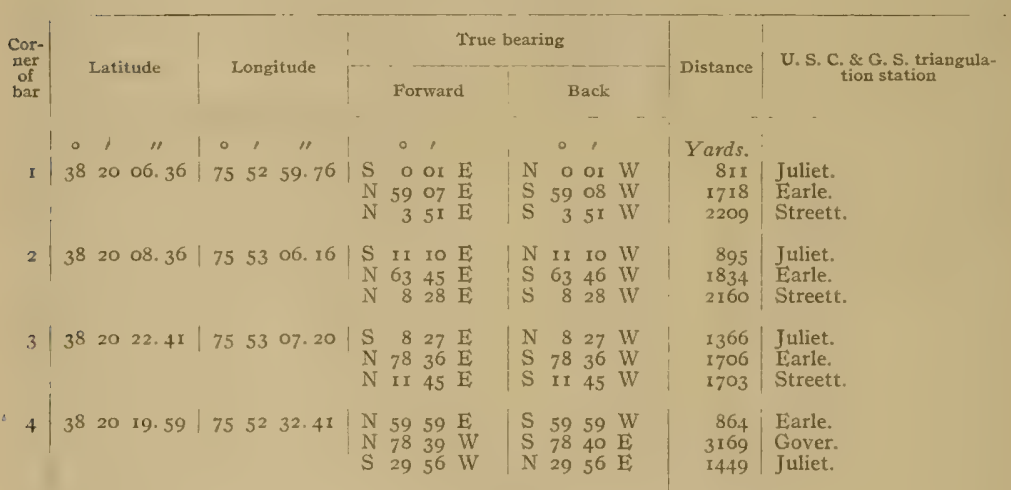

WETIPQUIN.

(Nanticoke River-Chart No. IT.)

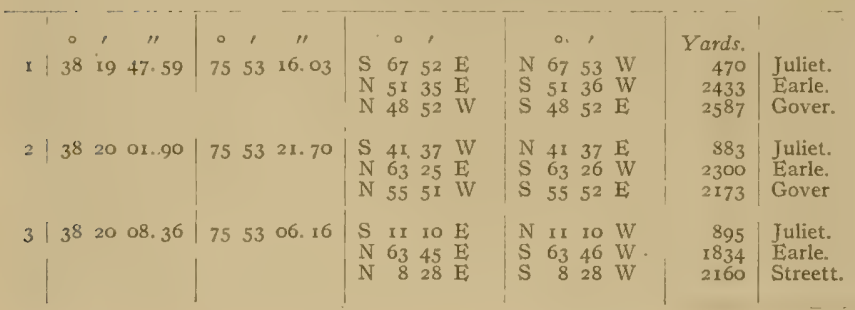


Survey of Oyster Bars, Wicomico Connty, Md.

BOUNDARIES OF NATURAL OYSTER BARS-continUEd.

SAND LUMP.

(Nanticoke River-Chant No. IT.)

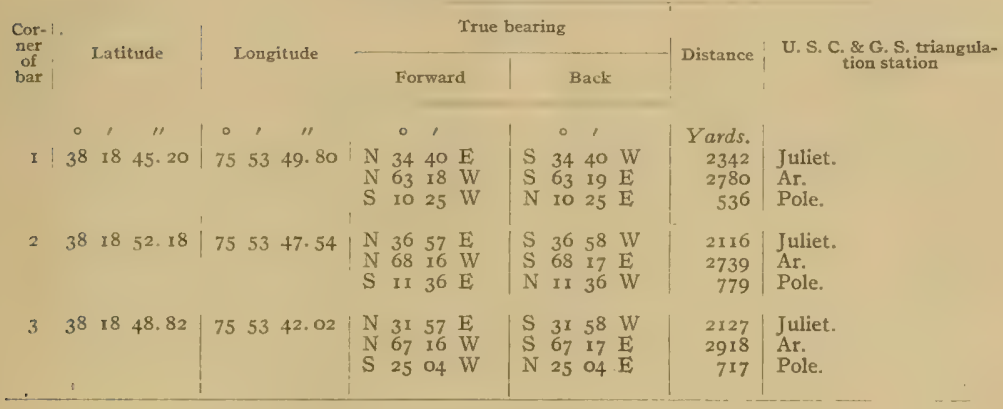

\section{HICKORY NUT.}

(Nanticoke River-Chart No. II.)

\begin{tabular}{|c|c|c|c|c|c|c|c|c|c|c|c|c|c|c|}
\hline I & $\begin{array}{l}0 \\
38\end{array}$ & I 8 & $\begin{array}{c}\prime \prime \\
35.22\end{array}$ & $\begin{array}{c}0 \\
75\end{array}$ & $\begin{array}{c}\prime \\
53\end{array}$ & $\begin{array}{c}\prime \prime \\
50.5^{8}\end{array}$ & $\begin{array}{l}N \\
N \\
S\end{array}$ & $\begin{array}{l}0 \\
30 \\
57 \\
21\end{array}$ & $\begin{array}{ll}52 & E \\
14 & W \\
47 & W\end{array}$ & $\begin{array}{l}\mathrm{S} \\
\mathrm{S} \\
\mathrm{N}\end{array}$ & $\begin{array}{l}0 \\
30 \\
57 \\
21\end{array}$ & $\begin{array}{ll}53 & W \\
14 & E \\
47 & E\end{array}$ & $\begin{array}{r}\text { Yards. } \\
2637 \\
2930 \\
206\end{array}$ & $\begin{array}{l}\text { Juliet. } \\
\text { Ar. } \\
\text { Pole. }\end{array}$ \\
\hline 2 & $3^{8}$ & I 8 & 38.40 & 75 & 54 & 08. I5 & $\begin{array}{l}\mathrm{S} \\
\mathrm{S} \\
\mathrm{N}\end{array}$ & $\begin{array}{l}52 \\
40 \\
53\end{array}$ & $\begin{array}{ll}39 & \mathrm{E} \\
\text { I0 } & \mathrm{E} \\
29 & \mathrm{~W}\end{array}$ & $\begin{array}{l}\mathrm{N} \\
\mathrm{N} \\
\mathrm{S}\end{array}$ & $\begin{array}{l}52 \\
40 \\
53\end{array}$ & $\begin{array}{ll}39 & W \\
10 & W \\
29 & E\end{array}$ & $\begin{array}{r}491 \\
2821 \\
2485\end{array}$ & $\begin{array}{l}\text { Pole. } \\
\text { Juliet. } \\
\text { Ar. }\end{array}$ \\
\hline 3 & $3^{8}$ & 18 & 45.20 & 75 & 53 & +9.80 & $\begin{array}{l}\mathrm{N} \\
\mathrm{N} \\
\mathrm{S}\end{array}$ & $\begin{array}{l}34 \\
63 \\
10\end{array}$ & $\begin{array}{ll}40 & \mathrm{E} \\
18 \mathrm{~W} \\
25 \mathrm{~W}\end{array}$ & $\begin{array}{l}\mathrm{S} \\
\mathrm{S} \\
\mathrm{N}\end{array}$ & $\begin{array}{l}34 \\
63 \\
10\end{array}$ & $\begin{array}{ll}40 & W \\
19 & E \\
25 & E\end{array}$ & $\begin{array}{r}2342 \\
2780 \\
536\end{array}$ & $\begin{array}{l}\text { Tuliet. } \\
\text { Ar. } \\
\text { Pole. }\end{array}$ \\
\hline
\end{tabular}

OLD WOMANS PATCH.

(Nanticoke River-Chart No. II.)

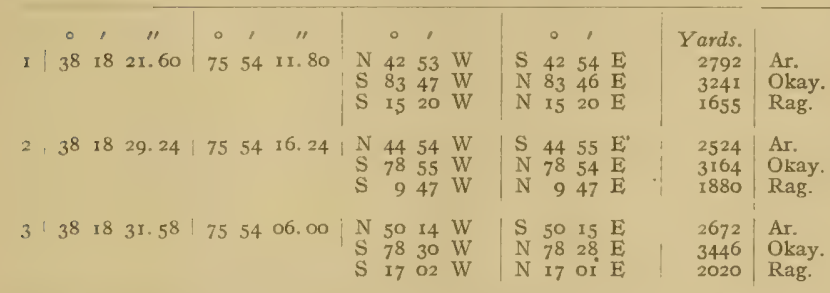


BOUNDARIES OF NATURAL OYSTER BARS-continued.

CEDAR SHOAL.

(Nanticoke River-Chan No. II.)

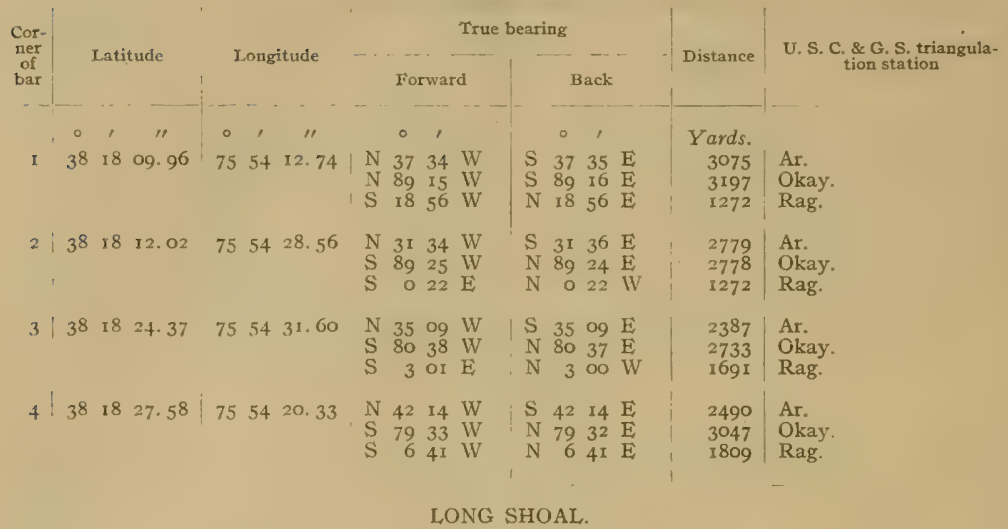

(Nanticoke River-Chart No. II.)

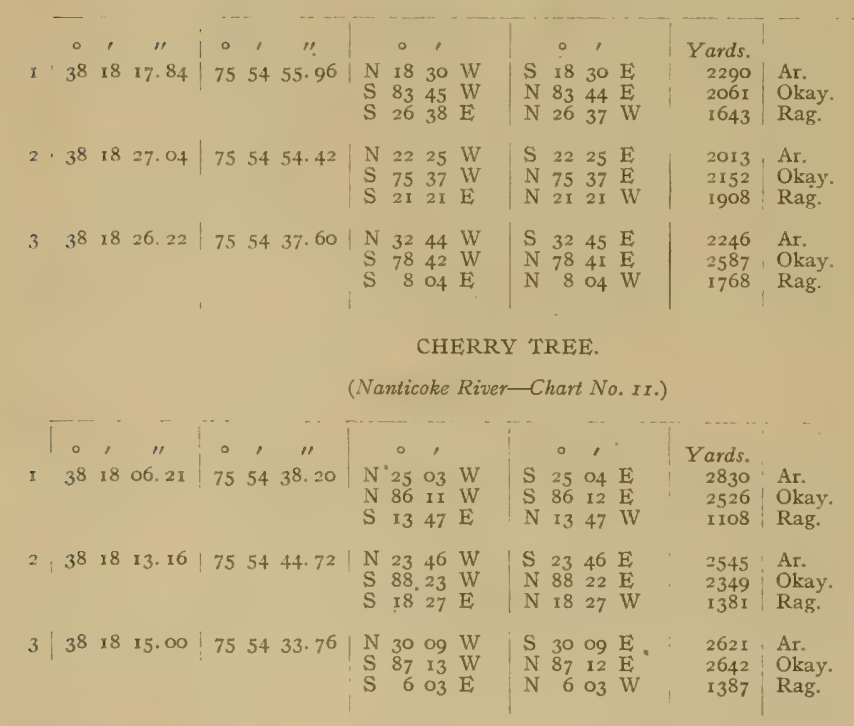


Survey of Oyster Bars, Wicomico County, Md.

BOUNDARIES OF NATURAL OYSTER BARS-continued.

WILSON SHOALS.

(Lozer Nanticoke River-Chart No. Ix.)

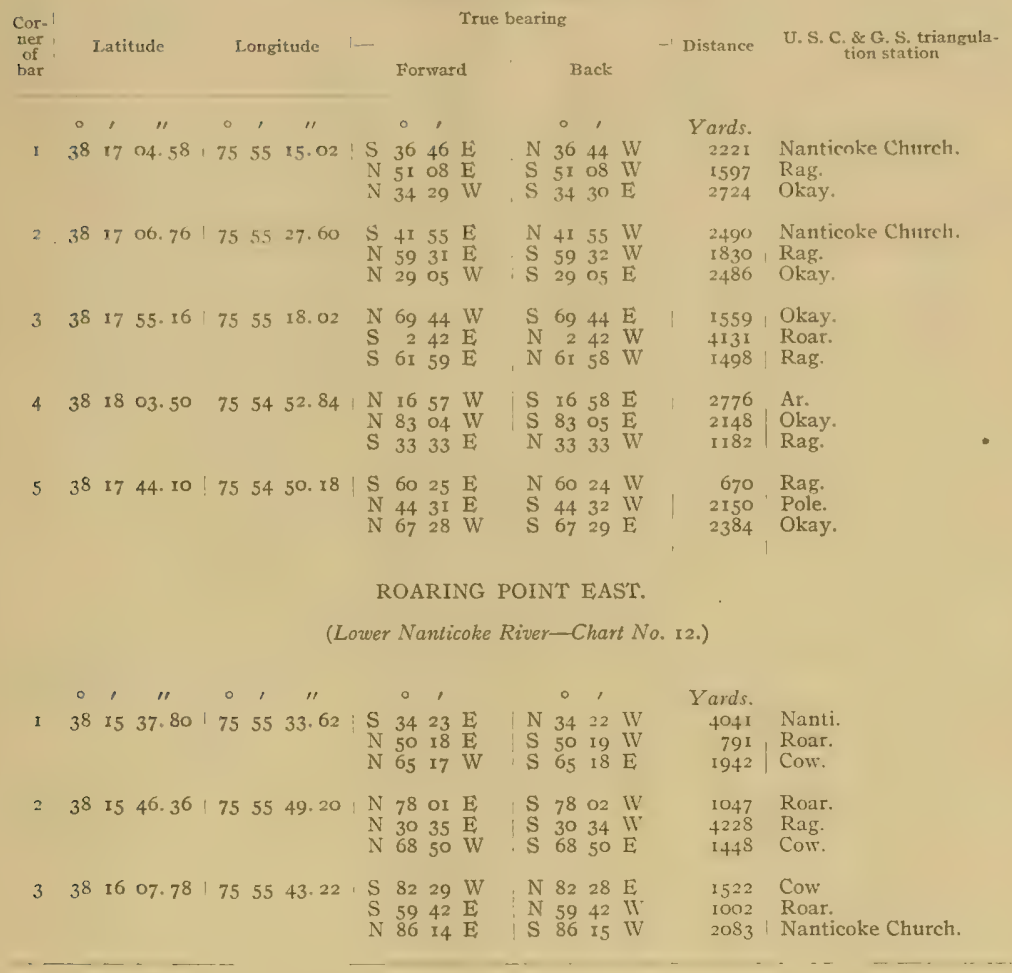


BOUNDARIES OF NATURAL OYSTER BARS - continHEd.

MIDDLEGROUND.

(Mouth Nanticoke River-Chart No. 12.)

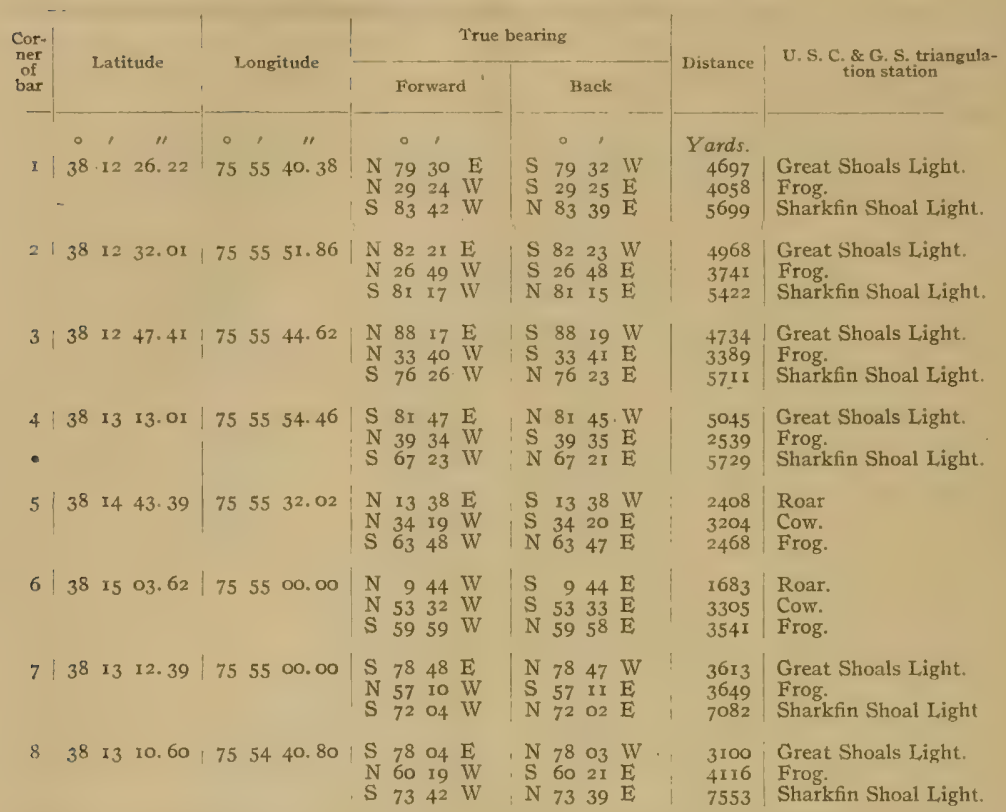

\section{BIG HILL.}

(Mouth Nanticoke River-Chart No. I2.)

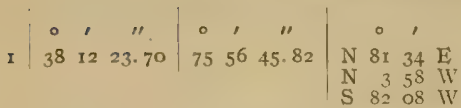
$\begin{array}{rrrr} & & & \\ \mathrm{S} & 81 & 37 & \mathrm{~W} \\ \mathrm{~S} & 3 & 58 & \mathrm{E} \\ \mathrm{N} & 82 & 07 & \mathrm{E}\end{array}$

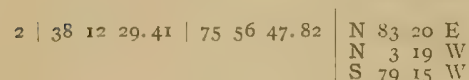
\begin{tabular}{l|llll|lll|llll}
3 & 38 & 12 & 32.10 & 75 & 56 & 32.89 & $\mathbf{N}$ & 83 & 45 & $\mathrm{E}$ \\
$\mathrm{N}$ & 10 & 07 & $\mathrm{~W}$ \\
$\mathrm{~S}$ & 79 & 04 & $\mathrm{~W}$
\end{tabular}
\begin{tabular}{lllllll|llll}
4 & 38 & 12 & 25.42 & 75 & 56 & 36.84 & $\mathrm{~N}$ & 81 & 47 & $\mathrm{E}$
\end{tabular}
$\begin{array}{lrrr}N & 81 & 47 & E \\ N & 7 & 50 & W \\ S & 8 I & 48 & W\end{array}$
Yards.
6429 Great Shoals Light. 3629 Frog
3960 Sharkfin Shoal Light.
6457 Great Shoals Light.
3433 Frog.
3938 Sharktin Shoal Light.
6052 Great Shoals Light.
3397 Frog.
4346 Sharkfin Shoal Light.
6 r84 Great Shoals Light.
3596 Frog
4205 Sharkfin Shoal Light. 
Survey of Oyster 'Bars, Wiconico Connty, $M d$.

BOUNDARIES OF NATURAL OYSTER BARS-continued.

GREAT SHOALS.

(Mouth Wicomico River-Chant No. I2.)

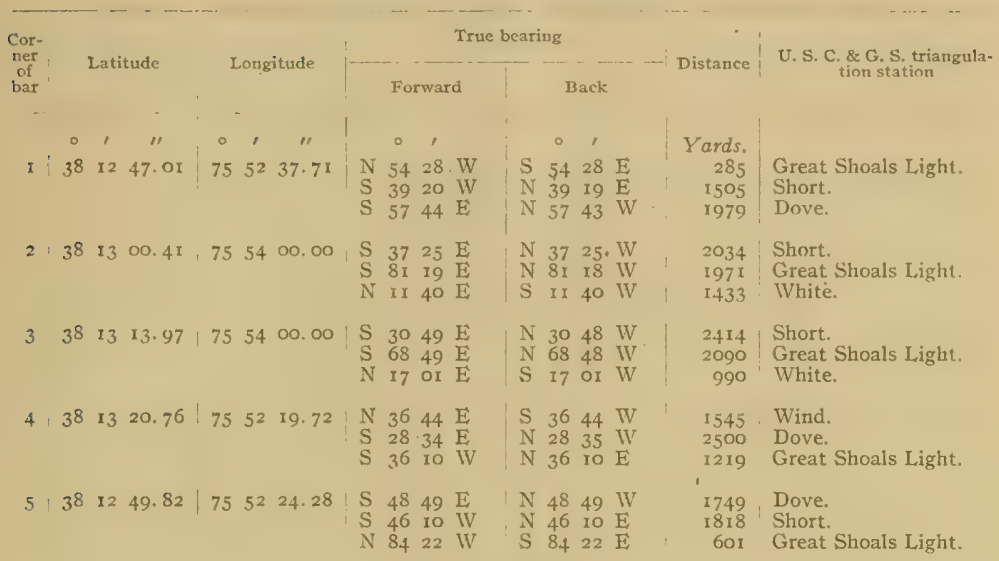

\section{INGRAM SHOAL.}

(Lower IVicomico River-Chart No. I2.)

\begin{tabular}{|c|c|c|c|c|c|c|c|c|c|c|c|c|c|c|}
\hline & 0 & , & $\prime \prime$ & 0 & , & "I & & $\circ$ & , & & 。 & , & Yards. & \\
\hline & 38 & 13 & $38.6 \mathrm{r}$ & 75 & 52 & 23.64 & $\begin{array}{l}\mathrm{S} \\
\mathrm{N} \\
\mathrm{N}\end{array}$ & $\begin{array}{r}21 \\
58 \\
0\end{array}$ & $\begin{array}{ll}12 & \mathrm{WV} \\
\mathrm{I} 4 & \mathrm{E} \\
3 \mathrm{I} & \mathrm{WV}\end{array}$ & S & $\begin{array}{r}21 \\
58 \\
0\end{array}$ & $\begin{array}{ll}\text { I2 } & \mathrm{E} \\
\mathrm{I} 4 & \mathrm{WI} \\
3 \mathrm{I} & \mathrm{E}\end{array}$ & $\begin{array}{l}1702 \\
1210 \\
1877\end{array}$ & $\begin{array}{l}\text { Great Shoals Light. } \\
\text { IVind. } \\
\text { Filla. }\end{array}$ \\
\hline 2 & 38 & 13 & 51.98 & 75 & $5^{2}$ & 31.90 & $\begin{array}{l}\mathrm{S} \\
\mathrm{N} \\
\mathrm{N}\end{array}$ & $\begin{array}{r}10 \\
8 \mathrm{I} \\
8\end{array}$ & $\begin{array}{ll}59 & \mathrm{IV} \\
31 & \mathrm{E} \\
06 & \mathrm{E}\end{array}$ & $\begin{array}{l}\mathrm{N} \\
\mathrm{S} \\
\mathrm{S}\end{array}$ & $\begin{array}{r}10 \\
8 I \\
8\end{array}$ & $\begin{array}{ll}59 & \mathrm{E} \\
32 & \mathrm{IV} \\
\text { o6 } & \mathrm{IV}\end{array}$ & $\begin{array}{l}2075 \\
1262 \\
1439\end{array}$ & $\begin{array}{l}\text { Great Shoals Light. } \\
\text { IVind. } \\
\text { Ella. }\end{array}$ \\
\hline 3 & 38 & 13 & $57 \cdot 26$ & 75 & 52 & 18.97 & $\begin{array}{l}\mathrm{S} \\
\mathrm{N} \\
\mathrm{N}\end{array}$ & $\begin{array}{r}18 \\
89 \\
6\end{array}$ & $\begin{array}{ll}28 & \mathrm{WV} \\
29 & \mathrm{E} \\
28 & \mathrm{~W}\end{array}$ & $\begin{array}{l}\mathrm{N} \\
\mathrm{S} \\
\mathrm{S}\end{array}$ & $\begin{array}{r}18 \\
89 \\
6\end{array}$ & $\begin{array}{ll}28 & \mathrm{E} \\
30 & \mathrm{~W} \\
28 & \mathrm{E}\end{array}$ & $\begin{array}{r}2335 \\
904 \\
\times 255\end{array}$ & $\begin{array}{l}\text { Great Shoals Light. } \\
\text { IVind. } \\
\text { Ella }\end{array}$ \\
\hline
\end{tabular}


Survey of Oyster Bars, Wicomico Connty, Md. BOUNDARIES OF NATURAL, OYSTER BARS-continued.

HOLIAND.

(Lower Wicomico River-Chart No. I2.)

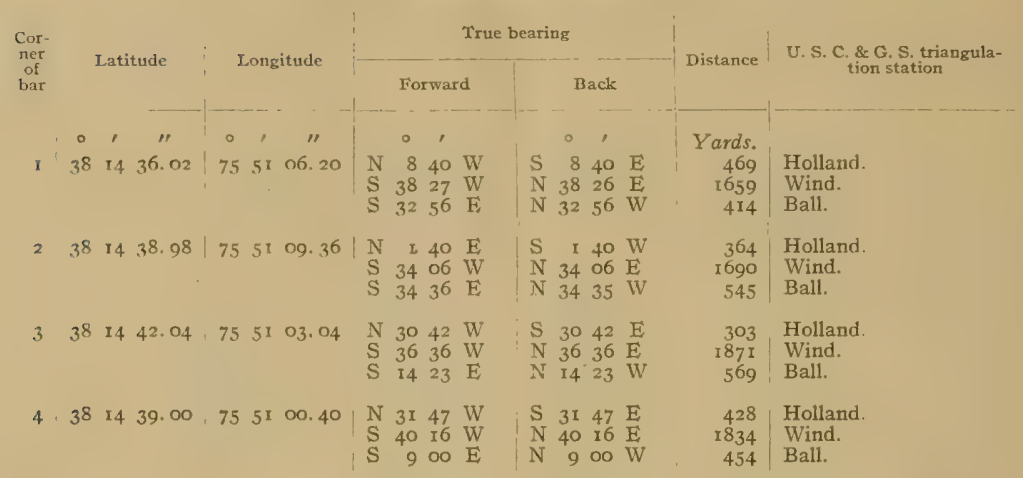




\section{A P P E N D I X ES.}

\section{APPENDIX A.-IAIVS RELATING TO THE COOPERATION OF THE COAST AND GEODETIC SURVEY AND BUREAU OF FISHERIES WITH THE MARYLAND SHELI, FISH COM- MISSION.}

The work of the Coast and Geodetic Survey and of the Bureau of Fisheries, in cooperation with the Maryland Shell Fish Commission, in surveying the oyster bars, establishing permanent landmarks at triangulation stations, and preparing for publication the necessary charts and technical and legal descriptions of boundaries and landmarks shown on these charts, has been executed in compliance with a request from the governor of the State of Maryland to the Secretary of Commerce and Labor, and by the authority of the following laws of the United States and Maryland:

[Act of Congress approved May 26, r906.]

AN ACT To authorize the Secretary of Commerce and Labor to cooperate, through the Bureau of the Coast and Geodetic Survey and the Bureau of Fisheries, with the shellfish commissioners of the State of Maryland in making surveys of the natural oyster beds, bars, and rocks in the waters within the State of Maryland.

Be it enacted by the Senate and House of Representatives of the United States of America in Congress assembled, That the Secretary of Commerce and Labor be, and he is hereby, authorized and directed, upon the request of the govennor of the State of Maryland, to designate such officers, experts, and employees of the Bureau of the Coast and Geodetic Survey and of the Bureau of Fisheries as may be necessary to cooperate with the Maryland State board of shellfish commissioners in making a survey of and locating the natural oyster beds, bars, and rocks in the waters within the State of Maryland; and the Secretary of Commerce and Labor is hereby authorized and directed to furnish to the officers, experts, and employees of said Bureaus so detailed as aforesaid such instruments, appliances, and steam launches as may be necessary to make the survey aforesaid; and the Secretary of Commerce and Labor is hereby authorized to have made in the Bureau of the Coast and Geodetic Survey all the plats necessary to show the results of the aforesaid survey and the locations of the said natural oyster beds, bars, and rocks in the waters within the State of Maryland, and to furnish to the board of shellfish commissioners of the State of Maryland such copies as may be necessary, and for this purpose to employ, in the District of Columbia and elsewhere, such technically qualified persons as may be necessary to carry out the purpose of this act.

SEC. 2. That the Secretary of Commerce and Labor is hereby further authorized to have erected or constructed by the officers so detailed as aforesaid, while making such survey, such structures as may be necessary to mark the points of triangulation, so that the same may be used for such future work of the Coast and Geodetic Survey as the said Bureau may be hereafter required to perform in prosecuting the Government coast survey of the navigable waters of the United States located within the State of Maryland.

SEc. 4. That this act shall take effect from the date of its passage. 
[Act of Congress approved June 30, 1906.]

AN AC'T Making appropriations for sundry civil expenses of the Government for the fiscal year ending June thirtieth, nineteen hundred and seven, and for other purposes.

Be it enacted by the Senate and House of Representatives of the United States of America in Conqress assembled, That the following sums be, and the same are hereby, appropriated, for the objects hereinafter expressed, for the fiscal year ending June thirtieth, nineteen hundred and seven, namely: * * *

COASt AND GeOdetic Survey: * * * For any special surveys * * * including the expenditures authorized under Public Act Numbered One hundred and eighty-one, approved May twenty-sixth, nineteen hundred and six, and contingent expenses incident thereto, five thousand dollars, together with the unexpended balance under this appropriation for nineteen hundred and six and prior years which is hereby reappropriated and made available on this account for the fiscal year nineteen hundred and seven. $* * *$

[Act of Congress approved March 4, r907.]

AN ACT Maklng appropriations for sundry civil expenses of the Government for the fiscal year ending June thirtieth, nineteen hundred and eight, and for other purposes.

Be it enacted by the Senate and House of Representalives of the United States of America in Congress assembled, That the following sums be, and the same are hereby, appropriated, for the objects hereinafter expressed, for the fiscal year ending June thirtieth, nineteen hundred and eight, namely: * * *

COAST AND GeOdetic SURvey: * * * For any special surveys * * * including expenses of surveys in aid of the shellfish commission of the State of Maryland, to be immediately available and to continue available until expended, twenty-five thousand dollars. * * *

[Act of Congress approved May 27, 1908.]

AN ACT Making appropriations for sundry civil expenses of the Government for the fiscal year ending June thirtieth, nineteen hundred and nine, and for otber purposes.

Be it enacted by the Senate and House of Representatives of the United States of America in Congress assembled, That the following sums be, and the same are hereby, appropriated, for the objects hereinafter expressed, for the fiscal year ending June thirtieth, nineteen hundred and nine, namely: * * *

COAST AND GEODETIC SURvEY: *** For any special surveys * * * including expenses of surveys in aid of the shellfish commission of the State of Maryland, which expenses, including cost of plats and charts, shall not exceed fifteen thousand dollars in any one year, to be immediately available, twenty thousand dollars.

[Act of the legislature of Maryland approved April 2, 3906.] ,

AN ACT to establish and promote the industry of oyster culture in Maryland, to define and mark natural oyster beds, bars and rocks lying under the waters of this State, to prescribe penalties for the infringement of the provisions of this Act, and * * *

SECTION 1. Be it enacted by the General Assembly of Maryland, That the following sections be, and they are hereby, added to Article 72 of the Code of Public General Laws, title "Oysters." * * *

SEC. 86. The Board of Shell Fish Commissioners shall, as soon as practicable after the passage of this Act, cause to be made a true and accurate survey of the natural oyster beds, bars and rocks of this State, said survey to be made with reference to fixed and permanent objects on the shore, giving courses and distances, to be fully described and set out in a written report of said survey, as hereinafter required. A true and accurate delineation of the same shall be made on copies of published maps and charts of the United States coast and geodetic survey, which said copies shall be filed in the oftice of the said commissioners in the city of Annapolis: and the said commissioners shail further cause to be 


\section{Survey of Oyster Bars, Wicomico County, $M d$.}

delineated upon copies of the published maps and charts of the United States coast and geodetic survey, of the largest scale, one copy for each of the counties of this State in the waters of which there are natural oyster beds, bars and rocks, all natural beds, bars and rocks lying within the waters of strch county, which maps shall be filed in the offices of the clerks of the Circuit Court for the respective counties wherein the grounds so designated may lie.

* * * * *

SEC. 87. The Governor of this State is hereby requested to ask the assistance of the United States coast and geodetic survey, and of the United States Fish Commissioner, to aid in the carrying out of the provisions of the preceding section. *** *

SEc. 89. As soon as practicable after the first day of April, 1906, the said commissioners shall organize, and shall at once proceed, with the assistance of such person or persons as may be-detailed by the United States coast and geodetic survey, and the United States Fish Commissioner, to aid them in their work, and of such persons as may be appointed under the preceding section, to have laid out, surveyed and designated on the said charts, the natural beds and bars, and shall cause to be marked and defined as accurately as practicable, the limits and boundaries of the natural beds, bars and rocks, as established by said survey, and they shall take true and accurate notes of said survey in writing, and make an accurate report of said survey, setting forth such a description of landmarks as may be necessary to enable the said board, or their successors, to find and ascertain the boundary lines of the said natural oyster beds, bars and rocks, as shown by a delineation on the maps and charts provided in this Act; said report shall be completed and filed in the office of the board in the city of Annapolis within ninety days after the completion of the survey of any county. Said commissioners shall cause the same to be published in pamphlet form, and transmit copies of the same to the clerks of the Circuit Court for the respective counties, where the charts have been filed or directed to be filed as hereinafter provided; the said report to be filed by the clerks of the several counties in a book kept for that purpose. And the said survey and report, when filed, subject to the right of appeal hereafter provided for in this Act, shall be taken in all of the courts of this State as conclusive evidence of the boundaries and limits of all natural oyster beds, bars and rocks, lying within the waters of the county wherein such survey and report are filed, and shall be construed to mean in all of the said courts that there are no natural oyster beds, bars or rocks lying within the waters of the counties wherein such report and survey are filed, other than those embraced in the survey authorized by this Act, and that all areas of the Chesapeake Bay and its tributaries within the State of Maryland, not shown in the survey to be natural oyster beds, bars or rocks, shall be construed in all the courts of the State to be barren bottoms, and open for disposal by the State for the purpose of private planting or propagation of oysters thereon nnder the provisions of this Act; provided, that the said survey and report shall not be so construed as to affect in any manner the holdings by citizens of this State in any lot which may have been appropriated or taken up under the laws of this State prior to the approval of this Act. * * *

The law of the State of Maryland, passed March 9, 1842, authorizing officers of the United States Coast and Geodetic Survey to enter upon the lands within the State limits for the purposes of the Survey, is as follows:

An Act Concerning the Survey of the Coast of Maryland.

SECTION I. Be it enacted by the General Assembly of Maryland, That it shall and may be lawful for any person or persons employed under and by virtue of an act of the Congress of the United States, *** at any time hereafter to enter upon lands within this State for the purpose of exploring, surveying, triangulating, or levelling, or doing any other matter or thing which may be necessary to effect the objects of said act, and to erect any works, stations, buildings, or appendages requisite for that purpose, doing no unnecessary injury to private or other property.

Sec. 2. a And be it enacted, That in case the person or persons employed under the act of Congress aforesaid, can not agree with the owners or possessors of the land so entered upon and used as to the amount of damage done thereto by reason of the removal of fences, cutting of trees or injury to the

$a$ Under the rulings of the Comptroller of the Treasury no damages can be collected except through the United States Court of Claims unless an agreement has been made in advance. 
crop or crops growing on the same, it shall and may be lawiful for the said parties or either of them to apply to the chief justice for the time being or one of the associate judges of the judicial district in which such land may be situated, who shall thereupon appoint three disinterested and judicious freeholders, residents of the same judicial district, to proceed with as much despatch as possible to the examination of the matter in question, and the faithful assessment of the damages sustained by the owners or possessors aforesaid, and the said freeholders or a majority of them, having first taken and subscribed an oath or affirmation before the chief or associate justice aforesaid or other person duly authorized to administer the same, that they will well and truly examine and assess as aforesaid, and having given five days' notice to both parties of the time of their meeting, shall proceed to the spot, and then and there upon their own view and if required, upon the evidence of witnesses, (to be by them sworn or afirmed and examined) shall assess the said damages, and shall afterward make report thereof and of their proceedings in writing under their hands and seals and file the same within five days thereafter in the office of the clerk of the county in which the land aforesaid is situated, subject to an appeal by either party to the county court of the said county within ten days after filing as aforesaid, and the said report so made as aforesaid, if no appeal as aforesaid be taken, shall be held to be final and conclusive as between the said parties, and the amount so assessed and reported shall be paid to the said owners or possessors of the land so damaged within twenty days after the filing of said report, and the said chief or associate justice as aforesaid, shall have authority to tax and allow upon the filing of said report, such costs, fees and expenses to the said freeholders for the performance of their duty as he shall think equitable and just, which allowance shall be paid by the person or persons employed under the act of congress aforesaid, within the time last above limited, but if an appeal as aforesaid be taken, the case shall be set down for hearing at the first term of county court aforesaid, ensuing upon and after appeal, and it shall be lawful for either party immediately after the entry of such appeal, to take out summons for such witnesses as may be necessary to be examined upon the hearing aforesaid, and the said court shall have power in its discretion to award costs against which ever the final judgment shall be entered, and such appeal at the option of either party may and shall be heard before and the damage assessed by a jury of twelve men to be taken from the regular panel and elected as in other cases.

SEC. 3. And be it enacted, That if any person or persons shall wilfully injure or deface or remove any signal, monument or building or any appendage thereto, erected, used or constructed under and by virtue of the act of congress aforesaid, such person or persons so offending shall severally forfeit and pay the sum of fifty dollars with costs of suit to be sued for and recovered by any person who shall first prosecute the same before any justice of the peace of the county where the person so offending may reside, and shall also be liable to pay the amount of damages thereby sustained, to be recovered with costs of suit in an action on the case, in the name and for the use of the United States of America, in any court of competent jurisdiction.

\section{APPENDIX B.-THE HAMAN OYSTER CULTURE LAW.}

[Extract from First Report of Shell Fish Commission.]

OBJECT.

"The legislature in placing chapter 711 of the acts of 1906 , better known as the Haman Oyster Culture Law, upon the statute books of Maryland had a twofold object in view:

I. To encourage an industry in oyster culture upon the barren bottoms beneath the tidewaters of the State.

2. To prevent the leasing of natural oyster bars for the purpose of oyster culture."

SURVEY.

"To make the leasing of barren bottoms possible and the leasing of natural bars impossible, provision was made for a survey of the natural bars for the purpose of accurately locating and marking the same. It was definitely provided that no barren bottoms should be leased in any part of the State until the natural bars of that region had been surveyed, charted, and marked with buoys." 
NATURAL BAR NOT DEFINED.

"The Shell Fish Commission is instructed by section go of the Haman Oyster Culture Law to exercise its judgment liberally in favor of the natural bars when surveying, charting and buoying them, but other than this the Commission is uninstructed in this important matter. The responsibility of defining a natural bar is placed upon the Commission."

\section{DEFINITION OF A NATURAL OYSTER BAR.}

\section{DIVERSITY OF OPINION.}

"No definition of a natural oyster bar could be formulated by any man or body of men which would meet with the approval of all parties concerned. Oystermen, as a rule, hold that all bottoms where oysters grow or have grown naturally even though now practically barren of oysters should be considered natural bars. Other citizens of the State who are not directly interested in the oyster business, but. interested in the oyster industry from the standpoint of revenue, hold, as a rule, that no bottoms should be excluded from leasing for oyster culture which, by methods known to oyster culturists, may be made to yield a greater number of oysters than they now produce."

"It should be evident to every one that neither of these definitions could be adopted by the Commission as a working basis for determining which of the grounds surveyed are natural oyster bars."

\section{THE GOLDSBOROUGH DEFINITION.}

"The definition of a natural bar which very nearly approaches a reasonable and satisfactory compromise between the extreme views given above and which has therefore been adopted by the Commission, is that contained in an opinion rendered by Judge Charles F. Goldsborough in the circuit court for Dorchester County in the July term, $188 \mathrm{I}$, in the case of William $\mathrm{T}$. Windsor and George R. Tood, v. Job T. Moore. It is as follows:

What then is a natural bar or bed of oysters? It would be a palpable absurdity for the State to attempt to promote the propagation and growth of oysters and to encourage its citizens, by a grant of land, to engage in their culture, if the lands authorized to be taken up were only those upon which oysters do not and can not be made to grow. That there may be lands covered by water in the State where no oysters can be found, but where, if planted, they could be cultivated successfully, may be possible, but, if so, 1 imagine that their extent must be too limited for them to be of much practical, general advantage for the purposes of such a law as the one under discussion; but there are thousands of acres of hard and shifting sands where oysters not only are not found, but where it would be folly to plant them; and these latter it can not be supposed that the State intended to offer to give away, for the simple reason that the State could not help knowing that nobody would have them.

Upon the other hand there are large and numerous tracts where oysters of natural growth may be found in moderate numbers, but not in quantities sufficient to make it profitable to catch them, and yet where oysters may be successfully planted and propagated. In my opinion these can not be called natural bars or beds of oysters, within the meaning of the Act of Assembly, and it is just such lands as these that the State meant to allow to be taken up under the provisions of the above-mentioned section of the Act.

But there is still another class of lands where oysters grow naturally and in large quantities and to which the public are now and have been for many years in the habit of resorting with a view to earning a livelihood by catching this natural growth, and here, I think, is the true test of the whole question. Land can not be said to be a natural oyster bar or bed merely because oysters are scattered here and there upon it, and because if planted they will readily live and thrive there; but whenever the natural growth is so thick and abundant that the public resort to it for a livelihood, it is a natural oyster bar or bed and comes within the above-quoted restriction in the law, and cannot be located or appropriated by any individual."

\section{APPENDIX C.-STATISTICS OF RESULTS OF THE COMBINED OPERATIONS OF THE GOVERNMENT AND STATE.}

For a further understanding of the character of the oyster survey work that is being carried on in Maryland, the following statistical tabulation of the combined results of the various operations of both the Government and State will be of value. In this connection it should be remembered that 
these statistics only include the new work required to supplement the large amount of existing data obtained from the archives of the Coast and Geodetic Survey and utilized in the preparation of the charts and technical records.

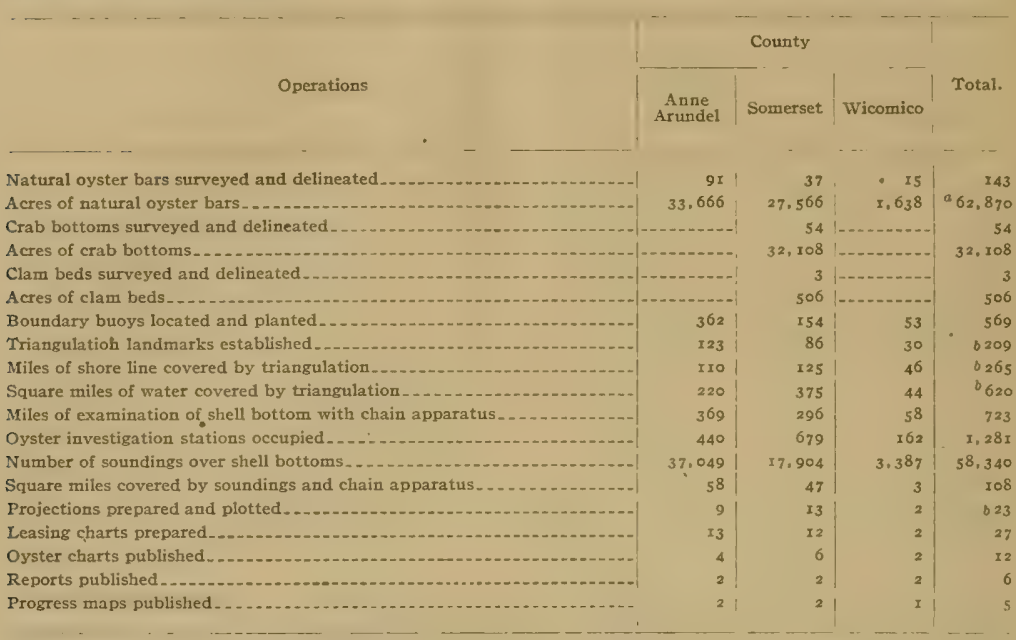

a Total area of natural oyster bars of Connecticut is 5.770 acres. $b$ Less quantities covered by statistics of more than one county. 






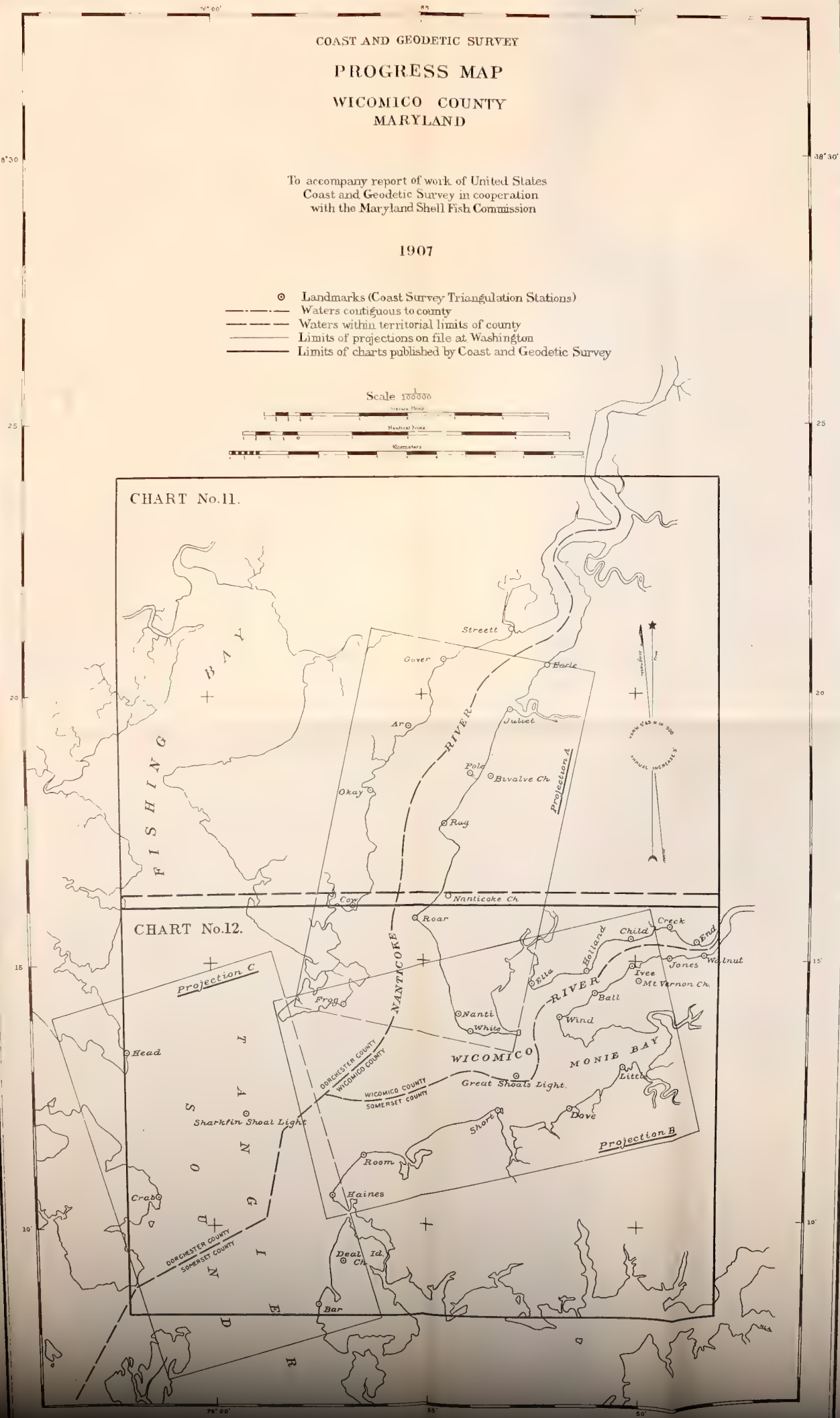



DEPARTMENT OF COMMERCE AND LABOR

COAST AND GEODETIC SURVEY

O. H. TITTMANN, Superintendent

\section{SURVEY OF OYSTER BARS WORCESTER COUNTY MARYLAND}

DESCRIPTION OF BOUNDARIES AND LANDMARKS AND REPORT OF WORK OF UNITED STATES COAST AND GEODETIC SURVEY IN COOPERATION WITH UNITED STATES BUREAU OF FISHERIES AND MARYLAND SHELL FISH COMMISSION

By C. C. YATES

CHIEF OF COAST AND GEODETIC SURVEY PARTY ASSISTANT, COAST AND GEODETIC SURVEY

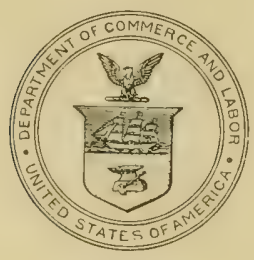

WASHINGTON

GOVERNMENT PRINTING OFFICE

1909 



\section{LE'TTER OF SUBMIT'TAL.}

\section{DEPARTMENT OF COMMERCE AND LABOR, \\ Coast and Geodetic Survey, W'ashington, April I0, 1909 .}

SiR: I have the honor to transmit herewith a report of the officer detailed from the Coast and Geodetic Survey to cooperate with the Bureat of Fisheries and the Maryland Shell Fish Commission in surveying the oyster bars of the State of Maryland, and certain technical results which are necessary for the interpretation and use of the plats of the survey made by the Government.

This work has been done under the provisions of the act of Congress entitled "An act to authorize the Secretary of Commerce and Labor to cooperate, through the Bureau of the Coast and Geodetic Survey and the Bureau of Fisheries, with the shell fish commissioners of the State of Maryland in making surveys of the natural oyster beds, bars, and rocks in the waters within the State of Maryland," approved May 26, I go6, and of the acts of Congress making appropriations for sundry civil expenses of the Government for the fiscal years ending June 30 , 1907, 1908, and 1909.

Respectfully,

To Hon. Charles Nagel,

O. H. Titmann, Superintendent.

Secretary of Commerce and Labor. 



\section{CERTIFICATION.}

Annapolis, Md, A pril 8, 1909 .

The following publication is certified to contain correct technical descriptions of all boundaries and landmarks established in the waters of Worcester County by the Maryland Shell Fish Commission in cooperation with the United States Coast and Geodetic Survey.

$$
\text { C. C. YATES, }
$$

Chief of Coast and Geodetic Survey Party, Assistant, Coast and Geodetic Survey.

Examined and certified to be correct.

$$
\text { AnNAPOLIS, MD., April 8, } 1909 .
$$

$$
\begin{gathered}
\text { WALter J. Mitchel, } \\
\text { CASWEl, Grave, } \\
\text { Benjamin K. GReEN, } \\
\text { Maryland Shell Fish Commission. } \\
\text { SwePson EARLe, } \\
\text { Hydrographic Engineer. }
\end{gathered}
$$

NOTE.-Certified copies of this publication and of the charts of the natural oyster bars of Worcester County were filed in the office of the clerk of the circuit court of Worcester County and in the office of the Board of Shell Fish Commissioners, at Annapolis, on April 12, 1909. 



\section{CON'TENTS.}

PROGRESS MAP.

LETTER OF SEBMTTAL.

CERTIFICATION

INTRODUCTION:

Publications

Cooperation of the Coast and Geodetic Survey

Cooperation of the Bureau of Fisheries

General statement of work of Coast and Geodetic Survey

REPORT OF THE WORK OF THE COAST AND GEODETIC SURVEY:

Instructions

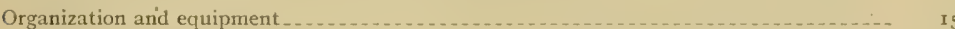

Chronological statement of work .............. . . . . . 15

Statistics.

General remarks _._.

ChaRTS AND MAPS:

Charts of natural oyster bars

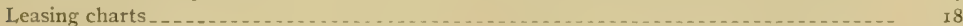

Projections _...

Progress maps_._._.

BOUNDARIES OF THE COUNTY WATFRS:

Waters within territorial limits of county _ . . . . . . . . . 20

Waters contiguous to county ........ 20

LANDMARKS (U. S. COAST AND GeOdetic SURvey Triangulation stations):

Explanation .... . . . . . . . . . . . . . . 2 I

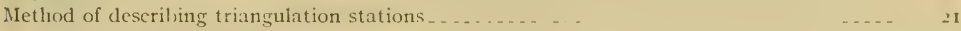

Descriptions of triangulation stations-

Thorofare (see progress map)

Collier (see progress map)

Convent Water Tower (see progress map)

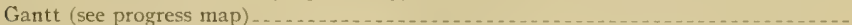

Killick Shoal Light (Virginia) (see progress map)

Chester (Virginia) (see progress map) _...

Assateague Light (Virginia) (south of chart limits, see progress map) _........ 40

Chart No, 13 (Sinepuxent Bay)-

Hamilton

Ocean City Water Tower

Harmon _. . .

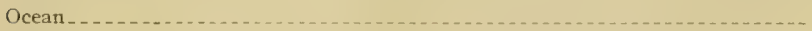

Buffington Wind

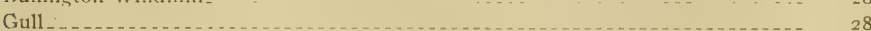

Inkquill

Seaside _ 
Landmarks (U. S. Coast and Geodetic Survey triangulation stations)-Continued. Descriptions of triangulation stations--Continued.

Chart No. 73 (Sinepuxent Bay)-Continued.

Ellpow

Fassett

Shore

Nellys

Bar.

Longwells Windmill.

Sanpoi

Mud

Ingraya

Salt

North Beach Life-Saving Station (see also Chart No. 14)

Birch (see also Chart No. I4)

Neck -

Newport . . . . . . . . . . . . . . . .

Handys Hammock (see also Chart No. I4)

Chart No. If (Upper Chincoteague Bay)-

Birch (see also Chart No. 13) _... 35

North Beach Life-Saving Station (see also Chart No. I3)

Beacon Clumps._. 37

Turnagain (see also Chart No. 15)

Green Run Inlet Life-Saving Station Flagstaff (see also Chart No. 15) _....... 38

Landlet_._.

Guilberts Cupola _... 38

Ricks... - ...... ... . . . . . . . . . . 38

Handys Hammock (see also Chart No. 13) _... . . 36

Chart No. ${ }_{5}$ (Lower Chincoteague Bay)-

Turnagain (see also Chart No. 14) _... . . . . . . . . . . . . . 37

Green Run Inlet Life-Saving Station Flagstaff (see also Chart No. 1.4) - . . . . . 38

Maryland-Virginia (Life-Saving Station Beach) _._. 39

Maryland-Virginia (Pope Island) _.

Pope Island Life-Saving Station (Virginia) _. 40

Wildcat (Virginia) _... . . . 40

Long Point (Virginia)

Grace M. E. Church (Virginia)

Money (Virginia)

Maryland-Virginia (Railroad) _.

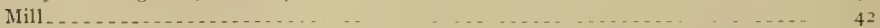

Tizz_.

BOUNDARIES OF OXSTER BARS:

Explanation

Method of describing boundaries

Surveying methods for relocation of boundaries .

Boundaries of natural oyster bars-

Chart No. 73 (Sinepuxent Bay)-

South Point (see also Chart No. I4)

Handys Hammock (see also Chart No. 14)

Newport (see also Chart No. 14)

Chart No. I $_{4}$ (Upper Chincoteague Bay)-

South Point (see also Chart No. $\mathrm{r}_{3}$ ) .............

Handys Hammock (see also Chart No. 13) .

Newport (see also Chart No. 13) 
BOUNDARIES OF OYSTER BARS-COntinued.

Boundaries of natural oyster bars-Continued.

Chart No. 14 (Upper Chincoteague Bay)-Continued. I'age

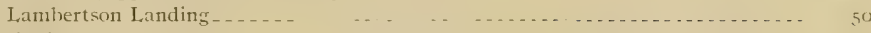

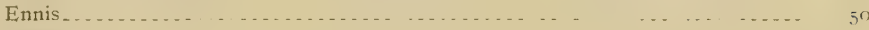

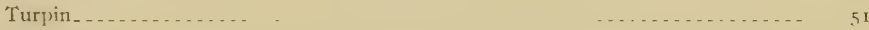

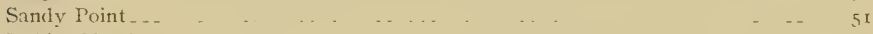

Robins Marsh........... . . . . . . . 53

Scarboro Creek_.

Southwest ...

Purnell Hammock.. ... $\quad \ldots \ldots \ldots \ldots \ldots . . .53$

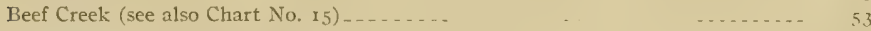

Rattlesnake (see also Chart No. 15 ) _._.

Martin Point (see also Chart No. 15) _... . . . . . . . . . . 54

Diamond (see also Chart No. I5) _...

Chart No. 15 (Lower Chincoteague Bay)-

Beef Creek (see also Chart No. 14) _... . . . . . $\quad \ldots \ldots \ldots . . .5$

Rattlesnake (see also Chart No. I4)

Martin Point (see also Chart No. 14) _. . . . . . . $\quad . . .54$

Diamond (see also Chart . No. If) ...

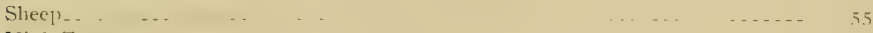

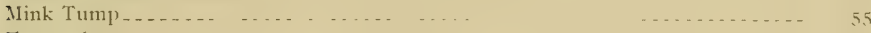

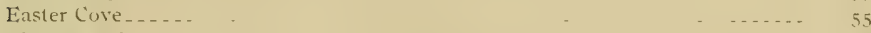

Big Bay Point _ _. _ _ _... 56

Kennel ...... . . . . . . . . . . . . 56

Drum ... - $\quad$ - $\quad \ldots \ldots \ldots 6$

Toly _... $\quad \ldots \ldots \ldots \quad \ldots$

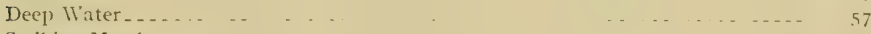

Striking Marsh_... $\quad \ldots \ldots \ldots \ldots \ldots$

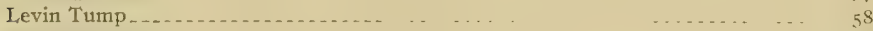

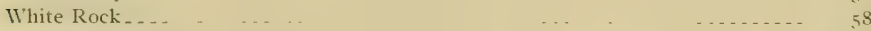

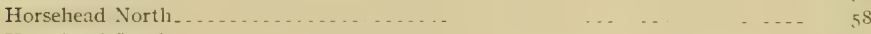

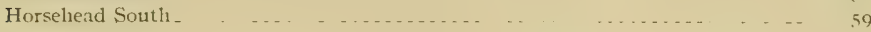

APPENDIXES:

Appendix A.-Laws relating to the cooperation of the Coast and Geodetic Survey and Bureau of Fisheries with the Maryland Shell Fish Commission ........................

Appendix B.-- "The Haman Oyster Culture Law" (extract from Second Report of Shell Fish Commission)

Appendix C.-Summary of the particular surveying operations which constitute an "oyster survey" as now being carriad on in Maryland

Appendix D.-Statistics of results of the combined operations of the Government and State- 



\title{
SURVEY OF OTSTER BARS, WORCESTER COUNTY, MD.
}

\section{INTRODUCTION.}

\author{
PUBLICATIONS.
}

The preparation of publications relating to the survey of the oyster bars of Maryland has been divided between the Government and the State in accordance with the laws ${ }^{a}$ authorizing the work and the natural division of the surveying operations ${ }^{b}$ of the cooperating forces.

The publications prepared and issued by the Government under the direction of the Superintendent of the Coast and Geodetic Survey consist of a series of charts and a technical report for each county surveyed. ${ }^{c}$ The charts show all legal boundaries of oyster bars within the adopted botndaries of the waters opened up for leasing with each county, and the location of all landmarks (Coast and Geodetic Survey triangulation stations) used as a foundation for the delineation of these various boundaries. The technical report gives technical and legal descriptions of all oyster-bar and other boundaries, and descriptions of all landmarks shown on the charts, and includes the report of the representative of the Coast and Geodetic Survey in charge of the work of that Service in cooperation with the Bureat of Fisheries and the Maryland Shell Fish Commission. These charts and technical reports are prepared and certified for file with the courts and the Commission, as required by the laws of the State, and contain all information necessary to make a permanent record of the work of the Commission and the Government for all future requirements of the courts, or for any resurveys that may become necessary. ${ }^{d}$

The publications prepared and issued by the State under the direction of the Shell Fish Commission consist of annual reports ${ }^{e}$ of all the operations of the Commission

$a$ See Appendix A for laws relating to the cooperation of the Coast and Geodetic Survey and Bureau of Fisheries with the Maryland Shell Fish Commission.

$b$ See Appendix C for a summary of the particular surveying operations which constitute an "oyster survey" as now being carried on in Maryland.

$c$ These charts and technical reports can be obtained by application to the Superintendent of the Coast and Geodetic Survey, at Washington, D. C. The publications ready for issue are those for Anne Arundel, Somerset, Wicomico, and Worcester counties; those for Calvert, St. Marys, and Charles counties are now being prepared.

$d$ The technical records and charts for each county are published separately on account of the requirements of the oyster-culture laws of the State and the practical considerations which make it desirable to have each county "opened up" for oyster culture as soon as practicable after the completion of its survey. For these reasons and the fact that these reports are each arranged for distribution and use in one county only without reference to other published records, much of the text of this publication is of necessity identical with similar previous publications for other counties.

e These reports can be obtained by application to the Shell Fish Commission, Annapolis, Md. They are issued annually in October, and the first and second reports are now available for distribution. 
performed under the provisions of the laws of Maryland, ${ }^{a}$ including results of biological and economic oyster investigations, methods and results of the hydrographic survey of the boundaries of oyster bars and crab bottoms, the administrative report and financial statement of the Commission, information relating to oyster culture, methods of surveying and leasing of oyster lots, and much other important matter of legal and scientific value.

These two sets of publications are planned and arranged to supplement each other without unnecessary duplication, and when combined they form a complete report of operations, methods, and results of the work of both the Government and State. ${ }^{b}$

\section{COOPERATION OF THE COAST AND GEODETIC SURVEY.}

The work of the Coast and Geodetic Survey, as the name of the Service indicates, includes a survey of the coasts of the United States made on a geodetic basis. This has involved the gradual construction of a great framework of interstate triangulation for use as a foundation for detail hydrographic and topographic surveys, from which there has been compiled and published a complete set of charts of the coasts of the United States, including all waters of Maryland where oysters grow. This existing triangulation, hydrography, and topography is essential as a foundation for a correct and practical survey of natural oyster bars; and it being one of the fundamental functions of the Coast and Geodetic Survey to furnish such data, the cooperation of the Coast and Geodetic Survey with the Bureau of Fisheries and the Maryland Shell Fish Commission is a practical and natural development of Government work leading to the conservation and increase of the supply of food.

\section{COOPERATION OF THE IUREAU OF FISHERIES.}

The Bureau of Fisheries has cooperated with the Coast and Geodetic Survey and the Maryland Shell Fish Commission principally as an adviser in matters relating to the biological and economic survey of oyster bars and the methods to be employed for that purpose. $^{c}$ A steam launch, rowing boat, and certain apparatus have also been furnished.

The primary function of the Bureau of Fisheries is to increase the productiveness of marine and fresh waters by such measures as may be best suited to the purpose, and the services rendered in connection with the survey of the oyster bars of Maryland are strictly in line with the fundamental law under which it acts. In certain States other than Maryland similar work has been conducted by the Bureau acting independently, the same ends being attained at greater expense to the Government.

\section{GENERAL STATEMENT OF WORK OF COAST AND GEODETIC SURVEY. ${ }^{d}$}

The results obtained from the work of the Coast and Geodetic Survey in cooperation with the Bureau of Fisheries and the Maryland Shell Fish Commission need very

$a$ See Appendix B for an extract from the "Second Report of the Maryland Shell Fish Commission," giving a concise summary of the "Haman Oyster Culture Law."

$b$ See Appendix D of this publication for "Statistics of results of combined operations of the Government and State."

$c$ Hon. George M. Bowers, Commissioner of Fisheries, has detailed for this service Dr. H. F. Moore, Assistant, Bureau of Fisheries.

d For a detail statement of the very large amount of excellent oyster survey work of the Maryland Shell Fish Commission see the "Annual Reports of the Maryland Shell Fish Commission," 
little other summary than is indicated by the published "Charts of Natural Oyster Bars" and the scheme of hydrographic projections and triangulation stations shown on the county progress maps attached to each report.

The triangulation has been carried on in accordance with the standard methods of the Coast and Geodetic Survey, making this work and that of the "Descriptions of Triangulation Stations" of permanent value, not only to the State of Maryland in the survey of her oyster bars, but also to the Government for any future work it may do in the regions covered by the oyster-survey operations.

The hydrographic projections and published charts are prepared with all the accuracy permitted by their large scale, especially as to the boundaries of the various shellfish bottoms in relation to landmarks, but this accuracy of location on the charts is further added to and permanently fixed by published technical descriptions which should minimize the probability of any future dispute as to either landmarks or boundaries.

Stated another way and quoting from the report of the "Survey of Oyster Bars of Anne Arundel County:"

The geographic positions of the permanent landmarks and signals have been determined with the usual precision of a trigonometric survey, and their locations at all points necessary to provide ample foundation for the surveying and sharting operations permitted great accuracy of definition and location for the natural oyster bar and other boundaries established. At the same time, the very important element of permanency of the positions of boundaries has been secured, as the relocation of geodetic positions can always be accomplished by a competent surveyor, even though the original landmarks and monuments have been washed away, as has been the fate of hundreds of such points established by the Coast and Geodetic Survey on the shores of the Chesapeake Bay during the last sixty-five years.

In fact, when the survey of the oyster bars of Maryland is completed, it is believed that it will stand the test of time and practical use as a working foundation for whatever form the oyster legislation of the future may assume, and that the doing of the work systematically and accurately, once for all, means the establishment of a foundation of a great oyster industry by ineradicably locating the natural oyster bars for the use of the public, and a still greater permanent superstructure of real oyster culture as a reward for individual enterprise, by reason of the integrity of the survey by which the rights of the public are secured. 


\title{
REPORT OF THE WORK OF THE COAST AND GEODETIC SURVEY IN WORCFSTER COUNTY.
}

\section{INSTRUCTIONS.}

The following two letters, together with the laws ${ }^{a}$ of the United States relating to the subject, constitute the "instructions" received by the chief of the Coast and Geodetic Survey party engaged on work in connection with the Maryland Shell Fish Commission. They are short and definite, but furnish ample authority and leeway for all legitimate development of the cooperation of the Government and the State in the survey of oyster bars. "The "free hand" permitted by these orders, together with the aid and many valuable suggestions received from the officers of the Survey at Washington, have proved very beneficial to the work, and are greatly appreciated.

\section{DEPARTMENT OF COMMERCE AND LABOR, OFFICE OF THE SECRETARY, IVashington, June 2, I9o6.}

SiR: In reply to your letter of May 28, requesting me to designate officers of the Coast and Geodetic Survey and of the Bureau of Fisheries to cooperate with the State of Maryland in making survey of and locating the natural oyster beds, I have the honor to inform you that Mr. C. C. Yates will be designated to cooperate on the part of the Coast and Geodetic Survey as soon as Congress makes the provisions of the act effective by providing an appropriation for the purpose.

Respectfully,

His Excellency Hon. EDWIN WARFIELD,

LAWRENCE O. MURRAY, Assistant Secretary.

Governor of Maryland, Annapolis, Md.

\author{
DEPARTMENT OF COMMERCE AND LABOR, \\ Coast and Geodetic Surver, \\ W ashington, July 3, rgo6.
}

SIR: Upon the receipt of these instructions you will surrender the command, accounts, etc., of the steamer Endeavor to the Hydrographic Inspector.

As soon as this transfer is completed you will enter upon the duties of Coast Survey representative on the Shell Fish Commission of Maryland.

You will consult the commissioners, prepare a programme of work, and submit estimates in the usual form.

You are authorized to come to Washington for consultation from time to time as may be necessary.

*

Very respectifully,

O. H. Titminan, Superintendent.

Capt. C. C. Yates,

II. S. C. and G.S Steamer Endeavor, Baltimore, Md.

a For these laws see Appendix A. 
ORGANIZATION AND EQUIPMENT.

The personnel and occupation of the party of the Coast and Geodetic Survey have remained practically unchanged since the beginning of the "oyster survey." Besides the chief of party, it consists of the necessary triangulators, computers, draftsmen, and temporary employees required to carry on both the surveying operations in the field and the preparation for publication of oyster charts and technical records in the Office at Washington.

The transportation equipment for the field work of the party in Worcester County was confined to hired launches and boats, as the waters of that region are too shallow for the use of the type of boats utilized by the Survey and the Commission in Chesapeake Bay.

It being impracticable to move the Shell Fish Commission house boat Oyster to the ocean coast of Maryland, the convenient living and office quarters furnished the Government on that vessel had to be exchanged for temporary quarters on shore.

The greater part of the equipment of instruments for the operations of both the Government and State has been furnished by the Coast and Geodetic Survey, and consists of all necessary theodolites, levels, sextants, drafting instruments, hydrometers, etc., required for all field and office work.

CHRONOLOGICAL STATEMENT OF WORK.

The field work in Worcester County dates from November 8, 1907, when the survey in Wicomico County was completed and the entire party moved to Chincoteague, Va. where headquarters were established.

On December 6, I907, a subparty was organized for field work in the upper part of the county, the work of this party being done from a small house boat which was towed by a gasoline launch.

On December 19, I907, all field work was closed for the season and office quarters established in Baltimore. ${ }^{a}$

No further field work was done in Worcester County until March 23, I908, when a subparty was organized to complete the triangulation, which work was finished on April I 8 , 1908 .

On March 8, 1909, a subparty was organized to do some additional feld work in Somerset County, and at the same time to inspect and replace certain triangulation monuments in Worcester County which were reported to have been injured. This latter work occupied thirteen days and was completed March 30, I909.

The office work connected with Worcester County, including the preparation of the oyster charts and technical records for publication, has been continued intermittingly from the beginning of the field work, on November S, 1907, to the present time. The delay in the completion of the office work was due to various causes, but chiefly to the desirability of utilizing the new shore line being surveyed for other purposes by a topographic party of the Coast and Geodetic Survey. This topographic work was available for use in the preparation of publications in beginning of present year, and adds greatly to the accuracy and value of the published oyster charts of Worcester County.

" ()ffice rom were furnished for the work of the const and fendetic Survey in the new customliouse by courtesy of Hon. William I: Stone, collector of customs. 
Landmarks and triangulation signals erected

Monuments planted to mark triangulation stations

Triangulation stations occupied for observations of horizontal angles

Old triangulation stations recovered

New triangulation stations established.

Total old and new triangulation stations marked and described

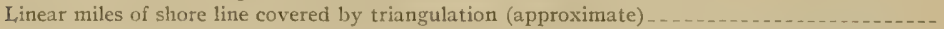

Square miles covered by triangulation (approximate)

Hydrographic projections prepared and completed as records of oyster boundaries...........

Triangles computed

Geographic positions computed _.

Corners of oyster boundaries established by computation.

Back azimuths and distances computed from corners of boundaries to triangulation stations....

Descriptions of triangulation stations prepared for publication

Descriptions of oyster boundaries prepared for publication

"Charts of Natural Oyster Bars" prepared for publication.

Progress map prepared for publication.

\section{GENERAL REMARKS}

Before ending this report the representative of the Coast and Geodetic Survey wishes to renew his statement of appreciation of the courteous assistance received from various Government and State officials and others interested in the oyster industry of Maryland, especially to the following:

To his colleague from the Department of Commerce and Labor, Dr. H. F. Moore of the Bureau of Fisheries, whose well-known scientific knowledge of all matters relating to oysters has been of great value to the work.

To Mr. Walter J. Mitchell, chairman of the Maryland Shell Fish Commission, who, by his administrative ability in carrying out the complicated requirements of the oyster laws and by his unfailing tact, has made the cooperation of the various services engaged on the work both agreeable and effective.

To Dr. Caswell Grave, secretary of the Commission, who, as editor of the Commission's annual report and Commissioner in charge of the biological and economic oyster investigations, has been brought into constant contact with the Government work and aided its operations in every way.

To Benjamin K. Green, treasurer of the Commission, who has looked after the equipment and commissary of the house boat in such a way as to add greatly to the comfort and convenience of the party of the Coast and Geodetic Survey.

To Swepson Earle, hydrographic engineer to the Commission, whose knowledge of the work from former service in the Coast and Geodetic Survey has greatly facilitated his practical use of the technical data furnished by the Government.

To Thomas H. Robinson, counsel to the Commission, for courteously furnishing valuable information relating to county boundaries.

And to the many others connected with the Cormission or who as residents in the locality where the work was being carried on have greatly assisted by furnishing important information or willing services.

"These statistics unly include field and oflice work directly performed by the party of the Coast and Geodetic Survey in connection with the oyster survey of Worcester County, and do not incltide the many thousands of soundings and examinations of the character of the bottom made by the engineers of the Commission, which are of considerable value to the Coast and Geodetic Survey as hydrographic records for future use in connection with the preparation of new editions of charts of the waters of Maryland. 


\section{CHARTS AND MAPS.}

\section{CHARTS OF NATURAL, OYSTER BARS.}

The charts ${ }^{a}$ of the natural oyster bars of Worcester County, published by the Coast and Geodetic Survey from results of surveys of the Government in cooperation with the Maryland Shell Fish Commission, consist of three sheets covering the greater part of the shores of Chineoteague and Sinepuxent bays, including all oyster-producing bottoms of Worcester County. They are published on a scale of I part in 20,000 (approximately 3 " inches to a statute mile) and are constructed on polyconic projections which are based on the United States standard datum of the Coast and Geodetic Survey.

These charts show all oyster bars and other boundaries established by the Commission, and are certified for the purpose of filing in the office of the clerk of the circuit court of Worcester County and in the office of the Commission at Annapolis, as required by the oyster laws of Maryland.

In addition to the oyster-bar and other boundaries, the charts show the location and name of all landmarks (U. S. Coast and Geodetic Survey triangulation stations) used in making the survey, together with the hydrography and topography ${ }^{b}$ necessary to make the technical definitions and delineations of boundaries readily understandable both by the people engaged in the oyster industry and the general public who may become interested through leasing of barten bottoms for oyster culture.

The names of the oyster bars are those used locally, as nearly as could be ascertained by the hydrographic engineer of the Commission. When there was no local name in common use, a name was selected from one of the prominent features of the vicinity. By the use of recognized names or those that would naturally suggest certain sections of water, it is believed that much confusion will be avoided in the location on the charts of the oyster bars, especially by those not familiar with the use of maps.

The corners of the oyster bars are numbered from i to the total number of corners in each area under consideration. Where boundaries adjoin, making ore point a corner of two or more oyster bars, these points have two or more numbers, each number corresponding to the bar in which the figure is located. The numbers of the comers correspond with the technical and legal descriptions of this publication under the heading "Boundaries of natural oyster bars."

The landmarks and oyster bars have been grouped in the "Contents" of this publication in accordance with the charts upon which they are shown. To find a

$a$ These charts can be obtained by application to the Superintendent of the Coast and Geodetic Survey, at Washington, D. C.

$b$ Much of the detail of the inshore topography was obtained from the excellent map of Worcester County prepared and published by the Maryland Geological Survey under the direction of Dr. William Bullock Clark from surveys of the Maryland Creological Survey in cooperation with the U. S. Geological Survey. 
particular oyster bar or landmark which is only known by name, consult the "Contents" and the desired chart and general location will be indicated. To find the name of a bar or landmark which is only known by location, consult the progress map at the end of this publication for the number of the chart on which it is to be found, and then examine the known locality on the chart for the name of the bar or landmark in question.

The contours on the charts showing the depth of water at mean low tide have been taken from the hydrographic sheets of former work of the Coast and Geodetic Survey.

The boundaries of the waters within the "territorial limits of the county" opened up for the leasing with Worcester County are plainly indicated on the charts. A description of this boundary is given in this publication under the heading "Boundaries of the county waters."

The areas in acres of the oyster bars were determined under the direction of the hydrographic engineer of the Commission by two independent planimeter measurements of the areas as delineated on the smooth projections of the Coast and Geodetic Survey. These areas are given in small figures in parentheses on the face of the chart within the boundaries of the different shellfish bottoms.

The symbols used on the charts for the different kinds of boundaries, triangulation stations, contours of depth of water, etc., require no other explanation than that given in the legend and other notes on the face of the charts.

\section{I.EASING CHARTS.}

The leasing charts of Worcester County, like those for Anne Arundel, Somerset, and Wicomico counties, have been prepared under the direction of the hydrographic engineer of the Commission. These charts are constructed on polyconic projections which are based on the United States standard datum of the Coast and Geodetic Survey. They are made on the scales of I part in 5,000 or I part in 10,000 , as the needs of oyster culture may require. Anne Arundel County required 13 leasing charts, Somerset County 12, Wicomico County 2, and Worcester County 3 to cover their oyster bottoms.

These charts show all the oyster bars, crab bottoms, and clam beds and other boundaries established by the Commission, and also all boundaries of oyster lots leased for the purpose of oyster culture, thus making them comprehensive and valuable records of the results of the operations of the oyster-culture laws.

The lots leased under the provision of the "old 5 -acre law" are frequently of irregular shape, but the lots leased under the provision of the new oyster laws must be of rectangular shape by the terms of that act. For this latter purpose the leasing charts have been divided by parallels of latitude and meridians of longitude into small rectangles of $\mathrm{I}$ acre or 5 acres, as may be best suited to the area under consideration, and prospective leaseholders by the rules of the Commission are compelled to select whole rectangles as far as practicable.

For reasons of the present changeable nature of the number of lots leased and the large number of charts required, the leasing charts are not likely to be published for some years, but they can be seen at any time on file at the offices of the Commission, in Annapolis. 
IROJFCTIONS.

The polyconic projections ${ }^{a}$ covering Worcester County waters are 5 in number and on the scale of I part in 10,000. They were constructed by draftsmen of the Coast and Geodetic Survey, who also plotted the sextant positions which determine the location of the legal boundaries of the oyster bars as delineated by the Shell Fish Commission.

A copy of each of these projections, with all the plotted positions of triangulation stations, shore line, sextant positions, and boundaries of oyster bars, was made under the direction of the hydrographic engineer of the Commission by pricking through with a sharp needle the intersections of the projection lines and all other points as plotted on the original sheets.

These projections (in duplicate) are the original records of all oyster-bar and other boundaries established by the Commission, one set being filed in the archives of the Coast and Geodetic Survey, at Washington, and the other set in the office of the Shell Fish Commission, at Annapolis.

\section{PROGRESS MAPS.}

The progress map to be found at the end of this publication is on a scale of $x$ part in 100,000, and shows in outline the work accomplished by the U. S. Coast and Geodetic Survey in Worcester County and contiguous waters. It gives the scheme of all the charts and smooth projections constructed in connection with the survey, the location and names of all triangulation stations used as a basis for the surveying work, and the "boundaries of county waters" established by the Commission for the purpose of carrying out the laws of Maryland relating to oyster culture.

Besides indicating the amount of work done by the Coast and Geodetic Survey in connection with the work of the Shell Fish Commission, this progress map will be of special value for index purposes to engineers and others searching for the particular chart or projection covering the locality of the oyster bars or landmarks that may be under consideration.

The progress maps ${ }^{b}$ accompanying the first and second annual reports of the Maryland Shell Fish Commission were prepared under the direction of the hydrographic engineer of the Commission. They are on the scale of I part in 400,000 , and show the outline of the tide-water counties of Maryland, with shaded areas to indicate the waters already covered by the operations of the oyster survey.

a For the scheme of these projections sec the progress map at the end of this publication.

$b$ These maps and reports can be obtained by application to Maryland Shell Fish Commission, Annapolis, Md. 


\section{BOUNDARIES OF THE COUNTI WATERS. ${ }^{a}$}

\section{WATERS WITHIN TERRITORIAL, LIMITS OF COUNTY.}

The laws of Maryland relating to oyster culture provide that "no person shall be permitted, by lease, assignment, or in any other manner, to acquire a greater amount of land than ten acres situated within the territorial limits of any of the counties, or one hundred acres in any other place."

The boundary line between the waters "within the territorial limits" of Worcester County and the waters in "any other place," as established by the Shell Fish Commission for the purpose of carrying out the oyster laws, and delineated on the charts and the smooth projections of the Coast and Geodetic Survey, is identical with the boundary line between the waters of Worcester County and the waters of the adjacent States of Delaware and Virginia excepting the waters of the Atlantic Ocean. Therefore technically all waters opened up for leasing with Worcester County are within the "territorial limits" of that county.

\section{WATERS CONTIGUOUS TO COUNTY.}

The oyster laws of Maryland provide that a true and accurate delineation of all natural oyster bars shall be made on copies of charts of the U. S. Coast and Geodetic Survey, "which said copies shall be filed in the office of the said Commissioners in the city of Annapolis," and "in the office of the clerks of the circuit courts for the respective counties wherein the grounds so designated may lie."

For the purpose of carrying out the latter part of this section of the law and for the purpose of establishing the limits of the oyster-culture area to be opened up for leasing with each county surveyed, it is necessary for the Shell Fish Commission to establish a boundary line between the waters contiguous to but not within the territorial limits of each county, and the waters contiguous to but not within the territorial limits of adjacent counties. But technically, as explained under the preceding heading of "Waters within territorial limits of county," there are no "waters contiguous to the county" in Worcester County excepting the waters of the ocean, and therefore there are no waters opened up for leasing with that county in which a person can lease "a greater amount than ten acres."

$a$ For a complete historical and legal description of the boundaries of the counties of Maryland, the valuable publication entitled "The Counties of Maryland-Their Origin, Boundaries, and Election Districts," prepared by Dr. Edward B. Mathews and published by the Maryland Geological Survey under the direction of Dr. Wlliam Bullock Clark, Superintendent, should be consulted, as the boundaries described in this publication have been established and technically defined for the purpose of carrying out the oyster laws of the State, and may or may not be correct for other purposes.

$b$ See "Charts of Natural Oyster Bars," published by the Coast and Geodetic Survey, and the progress map at the end of this publication. 


\section{LANDMARKS (U. S. COAST AND GEODETIC SURVEY TRIANGUIATION STATIONS).}

FXPLANATION.

The oyster laws of Maryland authorizing the survey to be made by the Shell Fish Commission provide for "an accurate report of said survey, setting forth such a description of landmarks as may be necessary to enable the said board, or their successors, to find and ascertain the boundary lines of said natural oyster beds, bars, and rocks, as shown by delineation on the maps and charts." The law of the United States authorizing the cooperation of the Department of Commerce and Labor in the survey of natural oyster bars of Maryland provides for the erection of "such structures as may be necessary to mark the points of triangulation, so that the same may be used for such future work of the Coast and Geodetic Survey as the said Bureau may be hereafter required to perform in prosecuting the Government coast survey of the navigable waters of the United States located within the State of Maryland."

Under the provisions of the sections of the laws stated above, the markings and descriptions of landmarks must be sufficient for the present and future needs of both the Government and the State. With this end in view, considerable work has been expended in erecting permanent monuments at the triangulation stations and in the proper description of their location.

An effort has been made to arrange the descriptions of location and character of landmarks in a uniform and logical manner. The descriptions start 'with the assumption that the individual seeking a landmark has only an indefinite idea of its location. They gradually proceed from description of the general locality of a landmark to the descriptions of its immediate surroundings. This is followed by specific details of the character of the center and reference marks and a "round" of reference angles and distances which in themselves frequently contain enough information to furnish an independent and reliable location of the triangulation station.

METHOD OF DESCRIBING TRIANGULATION STATIONS.

The separate descriptions of triangulation stations should not be used without reading the following explanation of the method of describing the triangulation stations, as it contains certain details that are common to all the lantmarks described in this publication and which are omitted in the separate descriptions as being needless repetitions.

Name.-The title at the top of each separate description is the name by which the landmark or triangulation station is known and designated in all work and published oyster records or oyster charts of both the Government and State. The selection of the name is usually left to the triangulator establishing the station, and it may or may not have geographic or other significance in reference to the locality. 
General locality.-Under this heading is given the general locality of the landmark in reference to well-known and prominent natural or artificial features, such as the nearest body of water, town, river, steamer wharf, well-defined point of land, church, or any other feature that is likely to remain both permanent and prominent.

This heading also covers a reference to the published chart or map which shows the location of the station most clearly. Nearly all the triangulation stations described in this publication are plainly indicated by name and a triangulation symbol on the published charts of oyster bars of Maryland. In this case they are referred to by serial number only, the words "charts of oyster bars of Maryland" being omitted to avoid needless repetition. These published oyster charts are on the large scale of I part in 20,000 (approximately $3 \%$ inches to a statute mile) and show the location of the triangulation stations so clearly that in many cases the written descriptions will not be required to find them.

Immediate locality.-Under this heading is given the description of the "observed station" in reference to its immediate surroundings. This is supposed to include a statement of the station's estimated elevation above high water or some other welldefined level of the locality, such as a road or house; the character of the ground on which it is located, such as marsh land, sand beach, cultivated field, or meadow; estimated bearings in points of the compass and estimated distances in yards from (not to) easily recognized features, such as extreme end of point, edge of bluff, bank of creek, line of telephone poles, shore line, barn, house, fence, ditch, trees, or any other definite detail, such as being on range with the tangent of an island and a church; and so forth.

When a standard monument has been established near the station as a "reference station," this heading also covers a statement of the true bearing of the monument in degrees and minutes and its measured distance in meters, as it is the first object that is likely to catch the eye when the immediate vicinity of the desired station is reached and might be mistaken for the center mark of the "observed station" unless special attention is called to it.

The distinction between the "observed station" and "reference station" should be carefully noted by anyone making use of the description of stations for any future surveying operations.

The "observed station" is located at the particular triangulation point covered by the description of stations, and is the one whose geographic position is first computed, as it is the point which was "occupied" and "observed on" for horizontal angles. However, in spite of the primary importance of the location of the "observed station," it will be noted from the description of stations that frequently it is not marked as well as the "reference station," and in many instances has only a pine stub to indicate its position. This is the case for the reason that the necessity of intervisibility of landmarks usually made it compulsory to locate "observed stations" on edges of banks and ends of points of land, which in the tide-water section of Maryland generally means they will be washed away in a short period of years. The past experience of the Coast and Geodetic Survey in this region has shown the great need of "reference stations," if the frequent reestablishment of a new framework of triangulation is to be avoided.

The chief reason and need for the establishment of the "reference station," or secondary station, as it might be well named, is explained in the preceding paragraph, but in several instances other reasons, such as the location of the "observed station" 
on an unstable sand dune, in a cultivated field, in front of a residence, or other places objectionable to the landowner, have led to establishment of "reference stations." The location of the "reference station" in relation to the "observed station" is fixed for plotting on charts or for computation of its geographic position by checked measurements of its distances and azimuth from the "observed station." a

Marks.-Under this heading is given a description of the character of the permanent monuments or other marks of the location of the "observed station," and of the "reference station" where one has been established.

All the marks designated in the descriptions as "the center point of triangle on standard cement monument" are exactly alike. These monuments are made of cement, sand, and gravel, and are 2 feet long and 8 inches square at top and bottom. Their tops are all marked with the same brass mold and show a center hole surrounded by a triangle, with the letters "M. S. F. C." arranged around the vertex and the letters "U. S. C. S." underneath the base of the triangle. The center hole is always in the center of the top of the monument by construction, and if this is found to have been broken off without disturbing the bottom the center of its square section can be used as the location of the station.

All the "standard cement monuments," whether used for marking the "observed station" or "reference station," have been planted upright in exactly the same manner, with their tops projecting 3 or 4 inches above the surface of the ground, unless otherwise stated.

Therefore, as the above facts in reference to the "standard cement monuments" are a constant element in all cases, the repetition of these facts in the description of stations is made needless by this one statement.

References.-Under this heading are given the "rounds" of directions and distances to all objects that might be useful in locating the stations when the surface marks can not be found. It is also contemplated that for general purposes of topography, hydrography, or location of boundaries of oyster bars these references will be sufficient in many cases to relocate the position of an "observed station" or "reference station" when both of them have been destroyed.

The first reference object given in the descriptions is always a triangulation station visible from the station being described, this, if possible, being a light-house, church spire, or other permanent and prominent point. Its direction is taken as being $\mathrm{O}^{\circ} \mathrm{Oo}^{\prime} \mathrm{Oo}^{\prime \prime}$, and the directions of all other objects are measured from it as an initial point, the angles being taken in a clockwise direction (left to right).

The true bearing ${ }^{b}$ of the initial object is always given in parentheses alongside its name. This furnishes means for the calculation of the bearings of any of the other reference objects for the purposes of locating a station by horizontal angles or for the relocation of corner buoys of oyster-bar boundaries by the method of compass directions described in this publication under the heading of "Boundaries of oyster bars."

a Geographic coordinates (latitude, longitude, distance, and azimuth) relating to any of the "observed stations" or of the "reference stations" described in this publication can be ohtained by application to the Superintendent of the Coast and Geodetic Survey, at Washington, D. C.

$b$ The mean magnetic variation for Worcester County was $5^{\circ} 55^{\prime}$ west of north in 1909 and increasing at the rate of $31 / 3^{\prime}$ yearly. 
The distances in the last column under "References" are given in three different units, which vary according to their accuracy. The "miles" are statute miles and may be considered only as rough estimates. The "yards" are more accurate, but must be looked on as results generally obtained by pacing or careful estimating. The "meters," however, are accurate to the degree indicated by their decimals and in every case have been measured with a steel tape. In the same manner the accuracy of the directions are indicated by the refinement of angular measure with which they are recorded.

\section{DESCRIPTIONS OF TRIANGULATION STATIONS.}

\section{THOROFARE.}

General locality.-Western shore of Sinepuxent Bay and southern shore of Isle of Wight Bay on land known as Drum Point. (See progress map.)

Immediate locality.-Observed station is on "Thorofare Farm," about 400 yards from Sinepuxent Bay and $x_{5}$ yards southwest from the Thorofare. It is in a cultivated field about 8 fect above highwater mark on the second knoll southwest from the Thorofare, 400 yards north of "Thorofare Farm" house, 200 yards west of a wagon trail, and 32 yards southwest of the lowest point of the hollow between the two knolls.

Marks.-Observed station is center point of triangle on standard cement monument buried with top 12 inches below surface of ground. Cement monument marking reference station is in bottom of hollow between the two knolls 51.032 meters $N 65^{\circ} 2 I^{\prime} \mathrm{F}$ of ohserved station and about on range with Isle of Wight Life-Saving Station.

References.-

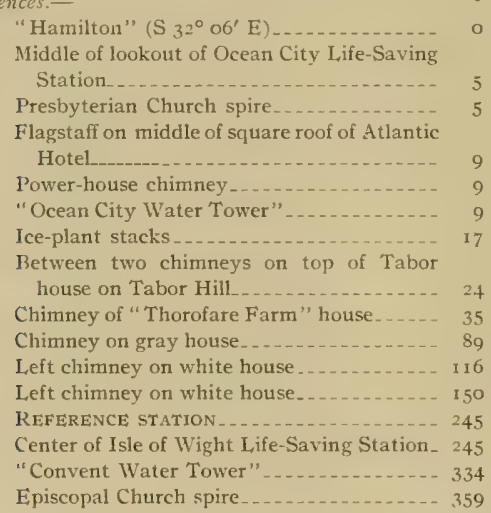

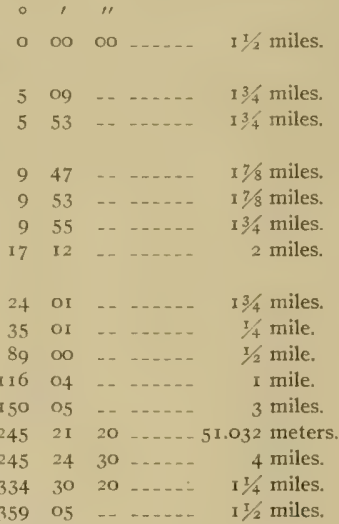

COLLIER.

General locality - Eastern shore of Sinepuxent Bay about one-half way between bay and ocean, I/4 mile north-northeast of "Convent Water Tower" and $1 / 2$ mile south of Collier Islands. (See progress map.)

Immediate locality.-Observed station is on sand and grass beach land about 3 feet above high water, about 65 yards west of top of sand dunes, 8 yards north of a high-water overflow, and 42 yards west of line of telephone poles. 
Marks.-Observed station is center point of triangle on standard cement monument buried with top 4 inches below surface of sand.

References.-

\begin{tabular}{|c|c|c|c|c|}
\hline "Thorofare" $\left(\mathrm{N} 71^{\circ} 43^{\prime} \mathrm{W}\right)$ & o & $\infty$ & $\infty$ & I $1 / 4$ miles. \\
\hline Right tangent of Dog and Bitch islands ........ & 22 & 33 & -- & $3 / 8$ mile. \\
\hline Left tangent of Collier Islands & 46 & 12 & & $1 / 2$ mile. \\
\hline Isle of Wight Life-Saving Station ... & 86 & 55 & & $33 / 4$ miles. \\
\hline Eighth telephone pole north of convent....... & I37 & 40 & ro & 50 yards. \\
\hline Seventh telephone pole north of convent ...... & 233 & or & 40 & 65 yards. \\
\hline Convent chimney & 263 & 35 & $\cdots$ & $1 / 4$ mile. \\
\hline "Convent Water Tower". & 268 & 53 & 30 & $1 / 4$ mile. \\
\hline Episcopal Church spire..... & 271 & 19 & 30 & sile. \\
\hline Flagstaff on Atlantic Hotel ........... & 272 & Of & - & I $1 / 2$ miles. \\
\hline Power-house climney ...... & 272 & 55 & - & $\mathrm{I} / 2$ miles. \\
\hline "Ocean City Water Tower" ......... & 274 & 05 & -. & 13.8 miles. \\
\hline Ice-plant stacks & 275 & 36 & .. & $13 / 4$ miles. \\
\hline $\begin{array}{l}\text { Left tangent of water tank at Ocean City bridge - } \\
\text { Between chimneys on Tabor house on Tabor }\end{array}$ & 281 & 53 & - & I $5 / 8$ miles. \\
\hline Hill & 288 & 06 & $\cdots$ & \\
\hline Chimney of "Thorofare Farm" house........ & 345 & I I & -- & - \\
\hline
\end{tabular}

\section{CONVENT WATER TOWER.}

General locality.-Between Sinepuxent Bay and Atlantic Ocean, about I mile north-northeast of "Ocean City Water Tower." (See progress map.)

Immediate locality:-Observed station is on a large wooden water-tower structure belonging to the Convent of Saint Rose, at Ocean City. This tower is detached from the main building and is a very prominent object.

Marks.-Observed station is center point of top part of water-tank structure.

References.-None necessary.

GANTT.

General locality.-Western shore of Sinepuxent Bay, opposite Ocean City and about 1/2 mile back from the water. (See progress map.)

Immediate locality.-Observed station is in cultivated field on Gantt (formerly Davis) farm, and is about to feet above high water. It is about 300 yards north by west of the old Davis farmhouse, on a ridge or slight rise of ground making out from woods, 260 yards east-southeast of old woods and 90 yards east of a young growth of pines adjacent to old woods. It is also about 70 yards north of east-and-west wire fence and ditch and 83 yards west of a north-and-south fence and road running to farmhouse. Cement monument marking reference station is 85.44 meters S $89^{\circ} 48^{\prime}$ IV of station in the edge of young growth of pines.

Marks.-Observed station is center point of triangle on standard cement monument buried with top 2 feet below the surface of the ground. Reference station is center point of triangle on standard cement monument with top about 4 inches above the ground.

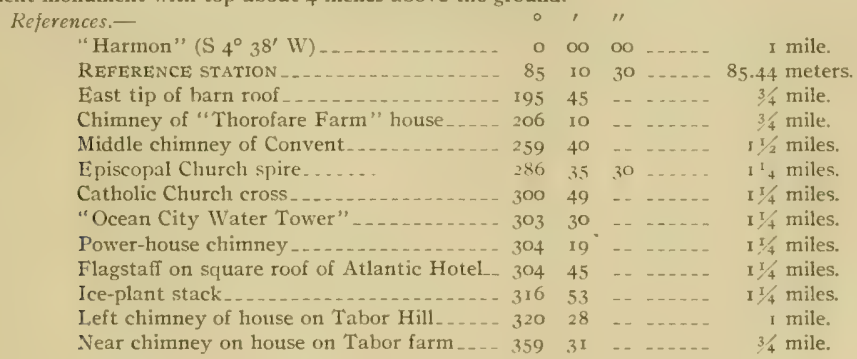




\section{HAMILTON.}

General locality,-Eastern shore of Sinepuxent Bay, in Ocean City, about $1 / 2$ mile northeast of the railway bridge and two-thirds the way from Sinepuxent Bay to the board walk on the ocean side. (See progress map.)

Immediate locality.-Observed station is on sand and grass land about 6 yards east-southeast of the extension of the east curb line of Philadelphia avenue, 145 yards northwest of Episcopal Church spire, 16 yards east-southeast of the telephone line edge of wagon trail along proposed Philadelphia avenuc, and to yards north of an exposed line of sewer pipe.

Marks.-Observed station is center point of triangle on standard cement monument.

References...

"Harmon" (S $66^{\circ} 20^{\prime} \mathrm{W}$ )

Light tangent of Drun Point ............... $9 x$

of island...................... I ro

"Convent Water Tower" ..................... I40

South end of roof of Quillin's cottage_...... 183

Peak on tower of Doyle cottage _........... 198

Chimney of Mervue cottage-_._._._._. 226

Chimney of Hotel Hamilton .......... 229

Episcopal Church spire................. 24 I

Chimney on Atkins cottage

Flagstaff on left end of Mount Pleasant Hotel_. 287

Presbyterian Church spire_._._._._._._._. 305

Power-house chimney ...................... 308

"Ocean City Water Tower" ................. 312

Between two chimneys on Tabor house...... $3+7$

Left chimney of Gray's house ............ 357

$$
\begin{array}{rrrr}
\text { II } & 00 & \ldots \ldots & \text { I } 1 / 4 \text { miles. } \\
\text { I4 } & \ldots & \ldots & \text { I } 1 / 2 \text { miles. } \\
31 & \ldots & \ldots & \text { I mile. } \\
43 & \ldots & \ldots & 3 / 4 \text { mile. } \\
33 & \ldots & \ldots & 3 / 4 \text { mile. } \\
09 & \ldots & \ldots & 400 \text { yards. } \\
40 & \ldots & \ldots \ldots & 350 \text { yards. } \\
53 & \ldots & \ldots \ldots & 350 \text { yards. } \\
44 & \ldots & \ldots \ldots & 145 \text { yards. } \\
50 & \ldots & \ldots \ldots & 175 \text { yards. } \\
36 & \ldots & \ldots \ldots & 1 / 4 \text { mile. } \\
42 & 50 & \ldots \ldots & 1 / 4 \text { mile. } \\
56 & \ldots & \ldots \ldots & 1 / 4 \text { mile. } \\
31 & \ldots & \ldots \ldots & 1 / 2 \text { mile. } \\
40 & \ldots & \ldots \ldots & \text { I mile. } \\
14 & \ldots \ldots \ldots & \text { I } 1 / 4 \text { miles. }
\end{array}
$$

\section{OCEAN CITY WATER TOWER.}

General locality.-Between Atlantic Ocean and Sinepuxent Bay, in Ocean City, Md. (See Chart

\begin{tabular}{|c|c|c|c|c|}
\hline $\left.\mathrm{N}_{4}^{\circ} 38^{\prime} \mathrm{E}\right)$ & o & & 00 & I mile. \\
\hline Near chimney of Harmon house & I & $4^{6}$ &.- & $1 / 4$ mile. \\
\hline "Convent Water Tower" - - & 48 & 59 & 30 & $13 / 4$ \\
\hline Convent high chimney (not ventilator) -. & 49 & $5 \mathrm{I}$ &.- & $13 / 4$ mile \\
\hline Episcopal Church spire $\ldots \ldots$ & 64 & 27 & $\cdots$ & $x^{3} / 4$ \\
\hline Presbyterian Church spire .... & 71 & 26 & -. & $\mathrm{I} / \mathrm{m} / \mathrm{mil}$ \\
\hline Right chimney of Tabor house... & 75 & -. & -- & $3 / 4$ mile \\
\hline
\end{tabular}
No. 13.)

Immediate locality.-Observed station is located about 80 yards north by east of Ocean City railroad station, 30 yards south by west from curb of Talbot street, and 60 yards west by north from curb of Baltimore avenue. It is on a steel structure roo feet high, supporting a large round water tank 25 feet deep, which is known as "Ocean City Water Tower."

Marks.-Observed station is center point of upper end of standpipe.

References.-None necessary.

\section{HARMON.}

General locality.-West shore of Sinepuxent Bay, about $3 / 4$ mile back from west end of railroad bridge and just south of the B. C. \& A. railway tracks. (See Chart No. 13.)

Immediate locality.-Observed station is about i 70 yards east of the first pine woods from the bay shore and about 145 yards east of some young growth pines adjacent to the woods. It is in a field about 72 yards south of the east and west railway tracks and about 65 yards south of the railway fence.

Marks.-Observed station is center point of triangle on standard cement monument buried with top about 12 inches below the surface of the ground.

References.- 


\begin{tabular}{|c|c|c|c|c|}
\hline "Ocean City Vater Tower" & 77 & 04 & Io & I $1 / 8$ miles. \\
\hline Power-house chimney .............. & 79 & or & -- & I mile. \\
\hline Flagstaff on square roof of Atlantic Hotel..... & 80 & 18 & $\ldots$ & 1 mile. \\
\hline Cropper's ice-plant stacks _............. & 92 & 31 & - & I mile. \\
\hline Corner of fence and woods. & $2 \mathrm{I} 8$ & -0 & -. - & 242 yards. \\
\hline Corner of railroad fence and woods & 291 & & - - - & 138 yards. \\
\hline 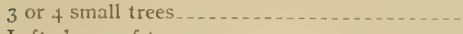 & 126 & & -- & I/s mile. \\
\hline Left clump of trees & 157 & & ........ & 1/8 mile. \\
\hline
\end{tabular}

OCEAN.

General locality.-Eastern shore of Sinepuxent Bay, about one-third way from bay to ocean and about 3/8 mile south-southwest of "Ocean City Water Tower." (See Chart No. 13.)

Immediate locality.-Observed station is on sand and grass land about 8 yards east of telephone line and about 2 yards west of an old line of poles formerly used to support wires. It is apparently in proposed extension of Philadelphia avenue, but this is uncertain, as the street lines are indefinite in this locality.

Marks.-Observed station is center point of triangle on standard cement monument buried with top 12 inches below surface of sand.

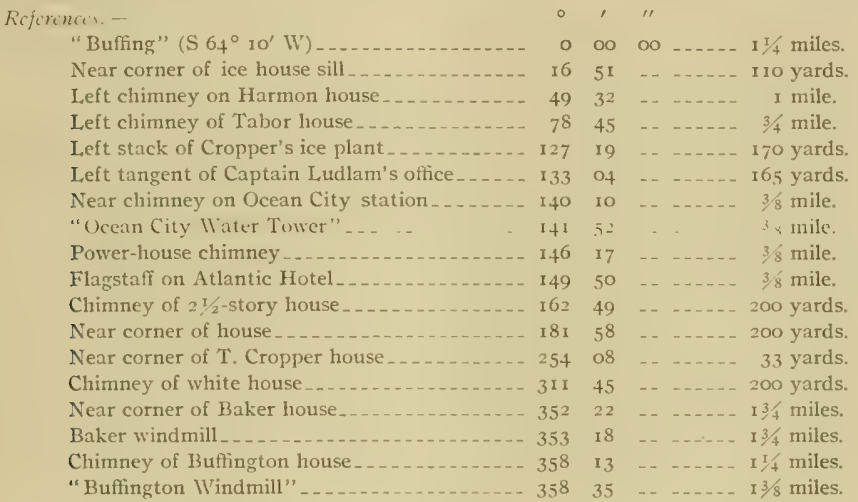

BUFFING

General locality. - Western shore of Sinepuxent Bay, on lowland about 200 yards northeast of knoll known locally as "Steam Mill Hill" and about $\mathrm{t} 1 / 2$ miles southwest of Ocean City. (See Chart No. 13.)

Immediate locality. - Observed station is on sand and loam land about 2 feet above high water, 25 yards west from shore, 65 yards northwest of where wire fence meets shore, 30 yards northeast of nearest point of fence, and 60 yards from junction of fence and pine woods.

Marks.-Observed station is center point of triangle on standard cement monument.

Rejerences.-

"Harmon" (N $\left.13^{\circ} 19^{\prime} \mathrm{E}\right)$

"Convent Water Tower"

Between chimneys on Tabor house on Tabor Hill - , "

Épiscopal Church spire

Middle of Ocean City Life-Saving Station tower-

"Ocean City Water Tower"

o 00 o0 _.... $7 / 8$ mile.

2902 _. . . $25 / 8$ miles.

$30 \quad 34 \quad \ldots \ldots \ldots$ II/4 miles.

$36 \quad 31 \quad \ldots \ldots \ldots \quad 2$ miles.

4135 .. .... 2 miles.

fI 2 I ...... I $1 / 2$ miles. 


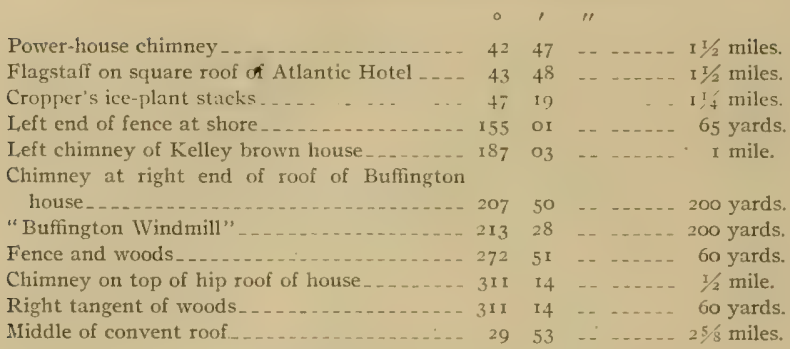

\section{BUFFINGTON WINDMILL.}

General locality.-Western shore of Sinepuxent Bay, on knoll known locally as "Steam Mill Hill" and about $I \frac{1}{2}$ iniles southwest of Ocean City. (See Chart No. 13.)

Immediate locality.-Near house belonging to Mr. Buffington.

Marks.-Observed station is center of windmill tower.

References.-None necessary.

\section{GULL.}

General locality.-Eastern shore of Sinepuxent Bay nearly halfway between bay and ocean and about I mile south-southwest of Ocean City. (See Chart No. 13.)

Immediate locality.-Observed station is on sand and grass beach land about 2 feet above high water, 130 yards west of Life-Saving Service telephone line, 200 yards west of top of sand dunes and 65 yards south of a square marble pillar projecting above ground in middle of a bare washed space. Cement monument marking reference station is 7.68 meters $S 88^{\circ} 58^{\prime}$ VV of observed station and about on line with left end of woods below Buffington farmhouse.

Marks.-Observed station is nail in stub flush with sand and grass. Reference station is center point of triangle on standard cement monument.

References.-

"Buffing" (N $67^{\circ}$ of' $\left.\mathrm{WV}\right)$

Right end of barn roof . . . .

Chimney on near side of roof of gray house.

Near chimney of Harmon house..........

Near chimney of Gantt farm house.......

Near chimney of gray house Hill

Left tangent of water tank on left end of Ocean City bridge

Between stacks of Cropper's ice plant.....

"Ocean City Water Tower" .............

Power-house chimney _._._._............ 94

Flagstaff on square roof of Atlantic Hotel _ 95

Near chimney of Kelley house.......... 30

Left chimney on Baker house _....... 329

Baker windmill.

REFERENCE STATION ............ 336

Chimney on Buffington house

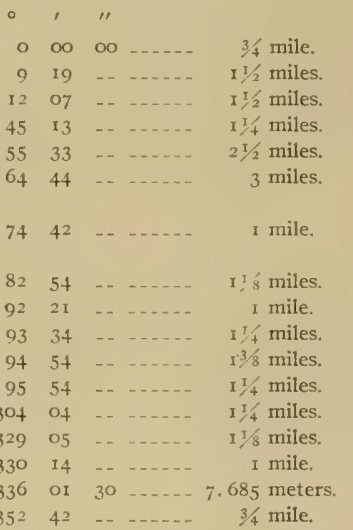

INKQUILI.

General locality.-Western shore of Sinepuxent Bay, near Coffins Point, about $2 \frac{3}{8}$ miles sonthwest of Ocean City. (See Chart No. 13.) 
Immediate locality-Observed station is on top of a shell knoll about ro feet above high-water mark, 30 yards west of shore, roo yards from corner of fence near Kelley house, i5o yards from near corner of Kelley house, and about 55 yards southeast of a ditch. *

Marks.-Observed station is center point of triangle on standard cement monument buried with top 12 inches below surface of ground.

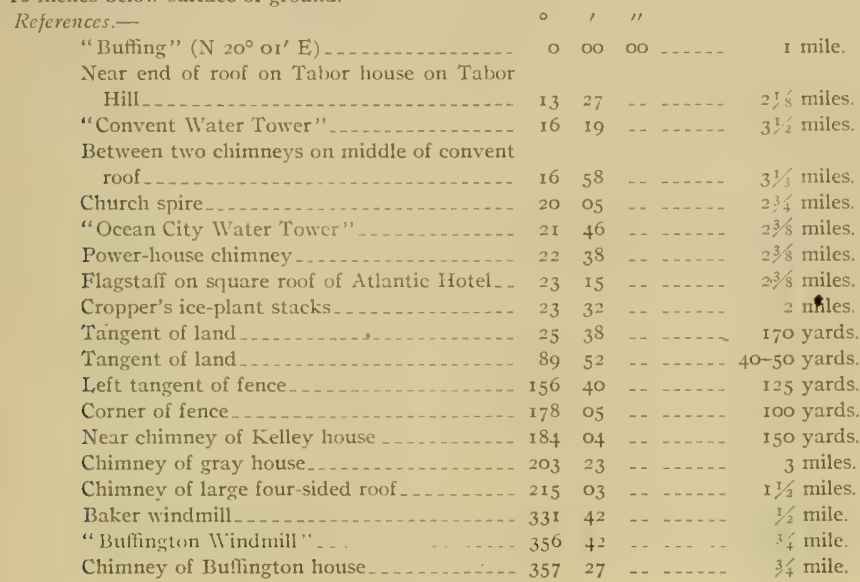

SEASIDE.

General locality.-Eastern shore of Sinepuxent Bay, about halfway between bay and ocean and about $21 / 4$ miles south-southwest of Ocean City. (See Chart No. 13.)

Immediate locality.-Observed station is on sand and grass land about 4 feet above high water. It is on the north side of an overflow from the ocean, about 200 yards from Sinepuxent Bay and 120 yards west-northwest of sand dunes between the ocean and the station. Cement monument marking reference station is 10.32 meters N $52^{\circ} 39^{\prime} \mathrm{E}$ of observed station. No other permanent reference objects near station.

Marks.-Observed station is nail in stub flush with ground. Reference station is center point of triangle on standard cement monument with top 4 inches above ground.

Lieferences.-

\begin{tabular}{|c|c|c|c|c|c|}
\hline "Inkquill" $\mathrm{N} 66^{\circ} 35^{\prime}(\mathrm{W}) \ldots \ldots \ldots$ & 0 & $\infty 0$ & oo & & $3 / 4$ mile. \\
\hline Baker house & 22 & -- & -. & & I mile. \\
\hline Chimney on Buffington house & 43 & 56 & $\ldots$ & & I $1 / 4$ miles. \\
\hline Tabor house on Tabor Hill ... & $7^{8}$ & 35 & -- & & niles. \\
\hline "Ocean City Water Tower" & 89 & 18 & -. & & $21 / 4$ miles. \\
\hline Power-house chimney & 90 & or & $\cdots$ & & $21 / 4$ miles. \\
\hline Flagstaff on square roof of Atlantic Hotel _ & 90 & 35 & -. & & $21 / 4$ miles. \\
\hline Telephone pole.... & 106 & 40 & xo & & 8 I. 4 meters. \\
\hline REFERENCE STATION $\ldots \ldots$ & rog & If & 20 & & 10. 32 meters. \\
\hline Telephone pole. & 141 & 07 & $\infty$ & & 39.5 meters. \\
\hline Teiephone pole.... & 217 & $5 I$ & 10 & & 47.8 meters. \\
\hline Right chimney of Cofrin Hotel & 321 & 47 & -- & $\ldots$ & 2 miles. \\
\hline Right chimney of Kelley brown house.. & 353 & 40 & $\ldots$ & $\ldots$ & $3 / 4$ mile. \\
\hline
\end{tabular}




\section{ELLPOW.}

General locality.-Western shore of Sinepuxent Bay, about $1 / 4$ mile inland from what is known locally as Powell Point and about $3 \frac{1}{2}$ miles southwest of Ocean City. (See Chart No. i3.)

Immediate locality. - Observed station is on marshy grass land well back from bay, near a property line indicated by crab apple trees and a wire fence which runs from bay to crab apple trees and joins a snake fence. It is about $1 / 4$ mile southeast of Hastings house, about $1 / 4$ mile southwest of Kelley house, and about $1 / 4$ mile northeast of Coffin Hotel (a large, unpainted, square house with four-sided roof). Cement monument marking reference station is 7.20 meters $\mathrm{S} 83^{\circ} 50^{\prime} \mathrm{W}$ of observed station.

Marks.-Observed station is nail in pine stub flush with the ground. Reference station is center point of triangle on standard cement monument.

References.-

"Fassett" (S $10^{\circ} 32^{\prime} \mathrm{WV}$ )
Chimney of Henry brick house
Chimney on right side of four-sided roof of
Coftin Hotel
REEERENCE STATION
Chimney on left end of roof of Hastings

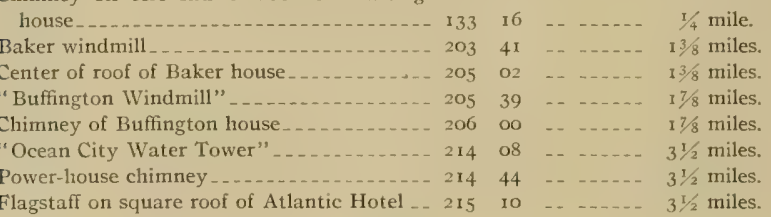

$\mathrm{BEACH}$.

General locality._Eastern shore of Sinepuxent Bay, about halfway between bay and ocean and about 3 miles south-southwest of Ocean City. (See Chart No. 13.)

Immediate locality.-Observed station is on sand and grass beach land about 3 feet above high water, 250 yards west of shore of Sinepuxent Bay and 2 feet east of line of telephone poles. Cement monument marking reference station is 6.40 meters $\mathrm{N} \mathrm{O}^{\circ} 23^{\prime} \mathrm{E}$ of observed station. No other permanent reference objects near station.

Marks.-Observed station is center point of triangle on standard cement monument. Reference station is center point of triangle on standard cement monument. (NOTE.-Reported lost in shifting sand at date of publication.)

References.-

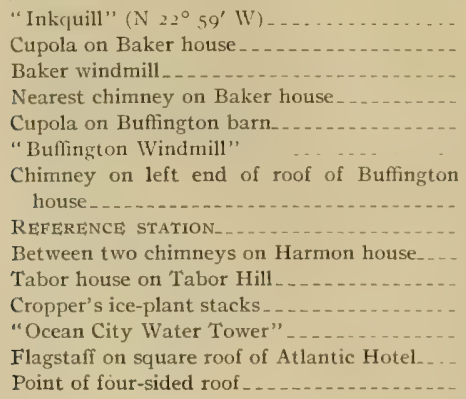

$$
\begin{array}{lllll}
0 & 00 & 00 & \ldots \ldots & 1 / 4 \text { miles. } \\
0 & \text { 10 } & 30 & \ldots \ldots & 65 / 8 \text { miles. } \\
9 & 48 & \ldots \ldots \ldots & 17 / 8 \text { miles. }
\end{array}
$$

$59 \quad 46 \quad \ldots \ldots 1 / 4$ mile.

73 I 8 o0 $1 . . .7 .20$ meters

.

.




\begin{tabular}{|c|c|c|}
\hline "Longwells WVindmill" - & 45 & $33 / 8$ miles. \\
\hline Chimney on near end of Henry brick house_- 287 & 40 & 2 miles. \\
\hline Left tangent of Coffin Hotel _........... 30 I & 13 & miles. \\
\hline Right chimney of large white house... & 37 & 2 miles. \\
\hline Left chimney on Kelley brown house.. & 21 & - I Is miles. \\
\hline
\end{tabular}

\section{FASSETT}

General locality.-Western shore of Sinepuxent Bay about 1/2 mile north-northeast of Fassett Point. (See Cliart No. I3.)

Immediate locality. - Observed station is on shell and marsh land about 2 feet above high water, $\mathrm{x} 20$ yards south by east from slough making into marsh, about 140 yards west of side of point, and I ro yards north of side of point. It is about 200 yards northeast of a fence with a clump of trees beyond it.

Marks.-Observed station is center point of triangle on standard cement monument.

References.--

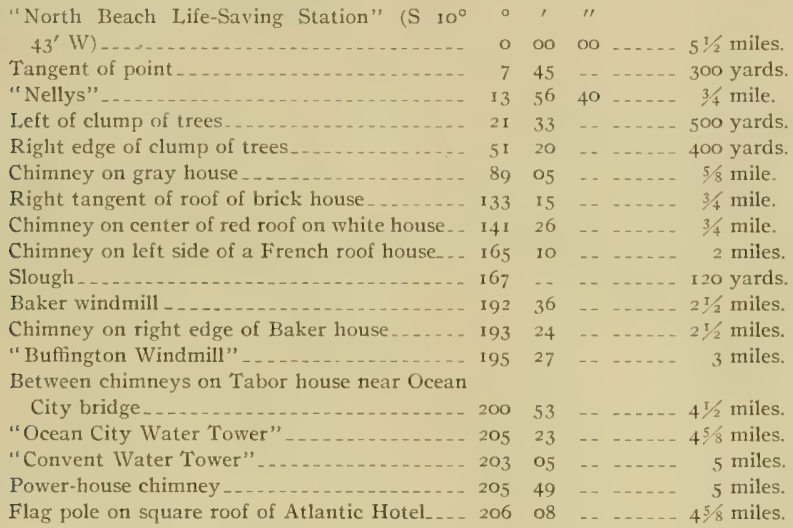

\section{SHORE.}

General locality.-Eastern shore of Sinepuxent Bay, about halfway between the bay and the ocean and about $4 \frac{1}{4}$ miles south-southwest of Ocean City. (See Chart No. 13.)

Immediate locality.-Observed station is on sand and grass beach land about 2 feet above high water and 16 yards east of line of Life-Saving Service telephone line poles. Cement monument marking reference station is 6.78 meters $\mathrm{N} 72^{\circ} 59^{\prime} \mathrm{E}$ of observed station. No other permanent objects near station.

Marks.-Observed station is nail in stub about 3 inches above sand. Reference station is center point of triangle on standard cement monument.

References.-

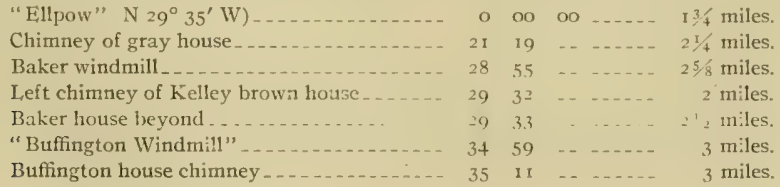




Chimney of Tabor house on Tabor Hill _...
"Ocean City Water Tower"

NELLYS.

General locality. - Western shore of Sinepuxent Bay, about $1 \frac{1}{4}$ miles north of Sandy Point on a point of land near place called Nellys Bar. See Chart No. 13.)

Immediate locality.-Observed station is about 5 feet above high water, 45 yards west-nortliwest of extreme end of point, 25 yards from north side of point and 20 yards from south side of point. It is on the edge of a cultivated field and about $1 / 4$ mile southeast of a large old-fashioned $21 / 2$-story brick house.

Marks.-Observed station is center point of triangle on standard cement monument.

References.-

\begin{tabular}{|c|c|c|c|c|c|}
\hline $\begin{array}{l}\left.\text { "Fassett" } \mathrm{N} 24^{\circ} 4 \mathrm{O}^{\prime} \mathrm{E}\right) \\
\text { "Buffington Windmill" }\end{array}$ & I & II & $\begin{array}{l}00 \\
30\end{array}$ & & \\
\hline Climney of Buffington house & 1 & 22 & & & 4 miles. \\
\hline Between two chimneys on Kelley house & 3 & 54 & -. & & $27 / 8$ miles. \\
\hline Near end of roof of Tabor house & 5 & $5 I$ & -. & & niles. \\
\hline "Convent IVater Tower" & 8 & oo & - & & iles. \\
\hline Middle of convent _. & 8 & $2 I$ & -. & & $61 / 2$ \\
\hline Church spire $\ldots$ & 9 & 24 & - & & tiles. \\
\hline Church spire... & 9 & 36 & $\ldots$ & & \\
\hline "Ocean City Water Tower" - & 9 & 43 & -- & & s. \\
\hline Power-house chimney & 10 & 05 & -- & & es. \\
\hline Middle of square roof of Atlantic Hotel .... & 10 & 22 & - & & niles. \\
\hline "North Beach Life-Saving Station" ... & 163 & to & to & & $45 / 8$ \\
\hline Tangent of Sandy Point & 174 & .02 & $\ldots$ & & $x 1 / 4$ \\
\hline r vane on Longwell house ........ & 192 & 40 & -. & & \\
\hline "Longwells Windmill" ............... & 194 & 06 & - & & nile \\
\hline Left chimney of Henry brick house & 300 & 02 & -. & & $1 / 4$ mile \\
\hline
\end{tabular}

BAR.

General locality.-Eastern shore of Sinepuxent Bay, about halfway between bay and ocean and about $51 / 4$ miles south-southwest of Ocean City. (See Chart No, 13.)

Immediate locality.-Observed station is on sand and grass beach land about 3 feet above high water, I ro yards west of top of sand dunes, and 5 yards east of line of Life-Saving Service telephone poles. There are no permanent objects near the station.

Marks.-Observed station is center point of triangle on standard cement monument.

References.-

"Nellys" (N 660 I4' W)

Southerly chimney of Henry brick house.....

Chimney on northerly end of roof with two gable windows.

Chimney on middle of red roofed white house...

Left chimney of large white house............

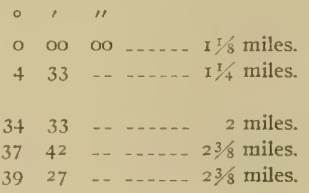


Chimney on southerly corner of four-sided roof of gray house

Baker windmill

"Buffington Windmill".

Buffington house chimney.

"Ocean City Water Tower"

Telephone pole.

Middle of roof of Longwell house

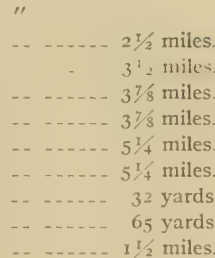

LONGWELIS WINDMILL.

General locality.-Western side of Sinepuxent Bay, about $1 / 2$ mile notth by west from Sandy Point. (See Chart No. 13.)

Immediate locality.-Observed station is on tower in rear of house on "Longwell Farm."

Marks.-Observed station is center of windmill.

References.-None necessary.

\section{SANPOI.}

General locality.-IVestern shore of Sinepuxent Bay, on Sandy Point. (See Chart No. I3.)

Immediate locality.-Observed station is on sage land 2 feet above high-water mark, about 80 yards west of extreme end of point, which is well rounded, 40 yards north of one shore of the point and IIo yards south of the other shore of the point. It is about 25 yards east-southeast of one end of a grove of crab-apple trees and about $r$ Io yards south of the other end. Small bushes about 18 inches high surround station.

Marks.--Observed station is center point of triangle on standard cement monument.

References.-

North Beach Life-Saving Station flagstaft ....

Tangent to "Indian Graveyard Point" ......

Crab-apple tree.......................... 64

Southerly chimney of stone house...........

Left end of grove of crab-apple trees......... II8

Dark brown house...................... 19 I

"Ocean City Water Tower" _.._._..._._. 208

Chimney on Baker barn .................. 199

Chimney on Baker house. _. _. _. _. _ _ _ _ _. _ _ 199

Tabor house near Ocean City bridge... . . . . . 20.4

\begin{tabular}{|c|c|c|}
\hline 00 & oo & _.... 33/8 miles. \\
\hline 15 & -- & …... $33 / 8$ miles. \\
\hline 44 & -- & $\ldots$ \\
\hline-- & + & ...... 70 yards \\
\hline 15 & -- & $1 / 2$ mile \\
\hline-- & -- & 25 yar \\
\hline$\cdots$ & - & - $1 / 2$ miles. \\
\hline Io & -. & ..... 61/4 miles. \\
\hline 19 & -- & $-4^{3} / 4 \mathrm{mil}$ \\
\hline 41 & -- & $\ldots-\ldots 3 / 4$ \\
\hline $5^{8}$ & & $-63 / 8 \mathrm{I}$ \\
\hline
\end{tabular}

MUD.

Gencral locality.-Eastern shore of lower Sinepuxent Bay, about two-thirds way from bay to ocean and I mile east-southeast of Sandy Point. (See Chart No. 13.)

Immediate locality. - Observed station is on sandy ground about 3 feet above high water, 60 yards west-northwest from top of a sand dune, roo yards east of head of a small, narrow inlet from Sinepuxent Bay, and 110 yards east-southeast of a line of Life-Saving Service telephone poles which pass about 18 yards to the east of the wagon trail. Cement monument marking reference station is 18.84 meters $\mathrm{N} 57^{\circ} 5 t^{\prime} \mathrm{W}$ of observed station. No other permanent reference objects near station.

Marks.-Observed station is a nail in a stub flush with the sand. Reference station is center point of triangle on standard cement monument.

References,-

"North Beach Life-Saving Station" (S. $2 I^{\circ} \quad{ }^{\circ}$
$39^{\prime}$ W)

$82497-09-3$ 


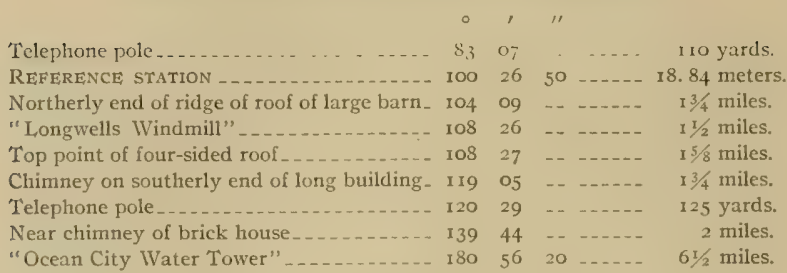

\section{INGRAYA.}

General locality.-Western shore of Sinepuxent Bay, on easterly side of Sinepuxent Neck, on point known locally as Indian Graveyard. (See Chart No. 13.)

Immediate locality.-Observed station is about 5 feet above high water, 55 yards north of nearest shore, 180 yards west of extreme end of point near bushes, and 80 yards east of where a ditch coming from the northward turns to westward. Two trees, eacli about 75 yards distant, are located on the line of the ditch.

Marks.-Observed station is center point of triangle on standard cement monument buried with top if inches below surface of ground.

References.-

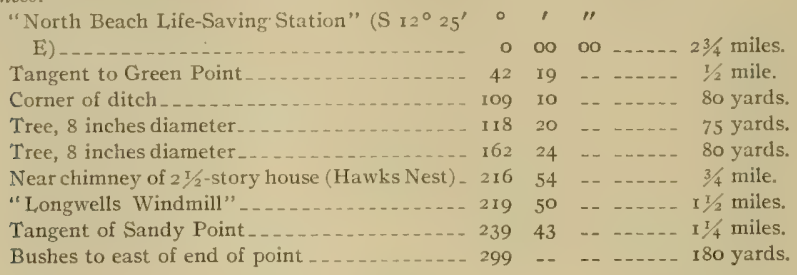

SALT.

General locality.-Eastern shore of lower Sinepuxent Bay, about two-thirds way from bay to ocean and $\mathrm{I}^{\mathrm{T} / 2}$ miles south-southeast of Sandy Point. (See Chart No. 13.)

Immediate locality.-Observed station is on sand and marsh beach land about 3 feet above high water, xo5 yards east by south of line of poles of Life-Saving Service telephone line, and 175 yards east of a small creek known as "Jones Salt Works Drain." No permanent objects near station.

Marks.-Observed station is center point of triangle on standard cement monument.

References.-

\begin{tabular}{|c|c|c|c|c|}
\hline $\left.36^{\prime} \mathrm{W}\right)$ & o & oo & $\infty$ & 2 miles. \\
\hline North Beach Life-Saving Station flagstaff_-_. & o & 14 & 20 & 2 miles. \\
\hline Telephone pole & 50 & 36 & -. & $\ldots \ldots$.... 175 yards. \\
\hline Telephone pole........... & 72 & 36 & -. & -135 \\
\hline Jones Salt Works Drain_. & 80 & - & -- & -. 175 yards. \\
\hline Telephone pole. & III & 48 & - & - I35 yards. \\
\hline Left chimney of stone house $\ldots . . .$. & 121 & 44 & -- & - $13 / 4$ miles. \\
\hline Telephone pole & 137 & 07 & -- & - 200 yards. \\
\hline "Longwells Windmill" & 141 & 23 & -- & 2 miles. \\
\hline Center of roof of white house & 141 & 44 & -- & _..... $2 \frac{1}{2}$ miles. \\
\hline Near chimney of $21 / 2$-story house..... & 150 & 21 & -- & - $4^{T / 2}$ miles. \\
\hline "Ocean City Water Tower" & 182 & 07 & 40 & - $73 / 4$ miles. \\
\hline
\end{tabular}




\section{NORTH BEACH LIFE-SAVING STATION.}

Gencral locality.-Atlantic coast side of strip of beach land between lower Sinepuxent I3ay and the ocean. (See Charts Nos. 13 and 14.)

Inmediate locality.-Observed station is on lookout cupola on the North Beach Life-Saving Station. This cupola is a gable-roof structure on a gable-roof $2^{1 / 2}$-story house.

Marks.-Observed station is a black and white 4 by 4 inch pole secured temporarily to the exact middle of ridge of gable roof of lookout cupola.

Reforences.-None necessary.

\section{BIRCH.}

Gencral locality.-Southern part of Sinepuxent Neck, between Sinepuxent Bay and Newport Bay, about $\mathrm{I} / 2$ mile north-northwest of South Point. (See Charts Nos. 13 and 14 .)

Immediate locality.-Observed station is on the northwest and higher of two knolls about 20 feet above high-water mark, 600 yards east of Island Point, 200 yards northeast of shore of upper Chincoteague Bay, 75 yards east-southeast of where a ditch and fence meet, and about 400 yards southwest of a house and barn.

Marks.-Observed station is center point of triangle on standard cement monument.

References.-

"Guilberts Cupola" (S $48^{\circ}$ og' W)

Chimney on left of a small house ......

Nail in blaze in walnut tree $(20$ inches diameter) _............ 25

Chimney on black roof of white house _... 28

"Handys Hammock" .................

Cedar tree

Jones windmill ......................... 47

Nail in blaze in walnut tree............ 66

Chimney of house near "Newport" ....... 83

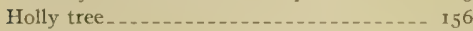

Cedar tree near Birch farm buildings_._._. 18.4

Chimney of Birch farm house . . . . . . . . 192

Cedar tree............................. 229

Chimney of hotel near "North Beach

Life-Saving Station"

Nail in blaze in walnut tree......... $34 \mathrm{r} 34 \ldots 12.72$ meters.

NECK.

Gencral locality:- Northeastern shore of Newport Bay, on easterly side of Newport Neck between Greys Inlet and Spence Cove. (See Chart No. 13.)

Immediate locality.-Observed station is on marsh land about 400 yards northeast of Knot Point, Ioo yards north from shore of Spence Cove, 50 yards northwest of small marsh inlet, and ro yards south of edge of a prominent grove of old oaks. There are bushes between the station and the oak grove. Cement monument marking reference station is 12.72 meters $\mathrm{N} 7^{\circ} 23^{\prime} \mathrm{W}$ from observed station.

Marks.-Observed station is center point of triangle on standard cement monument. Reference station is center point of triangle on standard cement monument. (NOTE.-Top disconnected, but recemented.)

References.-

"Handys Hammock" (S $53^{\circ} 53^{\prime} \mathrm{WV}$ ) -.....

Tall water bushes.......

House behind bushes

Left chimney of large house............

Chimney of $1 / 2$-story white house $\ldots . . . . .-$

Left edge of oak grove diameter)

$\begin{array}{rrrrr}0 & \text { ' } & & \\ 0 & 00 & 00 & \ldots \ldots & 3 \text { miles. } \\ 17 & \ldots & \ldots & \ldots \ldots & 75 \text { yards } \\ 17 & 33 & \ldots & \ldots \ldots & 41 / 2 \text { miles. } \\ 29 & 37 & \ldots & \ldots \ldots & 23 / 4 \text { miles. } \\ 43 & 48 & \ldots & \ldots \ldots & 11 / 2 \text { miles. } \\ 81 & 14 & \ldots & \ldots \ldots & 25 \text { yards. }\end{array}$

100 $36 \quad 50 \quad \ldots \ldots .12 .24$ meters 
Nail in blaze in oak tree ( 12 inches di- 0 , ",

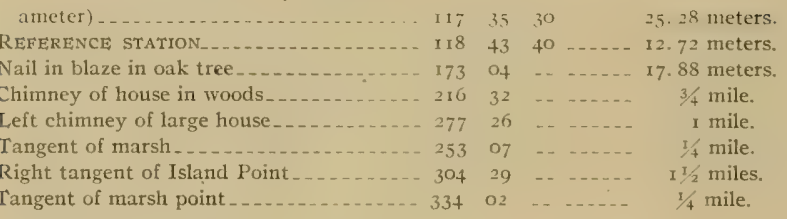

\section{NEIVPORT.}

General locality.-Northwestern shore of Newport Bay on easterly side of elevated land known as Cropper Island. (See Chart No. 13.)

Immediate locality.-Observed station is on elevated tilled land about 5 feet above high-water mark, 200 yards west of mouth of marsh creek in bay shore, and $r_{50}$ yards south of the only house on the island. It is near east edge of tilled land, about 70 yards west from edge of marsh. The tilled and marsh land is separated by a strip of land covered with trees.

Marks.-Observed station is center point of triangle on standard cement monument.

References.--

\begin{tabular}{|c|c|c|c|c|c|}
\hline "Neck" (S $86^{\circ}$ 10' E) - & o & 00 & oo & & $1 / 2$ miles. \\
\hline At house $\ldots . . .$. & 22 & 42 & -. & & iles. \\
\hline Chimney of Birchs house & 32 & 29 & -- & - & $21 / 2$ miles. \\
\hline Walnut tree $(2+$ inches diameter $)$ & 83 & 53 & ... & & 70 \\
\hline 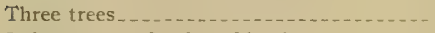 & 94 & -. & -. & & aras \\
\hline Left tangent of point of land... & 115 & 07 & .. & & aile. \\
\hline New barn . . . . . . . . . . & I 20 & ab & & & $2^{1}=$ miles. \\
\hline Chimney on house .. $\ldots .$. & 13.3 & .39 & & & $\mathrm{Y}^{\mathrm{T}} 2$ miles. \\
\hline Chimney on left end of house & $15^{8}$ & 36 & -. & - & , \\
\hline Thorn bushes & I 71 & 44 & -. & & 150 \\
\hline Chimney on house & 266 & 57 & -. & .... & 150 \\
\hline$+\infty, \ldots+\infty$ & 297 & 41 & .. & & \\
\hline Well sweep & $2 \mathrm{I} 4$ & II & -. & & 200 yard \\
\hline
\end{tabular}

HANDYS HAMMOCK.

General locality.-IVestern shore of upper end of Chincoteague Bay and western side of entrance to Newport Bay on solid land partly surrounded by marsh known as Handys Hammock. (See Charts Nos. 13 and 14. .)

Immediate locality.-Observed station is on a sand knoll about 10 feet above high water and 140 yards west-northwest from the extreme end of the narrow point on which it is situated. It is about 35 yards west of another short point, 30 feet south-southwest of shore at a sand beach, 20 yards north of a thorn bush and 50 yards north-northwest of a small pool 20 feet square.

Marks.-Observed station is center point of triangle on standard cement monument.

References.-

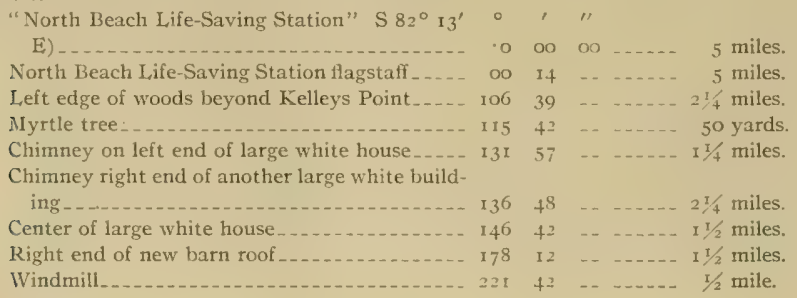




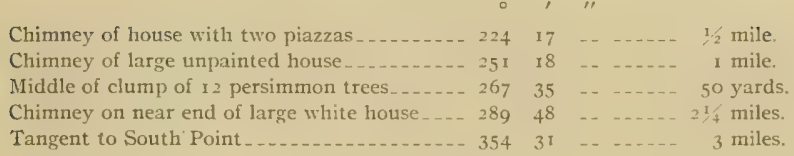

\section{BEACON CLUMPS.}

General locality.-Easterly side of upper Chincoteague Bay, on the southern and larger of the two small marsh islands called Beacon Clumps. (See Chart No. 14.)

Immediate locality.-Observed station is on a small marsh island covered at extreme high water. It is situated about 35 yards south of shore, 22 yards west of shore, 28 yards north of shore, and 75 yards east of shote.

Marks.-Observed station is center point of triangle on standard cement monument.

References.-

"Guilberts Cupola" S $\left.78^{\circ} 5 \mathrm{o}^{\prime} \mathrm{E}\right) \ldots \ldots \ldots \ldots$

Modern house being constructed .............

Silo building

Chimney of Jones house on Newport Bay .....

Near enid of roof of house on South Point.....

First tree near North Beach Life-Saving Station_................ $10321 \quad 5$ miles.

North Beach Life-Saving Station flagstaff .... III $13 \ldots \ldots . . .5$ miles.

"North Beach Life-Saving Station" _...... 111 15 $20 \ldots \ldots$ miles.

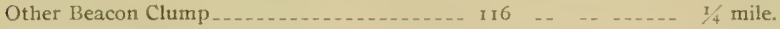

Green Run Inlet Life-Saving Station lookout_.. $255 \quad 46 \quad \ldots \ldots \ldots 31 / 2$ miles.

Right end of Green Run Inlet woods _...... 27 I 31 _. . . $31 / 2$ miles.

Between two chimneys on cream-colored house 339 -.

\section{TURNAGAIN.}

General locality.-Eastern shore of Chincoteague Bay, on main land marsh about I mile southeast of Whittington Point. (See Charts Nos. I4 and 15.)

Immediate locality.-Observed station is on marsh land awash at high water, about 75 yards south from shore, 55 yards east from shore, and about 83 yards west from shore of a small bay. A creek runs nearly around this piece of marsh, but does not make an island of it. No permanent reference marks near station.

Marks.-Observed station is center point of triangle on standard cement monument.

References.-

"Pope Island Life-Saving Station" (S $15^{\circ} 22^{\prime} \circ$
IV)

Point of land

Point of land ................... 34

Point of marsh .............................. 91

Point of land ......................... 9

Point of land _............... 164

Point of this marsh_.................. 194

Beginning of woods

Cut in top of woods........... 28 I

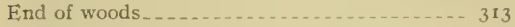

Sand dune behind woods . . . . ............. 330

Clump of trees ........ 336

Duck blind _........ 355

$$
\begin{aligned}
& \text { oo ..... } 4 \frac{3 / 4}{4} \text { miles. } \\
& \text { _. _.... } 1 / 4 \text { mile. } \\
& \text {....... } 2 \text { miles. } \\
& \text {...... } 1 / 8 \text { mile. } \\
& \text { _...... I/4 milie. } \\
& \text { _. ...... 1/4 mile. } \\
& \text {....... 1/8 mile. } \\
& \text {....... I mile. } \\
& \text {.. _.... 3/4 mile. } \\
& \text { _. ..... } 1 / 2 \text { mile. } \\
& \text { _. _..... } 13 / 4 \text { miles. } \\
& \text {....... } 13 / 4 \text { miles. } \\
& \text {-. -..... I mile. }
\end{aligned}
$$




\section{GREEN RUN INLET LIFE-SAVING STATION FLAGSTAFF.}

General locality.-Atlantic coast, about 18 miles south-southwest of Ocean City and about 15 miles northeast by north of "Assateague Light." (See Charts Nos. 14 and 15.)

Immediafe locality.-Observed station is detached flagstaff with a topmast belonging to Green Run Inlet Life-Saving Station.

Marks.-Observed station is center of flagstafi.

References.-None necessary.

\section{LANDLET}

General locality. - Western shore of Chincoteague Bay, about $2 \frac{1}{4}$ miles south of Snow Hill Landing, on point of land known locally as Watermelon Point. (See Chart No. If.)

Immediate locality.-Observed station is on a small sandy island surrounded by marsh land and about 20 yards west of shore. This so-called island is the only hard land on the marsh point and is about $1 / 3$ mile to the east of the nearest solid land.

Marks.-Observed station is center point of triangle on standard cement monument buried with top 2 inches below surface of ground.

Rejerences. -

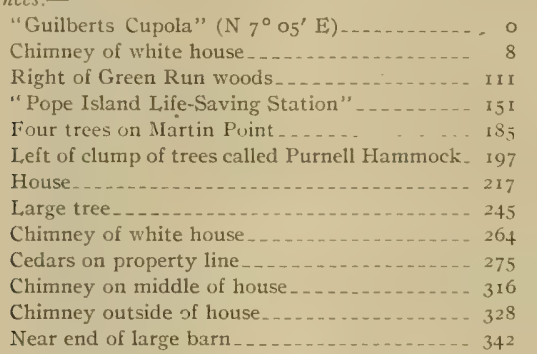

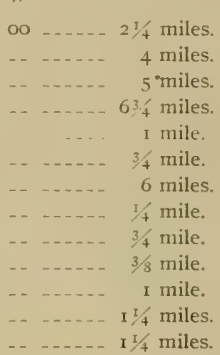

GUILBERTS CUPOLA.

General locality.-Western shore of Chincoteague Bay, close to Snow Hill Landing. (See Chart No. If.)

Immediale locality.-Observed station is on a large mansion house located about roo yards northwest of the land end of Snow Hill Landing.

Marks.-Observed station is center point of top of cupola.

References.-None necessary.

\section{RICKS.}

General locality. - Western shore of upper Chincoteague Bay, on point of marsh land about $11 / 2$ miles northeast of Snow Hill Landing called Ricks Point. (See Chart No. 14.)

Immediate locality.-Observed station is on a marsh point about 20 yards west from a pool making into marsh, 20 yards south from shore and 90 yards north of shore.

Marks.-Observed station is center point of triangle on standard cement monument.

References.-

\begin{tabular}{|c|c|c|c|c|}
\hline $\begin{array}{l}\text { Green Run Inlet Life-Saving Station flag- } \\
\text { staff" }\left(\text { S } 31^{\circ} 48^{\prime} \mathrm{E}\right)\end{array}$ & & & & \\
\hline Green Run Inlet Life-Saving Station cupola.- & o & 08 & 05 & $65 / 4$ miles. \\
\hline Right tangent of Green Run woods & 7 & 45 & -- & \\
\hline Right tangent of pool $\ldots . .$. & 32 & I 8 & & 20 \\
\hline Right tangent of Martin Poin & 52 & 30 & -. & s. \\
\hline Center of Purnell Hammock. & 57 & 22 & -- & $41 / 2$ miles. \\
\hline Left tangent of point ...... & 61 & 07 & & if $\mathrm{mil}$ \\
\hline Guilbert v & 83 & 26 & 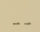 & I $1 / 2$ mile \\
\hline
\end{tabular}




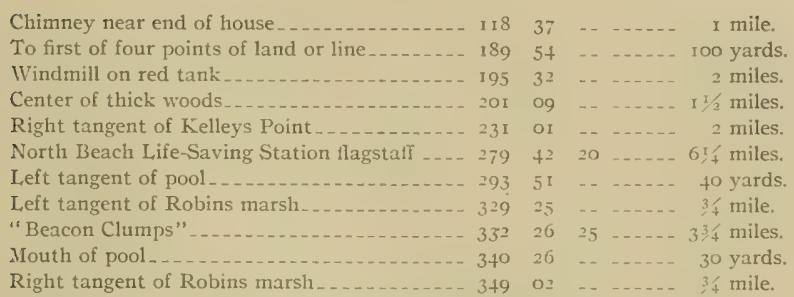

\section{MARYLAND-VIRGINIA LIFE-SAVING STATION BEACH).}

General locality.-Atlantic coast near ocean beach, on boundary line between Maryland and Virginia and about $1 / 4$ mile north-northeast of Pope Island Life-Saving Station. (See Chart No. I5.)

Immcdiate locality.-Observed station is on marsh and sand land about 230 yards northwest of high-water mark on beach, 75 yards west of top of sand dunes on inner edge of beach, and about 50 yards northwest of the Life-Saving Service telephone line which runs along the beach in midst of bushes at this point.

Marks. - Observed station is the center of an old granite monument (said to have been established many years ago) which marks the boundary between Maryland and Virginia. Top of monument is 6 by 6 inches square and projects 18 inches above the ground. The top is marked with an east-andwest line from corner to corner and the letters " $M$ " and " $V$ " to indicate the Maryland and Virginia sides of the boundary, respectively.

References.-

\begin{tabular}{|c|c|c|c|c|}
\hline $\begin{array}{l}\text { Pope Island Life-Saving Station" S } 20^{\circ} \\
12^{\prime}(\mathrm{V})\end{array}$ & $\begin{array}{l}\circ \\
0\end{array}$ & & & $1+$ \\
\hline Left peak of barn roof ...... & 5 & 39 & -. & $1 / 4$ mile. \\
\hline "Maryland-Virginia Boundary, Pope Islan & 63 & 55 & -. & ile. \\
\hline Chimney on old house on Pope Island_. & 68 & $4 I$ & -- & $3 / 4$ mile. \\
\hline Pine tree in cut toward "Mill" & 92 & 55 & -- & iile. \\
\hline First telephone pole from end of bushes & 195 & $5^{2}$ & -- & 190 yards. \\
\hline Fifth telephone pole from end of bushes. & 205 & 25 & -. & I Ió yards. \\
\hline Sixth telephone pole from end of bushes...... & 263 & 06 & -- & 52 yards. \\
\hline Seventh telephone pole from end of bushes & & & & \\
\hline fourth from life-saving sta & & 58 & -- & 88 \\
\hline Eighth pole signal pole at lif & & 03 & -- & $1 / 4$ mile. \\
\hline
\end{tabular}

\section{MARYLAND-VIRGINIA (POPE ISLAND).}

General locality.-Western side of Pope Bay on eastern side of Pope Island, about 1/4 mile northeast of its southern extremity and on boundary between Maryland and Virginia. (See Chart No. 15.)

Immediate locality.-Observed station is on hard land 3 feet above high-water mark, about ro yards west of shore, 85 yards south of an old louse, and ro yards east of bushes.

Marks.-Observed station is the center of an old granite monument projecting 18 inches above ground which marks the boundary between Maryland and Virginia. Top of monument is cut in a square 6 by 6 inches with an east-and-west line from corner to corner and the letters " $I$ " and "V" to indicate the Maryland and Virginia sides of the boundary, respectively.

Rejerences.-

\begin{tabular}{|c|c|c|c|}
\hline Island Life-Saving Station" ( $\left.73^{\circ} 45^{\prime} \mathrm{E}\right)$ & o & & oo \\
\hline Right tangent of shanty & $1_{5}$ & 32 & mile. \\
\hline Right tangent of bouthouse. . & to & $\therefore 2$ & ile. \\
\hline Center of small island...... & 101 & & 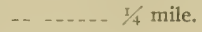 \\
\hline nt of Pope Island.... & It 3 & $3 S$ & \\
\hline
\end{tabular}




\begin{tabular}{|c|c|c|c|}
\hline & ○ & , & $\prime \prime$ \\
\hline Two large pines. & 139 & 07 & 1/4 mile. \\
\hline Left of bushes............ & 191 & $5^{6}$ & ro yards. \\
\hline Nent corner of old house & 283 & os & 85 yards. \\
\hline Point of land near life-saving station wharf_. & 336 & 22 & $1 / 4$ mile. \\
\hline Drill pole near life-saving station & 355 & 29 & $1 / 2$ mile. \\
\hline
\end{tabular}

POPE ISLAND LIFE-SAVING STATION (VIRGINIA).

General locality.-Atlantic coast, on Pope Island Beach, about $93 / 4$ miles northeasterly from "Assateague Light." (See Chart No. I5.)

Immediate locality.-Observed station is on the main building of the Pope Island Life-Saving Station, which is a gable roofed $1 / 2$-story wooden structure with a square lookout cupola. Pointed cap piece of cupola supports a weather vane in the form of a fish.

Marks.-Observed station is center of weather-vane spindle.

References.-None necessary.

\section{WILDCAT (VIRGINIA).}

General locality.-Northerly end of Chincoteague Island, on westerly side of Assateague Bay. (See Chart No. 15-)

Immediate locality. - Observed station is on marsh land, about $1 / 2$ mile south of upper end of island, known locally as Wildcat Point. It is inshore about roo yards northwest of mouth of small marsh drain emptying into Assateague Bay. The marsh creek or drain makes a decided turn about 12 yards south of station.

Marks.-Observed station is center point of triangle on standard cement monument.

References.-

"Assateague Light" (S $\left.26^{\circ} 06^{\prime} \mathrm{W}\right)$...........

Right tangent of woods

"Killick Shoal Light" ...................... 30

First cedar_......................... 44 miles.

Clump of cedars............ $11 / 4$ miles.

A marshy island ................... $100 \ldots 11 / 4$ miles.

Right tangent of marshy island _......... 130 I4 ...... $11 / 4$ miles.

Left tangent of Ragged Point_.......... 172 o8 _. _.... I mile.

Shanty on Ragged Point ............... I76 $42 \ldots \ldots$ I mile.

First tree on Ragged Point_...... 209 II _..... I mile.

Second tree on Ragged Point _._._....... 210 4I _. _..._. I mile.

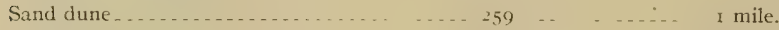

Smith Hammock sand dune ........... $323 \ldots \ldots$... .... I $1 / 4$ miles.

Middle of boathouse on beach_......... $335 \quad 52 \ldots 3$ miles.

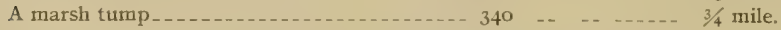

ASSATEAGUE LIGHT (VIRGINIA).

General locality.-Southerly part of Assateague Island, seacoast of Virginia, about $21 / 2$ miles from its southwesterly point. (See progress map.)

Immediate locality.-Red tower, ${ }_{54}$ feet above sea level and 129 feet above its own base, known as Assateague Light-House.

Marks.-Observed station is center of black lantern.

References.-None necessary.

\section{KILLICK SHOAL LIGHT (VIRGINIA).}

General locality.-Southerly end of Chincoteague Bay, on Killick Shoals, off entrance of Chincoteague Channel. (See progress map.)

Immediate locality.-Screw pile structure known as Killick Shoal Light-House.

Marks.-Observed station is center of black lantern.

References.-None necessary. 
CHESTER (VIRGINIA).

General locality.-Southern and western shores of Chincoteague Bay, about $1 / 2$ mile south of shore of bay and $1 / 4$ mile east of solid land known locally as Mosquito Point Farm. (See progress map.)

- Immediate locality.-Observed station is on a mound of dry land surrounded by marsh, known locally as Fox Hill. It is on the highest point and near the apex of the mound, which is V-shaped and about ${ }_{5}$ feet above high water at the station. The mound gradually falls off to the level of the marsh from the station to the ends of the $V$, which are both about I5O yards distant, and at the extreme apex, which is about 25 yards to the north. Reference station is 5.82 meters $\mathrm{N} 80^{\circ} 5 \mathrm{I}^{\prime} \mathrm{W}$ of the observed station.

Marks,-Observed station is center of tile pipe surrounded by cement with top flush with ground. Reference station is center point of triangle on standard cement monument.
References.-
"Assateague Light" (S $\left.59^{\circ} 59^{\prime} \mathrm{E}\right)$.....-
Tower on Wallops Beach Life-Saving Sta-
Tower on Wallops Beach Life-Saving Sta-
Cupola of barn
REFERENCE STATION - ... - . . . . 150 o8 $10 \quad$. 5. S2 meters.

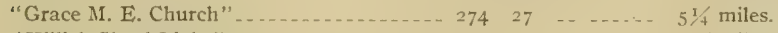
"Killick Shoal Light" ............... 333 30 _. .... $3 \frac{1}{2} / 2$ miles.
West spire of Union Baptist Church at Chin-
coteague _......... 4 miles.

\section{LONG POINT (VIRGINIA).}

General locality. - Western shore of lower Chincoteague Bay, near Long Point, about 1/2 mile east of Franklin City. (See Chart No. 15.)

Immediate locality. - Observed station is on marsh land about 40 yards from end of point of mainland, 30 yards southwest of shore and 20 yards north of shore. A small marsh island is located about 200 yards east of the station, which was once a part of the mainland and known as Long Point. Reference station is 11.81 meters $\mathrm{N}_{42}{ }^{\circ} 37^{\prime} \mathrm{W}$ of the observed station.

Marks.-Observed station is center of tile pipe set in cement with top flush with the ground. Reference station is center point of triangle on standard cement monument.

References.-
"Mill" (N $388^{\circ}$ o7' E)
"Assateague Light"
"Killick Shoal Light"

\section{GRACE, M. E. CHURCH (VIRGINIA).}

General locality. - Western shore of lower Chincoteague Bay, about $1 / 2$ mile northwest of railway wharf at Franklin City. (See Chart No. 15.)

Immediate locality.-Observed station is the taller of two towers on church known as Grace M. E. Church.

Marks,-Observed station is center of pointed tower or spire.

References.-None necessary.

\section{MONEY (VIRGINIA).}

General locality.-Western shore of lower Chincoteague Bay, about I mile west-northwest of Long Point, on northern edge of town of Greenbackville, and just south of Maryland-Virginia boundary. (See Chart No. 15.) 
Immediate locality.-Observed station is about 70 yards northeast of railway on a sandy rise of ground aboul $r 5$ feet above level of track. It is about 25 yards south of the Maryland-Virginia boundary and 30.43 meters $\mathrm{S} 38^{\circ} 28^{\prime} \mathrm{E}$ of broken stone boundary monument. At the station, "Assateague Light" shows almost tangent to third house north of Grace M. E. Church.

Marks.-Observed station is center point of triangle on standard cement monument buried with top 30 inches below surface of ground
References.-

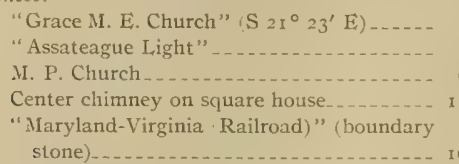
"Long Point"
Left chimney of two close together....... 330
Small tower Greenbackville Church _. . . . . 359

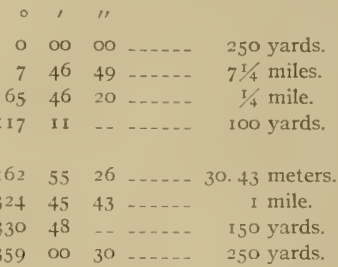

\section{MARYLAND-VIRGINIA (RAILROAD).}

General locality.-Western shore of lower Chincoteague Bay, inland about I mile west-northwest of Long Point, on boundary line between Maryland and Virginia. (See Chart No. 15.)

Immediate locality.-Observed station is about 80 yards northeast of railroad on a sandy rise of ground about 15 feet above level of track. It is on the edge of an excavation in this sand hill and is likely to be undermined any time by the carting away of sand for building purposes. The standard cement monument marking triangulation station "Money" is buried with its top 30 inches below surface of ground 30.43 meters $\mathrm{S}_{3} 8^{\circ} 28^{\prime} \mathrm{E}$ true from station.

Marks.-Observed station is the center of a square-top granite monument projecting 18 inches above ground which marks the boundary between Maryland and Virginia. Top of monument when visited in December, 1907 , was broken loose and resting on the undisturbed part of the stone buried in the ground. This top was cut in a square 6 by 6 inches with an east-and-west line from side to side and the letters " $\mathrm{I}$ " and "V" to indicate the Maryland and Virginia side of the boundary, respectively

References.-None observed.

MII.L.

General locality.-Western shore of Chincoteague Bay, on the northern part of Mill Island. (See Chart No. I5.)

Immediate locality. - Observed station is the highest point of the island, on a hill about 20 feet above high water which is located about $1 / 2$ mile southwest of the upper end of the island. It is about to yards east by south of an abandoned house and sheds and about $1 / 4$ mile north of another abandoned house.

Marks.-Observed station is center point of triangle on standard cement monument.

Refercnces.-

"Assateague Light" (S $\left.8^{\circ} 59^{\prime} \mathrm{W}\right) \ldots \ldots \ldots$

Right tangent of Chincoteague Island ..... I

Knoll on this island .................

Tree (8 inches diameter) . . . . . . . . . . . . .

Tree ( 8 inches diameter) ................

Tree ( 18 inches diameter) ...............

Near corner of old house

Next corner of old house

Cupola on large house ................. I

Chimneys on white house

"Lear end of large barn

Hammock.........................

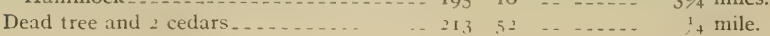




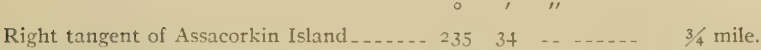

Left of "Green Run" woods_........... $238 \quad 40 \quad \ldots \ldots \ldots 63 / 4$ miles.

"Pope Island Life-Saving Station" _.... 286 05 _. . .... $43 / 4$ miles.

Left tangent of first building on Ragged

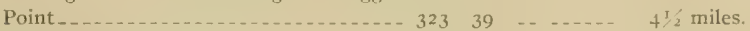

Left tangent of Chincoteague Island ..... 34 I $06 \quad \ldots \ldots \ldots .5$ miles.

Chimney of old house .............. $34927 \ldots \ldots$ to mile.

- TIZZ.

General locality.-Western side of Chincoteague Bay on Tizzard Island. (See Chart No. 15.)

Immediate locality. - Observed station is on the highest point on the island, about 15 feet above high water, about 1/4 mile from extreme southeastern point of island, and about 75 yards north of shore line of island.

Marks,-Observed station is center point of triangle on standard cement monument.

References.-

"Assateague Light" (S $\left.6^{\circ} 35^{\prime} \mathrm{WV}\right)$

Smoke pipe of shanty ....................

Chimney on first house at Stockton ........ 23

Church steeple at Franklin City ............ 28

Church steeple, Greenbackville _......... 3

Two chimneys on gambrel roof _.......... 40

Near chimney of white house............ IOI

Near chimney of another white house _._.... 106

Chimney on large unpainted barn _._._._._. II

Two chimneys on large house ............. II

Chimney of yellow building _............. 165

Large white barn _.............._. _. 199

Purnell Hammock_...................... 2 I3

Green Run Inlet Life-Saving Station flagstaff _ 256

"Pope Island Life-Saving Station" _. _. _-_._. - 299

Left tangent Assacorkin Island ............ 316

Left tangent of Mill Island_... _._._._._._. 325

Left of woods at Chincoteague

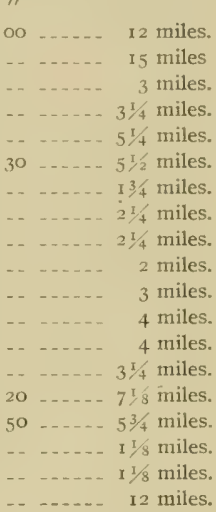




\section{BOUNDARIES OF OYSTER BARS.}

\section{EXPLANATION.}

The law of the United States authorizing the cooperation of the Department of Commerce and Labor in the survey of natural oyster bars of Maryland provides for the designation and employment by the Department of Commerce and Labor of such officers, experts, and other technically qualified persons "as may be necessary to cooperate with the Maryland State Board of Shell Fish Commissioners in making a survey of and locating the natural oyster beds, bars, and rocks in the waters within the State of Maryland." The oyster laws of Maryland provide that the Maryland Shell Fish Commissioners, with the aid of such persons as may be designated by the Government, shall proceed "to have laid out, surveyed, and designated on the said charts the natural beds and bars, and shall cause to be marked and defined as accurately as practicable the limits and boundaries of the natural beds, bars, and rocks as established by said survey, and they shall take true and accurate notes of said survey in writing, and make an accurate report of said survey, setting forth such a description of landmarks as may be necessary to enable the said board, or their successors, to find and ascertain the boundary lines of the said natural oyster beds, bars, and rocks, as shown by a delineation on the maps and charts." The oyster laws of Maryland also provide in another section that there shall "be made a true and accurate survey of the natural oyster beds, bars, and rocks *** with reference to fixed and permanent objects on the shore, giving courses and distances, to be fully described and set out in a written report of said survey."

Under the provisions of the laws quoted above the State of Maryland, in cooperation with the Department of Commerce and Labor, must define the boundaries of the natural oyster bars "as accurately as practicable" and also "with reference to fixed and permanent objects on the shore, giving courses and distances." The requirement of "as accurately as practicable" is easily fulfilled by definition of the location of the corners of the oyster bars by latitude and longitude. In fact, this method is probably the most satisfactory and accurate one that could be used for all purposes of legal definition or for relocation of the oyster-bar boundaries by competent engineers. Therefore the additional requirement of "giving courses and distances" is superfluous and is only fulfilled in the published definitions on account of the specific provisions of the law making it compulsory. This part of the description of boundaries has involved an immense amount of extra computations in order to prevent technical discrepancies between the latitude and longitude of a corner of an oyster bar and its distance and bearing from objects on shore of known latitude and longitude without adding anything to the accuracy and very little to the convenience of practical use of the descriptions of the oyster-bar boundaries.

As provided by law the boundaries of the oyster bars are all straight lines, but in the work already completed they have inclosed areas of all shapes from triangles to complicated 14 -sided figures, and of all sizes from 4 acres to 7,548 acres. The sides 
have varied in length from 93 to 7,529 yards, and in some cases the corners of the boundaries have been practically at the triangulation stations from which they are located, while in other instances they were over 13,600 yards from the landmarks most available for the purpose of fixing their position.

The varied characteristics of the legal boundaries of the oyster bars indicated by the above statement, together with the complicated requirements of the law under which the survey has been made and the magnitude of the work with the consequent need of fixed and uniform methods, have made the problem of describing the boundaries one of considerable difficulty and great importance.

The boundaries of the oyster bars of Maryland, as established by the Shell Fish Commission and celineated on the Coast and Geodetic Survey charts and projections and on the leasing charts of the Commission, are technically defined and described by a method somewhat different from that used in other oyster surveys. But it is believed that the forms finally adopted will fulfill all needs of the survey for both the present and future.

\section{METHOD OF DESCRIBING BOUNDARIES.}

The descriptions have been arranged in tabular form, thus avoiding many hundred repetitions of the same words by making one explanation of the tables sufficient for all oyster bars in each county.

Title.-At the top of each tabular form is given the legal name of the oyster bar to be described, and the one by which it is known and designated in the published oyster records and on the oyster charts. The adopted name of the oyster bar is the one used locally, as nearly as could be ascertained by the hydrographic engineer of the Commis- sion; and when there was no local name in common use a name was selected from one of the prominent features of the vicinity that would naturally suggest the section of the waters where the oyster bar was located.

Underneath the name, in parentheses, is given the general locality of the oyster bar and the serial number of the "Maryland Oyster Chart " on which its legal boundaries are shown. ${ }^{a}$

First column.-This column, under the heading of "Corner of bar," gives the number corresponding to the corner of the boundary as shown on the charts and to the number on the buoy marking the actual corner of the bar. The numbers of the corners have been assigned by naming the southernmost point No. $\mathrm{I}$, thence proceeding in a clockwise direction around the bar; but where a corner of one oyster bar is identical with the corner of the boundaries of one or more other oyster bars only the number of the corner of the oyster bar being described in the table is given in this column.

Second and third columns. - These two columns, under the headings of "Latitude" and "Longitude," give the geographic positions of the corners. These positions have been adopted by the Commission as the primary technical definition of the location of the corners, and should be considered as final in case of a dispute arising from discrepancies caused by other means of location. The latitudes and longitudes given in these columns are based on the United States standard datum of the Coast and Geodetic Survey, and the points thus defined can be relocated from distant triangulation stations

a These charts can be obtained by application to the Superintendent of the Coast and Geodetic Survey at Washington, D. C. 
of the Survey, even though all the landmarks and buoys originally used for their location have been destroyed by natural or other causes.

Fourth and fifth columns. - These two columns, under the general heading of "True bearing" "and the specific headings "Forward" and "Back," give bearings measured from a true north-and-south line. The three "Forward" bearings are from the corner of the boundary designated in the first column to the triangulation stations named on the corresponding lines in the last column, and the three "Back" bearings are from these same stations in the last column to the corresponding corner of boundary in the first column. The difference in minutes of are between the forward and back bearings shown in some cases is actual and not accidental, and is due to the fact that the computations took into account the spheroidal shape of the earth.

Sixth column.--This column, under the heading of "Distance," gives the three computed distances in yards from the corner of the bar noted in the first column to the three triangulation stations named on the corresponding lines in the last column, and vice versa.

Seventh column.-This column, under the heading of "U. S. C. \& G. S. triangulation station," $b$ gives the names of the landmarks from which were computed the corresponding "Latitude," "Longitude," "True bearing," and "Distance" of the "Corner of the bar" designated in the first column. A full description of the location and markings of these triangulation stations is given in another part of this publication under the heading of "Descriptions of triangulation stations."

\section{SURVEYING METHODS FOR RELOCATION OF BOUNDARIES.}

There are a number of methods that can be used in the relocation of the actual boundaries of the natural oyster bars as technically described in this publication and delineated on the published charts of the Coast and Geodetic Survey and the leasing charts of the Shell Fish Commission.

The following brief descriptions of five of these more or less different methods assume a certain amount of experience and knowledge on the part of the engineer in the particular kind of surveying under consideration, and are only intended as reminders of ways and means that can be used.

There are two problems that are likely to present themselves to those interested in the boundaries of natural oyster bars: One, to determine whether the buoys marking the corners have been dragged or otherwise moved from their correct positions, and the other, to relocate or reestablish a buoy at the point from which it was removed. The different ways of solving these two problems partly depend upon the instruments possessed by the engineer and his assistants and partly on his training and experience.

(I) Triangulation.-This method is the one that will give the greatest accuracy, but on account of its requiring special data and instruments, and being an operation rarely used by engineers not engaged in geodetic surveying, it is recommended only for cases in dispute that can not be settled satisfactorily by some other method. An explanation of this class of work would be too long for a report of this sort, and those

a The mean magnetic variation for WVorcester County was $5^{\circ} 55^{\prime}$ west of north in 1909 and increasing at the rate of $33^{1} 2^{\prime}$ yearly.

$b$ Geographic positions of these triangulation stations can be obtained by application to the Superintendent of the Coast and Geodetic Survey, Washington, D. C. 
not familiar with this method are referred to the publications on the subject by the Coast and Geodetic Survey.

(2) Hydrographic.-This method is the most simple and satisfactory one that can be adopted if the surveyor can obtain the use of the necessary instruments and assistants. It is the one best suited for the work of the engineers of the Commission in relocating corners of boundaries, as it gives results of the accuracy ordinarily required and is rapid in execution. Besides, it has the advantage of being available whenever three triangulation stations of suitable relative positions are visible from the offshore points needing relocation.

Most navigators and others familiar with the use of a sextant are well acquainted with the graphic three-point method of fixing a position on water, and only a brief description of the operation will be stated.

In the case where there is only one engineer having a single sextant, the three-point method can be used if the two angles determining the position of a buoy are first derived from the "Forward" bearings given in the tabular forms describing the boundaries of the oyster bars. For example, take "South Point" bar, which is the first one described in this publication, and assume that "Corner No. 3 ," is to be examined as to its position. The angle between the two landmarks "Birch" and "Neck" as determined from right to left from the forward bearings from this corner is $59^{\circ} \mathrm{II}$ ' and the angle between "Neck" and "Newport" is $49^{\circ} 44^{\prime}$. Having these two angles, the engineer proceeds to the buoy of doubtful location and measures the actual sextant angles between the landmarks for which the calculations were made. If the measured and calculated angles do not agree the buoy is not in its correct position and the boundary corner must be relocated. This is accomplished by moving the boat about until a point is reached where the angles do agree, and this point being the desired location, the buoy can be placed in its correct position.

If the engineer can obtain the use of both a sextant and a three-arm protractor ("position finder"), the availability of the hydrographic method is increased, as the use of the protractor is essential in case of the washing away or destruction of one or more of the landmarks originally used in describing the boundaries. Under these circumstances, any three landmarks of suitable relative position that are visible from the point to be located can be utilized. For example, the engineer can proceed to the buoy of doubtful position and measure the two adjacent sextant angles between the three landmarks selected. These two angles are set off on the three-arm protractor and the actual position of the buoy plotted on the chart by shifting the protractor about until the edge of each of the three arms passes through the center of the symbols on the chart marking the position of the three landmarks selected. The center of the hub of the protractor will indicate on the chart the actual position of the buoy, and if the point thus obtained does not coincide with the true position of the corner of the boundary as given on the chart, the surveyor can proceed to locate the buoy correctly by reversing the operation. This is done by placing the center point of the hub of the protractor over the corner of the boundary in question and measuring on the chart the two adjacent protractor angles between the three selected landmarks. One of the angles thus obtained is set on the sextant and the boat moved about until the two landmarks are shown by the sextant to subtend the same angle obtained from the 
protractor. The second angle is then placed on the sextant and the same operation gone through, and so on, first using one angle on the sextant then the other until a point is reached where both observed sextant angles are practically identical with the protractor angles. The point thus located is the desired one and the buoy can be placed to mark the true position of the corner of the boundary in question.

If the engineer possesses two sextants and a protractor, this problem is far easier of solution, as the two angles can be set off on separate sextants and the observer can quickly find the desired point where they agree with the protractor angles by using one sextant after the other without the need of resetting either.

If there are two observers, two sextants, and a protractor, it can be seen that the best conditions for both rapid and accurate hydrographic locations of points are attained; in fact, this is the method by which the buoys at the corners of the boundaries were originally placed by the hydrographic engineer to the Commission.

(3) Magnetic bearings from offshore.-This method of fixing a position on water is a simple and well-known one in navigation. It is available to anyone having a boat compass and will be of special use to the State fishery force in investigating cases where buoys are supposed to have been moved for illegal purposes.

In the case where a buoy is supposed to have been moved from its true position the observer takes compass bearings to the three landmarks given in the last column of the tables opposite the boundary corner in question. These bearings are then corrected for the local declination, "and if the results agree with the published bearings the buoy is correctly located.

In the case where the buoy is not in its correct position, or has disappeared altogether, the desired point can be determined by maneuvering the vessel until the corrected bearings agree with the ones in the tabular descriptions, when the buoy can be anchored in its proper location.

In the case where the landmarks for which the bearings are published have been destroyed or washed away, any landmarks whose positions are indicated on the charts can be used by getting their bearings directly from the chart by parallel rulers or a protractor and then applying them in the same manner as the ones published in the tables.

(4) Magnetic bearings from shore.-This method will be of special value to engineers having an ordinary surveyor's compass. The compass can be set over the point marking a "triangulation station" on shore, the name of which is given in the last column opposite the "corner" in question. The instrument is then set at the corresponding "back" bearing (corrected for local magnetic declination) given in the fourth column of the tables opposite the "corner" in question, and the direction thus determined will give one range on which the desired point must be located. The compass can then be moved to a second triangulation station and another range located in a similar manner. The intersection of these two range lines will give the desired point; but in general it should be checked by an additional range line determined from a third station.

(5) Horizontal angles measured at landmarks.-This process is a modification of the triangulation method, and will be useful to engineers who have a transit and desire considerable accuracy.

$a^{\prime}$ The mean magnetic variation for Worcester County is $5^{\circ} 55^{\prime}$ west of north in 1909 and increasing at the rate of $3^{1 / 2}$ yearly. 
The instrument is placed over a "triangulation station," the name of which appears in the last column of the tabular description opposite the "corner" in question. The telescope is then pointed to the landmark indicated in the "Descriptions of landmarks" as having a direction of $\mathrm{O}^{\circ} \mathrm{OO}^{\prime} \mathrm{OO} \mathrm{O}^{\prime \prime}$ from the triangulation station being oceupied by the transit. The tabular description of the boundaries is next examined and the "back" bearing of the questionable boundary "corner" from the landmark being occupied is taken out. The angle calculated from this "back" bearing and the bearing given in parentheses alongside the zero landmark in the "Descriptions of landmarks" is then set off on the transit, and a range line established on which the desired point must be located. A similar process is then carried on at a second station, and so on until the position of the buoy is satisfactorily fixed.

BOUNDARIES OF NATURAL OYSTER BARS.

SOUTH POINT.

(Newport Bay-Charts Nos. I3 and I4.)

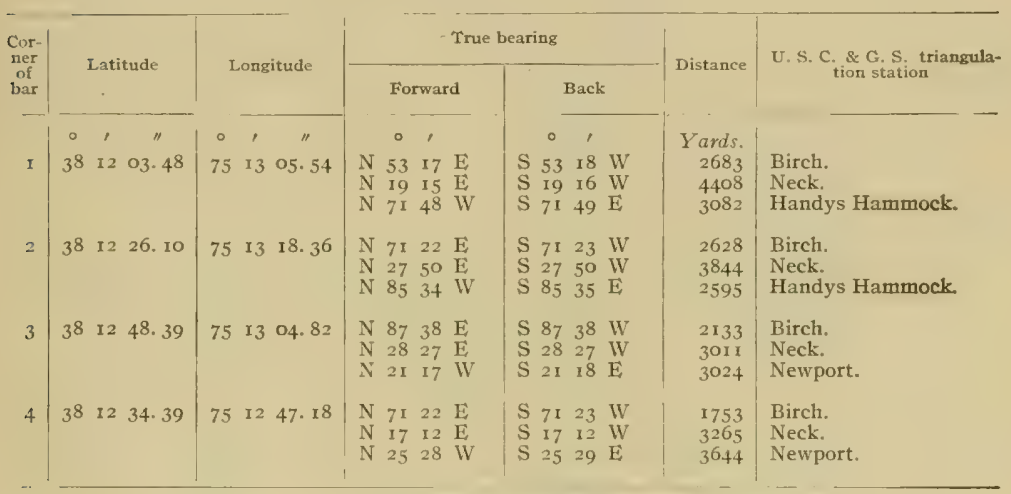

\section{HANDYS HAMMOCK.}

(Newport Bay-Charts Nos, I3 and I4.)

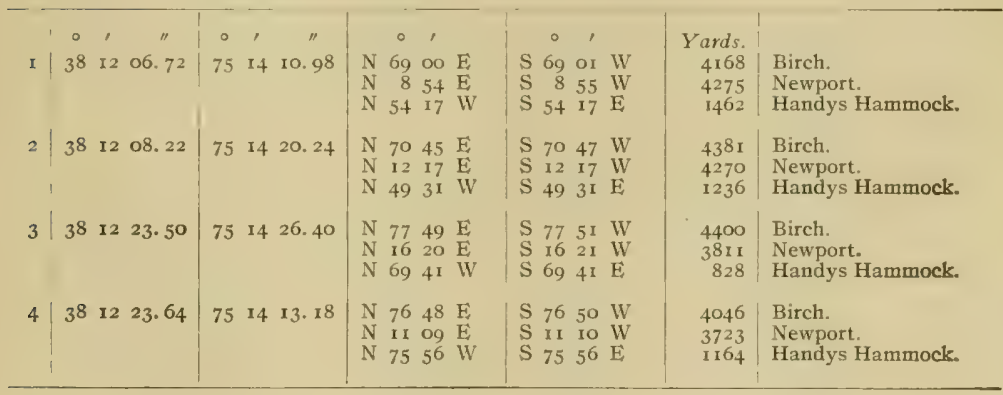

$82497 \longrightarrow 09-4$ 


\section{NEWPORT.}

(Newport Bay-Charts Nos. 13 and 14.)

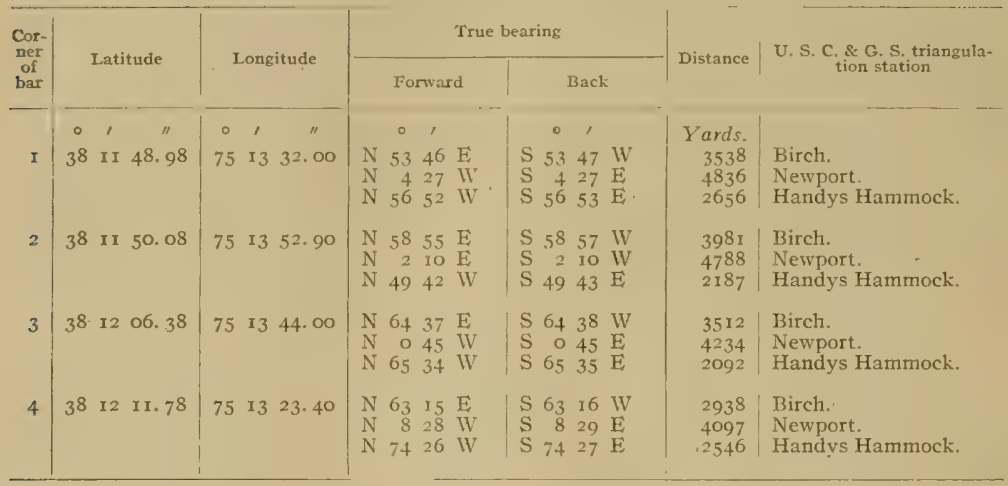

\section{LAMBEZRTSON LANDING.}

(Upper Chincoteague Bay-Chart No. I4.)

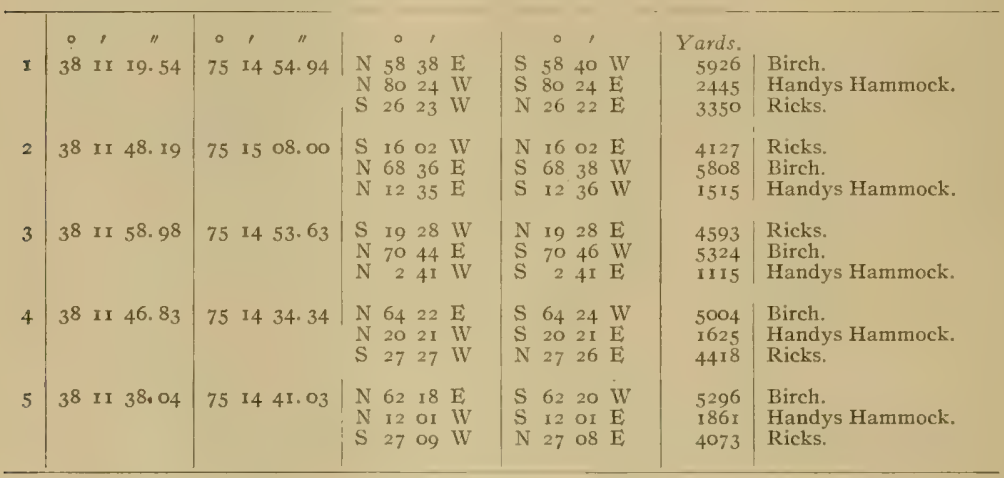

ENNIS.

(Upper Chincotcague Bay-Chart No. 14.)

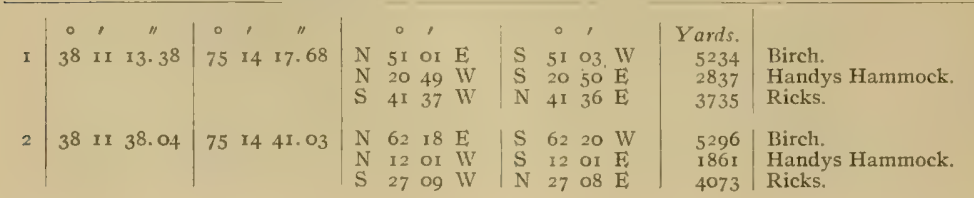


ENNIS-Continued.

(Upper Chincoteague Bay-Chart No, I4)-Continued.

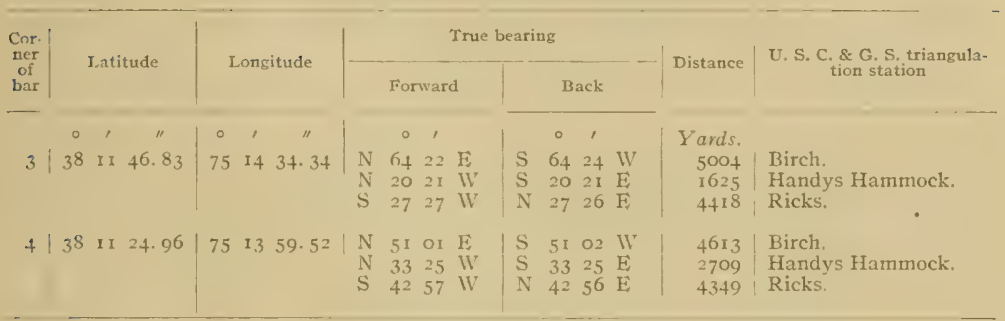

\section{TURPIN.}

(Upper Chincotcague Bay-Chart No. 14.)

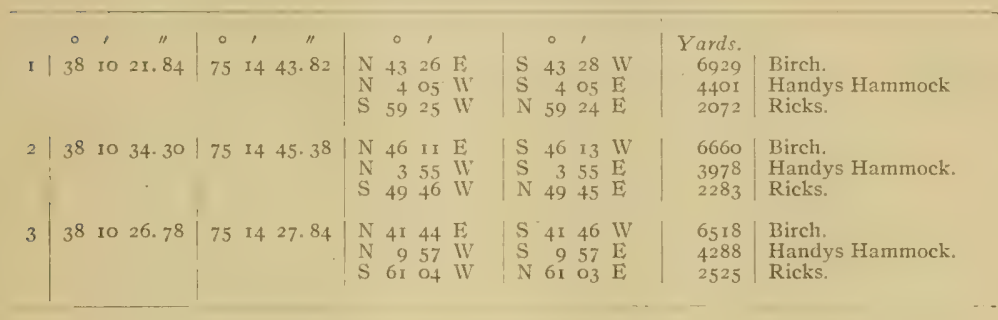

SANDY POINT.

(Upper Chincotcague Bay-Chart No. 14.)

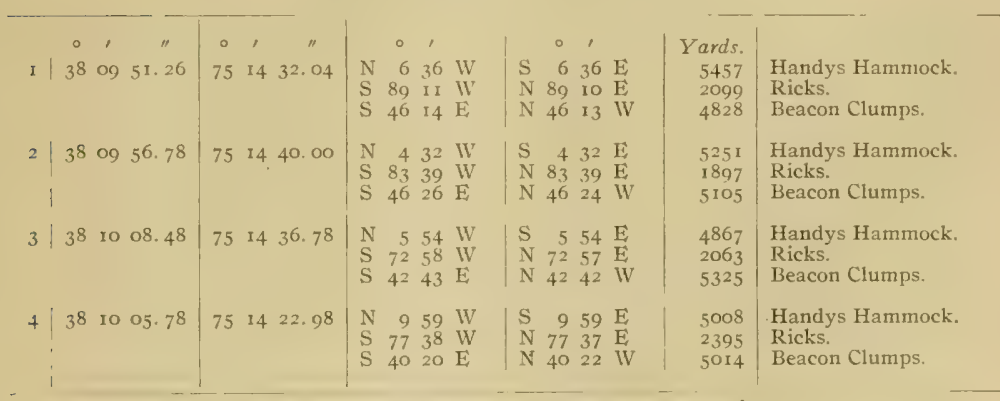


ROBINS MARSH.

(Upper Chincoteague Bay-Chart No. 14.)

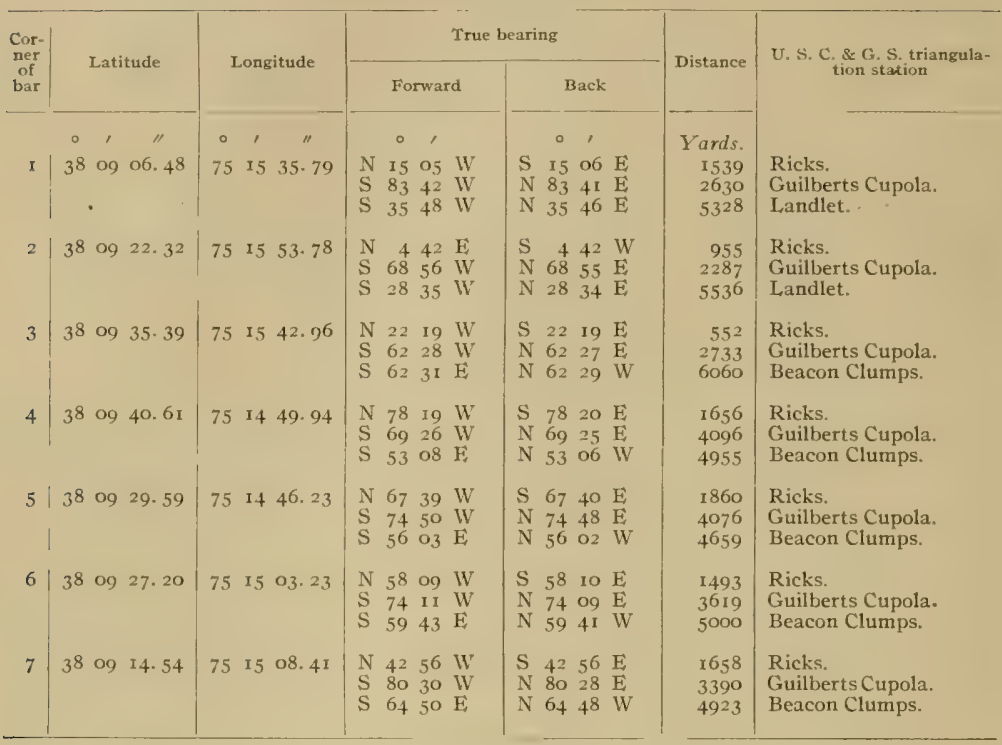

SCARBORO CREEK.

(Upper Chincoteague Bay-Chart No. I4.)

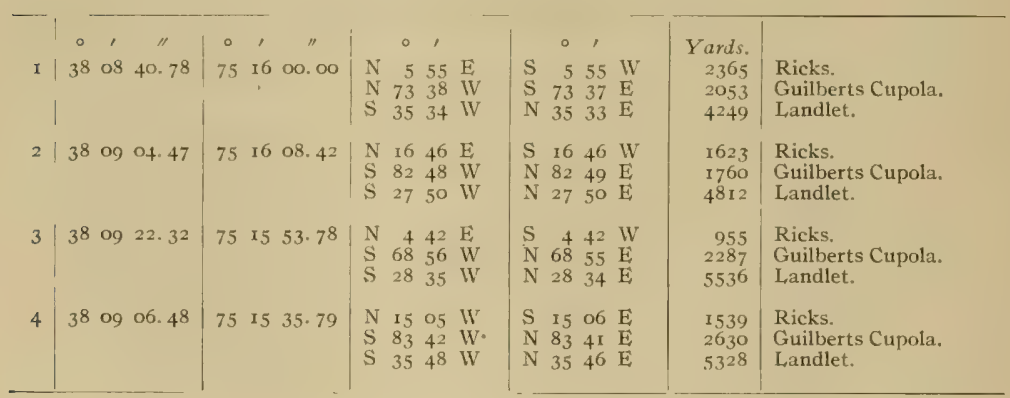


SOUTHWEST.

(Upper Chincotcague Bay-Chart No, I4.)

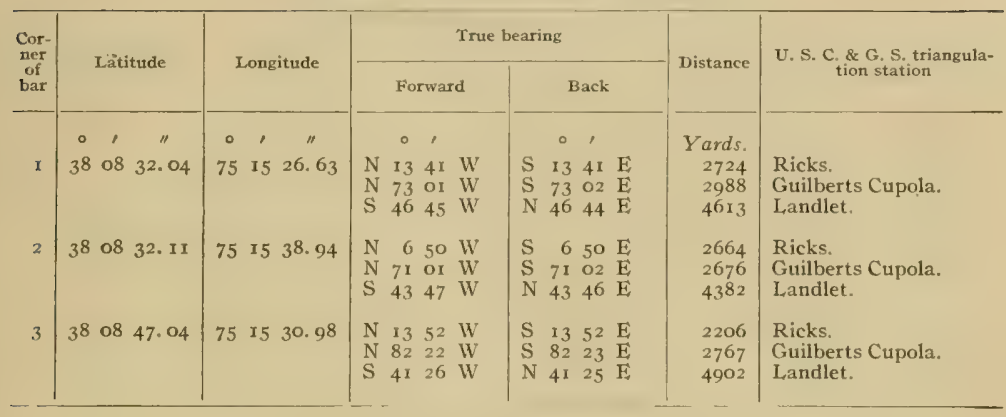

PURNELL, HAMMOCK.

(Middle Chincoteague Bay-Chart No. 14.)

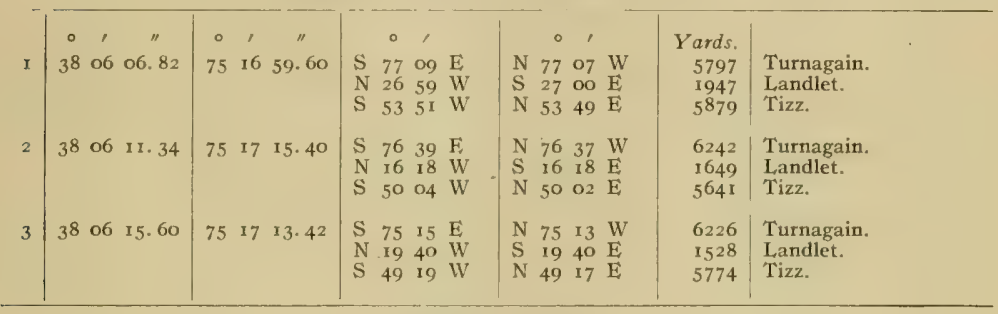

\section{BEEF CREEK.}

(Middle Chincoteague Bay-Charts Nos. I4 and I.5.)

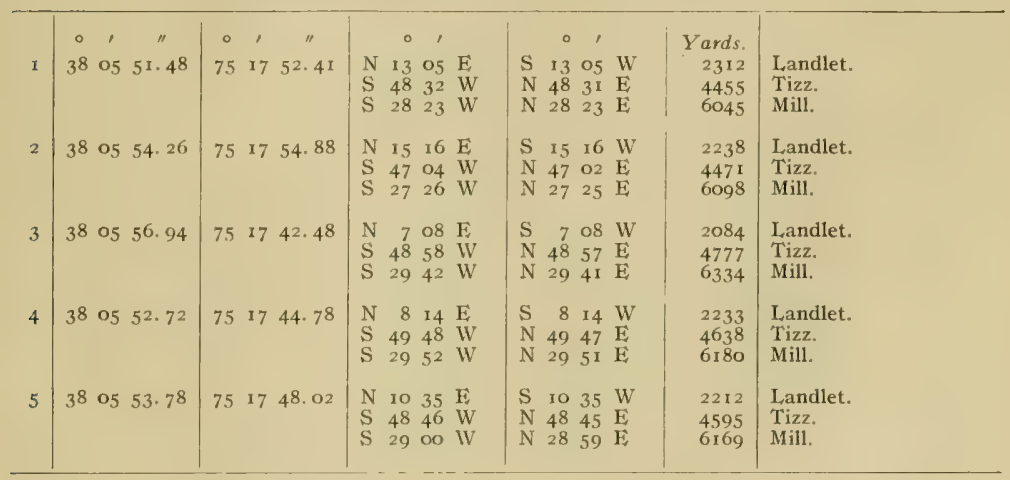


RATTLESNAKE.

(Middle Chincotcague Bay-Charts Nos. It and I5.)

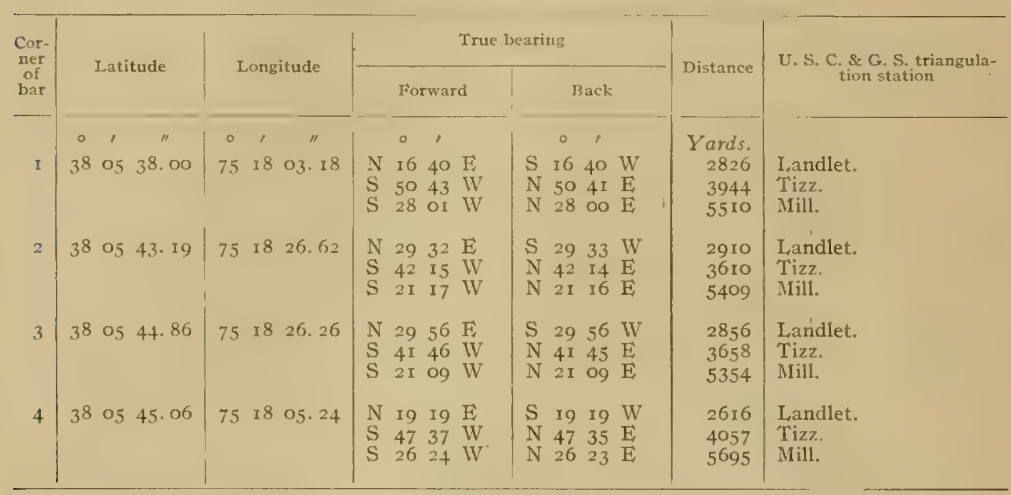

\section{MARTIN POINT.}

(Middle Chincoteague Bay-Charts Nos. I4 and 15.)

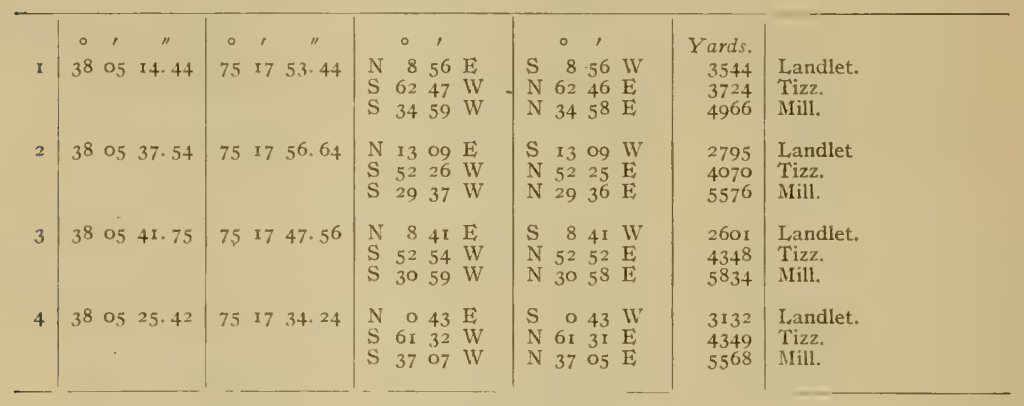

DIAMOND.

(Middle Chincoteague Bay--Charts Nos. 14 and 15.)

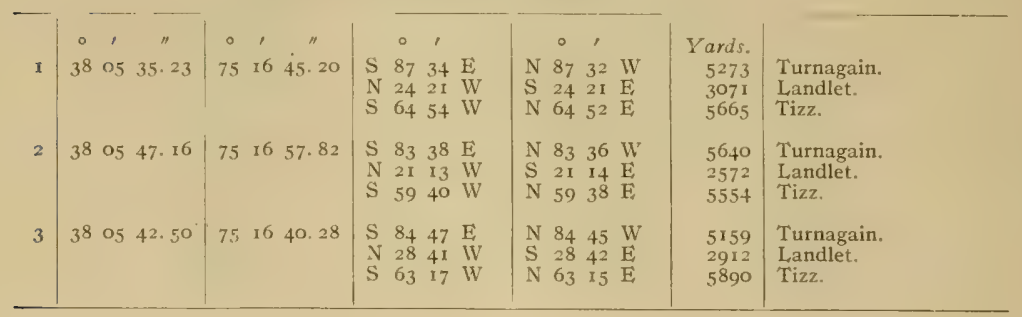


SHEEP.

(Middle Chincoteague Bay-Chart No. 15.)

\begin{tabular}{|c|c|c|c|c|c|c|c|c|c|c|c|c|c|c|c|}
\hline \multirow{3}{*}{$\begin{array}{l}\text { Cor- } \\
\text { ner } \\
\text { of } \\
\text { bar }\end{array}$} & \multirow{2}{*}{\multicolumn{3}{|c|}{ Latitude }} & \multirow{2}{*}{\multicolumn{3}{|c|}{ Longitude }} & \multicolumn{7}{|c|}{ True bearing } & \multirow{2}{*}{ Distance } & \multirow{2}{*}{$\begin{array}{c}\text { U. S. C. \& G. S. triangula- } \\
\text { tion station }\end{array}$} \\
\hline & & & & & & & \multicolumn{4}{|c|}{ Forward } & \multicolumn{3}{|c|}{ Back } & & \\
\hline & 0 & t & $n$ & $\circ$ & , & $" \prime$ & & & & & 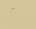 & 0 & , & Yards. & \\
\hline I & 38 & of & 03.59 & 75 & 19 & 09.02 & $\begin{array}{l}\mathrm{N} \\
\mathrm{N} \\
\mathrm{S}\end{array}$ & $\begin{array}{l}23 \\
62 \\
26\end{array}$ & $\begin{array}{l}31 \\
08 \\
20\end{array}$ & $\begin{array}{l}\mathrm{E} \\
\mathrm{W} \\
\mathrm{W}\end{array}$ & $\begin{array}{l}\mathrm{S} \\
\mathrm{S} \\
\mathrm{N}\end{array}$ & $\begin{array}{l}23 \\
62 \\
26\end{array}$ & $\begin{array}{l}32 \mathrm{WV} \\
09 \mathrm{E} \\
20 \mathrm{E}\end{array}$ & $\begin{array}{l}6425 \\
1766 \\
1876\end{array}$ & $\begin{array}{l}\text { Landlet. } \\
\text { Tizz. } \\
\text { Mill. }\end{array}$ \\
\hline 2 & 38 & 0.4 & I9. 44 & 75 & I9 & $20.5^{8}$ & $\begin{array}{l}\mathrm{N} \\
\mathrm{N}\end{array}$ & $\begin{array}{l}28 \\
81 \\
13\end{array}$ & $\begin{array}{l}12 \\
19 \\
19\end{array}$ & $\begin{array}{l}E \\
W \\
W\end{array}$ & $\begin{array}{l}\mathrm{S} \\
\mathrm{S}\end{array}$ & $\begin{array}{l}28 \\
81 \\
13\end{array}$ & $\begin{array}{ll}13 & \mathrm{~W} \\
19 & \mathrm{E} \\
19 & \mathrm{E}\end{array}$ & $\begin{array}{l}6077 \\
1000 \\
2277\end{array}$ & $\begin{array}{l}\text { Landlet. } \\
\text { Tizz. } \\
\text { Mill. }\end{array}$ \\
\hline 3 & 38 & 0.4 & I6. 94 & 75 & 19 & 05.45 & $\begin{array}{l}\mathrm{N} \\
\mathrm{N} \\
\mathrm{S}\end{array}$ & $\begin{array}{l}24 \\
80 \\
23\end{array}$ & $\begin{array}{l}24 \\
24 \\
31\end{array}$ & $\begin{array}{l}\mathrm{E} \\
\mathrm{W} \\
\mathrm{W}\end{array}$ & $\begin{array}{l}\mathrm{S} \\
\mathrm{S} \\
\mathrm{N}\end{array}$ & $\begin{array}{l}24 \\
80 \\
23\end{array}$ & $\begin{array}{l}26 \mathrm{~W} \\
25 \mathrm{E} \\
30 \mathrm{E} .\end{array}$ & $\begin{array}{l}5974 \\
1412 \\
2324\end{array}$ & $\begin{array}{l}\text { Landlet. } \\
\text { Tizz. } \\
\text { Mill. }\end{array}$ \\
\hline 4 & 38 & 04 & I I. 44 & 75 & I 8 & $5^{8} .79$ & $\underset{\mathrm{N}}{\mathrm{N}}$ & $\begin{array}{l}22 \\
74 \\
29\end{array}$ & $\begin{array}{l}10 \\
59 \\
35\end{array}$ & $\begin{array}{l}\mathrm{E} \\
\mathrm{IV}^{+} \\
\mathrm{W}\end{array}$ & $\begin{array}{l}\mathrm{S} \\
\mathrm{S} \\
\mathrm{N}\end{array}$ & $\begin{array}{l}22 \\
75 \\
29\end{array}$ & $\begin{array}{l}\text { I I } \mathrm{W} \\
\text { OO E } \\
35 \mathrm{E}\end{array}$ & $\begin{array}{l}6075 \\
1625 \\
2238\end{array}$ & $\begin{array}{l}\text { Landlet. } \\
\text { Tizz. } \\
\text { Mill. }\end{array}$ \\
\hline
\end{tabular}

MINK TUMP.

(Middle Chincoteague Bay-Chan No. I5.)

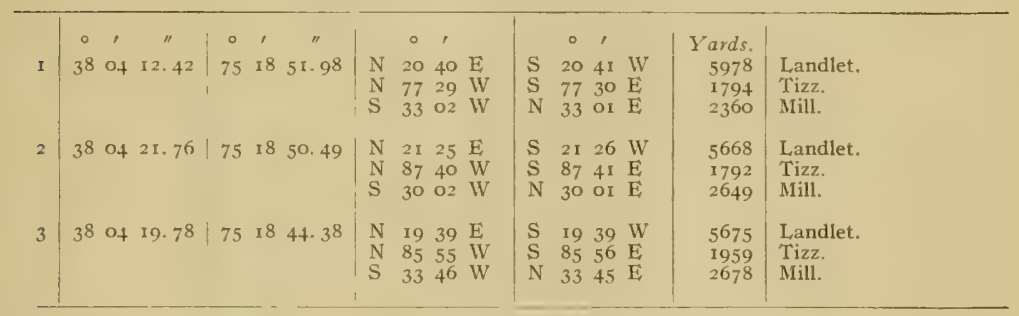

\section{EASTER COVE.}

(Middle Chincoteague Bay-Chart No. I5.)

\begin{tabular}{|c|c|c|c|c|c|c|c|c|c|c|c|c|c|c|}
\hline & 。 & , & $"$ & 。 & , & " & & 。 & , & & 。 & , & Yards & \\
\hline I & 38 & 04 & 22.64 & 75 & 18 & 40.08 & $\begin{array}{l}\mathrm{N} \\
\mathrm{N} \\
\mathrm{S}\end{array}$ & $\begin{array}{l}18 \\
88 \\
34\end{array}$ & $\begin{array}{ll}52 & \mathrm{E} \\
48 & \mathrm{~W} \\
37 & \mathrm{~W}\end{array}$ & $\begin{array}{l}\mathrm{S} \\
\mathrm{S} \\
\mathrm{N}\end{array}$ & $\begin{array}{l}18 \\
88 \\
34\end{array}$ & $\begin{array}{ll}53 & W \\
49 & E \\
36 & E\end{array}$ & $\begin{array}{l}5546 \\
2069 \\
2823\end{array}$ & $\begin{array}{l}\text { Landlet. } \\
\text { Tizz. } \\
\text { Mill. }\end{array}$ \\
\hline 2 & 38 & 04 & 26. $5^{8}$ & 75 & 18 & $45 \cdot 34$ & $\begin{array}{l}\mathrm{N} \\
\mathrm{S} \\
\mathrm{S}\end{array}$ & $\begin{array}{l}20 \\
87 \\
30\end{array}$ & $\begin{array}{ll}42 & E \\
20 & W \\
47 & W\end{array}$ & $\begin{array}{l}\mathrm{S} \\
\mathrm{N} \\
\mathrm{N}\end{array}$ & $\begin{array}{l}20 \\
87 \\
30\end{array}$ & $\begin{array}{l}43 \mathrm{~W} \\
\mathrm{I} 9 \mathrm{E} \\
47 \mathrm{E}\end{array}$ & $\begin{array}{l}5468 \\
1930 \\
2859\end{array}$ & $\begin{array}{l}\text { Landlet. } \\
\text { Tizz. } \\
\text { Mill. }\end{array}$ \\
\hline 3 & 38 & 04 & 31.64 & 75 & 18 & 32.15 & $\begin{array}{l}\mathrm{N} \\
\mathrm{S} \\
\mathrm{S}\end{array}$ & $\begin{array}{l}17 \\
83 \\
34\end{array}$ & $\begin{array}{ll}44 & \mathrm{E} \\
30 & \mathrm{~W} \\
38 & \mathrm{~W}\end{array}$ & $\begin{array}{l}\mathrm{S} \\
\mathrm{N} \\
\mathrm{N}\end{array}$ & $\begin{array}{l}17 \\
83 \\
34\end{array}$ & $\begin{array}{l}45 \mathrm{~W} \\
29 \mathrm{E} \\
38 \mathrm{E}\end{array}$ & $\begin{array}{l}5190 \\
2294 \\
3193\end{array}$ & $\begin{array}{l}\text { Landlet. } \\
\text { Tizz. } \\
\text { Mill. }\end{array}$ \\
\hline
\end{tabular}


BIG BAY POINT.

(Middle Chincoteague Bay-Chart No. 15.)

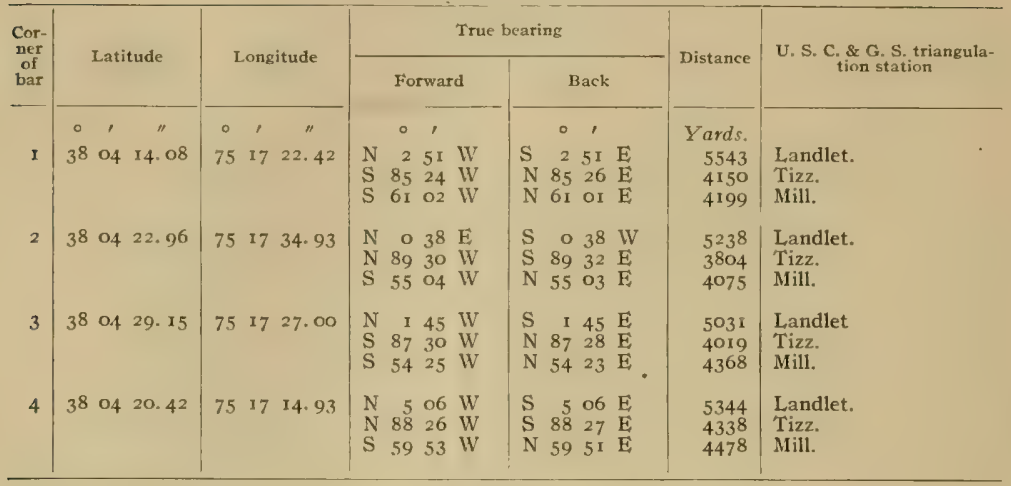

KENNEL.

(Middle Chincoteague Bay-Chart No. 15.)

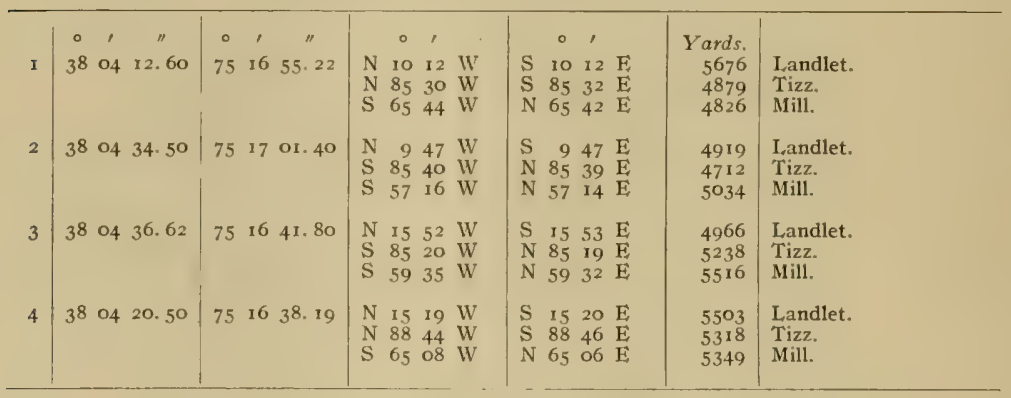

DRUM.

(Middle Chincoteague Bay-Chari No. 15.)

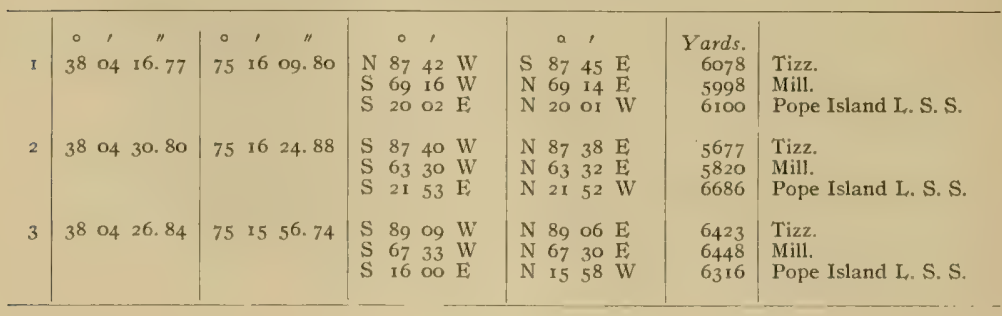


TOBY.

(Middle Chincoteague Bay-Chart No. 15.)

\begin{tabular}{|c|c|c|c|c|c|c|c|c|c|c|c|c|}
\hline \multirow{2}{*}{$\begin{array}{l}\text { Cor- } \\
\text { ner } \\
\text { of } \\
\text { bar }\end{array}$} & \multirow{2}{*}{\multicolumn{3}{|c|}{ Latitude }} & \multirow{2}{*}{\multicolumn{3}{|c|}{ Longitude }} & \multicolumn{4}{|c|}{ True bearing } & \multirow{2}{*}{ Distance } & \multirow{2}{*}{$\begin{array}{c}\text { U.S. C. \& G. S. triangula } \\
\text { tion station }\end{array}$} \\
\hline & & & & & & & & Forward & & Back & & \\
\hline & 0 & , & " & 0 & , & $" \prime$ & & 01 & & 0,1 & Yards. & \\
\hline I & $3^{8}$ & O3 & 53.19 & 75 & 17 & $41 \cdot 43$ & $\begin{array}{l}\mathrm{N} \\
\mathrm{S} \\
\mathrm{S}\end{array}$ & $\begin{array}{lll}74 & 04 & W \\
67 & 14 & W \\
42 & 34 & E\end{array}$ & $\begin{array}{l}\mathrm{S} \\
\mathrm{N} \\
\mathrm{N}\end{array}$ & $\begin{array}{lll}74 & \text { O5 } & \mathrm{E} \\
67 & \text { I } 3 & \mathrm{E} \\
42 & 33 & \mathrm{~W}\end{array}$ & $\begin{array}{l}3776 \\
3435 \\
6702\end{array}$ & $\begin{array}{l}\text { Tizz. } \\
\text { Mill. } \\
\text { Pope Island L. S S. }\end{array}$ \\
\hline 2 & $3^{8}$ & 04 & 1 8.79 & 75 & 17 & 52.86 & $\begin{array}{l}\mathrm{N} \\
\mathrm{S} \\
\mathrm{S}\end{array}$ & $\begin{array}{lll}87 & \text { OI } & \mathrm{W} \\
52 & 33 & \mathrm{~W} \\
39 & 50 & \mathrm{E}\end{array}$ & $\begin{array}{l}\mathrm{S} \\
\mathrm{N} \\
\mathrm{N}\end{array}$ & $\begin{array}{lll}87 & 02 & \mathrm{E} \\
52 & 32 & \mathrm{E} \\
39 & 48 & \mathrm{~W}\end{array}$ & $\begin{array}{l}3331 \\
3606 \\
755^{2}\end{array}$ & $\begin{array}{l}\text { Tizz. } \\
\text { Mill. } \\
\text { Pope Island L. S. S. }\end{array}$ \\
\hline 3 & $3^{8}$ & 04 & $\mathrm{I} 2.2 \mathrm{I}$ & 75 & 17 & 35.28 & $\begin{array}{l}\mathrm{N} \\
\mathrm{S} \\
\mathrm{S}\end{array}$ & $\begin{array}{lll}84 & 03 & \mathrm{WV} \\
59 & 23 & \mathrm{~W} \\
38 & 04 & \mathrm{E}\end{array}$ & $\begin{array}{l}\mathrm{S} \\
\mathrm{N} \\
\mathrm{N}\end{array}$ & $\begin{array}{lll}84 & 05 & E \\
59 & 22 & E \\
38 & 04 & W\end{array}$ & $\begin{array}{l}3816 \\
3870 \\
7084\end{array}$ & $\begin{array}{l}\text { Tizz. } \\
\text { Mill. } \\
\text { Pope Island L. S. S. }\end{array}$ \\
\hline 4 & $3^{8}$ & $\mathrm{O}_{3}$ & 55.12 & 75 & 17 & 30. 78 & $\begin{array}{l}\mathrm{N} \\
\mathrm{S} \\
\mathrm{S}\end{array}$ & $\begin{array}{lll}76 & 04 & W \\
68 & 00 & W \\
40 & 2 I & E\end{array}$ & $\begin{array}{l}\mathrm{S} \\
\mathrm{N} \\
\mathrm{N}\end{array}$ & $\begin{array}{lll}76 & 05 & \mathrm{E} \\
67 & 59 & \mathrm{E} \\
40 & 19 & W\end{array}$ & $\begin{array}{l}4034 \\
3723 \\
6562\end{array}$ & $\begin{array}{l}\text { Tizz. } \\
\text { Mill. } \\
\text { Pope Island L. S. S. }\end{array}$ \\
\hline
\end{tabular}

DEEP WATER.

(Middle Chincoteague Bay-Chart No. 15.)

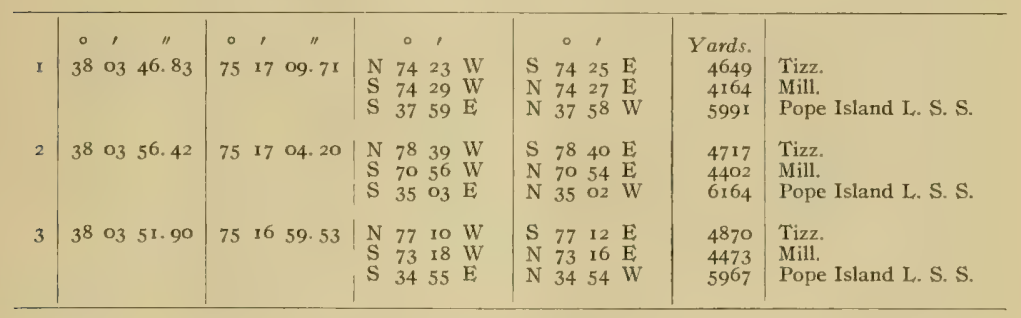

STRIKING MARSH.

(Middle Chincotcague Bay-Chart No. 15.)

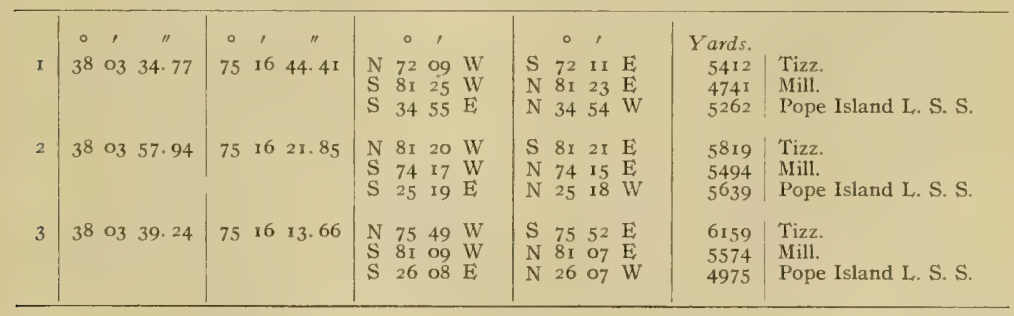


LEVIN TUMP.

(Middle Chincoteague Bay-Chart No. r5.)

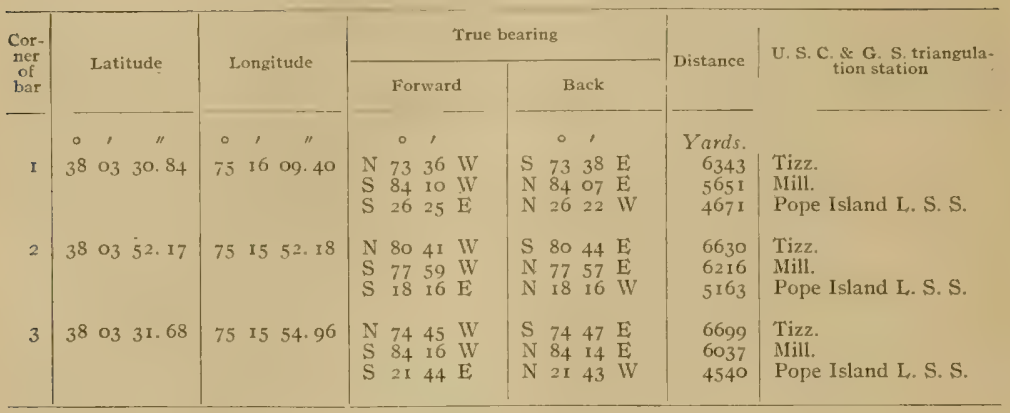

\section{WHITE ROCK.}

(Middle Chincoleague Bay-Chart No. I5.)

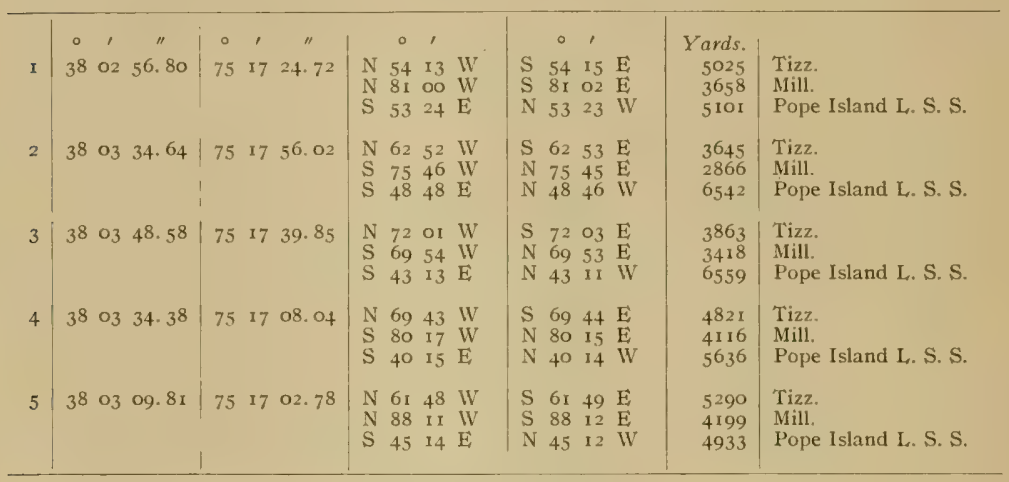

\section{HORSEHEAD NORTH.}

(Middle Chincoteague Bay-Chart No. I5.)

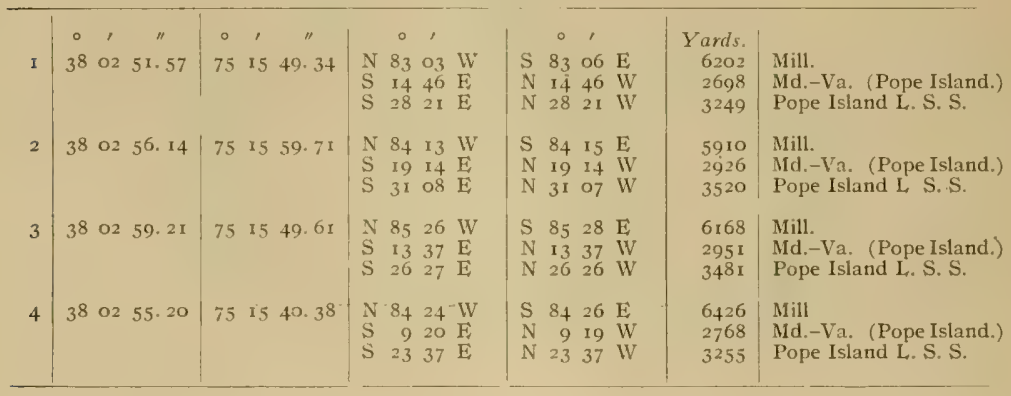


Survey of Oyster Bars, Worcester County, Md.

HORSEHEAD SOUTH.

(Middle Chincoteague Bay-Chart No. 15.)

\begin{tabular}{|c|c|c|c|c|c|c|c|c|c|c|c|c|c|}
\hline \multirow{3}{*}{$\begin{array}{l}\text { Cor- } \\
\text { ner } \\
\text { of } \\
\text { bar }\end{array}$} & \multirow{2}{*}{\multicolumn{3}{|c|}{ Latitude }} & \multirow{2}{*}{\multicolumn{3}{|c|}{ Longitude }} & \multicolumn{5}{|c|}{ True bearing } & \multirow{3}{*}{$\begin{array}{l}\text { Distance } \\
\text { Yards. } \\
5838 \\
2340 \\
3045\end{array}$} & \multirow{2}{*}{$\begin{array}{c}\text { U. S. C. \& G. S. triangula- } \\
\text { tion station }\end{array}$} \\
\hline & & & & & & & \multicolumn{3}{|c|}{ Forward } & \multicolumn{2}{|r|}{ Back } & & \\
\hline & $\begin{array}{c}0 \\
38\end{array}$ & $\begin{array}{l}\text { ' } \\
02\end{array}$ & 34.50 & $\begin{array}{c}\circ \\
75\end{array}$ & 16 & $\begin{array}{c}\prime \prime \\
07.00\end{array}$ & $\begin{array}{l}\mathrm{N} \\
\mathrm{S} \\
\mathrm{S}\end{array}$ & $\begin{array}{ccc}0 & 1 \\
76 & 53 & \mathrm{I} \\
29 & 40 & \mathrm{E} \\
+\mathrm{T} & 25 & \mathrm{E}\end{array}$ & $\begin{array}{l}\text { W } \\
\mathrm{E} \\
\mathrm{E}\end{array}$ & $\begin{array}{ll}\mathrm{S} & 7 \\
\mathrm{~N} & 2 \\
\mathrm{~N} & 4\end{array}$ & $\begin{array}{lcl}\circ & 1 \\
76 & 55 & \mathrm{E} \\
29 & 40 & \mathrm{WV} \\
4 \mathrm{I} & 24 & \mathrm{~W}\end{array}$ & & $\begin{array}{l}\text { Mill. } \\
\text { Md.-Va. (Pope Island.) } \\
\text { Pope Island L. S S. }\end{array}$ \\
\hline 2 & 38 & 02 & $42.5 \mathrm{I}$ & 75 & 16 & 17.94 & $\begin{array}{l}N \\
S \\
S\end{array}$ & $\begin{array}{lll}78 & 56 & \text { I } \\
32 & 12 & \text { E } \\
42 & 05 & \mathrm{E}\end{array}$ & $\begin{array}{l}\text { W } \\
\mathrm{E} \\
\mathrm{E}\end{array}$ & $\begin{array}{ll}\mathrm{S} & 7 \\
\mathrm{~N} & 3 \\
\mathrm{~N} & 4\end{array}$ & $\begin{array}{lll}78 & 58 & \mathrm{E} \\
32 & 11 & \mathrm{~W} \\
42 & 04 & \mathrm{~W}\end{array}$ & $\begin{array}{l}5495 \\
2723 \\
3440\end{array}$ & $\begin{array}{l}\text { Mill. } \\
\text { Md.-Va. (Pope Island.) } \\
\text { Pope Island L. S. S. }\end{array}$ \\
\hline 3 & 38 & 02 & 46.34 & 75 & 15 & 57.02 & $\begin{array}{l}\mathrm{N} \\
\mathrm{S} \\
\mathrm{S}\end{array}$ & $\begin{array}{lll}81 & 09 & \mathrm{H} \\
20 & 09 & \mathrm{H} \\
33 & 05 & \mathrm{E}\end{array}$ & $\begin{array}{l}\text { W } \\
\mathrm{E} \\
\mathrm{E}\end{array}$ & $\begin{array}{ll}\mathrm{S} & 8 \\
\mathrm{~N} & 2 \\
\mathrm{~N} & 3\end{array}$ & $\begin{array}{lll}8 \mathrm{I} & \mathrm{I} 2 & \mathrm{E} \\
20 & 08 & \mathrm{WV} \\
33 & 05 & \mathrm{~W}\end{array}$ & $\begin{array}{l}6022 \\
2592 \\
3202\end{array}$ & $\begin{array}{l}\text { Mill. } \\
\text { Md.-Va. (Pope Island.) } \\
\text { Pope Island L. S. S. }\end{array}$ \\
\hline 4 & 38 & 02 & 38.46 & 75 & 15 & 56.34 & $\begin{array}{l}\mathrm{N} \\
\mathrm{S} \\
\mathrm{S}\end{array}$ & $\begin{array}{lll}78 & 43 & \mathrm{~V} \\
2 \mathrm{I} & 59 & \mathrm{E} \\
35 & 36 & \mathrm{E}\end{array}$ & $\begin{array}{l}W \\
\mathrm{E} \\
\mathrm{E}\end{array}$ & $\begin{array}{ll}\mathrm{S} & 7 \\
\mathrm{~N} & 2 \\
\mathrm{~N} & 3\end{array}$ & $\begin{array}{lll}78 & 45 & \mathrm{E} \\
2 \mathrm{I} & 59 & \mathrm{~W} \\
35 & 36 & \mathrm{~W}\end{array}$ & $\begin{array}{l}6087 \\
2337 \\
2972\end{array}$ & $\begin{array}{l}\text { Mill. } \\
\text { Md.-Va. (Pope Island.) } \\
\text { Pope Island L. S. S. }\end{array}$ \\
\hline
\end{tabular}





\section{A P PENDIXES.}

\section{APPENDIX A.-LAWS RELATING TO THE COOPERATION OF THE COAST AND GEODETIC SURVEY AND BUREAU OF FISHERIES WITH THE MARYLAND SHELL FISH COM- MISSION.}

The work of the Coast and Geodetic Survey and of the Bureau of Fisheries, in cooperation with the Maryland Shell Fish Commission, in surveying the oyster bars, establishing permanent landmarks at triangulation stations, and preparing for publication the necessary charts and technical and legal descriptions of boundaries and landmarks shown on these charts, has been executed in compliance with a request from the governor of the State of Maryland to the Secretary of Commerce and Labor, and by the authority of the following laws of the United States and Maryland:

[Act of Congress approved May 26, 1906.]

AN ACT To authorize the Secretary of Commerce and Labor to cooperate, through the Bureau of the Coast and Geodetic Survey and the Bureau of Fisheries, with the shellfish commissioners of the State of Maryland in making surveys of the natural oyster beds, bars, and rocks in the waters within the State of Maryland.

Be it enacted by the Senate and House of Representatives of the United States of America in Congress assembled, That the Secretary of Commerce and Labor be, and he is hereby, authorized and directed, upon the request of the governor of the State of Maryland, to designate such officers, experts, and employees of the Bureau of the Coast and Geodetic Survey and of the Bureau of Fisheries as may be necessary to cooperate with the Maryland State board of shellfish commissioners in making a survey of and locating the natural oyster beds, bars, and rocks in the waters within the State of Maryland; and the Secretary of Commerce and Labor is hereby authorized and directed to furnish to the officers, experts, and employees of said Bureaus so detailed as aforesaid such instruments, appliances, and steam launches as may be necessary to make the survey aforesaid; and the Secretary of Commerce and Labor is hereby authorized to have made in the Bureau of the Coast and Geodetic Survey all the plats necessary to show the results of the aforesaid survey and the locations of the said natural oyster beds, bars, and rocks in the waters within the State of Maryland, and to furnish to the board of shellfish commissioners of the State of Maryland such copies as may be necessary, and for this purpose to employ, in the District of Columbia and elsewhere, such technically qualified persons as may be necessary to carry out the purpose of this act.

SEC. 2. That the Secretary of Commerce and Labor is hereby further authorized to have erected or constructed by the officers so detailed as aforesaid, while making such survey, such structures as may be necessary to mark the points of triangulation, so that the same may be used for such future work of the Coast and Geodetic Survey as the said Bureau may be hereafter required to perform in prosecuting the Government coast survey of the navigable waters of the United States located within the State of Maryland.

\footnotetext{
SEC. \&. That this act shall take effect from the date of its passage.
} 
[Act of Congress approved June 30, 1906.$]$

AN ACT Making appropriations for sundry civil expenses of the Goverument for the fiscal year ending June thirtieth, nineteen hundred and seven, and for other purposes.

Be it cnacted by the Senate and House of Represcntatives of the United States of America in Congress asscmbled, That the following sums be, and the same are hereby, appropriated, for the objects hereinafter expressed, for the fiscal year ending June thirtieth, nineteen hundred and seven, namely: $* * *$

COASt And Geodetic Survex: * * * For any special surveys * * * including the expenditures authorized under Public Act Numbered One hundred and eighty-one, approved May twenty-sixth, nineteen hundred and six, and contingent expenses incident thereto, five thousand dollars, together with the unexpended balance under this appropriation for nineteen hundred and six and prior years which is lereby reappropriated and made available on this account for the fiscal year nineteen hundred and seven. $* * *$

[Act of Congress approved March 4, r907.]

AN ACT Making appropriations for sundry civil expenses of the Government for the fiscal year ending June thirtieth, nineteen hundred and eight, and for other purposes.

Be it enacted by the Senate and House of Representatives of the United States of America in Congress assembled, That the following sums be, and the same are hereby, appropriated, for the objects hereinafter expressed, for the fiscal year ending June tlirtieth, nineteen hundred and eight, namely: * * *

COAST AND GeOdetrC SURver: * * *. For any special surveys * * * including expenses of surveys in aid of the shellfish commission of the State of Maryland, to be immediately available and to continue available until expended, twenty-five thousand dollars. $* * *$

[Act of Congress approved May 27, 1908.]

AN ACT Making appropriations for sundry civil expenses of the Government for the fiscal year ending June thirtietb, nineteen hundred and nine, and for other purposes.

Be it enacted by the Senate and House of Representatives of the United States of America in Congress assembled, That the following sums be, and the same are hereby, appropriated, for the objects hereinafter expressed, for the fiscal year ending June thirtieth, nineteen hundred and nine, namely: ***

COAST AND GEODETrC SURvey: * * * For any special surveys * * * including expenses of surveys in aid of the shellfish commission of the State of Maryland, which expenses, including cost of plats and charts, shall not exceed fifteen thousand dollars in any one year, to be immediately available, twenty thousand dollars.

[Act of the legislature of Maryland approved April 2, 1906.]

AN ACT To establish and promote the industry of oyster culture in Maryland, to define and mark natural oyster beds, bars and rocks lying under the waters of this State, to prescribe penalties for the infringement of the provisions of this Act, and * * *

SEctron I. Be it enacted by the General Assembly of Maryland, That the following sections be, and they are hereby, added to Article 72 of the Code of Public General Laws, title "Oysters." * * *

SEC. 86. The Board of Shell Fish Commissioners shall, as soon as practicable after the passage of this Act, cause to be made a true and accurate survey of the natural oyster beds, bars and rocks of this State, said survey to be made with reference to fixed and permanent objects on the shore, giving courses and distances, to be fully described and set out in a written report of said survey, as hereinafter required. A true and accurate delineation of the same shall be made on copies of published maps and charts of the United States coast and geodetic survey, which said copies shall be filed in the office of the said commissioners in the city of Annapolis; and the said commissioners shall further cause to be 
delineated upon copies of the published maps and charts of the United States coast and geodetic survey, of the largest scale, one copy for each of the counties of this State in the waters of which there are natural oyster beds, bars and rocks, all natural beds, bars and rocks lying within the waters of such county, which maps shall be filed in the offices of the clerks of the Circuit Court for the respective counties wherein the grounds so designated may lie. * * *

SEC. 87. The Governor of this State is hereby requested to ask the assistance of the United States coast and geodetic survey, and of the United States Fish Commissioner, to aid in the carrying out of the provisions of the preceding section.

SEC. 89. As soon as practicable after the first day of April, 1906, the said commissioners shall organize, and shall at once proceed, with the assistance of such person or persons as may be detailed by the United States coast and geodetic survey, and the United States Fish Commissioner, to aid them in their work, and of such persons as may be appointed under the preceding section, to have laid out, surveyed and designated on the said charts, the natural beds and bars, and shall cause to be marked and defined as accurately as practicable, the limits and boundaries of the natural beds, bars and rocks, as established by said survey, and they shall take true and accurate notes of said survey in writing, and make an accurate report of said survey, setting forth such a description of landmarks as may be necessary to enable the said board, or their successors, to find and ascertain the boundary lines of the said natural oyster beds, bars and rocks, as shown by a delineation on the maps and charts provided in this Act; said report shall be completed and filed in the oflice of the board in the city of Annapolis within nirety days after the completion of the survey of any county. Said commissioners shall cause the same to be published in pamphlet form, and transmit copies of the same to the clerks of the Circuit Court for the respective counties, where the charts have been filed or directed to be filed as hereinafter provided; the said report to be filed by the clerks of the several counties in a book kept for that purpose. And the said survey and report, when filed, subject to the right of appeal hereafter provided for in this Act, shall be taken in all of the courts of this State as conclusive evidence of the boundaries and limits of all natural ayster beds, bars and rocks, lying within the waters of the county wherein such survey and report are filed, and shall be construed to mean in all of the said courts that there are no natural oyster beds, bars or rocks lying within the waters of the counties wherein such report and survey are filed, other than those embraced in the survey authorized by this Act, and that all areas of the Chesapeake Bay and its tributaries within the State of Maryland, not shown in the survey to be natural oyster beds, bars or rocks shall be construed in all the courts of the State to be barren bottoms, and open for disposal by the State for the purpose of private planting or propagation of oysters thereon under the provisions of this Act; provided, that the said survey and report shall not be construed as to affect in any manner the holdings by citizens of this State in any lot which may have been appropriated or taken up under the laws of this State prior to the approval of this Act.

The law of the State of Maryland, passed March 9, 1842, authorizing officers of the United States Coast and Geodetic Survey to enter upon the lands within the State limits for the purposes of the Survey, is as follows:

AN ACT Concerning the Survey of the Coast of Maryland.

Secrion $x$. Be it enacted by the General Assembly of Maryland, That it shall and may be lawful for any person or persons employed under and by virtue of an act of the Congress of the United States, * * * at any time hereafter to enter upon lands within this State for the purpose of exploring, surveying, triangulating, or levelling, or doing any other matter or thing which may be necessary to effect the objects of said act, and to erect any works, stations, buildings, or appendages requisite for that purpose, doing no unnecessary injury to private or other property.

SEC. 2,a And be it enacted, That in case the person or persons employed under the act of Congress aforesaid, can not agree with the owners or possessors of the land so entered upon and used as to the

a Uader the rulings of the Comptroller of the Treasury no damages can be collected except through the United States Court of Claims unless an agreement has been made in advance. 
amount of damage done thereto by reason of the removal of fences, cutting of trees or injury to the crop or crops growing on the same, it shall and may be lawful for the said parties or either of them to apply to the chief justice for the time being or one of the associate judges of the judicial district in which such land may be situated, who shall thereupon appoint three disinterested and judicious freeholders, residents of the same judicial district, to proceed with as much despatch as possible to the examination of the matter in question, and the faithful assessment of the damages sustained by the owners or possessors aforesaid, and the said freeholders or a majority of them, having first taken and subscribed an oath or affirmation before the chief or associate justice aforesaid or other person duly authorized to administer the same, that they will well and truly examine and assess as aforesaid, and having given five days' notice to both parties of the time of their meeting, shall proceed to the spot, and then and there upon their own view and if required, upon the evidence of witnesses, (to be by them sworn or affirmed and examined) shall assess the said damages, and shall afterward make report thereof and of their proceedings in writing under their hands and seals and file the same within five days thereafter in the office of the clerk of the county in which the land aforesaid is situated, subject to an appeal by either party to the county court of the said county within ten days after filing as aforesaid, and the said report so made as aforesaid if no appeal as aforesaid be taken, shall be held to be final and conclusive as between the said parties, and the amount so assessed and reported slall be paid to the said owners or possessors of the land so damaged within twenty days after the filing of said report, and the said chief or associate justice as aforesaid, shall have authority to tax and allow upon the filing of said report, such costs, fees and expenses to the said freeholders for the performance of their duty as he shall think equitable and just, which allowance shall be paid by the person or persons employed under the act of congress aforesaid, within the time last above limited, but if an appeal as aforesaid be taken, the case shall be set down for hearing at the first term of county court aforesaid, ensuing upon and after appeal, and it shall be lawful for either party immediately after the entry of such appeal, to take out summons for such witnesses as may be necessary to be examined upon the hearing aforesaid, and the said court shall have power in its discretion to award costs against which ever the final judgment shall be entered, and such appeal at the option of either party may and shall be heard before and the damage assessed by a jury of twelve men to be taken from the regular panel and elected as in other cases.

SEC. 3. And be it enacted, That if any person or persons shall wilfully injure or deface or remove any signal, monument or building or any appendage thereto, erected, used or constructed under and by virtue of the act of congress aforesaid, such person or persons so offending shall severally forfeit and pay the sum of fifty dollars with costs of suit to be sued for and recovered by any person who shall first prosecute the same before any justice of the peace of the county where the person so offending may reside, and shall also be liable to pay the amount of damages thereby sustained, to be recovered with costs of suit in an action on the case, in the name and for the use of the United States of America, in any court of competent jurisdiction.

\section{APPENDIX B.-THE HAMAN OYSTER CULTURE I,AW}

[Extract from Second Report of Shell Fish Commission.]

OBJECT.

"The legislature in placing chapter 711 of the acts of 1906 , better known as the Haman Oyster Culture Law, upon the statute books of Maryland had a twofold object in view:

I. To encourage an industry in oyster culture upon the barren bottoms beneath the tidewaters of the State.

2. To prevent the leasing of natural oyster bars for the purpose of oyster culture."

$$
\text { SURVEY. }
$$

"To make the leasing of barren bottoms possible and the leasing of natural bars impossible, provision was made for a survey of the natural bars for the purpose of accurately locating and marking the same. It was definitely provided that no barren bottoms should be leased in any part of the State until the natural bars of that region had been surveyed, charted, and marked with buoys." 
Definition of a Natural Oyster Bar.

NATURAL BAR NOT DEFINED.

"The Shell Fish Commission is instructed by section 90 of the Haman Oyster Culture Law to exercise its judgment liberally in favor of the natural bars when surveying, charting and buoying them, but other than this the Commission is uninstructed in this important matter. The responsibility of defining a natural bar is placed upon the Commission."

DIVERSITY OF OPINION.

"No definition of a natural oyster bar could be formulated by any man or body of men which would meet with the approval of all parties concerned. Oystermen, as a rule, hold that all bottoms where oysters grow or have grown naturally even though now practically barren of oysters should be considered natural bars. Other citizens of the State who are not directly interested in the oyster business, but interested in the oyster industry from the standpoint of revenue, hold, as a rule, that no bottoms should be excluded from leasing for oyster culture which, by methods known to oyster culturists, may be made to yield a greater number of oysters than they now produce."

"It should be evident to every one that neither of these definitions could be adopted by the Commission as a working basis for determining which of the grounds surveyed are natural oyster bars."

THE GOLDSBOROUGH DEFINITION

The definition of a natural oyster bar which very nearly approaches a reasonable and satisfactory compromise between the views of the subject held by oystermen on one hand and by oyster culturists on the other is that contained in an opinion rendered by Judge Charles F. Goldsborough in the circuit court for Dorchester County in the July term, x88I, in the case of William T. Windsor and George R. Todd $v$. Job T. Moore.

This definition has been adopted by the Shell Fish Commission as the basis for the determination of the status of the various oyster bottoms surveyed and is as follows:

What then is a natural bar or bed of oysters? It would be a palpable absurdity for the State to attempt to promote the propagation and growth of oysters and to encourage its citizens, by a grant of land, to engage in their culture, if the lands authorized to be taken up were only those upon which oysters do not and can not be made to grow. That there may be lands covered by water in the State where no oysters can be found, but where, if planted, they could be cultivated successfully, may be possible, but, if so, I imagine that their extent must be too limited for them to be of much practical, general advantage for the purposes of such a law as the one under discussion; but there are thousands of acres of hard and shifting sands where oysters not only are not found, but where it would be folly to plant them; and these latter it can not be supposed that the State intended to offer to give away, for the simple reason that the State could not help knowing that nobody would have them.

Upon the other hand there are large and numerous tracts where oysters of natural growth may be found in moderate numbers, but not in quantities sufficient to make it profitable to catch them, and yet where oysters may be successfully planted and propagated. In my opinion these can not be called natural bars or beds of oysters, within the meaning of the Act of Assembly, and it is just such lands as these that the State meant to allow to be taken up under the provisions of the above-mentioned section of the Act.

But there is still another class of lands where oysters grow naturally and in large quantities and to which the public are now and have been for many years in the habit of resorting with a view to earning a livelihood by catching this natural growth, and here, I think, is the true test of the whole question. Land can not be said to be a natural oyster bar or bed merely because oysters are scattered here and there upon it, and because if planted they will readily live and thrive there; but whenever the natural growth is so thick and abundant that the public resort to it for a livelihood, it is a natural oyster bar or bed and comes within the above-quoted restriction in the law, and can not be located or appropriated by any individual.

APPLICATION OF DEFINITION.

Before this definition may be of use in determining, accurately and scientifically, the status of an oyster ground, its central idea, "livelihood," must be expanded into accurately determinable factors, and these factors must be combined into a practical scheme of investigating the condition of the ground under consideration.

Stated brielly, a livelihood is represented by a sum of money obtained from the sale, at a fixed price, of a certain quantity of oysters gathered in a given time from an allotted area of ground.

$$
82497-09-5
$$


Knowing the value of each of these factors it becomes possible to calculate the number of oysters an oyster ground must produce per square yard in order that oystermen may secure a livelihood by working upon it.

NoTE.-The factors into which the Commission resolved the livelihood problem, the value assigned to each factor, and the scheme devised for practical use in examining and applying the definition to oyster bottoms are given in outline in their Second Report under the heading of the preceding extract, and in detail in their First Report on pages 32 to 69.

\section{APPENDIX C.-SUMMARY OF THE PARTICULAR SURVEYING OPERATIONS IVHICH CON- STITUTE AN "OYSTER SURVEY" AS NOW, BEING CARRIED ON IN MARYLAND.}

Explanation.-A brief account of the particular surveying operations which constitute an "oyster survey" as now being carried on in Maryland will assist in the interpretation of records contained in the technical part of this report, and will be of interest to many who may not understand the necessity for the great amount of work being done or its complicated character.

To those familiar with methods used in surveying and charting the characteristic features of large bodies of water there is an evident necessity for the various operations performed, especially when it is known that the boundaries of the public oyster bars and of the private lots leased for purposes of oyster culture must be surveyed and charted with the greatest practical accuracy. To others it will be sufficient to state that the actual experience gained from oyster surveys in other States has proven that in order to avoid endless dissatisfaction and litigation it is necessary to accurately locate and permanently establish oyster boundaries as is now being done in Maryland.

Triangulation survey.-Such refinement of survey work as that demanded by the conditions of an oyster survey when carried on at considerable distances offshore can only be obtained by the use of a system of triangulation as a frame work or foundation. Therefore, a triangulation survey including the permanent marking of the positions of landmarks with monuments and a record of the descriptions of their locations for future recovery is a necessary operation of a complete oyster survey.

Topographic survey. - The technical records which establish the relation between the offshore oyster boundaries and triangulation landmarks are sufficient for the requirements of engineers in making resurveys, but do not supply the needs of others who are interested in the same boundaries by reason of their occupation as oystermen concerned as to the public oyster bars, or oyster culturists concerned as to the leasable bottoms. For these it is necessary to have the charts of the survey show the relation of the shore line and other topographic features to the boundaries of the public oyster bars and private oyster farms. Therefore, a topographic survey is a necessary operation of a complete oyster survey.

Hydrographic survey.-In the settlement of the important question of what is, or what is not, a natural oyster bar, and in the consideration of bottoms to be selected for purposes of oyster culture, information as to the depth of water and the character of the bottom is required. Therefore, a hydrographic survey is a necessary operation of a complete oyster survey.

Necessary foundation for an oyster survey.-Consequently, the necessary components of a satisfactory foundation for a complete oyster survey are the three classes of survey operations technically named triangulation, topography, and hydrography, or, stated in another way, the foundation of a practical oyster survey includes the surveying operations usually followed by the Coast and Geodetic Survey leading up to the preparation and publication of nautical charts.

Special surveys and investigations pertaining to oysters.-Having obtained this cartographic suryey for a foundation, partly by new work and partly from records of previous work of the Government, the combined operations $a$ making up an "oyster survey" are completed by superimposing on this foundation special surveys and investigations pertaining particularly to oysters or other shell fish.

The special surveys pertaining to oysters furnish information as to the location and outline of oyster-shell bottoms, and are carried on by the sounding boat party in addition to the usual hydrographic work. $b$ This operation consists of the observation and record of the character of vibration of a wire and chain apparatus which is dragged over the bottom, the vibrations or lack of vibrations indicating the presence and quantity of shells or absence of shells.

a See Appendix D of this publication for "Statistics of results of combined operations of the Government and State."

oSee pages 104 to 123 of "First Annual Report of Maryland Shell Fish Commission." 
The special oyster investigations ${ }^{a}$ consist of the actual determination of the kind and quantity of oysters on the bottom, and such economic and biological studies of the supply of oyster food, density of water, character of the bottom, and other important matters as affect the growth of oysters. In this work the oyster investigation stations are located and buoyed by the hydrographic party while engaged in the survey of the oyster-shell limits. They are selected with the view of obtaining characteristic data which can be used for the interpretation of the recorded vibrations of the chain apparatus at all other points covered by the survey.

Preparation of results.- The actual surveying operations and oyster investigations having been completed for any one county, there still remains technical work of nearly equal magnitude to that described. $b$ This work consists of the preparation of charts and 'technical descriptions of boundaries and landmarks for publication by the Government, the preparation of that part of the annual report of the Commission covering the special oyster surveys and investigations, the making of the leasing charts and finished projections, and finally the filing of the oyster charts and records with the courts and the Commission, thus opening a county for oyster culture.

Summary:-From the foregoing account it can be seen that a complete oyster survey properly conducted so as to answer all practical requirements of the present and permanency of results for the future is a very complicated affair, involving many lines of surveying and other scientific work, and requiring the professional services of experts in the various operations of cartographic surveying and shell-fish investigations.

APPENDIX D.-STATISTICS OF RESULTS OF THE COMBINED OYSTER SURVEY OPERATIONS OF THE GOVERNMENT AND STATE.

\begin{tabular}{|c|c|c|c|c|c|}
\hline Opetations & $\begin{array}{l}\text { Anne } \\
\text { ArundeI } \\
\text { County } d\end{array}$ & $\begin{array}{l}\text { Somerset } \\
\text { County } d\end{array}$ & $\begin{array}{l}\text { Wicomico } \\
\text { County } d\end{array}$ & $\begin{array}{l}\text { Worcester } \\
\text { County } d\end{array}$ & Total \\
\hline Natural oyster bars surveyed and delineated & 91 & 37 & I5 & 28 & \\
\hline Acres of natural oyster bars & 33,666 & 27.566 & 2,038 & 1,655 & $c 64.925$ \\
\hline Crab bottoms surveyed and delineated .- & & 54 & & & \\
\hline Acres of crab bottoms & --- & 32.108 & & & 32,108 \\
\hline Clam beds surveyed and delineated .... & $\ldots$ & 3 & & & \\
\hline 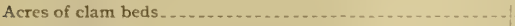 & $\ldots . .$. & 506 & & $\ldots$ & 500 \\
\hline Joundary buoys located and planted ............ & 362 & 154 & 53 & 108 & \\
\hline 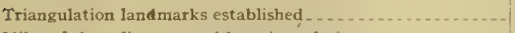 & 123 & 86 & 30 & 48 & $f_{257}$ \\
\hline Miles of shore line covered by triangulation ................ & 110 & I 25 & 46 & 95 & $f_{3} 60$ \\
\hline Square miles of water covered by triangulation........... & 220 & 375 & 44 & 110 & $f 730$ \\
\hline Miles of examination of shell bottom with chain apparatus. - & 369 & 296 & 58 & 63 & \\
\hline Oyster investigation stations occupied & 440 & 679 & 162 & 147 & I. 428 \\
\hline Tide stations established $\ldots \ldots \ldots$ & 4 & 3 & I & I & \\
\hline Number of soundings over shell bottoms .................... & 37.049 & 17,904 & 3,387 & 3,649 & $6 r, 989$ \\
\hline Square miles covered by soundings and chain apparatus.... & 58 & 47 & 3 & 3 & \\
\hline I'rojections prepared and plotted & 9 & 13 & 2 & 5 & $f_{2}$ \\
\hline Leasing charts prepared & 13 & 12 & 2 & . 3 & \\
\hline Oyster charts published & 4 & 6 & 2 & 3 & \\
\hline Reports published & 2 & 2 & 2 & 21 & \\
\hline Progress maps published & 2 & 2 & 2 & 21 & \\
\hline
\end{tabular}

a See pages 30 to 67 and I 29 to 199 of "First Annual Report of Maryland Shell Fish Commission."

$b$ No mention is made here of the large amount of administrative work of the Commission, which is greatly complicated and increased by the effect of the oyster-survey operations on many thousands of people whose interests are more or less involved: or of the large amount of survey work involved in the survey and record of the boundaries of oyster lots leased from the State by private individuals for the purposes of oyster culture.

$c$ These statistics do not include the large amount of triangulation, topography, and hydrography resulting from previous work of the Coast and Geodetic Survey which was utilized in the preparation of the published oyster charts and records.

$d$ Work in Calvert, St, Marys, and Charles counties has been finished, but final statistics of results will not be published until these counties are opered for oyster culture.

$e$ Total area of natural oyster bars of Connecticut is 5.770 acres.

$f$ Less quantities covered by statistics of more than one county. 









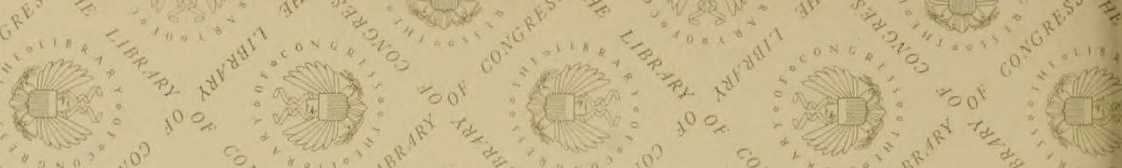
(1) 1) TRA

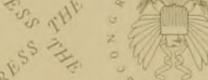

(C)

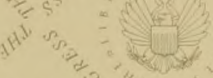

$\lim _{\rightarrow \rightarrow \infty}$

atily

Len

An

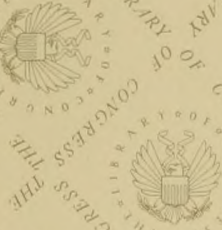

int

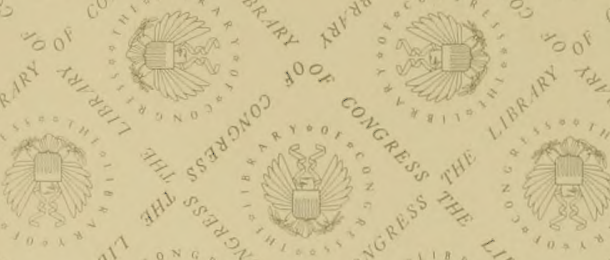

(2)

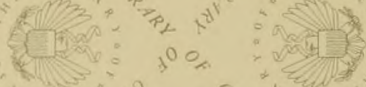

thes

तin?

trits

1大in

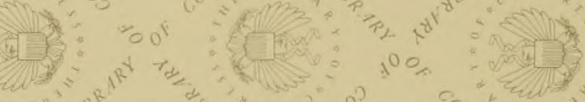

3001

of

(I)

$300^{\circ}$

(fm

(ning) 
